\title{
The Varga Site: A Multicomponent, Stratified Campsite in the Canyonlands of Edwards County, Texas
}

\author{
J. Michael Quigg \\ Jeffrey D. Owens \\ Paul M. Matchen \\ Grant D. Smith \\ Robert A. Ricklis
}

See next page for additional authors

Follow this and additional works at: https://scholarworks.sfasu.edu/ita

Part of the American Material Culture Commons, Archaeological Anthropology Commons, Environmental Studies Commons, Other American Studies Commons, Other Arts and Humanities Commons, Other History of Art, Architecture, and Archaeology Commons, and the United States History Commons

Tell us how this article helped you.

This Article is brought to you for free and open access by the Center for Regional Heritage Research at SFA ScholarWorks. It has been accepted for inclusion in Index of Texas Archaeology: Open Access Gray Literature from the Lone Star State by an authorized editor of SFA ScholarWorks. For more information, please contact cdsscholarworks@sfasu.edu. 


\title{
The Varga Site: A Multicomponent, Stratified Campsite in the Canyonlands of Edwards County, Texas
}

\author{
Authors \\ J. Michael Quigg, Jeffrey D. Owens, Paul M. Matchen, Grant D. Smith, Robert A. Ricklis, Mercedes C. Cody, \\ and Charles D. Frederick

\section{Licensing Statement} \\ This is a work for hire produced for the Texas Department of Transportation (TxDOT), which owns all \\ rights, title, and interest in and to all data and other information developed for this project under its \\ contract with the report producer. The report may be cited and brief passages from this publication may \\ be reproduced without permission provided that credit is given to TxDOT and the firm that produced it. \\ Permission to reprint an entire chapter, section, figures or tables must be obtained in advance from the \\ Supervisor of the Archeological Studies Branch, Environmental Affairs Division, Texas Department of \\ Transportation, 125 East 11th Street, Austin, Texas, 78701.
}




\section{The Varga Site: \\ A Multicomponent, Stratified Campsite in the Canyonlands of Edwards County, Texas Volume I}

By:

J. Michael Quigg, Jeffrey D. Owens, Paul M. Matchen,

Grant D. Smith, Robert A. Ricklis, Mercedes C. Cody, and Charles D. Frederick

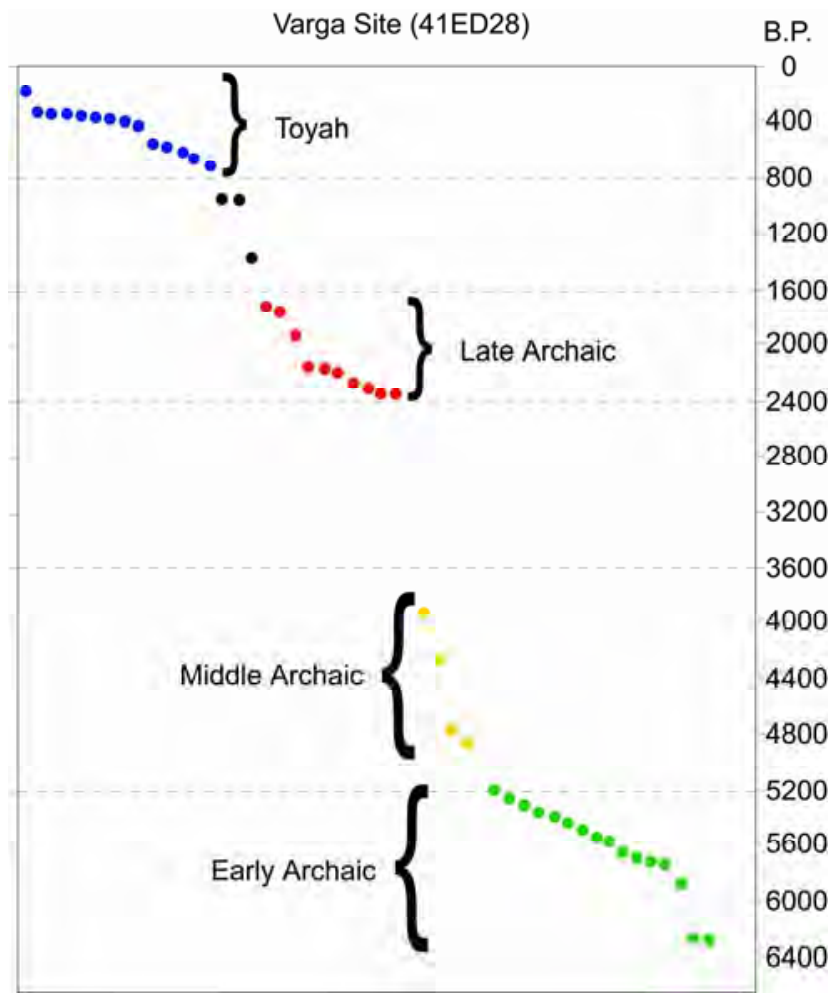

Prepared for:

Prepared by:

Texas Department of Transportation

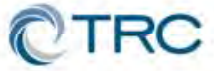

Texas Department of Transportation

Environmental Affairs Division

Austin, Texas

TRC Environmental Corporation Austin. Texas

Technical Report No. 35319

Texas Antiquities Committee Permit No. 2779

Texas Department of Transportation Archeological Studies Program Report No. 110 


\title{
The Varga Site: \\ A Multicomponent, Stratified Campsite in the Canyonlands of Edwards County, Texas
}

\author{
By: \\ J. Michael Quigg, Jeffrey D. Owens, Paul M. Matchen, \\ Grant D. Smith, Robert A. Ricklis, Mercedes Cody, and Charles D. Frederick \\ Prepared for:

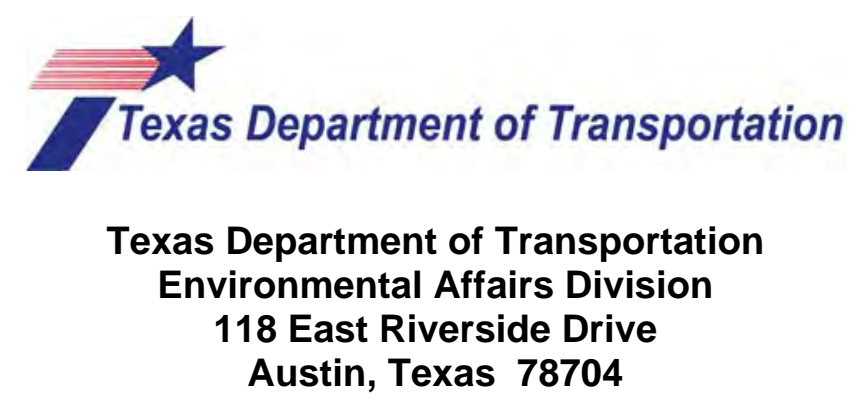 \\ Prepared by:

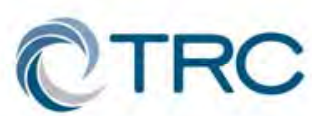 \\ 505 East Huntland Drive, Suite 250 \\ Austin, Texas 78752
}

J. Michael Quigg, Principal Investigator

Technical Report No. 35319

Texas Antiquities Committee Permit No. 2779

Scientific Services Contract No. 572XXSA004

Texas Department of Transportation Archeological Studies Program Report No. 110

CSJ: 0830-01-014

November 2008 
Copyright (C) 2008

Texas Department of Transportation

All rights reserved. TRC Environmental Corporation (TRC) and the Texas Department of Transportation (TxDOT) jointly own all rights, title, and interest in and to all data and other information developed for this project under TxDOT Scientific Services Contract No. 572XXSA004. Brief passages from this publication may be reproduced without permission provided that credit is given to TRC and TxDOT. Permission to reprint an entire chapter, section, figures, or tables must be obtained in advance from the Supervisor of the Archeological Studies Program, Environmental Affairs Division, Texas Department of Transportation, 118 East Riverside Drive, Austin, Texas, 78752.

Printed by:

Ginny’s Printing

Austin, Texas

Printed on acid-free, 60-lb. paper

November 2008

Jointly published by:

Texas Department of Transportation

Environmental Affairs Division

Archeological Studies Program

Scott Pletka, Ph.D., Supervisor

Archeological Studies Program Report No. 110

Al McGraw, Series Editor

and

TRC Environmental Corporation

Technical Report No. 35319

Austin, Texas

ISBN 1-930788-79-7 


\section{EXECUTIVE SUMMARY}

Data recovery excavations at the Varga Site were conducted in two phases during 2002 by archeologists from the Cultural Resources Department of TRC Environmental Corporation's (TRC's) Austin office under contract to Texas Department of Transportation (TxDOT) Scientific Service Contract No. 572XXSA004. This mitigation program was necessitated by the proposed reconstruction of the crossing of a Ranch to Market Road over Hackberry Creek, immediately south of the site in northeastern Edwards County. These archeological investigations were conducted as part of the responsibilities of TxDOT under existing federal and state legislation for the protection of cultural resources.

Geoarcheological trenching and handexcavations within the existing $31 \mathrm{~m}$ wide road right-of-way of 7- m-wide paved Ranch to Market Road focused on the alluvial fines in the first terrace overlooking Hackberry Creek immediately adjacent to a spring. The southern edge of the terrace contains relatively finegrained sediments ranging from 15 to 150 centimeter $(\mathrm{cm})$ thick that overlie coarse stream gravels that extend to an unknown depth. The modern ground surface had been impacted by road construction and maintenance activities, as well as by light erosion.

Block Excavations were conducted on both sides of the pavement and resulted in the handexcavations of a total of 207.75 square meters $\left(\mathrm{m}^{2}\right)$, including $83 \mathrm{~m}^{2}\left(66.2 \mathrm{~m}^{3}\right)$ in Block A on the western side and a $124.75 \mathrm{~m}^{2}\left(38.26 \mathrm{~m}^{3}\right)$ area in Block B on the eastern side. Archeological deposits in the investigated part of the site extend to the southern lip of the first terrace and extend about $50 \mathrm{~m}$ to the north. The excavations yielded evidence of a multiple component campsite with three distinct and a fourth less distinct prehistoric components. In Block A, the 100 to $150 \mathrm{~cm}$ thick fine-grained sediments yielded four intact cultural components. Block B only targeted the youngest, Toyah component. The fine-grained alluvial sediments that comprise the first terrace contain discrete occupations radiocarbon dated to the Late Prehistoric period Toyah phase (ca. 290 to 660 B.P.), the Late Archaic period (ca. 1,700 to 2,300 B.P.), and the Early Archaic period (ca. 5,200 to 6,300 B.P.). A Middle Archaic period (ca. 3,900 to 4,800 B.P.) component was also recognized, but was not as clearly defined as were the other three components. Krotovina disturbance was relatively extensive in parts of the investigated site area. Nevertheless, the archeological deposits exhibited a high degree of contextual integrity.

The Toyah phase component contains a rich assemblage of cultural material (ca. 65,000 pieces), including lithic debitage (ca. 26,000), quantities of highly fragmented bones (ca. 18,700), small burned rocks (ca. 16,000), formal and informal stone tools (ca. 1,850), scattered ceramic sherds (ca. 100), and 11 burned rock features. This component was radiocarbon dated by 14 accepted dates to between 290 and 660 B.P. Preservation was generally good, but mixing and probable overprinting contributed to poor horizontal patterning and an inability to identify discrete activity areas.

The Late Archaic period component consists primarily of a large, nearly $6 \mathrm{~m}$ diameter lens of burned rock that is interpreted as an incipient burned rock midden with an indistinct central pit oven. This feature was associated with a buried A horizon and exhibited a high degree of stratigraphic integrity. However, beyond the illdefined boundaries of this burned rock feature, 
the Late Archaic period component yielded a limited lithic debitage assemblage (ca. 1,800), a few mussel shell fragments, five isolated burned rock features, scattered burned rocks, and occasional chipped stone tools (ca. 30) totaling less than 6,000 pieces. Identified dart point styles associated with this midden include Frio, Marcos, Ensor, Castroville, and Edgewood. This component was radiocarbon dated by 11 accepted dates to a 600-year period between 1,700 and 2,310 B.P.

The Middle Archaic component was not welldefined, but definitely present and dispersed below the Late Archaic component and above the Early Archaic component. These materials were vertically distributed over a 20 to $40 \mathrm{~cm}$ thick zone that lacked completely sterile levels or visible breaks in the stratigraphy between the other cultural events. Lithic debitage (ca. 4,400) dominates the recovered assemblage (ca. 6,000), with limited burned rocks (ca. 3,000), a few formal chipped stone tools (ca. 25), and moderate frequency of vertebrate remains (100 g) also present. Two poorly organized burned rock features were also identified and documented. Five Early Triangular projectile points and one Carrizo point fragment occurred within this component. Two wood charcoal assays and one radiocarbon date on a deer bone directly date this Middle Archaic component to ca. 900-radiocarbon year period between 3,910 and 4,820 B.P. These three absolute dates are stratigraphically in order compared to the radiocarbon dates from the cultural components above and below.

The Early Archaic component was defined by quantities of dense cultural debris (ca. 135,000) within a roughly $30 \mathrm{~cm}$ thick zone directly on top and mixed into coarse river gravels and below the Middle Archaic component. The cultural material varied in depth from a shallow $50 \mathrm{~cm}$ below datum (bd) at the north end to a much deeper $120 \mathrm{cmbd}$ in the southern end of
Block A. The recovery of a robust assemblage of dart points (170 specimens) that consisted of Group 2-Early Corner-Notched, Bandy, Martindale, Gower, and Merrell dart points indicates that this zone represents many occupations that occurred over a relatively broad time frame. The dart points were associated with a diverse tool assemblage (ca. 1,300). Organic preservation was poor in this lower stratum, but occasional fragments of animal bone, plant seeds, and wood charcoal were recovered. Fifteen organic samples of diverse materials yielded radiocarbon dates that document a minimum use period of 1,080radiocarbon years from 5,200 B.P. to 6,280 B.P.

Greater insight and understanding of each of these four components represented was made possible through the employment of numerous technical analyses, including the radiocarbon dating of 66 samples, six optically stimulated luminescence dates, use-wear analysis and organic residue identifications on 156 stone specimens, petrographic analyses on 18 pottery and one local sediment samples, pollen and phytolith analyses on 25 paired samples, instrumental neutron activation analysis on 261 chert samples and 18 pottery sherds, fatty acid composition on eight pottery sherds and 94 burned rocks, stable carbon and nitrogen analyses on 112 samples, macrobotanical analyses on 44 float and 75 individual charcoal samples, and granulometric and compositional studies on 10 sediment samples. The combined results have contributed significantly to a greater understanding of the Varga Site as a whole and documented specific information concerning the behaviors of the people who occupied the site. These and other technical analyses are urged for other excavated sites in the future to continue to broaden our understanding of the human behaviors at specific sites and throughout the broader region. This will add to a growing database that will foster a better understanding of prehistoric lifeways across Texas. 


\section{TABLE OF CONTENTS VOLUME I}

EXECUTIVE SUMMARY

ACKNOWLEDGMENTS XXIV

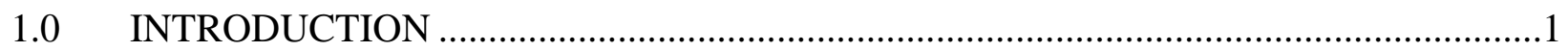

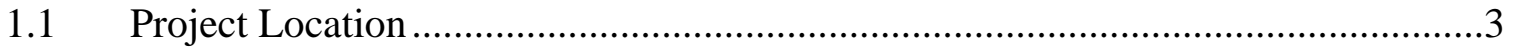

1.2 Previous Investigations ................................................................................

1.3 Data Recovery Excavations_-Phase I .............................................................

1.4 Data Recovery Excavations — Phase II .......................................................11

2.0 ENVIRONMENTAL BACKGROUND................................................................13

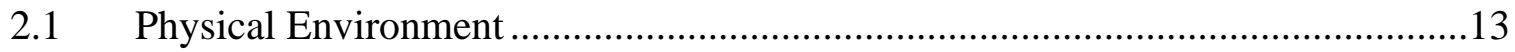

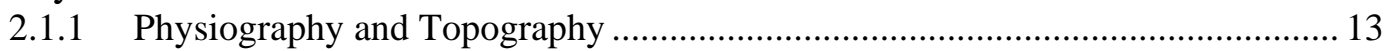

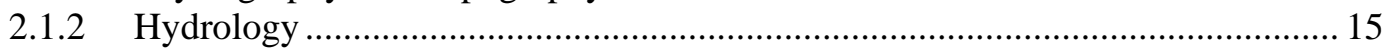

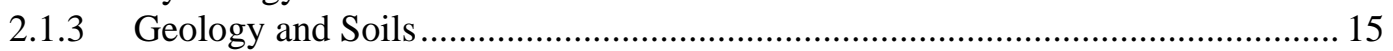

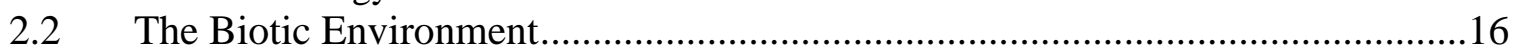

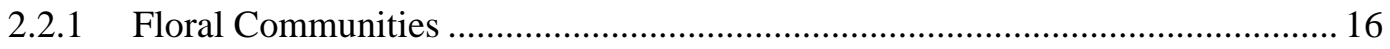

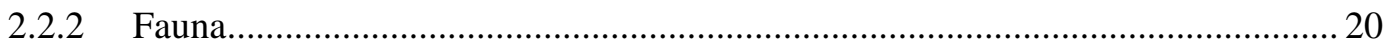

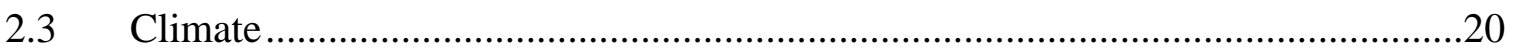

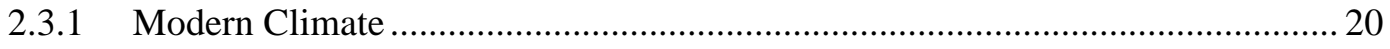

2.3.2 Paleoenvironment and Indications of Paleoclimate ............................................. 21

2.3.2.1 Central Texas Paleoenvironments ..................................................... 21

2.3.2.2 Lower Pecos Paleoenvironments ................................................... 23

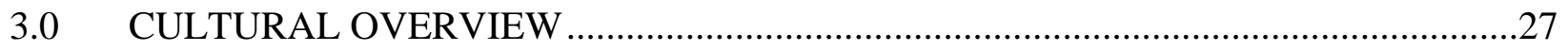

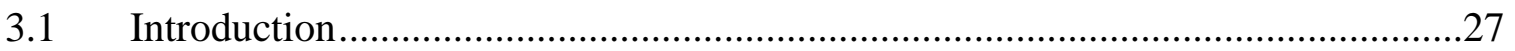

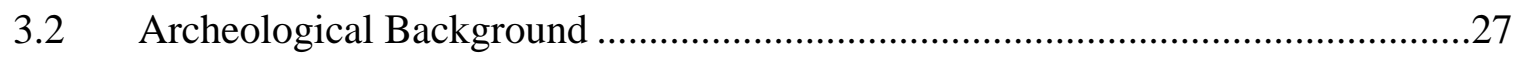

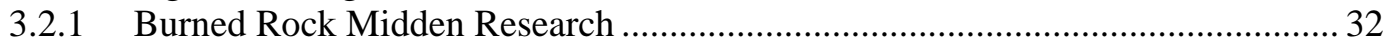

3.2.1.1 Burned Rock Midden Ages ........................................................ 35

3.2.1.2 Function of Burned Rock Middens ............................................... 35

3.2.1.3 Foodstuffs Processed in Burned Rock Middens................................. 36

3.2.1.4 Burned Rock Midden Formation..................................................... 36

3.2.1.5 Distribution of Burned Rock Middens ........................................... 37

3.3 The Early Archaic Period (8,800 to 5,500 B.P.) .............................................37

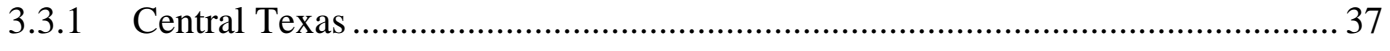

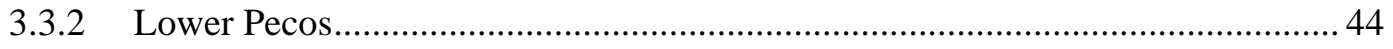

3.4 The Middle Archaic Period (ca. 6,000 to 4,000 B.P.) …....................................49

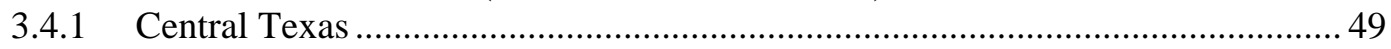

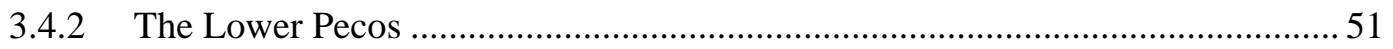

3.5 The Late Archaic Period (4,000 to 1,300 B.P.) …...........................................52

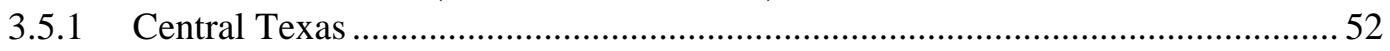

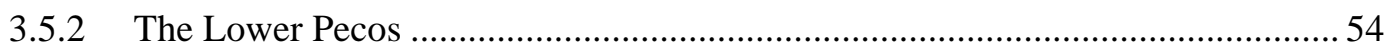


3.6 The Late Prehistoric Period (1,300 to 300 B.P.)..............................................57

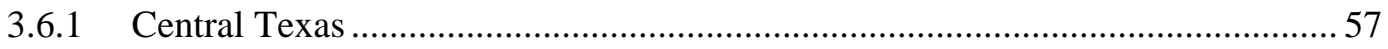

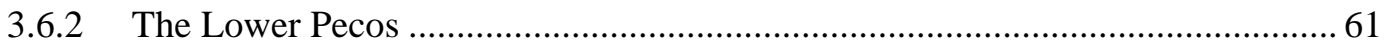

3.6.3 Protohistoric and Historic Periods (400 to 200 B.P.)........................................... 63

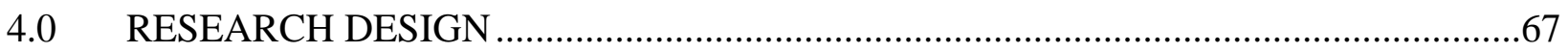

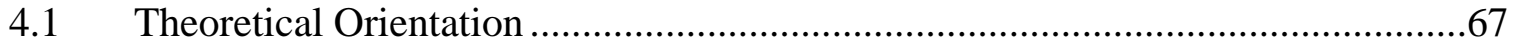

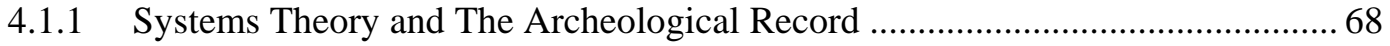

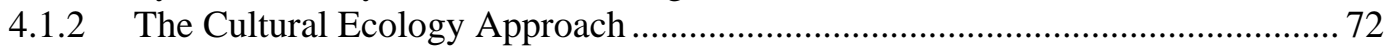

4.1.2.1 The Collector-Forager Dichotomy ……............................................ 73

4.1.2.2 Optimal Foraging Models ............................................................ 76

4.1.2.3 A Note on the Explanatory Potential of Models ............................ 77

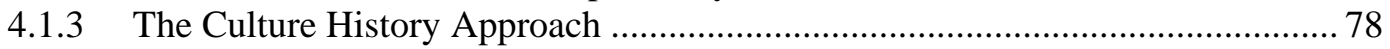

4.1.3.1 The Chaîne Opératoire and the Ancient Mind ................................ 79

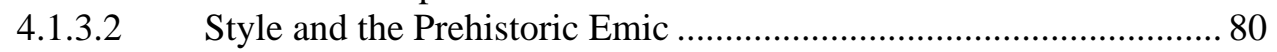

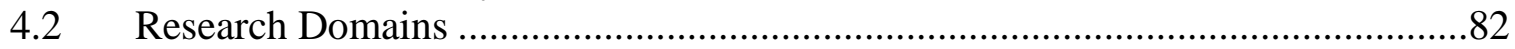

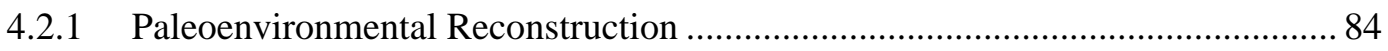

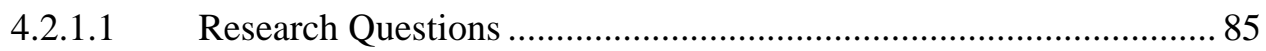

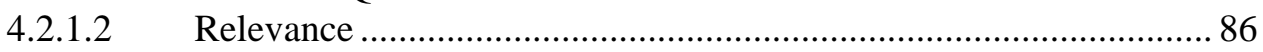

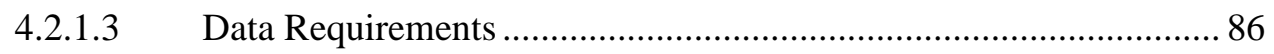

Stratigraphic Profiles and Sediment Samples ...................86

Chronometric Assays .......................................................86

Faunal and Floral Subsistence Data...............................87

Pollen and Phytolith Analyses .......................................87

Granulometric Data.....................................................8

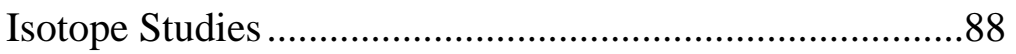

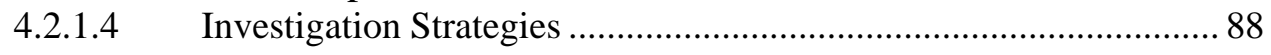

Stratigraphy and Chronology ........................................88

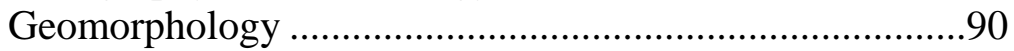

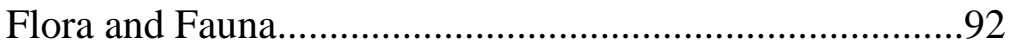

Pollen and Phytoliths ...................................................92

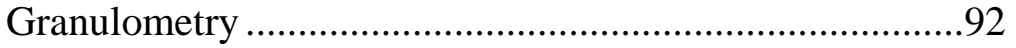

Stable Isotopes ….......................................................93

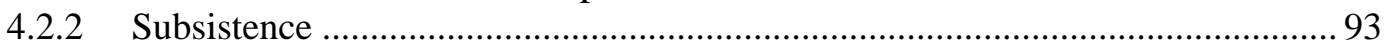

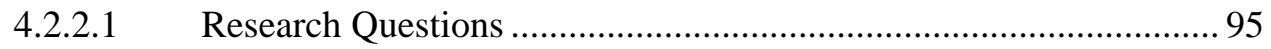

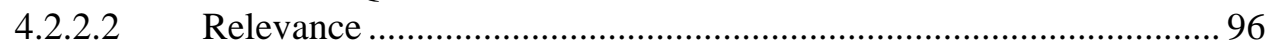

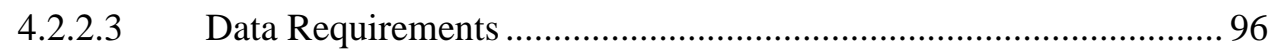

Floral Subsistence Base ................................................96

Faunal Subsistence Base ................................................96

Chemical-Residue Evidence ............................................96

Isotope Studies ............................................................97

Stone Tool Analyses .................................................97

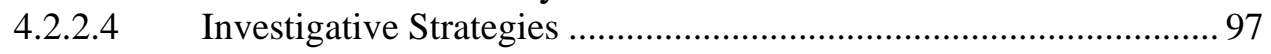

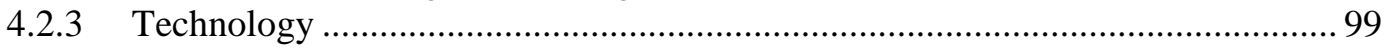

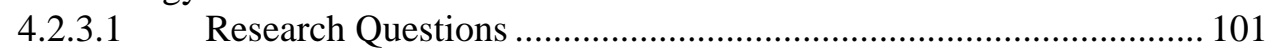

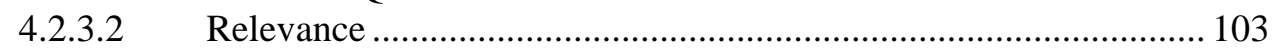




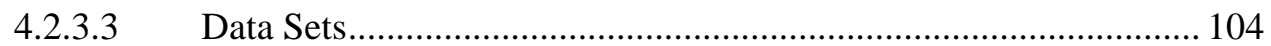

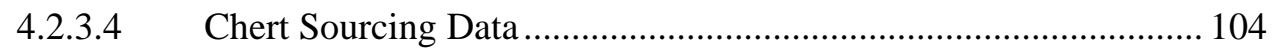

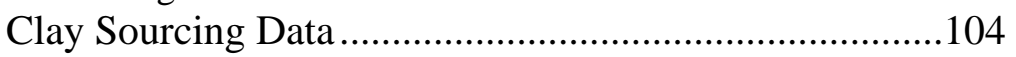

Petrographic Thin-Sections.........................................104

Tool Identifications and Use-Wear Data .......................105

Feature Form, Function, and Formation ........................105

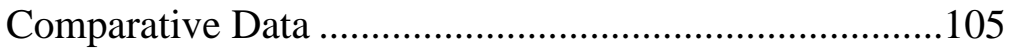

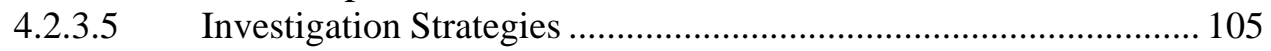

Raw Material Sourcing Analyses...................................105

Chert Resources .............................................................105

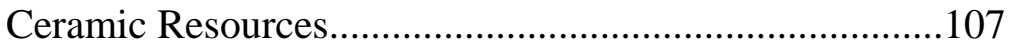

Wood Resources ........................................................107

Tool Design and Manufacture ......................................108

Projectile Points and Bifaces ........................................110

Unifaces and Edge-Modified Flakes..............................112

Other Formal Tools...................................................112

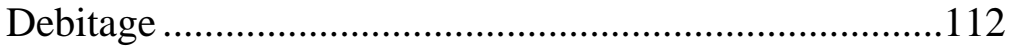

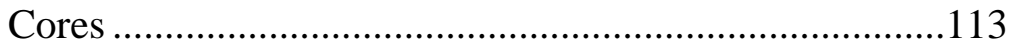

Ceramics ................................................................113

Tool Use and Maintenance ..........................................113

Resource Preparation and Processing ............................115

Burned Rock Features.....................................................115

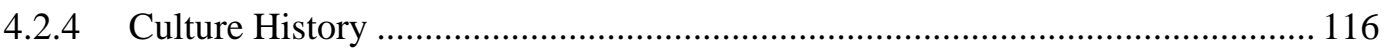

4.2.4.1 Research Questions ..................................................................... 116

General..................................................................116

Late Prehistoric Period (Toyah Phase) ..........................117

Late Archaic Period .....................................................117

Middle Archaic Period.................................................118

Early Archaic Period..................................................118

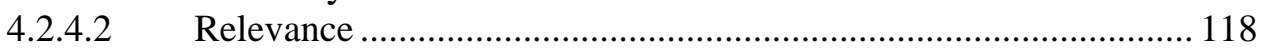

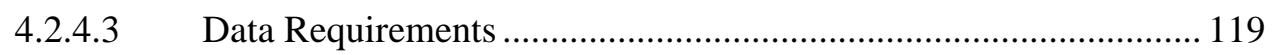

4.2.4.4 Investigation Strategies ............................................................... 119

4.2.5 Factors Influencing Archeological Site Interpretation................................... 120

Site Formation Processes ...........................................120

Site Structure and Function.........................................122

Settlement and Land Use Patterns .................................122

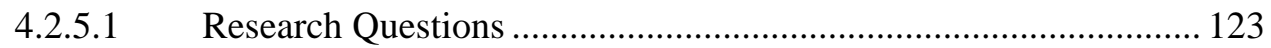

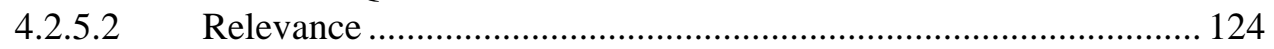

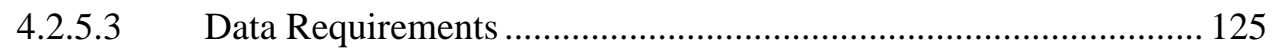

4.2.5.4 Investigation Strategies ............................................................. 126

Site Formation Processes ...........................................126

Site Structure and Function..........................................126

Settlement and Land Use Patterns .................................127

Hunter-Gatherer Mobility and Foraging Strategies .........127

4.3 Summary .129 


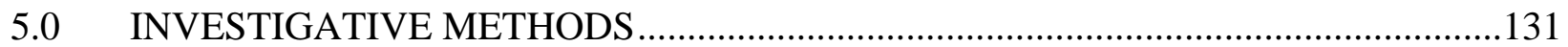

$5.1 \quad$ Introduction.............................................................................................131

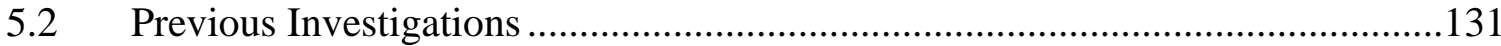

5.3 Phase I of Data Recovery Investigations …………...........................................132

5.3.1 Archeological Field Procedures........................................................................ 132

5.3.2 Geoarcheological Field Procedures ................................................................... 136

$5.4 \quad$ Phase II Data Recovery Investigations …………………….................................137

5.4.1 Archeological Field Procedures......................................................................... 137

5.4.1.1 Block A Excavations..................................................................... 137

5.4.1.2 Block B Excavations ....................................................................... 145

5.4.2 Geomorphologic Field Procedures ................................................................... 149

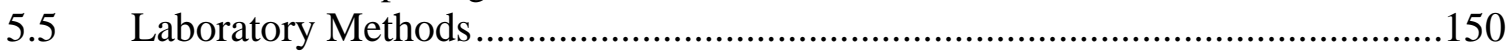

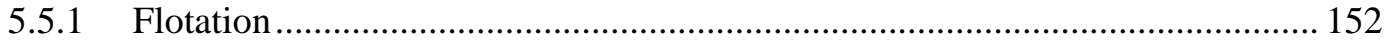

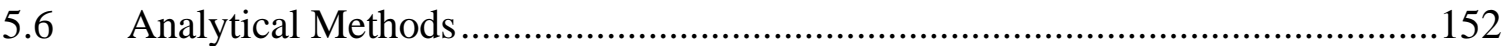

5.6.1 Chipped Stone Tool Analyses.......................................................................... 153

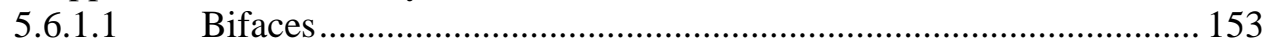

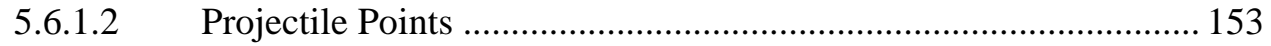

5.6.1.3 Drills................................................................................ 154

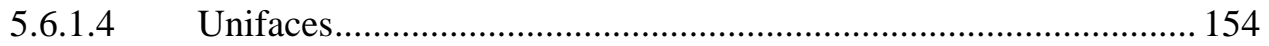

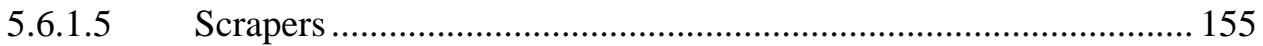

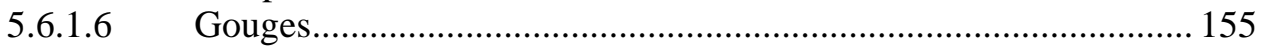

5.6.1.7 Edge-Modified Flakes ..................................................................... 156

5.6.1.8 Gravers and Spokeshaves............................................................ 156

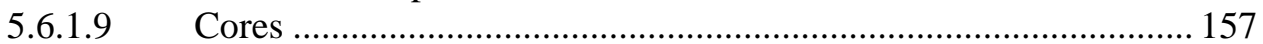

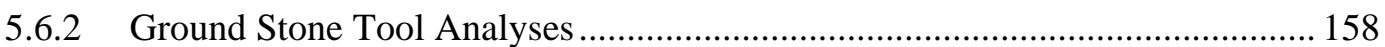

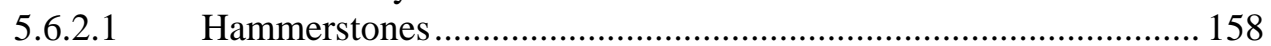

5.6.2.2 Manos and Metates.................................................................. 158

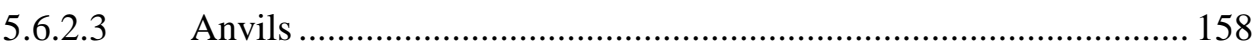

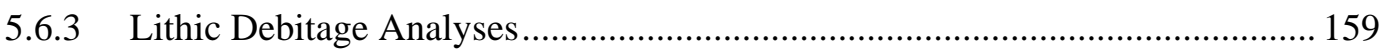

5.6.3.1 Core Preparation Flakes ............................................................. 159

5.6.3.2 Biface Manufacture Flakes......................................................... 159

5.6.3.3 Tertiary Thinning/Retouch Flakes....................................................... 159

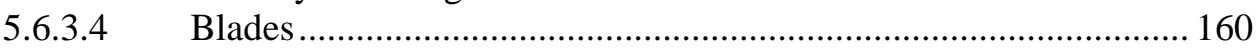

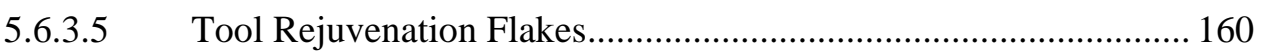

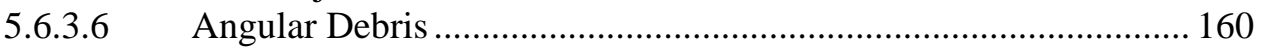

5.6.3.7 Indeterminate Flakes ................................................................... 160

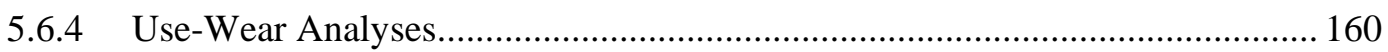

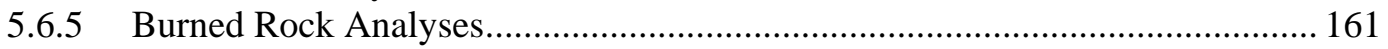

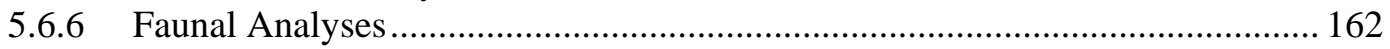

5.6.6.1 Faunal Bone Analysis.................................................................. 162

5.6.6.2 Mussel Shell Analysis ................................................................ 163

5.6.6.3 Snail Shell Analysis ........................................................................ 163

5.6.7 Flotation Macrobotanical Analyses ………………………………………….... 163

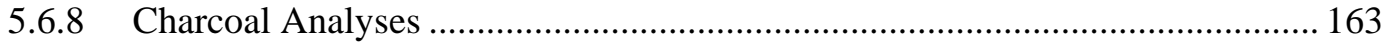

5.6.9 Petrographic Analyses .................................................................................. 164

5.6.10 Granulometry Studies .................................................................................. 164

5.6.11 Pollen and Phytolith Analyses ........................................................................ 164 


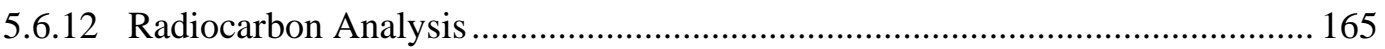

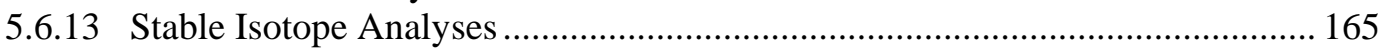

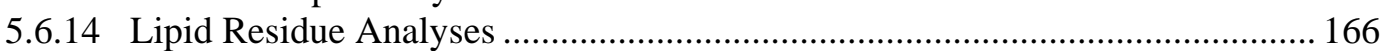

5.6.15 Optically Stimulated Luminescence (OSL) Dating ......................................... 167

5.6.16 Instrumental Neutron Activation Analysis (INAA) ......................................... 167

5.6.17 Possible Human Remains Analyses................................................................ 168

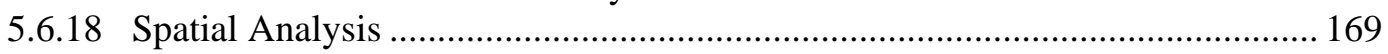

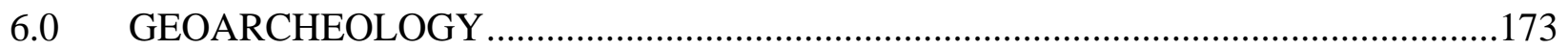

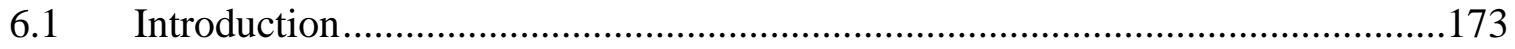

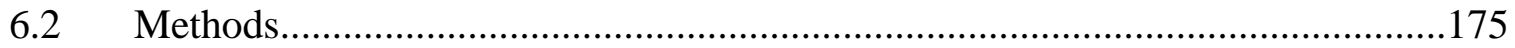

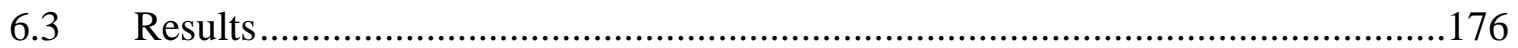

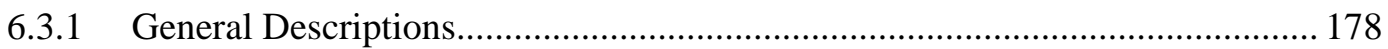

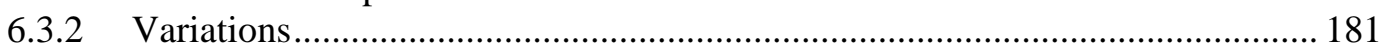

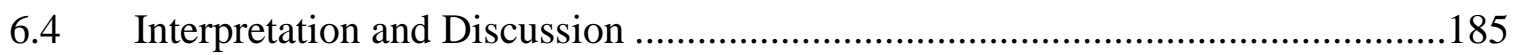

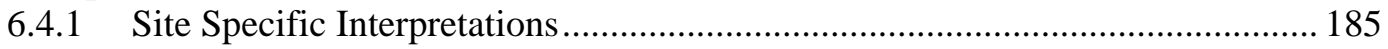

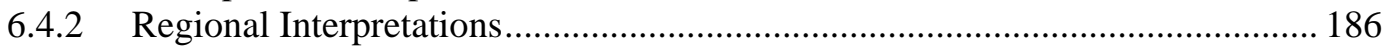

6.4.2.1 Regional Alluvial Chronology ............................................... 187

Southern Edwards Plateau ............................................187

The Dry Frio River, Uvalde County ..............................187

Sabinal River, Bandera County.....................................188

San Antonio Vicinity ................................................188

Culebra Creek, Bexar County ......................................188

Medio Creek, Bexar County .........................................188

Panther Springs and Salado Creeks, Bexar County ..........189

Medina River, Bexar County ........................................189

Greater Central Texas Region........................................189

Pedernales River .........................................................190

The Colorado River.....................................................190

Brushy Creek, Williamson County .................................190

Fort Hood, Bell and Coryell Counties ............................191

6.4.2.2 Regional Correlations: Alluvial Chronology ................................. 191

Depositional Unit 5 ....................................................191

The Depositional Unit 2-Unit 1 interface .......................192

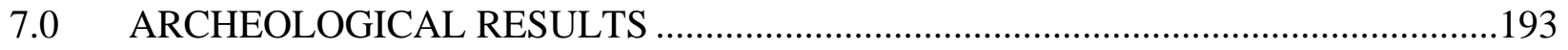

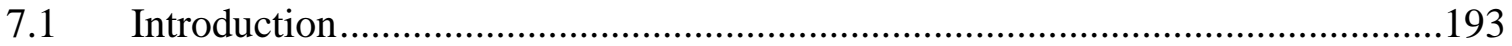

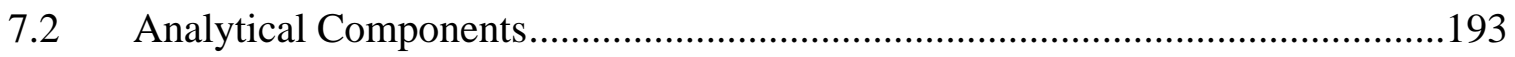

8.0 THE TOYAH COMPONENT ...........................................................................22

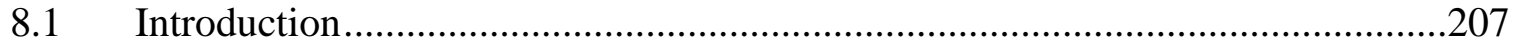

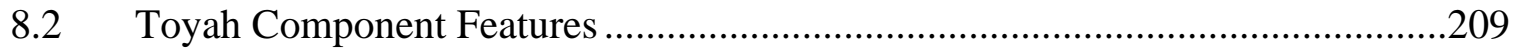

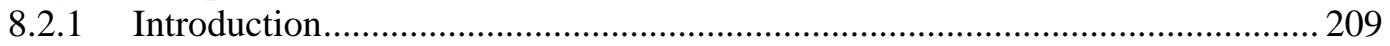

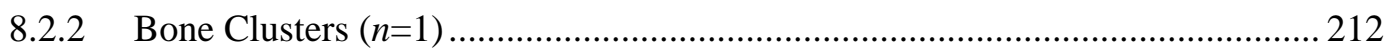

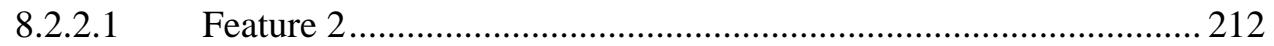




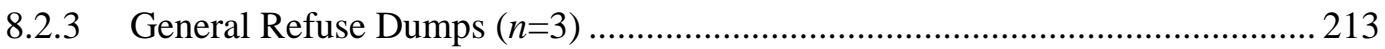

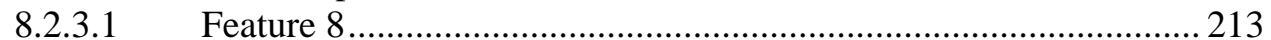

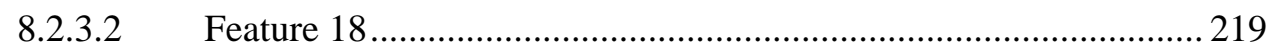

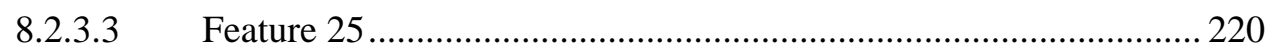

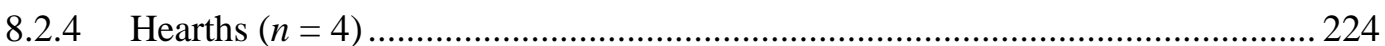

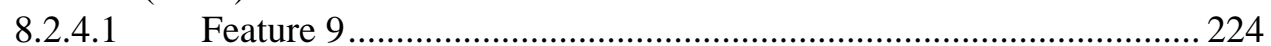

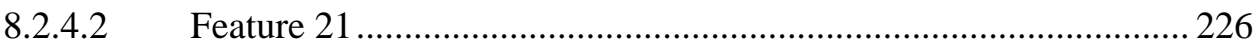

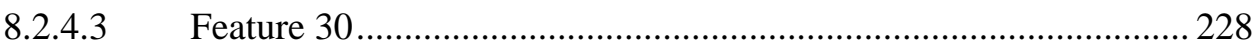

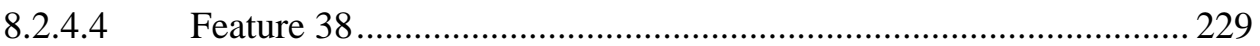

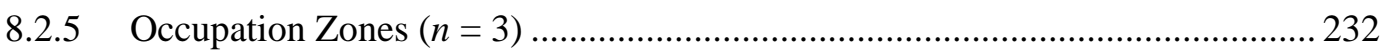

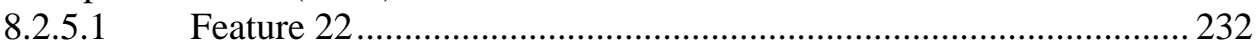

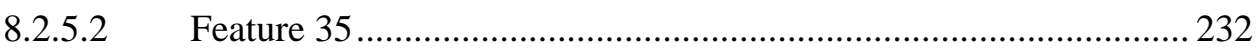

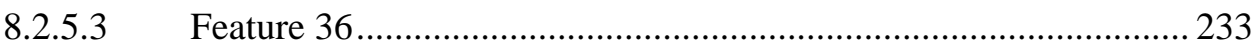

8.2.6 Summary and Discussion of Features............................................................. 236

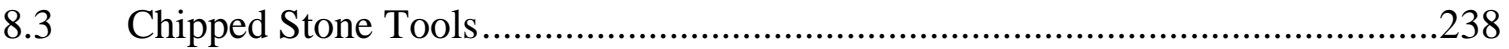

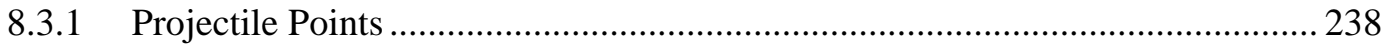

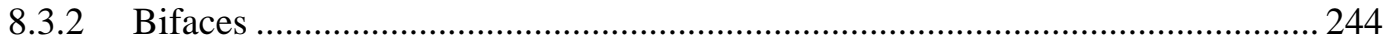

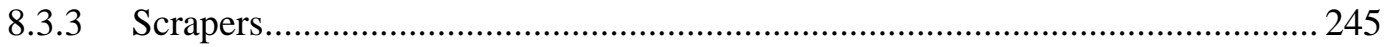

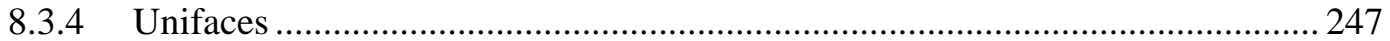

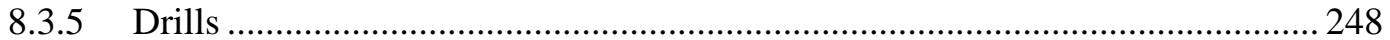

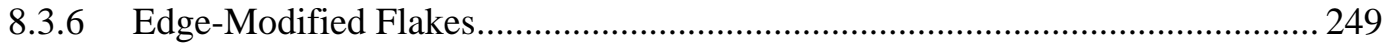

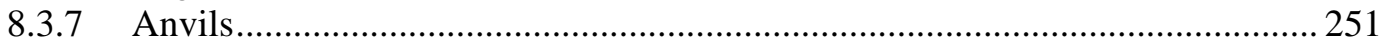

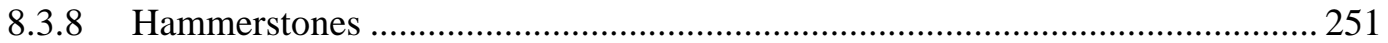

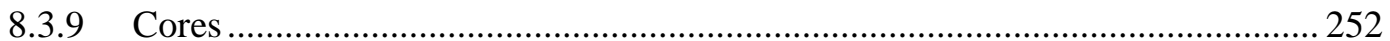

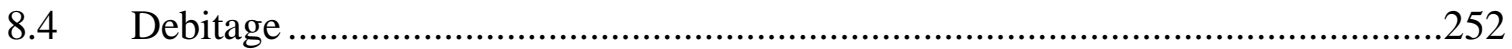

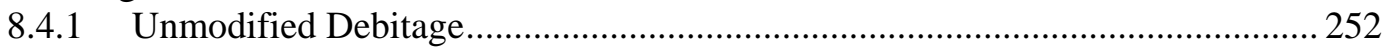

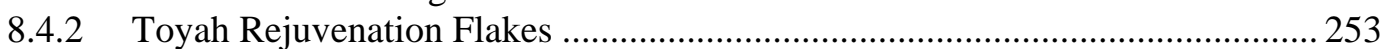

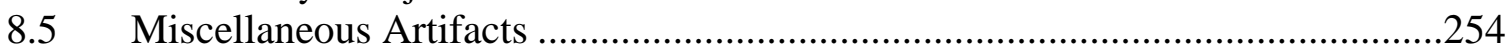

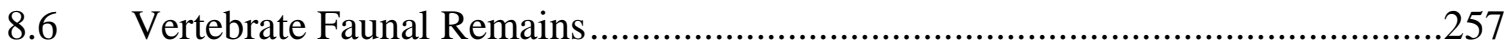

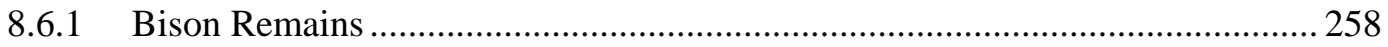

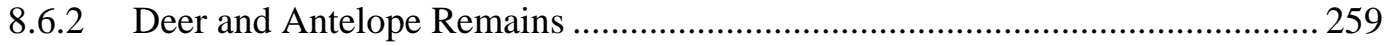

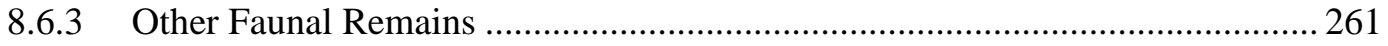

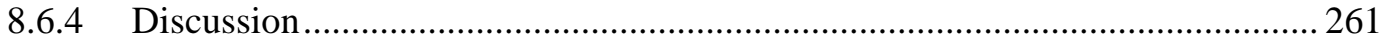

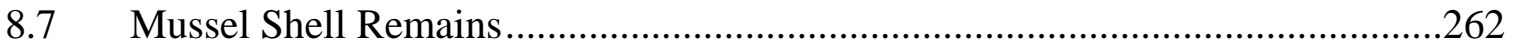

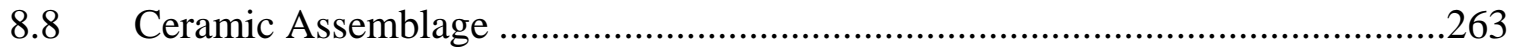

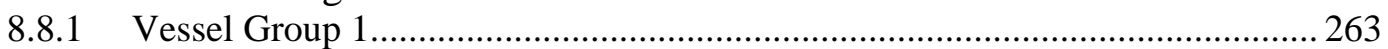

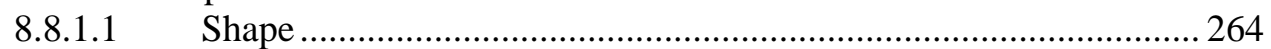

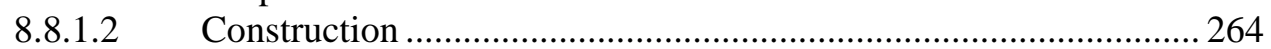

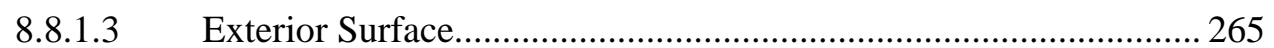

8.8.1.4 Interior Surface........................................................................ 265

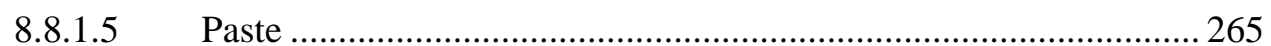

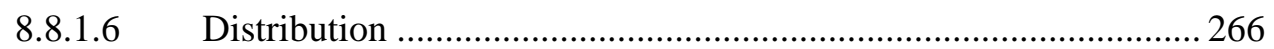

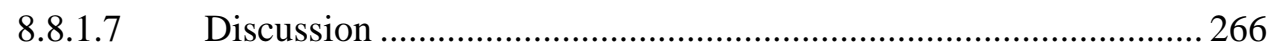

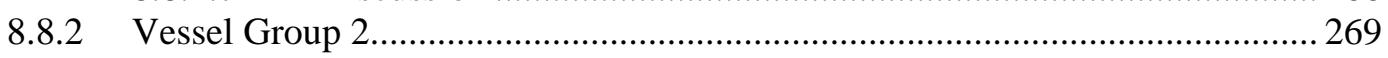

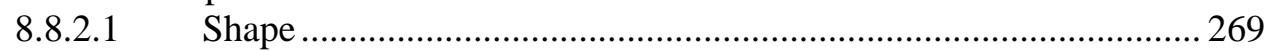

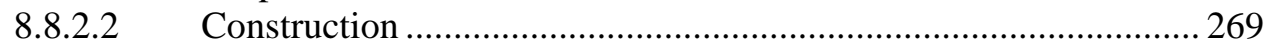

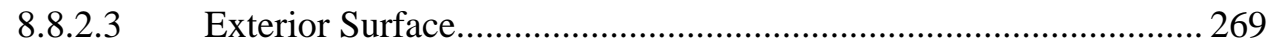

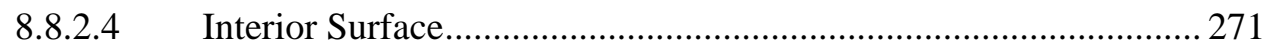




\begin{tabular}{|c|c|c|}
\hline & 8.8.2.5 & Paste ..... \\
\hline & 8.8.2.6 & Distribution \\
\hline & 8.8.2.7 & Discussion . \\
\hline \multirow[t]{7}{*}{8.8 .3} & \multicolumn{2}{|c|}{ Vessel Group 3.... } \\
\hline & 8.8.3.1 & Construction .. \\
\hline & 8.8.3.2 & Exterior Surface.. \\
\hline & 8.8.3.3 & Interior Surface... \\
\hline & 8.8.3.4 & Paste.. \\
\hline & 8.8.3.5 & Distribution \\
\hline & 8.8.3.6 & 275 \\
\hline \multirow[t]{8}{*}{8.8 .4} & \multicolumn{2}{|c|}{ Vessel Group 4... } \\
\hline & 8.8.4.1 & Shape. \\
\hline & 8.8.4.2 & 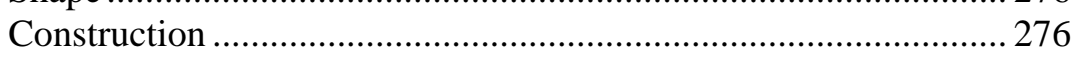 \\
\hline & 8.8.4.3 & face.. \\
\hline & 8.8.4.4 & 277 \\
\hline & 8.8.4.5 & 277 \\
\hline & 8.8.4.6 & Distri \\
\hline & 8.8.4.7 & Discus \\
\hline \multirow[t]{8}{*}{8.8 .5} & \multicolumn{2}{|c|}{ Vessel Group 5... } \\
\hline & 8.8.5.1 & Shape... \\
\hline & 8.8.5.2 & ... 279 \\
\hline & 8.8.5.3 & Exterior Surface.. \\
\hline & 8.8.5.4 & Interior Surface.... \\
\hline & 8.8.5.5 & 279 \\
\hline & 8.8.5.6 & ..................... 279 \\
\hline & 8.8.5.7 & 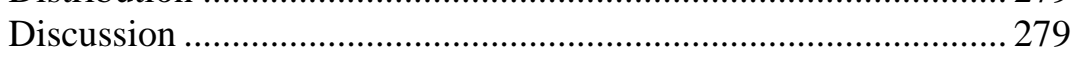 \\
\hline 8.8.6 & Radioc & 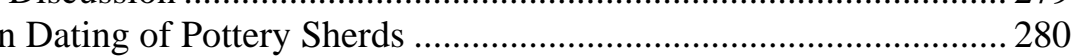 \\
\hline 8.8.7 & Cerami & 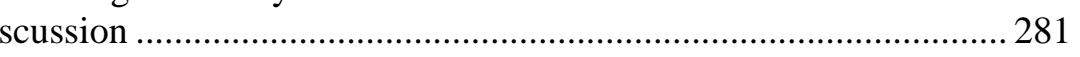 \\
\hline \multicolumn{3}{|c|}{ Burned Rocks.. } \\
\hline \multicolumn{3}{|c|}{ 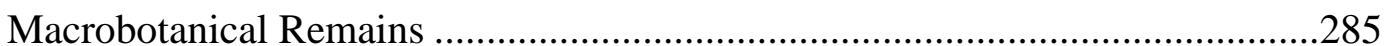 } \\
\hline \multicolumn{3}{|c|}{ 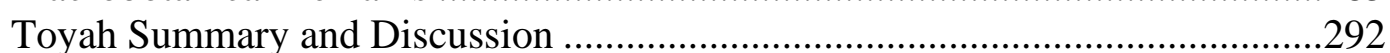 } \\
\hline 8.11 .1 & \multicolumn{2}{|c|}{ Chronology Issues } \\
\hline 8.11 .2 & \multicolumn{2}{|c|}{ Subsistence Issues.... } \\
\hline 8.11 .3 & \multicolumn{2}{|c|}{ 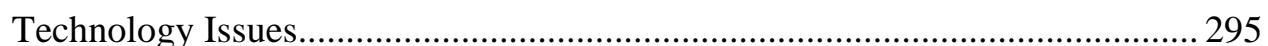 } \\
\hline 8.11.4 & \multicolumn{2}{|c|}{ 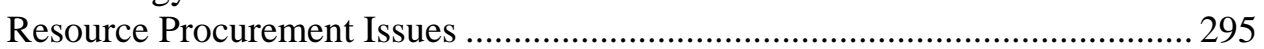 } \\
\hline 8.11 .5 & \multicolumn{2}{|c|}{ Processing and Consumption Issues } \\
\hline 8.11 .6 & \multicolumn{2}{|c|}{ 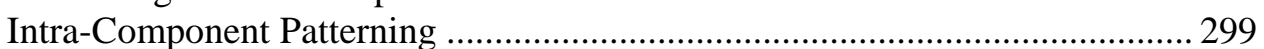 } \\
\hline 8.11 .7 & \multicolumn{2}{|c|}{ 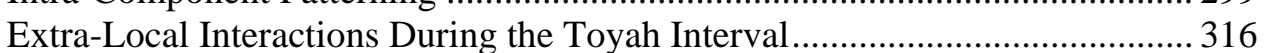 } \\
\hline 8.11 .8 & \multicolumn{2}{|c|}{ 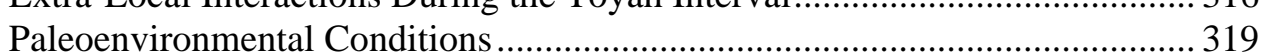 } \\
\hline
\end{tabular}

9.0 LATE ARCHAIC COMPONENT …………………………………………...........323

9.1 Introduction: identification and dating of the late archaic component ..................323

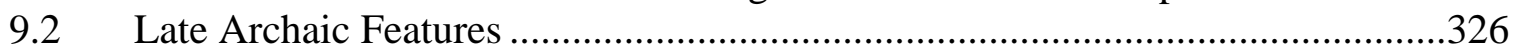

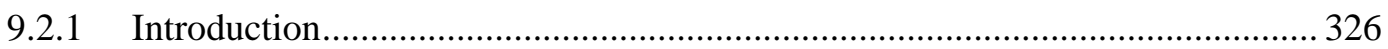

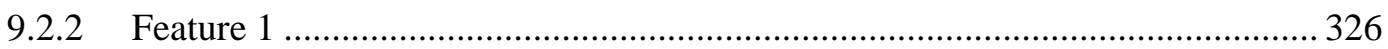

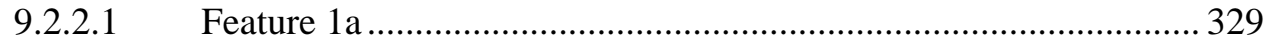

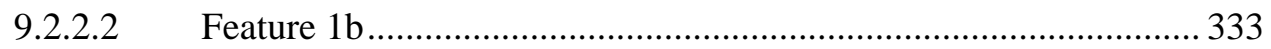




\begin{tabular}{|c|c|c|c|}
\hline & & 9.2.2.3 & 334 \\
\hline & & 9.2.2.4 & 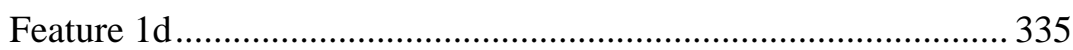 \\
\hline & & 9.2.2.5 & Flotation Results, Feature 1 \\
\hline & 9.2 .3 & Feature 7 & 340 \\
\hline & 9.2 .4 & Feature 15 & ....................... 341 \\
\hline & 9.2 .5 & Feature $2 \varepsilon$ & . \\
\hline & 9.2 .6 & Feature $2 s$ & .344 \\
\hline 9.3 & Stone & Tool Desc & ptions and Discussions... \\
\hline & 9.3 .1 & Projectile & oints \\
\hline & 9.3 .2 & Bifaces ... & (1) \\
\hline & 9.3 .3 & Scrapers.. & 349 \\
\hline & 9.3 .4 & Edge-Moc & fied Flakes..................................... \\
\hline & 9.3 .5 & Cores...... & 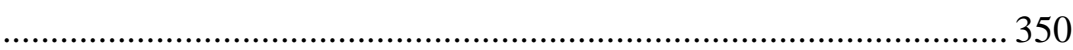 \\
\hline 9.4 & Debita & & $\boldsymbol{s}_{1}$ \\
\hline & 9.4 .1 & Unmodifi & 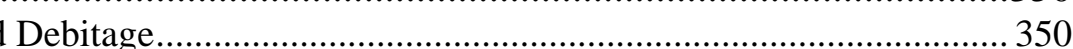 \\
\hline & 9.4 .2 & Late Arch & c Rejuvenation Flakes.... \\
\hline 9.5 & Other & Artifacts .. & 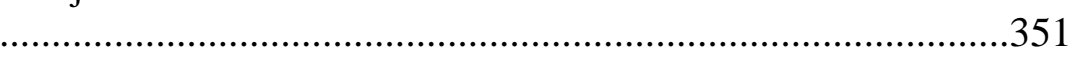 \\
\hline 9.6 & Verteb & rate Faun & 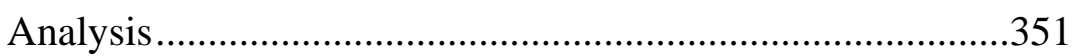 \\
\hline & 9.6 .1 & Discussio & (n) \\
\hline 9.7 & Musse & l Shell Re & lains \\
\hline 9.8 & Burnec & d Rocks.... & 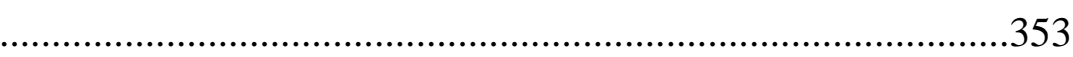 \\
\hline 9.9 & Macro & botanical & . \\
\hline 9.10 & Late A & rchaic Suı & 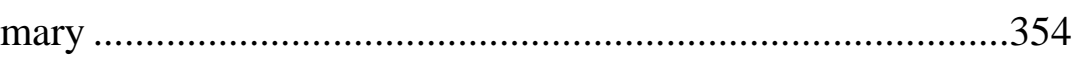 \\
\hline & 9.10 .1 & Chronolo & 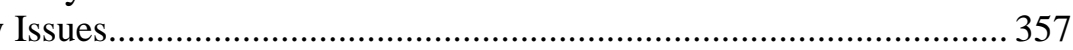 \\
\hline & 9.10 .2 & Subsisten & 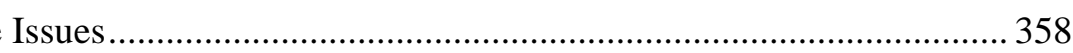 \\
\hline & 9.10 .3 & Technoloø & 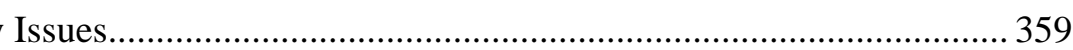 \\
\hline & & 9.10.3.1 & 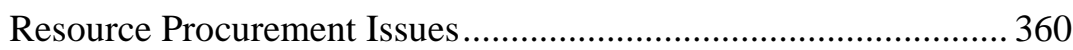 \\
\hline & & 9.10.3.2 & 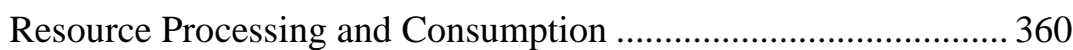 \\
\hline & 9.10 .4 & Intra-com & onent Patterning \\
\hline & 9.10 .5 & Mobility a & d Land Use Issues \\
\hline & 9.10 .6 & Environm & atal Conditions \\
\hline & 9.10 .7 & Late Arch & 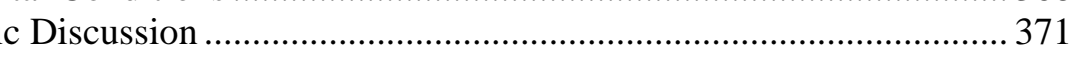 \\
\hline
\end{tabular}

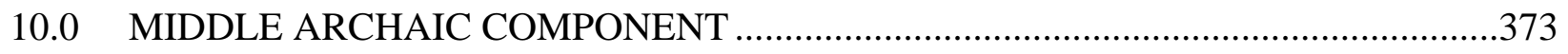

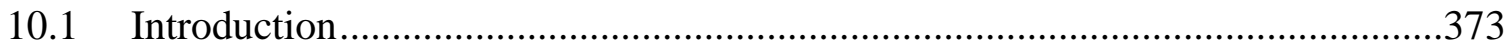

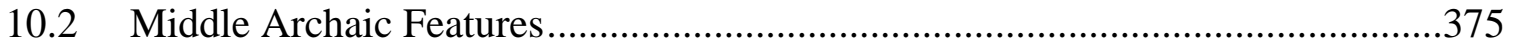

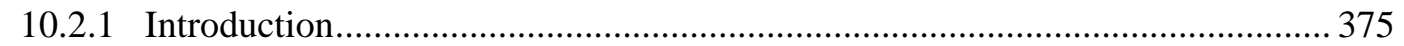

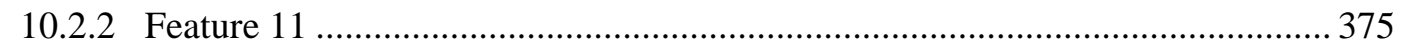

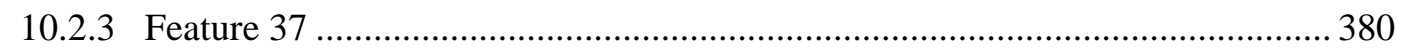

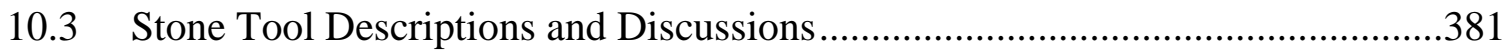

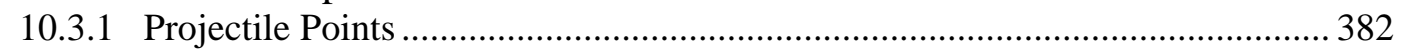

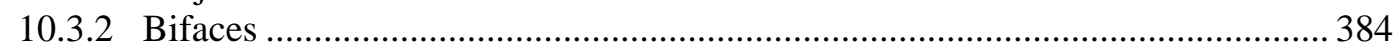

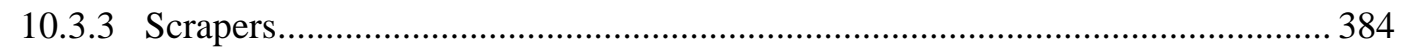

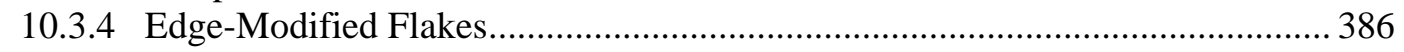

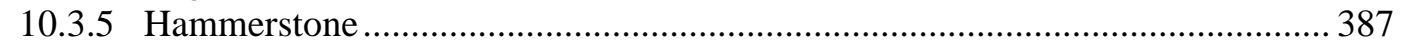

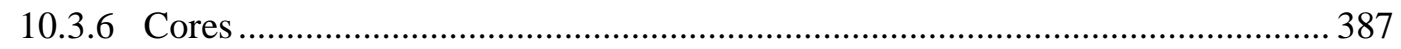

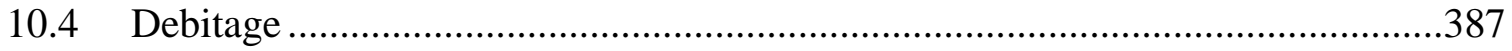




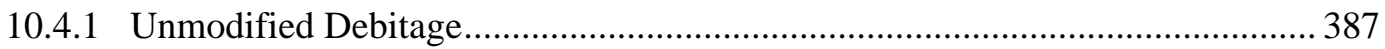

10.4.2 Middle Archaic Rejuvenation Flakes....................................................... 388

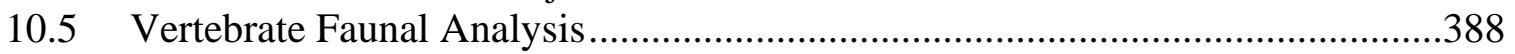

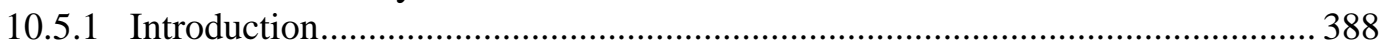

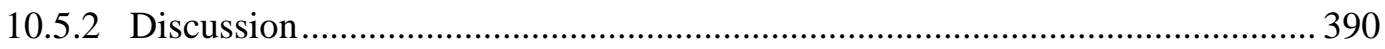

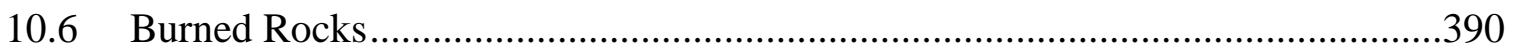

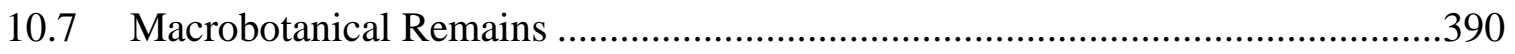

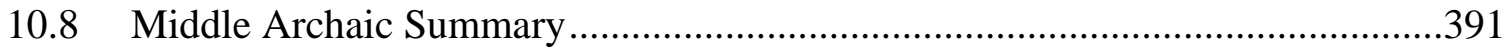

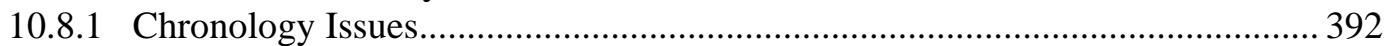

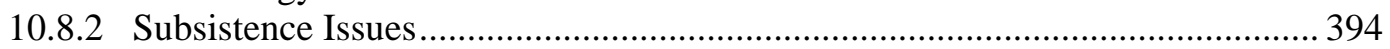

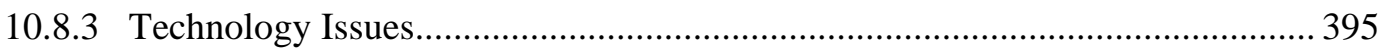

10.8.3.1 Resource Procurement Issues ...................................................... 395

10.8.3.2 Resource Processing and Consumption ........................................ 395

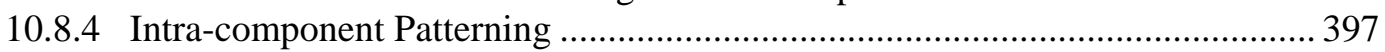

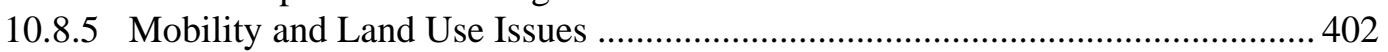

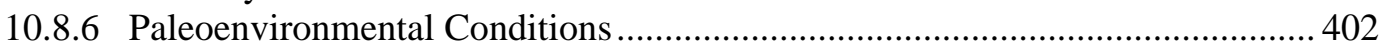

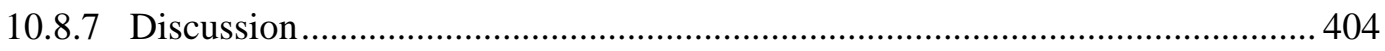

11.0 THE EARLY ARCHAIC COMPONENT...............................................................407

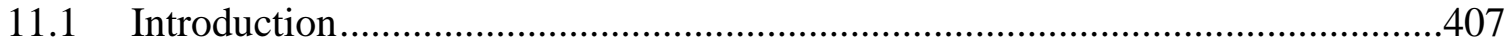

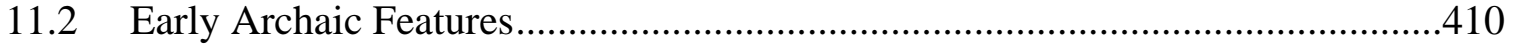

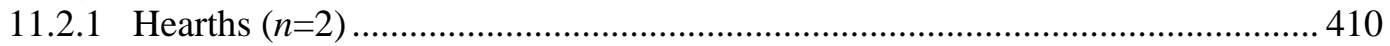

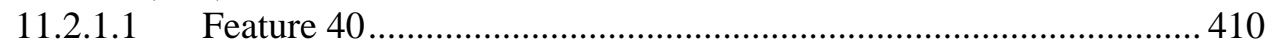

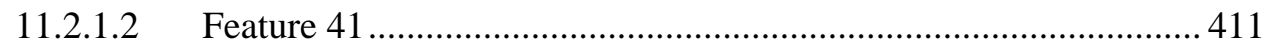

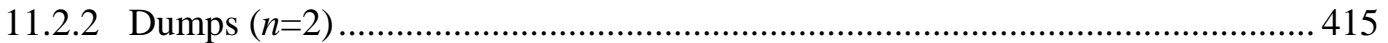

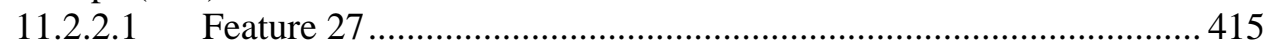

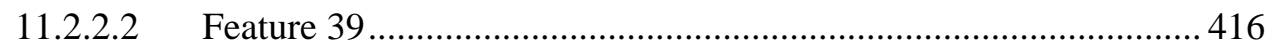

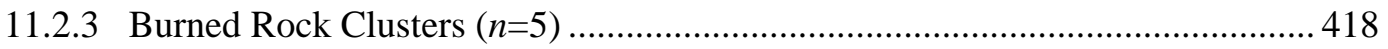

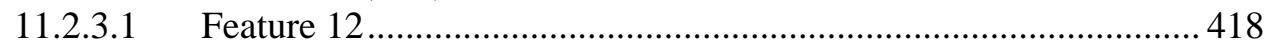

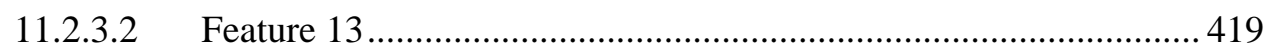

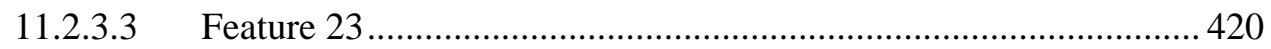

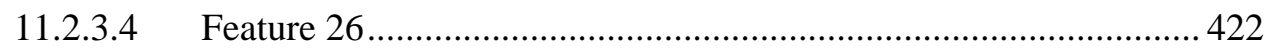

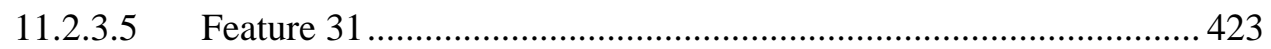

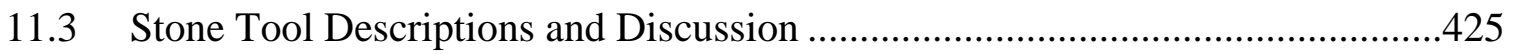

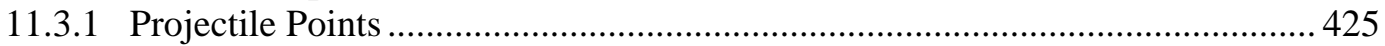

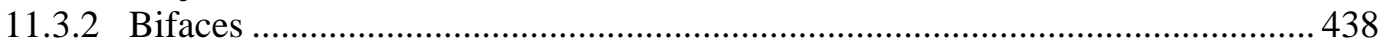

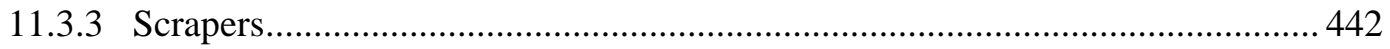

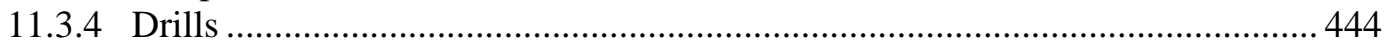

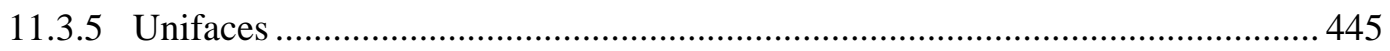

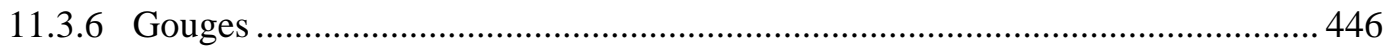

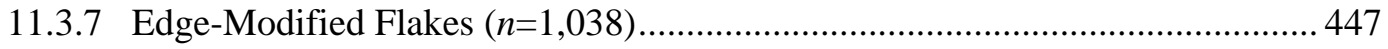

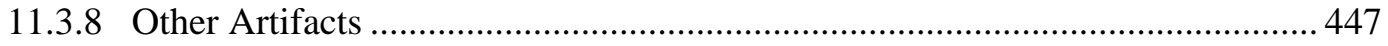

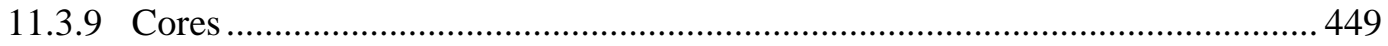

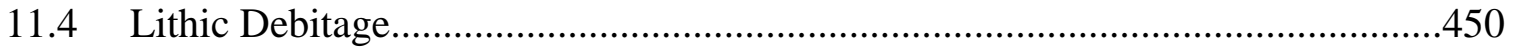

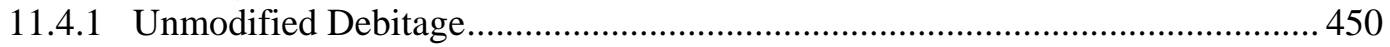

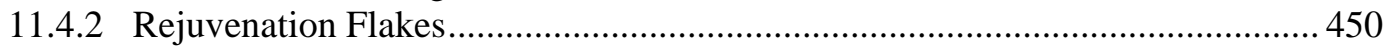

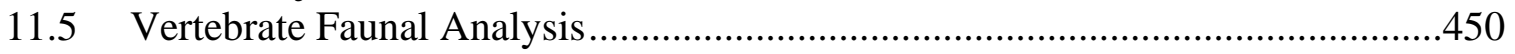




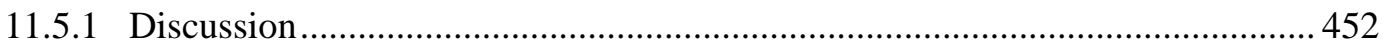

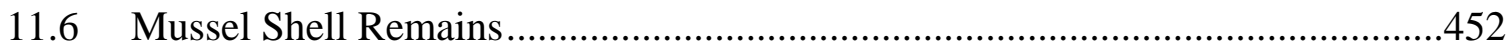

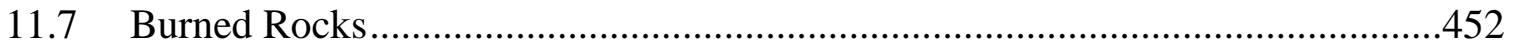

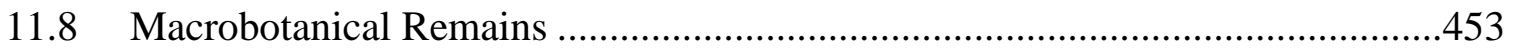

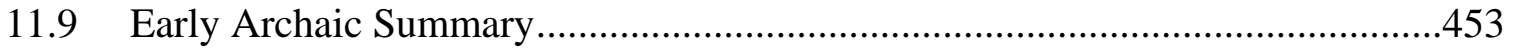

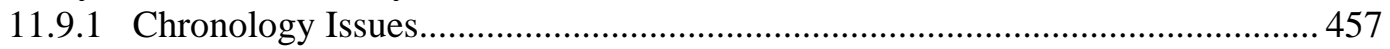

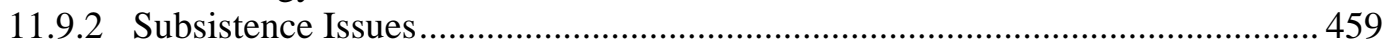

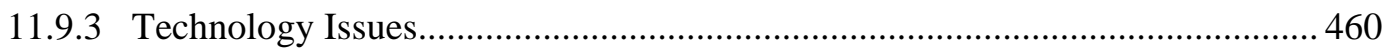

11.9.3.1 Resource Procurement Issues ......................................................... 460

11.9.3.2 Resource Processing and Consumption .......................................... 461

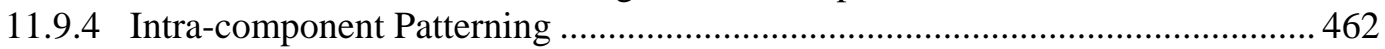

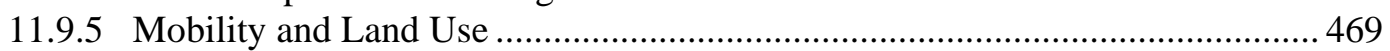

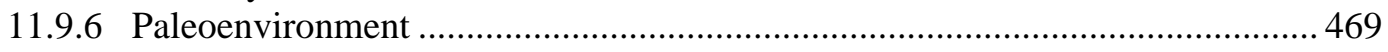

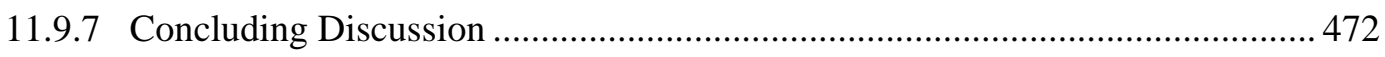

12.0 MISCELLANEOUS MATERIALS ................................................................475

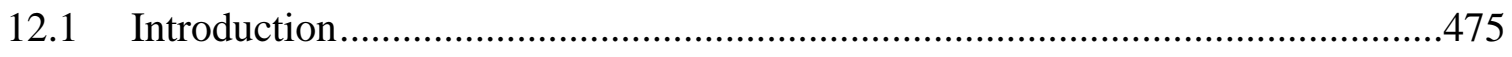

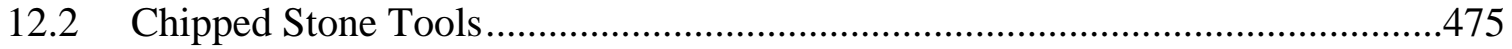

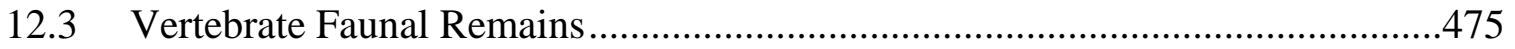

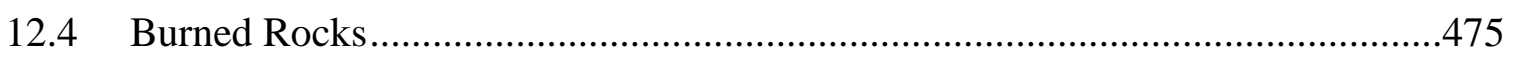

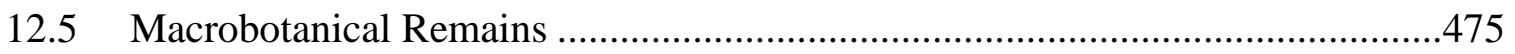

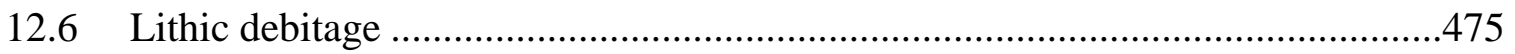

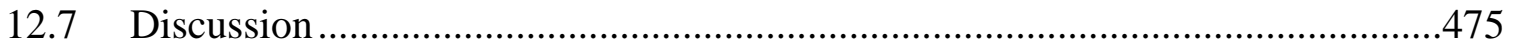

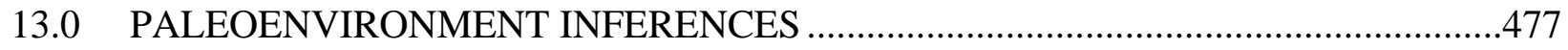

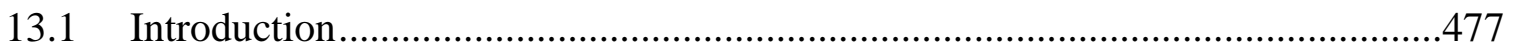

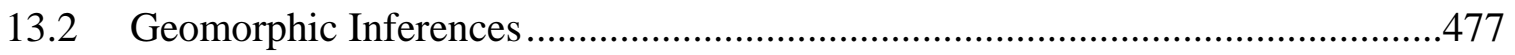

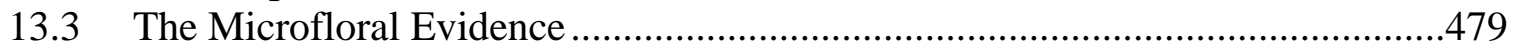

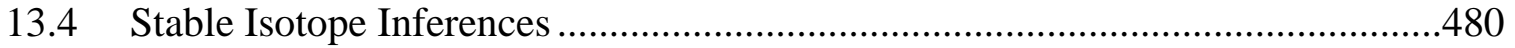

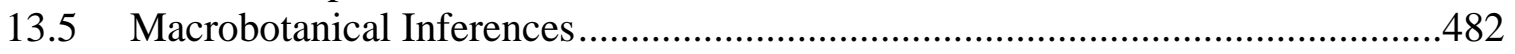

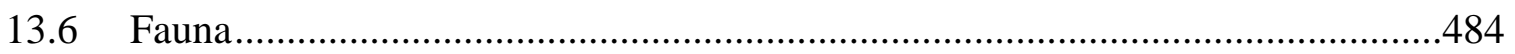

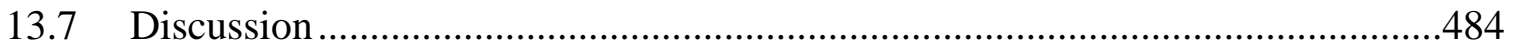

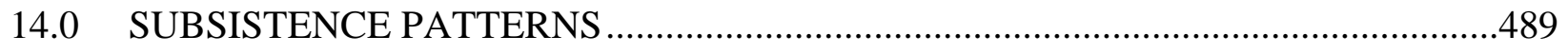

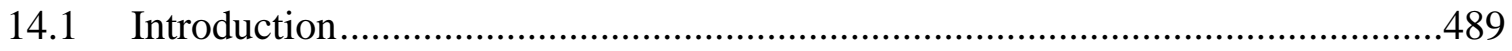

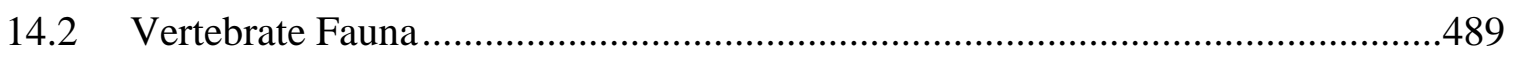

14.3 Evidence for The Use of Plants .................................................................493

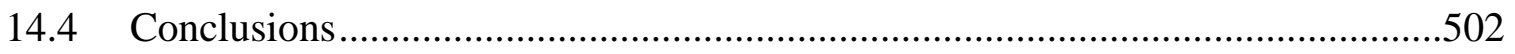

15.0 TECHNOLOGICAL SYSTEMS AND ORGANIZATION .......................................505

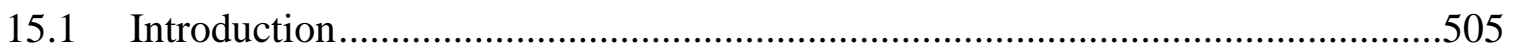

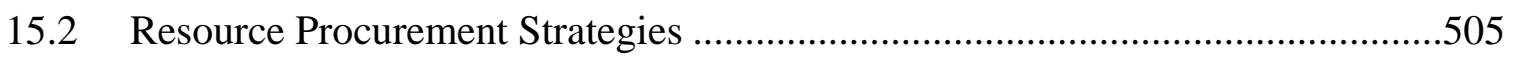

15.2.1 Tool Stone Procurement and Exploitation ....................................................505

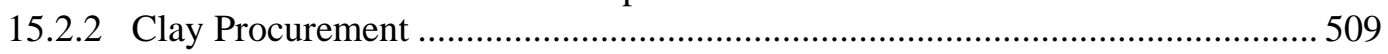




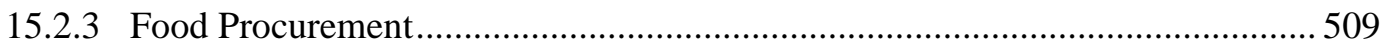

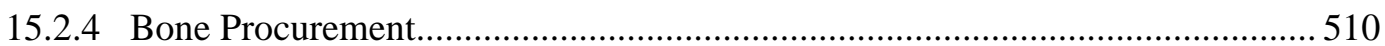

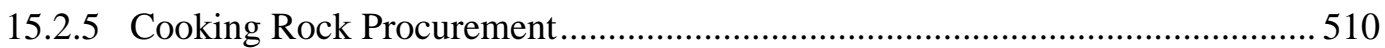

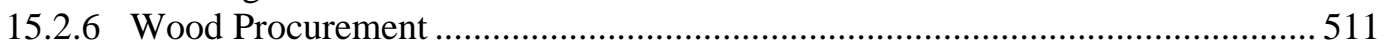

15.3 Resource Processing, Consumption, and Storage ............................................511

15.3.1 Generalized Lithic Technology ……….......................................................... 511

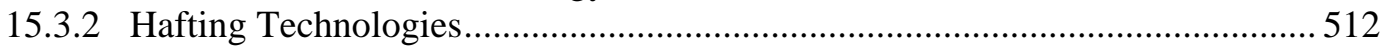

15.3.3 Cliffton Point Type Discussion...................................................................... 514

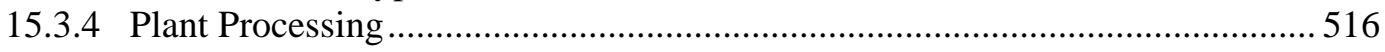

15.3.5 Burned Rock Cooking Technology ................................................................. 518

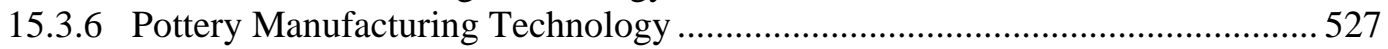

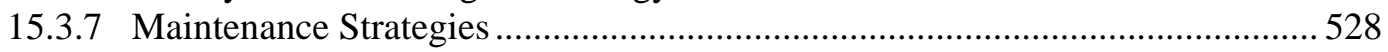

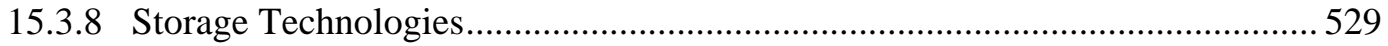

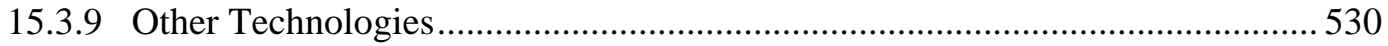

15.4 Summary: Basic, long-term continuities in technoeconomic behavior ...............530

16.0 CULTURAL-HISTORICAL CONSIDERATIONS: THE VARGA SITE

ARTIFACT TYPES IN DIACHRONIC PERSPECTIVE .........................................533

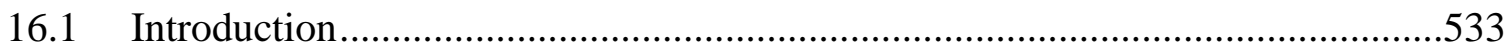

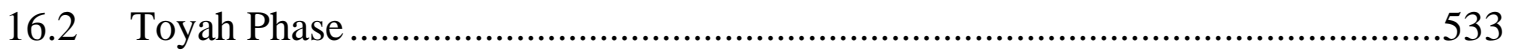

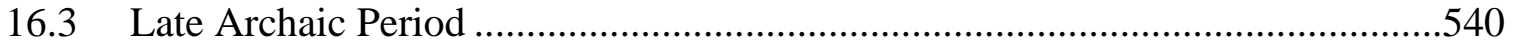

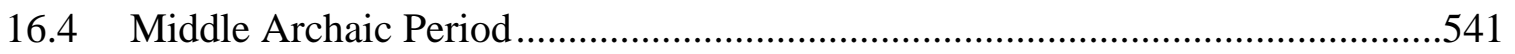

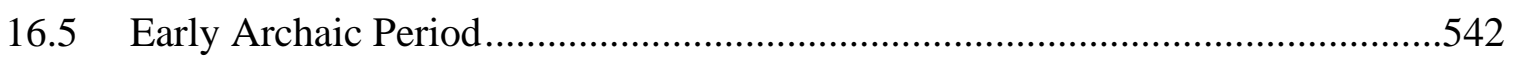

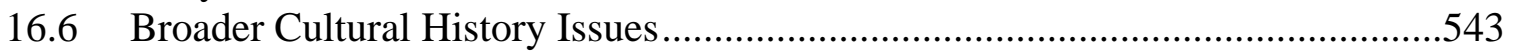

17.0 FUNDAMENTAL PATTERNS OF ARCHAIC AND LATE PREHISTORIC

LAND USE AND MOBILITY AT THE VARGA SITE AND ITS ENVIRONS ..........547

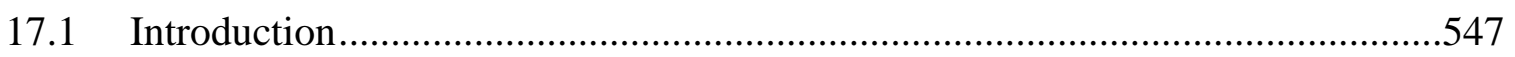

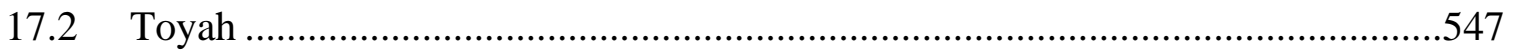

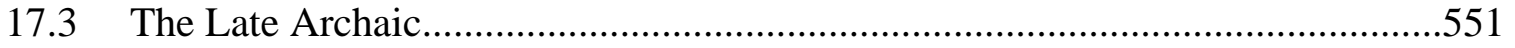

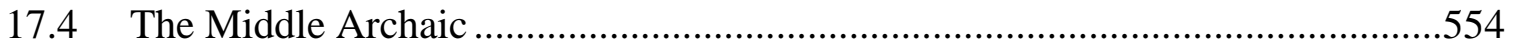

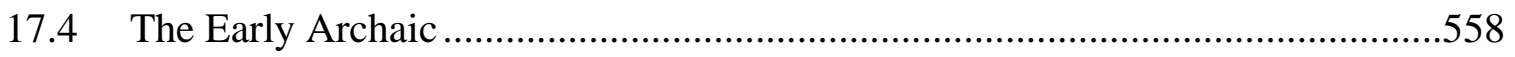

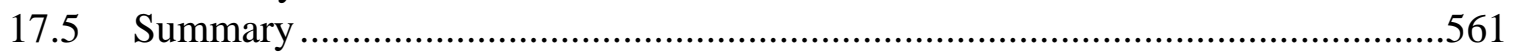

18.0 THE HUMAN ECOSYSTEMS REPRESENTED AT THE VARGA SITE .................563

18.1 Summary Interpretation of Paleoenvironmental Data ....................................563

18.2 The Human Ecosystems as Represented at 41ED28 .......................................563

18.2.1 Hunter-Gatherer Resource Procurement Practices ........................................... 564

18.2.1.1 Collector-Forager Dichotomy …................................................ 564

18.2.1.2 The Utility of Optimal Foraging Models ..................................... 565

18.2.1.3 Diet Breadth and Environmental Constraints on Human Populations566

18.2.1.4 Subsistence Strategies and Prehistoric Human Diet Breadth ......... 567

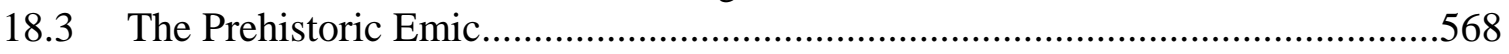

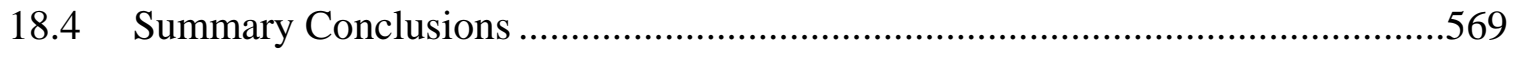


19.0 EVALUATIONS AND ASSESSMENTS OF ANALYTICAL TECHNIQUES............573

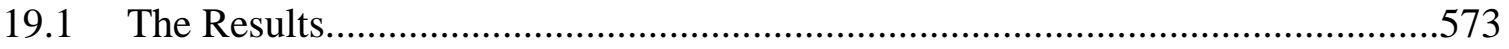

19.2 The Technical Analyses: Assessments of Results …......................................573

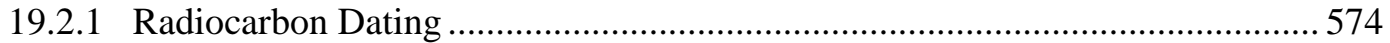

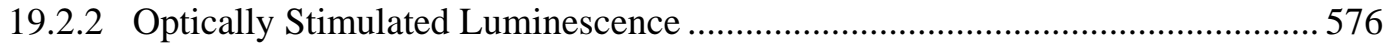

19.2.3 Use-Wear Analysis and Residue identifications ..............................................5 576

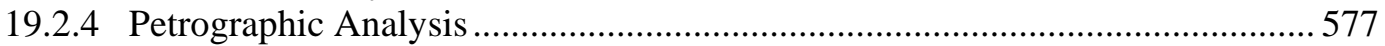

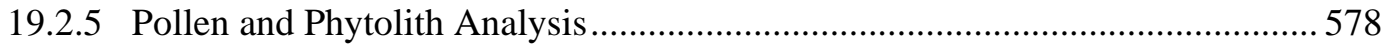

19.2.6 Instrumental Neutron Activation Analysis ....................................................578

19.2.7 Lipid Residue Analysis of Pottery and Burned Rocks..................................... 580

19.2.8 Stable Carbon and Nitrogen Isotope Analyses ............................................... 581

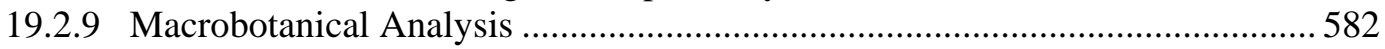

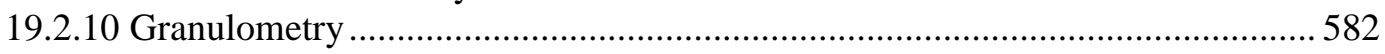

20.0 MANAGEMENT CONSIDERATIONS AND RECOMMENDATIONS.....................583

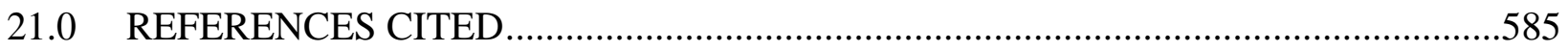

22.0 GLOSSARY OF TECHNICAL TERMS ...........................................................627

APPENDICES A - O see Volume II 


\section{LIST OF FIGURES}

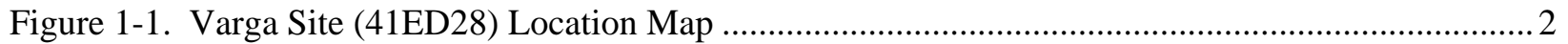

Figure 1-2. Overview of Varga Site Looking North ...................................................................... 4

Figure 1-3. East to West and North to South Trenches Through Low Mound Area at South End of Site (Subsequently Block A Area) .................................................................................... 8

Figure 1-4. Phase I Hand-Excavations Along Initial Trenches with Burned Rock Lens Exposed in Profiles at South End of First Terrace (Eventually Block A Area).................................... 8

Figure 1-5. Varga Site (41ED28) Phase I Investigation Areas In Impact Area ........................................ 9

Figure 2-1. Overview of the Varga Site (41ED28) Looking North .................................................... 14

Figure 2-2. Road Damage Following Recent Flood Event ............................................................. 14

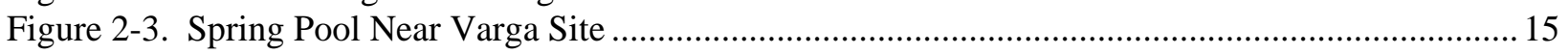

Figure 2-4. Comparison of Multiple Interpretations of Changing Environments in Central Texas Using Different Data Sets ......................................................................................... 23

Figure 3-1. Prewitt’s (1981a) Central Texas Archeological Region Overlaying Physiographic

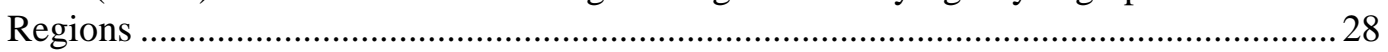

Figure 3-2. Selected Early Archaic Sites Near Varga Site............................................................... 40

Figure 3-3. Selected Late Archaic Sites Near Varga Site ...................................................................... 53

Figure 3-4. Selected Late Prehistoric Sites Near Varga Site ................................................................... 58

Figure 5-1. Varga Site (41ED28) Phase II Investigation Areas ......................................................... 138

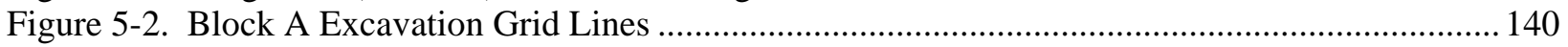

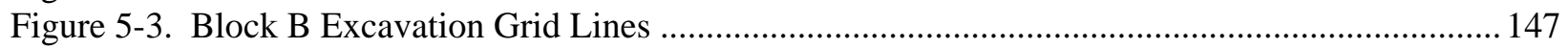

Figure 6-1. Soil and Sediment Relationships at the Transition from T0 to T1 in Trench M-1............... 174

Figure 6-2. Soil and Sediment Relationships in T2 in Trench M-2 ...................................................175

Figure 6-3. Stratigraphic Profile of Block A (East Wall) ...................................................................... 177

Figure 6-4. Stratigraphic Profile of Backhoe Trench 7 (T1) .................................................................... 182

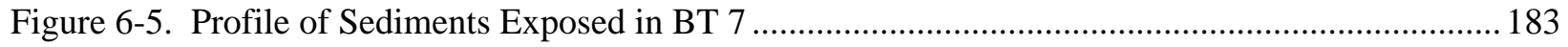

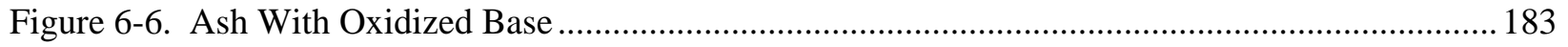

Figure 6-7. Correlations of Alluvial Stratigraphic Sequences Across Central Texas ............................. 187

Figure 7-1. West-East Line-Plotted Materials Across 1-by-1-m Test Units ......................................... 195

Figure 7-2. West-East Line-Plotted Materials Across 1-by-1-m Test Units ....................................... 197

Figure 7-3. North-South Line-Plotted Materials Across 1-by-1-m Test Units..................................... 199

Figure 7-4. North-South Line-Plotted Materials Across 1-by-1-m Test Units......................................201

Figure 7-5. Vertical Concentration of Cultural Materials Along the N101 Line, Block A...................... 203

Figure 7-6. Vertical Concentration of Cultural Materials Along the E56 Line, Block A ........................204

Figure 7-7. Vertical Concentration of Cultural Materials in Unit N103/E56, Block A ...........................205

Figure 7-8. Vertical Concentration of Cultural Materials in Unit N104/E56, Block A ...........................205

Figure 7-7. Vertical Concentration of Cultural Materials in Unit N103/E56, Block A ...........................205

Figure 7-8. Vertical Concentration of Cultural Materials in Unit N104/E56, Block A ..........................205

Figure 7-9. View West of N118/E71 Showing Light Gray Toyah Zone Over Dark Buried A Horizon that Contained the Late Archaic Component..............................................................206

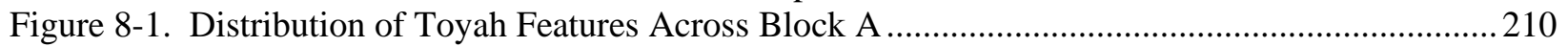

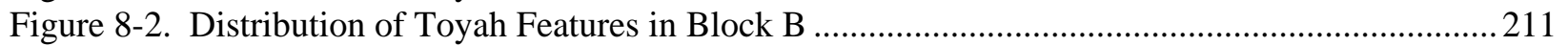

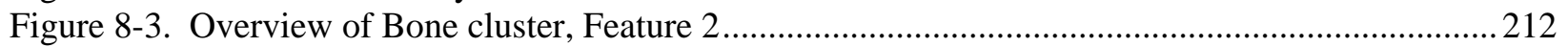

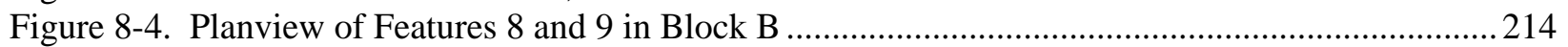

Figure 8-5. Planview of Feature 18 in Block A ........................................................................... 219

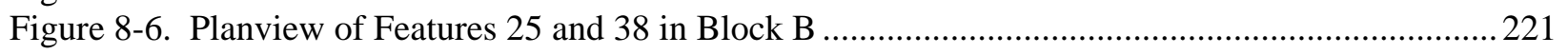

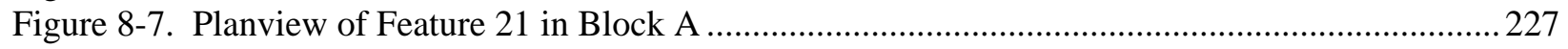




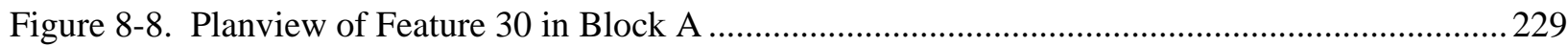

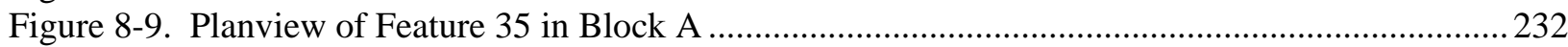

Figure 8-10. Selected Perdiz, non-Perdiz, and Cliffton Arrow Points................................................ 239

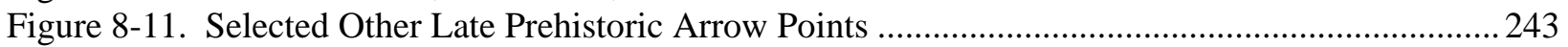

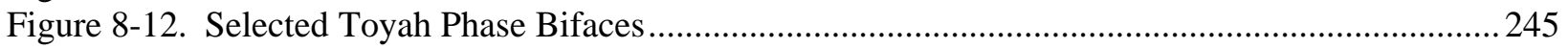

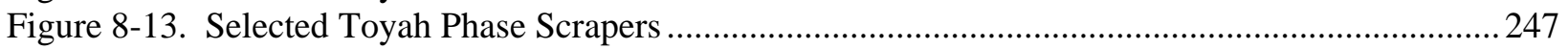

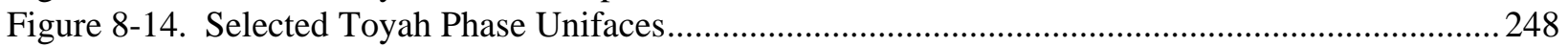

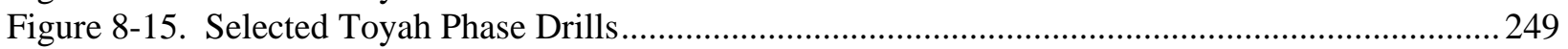

Figure 8-16. Miscellaneous Toyah Phase Artifacts .......................................................................... 250

Figure 8-17. Selected Toyah Phase Rejuvenation Flakes ................................................................... 253

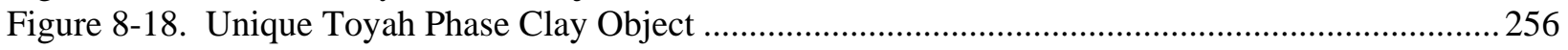

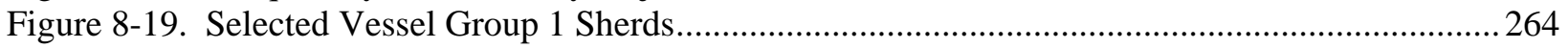

Figure 8-20. Distribution of Vessel Group Sherds in Block A ......................................................... 267

Figure 8-21. Distribution of Vessel Group Sherds in Block B ......................................................268

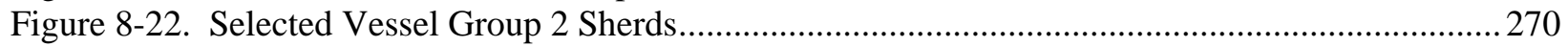

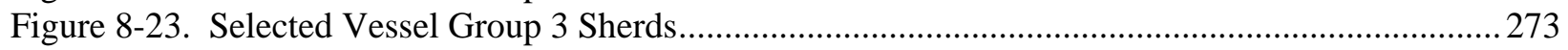

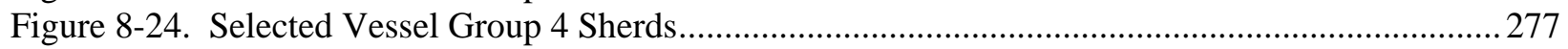

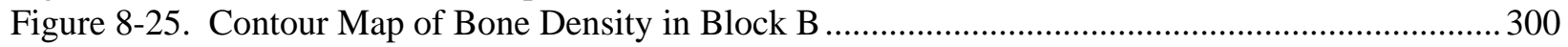

Figure 8-26. Contour Map of Lithic Debitage Density in Block B ........................................................300

Figure 8-27. Contour Map of Edge-Modified Flake Density in Block B …........................................... 301

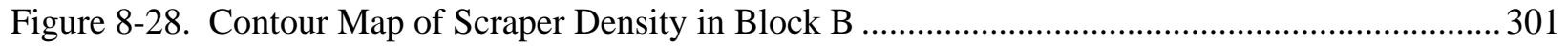

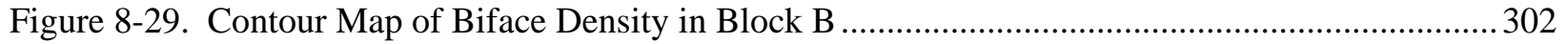

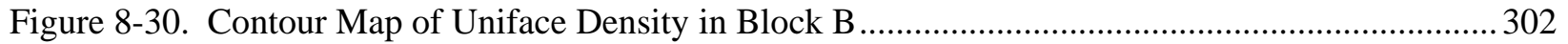

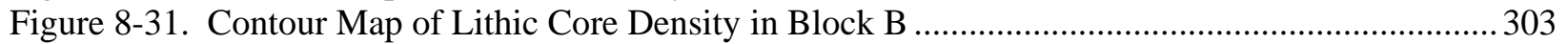

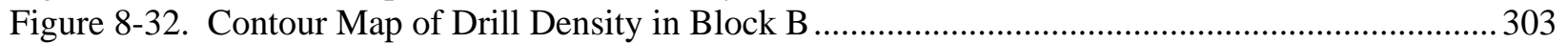

Figure 8-33. Contour Map of Burned Rock Density in Block B ........................................................... 304

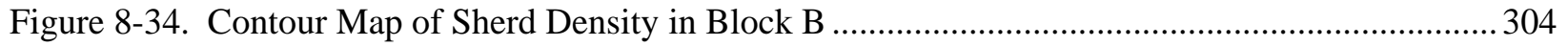

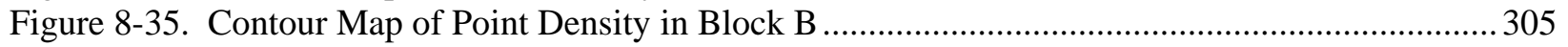

Figure 8-36. Contour Map of Sherd Density in Block A ........................................................................ 310

Figure 8-37. Contour Map of Lithic Core Density in Block A ............................................................... 310

Figure 8-38. Contour Map of Lithic Debitage Density in Block A ….................................................... 310

Figure 8-39. Contour Map of Edge-Modified Density in Block A .......................................................... 310

Figure 8-40. Contour Map of Burned Rock Density in Block A ......................................................... 311

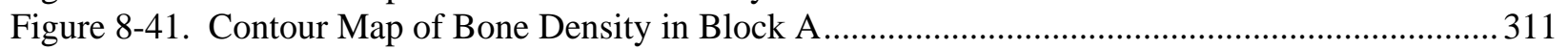

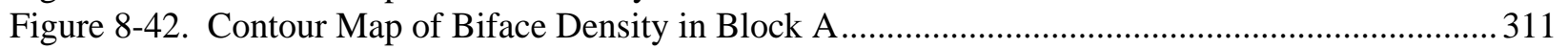

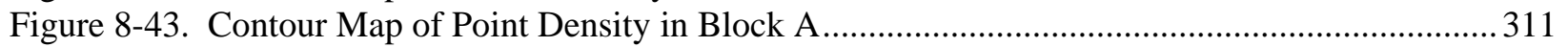

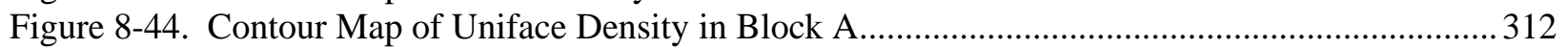

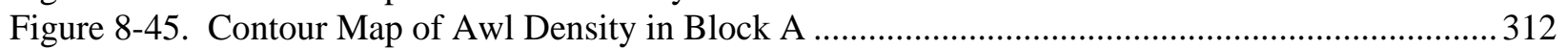

Figure 8-46. Contour Map of Scraper Density in Block A …........................................................... 312

Figure 9-1. Late Archaic Component in Dark Buried A Horizon.............................................................. 324

Figure 9-2. Composite profile of Burned Rock Lens Discovered in Backhoe Trench 1 During First

Phase of Investigations in 2002 (view west)............................................................... 327

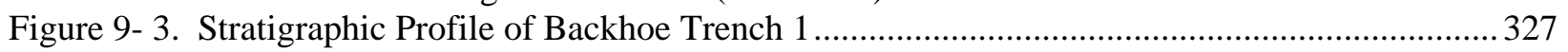

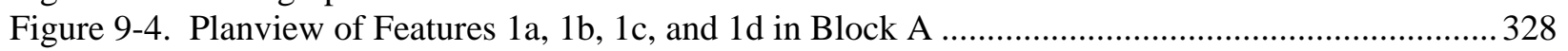

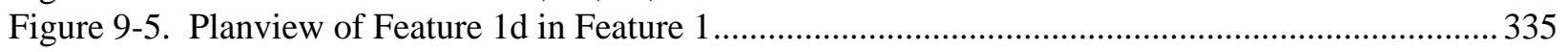

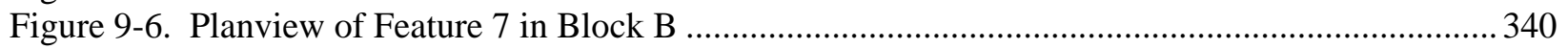

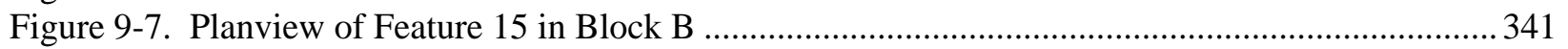

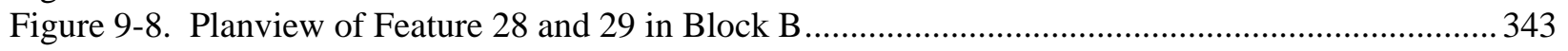




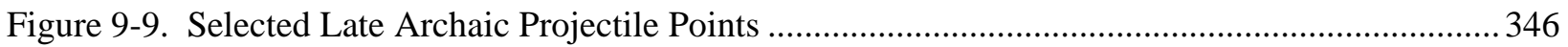

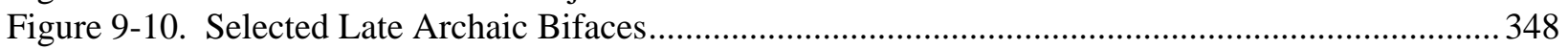

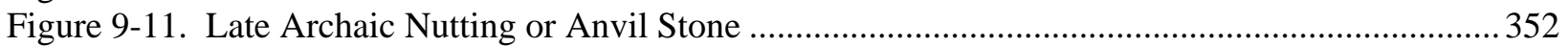

Figure 9-12. Contour Map of Burned Rock Density from Late Archaic in Block A............................... 363

Figure 9-13. Contour Map of Bone Density from Late Archaic in Block A ........................................ 363

Figure 9-14. Contour Map of Lithic Debitage Density from Late Archaic in Block A.......................... 363

Figure 9-15. Contour Map of Biface Density from Late Archaic in Block A ........................................ 364

Figure 9-16. Contour Map of Scraper Density from Late Archaic in Block A....................................... 364

Figure 9-17. Contour Map of Lithic Core Density from Late Archaic in Block A ................................ 364

Figure 9-18. Contour Map of Point Density from Late Archaic in Block A .......................................... 364

Figure 10-1. Planview of Profile of Feature 11, Middle Archaic .......................................................... 376

Figure 10-2. Overview of Excavated Feature 11 Showing Burned Rock Associations ........................... 377

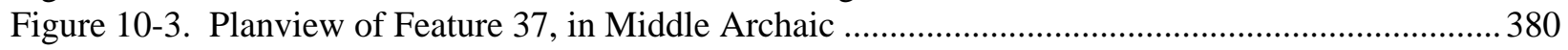

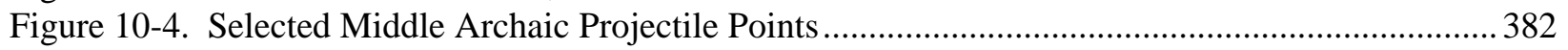

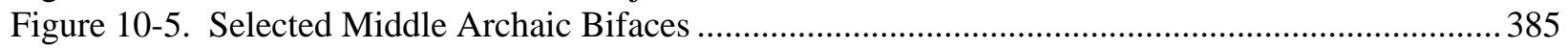

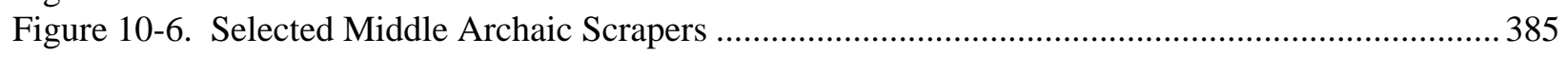

Figure 10-7. Contour Map of Bone Density for Middle Archaic in Block A ........................................398

Figure 10-8. Contour Map of Lithic Debitage Density for Middle Archaic in Block A.......................... 398

Figure 10-9. Contour Map of Biface Density for Middle Archaic in Block A .......................................398

Figure 10-10. Contour Map of Edge-Modified Density for Middle Archaic in Block A ........................398

Figure 10-11. Contour Map of Burned Rock Density for Middle Archaic in Block A .......................... 399

Figure 10-12. Contour Map of Lithic Core Density for Middle Archaic in Block A .............................. 399

Figure 10-13. Contour Map of Point Density for Middle Archaic in Block A .........................................399

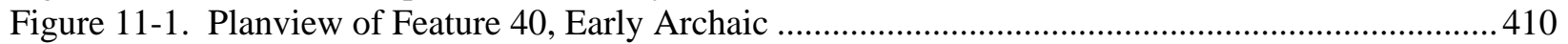

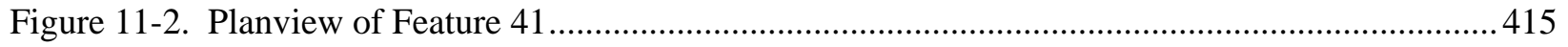

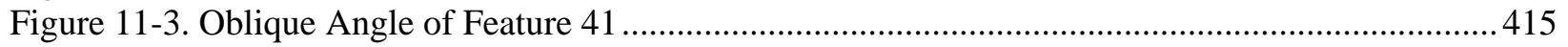

Figure 11-4. Planview of Feature 27, Early Archaic ............................................................................416

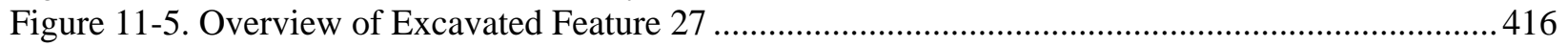

Figure 11-6. Planview of Feature 39, Early Archaic ….........................................................................417

Figure 11-7. Planview of Feature 12, Early Archaic ….......................................................................... 418

Figure 11-8. Planview of Feature 13, Early Archaic ............................................................................419

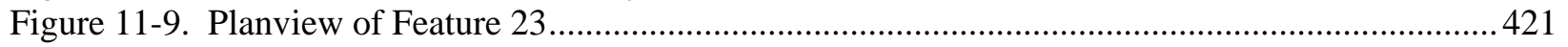

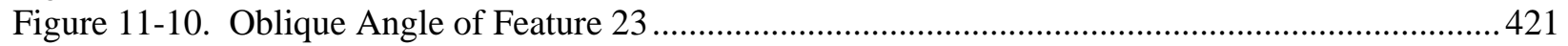

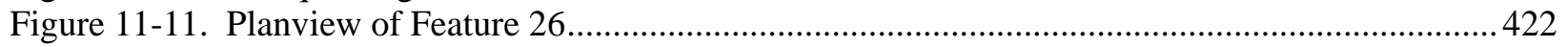

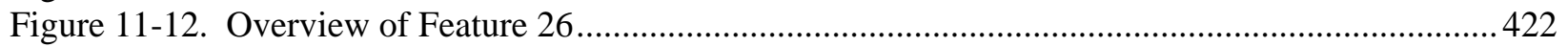

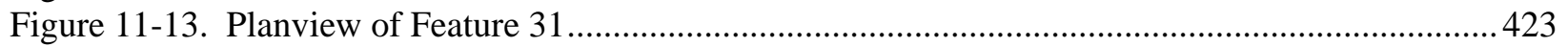

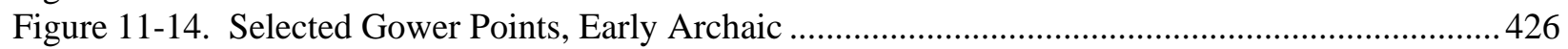

Figure 11-15. Selected Martindale Points, Early Archaic.................................................................... 428

Figure 11-16. Selected Bandy Points, Early Archaic......................................................................... 430

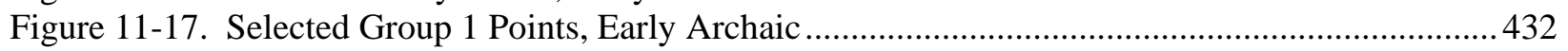

Figure 11-18. Selected Baker Points, Early Archaic...............................................................................433

Figure 11-19. Selected Merrell Points, Early Archaic ......................................................................... 435

Figure 11-20. Selected Group 2—Corner-Notched, Carrizo, and Pandale Points, Early Archaic.......... 437

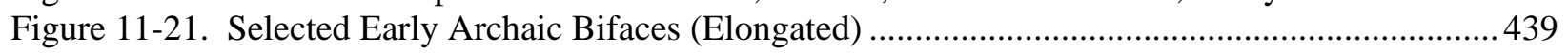

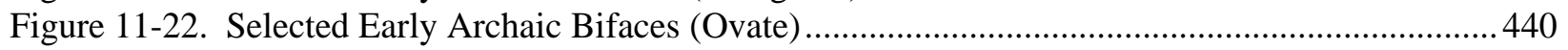

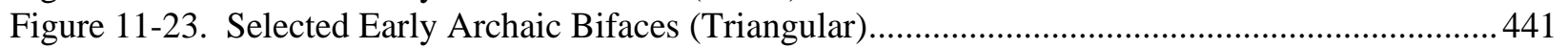

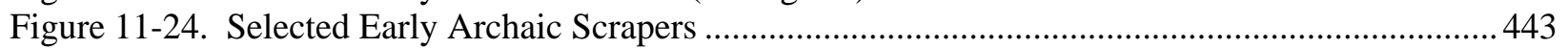

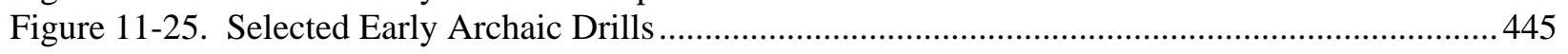


Figure 11-26. Selected Early Archaic Unifaces and Gouges............................................................ 446

Figure 11-27. Selected Early Archaic Bone Awl (\#76-2-11) and Crinoid Section (\#637-16)................. 449

Figure 11-28. Selected Early Archaic Rejuvenation Flakes ............................................................... 451

Figure 11-29. Contour Map of Lithic Debitage Density in Early Archaic ............................................463

Figure 11-30. Contour Map of Edge-Modified Density in Early Archaic .............................................464

Figure 11-31. Contour Map of Point Density in Early Archaic........................................................ 464

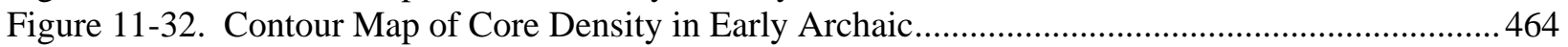

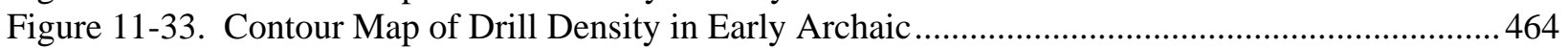

Figure 11-34. Contour Map of Burned Rock Density in Early Archaic .................................................465

Figure 11-35. Contour Map of Scraper Density in Early Archaic .............................................................65

Figure 11-36. Contour Map of Bone Density in Early Archaic ..........................................................465

Figure 11-37. Contour Map of Uniface Density in Early Archaic...........................................................465

Figure 13-1. Stable Carbon and Nitrogen Isotope Results from a Matrix Column Near Middle of

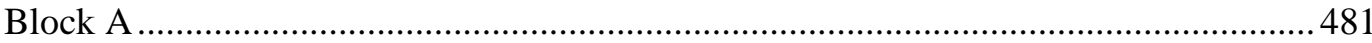

Figure 14-1. Stable Carbon and Nitrogen Isotope Results from Burned Rocks and Natural Sediments. 500

Figure 14-2. Stable Carbon and Nitrogen Isotope Results on Modern Plants and Animals for

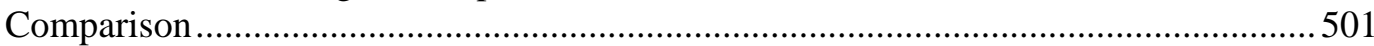

Figure 14-2. Stable Carbon and Nitrogen Isotope Results on Modern Plants and Animals for

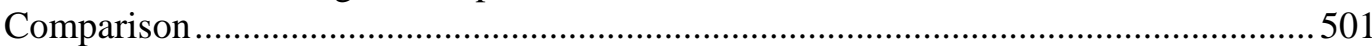

Figure 15-1. Average Diameter of Each Cultural Feature …............................................................... 521

Figure 15-2. Average Burned Rock Weight of Cultural Features (Grams) ...........................................525

Figure 16-1. Summary of Varga Site Radiocarbon Dates Plotted through Time ....................................539

Figure 17-1. Schematic Diagram of Hypothesized Annual Cycle of Seasonal Emphases in Resource

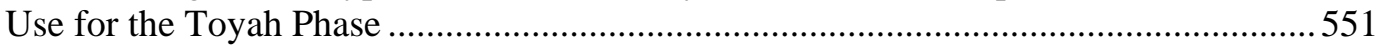




\section{LIST OF TABLES}

Table 3-1. Archeological Sites in the Vicinity of the Varga Site in Northern Edwards and Western

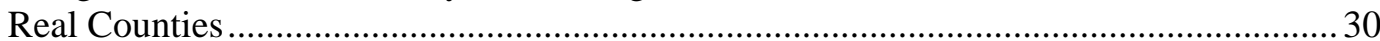

Table 3-2. Central Texas Chronology (from Collins 1995) ..................................................................... 38

Table 3-3. Lower Pecos Chronology (from Turpin 1991) .................................................................... 45

Table 4-1. Summary of Artifact Assemblages Recovered from Two Phases of Data Recovery

Excavations at the Varga Site (41ED28) ........................................................................ 94

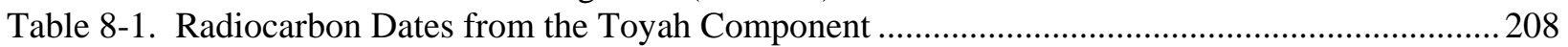

Table 8-2. Burned Rock Characteristics from Features 8 and 18 ......................................................215

Table 8-2. Burned Rock Characteristics from Features 8 and 18 ......................................................2 215

Table 8-3. Lipid Residue Results from Burned Rock Samples from the Toyah Component .................. 216

Table 8-4. Isotope Results from Burned Rocks in Toyah Context ....................................................... 217

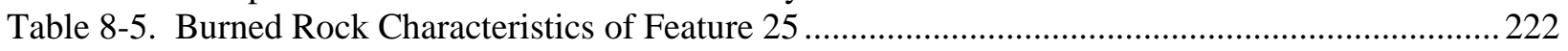

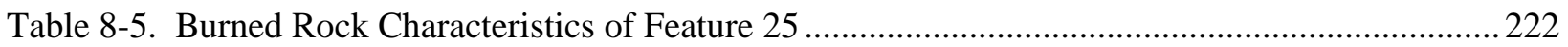

Table 8-6. Burned Rock Characteristics of Features 9, 21, 30, 38, and 35............................................ 225

Table 8-6. Burned Rock Characteristics of Features 9, 21, 30, 38, and 35.......................................... 225

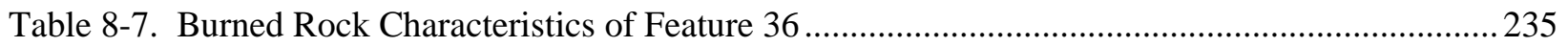

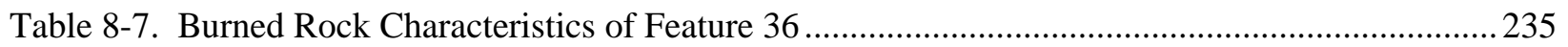

Table 8-8. Metric and Non-metric Observations on Perdiz Projectile Points from 41ED28...................240

Table 8-9. Metric and Non-metric Observations on Cliffton Points from 41ED28 .............................. 241

Table 8-10. Metric and Non-metric Observations on Bonham Projectile Points from 41ED28..............242

Table 8-11. Metric and Non-metric Observations on Scrapers from 41ED28......................................246

Table 8-12. Radiocarbon Results on Pottery Sherds from Buckhollow and Mission Sites ..................... 282

Table 8-12. Radiocarbon Results on Pottery Sherds from Buckhollow and Mission Sites ..................... 282

Table 8-14. Correlation Matrix for Block B-Toyah Component ......................................................... 307

Table 8-14. Correlation Matrix for Block B-Toyah Component .........................................................307

Table 8-15. Principal Component Matrix for Block B-Toyah Component............................................308

Table 8-16. Correlation Matrix for Block A - Late Prehistoric Component ............................................ 314

Table 8-16. Correlation Matrix for Block A - Late Prehistoric Component ........................................... 314

Table 8-17. Principal Component Matrix for Block A-Late Prehistoric Component ........................... 315

Table 8-18. Summary of the Toyah Assemblage from the Varga Site (41ED28) Investigations............. 320

Table 8-19. List of Faunal Species Identified in the Toyah Component ................................................321

Table 8-20. List of Floral Species Identified in the Toyah Component...................................................321

Table 9-1. Varga Site Radiocarbon Dates from the Late Archaic Component........................................325

Table 9-1. Varga Site Radiocarbon Dates from the Late Archaic Component........................................325

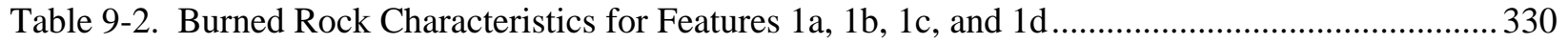

Table 9-2. Burned Rock Characteristics for Features 1a, 1b, 1c, and 1d...............................................330

Table 9-3. Lipid Residue Results from Burned Rock Samples from Late Archaic Component ..............331

Table 9-4. Isotope Results from Burned Rocks in Late Archaic Context.................................................332

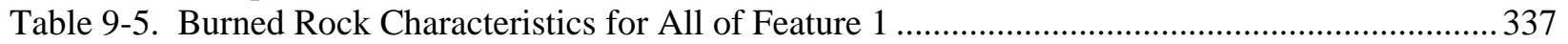

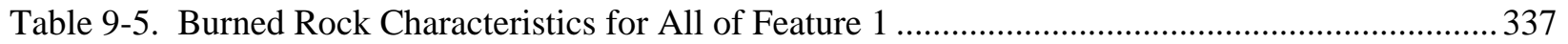

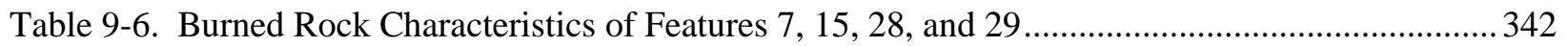

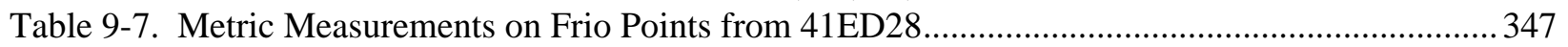

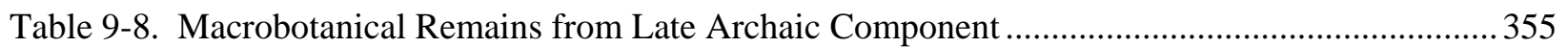

Table 9-9. Summary of the Late Archaic Materials from the Varga Site (41ED28) Investigations ......... 357

Table 9-10. Floral Species Identified from the Late Archaic Component .............................................359

Table 9-11. Correlation Matrix for Block A—Late Archaic Component.................................................. 365 
Table 9-12. Principal Component Matrix for Block A-Late Archaic Component ................................ 366

Table 10-1. Varga Site Radiocarbon Dates from the Middle Archaic Component ................................374

Table 10-1. Varga Site Radiocarbon Dates from the Middle Archaic Component ..................................374

Table 10-2. Burned Rock Characteristics of Features 11 and 37 ..........................................................378

Table 10-2. Burned Rock Characteristics of Features 11 and 37 .......................................................... 378

Table 10-3. Lipid Residue Results from Burned Rock Samples from the Middle Archaic Component . 379

Table 10-4. Isotope Results from Burned Rocks in Middle Archaic Features ........................................ 379

Table 10-5. Macrobotanical Remains from the Middle Archaic Component......................................... 391

Table 10-6. Summary of the Middle Archaic Assemblage from the Varga Site (41ED28)

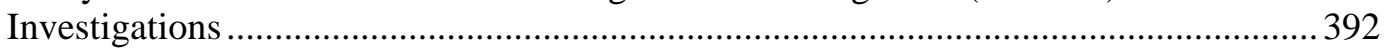

Table 10-7. Correlation Matrix for Block A-Middle Archaic Component ........................................ 400

Table 10-8. Principal Component Matrix for Block A-Middle Archaic Component ........................... 400

Table 11-1. Radiocarbon Dates from the Early Archaic Component ................................................... 408

Table 11-1. Radiocarbon Dates from the Early Archaic Component ................................................. 408

Table 11-2. Burned Rock Characteristics from Features 40, 41, 27, 39, 12, 23, 26, and 31 ................. 412

Table 11-3. Lipid Residue Results from Burned Rock Samples from the Early Archaic Component .... 413

Table 11-4. Isotope Results from Burned Rocks in Early Archaic Context ........................................... 414

Table 11-5. Metric Measurements on Gower Points from 41ED28 …................................................. 427

Table 11-6. Metric Measurements on Martindale Points from 41ED28 ............................................... 429

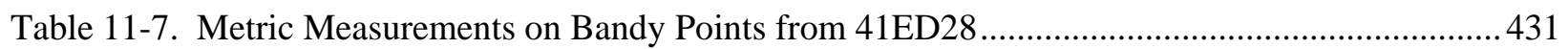

Table 11-8. Metric Measurements on Group 1 Points from 41ED28 …................................................ 431

Table 11-9. Metric Measurements on Baker Points from 41ED28 ....................................................... 434

Table 11-10. Metric Measurements on Merrell Points from 41ED28 …............................................... 436

Table 11-11. Metric Measurements on Group 2 Points from 41ED28 …............................................436

Table 11-12. Metric Data, Early Archaic Scrapers from 41ED28 …................................................. 444

Table 11-13. Data on Residues and Use-Wear, Early Archaic Modified Debitage................................. 448

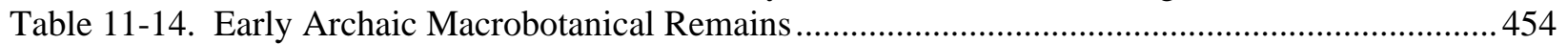

Table 11-15. Summary of Early Archaic Assemblage from the Varga Site (41ED28) Investigations.... 456

Table 11-16. Correlation Matrix for Block A-Early Archaic Component ...........................................466

Table 11-16. Correlation Matrix for Block A-Early Archaic Component ............................................466

Table 11-17. Principal Component Matrix for Block A-Early Archaic Component ........................... 467

Table 13-1. Wood and Pollen Taxa Identified by Cultural Period............................................................483

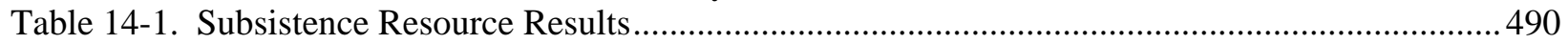

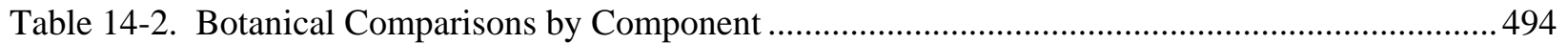

Table 14-3. Summary of Interpretations of Foods Cooked by Burned Rocks Analyzed from Selected

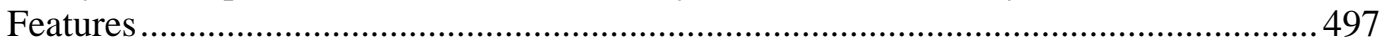

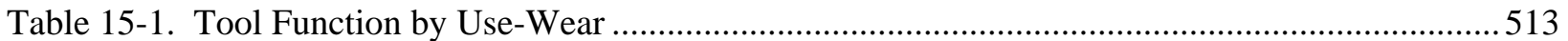

Table 15-2. Use-wear Summary on Artifacts from Varga Site Components........................................... 517

Table 15-3. Summary of Burned Rock Features at the Varga Site ...................................................... 519

Table 15-3. Summary of Burned Rock Features at the Varga Site .........................................................5 519

Table 15-4. Cultural Feature Types by Component at the Varga Site ..................................................5 523

Table 16-1. Summary of Varga Site Radiocarbon Data and Results ...................................................536

Table 16-1. Summary of Varga Site Radiocarbon Data and Results ...................................................536

Table 16-1. Summary of Varga Site Radiocarbon Data and Results (continued)...................................537

Table 16-1. Summary of Varga Site Radiocarbon Data and Results (continued)..................................538

Table 17-1. Selected Toyah Sites Indicating Subsistence and Settlement Data .....................................548

Table 17-2. Selected Late Archaic Excavated Sites Indicating Subsistence and Settlement Data ...........552 
Table 17-3. Archeological Sites in the Vicinity of the Varga Site in Northern Edwards and Western

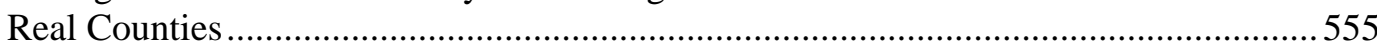

Table 17-4. Selected Middle Archaic Excavated Sites and Selected Characteristics ...............................557

Table 17-5. Selected Early Archaic Excavated Sites Indicating Subsistence and Settlement Data.........559

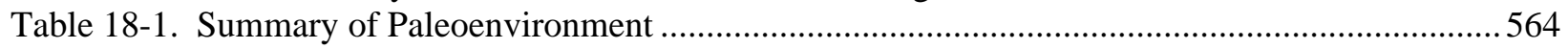

Table 18-2. A Comparison of Toyah Reproduction Trait Compositions Using Identified Faunal

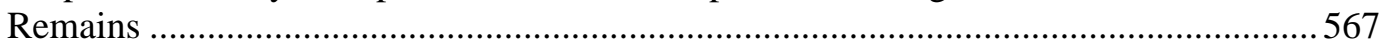

Table 19-1. Summary of Cultural Materials by Component from the Varga Site (41ED28)

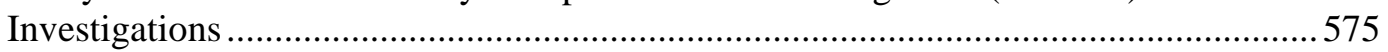




\section{ACKNOWLEDGMENTS}

The Texas Department of Transportation (TxDOT), Environmental Affairs Division, Archeological Studies Program sponsored and guided this archeological mitigation project. Many individuals and organizations worked together and contributed significantly to making this mitigation program a success. We would like to thank all of them for their help in completing this project and helping to preserve a part of Texas prehistory.

We would like to express our gratitude to the many personnel in TxDOT's Environmental Affairs Division, Archeological Studies Program in Austin, Texas, for their support and guidance. Dr. Owen Lindauer and Dr. Lain Ellis worked with TRC Environmental Corporation's (TRC's) archeological staff over the years to facilitate the many individual work authorizations, supplemental agreements, and other paperwork necessary to successfully complete the excavation and analysis for this project. Both individuals offered insights throughout the analysis of materials from the Varga Site. Dr. Lindauer organized a symposium for the October 2003 Texas Archeological Society conference in Dallas on Late Prehistoric Period investigations. Mr. Jesse Owens, TRC's Project Archeologist for this project, presented a paper on ongoing investigations of the Toyah Phase component at the Varga Site in this symposium. Dr. James Abbott worked closely with TRC personnel on several individual work authorizations, especially facilitating the radiocarbon dating of materials. Dr. Nancy Kenmotsu and Ms. Barbara Hickman worked closely with TRC personnel during the public outreach programs conducted in August 2002 that involved an open-house media day and educational programs for school children from Rocksprings, Texas. They planned and organized the outreach programs, including the development of a brochure and display boards produced by TRC, and hosted on-site presentations for groups of school classes during the field investigations to inform them about the history of the area and the process of finding, recording, and collecting artifacts from archeological sites. Ms. Barbara Hickman coordinated the internal TxDOT review of the draft final report and we would like to thank all those who contributed comments on the draft. The thoughtful comments helped to make this a more precise and readable report. John Arnn, TxDOT Archeologist, helped in the final stages to facilitate the final report process. Thanks to all these individuals for their various contributions.

Individuals from TxDOT district offices in San Angelo and Junction, Texas, also provided invaluable assistance during the fieldwork for this project. Ms. Nancy Fisher, Environmental Coordinator of TxDOT's San Angelo District Office, helped set up meetings, directed TxDOT personnel, and provided useful background information. A number Gradall ${ }^{\circledR}$ and backhoe operators provided much needed assistance during both phases of the data recovery operations, including initial removal of overburden and ongoing movement of backdirt piles away from the excavation areas and roadway as they became increasingly voluminous.

The hard-working field staff from the Cultural Resources Department of TRC's Austin and El Paso, Texas, offices completed the two phases of data recovery excavations at the Varga Site, making significant contributions to the timely and efficient completion of the fieldwork. During the initial (Phase I) data recovery investigation, conducted from January 14 to 
February 10, 2002, the field crew was directed by Dr. Chris Lintz (Principal Investigator). Ms. Elia Perez, served as Project Archeologist, and supervised the crew of archeological technicians, which included Mr. Don Badon, Mr. Steve Baird, and Mr. Roman Clem. Mr. Grant Smith, TRC's geoarcheologist, conducted the in-field stratigraphic documentation of alluvial terrace sediments on the site and in the surrounding environment through backhoe trenching and profile recording. Dr. Lintz assisted by Roman Clem prepared the interim report from the Phase I investigations. The second stage (Phase II) of data recovery investigations conducted between July 22 and October 9, 2002, was directed by Mr. J. Michael Quigg (Principal Investigator) who planned the fieldwork, directed the data analyses, coordinated with the various technical analysts, managed the budget, and guided this project to its conclusion. Mr. Jesse Owens served as Project Archeologist, overseeing a field crew composed of Mr. Badon, Mr. Ron Charles, Mr. Clem, Mr. Steven Schooler, Mr. Jason Smart, Mr. John Spencer, and Ms. Sylvia Reyna. Again, Mr. Smith conducted geomorphological investigations on the lower terrace adjoining the deeply stratified cultural deposits on the site and in the immediate area.

The fieldwork was made much more enjoyable through the kindness and hospitality of the Varga family, in whose honor this site has been named. Mr. Todd Varga and family provided several home-cooked feasts for the field crew in the summer of 2002. Mr. Varga continually stopped by to see the excavations in progress and to visit with the field crew, asking many questions and providing many insights regarding artifact discoveries and other archeological sites in the immediate vicinity. He also conducted a tour of local upland settings, facilitating the collection of local upland chert samples used in this study. Mr. Varga allowed Dr. Lintz access to his extensive artifact collection for initial identification and recording, which helped to refine early interpretations of the sequence of prehistoric occupations in the vicinity of the Varga Site. Mr. Varga also provided the picture of the recent flood event that destroyed the road (Figure 2-2).

Upon completion of the Phase I excavations, Mr. Clem processed the collections from the site, helped assemble the initial database, and contributed to the Phase I interim report submitted to TxDOT in April 2002. After the Phase II field investigations were completed, all materials collected from the Varga Site were transported to TRC's laboratory in Austin, Texas. There, Mr. Smart and Mr. Clem sorted, washed, and catalogued artifacts and input data; and they are thanked for their hard work. Mr. Clem also conducted the flotation of the sediment matrix samples. Ms. Mercedes Cody coded and entered data on dozens of attributes on hundreds of artifacts under the direction of Mr. Owens, with technical assistance from Mr. Shane Pritchard in 2003 and 2004. Ms. Cody is thanked for her attention to detail in cleaning up and maintaining the database, searching for and resolving errors, correcting and ensuring that all paperwork was correct and properly labeled, and maintaining the database and artifact collections throughout the analysis, reporting, and curation processes. Mr. Pritchard produced the initial drafts of cultural feature drawings and site maps, and Ms. Cody was responsible for producing some of the remaining figures and illustrations in this report. Ms. Cody also conducted the analyses on the chipped stone tools, managed the data base entry, conducted the curation preparation on the artifacts, notes, records, and photographs, helped with many of the tables and ran a very controlled laboratory. Mr. Owens performed statistical analyses of artifact distributions and stone tool attributes, photographed most artifacts, and was responsible for the technical editing and initial production of the draft report. Mr. Owens wrote 
several chapters including the Introduction, much of the Methods chapter, the Research Design that guided the analyses and interpretive effort for the project, the majority of metric analyses of the projectile points presented in Appendix A, conducted the spatial analyses, and wrote the interpretations of those analyses that are integrated into the component chapters, and formatted and edited about half the draft document. Mr. Smith wrote the geoarcheological portions of this report. Dr. Charles Frederick contributed the comparison of the Varga Site stratigraphy to other regional stratigraphic sequences. Mr. Eric Oksanen helped to complete and interpret the quantitative results of the projectile point analyses in Appendix A. Mr. Paul Matchen helped to answer and address the various comments provided by the TxDOT following their review of the draft document and was a major contributor to Chapter 19 that addresses the various research questions presented in the Research Design. Dr. Robert Ricklis stepped in during the final stages and conducted a through edit of the entire report and his broad knowledge of Texas archeological and editorial skills made a significant contribution to the readability of the final report. Dr. Lintz assembled the data from the Phase I investigations, directed the analyses of the unknown mineral deposits initially believed to be possible human bones, prepared the public information brochure on the Varga Site used in the public outreach programs, and co-authored the interim report describing the results of the Phase I data recovery excavations. That report provided the recommendations, scope of work, and general research direction for the subsequent Phase II effort. Ms. Marie Archambeault also helped in enumerable ways from December 2004 on through the submission of the draft report to TxDOT with the extensive reporting process, creating illustrations, inserting the figures, formatting and editing of about half the draft document, helping in final stages of laboratory analyses, and providing quality control of the draft report. Mr. Ben Herdeman did the final editing of the final report and is thanked for his attention to detail.

Dr. Darrell Creel, Director of the Texas Archeological Research Laboratory (TARL) in Austin, Texas, visited the site during the field investigations and provided insightful comments and welcome levity. Ms. Laura Nightingale, Head of Curation at TARL, provided assistance in locating ceramic artifacts from other archeological sites in southwest Texas and in checking out other material requested for loan by TRC during the course of this research. Dr. Charles Frederick provided valuable insights into the optically stimulated luminescence (OSL) dating technique and provided directions as to which processes were likely to yield the best results. Ms. Margaret Howard, Ms. Amy Ringstaff, and Ms. Aina Dodge of the Texas Parks and Wildlife Department, Public Lands Division, Cultural Resource Program were helpful in obtaining recent publications and providing lithic materials from the Devil's Sinkhole area investigations (sites 41ED54, 57, 58, and 141) to be used in instrumental neutron activation analyses (INAA). Ms. Susan Snow of the National Park Service office in San Antonio, Texas, facilitated the process of obtaining permission for Mr. Quigg to use Native American ceramic materials from Mission San Juan for analyses. Ms. Marybeth Tomka, Head of Curation at the Center for Archeological Research (CAR) at the University of Texas at San Antonio found, selected, and documented the ceramic sherds from the Mission San Juan used in the analyses. Ms. Tomka also helped various TRC personnel in the preparation of the materials and records for curation at CAR.

We would also like to thank the many professional individuals and facilities whose technical expertise provided valuable contributions to interpreting the data sets that 
allowed us to provide greater and more in-depth insights into the prehistory of the Varga Site. Mr. Elton Prewitt lent his vast experience in Texas projectile point typology to the task of identifying the suite of projectile points collected during this mitigation project. Mr. Prewitt also provided insights into the research conducted at Devil's Rockshelter Site. Ms. Mary Jo Schabel, owner and operator of the Soils \& Physical Geography Laboratory in Milwaukee, Wisconsin, conducted the chemistry and texture analyses of the site sediments. Dr. Bruce Hardy, previously Professor in the Department of Anthropology, Grand Valley State University, Allendale, Michigan conducted high-powered-microscopic use-wear and residue analyses on a sample of stone tools from the site. Dr. Hardy's ability to detect, identify, and interpret use-wear and residues have greatly advanced our understanding of the function of many tools and our overall assessment of site structure and function. Mr. Eric Schroeder of Paul Price Associates, Inc., of Austin, Texas, decalcified many sediment matrix samples before their submission for stable carbon and nitrogen isotope analyses. Dr. David Harris of the Stable Isotope Facility at the University of California at Davis provided the stable carbon and nitrogen isotope data together with insights and direction for interpreting the data. Dr. J. Philip Dering of Shumla Archeobotanical Services in Comstock, Texas, identified and interpreted a sample of macrobotanical remains from the site. Dr. Mary Malainey and Dr. K. L. Malisza conducted the lipid residue extractions and analyses on a sample of burned rocks and ceramic sherds. Dr. John Jones of the Palynology Laboratory at Texas A\&M University conducted the pollen and phytolith extractions from sediment samples, which were subsequently sent to Dr. Richard Holloway of Quaternary Services in Flagstaff, Arizona, for analysis. Dr. Holloway lent his extensive experience to the task of interpreting and documenting the pollen and phytolith data. Dr. Lee Bement of the Oklahoma Archeological Survey in Norman identified about one-halfdozen animal bones whose species could not be positively determined. Dr. Marvin Kay, Associate Professor of Anthropology at the University of Arkansas in Fayetteville, Arkansas, conducted high-powered-microscopic use-wear analyses and provided technical expertise in use-wear analysis to the interpretation of two Toyah-aged stone tools from the Varga Site that were believed to have special functions. Dr. Michael Glascock of the Archaeometry Laboratory at the University of Missouri Research Reactor Center, in Columbia conducted the instrumental neutron activation analysis on cultural and natural chert samples from the Varga Site and surrounding southwest and central Texas locales. Dr. David Robinson of Austin, Texas, undertook petrographic analyses of a sample of ceramic sherds from the Varga Site and other Late Prehistoric to Protohistoric period sites to provide information on the technical manufacturing attributes of Toyah Phase ceramics. Geochron Laboratories, a division of Krueger Enterprises, Inc., of Cambridge, Massachusetts, provided the carbon, nitrogen, and bioapatite isotope data on a bone sample from the Toyah component. Dr. James Feathers, Professor of Anthropology at the Luminescence Dating Laboratory of the University of Washington in Seattle, conducted the single-grain optically stimulated luminescence dating of six sediment samples from the Varga Site for comparison with the standard radiocarbon dates from each of the main components.

The mineral deposits, originally suspected to be possible human remains, collected during the Phase I investigations and labeled Feature 6 were carefully scrutinized by various experts to provide interpretations of this material. Dr. John Kappleman, a consulting anthropologist in Austin, Dr. David Glassman a physical 
anthropologist at Texas State University in San Marcos, Dr. Robert R. Paine a physical anthropologist at Texas Tech University, Dr. Gary W. Rutenberg of Anthropos, in Austin, and Mr. Greig Parker an anthropologist in California all provided expert opinions concerning the questionable materials.
To all the above people and institutions I am grateful and appreciate their individual expertise and contribution to the multi dimensional aspects of this mitigation project. Thanks to all.

Mike Quigg

Project Manager 


\subsection{INTRODUCTION}

Jeffrey D. Owens

This report describes the results of two phases of data recovery excavations at the Varga Site (41ED28), a multicomponent prehistoric archeological site in Edwards County, Texas (Figure 1-1). The first phase of data recovery operations occurred from January 14 to February 10, 2002, and the second phase was conducted from July 22 to October 9, 2002. These cultural resource investigations were carried out by personnel from the Austin and El Paso, Texas, offices of TRC Environmental Corporation (TRC) on behalf of the Texas Department of Transportation (TxDOT), Environmental Affairs Division, Archeological Studies Program under Scientific Services Contract No. 572XXSA004. The cultural resource study was necessary due to the proposed reconstruction of the crossing of the Ranch to Market Road over Hackberry Creek in northeastern Edwards County, Texas, and was carried out as part of the responsibilities of TxDOT under existing federal and state guidelines, including Sections 106 of the National Historic Preservation Act (NHPA) of 1966 (P.L. 89-665; 80 Stat. 915; 16 USC §470 et seq.); and the Texas Antiquities Code (Texas Natural Resource Code of 1977 [revised 1987], Title 9, Chapter 191, VACS, Art. 6145-9).

Data recovery excavations were conducted in two separate phases. The first phase of fieldwork included mechanical stripping and trenching as well as manual excavation of a small part of the potentially affected part of the site. Upon completion of the first phase of fieldwork, TRC submitted an interim report to TxDOT that summarized the archeological and geoarcheological investigations conducted to date (i.e., February 2002) and presented a preliminary tabulation and limited analysis of artifacts and feature data recovered from the site (Lintz et al. 2002). This report documented the significant research potential of the site, recommended a second phase of data recovery excavations to mitigate the proposed construction impacts, and presented a data recovery plan that guided the second phase of excavations.

A second interim report described the second phase of fieldwork, which included manual excavation of a large part of the potentially affected part of the site as well as additional mechanical trenching (Owens et al. 2002). It also presented a preliminary tabulation and assessment of the entire assemblage of data recovered from both phases of excavations as it applies to the research design outlined in the data recovery plan. Following a brief description of the natural setting and history of archeological investigations at the Varga Site, this second interim report briefly summarized the archeological and geoarcheological investigations conducted by TRC personnel. Then, the report presented an overview of the site's stratigraphy and a preliminary summary of the assemblage of cultural material (including artifacts and feature data) recovered from both phases of data recovery excavations. Finally, the data assemblage was critically evaluated for its potential to address selected major research domains.

This document begins with a brief introduction to the archeological investigations at prehistoric site 41ED28. Chapter 2.0 provides a general environmental background that briefly discusses the physiographic setting, geology and geoarcheology, climate, and economic resources in the region. Chapter 3.0 provides a general 


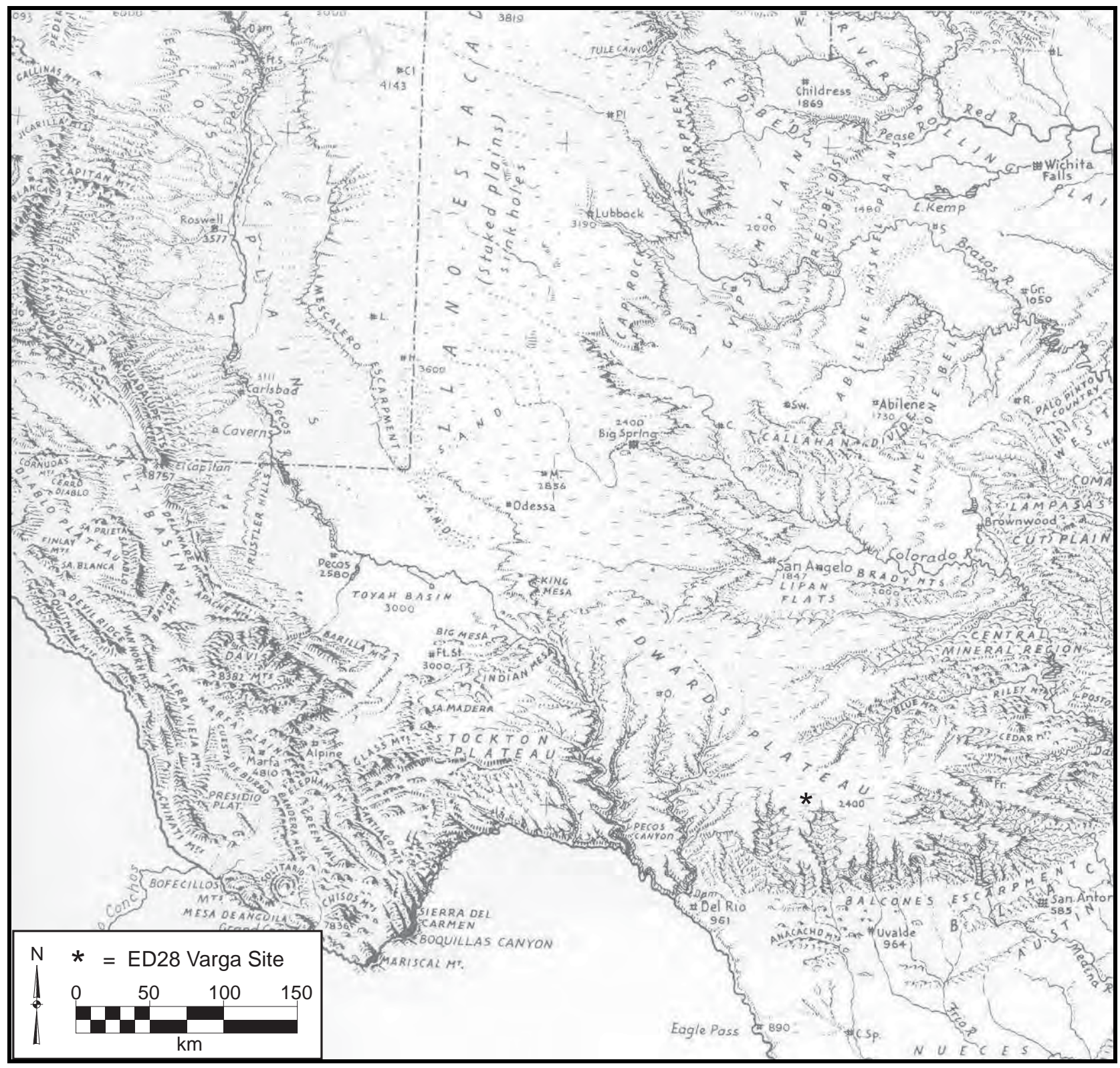

Figure 1-1. Varga Site (41ED28) Location Map

cultural background for the Lower Pecos and Central Texas archeological regions that focused on the four main time periods: Early, Middle, and Late Archaic, plus the Toyah interval represented at the Varga Site. Broad theoretical perspectives and specific research orientations are presented in Chapter 4.0. Chapter 5.0 describes the field and laboratory methods used to obtain and analyze the cultural materials recovered. The geoarcheological investigations, results, and interpretations are presented in Chapter 6.0, which provides the context for 
enabling understanding of the recovered archeological materials. Chapter 7.0 introduces the archeological results and provides the discussion of the analytical components to be presented in the following chapters. Chapters 8.0 through 11.0 present the detailed descriptions, analysis results, and interpretations of the cultural materials recovered from the four identified components. Chapter 12.0 provides the data descriptions of the materials that for one reason or another were not assigned to one of the identified components. Chapters 13.0 through 17.0 utilize the recovered data from across 41ED28 to address the major research issues and specific research questions presented in Chapter 4.0. Chapter 18.0 presents a broad view of the human ecosystems represented at the Varga Site. Chapter 19.0 evaluates and assesses the multiple analytical techniques used in our analyses. Management considerations and recommendations are presented in Chapter 20.0. Chapter 21.0 lists the references cited throughout the body of the report. A glossary of technical terms is presented for the reader in Chapter 22.0.

The glossary is followed by 15 appendices labeled $\mathrm{A}$ through $\mathrm{O}$ that provide detailed data and analyses primarily from outside technical laboratories. These specific data sets include the projectile point analyses in Appendix A, detailed laboratory data concerning the radiocarbon dates in Appendix B, the high-powered use-wear analyses and interpretations in Appendix C, the petrographic analysis and results in Appendix D, pollen and phytolith analyses and interpretations in Appendix E, instrumental neutron activation analyses (INAA) is presented in Appendix F, lipid residue analysis is presented in Appendix G, stable carbon and nitrogen isotope data on cultural and modern plant and animal resources appears in Appendix $\mathrm{H}$, macrobotanical identifications are discussed in Appendix I, the expert opinions concerning the unknown material are presented in Appendix $\mathrm{J}$, the granulometry and chemical analyses are presented in Appendix K, the optically stimulated luminescence (OSL) data are presented in Appendix L, high-powered usewear analyses on two unique chipped stone tools is presented in Appendix $\mathrm{M}$, and INAA on ceramic sherds is presented in Appendix N. Appendix O is on a Compact Disk - read-only memory (CD-ROM) that contains individual tables with the individual metric and non-metric data for each stone tool by tool categories from the four defined components and the entire database for these investigations.

\subsection{Project Location}

The Varga Site (41ED28) is in southwestern Texas near the western edge of the Balcones Canyonlands, a physiographic and ecological subdivision of the Edwards Plateau Natural Region. Deep, rugged, parallel canyons that formed as southward-flowing streams characterize the Western Balcones Canyonlands where rivers cut through the limestone formations that compose the Edwards Plateau (Decker et al. 2000:1-2). Below the Balcones Escarpment and fault zone at the southern edge of the Edwards Plateau, these streams flow across the nearly level Rio Grande or Gulf Coastal plains, eventually discharging into the Gulf of Mexico.

The Varga Site is about 3.1 kilometer (km) (5.0 mile [mi]) below the rim of the Edwards Plateau in the dissected canyonlands associated with Hackberry Creek, a tributary of the Nueces River (Figure 1-2). Topography in the vicinity of the site is moderately strong, with variations of up to 136 meter (m) (ranging from 644 to $780 \mathrm{~m}$ above mean sea level [amsl]) across a distance of $3.1 \mathrm{~km}(5.0 \mathrm{mi})$. These dramatic changes in topographic relief are due to the entrenchment of Hackberry Creek and its tributaries into the local Cretaceous limestone 


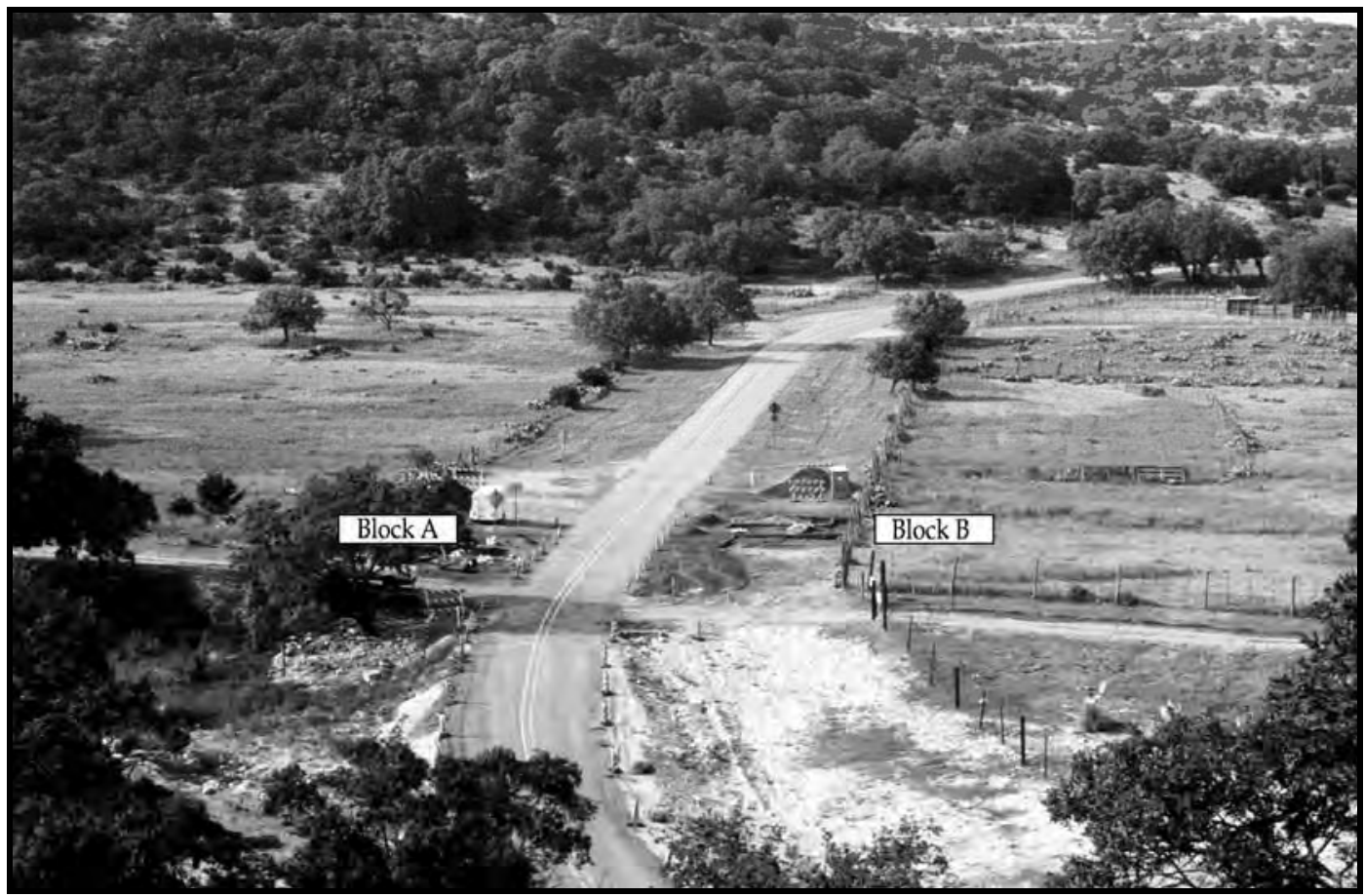

Figure 1-2. Overview of Varga Site Looking North

deposits. Local exposures of these limestone deposits include the chert-bearing limestone of the Segovia member, which is exposed on the ridges and upper slopes, and the underlying Fort Terrett member limestone of the Edwards Group, which is exposed along the lower valley walls (Barnes 1981).

The Varga Site is situated in the T1 terrace on the north bank of Hackberry Creek, overlooking the current stream channel from a height of about $6 \mathrm{~m}$ (19.7 feet [ft]). In the vicinity of the investigated part of the site, Hackberry Creek has three prominent alluvial terraces that form a broad, gently sloping, lowland landform that measures about $430 \mathrm{~m}(1,410 \mathrm{ft})$ in maximum width (i.e., north to south along the route of a Ranch to Market Road). The T1 terrace is a fill terrace that contains relatively fine-grained sediments ranging from 15 to 140 centimeter (cm) (1.3 to $11.7 \mathrm{ft})$ in depth. These fine sediments in turn overlie rounded to subrounded limestone stream gravels and boulders that were deposited under high-energy fluvial conditions. Archeological deposits in the investigated part of the site extend to the lip of the T1 surface and an undetermined distance to the north.

A deposit of coarse limestone gravel and boulders dominates the $\mathrm{T} 0$ terrace below the $\mathrm{T} 1$ terrace lip. These gravels are the result of the floodplain surface being scoured of its uppermost fine-grained sediments by highenergy flood events, the two most recent of which occurred in the winters of 2000/2001 and 2001/2002. These extremely coarse gravel deposits are similar to those beneath the finegrained sediments of the T1 terrace, which were probably deposited under analogous high-energy alluvial regimes in the past.

The T2 terrace hugs the base of nearby upland formations. The edge of the $\mathrm{T} 2$ terrace is 
located about $270 \mathrm{~m}(886 \mathrm{ft})$ north of the investigated part of the site.

The gross boundaries of the Varga Site were determined when the site was initially documented during a cultural resource reconnaissance more than 30 years ago (Marmaduke and Whitsett 1975:92; Texas Archeological Research Laboratory [TARL] Archeological Site Atlas). These boundaries describe a site that extends about $780 \mathrm{~m}$ $(2,558 \mathrm{ft})$ along the north terrace of Hackberry Creek, varying in width from roughly $60 \mathrm{~m}$ $(197 \mathrm{ft})$ near the site's center to 20 to $25 \mathrm{~m}$ (66 to $82 \mathrm{ft}$ ) at either end. TRC's investigations were limited to the part of the site that lies within TxDOT's right-of-way flanking the Ranch to Market Road, near the western end of the documented site area. TxDOT's right-of-

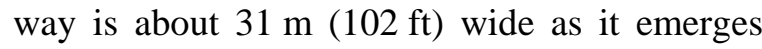
onto the $\mathrm{T} 1$ terrace from the creek crossing, including roughly $7 \mathrm{~m}$ (7.6 ft) of existing pavement and associated road shoulders that bisect the right-of-way. The investigated part of the right-of-way therefore includes two $12 \mathrm{~m}$ (39.4 ft) wide tracts on both sides of the pavement, defined on the inside by the existing roadway and on the outside by adjoining property fencelines.

The area of potential effect associated with the construction project extends northwards only a short distance onto the T1 terrace. Although Marmaduke and Whitsett (1975:92) reported that the northern boundary of the site was not determined when the site was originally discovered. The site files indicate that the northern edge extends about $65 \mathrm{~m}$ (213 ft) north of the T1 terrace lip within the right-of-way of the Ranch to Market Road. Based on TRC's investigations, cultural debris extends northwards from the terrace edge minimally $40 \mathrm{~m}$ (131 ft [i.e., to the northern limit of TRC's excavations]), and quite possibly farther. In fact, the mapped northern boundary of the site probably under represents the true extent of the debris scatter, at least in the western part of the site. In any event, TRC's investigations cover and can be considered to have mitigated any construction-related impacts to a horizontal area of about $1,240 \mathrm{~m}^{2}\left(4,067 \mathrm{ft}^{2}\right)$ within TxDOT's right-of-way (40 m [131 ft] north-south by $31 \mathrm{~m}$ [102 ft] east-west [including the existing pavement]).

\subsection{Previous Investigations}

The Varga Site was originally documented during a cultural resource reconnaissance of the upper Nueces River Natural Area near the Devil's Sinkhole (Kennard 1975; Marmaduke and Whitsett 1975). Although the original site forms are missing from TARL files, the survey report briefly describes site $41 \mathrm{ED} 28$ as a $250 \mathrm{~m}$ $(820 \mathrm{ft})$ long site of undetermined width that extends along a terrace on the north side of Hackberry Creek (Marmaduke and Whitsett 1975:92). The recorders identified two "burned rock middens" on the highest part of the terrace as well as several additional "fire hearths" on the lower parts of the terrace. Burned rock and lithic artifacts were observed scattered across the entire surface of the site (see Marmaduke and Whitsett 1975:107, Fig. 5). Following its initial discovery and documentation, no further cultural resource investigations occurred at the Varga Site until the current TxDOT undertaking.

\subsection{Data Recovery Excavations- PHASE I}

These archeological investigations were initiated in response to the planned reconstruction of a Ranch to Market Road crossing over Hackberry Creek immediately south of the site. The existing low-water crossing had washed out twice during severe flooding in the winters of $2000 / 2001$ and 2001/2002. At the time that archeological investigations were begun, final decisions had not yet been made regarding the 
long-term solution for repairing the creek crossing, but either a bridge or a reinforced lowwater crossing were considered to be options. Either way, the part of the Varga Site lying within the existing road right-of-way on the north terrace of the creek would be impacted by construction activities, so TxDOT initiated cultural resource investigations of the potentially affected part of the site.

In 2001, TxDOT's Environmental Affairs Division personnel contracted with TRC to investigate the part of the site that lies within TxDOT's right-of-way. TRC's scope of work was originally quite limited; it was designed to exhaust the information potential of a purported burned rock oven feature located at the surface near the rim of the first terrace of Hackberry Creek on the west side of the Ranch to Market Road (Lintz et al. 2002). During a field inspection of the damage to the low-water crossing following the most recent flood event in 2001, TxDOT archeologists noticed a low topographic mound within the right-of-way on the west side of the existing road. This apparent topographic anomaly was reported to be covered with lithic debris, burned and unburned rocks, and animal bones, and was suspected to be a prehistoric burned rock oven "midden.” Local informants apparently reported that this "midden" had been subjected to repeated collecting and digging activities over the years, though no obvious potholes were evident (the authors presently believe that these reports of pothunter excavations apply to other burned rock midden features located elsewhere on the site, beyond TxDOT's right-of-way). As this "midden" was located within the area of potential effect, regardless of the manner of highway repair construction of the low-water crossing, investigations of the area were warranted as required under Section 106 of the NHPA.
In an effort to streamline the regulatory procedures of NHPA Section 106, TxDOT archeologists entered into consultation with the Texas Historical Commission (THC). Based on these consultations and available information about the site, it was determined that any archeological testing of that part of the site within TxDOT's right-of-way would most likely result in the determination of the "midden" feature as eligible for inclusion in the National Register of Historic Places (NRHP). Consequently, the parties agreed that data recovery investigations should be initiated in the "midden" feature without implementing a formal testing phase.

In consultation with TxDOT, TRC developed a scope of work that employed mechanical stripping and trenching and manual excavation of up to $10 \mathrm{~m}^{3}\left(7.65 \mathrm{ft}^{3}\right)$ of the potentially affected part of the Varga Site to efficiently extract data from the intact parts of the purported "midden" feature. A work authorization for these investigations was issued to TRC under an existing statewide contract for general cultural resource services. TRC archeologists and geoarcheologist performed data recovery fieldwork between January 14 and February 10, 2002, under Texas Antiquities Commission Permit 2779. During these investigations, our understanding of what the site contained changed considerably and necessitated contract modifications to reallocate the $10 \mathrm{~m}^{3}\left(7.65 \mathrm{ft}^{3}\right)$ excavation area to examine the archeological potential on both sides of the Ranch to Market Road near the lip of the first terrace.

The initial plan for investigating this site was developed by TxDOT archeologists specifically to document what was thought to be an isolated burned rock "midden" exposed at the surface, to identify any intact cultural deposits, and to extract information from any intact portions of the feature (Lintz et al. 2002:6). Consequently, 
the initial work authorization called for TRC archeologists to restrict excavations to the "midden" feature. First, the assumed disturbed surface sediments overlying the "midden" feature on the west side of the road, which was described as being "armored" with lithic debris, burned and unburned rocks, and animal bones, were mechanically stripped using a Gradall ${ }^{\circledR}$. Next, a north to south oriented trench was excavated west of a small concentration of burned rocks revealed during the stripping. This trench exposed a 5 to $6 \mathrm{~m}$ (5.5 to $6.5 \mathrm{ft}$ ) long burned rock lens (designated as Feature 1) in a shallow basin completely buried under $30 \mathrm{~cm}$ of fine sediments and overlying about $60 \mathrm{~cm}$ (30 in) of fine sediments on top of a coarse gravel deposits. In accordance with the contract, a second, east-west-oriented trench was excavated perpendicular to the first trench through the northern half of the shallow burned rock lens. This trench reaffirmed the scarcity of burned rock in most of the deposits; the evidence clearly indicated that the topographic mound feature did not represent a burned rock midden (Figure 1-3). Subsequent manual excavations along the edges of the backhoe trenches documented the occurrence of elevated quantities of lithic debris in the fine sediments above the burned rock lens and again just above the basal gravels (Figure 1-4). The recovery of diagnostic projectile points dating to the Early Archaic and Late Prehistoric periods, multiple concentrations of artifacts above and below the thin, buried rock lens, and an overall lack of evidence for the reported vandalism of the site, all indicated that this part of the first terrace contained stratified cultural occupations with considerable integrity. Furthermore, the cultural deposits appeared to be intact and have the potential to extend laterally beyond the vicinity of the topographic mound.

Upon consultation with TRC, TxDOT altered the scope of work to include the investigation of deposits on both sides of the road to ascertain the geometry of the terrace deposits and the extent of archeological remains. TRC archeologists were asked to monitor additional backhoe trenches north of the original target area on the west side of the road as well as on the east side. TRC personnel were also granted latitude of professional judgment in the placement and distribution of 0.5-by- $0.5 \mathrm{~m}$ and 1-by-1 m manual excavation units. However, the level of effort expended to examine both sides of the road was restricted to the original excavation volume cap of $10 \mathrm{~m}^{3}$. During this first phase of field investigations, four backhoe trenches were excavated on the west side of the road and three additional trenches were excavated on the east side (Figure 1-5). Eight 0.5-by-0.5 m (1.5-to-1.5 ft) units were handexcavated along the edges of the deeper backhoe trenches (five on the west side and three on the east side of the road), a scatter of five 1-by-1 m units was hand-excavated on the east side of the road, and two 1-by-2 m units were handexcavated on the west side of the road near the initial backhoe trenches. Manual excavations were conducted using hand tools (i.e., picks and shovels), and all sediments were screened through various combinations of $6.4 \mathrm{~mm}$ (1/4 in) and $3.2 \mathrm{~mm}$ (1/8 in) mesh. Clusters of artifacts, such as faunal bone or burned rocks, and ashy stains were designated as cultural features. Seven features were originally documented in the field, though three were later attributed to natural causes (i.e., two burned root casts and one cluster of mineral deposits originally believed to possibly be decomposed human long bones). Documented cultural features included the buried burned rock lens (Feature 1), two sparse scatters of burned rock, and one bison and deer bone dump associated with burned rocks. All hand- excavated units were terminated upon reaching culturally sterile gravel deposits. In addition, soil samples were collected from various strata observed in the backhoe trenches to aid in preliminary geoarcheological 


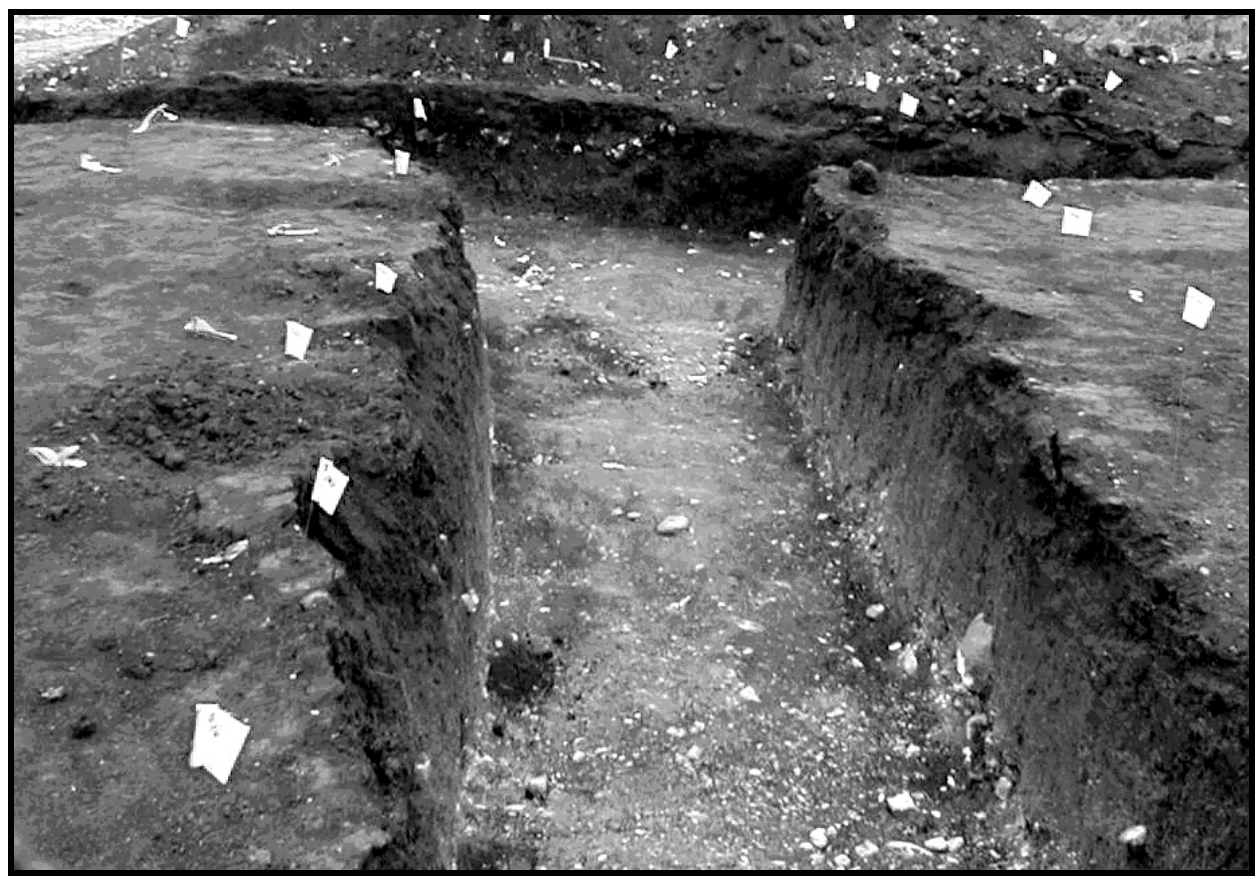

Figure 1-3. East to West and North to South Trenches Through Low Mound Area at South End of Site (Subsequently Block A Area)

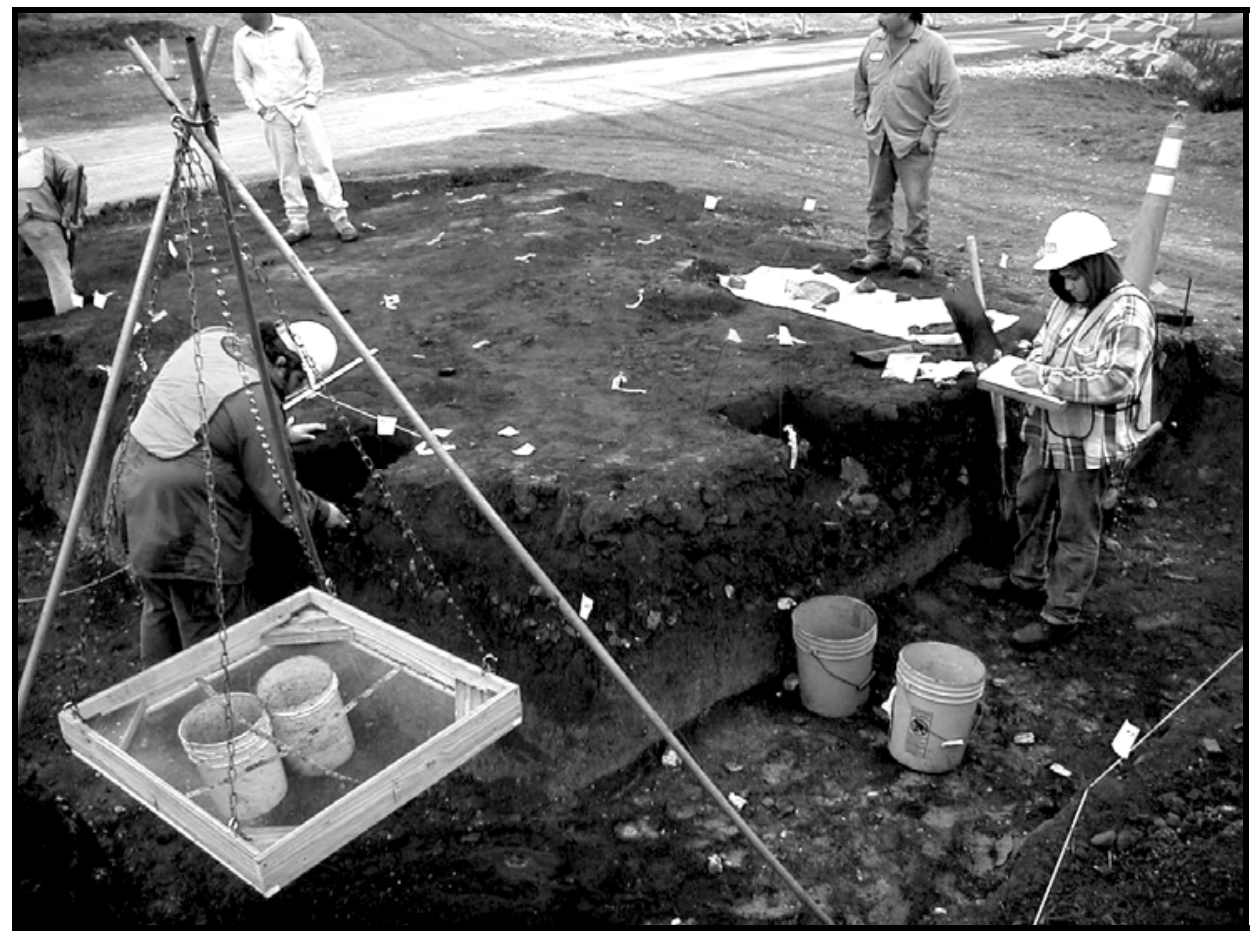

Figure 1-4. Phase I Hand-Excavations Along Initial Trenches with Burned Rock Lens Exposed in Profiles at South End of First Terrace (Eventually Block A Area) 


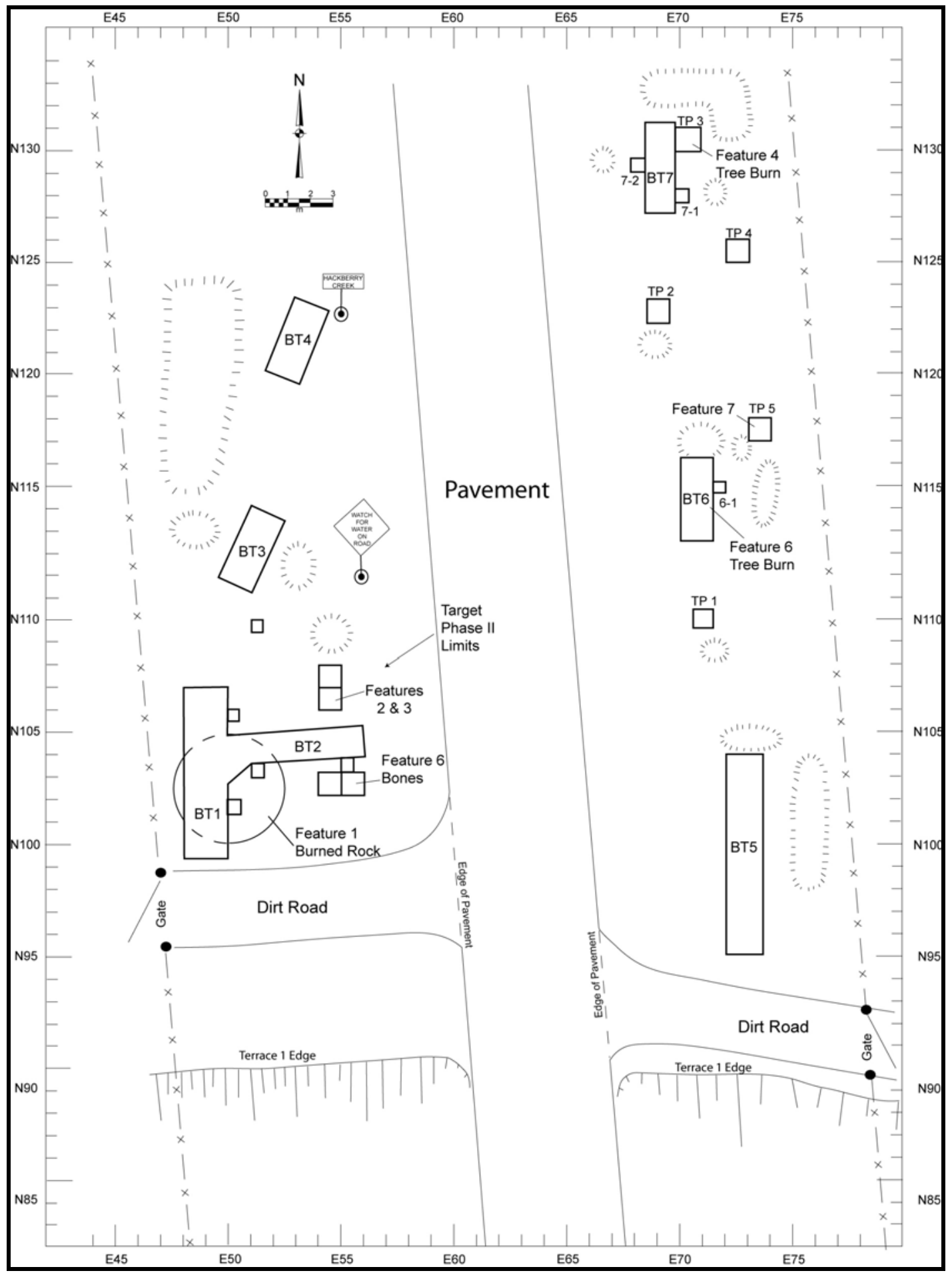

Figure 1-5. Varga Site (41ED28) Phase I Investigation Areas In Impact Area 
interpretations of site stratigraphy and terrace formation processes. The first phase of fieldwork was halted upon meeting the contractual excavation limit of $10 \mathrm{~m}^{3}$.

All lithic and ceramic artifacts, pieces of burned clay, and charcoal were collected. Excavators compiled preliminary field counts of collected materials to facilitate the compilation of information about material distributions. Laboratory work associated with the first phase of fieldwork, however, was limited to assessing the completeness and accuracy of field records and collected materials; no cleaning or cataloging of artifacts occurred at this stage. All material classes were examined, counts and weights were compiled for the unwashed artifacts, and an effort was made to identify the types of projectile points and pottery recovered from the excavations.

The results of this initial phase of fieldwork were summarized in an interim report (Lintz et al. 2002) and served as the basis for designing a second, more robust phase of data recovery excavations. The first interim report documented that the archeological setting and context were quite different than originally expected, and a second phase of fieldwork was recommended to fully investigate the dense and stratified cultural deposits within the area of potential effect.

The first phase of fieldwork established that thick $(70+\mathrm{cm})$ deposits of stratified fine sediments containing predominantly Late Prehistoric, Late Archaic, and Early Archaic archeological materials exist on both sides of the pavement within TxDOT's right-of-way. Despite some variability in depositional packages across the site, two major and one minor occupation zones were documented. The uppermost major occupation zone, attributed to the Late Prehistoric period (Toyah phase), was present in the uppermost 20 to $30 \mathrm{~cm}$ of deposits on both sides of the road. Large quantities of artifacts were recovered and the preservation of bone and organic remains was excellent in these upper sediments. Several associated cultural features (i.e., debris clusters) were documented.

The minor occupation was associated with the large, thin lens of burned rock (Feature 1) buried at depths of 30 to $60 \mathrm{~cm}$ below surface (cmbs). This occupation was tentatively assigned to the Middle Archaic period based on the presence of a possible Pedernales/Martindale point (subsequent investigations established that this feature and the surrounding cultural component actually date to the Late Archaic period; consequently, this cultural component will be referred to as Late Archaic throughout the remainder of this document). Even though associated artifacts were not abundant, this occupation zone was marked by superb stratigraphic clarity on both sides of the road (although high burned rock densities were limited to the immediate vicinity of Feature 1).

Finally, a substantial Early Archaic period occupation zone was identified at depths ranging from 60 to $80 \mathrm{~cm}$ east of the road and from 60 to $110 \mathrm{~cm}$ west of the road, near the base of the excavations above and just into the basal gravel deposits. Preservation of organic materials was not perceived to be especially good in these lower zones, and no associated features were found during the first phase of fieldwork, but artifact densities were extremely high.

Based on variability in artifact densities, the most productive areas to be examined in the second phase of fieldwork appeared to include all occupation zones on the west side of the road, including the Late Prehistoric, Late Archaic, and Early Archaic period occupations (as well as any general Middle Archaic components that may occur between the Early and Late Archaic period occupation zones), but only the Late Prehistoric occupation was 
targeted east of the road. Older occupations were documented on the east side, but the preservation appeared to be poor and temporal and cultural diagnostics and features appeared to be rare. Thus, the first interim report recommended that the second phase of fieldwork target all three components on the west side of the Ranch to Market Road and only the Late Prehistoric component on the east side of the road. The report presented a data recovery plan that guided the proposed second phase of excavations and outlined eight primary research domains to be addressed with the data recovered. Upon consultation with THC, TxDOT concurred with TRC's recommendations and issued a work order to proceed with the proposed second phase of data recovery excavations.

Before the second phase of excavations could begin, however, TxDOT entered into consultation with any interested parties (per Section 106 of the NHPA) regarding the possible human remains recovered during the first phase of fieldwork. At TxDOT's request, a sample of the possible human remains was examined by three physical anthropologists. The physical anthropologists concluded that the materials could not be assigned to a species, though one concluded that the size and position of the materials were consistent with human leg bones. Given the inconclusive results, TxDOT submitted a sample to a bone histologist for examination of the cellular structure of the material. The histologist and his academic advisor both concluded that the material was not bone. The histology information was also submitted to an osteologist in California who reaffirmed the conclusion that the material was not bone. After all opinions were gathered, TxDOT's archeological staff, TRC archeologists, and the THC concluded that the material was not human in origin (these materials are currently believed to be sediment cavities, probably root casts, that were subsequently filled with carbonates, see Appendix J). Based on this conclusion, it was determined that the second phase of data recovery excavations could proceed.

\subsection{Data Recovery Excavations- PHASE II}

The goals and methods applied during the second phase of data recovery excavations were based on the insights gained from the first phase of investigations (Lintz et al. 2002). The first phase of excavations clearly indicated that the stratigraphic structure of the first terrace of Hackberry Creek and the variety and extent of archeological deposits present were considerably more complex than originally expected. TRC's investigations demonstrated that the Varga Site contains stratified deposits with minimally three well-defined prehistoric occupation zones. The uppermost and lowest occupation zones contained abundant materials associated with the Late Prehistoric period (Toyah phase, ranging from 300 to 600 years ago) and one or more Early Archaic period components (ranging from 6,000 to 8,000 years ago). A buried 5-to-6 m diameter burned rock lens (Feature 1) denoted a third, intermediate, Late Archaic period occupation zone. Remains from other (presumably Middle Archaic period) components were suspected to exist, but associated features, tools, and other diagnostic materials were too sparse to confidently correlate the materials into meaningful analytical units.

The artifactual, ecofactual, feature-related, and geoarcheological data recovered during the first phase of investigations indicated that the Varga Site contained important information about the prehistoric past (Lintz et al. 2002; also see Chapter 4.0-Research Design). Therefore, a second phase of data recovery excavations was conducted to mitigate the proposed impacts from road replacement, to recover relevant data from 
minimally three clearly defined cultural components represented (as well as from any additional, less well-defined components that may occur), and to obtain additional geoarcheological information about the age and structure of the Hackberry Creek terraces. 


\subsection{ENVIRONMENTAL BACKGROUND}

\author{
J. Michael Quigg and Jeffrey D. Owens
}

\subsection{Physical EnVIRonment}

The Varga Site lies $0.8 \mathrm{~km}(0.5 \mathrm{mi})$ below the rim of the Edwards Plateau in the dissected canyonlands associated with Hackberry Creek, a headwater tributary of the Nueces River. Topography in the vicinity of the site is moderately pronounced, with local relief of up to $136 \mathrm{~m}$ (ranging from 644 to $780 \mathrm{~m}$ above mean sea level [amsl]) across a distance of $0.8 \mathrm{~km}$ (Figure 2-1). These dramatic changes in topographic relief are due to the entrenchment of Hackberry Creek and its tributaries into the Cretaceous limestone deposits.

The Varga Site lies within the T1 on the left (north) bank of Hackberry Creek, overlooking from a height of approximately $8 \mathrm{~m}$ and is about $30 \mathrm{~m}$ from the current stream channel. In the site's vicinity, Hackberry Creek has three prominent alluvial terraces that form a broad, gently sloping, lowland landform that measures about $430 \mathrm{~m}$ in maximum width (i.e., north to south along the route of the Ranch to Market Road). The $\mathrm{T} 1$ is a fill terrace that contains relatively fine-grained sediments ranging from 15 to $150 \mathrm{~cm}$ in depth. These fine sediments in turn overlie rounded to subrounded limestone stream gravels and boulders that were deposited under high-energy fluvial conditions. Archeological deposits in the investigated part of the site extend to the lip of the $\mathrm{T} 1$ and an undetermined distance to the north.
Channel deposits of coarse limestone gravel and boulders measuring at least $2.5 \mathrm{~m}$ in thickness dominate the T0 below the T1 lip. Based on one humate date from just above the gravel deposit, these T0 gravels were deposited before ca. 6,300 B.P. The floodplain surface was subsequently scoured of its uppermost finegrained sediments during high-energy flood events between 6,300 and 2,000 B.P. The upper $1.5 \mathrm{~m}$ of fine-grained sediments, which overlays these gravel deposits were laid down over the last 2,000 years. The two most recent flood events occurred in the winters of 2000/2001 and 2001/2002 (Figure 2-2). The lower coarse gravel deposits on the modern Hackberry Creek floodplain (T0) are similar to those beneath the fine-grained sediments of the $\mathrm{T} 1$ and probably were deposited under analogous high-energy alluvial regimes in the past.

The limited T2 is restricted to the outer margins of the valley and lies at the base of steep valley walls. The southern edge of $\mathrm{T} 2$ is approximately $270 \mathrm{~m}$ north of the investigated part of the Varga Site. Only a very limited part of T2 lies within the TxDOT right-of-way.

\subsubsection{Physiography and Topography}

The Varga Site is near the western edge of the Balcones Canyonlands, a physiographic and ecological subdivision of the Edwards Plateau. Southward-flowing rivers and streams cut through the limestone formations that compose the Edwards Plateau thereby creating deep, rugged, parallel canyons that characterize the Western Balcones Canyonlands (Decker et al. 2000:1-2). Below the Balcones Escarpment and fault zone at the southern edge of the Edwards Plateau, these streams flow across the more nearly level Rio Grande or Gulf Coastal plains, eventually discharging into the Gulf of Mexico. 


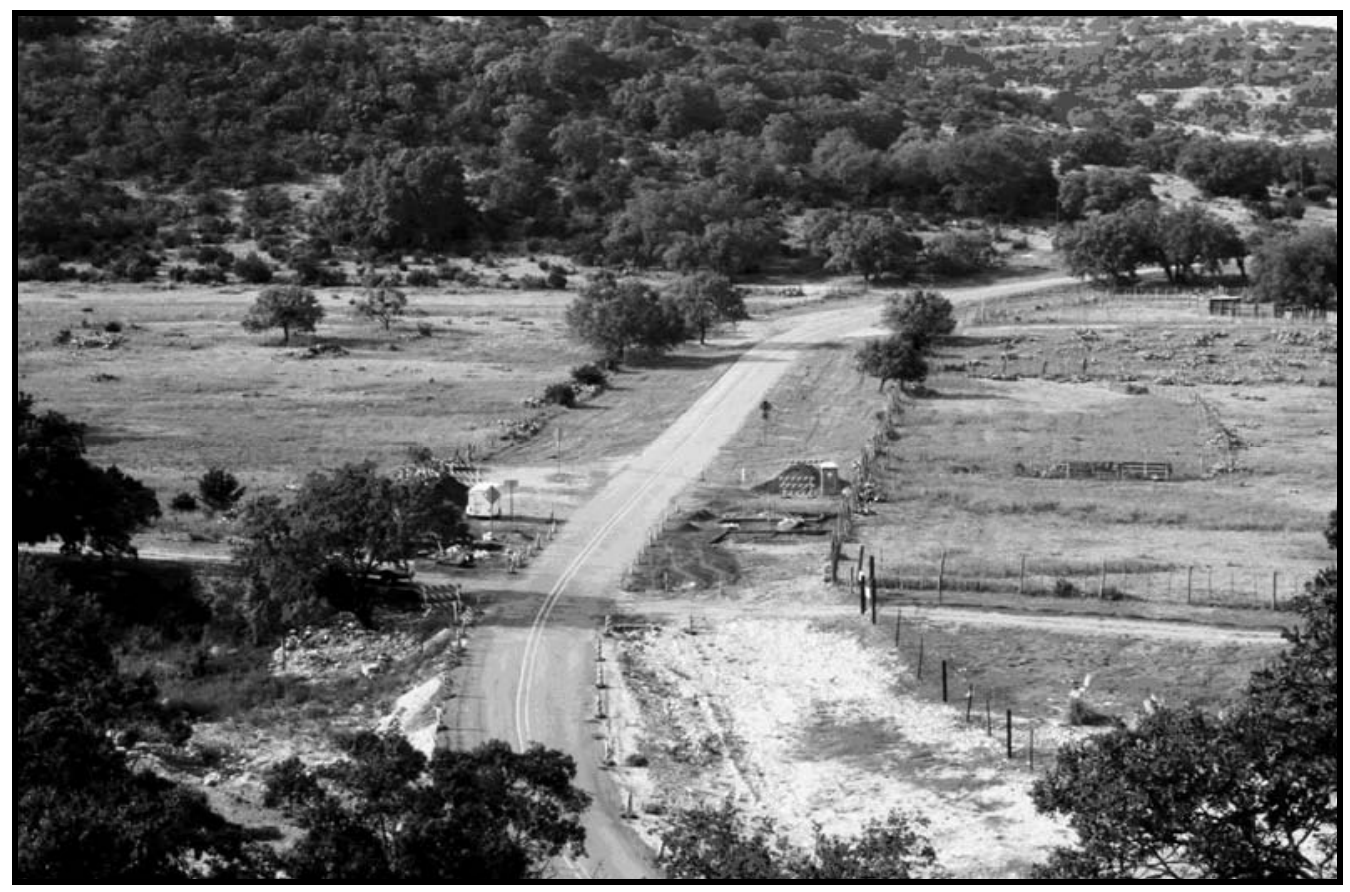

Figure 2-1. Overview of the Varga Site (41ED28) Looking North

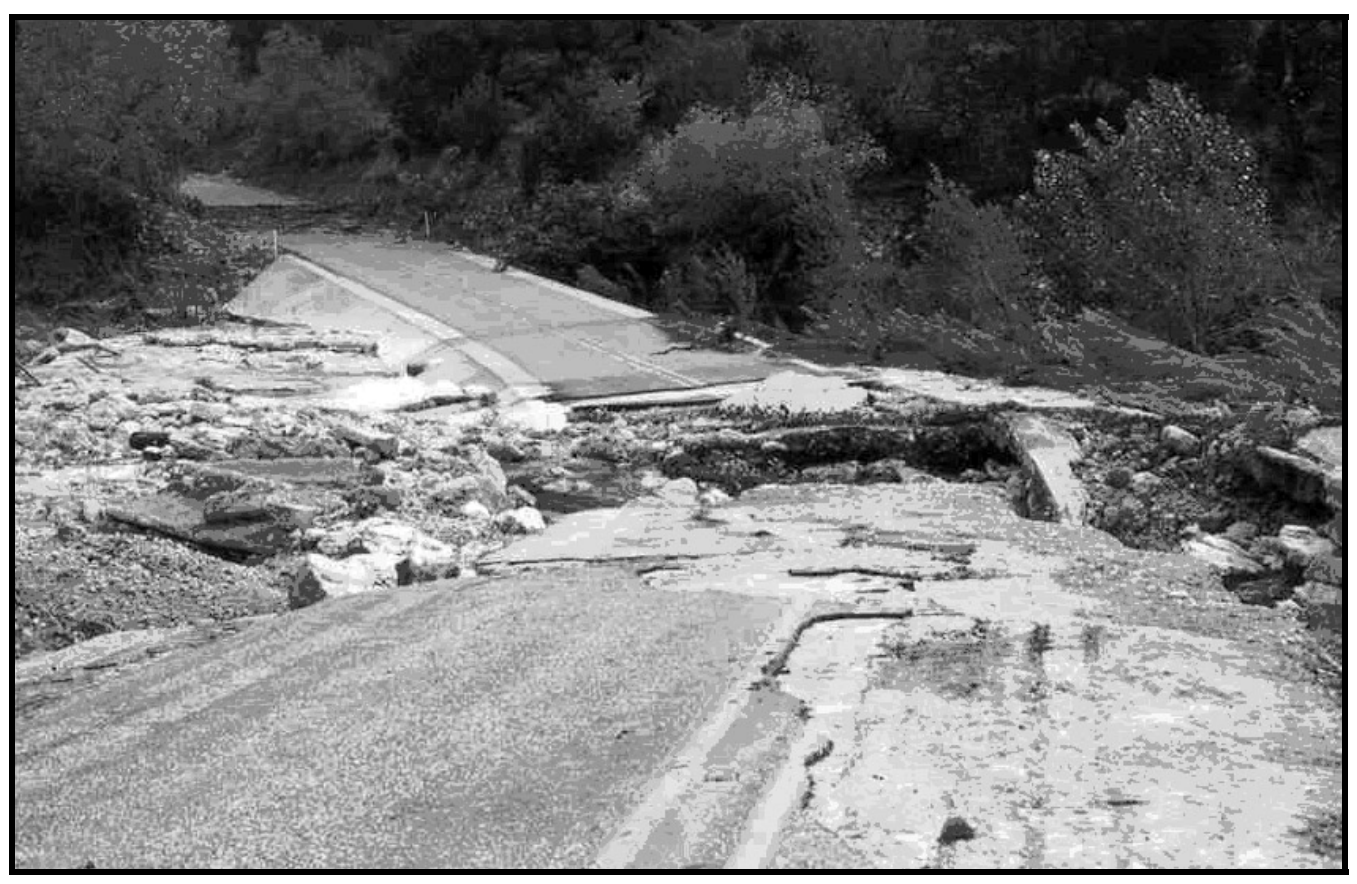

Figure 2-2. Road Damage Following Recent Flood Event 


\subsubsection{Hydrology}

The Varga Site is approximately $3.1 \mathrm{~km}$ south of the upland divide that separates the southwardflowing waters that drain into the Nueces River catchment from those that flow eastward into the Llano River basin. The site is near the headwaters of Hackberry Creek; about 12.5 km east of its drainage divide near the eastern margin of Edwards County. Hackberry Creek flows southward into the Nueces River roughly $12.1 \mathrm{~km}$ south of the site. The Nueces and the West Nueces rivers parallel one another and then merge in southern Uvalde County. The Nueces River parallels several other major rivers that lie to the east that also flow southwards out of the Edwards Plateau, winding across the Gulf Coastal Plain and ultimately discharging into the Gulf of Mexico at Corpus Christi, Texas. United States Geological Survey (USGS) topographic maps indicate (and field observations confirm) the presence of three active springs in the vicinity of the Varga Site. One is located immediately downslope from the project area on the west side of the road crossing over Hackberry Creek (Figure 2-3). Two additional springs are 175 and $280 \mathrm{~m}$ east of the project area (i.e., along the eastern part of the site). These three natural springs are the northernmost sources of permanent water along Hackberry Creek. Brume (1981:175) references a spring labeled "Hackberry Springs" in this approximate location. According to local lore, these springs are connected to the underground water channel in the Devil's Sinkhole, which is approximately $5.3 \mathrm{~km}$ northwest of the site. Six additional active springs issue along the $5.4 \mathrm{~km}$ long segment of Hackberry Creek south of the project area. The water flow from these springs is strong, ranging from 72 to 180 liters per second during the period from 1939 to 1954 (Brune 1975:41, 1981:175). Large pools of water currently stand immediately upstream and downstream from the site. This abundance of water contrasts markedly with the scarcity of natural water resources farther upstream.

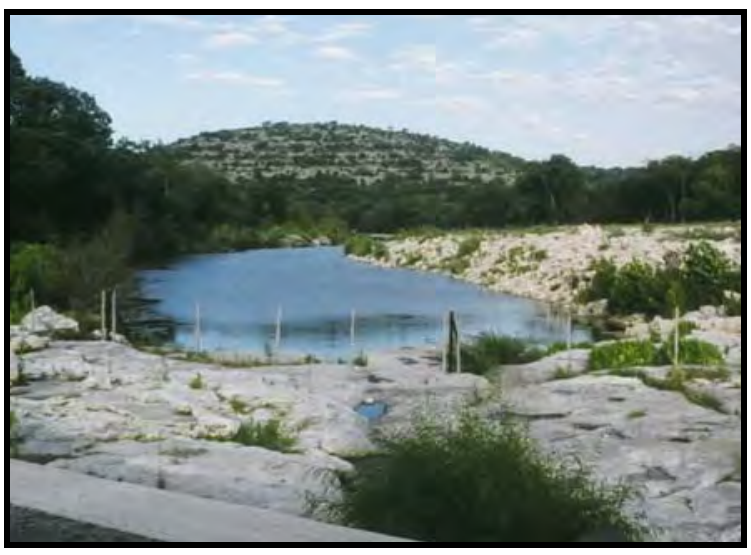

Figure 2-3. Spring Pool Near Varga Site

\subsubsection{Geology and Soils}

The dissected escarpment of the Edwards Plateau in the vicinity exposes Upper Cretaceous period Buda Formation limestone. These exposures occur at the highest elevations and are more prominent to the north and northwest of the project area. In this region, the Buda limestone forms the flat-lying portions of the plateau, such as those in the vicinity of Rock Springs, Texas. Underlying the Buda limestone is the chert-bearing limestone of the Segovia Member of the Edwards Limestone of the Lower Cretaceous, which is exposed on the ridges and upper slopes. The Segovia Member limestone in turn overlies the Fort Terrett Member limestone of the Edwards Group. The Fort Terrett limestone is exposed along the lower valley walls and dates to the Lower Cretaceous period (Barnes 1981). The Edwards Formation extends over a broad area of Texas and extends northward to Fort Worth. The Edwards Formation limestone is present in both the Central Texas and Lower Pecos regions and contains quantities of chert-bearing locations. Silicified wood also occurs in basal Edwards Group deposits in southern Real County (Sellards et al. 1990). Microscopically, the 
Edwards Group limestones show much diversity. The formation is from $159+\mathrm{m}$ $(520+\mathrm{ft})$ thick within the area represented on the Uvalde, Texas, U.S.G.S. quadrangle. The Lower Cretaceous formations continue to the southwest into Mexico. The geological deposits of this region are identical to deposits farther west in northern Val Verde County and adjacent counties, indicating geological continuity across these regions.

The natural chert outcrops associated with the Edwards Formation limestone were valuable resources throughout prehistory for native populations, who used these cherts for tool manufacture. Frederick and Ringstaff (1994) identified the broad horizontal distribution of the Edwards Formation and its chert-bearing deposits. The "Edwards chert" is a component of Lower Cretaceous limestones throughout Central and West Texas and northern Mexico. Frederick and Ringstaff (1994) also developed an initial taxonomy of 16 distinct types of "Edwards chert" from Fort Hood, which is located near the eastern margin of the Edwards Group. The 16 defined types of "Edwards chert" show a wide range of physical variability within the bedrock. These initial 16 types have since been expanded to include more types and variations within the region, including rivertransported gravels. To obtain a general understanding of the chemical variability within "Edwards chert," instrumental neutron activation analysis (INAA) was conducted on 121 samples representing six bedrock sources within the Edwards Group at Fort Hood (Frederick et al. 1994). The results indicated that 21 of the 31 measured elements were potentially useful in pattern recognition. The bivariate plots indicated some overlap in characteristics among the six Fort Hood chert types, but a general chemical separation was detected between the Edwards cherts and other analyzed sources north of Texas. Apparently, varying concentrations of metals and rare earth elements occur in Edwards cherts that can be used to distinguish cherts from different regions across the Edwards Formation.

Recent Holocene alluvial deposits occur immediately adjacent to most of the narrow stream channel margins within the river basins of the Balcones Escarpment. As discussed above in the Hackberry Creek section at the Varga Site, at least three alluvial terraces are represented in some parts of the valleys. Coarse gravels with considerable chert nodules, some of sufficient size for use as tool stone, dominate the streambed of Hackberry Creek adjacent to the Varga Site.

The northern part of Edwards County is dominated by Ector-Rock Outcrop-Real soils. These are very shallow, undulating to very steep, stony loamy soils underlain by limestone or marl and limestone outcrops on uplands. The Ector soils are typically grayish brown stony loam over fractured limestone. Real soils have dark grayish brown gravelly clay loam surfaces over weakly cemented limestone. The soils in the alluvial terraces are mostly Nuvalde-Del-Frio soils. These are deep, nearly level to gently undulating loamy and gravelly soils with slopes less than three percent (Soil Survey Staff 1982).

\subsection{The Biotic EnVIRONMENT}

\subsubsection{Floral Communities}

The plant and animal life of the western portions of the Edwards Plateau and Balcones Escarpment are sufficiently diverse that they defy simple characterization. Blair (1950:112114) characterizes this region, which he includes within his Balconian biotic province (which includes the Edwards Plateau and some of the surrounding areas), as an intermixture of floral and faunal elements of other major provinces, including woodland, plains, and desert. As such, the Balconian province can best be characterized as a broad ecotone (Johnson 1994:8-9; Odum 1959), offering a complex cross-section of floral 
and faunal resources adapted to different ecological niches. The western half is semiarid, whereas the eastern half is a dry, subhumid zone. The Tamaulipan biotic province lies south of the Edwards escarpment and the Chihuahuan biotic province lies to the west near the Pecos River. These nearby provinces potentially contributed various plants and animals to this region in the past depending upon the changes in the past climates and environments.

Kuchler (1964:86) classifies the regional vegetation as a juniper-oak savannah, with a dense to open canopy of broadleaf deciduous and needleleaf evergreen shrubs and low trees. Dominant vegetation throughout upland settings includes little bluestem grass (Andropogen scoparius), mountain juniper (Juniperus sp.), and live oak (Quercus virginiana). Mesic forests that include several species of oak (Quercus sp.), elm (Ulmus sp.), pine, (Pinus sp.), hackberry (Celtis sp.), pecan (Carya illinoinensis), walnut (Juglans microcarpa), and various berry-bearing shrubs cover stream floodplains. Other economically important xeric plants in parts of the region include lechuguilla (Agave lechuguilla), sotol (Dasylirion wheeleri), beargrass (Nolina sp.), and prickly pear cactus (Opuntia sp.). Vast expanses of the native vegetation have disappeared as the result of overgrazing by sheep and goats throughout historic and modern times.

Auken et al. (1980) discovered that the density, dominance, frequency, and importance of trees and shrubs covering the Edwards and Glen Rose Limestone formations were similar near San Antonio. In all, they identified 24 woody species. Twenty-nine percent occurred exclusively on the Edwards Formation, 42 percent were common to both areas, and 29 percent occurred exclusively on the Glen Rose Formation. Both areas were dominated by juniper (Juniper ashei [52 percent]), live oak
(Quercus fusiformis/virginiana [15 percent]), and sotol (Diospyros texana [11 percent]).

In vegetation studies in the Balcones Scarp zone near Waco, Gehlbach (1988) found that fire promoted the sprouting of Texas oak (Quercus texana), live oak, flameleaf sumac (Rhus copallina), skunkbush sumac (Rhus flabelliformis), and redbud (Cercis sp.) Fire killed the juniper. Thus, fire may be the natural cause of oak dominance over juniper.

The aboriginal use of many native plants is well documented for the southwest (Castetter 1935; Castetter and Opler 1936), with specific references to lechuguilla and agave (Agave neomexicana [Castetter and Bell 1937; Castetter et al. 1938; Castetter and Opler 1936]), yucca (Yucca sp.), sotol (Dasylirion wheeleri), beargrass (Nolina microcarpa [Bell and Castetter 1941]), mesquite (Prospers spp.), and screwbean (Prosopis pubescens [Bell and Castetter 1937]). Duisberg (1952) also discusses desert plant utilization, including such species as Candelilla (Euphoria antisyphilitica), beargrass, creosote bush (Larrea divaricata), jojoba (Simmondsia chinensis), gourds (Cucurbita foetidissima), and devils claw (Martynia parviflora). Yanovsky (1936) provides a thorough compilation of food plants used by the aboriginal populations across Canada and the United States. An in depth discussion on yucca is provided by Webber (1953) and should be consulted for background.

The following examines a few selected plants in detail and focuses on ethnohistorically documented strategies of gathering and preparing these food resources since the resulting burned rock cooking features are commonly found in the region. Most plants with rosette foundations are commonly called mescal in the early literature. For clarification, the term "mescal" refers to the crowns of agave and similar plants. However, this should not be 
confused with mescal beans that are derived from a Texas mountain laurel tree (Sophora Secundiflora). This tree is part of the Leguninosae (Fabaceae) family. The native use of mescal beans is documented for a very broad region that includes the Varga Site project area (Merrill 1977). The mountain laurel is a perennial herb with dense, alternate, dark green leaves on smooth stems that grow as shrubs or small trees. The fruit is a woody seedpod 2 to $12 \mathrm{~cm}$ long that is moderately to strongly constricted between seeds. The pods contain one to several dark red seeds (Correll and Johnston 1979). The seeds are ovoid in shape, and range in size from 8 to 20 millimeter (mm) long and 5 to $15 \mathrm{~mm}$ wide, with a distinctive seed scar deeply impressed on one side. The seeds range in color from maroon to orange-red through yellow. The bright red seeds or beans are hallucinogenic and are used in ceremonies and as decorations (Merrill 1977).

Yuccas are among the most valuable plants of the southwestern desert (Bell and Castetter 1941). They provide food, shade, and wind protection for many desert species. They are distributed over vast areas of the southwest, plains, valleys, and mountains and occur in all types of soil, but are more common in sands and gravels. Soaptree yucca (Yucca eleta) and Great Plains yucca (Yucca glauca) commonly occur in extensive belts that extend for kilometers and are particularly common on more compact sandy soils (Webber 1953). Humans have relied on this plant for thousands of years. The uses include food, beverages, medicines, and clothing. In general, the yucca plant consists of long, narrow, rigid leaves that extend outwards from a central crown. A stem or stock grows from the base and yields a fleshy fruit and seeds. The seedpods were prepared in a variety of ways, including boiling and roasting (Bell and Castetter 1941).
Sotol (Dasylirion spp.) has a rosette-leaf base surrounding the center or heart of the plant. These bases contain sugar. The leaves, up to $100 \mathrm{~cm}$ long and $4 \mathrm{~cm}$ wide, are narrow, linear, elongated, rigid, and pointed at the end with small, claw-like teeth 1 to $3 \mathrm{~cm}$ apart along the leaves. The plant develops a tall, leafy, flowering stem terminating in a stout, cylindrical stem. The stem can reach up to $5 \mathrm{~m}$ in height. The plants primarily grow on limestone or granite slopes in the Trans-Pecos region, the Edwards Plateau, West Texas, and into Mexico (Correll and Johnston 1979:404-405), but they tolerate a wide range of moisture conditions. Sotol hearts are most tender and contain their highest food value in the spring, but they can be gathered and cooked at any time. The seeds on the stalks usually ripen in August.

Lechuguilla (Agave lechuguilla) is a century plant commonly found throughout the Chihuahuan Desert. It is generally thought to be rare east of the Devils River. It often occurs in light-colored, highly calcareous, limestonederived soils with a current range in extreme southern New Mexico continuing southward into Mexico across western Chihuahua and Durango provinces, throughout Coahuila, and continuing to the south (Freeman 1973). Like other agaves and sotol, it has a rosette-leaf base radiating outwards from the center or heart of the plant. It produces large numbers of capsules along a spike-like panicle, with each capsule producing up to several hundred seeds. It germinates readily over a wide range of conditions, even under water stress, not from the seeds but almost entirely by rhizomes (Freeman 1973). These are perennials with May through June as the primary reproductive season and flowers when there is sufficient rainfall. This plant contains a toxin called sapogenin that requires breakdown through cooking to make it edible.

The importance of these plants can be distilled from the following passage from Castetter and 
Opler (1936:35-37) concerning the gathering of agave by the Mescalero Apache. Agave was usually collected in the spring for roasting when the stored sugars made it sweeter.

"The crowns of the mescal plants were dug out with three-foot sticks cut from oak branches and flattened at the end. This end, when pounded with a rock into the stem of the plant just below the crown, permitted the crown to be removed readily. A broad stone knife was used to chop off the leaves, two being left for trying the crown together, and making transportation move convenient. The naked crowns were bulbous, white in color, and one to two feet in circumference.

"Pits in which the crowns are baked are about ten to twelve feet in diameter and three or four feet deep, lined with large flat rocks. On the largest rock, which is placed in the center, a cross is made with black ashes. Rocks are piled on the flat stones, but care is always taken that the top level shall be level. Upon this, oak (Quercus sp.) and juniper wood (Juniperus sp.) are placed. Before the sun comes up this is set on fire and by noon the fire has died down.

"On these hot stones is laid moist grass, such as bunch-grass (Sporobolus airoides), side-oats grama (Bouteloua curtipendula), texan crab-grass (Schedonardus paniculatus), big blue stem (Andropogon furcatus), mesquite grass (Mhlenbergia wrightii), marsh foxtail (Alopecurus aristulatus), Muhlenbergia neomexicana, or the leaves of bear grass (Nolina microcarpa), but bear grass is usually preferred since it does not burn readily. The largest mescal crown is selected and a cross make on it with tule or cat-tail pollen (Typha latifolia), when this is available, the pollen always being placed on the crown from east to west and north to south. The Indians then pray. Holding the large crown toward the opening of the pit four times, they toss it in and throw the other crowns in after it. Next they have the youngest child present stand at the east of the pit and throw four stones into it. ..... After the mescal has been covered with the long leaves of bear grass and the whole with earth to a depth sufficient to prevent steam from escaping, the crowns are allowed to bake the rest of the day and all night. Early in the morning the pit is opened and a crown examined and eaten. The pit is again closed and the Indians refrain from drinking until noon of this day so as to prevent rain. The following morning all the mescal is removed.

"The pulpy centers of the black, crowns are released from their charred leaf base and pounded vigorously into thin sheets on a rock. This brown, juicy pulp is spread out to dry on "mescal cradles", very loosely woven shallow or tray baskets made from the leaves of Yucca elata, and in these the prepared mescal is carried home. Unfermented mescal juice is often sprinkled over mescal when being dried. This gives it a glaze, which aids in preserving it. It may be eaten as soon as baked or dried and stored for future use in hide containers (parfleches). When wanted, the desired amount is cut off, soaked in water, and when softened the water is squeezed out and the mass eaten without further preparation. A piece of crown is cut off and chewed and the inner side of the leaves chewed and scraped, much as we eat globle artichokes. When the pithy center of the leaf is reached it is discarded. Mescal is sweet, having an agreeable taste somewhat like molasses, and a mild laxative effect.

"Many are the combinations in which mescal is used. After the dried product has been softened by soaking it is kneaded together with ground pinon seeds or walnuts (at present peanuts may be used) until the whole is of a doughy consistency; it is then ready for consumption. Mescal mixed with juniper berries (Juniperus scopulorum) is another favorite food, whereas the fruits of the three-leaved sumac (Rhus trilobata) are 
also ground with mescal and the mixture dried and stored for future use.”

In discussing the Maguey (Agave americana) plant, Castetter and Opler (1936:38) state "[T]hey prepare it by boiling it until it is soft, then mash it into a paste.... Another well known desert plant, sotol (Dasylirion wheeleri) was utilized in much the same way as mescal.”

The following quote is from Bell and Castetter (1941:19) and concerns an ethnographic account of Yucca elata being roasted by the Chiricahua and Mescalero Apache in New Mexico.

"The crowns of $Y$. elata were gathered any time from the middle of March until the end of summer and the portion of the stem between the ground and the leaves was peeled and baked overnight in an underground oven in a manner similar to that in which the mescal was prepared. The yellow or brown product was then fried in the sun, broken into pieces, and after softening in water the rather sweet product was ready to be eaten. The tender central leaves of $Y$. baccata were cooked in soups, boiled with meat, or used in various other similar combinations.”

In addition to the edible hearts of these plants, the stalks and fruits were also used as foods (Castetter and Opler 1936:38-39).

\subsubsection{Fauna}

Faunal resources include 57 species of mammals, 36 species of snakes, 15 species of frogs and toads, 16 species of lizards, and one species of turtle. Minimally 65 species of birds and three species of mussels, as well as a considerable variety of crustaceans, are also present (Blair 1950:133, 115; Kennard 1975). The dominant economically important indigenous game animals presently available include whitetail and mule deer and javelina. Bison also roamed this area periodically in early historic times.

\subsection{Climate}

\subsubsection{Modern Climate}

Regional climatic variability in Texas is quite high. Southwest Texas is typified by a semiarid climate. Modern climatic data show that the average annual precipitation ranges from $20.3 \mathrm{~cm}$ (8 in) in extreme West Texas to $142.2 \mathrm{~cm}$ (56 in) in east Texas (Bomar 1983; Larkin and Bomar 1983). The Lower Pecos region receives an average of about $48 \mathrm{~cm}$ (18 in) per year, whereas the Varga Site area receives about $61 \mathrm{~cm}$ (24 in) per year, and at the eastern side of the Edwards Plateau near Austin, the precipitation is about $81 \mathrm{~cm}$ (32 in) per year. This reveals a clear increase in the amount of rain from the dry west Texas to the wet east Texas, which has a strong influence on the type and growth of vegetation.

Rainfall in nearby Junction, Texas, averages $57.20 \mathrm{~cm}$ (22.52 in) per year, with two dominant rainfall periods occurring in spring (April through June) and fall (August through October). Average monthly rainfall during the spring rainy season varies from 5.41 to $8.33 \mathrm{~cm}$ (2.13 to 3.28 in), with May generally being the wettest month at $8.33 \mathrm{~cm} \mathrm{(3.28} \mathrm{in} \mathrm{[Bomar}$ 1983:221-222, Table C-2]). Average monthly rainfall during the fall rainy season ranges from 5.99 to $7.32 \mathrm{~cm}$ (2.36 to 2.88 in), with August generally having the most rainfall at $7.32 \mathrm{~cm}$ (2.88 in). Snowfall in Edwards County averages only $2.5 \mathrm{~cm}$ (0.98 in) per year, and annual potential evapotranspiration ranges from 60 to $90 \mathrm{~cm}$ (24 to 36 in [Geraghty et al.1973]).

Average annual low temperatures range from $4^{\circ}$ to $19^{\circ} \mathrm{C}\left(40^{\circ}\right.$ to $\left.65^{\circ} \mathrm{F}\right)$, and average annual highs range from $21^{\circ}$ to $30^{\circ} \mathrm{C}\left(70^{\circ}\right.$ to $\left.86^{\circ} \mathrm{F}\right)$, increasing along a gradient from north to south (Decker et al. 2000:39). The coldest months currently occur from December through February, with average low temperatures ranging between $0^{\circ}$ and $2^{\circ} \mathrm{C}\left(31.7^{\circ}\right.$ and $\left.35.4^{\circ} \mathrm{F}\right)$, as documented for 
the nearby town of Junction, Texas (Bomar 1983:212-213, Table B-5). January is the coldest month, with an average temperature of $0^{\circ} \mathrm{C}\left(31.7^{\circ} \mathrm{F}\right)$. The warmest months occur from June through August, with average high temperatures ranging between $34^{\circ}$ and $36^{\circ} \mathrm{C}$ (93.3 ${ }^{\circ}$ and $95.9^{\circ} \mathrm{F}$ [Bomar 1983:215-216, Table B-7]). July is the warmest month, with an average temperature of $36^{\circ} \mathrm{C}\left(96.7^{\circ} \mathrm{F}\right)$. Extreme temperatures beyond these ranges are common, ranging from $-22^{\circ} \mathrm{C}\left(-7^{\circ} \mathrm{F}\right.$; January 31,1949$)$ to $43^{\circ} \mathrm{C}\left(110^{\circ} \mathrm{F}\right.$; July 27,1954$)$, as documented for the nearby city of Kerrville, Texas (Bomar 1983:214, Table B-6). The Varga site area has an average of 20 days with temperatures over $38^{\circ} \mathrm{C}\left(100^{\circ} \mathrm{F}\right)$.

Relative humidity has a daily average range of 73 to 74 percent in the morning to 36 to 48 percent in the afternoon from January to April, while the daily range in humidity is slightly higher from July to October, with ranges of 75 to 82 percent in the morning and 36 to 50 percent in the afternoon, as documented for the nearby city of San Angelo, Texas (Bomar 1983:234, Table F-4).

Wind velocity comes from the Arctic Air Mass of the north during October through January with an average speed of $14.5 \mathrm{~km}$ per hour (9 mph), but summertime winds (i.e., during April through July) are dominated by the Maritime Tropical Air Mass and come from the Gulf of Mexico to the southeast and south/southeast with an average speed of $16 \mathrm{~km}$ per hour (10 mph).

\subsubsection{Paleoenvironment and Indications of Paleoclimate}

The Varga Site is near the western end of the Edwards Plateau, but only about $50 \mathrm{~km}$ from the Lower Pecos region. These two archeological regions are discussed as separate and distinct regions in the literature and therefore, their respective paleoenvironments may also be different, as implied by Bryant and Holloway (1985). Interpretations of paleoenvironments in these two regions differ somewhat from each other, and it is not clear which paleoenvironmental interpretation is more appropriate for the Varga Site area. It is also possible that paleoenvironments at certain times in the past were very similar in the two regions. The following discussions summarize current reconstructions of paleoenvironments in the Edwards Plateau and the Lower Pecos regions.

\subsubsection{Central Texas Paleoenvironments}

In Central Texas, across the Edwards Plateau, and along its eastern margins in the adjacent Post Oak Savanna region, the paleoclimate records are somewhat better known. Many pollen cores from bogs in the Post Oak Savanna (Larson et al. 1972; Bryant 1977b; Holloway et al. 1987), some data from geomorphic investigations of river valleys (Blum 1987; Blum and Valastro 1989; Toomey et al. 1993; Nordt 1992; Johnson 1995; Johnson and Goode 1994; Mear 1998), and cave deposits (Toomey 1993) provide a variety of proxy data for reconstructing paleoenvironment. These proxy data have been summarized several times and much of the discussion that follows has been extracted from the overviews by Bryant and Holloway (1985) and the more specific trends observed by Bousman (1998).

Bousman (1998), using secondary counts, requantified the pollen results from Boriack and Weakly bogs just east of the Edwards Plateau. These two bogs provide a 16,000-year sequence of fluctuations between grass and arboreal pollen that indicate shifts between forest, woodland, and open plant communities. Bousman's interpretations of his recalculations indicate that open vegetation communities were present during the Late Glacial Maximum and between 13,000 and 12,000 B.P., 10,000 and 
9,000 B.P., and 8,000 and 2,500 B.P. (Figure 24). A key factor in understanding these shifts in vegetation is that the mesic woody species invaded grasslands during the moist climates intervals, but woody species died during droughts (Coupland 1958). Apparently, between 8,000 and 7,000 B.P. the region became grassland. The phytolith data from the WilsonLeonard Site also supports a grassland composition similar to today during the period from ca. 8,700 to 6,000 B.P. (Fredlund 1998). Along the Texas Gulf Coast, it appears that, between about 6,700 and 6,000 B.P., the sea level was rising rapidly (Ricklis and Blum 1997). A two-phased, mid-Holocene dry interval occurred, with extremes recorded at 6,500 B.P. and 5,000 B.P. (Bousman 1998). Alternatively, Johnson and Goode (1994) see no long-lasting, dry hypsithermal climate in the eastern Edwards Plateau; consequently, little change occurred in the climate between the Early and Middle Archaic cultural periods. Johnson and Good (1994) do acknowledge, however, that some drying occurred in late Early Archaic times.

The faunal record from Hall's Cave near the center of the Edwards Plateau indicates conditions that were dryer than modern from ca. 5,000 to 2,500 B. P. (Toomey et al. 1993). About the time of this dry interval, the upland soil mantles in Central Texas were being rapidly stripped (Toomey et al. 1993), as Nordt (1992) interpreted for the Fort Hood area. Fredlund (1998), using phytolith data, sees the overall vegetation composition of Central Texas reach its modern balance of woodlands and grassland by about 4,000 B.P. Between 4,000 and 3,200 B.P. was a period of rapid sea level rise (Ricklis and Blum 1997). Johnson and Goode (1994) propose that a dry Edwards Interval lasted from about 5,000 to 3,000 B.P.

For the last 3,000 years of the Weakly Bog sequence, grass and oak pollen are equally represented. Starting at roughly 3,000 B.P., the pollen frequencies indicate that oak woodland was followed by oak-hickory woodland. Bousman (1998) interprets this change to indicate that the climate became progressively moister through the Late Holocene. This is in direct contradiction to the interpretation offered by Holloway et al. (1987) on the same bog pollen. Toomey et al. (1993) also appear to differ in that they see drier conditions culminating between ca. 5,000 and 2,500 B.P. To date, research has not definitively proven whether flood plain aggradation is related to dry periods or to moist conditions (Johnson and Goode 1994). Toomey et al. (1993) see more mesic conditions from about 2,500 to 1,000 B.P., with modern conditions predominating from 1,000 B.P. to the present. The phytolith assemblage from the WilsonLeonard Site indicates that local conditions became less open after 2,000 B.P. (Fredlund 1998).

Two significant grass spikes occurred in the Weakly Bog data, one dated to 1,500 B.P. and the other estimated at 500 to 400 B.P. (Bousman 1998). These grass spikes are linked to alluvial pedogenesis in floodplain deposits during these periods in Freestone and Leon counties to the east of the Edwards Plateau. This point is significant to the extent that grassy intervals can be associated with alluvial stability, but not all researchers agree on this issue. As an outgrowth of his Quaternary work in the upper Sabinal River valley, Mear (1998) believes that downcutting and deposition can occur simultaneously along a stream during both dry and humid climate regimes.

Caran (1998) provides a cautionary note to interpretation of data used in the reconstruction of paleoenvironments and reminds us that the data generally represent second, third, or higherorder extrapolations from the database. This might account for some of the differing 


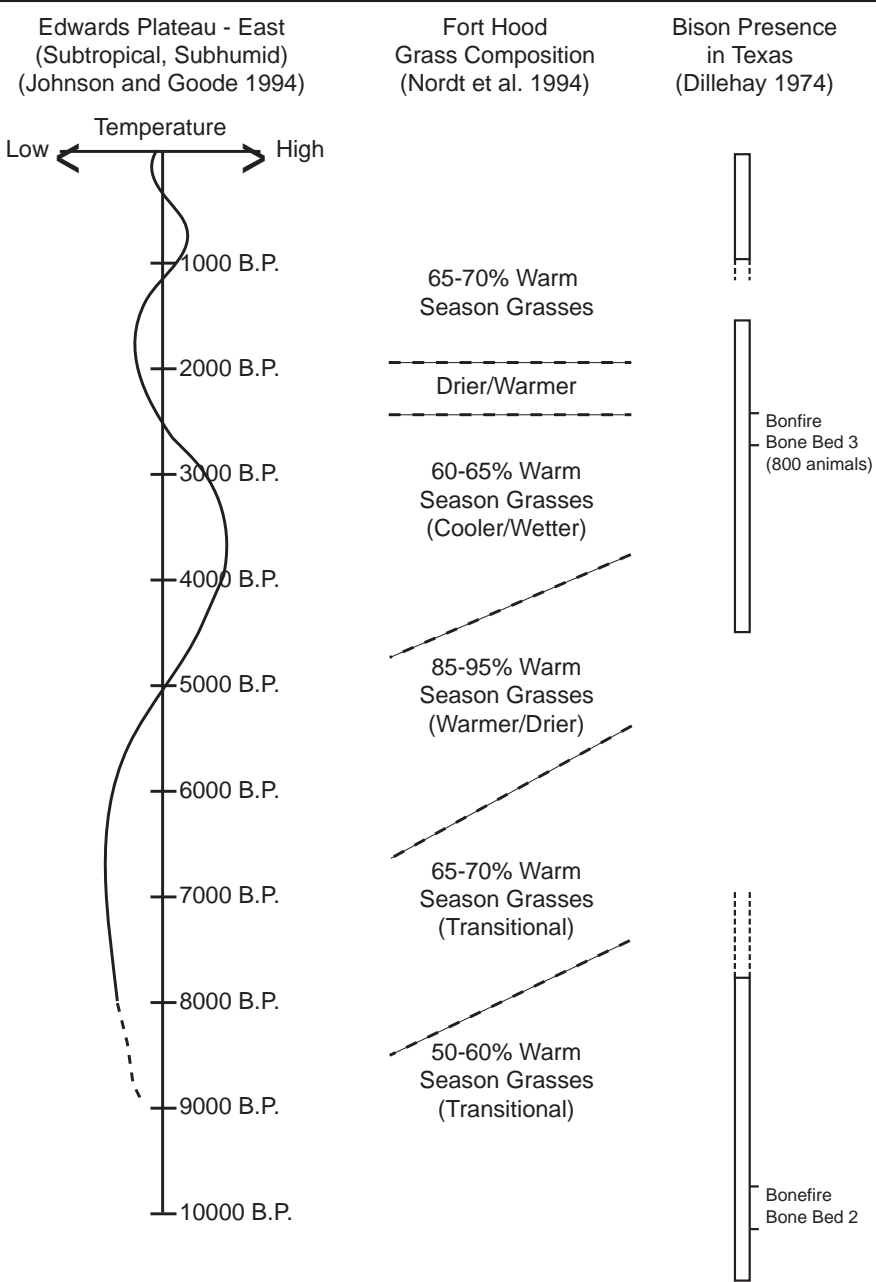

Estimated Arboreal Canopy Cover
Based on Central Texas Boriack and Weakly Bogs (Bousman 1998)

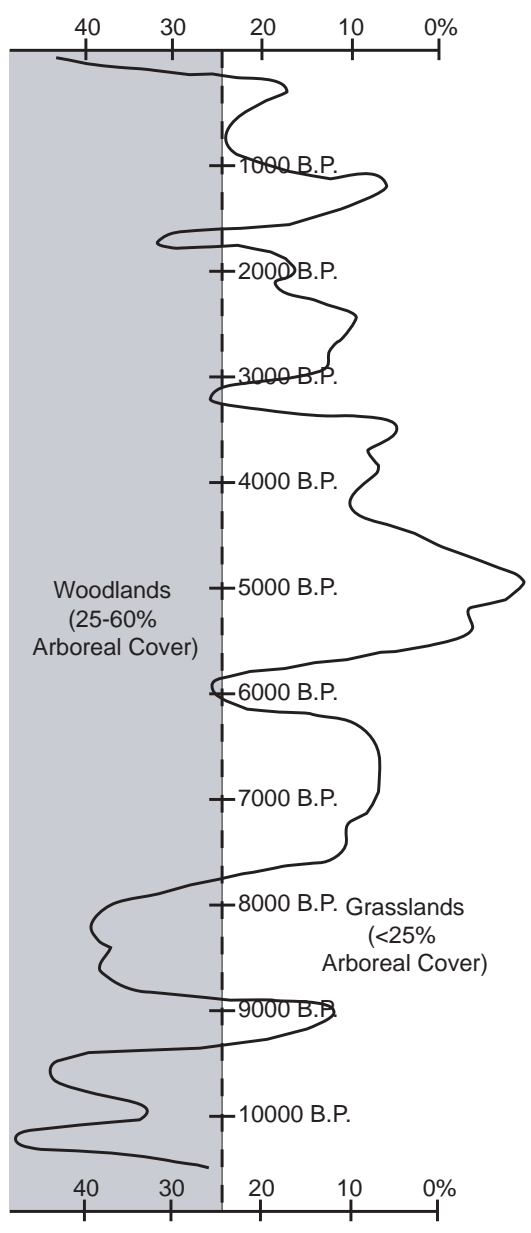

Figure 2-4. Comparison of Multiple Interpretations of Changing Environments in Central Texas Using Different Data Sets

interpretations together with multiple causes for end product. Currently, it appears that Johnson's and Goode's (1994) projection of temperature shifts is out-of-step with Bousman's (1998) canopy cover estimates and the phytolith assemblage at Morgan Playa (Fredlund et al. 1998) in the Rolling Plains to the north of the Edwards Plateau. Fredlund's (1998) results from the Wilson-Leonard Site indicate that phytolith analyses for the Texas region are warranted.

\subsubsection{Lower Pecos Paleoenvironments}

The Pecos River divides the Edwards Plateau from the Stockton Plateau to the west. The Varga Site is near the boundary of three major biotic provinces and therefore, exhibits considerable ecological diversity. The Lower Pecos region has received extensive excavations of large rockshelters, but has not yielded a detailed paleoenvironmental history. Bryant 
(1966, 1969, 1977a) has led the way with several site-specific pollen investigations directed at reconstruction of the paleoenvironment (i.e., at Arenosa Shelter, Hinds Cave). Several factors contribute to a lack of pollen data. First, pollen is generally poorly preserved in the rockshelters and the deep alluvial terraces. Second, considerable mixing of the deposits has caused context concerns. Other approaches and techniques, such as phytolith and isotope studies, have not been attempted. What has come from the rockshelter deposits are considerable plant remains (Dering 1977, 1979) and human coprolites (Bryant 1974; Williams-Dean 1978) that can be used as proxy data to extrapolate past environmental conditions.

The pollen evidence from the Lower Pecos region is quite spotty, but provides general trends presumably reflecting the regional record and not just the local conditions. Some cultural activities in these archeological sites potentially skewed concentrations of certain pollens. For the period between 10,000 and 7,000 B.P., Bryant and Shafer (1977), Dering (1979), and Bryant and Holloway (1985) interpret the decreases in fossil pine pollen coupled with the rise in pollen from herbaceous plants and grasses as indications that the previous Late Glacial Period mosaic vegetation of woodlands, parklands, and scrub grasslands was being gradually replaced by expansion of scrub grasslands. The pine pollen was thought to reflect relic stands of pinyon pine in some of the protected canyons.

From about 7,000 to 4,000 B.P., the pollen records are incomplete and inadequate (see Johnson 1963; Bryant and Holloway 1985). The evidence from Hinds Cave reflects decreases in the percentages of grass pollen, rises in the percentages of pine pollen, and an overall increase in arboreal pollen between 7,000 and 6,000 B.P. that may reflect the beginning of widespread soil erosion (Dering 1979; Bryant and Holloway 1985). Although it is not clear what the specific paleoclimatic conditions were between 7,000 and 4,000 B.P., this was a period of erosion and severe flooding along the Rio Grande, as evidenced at Devil's Mouth Site (Johnson 1964) and Arenosa Shelter (Dibble 1967). Between about 6,700 and 6,000 B.P. is a time of rapid sea level rise (Ricklis and Blum 1997) that indicates a general global warming trend. In the Southern High Plains at Lubbock Lake, the Firstview Soil formed during a period between 8,500 and 6,300 B.P. (Holliday 1985). The Yellowhouse Soil developed between 6,300 and 5,000 B.P.

The last 4,000 years indicates a gradual and continual trend towards increased aridity (Bryant and Holloway 1985). Apparently another period of sea-level rise occurred between 4,000 and 3,200 B.P. (Ricklis and Blum 1997), again, that indicates a general global warming trend. One brief reversal in this drying trend was identified around 2,500 B.P. from pollen at Bonfire Shelter and Devil's Mouth, which shows a marked increase in the percentage of both pine and grass pollen. This has been interpreted as a brief return to somewhat cooler and more mesic conditions (Bryant 1969; Bryant and Shafer 1977; Bryant and Holloway 1985).

Looking further west across the American Southwest, the evidence from packrat middens has provided vast assemblages of plant remains that have been used to interpret past vegetation sequences (Van Devender and Spalding 1979). After 11,500 B.P. in the Guadalupe Mountains, a Douglas fir/southwestern white pine forest at $2,000 \mathrm{~m}$ amsl was replaced by a juniper grassland community (Van Devender and Spalding 1979). In general, the middle Holocene woodland species migrated northward, retreating to elevations in the mountains and disappeared in the lowlands. Desert-adapted species increased in abundance and dispersed 
into new areas (Van Devender and Spalding 1979).

From the packrat evidence in the American Southwest, Van Devender and Spalding (1979) believe that the present climate and vegetation regimes of the modern Chihuahuan Desert were established after about 8,000 B.P. Winter precipitation was reduced in or withdrawn from much of the Southwest, whereas summer monsoons expanded. Middle Holocene wet climates probably favored development of grassland. However, widespread loss of welldeveloped mature soils on bedrock during the middle and late Holocene probably augmented the development of xeric microhabitats and desert vegetation. Van Devender and Spalding (1979) also demonstrated that the desert succulents coexisted with the juniper-oak and pinyon woodlands in the Trans Pecos region.

Precipitation reconstruction from dendrochronology in the American Southwest, specifically for the southern Rio Grande Basin in southeastern New Mexico, reveals that the most severe long-term drought during the last 1,373 years occurred between 1,010 and 910 B.P. (A.D. 940 and 1040 [Grission-Mayer et al. 1997]). Following this drought was a wet period that lasted to about 740 B.P. (A.D. 1210). However, within this wet period was a shortterm drought of about 15 years from 825 to 810 B.P. (A.D. 1125 to 1140). A second drought period occurred between 740 and 645 B.P. (A.D. 1210 and 1305). In general, the dendrochronology reveals major swings in precipitation over the last 1,400-year period. In fact, the drought history from old post oak trees in Texas reveals oscillating precipitation levels across South Texas (Stahle and Cleaveland 1988).

Plant remains provide direct evidence of the paleoenvironment and are well-documented from many archeological sites in the Lower
Pecos region. In the period radiocarbon dated from 9,120 \pm 90 B.P. (Tx-2866) to $6,750 \pm 100$ B.P. (Tx-2316) at Hinds Cave, Dering $(1977,1979)$ has identified many plants from Analysis Unit 7. These include oak (Quercus), juniper (Juniperus), walnut (Juglans), mesquite (Prosopis), hackberry (Celtis), coyotillo (Karwinskia humboldtiana), onion (Allium), lechuguilla (agave lechuguilla), yucca, sotol (Dasylirion), Condalia sp., grasses, and prickly pear (opuntis), all of which are thought to have been exploited by the early inhabitants. These data, together with the drop in percentages of arboreal pollen below the herbaceous pollen frequencies, were interpreted to represent a reduction in the pinyon pine stands in northern Val Verde County (Dering 1979). Dering also believes that juniper tree was abundant in the area.

The short interval between $6,540 \pm 70$ B.P. (Tx2744) and 6,160 \pm 80 B.P. (Tx-2735), in Analysis Unit 6, exhibited these same plants with the addition of acacia, yucca, chenopodium, buffalo gourd (Cucurbita foetidissima), sumac (Rhus virens), and Texas mountain laurel (Sophora secundiflora). Shortly thereafter, between 4,990 \pm 70 B.P. (Tx-2743) and 4,410 $\pm 70(\mathrm{Tx}-2749)$ in Analysis Unit 5, these same plants together with beargrass (Nolina), redbud (Cercis), yaupon (Schaefferia), and dominated by lechuguilla, continue in the archeological record. At this time, a sudden drop in pine pollen occurred, but several factors could have contributed to this drop and one explanation is not sufficient. Apparently, major vegetation changes occurred in the Lower Pecos region between 5,000 and 4,400 B.P.

After 4,000 B.P. (Analysis Units 2, 3, and 4), the record at Hinds Cave was again rich in plant macrofossils. Radiocarbon dates of 2,280 \pm 60 B.P. (Tx-2746) and 3,780 \pm 70 B.P. (Tx-2741) document this period. In general, the same suite of plants continued in the 
archeological record with the addition of a grassland component that contained bristlegrass (Setaria leucopila) and tanglehead (Heteropogon contortus). The major differences in plant content during this period are the drop in lechuguilla and the increase in sotol (Dering 1979). Dering proposed two possible explanations for this shift: (1) a change in the prehistoric technology or (2) a change forced by a shift in the distribution and abundance of sotol and lechuguilla. Dering (1979) argues that the environment of the Lower Pecos has not changed as drastically as had been previously thought (Bryant 1977a). 


\subsection{CULTURAL OVERVIEW}

\author{
J. Michael Quigg
}

\subsection{INTRODUCTION}

The Varga Site lies in eastern Edwards County towards the western end of the Edwards Plateau physiographic region, which is generally considered part of the Central Texas archeological region (Prewitt 1981a, 1985; Figure 3-1). However, the site lies only $50 \mathrm{~km}$ (80 miles) east of the heart of the Lower Pecos archeological region (see Perttula 1995: Figure 1 for proposed archeological regions). The geographic position of the Varga Site within the southwestern dissected plateau region may lend itself to cultural influences and/or specific uses by human populations from either or both of the Central Texas and Lower Pecos cultural areas.

This chapter provides a general overview of what is known about the cultural history of the Edwards Plateau and Lower Pecos cultural areas. In general terms, human occupation in the region spans some 13,000 years, but there are key differences in the tool assemblages and other aspects of the cultural systems among the different areas that form the basis for defining different chronological sequences. Prehistoric sites with rich and diverse assemblages, such as the Varga Site, have potential for the examination of prehistoric human adaptation to this complex ecological setting through time and investigation of the relationships with adjacent culture areas.

This chapter presents the relevant cultural background for the general cultural/chronological units pertinent to the major components discovered as a result of data recovery excavations at the Varga Site. The three principal chronological units upon which this discussion focuses are the Early Archaic period, the Late Archaic period, and the latter part of the Late Prehistoric the succeeding Protohistoric period (i.e., the Toyah phase or horizon). The site also contains a diffuse Middle Archaic period component marked by Early Triangular projectile points, but is not as welldefined as the three primary components. Brief background statements concerning the Middle Archaic are also presented. Available information on the three principal cultural periods provides a broad foundation upon which to build. It is anticipated that the materials recovered from the Varga Site excavations, the results of the various analyses, and the presentation of component and artifact data will significantly advance our understanding of the Early Archaic, Late Archaic, and Late Prehistoric periods and contribute to a greater understanding of human adaptations to this complex and poorly understood region.

\subsection{ARCHEOLOGICAL BACKGROUND}

The western edge of the Edwards Plateau has received relatively little archeological attention and archeological knowledge of the area is correspondingly rather poor (Decker et al. 2000). However, some sites in this region, most of which are located just south of the escarpment, have undergone archeological excavations (e.g., the La Jita Site [41UV21; Hester 1971], the Leona River watershed [Lukowski 1987], the Smith Site [41UV132; cited in Mueggenborg 1994], the Blue Hole Site [41UV159; Mueggenborg 1994], the Heard Schoolhouse Site [41UV86; Goode 1991; Black et al. 1997], the Woodrow Heard Site [41UV88; Decker et al. 2000], the Anton Site [41UV60; Goode 2002]) in Uvalde County. However, with 


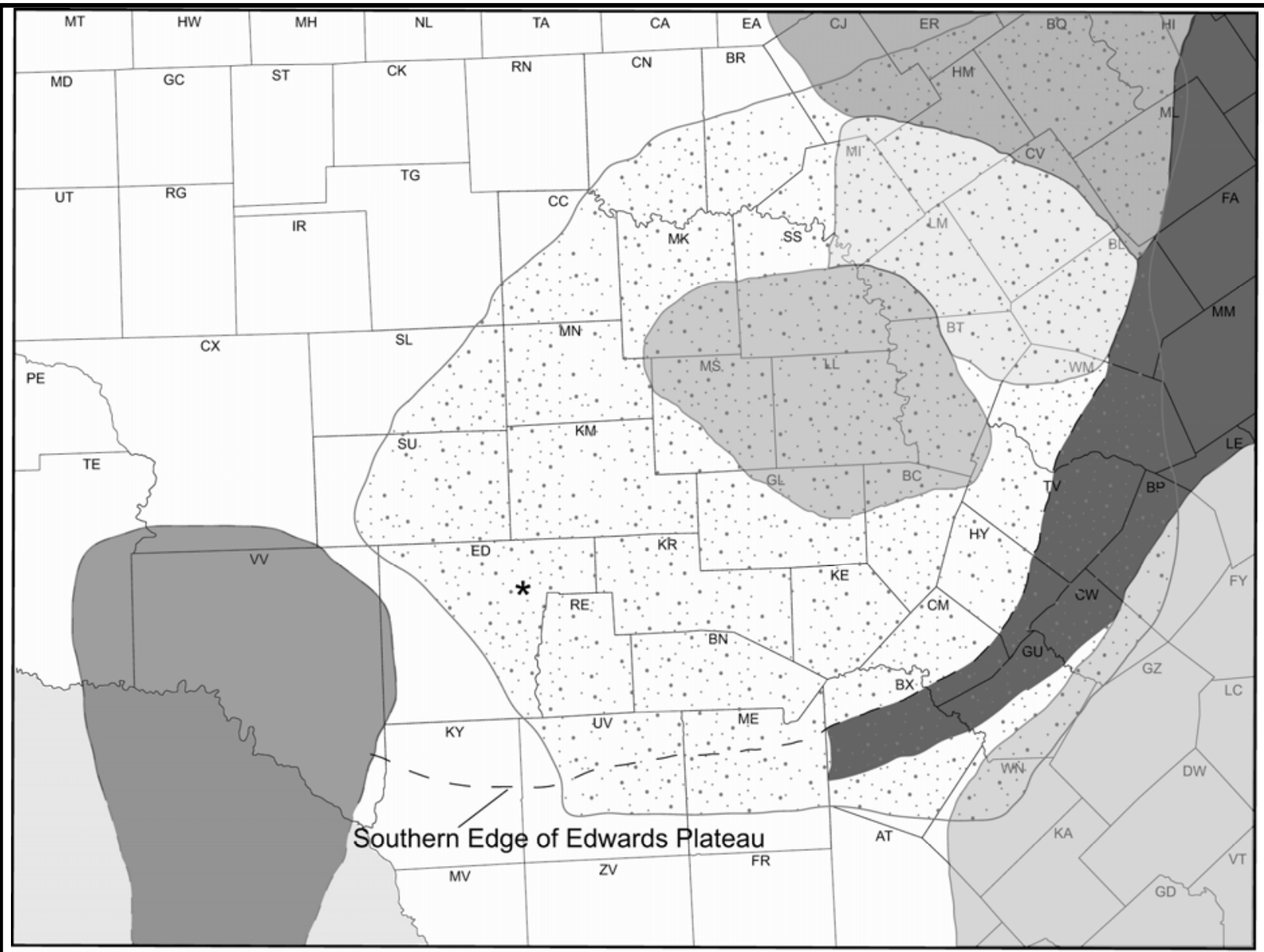

$=$ Blackland Prairie

$=$ Grande Prairie

= Lampasas Cut Plain

$=$ Llano Uplift

= Lower Pecos Canyonlands

= Oak Woodlands

= Prewitt's Central Texas Archeological Region

$\mathrm{N}$

* = ED28 Varga Site

Figure 3-1. Prewitt's (1981a) Central Texas Archeological Region Overlaying Physiographic Regions 
the exception of the Nueces River Natural Area survey (Marmaduke and Whitsett 1975) and the Devil's Sinkhole State Natural Area survey (Howard et al. 1996), relatively few systematic surveys or recent excavation projects have been completed in this region. As of January 2003, slightly more than 200 archeological sites have been recorded in Edwards County. The site types include open upland camps, terrace camps, lithic scatters and workshops, lithic procurement areas, rockshelters, burned rock middens, sinkholes, and pictographs. Howard et al. (1996) provides histories of the archeological investigations in Edwards, Real, Uvalde, Kerr, Kimble, and Sutton counties, which will not be repeated here.

The survey at Devil's Sinkhole provides an indication of the site types and densities for the uplands in the immediate canyonland region (Howard et al. 1996). The 736.3 hectare (ha) (1,827 acres [ac]) survey revealed the presence of 21 prehistoric sites, or one site per 35 ha ( 1 site/87 ac). Of the 21 sites recorded, 43 burned are burned-rock middens and another 15 are burned-rock scatters. Natural chert outcrops occur at 38 percent of the sites. Most burned rock middens are circular and have maximum diameters of $20 \mathrm{~m}$ or less. Over half the sites yielded diagnostic projectile points (a total of 45 specimens). Only about nine percent were arrow points and the rest were dart points, with a majority of those representing the Late Archaic period.

Although the region lacks systematic surveys, a sample of 106 sites listed in the vicinity of the Varga Site and adjacent to Hackberry Creek and the Nueces River represents diverse site types situated on different landforms (Table 3-1). Sites include rockshelters, burned-rock middens, lithic scatters, lithic procurement areas, and buried camps. These prehistoric sites occur on/in terraces (58 percent), in the uplands (38 percent), and in the intervening slopes
(4+ percent). Campsites buried in depositional sediments are limited to the alluvial terraces, whereas rock shelters and lithic procurement sites are found primarily on slopes. Burned-rock middens have been found in both upland and the terrace settings.

Archeological investigations have been spotty in both the Central Texas and the Lower Pecos regions, with excavated sites yielding cultural materials that are quite variable in time, context, and artifacts. Most excavated sites lack one or more key data sets that would contribute to broad comparisons. For example, some sitespecific investigations have yielded very limited cultural assemblages containing few diagnostic artifacts (e.g., Devils Rockshelter [Prewitt 1966], Camp Pearl Wheat [Collins et al. 1990], Turkey Bend Ranch [Treece et al. 1993a], 41TG309 [Quigg et al. 1996], Cibolo Crossing [Kibler and Scott 2000]), limited numbers of, or no radiocarbon dates (e.g., Youngsport [Shafer 1963], Landslide [Sorrow et al. 1967], Devils Mouth [Sorrow 1968], Camp Pearl Wheat [Collins et al. 1990], Devils Rockshelter [Prewitt 1966], Eagle Cave [Ross 1965], Sleeper [Johnson 1991]), have not been fully reported (e.g., Arenosa Shelter, Hinds Cave), have compressed stratigraphy (e.g., Barton Creek [Ricklis and Collins 1994], Camp Pearl Wheat [Collins et al. 1990], Sleeper [Johnson 1991], Wilson-Leonard [Collins 1998], WoodrowHeard [Decker et al. 2000]), or have yielded hundreds of specimens from mixed context (e.g., La Jita [Hester 1971], Panther Springs [Black and McGraw 1985], Barton Creek [Ricklis and Collins 1994], Woodrow-Heard [Decker et al. 2000]).

As a result, our understanding of the different time periods and associated assemblages is quite limited. Even the ages of relevant cultural/chronological units are not clearly defined in most cases. Some sites provide better context and more information than other sites. 
Table 3-1. Archeological Sites in the Vicinity of the Varga Site in Northern Edwards and Western Real Counties

\begin{tabular}{|c|c|c|c|}
\hline Time Period & Upland Setting & $\begin{array}{l}\text { Canyonlands } \\
\text { Rock Outcrops }\end{array}$ & Alluvial/Colluvial \\
\hline \multicolumn{4}{|l|}{ Paleoindian } \\
\hline \multicolumn{4}{|l|}{ Early Archaic } \\
\hline Middle Archaic & 2 middens - ED50 (Pandale) & & \\
\hline \multirow[t]{2}{*}{ General Archaic } & 3 middens - ED147 (dart) & & 2 middens - ED141 (dart) \\
\hline & 2 middens - ED141 (dart) & & \\
\hline \multirow[t]{9}{*}{ Late Archaic } & 1 midden - ED67 (Pedernales) & & 9 middens + procurement - ED58 (Pedernales) \\
\hline & 4 middens - ED65 (Pedernales) & & 4 middens + procurement - ED54 (Pedernales) \\
\hline & 4 middens - ED55 (Arenosa) & & 1 midden - ED78 (Castroville) \\
\hline & 1 midden - ED74 (Marshall) & & 1 midden - ED83 (Montell) \\
\hline & 2 middens - ED39 (Pedernales) & & 1 midden - ED70 (Frio) \\
\hline & 1 midden - ED75 (Frio) & & 2 midden - RE23 (Frio) \\
\hline & 1 midden - ED76 (Frio) & & 2 middens - RE26 (Bulverde) \\
\hline & 1 midden - ED81 (Bulverde) & & \\
\hline & 1 midden - ED44 (Darl/Marshall) & & \\
\hline \multirow[t]{3}{*}{ Late Prehistoric } & Lithics - ED145 (arrow) & & \\
\hline & 4 middens - ED65 (dart) & & \\
\hline & Camp - ED40 & & \\
\hline \multirow[t]{14}{*}{ Unknown } & Lithics - ED149 & $\begin{array}{l}\text { Procurement - } \\
\text { ED146 }\end{array}$ & Buried camp - ED25 \\
\hline & Lithics - ED148 & $\begin{array}{l}\text { Procurement - } \\
\text { ED144 }\end{array}$ & 1 midden - ED26 \\
\hline & 1 midden - ED143 & Lithics - ED140 & Buried camp - ED29 \\
\hline & Lithics - ED142 & Rockshelter - ED24 & 1 midden - ED31 \\
\hline & 1 midden - ED56 & Rockshelter - ED85 & Lithics - ED32 \\
\hline & Lithics - ED30 & & Lithics - ED33 \\
\hline & Procurement - ED41 & & Buried camp - ED34 \\
\hline & 1 midden - ED43 & & Lithics - ED35 \\
\hline & Procurement - ED46 & & Buried camp - ED36 \\
\hline & 1 midden - ED47 & & Buried camp - ED37 \\
\hline & Procurement - RE41 & & Lithics - ED38 \\
\hline & 1 midden - ED51 & & 2 middens - ED45 \\
\hline & 2 middens - ED71 & & 1 midden - ED48 \\
\hline & 1 midden - ED72 & & 1 midden - ED49 \\
\hline
\end{tabular}


The Varga Site

Texas Department of Transportation

\section{Table 3-1. Archeological Sites in the Vicinity of the Varga Site in Northern Edwards and} Western Real Countries (Continued)

\begin{tabular}{|l|l|l|l|}
\hline Time Period & \multicolumn{1}{|c|}{ Upland Setting } & $\begin{array}{c}\text { Canyonlands } \\
\text { Rock Outcrops }\end{array}$ & \multicolumn{1}{|c|}{ Alluvial/Colluvial } \\
\hline & & & Buried midden - RE46 \\
\hline & & & Buried camp - RE47 \\
\hline Multicomponent & 6 middens - ED53 & & Buried camp - ED23 \\
\hline & 4 middens - ED52 & & Buried camp - ED27 \\
\hline & & & Buried camp - ED28 \\
\hline & & & 3 middens - RE30 (Cliffton) \\
\hline
\end{tabular}

ED = Edwards County, RE = Real County, 2 middens = the number of middens per site, (Pandale) $=$ point recovered at site

Site 41ED58 presently encompasses 58, 59, 60, 61, 62, 63, 64; Site 41ED65 presently encompasses 65 and 66 ; ED88 farmstead;

Number refers to site number

and those with larger data sets have provided the bulk of currently available information. Sufficient time and space is not available to review all sites or components that have been investigated; therefore, this presentation mainly relies upon the more complete data.

In 1995, the Texas Archeological Society (TAS) published a comprehensive volume that summarizes much of what is known about Texas prehistory. Many papers in that volume provide excellent background information for the current study, specifically those by Collins (1995) on Central Texas and by Turpin (1995) on the Lower Pecos region. Other key and relevant publications from which chronological information has been extracted include Turpin's (1991) synthesis of the Lower Pecos chronology, earlier work by Prewitt (1981a, 1985), the Wilson-Leonard Site report (Collins 1998), Johnson and Goode's (1994) reevaluation of the Eastern Edwards Plateau climates and archeologically defined culture periods, and the Woodrow-Heard Site report (Decker et al. 2000), which includes a comprehensive summary of excavated sites in the region surrounding the Varga Site. These publications provide much of the background information presented in this chapter.

Archeological investigations have not produced many well-stratified sites that exhibit good context with tool types and/or cultural assemblages that have been securely radiocarbon dated to the Early Archaic period. McKinney's (1981) assessment of early Holocene adaptations lists only 45 Early Archaic sites for Central and Southwestern Texas, and his discussion is based on materials from surface contexts for nearly half of his sites $(n=21)$. Preliminary assessments of the Early Archaic projectile point types recovered from the Varga Site generally indicate occupations post-dating components containing Angostura projectile points and associated assemblages. Recent assessments of the terminal age for Angostura points provides a reasonable chronological baseline for the earliest (post-Angostura) occupations at the Varga Site.

The Angostura interval has been radiocarbon dated to roughly 8,900 to 7,900 B.P. (Decker et al. 2000) at sites including Woodrow Heard, Richard Beene, Wilson-Leonard, and Armstrong (Schroeder and Oksanen 2002). In Central Texas, the Middle Archaic period begins at approximately 5,500 B.P. (Johnson and Goode 
1994). Therefore, the Early Archaic period horizon at the Varga Site must generally fall between 8,000 and 5,500 B.P. The following discussion centers on this later part of the Early Archaic period for both the Central Texas and Lower Pecos archeological regions. The two regions have many similarities. As archeological research has progressed in each region over the years, chronological information from one region has often been transposed to the adjacent region based on new findings (e.g., Sorrow et al. 1967). However, McKinney (1981) argues that these two areas represent distinctive adaptations that are not readily equated.

\subsubsection{Burned Rock Midden Research}

Massive accumulations of burned rocks were recognized very early in Texas archeology. In 1919, Pearce had excavated burned-rock middens and presented a model of their construction. He suggested that burned rocks had accumulated around a "central feature" or hearth, and that as hearth rocks became fractured from use they were tossed out and replaced with new rocks. The continued use of the hearth over time resulted in a massive accumulation of burned rocks around the hearth. He also suggested that the central hearth was used for cooking or boiling various foods. Since the beginning, and over the course of nearly 50 years of intermittent investigation, the age of these middens was established by estimating the ages of the various types of projectile points found mixed with the burned rocks (Wilson 1930; Huskey 1935; Pearce 1938; Kelley and Campbell 1942; Kelley 1961; Hester 1970, 1971). In 1935, Huskey, reporting on middens in the upper Nueces Canyon of Edwards, Real, and Uvalde counties, had documented that one group, or "Type A", middens was most often associated with various Archaic projectile point types. A second group, “Type B” middens, contained only arrow point representing later cultures. He thought that the "Type B" middens were relatively few (often only one per site), and generally smaller in size and thinner (often consisting of only a single stratum of burned rocks).

Most early archeological work emphasized establishing the relative age of the burned-rock middens/mounds via correlations of associated point types with estimated ages. Thus, there was only limited documentation of the physical form/structure of burned-rock deposits, and little concern with their function. Consequently, early publications provide cursory descriptions of the features themselves, making it difficult to ascertain what the features actually looked like. Currently, it is unclear if investigated features fall into more than one formal category. The terminology used over the years, in referring to these as mounds or middens, was also a concern and led to ambiguities, as some researchers tended to associate specific forms of human behavior on the basis of the terms used (Wilson 1930; Krieger 1945; Suhm et al. 1954; Kleinback et al. 1995).

For example, although Wilson (1930) had accumulated no direct evidence, he related the distribution of mounds to the distribution of sotol as the primary food being cooked in these features, and used ethnographic data to propose that these features were functionally similar to earth ovens. As more work was done on burned-rock middens, Kelley and Campbell (1942) presented an alternative to Pearce's (1919) "central feature" idea, suggesting that the middens accreted through construction of "intersecting hearths" over a long span of time, with redundant use of these areas for cooking accounting for middens lacking central features and/or clear stratigraphy middens. Kelley and Campbell (1942) thought most of the hearths were used for baking and roasting. As research evolved over time, several different suggestions were offered to explain midden formation. 
Greer (1967), working in far west Texas and southern New Mexico, distinguished subtle differences in the doughnut-shaped (ring) middens, those with subsurface pits ("mescal pits") and those with surface hearths ("midden circles"). His mescal pits were the remains of earth ovens, and he inferred that the others were represented some other use. Another hypothesis concerning the development of middens was presented by Sorrow (1969) who believed these features were simply dump areas where various kinds of cultural debris were discarded, accounting for all the different types of materials discovered in some cases.

Weir (1976:35-40) established four types of burned rock middens to account for the variations observed in the field. Burned rock midden (BRM) Type 1 was "oval and mounded in shape with no surface indications of any subsurface feature." Often these had a high artifact content. Type 2 was a "circular aggregation of burned rocks around a central pit” that was generally smaller, in the range of 7 to $15 \mathrm{~m}$ in diameter. Also these were generally associated with more charcoal and fewer artifacts than Type 1 . Burned rock midden Type 3 was generally a ring of burned rocks around a central slab-lined subsurface pit. Type 4 was a general scatter of burned rock with no obvious shape or form and generally only one rock thick. In addition to the visual differences and the establishment of different types of middens, Weir also noted that the observed types showed differential distribution across the landscape. Type 1 middens were dominant in Central Texas. Type 2 middens were mostly in western and northwest parts of Central Texas. Type 3 middens were mostly along the western edge of Central Texas and toward the southwest. Weir (1976) also believed that most of the middens were of Archaic age, ranging in age from 5,000 to 1,800 B.P.
Projectile points were still being relied upon for age determination of middens when Weir (1976) provided his midden typology. Over the years researchers had recognized that there were different types of middens, some were of different ages, and variability in contents was noticed as some contained many stone artifacts and others reflected plant processing.

After the late 1970s, interest and excavations continued to increase and were directed towards these controversial and frequently occurring cultural features (Weir 1979; Peter 1982; Howard 1983; Black and McGraw 1985; Creel 1986; Gearhart 1987; Lukowski 1987). Researchers generally referred to two primary types of middens in the literature, the domed form, or Type 1 (Gearhart 1987) and the ring/annular midden, or Type 2 (Treece 1992).

In a synthesis of Central Texas archeology, with over 200 burned rock middens having been excavated in the region (Howard 1991), Prewitt (1981a, 1985) incorporated burned rock middens into his formulation of culture chronology as key index markers of different cultural phases. Following the lead of Weir (1976) Prewitt also believed that the most intense use of middens was during the Archaic, beginning in the Early Archaic and continuing throughout the Middle Archaic (Prewitt 1981a). However, few burned rock features had been directly radiocarbon dated, so most middens were assigned an approximate age based on the extrapolated and general age of projectile points collected from them. As recently as 1991, Prewitt stated that "the general age range of Central Texas burned rock middens is fairly well established to be Middle Archaic, or roughly 5,000 to 2,250 B.P.” however, the full age range has yet to be precisely defined (Prewitt 1991:26).

In a 1988 symposium on burned rock middens, five authors attempted to provide a synthesis of investigations and results, as well as directions 
for future work (Hester 1991). The general consensus was that very little new had been learned about burned rock middens over the previous years and innovative field methods would be necessary to generate new and more informative results. Work continued on burned rock middens across Central Texas (Treece 1992; Treece et al. 1993a; Collins 1994; Mueggenborg 1994, Black et al. 1997; Black et al. 1998). One testing and excavation project in Bexar County employed the use of an experimental approach in excavation and fieldrecordation strategy (Black et al. 1998).

Analyses of data from testing and data recovery at five burned rock midden sites across the Edwards Plateau provides an in depth view of these features and brought new insights to their age and function (Black et al. 1997). A compilation of data centering on burned rock middens was conducted and presented for an 18 county area in Central Texas. A total of 156 radiocarbon dates from 36 middens at 29 sites (Decker 1997) yielded results that indicate that just over 80 percent of the radiocarbon dates fall after 2,000 B.P. (A.D. 1) and 53 percent fall after 1,150 B.P. (A.D. 800)(Black and Creel 1997:273). Although the bulk of the dates represent the last 2,000 years, radiocarbon dates are as old as 8,500 to 9,000 B.P. (6,500 to 7,000 B.C.) at 41BL598 (Quigg and Ellis 1994; Black and Creel 1997). However, the number of radiocarbon dates shows an essentially logarithmic increase toward the present, suggesting that the observed pattern may be more a function of limited long-term preservation of datable charcoal than a real indication of an actual long-term increase in the use/creation of burned rock midden deposits. Thus, while the tendency for the radiocarbon dates to cluster toward the more recent end of the chronological spectrum does contrast with earlier-stated suggestions that most middens were used in the Middle Archaic, this may be more apparent that real.

Recent testing at 16 sites containing burned rock middens in Bowie County, on the northern edge of the Central Texas archeological region has, to a degree, elucidated midden development. Several characteristics were noted: middens represent re-use and maintenance of a central feature; rock sizes in middens are not random, but rather appear to be patterned; the presence of bone and mussel shell in low frequencies is consistent with the use of earth used to cap a cooking feature or oven; the primary food cooked in such earth ovens consisted of geophytes (i.e., bulbs and tubers); the most intensive use of the Bowie middens occurred between 500 and 1,200 B.P. (A.D. 750 and 1400) (Mauldin et al. 2003). Investigations like this one are documenting particular characteristics of the middens in one localized area, but there is still need for similar detailed investigation in middens in others parts of Texas. It cannot presently be assumed that the information from these middens is representative of all other middens. In a broad encompassing midden distribution study by Mauldin et al. (2003), Edwards, Real, Val Verde and Crockett counties formed one of three high-density areas. There is mounting evidence that these highdensity areas may be related to the distribution of different types of food resources. The more northern areas may be related to geophytes, whereas the more southwestern areas may be related to sotol, agave, and lechuguilla.

After nearly 90 years, where does burned rock midden research presently stand, and what are the key questions still in need of answers? The ideas for future investigation strategies presented by Collins (1991) in the symposium volume have only been applied in a few instances since their publication. In most instances those investigative methodologies have brought about a greater understanding and have raised more 
questions that require considerably more data to address. This does suggest that progress is being made to understand these features. Obviously, much remains to be learned and certainly more specific data are required to address the more specific questions, and determine the cultural and social implications of these features.

\subsubsection{Burned Rock Midden Ages}

Most burned rock middens were assigned a general age based on estimated projectile point ages, that placed these features during the Early, Middle, and Late Archaic periods. More recently, in Central Texas, the primary use period is presently radiocarbon documented to the Late Prehistoric period from about 500 to 1,250 B.P. (A.D. 700 to 1450) (Treece 1992; Treece et al. 1993b; Quigg and Ellis 1994; Black and Creel 1997; Decker 1997; Mauldin et al. 2003), though, as already noted, this impression may be an artifact of the limited preservation of datable charcoal. Thus, as revealed by the data from the five investigated middens at $\mathrm{O}$. $\mathrm{H}$. Ivie Reservoir, the diagnostic projectile points recovered from the middens indicate ages are slightly too considerably older than the ages indicated by the radiocarbon dates (Treece 1992). In the Trans-Pecos region, the annular or ring middens have also been documented to the Late Prehistoric period, 400 to 1,400 B.P. (A.D. 630 and 1559) (Young 1981, 1982; Wiseman 1999). Wiseman (1999) points out that of the 18 dates obtained from middens in the Guadalupe Mountains only three date earlier than 1,450 B.P. (A.D. 500). He also documents one site in Eddy County, New Mexico that radiocarbon dates a 250- to 300-year period of use during the Late Archaic, between 2,900 and 3,100 B.P. (900 and 1,150 B.C.), based on nine charcoal dates that represented the horizontal and vertical breath of the midden.

Only a relatively small percentage of investigated middens have been radiocarbon dated, and there is a definite need to radiocarbon date many more middens across broad regions of Texas. To highlight this point, well over 200 middens have been excavated in Central Texas (see Howard 1991), but Black and Creel (1997) only employ 141 dates from 35 middens (about 18 percent of those investigated) in their assessment of the age of these features.

To address the length of midden use it is also important to run many radiocarbon dates on each midden to gain a complete understanding of the use period. The dated samples must represent a broad horizontal area of each midden as well the vertical height of the midden to enable one to address this complex accumulation of cultural debris over time. However, the abovementioned problem of limits to charcoal preservation, and its potential to provide misleading assessments of site/feature ages, must be kept in mind as we continue to attempt to better define the temporal range of Texas burned rock middens.

\subsubsection{Function of Burned Rock Middens}

Profusions of highly fractured rocks at prehistoric archeological sites are primarily the result of localized cooking activities, and probably represent a suite of recurrent human activities. It is still debated if cooking activities are represented only by the remains of earth ovens, or if some middens represent a variety of other types of cooking and discard activities. Even in the more rigorous investigations, the analyses of artifacts and residues generally reveal ambiguous results. Most middens lack the direct botanical remains to indicate one or more specific functions, whereas others provide limited evidence for processing of a variety of resources. Most research in Central Texas has been focused on the small domed middens, and it is conceivable that the very large middens/mounds at places like Fort Hood 
represent a variety of other activities. Over the years and across broad parts of Texas, burnedrock midden excavations have yielded different frequencies of cultural debris associated with the burned rocks. Some features have yielded considerable quantities of other material, whereas other features have produced little in the way of other classes of debris. Although differences in midden form and contents have been documented, few researchers have paid serious attention to the likely hood that more than one type of midden probably exists (Peter 1982; Kleinbach 1995). In some instances the lack of camp debris around a midden is indicative of localized processing activity, and some middens document long use-life indicating the resource was available for long periods.

\subsubsection{Foodstuffs Processed in Burned Rock Middens}

A whole variety of foods are thought to have been cooked in the central earth ovens including, but not limited to, sotol, yucca, prickly pear, acorns, seeds, onions, camas, tubers, and animal meat (Wilson 1930; Creel 1986, 1991, 1997; Hines 1994; Dering 1998a; Decker 1997; Black and Creel 1997; Mauldin et al. 2003). However, in most cases, such assumptions are not empirically based, and only in the last 10 to 15 years have some specific plant remains actually been documented from middens. Potential food resources that have recently been documented on a rather consistent basis include eastern camas and onion bulbs. These bulbs have been recovered in direct association with burned rock features that date back to least 8,000 years at the Wilson-Leonard Site (Collins 1998; Dering 1998b) and were being cooked in middens dated to the Late Prehistoric in Bowie County (Mauldin et al. 2003). The postulation that acorns were one of the resources processed in the middens (Creel 1986, 1991) has recently been questioned by Maudlin et al. (2003), who suggests that the few recovered pieces of of burned acorns may be linked to the oak wood that was employed as fuel wood. In far West Texas, several middens have yielded a range of charred plants including pinyon nutshell, yucca fruit, prickly pear fruit, agave fibers, juniper fruit, and hedgehog cactus spines (Echinocereus) (Bohrer 1994). Flotation of matrix from the central cooking features in middens is definitely one of the principal means of recovering charred food remains. However, the older middens may not have good organic preservation; and therefore, there is a need to continue other lines of investigations such as identification of phytoliths, and chemical residue analyses of the rocks and matrix.

\subsubsection{Burned Rock Midden Formation}

Many burned rock middens are documented to have been the result of a central-feature cooking apparatus-postulated as an earth oven. Hypotheses for other types of midden construction-the communal dumps or the intersecting hearth models-are still discussed, but have very little direct empirical support. Apparently most middens formed over relatively long periods of time, but in some cases there were periods of peak use represented in the formation process. The specific processes in construction/formation have not often been studied in great detail and much remains to be learned about the sequences of heating, cooking, and discard of the burned rocks. The annular form of the five investigated middens at Ivie Reservoir narrowed the use of those structures but, with the exception of the midden at 41RN169, no central hearth/pit features were located (Treece 1992; Treece et al. 1993a). Several investigations have identified what are referred to as incipient middens, such as Feature 7 at 41CC167 and 41CN95 (Treece et al. 1993a). With continued use of some annular middens and debris filled the central basins, smaller pits were excavated into the midden 
matrix (Treece 1992). Experimental earth-oven and hot-rock have contributed to an understanding of the process and such experimentation will continue to play a role in functional interpretations (Witkind 1977; Bond 1978; Lintz 1989; Stark 1997; Lucas and Frederick 1998; Leach et al. 1998; Jackson 1998; Leach et al. 2001; Stark 2002).

\subsubsection{Distribution of Burned Rock Middens}

Mauldin et al. (2003) documents that burned rock middens are largely confined to the Edwards Plateau and West Texas. The sites in West Texas are in proximity to sotol, yucca, and lechuguilla, and those middens across the Edwards Plateau, in some instances, have been documented for the cooking of geophytes. One recognized high frequency of middens is centered in the Real, Edwards, Val Verde, and Crockett counties (Mauldin et al. 2003). Now that there appears to be some apparent linkage between different foods in different regions, this association requires exploration and documentation to determine if this is real or related to some other phenomenon.

Although the answers have come slowly over the years, recently the more thorough midden investigations and more detailed analyses of midden debris have just began to shed light on these more obvious cultural features. Still, the unanswered questions remain much the same, with some more specific questions added to the list. What was the midden construction process, and is there just one process to account for the types of middens? What is the temporal span of the burned rock middens, and is it the same across Texas? Were there peak periods of use in the past, and, if so, how should this be explained? What are the landscape conditions that cause the placement of burned rock middens within a specific region and across Texas? Are regional differences present in types of middens and foods cooked in the middens? Can middens be attributed to one specific season of procurement of certain foods? Are the peak periods of use of middens linked to fluctuating resource availability of environmental changes? Is the dominance of Late Prehistoric radiocarbon dates reported by Black and Creel a real reflection of the history of burned-rock midden use intensity, or is it rather merely a bias introduced by preservation factors? If the middens are in fact largely of Late Prehistoric age, how can we account for the profusions of earlier Archaic dart points found therein? How or why do the older dart points get into the Late Prehistoric middens? Do middens reflect only earth oven cooking? What other camp activities may the middens reflect?

\subsection{The Early Archaic Period $(8,800$ TO 5,500 B.P.)}

\subsubsection{Central Texas}

In the Central Texas archeological region, the Early Archaic period is thought to date from ca. 8,800 to 5,500 B.P. (Johnson and Goode 1994; Collins 1995; Table 3-2). The specific beginning and ending dates are still unclear, and these ages may fluctuate as more radiocarbon dates from good contexts are presented. We may expect to see slightly different beginning and ending dates for this cultural period in different parts of Central Texas as archeological assemblages are further reported. Recently published syntheses of Early Archaic period archeology in Central Texas, such as those for the Sleeper (Johnson 1991) and Woodrow-Heard (Decker et al. 2000) sites, provide valuable insights into this culture period and also contain comprehensive summaries of Early Archaic period sites and assemblages in this region.

In broad terms, the Early Archaic period marks the beginning of what archeologists have previously considered a diversification and intensification of hunting and gathering 
economy or an adaptation to relatively broad spectrum of resources. This period is considered to represent the transformation from some emphasis on highly mobile, big-game hunting of Paleo-Indian times, toward adaptations involving a more diversified subsistence economy that included more reliance on smaller game and diverse plant resources. This period appears to have seen a reduction in the biomass of large herbivores such as bison (Dillehay 1974). Dart points changed from primarily lanceolate forms to notched and/or stemmed forms.

Table 3-2. Central Texas Chronology (from Collins 1995)

\begin{tabular}{|c|c|c|}
\hline \begin{tabular}{|c} 
Archeological \\
Periods
\end{tabular} & $\begin{array}{l}\text { Years } \\
\text { B.P. }\end{array}$ & $\begin{array}{l}\text { Diagnostic } \\
\text { Artifacts }\end{array}$ \\
\hline \multicolumn{3}{|l|}{ Historic } \\
\hline \multirow{3}{*}{$\begin{array}{l}\text { Late } \\
\text { Prehistoric }\end{array}$} & & Perdiz \\
\hline & $-1,000-$ & Scallorn, Edwards \\
\hline & $-2,000$ & $\begin{array}{l}\text { Darl } \\
\text { Ensor, Frio, Fairland } \\
\text { Marcos, Montell, Castroville }\end{array}$ \\
\hline \multirow{4}{*}{$\begin{array}{l}\text { Late } \\
\text { Archaic }\end{array}$} & & Lange, Marshall, Williams \\
\hline & $-3,000-$ & Pedernales, Kinney \\
\hline & & Bulverde \\
\hline & 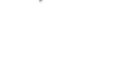 & Nolon, Travis \\
\hline \multirow{3}{*}{$\begin{array}{l}\text { Middle } \\
\text { Archaic }\end{array}$} & $-5,000-$ & Taylor _ _ _ _ . . . \\
\hline & & Bell, Andice, Calf Creek \\
\hline & $-6,000$ & Martindale, Uvalde \\
\hline \multirow{5}{*}{$\begin{array}{l}\text { Early } \\
\text { Archaic }\end{array}$} & $-7,000--$ & ---- \\
\hline & & Early Split Stem \\
\hline & $-8,000--$ & -------------- \\
\hline & & Angostura \\
\hline & $-9,000-$ & St. Mary's Hall \\
\hline \multirow{2}{*}{$\begin{array}{l}\text { Late } \\
\text { Paleoindian }\end{array}$} & & Golondrina, Barber \\
\hline & $-10,000$ & $\begin{array}{l}\text { Wilson } \\
\text { Dalton San Patrice Plainview }\end{array}$ \\
\hline \multirow{3}{*}{$\begin{array}{c}\text { Early } \\
\text { Paleoindian }\end{array}$} & $-11,000-$ & Folsom \\
\hline & (1, & Clovis \\
\hline & $-12,000$ & \\
\hline
\end{tabular}

Tool assemblages became more diverse, incorporating groundstone tools together with hunting and game-processing tool kits. Cooking technology also appears to have changed, as burned rocks became more prominent in the archeological record, indicating more extensive use of stones to cook foodstuffs. Burned rocks appear in a variety of features, including general scatters, small hearths, large ovens, and middenlike accumulations that become much more prevalent (and larger) over time.

Another significant aspect of this period is the apparent increase in the number and variety of projectile point types. The "diagnostic" points of the Early Archaic period include Angostura, Baker, Bandy, Gower, Hoxie, Jetta, Martindale, Uvalde, and possibly Early Triangular and Bell/Andice. Johnson and Goode (1994) and Collins (1995) presently believe the Early Triangular and Bell/Andice points pertain to the Middle Archaic. However, several factors render the art and science of typology of Early Archaic period points a dubious enterprise, including the limited frequency of any one point type from any one site, the often poor context and mixing of components that yield these point types, the questionable accuracy of some projectile type identifications, and the general lack of supporting radiocarbon dates. Together, these various problems have contributed to our poor understanding of the precise age and chronological sequencing of the point types within this period.

Nevertheless, general trends in certain projectile point types have been recognized. With the complexity of styles and various abilities of individuals to categorize the several projectile types, broad encompassing point categories, such as Early Barbed (Johnson 1964), Early Corner-Notched (Hester 1971), Early Split-stem (Johnson 1991), Contracting Stem (Dial et al. 1998), Expanding Stem (Dial et al. 1998), and Bifurcate Stemmed (Dial et al. 1998), are terms 
often used in the literature. Johnson (1964) originally used his Early Barbed construct as a catch-all group, but presently this and other broad categories have become a means of grouping points. Although these terms are useful for observing broad trends in point forms, the use of broad categories may mask cultural patterns that may be discernable in this cultural period based on stylistic variation within and between individual point types. With various statistical tests it may be possible to establish the stylistic variations within and between the broader groupings.

Specific projectile point types are generally considered diagnostic of specific time periods. However, many individually named Early Archaic point types are currently not well dated, and excavations have yielded many different forms from the same stratum or zone. The grouping of named types into broader categories has hindered the determination of specific ages and distribution of the individual forms/types that may contribute to the advancement our understanding of the variations. The process of lumping different types of projectiles into broad categories will not contribute to our understanding of prehistoric population movements, interactions, or behaviors, although it may be easier for some in the presentation of data.

Angostura points are the earliest of the Early Archaic types and have been dated between 7,900 and 8,900 B.P. based on specimens recovered from Woodrow-Heard (Decker et al. 2000), Richard Beene (Thoms 1992), and Armstrong (Schroeder and Oksanen 2002). Previously, some researchers have considered the Angostura point to be part of the Late Paleoindian sequence based on its lanceolate form (e.g., Johnson 1991, 1994). Angostura points occur stratigraphically below most of the other named points in Early Archaic sites. At the well-stratified Richard Beene Site, charcoal associated with Angostura points was dated to $8,805 \pm 75$ B.P. in the Perez paleosol that dated between about 9,600 and 9,800 B.P. (Thoms 1992). At the Armstrong Site (41CW54), an Angostura point was found in Occupation Zone 4 with a Hoxie point, a Golondrina point, and three charcoal dates averaging about 8,100 B.P. (Schroeder and Oksanen 2002). The fact that three different point types, one of which is a stemmed type, were recovered in a single, thin stratum may indicate that time period around 8,000 B.P. was transitional between the lanceolate and stemmed projectile points. Although many of the Early Archaic points from the latter portions of the Early Archaic sequence are not well dated, some site contexts and stratigraphic positions provide an indication as to which types occurred earlier than other types and provide general chronological context.

Above the well-dated and sealed Angostura component in the Upper Perez Paleosol at the Richard Beene Site lie several Early Archaic occupations beginning with a 6,930 \pm 665 B.P. (Beta-47525) date associated with stemmed, indented-base points (Gower-like [Thoms et al. 1996]). An estimated age of 5,500 B.P. for a hearth buried in the Median Paleosol, which yielded a soil humate date of $6,450 \pm 135$ B.P., was believed to be the youngest of the Early Archaic materials at the Richard Beene Site (Thoms 1992).

Gower and Martindale points, as well as other split-stem types, occur primarily below Bell points at the Cibolo Crossing and Landslide sites (Figure 3-2). Two complete Martindale and one broken Bandy point occurred in a sealed component at Cibolo Crossing that lacked acceptable radiocarbon dates, but which was separate and below the Bell/Andice component that was dated to 4,400 B.P. (Kibler and Scott 2000). The Martindale component at Cibolo Crossing yielded three end-/side- scrapers, one biface, seven edge-modified flakes, 385 pieces 


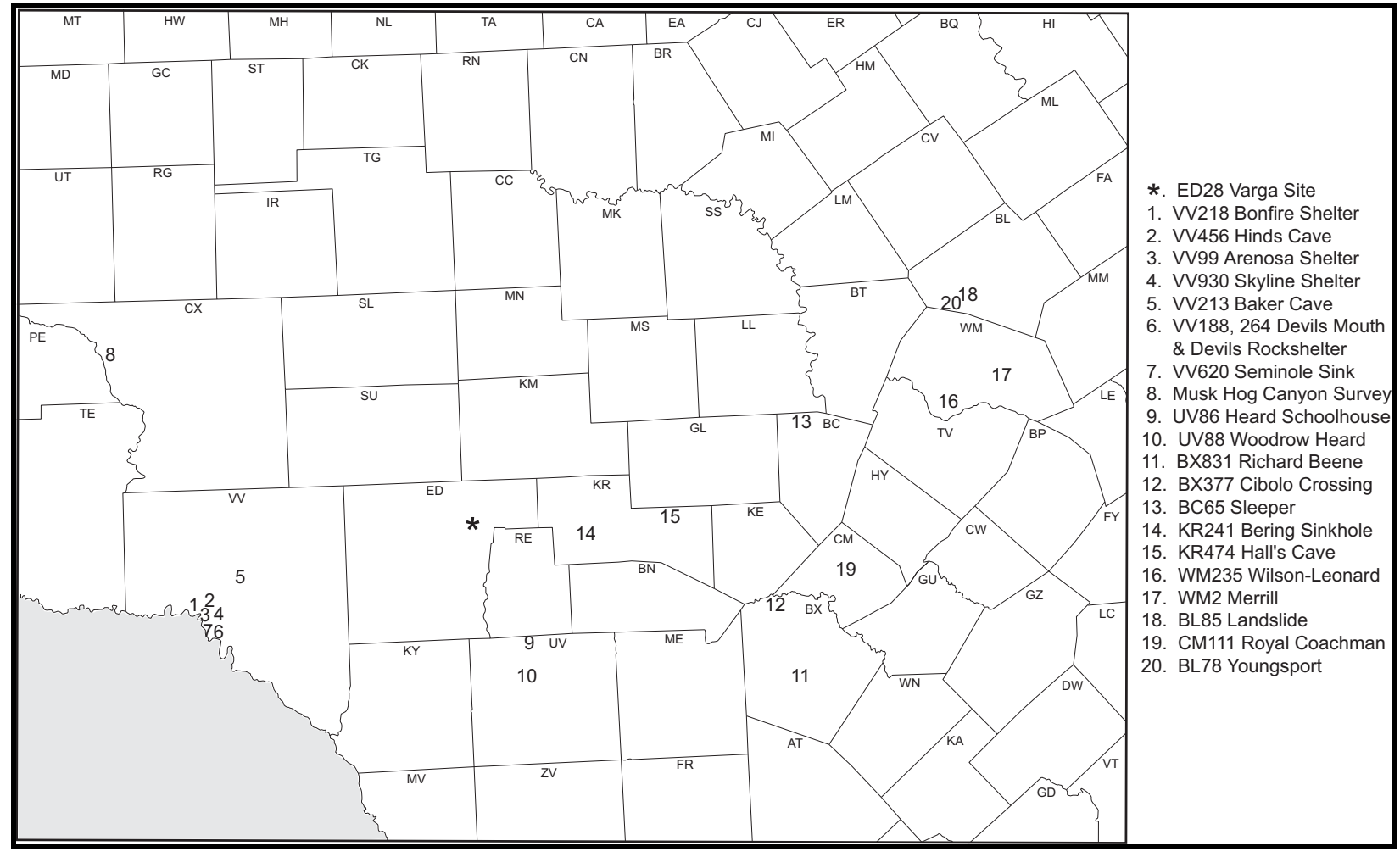

Figure 3-2. Selected Early Archaic Sites Near Varga Site

of unmodified debitage, one ground/battered stone tool (possible mano), one bone fragment, one freshwater mussel shell fragment, and five burned rock features. Intact Feature 26 was a slab-lined, basin-shaped hearth. Kibler and Scott (2000) interpret this component, as a shortterm camp where production of tools-primarily bifaces—was a major activity.

Bifaces were reduced from fully corticated Edwards chert cobbles using a hard hammer percussion tool along with limited soft hammer or billet work.

At Eckols (41TV528), a mixed Martindale and Bell zone was above an Early Split-Stem component (Karbula 2000). The Bering Sinkhole yielded two Martindale points and one Uvalde point that were generally associated with three charcoal dates of 5,840 \pm 190 (Tx-6282),
$6,660 \pm 110$ (Tx-6831), and 6,860 \pm 170 B.P. (Tx-6526, Bement 1994). The two points labeled as Martindale were stratigraphically below the single Uvalde point. However, these two tentatively identified Martindale points have attributes that more closely resemble Early Corner-Notched forms that have not yet been named.

An Uvalde point was associated with a charcoal date of 7,260 \pm 90 B.P. (Tx-7050) at Turkey Bend Ranch (Treece et al. 1993a). If the Early Split-Stem points from the Sleeper Site are primarily Uvalde/Gower forms, they appear before the Bell/Andice/Calf Creek series, but absolute dates are lacking from the Sleeper Site. The Gower point was first recognized at the Youngsport Site in Bell County (Shafer 1963). A total of 14 specimens from the lowest stratum (Stratum 8) revealed some morphological 
variations. The points were described as crudely made, with indented bases; short, parallel-edged stems; and markedly concave bases apparently made by the removal of a single flake (Shafer 1963). These points were stratigraphically below point forms such as Bulverde, Nolan, Wells, and Uvalde, and are morphologically similar to Uvalde and Hoxie forms. Radiocarbon dates associated with the Gower form are lacking. Fourteen Gower points were recovered from the Wilson-Leonard Site and potentially were associated with the latter part of the Early Archaic period (Dial et al. 1998). However, over the years since the formulation of the Gower type, the identification of Gower points appears to have maintained little consistency, making it difficult to place these in a specific timeframe. Ricklis and Collins (1994) observed a technological difference between the earlier Uvalde/Martindale points and the later Bell/Andice/Calf Creek forms, indicating a definite break in the styles.

At Wilson-Leonard, the Hoxie points appear earlier than the Bandy and Martindale points. Apparently, the wide, relatively thick, straightstemmed, bifurcate points are earlier than the expanding-stemmed bifurcates (Kerr and Dial 1998). This is also supported at the Armstrong Site, where Hoxie points were recovered above Barber and St. Mary's Hall points that were radiocarbon dated to 8,560 to 8,720 B.P. (Schroeder and Oksanen 2002). However, the Hoxie points were associated with Golondrina and Angostura points in Occupation Zones 2, 3, and 4 , which were dated between 8,490 and 6,780 B.P.

The Merrell point, which was defined by Prewitt (1985), is rare in the literature as it is not referenced in Prewitt's 1981 chronology; however, it appears in Prewitt's (1995) article. Five similar dart points occur in a stratum referred to as Merrell 3 (Upper Gravel) together in mixed alluvial contexts with a variety of
Archaic point styles at the Merrell Site in Williamson County (Campbell 1948). This gravel deposit apparently was a high-energy alluvial deposit and may contain redeposited and/or mixed cultural materials. Although not specifically defined in the Merrell Site report, this projectile point form exhibits U-shaped side notches and an expanding stem that has large, rounded ears and a deep, U-shaped notch along the basal edge. Prewitt (1995) reveals a high concentration of Merrell points in Val Verde County in the Lower Pecos region and a few points scattered over six other Central Texas counties. The Merrell point also appears in a list of Middle Archaic point styles in Johnson and Goode (1994:27). However, Johnson and Goode (1994) acknowledge that this type may date to either the Early or Middle Archaic periods (Johnson 1995:88). The Merrell point is not well known, is poorly described, and has not been securely dated. Much remains to be learned about this type.

Confusion in the Early Archaic point identification system stems from a variety of contributing factors, including, but not limited to, limited frequencies of projectiles from many investigated sites, poor or limited understanding of their contexts, limited radiocarbon dates associated with individual types, difficulties in identifying types because of reworking of many specimens, poor or limited type definitions in the literature, and subjectivity by individuals classifying projectile points. In trying to deal with these problems at Wilson-Leonard, Kerr and Dial (1998) employed more rigorous analytical methods to investigate the complexity and to help sort out the confusion over these many Early Archaic point types. A total of 102 projectiles was subjected to cluster and discriminate function analyses, which resulted in the identification of 11 major morphological clusters or groups. These statistical analyses of Early Bifurcated Stem projectiles at WilsonLeonard exhibited several distinct clusters 
exhibiting varying degrees of similarity. Although many of the identified clusters contained several different point types, some clusters yielded tight groupings. The Bandy type formed a highly discrete cluster (Cluster 1) based on thinness and short, slightly too moderately expanding and thin stems. The Martindale points also formed a relatively distinct group (Cluster 2) that exhibited relatively thin, expanding stems with a low arcuate to V-shaped base. Cluster 4 contained the traditional Hoxie and Gower forms that exhibited slightly expanding stems of medium length and general thinness. However, Cluster 5 also contained some Gower-type points along with Uvalde points. Members of Cluster 6 revealed similar outlines and dimensions but included diverse types such as Baker, Uvalde, and Gower points. Cluster 11, distinguished by its large size appears to correlate with the Jetta type. Other clusters generally contained points that belonged to more than one morphological type. In the end, the analyses indicated that there is considerable variation in the Early Archaic stemmed points, which grade morphologically from one type to another (Kerr and Dial 1998). The Bandy and Jetta types were the most morphologically distinctive, followed by the Martindale and Hoxie types.

In addition to the projectile points, other items commonly found in Early Archaic period tool assemblages include various bifaces, end- and side-scrapers, Guadalupe tools, gouges, grinding implements such as manos and metates, drills, flake tools, burins and burins spalls, and edgemodified flakes. Clear Fork tools/gouges were once thought to be indicative of specialized use, that of wood working (Hester et al. 1973; Howard 1973), but recent high-powered microwear studies indicate that Clear Fork tools had different functions, including woodworking, defleshing, and scraping (Hudler 1997; Church 2000; Hardy 2002). Some sites have gouges (e.g., Wilson-Leonard), whereas other sites lack this tool (e.g., Sleeper). This differential occurrence pattern may indicate that different tasks were performed at different sites using the same tool form. Guadalupe tools are also thought to reflect primarily woodworking and "percussive cutting tools" (Brown 1985). Grinding implements are also quite frequent at a few sites (i.e., 47 metate fragments and 70 manos at the Sleeper Site), but are not present at other sites (i.e., Camp Pearl Wheat), which may again indicate task-restricted sites/components and/or different exploitative strategies. An engraved pebble was recovered in Early Archaic context at the Turkey Bend Ranch Site (Lintz et al. 1995) and probably was a nonutilitarian object. If so, this object implies the users had time for some kind(s) of nontechnoeconomic activities.

Chipped stone debitage is frequent at many of the Early Archaic sites, but is often not discussed beyond the mention of its presence. Sometimes this class of material is sorted into billet and hammerstone flakes and divided into size categories (Johnson 1991). Burned debitage has also been recognized at several sites (i.e., the Sleeper Site). Unprepared cores, the near absence of blades and broad bifaces, reflect the general tool reduction strategy. Small blades were recovered at the Sleeper Site.

Human remains are scarce with the exception of what has been recovered from sinkholes such as the Bering sinkhole (Bement 1991, 1994) in Kerr County, which provides the bestdocumented evidence of human disposal patterns. Apparently 20 bodies, one bundle, two cremations and 17 others, were dropped or lowered into these sinkholes as their final resting place during a period from 5,100 to 7,100 B.P. The caries rate per person is a relatively low (0.69) for this San Geronimo phase (Bement 1994:93). The low ratio is indicative of a diet relatively low in carbohydrates. The stable carbon isotope analyses of the individuals from 
Bering Sinkhole indicate that diet consisted of 54 percent $\mathrm{C}_{3}$ and 46 percent $\mathrm{CAM} / \mathrm{C}_{4}$ foodstuffs. Although a sizeable cemetery dating to between 7,300 and 6,300 B.P. (calibrated) has recently been reported at the Buckeye Knoll Site (41VT98) on the central coastal plain of Texas (Ricklis 2007), Early Archaic cemeteries are as yet unreported in the Central Texas region.

Direct subsistence data is sparse because preservation of organic materials is poor in most Early Archaic components. In 1981 Prewitt suggested that hunting and gathering occurred with an emphasis on gathering for the period between about 6,000 and 5,000 B.P. The recovered data provides a very skewed picture of past resource-utilization patterns. When bone has been preserved and recovered from an early occupation zone, some researchers have failed to address the potential for incorporation of natural species into archeological deposits. Deer, various small animals, and fish are all indicated as probable resources (Collins 1995). Mussel and snail shells are common in many components such as the Landslide Site (Sorrow et al. 1967), and Sleeper Site (Johnson 1991). Deer and turtle bones were present in stratigraphic association with the Martindale and Uvalde points at the Bering Sinkhole (Bement 1994:82) and deer elements dominated in the lowest levels associated with 11 Uvalde/Martindale points at Panther Springs (Black and McGraw 1985). Burned taxa at the Wilson-Leonard Site include turtle, rabbit, carnivore, and deer/antelope (Collins et al. 1998). Analyses of organic residues in burned rocks from Camp Pearl Wheat indicate that plant, as well as animal products, were processed during this period (Collins et al. 1990). At least 10 charred wild hyacinth bulbs from a burned rock oven (Feature 181) in the Early Archaic strata at the Wilson-Leonard Site were dated to 7,870 to 8,420 B.P. (Collins et al. 1998). The Angostura component at Richard Beene Site, just south of the southern edge of the
Edwards Plateau, yielded a charred sotol or yucca leaf bases that dated to 8,000 B.P. (Thoms et al. 1996). Although not radiocarbon dated, the Early Archaic Sleeper Site did yield two mano caches that would imply that plant processing was an activity pursued at that site. Apparently, the subsistence base was very broad, and peoples exploited diverse river and land resources. In northwest Texas at the Lubbock Lake Site, during at least one Early Archaic event radiocarbon dated between 8,400 and 6,500 B.P. a minimum of three bison were processed (E. Johnson 1987). That discovery indicates that bison were in at least parts of Texas at that time and potentially in Central Texas as well.

The discovery of large cooking features, burned rock hearths or ovens at many sites (i.e., Sleeper, Richard Beene, Wilson-Leonard, Woodrow Heard; and Cibolo Crossing) indicate that large quantities of plant foods were cooked. Small basin hearths such as those at Sleeper Site, Barton Creek, and 41TG307 may reflect different cooking processes for different types of foods. The "baking heaps" at the Sleeper Site are said to have been mostly one stone thick, generally elongated, lacking organic stains, with flat bottoms (Johnson 1991:49), and attributes seemingly not indicating use as ovens. The three cooking hearths at the Sleeper Site are smaller than the "baking heaps", lined with flat slabs, and slightly basin shaped (Johnson 1991:51). Large burned rock mounds or middens have not been recognized during this time in Central Texas.

At the Turkey Bend Site along the Colorado River, a 5.8-by-5.4 m circular rock structure was charcoal dated to 7,500 B.P. and contained a large, 3.1-by-2.7 m, and $33 \mathrm{~cm}$ thick, rock hearth like feature that encompassed most of the structure's interior space (Treece et al. 1993a; Lintz et al. 1995). The function of this internal feature is unknown, but the central rock mass 
was probably a plant cooking feature. Feature 22 at Cibolo Crossing, a large 200 x 380 $\mathrm{cm}$ flat concentration of burned rocks contained 24 pieces of lithic debitage, and 700 Rabdotus shells, but that lacked charcoal staining, was interpreted to have been used in cooking Rabdotus snails (Kibler and Scott 2000). Collins (1995) sees this as a period of specialized cooking appliances, which he suggests were antecedents of the larger burned rock middens.

Some researchers have postulated broad regional distributions of Early Archaic sites and materials. Many artifact forms from this period appear widely distributed across much of Texas. For example, Gower and Gower-like points and Guadalupe tools have been recovered from central and southwestern parts of Texas (McKinney 1981), as well as from the central Coastal Plain. Weir (1976) postulated that population density was low in Central Texas and reflects small nomadic bands. In comparison to the previous Late Paleoindian period, group mobility appears to have lessened. Subsistence patterns appear to have become more diversified to include deer and a range of unspecified plants. Using optimal foraging theory, Kibler and Scott (2000) suggest that Early Archaic site distribution at Camp Bullis revolved around subsistence activities, with the locations of Early Archaic sites with Martindale points concentrated in and along the fringes of the Balcones Canyonlands reflecting a generalized foraging pattern. This is similar to the distributional pattern observed by McKinney (1981) for Gower points.

McKinney's (1981) findings revealed that many known Early Archaic sites appear concentrated along the southern edge of the Edwards Plateau. It was thought that this concentration might be linked to the greater abundance of resources, including water, at a time when the climate was somewhat dryer. In 1991, Johnson reviewed and discussed 11 important excavated Early Archaic sites that were distributed from the eastern edge of the Edwards Plateau around the Austin area, westward across the Edwards Plateau to include the Lower Pecos region. The distribution of sites form a crescent-shaped pattern along an east-west section through Central Texas. This distribution may be more a reflection of where sites have been investigated, more than it represents an actual distribution of Early Archaic population and land-use patterns. The two extreme ends of this Johnson's crescent are currently in two different archeological regions, the Central Texas and Lower Pecos regions. The Varga Site falls within the crescent-shaped area toward the western side of the Central Texas archeological region.

\subsubsection{Lower Pecos}

The Lower Pecos is a more restricted geographical region at the extreme southwestern end of the Edwards Plateau that encompasses primarily the southern part of Val Verde County. Three large rivers dissect this area and have created very large caves and rock shelters and deep terraces along streams. Archeological excavations have focused largely on the rock shelters (i.e., Arenosa Shelter, Baker Cave, Bonfire Shelter, Hinds Cave, and Skyline Shelter) and one of the deeply stratified sites (i.e., Devil's Mouth). The shelters have yielded excellent preservation of perishable goods and extraordinary rock art, but often lacked welldefined sealed strata containing a single type of diagnostic projectile with clearly associated cultural assemblages. Various natural and human disturbances have often mixed cultural materials in these settings. Also some investigated sites have not been fully analyzed and detailed reports still remain to be published. Time-period terminology has changed over the years, complicating communication efforts. Projectile point identification has also contributed difficulties as different researchers 
have typed some point styles differently than have others, when referring to the same morphological type. This region has been discussed and summarized as a separate and distinct archeological region (Turpin 1984a, 1991, 1995; Shafer 1986; Bement 1989). Although the cultural historical sequence has been developed, it is still in need of good supporting radiocarbon dates from good contexts, fully analyzed cultural assemblages, and well-described diagnostic artifacts.

Based on the results of 268 radiocarbon dates from archeological sites in or adjacent to the Lower Pecos region, it appears humans continually occupied this region throughout prehistory without hiatus (Table 3-3). The following overview focuses on what is known about the Early Archaic material remains and relies heavily on the more recent summaries for the region (Turpin 1991, 1995).

The Early Archaic has been most recently labeled the Viejo Period, which encompasses a long span of 3,400 years between 8,900 and 5,500 B.P., based on 29 radiocarbon dates from seven sites (Turpin 1991, 1995). This time frame is roughly similar to that identified for Central Texas. Although these 29 dates appear to provide a good foundation to build upon, "only six of the core dates for this period are from levels or features that are clearly and solely associated with Early Archaic index fossil" (time-diagnostic points) (Turpin 1991:27). Projectile point styles identified for this period include Early Barbed, Early Stemmed, and Early Corner-Notched. The Early Barbed category often includes Baker and Bandy types, which are sometimes confused with each other, Uvalde types, and Martindale types. A wide variety of other types also occurs. Most point forms are not well-defined, were recovered from poor stratigraphic context, and have a limited number associated radiocarbon dates. The named projectile points are often not dated to a specific
Table 3-3. Lower Pecos Chronology (from Turpin 1991)

\begin{tabular}{|c|c|c|c|}
\hline $\begin{array}{l}\text { Time } \\
\text { Units }\end{array}$ & $\begin{array}{l}\text { Years } \\
\text { B.P. }\end{array}$ & $\begin{array}{l}\text { Named } \\
\text { Periods }\end{array}$ & $\begin{array}{l}\text { Diagnostic } \\
\text { Artifiacts }\end{array}$ \\
\hline & Infierno & $\begin{array}{l}\text { Stemmed Arrow Points } \\
\text { Plain Brown Ceramics }\end{array}$ \\
\hline \multirow{2}{*}{ Prehistoric } & $-1,000$ & Flecha & Arrow Points \\
\hline & & Blue Hill & Ensor, Frio \\
\hline \multirow{3}{*}{$\begin{array}{l}\text { Late } \\
\text { Archaic }\end{array}$} & $-2,000$ & Flanders & Shumla \\
\hline & $-3,000$ & Cibola & Marshall, Montell, Castroville, Marcos \\
\hline & $-4,000$ & San Felipe & Lantry, Val Verde, Almagre \\
\hline \multicolumn{4}{|l|}{ Middle } \\
\hline Archaic & $-5,000$ & Eagle Nest & Pandale \\
\hline \multirow{2}{*}{\multicolumn{4}{|c|}{$\begin{array}{l}\text { Early Corner-Notched } \\
\text { Early Stemmed (Barker, Uvalde + Others) } \\
\text { Early Barbed (Bandy + Others) }\end{array}$}} \\
\hline & & & \\
\hline & . & Oriente & Golondrina \\
\hline & ${ }^{-10,000}$ & Bonfire & Folsom, Plainview \\
\hline & $-11,000$ & & --- \\
\hline & & $? ?$ & $? ?$ \\
\hline Paleoindiar & $-12,000$ & & \\
\hline & $-13,000$ & Aurora & Clovis \\
\hline & $-14,000$ & & \\
\hline
\end{tabular}

time period, but are bracketed by broader time frames. Hinds Cave is the exception with 24 radiocarbon dates, but the associated artifact assemblages that include Bandy and Early Barbed points have not been fully described or published.

Early on, Collins (1976) reviewed the Bandy point type in the Lower Pecos and found this type fell consistently between 5,000 and 
5,500 B.P. At Skyline Shelter, an Early Archaic component yielded 14 triangular dart points from levels 23 through 27 . These unnotched forms have been named Devils Triangular and dated by charcoal from an adjacent hearth to at least 5,210 \pm 70 B.P. (Tx-6878) (Turpin and Bement 1992). However, levels 23 through 28 also yielded six Bandy/Martindale, four Baker/Uvalde, three Gower, one Early Barbed, two Golondrina, and five untyped projectile points. A charcoal date from a $30 \mathrm{~cm}$-deep pit originating in level 28 yielded a date of 5,920 \pm 120 B.P. (Tx-6947). Level 28 lacks Devils Triangular points, but yielded three Bandy/Martindale, one Barker/Uvalde, and one Gower point. The dated charcoal appears to be from good context, but it is unclear of the relationship of the different point types throughout the $50 \mathrm{~cm}$ thick deposit. Often the Bandy/Martindale reference is used with out specific reference to one or the other point types, because there has been some disagreement over how these similar types were identified and how researchers apply the various definitions. As recently as 1993, archeologists were still disagreeing on classification of these two point types when McReynolds (1993) made an effort to clarify what he thought were Bandy point variations by illustrating 24 specimens.

At Bonfire Shelter an apparent living surface yielded a corner-notched point (not depicted) directly associated with a charcoal date of 7,240 \pm 220 B.P. (Tx-152) from Hearth 2 in the Intermediate Horizon (Dibble and Lorrain 1968). The date was stratigraphically situated above older charcoal dates and below younger charcoal dates in well-stratified context. This so-called corner-notched point has a relatively long, and slightly expanding stem with a shallow concave base and a reworked blade. It is considerably different from the Bandy, Martindale, and Baker points, being most similar to the Uvalde type.
In Seminole Sink, a single Early CornerNotched point (unlike the Bandy and Martindale points) was recovered from the very base of the cultural matrix directly associated with human burials (Turpin 1988). Three human bone dates were believed associated with this cornernotched point, and they are 4,671 \pm 64 B.P. (AA-1314), 5,590 \pm 180 B.P. (AA-1313), to $5,750 \pm 140$ B.P. (AA-1315) (Turpin 1988). Two corner-notched points referred to as Martindale points by Bement (1994) were recovered from the lower levels of Bering Sinkhole (Levels 36 and 39 in Unit III) with a charcoal date of 5,840 \pm 190 B.P. (Tx-6282) from Level 37 and two charcoal dates of 6,660 \pm 110 B.P. (Tx-6831) and 6,860 \pm 170 B.P. (Tx-6526) from Level 40.

At Wroe Ranch Rockshelter, three Martindale points (one illustrated specimen appears to be a Bandy point) were from the lower levels. At least one Martindale point was recovered from Feature 21, which yielded two radiocarbon dates, one of $5,730 \pm 70$ B.P. (TX-9180) and $6,400 \pm 180$ B.P. (Tx-9104) on prickly pear pads (Turpin 1998). Early Barbed and Bandy points are said to have come from Analytical Unit 7 at Hinds Cave, dated by 11 radiocarbon dates to between $8,490 \pm 130$ B.P. (Tx-2734) and $6,750 \pm 100$ B.P. (Tx-2316). The earlier date potentially came from mixed context. However, a date of $7,470 \pm 120$ B.P. (Tx-2738) was definitely associated with Bandy points (Valastro et al. 1979:267). Analytical Unit 6 also yielded Bandy points, which were radiocarbon dated on charcoal by three samples to between 6,540 \pm 70 B.P. (Tx-2744) and 6,160 \pm 80 B.P. (Tx-2735)(Lord 1984; Turpin 1991).

The Eagle Cave deposits yielded a variety of projectiles including Early Barbed, bifurcated base, in Stratums IV and V associated with six radiocarbon dates ranging from $6,060 \pm 120$ B.P. (Tx-139) in Stratum IV to $8,760 \pm 150$ B.P. in 
Stratum V (Tx-107; Turpin 1991). These examples reveal the broad structure of the chronology for Early Archaic point styles in the Lower Pecos region. However, the limited data and questionable context do not provide specific linkages between individual point types and radiocarbon dates.

Prewitt (1995:91) reveals that the distribution of Bandy points is restricted to seven counties. Bandy points are most frequent from Val Verde County, but specimens also come from counties within the Edwards Plateau and in the northern part of South Texas. Martindale points have been recovered from the same counties as the Bandy points, but show a much broader distribution (41 counties) and are much more numerous (Prewitt 1995:117). The Devils Triangular points are similar to the Taylor and Baird/Early Triangular points in Central Texas and appear at about the same time period. These unnotched forms occur over a very broad region of central and south Texas, the Lower Pecos, and beyond (Prewitt 1995:91). Baker points are very restricted in distribution to just two counties, one is Central Texas, and the other is Val Verde County, where there is a high concentration (Prewitt 1995:91). Uvalde points are widely distributed across central and part of South Texas with some in the Lower Pecos and Trans-Pecos regions. The highest concentrations appear in Val Verde and Williamson counties (Prewitt 1995:91). Confusions with the identifications of the Baker and Uvalde points make it unclear if Prewitt's distributions reflect reality.

Other than the projectile points, a diverse stone tool assemblage is also represented. Tools including biface preforms, finished knives, Guadalupe bifaces, large flake scrapers, various end- and side- scrapers, edge-modified flakes, spokeshaves, drills, gravers, hammerstones, burin spalls, cores, scratched cobbles, and a grooved stone ball are attributed to the Early
Archaic period. One Guadalupe biface from Skyline Shelter appeared to be associated with the Devils Triangular points, and possibly Bandy/Martindale and Baker/Uvalde points and was dated to about 5,200 B.P. (Turpin and Bement 1992). Under 160X magnification, this tool exhibited polish that resembles polish produced by working wood or other plant substances (Turpin and Bement 1992). Guadalupe bifaces seem to be more frequent in the Central Texas region and date to about the same time.

Collins (1974) has determined that at Arenosa Shelter, chert river cobbles were the primary source of tool stone. These were reduced by direct percussion, as used in much of the tool making process. He also determined that heattreating of the raw material was uncommon. Projectile points were thinned by soft hammer percussion technique, which produced bifaces with bi-convex cross sections. Some bifaces exhibit further modification of edges through beveling (Collins 1974).

Early Archaic human remains are very sparse and generally found in vertical shaft sinkholes or dry rock shelters (Turpin 1991). A population of 21 individuals from Seminole Sink provides the best information on mortuary practices and biological conditions (Turpin 1988). Nonperishable remains were extremely rare with these bodies, but it is possible that perishable items were included, although this cannot be demonstrated. The three most acceptable radiocarbon dates for this population were obtained on human petrous bones recovered in the lower stratum and are 4,671 \pm 64 B.P. (AA1314), 5,590 \pm 180 B.P. (AA-1313), and $5,750 \pm 140$ B.P. (AA-1315). The individuals were apparently quite healthy, as they lacked evidence of any serious debilities (Marks et al. 1988). The caries rate is a high 1.8 per person for the 10 Early Archaic bodies (Marks et al. 1988). The high rate is attributed to the 
consumption of carbohydrate-rich desert succulents. Based on stable carbon isotope analyses, this population exhibits a heavy dietary reliance on $\mathrm{C}_{4} / \mathrm{CAM}$ vegetation; largely desert succulents such as prickly pear cactus, agave, and sotol (Turpin 1988:120). The dental pathologies from the Early Archaic through Late Archaic times in the Lower Pecos have demonstrated stability in the diet that reflects adaptation to xeric biota (Turpin 1888:120). Turpin (1988) suggests that the population, an egalitarian society, using Seminole Sink lived in the region year round as supported by the individuals that were interred having died at different times of the year.

This long Early Archaic time period exhibits a broad resource base. Coprolites from Zone 17, Level 6 in Baker Cave that dated to $8,080 \pm 80$ B.P. (Tx-2931) and associated with Early Triangular points (Turpin 1991) revealed various consumed resources. The more significant foods include: onion, persimmon, walnuts, fish, rodents, and a dominance of prickly pear (Stock 1983 cited in Sobolik 1991a). The 100 coprolites analyzed from Lens 13 at Hinds Cave, dating to between $5,590 \pm 80$ B.P. (Tx-2458) and 5,710 \pm 80 B.P. (Tx-2459), reveal consumption of desert plants and animals such as rodents, rabbits, birds, reptiles, fish, prickly pear, walnuts, onion bulbs, lechuguilla, sotol, persimmon, and other species (Williams-Dean 1978). General plant identification for a period around 8,500 B.P. also documents the use of many of these same resources (Dering 1977). Large herbivores such as deer were present, but in Analytical Unit 7 at Hinds Cave, large herbivore remains only account for about 1.6 percent of the faunal remains, whereas the rodent material accounts for 58.2 percent of the faunal assemblage (Lord 1984). Baker Cave also yielded a variety of edible foods including mescal beans, pecans, walnuts, and acorns together with netting, matting, cordage, wooden dart shafts and foreshafts (Word and Douglas 1970). The excellent preservation of perishable remains has allowed for a chronology of the changing forms of basketry and matting through time. At Wroe Ranch, a grass nest (Feature 11) and a fiber nest (Feature 21) were radiocarbon dated to $5,410 \pm 50$ B.P. (Tx-9181) and 5,730 \pm 70 B.P. (Tx-9180), respectively. These nests contained grass, prickly pear pads, sotol leaves, walnut, mesquite, matting, and a sandal (Turpin 1998). The data indicates a very broad, diverse resource base that included both plants and animals for the Early Archaic period with an intense focus on prickly pear.

A burned rock midden, a prickly pear floor, and latrines that contained many coprolites recognized at Hinds Cave (Lord 1984; WilliamsDean 1978) indicate specific activity areas were in use. The Hinds Cave burned rock midden was about one meter thick with no obvious central pit, yielded massive charcoal deposits together with charred bases of lechuguilla remains, quids of lechuguilla and sotol, and cut leaf bases on the western edge, and was in Analytical Unit 6. The midden was radiocarbon dated to between 6,540 \pm 70 B.P. (Tx-2744) and 6,160 \pm 80 B.P. (Tx-2735) and apparently associated with Bandy points (Shafer and Bryant 1977; Lord 1984; Turpin 1991). This may be one of the earliest dated burned rock middens. Lechuguilla and sotol probably were the main plants cooked with the burned rocks in the midden. Also Hinds Cave yielded a pit lined with a large checkered-woven tray of unsplit sotol leaves (Shafer and Bryant 1977). Small burned rock concentrations and hearths have also been identified at sites dating to this period. Further west in Terrell County, the Wroe Ranch Site yielded a grass and prickly pear pad basin about $70 \mathrm{~cm}$ in diameter and a nearly $50 \mathrm{~cm}$ diameter basin lined with grass (Feature 21) accompanied by a sandal, matting, sotol stake, and leaves, with a Martindale point nearby. Feature 21 was radiocarbon dated by two 
samples that yielded dates of 5,730 \pm 70 B.P. (Tx-9180) on sotol stalks and 6,400 \pm 180 B.P. (Tx-9104) on prickly pear pads (Turpin 1998).

Mobile art in the form of painted pebbles and unbaked or poorly fired clay figurines (Dibble 1967; Shafer ,and Speck 1974; Shafer 1975; Shafer and Bryant 1977) are attributed to the Archaic in general and were potentially initiated at this time (Turpin 1995). Painted pebbles were recovered from early contexts at Arenosa Shelter, Hinds Cave, and Eagle Cave. A proposed chronology on painted pebbles has been also presented (Parsons 1986; Mock 1987). The clay figurines are quite rare, and limited information is available concerning them. How these non-utilitarian items were intergraded into the societies is unknown, but their presence indicates human activities extended beyond the constant pursuit of subsistence.

The Viejo period comes to an end with the appearance of Pandale points, the index marker for the Eagle Nest period of the Middle Archaic. This distinct beveled point has regionally restricted distribution, and is prominent in Val Verde and adjacent counties. The Middle Archaic period begins possibly around 6,100 B.P. or more likely around 5,500 B.P. (Turpin 1991:28, 1995). Pandale points were recovered from Stratum 32 in Arenosa Shelter, which yielded a radiocarbon date of 5,360 \pm 170 B.P. (Tx-313, Johnson 1991). However, Dibble (1967) reports Pandale points at Arenosa Shelter from Strata 21 through 30 during a period from ca. 4,000 to 5,300 B.P. This is about the time period that the Bell/Andice points appear in Central Texas and other parts of the state.

\subsection{The Middle Archaic Period (CA. 6,000 TO 4,000 B.P.)}

\subsubsection{Central Texas}

Johnson and Goode (1994) present a tentative revision of the cultural Archaic for the eastern parts of the Edwards Plateau from that diverges from chronologies previously presented by Weir (1967) and Prewitt (1981a, 1985). A significant change comes with the reassignment of certain of Prewitt's Early Archaic point types, including Bell/Andice, Baird, and Taylor triangular points to the Middle Archaic and Middle Archaic types, such as Bulverde, Pedernales, Marshall, and Williams, to the Late Archaic period. This may confuse many readers as much of the current literature refers to these points according to Prewitt's chronology. Although still using the terms Early, Middle, and Late for divisions within the Archaic, Johnson and Goode (1994) attempt to link the revised periods together based on broad patterns of human behavior. Johnson and Goode (1994) propose a period of about 1,300 years from about 5,600 to 4,300 B.P. for the Middle Archaic.

Johnson and Goode (1994) see the Bell/Calf Creek dart points as dominant at the beginning of the Middle Archaic period at ca. 5,600 B.P. and correlate these points with bison hunting. The bison occurrence at this time is best demonstrated at the Landslide Site (41BL85), where a bison bone was found in apparent association with one Calf Creek/Bell point (Sorrow et al. 1967). A second possible association was at Cervenka Site (41WM267) that also yielded several bison bones scattered around a small, shallow basin hearth, Feature 26, estimated to fall into a time period between 6,000 and 5,000 B.P. (Peter et al. 1982b).

At Cibolo Crossing (41BX377), the $16.8 \mathrm{~m}^{3}$ Bell component contained nine Bell points, one Andice point, and two Baird triangular bifaces, and was radiocarbon dated to 4,400 B.P., based 
on the average of three charcoal dates from Feature 19 (Kibler and Scott 2000). The BellAndice component yielded 13 dart points, 13 bifacial tools, three end-/side- scrapers, one side-scraper, one end-scraper, one cobble chopper, two multidirectional cores, 19 edgemodified flakes, 897 pieces of unmodified debitage, 41 bone fragments of which 17 percent are burned, one freshwater mussel shell, a piece of hematite, 12 burned rock features, and $715 \mathrm{~kg}$ of burned rocks. One point labeled as Bell (Kibler and Scott 2000; Figure 28, g) resembles Early Corner-Notched points. The variety of burned rock features indicates plant and possible meat cooking activities, activities associated with a variety of stone tools. Kibler and Scott (2000) suggest this area was used as base camp. At the Granberg II Site (41BX271), a Bell point was dated to $4,770 \pm 110$ B.P. (uncorrected, Tx3606 [Black and McGraw 1985]). A Bell component at the Richard Beene Site has been dated to ca. 4,500 B.P. (Thoms et al. 1996:1516). Beyond the Central Texas archeological region, a Bell point was dated between 5,900 and 5,300 B.P. (calibrated) based on radiocarbon assays on associated Rangia flexuosa shells at the McKinzie Site (Zone 3) in Nueces County along the coast (Ricklis 1988, 1993:49). At the Royal Coachman Site (41CM111), three Bell/Andice points were recovered from excavation levels that also contained nine Early Triangular, five Pandale, and five Nolan points with five charcoal dates ranging in age from about 5,000 to 4,700 B.P. (Mahoney et al. 2002).

Later in this period Johnson and Goode (1994) see the occurrence of Early Triangular, La Jita, Travis, and Nolan points, and possibly the appearance of Merrill points. The Nolan and Travis points become the dominant type in the latter part of the Middle Archaic (Johnson and Goode 1994). Although not well documented, Johnson and Goode believe that the Nolan and Travis points date to no earlier than about 5,000 B.P. Goode believes the La Jita and the
Travis points are of the same age, as they share specific manufacturing features (Johnson and Goode 1994:27).

Variations in the terms used to refer to unnotched triangular point forms recovered across broad regions of Texas have caused typological problems. Much remains to be learned about the relationships of these various unnotched forms, their function, and their ages. Use and impact wear on Early Triangular specimens from the Royal Coachman Site show these tools functioned as both projectile points and knives (Shafer and Tomka 2003). In South Texas, the triangular Tortugas points have also revealed multifunctional wear patterns (Church 2000; Hardy 2002). In at least two instances, narrow triangular Tortugas points revealed usewear on the straight proximal end, whereas the pointed distal end revealed abraded ridges and striations that indicate the half location (Hardy 2002). It has also been suggested that Tortugas points have important adaptive advantages with their wider blades allowing for more numerous resharpenings, and the triangular form may be more resistant to impact failure (Mahoney et al. 2002).

In earlier research, Prewitt (1981a, 1985) placed the Baird (a beveled triangular form) and Taylor (non-beveled triangular form) types between about 5,100 and 4,600 B.P. Turner and Hester (1993) place the Early Triangular within the Early Archaic period, dating roughly between 8,000 and 4,500 B.P. In Central Texas, the triangular Taylor and Baird points are presently considered Middle Archaic, dating from roughly 5,500 to 4,000 B.P. (Johnson and Goode 1994; Collins 1995; Mahoney et al. 2002). Mahoney et al. (2002) believe that the Royal Coachman Site yielded one of the more securely dated Early Triangular components in Texas with five of six radiocarbon assays from wood charcoal returning one-sigma dates ranging from 5,600 to 5,460 B.P. These ages appear earlier than most 
known ages, but it may be that these styles have a long use period that is contributing to the difficulty in trying to narrow down the time frame in which these they were used. Goode (2002) interprets Triangular bifaces, specifically specimens referred to Kinney bifaces-Groups 1 through 4 , as a series of bifaces that were used and repeatedly resharpened, and reused. He indicates that there is no wear on the bases to indicate hafting, although he also indicates that there is minor smoothing of the flake scar ridges on some specimens. Some Kinney bifaces resemble the points Quigg et al. (2002a) labeled Anton/Tortugas from the Boiler Site in South Texas. As discussed under the Bell/Andice/Calf Creek point series, some Early Triangular points appear in the same stratigraphic zones as some Bell/Andice/Calf Creek forms, indicating they are probably of comparable age.

Johnson and Goode (1994) see the Middle Archaic as a time of considerable borrowing of alien artifact styles or new artifact styles physically brought into the area. They project mixed economics with burned rock middens reflecting intensive periods of collection and processing and link the burned rock middens with Nolan and Travis points.

Evidence for burial practices in the eastern Edwards Plateau are nearly non-existent. The Mason Burial Cave (41UV4), a sinkhole just west of the dividing line in Uvalde, revealed some 25 to 50 bodies with a few Travis, Nolan, and Early Triangular points (Bender and Bender 1962 cited in Johnson and Goode 1994).

Johnson and Goode (1994) see this period as moderately moist but drying. This contrasts with the data from Fort Hood, which Nordt $(1992,1993)$ interprets as a xeric period that had increases in $\mathrm{C}_{4}$ grasses at the expense of $\mathrm{C}_{3}$ trees and shrubs.

In the most recent overview of this period, Collins (1995) divides the Middle Archaic into three subdivisions based on projectile point types similar to a position taken by Johnson and Goode. The earliest is the Bell/Andice/Calf Creek style that reflects a period of bison hunting that occurred as bison moved into the region. Bison hunting may have carried over into the subsequent period when Taylor points were used. All these points are generally triangular forms with thin blades. The Taylor points are unnotched, whereas the Bell/Andice/Calf Creek forms are distinctive, deeply basally notched forms. Taylor points were the dominant projectile $(n=27$ or 51 percent of the total) at the burned rock midden excavated at Wounded Eye Site (41KR107) in Kerr County (Luke 1980). However, this midden yielded no radiocarbon dates with which to make a precise chronological placement.

It is not clear when bison moved from the region, but toward the latter part the Taylor period and into the Nolan and Travis point type period this animal disappeared from Central Texas. This author interprets the current data as indicating that the Nolan and Travis points are the prominent indigenous types in the Central Texas region at this time, whereas Bell/Andice/Calf Creek points originated to the north and Early Triangular points came from the south. The events reflected by the different point types may all be very close in time and poor stratigraphic context has not allowed individual events to be identified. The lack of significant time between events, coupled with the erosional and depositional sequences, have often mixed these points types together. Therefore, until single-event sites are located and excavated, our understanding of the issue will be constrained.

\subsubsection{The Lower Pecos}

Most recently Turpin $(1991,1995)$ indicates this period extends from about 5,500 to 3,200 B.P. 
using uncalibrated ages and from 6,500 to 4,000 B.P. with calibrated assays. She labels the first half of this period from 5,500 to 4,100 B.P. (uncalibrated) as the Eagle Nest subperiod, which is characterized by Pandale points. This is a distinctive beveled, stemmed point with a restricted, regional distribution. Pandale points have been recovered from radiocarbon-dated strata at Arenosa Shelter, Eagle Cave, Conejo Shelter, Hinds Cave, Skyline Shelter, and Fate Bell Shelter (Turpin 1991). At Eagle and Hinds caves, Pandale points appear in mixed strata attributed to time of about 6,100 to 5,500 B.P.

Turpin (1991, 1995) believes this period coincides with the culmination of Bryant's Stockton Stage in an extremely hot, dry interlude he called Ozona Erosional, as evidenced at Arenosa Shelter and Devils Mouth Site. This may also coincide with what Brown (1991) observed at Baker Cave with an apparent shift to labor-intensive processing of lechuguilla, sotol, and yucca at around 5,000 B.P.

The second half of this period, from 4,100 to 3,200 B.P. (uncalibrated) or 4,850 to 3,350 B.P. (calibrated) Turpin (1991, 1995) labels the San Falipe subperiod, which is characterized by point types such as the Langtry, Val Verde, and Almagre. These three types were recovered from dated contexts at Arenosa ShelterStratum 21, 22C, 22X, 23, 23D; Eagle CaveStratum IIA; Conejo Shelter-Lens 50; Hinds Cave-Analytical Unit 3; and Fate Bell Shelter-Zone 3, Level 1.

Turpin (1990) suggests this is the period in which the regional Pecos River style of rock art originated, examples of which include polychrome pictographs thought to be religious (shamanistic) art forms (Kirkland and Newcomb 1967; Turpin 1994a, 1994b). These glyphs are quite diverse, with mountain lions, deer, birds, fish, insects, and anthropomorphs thought to represent shamans. The shaman figures exhibit animal characteristics such as feathers, wings, claws, fur, and horns and are equipped with atlatls, darts, fending sticks, and pouches (Turpin 1995).

This period sees intensive flooding of the Pecos River as revealed at Arenosa Shelter (Bryant and Shafer 1977), perhaps catalyzed by increased runoff on a landscape that was partially devegetated during a hot, dry interval that Bryant (1966) termed the Sanderson Stage.

Turpin $(1991,1995)$ suggests that there was an increase in population density, which created societal stresses that were mitigated by the creation of the rock art and its ideational corollaries. Boyd (2003) believes that through documentation and analyzing rock art we can begin to recognize the myriad ways in which it was integrated into the lifeways of the Lower Pecos socio-cultural systems.

\subsection{The Late Archaic Period $(4,000$ TO 1,300 B.P.)}

\subsubsection{Central Texas}

In Central Texas, the Late Archaic, roughly 4,000 to 1,300 B.P., is divided into six intervals based on projectile point types (Collins 1995). Prewitt's (1981a) original chronological sequence consisted of three phases: Uvalde (Castroville, Marcos, and Montell points), Twin Sisters (Ensor points), and Driftwood (Mahomet [Darl] points). Many archeological sites of this time have been excavated, although few wellstratified components are represented or reported (Collins 1995; Figure 3-3).

Johnson and Goode (1994) provide a slightly different view by subdividing this period into early ("Late Archaic I") and late ("Late Archaic II") subperiods. The division is based on perceived changes in the archeological record. Common dart points include Bulverde, Pedernales, Marshall, Montell, and Castroville 


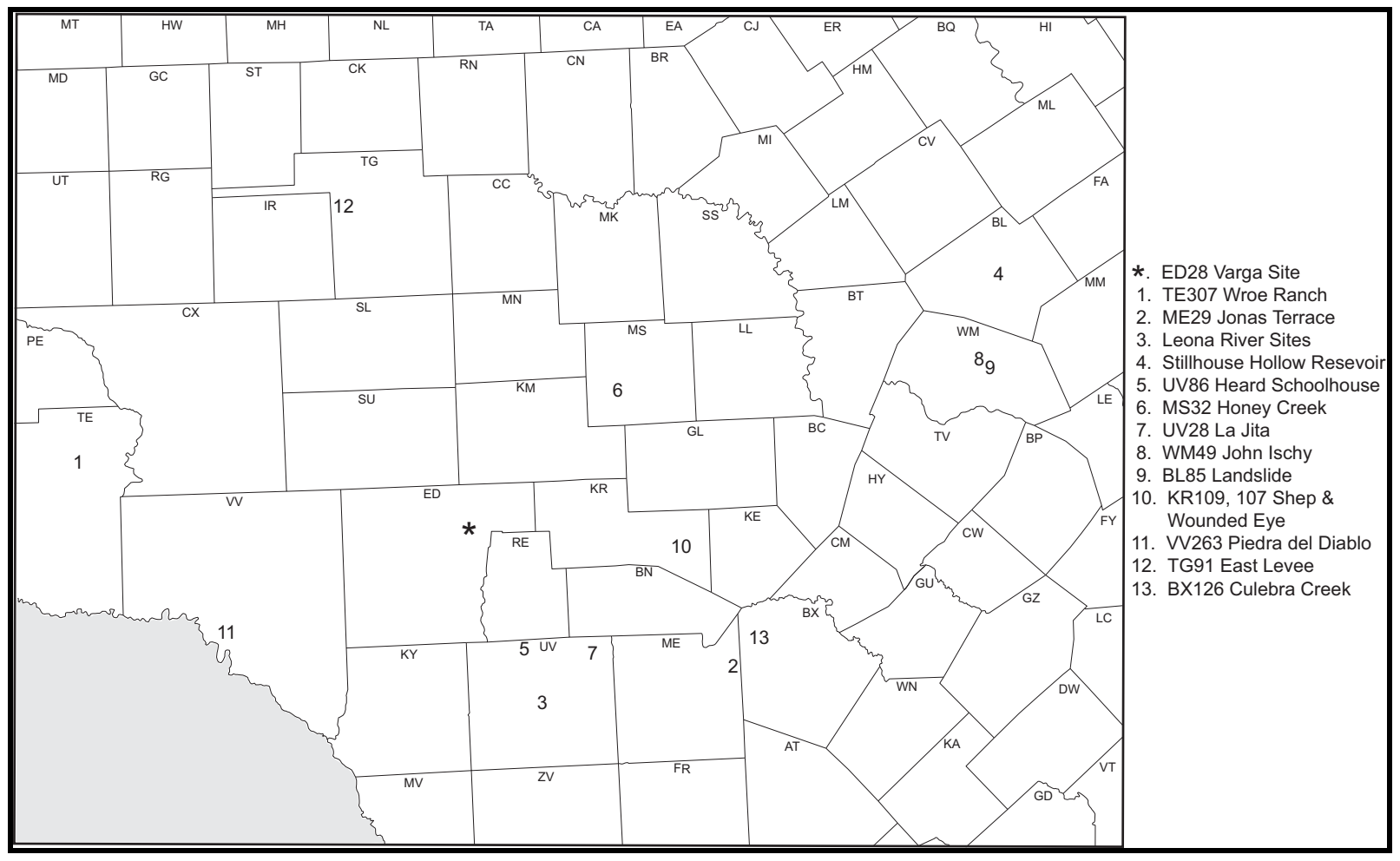

Figure 3-3. Selected Late Archaic Sites Near Varga Site

in the Late Archaic I, with Marcos, Ensor, Frio, Darl, and Figueroa in Late Archaic II. Johnson and Goode (1994) indicate a time of about 2,500 B.P. for the division of the two subperiods. Although the projectile point sequence has not changed drastically from Prewitt's original work (1981a, 1985), Johnson and Goode (1994) placed the Bulverde, Pedernales, and Marshall points of Prewitt's Middle Archaic into their Late Archaic period. The Johnson and Goode (1994) division, with the Marcos type occurring later than the Montell and Castroville, is potentially problematic as many researchers consider these points to be about the same age. Two of the better contexts with radiocarbon dates and Uvalde phase projectiles are found at 41GT91 and Culebra Creek Site. At 41TG91 (East Levee), Marcos points are associated with three radiocarbon dates of $2,910 \pm 270$ B.P. $\quad(\mathrm{Tx}-4764 \mathrm{~B})$,
2,540 \pm 80 B.P. $\quad$ (Tx-4764A), and 2,480 \pm 60 B.P. (Tx-4761) (Creel 1990). At Culebra Creek Site, three Montell and one Marshall point came from a thin burned rock midden associated with two charcoal dates of 2,700 \pm 50 B.P. (NSRL-3520) and 2,780 \pm 50 B.P. (NSRL-3519) (Nickels et al. 2001). These later two sites and associated radiocarbon dates indicate these point types can occur as separate entities.

Burned rock middens, thought to have appeared in the Middle Archaic (Weir 1976; Prewitt 1981a), continue through this period, some with well-defined central pit features or rock ovens (i.e., Ricklis and Collins 1994; Black et al. 1997; Mauldin et al. 2003). The Culebra Creek Site contains one 35 -cm-thick by 5 - m-long burned rock concentration with what the researcher refers to as the remains of a central heating 
element, but no direct evidence of food resources, that is associated with Montell points (Nickels et al. 2001). Many researchers believe that the rock ovens and large middens represent the cooking of bulk plant resources such as sotol or lechuguilla that require long periods of heating to make consumption a possibility. An alternate hypothesis based on the broad distribution of oak trees and burned rock middens is that these features were used to process acorns (Creel 1986, 1991). More recently it has been directly demonstrated by the identification of burned plant parts that geophytes (tubers, bulbs and roots) were also cooked in burned rock middens (Dering 1997, 1998b, 2003a; Mauldin et al. 2003). Chemical residue analysis on burned rocks from a central cooking features at Mustang Branch midden near the Balcones Escarpment revealed animal residues were present (Loy 1994). Other smaller burned rock dumps, scatters, basin, and flat hearths have been recognized at various sites during the Late Archaic.

Other than various plant resources that were bulk processed in earth ovens associated with middens, buffalo were also part of the subsistence base for periods within the Late Archaic, principally associated with Montell points. Bison bones from Barton Site yielded bone collagen radiocarbon dates between about 1,800 and 2,150 B.P. (Ricklis and Collins 1994). This is the same period that bison were also present in the Lower Pecos region, as evidenced by the bison-jump kill at Bonfire Shelter. Therefore, bison were widely distributed across much of Texas during the Late Archaic. Deer continued to be a part of the consumed resources, as were riverine resources such as mussels.

Cemeteries were in use in Central Texas during the Late Archaic, as indicated at sites like Olmos Dam (41BX1) (Lukowski 1988) where some, if not all 13 burials, date to this period. At least two infant burials, one flexed and associated with grave inclusions, including white-tail deer antlers, traces of ochre, and chert cobbles, were associated with charcoal radiocarbon dates of 2,200 \pm 70 B.P. (Tx-3989) and 1,920 \pm 160 B.P. (Tx-3993). Isolated burials are also present as indicated by a semiflexed male skeleton buried $2.2 \mathrm{~m}$ deep in an alluvial terrace in Llano County (Bement 1993). This body was associated with a complete Ensor dart point near the dorsal side of the spine opposite the lower thoracic vertebrae, which might have been the cause of death.

The Late Archaic is generally viewed as a continuation of a generalized collection adaptation strategy with population densities increasing from the proceeding period. The regional data show use of diverse plant and animal resources, and demonstrate that burned rock features continued to be used for cooking.

\subsubsection{The Lower Pecos}

In the Lower Pecos archeological region, the Late Archaic is again a relatively long period dating from about 3,150 to 1,300 B.P. (Turpin 1991). However, no one artifact or technological change marks the essentially arbitrary divide between Middle and Late Archaic periods. Based on projectile point styles, Turpin (1991) has subdivided the Late Archaic into the Cibola period (3,150 to 2,300 B.P.) characterized by Marshall, Montell, Marcos, and Castroville points; the Flanders period (2,300 B.P. to unknown) characterized by Shumla points; followed by the Blue Hills period (2,300 to 1,300 B.P.) with Ensor and Frio points. A Frio point was recovered from next to a fiber nest at Wroe Ranch, and the fiber was radiocarbon dated to $1,710 \pm 40$ B.P. (Tx-9120) (Turpin 1998). Also at Wroe Ranch at least five features (2, 12, 19A, 22, and 24) were attributed to the Blue Hills period with five radiocarbon dates that fell into the stated temporal interval. 
At Arenosa Shelter, the Marcos points were stratigraphically higher than the Montell points (Dibble 1967). Some 51 Montell came from Stratum 11, radiocarbon dated to $2,440 \pm 140$ B.P. (Tx-311) and 2,410 \pm 140 B.P. (Tx-286) (Dibble 1967). At Bonfire Shelter, 25 points of the Montell and Castroville types were found in Bone Bed 3, which produced two charcoal and two burned bone samples dating to $2,310 \pm 210$ B.P. (Tx-46), $2,510 \pm 100$ B.P. (Tx131), 2,780 \pm 110 B.P. (Tx-106), and 2,810 \pm 110 B.P. (Tx-47), respectively (Dibble and Lorrain 1968:51). Possible mixing of deposits in the excavated sites has caused some confusion over which points might be associated with other point types, and the exact beginning and ending dates for these subperiods. The Shumla point type is poorly dated in the Lower Pecos primarily because of poor excavated contexts, though radiocarbon dates from Mexico place this type between 3,100 and 1,850 B.P. (Turpin 1991, 1995). The terminal dating of the Late Archaic is not well-defined, since many of the deposits of this period are disturbed.

Most rockshelter sites that contain Earlier Archaic occupations have also yielded Late Archaic materials (i.e., Hinds Cave, Conejo Shelter, Wroe Ranch) indicating continuity in land use throughout this area. Preservation is good in most rockshelters and the fiber industry is well represented. At Wroe Ranch there were fiber "nests" (Features 2 and 24) with grass and prickly pear pads, shredded agave, matting, and a sandal (Turpin 1998). The fiber layer at Bonfire Shelter was a discrete layer of occupational debris with lechuguilla leaves, prickly pear seeds, yucca fiber, black walnut shells, mescal beans, mesquite hackberry, and buffalo gourd materials (Dibble and Lorrain 1968). This layer yielded radiocarbon dates on charcoal of $1,400 \pm 130$ B.P. (Tx-151) and $1,690 \pm 80$ B.P. (Tx-194).
Human coprolites from Conejo Shelter (41VV162) provide a glimpse at the foods that were consumed in the Late Archaic, specifically during what Turpin (1991) refers to as the Blue Hill period. Bryant (1974) discovered that pollen from coprolites dating from 2,400 to 1,150 B.P. indicates that flowers from plants such as yucca, agave, sotol, cactus, persimmons, leadtree, and mesquite, were consumed. Also part of the diet were wild onion bulbs, millet seeds, small reptiles, grasshoppers, cactus fruits, goosefoot seeds, minnow-size fish, and mammals. The 1,820 B.P. crescent shaped burned rock midden at Hinds Cave with associated Ensor and Frio points yielded about 1,600 seeds and fruit fragments from 9.5 liters of matrix (Dering 1996).

During the Cibolo period, bison returned to this region as evident by bones of this species in the archeological records at Eagle Cave (Ross 1965), Castle Canyon (Greer 1966), Bonfire Shelter (Dibble and Lorrain 1968), and Arenosa and Skyline shelters (Turpin 1991). At Bonfire Shelter a massive, nearly 30-cm-thick bone bed estimated to contain remains of about 800 bison represents a major bison jump kill (Dibble and Lorrain 1968). The bison bones were in direct association with 25 Montell and Castroville points. Bison was clearly added to the existing repertoire of plant and animal resources from previous periods. Turpin (1995) sees an abrupt change in the economic, technological, and site distributional patterns at this time. Dibble (Dibble and Lorrain 1968) postulated that wetter and cooler conditions permitted the emergence of a grassland environment suited to the needs of bison, giving rise to the influx of human populations following migrating herds. The presence of burned rock middens across much of the region also indicate that plant processing in mass quantities also occurred at this time. Besides bison, the use of deer, rabbit, squirrel, fish, and mussels as food resources is indicated 
by bones and shells from the fiber layer at Bonfire Shelter (Dibble and Lorrain 1968).

Little is known about the range of cooking facilities used during this period. This might stem from the lack of excavations at wellstratified components pertaining to this period, as well as a lack of dates for individual cooking features. The fiber layer at Bonfire Shelter contained at least two hearths, Hearths 6 and 7. Hearth 6 consisted of three superimposed stone lined constructions, circular in outline and about $115 \mathrm{~cm}$ in diameter and $15 \mathrm{~cm}$ deep. Hearth 7 was an unlined concentration of compacted ash, lump charcoal, and a few burned limestone rocks about $65 \mathrm{~cm}$ in diameter (Dibble and Lorrain 1968). Burned rock middens are often attributed to this period based on projectile point types, but many have not been directly radiocarbon dated (i.e., Hinds Cave). Often these middens contain multiple types of projectile points, leaving some uncertainty as to the period represented by a given midden. Excavations at Piedra del Diablo Site (41VV263) encountered a 30 to $45 \mathrm{~cm}$ thick burned rock midden about $10 \mathrm{~m}$ in diameter (Prewitt 1970). This yielded charcoal as well as Marshall and Castroville points. Excavations of ring middens in Crockett County revealed central cooking features and yielded a few Late Archaic materials (Moore 1983). Recent eligibility-testing excavations at many burned rock middens in Brown County, at the northern edge of the Central Texas region, have been radiocarbon dated to this period (Mauldin et al. 2003). Further west in Terrell County, the Wroe Ranch site yielded six radiocarbon-dated features of this period, including a layer of dense burned rocks, a cluster of 10 burned rocks on a large fiber mat, a $44 \mathrm{~cm}$ diameter by $12 \mathrm{~cm}$ deep ash pit, a circular fiber "nest", and a circular grass-lined basin (Turpin 1998). Dering (1996) interprets the crescent midden at Hinds Cave as having functioned as an oven, and concludes that lechuguilla, sotol, onions, and possibly
Yucca Torreyi are the most likely candidates for baking in the oven.

In addition to the characteristic Ensor and Frio points in the Blue Hill period, the stone tool assemblage also includes a variety of forms including: bifaces, various scrapers, choppers, drills, edge-modified flakes, gravers, burin spalls, painted pebbles, and abraded stones (Collins 1974, Period H). At Arenosa Shelter, this period focused on tool stones recovered from river gravels. Cobbles were shaped into bifacial preforms with limited secondary trimming and no heat treatment (Collins 1974). Tool maintenance and modification are present. Projectile points appear to exhibit poorly controlled percussion and pressure flaking and relatively thick biconvex cross sections. Many edge-modified tools exhibit a highly glossy sheen apparently imparted by cutting, interpreted by Collins (1974) to be the result of harvesting plants.

Clay figurines apparently are part of some Late Archaic assemblages, although most occur with Middle Archaic dart points (Shafer 1975). Shafer tentatively estimated an age range from about 4,000 to 2,000 B.P. based primarily on associated diagnostic projectile points. Specific functions or use of these objects are conjectural (Shafer 1975).

Bundle burials occur in the Blue Hills subperiod with individuals wrapped in painted mats (Turpin 1991, 1995). Stable carbon and nitrogen isotope analyses on two Late Archaic individuals indicate a diet based on CAM plants and $\mathrm{C}_{3}$ animals (Huebner 1991a).

The Red Linear pictographs have been initially radiocarbon dated to the Blue Hills subperiod (Ilger et al. 1994), although Turpin postulates they may have been initiated earlier in the Cibola subperiod. Painted mats were also recovered with bundle burials. 


\subsection{The Late Prehistoric Period (1,300 TO 300 B.P.)}

\subsubsection{Central Texas}

In the Central Texas archeological region, the Late Prehistoric, dating between ca. 1,300 and 300 B.P., is recognized by the introduction of the bow and arrow. This period is divided into two subperiods, early and late, which correspond to the Austin and Toyah "phases" or "intervals," respectively. The Austin period, characterized by the Scallorn and Granbury arrow points, lacks evidence of pottery, though pottery is common in the later Toyah period sites. When there is good stratigraphy and context at sites that contain both intervals, the Austin material is below the Toyah. However, some radiocarbon dates overlap in time in some parts of Texas and indicate that these two cultural patterns had a degree of temporal overlap (Prewitt 1982b). Toyah materials are primarily dated to between 650 to 300 B.P. (A.D. 1300 and 1650) (Prewitt 1981a, 1985; Creel 1990; Treece et al. 1993b; Johnson 1994; Ricklis 1994b; Quigg and Peck 1995).

Although four projectile point types-Scallorn and Edwards in the Austin phase and Perdiz and Cliffton in the Toyah-- are linked to these two time intervals, there appears to be some uncertainty as to the temporal position of the Edwards type. Prewitt (1981a) does not mention Edwards in his Central Texas chronology. However, the Edwards type was defined by Sollberger in 1967 (1971), stemming from excavations in rockshelters and burned rock mounds in Kerr County of the southern margin of Central Texas. Hester (1978) sees the Edwards type as the earliest arrow point form in southwestern Edwards Plateau based on radiocarbon dates from the La Jita Ste in Uvalde County that are around 1,000 B.P. and their stratigraphic occurrence primarily below other arrow point types. Prewitt (1995) indicates the
Edwards points are primarily distributed across most of South Texas and into the Central Texas region, with some as far west as the Trans-Pecos region.

The Rainey Site (41BN33) in Bandera County (Figure 3-4) is one of the few well-stratified Late Prehistoric sites in Texas, with multiple discrete events containing Edwards points below the Perdiz points and sometimes associated with Scallorn and Sabinal points (Henderson 2001). Many radiocarbon dates on charcoal from the Rainey Site provide ages for the Edwards points around 900 to 1,000 B.P. Two dates associated with Perdiz occupations (Zone IVe) revealed ages between 670 and 790 B.P. These ages are some of the earliest dates for Toyah occupations in the region. Above this dated zone were other, presumably younger, Perdiz occupations (Zones III, IVa, IVb, IVc, and IVd).

The Toyah archeological manifestation is represented by many sites scattered across a broad area of Texas, except for the panhandle region. Most excavated Toyah sites probably were short-term camps that focused on limited activities such as meat processing (Mustang Branch Site-Terrace; Ricklis 1994b), tool production (Barton Site-North; Ricklis 1994b) and bone grease/pemmican processing (Rush Site, Quigg and Peck 1995; Quigg 1997b).

The material assemblage consists of a constellation of items including large thin bifaces, two and four beveled Harahey knives, Perdiz arrow points, arrow point preforms (the so-called Cliffton point type), end-scrapers, flake drills, prismatic blades, utilized and edgemodified flakes, spokeshaves, choppers/mullers, and hammerstones (Johnson 1994; Collins 1995). Large slabs have also been recovered from campsites, and their context and visual attributes support their use as anvils and/or butcher blocks used for processing meat products (Quigg and Peck 1995). 


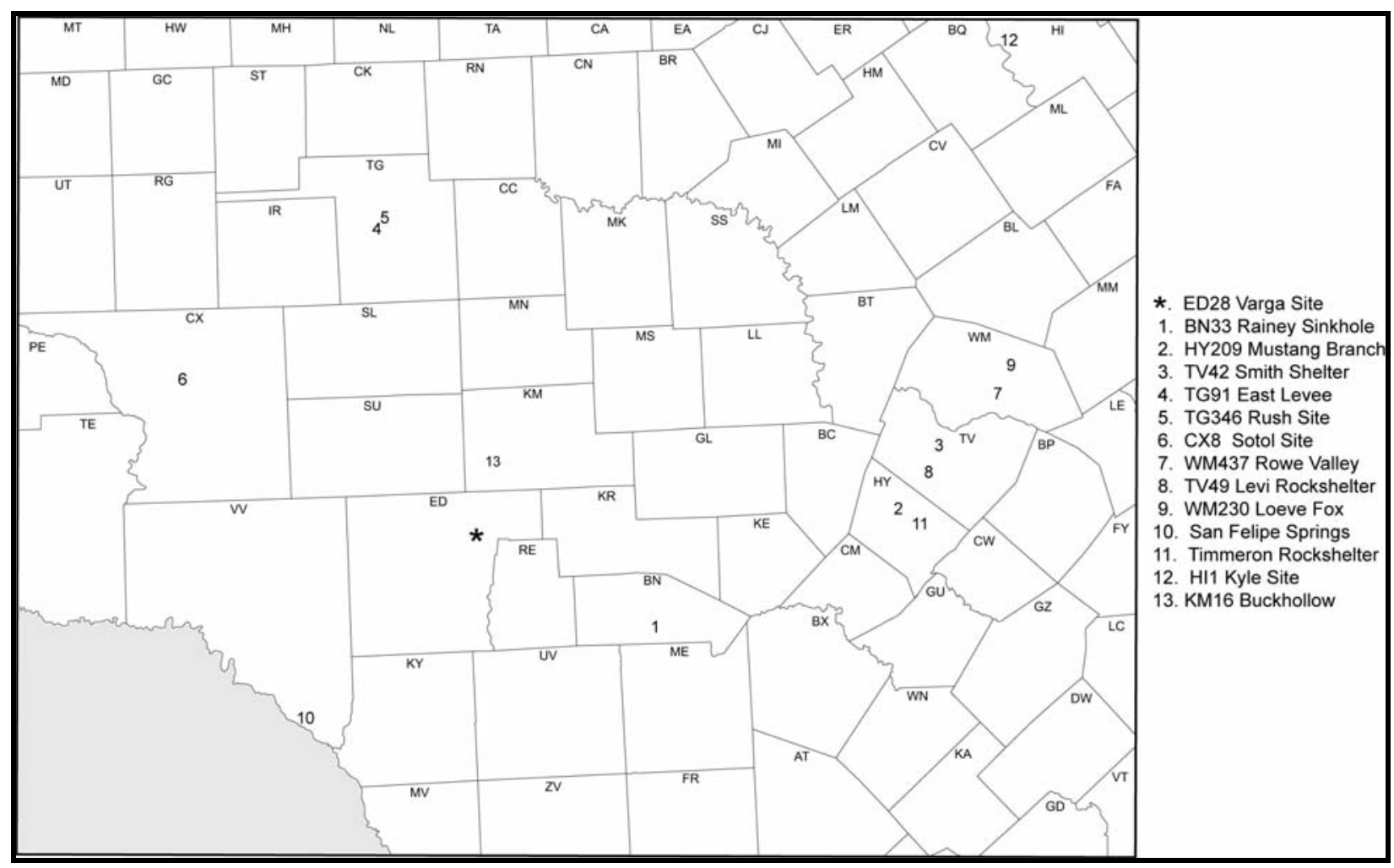

Figure 3-4. Selected Late Prehistoric Sites Near Varga Site

Grinding implements, metates, manos, and abrading stones are present at many sites (i.e., Johnson 1994). A soapstone pipe was recovered from 41TG91 (Creel 1990), and a ceramic bonetempered pipe was recovered from Mustang Branch (Ricklis 1994b). Other types of items include bone beads and awls, various bone tools, antler sections, and mussel shell pendants and beads as integral parts of the artifact assemblage (Prewitt 1981a; Creel 1990; Treece et al. 1993b; Johnson 1994).

Also present are Cliffton points (Suhm et al. 1954) that are often referred to as unfinished points or preforms for the Perdiz point (Turner and Hester 1993; Johnson 1994), but apparent impact breaks on some specimens hint that this was a finished tool. In several sites, a small number of different arrow point types occur in direct association with the more frequent Perdiz points and include Harrell, Lott, and Garza points (Creel 1990; Quigg and Peck 1995). Johnson (1994:91-93) illustrates several small triangular specimens that he refers to as preforms for notched type arrow points. The presence of multiple point types may indicate the interaction of different groups.

The tool industry appears to represent a coreblade technology (Bond 1978; Ricklis and Collins 1994). Apparently, byproducts of biface manufacture in the form of thin flakes, were selected for arrow point production (Ricklis 1994b:236), and probably other tools as well. This is an interesting adaptive pattern and reflects an optimally efficient use of the raw 
material. Cores are most often largely unidirectional with more or less flat platforms.

Bone tools have also been recovered from many Toyah sites, although not in large quantities. These include items such as awls, flakers, needles, beads, and various shaped and worked bone pieces (i.e., Jelks 1962; Creel 1990; Treece et al. 1993b; Johnson 1994; Ricklis and Collins 1994; Quigg and Peck 1995).

Pottery has long been recognized as a key component of the Toyah assemblage (e.g., Suhm 1955, 1957). In Prewitt's (1981a) synthesis, he identified the pottery as Leon Plain and Doss Redware. Recently, Johnson (1994) refers to these typological categories as outdated and collectively refers to Toyah ceramics not by name, but rather its attributes, including thinwalled vessels, surficial smoothing with a flat wide stick or cane instrument, and fine crushedbone temper. Colors vary from a light reddishtan, to orange or brown, and vessel surfaces were generally undecorated. Wide-mouthed bowls and relatively deep jars are recognized vessel forms. Bowls often exhibit distinctive matte-finish wash on the interiors, and vessel surfaces were occasionally slipped. Rims are usually thin and beveled on their inside edges. Forming clay ropes/coils and attaching these on top of one another and then smoothing out the joints was the primary method of construction. The aplastic additives to the clay are dominated burned and calcined bone, but various quantities of quartz sand and other particles have been detected as well (Reese-Taylor 1993, 1995; Robinson 1999).

Despite only a few petrographic and other source studies that have been conducted on Toyah ceramics, Johnson (1994) stated pottery did not often move across drainage systems. Petrographic analysis on seven sherds from San Felipe Springs (41VV444) and previous petrographic analysis on nine sherds from
Infierno sites (Turpin and Robinson 1998), all in Val Verde County, were compared (Robinson 1999). At the petrographic level, Robinson (1999) sees fundamental technological similarities with only minor, regional variations in the matrix, but sees no distinctive or even subtle differences between the Infierno and Toyah phase pottery from San Felipe Springs. The regional variations probably represent different areas of localized production.

A large INAA has recently been completed on a variety of Late Prehistoric pottery sherds collected from many sites across the southwestern and central part of Texas. The results of the INAA on the sample of nearly 400 sherds reveal at least six compositional groups, and provide some interesting geographical distributions (Creel and Johnson 2002). The distribution provides insights into pottery production localities and movement of vessels across the landscape.

The frequency of ceramic sherds varies considerably at Toyah sites, as does the number of vessels represented. As examples, 480 sherds were recovered from Mustang Branch, and they represent five distinct vessels (Ricklis 1994b). At the Rush Site, only 184 sherds were recovered from Occupation 4, and they represent at least seven vessels (Quigg and Peck 1995). Interactions with other groups are indicated in the ceramic assemblage as brushed exterior vessels similar to Caddo types have been recovered in low numbers at several Toyah sites (Quigg and Peck 1995; Ricklis 1994b). However, painted trade vessels from the southwestern part of the U.S. have not been detected in any Toyah components.

Chemical analyses (fatty acids) on sherds have been infrequent, but have yielded animal lipids indicating that vessels were used to cook meat products (Loy 1994). Stable carbon and nitrogen isotope analyses on residues extracted 
from sherds have also indicted vessels were used in cooking meat products and in the rendering of bone grease (Quigg and Peck 1995).

Burned rock features including large and small hearths, rock lined and filled hearths, burned rock dumps, and although not many, at least one large burned rock midden (Honey Creek Midden at 41MS32) have been attributed to the Toyah period (Black and Creel 1997). Most archeologists do not see the larger burned rock middens as part of the Toyah Interval, although often a Toyah component lies directly on top of a midden deposit (Ricklis and Collins 1994; see Black et al. 1997 for different view). Limited burned rocks have been subjected to chemical residue analyses. The few chemical results support their use in cooking meat products (Loy 1994). Various other features identified include ash, charcoal and bone concentrations, bison rib alignments, clay-lined pits, knapping stations, organic stains, oxidized areas, and unlined pits (Treece et al. 1993b).

Sizeable quantities of animal bones such as bison, deer, and antelope are often associated with the Toyah sites and reflect a population focused on large game animals (i.e., Creel 1990; Shaffer 1994; Ricklis and Collins 1994; Quigg and Peck 1995). This represents a dramatic shift in subsistence from the earlier Austin phase with its broad-based hunting and gathering economy. At Mustang Branch Site, extensively butchered bone in great quantities was detected and represented a minimum of 19 adult deer, six fetal deer, eight antelope, and two bison. The presence of this many animals processed at one event are testament to group cooperation in the procurement and processing of bulk resources (Masson and Holderby 1994). The frequent fragmentation of bones at sites like Barton and Rush indicate that bone grease production was also undertaken (Masson and Holderby 1994; Quigg and Peck 1995; Quigg 1997b). The tool assemblage documents the intense procurement, butchering, and processing of the meat products.

Although there has been a tendency to view Toyah groups as hunters of large game, it is clear that they also collected mussels from streams for use as food (Creel 1990). Presumably, plants were gathered as sources of key nutrients and fiber. Fish, turkeys, rabbits, and turtles were also food resources, as indicated by their presence at several Toyah sites (Creel 1990; Shaffer 1994; Quigg and Peck 1995). Charred mesquite seeds and pods were recovered from the Rush Site (Quigg and Peck 1995). Although very late in time, and with agricultural practices underway in the northeast part of Texas, minimal evidence is available for agricultural crops through a few corncobs (Jelks 1962; Harris 1985) were found in Toyah contexts at the Kyle Rockshelter (Jelks 1962) and at Timmeron Rockshelter (Harris 1985). These may represent agricultural produce that was obtained via exchange between Toyah groups and Caddo farmers to the east. The Kyle Site yielded perishable materials including twisted cordage, pieces of mats, coiled basketry fragments, arrow fragments, a notched stick, pointed sticks, pointed wooden splinters, wood shavings, and pieces of tanned deer skins (Jelks 1962).

Human burials have been found as isolated interments (i.e., Kyle, Jelks 1962) and in cemeteries (i.e., Loeve-Fox, Prewitt 1974, 1982b) with interred bodies in various positions and 10 cremations. The burial at Kyle was a cremation that had been wrapped in an unwoven fiber mat and lacked mortuary offerings. Several bodies reflect conflict and/or hostilities between groups as different arrow point types such as Perdiz points in bodies at Asa Warner \#2 (Watt 1956), as well as Scallorn points embedded in human remains (Prewitt 1974; Huebner and Comuzzie 1992). Some interaction probably occurred with Caddoan groups to the 
northeast as indicated by some Caddoan vessel types. Some contact probably was with coastal groups as the bodies in Loeve-Fox were associated with conch shell pendants (Prewitt 1982a, 1982b). Radiocarbon dates from LoeveFox indicate a period between 1,300 and 700 B.P. (Prewitt 1982b), thus placing this cemetery within the time range of the Austin phase.

It has been suggested that Toyah represents bison hunters who migrated into the area bringing their own technology and changes in adaptive strategies (Prewitt 1981a, 1985; Johnson 1994), or, conversely, that the Toyah assemblage represents the adoption of a particular tool kit, well-suited to large-game hunting and processing, by a wide range of hunter-gatherer groups who were indigenous to the region (Ricklis 1992, 1994b; Collins 1995). The adaptive system involved relatively high subsistence mobility as a correlate of extensive use of large game such as bison, deer, and antelope. The wide distribution of Perdiz interval assemblages across the Texas landscape opens the debate as to whether or not the Toyah interval represents the spread of ideas or people. Black (1986) and Ricklis (1992, 1994b) see it more as a widely adopted techno-complex, whereas Johnson (1994) sees it as a single ethnic group.

\subsubsection{The Lower Pecos}

In the Lower Pecos archeological region, this time interval is divided into two periods, the Flecha period (1,320 to 450 B.P.) and the Infierno phase (450 to 250 B.P.) (Turpin 1988, 1991). The change from Late Archaic times is characterized by the introduction of the bow and arrow and in the case of the Infierno phase the addition of pottery. Various small arrow points such as, Scallorn, Perdiz, Livermore, and Toyah styles, characterize the Flecha period (Turpin 1988:8), but individual components with only one type of projectile have not been identified. Circular stone rings and the distinctive Red Monochrome pictographs have been attributed, but not demonstrated, for this period (Turpin 1988). A child burial from Wroe Ranch in nearby Terrell County has yielded two radiocarbon dates of about 660 B.P. (Tx-5430 and Tx-6431) on plant fibers from a grave pit and falling within this period (Turpin 1998). The grave also contained sotol stakes, grass, prickly pear pads, and an antelope robe. Thirtyeight coprolites from Baker Cave, dating to about 1,050 B.P., indicate that the diet included prickly pear cactus, onion bulbs, fish, bird, rodents, and fiber from sotol, prickly pear, and yucca (Sobolick 1991a, 1991b). Diet in the Lower Pecos does not appear to have substantially changed through time as many of these same resources were documented for the Early Archaic period back to about 9,000 B.P. Pollen from grasses, sagebrush, and Brassicaceae were also in the coprolites. No cultivated species were identified. Overall, very little is known about this period in Western Texas. Turpin (1995) attributes the limited information for this period to highly disturbed deposits in the upper levels of the investigated rockshelters. The rock art changes to a Red Monochrome style and Bold Line Geometrics (Turpin 1991, 1995).

The Infierno period is said to be distinguished by small triangular stemmed arrow points (not typed) together with plain brownware pottery, steeply beveled end-scrapers, prismatic blades, and circles of stones forming house foundations (Turpin 1988, 1991). The Infierno phase has not been securely dated by radiocarbon dates and much remains to be learned about the artifact assemblage. The estimated age is post 450 B.P. (Turpin 1991:36-37).

The plain pottery, although not clearly defined, has been thought of as the key index marker. Only 12 ceramic-bearing sites, yielding less than 
100 sherds nearly all of which are bone tempered, have been located in the Lower Pecos region. This ware is described as coil made, low fired in open oxidizing atmosphere, with surface colors ranging from orange-red through yellowish-brown to pinkish and light tan, the cores have black and gray carbon streaks, the exterior surfaces show smoothing and polishing, vessel walls range in thickness from 2 to $9 \mathrm{~mm}$, and vessel form is unknown (Turpin and Robinson 1998). Petrographic analysis on 11 prehistoric sherds indicates a combination of bone and calcium carbonate aplastic additives (Turpin and Robinson 1998). The pottery consists of plainware sherds with surface smoothing and polishing, occasional red-slipped surfaces, poor firings, bone and calcite-tempered brownwares with dark cores (Turpin 1995; Turpin and Robinson 1998).

Petrographic analyses on Infierno phase and Mission pottery sherds indicate the presence of similar tempering agents and potentially some continuity in the ceramic assemblage over time or between groups of Natives (Turpin and Robinson 1998). Recent petrographic analysis on seven plainware sherds thought to represent the Toyah phase ceramic industry from San Felipe Springs (41VV444) were compared with petrographic analysis of nine Infierno phase sherds from five sites in the Lower Pecos region. The results indicate no distinctive or even subtle differences in the Toyah and Infierno sherds sampled (Robinson 1999). Robinson (1999:188) interpreted this to indicate that there are no discernable technological or compositional differences between the bone-tempered pottery of classic Toyah phase and the bone tempered pottery of the western Toyah and Infierno phases of the Lower Pecos proper. At 41VV444, one charcoal sample from the base of same stratigraphic position in the A horizon that yielded 97 percent of the Toyah sherds yielded a radiocarbon date of $600 \pm 80$ B.P. (Beta-116161E; Mehalchick et al. 1998). It appears that the plainware ceramic technology was shared knowledge across a vast region, and production occurred at many different places as evident in slightly different percentages of additives.

Tool technology is seldom discussed with a few exceptions such as the work by Collins (1974) on materials from Arenosa Shelter. Though not directly attributed to the Flecha period, the technology observed for the Late Prehistoric was that of cobble reduction by direct percussion. The cores and flakes served as blanks for further unifacial and bifacial reduction. Most arrow points were produced on flakes. Unifaces, bifaces, burins, and gravers are represented.

Burned rock was still a very important aspect of this period with small clusters, hearths, large crescent shaped concentrations, and circular ring middens. Information concerning these and other features is constrained by the limited number of components excavated and dated to this period. North of the Lower Pecos region in Crocket County, slab lined hearths 1 to $1.5 \mathrm{~m}$ in diameter, with basin-shaped cross sections have been radiocarbon dated to this period (Word 1971). The charcoal dates from hearth 1 (A) were $940 \pm 120$ B.P. (Tx-310), $630 \pm 90$ B.P. (Tx-357), and $540 \pm 80$ B.P. (Tx-358). A second series of slab lined basin hearths were observed in profiles and charcoal from between the two was dated to $670 \pm 80$ B.P. (TX-351), $570 \pm 100$ B.P. (Tx-359). Diagnostic projectile points include Perdiz arrow points and Ensor dart points, although the dates place these features in the Late Prehistoric period.

The burial patterns are diverse and include cremations (Turpin 1988), cairn burials (i.e., Las Haciendas, Mallouf 1987), flexed, and seated bodies, which may reflect movement of different peoples into the region. A single cremation from Zone 1 at Seminole Sink yielded two radiocarbon dates on charcoal from the cremation of $390 \pm 80$ B.P. (Beta-10472) and 
$470 \pm 150$ B.P. (AA-946) (Turpin 1988:32). No artifacts were found in association, though the two dates correspond to the Flecha and Infierno periods. An infant burial from Wroe Ranch had been wrapped in an antelope skin robe, lined with hair. At the same site, a flexed child burial was placed in a grass-lined pit outlined with bent sotol stalks, and covered by an antelope robe, two mats, a large rock, and a scattering of prickly pear pads. This burial yielded two radiocarbon dates of $700 \pm 135$ B.P. (Tx-5430) and $760 \pm 160$ B.P. (Tx-5431) (Turpin 1998). Although some distance to the southwest in Mexico, the Las Haciendas cairn burial implies some degree of care extended to the dead. Besides a prominent location and the energy and time invested in construction of the burial placement, the interred individual was provided with an extraordinary large assemblage of Perdiz arrow points $(n=180)$ directly associated with 14 points representing four other types. These attributes from this cairn burial and those elsewhere point to a belief in the after life.

In general, the inhabitants of the Lower Pecos region are thought of as foragers. These folk collected and hunted a wide range of plants and animals, and lacked any cultivated crops. They were also extremely mobile, relocating to where resources were plentiful. Turpin (1991 and personnel communication 2007) believes the Infierno phase of the Lower Pecos is distinctive from the Classic Toyah of Central Texas, based on the presence of circular stone tipi rings, calcite temper in pottery, and a dearth of Perdiztype arrow points.

\subsubsection{Protohistoric and Historic Periods (400 to 200 B.P.)}

The end of prehistory is marked by the arrival of the written record to the region and contact between Native Americans and Europeans. The Spanish were the first Europeans to encounter and describe Apaches during Coronado's expedition in A.D. 1541. A Spanish expedition under the direction of Gaspar Castano de Sosa passed through the Lower Pecos region on their way to Pecos Pueblo in A.D. 1590 (Hammon and Rey 1966; Wade 2003). However, Native Americans remained in control of the region until the Europeans began to establish settlements and the arrival of the railroad in the region in the middle of the nineteenth century. The initial period of only very limited EuropeanNative interaction is referred to as the Protohistoric period. One would expect to see trade goods of metal and glass, such as metal arrow points or knives, and glass trade beads, appearing in native campsites if sites of this period. Few sites of this age have been recognized or documented, however.

Mission San Lorenzo de la Santa Cruz was founded by Franciscan missionaries of the College of Queretaro in the winter of A.D. 1762 near Camp Wood about $21 \mathrm{~km}$ (35 mi) south of the Varga Site. The mission was established to convert Lipan Apache Indians. Investigations, both archeological and ethnohistorical, were pursued in A.D. 1962, culminating in a report by Tunnell and Newcomb (1969). The Native cultural assemblage includes sandy paste potsherds, Perdiz and triangular arrow points, chert blade scrapers, a tubular stone pipe, and chert flake tools.

Some 27 federally recognized tribes and several Native American organizations have been linked to the Lower Pecos archeological region (Kenmotsu and Wade 2002), having ranged through the area in historic times. In their extensive studies of the early literature for that region, researchers have not been able to link one specific group to the archeological remains in the region (Kenmotsu 1994, 2001; Kenmotsu and Wade 2002, 2003).

Collins (1995:373) acknowledges the difficulty in tying the prehistoric record to the 
ethnographic records and stated that Central Texas archeological materials cannot be linked with ethnohistorically recorded indigenous groups. Attempts to link the archeological Toyah assemblage to the Tonkawan populations has been unsupported, since ethnohistorical information indicates that the Tonkawas moved into Central Texas from the north during the Seventeenth Century (Campbell 1988; Newcomb 1993).

The Bosque-Larios Expedition, undertaken between April 30 and June 12, 1675, traveled within the general vicinity of the Varga Site (Wade 2003:24-52). The fundamental aspects of Native lifeways in this area, revealed by the records of this expedition are 1) bison hunting was an important subsistence activity that permitted, or at least helped to facilitate, relatively large aggregations of people, 2) Native settlement/subsistence patterns involved a fission-fusion (aggregation-dispersal) residence pattern, 3) aggregate-group populations may have numbered from several hundred to over one-thousand people, 4) constituent groups tended to form "coalitions" for the purpose of mutual defense against common enemies; 5) intergroup conflicts were fairly common, and involved killing of enemies, cannibalism, and the taking of captives, and, 6) very interestingly, the Mexican language (i.e., Nahuatl) was spoken as a lingua franca, if not on the southern Edwards Plateau, at least as far north as the Rio Grande Plain immediately to the south of the Plateau. This, along with the pattern of group coalitions, warns against a simplistic assumption that the hunter-gatherers of the region lived in geographic or cultural isolation from a larger, more inclusive world It is not clear, however, whether or not the natives observed by BosqueLarrios made use of horses for travel and/or transport; were this the case, it would have dramatically affected residential mobility patterns and long-distance interactions between groups. Further, the speaking of Nahuatl in this area might actually reflect little-understood postconquest shifts in cultural geography as, for example, Nahuatl-speaking Tlaxcalan people were relocated northward under the auspices of the Spanish Colonial authorities.

While the historic documentation provided by Wade (2003) widens our anthropological perspective, it does not provide us with specific empirical tools for interpreting most of our inherently limited archeological data, as the patterns she reveals are not the sort that will be directly represented in the material record within an archeological site context. Indeed, Wade's material is yet another cautionary signal that the limits of archeological data should not be assumed to represent directly corresponding limits on the cultural experience of the past people we are trying to study and understand. For example, there is no clear indication at Varga that the Toyah group(s) that occupied the site could have been members of a larger population (or “coalition”). As far as we know, the Toyah component is spatially restricted, and there is very little in the way of exogenous cultural material that might alert us to interaction with people beyond the local group, or perhaps a number of groups that comprised a relatively local population.

Wade's presentation of the documentary record does, however, alert us to the possibility that the extremely scarce archeological evidence for widespread interactions at Varga (i.e., the very scant marine-shell items and a single sherd of El Paso Polychrome pottery), may represent extensive, inter-group exchange and concomitant information flow that archeologists might not otherwise fully appreciate, given the quantitatively rare occurrences of such materials at the site. And, of course, the extensive distribution of the Toyah artifact assemblage in itself probably represents wide-ranging information flow across smaller-scale social boundaries, as has already been implied or 
explicitly discussed at some length in the Texas archeological literature (e.g., Black 1986; Ricklis 1992, 1994; Arnn 2007). Additionally, Wade notes several instances of documented inter-group gift-giving, in which regional hunter-gatherers offered presents/gifts to
Spaniards. It is not too far-fetched to assume the Indians did this among themselves, as well, and this might account, as a specific mechanism, for the just-mentioned rare exotic artifacts from the Varga Toyah component. 



\subsection{RESEARCH DESIGN}

Jeffrey D. Owens

This research design is organized in two major sections. Following this introduction, Section 4.1 discusses the general theoretical research orientation that informed this project, including the cultural- ecological and culturehistorical perspectives that underlie the proposed program of research. Section 4.2 presents detailed discussions of specific research questions, underlying assumptions, data needs, and investigative strategies. These research questions are organized according to several general research domains, including Paleoenvironmental Reconstruction, Subsistence, Technology, Culture History, and Mobility and Land Use. The specific research questions posed within each of these topical sections are relevant to overall theoretical concerns, and many of them are more pertinent to some archeological components or to some subsets of data than to others.

The proposed research design was submitted to TxDOT following the second interim report from the second phase of data recovery. That research design was accepted by TxDOT and presented in the initial draft of this report. Subsequently, this research design was slightly reworded to read as to what eventually occurred in the final analysis.

\subsection{Theoretical Orientation}

The proposed research program for the Varga Site takes advantage of the unique opportunity afforded by a site that contains multiple cultural components that can be relatively clearly defined both stratigraphically and chronologically. In addition, data recovery excavations at the Varga Site yielded substantially larger samples of material for some cultural periods than any that are known in southwestern Texas (especially the Early Archaic). The Varga Site stands, therefore, to make a substantial contribution to our understanding of prehistoric hunter-gatherer systems in southwestern Texas, a region that has remained less well-studied than adjoining, better-researched culture areas (i.e., Central Texas, Lower Pecos).

The general theoretical orientation adopted in this study combines cultural-ecology, a contextual framework that seeks to identify and explain the adaptive relationships of human populations to their environments, and the culture historical approach, which views culture history as a succession of cultures as normative patterns. These two paradigms provide complementary perspectives, insofar as the sequential ordering of cultures emphasized by culture history overlaps with a historical human ecology that sees cultural changes as adaptive processes that, over the long-term, result in alterations in the complex adaptive system that is culture (see Butzer 1982). While these two fields of inquiry can be misunderstood to be mutually exclusive, they in fact simply represent different modes of interpretation that entail different assumptions about the meaning and causes of variability in the archeological record. The ways in which these two interpretive strategies will be operationalized in the present study will be highlighted throughout the following discussion and throughout the consideration of specific research questions presented in Section 4.2. 


\subsubsection{Systems Theory and The Archeological Record}

As with any formal undertaking, this archeological research program was guided by several assumptions of a basic theoretical nature. First and foremost, as alluded to above, culture is envisioned as a complex adaptive system by which human populations interact, via adaptive decisions and behavior, to the opportunities and constraints afforded by the resource mosaics within their environments. Specifically, a cultural system can be characterized as a system by reference to its structure and organization. The structure of a system derives from the number, nature, and arrangement of its dynamically interdependent components at a given point in time. The patterned interactions among these constituent parts comprise the organization of the system (cf. Clarke 1968; Ellen 1982; Firth 1975; Geertz 1973; Tainter 1977; Butzer 1982).

In this context, the abstract, composite dimensions that permit the characterization of the structure and organization of a system are denoted in terms of the integration and differentiation of the system as a whole (Lawrence and Lorsch 1980). Differentiation is defined as the state of segmentation of the entire system into subsystems, and integration refers to the unity of effort among various subsystems in the accomplishment of adaptive tasks (cf. Flannery 1968). A task refers to a complete input-transformation-output cycle. Thus, an organization is a system composed of the interrelated behaviors of people who are performing a task that has been differentiated into several distinct subsystems, each subsystem performing a portion of the task, with the efforts of each being integrated to achieve effective performance of the system. The totality of the differentiated subsystems and the relationships among them comprise the organizational system (Lawrence and Lorsch 1980).
The meanings of these terms, as operationalized in this discussion, are most closely approximated by definitions derived from the fields of systems theory and cybernetics. The fundamental theme underlying the analysis of culture systems in these fields concerns the assumption that cultural systems are basically analogous to biological systems (Cadwallader 1980). As "living" systems, both organisms and societies are essentially open systems (Miller 1978). An open system, as defined by Bertalanffy, is "a system in exchange of matter with its environment, presenting import and export, building-up and breaking down of its material components" (1978:141). The basis of the open system model is the dynamic interaction of its components. In an open system, increase of order and decrease of entropy is thermodynamically possible, and an open system may "actively" tend toward a higher state of organization.

Open systems maintain homeostasis or stability through "dynamic equilibrium," the establishment and maintenance of an approximation of parity between inflow and outflow, with the external environment (Bertalanffy 1968; Miller 1978). In this way, certain components will continuously break down, thereby releasing energy, and new energy will be imported, making it impossible for the system to establish the true equilibrium (i.e., "heat death") of the closed system model. In an organism, failure to maintain a relatively even balance between the inflow and outflow of energy results in death; in a species, extinction. Thus, processes of regulation and control represent the unifying mechanisms in systems theory and cybernetics that account for the disparate internal movements of an open system.

By definition, all systems are more or less dynamic phenomena as they are maintained by movement of matter, energy, and information into and out of the system and between internal 
subsystems. In complex adaptive systems, dynamism is expressed in terms of multiple, definable system states, any one of which probably never achieves sufficient stability to represent true homeostasis (Clarke 1968). The steady state, in which negative feedback prevents rapid change in the structure of the system, is probably the most stable equilibrium that living systems ever achieve (Ricklis and Collins 1994). When negative feedback mechanisms give way to positive feedback loops that promote ongoing, directional change, the system is in a state of dynamic equilibrium. When drastic or abrupt change occurs in the environment, or when the flow of free energy through the system dramatically increases or decreases, the basic organizational structure of the system may become destabilized. Apparently small perturbations in the environment or within the system itself can produce minor modifications to system structure or lead to catastrophic collapse depending on the initial conditions of the system and the variability of circumstances surrounding the perturbations; conversely, the system may rapidly reorganize itself to a higher level of organization that is capable of operating within the new energetic conditions. Such changes may be attended by greater internal organizational complexity, the emergence of higher scales of order involving higher-level integrative mechanisms, and/or increased specialization or simplification of certain subsystems.

Theoretically, cultures as complex adaptive systems may remain relatively stable or change at varying rates depending upon the overall equilibrium states of the human ecosystem, the initial conditions of the system, and the energetic circumstances of episodic change. Simple mechanical models of complexity have been developed that have implications for the analysis of cultural systems. Laszlo's (1987) formulation, for instance, is predicated on a definition of system complexity in which higher levels of complexity are produced by the development of mechanisms that integrate numerous complex subsystems into a systemic whole. In this sense, integrative mechanisms can be used as measures of the scale of complexity within a human organizational system. Examining the timing among the emergences of these mechanisms provides one avenue for building arguments about the tempo and mode of cultural evolution. Culture, then, is conceptualized as an organizational system composed of various regulatory mechanisms responsible for managing the transference of energy from the environment to the social sphere and for directing the flow of energy between segments of the social universe. This emphasis on the relationship between culture and the natural environment is considered to be of fundamental importance in understanding the structure and organization of hunter-gatherer, as well as more complex types of, societies. In the case of hunting and gathering adaptations, the distribution of natural resources, which represent sources of available energy, act as primary determinants in the distribution of population across a landscape. Although the range of potential energy sources varies regionally and through time, such resources as vegetation and animal communities and the source locations of lithic materials used in the production of technomic artifacts were probably of fundamental importance throughout prehistory.

In emphasizing the primacy of environmental considerations, it is not deterministically assumed that human populations are at the mercy of their environment. Quite to the contrary, the redundant and diversified components of cultural systems tend to buffer the effects of environmental fluctuations, providing human populations with a range of possible solutions through which equilibrium of the culture may be maintained. Still, the ethnographic literature has largely borne out the 
notion that the "logistical strategies" of huntergather systems, in particular, tend to be organized around the distribution of natural resources (Binford 1983; Kelly 1983, 1995; Hayden 1986, 1987). More complex social organizations, such as those that correlate with, pastoral, or industrial modes of adaptation, must be viewed in the same terms at some level, but the degree of differentiation and integration and the scale at which such systems are organized necessarily tends to be more complex along both horizontal and vertical dimensions. In other words, complex societies are, by definition, generally characterized by greater rank differentiation and economic specialization and are therefore increasingly capable of regulating greater variability in task delegation and in performance and management of energy flow (Tainter 1977). Although exceptions to the rule have been documented (cf. Lee 1979; Lee and DeVore 1976), hunter-gatherer societies are generally characterized by less complex organizational systems and tend to exhibit less status differentiation, lower population levels, and smaller population aggregates. Consequently, the logistical strategies of huntergatherer systems are more directly articulated with the distribution of natural resources. As such, the adaptive responses of hunter-gatherer systems are more likely to manifest either in the form of increased mobility and/or transformations in other social mechanisms, such as increased vertical or horizontal sociopolitical development or enhancement of intergroup trade and interaction networks, to maximize the capture of natural resources. As Cadwallader (1980:342) has pointed out, "an open system, whether social or biological, in a changing environment either changes or perishes. In such a case the only avenue to survival is change.”

Ultimately, the spectrum of activities involved in the procurement and processing of natural resources, the organization of these activities at certain locations that correspond to natural resource availabilities, and the distribution of activity loci across the landscape comprise the subsistence-settlement system of a huntergatherer society at a particular point in time. Delineating the organization of subsistencesettlement systems consequently represents the first step in understanding hunter-gather adaptations. Arguably, understanding how and why cultures change is one of the primary goals of archeological research; however, the examination of culture change over time properly comes only after the elucidation of organizational systems at particular points in time. This means that the variable system states, or "postures" (Binford 1980), that characterize a particular cultural system at more or less one point in time must be fully delimited before significant temporal variation, such as would be of interest in the investigation of cultural evolution, may even be discerned.

The second major premise underlying this study concerns the relationship between human behavior and the archeological record. Specifically, the structure of the archeological record is assumed to reflect the behaviors and behavioral processes that characterize a cultural system in its pursuit of equilibrium. Sackett has outlined the epistemological consequences of this perspective as follows:

Activities are culturally patterned segments of human behavior that have received ordered expressions in the archaeological record. They are isolated in terms of clusters of associated elements-more specifically, the presence and non-random variation in the complementary distributions of attributes and/or classes of...the "dimensions" of archaeology: space, time, and form. Time and space define the loci of activities, while the activities themselves are formally expressed by artifacts-concrete manifestations of human behavior (1968:69). 
In other words, the spatial and chronological structure of material remains, properly identified, serve as indicators of the activities responsible for the production of observed patterning in the archeological record. Stated another way, archeological materials are the physical residues of the dynamics involved in regulating the flow of energy into, within, and out of organizational systems (Binford 1965, 1980).

Extrapolating from the assumption that many of the activities in which hunter-gatherer populations are engaged across time and space function integrally in articulating effective interrelations with both the natural environment and with other social systems, it follows that archeological remains can properly be considered in terms of an analytical regime designed to detect functional relationships among components of an archeological assemblage (e.g., artifacts, features, ecofacts). Each functional unit within an assemblage reflects a task, or some phase of a task, undertaken by a particular segment, or subsystem, of a society. Relationships among functional units represent activities that may range in specificity, depending upon the scale of analysis, from an individual event, such as the butchering of an animal, to an entire range of behavioral processes that serve as antecedents to observable events, such as lithic procurement practices, organization of stone tool production, and seasonal resource scheduling involved in the capture of the animal.

All other things, including time, being equal, the spatial relationships among functional units of an assemblage, each representing a particular activity, define the structure of activity loci, either within a single site or across a landscape. The spatial relationships among activity loci within a single site define the structure of the site (or components of the site) in twodimensional space. The analysis of site structure, taken together with the relative emphasis on particular activities in relation to others and the spatial organization of activity loci, serve as the basis for interpreting site function. Site function ultimately refers to the relationships among the range of activities performed at one site and those that characterize the occupation of other sites occupied more or less contemporaneously by a single group or by comparable human populations (Winters 1969). Although site function is not, by definition, necessarily a comparative concept, it is most fruitfully understood within a comparative framework. Taken in this context, the study of site function lends itself to the delineation of settlement systems and, ion the case of hunter gatherers, the patterns of mobility that mark the movement of people between temporary settlements, which are nodal points upon the landscape. Ultimately, transformation of any component variable internal or external to an organizational system (which introduces time into the equation), taken together with the reaction of the system to the change, comprises the basis for evaluating variation in system states and/or cultural change. Through the development and testing of hypotheses designed to explain the variability observed, the process of building theory about the processes that catalyze changes in human societies throughout space and time becomes possible.

A note of caution must be advanced within any study oriented toward the delineation of site function. Binford (1978, 1979, 1980), for instance, has demonstrated that site function cannot necessarily be determined in all cases, such as at small, temporarily occupied sites, based exclusively on the material culture inventory observed at the site. On the same note, it may not be possible to detect the full range of functional behaviors undertaken at a locality, particularly if certain behaviors do not have non-perishable material correlates or if the material correlates of an activity exit the 
systemic context (Schiffer 1976) at another location. Furthermore, some natural processes, most notably erosion, may tend to collapse multiple, discrete occupational components of a site, resulting in a situation in which long spans of time and/or multiple system states are collapsed into a single stratigraphic horizon. Thus, one of the central tasks of archeology is the development of methods and techniques designed to detect patterning within the archeological record that is relevant to the elucidation of organizational systems. The relevance of such patterns is necessarily a function of the middle-range arguments that link the observed patterning to behavioral or systemic inferences.

Based on this consideration of first principles, our discussion now shifts to a more explicit examination of the way in which these general theoretical perspectives are operationalized in this research undertaking.

\subsubsection{The Cultural Ecology Approach}

The first theoretical paradigm upon which the current study is based is that of cultural ecology, also known as human ecology. Historically, this perspective derives in large part from the work of Julian Steward (1955), who formulated the theoretical framework of cultural ecology to elucidate the interrelations among subsistence practices, other economic behaviors, and other fundamental cultural patterns, such as social organization. Modern cultural ecology is a diversified field of inquiry that draws upon numerous fields of social science, economics, ecology, and geography. The conceptual threads of the paradigm are too diverse and complex to review in the present context; consequently, only those threads that lead to the basic principles of direct relevance to the present investigation are discussed.

As formulated by Ricklis and Collins (1994:5):
The cultural ecology approach focuses on the adaptive relationships of a culture or group to its environment (Anderson 1973; Helm 1962; Vayda and Rappaport 1968). While derived ultimately from the biological sciences, the ecosystem concept as applied in the archeological and social sciences necessarily incorporates some cultural and cognitive dimensions (Butzer 1990; Moran 1990). Based on the principles of systems theory discussed above, the human ecosystem, as defined here, involves three interrelated components (following Ricklis and Collins 1994:5): (1) human population as a biological phenomenon; (2) the population's environment and the opportunities offered by and the constraints imposed by the geographic and temporal heterogeneity of resources; and (3) culture as the complex adaptive system through which human populations articulate with the opportunities and manage the constraints of the environment to ensure collective survival.

Each of these three dimensions is composed of subcomponents and variables that must be taken into consideration. In general, population reflects adaptive viability by its relative size. Other things being equal, expanding populations result from favorable levels of essential matter and energy flow within the ecosystem, whereas declining populations signal serious systemic problems related either to environmental carrying capacity, disease, or cybernetic difficulties in one or more cultural components. In addition, the patterns of distribution of a population within its environment are key indicators of patterns of socioeconomic organization. In other 
words, patterns of settlement are closely linked, though they may not directly reflect, the geographic and seasonal distribution and availability of resource extraction and processing opportunities.

As previously discussed, culture is the extrasomatic adaptive system involved in connecting a human population with its natural and cultural environment. Among the interrelated subsystems that may come into play in the extraction, processing, and distribution of energy in hunter-gatherer systems are technology, mobility and settlement strategies, social interaction patterns (e.g., intra- and intergroup relationships, marriage and kinship patterns, family and task group structure), political systems and decision-making structures, cosmological and mythological systems, and codes of morality. In archeology, especially prehistoric hunter-gatherer archeology, the more abstract social and cognitive dimensions of cultural systems tend to be very difficult to discern, but it is not theoretically impossible to do so.

Environment is both spatially heterogeneous and temporally dynamic. The spatial availability of resources provides a given population with adaptive opportunities as well as constraints, depending on the variability of availability and/or accessibility. Particularly for hunter-gatherers operating with more or less limited extraction, processing, and transportation technologies, the predictability and concentration (or patchiness) of resources strongly influences the timing, size, and location of socioeconomic groupings. Patterns of settlement and socioeconomic organization are thus closely interlinked with spatial and seasonal patterns of resource availability.

The warranting assumption underlying organizational approaches to explaining cultural variability is that humans seek to maximize certain currencies in their responses to environmental conditions. As Jochim has observed:

\begin{abstract}
Evolutionary ecology is the most coherent of current theoretical frameworks for explaining huntergatherer organization and change. Its underlying assumption is that if behavior has been shaped by natural selection to maximize fitness, certain optimal behavioral strategies may be expected and predicted. Most applications assume further that net energetic efficiency in foraging is a valid proximate measure of fitness, and consequently is maximized by natural selection. This is a simple, reductionist approach that suggests that the allocation of time or energy is determined by the spatiotemporal structure of the system (1989:106).
\end{abstract}

This perspective has been operationalized in archeology in numerous ways. Two of the lines of investigation that have proved most fruitful, and which also appear to have the most potential to make significant contributions to archeological theory building, are Binford's (1980) collector-forager dichotomy and optimal foraging models. A brief consideration of these research strategies will set the stage for the current study.

\subsubsection{The Collector-Forager Dichotomy}

The scheduling and nature of resource acquisition depends on (1) the regional extent and spatial structure of the targeted resource(s), 
and (2) the seasonality and temporal extent of resource availability. In regions in which resources are abundant and available on a yearround basis, hunting-and-gathering groups can theoretically operate without a complex system of resource-acquisition scheduling. As population increases and/or resources become available on a seasonal basis, other strategies are required for the group to remain economically viable (Testart 1982). In areas with low resource productivity and/or irregular availability, complex scheduling of group foraging activities may be necessary to successfully extract and obtain critical resources over the entire year (Rafferty 1985). Research by Binford (1980), Kelly (1983, 1995), and Hayden (1986, 1987) illustrates how resource acquisition strategies among ethnographically documented hunter-gatherer groups can be characterized along a continuum ranging from forager- to collector-oriented.

The foraging strategy consists of a system of moving people to resources for consumption, wherever they occur in space and through time. This strategy involves relatively unrestricted scheduling; rather, the timing of group movement is dictated by resource depletion and the direction of movement is dictated by the location of the next resource or resource patch to be exploited (Binford 1980). This resource acquisition pattern tends to arise when resources are ubiquitously distributed across the landscape or are available over considerable periods of time. In cases in which critical resources discretely occur within an otherwise homogeneous region, settlements may be reused over long periods of time. When critical resources occur discretely within an otherwise homogeneous region (i.e., in "patches"), settlements near critical resource patches may display redundancy in use over long periods of time (Taylor 1964). Under such "tethered" conditions, foragers may develop a settlement pattern composed of two site types, with residential camps located near critical resources and "low-bulk" procurement locations located near a wide range of short-term resources. Group size among foragers tends to be very fluid, and considerable coalescence and fission mark the foraging strategy. Storage plays a minor role in foraging economies because few resources are available in sufficiently large quantities to permit bulk acquisition and processing for lean-period consumption.

Tight resource procurement scheduling, as manifested by "seasonal rounds" of exploitation, is likely to occur when incongruently distributed resources are predictably available from limited zones within a broad, ecologically diverse region. Binford (1980) has designated this logistical strategy as a collector's model, which is characterized by the planned exploitation of predictable, periodically available resources. Collectors use logistical strategies to resolve spatial or temporal conflicts in availability among critical resources, moving resources to the consumers through the employment of task groups to exploit resources that are discontinuously distributed but that occur in bulk. In regions inhabited by collectors, the scarcity of lean-season resources is often sufficiently pronounced that storage is necessary; ideally, the quantities of resources obtained through logistical foraging are sufficient to permit storage for delayed consumption. Storage extends the availability of a resource into resource-scarce seasons. The extreme lack of resources during the winter in temperate and colder environments, for instance, may be resolved through increased seasonal sedentism and increased storage dependence (Goland 1983).

Most of the extensively studied ethnographic groups fall toward the foraging end of the spectrum, while a few practice strategies that strongly emphasize collection. More importantly, some groups are foragers during a 
part of their annual cycle and collectors during the remainder. Thus, the forager-collector dichotomy characterizes resource acquisition at the two extremes of a continuum (Bousman et al. 1990). A wide range of variation can occur between the dichotomous forager-collector adaptive strategies; indeed, some options may involve a seasonal shift from one strategy to another depending on resource scheduling and availability. In addition, whole regions or portions of regions may be "simultaneously" exploited by multiple societies with different foraging economies (Syms 1977:1-13). The relationships that develop among such archeologically contemporaneous groups depend on the nature, abundance, and importance of the target resources.

Various researchers have addressed the factors that generate logistically organized systems in temperate climates (Conaty 1987; Hayden 1986). In general, foraging strategies appear to correlate with the exploitation of evenly distributed and relatively stable resources, whereas collecting strategies appear to be more commonly employed in the exploitation of clumped and transient resources. In other words, logistical collection strategies become necessary as the patchiness of key resources increases and/or the duration of availability decreases. Foraging tends to generate a highly nomadic land-use pattern, whereas collecting lends itself toward more sedentary or semisedentary settlement strategies. Beyond these generalizations, researchers vary in their assessment of the critical characteristics of resources that cause hunter-gatherer populations to exploit them according to these two models. Hayden suggests that the reliability, richness, and seasonal nature of the resources are the critical aspects conditioning the mode of resource acquisition. Other researchers (Conaty 1987; Horn 1968) view availability and distribution (evenly distributed and stable versus highly clumped and transient) rather than density as the critical variables.

Heffley (1981) suggests that three resource availability/distribution modes are the primary determinants of settlement patterns: (1) evenly spaced and stable; (2) mobile, clumped, and unpredictable; and (3) clumped and predictable. Evenly spaced and stable resources appear to be exploited by small groups under a dispersed, relatively mobile settlement pattern (i.e., foragers). Mobile, clumped, and unpredictable resources are often exploited in bulk by larger mobile groups, but the larger return for the energy invested generates storable surplus that permits some degree of seasonal sedentism (i.e., collectors). The highest degree of sedentism is found in the context of clumped and predictable resources (e.g., salmon runs by Northwest Coast groups). Seasonal variations in the mobility and patchiness of the resource base can stimulate a shift in mobility strategies by hunter-gatherers within a single annual cycle. Thus, groups such as the Tanana (Heffley 1981) exploit mobile, clumped, and unpredictable resources for short periods in the spring, summer, and fall and evenly spaced, stable resources throughout the remainder of the year; thus, a seasonally varying mix of logistical collecting and residential foraging strategies is possible.

One of the components of this discussion that is important in the current research undertaking concerns the strategies involved in gathering chert for stone tools and clay for pottery. Procurement of geological materials (in contrast to biotic and animal resources) is often attributed to incidental, or "embedded," activities that are conducted while individuals are engaged in other economic pursuits (Binford 1980). Embedded collection behavior is especially evident where geological resources occur in areas with easily accessible subsistence resources and where materials are of sufficient size for manual transport. Other modes of 
acquisition of non-biotic resources include group interaction and trade networks.

The forager-collector continuum is particularly useful for developing expectations about the relationships among resource acquisition and mobility strategies, site function, assemblage composition, occupation length, group size, and regional settlement and subsistence patterns (Ellis et al. 1993; Lintz et al. 1993). The archeological signatures of foraging strategies should differ from collecting strategies and should be marked by such things as lowintensity occupations except at tethered sites, low rates of curation and maintenance activities, a lack of stored or cached goods and other site furniture, evidence of highly generalized and portable assemblages, and possibly less assemblage variability at any given location because of the generalized approach toward resource procurement. In contrast, the collector strategy includes a hierarchy of sites in which base camps are situated near the most stable and abundant resource in the area, with field camps, observation points, and specialized work stations located near various other resources. Base camps can be archeologically distinguished by their greater intensity and duration of occupation, a wider range of site functions, evidence of curation and maintenance activities, storage facilities, communal processing areas, and other kinds of site furniture. Base camps should also tend to have a greater density and diversity of implements and residues than the satellite procurement loci and work stations.

\subsubsection{Optimal Foraging Models}

One aspect of resource procurement that is not explained directly by these broad models is the actual mix of resources utilized by prehistoric groups given the regional resource structures and procurement strategies outlined above. Furthermore, the specific constraints that influence hunter-gatherer decisions about mobility and resource scheduling are only dealt with in a general descriptive fashion. Developments in optimal foraging theory help to fill in some of these gaps.

Optimal foraging theory is concerned with building and testing models of optimal strategies of energy acquisition. The concept of optimality, originally borrowed from microeconomics, is central to contemporary evolutionary theory, where it is recognized that natural selection operates on complex organisms in complex and variable environments, so that questions of adaptive response to any one problem or opportunity involve many other sets of adaptive responses and environmental factors. Since the complexity of most environmental situations leads to a multitude of constraints, the theoretically optimal solution favored by natural selection will balance various conflicting and/or interdependent demands (e.g., for growth, reproduction, avoiding hazards, capturing energy, competing, cooperating) to maximize fitness (cf. Smith 1979).

Optimal foraging models were originally developed by ecologists interested in understanding the factors affecting non-human foraging behavior (Kelly 1995). The utility of these models to the study of human foragers rapidly became apparent, especially since diversity in human diets cannot be attributed to differences in physical perceptual abilities, preycapturing appendages, or predator size, all of which are sources of diversity in the non-human world (Hames and Vickers 1982, 1983; Hawkes et al. 1982; Kelly 1995; O’Connell and Hawkes 1984; Smith 1983, 1991; Smith and Winterhalder 1992; Winterhalder 1986a, 1986b, 1987; Winterhalder and Smith 1981).

Optimal foraging models include a goal, a currency, a set of constraints, and a set of options (Kelly 1995). In studies of huntergatherer foraging behavior, the goal is normally 
maximization of foraging efficiency (i.e., food gathered per unit of time), though foraging efficiency need not be the goal. The currency most commonly used is caloric value, though again goals other than caloric intake are possible. Constraints include such things as the maximum amount of time that can be spent foraging or the forager's capacity to digest certain foods. Options include the range of potential food resources and other choices about how to spend time (e.g., childcare). Given a set of resources with specified characteristics (e.g., nutritional content, harvest and processing times), optimal foraging models propose how those resources were acquired and used.

While optimal foraging research has made substantial progress in measuring some of the trade-offs that modern human foragers make in managing the opportunities and constraints of their environments, optimal foraging models generally require a high degree of resolution that currently is not available in the archeological record. Specifically, the detailed botanical and faunal information needed to develop rigorous and quantified expectations regarding the resources utilized by prehistoric populations simply does not exist. Furthermore, the finely tuned time scale implicit in optimal foraging models is far beyond the reach of most archeological investigations.

However, this discussion of optimal foraging theory draws attention to the basic assumption that the limiting factors in energy capture are the availability of energy at the right time and at the right place (i.e., given where people are located and the mode of exploitation) rather than the abundance of energy itself (Smith 1979; Torrence 1983, 1989). Given the basic assumption that time-budgeting is crucial to hunter-gatherer behavior; organizational (i.e., cultural) responses to variability can be expected to vary according to both the character and the severity of stresses in the environment. As summarized by Torrence:

[T]he degree of stress will mainly condition the quantity of the response, whereas the type of stress will determine the quality of adaptive...behavior....[I]f the total amount of time available is limited, tools which increase the speed at which the activity is carried out will be employed....In other cases, the overall quantity of time may be sufficient, but it may be necessary to schedule certain types of behavior in order to avoid competition among various activities for particular periods of time (1983:12).

\subsubsection{A Note on the Explanatory Potential of Models}

It is important to note when discussing models that models are not intended to be used as classificatory devices that describe and account for all possible dimensions of variability in the phenomena they are used to explain. Rather, models are intellectual constructs that are used to assess variability against a set of expectations, holding some variables constant while allowing others to vary. The implicit assumption in working with models is that the expectations of the model should hold only when other things remain equal. Thus, a model is a closed system used to measure variability in an open system. Because other things usually are not, in fact, equal, naturally occurring phenomena often will not conform to modeled expectations. Thus, models provide a baseline for identifying and investigating variability. The processes and assumptions that underlie the variability allowed by the model are known; variability not accounted for by the model represents a point of departure, pointing to phenomena that reasoned arguments, hypothesis building, and hypothesis testing must seek to explain. In other words, models are intellectual constructs and are not 
designed to account for the full possible range of variability that occurs in nature.

However, archeologists often use models as descriptive and classificatory devices rather than as tools that help to measure the variability of organizational systems. Variability that cannot be accounted for by modeled expectations tends to be discarded, and the known variability becomes the focus for subsequent discussion. The use of modeled expectations about specified dimensions of behavior often results in the discovery that some organizational patterns at various points in space and time fail to conform to expectations. While these discoveries should properly represent the springboard for investigations into the causes of the observed similarities and differences, they are commonly used, erroneously, to argue for dismissing the models used.

This type of argument, in which a model is rejected because empirical evidence has been encountered that does not support it, is extremely common in archeology. It is unrealistic to expect all of reality to conform to the expectations generated from a limited set of observations and assumptions. Empirical evidence can always be found that contradicts generalizations based on other empirical evidence; this, in fact, is the point of the scientific method. It is the variability that we encounter that has the most potential to inform us about the differential organization of cultural systems through time and across space. If all cultural systems conformed to our expectations, there would be nothing left to learn.

\subsubsection{The Culture History Approach}

The underlying assumptions of culture historical research are (1) that identifying/defining sociocultural manifestations as normative phenomena and describing what happened to them are appropriate goals of archeology, (2) that stylistic variability within and among artifact types denotes different sociocultural groups, and (3) that investigation of stylistic variation in material culture is the proper method for investigating the histories and interactions of specific sociocultural groups across space and through time. Thus, the culture historical approach is based on the idea that cultures encompass measurable dimensions that can be "mapped" across space and time based on "types" and "varieties" of classes of material culture (cf. Gifford 1960). These units represent the building blocks for constructing cultural taxonomies - the "periods," "phases," and "foci" of the Midwest Taxonomic System (McKern 1939). In turn, the arrangement of these cultural taxonomies in space forms the basis for building cultural chronologies through time.

Willey and Phillips (1958) developed the procedural guide for chronology building that was subsequently used throughout North American archeology. The Willey and Phillips approach assumes identities between archeological assemblages and specific groups of people that are presumed to be equivalent to the ethnic groups or emically defined cultures documented by ethnographers (cf. Binford and Sabloff 1982). The approach establishes such identities under the assumption that stylistic expressions are generally specific to sociocultural groups. Thus, according to the Willey and Phillips procedures, an accurately defined phase represents a socioculturally integrated group of people who share a stylistic tradition by virtue of their sociocultural integration. A "phase," therefore, is a representation of a single group of people who occupied a given geographic area for a given length of time. By extension, the process of building chronologies using Willey's and Phillips' procedures is the process of building "social taxonomies" (Johnson 1987:20) that place a chronological sequence of particular societies within known spatial and temporal boundaries. Patterned changes within classes of 
material culture are therefore presumed to represent changes through time within a single group and/or the movement and influence (i.e., diffusion) of different groups of people across the landscape (cf. Gifford 1960).

The degree to which studies of cultural chronology can be considered successful must be measured in terms of their ability to isolate and define particular sociocultural groups in the archeological record. This is not a functional or evolutionary mode of explanation. As chronological investigations are usually built on studies of one or more classes of material culture, criticism of the approach focuses on the issue of whether or not a chronology of projectile points, for instance, is anything more than a chronology of projectile points (cf. Peter et al. 1982a). In other words, the warranting argument that links variability in projectile point morphology to definable sociocultural units is that stylistic variability correlates directly with sociocultural or ethnic variability. To illustrate the epistemological basis of this argument, a review of the operative assumptions that are implicit in stylistic approaches to archeology is warranted. Ellis (1993) presents a thorough survey of the development of chronology building in Central Texas archeology, and the interested reader is directed to his work for details on the historical trajectory of culture historical research in Central Texas. The present discussion focuses on the epistemological framework within which culture historical research operates.

As a prelude to the following discussion, it is worth noting that studies of material culture were quite fashionable in the nineteenth and early twentieth centuries, often to the exclusion of other components of cultural systems. Ethnographic work conducted during this period included extensive, albeit rather sterile, descriptive inventories of material culture. As the field of anthropology matured, attempts to understand how classes of material culture, such as fishing, hunting, or cooking technology, fitted into larger social, economic, and symbolic systems were rare, and interest eventually shifted away from material culture to new domains, such as kinship, sociopolitical organization, and ideology (Lemonnier 1992). As the field of culture historical research developed, the most common approaches to the study of material culture have tended to use "cognitive" and "stylistic" frames of reference in which stone tools, pots, and other aspects of material culture are used as more or less direct indicators of cognitive or social processes. While "cognitive" approaches to the study of material culture are more characteristic of Old World archeology, a brief review of their underlying assumptions are useful as elements of this paradigm tend to creep into the reasoning that supports many studies of "style" and sociocultural organization.

\subsubsection{The Chaîne Opératoire and the Ancient Mind}

The central assumption of cognitive approaches to the study of material culture is that a necessary relationship exists between the material expressions of human behavior and the mental processes of the actors. In the study of techno-economic artifacts---the most ubiquitous class of material available throughout most of the prehistoric archeological record-where this paradigm has achieved the greatest currency, ancient cognition is accessed through the chaîne opératoire, or behavioral chain (Lemmonier 1976; Leroi-Gourhan 1943, 1945; Schlanger 1994). The chaîne opératoire consists of a series of steps in the production of tools, beginning with raw material procurement and continuing through core preparation, blank production, retouch, use, resharpening and recycling, and discard. The act of fabrication is seen as a dialogue between the artisan and the worked material, with each step in the sequence 
both facilitating and constraining the next. The trajectory between each link in the chain, such as between raw material acquisition and tool manufacture, is not linear, and the choices of the artisan, as conditioned by the physical properties of the raw material and the norms of the cultural tradition, are enacted at certain strategic moments. Based on the material evidence of past human actions, then, an "archeology of the mind" is possible.

Methodologically, analyses of the chaîne opératoire use the same classificatory and contextual devices as do most studies of material culture, but they invoke a radically different set of explanatory principles than those that are brought to bear in organizational approaches to past cultural systems. Variability in lithic technology, for instance, is explained in terms of the decision-making capabilities, as conditioned by the physical properties of raw material, and the motivations, as conditioned by cultural morés, of prehistoric flintknappers. By way of a brief critique, it is not clear what is to be learned from the chaîne opératoire aside from the idea that cognitive activity and decision-making represent part of the technological process. The operating assumption seems to be simply that knowledge is brought to bear and operationalized in technique. However, variability is attributed to the idiosyncratic behavior of individual flintknappers operating within a virtually infinite series of unique events rather than to any social dimension that necessarily involves broader cultural processes. Assuming, for the sake of argument, that knowledge of the idiosyncratic behavior of individual actors is germane to the explanation of organizational systems or cultural change, a necessary causal link between mental templates and technological behavior has not been demonstrated. In addition, this logical framework is purely accommodative, and analytical results do not appear to possess any objective or replicable properties, rendering them largely useless in the process of hypothesis formation and testing.

\subsubsection{Style and the Prehistoric Emic}

In contrast to the chaîne opératoire, which is believed to represent a material map of the "mental templates" of prehistoric craftsmen, stylistic approaches deal primarily with informational aspects of material culture. Stylistic analysis of archeological assemblages are predicated on a dichotomous distinction that is presumed to exist between function, which is associated with evolutionary processes, and style, which results from stochastic processes with no "detectable selective value" (Dunnel 1978). Stylistic aspects of technological behavior are considered to involve arbitrary choices, physical actions, and materials that are not dictated by function, but which are instead an integral feature of larger symbolic systems.

Although rarely explicitly stated, the underlying assumption of stylistic analyses is often that the etic can be recreated through analysis of the emic, rather than the other way around, as expressed in the choices and symbology of technological productions. The influence of post-processual archeology can be clearly discerned here (cf. Hodder 1986). Style is defined as the manifest expression on the behavioral level of cultural patterning that is neither cognitively apprehended, nor even necessarily knowable, by the members of a cultural community (Close 1978). Thus, penetrating through to the emic so that the etic can be reconstructed is the duty of the archeological community. Implicit within this approach is the assumption that the emic component of past systems, the perceptions of the actors, can be accessed by "interviewing" prehistoric flintknappers or potters through the medium of the refitted core or the arrangement of punctuations on a ceramic vessel. As causal links between cognition or received knowledge 
and technological consequences have proved to be difficult to demonstrate, the reconstruction of past systems or sociocultural groups tends to be true by definition and is not available to public scrutiny, testing, reproduction, or falsification. As such, stylistic studies of sociocultural systems tend toward "paleoethnology" rather than science.

To illustrate the pitfalls of this approach, this discussion turns to an examination of an oftencited study of variability in North African lithic assemblages. Close (1978) argues that a single end, or function, can frequently be achieved by any one of several, equally valid means (cf. Sackett 1977). The specific method chosen, then, is independent of functional considerations, and is determined by what has been learned in the broader sociocultural context. To test this assumption, Close considers several alternate explanations for lithic variability, including the "handedness" of the toolmakers. After discounting as many alternate hypotheses as possible, Close accepts the only remaining hypothesis on the list, which posits stylistic preference as the explanation for variability. Beside the fact that this form of argument is largely specious, a necessary link between style and variability is not demonstrated and the causal "social factors" are never identified. The argument, true by stipulation, is not constructed in such a way as to be falsifiable, yet it is nevertheless used to support the assertion that stylistic variability provides the most reliable means of identifying social groups in the archeological record.

A rare exception to the rule is presented in Johnson's (1994) study of Late Prehistoric Toyah phase projectile points in southwestern Texas. Through rigorous application of patterndetecting techniques and statistical validation, Johnson demonstrates that patterned variability exists within a certain class of artifacts-Late Prehistoric Perdiz points-that has both a morphological component (i.e., patterned variability within the artifact class) and a related spatial component (i.e., geographic segregation of detected pattern clusters). To explain this variability, Johnson hypothesizes that the morphological and spatial patterning observed in Perdiz points represents sociocultural variability, perhaps even distinctiveness among emically defined cultural groups living in a landscape at the same point in time. As a hypothesis, this argument is valid, though it is possible that the observed variability may be equally well explained in reference to a functional argument. This is the point from which hypothesis building and testing must necessarily be launched.

In defense of stylistic approaches to reconstructing culture history, there can be no doubt that symbolic systems represent important components of any human culture, and that these symbolic systems are encoded, among other things, in stylistic material expressions. The problems that arise in identifying and interpreting style in archeology are that (1) only the non-perishable components of material culture tend to survive in the archeological record, (2) identifying non-functional variability that is truly stylistic in its origin and frame of reference is problematic, and (3) demonstrating a necessary link between stylistic variation and some meaningful dimension of sociocultural distinctiveness has not yet been conclusively demonstrated (in most cases, it is not even hinted at). While ethnographic studies of potters have demonstrated a possible link between the process of transmitting pottery-making skills (i.e., ceramic variability) and specific sociocultural groups (defined by matrilines in many cases [cf. Rice 1984]), the problem is significantly more complicated with projectile points, the artifact class that is used most often as an indicator of stylistic variability in Central Texas and upon which most of the cultural chronologies are built (cf. Hudler 2003a). 
Despite these difficulties, the historical perspective is a valid mode of interpretation in archeological research (cf. Sahlins 1985). In addition to elucidating the organization of economic systems in prehistory, the movement of specific sociocultural groups across the landscape and their interactions with other groups are important modes of analysis for understanding the human past. It is conceivable that some kinds of patterning in the archeological record might, in the end, be better explained by reference to a sociological or historical mode of reasoning than an adaptive or scientific one. For prehistoric cultures that existed before any ethnohistoric records were recorded, style may be the only source of information with the potential to offer insights into the origins, development, behavior, and fate of specific groups of people. Thus, historical exegesis is a mode of explanation that deserves to be more fully elucidated and supported with middle-range theory than it has so far enjoyed in archeology.

\subsection{Research Domains}

The scope of research within which cultural resource management- (CRM-) based archeology usually operates tends to be somewhat narrowly defined. This is as much, if not more, the result of the site-focused nature of CRM archeology than it is due to the biases or interests of specific researchers. While largescale survey, testing, and data recovery projects, such as reservoir studies, provide rare opportunities to investigate entire settlement systems, most CRM studies are based on limited investigations of single sites or a small number of sites, and the resulting range of research parameters tends to be largely site-specific. Even on multiple-component sites, the "system states" or "postures" represented by definable components represent only a part of the cultural system of which they form a part. Thus, examining components within single-sites, even under ideal circumstances in which they can be clearly defined stratigraphically and chronologically, does not necessarily provide a substantive basis for evaluating larger-scale organizational systems or cultural change. For example, a definable bison-processing "episode" in one component may be clearly stratigraphically separated from an underlying component containing a diversified base-camp. Other things being equal, such diverse "system states" might represent two events within the seasonal round of a single cultural group, different site types representative of distinct contemporaneous groups, or an economic shift over time from generalized foraging to specialized bison hunting. Evaluations of systemic organization and cultural change must be based on the investigation of entire organizational systems at definable moments in time. While larger-scale organizational systems and historical processes can be addressed from the perspective of site-based archeology to some degree, opening up the scope of research provides a broader comparative framework within which to build better-informed hypotheses about systemic phenomena.

With this in mind, the research program for the Varga Site incorporates site-specific lines of investigation as well as reference to a more regional base of information. While there are avenues that can be profitably explored from the perspective of site-based archeology, studies of settlement and mobility patterns are best approached from a comparative, multi-site program of research. Thus, while most of the database in this research design derives from data recovery excavations at the Varga Site, several lines of investigation involve studies of archeological and geomorphological materials from other sites and locations in southwestern Texas. The proposed supplemental database provides a cost-effective way to develop a more comprehensive suite of data relevant to this 
research program, and it will provide a broader comparative base for other researchers.

The following discussion is organized into five general research domains-Paleoenvironmental Reconstruction, Subsistence, Technology, Culture History, and Mobility and Land Use. These research domains encompass general problem areas within which focused research questions are explored to provide the foundational data upon which archeological inferences are based. These domains do not represent exclusive avenues of research in their own right; rather, they serve as means to organize research questions that share certain operative assumptions, modes of analysis, and data requirements.

The first three research domainsPaleoenvironmental Reconstruction, Subsistence, and Technology-ask basic questions about paleoenvironmental conditions, site formation processes, tool and feature functions and production processes, lithic procurement and manufacturing strategies, and subsistence resources. The answers to specific questions posed within each of these domains comprise the data set upon which hypotheses about adaptation and culture historical relationships are built. The final two research domains-Culture History and Mobility and Land Use-represent secondary domains within which the primary data sets are manipulated to answer questions that pertain specifically to the historical/sociological and organizational/adaptive spheres of research.

Within each broad research domain, specific research questions are posed. Some of these questions have relevance to more than one domain of research; this is to be expected, as cultural systems incorporate integrated systems of behavior and archeological data sets are often pertinent to more than one research category. For the sake of clarity and brevity, formal "null" hypotheses are not presented, although these may be fairly easily deduced. The research questions are merely testable propositions to which alternate answers or modes of interpretation are appropriate. This research has not set out to "prove" any single idea; rather, the approach is to propose various alternative explanations of observed patterning and to gather evidence needed to confirm or disprove them. As the following discussion will show, some research questions are explicitly sociological or ecological in reference, whereas other questions lend themselves equally well to culture historical and ecological lines of investigation. Unless otherwise noted, all research questions pertain to all identifiable components at the Varga Site, including the Late Prehistoric (Toyah phase), Late Archaic, Middle Archaic, and Early Archaic components. Clearly, the available data sets are more robust for some components than for others as the result of differential preservation conditions, and the range and depth of results are correspondingly richer for some time periods than for others. As the following discussion will illustrate, proxy indicators of important data sets are proposed for components that may lack one or more direct lines of evidence (i.e., using lipid residue analysis as a proxy measure in components with poor organic preservation). This is considered to be a critical mode of investigation as it contributes to the development of middle-range arguments that can be operationalized on other sites that lack one or more classes of primary data.

Following the listing of specific research questions within each research domain is a brief consideration of the relevance of the research domain to the broader theoretical issues of concern. Next, the data requirements for answering the research questions are outlined. Finally, the investigative strategies that were used to generate and to detect patterning within the necessary data are discussed. This section 
includes a discussion of the specific data (i.e., range of observations) that are needed, the analytical methods, and the middle-range warranting arguments, as appropriate, that provide the justifications for using the data to address the questions asked. The investigative strategies section also presents available information about data recovered from the Varga Site that are relevant to the research domain. This information derives from the previously submitted interim reports that describe the results of data recovery excavations at the Varga Site (Lintz et al. 2002; Owens et al. 2002) as well as from preliminary assessments that have been conducted of specialized data sets to determine whether or not data would be available (i.e., lipid residues in burned rock, pollen, phytoliths). Actual counts and the presence and absence of certain data sets are known and specific counts of samples are presented for specialized analyses.

\subsubsection{Paleoenvironmental Reconstruction}

The theoretical foundations of this research program regard environmental conditions as a primary context of opportunities and constraints to which hunter-gatherer subsistence and mobility strategies represent responses. The climatic conditions, spatial (i.e., geographic) and temporal (i.e., seasonal) structure of biotic resources across the landscape, and hydrologic conditions at any given point in time represent strong causal factors in the organizational behavior of hunter-gatherers. Similarly, changes in one or more dimensions of the natural setting may represent important sources of change in human adaptive systems over time. Consequently, paleoenvironmental reconstruction is an essential component of this research design. Reconstruction of past environments and climates provides the backdrop for understanding the relationships between human activities and the environment.
The seasonal availability and geographic distribution of resources in the natural environment directly and significantly affect the foraging, settlement, and technological strategies employed by hunting and gathering populations. Thus, one objective of this research program is to recreate the mosaic structure of natural resources with the highest possible degree of resolution so that it is possible to document changes in the floral, faunal, and physical environment over time, which in turn will serve as the basis for evaluating the effects of spatial and temporal resource variability upon prehistoric organizational systems. The other chief concern of this project is the reconstruction of the depositional and erosional regimes that characterized and influenced the formation of the terrace deposits that contain the archeological materials at the Varga Site and the degree to which these were local versus regional processes. The task of paleoenvironmental reconstruction is therefore, a function of local landscape factors as well as regional, and possibly even global, environmental characteristics, as well as, the preservation of primary data sets.

Paleoenvironmental reconstruction is concerned with establishing the nature of the non-human environment to identify the natural conditions upon which human populations depended. In this way, the study of paleoenvironmental conditions provides an independent frame of reference for making inferences about cultural systems. This is not to say that humans did not form an integral component of the natural environment or that the behavior of human populations had no impact on the environment (cf. Butzer 1982). Rather, it is to make a heuristic distinction that somewhat simplifies the description and explanation of human ecology by first isolating its non-human components and then placing the human components in context (Ellis et al. 1993). Thus, the object of this domain of research is to develop as detailed an 
understanding as possible of the environmental conditions and processes with which humans interacted.

Thus having established the importance of paleoenvironmental conditions as an independent frame of reference, it is important to note the limitations imposed upon this task by site-based archeology. Ideally, paleoenvironmental reconstruction would be undertaken from a regional perspective using data from non-cultural contexts (i.e., data gathered from natural as opposed to archeological contexts). However, it is not always possible to undertake comprehensive regional paleoenvironmental investigations within the context of site-based archeology; consequently, this task is necessarily dependent on previous regional research and on data recovered from on-site archeological deposits. While the paleoclimatic indicators recovered from archeological deposits may directly reflect past environmental conditions, they can be skewed as the result of cultural and taphonomic factors. Though some organic data sets (e.g., pollen) are somewhat more resistant to cultural factors than others (e.g., macrobotanical remains), the cultural and natural taphonomic factors that influence the formation of archeological assemblages must be carefully evaluated. In this context, the differential rates of preservation of such things as bone, shell, and floral remains must be taken into consideration, and questions of context must be resolved. When one or more primary data sets (e.g., faunal bone, macrobotanical remains) are poorly preserved, proxy indicators of plant and animal resources may be necessary (e.g., lipid residues, stable carbon and nitrogen isotopes). Following this, reconstructing the actual potential of the general region to supply various food and material resources is an analytically distinct task, though it is necessarily based on much of the same data. Clearly, any assemblage of subsistence remains on an archeological site reflects the selection processes of the occupants of the site and preservation processes more strongly than it reflects the natural structure of the surrounding environment. Thus, it is necessary to use as many alternate lines of investigation as possible in reconstructing paleoenvironmental conditions.

\subsubsection{Research Questions}

- Did local and/or regional climatic change occur over time in the vicinity of the Varga Site? If so, what were the characteristics and trajectories of change?

- What floral and faunal communities characterized the local and regional natural settings of the Varga Site through time?

- What animal populations existed (locally and regionally) in the vicinity of the Varga Site through time? What migratory animal species may have been available? What relative degree of emphasis on $r$-selected versus $k$-selected species is evident?

- What geographical and temporal patterns of resource availability characterized the biotic communities surrounding the Varga Site through time at local and regional scales? Which resources were available on a seasonal basis? Which resources were available year-round? Which resources were available locally? Which resources were not available locally? Which resources were available continuously (geographically)? Which resources were available in discontinuous patches?

- Do the floral and/or faunal assemblages show changes in climatically sensitive species over time?

- What topographic and geomorphological features characterized the Hackberry Creek floodplain and nearby upland settings 
through time? What topographic features did fluvial processes produce in the Hackberry Creek floodplain?

- At any given time, did colluvial processes at the interface between upland and fluvial surfaces create surfaces that would affect biotic diversity and/or patchiness?

- Were the depositional and attritional geomorphological processes that influenced the development of the Hackberry Creek floodplain and nearby uplands local processes (i.e., specific to Hackberry Creek) or regional processes? How do the sediments on and near the Varga Site relate to other alluvial chronologies in the region?

- What was the distribution of water sources in the vicinity of the Varga Site?

- Can human influences on the landscape be identified in the archeological record?

- Did the composition, spatial patterning, and/or seasonal structure of ecological communities change over time?

\subsubsection{Relevance}

Paleoenvironmental reconstruction is necessary because the natural environment provides the array of biotic and geological materials used by hunter-gatherers, and the spatial (i.e., geographic) and temporal (i.e., seasonal) arrangements of these resources across the landscape and through time represent the opportunities and constraints that conditioned the organizational responses of cultural groups with hunting and gathering economies. Thus, understanding the difference between what was available and what was chosen for subsistence is a major factor in developing hypotheses about hunter-gatherer adaptations and the potential environmental causes for change in subsistence strategies. In addition, understanding environmental conditions that affected the nature, timing, and rate of sediment deposition and incision through time is important in developing hypotheses about hunter-gatherer land-use strategies and site formation processes.

\subsubsection{Data Requirements}

\section{Stratigraphic Profiles and Sediment Samples}

Detailed stratigraphic profiles of relevant contexts in the T0, T1, and T2 terraces of the Hackberry Creek valley were recorded during data recovery excavations and geoarcheological trenching. These profiles will serve as the basis for defining sedimentary units and archeological components, establishing the chronology of sediment deposition and site occupation (together with chronometric dating techniques), and selecting samples of data sets for specialized analyses that are pertinent to the task of paleoenvironmental reconstruction. Samples of sediment from on-site control columns as well as from a variety of feature and non-feature contexts were collected to support these studies.

\section{Chronometric Assays}

Radiocarbon assays of organic remains, such as faunal bone, charred wood, shell and organic inclusions in sherds and burned rocks from cultural and non-cultural contexts, as well as sediment humate assays from more generalized contexts, as necessary, serve as the primary basis for evaluating a broad range of questions about site chronology. Optically stimulated luminescence (OSL) dating of quartz grains in sediments collected from definable strata also were used as a proxy dating method. In reference to the paleoenvironmental research domain, a comprehensive chronometric dating framework is needed throughout the stratigraphic sequence at the site to firmly establish the spans of time over which discrete 
sediment units formed. In addition, three ceramic sherds from the Buckhollow Site, two sherds from the San Lorenzo Mission Site (41RE1) in Camp Wood, Texas, and two sherds from the San Juan Mission (41BX5) in San Antonio were processed (see below).

\section{Faunal and Floral Subsistence Data}

While analyses of the floral and faunal remains from the Varga Site are primarily relevant to studies of prehistoric diet and, secondarily, to resource procurement strategies, faunal and floral subsistence data comprise a proxy data set for reconstructing paleoenvironmental conditions. Thus, most of the analyses conducted in reference to the subsistence research domain (discussed in Section 4.2.2) are also relevant to paleoenvironmental reconstruction.

Macrobotanical evidence collected from various on-site contexts, including feature and nonfeature contexts, were identified and quantified. Clearly, data from discrete stratigraphic contexts (e.g., features, securely dated sediment zones) provide the best basis for reconstructing paleoecological communities, but samples from less discrete contexts (e.g., general sediment zones) also provided significant supporting evidence.

Evidence of faunal subsistence resources were identified and quantified from on-site features as well as from less discrete on-site contexts. Macroscopic data such as faunal bone, mammal teeth, and shell represent the best data for evaluating the range of animal resources exploited by the inhabitants of the site and provide a method for investigating paleoenvironmental conditions.

Evidence of faunal and floral resources were analyzed based on extraction of lipids (fatty acids) from burned rock and ceramic sherds.
Previous research has demonstrated that organic residue samples can be extracted from burned rocks (including limestone, the predominant form of cooking stone at the Varga Site) used by prehistoric peoples to process foodstuffs (cf. Malainey and Malisza 2003; Quigg et al. 2001). This proxy line of investigation may be helpful when conditions are not conducive to the preservation of primary organic data, such as macrobotanical remains and faunal bone, and in older deposits in which organic preservation generally is not good.

\section{Pollen and Phytolith Analyses}

Analyses of phytolith and pollen data collected from T0 terrace sediments, the fine-grained sediments in which the cultural components are situated, were analyzed. While pollen and phytolith profiles from non-cultural settings are preferred in reconstructing plant communities, site-based data can also be profitably used for this purpose. Changes in pollen profiles can often be interpreted reliably as corresponding to changes in the general character of an area's vegetation (Bryant and Holloway 1985). Similarly, phytolith analysis can provide information about the basic structure of plant communities at least to a level of resolution that distinguishes between forested and grassy environments (Rovner 1988). Phytolith analysis, therefore, may be useful in identifying basic shifts in the composition of vegetation communities at large scales. Twenty paired sediment samples collected from a column in excavation Block A and five paired sediment samples from dated context were analyzed for pollen and phytoliths (as well as for stable carbon and nitrogen isotopes).

\section{Granulometric Data}

Granulometric studies (six samples) were conducted on the same column sediment samples from excavation Block A on and four 
other dated sediment samples which pollen, phytolith, and stable isotope studies were performed. Grain-size analyses are pertinent to reconstructing the fluvial conditions under which sediments were deposited.

\section{Isotope Studies}

Stable carbon and nitrogen isotope data collected from a variety of contexts was analyzed. Twenty sediment samples collected from a column in excavation Block $\mathrm{A}$ and five sediment samples from other dated context within the site were analyzed for stable isotopes (as well as for pollen and phytoliths). In addition to the sediment column samples, isotope studies were conducted on one sample of faunal bone from archeological contexts. Specifically, bison bone from the Late Prehistoric component and deer and/or antelope bone were analyzed for stable isotopes from any component in which they occur. Finally, the organic residues recovered from 13 ceramic sherds and 87 burned rock matrices were analyzed for stable isotopes. Evidence of carbon and nitrogen isotopes extracted from burned rock were used in conjunction with the lipid residue evidence from the exact same samples of burned rock to help interpret the results of the fatty acid analyses. This varied suite of carbon and nitrogen isotope studies provides multiple lines of investigation that serve as proxy indicators of local and regional vegetation communities and also helps to interpret the results of other analyses.

\subsubsection{Investigation Strategies}

Strategies for the extraction of paleoenvironmental information included stratigraphic analysis of sediments in the T0, T1, and T2 of Hackberry Creek, analyses of macroand microfloral and faunal remains from excavations (that included screened and floated samples); phytolith, pollen, and grain-size analyses of sediments from a column sample in the first terrace at Block A (as well as supplementary pollen and phytolith data from feature sediments); and stable carbon and nitrogen isotope analyses from sediment column samples, faunal bones, and organic residues recovered from ceramic sherds and burned rock matrices. This suite of analytical techniques is tightly integrated, and several of the techniques contribute information relevant to subsistence studies as well as to paleoenvironmental reconstruction.

\section{Stratigraphy and Chronology}

Stratigraphic and chronometric analyses are the backbone of this research program. Consequently, they are discussed in detail in this section, though they apply equally to all research domains. Stratigraphic interpretations are necessary to reconstruct the dominant sedimentation environments through time. Preliminary stratigraphic interpretations were presented in the two interim reports submitted following the two episodes of data recovery fieldwork (Lintz et al. 2002; Owens et al. 2002). Additional studies focused on refining existing interpretations of stratigraphic units, and possible erosional episodes, delineating floodplain and terrace formation processes at the site, assessing the ages and development of the terrace sediments, and evaluating whether alluvial processes are unique to the Hackberry Creek Valley or operated at a regional scale.

Absolute dating techniques established bracketing dates for depositional events associated with the archeological components and with episodes of terrace formation and incision. The framework established by the absolute dates was used to anchor relative dating strategies based on typological seriation. The radiocarbon dating program consisted of a multistage process. Sixty-six radiocarbon dates were obtained for the Varga Site. 
The dating program advocated relied heavily on AMS radiocarbon dating. AMS methods are capable of providing accurate assays on small samples, but the accuracy of the resulting age estimates depends on the degree to which the samples can be securely linked to geological events. In other words, large, immobile, and stratigraphically secure objects provide more reliable age estimates than materials that have been significantly altered chemically by weathering or pedogenic processes (cf. Stafford et al. 1987). In addition, the viability of radiocarbon studies is entirely dependent on the preservation of organic materials in the archeological record.

Based on the stratigraphic interpretation of the Varga Site deposits, organic preservation is excellent for the Toyah phase component but somewhat patchier for more deeply buried strata. Faunal bone, wood charcoal, and carbonized seeds and nutshells are present in the most of the four assemblages, but to different degrees. Flotation of sediment samples collected from individual features provided macrobotanical samples suitable for radiocarbon dating. Occasional chunks of wood charcoal were recorded from feature contexts in the Late Archaic and Early Archaic components, but most of the organic materials that were recovered from the lower (i.e., sub-Toyah) sediment zones occurred in non-feature contexts. Whether these materials were in situ or translocated from overlying events was of abiding concern.

Thus, the strategy that was employed for radiocarbon sample selection focused on directly resolving chronological issues and also on providing a set of "tie-ins" for radiocarbon assays determined on non-charcoal samples (e.g., faunal bone, sediment dates, snail shell, pottery and burned rock residues), which are thought to have larger degrees of error and a broader range of potential interpretive problems.
Large pieces of in situ charcoal were the preferred materials, and burned rock features were the preferred contexts. Other materials selected for radiocarbon dating included faunal bone, snail shell, sediment humates, and organic residue from burned rocks and pottery sherds, as applicable, ideally from secure stratigraphic contexts. To provide the most secure context for interpreting radiocarbon dates on such materials, an attempt was made to run dates on carbonized wood, nuts, and/or seeds as well as on bone, shell, sediment humates, and/or pottery and burned rock residues from comparable contexts in order to determine the range of potential chronometric variance in different sample types. Thus, a broad range of material types were radiocarbon dated from the Toyah phase component, which contains the entire suite of dateable materials recovered. The suite of dates thereby served as a frame of reference for radiocarbon dates derived from the lower components, which contained more limited range of potentially dateable materials (i.e., aside from scattered charcoal, bone, and nut shells recovered from non-feature contexts in the Early Archaic component. Understanding the relationships among radiocarbon dates on a range of materials from a secure context like the Toyah component helped in the interpretation of dates obtained from a more limited range of sample types from earlier components in which organic preservation is poorer.

The radiocarbon dating strategy was a multistaged process between the radiocarbon specialists and the archeological analysts. An initial run of radiocarbon samples was submitted and processed while the second phase of excavations was still underway. The initial run consisted of one sample from each of the Late Prehistoric, Late Archaic, and Early Archaic components selected from materials recovered during the first data recovery phase. Following submission of the second interim report (Owens et al. 2002), 24 additional samples were run, 
yielding seven Late Prehistoric dates, six Late Archaic dates, four Early Archaic dates, and five sediment humate dates. The radiocarbon dates were derived from the three primary cultural components (i.e., Late Prehistoric, Late Archaic, and Early Archaic), but several dates were obtained from the Middle Archaic component.

In addition to the robust radiocarbon dating program undertaken, this research program developed an independent frame of reference for chronology building based on OSL dating. OSL is still a somewhat experimental technique, but it has provided potentially promising results and offers an alternative to radiocarbon dating at sites or in specific stratigraphic contexts that do not offer well preserved organic carbon (cf. Bruseth and Martin 2001). Basically, OSL measures the amount of light emitted by crystal grains in sandy sediments and determines the amount of time that has elapsed since the grains were last exposed to daylight. The technique can be used to provide dates on sediments that are composed of or contain quartz or feldspar within a range of 100 to 200,000 years. To demonstrate the utility of this technique for dating the more deeply buried sediment units at the Varga Site (i.e., the units that do not have good organic preservation), it was necessary to run a control set of OSL dates for the components that yielded a reliable radiocarbon chronology (i.e., Toyah, and Late Archaic) to establish an interpretive framework. Seven sediment samples were collected for OSL dating during the second phase of data recovery excavations, which included two from the Late Prehistoric Toyah component, two from the Late Archaic component, and three from the Early Archaic component.

Thus, the chronological framework for the Late Prehistoric component was built using multiple radiocarbon dates on various kinds of organic materials that included burned rock and ceramic residues, wood charcoal, carbonized seeds/nuts, sediment humates, and OSL. This established both an alternate framework of dates for the Toyah phase component itself, as well as a set of links between charcoal dates and dates run on a variety of other materials. The Late, Middle, and Early Archaic period components yielded some wood charcoal, nut shells, and faunal bone, which were dated, thus allowing us to rely more heavily on the reliable organic materials and not on humate dates as is often the case at so many older sites. The robust radiocarbon dating program allowed us to determine that some charcoal and bone pieces were translocated downward.

\section{Geomorphology}

A major geomorphic research question for the Varga Site concerns how the sediments within and adjacent to the site relate to other alluvial chronologies in the region. Nine backhoe trenches were excavated in the $\mathrm{T} 0, \mathrm{~T} 1$, and $\mathrm{T} 2$ terraces to obtain relevant geomorphological data. Radiocarbon-dateable sediments were recovered from trenches in the $\mathrm{T} 0$ and $\mathrm{T} 1$ terraces in the interest of developing an alluvial chronology for this part of the Hackberry Creek valley. The question then arises as to whether this chronology correlates with others in the region or if it is relatively unique.

While it is not within the scope of this research design to conduct a systematic study of alluvial chronologies for southwestern Texas, two avenues of investigation provided at least a preliminary basis for establishing a regional geomorphic context for the Varga Site. First, previous research conducted on floodplain and terrace formation processes in the region was evaluated and discussed in the context of the results from investigations at the Varga Site. As discussed in the first interim report (Lintz et al. 2002), relatively little is known about the geomorphological conditions of the rivers within the southern Balcones Escarpment region (Blum 
et al. 1993; Mear 1953, 1998). In general, previous research has concluded that the relative height of terraces does not permit the correlation of ages due to the differential stream gradients. Thus, it is conceded that the results from one stream valley can not be used as a measure of alluvial chronologies in adjacent systems.

The second means used to establish a regional geomorphic context was to determine if chronologies can be correlated across stream valleys in the deeply dissected Balcones Canyonlands. Specifically, Johnson (1994:17) describes a buried soil horizon in the Copperas Creek terrace at the Buckhollow Site (41KM16) in Kimble County, Texas. The Buckhollow Site is located on an alluvial terrace that overlooks the confluence of Copperas Creek and the North Llano River approximately 96 km (60 miles) north of the Varga Site. Based on the preliminary results of geomorphological analysis of the Varga Site sediments, the Varga and Buckhollow sites appear to have experienced similar depositional sequences. Specifically, the sediment zones designated as Units II and III in Block A of the Varga Site appear to be similar, if not identical, to the Buckhollow Site's Components 4 and 3, respectively (Johnson 1994:17, Fig. 5). At the Varga Site, Unit II is currently being interpreted as a buried A horizon underlain by a thin lens of pea-sized gravels (Unit III), which in turn constitutes the capping layer of a thick $\mathrm{Bk}$ horizon that shows considerable evidence of pedogenic development (Owens et al. 2002). At the Buckhollow Site, Johnson (1994:17) describes the stratigraphy as follows:

The next episode of flooding saw the slow build-up of a very compact clayey silt with some sand, about $10 \mathrm{ft}$. (3 m) thick (Component 2). The growth of this alluvium is thought to have been fairly constant, occurring at a slow but steady rate.... Above this clayey silt is a very thin lens of pea-sized gravel and small river cobbles (Component 3), bespeaking a largescale flood on Copperas Creek itself. In contrast, the underlying fine-grained sediments [Component 2] were derived largely from the North Llano River and its headwaters....Above the pea gravel, milder flooding again created a stratum of clayey silt with sand which is about $4 \mathrm{ft}$. $(1.2 \mathrm{~m})$ thick (Component 4). The lack of internal bedding argues for a very slow rate of deposition and growth-so slow that small lenses of graded sediments have had plenty of time to become homogenized by bioturbation and the formation of an A soil horizon that moved ever upward as the terrace surface increased very slowly in elevation.

The similarities between the Varga and Buckhollow stratigraphic sequences are intriguing. Other correlations besides the buried A horizons and underlying pea-gravel lenses may also exist between the two sequences. While the deposits at the Buckhollow Site are considerably thicker than those in the investigated portion of the Varga Site, the relative proximity of these two sites raises the distinct possibility that investigations of sediments at both sites are directly relevant to the evaluation of regional paleoclimatic patterns. The buried A horizon (Component 4) at the Buckhollow Site was not systematically investigated by Johnson as he was primarily concerned with the overlying Toyah phase component; consequently, radiocarbon dates were not run on Component 4 sediments or associated cultural materials. Nevertheless, Johnson identifies Component 4 as being associated with the Late Archaic period; at the Varga Site, Unit II is the buried A horizon that contains Feature 1, the Late Archaic feature that is being tentatively identified as an incipient burned rock midden. We intended to investigate and compare the two sediment zones from these two sites, but we could not locate a wellprovenienced sediment sample from the curated 
Buckhollow materials in which to pursue this line of investigation.

\section{Flora and Fauna}

Analyses of archeofaunal and archeobotanical remains form an important component of paleoenvironmental as well as subsistence studies. As discussed above, the plant and animal remains recovered from archeological deposits generally do not directly reflect the structure or distribution of plant and animal communities in the local and/or regional environment, but they can serve indicators of the kinds of natural resources in the past environment. The assemblages of archeofaunal and macrobotanical remains from the Varga Site were recovered from coarse $(6.4 \mathrm{~mm})$ and fine (3.2 mm) screening and from flotation of matrix samples. The range of analyses that were conducted on the floral and faunal assemblages from archeological deposits at the Varga Site is discussed in Section 4.2.2, "Subsistence", and will not be repeated here. In addition, the lipid residue and carbon isotope studies for ceramic sherd and burned rock matrices, as well as usewear analyses, are discussed in reference to the subsistence and technology research domains.

\section{Pollen and Phytoliths}

Two columns of matrix sediment samples were collected from Block A for detailed analyses of such data sets as soil texture, sediment grain size, stable carbon and nitrogen isotopes, humate dating, and phytoliths. These sediment column samples were collected from two separate locations in Block A. One sample column is intended for use in sediment studies (i.e., grainsize analysis), whereas the second column was collected primarily for use in phytolith, pollen, and stable carbon and nitrogen isotope analyses.

Phytoliths are opal silicate bodies that form as inclusions in plant cells. The taxonomic distinctiveness of various types of phytoliths varies, but the grasses are among the most distinctive, diverse, and easily recognized. Specifically, three diagnostic grass phytoliths occur: panicoid, festucoid, and chloridoid. Recent studies in the eastern portion of Central Texas have shown that panicoid forms occur in greater frequencies in open, grassy communities, whereas both festucoid and chloridoid forms are common in forested environments (ScottCummings 1991). Phytolith studies are important in reconstructing the general vegetation structure in local environments through time (in contrast to pollen studies, which are more attuned to regional reconstructions).

Because pollen preservation is often poor in southwestern Texas, five pollen and five phytolith samples from the sample columns were submitted for preliminary processing to assess whether or not pollen and phytolith data would be available for study. Fossil pollen was observed in all five initial samples that ranged in depth from 23 to 96 cmbs (Jones 2003). The presence of pecan (Carya sp.) pollen in the samples is significant as these grains are fairly fragile and would not be expected to occur in poorly preserved assemblages. It was noted, however, that pollen preservation appears to decrease with depth. Phytoliths were also noted in all samples, and preservation was quite good throughout the column. Thus, pollen and phytolith analyses make a substantial contribution to this poorly studied region. A total of 25 paired pollen and phytolith samples, 20 from a single column from Block A, two dated sediment samples from Trench 1 , and three dated samples from Trench 7 were analyzed and provide indications of past biota.

\section{Granulometry}

Grain size analysis is used to help differentiate the basic soil properties of each horizon, to indicate patterns of pedogenic development, and 
to define major depositional breaks in sediment accumulation. Specifically, soil textures are determined empirically based on percentages of gravel, sand, silt, and clay as obtained by sieve and hydrometer methods, and percentages of organic matter and calcium carbonate equivalent are calculated. Grain-size data were useful in estimating the depositional environments within which sediments were deposited (e.g., colluvial, alluvial, lacustrine, eolian), and are consequently an important, empirical supplement to conventional stratigraphic interpretation and macroscopic observations of soils/sediments. Here, 10 sediment samples from a column in Block A were analyzed and these were the same sediments that were used for the pollen, phytolith, and stable isotope analyses.

\section{Stable Isotopes}

Differences in stable carbon isotope values reflect variations in the integration of atmospheric carbon by plants through three photosynthetic pathways, which are designated as $\mathrm{C}_{3}, \mathrm{C}_{4}$, and CAM. Although much less is known about nitrogen isotopes, they have been shown to be important in distinguishing between $\mathrm{C}_{3}$ legumes (bean-producing plants such as mesquite [Prosopis glandulosa], Texas ebony trees [Pithecellobium ebono], huisache [Acacia farnesiana], Texas Kidneywood [Eysenhardtia texana Scheele], and many others) and $\mathrm{C}_{4}$ nonleguminous plants (DeNiro and Epstein 1981). Taken together, isotopic analyses provide data on the plant and animal resources that were potentially used for food by prehistoric peoples and complement other types of analysis. For instance, if studies of the lipid residues contained within burned rocks from a single feature return a general interpretation such as "large herbivore," isotopic analyses can help refine that interpretation (e.g., if isotopic analyses return a result of " $\mathrm{C}_{4}$ pathway," then it is likely that the "large herbivore" indicated by lipid studies was a bison). Stable carbon and nitrogen isotope analyses were conducted on 158 samples to assess the relative proportion of $\mathrm{C}_{3}$ or $\mathrm{C}_{4} / \mathrm{CAM}$ photosynthetic pathways of the plant residues, or animals that ate these plants, and were cooked by these artifacts. The selected samples included the interiors of 87 burned limestone rocks, six Toyah ceramic sherds from Varga, five ceramic sherds from Mission San Lorenzo, two ceramic sherds from Mission San Juan, 20 sediment samples from the sediment column in Block A, five other dated sediment samples from trenches, and 33 modern plant samples to facilitate the interpretations. The stable isotope samples were extracted from the same sediment samples that were used for pollen and phytolith studies, and the same samples of burned rock and ceramic sherds that were analyzed for lipid residues (see Section 4.2.2, Subsistence).

\subsubsection{Subsistence}

Determining the range of natural resources exploited by prehistoric populations, including plant, animal, and mineral resources, is a necessary component of any archeological investigation of hunter-gatherer adaptive systems. The exploitation patterns employed by hunter-gatherer groups are differentially conditioned and constrained by numerous environmental and cultural factors, including the distribution, density, and patchiness of natural resources on the landscape; the seasonality of economically important species of plants and animals; the location of important sources of tool and cooking stone; the size (i.e., range) of exploited territory; and group size. The presence and variability of faunal and floral remains in an archeological assemblage (1) reflect the resources that were hunted, collected, or grown by the prehistoric inhabitants of the site, (2) provide the basis for estimating how intensively those resources were exploited, and (3) supply inferential tools for developing hypotheses about the organizational strategies 
involved in trapping energy from the environment and distributing it within the cultural system. As discussed in Section 4.2.1, Paleoenvironmental Reconstruction, these data also serve as proxy indicators of paleoenvironmental conditions.

Research conducted over the past 30 years has demonstrated that taphonomic issues must be carefully evaluated before advancing any interpretations about prehistoric behaviors. Reconstructing patterns of subsistence is a matter of establishing a human rather than natural origin for the biotic items in an archeological context. A broad range of possible natural and post-depositional processes can introduce naturally occurring plant and animal specimens into a cultural assemblage. For instance, burrowing activity is known to be relatively extensive in some parts of the investigated area of the Varga Site, so the presence of rodent bones in the faunal assemblage would not necessarily indicate that the prehistoric occupants consumed any or all of the rodents (Table 4-1).

Table 4-1. Summary of Artifact Assemblages Recovered from Two Phases of Data Recovery Excavations at the Varga Site (41ED28)

\begin{tabular}{|c|c|c|c|}
\hline Artifact Category & $\begin{array}{c}\text { Block A } \\
\text { (West of Road) }\end{array}$ & $\begin{array}{c}\text { Block B } \\
\text { (East of Road) }\end{array}$ & Total $^{1}$ \\
\hline $\begin{array}{l}\text { Lithics } \\
\text { Projectile Points } \\
\text { Bifaces } \\
\text { Unifaces/Edge-Modified Flakes } \\
\text { Cores } \\
\text { Debitage }\end{array}$ & $\begin{array}{c}215 \\
166 \\
95 \\
50 \\
69,444\end{array}$ & $\begin{array}{c}68 \\
50 \\
34 \\
14 \\
19,197\end{array}$ & $\begin{array}{c}283 \\
216 \\
129 \\
64 \\
88,641\end{array}$ \\
\hline $\begin{array}{l}\text { Other Tools } \\
\text { Groundstone Tools } \\
\text { Bone Tools }\end{array}$ & $\begin{array}{l}6 \\
2\end{array}$ & $\begin{array}{l}3 \\
3\end{array}$ & $\begin{array}{l}9 \\
5\end{array}$ \\
\hline Burned Rocks & $1,214.19 \mathrm{~kg}$ & $834.40 \mathrm{~kg}$ & $2,048.59$ \\
\hline $\begin{array}{l}\text { Faunal Remains } \\
\text { Bone } \\
\text { Mussel Shell } \\
\text { Snail Shell }\end{array}$ & $\begin{array}{c}8,451 \\
30 \\
5,378\end{array}$ & $\begin{array}{c}11,496 \\
11 \\
439\end{array}$ & $\begin{array}{c}19,947 \\
41 \\
5,817\end{array}$ \\
\hline $\begin{array}{l}\text { Floral Remains } \\
\text { Wood Charcoal, } \\
\text { Carbonized Seeds and Nutshells }\end{array}$ & $386.2 \mathrm{~g}$ & $134.2 \mathrm{~g}$ & 520.4 \\
\hline $\begin{array}{l}\text { Ceramics } \\
\text { Sherds }\end{array}$ & 16 & 76 & 92 \\
\hline Historic/Modern Objects & 44 & 18 & 62 \\
\hline Soil/Sediment Samples & $446.80 \mathrm{~kg}$ & $192.85 \mathrm{~kg}$ & $639.65 \mathrm{~kg}$ \\
\hline
\end{tabular}

${ }^{1}$ Unless otherwise noted, all quantities are reported in raw frequencies (i.e., number of items). Numbers do not include tiny materials recovered from the floated sediments. 
In addition, the effects of carnivore activity have been repeatedly demonstrated to be an important post-depositional factor in the formation of some archeofaunal assemblages (cf. Binford 1981; Klein and Cruz-Uribe 1984). Any analysis of faunal and botanical remains must identify the various agents responsible for introducing the specimens into the site as well as the events and processes that may have chemically altered the materials following their deposition.

As Ellis et al. (1993:151-152) succinctly illustrates, investigations of subsistence in archeological research designs tend to collapse two distinct research topics - the identification of subsistence resources and the description/explanation of subsistence strategies-into a single analysis. Identification of the subsistence resources that actually were used must logically occur prior to beginning the discussion of subsistence strategies. Indeed, describing a subsistence base can be a sufficiently complex task to warrant individual treatment. Furthermore, it is necessary to have a description of the actual resource base before it is possible to hypothesize about the procurement strategies that might account for the assemblage of subsistence resources. Describing a subsistence strategy involves a high level of analysis that necessarily relies on inferences from an array of data of which faunal and floral resources form only a subset (Winterhalder and Smith 1981; Jochim 1976). Thus, identifying the subsistence resource base is here treated as a research domain in its own right to establish a set of reliable empirical claims about the nature and range of exploited resources. The task of investigating the decision-making structures and other elements that went into procuring and processing the resources is discussed in Section 4.2.5, Mobility and Land Use.

While analyses of macro- and microfloral and faunal materials are primarily useful for reconstructing prehistoric subsistence economies, these data sets can provide proxy indicators of the resource communities exploited by hunter-gatherers, thereby contributing to the task of paleoenvironmental reconstruction. Furthermore, specialized analyses of biotic remains can provide information about resource processing strategies, butchery patterns, and the nutritional value of the exploited resources.

It should be noted that the subsistence research domain addresses only biological resources used for food. Such items as lithic resources and technological patterns may also be directly related to the subsistence process. A parallel treatment of lithic resources and procurement strategies is discussed in Section 4.2.3, Technology.

\subsubsection{Research Questions}

- What economically important plant and animal species are represented? What naturally occurring flora and fauna are present in the assemblage?

- What season(s) of occupation do faunal and floral remains recovered from cultural contexts represent?

- What regional resources are present that would not have been available locally?

- What potentially available subsistence resources were not exploited?

- What evidence supports the idea that various biotic resources were consumed immediately versus processed for storage?

- How were specific kinds of animal resources butchered? For larger game animals, are entire animals represented at the site or were selected parts transported to the site for processing from kill or procurement sites?

- What types of wood were used for fuel? 
- What relative degree of emphasis on animal versus plant subsistence resources can be detected?

- Are organic remains in lower components contemporaneous with those components or have they been translocated from overlying components in which organic preservation is demonstrably better?

\subsubsection{Relevance}

Identification of the nature and range of resources that compose the subsistence base is a critical dimension of hunter-gatherer research because the nature and location of subsistence resources is a major determinant of huntergatherer behavior. The subsistence resource base also serves as a direct, if partial, record of the exploitative decisions made by human populations. Therefore, the subsistence data collected from various sources provides direct information that will inform hypotheses about the spatial and temporal dimensions of resource procurement strategies. Consequently, the data obtained in this domain is roughly equivalent to a catalog of subsistence goals toward which people directed their activities and organized their strategic decisions about resource capture. Thus, by the time that research in the paleoenvironmental and subsistence domains is well advanced, the researcher has in hand evidence for the nature of the environmental context of human activity and a basis for beginning to investigate the patterns of subsistence strategies operationalized by human populations. The hypothesized organizational systems through time then serve as the basis either for further investigations into diachronic variability in the organization of resource procurement systems (i.e., spatial/cultural variability across space) and/or synchronic variability (i.e., spatial/cultural variability through time).

\subsubsection{Data Requirements}

\section{Floral Subsistence Base}

Macrobotanical, pollen, and phytolith evidence collected from various on-site contexts, including feature and non-feature contexts, were analyzed. Clearly, data from discrete stratigraphic contexts (e.g., features, securely dated sediment zones) provide the best basis for reconstructing the subsistence base, but samples from less discrete contexts (e.g., general sediment zones) provide supporting evidence.

While wood is not necessarily a component of the subsistence base, species identifications of wood samples from cultural contexts provided evidence both of the kinds of wood located in the vicinity of this archeological site as well as the range of preferred fuel wood types. Samples of wood charcoal from 44 float samples extracted from 18 cultural features and 75 individual pieces of charcoal from across the excavations were analyzed.

\section{Faunal Subsistence Base}

Faunal bone fragments $(19,947$ pieces or 17,879 g) were analyzed from on-site features as well as from less discrete on-site contexts. Macroscopic data such as faunal bone, teeth, and mussel shell represent the best data for evaluating the range of potential animal resources in the prehistoric diet. Analyses of faunal elements also contribute to the formulation of hypotheses about procurement and processing strategies, discard patterns, and secondary uses of faunal materials for technological (e.g., awls) and ornamental (e.g., beads, pendants) items.

\section{Chemical-Residue Evidence}

Faunal and floral resources were further studied through extraction of 94 lipid residues (fatty acids) from burned rock and eight ceramic sherd matrices. Previous research has demonstrated 
that organic residue (fatty acids) samples can be extracted from burned rocks and pottery used by prehistoric peoples to process foodstuffs (cf. Quigg et al. 2001). This proxy line of investigation is critical when chemical and environmental conditions are not conductive to the preservation of organic data, such as faunal and floral remains, and in older deposits in which organic preservation generally is relatively poor.

\section{Isotope Studies}

Carbon and nitrogen isotope evidence extracted from 87 burned rocks, six Varga Site Toyah sherds, and seven Mission sherds were used in conjunction with the lipid residue evidence from the exact same samples of burned rocks and ceramic sherds to help interpret the results of the lipid residue chemical analyses.

\section{Stone Tool Analyses}

Analyses of stone tool variability and use-wear analyses of stone tools contributes information on subsistence extraction and processing activities, which in turn can aid in reconstructing subsistence bases. The presence or absence and relative proportions of certain tool forms indirectly indicates subsistence practices. While tool assemblage variability is more directly articulated with procurement and processing strategies, some results may lend themselves to reconstructing the subsistence base. Also, usewear analyses contributed results that are relevant to identifying the resources processed, given that use-wear studies resulted in the recovery of identifiable plant fibers or animal hairs. Analyses of stone tools are discussed in detail in Section 4.2.3, Technology.

\subsubsection{Investigative Strategies}

Data recovery excavations yielded a rich faunal assemblage associated with the Late Prehistoric period Toyah phase component. While the Late
Prehistoric faunal assemblage is quite robust (in terms of raw counts), many of the bone elements represented are highly fragmented. Organic preservation in the soil/sediment units associated with the earlier components is much poorer. Scattered pieces of faunal bone were recovered from the lower components, but many were determined not to be directly associated with these earlier occupations, having been translocated downward from the overlying later components.

Macrobotanical remains, primarily wood charcoal, were recovered during the field investigations and subsequent flotation of collected sediment samples. Wood charcoal was relatively common in the upper components (i.e., Late Prehistoric and Late Archaic period components), though it became increasingly infrequent outside of feature contexts in the lower occupation zones (i.e., Middle Archaic and Early Archaic period components), presumably due to time-dependant attrition. Rare specimens of carbonized seeds and nuts were also identified.

The composition of the faunal and floral assemblages recovered from data recovery excavations, the subsistence base of the Toyah phase inhabitants was evaluated through the analyses of faunal bone and macrobotanical remains. However, because of the relatively poor organic preservation conditions in the lower components, understaning of subsistence is largely dependent on proxy indicators of plant and animal exploitation, such as lipid residues from burned rocks, microwear analyses of stone tools, and studies of stable carbon and nitrogen isotopes. To establish an epistemological link between the primary and proxy data sets, it was also necessary to perform the proxy studies (i.e., lipid residue, use-wear, and isotope analyses) for the upper components, in which organic preservation is good. This helped to interpret the resource processing techniques for the later 
components; more importantly, it provided the confirmatory links among the primary and proxy data sets upon which sound inferences were made for the lower components, which relied more heavily on the proxy data.

The faunal bone assemblage was analyzed for species identifications, bone element size classes, cultural modifications (e.g., cut marks, impact fractures), burning patterns, and minimum number of individuals (MNI) estimates. Floral analyses focused on species identifications.

Aside from the studies of faunal bone and macrobotanical remains (for those components that produced them), analyses of lipid residues (fatty acids) in burned rock were completed. Previous research has demonstrated that organic residue samples can be extracted from burned rocks and groundstone tools used by prehistoric peoples to process foodstuffs (cf. Quigg et al. 2001). Basically, this technique involves extracting and identifying the fatty acids that are preserved within the matrices of porous rocks used in cooking and other food preparation activities. Fatty acids are the major constituent of fats and oils (lipids). Their insolubility in water and relative abundance compared to other classes of lipids, such as sterols and waxes, make fatty acids suitable for residue analysis. When the fatty acid residues recovered from burned rock matrices are compared to decomposed fatty acid compositions of modern potential food plants using gas chromatography, general categories of lipid residues can be determined. Although the degree of resolution of lipid analysis is still quite general (e.g., "large herbivore," "fish/corn," "large herbivore/plant”), the potential of this research for subsistence studies is significant for archeological assemblages that do not have adequate preservation of organic materials. While most burned rock lipid studies conducted to date have focused on sandstone, recent research has demonstrated that limestone, the primary cooking stone material at the Varga Site, also yields lipid residues amenable to this type of research (Malainey and Malisza 2003). Other analytical techniques, such as stable carbon and nitrogen isotope analysis, help to refine the general determinations provided by analyses of lipid residues. While neither approach is sufficiently precise to directly identify specific species, together they permit the development of inferences concerning broad subsistence patterns when used in combination (Quigg et al. 2002:365).

The sampling strategy for burned rock lipid studies was to process three to four rocks from each of the smaller cultural features to provide a representative sample of each selected feature. Feature 1, the Late Archaic incipient burned rock midden, was more extensively sampled. A total of ninety-four lipid residue samples were extracted from burned rocks from the four identified site components. In addition, six sherds from the Late Prehistoric component were submitted for lipid residue analysis. Samples from all of the burned rocks and sherds submitted for lipid residue analysis were also run for stable carbon and nitrogen isotopes to develop a corroborative data set.

Pattern-recognition studies of the artifact assemblage provide a basis for defining "kits” of tools involved in specific resource procurement and processing activities. Studies of feature function also contributed to studies of subsistence. In addition, use-wear analyses of selected stone tools from each component provided data on the range of materials on which the stone tools in the assemblage were used. When tools were recognized during data recovery excavations, they were often bagged with minimal handling to protect the edges from incidental damage that might skew the results of use-wear analyses. These same tools were not washed or handled prior to being examined for 
use-wear patterns. High-powered microscopy was the primary method used in use-wear studies. See Section 4.2.3, Technology, for a full discussion of technological research questions and investigative strategies.

Seasonality studies are more strongly dependent upon good organic preservation as they focus on seasonally sensitive faunal elements and floral specimens. Seasonality information is often difficult to obtain in warm regions like southwestern Texas, where only slight changes in temperature and moisture occur throughout the year; seasonal information is more easily defined in regions with more marked seasonal differentiation. Seasonally sensitive indicators include growth patterns in fish otoliths and mussel shells; dentine layers in deer, antelope, and bison teeth; the presence/absence of deer antlers; the presence/absence of extra calcium build-up in bird bones; macrobotanical remains; and chemical signatures of isotopes and lipid residues in burned rocks and pottery. As noted above, the Late Prehistoric period Toyah phase component yielded a rich archeofaunal assemblage that contained minimal indicators of seasonal availability of specific resources. The recovery of macrobotanical remains, especially seasonally restricted plant parts such as charred berries and fruits from such plants as juniper trees, walnuts, and geophytes, would also contribute to seasonality studies. A few charred walnuts and cactus seeds were identified within the assemblage.

\subsubsection{Technology}

Arguably, one of the most critical dimensions of hunter-gatherer archeology is the study of how past humans obtained, produced, maintained, and discarded their technological devices. Technology is an topic especially amenable to investigation because the products of technological behavior tend to be the most easily recognizable and best-preserved units in the archeological record. "Technology" refers to almost any aspect of material culture, ranging from irrigation systems, roads, and houses to textiles, tools, and hearths. In prehistoric archeology, technology tends to be understood to refer more or less exclusively to those components of material culture that are directly involved in procuring and processing resources (e.g., hunting gear, agricultural equipment, cooking utensils) and fabricating and maintaining other implements (woodworking tools, weaving devices). These materials tend to be made of various types of tool stone, which are well preserved in the archeological record. Whereas other technological components, such as basketry, textiles, clothing, organic tools, and domiciles are no less important to understanding prehistoric economies, they tend not to be preserved in most archeological contexts. Operationally, this research design understands "technology" to refer to the entire range of objects and strategies manipulated by humans to achieve specific goals. In addition to stone tools (and a small number of bone tools), this research program was concerned with exploring pottery and burned rock features as intrinsic components of the technological system. Thus, both artifacts and cultural features are included in the scope of research.

For the investigation of technological systems under this research design, technomic artifacts are presumed to reflect the strategies used by prehistoric humans to exploit and process resources and to perform fabrication and maintenance activities. The composition of artifact assemblages and other characteristics of toolkit design are investigated in reference to the constraints imposed upon the technological system by external factors, such as environmental and ecological conditions; resource distributions and availability; mobility requirements; raw material locations, quality, and availability; and tool design, production, maintenance, and replacement strategies 
(Ammerman and Feldman 1974; Bleed 1986; Kuhn 1989; Nelson 1991; Shott 1989; Torrence 1989). Theoretical models of hunter-gatherer adaptations have highlighted the articulation of technological systems with other components of hunter-gatherer adaptive strategies, such as food procurement and processing, mobility patterns, and territorial organization (Binford 1977, 1979; Collins 1975; Gould 1980; Kelly 1988, 1995; Shott 1986, 1989; Torrence 1983, 1989; Ricklis and Cox 1993). Many archeological studies have concentrated on extractive tools (Bleed 1986), or tools used to extract resources from the environment (such as weapons), but other efforts have focused on maintenance tools (Bousman 1993), or tools used to manufacture and repair other tools or devices. Furthermore, while cooking features have not traditionally been extensively mined as a primary source of data for technological studies, recognition of the importance and ubiquity of burned rock features across the Greater Edwards Plateau of Central Texas has catapulted cooking and heating technology to the forefront of Central Texas archeology.

Still, while investigations into the systemic organization of technological systems may represent the forefront of current ecological research in archeology, questions about artifact typology and cultural systematics cannot, nor should they necessarily, be avoided. Many investigators have posited that technological devices may reflect non-functional dimensions of variability, such as style, ethnic distinctiveness, symbolic systems, and "cognitive templates." The delineation of cultural taxonomies and debate over their meaning has interested Central Texas archeologists since the inception of the discipline. Numerous researchers have developed regional syntheses and overviews of Central Texas cultural sequences over the years (cf. Suhm et al. 1954; Suhm 1960; Johnson 1967; Weir 1976; Jelks 1978; Prewitt 1981a,
1985). While this research may suffer from some problematic assumptions about the relationship of tool morphology to emic distinctiveness among prehistoric cultural groups, the study of cultural-taxonomic sequences has historically garnered the larger part of most archeologists' attention in Central Texas. In addition, it is perhaps the mode of investigation with the most potential to contribute to diachronic perspectives on prehistory.

This research design employed both an "organizational" approach and a "stylistic" approach to the study of technology. The "organizational" approach characterized the research questions and methods discussed in this research domain, while the "stylistic" approach came into play in the investigation of culture historical concerns presented in Section 4.2.4, Culture History. Both analytical frameworks rely on many of the same data sets, so the investigative strategies outlined here pertain equally to the organizational and culture historical investigations.

In general terms, the theoretical approach adopted in this study treats technology as an integrated system of knowledge and techniques through which humans solve problems and/or respond to changes in their natural and social environments. Thus, investigations were organized according to components, or subsystems, of the overall technological system and included raw material procurement strategies, tool/feature design and manufacturing strategies, tool/feature use and maintenance strategies, and resource preparation and processing strategies. In this context, the descriptive categories typically used in CRM reporting, such as "Lithic Technology" or "Ceramic Artifacts," were used only secondarily. The "organizational" structure implemented here is preferred to the "artifact class” structure often employed in archeological 
reporting. Investigating archeological assemblages according to artifact classes may be well suited to studies of manufacturing techniques on specific raw materials, but technological systems are not organized or operationalized according to artifact classes. Rather, raw material procurement, tool design and production, toolkit design and use, and tool maintenance occupy different sequential positions within a technological system, and each stage is differentially influenced by, constrained by, and responsive to external factors.

In other words, there is a difference between the physical components of technology and the operational knowledge implemented by huntergatherers in the actualization of specific goals. For instance, the numerous stages in the process of procuring and processing the meat from a large animal, such as a bison, cross-cut so many specific artifact class categories as to render them virtually useless in delimiting the strategic decisions implemented by prehistoric huntergatherers in obtaining and consuming food resources. Prehistorically, tool stone, wood, and other hunting tool components (i.e., bow, atlatl) were obtained to manufacture spears, darts, or arrows. The community must position itself in a particular place on the landscape where (and when) buffalo would were available. A projectile point must either be freshly manufactured from a raw material nodule or bifacial preform or reworked from a preexisting tool. Wood must be shaped into a hafting device and the dart or arrow must be constructed from composite elements. The individual hunter or hunting party must locate, track, and kill the bison. The animal must be butchered and reduced into portable, consumable, and/or storable size elements. A processing/cooking technology must be implemented to transform the edible parts of the animal into a consumable form. If leftover meat is to be stored for a period of time, a form of storage technology must be implemented (e.g., pemmican production). Other raw materials from the animal, such as sinew, hide, and bone grease, may need to be extracted and processed. Thus, at its most simplistic level, this process involves numerous components of what would generally be called tool production/use, raw material procurement, butchering, cooking, ceramic, and storage technologies. The procurement and consumption of an animal involves a series of distinct technological subsystems, each of which is interdependently articulated with other subsystems that are operationalized to achieve specific goals related to the capture of energy from the environment and its distribution among the human population.

\subsubsection{Research Questions}

- What lithic quarry sources were exploited by the inhabitants of the Varga Site through time? Were local bedrock and gravel chert sources emphasized at particular times, for particular grades of raw material, or for the manufacture of particular types of tool? Were non-local sources emphasized for any of these purposes?

- How large is the lithic raw material procurement area?

- Are locally peculiar tool production techniques evident that may imply local cultural or environmental influence on tool manufacture?

- What components of the artifact and feature assemblages indicate procurement, preparation, and processing activities related to subsistence practices? What means of procurement, preparation, and processing are indicated? Is there a basis for distinguishing between primary activity areas and discard areas based on the spatial distributions of tools? 
- What types of artifacts (e.g., tool rejuvenation flakes) and/or components of artifacts (e.g., reworked tool edges) represent tool maintenance activities? What kinds of maintenance activities are indicated?

- To what degree are tool assemblages at various time periods based on formal versus informal or expedient tool production strategies? Do different segments of the tool assemblage within any given component vary in relation to formal versus informal techniques? What tool production strategies are evident?

- What were Late Prehistoric period Cliffton points used for? Cliffton points have often been interpreted as preforms for Perdiz points; however, the authors suspect that Cliffton "points" are actually a distinctive tool type.

- How did Feature 1, the Late Archaic period burned rock feature that has been preliminarily identified as an incipient burned rock midden, form? What range of functions does Feature 1 serve? Are discrete dumping or use episodes distinguishable within the feature? Are there detectable differences in the size of burned rock clasts in the core versus the periphery of the feature? Does the center, or core, of the feature have evidence for in situ burning, such as oxidized sediments, ash, or basin features? Are there activity-free zones denoted by a relative lack of artifacts surrounding this feature? Are there associated activity areas farther away?

- Can individual activity areas be identified within each occupation zone? Are functionally specific activity areas represented? Do activity areas that exhibit evidence of multiple functions appear to have formed as the result of activity area overprinting, successive occupations, or erosional processes?

- What temporally diagnostic tool forms are present in the assemblage? Are any tool types or forms that are considered to be diagnostic of pertinent time periods missing from the assemblage?

- Does the diversity of points within various components represent contemporaneous point styles or sequential point forms? Do morphologically similar "types" (e.g., Martindale/Bandy, Gower/Merrell, Perdiz/Cliffton) represent typologically distinct tool styles or a continuum of variability with a single type?

- Is ceramic technology at the Varga Site similar to Infierno phase (Lower Pecos Late Prehistoric), Classic Toyah (Central Texas Late Prehistoric), and/or Protohistoric/Historic (Mission) period ceramics? Is there continuity between regions and/or between the Late Prehistoric and Protohistoric periods? Is the same technology being used across these different culture areas and/or through time?

- What arguments best account for variability in the lithic and ceramic assemblages? Is variability stylistic or functional?

- What tool production strategies can be discerned within each component? What specific flintknapping techniques, tool manufacturing strategies, and/or patterns of tool maintenance and/or discard are associated with each component?

- What raw material procurement strategies are evident in the various components? Do patterns and/or source areas of raw material procurement change through time? Can instrumental neutron activation analysis 
(INAA) help determine source areas for lithic raw materials and/or ceramic pastes?

- Why are so many complete projectile points (i.e., points that could have remained in use) present at the Varga Site?

\subsubsection{Relevance}

Technological studies at the Varga Site are organized according to components, or subsystems, of the overall technological system rather than to specific artifact categories. These subsystems include raw material procurement strategies, tool/feature design and manufacturing strategies, tool/feature use and maintenance strategies, and resource preparation and processing strategies. The first of these subsystems, raw material procurement, represents an area of study that is not only important in technological studies, but also forms the basis for estimating the geographic extent of the area across which the prehistoric inhabitants of the Varga Site ranged and/or accessed through interaction with other groups. Raw materials were often chosen according to specific criteria that may have included expediency and/or immediate availability as well as functional suitability for an intended production process or tool category. In addition, in site-based archeology, the geographic range of raw material resources is often the only available set of data that directly demonstrates the spatial extent of the procurement area. Thus, it is necessary to identify which sources of chert for tool stone and clay for pottery were selected and which were not selected for use by prehistoric peoples. Limestone, the primary constituent of burned rock features at the Varga Site, is extensively available in the immediate vicinity of the site in bedrock and stream gravel exposures. Consequently, it is assumed that this resource was procured locally Similarly, wood probably was procured from a relatively limited catchment area around the site; while the exact locations of fuel wood sources are not specifically of interest, the overall range of wood species that were selected for use provides information about the arboreal composition of the surrounding area.

Techniques of tool design and manufacture are important in developing an understanding of tool function, as the techniques of tool production are the steps through which the producer establishes the basic characteristics of tool morphology and suitability for intended uses. Hence, an understanding of artifact production techniques serves as the basis for determining whether morphology and/or suitability for an intended use were related to functional decisions. Furthermore, it is necessary to discover whether formal tool classes such as projectile points and ceramics are characterized by locally peculiar production techniques that may imply distinctive local cultural or environmental influences on tool-making. Tool and toolkit design may also serve as the basis for inferences about the mobility strategies employed by prehistoric groups in procuring important resources, and tool manufacture and its derivatives (e.g., debitage, broken preforms) often provide important sources of information for delimiting activity areas on a site and in assessing site function.

The attributes of tool use and maintenance are distinct from the attributes of artifact morphology associated with production because the latter are acquired during manufacture, while the former are acquired after manufacture. While attributes of manufacture may represent the intended use of a tool, the attributes of use reflect the actual range of uses to which the tool was applied. Note that artifacts that may not have been manufactured prior to use (e.g., hammerstones, manos, metates) are subject to analysis within this framework. In this case, the artifact enters the technological system directly from nature without passing through a tool 
production process. Strictly speaking, such tools are identifiable only on the basis of their userelated attributes. Tool maintenance and recycling represent two potentially distinct processes. Tool maintenance generally refers to refreshing the working edges of a tool to prolong its use life for its designated function(s), whereas recycling refers to reworking a used tool to serve a different range of functions. Thus, in the case of recycled artifacts, the userelated attributes resulting from use before recycling are distinct from the use attributes after recycling. For example, the use-related attributes of a projectile point are distinct from the drilling function of a point that was reworked into a drill.

Resource preparation and processing include those aspects of the technological system involved in transforming resources into energy that can be consumed by the population. Thus, it is important to understand the resource preparation, processing, and storage technologies of a society. Resource preparation and processing may include the butchery patterns used to obtain economically important animal elements; methods of grinding plant resources; techniques for extracting desired or removing unwanted components of specific resources (e.g., extracting grease from bones, removing tannin from acorns); and the cooking techniques used to prepare resources for consumption (e.g., heating features). Some aspects of resource processing are represented by use-related characteristics of artifacts, while other aspects are properly considered through analyses of feature function and formation processes.

\subsubsection{Data Sets}

\subsubsection{Chert Sourcing Data}

A comprehensive suite of source location assessments for cherts present in the various components of the Varga Site was completed. Sourcing data served as the basis for identifying the general quarry regions or areas from which the site's inhabitants obtained raw material for stone tools and provided a means for estimating the size of the resource acquisition territory. An extensive set of sourcing analyses was conducted to obtain a representative sample of the different raw materials and types of tools represented in each of the site's components. In addition, the chemical signatures of cherts available in the immediate vicinity of the site (upland outcrops of cherts and chert from the Hackberry Creek) were determined. These signatures served as the baseline for identifying locally available cherts in the cultural assemblages. Furthermore, the chemical signatures for additional chert sources located in the region surrounding the Varga Site were obtained.

\section{Clay Sourcing Data}

The source locations of the clay paste used in the manufacture of pottery during the Toyah phase occupation of the Varga Site was minimally pursued. A regional database of Toyah phase pottery paste sources is not readily available and is difficult to provide from individual site investigations. Here a single sample of sediment from the Varga Site was investigated through INAA and petrography. It is still necessary to perform broad regional wide sourcing analyses on a control set of clays from natural settings to further address the movements of the vessels and or peoples across the landscape.

\section{Petrographic Thin-Sections}

Thin sections of 11 ceramic sherds from the Toyah phase component and one local matrix sample from the Varga Site were part of the analysis of pottery technology and production techniques. A comparative set of thin-sections for petrographic thin-section analysis was also 
conducted for Protohistoric sites (i.e., San Lorenzo Missions and San Juan Mission) in the surrounding region. Previously conducted and published petrographic analysis was from various Toyah sites and site in the region were also consulted and compared with the Varga Site sample.

\section{Tool Identifications and Use- Wear Data}

A broad range of data is needed on the tools in the recovered assemblage, including typological designations for diagnostic tools from each component, functional determinations of tools based on morphological, macroscopically and microscopically observable use-wear characteristics, and metric and non-metric characterizations of attributes of various temporally and functionally diagnostic tools. In addition, various derivative measures of relationship among classes of artifacts (e.g., ratios of specific tool types to other tool types, ratios of tools to features, ratios of cores to debitage, ratios of scrapers to bone, statistical measures of correlation and covariation) provide the basis for analyses of inter- and intraassemblage variability. In addition to studies of tools, analysis of a small percentage of the debitage assemblage was performed for studies to address lithic reduction sequences and techniques.

\section{Feature Form, Function, and Formation}

For each of the burned rock features excavated here, a range of data was acquired for definitions of function and formation processes. Definitions of feature form were based on mapped distributions of burned rocks (vertically and horizontally). Clast-size data and the results of specialized analyses of organic residues (i.e., lipids) and stable carbon and nitrogen isotopes in burned rock were collected for interpretation of feature function and formation processes.

\section{Comparative Data}

As a possible avenue of investigating relationships between the Varga Site's Toyah phase inhabitants and those of other Toyah phase sites to Protohistoric populations in the surrounding region, a limited collection of data (petrographic and INAA) was generated from three non-bone tempered sherds from the San Lorenzo Mission (41RE1) in Camp Wood, Texas; and five bone tempered sherds from the San Juan Mission (41BX5) in San Antonio.

\subsubsection{Investigation Strategies}

\section{Raw Material Sourcing Analyses}

\section{Chert Resources}

One major element in the study of technological organization relates to the amount of time and energy expended in the manufacture of stone tools. Arguments have been offered that demonstrate a link between prehistoric mobility and the level of effort expended in procurement of raw materials for, and the production of, stone tools (Andrefsky 1991; Bamforth 1986; Kelly 1988; Morrow and Jefferies 1989; Parry and Kelly 1987; Torrence 1983, 1989; Ricklis and Cox 1993). Other research indicates that the availability of lithic raw materials, defined by both abundance and quality, may be an even more important variable with regard to tool morphology, production effort, and time budgeting (cf. Andrefsky 1994). As the organization of systems of raw material procurement is clearly and strongly dependent on spatial patterns of raw material availability, it is beyond the scope of investigations of a single archeological site to fully define the raw material exploitation strategies embedded in broader patterns of mobility, presuming that it is 
embedded. However, determining the locations for technologically important raw materials can establish important inroads into this critical dimension of hunter-gatherer technological organization. While it may not be possible to determine all quarry locations utilized by a group, it is sufficient to determine a representative sample in order to broadly outline the extent of the procurement territory. Excavations at the Varga Site yielded two data sets that are amenable to raw material sourcing studies, deriving from INAA analyses on chert and pottery.

The general environmental setting of the Varga Site within the Greater Edwards Plateau region is marked by one of the most extensive outcrops of chert resources in mid-continental North America-the Edwards Group cherts (Frederick and Ringstaff 1994), which occur within the Cretaceous-age limestone that crops out along the Balcones Escarpment. Previous INAA research has resulted in the development of a database of chemical signatures of cherts deriving from various locations within the Edwards Group chert resource area, primarily from the vicinity of Fort Hood in Bell and Coryell counties, Texas (Frederick et al. 1994). This research indicates that Edwards Group chert samples are heterogeneous and that differences occur among samples of various types or from different geographic areas within the Edwards Formation. INAA studies consist of irradiating chert samples and calculating the concentrations of various trace elemental constituents. Differential proportions of these trace elements among samples form the basis for defining groups within the sample set.

Because the existing INAA database for Edwards Group chert was compiled based on samples from the eastern portion of Central Texas, research on the Varga Site cherts involved INAA studies on chert from the site as well as surrounding localities. Here, we submitted 261 chert samples for INAA studies, including 154 chert tools from the four cultural components from the Varga Site, and control samples of chert materials from non-cultural contexts at the Varga Site, control samples of chert from the surrounding region, with a total of 107 off-site samples.

While the size of this sample population may appear to be large, this sample size allowed for submission of samples representing a broad variety of artifact types, including projectile points, bifacial tools and preforms, unifacial tools, edge-modified flake tools, and unmodified lithic debitage, from each of the four components at the site. Specimens from securely dated contexts, such as features and definable site components were selected. All totaled, 48 Toyah phase tools, 23Late Archaic, 17 Middle Archaic and 66 Early Archaic specimens were analyzed, for a total of 154 specimens from cultural contexts. Sample selection was directed towards a representative sampling of tools, as well as of debitage categories as identified on the basis of macroscopically observable characteristics of chert color and structure. It was important to submit samples from a variety of tools as well as tool manufacturing debris (i.e., debitage) to investigate the relationships among local and non-local source areas and the types of tools that were manufactured from each. Because INAA is a destructive analytical technique, chert samples were often from non-diagnostic portions of tools whenever possible (i.e., portions that do not contain use-wear or diagnostic attributes). As INAA requires only about one gram of sample material, the impact on individual artifacts from sample removal was minimal.

In addition, it was necessary to run numerous samples from naturally occurring chert sources in the immediate vicinity of the site to provide a comparative database of locally available chert. During the second phase of excavations a 
collection of chert samples from a variety of non-cultural contexts in the site environs was undertaken. Samples of water-worn cobbles, including chert-bearing and non-chert-bearing specimens, were collected from on-site and offsite contexts. Natural chert samples were collected from the basal gravel lens of the first terrace of Hackberry Creek within Block A (mainly, but not exclusively, from the seven "sample units"); from exposed gravel deposits along the T0 and floodplain of Hackberry Creek near the site; and from chert-bearing lenses exposed in the uplands south of the Hackberry Creek terrace. Chert gravel samples were also collected from gravel bars along the Nueces River in Camp Wood, Texas, located approximately $29 \mathrm{~km}$ (18 miles) south of the Varga Site. In addition, chert samples were obtained from a bedrock exposure located near Devil's Sinkhole approximately $5.5 \mathrm{~km}$ (3.4 miles) northwest of the Varga Site. Also, numerous chert samples from the surrounding region had been previously collected by TRC in conjunction with an earlier study of Edwards Chert chemical characteristics (Frederick et al. 1994). These samples were not processed for this earlier study, but selected samples were submitted in the present study. Specifically, these include samples from Val Verde, Kerr, Real, and Pecos counties. Some 107 samples from source locations at and near the Varga Site and from the surrounding region were submitted for INAA studies. Finally, the INAA results published by Frederick et al. (1994) provide an existing body of research which was amenable to incorporation into the Varga Site analyses. The INAA studies conducted here not only bear directly on the research issues of interest in the Varga Site investigations, but enhance an existing database that other researchers may use, thus broadening the scope of future inquiries of this nature.

\section{Ceramic Resources}

A modest number of pottery sherds $(n=119)$ was recovered from the Varga Site Toyah phase component. A total of 18 sherds plus one sediment sample were submitted for INAA studies. The ten sherds from the Varga Site were associated with the Toyah component. For ceramic INAA studies, it was not necessary to submit a set of ceramic control samples. Chemical compositional analyses based on INAA studies have recently been completed for more than 400 samples of Late Prehistoric period pottery from across Central Texas (Creel and Johnson 2002). Most samples consisted of plain, bone-tempered vessels generally identified as Leon Plain, the primary Toyah phase pottery type. Six major compositional groups have been defined to date, and the geographic distribution of the members of these groups provides insights on how the production and movement of pottery vessels reflects the movement of or interactions among prehistoric populations over hundreds of kilometers.

Finally, three non-bone tempered sherds from the San Lorenzo Mission site in Camp Wood, Texas, and five bone tempered sherds from the San Juan Mission in San Antonio were submitted for INAA studies. The purpose in selecting these samples was to provide comparative samples from Toyah phase components from investigated sites near the Varga Site to address certain culture historical questions. The selected 19 analyzed samples have contributed to the growing Central Texas ceramics database and to an understanding of the mobility strategies of the Varga Site's Toyah period inhabitants.

\section{Wood Resources}

As discussed in Section 4.2.1, Paleoenvironmental Reconstruction, and Section 4.2.2, Subsistence, samples of wood charcoal were quantified and identified for the 
species of wood exploited by the inhabitants of the Varga Site. Identifying the types of fuel wood used by the site's inhabitants provides a general indicator of the kinds of microenvironments that were exploited for wood through time in the vicinity of the site. The analyses, discussed in detail earlier in this research design (see Sections 4.1 and 4.2) and are not repeated here.

\section{Tool Design and Manufacture}

The degree to which archeologists have succeeded in reconstructing past human organizational systems and isolating and explaining systemic change in these systems is, in some sense, a measure of the interpretive devices that have been brought to bear in the construction of arguments. The instruments of measurement that are most commonly used to define units of analysis in archeology, particularly in the study of technology, are typologies and ordinal scales of classification. These classification schemes often build selffulfilling interpretive conventions into the process of measurement and classification that present serious obstacles to the expansion of knowledge about human technological activities. This problem has seriously hampered the progression of archeological science in Central Texas (cf. Ellis et al. 1993), which has perhaps dwelled on the classification and seriation of projectile point styles at the expense of more expansive avenues of research. While it is beyond the scope of this research design to provide a thorough survey of the epistemological tangles of the study of technology in archeology, several points of relevance are discussed below.

Research on the organization of technology often posits a linkage between lithic technology and patterns of mobility and sedentism in the form of artifact curation (i.e., maintenance and reuse), the functions of bifacially retouched tools, and core technology (cf. Henry 1989; Parry and Kelly 1987). Many such studies have focused on the relationship between the amount of effort expended in tool production and the settlement strategies of the toolmakers. A primary and important distinction has been drawn between tools with little effort expended in their production ("informal" or "expedient" tools) and tools with more effort and planning expended in their production ("formal" tools [Andrefsky 1994]).

In technological studies, the term "formal" is generally used to encompass a wide variety of tools that have undergone relatively intensive planning and production effort, whether the manufacturing occurred over the course of multiple resharpening or rehafting episodes or in a single episode of production from raw material to finished product. Formal tools occupy one end of a production continuum, while "expedient" or "informal" tools_-tools that are manufactured with relatively little effortoccupy the opposite end. Some researchers characterize formal tools as "flexible" or "reliable" tools, or tools that are designed to be rejuvenated and have the potential to be redesigned for use in unanticipated contexts (Bleed 1986; Torrence 1983). These tools have been hypothetically linked to populations that practice more mobile settlement strategies with short-term site occupations based on a relationship that is presumed to exist between restricted raw material availability and unforeseen tool needs or uses (Andrefsky 1994). As mobile groups tend to occupy relatively larger areas, they may periodically find themselves in regions where lithic raw materials are not available or are unsuitable for specific tool needs; thus, they must have ready-made and/or adaptable tools at hand. According to this line of thought, portable tools, tools that can be modified or redesigned as needed, or tools that have variable functions would be best suited for such situations. 
Tools that meet these specifications include such items as bifaces, formally prepared cores, and retouched flakes. Bifaces can be used repeatedly, even after they become dull, by resharpening some or all of their working edges (Andrefsky 1986; Sollberger 1971). Bifaces can be used for many different tasks (Ahler 1971) and have the added benefit of serving as highly efficient cores (i.e., less overall mass per amount of cutting edge). Some researchers suggest that such cores represent the most efficient form of usable cutting-edge storage (Clark 1987), a desirable characteristic for mobile populations that must restrict excess weight. Retouched flake tools have also been proposed as a practical tool type for mobile groups. Retouched flake tools can be used for a wide variety of functions; archeologically, the presence of retouch on flake tools is, in many cases, an indication of how the tool was adapted for specific uses (Odell 1981; Siegel 1984; Keeley 1982).

By contrast, "informal” tools are nonstandardized or casual with regard to form and/or production strategy, and they are manufactured, used, and discarded over a relatively short period of time. Expediently produced tools are included in this category. Binford (1979) characterizes such tools as "situational gear," or tools that are put to use in response to conditions rather than in anticipation of events or situations. This kind of technology tends to be wasteful of raw material and tends to produce tools that have less formal patterning of shape or design. Informal or expedient technologies are thought to be associated with more sedentary populations characterized by longer-term occupations (based on the presumed availability of raw material and lack of the need to expend much effort in tool design), but these tool technologies are in fact also common components of hunter-gatherer toolkits.
It must be pointed out that these categories are, in some fashion, relative to specific contexts. For instance, whereas few would dispute that a large dart or spear point is a formal tool that results from a well-planned and standardized sequence of lithic reduction, other artifact classes might be properly viewed as either formalized or expedient depending on circumstances. Prismatic blade cores are a good example of the latter case. Prismatic blade cores are highly formalized cores that are designed to yield large numbers of expediently produced flakes that may be adapted to specific situations. Thus, prismatic blade technology incorporates elements of formalized planning as well as expedient production. As with any heuristic classification device, the dichotomy of formal versus informal or expedient is best viewed as a model against which the empirical realities of archeological assemblages should be permitted to vary.

Ultimately, while technological research varies in emphasis, the study of technology has led archeologists to the realization that the organization of technology is differentially constrained by different factors in different contexts. Raw material availability may represent the primary constraint on toolkit design in one area, time period, or phase of an overall seasonal settlement cycle, whereas it may not impose any constraints at all in other contexts. This conclusion may appear trite, but it illustrates a fairly important point. Based on the research that has been conducted, several environmental and technological properties have been suggested as determinants in tool design and manufacture, but the constraints that condition specific patterns of technological variability appear to be quite complex and have so far eluded systemization. Much patternrecognition work remains to be done upon which arguments of referral can be built between the domains of variability and causality. 
Researchers vary somewhat in their use of the terms "formal," "informal," and "expedient." In the current study, these terms are understood to represent extremes along a continuum of morphological variability. Specifically, "formal" and "informal" tools reflect opposing categories that describe the relative intensity of design planning and manufacturing input. Formal tools include implements that tend to exhibit a complex and/or standardized lithic reduction strategy, to exhibit regular patterning along working edges, and to have a high degree of formalized patterning in the finished object (e.g., most projectile points, formalized unifaces, bifaces, bifacial drills). Specialized or prepared cores (e.g., prismatic blade cores) would also fit this definition. Informal tools are those that tend to exhibit less overall planning prior to lithic reduction, to exhibit unpatterned working edges and/or irregular use-related damage patterns along working edges, and to lack formalized patterning in the finished object (e.g., edgemodified flakes, most retouched flakes, multidirectional cores). In this context, "expedient" is used interchangeably with "informal." In some senses, "expediency” refers to a more strategic level of technological organization than to morphological characteristics; however, separating out "strategy" from "morphology" in this context would seem to imply that it is possible to distinguish a flintknapper's intentions from the physical results of the process of tool production itself. Whereas tool design and manufacturing can be processually distinguished to some degree in ethnoarcheological research, they tend to form a single dimension of variability in archeological assemblages.

Studies of tool design and manufacturing strategies at the Varga Site will attempt to outline some of the dimensions of variability represented in the tool assemblages contained within the various cultural components on the site. Each of the three primary cultural components (i.e., Toyah, Late Archaic, and Early Archaic) are represented by substantial assemblages of projectile points, finished and unfinished bifacial tools and preforms, scrapers and edge-modified flakes of all shapes and sizes, and scattered fragments of groundstone tools. The Toyah phase component even contains a few bone tools, and one bone tool may be present in the Early Archaic period component (though its context is currently in question). The Middle Archaic component contains a few formal tools, including Early Triangular projectile points, but the densities are relatively low compared to the other components and their stratigraphic associations are less unclear.

\section{Projectile Points and Bifaces}

As Turner and Hester (1993:3) have noted, projectile points are among the most "distinctive and popular artifacts sought by amateur and professional alike." Traditionally, archeologists have used projectile points as the basis for building chronologies and reconstructing culture history; however, the relationships between projectile point types, or identifiable varieties within broader types, and sociocultural groups remains elusive, and it is demonstrable that the geographic distribution of specific point types often crosscuts known contemporaneous sociocultural boundaries. In an attempt to define a new tradition of projectile point research, Hudler (2003a) outlines a system for investigating variability in Central Texas projectile point assemblages that does not depend on traditional typological systems to define variability among projectile points. Rather than defining the unit of analysis in the classification system, which is usually the “type," Hudler's (2003a) proposal is to collect various metric and non-metric data from a collection of projectile points, subject the corpus of measurements to multivariate patterndetecting techniques, and to allow the statistical methods to detect groups or clusters within and 
between the variable set. A similar technique was applied in the analysis of chipped stone artifacts from the Wilson-Leonard Site (Collins 1998). While this tradition of research is still somewhat in its infancy in Texas, it provides a tantalizing alternative to type-based approaches in which the interpretive conventions are built into the taxonomic system.

This research program used both methodologies in the study of projectile points from the Varga Site. First, the point assemblages from each component were typed according to accepted taxonomic systems in use in Central Texas archeology (cf. Davis 1995; Suhm et al. 1954; Suhm and Jelks 1962; Suhm 1960; Johnson 1967; Weir 1976; Jelks 1978; Prewitt 1981a, 1985; Turner and Hester 1999). The traditional method for discerning patterning in projectile point collections was to visually inspect the artifacts and divide them into groups of morphologically similar objects. To ensure that the points were relegated to the proper subjective type categories, the Varga Site research program incorporated examination of points by Elton Prewitt to confirm our use of typological designations. Mr. Prewitt is a leading expert in projectile point typology in the region.

Following the typological identifications, a detailed analysis was performed on the points. First, a comprehensive suite of metric and nonmetric attributes was recorded for the entire assemblage of projectile points from each component at the Varga Site. The data sets recorded generally followed those discussed in the Hudler (2003a) and Collins (1998) research programs, though some categories that did not prove to be productive in previous research were eliminated and a few new categories were added. Decisions about additions or deletions of categories from the variable sets defined in earlier research were based on initial inspections of the Varga Site collections to ensure that variables are defined for representative dimensions of point variability. In addition to metric (i.e., quantitative) and non-metric (i.e., qualitative) variables, several derivative variables, such as ratios, were included as variables.

Next, the recorded variables were subjected to various pattern-detecting techniques to define dimensions of variability in the data. First, multivariate statistics such as principal components analysis (i.e., factor analysis) and cluster analysis were used to identify major axes of variability. Once these were defined, the next proper step was to utilize a variety of bivariate and multivariate investigations of small sets of variables to detect the nature and direction of patterning indicated by the large-scale multivariate statistical methods (in this latter procedure, this research program varies from the Hudler (n.d.) program, which uses the multivariate analytical results as the springboard for further discussion).

The projectile point assemblages from the Late Prehistoric and Early Archaic components at the Varga Site are extremely robust. In fact, to our knowledge, the Early Archaic point assemblage is the largest that has yet been excavated in southwestern Texas. Most other sites have relatively limited ranges of types and/or numbers of specimens. Consequently, the taxonomic investigations of the Varga Site collections shed light upon projectile point variability in the region. However, only the Late Prehistoric and Early Archaic point populations are sufficiently large to run valid statistical studies on them. While several different point styles are present in the Late Archaic and Middle Archaic components, these collections are significantly smaller. Thus, the Late Archaic points were added into the overall collections to determine if they have any associations with the early types/styles. 
Quantities of bifaces were recovered during the excavations and these were subjected to documentation of metric and non-metric observations similar to the projectile points, though the range of variables that were recorded on the bifaces was much narrower. To the extent that bifaces are projectile point preforms, preforms for other tools, or tools in their own right, these characteristics did not provide meaningful dimensions of variability that could be compared to the results of the point study as a baseline for investigating the earlier stages in the biface reduction process.

The "groups" of items that are defined based on the results of the typological and statistical analyses were used as units of analyses against which other variables from the Varga Site research program was compared and contrasted. Rather than defining the significance of any detected "groups" or "clusters" of objects before undertaking the analysis, a program of patternrecognition work provided the correlation and covariation among the defined "types" and "groups" and between various "types" or "groups" and other data sets served as the basis for inference.

\section{Unifaces and Edge-Modified Flakes}

Formal unifaces, such as gouges, side-scrapers, end-scrapers, and discoidal scrapers, were subjected to a detailed documentation comparable to the projectile point and biface study. In other words, an array of metric and non-metric variables were recorded, certain derivative measures (e.g., ratios) were calculated and added to the data set.

All informal and expedient tools, such as edgemodified flakes, were not subjected to these more rigorous documentations.

\section{Other Formal Tools}

Other formal tools (i.e., tools exhibiting a high degree of morphological patterning such as gouges and drills) were investigated and classified in reference to metric and non-metric variability. As the sample sizes of other formal tool categories are small, statistical analyses were not performed.

\section{Debitage}

Samples of lithic debitage were examined to determine which stages of the raw material reduction and tool production processes are represented at the site. Excavations yielded extensive collections of debitage. As the focus of the technological studies proposed in this research design were primarily focused on formal tools, it was not desirable to analyze all 85,483 pieces of debitage recovered. Consequently, approximately 15 percent of the debitage was subjected to detailed analysis. The samples were selected according to provenience (i.e., excavation unit and level), such that each sampled unit would consist of one $10-\mathrm{cm}$ excavation level in a 1-by-1 m excavation unit that had been assigned to one of the four identified components. Sample selection was non-random and biased towards sampling a variety of features and non-feature contexts, high- and low-density areas, from the best context possible in the four cultural components.

However, all of the debitage from the site was examined to separate out the informal tools and specific kinds of flakes that are relevant to studies of tool resharpening. Specifically, the entire collection of debitage was scanned for two kinds of specialized flakes-bifacial and unifacial tool rejuvenation flakes. When identified, these flakes were removed from their source bags and treated as individual specimens as they are directly relevant to issues of tool resharpening and maintenance. The rest of the debitage-that which is not part of the 15 
percent detailed analysis nor identified as a specialized flake type-were quantified and weighed, but no further analyses were conducted.

The focus of the 15 percent debitage analysis was on reduction strategies involved in tool production. Biface production flakes were identified and sorted into production-related stages, such as early- versus late-stage. All flakes were categorized according to percentages and type of observable cortex. In addition, information about heat alteration was documented. While it was difficult to recognize heat treatment in raw materials for which a heattreated comparative collection is not available, the clear presence or absence of heat-treatment was recorded, and indeterminate specimens were noted as such.

\section{Cores}

Cores were examined and classified according to the reduction trajectories apparent on them. Various metric and non-metric variables were recorded, including variables relating to size and the number and direction of flake scars.

\section{Ceramics}

Analyses of the pottery sherds from the Toyah phase component provided information on ceramic technology at the Varga Site. By incorporating samples of ceramic sherds from other Toyah and Protohistoric sites in the region, this research design proposes to build a broader comparative sample for the investigation of ceramic technology.

Analyses of the ceramic sherds from the Varga Site included the determination of the Minimum Number of Vessel (MNV). The MNV assessment was based on color, thickness, temper, paste, firing characteristics, and, when possible, refitting. Metric and non-metric characterizations were recorded for the ceramic assemblage. In addition, petrographic, organic residue (e.g., fatty acid), and stable carbon and nitrogen isotope analyses were employed to help identify the techniques used in pottery manufacture and the functional contexts of the pots represented.

In addition to the INAA studies discussed above, a sample of 18 ceramic sherds and one local sediment sample were thin-sectioned for petrographic analysis. This sample included 10 sherds from the Toyah component at the Varga Site; three non-bone tempered sherds from the San Lorenzo Mission Site in Camp Wood, Texas, and five bone tempered sherds from the San Juan Mission in San Antonio. Included in the ceramic sample for INAA and petrographic analyses was one fragment of what appears to be a non-vessel, possible ceramic figurine recovered from the Varga Site. The selection of ceramic sherds from the site for petrographic and INAA analyses was an attempt to sample the different vessel groups identified.

\section{Tool Use and Maintenance}

Conceptually, the attributes of tool use are distinct from the attributes of tool morphology; the latter are presumed to be associated with manufacture (or maintenance), while the former are presumed to be acquired after manufacture (or maintenance). In reality, manufacture may, to some degree, be an ongoing process, as generalized tool forms may be carried "into the field," as it were, and modified for use in specific contexts depending upon situational needs. However, the processes of tool manufacture and use can be conceptually distinguished based on the presence of userelated wear patterns overlying manufacture- or maintenance-related attributes.

Two avenues of investigation were used to identify the range of functions or uses to which the tools in the Varga Site assemblages were applied-analysis of assemblage variability and 
use-wear analysis. First, analyses of variability within the assemblages excavated from each component were based on identifying functionally related "clusters" of objects within each component. Clearly, this task is intrinsically connected with the analysis of site structure as it involves an explicitly spatial component, but functional "clusters" of objects may or may not occur in spatially discrete areas (see Section 4.2.5, Mobility and Land Use, for more details about spatial analysis studies at the Varga Site). First, the relative proportions of different classes of artifacts were examined in an attempt to identify "toolkits," which in this context refers to functionally related segments of the assemblage rather than to the suite of tools that a hunter may take on an expedition. These "toolkits" may or may not have a discrete spatial dimension; spatially discrete clusters of functionally related artifacts were defined as activity areas, which serve as distinct units for further spatial analyses, whereas "toolkits" that were generally spread across the occupation were simply treated as general functional segments of the assemblage. This line of investigation was conducted primarily on the basis of subjective evaluations of artifact distributions across each component, although statistical pattern-detecting techniques were used to examine correlation and covariation among specific artifact classes.

In addition to general observations of tool morphology and macroscopically observable indicators of use, interpretations of the range of organic and inorganic materials processed with lithic tools were derived through an integrated study of macroscopic and microscopic userelated scars, scratches, abrasions, and polish on the surfaces of stone tools. In use-wear studies, distinctions are drawn between tool action and the material(s) processed based on careful examination of wear patterns on tools. Microscopic use-wear and polishing provide indications of the tool surfaces that were selected and used as working surfaces and the direction of tool movement. Tool edges used to process plant versus animal tissues were distinguished through microwear analyses, as were non-technological modifications produced through natural processes. Under ideal conditions, the type of animal (e.g., muscle, hide, antler, bone) or plant (e.g., wood, soft plant) material that was processed with a tool can be identified, although this level of specificity could not be attained with the Varga Site material. It was possible to characterize tools used for single and multiple functions based on the extent and location of edge-wear, reduction techniques, composite tool construction (e.g., hafting wear), and the presence and extent of reworking or resharpening. Finally, the functional, behavioral, and technical diagnoses made through use-wear analysis may be verified, refined, or questioned through additional studies, such as evaluations of archeological contexts and spatial relationships with other artifact categories.

A total of 156 individual tools was submitted for use-wear analysis. A representative range of tools including points, bifaces, end scrapers, drills, gouges, and edge modified flakes was analyzed. Microscopically observable, userelated wear patterns on the archeological specimens were compared to experimentally replicated specimens to determine the range of functions and contexts of use of the tools. These studies provide qualitative measures of tool use that may be usable as a basis for quantitative studies of the entire assemblage. Sample selection emphasized the two components with the most robust assemblages (i.e., Late Prehistoric and Early Archaic), though the Late Archaic and Middle Archaic components were also sampled. Samples were selected from a representative range of feature- and non-feature contexts and areas of high and low debris density. 
Tool maintenance or resharpening was investigated to the maximum possible degree in this study. While recognizing whether or not an individual tool has been resharpened is problematic, certain types of secondary or derivative artifacts serve as direct indicators of the resharpening process. Resharpening flakes are often difficult to distinguish from manufacturing debitage; however, some resharpening flakes retain remnants of former use-worn edges on their dorsal surfaces and/or on their platforms. Bifacial and unifacial rejuvenation flakes are two of these specialized flake types that directly represent resharpening activities. The debitage assemblage was examined for these types of flakes to aid in assessing the relative presence and degree of emphasis on tool maintenance activities in the various components. Resharpening trajectories can sometimes be identified within single artifact categories or tool types if a sufficiently large assemblage of unbroken specimens is recovered (i.e., within a single projectile point type).

\section{Resource Preparation and Processing}

\section{Burned Rock Features}

Whereas most studies of technological organization focus on chipped stone (and groundstone) technologies, there has been a growing realization in Central Texas archeology that burned rock features are an important part of the archeological record of prehistoric huntergatherer behavior (Black and Ellis 1997; Quigg et al. 2002a). In all likelihood, burned rock technology can profitably be studied in was analogous to those proposed for analyses of chipped stone tools. For instance, although the annular and domed varieties of limestone burned rock middens are more common in areas where limestone is readily available, ostensibly similar cooking features in adjacent regions of Texas that use burned clay nodules, sandstone, or other thermal storage devices have been documented. To some degree, the varying morphologies of burned rock middens and the thermal storage devices used in them may be related to raw material availability, the resources being processed, and/or cooking techniques. Clearly, this is a provocative field of research that can be undertaken using many of the same theoretical frameworks as have been implemented in the study of chipped stone toolkits.

As the majority of the cultural features in much of Texas, and specifically in the Varga Site (among all four documented cultural components) are clusters, scatters, and/or incipient middens of burned limestone rocks, the study of burned rocks was a major focus of our research. The only extensive burned rock feature was Feature 1, a burned rock lens, five to six meters in diameter, associated with the Late Archaic component. This feature appeared to represent a relatively discrete episode of cooking activity (i.e., it cannot be described as a structureless, domed midden of burned rocks). Several discrete clusters of burned rocks were apparent within the overall matrix of this feature, which is classified as an incipient burned rock midden, and there appears to have been a central pit oven or core in the center of the feature (unfortunately, most of the central pit was excavated in a backhoe trench during the first phase of fieldwork). The remaining burned rock features on the site consist of more isolated clusters and scatters of burned rock. Furthermore, scattered burned rocks were encountered across each component in nonfeature contexts. As burned rocks represent one of the most common artifact and raw material types on hunter-gatherer sites in Central Texas specifically and on the Great Plains in general, a promising focus of research has developed around the recognition that burned rock features may be among the most informative elements of the archeological record in these areas. 
Analyses of the burned rock features at the Varga Site were focused on delimiting the form, function, and formation processes represented by each feature.

Analyses of burned rock features focused on three primary characteristics-form, function, and formation processes. Feature form was addressed based on various empirical characteristics, such as the horizontal shape and size, depth, and structure of the feature. Feature function was investigated using a range of analyses that included analyses of lipid residues and stable carbon and nitrogen isotopes recovered from burned rock matrices. As discussed previously in this research design, three to four rocks were submitted for these analyses from each of the smaller features, though a greater number of samples was necessary to sample the anticipated range of variability in Feature 1. Within Feature 1, a wide range of different contexts was sampled, including definable clusters of rocks (i.e., possible dumping episodes), the central pit feature, and undifferentiated scatters of rocks. Seventy-three burned rock samples were analyzed to obtain the necessary representation from all documented features. In addition to the specialized analyses, a range of contextual considerations, including relationships to other features, artifacts, and/or artifact clusters, informed studies of feature functions. Analyses of feature formation processes focused on identifying whether burned rock clusters represent in situ features (e.g., hearths) or secondary deposits (e.g., dumps/discard piles) and evaluating the processes involved in formation. For most smaller burned rock features, the question focused primarily on whether or not the features have been redeposited. For Feature 1, detailed analyses of different parts of the feature were important to develop an overall understanding of the range of use episodes represented in the rock cluster. An attempt was made to differentiate among episodes of cleaning out the central pit feature, although one was never clearly identified, versus identifying discrete clusters of rocks that may represent unique dumping or cooking episodes. Clast-size analysis and detailed vertical and horizontal mapping of rock distributions were the primary data used in analyzing feature formation processes. All burned rocks excavated were sorted into standard size categories (i.e., 0 to $4 \mathrm{~cm}, 4$ to $9 \mathrm{~cm}, 9$ to $15 \mathrm{~cm}$, and $>15 \mathrm{~cm}$ ) in the field, quantified, and weighed. Samples of burned rock from each feature and from non-feature contexts were retained for specialized analyses.

\subsubsection{Culture History}

The underlying assumptions and epistemological framework of studies of culture history have been discussed in some detail in Section 4.1, Theoretical Orientation. As this research domain does not have any unique data requirements that have not been discussed in previous sections, this section is driven largely by the specific research questions. Some questions posed below pertain to specific time periods, whereas others are equally applicable to all of the cultural components at the Varga site.

\subsubsection{Research Questions}

\section{General}

- Do the uses of specific classes or forms of artifacts change in time-sensitive ways?

- Do subsistence activities and/or utilization of one or more specific biotic resources change in time-sensitive ways? Are one or more specific biotic resources utilized during one or more periods but not during other periods?

- Does the overall geographic range (i.e., catchment area) of lithic raw material procurement change over time in time- 
sensitive ways? Are one or more lithic source areas utilized during one or more periods but not during other periods?

- Do segments of the tool assemblage change in nature or proportion over time in timesensitive fashions?

- Do mobility patterns change over time in time-sensitive ways?

- Does burned rock technology change over time in time-sensitive ways?

\section{Late Prehistoric Period (Toyah Phase)}

- Does the diversity of points in the Late Prehistoric component represent contemporaneous point styles or sequential use of different point forms?

- Does the Toyah phase component at the Varga Site significantly predate the Protohistoric period or does it fall within the period of late prehistory? In the latter case, were the Toyah phase occupants of the Varga Site the same people, or part of the same large sociocultural group, that occupied one or more of the Protohistoric period mission sites in the area.

- Does the ceramic evidence at the Varga Site conform to "Classic Toyah" ceramic technology (cf. Johnson 1994)? Are the Classic Toyah assemblages in Central Texas the same age and composition as the Varga Site assemblage? Does Toyah ceramic technology at the Varga Site fall within one of the ceramic groups defined by Johnson (1994)? If so, are the Varga Site inhabitants part of the same large sociocultural group, as those represented by the similar ceramic group in Johnson's (1994) study? If not, did the Varga Site inhabitants possess a distinctive ceramic tradition?
- Are there time-sensitive (i.e., diagnostic) formal tools in the assemblage that have not been previously documented for this time period? Are any classes or types of artifacts that are normally considered diagnostic of the Late Prehistoric period absent from the assemblage?

- Are one or more point styles present on-site that are intrusive to the region?

- Is the Toyah phase ceramic technology local in origin? Does the Toyah phase component at the Varga Site represent a spread of ideas (i.e., a technocomplex) into southwestern Texas (cf. Ricklis 1994) or a distinct group of people (cf. Johnson 1994)?

- Do the Perdiz points conform to the Classic Toyah points (Johnson 1994) or are they regionally or locally distinctive?

- Are Toyah phase tool manufacturing strategies based on blade-based technologies such as those observed at Classic Toyah sites?

- Are Cliffton points preforms for Perdiz points or do they represent a distinctive type of tool?

- Does the Varga Site conform to either Classic Toyah or Lower Pecos models? Does it reflect a cultural boundary zone between Central Texas and the Lower Pecos regions? Does it represent a distinctive tradition?

- Is the Toyah phase ceramic technology at the Varga Site carried over into the Protohistoric period?

\section{Late Archaic Period}

- Does the diversity of points in the Late Archaic component represent 
contemporaneous point styles or sequential point forms?

- Are there time-sensitive (i.e., diagnostic) formal tools in the assemblage that have not been previously documented for this time period? Are any classes or types of artifacts that are normally considered diagnostic of the Late Archaic period absent from the assemblage?

- Are one or more point styles present on-site intrusive to the area?

- Why were relatively large numbers of projectile points discarded in Feature 1, the incipient burned rock midden?

\section{Middle Archaic Period}

- Are there time-sensitive (i.e., diagnostic) formal tools in the assemblage that have not been previously documented for this time period? Are any classes or types of artifacts that are normally considered diagnostic of the Middle Archaic absent from the assemblage?

- Are one or more point styles present on-site intrusive to the area?

- Are the Early Triangular points in the assemblage later than Early Archaic materials?

\section{Early Archaic Period}

- Does the diversity of points in the Early Archaic component represent contemporaneous point styles or sequential point forms?

- Are there time-sensitive (i.e., diagnostic) formal tools in the assemblage that have not been previously documented for this time period? Are any classes or types of artifacts that are normally considered diagnostic of the Early Archaic absent from the assemblage?

- Are Martindale and Bandy points distinctive point types or do they represent variability within a single point type?

- Are Gower and Merrell points distinctive point types or do they represent dimensions of variability within a single point type?

- Did the idea of heating and cooking with hot rocks begin in the Early Archaic period?

- Are one or more point styles present on-site intrusive to the area?

\subsubsection{Relevance}

Typological investigations are based on the assumption that distinct types can be defined within a given artifact class, such as projectile points, that can be shown to belong to limited spans of time on the basis of reliable stratigraphic and chronometric evidence. Thus, it is necessary to show a correlation between stylistic variability on the one hand and definable chronological periods on the other. Theoretically, any aspect of material culture, such as features, tool production strategies, house patterns, or artifact classes, may exhibit time-sensitive characteristics and therefore be considered diagnostic of a particular cultural period or span of time within a cultural period. Other aspects of material culture do not show significant changes over broad spans of time. Alternatively, one basic class of material culture may not change in form over time, but it may be applied within exclusive functional contexts during different time periods. Thus, the concept of identifying chronologically sensitive markers in material culture need not be limited to the traditional concern over "types" and "varieties" within specific classes of tools; the important 
connection that needs to be made is a clear association between some dimension of culturally meaningful variability and definable periods of time.

\subsubsection{Data Requirements}

This research domain does not have any unique data requirements that have not been discussed in previous sections. See Section 4.2.1, Paleoenvironmental Reconstruction; Section 4.2.2, Subsistence; and Section 4.2.3, Technology, for complete presentations of data requirements under this research program. The specific data needs for this research domain are as follows:

- Data relevant to paleoenvironmental conditions, subsistence, and technology

- Designations of feature form, function, and formation for all features within each component

- Pattern-recognition studies of cultural materials associated with various cultural periods, phases, and soil/sediment units based on a variety of pattern-detecting measures, such as stratigraphic interpretation, vertical distributions of plotted artifact elevations, and statistical indicators

- Secure chronological assessments of definable sediment units and cultural features

- Measures of correlation and covariation among artifact types, features, and raw material types within each component

- Analyses of clast sizes, organic residues, and spatial patterning in burned rock features and a sample of burned rock recovered from non-feature contexts
- Functional and typological designations for tools from each component

- Distributional data (vertical and horizontal) for the artifact assemblages from each component

- Spatial analyses of distributions of tools, lithic debitage, cores, bone, pottery, and other artifact classes within each component (qualitative and quantitative)

- Analysis of a sample of the lithic debitage assemblage (e.g., raw counts, size-class designations, flake types) and classifications of flake characteristics (e.g., core preparation techniques, percussion techniques, reduction stage, technological strategies)

- Measures of relationship among various classes of artifacts (e.g., ratios of specific tool types to other tool types, ratios of tools to features, ratios of cores to debitage, ratios of scrapers to bone, measures of correlation and covariation)

- Distributional data (vertical and horizontal) for the artifact assemblages from each component

\subsubsection{Investigation Strategies}

Studies of artifact typology, and culture historical studies in general, are ultimately built on the assumption that morphological variation in particular tool categories, especially projectile points, represent (1) an ordered sequence of changing styles of tool production through time and (2) a hypothetical model of the succession of sociocultural. Chronological investigations based on typological studies do not generally purport to model the succession of adaptive or organizational systems through time, though they may indirectly make the assumption that such is the case. 
Typological studies at the Varga Site progressed according to generally accepted classifications of diagnostic tool categories developed for the Central Texas and surrounding regions (e.g., Davis 1995; Prewitt 1995; Turner and Hester 1983). Most chronological research in Central Texas applies primarily to projectile point typology, but other time-sensitive artifacts have been recognized and defined (e.g., Clear Fork gouges for the Early Archaic, Harahey knives for the Toyah phase). The chronometric and stratigraphic investigation strategies described in Section 4.2.1, Paleoenvironmental Reconstruction, serve as the backbone of chronological investigations here and serve to anchor the relative framework based on diagnostic tools in time.

Culture historical investigations was used to integrate suites of data that have been generated based on the requirements discussed in the paleoenvironmental, subsistence, and technological research domains (Sections 4.2.1 through 4.2.3, respectively), with emphasis on the technological domain. Units of analysis that were assumed to represent socioculturally or historically relevant groups of people or time periods were defined based on traditional typologies in use in Central Texas, though other categories of artifacts and statistical groups or clusters of artifacts were investigated in this context. Research proceeded by comparing and contrasting relevant variables within the Varga Site assemblage.

\subsubsection{Factors Influencing Archeological Site Interpretation}

Ultimately, the primary objective of this research design is to identify those dimensions of variability within the assemblage of excavated data from four cultural components at the Varga Site that could contribute meaningfully to the process of building hypotheses about the organizational systems of prehistoric hunter-gatherers in southwestern Texas. As discussed in Section 4.1, "Theoretical Orientation", the dimensions of those past organizational systems that are most directly of interest in the present context concern resource procurement strategies, mobility strategies, and patterns of land use. The process of building hypotheses about organizational systems is a knowledge-building activity that must necessarily be based on dimensionalized data that can be inferentially substantiated as circumstantial evidence of past human activities. The paleoenvironmental reconstruction, subsistence, and technology research domains discussed previously represent the source main areas of the dimensionalized data. However, before issues of hunter-gatherer mobility strategies and landscape use can be approached, it was first necessary to complete the task of establishing the necessary linkages between the static data of the archeological record to the dynamic conditions of past cultural systems. Thus, this discussion now turns to a consideration of site formation processes and intrasite structure.

\section{Site Formation Processes}

Schiffer (1987) divides archeological site formation processes, the suite of factors that act upon soils/sediments and cultural materials to produce the archeological record, into natural and cultural processes. Natural formation processes include the environmental dynamics that affect the structure of a site or an artifact assemblage. Cultural formation processes include the effects of past human activities on the distribution and character of an archeological assemblage. This research objective is an outgrowth of paleoenvironmental reconstruction as it uses many of the same data sets and analytical techniques. However, the emphasis of study is substantially different in determining the processes that contributed to the formation of site deposits than that involved in the 
reconstruction of past environmental settings. In the current context, the study of site formation processes included (1) the study of landscape evolution and alluvial geomorphology as it relates to the depositional clarity of human occupational residues within the fine-grained sediments that comprise the first terrace of Hackberry Creek and (2) natural postdepositional factors human activities that affected the structure and integrity of sediment deposits and the archeological materials contained within them.

Patterns of landscape stability and change have an enormous effect on the formation of the archeological record by influencing the depositional context of archeological materials. Differential patterns of sediment deposition, soil development, and erosion are primary determinants in the preservation of intact archeological deposits, and presumably also constrained prehistoric hunter-gatherers' selection of landforms suitable for habitation. Consequently, natural landscape formation factors can strongly influence archeologists' interpretations of the archeological record. For example, some researchers have argued that deposition rates are the primary factor resulting in the formation of different "types" of burned rock middens in Central Texas (cf. Black and Ellis 1997:7; Suhm 1959:247). The domed form of midden, for instance, often appears amorphous when sectioned, lacking obvious internal structure, whereas the annular, or ringshaped, midden form retains a high degree of structural integrity. Some researchers have argued that these are two fundamentally different forms of burned rock middens (Collins 1991), whereas others believe that the domed middens occur in stable or slowly aggrading sedimentary contexts in which discrete and brief depositional or behavioral events are not likely to be separated (Black and Ellis 1997). Although both midden forms are assumed to relate to the processing of foodstuffs, factors such as the overt structural differences mentioned above (among other things) have led archeologists to radically diverging conclusions about the function and temporal and geographic distributions of these enigmatic features.

The activities of prehistoric humans also have significant effects on the distribution and preservation of archeological materials. Humans engage in an enormous range of activities that obscure the patterning of cultural materials. Even on single-occupation campsites, humans tend to remove trash from living areas ("sweeping up”); rework and reuse "diagnostic" tools dating from earlier time periods that they encountered and picked up in their travels; recycle "site furniture," such as rocks for cooking stone and construction elements, from nearby sites; and engage in multiple activities whose material results tend to overlap spatially. The problem of isolating clear patterns is compounded on sites that were reoccupied over several seasons or over hundreds or thousands of years, which is commonly the case in the rich alluvial environments that characterize much of the greater Edwards Plateau in Central Texas.

Sites of prehistoric human activity that were reoccupied over time tend to be subjected to numerous post-depositional sources of disturbance, such as trampling (the downward displacement of artifacts exposed on the surface due to normal foot traffic). Even normal pedogenic soil development on stabilized land surfaces tends to result in some downward translocation of smaller artifacts. Rodents, other burrowing animals, and insects can have massive impacts on the integrity of archeological deposits by displacing features of all shapes and sizes to move below the surface.

Clearly, in order to place any confidence in arguments about the cultural significance of observed patterning, archeologists must be careful to isolate and explain the cultural and 
non-cultural post-depositional factors that may have altered the record of past human activities. Some post-depositional processes have been documented rather extensively and have clear, recognizable signatures; others have less wellunderstood effects on the archeological record.

\section{Site Structure and Function}

The goal of the analysis of intrasite structure is to identify distributions of artifacts and features on ancient "living surfaces" so as to obtain insights into the activities, behaviors, and processes for which material remains are the surviving evidence. As decades of research have demonstrated, problems of taphonomy and site formation processes must be taken into account before any cultural or behavioral explanations may be advanced. In the early days of spatial analytical studies, archeologists and paleoanthropologists developed complicated scenarios about the behaviors of early hominids based on the patterns of debris exposed on "living floors" without considering that other, non-hominid forces may have been responsible for producing the patterning. While spatial analyses have become more scientifically rigorous, much yet remains to be done in developing reliable linkages between observed patterning and the human activities that produced the available record.

Models of modern hunter-gatherer organization have provided useful starting places for explaining variability encountered in the archeological record (cf. Bartram et al. 1991; Binford 1977, 1980; Cahen et al. 1979; Keeley 1991; O’Connell et al. 1991; Stevenson 1991; Whitelaw 1991, 1994; Yellen 1977). Observations of the spatial organization of activities at ethnographically documented hunter-gatherer sites have permitted identification of material correlates of specific activities, such as the arrangement of site facilities, trash-discard behavior; dispersion of artifacts via human, animal, insect, and natural processes; and variability in site functions on landscapes. Various researchers have proposed a wide range of potentially informative determinants of site structure and size, including residential mobility patterns, length of camp occupation, number of site occupants, seasonal weather variability, degree of food-sharing among households, kinship structure, reliance on food storage, social ranking, and risk from large predators. A central aspect of the ethnographic site structure work that has been conducted is that much of it has occurred on sites that are the products of single occupations. While it is important to build warranting arguments at this level, archeological deposits, even within relatively distinct stratigraphic contexts, often contain material remains from multiple occupations that may have accumulated through a combination of site reuse and erosional processes (which produce palimpsests of artifacts that contain heavily overprinted activity areas). Clearly, much work remains to be done at the pattern-recognition level.

\section{Settlement and Land Use Patterns}

In ethnoarcheology, hunter-gatherer mobility and land-use patterns can be recorded for a single group of people as they move across the landscape during their seasonal cycle. In archeology, mobility, settlement, and land-use strategies represent an organizational domain that may only be reconstructed through the process of building well reasoned arguments about human behavior derived from the static archeological record. Building hypotheses about prehistoric settlement systems and land-use strategies is strongly conditioned by the breadth of available information from investigations conducted at various types of sites dating to specific time periods. Thus, in some areas, such as parts of the American Southwest in which virtually every site that has been preserved in the 
archeological record has been recorded and subjected to at least survey-level archeological investigations, the task of hypothesis building is strengthened by the sheer wealth of available settlement data. Other regions have not been as fortunate. In the American Midwest, for example, large-scale investigations historically focused on the mortuary centers and earthen mounds of the Middle Woodland and Mississippian periods to the exclusion of generalized base camps and limited-use, resource extraction sites. In Central Texas, burned rock middens have been the favored type of site for excavations. In southwestern Texas, only a few sites have received systematic archeological investigation; consequently, the array of information available for building hypotheses about past organizational systems is extremely limited.

Nevertheless, hypothesis building must always begin somewhere regardless of the quantity of available data upon which inferences may be based. The reconstruction of settlement systems is necessarily approached from a multi-site or regional level of investigation. Since so few sites in southwestern Texas have been subjected to systematic excavation and analysis by professional archeologists, the current study is by necessity based on an incomplete database. Nevertheless, previous cultural resource surveys of the region surrounding the Varga Site have resulted in the documentation of numerous types of sites in both riverine and upland settings (cf, Devils Sinkhole by Howard et al. 1996). In addition, very few archeological sites in the surrounding region have been excavated and the results of analysis have been published. Based on these sources of information and the data derived from excavations at the Varga Site, the process of building hypotheses about prehistoric hunter-gatherer mobility, resource procurement, and land-use strategies can be reasonably undertaken.

\subsubsection{Research Questions}

- How much confidence can be placed on identifying the integrity and association of artifacts from various occupation zones?

- To what degree do the densities of cultural materials within various occupation zones relate to differential habitation intensity versus differential rates of sedimentation and/or erosion?

- What degree of post-depositional mixing of materials has occurred on the site? Is it possible to isolate individual occupations within broad occupation zones? Can laminae, microstrata, and/or individual occupation surfaces be discerned within overall occupation zones (i.e., components) based on stratigraphy, vertical distributions of plotted artifact elevations, and/or statistical indicators?

- Do the four cultural components on the site represent palimpsests of occupations or do they contain discrete, definable occupation episodes?

- Can distinct activity areas be defined within various cultural components based on feature distributions and/or the horizontal patterning of different artifact and/or material types?

- To what degree does overprinting of features and/or activity areas affect interpretations of the spatial structure of various occupation zones? Can individual activity areas or specific activities be detected within occupation zones that may be palimpsests of multiple occupations?

- To what degree do the densities of cultural materials within various occupation zones relate to differential habitation intensity 
versus differential rates of sedimentation and/or erosion?

- Can horizontal and/or vertical patterning be detected based on the distribution of and correlation and covariation among features, tools, residues, and other classes of artifacts across various occupation zones?

- What kinds of features typify each component? What range of functions do features within each component indicate? Do feature functions and/or forms vary in regular ways across time (i.e., among components)?

- Which segments of the assemblages from each component represent collector-based strategies? Forager-based strategies?

- Which segments of the tool assemblages from each component represent formal or standardized technologies? Which segments represent informal or expedient technologies?

- What relative emphases are evident on curated versus expendable tool technologies?

- Are subsistence economies through time focused on local versus regionally distributed resources?

- Are the subsistence economies through time focused on specific resources or limited ranges of resources (i.e., specialized) or are they more diversified (i.e., broad-based) economies?

- What was the surface distribution of geological materials (e.g., chert for stone tools, clay for pots) on the prehistoric landscape through time? Which resource localities were used? Which were not used?
Was lithic raw material procurement embedded in other economic activities?

- Were specific types of material, such as lithic raw materials, pottery, or sociotechnic objects, obtained and/or manufactured by the inhabitants of the Varga Site or obtained through trade? Were they manufacture at the Varga site or elsewhere?

- What types of sites characterize various time periods in the middle to upper Hackberry Creek Valley and the surrounding uplands?

- At various points in time, was the Varga Site part of a locally-based settlement system (i.e., the Hackberry Creek Valley and environs) or a regionally-based system (i.e., trans-valley)?

- What was the seasonal structure of group mobility?

- Were the cultural components at the Varga Site formed during intensive, long-term occupations or did they result from multiple short-term occupations.

- Are the inhabitants of the Varga Site a large family, multi-family, or other large social unit or a specialized task group?

\subsubsection{Relevance}

The primary data generated in pursuit of answers to the questions outlined in the paleoenvironmental, subsistence, and technology domains are of direct relevance to the task of tracing the formation of archeologically significant sediments and delimiting the organization of activities at the Varga Site. The spatial distributions of various tool classes, debitage, features, faunal bone, and other artifacts across each site component provide the foundation upon which assessments of site function may be made. The differential 
function, or range of functions, that characterize the site at a given point in time, in turn, provide for a range of inferences about the role of the site in the overall settlement system of which it formed a part through time. Explorations of such hypotheses may eventually lead to qualified characterizations of hunter-gatherer organizational systems in southwestern Texas.

\subsubsection{Data Requirements}

Although this research domain has a few unique data requirements that have not been discussed in previous sections, most data needed to answer questions pertaining to hunter-gatherer mobility and land-use systems have been discussed previously. See Section 4.2.1, Paleoenvironmental Reconstruction; Section 4.2.2, Subsistence; and Section 4.2.3, Technology, for complete presentations of data requirements under this research program. The specific data needs for this research domain are as follows:

- Data pertaining to paleoenvironmental conditions, subsistence, and technology

- Studies of floodplain formation processes and alluvial geomorphology of the Hackberry Creek terrace system

- Designations of feature form, function, and formation for all features within each component

- Pattern-recognition studies of cultural materials associated with various cultural periods, phases, and soil/sediment units based on a variety of pattern-detecting measures, such as stratigraphic interpretation, vertical distributions of plotted artifact elevations, and statistical indicators
- Secure chronological assessments of definable sediment units and cultural features

- Measures of correlation and covariation among artifact types, features, and raw material types within each component

- Presence/absence and extent of signs of burning, weathering, and patination on cultural materials

- Analyses of clast sizes, organic residues, and spatial patterning in burned rock features and a sample of burned rock recovered from non-feature contexts

- Functional and typological designations for tools from each component

- Distributional data (vertical and horizontal) for the artifact assemblages from each component

- Spatial analyses of distributions of tools, lithic debitage, cores, bone, pottery, and other artifact classes within each component (qualitative and quantitative)

- Analysis of a sample of the lithic debitage assemblage (e.g., raw counts, size-class designations, flake types) and classifications of flake characteristics (e.g., core preparation techniques, percussion techniques, reduction stage, technological strategies)

- Measures of relationship among various classes of artifacts (e.g., ratios of specific tool types to other tool types, ratios of tools to features, ratios of cores to debitage, ratios of scrapers to bone, statistical measures of correlation and covariation)

- Distributional data (vertical and horizontal) for the artifact assemblages from each component 
- Spatial analyses of distributions of tools, lithic debitage, cores, bone, pottery, and other artifact classes within each component (qualitative and quantitative)

\subsubsection{Investigation Strategies}

\section{Site Formation Processes}

The data requirements and analytical needs for studies of site formation processes mirror those involved in paleoenvironmental reconstruction; the study of site formation processes is distinct from the latter research domain in emphasis rather than in kind. Studies of site formation processes at the Varga Site consisted of three separate investigative activities: (1) alluvial geomorphology and its effect on the resolution of archeological deposits and the sequencing of prehistoric occupations; (2) the effects of postdepositional natural factors, such as pedogenesis and bioturbation; and (3) the effects of prehistoric cultural behavior on the integrity of deposits.

Some data needed for these investigations are similar to those involved in the paleoenvironmental investigations described in Section 4.2.1, including rates of deposition of the fine-grained sediments that comprise the first terrace of Hackberry Creek and the presence/absence and periodicity of erosional episodes. Other natural phenomena that need to be assessed include the impact of krotovina and historic and modern farming, ranching, and construction activities on the integrity of deposits. Other data needed for evaluating site formation processes are derived from patternrecognition studies, as discussed below in conjunction with analyses of intrasite structure. Among the cultural formation processes considered were curation of tools and "site furniture" by the prehistoric occupants (e.g., reuse of items from earlier components), overprinting of features and activity areas, and the periodicity of occupations.

In large part, evaluating site formation processes was an outgrowth of pattern-recognition studies. The existence of certain post-depositional factors is known based on fieldwork, such as the presence of extensive rodent and insect activity in some parts of the investigated site area, but the process of building arguments about observed patterning in the archeological record must begin with the elucidation of the patterning itself. The spatial analysis techniques that were brought to bear in the current study are discussed in more detail below.

\section{Site Structure and Function}

Spatial analysis studies at the Varga Site focused on elucidating the spatial organization of activities within each of the cultural components defined. It was not possible to discriminate among separate occupation episodes within broad cultural components; therefore the scale of spatial studies was directed towards the identified components. Thus, the suite of investigative strategies described below was applied to each of the four analytical units in the study, including the Toyah phase, Late Archaic period, Middle Archaic period, and Early Archaic period components in general.

The study of intrasite structure at the Varga Site was the use of functional and typological variables that represent the range of tools types, features, and other artifact and ecofact classes. In this sense, these spatial analysis studies were necessarily predicated upon the classification systems applied to the assemblage of artifact, ecofact, and feature data. In the current context, investigations of site structure were therefore heavily dependent upon the results of technological research (see Section 4.2.3, Technology). The technology research domain generated most variables that were used in spatial studies, such as determinations of feature 
form and function, tool types, debitage categories, projectile point types or morphological clusters, burned rock size categories, scraper varieties, and so forth. Other dimensions of variability for use in spatial analyses arose from studies of faunal butchering patterns, plant and animal processing techniques, and/or flintknapping activities.

The primary mode of spatial analysis consisted of examinations of the horizontal and vertical distributions of features and various artifact classes, such as burned rock (non-feature); tools (chipped stone, groundstone, and bone), ceramic sherds, cores, lithic debitage, and faunal remains. Vertical provenience was based on broad soil/sediment units (which are largely correlated with the occupation zones) as well as the point-elevation data recorded on larger artifacts during excavation. Field personnel were instructed to record the bottom elevations of all larger cultural specimens that were encountered in situ during excavation. The assumption underlying this practice is that larger items (i.e., larger than a golf ball) probably experienced relatively less post-depositional movement than smaller items; therefore, the elevations of these items may serve as a basis for identifying occupation surfaces that do not have any other stratigraphic indicators.

Within each component, horizontal distributions were plotted and examined based on densities of various material categories. Densities were measured in terms of numbers of items per cultural component per 1-by- $1 \mathrm{~m}^{2}$ excavation unit across the excavations. These density were measured in terms of raw counts per $\mathrm{m}^{2}$ (for area measurements) or item counts per $\mathrm{m}^{3}$ (for volume estimates) interchangeably based on the degree of vertical resolution that was determined within each component and on the goals and requirements of specific analyses (i.e., raw item counts work better with some pattern-detecting techniques, whereas others require density- corrected data). The block excavation strategy that was implemented during data recovery excavations, emphasized exposing large, continuous occupational areas, resulted in a data set that is strongly suited for a robust suite of spatial analysis techniques.

Spatial studies employed various qualitative and quantitative measures of correlation and covariation among artifact and material type classes. Plan maps of artifact distributions were examined for subjective impressions of association among variables, and quantitative techniques designed to detect patterning within data sets organized according to grid cells were implemented. Ratios among various classes of artifacts, features, raw material, and/or ecofacts were examined from a spatial perspective to aid in the process of defining functional and spatial patterning within the assemblage.

\section{Settlement and Land Use Patterns}

As discussed at the beginning of this section, the process of building hypotheses about huntergatherer mobility, settlement, and land use patterns based on the limited perspective of a single archeological site (complemented by a small body of relevant data from other sites in the region) is based entirely on inferences. The empirical data requirements for this task derive from the paleoenvironmental, subsistence, and technology domains discussed in Sections 4.2.1 to 4.2.3 of this research design. This discussion will therefore turn to the frames of reference and the epistemological framework of knowledge building advocated in this research design.

\section{Hunter-Gatherer Mobility and Foraging Strategies}

Having completed the empirical analyses of data from the various cultural components at the Varga Site and armed with independent 
ecological and ethnographic frames of reference, the process of building hypotheses about huntergatherer mobility, foraging strategies, and land use patterns may begin. In this context, it is perhaps more germane to understand how archeological inferences are constructed and used rather than to discuss the specific hypotheses that may result from this research. After all, archeological inference necessarily arises from dimensionalized data, and it would not do to impose interpretive frameworks upon the data before it has been analyzed.

In his most recent book, Binford (2001) likens the scientific investigation of the human past and ethnographic present to a theatrical presentation whose theme is the growth of knowledge. Unlike the conventional stage, however, where action is organized in terms of a plot with a beginning, a middle, and an end, this drama is open-ended and improvisational. It depends for its direction and pace on the goals and strategies of the dramatis personae-a group of scientific researchers with a common interest in huntergatherers - who work to reduce their ignorance about the past. In the prologue of this performance, the players describe the steps they have taken to define a class of observations. These operational definitions are intended to prevent confusion and misunderstanding as the play of ideas develops. Not all of the descriptive criteria that will later play a part in argument and analysis can be identified initially, however, since the direction that research will sometimes take is dependent on what the players learn about the validity of their ideas as the action of the play unfolds. If some or all of a player's corpus of knowledge is discovered to be irrelevant to the investigation of a particular problem, he or she must develop another set of propositions that are more germane to the trajectory of research. Mid-stream regrouping of this nature does not necessarily represent failure; in fact, the process of recognizing one's ignorance, or the limits of one's knowledge, or the inadequacies of one's operational definitions, is a profound form of knowledge that allows the player to search for new, more relevant information and then to reformulate the argument.

Once a researcher has recorded observations on material phenomena and has selected the initial dimensions in terms of which these observations are going to be organized, the scientific dialogue can begin. This is the juncture at which, if one resists the temptation to make accommodative arguments that stipulate what the data represent, the data have the opportunity to "talk back." The generic term for all subsequent investigation is analysis, which embraces all of the tactics and strategies that a researcher may implement in the search for relationships in the data set. Analysis is the study of how vectors of dimensionalized data interact with other, independently dimensionalized data either in the same or another data set. Once relationships are identified, the "conversation" between the researcher and the data begins as the researcher attempts to link the identified patterns to other sources of knowledge.

In archeology, investigations all to often fails to make it past this point. Good science consists of the strategic use of prior knowledge to make projections from better-known domains to less well-known domains. When observations on the lesser well-known phenomena are inconsistent with our projections, this is an important clue to the way in which the world may have been different from our conception of it. When ideas that we have considered germane are shown to be irrelevant, or at least poorly conceived relative to the way the world is organized, an opportunity for learning has been identified. Tactically, the tools that may be used to develop a dialogue with the data include independent frames of reference and pattern-recognition techniques. Interpretive conventions must not be imposed on detected patterning a priori; 
rather, the role of the scientist is to identify correlation and covariation among patterns and to build arguments about causality.

\subsection{SUMmARY}

The Varga Site (41ED28) is a multicomponent prehistoric archeological site on the northern T1 of Hackberry Creek in Edwards County, Texas. A two phase data recovery excavation conducted in a limited portion of this site by TRC archeologists under contract to TxDOT in 2002 resulted in the documentation of four prehistoric archeological components. The three most robust and clearly defined components date to the Late Prehistoric period Toyah phase (ca. 300 to 600 B.P.), the Late Archaic period (ca. 1,700 to 2,300 B.P.), and the Early Archaic period (ca. 5,200 to 6,300 B.P.). A specific Middle Archaic period (ca. 3,900 to 4,800 B.P.) component was also recognized, but was not as clearly defined as the other three components.

Whereas the undocumented boundaries of the Varga Site extend hundreds of meters along the northern terrace of Hackberry Creek, TRC's investigations were limited to a narrow part of the site that lies within the area of potential effect in the TxDOT right-of-way of a small county road. Block area excavations conducted on both sides of the pavement resulted in the excavation of a total of $207.75 \mathrm{~m}^{2}$, including an $83.00 \mathrm{~m}^{2}$ block excavation area on the west side of the road (Block A) and a $124.75 \mathrm{~m}^{2}$ block excavation area on the east side of the road (Block B). A total of $104.46 \mathrm{~m}^{3}$ of sediment was manually excavated, including $66.20 \mathrm{~m}^{3}$ in Block A and $38.26 \mathrm{~m}^{3}$ in Block B. Nine backhoe trenches were mechanically excavated to aid in the task of interpreting the site's stratigraphy, including seven trenches in the investigated site area on the first terrace, one in the T0/T1 terrace interface just south of Block $\mathrm{A}$, and one in the T1/T2 terrace interface about 100 m north of Block A.

The fine-grained, overbank alluvial sediments that contain the archeological components appeared relatively intact. However, krotovina disturbance was relatively extensive in parts of the investigated area, and the modern ground surface had been impacted by road construction and maintenance activities as well as some degree of erosion. Nevertheless, the archeological deposits exhibited a high degree of contextual integrity. Based on the site's stratigraphy, the Varga Site provides a rare opportunity to study definable cultural components in a region that is largely unknown archeologically. Furthermore, the site yielded a robust but mixed Early Archaic period assemblage. Unmixed Early Archaic assemblages have been documented in only a few investigated sites in Central Texas.

This research design was developed and served as a focus for profitably studying the recovered assemblages of artifact, ecofact, feature, and geomorphological data. Specific research avenues have made meaningful contributions to current studies of hunter-gatherer paleoecology and to culture historical studies near the interface of two archeological regions, Central Texas and the Lower Pecos regions, of southwest Texas. Research contributions were made towards understanding the paleoenvironment, subsistence, technology, culture history, and people's mobility and land use during specific use periods over the last 6,300 years. 



\subsection{INVESTIGATIVE METHODS}

Jeffrey D. Owens, J. Michael Quigg, and Mercedes C. Cody

\subsection{INTRODUCTION}

Data recovery excavations at the Varga Site were undertaken in two separate phases. The first phase of fieldwork included mechanical stripping and trenching as well as manual excavation of a small part of the site. Upon completion of the first phase of fieldwork, TRC submitted an interim report to TxDOT that summarized the archeological and geomorphological investigations undertaken to date (i.e., February 2002) and presented a preliminary tabulation and limited assessment of artifacts and feature data recovered (Lintz et al. 2002). This report documented the significant research potential of this site, recommended a second phase of data recovery excavations to mitigate the proposed construction impacts, and presented a data recovery plan that guided the second phase of excavations.

The field tactics employed during the second phase of fieldwork emphasized opening up large block excavations on both sides of the road. The excavation blocks enabled TRC archeologists to expose large portions of each occupation zone at once, providing a window on the spatial patterning of features and artifacts, rather than sinking a series of adjacent "telephone booth"type pits in discontinuous areas. Excavations on the west side of the Ranch to Market Road (Block A) targeted the entire sequence of occupations at the Varga Site, including the
Early Archaic through Toyah period components, while excavations on the east side of the road (Block B) focused exclusively on the Toyah period component.

\subsection{Previous InVestigations}

The Varga Site was originally documented during a cultural resource reconnaissance of the upper Nueces River Natural Area near the Devil's Sinkhole (Kennard 1975; Marmaduke and Whitsett 1975). Although the original site forms are missing from TARL files (or were never submitted), the survey report briefly describes site 41ED28 as a 250-meter-long site of undetermined width that extends along a terrace on the north side of Hackberry Creek (Marmaduke and Whitsett 1975:92). The recorders identified two "burned rock middens" on the highest portion of the terrace as well as several additional "fire hearths" on the lower parts of the terrace. Burned rock and lithic artifacts were observed scattered across the entire surface (see Marmaduke and Whitsett 1975:107, Fig. 5).

Following its initial discovery and documentation, no further cultural resource investigations occurred at the Varga Site until the current TxDOT undertaking. These archeological investigations were initiated in response to the planned reconstruction of the Ranch to Market Road crossing over Hackberry Creek immediately south of the site. The existing low-water crossing had washed out twice during severe flooding in the winters of $2000 / 2001$ and 2001/2002. At the time that archeological investigations began, final decisions had not yet been made regarding the long-term solution for repairing the creek crossing, but either a bridge or a reinforced lowwater crossing were considered to be options. Either way, the portion of the Varga Site lying within the existing road right-of-way on the northern terrace of the creek would be impacted 
by construction activities, so TxDOT initiated cultural resource investigations of the potentially affected part of the site.

\subsection{Phase I of Data Recovery INVESTIGATIONS}

\subsubsection{Archeological Field Procedures}

In 2001, TxDOT's Environmental Affairs Division contracted TRC to investigate the part of the site that lies within TxDOT's right-ofway. TRC's scope of work was originally quite limited; it was designed to exhaust the information potential of a purported burned rock oven feature located on the rim of the first terrace of Hackberry Creek on the west side of the Ranch to Market Road (Lintz et al. 2002). During a field inspection of the damage to the low-water crossing following the most recent flood event in the winter of 2001/2002, TxDOT archeologists noticed a low topographic mound within the right-of-way on the west side of the existing road. This topographic anomaly was reported to be covered with lithic debris, burned and unburned rocks, and animal bones and was suspected to be a prehistoric burned rock oven "midden.” Local informants apparently reported that this "midden" had been subjected to repeated collecting and digging activities over the years, though no obvious potholes or other evidence of vandalism were evident (the authors now believe that these reports of pothunter excavations apply to other burned rock midden features located elsewhere on the site, beyond TxDOT's right-of-way). As this "midden" was located within the area of potential effect regardless of the manner of highway repair construction of the low-water crossing, investigations of the area were warranted as required under Section 106 of the NHPA.

In an effort to streamline the regulatory procedures of NHPA Section 106, TxDOT archeologists entered into consultation with the THC. Based on these consultations and available information about the site, it was determined that any archeological testing within TxDOT's right-of-way would most likely result in the determination of the "midden" feature as eligible for inclusion in the National Register of Historic Places (NRHP). Consequently, the parties agreed that data recovery investigations should be initiated in the "midden" feature without implementing a formal testing phase.

In consultation with TxDOT, TRC developed a scope of work that employed mechanical ground surface stripping and backhoe trenching as well as manual excavation of up to $10 \mathrm{~m}^{3}$ to efficiently extract data from the intact parts of the purported "midden" feature. A delivery order for these investigations was issued to TRC under an existing scientific services contract for cultural resource services. TRC archeologists and a subcontracted geoarcheologist performed data recovery fieldwork at the Varga Site between January 14 and February 10, 2002, under Texas Antiquities Committee Permit 2779. During these investigations, changes in site conditions necessitated contract modifications to reallocate the $10 \mathrm{~m}^{3}$ excavation area to examine the archeological potential on both sides of the Ranch to Market Road near the lip of the second terrace.

The initial plan for investigating the site was developed by TxDOT archeologists specifically to document the burned rock "midden," to identify any intact cultural deposits, and to extract information from any intact portions of the feature (Lintz et al. 2002:6). Consequently, the initial work authorization called for TRC archeologists to restrict excavations to the "midden" feature. First, the presumed, disturbed surface sediments overlying the "midden" feature on the west side of the Ranch to Market Road, which was described as being "armored" with lithic debris, burned and unburned rocks, and animal bones, were mechanically stripped using a Gradall ${ }^{\circledR}$. The initial stripping showed 
that very sparse burned rocks, and deer and bison bones were present under the armor of surface rocks. Thus, these sediments appeared to lack the stratigraphic integrity necessary to contribute information about the site. In addition, the light brown sediments showed little evidence of the reported vandalism in the topographic mound.

Although the true nature of the site was not known at this time, it appears in retrospect that the surface stripping may have removed portions of the Toyah component at the site, especially on the west side of the Ranch to Market Road (i.e., Block A). The initial interim report states that the upper 10 to $20 \mathrm{~cm}$ of sediment was removed from the site surface on the west side of the road. These sediments were determined to consist largely of roadway gravel and/or sediments that had been moved during road construction and subsequent maintenance activities. The ground surface in the Ranch to Market Road right-of-way is highest along the bordering fence lines and slopes down toward the existing pavement in the center, resulting in elevation differences of about $40 \mathrm{~cm}$ on the west side and about $20 \mathrm{~cm}$ on the east side of the road. While the original surface contour prior to stripping was not known, the uppermost alluvial sediments containing the Toyah component are $40+\mathrm{cm}$ thick along the fence lines at the edges of the right-of-way, but the depth of these sediments decreases rapidly moving inwards toward the road. In some areas on the west side of the road (Block A), the Toyah component was entirely absent. In addition, most of the faunal bones recovered from the Toyah component are highly fragmented, possibly as the result of heavy equipment movement. Surface stripping on the east side of the road was not conducted during the first phase of data recovery excavations.

After surface stripping on the west side of the road was completed, a north-to-south-oriented trench (BT 1) was excavated west of the small concentration of burned rocks revealed during the stripping (i.e., through the west half of the topographic anomaly interpreted as a burned rock “midden”). For mechanical excavations, TxDOT provided a Gradall ${ }^{\circledR}$ with a 1.2 m wide, straight-edged bucket and an operator. BT 1 exposed a 5-to-6 $\mathrm{m}$ long rock lens (designated as Feature 1) in a shallow basin buried under $30 \mathrm{~cm}$ of fine sediments and overlying about $60 \mathrm{~cm}$ of fine sediments and coarse gravel deposits. In accordance with the work authorization, a second, east-to-west-oriented trench (BT 2) was excavated perpendicular to the first trench through the northern half of the shallow burned rock lens. This trench reaffirmed the scarcity of burned rock in most of the deposits. The evidence clearly indicated that the topographic mound feature did not represent a classic burned rock midden. The trench walls were profiled and photodocumented. The project geoarcheologist, Mr. Grant Smith of TRC's El Paso office, described and drew profiles of both trenches. He also collected a series of sediment samples from the west end of BT 2 to assist in characterizing the texture and chemistry of the sediments near Feature 1.

In addition to the excavation of BTs 1 and 2, the initial work authorization called for manual excavation of up to $10 \mathrm{~m}^{3}$ of site sediments. Thus, upon completing the excavation of BTs 1 and 2, a grid system composed of $1 \mathrm{~m}$ square units was laid out over the "mound area" on the west side of the road. The southwest corner of the "mound" near the edge of the TxDOT rightof-way boundary was arbitrarily assigned the designation of N100/E50, and the grid was extended north and east to cover the entire area. All 1-by-1 m units were designated according to the coordinate of their southwest corner in relation to the reference point, while the 0.5-by$0.5 \mathrm{~m}$ units were designated using the quadrant's position within the larger 1-by-1 m unit (e.g., NW 1/4 of N103/E52). Vertical depth was 
maintained in reference to a site datum installed along the fence line and extrapolated to a subdatum placed near the west side of the intersection of BTs 1 and 2.

Initially, TRC's scope of work called for excavating 0.5 -by- $0.5 \mathrm{~m}$ columns at two-meter intervals along the edges of BTs 1 and 2 . These excavation columns were designed to obtain information on the internal structure of the midden feature as well as any associated features or occupation zones. Four 0.5-by- $0.5 \mathrm{~m}$ units were initially excavated - two on the eastern side of BT 1 and two along the southern edge of BT 2. Sediments excavated from these four columns were screened through $3.2 \mathrm{~mm}$ (1/8 in) hardware cloth. The manual excavations of these two columns documented the occurrence of elevated quantities of chert debitage above the burned rocks and again just above the basal gravels. The recovery of diagnostic Early Archaic dart points and Late Prehistoric Perdiz arrow points, high densities of prehistoric artifacts above and below the thin rock lens, and the lack of vandalism all suggested that the second terrace area contained stratified occupations with considerable integrity. Furthermore, the cultural deposits appeared to extend laterally beyond the topographic mound.

TRC entered into field consultation with TxDOT archeologists, and the original scope of work was altered to include the investigation of deposits on both sides of the Ranch to Market Road to ascertain the geometry of the terrace deposits and the extent of archeological remains. TRC archeologists were asked to excavate additional Gradall ${ }^{\circledR}$ trenches north of the original target area on the west side of the road and to extend investigations to the east side. In addition, the original requirement to screen all excavated sediments through $3.2 \mathrm{~mm}$ mesh was waived, and TRC personnel were granted latitude of judgment in the placement and distribution of $0.5-$ by- $0.5 \mathrm{~m}$ and 1-by- $1 \mathrm{~m}$ manual excavation units. However, the level of effort expended to excavate on both sides of the road was restricted to the original volume limit of $10 \mathrm{~m}^{3}$.

Two additional Gradall $^{\circledR}$ trenches were excavated on the west side of the Ranch to Market Road (BTs 3 and 4) and three trenches were excavated on the east side (BTs 5 to 7). A total of seven 0.5 -by- $0.5 \mathrm{~m}$ units was excavated along the edges of the deeper backhoe trenches (four on the west side of the Ranch to Market Road and three on the east side of the road), and an eighth 0.5 -by- $0.5 \mathrm{~m}$ unit was excavated just south of BT 3 on the west side of the road. A scatter of five 1-by-1 m units was excavated on the east side of the road, and two 1-by-2 m units were excavated on the west side of the road near the initial backhoe trenches (BTs 1 and 2). Manual excavations were conducted using hand tools (i.e., picks, shovels, and trowels). The fill from $2310 \mathrm{~cm}$ levels from four 0.5-by-0.5 m units was screened through $3.2 \mathrm{~mm}$ mesh; and two of these columns were systematically finescreened from top to bottom to obtain a consistent sample. All other fill was screened through $6.4 \mathrm{~mm}$ (1/4 in) hardware cloth.

Clusters of artifacts, such as faunal bone or burned rocks, and ashy stains were designated as cultural features. Seven such features were originally documented in the field, though three were attributed during later analyses to natural causes (i.e., two were burned root casts and one was a cluster of mineral deposits originally believed to possibly be decomposed human long bones). The four remaining cultural features included the burned rock lens (Feature 1), two sparse scatters of burned rock, and one bison and deer bone dump associated with burned rocks. Samples of sediments comprising the features were often collected, but not in all instances. All hand-excavated units were terminated upon encountering culturally sterile gravel deposits. The first phase of fieldwork was halted upon 
fulfilling the contractual excavation limit of $10 \mathrm{~m}^{3}$.

Information about all levels was recorded on standard excavation level forms. Observed rocks and other materials found in situ were plotted on the level forms, and elevations were collected from the bottom of the plotted artifacts. Burned rocks were sorted according to size, shape, and material class in the field, and these attributes were recorded on the level forms. After being counted and weighed, most burned rocks were discarded on-site.

All flakes, bones, ceramic sherds, pieces of burned clay, charcoal, and tools were placed in clear line seal top bags with completed provenience tags. Excavators compiled preliminary field counts of collected materials in the field to facilitate the compilation of information about material distributions for the first interim report (Lintz et al. 2002). Laboratory work associated with the first phase of fieldwork, however, was limited to assessing the completeness and accuracy of field records and collected materials; no cleaning or cataloging of artifacts occurred at this stage. All material classes were examined, counts and weights were compiled for the unwashed artifacts, and an effort was made to identify the types of projectile points and pottery recovered from the excavations. In addition, soil samples were collected from various strata observed in the backhoe trenches to aid in preliminary geomorphological interpretations of site stratigraphy and terrace formation processes.

The results of this initial phase of fieldwork have been summarized in an interim report (Lintz et al. 2002) and served as the basis for designing a second, more robust phase of data recovery excavations at the site. The first interim report documented that the archeological setting and context of the Varga Site were quite different than originally expected, and a second phase of fieldwork was recommended to fully investigate the cultural deposits within the area of potential effect. In anticipation of a second phase of data recovery excavations, all Gradall ${ }^{\circledR}$ trenches and hand-excavated test units were lined with plastic and backfilled with excavated sediments and sterile sand upon completion of excavations under the supervision of an archeological monitor.

The first phase of fieldwork established that thick $(70+\mathrm{cm})$ deposits of stratified fine sediments containing predominantly Toyah, Late Archaic, and Early Archaic archeological materials existed on both sides of the Ranch to Market Road within TxDOT's right-of-way (the sparse Middle Archaic component was identified only during the second phase of fieldwork). Despite some variability in depositional packages across the site, two major and one minor occupation zones were documented. The uppermost major occupation zone, attributed to the Toyah phase, was present in the uppermost 10 to $40 \mathrm{~cm}$ of deposits on both sides of the road. Large quantities of artifacts were recovered from this component, and the preservation of bone and organic remains was excellent in these upper sediments. Several associated cultural features (i.e., debris clusters) were documented.

The minor occupation was associated with the large, shallow lens of burned rock (Feature 1) at depths of 30 to $60 \mathrm{~cm}$ below surface (cmbs). This occupation was tentatively dated to the Middle Archaic period based on the presence of a possible Pedernales/Martindale point (subsequent investigations established that this feature and the surrounding cultural component actually date to the Late Archaic period; consequently, this cultural component is referred to as Late Archaic throughout this report). Even though associated artifacts were not abundant, this occupation zone was marked by superb stratigraphic clarity on both sides of the road 
(although high burned rock densities were limited to the immediate vicinity of Feature 1).

Finally, a substantial Early Archaic occupation zone was identified at depths ranging from 60 to $80 \mathrm{cmbs}$ east of the Ranch to Market Road and from 60 to $110 \mathrm{cmbs}$ west of the road, near the base of the excavations above the basal gravel deposits. Preservation of organic materials was not perceived to be especially good in these lower zones, and no associated features were found during the first phase of fieldwork, but artifact densities were observed to be extremely high.

Based on variability in artifact densities, the most productive areas to be examined in the second phase of fieldwork appeared to include all occupation zones on the west side of the Ranch to Market Road, including Toyah, Late Archaic, and Early Archaic occupations (as well as any general Middle Archaic components that may occur between the Early and Late Archaic period occupation zones), but only the Toyah component was targeted on the east side of the road. Older occupations were documented on the east side of the road, but the preservation appeared to be poor and temporal and cultural diagnostics and features were rare. Thus, the first interim report recommended that the second phase of fieldwork target all three components on the west side of the Ranch to Market Road and only the Toyah component on the east side of the road. The report presented a data recovery plan that guided the proposed second phase of excavations at the Varga Site and outlined eight primary research domains to be addressed with the data recovered. Upon consultation with THC, TxDOT concurred with TRC's recommendations and issued a work order to proceed with the proposed second phase of data-recovery excavations.

Before the second phase of excavations could begin, however, TxDOT entered into consultation with any interested parties (per Section 106 of the NHPA) regarding the possible human remains recovered during the first phase of fieldwork. At TxDOT's request, a sample of the possible human remains was examined by three physical anthropologists. The physical anthropologists concluded that the materials could not be assigned to a species, though one concluded that the size and position of the materials were consistent with human leg bones (Appendix J). Given the inconclusive results, TxDOT submitted a sample of the material to a bone histologist for examination of the cellular structure of the material. The histologist and his academic advisor both concluded that the material was not bone. The histology information was also submitted to osteologists in California who reaffirmed the conclusion that the material was not bone. Once all opinions were gathered, TxDOT's archeological staff, TRC archeologists, and the THC concluded that the material was not human in origin (these materials are now believed to be sediment cavities, probably root casts that were subsequently filled with carbonates [see Appendix $\mathrm{J}$ for a full report]). Based on this conclusion, it was determined that the second phase of data recovery excavations could proceed.

\subsubsection{Geoarcheological Field Procedures}

Geoarcheological investigations were conducted during the first phase of fieldwork at the Varga Site to evaluate site integrity, to identify the soil/depositional units relevant to the archeological investigations, and to characterize the natural setting (Lintz et al. 2002). These investigations were accomplished primarily through examination of Gradall $^{\circledR}$ trench exposures, inspection of hand-excavated unit profiles, and pedestrian observation of the surrounding terrain. Seven backhoe trenches, including four on the west side of the Ranch to 
Market Road and three on the east side of the road, and $10 \mathrm{~m}^{3}$ of hand-excavated units were excavated at the Varga Site during the first phase of fieldwork. Although the initial backhoe trenches were excavated in areas directly related to known cultural materials, additional trenches on the east side of the roadway helped delineate the extent of soil/depositional units with the potential to yield prehistoric cultural materials. Based on these investigations, several distinct, relatively intact sediment packages were identified on the first terrace on both sides of the roadway. Although some variability in the depth of the various depositional units was observed, the stratigraphic sequence was similar across the investigated site area.

Field descriptions followed standard sedimentologic and pedogenic procedures established by the Soil Survey Staff (1962, 1975), Krumbein and Sloss (1963), Gile et al. (1966), Reineck and Singh (1980), Birkeland (1984), Birkeland et al. (1991), and Waters (1992). Field investigations were recorded on standardized profile-exposure forms.

At the time of the first-phase geomorphological investigations, the sediments were moist due to precipitation. This tended to obscure the stratigraphic boundaries in the upper portions of the profiles. Some profiles dried out later during the excavations, and additional observations from the archeologists were included as part of the geomorphological investigations.

Four backhoe trenches (BTs 1 through 4) were placed on the west side of the road, and three more (BTs 5 through 7) were excavated on the east side of the road. All trenches were examined by the project geoarcheologist, Mr. Grant Smith of TRC's El Paso office, and were profiled and photographed. In general, 0.5-by$0.5 \mathrm{~m}$ units were placed adjacent to the deeper backhoe trenches (BTs 1, 2, 6, and 7).
Two 1-by-2 m units within the grid system looked at cultural features on the west side of the road, and one 1-by-1 m unit was excavated east of the road to investigate an ash stain exposed in BT 7. A few other 1-by-1 m units were opened on the east side of the road in areas between backhoe trenches to obtain a larger sample of deposits. Most of these units were not placed with regard to the vertical datum established on the west side of the road, and only after excavations were underway was the horizontal grid system expanded to encompass the units on the east side of the road (this resulted in some problems in correlating all excavation units to a single grid system during the second phase of fieldwork).

\subsection{Phase II Data Recovery INVESTIGATIONS}

\subsubsection{Archeological Field Procedures}

The tactics employed during the second phase of fieldwork emphasized large block excavations on both sides of the road. The excavation blocks enabled TRC archeologists to expose large parts of each occupation zone at once, providing a window on the spatial patterning of features and artifacts. Excavations on the west side of the road (Block A) targeted the entire sequence of occupations at the Varga Site, including the Early Archaic through Toyah period components, while excavations on the east side of the roadway (Block B) focused exclusively on the Toyah period component (Figure 5-1).

\subsubsection{Block A Excavations}

Block A was excavated west of the road to capture data from all three previously identified cultural components (i.e., Toyah, Late Archaic, and Early Archaic) as well any additional, less well-defined components might exist in that part of the site. Block A was designed to cover a horizontal area of approximately $80 \mathrm{~m}^{2}$, though the actual volume of matrix to be excavated was 


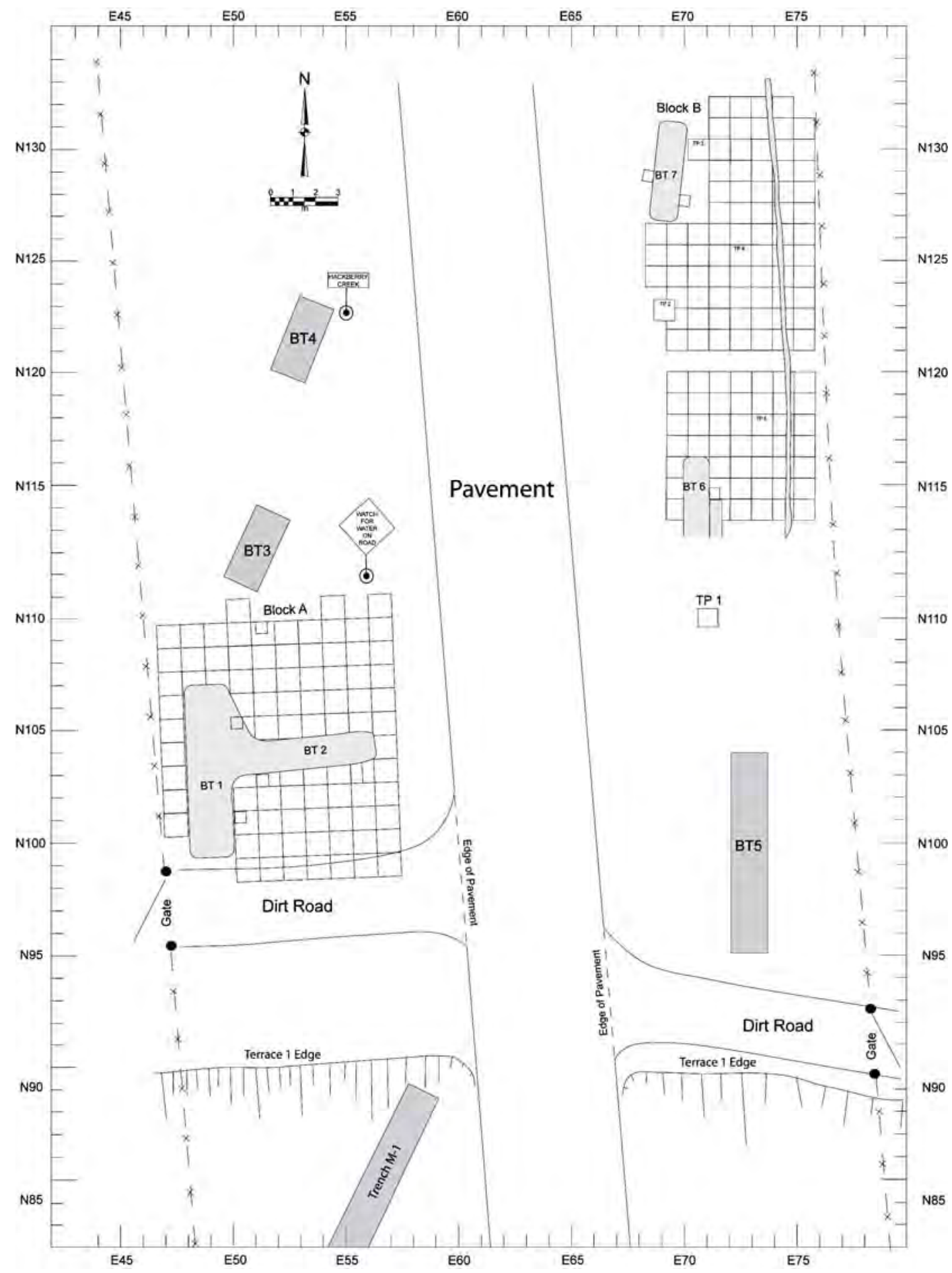

Figure 5-1. Varga Site (41ED28) Phase II Investigation Areas 
not specified in the scope of work as the depth of the basal gravel layer was known to vary considerably across the project area (ranging from ca. 35 to $130 \mathrm{cmbs}$ within Block A). Block A was excavated into gravels at whatever depth they occurred.

The natural and artificial features of the road right-of-way largely determined the boundaries of Block A (Figure 5-1). The southern boundary was defined by the northern edge of a gravel driveway that runs along the rim of the terrace, providing access to the ranchlands lying to the west. The western boundary was demarcated by the fence line that marks the edge of TxDOT's right-of-way; and the eastern boundary fell 1 meter shy of the road shoulder. The northern boundary was the only open boundary of the excavation block. Artifact densities along the northern boundary remained high, and the archeological deposits appear to extend an undetermined distance to the north; however, the depth of deposits thinned considerably along the northern edge.

The final outline of Block A formed an irregular rectangle, measuring approximately $11 \mathrm{~m}$ northto-south by $10 \mathrm{~m}$ east-to-west (Figure 5 -2). The northern boundary exhibited a somewhat denticulated silhouette produced by three noncontiguous 1-by-1 m units that were excavated to provide larger exposures of features that extended into the northern wall of the excavation block. In addition, a portion of the southwestern corner remained unexcavated due to the convergence of the ranch gate, the gravel driveway, and the distal end of BT 1 that left no room for the block to be squared out in this area. Internally, the continuity of the excavation block was interrupted by backfilled BTs 1 and 2 as well as by blocks of sterile sand used to backfill the manually excavated 0.5 -by- $0.5 \mathrm{~m}$ and 1 -by-2 $\mathrm{m}$ units from the first phase of fieldwork.
Prior to initiating the second phase of excavations, TRC archeologists relocated the previous backhoe trenches and manual excavation units. BTs 1 and 2, which formed a "T" that transected Feature 1 (the burned rock lens) along two axes, and the hand-excavated units, had been lined with clear plastic prior to being backfilled during the first phase of fieldwork. The backhoe trenches were then backfilled with the matrix that had been excavated from them, whereas the manually excavated units had been backfilled with sterile sand. In addition, some of the pin flags and nails used to mark the corners and edges of the excavation units and backhoe trenches were still in the ground. Consequently, the previous excavations were easily relocated and remarked with pin flags during the second phase of fieldwork. In sum, TRC's prior investigations on the west side of the road included four mechanically excavated backhoe trenches (two of which transected the buried burned rock lens [Feature 1]) and five 0.5-by-0.5 $\mathrm{m}$ and two 1-by-2 m hand-excavated units.

Next, a grid composed of one-meter-square units was laid out within the designated Block A area based on the site datum that had been installed along the western right-of-way fence line during the first phase of fieldwork. This datum stake consisted of a length of rebar set in a concretefilled posthole. Although the datum was not marked on the field maps published in the first interim report (Lintz et al. 2002), it is located on the N112 line of the grid where it intersects with the fence line a few centimeters west of the W47 grid line. The final boundaries of Block A encompassed all of the manually excavated units and BTs 1 and 2 from the first phase of fieldwork. 


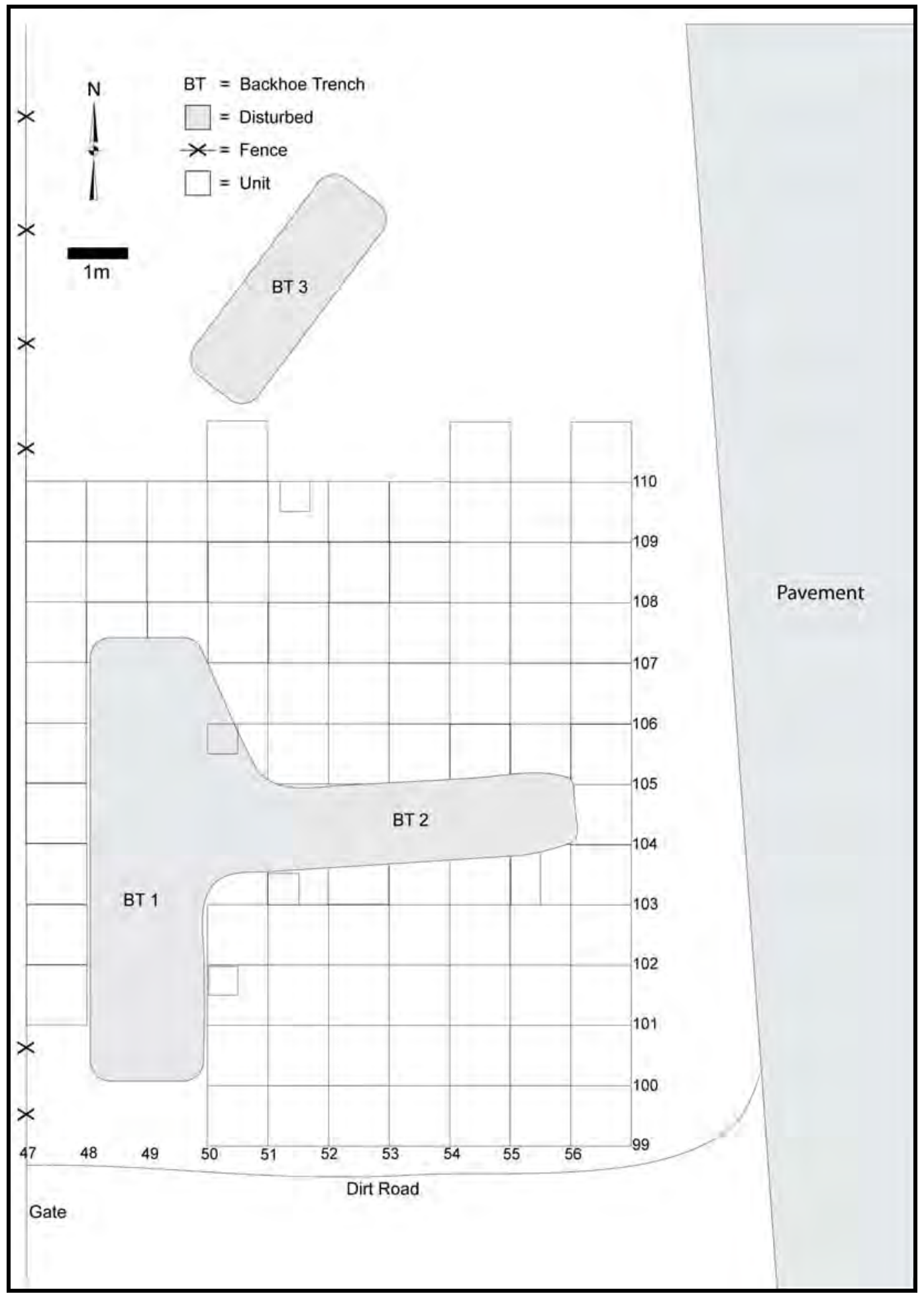

Figure 5-2. Block A Excavation Grid Lines 
The same grid system that was used during the first phase of investigations was used for the second phase. Both grids were based on the datum stake installed along the western fence line. The arbitrary coordinates of the datum stake were rounded to N112/E47, with grid coordinates increasing to the north and east (the origin of the grid was the southwest corner of the topographic mound, which was arbitrarily designated as N100/E50 during the first phase of investigations). While setting up the grid for the second phase of excavations, it quickly became apparent that the hand-excavated, 0.5-by- $0.5 \mathrm{~m}$ units from the first phase did not align correctly with the new grid (i.e., many were offset by as much as $20 \mathrm{~cm}$ along one or both grid axes). The 1-by-2 $\mathrm{m}$ units from the first phase of fieldwork, however, did align with the grid. The reason for this was that the original contract for the first phase of fieldwork called for placing the 0.5-by- $0.5 \mathrm{~m}$ units at $2 \mathrm{~m}$ intervals along the edges of the backhoe trenches excavated into Feature 1 (the burned rock lens). The backhoe trenches were excavated prior to setting up the site grid, which was consistent with the limited scope of work of the original work authorization (i.e., to investigate only the purported burned rock "midden"). The site grid was established only after the original scope of work was modified to expand the excavations beyond the vicinity of the burned rock feature. Thus, the 1-by-2 m units were excavated on the grid, whereas the 0.5 -by- $0.5 \mathrm{~m}$ units and the backhoe trenches were not.

During the first phase of TRC's investigations, the upper 10 to $20 \mathrm{~cm}$ of sediments on the west side of the road, including the Block $\mathrm{A}$ area, were removed using a Gradall ${ }^{\circledR}$ because it had been thought that they consisted largely of roadway gravel and/or sediments that had been moved during road construction (Lintz et al. 2002:8). This procedure enabled TRC archeologists to identify dense bone or burned rock concentrations and ashy areas that could be designated as features and serve as guides for placing the two 1-by-2 $\mathrm{m}$, hand-excavated units. Thus, data for compiling a detailed topographic map was not collected at the outset of the second phase of investigations because the surface had been substantially altered. Eventually, however, the elevations of the grid coordinates relative to the site datum (i.e., the top of the concrete slab used to encase the rebar stake) were determined using a transit so that excavation depths could be tied into absolute centimeters below datum (cmbd) across the entire project area (i.e., Blocks A and B).

A total area of $83.00 \mathrm{~m}^{2}$ was hand-excavated in Block A, including $5.25 \mathrm{~m}^{2}$ during the first phase of fieldwork and an additional $77.75 \mathrm{~m}^{2}$ during the second phase. This figure does not include the area encompassed by the two backhoe trenches excavated in Feature 1 during the first phase of fieldwork, nor the baulks that were left standing along the edges of these backfilled trenches during the second phase to prevent them from collapsing; however, it does include all of the manually excavated 0.5 -by- 0.5 $\mathrm{m}$ and 1-by-2 $\mathrm{m}$ units excavated during the first phase of fieldwork, as well as all of the complete and partial 1-by-1 m units excavated during the second phase. In sum, $66.20 \mathrm{~m}^{3}$ of sediment matrix was excavated in Block $A$, including $4.69 \mathrm{~m}^{3}$ during the first phase of fieldwork and an additional $61.51 \mathrm{~m}^{3}$ during the second phase.

Due to the shallowness of the upper occupation (i.e., the Toyah component), the spacing of underlying occupation zones, and the previous mechanical stripping of surface sediments, no additional mechanical stripping was performed in Block A during the second phase of fieldwork. All 1-by-1 m units were hand excavated using primarily shovels and picks, with trowels and brushes used to expose and excavate features. Each 1-by-1 m excavation unit was designated by the coordinate of its southwest corner (e.g., N109/E53). Excavations 
proceeded in arbitrary $10 \mathrm{~cm}$ levels. Vertical elevations were determined using level lines strung from subdatum nails in the vicinity of each excavation unit. Whenever possible, the subdatums were located at the southwestern corner of each excavation unit, but it was not always possible to locate the subdatums in the southwestern corner-sometimes, adjoining units had already been excavated and no ground surface was present in which a subdatum nail might be secured. In these cases, another corner of the excavation unit or the nearest intact subdatum nail served as the subdatum. All elevations were recorded in centimeters below the appropriate subdatum nail. Later, these elevations were tied into the primary site datum and translated into cmbd.

To the extent practicable, subdatum nails were placed on or near the grid coordinate with the highest topographic elevation. The southwestern corner was preferred as a subdatum location, though strong topographic relief strongly influenced subdatum placement. On occasion, this practice resulted in the first excavation level of some units being less than $10 \mathrm{~cm}$ thick (i.e., because of strong topographic relief, the first level would have been a partial level). In these cases, the first two excavation levels were sometimes excavated together. Also, individual $10 \mathrm{~cm}$ levels were occasionally broken into two separate five-cm levels to more clearly demarcate transitions between major stratigraphic zones or to provide tighter vertical control within features.

The excavation strategy favored the exposure of broad horizontal areas to allow for identification of the spatial juxtipositions of features and artifacts. Thus, multiple, adjacent, 1-by-1 m units in Block A were excavated together a few levels at a time rather than as individual units excavated from top to bottom one at a time. The constraints of individual 10-day field sessions, the logistics of organizing excavations within the spatially restricted confines of Block A, and the need to manage varying excavation rates in feature and non-feature contexts limited the extent of continuous, horizontal areas that could be opened at one time. Nevertheless, excavations proceeded in at least four square meter blocks whenever possible, exposing comparable excavation level floors in adjacent units before proceeding downward. The amount of area being excavated at any one time ranged from 4 to $12 \mathrm{~m}^{2}$ throughout most of Block A. Along portions of the western and eastern edges of the excavation block, however, the excavation area narrowed to as little as $1 \mathrm{~m}$ in width due to the extent and orientation of the backhoe trenches. In these areas, linear (i.e., $1 \mathrm{~m}$ wide) series of two to four units were excavated together in this manner.

All sediments were screened through $6.4 \mathrm{~mm}$ (1/4 in) hardware cloth during the second phase of excavations (i.e., none of the sediments excavated during the second phase of investigations were fine-screened). During the excavation of Block A, screened sediments were periodically moved to a backfill pile located well to the north of the excavation area using frontend loaders provided and operated by TxDOT personnel under the supervision of TRC archeologists.

Information about all excavation levels was recorded on standard excavation level forms in the field. Rocks and other materials found in situ were plotted on the level forms and elevations were collected from the bottoms of the items. As a rule, systematic attempts to determine artifact elevations applied only to those artifacts that were larger than a golf ball. It was presumed that the larger size of such items would mean that they had been subjected to less vertical translocation than smaller artifacts; consequently, they may serve as indicators of buried occupation surfaces. Any diagnostic artifact found in situ was also plotted 
on the level sketch map along with its bottom elevation.

Field tactics during the second phase of excavations included the designation of seven “sample units” in Block A. As a rule, TRC's excavation strategy included discarding certain classes of material in the field after counting and weighing them. Discarded material types included most non-feature burned rocks, some burned rocks from features, snail shells (both Rabdotus and Helicina species), and natural gravels. In general, these materials were counted and/or weighed, as appropriate, the information was recorded on excavation level forms, and then the materials were discarded in backfill piles. However, in the seven "sample units," all of these materials were collected. The "sample units" were designed to provide a control sample of data classes that may be used for specialized analyses.

Burned rocks were analyzed for size, shape, and raw material class (almost always limestone) in the field, and these attributes were recorded on the excavation level forms. After being counted and weighed, most burned rocks recovered from non-feature contexts, as well as some of the rocks from feature contexts, were discarded. However, random samples of non-feature burned rocks, in addition to large samples of burned rocks from features, were collected for analyses.

All lithic debris, faunal bone, ceramic sherds, pieces of burned clay, mussel shells, charcoal, tools, and other artifacts and ecofacts were placed in clear seal-top plastic bags with completed provenience tags. Upon completing each excavation level, field personnel counted and/or weighed the material collected and included these preliminary tabulations on the excavation level forms. These field counts served as the basis for the preliminary assemblage tabulations presented in the second interim report.

All units in Block A were excavated at least $10 \mathrm{~cm}$ into the layer of limestone gravels that defines the lower limit of artifact-bearing sediments at the Varga Site. As will be discussed more thoroughly in Chapter 6.0Geomorphology, the lowest occupation zone (the Early Archaic component) continues 5 to $10 \mathrm{~cm}$ into the basal gravel stratum. Excavations were terminated when the density of artifacts in the lowest occupation zone decreased markedly. Excavations in some units (every fourth or fifth unit) pushed deeper into the gravel substrate to verify that the drop in artifact density served as a consistently valid marker of the bottom of the occupation zone. In all instances, artifact recovery below this point resulted in no more than a few small chert flakes per $10 \mathrm{~cm}$ excavation level excavated into the sterile gravels. Clearly, some artifacts had been translocated downwards into the gravel deposits, but the bulk of the occupation zone was associated with the soil zone immediately overlying the gravels and interdigitated with the upper 5 to $10 \mathrm{~cm}$ of the gravels.

Whenever stone tools were identified in the field, whether they were found in situ or recovered from screens, they were minimally handled and bagged immediately so as not to contaminate them. Furthermore, many of these were neither handled nor washed in the laboratory. A sample of these pristine tools was submitted for use-wear analyses.

The criteria for recognizing and designating cultural features during the second phase of field operations differed from those used during the first phase. During the first phase of fieldwork, any dense bone or burned rock concentration or ashy stain was designated as a feature (Lintz et al. 2002:8). During the second phase, it quickly became apparent that the artifact densities 
associated with various occupation zones were either extremely high or extremely low. Using these criteria, almost any cluster of materials would constitute a feature when surrounding densities were extremely low (i.e., at the level of Feature 1 [the burned rock lens] and in the thick, culturally sterile deposits separating the lowest, Early Archaic period occupation zone from overlying occupation zones). When artifact densities were high (i.e., in the Toyah and Early Archaic period components), however, this strategy would have resulted in the designation of hundreds, if not thousands, of "features" of dubious validity. Consequently, the highdensity, Toyah and Early Archaic components are designated generally as "occupation zones." Features within these occupation zones were required to demonstrate clear patterning beyond a general clustering of artifacts or burned rocks. In practice, the criteria for designating features varied somewhat among the components, but generally included clear clustering of rocks and/or artifacts, the presence of charcoal, changes in soil color and/or texture, vertical internal feature structure, and/or the relative density of "artifact clusters" compared to the density of artifacts in the surrounding matrix.

After features were identified and designated as such, each feature was carefully exposed horizontally using small hand tools (e.g., trowels and brushes) and a detailed plan map was drawn. Next, the feature was sectioned along one axis and half of it was excavated with hand tools to expose the vertical cross-section of the feature. Profiles of these cross-sections were drawn for those features that exhibited some vertical structure. Observations about the form, construction, content, context, integrity, and associations of burned rocks, bone, charcoal, or other artifact classes were recorded on individual feature forms. In some cases, scatters of burned rock and artifacts lacked clear, recognizable boundaries. The Principal Investigator or Project Archeologist used their judgment to decide on the boundaries of such ambiguous features. Artifacts associated with features and sediment matrix samples were collected, bagged, and labeled separately for each feature. Feature fill was collected for subsequent flotation, fine-screening and/or wetscreening, and other possible analyses (e.g., phytoliths, stable carbon and nitrogen isotopes) in the laboratory.

Samples of burned rocks from feature and nonfeature contexts were collected and returned to the laboratory. Sampling of burned rocks emphasized collecting of rock by size categories ( $<4 \mathrm{~cm}, 4.1$ to $9 \mathrm{~cm}, 9.1$ to $15 \mathrm{~cm}$, and $>15 \mathrm{~cm}$ in diameter). A suite of residue and dating analyses was conducted on these burned rocks that provided data on cooking technology, feature function, feature age, and prehistoric subsistence practices.

Two columns of matrix sediment samples were collected from Block A for detailed analyses of soil texture, grain size, stable carbon and nitrogen isotopes, humate dating, and pollen and phytoliths. These sediment column samples were collected from two separate locations in Block A from baulks left standing on either side of the intersection of the two backhoe trenches. One column sample, intended for use in sediment studies (e.g., humate dating, grain-size analysis), was collected from a balk located on the northern side of the intersection of the trenches (the west wall of excavation Unit N105/E51). The second column sample, collected primarily for use in phytolith analysis, was collected from the southern side of the trenches' intersection (the south quarter of the west wall of excavation Unit N103/E51 [a 1-by$0.25 \mathrm{~m}$ unit]). Sediment samples were collected at five-cm levels within each sample column.

Additionally, seven sediment samples were collected for optically stimulated luminescence (OSL) dating, including two from the Toyah 
component, two from the Late Archaic component (associated with the burned rock lens), and three from the Early Archaic component. Since these samples were collected near the end of the Block A excavation work, they were taken from locations around the outer walls of the excavation block.

A sample of water-worn cobbles, including chert-bearing and non-chert-bearing specimens, was collected from on-site and off-site contexts for instrumental neutron activation analyses. These samples were collected from (1) the basal gravel lens of the second terrace within Block A (mainly, but not exclusively, from the seven "sample units"); (2) from exposed, non-cultural gravel deposits along the floodplain of Hackberry Creek near the site; (3) from noncultural, chert-bearing lenses exposed along the upper slopes of ridges in the vicinity; and (4) from gravel beds exposed along the banks of the Nueces River in the vicinity of the town of Camp Wood, Texas, approximately $29 \mathrm{~km}$ (18 mi) south of the Varga Site. Natural chert samples were collected from additional locations following the completion of fieldwork to provide a more comprehensive set of Edwards chert source data from the western portion of the Balcones Escarpment (see Appendix F)

Various rare and anomalous objects encountered during excavations were collected for further examination in the laboratory. While the determination of whether these objects were contextually cultural or natural was allowed to remain open until confirmed by later analyses, such items were collected based on their potential to provide additional insights into site stratigraphy, site formation processes, and/or cultural activity as analyses proceed. Items in this category include mineral deposits (e.g., red and yellow ochre), exotic (i.e., non-local) gravels, and natural calcium carbonate concretions (believed to be mineralized root casts).
Finally, one last activity was planned for the second phase of excavations that did not, in the end, bear any fruit. As discussed in detail in Section 6.2-Methods and in Section 6.4Interpretation and Discussion, an additional backhoe trench was excavated in the slope of the T0 immediately south of the gravel driveway that defines the southern boundary of Block A. This trench was excavated primarily to investigate the juxtaposition of the $\mathrm{T} 0$ and $\mathrm{T} 1$, but it was hoped that cultural material might be observed in this area (Lintz et al. 2002). If present, cultural features and artifacts below the terrace rim may have provided data relevant to prehistoric trash disposal patterns at the Varga Site. It was hoped that the proximity of the terrace edge to the occupations indicated by the high artifact densities and cultural features present in Block A might offer a chance to determine whether the terrace escarpment was used as a discard area. Such discard patterns may have offered significant insights into the structure of activity areas and occupation zones within Block A. Unfortunately, careful monitoring of the excavation of this backhoe trench by TRC archeologists and geoarcheologist did not reveal any indications of cultural material below the terrace lip (aside from a few chert flakes). The trench profile was scrutinized for any indications of cultural deposits, and sediments deposited in the backfill pile during the trench excavations were randomly sampled for artifacts, but no substantial indications of cultural activity appeared. Consequently, the placement of handexcavated, 1-by-1 $\mathrm{m}$ and 1-by-2 $\mathrm{m}$ units along the edge of this trench, as indicated in the first interim report and the scope of work for the second phase of fieldwork, was deemed inadvisable.

\subsubsection{Block B Excavations}

Block B was excavated on the east side of the Ranch to Market Road to obtain data from the 
Toyah component at the Varga Site. Block B was scoped to cover an area of approximately $108 \mathrm{~m}^{2}$, targeting the Toyah occupation in the upper 20 to $30 \mathrm{~cm}$ of sediment. The first phase of investigations determined that the Toyah period component was associated exclusively with a sediment zone composed of relatively unconsolidated overbank deposits (designated as Depositional Unit I) overlying a well developed A horizon composed of black, granular soil (designated as Depositional Unit II). The Late Archaic burned rock lens (Feature 1) sits atop this darker, granular soil unit on the west side of the road (see Section 6.0-Geomorphology for detailed descriptions of stratigraphic units). In the first interim report, the boundary between these two depositional units was described as abrupt and very easily recognized once soils dried out to some degree. Thus, the bottom of the Toyah period component was signaled by the appearance of the underlying black soil unit.

The boundaries of Block B were determined by the locations of natural and artificial features of the road right-of-way, characteristics of the archeological deposits, and time constraints (Figure 5-3). The fence line that marks the edge of TxDOT's right-of-way defined the eastern boundary. Along the western boundary, the depositional unit that contains the Toyah component became very thin (less than $10 \mathrm{~cm}$ thick) and highly disturbed as it approached the road shoulder (much of the ground surface in this area had probably been stripped during road construction and/or maintenance activities). The western boundary, therefore, fell a minimum of $4 \mathrm{~m}$ short of the road shoulder. The southern boundary was determined by a pronounced decrease in artifact densities. Artifact densities along the northern boundary remained high, and the Toyah component appears to extend an undetermined distance north of Block B. Excavations continued in this direction until the end of the second phase of fieldwork. As a result, Block B excavations covered a substantially larger area than originally proposed.

Before beginning the second phase of excavations, TRC archeologists relocated the previous backhoe trenches and manual excavation units on the east side of the road. The backhoe trenches and the hand- excavated units had been lined with clear plastic prior to being backfilled following the first phase of fieldwork. The backhoe trenches had been backfilled with the matrix that had been excavated from them, whereas the manually excavated units had been backfilled with sterile sand. In addition, some pin flags and nails used to mark the corners and edges of the excavation units and backhoe trenches were still in the ground. Consequently, the previous excavations were easily relocated and remarked with pin flags during the second phase of fieldwork. In sum, TRC's prior investigations east of the road included three mechanically excavated backhoe trenches and three 0.5 -by- $0.5 \mathrm{~m}$ and five 1-by-1 $\mathrm{m}$ hand-excavated units.

A grid composed of one- $\mathrm{m}^{2}$ units was laid out within the designated Block B area based on the site datum that had been installed along the western right-of-way fence line during the first phase of fieldwork. Due to a mapping error, the Block B grid was not continuous across the entire excavation area. The reason for this pertains to the sequence of activities during the first phase of fieldwork. As discussed in Section 5.4.1.1-Block A Excavations, when TRC archeologists were reestablishing the site grid in Block A for the second phase of investigations, it became apparent that the previously excavated 1-by-2 m excavation units on the west side of the road were on-grid. 


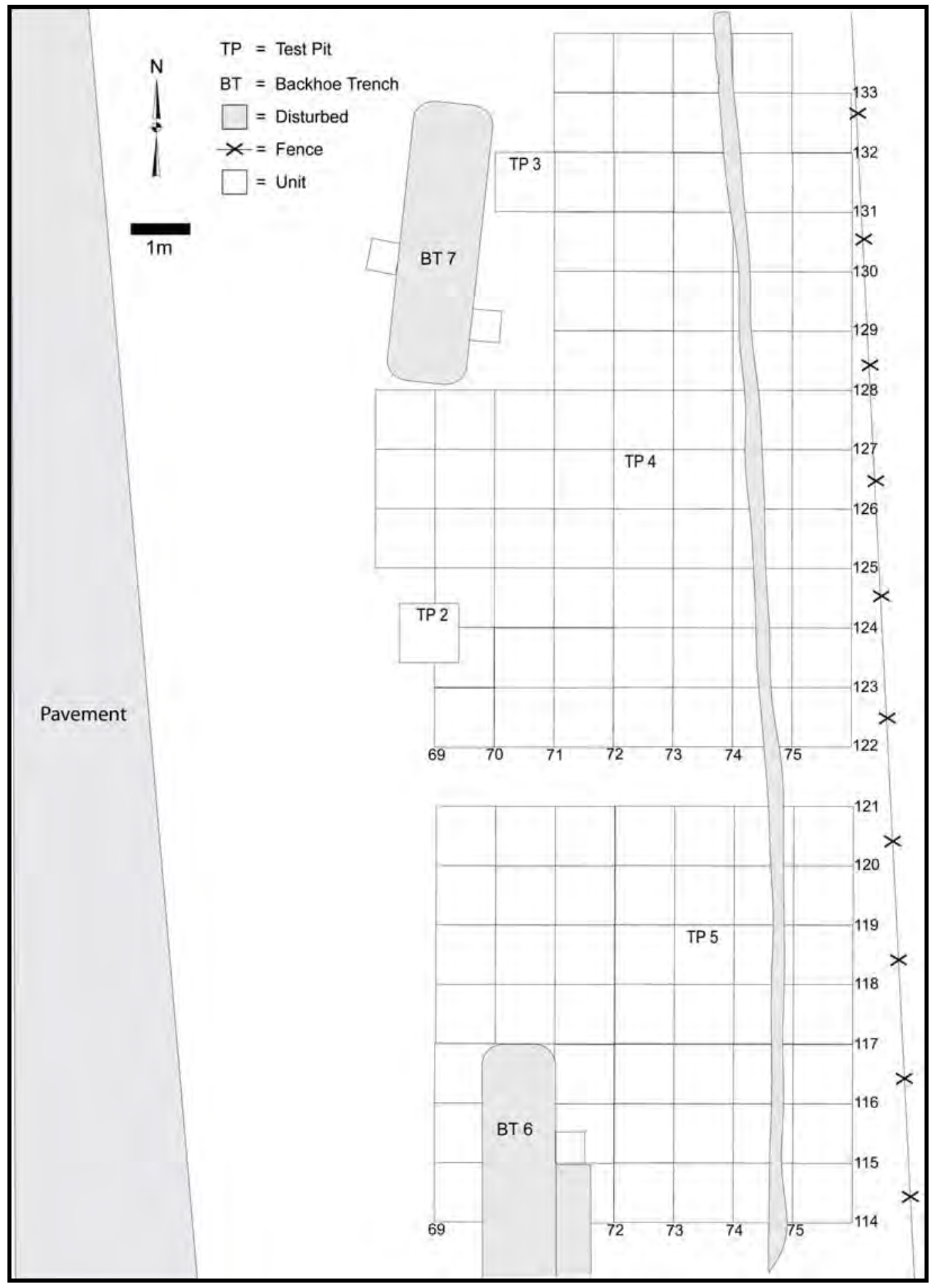

Figure 5-3. Block B Excavation Grid Lines 
Consequently, it was assumed that the previously excavated 1-by-1 m units on the east side of the road would be on-grid as well. Thus, during the second phase, field personnel began to excavate in Block B while the grid was still being established on the west side. Two of the 1-by-1 m excavation units from the first phase of investigations, one in the north half and one in the south half of Block B, were used as the reference points for beginning the Block B excavations. New excavation units were set up adjacent to these two previously excavated units, and additional units were added on as needed until the site grid could be extended to the east side.

As it turned out, the assumption that the previously excavated 1-by-1 m units on the east side were on-grid was incorrect. The original scope of work for the first phase of fieldwork called for limited investigations of the burned rock "midden" on the west side of the road. The site grid was established later, after modifications to the work authorization expanded the scope of investigations to include archeological deposits on the east side. The backhoe trenches and manually excavated units on the east side were placed before the site grid was extended to this side. As a result, none of the backhoe trenches or hand-excavated units on the east side of the roadway were actually ongrid. This unfortunate fact did not become apparent until the second phase of investigations was already underway, with discontinuous excavation areas open in the north and south halves of Block B. As a result of this mapping discrepancy, the northern and southern excavation areas in Block B did not match up. The two halves of the Block $B$ excavations ran into each other in the vicinity of the N121/N122 lines, leaving a linear, east-to-west-oriented row $0.5 \mathrm{~m}$ in width between the N121 and N122 lines (i.e., the N121 row was composed of 0.5by-1 m units rather than 1-by-1 m units). Rather than excavate partial units, it was decided that the N121 row of excavation units should remain unexcavated. The final boundaries of Block B included part of one of the three backhoe trenches (i.e., BT 6), one of the three 0.5 -by- 0.5 $\mathrm{m}$ hand-excavated units, and all or parts of three of the five manually excavated 1-by-1 m units from the first phase of fieldwork.

No surface stripping had been conducted on the east side during the first phase of fieldwork. However, the central portion of Block B, which is roughly coterminous with the southern half of the northern half of the excavation block, was covered with a dense layer of pea-sized road gravels. Local informants told TRC archeologists that a dump truck full of road gravel had accidentally dumped its load in this general vicinity at some point in the recent past. This layer of road gravel varied in depth from 1 to $12 \mathrm{~cm}$ across an approximately $7 \mathrm{~m}$ diameter area. At the outset of Block B excavations, the surficial layer of pea gravels was screened as an ordinary excavation level. The pea gravels did not contain any artifacts (indicating that the gravels had not been mixed with sediments from the site), but they did contain broken pieces of non-cultural chert (presumably from the quarry from which the gravels originated). Thus, after the pea gravel layer was systematically excavated and screened in a few preliminary units, the surficial pea gravels from all subsequent units were removed without screening.

A total of $124.75 \mathrm{~m}^{2}$ was hand-excavated in Block B, including $5.75 \mathrm{~m}^{2}$ during the first phase of fieldwork and an additional $119.00 \mathrm{~m}^{2}$ during the second phase. This figure does not include the area encompassed by a portion of BT 6 that extends into Block B, nor does it include the unexcavated N121 line of partial units; however, it does include one of the three 0.5-by- $0.5 \mathrm{~m}$ hand-excavated units, the entirety of two of the five manually excavated 1-by-1-m units, and approximately one-half of a third 
hand-excavated 1-by-1 m unit from the first phase of fieldwork, as well as all of the 1-by-1 m units excavated during the second phase. In sum, $38.26 \mathrm{~m}^{3}$ of sediment matrix was excavated in Block B, including $5.49 \mathrm{~m}^{3}$ during the first phase of fieldwork and an additional $32.77 \mathrm{~m}^{3}$ during the second phase.

The field methods employed during Block B excavations were identical to those used in Block A with two exceptions. First, because excavations in Block B targeted only the upper occupation zone, excavations were terminated 5 to $10 \mathrm{~cm}$ into the black, granular soil zone (Depositional Unit II) that underlies the Toyah component. Depositional Unit II contained only moderate densities of artifacts across the entire site (except for the immediate vicinity of Feature 1), so there was limited danger of contaminating the material collections from the upper sediment zone (Depositional Unit I). Therefore, excavations continued a short distance into Depositional Unit II to capture the Toyah material that had penetrated into this unit and to confirm that the artifact densities associated with the Toyah component had, in fact, dropped off.

Second, field tactics during the second phase of excavations included the designation of 10 "sample units" in Block B. As a rule, TRC's excavation strategy included discarding certain classes of material in the field after counting and weighing them. Discarded material types included most non-feature burned rocks, some burned rocks from features, snail shells (both Rabdotus and Helicina species), and natural gravels. In general, these materials were counted and/or weighed, as appropriate, the information was recorded on excavation level forms, and then the materials were discarded in the field. However, in the 10 "sample units," all burned rocks were collected. The "sample units" were designed to provide a control sample of data classes that could be used for special analyses. Because the excavations in Block B were much shallower than those in Block A, the deeper depositional units that contained high densities of some of these material classes, such as snail shells and natural gravels, were not encountered in Block B. Consequently, most of the extra material collected from Block B "sample units" consisted of burned rock, with only rare snail shells or natural gravels.

\subsubsection{Geomorphologic Field Procedures}

Geomorphologic investigations for the second phase of data recovery excavations focused on obtaining information relevant to the investigation of floodplain and terrace formation processes along Hackberry Creek. As discussed in more detail in Chapter 6.0, Geomorphology, very little is known about the geomorphologic conditions of the rivers within the southern Balcones Escarpment region. Based on his investigations of the Sabinal River terraces, Mear's (1953) suggested that the relative height of terraces in the Hill Country of Central Texas does not permit the correlation of ages due to differential stream gradients. Nevertheless, in a later article, he adopted the chronological sequence of the Pedernales River, which was initially defined based on the earlier dating program from the O. H. Ivie Reservoir, and identified three major erosional events at pre$11,500,5,000$, and 1,000 years ago (Mear 1998).

The geoarcheological studies conducted during the first phase of mitigation efforts at the Varga Site concentrated on the fine sediments within the first terrace, but further textural, chemical, and chronometric studies were needed to delineate the ages and development rates and processes associated with these sediments. Consequently, additional geoarcheological fieldwork was recommended to discern the age of the cutting of the first terrace and the initial construction of the $\mathrm{T} 0$ terrace. The $\mathrm{T} 0$ terrace is 
armored by boulders and gravels scoured during frequent flood events, but it was unclear whether or not finer sediments might exist near the base of the T0 terrace that could be used to date the initial terrace-filling episodes. Such dates would be important, as they would pertain directly to the prehistoric landscape setting and the human use of the Varga Site and the Hackberry Creek valley. In addition, geomorphological information from the intersection of the first and older second terraces was considered equally important in developing an understanding of the morphology of the upper Hackberry Creek valley, though these surfaces are probably too old to be directly relevant to the prehistoric occupations along the rim of the first terrace.

With these research considerations in mind, the work authorization for the second phase of fieldwork called for TRC's geoarcheologist to conduct additional investigations to ascertain the age of the terraces along Hackberry Creek. This involved excavating a backhoe trench (M-1) west of the road and south of the gravel drive to private lands in an attempt to understand the juxtaposition of the $\mathrm{T} 0$ and $\mathrm{T} 1$ interface that may help resolve the antiquity of the terrace cutting and filling sequence (Figure 5-1). One additional backhoe trench (M-2) was excavated at the interface of the T1 and T2 approximately $100 \mathrm{~m}$ north of the Block A excavations to investigate the intersection of these two terrace facies.

Both backhoe trenches were excavated using a backhoe operated by TxDOT personnel under the supervision of the TRC geoarcheologist and Project Archeologist. Trench profiles were carefully examined for features, artifacts, or any other indications of prehistoric cultural activity. In addition, sediment that was excavated from the trenches and deposited in nearby backfill piles was randomly inspected for cultural materials. No indications of significant cultural activity were observed in either backhoe trench.
After excavation, each trench profile was thoroughly examined, sketch maps showing major stratigraphic divisions as well as localized sediment anomalies were drawn, profiles were photodocumented, and sediment samples were collected from major soil/depositional units. After each trench profile had been recorded and sampled, the trenches were backfilled using the matrix that had been excavated from them.

Finally, limited additional geomorphological investigations were undertaken within the excavation blocks to refine and assess existing interpretations of the stratigraphic structure of the fine sediments that comprise the first terrace. Detailed profile maps were drawn of extensive areas within each excavation block to provide a data set for refining the stratigraphic profiles recorded during the first phase of excavations and published in the first interim report (Lintz et al. 2002). Also, as discussed in Section 5.3.1.1-Block A Excavations, sediment samples were collected from two columns in Block A for specialized analyses of selected sediment characteristics, such as grain size and stable carbon and nitrogen isotope analyses.

\subsection{LABORATORY METHODS}

All materials collected during the first and second phases of data recovery excavations at the Varga Site were transported back to TRC's laboratory facilities in Austin, Texas, for processing, cataloging, analysis, and temporary curation.

In general, artifact processing entailed washing and cataloging most of the cultural material recovered including lithic debitage, stone tools, and most bones. Washing involved lightly scrubbing the dirt from artifact surfaces using tap water and soft-bristled toothbrushes, arranging wet artifacts on fine mesh screen-lined drying trays, and allowing them to dry. Fragile material such as burned clay, ochre, mussel shells, and charcoal were not washed. In 
addition, some stone tools identified in the field were bagged with minimal handling and were not washed. A subset of these tools was submitted for use-wear analysis and others were set aside for long-term curation with only minimal handling by laboratory and analytical personnel. All personnel wore nitrile gloves when handling these unwashed tools.

Individual artifacts and artifact lots from within single provenience units were assigned unique catalog numbers. TRC's cataloging system assigns strings of numbers to artifacts that encode information on provenience, artifact class, a unique identifier, and samples taken from the artifact or lot for specialized analyses. Unique provenience numbers (PNUMs) were assigned to lithic debitage, stone tools, burned rocks, sediment, burned clay, faunal bones, ceramic sherds, historic artifacts, and mussel shells. PNUMs are sequential integers that designate the overall provenience unit (i.e., excavation unit, backhoe trench, modern ground surface) and level, or depth, within that provenience unit by reference to a master list of PNUMs. All of the cultural material recovered from a single excavation level within an excavation unit was assigned a unique PNUM designation (e.g., \#1261). Within each PNUM, the various artifact classes were assigned a secondary designation (i.e., lithic debitage [001], faunal bone [002], burned rock [003], soil [004], feature [005], shell [006], macrobotanical remains [007], ceramic sherds [008], and historic material [009]) referred to as the artifact class number. Individual tools and other unique items were assigned individual artifact numbers starting with the number 10 within the same unit and level designated by the PNUM. Thus, individual tools, and other unique objects were assigned a material class number appended to the provenience number (e.g., \#1261-001, \#1261-002, and \#1261-003).
In many cases, individual samples were removed from larger bags or objects of sample material for specialized analyses (e.g., radiocarbon dating, wood identifications, and instrumental neutron activation analysis). For example, if a single burned rock was extracted from the collection of burned rocks designated as \#1261003 for lipid residue analysis, then that burned rock would be designated as \#1261-003-001 to indicate it constituted the first sample from that provenience. In another words, a catalogue number such as \#1261-003-001 would identify that specific rock as the first sample (001) taken from the burned rock class of artifacts (003) within a specific provenience unit (\#1261). If burned rock \#1261-003-001 was subdivided into two pieces for different types of analyses, such as lipid residue and stable carbon and nitrogen isotope analyses, then lower case letter designations (i.e., a and b) would be added following the last number in the sequence (i.e., \#1261-003-1a and \#1261-003-1b) to signify that two parts (part a and b) were taken from burned rock \#1261-003-1. The complete two or three part number sequence assigned to each object or class of objects constitutes the catalog number. This process allows individual pieces of large collections of various materials to be individually handled and tracked.

Cultural materials in the Varga Site collection were labeled according to the curation standards of the Center for Archeological Research (CAR) of The University of Texas at San Antonio (UTSA). Individual catalog numbers were given to each unique tool identified in the overall assemblage, and each such unique object was labeled. Approximately one in 10 artifacts (10 percent) occurring in bulk classes (e.g., chert debitage, faunal bones) within specific provenience units (e.g., a level) were labeled. Size of the object was also a major consideration for labeling purposes. Artifact labeling consisted of inscribing the State of Texas Archeological Site Trinomial for the Varga Site 
(41ED28) and the catalog number on designated artifacts using black indelible ink. After the ink was dry, the artifact labels coated with clear acetone to preserve the inscriptions.

Permanent tags were included with each individual artifact or class of artifacts collected from a single provenience. These tags include the Varga Site's trinomial (41ED28), provenience information, the class or type of artifact(s), the date of excavation, the excavator's initials, and the quantity of items in the bag. These permanent tags were printed on acid-free, $30.4 \mathrm{~kg}$ (67-lb) card stock and filled out using No. 2 pencils.

All stone tools, samples of lithic debitage, samples of matrix from features, samples of burned rocks, all field records, and photographs from the two phases of investigations are permanently curated at CAR. Two to three burned rocks from each of the burned rock features are also curated. Individual artifacts and artifact lots, including all stone tools, ceramic sherds, sociotechnic items (e.g., bone beads), debitage, burned rocks, faunal bones, and mussel and snail shells, are in clear line seal-top plastic bags according to provenience. Upon completion of laboratory processing, cataloging, and analysis, these bags of artifacts were placed in acid-free cardboard boxes with lids for permanent curation. Small samples of sediment from various proveniences were stored in a similar fashion. Each polyethylene bag contains an archival-quality, acid-free curation tag that lists the site number, provenience data, date of excavation, excavator(s) initials, artifact type, and quantity. Color slides, black and white negatives, black-and-white photographs, and copies of digital photographs printed out on a color printer were placed in CAR-approved, acid-free plastic preservers for curation. All original field records are on acid-free paper and placed in acid-free reinforced file folders for curation.

\subsubsection{Flotation}

Sixty-eight bags of sediment totaling 573 liters, including matrix samples from 22 feature proveniences and two non-feature proveniences across the four major temporal components at the Varga Site, were floated to maximize the recovery of macrobotanical and small artifactual remains that would not be recoverable in $6.4 \mathrm{~mm}$ (1/4 inch) or $3.2 \mathrm{~mm}$ (1/8 inch) mesh screens. These matrix samples were processed using a Dousman Flotation System at TRC's laboratory facilities. The recovered light and heavy fractions were dried and then sorted by material class into flakes, mussel and/or snail shell, burned rock, and macrobotanical remains. The floated feature matrices were thoroughly inspected following flotation and drying. Some samples did not yield any visible macrobotanical remains. Forty-seven light fraction samples from 18 cultural features, encompassing 10 Toyah features, two Late Archaic features (including Feature 1 and its subfeatures 1a, 1b, and 1d), two Middle Archaic features, and four Early Archaic features were sent to Dr. Dering for analysis. Besides the light fractions from these features, 75 individual samples of wood charcoal collected from various proveniences, including 35 from Toyah contexts, 11 from Late Archaic contexts, three from Middle Archaic contexts, and 26 from Early Archaic context were submitted to Dr. Dering for identification. Dr. Dering's analytical procedures and results are presented in Appendix I.

\subsection{Analytical Methods}

Artifacts were subjected to different metric, nonmetric, typological, and other special analyses, including use-wear and neutron activation analyses. In some instances, artifact quantities within specific classes were so high that only a sample of the class could be subjected to more detailed analyses. A set of predefined attributes for each material class was first encoded on 
paper, then entered into TRC's electronic database management system based on Microsoft's (MS) Access 2000 software. This MS Access 2000 database constitutes the master database for this project. A copy of this database is provided on the CD-ROM attached to the back cover of Volume II of this report. The specific data recorded for each class of artifacts are presented below. Analytical methods pertinent to each data class and the various secondary suites of software used for specialized analyses are discussed in detail in the appropriate parts of this report. The materials from Phases I and II were integrated into one database.

\subsubsection{Chipped Stone Tool Analyses}

The edges and surfaces of each piece of chert were macroscopically examined for signs of use as a tool. If worked areas were identified, the artifact was assigned to a morphological and/or technological category based on general form and inferred function. Sets of observations were recorded for the entire tool classes recovered, though it was necessary to sample some classes of tools that were recovered in exceptionally large quantities. The following subsections provide definitions of major tool classes.

\subsubsection{Bifaces}

Finished bifacial tools are those finely or crudely worked pieces in which the manufacturing process has apparently been brought to completion, as evidenced by secondary retouch, edge straightening, hafting preparation, notching, and similar characteristics. Bifaces are defined based predominantly on morphological characteristics, but they may also have functional associations (e.g., cutting, piercing, chopping, drilling). Bifacial tools exhibit purposeful, usually patterned flake removals on both faces of the object. Most or all of each facet may be covered with flake scars, and in some cases one face may be completely modified while the opposite face exhibits only partial modification. Bifaces may be fashioned either from large bifacial cores or from flakes; however, if only the margin of a specimen exhibits modification rather than most or all of at least one face, then the tool would be classified as an edge-modified flake tool. Included within this overall morphological category is such diverse functional groups as projectile points and drills (see below).

Data on 22 distinct dimensions of variability were recorded for bifaces. Attributes included non-metric observations concerning the completeness of the specimen, overall morphology, manufacturing characteristics, and manufacturing stage based on morphological classes adapted from Callahan (1979). Metric measurements of length, width, thickness, and weight also were recorded. Measurements of appropriate dimensions were taken only when the dimension in question was completely represented and/or could be reasonably estimated.

\subsubsection{Projectile Points}

Projectile points are a functional subset of the biface class specifically designed to be hafted to the distal end of a shaft used in stabbing, throwing, or shooting to penetrate animal hides and flesh. Projectile points are bifacial tools formed by fine secondary retouch, usually with basal modification in the form of notching, stemming, or thinning of the proximal end for purposes of hafting. Dart points, arrow points, and indeterminate points are all classes of projectile points. Dart points are those employed to tip hand-held darts or spears; arrow points are used to tip arrows; and indeterminate points are, as the name implies, of uncertain usage. While dart points are usually manufactured from bifacial preforms, arrow points are often manufactured on thin flakes. 
Projectile points were assigned to recognized types whenever possible. In traditional archeological literature, projectile points are normally referred to by their typological designation, which usually connotes a set of morphological characteristics (most of which relate to hafting modification) shared in common by groups of similar points. Initial point classifications were accomplished by TRC's laboratory personnel in reference to established point typologies in use in Texas archeology (Davis 1995; Suhm et al. 1954; Prewitt 1985; Turner and Hester 1993). On September 30, 2003, Mr. Elton Prewitt came to TRC's Austin office to examine the entire projectile point assemblage from the Varga Site to finalize and confirm the typological designations. Some recovered projectile points did not exhibit characteristics that allowed their assignment into previously named types. One group of points exhibits a cluster of similar characteristics and therefore is assigned to a single group - Group 1. Group 1 points exhibit generally wide bodies with expanding stems that exhibit rounded basal corners and deep concave bases. A second group of points exhibits a different cluster of characteristics (deep cornernotches) and are assigned to Group 2. Similar point have been referred to as Early CornerNotched in other literature, but these early corner-notched forms have not been officially named.

A comprehensive suite of 33 metric and nonmetric observations was recorded for all projectile points recovered from the Varga Site. Non-metric attributes recorded include descriptors of overall morphology and manufacturing and reworking characteristics. Numerous metric measurements also were recorded. Measurements of appropriate dimensions were taken only when the dimension in question was completely represented and/or could be reasonably estimated. In addition to the typological classifications of individual specimens, the projectile points from this site have been subjected to a battery of measurements designed to detect patterning in the assemblage that may or may not be linked to the criteria usually employed in typological studies. The results of this analysis are presented in Appendix A.

\subsubsection{Drills}

Drills are another functionally specific subset of the biface class. Drills generally consist of two sections - the distal bit (or working edge) and the proximal stem or end section. Distal bits are typically long, tapered, and bifacially flaked, resulting in a diamond-shaped cross-section that distinguishes this type of tool. The bit is usually relatively thick and is designed to produce a stable base for rotary motion. Drills are usually presumed to have been used on hard substances, such as wood, shell, or bone, and spun in a rotating fashion to penetrate the material; therefore, drill tips usually exhibit heavy rounding and/or polishing of bit edges.

Drills are often subdivided into specific types, such as T-butt, irregular, or notched, but this typology was not employed in this analysis. Twenty-one metric and non-metric observations were recorded for drills from the Varga Site. Measurements of dimensions were taken only when the dimension in question was completely represented and/or could be reasonably estimated.

\subsubsection{Unifaces}

Unifaces are those tools that exhibit flake scars on one face only. Like bifaces, unifaces are defined based predominantly on morphological characteristics, but they also tend to have functional associations (e.g., scraping, planing, cutting, engraving). Unifacial tools exhibit purposeful flaking across most or all of one face, while the opposite face most often remains flat and unmodified. Unifaces may be fashioned 
from cobbles or flakes. This category includes such functionally diverse groups as scrapers, gouges, edge-modified flakes, gravers, and spokeshaves. One or more edges of a unifacial tool may exhibit manufacture- and/or use-related flake removals that may be patterned or unpatterned. To some degree, unifacial tools form a continuum from formal tools exhibiting intentional, patterned, manufacture-related edge flaking to informal, ephemeral tools that show only use-related edge scarring. The former tend to fall within the scraper and gouge categories, whereas the latter are generally classified as edge-modified flakes.

\subsubsection{Scrapers}

Scrapers are a specific type of unifacial tool that have at least one intentionally modified working edge. In some instances, bifacial modification may be present, but in such cases the intentional retouch tends to be located on the dorsal flake surface while the ventral surface tends to exhibit primarily use-related flake scars. Based upon the location of the primary working edge, scrapers are subdivided into end, side, or combination types. End scrapers are pieces with retouch restricted to either the distal or proximal end of the flake blank, generally producing a convex working edge. The opposing end of the piece may bear some minimal retouch, presumably to facilitate hafting the piece. Side scrapers are pieces with retouch present on one or both lateral edges of the flake blank. Working edges may be convex, straight, or concave. On combination scrapers, marginal retouch may appear along the end as well as along one or more lateral edges of the blank. As implied by the name of this tool, the primary function of scrapers is presumed to relate to scraping relatively soft materials such as animal hides or vegetable matter, or slightly harder materials, such as wood or possibly antler or bone.
Twenty-four metric and non-metric attributes were recorded for scrapers. Many of these measurements relate to the number, location, and characteristics of the various working edges on the tool. Among the measurements, the total number of identifiable working edges on the tool was noted, and then multiple observations pertaining to the characteristics of a maximum of three of these edges were recorded. For example, if five working edges were identified on a single implement, detailed measurements of edge characteristics would be recorded for only the three primary edges, but the total number of five working edges would be listed. Measurements of dimensions were taken only when the dimension in question was completely represented and/or could be reasonably estimated.

\subsubsection{Gouges}

Gouges are chisel-like woodworking tools that may be either bifacially or unifacially flaked, are usually triangular in shape, and are worked along the wider end to produce a steep, beveled, straight working edge or bit. The wide distal edge may be convex, straight, or slightly concave. The edge angles of the bit and lateral edges tend to be relatively steep. The end opposite the bit, at the point of the triangle, represents the end of the tool that would be hafted (generally perpendicularly) into a handle. In cross-section, gouges are usually planoconvex to pyramidal (for which reason they are included among the unifacial tools). These tools are generally associated with woodworking tasks as scrapers or adzes rather than as true gouges. Some gouges, such as Clear Fork bifaces or unifaces, are considered diagnostic of various cultural periods in Texas prehistory.

For purposes of data coding and analysis, gouges were considered to be generally equivalent to scrapers, and the same 24 metric and non-metric attributes encoded for scrapers 
were also recorded for gouges. Measurements of dimensions were taken only when the dimension in question was completely represented and/or could be reasonably estimated.

\subsubsection{Edge-Modified Flakes}

Edge-modified flakes are minimally modified flakes, flake fragments, or pieces of angular debris that are characterized by one or more areas of flake scarring along margins. The edge flaking may be patterned or unpatterned, continuous or discontinuous, and may result from intentional pressure retouching to prepare an edge for use or may result exclusively from use-related activities. Many edge-modified flake tools exhibit combinations of these characteristics, and most have more than one working edge. The edge modifications, however, usually are restricted to the edges of the piece and do not significantly alter the original flake form. Edge modifications may be either unifacial or bifacial. Edge-modified flakes are usually considered to be "expedient" tools, or pieces of raw material that are picked up, utilized for a short-time with or without first being minimally modified, and subsequently discarded at the location of use or soon after use.

Twenty-four metric and non-metric attributes were recorded for edge-modified flakes. Many measurements relate to the number, location, and characteristics of the various working edges on the tool. Among the measurements, the total number of identifiable working edges on the tool was noted, and then multiple observations pertaining to the characteristics of a maximum of three of these edges were recorded. For example, if five working edges were identified on a single implement, detailed measurements of edge characteristics would be recorded for only the three primary edges, but the total number of five working edges would be listed. Measurements of dimensions were taken only when the dimension in question was completely represented and/or could be reasonably estimated. Due to the large number of edgemodified flake tools recovered from the Varga Site, only a sample of this artifact class was selected for detailed data encoding and analyses.

\subsubsection{Gravers and Spokeshaves}

Many types of specialized working edges are commonly found on tools otherwise identified as scrapers or edge-modified flakes. While it is possible that only one such specialized bit may exist on a tool, these types of tools are considered to primarily fall within the appropriate scraper or edge-modified flake category, while the specialized working edge would be classified as one of the working edges. Types of specialized working edges that are often recognized include perforators or borers, graver spurs, spokeshaves or notches, and burins. For purposes of this analysis, graver spurs and borers are combined into a single category, as are spokeshaves and notches.

Graver spurs, or gravers, are additional carefully flaked, prominent, sharp protrusions formed on scrapers or edge-modified flake tools by the creation of adjacent shallow concavities or notches. Graver spurs may be quite short, only a millimeter or two in length, or rather prominent, in which case they grade into the category of tools often referred to as borers or perforators. Graver spurs may exhibit alternating edge retouch, but this is usually present only on longer specimens. The function of graver spurs is assumed to be engraving relatively hard substances such as wood, bone, and antler.

Spokeshaves, or notches, are working edges on scrapers or edge-modified flakes formed by the removal of numerous small flakes in a limited area along the lateral edge of a piece to form a single, relatively deep, concave area. Such notches may be relatively small or quite large, shallow or deep. The function of spokeshaves is 
assumed to relate to scraping or planing relatively hard substances, such as wood, bone, and antler, that are either tubular in shape or for which a convex outer surface is desired (e.g., dart or arrow shafts).

By definition, graver spurs, spokeshaves, and burins are considered to be specialized tools made on objects that may otherwise be classified as scrapers or edge-modified flake tools. As such, the metric and non-metric data encoded regarding that working edge would follow the procedures used for scrapers or edge-modified flakes, as appropriate.

\subsubsection{Cores}

A core is a cobble, pebble, or other mass of lithic raw material (usually chert) that exhibits one or more flake scars resulting from the systematic removal of flakes by flint knappers. Technically, any chipped stone tool may properly be classified as a core as it is the object created through the removal of flakes from the exterior surface of the original mass of lithic material. In common parlance, however, cores are generally considered to be those masses of material from which one or more flakes were removed. In other words, cores do not exhibit any intentional or use-related flake scarring along any of their edges, though scars resulting from platform preparation may be evident, and a core might be expediently used as a tool (e.g., extensive crushing damage along one or more thick edges of a core would probably result in classification of the object as a chopper).

Various types of cores are recognized according to the degree of knapping and the flake removal strategy. Four basic types of cores are unifacial, bifacial, multidirectional, and blade core. The last-named type often has a distinctive conical polyhedral shape, the result of the repeated, parallel removal of long, narrow flakes known as prismatic blades.
Tested cobbles are natural clasts of tool stone that exhibit only a very limited number of flake scars, often just one or two, removed by hardhammer percussion. Generally, these scars removed the exterior, cortical surface of the cobble, exposing the interior structure of the cobble. The edges of the flake scars do not evince any further alteration, such as edge grinding, dulling, or crushing that may be indicative of additional modification or use. Tested cobbles most likely represent intentional exposure of the interior of the stone for the purpose of evaluating its quality and suitability for manufacturing stone tools.

A unifacial core is one that exhibits flake scars removed from only one face. The flake removals may be in various directions and exhibits no pattern or structure to the removals. There are usually only one or two platforms.

A bifacial core exhibits flake removals from both faces and again these may be in multiple directions. The parent rock is generally a cobble that exhibits two detectable faces. The flakes were driven from the lateral edges, thus the platforms are along the edges.

The multidirectional core is generally a chunk of raw material that does not necessarily exhibit two obvious faces. Generally there are a number of platforms from which flakes were removed.

Blade cores are intentionally prepared chunk of raw material to facilitate the removal of a specifically desired flake. These generally exhibit two or more parallel scars driven from the same platform in the same direction with the same overall shape.

Fifteen metric and non-metric observations were recorded for cores. Measurements of dimensions were taken only when the dimension in question was completely represented and/or could be reasonably estimated. 


\subsubsection{Ground Stone Tool Analyses}

This broad artifact class includes pieces of natural rock that have been modified by grinding, pecking, or battering either to intentionally form an implement or through use. Ground stone tools are recognized by the presence of non-natural abrasions, grooves, and striations and/or smoothing. Significant rounding, flattening, and/or pitting of used surfaces may also usually be identified. Categories of ground stone tools recognized among the Varga Site assemblage included hammerstones, manos and metates (milling stones), and anvils.

The edges and surfaces of each piece of rock were macroscopically examined for signs of use as a tool. If battered, smoothed, unnaturally flattened, pitted, ground, striated, incised, or pecked areas were identified, then the artifact was assigned to a morphological and/or functional category based on general form and inferred function. Sets of observations were recorded for the tool classes recovered. The following subsections provide definitions of major tool classes.

\subsubsection{Hammerstones}

A hammerstone is a hard nodule of lithic material, usually of hard and dense siliceous rock such as quartzite, used for direct percussive fracturing of tool stone during lithic reduction. These pieces usually exhibit limited or extensive areas of battering, crushing, and/or pitting on one or more surfaces of the natural cobble. In some cases, small flake scars may form as the result of hard-hammer percussion, creating an appearance similar to a tested cobble core.

Metric and non-metric observations were recorded for hammerstones. Measurements of dimensions were taken only when the dimension in question was completely represented and/or could be reasonably estimated.

\subsubsection{Manos and Metates}

A mano is a round to ovate-shaped nodule of rock, usually of dense siliceous rock such as quartzite or sandstone, with one or more surfaces that have been smoothed and possibly flattened through grinding. A metate is a large, thick slab, also usually of dense siliceous rock such as quartzite or sandstone, that has been ground smooth on one or both surfaces. Manos and metates are used together to grind friable materials into powder, such as vegetable matter or pigments. Manos are hand-held grinding stones, and the utilized facets usually have a smoothed appearance and may be convex to flat. Metates are grinding slabs, and the use facets may have either a flat or basin-shaped appearance.

Metric and non-metric observations were recorded for manos and metates. Measurements of dimensions were taken only when the dimension in question was completely represented and/or could be reasonably estimated.

\subsubsection{Anvils}

Anvils are cobbles or slabs of rock with one or more small, circular indentations in the center of one or more faces. Anvils were presumably used as a base in the processing of nuts and/or grains. Over time, anvil pits used to repeatedly crack open nuts of specific species take on distinctive shapes. Anvil pits are often found on the flattened, smoothed surfaces of other ground stone tools, such as manos and metates.

Metric and non-metric observations were recorded for anvils. Measurements of appropriate dimensions were taken only when the dimension in question was completely represented and/or could be reasonably estimated. 


\subsubsection{Lithic Debitage Analyses}

Chipped stone debitage is the unmodified debris that results from lithic reduction activities associated with the manufacture and maintenance of stone tools. Lithic debitage lacks any macroscopic indications of use or modification. Pieces that exhibit any sign of use-wear or intentional modification would be placed in the appropriate tool category. All debitage was counted and weighed. Due to the large quantities of debitage recovered from the Varga Site, it was necessary to designate a sample of the overall debitage collection for detailed analysis. In the detailed analysis, debitage was sorted into each of the following classes.

\subsubsection{Core Preparation Flakes}

This category includes flakes, flake fragments, and pieces of angular debris associated with initial core preparation activities, such as removing test flakes to determine the quality of raw material within a cobble as well as decorticating a cobble for further reduction. Items in this category tend to have cortex covering more than 50 percent of their dorsal surfaces. By definition, most of these items tend to be relatively large (smaller flakes with dorsal cortex often fall within other categories, such as early- and late-stage biface flakes or indeterminate flakes, depending on their diagnostic characteristics). Core preparation flakes may or may not exhibit pronounced platforms, bulbs of percussion, or ventral concussion rings, though most do have one or more of these characteristics.

\subsubsection{Biface Manufacture Flakes}

Biface manufacture flakes were classified based on the presence of multifaceted striking platforms, multidirectional dorsal flake scars, parallel to slightly expanding flake margins, and slight to moderate longitudinal curvatures. This category was subdivided into early- and latestage biface manufacture flakes. Early-stage biface flakes tend to be somewhat larger than late-stage biface flakes, have fewer and larger dorsal flake scars, and may retain a considerable amount of cortex on their dorsal surfaces. As employed in this analysis, early-stage biface flakes correlate roughly with Callahan's (cf. 1979) revised Stage 1, 2, and 3 bifaces ("blank," "rough out," and "primary preform” stages) while late-stage biface flakes correlate with Callahan's revised Stage 4 and 5 bifaces ("secondary preform" and "final preform" stages). In practice, Stage 1 ("blank”) flakes are more likely to fall within the core preparation flake category due to the lack of clear diagnostic characteristics on many such specimens. Final percussion thinning, pressure thinning, and retouch flakes that do not clearly exhibit biface manufacture characteristics due to their small size would likely be included in the tertiary thinning/retouch flakes category. The early- and late-stage biface flake categories may contain complete flakes, proximal and distal flake fragments, and/or small pieces of angular debris that exhibit clear characteristics of the biface manufacture process (in practice, the latter type of debitage-angular debris bearing bifacial traits-is rare in the biface manufacture flake categories).

\subsubsection{Tertiary Thinning/Retouch Flakes}

This category includes flakes and proximal and dorsal flake fragments resulting from the final stages of tool manufacture, including final percussion thinning and any subsequent pressure retouch. By definition, flakes in this category tend to be quite small, and it is difficult to distinguish whether they result from biface manufacture, uniface manufacture, or resharpening. 


\subsubsection{Blades}

Blades are long flakes that are at least twice as long as they are wide with single-faceted striking platforms (either corticate or decorticate), parallel unidirectional or opposed bidirectional dorsal flake scarring, dorsally trimmed platform preparation, and straight rather than curving longitudinal cross sections.

\subsubsection{Tool Rejuvenation Flakes}

Tool rejuvenation flakes are resharpening flakes removed through percussion or pressure flaking from the working bits of bifacial or unifacial tools in order to restore the working edge of the tool. They may occur in a variety of shapes and can be either bifacial or unifacial depending upon the type of tool being rejuvenated. Most rejuvenation flakes are narrow and curved. Tool resharpening flakes bear use-related scarring indicative of tool use on the former bit edge. At least one worked tool surface or face is always present, and a major hinge fracture usually occurs along one edge. In addition to bit damage, tool rejuvenation flakes of sufficient size may also bear characteristics that reflect the overall morphology of the tool from which they were struck. Rejuvenation flakes are presumably the result of tool resharpening and refurbishing processes whereby a working edge that has become dull, broken, or otherwise compromised is removed from the parent tool so that a new working edge may be crafted. Thus, while rejuvenation flakes exhibit manufacture and use-wear patterns consistent with the original tool's functions, the rejuvenation flakes themselves presumably were not used as tools.

\subsubsection{Angular Debris}

Angular debris, or "shatter," includes angular pieces of lithic raw material that break away from the core as flakes are struck. In contrast to flakes, angular debris does not generally retain any diagnostic characteristics of the flintknapping process (i.e., platforms, bulbs of percussion, concussion rings, and definable dorsal or ventral surfaces). In this analysis, those few pieces of angular debris that exhibit characteristics diagnostic of biface manufacture were included in the appropriate bifacemanufacturing category (i.e., early- versus latestage biface flakes).

\subsubsection{Indeterminate Flakes}

This category includes flakes and flake fragments that lack diagnostic traits that would permit their placement into one of the other categories. Generally, these flakes are small fragments of flakes and/or thin pieces of angular debris that do not display clear evidence of a platform, concussion rings, or flake scar patterning on their dorsal surfaces. This category also includes a small number of potlid flakes and fractured heat spalls resulting from thermal alteration of raw materials.

\subsubsection{Use-Wear Analyses}

Chipped stone tools from both excavation blocks (Blocks A and B), sampled from within each of the four cultural components represented at the Varga Site, were selected and sent to Dr. Bruce Hardy at Grand Valley State University in Allendale, Michigan, for high-power, microscopic use-wear analysis. Most tools were selected from the group of tools that were minimally handled in the field and not washed in the laboratory. All chipped stone tool classes present in the Varga Site assemblage were sampled and submitted for use-wear analysis. The analytical methods and results of Dr. Hardy's findings are presented in Appendix C. Two unusual chipped stone tools (\#726-010 and \#837-001) from the Toyah component were sent to Dr. Marvin Kay at the University of Arkansas for detailed use-wear analysis. His results are presented in Appendix M. Use-wear results from specific tools are also summarized in the 
descriptions and discussions of various tool categories and cultural components in this report.

The use-wear analyses included 59 chipped stone tools from the Toyah component, 17 tools from the Late Archaic component, 17 tools from the Middle Archaic component, and 63 tools from the Early Archaic component. The number of tools submitted per component is a general reflection of the number of tools representing that particular period. A diverse assemblage of points, scrapers, bifaces, unifaces, drills, and edge-modified flakes were submitted from each of the four components. Projectile points were one of the classes of tools least selected as most have a previously defined and demonstrated use as projectiles. In general, the Perdiz points are assumed to have functioned in a piercing motion and presumably the penetration occurred so few times prior to breakage that use-wear would not be present on a Perdiz specimen, thus, Perdiz points were not intensively sampled. On the other hand, there is some disagreement about the function of Cliffton points and thus, they were more intensively sampled to address their function. Edge-modified flakes were intensively sampled as they presumably functioned in a variety of tasks and on a variety of materials. Therefore, it was thought that most functional diversity would be apparent in the edgemodified tool class. The edge-modified tools included a variety of shapes to the various edges and we tried to selected flake tools that would be classified as gravers, spokeshaves, and rejuvenation pieces. Within the projectile point group for each period, multiple point types were submitted for analyses, but because of the extensive number of projectile points and the limited number of specimens that could undergo use-wear analyses some trade offs were made.

\subsubsection{Burned Rock Analyses}

Burned rocks are natural rocks that have been heated and often rapidly cooled as the result of involvement in cooking or other heating activities. While it is occasionally difficult to distinguish burned from unburned rocks in the field, many burned rocks exhibit cracking, discoloration, crazing, and angular, fragmented edges. During excavation, burned rocks were treated as cultural artifacts.

Burned rocks were first sorted according to raw material type, usually limestone, in the field. All burned rocks were then sorted into four size categories (i.e., 0 to $4 \mathrm{~cm}, 4.1$ to $9 \mathrm{~cm}, 9.1$ to $15 \mathrm{~cm}$, and greater than $15 \mathrm{~cm}$ ) based on maximum diameter, and then counted and weighed by size class. Burned rock clasts were further categorized according to the angularity of their fracture planes (i.e., angular, subangular, subrounded). Most burned rocks from feature contexts and a sample of burned rocks from nonfeature contexts were collected, bagged, and returned to the laboratory for processing, cataloging, and analysis. Some burned rocks from features and most burned rocks from nonfeature contexts were discarded in the field after being counted and weighed. Thus, while the entire volume of burned rock encountered during excavation is known, only a sample of this volume was retained for possible further analyses.

Ninety-four burned rocks were selected and submitted for lipid residue and stable carbon and nitrogen isotope analyses. One piece of a limestone burned rock (\#1030-5-3-2c) weighing about $103 \mathrm{~g}$ from 30 to $40 \mathrm{cmbs}$ in Feature 38 in the Toyah component was submitted to the Center for Applied Isotope Studies (CAIS) at the University of Georgia in Athens (UGA) for direct radiocarbon dating.

All four major time periods were represented by the 94 burned rocks submitted for lipids residue 
analysis. Twenty-nine burned rocks from seven features and three non-feature burned rocks were form the Toyah component. Thirty-four burned rocks from eight features were submitted from the Late Archaic component. Nine burned rocks from two features were submitted from the Middle Archaic. Twenty-two burned rocks from six features were submitted from the Early Archaic. The detailed sample preparation, analysis, and interpretations of the lipid residues are presented in Appendix G.

The exact same rocks that were selected for lipid residue analysis were also used for the stable carbon and nitrogen isotope analysis. Once a burned rock was selected, about 1 to $2 \mathrm{~g}$ of matrix was ground off using a Dremel ${ }^{\circledR}$ tool from the spot targeted for lipid residue analysis. The idea being that the matrix for both analyses would come from the same spot and thus the results would complement each other. These tiny matrix samples were first submitted to Paul Price Associates, Inc. in Austin, for decalcification. Once the carbonates had been removed the samples were submitted to University of California at Davis, Stable Isotope Facility, for stable carbon and nitrogen isotope analyses under the supervision of Dr. David Harris.

\subsubsection{Faunal Analyses}

\subsubsection{Faunal Bone Analysis}

The faunal remains from each component were divided into ten major taxon groups based on the size and type of animal represented. The 10 groups include mammals in size class 1 that are mole and mice (Soricidae and Critcetidae) size, size class 2 includes rabbit (Leporidae) size mammals, size class 3 includes raccoon (Procyon) size animals, size class 4 includes dog/coyote size (Canis), size class 5 includes deer (Odocoileus sp.) and antelope (Antilocapra americana), and size class 6 includes bison
(Bison bison) size animals, with turtles (Testudines) in class 7, snakes (Serpentes) represented in class 8, birds (Aves) in class 9, and fish (Osteichthyes) in class $10 . \quad$ The assignment of a bone fragment into a specific size class was based primarily on cortical wall thickness, bone shape and structure, and specific observed attributes. If these attributes were not sufficient to confidently assign a bone into one of the 10 classes, then the fragment was assigned to an unknown category. Bones were identified as to element and symmetry where possible, but many pieces are small long bone fragments (LBF) that could not be identified. The counts and weights of each group or types of bones were recorded.

The bones were also recorded according to size categories that range from 0 to $3 \mathrm{~cm}, 3.1$ to $6.0 \mathrm{~cm}, 6.1$ to $9.0 \mathrm{~cm}, 9.1$ to $12.0 \mathrm{~cm}$, and greater than $12.1 \mathrm{~cm}$. Knowing the size of a bone helps in the descriptive discussion and provides an indication to the type or potential cultural processing that occurred. The bones were inspected for various alterations that include burning and cut marks. The cut marks include various types such as thin and thick lines from small tool marks, broad chop marks from larger tools, and impact location from smashing the bones. Burning results in a variety colors that are generally related to the temperatures (degrees Celsius [C]) that the bone was subjected too. This includes bones burned to a solid black, a solid brown, a mixture of brown and black, a calcined white, and a mixture of black and white. Generally speaking, the bones of an ungulate turn to a brown color in the range around 200 degrees $\mathrm{C}$, black in the 300 degrees $C$ range, gray in the 300 to 400 degrees $\mathrm{C}$ range, and white above about 700 degrees $C$ range (Nicholson 1993). 


\subsubsection{Mussel Shell Analysis}

Fresh water mussel shell fragments were rare occurrences in the terrace deposits at the Varga Site, and those that were recovered consist predominantly of small, unidentifiable fragments. Larger and more complete mussel shell fragments, usually those on which the hinge or major portions of the shell are represented, were identified to genus and/or species whenever possible using TRC's comparative collection of mussel shells. Valves were counted, identified as to side, and examined for signs of human modification. The fragments were counted and weighed.

\subsubsection{Snail Shell Analysis}

Rabdotus, Polygyridae sp. and Helcina sp. snail shells and shell fragments were recovered. The data recovery plan and research design for this project have not specifically targeted snail shells as an analytical medium for deriving information about the prehistoric occupations at the Varga Site. Consequently, snail shells were sorted by species in the field, general notes were recorded about the relative density of snail shells in each excavation level, and the snail shells were discarded. In the 17 designated "sample units," including seven 1-by-1 m units in Block A and 10 1-by-1 m units in Block B, all snail shells were collected, counted, and weighed. However, snail shells were not further analyzed.

\subsubsection{Flotation Macrobotanical Analyses}

Bulk matrix samples, incorporating 573 liters of matrix, from 44 proveniences including 24 selected cultural features, were collected in the field for flotation and/or fine-screening in the laboratory. Most features did not exhibit any basin-like internal structure that may have helped to trap small materials within the feature. Based on the absence of basins and the demonstrable tendency for some small objects to translocate through the profile (especially seeds and charcoal flecks), flotation was the sole method used to recover materials from matrix samples. As discussed above in this chapter, fine-screening (i.e., screening through $3.2 \mathrm{~mm}$ [1/8 in] hardware cloth) was employed in some manually excavated units during the first phase of fieldwork. The relative abundance of materials smaller than $6.4 \mathrm{~mm}$ (1/4 in) recovered in these fine-screened samples was quantified to provide a general estimate of the kinds of material that were not recovered through use of $6.4 \mathrm{~mm}$ (1/4 in) hardware cloth during the rest of the data recovery excavations.

Forty-four light fraction samples from the flotation process were selected and sent to Dr. Phil Dering of Shumla Archeobotanical Services in Comstock, for sorting and identification of organic materials. Dr. Dering's detailed technical report is presented in Appendix I.

The heavy fractions were carefully picked for charcoal, burned seeds, bone, lithic debitage, burned rock fragments, and snail shells. These materials were then counted and weighed by material class and the results presented in the appropriate feature discussions within the test of the report.

\subsubsection{Charcoal Analyses}

A total of 75 macrobotanical or charcoal samples with sufficient mass for potential identification from feature and non-feature context were selected and submitted to Dr. Dering of Shumla Archeobotanical Services in Comstock for identification. Parts of charcoal pieces used in radiocarbon analysis were also identified as to species thereby, the age of specific species was also known and could contribute to our understanding of past vegetation changes and or cultural selection. Dr. Dering presents the detailed methods, 
macrobotanical identifications, and interpretations in Appendix I.

\subsubsection{Petrographic Analyses}

A total of 20 samples, 19 plainware pottery sherds and one local sediment sample were selected for petrographic analyses. These samples were first submitted to National Petrographic Services, Inc. of Houston, for slide preparation. The thin sections were stained for carbonates, and the finished thin sections were not covered. These slides were submitted to Dr. David Robinson, Research Fellow at the Texas Archeological Research Laboratory (TARL) at The University of Texas (UT) at Austin, for analysis. Microscopic thin section analysis has been around for over 50 years and provides a means of quantifying the details concerning the sherds through point counts of materials for interpreting and addressing questions concerning manufacturing, production techniques, and cultural differences.

The 19-plainware sherds include 12 ceramic samples from the Varga Site Toyah component, five samples from the historic Mission San Juan (41BX5) in San Antonio, and three samples from the historic Mission San Lorenzo de la Santa Cruz (41RE1) in Camp Wood. The 12 Varga Site sherds were thought to represent at least five separate vessels or vessel groups identified prior to submission for analysis. The vessel group identifications were not provided to Dr. Robinson, so his efforts were conducted without knowledge to previously determined groupings. One of the 12 ceramic sherds (\#84081) from the Varga Site was known to be of an object that was not from a cooking vessel, but represents an ornament or figurine-like object. Dr. Robinson's detail technical report is presented in Appendix D, and the information contained therein is incorporated into the body of this text.

\subsubsection{Granulometry Studies}

Ten matrix samples were submitted to Ms. Mary Jo Schabel of Milwaukee Soil Laboratory, LLC in Milwaukee, for grain-size analyses and a variety of chemical analyses. Included are five 1 to $2 \mathrm{~cm}$ thick matrix samples from a single column through dated cultural deposits immediately south of BT 2 near the middle of Block A, plus five radiocarbon-dated matrix samples extracted from specific soil horizons identified in backhoe trenches across the site. Parts of these same matrix samples were those used for the pollen and phytolith analyses, and radiocarbon assays.

The various chemical analyses conducted include: percent of organic matter, percent carbonate, percent of available phosphate, and total phosphate. These data contribute to the descriptive aspects necessary to develop interpretations of the various site soils and matrices. Individual sample results are presented in Table K-1 in Appendix K.

\subsubsection{Pollen and Phytolith Analyses}

Twenty matrix samples of about $100 \mathrm{~g}$ each were initially sent to Dr. John Jones at the Palynology Laboratory at Texas A\&M University in College Station, to process paired samples for pollen and phytolith extraction. A conservative extraction technique was employed. Dr. Richard Holloway of Quaternary Services in Flagstaff presents the details of the extraction procedures for pollen and phytoliths in Appendix E. Once extracted, the paired pollen and phytolith samples were then sent to Dr. Holloway for counting and interpretation.

Twenty samples were from a vertical column on the southern edge of BT 2 that penetrated through the entire cultural sequence that spans some 6,000 years. Care was taken to collect the original matrix from 1 to $2 \mathrm{~cm}$ thick horizons at about $10 \mathrm{~cm}$ intervals down through the column. 
The column-contained radiocarbon dated and associated materials from the Toyah component, the Late Archaic, Middle Archaic, and Early Archaic components. Two samples (\#1207 and \#1208) came from radiocarbon-dated matrix extracted from BT 1 located in Block A. Sample \#1208 was from a 1,870-year-old 2Ab soil horizon, whereas sample \#1207 was from a 6,279-year-old a 2Bw soil horizon. Three samples (\#1209, \#1210, and \#1211) came from radiocarbon matrix extracted from BT 7 at the north end of Block B. Sample \#1211 was from a 1,900-year-old buried A soil horizon, sample \#1210 was on a 4,820-year-old 2Bk soil horizon, and sample \#1209 was a 5,230-year-old Bk2 soil horizon. Dr. Holloway presents the pollen and phytolith methods, results, and interpretations in Appendix E.

\subsubsection{Radiocarbon Analysis}

A total of 66 radiocarbon assays were conducted in two laboratories-Beta Analytic Inc. of Miami, and the Center for Applied Isotope Studies (CAIS) at the University of Georgia in Athens (UGA). The submitted samples primarily targeted three principal componentsToyah, Late Archaic, and Early Archaic-with limited effort directed to materials from the Middle Archaic component. Charcoal and bone were plentiful in the Toyah component, but relatively sparse in the earlier components. The radiocarbon dating focused on the charcoal with 34 charcoal samples, with other materials including 11 ceramic sherd samples, eight bone samples, five walnut shells, five sediment samples, one Rabdotus snail shell, one burned prickly pear seed sample, and one limestone burned rock.

Of the total assays, 20 samples relate to the Toyah component, 13 relate to the Late Archaic, five relate to the Middle Archaic, 17 relate to the Early Archaic, two to the historic mission period, and the others are subject to discussion elsewhere in the report. The results from charcoal dating help assess the age of selected individual features, provide age ranges for the cultural components, provide concrete data to discuss turbation problems, and provide a comprehensive basis for assessing the absolute ages of burned rock residues identified.

In a continuing effort to assess the potential for direct dating of organic materials other than charcoal and bone, two other organic bearing materials-ceramic sherds and a limestone burned rock-were submitted for AMS dating. It was anticipated that individual ceramic sherds and the burned rock would yield absolute ages from cultural residues within the walls of these objects that had been culturally used and may have more secure contexts than tiny pieces of charcoal. Nine sherds were selected for radiocarbon analysis in order to help narrow the range of time represented by the Toyah component, potentially refine the ages of individual Toyah events, and overcome some potential dating problems deriving from the use of old wood by site occupants. The individual charcoal results from the laboratories are presented in Appendix B, with results also presented in various parts of the text.

\subsubsection{Stable Isotope Analyses}

Matrix from the interiors of 87 burned limestone rocks, six Varga Site Toyah sherds, two Mission San Juan sherds, five Mission San Lorenzo sherds, all believed to contain cultural organic residue were extracted for stable carbon and nitrogen isotope analyses. Isotope samples were extracted from those same burned rocks and ceramic sherd samples employed in lipid residue analysis. Also 25 sediment samples, 20 from the one column in Block A and five from dated sediments were analyzed. These tiny matrix samples (about $1.0 \mathrm{~g}$ ) were submitted to University of California at Davis, Stable Isotope Facility, for stable carbon and nitrogen isotope 
analyses. About 33 modern plant samples were also isotopically analyzed to enlarge the current comparative database and facilitate the interpretations of the cultural materials. The isotope results from the modern specimens supplement and support the recent stable isotope data gathered on modern edible plant parts, animals, and nuts from the Central, South, and West Texas regions (Quigg and Cordova 2000; Quigg et al. 2000; Quigg et al. 2002a, 2002b).

The selected burned rock matrix submitted for isotope study came from 23 recognizable cultural features unevenly representing the 6,000 years of prehistory at the Varga Site. The limestone burned rocks were broken and the outer edge matrices were broken off or ground using a Dremel ${ }^{\circledR}$ tool with a variety of metal bits. The ground rock matrix was placed in a 3.5 dram plastic vial and sent to Paul Price Associates, Inc. of Austin, for calcium carbonate removal. The laboratory processing to remove the calcium carbonates from the extracted residues involved: at least two acid washes with a 20 percent hydrochloric acid $(\mathrm{HCl})$ solution. After each acid wash the sample was allowed to settle overnight (ca. 12 hours). After settling, excess solution was poured off of the sample and a subsequent acid treatment was conducted until a reaction was no longer visible. Upon completion of the acid treatment, each sample was thoroughly washed with distilled water and placed in a drying oven approximately two to three hours and allowed to dry. Sample vials were rinsed thoroughly with distilled water and allowed to dry before repacking each sample within their respective vial. Less than $1 \mathrm{~g}$ of decalcified matrix from each sample was sent to University of California at Davis, Stable Isotope Facility for encapsulation and stable isotope analyses.

Carbon isotope results derived from the organic residues inside the burned rocks and ceramic sherds are used to assess the relative proportion of $\mathrm{C}_{3}$ or $\mathrm{C}_{4} / \mathrm{CAM}$ photosynthetic pathway of the plant residues, or animals that ate these plants, and were cooked by these items. The isotopes provide relative abundance proxies of each photosynthetic community and probably reflect a mixture of food resources. The stable nitrogen isotope results are believed to be informative for the identification of legume versus non-legume plants. The values derived probably reflect a mixture of food resources. The specific stable isotope results derived from the isotope laboratory are presented in Appendix $\mathrm{H}$ with results presented in appropriate sections of the text.

\subsubsection{Lipid Residue Analyses}

A total of 102 samples was submitted to Dr. Mary Malainey in Winnipeg, Manitoba, for lipid residue analysis. These include 94 limestone burned rock samples from 23 identified features and eight ceramic sherds that include two sherds from Mission San Juan in San Antonio. The Late Archaic burned rock midden Feature 1 and its subdivisions Feature 1a, 1b, 1c, and 1d was intensively investigated through 27 individual samples. Seven Toyah features were investigated through multiple samples, whereas two Middle Archaic features and six Early Archaic features were sampled. Chunks of the burned rocks, weighing from 11 to $134 \mathrm{~g}$, were broken from the parent burned rock for submission. The parent rock was retained and is curated for future reference. The selected burned rocks were mostly from burned rock features that are radiocarbon dated. These same burned rocks were also used to extract matrix for stable carbon and nitrogen isotope analyses. The six sherds from the Varga Site were thought to reflect Toyah period events. These eight sherds were thought to represent at least three vessel groups; \#1030 and \#1055 were assigned to Vessel Group 1, \#965 and \#1157 were assigned to Vessel Group 2, and \#900 and \#901 were assigned to Vessel Group 3. The two 
sherds from the Mission San Juan reflect the Native American manufacture and use during the historic period around A.D. 1731 to about A.D. 1823 (Habig 1968). The lipid analysis was conducted to identify the cultural lipids within the organic residues that remained inside the burned rock or ceramic sherd, which may indicate the kinds of foods that were cooked. These data potentially reflect changes in subsistence practices or species available over the nearly 6,000 years of prehistory represented. Drs. Malainey and Malisza present the detailed procedures, results, and interpretations of the lipid analyses in Appendix G. Their results have been incorporated into the appropriate sections within the body of the text.

\subsubsection{Optically Stimulated Luminescence (OSL) Dating}

We anticipated that charcoal or other organic materials would not be preserved from the Early Archaic component; and therefore, we would lack the necessary organic material to radiocarbon date this important early component. In anticipation of not being able to procure radiocarbon dates for early occupations at Varga, we collected six to eight OSL samples from the three primary components during the field investigation and proposed this strategy to TxDOT in our research proposal. The proposal was accepted and six sediment samples for dating were submitted for OSL analyses. We anticipated the combined radiocarbon and OSL results from the Toyah and Late Archaic components would provide the necessary crosscheck for the OSL dates derived from the Early Archaic component. The comparison of the results from the two dating techniques in the upper two components would provide the foundation for determining the validity and interpreting the OSL dates from the Early Archaic.
Six matrix samples incased in light-tight, $5 \mathrm{~cm}$ diameter plastic tubing with sealed ends were submitted to Dr. James Feathers at the Luminescence Dating Laboratory at the University of Washington in Seattle, for singlegrain OSL dating. Two samples were collected from each of the three major components, two from the Toyah (\#1237 and \#1238), two from the Late Archaic (\#1239 and \#1240), and two from the Early Archaic (\#1242 and \#1243). Separate sediment samples from immediately adjacent to each collected sample for dating were also sent to the laboratory for determination of environmental dose rate and moisture content. The details of the methods and procedures for the OSL dating and the interpretation by Dr. Feathers are presented in Appendix L.

\subsubsection{Instrumental Neutron Activation Analysis (INAA)}

A total of 280 samples (TRC001 through 280) were submitted to the Archaeometry Laboratory at the University of Missouri Research Reactor in Columbia. A total of 107 natural chert samples (TRC001 through 107) were from known source localities across the southwestern part of the Edwards Plateau and were submitted to establish signatures for natural Edwards chert. Thirty-six natural chert samples came from nine different localities (TRC047 through 082) originally collected by Dr. Charles Frederick as part of his work in defining the Edwards chert area of exposure. The provenience information of these nine localities was first published by Frederick and Ringstaff (1994). The "sample number" used in the original publication was again used here along with the sufficix of CF. The localities from which natural chert samples were submitted at this time include sample number 6 (TRC061 through 065), 7 (TRC047 through 051), 9 (TRC052 through 055), 10 (TRC056 through 060), 11 (TRC066 through 071), 12 (TRC072 through 074), 16 (TRC075 
through 078), 17 (TRC079 through 081), and 19 (TRC0082). These samples purposely focused on the southwestern end of the Edwards chert exposure since this is the location of the Varga Site. Another natural chert sample consisting of six pieces (TRC001-006) came from a road cut along State Highway 377 in western Edwards County and was collected by Mr. Quigg. Seven natural chert pieces (TRC007 through 012 and 016) came from 41ED58, one pieces was from 41ED54 (TRC013), one from 41ED57 (TRC014), and one from 41ED141 (TRC015), all of which are located in an upland setting at the Devil's Sinkhole State Natural Area (Howard et al. 1996). The Texas Parks and Wildlife Department, cultural resource archeologists in Austin, provided these samples. Another 21 natural chert cobble samples (TRC083 through $103=\# 1252$ ) were collected from the gravel deposit exposed in the bottom of Hackberry Creek immediately adjacent to the Varga Site. Ten pieces of upland chert (TRC017 through $026=\# 1274-1$ through 10) were collected from eroding uplands exposure on a slope south of the Varga Site. Twenty natural chert cobbles (TRC029 through $0046=\# 1253$ ) were also collected from the Nueces River bottom just south of Camp Wood. Three pieces of Georgetown chert in three different colors (TRC104 through 106) and one piece of Burro Mesa chert (TRC107) were also submitted.

A total of 154 samples of cultural chert from the four components at the Varga Site were submitted to investigate the original sources of the stone tool material used over time. These cultural samples included parts of stone tools that represent a wide variety of tool classes from each component. Parts of 17 chipped stone tools from the Middle Archaic (TRC108 through 124) were submitted. Parts of 66 chipped stone tools from the Early Archaic (TRC125 through 190) were submitted. Twenty-three chipped stone tool pieces from the Late Archaic (TRC191 through 213) were submitted. Fragments of
48 chipped stone tools from the Toyah component (TRC214 through 261) were submitted. The results of the INAA on the lithic materials are presented in Appendix F.

Eighteen plainware ceramic sherd samples (TRC262 through 279) and one matrix sample (TRC280) were also submitted for analysis. These included three non-bone tempered sherds from the historic Mission San Lorenzo (41RE1) in Camp Wood (TRC262 through 264), five bone tempered sherds from the historic Mission San Juan (41BX5) in San Antonio (TRC265 through 269), and ten mostly bone tempered sherds from the Toyah component at the Varga Site (TRC270 through 279). The ten samples from Varga represent at least five vessel groups. The matrix sample (TRC280 = \#1259-4b) was a dark gray silty loam $\mathrm{Bk}$ soil horizon at 65 to $70 \mathrm{cmbs}$ and part of geomorphic Unit 3 from BT 2. This local alluvial sediment was used for comparison to assess the presence of locally made pottery versus pots of non-local production. The results of the INAA of the pottery are presented in Appendix $\mathrm{N}$.

\subsubsection{Possible Human Remains Analyses}

During the first phase of investigation, some unidentifiable materials were discovered. Since there was a possibility that this material was highly degraded human bone, three physical anthropologists were consulted to view and comment on the unknown material. Additionally, samples a number of other specialists. The physical anthropologists concluded that the materials could not be assigned to a species, while a bone histologist determined that the unknown material was definitely not bone. Once the analyses were completed and all opinions were gathered, TxDOT's archeological staff, TRC's archeologists, and the THC concluded that the material was not human in origin, but rather was 
more likely carbonate-filled root casts. The various technical opinions on this material are presented in Appendix J.

\subsubsection{Spatial Analysis}

The primary data utilized for analyses of spatial distributions at the Varga Site derive from the distributions of various tool classes, burned rock, debitage, faunal bone, and other artifacts across each site component, or "analytical unit." The differential function, or range of functions, that characterize the site at a given point in time, in turn, provide for a range of inferences about the role of this site in the overall settlement system of which it formed a part through time. Finally, outlining the structure of the settlement system at a given time provides the general structure within which hypotheses may be developed and tested to explain the patterns of mobility and differential use of the regional landscape. Explorations of such hypotheses may eventually lead to qualified characterizations of hunter-gatherer organizational systems in southwestern Texas.

The cultural material distributions analyzed in this study were recovered from hand-excavated units in two separate block areas-Blocks A and $\mathrm{B}$ - on the west and east sides, respectively, of the road. These excavations yielded a rich and complex array of cultural materials. Twenty-seven cultural features were documented during the first and second phases of investigations. Originally, 41 cultural features were documented in the field; however, five of these features are actually part of Feature 1, the large burned rock lens in Block A (i.e., these are burned rock clusters and scatters within a larger, incipient burned rock midden), and were subsequently combined for analytical purposes. In addition, nine of the features that were designated, as cultural features during the first phase of fieldwork were later removed from the list of features. These nine features consist of clusters of bones, burned rocks, and/or artifacts and natural soil anomalies (e.g., burned root casts, natural mineral concretions) that failed to meet the criteria for feature designation used during the second phase of fieldwork. Finally, features dating to the historic and modern periods (fence post molds) were not included in this count.

An extensive collection of artifacts was recovered during the data recovery excavations, including chipped stone projectile points, bifacial tools and preforms, unifacial tools, and edge-modified flakes; cores; lithic debitage; groundstone tools; bone implements; faunal remains (including bone, mussel shell, and snail shell); floral remains (wood charcoal, carbonized seeds, and nutshells); ceramic sherds; historic objects; and burned rock. It should be noted that these item counts might differ slightly from the final tabulations presented elsewhere in this report. Data were tabulated in preparation for the spatial analyses before all artifact analyses were completed, and artifact frequencies within some categories may have changed slightly as a result of the latter studies. For example, a few edge-modified flake tools were identified during analysis of the lithic debitage, thereby changing the frequencies of each category slightly; however, the altered frequencies of these two artifact categories are not reflected in the data analysis. It is assumed that the resulting small number of changes to final artifact category counts do not substantially alter the findings of spatial analytical studies presented here. Also, the artifact category summaries do not differentiate between materials recovered from feature versus nonfeature contexts. For purposes of the spatial analyses, artifact counts from features and nonfeature matrix within a single excavation unit have been combined.

For the purposes of spatial studies, five separate data sets representing the four recognized 
analytical units across the two excavation blocks were developed. Only those cultural materials recovered from continuous excavation areas were used in the spatial analysis; thus, all four cultural components from Block A are represented, whereas only the Toyah component was included from Block B. Cultural materials from the deeper (i.e., Late Archaic, Middle Archaic, and Early Archaic) components in Block B were recovered only from scattered excavation units during the first phase of excavations-they provide discontinuous representation of artifact densities across Block B and were consequently excluded from spatial analyses. The five data sets therefore consist of all four analytical units in Block A plus the Toyah component in Block B.

In tabulating counts of cultural materials for spatial analyses, all of the individual $10 \mathrm{~cm}$ thick excavation levels assigned to a particular analytical unit were collapsed, and their artifact counts were combined within each excavation unit. Thus, if the upper four $10 \mathrm{~cm}$ excavation levels from Unit N100/E47 were assigned to the Toyah component, then the counts of lithic debitage from all four levels were combined into a single count. Excavation levels that could not be confidently assigned to either the overlying or underlying analytical unit were excluded from spatial studies. In addition, cultural materials encountered in lower portions of the stratigraphic profile that could be demonstrated to have translocated downward from their original positions farther up the profile were excluded from study. Most often, materials falling into this category were faunal bones encountered in lower levels that could reasonably be assigned to overlying analytical units based on their state of preservation. Demonstrably Early Archaic faunal bone was substantially more eroded than Toyah bone, so an isolated, well-preserved bone found in the Early Archaic component could reasonably be assigned to the Toyah component. To avoid introducing confusing "noise" into the data, such out-of-context specimens were summarily excluded from analyses. The only exception to this rule was faunal bone recovered from the upper portion of the Late Archaic component. The interface of the sediment zones comprising the Toyah and Late Archaic analytical units (depositional Units I and II, respectively) was relatively abrupt, and the loosely consolidated, fine-grained depositional Unit I sediments were interdigitated with the upper portion of depositional Unit II, especially in the vicinity of Feature 1, where depositional Unit II consists primarily of large clasts of fire broken limestone. As faunal bone is otherwise common throughout the Toyah component and correspondingly rare in the Late Archaic component, faunal bone recovered from such contexts was summarily included in the Toyah component for analytical purposes.

Preliminary examination of raw artifact frequencies and weights (i.e., data that were not corrected for the volume of sediment from which they were recovered) revealed patterns in the spatial distribution of artifacts categories that appear to be primarily density-dependent. Artifact frequencies within any given category tend to increase across space as a function of increases in artifact counts within other categories. In other words, cells that contain high frequencies of one artifact type are likely to contain high frequencies of other artifact types as well. Thus, an increase in the frequency of one artifact category across space provides a fairly accurate prediction of the frequencies of other types. This pattern is consistent among typological categories and among spatial units, indicating that the variability represented in the raw data is primarily a function of artifact density, the volume of recovery units, and sample size. The analytical utility of these data is severely restricted. Put simply, 100 artifacts recovered from a $10 \mathrm{~cm}$-thick analytical unit in a 0.25-by- $0.25 \mathrm{~m}$ excavation unit means 
something very different than 100 artifacts recovered from a 40 -cm-thick analytical unit in a 1-by-1 m excavation unit.

To remove the biasing effects of sample size, excavation unit size, and analytical unit thickness across space, the raw data frequencies were transformed into density-corrected volumetric measures. Within each excavation unit, the average depth of the top of each analytical unit was subtracted from the average depth of the bottom of that analytical unit, and the difference was multiplied by the average size of the excavation unit within the levels covered by the analytical unit. Most excavation units were consistently sized from top to bottom (e.g., 0.25 -by- $0.25 \mathrm{~m}$, 0.5 -by- $0.5 \mathrm{~m}$, or 1.0 -by- $1.0 \mathrm{~m}$ ), although local unconformities, such as the edges of previously excavated backhoe trenches, sometimes cut into one or more levels. The resulting measure of the volume of each analytical unit within each individual excavation unit was then divided into the raw counts of each artifact category, resulting in a measure of the density of each artifact category per $\mathrm{m}^{3}$. As density-corrected data represent a relative measure of the abundance of an artifact category per unit of space without the biasing influence of excavation unit size or depth, the densitycorrected data were directly comparable and formed the basis for all further data manipulations.

Next, principal components analyses were conducted using the statistical package for the social sciences (SPSS, version 12.0). Within each of the five data sets, the density-corrected data array was used as the basis for calculating a matrix of correlation coefficients. In each data set, individual excavation unit designations formed the cases (i.e., rows), and the artifact categories defined for the analysis formed the variables (i.e., columns). The first step in principal components analysis is the computation of a matrix of correlation coefficients that represents the relative correlation or covariation of each variable (in this case, artifact categories) with every other variable, measured on a scale of -1.0 (perfect disassociation) to 1.0 (perfect association). Before generating the matrices of correlation coefficients, however, one final data manipulation was necessary.

A high ratio of zeroes (in this case, excavation units or entire analytical units that failed to yield any of a particular artifact category) in data matrices presents serious problems in calculating a statistically valid matrix of correlation coefficients. As the number of zeroes manifested in the original data matrix increased, the percentage of total variability in the assemblage accounted for by zeroes, or the nonoccurrence of a data class, also increased. To minimize the effect of zeroes on analytical results, it was necessary to minimize the number of zeroes before generating the matrix of correlation coefficients. This was accomplished either (1) by combining variables and cases in ways that increased the probability that at least one occurrence of every variable (or column) was present in every case (or row), or (2) by selectively deleting variables and/or cases to accomplish the same result. In the current study, the most effective means of eliminating zeroes from the original data matrices was the deletion of artifact categories that were completely absent from particular analytical units. The specific artifact categories that were deleted from each data matrix are listed within the discussion of statistical results for each analytical unit.

Principal components analysis is a factor extraction method used to form uncorrelated linear combinations of the observed variables. The first component has maximum variance. Successive components explain progressively smaller portions of the variance and are all uncorrelated with each other. Principal 
components analysis was used to obtain the initial factor solution, and it was used when a correlation matrix was singular. The commonly used procedure of varimax orthogonal rotation for factors whose eigenvalues were greater than 1.0 was employed in the analysis (cf. Vierra and Carlson 1981). The varimax method seeks such orientations that as many of the variables as possible have either a very high or a very low loading on each factor, rendering each factor as mutually exclusive as possible and making them easier to interpret as a result (Cowgill 1968). Three- to six-factor solutions were extracted for the various data arrays analyzed, accounting for 60.59 to 66.22 percent of the total variance in the data sets. Within each factor loading, only those variables exceeding 0.5 (positive or negative) were considered to represent diagnostic variables for each factor.

Contour maps of density-corrected artifactual data were generated for each variable within each component, using Surfer (version 5.01) mapping software. These maps were used as a visual reference to aid in the interpretation of the spatial distribution of each artifact category and to provide additional depth to interpreting the results of the principal components analyses. These maps are included in the summary section of each of the individual components. 


\subsection{GEOARCHEOLOGY}

\author{
Grant Smith and Charles Frederick
}

\subsection{INTRODUCTION}

Grant Smith

The geoarcheological investigations of the Varga Site (41ED28) were conducted to evaluate the integrity of the site, determine soil/depositional units relevant to the archeological investigations, and to characterize the site setting. These investigations were done primarily through investigation of backhoe trench (BT) exposures, observation of handexcavated excavation blocks, and pedestrian examination of the site and surrounding terrain. Though initial backhoe trenches were excavated in areas directly related to known cultural materials centered on the surface burned rock, additional trenches on the east side of the roadway helped delineate the extent of soil/depositional units with the potential to yield prehistoric cultural materials. In addition to investigation into the first terrace (T1), in which the archeological site was contained, the gravel strath terrace (T0) immediately below it, and the terrace immediately behind the first terrace (T2) were examined with the hopes of identifying dateable sediments that would help bracket the age of the second terrace.

Site 41ED28 is located in the T1 on the left (north) bank of Hackberry Creek and is approximately $8 \mathrm{~m}$ above the current stream channel. The T1 surface is dominated by relatively fine-grained sediments, approximately a meter thick, that overlie rounded stream gravels and boulders. The T1 is considered a fill terrace and contains sediments with the potential to yield prehistoric archeological materials. Such materials had already been identified during previous archeological investigations of the area.

Coarse gravel and boulder deposits dominate the lower T0 surface, but immediately adjacent to the $\mathrm{T} 1$ some finer-grained sediments cap the boulders (Figure 6-1). The reason for the absence of finer-grained sediments closer to the river channel is probably due to erosional scouring by floods in the years of A.D. 2001 and 2000. A backhoe trench at the T1/T0 margin (Trench M-1, Figure 5-1) appears to indicate that the basal boulders and gravels extend underneath the $\mathrm{T} 1$ and are, thus, the result of deposition during the construction of the T1 (Figure 6-1). The finer-grained sediments that cap the gravels appear to be a mixture of slopewash and overbank alluvium that post dates the incision that resulted in the development of the T0. Multiple dates on a variety of Early Archaic materials from the overlying finegrained sediments indicate that the fines are younger than 6,300 B.P. Thus, the T0 gravels are older than 6,300 B.P. whereas, the $\mathrm{T} 1$ developed over at least the last 6,300 years. The down cutting and erosional scouring that followed the deposition of the gravels likely removed some deposits from this sequence.

The T2, located approximately $100 \mathrm{~m}$ to the north of the study area, is dominated by colluvial deposition from the adjacent valley wall though some alluvial deposition has almost certainly occurred (Figure 6-2).

The sediments appear to be largely derived from the surrounding limestone bedrock. The occurrence of what appears to be limestone residuum at the base of the backhoe trench helps confirm this hypothesis. 


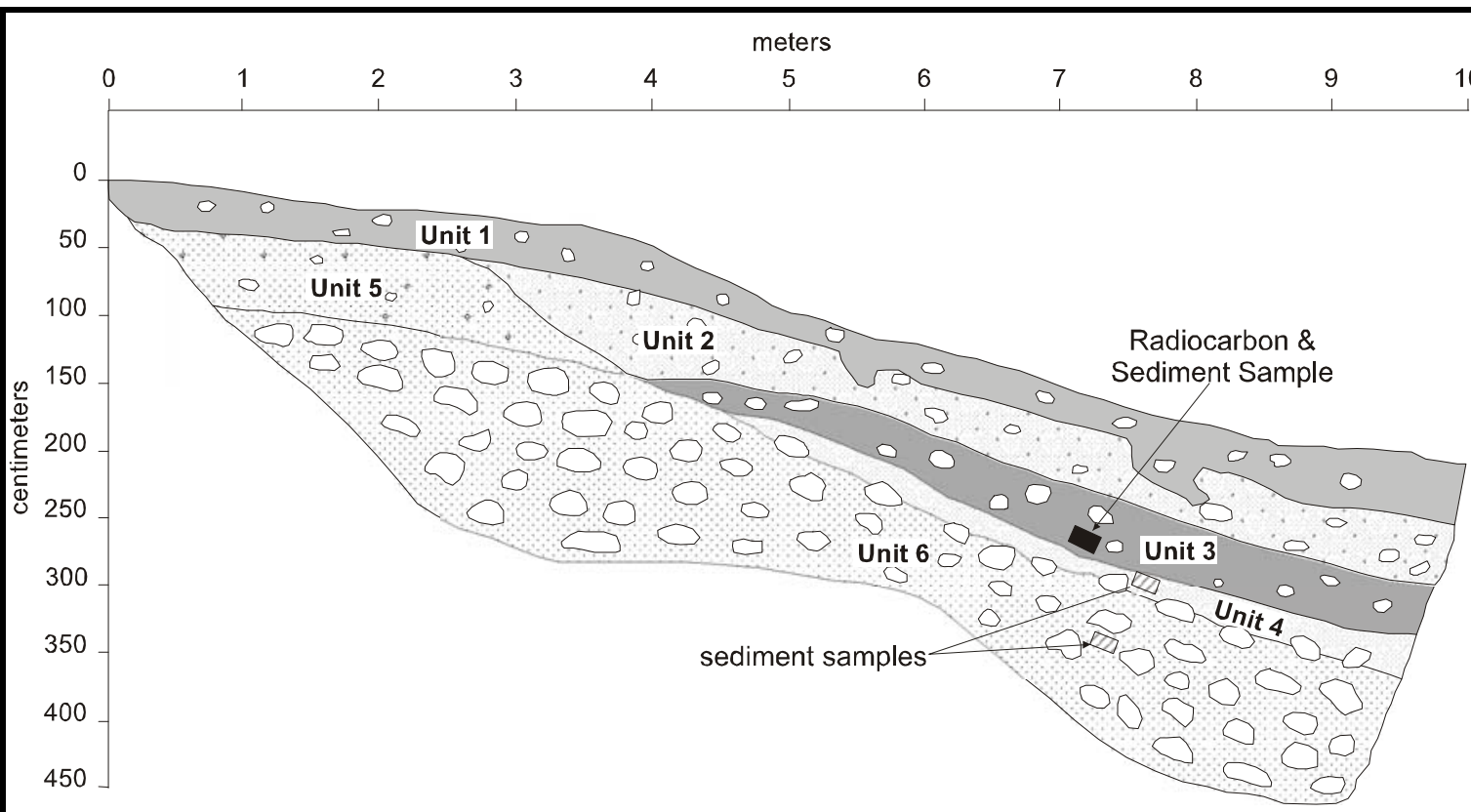

Unit 1 - A horizon/fill - Dark grayish brown (10YR 4/2, dry) gravelly silty clay loam; 40\% gravel with cobbles up to 30 $\mathrm{cm}$ in diameter; massive; slightly effervescent, disseminated carbonate; abrupt to clear smooth boundary. Slopewash and road fill.

Unit 2 - slopewash/fill - Brown (10YR 5/3, dry) gravelly silty loam; $60 \%$ gravel up to $30 \mathrm{~cm}$ in diameter; massive; mixed with portions of silty clay loam textured sediments that are dark grayish brown (10YR 4/2); slightly effervescent, disseminated carbonate; abrupt, smooth boundary. Slopewash and road fill .

Unit 3 - 2Ab horizon - Dark brown (7.5YR 3/3, moist) gravelly clay loam; $60 \%$ gravel up to $15 \mathrm{~cm}$ in diameter; massive; slightly effervescent, disseminated carbonate. Lower $5 \mathrm{~cm}$ sampled for $14 \mathrm{C}$ dating. Clear, smooth boundary. Flood \& overbank sediments.

Unit 4 - 2Bw horizon - Brown (7.5YR 5/4, dry) gravelly sandy clay loam; 70\% gravel up to $30 \mathrm{~cm}$ in diameter; massive; slightly effervescent, disseminated carbonate; a few stringers of sandy sediment. Flood and overbank sediments.

Unit 5 - 3Bk horizon - Brown (7.5YR 5/3, dry) clay loam; weak, fine, subangular blocky structure; strongly effervescent; common, fine, irregular carbonate filaments; few chert flakes dispersed through unit. Overbank sediments ( $\mathrm{T} 1$ terrace) .

Unit 6 - 3C horizon - Strong brown (7.5YR 4/6, dry) very gravelly coarse sandy loam; boulders up to $40 \mathrm{~cm}$ in diameter; massive; strongly effervescent, disseminated carbonate. Terrace gravels.

Figure 6-1. Soil and Sediment Relationships at the Transition from T0 to T1 in Trench M-1 


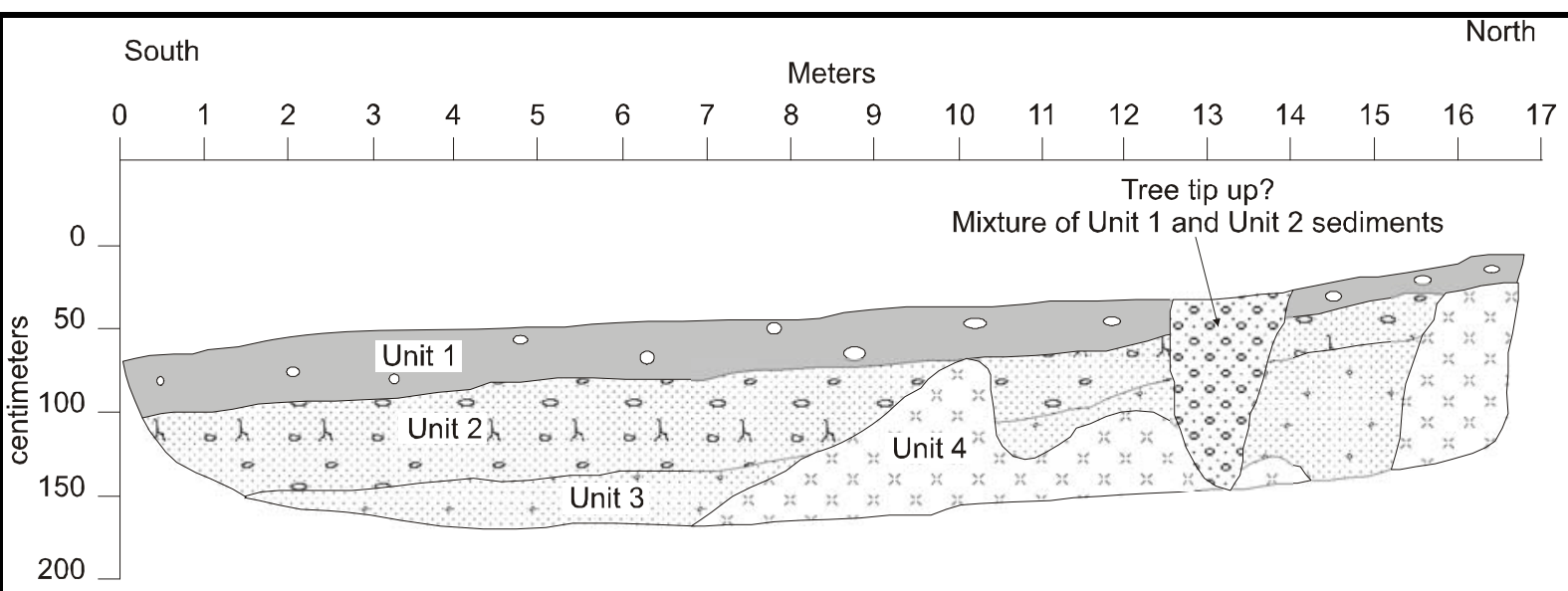

Unit 1 - A horizon - Dark brown (10YR 3/3, moist) clay loam; gravelly (20\%); gravels up to $5 \mathrm{~cm}$ in diameter; weak, medium, granular to subangular blocky structure; slightly effervescent, disseminated carbonate; clear, smooth boundary. Colluvium and Alluvium

Unit 2 - Bk horizon - Yellowish brown (10YR 5/4, dry), coarse sandy clay loam; gravelly (40\%); gravels up to $5 \mathrm{~cm}$ in diameter; weak, fine, subangular blocky structure; strongly effervescent; common (3\%), fine, irregular, carbonate filaments; clear, smooth boundary. Colluvium and Alluvium

Unit 3 - 2C1 horizon - Pale brown (10YR 6/3, dry), silty clay loam; gravelly (50\%); gravel clasts up to $15 \mathrm{~cm}$ diameter); massive; strongly effervescent, disseminated carbonate; abrupt, sharp boundary. Mixture of limestone colluvium and residuum.

Unit 4 - 2C2 horizon - Very pale brown (10YR 7/3, dry), silty clay loam; gravelly (60\%), gravel clasts up to boulder-sized (50 $\mathrm{cm}$ daimeter); massive, strongly effervescent; disseminated carbonate. Limestone residuum.

Figure 6-2. Soil and Sediment Relationships in T2 in Trench M-2

The backhoe trench (Trench $\mathrm{M}-2$ ) excavated in the right-of-way, however, may not be representative of the T2 for the majority of the nearby area. In the right-of-way, the $\mathrm{T} 2$ is particularly narrow (ca. $25 \mathrm{~m}$ wide) and immediately abuts limestone bedrock. This would appear to be an ideal position for maximizing colluvial input and may have retarded soil formation in comparison to portions of the $\mathrm{T} 2$ that received the majority of their sediment from overbank flooding episodes. The agricultural fields adjacent to the right-ofway often have $\mathrm{T} 2$ surfaces that are at least twice as wide as where the backhoe trench was excavated. Thus, while our backhoe trench within the right-of-way did not reveal any evidence of buried paleosols that would assist in our temporal understanding of the $\mathrm{T} 1$, other portions of the $\mathrm{T} 2$ might prove to be more helpful.

\subsection{Methods}

Grant Smith

The geomorphic/geoarcheologic investigation of the study area consisted of examination of backhoe trenches, hand-excavated test units, and pedestrian examination of the surrounding terrain. Field descriptions follow standard sedimentologic and pedogenic procedures established by the Soil Survey Staff (1962, 1975), Krumbein and Sloss (1963), Gile et al. 
(1966), Reineck and Singh (1980), Birkeland (1984), Birkeland et al. (1991), and Waters (1992). Field investigations were recorded on standardized profile exposure forms. In the vicinity of the hand-dug excavation blocks, the upper 10 to $20 \mathrm{~cm}$ of sediments were removed by a Gradall ${ }^{\circledR}$ because it was determined that they consisted largely of roadway gravel and/or sediments that had been moved during road construction. Thus, these sediments lacked the stratigraphic integrity to contribute significant information to understanding 41ED28.

During the first phase, geomorphic investigations of the T1 were conducted in moist to wet conditions which tended to obscure the stratigraphic boundaries in the upper portions of our profiles. Examinations during the second field phase occurred only a few weeks into the hand-excavations and, while it did provide some opportunity to study of the soils and sediments, every exposure was not observed. Some observations included here are from the archeologists that helped excavate the site and who had a longer time in which to develop their own observations.

\subsection{Results}

\section{Grant Smith}

The first phase investigations typically identified four depositional units on the T1 and site. The second phase of the investigations typically identified five. Part of this discrepancy is probably due to the wet field conditions during the first phase that obscured some of the unit boundaries. For comparison with the previous investigations, what was formerly called Depositional Unit 3 has now been split into Depositional Units 3 and 4 (Figure 6-3). It also became apparent, after receiving radiocarbon dates from some of the soil horizons, that Depositional Units 3 and 4 were recognized within BT 7 during the initial investigations. The reason for easier visibility in this location was that the units are thicker in this area; possibly due to infilling of a swale on the terrace surface, and that the boundary in question was below the wetting line caused by recent precipitation. For the purposes of discussion, the soil/sediment profile in excavation Block A (and BT 2) is described first and used as the primary reference for $\mathrm{T} 1$ sediments. As our trenches got farther away from the terrace margin (e.g., BT 7) the soil/sediment properties changed somewhat. These deviations away from the "standard" T1 soil/sediment sequence are discussed in a "variations" section that follows the reference profile description.

The uppermost unit (Depositional Unit 1) consists of fine-grained overbank sediments and only sparsely distributed prehistoric cultural materials. The Late Prehistoric Toyah component, with radiocarbon ages ranging between ca. 660 and 290 B.P., are associated with Unit 1 . In the vicinity of Bock B, small pea-sized gravel from previous road construction and shoulder stabilization practices was compressed into the surface of Depositional Unit 1 but, many areas are still relatively intact. Depositional Unit 2, which underlies Depositional Unit 1 , is the most distinct cultural layer observed in our studies, but also appears to be a buried A horizon. This unit contained the Late Archaic component at the site, radiocarbon dated to between 2,290 and 1,390 B.P. While composed of clay loam to silty clay loam textured overbank sediments (Appendix K), Depositional Unit 2 is most notable for its dark, charcoal and humate-rich appearance and abundance of fire-cracked rock (FCR). Depositional Unit 3 is notable for the abundance of small $(<1 \mathrm{~cm})$ gravels within a clay loam matrix. While still relatively dark in color, this unit lacks the charcoal staining and/or A horizon characteristics observed in Depositional Unit 2. It appears that Depositional Unit 3 marks an episode of fairly high-energy overbank deposition in order to deposit pea-gravel on the 


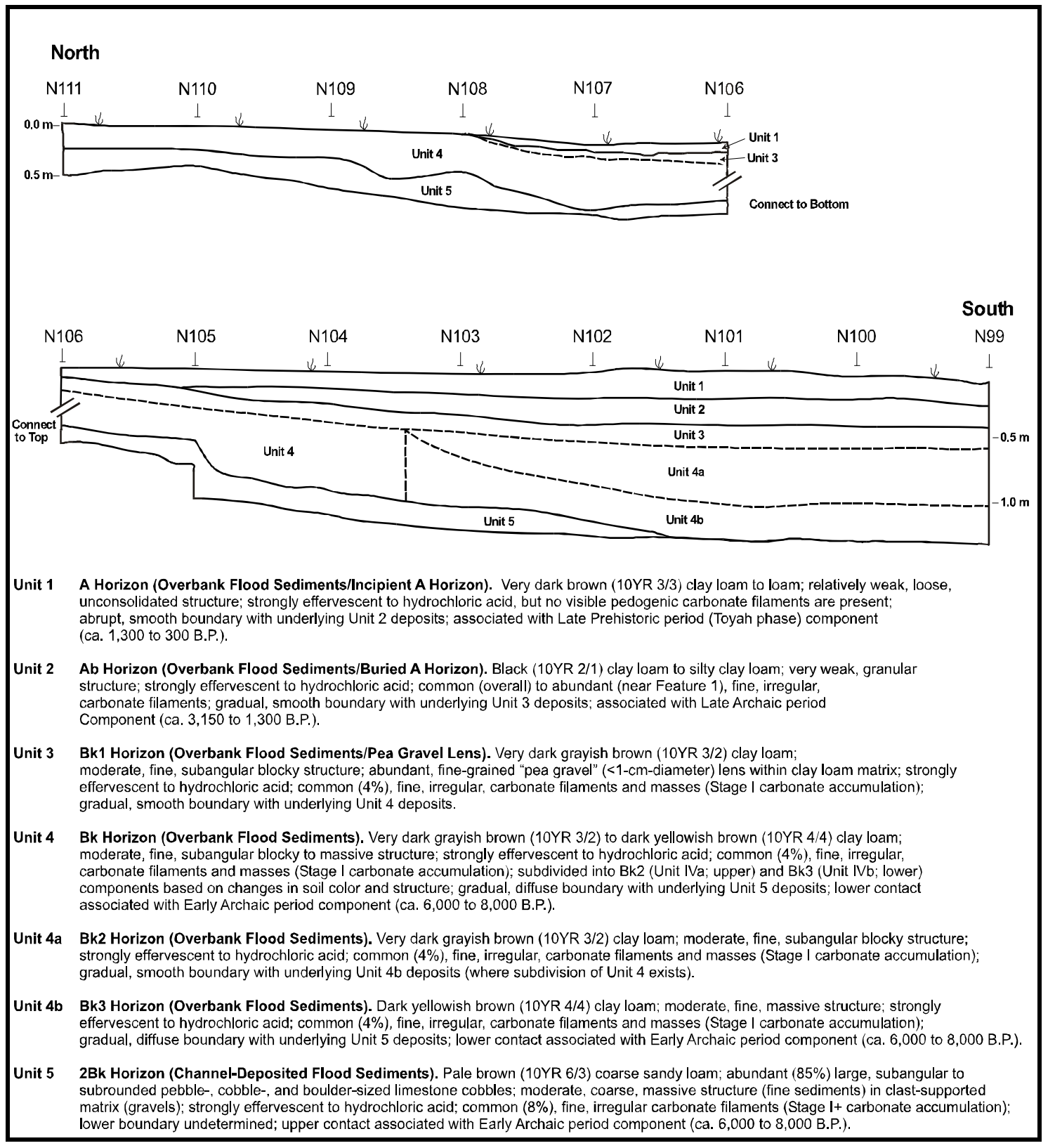

Figure 6-3. Stratigraphic Profile of Block A (East Wall)

terrace surface. Such high-energy may have also caused some erosion on the surface of the underlying unit. Depositional Unit 3 contained cultural materials assigned to the Middle Archaic, dating to 4,900-3,800 B.P. Depositional Unit 4 is silty clay loam that, in some profiles, has been subdivided into two units based on changes in soil structure. Cultural materials in Depositional Unit 4 tend to be infrequent to absent. The one exception appears to be a higher concentration of cultural materials on its lower contact with the underlying gravels. Depositional Unit 5 consists of coarse gravel deposits that are associated with 
channel deposition. The only cultural materials found in association with Depositional Unit 5 are those that rest on its upper surface or between the larger pieces, and almost certainly represent occupations after the deposition of the gravels. Early Archaic cultural materials, dating to between 6,300 and 5,200 radiocarbon years B.P., were found in the lower part of Unit 4 and were partially interspersed among the gravels in Unit 5. The following section provides a generalized description of each unit followed by a discussion of variations seen within the project study area.

\subsubsection{General Descriptions}

The uppermost soil observed on the site, Depositional Unit 1 , is typically very dark brown (10YR 3/3) clay loam to loam. In more pristine locations, this unit is entirely composed of these finer, but heavily impacted areas often have a substantial amount (up to 75 percent) of roadway gravel compressed and mixed into the loam. This gravel also tends to form an armored surface over most of the site and this upper portion was removed by a Gradall ${ }^{\circledR}$ in the vicinity of Block A excavations at the beginning of Phase 1. Depositional Unit I typically exhibits a weak, coarse, subangular unconsolidated structure that grades to platy structure in areas that appear to have been mechanically compacted. The sediments are strongly effervescent to hydrochloric acid, but no visible pedogenic carbonate filaments are present. This calcareous nature is almost certainly due to sediments largely being derived from the surrounding limestone bedrock. The relatively dark color, surface position, and vegetative cover on this unit result in its classification as a soil A horizon. In comparison to the underlying sediments, the A horizon development is relatively weak and it may be suitable to call this an incipient A horizon (A). It does support the current grassland vegetation, however, and without unaltered parent material with which to compare humic enrichment, it may be just as suitable to call this an A horizon. Due to the fine-grained nature of the sediments, their position on an alluvial terrace and proximity to perennial Hackberry Creek, Depositional Unit 1 is interpreted as being an overbank flood deposit. Accumulation of these sediments is almost certainly due to multiple flood events over time, but bioturbation and other pedogenetic processes have masked or destroyed any primary sedimentary strata resulting from flooding (e.g., laminae). Depositional Unit 1 has an abrupt, smooth boundary with underlying Depositional Unit 2, a property that suggests a hiatus between the depositions of the two units.

Prehistoric cultural materials in Depositional Unit 1 tend to be dense and randomly distributed. The archeologists indicated that this unit contained Toyah phase materials. The radiocarbon results from cultural carbon provide an age range from approximately 290 to 660 B.P. for the cultural materials. A couple of slightly earlier dates, both on charcoal, 920 and 940 B.P. may indicate the maximum age of Depositional Unit 1 deposits is closer to 1000 B.P. In some portions of the right-of-way investigations, the presence of some cultural materials on the surface appears to be the result of bioturbation, road maintenance disturbances, or slopewash onto the site from slightly higher elevation locales near to the roadway. Observation of the adjacent pastures compared to the roadway shoulder areas indicates that ca. 10 to $20 \mathrm{~cm}$ of sediments may be missing from areas immediately adjacent to the road, probably due to erosion. Thus, components that originally may have had a few centimeters of stratigraphic separation may now be concentrated on or near the surface of Depositional Unit 1.

Depositional Unit 2 is a distinct change because of its apparent high degree of charcoal staining and abundant FCR in the vicinity of Block A. 
This unit is typically a black (10YR 2/1) clay loam to silty clay loam that exhibits a very weak, fine, subangular blocky structure. The average thickness of the unit is $30 \mathrm{~cm}$. In the main activity area of Block A, cobbles of FCR comprise approximately 35 percent of this unit and in some portions the FCR forms a clastsupported package that contains little of the finegrained matrix. A few chert flakes also appear to be randomly preserved within this unit. The nine accepted charcoal and two bone dates obtained from the Late Archaic cultural materials in Depositional Unit 2 provide an age range from 1,390 to 2,290 B.P. with an average age close to 2,040 B.P. A humate date from this $\mathrm{Ab}$ sediment yielded a mean residence time of 1,900 B.P. Depositional Unit 2 appears to have accumulated over a 600-year long period. The overall shape of Depositional Unit 2, including those areas high in FCR, is that of a large (6+ m diameter), lens of organic and charcoal-rich sediments. A key observation is that the charcoal-stained appearance of this unit appears to gradually decrease away from the FCR lens (Features 1, 1b, 1c, and 1d) yet a relatively dark colored unit is still present. It is our interpretation that the FCR lens was associated with a stable A horizon on the terrace surface and that charcoal was dispersed away from this feature, thus blurring the boundaries of where Depositional Unit 2 should be classified as a cultural horizon and where it should be considered an A horizon. The change is so gradual away from the feature that it is difficult to determine where such a boundary should be placed. Only by observing "end member" samples of the same Unit's sediments can a clear difference be observed. It is understandable that people would occupy a stable surface on which soil formation was occurring. Indeed it would tend to indicate an environment suitable for occupation. The only trouble is in defining where cultural influence no longer exists. It may be more suitable to use FCR and other cultural materials to define the site boundaries than use the charcoal staining.

In some portions of the exposures the finegrained matrix exhibits an abundance of small white masses that do not appear to be calcium carbonate or root filaments. The general impression is that these white masses slightly resemble ash flecks, but never occur in a mass that could be considered an ash deposit. It is tentatively suggested that these may be oxalate crystals resulting from the burning of plant material. Anything more specific would be pushing the credibility of such an interpretation, but if other proxy data regarding plant utilization is forthcoming, this hypothesis might allow corroborating evidence. Depositional Unit 2 has an abrupt to clear, smooth boundary with the underlying Depositional Unit 3 deposits.

Underlying the charcoal and humic-rich sediments of Depositional Unit 2 is Depositional Unit 3, which is notable for the presence of finegrained "pea gravel” ( $<1 \mathrm{~cm}$ diameter) within a clay loam matrix. Broken snail shell fragments are also common within this unit. The most likely explanation for this deposit of gravelly sediments is a relatively high-energy flood event that resulted in relatively coarse sediments to be washed out beyond the confines of the stream channel. Such a high-energy event may have caused some erosion of the underlying sediments (Depositional Unit 4), but it is difficult to assess how much, if any, material was removed. The result, however, caused the surface of the terrace to be gravel armored, for a time, and may have helped protect the underlying sediments after the initial depositional episode. Such a high-energy of deposition and the fact that this was probably a very quick event, indicates that the deposition of cultural materials in this unit is limited. Limited cultural materials are present, mostly in the upper portion of Depositional Unit 3. Two radiocarbon dates on charcoal and one on deer 
bone from the upper portion of Depositional Unit 3 are 3,850 to 4,740 B.P. with a humate date on sediments yielding a 4,790 B.P. mean residence age. Depositional Unit 3 has a clear boundary with the underlying sediments. These ages reveal a period of some 1,000 years for the development of this unit with the high energy event near the beginning of the period.

Depositional Unit 4 is present in every backhoe trench, but lacks FCR concentrations and charcoal staining. Cultural materials were much less common in these sediments than in the overlying units. In general, Depositional Unit 4 is a dark yellowish brown (10YR 4/3) clay loam that exhibits a moderate, fine, subangular blocky structure. In some locales, particularly those where Depositional Unit 4 is over $50 \mathrm{~cm}$ thick, a change to massive soil structure was noted by the archeologists in the lower portions of the unit. This may indicate relatively unaltered parent material and, thus, may actually be a $\mathrm{C}$ horizon. Given the gradual accumulation of floodplain sediments, however, it may be that these massive sediments actually started as a $\mathrm{B}$ horizon, but were subsequently buried to the point where they no longer continued to develop B horizon characteristics. It may be more appropriate to designate these horizons as $\mathrm{Bk} 1$ and $\mathrm{Bk} 2$, based on the changes in soil structure. Regardless of any subdivisions, these sediments strongly effervesce when tested with hydrochloric acid and have common (four percent), fine, irregular, carbonate filaments and masses. This is considered a Stage I carbonate accumulation (after Birkeland 1984; Gile et al. 1966; Machette 1985) and it is because of this accumulation that Depositional Unit 4 is considered a soil Bk horizon. In general, Stage I carbonate accumulations are typically associated with soils that are middle to late Holocene in age (e.g., Karlstrom 1988, Machette 1985, Smith and McFaul 1997). However, the abundance of carbonate from the local limestone may have resulted in faster development of pedogenic carbonates.

Cultural materials within Depositional Unit 4 tend to be somewhat randomly distributed, though there may be more of a concentration of some of the earliest cultural components near the lower contact of this unit. Otherwise, chert flakes, FCR, rare pieces of limonite ochre, and Rabdotus are distributed throughout this unit. The general impression is that either these materials were displaced vertically in the profile by bioturbation or that their occurrence throughout the profile may represent multiple occupations over time. In fact, both possibilities may be true. These fine-grained sediments are interpreted as overbank flood deposits and probably represent gradual floodplain aggradation over time. In such a scenario, it is entirely plausible that multiple occupations could have occurred in between flood events. Due to pedogenesis, including bioturbation, primary stratigraphic boundaries have been destroyed; so individual flood events cannot be distinguished. Likewise, this obscuring of boundaries probably applies to the cultural occupations as well. That is not to say that some vertical chronology cannot be developed from diagnostic artifacts, just that discrete strata with individual identifiable cultural events (e.g., a lens of Early Archaic materials) were not visible in Depositional Unit 4. The 17 radiocarbon assays from a variety of materials extracted from Depositional Unit 4 reveal an age range from about 5,180 to 6,290 B.P. This is perceived as minimum time range for this unit as potentially older organic materials may not have been preserved, and therefore, not dated.

Depositional Unit 5 is present at depth throughout the site, though its depth below surface is highly variable. This variability was demonstrated in the interim report (Lintz et al. 2002) where this deposit was shown to vary from roughly $30 \mathrm{~cm}$ deep at the north edge of 
BT 3 to about $130 \mathrm{~cm}$ deep next to BT 7 less than $20 \mathrm{~m}$ away. In contrast to the fine-grained sediments of the overlying units, Depositional Unit 5 is composed of gravel and cobble-sized (up to $15 \mathrm{~cm}$ in diameter), subrounded clasts of limestone and chert. The matrix surrounding these coarse sediments is characterized as a pale brown (10YR 6/3) coarse sandy loam. Carbonate filaments are common (8 percent) within this fine-grained matrix and appear to be more abundant than in the overlying units. This is considered to be a Stage $\mathrm{I}+$ carbonate accumulation (after Birkeland 1984). Stage I+ carbonates are often associated with middle Holocene (6,000+ years old) and older sediments (e.g., Karlstrom 1988). Though these gravels may be young enough to be contemporaneous with cultural occupations in the area, the high-energy depositional environment represented by such large clasts indicates an environment unsuitable for human occupation. Thus, Depositional Unit 4 was considered to be the basal unit for archeological excavations. The radiocarbon dates derived from the cultural materials on top and mixed into the top $5 \mathrm{~cm}$ of these gravels indicated these gravels are older than 6,300 B.P. and potentially much older.

\subsubsection{Variations}

The previous descriptions are provided as general characterizations of the sediments observed at 41ED28. Significant variations from these typical descriptions do occur. In particular, variations to Depositional Units 2, 3, and 4 occur within the study area, and, since these are the units primarily associated with cultural materials, these deviations are described here.

With respect to Depositional Unit 2, the generalized description given above is largely for excavation Block A on the west side of the road. Backhoe trenches and test units east of the road, however, were not as clearly cultural in origin. In BT 6, a charcoal-rich stain at the appropriate stratigraphic level exhibited a few randomly distributed pieces of FCR and was initially thought to be a feature (Feature 5). Further examination of the profile as it dried revealed oxidized woody material that occurred in the serpentine pattern of tree roots throughout the exposure. As a result, this charcoal-rich zone was probably the result of a natural root burn as opposed to a cultural feature. The exposure is somewhat basin-shaped, however, and that raises some questions as to whether it may be cultural in origin. That cannot entirely be ruled out, but test unit 6-1 into the burn failed to recover any cultural materials. Another possibility is that this is a natural swale that filled with charcoal-rich material from a nearby natural burn. Without definitive cultural material, the detected burn in BT 6 remains questionable as to whether it was natural or cultural in origin.

Another variation in Depositional Unit 2 sediments occurs at BT 7. In this exposure, Depositional Unit 2 sediments were encountered at the proper depth and in the proper stratigraphic position, but did not appear to have significant charcoal staining as observed in trenches on west of the road near Block A (Figures 6-4 and 6-5). A few pieces of bone and a rare chert fragment were encountered in Depositional Unit 2, but otherwise it was not very remarkable. Though dark, Depositional Unit 2 in BT 7 is more indicative of a natural soil A horizon than a cultural unit. This is the same A horizon associated with the cultural occupations responsible for the other clearly culturally influence Depositional Unit 2 sediments observed on the west side of the road. In other areas, the cultural staining was strong enough to overprint this unit and result in its classification as a cultural stratum. At BT 7, however, it appears that Depositional Unit 2 was 


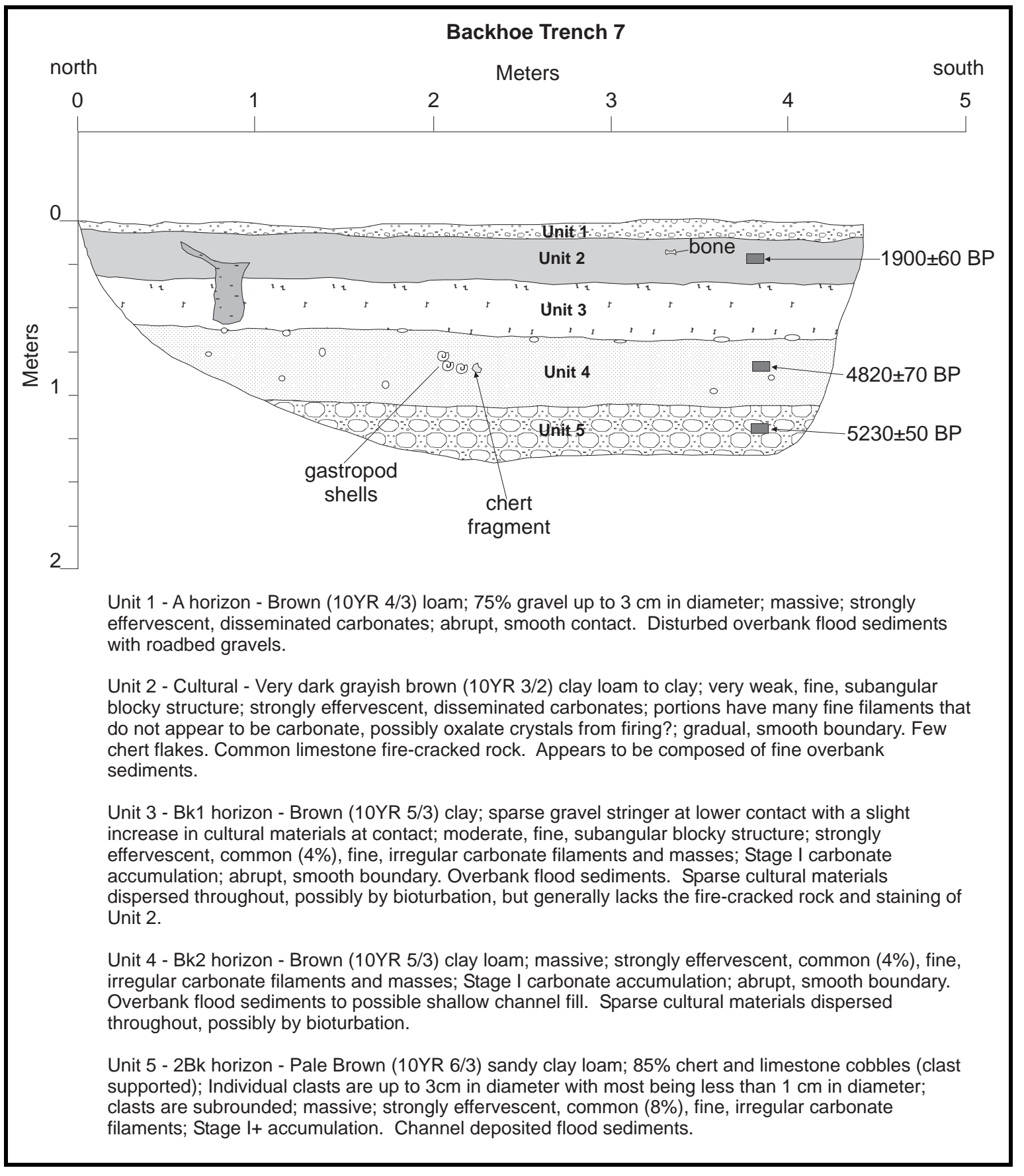

Figure 6-4. Stratigraphic Profile of Backhoe Trench 7 (T1) 
far enough away from cultural influences that it remains largely unaffected by cultural staining. For this reason it is considered to be a natural unit. Also of note was an ash filled zone with and oxidized base towards the base of Depositional Unit 2 and into Depositional Unit 4 towards the northern end of the trench (Feature 6-6). It was initially entertained that this might be a cultural feature (Feature 4), but the shape of the ash-filled area and the presence of some woody charcoal within it indicates that this was the result of a natural tree root burn instead of cultural activity.

Backhoe trench 7 also contained the most significant variation in the Depositional Unit 3. Within the archeological excavation Block A, Depositional Unit 3 is typically a ca. $15 \mathrm{~cm}$ thick stratum that is noted as a thin gravel layer. Within BT 7 this unit thickens to approximately $30 \mathrm{~cm}$ thick and the gravels are mostly limited to the lower contact. Given the proximity of excavation Block A near the front edge of $\mathrm{T} 1$ and the position of the BT 7 some $35 \mathrm{~m}$ north of the terrace edge, these properties appear consistent with the alluvial deposition of a single flood unit. The coarser grained pea-gravels in excavation Block A area represent a slightly higher energy of deposition near the terrace margin while the clay-rich and lower gravel content of this unit further to the north indicates a loss of energy for the floodwaters to carry larger materials further away from the stream channel.

Depositional Unit 4 in BT 7 also vary somewhat from the Depositional Unit 4 observed in the excavation Block A. Whereas Depositional Unit 4 near the T1 margin exhibits a clay loam texture, this grades into sandy clay loam sediments in BT 7. The reason for this apparent disparity is that the BT 7 area appears to be either a swale fill or possible a weakly defined ephemeral drainage channel on the surface of the terrace. It does not appear that this area still

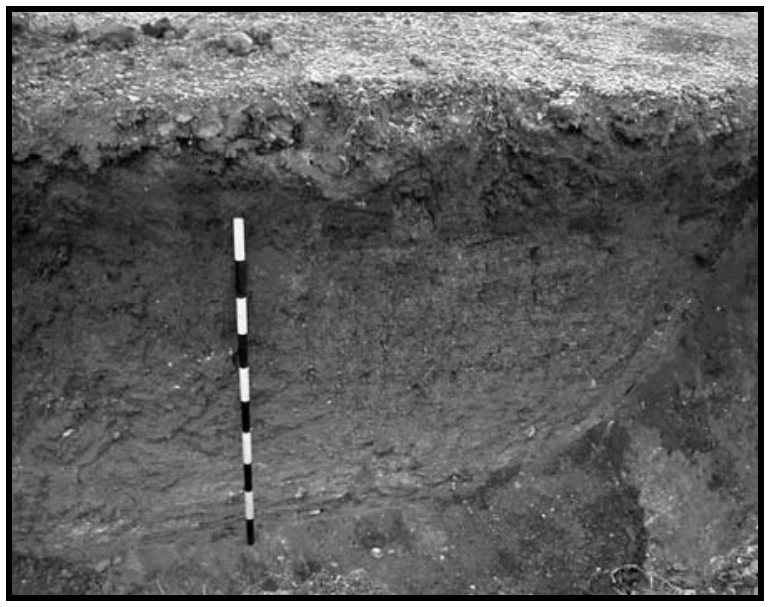

Figure 6-5. Profile of Sediments Exposed in BT 7

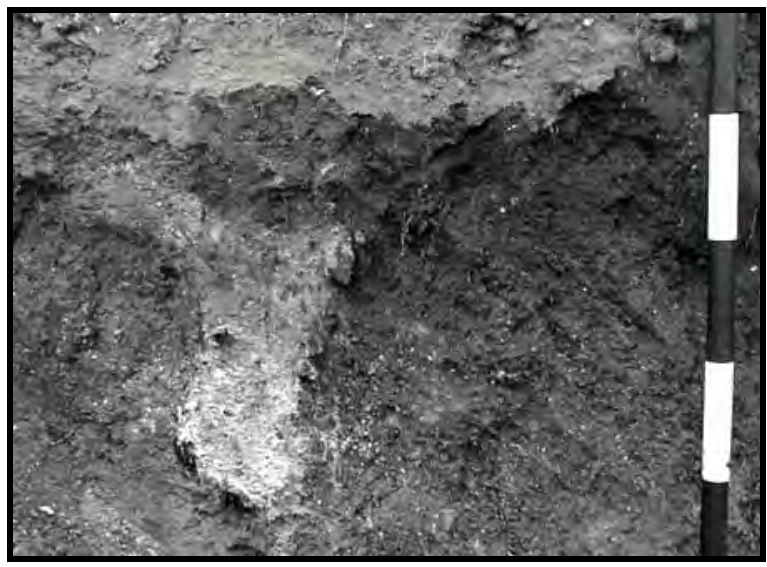

Figure 6-6. Ash With Oxidized Base

serves this function, but it may be that a shallow, poorly defined channel traversed this portion of the terrace during the middle Holocene (based on radiocarbon dates provided below). Considering the hummocky appearance of the gravels on the recently scoured $\mathrm{T} 0$, it is not surprising that similar undulations could occur on the surface of the gravels comprising the T1. Additional support for this hypothesis is provided by Depositional Unit 5 of BT 7. Depositional Unit 5 is a gravelly unit that would appear consistent with gravels expected at the base of a small channel fill. These gravels are not as coarse as those observed underlying excavation Block $\mathrm{A}$ and the rest of the terrace. 
They are typically 1 to $2 \mathrm{~cm}$ in diameter as opposed to the cobble-sized (6 $\mathrm{cm}$ and larger) clasts observed elsewhere. This would appear to be consistent with an inset gravel unit that postdates the coarser gravels and boulders that comprise the core of the $\mathrm{T} 1$.

Cultural materials were recovered from both Depositional Units 3 and 4, though worked pieces of chert were slightly more abundant on the stone line surface separating the two units. Whether these chert pieces were due to people occupying this surface or were concentrated onto the surface by erosional processes remains unclear.

The radiocarbon dates obtained from soil humates helps clarify the age and relationships of the sediments observed in BT 7 and elsewhere on the site. A radiocarbon date on humic material from Depositional Unit 5 basal gravels of BT 7 yielded a mean residence age of 5,230 \pm 50 B.P. (Beta-175391). It should be repeated that these gravels are not considered to be contemporaneous with the gravels that underlie most of the terrace, but are, instead, a younger channel fill gravel on the terrace. These sediments do, however, help provide an approximate baseline age for the oldest sediments overlying the terrace gravels. The humic material within the 2Bk horizon of BT 7 may have been translocated downward in the profile; and thus, these gravels are older than the 5,230 B.P. age would indicate, but this age is considered to be a rough estimate of when finergrained sediments began to aggrade on the $\mathrm{T} 1$. In addition, a 6,270 \pm 50 B.P. age was acquired from sediment in similar stratigraphic context (i.e., fine gravel unit overlying coarse T0 gravels) at the T1 to T0 step (Figure 6-1). Thus, aggradation on the T1 appears to have started even earlier, but still after or near the end of any Early Archaic occupations.
Depositional Unit 4 also provided a radiocarbon age that appears consistent with continued aggradation on the surface of the T1. An age of $4,820 \pm 70$ B.P. was acquired from humic material from this Bk2 horizon. In comparison with the observations in the cultural excavation blocks, this date appears consistent. It may appear troubling that an Early Archaic component was associated with Depositional Unit 4 in excavation Block A, but this component was only observed near the basal contact. This would appear to indicate that these cultural materials were deposited on the contact with the underlying gravels before Depositional Unit 4 was deposited. Thus, there may be 5,000 to 7,000 B.P. year old cultural materials at the lower contact of Depositional Unit 4, but the overlying sediments are a few thousand years younger. This indicates there is significant time missing from the depositional record for the site, but it also may indicate that the coarse gravels comprising the core of the T1 were exposed on the surface for an extended period of time before finer grained alluvium was deposited. This would also appear consistent with the possibility that Early Archaic inhabitants may have utilized the gravels as a readily available chert supply, possibly over an extended period of time.

A humate sample from Depositional Unit 2 in BT 7 yielded a mean residence age of 1,900 \pm 60 B.P. (Beta-175390). This is consistent with the proposed 3,150 to 1,300 B.P. age of Depositional Unit 2 in excavation Block A that is indicated by the Late Archaic cultural materials recovered. Since humates represent a mean residence age for soil development within the sediments, it is entirely possible that deposition of this unit may have begun a few thousand years prior, but this is constrained by the 4,820 B.P. age acquired from Depositional Unit 4 sediments. Using these radiocarbon ages and the depositional interpretations given earlier, it appears that Depositional Unit 3 was deposited in a single 
flood event sometime after 4,820 B.P., but prior to 2,300 B.P. In addition, Depositional Unit 2 was also deposited, probably from multiple overbank flood events, and experienced pedogenesis prior to 2,300 B.P. Given the inaccuracies of the mean residence ages provided by soil humates, particularly for a soil that developed over an extended period of time, it is quite likely that pedogenesis within Depositional Unit 2 continued for a few hundred years beyond that date. These ages are, however, still consistent with the ca. 300 to 1,000 B.P. time frame proposed for the overlying Depositional Unit 1 sediments based on the Toyah phase radiocarbon dates and materials from those deposits.

\subsection{INTERPRETATION AND DISCUSSION}

\section{Grant Smith}

The geomorphic questions regarding this archeological site can be divided into two general categories. The first category concerns site-specific questions such as the age of the depositional units and the integrity of cultural materials on the site. The second category of questions concerns how these sediments relate to other regional chronologies, and how the Varga Site data may aid in prediction of the position and context of other archeological sites within the area.

\subsubsection{Site Specific Interpretations}

Overall, the sediments in T1 appear to be relatively intact. One of the major concerns by TxDOT initially was whether the surface and near-surface deposits were intact or had been disturbed by recent pothunter activity. The fact that Depositional Unit 2, with its dark, charcoalrich appearance and abundance of FCR, did not show intrusive potholes in any of our profiles indicates that at least the Late Archaic component in Depositional Unit 2 is relatively undisturbed, and those below that should also be undisturbed.

Radiocarbon ages from humic material and charcoal dates associated with cultural components recovered provide a chronology for sediment deposition and cultural occupation at this location. The gravels that comprise the core of $\mathrm{T} 1$ yielded no dateable radiocarbon material. However, given the stratigraphic position and the presence of the overlying Early Archaic components, these gravels are probably late Pleistocene to early Holocene in age. If any paleosols existed over these gravels during this early phase, they must have been removed by erosion prior to ca. 6,300 B.P. because Early Archaic cultural materials occur on the upper contact with the gravels. Either after or near the end of the Early Archaic occupation sandy sediments started to be deposited on some portions of the T1. Sediments in this context on the $\mathrm{T} 1$ to $\mathrm{T} 0$ margin provided an age of 6,270 B.P., while those in a small channel fill immediately north of the site provided an age of 5,230 B.P. There does not appear to be a depositional unit that corresponds to these dated units immediately under the archeological excavation blocks. Instead, the late Pleistocene/early Holocene gravels are directly overlain by a slightly younger depositional unit that, from correlation to BT 7, dates to ca. 4,800 B.P. To state it in a slightly different way, areas flanking the Varga Site to the north and south exhibit depositional units that date to the 6,270 to 5,230 B.P. time frame, but the first finegrained depositional unit (Depositional Unit 4) that occurs in both the marginal areas and on the site is one that dates to ca. 4,800 B.P. However, Depositional Unit 4 is very sparse in cultural materials with the exception of Early Archaic materials that occur at the basal contact of the unit and pre-date its deposition.

Sometime after 4,800 B.P., but prior to 2,300 B.P., a high energy flood event deposited 
pea-gravel across T1, which transitioned into a clay loam with pea gravel at its base slightly further to the north. Also before 2,300 B.P., clay-rich overbank sediments were deposited on the site which experienced pedogenesis and resulted in the formation of an A horizon. Late Archaic materials from the 2,300 to 1,700 B.P. time frame are associated with these clay-rich overbank deposits. Finally, a younger deposit of clay loam to loam textured sediments caps the stratigraphic profile and forms the modern A horizon. Toyah phase materials associated with the 290 to 660 B.P. time frame are associated with this surficial unit that is less than 1,000 B.P.

\subsubsection{Regional Interpretations}

Charles D. Frederick

Studies of alluvial stratigraphy in Central Texas can generally be lumped into two types of works: 1) site specific studies, and 2) regional scale studies. Site specific studies, like the work reported here for the Varga Site, represent fieldwork performed at a single locality, usually an archeological site, in association with either testing or data recovery excavations. These works are often well-dated and provide good impressions of the historical behavior of the studied stream at a specific point in a specific valley. But because they represent work done at a single point, extrapolation of these stratigraphic sequences to larger reaches of the same stream should be done cautiously and the alluvial chronologies may not be representative of the stream as a whole. Regional studies typically involve stratigraphic work along one or more reaches of a stream and therefore, generally provide a more accurate image of the long-term nature of alluvial erosion and sedimentation. Regional-scale studies are much less common than site specific studies and most often are either masters thesis or doctoral dissertations, or in support of cultural resource projects on aerially extensive landscapes such as military bases.

In order to evaluate how the record of alluvial sedimentation at the Varga Site compares with other records in the region, we summarized the chronology of alluvial sedimentation from 10 streams in the Central Texas region. First, we examined the streams nearest the Varga Site which drain the southern Edwards Plateau, and then we examined at the records of several streams in the San Antonio region. Finally, we examined the alluvial chronologies of four streams in Central Texas. The timing of sedimentary events at each locality is depicted in Figure 6-7 and can be visually compared with the timing of sedimentation at the Varga Site on Figure 6-4.

But before considering the alluvial chronology in detail, it is worth noting the structural differences between the Varga site and many of the studies cited below. The alluvial deposits at the Varga Site are considerably thinner and more fragmentary than most of the alluvial studies in this region. Most studies cited below have recognized allostratigraphic deposits which may range from as little as $2 \mathrm{~m}$ thick to more than 10 $\mathrm{m}$, depending upon the stream. This is considerably thicker than the Varga Site deposits that are generally less than $1.5 \mathrm{~m}$ thick.

In terms of landscape position, the Varga Site probably most closely resembles Nordt's (1994) work on Henson Creek at Fort Hood, which is a low-order tributary of the Leon River. Although Nordt was able to correlate the depositional events of Henson Creek with the much larger Cowhouse Creek, he noted that there are several differences between the deposits of low-order tributaries and larger streams. In particular, Nordt notes that small streams are likely to contain more erosionally bounded units, are more likely to record more variability in discharge and depositional environments, and 


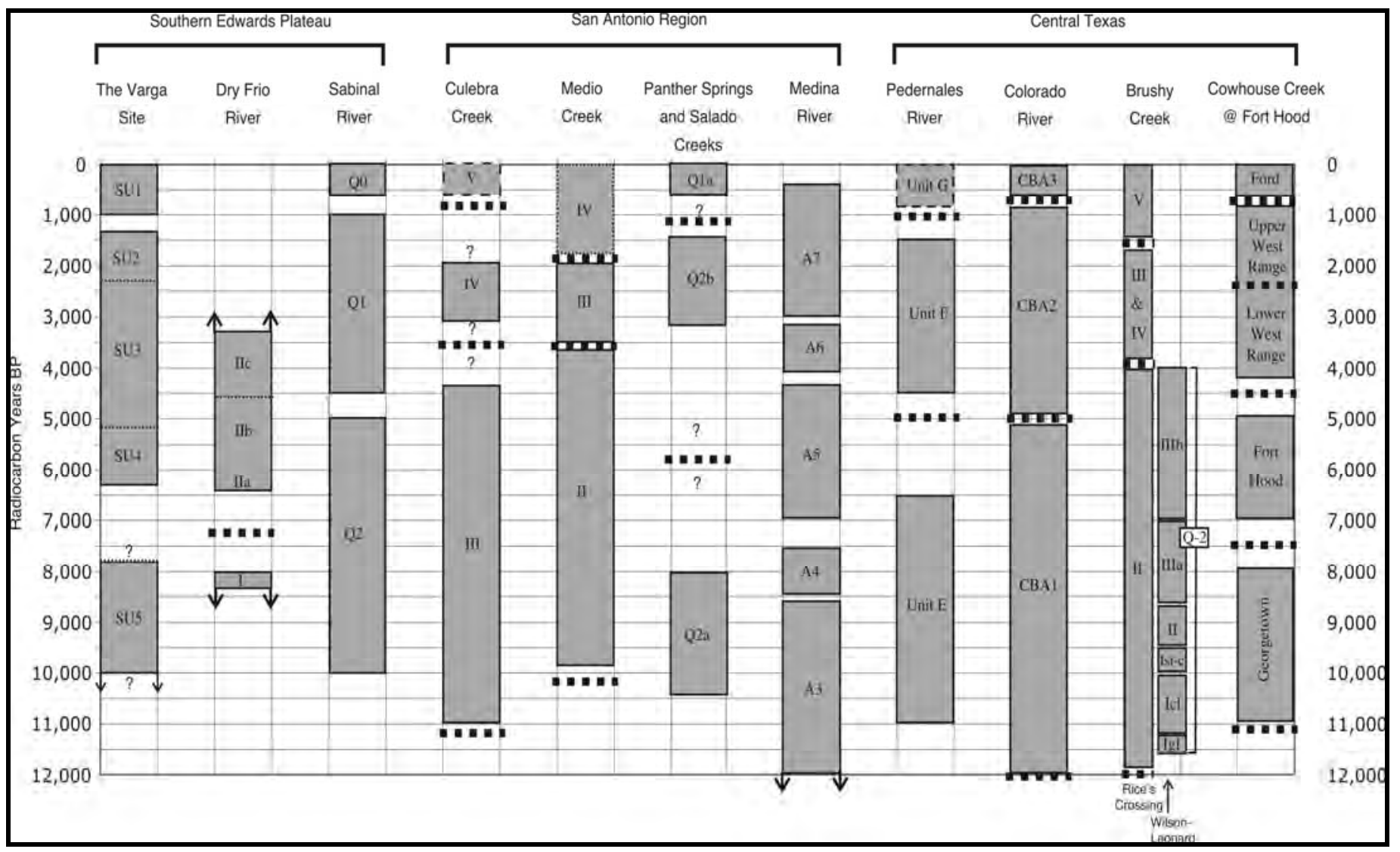

Figure 6-7. Correlations of Alluvial Stratigraphic Sequences Across Central Texas

may contain widespread colluvial and alluvial fan deposits. Nordt also recorded considerably thinner alluvial deposits along Henson Creek, a point the two studies clearly share.

\subsubsection{Regional Alluvial Chronology}

\section{Southern Edwards Plateau}

There are alluvial stratigraphic records for several streams along the southern Edwards Plateau, among which are the Dry Frio, the Sabinal, as well as several streams in the vicinity of San Antonio. Unfortunately, many of these are either fragmentary, or poorly dated. Below we present a brief summary of the results of these studies.

\section{The Dry Frio River, Uvalde County}

Decker et al., (2000) document two discrete alluvial deposits at the Woodrow Heard Site (41UV88) on the Dry Frio River. These two deposits, termed scroll bars, represent alluvial deposition during two distinct periods in the early and middle Holocene. The upper part of Unit I was deposited around 8,000 years B.P. but the early phases of Unit I deposition were not dated. Unit II was separated into four distinct phases named IIa through IId. The majority of Unit II (specifically Units IIa, and IIb) was deposited in the period between approximately 6,500 to 4,500 years B.P., with incremental 
sedimentation occurring since 4,500 years B.P. It is clear that the Dry Frio River sedimentary record as documented at the Woodrow Heard Site is incomplete, with sedimentation during the later Holocene not well represented.

\section{Sabinal River, Bandera County}

Mear (1995, 1953) documented the late Quaternary alluvial deposits of the Sabinal River from south of Vanderpool to just south of Utopia. Mear identified three Holocene age alluvial deposits which he named Q2, Q1 and Q0. Using radiocarbon dates from excavated archeological sites associated with these deposits, Mear placed deposition of the Q2 unit in the early to middle Holocene between approximately 10,000 and 5,000 years B.P. The Q1 deposit was placed in the period between 4,500 and 1,000 years B.P., and the Q0 surface was considered to be the modern floodplain. Although neither firmly nor directly dated, Mear's work on the Sabinal indicates a clear correlation with other Central Texas streams such as the Colorado River.

\section{San Antonio Vicinity}

There have been several studies of stream deposits in the San Antonio metropolitan region that provide information on the historical behavior of local streams. The studies cited below are the most comprehensively dated, but several other less well-dated studies exist, such as Nordt's work on upper Leon Creek (Nordt 1996) or several projects on the San Antonio River (e.g. Meskill and Frederick 1998; Meskill et al 2000; Nordt 1999; Frederick 2007; Caran n.d.). Although eventually these studies may contribute to the larger picture, they are, as of this time, too fragmentary (either spatially, or temporally) to provide a clear image of the behavior of these streams.

\section{Culebra Creek, Bexar County}

The alluvial deposits of Culebra Creek were examined in detail at the Culebra Creek Site (41BX126), first by Frederick (2001) and subsequently by Nordt (2001). This work identified three Holocene depositional units which Nordt (2001) termed III, IV, and V. Unit III appears to have been deposited in the early to middle Holocene between approximately 11,000 and 4,000 years B.P. Unit IV yielded bulk sediment radiocarbon ages of 3,190 and 2,700 B.P. near its base, and 2,080 B.P. near its midpoint, and Nordt bracketed this deposit to the period between 4,000 and 2,000 B.P. although the end of Unit IV deposition was not dated. No radiocarbon ages were obtained for Unit V, but it was considered to be less than 500 years old.

\section{Medio Creek, Bexar County}

Nordt (1997) examined the deposits of Medio Creek at Lackland Air Force Base, and recognized three Holocene-age alluvial units. The oldest of these, Unit II, yielded bulk humate radiocarbon ages of approximately 4,900 and 3,800 B.P., and Nordt (1997:33; shown on Figure 4-2) inferred a beginning date in the Early Holocene (10,000 to 3,500 B.P.). Unit III yielded a single bulk soil radiocarbon date of 1,830 B.P., and was bracketed by radiocarbon dates on Units II and IV to the period between approximately 3,500 and 1,800 B.P. Two radiocarbon ages were obtained on buried soils within Unit IV, and these dates of 1,780 B.P. and 1,220 B.P. placed deposition of this deposit in the last 1,800 years, which is considerably older than the modern floodplain deposits of most streams in Central Texas region. 


\section{Panther Springs and Salado Creeks, Bexar County}

Mear and Frederick (1998) described the alluvial deposits associated with Panther Springs and Salado Creeks, near several archeological sites in the path of the Wurzbach Parkway in San Antonio. Three Holocene deposition units were described: Q2a, Q2b, and Q1a. Each depositional event appeared to have been preceded by a period of channel incision. Bulk sediment samples from the oldest deposits, Q2a, was radiocarbon dated to the period between 10,450 B.P. and a series of charcoal samples collected from a prehistoric occupation near the top of this fill that provided radiocarbon ages slightly older than 8,500 B.P. This deposit appears to have accumulated in an episodic fashion through a series of large magnitude floods during this period, and received only very minor amounts of overbank fines after 8,500 B.P. The next youngest unit, Q2b, was radiocarbon dated at a single locality by four charcoal samples, which indicate sedimentation occurred between 3,200 B.P. and slightly later than 1,490 B.P. The youngest fill (Q1a) yielded three charcoal radiocarbon ages dating between 310 and 450 B.P. in the top $50 \mathrm{~cm}$, but the base of this unit is undated, but certainly no older than 1,490 B.P. Deposition of Q1a was considered to be ongoing today.

\section{Medina River, Bexar County}

Excavations at the Richard Beene Site (41BX831), which was discovered in the dam axis of proposed Applewhite Reservoir south of San Antonio, yielded a detailed record of alluvial overbank sedimentation for a single point on the Medina River (Mandel et al., 2005). The most detailed results were obtained from the Applewhite Terrace, beneath which were multiple sedimentary units typically capped by

paleosols. Radiocarbon dating of bulk sediment and soils as well as charcoal from cultural features provides a clear image of the age error associated with bulk sediment/soil radiocarbon dates, especially from the early Holocene depositional units.

A total of five depositional units (named A3 through A7) comprise Holocene sedimentation beneath the Applewhite Terrace. The terminal Pleistocene-early Holocene sedimentation is represented by Unit A3, and the soil formed at the top of this unit was named the Perez Paleosol. Radiocarbon ages from Unit A3 ranged from approximately 15,000 and 8,600 B.P. The Perez soil was buried sometime after 8,600 B.P. as Unit A4 began to aggrade. Deposition of A4 ended around 7,645 B.P., when the Elm Creek Soil formed within it was buried. Deposition of the next younger deposit, Unit A5, spanned a 2,600 year period between approximately 7,000 to 4,400 B.P. A complex cumulic soil named the Medina Pedocomplex was formed within this deposit. Around 4,100 B.P. the Medina soil was buried and deposition of Unit A6 began. Deposition of Unit 6 persisted for almost 1,000 years, as the soil formed within it; the Leon Creek paleosol was buried sometime around 3,000 B.P. The most recent depositional unit beneath the Applewhite Terrace, A7, spanned the period between roughly 3,000 and 400 B.P., and comprised a thin veneer across the Applewhite Terrace within which the modern surface soil is formed. It is probable that a more complete record of late Holocene sedimentation exists beneath the Miller Terrace and the Modern Floodplain, both of which are inset below the Applewhite surface, but were not investigated in detail.

\section{Greater Central Texas Region}

Away from the southern rim of the Edwards Plateau, there are at least four other stratigraphic sequences worth examining. These four sequences are briefly discussed below. 


\section{Pedernales River}

Blum (1987, 1989; Blum and Valastro 1989) documented the alluvial stratigraphy of the Pedernales River near Fredericksburg and identified three Holocene alluvial deposits named Units E, F and G. Unit G was radiocarbon dated to the period between 11,000 and 6,500 B.P., where as Unit F was dated to the period between 4,500 and 1,000 B.P. The youngest unit (E) was described as representing sedimentation during the last millennium. As with Blum's work on the Colorado, all of the dates on the Pedernales sequence were obtained on bulk sediments which may overestimate the age of the depositional event.

\section{The Colorado River}

The late Quaternary stratigraphy of the Colorado River has been documented by Blum (1992; Blum and Valastro [1994, 1992]; Blum et al., [1994]) who identified three Holocene alluvial deposits, which Blum and Valastro 1994 formally named the Columbus Bend Alloformation Members 1, 2, and 3 (abbreviated hereafter CBA1, CBA2, and CBA3). All of Blum's radiocarbon ages were obtained from bulk sediment samples and therefore, may be older than the true age of the depositional event. The magnitude of this age error is unknown for these ages, but this factor should be considered when discussing this alluvial chronology. Secondly, the dates presented here are from the most recently published work, and it should be noted that the chronology for Colorado River deposits upstream of Austin are slightly different than those below Austin. The oldest radiocarbon age obtained by Blum for the first Holocene units, CBA1, was 12,970 B.P. and the youngest age for this fill was 5,350 B.P. (Blum and Valastro 1992:1010). The next younger alluvial deposit, CBA2, began to aggrade around 5,120 B.P. and deposition of this unit ceased sometime after 820 B.P. The most recent deposit, CBA3, began to form around 600 B.P. and deposition of this unit continues today.

\section{Brushy Creek, Williamson County}

The alluvial deposits of Brushy Creek, a tributary of the San Gabriel River, have been examined in two localities: in the limestone bedrock confined reach north of Cedar Park at the Wilson Leonard Site (Collins and Mear 1998; Goldberg and Holliday 1998), and at Rice's Crossing, $40 \mathrm{~km}$ (25 mi) downstream on the Blackland Prairie in the southeastern corner of Williamson County (Abbott 2001).

In the upper reaches of Brushy Creek the alluvial deposits have been documented during archeological excavations at the Wilson-Leonard Site. Collins and Mear (1998) describe the large-scale stratigraphy, recognizing three late Quaternary deposits, they termed them Q-1, Q-2 and Q-3. The highest and oldest of these deposits, Q-3, is thought to be of late Pleistocene age. The Wilson-Leonard archeological site was fully contained within the Q-2 deposit and appears to represent deposition in the period between approximately 11,500 and 4,000 B.P. Excavations at the Wilson-Leonard Site resulted in a detailed stratigraphic dissection of the Q-2 deposits (Goldberg and Holliday 1998) with three major deposits recognized within it (I, II and III). The Q-1 deposit, which lies inset against the Q-2 deposit, is of an unknown but likely late Holocene age, and probably separated from it by a period of channel erosion, which based on the change in sedimentation rate with the Q-2 deposits probably occurred around 4,000 B.P.

Abbott (2001) recorded five distinct alluvial deposits (termed Units I through V) in the Brushy Creek valley at Rice's Crossing in southeastern Williamson County, and four of these deposits appear to be of Holocene age. The oldest Holocene deposit, Unit II, was dated 
by Abbott to the period between approximately 12,000 and 4,000 B.P., with a period of relatively rapid period of alluvial aggradation occurring between 11,900 and 5,200 B.P. The next younger deposit, Unit III, was divided into two parts (III-a and III-b) which were separated by a paleosol. Unit III was dated to the period between 3,400 and 1,900 B.P. No useful radiocarbon ages were obtained by Abbott for Unit IV, but together with Unit III, Abbott placed deposition of these two units in the period between 4,000 to 1,500 B.P. Two charcoal radiocarbon ages place deposition on Unit V into the period after 1,420 B.P.

\section{Fort Hood, Bell and Coryell Counties}

One of the best-dated regional scale alluvial stratigraphic sequences in Central Texas may be found at Fort Hood, where Nordt (1992, 2004) has documented the historic behavior of Cowhouse Creek, a tributary of the Leon River in the Brazos River basin, as well as some of its smaller tributaries (Nordt 1995). Unlike many alluvial sequences in Central Texas, Nordt's work is largely anchored by radiocarbon ages on charcoal, often from cultural contexts.

On Cowhouse Creek, Nordt identified four Holocene alluvial deposits: the Georgetown, Fort Hood, West Range and Ford alluvia. The Georgetown Alluvium is buried throughout the catchment, and was dated by Nordt to the period between approximately 11,000 and 8,000 B.P. This deposit is capped by a prominent soil named the Royalty paleosol. The Fort Hood Alluvium that follows was dated to the period between 7,000 and 5,000 B.P. and a period of channel incision separates it from deposition of the Georgetown. Following another period of channel entrenchment in the middle Holocene, the West Range alluvium was deposited. Nordt recognizes two phases of West Range deposition (Upper and Lower West Range) separated by a brief period of channel erosion around 2,400 B.P. The modern depositional regime is represented by the Ford alluvium, which is less than 600 years old.

Nordt (1994) also examined a small tributary of the Leon River named Henson Creek and found that the periodicity of sedimentation was largely similar to Cowhouse Creek, but there were a few differences in the timing, the nature of the facies present, and their archeological potential. For instance, Nordt notes that the deposits associated with the Fort Hood alluvium during the early Holocene were episodic and often gravelly. Conspicuously absent from the lower reaches of Henson Creek were deposits of the West Range alluvium, which given that deposits of this age were preserved in the upper reaches of this stream, Nordt inferred that they had been eroded from the lower reaches. Nordt also found that where present, the upper West Range alluvium had been buried by deposition of the Ford alluvium, with the interface between these two deposits marked by a paleosol named the Tank Trail Paleosol. Nordt also noted the greater relative importance of colluvial and alluvial fan sedimentation within the Henson Creek drainage.

\subsubsection{Regional Correlations: Alluvial Chronology}

In terms of evaluating the regional correlations of the alluvial chronology at the Varga Site, the interpretation of two key features are critical: 1 ) the age of Depositional Unit 5, and 2) the geomorphic significance of the apparent buried soil that is Depositional Unit 2.

\section{Depositional Unit 5}

Smith notes that Depositional Unit 5 is of variable depth and thickness and that the maximum age of archeological material found above this deposit is 6,300 B.P. but notes that these gravels are "potentially much older" 
(Smith, this chapter). In Backhoe Trench 7 a bulk sediment radiocarbon age of 5,230 \pm 50 B.P. (Beta-175391) was obtained from this deposit, but Smith considered this age to be in error (owing to humic material that had been translocated to this depth). In the site specific interpretations, Smith (this Chapter) states that the Depositional Unit 5 gravels are "probably late Pleistocene to early Holocene in age" although there is no geomorphic or pedogenic rationale provided for this interpretation. Smith does not consider that Depositional Unit 5 could be associated with the overlying overbank sediments and does not provide a firm reason for assuming these gravels are not associated with the fill event that subsequently deposited the fines. Nevertheless, for the sake of this discussion it is assumed that Smith's contention is correct.

\section{The Depositional Unit 2-Unit 1 interface}

If Depositional Unit 2 is a buried soil then it is appropriate to consider Depositional Unit 1 a discrete phase of deposition and part of a different phase of alluvial aggradation (an allostratigraphic unit or AU). The radiocarbon ages from Depositional Unit 1 and Depositional Unit 2 indicate an approximate depositional hiatus of 400 years separates these deposits, and this would seem to be enough time for the formation of the buried soil. Hence, Depositional Unit 1 is here considered to be a separate allostratigraphic unit.

Considered together, there appears to be three main periods of alluvial deposition at the Varga
Site: 1) the "late Pleistocene to early Holocene" Depositional Unit 5 gravels, 2) the overbank fines comprising Depositional Units 2, 3 and 4; and 3) Depositional Unit 1. Comparison of this basic sedimentary sequence with other streams in the region, specifically the southern rim of the Edwards Plateau, as well as stratigraphic sequences in Central Texas, indicates that the Varga Site deposits are broadly correlative with other sites in the region. Given the lack of dates for Depositional Unit 5, this deposit will not be discussed in detail other than to say that most streams in the central and southern Edwards Plateau exhibit one or more depositional phases in the late Pleistocene to early Holocene period.

Deposition of the overbank fines (Depositional Units 2, 3 and 4) is broadly correlative with middle to late Holocene sedimentation in this region. Although no single stream shows a period of alluviation that directly corresponds with the overbank fines at the Varga Site, the starting and ending dates are seen elsewhere in the region. In particular, the early phase of deposition of Depositional Unit 4 begins about the same time as Unit II at the Woodrow Heard Site on the Dry Frio River. Slightly earlier sedimentary phases are also seen on the Medina River and at Fort Hood. The end of deposition around 1,400 B.P. is relatively common, as is alluvial aggradation in the last millennium, but especially in the last 600 years, which is observed at most streams in the region. Hence it is possible to say that the alluvial chronology from the Varga Site shares some attributes with other streams in the region. 


\subsection{ARCHEOLOGICAL RESULTS}

J. Michael Quigg

\subsection{INTRODUCTION}

This section presents an overview of the cultural stratigraphy followed by definitions of the cultural components that have been formulated to provide an overall structure for analyses and reporting in relatively narrow time units. Once the components were finalized in the laboratory, the cultural materials from each excavation level were assigned to one of four cultural components. If cultural materials appeared to represent a mixture of two components, or could not be confidently assigned to one particular component, the materials from that level have been left unassigned and placed in a miscellaneous category. The materials from the four individual components and the miscellaneous category are presented in detail the subsequent chapters.

\subsection{Analytical Components}

Projectile points recovered during the first phase revealed the presence of Late Prehistoric Toyah, and Late, Middle, and Early Archaic components. These components were represented at different vertical elevations by different densities of cultural debris, and were distributed differently across the investigated parts of the right-of-way. So much cultural material was present in the top 30 to $40 \mathrm{~cm}$ of the deposit that it was difficult to always distinguish between major cultural events represented by the Toyah and Late Archaic components. Late Archaic materials were directly associated with an observable soil horizon, which facilitated its identification. However, the northern half of Block A revealed compressed stratigraphy and lacked visible soil stratification. Combined with the discernible turbation activities in that area, this necessitated definition of arbitrary vertical boundaries between the cultural components in the northern part of Block A. Various data sets were examined to help determine the assignment of arbitrary excavation levels to the recognized components. Many larger pieces of cultural material, generally burned rock, were piece plotted during the hand-excavations. From the individual pieces plotted on individual level records, we were able to constructed back plots to help determine the depths of the components, possible sloping aspects to the materials, and what materials or concentrations might be traceable horizontally across Block A (Figures 7-1through 7-4), although the lack of plotted burned rocks near the middle and lower parts of the deposits in some areas hindered this approach. To further investigate the vertical positions of the components, we plotted the frequencies of the lithic debitage, burned rock, and bone counts at various locations across Block A. Examples of these vertical plots are represented in Figures 7-5 through 7-8. Figure 7-5 reveals three units along north line 101 that reveals the lack of a clear, vertical separation in the top $30 \mathrm{~cm}$ of the Toyah and Late Archaic components. It does reveal a welldemarcated Early Archaic component in the lowest part of the profile. Figure 7-6 also reveals the pronounced Early Archaic component, a the light concentration of the Middle Archaic component near the middle of the profile, and limited materials representing the Late Archaic and Toyah components in the top of the profile, in the southeastern corner of Block A. 
Figure 7-7 reveals the well-defined Toyah, Middle Archaic and Early Archaic components, which are in contrast to the very sparse Late Archaic component along the eastern edge of Block A. Figure 7-8 reveals the very welldefined Middle and Early Archaic components, and the apparent absence of the Late Archaic component at this location in Block A. It is believed that the smaller cultural items such as flakes, tiny bones, and small tools potentially were displaced over time. Therefore, the larger burned rocks were relied on to provide the vertical position of cultural components.

The recovered cultural materials were grouped into four major time components, more or less vertically distinct, to provide useful data by time period. This was necessitated by the lack of patterning representing distinct cultural activities over a substantial horizontal area. In very limited areas, sometimes within one excavation unit, such as along the very western edge of Block A, vertically discrete and separated events in the Toyah component were detected. However, most often in the adjacent unit, these separate events were indistinguishable from one another. The middle part of this alluvial deposit yielded sparse and dispersed cultural materials, although occasionally, horizontally and/or vertically restricted areas yielded relatively dense material. Generally, the relatively shallow depth of the alluvial fines that accumulated over a long time span, combined with some turbation, hindered our ability to separate individual cultural events within a component.

As already noted, four analytical components have been defined at the Varga Site-Late Prehistoric, specifically a Toyah phase component, a Late Archaic component, a Middle Archaic component, and an Early Archaic component. The Toyah component was unevenly represented starting from the exposed (and mechanically altered) surface to depths of 20 to $30 \mathrm{cmbs}$ in loose brown (10YR 4/3) overbank deposits that extended over most of the southern end of the first terrace and across most of the current right-of-way. This upper cultural component/sediment deposit suffered from disturbances from the Phase I mechanical trenching and stripping west of the road, previous TxDOT road construction and maintenance activities, and phone cable installation east of the pavement. In fact, large quantities of scattered burned rocks and other cultural materials representing the Toyah component were exposed on the disturbed surface and mislead TxDOT personnel to assume that a disturbed burned rock midden was present. No burned rock midden was identified in this near-surface component, just quantities of scattered cultural materials and 11 cultural features that represented a broader Toyah component. Blocks A and B targeted this extensive and dense cultural zone.

A sharp break in matrix color and texture demarcated the top of a buried A horizon at the bottom of the Toyah component. The buried A horizon, a very dark gray (10YR 3/1) to black (10YR 2/1) clay loam to silty clay loam, contained cultural materials pertaining to the Late Archaic (Figure 7-9). No sterile sediment existed between the two visibly distinct horizons, and so some mixing of the materials from the two components was expected and later detected. In Block A, a broad, buried burned rock lens that is interpreted to reflect an incipient burned rock mound dominated the Late Archaic component. However, beyond the illdefined margins of this feature, the component was impossible to follow as the frequency of cultural material - the burned rocks, dropped off sharply. Only in widely dispersed places was this component recognized outside this one broad burned rock feature. In Block B, the dark buried A horizon was detected between 8 and 30 cmbs. 


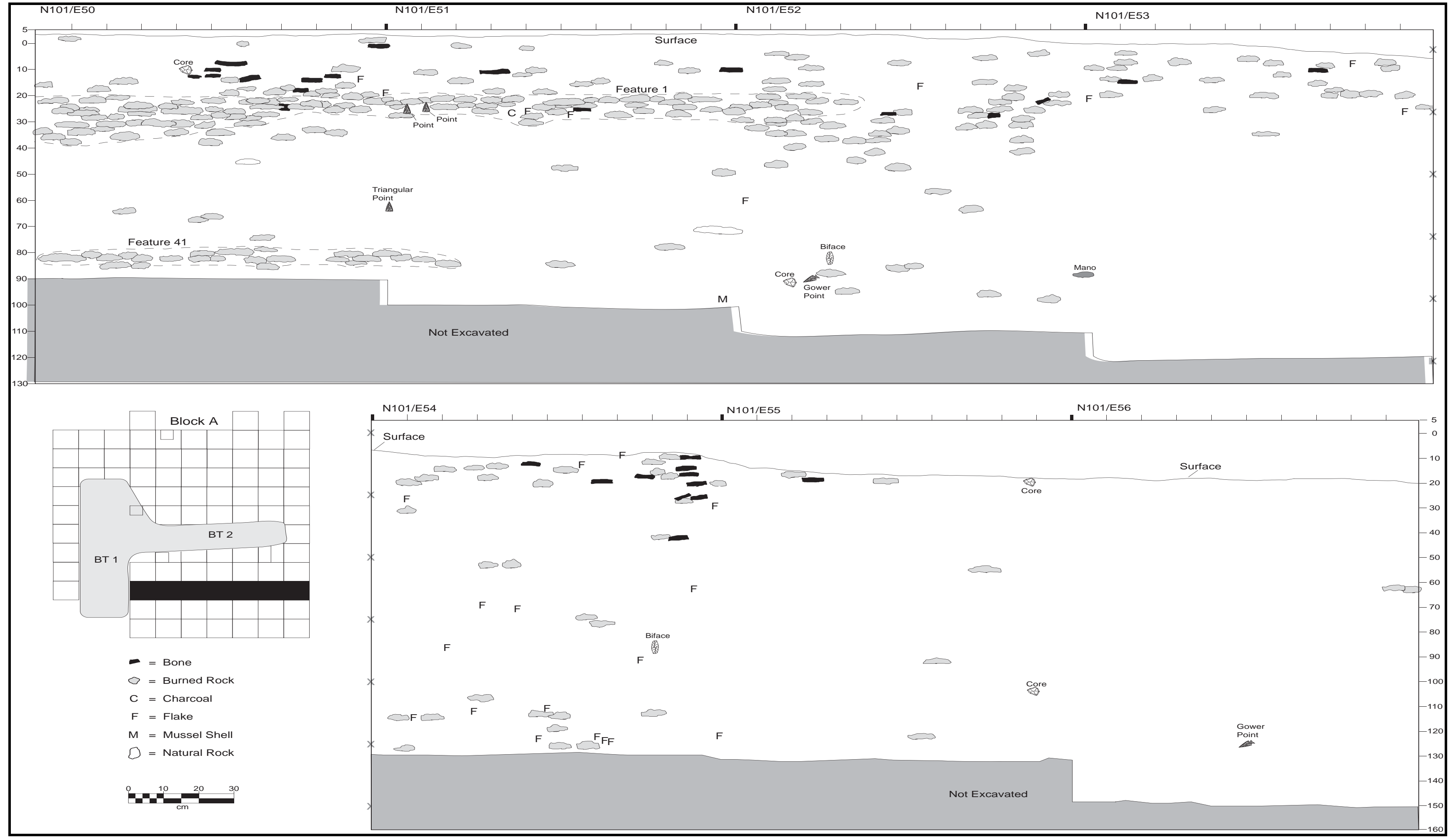

Figure 7-1. West-East Line-Plotted Materials Across 1-by-1-m Test Units 



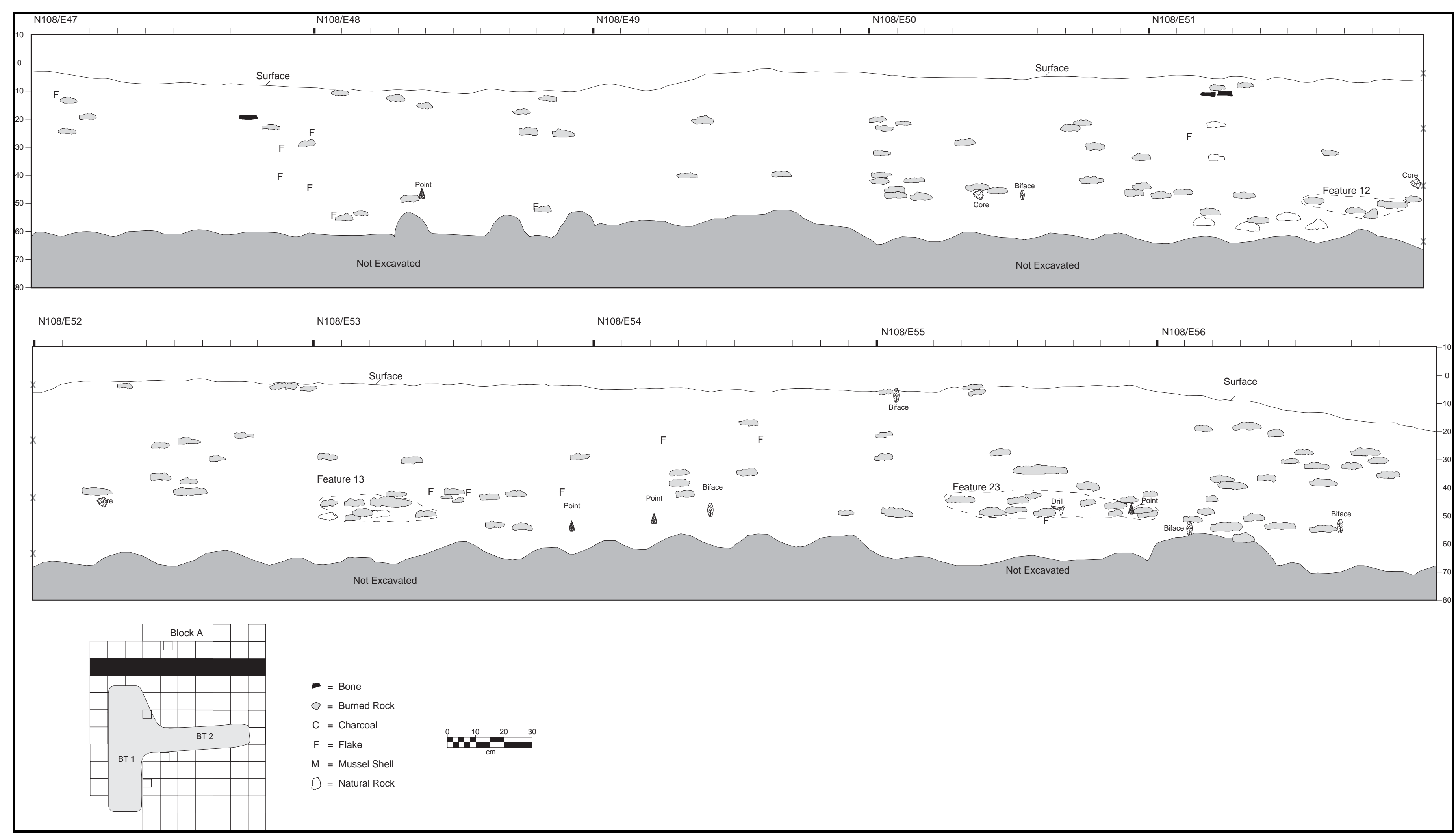

Figure 7-2. West-East Line-Plotted Materials Across 1-by-1-m Test Units 



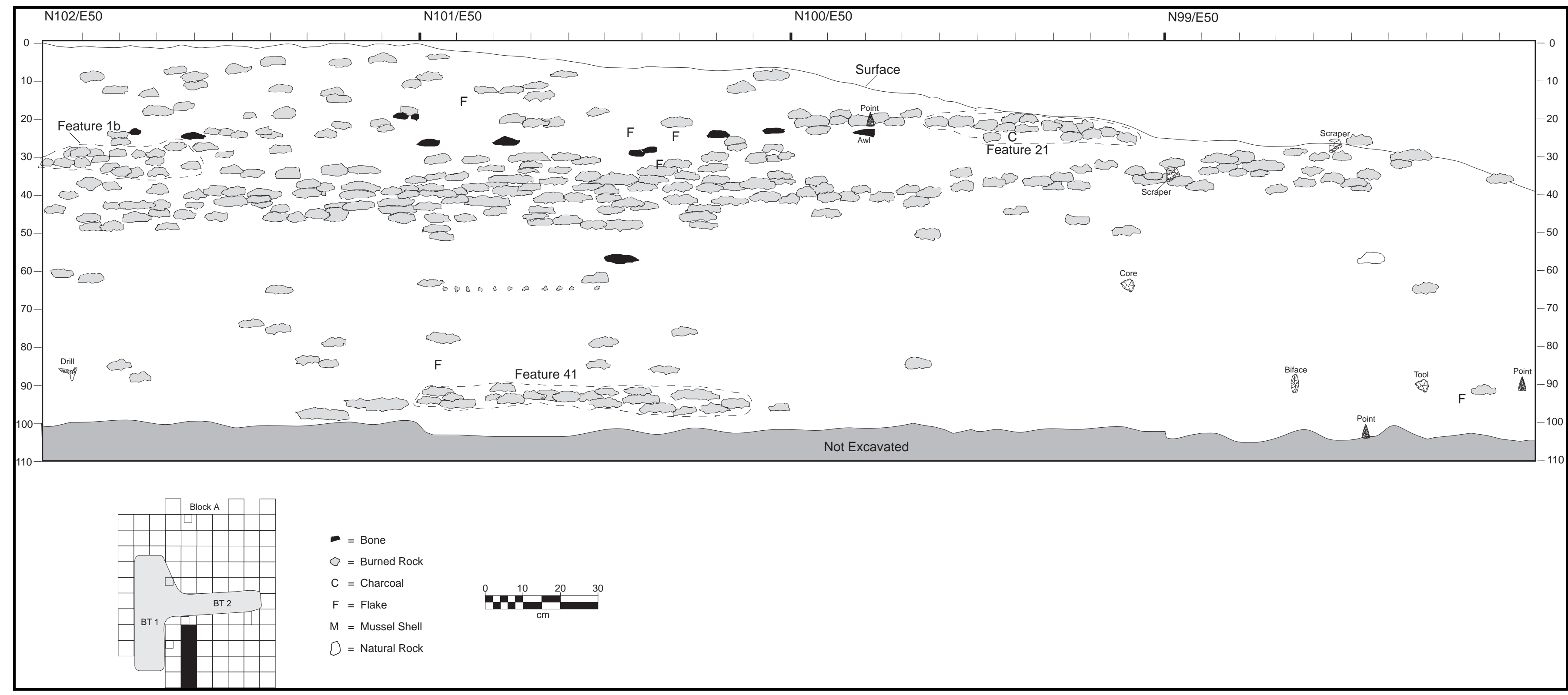

Figure 7-3. North-South Line-Plotted Materials Across 1-by-1-m Test Units 



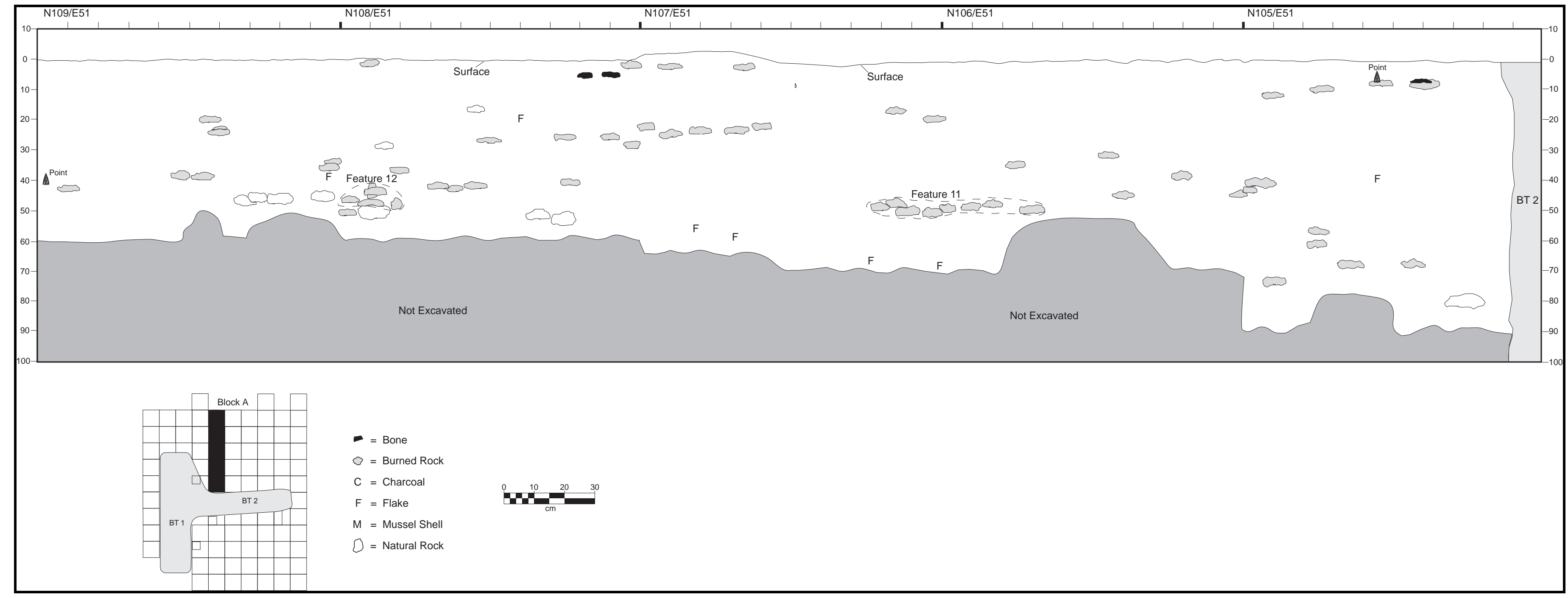

Figure 7-4. North-South Line-Plotted Materials Across 1-by-1-m Test Units 



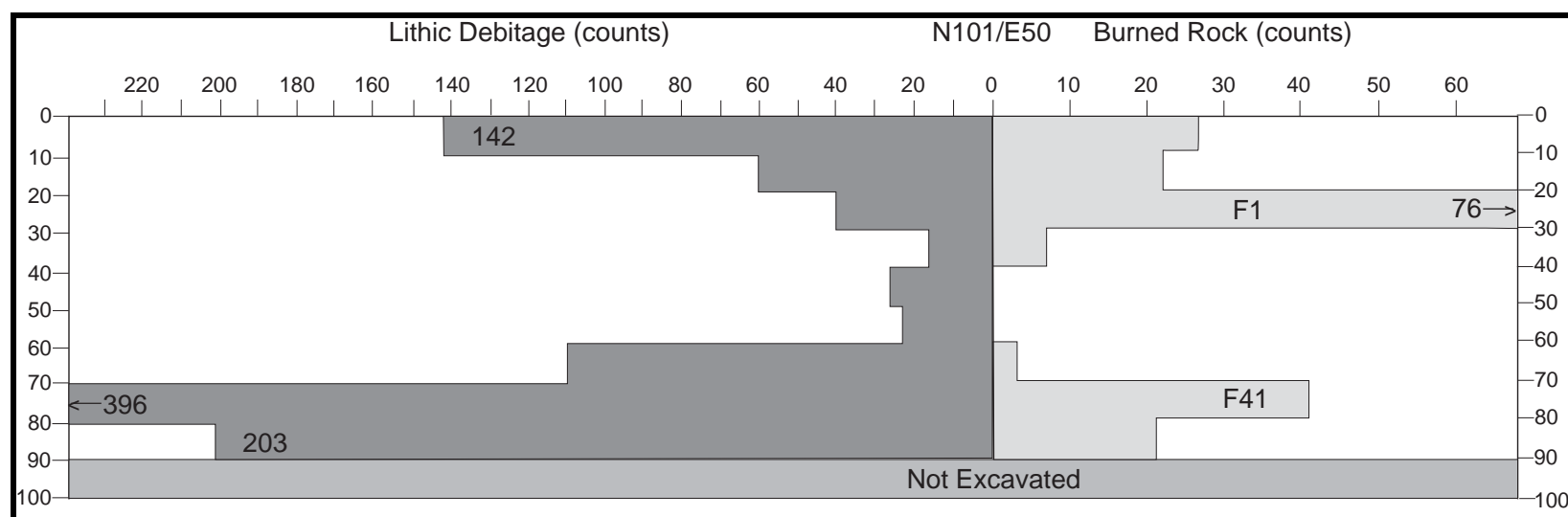

Lithic Debitage (counts) N101/E51 Burned Rock (counts)

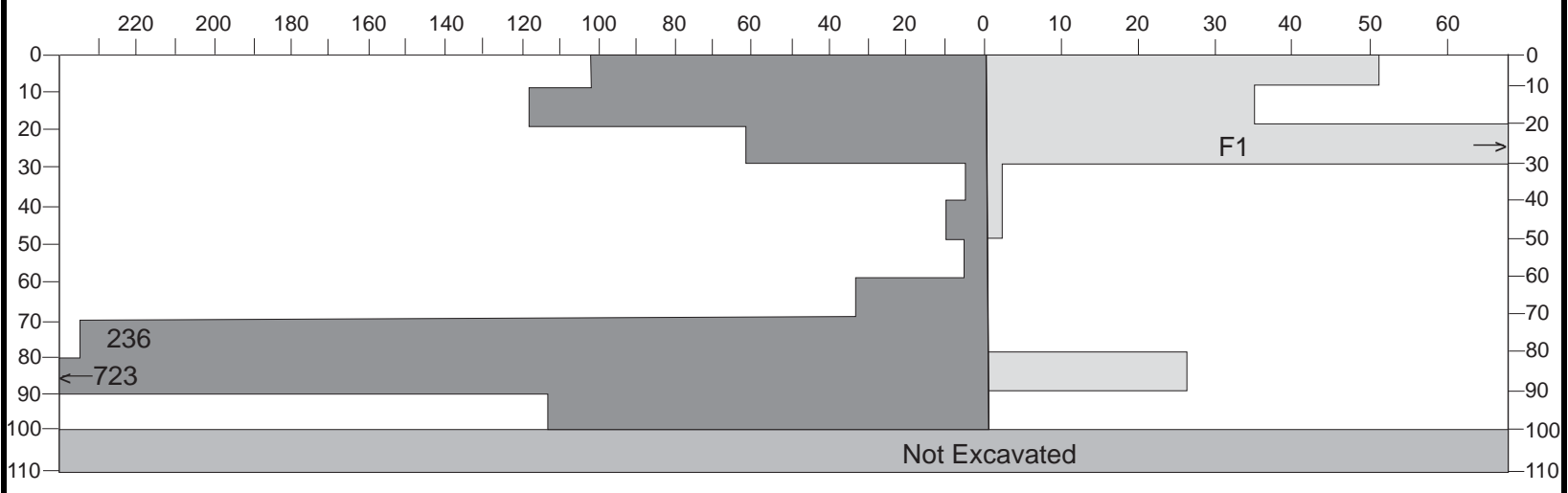

Lithic Debitage (counts) N101/E54 Burned Rock (counts)

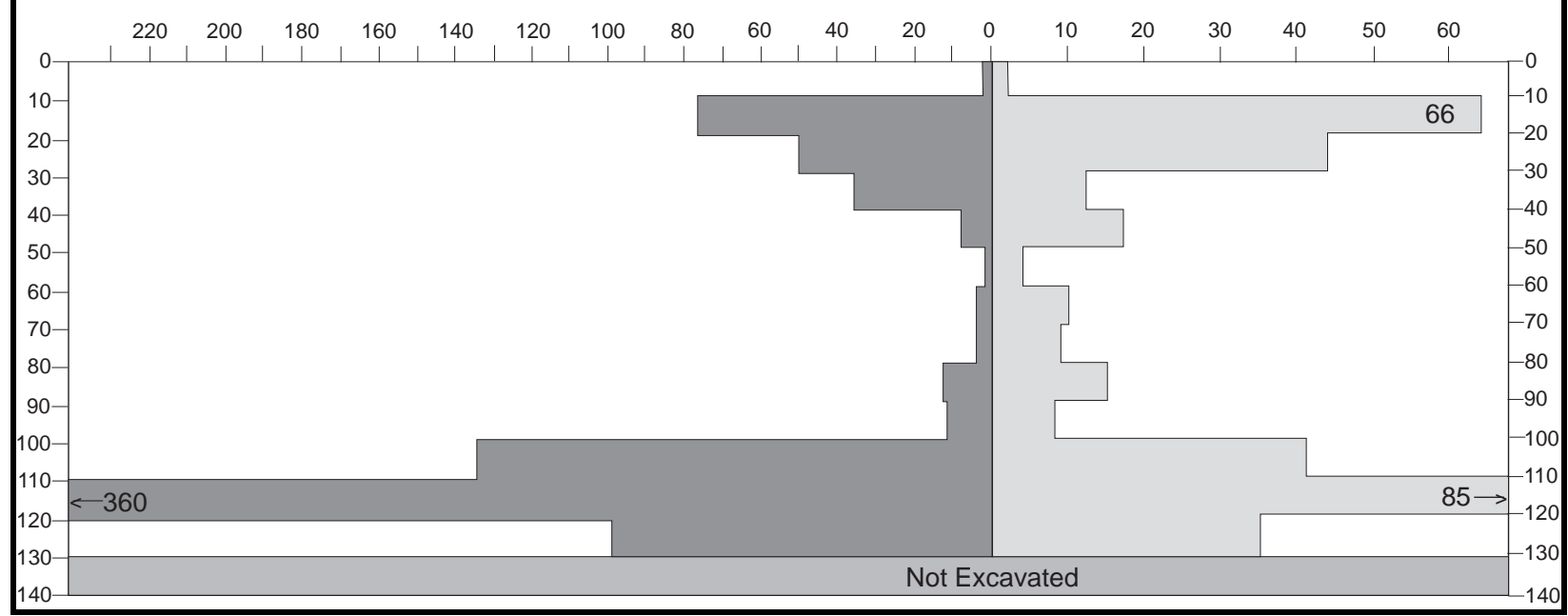

Figure 7-5. Vertical Concentration of Cultural Materials Along the N101 Line, Block A 


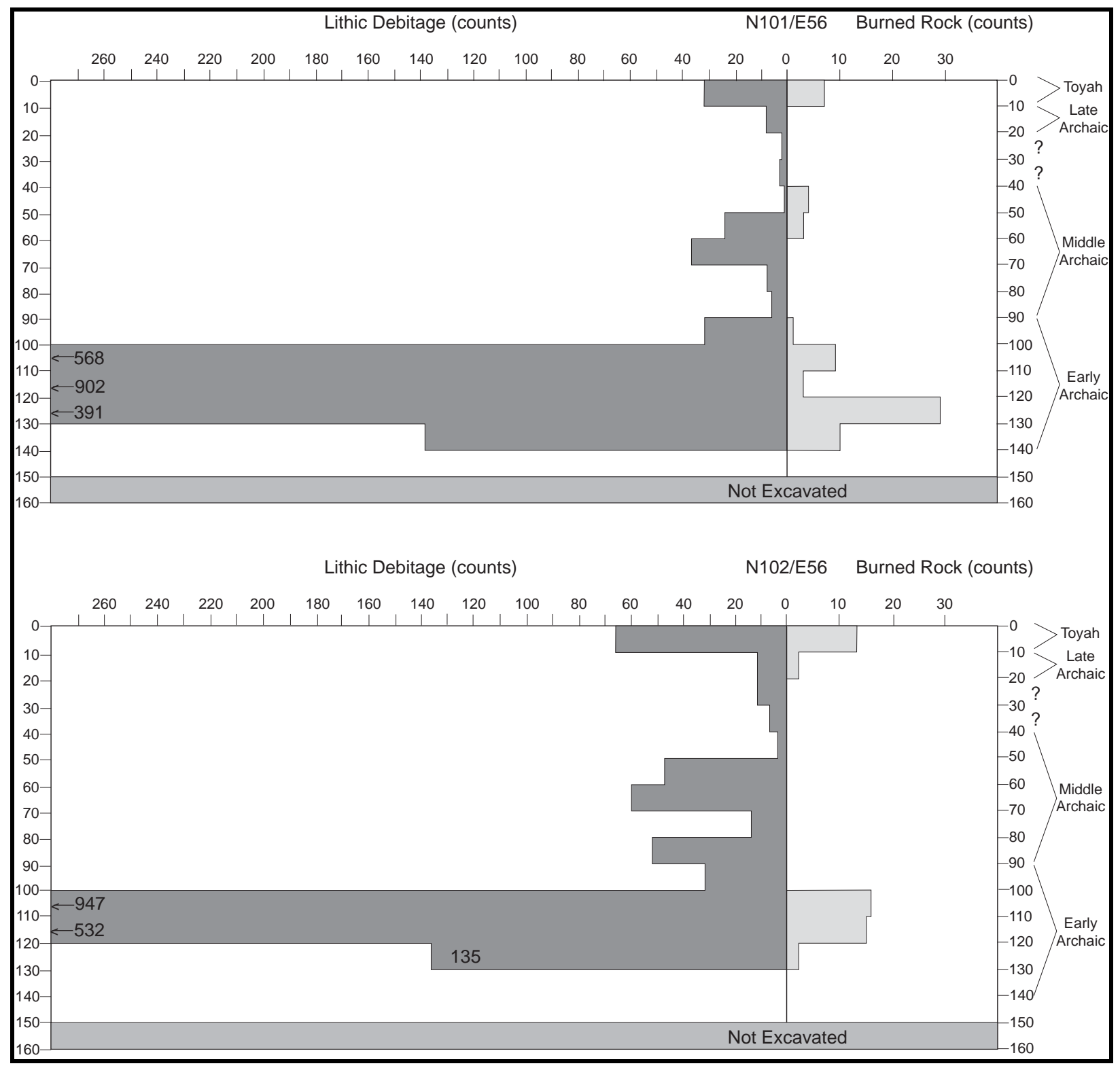

Figure 7-6. Vertical Concentration of Cultural Materials Along the E56 Line, Block A 

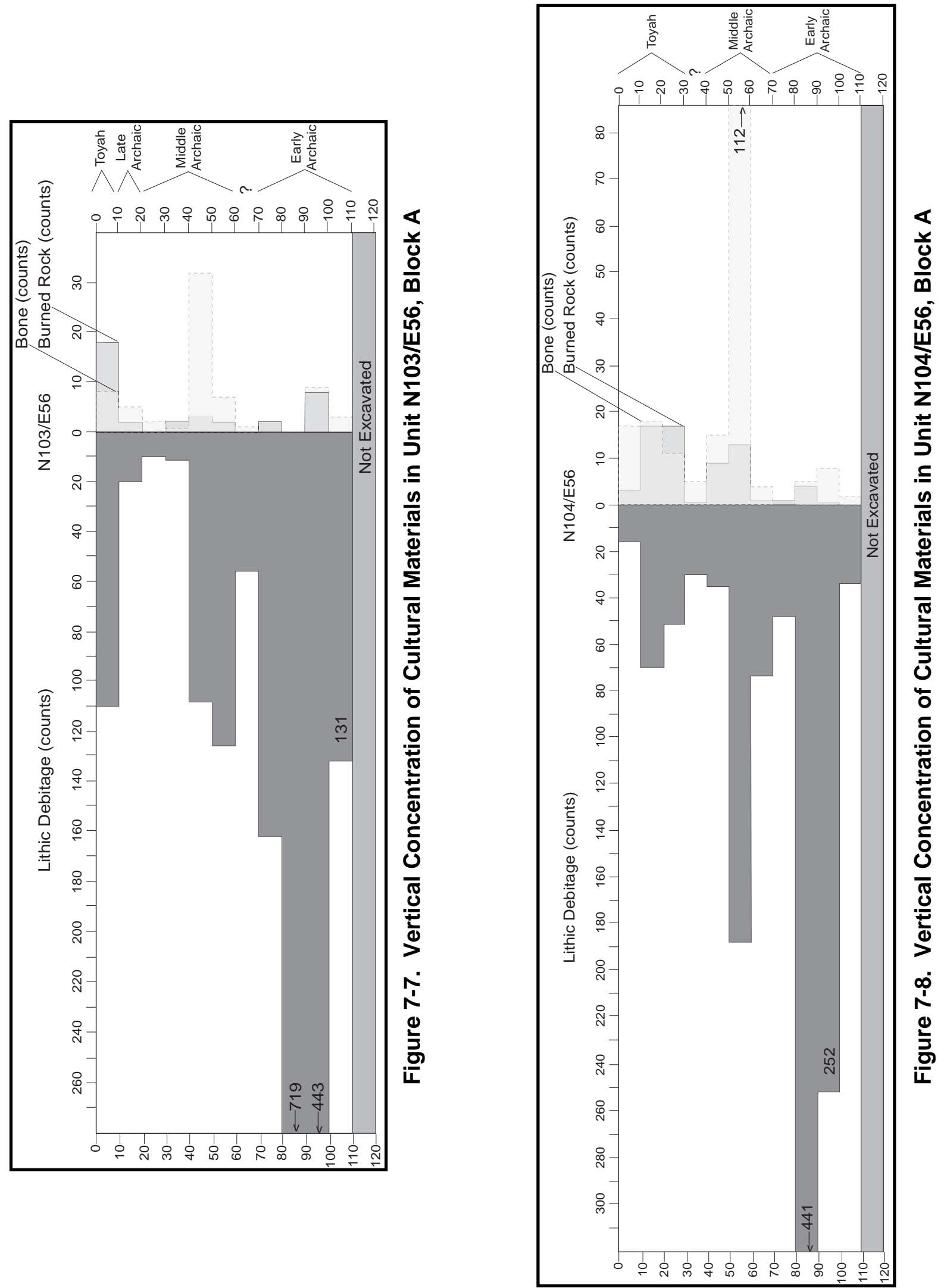


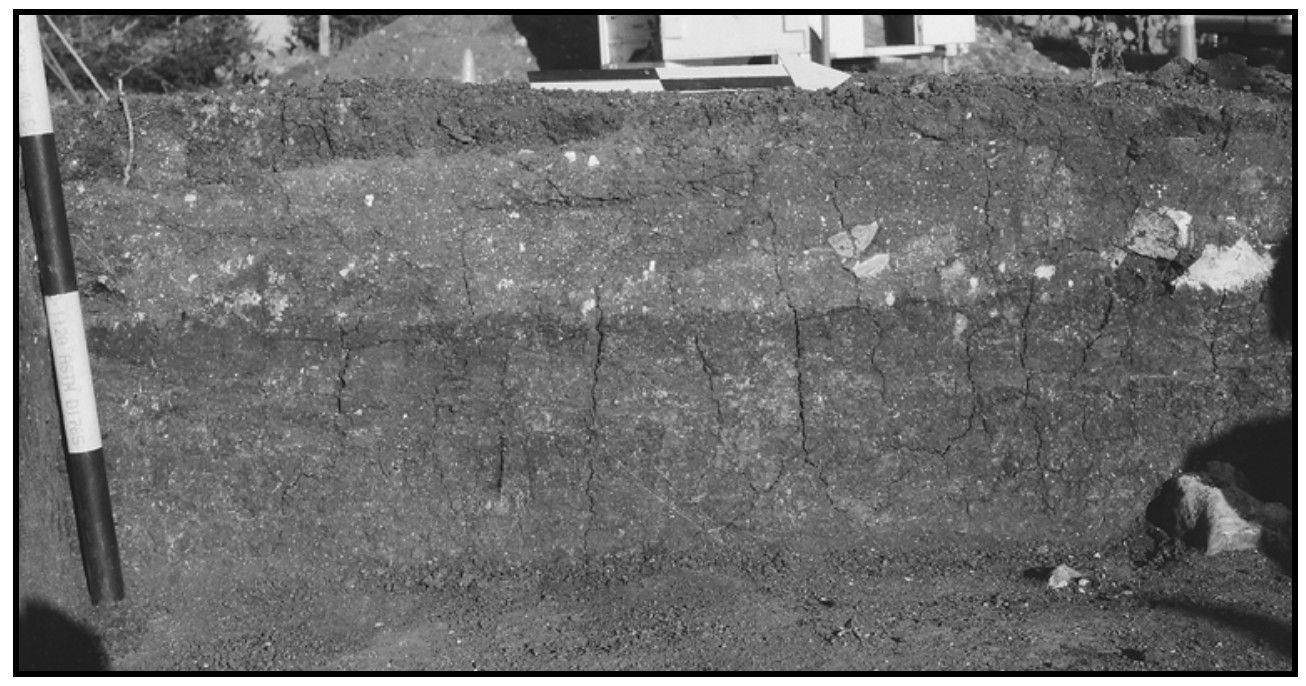

Figure 7-9. View West of N118/E71 Showing Light Gray Toyah Zone Over Dark Buried A Horizon that Contained the Late Archaic Component

Again, Late Archaic materials were detected, but very sporadically and in relatively low frequencies. Therefore, the Late Archaic was not targeted in Block $\mathrm{B}$ during Phase II investigations. A few Middle Archaic projectiles from deposits on both sides of the road signaled the presence of a Middle Archaic component. This component is represented by relatively sparse materials in the upper part of Depositional Unit 3, the brown (10YR 5/3) clay loam. This material was horizontally patchy and showed up prominently in only a few square meters, but not a continual basis. Along the southern edge of Block A the Middle Archaic deposits were up to $40 \mathrm{~cm}$ thick, between ca. 40 and $80 \mathrm{cmbd}$, but thinned quickly across the northern part Block A. This zone was so sporadic on the eastern side of the pavement that these deposits of this age were not targeted during the Phase II excavations.
A dense and artifact-rich Early Archaic component was represented in the lowest most part of geoarcheologically defined Unit 3 , the brown (10YR 5/3) clay loam Bk soil horizon, primarily on the western side of the pavement. Some cultural materials were mixed in with geoarcheological Unit 4, the pale brown (10YR 6/3) coarse sandy loam 2Bk soil horizon. The depth of the cultural material varied from 50 to $130 \mathrm{cmbd}$, which followed the uneven basal gravel deposit. Block A captured a part of this lowest component that contained at least nine different types of projectile points.

In the following four chapters each recognized component is presented individually, with detailed descriptions and discussions of the materials recovered, together with analytical and technical results that pertain to material from that component, followed by a summary at the end of the chapter. 


\subsection{THE TOYAH COMPONENT}

\author{
J. Michael Quigg
}

\subsection{INTRODUCTION}

The Toyah component was first identified during the initial phase of data recovery investigations (Lintz et al. 2002). Initial mechanical stripping revealed that, in addition to scattered burned rocks and butchered bones on the disturbed surface, these same material categories were encountered in the fine sediments immediately beneath the surface and represented Late Prehistoric occupation of the site. Subsequent Gradall ${ }^{\circledR}$ stripping and handexcavations revealed a loose concentration of deer and bison bones (Feature 2), a burned rock cluster (Feature 3), eight Perdiz points, several arrow point fragments, six prehistoric pottery sherds, and other associated cultural debris near the surface on both sides of Ranch to Market Road. These cultural materials were in a brown (10YR 4/3) clay loam layer of overbank deposits, which corresponds to Depositional Unit1. This 20 to $30 \mathrm{~cm}$ thick deposit extended over most of the southern end of the first terrace and the current right-of-way. The bottom of this cultural zone exhibited an abrupt smooth lower boundary demarcating a time hiatus, but not a sterile zone above the lower cultural deposits (Lintz et al. 2002).

The Phase II investigations yielded a large sample of Toyah materials from Blocks A and B. In Block A, the entire vertical Holocene deposit was sampled through the handexcavations of $83 \mathrm{~m}^{2}$ which captured the Toyah component in the upper $30 \mathrm{~cm}$. The initial two backhoe trenches (BTs 1 and 2) and subsequent mechanical stripping of the top deposits during Phase I across much of Block A, made it difficult to determine the exact elevation of the surface of this component. Block B only targeted the shallow Toyah component, which was just beneath the surface, much of which was covered by a lens of gravel emplaced by recent TxDOT activities. The Toyah component was mostly in a loose brown (10YR 4/3) sediment between 0 and 35 cmbs, with an abrupt lower sediment boundary. Some Toyah materials had filtered downward a few centimeters in the profile into the dark black buried A horizon that contained mostly a Late Archaic component.

The chronometric age of the Toyah component is derived primarily from radiocarbon dating of 21 organic-rich samples recovered from this cultural component across both excavation blocks (Table 8-1). Radiocarbon dates on one burned rock (\#1030-5-3-2c; 11,690 \pm 40 B.P.) extracted from Feature 38 and two of four dated ceramic sherds (\#159-5-8-1a and \#987-8-1a; 930 \pm 40 B.P. and 26,960 \pm 40 B.P.) are obviously much too old and beyond the realm of any reasonable possibility, and are not acceptable (Table 8-1). Three other samples, two charcoal (\#843-5-7-1a and \#1055-5-7-1a) and one ceramic sherd (\#118-8-1a), yielded radiocarbon ages that are less than 200 years old and are also not acceptable for this component. Two charcoal dates of $920 \pm 40$ B.P. (Beta-175399) and $940 \pm 40$ B.P. (Beta-175398) from the lowest and best defined stratigraphic context in the Toyah component, that in Feature 36 (an occupation zone, see below) along the western margin of Block A, are older than the presumed age for Toyah events and younger than the welldated Late Archaic component that is older than 1,700 B.P. Therefore, these two ca. 930 B.P. ages may be dating an unrecognized Late Prehistoric event or component that dates to slightly earlier than the Toyah occupation. 


\begin{tabular}{|c|c|c|c|c|c|c|c|c|c|c|c|c|c|c|c|c|c|c|c|c|c|}
\hline 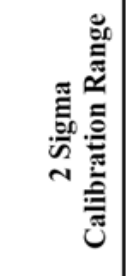 & 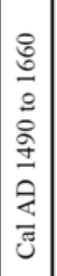 & 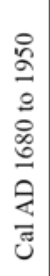 & 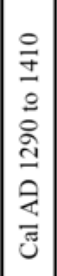 & 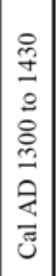 & 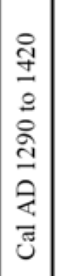 & 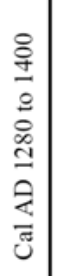 & 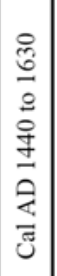 & 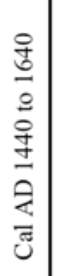 & 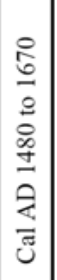 & 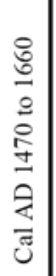 & 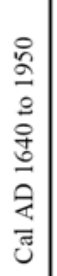 & 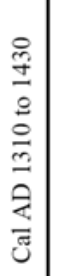 & 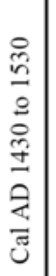 & 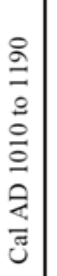 & 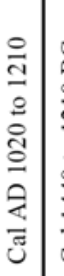 & 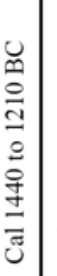 & 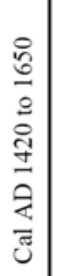 & 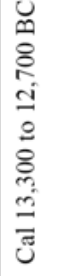 & 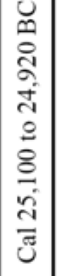 & 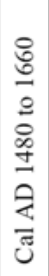 & 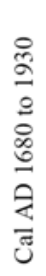 \\
\hline 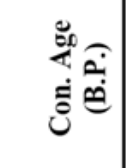 & 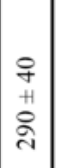 & $\begin{array}{l}8 \\
+1 \\
+ \\
\infty\end{array}$ & 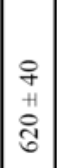 & $\begin{array}{l}q \\
+ \\
+1 \\
o \\
i n\end{array}$ & $\begin{array}{l}f \\
+ \\
+1 \\
8 \\
\end{array}$ & $\begin{array}{l}9 \\
+ \\
+1 \\
0 \\
0\end{array}$ & $\begin{array}{l}0 \\
0 \\
+1 \\
0 \\
\infty \\
\infty\end{array}$ & 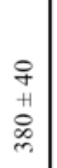 & $\begin{array}{l}q \\
+ \\
+1 \\
8 \\
\delta\end{array}$ & 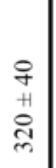 & $\begin{array}{l}8 \\
+ \\
+1 \\
0 \\
=\end{array}$ & $\begin{array}{l}o \\
+ \\
+1 \\
: \\
n\end{array}$ & $\begin{array}{l}q \\
+ \\
+1 \\
8 \\
+\end{array}$ & $\begin{array}{l}q \\
+ \\
+ \\
q \\
a\end{array}$ & $\begin{array}{l}\text { + } \\
+ \\
\text { ลे }\end{array}$ & $\begin{array}{l}9 \\
+ \\
+1 \\
0 \\
0 \\
0 \\
0\end{array}$ & $\begin{array}{l}8 \\
0 \\
+1 \\
8 \\
0\end{array}$ & $\begin{array}{l}\stackrel{P}{+} \\
+1 \\
\stackrel{0}{0} \\
\stackrel{2}{=}\end{array}$ & 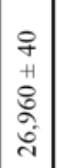 & $\begin{array}{l}\stackrel{9}{+} \\
+ \\
\stackrel{\circ}{m}\end{array}$ & $\begin{array}{l}8 \\
+ \\
8 \\
8\end{array}$ \\
\hline 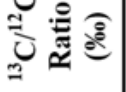 & ฟุ| & ণิ & 宊 & ণ்̃ & $\begin{array}{l}0 \\
\stackrel{0}{0} \\
\end{array}$ & 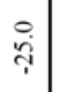 & पi & ذे & $\stackrel{\overbrace{}}{\stackrel{\sim}{i}}$ & $\begin{array}{l}\infty \\
\stackrel{+}{i} \\
i\end{array}$ & 苟 & जิ & "ู & "ู & ત઼ & ?ֶ. & วิ & $\vec{T}$ & $\mathrm{~N}$ & $\stackrel{\infty}{\stackrel{一}{丂}}$ & 京 \\
\hline 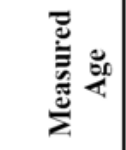 & $\begin{array}{l}q \\
+ \\
+ \\
\stackrel{2}{\text { I }}\end{array}$ & $\begin{array}{l}8 \\
+ \\
+ \\
+\end{array}$ & \begin{tabular}{|l|} 
\\
$q$ \\
+1 \\
+ \\
\\
\\
\end{tabular} & $\begin{array}{l}q \\
+ \\
+1 \\
o \\
n \\
n\end{array}$ & $\begin{array}{l}q \\
+ \\
+1 \\
0 \\
0\end{array}$ & $\begin{array}{l}9 \\
+ \\
+1 \\
0 \\
0\end{array}$ & $\begin{array}{l}0 \\
\text { D } \\
+1 \\
\stackrel{0}{0}\end{array}$ & 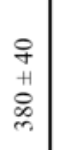 & $\begin{array}{l}q \\
+ \\
+1 \\
o \\
0\end{array}$ & $\begin{array}{l}q \\
+ \\
+1 \\
\text { ले }\end{array}$ & $\begin{array}{l}8 \\
0 \\
+1 \\
8 \\
=\end{array}$ & 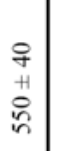 & $\begin{array}{l}\text { q } \\
+1 \\
\text { ศे }\end{array}$ & 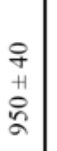 & $\begin{array}{l}f \\
+ \\
+1 \\
\vdots \\
\sigma\end{array}$ & 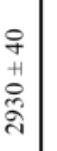 & $\begin{array}{l}8 \\
0 \\
+1 \\
8 \\
0\end{array}$ & $\begin{array}{l}\stackrel{9}{+} \\
+1 \\
\stackrel{8}{0} \\
\stackrel{-}{=}\end{array}$ & 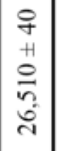 & $\begin{array}{l}\stackrel{9}{+} \\
+ \\
\vdots \\
\vdots\end{array}$ & $\begin{array}{l}\frac{O}{+} \\
\frac{+}{N}\end{array}$ \\
\hline $\begin{array}{l}\dot{8} \\
\text { 穿 }\end{array}$ & 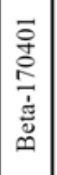 & 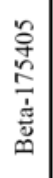 & 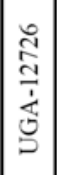 & 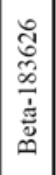 & 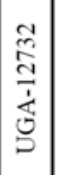 & 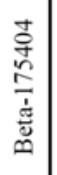 & 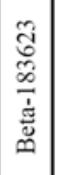 & 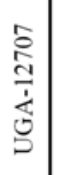 & 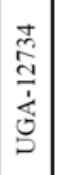 & 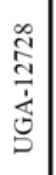 & 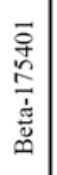 & 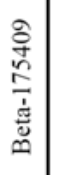 & 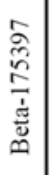 & 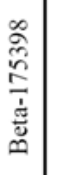 & 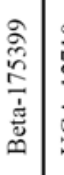 & $\frac{O}{\stackrel{Q}{a}}$ & 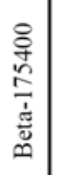 & & 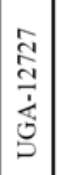 & 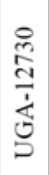 & 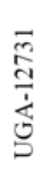 \\
\hline$=0$ & $\overrightarrow{0}$ & $\overrightarrow{0}$ & 舟 & สุ & $\tilde{0}$ & $\overrightarrow{0}$ & $\overrightarrow{0}$ & $\overrightarrow{0}$ & $\overrightarrow{0}$ & ชี & $:$ & $\overrightarrow{0}$ & $\overrightarrow{0}$ & $\overrightarrow{0}$ & $\overrightarrow{0}$ & 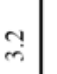 & : & $\stackrel{m}{\varrho}$ & $\vec{m}$ & $\vec{i}$ & $\stackrel{\infty}{\circ}$ \\
\hline 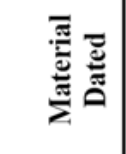 & 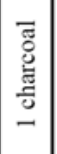 & 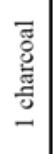 & 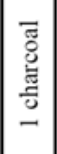 & 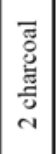 & 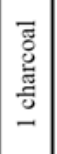 & 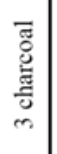 & 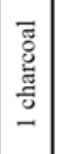 & 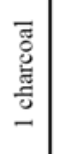 & 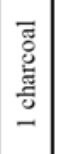 & 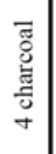 & 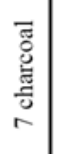 & 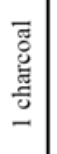 & 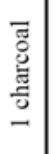 & 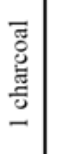 & 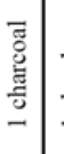 & $\frac{\vec{b}}{n}$ & 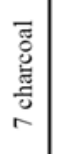 & 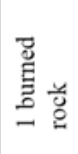 & $\frac{\bar{m}}{\frac{5}{n}}$ & $\begin{array}{l}\frac{\vec{z}}{2} \\
\frac{\pi}{5} \\
-\end{array}$ & $\frac{\vec{g}}{5}$ \\
\hline 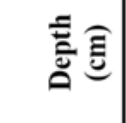 & 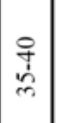 & 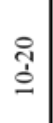 & 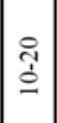 & 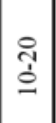 & 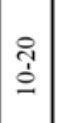 & $\begin{array}{l}\text { Iี } \\
\dot{I}\end{array}$ & $\begin{array}{c}0 \\
\stackrel{0}{0} \\
\vdots \\
\vdots \\
+\end{array}$ & $\begin{array}{l}0 \\
\stackrel{0}{0} \\
\stackrel{2}{p} \\
+\end{array}$ & \begin{tabular}{c|}
0 \\
0 \\
$\vdots$ \\
$\vdots$ \\
+
\end{tabular} & 尺ें & 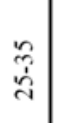 & $\begin{array}{l}\text { qे } \\
\vdots \\
\text { d. }\end{array}$ & 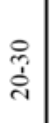 & 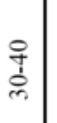 & 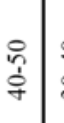 & $\begin{array}{l}\text { q } \\
\text { d. }\end{array}$ & 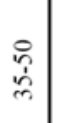 & 导 & ণิ & हे & ڤి \\
\hline 竞 & 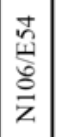 & 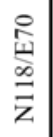 & 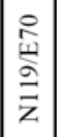 & 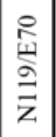 & 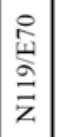 & 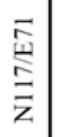 & 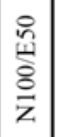 & 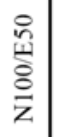 & 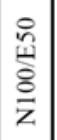 & 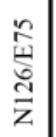 & $\begin{array}{c}\stackrel{n}{c} \\
\stackrel{c}{c} \\
\frac{a}{z}\end{array}$ & 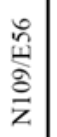 & 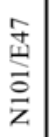 & 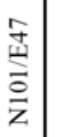 & 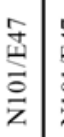 & 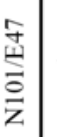 & 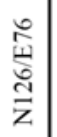 & 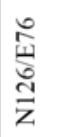 & 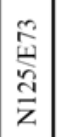 & $\begin{array}{l}\overrightarrow{\mathrm{T}} \\
\stackrel{\mathrm{c}}{\mathrm{i}} \\
\vec{z}\end{array}$ & $\begin{array}{l}\text { त्र } \\
\text { 兽 } \\
\text { Z }\end{array}$ \\
\hline$\dot{\vec{\mu}}$ & $\varangle$ & $\infty$ & $\infty$ & $\infty$ & $\infty$ & $\infty$ & $\varangle$ & $<$ & $\varangle$ & $\infty$ & $\infty$ & $\varangle$ & $\varangle$ & $\varangle$ & $\varangle$ & $\varangle$ & $\infty$ & $\infty$ & $\infty$ & $\infty$ & $\infty$ \\
\hline 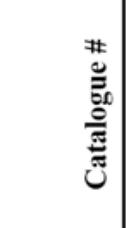 & 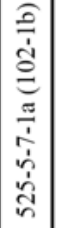 & 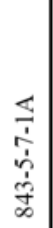 & 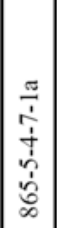 & 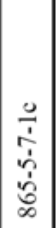 & 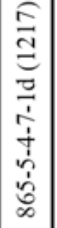 & 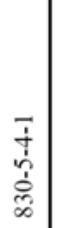 & $\begin{array}{l}\frac{0}{1} \\
\hat{i} \\
\dot{b} \\
\dot{2}\end{array}$ & $\begin{array}{l}\frac{\pi}{1} \\
\dot{1} \\
\dot{0} \\
\vdots\end{array}$ & 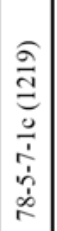 & 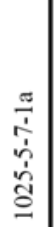 & 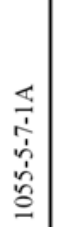 & के & 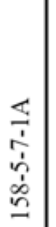 & 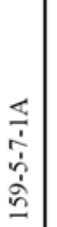 & - & 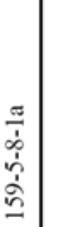 & 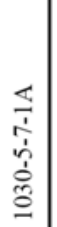 & 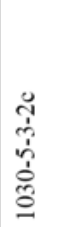 & \begin{tabular}{l|}
$\frac{\pi}{4}$ \\
$\dot{\alpha}$ \\
$\dot{0}$ \\
$\infty$ \\
$\alpha$
\end{tabular} & $\begin{array}{l}\frac{\pi}{\dot{\alpha}} \\
\dot{\alpha} \\
\stackrel{\alpha}{\varrho}\end{array}$ & $\begin{array}{l}\frac{\pi}{\dot{0}} \\
\dot{0} \\
\stackrel{0}{\Xi} \\
\Xi\end{array}$ \\
\hline ت் & $a$ & $\infty$ & $\infty$ & $\infty$ & $\infty$ & $a$ & $\vec{\sim}$ & $\vec{\sim}$ & $\vec{N}$ & $\therefore$ & $\approx$ & $i$ & & \% & & ల & $\infty$ & $\infty$ & $\Xi$ & $\cong$ & $\Xi$ \\
\hline
\end{tabular}


Consequently, 35 percent of the obtained radiocarbon ages from the Toyah component are considered unacceptable, whereas 65 percent provide a time range in which these Toyah events probably occurred. The 13 acceptable radiocarbon dates, all on wood charcoal, reveal a time range between 290 to 660 B.P. (Table 8-1), or A.D. 1280-1660, calibrated.

In an effort to investigate the possibility of using OSL as a dating technique in alluvial deposits, two sediment samples (\#1237 and \#1238) in thick plastic tubing from two opposite sides of the investigated Toyah component were collected. Sample \#1237 was collected from a dark brown (10YR 3/3) clay loam on the very western edge of Block A in Unit N104/E47 between 24 and 36 cmbs. Sample \#1238 was collected from the same dark brown (10YR 3/4) clay loam on the very eastern edge of Block B in Unit N125/E75 between 22 and 26 cmbs. These two samples were analyzed and dated by the OSL technique to compare with the many charcoal dates obtained from this component. The detailed methods and results of the OSL technique are presented in Appendix L and only a summary is presented in this chapter.

These two OSL samples did not yield many coarse grains to measure (less than 200 per sample). Of those present, many coarse grains failed to yield a measurable signal. Only 39 percent of the measured single grains in sample \#1237 (UW1047), and six percent of the measured grains in sample \#1238 (UW1048) were dated (Appendix L). The central age determination from the fine grains was also explored. The latter provided two average ages of $1,030 \pm 230$ years before A.D. 2004 for sample \#1237 and 1,130 \pm 186 years before A.D. 2004 for sample \#1238. These two average OSL age determinations on fine grains appear quite reasonable when compared to the charcoal dates documented for cultural materials in that same sediment and that definitely post dated the sedimentation.

\subsection{Toyah Component Features}

\subsubsection{Introduction}

Eleven clusters of cultural material were recognized and assigned feature numbers in the field and assigned to the Toyah component (Figures 8-1 and 8-2). These features were classified into four categories based on a combination of visible attributes and material present. The categories include a bone cluster $(n=1)$, general refuse dumps $(n=3)$, hearths $(n=4)$, and occupation zones $(n=3)$. Bone clusters are locations where bones were concentrated and indicate a particular in situ activity, in contrast to a broad scatter of bones across an occupied surface. General refuse dumps are definable areas where multiple classes of material (burned rocks, lithic debitage, broken tools, etc.) appear concentrated and inferably were purposefully discarded or dumped in one spot. Burned rock clusters reveal more concentrated burned rocks, but again lack indications that heating occurred in that spot. Hearths are areas where intentional in situ burning was evidenced by the presence of oxidized earth, ash, and/or charcoal lenses. Hearths may exhibit excavated basins, pits, or flat surface fires and may or may not contain burned rocks or other materials.

Occupations zones are broad scatters of various classes of material without well-defined boundaries or specific concentrations of material. These zones can usually be defined vertically, but unless exceptionally large areas are opened through excavations, exhibit illdefined and irregular horizontal margins.

The features were numbered as they were found. Additional detailed documentation was completed, and a suite of samples was collected from most features. Eleven features were discovered over a broad area in both excavation blocks. 


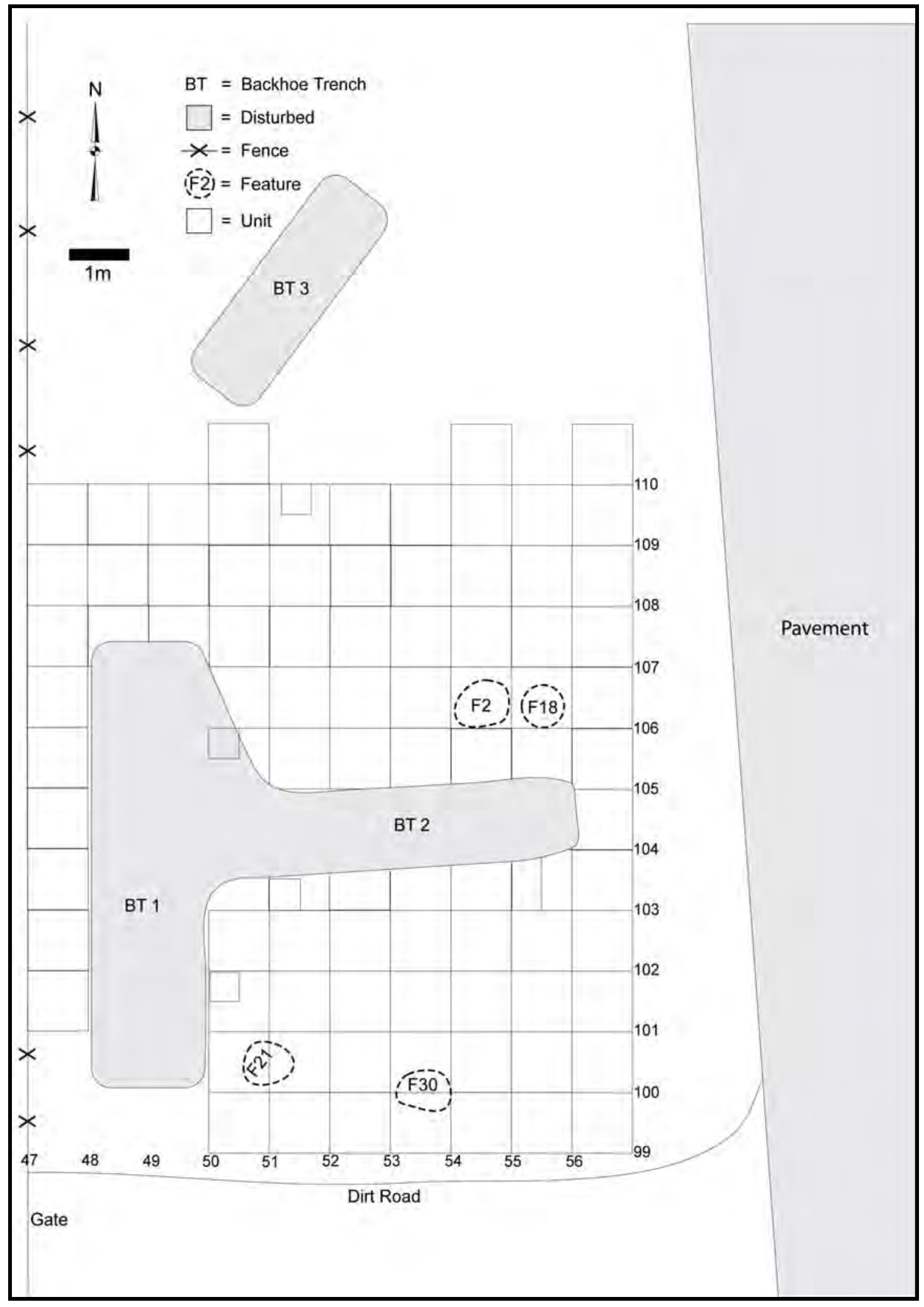

Figure 8-1. Distribution of Toyah Features Across Block A 


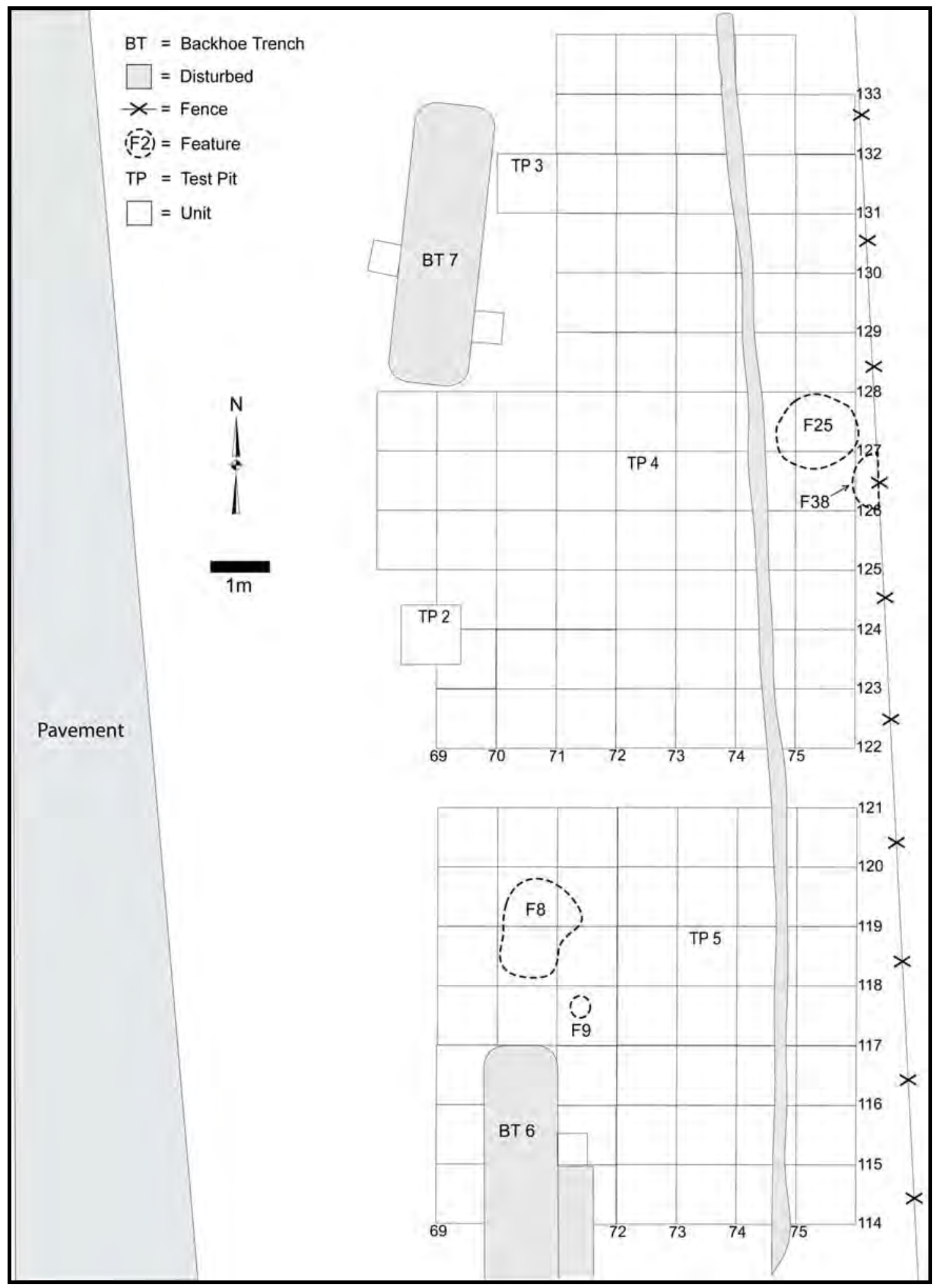

Figure 8-2. Distribution of Toyah Features in Block B 
Features 8, 9, 25, 30, and 38 were in Block B, whereas Features 2, 18, 21, 22, 35, and 36 were in Block A. These are described individually below according to the aforementioned four categories.

\subsubsection{Bone Clusters $(n=1)$}

\subsubsection{Feature 2}

Feature 2 was exposed during Phase I investigation by the backhoe as sediment was being stripped from the top of the deeper, targeted burned rock midden deposit. This nearsurface feature was partially impacted by the mechanical scraping, but was still discernible as a cluster of butchered bison bones, several burned rocks, lithic debris, a few tiny chunks of charcoal, and stone tools across much of Unit N106/E54 from 5 to $10 \mathrm{cmbs}$ (Figure 8-3). Since the upper deposits were removed before identification, the top could not be precisely defined. The exact bottom of the feature was not clear either as some cultural material continued deeper than this $5 \mathrm{~cm}$ thick zone assigned to Feature 2. No precise boundaries were evident, and boundaries are perforce arbitrary.

Sixty-three percent of the bones are small, unidentifiable fragments less than $3 \mathrm{~cm}$ long. Some pieces are identifiable as to an element, or type, and a few to a specific species. These pieces include rib fragments and a deer mandible fragment. About 36 percent of these fragments are burned black or a black and brown color. These colors indicate heating the bones to temperatures of no more than about 400 degrees Celsius (Nicholson 1993). None of the bones were articulated. A bone fragment (\#525-5-21a) from this cluster was submitted to Geochron Laboratories in Cambridge for stable carbon and nitrogen isotope analyses. The laboratory results indicate a carbon isotope value of $-8.6 \%$ on collagen, a nitrogen isotope value of $5.1 \%$, and a carbon isotope value $-4.0 \%$ on bioapatite. These values indicate an animal, probably bison,

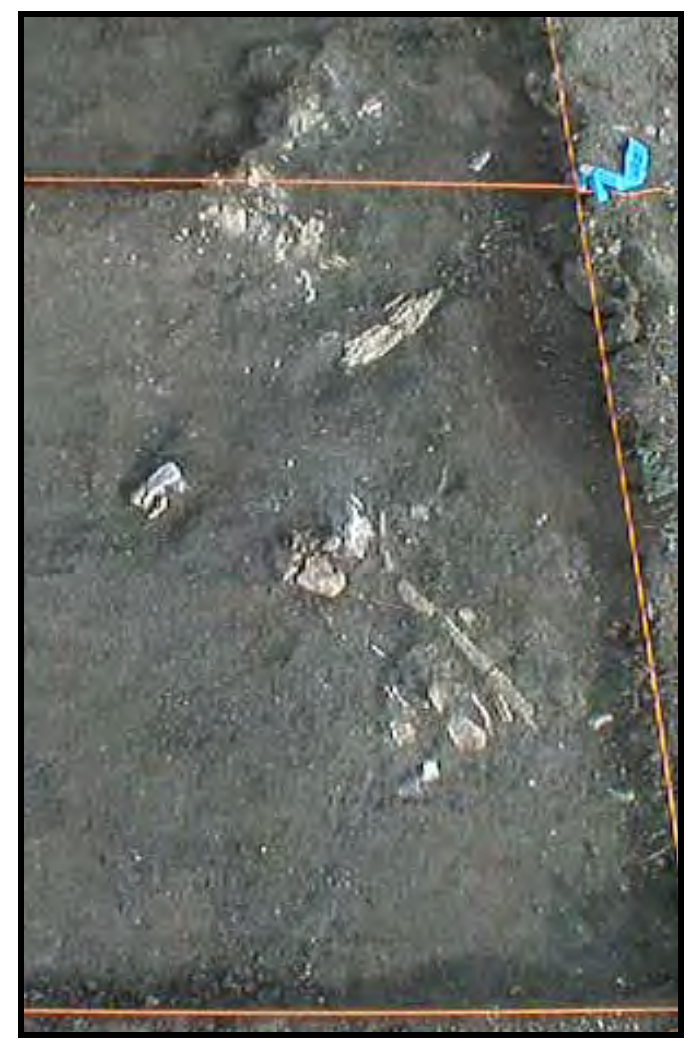

Figure 8-3. Overview of Bone cluster, Feature 2

which ate nearly 80 percent $\mathrm{C}_{4}$ vegetation, presumably grasses.

Several tools were encountered in Feature 2. Tools within the same unit and level include one Perdiz point (\#525-10), one Frio dart point fragment (\#525-13), one untypable arrow point fragment (\#525-11), and one edge-modified flake (\#525-12). Fifty-four pieces of lithic debitage were also recovered. Ten burned rocks that weighed just slightly over $1 \mathrm{~kg}$ were scattered in the vicinity of the bone fragments.

Tiny chunks of charcoal were scattered in the vicinity of the bones. One chunk $(0.1 \mathrm{~g})$ of charcoal from near the bones was sent for radiocarbon dating and yielded a $\delta^{13} \mathrm{C}$ corrected (-25.2\%) AMS radiocarbon date of $290 \pm 40$ B.P. (Table 8-1: Beta-170401). A 
piece of that dated sample (\#525-5-7-1b) was identified as oak wood (Appendix I).

This loose cluster of burned and unburned bone fragments, scattered charcoal, and other cultural debris appears to represent part of a broader spread of occupational debris. As individual events were not identifiable following the mechanical stripping conducted during Phase I, it is unclear if other bone concentrations were in the vicinity or which other Toyah features may directly relate to Feature 2.

\subsubsection{General Refuse Dumps ( $n=3)$}

\subsubsection{Feature 8}

Feature 8 was detected in Block B across parts of three adjacent units, including N118/E70, N119/E70, and N119/E71, between 0 and 22 cmbs. This feature included diverse types and quantities of cultural debris concentrated in an area measuring approximately 150 by $200 \mathrm{~cm}$ with an average thickness of about $10 \mathrm{~cm}$ (Figure 8-4). No obvious definable edge could be defined, and there was no sign of in situ heating such as oxidized matrix or lenses of charcoal. However, one small pocket of ash, 10 $\mathrm{cm}$ in diameter and was recovered from Unit N119/E70. Most debris was contained within an 8-cm-thick layer, but under the central part of this cluster was a of burned rocks that covered an area of about 100 by $90 \mathrm{~cm}$. Parts of this concentration were cross-sectioned along the excavation grid lines, but no basin or pit was detected, and the cultural debris appeared to rest on a relatively flat plane.

This feature contained diverse cultural debris including large quantities of small burned rocks $(n=289)$ (Table 8-2), many pieces of lithic debitage $(n=294)$, scattered charcoal pieces, several stone tools $(n=14)$, a few pieces of pottery $(n=4)$, sparse mussel shell fragments $(n=2)$, and relatively limited quantity of smashed bone fragments $(n=135)$.
The 289 pieces of burned rocks ranged in size from 1 to nearly $15 \mathrm{~cm}$ in diameter with their weight varying from 5 to $455 \mathrm{~g}$. About 85 percent were in the small 0 to $4 \mathrm{~cm}$ size class, with another 10 percent in the 4.1 to $9 \mathrm{~cm}$ size class, and only five percent were in the 9.1 to $15 \mathrm{~cm}$ size class (Table 8-2). The average weight of an individual piece was a low $65 \mathrm{~g}$. Seventy percent were classified as tabular in their overall shape. All the pieces were identified as limestone.

A sample of six burned rock pieces, three each from two adjacent units, was analyzed for lipid residue. Drs. Malainey and Malisza's detailed findings and interpretations are presented in Appendix G with a summary of the results presented here (Table 8-3). One sample (\#8655-3-1a) yielded moderate to high fat content. Another sample (\#865-5-3-2a) yielded borderline medium and moderate to high fat content. Two samples (\#865-5-3-3a and \#843-53-2a) yielded high fat content implying plant residue. Two more samples (\#843-5-3-1a and \#843-5-3-3a) yielded residue of large herbivores. The variation in the lipid interpretations from the burned rocks implies that the rocks were used to cook multiple types of foods. These results also indicate that the rocks probably were used in several different cooking events, possibly in more than one cooking feature.

The isotope results from the same four burned rock pieces used in the lipid analysis yielded $\delta^{13} \mathrm{C}$ values from -18.4 to $-26.1 \%$ indicating $\mathrm{C}_{3}$ plants or animals that ate $\mathrm{C}_{3}$ plants (Table 84). The $\delta^{15} \mathrm{~N}$ values vary from -4.2 to $5.7 \%$ and reflect similar plants. The low $\delta^{15} \mathrm{~N}$ value of 4.2\%o from sample \#865-5-3-1b indicates a $\mathrm{C}_{3}$ plant similar to various species of legumes, or potentially like the small bulb Herbertia drummondii (Quigg et al. 2002). The broad range of values indicates that these rocks apparently cooked multiple plants. 


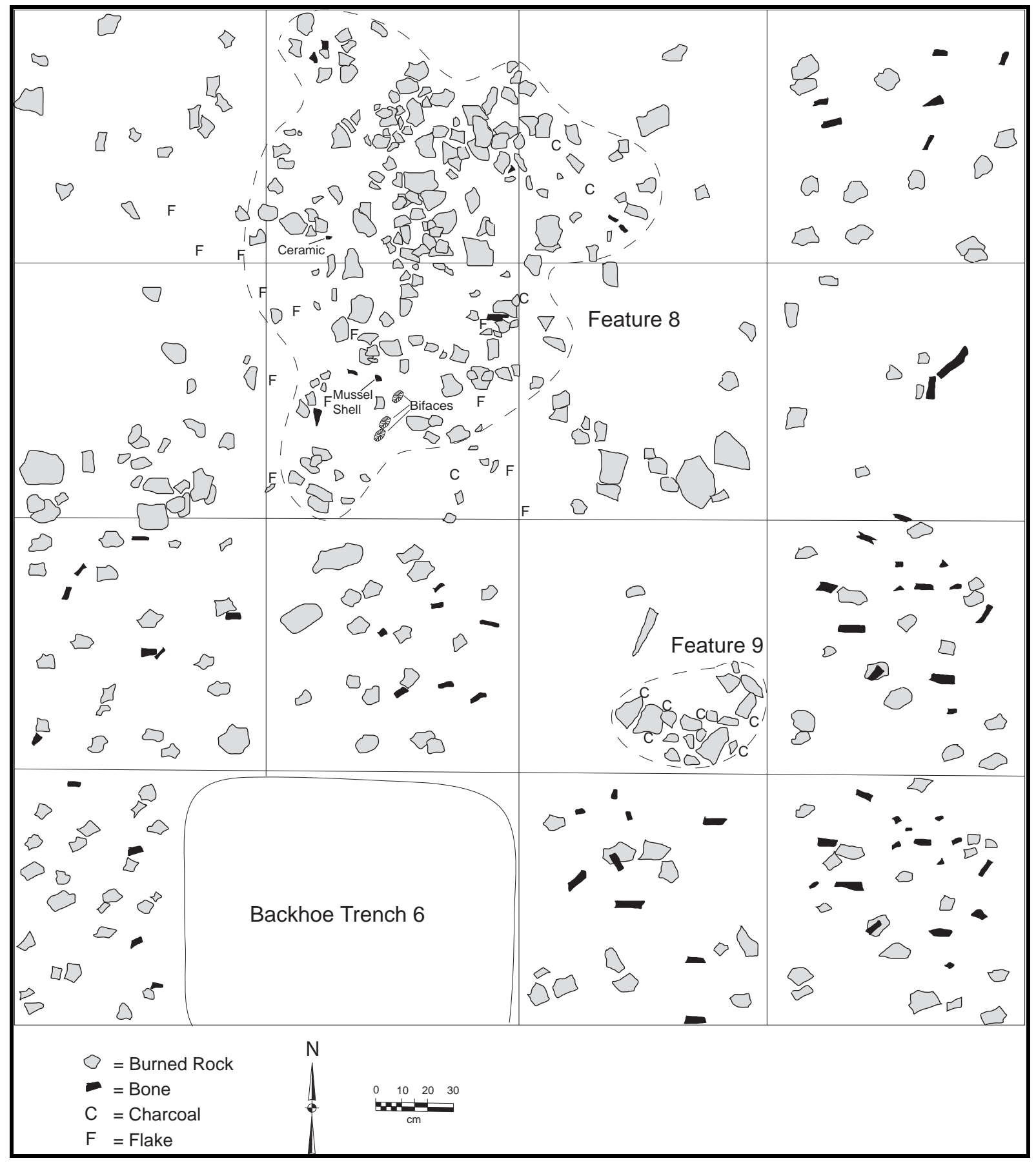

Figure 8-4. Planview of Features 8 and 9 in Block B 


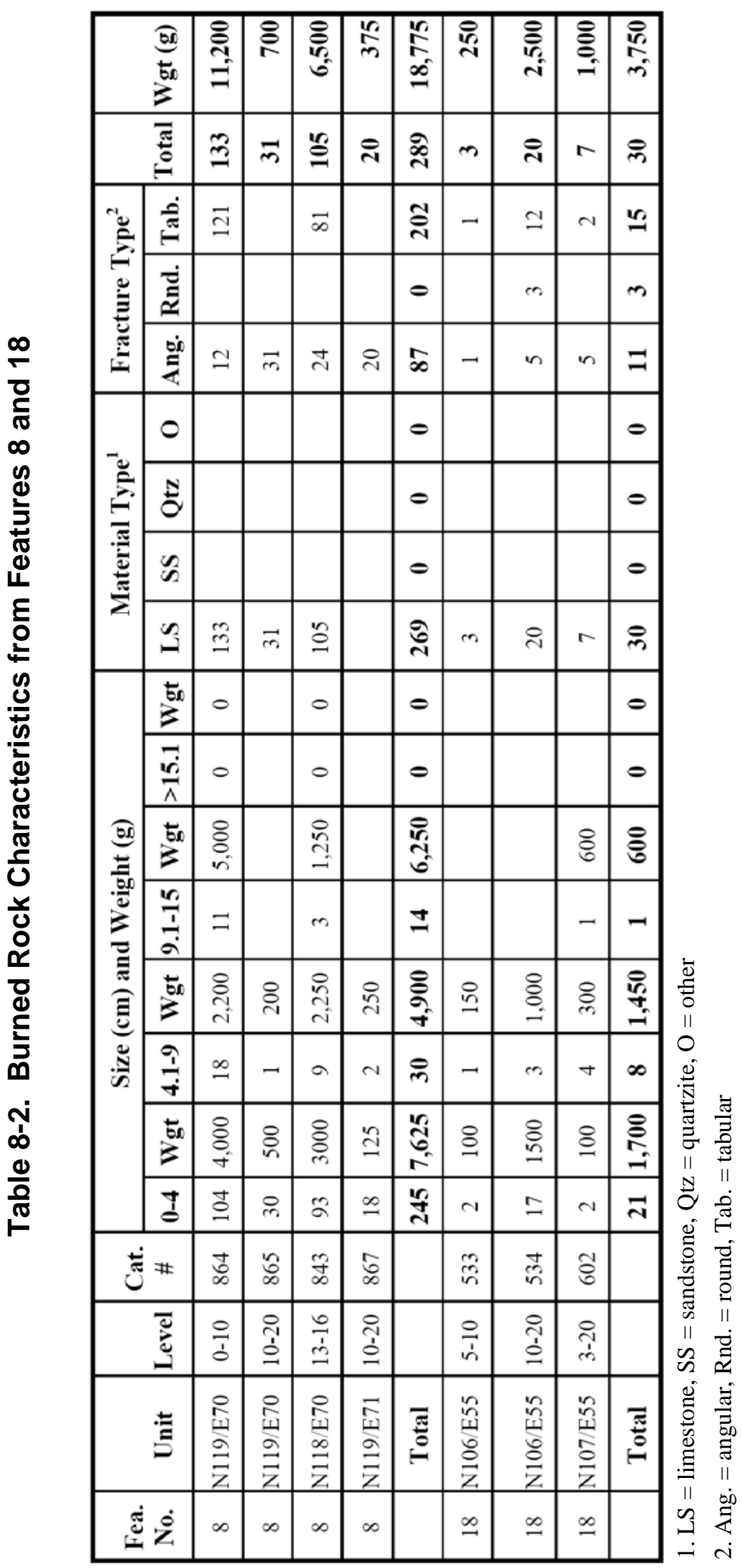


Table 8-3. Lipid Residue Results from Burned Rock Samples from the Toyah Component

\begin{tabular}{|c|c|c|c|c|c|}
\hline Lab. No. & Cat. \# & $\begin{array}{c}\text { Fea. } \\
\text { No. }\end{array}$ & Material & $\begin{array}{c}\text { Wgt } \\
\text { (g) }\end{array}$ & Interpreted Lipid Residue Results \\
\hline 4VG 9 & $865-5-3-1 a$ & 8 & Limestone & 33 & Moderate-high fat content \\
\hline 4VG 10 & $865-5-3-2 a$ & 8 & Limestone & 33 & Borderline medium and moderate-high fat content \\
\hline 4VG 11 & $865-5-3-3 a$ & 8 & Limestone & 58 & High fat content \\
\hline 4VG 12 & $843-5-3-1 a$ & 8 & Limestone & 35 & Large herbivore -somewhat fatty \\
\hline 4VG 13 & $843-5-3-2 a$ & 8 & Limestone & 40 & High fat content - plant \\
\hline 4VG 14 & $843-5-3-3 a$ & 8 & Limestone & 53 & Large herbivore -fat meat \\
\hline 4VG 15 & $830-5-3-1 a$ & 9 & Limestone & 46 & Borderline medium and moderate-high fat content - plant \\
\hline $4 \mathrm{VG} 16$ & $830-5-3-2 a$ & 9 & Limestone & 61 & Large herbivore -fat meat, possibly plant \\
\hline 4VG 17 & 830-5-3-3a & 9 & Limestone & 77 & Large herbivore + plant or bone marrow \\
\hline 4VG 18 & $830-5-3-4 a$ & 9 & Limestone & 76 & Borderline medium and moderate-high fat content - plant \\
\hline 4VG 33 & $534-5-3-1 a$ & 18 & Limestone & 37 & Moderate-high fat content - plant \\
\hline 4 VG 34 & $534-5-3-2 a$ & 18 & Limestone & 18 & Moderate-high fat content - plant \\
\hline 4VG 30 & $79-5-3-1 a$ & 21 & Limestone & 55 & Moderate-high fat content - plant \\
\hline 4VG 31 & $79-5-3-2 a$ & 21 & Limestone & 23 & Medium fat content - plant \\
\hline 4 VG 32 & 79-5-3-3a & 21 & Limestone & 45 & Moderate-high fat content - plant \\
\hline 4VG 19 & 1051-5-3-1a & 25 & Limestone & 17 & High fat content - plant \\
\hline $4 \mathrm{VG} 20$ & $1051-5-3-2 a$ & 25 & Limestone & 18 & Borderline medium and moderate-high fat content - plant \\
\hline $4 \mathrm{VG} 21$ & 1051-5-3-3a & 25 & Limestone & 15 & Large herbivore - somewhat fatty, possibly plant \\
\hline $4 \mathrm{VG} 22$ & $1051-5-3-4 a$ & 25 & Limestone & 14 & Moderate-high fat content - plant \\
\hline 4VG 27 & $158-5-3-1 a$ & 36 & Limestone & 37 & Borderline moderate-high and high fat content - plant \\
\hline $4 \mathrm{VG} 28$ & $158-5-3-2 a$ & 36 & Limestone & 55 & Borderline moderate-high and high fat content - plant \\
\hline 4 VG 29 & 158-5-3-3a & 36 & Limestone & 24 & Moderate-high fat content - plant \\
\hline 4VG 23 & $1030-5-3-1 a$ & 38 & Limestone & 12 & Large herbivore - somewhat fatty, possibly plant \\
\hline 4 VG 24 & $1030-5-3-2 a$ & 38 & Limestone & 21 & Large herbivore - somewhat fatty, possibly plant \\
\hline $4 \mathrm{VG} 25$ & 1030-5-3-3a & 38 & Limestone & 37 & Moderate-high fat content - plant \\
\hline 4VG 26 & $1030-5-3-4 a$ & 38 & Limestone & 56 & High fat content - plant \\
\hline 4VG 35 & $1005-3-1 a$ & NA & Limestone & 23 & Borderline moderate-high and high fat content - plant \\
\hline 4VG 36 & $79-3-1 a$ & NA & Limestone & 27 & Borderline medium and moderate-high fat content - plant \\
\hline 4VG 37 & $79-3-2 a$ & NA & Limestone & 35 & High fat content - plant \\
\hline
\end{tabular}


Table 8-4. Isotope Results from Burned Rocks in Toyah Context

\begin{tabular}{|c|c|c|c|c|c|c|c|c|}
\hline Cat. \# & Unit No. & $\begin{array}{l}\text { Depth } \\
\text { (cmbs) }\end{array}$ & $\begin{array}{l}\text { Fea. } \\
\text { No. }\end{array}$ & $\begin{array}{l}\text { Wgt } \\
\text { (mg) }\end{array}$ & $\begin{array}{c}\mathrm{N} \\
\text { Wgt } \\
(\mu g)^{1}\end{array}$ & $\begin{array}{c}\delta^{15} \mathbf{N} \\
(\% 0)\end{array}$ & $\begin{array}{c}\text { C } \\
\text { Wgt } \\
(\mu g)\end{array}$ & $\begin{array}{c}\delta^{13} C \\
(\%)\end{array}$ \\
\hline $843-5-3-1 b$ & N118/E70 & $13-16$ & 8 & 5.316 & 49.1 & 5.75 & 730.7 & -18.43 \\
\hline $865-5-3-1 b$ & N119/E70 & $10-20$ & 8 & 40.381 & 19.3 & -4.21 & 354.8 & -26.11 \\
\hline $865-5-3-2 b$ & N119/E70 & $10-20$ & 8 & 7.623 & 88.4 & 5.61 & 1293.5 & -21.84 \\
\hline $865-5-3-3 b$ & N119/E70 & $10-20$ & 8 & 12.374 & 114.1 & 4.99 & 1416.1 & -23.93 \\
\hline $830-5-3-2 b$ & N117/E71 & $10-22$ & 9 & 41.813 & 36.7 & 3.83 & 522.2 & -23.57 \\
\hline $830-5-3-3 b$ & N117/E71 & $10-22$ & 9 & 4.438 & 33.0 & 6.44 & 413.3 & -25.75 \\
\hline $830-5-3-4 b$ & N117/E71 & $10-22$ & 9 & 12.351 & 83.3 & 6.67 & 1015.1 & -20.97 \\
\hline 534-5-3-1b & N106/E55 & $10-20$ & 18 & 26.876 & 54.9 & 1.89 & 1572.9 & -27.99 \\
\hline $534-5-3-2 b$ & N106/E55 & $10-20$ & 18 & 15.539 & 275.7 & 7.92 & 2384.6 & -25.29 \\
\hline $79-5-3-2 b$ & N100/E50 & $10-22$ & 21 & 5.808 & 35.3 & 2.80 & 368.5 & -21.16 \\
\hline $79-5-3-1 b$ & N100/E50 & $10-22$ & 21 & 7.805 & 39.1 & 3.59 & 706.9 & -24.80 \\
\hline $79-5-3-3 b$ & N100/E50 & $10-22$ & 21 & 42.012 & 28.4 & 3.56 & 417.9 & -24.87 \\
\hline $1055-5-8-1 b$ & N127/E75 & $32-38$ & 25 & 40.322 & 11.6 & -2.59 & 215.8 & -27.18 \\
\hline 1051-5-3-1b & N127/E74 & $25-35$ & 25 & 3.849 & 54.3 & 5.42 & 649.8 & -25.02 \\
\hline $1051-5-3-2 b$ & N127/E74 & $25-35$ & 25 & 23.835 & 244.4 & 4.85 & 3837.7 & -18.45 \\
\hline 1051-5-3-3b & N127/E74 & $25-35$ & 25 & 17.353 & 145.7 & 6.41 & 2660.6 & -20.45 \\
\hline $1051-5-3-4 b$ & N127/E74 & $25-35$ & 25 & 42.672 & 129.8 & 2.02 & 1984.4 & -25.70 \\
\hline $158-5-3-1 b$ & N101/E47 & $20-30$ & 36 & 15.883 & 122.3 & 6.08 & 1575.3 & -24.31 \\
\hline $158-5-3-2 b$ & N101/E47 & $20-30$ & 36 & 42.373 & 15.9 & 3.40 & 203.0 & -24.78 \\
\hline $158-5-3-3 b$ & N101/E47 & $20-30$ & 36 & 39.406 & 74.9 & 5.94 & 951.1 & -24.80 \\
\hline $1030-5-4-8-1 b$ & N126/E76 & $25-35$ & 38 & 40.237 & 8.7 & 2.80 & 122.5 & -24.27 \\
\hline $1030-5-3-1 b$ & N126/E76 & $25-35$ & 38 & 30.632 & 247.4 & 5.25 & 1520.4 & -18.58 \\
\hline $1030-5-3-2 b$ & N126/E76 & $25-35$ & 38 & 13.640 & 221.2 & 4.21 & 1808.5 & -22.07 \\
\hline $1030-5-3-3 b$ & N126/E76 & 25-35 & 38 & 2.983 & 0.5 & 11.36 & 6.1 & -23.23 \\
\hline $1030-5-3-4 b$ & N126/E76 & $25-35$ & 38 & 30.794 & 17.1 & -2.19 & 221.9 & -20.32 \\
\hline $900-8-1 b$ & N122/E70 & $0-10$ & na & 41.861 & 33.1 & 6.90 & 532.2 & -27.23 \\
\hline $965-8-1 b$ & N124/E74 & $10-20$ & na & 19.270 & 12.1 & -1.08 & 219.5 & -27.63 \\
\hline 1157-8-1b & N131/E73 & $10-20$ & na & 38.133 & 19.6 & 5.02 & 320.1 & -24.97 \\
\hline $1005-3-1 b$ & N126/E71 & $8-20$ & na & 4.901 & 71.6 & 4.80 & 1121.9 & -21.45 \\
\hline
\end{tabular}

1. Values below 10.0 make the results suspect

2. $\mathrm{C}=$ Carbon; $\mathrm{N}=$ Nitrogen 
The $\delta^{13} \mathrm{C}$ value of $-18.4 \%$ falls in the range of rabbits, but generally these small herbivores yield isotopic signatures similar to the plants they consume.

The 14 identified stone tools include eight edgemodified flakes (\#687-5-10, \#687-5-11, \#864-510, \#864-5-11, \#864-5-12, \#843-5-10, \#843-513 , and \#843-5-14), one perforator (\#867-5-10), one medial late-stage biface fragment (\#843-511), one complete late stage biface (\#843-5-12), two unidentifiable distal arrow point fragments (\#864-5-14 and \#864-5-15), one distal fragments of an end-scraper (\#864-5-13), and one small hammerstone (\#864-5-16).

In addition to lithic materials, four ceramic sherds were encountered in Feature 8. Three (\#867-5-8) of the four bone tempered sherds were assigned to Vessel Group 3, and the other sherd (\#865-5-8) was assigned to Vessel Group 1. The latter sherd was the largest at just over $2 \mathrm{~cm}$ in diameter and exhibits a polished interior and exterior, and contains gray and white bone temper. Vessel Group 3 sherds exhibit a polished reddish yellow (7.5YR 7/6) exterior. The interiors exhibit smoothing marks creating a slightly rough surface. A tiny sherd (\#867-5-8) 6.1 to $6.6 \mathrm{~mm}$ in diameter, with a reddish yellow (7.5YR 7/6) exterior, a pink (7.5YR 7/4) interior, a light brown (7.5YR 6/4) core, and representing Vessel Group 3, was subjected to INAA. The INAA results on \#8675-8 or TRC277 indicate that this sherd did not fit into any previously defined cluster of sherds and is not similar to other sherds analyzed from the Varga site or any other site (Appendix N).

The bone fragments, weighing $114.4 \mathrm{~g}$, are mostly small, less than $3 \mathrm{~cm}$ long, unidentifiable long bone fragments. Nine pieces, or nearly 7 percent, which weigh $49.4 \mathrm{~g}$, represent bisonsize elements. Of those, 67 percent are in the 0 to $3 \mathrm{~cm}$ size, one 6 to $9 \mathrm{~cm}$ long, and two 3 to $6 \mathrm{~cm}$ long. All nine pieces are unburned fragments. The remaining 93 percent were unclassifiable pieces less than $3 \mathrm{~cm}$ long. Two small fragments of tooth enamel were also identified. Nine pieces of bone, or seven percent, are burned to a black or brown color. This color reflects a general heating to less than 400 degrees Celsius (Nicholson 1993). Several chunks of charcoal were encountered in Feature 8, with individually collected chunks of charcoal sent for radiocarbon dating. One piece of oak wood (\#865-5-7-1a) yielded a $\delta^{13} \mathrm{C}$ corrected (-26.2\%) AMS radiocarbon date of $570 \pm 40$ B.P. (Beta-183626). A second oak piece (\#865-4-7) was split into two parts and both were sent to the same laboratory for dating. One-half (\#865-4-7-1a) yielded a $\delta^{13} \mathrm{C}$ corrected (-26.7 \%) AMS radiocarbon date of $620 \pm 40$ B.P. (UGA-12726; Table 8-1). The other half (\#865-4-7-1d) yielded a $\delta^{13} \mathrm{C}$ corrected (-26.6 \%) AMS radiocarbon date of $600 \pm 40$ B.P. (UGA-12732; Table 8-1). This split charcoal piece is statistically identical and provides verification of the reliability of laboratory processing techniques. These three radiocarbon dates on wood charcoal establish a relatively early Toyah age for Feature 8.

In addition to radiocarbon analysis, several sediment samples were collected from this feature for flotation. Ninety-one liters of matrix, which were collected from around and under the burned rocks, were collected and floated. Fortyeight liters of matrix (\#865-5-4) from between 10 and $20 \mathrm{cmbd}$ in Unit N119/E70 yielded considerable quantities of diverse cultural debris. This included 1,848 burned rock fragments weighing 2,217.3 g, 943 chert flakes and fragments weighing $97 \mathrm{~g}, 459$ tiny charcoal pieces weighing $3.7 \mathrm{~g}, 51$ more or less complete small snail shells weighing $4.9 \mathrm{~g}$, and 431 bone fragments weighing $49.4 \mathrm{~g}$. Some 93 bone fragments or 21.6 percent are burned. Identifiable bones include one bison element, one rabbit metapodial, and one rodent long bone fragment. Also included was one pottery sherd. The 2.9 liters of light fraction from three separate flotation samples and five individual chunks of charcoal were processed by Dr. 
Dering (Appendix I). These samples contain nine wood species including; oak, juniper, agarita, Condalia, elm, buttonbush, mesquite, and another woody legume-possibly leadtree or acacia, with lotebush and agarita being the most common wood (Appendix I). A single, charred littleleaf walnut shell was also present.

This amorphous concentration of diverse cultural debris lacks any sign of in situ burning or a formal basin or pit, implying that these items are a secondary deposit in a general surface refuse area. This, plus the range of debris classes present, indicates that this feature does not represent a primary-use event. Further, multiple dumping events are supported by the diversity in the identified charcoal pieces and the lipid residue results on the burned rocks that indicate the rocks were used to cook different types of foods-meat and plants. This refuse area may potentially have been on the periphery of a primary activity area or areas from which the debris originated. The appearance of a second layer of burned rocks implies at least two or more dumping episodes.

\subsubsection{Feature 18}

Feature 18 was discovered in Block A in Unit N106/E55 between 3 and 13 cmbd and into the southern half of Unit N107/E55 between 3 and $20 \mathrm{cmbd}$. The recovered cultural debris was near the present surface which was previously mechanically stripped during Phase I investigations. This feature appeared as a nearly flat and ill-defined scatter of diverse cultural debris. In Unit N106/E55 (\#533 and \#534), this included burned rocks $(n=23)$, bone fragments $(n=200)$, lithic debitage $(n=124)$, 14 edge-modified flakes, one Perdiz arrow point (\#533-17), and one Scallorn arrow point (\#53414). Within Unit N107/E55 (\#602) were burned rocks $(n=7)$, bone fragments $(n=174)$, lithic debitage $(n=42)$, five edge-modified flakes, two medial biface fragments (\#602-13 and \#602-14), two nearly complete Perdiz points (\#602-17 and
\#602-18), two unclassifiable arrow point fragments (\#602-15 and \#602-16), and one unidentifiable dart point fragment (\#602-19).

These diverse items were loosely associated with no clearly discernible margin over an area that measured about 60 by $150 \mathrm{~cm}$. Feature boundaries were poorly defined with no sign of a pit or basin (Figure 8-5), implying that this feature is actually a relatively concentrated accumulation of materials within a broader spread of cultural debris. In situ burning was not indicated, as no oxidized matrix, charcoal, or ash concentrations were observed, though scattered pieces of charcoal were present. The surrounding sediment was a dark grayish brown (10YR 3/2) compact clay loam. Flotation samples were collected and processed.

The 30 burned rocks were limestone with 70 percent in the 0 to $4 \mathrm{~cm}$ size class and 27 percent in the 4.1 and $9 \mathrm{~cm}$ size class (Table 8-2). These weighed a total of 3,750 g for an average rock weight of $125 \mathrm{~g}$.

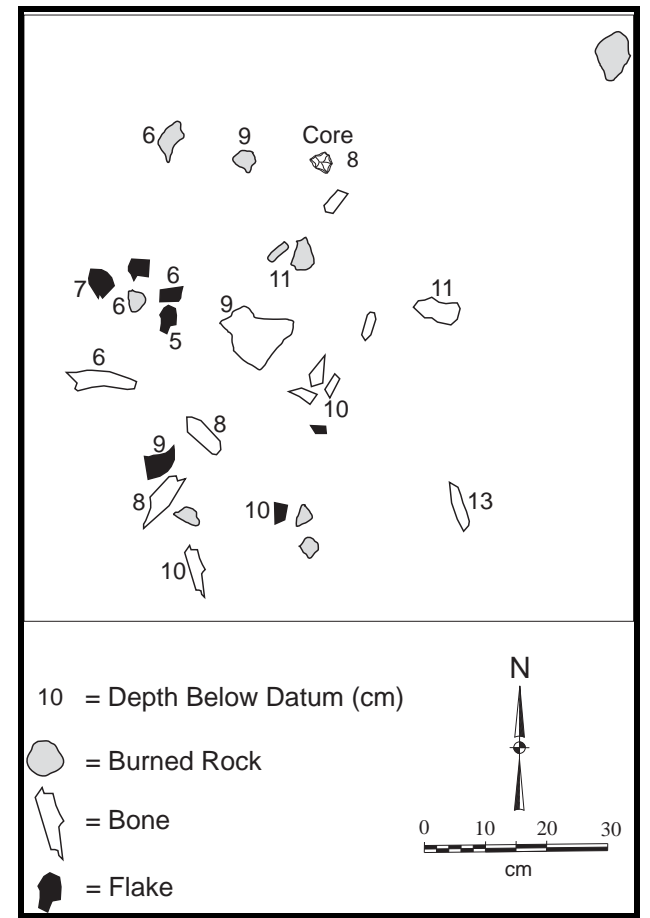

Figure 8-5. Planview of Feature 18 in Block A 
Two burned rock pieces were analyzed for lipid residue. Whereas a detailed report of the findings by Drs. Malainey and Malisza is presented in Appendix G, a summary of the results presented here (Table 8-3). Both pieces (\#534-5-3-1a and \#534-5-3-2a) yielded moderate to high fat content interpreted to represent plants. These interpretations imply that these rocks were used to cook plants only and may reflect a single cooking event. The isotope results from \#534-53 -2b with $\delta^{13} \mathrm{C}$ value of $-25.3 \%$ and $\delta^{15} \mathrm{~N}$ value of $7.9 \%$ indicate a $\mathrm{C}_{3}$ plant (Table 8-4). The low $\delta^{15} \mathrm{~N}$ value of $1.9 \%$ from sample \#534-5-3$1 \mathrm{~b}$ indicates a $\mathrm{C}_{3}$ plant similar to acacia beans.

The bones collected from Feature 18 included 18 bison-size fragments weighing $65.7 \mathrm{~g}$, which were mostly long bone fragments with one rib and a bison tooth fragment. Deer are represented by three lower premolars, and a calcanium epiphysial cap. Deer/antelope-size pieces weighing included a burned black dewclaw, a distal phalange, and a first phalange that was burned black and brown. Five rabbit size pieces weighing were identified, which include maxillary fragments and jackrabbit-size long bone pieces. Unidentifiable fragments ( $n=344$, weighing $149.2 \mathrm{~g}$ ) generally less than $3 \mathrm{~cm}$ in length dominate the bone assemblage.

Eleven liters of matrix (\#533-5-4) from between 8 and 13 cmbd in Unit N106/E55 were collected for floatation. The 0.3 liters of light fraction yielded 25 pieces of oak wood (Appendix I). The cultural debris greater than $6.4 \mathrm{~mm}$ includes 10 tiny burned rock fragments 29 pieces of lithic debitage, 3 tiny bits of charcoal, 20 complete small snail shells weighing, 222 bone fragments, and one tiny point fragment.

The presence of multiple types of cultural debris comprised mostly of lithic debris and bone scraps indicate this concentration reflects a refuse-dumping locality representing a secondary deposit rather than a primary activity area.

\subsubsection{Feature 25}

Feature 25 was a scatter of burned rock mixed with other cultural debris scattered across four adjacent units-N126/E74, N126/E75, N127/E74, and N127/E75 - in Block B towards the eastern margin of this project and immediately west of hearth Feature 38. Feature 25 is distinguished from Feature 38 based on the well-defined cluster of material in Feature 38 compared to the scattered nature of Feature 25. The cultural debris in Feature 25 covered an area measuring about 160 by $190 \mathrm{~cm}$, with most items at depths between 21 and 33 cmbs. The right-of-way fence line was $20 \mathrm{~cm}$ east of the excavation units and thus, these materials may have extended further east. The telephone line trench truncated the western margin (Figure 8$6)$.

All four units yielded diverse debris that lacked any detectable patterning or form in their distribution, although some smaller areas within in the feature boundaries showed clustering of materials (Figure 8-6). Debris included burned rocks $(n=542)$, abundant lithic debitage $(n=1,046)$ and bone fragments $(n=1,328)$, many stone tools $(n=56)$, ceramic sherds $(n=8)$, one bone bead blank (\#1054-21), and very sparse mussel shell fragments $(n=2)$.

Some 542 burned rocks, weighing 25,100 g, were collected from these four units. The burned rocks showed some varied in size from 1 to $15 \mathrm{~cm}$ in diameter. However, 85 percent fell into the smallest size class, with less than one percent larger than $9.1 \mathrm{~cm}$ (Table 8-5). Limestone was the only rock type identified with at least 88 percent exhibiting broken angular shapes. The average rock weight was a low $46 \mathrm{~g}$. Parts of four burned rocks were selected for lipid residue and stable carbon and nitrogen analyses. 


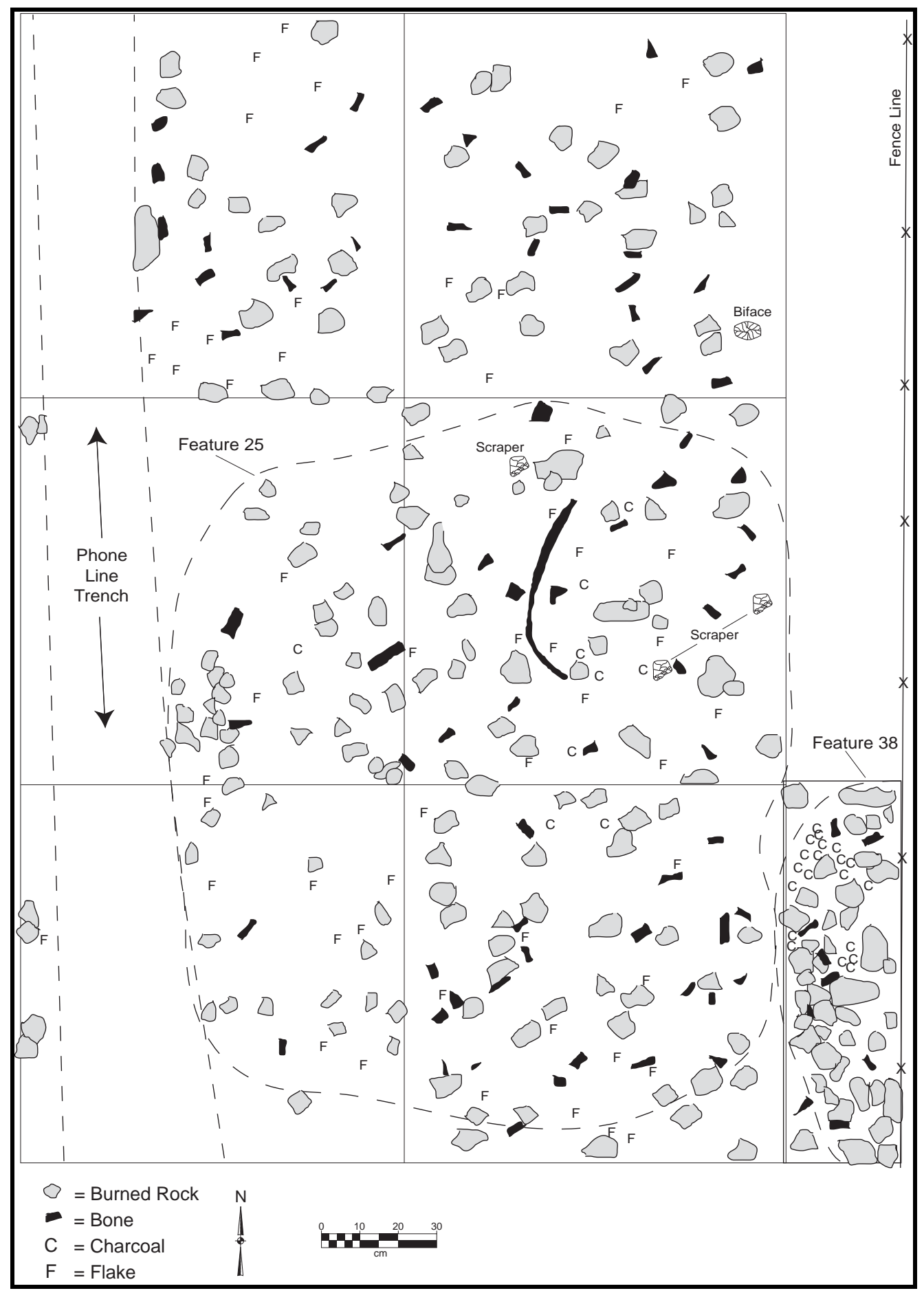

Figure 8-6. Planview of Features 25 and 38 in Block B 


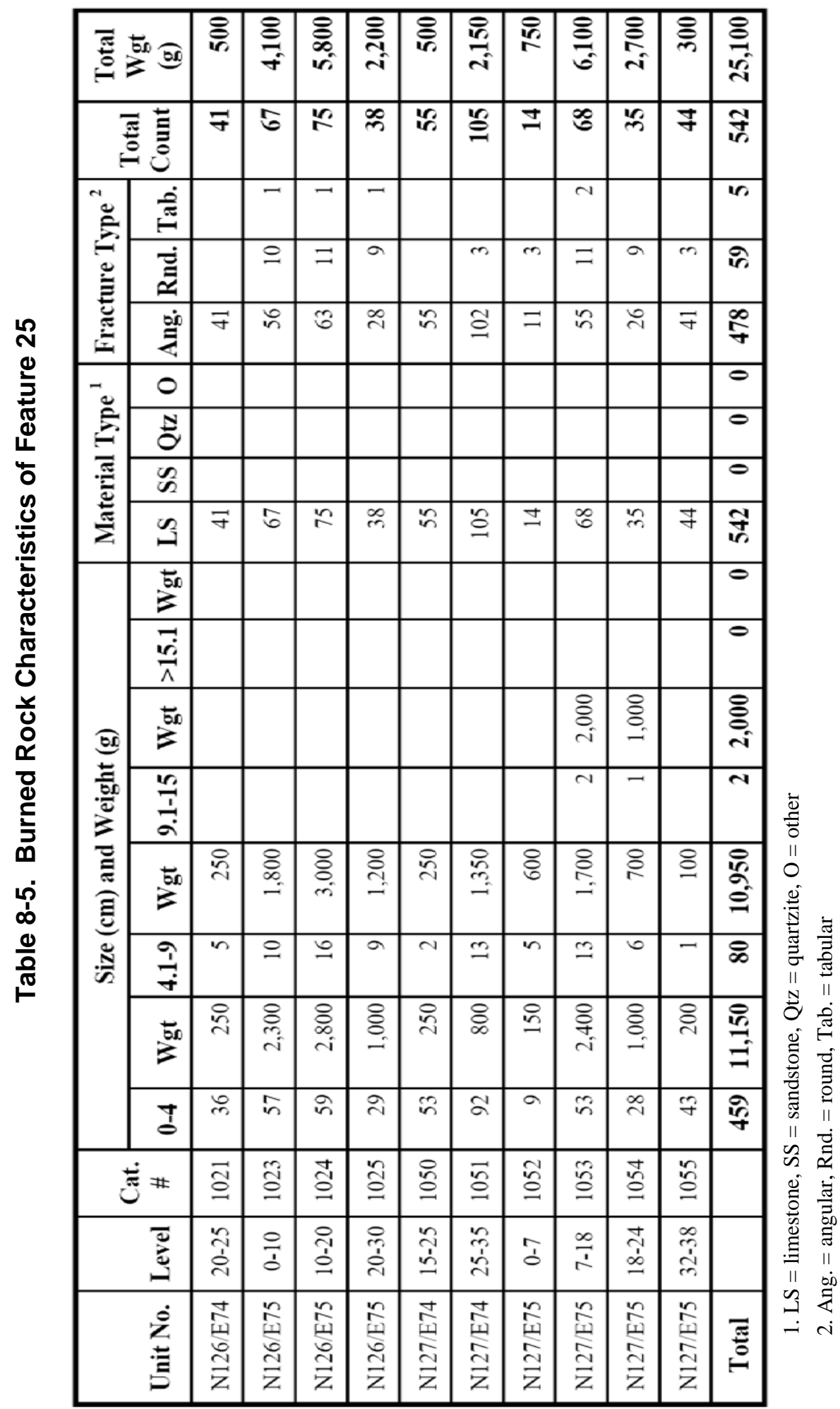


Drs. Malainey and Malisza's detailed findings and interpretations are presented in Appendix G, with a summary of the results presented here (Table 8-3). Each sample yielded slightly different results. One sample (\#1051-5-3-1a) yielded high fat content interpreted as representing plants. Sample \#1051-5-3-2a yielded borderline moderate to high fat content, also interpreted as plant. A third sample (\#10515-3-3a) represented large herbivore, and was somewhat fatty indicating intermixture with plant residue. The last sample (\#1051-5-3-4a) yielded moderate to high fat content interpreted as plant residue. The variation in the interpretations of the lipid residues from the four burned rocks implies that the rocks were used to cook multiple foods. This supports the idea that the burned rocks probably were used in multiple cooking events.

The $\delta^{13} \mathrm{C}$ values from these same burned rocks range from -18.5 to $-27.2 \%$, whereas the $\delta^{15} \mathrm{~N}$ values range from 2.0 to $6.4 \%$ (Table $8-4$ ). All the $\delta^{13} \mathrm{C}$ values imply these burned rocks cooked $\mathrm{C}_{3}$ plants. The low $\delta^{15} \mathrm{~N}$ value (2.6\%) from sample \#1055-5-8-1b is suspect, as the measured nitrogen weight is lower than the expectable range. The isotope values from \#1051-5-3-2b may represent rabbit, for which the meat often reflects values similar to the plants the rabbit ate. Sample \#1051-5-3-3a yielded possible large herbivore lipid residues with isotope values that can be interpreted several ways. If the residues are considered to represent meat, then the species was probably deer or pronghorn or, possibly, javelina, based on the obtained isotope values. Other possible interpretations are presented in Appendix G.

The 1,328 bone fragments weigh 1,101.5 g, revealing the very fragmented nature of the bones with an average weight of $0.8 \mathrm{~g}$ and lengths generally less than $3 \mathrm{~cm}$. Identifications include bison and bison-size pieces ( $n=84$ pieces, weighing $452.8 \mathrm{~g}$ ), deer/antelopesize pieces ( $n=68$ pieces, weighing $55.6 \mathrm{~g}$ ), two unburned snake vertebrae (weighing $0.2 \mathrm{~g}$ ), two rabbit-size long bone fragments, and 1,171 unidentifiable fragments weighing 592.6 g. One right bison scaphoid, one bisonsize hyoid, two deer/antelope caudal vertebrae, and one antelope $1^{\text {st }}$ phalange were the only elements identifiable as to species. Nearly all the fragments are long bone splinters, with rib and spine sections, and a few pieces of tooth enamel also present. Just over 16 percent of the fragments are burned, with four percent of the total being calcined. The calcined bones indicate temperatures in excess of about 700 degrees Celsius, and the brown and black colors are indications of temperatures less than about 400 degrees Celsius (Nicholson 1993).

The stones tools from these four units include 36 edge-modified flakes including a perforator (\#1050-10), spokeshave, a graver (\#1053-12), seven projectile points including a proximal Cliffton point fragment, six scrapers, two unifaces, two bifaces, two cores, and one drill. The spokeshave (\#1024-11) and one complete end-/side-scraper (\#1023-12) were subjected to use-wear analysis. The spokeshave revealed use residues in the form of wood fragments, and exhibited high silica polish with striations parallel and perpendicular to the long axis that implies use on wood (Appendix C). The end/side-scraper revealed high silica polish and edge rounding to indicating planing of hard, high silica material (Appendix C). The proximal Cliffton point fragment (\#1054-16) was sent for INAA.

The eight potsherds were all assigned to Vessel Group 1 based on visual characteristics. The largest sherd (\#1055-5-8-1a), about $40 \mathrm{~mm}$ in diameter, was sent for lipid residue analysis. The obtained lipids indicate borderline moderate to high and high fat content interpreted to represent plant products (Appendix G). Following decalcification, ground matrix from that same sherd was sent to the isotope laboratory for stable carbon and nitrogen isotope 
analysis. The derived $\delta^{13} \mathrm{C}$ value is $-27.2 \%$ and the $\delta^{15} \mathrm{~N}$ value is $-2.6 \%$. As noted above, the latter value is somewhat suspect because of the very low proportion of the nitrogen. If the $\delta^{15} \mathrm{~N}$ value is accepted, the combined values indicate $\mathrm{C}_{3}$ plants, probably legumes, were cooked in this vessel. Potential legumes include acacia and mesquite beans. Part of another sherd (\#1054-81b) was subjected to petrographic analysis. The overall results document the paste is tempered with bone and limestone. The clay body matrix is tan to greenish gray and anisotropic. This sherd was assigned to Paste Group, B-c, based on 17.5 percent bone, 8.5 percent limestone 8.5 percent ferrous iron, four percent calcite, 3.5 percent clay balls, 2.5 percent quartz, and 1.5 percent orthoclase (Appendix D). A second part of that same sherd (\#1054-8-1a) was sent for INAA. The INAA results indicate that this sherd (TRC270) together with two other sherds (another Vessel Group 1 sherd [\#1030-8-a = TRC271], and a Vessel Group 3 sherd [\#840-8-1 = TRC276]) form a separate and distinct chemical group currently assigned to Varga-1, distinguishable from all other INAA analyzed pottery sherds from across Central Texas (Appendix N). These data indicate clay from a source area that has not been previously identified for the manufacture of other Toyah pottery.

Charcoal was abundant across these four units and two samples were sent for AMS radiocarbon dating. Four pieces (\#1025-5-7-1a) yielded a $\delta^{13} \mathrm{C}$ corrected (-24.8\%) AMS radiocarbon date of $320 \pm 40$ B.P. (UGA-12728). Seven tiny pieces of mesquite (\#1055-5-7-1a) yielded a $\delta{ }^{13} \mathrm{C}$ corrected (-25.4\%o) AMS radiocarbon date of $170 \pm 60$ B.P. (Beta-175401). These two dates indicate relatively recent occupation(s).

Five liters of sediment matrix from 25 to $35 \mathrm{cmbd}$ in Unit N127/E74 were floated. The heavy fraction (\#1051-5-4) yielded 181 pieces of debitage less than $6.4 \mathrm{~mm}$ in length and 360 tiny bone fragments. Fifty-five of the bone fragments (15 percent) were burned. The 0.1 liters of light fraction yielded tiny pieces of wood charcoal identified as cottonwood/willow, elm, oak, sycamore, mesquite, and juniper (Appendix I), with mesquite the most abundant. Littleleaf walnut shell fragments were also identified.

The multiple classes of cultural debris in this feature are taken to indicate secondary deposit of cultural debris at a refuse-disposal locality. All the material came from one occupational event, but represents a variety of activities. This feature represents the cleaning and maintenance of other primary activity areas in the general camp.

\subsubsection{Hearths $(n=4)$}

\subsubsection{Feature 9}

Feature 9 was discovered in Block B in Unit N117/E71, slightly over one meter southeast of the debris dump labeled Feature 8. It consisted of a few tightly spaced burned rocks and large charcoal chunks within a semi-circular are measuring 44 by $56 \mathrm{~cm}$ and situated about $22 \mathrm{~cm}$ below the surface. Thickness of the feature was approximately $8 \mathrm{~cm}$ (Figure 8-4). No oxidized matrix or ash was observed. The cross section did not reveal a basin configuration, but showed all materials to be resting on a level plane that indicates placement on a flat surface. The charcoal pieces were found mainly between the burned rocks. The surrounding matrix was a very dark grayish brown (10YR 3/2), whereas the matrix between the burned rocks was a dark yellowish brown (10YR 4/4).

The 28 burned rocks were of various sizes with 50 percent in the smallest size class of 0 to $4 \mathrm{~cm}$ in diameter (Table 8-6). The average rock weight was $375 \mathrm{~g}$. Four of the larger burned rocks were complete, rounded water worn cobbles. Six larger pieces exhibited 1 to 3 breaks, but none of the smaller pieces refit to 


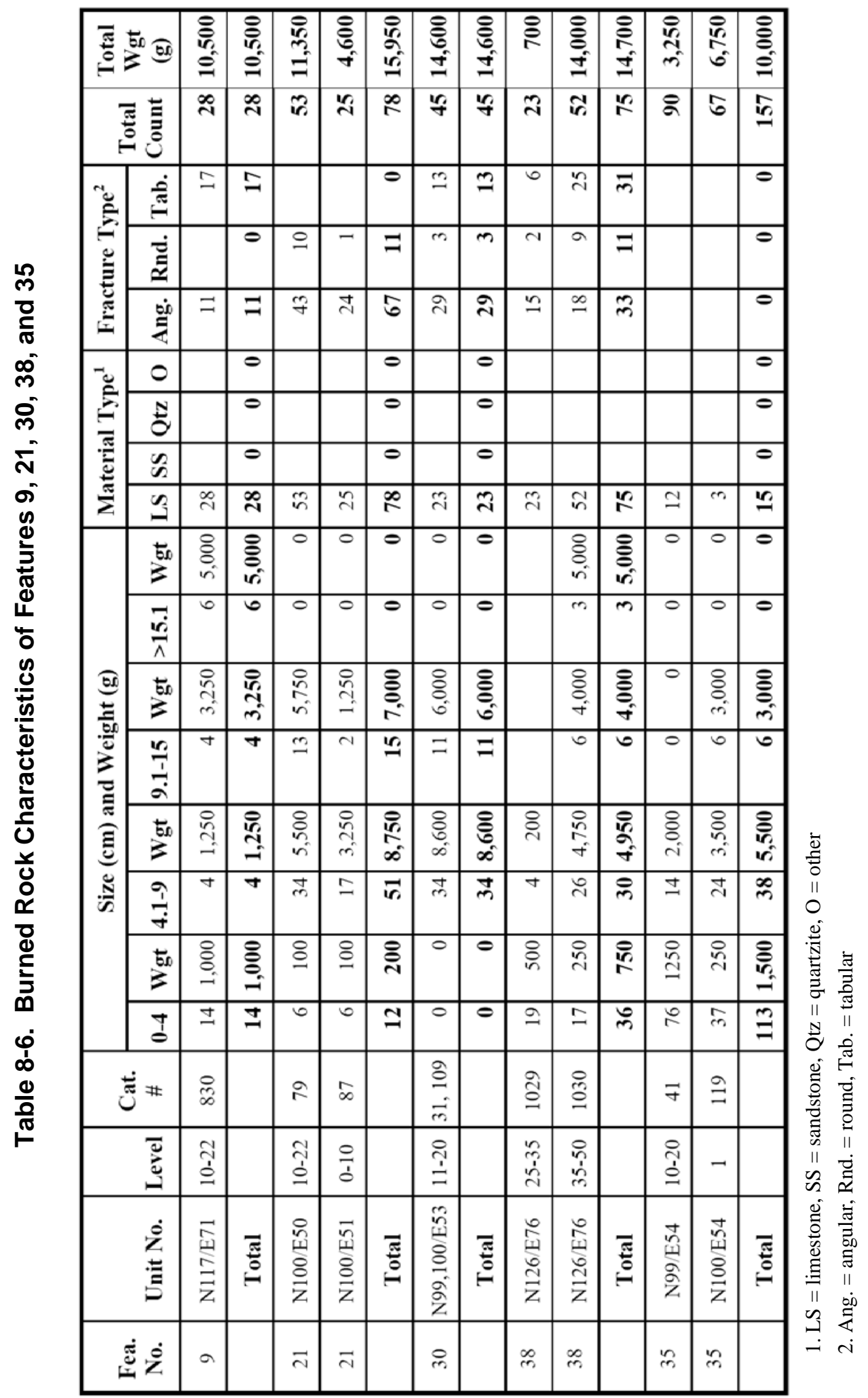


these pieces. Three pieces appeared quite similar in color, angularity and shape, but could not be refit.

Four burned rocks were selected for lipid residue and isotope analyses. Dr. Malainey and Malisza's detailed findings and interpretations of the lipid residues are presented in Appendix G, and a summary is presented here (Table 8-3). Two samples (\#830-5-3-1a and \#830-5-3-4a) yielded borderline medium and moderate to high fat content, interpreted as plant residue. Sample \#830-5-3-2a yielded residue of either a large herbivore with fatty meat or plant. The final sample (\#830-5-3-3a) represented large herbivore plus either plant or bone marrow. The slightly different results indicate that these burned rocks were used to cook a variety of foods. The isotope results from three of the same burned rock pieces used in the lipid analysis yielded $\delta^{13} \mathrm{C}$ values ranging from -21.0 to $-25.8 \%$, indicating $\mathrm{C}_{3}$ plants or animals that ate $\mathrm{C}_{3}$ plants (Table 8-4). If the interpretations from the lipid residues are correct and indicate large herbivore meat, then it would most likely represent deer or pronghorn. However, the isotope values are not clear indicators of this. The $\delta^{15} \mathrm{~N}$ values range from 3.8 to $6.7 \%$ o (Appendix H). These values are not clear indicators of what specific foods were cooked, and more likely represent a mixture of foods.

Individual pieces of charcoal were sent for identification, and some were radiocarbon dated. Three chunks of oak charcoal (\#830-5-4-1a) yielded a $\delta^{13} \mathrm{C}$ corrected (-25.0\%) AMS radiocarbon date of $660 \pm 40$ B.P. (Beta175404).

Feature matrix was sampled at two levels. Eighteen liters were collected from 10 to 20 cmbd and floated (\#830-5-4-1). The cultural materials greater than $6.4 \mathrm{~mm}$ (1/4 in) in size included 93 burned small burned rock fragments, five pieces of lithic debitage and one bone fragment. The heavy fraction sample (\#830-5-4) yielded 24 tiny burned rock fragments, 40 pieces of lithic debitage, 37 tiny charcoal pieces weighing $0.6 \mathrm{~g}$, and 17 very small bone fragments. The 0.3 liters of light fraction (\#830-5-4-1) yielded diverse species of charcoal including agarita, lotebush, cottonwood/willow, juniper, oak, sycamore, Mexican buckeye, pinyon, and a woody legume (Appendix I).

Three liters of matrix (\#830-5-4) from 12 to $15 \mathrm{cmbd}$ was also floated. The cultural material greater than $6.4 \mathrm{~mm}$ included 20 burned rock fragments, five pieces of lithic debitage, and four bone fragments. The heavy fraction yielded six tiny burned rock fragments, 22 pieces of lithic debitage, 28 tiny charcoal pieces, and seven bone fragments.

The matrix around the burned rocks was not oxidized and no pit was detected, but the tight clustering of burned rocks directly associated with relatively large and numerous chunks of charcoal supports an interpretation that this feature was the location of an in situ burning event. The lack of oxidation probably indicates a short-term burning episode.

\subsubsection{Feature 21}

Feature 21 was discovered in Block A in Units N100/E50 and N100/E51 between 7 and 17 cmbs. It consisted of a tight cluster of burned rocks and many pieces of charcoal mixed together in an oval-shaped area (Figure 8-7). The variable depths of the burned rocks and the slightly deeper pieces of charcoal indicate a shallow basin beneath the burned rocks. This cluster measured 62 by $68 \mathrm{~cm}$ in diameter and about $8 \mathrm{~cm}$ thick. Tiny rootlets were the only observed disturbance in the feature. Cactus root and rodent burrows were detected in the northwestern quadrant of Unit N100/E51, but outside the feature. Only a few centimeters vertically separated the base of this feature from the underlying burned rock lens (Feature 1) dated to the Late Archaic period. 


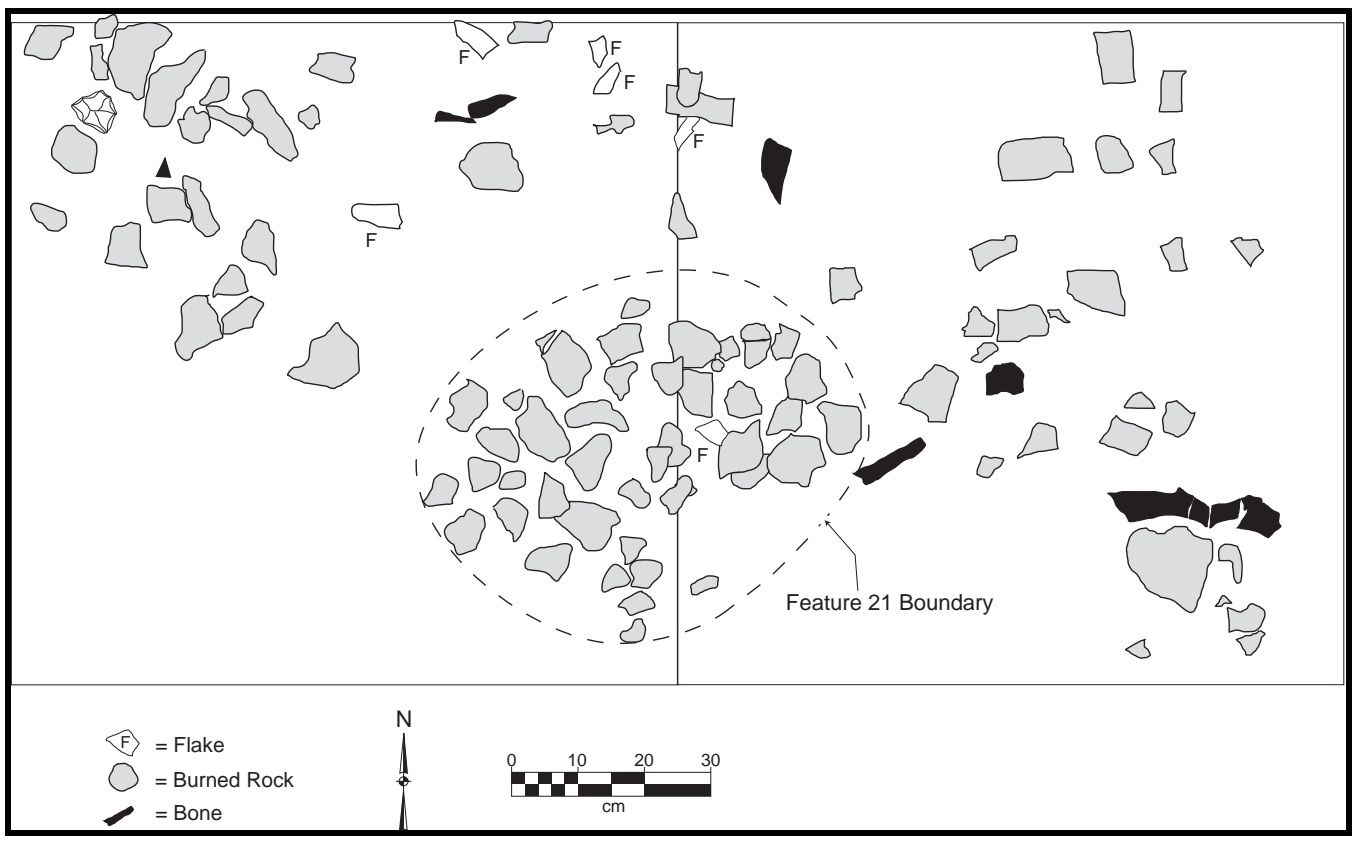

Figure 8-7. Planview of Feature 21 in Block $A$

A total of 78 burned rocks, all angular limestone fragments and weighing $15,950 \mathrm{~kg}$, was recovered from this feature. Nearly 65 percent were in the 4.1 to $9.0 \mathrm{~cm}$ size class with the remaining pieces nearly equally divided into two other size classes (Table 8-6). Three burned rocks (\#79-5-3-1a, \#79-5-3-2a, and \#79-5-3-3a) were analyzed for lipid residues (see Appendix $\mathrm{G}$ for detailed information). Two samples (\#795-3-1a and \#79-5-3-3a) yielded moderate to high fat content interpreted as plant residue. The third piece (\#79-5-3-2a) yielded medium fat content, also interpreted as plant. The slightly different results imply that these burned rocks were used to cook different plant foods. The isotope results on these same three burned rock pieces yielded $\delta^{13} \mathrm{C}$ values from -21.2 to $-24.9 \%$ with $\delta^{15} \mathrm{~N}$ values from 2.8 to 3.6\% (Table 8-4). The $\delta^{13} \mathrm{C}$ values are interpreted to reflect $\mathrm{C}_{3}$ plants or animals that ate $\mathrm{C}_{3}$ plants. The $\delta^{15} \mathrm{~N}$ values also indicate the cooking of plants, with various nuts and seeds falling into to these isotope ranges.
About 111 liters of sediment matrix from four proveniences around the burned rocks was collected and floated in the laboratory. Eighteen liters of sediment from the top $10 \mathrm{cmbd}$ of Unit N100/E50 (\#78) were floated. The cultural debris greater than $6.4 \mathrm{~mm}$ in size includes 94 tiny burned rock, 50 pieces of lithic debitage, 145 tiny bits of charcoal, 23 complete small snail shells, and 97 bone fragments. Eighteen or the bone fragments are burned. Two stone tool fragments are present. The heavy fraction yielded 71 tiny burned rock fragments, 596 pieces of lithic debitage, 60 tiny charcoal pieces, five mostly complete snail shells, and 388 bone fragments. Seventy-one, or 18.3 percent, of the bone fragments are burned. The tiny bone fragments include a single small unburned fish vertebra.

The 83 liters of matrix from the lower part of Unit N100/E50, between 10 and $20 \mathrm{cmbd}$, were floated. Cultural materials greater than $6.4 \mathrm{~mm}$ in size includes 276 tiny burned rock fragments, 65 pieces of lithic debitage, 197 tiny bits of charcoal, 50 complete small snail shells, and 
86 bone fragments, which includes a burned deer dewclaw. Nineteen pieces of bone are burned. The heavy fraction yielded 317 tiny burned rock fragments, 623 pieces of lithic debitage, 1,795 tiny charcoal pieces, and 495 bone fragments. Eighty-two bones are burned.

Twenty-seven liters of sediment from Unit N100/E51, between 0 and $10 \mathrm{cmbd}$, yielded cultural debris greater than $6.4 \mathrm{~mm}$ in size, including 21 tiny burned rock, 34 tiny chert fragments, 48 tiny charcoal pieces, 17 more or less complete snail shells, and 27 bone fragments. Eight flakes and nine bone fragments are burned. The bones include one turtle shell fragments and one rodent long bone. The heavy fraction yielded 14 tiny burned rock fragments, 439 pieces of lithic debitage, 116 tiny charcoal pieces, 3 mostly complete small snail shells, and 168 very small bone fragments. The charcoal pieces include a thin burned nutshell fragment. The bones include a tiny fish vertebrae and a distal humerus of a rabbit. Thirty-eight bone fragments are burned.

Still in Unit N100/E51, but slightly lower, between 10 and $15 \mathrm{cmbd}$, the four liters floated (\#88) yielded cultural debris greater than $6.4 \mathrm{~mm}$ in size consisting of 67 tiny burned rock fragments, 71 tiny charcoal pieces, five complete snail shells, and four bone fragments. One bone fragment was burned black. Larger chunks of charcoal were added to the light fraction for identification. The heavy fraction yielded 74 tiny burned rock fragments, 62 pieces of lithic debitage, 116 tiny charcoal pieces, and 50 bone fragments. Six pieces, or 12 percent, of the bone fragments are burned.

The 2.2 liters of light fraction from the four samples and six individual charcoal pieces were sent to Dr. Dering for identification of macrobotanical materials. These samples contained seven wood types including Carya family (possibly pecan), mesquite, oak, elm, woody legume (leadtree or acacia), and juniper (see Appendix I). Oak is the most abundant wood followed by juniper and both woods are well-suited for use as fuel. Littleleaf walnut and pecan nut fragments, as well as stool/yucca/agave caudex (stem) fragments, were also identified. The charred stem fragments may represent food remains that were accidentally burned, as they are not good fuel sources. The nutshell fragments may or may not be food resources, with the walnut providing very minimal meat compared to pecan nut.

Chunks of charcoal were abundant and pieces were sent for AMS radiocarbon dating. One large chunk of juniper wood was split into three pieces to obtain three individual dates from two laboratories. One piece (\#78-5-7-1b) yielded a $\delta^{13} \mathrm{C}$ corrected (-24.0\%) AMS radiocarbon date of $380 \pm 30$ B.P. (Beta-183623). A second piece (\#78-5-7-1a) yielded a $\delta^{13} \mathrm{C}$ corrected (-24.9\%o) AMS radiocarbon date of $380 \pm 40$ B.P. (UGA12707). The third piece (\#78-5-7-1c) yielded a $\delta^{13} \mathrm{C}$ corrected (-24.7\%) AMS radiocarbon date of $300 \pm 40$ B.P. (UGA-12707; Table 8-1).

The hint of a basin under this tight concentration of burned rocks, coupled with quantities of chunks of charcoal, implies that Feature 21 was an in situ burning event, which lacked visual signs of oxidation. This hearth is thus interpreted as representing a primary activity locus in the Toyah component dating to about 300 to 400 years B.P. Although this was an in situ hearth feature, incidental cultural debris of various classes (i.e., lithic debris and bones) was discarded into it.

\subsubsection{Feature 30}

Feature 30 was a loose cluster of limestone burned rocks that straddled the north-south boundary of Units N99/E53 and N100/E53 in Block A (Figure 8-8). This cluster was in an irregular oval, which measured 87 by $110 \mathrm{~cm}$ in diameter and was about 6 to $8 \mathrm{~cm}$ thick. Light charcoal staining was present between the rocks and in the profile, indicating a shallow basin 
with a flat bottom and moderately steep walls. The scattered charcoal defined the basin-shaped base, which was not easily detected. The burned rocks were predominately in one layer, but occasionally one burned rock was atop another. Rodent and root disturbances were noted, but had not significantly disturbed the feature.

Forty-five burned rocks, weighing 14,600 g, dominated the feature fill, with 75 percent in the 4.1 to $9 \mathrm{~cm}$ size range (Table 8-6). Surprisingly, no burned rocks were in a smaller size class, possibly the result of a biased collection or recording process. The average rock weight was $324 \mathrm{~g}$. No burned rocks were sampled for their lipid residue contents.

Fourteen flakes, one edge-modified tool (\#1095-10), and four bone fragments were in the fill. The four bone fragments were all less than $3 \mathrm{~cm}$ in diameter, with two taxonomically unidentifiable pieces and two falling within the deer/antelope size range. One piece was burned black and brown, and another was black and white in color.

Six liters of feature fill (\#109-5-4) from 11 to 22 cmbd in Unit N100/E53 were floated. The heavy fraction yielded 15 tiny burned rock fragments, 32 pieces of lithic debitage, 88 tiny charcoal pieces, and nine bone fragments. Three bones and a tiny nutshell fragment were burned.

About 0.1 liters of light fraction yielded oak and mesquite wood, a mesquite seed fragment, and eight tiny pieces of slag (Appendix I). The burned mesquite seed may or may not indicate that mesquite seeds were being processed as food, since seeds potentially were attached to mesquite wood being used as a fuel wood.

Outside the northern edge of Feature 30 in Unit N100/53, material including burned rocks ( $n=35$; weighing $5850 \mathrm{~g}$ ), charcoal, bones ( $n=65)$, lithic debris $(n=77)$, and stone tools were recovered. The tools include one medial section of an untyped dart point (\#109-10) and two edge-modified flakes (\#109-11 and \#109-

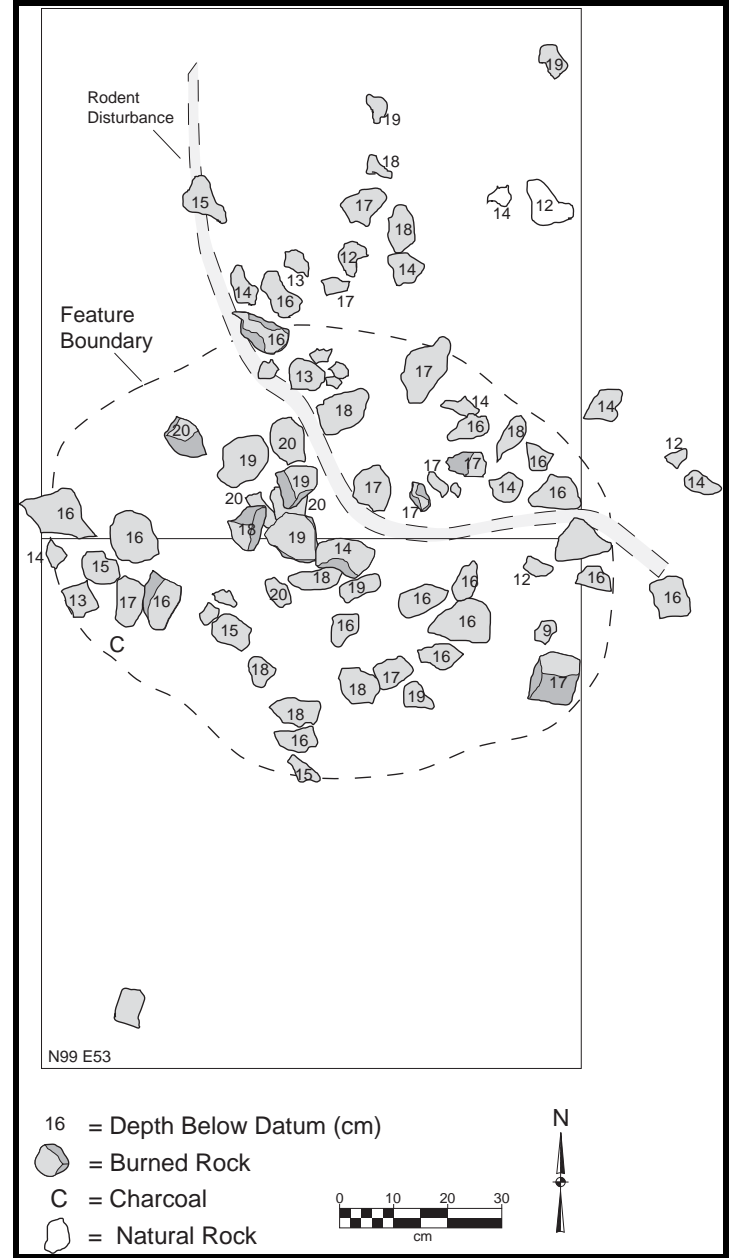

Figure 8-8. Planview of Feature 30 in Block A

12). Outside the southern edge, in Unit N99/E53, were scattered burned rocks

( $n=15$; weighing about $500 \mathrm{~g}$ ) another 56 pieces of debitage, and 12 bone fragments. These items indicate that various other activities were carried out immediately adjacent to this hearth. The concentration of burned rocks in direct association with charcoal, in what appeared to be a shallow basin, indicates this feature represents primary in situ heating.

\subsubsection{Feature 38}

Feature 38 was along the very eastern edge of the right-of-way, immediately under the fence line in Block B, and immediately east of burned 
rock scatter Feature 25 (Figure 8-6). It was in Unit N126/E76, of which the western $30 \mathrm{~cm}$ section was excavated (the only part of this unit within the highway right-of-way). Initially, a row of three burned rocks were exposed in the very eastern edge of Unit N126/E75, all resting at the same elevation in the wall profile, which hinted at some type of feature within the adjacent unit. The $30 \mathrm{~cm}$ east-west width by the one-meter long unit proved to contain a tight cluster of burned rocks, dense charcoal, many bone fragments, and lithic debitage distributed in an arcuate pattern. This arc of burned rocks extended across the entire unit with cultural debris found in the 15 to $18 \mathrm{~cm}$ thickness that bracketed the top and bottom of the feature. Although not obvious, slight elevation differences in the bottoms of the burned rocks marked the base a shallow pit or basin. The matrix directly above the feature was a dark yellowish brown (10YR 3/4) compared to the internal feature matrix that was a very dark gray (10YR 3/1). The feature's maximum dimensions and shape are unknown, and the material frequencies are for an undetermined percentage of a larger feature.

This arc shaped part of Feature 38 that covered an area $30 \mathrm{~cm}$ wide, $100 \mathrm{~cm}$ long, and about $20 \mathrm{~cm}$ in depth yielded 75 limestone burned rocks weighing $14,700 \mathrm{~g}$. Forty-eight percent of the burned rocks were within the 0 to $4.0 \mathrm{~cm}$ size class and 40 percent within the 4.1 to $9.0 \mathrm{~cm}$ size class (Table 8-6). The average burned rock weight was $196 \mathrm{~g}$.

Parts of four selected burned rocks were sent for lipid residue and stable isotope analyses. Drs. Malainey and Malisza's detailed findings on the lipid residues and their interpretations are presented in Appendix G, with a summary of the results presented here (Table 8-3). Two burned rocks (\#1030-5-3-1a and \#1030-5-3-2a) yielded residues interpreted as representing large herbivore. However, it is possible that the somewhat fatty residues might reflect plant residues. A third piece (\#1030-5-3-3a) yielded a moderately high fat content interpreted as plant. The forth piece (\#1030-5-3-46a) yielded high fat content interpreted as plant. The different results imply that these burned rocks were used to cook various plant foods, and possibly meat of a large herbivore.

The isotope results on these same burned rock pieces yielded $\delta^{13} \mathrm{C}$ values from -18.6 to $-24.3 \%$ with $\delta^{15} \mathrm{~N}$ values from -2.2 to $11.4 \%$ (Table 84). The $\delta^{13} \mathrm{C}$ values are interpreted to reflect $\mathrm{C}_{3}$ plants or animals, which ate $\mathrm{C}_{3}$ plants. The $\delta^{15} \mathrm{~N}$ values also imply that plants were cooked. Nuts and seeds from a variety of plants would fall within these isotope ranges.

One fragment of burned limestone (\#1030-5-32c) was selected for radiocarbon dating. This yielded a $\delta^{13} \mathrm{C}$ corrected (-7.1\%) AMS radiocarbon date of $11,980 \pm 40$ B.P. (UGA12729;

Table 8-1). Obviously this is not the true age of Feature 38 since this date did not apparently capture the organic residues thought to be present from this recent Toyah event. This date is not acceptable, as it is much too old for this component. Obviously, much older residues resided in this burned rock matrix and were not destroyed during the Toyah heating event that must have occurred.

About $12.7 \mathrm{~g}$ of charcoal was recovered from Feature 38. Many pieces were relatively large chunks between 5 and $20 \mathrm{~mm}$ in length. Selected charcoal pieces were radiocarbon dated and identified as to species represented. Seven pieces of wood charcoal (\#1030-5-7-1a) from the lower part of this feature were sent for radiocarbon dating. These pieces yielded a $\delta^{13} \mathrm{C}$ corrected (-25.3\%) an AMS radiocarbon age of $390 \pm 60$ B.P. (Beta-175400; Table 8-1). This is an acceptable date for this Toyah feature as it fits well with most of the other radiocarbon dates obtained from Toyah components at this and other Toyah sites. The wood was identified as willow/cottonwood (Appendix I). 
Bone fragments ( $n=104)$, lithic debitage $(n=7)$, ceramic sherds $(n=4)$, and stone tools $(n=3)$ were scattered among the burned rocks and charcoal chunks. The stone tools include a complete Padre point (\#1030-5-10) and two edgemodified flakes (\#1030-5-11 and \#1030-5-12). The Padre point was submitted for use-wear analysis, which revealed oblique striations and polish plus plant fragments in the haft area that show this specimen was hafted. However, the inferred use and contact material are unknown (Appendix C). Small, unidentifiable bone fragments (94 percent) dominated the sample of 104 recovered pieces. Nearly 10 percent $(n=10)$ were burned black, and nearly 11 percent $(n=11)$ were burned to a black and brown color. Five pieces fall into the bison size range.

The four potsherds discovered in this feature were assigned to Vessel Group 1 based on visible characteristics. This vessel group generally exhibits a dark unpolished exterior with a roughly finished interior. Petrographic analysis on a sherd from Vessel Group 1 indicates a locally manufactured vessel. These four sherds are larger than most of the other sherds collected from the Varga Site. The largest sherd, weighing $10 \mathrm{~g}$ (\#1030-5-4-8-1a), was sent for lipid residue analysis. The lipid results yielded moderate to high fat content that is interpreted as indicating plant residues (Appendix G). Ground matrix extracted from the interior of that same sherd (\#1030-5-3-1b) was sent for stable carbon and nitrogen isotope analysis. The $\delta^{13} \mathrm{C}$ value is $-14.3 \%$ and is interpreted to reflect use of $\mathrm{C}_{3}$ plants or animals that ate $\mathrm{C}_{3}$ plants. The $\delta^{15} \mathrm{~N}$ value is $2.8 \%$, but is suspect as the measured nitrogen weight was quite low. These values generally appear to indicate the cooking of plants. A second sherd (\#1030-8-a), weighing $1.6 \mathrm{~g}$, and from just outside the feature, was sent for INAA. The INAA results indicate that this sherd (TRC271) together with two other sherds (\#1054-8-1a or TRC270 and \#840-8-1a or TRC276) form a group from this one location designated as
Varga-1 (Appendix N), quite distinct from other analyzed Toyah sherds from Central Texas.

Nineteen and one-half liters of matrix (\#1030-57) from around the burned rocks in Feature 38 were collected for flotation. The material over $6.4 \mathrm{~mm}$ long included 151 pieces of lithic debitage, 28 tiny burned rock fragments, 130 tiny charcoal pieces, 52 more or less complete Polygyridae and Helicinidae snail shells, 10 Rabdotus snail shells, 203 tiny bone fragments and one tiny tip of a stone tool. The heavy fraction yielded 74 tiny burned rock fragments, 508 tiny pieces of lithic debitage, 242 tiny charcoal pieces, two ceramic sherds, seven seeds, 7 small more or less complete Polygyridae and Helicinidae snail shells, and 543 tiny bone fragments. The 0.4 liters of light fraction yielded two burned prickly-pear seeds and three carbonized sotol-yucca-agave leaf fragments, plus five burned cottonwood/willow pieces, five milliliters of buttonbush, 24 oak pieces, five juniper pieces, and 14 woody legume charcoal pieces (Appendix I). The largest sotol-yucca-agave leaf fragment, measuring 11 by $22 \mathrm{~mm}$, was most likely a part of the basal portion of a sotol leaf.

The observed pattern of distribution in the burned rocks, coupled with the relatively high quantities of charcoal between the rocks, indicates this feature was probably an in situ hearth. However, the presence of other forms of cultural debris creates some uncertainty in this interpretation, since the accumulation of a variety of debris might indicate trash-disposal. If multiple occupations with overprinting of activities took place, the result could well account for the somewhat ambiguous character of this hearth-like feature. It is also possible that the lithic debitage and bones were discarded into a hearth during its period of use. 


\subsubsection{Occupation Zones $(n=3)$}

\subsubsection{Feature 22}

Feature 22 was encountered at 20 to $21 \mathrm{cmbd}$ in Unit N107/E55 within Block A and is considered part of a broader spread of occupational debris. The material in Feature 22 consisted of scattered chunks of charcoal and relatively dark-colored sediment in a $3 \mathrm{~cm}$ thick zone across the southern third of the unit. This $3 \mathrm{~cm}$ thick zone was detected a few centimeters below the north part of Feature 18. The charcoal-rich area measured about $37 \mathrm{~cm}$ north south by $85 \mathrm{~cm}$ east west. No evidence of a pit or basin was observed around or beneath the charcoal staining, and no oxidized matrix was detected. Several small bone fragments $(n=6)$, and lithic debris $(n=7)$ were in this same unit. Burned rocks were not in direct association, although two burned rocks were immediately to the north, but at slightly lower elevations. Since the stratigraphy appears compressed here it is not clear which materials were associated with other materials, or the exact age of this charcoal.

Two liters of matrix (\#603-4-1) from 17 to $22 \mathrm{cmbd}$ in the area of the charcoal were collected for flotation. The heavy fraction yielded 29 tiny pieces of lithic debitage, 17 tiny pieces of charcoal g, and 57 tiny bone fragments. Ten bone fragments were burned. The less than 0.1 liters of light fraction yield 13 pieces of charcoal that could not be identified as to species (Appendix I).

It is not clear what this scattered charcoal area represents. This is due in part to the fact that it occurred just a few centimeters below and to the north side of burned rock dump Feature 18, which lacked any sign of in situ burning or basin. This may be the remains of a scattered surface hearth, part of the overlying occupation zone, or the remnant of another occupation not well represented across this area.

\subsubsection{Feature 35}

Feature 35 was located along the southern margin of Block A in Units N99/E54 and N100/E54 between 10 and 25 cmbd (Figure 8-9) and is considered part of a broader occupation zone. The southern edge of the Unit N99/E54 was partially disturbed as it lay along the northern margin of the bladed dirt entrance road to adjacent private property. Mechanical stripping of the ground surface during the initial investigations may have damaged this nearsurface feature.

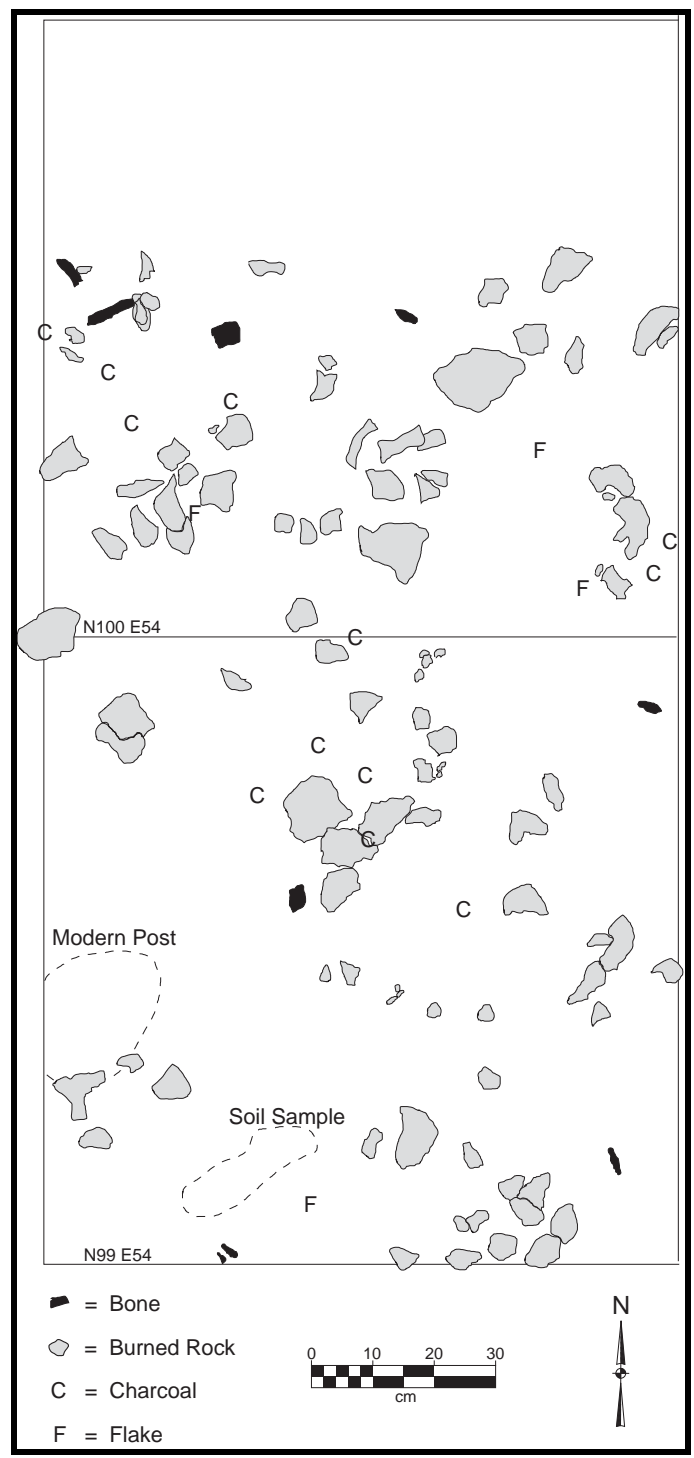

Figure 8-9. Planview of Feature 35 in Block A 
These two units revealed a loose distribution of diverse cultural debris, which represents $2 \mathrm{~m}^{2}$ of a broader area of occupational debris. This was immediately east of Feature 30; a shallow basinshaped hearth that contained mostly burned rocks and charcoal.

Scattered burned rocks dominated this area, and chunks of charcoal, lithic debitage, and bone fragments were found scattered across the two units (Figure 8-9). A modern fence post about $25 \mathrm{~cm}$ in diameter was detected along the western edge of Unit N99/E54, which caused some disturbance to the archaeological deposits, as did rodent and root activities. The matrix was a dry and crumbly light brownish gray (10YR 6/2) clay loam.

Level 2 of Unit N99/E54 yielded 71 bone fragments, 123 pieces of lithic debitage, chunks of charcoal, one edge-modified tool (\#41-10), and 90 burned rocks weighing 3,250 g. Level 2 of Unit N100/E54 yielded three bone fragments, 67 pieces of lithic debitage, and 98 burned rocks weighing 7,250 g. These two levels yielded 157 burned rocks weighing $10,000 \mathrm{~g}$ that ranged in size from 1 to $15 \mathrm{~cm}$ in diameter. The small 0 to $4 \mathrm{~cm}$ size class dominated with 72 percent, followed by 24 percent in the 4.1 to $9 \mathrm{~cm}$ size class (Table 8-6). The average burned rock weight is $64 \mathrm{~g}$.

The 74 pieces of bones include one deer ulna notch, six bison-size long bone fragments, two bison tooth fragments, one rabbit-size long bone fragment, and 90 unidentifiable fragments. Fifteen of the unidentifiable fragments were burned black and brown, with another 12 burned to a gray color. The gray- colored fragments reached temperatures between 400 and 600 degrees Celsius (Nicholson 1993). The bison long bone fragments were the largest fragments, with the largest piece measuring nearly $9 \mathrm{~cm}$ in length.

Eight liters (\#119-5-4) of matrix from 10 to 20 cmbd in Unit N100/E54 were collected and floated. The heavy fraction yielded 45 tiny burned rock fragments, 191 tiny pieces of chert, 140 tiny pieces of charcoal, 31 tiny burned clay pieces, and 50 tiny bone pieces. Sixteen bones, including a rabbit tooth and a rodent humerus, were burned. The 0.2 liters of light fraction yielded charred sotol-yucca-agave type caudex fragments plus oak, juniper, and woody legume charcoal (Appendix I). The woody legume dominated the sample.

This scattered and diverse cultural debris in no detectable pattern was part of the broader Toyah component that extended across much of the excavated area. This debris does not represent one specific recognizable activity, but rather general range of camp activity.

\subsubsection{Feature 36}

Feature 36, part of a more general zone of occupational debris, was detected in three adjacent units-N101/E47, N102/E47, and N103/E47-at the southern end of a one-meter wide north-south strip between BT 1 and the right-of-way fence line at the western edge of Block A. The occupation zone was easily recognized here through the high density of cultural debris, which drops sharply toward the northern limit of Unit N103/E47. This buried zone lies between 29 and $35 \mathrm{cmbd}$, and was at elevations similar to those of other Toyah features and material across the site. In this zone three distinct 1 to $2 \mathrm{~cm}$-thick lenses of cultural debris were detected; one at $33 \mathrm{cmbd}$, a second at 35 to $36 \mathrm{cmbd}$, and another at 38 to 39 cmbd. Each thin lens contained cultural debris lying relatively flat and extended across the entire unit, indicating that three separate occupations were present. North-south BT 1, excavated during Phase I, truncated the eastern side of these three units, which contained the thin lenses. East of BT 1 these individual lenses were not individually recognized in the broader block excavations. They potentially merged, or had been disturbed beyond recognition, outside 
this one limited area along the right-of-way margin, where deposition was the greatest and the deposits were the least disturbed.

The dense cultural debris from these three units includes 372 burned rocks, 1,362 small bone fragments, 1,212 pieces of lithic debitage, 74 stone tools, nine ceramic sherds, two mussel shell fragments, and charcoal. In this zone four small clusters of material were recognized in Unit N101/E47. One cluster consisted of burned bone fragments, which encompassed an area about a $20 \mathrm{~cm}$ diameter around a relatively large burned rock. A second cluster consisted of bones fragments and lithic debitage between 34 and $36 \mathrm{cmbd}$ and encompassed an area of about 30 by $40 \mathrm{~cm}$. A third cluster, which consisted of bone fragments and small burned rock pieces in an area of about 20 by $30 \mathrm{~cm}$, was in an apparent rodent burrow at 33 to $40 \mathrm{cmbd}$. The forth cluster consisted of mostly lithic debris, a large beveled biface, and a Perdiz point between 33 and $39 \mathrm{cmbd}$, and scattered over an area of about 35 by $20 \mathrm{~cm}$. These small dumps of diverse debris may represent discarded materials from primary activity areas in adjacent areas on the site.

Charcoal samples believed to represent each of these three thin, but recognizable cultural lenses across the southern two units were selected for radiocarbon dating to document the age range of these three Toyah events. The shallowest, piece of oak charcoal (\#158-5-7-1a), yielded a $\delta^{13} \mathrm{C}$ corrected (-26.5\%) AMS radiocarbon age of $400 \pm 40$ B.P. (Beta-175397). The charcoal piece from the middle lens (\#159-5-7-1a) yielded a $\delta^{13} \mathrm{C}$ corrected (-25.5\%) AMS radiocarbon age of $940 \pm 40$ B.P. (Beta-175398). The lowest piece (\#160-5-7-1a), a mesquite chunk, yielded a $\delta^{13} \mathrm{C}$ corrected (-25.6\%) AMS radiocarbon age of $920 \pm 40$ B.P. (Beta-175399; Table 8-1). The highest piece reveals the youngest age and fits well with the other Toyah component assays obtained here and documented elsewhere from other sites. The two lower pieces are older than documented Toyah occupations and may represent some earlier use of the site. Root and rodent disturbances were detected in these two units and it is possible that some mixing of charcoal occurred. However, a cultural component that dates to about 900 to 1,000 B.P. was not otherwise clearly defined at this site. A couple of arrow points recovered, including one Scallorn and one Edwards point, may indicate that an occupation did take place. In any case, the two older dates do not represent the Toyah component.

The 372 burned rocks exhibit a size range from $1 \mathrm{~cm}$ to just over $15 \mathrm{~cm}$ in length. The smallest size range comprises 56 percent of these, followed by nearly 38 percent in the 4.1 to $9 \mathrm{~cm}$ size class, with only five percent greater than $9.1 \mathrm{~cm}$ (Table 8-7). The average rock weight is a relatively light $80 \mathrm{~g}$.

Three burned rocks (\#158-5-3-1a, \#158-5-3-2a, and \#158-5-3-3a) were analyzed for their lipid residues. Details of findings and interpretations are presented in Appendix G, and a brief summary is offered here (see also Table 8-3). Two samples (\#158-5-3-1a and \#158-5-3-2a) yielded borderline moderate to high fat and high fat content, both interpreted as representing plant matter. The third piece (\#158-5-3-3a) yielded moderate to high fat content, also interpreted as plant. The slightly different results imply that these burned rocks may have been used to cook various plant foods.

The isotope results on the same three burned rocks yielded $\delta^{13} \mathrm{C}$ values from -24.3 to $-24.8 \%$ with $\delta^{15} \mathrm{~N}$ values from 3.4 to $6.1 \%$ (Table $8-4$ ). The $\delta^{13} \mathrm{C}$ values are fairly uniform and are interpreted to reflect $\mathrm{C}_{3}$ plants or animals that ate $\mathrm{C}_{3}$ plants. The $\delta^{15} \mathrm{~N}$ values show some variation, but generally indicate cooking of plants. Nuts and seeds from a variety of plants would fall within these isotope ranges. 


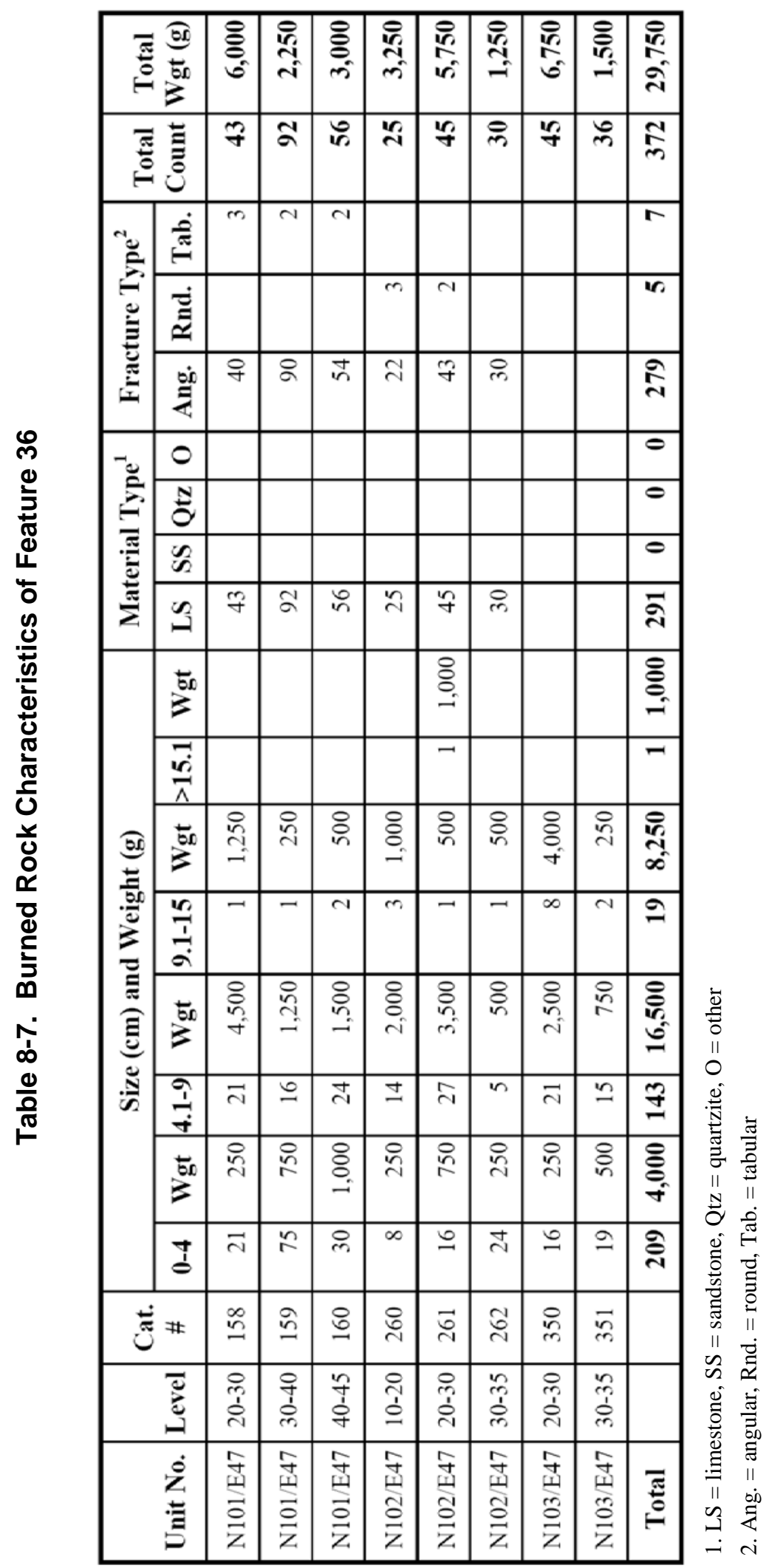


Small fragments dominate the 1,362 bone fragments weighing $1,128.7 \mathrm{~g}$. Some six percent are identifiable to five different size groups or recognizable species. Bison and bison size pieces are represented by 69 pieces weighing $464.4 \mathrm{~g}$, and include one left bison acetabulum, one $2^{\text {nd }}$ phalanx, one cuneiform, many long bone and rib fragments, and a few tooth fragments. Four bison-size long bone fragments were burned to a black and brown color. Deer/antelope size pieces are represented by 14 pieces weighing $59.5 \mathrm{~g}$, and include tooth fragments, two deer inner ear elements, one distal left deer humerus, one deer cuneiform, one deer $3^{\text {rd }}$ phalange, one dewclaw, and many long bone and rib fragments. A single skull fragment was attributed to an antelope. Also identified were one proximal metapodial of a rabbit, one rabbit-size long bone fragment, one bird-bone element, one turtle carapace fragment, and one proximal canid metapodial. The 94 percent unidentifiable fragments weighing $595.4 \mathrm{~g}$ were mostly tiny scraps, with eight percent burned to a black, or black and brown, color.

The 75 stone tools include 52 edge-modified flakes, 13 projectile points and point fragments, four bifaces including one complete fourbeveled knife, three cores, one drill, and one uniface. The projectile points, all arrow points, consist of three Perdiz, two Bonham, and eight untypable fragments.

The nine sherds include seven pieces assigned to Vessel Group 4, and one each assigned to Vessel Groups 1 and 3. All pieces are less than $3 \mathrm{~cm}$ in diameter. Two liters of matrix (\#262-5-4) from 30 to34 cmbd in Unit N102/E47 were collected and floated. The less than 0.1 liters of light fraction yielded oak and juniper charcoal (Appendix I). Individual charcoal chunks were identified as mesquite (\#160-5-7-1b) and oak (\#158-5-7-1b) (Appendix I). The heavy fraction yielded 14 tiny burned rock pieces weighing $0.8 \mathrm{~g}, 130$ tiny chert pieces weighing $2.0 \mathrm{~g}$, 23 tiny charcoal pieces weighing $0.2 \mathrm{~g}$, and
153 tiny bone fragments weighing $3.6 \mathrm{~g}$. Fifteen of the tiny bones were burned to a black and brown color.

This Toyah component lies immediately atop a Late Archaic burned rock midden dating between ca. 1,700 and 2,200 B.P. The Toyah burned rocks were noticeably smaller and the lithic debitage is much more extensive than the lower Late Archaic component. The Toyah cultural materials lie at the base of geomorphic Unit I, which is a loose, unconsolidated, very dark grayish brown (10YR 3/2) clay loam with very few natural inclusions. Below that is Depositional Unit II, a black granular matrix, which contained the Late Archaic materials. The break between the two geomorphic units is quite distinct and may represent an unconformity.

A barbwire fence was located immediately along the western edge of the hand-excavations and vertical fence posts have penetrated the subsurface. This disturbed part of the occupation zone. An occasional metal fence staple and metal nail were found mixed in with cultural materials. A modern entrance road into the adjacent property has destroyed the deposits at the south edge of Unit N101/E47 and truncated the upper cultural deposits at that end of the excavations. Rodent activity was noted in some limited areas.

\subsubsection{Summary and Discussion of Features}

These 11 Toyah component features undoubtedly reflect multiple camping events as indicated by the age differences reflected in the 15 acceptable radiocarbon dates (Table 8-1). The 15 radiocarbon dates from eight features indicate a general time age between about 170 to 660 B.P. This range does not consider the old wood factor that might have played a role in some age differences, or the possibility of mixing from modern activities, especially in a single feature. For example, the 80 B.P. date 
(Beta-175405) derived from charcoal from Feature 8 is much too recent for this prehistoric component, especially since this same feature also yielded three earlier dates that average about 600 B.P. This young charcoal is assumed to date a modern piece that became intermixed with the prehistoric materials.

These 11 features show some variability in onsite activities. The four hearths represent in situ heating, are nodal points of primary activity areas. The individual burned rocks in these primary heating features have an average weight of over $200 \mathrm{~g}$ whereas those in Feature 9 average $375 \mathrm{~g}$. The specific function served by the hearths is unclear, though cooking is certainly a likely candidate. The one identified bone pile and burned rocks scatters reflect minimally two other activities. The bone pile may reflect the location of various activities that included, but are not limited to, bones set aside for defleshing, bones set aside for marrow and/or grease extraction, or simply discard.

The burned rock piles and scatters may reflect different events, such as discard piles of one or more events, or other related cooking activities. The burned rocks in the three dumps average less than $125 \mathrm{~g}$, and generally less than $75 \mathrm{~g}$, a much lighter weight than those in the identified hearths. The dumping of unwanted diversified cultural debris (i.e., Feature 8 and 25) probably reflects the cleaning of primary activity areas and secondary disposal in one specific area. The latter type of cleaning activity may reflect a relatively extended stay in this campsite, since the cultural material must initially accumulate in primary use areas and then outlast is usefulness, prior to cleaning and removal of excess material to another location in the camp.

Botanical identifications of charred materials from about 299 liters of floated matrix extracted from 10 features and individual pieces of burned macrobotanical remains indicate a variety of exploited resources and correspondingly show something about environmental resource mosaic.
Minimally, 18 plant species were identified and include the only samples of pinyon wood, Mexican buckeye, elm, sycamore, cottonwood/willow, cheno-am, hickory, and agarita in the site. These eight species were not identified in earlier contexts at the Varga Site. This may be an indication that the environment changed over time, or that at least the selection process by the human groups became more diversified. Ten other plant species were also identified and include buttonbush, Condalia or buckthorn, woody legume, littleleaf walnut, juniper, mesquite, oak, lotebush, prickly pear seeds, and sotol-yucca-agave. These latter plant species were identified in earlier components and indicate some continuity of the available plant resources over time. Regardless of what the local environment was like, the Toyah peoples used diverse plant resources to fuel their fires and as part of their food consumption.

The interpretations from the lipid residue analyses imply that only about 27 percent of the 29 individual samples indicated large herbivore meat, and 57 percent of those could actually represent plant signatures (Table 8-3). The 27 percent figure for meat residue seems low when one examines the quantity of bone recovered. This low percentage interpreted in the lipid residues may be influenced by how the meat, marrow, etc. from the animals was processed. It may be that much of the meat, marrow, etc. was consumed without cooking by hot rocks. Many ethnographic and historic accounts indicate that peoples ate meat without cooking it, but other means of cooking meat are possible without the direct use of hot rocks. In contrast few plants can be directly consumed without cooking or preparation (seeds, nuts, and berries being exceptions), and this may be what is reflected in the lipid residue analyses. Most burned rocks yielded quantities of moderate to high fat residues interpreted as representing from plants; medium to borderline medium fat content is present in about 
21 percent of the burned rocks, whereas the rest have higher fat content.

In two instances, a burned rock scatter (Features 8 and 25) was next to an in situ heating element/hearth (Features 9 and 38). In each case these apparently paired features (Features 8 and 9, and Features 25 and 38) contained some burned rocks, which yielded residues that were interpreted as indicating large herbivore meat. These were only recovered from Block B, whereas no identified features in Block A yielded burned rocks with residues interpreted as representing large herbivores. This horizontal difference may signal specific activity localities, or different activities in different occupational episodes.

\subsection{Chipped Stone Tools}

The $207.75 \mathrm{~m}^{2}$ excavated area produced a range of informal tools, including 1,380 edge-modified flakes that include utilized flakes, gravers, rejuvenation flakes, spokeshaves, etc., as well as numerous formal stone artifacts, including 229 projectile points, 96 bifaces, 65 scrapers, 37 cores, 16 drills, seven unifaces, one anvil, and one hammerstone, and 26,323 pieces of lithic debitage, 18,698 bone pieces, 15,934 burned rocks, 115 ceramic sherds, and 45 mussel shell fragments. Each major class of lithic artifacts is described and discussed below.

The number of stone tools, formal and informal, totals 1,832. Individual attributes and metric characteristics are recorded for each piece, excepting edge-modified flakes. Summaries of attributes and metric measurements are provided for each tool class. The projectile point class is subdivided into identifiable point types to provide more detailed descriptions and characteristics. Tool classes are generally thought to represent specific activities, but several individual specimens from various tool classes were arbitrarily selected for use-wear analyses to investigate tool specific functions. Individual use-wear findings are presented following each class summary. Each group is presented below, beginning with the identifiable types of projectile points.

\subsubsection{Projectile Points}

Projectile points are subdivided into 216 arrow points and 13 dart points. Seventy-six of the arrow points can be typed. They fall into nine existing typological groups (53 Perdiz, 10 Cliffton, five Bonham, two Scallorn, two Guerrero, one Edwards, one Cuney, one Harrell, and one Padre), accounting for 35 percent of the arrow points, with remaining 140 (65 percent) consisting of untypable fragments. The 13 dart points, which make up slightly more than five percent of the total points, include four Frio, one Group 2, one Merrill, one Baker, and six unidentifiable dart point fragments. The nine different recognizable arrow point types are presented below as groups in order of their frequency. The dart points, Archaic-era objects assumed to have been either stratigraphically displaced or, alternatively, to have been picked up and used/discarded by Late Prehistoric site occupants, are subsumed under discussions of earlier components, according to their estimated chronological ages.

The 53 Perdiz points dominate (70 percent) the sample to typable arrow points (Figure 8-10). All recovered Perdiz points were from the Toyah component, including one that was found in backdirt. All were manufactured from finegrained chert, with no cortex remaining on any of the thin flake preforms employed for their production. Only one point exhibits surface patination. Heat-treatment was not observed on any specimen. Only one specimen exhibits edge beveling. Thirty-eight percent are more or less complete, with 36 percent are proximal fragments, 19 are percent medial fragments, and nearly eight percent are distal segments. Many lateral edges were damaged with those still intact exhibiting mostly straight edges. Use is believed to have caused all of the observed breakage. 


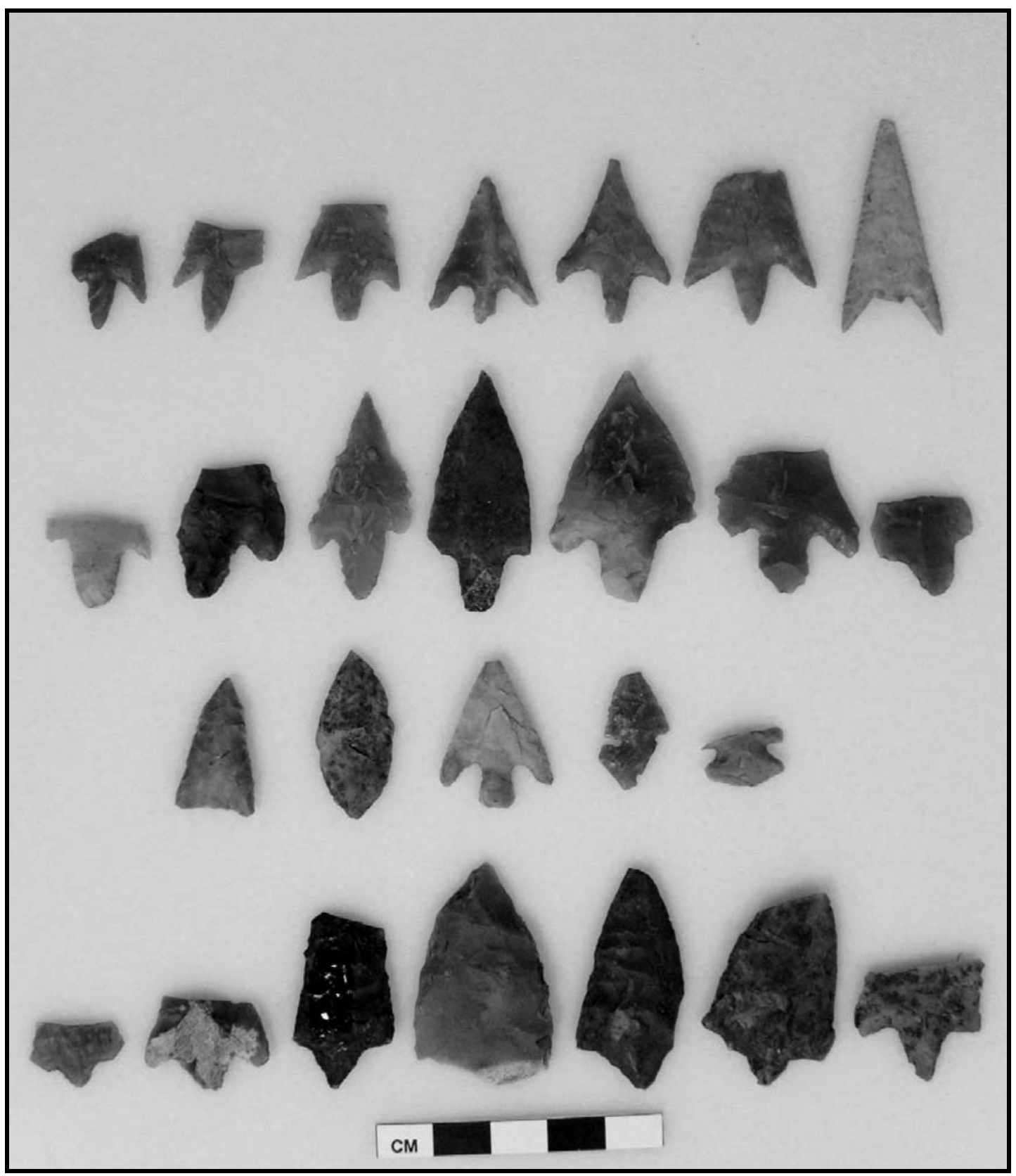

Figure 8-10. Selected Perdiz, non-Perdiz, and Cliffton Arrow Points

Left to Right: Top Row: \#726-011, \#922-016, \#158-021, \#405-016, \#159-025, \#930-016, \#534-014; Second Row: \#526-010, \#302-021, \#602-017, \#945-016, \#176-015, \#405-015, \#1098-010; Third Row: \#406-010, \#1030-005-01, \#473-010, \#882-011, \#1092-015;

Forth Row: \#814-016, \#12-010, \#1154-010, \#1183-010, \#914-011, \#943-018, \#913-017 
The metric measurements reveal size variability among the Perdiz points (Table 8-8). A complete Perdiz point (\#441-16) and a Perdiz base with a reworked tip (\#726-10) were subjected to use-wear analysis.

Specimen \#441-16 revealed hard, high-silica polish on the stem, which is an indication of haft wear. Use-wear was evident from hard, high silica polish, indicating use on hard, high-silica material plant material. Specimen \#726-10 is considered complete, although it exhibits a heavily reworked tip that has been narrowed to a fine point just above the shoulders. The usewear analysis with high-power microscopy indicates this was a hafted graver and probably used once as a drill against hard contact material (Appendix M). The graver tip is broken, probably during use, with some abrasion on the tip. The contracting stem has deliberately ground edges.

Seven Perdiz specimens (\#302-21, \#482-10, \#525-10, \#526-10, \#825-10, \#1031-13, and
\#1162-11) were subjected to for INAA. The results indicate that these were manufactured from Edwards chert obtained from the general Edwards Plateau region.

Ten Cliffton points comprise 13 percent of the identifiable arrow points from the Toyah component, and with two were recovered from immediately underlying Late Archaic component. These two points were probably originally associated with the Toyah component, but were subsequently displaced into the earlier context. Metric data for the Cliffton points is summarized in Table 8-9, with data on individual specimens in Appendix O. All were manufactured from fine-grained cherts and lack any sign of cortex or heat-treatment. Seventeen percent are complete, with the remaining 83 percent consisting of proximal ends. All breaks have probably occurred during use (Figure 8-9). Seventeen percent exhibit unifacial-beveled edges. The lateral edge shape varies from straight to slightly excurvate. All stems are contracting.

Table 8-8. Metric and Non-metric Observations on Perdiz Projectile Points from 41ED28

\begin{tabular}{|l|c|c|c|}
\hline \multicolumn{1}{|c|}{ Characteristics } & Range & Mean & $\begin{array}{c}\text { Standard } \\
\text { Deviation }\end{array}$ \\
\hline Maximum length & $23-40.8$ & 30.5 & 5.8 \\
\hline Maximum width & $10.1-26.7$ & 16.7 & 3.9 \\
\hline Maximum thickness & $2.1-5.5$ & 3 & 0.6 \\
\hline Blade length & $9.1-31.3$ & 21.4 & 5.1 \\
\hline Blade width & $2.6-25.5$ & 14.4 & 4 \\
\hline Shoulder width & $11.3-26.7$ & 17.7 & 3.8 \\
\hline Left notch depth & $1.7-7.6$ & 4.1 & 1.4 \\
\hline Right notch depth & $1.3-6.6$ & 4.1 & 1.4 \\
\hline Left notch width & $5.4-11.7$ & 8 & 1.8 \\
\hline Right notch width & $4.7-13.2$ & 8.1 & 2.1 \\
\hline Left notch angle & $10-45$ & 29 & 7 \\
\hline Right notch angle & $13-37$ & 26 & 7 \\
\hline Stem length & $4.8-14.9$ & 8.6 & 2.5 \\
\hline Distal stem width & $4.3-10.4$ & 6.9 & 1.6 \\
\hline Proximal stem width & $1.3-8.6$ & 4.2 & 1.7 \\
\hline Stem thickness & $1.1-3.2$ & 2.3 & 0.5 \\
\hline Measurements in mm & & &
\end{tabular}


Table 8-9 summarizes metric and non-metric observations to provide for a general size range of Cliffton points. Four Cliffton points were selected for use-wear analysis to determine if these points showed signs of use as tools (other than as projectile points), or that they were preforms lacking use-wear. Specimen \#22-14 is the proximal end of a Cliffton point with a contracting stem and a use break. Analysis revealed abraded ridges in the haft area that indicate it hafting in undetermined material (Appendix C). Specimen \#1154-10 is the proximal end of a Cliffton point with a contracting stem and an apparent use break. Striations were observed on the stem, inferably from hafting, but no other use-wear was detected. Specimen \#914-11 is complete, and has a contracting stem and some unifacial beveling along one edge. Hard, high silica polish was detected on the stem and use-related residue in the form of wood fragments was also detected along one edge. Striations in multiple directions indicate this specimen was use to cut wood (Appendix C). Specimen \#943-18 is the proximal section of a Cliffton point with a use break and two excurvate lateral edges. Plant fragments and striations in multiple directions were observed on the contracting stem. Observation indicates that this tool was hafted, probably with a plant binding, but the use and contact material are unknown (Appendix C). The use-wear analysis on these four Cliffton points indicates that the specimens in this type category functioned as tools. The use-wear data do not support the assumption that Cliffton points are Perdiz performs, so they probably can be viewed as part of the functional tool assemblage.

Parts of four Cliffton points (\#913-17, \#967-24, $\# 1002-13$, and \#1054-16) were sent for INAA to investigate source localities. The results consistently indicate manufacture from Edwards chert originating in the general Central Texas region (Appendix F).

Table 8-9. Metric and Non-metric Observations on Cliffton Points from 41ED28

\begin{tabular}{|l|c|c|c|c|}
\hline \multicolumn{1}{|c|}{ Characteristic } & Counts & Range & Mean & $\begin{array}{c}\text { Standard } \\
\text { Deviation }\end{array}$ \\
\hline Maximum width & 11 & $16.6-24.2$ & 20.5 & 2.9 \\
\hline Maximum thickness & 10 & $1.9-17.4$ & 5.2 & 4.4 \\
\hline Blade length & 11 & $14.5-22.7$ & 18.9 & 2.9 \\
\hline Shoulder width & & $17-24.2$ & 20.9 & 2.7 \\
\hline Left notch depth & & $1.4-3.8$ & 2.4 & 0.9 \\
\hline Right notch depth & & $1.1-4.2$ & 2.3 & 1.2 \\
\hline Left notch width & & $3.6-12.1$ & 9.5 & 3 \\
\hline Right notch width & & $4.0-11.1$ & 8.3 & 2.7 \\
\hline Left notch angle & & $27-47$ & 38 & 6 \\
\hline Right notch angle & & $19-54$ & 33 & 12 \\
\hline Stem length & & $3.5-8.4$ & 6.1 & 1.5 \\
\hline Distal stem width & & $6.0-14.2$ & 9.3 & 2.4 \\
\hline Stem thickness & & $1.6-3.7$ & 2.4 & 0.6 \\
\hline
\end{tabular}

Measurements in mm 
Five Bonham point fragments, or 6.6 percent of the identifiable arrow points, were recovered from the Toyah component, whereas two other complete Bonham points recovered from immediately underlying immediately matrix. All Bonham point metrics attributes are summarized here, and the metric data on individual specimens may be found in Appendix O. The seven fragments include one distal end, two proximal pieces, and four complete specimens (Figure 8-10). One proximal (\#282-17) and a distal end (\#159-23) refit to form a fifth complete specimen. All were manufactured from fine-grained cherts, and the finished points lack any trace of cortex. No specimens appear heat-treated, and none are patinated. The overall shape is triangular with variously shaped lateral edges that exhibit rounding. The stems are straight, distinguishing them from contracting-stem Perdiz specimens.

The Bonham point measurements are summarized in Table 8-10. A complete Bonham point (\#473-10) with a straight stem and straight lateral edges (Figure 8-10) was submitted for use-wear analysis. Resin and polish were detected on the stem. This, coupled with a small impact fracture, indicates this was a hafted point with unknown contact material (Appendix C).

Four Bonham point fragments (\#220-13, \#26220, \#282-17, and \#562-10) were subjected to INAA. The results indicate that these points were manufactured from Edwards chert from the general surrounding region (Appendix F).

Eight other identifiable arrow points, or 10.5 percent of the sample, were found within the Toyah component, but no more than two specimens are of any one type. These include two Scallorns, two Guerreros, one Edwards, one Cuney, one Harrell, and one Padre (Figure 810). Sufficient data are not available to meaningfully characterize any one type, though metric data on individual specimens are in Appendix $\mathrm{O}$.

Table 8-10. Metric and Non-metric Observations on Bonham Projectile Points from 41ED28

\begin{tabular}{|l|c|c|c|}
\hline \multicolumn{1}{|c|}{ Characteristic } & Range & Mean & $\begin{array}{c}\text { Standard } \\
\text { Deviation }\end{array}$ \\
\hline Maximum length & $26.8-40.2$ & 32 & 6.1 \\
\hline Maximum width & $11.2-20.8$ & 17.1 & 3.7 \\
\hline Maximum thickness & $2.5-3.5$ & 3 & 0.4 \\
\hline Blade length & $18.6-32.3$ & 24.4 & 6.1 \\
\hline Blade width & $11.0-20.1$ & 15.1 & 4 \\
\hline Shoulder width & $17.6-20.8$ & 19.3 & 1.6 \\
\hline Left notch depth & $3.2-6.4$ & 5.1 & 1.7 \\
\hline Right notch depth & $3.7-5.6$ & 4.8 & 1 \\
\hline Left notch width & $5.4-8.7$ & 6.6 & 1.8 \\
\hline Right notch width & $6.6-8.8$ & 7.7 & 0.9 \\
\hline Left notch angle & $14-47$ & 29 & 17 \\
\hline Right notch angle & $20-27$ & 24 & 3 \\
\hline Stem length & $7.2-8.2$ & 7.7 & 0.4 \\
\hline Maximum stem width & $5.3-6.4$ & 5.9 & 0.6 \\
\hline Proximal stem width & $5.3-6.7$ & 6.1 & 0.5 \\
\hline
\end{tabular}

Measurements in mm 
The two Scallorn points (\#534-14 and 1092-15) were manufactured from fine-grained cherts. Their slightly differing metric attributes are presented in Appendix O. Specimen \#109215(TRC257) revealed a chemical signature that is similar to other Edwards cherts from this southwestern area of the Edwards Plateau (Appendix F), suggesting that it was a locally produced point.

The two Guerrero points (\#291-14 and \#406-10) are small triangular pieces manufactured on flakes of fine-grained, unheated cherts. Both are quite small (Appendix O; Figure 8-10).

The Edwards point (\#783-10) is a proximal fragment that exhibits a use break. It was manufactured from a fine-grained, unheated chert (Appendix O; Figure 8-10).

The Cuney point (\#349-13) is complete and made from a flake of a fine-grained chert with straight lateral edges that are slightly worn or rounded. The point has a straight stem that is wedged shaped in cross section. The INAA results (TRC223) indicate a chemical signature that is similar to other Edwards chert from this southwestern region, generally similar to the sources in Kerr County (Appendix F). Therefore, the material appears to be from local sources.

The Harrell point (\#882-11) exhibits a use break. It was manufactured from a fine-grained chert.

The Padre point (\#1030-5-10) is complete and manufactured from a fine-grained, unheated chert. This small, complete bi-pointed point from Feature 38 has edge rounding on excurvate lateral edges (Figure 8-10). Use-wear analyses revealed oblique striations, polish, and plant fragments in the haft area, which indicates this bipointed tool was hafted and used on unidentified plant material (Appendix C).

Sixty-five percent, or 140 total of all arrow points recovered from the Toyah component, cannot be assigned to types, largely because of fragmentation. These fragments are quite similar in overall form and style to the Perdiz, Cliffton, and Bonham points. However, they lack specific morphological attributes, most notably the stem, to permit type identification. Of the 140 specimens, 45 percent represent distal fragments, 42 percent are medial fragments, nine percent are proximal fragments, nearly three percent are complete, but not assignable to type, and less than one percent are small indeterminate pieces. One complete specimen (\#967-23) is somewhat similar to a Cliffton, but the stem is broader than is generally the case with Cliffton points (Figure 8-11). A second complete specimen (\#303-15) is larger than most Perdiz, and the stem does not have the contacting form that characterizes the Perdiz type (Figure 8-11).

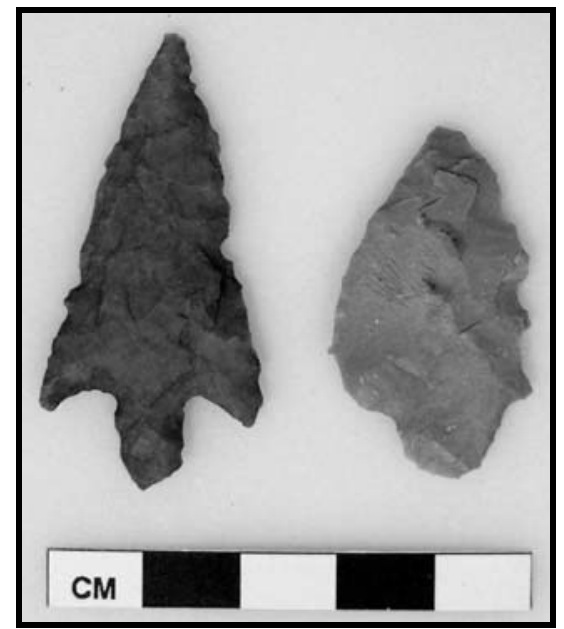

\section{Figure 8-11. Selected Other Late Prehistoric Arrow Points}

Left to Right: \#303-015, \#967-023

It is similar in overall form to a Bonham, but is much larger than other Bonham points. It has also been slightly reworked along some of the margins. Both of these points have ultraviolet fluorescence that is similar to the known Edwards chert colors. It is assumed that both materials were locally derived.

Three arrow point fragments (\#572-15 = TRC229, \#845-10 = TRC237, and \#1101-13 = 
TRC258) were selected for INAA. The INAA results indicate that these pieces were manufactured from Edwards chert from the general region (Appendix F).

Thirteen dart points were recovered from the Toyah component. This includes four Frio points (\#220-14, \#525-5-13, \#526-11, and \#91610) that are of Late Archaic age. These probably did not originate from this component, but were displaced from the underlying Late Archaic component. The data on these points are presented in the Late Archaic component section. One Group 2 dart point (\#324-16), one Baker point (\#653-12), and one Merrell point (\#157-11) are Early Archaic types that may have been curated items or displaced from the Early Archaic component, where all these types are represented. Six other unidentifiable dart point fragments were also recovered from the Toyah component.

\subsubsection{Bifaces}

Another class of chipped stone tools is bifaces. The 96 bifaces were all manufactured from finegrained cherts with cortex remaining on less than four percent (Appendix O). About five percent were heat-treated with another 17.5 percent burned. Seventeen percent are complete and unbroken, whereas 30 percent are distal fragments, 25 percent are medial fragments, 10 percent are proximal fragments, and nine percent are from indeterminate portions of the original artifacts. Forty-four percent exhibit use breaks, 15 percent have breaks of indeterminate origin, 17 percent are unbroken, 17 percent were thermally broken, and only seven percent were broken during manufacturing. Sixty-nine percent are late stage bifaces, 19 percent are middle stage, and only five percent are early stage, with another five percent indeterminate in terms of stage of manufacture (Figure 8-12). These bifaces show no rejuvenation scars, but seven percent exhibit some beveling along their edges. Five percent exhibit some patination, which includes two pieces that have completely patinated surfaces: one piece that is about 75 percent patinated and two that are about 25 percent patinated. Patination on material this relatively young age is unusual. It is possible that these five pieces were displaced from older contexts or were older pieces collected and brought into the site.

Only limited metric measurements could be made on these bifaces since 83 percent are fragments. Measurements that are available provide some indication as to the average size and range of variability. The lengths range from 40 to $123.5 \mathrm{~mm}$, with 20 measurements providing an average of $65.6 \mathrm{~mm}$ (Appendix O). The widths range from 21.3 to $58.3 \mathrm{~mm}$, with 43 pieces and providing an average of $34.4 \mathrm{~mm}$. The thicknesses range from 3.6 to $24 \mathrm{~mm}$, with 81 pieces yielding an average of $8.4 \mathrm{~mm}$.

Five bifaces were selected for use-wear analysis. Specimen \#159-5-28 is a complete, late stage biface that has alternate, unifacial beveling. This is a typical four-beveled knife that is often thought of as representative of the bisonprocessing during the Toyah phase. Wood residue and striations parallel and perpendicular were observed on the proximal end. Use-residue in the form of hair fragments and starch grains plus hard, high silica polish indicate multiple uses that included cutting and possibly piercing on high-silica plants and possibly animals (Appendix C).

Specimen \#220-15 is the distal end of a late stage biface with a use break and no evidence of reworking. Residue in the form of feather barbules and wood coupled with striations to the edge and light polish indicate cutting of wood and possibly bird (Appendix C). Specimen \#903-22 is a complete early stage biface with alternately beveled unifacial edges. Wood residue was observed and hard, high silica polish indicates whittling of wood (Appendix C). Specimen \#934-19 is a late stage distal section with a use break. 


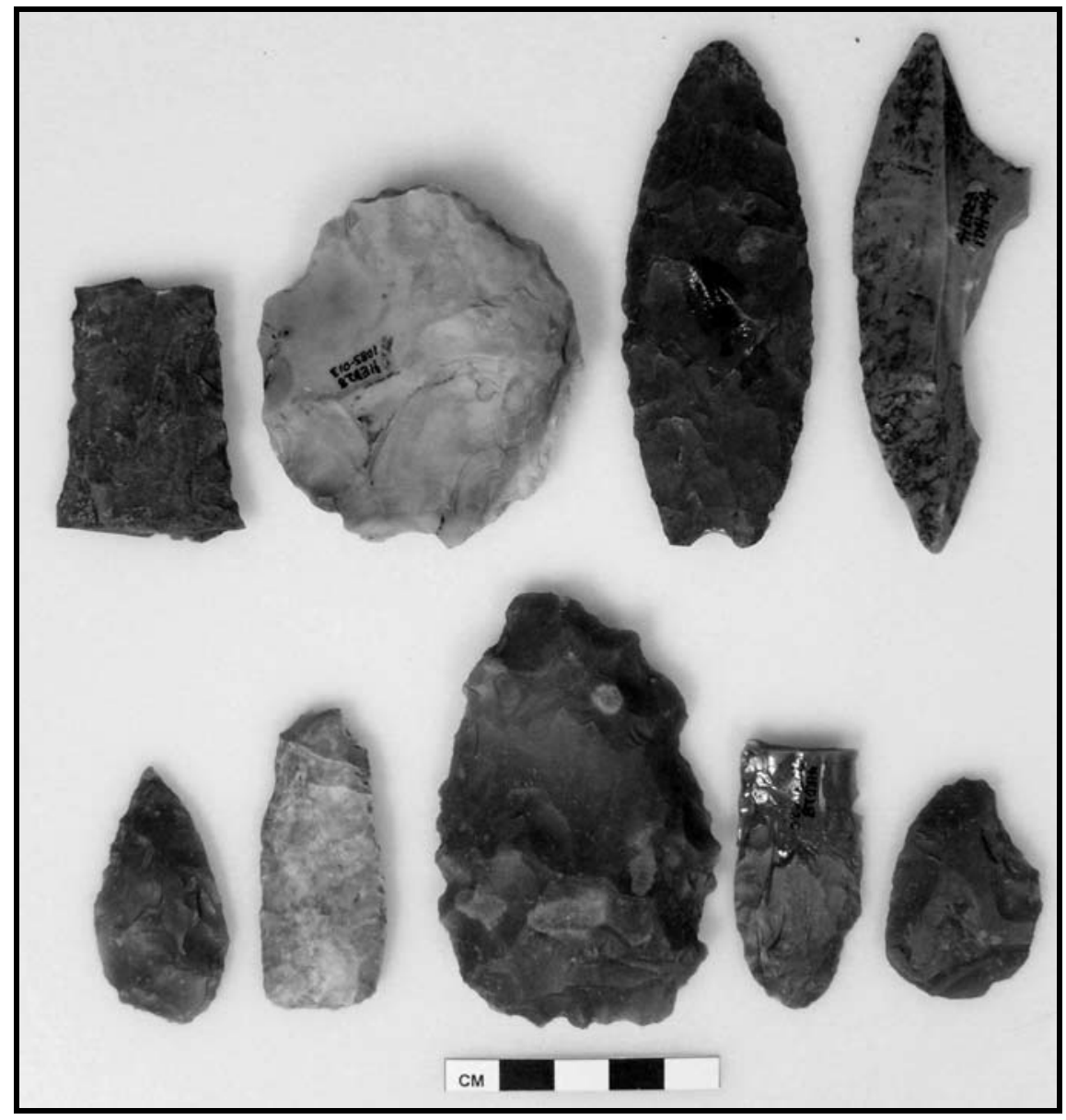

Figure 8-12. Selected Toyah Phase Bifaces

Left to Right: Top Row: \#1256-005-011, \#1085-013, \#159-005-28, \#1041-014; Second Row: \#878-021, \#835-013, \#244-013, \#969-020, \#945-011

Wood tissue and hard, high silica polish indicates cutting action on wood (Appendix C). Specimen \#937-10 is a proximal section of an early stage biface with unifacial edge beveling and a use break. Wood fragments and hard, high silica polish indicate scraping of wood (Appendix C).

Five bifaces $(\# 159-5-28=$ TRC214, \#220-15 = TRC218, \#903-22 = TRC243, \#934-19 = TRC246, and \#1041-14 = TRC253) were submitted for INAA. The chemical signatures appear to represent the Edwards chert group and are considered locally derived from the region.

\subsubsection{Scrapers}

Of a total of 65 scrapers, 69 percent are endscrapers, 22 percent are side-scrapers, and eight percent are combination end- and side-scrapers. Less than one percent cannot be assigned to any of these groupings (Figure 8-13; Appendix O). All were manufactured from fine-grained cherts with about eight percent appearing to have been heat-treated. Only five percent exhibit any sign of patination, whereas 30 percent exhibit some remaining cortex. The three partially patinated specimens probably do not originate in this component and may reflect specimens that were displaced from older components. Sixty-three 
percent are complete, 25 percent are distal fragments, eight percent are proximal fragments, two percent are medial fragments, and three percent are indeterminate fragments. Only three percent exhibit rejuvenation scars. The scrapers are in a variety of basic shapes with 33 percent indeterminate, 20 percent irregular, 14 percent ovate, nine percent lanceolate, eight percent teardrop, six percent round, and nine percent other shapes. Of the 14 broken specimens, 71 percent were apparently broken during use, 14 percent by thermal fracturing, seven percent have breaks of indeterminate origin, and seven percent were broken during manufacture. Fiftythree percent exhibit a single working edge (bit), 27 percent have two worked edges, 16 percent have three, and five percent have four working edges. Edge rounding was observed on 67 percent.

Table 8-11 provides a summary of metric measurements from the scrapers to provide information on their size range, variability, and specific attributes. The secondary working edge (bit 2) is located on 73 percent of the specimens, along the lateral side, on 13 percent along the distal end, and is along the lateral/proximal area on ten percent. The shape of the secondary working edge is straight on 60 percent of the specimens, excurvate on 30 percent, and incurvate on 10 percent. That working edge is regular and continuous on 60 percent, irregular and continuous on 30 percent, and discontinuous on 10 percent. The secondary working edge is also summarized in Table 8-11.

Six scrapers were selected for use-wear analyses. Specimen \#800-11 is a complete, irregularly shaped end-scraper. Resin and striations were observed on the edge, coupled with hard, high silica polish indicating planing and scraping of hard, high-silica material such as bone, antler, or wood. Specimen \#888-14 is a complete, teardrop-shaped end scraper. Resin and striations were seen on the proximal end, and plant fibers, striations parallel and
Table 8-11. Metric and Non-metric Observations on Scrapers from 41ED28

\begin{tabular}{|l|c|c|}
\hline \multicolumn{1}{|c|}{ Characteristic } & Range & Mean \\
\hline Maximum length & $32.5-108.4$ & 65 \\
\hline Maximum width & $21.6-84.3$ & 44.2 \\
\hline Maximum thickness & $5.2-26.5$ & 12.7 \\
\hline Weight & $8-187.7$ & 45.4 \\
\hline Worked edge 1 - length & $16.8-123.5$ & 47.6 \\
\hline Worked edge 1 - thickness & $2.4-16.5$ & 6.9 \\
\hline Worked edge 1 - angle & $44-8$ & 68 \\
\hline Worked edge 2 - length & $9.4-53.9$ & 29.6 \\
\hline Worked edge 1 - thickness & $1.2-7.4$ & 3.8 \\
\hline Worked edge 1 - angle & $38-77$ & 59 \\
\hline
\end{tabular}

Measurements in mm

perpendicular to the edge, together with high, hard silica polish indicate planing on a hard, high-silica plant (Appendix C). Specimen \#90312 is a complete, irregularly shaped side scraper with residue and soft polish indicating scraping of soft material (Appendix C). Specimen \#90324 is a distal section of an end-side scraper. Plant tissue and starch grains were observed together with hard, high silica polish and striations parallel and perpendicular to the edge that indicate planing hard, high-silica starchy plants starch (Appendix C). Specimen \#1023-12 is a distal section of an end-side-scraper. Hard, high silica polish and edge rounding was observed and indicates planing hard, high-silica material (Appendix C). Specimen \#1132-10 is a complete, teardrop shaped side-scraper. Hair and edge rounding and marginal polish indicate scraping of hide (Appendix C). The scrapers were apparently were frequently used for working plant and animal products, and were not restricted to scraping hides, as is often assumed.

Five scrapers (\#800-11 = TRC231, \#888-14 = TRC239, \#903-12 = TRC242, \#903-24 = TRC244, and \#1132-10 = TRC259) were sent for INAA. The chemical results indicate these were part of the known Edwards chert group from the southwestern area of the Edwards Plateau (Appendix F). 


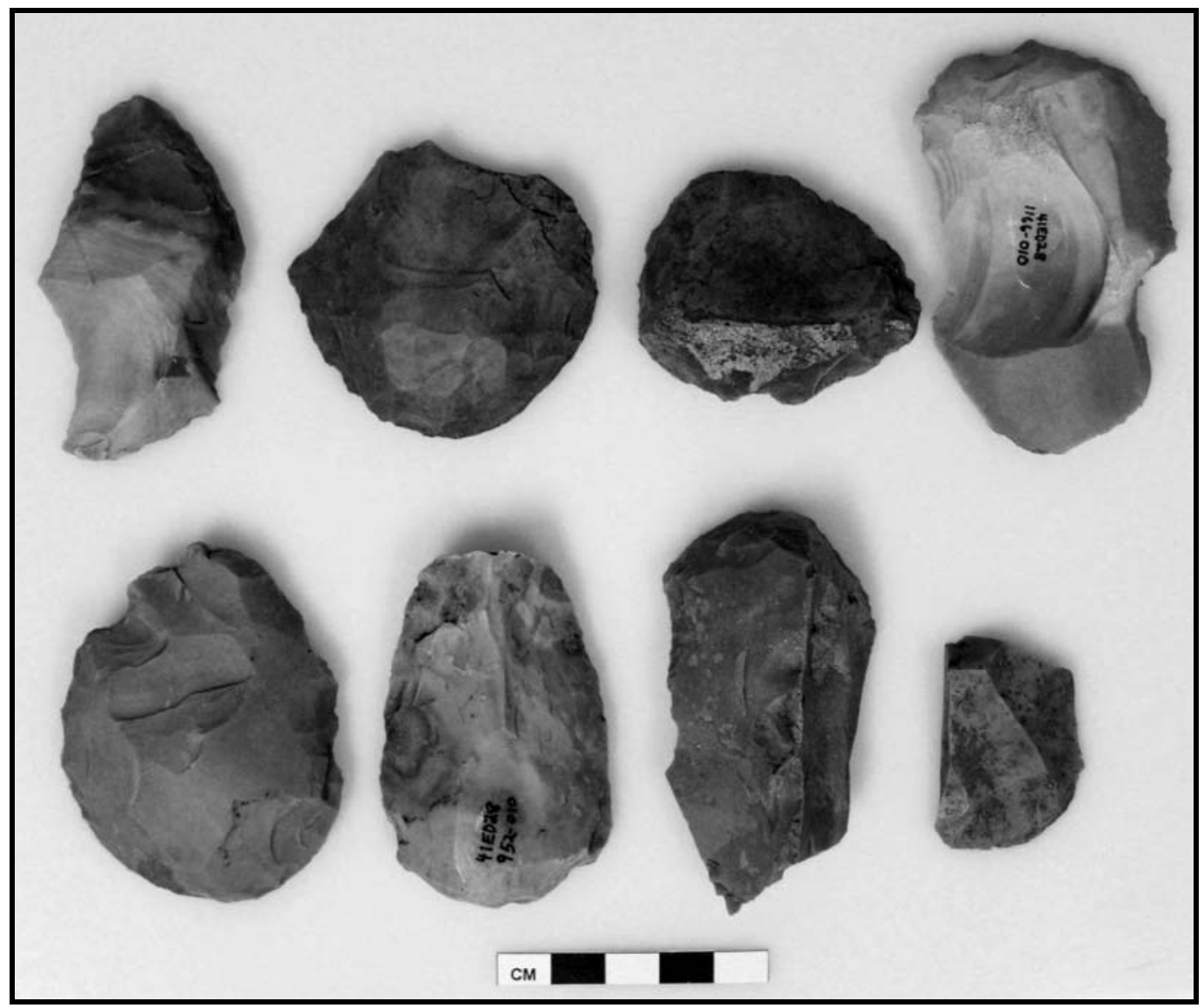

Figure 8-13. Selected Toyah Phase Scrapers

Left to Right: Top Row: \#1052-012, \#1270-010, \#1041-013, \#116-010; Second Row: \#967-021, \#952-012, \#982-012, \#1002-019

No specimens appear to have originated from outside the region and therefore, the chert was considered locally derived. One specimen (\#888-14 = TRC239) has a chemical signature that is towards the currently known southwestern edge of the Edwards Plateau (Edwards and Val Verde counties), but does not reveal the same yellow to orange ultraviolet fluorescence known for other Edwards chert. This dark green chert exhibits a dark purple fluorescence. This is one of the few pieces of chert that does not look like Edwards chert but that is in fact indicated to be such, based on INAA.

\subsubsection{Unifaces}

The seven unifaces exhibit most of one face completely worked and are a separate tool class from scrapers, as these tools do not exhibit a steep working edge (Figure 8-14). These unifaces include two specimens that are complete, two indeterminate sections, and one distal, one medial, and one proximal section (Appendix O). Eighty-six percent of the unifaces are of fine-grained chert, with the other an unidentified kind of fine-grained rock. No specimen exhibits any cortex or patination. The edge flaking is quite variable as is the location of the worked edge(s). Forty-three percent have two worked edges. Their overall size varies in 


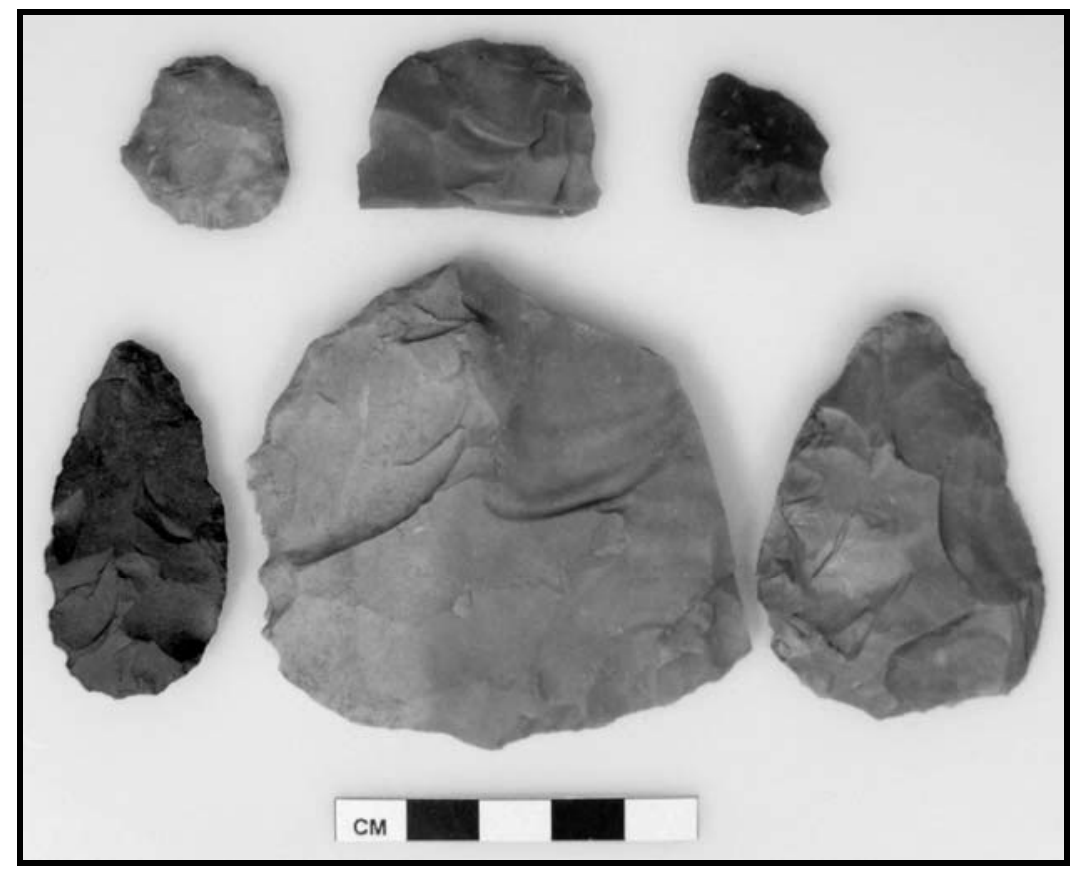

Figure 8-14. Selected Toyah Phase Unifaces

Left to Right: Top Row: \#990-015, \#196-011, \#1171-013; Second Row: \#1022-005-010, \#159-005-27, \#1055-013

length from 47.9 to $53.2 \mathrm{~mm}$, with an average of $50.2 \mathrm{~mm}$. The width ranges from 23.7 to $64.4 \mathrm{~mm}$, with an average of $37 \mathrm{~mm}$. The thickness ranges from 3 to $11.7 \mathrm{~mm}$, with an average of $6.4 \mathrm{~mm}$.

A single lateral, uniface fragment (\#159-5-27) was sent for use-wear analysis. This piece has two worked edges, one with irregular continuous flake scars along an excurvate lateral edge and one edge with regular discontinuous flake scars along an excurvate edge. The observed plant fiber and starch grains are use-residue together with hard, high silica polish that indicates scraping of hard, high silica plants with starch (Appendix C). No unifaces were sent for INAA.

\subsubsection{Drills}

The 16 drills were all manufactured from finegrained chert, none of which appears to be heattreated, and only 12.5 percent of which exhibits small areas of cortex (Appendix O). Ninety-four percent were manufactured from thin flakes (Figure 8-15). Only one specimen is complete, 25 percent are distal fragments, 31 percent are proximal fragments, and 37.5 percent are medial fragments. The break shapes indicate that these drills were broken during use. On the specimens with measurable sections, the metric attributes provide a general understanding of their size and shape. The six pieces with measurable proximal ends indicate an average length of $18.8 \mathrm{~mm}$, average stem width of 17.6 for nine pieces, and an average thickness of $4.2 \mathrm{~mm}$ on 13 specimens. Sixteen pieces indicate an average bit width of $6.1 \mathrm{~mm}$.

Two drills were subjected to use-wear analysis. Specimen \#800-10 is a proximal section including part of the bit, with edge rounding and a use break. Plant fragments and light polish were observed, but the action is undetermined (Appendix C). Specimen \#893-16 is a distal bit, which revealed hard, high silica polish and light 


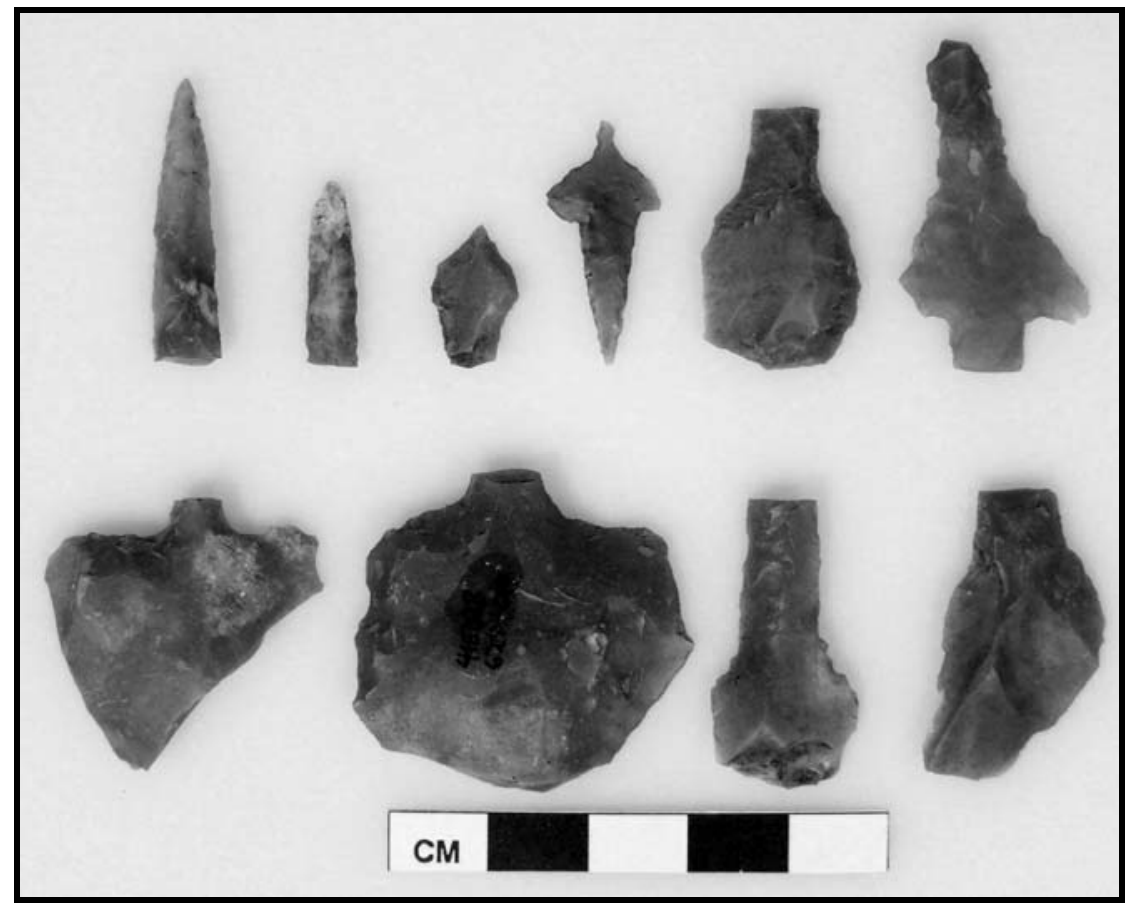

Figure 8-15. Selected Toyah Phase Drills

Left to Right: Top Row: \#1054-019, \#859-016, \#837-011, \#726-010, \#989-010, \#875-018; Second Row: \#260-014, \#624-014, \#827-012, \#1074-015

polish indicating a hafted tool used for cutting unknown material (Appendix C).

Two drills (\#895-12 = TRC241 and \#974-11 = TRC247) were also sent for INAA. Results indicate that these two specimens were manufactured on Edwards chert, probably from the general region of the Edwards Plateau (Appendix F).

\subsubsection{Edge-Modified Flakes}

A total of 1,380 edge-modified flakes were identified and represent a wide range of shapes, sizes, and tool functions.

One unique edge-modified flake (\#869-10) is manufactured from a $4.6 \mathrm{~g}$ piece of glass that exhibits a crushed platform and a tapered distal end with one relatively straight lateral edge that is partially modified (Figure 8-16). This piece measures $28.1 \mathrm{~mm}$ long, $25.7 \mathrm{~mm}$ wide, $6.2 \mathrm{~mm}$ thick and was recovered from 10 to $20 \mathrm{cmbd}$ in Unit N119/E72.

Thirty-three edge-modified flakes of various sizes and shapes, with different flake scar patterns, probably functioned variously as gravers, spokeshaves, cutting and scraping edges, were selected for use-wear analyses (Appendix C). Specimen \#109-11 has hard, high-silica polish that indicates scraping hard, high silica material. Specimen \#168-10 revealed wood fragments and hard, high-silica polish indicating it was used to scrape wood. Specimens \#207-11 and \#281-15 reveal hard, high-silica polish and edge rounding implying scraping of hard, high silica plant material. Specimens \#314-10 and \#781-10 reveal hard, high silica polish plus striation perpendicular and parallel to the edge, indicating whittling of hard, high-silica plant (wood?) material. Specimen \#781-10 exhibits striations in multiple 


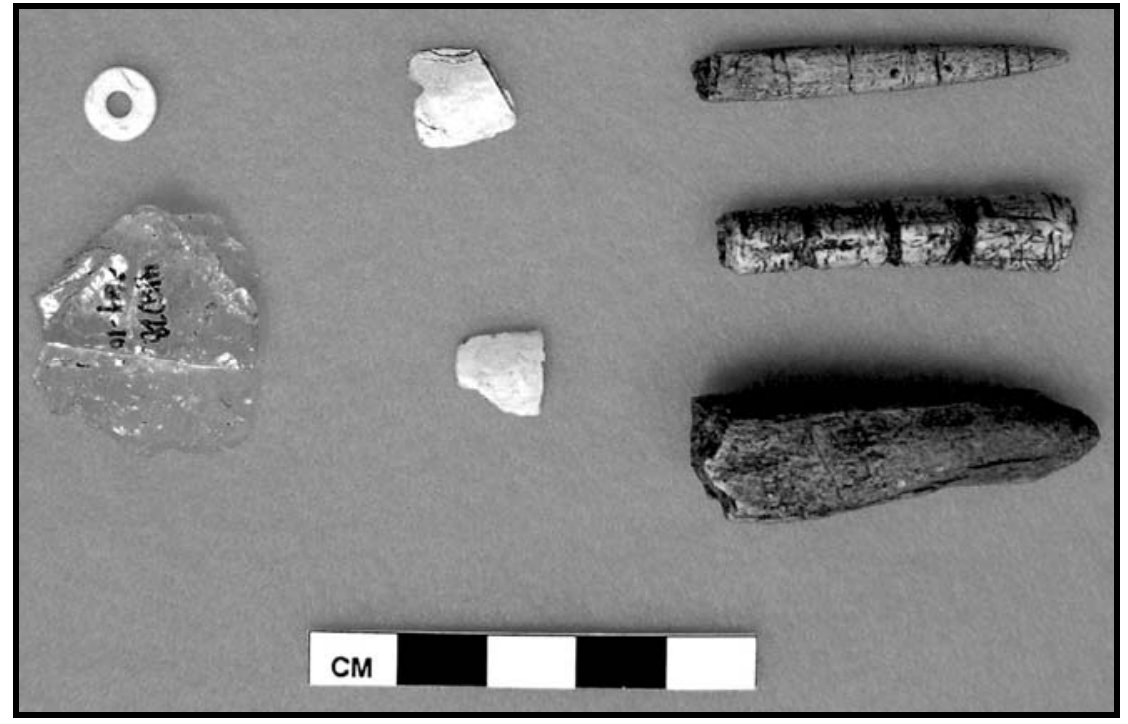

Figure 8-16. Miscellaneous Toyah Phase Artifacts

Clockwise from Top Left: \#1025-013, \#1042-006, \#79-005-002-015, \#1054-021, \#481-015, \#1075-006, \#869-010

directions and hard, high silica polish from hafting, and soft polish indicative of scraping soft material. Specimen \#800-12 exhibits hard, high silica implying cutting of hard, high silica material. Specimen \#806-17 reveals hair with scales and medulla plus oblique striations indicating slicing of animal hide. Specimen \#837-19 is a perforator with striations in multiple directions and hard, high silica polish implying boring of hard, high silica woody material. Specimen \#881-17 has wood fragments, hard, high silica polish, and microscaring implying whittling of wood. Specimen \#885-10 also has wood fragments, edge rounding, and oblique striations indicating slicing wood.

Specimen \#931-11 reveals hard, high silica polish that implies whittling of hard, high silica material. Specimen \#999-10 reveals hair and possible blood residue plus oblique striations indicating hide scraping. Specimen \#1019-10 exhibits hard, high silica polish and striations indicative of slicing hard, high silica material. Specimen \#1019-18 exhibits a polish that implies scraping soft material. Specimen \#1020-
10 reveals wood fragments and hard, high silica polish indicating scraping of wood. Specimen \#1029-5-11 has hard, high silica polish with striations parallel and perpendicular to the edge, implying scraping of hard, high-silica material. Specimen \#1032-10 exhibits hard, high silica polish indicating scraping of hard, high silica material. Specimen \#1074-11 has plant tissue and high silica polish indicating whittling of hard, and high-silica material. Specimens \#1190-10 and \#1194-10 show hard, high silica polish implying planing of hard, high silica material.

Three edge-modified pieces, which are classified as spokeshaves, were examined for use-wear. Specimen \#358-10 has plant fibers and hard, high-silica polish that indicates scraping hard, high silica plant material. Specimen \#1024-11 exhibits wood fragments, hard high silica polish, and striations parallel and perpendicular to the working edge implying use in scraping wood. Specimen \#1036-15 also has wood fragments, oblique striations parallel and perpendicular to the edge, indicating use in the planing of wood. 
Five edge-modified pieces are classified as rejuvenation flakes because they appear to have been removed as part of the rejuvenation of the tool edge. These edge-modified flakes were subjected to use-wear analyses. Specimen \#80513 is unifacial, with regular continuous scars along one excurvate edge. Use-wear exhibits hard, high polish that indicates planing hard, high silica material. Specimen \#811-12 is a bifacial edge with irregular continuous flake scars and edge rounding. along one excurvate edge. It exhibits hard, high polish that indicates scraping hard, high silica material. Specimen \#841-13 is unifacial with regular continuous flake scars along a straight edge. It exhibits soft polish and striations parallel and perpendicular to the edge, indicting scraping of soft material. Specimen \#999-13 is unifacial with regular continuous flake scars along a straight edge with edge rounding. Use-wear is present in the form of hard, high silica polish and striations parallel and perpendicular to the edge indicting scraping hard, high silica material. Specimen \#1038-12 is unifacial with regular continuous flake scars along three bits. It exhibits hard, high silica polish implying scraping hard, high silica material.

Three edge-modified pieces, which are classified as gravers, were subjected to use-wear analyses. Specimen \#836-10 is the distal end with three worked sections and a use break. It has hairs and striations in multiple direction and soft polish, which indicates cutting of animal parts. Specimen \#934-11 exhibits abraded flake-scar ridges indicating hafting plus hard, high silica polish, striations in multiple directions implying a hafted scraping tool used on a hard, high silica material. Specimen \#1088-10 exhibits plant cells with striations that indicate slicing wood (Appendix C).

Specimen \#837-11 exhibits a very short stem section with a relatively large base creating the appearance of a stubby, projectile point (Figure 8-15). The use-wear analysis revealed this functioned as a hafted graver (Appendix M). The graver tip is still present, and slightly rounded with striations in several directions at the edge, indicating a rotary motion. The contact material was soft to medium soft such as deciduous wood. The haft area exhibits striated use plating wash typical of wood contact (Appendix M).

Eight edge-modified flakes were sent for INAA. All specimens appear to have chemical signatures similar to known Edwards cherts from the southwestern region (Appendix F). It is assumed these pieces were all from locally available Edwards chert sources.

\subsubsection{Anvils}

The one anvil (\#405-17) is an irregularly shaped, complete water-worn limestone. Most of one face exhibits two or three areas less than $10 \mathrm{~mm}$ in diameter that appear to be artificial pits. These are relatively shallow and of ill defined shape. Much of this same face is generally pitted. The opposite face and part of the lateral edges are also pitted, but that face has a more natural appearance. No flake scars or impact fractures are apparent that would indicate this cobble was used as a hammerstone. It measures $10.9 \mathrm{~mm}$ long, $90.9 \mathrm{~mm}$ wide, $41.3 \mathrm{~mm}$ thick, and weighs $538.4 \mathrm{~g}$.

\subsubsection{Hammerstones}

The one hammerstone (\#864-16) is a complete, rather round, limestone cobble. It exhibits two worked areas on either end. One end exhibits an area about $18 \mathrm{~mm}$ wide and $50 \mathrm{~mm}$ long that is rough and pitted compared to the other natural surfaces. The opposite end exhibits one or two points where impact has resulted in the removal of some of the limestone. This impact area is about three centimeters in diameter. The overall cobble measures $60.4 \mathrm{~mm}$ long, $55.5 \mathrm{~mm}$ wide, $40.6 \mathrm{~mm}$ thick, and weighs $167.3 \mathrm{~g}$. The hammerstone was recovered from 0 to $10 \mathrm{cmbd}$ in Feature 8, in Unit N119/E70 of Block B. 


\subsubsection{Cores}

Thirty-seven cores were recovered from Blocks A and B. Eighty-one percent are complete, 11 percent are exhausted, and 5.4 percent are fragments (Appendix O). Bifacial cores account for 56.7 percent, multidirectional cores account for 40.5 percent, and unifacial cores account for 2.7 percent. All are of fine-grained cherts with 83.8 percent exhibiting some cortex. The cortex is smooth and water-worn, indicating the pieces were collected from alluvial contexts rather than upland locales. About six percent appear to have been heat-treated to improve their knapping quality. The complete cores range in length from 57.6 to $138.9 \mathrm{~mm}$ with an average of $89.4 \mathrm{~mm}$. The width ranges from 39.1 to $77.3 \mathrm{~mm}$ with an average of $68.5 \mathrm{~mm}$. The thickness ranges from 19.6 to $57.8 \mathrm{~mm}$ with an average of $43.2 \mathrm{~mm}$. No cores were subjected to any technical analyses.

\subsection{Debitage}

\subsubsection{Unmodified Debitage}

Just over 26,000 pieces of lithic debitage were recovered from this component, and this represents about 41 percent of the total cultural materials recovered from this component. If the bone class is subtracted from the total to enable comparisons with components without bone, then the lithic debitage represents about 59 percent of the non-perishable remains.

Each of the two excavation blocks in the Toyah component was sampled to determine what, if any, activity areas may be definable. About 10 percent $(n=1036)$ of the debitage from Block A was analyzed to determine which stages of raw material reduction and tool production, manufacturing, and maintenance processes are represented. The selected sample was derived from eight different units across the southern half of the block where cultural context was clearest.
About 84 percent of the sample from Block A exhibits some evidence of heat alteration in the form of spalling and cracking due to exposure to excessive heat. Blades are nearly non-existent in the sample, with only three identified. Early stage biface manufacturing flakes are comprise 14 percent of the analyzed debitage, whereas the late stage biface flakes are represent 20.8 percent. A moderately high frequency of angular debris/shatter is represented by 20.2 percent. Tertiary thinning and retouch flakes are moderately represented by 16.3 percent. Indeterminate pieces account for about 10.5 percent. The core reduction flakes, which reveal minimally 50 percent cortex, are represented by about 17.9 percent.

This sampled assemblage indicates moderate frequencies of unintentional heat alteration, which is difficult to explain. Only one unit of the sample was immediately adjacent to a hearth feature (Feature 21), but minimally five sampled units yielded relatively high frequencies of heataltered flakes. The relatively moderate representation of core flakes, early stage biface flakes, and thinning flakes indicates that cobbles with cortex were reduced and roughed out into bifaces, which were then thinned. The relatively high frequency of late stage biface flakes and angular debris further support the complete processing of tools, from the initial cobble reduction to finished forms. The near absence of blades indicates that the cores were reduced in a random and multidirectional fashion, without attention to the production of regularly shaped blades. No uniface resharpening flakes were identified in the sample.

In Block B, just over nine percent of the debitage $(n=1447)$ was analyzed to determine which stages of raw material reduction and tool production, manufacturing, and maintenance processes are represented. The selected sample was derived from 23 of the 125 units from across the entire block where context was best defined. 
Nearly 88.4 percent of the pieces exhibit some form of heat alteration, which is very similar to that detected in Block A. Relatively high frequencies of late stage biface flakes are present as indicated by the fact that these comprise 32.4 percentage of the sample. A moderate to high incidence of tertiary thinning and retouch flakes are represented by 22.1 percent. Moderate frequencies of the early stage biface thinning flakes are 15.1 percent of the total. Core reduction flakes represented by 10.4 percent, angular debris represented by 9.7 percent, and indeterminate pieces represented by 10.2, all relatively low percentages.

The frequencies represented here indicate a focus on late stage biface production. Bifaces appear to have been made from both flakes and cobbles, and the early stages of bifacial reduction, including initial cobble reduction, were conducted in this area. Flakes were also produced from cores. In general, similar types of core reduction flakes, biface production flakes, tool finishing and resharpening flakes occurred across Blocks A and B. The major difference is that some stages of the production sequences are higher in frequencies in some areas and lower in others.

\subsubsection{Toyah Rejuvenation Flakes}

The Toyah assemblage includes 28 pieces classified as rejuvenation flakes (Figure 8-17). These parts of chipped stone tools were intentionally removed from the parent tool as a step in resharpening the edge. These pieces generally show a small segment of the parent tool edge from which they were removed. Block A yielded 13 specimens compared to 15 specimens from Block B, which encompassed nearly 2.2 times the volume as Block A. Five rejuvenation flakes were selected for use-wear analysis. All pieces are finegrained cherts with mostly regular and continuous retouch along one edge. Three of the old worked edges exhibit some edge rounding.
Specimen \#805-13 was removed from a uniface and exhibits hard, high silica polish interpreted as a result of use in a planing action (Appendix C). Scraping actions are inferred based upon polishes exhibited on specimens \#811-12, \#999-13, and \#1038-12. Specimen \#841-13 exhibits similar hard, high silica polish consistent with use on soft material. The polish observed on these tool fragments generally indicates a dulled edge, primarily from scraping hard or soft materials, and therefore, supports their classification as rejuvenation flakes. The high frequency of dulled edges and intentional rejuvenation, indicates intensive use of scraping tools followed by resharpening and reworking of the new edge for continued use of the tool.

At least 25 percent of the rejuvenation flakes were removed from the steep faces of unifacial scrapers. The point of impact appears to have been directed into the face of the worked end of the working bit, thus removing part of the steep tool edge. The flat ventral surface is present on these pieces.

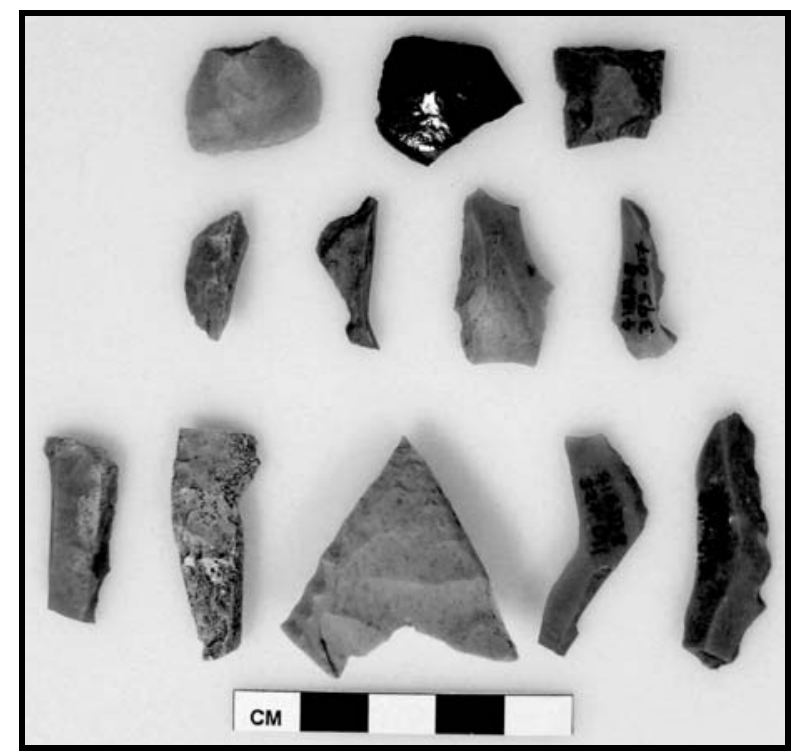

Figure 8-17. Selected Toyah Phase Rejuvenation Flakes

Left to Right: Top Row: \#999-017, \#943-015, \#999-013; Second Row: \#1078-014, \#1008-015, \#841-013, \#393-017; Third Row: \#376-012, \#805-013, \#1038-012, \#324-011, \#811-012 
Some 13 pieces, from 12 different units, were identified in the $83-\mathrm{m}^{2}$ of Block A. Another 15 were recovered from 14 units in the $124.75 \mathrm{~m}^{2}$ of Block B. In Block A, these rejuvenation flakes were concentrated (92 percent) within a 3-m-wide area just south of the BT 2 and may reflect a locus of stone tool maintenance activities or a general discard area. These pieces were not in direct association with the two burned rock features in the southern part of this block. A high percentage of those in Block $\mathrm{A}$ are the lateral edges of thin, edgemodified pieces. In Block $B$, none of the 15 pieces were encountered directly in either of the proposed discard areas (Features 8 and 25). Ten, or 67 percent, were discovered in the northern part of the block with only one unit that yielded more than one. The remaining five pieces were in the southern part of the block in five different units with minimally one meter between them. No apparent pattern was determined from their distribution across Block B. Minimally, 50 percent of these in Block B are steep unifacial edges removed from scrapers.

\subsection{Miscellaneous Artifacts}

Seven artifacts comprise this group, which includes three bone tools, one piece of drilled freshwater mussel shell, one drilled marine shell bead, one ground marine shell fragment, and a clay figurine-like object. Each item is described below, and this is followed by a general discussion.

The drilled mussel shell fragment (\#1042-6) was discovered in Unit N127/E71 in Block B at 20 to 26 cmbs. It measures $11.1 \mathrm{~mm}$ in diameter by $1.2 \mathrm{~mm}$ thick (Figure 8-15). Along one broken edge is about one half of a drilled hole that measures $3.1 \mathrm{~mm}$ in diameter. The hole appears to have been drilled from one side, the concave, or interior, side, and is slightly tapered. Both the current interior and exterior surfaces are bright and shiny and exhibit no other alterations. This mussel shell was perhaps a pendant or a bead.
Specimen \#1025-13 is a well made marine shell bead from Unit N126/E75 in Block B at 20 to 30 cmbs. It measures 8.05 by $8.16 \mathrm{~mm}$ in diameter, is $1.27 \mathrm{~mm}$ thick with a $2.73 \mathrm{~mm}$ diameter hole in the middle (Figure 8-16). The hole is not tapered, although the edges on both surfaces are rounded. The outer edge is also rounded. This bead appears to be a trade item from the Gulf coast, given that it was made from a marine shell.

Specimen \#1075-6 is a marine shell fragment discovered in Unit N128/E72 in Block B at 30 to 35 cmbs. It measures $9.8 \mathrm{~mm}$ long, $9.1 \mathrm{~mm}$ wide, $1.6 \mathrm{~mm}$ thick, and weighs $0.1 \mathrm{~g}$ (Figure 816). It is slightly curved with part of one edge artificially rounded. The other three edges are all broken. The broken edge opposite the rounded edge exhibits a two-layered appearance, indicative of the internal structure of the shell. The layer towards the interior side is relatively flat in cross section, whereas the outer layer is quite rough and jagged. It is not clear what the completed shell looked like. Often traded shell is used as a decorative ornament, which may be the case with this specimen.

Specimen \#79-5-2-15 is the distal end of a wellformed bone awl that was encountered in Feature 21, in Unit N100/E50 of Block A, at 12.5 cmbs. A piece of charcoal (\#78-5-7-1b) from Feature 21 was radiocarbon dated to $380 \pm 30$ B.P (Beta-183623). This pointed awl section measures $41.3 \mathrm{~mm}$ long, $5.8 \mathrm{~mm}$ wide near the broken proximal end, $4.0 \mathrm{~mm}$ thick near the middle of the segment, and tapers to a point of $1.3 \mathrm{~mm}$ thick at the distal end (Figure 8-16). The awl is ovate in lateral cross section, and the pointed distal end is missing the very tip. This awl is very smooth with polish over most of the surface. Microscopic observation reveals grinding/sanding striations over most all surfaces and only slight, shallow root etching. Along one of the flatter sides, a series of eight intentional cut marks are present perpendicular to the long axis. This edge reflects the interior 
of the bone fragment once containing cancellous tissue and exhibits a slightly rough surface. The cuts completely traverse the one flat surface and extend slightly onto the lateral edges, though they do not circumscribe the tool. These cut marks are not spaced evenly and vary in technique from one to the next. Beginning at the pointed distal end each cut line will be described. The first cut is a single line that extends along about half of the tool circumference. The second is a single cut line that extends to about half the circumference. The third looks like a mis-start, as it is a short single cut at the edge of the flat surface. The fourth line appears as multiple cuts in the same place that extend slightly farther around the circumference than the first two cuts. The fifth line is a series of four cuts that are not as deep or well-executed as the fourth, and do not extend onto the lateral sides. The sixth line is two, and possibly three cuts, not quite as deep as the fourth, and extends onto the lateral sides. The seventh and eighth cut lines are two closely spaced single, shallow cuts, which extend just onto the lateral edges. The broken proximal end exhibits a fry bone break that is stepped. It is not clear how the steps were created.

Specimen \#481-15 is a distal end of pointed bone tool that was recovered Unit N105/E56 in Block A between 10 and 20 cmbs. This is a long bone splinter that measures $46.0 \mathrm{~mm}$ long, $13.2 \mathrm{~mm}$ wide, $12.2 \mathrm{~mm}$ thick, and weighs $7.0 \mathrm{~g}$ (Figure 8-16). The thickness indicates that it is probably bison bone. The two opposite sides are broken edges, but they are quite flat. This breakage has yielded a relatively square foursided tool that tapers to a blunt end. Minimal polish covers the high spots on all sides. The blunt end does not appear to have been prepared, as no grinding striations are present. The broken proximal end exhibits an unknown break type with a slightly high spot near the middle.

Specimen \#1054-21 is a bone bead blank discovered in Unit N127/E75 in Block B between 20 and 30 cmbs. It measures $39.4 \mathrm{~mm}$ long, $8.9 \mathrm{~mm}$ wide, $7.3 \mathrm{~mm}$ thick, and weighs 2.1 g (Figure 8-16). The bone exhibits a $4.7 \mathrm{~mm}$ wide cavity at the broadest end and tapers to $3.3 \mathrm{~mm}$ at the opposite end. Based on its general shape, the bone resembles a jackrabbit tibia, although the diagnostic articular ends are missing. Most surfaces exhibit a polish, and the bone has been deeply incised by three cuts dividing it into four nearly equal sections. The ends of each section exhibit deep grooving that encircles the bone and cuts through most of the cortical wall; one of the grooves cuts through the cortical wall into the cavity. The deep grooves vary in thickness from about 0.9 to $1.6 \mathrm{~mm}$ wide. Remnants of similar grooves are located at each end of the bone indicating that other pieces were removed. Each potential bead is about $8.9 \mathrm{~mm}$ long.

Specimens \#840-8 and \#891-10 are two parts of the same well-made clay object with an unknown function (Figure 8-18). The smaller piece (\#840-8) was discovered in Unit N118/E69 and the larger piece (\#891-10) was found in Unit N120/E74. Together the two broken objects measure $42.9 \mathrm{~mm}$ tall, $30.3 \mathrm{~mm}$ wide, and weigh $22.1 \mathrm{~g}$. These two pieces were located 1 to $2 \mathrm{~m}$ apart and may reflect post depositional displacement. Combined, the two pieces represent about 95 percent of one unique clay object with a somewhat flat to irregular base, a bulbous main section that constricts to a narrower terminus (Figure 8-18). The very top is broken off, much of one side is missing, and two breaks are present on the opposite end. One break is located on what appears to be some type of an extension or protrusion extending beyond the main body. The other break appears to have removed part of the body. The shape provides few clues about the function of the object. The exterior surface is reddish brown (2.5YR 5/6), the core is gray (10YR 5/1), and the interior surface is grayish brown (10YR 5/2). 

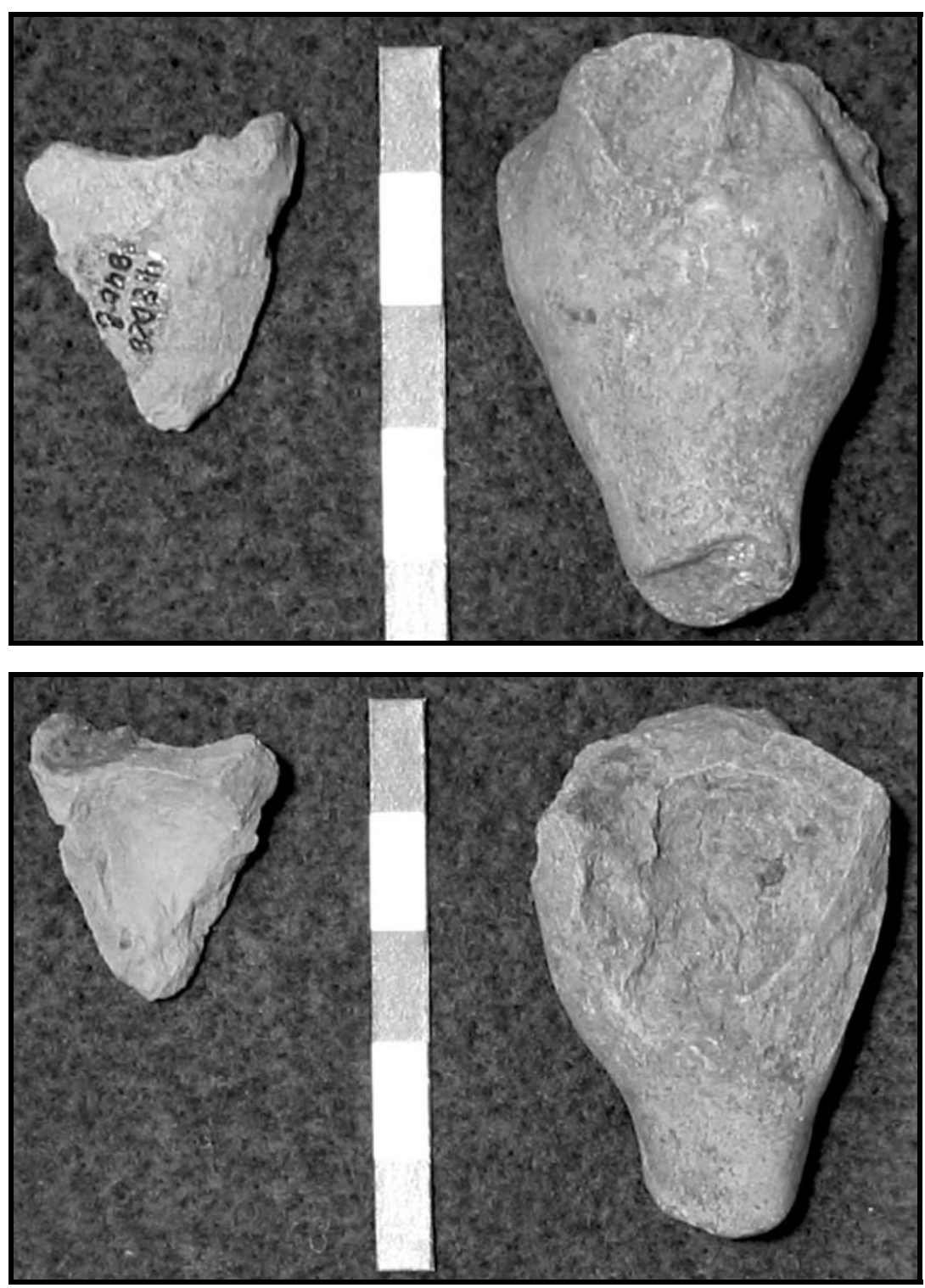

Figure 8-18. Unique Toyah Phase Clay Object

The interior reflects an irregular, slightly triangular concavity that is about $19.0 \mathrm{~mm}$ tall, about $16.5 \mathrm{~mm}$ wide, and is slightly offset from the center of the object. This interior concavity appears to have been intentionally shaped, but is not smoothed or polished and lacks any indication as to how it was formed.

The exterior is smooth, but bears three or four sets of very thin and faint striations that may be the result of a smoothing technique. The break located at the junction of the base and side, at what appears to be a protrusion, is about $12.6 \mathrm{~mm}$ tall by $11.4 \mathrm{~mm}$ wide. A finished area measuring about $6.5 \mathrm{~mm}$ wide separates one break from the other. The second break, also along the bottom edge juncture, covers an area measuring 14.1 by 12.5 . Aplastic inclusions are not macroscopically visible on the surfaces.

The smaller fragment was cut into two parts. One fragment (\#840-8-1b) was subjected to INAA, and the other (\#840-8-1a) was used in petrographic analysis. The petrographic results 
indicate this piece was tempered with 10 percent bone, significantly less frequent than the ceramic sherds from the Toyah component. Ferrous iron is the most abundant aplastic at 16 percent, followed by coarse silt and fine sand size particles of indeterminate mineralogy, presumably a natural clay resident. This mineral was not found in any of the examined potsherds from the site. This clay object is assigned to a separate and unique paste, Group-B-b. Other natural clay inclusions include 7.5 percent quartz, significant amounts (16 percent) of hematite, traces of limestone and orthoclase, and an unidentified mineral indicative of a non-local origin. The clay matrix is light tan to greenish gray and isotropic (Appendix D).

The INAA (TRC279) determined that this piece is chemically and statistically (less than 4 percent probability of membership) different from all Toyah potsherds from the Varga Site, the 201 sherds composing the Central Texas reference groups 1 and 2, as well as analyzed samples of historic native pottery from Mission San Juan and Mission San Lorenzo (Appendix F). It is currently unassigned to any known chemical group in this database, in accord with the petrographic analysis results, which separate this piece from all other pieces analyzed here, and establish a separate paste group (Appendix D). The combined petrographic and INAA results, thus appear to indicate that this piece was not manufactured in the same locales places as the other ceramics, suggesting that it was obtained through some avenue of exchange of trade.

\subsection{Vertebrate faunal Remains}

The $207.75 \mathrm{~m}^{2}$ of hand-excavations of Toyah component yielded a total of 20,438 vertebrate specimens weighing 17,348.9 g. This includes the bone fragments discovered directly associated with various Toyah events and most of the bone fragments from the upper part of the Late Archaic burned rock feature resting immediately under the Toyah component.
During excavation it was apparent that many small bone fragments had been displaced down profile into the matrix between the Late Archaic burned rocks. Virtually no bone was detected in the lower part of the Late Archaic component at or near the base of Feature 1. Most bone fragments recovered from the Late Archaic component are in the same condition as the bones from the Toyah component. Identical preservation, including size and color of the fragments combined with the type and species of bones recovered, was found in both components despite an age difference of nearly 1,000radiocarbon years between the two components.

One long bone fragment (\#89-5-2-1), recovered 20 to $30 \mathrm{cmbd}$ in Feature 1a in Unit N100/E51, was assigned to the Late Archaic component and was radiocarbon dated. This specimen exhibits a somewhat dark color, as though lightly burned, and bears acid etching on its interior and exterior surfaces. Cortical thickness ranges from 3.1 to $3.9 \mathrm{~mm}$ within the range of deer or antelope. This bone yielded a $\delta^{13} \mathrm{C}$ corrected $(-31.6 \%$ ) AMS radiocarbon age of $890 \pm 40$ B.P. (Table 81: UGA-12708), older than the Toyah component by some 300 years and some 800 years younger than the dates for the Late Archaic component. An extremely negative $\delta^{13} \mathrm{C}$ value of $-31.6 \%$ is nearly $10.0 \%$ more negative than expected for deer or antelope bones and indicates some type of contamination. This isotope value has caused the reported radiocarbon date to be younger than a bone with a more acceptable $\delta^{13} \mathrm{C}$ value of $-21.0 \%$. A second long bone sample (\#293-2-1) that was recovered from the Late Archaic context at 20 to $30 \mathrm{cmbd}$ in Unit N102/E52 yielded a $\delta^{13} \mathrm{C}$ corrected (-9.8\%) AMS radiocarbon date of $860 \pm 40$ B.P. (Table 8-1: UGA-12713), a nearly identical result. Although the light-colored appearance of this bone indicated it was potentially of Toyah, the assay is again around 300 years older than the Toyah component, but still much younger than the dated Late Archaic component. The isotope value of $-9.8 \%$ implies 
this bone was from an animal that had consumed mostly $\mathrm{C}_{4}$ grasses, which is indicative of a bison. The results of these two radiocarbon dates, the observations in the field, and the appearance of the fragments themselves guided our interpretation that most yellowish and fresh appearing bone fragments recovered from the Late Archaic component were originally associated with the Late Prehistoric component-Toyah materials. Inferable, they appeared to be associated with the Late Archaic burned rocks as the result of what amounts to minor downward translocation.

Generally, the Toyah bone assemblage was recovered from within $30 \mathrm{~cm}$ of the ground surface, except along the very eastern and western margins of the right-of-way next to the fence lines, where deposits were as much as 40 to $50 \mathrm{~cm}$ deep. This near surface assemblage appears to have suffered some from modern right-of-way maintenance activities and possibly also from cultivation. An unknown part of the Toyah component was also affected by mechanical trenching and ground stripping carried out over much of Block A during Phase I investigations. These presumed destructive activities may account for some of the fragmentation of this assemblage, so that the small size of much of the bone sample may not reflect prehistoric behavior.

Bone preservation was fair to good with some splitting and exfoliation caused from weathering, dry bone fracturing/exfoliation, and extensive root-etched surfaces. Most unburned bone is pinkish gray (5YR 7/2) in color. When burned, the colors vary from a dark brown, black, a combination of brown and black, to gray, or white depending on the temperatures the elements reached (Nicholson 1993). Although the bone sample is sizeable, the combined effects of prehistoric processing and possible modern mechanical breakage have resulted in considerable fragmentation. Ninety-six percent of the bones are less than $3 \mathrm{~cm}$ in length and less than one percent is complete elements. The largest pieces measure between 12 and $15 \mathrm{~cm}$ long, even though bison bones are often represented. This very fragmented assemblage is reflected in the average weight of a bone fragment being less than one gram.

Many tiny fragments could not be identified to species or assigned to general animal size classes. Unclassifiable pieces account for about 90 percent by number or about 54 percent by weight. Bison, deer, antelope, cottontail, jackrabbit, a canid/carnivore like coyote, turtle, snake, hawk size bird, and fish bones are positively identified. Individual species or groupings according to animal sizes are discussed in greater detail below.

\subsubsection{Bison Remains}

A total of 1,481 pieces weighing $6,268.9 \mathrm{~g}$ represent size class 6 , or bison size pieces. These 1,481 pieces represent about 7.3 percent of the total Toyah vertebrate assemblage by number, but comprise about 36 percent by weight. Sixty-seven percent are less than $3 \mathrm{~cm}$ long with less than one percent greater than $12 \mathrm{~cm}$, leaving about 30 percent in the 3 to $9 \mathrm{~cm}$ size category. Only 54 pieces, or 3.7 percent, were burned, and these weigh about $205 \mathrm{~g}$ or about $3.8 \mathrm{~g}$ per fragment. The appearance of most (76 percent) of the burned pieces is a combination of black and brown colors on the same bone fragment. Only one piece is all white, five are completely black, one piece is black and white, and six are brown. Heat intensity is the primary determinant of coloration, with less than one percent revealing intensive heating.

The identifiable elements in size class 6 include all major parts of the bison, but their fragmentary nature limited the identifiable elements to just a few pieces. The majority of specimens are long bone fragments, although a few cancellous tissue lumps were recognized, of which many are rib fragments. Occasionally 
other elements have been identified. Many identifiable elements are small, dense bones such as carpals, tarsals, sesamoids, and phalanges.

The axial skeleton is represented by a couple of caudal (tail) vertebrae, a few vertebrae fragments, one complete left acetabulum, a couple of other pelvic fragments, and tooth fragments. Tooth fragments are numerous and include incisors, premolars, and molars, although whole teeth exceptional and are often badly damaged. Both maxillary and mandibular teeth are present. The more seasonally sensitive deciduous teeth, or third molars, were not recognized. Other than teeth, skull parts were not identified, with the exception of the inner ear. Four nearly complete inner ear elements were identified, including two lefts and two rights. This element indicates the minimum number of individual bison is two. Thoracic spines were recognized in a few instances, but many pieces closely resemble the rib fragments, which, given the fragmentation factor, makes identification difficult. Only two rib heads are identified.

Scapula fragments, a right distal humerus fragment, a left proximal radius fragment, an ulna fragment, a right magnum, and a right scaphoid represent the appendicular skeleton. A proximal femur, a proximal tibia, a left distal tibia, a left patella, a right lateral malleolus, and a right navicular-cuboid represent rear legs. Other appendicular elements include distal metapodial fragments, sesamoids, and phalanges.

With the sample representing the entire skeletal anatomy, it can be inferred that the entire bison carcass was brought to camp and then further processed. However, the fragmentary condition of the bones precludes identification of a butchering sequence. In general, it can be assumed that, following the kill, skins were removed, then the meat was stripped from the skeleton, and finally the bones were broken for marrow removal and perhaps for bone-grease rendering. A couple of long bone fragments reveal impact fractures near their mid-shafts, but the root-etching has probably obscured evidence of stone-tool cut marks. The highly fragmentary nature of the bones may be partly attributable to smashing for marrow extraction and subsequent rendering of bone grease.

Fifty-four fragments (3.7 percent of the sample) of this size class were burned to varying degrees. This includes 41 pieces that are both black and brown, six pieces that are brown, five pieces that are black, one that is white, and one that is both black and white. As already noted, these color differences reflect burning at a fairly wide range of temperatures.

The identifiable teeth represent at least one medium-aged individual, judging by tooth wear. Individual tooth exhibit wear with their styles worn to loops. One upper molar that was badly preserved appears to be cupped and representative of a much older individual. Therefore, a middle-aged and mature adult are minimally represented.

A bison bone fragment (\#525-5-2-1a) from Feature 2 was submitted for stable isotope analyses. Geochron Laboratory reported that the stable carbon isotope on collagen was $-8.6 \%$, the nitrogen isotope was $5.1 \%$, and the stable isotope on bioapatite was $-4.0 \%$. These values indicate the bone was bison that had consumed about 80 percent $\mathrm{C}_{4}$ plants (grasses).

\subsubsection{Deer and Antelope Remains}

In most instances in this very fragmentary assemblage, specific elements representing one or the other of these two medium sized ungulates could not be distinguished. The more complete the element the greater chance to identify a particular species. First, we address the class as a whole, with more specific information on the individual species to follow. 
A total of 496 pieces, weighing 1,668.6 g, were assigned to size class 5 , accounting for about 2.4 percent of the total Toyah assemblage by number and nearly 9.6 percent by weight. Again, the pieces are highly fragmented, as indicated by the fact that 88 percent are less than $3 \mathrm{~cm}$ in length, and none measure greater than $9 \mathrm{~cm}$ in length. Some 67 pieces weighing $70.6 \mathrm{~g}$, or 13.5 percent, were burned.

Small fragments identified as ribs, long bones, teeth, and articular ends of long bones are represented. Most parts of the skeleton, and apparently, the entire animal(s) was brought to camp for processing.

Teeth and a few fragmentary elements represent deer species. Individual elements identified as deer, including 12 pieces of first, second, and third phalanges, a distal metapodial, a right and left navicular-cuboid, seven fragments of inner ear bones, one lumbar vertebra, two right astragali, a cuneiform pes, an ulna notch, a left distal humerus, a complete scaphoid, and various teeth including a complete third molar and maxillary teeth. A complete, burned dewclaw (recessed third phalanx) was recovered from the flotation sample (\#79-4) extracted from a hearth, Feature 21. Minimally two deer are represented based on two right astragali. Minimally one is a mature adult as indicated by a massive, worn third molar (\#32-2). The massive size of this third molar is in the size range of a mule deer. Minimally one adolescent is indicated by a complete deciduous third premolar (\#1103-2). This deciduous tooth is close to an animal in the age range of 1.5 years (Ramsey and Shult 1990). Using the tooth eruption and wear data presented by Ramsey and Shut (1990), the third molar would indicate an animal in the range of about 4.5 years old. However, recent studies by Gee et al. (2002) and others have cast considerable doubt on Severinghaus' (1949) original criteria for aging deer using tooth eruption. Therefore, the ages of these two individuals are only tentative.
Several first phalanges were butchered to remove the tiny bit of marrow from the inside cavity and/or to facilitate grease rendering. A medial section of a distal humerus shaft reveals an impact fracture, again direct evidence that long bones were intentionally broken open for marrow extraction. Many identifiable deer specimens are larger than the modern whitetail deer in Quigg's comparative collection from Central Texas and may represent the larger mule deer.

Antelope remains are recognized through teeth and a few individual elements. The identified elements include a right astragalus, scapula fragments, a left proximal metapodial, a lunate, first and third phalanges, occipital condyles, and the inner ear. Minimally one individual represented. One antelope first phalange was butchered indicating that the tiny lump of marrow in this cavity was sought. This element was recovered from Feature 25 in a good Toyah context.

Two fragments, both less than $2 \mathrm{~cm}$ long, appear as possible fetal bones, as they lack solidified cortical walls and exhibit a honeycomb bony structure. However, they are too small and lack sufficient characteristics to clearly allow assignment to one of the specific ungulate species identified here. One piece (\#1187-2) is similar in size and shape to a fetal deer radius, with an ovate cross section that slightly expands toward one end. It measures $12.3 \mathrm{~mm}$ wide by $8.0 \mathrm{~mm}$ thick toward the articular surface and weighs $0.7 \mathrm{~g}$. The other fragment is approximately $15 \mathrm{~mm}$ long by about $5 \mathrm{~mm}$ wide and expands slightly at both ends. This tiny piece appears to have two and possibly three short, potential cut marks on the mid-shaft, indicating it is definitely cultural. If these two elements represent fetal bison, then that would indicate a possible February to March death period for the female carrying the fetus. If they actually are from fetal deer or antelope, then 
they may represent a death period more later in the spring.

\subsubsection{Other Faunal Remains}

This general group includes 49 fragments representing a variety of other, non-ungulate species. They comprise a mere 0.2 percent of the total Toyah bone assemblage. Because of their very limited frequency, their very small size, and the potential for small bones to be naturally deposited in the stream alluvium, it is not certain that these few fragments represent human procurement/processing as opposed to naturally deposited remains.

Turtles are represented by two each of plastron (\#43-2 and \#58-2), and two carapace (\#324 and \#119-2) fragments. Specimen \#119-2 is burned to a brown color and includes a small part of the vertebra on its interior, supporting human use/processing of at least one turtle. A tiny fragment of turtle shell was recovered from float sample (\#87) obtained from hearth Feature 21 in Unit N100/E50/51. Minimally, two turtles are represented.

Snakes are represented by six tiny, unburned vertebrae (\#119-2, \#919-2, \#1021-2, \#1039-2, \#1055-2, and 1197-2). Two unburned snake vertebrae were recovered from a float sample (\#185) recovered from 0 to $10 \mathrm{cmbd}$ in Unit N100/E51. Minimally two snakes are represented.

A large unknown bird of raptor/hawk (possibly a red-tail hawk) size is represented by a large 23.5 mm long, complete third phalanx (\#377-2). A small hole on one side appears similar to a tooth puncture. This element is not burned, but does exhibit a light polish or shine over its surface. Three other thin, medial long bone fragments (\#159-5-2, \#219-2, and \#1088-2) may represent birds, but identification is uncertain.

Four medial long bone fragments (\#955-2, \#9712, \#981-2, and \#1137-2) one of which is burned to a brown color, were assigned to size class 4 that could include animals such as dogs and coyotes, though positive identification is not possible. One or more of these fragments may be from a slightly smaller animal in size class 3 . A second phalanx (\#981-2) is the size of a coyote or dog. A petrous or inner ear bone (\#981-2) may also be from a dog or coyote size animal. One coyote or dog is believed to be represented.

Two medial long bone fragments (\#78-5-2 and \#1084-2) were assigned to the size class 3 or 4, one of which was burned to a brown color. Size class 3 includes animals about the size of raccoons, and could also include small canids.

Thirty-three very thin, medial long bone are assigned to size class 2 , which includes animals in the size range of rabbits. These long bone shaft fragments are broad enough to possibly represent jackrabbits or reflect various species of birds. Without the more diagnostic articular ends, it is impossible to identify long bones to a species. A cottontail rabbit is represented by a left mandible fragment (\#526-2) and a maxilla fragment (\#533-2). One proximal metapodial fragment (\#159-5-2) is from a jackrabbit. As mentioned above, a bone bead blank (\#1054-21, see description below) is also a tibia midsection from a jackrabbit-size animal. The heavy fraction of float sample (\#87-4) from hearth Feature 21 also yielded a tiny distal end of a rabbit humerus. A rabbit metapodial was recovered from a float sample (\#843-5-4) from the debris dump, Feature 8.

\subsubsection{Discussion}

Fish are represented by two skull elements (\#109-2). Two tiny, unburned fish vertebrae were recovered from the heavy fractions of float samples (\#78 and \#87) from hearth Feature 21.

In summary, the very fragmented vertebrate remains indicate only one or two animals in the different groups or size categories. Minimally two deer, one bison, one antelope, one canid, 
one jackrabbit, one cottontail, two turtles, and possibly snakes, fish, and birds contributed to human subsistence. Potentially, multiple animals are represented for each taxon, but the limited numbers of bones identified for any one animal indicate that the occupants were not conducting massive communal type kill operations directed toward any one species. Individual stalking and hunting tactics directed towards the larger ungulates appear to have been the main targets of the Toyah occupants of this site. Smaller game, such as rabbits and turtles, were may have been procured with traps. It also appears that regardless of size, entire carcasses were to camp for processing. The findings imply that both bone marrow extraction and probably bone grease rendering were carried out.

A hint at seasonality is based on two small fragments of fetal bones, which are not identified to a specific species. These specimens indicate a spring to early summer kill, while deer tooth eruption and wear patterns may indicate a late fall (i.e., November through December) event. Since a series of Toyah occupations were recognized here, the different projected seasons of occupations are not in conflict. Seasonality has often been difficult to decipher in other relatively limited assemblages.

The Toyah-phase occupants of the Varga site focused their meat consumption on three ungulates, deer, antelope, and bison, and augmented these with small game such as turtles, canids, birds, fish, etc. This apparent subsistence regimen, is to other those indicated by findings at other Toyah sites investigated across Texas (Steele 1986; Scott and Creel 1990; Treece et al. 1993b; Masson and Holderby 1994; Shaffer 1994; Quigg and Peck 1995; Henderson 2001). Not only is the subsistence resource base similar in most Toyah components, the discarded faunal assemblage is also similar insofar as vertebrate remains are highly fragmented and frequently burned, with the fragmentation inferably reflecting marrow extraction and grease rendering activities.

Most investigated Toyah components have yielded a relatively limited number of individual animals, indicating the hunting technique and practice was often limited to stalking or trapping the animal by one or a few hunters. An exception is found at the Toyah component at the Mustang Branch site (41HY209T) where some 19 adult deer, eight antelope, and two bison were identified within the limits of a processing area (Masson and Holderby 1994). The deer population at Mustang Branch was determined to characterize a catastrophic kill episode, implying a communal effort requiring a relatively large group of individuals. Although communal hunting does not appear as a common practice for the Toyah population, apparently the Toyah people did understand sometimes practice this kind of procurement strategy.

\subsection{Mussel Shell Remains}

Mussel shell fragments were quite limited in number and in size, with only 19 individual pieces collected from the Toyah component. In a few instances during field excavations, tiny shell fragments were observed, but not collected, as they were often just tiny, thin flakes. The 19 collected fragments weigh $25.5 \mathrm{~g}$ and consist of two umbo sections, a fragment of the lateral teeth. The rest are tiny unidentifiable fragments. One umbo fragment resembles Lampsillis sp., but this identification is inconclusive. A second umbo (2.8 g) exhibited characteristics similar to the Tampico pearl mussel (Cytonaisa tampicoensis), a species native to the Rio Grande, Nueces, Frio, San Antonio, Guadalupe, and Brazos river systems (Howells et al. 1995:48). Both species tolerate diverse habitats. The limited number of shell specimens indicates that this resource was not being intensively sought as a food or other resource. It is quite possible that many of the pieces recovered were natural occurrences in the alluvial deposits. However, the presence of one or two culturally 
altered pieces of shell indicates mussel shell was at least used in limited ways. It was not a significant part of the dietary repertoire.

\subsection{Ceramic Assemblage}

A total of 119 ceramic sherds, weighing $270.4 \mathrm{~g}$, were collected from the Varga Site. Of those, 115 , were directly recovered from the Toyah component. Three sherds (\#1261) were collected from the surface, and one (\#962) was recovered from the Late Archaic context in Block B (presumably displaced).

Sherds are small, with an average diameter of $19.8 \mathrm{~mm}$, with an average weight of $2.1 \mathrm{~g}$, reflecting their very small size. A few pieces were too small to record basic attributes and assign to a vessel group. The entire sherd assemblage has been sorted into five vessel groups (1 through 5) based on a combination of observed attributes of color, paste, texture, interior and exterior surface treatment, thickness, and aplastic inclusions. Some sherds were easily assigned to one group or another, whereas others shared similarities with two groups. While a number of attributes were taken into consideration for sorting, in some instances one obvious and prominent attribute formed the primary criterion for placement of a given sherd into a group. For example, the Vessel Group 2 contained tiny black bone temper, whereas in most other sherd groups the bone temper was white. However, given the small size of most sherds, improper assignment of some specimens is quite possible. The sorting of the sherds was done to facilitate the selection of samples for the various technical analyses. Selecting sherds from the different vessel groups would help insure that technical analyses were conducted on a representative sample of ceramic vessels. The creation of these groups also permits and approximation of the number of vessels represented. The five sherd groups should probably be considered as representing a minimum of five vessels, since we believe it is possible that more than one vessel is represented in Groups 1, 3 and 4. Appendix O provides metric and non-metric attributes for individual sherds as the basis for their assignment to groups. The vessel groups are discussed below, followed by a general discussion of the ceramic assemblage.

Special technical analyses were conducted on a few selected sherds from different vessel groups. Organic residues in four sherds were AMS dated. Parts of 10 sherds were examined through petrographic analysis to investigate the production technology and range of variation in the clay and temper being employed. Parts of eight sherds were subjected to INAA to determine if they were manufactured using local or non-local clays, as well as to determine the number of source areas for clays. Six sherds were used for lipid residue analysis to ascertain the basic kinds of foods that may have been cooked in these vessels. Parts of the same sherds used in the lipid residue studies were also used to determine stable carbon and nitrogen isotope values, which aids in narrowing the range of foods groups identified in the lipid residue analysis. In a few instances a single sherd was broken into multiple pieces for use in the different technical analyses to reinforce confidence in the overall results. Where that was not possible, a sherd with similar visual characteristics from the same vessel group was used for the different types of analyses.

\subsubsection{Vessel Group 1}

Forty-six body sherds were assigned to Vessel Group 1 (Figure 8-19). Sherds are mostly quite small (average diameter is $20.1 \mathrm{~mm}$ ), with an average thickness of $5.2 \mathrm{~mm}$. Sherds \#1030-8-1 (10 g) and \#1055-8-1 (8.8 g) were sent for lipid residue analysis, small fragments of sherds \#1030-8-a (TRC271) and \#1054-8-1 (TRC270) were sent for INAA, and less than $1 \mathrm{~g}$ of each interior of the two sherds used for lipid analysis (\#1055-5-4-8-1a and \#1030-5-4-8-1a) were also subjected to stable carbon and nitrogen isotope analyses. Sherd \#1089-8-1a (2.7 g) was sent for 


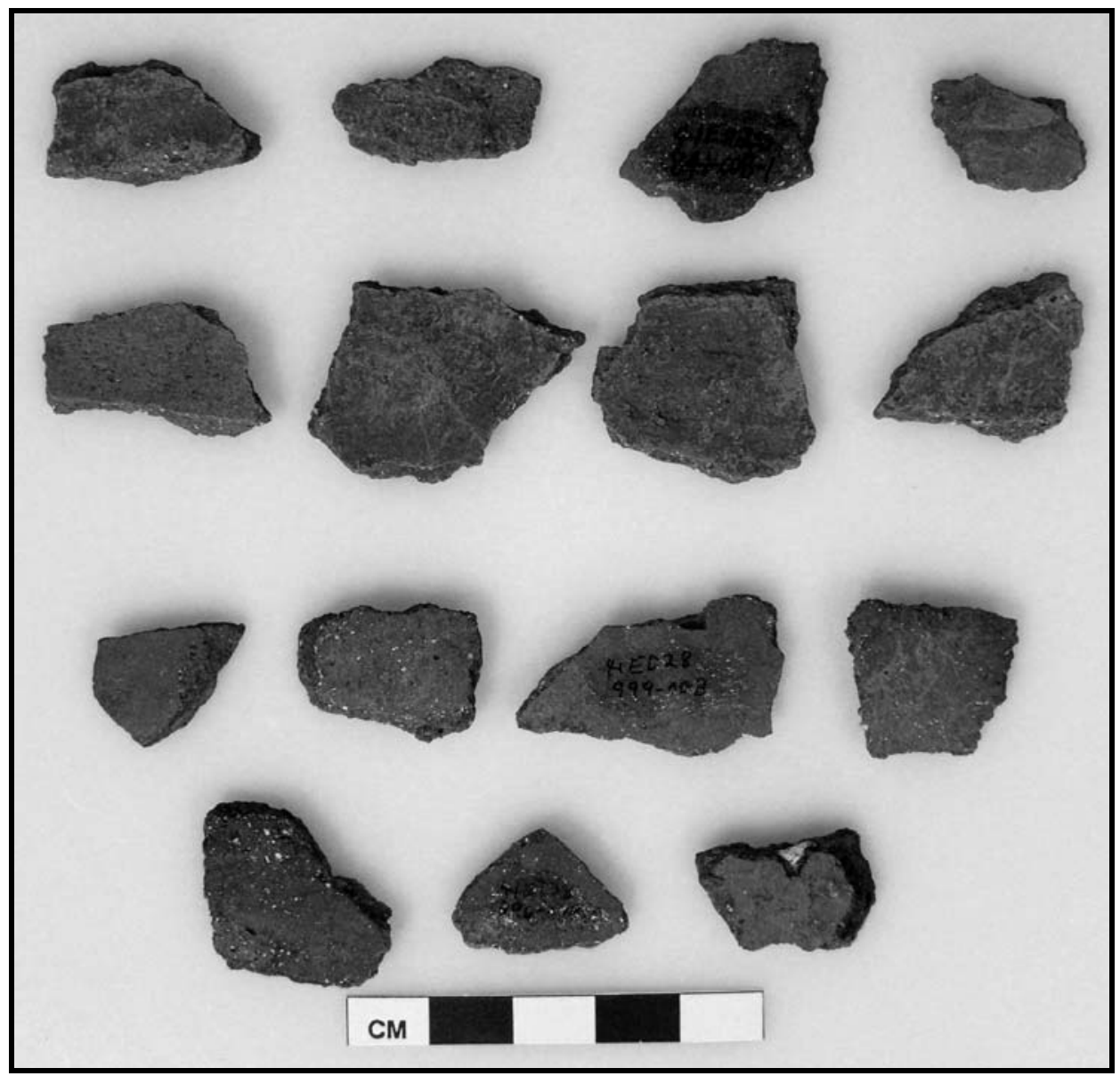

Figure 8-19. Selected Vessel Group 1 Sherds

Left to Right: Top Row (Interior Surface): \#1081-008, \#843-008, \#841-008-1, \#1162-008-3; Second Row (Interior Surface): \#845-008, \#1030-005-008, \#1030-005-004-008-2, \#1050-008-2

Third Row (Exterior Surface): \#841-008-2, \#1008-008-2, \#999-008, \#1050-005-008-1 Forth Row (Exterior Surface): \#1023-008-2, \#996-008, \#865-005-008

radiocarbon dating of inclusive organic residue (see discussion below).

\subsubsection{Shape}

The overall vessel shape is cannot be determined, since very few of the small sherds could be refit to obtain a reliable impression of curvature or vessel form. Most sherds have minimal curvature, but an unusually large body sherd (\# 1054-8-2) suggests a vessel diameter about $28 \mathrm{~cm}$. Sherd thickness measurements range from 3.9 to $7.1 \mathrm{~mm}$, which is quite variable and may indicate that multiple vessels are represented or, that the different parts of the same vessel-base and body-are present in this group. $\quad$ Five sherds have thickness measurements over $6.0 \mathrm{~mm}$, whereas only two sherds have thickness measurements less than $4.0 \mathrm{~mm}$. The thickness variation indicates that a thick bottom may be represented.

\subsubsection{Construction}

Most broken edges are angular and indicate clean, sharp, generally perpendicular breaks without indication of breakage along coil lines. However, two sherds (\#1050-5-8-1 and -2) that 
refit, exhibit an angled break along the common edges. Sherd \#1162-8-3 exhibits one angled break that might also be considered indicative of a possible coil edge, but the very edge is not rounded. A third sherd (\#1008-8-2) exhibits two opposite edges that are angled at nearly 60 degrees and parallel one another. This sherd also exhibits a narrow, low, rounded ridge on the interior surface, which is equi-distant between the two angular breaks. The broken edges opposite the angled breaks hint at the presence of the margins of the welded coil by slight changes in the paste. If these two angled breaks, coupled with the low interior ridge and hint of the coil in the profile, actually represent the nearly obliterated margins of welded coils, then the width of the welded coil is about 8 to $9 \mathrm{~mm}$. These observations at least indicate that this vessel was constructed with coils and subsequently smoothed with nearly total obliteration of evidence of the original coils.

\subsubsection{Exterior Surface}

Seventy-four percent of the sherds exhibit smooth, plain exterior surfaces, whereas 26 percent exhibit polished/burnished surfaces (Figure 8-19). Often tiny temper particles are visible on the surface. Surface colors vary from olive (5YR 5/4), to pale olive (5YR 6/4), to olive gray (5YR $5 / 2$ ), to gray (10YR $5 / 1$ ), to brown (7.5YR 5/2) to light brown (7.5YR 6/4). Some dark surfaces may represent firing clouds, but the small sherd size hinders definition of cloud edges. The largest sherd (\#1054-2) exhibits two different colors, clearly indicating fire clouding. It also exhibits faint horizontal smoothing as indicated by very shallow grooves of various widths between very low ridges across the surface, but the subsequent smoothing process has made them nearly invisible. The tool that produced these mostly obliterated marks cannot be identified.

\subsubsection{Interior Surface}

Interior surfaces also vary, with 63 percent smooth, 33 percent rough, and four percent polished. The rough interiors exhibit a variety of conditions. The above-mentioned sherd (\#1008-8-2) with the hint of coil breaks, has a narrow, low rounded ridge parallel to the possible coil breaks that could be the partially smoothed edge of a wedged coil. It also exhibits thin striations parallel to the low ridge and slight concave surfaces between the low ridge and the broken margins. Sherd \#1030-5-4-8-1a exhibits mostly a rough interior with very low, subdued ridges, thin striations, and an uneven surface. The largest sherd (\#1054-2) exhibits a slightly irregular interior surface with faint horizontal and parallel wiping ridges. Two refit sherds (\#1050-5-8-1 and 2) show a slightly irregular surface with a slightly concave area and drag marks made on a tacky surface. The variability in interior surface treatments hint at multiple vessels, although one vessel possibly was finished differently depending on the ease of access to the interior. Infrequently, a fingertip size concave area was observed. Interior colors vary from reddish brown (5YR 5/3), to pinkish gray (7.5YR 6/2), to reddish yellow (5YR 6/6).

\subsubsection{Paste}

The paste color varies from a dark gray (10YR 4/1), to gray (5YR 5/1), to reddish brown (5YR 5/3), to a very pale brown (10YR 7/4) with some that appear banded. In the banded cases, the innermost core is the darkest, although in two sherds, \#865-5-8 and \#1023-8, colors become lighter toward the central core. The dark interior core reflects the temperatures reached during the firing process and perhaps the organic content of the clay.

Petrographic analysis was conducted on two body sherds (\#1089-8-1b and \#1054-8-1b) from Vessel Group 1. Sherd \#1054-8-1b is tempered with 28 percent bone and 8.5 percent limestone. Distinctive clay aplastic inclusions include 
quartz (2.5 percent quartz), iron (8.5 percent), tiny clay nodules (3.5 percent) and a trace of orthoclase (1.5 percent). The clay matrix is tan to greenish gray and anisotropic (Appendix D). Sherd \#1089-8-1b was quite similar and is tempered with crushed bone (24 percent) (no bone in previous sherd??), limestone (9.0 percent), tiny clay nodules (0.5 percent) and orthoclase. The matrix is moderate, greenish gray to gold, and isotropic (Appendix D). Both sherds were subsequently assigned to the same Paste Group-B-c, since they exhibited the same aplastics in similar quantities. The bone inclusions are calcined and generally quite tiny, although an occasional piece is relatively large, at up to $3 \mathrm{~mm}$ in diameter (\#865-5-8).

\subsubsection{Distribution}

Only two sherds, or about four percent of Vessel Group 1, were recovered from Block A. Each of these was found in a separate unit, one on each side of the southern end of BT 1 (Figure 8-20). Nearly 96 percent of Vessel Group 1 sherds were widely scattered in Block B. Seventeen units yielded single sherds, with seven units yielding multiple sherds. The highest concentration was in and around Features 25 and 38 (Figure 8-21). No other sherds from other vessel groups were located in, or immediately adjacent to, these two features. Another four sherds were located in the adjacent unit that contained Feature 38. Feature 8, about $8 \mathrm{~m}$ to the southwest, also yielded one sherd from this group.

\subsubsection{Discussion}

Petrographic analyses on two sherds (\#1054-81b and \#1089-8-1b), assigned to Vessel Group 1, confirmed their similarity. Subsequently, they were assigned to the same Paste Group-B-c. The petrographic results also indicate that the two analyzed sherds and, by implication, all of Vessel Group 1, were manufactured locally. This same paste group is quite similar to a Toyah vessel from 41CC131 at O. H. Ivie
Reservoir $180 \mathrm{~km}$ to the north, a vessel from 41 HY209 at Onion Creek $210 \mathrm{~km}$ to the east, and a historic sherd from Mission San Lorenzo about $40 \mathrm{~km}$ to the south (Appendix D). The implication of this is not clear, though it is possible that the results reflect the movement of people across the Central Texas landscape.

The INAA on two Vessel Group 1 sherds (\#1054-8-1a = TRC270 and \#1030-8-a = TRC271) determined both to be part of a limited number of analyzed sherds $(n=3)$ composing the Varga-1 chemical group (Appendix F). This group is chemically and statistically (less than 4 percent probability of membership) different from most other Toyah sherds from the Varga Site and the Central Texas 1 and 2 reference groups. This indicates that these two specific sherds and, by implication, all of Vessel Group 1 sherds, were manufactured from clay sources other than those identified previously from the ca. 200 INAA samples from the Central Texas region. The INAA chemical findings thus do not parallel the petrographic findings that indicate similarity in pastes with sherds from other Toyah sites. This suggests that the petrographic analysis may simply be tracking coincidental similarities in paste constituents, as opposed to identifying meaningful commonalities among Toyah pottery. Lipidresidue analysis on two sherds from this group (\#1055-5-4-8-1a and \#1030-5-4-8-1a) produced only slightly different results. Sherd \#1055-5-48-1a indicates borderline moderate-to-high and high fat content interpreted to reflect plant products (Appendix G). Sherd \#1030-5-4-8-1a indicates moderate to high fat content interpreted to reflect plant products (Appendix G). Both outcomes support the conclusion that plants were being cooked in this vessel.

The stable isotope analysis on the two sherds revealed nitrogen isotope results of -2.6 and $2.8 \%$ from very low amounts of measured nitrogen, which make the results suspect. 


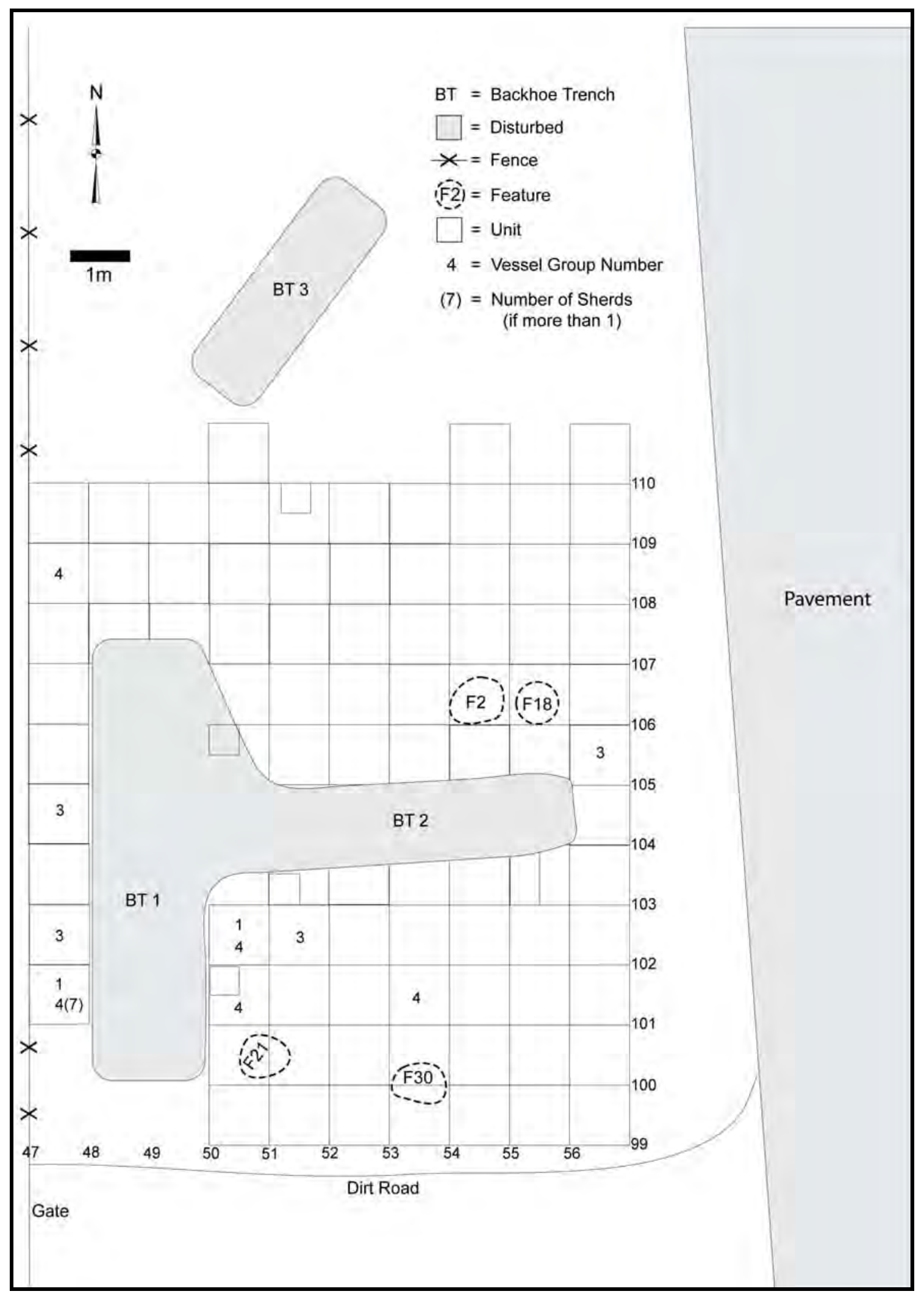

Figure 8-20. Distribution of Vessel Group Sherds in Block A 


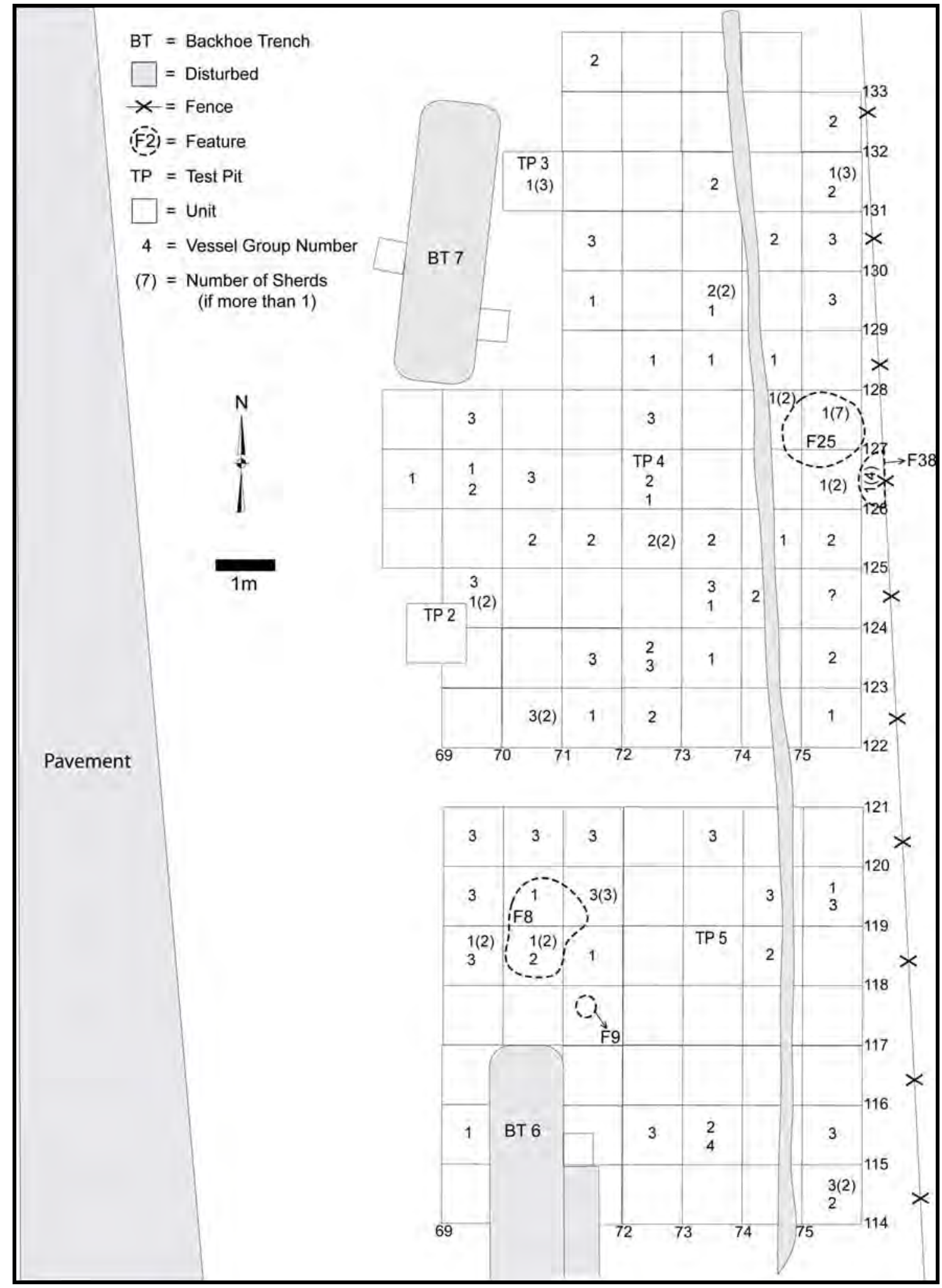

Figure 8-21. Distribution of Vessel Group Sherds in Block B 
The two carbon isotope values of -27.2 and $24.3 \%$ indicate very high levels of $\mathrm{C}_{3}$ contributions to the materials cooked. The isotope values support the lipid residue analysis and indicate that plants, possibly $\mathrm{C}_{3}$ legumes such as mesquite beans, were cooked in this vessel.

Sherd \#1089-8-1a (2.7 g) from Block B was sent for radiocarbon dating and yielded a $\delta^{13} \mathrm{C}$ ($17.8 \%$ ) corrected age of $310 \pm 40$ B.P. (UGA12730) (Table 8-1). This age calibrates to the Sixteenth Century, at the temporal boundary of the Prehistoric and the Protohistoric periods.

In summary, the 46 sherds assigned on the basis of macroscopic observation to Vessel Group 1 may represent multiple vessels. Their thicknesses reveal a range that might suggest that at least two vessels are represented. In support of multiple vessels present in Vessel Group 1 is the stable isotope data that reveals differences in the organic residues in the two analyzed sherds. In addition, the lipid residues from the two sherds were slightly different. The fact that only four percent of these sherds were in Block A may also imply multiple vessels are represented. In contrast, the petrographic findings and the INAA indicate that the two Vessel Group 1 sherds analyzed were assigned to the same paste group and the same chemical group, respectively. Therefore, if more than one vessel is represented in this group they were very much alike, and apparently were manufactured from similar materials from similar sources.

\subsubsection{Vessel Group 2}

Twenty-five body sherds were assigned to Vessel Group 2 (Figure 8-22). Sherds are, again, quite small, with the largest (\#965-8) measuring $39.4 \mathrm{~mm}$ in diameter. Sherds \#936-8a and \#1181-8-1 refit. Two sherds from the same provenience in \#1096-8 also refit, as do two sherds in a second provenience \#984-8. Sherds \#799-8-2a and \#1181-8-1b were subjected to petrographic analyses. Two sherds, \#936-8-a and \#1129-8-1a, were sent for INAA. Two sherds, \#965-8-1a and \#1157-8-1a, were analyzed for lipid residue and less than $1 \mathrm{~g}$ of each was submitted for stable carbon and nitrogen isotope analyses. Sherd \#987-8-1a was sent for AMS radiocarbon dating. Sherds in this group were rather widely scattered, and two specimens were found 8-9 meters apart (\#936-8a from Unit N123/E72 and \#1181-8-1 from Unit N132/E75).

\subsubsection{Shape}

Vessel shape is indeterminate, with only a couple of refits providing any indication of curvature. Curvature varies, with some sherds showing greater curvature than others. Sherd thickness measurements range from 4.8 to $8.1 \mathrm{~mm}$, with the average thickness $1.0 \mathrm{~mm}$ greater than that of Vessel Group 1. Only 21 percent of Group 2 sherds have thickness measurements less than $5.5 \mathrm{~mm}$, whereas 21 percent have thickness measurements greater than $6.7 \mathrm{~mm}$. Therefore, 58 percent have thickness measurements between 5.5 and $6.7 \mathrm{~mm}$. The different thicknesses and the different curvatures may indicate a shouldered vessel.

\subsubsection{Construction}

The edges of sherd are perpendicular to the interior and exterior surfaces. Four sherds exhibit one or more edges that are not quite perpendicular and hint at a curved, or possibly a welded, coil edge. The $3.3 \mathrm{~mm}$ variation in thickness measurements probably represents different parts of the same vessel.

\subsubsection{Exterior Surface}

The exterior surfaces are all quite similar and exhibit smooth, polished surfaces with no decorations, few imperfections or striations, and almost no visible particles of temper. Sherd $\# 1000-8-1$ is the exception with a very pitted 


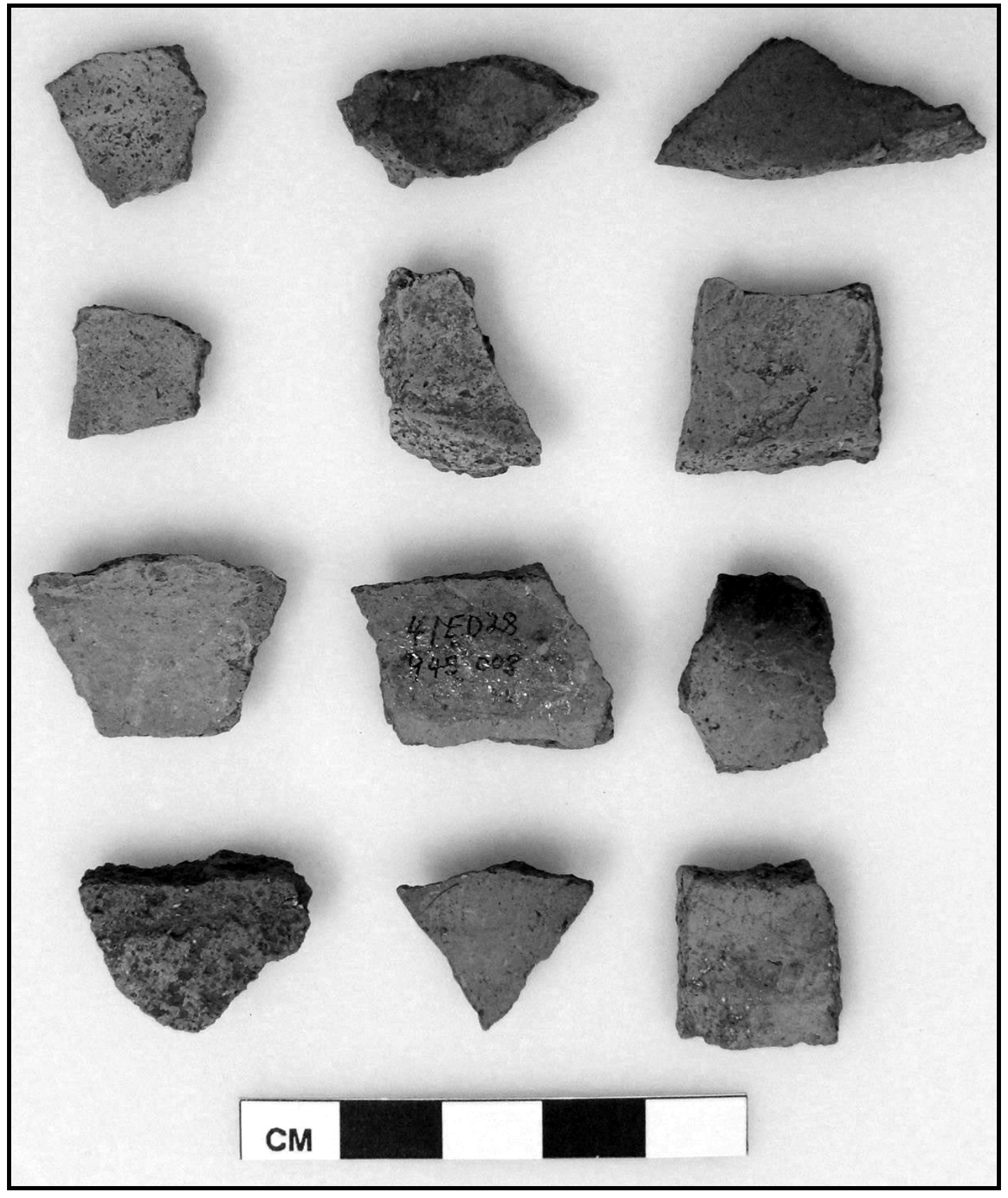

Figure 8-22. Selected Vessel Group 2 Sherds

Left to Right: Top Row (Interior): \#908-008, \#856-008, \#1187-008;

Second Row (Interior): \#781-008, \#992-008, \#842-008-1;

Third Row (Exterior): \#977-008, \#945-008, \#984-008-1;

Forth Row (Exterior): \#1000-008, \#1008-008-1, \#1096-008-3 
surface. Surface colors are also quite similar and generally are pink (7.5YR 7/4), to reddish yellow (7.5YR 7/6), to light yellowish brown (10YR 6/4). Some dark surfaces (gray; 5YR 6/1) are present on minimally three sherds (\#984-8 and \#1187-8) and may represent firing clouds.

\subsubsection{Interior Surface}

The colors of the interior surfaces vary from pink (7.5YR 7/4), to light brown (7.5YR 6/4), to light reddish brown (5YR 6/4), to pale yellow (5YR 7/3). Three sherds (\#856-8, \#1008-8-2, and \#1187-8) also exhibit what appear to be burned areas or firing clouds that are light reddish brown (5YR 6/4). Interiors are quite smooth; some are polished and some are not. Slight imperfections are present, but they are tiny and exhibit no patterning or identifiable tool marks. Tiny dark temper particles are scattered across most interior surfaces.

\subsubsection{Paste}

Interior paste color is similar to the interior and exterior surfaces. It varies from pink (5YR 7/4 and 7.5YR 7/4), to light reddish brown (5YR 6/3), to gray (5YR 5/1), to very pale brown (10YR 7/4). Two colors are visible in 33 percent of the sherds.

Two body sherds from Vessel Group 2 (\#799-82a and \#1181-8-1b) were subjected to petrographic analysis. Sherd \#799-8-2a is heavily tempered with 28 percent bone, 11.5 percent limestone, and 2.5 percent calcite. It exhibits low frequencies (12.5 percent) of voids and iron stains ( 4.5 percent). The matrix is greenish brown to gold and anisotropic (Appendix D). Sherd \#1181-8-1b was quite similar to the first sherd and is heavily tempered with 28 percent bone, 10 percent limestone, and 4.5 percent calcite. Scarce voids and limited iron stains are present. The clay matrix is medium greenish brown to gold, and anisotropic (Appendix D). Both sherds were assigned to
Paste Group-B-a. The bone temper is burned to a dark gray or black color with only a few white calcined pieces.

\subsubsection{Distribution}

No sherds from this vessel group were recovered from Block A. The sherds were in Block B, widely distributed from the very northern end to the southern end and scattered through 21 different units (Figure 8-21). Only two units, N125/E72 and N129/E73, yielded more than one sherd. Only one recognized feature, Feature 8, yielded a sherd from this group.

\subsubsection{Discussion}

This relatively small group of sherds appears to represent a single vessel with a rather homogenous color, except for the smudges and consistent dark-colored bone temper that stands apart from the other calcined/white bone tempering in other vessels. The petrographic analysis placed both assigned sherds of this group into Paste Group-B-a. This paste group is similar to petrographically analyzed sherds from sites $41 \mathrm{RN} 3$ and $41 \mathrm{CN} 95$ at O. H. Ivie Reservoir, two sherds from 41HY209 at Onion Creek, and one sherd from San Felipe Springs that is $65 \mathrm{~km}$ to the southwest (Appendix D).

The INAA on two Vessel Group 2 sherds (\#9368-a = TRC272 and \#1129-8-1a = TRC273) determined that they are chemically part of the same Varga-2 chemical group together with sherds from Vessel Group 4 and the natural sediment sample (\#1259 = TRC280) collected from 65 to $70 \mathrm{cmbd}$ in the $\mathrm{Bk}$ soil horizon (Appendix F). This group is chemically and statistically (less than 4 percent probability of membership) different from Vessel Group 1 sherds from the Varga Site and the Central Texas 1 and 2 reference groups. This indicates that these two sherds, and by implication all of Vessel Group 2 sherds, were manufactured from different clays than currently identified from the ca. 200 reference group samples for the Central 
Texas region. The INAA chemical findings partially support the petrographic findings of these two sherds, which were placed in the same Paste Group-B-a. The INAA chemical results support the petrographic observations that Vessel Groups 1 and 2 are different. This indicates they were probably manufactured in different localities, used different clay sources, and are also different from the Central Texas reference group. These two sherds exhibit chemical similarity to the natural sediment sample analyzed (\#1259-4b = TRC280) and were probably locally manufactured. The divergence from all other Central Texas reference groups indicates that Toyah pottery may have generally been locally manufactured and that vessels were not widely transported.

The lipid residue analysis on two sherds (\#9658-1a and \#1157-8-1a) revealed very similar results. Sherd \#965-8-1a revealed moderate-tohigh fat content that is interpreted as indicating plants were cooked in the vessel (Appendix G). Sherd \#91157-1a revealed borderline moderateto-high fat and high fat content that is also interpreted as indicating plants were cooked in the vessel (Appendix G). Plants appear as the principal products cooked in this vessel.

The nitrogen isotope values from sherds \#965-81b and \#1157-8-1b yielded values of -1.2 and $5.0 \%$, respectively. The negative value indicates that legumes were probably cooked in the vessel. The relatively large difference indicates that different foods in the same vessel. The carbon isotope values of -27.6 and -25.0 , respectively, indicate nearly total contributions from $\mathrm{C}_{3}$ plants or animals. These isotope values coupled with the lipid residue results indicate that $\mathrm{C}_{3}$ plants, most likely some type of legumes, were being cooked in this vessel.

Sherd \#987-8-1a was sent for AMS radiocarbon dating and yielded a $\delta^{13} \mathrm{C}$ (2\%o) corrected age of $26,960 \pm 40$ B.P. (UGA-12727; Table 8-1). This age is well beyond the temporal range of known prehistory and is therefore, unacceptable. Most likely, some unidentified substance that was not removed during the laboratory cleaning process contaminated the sample.

In summary, the 25 body sherds visually assigned to Vessel Group 2 are quite homogenous and probably represent a single vessel. The black bone particles in these sherds set this group apart from most Toyah vessels, which exhibit white/calcined bone temper. The petrographic analysis place both analyzed sherds in Paste Group B-a. The INAA findings place the two analyzed sherds in the same chemical group. While the lipid residues and stable isotope results yielded somewhat different findings, but both indicate that plants, probably legumes, were cooked in this vessel.

\subsubsection{Vessel Group 3}

A total of 30 sherds, one rim sherd (\#782-8-1) and 29 body sherds, were assigned to Vessel Group 3 (Figure 8-23). Sherds are very small, with an average diameter measures of only $14.7 \mathrm{~mm}$, Average thickness is $6.0 \mathrm{~mm}$. None of the sherds could be refit. Sherds \#900-8-1 (3.4 g) and \#901-8-1 (3.3 g) were sent for lipid residue analysis, and a small part of each interior was sent for stable carbon and nitrogen isotope analyses. Sherd \#1118-8-1a was used in procuring an AMS radiocarbon date (see discussion below). Sherds \#840-8-1a (TRC276; $1.2 \mathrm{~g}$ ) and \#867-8-1a (TRC277; $1.0 \mathrm{~g}$ ) were submitted for INAA. 


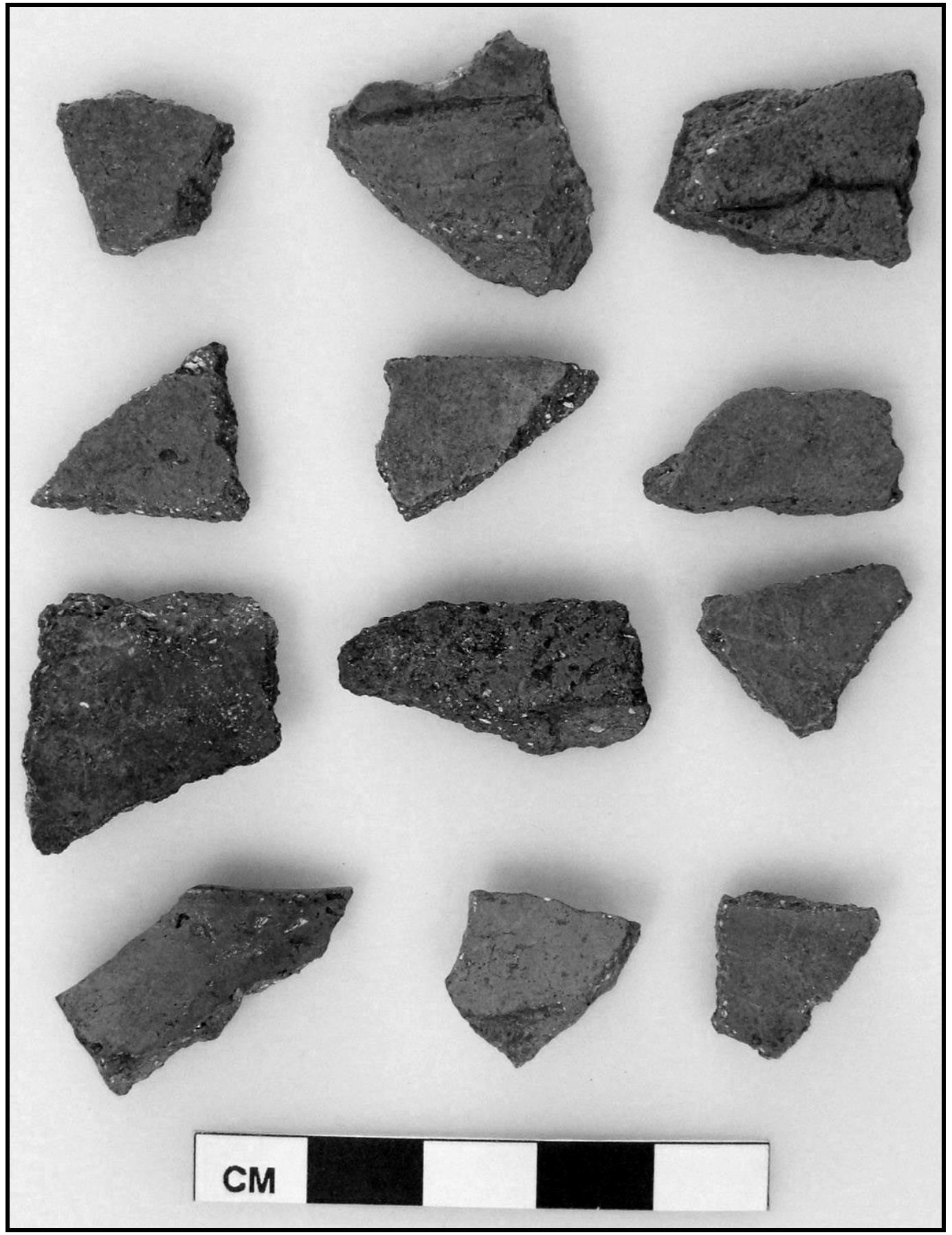

Figure 8-23. Selected Vessel Group 3 Sherds

Left to Right: Top Row (Interior): \#1036-008, \#881-008, \#879-008;

Second Row (Interior): \#875-008, \#1044-008, \#1100-008;

Third Row (Exterior): \#1133-008, \#880-008, \#884-008;

Forth Row (Exterior): \#782-008-1 (Rim), \#782-008-2, \#949-008 


\subsubsection{Construction}

The broken edges are perpendicular to the two surfaces, with one apparent exception. Sherd \#880-8 exhibits a twisting and curved break along two opposing edges. Linear impressed lines on the interior surfaces of sherds \#879-8 and \#881-8 may be signs of imperfectly welded coil margins. The broken edges of both sherds also hint at possible welded coil locations. Thickness measurements range from 4.4 to $7.5 \mathrm{~mm}$ and reflect unevenness over a single vessel or that more than one vessel is represented.

\subsubsection{Exterior Surface}

The exterior surfaces are all quite similar with smooth, sometimes polished, surfaces that exhibit no decorations or finishing striations, and only a few temper particles exposed on the surfaces. One exception is sherd \#880-8 that exhibits a badly pitted and scared surface, which has removed the majority of the exterior surface. Surface colors range from pinkish gray (5YR 6/2), to light reddish brown (5YR 6/4), to reddish yellow (5YR 7/6), to brown (7.5YR 5/2), to light brown (7.5YR 6/4), to gray (10YR 5/1), to light yellowish brown (10YR 6/4). Dark surfaces (gray; 5YR 6/1) are present on three sherds (\#984-8 and \#1187-8) and appear to be small areas of firing clouding.

\subsubsection{Interior Surface}

The interior surfaces are somewhat more variable, with some polished and some with tiny striations, but most are smooth. Sherd \#879-8 exhibits what appears to be a line demarking the edge of a partially welded coil, whereas the rest are smooth and finished, and lack polish. A second sherd (\#881-8) exhibits a long, narrow linear line that may also represent the edge of a partially welded coil. In this instance the rest of the interior is polished to a high sheen, and lacks any visible temper. Sherd \#862-8 exhibits possible smoothing or wiping striations across a dull, smoothed surface, which exhibits two temper particles. Sherd \#405-8 also exhibits possible wiping striations across a well-finished and polished surface. The interior of the rim sherd (\#782-8-1) is well finished and polished. A few tiny striation lines occur just below and parallel to the rim, and tiny pits are visible. The colors range from light reddish brown (5YR 6/3), to pink (5YR 7/4), to brown (7.5YR 5/2), to dark brown (7.5YR 5/4), to light yellowish brown (10YR 6/4), to gray (10YR 5/1).

\subsubsection{Paste}

The paste color is quite similar to the interior and exterior surfaces. It varies from pink (5YR 7/4 and 7.5YR 7/4), to light reddish brown (5YR 6/3), to gray (5YR 5/1; 10YR 5/1), to grayish brown (10YR 5/2), to brown (7.5YR 5/4). These colors are found in sherds that have traces of firing clouds on either the interior or exterior surfaces.

Two body sherds from Vessel Group 3 (\#481-8$1 \mathrm{~b}$ and \#937-8-1b) were subjected to petrographic analysis. Sherd \#481-8-1b contains 39 percent bone temper, eight percent quartz, five percent limestone, four percent ferrous iron, one percent calcite, and less than one percent ooids. It also exhibits low frequencies (five percent) of voids in a matrix that is reddish tan to gold and anisotropic (Appendix D). This sherd was assigned to Paste Group-B-c. Sherd \#937-8-1b is tempered with 38.5 percent bone, 10 percent limestone, 10 percent quartz, eight percent ferrous iron, 2.5 percent calcite, and one percent ooids. Minimal amounts (7.5 percent) of voids are visible within a reddish gray and brown matrix that is isotropic (Appendix D). This sherd was assigned to Paste Group-B-a. Even though Dr. David Robinson assigned these two sherds to different paste groups, the reported data concerning each is quite similar with only slight percentage differences. The bone tempering particles are tiny, and are burned to a white (calcined) color. Sherd \#481-8-1b 
assigned to Paste Group-B-c is similar to a vessel from 41CC131 at O.H. Ivie Reservoir, a sherd from 41HY209 at Onion Creek, and a sherd from the Lower Pecos region (Appendix D).

\subsubsection{Distribution}

Three sherds, or about 10 percent of this vessel group, were recovered from three units in Block A that were around the southern end of BT 1 (Figure 8-20). Ninety percent were widely scattered across Block B in some 23 different units. Only three units yielded more than one sherd in this Group (Figure 8-21). Although no Vessel Group 3 sherds were in Feature 8, eight sherds were found in the surrounding units. The one rim sherd (\#782-8-1), together with one other sherd from this group, and a single sherd assigned to Vessel Group 2, were recovered from Unit N114/E75 in the very southeastern corner of Block B.

\subsubsection{Discussion}

The petrographic analysis on two sherds visually assigned to Vessel Group 3 indicated these two analyzed sherds were actually part of different paste groups. This indicates that more than one vessel may be represented in this group, or that one of the two sherds was miss-assigned to this group. Petrographically, sherd \#937-8-1b was assigned to the same paste group as the Vessel Group 2 sherds. Sherd \#481-8-1b was assigned to the same paste group as the Vessel Group 1 sherds. Both petrographic paste groups probably were locally manufactured, just with slightly different tempering agents, but both contained primarily bone temper.

The INAA on two Vessel Group 3 sherds (\#8408-1a = TRC276 and \#867-8-1a = TRC277) determined that they are chemically different from each other. The former sherd shares chemical similarities with sherds from Vessel Group 1, and is part of Varga-1 chemical group (Appendix F). Sherd \#867-8-1a is unassigned to a specific chemical group since it is an outlier from all other sherds. It is not chemically or statistically similar to any of the ca. 200 Central Texas reference group sherds previously analyzed. The INAA chemical findings on the latter sherd may indicate it represents a totally different vessel from Vessel Group 3, to which it was initially assigned. The INAA chemical results partially support the petrographic observations that Vessel Group 1 and 3 are similar. This indicates they probably were manufactured from similar sediments, but they do not match other analyzed Central Texas samples.

Lipid residue analysis on two sherds (\#900-8-1a and \#901-8-1a) produced very similar results. Sherd \#900-8-1a indicates borderline moderateto-high and high fat content, which is interpreted as representing plants (Appendix G). Sherd \#901-8-1a indicates borderline moderate-to-high and high fat content, also interpreted as representing plants (Appendix G). As with Sherd Groups 1 and 2, the lipids indicate that plants were the primary food products being cooked in this vessel.

The carbon isotope value from sherd \#900-8-1b is $-27.2 \%$, indicating nearly complete $\mathrm{C}_{3}$ contributions. The corresponding nitrogen isotope value of $6.9 \%$ would support an interpretation of an animal consuming predominately $\mathrm{C}_{3}$ plants contributed to this residue. The carbon isotope value, coupled with the lipid residue values, document that $\mathrm{C}_{3}$ plants were cooked in this vessel. The nitrogen value appears to reflect a plant in the range of huisache bean (Quigg et al. 2002). These chemical results support an interpretation that seeds/nut meat from $\mathrm{C}_{3}$ plants was likely cooked in this vessel.

Sherd \#1118-8-1a was selected for AMS radiocarbon dating. This sherd yielded a $\delta^{13} \mathrm{C}(-$ $22.8 \%$ ) corrected age of $60 \pm 40$ B.P. (UGA12731; Table 8-1). This age is too young to be considered acceptable, and was perhaps contaminated with an unknown substance. At 
230 B.P., the early end of the calibrated 1-sigma age range does fall within the Colonial period, so it is possible that this data may have validity.

In summary, the 29 body sherds and one rim sherd visually assigned to Vessel Group 3 represent more than one vessel. The exteriors are quite similar, with more variability exhibited on sherd interiors. Possible welded coil lines are present on the interiors together with wiping or finishing marks. The petrographic analysis assigned each of the two analyzed sherds to different paste groups, with only minor differences in the observed additives. The INAA findings placed each analyzed sherd into different chemical groups. The lipid residue results and stable isotope analysis provided slightly different findings also, but both indicate that $\mathrm{C}_{3}$ plants, some probably legumes, were cooked in the vessel(s).

\subsubsection{Vessel Group 4}

Ten body sherds, one cut or rim simulated sherd, and one possible base sherd were assigned to Vessel Group 4 (Figure 8-24). Sherds are small, with an average diameter of only $23.3 \mathrm{~mm}$. Average thickness is $7.6 \mathrm{~mm}$. The single largest sherd (\#618-8-1) measures $33.3 \mathrm{~mm}$ in diameter. No refits were possible. Three sherds, \#159-5-81, \#168-8-1 and \#799-8-1 were sent for petrographic analysis. About $1 \mathrm{~g}$ each of sherds \#272-8-a (TRC274) and \#159-5-8-1c (TRC275) were sent for INAA. The cut piece appears similar to a rim because the cut edge has been slightly rounded, creating an appearance similar to a rim. The darker core with lighter margins is an obvious indication that this specimen is not a true rim. Sherd \#159-5-8-1a was submitted for AMS dating with inclusive organics.

\subsubsection{Shape}

The overall shape is indeterminate, since most sherds are too small to indicate vessel curvature/form. The curvature of the largest sherd (\#206-8-1) is very slight, indicating a medium-size to large vessel. The cut sherd exhibits a slight curvature, representing a diameter of 14 to $16 \mathrm{~cm}$. Sherd thickness measurements range from 5.2 to $9.0 \mathrm{~mm}$, with only 17 percent revealing thickness measurements under $6.4 \mathrm{~mm}$, and 67 percent having thickness measurements greater than $7.3 \mathrm{~mm}$. This indicates these sherds are part of a thicker vessel than the other vessel groups, or that these sherds are part of a thick base. Sherd \#159-8-2, which appears similar to a rim section, is the thinnest, and may not belong to this vessel group or, alternatively, may represent another section of this relatively thick-walled vessel.

\subsubsection{Construction}

The broken edges are generally perpendicular to the interior and exterior surfaces, with one possible exception on one edge on the largest sherd (\#206-8-1), which about a 60 degree angled break. This is the only edge break that might that a coiling technique was employed to construct this vessel. Most sherd interiors in Vessel Group 4 are not as well finished as in the other vessel groups, and it is not clear if this indicates that these represent the base of the vessel, or they are from a separate, thicker vessel. The cut sherd (\#159-8-2) indicates reuse or rejuvenation through an attempt to salvage the vessel by creating a new rim area, or use of the sherd as some sort of a tool. The cut is at a 50 to 60 degree slope towards the exterior, and the interior and exterior edges were rounded off.

\subsubsection{Exterior Surface}

The exterior surfaces are all similar, with smooth surfaces exhibiting no decorations or finishing striations, very few temper particles, and few imperfections. Surface colors range from pink (5YR 7/3), to light brown (7.5YR 6/4), to grayish brown (10YR 5/2). The color, coupled with an absence of polish, set these sherds apart from the other vessel groups. 


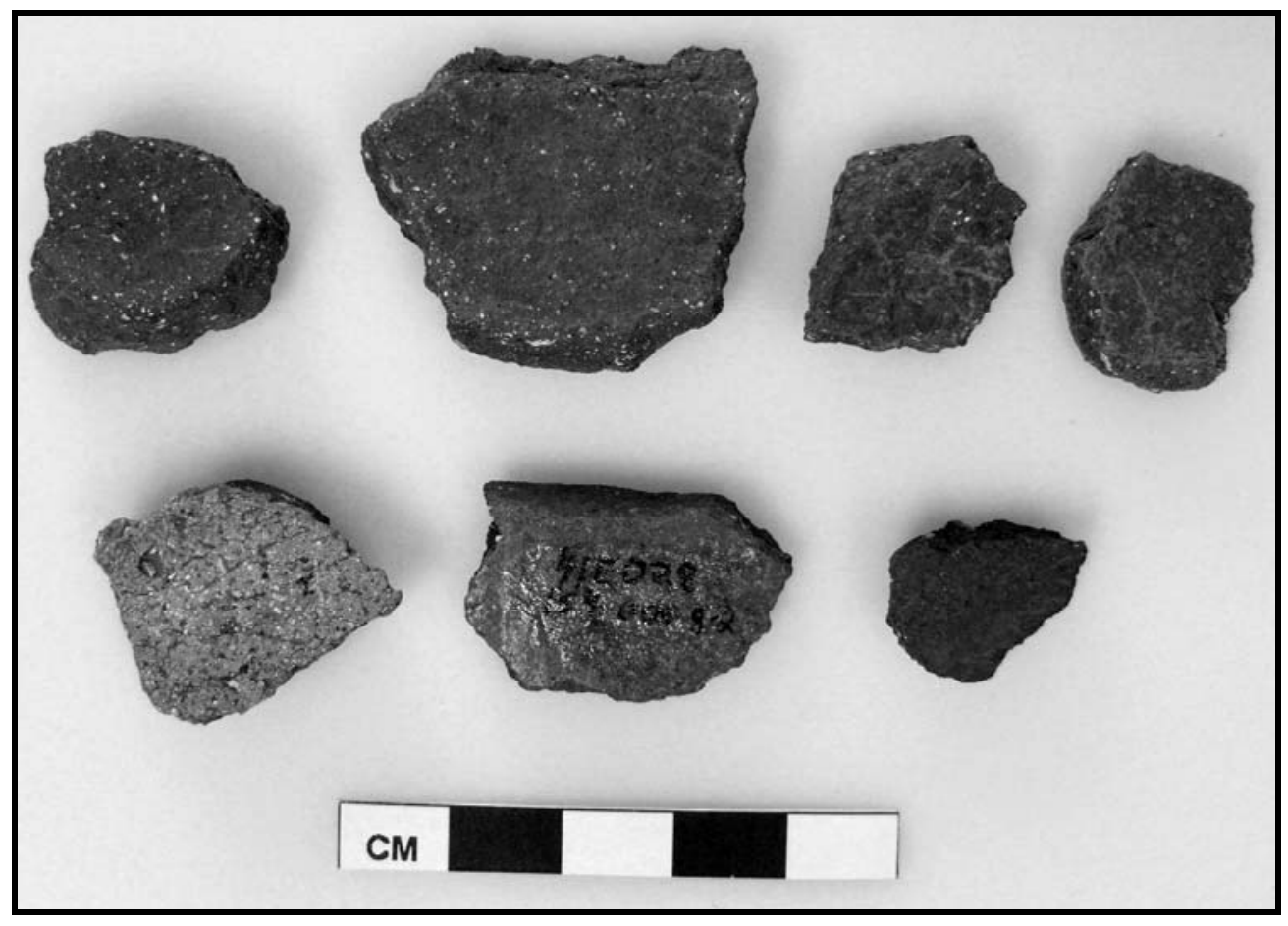

Figure 8-24. Selected Vessel Group 4 Sherds

Left to Right: Top Row (Interior): \#206-008, \#618-008, \#159-005-008-3, \#159-005-008-4 Second Row (Exterior): \#799-008-1, \#159-005-008-2 (Cut-Edge), \#159-005-008-5

\subsubsection{Interior Surface}

Interior surfaces are more variable than the exterior surfaces, with some rough and others smooth. The thicker sherds, such as \#210-8-1 and \#206-8-1, exhibit considerable tiny white bone temper particles, whereas most others do not show such particles. The largest sherd exhibits very faint wiping marks in the form of very shallow troughs parallel to very slight ridges. The cut sherd has a relatively uneven interior surface with two or three small, irregular pits or imperfections. The interior colors range from light reddish brown (5YR 6/3), to brown (7.5YR 5/4), to light brown (7.5YR 6/2), to pink (7.5YR 7/4), to grayish brown (7.5YR 5/2).

\subsubsection{Paste}

The interior paste color is similar to the interior and exterior surfaces. It varies from dark gray
(5YR 4/1), to gray (10YR 5/1). These colors are found on sherds that exhibit firing clouds on either the interior or exteriors. The cut section exhibits a dark gray (5YR 4/1) core that contrasts with brown (7.5YR 5/4) surfaces, whereas most other sherds have cores with colors similar to those of the interior and exterior surfaces.

Three sherds, \#159-5-8-1, \#168-8-1 and \#799-82a were employed in the petrographic analysis. Sherd \#159-5-8-1b reveals 47 percent bone, 10 percent quartz, 4 percent limestone, 3 percent calcite, and 2.5 percent ferrous iron. These particles are in a light greenish tan colored paste with 6.5 percent voids and considered isotropic (Appendix D). Sherd \#168-8-1b is tempered with 52.5 percent bone, 5 percent limestone, 4 percent quartz, 2 percent calcite, 1.5 percent ferrous iron, and 1.5 percent orthoclase. It also exhibits 11 percent voids in a matrix that is light 
greenish tan and is anisotropic. Sherd \#799-8-2a reveals 28 percent bone temper, 11.5 percent limestone, 6 percent ooids 5.5 percent quartz, 2.5 percent calcite, 2.5 percent ferrous iron, and 2 percent iron stains. These particles were in a greenish brown to gold matrix that is anisotropic with 2.5 percent voids. Sherds \#159-5-8-1b and \#168-8-1b were assigned to the Paste GroupB-c, whereas \#799-8-2a was assigned to the Paste Group-B-a. The difference between the two paste groups is the slight variations in the amounts of non-bone aplastic particles (see Appendix D).

\subsubsection{Distribution}

Ninety-two percent of Vessel Group 4 sherds were recovered from Block A, including the cut sherd (\#159-005-008-2). Of those, nearly 64 percent were from one unit, N101/E47, with the others about $6 \mathrm{~m}$ north and 3 to $6 \mathrm{~m}$ east of this one apparent concentration. Only a single sherd from this group was recovered from Block B in the southern part, Unit N115/E73 (Figure 8-21).

\subsubsection{Discussion}

Cut sherds are not unknown in Toyah ceramic assemblages across Texas. A grooved and snapped edge was discovered on a relatively large sherd (213P2) from the Rush Site (Quigg and Peck 1995). Nearly a quarter of a bone tempered plainware globular jar, Vessel C at 41RN169 in O. H. Ivie Reservoir also exhibits a grooved and snapped section that appears to reflect rejuvenation of the lower section of a vessel (Treece et al. 1993b:78-80). The petrographic analysis indicates that the two analyzed sherds from Vessel Group 4 were part of the same paste group, and similar in paste to Vessel Group 1 sherds (Appendix D).

The INAA on two Vessel Group 4 sherds (\#2728-a = TRC274 and \#159-5-8-1 = TRC275) determined both to be part of a limited number of sherds $(n=5)$ composing the Varga-2 chemical group, which also includes sherds from Vessel Group 2 (Appendix F). This group is chemically and statistically different from Vessel Group 1 sherds from the Varga Site and the Central Texas 1 and 2 reference groups. The INAA chemical results do not support the petrographic observations indicating similarities with Vessel Group 1 sherds. This indicates that these two sherds and, by implication, all of Vessel Group 4 sherds, were manufactured from different clays than currently identified in the ca. 200 samples for the Central Texas region. The similarity with the local sediment sample $(\# 1259-4 \mathrm{~b}=$ TRC280) indicates that these sherds come from locally manufactured vessels.

Sherd \#159-5-8-1a was sent for AMS radiocarbon dating and yielded a $\delta^{13} \mathrm{C}(-15.5 \%)$ corrected age of 3,080 \pm 40 B.P. (UGA-12710; Table 8-1), much too old to be considered acceptable for this component. It was undoubtedly contaminated with an unknown substance that was not removed during the cleaning process by the laboratory. This was the second sherd that yielded an AMS date that was considered much too old for this component, hinting at inherent problems in the dating residues in potsherds.

In summary, the 10 body sherds, one cut sherd, and one basal sherd assigned to Vessel Group 4 represent more than one vessel. The exteriors are quite plain, smoothed but not polished, and similar to one another, with more variability visible on the interiors. The petrographic analysis assigned one of the analyzed sherds to Paste Group-B-c, and one sherd to Paste Group-B-a, although only minor differences in the percentage of bone additives were detected. The INAA findings placed each analyzed sherd into the same chemical group, which also contains sherds from Vessel Group 2. Vessel Group 4 sherds were made from local clays, based on comparison with the matrix samples recovered from the Varga Site. 


\subsubsection{Vessel Group 5}

Only two tiny body sherds (\#1261-8-2 and -3a) comprise this group, and they fit together. The combined refit measures about $24 \mathrm{~mm}$ long with a thickness that measures $3.1 \mathrm{~mm}$. The sherds were recovered from the disturbed surface, and it is unclear if they once belonged to the Toyah component or represent some other event. One piece (\#1261-8-3a) was sent for INAA (TRC278) and the other (\#1261-8-2a) was sent for petrographic analysis.

\subsubsection{Shape}

The shape of this vessel could not be determined. These sherds reveal almost no curvature, since they are extremely small.

\subsubsection{Construction}

The broken edges are nearly perpendicular to the two surfaces, but exhibit no obvious sign of breakage along coils. The walls are quite thin at $3.1 \mathrm{~mm}$ and may indicate these pieces represent something other than a cooking vessel, possibly a small cup.

\subsubsection{Exterior Surface}

The exterior is dull and rough. The color is a reddish brown (5YR 5/3).

\subsubsection{Interior Surface}

The interior is smooth with no indications of the smoothing process. The color is a yellowish red (5YR 5/6).

\subsubsection{Paste}

The core color is black (7.5YR N/2). Sherd \#1261-8-2 exhibits no bone temper and the additives are unlike those from the other Toyah pottery from this site. The additives include various volcanic rocks and minerals including 27.5 percent orthoclase, 5.5 percent microcline, 5.5 chlorite, 4 percent granite, 2 percent biotite, and 8 percent iron (Appendix D). The
17.5 percent quartz grains are mostly weathered, but it is not clear if the quartz grains were part of the additives or resident within the original clay. The matrix is a greenish gray to black and anisotropic. This sherd was assigned to Paste Group-B-a with no other sherds petrographically investigated assigned to this group. This granitic rock temper is considered non-local.

\subsubsection{Distribution}

These two pieces were recovered from repositioned backdirt along the western edge of Block A. Since the backdirt was often moved by heavy equipment from the sites' surface next to the roadway, the original location of these sherds is not clear.

\subsubsection{Discussion}

It is clear that these two refit sherds, with their very thin walls, igneous temper, light exterior color, and black core, represent a unique vessel, unlike the other Toyah ceramics. Therefore, the vessel represented by these sherds is not likely part of the Varga Site Toyah component. The igneous additives indicate this vessel was not locally manufactured and was transported here from an area rich in volcanic rocks. That region may be to the southwest, possibly in the Big Bend region where volcanic rocks are concentrated, or even further west in the El Paso region where volcanic activity has created greater access to these rocks. Currently much of the El Paso Polychrome wares have been shown to be manufactured in the area of El Paso (Speakman and Glascock 2005). The recovery of these sherds from the surface makes it unclear how recent an event they be, but they are probably not associated with the prehistoric Toyah component.

The INAA on one Vessel Group 5 sherd (\#12618-3a $=$ TRC278) determined it was chemically associated with the El Paso Polychrome reference group as it plots consistently in the 
90 percent confidence ellipse (Appendix F). The chemical analysis agrees with the petrographic analysis, which identified igneous temper in this same sherd. This was not a locally vessel, and it was quite distinct from Toyah phase pottery.

El Paso Polychrome wares terminate at ca. 500 years ago in western Texas. The charcoal radiocarbon dates from the Toyah component indicate just over 50 percent of the assays are younger than 400 years old. This would place minimally one of the events included in the Toyah component slightly before those dates. It is not clear if the El Paso Polychrome vessel was procured via trade by the site's Toyah occupants, or if it represents a different group of people not otherwise detectable in the materialculture assemblage.

\subsubsection{Radiocarbon Dating of Pottery Sherds}

The AMS radiocarbon dating of pottery sherds was a new and direct approach to try and refine the time frame in which the Toyah ceramic tradition was in operation, and to investigate its continuation into the Protohistoric and Historic periods. Direct AMS radiocarbon dating of prehistoric ceramic sherds has previously been conducted on El Paso brownware sherds from the El Paso region. In that study, nine of the 10brownware sherds AMS dated by Beta Analytic provided assay results in or near the projected and established time range for that ware (Quigg et al. 2002b).

With that success in mind, it was anticipated that Toyah sherds, which are thought to represent cooking vessels containing sufficient organic food residues, would provide useful radiocarbon dates. This direct dating would enable the specific ages of pottery use at the Varga Site and at other Toyah pottery sites (i.e., Buckhollow), to be identified. Consequently, four sherds (\#159-5-8-1a, \#987-8-1a, \#1089-8-1a, and $\# 1118-8-1$ a) from four of the five vessel groups
(1, 2, 3, and 4) defined for the Varga Site, were sent to The University of Georgia (UGA), Center for Applied Isotope Studies, for processing and AMS dating.

All four Varga Site sherds yielded sufficient organic carbon to provide AMS results. However, they provided mixed results. From Vessel Group 1, a bone tempered sherd (\#10898-1a) yielded an AMS radiocarbon date of $310 \pm 40$ B.P. (Table 8-1: UGA-12730). This is an acceptable age for a Toyah phase manufactured vessel. From Vessel Group 2, a bone tempered sherd (\#987-8-1a) was AMS radiocarbon dated to $26,960 \pm 40$ B.P. (Table 81: UGA-12727), an unacceptable result that is considerably outside the range for any known human presence. The age is potentially contaminated with much older organic matter. From Vessel Group 3, bone tempered sherd (\#1118-8-1a) produced an AMS radiocarbon date of $60 \pm 40$ B.P. (Table 8-1: UGA-12731). This result is also unacceptable as the sherd is thought to be prehistoric in age, or minimally 200 years or older, though, as noted above, the early end of the calibrated age range does fall slightly earlier than that age. From Vessel Group 4, a bone tempered sherd (\#159-5-8-1a) yielded an AMS radiocarbon date of $3,080 \pm 40$ B.P. (Table 8-1: UGA-12710), is much too old to be reflecting Toyah age organic residues and therefore unacceptable.

Two, or one-half, of the dated Toyah period sherds provide AMS results that are not within the acceptable age range for this prehistoric Toyah assemblage. Both are much too old, thus indicating problems of contamination with older organics. A 50 percent success rate seems less than desirable, and further work is necessary to try and resolve problems related to contamination by older organics. Perhaps sample preparation was inadequate and did not allow sufficient time for all the inclusive carbonates to completely dissolve. Vessel Groups 2 and 3 belong to petrographically 
identified bone Paste GroupB-a, which had significant amounts of limestone and other carbonates. Possibly, extended time in the dissolving of the carbonates and other potential age-distorting inclusions is required to ensure complete and through elimination of any non-cultural organic inclusions.

As an ancillary aspect of our research, we dated three bone tempered potsherds from the Toyah component at Buckhollow (41KM16, sherds \#25, \#385, and \#481), two non-bone tempered sherds (41RE1, artifacts \#1872-6a and \#187248a) from Mission San Lorenzo located $29 \mathrm{~km}$ south of the Varga Site, and two bone tempered sherds (41BX5, artifacts \#13002c and \#130011a) from Mission San Juan in San Antonio. The results from these seven sherds are presented in Table 8-12. The three bone tempered pottery sherds from Buckhollow yielded results from 850 to 1,200 B.P., all several hundred years too old in comparison to most accepted radiocarbon dates for Buckhollow and other Toyah phase sites. The two non-bone tempered sherds from Mission San Lorenzo range from 1,200 to 2,500 B.P., much too old for this Colonial-era mission site. The two bone tempered sherds from Mission San Juan range in age from 490 to 1,900 B.P. and are again too old. It is clear, then, that the radiocarbon results are not dating organic matter relating to the cultural events of which the sherds were a part. The radiocarbon results are unacceptable and are not useful in defining or refining the age of Toyah ceramic technology. Additional research would be needed to determine the causes of these erroneous results.

\subsubsection{Ceramic Discussion}

The 115 sherds from the Toyah component, representing a minimum of five and possibly as many as eight vessels, may also represent multiple occupations during the Toyah interval. If this is the case, the ceramic assemblage is not a major part of the Toyah material culture, given that not many individual vessels are represented for this component, or for any one episode of occupation. The moderate frequency of 184 sherds recovered from the Rush Site, or four sherds $/ \mathrm{m}^{2}$, represents 1.1 percent of the total Occupation 4 assemblage, reflecting a similar use pattern in a cooking and bone grease processing activity area (Quigg and Peck 1995; Quigg 1997b). Vessel/sherd frequency may be greater at sites that represent multiple events and/or a specific activity that involved intensive use of ceramic vessels.

The Toyah component sherds at the Varga Site are tempered with about 35 to 38 percent ground bone particles, with the exception of the one figurine-like object (\#840-8-1), which only has about 10 percent ground bone. The 35 to 38 percent bone tempering is common to petrographic findings at other Central Texas Toyah components (Reese-Taylor 1993, 1995; Reese-Taylor et al. 1994; Kittleman 1994; Robinson 1999). However, the average amount of bone, near 36 percent, for the Varga Site Toyah sherds is some 12 percent higher than that detected at the Rush Site, O. H. Ivie Reservoir sites, and the Onion Creek sites, where the average is about 24 percent, with a standard deviation of five percent (Reese-Taylor 1995).

The shared paste groups identified in the petrographic analysis for the Varga Site Toyah sherds indicate similarity of technology (Appendix D). The current evidence supports a widely employed and basic Toyah technology that employed bone temper across most of Central Texas. Variations in the amounts of bone temper and other additives reflect minor construction variability from the acquisition of materials used. Bone is definitely a characteristic of the Toyah ceramic assemblage, with variations in the amounts potentially reflecting behavioral variation between individual potters, vessel function, and/or clay conditions. 


\begin{tabular}{|c|c|c|c|c|c|c|c|}
\hline 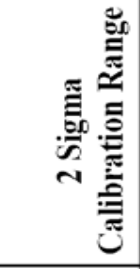 & 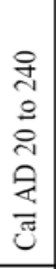 & 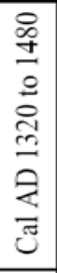 & 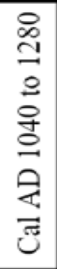 & 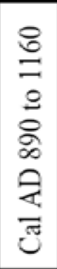 & 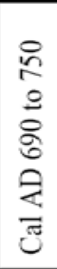 & 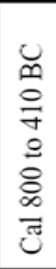 & 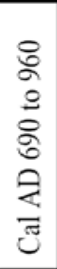 \\
\hline 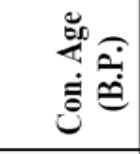 & $\begin{array}{l}\stackrel{P}{f} \\
+1 \\
\stackrel{\Xi}{\Xi} \\
\vdots\end{array}$ & $\begin{array}{l}q \\
+ \\
+1 \\
\stackrel{9}{a} \\
\dot{q}\end{array}$ & 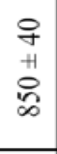 & $\begin{array}{l}\text { O } \\
+1 \\
0 \\
0 \\
0\end{array}$ & $\begin{array}{l}\text { P } \\
+1 \\
\text { Oे } \\
\text { I }\end{array}$ & $\begin{array}{l}\text { P } \\
+1 \\
8 \\
8 \\
\end{array}$ & 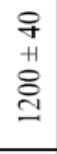 \\
\hline 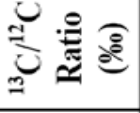 & $\stackrel{\vec{\sigma}}{\because}$ & $\vec{\Xi}$ & ๙ิ & તี & $\stackrel{n}{\bar{r}}$ & $\stackrel{\frac{\partial}{1}}{1}$ & $\stackrel{\infty}{\frac{\infty}{1}}$ \\
\hline 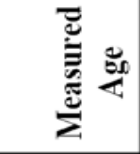 & $\begin{array}{l}q \\
+ \\
+1 \\
0 \\
\vdots \\
=\end{array}$ & $\begin{array}{l}9 \\
+ \\
+ \\
\\
0 \\
\text { r }\end{array}$ & $\begin{array}{l}\stackrel{q}{+} \\
+ \\
\stackrel{+}{\circ}\end{array}$ & $\begin{array}{l}\text { \& } \\
\text { H } \\
\stackrel{8}{\circ}\end{array}$ & 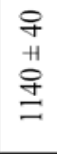 & $\begin{array}{l}\text { O } \\
\text { H } \\
\stackrel{1}{1} \\
\text { ป }\end{array}$ & $\begin{array}{l}\text { f } \\
+1 \\
\text { Oे } \\
=\end{array}$ \\
\hline 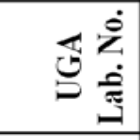 & $\stackrel{m}{\stackrel{2}{\beth}}$ & 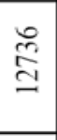 & $\stackrel{\widetilde{2}}{\stackrel{\Xi}{=}}$ & $\stackrel{\infty}{\stackrel{\infty}{\beth}}$ & 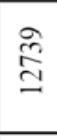 & 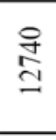 & $\underset{\Xi}{\underset{\Xi}{\Xi}}$ \\
\hline$E^{+\infty}$ & $n$ & $\circ$ & $\vec{m}$ & in & $\stackrel{m}{n}$ & $\vec{m}$ & $\ddot{n}$ \\
\hline 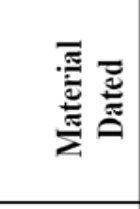 & 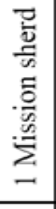 & 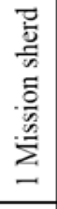 & 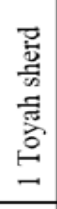 & 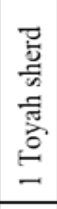 & 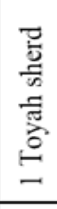 & 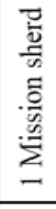 & 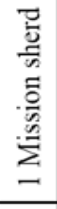 \\
\hline 离氞 & - & & & & & & \\
\hline 莺安 & $\vec{\sim}$ & & & & & & \\
\hline 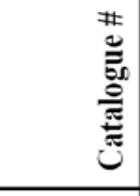 & 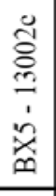 & 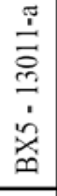 & $\begin{array}{l}2 \\
\vdots \\
\dot{0} \\
\stackrel{3}{*}\end{array}$ & 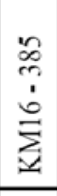 & 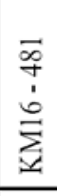 & 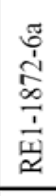 & 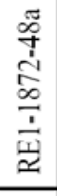 \\
\hline 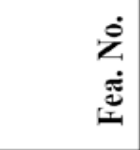 & $\begin{array}{l}\vec{m} \\
\vdots \\
\vdots \\
\dot{0}\end{array}$ & 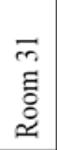 & $\begin{array}{l}5 \\
3 \\
\\
\vdots \\
\vdots\end{array}$ & 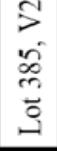 & 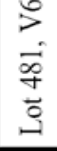 & 总 & 㤣 \\
\hline
\end{tabular}


The results of INAA indicate that the Varga Site Toyah sherds are not chemically similar to the ca. 200 samples currently part of the database that constitute most of Central Texas 1 and 2 reference groups (Appendix N; Creel 2002, 2003). The Varga Site Toyah sherds have less than a four percent probability of being part of INAA Central Texas 1 and 2 reference groups. One anomalous sherd from Vessel Group 5 (\#1261-8-3a = TRC278) recovered from the disturbed surface is chemically similar to the El Paso Polychrome reference group identified for far-western Texas. The ten other INAA samples from the Varga Site sherds resulted in the formulations of two separate and very distinct chemical groups-Varga-1 and Varga-2 with two unassigned Varga samples (Appendix N). Varga- 1 is composed of three sherds, two from Vessel Group 1 and one from Vessel Group 3. Varga-2 is composed of four sherds, two sherds from Vessel Group 2, two sherds from Vessel Group 4, plus one local sediment sample. This appears to indicate that minimally two vessels represented in Vessel Groups 2 and 4 were manufactured using local clay sources. Two Varga Toyah sherd samples were unassigned to either one of these two particular Varga Site chemical groups. One sample represents the figurine-like object (\#840-8-1b = TRC279) and one is from Vessel Group 3 (\#867-8-1 = TRC277). The INAA indicates the two Varga Site compositional groups and the two unassigned sherds are chemically separate from the eight historic Mission sherds analyzed here (Appendix N). The five Mission San Juan sherds are chemically separate and distinct from the three Mission San Lorenzo sherds. These findings all combine to indicate that Native ceramic production in the Central Texas Late Prehistoric involved widely shared technological procedures that were carried out largely within the localized operational areas around specific occupation sites.

Paste groups recognized in the petrographic studies by Dr. Robinson (Appendix D) indicate that only the one sherd that constitutes Vessel Group 5 at the Varga Site did not contain bone temper. The lack of bone temper and its nonlocal igneous additives combined with the chemical INAA indicate this sherd, which is definitely not part of the Varga Site Toyah component, falls within the El Paso Polychrome reference group (Appendix F). Thus, this sherd probably represents a trade vessel. Other investigated Toyah components have also yielded ceramic sherds that are considered to be non-Toyah in origin. An example includes Vessels 12 and 13 at the Buckhollow Site, thought to reflect Apachean or Puebloan groups (Johnson 1994:203). Caddoan pottery was identified at the Mustang Branch and Barton sites on the eastern margin of the Edwards Plateau (Ricklis 1994; Reese-Taylor et al. 1994). At the Rush Site, Vessel 6 was considered nonToyah as it contained volcanic rock as part of the tempering agent, indicating a non-local origin (Reese-Taylor 1995).

The INAA of the figurine-like object (\#840-8-1b $=$ TRC279) indicates this piece is chemically distinct from the identified Varga- 1 and Varga-2 compositional groups, and the Central Texas 1 and 2 reference groups (Appendix N). It is also chemically distinct from the local sediment sample, which means it was probably not manufactured from local clays. Most likely this was a trade item, but the manufacturing locality is not known. As this object has a chemical signature tending only very weakly towards the Central Texas 1 and 2 reference groups. Therefore, we suggest that this object arrived at the Varga Site from some origin other than Central Texas.

The INAA appears to be separating different clay sources/manufacturing localities for these various sherds and vessels. Now it is the archeologist's responsibility to find and sample the source localities for these various pastes to begin to trace the movements of these peoples and their vessels across the landscape. 
Interestingly, the five Mission San Juan sherds petrographically analyzed also reveal relatively high percentages of bone temper in the range of 23 to 30 percent (Appendix D). The INAA indicate these five mission sherds were all part of the same chemical compositional group. Although not identical in thickness, paste, or amount of bone temper, these attributes still support a connection to the construction process employed in the prehistoric Toyah phase vessels. The use of bone temper during the manufacture of Toyah phase sherds was definitely carried forward into the Historic period in the production of the Mission San Juan pottery. One may conclude that the Natives who manufactured the bone-tempered pottery during the Historic mission period were descendents of the people who produced Toyah ceramics.

The three Mission San Lorenzo sherds analyzed here did not reveal any bone temper whatsoever. The lack of bone temper, the employment of igneous inclusions as additives, and the slightly higher quantities of silicates including quartz inclusions, indicate the Native Americans manufacturing these sherds had different approached to tempering clay. The INAA on two of the three analyzed sherds from Mission San Lorenzo form a completely separate chemical composition group than those from Mission San Juan. The other Mission Lorenzo sherd (\#1872-6c = TRC263) was unassigned to a particular chemical group. Spanish Mission San Lorenzo de la Santa Cruz, founded in A.D. 1762, was established specifically for the Lipan Apache Indians (Tunnell and Newcomb 1969). Consequently, the two missions housed predominately two different Native populations, and this seems to be reflected by differences in ceramics.

The pottery sherds from the two Mission sites petrographically analyzed here documents the essentially contemporaneous use of two different kinds of aplastic additives. If the different additives reflect a cultural, and not functional difference, then the difference in the two Mission samples implies that two separate Native American groups occupied the two missions. The non-Toyah phase sherd of Vessel Group 5 from the Varga Site is more closely related to the Mission San Lorenzo sherds, based on the additives, than any other group of sherds.

The lipid residue analysis on six sherds, two each from Vessel Groups 1, 2, and 3, reveals very similar results. The detected residue signatures were interpreted as ranging from borderline moderate-to-high and high fat content implying that fatty plant parts were cooked in these vessels. These results, combined with the stable carbon isotope values that range from 24.3 to $-27.6 \%$ and nitrogen isotope values that range from -2.6 to $6.9 \%$ imply that some plants cooked in these vessels were probably legumes such as mesquite beans, whereas in one case the nitrogen isotope value (6.9\%o) supports a plant that is in the range of huisache bean. The detected carbon isotope values of $-27.2 \%$, plus the nitrogen isotope value of $6.9 \%$, are very close to the carbon isotope value of $-27.3 \%$ and nitrogen value of 6.2 and $7.5 \%$ derived from modern huisache bean meat from Maverick County, Texas (Quigg et al. 2002a). The products cooked in the vessels appear to reflect fatty plants rather than animals, even though a relatively large and fragmented bone assemblage was recovered from this Toyah component.

\subsection{BURNED ROCKS}

Large quantities of scattered burned rocks, plus 10 burned rock features, were encountered in this component. The burned rocks total 15,934 pieces and weigh 1,082,147 g, including those in features, which account for 1,635 pieces that weighed $145,352 \mathrm{~g}$. The feature rocks account for only 10.3 percent by count of the total count, and 13.4 percent by weight of the total weight. Clearly, the greatest percentage was encountered outside the recognized features. 
The average density of burned rocks was about 77 pieces per $\mathrm{m}^{2}$.

The scattered burned rocks total 14,299 pieces weighing 936,795 g, for an average burned rock weight of $65.5 \mathrm{~g}$. The scattered burned rocks are comprised mostly of the smallest size class with 76.5 percent by count, followed by the next smallest size class at 28.8 percent, then 1.7 percent in the next size class, and less than one percent in the largest size class. This indicates the scattered burned rocks were quite small with less than two percent greater than $9 \mathrm{~cm}$ in diameter.

The average burned rock weight in the features was $89 \mathrm{~g}$ compared to about $66 \mathrm{~g}$ for those scattered outside features. Whereas this is not a great difference, it may in fact reflect the type of features discovered. Most features were interpreted as discard areas or parts of the broader component, rather than discrete, intact hearths. Only four hearths, Features 9, 21, 30, and 38, were identified, and these yielded average burned rock weights of $375 \mathrm{~g}, 204 \mathrm{~g}$, $324 \mathrm{~g}$, and $196 \mathrm{~g}$, respectively. These four hearths provide an overall average rock weight of $274 \mathrm{~g}$, which is four times the weight of the average rock amongst the scattered burned rocks. This significant size difference is the result of large rocks breaking apart during use and prior to discard.

\subsection{MaCROBOtANICAL REMAINS}

The carbonized plant remains from this component were abundant in comparison to the older components, presumably a factor of lesser preservation with greater age. Most identified burned rock clusters, hearths, dumps, other features, and the general occupation areas yielded charcoal chunks, but well-defined charcoal lenses were absent.

During the hand excavations individual charcoal samples were often plotted and bagged separately, but in recognizable features the entire feature matrix was often collected and floated. Individual samples and float samples are available for dating and identification. Eleven light fractions from Features 8, 9, 18, 21, 22, 25, 26, 30, 35, 36, and 38 were submitted to Dr. Phil Dering for identification of charred remains. Individual pieces of charcoal were also sent for identification, including parts of the pieces that were radiocarbon dated (Appendix I).

About $196 \mathrm{~g}$ of carbonized plant remains were recovered (Table 8-13). From the Toyah component seventeen radiocarbon dates were obtained. This includes multiple dates from a single piece of carbonized plant material. The radiocarbon analysis yielded 75 percent acceptable dates between 290 and 660 B.P. Two samples, or 12.5 percent, were older than this range and dated to the 920 to 940 B.P. time period. Two other samples dated yielded ages younger than 290 B.P., though the age ranges on these samples may fall within the recent end of the Toyah interval once they are calibrated. The ages indicate that some mixing has occurred, or that the burning of old wood might be a factor.

Dr. Dering's identifications indicate that at least 17 species were burned, implying their cultural use. These species include agave heart and leaves (likely sotol or yucca), agarita, buttonbush, cheno-am seeds, condalis, elm, juniper, littleleaf walnut, lotebush, mesquite, Mexican buckeye, oak, pecan, pinyon, prickly pear seeds, sycamore, and willow/cottonwood (Appendix I). The agave pieces were recovered from three different hearth-like features (Features 21, 35, and 38). Their presence may indicate accidentally burned food remains, use as fuel, or use as packing or protective wrap around other foods. The littleleaf walnut is only identified from charred nutshells and not charred wood. The lack of burned walnut wood implies the walnuts were not attached to wood burned for fuel. 
Table 8-13. Toyah Macrobotanical Remains

\begin{tabular}{|c|c|c|c|c|c|c|}
\hline Cat. \# & Unit No. & $\begin{array}{c}\text { Depth } \\
\text { (cmbd) }\end{array}$ & $\begin{array}{l}\text { Fea. } \\
\text { No. }\end{array}$ & $\begin{array}{l}\text { Wgt } \\
\text { (g) }\end{array}$ & Comments & Identifications \\
\hline $31-007$ & N99/E53 & $14-20$ & & 0.1 & & \\
\hline $41-007$ & N99/E54 & $10-20$ & 35 & 3.2 & & \\
\hline $52-007$ & N99/E55 & $0-10$ & & 1 & & \\
\hline $52-007-1 a$ & N99/E55 & $0-10$ & & 0.1 & Sent to Dering for ID & Oak $(n=7)$ \\
\hline $53-007$ & N99/E55 & $10-20$ & & 1 & & \\
\hline $78-007$ & N100/E50 & $0-10$ & & 5 & Sent to Dering for ID & $\begin{array}{l}\text { Juniper }(n=1) \text {, sycamore }(n=7) \text {, } \\
\text { mesquite }(n=17) \text {, oak }(n=9) \text {, } \\
\text { indeterminate }(n=16)\end{array}$ \\
\hline $78-5-7-1$ & N100/E50 & $10-20$ & 21 & 0.9 & Sent to Dering for ID & $\begin{array}{l}\text { Juniper ( } n=4) \text {, mesquite }(n=2) \text {, oak } \\
(n=7) \text {, elm }(n=2) \text {, }\end{array}$ \\
\hline $78-5-7-1 a$ & N100/E50 & $0-10$ & 21 & 0.1 & $\mathrm{C}^{14}$ dated to $380+40$ B.P. & \\
\hline $78-5-7-1 b$ & N100/E50 & $0-10$ & 21 & 0.1 & $\mathrm{C}^{14}$ dated to $380+30$ B.P. & \\
\hline $78-5-7-1 c$ & N100/E50 & $0-10$ & 21 & 0.1 & $\mathrm{C}^{14}$ dated to $300+40$ B.P. & \\
\hline $78-5-4-1$ & N100/E50 & $10-20$ & 21 & 0.9 & $\begin{array}{l}\text { Light fraction sent to Dering } \\
\text { for ID }\end{array}$ & $\begin{array}{l}\text { Oak ( } 8 \mathrm{ml}) \text {, hickory family }(n=3) \text {, } \\
\text { juniper }(n=9) \text {, lotebush }(n=6) \text {, } \\
\text { indeterminate }(4 \mathrm{ml}) \text {, pecan }(\mathrm{cf}) \text { nut } \\
\text { shell }(n=3)\end{array}$ \\
\hline $\begin{array}{l}\text { 79-005-004- } \\
007-1 \mathrm{a}\end{array}$ & N100/E50 & $10-20$ & 21 & 1 & Sent to Dering for ID & Juniper $(n=2)$ \\
\hline $79-5-4-1$ & N100/E50 & $10-20$ & 21 & 5.1 & $\begin{array}{l}\text { Light fraction sent to Dering } \\
\text { for ID }\end{array}$ & $\begin{array}{l}\text { Oak }(9 \mathrm{ml}) \text {, elm }(4 \mathrm{ml}) \text {, mesquite } \\
(n=14) \text {, juniper }(15 \mathrm{ml}) \text {, woody legume } \\
(n=1) \text {, indeterminate }(n=20) \text {, cheno-am } \\
\text { seed }(n=2)\end{array}$ \\
\hline 79-005-007 & N100/E50 & $10-22$ & 21 & 2 & & \\
\hline $87-005-007$ & N100/E51 & 10 & 21 & 1.7 & & \\
\hline $87-5-4-1$ & N100/E51 & 10 & 21 & 6.2 & $\begin{array}{l}\text { Light fraction sent to Dering } \\
\text { for ID }\end{array}$ & $\begin{array}{l}\text { Agave heart }(n=13) \text {, juniper }(n=21) \text {, } \\
\text { indeterminate }(n=7) \text {, elm }(n=9) \text {, hickory } \\
\text { family }(n=9) \text {, woody legume }(n=5) \text {, } \\
\text { pecan }(\mathrm{cf}) \text { nut }(\mathrm{n}=2) \text {, walnut nut }(n=1) \text {, } \\
\text { lotebush }(n=17)\end{array}$ \\
\hline $87-5-4-1$ & N100/E51 & $10-20$ & 21 & 6.4 & $\begin{array}{l}\text { Light fraction sent to Dering } \\
\text { for ID }\end{array}$ & $\begin{array}{l}\text { Oak }(10 \mathrm{ml}) \text {, elm }(n=2) \text {, lotebush }(n=2) \text {, } \\
\text { juniper }(13 \mathrm{ml}) \text {, indeterminate }(11 \mathrm{ml}) \text {. } \\
\text { Woody legume }(n=5)\end{array}$ \\
\hline $97-007$ & N100/E52 & $0-10$ & & 1.9 & & Walnut nut $(n=1)$ \\
\hline $109-007$ & N100/E53 & 19 & 30 & 1 & & \\
\hline $109-007-1 \mathrm{a}$ & N100/E53 & 19 & 30 & 1 & Sent to Dering for ID & $\begin{array}{l}\text { Juniper ( } n=1) \text {, mesquite }(n=4) \text {, } \\
\text { indeterminate }(n=5)\end{array}$ \\
\hline $109-5-4-1$ & N100/E53 & 19 & 30 & 1.2 & $\begin{array}{l}\text { Light fraction sent to Dering } \\
\text { for ID }\end{array}$ & $\begin{array}{l}\text { Oak }(n=8), \text { mesquite }(n=2) \text {, } \\
\text { indeterminate }(n=21) \text {, mesquite seed } \\
(n=1) \text {, slag }(n=8)\end{array}$ \\
\hline
\end{tabular}


Table 8-13. Toyah Macrobotanical Remains

\begin{tabular}{|c|c|c|c|c|c|c|}
\hline Cat. \# & Unit No. & $\begin{array}{c}\text { Depth } \\
\text { (cmbd) }\end{array}$ & $\begin{array}{l}\text { Fea. } \\
\text { No. }\end{array}$ & $\begin{array}{l}\text { Wgt } \\
\text { (g) }\end{array}$ & Comments & Identifications \\
\hline $119-005-007$ & N100/E54 & 15 & 35 & 4.7 & & \\
\hline 119-005-007-1a & N100/E54 & $10-20$ & 35 & 0.1 & Sent to Dering for ID & Oak $(n=7)$ \\
\hline $119-5-4-1$ & N100/E54 & $10-20$ & 35 & 1.4 & $\begin{array}{l}\text { Light fraction sent to Dering } \\
\text { for ID }\end{array}$ & $\begin{array}{l}\text { Indeterminate }(8 \mathrm{ml}) \text {, oak }(n=2) \text {, woody } \\
\text { legume }(n=12) \text {, juniper }(n=1) \text {, agave } \\
\text { heart }(n=4) \text {, }\end{array}$ \\
\hline 158-005-007 & N101/E47 & $20-30$ & 36 & 2.1 & & \\
\hline 158-005-007-1a & N101/E47 & $20-30$ & 36 & 0.1 & $\mathrm{C}^{14}$ dated to $400+40$ B.P. & \\
\hline $158-005-007-1 b$ & N101/E47 & $20-30$ & 36 & 0.1 & Sent to Dering for ID & Oak $(n=3)$ \\
\hline 159-005-007 & N101/E47 & $30-40$ & 36 & 12.6 & & \\
\hline 159-005-007-1a & N101/E47 & $30-40$ & 36 & 0.1 & $\mathrm{C}^{14}$ dated to $940+40$ B.P. & \\
\hline 159-005-007-1b & N101/E47 & $30-40$ & 36 & 0.1 & Sent to Dering for ID & \\
\hline 160-005-007 & N101/E47 & $40-50$ & 36 & 0 & & \\
\hline 160-005-007-1a & N101/E47 & $40-50$ & 36 & 0.1 & $\mathrm{C}^{14}$ dated to $920+40$ B.P. & \\
\hline $160-005-007-1 b$ & N101/E47 & $40-50$ & 36 & 0.1 & Sent to Dering for ID & Mesquite ( $n=3$ ) \\
\hline $168-007$ & N101/E50 & $20-30$ & & 0.1 & & \\
\hline $176-007$ & N101/E50 & $0-10$ & & 0.2 & & \\
\hline 186-005-007 & N101/E51 & $10-20$ & & 0.4 & No Feature; not handled & \\
\hline $186-007$ & N101/E51 & $10-20$ & & 0.5 & No Feature & \\
\hline $196-007$ & N101/E52 & $10-20$ & & 1.4 & & \\
\hline $232-007$ & N101/E55 & $10-20$ & & 0.3 & & \\
\hline 262-005-007 & N102/E47 & $30-40$ & 36 & 0.8 & & \\
\hline $262-5-4-1$ & N102/E47 & $30-40$ & 36 & 0.2 & $\begin{array}{l}\text { Light fraction sent to Dering } \\
\text { for ID }\end{array}$ & Oak ( $n=5)$, juniper $(n=2)$ \\
\hline $292-007$ & N102/E52 & $10-20$ & & 0.1 & & \\
\hline $313-007$ & N102/E54 & $30-40$ & & 0.1 & & \\
\hline 314-007 & N102/E54 & $40-50$ & & 0.1 & & \\
\hline $348-007$ & N103/E47 & $0-10$ & & 0.2 & & \\
\hline $349-007$ & N103/E47 & $10-20$ & & 1.7 & & \\
\hline $350-007$ & N103/E47 & $20-30$ & & 0.1 & & \\
\hline $358-007$ & N103/E51 & $10-20$ & & 0.1 & & \\
\hline $376-007$ & N103/E52 & $0-10$ & & 0 & & \\
\hline $377-007$ & N103/E52 & $10-20$ & & 0.1 & & \\
\hline $377-007-1 \mathrm{a}$ & N103/E52 & $10-20$ & & 0.1 & Sent to Dering for ID & Oak $(n=1)$ \\
\hline
\end{tabular}


Table 8-13. Toyah Macrobotanical Remains

\begin{tabular}{|c|c|c|c|c|c|c|}
\hline Cat. \# & Unit No. & $\begin{array}{c}\text { Depth } \\
\text { (cmbd) }\end{array}$ & $\begin{array}{l}\text { Fea. } \\
\text { No. }\end{array}$ & $\begin{array}{l}\text { Wgt } \\
\text { (g) }\end{array}$ & Comments & Identifications \\
\hline $405-007$ & N104/E47 & $10-20$ & & 0.5 & & \\
\hline 406-007 & N104/E47 & $20-30$ & & 0.2 & & \\
\hline $407-7-1 \mathrm{a}$ & N104/E47 & $30-40$ & & 0.7 & Sent to Dering for ID & Oak $(n=3)$ \\
\hline $450-007$ & N105/E52 & $0-10$ & & 0 & & \\
\hline $450-007-1 \mathrm{a}$ & N105/E52 & $0-10$ & & 0.1 & Sent to Dering for ID & Mesquite ( $n=1)$ \\
\hline $466-007$ & N105/E54 & $0-10$ & & 0.1 & & \\
\hline $481-007$ & N105/E56 & $10-20$ & & 0 & & \\
\hline $481-007-1 \mathrm{a}$ & N105/E56 & $10-20$ & & 0.1 & Sent to Dering for ID & Indeterminate ( $n=17)$ \\
\hline $490-007$ & N106/E47 & $20-30$ & & 0 & & \\
\hline $490-007-1 \mathrm{a}$ & N106/E47 & $20-30$ & & 0.1 & Sent to Dering for ID & Juniper $(n=1)$ \\
\hline 525-005-007 & N106/E54 & $35-40$ & 2 & 0 & & \\
\hline 525-005-007-1a & N106/E54 & $35-40$ & 2 & 0.1 & $\mathrm{C}^{14}$ dated to $290+40$ B.P. & \\
\hline $525-005-007-1 b$ & N106/E54 & $35-40$ & 2 & 0.1 & Sent to Dering for ID & Oak $(n=1)$ \\
\hline $533-007$ & N106/E55 & $3-20$ & 18 & 3.6 & & \\
\hline $533-5-4-1$ & N106/E55 & $3-20$ & 18 & 0.2 & $\begin{array}{l}\text { Light fraction sent to Dering } \\
\text { for ID }\end{array}$ & Oak $(n=25)$ \\
\hline 534-007 & N106/E55 & $10-20$ & & 0.5 & & \\
\hline $550-007$ & N107/E47 & $20-30$ & & & & \\
\hline $550-007-1 \mathrm{a}$ & N107/E47 & $20-30$ & & 0.1 & Sent to Dering for ID & Oak $(n=1)$ \\
\hline $573-007$ & N107/E51 & $10-20$ & & 0 & & \\
\hline $573-007-1 a$ & N107/E51 & $10-20$ & & 0.1 & Sent to Dering for ID & Oak $(n=4)$ \\
\hline 594-007 & N107/E54 & $40-50$ & & 0.1 & & \\
\hline $603-5-4-1$ & N107/E55 & $17-22$ & 22 & 0.2 & $\begin{array}{l}\text { Light fraction sent to Dering } \\
\text { for ID }\end{array}$ & Indeterminate ( $n=13$ ) \\
\hline 739-5-7 & N109/E56 & $30-40$ & 27 & 0.1 & $\mathrm{C}^{14}$ dated to $550+40$ B.P. & \\
\hline $748-007$ & N110/E54 & $0-10$ & & 0 & & \\
\hline $748-007-1 a$ & N110,E54 & $0-10$ & & 0.1 & Sent to Dering for ID & Juniper $(n=1)$, oak $(n=5)$ \\
\hline 749-005-007 & N110/E54 & 10 & 32 & 0.2 & & \\
\hline 800-007 & N115/E73 & $10-20$ & & 0 & & \\
\hline $800-007-1 \mathrm{a}$ & N115/E73 & $10-20$ & & 0.1 & Sent to Dering for ID & Oak $(n=2)$ \\
\hline $825-007$ & N117/E69 & $0-10$ & & 0 & & \\
\hline $825-007-1 a$ & N117/E69 & $0-10$ & & 0.1 & Sent to Dering for ID & Willow/cottonwood $(n=2)$ \\
\hline
\end{tabular}


Table 8-13. Toyah Macrobotanical Remains

\begin{tabular}{|c|c|c|c|c|c|c|}
\hline Cat. \# & Unit No. & $\begin{array}{c}\text { Depth } \\
\text { (cmbd) }\end{array}$ & $\begin{array}{l}\text { Fea. } \\
\text { No. }\end{array}$ & $\begin{array}{l}\text { Wgt } \\
\text { (g) }\end{array}$ & Comments & Identifications \\
\hline $830-5-4-1$ & N117/E71 & $12-22$ & 9 & 4.4 & Sent to Dering for ID & $\begin{array}{l}\text { Agarita }(n=11) \text {, lotebush }(n=7) \text {, } \\
\text { cottonwood/willow }(n=10) \text {, juniper } \\
(n=9) \text {, sycamore }(n=4) \text {, oak }(n=30) \text {, } \\
\text { buckeye }(9 \mathrm{ml}) \text {, woody legume }(n=9) \text {, } \\
\text { pinyon }(n=1) \text {, indeterminate }(n=1)\end{array}$ \\
\hline $\begin{array}{l}830-005-004- \\
007-1 a\end{array}$ & N117/E71 & $12-22$ & 9 & 0.1 & $\mathrm{C}^{14}$ dated to $660+40$ B.P. & Oak $(n=4)$ \\
\hline $\begin{array}{l}830-005-004- \\
007-1 b\end{array}$ & N117/E71 & $12-22$ & 9 & 0.1 & Sent to Dering for ID & Oak $(n=21)$ \\
\hline 830-005-007 & N117/E71 & $12-16$ & 9 & 0.9 & & \\
\hline 830-005-007-1a & N117/E71 & $12-16$ & 9 & 0.1 & Sent to Dering for ID & \\
\hline $841-007$ & N118/E69 & $10-20$ & & 1 & & \\
\hline $841-007-1 a$ & N118/E69 & $10-20$ & & 1 & Sent to Dering for ID & $\begin{array}{l}\text { Indeterminate }(n=2) \text {, mesquite }(n=4) \text {, } \\
\text { oak }(n=3)\end{array}$ \\
\hline $842-007$ & N118/E70 & $0-10$ & & 0.4 & & \\
\hline 843-005-007 & N118/E70 & $10-20$ & 8 & 3.4 & & \\
\hline $843-5-4-1$ & N118/E70 & $10-20$ & 8 & 3.6 & $\begin{array}{l}\text { Light fraction sent to Dering } \\
\text { for ID }\end{array}$ & $\begin{array}{l}\text { Lotebush }(10 \mathrm{ml}) \text {, buttonbush }(n=8) \text {, } \\
\text { juniper }(n=3) \text {, woody legume }(n=5) \text {, } \\
\text { indeterminate }(n=6)\end{array}$ \\
\hline 843-005-007-1a & N118/E70 & $10-20$ & 8 & 0.1 & $\mathrm{C}^{14}$ dated to $80+30$ B.P. & \\
\hline 843-005-007-1b & N118/E70 & $10-20$ & 8 & 0.2 & Sent to Dering for ID & Walnut shell $(n=1)$ \\
\hline 843-005-007-2a & N118/E70 & $10-20$ & 8 & 0.1 & Sent to Dering for ID & Indeterminate $(n=7)$, oak $(n=6)$ \\
\hline 844-007 & N118/E71 & $0-10$ & & 0.7 & & \\
\hline $847-007$ & N118/E72 & $0-10$ & & 0.1 & & \\
\hline $848-007$ & N118/E72 & $10-20$ & & 12.8 & & \\
\hline $848-007-1 a$ & N118/E72 & $10-20$ & & 2 & Sent to Dering for ID & Oak $(n=4)$, mesquite $(n=15)$ \\
\hline 863-007 & N119/E69 & $10-20$ & & 0.3 & & \\
\hline $\begin{array}{l}865-005-004- \\
007-1 a\end{array}$ & N119/E70 & $10-20$ & 8 & 0.1 & $\begin{array}{l}\text { From heavy fraction; } C^{14} \\
\text { dated to } 620+40 \text { B.P. }\end{array}$ & \\
\hline $\begin{array}{l}865-005-004- \\
007-1 b\end{array}$ & N119/E70 & $10-20$ & 8 & 0.1 & $\begin{array}{l}\text { From heavy fraction; sent to } \\
\text { Dering for ID }\end{array}$ & Oak $(n=1)$ \\
\hline $\begin{array}{l}865-005-004- \\
007-1 c\end{array}$ & N119/E70 & $10-20$ & 8 & 0.1 & $\begin{array}{l}\text { From heavy fraction; } C^{14} \\
\text { dated to } 570+40 \text { B.P. }\end{array}$ & \\
\hline $\begin{array}{l}865-005-004- \\
007-1 d\end{array}$ & N119/E70 & $10-20$ & 8 & 0.1 & $\begin{array}{l}\text { From heavy fraction; } C^{14} \\
\text { dated to } 600+40 \text { B.P. }\end{array}$ & \\
\hline 865-005-007 & N119/E70 & 14 & 8 & 1.1 & & \\
\hline $865-5-4-1$ & N119/E70 & 14 & 8 & 0.5 & $\begin{array}{l}\text { Light fraction sent to Dering } \\
\text { for ID }\end{array}$ & Lotebush ( $n=9)$ \\
\hline
\end{tabular}


Table 8-13. Toyah Macrobotanical Remains

\begin{tabular}{|c|c|c|c|c|c|c|}
\hline Cat. \# & Unit No. & $\begin{array}{c}\text { Depth } \\
\text { (cmbd) }\end{array}$ & $\begin{array}{l}\text { Fea. } \\
\text { No. }\end{array}$ & $\begin{array}{l}\text { Wgt } \\
\text { (g) }\end{array}$ & Comments & Identifications \\
\hline $865-005-007-2 a$ & N119/E70 & 14 & 8 & 0.1 & Sent to Dering for ID & Indeterminate $(n=4)$ \\
\hline $866-007$ & N119/E71 & $0-10$ & & 0.1 & & \\
\hline 867-005-007 & N119/E71 & $10-20$ & 8 & 2 & & \\
\hline 867-005-007-1a & N119/E71 & $10-20$ & 8 & 2 & Sent to Dering for ID & $\begin{array}{l}\text { Green condalis ( } n=3) \text {, juniper }(n=3) \text {, } \\
\text { mesquite }(n=5) \text {, elm }(n=5), \\
\text { indeterminate }(n=4)\end{array}$ \\
\hline $867-5-4-1$ & N119/E71 & $10-20$ & 8 & 6.6 & $\begin{array}{l}\text { Light fraction sent to Dering } \\
\text { for ID }\end{array}$ & Oak $(n=10)$, agarita $(n=25)$ \\
\hline 899-007 & N122/E69 & $20-30$ & & 0 & & \\
\hline 899-007-1a & N122/E69 & $20-30$ & & 0.1 & Sent to Dering for ID & Juniper $(n=1)$ \\
\hline $912-007$ & N122/E74 & $0-8$ & & 0.2 & & \\
\hline $919-007$ & N123/E68 & $19-29$ & & 0.6 & & \\
\hline $944-007$ & N123/E74 & $26-35$ & & 0 & & \\
\hline $944-007-1 \mathrm{a}$ & N123/E74 & $26-35$ & & 0.1 & Sent to Dering for ID & Mesquite $(n=1)$, oak $(n=26)$ \\
\hline $980-007$ & N125/E71 & $0-10$ & & 0.4 & & \\
\hline $984-007$ & N125/E72 & $10-20$ & & 0.6 & & \\
\hline $991-007$ & N125/E74 & $18-28$ & & 0.1 & & \\
\hline $1006-007$ & N126/E71 & $20-26$ & & 0.2 & & \\
\hline $1021-005-007$ & N126/E74 & $20-25$ & 25 & 8 & & \\
\hline $\begin{array}{l}\text { 1021-005-007- } \\
1 \mathrm{a}\end{array}$ & N126/E74 & $20-25$ & 25 & 2 & Sent to Dering for ID & $\begin{array}{l}\text { Mesquite }(n=11) \text {, juniper }(n=4) \text {, } \\
\text { indeterminate }(n=2)\end{array}$ \\
\hline $1025-005-007-1$ & N126/E75 & $20-30$ & 25 & 5.2 & & \\
\hline $\begin{array}{l}1025-005-007- \\
1 \mathrm{a}\end{array}$ & N126/E75 & $20-30$ & 25 & 0.1 & $\mathrm{C}^{14}$ dated to $320+40$ B.P. & \\
\hline $\begin{array}{l}\text { 1025-005-007- } \\
1 \mathrm{~b}\end{array}$ & N126/E75 & $20-30$ & 25 & 0.1 & Sent to Dering for ID & Mesquite $(n=1)$ \\
\hline $1025-005-007-2$ & N126/E75 & 30 & 25 & 6.6 & & \\
\hline $1030-005-007-1$ & N126/E76 & $35-50$ & 38 & 8 & & \\
\hline $\begin{array}{l}1030-005-007- \\
1 \mathrm{a}\end{array}$ & N126/E76 & $35-50$ & 38 & 0.1 & $\mathrm{C}^{14}$ dated to $390+60 \mathrm{BP}$ & \\
\hline $\begin{array}{l}1030-005-007- \\
1 \mathrm{~b}\end{array}$ & N126/E76 & $35-50$ & 38 & 0.1 & Sent to Dering for ID & Willow/cottonwood $(n=2)$ \\
\hline $1030-005-007-2$ & N126/E76 & $30-40$ & 38 & 0.4 & & \\
\hline $\begin{array}{l}\text { 1030-005-007- } \\
2 \mathrm{a}\end{array}$ & N126/E76 & $30-40$ & 38 & 0.1 & Sent to Dering for ID & Woody legume (20 ml) \\
\hline
\end{tabular}


Table 8-13. Toyah Macrobotanical Remains

\begin{tabular}{|c|c|c|c|c|c|c|}
\hline Cat. \# & Unit No. & $\begin{array}{c}\text { Depth } \\
\text { (cmbd) }\end{array}$ & $\begin{array}{l}\text { Fea. } \\
\text { No. }\end{array}$ & $\begin{array}{l}\text { Wgt } \\
\text { (g) }\end{array}$ & Comments & Identifications \\
\hline $1030-5-4-1$ & N126/E76 & $30-40$ & 38 & 4 & $\begin{array}{l}\text { Light fraction sent to Dering } \\
\text { for ID }\end{array}$ & $\begin{array}{l}\text { Oak }(n=24) \text {, buttonbush }(5 \mathrm{ml}) \text {, } \\
\text { cottonwood/willow }(n=5), \text { juniper } \\
(n=5), \text { indeterminate }(n=8) \text {, woody } \\
\text { legume }(n=14) \text {, agave leaf }(n=3), \\
\text { prickly pear seed }(n=2), \text { indeterminate } \\
\text { seed }(n=1)\end{array}$ \\
\hline 1050-005-007 & N127/E74 & $15-27$ & 25 & 0.6 & Feature 25 in NW corner & \\
\hline 1051-005-007 & N127/E74 & $27-30$ & 25 & 1.8 & Inside Feature & \\
\hline $1051-5-4-1$ & N127/E74 & $27-30$ & 25 & 1.7 & $\begin{array}{l}\text { Light fraction sent to Dering } \\
\text { for ID }\end{array}$ & $\begin{array}{l}\text { Cottonwood/willow ( } n=5) \text {, juniper } \\
(n=1) \text {, elm }(n=1) \text {, oak }(n=11) \text {, mesquite } \\
(n=15) \text {, indeterminate }(n=24) \text {, } \\
\text { sycamore }(n=2) \text {, walnut nut }(n=3)\end{array}$ \\
\hline $1054-007$ & N127/E75 & $20-30$ & 25 & 6.3 & & \\
\hline $1055-005-007$ & N127/E75 & $25-35$ & 25 & 20.6 & Lower part of Feature & \\
\hline $\begin{array}{l}1055-005-007- \\
1 \mathrm{a}\end{array}$ & N127/E75 & 25-35 & 25 & 6 & $\mathrm{C} 14$ dated to $170+60 \mathrm{BP}$ & \\
\hline $\begin{array}{l}1055-005-007- \\
1 \mathrm{~b}\end{array}$ & N127/E75 & 25-35 & 25 & 2 & Sent to Dering for ID & Mesquite $(n=1)$ \\
\hline $1123-007$ & N130/E72 & $30-35$ & & & Modern tree root sample & $54.5 \mathrm{~g}$ \\
\hline 1123-007-1a & N130/E72 & $30-35$ & & & $\begin{array}{l}\text { Sent to Dering for ID; } \\
\text { modern tree root }\end{array}$ & $9.0 \mathrm{~g}$ \\
\hline
\end{tabular}

Pecan nuts, represented by a few thin shells, provide sufficient meat to imply use as food, with discard of shells into fire as a means of disposal. Burned cheno-am seeds (goosefoot or pigweed) and prickly pear seeds, each from single proveniences, were also identified, though in very limited numbers.

The one burned mesquite seed in Feature 30 may be an indication that this resource was processed for food. Mesquite wood was identified from the same feature as the mesquite seed, indicating the seed probably was just part of the fuel wood. It is uncertain if these different seeds were accidentally burned or if they truly represent the preparation of food.

The identifications of carbonized remains document a tremendous range of woods employed for what is thought to be fuel for fires.
The 17 species represented reflect both upland and riparian environments, and thus, the use of diverse environmental zones and non-specific selection. This broad diversity is not just a reflection of the number of features present at this site, since a few individual features yielded seven to eight different species (i.e., Features 8, 9, and 21). Dr. Dering interprets the abundance and diversity of woods to indicate repeated use of these features (Appendix I). This may be a correct interpretation in the case of dumps such as Features 25 and 28, but Features 9 and 21 are tight clusters of burned rocks that would imply a single use episode of fairly short duration. It appears that the occupants did not select a single species of wood for fuel. 


\subsection{TOYAH SUmmary AND DISCUSSION}

This horizontally extensive and dense component was recognized through many stone tools, quantities of lithic debitage, quantities of bone fragments, thousands of burned rocks, and a number bone and burned rock features. These cultural materials were partially exposed on the disturbed surface, but were mostly in a loose, brown (10YR 4/3) clay loam layer of overbank deposits, which correspond to Depositional Unit 1. This mostly 12- to 18-cm-thick deposit extends over most areas investigated on both sides of the pavement. General TxDOT road maintenance activities, bladed access roads to private properties, and Phase I backhoe trenching all impacted the original surface and the top part of this component. An abrupt, smooth lower boundary and soil color change demarcated the base of Depositional Unit 1, which lay immediately atop the Late Archaic cultural deposits that contained the burned rock concentration, designated as Feature 1. A few Toyah age materials were had moved downward to become mixed with Late Archaic materials.

The hand-excavated $207.75 \mathrm{~m}^{2} \quad$ yielded 26,323 pieces of lithic debitage; 20,438 bones; 15,934 burned rocks; informal tools including 1,380 edge-modified flakes; formal tools including 216 arrow points (140 unidentifiable fragments, and 53 Perdiz, 10 Cliffton, five Bonham, two Scallorn, two Guerrero, one Edwards, one Cuney, one Harrell, and one Padre); 13 dart points (four Frio, one Group 2, one Baker, one Merrell, and six unidentifiable fragments); $\quad 96$ bifaces; 65 scrapers (one missing); 37 cores; 16 drills; seven unifaces; one anvil; and one hammerstone. Also recovered were 115 ceramic sherds, $196 \mathrm{~g}$ of carbonized plant remains, and seven relatively unique artifacts of various materials.

\subsubsection{Chronology Issues}

The chronometric age is derived through radiocarbon dating of 21 samples recovered from this cultural zone. Two radiocarbon dates, one on burned rock (\#1030-5-3-2c) at 11,980 B.P. and one of three dated ceramic sherds (\#987-8-1a) at 26,960 B.P., are obviously much too old and beyond the realm of any realistic cultural association (Table 8-1). The four dated Toyah sherds plus, the Toyah burned rock, yielded ages that appear contaminated in one way or another. The burned rock assay is so far beyond the known range of human occupation that it surely is contaminated. Three, or 75 percent, of the dated Toyah sherds provide AMS results that are largely or completely outside the acceptable age range for this prehistoric Toyah assemblage.

The dating results from four Varga Site Toyah sherds, and the sherds from other context, were intended to enable us to address the arrival and use of ceramics in the region, to investigate their continued use into the Historic period, and to assist in refining the age range of Toyah components. The mixed results from our efforts to directly date the sherds prevent us from addressing these and other questions, which were proposed in the research design.

Three samples, two charcoal dates of 80 B.P. and 170 B.P. (\#843-5-7-1a and \#1055-5-7-1a) and one ceramic sherd date of 60 B.P. (\#118-8$1 \mathrm{a})$, which is suspect to begin with, yielded ages that are less than 200 years old. These three ages are considered too recent and unacceptable for this Toyah component. However, both produce calibrated age ranges that, at one sigma, fall within decades of A.D. 1700, indicating that they may be accurate indicators of an Early Historic, Toyah or Toyah-like cultural component at the site.

Two other charcoal dates of 920 B.P. (Beta175399) and 940 B.P. (Beta-175398) from Feature 36 (a dense occupation zone) along the western margin of Block $\mathrm{A}$, are older than the presumed age for Toyah and younger than the well-dated Late Archaic component here. These two ca. 930 B.P., even when calibrated, are pre- 
Toyah in age, indicating the possibility of an unrecognized cultural occupation just before the Toyah events and associated with one or more of the non-Perdiz arrow points recovered. It is also possible that these may reflect some naturally burned wood.

Overall, 35 percent of the radiocarbon ages on materials derived from the Toyah component are considered marginal or unacceptable for this particular cultural component. The 13 acceptable radiocarbon dates, which comprise 65 percent of the Toyah samples, reveal a time range from 290 to 660 B.P. (Table 8-1), with a calibrated 1-sigma range of A.D. 1280-1660. Acceptable assays were all derived from wood charcoal. Forty-six percent fall between 400 and 660 years B.P. Fifty-four percent, or seven wood charcoal dates, are less than 400 B.P. These seven dates indicate that the Toyah occupations at the site could easily have extended into the Protohistoric period. The glass edge-modified flake (\#869-10) together with two Guerrero points, adds support to the Protohistoric event(s) at the Varga Site. The two mentioned late radiocarbon ages that both have early-end calibrated ranges in the late Seventeenth Century, could easily represent occupation of the site during this time period.

A total of 229 projectile arrow points and arrow point fragments were recovered from this component, with nearly 61.4 percent consisting of untypable fragments. The single most frequent identifiable point type is Perdiz, which accounts for 70 percent of the identifiable specimens. Cliffton points follow in frequency at 13 percent, Bonham points at 6.6 percent, Frio points at 5.3 percent. Less than six percent of the total identifiable arrow points are represented by seven other point types that include Scallorn, Edwards, Guerrero, Cuney, Harrell, Padre, and a Group 2 (Early CornerNotched) dart point.

The one Edwards and two Scallorn points account for less than four percent of the identifiable arrow points and are considered just slightly older than other points recovered from the Toyah component. The Rainey Site, just to the east in Bandera County, provides absolute radiocarbon dates and good stratigraphic context to document that Scallorn and Edwards points are slightly older than the Perdiz points (Henderson 2001). At the Rainey Site the Scallorn and Edwards point types are associated with absolute radiocarbon dates that range from about 800 to 1,400 B.P. These three points recovered from the Varga Site may indicate a limited use period just before the Toyah component. The above-mentioned charcoal radiocarbon ages of 920 and 940 B.P. (Beta175399 and Beta-175398) from the lowest part of the Toyah component, three radiocarbon dates from the Late Archaic component from two bone dates of 860 and 890 B.P. (UGA-12713 and UGA-12708), plus a charcoal date from Feature 1d of 1,390 B.P. (UGA-12704), are considered too recent for the Late Archaic and too old for the Toyah component. These seven absolute dates from the Varga Site may well represent a use period by group(s) using the Scallorn and/or Edwards points, unrecognizable due to admixture with non-contemporaneous materials.

\subsubsection{Subsistence Issues}

Although only about three percent of the Toyah chipped stone tools were analyzed for use-wear, a wide range of organic materials detected on their surfaces supports diverse uses. The detected materials include wood, starchy plants (possibly roots or tubers), mammals, birds, and other various plants. These detected resources do not clarify which specific plants and animals were consumed, but document a wide range of resources were procured and processed. From this finding, it is assumed that both meat and plant products were part of the subsistence economy.

Bison, deer, antelope, cottontail, jackrabbit, a canid/carnivore like coyote, turtle, snake, hawk- 
size bird, and fish bones are positively identified. Minimally two bison, two deer, one antelope, two turtles, two snakes, one bird, one coyote/dog, one cottontail rabbit, one jackrabbit, and one fish are represented. It is not clear if all these species were directly part of the Toyah subsistence base. Several of these species could be intrusive, natural occurrences, especially those species represented by less than four identified pieces. Bison, deer, antelope, and rabbits are definitely part of the cultural food resources. In terms of meat weight, it is apparent that bison was the greatest contributor, possibly more so than all other mammals combined.

About $196 \mathrm{~g}$ of carbonized plant remains were recovered. Identifications indicate that at least 17 species were burned, implying use by humans. The burned species include agave heart and leaves (likely sotol or yucca), agarita, buttonbush, cheno-am seeds, condalis, elm, juniper, littleleaf walnut, lotebush, mesquite, Mexican buckeye, oak, pecan, pinyon, prickly pear seeds, sycamore, and willow/cottonwood. Although these species were present, it is unclear which specific ones represent food consumption. The most likely candidate is the agave heart, as the ethnographic record documents considerable use of this part of the plant for food. The littleleaf walnut is also a possibility, but it actually has limited meat inside the small, dense shell, although it does contain some valuable oils. The cheno-am seeds and prickly pear seeds are two more possibilities for food given that they are known to have served as food products. Most other species probably did not serve as foods, with the majority of these being tree parts, which would have been used as fuel for fires. Even though the wood probably was so used, the presence of mesquite, juniper, and prickly pear would have provided other parts, which could have served as food resources.
The lipid residue analyses on 29 burned rocks and six ceramic sherds indicate that only about 24 percent of the samples yielded residues interpreted as reflecting large herbivore or javelina meat. None of the potsherds bore residues that reflect the cooking of large herbivore meat. The sherd residues were characteristic of moderate-high fat content foods likely to be of plant origin. Overall, approximately six percent of the residues were similar to fatty or somewhat fatty meat prepared alone. Just over 11 percent of the residues resemble somewhat fatty large herbivore meat prepared with plants. Nearly three percent of the residues are similar in composition to large herbivore meat prepared with moderate-fatcontent plant or bone marrow. The remaining 76 percent are interpreted to reflect plant residues. None of the Toyah burned rocks contained residues identified as very high-fatcontent foods. The relatively high fat content residues indicate that seeds and nuts are likely candidates for being cooked in the pots or by using heated rocks.

The stable isotope analysis on the same sherds and burned rocks generally supports the lipid residue analysis, and reveals that all the plants appear to represent $\mathrm{C}_{3}$ type plants. Not surprisingly, the carbon isotope values obtained from these samples show no sign of corn/maize. Even the large herbivore represented appears to have been consuming mostly $\mathrm{C}_{3}$ plants. The large herbivore interpreted in the lipid residues is associated with carbon isotope values of $18.4 \%$ or more negative. These values indicate that if bison were present, as indicated in the bone assemblage, they were consuming nearly equal amounts of $\mathrm{C}_{3}$ and $\mathrm{C}_{4}$ vegetation. However, a bison bone (\#525-5-2-1) recovered from Feature 2 (a bone cluster) in the Toyah component yielded a $\delta^{13} \mathrm{C}$ value of $-8.6 \%$ and a $\delta^{15} \mathrm{~N}$ value of $5.1 \%$. These isotopic results indicate bison meat should have reflected carbon isotope values in the range of about -13 to 14\%. These more positive carbon isotope 
values are not reflected in the isotope values derived from either the ceramic sherds or the burned rocks. Therefore, the $\delta^{13} \mathrm{C}$ values that are more negative than $-18.4 \%$ and derived from samples interpreted as large herbivore residues are most likely deer/pronghorn meat. It is not clear why the carbon isotopes from the burned rocks and ceramic sherds did not reflect any values that would indicate that bison meat was cooked. The obvious interpretation would be that bison meat was not cooked in the pots or by the use of hot rocks.

The Varga Site subsistence for this Toyah component reflects a mixture of plant and animal resources with diversity in both groups. The seasonality for these multiple events is not clear. The site was potentially used during spring and late summer/fall, based on the presence of plant resources (i.e., nuts) with many of the identified animal resources available year round.

\subsubsection{Technology Issues}

Technology issues are addressed through the preserved materials; however, only a small (but unknowable) percentage of the total cultural assemblage is preserved. The stone tool assemblage is plentiful, with many formal and informal tools recovered, but not it shows little formal diversity. Burned rocks, ceramic sherds, and bone tools were also recovered. Many diverse daily tasks such as resource procurement, processing, and consumption are represented and will be discussed below.

\subsubsection{Resource Procurement Issues}

Plant and animal procurement is primarily interpreted from the recovered stone tools. The relatively extensive bone assemblage $(n=20,438)$ that represents minimally five and potentially 15 individual animals combined with the high frequency of projectile points (13.1 percent of the total tools) indicates the killing/procurement of animal resources. Use-wear analyses on a few selected arrow points did not reveal the specific material that the points came in contact with. However, this is consistent with their use as projectile points, where contact with the usematerial is very brief and does not often leave sufficient indicators (polish and/or striations) for determination of contact matter. Most points show some form of modification to the proximal end to facilitate hafting. The use-wear analyses support this observation with evidence of hafting in the form of plant fibers involved in binding, use of resin as mastic, and abraded flake scar ridges from movement against the haft material (Appendix C). The hafting was done to a small diameter shaft, confirming use of arrows propelled with a bow in contrast to the larger shafts (i.e., darts) used with an atlatl or spearthrowing stick. Based on the minimum numbers of individual animals documented in the Toyah component ( $\mathrm{n}=5$ to 15 ), the principal hunting strategy was directed towards procurement of individual animals, rather than groups of animals, which would necessitate communal operations that potentially involved traps or pounds. This individual killing strategy goes for all species identified, from small rabbits to the large bison. Based on the percentage of projectile points compared to the total number of stone tools recovered, in combination with abundant evidence for plant cooking, this procurement strategy appears to represent only one aspect of the subsistence strategy employed by Toyah occupants of the site.

Other food resource procurement activities probably occurred, such as trapping individual animals with snares or nets, or digging up of tubers with a digging instrument, but the direct evidence is lacking. Many potential foods such as berries, seeds, nuts, prickly pear fruits, and various other natural resources such as mussels, rocks, and wood require no formal tools to acquire. Consequently, the lack of stone tools designed for such purposes does not indicate that such activities were not undertaken as parts of a broader pattern of subsistence. 
Lithic resources for the manufacture of stone tools and clay resources for the manufacture of ceramic vessels were procured as evident by the quantities of artifacts and manufacturing residues of these materials. Perishable tools such as wooden or antler digging sticks were probably used, but were not recovered from this component. It can be assumed that wood was one resource procured for use as handles for many of the stone tools, the construction of a multitude of various objects including, but not limited to, bows and arrows, traps, awls, pins, gaming pieces, and digging sticks. Most projectile points exhibit alterations to facilitate hafting, some 15 percent of the tools that were analyzed for use-wear exhibited evidence of wood fibers supporting the processing of wood products. The use-wear analysis also revealed that a small percentage of the tools actually were hafted. Wood is also presumed to have been a substance that would leave a hard high silica polish, which was identified on minimally 30 percent of the analyzed stone tools.

As part of the procurement of natural resources, whether it was wood for fires and other uses, or plants and animals for food, it was first necessary to produce the required equipment to acquire these various resources. The recovered assemblage is composed of non-perishable cultural materials from which insights into the production of implements to acquire other resources are gained. The cores indicate that raw tool stone was collected and used. The collected chert cobbles were reduced and flakes from those cobbles were manufactured into various stone tools, including points and bifaces that were then used to procure other natural resources. The different stages of biface production represented in the collected assemblage, from the initial alteration to the finished form, documents the manufacturing of this specific tool class. Use-wear analysis reveals this tool class was used in the acquisition and processing of various resources. The large suite of arrow points (about 13 percent of the total tools) is another example of a general class of tools, which were undoubtedly manufactured here to facilitate the procurement of animal resources. Multiple lines of evidence indicate production of primary tool classes, which once produced, were employed in the acquisition of other resources.

\subsubsection{Processing and Consumption Issues}

The general classes of stone tools represented, such as the points, scrapers, bifaces, edgemodified flakes, and drills, demonstrate a wide range of processing activities/tasks. If theses broad classes of stone tools represent general tasks, then the edge-modified flake class, which represents diverse tasks (at 76.8 percent of the total tools), was by far the most dominant. This broad, general class is followed in abundance by projectile points (12.8 percent), bifaces (5.3 percent of the tools), scrapers (3.6 percent of the tools), and drills (0.9 percent), with the few other tools combined representing less than one-half percent. The frequency of tools in a class is generally used as an indication of the amount of activity/tasks performed at the locality. However, the use-wear analyses on a suite of formal and informal tools documented a variety of different uses for each general tool class. For example, scrapers were used exclusively for scraping and planing, but worked a variety of materials that included both plant and animal products. Edge-modified flakes exhibit a wide range of use-actions which include scraping, planing, whittling, slicing, and cutting. Bifaces were used on a similarly wide range of materials, with a variety of use actions. High-powered use-wear analysis has demonstrated that formal tool classes were not used exclusively for only one task or on one kind of material.

The use-wear analyses generally documented a higher frequency of plant processing (72 percent) than meat/hide processing (14 percent) on the 59 analyzed tools. Edge- 
modified flakes dominated the analyzed group of tools. The different contact materials include plants, meat, bone/antler, mineral, wood, hide, hard and soft material, and completely unidentified materials. Since tool selection for use-wear analyses was biased and represents only 3.3 percent of the total tool assemblage, the frequencies of contact materials cannot be used for projecting the frequency of the type of resources processed. Based on their form, only one or two formal tools may be indirectly linked to plant processing. Again this indicates our inability to address plant use based on tool forms.

Two small, sharply pointed stone tools (\#726-10 and \#837-11) were selected for use-wear analysis because it was thought they might relate to specific tasks/functions. Both items were identified, according to their shapes, as hafted gravers, presumably used on wood (Appendix M). Specimen \#726-10 was originally a Perdiz point that exhibits a distal end reworked a tiny sharp point which was subsequently broken in use. The second graver was a small flake with a pointed tip. These two items are believed to represent engraving action on wooden items.

In addition to the two gravers discussed above, an additional 15 tools have been shown, through use-wear analysis, to have been hafted. These include all four Cliffton points, one Padre point, one graver, two bifaces, one Perdiz point, one Bonham point, one scraper, one drill, and one edge-modified flake tool. The scraper was secured to its haft with resin mastic, and at least one of the Cliffton points was secured with a plant binding. These observations indicate that many different types of tools were hafted with in various ways. The hafting was not limited to the formally shaped and notched tools that are recognized as projectile points, but extended to even some edge-modified flake tools.

One of our specific research questions was to determine the function of so-called Cliffton points. Were these items actually Perdiz performs, as is often assumed, (e.g., Turner and Hester 1993), or were they actually used as finished tools? High-powered use-wear and residue analyses on four Cliffton pieces served to address this question, showing that all four of the examined specimens bore some type of haft wear. One piece also revealed wood fragments and striations in multiple directions implying that it was used to cut wood. The three other pieces revealed no observable use-wear, thus indicated no discernible kind of utilization. Nonetheless, the hafting wear documented on all four specimens does indicate some sort of use, indicating that these items cannot be assumed to be unused performs. Possibly, the three specimens lacking observable wear patterns in fact served as arrow points, given that such use could be short-term and episodic so as to leave no discernible evidence of wear.

Twenty-eight pieces were classified as rejuvenation flakes. As the name implies, these pieces are the result of the intentional rejuvenation of worn-out chipped stone tools rather than unintentional breakage from use. Thus, tool resharpening occurred as worn tool edges were intentionally refurbished. The identified specimens appear to have been removed primarily from unifacial side- and endscrapers. The high-powered use-wear analyses on five rejuvenation flakes indicate that all five pieces have worn edges once used in scraping and/or planing tasks. Four analyzed specimens were used on hard-high silica plant materials, and one on soft material such as hide.

The extensive faunal bone assemblage that consists of 20,438 specimens weighing $17,348.9$ g, reflects extensive animal processing activities. However, the extremely fragmentary nature of most of the sample places constraints on taxa identifications, with nearly 90 percent of the fragments unidentifiable. While the modern mechanical disturbances of the Toyah component, discussed previously, may account 
for some of the breakage, the consistently small size of the bone fragments indicates that prehistoric human behavior was also a significant taphonomic factor. Thus, the high degree of bone fragmentation is interpreted to represent intentional breakage for marrow extraction and, significantly, for the rendering of bone grease, an action posited for bone samples at other Toyah sites in Central Texas (e.g., Ricklis 1994b; Masson and Holderby 1994).

The occupants of the Varga site also used long bone splinters for the production of bone tools. Two bone tools, one narrow awl-like object and one thick, pointed punch-like object, were probably used in the manufacture and processing of other cultural items such as clothing.

Clothing was not, of course, preserved, but items that might have decorated their clothing were present in the artifact assemblage. A bone bead blank used in the manufacturing of short bone beads was present. The intended beads may have been for the adornment of clothing, in addition to use as beads in necklaces and/or bracelets. A drilled mussel shell and a very thin marine shell bead were also recovered, which were doubtless also ornaments. Potentially, other bone tools were manufactured, but still functioning tools were probably curated and removed from the site upon abandonment.

The extensive presence of burned rock assemblage $(n=15,934)$ suggests that hot rocks were employed for much of the cooking and heating carried out at the site. As discussed above in Section 8.11.2, this is supported by the analyses of the lipid residues extracted from 29 burned rocks from hearths and discard locations. The exact techniques of cooking are not identified, but likely included boiling, roasting, and/or grilling. Four identified hearths represent in situ heating and the location of primary activity areas. The burned rocks in these primary heating features averaged greater than $200 \mathrm{~g}$, with those rocks in Feature 9 somewhat larger, averaging $375 \mathrm{~g}$. Burned rocks found in clusters interpreted as discard locations, all probably used in cooking tasks, were on average smaller, with average weights of less than $125 \mathrm{~g}$, indicating that the functional usefulness of the rock had been exhausted at the time of discard. Presumably, the discarded rocks had been heated and cooled multiple times, with repeated heating and fracturing reducing the size of the fragments.

Although not plentiful, the 115 ceramic sherds, representing some five to eight vessels, also testify to cooking activity, given the organic lipid residues extracted from a sample of six sherds. The interpretations of Drs. Malainey and Malisza, that the lipid residues from the majority of sherds and burned rocks indicate cooking of plants, are a significant contribution to a more realistic assessment of Toyah phase adaptive patterns than is the assumption that large herbivore meat was consistently of primary dietary importance (see Appendix G). Judging from the ubiquity of burned rocks across the Toyah component, along with the general scarcity of pottery, it may be suggested that most cooking was carried out through the use of hotrock technology. This combined use of ceramic vessels and burned rocks to cook foods has been observed at other Toyah campsites such as the Rush Site (Quigg and Peck 1995) and the Mustang Branch Site (Ricklis 1994b).

Sufficient organic residues were detected in the sherds to provide interpretations as to the type of foods cooked in ceramic containers. Although the use of the ceramic vessel cooking technology might be assumed to be functionally superior to the pre-existing use of hot rocks, it is clear that the introduction of ceramic technology did not replace the long-standing use of hot-rock cooking. The ceramic vessels were perhaps only gradually integrated into technological behavior, or perhaps even more likely, pottery containers were utilized for specific and limited kinds of food preparation. 
The minor variations observed and detected in the paste constituent of the five different vessel groups are mostly attributed to slight differences in the clay sources, tempering agents, and variability in the behavior of individual potters. Although the petrography detected variations in the clay sources and aplastic additives, stylistic differences are not detected in the Toyah assemblage. The INAA reveals that different paste groups originated from both local and nonlocal source areas, though the non-local category remains only vaguely defined. Local clays were used to make at least Vessel Groups 2 and 4 probably were manufactured using local clay sources.

The clay figurine-like object is a rare piece and has no clearly identifiable function. The petrographic results indicate this piece was tempered with only 10 percent bone, significantly less than the percentage of bone temper in vessels from the Toyah component. The mineral content identified in this object indicates this piece was not locally manufactured, and that it was not manufactured from the same clays the vessels, indicating that it was a traded object. It may be an item that had significance outside of the technoeconomic dimension as an artifact associated with either leisure or ritual.

General camp maintenance activities are visible through the identification of debris dumps, such as Features 8 and 25 in Block B. These areas contained diverse classes of cultural detritus believed to reflect multiple cleaning activities within the surrounding habitation area. Although not visibly identified during the excavations, areas for different activities including tool production area, animal processing, food preparation, and cooking are all envisioned to have been maintained through collecting unwanted materials from these different areas and dumping them in selected discard locations.

\subsubsection{Intra-Component Patterning}

The ca.370-years of documented radiocarbon time, the discovery of potentially three vertically separated occupation events in a small part of this component, combined with the probability for surface and subsurface disturbances to this shallow deposit, make interpretations of horizontal patterning of the cultural items a challenging task. However, the examination of the spatial patterns in the excavated area may provide insight into some of these questions. To examine the spatial relationship in the Toyah component, it is assumed that all the cultural materials represent a synchronous time unit. Each class or functional unit in the assemblage reflects a task, some phase of a task, or a group of tasks conducted by a particular segment of the resident population. The overall spatial relationships among the activity areas in a single component define the structure of the component, and contribute to an understanding of site function.

The conceptual underpinnings for the spatial analyses presented here are provided in the research design and in the method chapters. Analyses were conducted on the two block excavation areas for this component. Contour maps of density-corrected artifactual data for Block B were generated for each variable (Figures 8-25 through 8-35), using Surfer (version. 5.01) mapping software. These maps serve as visual references to aid in the interpretation of the spatial distribution of each artifact category, and augment interpretation of the results of the principal component analyses. The locations of individual recognized features are also plotted on the density-contour maps as part of the spatial juxtapositions of various materials. 


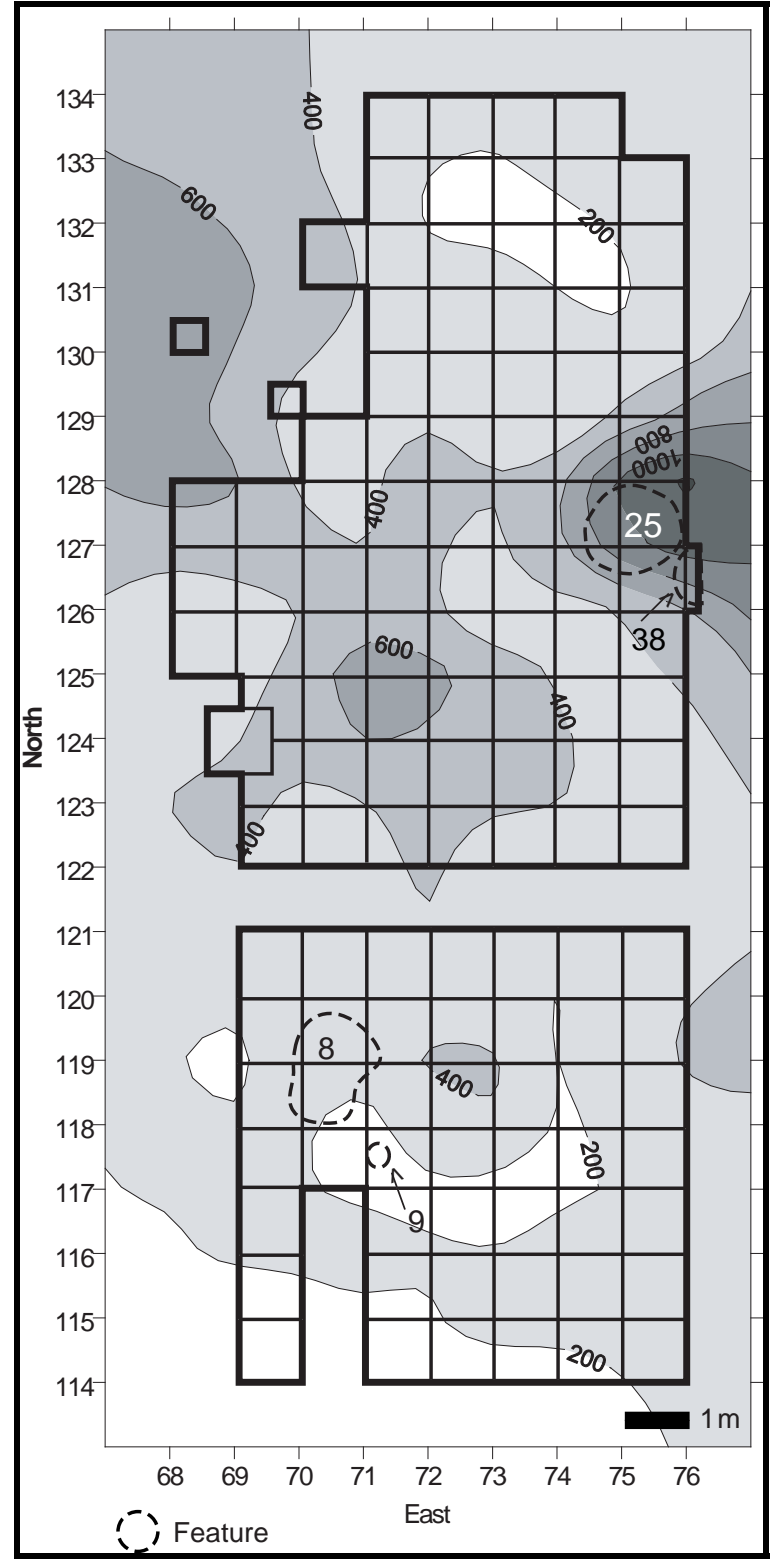

Figure 8-25. Contour Map of Bone Density in Block B

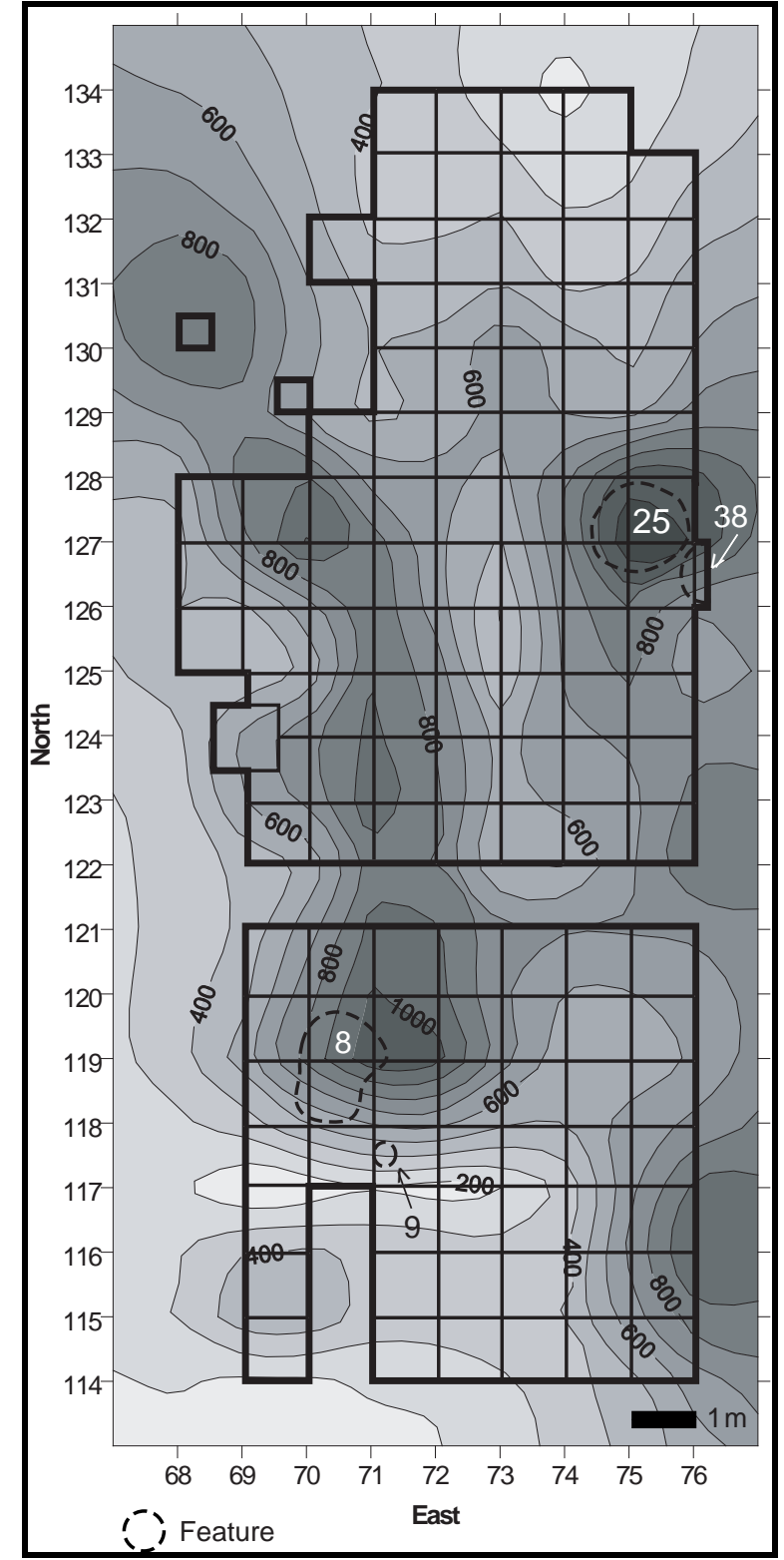

Figure 8-26. Contour Map of Lithic Debitage Density in Block B 


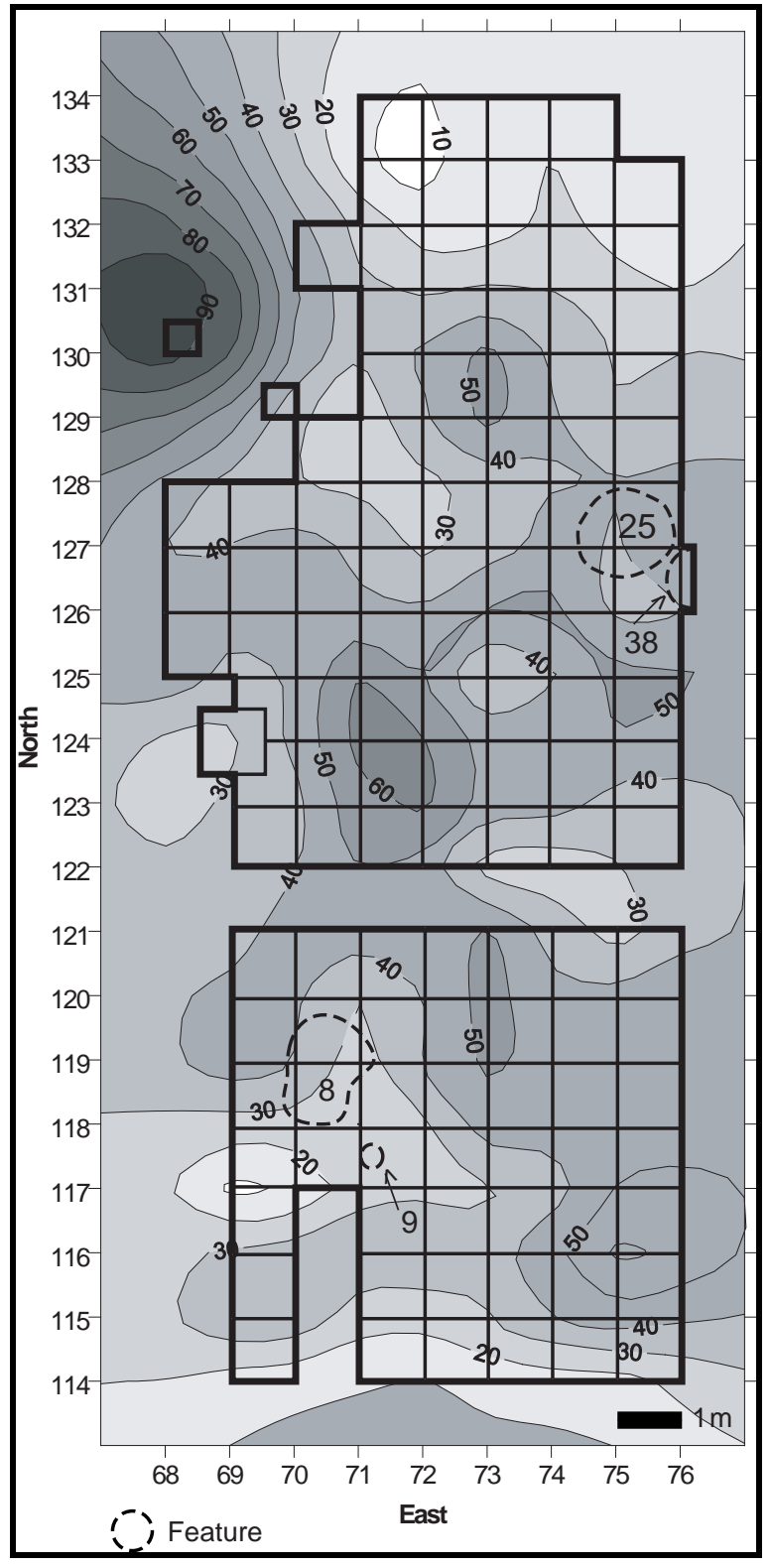

Figure 8-27. Contour Map of EdgeModified Flake Density in Block B

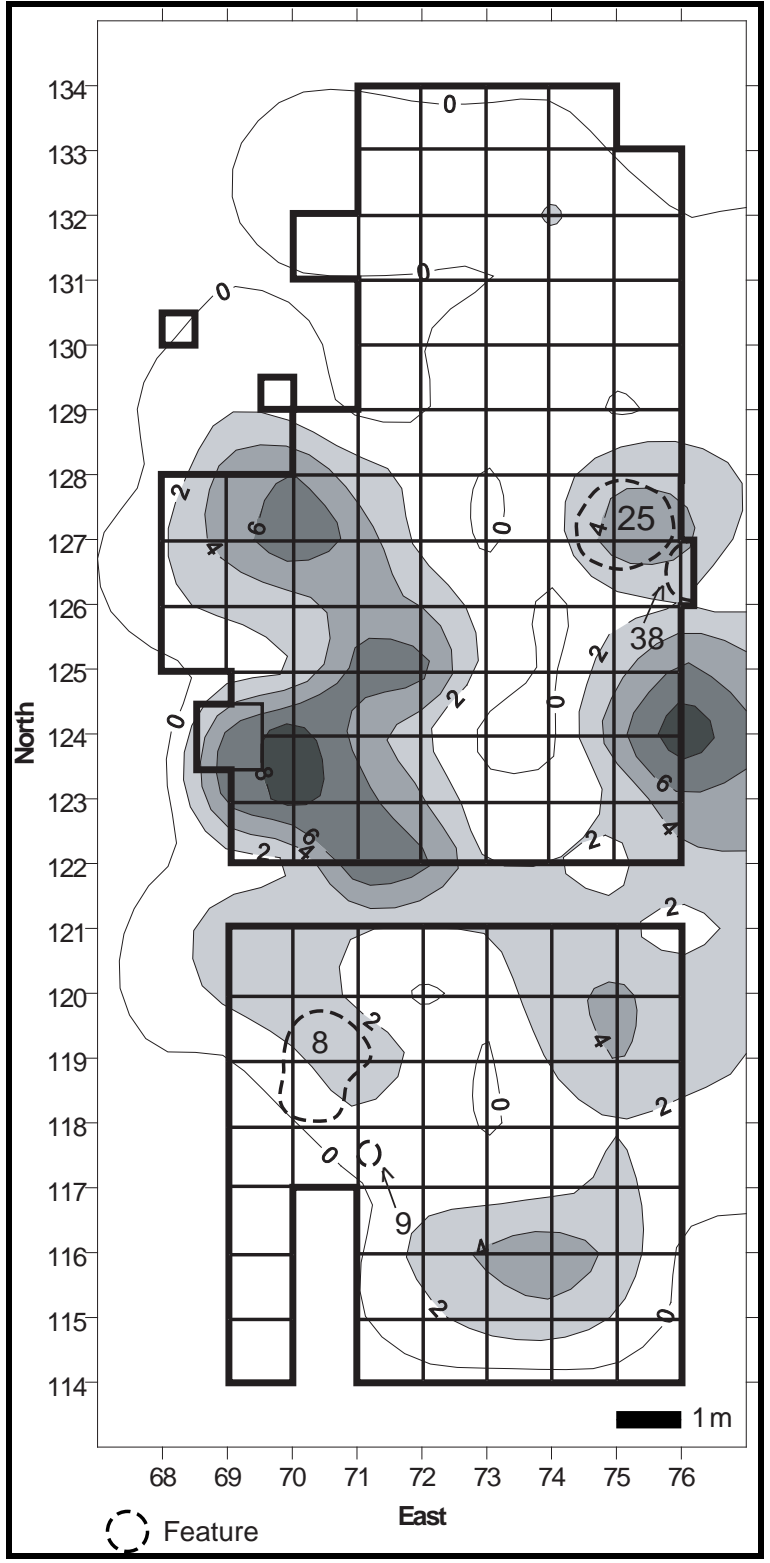

Figure 8-28. Contour Map of Scraper Density in Block B 


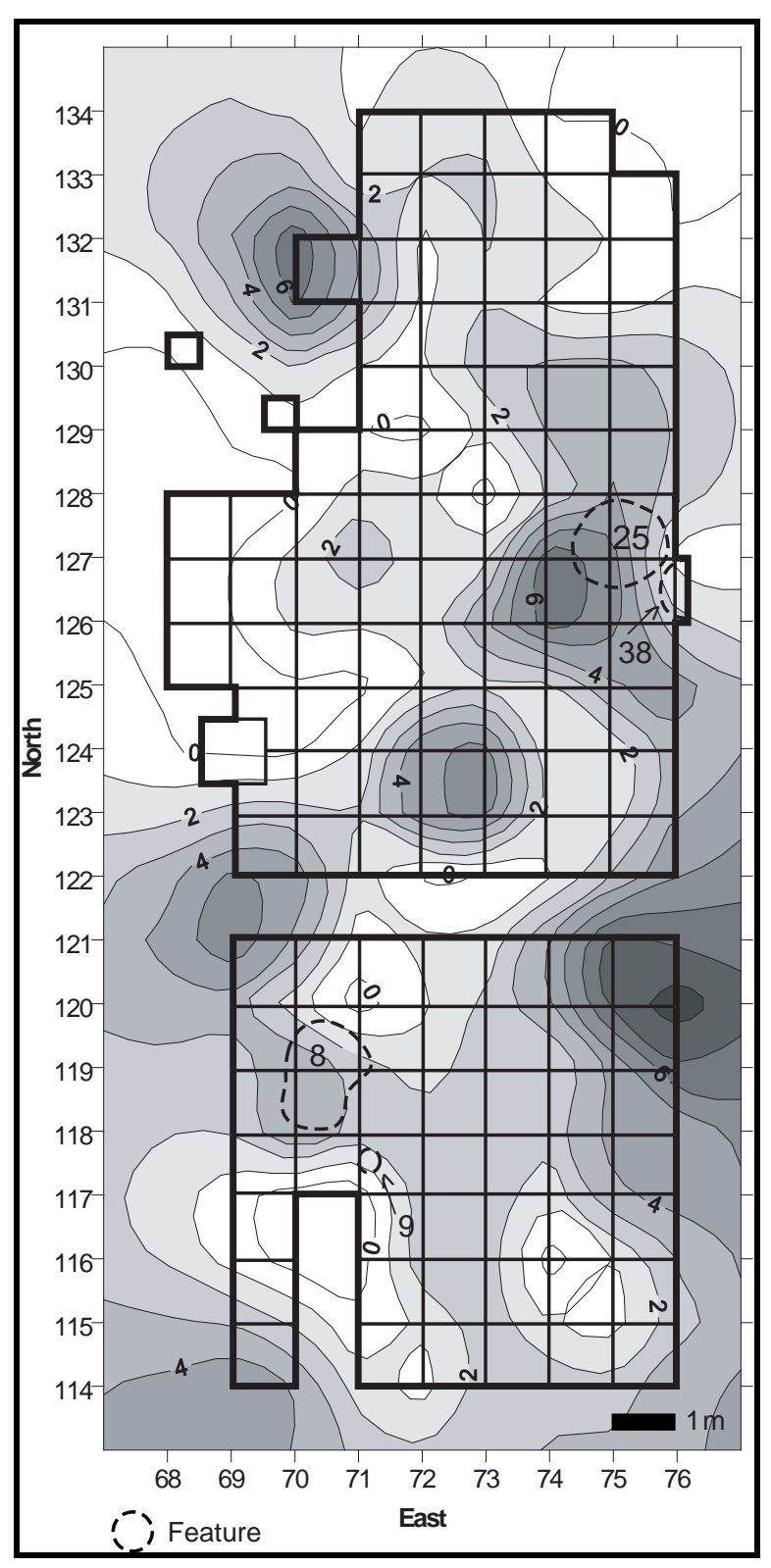

Figure 8-29. Contour Map of Biface Density in Block $B$

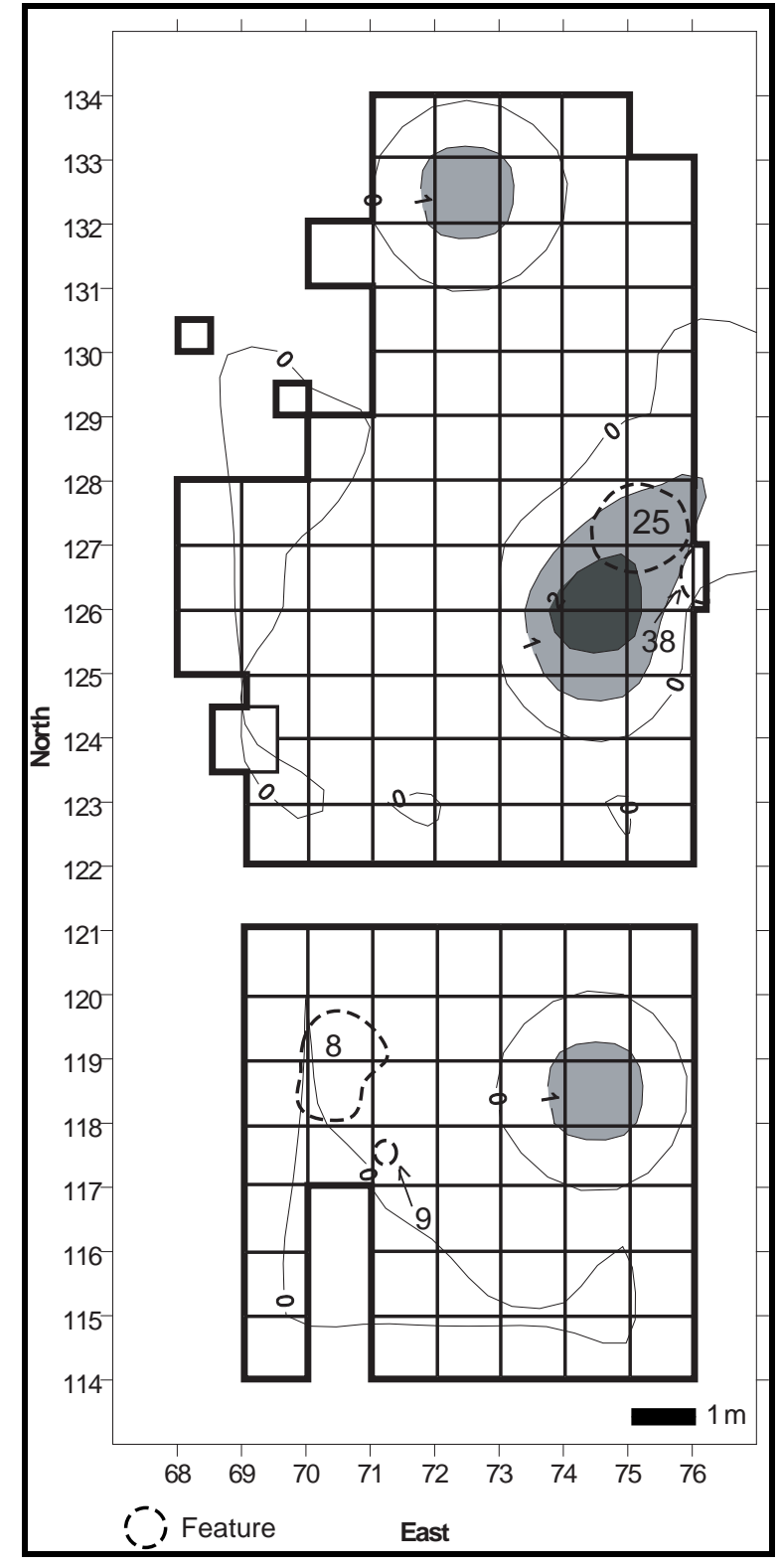

Figure 8-30. Contour Map of Uniface Density in Block B 


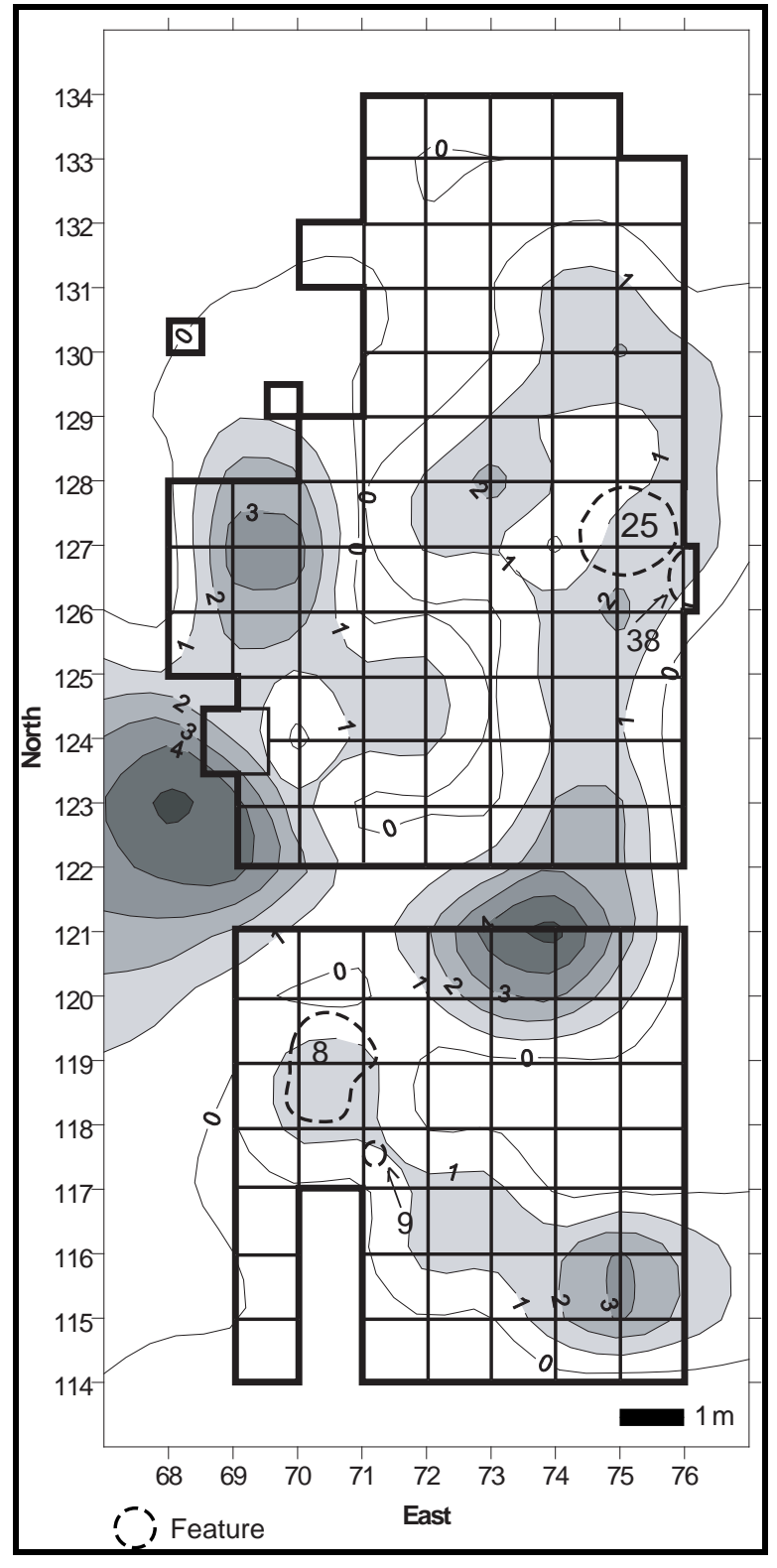

Figure 8-31. Contour Map of Lithic Core Density in Block B

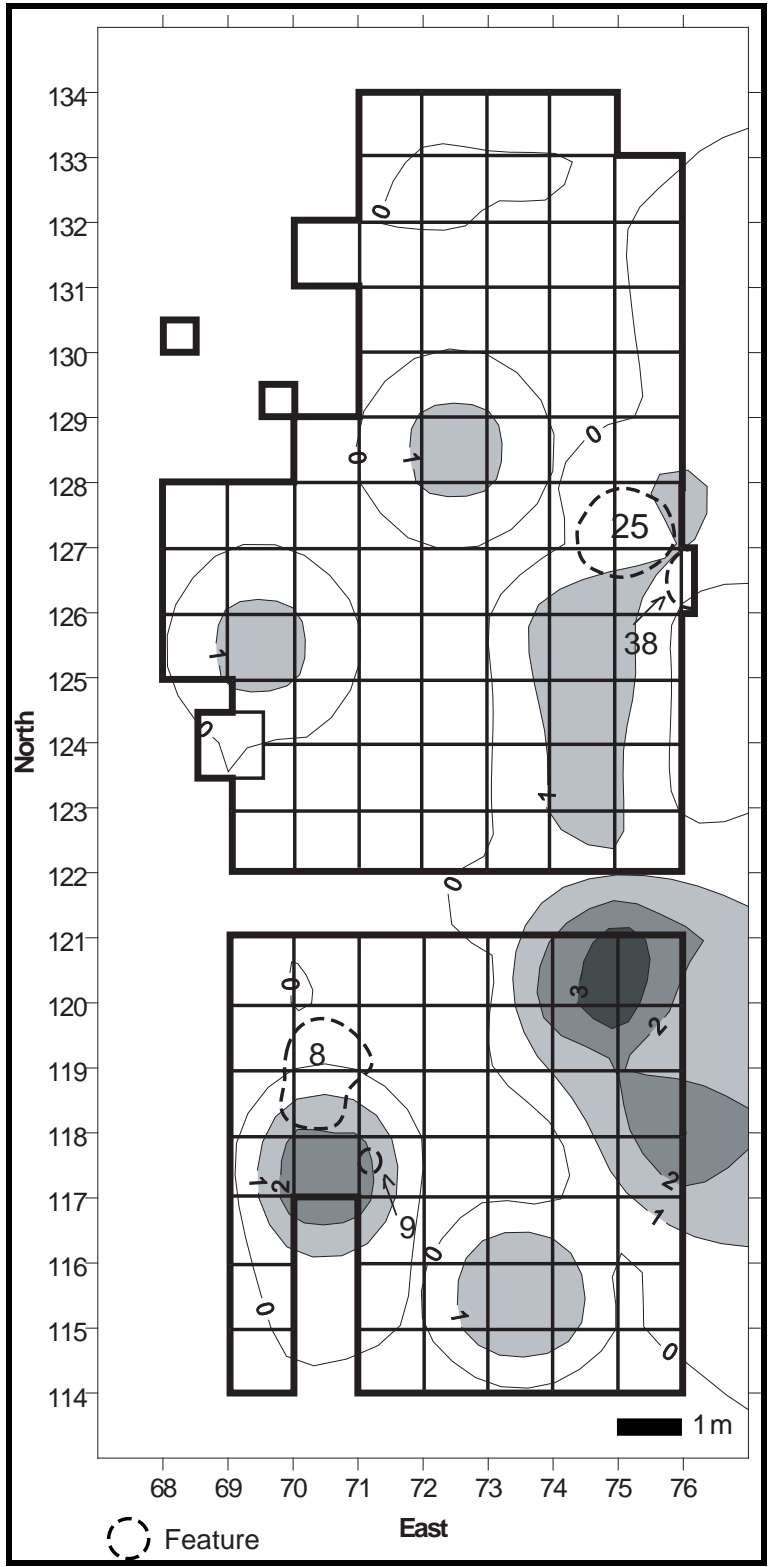

Figure 8-32. Contour Map of Drill Density in Block B 


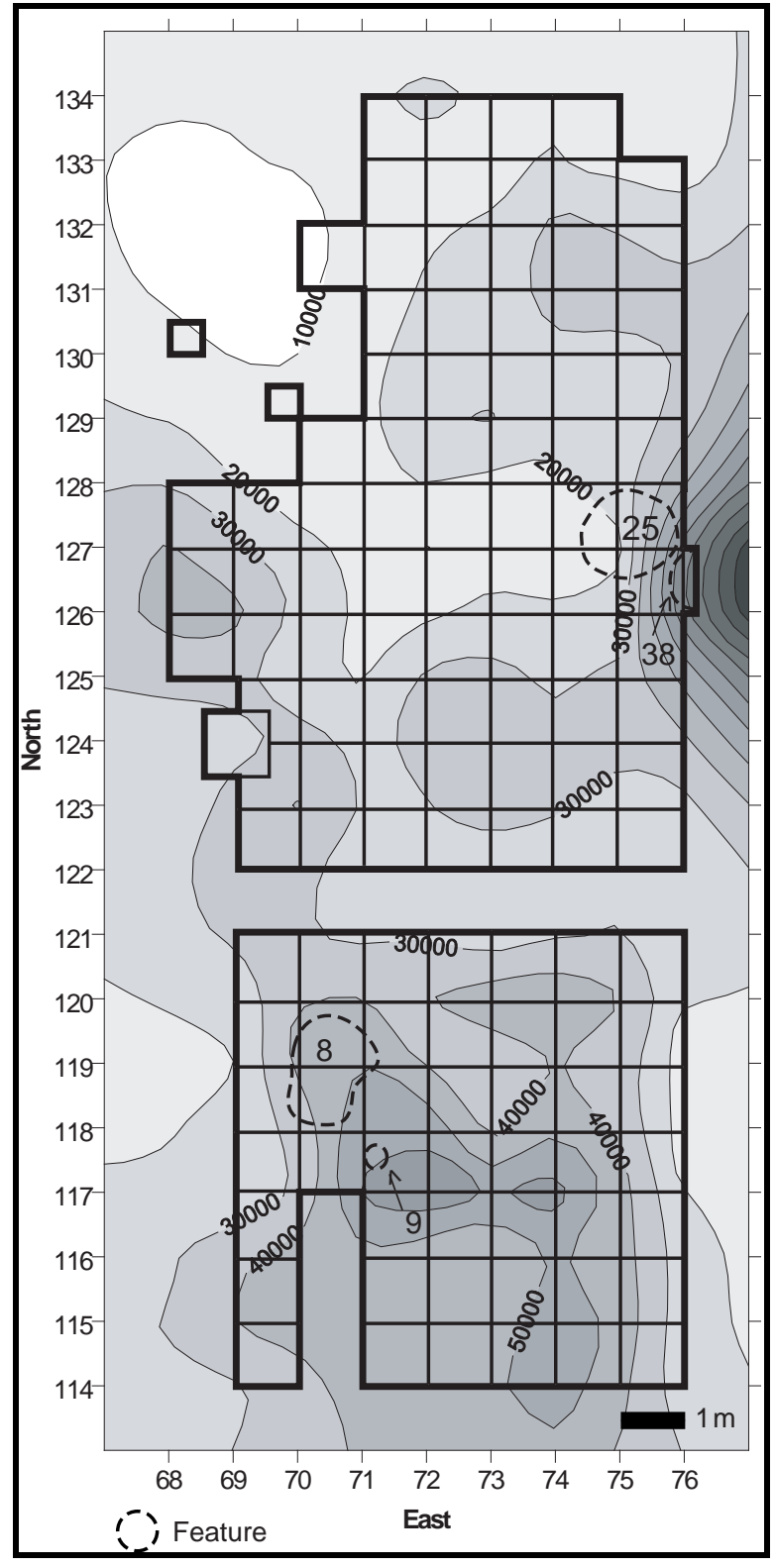

Figure 8-33. Contour Map of Burned Rock Density in Block B

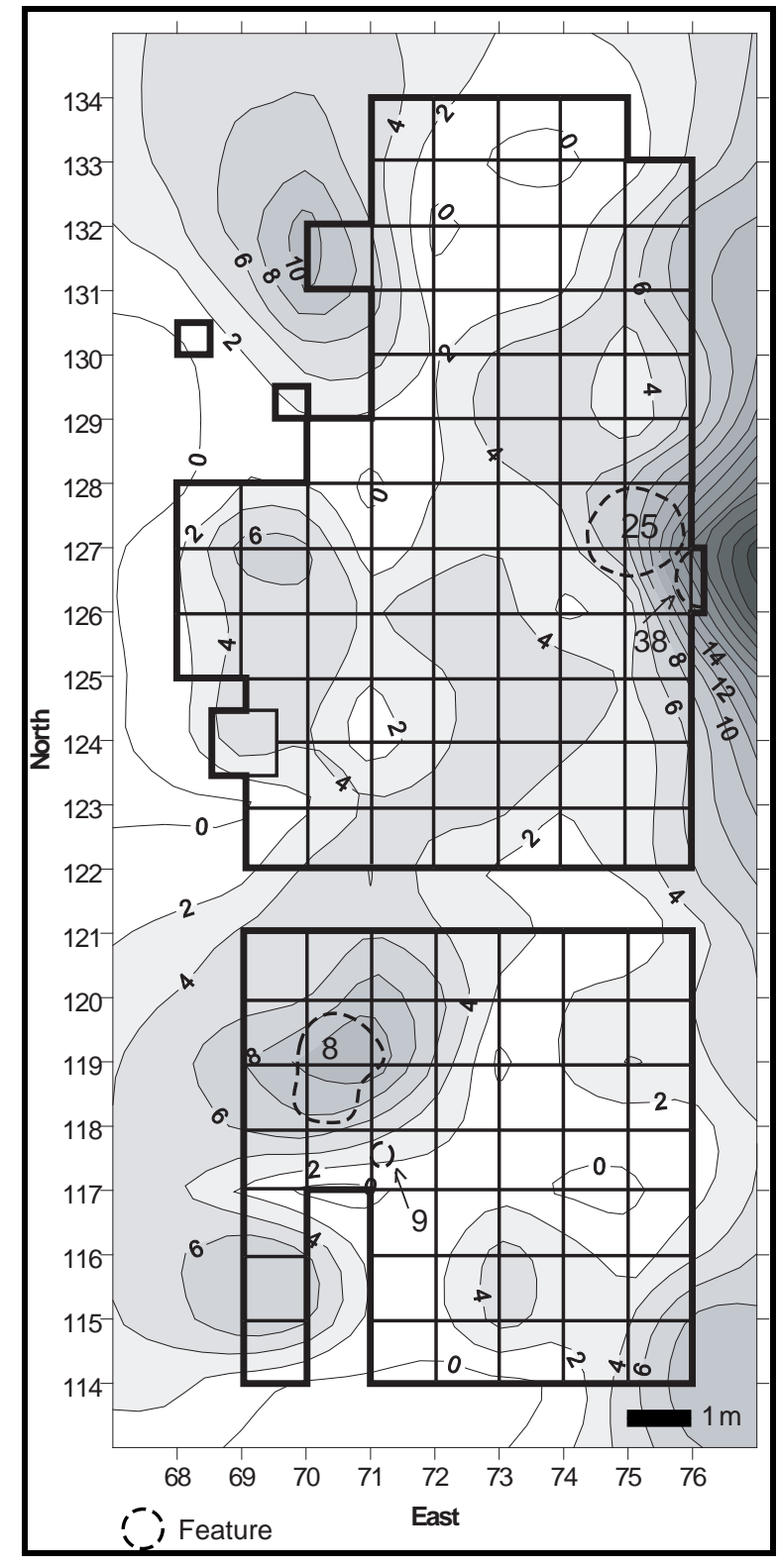

Figure 8-34. Contour Map of Sherd Density in Block B 


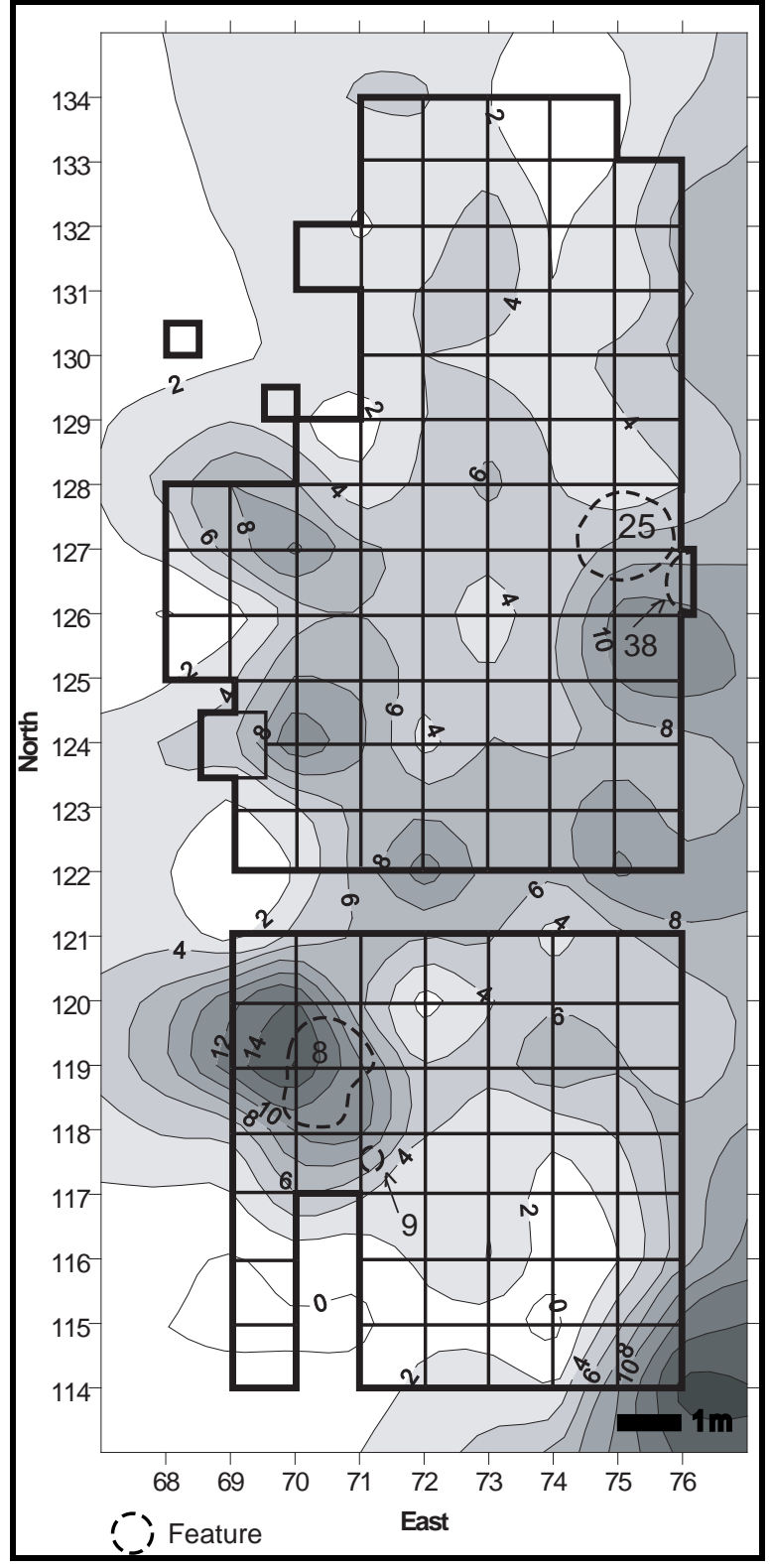

Figure 8-35. Contour Map of Point Density in Block B
In Block B, four features, Features 8, 9, 25 and 38, which formed two separate clusters, potentially had some functional relationship (Figure 8-25). Features 8 and 9 were less than $1 \mathrm{~m}$ apart in the southern part of the block. Feature 9 was a small, tight cluster of burned rocks that contained lumps of charcoal indicating a short-term heating element, or hearth. Feature 8 was a nearly $1.5 \mathrm{~m}$ wide area with irregularly shaped boundaries that contained a variety of cultural debris, including numerous small pieces of burned rocks, lithic debitage, broken stone tools, scattered ceramic sherds, fragmented bones, and bits of charcoal. This is interpreted as a dump or discard area. Features 8 and 9 are less than 100 radiocarbon years apart in age, with similar diverse wood charcoal types identified from each. The similarity in wood types and the closeness of their ages may link these two features together.

Features 25 and 38 are also less than $1 \mathrm{~m}$ apart. They are located in the northeastern part of Block B about $6 \mathrm{~m}$ north of Features 8 and 9. Feature 25 reflected a nearly 1.5 m-diameter debris dump, which is similar to Feature 8, with quantities of small burned rocks, lithic debitage, broken stone tools, a few ceramic sherds, fragments bones, and charcoal chunks. Feature 38, although only partially excavated, is interpreted as a heating element, or hearth, with diverse cultural material in direct association. The ages of Features 25 and 38 are less than 100 radiocarbon years apart with similar types of wood charcoal represented. These similar findings may connect Features 25 and 38 together. In both pairs of features, a heating element was less than $1 \mathrm{~m}$ east of an irregular debris dump. These two pairs of features both represent hearth-refuse couplets, suggested a recurrent pattern of debris disposal near hearths which may have been nodal points of domestic activity.

Bone awls, choppers, and gouges were excluded from the spatial analysis due to the non- 
occurrence of these artifacts in this component in Block B. The resulting data matrix consists of 12 variables (artifact categories) and 125 rows $\left(1 \mathrm{~m}^{2}\right.$ excavation units). The principal component analysis extracted a five-factor solution representing a cumulative total of 61.74 percent of the variability present in the array of data. The matrix of correlation coefficients is presented in Table 8-14, and the factor solution is presented for modified flakes, and scrapers-collectively composing 19.63 percent of the total variance in the matrix of correlation coefficients (Table 8-15). All four variables exhibit moderate to strong positive factor loadings ranging from .564 to .858; none of the diagnostic variables in Factor 1 are negative.

The association of lithic debitage and edgemodified flakes may be best explained by the assumption that both artifact categories are derivative of the primary task of lithic reduction (i.e., lithic flakes were produced from cores and subsequently modified for expedient use in various cutting and scraping tasks). Whether lithic reduction strategies in this context are oriented toward producing flakes specifically for modification and use, or the flakes simply represent secondary byproduct of producing other tool forms, such as bifaces, is unclear. For spatial studies, no differentiation was made among various flake or core types such as might add clarity to this issue. It is tempting to include the scrapers in this discussion, but scrapers have not been associated with the lithic reduction/debitage/edge-modified flake continuum in any of the other analyzed components, so there seems to be no a priori reason for assuming it here. Furthermore, in this study, scrapers are by definition formal tools as opposed to expedient tools such as edgemodified flakes, and the results of the spatial analysis seems to provide a quantitative basis for treating them as separate tool types that do not share a common manufacturing-use-discard trajectory. In any case, six recognizable highdensity peaks of lithic debitage are recognizable across Block B. Although there are only four or five recognizable edge-modified flake highdensity peaks, they largely overlap the areas where debitage is particularly abundant, suggests that edge-modified flakes were expediently manufactured from discarded debitage, used, and discarded in more or less the same place. Thus, the production and use of edge-modified flakes as tools is a good example of a least-effort, opportunistic behavioral strategy. Despite the preceding argument about scrapers, four of the six identified high-density peaks of scrapers coincide with debitage peaks, possibly hinting at a degree of expediency in scraper production/use, as well. Finally, faunal bone was recovered from across the entire extent of Block B, but only three, or possibly four, high-density peaks are represented. Three peaks coincide with concentrations of the three other artifact categories constituent of this factor. The factor is interpreted to represent specialized activity areas in which animal resource processing activities occurred and involved the manufacture and use of small cutting and scraping implements. At least three or four such areas are represented, spaced at intervals of three to four meters. One or more of these concentrations presumably corresponds to cultural features identified in this cultural component.

Factor 2 is composed of two diagnostic variables-bifaces and unifaces-collectively composing 10.74 percent of the total variance in the matrix of correlation coefficients (Table 815). Both variables exhibit moderate to moderately strong positive factor loadings of .572 and .706. To some extent, the spatial association of these two variables would appear to be somewhat specious, as 60 bifaces and only five unifaces were recovered from the Late Prehistoric component of Block B. Five clearly distinguishable concentrations of bifaces occur across the block spaced, once more, at intervals of three to four meters. 


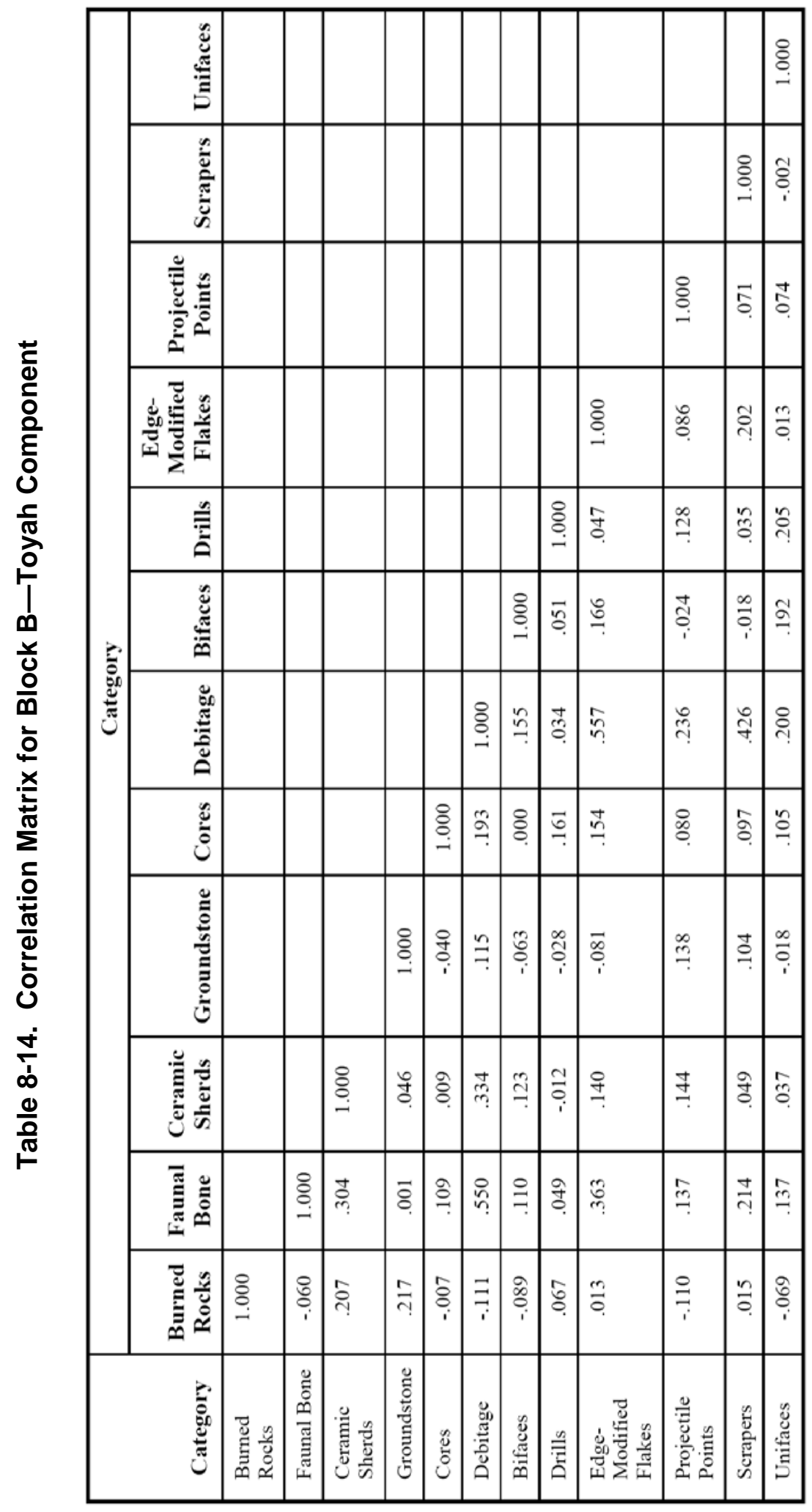


Table 8-15. Principal Component Matrix for Block B-Toyah Component

\begin{tabular}{|l|c|c|c|c|c|}
\hline \multirow{2}{*}{\multicolumn{1}{|c|}{ Variable }} & \multicolumn{5}{c|}{ Factor $^{\mathbf{1}}$} \\
\cline { 2 - 7 } & $\mathbf{1}$ & $\mathbf{2}$ & $\mathbf{3}$ & $\mathbf{4}$ & $\mathbf{5}$ \\
\hline Burned Rock & -.076 & -.118 & .116 & .892 & -.081 \\
\hline Faunal Bone & .699 & .217 & -.009 & .021 & .104 \\
\hline Ceramic Sherds & .376 & .376 & -.193 & .508 & .165 \\
\hline Groundstone & -.021 & -.203 & -.080 & .397 & .628 \\
\hline Cores & .260 & -.166 & .658 & -.044 & -.111 \\
\hline Debitage & .858 & .119 & .064 & -.026 & .223 \\
\hline Bifaces & .156 & .706 & -.038 & -.026 & -.155 \\
\hline Drills & -.064 & .171 & .758 & .095 & .112 \\
\hline Edge-Modified Flakes & .738 & .053 & .083 & .010 & -.204 \\
\hline Projectile Points & .157 & .058 & .103 & -.195 & .760 \\
\hline Scrapers & .564 & -.377 & .112 & -.005 & .124 \\
\hline Unifaces & .016 & .572 & .420 & -.102 & .205 \\
\hline \% Variance & $\mathbf{1 9 . 6 3}$ & $\mathbf{1 0 . 7 4}$ & $\mathbf{1 0 . 6 4}$ & $\mathbf{1 0 . 6 0}$ & $\mathbf{1 0 . 1 3}$ \\
\hline Cum. \% Variance & $\mathbf{1 9 . 6 3}$ & $\mathbf{3 0 . 3 7}$ & $\mathbf{4 1 . 0 1}$ & $\mathbf{5 1 . 6 1}$ & $\mathbf{6 1 . 7 4}$ \\
\hline Rotation method-Varian \\
Based on rotation sums of squared loadings & & \\
\hline
\end{tabular}

Two to three of these concentrations correspond to the locations of artifact clusters associated with Factor 1, including faunal bone, lithic debitage, and edge-modified flakes in one instance; lithic debitage and faunal bone in a second instance; and possibly scrapers in a third instance. Three "clusters" of unifaces occur in Block B, although only one of these "clusters" contains more than one item. Two of these "clusters" correspond to biface concentrations, whereas the third is located at the northern end of the block, more or less isolated from every other artifact class in the Toyah component. The associations of these formal tool types with areas that exhibit relatively clear functional associations with resource processing suggest that they formed part of a generalized tool kit designed to process animal and/or other types of resources. The tendency for spatial cooccurrence implies horizontal overlapping of activity areas and a corresponding absence of well-defined spatial segregation of activities, as would be expected in a multifunctional and short-term camp occupied by a more or less highly mobile population.

Factor 3 is also composed of two diagnostic variables-lithic cores and drills-collectively composing 10.64 percent of the total variance in the matrix of correlation coefficients (Table 815). Both variables exhibit moderately strong positive factor loadings of .658 and .758. Three to four concentrations of lithic cores occur in Block B scattered across the Toyah component. It is notable that the locations of these concentrations of lithic cores do not appear to correlate with either lithic debitage or edgemodified flakes. Drills are scattered somewhat ubiquitously across Block B, but two concentrations of drills are discernable, and these two concentrations correlate with the locations of lithic cores. Although it is possible 
that drills, as relatively formal implements, and cores, one of the end results of lithic reduction, are simply indicative of lithic reduction activities, it is also possible that these artifacts are markers of activity areas that are spatially segregated from the resource processing activity areas reflected in Factor 1. At the same time, the two items cannot be construed as serving common functions, once again indicating spatial overlap of discrete activities.

Factor 4 is similarly composed of two diagnostic variables-burned rocks and ceramic sherdscollectively comprising 10.60 percent of the total variance in the matrix of correlation coefficients (Table 8-15). Both variables exhibit moderate to strong positive factor loadings of .508 and .892. Although multiple high-density peaks of both artifact types occur in Block B, the highest concentration of these two materials cooccurs in the vicinity of Feature 38. This feature has been interpreted as an in situ hearth feature, though it extends under the fence line marking the edge of TxDOT's right-of-way and could not be fully exposed. The association of burned rocks and ceramic sherds, both believed to have been associated with cooking, in this area reinforces this interpretation. Furthermore, high-density, discrete concentrations of scrapers, animal bone, lithic debitage, projectile points, unifaces, and bifaces all occur within two meters of this feature, suggesting the presence of an multi-purpose activity area associated with processing of animal (and possibly other) resources. Additional concentrations of burned rocks occur near the west-central edge of Block B. They also occur across a broad area in the south part of the northern unit of the block, and two to three more concentrated clusters of burned rocks are present near the southern end of the block. Interestingly, the association of these two variables in this factor is probably mainly a function of their co-occurrence in Feature 38, as the three or four discernable concentrations of sherds in the rest of Block B do not appear to correlate with burned rock concentrations very closely.

Factor 5 is composed of two diagnostic variables - groundstone and projectile pointscollectively composing 10.13 percent of the total variance in the matrix of correlation coefficients (Table 8-15). Both variables exhibit moderate to moderately strong positive factor loadings of .628 and .760. As only one groundstone item was recovered from the Toyah component of Block B, and this item was recovered from Unit N119/E69, the center of the densest concentration of projectile points, this factor is probably largely specious and not very meaningful. Projectile points form six to seven discernable concentrations across Block B, but they are scattered across the entire block in low numbers. In some cases, a projectile point cluster correlates with a concentration of another artifact category, though rarely twice with the same artifact category. Centered on Unit N119/E69, points appear to be most strongly associated with lithic debitage, and in the southeast corner of Block B points are loosely associated with lithic cores and lithic debitage, possibly suggesting that at least two tool manufacturing loci are represented. One cluster of projectile points is located about $1 \mathrm{~m}$ south of Feature 38, and may represent activity around that campfire. Points and scrapers are loosely associated in the southwestern corner of the northern part of Block B, which may represent a specialized activity that was spatially segregated from others represented (assuming contemporaneity of use and discard).

Contour maps of density-corrected artifactual data for Block A were generated for each variable in this component (Figures 8-36 through 8-46), again using Surfer (version 5.01) mapping software. The locations of four individual features (Features 2, 18, 21, and 30) are also plotted on the contour maps as potential parts of the spatial relationship of the activities. 


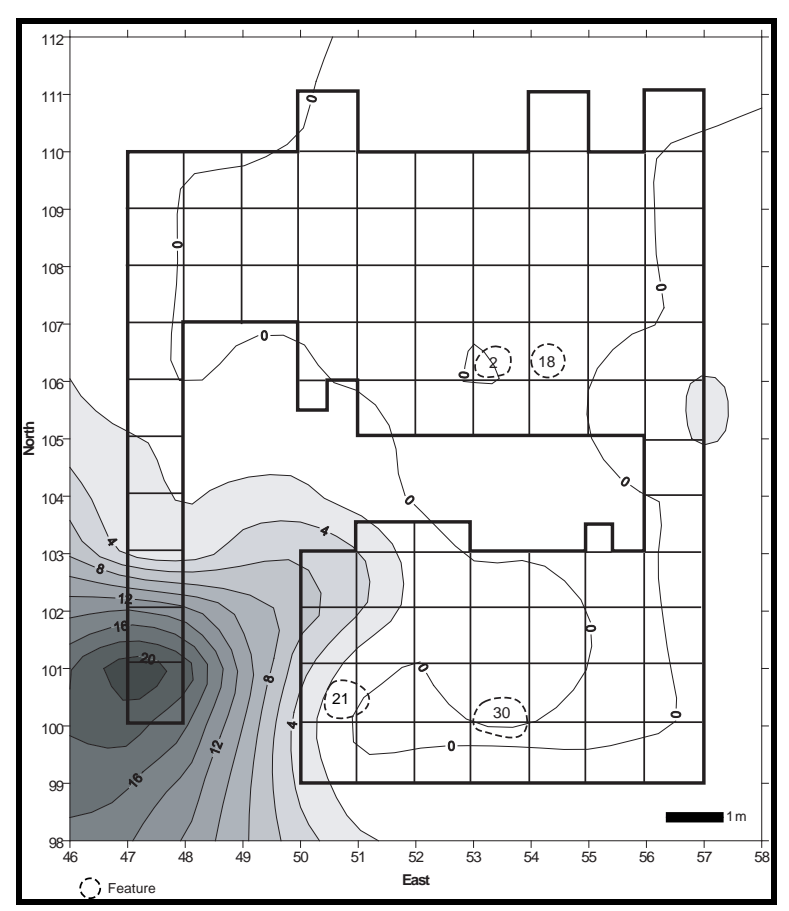

Figure 8-36. Contour Map of Sherd Density in Block A

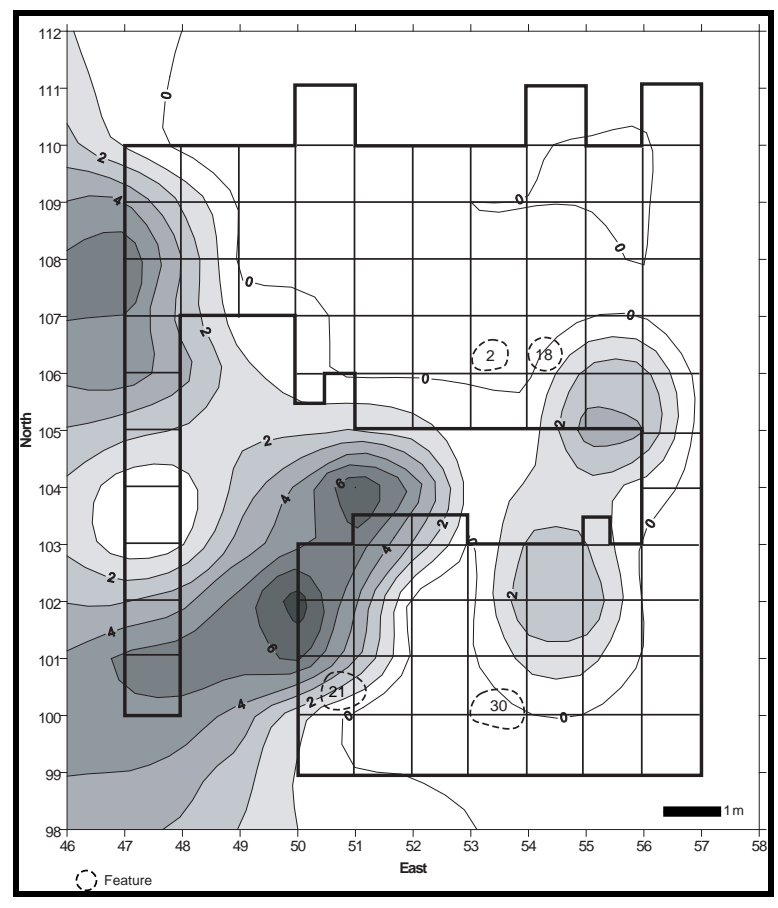

Figure 8-37. Contour Map of Lithic Core Density in Block A

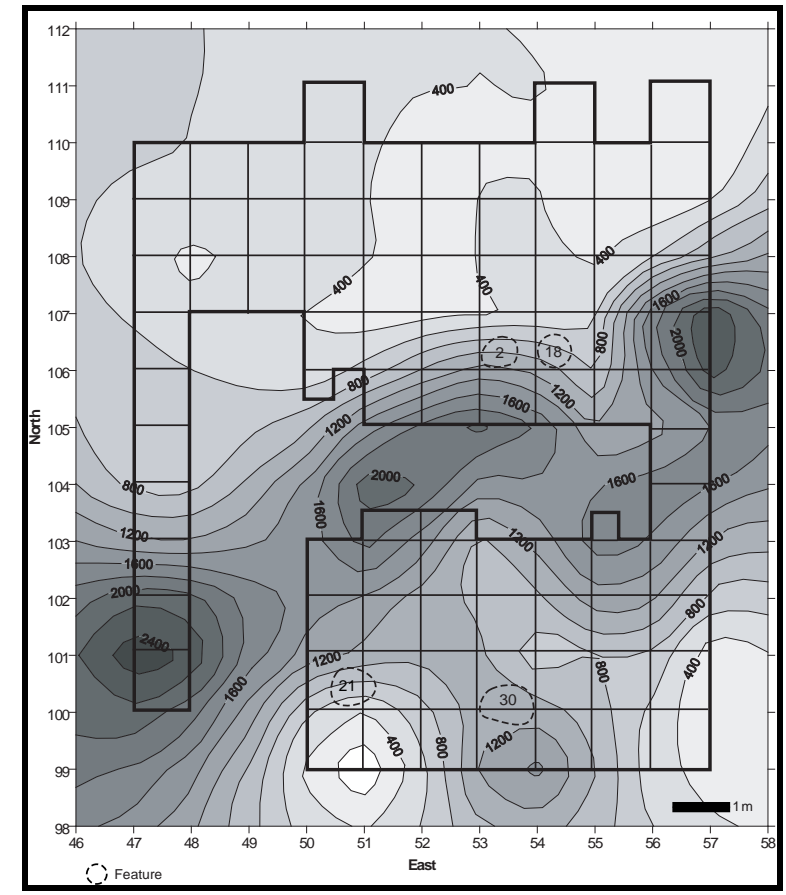

Figure 8-38. Contour Map of Lithic Debitage Density in Block A

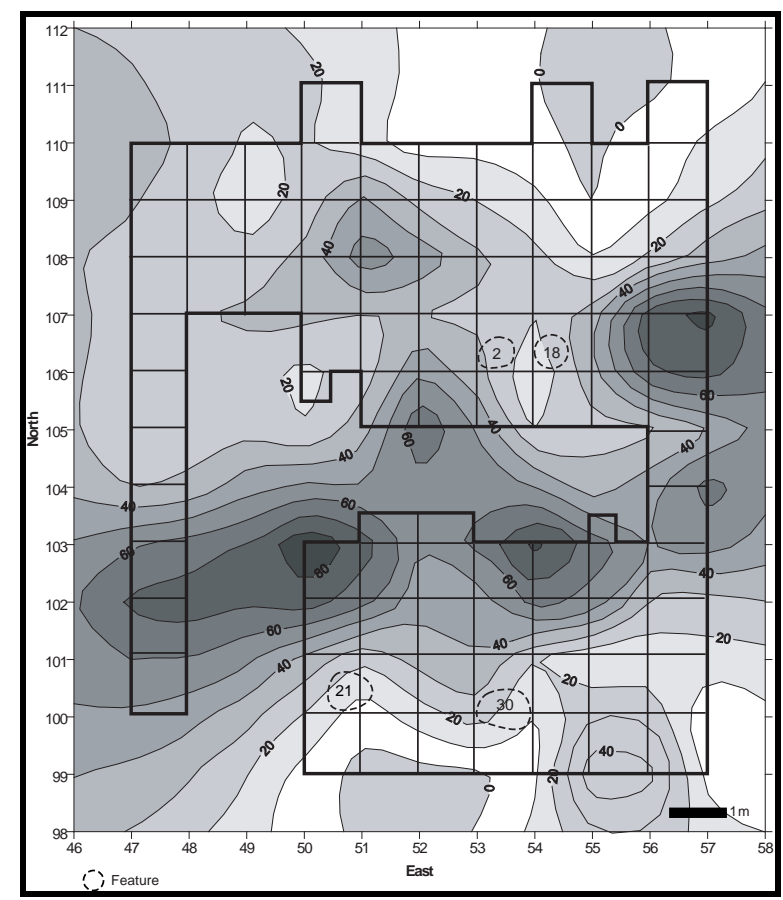

Figure 8-39. Contour Map of EdgeModified Density in Block A 


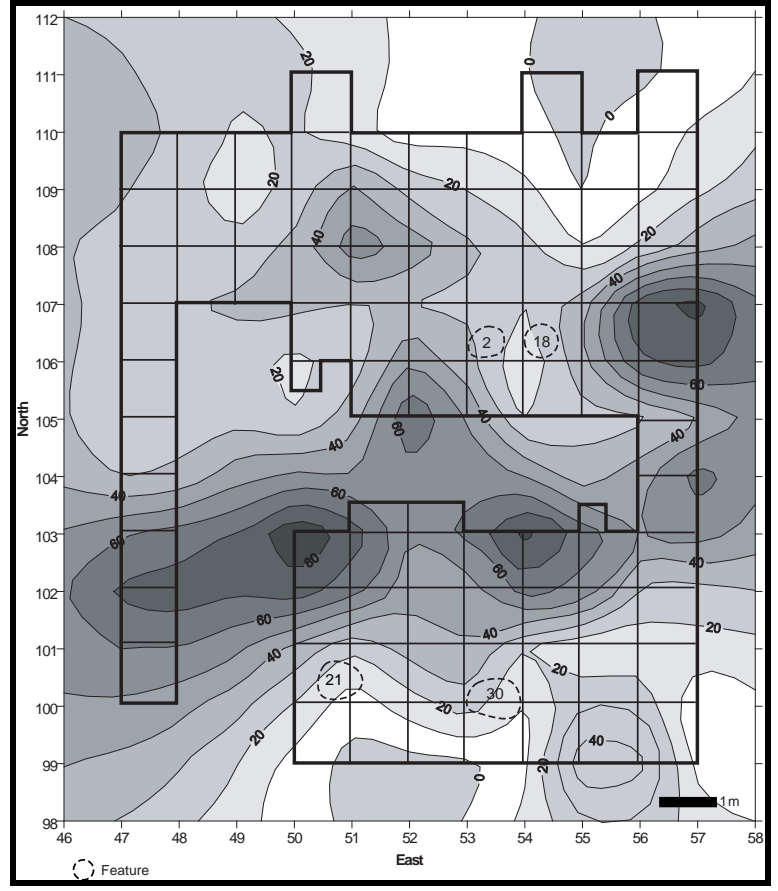

Figure 8-40. Contour Map of Burned Rock Density in Block A

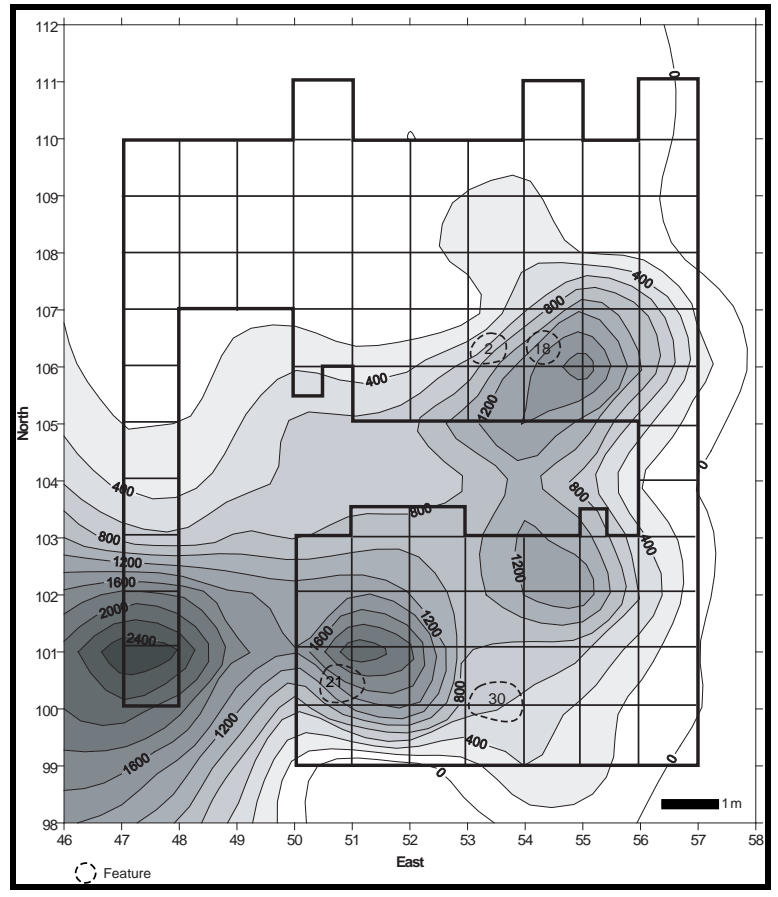

Figure 8-41. Contour Map of Bone Density in Block A

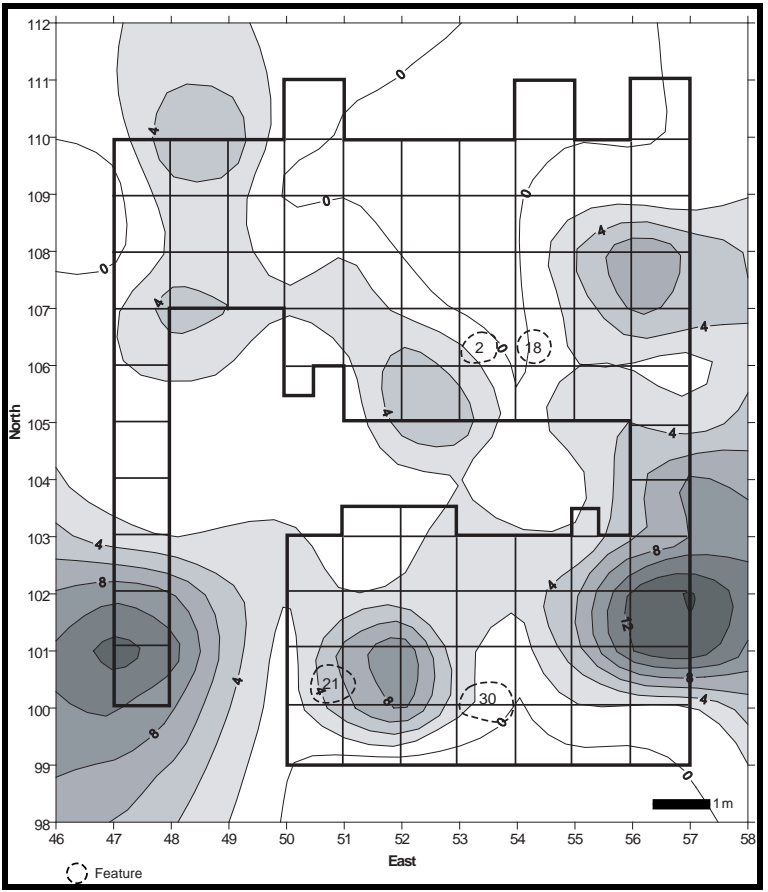

Figure 8-42. Contour Map of Biface Density in Block $A$

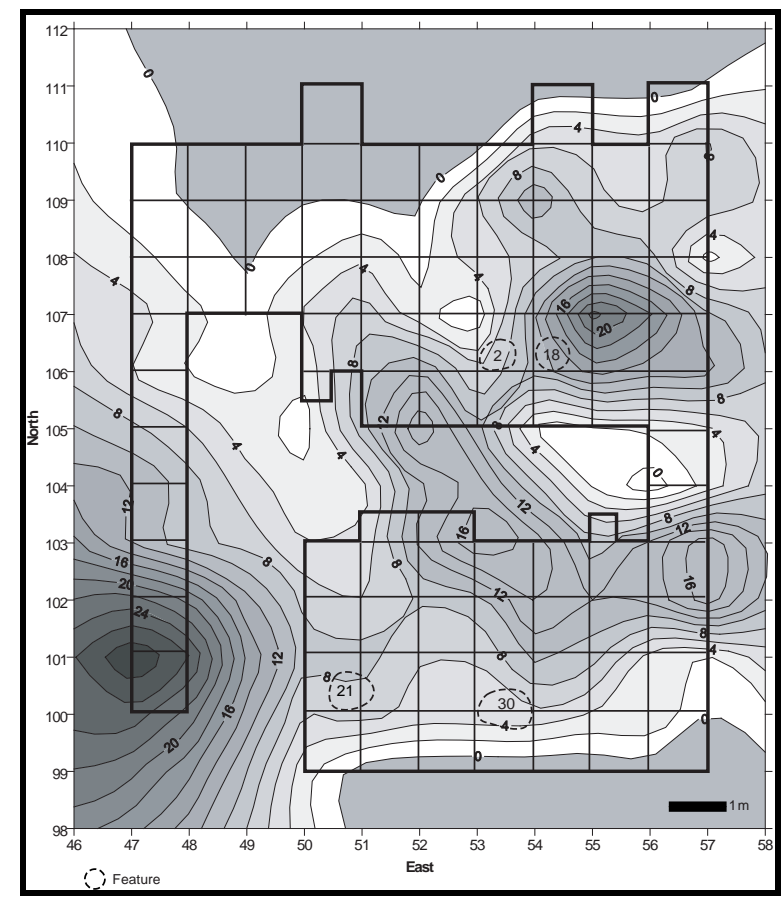

Figure 8-43. Contour Map of Point Density in Block A 


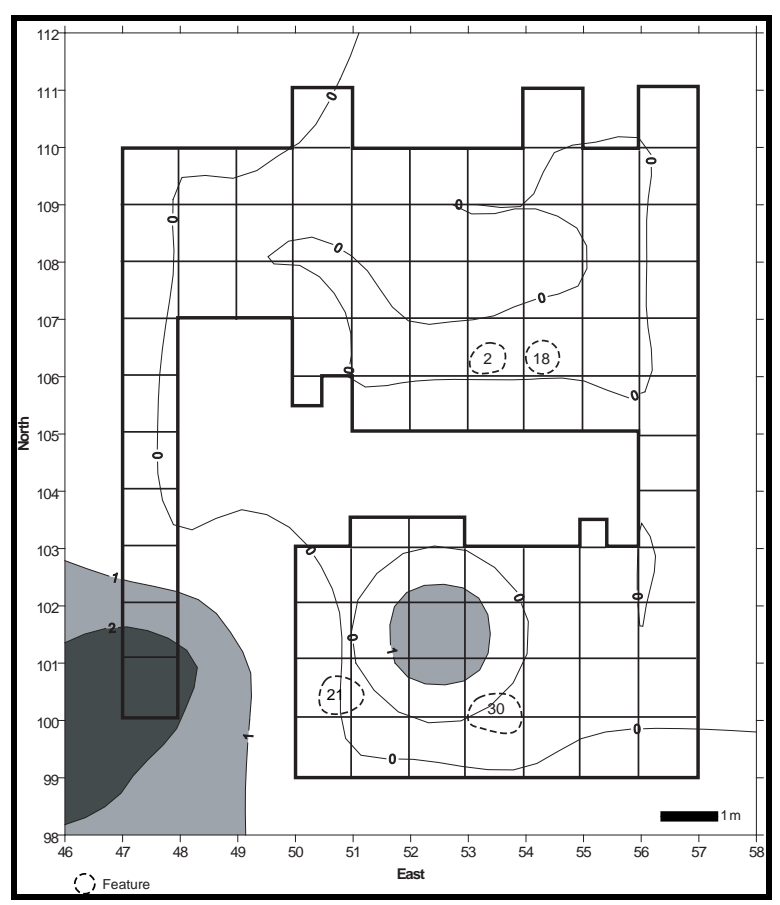

Figure 8-44. Contour Map of Uniface Density in Block A

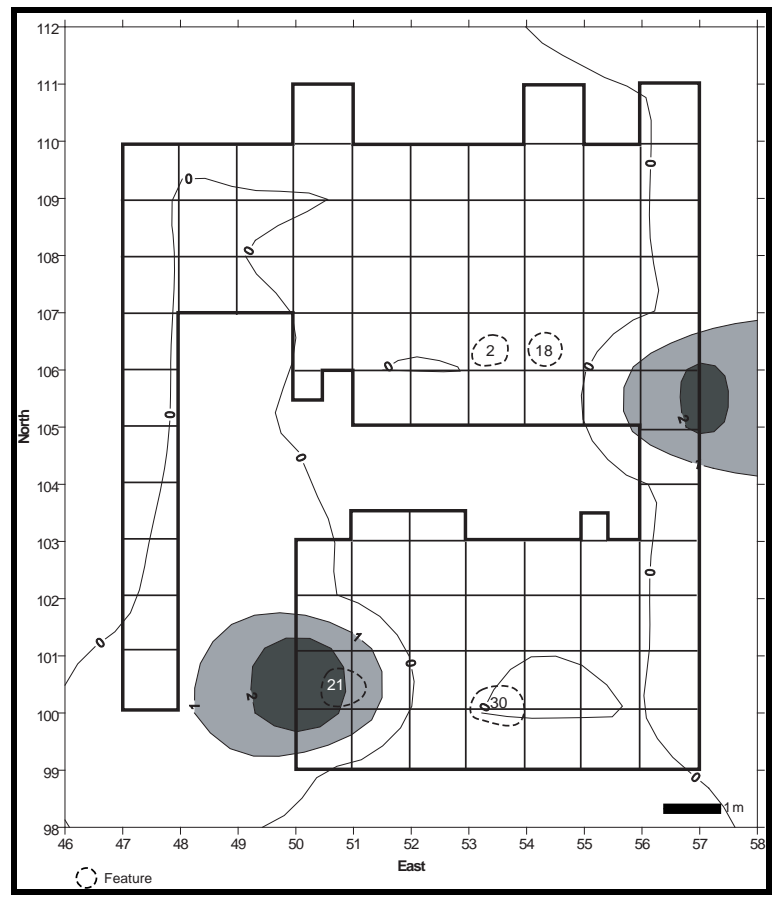

Figure 8-45. Contour Map of Awl Density in Block $A$

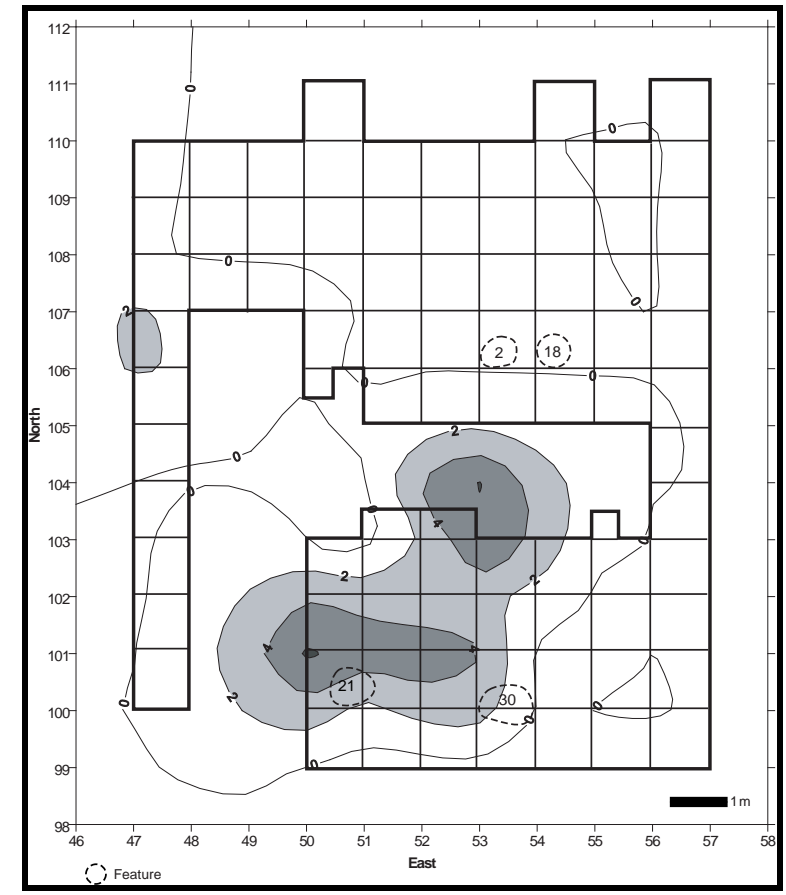

Figure 8-46. Contour Map of Scraper
Density in Block A

Feature 2 represented a loose concentration of bone with irregular and ill-defined boundaries. Feature 18, less than one meter away, was interpreted as a small dump containing lithic debitage, charcoal, broken formal tools, and burned rocks. Feature 21 was about a $70 \mathrm{~cm}$ diameter hearth, filled with burned rocks and limited charcoal, in a shallow, poorly defined basin. Feature 30 was a burned rock cluster in an ovate area.

The Toyah component in Block A covers a total area of $79.68 \mathrm{~m}^{2}$ and had a total excavated volume of $11.67 \mathrm{~m}^{3}$ of sediment. Choppers and gouges were excluded from the analysis due to the non-occurrence of these artifacts in this component in Block $\mathrm{A}$. The resulting data matrix consists of 13 variables (artifact categories) and 86 rows ( $1 \mathrm{~m}^{2}$ excavation units). The principal components analysis extracted a five-factor solution representing a cumulative total of 61.11 percent of the variability present in the data array. The matrix of correlation 
coefficients is presented in Table 8-16, and the factor solution is presented in Table 8-17.

Factor 1 is composed of four diagnostic variables-ceramic sherds, cores, debitage, and edge-modified flake tools-collectively composing 16.25 percent of the total variance in the matrix of correlation coefficients (Table 817). All four variables exhibit moderately strong positive factor loadings ranging from .566 to .756; none of the diagnostic variables in Factor 1 are negative. The association of lithic cores, debitage, and edge-modified flakes may be best explained based on the assumption that all three artifact categories reflect the task of lithic reduction; specifically, producing lithic flakes from cores and subsequently modifying some of the flakes for use in various cutting and scraping tasks. Whether lithic reduction strategies in this context are oriented toward producing flakes specifically for modification and use, or the flakes simply represent a byproduct of producing other tool forms, such as bifaces, is unclear. For spatial studies, no differentiation was made among various flake or core types that might clarify this issue. Examination of density maps for these artifact categories suggests that lithic debitage and edgemodified flakes, and to a lesser extent cores, do show a marked tendency to co-occur in well defined, high-density peaks located along the east edge of Block $A$, the southeast corner of BT 2, just east of the intersection of BTs 1 and 2, and in the general vicinity of the southwest corner of Block A. Cores also have a high-density peak in the northwest corner of Block $\mathrm{A}$, an area where the other three variables composing this factor are largely absent. The association of ceramic sherds with this cluster of variables appears to be largely a function of a primary high-density peak of sherds in the southwestern corner of Block A, and a secondary peak along the east edge. These two sherd high-density areas correlate directly with two debitage high-density peaks, and the eastern peak correlates with an edge-modified flake high-density peak. A moderate-density core peak occurs near the latter area. The patterning of this four-variable suite suggests that activity areas associated with these artifact categories are indicated in Block A. Although the association of the three lithic categories appears to reflect lithic reduction activity areas, with subsequent transformation and utilization of the byproducts of flint knapping, the distribution of ceramic sherds appears to be more closely associated with lithic debitage and edge-modified flakes, which may suggest that resource processing activity areas are present in at least two specific parts of Block A; specifically, in the southwest corner (centered on Units N100/E47 and N101/E47) and along the east edge (centered on Units N106/E56 and N107/E56). Whether these patterns are indicative of primary use areas versus disposal areas is less clear, though it does raise the possibility that flint knapping and at least some resource processing or preparation activities co-occurred spatially in Block A.

Factor 2 is composed of four diagnostic variables-burned rock, faunal bone, bifaces, and projectile points-collectively composing 15.79 percent of the total variance in the matrix of correlation coefficients (Table 8-17). All four variables exhibit moderately strong positive factor loadings ranging from .538 to .748; none of the diagnostic variables in Factor 2 are negative. The generalized variability represented by this suite of variables actually appears to consist of differential spatial pairing among subsets of the individual variables across Block A. For example, faunal bone, bifaces, and projectile points co-occur in a cluster in the southwestern corner of Block A. Faunal bone, burned rocks, and bifaces co-occur in two high density clusters in the south half of the block. Faunal bone and projectile points co-occur in two clusters, including the one in the southwest corner and in a second cluster in the northeastern quadrant of the block. 


\begin{tabular}{|c|c|c|c|c|c|c|c|c|c|c|c|c|c|c|}
\hline \multirow{13}{*}{ 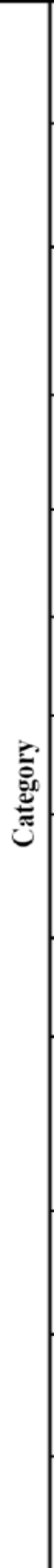 } & 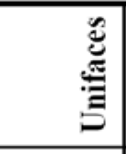 & & & & & & & & & & & & & $\underset{-}{\circ}$ \\
\hline & 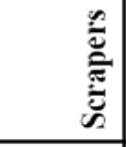 & & & & & & & & & & & & $\underset{-}{\stackrel{-}{0}}$ & 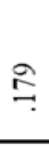 \\
\hline & 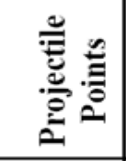 & & & & & & & & & & & $\stackrel{\text { ఏ }}{.}$ & 列 & $\stackrel{\infty}{\stackrel{+}{+}}$ \\
\hline & 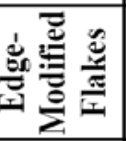 & & & & & & & & & & $\stackrel{\text { ¿ }}{.}$ & $\vec{\sim}$ & $\tilde{n}$ & $\overrightarrow{o g}$ \\
\hline & 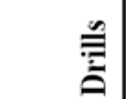 & & & & & & & & & 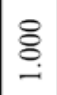 & 导 & $\hat{c}$ & $\vec{\square}$ & 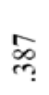 \\
\hline & 象 & & & & & & & & 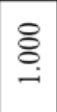 & 声 & $\stackrel{\infty}{\Xi}$ & 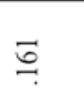 & 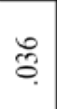 & ถి \\
\hline & $\frac{\infty}{\dot{B}}$ & & & & & & & $\underset{-}{\circ}$ & $\begin{array}{l}\infty \\
\vdots \\
\vdots \\
i\end{array}$ & $\stackrel{m}{0}$ & 웅 & $\stackrel{\circ}{\dddot{0}}$ & $\stackrel{\infty}{\sim}$ & $\stackrel{\tilde{o}}{i}$ \\
\hline & 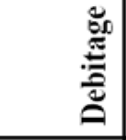 & & & & & & 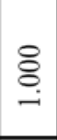 & $\stackrel{m}{0}$ & 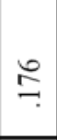 & કे. & $\underset{+}{+}$ & $\overrightarrow{\hat{n}}$ & $\ddot{g}$ & $\tilde{\vartheta}$ \\
\hline & $\stackrel{\mathscr{0}}{3}$ & & & & & $\stackrel{\text { ڤ్ }}{.}$ & స़े & مֶ. & $\cong$ & : & $E$ & $\stackrel{t}{b}$ & $\stackrel{I}{I}$ & $\ddot{\delta}$ \\
\hline & 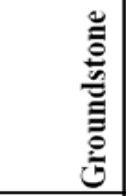 & & & & ¿̊. & $\stackrel{\infty}{\dddot{0}}$ & t. & $\vec{\partial}_{i}$ & : & ত্ড & ర్ర & 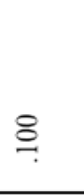 & $\ddot{b}$ & $\stackrel{0}{\circ}$ \\
\hline & 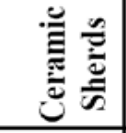 & & & $\underset{\text { ¿ }}{.}$ & $\cong$ & ๙ิ & 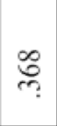 & $\overline{8}$ & $\stackrel{\infty}{\circ}$ & ¿े & 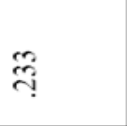 & $\underset{\sim}{\stackrel{\circ}{\oplus}}$ & ळ. & 等 \\
\hline & 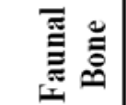 & & $\stackrel{\Xi}{\circ}$ & ঙิ & $\stackrel{0}{0}$ & ণุ & $\stackrel{\infty}{+}$ & $\hat{0}$ & $\vec{m}$ & : & $\underset{\overbrace ָ}{\stackrel{T}{*}}$ & 年 & $\stackrel{\text { ํ }}{\circ}$ & วิ \\
\hline & 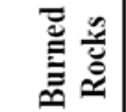 & ¿ & శ్రి & $\stackrel{0}{0}$ & $\frac{2}{6}$ & $\stackrel{\infty}{\circ}$ & స్ & $\stackrel{ \pm}{\leftrightarrows}$ & $\stackrel{\infty}{\stackrel{\infty}{\longrightarrow}}$ & 筞 & $\bar{o}$ & $\stackrel{n}{n}$ & $\tilde{\delta}$ & 它 \\
\hline & 悹 & 䓌 & 急 & 总 & 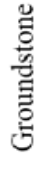 & 气̆ & 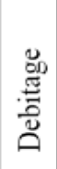 & 告 & 总 & 言 & 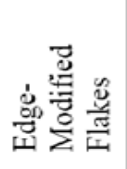 & 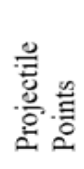 & 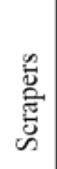 & $\begin{array}{l}\text { 总 } \\
\text { 范 } \\
5\end{array}$ \\
\hline
\end{tabular}


Table 8-17. Principal Component Matrix for Block A-Late Prehistoric Component

\begin{tabular}{|l|c|l|l|l|l|}
\hline \multirow{2}{*}{ Variable } & \multicolumn{5}{|l}{ Factor $^{\mathbf{1}}$} \\
\cline { 2 - 6 } & $\mathbf{1}$ & $\mathbf{2}$ & $\mathbf{3}$ & $\mathbf{4}$ & $\mathbf{5}$ \\
\hline Burned Rock & -.114 & .748 & -.074 & .297 & .034 \\
\hline Faunal Bone & .487 & .635 & .065 & .133 & .005 \\
\hline $\begin{array}{l}\text { Ceramic } \\
\text { Sherds }\end{array}$ & .566 & .251 & .301 & -.048 & .413 \\
\hline Groundstone & -0.55 & .011 & -.029 & -.047 & .832 \\
\hline Cores & .756 & -.124 & -.126 & .140 & .078 \\
\hline Debitage & .639 & .398 & .113 & -.028 & -.091 \\
\hline Awls & -.131 & .106 & -.049 & .791 & .092 \\
\hline Bifaces & .116 & .538 & .000 & -.234 & -.244 \\
\hline Drills & -.148 & -.086 & .822 & .010 & -.122 \\
\hline $\begin{array}{l}\text { Edge-Modified } \\
\text { Flakes }\end{array}$ & .576 & .226 & .061 & -.094 & -.273 \\
\hline $\begin{array}{l}\text { Projectile } \\
\text { Points }\end{array}$ & .199 & .692 & .058 & -.039 & .195 \\
\hline Scrapers & .279 & -.044 & .144 & .677 & -.202 \\
\hline Unifaces & .239 & .111 & .815 & .055 & .199 \\
\hline \% Variance & $\mathbf{1 6 . 2 5}$ & $\mathbf{1 5 . 7 9}$ & $\mathbf{1 1 . 5 3}$ & $\mathbf{9 . 8 6}$ & $\mathbf{8 . 6 8}$ \\
\hline $\begin{array}{l}\text { Cum. } \\
\text { Variance }\end{array}$ & $\mathbf{1 6 . 2 5}$ & $\mathbf{3 2 . 0 4}$ & $\mathbf{4 3 . 5 7}$ & $\mathbf{5 3 . 4 3}$ & $\mathbf{6 2 . 1 1}$ \\
\hline
\end{tabular}

1 Rotation method-Varimax with Kaiser normalization

2 Based on rotation sums of squared loadings

Bifaces and burned rocks are strongly correlated in one high-density cluster in the south half of the block, and moderately associated in two clusters in the northwest quadrant of the block, an area where the other two artifact types are largely absent.

Finally, the strongest high-density peak of burned rock in the south half of Block A is not associated with any of the other three variables constituent of this factor. Although the associations among the categories in this variable cluster are provocative, it is also notable that lithic debitage and cores, which display an association in Factor 1, do not appear to be correlated with projectile points and bifaces. This implies that much of the flint knapping activity that occurred on-site either was oriented toward the production of expedient flake tool forms as opposed to bifaces, or that any bifaces utilized and discarded on-site were not found in exactly the same locations in which they were made. Of course, this variability occurs over a relatively small spatial scale (i.e., meters), so it would be unwise to overemphasize this point. Based on the small spatial scale over which spatial variability occurs in Block A, it is highly possible that patterns among burned rocks, faunal bone, bifaces, and projectile points expressed in this factor indicate specific activity areas relating to resource processing.

Factor 3 is composed of two diagnostic variables-drills and unifaces-collectively composing 11.53 percent of the total variance in the matrix of correlation coefficients (Table 817). Both variables exhibit strong positive factor loadings of .822 and .815 , respectively. The artifact categories represented in this factor loading include a total of only six individual tools, including four drills and two unifaces. Spatially, each of the unifaces occurs within one meter of a drill in two areas-the southwest corner (N101/E47 and N102/E47) and in the south-central (N101/E52) part of Block A. The remaining two drills are scattered across the northern half of Block A. Both of the drill/uniface pairs occur near high-density peaks observed in some of the artifact categories composing Factors 1 and 2, reinforcing the idea that multi-task activity areas are present in these two areas. The fabrication and/or resource processing functions of drills and unifaces round out the generalized resource processing activities indicated by the previous two factors.

Factor 4 is composed of two diagnostic variables-awls and scrapers-collectively composing 9.86 percent of the total variance in the matrix of correlation coefficients (Table 817). Both variables exhibit moderately strong, to strong positive factor loadings of .791 and 
.677, respectively. Only two awls and nine scrapers were recovered from the Toyah component in Block A. The awls are located along the east edge of the block and in the southwestern quadrant. The latter awl correlates with a cluster of scrapers present in this area. Two other high-density scraper clusters are present in the approximate center of BT 2, and along the west edge of the block north of center. With such low densities, it seems inadvisable to over-interpret the patterning represented by this factor. It may be more interesting to simply note the correlation of these fabricating and processing implements with multi-task activity areas suggested by high-density clusters exhibited by certain artifact categories discussed in Factors 1 and 2.

Factor 5 is composed of only one diagnostic variable-groundstone-representing

8.68 percent of the total variance in the matrix of correlation coefficients (Table 8-17). This variable exhibits a strong positive factor loading of .832. As only one piece of groundstone was identified in the Toyah component of Block A, the variability represented by this factor would not appear reliably meaningful. This specimen occurs in Unit N104/E47 in a part of Block A where no other artifact category so far discussed displays a high-density peak.

It is important to remember that demonstrable spatial associations of different variables, which form the basis of the preceding discussion, do not inherently indicate the nature of the relationships among some, or all, of the variables. The statistics reveal numerical tendencies among variables to co-occur or to covary in space. The statistics "force" patterning upon an assemblage of data, regardless of whether or not it innately existed in the dimension being examined. However, patterning is always present in archeological data, so it seems a minor crime to accentuate it where it exists in order to make the task of detection and interpretation easier. The analyst is responsible for inferring whether such patterning may be indicative of past behavior, such as that reflected in situ activity or discard areas; post-depositional processes, such as plowing or erosion; or a combination of both.

Overall, the principal component analyses included in this spatial study have yielded relatively unambiguous patterning among artifact categories. Although the patterns appear to be constrained and influenced by different factors, several generalizations apply. First, the observed associations among artifact categories appear to be regular, patterned, and often exclusive of other categories. If postdepositional factors, such as erosion, plowing, or animal burrowing, had resulted in extensive mixing of sediments, one would expect there to be less distinctive patterning among specific classes of variables and more pervasive mixing of classes. Similarly, extensive mixing of deposits would tend to blur the relatively clear spatial clusters of cultural materials observed in this component. Thus, it appears that the sediment deposits containing the Toyah component are relatively intact, and that the spatial patterning apparent among artifact categories is referable more to the organization of the prehistoric human behavior than to postoccupational natural influences.

\subsubsection{Extra-Local Interactions During the Toyah Interval}

Although not numerous, the three marine shell pieces and the clay figurine-like object are nonlocal in origin, and indicate population movement and/or trading across a broad region. The marine shells undoubtedly originated along the Texas coast, at least $410 \mathrm{~km}$ to the southeast. The clay figurine-like object could have originated from a variety of localities, but it apparently did not come from Central Texas. Even though specific origins cannot be pinpointed for these objects, geographically extensive Toyah population interactions are apparent, regardless if they originated from trading connections and/or population 
movements. Toyah material-culture assemblage has a very extensive distribution, from near the middle Texas coast (Ricklis 1996), across parts of South Texas (Black 1986), throughout Central Texas (Johnson 1994), and into Northeastern Texas, but apparently they did not west of the Edwards Plateau region, unless one considers the Cielo complex (Mallouf 1985, 1992) to be part of this pattern, not did it extend northward into the Texas panhandle.

One Harrell and one Padre point were recovered from the Varga Site. These same point types have been recovered in limited numbers from other Toyah components across Central Texas. For example, two Harrell points were associated with the main Toyah component at the Rush Site near San Angelo (Quigg and Peck 1995). Harrell points, and an associated material cultural complex, have a relative broad distribution across northwestern Texas. They are concentrated hundreds of kilometers due north of Edwards County, and are linked to the Garza complex (see Boyd 1997 for recent overview). Harrell points are thought to represent a separate and distinct plains group. The occurrence of a Harrell point at the Varga Site is near the southern known extent of the distribution of the type (Prewitt 1995:109). This point may have reached the site through trade or some other form of interaction with peoples to the north. One assumes some type of contact with peoples employing this point type, although it is possible that this was a curated item from a chance discovery.

The Padre point is a considerable distance from its normal distribution, given its documented distribution within a relatively localized area along the extreme southern portion of the Texas coastal zone (Prewitt 1995:124). If this was the normal range of the type, then either travel by individuals or exchange would have to account for this Padre point in Edwards County, some $350 \mathrm{~km}$ to the northwest. Although no specific mechanism can be identified, one may suggest that if the people associated with the Padre point originated along the lower Texas coast then this specimen reached the Varga Site by a similar route and similar forms of interaction or travel as did the marine shell items. The Padre point and the marine shell do at least indicate some sort of interaction with peoples along the southern Texas Gulf coast.

The Cuney point type is generally concentrated in northeastern Texas, though its range extends southward into the middle coastal zone. The one recovered here is considered beyond the western limits of the type's primary distribution (Prewitt 1995). Its arrival at the Varga Site was likely either through trade or some form of direct contact with peoples from northeastern or middle-coastal Texas.

Guerrero points are generally thought to reflect the Protohistoric period, or the subsequent Spanish Colonial period (Turner and Hester 1993). This point type has most often been recovered from Spanish mission contexts across the southern part of Texas. Similar small triangular arrow points and one Perdiz point were recovered from the ca.180-year old Mission San Lorenzo $40 \mathrm{~km}$ south of the Varga Site (Tunnell and Newcomb 1969) and from missions in the San Antonio area as well as to the east in coastal plain missions near Goliad (e.g., Ricklis 1999). The presence of Guerrero points may reflect more recent Protohistoric or Colonial-period occupation(s) which, though mixed with and indistinguishable from the main Late Prehistoric Toyah component, could also be represented by the small number of relatively recent radiocarbon dates with calibrated age ranges whose early ends fall within the late 1600 s or the 1700 s.

Harrell points are generally found farther north on the plains, the Cuney point from the northeast/east in Caddo country and the coastal plain, the Padre point, plus the marine shells, from the southeast along the lower coast. If the different projectile point types can be viewed as indications of the direction of contact and/or 
trade, then the interactions were in various directions, excepting to the west and south. The presence of these, and other projectile point types such as the Bonham and possibly the Edwards points, may indicate broad regional interaction and/or inter-mixing of peoples. Although one Cuney point may indicate a possible interaction with peoples to the northeast, the lack of other obvious trade items such as corn or Caddo ceramic vessels implies that the interaction was not intensive or continuous. If the interactions with groups from other regions were limited to social events and non-perishable goods, then archeological visibility would be non-existent. Based on the very few points and limited other items represented in the recovered assemblage, in association with the dominant Perdiz and Cliffton points, the social interaction appears to have been extensive, but limited.

The INAA on a sample of 10 ceramic sherds from the Varga Site was compared to the current INAA of some 200 sherds from Central Texas. The chemical results reveal that the four identified Varga Site Toyah vessels were not manufactured from the same clay sources that were used in the manufacture of most sherds from the Central Texas region. Apparently, the four Varga Site vessels were not manufactured and brought into this region or site from Central Texas. The Varga Site sherds formed two separate subgroups that indicate they were manufactured from at least two separate clay sources or regions. One subgroup was apparently manufactured from local clay sources, based on the fact that one clay sample from the Varga Site was within the limits of the one of the Varga subgroups. The other subgroup was manufactured from non-local clays. One other sherd and the clay figurine-like object were distinct from one another, and distinct from the two identified Varga subgroups. These latter two items were not assigned to any previously identified INAA ceramic group, probably indicating yet another clay source.
The petrographic analysis on the same sherds used in the INAA also reveals different paste groups that reflect acquisition of the raw clay materials from different sources. Comparisons with petrographic results from other Toyah sites reveal five identified paste groups that are shared among two or more Toyah archeological sites across the broader Central Texas region. Since sherds of the same paste groups appear in different archeological sites, this implies transport of vessels across the landscape. Some vessels from the Varga Site probably were locally manufactured, whereas other vessels were manufactured elsewhere, and brought to this site as finished products. From exactly where or how far these pots were derived cannot be ascertained, but continuing investigations into various natural clay source locals and continued INAA may eventually enable us to more better define such patterns.

The extreme scarcity of southwestern ceramic vessels, such as the El Paso brownwares, Chupadero Black-on-white, and various painted or corrugated wares from the Jornado region to the west, implies that western contacts were very limited. It is not clear if this paucity of interaction with populations to the west was due to a cultural or environmental barrier, or is simply a factor of distance. The Chihuahuan Desert to the west potentially contained low population density during Late Prehistoric times, which limited or restricted the interactions with groups in that region.

Interactions with Puebloan peoples from to the northwest are not apparent. No obsidian or painted southwestern ceramic vessels were recovered from the Varga Site, or for that matter, at other sites along the western periphery of the Toyah area such as at the Rush Site (Quigg and Peck 1995) and at 41TG91 (Creel 1978).

The INAA on 48 Toyah phase tools indicate that the raw materials used in the manufacture of a broad suite of formal and informal tools have 
chemical signatures that are similar to Edwards cherts, probably from the local southwestern outcrops of Edwards chert. Judging from the bivariate plots of principal components 1 and 2, none of the lithic materials originated in western Edwards County or in Val Verde County. Several pieces have chemical signatures similar to Edwards chert from Kerr County. A few pieces have signatures similar to chert gravels from the Nueces River bed near Camp Wood in southern Edwards County. The Cuney point (\#349-13 = TRC223) yielded a chemical signature similar to Edwards chert found in the vicinity of the headwaters of Hackberry Creek near 41ED58. This implies that although the Cuney point type is most often found in more northeastern counties (see Prewitt 1995), this particular specimen was probably manufactured from local materials. Apparently, the regionally available Edwards cherts were plentiful and of such good quality that imported lithic materials were not needed or traded for. If trade was occurring with groups outside this immediate southwestern region, then trade goods coming into this region must have been in the form of perishable goods not visible in the archeological record. The chemical differences detected in the Varga Site lithic materials, and in the ceramic materials, indicate the Varga Site Toyah population was relying on multiple source areas in the general region. This indicates a restricted home range, or movement only within a relatively limited area.

\subsubsection{Paleoenvironmental Conditions}

The pollen data from the Toyah samples at the Varga Site reflects a mosaic of various plants, with a mixture of arboreal and grassland communities reflected in 10 identified taxa. Oak pollen is well represented, and pecan pollen is also present. Hackberry and walnut pollen were present in the lowest-oldest Toyah sample. The presence of Apiaceae pollen implies a riparian habitat, whereas the clumps of Cheno-am pollen indicate that this taxon was common in the environs of the site.

The phytolith assemblage reflects a dominant $\mathrm{C}_{3}$ (pooideae) grass community. Stipa-type $\left(\mathrm{C}_{3}\right)$ phytoliths reveal a dramatic increase to about eight percent of the total in the uppermost (most recent) sample. $\mathrm{C}_{4}$ grasses, as indicated by saddle, lobate, and cross-shaped forms, also increased during this period.

The carbon isotope values on sediments also reflect a dominance of $\mathrm{C}_{3}$ vegetation during this period. Minimally, 18 taxa were identified from the macrobotanical remains. These taxa were comprised mostly of tree species, including five potential food taxa. The density of these species, and the composition of the actual vegetation community are not clear, but a mixture of vegetation is represented by three or four nut-bearing trees, woody legumes, prickly pear, agave, agarita, and cheno-ams. The identified types provide a general picture of the plant community, which appears to have been rather similar to the modern vegetation mosaic. These data are supportive of the pollen and phytolith data and indicate a mixture of plant species. The vertebrate faunal remains, including bison, deer, antelope, and rabbits, also imply mixed vegetation in the immediate area. Fish, turtle, and mussel shells indicate that nearby Hackberry Creek was a perennial stream.

At Hall's Cave in adjacent Kerr County, Toomey (1993) documented a sharp increase in the Arizona Desert Shrew (Notiosorex crawfordi) after 1,000 B.P. and implies that this was related to drying trend. In the southern High Plains region of Northwestern Texas, Holliday (1995) sees some eolian deposition between 1,000 and 500 B.P. with a return to increased effective moisture around 500 B.P. In the Fort Hood region of Central Texas, Nordt (1992, 1993) detects no discernable shift in vegetation between about 400 and 2,000 B.P. based on carbon isotope data from alluvial sediments. In general, he detected a mixed 
assemblage of $\mathrm{C}_{3}$ and $\mathrm{C}_{4}$ plant species contributing to the isotopic data throughout this time interval.

It is clear that additional data are needed to help clarify vegetation and climatic changes during this latest period of prehistory across Texas. Environmental data from different regions provide somewhat variable paleoenvironmental scenarios, and the examination of different kinds of data (e.g., phytoliths verses isotope data), have contributed to perceived differences.

In summary, this partially disturbed, but moderately rich Toyah phase/interval component may represent multiple episodes of Late Prehistoric occupation. The 14 radiocarbon dates indicate a nearly 300-year long period of intermittent occupation between 290 and 600 B.P. Analysis of horizontal patterns of debris-class distributions suggest that the component is reasonably intact, and that the spatial patterning apparent among artifact categories is potentially more reflective of the organization of the prehistoric occupations than to post-occupational natural influences. This location served as a campsite of limited duration in an unknown season(s). As noted, the overlaps in distribution of materials representing different activities indicate minimal spatial segregation in the organization of activities, as should be expected in the case of relatively short-term occupations by people whose adaptation entailed a correspondingly high degree of residential mobility. The extensive and diverse chipped stone tool assemblage reflects activities directed at the procurement and processing of tool stone, and plant and animal products (Tables 8-18, 819, and 8-20).

From this locality the Toyah population exploited a broad base of resources that included meat and other byproducts from deer, antelope, bison, rabbits, and possibly other animals as well as significant reliance on a range of plants including agave hearts, probably sotol or yucca leaves, littleleaf walnut, and prickly pear.

\section{Table 8-18. Summary of the Toyah Assemblage from the Varga Site (41ED28) Investigations}

\begin{tabular}{|c|c|}
\hline Cultural Material Classes & $\begin{array}{c}\text { Toyah } \\
\text { Component } \\
\text { (200 to } 700 \\
\text { B.P.) Counts } \\
\end{array}$ \\
\hline Bone Fragments* & $\begin{array}{c}17,348.9 \mathrm{~g}, \\
18,698 \text { pieces }\end{array}$ \\
\hline Mussel Shell* & 25.5 g, 45 pieces \\
\hline Burned Rock & 15.934 \\
\hline Features & 11 \\
\hline Bone Cluster & 1 \\
\hline General Refuse Dumps & 3 \\
\hline Hearths & 4 \\
\hline Occupation Zone & 3 \\
\hline Dart Points and Fragments & 13 \\
\hline Frio & 4 \\
\hline Merrill & 1 \\
\hline Baker & 1 \\
\hline Group 2 & 1 \\
\hline Arrow Points and Fragments & 216 \\
\hline Perdiz & 53 \\
\hline Cliffton & 10 \\
\hline Bonham & 5 \\
\hline Scallorn & 2 \\
\hline Guerrero & 2 \\
\hline Cuney & 1 \\
\hline Harrell & 1 \\
\hline Padre & 1 \\
\hline Bifaces & 96 \\
\hline Scrapers & 65 \\
\hline Drills & 16 \\
\hline Edge-Modified Flakes & 1,380 \\
\hline Lithic Debitage & 26,323 \\
\hline Cores & 37 \\
\hline Unifaces & 7 \\
\hline Anvil & 1 \\
\hline Hammerstone & 1 \\
\hline Ceramic Sherds & 115 \\
\hline Bone Tools & 3 \\
\hline Clay Object & 1 \\
\hline Exotic Materials - marine shells & 3 \\
\hline Carbonized Plant Remains & $196 \mathrm{~g}$ \\
\hline Total Materials & 64,679 \\
\hline Average Thickness (cm) & 30 \\
\hline Spatial Extent Excavated $\left(\mathrm{m}^{2}\right)$ & 207.75 \\
\hline Volume Excavated $\left(\mathrm{m}^{3}\right)$ & 42.9 \\
\hline
\end{tabular}


Table 8-19. List of Faunal Species Identified in the Toyah Component

\begin{tabular}{|l|l|}
\hline Animal/Species & Counts \\
\hline Bison & 1481 pieces $\mathrm{MNI}=1$ \\
\hline Deer/Antelope & 496 pieces \\
\hline Deer & 12 pieces $\mathrm{MNI}=2$ \\
\hline Antelope & 6 pieces $\mathrm{MNI}=1$ \\
\hline Turtles & 4 pieces $\mathrm{MNI}=2$ \\
\hline Snake & 6 pieces $\mathrm{MNI}=2$ \\
\hline Dog/Coyote & 6 pieces \\
\hline Small Mammal & 33 pieces \\
\hline Cottontail & 2 pieces $\mathrm{MNI}=1$ \\
\hline Jackrabbit & 1 piece $\mathrm{MNI}=1$ \\
\hline Fish & 2 pieces \\
\hline
\end{tabular}

MNI = Minimum number of individuals

Table 8-20. List of Floral Species Identified in the Toyah Component

\begin{tabular}{|l|}
\hline Agava heart and leaves \\
\hline Agarita \\
\hline Buttonbush \\
\hline Cheno-am seeds \\
\hline Condalis \\
\hline Elm \\
\hline Juniper \\
\hline Littleleaf walnut \\
\hline Lotebush \\
\hline Mesquite \\
\hline Mexican buckeye \\
\hline Oak \\
\hline Pecan \\
\hline Pinion \\
\hline Prickly pear seeds \\
\hline Sycamore \\
\hline Willow/Cottonwood \\
\hline
\end{tabular}

The people employed burned rocks and ceramic vessels to cook their foods. Much of the procured meat was apparently not cooked through the use of hot rocks and no meat was cooked in the ceramic vessels, since the chemical residues indicate that minimally 70 to 75 percent of the identified residues from burned rocks, and 100 percent of the residues from the vessels, represent plant matter. Poorly preserved burned rock hearths were present, as were general refuse dumps that contained diverse cultural debris. These dumps, presumably created from maintenance activities, combined with chipped stone tool manufacturing and maintenance tasks, and diverse vertebrate remains, reflect general camp activities.

The Varga Site Toyah populations apparently had limited contact with other peoples/groups from other regions, as indicted by the presence of a few projectile points that are of types characteristic of other regions. Contact, direct or indirect, occurred with coastal groups as indicated by the presence of three marine shell artifacts, and possibly by the Padre arrow point. Thus, although the Toyah population apparently operated within a limited home range, evidenced by the use of local and regional raw material sources for the manufacture of ceramic vessels and tool stones, they did maintain at least minimal contact with peoples in outside areas.

The pollen, phytolith, stable carbon isotope, and macrobotanical data sets from the Toyah age sediments reflect a vegetation community consisting of a mixture of arboreal and grassland communities. Oak, pecan, hackberry, and walnut were present, together with mostly $\mathrm{C}_{3}$ grasses, although $\mathrm{C}_{4}$ grass species were present in increasing numbers. The proposed vegetation community in which the Toyah people lived was similar to the current natural environment of the region. 



\subsection{LATE ARCHAIC COMPONENT}

\author{
J. Michael Quigg
}

\subsection{INTRODUCTION: IDENTIFICATION AND DATING OF THE LATE ARCHAIC COMPONENT}

The Late Archaic component was first identified during the Phase I investigations, when a Frio point was found near the bottom of Feature 2 west of the road, and a possible Carrizo point was recovered from east of this road. No features or identifiable occupation zones associated with this time were identified during Phase I (Lintz et al. 2002).

Subsequently, Phase II investigations west of the road targeted the entire range of cultural deposits through the 83- $\mathrm{m}^{2}$-block excavation (Block A) that encompassed most of burned rock concentration designated Feature 1, which was determined to pertain to the Late Archaic, based on its association with projectile points of established Late Archaic types (three Frio, one Marcos, one Ensor, one Montell). The inferred Late Archaic ascription was later substantiated by eight radiocarbon dates. Stratigraphically, Feature 1 was situated immediately beneath the Late Prehistoric Toyah component within a very dark gray (10YR 3/1) to black (10YR 2/1) clay loam to silty clay loam. A sharp break in soil color and texture separated the two cultural components (Figure 9-1). As noted in the previous chapter, some mixing of materials had occurred, as evidenced by the presence of two Toyah phase potsherds, two Cliffton points, minimally two pieces of dated charcoal, and quantities of tiny bone fragments that are confidently ascribed to Toyah component.

Late Archaic materials in Block A were concentrated in and immediately around Feature 1 and could not be traced more than a meter or so beyond that deposit of burned rock. The horizontally restricted Late Archaic occupation is mainly evidenced by the ca. $6 \mathrm{~m}$ diameter burned-rock concentration, Feature 1, secondary burned rock clusters, and a relatively small sample of lithic debitage and stone tools.

In Block B, east of the road, excavation targeted mainly the Late Prehistoric Toyah component in the upper 10 to $30 \mathrm{cmbs}$. However, during the hand-excavations many levels $\left(35.5 \mathrm{~m}^{2}\right)$ penetrated the very dark gray to black A horizon (detected between 8 and $30 \mathrm{cmbs}$ ) that signaled the older Late Archaic deposits and captured limited quantities of cultural materials attributed to the Late Archaic. These Late Archaic cultural materials from Block B are discussed in the descriptions and total counts below.

The chronometric age of the Late Archaic component has been determined through absolute dating of organic material retrieved from the cultural zone. Eleven radiocarbon ages fall within the relevant period, ranging from 1,700 to 2,310 B.P., presumably documenting the age range of the Late Archaic component (Table 9-1). A date on sediment organics of 1,900 B.P. (Beta-175390), from the black clay loam on the eastern side of the road, accords with and supports this age range for the Late Archaic cultural materials. Six of the eleven dated charcoal samples were on wood charcoal collected from Feature 1 (Table 9-1). The oldest radiocarbon age of 2,310 B.P. (Beta-175412), came from a single chunk of charcoal from between 26 and $46 \mathrm{cmbd}$ in Feature $1 \mathrm{~b}$ in what is considered to be good Late Archaic context. 


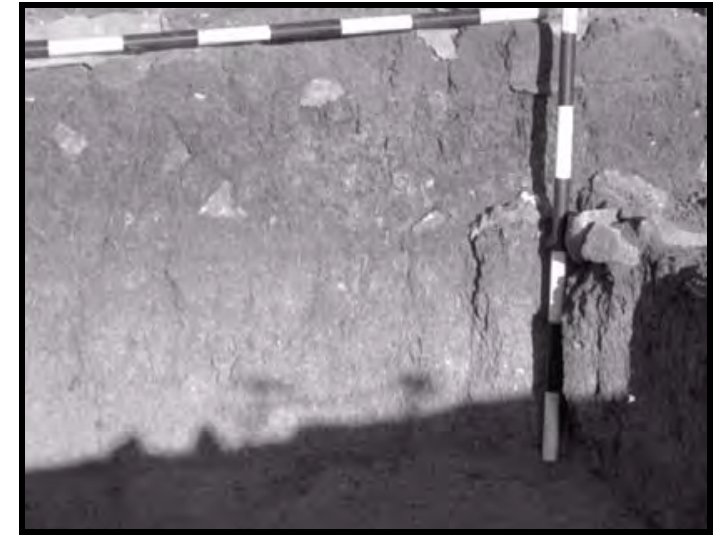

Figure 9-1. Late Archaic Component in Dark Buried A Horizon

The youngest radiocarbon date, 1,700 B.P. (Beta-175412), was derived from a single chunk of charcoal collected from 20 to $30 \mathrm{cmbd}$ in Feature $1 \mathrm{a}$ and also in good context.

However, some vertical displacement of materials was evident in the Late Archaic deposits as well. The second oldest date, 2,290 B.P. (UGA-12716), was obtained from one deer/antelope bone fragment (\#418-2-1) that was collected from between 50 and $60 \mathrm{cmbd}$ in the Middle Archaic component. This bone is of Late Archaic age, but was apparently displaced downward into the lower component. Other evidence of displacement is detected in a charcoal chunk (\#203-5-4-2-1) dated to the Late Archaic that came from burned rock Feature 39 in the Early Archaic component. It is unlikely the burned rocks in Feature 39 move downward, so we assume the tiny charcoal pieces were displaced downward.

Two other radiocarbon dates on charcoal pieces recovered from the Late Archaic component yielded ages of $550 \pm 40$ B.P. (\#293-5-7-1a) and 1,390 \pm 40 B.P. (\#11-5-4-7-1a), which are not acceptable ages for this component. The 550 B.P. (UGA-12714) age was derived from tiny charcoal pieces from Feature $1 \mathrm{c}$ at an elevation of 20 to $30 \mathrm{cmbd}$. Apparently this charcoal was displaced a few centimeters downward from the overlying Toyah component. The 1,390 B.P. (UGA-12704) age was also on charcoal at an elevation of 7 to $20 \mathrm{cmbs}$ and originally was thought to be associated with Feature 1d. This charcoal piece may represent an occupation that occurred between the Late Archaic and the Toyah interval.

To evaluate the reliability of OSL dating of alluvial sediments, TRC personnel collected two sediment samples (\#1239 and \#1240) from two horizontally different parts of the Late Archaic component. Sample \#1239 was collected from a brown (10YR 3/1) clay loam on the very eastern edge of Block B in Unit N125/E75 between 28 and $33 \mathrm{cmbs}$ and stratigraphically just below the OSL Toyah sample. Sample \#1240 was collected from a brown (10YR 2/1) clay loam on the very western edge of Block $A$ in Unit N104/E47 between 36 and 42 cmbs and stratigraphically below the Toyah sample. These two samples were dated with the OSL technique. The detailed methods and results are presented in Appendix L, and only a summary is presented here. The two sediment samples from the Late Archaic context did not yield many single dateable quartz grains. Only 24 percent of the measured grains in sample \#1239 or UW1049 and 15 percent of the measured grains in sample \#1240 or UW1050 were dateable grains (Appendix L). The central age determination from the fine grains provided an average age for each sample. Sample $\# 1239$ /UW1049 yielded an age of 2,210 \pm 392 years before A.D. 2004. Sample $\# 1240 / \mathrm{UW} 1050$ yielded an age of $2,400 \pm 399$ years before A.D. 2004. These two OSL age determinations on fine grains are congruent with the results from the charcoal assays for the Late Archaic component. 


\begin{tabular}{|c|c|c|c|c|c|c|c|c|c|c|c|c|c|}
\hline 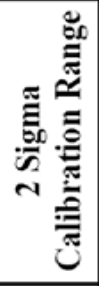 & 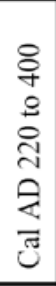 & 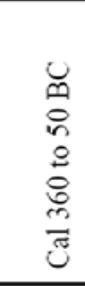 & 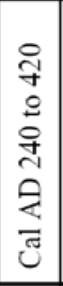 & & 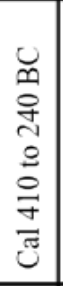 & 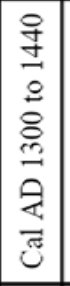 & 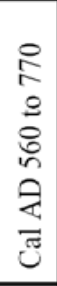 & 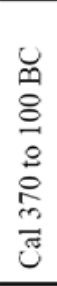 & 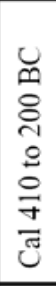 & 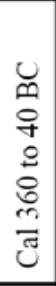 & 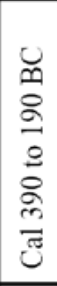 & 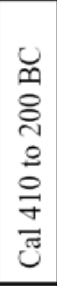 & 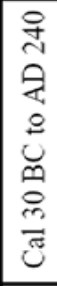 \\
\hline 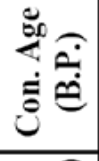 & 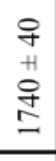 & $\begin{array}{l}q \\
+ \\
\text { + } \\
\stackrel{+}{v} \\
\end{array}$ & $\begin{array}{l}\stackrel{P}{+} \\
+ \\
\& \\
\Xi \\
\end{array}$ & & 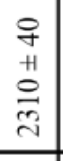 & $\begin{array}{l}o \\
+ \\
+1 \\
8 \\
n \\
n\end{array}$ & $\begin{array}{l}q \\
+1 \\
+ \\
\stackrel{2}{0} \\
-1 \\
\end{array}$ & 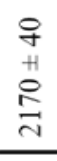 & 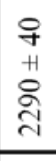 & $\begin{array}{l}\stackrel{+}{+} \\
+ \\
\stackrel{+}{+} \\
\stackrel{+}{1} \\
\end{array}$ & 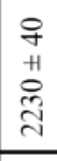 & $\begin{array}{l}\stackrel{+}{+} \\
+1 \\
\& \\
\text { ते } \\
\end{array}$ & $\begin{array}{l}8 \\
+1 \\
8 \\
\Xi \\
\end{array}$ \\
\hline 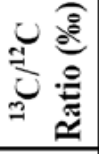 & $\overrightarrow{\mathrm{i}}$ & $\vec{\overbrace{}}$ & $\begin{array}{l}n \\
\\
\end{array}$ & & $\stackrel{n}{\stackrel{\sim}{i}}$ & ڤె & $\stackrel{m}{\stackrel{T}{T}}$ & $\widehat{\widetilde{i}}$ & $\stackrel{r}{\stackrel{r}{r}}$ & $\stackrel{n}{\stackrel{\leftrightarrow}{r}}$ & 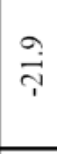 & $\stackrel{n}{\stackrel{n}{r}}$ & $\stackrel{\infty}{\underset{\tau}{\tau}}$ \\
\hline 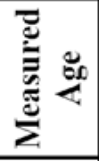 & 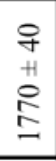 & $\begin{array}{l}q \\
+1 \\
\stackrel{+}{1} \\
\stackrel{N}{N}\end{array}$ & 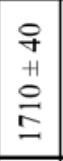 & & $\begin{array}{l}q \\
+ \\
+1 \\
0 \\
\text { d } \\
\end{array}$ & $\begin{array}{l}\text { o } \\
+1 \\
8 \\
0 \\
n\end{array}$ & $\begin{array}{l}\mathcal{Y} \\
+1 \\
0 \\
0 \\
-1 \\
\end{array}$ & 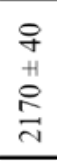 & $\begin{array}{l}\text { + } \\
+1 \\
\stackrel{+}{+} \\
\text { ה }\end{array}$ & $\begin{array}{c}P \\
+ \\
+ \\
\stackrel{+}{0} \\
\stackrel{2}{N}\end{array}$ & 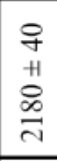 & 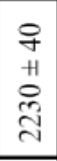 & 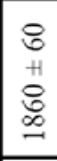 \\
\hline$\dot{\Xi}$ & 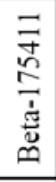 & 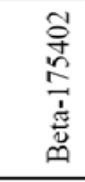 & 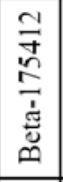 & ப் & 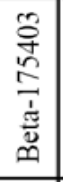 & 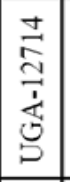 & 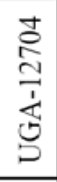 & 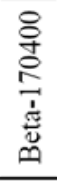 & 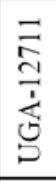 & 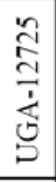 & 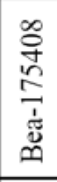 & 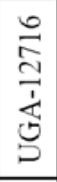 & 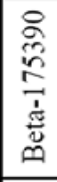 \\
\hline$E^{50}$ & $\overrightarrow{0}$ & $\overrightarrow{0}$ & $\overrightarrow{0}$ & ชู & $\overrightarrow{0}$ & $\stackrel{\infty}{\circ}$ & $\overrightarrow{0}$ & $\overrightarrow{0}$ & $\overrightarrow{0}$ & $\overrightarrow{0}$ & $\overrightarrow{0}$ & $\stackrel{\vec{i}}{\mathrm{i}}$ & 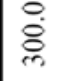 \\
\hline & $\begin{array}{l}\overline{0} \\
\stackrel{0}{\tilde{J}} \\
\bar{J} \\
-\end{array}$ & $\begin{array}{l}\overrightarrow{0} \\
\stackrel{0}{0} \\
\stackrel{3}{0} \\
- \\
\end{array}$ & 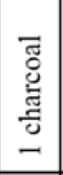 & $\begin{array}{l}\stackrel{\Xi}{0} \\
\beth \\
=\end{array}$ & 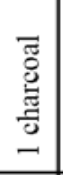 & 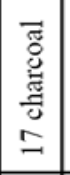 & $\begin{array}{l}\overline{0} \\
\stackrel{0}{\tilde{Z}} \\
\tilde{J} \\
0 \\
0\end{array}$ & 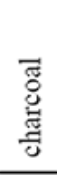 & 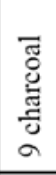 & 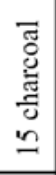 & 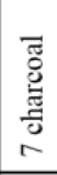 & $\begin{array}{l}\mathscr{Z} \\
\stackrel{\Xi}{-} \\
\end{array}$ & 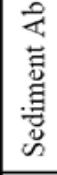 \\
\hline 恴氞 & 古 & $\begin{array}{l}80 \\
\stackrel{1}{1}\end{array}$ & $\begin{array}{l}\text { Oे } \\
\stackrel{\tilde{\nu}}{1}\end{array}$ & 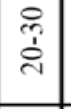 & 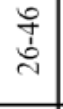 & 宔 & ิㅗㄴ & $\begin{array}{l}\text { के } \\
\text { ó }\end{array}$ & 导 & 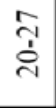 & §ิ & $\begin{array}{l}8 \\
\text { ì } \\
\text { in }\end{array}$ & ڤั \\
\hline 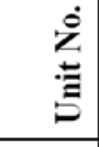 & 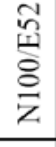 & 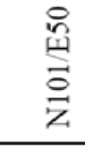 & $\begin{array}{l}\vec{n} \\
\stackrel{1}{\mathbf{1}} \\
\text { ठ } \\
z \\
\end{array}$ & 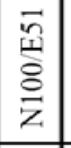 & 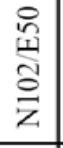 & 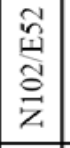 & 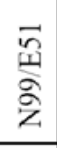 & 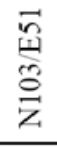 & $\begin{array}{l}\text { 号 } \\
\text { 至 } \\
\text { 을 } \\
\text { z }\end{array}$ & $\begin{array}{l}\stackrel{m}{I} \\
\stackrel{\vec{n}}{\bar{z}} \\
\end{array}$ & 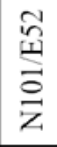 & 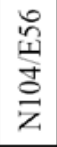 & $\stackrel{n}{n}$ \\
\hline$\dot{\overline{\underline{m}}}$ & $\varangle$ & $\varangle$ & $<$ & $\ll$ & $\varangle$ & $\varangle$ & $\varangle$ & $\varangle$ & $\ll$ & $\infty$ & $\varangle$ & $\varangle$ & $\infty$ \\
\hline 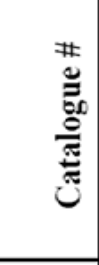 & $\begin{array}{l}\overrightarrow{1} \\
\stackrel{5}{0} \\
\vdots \\
0 \\
\end{array}$ & 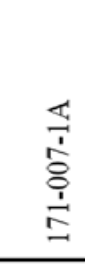 & $\begin{array}{l}\overrightarrow{1} \\
\stackrel{\mathbf{o}}{1} \\
\grave{1} \\
\end{array}$ & 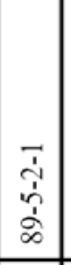 & 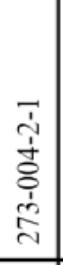 & 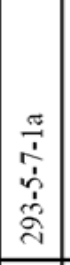 & $\begin{array}{l}\frac{\pi}{1} \\
\frac{1}{\dot{1}} \\
\dot{1} \\
\stackrel{1}{=} \\
=\end{array}$ & 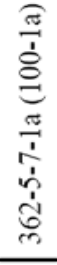 & 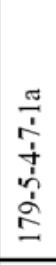 & 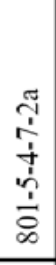 & 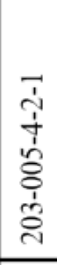 & $\begin{array}{l}\overrightarrow{\tilde{I}} \\
\dot{0} \\
\vec{\nabla}\end{array}$ & $\begin{array}{l}\overrightarrow{4} \\
\dot{I} \\
\stackrel{\Xi}{\Xi}\end{array}$ \\
\hline$\dot{8}$ & - & 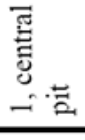 & $\Xi$ & $\Xi$ & $=$ & $\stackrel{0}{-1}$ & - & 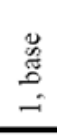 & - & 气 & ले & $\Xi$ & $\cong$ \\
\hline
\end{tabular}




\subsection{Late Archaic Features}

\subsubsection{Introduction}

Nine clusters of burned rocks were recognized during the fieldwork, assigned feature numbers in the field, and assigned to the Late Archaic component. These features fall into two categories based on a combination of visible attributes and constituent materials. The categories include in situ cooking facilities $(n=1)$ and burned rock dumps $(n=8)$. Burned rock dumps consisted of concentrations of burned rocks, but lacked indications of in situ heating, indicating secondary that deposition, or discard, is represented. The cooking facility is so identified based on the presence of basins/pits, and burned rock concentrations associated with oxidized earth, ash, and/or charcoal lenses.

Features received more detailed documentation than scattered cultural materials through a suite of observations, measurements, and samples collected. The nine features were discovered in both excavation blocks. Feature 1 and its subdivisions 1a, 1b, 1c, and 1d were discovered in Block A. All four other features (7, 15, 28, and 29) were discovered in Block B below the Toyah component. The nine recognized features are described individually below.

\subsubsection{Feature 1}

Feature 1 and its subdivisions 1a, 1b, 1c, and 1d constitute one horizontally distributed burned rock lens that was the primary target of the Phase I investigations. Because this feature was originally thought to be a burned rock midden, TxDOT directed TRC to scrape off the overlying sediments, and to then excavate trenches into the "midden" in two directions in order to define its horizontal and vertical dimensions as well as to allow visual inspection and documentation of its form. BT 1, a north-south-trending backhoe trench, revealed a relatively thin lens of burned rocks with maximum thickness of $30 \mathrm{~cm}$, which was also visible in the intersecting, east-westtrending BT 2 (Figures 9-2 and 9-3). The initial exposure in the profiles in BT 1 revealed a nearly 15-cm-deep basin. The horizontal distribution of the highest concentration of burned rocks extended for about $6 \mathrm{~m}$, as revealed in the wall profiles of the two trenches. The backhoe trenches removed a significant portion of feature.

During Phase I, two 50-by-50 cm test pits (N103/E51 and N101/E50) were excavated from the sides of BTs 1 and 2, into and through Feature 1. One projectile point, resembling the Pedernales type, point was collected from the burned rock zone as exposed in the eastern profile of BT 1. Quantities of burned rocks and a few tiny pieces of charcoal were recovered from the burned rock lens during the Phase I excavations. Cultural materials were also encountered in the fine sediments above and below the burned rocks, which prompted more extensive investigation during the Phase II excavations.

Eight liters of matrix (\#370-5-4) from around and below the burned rocks at 28 to $40 \mathrm{cmbd}$ in Unit N103/E51 were collected for flotation in the laboratory. The $6.4 \mathrm{~mm}$-size fraction yielded six tiny burned rock pieces that weigh $44.8 \mathrm{~g}$, four pieces of chert, 44 nearly whole snail shells $\mathrm{g}$, and one small bone fragment. The heavy fraction yielded 41 tiny burned rock fragments that weigh $4.3 \mathrm{~g}, 112$ chert pieces, four tiny charcoal pieces, 11 whole snail shells, and 48 bone fragments, seven of which are burned.

Phase II work continued the investigation of Feature 1, and the cultural zones above and below, through hand-excavations in Block $\mathrm{A}$. These excavations showed the burned rock concentration to be unevenly dispersed across roughly 16 excavation units in the southwestern corner of Block A, south of BT 2 and on either side of the southern end of BT 1 (Figure 9-4). 


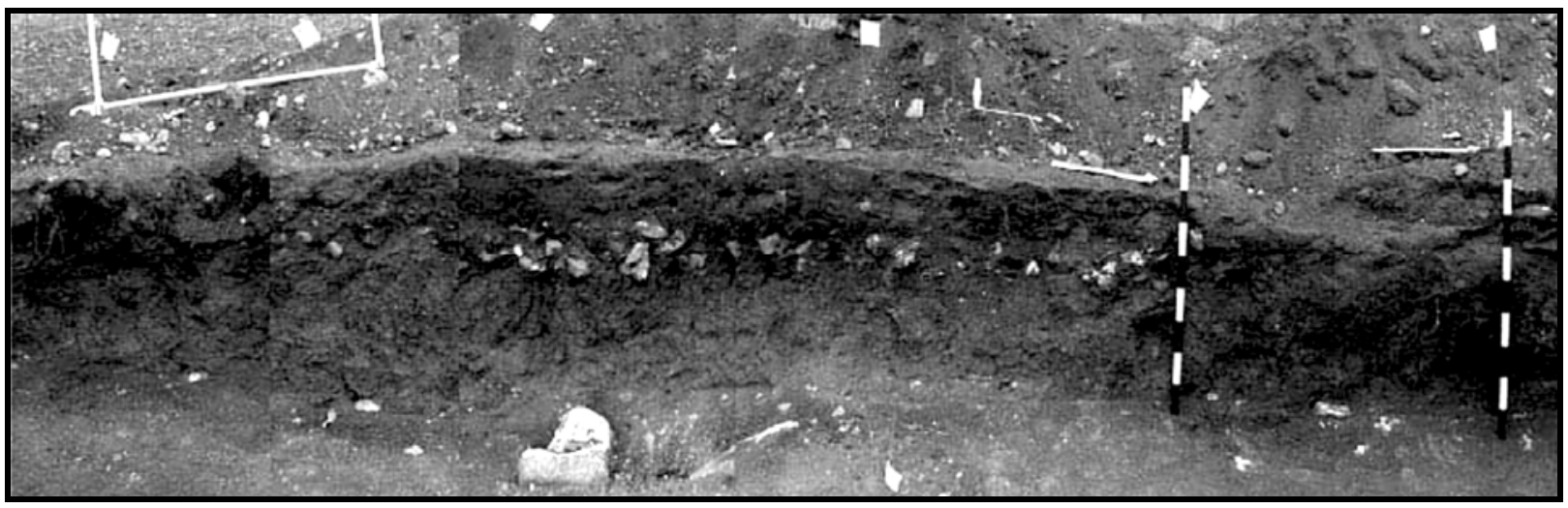

Figure 9-2. Composite profile of Burned Rock Lens Discovered in Backhoe Trench 1 During First Phase of Investigations in 2002 (view west)

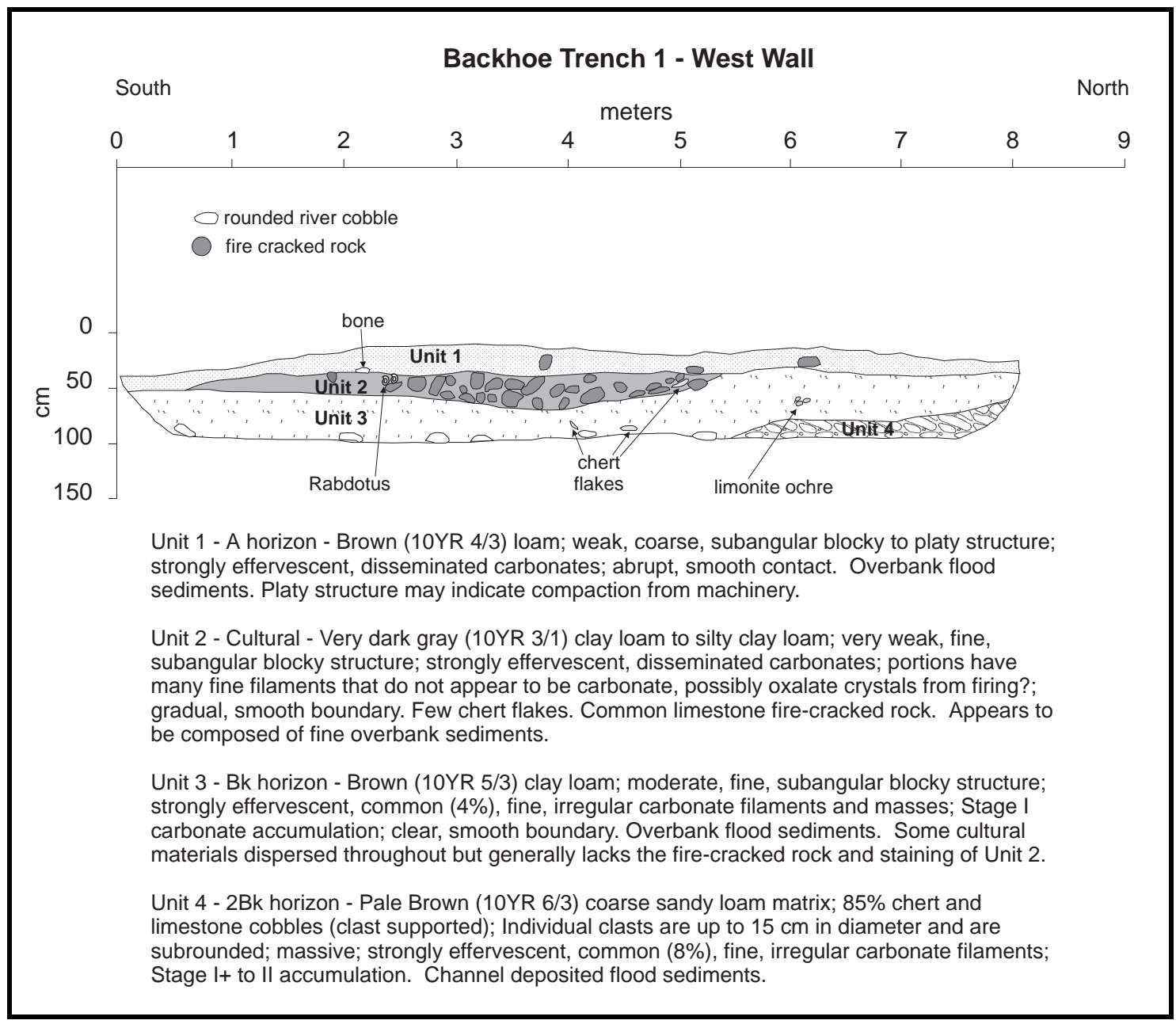

Figure 9- 3. Stratigraphic Profile of Backhoe Trench 1 


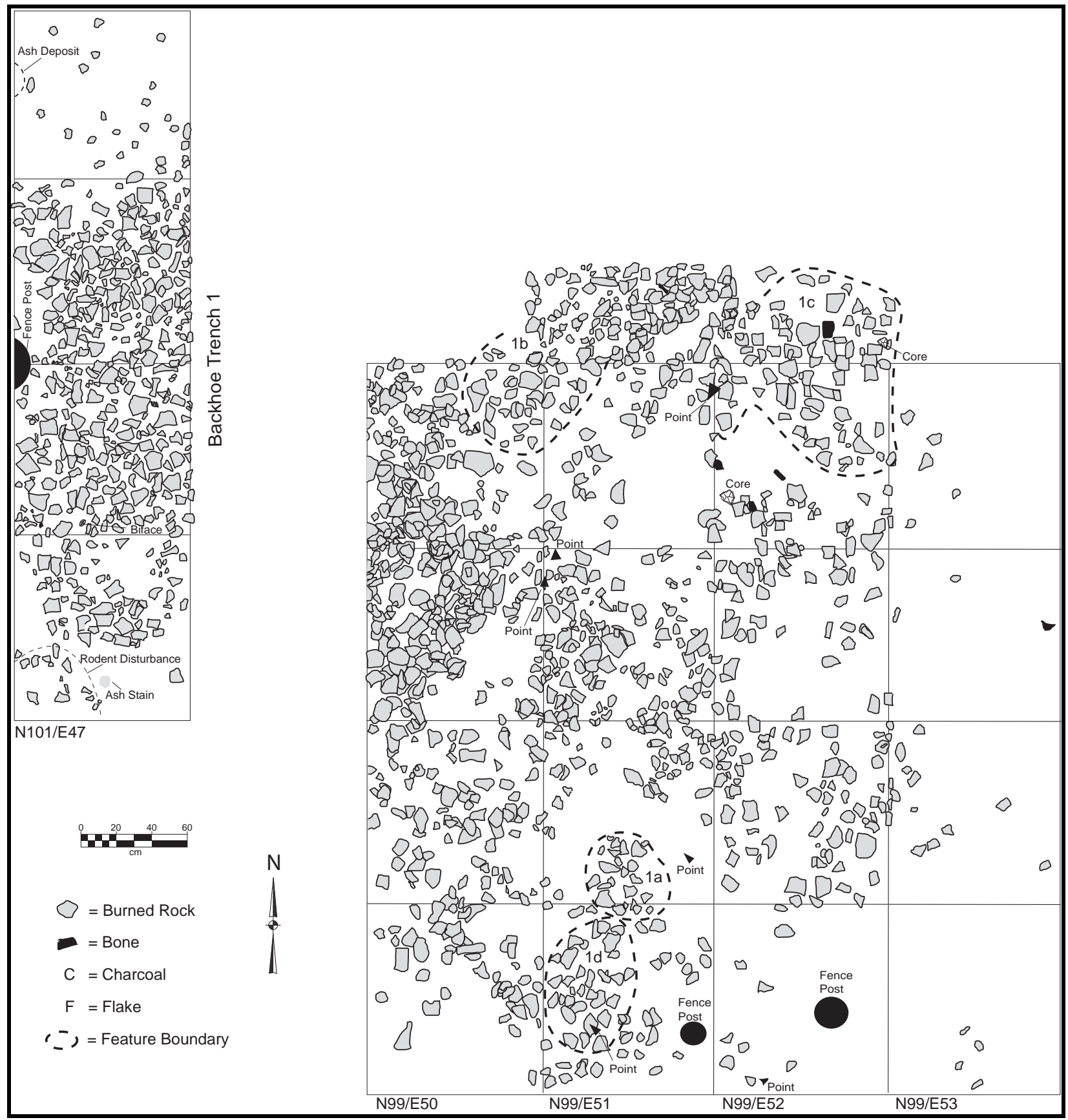

Figure 9-4. Planview of Features 1a, 1b, 1c, and 1d in Block A 
The excavations ultimately exposed a horizontally extensive burned rock feature that measured nearly $6 \mathrm{~m}$ in diameter. Although the maximum thickness was about $30 \mathrm{~cm}$ and as many as four rocks thick, this was the case in a restricted area less than $1 \mathrm{~m}$ in diameter. Most burned rocks were found within only a single layer that exhibited variable density across the relevant 16 units. Within the broader boundaries of Feature 1, small clusters of burned rocks less than $1 \mathrm{~m}$ in diameter were observed and designated 1a, 1b, 1c, and 1d. These smaller clusters were treated as subfeatures within Feature 1 in anticipation that these clusters might provide information that would contribute to functional interpretation of the larger feature. Each subfeature will be briefly discussed below, followed by a discussion of Feature 1 as a whole.

\subsubsection{Feature 1a}

Feature 1a, a cluster of 23 burned rocks, was detected in the southern part of Unit N100/E51 towards the southeastern side of the broader burned rock distribution (Figure 9-4). This oval cluster measured 42 by $47 \mathrm{~cm}$ in diameter and had a depth range of 19 to $26 \mathrm{cmbd}$. The burned rocks were located mostly in one layer, but several pieces were found below other rocks, generally near the middle of the cluster. No basin was detected, and no charcoal, ash staining, or oxidation was observed. The matrix that surrounded the burned rocks was a very dark grayish brown (10YR 3/2).

The 23 burned rocks collected from Feature 1a ranged in size from small (less than $4 \mathrm{~cm}$ in diameter) to larger pieces close to $15 \mathrm{~cm}$ in diameter. Nearly 65 percent of the burned rocks were in the 4.1 to $9 \mathrm{~cm}$ size class, but only two rocks were less than $4 \mathrm{~cm}$ in size (Table 9-2). The average burned rock weighed $196 \mathrm{~g}$. All but one burned rock was angular in general shape with minimally five pieces representing heat spalls. Hackled edges were observed on three pieces. A few pieces actually refit with other pieces, and in two instances three pieces fit together to form the parent rock.

Parts of three limestone burned rocks were sampled for lipid residues (Table 9-3). All three pieces (\#89-5-3-1a, \#89-5-3-2a, and \#89-5-5-33a) yielded very high fat content that is interpreted as representing plants. The consistency in these results implies that a single kind of plant was cooked, possibly during one event. Parts of two of these rocks (\#89-5-3-1b and \#89-5-3-2b) were also sampled for stable carbon and nitrogen isotopes (Table 9-4), with nearly identical results, which show an average $\delta^{13} \mathrm{C}$ value of $-25.7 \%$. The average $\delta^{15} \mathrm{~N}$ value is $2.7 \%$, with both values relatively low. The isotope values generally indicate the presence of $\mathrm{C}_{3}$ plants, possibly seeds, berries, and/or nuts.

Unit N100/E51 that contained Feature 1a also yielded several other cultural items including 42 pieces of lithic debitage, two bone fragments, a few Rabdotus snail shells, tiny chunks of charcoal, one nearly complete Frio projectile point (\#89-10), and scattered burned rocks across the north part of the unit. The Frio point was recovered from about $20 \mathrm{~cm}$ east of the cluster and 3 to $4 \mathrm{~cm}$ below the burned rocks (Figure 9-1). One tiny piece of wood charcoal (\#89-7-1) collected from just outside the clustered rocks was submitted for radiocarbon dating. It yielded a $\delta^{13} \mathrm{C}$ corrected (-25.5\%) AMS radiocarbon age of $1,710 \pm 40$ B.P. (Table 9-1: Beta-175412). Part of that dated sample (\#89-5-7-1b) was identified as mesquite wood (Appendix I).

Five liters of matrix collected from around and below the burned rocks between 19 and $26 \mathrm{cmbd}$ in Unit N100/E51 was floated in the laboratory. The heavy fraction was sorted and the light fraction was sent to Dr. Dering for macrobotanical analysis. 





Table 9-3. Lipid Residue Results from Burned Rock Samples from Late Archaic Component

\begin{tabular}{|c|c|c|c|c|c|}
\hline Lab. No. & Cat. \# & Fea. No. & Material & Wgt (g) & Interpreted Lipid Residue Results \\
\hline $4 V G 44$ & $89-5-3-1 a$ & $1 \mathrm{a}$ & Limestone & 74 & Very high fat content - plant \\
\hline $4 \mathrm{VG} 45$ & $89-5-3-2 a$ & $1 \mathrm{a}$ & Limestone & 74 & Very high fat content - plant \\
\hline $4 \mathrm{VG} 46$ & $89-5-3-3 a$ & $1 \mathrm{a}$ & Limestone & 52 & Borderline high and very high fat content - plant \\
\hline 4VG 38 & $273-5-3-1 a$ & $1 b$ & Limestone & 38 & Borderline moderate-high and high fat content - plant \\
\hline 4VG 39 & $273-5-3-2 a$ & $1 b$ & Limestone & 23 & High fat content \\
\hline $4 \mathrm{VG} 40$ & $273-5-3-3 a$ & $1 b$ & Limestone & 44 & Borderline high and very high fat content - plant \\
\hline $4 \mathrm{VG} 41$ & 293-5-3-1a & $1 c$ & Limestone & 62 & High fat content - plant \\
\hline $4 \mathrm{VG} 42$ & $293-5-3-2 a$ & $1 \mathrm{c}$ & Limestone & 22 & Very high fat content - plant \\
\hline $4 V G 43$ & 293-5-3-3a & 1c & Limestone & 41 & Borderline moderate-high and high fat content - plant \\
\hline $4 V G 49$ & $11-5-3-1 a$ & $1 d$ & Limestone & 45 & High fat content - plant \\
\hline 4VG 50 & $11-5-3-2 a$ & $1 d$ & Limestone & 43 & High fat content - plant \\
\hline 4VG 51 & $11-5-3-3 a$ & $1 d$ & Limestone & 60 & Very high fat content - plant \\
\hline 4 VG 57 & $263-5-3-1 a$ & 1 & Limestone & 56 & Borderline medium and moderate-high fat content - plant \\
\hline 4VG 58 & $274-5-3-2 a$ & 1 & Limestone & 35 & Borderline moderate-high and high fat content - plant \\
\hline 4VG 59 & $187-5-3-2 a$ & 1 & Limestone & 93 & Very high fat content - plant \\
\hline $4 V G 60$ & $80-5-3-1 a$ & 1 & Limestone & 46 & Very high fat content - plant \\
\hline 4VG 61 & $187-5-3-1 a$ & 1 & Limestone & 16 & Medium fat content - plant \\
\hline 4VG 62 & $179-5-3-2 a$ & 1 & Limestone & 22 & Low fat plant \\
\hline $4 V G 63$ & $98-5-3-1 a$ & 1 & Limestone & 19 & Borderline medium fat content and large herbivore + plant \\
\hline $4 V G 64$ & $179-5-3-1 a$ & 1 & Limestone & 35 & High fat content - plant \\
\hline $4 \mathrm{VG} 65$ & $274-5-3-1 a$ & 1 & Limestone & 26 & High fat content - plant \\
\hline 4 VG 66 & $178-5-3-1 a$ & 1 & Limestone & 25 & Borderline medium and moderate-high fat content - plant \\
\hline 4VG 67 & $370-5-3-1 a$ & 1 & Limestone & 14 & Borderline moderate-high and high fat content \\
\hline 4VG 68 & $161-5-3-1 a$ & 1 & Limestone & 48 & Borderline high and very high fat content - plant \\
\hline 4 VG 69 & $352-5-3-1 a$ & 1 & Limestone & 32 & Borderline high and very high fat content - plant \\
\hline $4 \mathrm{VG} 70$ & $352-5-3-2 a$ & 1 & Limestone & 58 & High fat content - plant \\
\hline 4VG 71 & $81-5-3-1 a$ & 1 & Limestone & 19 & High fat content - plant \\
\hline 4VG 54 & $801-5-3-1 a$ & 15 & Limestone & 45 & High fat content - plant \\
\hline 4VG 55 & $801-5-3-2 a$ & 15 & Limestone & 39 & Moderate-high fat content -plant \\
\hline 4VG 56 & $801-5-3-3 a$ & 15 & Limestone & 55 & Borderline moderate-high and high fat content - plant \\
\hline 4VG 52 & $941-5-3-1 a$ & 28 & Limestone & 34 & Insufficient lipid for analysis \\
\hline 4VG 53 & $941-5-3-2 a$ & 28 & Limestone & 15 & Very high fat content - plant \\
\hline $4 \mathrm{VG} 47$ & $966-5-3-1 a$ & 29 & Limestone & 15 & Very high fat content - plant \\
\hline $4 \mathrm{VG} 48$ & $962-5-3-1 a$ & 29 & Limestone & 42 & Very high fat content - plant \\
\hline
\end{tabular}


Table 9-4. Isotope Results from Burned Rocks in Late Archaic Context

\begin{tabular}{|c|c|c|c|c|c|c|c|c|}
\hline Cat. \# & Unit No. & $\begin{array}{l}\text { Depth } \\
\text { (cmbs) }\end{array}$ & $\begin{array}{c}\text { Fea. } \\
\text { No. }\end{array}$ & $\begin{array}{l}\text { Wgt } \\
\text { (mg) }\end{array}$ & $\begin{array}{c}\mathrm{N} \\
\mathbf{W g t} \\
\mu^{1}\end{array}$ & $\begin{array}{l}\delta^{15} N \\
(\% o)\end{array}$ & $\begin{array}{c}\text { C } \\
\text { Wgt } \\
\mu g\end{array}$ & $\begin{array}{l}\delta^{13} \mathrm{C} \\
(\% o)\end{array}$ \\
\hline $80-5-3-1 b$ & N100/E50 & $30-40$ & 1 & 7.606 & 43.5 & 4.78 & 778.4 & -23.88 \\
\hline $81-5-3-1 b$ & N100/E50 & $40-50$ & 1 & 2.161 & 11.4 & -3.15 & 180.4 & -26.02 \\
\hline $98-5-3-1 b$ & N100/E52 & $10-20$ & 1 & 16.006 & 130.1 & 7.65 & 1019.3 & -24.19 \\
\hline 161-5-3-1b & N101/E47 & $45-50$ & 1 & 26.233 & 91.0 & 6.08 & 2569.7 & -30.62 \\
\hline $178-5-3-1 b$ & N101/E50 & $20-25$ & 1 & 30.115 & 41.5 & 5.22 & 642.5 & -21.78 \\
\hline $179-5-3-1 b$ & N101/E51 & $30-40$ & 1 & 8.294 & 98.0 & 4.55 & 1470.3 & -24.67 \\
\hline $179-5-3-2 b$ & N101/E51 & $30-40$ & 1 & 17.820 & 161.7 & 6.12 & 1841.0 & -24.65 \\
\hline $187-5-3-1 b$ & N101/E51 & $20-30$ & 1 & 42.543 & 145.3 & 3.91 & 2350.2 & -25.47 \\
\hline $187-5-3-2 a$ & N101/E51 & $20-30$ & 1 & 40.472 & 10.1 & 4.63 & 162.8 & -23.45 \\
\hline 263-5-3-1b & N102/E47 & $35-40$ & 1 & 7.058 & 43.3 & 8.23 & 538.6 & -24.13 \\
\hline $274-5-3-1 b$ & N102/E50 & $40-50$ & 1 & 2.998 & 21.4 & 5.63 & 376.8 & -23.69 \\
\hline $274-5-3-2 b$ & N102/E50 & $40-50$ & 1 & 24.516 & 223.7 & 7.05 & 2656.4 & -23.30 \\
\hline $352-5-3-1 b$ & N103/E47 & $35-40$ & 1 & 40.293 & 171.1 & 2.00 & 2597.1 & -26.33 \\
\hline $352-5-3-2 d$ & N103/E47 & $35-40$ & 1 & 1.650 & 23.0 & 4.64 & 396.6 & -24.63 \\
\hline $370-5-3-1 b$ & N103/E51 & $28-40$ & 1 & 30.608 & 96.5 & 7.09 & 1254.1 & -23.19 \\
\hline $89-5-3-1 b$ & N100/E51 & $20-30$ & $1 \mathrm{a}$ & 23.362 & 26.0 & 2.49 & 475.5 & -25.97 \\
\hline $89-5-3-2 b$ & N100/E51 & $20-30$ & $1 \mathrm{a}$ & 8.625 & 51.4 & 2.89 & 840.2 & -25.37 \\
\hline 271-5-3-1b & N102/E50 & $10-20$ & $1 \mathrm{~b}$ & 6.751 & 13.7 & 1.08 & 203.9 & -25.66 \\
\hline $273-5-3-2 b$ & N102/E50 & $28-40$ & $1 \mathrm{~b}$ & 19.183 & 182.6 & 5.93 & 2186.9 & -25.09 \\
\hline $273-5-3-3 b$ & N102/E50 & $28-40$ & $1 \mathrm{~b}$ & 30.054 & 79.7 & 6.81 & 1062.6 & -22.55 \\
\hline 293-5-3-1b & N102/E52 & $20-30$ & $1 c$ & 3.645 & 17.3 & 5.78 & 370.4 & -24.18 \\
\hline $293-5-3-3 b$ & N102/E52 & $20-30$ & $1 \mathrm{c}$ & 22.800 & 114.3 & 3.94 & 1746.7 & -24.89 \\
\hline 293-5-3-1b & N102/E52 & $20-30$ & $1 c$ & 5.439 & 32.3 & 6.72 & 533.1 & -24.54 \\
\hline $11-5-3-1 b$ & N99/E51 & $9-20$ & $1 d$ & 40.574 & 66.5 & 7.83 & 1033.4 & -23.24 \\
\hline $11-5-3-2 b$ & N99/E51 & $9-20$ & $1 \mathrm{~d}$ & 30.178 & 376.7 & 3.41 & 2891.2 & -24.97 \\
\hline $11-5-3-3 b$ & N99/E51 & $9-20$ & $1 d$ & 47.687 & 26.0 & 3.17 & 516.7 & -25.90 \\
\hline $801-5-3-3 b$ & N115/E73 & $20-27$ & 15 & 32.874 & 164.6 & 7.92 & 2094.2 & -23.21 \\
\hline $801-5-3-1 b$ & N115/E73 & $20-27$ & 15 & 40.271 & 43.8 & 5.53 & 752.6 & -24.48 \\
\hline $801-5-3-2 b$ & N115/E73 & $20-27$ & 15 & 3.360 & 24.6 & 6.62 & 378.6 & -25.34 \\
\hline $941-5-3-1 b$ & N123/E73 & 26-37 & 28 & 7.756 & 25.7 & 2.38 & 717.3 & -24.69 \\
\hline $941-5-3-2 b$ & N123/E73 & $26-37$ & 28 & 30.576 & 211.3 & 8.66 & 2010.8 & -22.05 \\
\hline $962-5-3-1 b$ & N124/E73 & $20-30$ & 29 & 1.346 & 16.3 & 5.68 & 313.9 & -26.71 \\
\hline $966-5-3-1 b$ & N124/E74 & $19-31$ & 29 & 12.626 & 6.1 & -5.96 & 54.6 & -28.39 \\
\hline
\end{tabular}

1. Values below 10.0 make the results suspect

2. $\mathrm{C}=$ Carbon; $\mathrm{N}=$ Nitrogen 
The 0.1 liters of light fraction (\#89-5-4-1) yielded only 11 indeterminate charcoal flecks (Appendix I). The heavy fraction yielded four tiny burned rock fragments, 42 chert, 28 tiny charcoal pieces, and eight tiny bone fragments. The $6.4 \mathrm{~mm}$ mesh fraction yielded 10 burned rock pieces, one chert flake, two pieces of charcoal, four complete snail shells, and one small bone fragment.

A $4.5 \mathrm{~cm}$-long bone fragment (\#89-5-2-1) of deer/antelope size animal radiocarbon dated, producing a ${ }^{13} \mathrm{C}$-corrected (-31.6\%) AMS radiocarbon date of $890 \pm 40$ B.P. (Table 9-1: UGA-12708). The age of this one bone is thus much younger than the charcoal dates obtained from elsewhere in Feature 1, and is considered unacceptable as the true age of Feature 1.

\subsubsection{Feature $1 b$}

Feature 1b, a cluster of 53 burned rocks, was identified in Unit N102/E50 towards the northern edge of the broader Feature 1 burned rock distribution (Figure 9-4). It was mostly recognized in the northeastern quadrant of Unit N102/E50, but part of it probably extended into the Phase I 50-by- $50 \mathrm{~cm}$ test pit (the southwestern quarter of Unit N103/E50) along the southern edge of BT 2 . This cluster is not easily distinguished from the rest of Feature 1 in this unit, but the burned rocks appeared to be somewhat more clustered. Most of the rocks were at a depth between 28 and $35 \mathrm{cmbd}$ and formed a single layer. The general cluster was oval in outline and lacked any indication of a basin, charcoal or ash concentrations, or other signs of in situ heating.

Five limestone burned rocks were sampled for lipid residues. The detailed results are presented in Appendix G, with a summary presented here (Table 9-3). Samples \#273-5-3-2a and \#274-53-1a both yielded high fat content. Samples \#273-5-3-1a and \#274-5-3-2a yielded borderline moderate-to-high and high fat content, all interpreted as representing plants. Sample \#2735-3-3a yielded borderline high and very high fat content also interpreted as representing plants. All five results are similar, implying that these rocks were used to cook similar plants. Parts of these same burned rocks (\#271-5-3-1b, \#273-53-2b, and \#273-5-3-3b) were also sampled for stable carbon and nitrogen isotopes (Table 9-4). The three samples have an average $\delta^{13} \mathrm{C}$ value of $-24.5 \%$. The average $\delta^{15} \mathrm{~N}$ value is $4.6 \%$, with one very low value and two moderately high values. The isotope values generally indicate $\mathrm{C}_{3}$ plants.

Following the removal of the burned rocks, the matrix from around the rocks was collected for subsequent flotation in the laboratory. Twentyone liters of floated matrix (\#273-5-4) from the upper part of this feature (between 26 and $38 \mathrm{cmbd}$ ) yielded a heavy and light fraction. The $6.4 \mathrm{~mm}$-size mesh yielded 16 tiny burned rocks, 37 pieces of chert, one tiny fleck of charcoal, 11 snail shells, and eight tiny bone fragments that weigh $1.9 \mathrm{~g}$. Two bones are burned a brown color. Ten, or 27 percent, of the flakes are burned. The heavy fraction yielded 108 tiny burned rock fragments, 138 chert pieces, 28 tiny charcoal pieces, three complete snail shells, and 96 tiny bone fragments. Twelve bones were burned. The 0.2 liters of light fraction yielded quantities of charcoal, which included $10 \mathrm{ml}$ of juniper, three pieces of mesquite, one burned prickly pear seed, one buttonbush piece, one piece of oak, six agave leaf fragments, and 12 indeterminate pieces (Appendix I). A charred littleleaf walnut shell (\#273-5-7) was found at the very top part of Feature 1b (Appendix I).

One tiny piece of charcoal (\#273-4-2-1) yielded a $\delta^{13} \mathrm{C}$ corrected (-24.5\%) AMS radiocarbon age of 2,310 \pm 40 B.P. (Table 9-1: Beta-175403). This is an acceptable age for the Late Archaic. 
The 12 liters of matrix from the lower part of the feature (\#274-5-4-1) yielded a considerable quantity of cultural material. The 0.1 liters of light fraction yielded one piece of buttonbush, one piece of oak, 14 milliliters of juniper, and 12 pieces that were of indeterminate species (Appendix I). Juniper dominated the charcoal. The heavy fraction yielded 33 tiny burned rock fragments, 153 tiny chert pieces, 53 tiny charcoal fragments, five complete snail shells, and no bones. The $6.4 \mathrm{~mm}$ mesh fraction yielded 17 tiny burned rock pieces, five pieces of chert debris, 20 completed snail shells, but no bone fragments. Two chert flakes that were recovered from the float sample were burned.

Outside Feature 1b, the rest of Unit N102/E50 yielded nearly 39 pieces of lithic debitage, one bone fragment, five Rabdotus shells, and one edge-modified tool (\#273-10). The lower level, between 40 and $50 \mathrm{cmbd}$, yielded the distal part of a late stage chert biface (\#274-5-11), an edgemodified flake (\#274-5-11), five pieces of chert debitage, and seven nearly complete Rabdotus shells.

\subsubsection{Feature 1c}

Feature 1c, a cluster of 323 burned rocks, was recognized in the northern half of Unit N102/E52 and the southern half of Unit N103/E52 along the northeastern edge of the broader burned rock distribution (Figure 94). Backhoe trench 2 truncated this cluster; therefore, the overall shape and original size is not clear. These burned rocks appeared more tightly clustered than surrounding burned rocks, but no obvious boundary or easy demarcation line was observed between these burned rocks and those in the broader Feature 1. This cluster appeared to extend to the west and north, but terminated near the eastern edge of Unit N103/E52. The excavated part measured $100 \mathrm{~cm}$ east west and 60 to $200 \mathrm{~cm}$ north-south, with most burned rocks between elevation 18 and $25 \mathrm{cmbd}$. These burned rocks primarily formed a single layer with only a few rocks lying on top of one another. No basin was detected, no charcoal, ash, or oxidized matrix was observed.

The 323 burned rocks are all limestone. Nearly 57 percent fell in the 4.1 to $9 \mathrm{~cm}$ size class, whereas nearly 35 percent were in the smallest, 0 to $4 \mathrm{~cm}$ size class. The average weight of the burned rocks was $108 \mathrm{~g}$.

Three burned rocks from this cluster were sent for lipid residue analysis. The detailed results are presented in Appendix G, with a summary presented here (Table 9-3). All three yielded high fat content, again interpreted as representing plants. Similar results imply these rocks cooked the same plants. Parts of the same three burned rocks were also sampled for stable carbon and nitrogen isotopes (Table 9-4). The three samples have an average $\delta^{13} \mathrm{C}$ value of $24.5 \%$. The average $\delta^{15} \mathrm{~N}$ value is $5.5 \%$, with one relatively low value and two moderate high values. The isotope values generally indicate $\mathrm{C}_{3}$ plants.

Following the removal of the rocks, the remaining matrix that surrounded the burned rocks was collected and subsequently floated in the laboratory. The light fraction yielded no sign of charred material.

Unit N102/E52 yielded 47 pieces of lithic debitage, 39 bone fragments, two edge-modified flakes (\#293-5-10 and 11), one middle stage biface (\#293-5-12), one end-side scraper (\#2935-13), and three mussel shell fragments. The scraper and mussel shell came from the southern margin of this cluster.

A long bone fragment (\#293-2-1a), weighing $6.8 \mathrm{~g}$, was also found in Feature 1c. It is pinkish gray (5YR 7/2) in color, which implies that it was potentially part of the overlying Toyah component, and was submitted for radiocarbon 
dating. This bone yielded a $\delta^{13} \mathrm{C}$ corrected (9.8\%) AMS radiocarbon date of $860 \pm 40$ B.P. (Table 9-1: UGA-12713). The carbon isotope value obtained on this element indicate that it is from a bison, which yields a significantly more positive carbon value than do deer or antelope bones. The probability of this bone representing a bison supports the belief that this bone originated in the overlying Toyah component and was not associated with the Late Archaic component. The date would indicate this bone came from an occupation younger than the Late Archaic component, was displaced downward, and again is not representative of the Late Archaic component.

\subsubsection{Feature 1d}

Feature 1d, a cluster of 30 burned rocks, was identified at the extreme southern edge of Feature 1 in the western half of Unit N99/E51 (Figures 9-4 and 9-5). Again, these burned rocks were closer together than those in the rest of the unit. This oval cluster measured 75 by $50 \mathrm{~cm}$ in diameter with depths concentrated between 12 and $23 \mathrm{cmbd}$. The burned rocks appeared to form two layers.

The matrix inside Feature 1d appeared similar to that outside. No matrix oxidation, ash or charcoal lens was detected, and no basin was discernible.

The 30 burned rocks collected from Feature 1d were all limestone and nearly equally divided into angular and tabular pieces (Table 9-2). Nearly 77 percent are in the 4.1 to $9 \mathrm{~cm}$ size class. The lack of any rocks in the smallest size class may indicate a biased collection procedure. The average burned rock weighs $208 \mathrm{~g}$.

Three burned rocks from this cluster were sent for lipid residue analysis. The detailed results are presented in Appendix G, with a summary presented here (Table 9-3). All three samples (\#11-5-3-1a, \#11-5-3-2a, and \#11-5-3-3a)

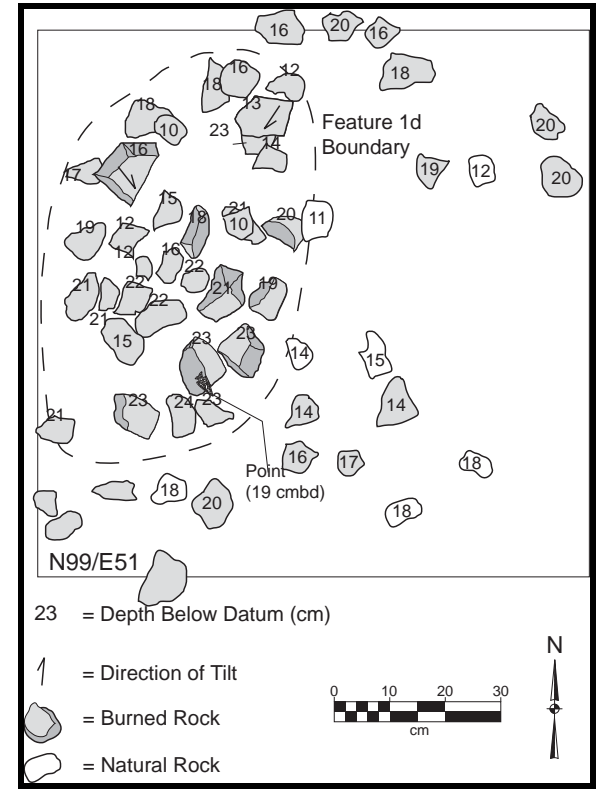

Figure 9-5. Planview of Feature 1d in Feature 1

yielded high fat content interpreted as reflecting plants.

The similar results imply that these rocks were used to cook the same plants, potentially during the same event. Parts of the same three burned rocks were also sampled for stable carbon and nitrogen isotopes (Table 9-4). The three samples have an average $\delta^{13} \mathrm{C}$ value of $-24.7 \%$. The average $\delta^{15} \mathrm{~N}$ value is $4.8 \%$, with two relatively low values and one moderate high value. The isotope values generally indicate $\mathrm{C}_{3}$ plants.

Following the removal of the burned rocks, about nine liters of remaining matrix (\#11-4-1) from between 11 and $24 \mathrm{cmbd}$ was collected and floated in the laboratory. The 0.15 liters of light fraction was sent to Dr. Dering for analysis, but no charred remains were detected (Appendix I). The heavy fraction yielded seven tiny burned rocks, 63 chert pieces, one snail shell, and 21 tiny bone fragments. The $6.4 \mathrm{~mm}$ fraction yielded 14 tiny burned rocks, six chert pieces, and four complete snail shells. 
Six tiny pieces of charcoal (\#11-5-4-7-1a) yielded a $\delta^{13} \mathrm{C}$ corrected (-24.3\%o) AMS radiocarbon date of 1,390 \pm 40 B.P. (Table 9-1: UGA-12704). This charcoal came from the floated matrix sample.

Unit N99/E51 yielded 48 pieces of lithic debitage, seven bone fragments, tiny charcoal chunks, three edge-modified flakes (\#11-5-10, $\# 11$, and \#12), one Gower point (\#11-5-13), and one Edgewood point (\#11-5-14). The Edgewood point was discovered at $19 \mathrm{cmbd}$ and within the clustered burned rocks along the southern edge. The Gower point was probably displaced from lower in the profile, whereas the Edgewood point would fit well chronologically with the charcoal date. It was the only point of this type recovered at the Varga Site.

\subsubsection{Flotation Results, Feature 1}

These four subfeatures that exhibited slightly more clustering of constituent rocks, as compared to the rest of Feature 1, were part of the broader distribution of rocks that comprised the feature, which extended across 18 different 1-by-1 m hand-excavation units and an unknown distance to the west of the limits of the Block A excavation. The feature had an overall diameter of approximately $6 \mathrm{~m}$ and was irregularly elliptical in plan view. In total, 3,196 burned rocks that weighed $468.15 \mathrm{~kg}$ were recovered from Feature 1, including all four subfeatures (Table 9-5). This is a minimum number and weight, since part of Feature 1 was removed by BTs 1 and 2 (at least $6 \mathrm{~m}^{2}$ ), and since the feature was not entirely exposed. The average individual weight of the documented burned rocks was $146 \mathrm{~g}$.

Parts of 15 other burned rocks that came from outside the small sub-feature clusters were also submitted for lipid residue analysis (see details in Appendix G). Only a summary of those findings is presented here (Table 9-3). Six pieces (\#80-5-3-1a \#187-5-3-2a, (\#81-5-3-1a, \#179-5-3-1a, \#274-5-3-1a, and \#352-5-3-2a) yielded very high fat content interpreted as plant. Three pieces (\#161-5-3-1a and \#352-5-31a, (\#370-5-3-1a) yielded borderline high and very high fat content also interpreted as plant. One piece (\#274-5-3-2a) yielded borderline moderate to high and high fat content interpreted as plant. Two pieces (\#263-5-3-1a and \#178-53-1a) yielded borderline medium and moderate to high fat content interpreted as plant. One piece (\#98-5-3-1a) yielded borderline medium fat content and large herbivore plus plant residues. One other piece (\#179-5-3-2a) yielded low fat content interpreted as reflecting plant. In sum, most pieces revealed moderate to high fat residues from plants. Only two pieces show low fat content and one yielded possible indications of large herbivore. The general consistency identified in 85 percent of the lipid residues implies that the majority of the burned rocks scattered around in Feature 1 were probably used to cook similar types of high-fat plants, the expected result from a single large cooking feature.

Tiny parts of these same 15 burned rocks analyzed for lipid residues, were also sampled for stable carbon and nitrogen isotopes (Table 94). The 15 samples yielded an average $\delta^{13} \mathrm{C}$ value of -23.2\%. One sample (\#161-5-3-1b) yielded a very negative $\delta^{13} \mathrm{C}$ value of $-30.6 \%$. Sample \#178-5-3-1b yielded a $\delta^{13} \mathrm{C}$ value of $21.8 \%$, which is toward the more positive end of these averages. The average $\delta^{15} \mathrm{~N}$ value for the 15 samples is $5.6 \%$. The isotope values generally indicate cooking of $\mathrm{C}_{3}$ plants.

Individual charcoal pieces collected from across the $21 \mathrm{~m}^{2}$ excavated in the southwestern corner of Block A and associated with Feature 1 were submitted to Dr. Dering for identification. The burned plants identified include mesquite, 


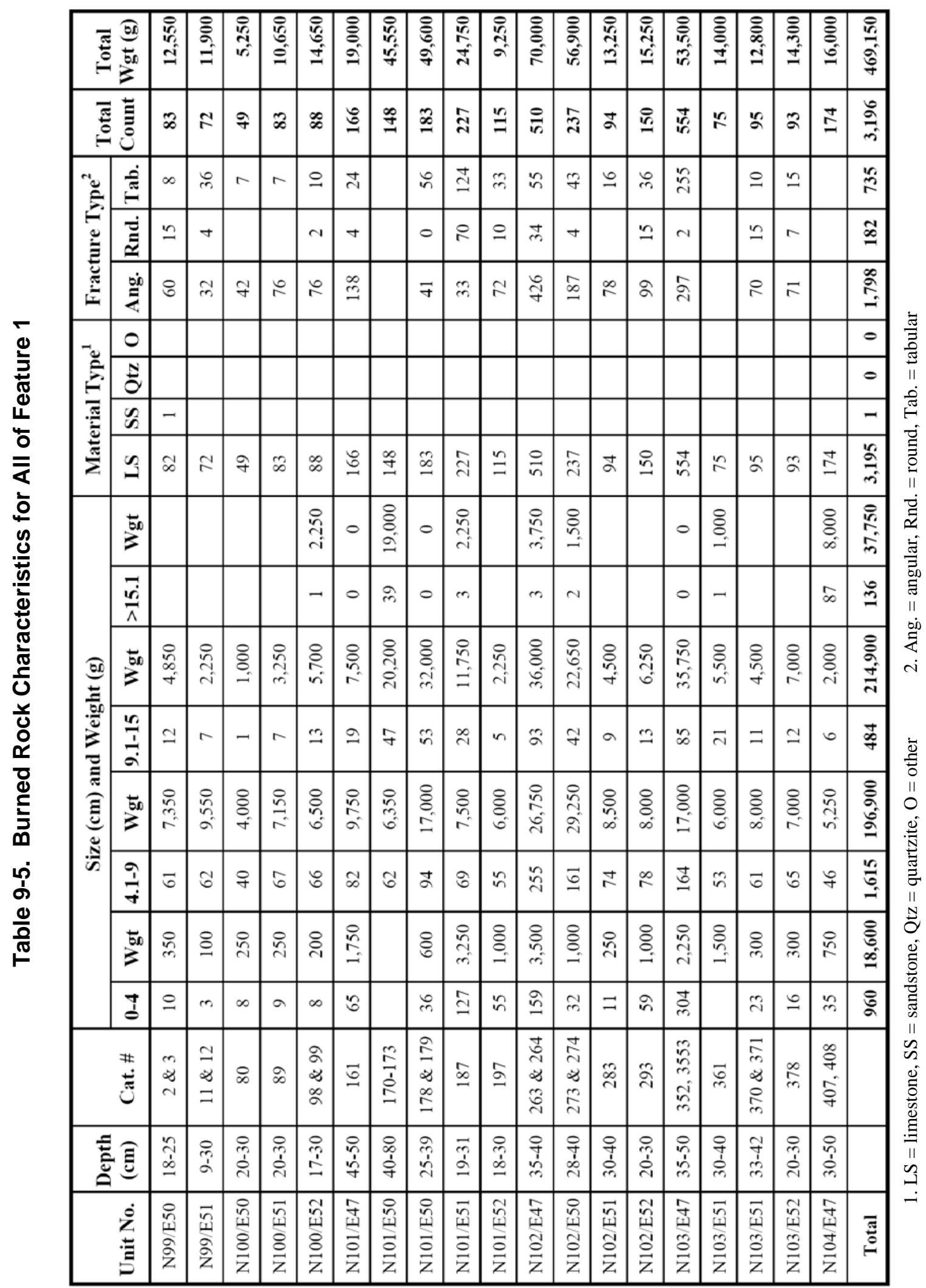


juniper, oak, green Condalia, and woody legume, with mesquite dominating. A total of 96 liters of floated matrix from 12 proveniences across Feature 1 yielded only 1.4 liters of light fractions. The light fractions yielded 183 individual pieces plus 19 milliliters of burned macrobotanical remains weighing $4.4 \mathrm{~g}$ (Appendix I). The identifiable charred plants include woods such as mesquite (37 pieces plus $34 \mathrm{ml}$ weighing $16 \mathrm{~g}$ ), juniper (34 pieces plus $14 \mathrm{ml}$, weighing a total of $2.7 \mathrm{~g}$ ), oak (19 pieces) buttonbush, lotebush plus one burned mesquite seed from Unit N101/E47; four burned prickly pear seeds from Units N101/E50 and N102/E50; and nine burned sotol-yucca-agave leaf fragments from Units N101/E50, N102/E47, and $\mathrm{N} 102 / \mathrm{E} 50$. One or all three of the latter plants, may have been food resources, especially the stool-agave-yucca leaves, which have been ethnohistorically documented as cooked in earth ovens. Mesquite wood was the dominant fuel source.

Bulk matrix samples from various locations within the broader Feature 1 were collected and floated. Along the southern margin in Unit N100/E50, six liters of sediment (\#80-5-4) were collected for flotation from near the base of the burned rocks at between 20 and $30 \mathrm{cmbd}$. The less than 0.1 liters of light fraction yielded charcoal including one piece of mesquite, one piece of juniper, one piece of buttonbush, and 21 indeterminate pieces (Appendix I). The heavy fraction yielded 14 tiny burned, 74 chert debitage pieces, 24 tiny charcoal pieces, five complete snail shells, and 14 tiny bone fragments g. Two tiny walnut shell fragments were recognized in the charcoal. The $6.4 \mathrm{~mm}$ size mesh yielded 17 burned rock fragments, five pieces of chert debitage, five pieces of charcoal, and 10 complete snail shells.

In the next lower level, less than 0.1 liters light fraction (\#81) yielded eight tiny indeterminate charcoal pieces. Heavy fraction yielded 32 tiny burned rocks, 153 chert debitage pieces, 8 tiny charcoal pieces, and four tiny bone fragments. The $6.4 \mathrm{~mm}$ size mesh yielded four burned rocks fragments, and four complete snail shells. Two liters of matrix (\#161-5-4) was collected from under and around the burned rocks in Unit N101/E47 along the very southwestern edge of Feature 1 for flotation. The $6.4 \mathrm{~mm}$ size mesh yielded only three chert flakes and five whole snail shells. The heavy fraction yielded 59 tiny chert pieces, six tiny charcoal flecks, and four whole snail shells. A tiny piece of burned walnut shell was present. The less than 0.1 liters of light fraction yielded one burned mesquite seed and eight indeterminate wood pieces (Appendix I). Also, a small pocket of ash or decaying limestone burned rock (\#161-4) was in this same unit between 45 and $50 \mathrm{cmbd}$.

Just north of the previous unit, in Unit N102/E47, five liters of matrix (\#263-5-4) from 30 to $40 \mathrm{cmbd}$ was also collected and floated. The $6.4 \mathrm{~mm}$ size mesh yielded 15 tiny burned rocks, seven chert pieces, four charcoal pieces, 14 complete snail shells, and two tiny bone fragments. Two flakes were burned and two tiny burned walnut shell fragments were present. The heavy fraction yielded 34 tiny burned rocks pieces, 72 chert pieces, 21 tiny charcoal pieces, three complete snail shells, and 35 tiny bone fragments, two of which are burned. The less than 0.1 liters of light fraction yielded three types of wood that include one piece of mesquite, one lotebush, one agave leaf fragment , and 14 indeterminate pieces (Appendix I).

One meter north in Unit N103/E47, another float sample (\#352-5-4) was collected from 30 to $40 \mathrm{cmbd}$ at what appeared the northwestern edge of Feature 1. The less than 0.1 liters of light fraction yielded two oak wood fragments, eight juniper fragments, and 19 indeterminate pieces (Appendix I). The heavy fraction yielded 11 tiny burned rock fragments, 63 chert pieces, 
61 tiny charcoal pieces, two complete snail shells, and 15 tiny bone fragments. Three of the chert pieces have been heat-altered. The $6.4 \mathrm{~mm}$ mesh yielded 24 tiny burned rock fragments, five chert pieces, four tiny charcoal pieces, and 15 complete snail shells. No bone was recovered from the floated matrix.

From along what appeared to be the southeastern rim of the possible central pit, two levels were sampled for floatation. A nine-liter matrix sample (\#178-5-4) was collected from between 20 and $25 \mathrm{cmbd}$ near the top of the feature. The $6.4 \mathrm{~mm}$ mesh fraction yielded 32 tiny burned rock fragments, 20 chert flakes, and 11 complete snail shells. Two of the chert pieces were heataltered. The heavy fraction yielded another 29 tiny pieces of burned rock fragments, 126 chert pieces, 61 tiny pieces of charcoal, 11 complete snail shells, and 32 tiny bone fragments. Six of the bones recovered from the floated matrix were burned. The less than 0.1 liters of light fraction yielded $5 \mathrm{ml}$ of tiny charcoal pieces that were not identifiable to species (Appendix D).

A 12 liter matrix sample (\#179-5-4) was collected from between 25 and $39 \mathrm{cmbd}$ in the lower level. The $6.4 \mathrm{~mm}$ size mesh yielded eight chert flakes, one tiny charcoal piece, and 13 complete snail shells. The heavy fraction yielded 41 tiny burned rock fragments, 163 chert pieces, 56 charcoal pieces, 11 complete snail shells, and 23 tiny bone fragments, of which two are burned. The 0.1 liters of light fraction yielded three prickly pear seeds, two agave leaf fragments, two pieces of oak wood, one piece of juniper, and 12 indeterminate plant pieces (Appendix I).

One meter east in Unit N101/E51, another float sample (\#187-5-4) of about five liters was collected from 20 to $30 \mathrm{cmbd}$ around and below the burned rocks. The $6.4 \mathrm{~mm}$ size mesh yielded 45 tiny burned rock fragments, 39 tiny pieces of chert, one charcoal piece, 28 complete snail shells, and 39 tiny bone fragments. Nine bone fragments and four chert pieces recovered from the float were burned. The heavy fraction yielded 113 tiny burned rock fragments, 756 pieces of chert, 63 tiny charcoal pieces, four complete snail shells, and 517 tiny bone fragments, sixty-four of which were burned. One burned walnut and possibly one burned pecan shell are present. The 0.1 liters of light fraction yielded one piece of juniper, six pieces of lotebush, and 20 indeterminate pieces (Appendix I).

\subsubsection{Discussion of Feature 1}

With four recognizable clusters of burned rocks and areas nearly void of burned rocks all within Feature 1, the density of burned rocks was quite variable. The trench profiles revealed that the thickest section of Feature 1 was located near the eastern side of BT 1 . The original 50-by$50 \mathrm{~cm}$ test pit in Unit N101/E50 encountered nearly $30 \mathrm{~cm}$ of stacked burned rocks in that small area. These dense concentrations indicate that Feature 1 may be an incipient burned rock midden. A basin was not detected in any of the individual excavation units, though burned rock lens does have a saucer-shaped profile.

The hand-excavations in Unit N100/E50 revealed a concentration of burned rocks that formed a broad curving arc. The rocks unit had an average weight of $362 \mathrm{~g}$, and the average weight of the burned rocks in the 50 -by-50 cm test pit were even greater, at $470 \mathrm{~g}$. The average rock weights reveal that the burned rocks in this particular area were the largest pieces documented and may represent the central core area of the broader incipient midden (see Figure 9-4). If Feature 1 represents the remains of an earth oven and the shallow (15 cm deep), basin was used in the cooking process, then this would account for the broad scatter and a few clusters of burned rocks in the immediately 
surrounding area. Based on the presence of at least four clusters of burned rocks, the quantities of burned rock present, the relatively small average size of the individual rocks (147 g), it is quite likely that this cooking feature was used on more than one occasion. As the limestone rocks were used over and over again, they fractured, resulting in smaller sizes (Leach et al. 1998).

Ten radiocarbon dates were obtained from Feature 1. If the three significantly younger dates (550 B.P., 890 B.P. and 1,390 B.P.) are assumed to be from intrusive materials, then the radiocarbon results indicate a 590-year time range, from 1,700 to 2,290 B.P., during which Feature 1 developed. The seven acceptable radiocarbon ages place the feature securely within the Late Archaic.

Nine dart points and two Cliffton arrow points were recovered from the area Feature 1 . The nine dart points include one Early CornerNotched point (\#283-14), one Marcos (\#187-10), one Montell (\#198-10), three Frio points (\#2215 , \#89-10, and \#187-11), one Edgewood point (\#11-14), one untyped Group 2 (\#170-10), and one untypable dart point that is similar to a Frio or a Montell (\#53-11). The two Cliffton points (\#12-10 and \#22-14) are thought to have been displaced downward and are considered intrusive from the immediately overlying Toyah component. It is not clear if the Group 2 and Early Corner-Notched point is intrusive or a point that was picked up and used/curated during the Late Archaic. In addition to the projectile points, six bifaces (\#2-12, \#263-10, \#178-10, \#197-16, \#283-15, and \#293-12), three scrapers (\#2-10, \#3-10, and \#293-14), four cores (\#16111, \#162-14, \#352-10, and \#293-14), and 47 edge-modified flakes were scattered across the hand-excavated area of Feature 1. Lightcolored and non-weathered bone fragments that are identical in appearance to the bones in the overlying Toyah component were also encountered in the top part of the Feature, and these also indicate some downward translocation of materials.

If Feature 1 was the remains of a cooking feature, then the few leaf fragments of sotolyucca-agave might be the best indication as to what was cooked. Plants of the agave family are best cooked in an earth-covered oven. Mesquite apparently was the principal fuel source, although other woods were also used. The inclusion of burned prickly pear seeds and mesquite beans may be accidental burning of other cooked food resources.

\subsubsection{Feature 7}

Feature 7 was discovered and excavated in the southeastern corner of Test Pit 5 as part of the Phase I investigation; a unit that was later designated Unit N118/E73 within Block B. It consisted of an irregularly ovate, loose cluster of 11 burned rocks measuring approximately 55 by $45 \mathrm{~cm}$ and resting between 26 and $30 \mathrm{cmbs}$ (Figure 9-6).

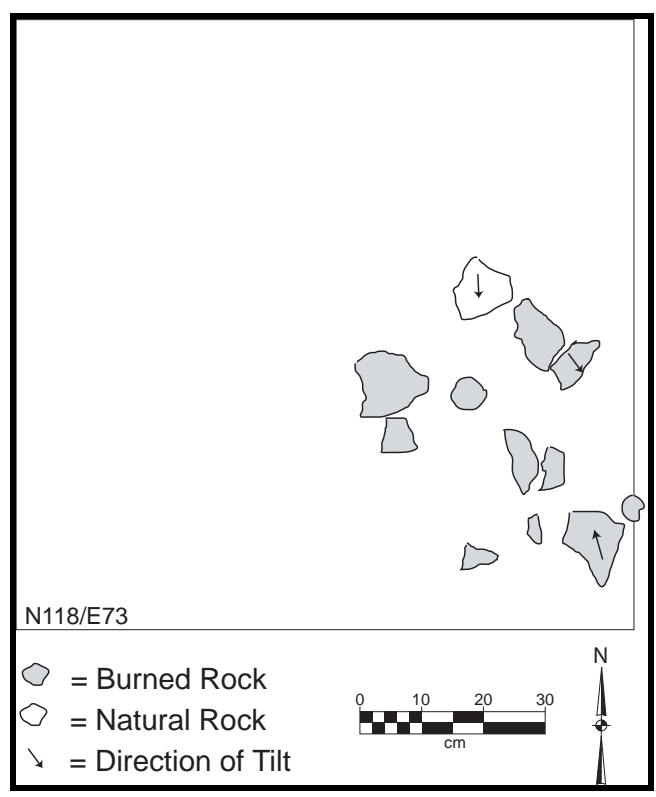

Figure 9-6. Planview of Feature 7 in Block B 
The 11 burned rocks were all limestone and formed a single layer. The rocks are nearly equally divided between the 4.1 to $9 \mathrm{~cm}$ and the 9.1 to $15 \mathrm{~cm}$ size classes (Table 9-6). The average weight of the rocks is $295 \mathrm{~g}$.

No basin/pit, charcoal, or ash was noted among the burned rocks. Flotation samples and burned rock residue samples were not collected. The only artifacts found in proximity are chert flakes. Feature 7 appears isolated from other Late Archaic features, and probably represents a discard location.

\subsubsection{Feature 15}

Feature 15 was a small cluster of burned rocks located in Unit N115/E73 in Block B. It consisted of 31 burned rocks in an ovate area that measured 25 by $35 \mathrm{~cm}$ in diameter (Figure 9-7). The bottoms of the burned rocks were between 21 and $28 \mathrm{cmbs}$ and appeared to have limited vertical displacement on an irregular surface, since no pit was detected. The 31 rocks were all limestone and in three different size classes with the larger 9.1 to $15 \mathrm{~cm}$ size class represented by the fewest pieces (Table 9-6). The specimens include seven spalls from larger rocks, three angular pieces, and two pieces that show no obvious fractures. No pieces refit to other pieces. The average rock weight is $126 \mathrm{~g}$.

A very dark grayish brown (10YR 3/2) matrix surrounded the burned rocks and lacked visible charcoal or oxidation as would indicate in situ burning. No other cultural materials were observed between the burned rocks and very little was recovered from the rest of the unit. The matrix (\#801-5-4) that surrounded the burned rocks at 20 to $27 \mathrm{cmbd}$ was collected for flotation in the laboratory. The heavy fraction from the western side of Feature 15 yielded 16 tiny pieces of lithic debitage and one whole, but unburned, hackberry seed. The heavy fraction from the eastern side yielded six burned

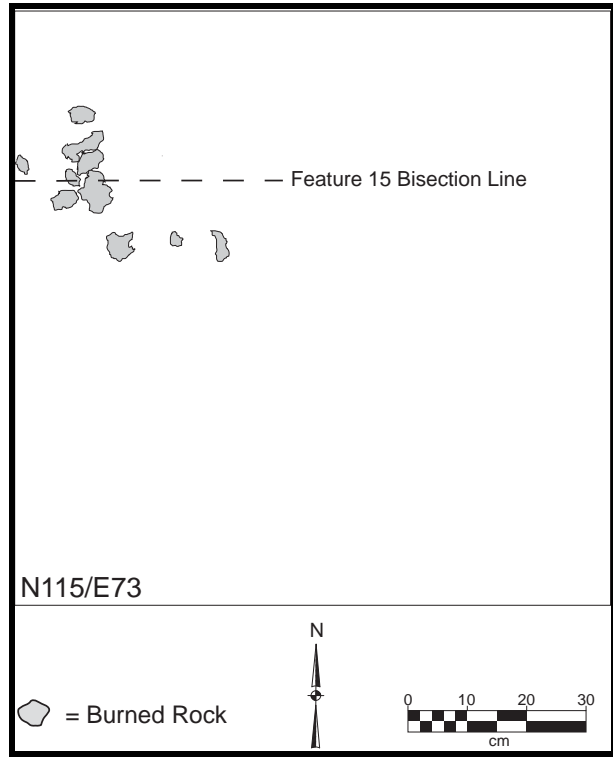

\section{Figure 9-7. Planview of Feature 15 in Block B}

rock fragments, 23 pieces of lithic debitage, four tiny pieces of charcoal g, and 11 tiny bone fragments, two of which were burned. The 0.2 liters of light fraction failed to yield any charred organic remains (Appendix I). The $6.4 \mathrm{~mm}$ size fraction from the western side yielded two pieces of burned chert debitage and two nearly complete snail shells. The $6.4 \mathrm{~mm}$ size fraction from the eastern side yielded one piece of chert and 12 nearly complete snail shells.

One wood charcoal piece (\#801-5-4-7-2a) from the floated matrix of Feature 15 yielded a $\delta^{13} \mathrm{C}$ corrected (-24.5\%) AMS radiocarbon date of 2,140 \pm 40 B.P. (Table 9-1: UGA-12725). This age determination documents Feature 15 as representing a Late Archaic event and is equivalent in age with Feature 1 in Block A. 


\begin{tabular}{|c|c|c|c|c|c|c|c|c|c|c|}
\hline \multirow{2}{*}{\multicolumn{2}{|c|}{ 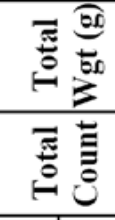 }} & 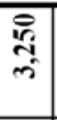 & $\begin{array}{l}\text { 赵 } \\
\text { m. }\end{array}$ & ले & $\begin{array}{l}\text { ले } \\
\text { ले }\end{array}$ & $\begin{array}{l}\bar{\Xi} \\
\text { si }\end{array}$ & 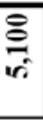 & 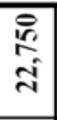 & $\begin{array}{l}\text { लै } \\
\text { लิ }\end{array}$ & 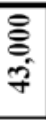 \\
\hline & & $=$ & $\exists$ & $\bar{m}$ & $\vec{m}$ & $\cong$ & 2 & $\widetilde{\sigma}$ & $\stackrel{\bullet}{\circ}$ & $\stackrel{2}{2}$ \\
\hline \multirow{3}{*}{ 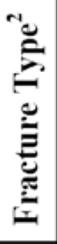 } & $\dot{\vec{E}}$ & $\sim$ & $N$ & $n$ & $n$ & 0 & 0 & $\Xi$ & $\nabla$ & $\bar{v}$ \\
\hline & $\dot{\vec{\Xi}}$ & - & - & + & + & + & + & $m$ & - & $\sigma$ \\
\hline & 它 & $\infty$ & $\infty$ & $\tilde{\lambda}$ & $\tilde{N}$ & $m$ & $m$ & $\mathcal{\gamma}$ & $=$ & $\because ?$ \\
\hline \multirow{4}{*}{ 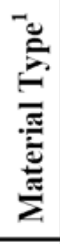 } & 0 & & 0 & & 0 & & 0 & & & 0 \\
\hline & పे & & $\theta$ & & 0 & & $\theta$ & & & 0 \\
\hline & 2 & & $\theta$ & & 0 & & $\theta$ & & & 0 \\
\hline & 3 & $=$ & $\approx$ & $\vec{m}$ & $\vec{m}$ & $\cong$ & 2 & $\widetilde{\sigma}$ & 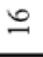 & $\stackrel{\infty}{\sim}$ \\
\hline \multirow{8}{*}{ 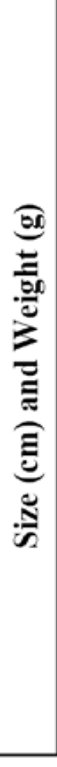 } & $\vec{b}^{5}$ & & $\theta$ & 0 & 0 & 0 & 0 & 号 & $\begin{array}{l}\text { ¿े } \\
=\end{array}$ & $\begin{array}{l}\stackrel{8}{\circ} \\
= \\
=\end{array}$ \\
\hline & 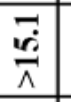 & & $\theta$ & 0 & $\theta$ & 0 & $\theta$ & $\sim$ & $N$ & $\nabla$ \\
\hline & $\vec{z}^{+\infty}$ & 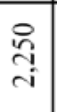 & 突 & $\stackrel{n}{=}$ & 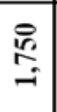 & $\begin{array}{l}8 \\
\text { n. } \\
m \\
m\end{array}$ & 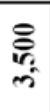 & $\stackrel{8}{\circ}$ & $\begin{array}{l}\stackrel{8}{6} \\
6 \\
6\end{array}$ & $\begin{array}{l}\stackrel{8}{\mathbb{4}} \\
\stackrel{+}{ \pm}\end{array}$ \\
\hline & $\frac{0}{1}$ & in & 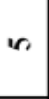 & $r$ & $r$ & 0 & 0 & $a$ & $r$ & $\cong$ \\
\hline & $\sum^{5}$ & $\underset{\hdashline}{\stackrel{\Xi}{-}}$ & $\stackrel{\Xi}{\stackrel{E}{-}}$ & 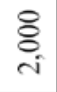 & $\underset{\mathrm{i}}{\mathrm{i}}$ & 号 & 莺 & 空 & $\stackrel{n}{a}$ & ڤ్ \\
\hline & $\stackrel{i}{+}$ & 0 & 6 & 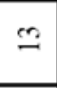 & 2 & $\nabla$ & $\sigma$ & $\hat{\sim}$ & in & లె \\
\hline & $E^{5}$ & & & $\because$ & $\stackrel{8}{9}$ & 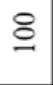 & $\stackrel{乛}{\Xi}$ & 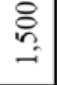 & iㅗ & $\begin{array}{l}\mathbb{N} \\
\text { i }\end{array}$ \\
\hline & $\stackrel{I}{0}$ & & & $\exists$ & $=$ & $m$ & $n$ & $\dot{\sim}$ & $N$ & $\stackrel{\sim}{*}$ \\
\hline \multicolumn{2}{|r|}{ 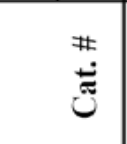 } & $\tilde{\infty}$ & & $\vec{\infty}$ & & $\vec{g}$ & & 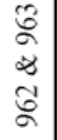 & ஜ & \\
\hline \multicolumn{2}{|c|}{ 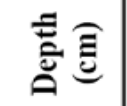 } & ஓे & & ஸे̀ & & 宊 & & હे & $\vec{\Omega}$ & \\
\hline \multicolumn{2}{|c|}{$\begin{array}{l}\dot{\delta} \\
\dot{G} \\
\dot{B}\end{array}$} & 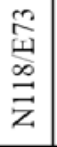 & 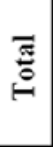 & $\begin{array}{l}\stackrel{m}{9} \\
\stackrel{n}{z} \\
\vec{z}\end{array}$ & $\stackrel{\bar{\pi}}{\circ}$ & 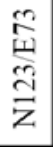 & है & 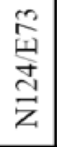 & 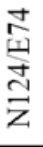 & 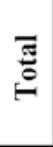 \\
\hline \multicolumn{2}{|c|}{ 远 } & $n$ & & $\cong$ & & $\stackrel{\sim}{\sim}$ & & নి & సి & \\
\hline
\end{tabular}


Parts of three burned rocks from this cluster were sent for lipid residue analysis. The detailed results are presented in Appendix G, with a summary presented here (Table 9-3). All three samples (\#801-5-3-1a, \#801-5-3-2a, and \#801-53-3a) yielded high fat content, interpreted as representing plants. The similar results imply these rocks cooked similar kinds of plants. Parts of these same three burned rocks were also sampled for stable carbon and nitrogen isotopes (Table 9-4). The three samples yielded an average $\delta^{13} \mathrm{C}$ value of $-24.3 \%$ and an average $\delta^{15} \mathrm{~N}$ value of $6.7 \%$ indicating $\mathrm{C}_{3}$ plants.

This cluster of burned rock is interpreted to represent discarded cooking rocks, rather than an in situ cooking facility. The lack of any appreciable amount of charcoal, or other evidence of in situ burning indicates these rocks were dumped here. Based on the lipid residue results the rocks were used in cooking plants, mostly $\mathrm{C}_{3}$ type plants.

\subsubsection{Feature 28}

Feature 28 was located in the southwestern corner of Unit N123/E73 in Block B and immediately beneath the overlying Toyah Component. This was a cluster of 13 burned rocks in no apparent pattern in an area that generally measured 40 by $50 \mathrm{~cm}$ in diameter (Figure 9-8). The burned rocks were at 28 to 36 cmbs, but did not appear in a basin. No charcoal, ash, or oxidized matrix was observed, and no matrix was collected. The 13 burned rocks were generally greater than $4 \mathrm{~cm}$ in diameter with an average rock weight of $392 \mathrm{~g}$ (Table 9-6).

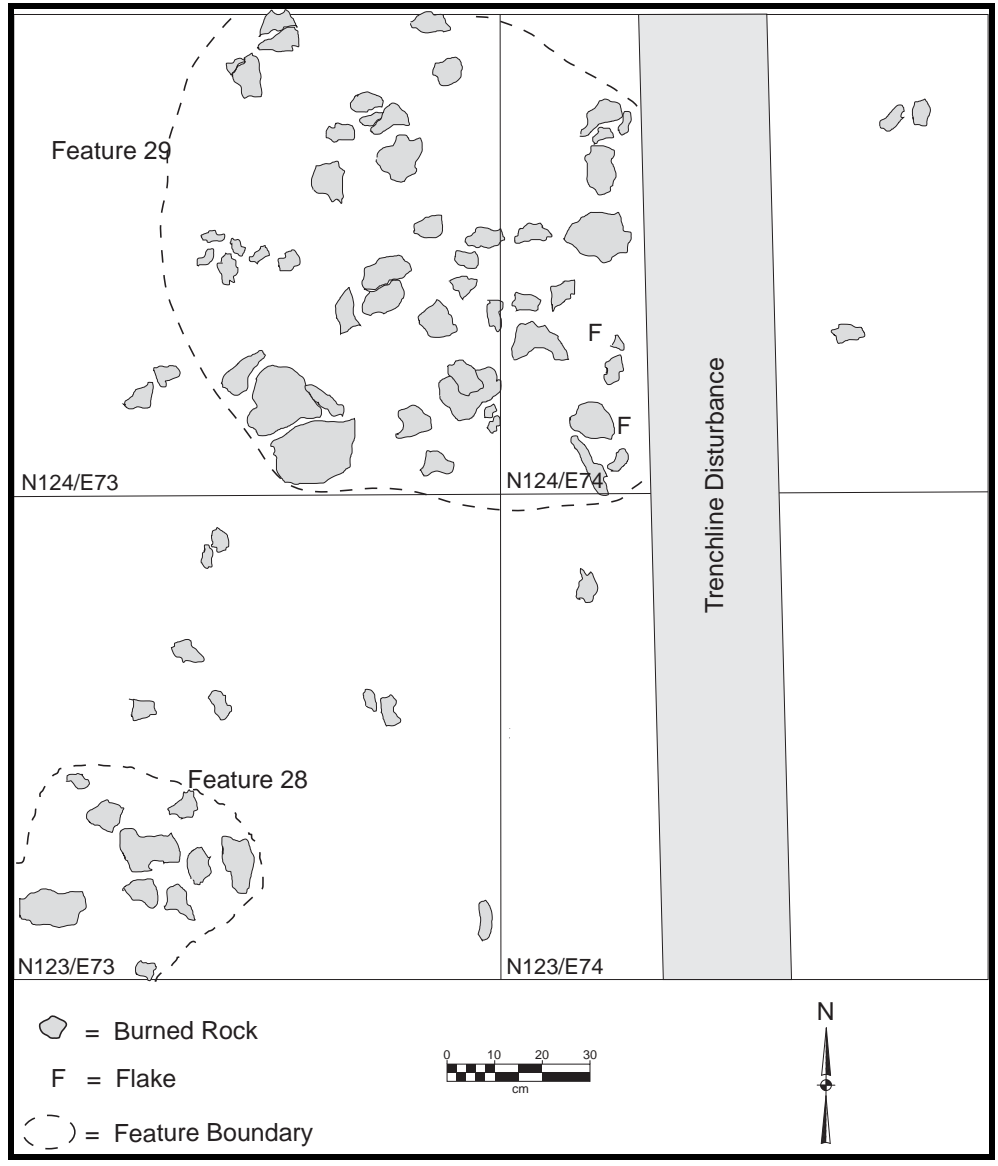

Figure 9-8. Planview of Feature 28 and 29 in Block B 
Parts of two burned rocks were sent for lipid residue analysis. The detailed results (Appendix G), are only briefly summarized here (see also Table 9-3). Sample \#941-5-3-1a yielded insufficient lipids for analysis. Sample \#941-5-3-2a yielded very high fat content interpreted as representing plants. Parts of the same two burned rocks were also sampled for their stable carbon and nitrogen isotopes (Table 9-4). The two samples have an average $\delta^{13} \mathrm{C}$ value of $-23.4 \%$ ond an average $\delta^{15} \mathrm{~N}$ value of 5.5\%o, indicating $\mathrm{C}_{3}$ plants.

A few other burned rocks and five pieces of lithic debitage were scattered across the rest of this unit. The soil across this level was a very dark grayish brown (10YR 3/2), distinguishable from the soil that contained the overlying Toyah materials. This burned rock cluster, with its lack of a containing basin or other evidence of in situ burning, is interpreted as a result of discard of rocks used to cook plants with a very high fat content.

\subsubsection{Feature 29}

Feature 29 was discovered in Units N124/E73 and N124/E74 in Block B and roughly $65 \mathrm{~cm}$ north of Feature 28. It consisted of a loose cluster of 78 burned rocks with no clearly definable boundaries and an irregular outline. The average burned rock weighs $551 \mathrm{~g}$ (Table 9$6)$. The burned rocks were clustered in an area of about 100-by- $90 \mathrm{~cm}$, but a telephone line trench truncated the eastern margin (Figure 9-8). The burned rocks were located between 22 and $38 \mathrm{cmbs}$, but not in a visible basin or pit. No charcoal, ash, or oxidized matrix was observed.

Parts of two burned rocks were sent for lipid residue analysis (Table 9-3). Both samples (\#966-5-3-1a and \#962-5-3-1a) yielded a very high fat content interpreted as representing plants.
Parts of these same two burned rocks sampled for lipid residues were also sampled for stable carbon and nitrogen isotopes (Table 9-4). Sample \#966-5-3-1b yielded a very limited nitrogen value, rendering the results suspect. The $\delta^{13} \mathrm{C}$ value is $-28.4 \%$ indicating a very negative $\mathrm{C}_{3}$ value. This value indicates a $\mathrm{C}_{3}$ plant. Sample \#962-5-3-1b yielded a $\delta^{15} \mathrm{~N}$ value of $5.7 \%$ with a $\delta^{13} \mathrm{C}$ value is $-26.7 \%$.

A bone was plotted near the same depth of the burned rocks, but based on it macroscopic appearance, it is thought to be intrusive from the overlying Toyah component. No matrix samples were collected from this very dark grayish brown (10YR 3/2) soil.

Although some lithic debitage and tiny bone fragments were in the upper part of this zone, they probably were displaced downward from the overlying Toyah component. This cluster represents a dump of burned rocks from cooking activities, since no in situ burning or basin was apparent. The rocks may have come from a single event, since the lipid residues were identical.

\subsection{StOne TOOL Descriptions AND Discussions}

The $83-\mathrm{m}^{2}$ hand-excavated sediments in Block A, plus another $35.5 \mathrm{~m}^{2}\left(3.5 \mathrm{~m}^{3}\right)$ handexcavated sediments in Block B, yielded 10 features including the four subfeatures in Feature 1 and 5,916 pieces of cultural material, including 1,801 pieces of lithic debitage, 3,965 burned rocks, 41 faunal bone fragments, 69 edge-modified flakes, 17 projectile points, 10 cores, nine bifaces, three scrapers, and one nutting stone. Each of these categories are described and discussed below, beginning with materials that appeared to be associated with the features. 
The 109 formal and informal stone tools are presented below by class, with summaries of observed attributes and metric measurements. Individual artifact data is presented in tables in Appendix O. The exception is the data on edgemodified flakes, as only a select number of specimens were individually documented. The projectile point class is subdivided into identifiable point types. Formal tool classes are generally thought to represent specific tasks/activities. Many individual specimens from various tool classes were arbitrarily selected for use-wear analysis to investigate specific tool functions. Individual use-wear results are presented following each class summary.

\subsubsection{Projectile Points}

The 17 projectile points include seven, or 41 percent, that are diagnostic of other time periods, indicating mixing, curation of anachronistic items, and/or incorrect assignments in the field of levels from which these tools were collected. The non-Late Archaic points include two Cliffton arrow points (\#12-10 and \#22-14) and one distal arrow point fragment (\#378-10) that are of Toyah age, the presence of which is most easily explained by slight downward displacement, given that only a couple of centimeters separate the two components. Three other points are classified as Early Archaic points and include a Gower (\#115-13) and two Group 2-Early Corner-Notched points (\#283-14 and \#370-10). It is possible that these Early Archaic point types were collected and curated by Late Archaic people. Another possibility is that in the preparation of a basincooking feature during Late Archaic times, sediments from deeper deposits that contained older artifacts were dug up, and thus redeposited. One Middle Archaic barb fragment from a Bell-like point (\#807-10) was also recovered from the Late Archaic context from east of the road in Block B, in quite shallow deposits that could have been displaced.

Ten, or 59 percent, of the points recovered from this component are attributable to the Late Archaic period, including one proximal Castroville fragment, one complete Edgewood, one proximal Ensor, three proximal Frio point fragments, one complete Marcos, one medial Montell fragment, and two untypable dart point fragments (Figure 9-9). The general characteristics of these items are summarized below, and data on specific specimens presented in Appendix O. All were manufactured from fine-grained cherts and lack any sign of cortex. None are patinated, and all breaks are attributed to use. No point appears to have been rejuvenated before discard, although the Edgewood, Marcos, and Ensor all exhibit beveled edges that may represent resharpening prior to final breakage. The Marcos and Montell points appear to have been made of heat-treated chert. One of the three Frio points was burned. Fifty percent potentially have edge-rounding, indicative of intensive use. The point diversity hinders any attempt to summarize the metric point data, except for the Frio points. These 10 points represent five different point types, but they all fit within the general Late Archaic time frame that is indicated by the 11 radiocarbon dates.

The entire Frio assemblage of seven points, four from the Toyah and three from the Late Archaic component, are summarized in here. Only one is complete. Of the six (86 percent) broken during use, proximal sections represent 57 percent. None have rejuvenation scars and only one exhibit edge beveling. All were manufactured from fine-grained cherts, and none retain traces of cortex. One specimen is burned, and none have been heat-treated. Fifty-seven percent exhibit a triangular blade with 14 percent lanceolate and 28 percent indeterminate. The flaking pattern is discernible 


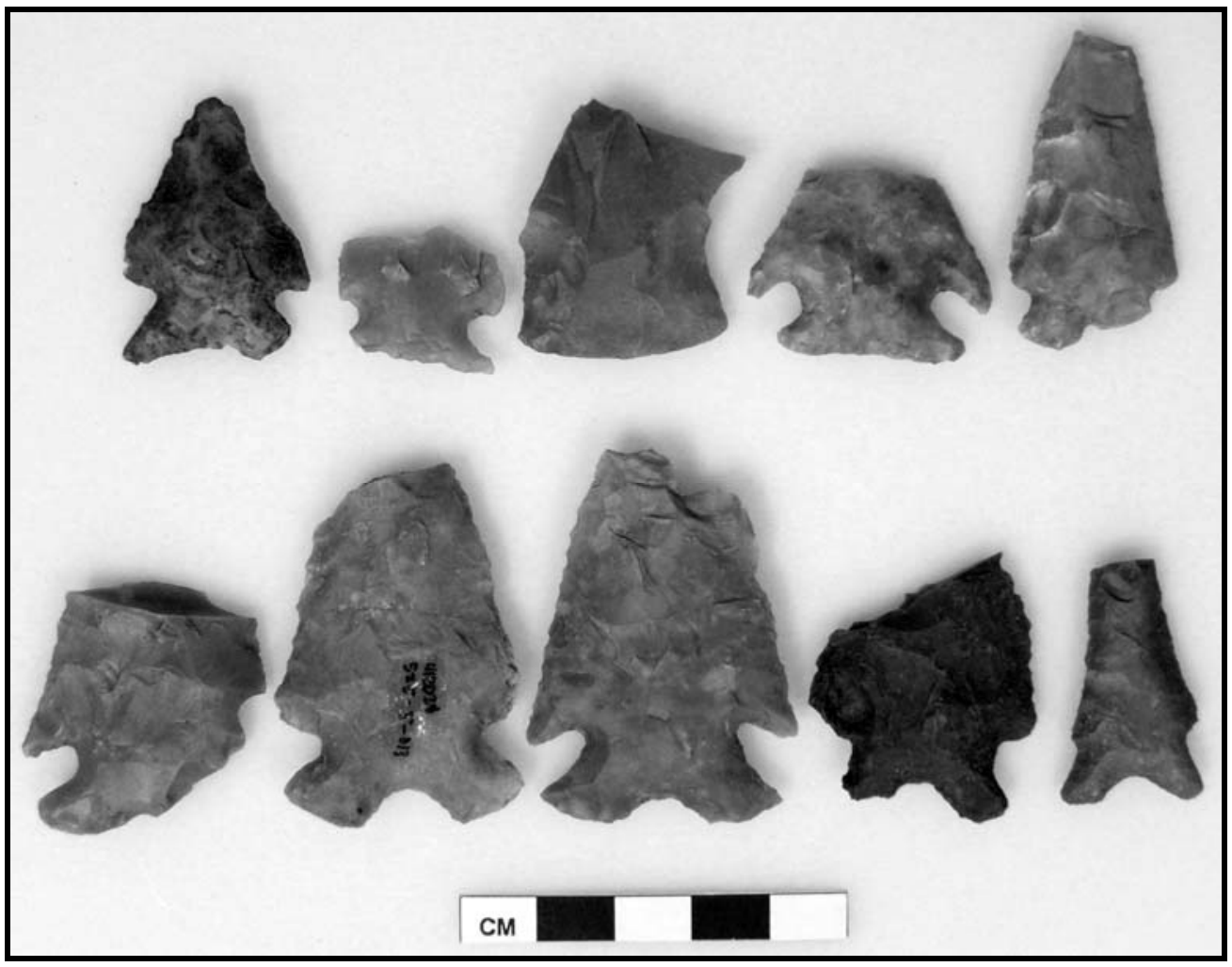

Figure 9-9. Selected Late Archaic Projectile Points

Left to Right: Top Row: \#11-5-14, \#691-011.\#394-010, \#187-010, \#198-010; Second Row: \#22-015, \#525-055-13 Joined with \#526-11, \#187-11, \#89-010, \#220-014

on 71 percent of the total with 80 percent of those exhibiting a subparallel flaking pattern. Fifty-seven percent of the edges show some rounding. Of the edges that were of sufficient length to observe their shape, 70 percent are straight, 20 percent are excurvate, and 10 percent are incurvate. All stems are markedly expanding, as is characteristic of this type.

Table 9-7 presents a summary of metric measurements concerning the seven Frio points to reveal their size variability. Only attributes with three or more values are presented.

The three Frio points from the Late Archaic component were within or near the outer edges of Feature 1. Two points (\#339-10 and \#22-15) were along the eastern margin with \#187-11 near the densest part of the burned rock. All three Frio points were between 25 and $30 \mathrm{cmbd}$. The Edgewood point (\#11-5-14) was inside burned rock cluster Feature 1d at about $19 \mathrm{cmbd}$. The Montell point (\#198-10) was found on the eastern edge of Feature 1. The Marcos point (\#187-10) was recovered from amongst scattered burned rocks and only a few centimeters away from one of the Frio points.

Two Late Archaic points were subjected to usewear analysis. The complete Edgewood point (\#11-5-14) revealed polish and striations on the stem with use-residue in the form of wood fragments. The latter, coupled with hard, high silica polish, indicates use in cutting wood 
Table 9-7. Metric Measurements on Frio Points from 41ED28

\begin{tabular}{|l|c|c|c|}
\hline \multicolumn{1}{|c|}{ Characteristic } & Range & Mean & $\begin{array}{c}\text { Standard } \\
\text { Deviation }\end{array}$ \\
\hline Maximum length & & & \\
\hline Maximum width & $16.5-34.2$ & 25.4 & 7.3 \\
\hline Maximum thickness & $5.5-12.4$ & 7.1 & 2.4 \\
\hline Blade length & & & \\
\hline Blade width & $13.3-31.2$ & 22.8 & 7.7 \\
\hline Shoulder width & $16.5-34.2$ & 25.4 & 7.2 \\
\hline Left notch depth & $2.3-9.6$ & 5.2 & 3.3 \\
\hline Right notch depth & $1.4-10.2$ & 5.6 & 3.9 \\
\hline Left notch width & $6.0-8.4$ & 7.5 & 1.1 \\
\hline Right notch width & $5.9-7.4$ & 6.6 & 0.6 \\
\hline Left notch angle & $57-78$ & 67 & 8 \\
\hline Right notch angle & $50-84$ & 63 & 14 \\
\hline Stem length & $8.7-13.1$ & 10.8 & 1.5 \\
\hline Distal stem width & $13.8-20.4$ & 17 & 2.6 \\
\hline Proximal stem width & $18.3-30.5$ & 24.6 & 6.6 \\
\hline Average stem width & $16.1-25.2$ & 20.8 & 4.9 \\
\hline Stem thickness & $3.4-6.2$ & 5 & 0.9 \\
\hline Base depth & $1.5-4.4$ & 3 & 1 \\
\hline Base notch width & $8.6-10.6$ & 10 & 0.9 \\
\hline
\end{tabular}

Measurements in mm

(Appendix C). The nearly complete Montell point (\#198-10) revealed heavy polish in the stem area, and the impact fracture at the distal end indicates this was used as a projectile point (Appendix C).

Parts of five projectiles, three proximal Frio points (\#22-15 = TRC196, \#89-10 = TRC198, and \#525-5-13 = TRC211), the complete Marcos (\#187-10 = TRC200), and the proximal Ensor (\#691-11 = TRC213) were subjected to INAA in an effort to identify material source locales. All the chemical signatures from these points are similar to those for Edwards chert from the southwestern region (Appendix F). Two of the three Frio points have relatively similar chemical signatures, whereas the third (\#89-10 = TRC198) appears to be from a different Edwards source. One Marcos point $(\# 87-10=$ TRC200) was chemically different from cherts from known source areas, as well as from the clustered chemical signatures of other analyzed Late Archaic pieces from the Varga site (Appendix F).

\subsubsection{Bifaces}

Nine specimens were classified as bifaces. All were manufactured from fine-grained cherts, and all lack patination (Appendix O). Five represent late stages of manufacturing and three represent the middle stage of biface reduction (Figure 910). One complete middle stage biface exhibits cortex over somewhat less than about 25 percent of its surface. Only two specimens, one late stage and one middle stage, are complete. None have been heat-treated to facilitate knapping. Nearly 63 percent probably have been manufactured from flakes. Overall shapes vary, and most exhibit random flaking patterns. 


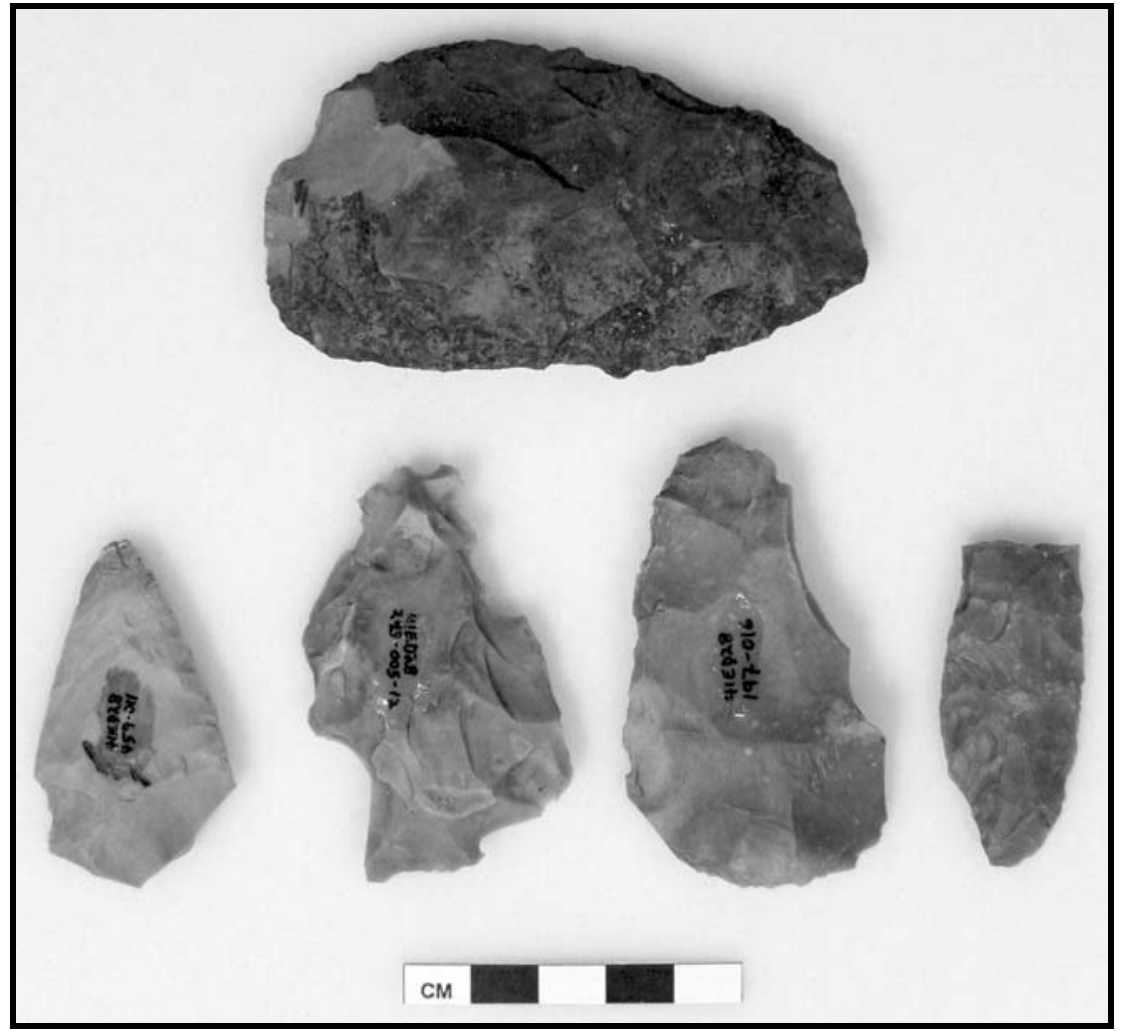

Figure 9-10. Selected Late Archaic Bifaces

Left to Right: Top Row: \#2-012;

Second Row: \#459-011, \#293-005-012, \#197-016, \#274-005-011

None have been appear to have been resharpened, and none exhibit rejuvenation scars. The eight bifaces were horizontally more widely scattered more than other tools, and 25 percent were clearly beyond the margins of Feature 1. Bifaces resting within the boundaries of that feature were generally mixed in with dense rock accumulations, with nearly 38 percent of the specimens occurring within the smaller clusters of burned rock Features $1 \mathrm{~b}$ and 1c. Specimen \#293-5-12 from Feature 1c was burned, presumably because it was deposited within the matrix of the feature prior to its use as a heating element.

Four bifaces, including the two complete specimens, and two late stage fragments were subjected to use-wear analysis. Use-wear analysis on a complete late stage biface (\#2-12) revealed wood fragments. Combined with striations in multiple directions and invasive hard/high silica polish, it is concluded that this time was used in multi-directional cutting of wood (Appendix C). A complete middle-stage biface (\#233-10) bore plant residues, and the heavy polish and edge rounding indicate scraping of hard, high silica plant(s) (Appendix C). A proximal fragment of a late stage biface (\#263-10) revealed plant residues and possibly animal skin, which was accompanied by soft polish indicating the cutting of skin/hide (Appendix C). The distal end of a late stage biface \#274-5-11 revealed a clear, additive residue and polish striations 
parallel to the long axis of the haft and polish use-wear that indicating a hafted tool used on unidentified material (Appendix C).

Small pieces were removed from six bifaces (\#212 = TRC193, \#197-16 = TRC201, \#233-10 = TRC204, \#263-10 = TRC205, \#274-5-11 = TRC206, \#283-12 = TRC207, and \#293-5-12 = TRC208) and subjected to INAA to identify the source locales of raw materials. All show chemical signatures resembling those of known Edwards chert sources (Appendix F). Biface \#263-10 has a chemical signature that is close to signatures of some chert samples from Kerr County. Another specimen (\#2-12) yielded a chemical signature similar to that of the Frio point \#389-10, indicating that both and may have originated from the same source area.

\subsubsection{Scrapers}

Only three scrapers were recovered from the Late Archaic component. Two are complete, and one is the distal end, with fragmentation resulting from a use break. Metric and nonmetric attributes are provided in Appendix O. The two complete specimens are side- and endscarpers of similar size. All three were manufactured from fine-grained chert and all lack patination. All three retain water-worn cortex on some portion of the surfaces. None appear to have been flaked from heat-treated material, nor do any exhibit rejuvenation scars. The two scrapers from Unit N99/E50 (\#2-10 and \#3-10) may have been translocated from the overlying Toyah component, as some mixing of materials was noted in this unit that resulted from mechanical disturbance along the entrance road. Scraper \#293-5-13 was located within Feature 1c along the northeastern margin of Feature 1 in what is believed to be a secure Late Archaic context.

All three scrapers were sent for use-wear analysis. Specimen \#2-10 is the distal end of an end-scraper that revealed hard, high-silica polish. It is interpreted as having scraped hard, high-silica material (Appendix C). Specimen \#3-10 is a lanceolate shaped, complete end-side scraper that exhibits wood fragments and hard, high-silica polish that is interpreted as resulting from the planing of wood (Appendix C). Specimen \#293-13 is an ovate complete end-side scraper that exhibits bore plant tissue and hard, high-silica polish and striations parallel and perpendicular to the edges that are interpreted as evidence for scarping action on hard, high-silica plant material such as wood (Appendix C).

All three scrapers were also sent for INAA. The three specimens $(\# 2-10=$ TRC191, \#3-10 = TRC194, and \#293-5-13 = TRC209) reveal chemical signatures similar to known Edwards chert (Appendix F). Scraper \#293-5-13 (TRC209) did not have a signature that was similar to the other two scrapers. Its signature was similar to natural chert cobbles collected from the adjacent Hackberry Creek, and the material may have come from that local source.

\subsubsection{Edge-Modified Flakes}

The 69 edge-modified flakes include one spokeshave (\#997-10) and three gravers (\#20810, \#491-10, and \#543-12). From these 69 informal tools, nine were selected for usewear analysis (Appendix C). Specimen \#2-11 is an irregularly shaped tool made from, heattreated chert, and exhibiting two worked edges that appear slightly rounded. It bore degraded hair and striations parallel and perpendicular to the long axis and is inferred to have been used to scrape hide. Specimen \#94-10 is a uniface rejuvenation flake that exhibits hard, high silica polish that indicates scraping of hard, high silica material. Specimen \#98-11 is an ovate piece with three worked edges that exhibit light polish indicating use in cutting an unidentified material. Specimen \#98-12 is a complete chert flake with two bifacial worked edges bearing irregular continuous flake scars. It has hair 
fragments and light polish and is interpreted to have been used to scrape hide. Specimen \#20810 is a complete round chert graver with two pointed tips and as many as four worked areas. It exhibits plant fibers and hard, high-silica polish with striations parallel and perpendicular to the long axis. It was used in scraping/boring a hard, high silica plant. Specimen \#283-12 is a complete, ovate chert flake with two worked bifacial edges. It reveals hard, high silica polish with striations interpreted to have resulted from the slicing of hard, high-silica material. Specimen \#353-10 is an irregularly shaped flake fragment with two worked edges. It exhibits hard, high-silica polish that was used for whittling of a hard plant material. Specimen \#491-10 is a complete secondary flake with a large platform, pronounced bulb, relatively parallel sides, an offset medial ridge, and a distal end worked into a point by removal of tiny retouch flakes. This flake exhibits soft polish and striations that indicate cutting of soft material. Specimen \#543-12 is a burned graver with five worked edges. Plant fibers and raphides and hard, high-silica polish indicate scraping and whittling of hard plant material.

Seven edge-modified pieces were selected for INAA. These yielded chemical signatures similar to other known Edwards chert from the southwestern area of the Edwards Plateau, except for two pieces that exhibit signatures that do not resemble those from the known INAA database for Edwards chert (Appendix F).

\subsubsection{Cores}

Eight cores were recovered from Block A and two were found in Block B. Five of the eight from Block A were found within the margins of the burned rock concentration, Feature 1. Sixty percent of the total are complete, while 20 percent are exhausted and 20 percent are fragmentary (Appendix O). All were finegrained cherts without any appearance of have been heat treated. Fifty percent exhibit some remaining cortex that is smooth and water rounded. None are patinated. Fifty percent are multi-directional and 50 percent are bifacial. The six complete cores range in length from 86.9 to $107 \mathrm{~mm}$, with an average of $96.6 \mathrm{~mm}$. The widths range from 53.5 to $78.5 \mathrm{~mm}$, with an average of $68.7 \mathrm{~mm}$. The thickness ranges from 35.4 to $62 \mathrm{~mm}$, with an average of $49.8 \mathrm{~mm}$. The weight ranges from 220.5 to $512.3 \mathrm{~g}$, with an average of $376.8 \mathrm{~g}$. The exhausted pieces are approximately half the size of the average complete core. No cores were subjected to any type of chemical or residue analyses.

Block A yielded eight cores from seven different units. Four units in the southeastern side of Feature 1 yielded five cores, with three cores recovered from Feature 1c just south of BT 2 . Two other cores were recovered from along the western margin of Feature 1. These cores were often from the same units that yielded edgemodified flakes. This general association may indicate that expedient flake tools were made, used, and discarded near the margins of Feature 1.

\subsection{Debitage}

\subsubsection{Unmodified Debitage}

A total of 1,801 pieces of lithic debitage were recovered, which represents about 31 percent of the total cultural materials from this component. Roughly 26 percent of this debitage class from Block A was analyzed to determine which stages of raw material reduction and tool production, manufacturing, and maintenance processes are represented. The selected sample was derived from 11 different units across the main area encompassed by Feature 1 in the southwestern part of Block A. The Late Archaic materials were best defined in this area; and thus, these selected levels probably reflect this specific time period. 
About 60 percent of the sample exhibited some evidence of heat alteration from being exposed to excessive heat. These pieces exhibit spalling and cracking that is considered not part of the intentional heat treatment process to increase their knappability. Blades are nearly nonexistent in the sample with less than one percent identified. Early and late stage biface manufacturing flakes are nearly equally represented with 13.9 and 14.2 percent, respectively. A high frequency of angular debris/shatter is represented by 26.6 percent. Tertiary thinning and retouch flakes are moderately represented by 19 percent. Indeterminate pieces account for about 9.4 percent. The core reduction flakes, which reveal at least 50 percent cortex, are represented by about 16.5 percent.

This sampled assemblage indicates that considerable quantities of the debitage was heataltered and may have been mixed in with the sediments surrounding the once hot rocks during actual cooking. It is also possible that lithic debitage was originally close to the fire that heated the rocks used in this cooking activity. The relatively moderate representation of core flakes indicates that cobbles with cortex were reduced here. The equal and moderate frequency of biface reduction flakes also indicates that some bifaces were manufactured in this area. These bifaces and other tools appear to have been worked into finished or nearly finished forms as indicated by the moderate frequencies of thinning and retouched flakes. The high frequency of angular debris reflects the reduction of cores and early stage biface thinning. Apparently, production of flakes from cores and bifaces occurred, and it may have been a goal to use them as small informal/expedient tools. Biface production also occurred, apparently from both cobbles and flakes. Evidence for the tool maintenance activities is minimal but present.

\subsubsection{Late Archaic Rejuvenation Flakes}

This assemblage does not include any pieces that were classified as rejuvenation flakes.

\subsection{Other ARtifacts}

One clast of ovate, dolomitic limestone, classified as a nutting stone (\#1251-10) was recovered from the lower part of burned rock midden Feature 1, immediately on the southern edge of BT 2, at $47 \mathrm{cmbd}$ in Unit N103/E50. This piece exhibits two pitted surfaces, possibly the result of chemical weathering (Figure 9-11). One corner, part of one lateral edge, and the center of both faces exhibit relatively deeper and larger areas of pitting that are probably artificial. The specimen measures $81.9 \mathrm{~mm}$ long, $60.5 \mathrm{~mm}$ wide, $39.4 \mathrm{~mm}$ thick, and weighs $215.1 \mathrm{~g}$. The largest pitted area is on one face and measures $26.3 \mathrm{~mm}$ long, $20.4 \mathrm{~mm}$ wide, and roughly $3.3 \mathrm{~mm}$ deep. On the opposite face the central pit measures $19.3 \mathrm{~mm}$ long, $18.5 \mathrm{~mm}$ wide and about $3.6 \mathrm{~mm}$ deep. Specimens with similar pits have been referred to in the literature as nutting stones. Turner and Hester (1993) use the term "pitted stone" and state similar pieces probably were used for nut-cracking platforms, whereas Johnson (1962) suggests that they were possibly used as anvils in the bipolar-flaking technique. Turner and Hester (1993) indicate similar objects are concentrated in the northeastern corner of Texas.

\subsection{Vertebrate Faunal Analysis}

The Late Archaic component yielded 41 vertebrate specimens weighing $13.6 \mathrm{~g}$. Many more bone fragments were recovered from this component, but these are believed, based on their color and lack of weathering, to have originated from the immediately overlying Toyah component.

Bone fragments attributed to Late Archaic occupation are in fair to good condition with 

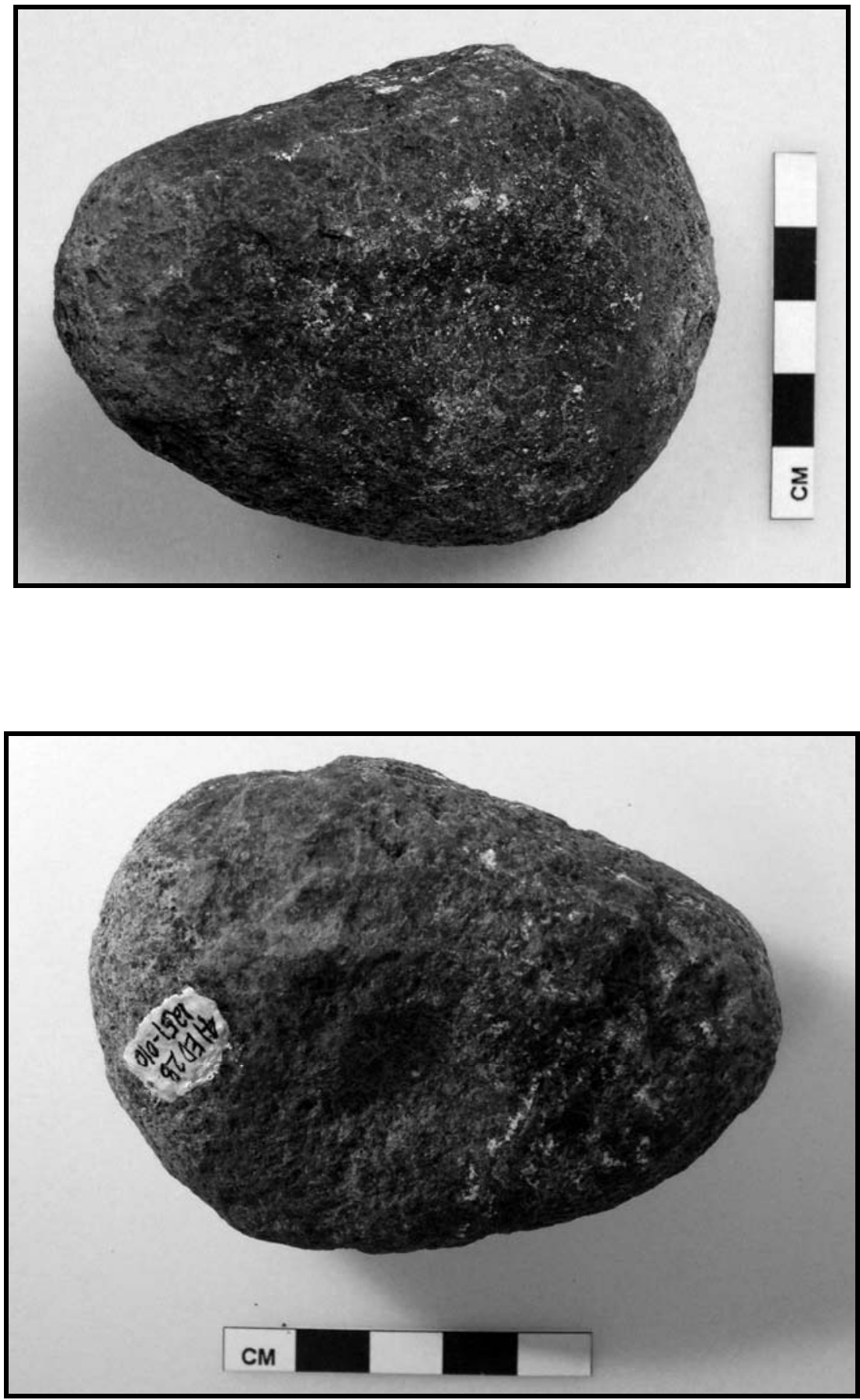

Figure 9-11. Late Archaic Nutting or Anvil Stone 
some splitting and exfoliation from weathering, moderately dry bone fractures, and extensive root etched surfaces. All fragments are less than $3 \mathrm{~cm}$ in length, with the average weight of $2.8 \mathrm{~g}$ reflecting their very small size. Nine pieces were burned brown to black in color and four pieces were burned to brown in color.

The majority of pieces (78 percent; $n=32$ ), weighing a total $8.3 \mathrm{~g}$, were assigned to an unknown taxonomic category. Only three small tooth enamel sections were in the bison size class, and these probably do represent bison. Six long bone fragments were assigned to the deer/antelope size class. No other size classes or species were identified in this small sample.

\subsubsection{Discussion}

Since most bones recovered from this component are thought to actually pertain to the overlying Toyah component, the interpretive potential of the Late Archaic faunal material is quite limited. The burned rock Feature 1 that dominates the material remains in this component is thought to reflect cooking of plant foods. This is not to say that some animal bones were not discarded into, or were somehow functionally linked with this cooking feature. It is also possible that in the construction of this shallow basin shaped burned rock feature some older bones may have accidentally been incorporated into this feature.

It is not unusual to find a few bones scattered in similar burned rock features. A $2 \mathrm{~m}$ diameter burned rock feature, interpreted as the remains of an earth oven dating to this same general time period in the Blackland Prairie to the east of the Edwards escarpment, also yielded some 500 vertebrate remains. About 66 percent of those bones were burned (Brownlow 2003). How the bones arrived in this setting and their functional connection to this burned rock feature is still not clear.

\subsection{Mussel Shell Remains}

The Late Archaic component only yielded two mussel shell fragments and one umbo (\#293-6), both in Feature 1c. These are the only mussel shell pieces from this component, whereas some 19 pieces were in the Toyah component immediate above Feature 1. The fact that the charcoal from Feature 1c was dated to the Toyah component indicates these few shell fragments may have also been displaced downward from the overlying component as well.

\subsection{BURNED ROCKS}

A moderate number of burned rocks, mostly from within Feature 1 and its four subfeatures, were encountered. A total of 3,965 pieces that weighed 607,236 g were recovered from the features and non-features in Blocks A and B. The average weight was about $153 \mathrm{~g}$ with an average density of about 32 pieces per $\mathrm{m}^{2}$.

Block A, dominated by Feature 1, yielded 3,390 pieces that weighed $492,250 \mathrm{~g}$. Feature 1 contained 3,196 pieces (469,150 g), accounting for nearly 94 percent by count and 95 percent by weight of the burned rocks from Block A. The average weight of Feature 1 burned rock was about $147 \mathrm{~g}$. The subfeatures recognized in Feature 1 (Features 1a, 1b, 1c, and 1d), yielded average burned rock weights of $295 \mathrm{~g}, 126 \mathrm{~g}$, $392 \mathrm{~g}$, and $551 \mathrm{~g}$, respectively.

Although the Late Archaic component was not targeted in Block B, nearly $3.5 \mathrm{~m}^{3}$ were excavated below the overlying Toyah component, yielding 575 pieces of burned rock that weighed 114,986 g. Of the Block B burned rock total, about 23 percent by count and 48 percent by weight were recovered from four recognized burned rock features. The average rock from the features weighed about $415 \mathrm{~g}$, compared to the average weight of $135 \mathrm{~g}$ for the scattered rocks outside the features. Again, the rocks identified as within features were about 
three times the weight of the scattered burned rocks, implying that they were repeatedly utilized, and therefore highly fragmented rocks were scattered around the features after their functional utility had been exhausted.

\subsection{Macrobotanical Remains}

Carbonized plant remains were quite sparse in this component. Most carbonized plant remains were derived from burned rock Feature 1, but this prominent feature lacked significant quantities of charcoal, recognizable lenses or pockets, or even burned matrix. With individual carbonized pieces scattered around or below the burned rocks, it was still uncertain as to how many of those filtered down from the younger and better-preserved Toyah component immediately above. The radiocarbon dating of individual pieces provided an excellent indication to the amount of Toyah charcoal moving down into this component, in addition to providing the age range of materials directly associated with this burned rock feature. Only one of nine dated samples (11 percent) from Feature 1 is of the Toyah age. Individual charcoal chunks were often piece-plotted in the field and bagged separately. Bulk matrix samples were also collected from different parts of Feature 1 and its subfeatures, and the floated material was inspected for carbonized plant remains. If the light fractions appeared to have potential for identifiable carbonized plant remains, the material was sent to Dr. Dering for taxa identification (Appendix I).

Only about $36 \mathrm{~g}$ of carbonized plant remains were recovered (Table 9-8). The species identified by Dr. Dering include agave leafs, oak, mesquite, juniper, woody legume, buttonbush, green Condalia, prickly pear seeds, and lotebush. The four burned prickly pear seeds came from two separate locations, which may support their direct association with the burned rock feature. These nine different types of plants indicate diverse fuel sources and/or packing material, if an oven was used. The burned prickly pear seeds probably represent something other than fuel.

\subsection{Late Archaic Summary}

The suspected large burned rock feature (subsequently labeled Feature 1) exposed on the surface was initially targeted by backhoe trenching during the initial mitigation phase. Following the excavation of Block A, Feature 1, which measured roughly $6 \mathrm{~m}$ in diameter by up to $30 \mathrm{~cm}$ thick and completely buried, was comprised mostly of burned rocks, and contained within a very dark gray (10YR $3 / 1)$ to black (10YR 2/1) clay loam to silty clay loam buried A horizon. Late Archaic materials in Block A were concentrated in and along the illdefined margins of Feature 1, but could not be horizontally traced significantly beyond this rock deposit.

The 83- $\mathrm{m}^{2}$ hand-excavations of the Late Archaic component in Block A yielded 1,685 pieces of lithic debitage, 3,402 burned rocks, 57 informal edge-modified stone tools, 26 formal chipped stone tools, 10 cores, 41 bone fragments, 10 burned rock features, three mussel shell fragments, one anvil/nutting stone, and two intrusive Toyah sherds (Table 9-9). The formal chipped stone tools include three Frio, one Castroville, one Edgewood, one Ensor, one Marcos, one Montell point, nine bifaces, and three scrapers, plus two intrusive Cliffton arrow points, one unidentified arrow point, one intrusive Gower dart point, and two Group 2 dart points. 
The Varga Site

Texas Department of Transportation

Table 9-8. Macrobotanical Remains from Late Archaic Component

\begin{tabular}{|c|c|c|c|c|c|c|}
\hline Cat. \# & Unit No. & $\begin{array}{c}\text { Depth } \\
\text { (cmbd) }\end{array}$ & $\begin{array}{l}\text { Fea. } \\
\text { No. }\end{array}$ & $\begin{array}{l}\text { Wgt } \\
\text { (g) }\end{array}$ & Comments & Identifications \\
\hline $2-007$ & N99/E50 & $10-20$ & 1 & 0.2 & & \\
\hline 11-005-004-007-1a & N99/E51 & $11-24$ & $1 d$ & 0.1 & $\mathrm{C}^{14}$ dated to $1390 \pm 40$ B.P. & No identifiable charcoal \\
\hline $80-5-4-1$ & N100/E50 & $20-30$ & 1 & 0.6 & $\begin{array}{l}\text { Light fraction sent to Dering } \\
\text { for ID }\end{array}$ & $\begin{array}{l}\text { Juniper ( } n=1) \text {, mesquite }(n=1) \text {, buttonbush } \\
(n=1) \text {, indeterminate }(n=21)\end{array}$ \\
\hline 81-007 & N100/E50 & $30-40$ & & 0 & & \\
\hline $81-007-1 a$ & N100/E50 & $30-40$ & & 0.1 & Sent to Dering for ID & \\
\hline $81-5-4-1$ & N100/E50 & $30-40$ & & 0.1 & $\begin{array}{l}\text { Light fraction sent to Dering } \\
\text { for ID }\end{array}$ & Indeterminate $(n=8)$ \\
\hline 89-005-007 & N100/E51 & $20-30$ & 1a & & & \\
\hline 89-005-007-1a & N100/E51 & $20-30$ & 1a & 0.1 & $\mathrm{C}^{14}$ dated to $1700 \pm 40$ B.P. & \\
\hline 89-005-007-1b & N100/E51 & $20-30$ & $1 \mathrm{a}$ & 0.1 & Sent to Dering for ID & Mesquite ( $n=5)$ \\
\hline $89-5-4-1$ & N100/E51 & $20-30$ & 1a & 0.1 & $\begin{array}{l}\text { Light fraction sent to Dering } \\
\text { for ID }\end{array}$ & Indeterminate $(n=11)$ \\
\hline $98-005-007$ & N100/E52 & $10-20$ & 1 & 2 & & \\
\hline $98-005-007-1 a$ & N100/E52 & $10-20$ & 1 & 2 & Sent to Dering for ID & $\begin{array}{l}\text { Juniper ( } n=7) \text {, oak }(n=8) \text {, woody legume } \\
(n=4) \text {, green Condalia }(n=5)\end{array}$ \\
\hline $98-007$ & N100/E52 & $10-20$ & 1 & 0.1 & & \\
\hline $100-007$ & N100/E52 & $30-40$ & 1 & 2 & & \\
\hline $100-007-1 \mathrm{a}$ & N100/E52 & $30-40$ & 1 & 0.1 & $\mathrm{C}^{14}$ dated to $1740 \pm 40 \mathrm{BP}$ & \\
\hline $100-007-1 b$ & N100/E52 & $30-40$ & 1 & 1 & Sent to Dering for ID & Mesquite $(n=14)$ \\
\hline $120-007$ & N100/E54 & $20-30$ & & 3.3 & Burned wood & \\
\hline $161-005-007$ & N101/E47 & $45-50$ & 1 & & & \\
\hline $161-5-4-1$ & N101/E47 & $45-50$ & 1 & 0.1 & $\begin{array}{l}\text { Light fraction sent to Dering } \\
\text { for ID }\end{array}$ & Mesquite seed $(n=1)$, indeterminate $(n=8)$ \\
\hline $162-007$ & N101/E47 & $50-60$ & 1 & & $\begin{array}{l}\text { Probably tree or root (14 g not } \\
\text { cultural) }\end{array}$ & \\
\hline $162-007-1 \mathrm{a}$ & N101/E47 & $50-60$ & 1 & 14 & Sent to Dering for ID & Mesquite (34 ml) \\
\hline $171-005-007-1$ & N101/E50 & $50-60$ & 1 & 0 & & \\
\hline $171-005-007-1 \mathrm{a}$ & N101/E50 & $50-60$ & 1 & 0.1 & $\mathrm{C}^{14}$ dated to $2140 \pm 40 \mathrm{BP}$ & \\
\hline $171-005-007-1 b$ & N101/E50 & $50-60$ & 1 & 0.1 & Sent to Dering for ID & Juniper $(n=5)$, \\
\hline $171-005-007-2$ & N101/E50 & $50-60$ & 1 & 0 & & \\
\hline $171-005-007-2 \mathrm{a}$ & N101/E50 & $50-60$ & 1 & 0.1 & Sent to Dering for ID & Juniper $(n=1)$ \\
\hline $178-5-4-1$ & N101/E50 & $15-25$ & 1 & 0.4 & Sent to Dering for ID & Indeterminate $(5 \mathrm{ml})$ \\
\hline
\end{tabular}


Table 9-8. Macrobotanical Remains from Late Archaic Component (Continued)

\begin{tabular}{|c|c|c|c|c|c|c|}
\hline Cat. \# & Unit No. & $\begin{array}{c}\text { Depth } \\
\text { (cmbd) }\end{array}$ & $\begin{array}{l}\text { Fea. } \\
\text { No. }\end{array}$ & $\begin{array}{l}\text { Wgt } \\
\text { (g) }\end{array}$ & Comments & Identifications \\
\hline $179-5-4-1$ & N101/E50 & $25-39$ & 1 & 0.4 & Sent to Dering for ID & $\begin{array}{l}\text { Agave leaf }(n=2) \text {, juniper }(n=1) \text {, oak } \\
(n=2) \text {, prickly pear seed }(n=3), \\
\text { indeterminate }(n=12)\end{array}$ \\
\hline 179-005-004-007-1a & N101/E50 & 25-39 & 1 & 0.1 & $\mathrm{C}^{14}$ dated to $2290 \pm 40$ B.P. & \\
\hline $187-005-007$ & N101/E51 & 27 & 1 & 0.5 & & \\
\hline 197-007 & N101/E52 & $20-30$ & 1 & 0.7 & & \\
\hline 203-007 & N101/E52 & $80-90$ & 1 & 1 & & \\
\hline 203-007-1a & N101/E52 & $80-90$ & 1 & 0.1 & $\mathrm{C}^{14}$ dated to $2230 \pm 40$ B.P. & \\
\hline 203-007-1b & N101/E52 & $80-90$ & & 1.2 & Sent to Dering for ID & Mesquite $(n=12)$ \\
\hline 204-7-1a & & & & 0.2 & Sent to Dering for ID & Oak $(n=6)$ \\
\hline $263-5-4-1$ & N102/E47 & $30-40$ & 1 & 0.5 & $\begin{array}{l}\text { Light fraction sent to Dering } \\
\text { for ID }\end{array}$ & $\begin{array}{l}\text { Mesquite }(n=1) \text {, lotebush }(n=1) \text {, agave } \\
\text { leaf }(n=1) \text {, juniper }(n=2) \text {, indeterminate } \\
(n=14)\end{array}$ \\
\hline $273-5-4-1$ & N102/E50 & $28-40$ & $1 b$ & 0.3 & $\begin{array}{l}\text { Light fraction sent to Dering } \\
\text { for ID }\end{array}$ & $\begin{array}{l}\text { Prickly pear seed ( } n=1) \text {, agave leaf }(n=6) \text {, } \\
\text { juniper }(n=2) \text {, mesquite }(n=3)\end{array}$ \\
\hline $273-5-7$ & N102/E50 & $28-40$ & $1 \mathrm{~b}$ & 0.4 & & Walnut $(n=1)$ \\
\hline $274-5-4-1$ & N102/E50 & $40-50$ & $1 \mathrm{~b}$ & 1.4 & $\begin{array}{l}\text { Light fraction sent to Dering } \\
\text { for ID }\end{array}$ & $\begin{array}{l}\text { Juniper }(14 \mathrm{ml}) \text {, oak }(n=1) \text {, buttonbush } \\
(n=1) \text {, indeterminate }(n=12)\end{array}$ \\
\hline 293-005-007 & N102/E52 & $20-30$ & $1 \mathrm{c}$ & 1 & & \\
\hline 293-005-007-1a & N102/E52 & $20-30$ & 1c & 0.1 & $\mathrm{C}^{14}$ dated to $550 \pm 40$ B.P. & \\
\hline 293-005-007-1b & N102/E52 & $20-30$ & $1 \mathrm{c}$ & 0.1 & Sent to Dering for ID & Juniper $(n=4)$ \\
\hline $352-5-4-1$ & N103/E47 & $30-40$ & 1 & 0.3 & $\begin{array}{l}\text { Light fraction sent to Dering } \\
\text { for ID }\end{array}$ & $\begin{array}{l}\text { Juniper }(n=8) \text {, oak }(n=2) \text {, indeterminate } \\
(n=19)\end{array}$ \\
\hline 361-005-007 & N103/E51 & $40-50$ & 1 & 0 & & \\
\hline 361-005-007-1a & N103/E51 & $40-50$ & 1 & 0.1 & $\mathrm{C}^{14}$ dated to $2170 \pm 40$ B.P. & \\
\hline $361-005-007-1 b$ & N103/E51 & $40-50$ & 1 & 0.1 & Sent to Dering for ID & Juniper $(n=2)$ \\
\hline $362-005-007$ & N103/E51 & $50-60$ & $1 \mathrm{~b}$ & 0 & & \\
\hline 362-005-007-1a & N103/E51 & $50-60$ & $1 b$ & 0.1 & Sent to Dering for ID & Juniper $(n=2)$ \\
\hline $407-007$ & N104/E47 & $30-40$ & & 0 & & \\
\hline 407-007-1a & N104/E47 & $30-40$ & & 0.1 & Sent to Dering for ID & \\
\hline 801-005-004-007-1a & N115/E73 & $20-27$ & $15 \mathrm{E}$ & 0.1 & From light fraction & No identifiable charcoal \\
\hline $801-005-004-007-2 a$ & N115/E73 & $20-27$ & $15 \mathrm{~W}$ & 0.1 & $\begin{array}{l}\text { From light fraction } \mathrm{C}^{14} \text { dated } \\
\text { to } 2140 \pm 40 \text { B.P. }\end{array}$ & \\
\hline
\end{tabular}


Table 9-9. Summary of the Late Archaic Materials from the Varga Site (41ED28) Investigations

\begin{tabular}{|c|c|}
\hline Cultural Material Classes & $\begin{array}{c}\text { Late Archaic } \\
\text { Component (1,700 to } \\
\text { 2,310 B.P.) }\end{array}$ \\
\hline Bone Fragments* & $13.6 \mathrm{~g}, 41$ pieces \\
\hline Bison size & 3 pieces \\
\hline Dear/Antelope size & 6 pieces \\
\hline Mussel Shell* & 5.9 g, 2 fragments \\
\hline Burned Rock & 3,965 pieces, 607,236 g \\
\hline Features & 9 \\
\hline Cooking Facility & 1 \\
\hline Burned Rock Dumps & 8 \\
\hline Dart Points and Fragments & 14 \\
\hline Frio & 3 \\
\hline Marcos & 1 \\
\hline Ensor & 1 \\
\hline Montell & 1 \\
\hline Untyped & 1 \\
\hline Arrow Points (intrusive) & 3 \\
\hline Cliffton & 2 \\
\hline Bifaces & 9 \\
\hline Scrapers & 3 \\
\hline Drills & 0 \\
\hline Edge-Modified Flakes & 69 \\
\hline Lithic Debitage & 1,801 \\
\hline Cores & 10 \\
\hline Nutting Stone/Anvil & 1 \\
\hline Unifaces & 0 \\
\hline Gouges & 0 \\
\hline Hammerstones/Choppers & 0 \\
\hline Ceramic Sherds (intrusive) & 2 \\
\hline Bone Tools & 0 \\
\hline Socialtechnic Objects & 0 \\
\hline Carbonized Plant Remains & $36 \mathrm{~g}$ \\
\hline Total Materials & 5,931 \\
\hline Average Thickness (cm) & 10 \\
\hline Spatial Extent Excavated & 90 \\
\hline Volume Excavated $\left(\mathrm{m}^{3}\right)$ & 9.2 \\
\hline \multicolumn{2}{|c|}{$\begin{array}{l}\text { * Bone, mussel shell, and carbonized remain totals are weights in } \\
\text { grams; }\end{array}$} \\
\hline
\end{tabular}

The $35.5 \mathrm{~m}^{2}$ random and scattered handexcavated units in Block B attributed to the Late Archaic component, plus the $5.0 \mathrm{~m}^{2}$ from the Phase I investigations that penetrated the Late Archaic zone, yielded the partial remains of four burned rock features (Features 7, 15, 28, and 29), one Bell point barb fragment, 11 edgemodified flakes, two cores, and about 563 burned rocks.

\subsubsection{Chronology Issues}

This Late Archaic component was directly dated by 11 radiocarbon assays on wood charcoal and bone to a ca. 600-radiocarbon-year period from 1,700 to 2,310 B.P. (Table 9-1). A sediment sample from Depositional Unit 2, or the Ab soil horizon, and stratigraphically equivalent to this zone, yielded a mean age of 1,900 B.P, in accord with cultural radiocarbon ages from this component. Six of the eleven dates are from charcoal collected from Feature 1 context. The oldest radiocarbon date, 2,310 B.P. (Beta175412), was on a single chunk of wood charcoal from Feature $1 \mathrm{~b}$ that was recovered from what is considered a valid Late Archaic context. The youngest radiocarbon date, 1,700 B.P. (Beta-175412), was derived from a single chuck of charcoal that was recovered from Feature 1a and also in a valid context. We are unsure how much old wood might be contributing to the difference in the radiocarbon dates. The multiple projectile point types and multiple radiocarbon dates indicate that multiple occupational episodes may be represented, but the thinness of the Late Archaic deposits do not allow for corresponding vertical separation of the projectile points or other associated artifacts.

Evidence for some vertical displacement of dateable materials in this component is present. The second oldest date, 2,290 B.P. (UGA12716), was obtained from one deer/antelope bone fragment (\#418-2-1) retrieved from below the Late Archaic component. This bone was 
encountered 50 to $60 \mathrm{cmbd}$ deep in a level attributable to the Middle Archaic. Apparently this bone was displaced downward into the lower component. A chunk of wood charcoal (\#203-5-4-2-1) dated to the Late Archaic was recovered from burned rock Feature 39 in the Early Archaic component. Two other radiocarbon dates (550 \pm 40 B.P. [\#293-5-7-1a] and 1,390 \pm 40 B.P. [\#11-5-4-7-1a]) on charcoal from an apparent Late Archaic context were derived from displaced charcoal that moved down in the profile. Two Toyah age Cliffton points and two tiny ceramic sherds from the Toyah component were also recovered from this midden or mixed context. Also an Early Archaic Martindale point was recovered from the burned rock midden context from immediately west of Feature 1c.

Since the 11 radiocarbon dates document the absolute timing of this component to the Late Archaic period, the three Early Archaic and one Middle Archaic projectile points are assumed to be displaced from their original contexts. It is not clear if these four points were curated items brought in by Late Archaic peoples or displaced from their original deposits during postdepositional times. The three Toyah age arrow points are surely intrusive. Only the 10 Late Archaic points are thought to be associated with these dates. It is not clear if any of the multiple Late Archaic point types were intrusive or curated items, especially since only the Frio type is represented by more than one specimen. It is possible that the Frio type equates with one of the two clusters of radiocarbon dates, and most likely this would be the three dates falling at 1,700-1,900 B.P. However, association with the older set of dates is not impossible. "Pure" Frio components have not been excavated and radiocarbon dated, so the age range for this point type is not precisely established.

\subsubsection{Subsistence Issues}

The Late Archaic projectile points and other tool classes represented generally appear to indicate hunting and processing of animals. No direct evidence is present for plant collecting. The indirect evidence for plant use comes from usewear analyses, which indicate hard, high silica plants, wood, and animals were all associated with Late Archaic tools (Appendix C). However, the mere fact that tools were used on these diverse materials does not directly connect the identified materials to actual food resources

Late Archaic bone fragments consist of 41 vertebrate specimens weighing $13.6 \mathrm{~g}, 22$ percent of which were burned brown to a black color and 10 percent of which were burned to a brown color. Seventy-eight percent could not be assigned to a general size category. Three tooth enamel sections are in the bison size class and probably represent bison. Six long bone fragments were assigned to the deer/antelope size class. No other species or size classes were identified. This limited bone assemblage may have originated from the immediately overlying Toyah component that contained quantities of animal bones including bison remains. However, these few fragments were assigned to the Late Archaic component on the basis of the depth of their recovery and upon observed characteristics. If this assessment is correct, then it can be inferred that meat was present and consumed.

Indirectly, burned rock Feature 1 indicates cooking bulk foods, most likely plant material. The roughly $6 \mathrm{~m}$ diameter size of Feature 1, the shallow basin detected in the backhoe trench profile, and the small clusters of burned rocks, which may represent dump locations, generally indicate that Feature 1 was a hot-rock oven. Ovens are generally thought to have been used for cooking bulk foods that require considerable cooking time, such as sotol, yucca, or 
lechuguilla bulbs. Four burned prickly pear seeds, a burned mesquite seed, burned walnut shell fragments, and seven burned agave leaf fragments were recovered from various locations in direct association with burned rock Feature 1 (Table 9-10). The prickly pear seeds potentially were from roasting prickly pear fruit. Possibly the walnuts were boiled to render the oil. However, the nuts may have been accidentally burned as part of the fuel needed in the cooking process. The agave hearts identified in the macrobotanical remains would be the most likely candidate to require long-term cooking (24 to 48 hours) in an oven before consumption.

Three tiny mussel shell pieces were recovered from Feature 1c, which potentially represent one half of one shell. Thus, there is no reason to believe that mussels were procured on a regular basis as a source of meat

Proxy evidence from the lipid residue results on the burned rocks reflects intensive use (94 percent) of the burned rocks for cooking high fat content plants. Only two samples, or six percent, reflect medium to low fat content. A single sample (\#98-5-3-1) yielded the only indication of large herbivore residue. The overall lipid residue results reveal the rocks cooked a narrowly focused food resource. Other chemical data in the form of stable carbon and nitrogen isotopes was combined with the lipid residue results to aid in the interpretations, but do not allow for specific identifications. The $\delta^{13} \mathrm{C}$ values range from -21.8 to $-30.6 \%$, with an average of $-24.8 \%$. These carbon isotope values indicate that the plants represented by the lipid residues were all $\mathrm{C}_{3}$ plants or animals that consumed $\mathrm{C}_{3}$ plants. The isotope results do not support the use of $\mathrm{C}_{4}$ prickly pear pads or fruit or lechuguilla as one of the targeted plants cooked in the oven. The single lipid residue that is interpreted as reflecting a large herbivore yielded a $\delta^{13} \mathrm{C}$ value of $-24.2 \%$ and a $\delta^{15} \mathrm{~N}$ value

\section{Table 9-10. Floral Species Identified from the Late Archaic Component}

\begin{tabular}{|l|}
\hline Agave leaves \\
\hline Buttonbush \\
\hline Green Condalia \\
\hline Juniper \\
\hline Littleleaf walnut \\
\hline Lotebush \\
\hline Mesquite seed \\
\hline Oak \\
\hline Prickly pear seeds \\
\hline Woody legume \\
\hline
\end{tabular}

of $7.7 \%$. Based on these isotope values, the large herbivore was probably deer or pronghorn.

Late Archaic human remains from Conejo Shelter in the Lower Pecos have revealed isotope evidence for a human diet rich (45 to 68 percent) in $\mathrm{CAM} / \mathrm{C}_{4}$ plants with roughly 32 to 55 percent of the diet comprised of $\mathrm{C}_{3}$ plants or animals that consumed $\mathrm{C}_{3}$ plants (Huebner 1991a: Bousman and Quigg 2006). The Conejo data supports the subsistence reliance detected at the Varga Site with deer meat supplying the $\mathrm{C}_{3}$ meat component and agave (probably sotol) supplying the CAM plant portion of the diet. This mixed subsistence pattern is more similar to that of the Lower Pecos region, than to Late Archaic diet in the Central Texas region, which shows an increased reliance on $C_{3}$ plants and animals that ate $C_{3}$ plants at this time (Bousman and Quigg 2006).

\subsubsection{Technology Issues}

Technology issues can only be addressed from the preserved assemblage. Some daily tasks such as resource procurement, resource processing, and consumption are represented in the limited tool assemblage, as discussed below. 


\subsubsection{Resource Procurement Issues}

Plant and animal procurement is generally interpreted here based on the recovered artifacts. The presence of a relatively high frequency of projectile points indicates that animals were hunted. Use-wear and the impact fracture detected on the Montell point document that this instrument was used as a projectile, though the actual contact material is unknown. Use-wear analysis, as in the case of the Edgewood point that was apparently used to cut wood, does indicate that some points were employed as multi-functional tools. The sparse bone assemblage could indicate that animal procurement did not play a major role at this location, or might simply reflect poor bone preservation.

The two projectile points submitted for usewear, the Montell point with heavy polish and the Edgewood with polish and striations, both reveal hafting wear. One biface (\#274-5-11) also reveals polish and striations plus clear additive residue that apparently resulted from hafting.

The raw lithic materials employed by the groups representing this component used Edwards chert exclusively as determined by INAA and macroscopic examination. The raw material employed in the manufacture of stone tools apparently came principally from water-rounded chert cobbles. Therefore, it is inferred that these chert cobbles were collected from surface outcrops such as streambeds rather than extracted from limestone bedrock sources. The presence of cores, the high frequency of core reduction flakes, the high frequency of angular debris, combined with the high frequency of early and late stage biface flakes documents that after tool stone cobbles were procured, they were reduced to produce finished tools at the site.
The natural limestone pieces employed in cooking activities probably were locally available and doubtless were collected from nearby outcrops.

\subsubsection{Resource Processing and Consumption}

Diverse processing activities are documented here through the different types of stone tools recovered which include bifaces, scrapers, anvil/nutting stone, and edge-modified tools. The small number of scrapers $(n=3)$ and the absence of drills indicates that tasks associated with these tools probably were limited. Usewear analyses on 17 Late Archaic stone tools comprised mostly of edge-modified flakes, represents a diverse range of processing tasks. Thirty percent of the inferred uses relate to scraping, 25 percent relate to cutting, 10 percent to whittling, and five percent indicate slicing, boring/drilling, planing, and/or other unidentified activities. Inferred contact materials include hard, high-silica plant material (44 percent), hide (17 percent), wood (17 percent), and unidentified materials (17 percent). The small remainder were used on unidentified soft material. No one tool class can be directly linked to one specific task on one material type. For example, the low frequency of formal scrapers does not indicate a paucity of scraping activity, since thirty percent of the analyzed tools reflecting scraping actions. Scraping tasks were performed with scrapers, edge-modified flakes, gravers, and bifaces.

Actual use-residue was detected on nearly 56 percent of the tools analyzed. Nearly 28 percent revealed plant residues compared to just 11 percent that revealed animal residues. This difference may be connected to differential preservation of residues, rather than a proportional reflection of the intensity of a given processing task. 
In the Lower Pecos region, where preservation in rockshelters is substantially better than at open camp sites, fiber nests (Features 2 and 24) were discovered at Wroe Ranch (Turpin 1998). These nests were constructed of twigs, agave leaves, grasses, and prickly pear pads and substantiate the collection and use of diverse plants during this same period. Such findings should caution against assumptions that could significantly underestimate the importance of intensive use of plant resources in surrounding regions where dry shelters are lacking.

The 3,965 burned rocks numerically dominate the cultural debris recovered in this component. Their presence also indicates that cooking was a major activity, and that cooking commonly involved on the use of hot rocks. Feature 1 is interpreted to represent an incipient burned rock midden. Although this feature was significantly impacted by two backhoe trenches dug during Phase I investigations, the configuration of the burned rocks indicates a shallow basin near the estimated center of the rock concentration. The presence of a central basin, the relatively large quantity of burned rocks encountered, the overall horizontal patterning of the burned rocks and the few burned prickly pear seeds and agave leaf fragments indicate Feature 1 was probably the remains of a rock oven employed to cook plant foods. This type of feature provides some indication of how foodstuffs were cooked and potentially the type of food(s) cooked, since certain foods are more efficiently cooked in rock ovens than others. Agave hearts were one of several foods that were often cooked in rock ovens. The fuel used in the heating of the rocks and/or cooking the food includes types, such as mesquite, juniper, and oak, and indicates that various woods were used as fuel. The prickly pear seeds may have been part of the insulation or packing materials used around the agave hearts during the actual cooking process (see Ellis 1997).
A small ovate nutting stone was recovered from just east of the projected central area of Feature 1. This item may have served as an anvil for smashing nuts. While no direct evidence exists to corroborate this suggestion, it may be relevant that burned walnut and pecans shells were recovered from this component.

The general scarcity of formal stone tools $(n=12)$, other than projectile points $(n=13)$ and informal edge-modified flakes $(n=69)$, and the absence of rejuvenation flakes around the cooking Feature 1 implies that non-cooking activities were limited in the immediate area of Feature 1. The presence of broken dart points, broken bifaces, and a few cores indicate various retooling tasks, which may have been carried out during the duration of the plant cooking process. Discarded broken tools and debitage were found from amongst the discarded burned rocks. The presence of broken tools appears to reflect a pattern of concurrent discard of exhausted tools and burned rocks.

\subsubsection{Intra-component Patterning}

The 600-years of documented radiocarbon time for this thin vertical zone, coupled with the presence of six different point types indicate the potential for at least a couple of different occupational episodes, though a lack of stratigraphic separation hinders interpretation. Deciphering what activities may have been associated with one another is thus difficult, especially if multiple events are represented. Multiple events would seem to be indicated by the extended time span represented by the radiocarbon dates, and by the fact that several different dart point types were recovered. On the other hand, there is apparent logical patterning in the findings, implying the possibility of a single episode of site occupation during the Late Archaic. 
The horizontal distribution of the small, identified burned rock clusters/piles (Features 1a, 1b, 1c, and 1d) within the overall boundaries of Feature 1 implies some type of discard or dismantling of exhausted rocks from Feature 1. This discard/dismantling is feasible in the case of a cooking oven, since the oven cover must be removed to retrieve the foodstuffs cooked inside. It is also possible that the interior of the oven, specifically the basin, was cleaned unwanted (i.e., functionally exhausted) burned rocks on occasion and prior to reuse. Such maintenance-oriented removal of rocks would have involved the dumping of those rocks that were sufficiently degraded so as to be longer functionally viable.

The tools and lithic debris potentially represent another event entirely, since it is not clear that the broken tools and other lithic debris were discarded concurrently with cooking activities. These objects may have already been on the ground at the time the shallow basin for the oven was constructed, or when the oven cover was dismantled. The horizontal distribution of the non-burned rock artifacts may have resulted from one or more of these activities. Eight-two percent of the formal tools were recovered from the defined limits of Feature 1, implying some correlation between the tools and the burned rocks. Only four formal tools appeared burned and two of those were older (Early Archaic). These heat-altered tools reflect either a direct discard into the oven or an accidental heating from a tool that was part of the sediments adjacent to the hot rocks or sediments used in covering the oven. The two burned Early Archaic points were likely present in the sediments during the heating of the rocks. The overall distributional pattern of the formal and informal tools and the small burned rock discard piles in and around Feature 1 indicate that most discards occurred to the southeastern side of the Feature 1. Relatively scant material remains were encountered across the north side of
Feature 1. A relatively high percentage of lithic debitage (about 41 percent) from around the burned rocks exhibit signs of unintentional heat alteration. Their spalled and crazed condition implies they were in close proximity to intense heat.

In Block A, hand-excavations outside the illdefined and irregular margins of Feature 1 yielded almost no cultural debris, except for burned rock Feature 11 about $2 \mathrm{~m}$ north of the Feature 1 near the middle of the northern part of Block A. Only five, or about 18 percent, of the formal tools were recovered outside the defined limits of Feature 1. Roughly 37 percent of the edge-modified flakes were also outside the Feature 1 boundaries. This horizontal distribution reveals that most of the artifacts were within/near the Feature 1 boundaries, implying that various non-cooking activities were carried out within proximity of the cooking feature.

In Block B, roughly 25 m northeast of Feature 1, some $35.5 \mathrm{~m}^{2}$ of scattered hand-excavated units penetrated the Late Archaic component immediately below the Toyah component. These excavations revealed four burned rock clusters, Features 7, 15, 28, and 29, and limited quantities of scattered burned rocks that relate to Late Archaic activities. Tiny charcoal flecks (\#801-5-4-7-2a) from Feature 15 yielded a $\delta^{13} \mathrm{C}$ corrected (-24.5\%) AMS radiocarbon date of $2140 \pm 40$ B.P. (Table 9-1: $\quad$ UGA-12725). However, with multiple events projected for this component, it is not clear if the use of one or more of these burned rock features was coeval with the use of Feature 1.

The details concerning the spatial analyses presented below, including the conceptual and methodological framework, are provided in the research design and in the method chapters. Contour maps of density-corrected artifactual data for Block A were generated for selected 
variables in this component (Figures 9-12 through 9-18) using Surfer (version 5.01) mapping software. No contour maps were attempted for the cultural materials recovered from Block B since the Late Archaic component was not targeted for excavation in that area and those materials were limited in number. These maps generated for Block A provide a visual reference to aid in the interpretation of the spatial distribution of each artifact category and provide additional depth to interpreting the results of the principal component analyses. The locations of individual recognized features are also plotted on the contour maps as part of the spatial relationship of the activities.

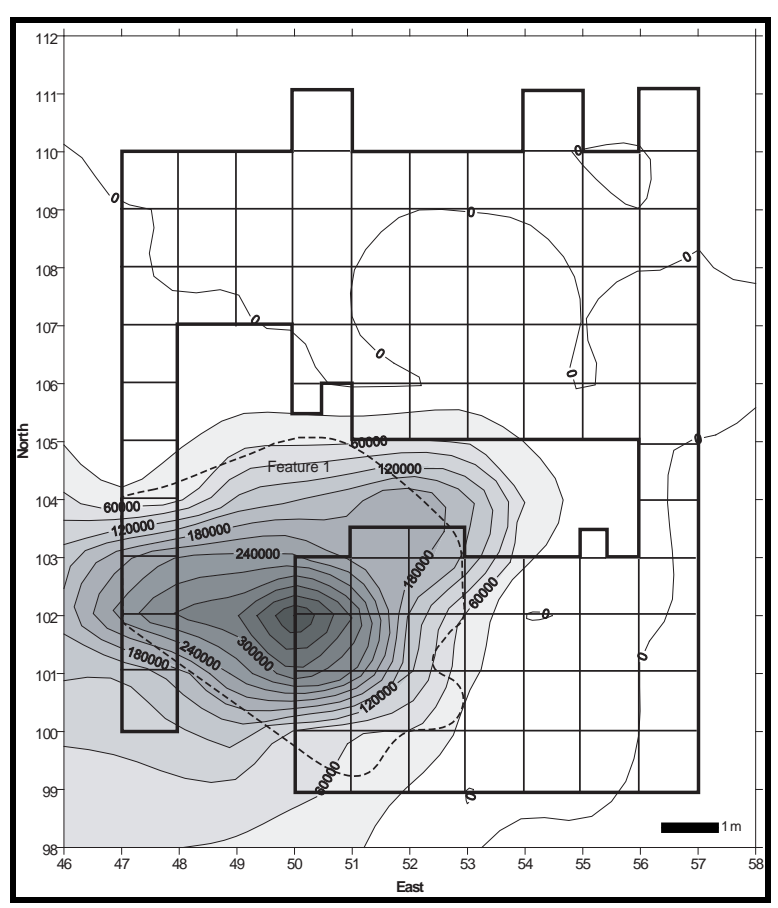

Figure 9-12. Contour Map of Burned Rock Density from Late Archaic in Block $A$

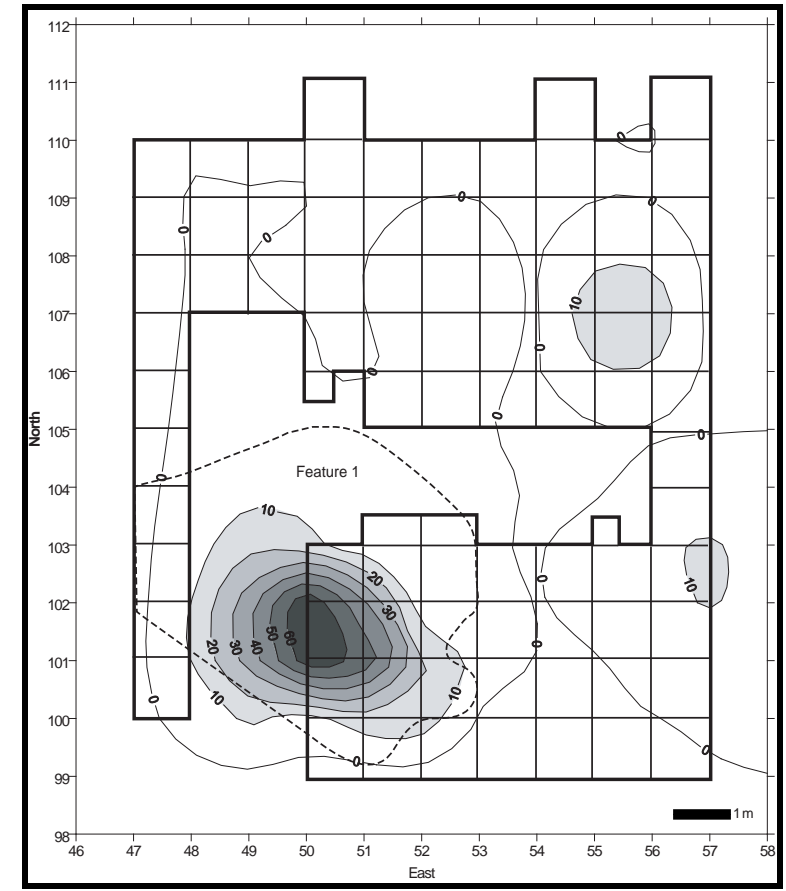

Figure 9-13. Contour Map of Bone Density from Late Archaic in Block A

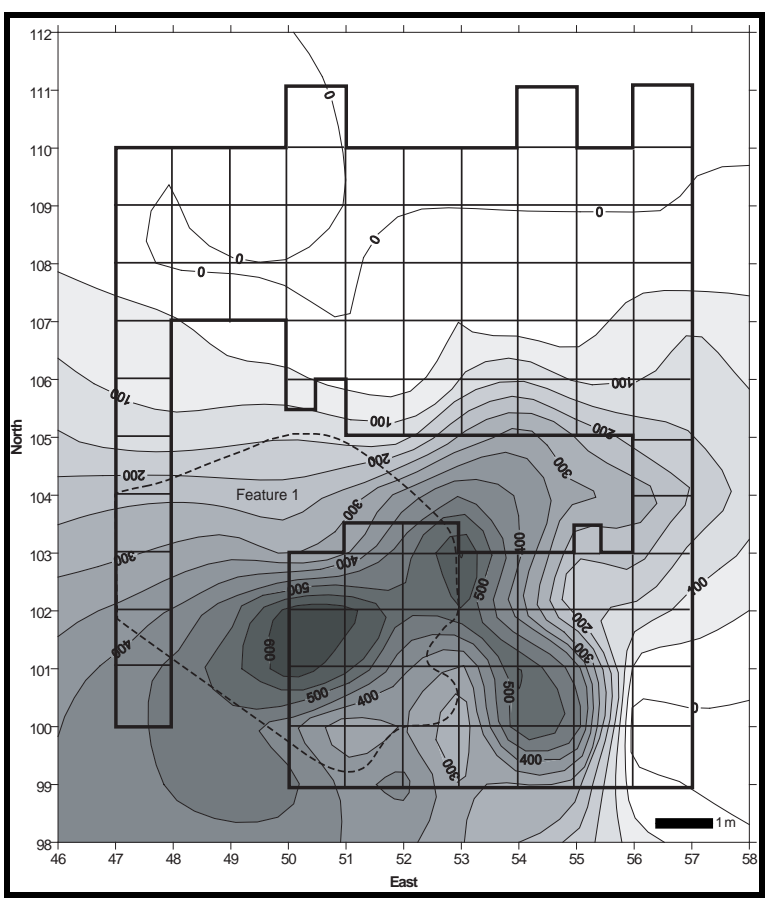

Figure 9-14. Contour Map of Lithic Debitage Density from Late Archaic in Block $A$ 


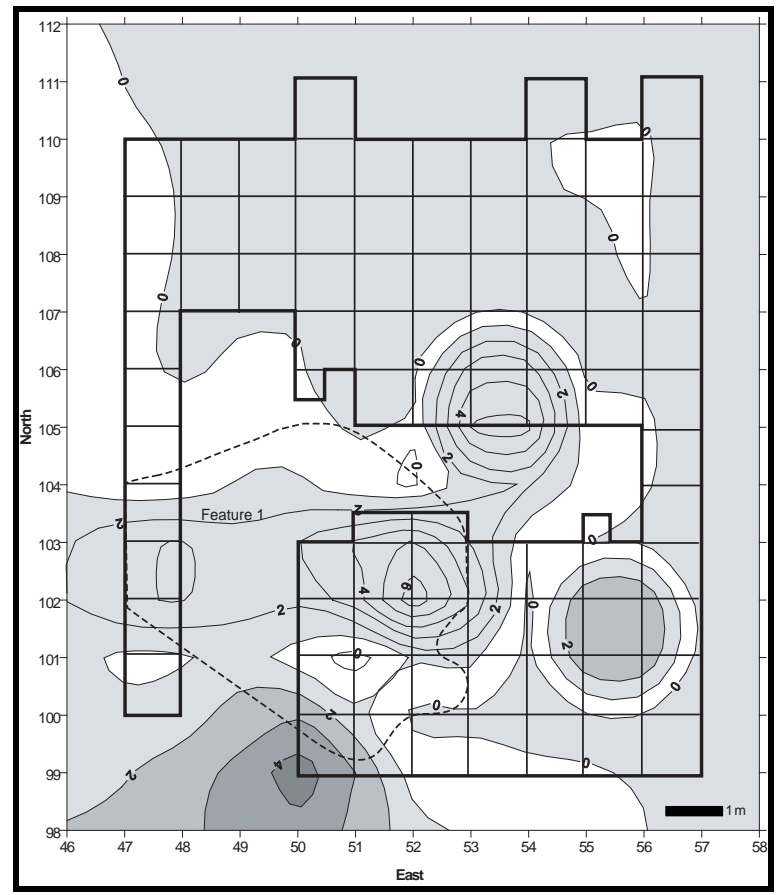

Figure 9-15. Contour Map of Biface Density from Late Archaic in Block A

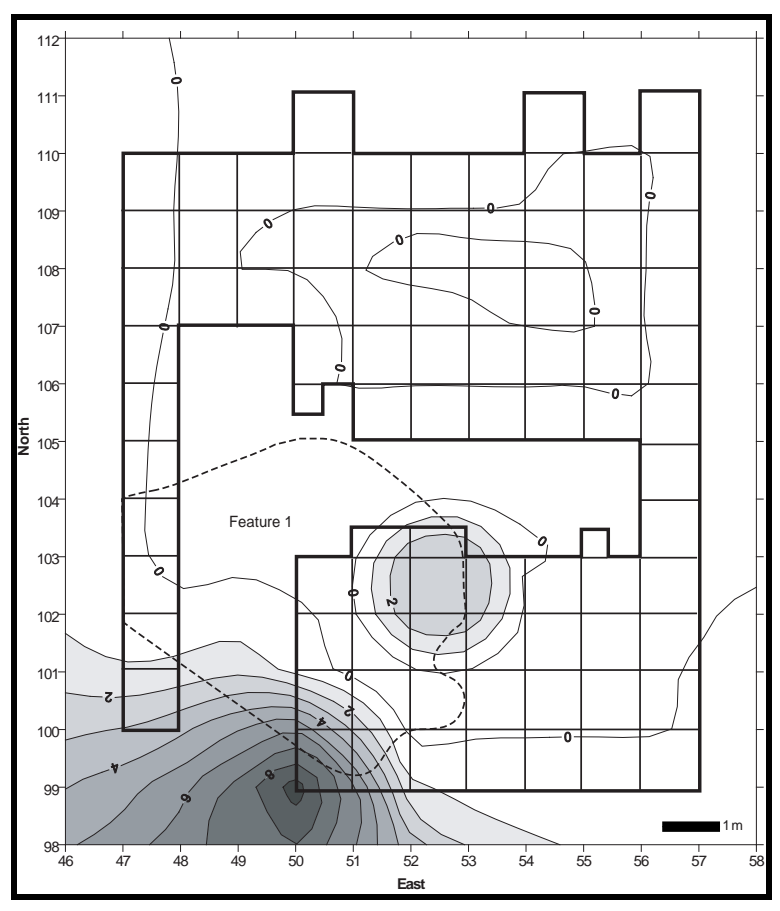

Figure 9-16. Contour Map of Scraper Density from Late Archaic in Block A

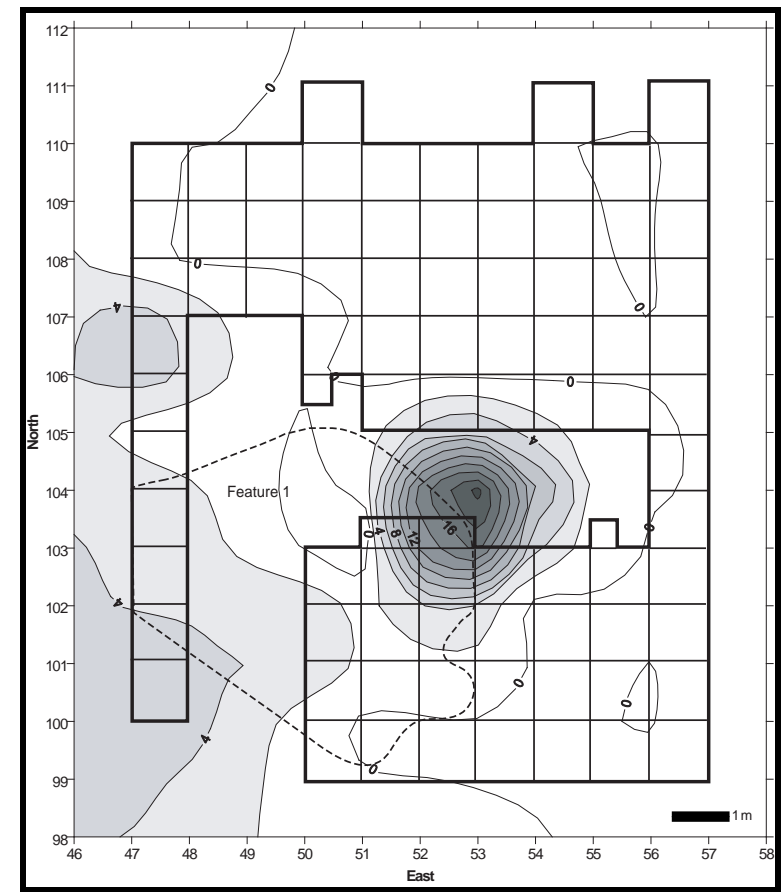

Figure 9-17. Contour Map of Lithic Core Density from Late Archaic in Block A

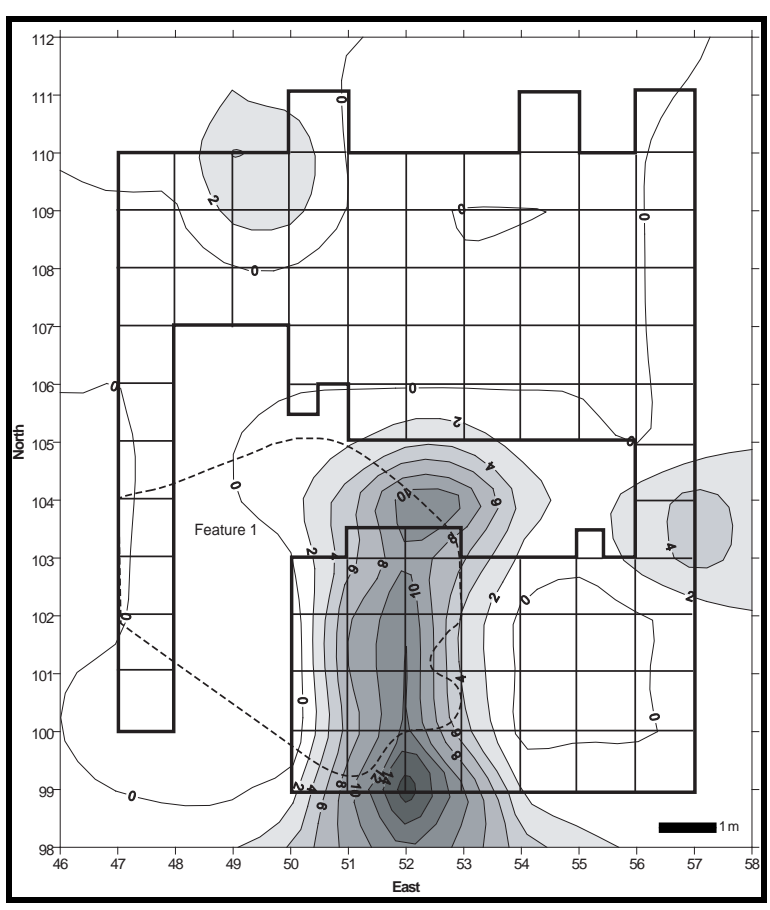

Figure 9-18. Contour Map of Point Density from Late Archaic in Block A 
The Late Archaic analytical unit in Block A covers a total area of $45.86 \mathrm{~m}^{2}$ and consists of a total volume of $5.69 \mathrm{~m}^{3}$ of sediment. Ceramic sherds, groundstone, awls, drills, gouges, unifaces, and choppers were excluded from this analysis due to the non-occurrence of these artifacts in the Late Archaic component in Block A. The resulting data matrix consists of eight variables (artifact categories) and 86 rows (excavation units), though only seven of the variables figure strongly in the resulting factor solution. The principal components analysis extracted a three-factor solution representing a cumulative total of 66.22 percent of the variability present in the data array. The matrix of correlation coefficients is presented in Table 9-11, and the factor solution is presented in Table 9-12.

Factor 1 is composed of three diagnostic variables-burned rock, faunal bone, and debitage-collectively composing 25.81 percent of the total variance in the matrix of correlation coefficients (Table 9-12). All three variables exhibit moderately strong to strong positive factor loadings ranging from .649 to .904; none of the diagnostic variables in Factor 1 are negative. This factor may be explained largely in reference to a single high-density peak of all three of these artifact categories in the southwestern quadrant of Block A-centered on the west edge of Unit N101/E50 (Figures 9-12 and 9-14). Lithic debitage displays two secondary peaks a few meters northeast and southeast of this central peak, whereas neither burned rock nor faunal bone have secondary peaks in this area. Faunal bone displays two minor peaks in the northeastern quadrant and farther south along the eastern edge of the block (Figure 9-13).

Table 9-11. Correlation Matrix for Block A-Late Archaic Component

\begin{tabular}{|l|l|l|l|l|l|l|l|l|}
\hline \multirow{2}{*}{ Category } & \multicolumn{7}{|c|}{ Category } & \\
\cline { 2 - 9 } & $\begin{array}{c}\text { Burned } \\
\text { Rocks }\end{array}$ & $\begin{array}{c}\text { Faunal } \\
\text { Bone }\end{array}$ & Cores & Debitage & Bifaces & $\begin{array}{c}\text { Edge- } \\
\text { Modified } \\
\text { Flakes }\end{array}$ & $\begin{array}{c}\text { Projectile } \\
\text { Points }\end{array}$ & Scrapers \\
\hline Burned Rocks & 1.000 & & & & & & & \\
\hline Faunal Bone & .618 & 1.000 & & & & & & \\
\hline Cores & .376 & .135 & 1.000 & & & & & \\
\hline Debitage & .573 & .405 & .302 & 1.000 & & & & \\
\hline Bifaces & .260 & -.030 & .071 & .249 & 1.000 & & & \\
\hline $\begin{array}{l}\text { Edge-Modified } \\
\text { Flakes }\end{array}$ & .210 & .168 & .115 & .573 & .244 & 1.000 & & \\
\hline Projectile Points & .283 & .084 & .349 & .381 & .053 & .190 & 1.000 & \\
\hline Scrapers & .112 & -.037 & .133 & .201 & .438 & .110 & -.053 & 1.000 \\
\hline
\end{tabular}


Table 9-12. Principal Component Matrix for Block A-Late Archaic Component

\begin{tabular}{|l|c|c|c|}
\hline \multirow{2}{*}{\multicolumn{1}{|c|}{ Variable }} & \multicolumn{3}{c|}{ Factor } \\
\cline { 2 - 4 } & $\mathbf{1}$ & $\mathbf{2}$ & $\mathbf{3}$ \\
\hline Burned Rock & .807 & .143 & .269 \\
\hline Faunal Bone & .904 & -.151 & -.074 \\
\hline Cores & .143 & .074 & .724 \\
\hline Debitage & .649 & .340 & .434 \\
\hline Bifaces & .084 & .823 & .029 \\
\hline Edge-Modified Flakes & .374 & .392 & .265 \\
\hline Projectile Points & .090 & -.057 & .849 \\
\hline Scrapers & -.022 & .807 & -.031 \\
\hline \% Variance & $\mathbf{2 5 . 8 1}$ & $\mathbf{2 0 . 6 3}$ & $\mathbf{1 9 . 7 8}$ \\
\hline Cum. \% Variance1 & $\mathbf{2 5 . 8 1}$ & $\mathbf{4 6 . 4 4}$ & $\mathbf{6 6 . 2 2}$ \\
\hline $\begin{array}{l}\text { 1 Rotation method-Varimax with Kaiser normalization } \\
2 \\
\text { Based on rotation sums of squared loadings }\end{array}$
\end{tabular}

Clearly, the primary determinant of the patterning observable in this factor is the presence of Feature 1, an incipient burned rock midden composed of a central pit feature and a surrounding scatter of burned rocks and associated debris. The location of the central pit feature corresponds to the high-density cluster of materials represented by this factor loading. This factor clearly represents the resource processing activities associated with use of this feature. The inclusion of lithic debitage in this factor is perhaps noteworthy, though it is possible that at least some of this debitage was translocated downwards from a noted highdensity peak of debitage and related artifacts from the overlying Toyah component. It is perhaps more interesting to observe that, in contrast to the strong association between debitage and edge-modified flakes observed in Factor 1 in the Toyah component in Block A, edge-modified flakes do not appear to be spatially associated with any other artifact category in the Late Archaic component. In fact, they do not appear in any of the three factor loadings resulting from the principal components analysis.

Factor 2 is composed of two diagnostic variables-bifaces and scrapers-collectively composing 20.63 percent of the total variance in the matrix of correlation coefficients (Table 912). Both variables exhibit strong positive factor loadings of .807 and .823. This factor can be explained largely in reference to a strong pairing between these two artifact categories in two high-density clusters, one in the southcentral part of Block A just south of Backhoe Trench 2 and one centered on the intersection of low- to moderate-density peaks in the southwestern corner and just north of BT 2 (Figures 9-15 and 9-16). All of these density peaks are located along the periphery of Feature 1 (contrasting with the concentrations of Factor 1 variables in the center of Feature 1). Scrapers and bifaces may form part of a constellation of tools used to process the resources associated with Feature 1

Factor 3 is composed of two diagnostic variables-cores and projectile pointscollectively composing 19.78 percent of the total variance in the matrix of correlation coefficients (Table 9-12). Both variables exhibit moderately strong to strong positive factor loadings of .724 and .849. The spatial patterning represented by this factor is accounted for by a strong correlation between cores and projectile points in one high-density cluster located in the approximate center of BT 2 (Figures 9-17 and 918). Whereas cores exhibit only this single peak, points extend in a linear high-density corridor southwards to a primary high-density peak centered on the intersection of the N99 and E52 grid lines. Like Factor 2, it seems likely that the patterning reflected in this factor represents activities conducted along the periphery of Feature 1 more strongly than any special association among these two artifact 
types. In the end, the spatial structure of the Late Archaic component appears to be comprised mostly of Feature 1, including the structure of the feature itself and related activities that occurred along its periphery.

It is important to remember that demonstrable spatial associations of different variables, which form the basis of the preceding discussion, do not inherently imply the nature of the relationships among some or all of the variables. The statistics reveal numerical tendencies among variables to co-occur or to co-vary in space. The statistics "force” patterning upon an assemblage of data regardless of whether or not it innately exists in the dimension being examined. However, patterning is always present in archeological data, so it is reasonable to accentuate it where it exists to expedite the task of detection and interpretation. The analyst is responsible for inferring whether such patterning may be indicative of past behavior, such as that reflected in situ activity or discard areas; postdepositional processes, such as plowing or erosion; or a combination of both.

Overall, the principal component analyses of this component included in this spatial study have yielded relatively unambiguous patterning among artifact categories. The patterns appear to be constrained and influenced by different factors. The observed associations among artifact categories appear to be regular, patterned, and often exclusive of other categories. If post-depositional factors, such as erosion, or animal burrowing, had resulted in extensive mixing of sediments, one would expect there to be less distinctive patterning among specific classes of variables and more general mixing of classes. Similarly, extensive mixing of deposits would tend to blur the relatively clear spatial clusters of cultural materials observed in components. Thus, it appears that the sediment deposits (the A horizon) that contained the Late Archaic component were relatively intact, and that the spatial patterning apparent among artifact categories in this Late Archaic component is referable more to the organization of the prehistoric occupation than to post-occupational factors.

\subsubsection{Mobility and Land Use Issues}

Inferences concerning the social structure during the Late Archaic at the Varga Site are difficult to make, since the tool assemblage and other material aspects are limited in numbers (except for the burned rocks) and biased towards the large cooking feature. The occurrence of the large burned rock oven feature may reflect the presence of female-dominated activity. If stone tool manufacturing and retooling tasks can be related to male activities, then one would assume that this occupation(s) consisted of group(s) composed of males and females. If the cooking feature reflects the cooking of bulk food items, then minimally a small group of people had to be present to collect the foodstuff and spend a few days cooking that resource and retooling their stone tool equipment. These tasks would imply a short-term event focused on plant collecting and cooking a single bulk plant resource.

No direct evidence of trade is identifiable, given that no marine shells or other exotic items of nonlocal origin were identified in the Late Archaic component assemblage. The lithic debitage and stone tools probably represent locally available Edwards chert based on macroscopic observations and INAA. The INAA reveals chemical signatures that, while variable, are similar to Edwards chert from several source areas across the southwestern part of the known Edwards outcrop. Only two or three signatures from different stone tools potentially represent other sources outside the current INAA database. This may indicate mobility within the region or at least contact 
with peoples/groups from this region. Therefore, the data relevant to stone procurement for tool production implies a mobile population operating within a relatively limited geographical range.

The 13 radiocarbon dates indicate at least two episodes of occupation during a 600-year period, possibly accounting for the presence of the multiple types of projectile points. However, one or more of the different point types may have been items of trade and/or exchange, or might actually represent curation/reuse of somewhat older points. Alternatively, either a single resident group made/used more than one style of point, or perhaps was comprised of different constituent subgroups, each with its own style of projectile point, residing together on some sort of temporary basis.

Although it is unclear how or why these multiple point types are represented here, such cooccurrence is seen at other Late Archaic sites across Texas. For example, site 41WM815 in the Blackland Prairie to the east yielded three point types-- Marshall, Castroville, and Montell- in and around a 2 m-diameter burned rock concentration interpreted as oven (Brownlow 2003). Brownlow offers multiple hypotheses to account for the apparent cooccurrence of the different point types.

In the eastern parts of Texas, across much of the Gulf Coastal Plain, and possibly along the eastern edge of the Edwards Plateau, Late Archaic peoples were thought to have been participating in a broader exchange network with peoples and groups further to the east (Hall 1981; Johnson 1982, 1994). The interaction is implied by the recovery of various nonlocal artifacts such as whelk pendants, stone gorgets, atlatl weights (boat stones) of exotic stone, and other exotic goods. No exotic artifacts were recovered from the Late Archaic component at the Varga Site to link the Varga population to any trade network, or even one of more local interactions. Potentially the rich material expression of this broader exchange network was religious and more restricted to the disposal of the dead, than it was connected to the technoeconomic dimension represented in domestic habitation sites. Since the local Varga group focused on cooking a bulk food product with other limited camping tasks present, expression of this trading or religious belief is not represented in the archeological record.

In the Lower Pecos region, two obsidian flakes from Stratum 9 at Arenosa Shelter that yielded Ensor and Frio Late Archaic points and two radiocarbon dates of 2,070 B.P. (Tx-285) and 2,230 B.P. (Tx-696) indicate a trade network at that location. Both obsidian flakes were traced to Cerro Toledo rhyolite in the Jemez Mountains of north-central New Mexico (Hester et al. 1991). Groups of this time undoubtedly participated in some trading networks, but no evidence of that exists at this Late Archaic component at the Varga Site. Consequently, from the artifact assemblage recovered, it appears that the inhabitances of the Late Archaic component were more focused on local resources with restricted mobility in a relatively restricted home range.

\subsubsection{Environmental Conditions}

This Late Archaic component documented to ca. 1,700 to 2,300 B.P. yielded limited environmental data. The Late Archaic pollen record here (extracted from three sediment samples in one vertical column and two radiocarbon-dated backhoe trench sediment samples) indicates the presence of at least eight different taxa that include three arboreal and five nonarboreal species. Pollen includes oak (Quercus), pecan (Carya sp.), pinyon (Pinus sp.), relatively abundant cheno-ams, Asteraceae, and Artemisia (Appendix E). 
The identified wood charcoal includes 11 taxa (pecan, walnut, juniper, and mesquite plus buttonbush, condalis, woody legume, lotebush, agavaceae, and prickly pear and mesquite seeds; see Appendix I). Juniper wood is the most abundant and comprises nearly 50 percent of the total weight of the charcoal from this component. The different taxa imply a mixed plant community of trees and small shrubs.

The phytolith record reveals 12 recognizable groups with shapes that represent $\mathrm{C}_{3}$ and $\mathrm{C}_{4}$ grasses and potentially other classes. This assemblage reveals the dominance of $\mathrm{C}_{3}$ Pooideae grasses (ranging from 33 to 68 percent) with some $\mathrm{C}_{4}$ grasses that included Panicoideae and Chloridaeae grasses (ranging from 26 to 64 percent). This is the only component that yielded a possible corn (Zea mays) phytolith (Appendix E), although the association with corn is questionable. The middle of the three Late Archaic sample, at 33 to $34 \mathrm{cmbs}$ from the vertical column, reveals a major change from the other two Late Archaic samples $5 \mathrm{~cm}$ above and $5 \mathrm{~cm}$ below this sample. The $\mathrm{C}_{4}$ grasses dominate the phytolith record accounting for nearly 63 percent of the record, whereas $\mathrm{C}_{3}$ grasses comprise about 33 percent of the phytolith record (Appendix E). This specific sample was not directly dated, so its precise age is unknown. This single phytolith record reflects a significant change in the grass composition regardless of how limited or brief a time period it may represent.

The carbon isotope data from these same three Late Archaic column samples reveal values from -28.9 to $-29.9 \%$ and document only organic matter derived from $\mathrm{C}_{3}$ plants. These values are the most negative of any carbon isotope values obtained from this 6,300-year old sediment column, indicating maximum $\mathrm{C}_{3}$ input. These very negative carbon isotope values may reflect the occurrence of a mesic period or indicate that the flora in this particular area was dominated by
$\mathrm{C}_{3}$ plants. This carbon isotope data contrasts with the carbon isotope data from Fort Hood, to the east in Central Texas, that Nordt (1992, 1993) interpreted to indicate a warming period with a mixture of $\mathrm{C}_{3}$ and $\mathrm{C}_{4}$ organic input for this general time period. The carbon isotope data also contrasts with the phytolith data from this same sample creating doubt in one or the other set of results.

The Late Archaic Varga Site phytolith assemblage indicates a mixture of $\mathrm{C}_{3}$ and $\mathrm{C}_{4}$ contributions, in contrast to the carbon isotope data that indicate a complete dominance of $\mathrm{C}_{3}$ contribution to the organic matter. The carbon isotope signal is strong and implies a moist and/or cool condition during this period or an area that was dominated by $\mathrm{C}_{3}$ plants.

In the Lower Pecos, the environmental conditions at around 2,500 B.P. were thought to have been more mesic and probably cooler during a period that Bryant and Holloway (1985) refer to as the Frio Interval. Even though this more mesic period was defined as having a relatively short duration, Bryant believes this provided a grassland environment suitable for supporting bison. The assumption is that the moister conditions provided better grazing, and therefore allowed for the expansion of the bisongrazing range. The massive bison Bone Bed 3 at Bonfire Shelter in the Lower Pecos region that yielded two charcoal and two bone dates between 2,300 and 2,800 B.P. documents the presence of bison in the Lower Pecos region at this time (Dibble and Lorrain 1967). Also in the Lower Pecos, the period following 2,300 B.P. saw a return to aridity, which Bryant (1966) referrers to as the Juno Stage. This period is characterized by xeric conditions as evidenced by pollen from Bonfire Shelter and Devil's Mouth Site, the beginning of a general drying trend that continued into historic times. This general drying trend would have been taking 
place during the time of Late Archaic occupations at the Varga Site.

At Hall's Cave in adjacent Kerr County, Toomey (1993) saw evidence for moister conditions at about 2,000 B.P. in the presence of the woodland mole (Microtus pinetorum). It is not clear if the slight timing differences for the moist conditions are a function of our imprecise dating of events or if more than one moist period is represented.

At Fort Hood in Central Texas, Nordt (1992, 1993) indicates the deposition of the upper West Range alluvium began as early as 2,800 B.P. and ending sometime between 800 and 600 B.P. He documents a mixed assemblage of $\mathrm{C}_{3}$ and $\mathrm{C}_{4}$ plant biomass as indicated by carbon isotope values from sediments during a period from about 2,000 to 2,400 B.P., and sees this mixed assemblage as evidence for a slight drying and warming trend.

Johnson and Goode (1994) also see posit change during the Late Archaic period. Before about 2,500 B.P., the eastern Edwards Plateau was thought to have been dryer than present, a period which Johnson and Goode refer to the "Dry Edwards Interval." After 2,500 B.P. and continuing to about 1,000 B.P., the region was slightly moister.

The possible corn phytolith in the Varga assemblage is highly unusual, and the fact that it was isolated in one buried sample at $33 \mathrm{cmbs}$ from Late Archaic context provides some confidence that it does not reflect modern activities. This author believes that this lobateshaped phytolith is not restricted to corn (see Rovner 2004). Although Turpin's (1991, 1995) discussions of the Blue Hills period in the Lower Pecos are brief, surely she would have mentioned corn if some had been associated with any components of this Late Archaic period. No corn or corn pollen was evidenced in the 43 coprolites analyzed from this period from
Conejo Shelter (Bryant 1974). However, carbon isotope data from four sets of human skeletal remains from this same Conejo Shelter indicate a diet rich in $\mathrm{C}_{4} / \mathrm{CAM}$ plants (Huebner 1991a) of which corn is a $\mathrm{C}_{4}$ plant. The CAM plants, such as prickly pear and agave lechuguilla, have been interpreted as major contributors to this more positive carbon isotope signature, based partially on the finding in the coprolites.

Similarly, Collins (1995) does not indicate that corn was part of the subsistence in the Late Archaic period across Central Texas. In fact, corn is extremely limited in Central Texas even in the Late Prehistoric period with only a couple of small cobs ever recovered from archeological context in rockshelters. The scant corn cobs at Kyle Site (Jelks 1962) and Timmeron Rockshelter (Harris 1985) are thought to reflect trade with Caddo groups to the northeast during the late Toyah period, sometime during the last 500 years or so.

Corn has been identified and directly dated in far west Texas, in the El Paso area at around 3,000 B.P. (Upham et al. 1987; Upham and MacNeish 1993; Tagg 1996), similar in age to corn kernels from the Cerro Juanaquena Site in Chihuahua, Mexico that have yielded multiple radiocarbon ages of ca. 3,000 B.P. (Hard and Roney 1998; Hard et al. 1999). These examples indicate that corn is possible during the Late Archaic, but known samples are from considerably west and south of the Varga Site. Exactly what the lobate-shaped phytolith reflects is not clear. The two phytoliths are the only line of evidence for corn. Extensive floating of matrix samples and identifications of the recovered materials revealed no support for the presence of corn in or around Feature 1, in any other Late Archaic context, or even in the later, overlying Toyah component. 


\subsubsection{Late Archaic Discussion}

The absence of Shumla type points at the Varga Site, which dominate the Lower Pecos region at this time, may indicate that the groups that employed the Shumla point type did not venture into northeastern Edwards County. This point type is not well dated, but appears to have occurred in a range from 2,000 to 2,800 B.P. and overlapping with immediately earlier and later periods (Turpin 1991, 1995). Most Lower Pecos sites that are dated and associated with these point types represent occupations a few hundred years earlier than the documented age of Feature 1 at the Varga Site.

In terms of the surviving material-culture record, the Late Archaic groups that occupied the Varga Site area were more similar to the Central Texas region. Supporting this are the Montell, Castroville, and Marcos points from the Varga Site. Although, these point types have also been found in the Lower Pecos region, often in association with bison bones, bison hunting in the area is generally attributed to intrusive hunting populations (Turpin 1991). Although the compressed natural and cultural stratigraphy in the Varga Site Late Archaic deposits prevents any specific clues to address the association between identified point types in Feature 1, the current interpretation is that these different point types were directly associated with this burned rock oven. Assuming the points from the Varga Site to have been associated with Feature 1, these point types can be linked to people who were collecting and processing plant foods, implying that they were not predominantly bison hunters, as various authors have suggested. In support of plant processing, near Rice's Crossing (41WM815) far to the east in the Blackland Prairie of Williamson County, two Montell, two Castroville, and two Lange points were recovered from a 2-m-diameter circular stone-lined pit thought to represent an earthen oven. This feature (Feature 9) was radiocarbon dated to a 290-year period between 2,240 and 2,530 B.P. (Brownlow 2003). In contrast, at 41TG91 north of here near San Angelo, Marcos points were associated with three radiocarbon ages falling between 2,480 and 2,910 B.P. (Creel 1990). This is just one indication that these Late Archaic groups exploited more than one food resource, and other localities that represent focus on a variety of resources are found across the broader region.

The most frequent point type associated with the Varga Site Late Archaic component is the Frio point, a type found throughout most of Central Texas and in the Lower Pecos region. The radiocarbon dates from the Varga Site correspond well with dated components that contained this same point type elsewhere and the Blue Hills period defined for the Lower Pecos region (Turpin 1991). At Arenosa Shelter the Frio and Marcos point types were in the same Stratum 9, lower part of Cut 3 (Dibble 1967).

In summary, the Late Archaic component was contained primarily in a buried A horizon, immediately below the younger Toyah component. Eleven acceptable radiocarbon dates document a 600-year use period between 1,700 and 2,310 B.P. The Late Archaic component in Block A was comprised mostly of a nearly 6 m-diameter poorly defined burned rock oven with a shallow central basin. A relatively limited cultural assemblage (ca. 6,000 pieces) was recovered, with burned rocks accounting for nearly 67 percent of the material recovered. Four small, amorphous rock clusters/concentrations were identified within the large burned rock oven boundaries. Lithic debitage was not abundant, and formal stone tools are few. Six different point types (Frio, Castroville, Marcos, Montell, Ensor, and Edgewood) were scattered just east of the estimated center of, and apparently associated with, the oven. The Late Archaic tool assemblage supports animal procurement and 
processing activities. The high frequency of core reduction flakes, angular debris, early and late stage biface flakes indicate that after chert cobbles were procured, they were reduced to produce tools for plant and animal procurement/processing.

The investigated part of the Late Archaic component functioned primarily as a cooking area. The burned rock oven reflects the preparation of bulk foods that required lengthy cooking. Limited macrobotanical remains in the forms of four burned prickly pear seeds, a burned mesquite seed, burned walnut shell fragments, and seven burned agave leaf fragments provide some hints of what was cooked in this oven. Indirect evidence in the form the lipid residues extracted from the burned rocks reflect the cooking of high-fat-content plants.

The horizontal distribution of debris indicates that while the oven was in use, general retooling activities were conducted along the eastern margins. No direct evidence of trade/exchange was identified. Macroscopic observations of the lithic debitage and INAA on selected stone tools indicate that locally available Edwards chert was procured for tool production. The current data points to small, mobile group(s) with a relatively limited home range occupying this local for a short period while carrying out limited hunting and conducting plant procurement and cooking activities. 


\subsection{MIDDLE ARCHAIC COMPONENT}

\section{J. Michael Quigg}

\subsection{INTRODUCTION}

The Middle Archaic component was initially identified during the Phase I investigations from deposits on both sides of the Ranch to Market Road by discoveries of a Pedernales point, a Carrizo point, and two Early Triangular points. Sparse cultural materials including scattered burned rocks, lithic debitage, and the occasional stone tool were found in the upper part of Depositional Unit 3, a brown (10YR 5/3) clay loam, between the Late Archaic burned rock Feature 1, and the dense Early Archaic materials at the base of Unit 3 . In the initial interim report, these cultural materials were considered too sparse to be considered to represent a distinct zone of occupation, with the result that this zone was not specifically targeted for Phase II investigations (Lintz et al. 2002).

The Phase II investigations yielded a relatively small sample of Middle Archaic materials from Block A, whereas Block B targeted only the Late Prehistoric deposits. The thickest Middle Archaic deposit, between ca. 40 and $80 \mathrm{cmbd}$, was along the southern edge of Block A. This deposit rapidly thinned to about $20 \mathrm{~cm}$ thick, between ca. 10 and $30 \mathrm{cmbs}$, towards the northern end of Block A. At this compressed northern end, the wedge-shaped Middle Archaic deposit was subjected to more disturbances and mixing with earlier and later materials.
The chronometric age of the Middle Archaic component was established by intensive dating of the cultural components immediately above and below, and through four radiocarbon dates derived from materials extracted from this component. The bracketing ages from the other components provide a time range in which these Middle Archaic events should have occurred. The overlying Late Archaic component is closely dated to less than ca. 2,300 B.P., whereas the lower Early Archaic component is dated to older than ca. 5,200 B.P. These radiocarbon ages provide a ca. 3,000-year temporal interval for the Middle Archaic materials.

Four radiocarbon assays narrow the potential 3,000-year window down to about a 900-year period that better defines the time range of the Middle Archaic component (Table 10-1). Tiny flecks of charcoal from burned rock cluster Feature 37, between 78 to $80 \mathrm{cmbd}$ in Unit N99/E53, yielded an AMS date of 4,260 \pm 40 B.P. (UGA-12705). Another charcoal chunk from 50 to $60 \mathrm{cmbd}$, in Unit N104/E56, yielded an AMS date of 4,770 \pm 40 B.P. (UGA-12717). These two wood charcoal dates provide the best evidence for the chronological placement of the Middle Archaic component at the site. A date on deer bone fragment collagen (\#522-7-2-1a), from 50 to $60 \mathrm{cmbd}$ in Unit N106/E53, yielded an age of $3,910 \pm 40$ B.P. (UGA-12719) and accords in a general way with the wood charcoal dates. The dating also provides direct evidence that the bones recovered from this component actually date to this period and were not displaced from other components. The fourth radiocarbon date of 4,820 \pm 40 B.P. (Beta-175393) was derived from organic sediment at 80 to $85 \mathrm{cmbs}$ in BT 7 on the east side of the road. This latter assay represents a mean resident time and provides further support for the general age of the alluvial fines from which the Middle Archaic materials were recovered. 


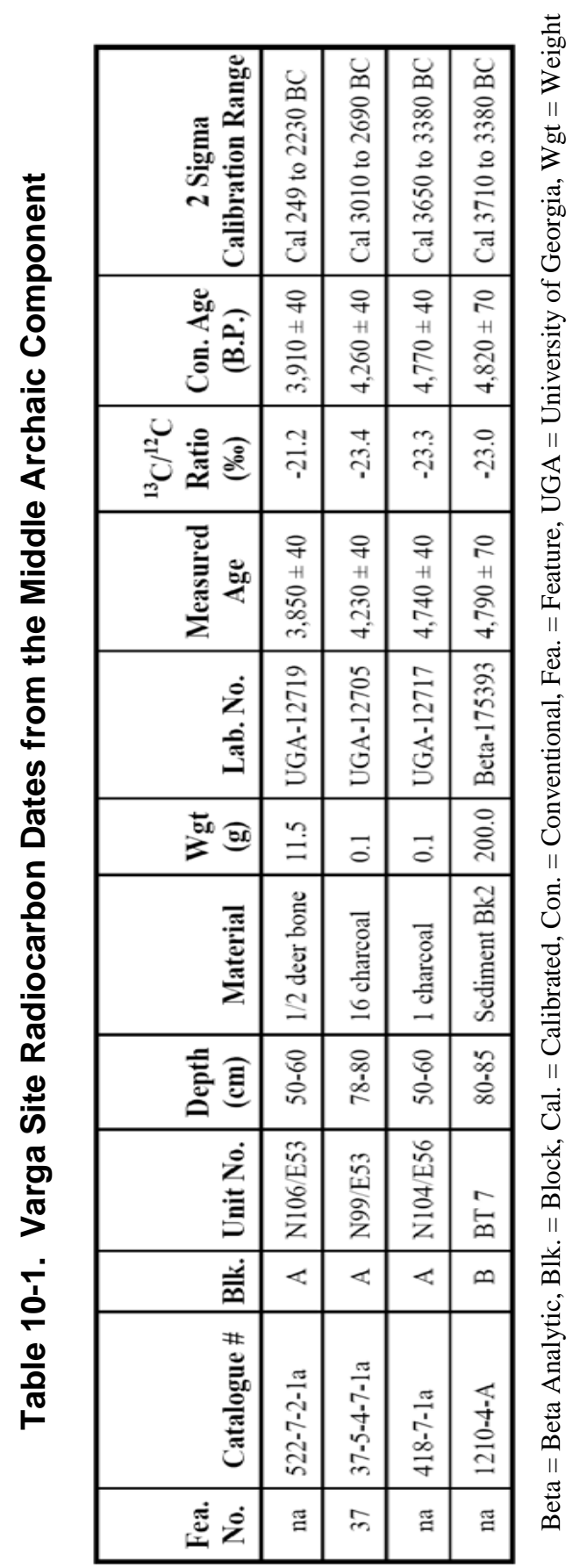


Based on the two wood charcoal dates, these four assays document a probable 900-year period for the Middle Archaic component that is perhaps more restricted to a 600-year period between about 4,200 and 4,800 B.P.

The 83- $\mathrm{m}^{2}$ hand-excavations in Block A yielded 6,079 cultural materials attributed to the Middle Archaic that include 4,387 pieces of lithic debitage, 810 pieces of burned rocks, 725 bone fragments, $2.5 \mathrm{~g}$ of organic remains, 122 edgemodified flakes, 11 bifaces, 10 projectile points, eight cores, three scrapers, one hammerstone/anvil, and two features. Each category of material is presented and discussed below.

\subsection{Middle ARChaic Features}

\subsubsection{Introduction}

Only two clusters of burned rocks, Features 11 and 37 were recognized and assigned feature numbers in the field. These were subsequently assigned to this component. Both features were discovered in Block A.

\subsubsection{Feature 11}

Feature 11 consisted of relatively large limestone burned rocks in a loose cluster near the intersection of four units, N106/E51, N106/E52, N107/E51, and N107/E52, near the middle of the northern half of Block A. Stratigraphically, this cluster was situated in relatively shallow and compressed sediments with vertically scattered materials, making identification and component assignment difficult. These burned rocks were clustered in an area that measured about $80-$ by $-70 \mathrm{~cm}$ in diameter with the tops of the rocks at $32 \mathrm{cmbs}$ and the bottoms near $52 \mathrm{cmbs}$. The burned rocks were located primarily in two clusters with a few rocks scattered in between (Figures 10-1 and 10-2). Since no obvious color change in the matrix was observed or other boundary was detected, no specific horizontal pattern was distinguished No basin was detected below the rocks. During excavation, no oxidized sediment, ash or charcoal lenses, and no visible chunks of charcoal were observed around the burned rocks.

Ten liters of matrix (\#515-5-4) from around the burned rocks were collected and floated. The floated material yielded a few tiny charcoal pieces, of which five were dated. These five pieces (\#515-5-4-7-1) yielded a $\delta^{13} \mathrm{C}$ corrected (25.7\% ) AMS radiocarbon date of 1,990 \pm 40 B.P. $\quad$ (Table 10-1: UGA-12718). These pieces were two small to identify the type of wood. The dated charcoal falls in the time period documented as the Late Archaic component at the Varga Site. Apparently, these tiny pieces filtered downward from the overlying Late Archaic component and became trapped between the burned rocks. This cluster of burned rock is stratigraphically within the Middle Archaic deposit, and therefore older than the date obtained on the charcoal. Consequently, for identifying the age of this Middle Archaic burned rock feature, the charcoal radiocarbon date is rejected.

The 0.2 liters of light fraction failed to yield any other charred macrobotanical remains (Appendix I). The heavy fraction yielded 45 pieces of chert, three tiny flecks of charcoal, and three tiny bone fragments. One of the burned pieces is a thick nutshell like walnut. The $6.4 \mathrm{~mm}$ size fraction yielded three tiny burned rocks, 10 chert pieces, and nine nearly whole snail shells (Polygyridae and/or Helicinidae).

Four more liters of matrix (\#583-5-4 and \#5075-4) were collected from the junction of two units and were also floated. The $6.4 \mathrm{~mm}$ size fraction yielded six burned rock fragments that weigh $35.3 \mathrm{~g}$, five pieces of chert, and five nearly whole snail shells (Polygyridae and/or Helicinidae). 

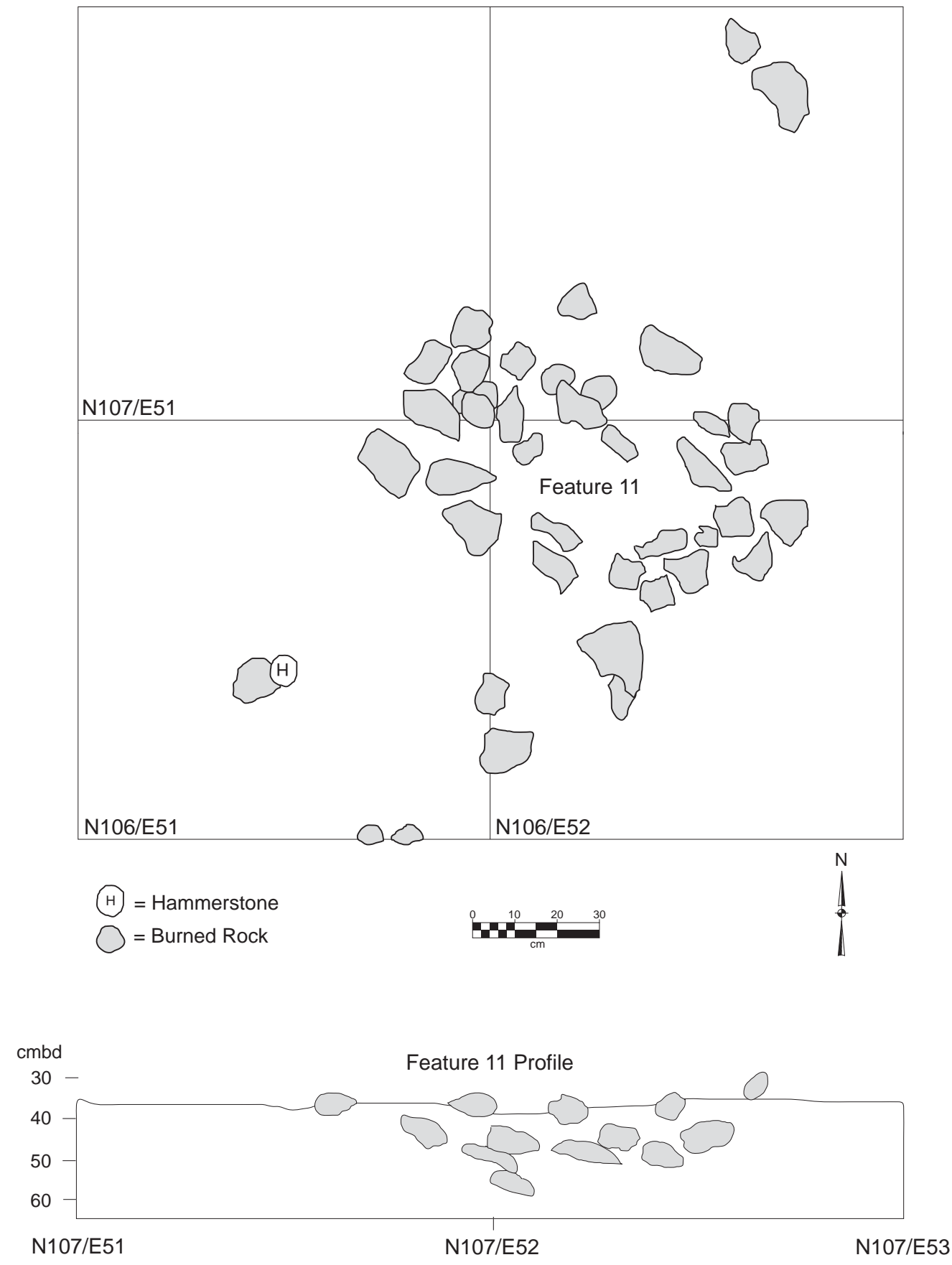

Figure 10-1. Planview of Profile of Feature 11, Middle Archaic 


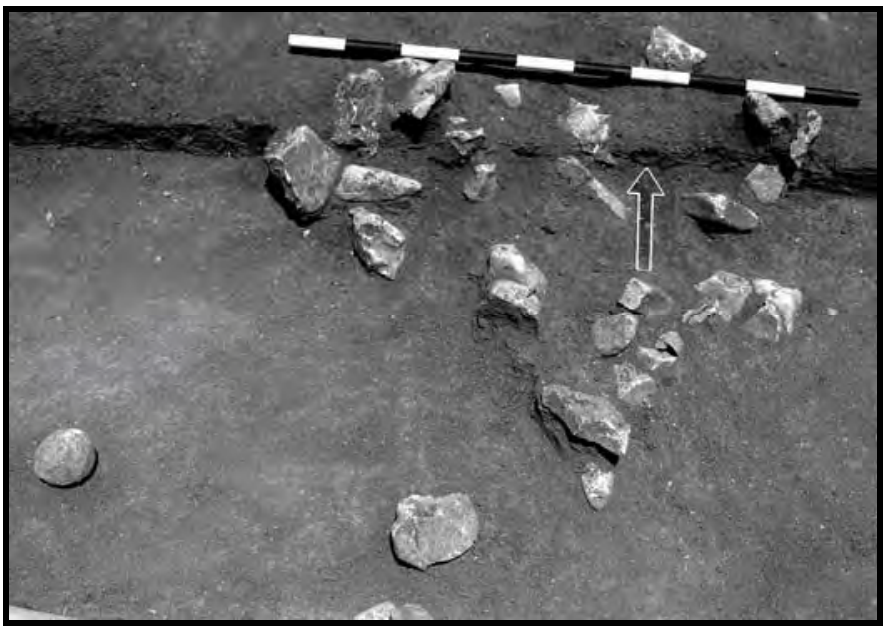

Figure 10-2. Overview of Excavated Feature 11 Showing Burned Rock Associations

Approximately 40 burned rocks were collected from this feature and they represent tabular slabs, rounded cobbles, and amorphous chunks of limestone. Fifty-five percent of the collected burned rocks from Feature 11 were in the 9.1 to $15 \mathrm{~cm}$ size class; whereas 18 percent were in the smallest size class between 0 and $4 \mathrm{~cm}$ (Table 10-2). The average burned rock weight was nearly $568 \mathrm{~g}$. Seven burned rocks are considered complete with rounded edges implying they were retrieved from the riverbed. Attempts at refitting the broken pieces resulted in piecing together four separate cobbles, two with three pieces each that recreated rounded cobbles, and two refits with two pieces each that were tabular slabs. A few rocks exhibited heatspalled edges, whereas others exhibited sharp angular or hackled edges. Generally, these two different break types are not thought to reflect the same type of use. Generally, spalled edges are most often thought to be caused by exposure to heat and/or slow cooling. The sharp angular or hackled edges are more often attributed to rapid cooling, as in a stone boiling process.

A sample of five burned rock pieces from five adjacent proveniences was analyzed for lipid residue. Drs. Malainey and Malisza's detail findings and interpretations are presented in Appendix G, with a summary presented here (Table 10-3). Two samples (\#583-5-3-1a, and \#276-5-3-2a) yielded high fat content interpreted as representing plant materials. Residues from sample \#276-5-3-1a yielded moderate to high fat content. Sample \#515-5-3-1a yielded very high fat content, also representing plant matter. Only slight variation is seen in the lipid residue interpretations, and this implies that the rocks were used to cook similar or the same foods, possibly during a single cooking episode.

The same burned rocks analyzed for lipid residues were also analyzed for isotope values. The stable carbon isotope values range from 22.9 to $-26.3 \%$ with a mean of $-24.7 \%$ o (Table 10-4). These values indicate that there is mostly $\mathrm{C}_{3}$ matter in the burned rocks. The nitrogen values range from 6.6 to $8.0 \%$, with a value of $2.4 \%$ derived from sample \#583-5-3$1 \mathrm{~b}$, is questioned because of the extremely low measured weight. Nothing in the nitrogen values indicate the cooking of legumes or nuts. 


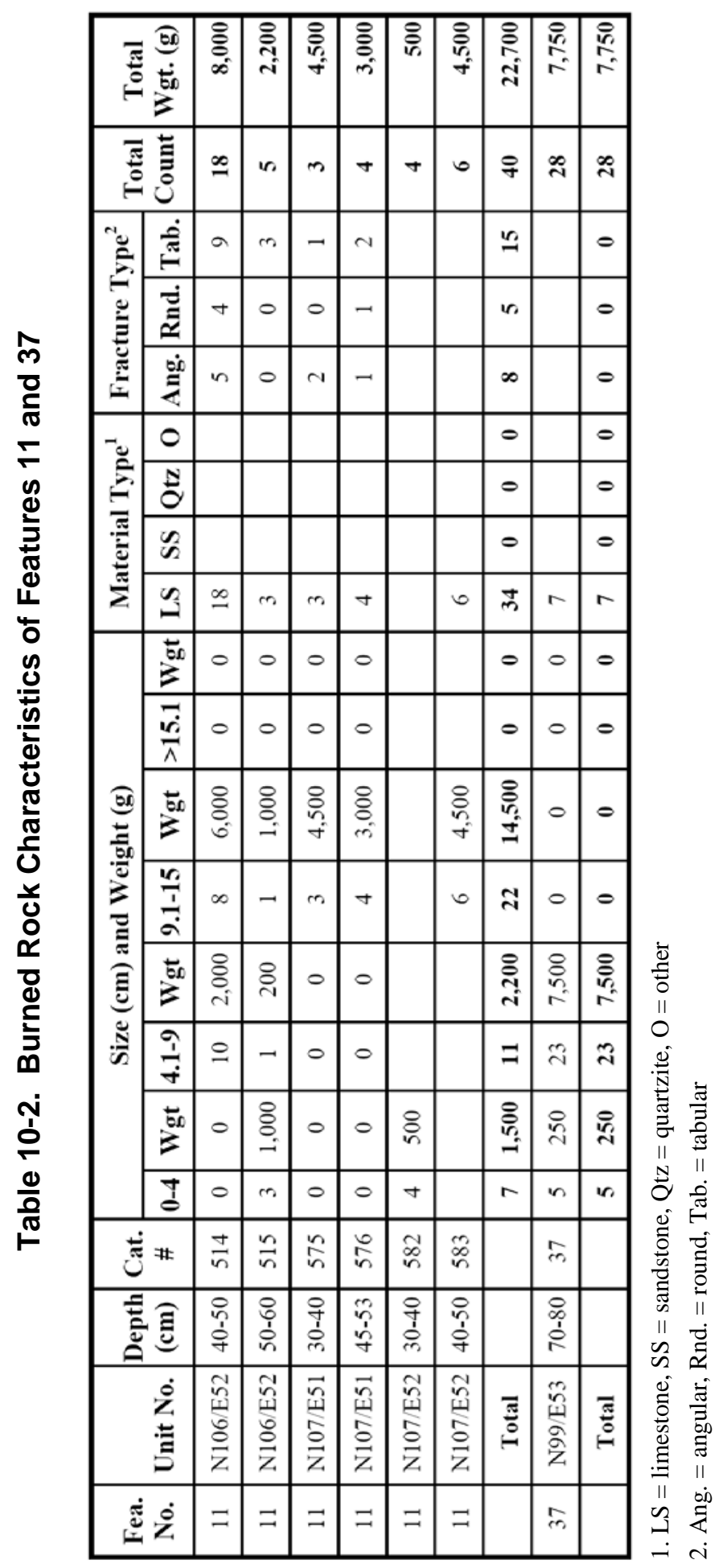


Table 10-3. Lipid Residue Results from Burned Rock Samples from the Middle Archaic Component

\begin{tabular}{|c|c|c|c|c|l|}
\hline Lab. No. & Cat. \# & $\begin{array}{c}\text { Fea. } \\
\text { No. }\end{array}$ & Material & $\begin{array}{c}\text { Wgt. } \\
\text { (g) }\end{array}$ & \multicolumn{1}{|c|}{ Interpreted Lipid Residue Results } \\
\hline 4VG 72 & 276-5-3-1a & 11 & Limestone & 17 & Moderate-high fat content \\
\hline 4VG 76 & 276-5-3-2a & 11 & Limestone & 61 & High fat content - plant \\
\hline 4VG 73 & 515-5-3-1a & 11 & Limestone & 29 & Very high fat content - plant \\
\hline 4VG 74 & 575-5-3-1a & 11 & Limestone & 20 & Borderline medium and moderate-high fat content - plant \\
\hline 4VG 75 & 583-5-3-1a & 11 & Limestone & 27 & High fat content - plant \\
\hline 4VG 77 & 37-5-3-1a & 37 & Limestone & 25 & Moderate-high fat content \\
\hline 4VG 78 & 37-5-3-2a & 37 & Limestone & 38 & High fat content - plant \\
\hline 4VG 79 & 37-5-3-3a & 37 & Limestone & 32 & High fat content - plant \\
\hline 4VG 80 & 37-5-3-4a & 37 & Limestone & 21 & Moderate-high fat content \\
\hline
\end{tabular}

Table 10-4. Isotope Results from Burned Rocks in Middle Archaic Features

\begin{tabular}{|c|c|c|c|c|c|c|c|c|}
\hline Cat. \# & Unit No. & $\begin{array}{c}\text { Depth } \\
\text { (cmbs) }\end{array}$ & $\begin{array}{c}\text { Fea. } \\
\text { No. }\end{array}$ & $\begin{array}{c}\text { Wgt } \\
\mathbf{( m g )}\end{array}$ & $\begin{array}{c}\mathbf{N} \\
\mathbf{W g t} \\
\mathbf{\mu g}^{\mathbf{1}}\end{array}$ & $\begin{array}{c}\boldsymbol{\delta}^{\mathbf{1 5}} \mathbf{N} \\
\mathbf{( \% o )} \\
\text { Value }\end{array}$ & $\begin{array}{c}\mathbf{C} \\
\mathbf{W g t} \\
\mathbf{\mu g}\end{array}$ & $\begin{array}{c}\boldsymbol{\delta}^{\mathbf{1 3}} \mathbf{C} \\
\mathbf{( \% o} \\
\text { Value }\end{array}$ \\
\hline 583-5-3-1b & N107/E52 & $40-50$ & 11 & 3.708 & $\mathbf{9 . 2}$ & $\mathbf{2 . 3 6}$ & 137.2 & -25.54 \\
\hline 276-5-3-1b & N102/E50 & $60-70$ & 11 & 20.335 & 107.9 & 6.59 & 1865.7 & -26.28 \\
\hline 276-5-3-2b & N102/E50 & $60-70$ & 11 & 20.327 & 99.5 & 7.36 & 1408.5 & -24.84 \\
\hline 515-5-3-1b & N106/E52 & $50-60$ & 11 & 20.101 & 170.3 & 6.85 & 2063.4 & -24.05 \\
\hline 575-5-3-1b & N107/E51 & $30-40$ & 11 & 30.066 & 146.6 & 7.98 & 1747.2 & -22.88 \\
\hline 37-5-3-4b & N99/E53 & $70-80$ & 37 & 22.228 & 40.9 & 8.35 & 655.7 & -24.10 \\
\hline 37-5-3-1b & N99/E53 & $70-80$ & 37 & 30.417 & 130.6 & 2.95 & 1630.9 & -24.81 \\
\hline 37-5-3-2b & N99/E53 & $70-80$ & 37 & 10.522 & 120.4 & -0.24 & 1470.3 & -26.67 \\
\hline 37-5-3-3b & N99/E53 & $70-80$ & 37 & 17.881 & 106.2 & 1.24 & 1921.3 & -25.53 \\
\hline
\end{tabular}

1. Values below 10.0 make the results suspect

2. $\mathrm{C}=$ Carbon; $\mathrm{N}=$ Nitrogen 
The generally high nitrogen values combined with the very negative carbon isotope values indicate cooking $\mathrm{C}_{3}$ plants or animals that ate $\mathrm{C}_{3}$ plants. These isotope results combined with the lipid interpretations indicate that $\mathrm{C}_{3}$ plants comprised the cooked food resources.

Surrounding this cluster of burned rocks were other cultural materials such as lithic debitage $(n=67)$, small bone scraps $(n=13)$, and tiny charcoal flecks. No formal stone tools were recovered from the four relevant units, but five edge-modified flakes were located in the southwest quadrant, and three edge-modified flakes were located in the northeast quadrant.

This burned rock cluster probably represents a disturbed hearth, as indicated by the few complete burned rocks, the presence of multiple pieces of the same rock, and the large size of the rocks represented. The lack of a definable basin (except for the variation in rock depths), the lack of patterning to the rocks, and other hearth characteristics might occasion some skepticism, however. The radiocarbon date on the obtained charcoal indicates the charcoal is Late Archaic in age and was displaced into this context. As mentioned earlier, this date is not acceptable for the true age of Feature 11, and it is in fact quite similar to the ages obtained from Feature 1 above and slightly to the south. As already noted, the stratigraphic position of the burned rocks was sufficiently deep to be vertically and stratigraphically associated with the Middle Archaic component, with cultural materials immediately below this assigned to the Early Archaic component.

In summary, Feature 11 is interpreted as a disturbed hearth based on the probable presence of a possible basin below the rock combined with the relatively large size of the individual rocks. The burned rocks were used to cook mostly high fat content, $\mathrm{C}_{3}$ plant foods. It is not clear whether or not this feature actually represents some type of oven.

\subsubsection{Feature 37}

Feature 37, a small burned rock cluster, was discovered in Unit N99/E53 at the very southern edge of Block A. At 70 and $80 \mathrm{cmbd}$, it was sufficiently deep to have escaped any disturbances from modern activities and is vertically correlated with other Middle Archaic materials. The burned rocks were in an irregular east-west linear alignment that measured about $55 \mathrm{~cm}$ long by $25 \mathrm{~cm}$ wide (Figure 10-3). The dark brown (10YR 4/3) clay loam matrix that surrounded the burned rocks was similar to that in the rest of the level. Other cultural materials such as stone tools, lithic debris, or bones were nearly absent from among the clustered rocks, although a few flakes and scattered burned rocks were located at this same level outside the feature. No basin or vertical-dimension pattern to the burned rocks was observed. The burned rocks were in a single layer with only slightly variable depths.

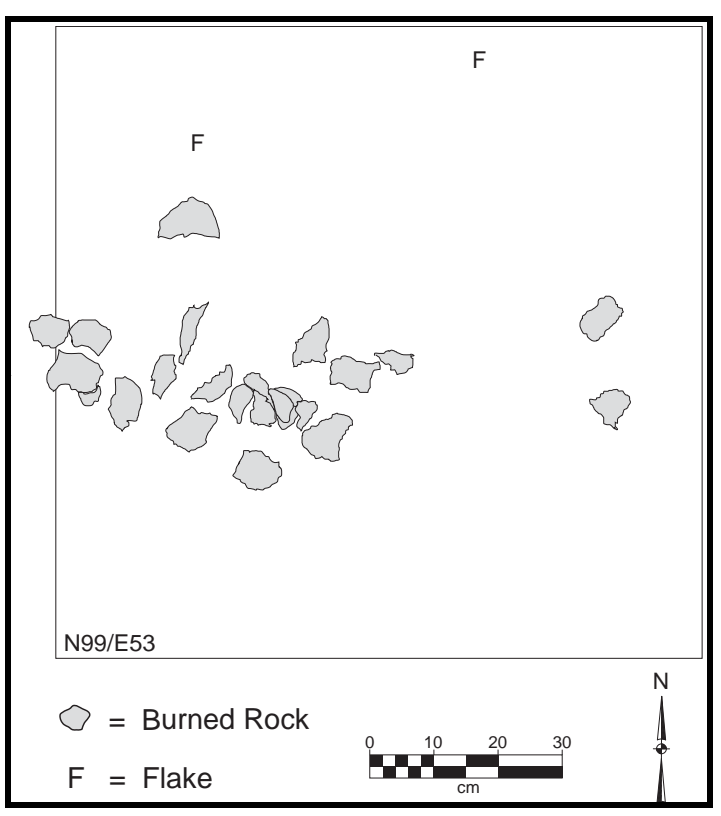

Figure 10-3. Planview of Feature 37, in Middle Archaic 
Feature 37 contained 28 burned limestone pieces with 82 percent in the 4.1 to $9.0 \mathrm{~cm}$ size class (Table 10-2). These limestone pieces had an average rock weight of $277 \mathrm{~g}$. Although not specifically recorded in the field, the small sample of collected burned rocks was seen to represent both rounded cobbles and tabular slabs.

A sample of four burned rock pieces was analyzed for lipid residue. The detailed findings and interpretations are presented in Appendix G, and only a summary is presented here. Two samples (\#37-5-3-1a and \#37-5-3-4a) yielded moderate to high fat content (Table 10-3). Two other samples (\#37-5-3-2a and \#37-5-3-3a) yielded high fat content implying the chemical residues of plants. These results indicate that the rocks probably contain two slightly different kinds of residue, implying possible use in multiple cooking events.

Stable carbon isotope values from the four rocks range from -24.1 to $-26.7 \%$, with a mean of 25.3\% (Table 10-4). These values indicate a very strong $\mathrm{C}_{3}$ signal in the diet of animals, or alternatively, they represent $\mathrm{C}_{3}$ plants (Appendix H). The nitrogen isotope values range from -0.3 to $8.4 \%$, a very large range. The combined isotope values suggest a legume plant, but there is no indication of the species. The $-0.3 \%$ value is in the range of plant matter such as buckeye seeds, oak nuts, Mexican plums, and huisache seeds. The highest nitrogen value of $8.4 \%$ generally reflects something similar to rabbit or deer meat. The other three nitrogen isotope values generally reflect plants. The range in isotope values is supportive of multiple items cooked by these burned rocks, mostly in the form of various plants.

Five liters of floated matrix (\#37-5-4-1), collected from around and below the burned rocks at 70 to $80 \mathrm{cmbd}$, yielded extremely limited charcoal flecks. Not even the light fraction (less than 0.1 liters) yielded identifiable carbonized plant remains (Appendix I). The heavy fraction yielded 32 tiny pieces of chert, one nearly whole snail shell, three unburned seed-like specimens, and two tiny unburned bone fragments. The $6.4 \mathrm{~mm}$ size fraction yielded one chert flake, and 12 nearly whole snail shells.

Sixteen tiny pieces of charcoal (\#37-5-4-7-1a) from 78 to 80 cmbd in Feature 37 were sent for radiocarbon dating. This sample yielded a conventional radiocarbon age of 4,260 \pm 40 B.P. (UGA-12705). Feature 37 was stratigraphically level with or slightly below elevations that yielded Early Triangular points (\#182-13 and \#308-11) and other types of cultural debris just a few meters north and northwest of Feature 37. It is assumed that this wood charcoal date is reflective of an occupational event that left behind the Early Triangular points.

In summary, Feature 37 is interpreted as a burned rock dump or discard pile from a separate primary cooking feature. The overall elongated shape of this cluster combined with the lack of a basin or other evidence for in situ burning supports this interpretation. The burned rocks were used to cook mostly $\mathrm{C}_{3}$ plant foods.

\subsection{Stone ToOl Descriptions AND Discussions}

The 155 stone tools are presented by classes, with summaries of attributes and metric measurements in tables in Appendix O. The exception is the category of edge-modified pieces, for which only select number of specimens have been recorded in detail. The projectile point class is subdivided into identifiable point types, as well as containing detailed descriptions. Tool classes are generally thought to represent specific activities, but several individual specimens from the different tool classes were arbitrarily selected for usewear analyses to investigate specific functions. 
Individual use-wear findings are presented following each class summary. Beginning with the identifiable types of projectile points each tool type is described below.

\subsubsection{Projectile Points}

The 10 projectiles from the Middle Archaic component fall into two groups. Four are untypable because they are small fragments that lack diagnostic characteristics, and six are identified as Early Triangular points (Figure 104). All specimens were manufactured of finegrained chert and lack cortex (Appendix O). Three other Early Triangular points were recovered from non-Middle-Archaic-contexts. Specimen \#138-12 was from a mixed or otherwise unclear context, and specimens \#27827 and \#729-10 were from the top part of the Early Archaic component. The attributes for these three points are combined with the six Early Triangular points from the Middle Archaic component to provide a more comprehensive summary of this point type. Only one is complete, whereas the remainder were probably broken during use. Two specimens exhibit some edge beveling. One specimen is burned, and one is heat-treated. Most have essentially straight lateral edges, although a few edges are excurvate.

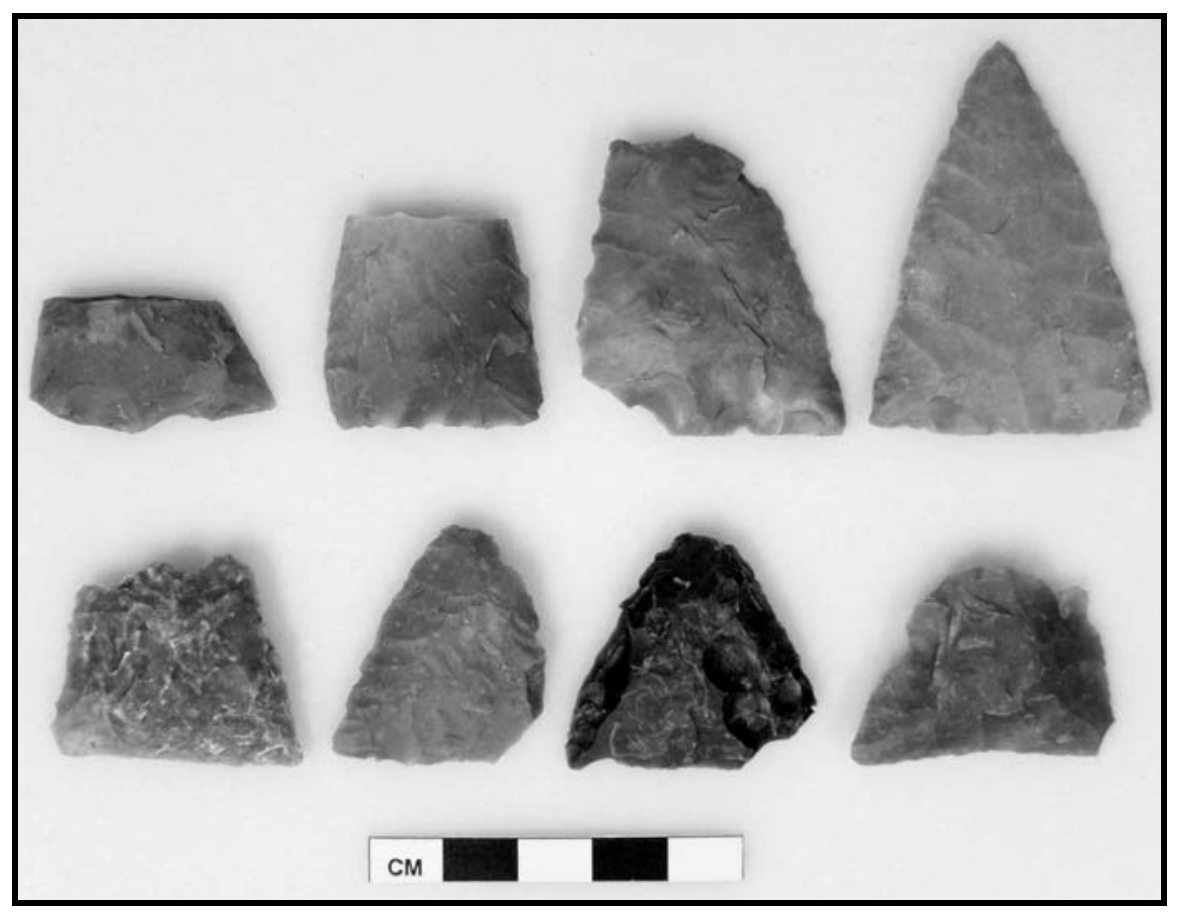

Figure 10-4. Selected Middle Archaic Projectile Points

Left to Right: Top Row: \#1140-010, \#537-017, \#308-011, \#182-013; Second Row: \#922-010, \#278-027, \#654-010, \#138-012 
A few metric attributes from the Early Triangular points are worth summarizing (individual metric and non-metric characteristics are presented in Appendix O). Maximum thickness ranges from 4.9 to $6.5 \mathrm{~mm}$, with a mean of $5.6 \mathrm{~mm}$ and a standard deviation of $0.6 \mathrm{~mm}$. The maximum width ranges from 28.3 to $38.3 \mathrm{~mm}$, with a mean of $33.3 \mathrm{~mm}$ and a standard deviation of $3.7 \mathrm{~mm}$. Maximum length measurements range from 31.0 to $52.9 \mathrm{~mm}$, with a mean of $38.4 \mathrm{~mm}$ and a standard deviation of $12.6 \mathrm{~mm}$. Blade width ranges from 28.3 to $38.3 \mathrm{~mm}$, with a mean of $33.3 \mathrm{~mm}$ and a standard deviation of $4.2 \mathrm{~mm}$.

Four Early Triangular points were subjected to use-wear analyses, briefly described below (with more details presented in Appendix C). Complete specimen \#182-13 lacks any sign of resharpening and exhibits one straight and one excurvate edge. It reveals hair fragments that are associated with use together with light polish at either end. The inferred use is unknown, and hide was the probable contact material. A proximal specimen (\#308-11) that exhibits a use break reveals abraded ridges that show haft wear, and a hard, high-silica polish and edge damage in the form of step fractures. These characteristics indicate use was probably gouging on hard, high-silica material. A second proximal piece (\#537-17) with a use break reveals striation in multiple directions from hard, high-silica material. The inferred use was cutting of some hard, high-silica material. Specimen \#729-10 is the proximal section of a heat-treated point that apparently broke during use and exhibits parallel flaking with no sign of rejuvenation or resharpening. Hafting wear is present, along with high-silica polish on the proximal end. Use-wear is evident by highsilica polish indicating a whittling motion on a hard, high silica material.

A piece from the proximal end of \#537-17 (TRC122) was subjected to INAA to detect the origin of the chert. That analysis revealed a chemical signature similar to known Edwards chert that was probably locally procured (see Appendix F). One specimen (\#654-10) is a dark gray color that has been through intensive heat and exhibits heat spalls. This piece reveals an ultraviolet fluorescence that is a darker (more purple) color than the amber-orange-yellow expected for most Edwards chert (Hofman et al. 1991). This color is potentially associated with cherts that originate from along the Rio Grande River Valley (Quigg and Cordova 2000; Quigg et al. 2000).

At least one untypable fragment (\#225-11) reveals a distal blade that is thicker than the other Early Triangular points and probably represents some other point type. The distal part of a Carrizo point (\#213-12) was subsequently refitted to a Carrizo base. However, the diagnostic basal portion was recovered from a level assigned to the Early Archaic component. Unknown distal dart point \#225-11 was the only heat-treated piece. Specimen \#675-10 appears to be a wide barb from a notched point and again represents a type other than an Early Triangular point. Its small size would easily permit vertical displacement from another component.

The six Early Triangular points that dominate the Middle Archaic projectile point assemblage from this component, and presumably the three Early Triangular projectile points from other contexts, correspond well with the radiocarbon dates obtained from this Middle Archaic component (Table 10-1). Two other slightly deeper Early Triangular points (\#138-12 and \#278-27) were recovered in the southern part of Block A. Specimen \#138-12 was recovered from 80 to 90 cmbd in Unit N100/E55 in a level that could not be confidently assigned to the Middle Archaic, but was near the bottom of the Middle or the very top of the Early Archaic component. This depth is comparable to the Middle Archaic zone even though this level 
could not be assigned with accuracy. The second specimen (\#278-27) was also located at 80 to $90 \mathrm{cmbd}$ in Unit N102/E50 in a level that was assigned to the Early Archaic component. It too was at approximately the same depth, though assigned to the Early Archaic component. This specimen may have been downwardly displaced, or it was in a mixed context that was arbitrarily assigned to the Early Archaic. The eight Early Triangular points are of sufficient number to indicate they represent human presence at the Varga Site during the Middle Archaic, rather than curated items. Also significant is the fact that they are the dominant point type recovered from this Middle Archaic component. Therefore, these eight, possibly nine, Early Triangular points are probably chronologically associated with at least one of the radiocarbon dates that document a 900-year period, between 3,910 B.P. (UGA-12719) and 4,820 B.P. (Beta175393).

\subsubsection{Bifaces}

The 11 bifaces were all manufactured from finegrained chert with only a small spot of cortex on one early stage specimens (Appendix O). Only three specimens are complete and proximal and distal fragments are roughly equally represented (Figure 10-5). Sixty percent represent late stages, 30 percent represent middle stages, and 10 percent represent early stage bifaces. The early and middle stage pieces are complete, whereas the late stage pieces revealed mostly use breaks. One middle stage biface was apparently heat-treated. The three complete specimens average $70 \mathrm{~mm}$ long, $51.3 \mathrm{~mm}$ wide, and $16.2 \mathrm{~mm}$ thick. The late stage bifaces are much thinner, averaging $8.8 \mathrm{~mm}$ thick. Most fragments provide at least some metric data.

Two bifaces, one fragmentary late stage specimen and one complete middle stage piece, were sent for use-wear analysis. Specimen \#418-28 is a late stage biface fragment with a use break that lacks any sign of resharpening or rejuvenation. It reveals polish and striation in multiple directions that indicate cutting in various directions on hard material (Appendix C). A complete, middle stage biface (\#419-12) that is $14.2 \mathrm{~mm}$ thick appears heattreated and shows no obvious indication of resharpening. It reveals wood fragments that are probably from use, and hard, high silica polish and striations perpendicular and parallel to the long axis. These attributes are interpreted as representing planing of wood (Appendix C).

Five bifaces $(\# 149-10=$ TRC110, \#417-13 = TRC115, \#418-28 = TRC116, \#419-12 = TRC117, and \#544-12 = TRC123) were sampled for sourcing through INAA. The chemical signatures were similar to known Edwards chert and these specimens probably originated from local sources in the region, but are apparently from different source localities (Appendix F). Two bifaces, a late-stage piece broken during use (\#418-28 = TRC116), and a complete middle-stage piece (\#419-12 = TRC117) have chemical signatures that are similar to those from natural chert samples collected from Hackberry Creek immediately adjacent to the Varga Site. It is possible the raw material for at least these two bifaces was derived from the local creek gravels.

\subsubsection{Scrapers}

Only three scrapers were recognized, and two are fragments that appear to have been broken during use (Figure 10-6). All three were manufactured from fine-grained cherts. Metric and non-metric attributes are provided in Appendix O. Specimen \#1124-10 is a fragment of a side-scraper that was heat-treated. The working edge is very steep at 82 degrees. 


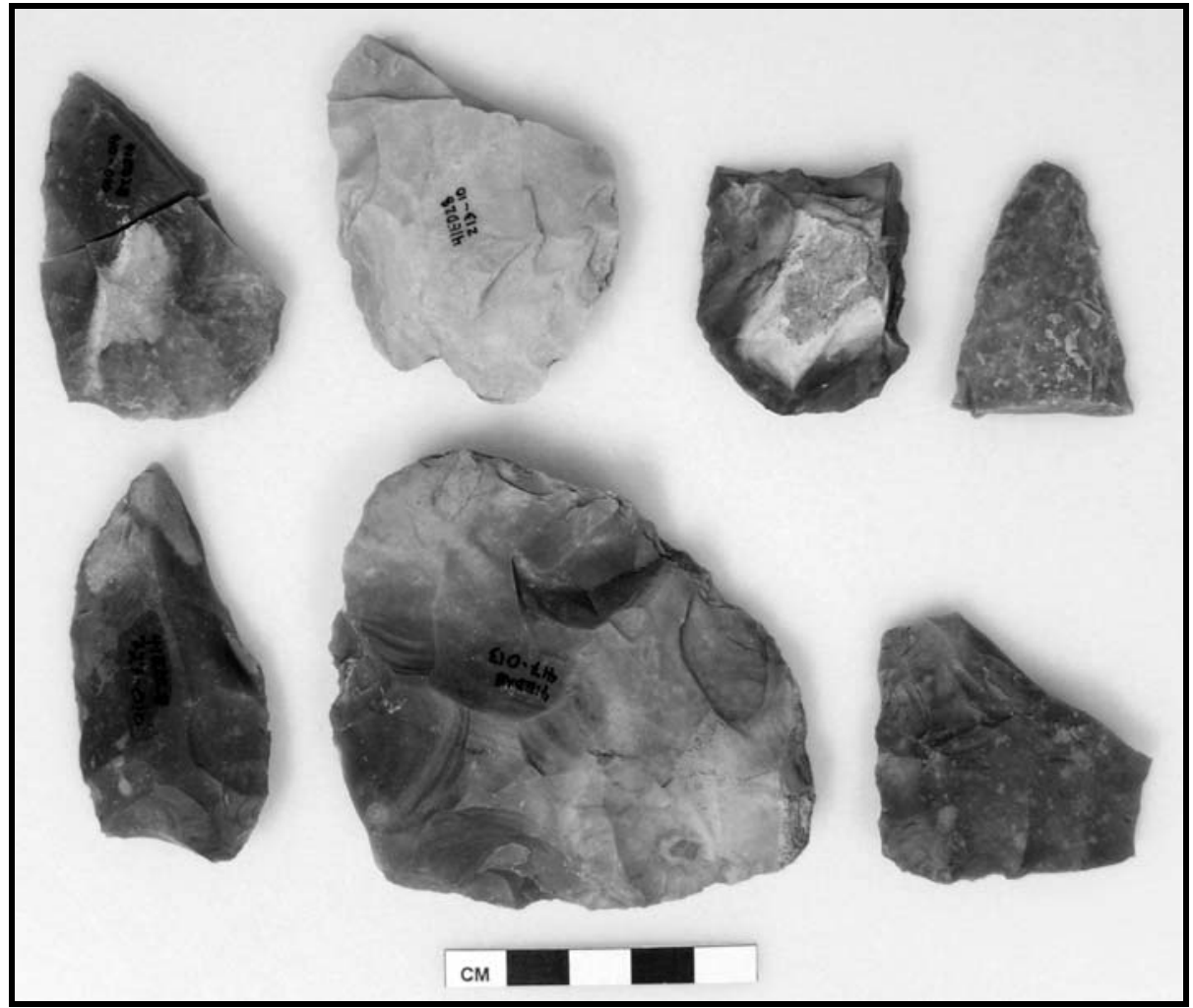

Figure 10-5. Selected Middle Archaic Bifaces

Left to Right: Top Row: \#410-010 Joins to \#428-010, \#213-010, \#287-010, \#545-010; Second Row: \#727-010, \#417-013, \#149-010

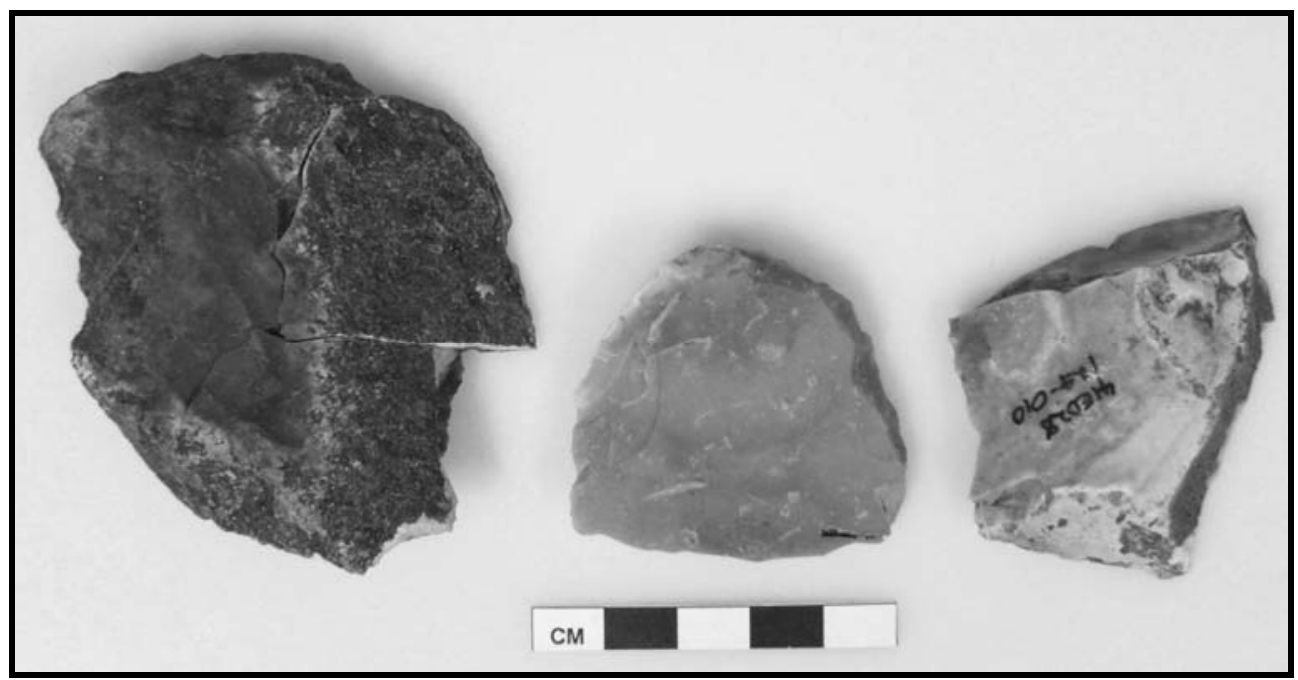

Figure 10-6. Selected Middle Archaic Scrapers

Left to Right: \#100-011, \#318-014, and \#124-010 
Specimen \#100-11 is complete and nearly round in outline with a continuous working edge that curves around to the sides, with three working bits. One lateral and the distal end have steeply angled working edges. This piece still retains cortex on over 50 percent of the dorsal surface. It has also been exposed to intensive heating as it exhibits heat spalls and cracks.

Specimen \#100-11 was sent for use-wear analysis and reveals a hair on the ventral surface together with striations that are parallel and perpendicular to the working edge. This piece is interpreted as a planing tool used on hide (Appendix C). Part of this burned scraper was sent for INAA. The chemical signature (TRC109) is similar to known Edwards chert, but is beyond the range of the known natural sources from the southwestern region of the outcrop (Appendix F). However, it does exhibit an ultraviolet fluorescence (UV) that is similar to other Edwards chert. Therefore, it is probably Edwards chert, but not from any currently known source areas.

\subsubsection{Edge-Modified Flakes}

The 122 edge-modified flakes include two rejuvenation flakes (\#83-10 and \#182-11) and one graver (\#56-11). Nine specimens were selected for use-wear analysis to investigate the range of activities that are represented. Each tool is briefly discussed here, with more specific use-wear information provided in Appendix C. The graver (\#56-11) reveals wood fragments from use and hard polish, and striations parallel and perpendicular to the working edge. These characteristics indicate whittling of wood. Specimen \#274-5-10 is a complete flake, irregular in shape with continuous tiny flake scars along a straight lateral edge that is rounded. The opposite edge is convex with a few tiny scars on the dorsal surface. Hard, highsilica polish is present and indicates cutting of hard, high-silica material. Specimen \#387-10 is a complete irregularly shaped piece with regular continuous scars along one straight lateral edge. It exhibits plant fibers as use residue and hard, high-silica polish and striations parallel and perpendicular to the working edge. It is interpreted as a planing tool used on hard, highsilica material. Specimen \#397-13 is a complete irregularly shaped piece with regular continuous flake scars along a recurvate lateral edge. It exhibits polish and striations in multiple directions that indicate scraping of hard highsilica material. Specimen \#409-11 is a complete irregular shaped piece with regular continuous flake scars along three edges. It retains plant fragments, and shows striations parallel and perpendicular to the working edges indicating the whittling of plants. Specimen \#417-10 is a complete, has a quadrilateral shape, and is made from the only coarse-grained material in the assemblage. It exhibits two straight lateral edges, one with regular continuous flake scars, and one with irregular continuous flake scars. It exhibits polish that indicates whittling of hard, high-silica material. Specimen \#484-16 is a complete irregularly shaped piece with continuous flake scars along a straight lateral edge that is slightly rounded. It exhibits wood fragments and striations parallel and perpendicular to the working edges implying planing of wood. Specimen \#484-17 is a complete irregularly shaped piece with regular continuous flake scars along a straight lateral/proximal edge that is slightly rounded. It exhibits plant fragments and polish with striations implying slicing of hard, high-silica material. Specimen \#662-10 is a complete ovate piece with two worked lateral edges; one is straight with irregular continuous flake scars, whereas the other is incurvate with regular and continuous flake scars. It exhibits soft use-wear indicating scraping on a soft material.

Eight edge-modified flakes were also sent for INAA. All eight pieces revealed chemical 
signatures that are in line with known Edwards chert from the southwestern region of the Edwards distribution (Appendix F). One specimen (\#649-11 = TRC124) is unlike most Edwards chert in having a matte gray color that did, however, yield a chemical signature similar to Edwards chert. The broken edge fluoresced under UV light, as does Edwards chert.

\subsubsection{Hammerstone}

One combination hammer-anvil stone (\#514-10) was recovered. This is a complete, somewhat rounded cobble that was recovered from Unit N106/E52 between 40 and $50 \mathrm{cmbd}$. It measures $92.7 \mathrm{~mm}$ long, $88.3 \mathrm{~mm}$ wide, $59.8 \mathrm{~mm}$ thick, and weighs $592.7 \mathrm{~g}$. The entire cobble was naturally pitted with a relatively rough surface creating positive identification of tool-use areas difficult. The more pointed end exhibits more pronounced pitting than adjacent areas. One face exhibits a central, oval pit that measures about 17 by $19 \mathrm{~mm}$ and is about $2 \mathrm{~mm}$ deep and surrounded by eroded or worked areas. This is a multi-purpose tool that was used as both a hammer and an anvil.

\subsubsection{Cores}

Eight cores were recovered from this component. Nearly 87 percent are complete, and one of these appears to have been exhausted. Six are multi-directional, and one each are bifacial and unifacial. All are of fine-grained chert with five specimens exhibiting some cortex that is smooth and water rounded. None appear to have been heat-treated. Two exhibit patination on less than 25 percent the surface. The complete cores range in length from 63.2 to $123.2 \mathrm{~mm}$, with an average of $93.2 \mathrm{~mm}$. The widths range from 52.7 to $91.9 \mathrm{~mm}$, with an average of $71.6 \mathrm{~mm}$. The thickness ranges from 36.1 to $68.5 \mathrm{~mm}$, with an average of $45.8 \mathrm{~mm}$.

The eight cores seemingly were distributed nonrandomly. Two excavation units on the western side of BT 1 yielded three cores, whereas three units in a line near the southern boundary each yielded a single core. Two adjacent units $1 \mathrm{~m}$ southeast of the end of BT 2 each yielded a single core. This apparent clustering of cores may indicate specific activity areas for core reduction and/or discard.

\subsection{Debitage}

\subsubsection{Unmodified Debitage}

A total of 4,387 pieces of lithic debitage, representing 74 percent of all cultural materials recovered from this component, were recovered. Roughly 13 percent of this debitage class from Block A was analyzed to determine which stages of raw material reduction and tool production, manufacturing, and maintenance are represented. The selected sample was derived from nine different units across the southern half of the block where the Middle Archaic context is most confidently defined.

All categories are represented; however, a single specimen represents the blade category. Low frequencies of core flakes (11.6 percent), early stage biface flakes (12.2 percent), and indeterminate pieces (11.1 percent) are represented. Angular debris is moderately represented (18.7 percent). A high frequency is represented in the late stage biface flakes (25 percent) and the tertiary and thinning flakes (21.3 percent). About 80 percent of the sample reveals unintentional heat alteration through spalling and crazing. Intense heat generated in the Late Archaic hot-rock cooking feature immediately above this component may be the cause of this high percentage.

The data of flake types, just summarized, suggests that significant effort was directed towards biface production to the finished stages. Cores were reduced, probably in the process of producing flakes and initial stage of biface shaping. The relatively high frequency of 
tertiary and biface-thinning flakes supports the finishing of bifaces and/or the resharpening of other tools.

\subsubsection{Middle Archaic Rejuvenation Flakes}

This assemblage includes only two pieces (\#8310 and \#182-11) that were classified as rejuvenation flakes. Both were recovered from the southern end of Block A and were associated with other lithic tools and debitage. Both were intentionally removed from the tool to facilitate resharpening. Each exhibits a small segment of the original working edge from which it was removed. Specimen \#83-10 was removed from a unifacial tool that had a flat ventral surface. A blow directed into the face of the steep working edge removed this rejuvenation flake and about $18.8 \mathrm{~mm}$ of tool edge. Specimen \#182-11 also represents removal from a uniface, possibly a long side scraper, which removed a considerable length $(40.5 \mathrm{~mm})$ of that working edge. The worked edge is not as steep as on the previous piece, but is somewhat dulled and irregular, indicating extensive use. Neither piece was selected for use-wear analysis.

\subsection{Vertebrate Faunal Analysis}

\subsubsection{Introduction}

The $83-\mathrm{m}^{2}$ excavations in of Middle Archaic component in Block A yielded 725 vertebrate specimens weighing $402.2 \mathrm{~g}$. Although more bone fragments were recovered from this component, they are thought to have been displaced from above, based on their color and condition. Pieces from this component with a pinkish gray (5YR 7/2) appearance were assigned to the overlying Toyah component. Pieces with a beige and calcium carbonatecoated are thought to be derived from the Early Archaic component. Brown bone fragments were visually distinct from the fresh pinkish gray pieces and the older beige and calcium carbonate coated pieces, and are thought to comprise most of the Middle Archaic assemblage. Therefore, similar brown bones from the lower Early Archaic period were also assigned to this Middle Archaic component. The Middle Archaic pieces vary in color from light reddish brown (5YR 6/4) to dark reddish gray (5YR 4/2). Although this approach may seem somewhat arbitrary, it is supported by the radiocarbon dates derived from bones.

If it were not for the partially burning of these fragments (resulting in the brown color), which is interpreted to have hardened these bones, it is probable that they would not have been preserved. Only 2.2 percent of the fragments assigned to this component are greater than $3 \mathrm{~cm}$ in length, and those are between 3 and $6 \mathrm{~cm}$ long. Their average weight of $0.4 \mathrm{~g}$ per fragment reflects the very small size of the individual pieces. Nearly 74 percent were burned, 80 percent were burned to a brown color, 16 percent are burned to a black and brown color, 1.3 percent are burned black, 1.3 percent are white, and less than 1.0 percent are black and white. Most larger size ungulate bones exhibit a black and brown color generally the result of burning at temperatures less than 400 degrees Celsius, whereas the white color signifies burning at temperatures above about 700 degrees Celsius (Nicholson 1993).

Bones were divided into ten major taxa based on the size and type of animal represented. The 10 groups include: Size Class 1, mole and mice size mammals; Size Class 2, rabbit-size mammals; Size Class 3. raccoon-size mammals; Size Class 4, dog/coyote-size; Size Class 5, deer and antelope size; Size Class 6, bison-size; Size Class 7, turtles; Size Class 8, snakes; Size Class 9, birds; and Size Class 10, fish. The assignment of a bone fragment into a specific size class was based primarily on cortical wall thickness and bone structure. If these attributes were not sufficient to place a bone into one of 
the 10 classes, then the piece was designated "unknown". Eighty-eight percent of the pieces ( $n=638$, weighing $151.5 \mathrm{~g}$ ) were assigned to the unknown category. Of the 638 pieces, 224 pieces, or 35 percent, were burned.

Six fragments weighing $7.4 \mathrm{~g}$ were assigned to size class 6 and probably represent bison. Two fragments are sizable pieces of tooth enamel. The other four long bone fragments are burned, three a black to brown color and one black. It is possible these six bison-size bones may not be part of the Middle Archaic component, as they potentially were displaced from above Toyah component. If they were actually part of this component, then their presence indicates at least one bison size individual.

Seventy-eight fragments, or 10.8 percent, were assigned to size class 5 and probably represent deer. These 78 pieces weigh a total of $99.1 \mathrm{~g}$ for an average of $1.3 \mathrm{~g}$ per fragment. Ninety-one percent are less than $3 \mathrm{~cm}$ long with the other nine percent being 3 to $6 \mathrm{~cm}$ long. Elements with sufficient attributes to allow species identification, such as deer, include: a left astragals, a left acetabulum, a proximal phalanx, a complete right third lower molar, two inner ear pieces, and a first phalanx that is butchered. Thirty-one percent of this size class is burned, with 50 percent burned a brown to black color, another 33 percent a brown color, and 17 percent are black. A complete third molar from a lower left mandible reveals a partially worn and slightly cupped third cusp indicating a relatively old deer.

One-half of a nearly complete, brown deer calcanium (\#522-2-1b), weighing $5.0 \mathrm{~g}$ from 50 to $60 \mathrm{cmbs}$ in Unit N106/E53 in what was considered valid Middle Archaic context, was sent to Beta Analytic Inc. for radiocarbon dating. However, following the careful dissolution of the bone mineral component Beta Analytic Inc. indicated they could find very little separable collagen, and as such, the sample could not be dated (Ronald Hatfield, personal communication, November 15, 2003). The other half of this same brown deer calcanium (\#522-2$1 \mathrm{a})$, weighing about $6.6 \mathrm{~g}$, was submitted to the University of Georgia Laboratory. This half of the deer calcanium yielded a $\delta^{13} \mathrm{C}$ corrected (21.2\%) AMS radiocarbon age of 3,910 \pm 40 B.P. (Table 10-1: UGA-12719).

A brown long bone fragment (\#418-2-1), weighing $2.4 \mathrm{~g}$ from 50 to $60 \mathrm{cmbs}$ in Unit N104/E56 and Middle Archaic context, was submitted to the University of Georgia Laboratory for dating. The bone collagen yielded a $\delta^{13} \mathrm{C}$ corrected (-21.5\%) AMS radiocarbon date of 2,290 \pm 40 B.P. (Table 10-1: UGA-12716). This age best reflects chronological position of the overlying Late Archaic component and is therefore, assumed to have been displaced. The stable carbon isotope data derived from the AMS radiocarbon dating of these two bones reflects animals that ate nearly 100 percent $\quad \mathrm{C}_{3}$ vegetation. The consumption of $\mathrm{C}_{3}$ vegetation is consistent with deer feeding habits; and therefore, these two elements probably are from deer.

Besides the two size groups discussed above, four specimens were assigned to the size class 2 that includes rabbit sized animals. This included two long bone fragments (\#470-2) that weigh $0.6 \mathrm{~g}$ and are burned black and brown. They are within the size range for jackrabbit. One other unburned long bone fragment (\#513-2) is of a similar size. An unburned distal humerus fragment that weighs $0.5 \mathrm{~g}$ is of cottontail size indicating that both jackrabbit and cottontails are represented.

Two fragments were assigned to the size class 4, which includes animals about the size of a dog. Specimens, \#397-2 and \#418-2 are brown in color and are proximal metapodial fragments 
with articular surfaces. These represent at least one nonungulate in the size range of dog/coyote.

A single piece of turtle shell (\#43-2), weighing $1.0 \mathrm{~g}$, was recovered from this component. It is a small, unburned segment that lacks root etching or obvious weathering. It is unclear if this turtle shell represents part of the Middle Archaic subsistence resource, or if it was displaced from some other context.

\subsubsection{Discussion}

Vertebrate remains from Middle Archaic assemblages across Texas are rare. Therefore, this small and limited bone assemblage is a unique discovery. One deer and at least two rabbits are definitely represented in this assemblage. It is not possible to state with certainty that bison was among the resources procured at this particular time, since evidence of mixing, especially for small bone fragments such as these, is present. Mixing may also account for the one turtle and two dog/coyote size specimens. If these bones actually do represent the Middle Archaic period, they imply a broad-base subsistence pattern during the 900year period represented.

The horizontal distribution of the vertebrate faunal assemblage appears to represent an intact cultural activity area. Nearly 34 percent of the bones were recovered from a single unit, N104/E56, at the eastern edge of BT 2. Two units to the north of that unit also yielded high percentages of bones. The three units combined account for over 58 percent of the vertebrate assemblage assigned to this component. This type of horizontal concentration inferably reflects a discard area of mostly deer-size bones that had been extensively smashed and burned.

\subsection{BURned Rocks}

A few scattered burned rocks and two burned rock features were found in the Middle Archaic component. In total, 810 burned rocks, weighing $96,733 \mathrm{~g}$, were recovered. The two features contained 68 pieces, weighing 30,450 g, for an average weight of $448 \mathrm{~g}$ per burned rock. The scattered burned rocks total 742 pieces weighing $66,283 \mathrm{~g}$, for an average burned rock weight of $89.3 \mathrm{~g}$. The scattered burned rocks are comprised mostly of the smallest size class with 69 percent by count, followed by the next smallest size class at 27.6 percent, then 3.9 percent in the next size class, and less than one percent in the largest size class.

In Feature 11, the average burned rock weight is $576.5 \mathrm{~g}$, and for Feature 37, the average is $276.8 \mathrm{~g}$. A noticeable size difference exists between the two features and the scattered burned rocks. This indicates a probable use/functional difference. The largest pieces were recovered from Feature 11, interpreted as a disturbed hearth. The second largest average was in Feature 27, interpreted as a discard pile. If these interpretations of the features are correct, then the scattered burned rocks are about 1/15 the weight of those recovered from the more or less intact hearth (Feature 11). The scattered pieces reflect the functionally exhausted pieces that had become too fragmentary for efficiently heat retention. The size of the burned rocks in Feature 37 may indicate that those burned rocks had been used several times, but not so many, that they were not still functionally viable.

\subsection{Macrobotanical Remains}

This component was largely devoid of charred plant remains with only about $2.5 \mathrm{~g}$ recovered (Table 10-5). The near absence of features hindered the potential preservation of such remains. Combined with the probable displacement of macrobotanical specimens from other components, the recovered pieces may come from questionable contexts. 
Table 10-5. Macrobotanical Remains from the Middle Archaic Component

\begin{tabular}{|l|l|c|c|l|l|}
\hline \multicolumn{1}{|c|}{ Cat. \# } & Unit No. & $\begin{array}{c}\text { Depth } \\
\text { (cmbd) }\end{array}$ & $\begin{array}{c}\text { Wgt. } \\
\text { (g) }\end{array}$ & Comments & Identifications \\
\hline 37-005-004-007-1a & N99/E53 & $70-80$ & 0.1 & From light fraction C ${ }^{14}$ dated to 4,260 \pm 40 B.P. & \\
\hline 188-007 & N101/E51 & $30-40$ & 0.7 & & \\
\hline 199-007 & N101/E52 & $40-50$ & 0 & & Mesquite $(n=10)$ \\
\hline 199-007-1a & N101/E52 & $40-50$ & 0.5 & Sent to Dering for ID & \\
\hline 200-007 & N101/E52 & $50-60$ & 0.9 & & \\
\hline 365-007 & N103/E51 & $80-90$ & 0.1 & & \\
\hline 418-007 & N104/E56 & $50-60$ & 0 & & Indeterminate $(n=1)$ \\
\hline 418-007-1a & N104/E56 & $50-60$ & 0.1 & C 14 dated to 4,770 \pm 40 B.P. & \\
\hline 418-007-1b & N104/E56 & $50-60$ & 0.1 & Sent to Dering for ID & \\
\hline
\end{tabular}

The two wood charcoal pieces selected for radiocarbon dating both yielded acceptable dates for this period. Tiny pieces of charcoal from Feature 37 yielded one of the radiocarbon dates. The two obtained ages support the contention that a Middle Archaic occupation(s) is represented. Mesquite and oak wood charcoal are positively identified (Appendix I).

\subsection{MidDle ARChaic SUMmary}

This component was identified by the occasional stone tool, dispersed lithic debitage, sparse bone fragments, occasional burned rock, and two burned rock features horizontally scattered throughout the brown (10YR 5/3) clay loam Bk soil horizon that is the upper part of geologic Unit 3 and sandwiched between the Late Archaic burned rock Feature 1 and the dense Early Archaic materials at the base of geologic Unit 3. In Block A, the Middle Archaic deposits had a maximum thickness of about $40 \mathrm{~cm}$ and this rapidly thinned to about $20 \mathrm{~cm}$ thick towards the north. The thin, northern portion of this wedge-shaped Middle Archaic component was more potentially mixed with materials from other cultural components. The cultural materials near the base of the Middle Archaic component may be partially mixed with the Early Archaic materials from below. The southern half of Block A provides the best context for the Middle Archaic materials, which included Feature 37, and about 50 percent of the recognizable formal tools including four Early Triangular projectile points.

The 83- $\mathrm{m}^{2}$ hand-excavations in Block A yielded 4,387 pieces of lithic debitage, 810 burned rocks, 122 informal edge-modified stone tools, 24 formal chipped stone tools, eight cores, 725 bone fragments, and two burned rock features (Features 11 and 37). Surprisingly, bone (402.2 g) and charcoal (2.5 g) remains were preserved, but in very limited quantities (Table 10-6). These organic remains allowed AMS radiocarbon dating to determine the absolute age of this component. The direct dating also demonstrated that some displacement had occurred vertically in the deposits. Younger bones and charcoal from the overlying components were displaced downward and became mixed with Middle Archaic materials. 
Table 10-6. Summary of the Middle Archaic Assemblage from the Varga Site (41ED28) Investigations

\begin{tabular}{|c|c|}
\hline Cultural Material Classes & $\begin{array}{c}\text { Middle Archaic } \\
\text { Component (2,930 } \\
\text { to } 4,820 \text { B.P. }) \\
\text { Counts } \\
\end{array}$ \\
\hline Bone Fragments* & 402.2 g, 725 pieces \\
\hline Deer & 7 pieces \\
\hline Rabbits & 1 piece \\
\hline Mussel Shell* & 0 \\
\hline Burned Rock & 810 \\
\hline Features & 2 \\
\hline Disturbed Hearth & 1 \\
\hline Burned Rock Dump & 1 \\
\hline Dart Points and Fragments & 10 \\
\hline Early Triangular & 6 \\
\hline Bifaces & 11 \\
\hline Scrapers & 3 \\
\hline Edge-Modified Flakes & 122 \\
\hline Lithic Debitage & 4,387 \\
\hline Cores & 8 \\
\hline Hammerstones/Anvil & 1 \\
\hline Carbonized Plant Remains & $2.5 \mathrm{~g}$ \\
\hline \multicolumn{2}{|l|}{ Mesquite wood } \\
\hline Total Materials & 6,079 \\
\hline Average Thickness (cm) & 25 \\
\hline Spatial Extent Excavated & 83 \\
\hline Volume Excavated $\left(\mathrm{m}^{3}\right)$ & 20.9 \\
\hline
\end{tabular}

This mixing resulted in subjectively reducing the recovered bone to a much smaller sample thought to represent Middle Archaic events.

\subsubsection{Chronology Issues}

Two assays on wood charcoal and one on a deer bone fragment directly date the Middle Archaic component to ca. 900-radiocarbon year period from 3,910 to 4,820 B.P. (Table 10-1). A humate sample from geologic Unit 3 , or the Bk soil horizon, and stratigraphically equivalent to this zone yielded a mean residence time of 4,790 B.P. that generally supports the cultural radiocarbon ages from this component. This relatively narrow time span has not been previously well documented in the archeological record in Central Texas or the Lower Pecos regions. The only diagnostic projectiles from this component include five Early Triangular points and one Carrizo point fragment. Since the cultural materials were somewhat vertically scattered roughly over 20 to $30 \mathrm{~cm}$, it is not certain that the three wood charcoal dates and ten projectile points are directly associated. It is assumed that the cultural materials represent multiple events during this 900-year time span. The Early Triangular points and associated cultural materials and the obtained radiocarbon dates are in stratigraphic agreement with radiocarbon dates and recovered diagnostic tools from above and below this component. The one exception is the charcoal date derived from Middle Archaic Feature 11 that yielded a Late Archaic age of 1,990 B.P. (UGA-12718). This age is similar to charcoal ages obtained from Feature 1. Therefore, the dated charcoal apparently was displaced downward and became lodged in this Middle Archaic cluster of burned rocks-Feature 11 . The radiocarbon documented 900-year period probably reflects the general age of the six Early Triangular points that dominate the sample of typable projectile points. 
In the Lower Pecos region, Early Triangular points from Unit 3, Level 24 in Skyline Shelter dated slightly earlier, to 5,210 \pm 70 B.P. (Tx6878). Those triangular forms were renamed Devils Triangular points (Turpin and Bement 1992). These same levels (23 through 28) also yielded six Bandy/Martindale, four Baker/Uvalde, three Gower, one Early Barbed, two Golondrina, and five unidentified projectile points. Level 28 that lacks Devils Triangular points, was dated to 5,920 \pm 120 B.P. (Tx-6947), and may predate the appearance of Early Triangular points in the Lower Pecos.

In Central Texas, the Royal Coachman Site (41CM111) in Comal County yielded dispersed occupation debris containing Early Triangular points and radiocarbon dates in associations (Mahoney et al. 2003). The 20 to $40 \mathrm{~cm}$ thick component yielded seven Early Triangular, two Bell, and at least three Nolan dart points in a very slowly aggrading alluvial deposit. Five of the six-radiocarbon assays from wood charcoal returned 1-sigma dates ranging from 5,460 to 5,600 B.P. This is referred to as "one of the more securely dated Early Triangular components in the State" (Tomka et al. 2003:89).

The Holt Site (41HY341) in Hays County contained a minimum of one occupation that is relevant including Zone II that yielded four Early Triangular points, two bifaces, and 145 pieces of lithic debitage. Unfortunately no faunal remains were preserved, but two charred, starchy plant fragments (possibly bulb parts) were recovered from Feature 4, a "rather large earth-oven” (Brownlow 2004). A charcoal sample from Feature 4 yielded a conventional age of 4,740 \pm 40 B.P. (Bets-191422), similar to the radiocarbon ages of charcoal from the Varga Site Middle Archaic component.

At Cibolo Crossing (41BX377) in Bexar County, two Baird bifaces (beveled triangular points or Early Triangular point) were associated with nine Bell and one Andice points in an isolated component above a Martindale component. Three reliable radiocarbon dates from Feature 19 that contained two Bell points yielded ages of 4,420 \pm 50 B.P. (Beta-126362), 4,400 \pm 60 B.P. (Beta-126364), and 4,370 \pm 80 B.P. (Beta-126367) (Kibler and Scott 2000). Biface production was prevalent as was evidenced by 74 percent biface-thinning flakes and indications were that biface reduction at the site was carried out on fully corticate cobbles. Cooking was inferred from several burned rock features including two basin-shaped hearths and a few flat burned-rock features.

At the Richard Beene Site (41BX831) on the Medina River, Block U excavations $\left(6 \mathrm{~m}^{2}\right)$ in the Upper Median component yielded several hearth features with minimal fire broken rock, a small sample of chipped stone tools, and mussel shell concentrations that dated to 4,430 \pm 55 B.P. (GX-21746, Thoms et al. 1996). Although no diagnostic artifacts were recovered, this is the same time period as the Middle Archaic component at the Varga Site and the Cibolo Crossing Bell/Andice component. The artifact concentration was about $15 \mathrm{~cm}$ below the Medina paleosol.

The distal Carrizo point fragment from Middle Archaic context, at 70 to $80 \mathrm{cmbd}$ in the middle of the southern part of Block A, fits with a proximal fragment from 40 to $50 \mathrm{cmbd}$ ca. $6 \mathrm{~m}$ north in the northern part of Block A. It is not clear if either piece was vertically displaced from its original context. Initially, the proximal section was assigned to Early Archaic context and the distal section was assigned to the Middle Archaic component. Two other Carrizo point fragments (\#391-10 and \#670-5-12) were recovered from Early Archaic contexts at 120 to $130 \mathrm{cmbd}$ in Unit N103/E55 and $49 \mathrm{cmbd}$ in Unit N108/E52. The latter point was associated with Early Archaic burned rock Feature 23. At 
the Varga Site, the overall stratigraphic context of the Carrizo points support an association with the Early Archaic period with one likely displaced distal fragment ending up in the Middle Archaic context. Turner and Hester (1993) indicate the Carrizo point is Middle to Late Archaic type that is primarily found in South Texas. The time range for this type has not been previously determined. One of the best contexts for the Carrizo point was at Loma Sandia where three Carrizo points were recovered from a charcoal dated zone to between 2,500 and 2,800 B.P. (ca. 850 to 550 B.C.; Highley et al. 1995). Although the context at Varga Site is not as secure, the three Carrizo points from a dated context help assign this point type to a chronological position that is earlier than previously thought. With this new data from the Varga Site, the Carrizo points potentially represents a broad time range from 2,500 to 2,800 B.P. in South Texas to ca. 5,200 B.P. in Edwards County. It may be that the Carrizo points in the burials at Loma Sandia were older, curated specimens that were included in the cemetery. More radiocarbon dates for the Carrizo point are necessary to clarify its chronological position.

\subsubsection{Subsistence Issues}

The sample of 725 fragments from the Middle Archaic context at Varga holds limited potential to contribute to our understanding of the resources employed in subsistence. Six fragments, or less than one percent, which include two pieces of tooth enamel and four burned long bone fragments weighing $7.4 \mathrm{~g}$, were assigned to size class 6 and probably represent bison. Seventy-eight fragments, or 10.8 percent, were assigned to size class 5 and probably represent deer. Identifiable deer elements include one left astragals, one left acetabulum, one proximal phalanx, one complete right third lower molar, two inner ear pieces, and a first phalanx that is butchered.
Four long bone fragments are assigned to the size class 2-- rabbit size animals. An unburned distal humerus fragment is cottontail size. The different sizes of rabbit elements represented indicates the presence of jackrabbit and cottontail species. Two long bone fragments were assigned to the size class 4 , that of dog/coyote size. A single piece of unburned, lightly weathered turtle shell was recovered from this component.

Deer and rabbits are definitely part of the Middle Archaic assemblage and represent consumed resources. Some uncertainty exists about the presence of bison, since potential mixing with younger materials may have occurred. Turtle and dog/coyote also may be represented, although without direct dating of these bones their context and chronological placement are uncertain.

The generally broad-bladed Early Triangular points are often associated or are considered contemporaneous with the broad bladed Bell/Andice points, indicating use for hunting large game that may have included bison (see Johnson and Goode 1994). The use-wear on three Early Triangular points from the Varga Site, two of which were broken during use, indicate at least cutting and scraping of hide and hard, high silica materials (Appendix C). Haft wear was detected on one specimen with another specimen that exhibits light polish at either end. Although a hair was observed on one specimen, species is unidentified.

As further evidence for the animal contribution to subsistence, the entire stone tool assemblage generally reflects hunting and processing of game. The use-wear studies indicate 12.5 percent of the analyzed tools were directly associated with animal products.

Plant-food products such as nuts and seeds, from pecan species, oak species, and mesquite beans potentially available, but we lack direct 
indication of their use. Whereas tools associated with the processing of nuts, seeds, or other plant resources, such as grinding implements, are lacking here. However, plant fibers were observed on three chipped stone tools (18.8 percent) and wood fiber was observed on 12.5 percent of the tools analyzed. Consequently, 31 percent of the analyzed stone tools document use of non-meat resources, though it is not clear whether the plant fibers and wear indicate plant consumption or just use of various plant products for other purposes.

Lipid residues were extracted from nine burned rocks recovered from Features 11 and 37. The findings do not imply that herbivores are represented. High fat content plant foods, which could include seeds and nuts, appear to be most commonly represented. The $\delta^{13} \mathrm{C}$ values obtained from fragments of the same burned rocks range from -22.9 to $-26.7 \%$ and probably represent $\mathrm{C}_{3}$ plants. The $\delta^{15} \mathrm{~N}$ values reveal a much broader range from -0.2 to $8.4 \%$, probably reflecting diverse foods that could include seeds, nuts, and perhaps legumes. These combined lipid and isotope results from the analyzed burned rocks do not reflect the cooking of deer or bison meat. The procurement and use of deer is represented only by bones. A few carbon isotope values are in the range for rabbit meat if the rabbits consumed mostly $\mathrm{C}_{3}$ plants, which is quite likely.

No mussel shells were recovered from this component, strongly indicating that this riverine resource was not part of the subsistence base at this location. Nor is there any indication that mussel shells were procured for making items such as scoops or ornaments.

\subsubsection{Technology Issues}

Technology issues are best addressed through the preserved materials, which presumably represent only a fraction of the original materialculture inventory. Some daily tasks such as resource procurement, resource processing, and consumption are represented, as discussed presently.

\subsubsection{Resource Procurement Issues}

Recovered stone tools generally provide the primary evidence for plant and animal procurement practices. The presence of ten projectile points and point fragments represents the killing of larger animals. Smaller game (e.g., rabbits and/or turtles) likely were obtained with the use of traps or nets that are not preserved.

No stone tool class is directly associated with plant procurement. This is not unusual, since most plants (i.e. seeds, nuts, berries, and bulbs) would have been easily procured without the use of specialized tools. If specialized tools, such as digging sticks and/or baskets were used to procure certain plants, they would not have survived in the archeological record at the Varga site.

Tools that might have been used in the procurement of lithic resources such as massive hammerstones, or antler prying bars and wedges are not represented in this assemblage. Their absence implies that lithic raw materials collected without specialized tools. Chert and other rocks would have been readily available in creek bottoms and/or in gravel terraces, so that they were easily collected without the use of special tools.

\subsubsection{Resource Processing and Consumption}

Chert was collected as a raw material and brought to the site for reduction into stone tools. The relatively low frequency of core reduction flakes and early stage biface flakes indicates that the early stages in tool production were quite limited, while the relatively high frequency of late stage biface flakes, tertiary thinning flakes, 
indicate that late stage knapping and finishing, flake production, or resharpening were more frequent. Finished and worn-out tools were resharpened, as indicated by the presence of rejuvenation flakes.

Various processing activities are documented through the different types of stone tools recovered. The stone tool assemblage is restricted to formal tools that include points $(n=10)$, bifaces $(n=11)$, scrapers $(n=3)$, and informal edge-modified flakes $(n=122)$. The latter are represented by different shapes forms that include, but are not limited to: gravers, punches, spokeshaves, and other classes. These edge-modified flakes indicate a range of processing tasks that included cutting, scraping, slicing, planing, gouging and whittling. These recognized tasks were conducted on wood, hide, plants, soft material, hard, high-silica plants, and other materials. The use-wear results provide greater insights into the diversity of tasks and products worked than is strictly indicated by the limited range of formal tools.

Use-wear on three Early Triangular points from the Middle Archaic context plus one from Early Archaic context reveals different uses on similar contact materials. The inferred uses include whittling, gouging, and cutting, whereas the inferred contact material includes hide on one specimen, and hard, high-silica plant material for three specimens. Since penetration of a projectile into hide and meat leaves, at best, only limited use-wear evidence, the observed usewear on these presumed projectiles likely indicate that they served multifunctional uses. Detected haft wear in the form of abraded ridges and hard, high-silica polish was observed on two of the four points.

Analyses and interpretations surrounding the similar triangular Tortugas points from across South Texas indicate these points had apparent adaptive advantage in their wide blades that allowed for higher numbers of resharpening events as the edges dulled. This resharpening while still in the haft would have extended their use life longer than stemmed points. Tortugas points may have also been more resistant to impact fractures, because they were frequently thickest near the distal end (Mahoney et al. 2002; Mahoney et al. 2003; Tomka 2002). Tortugas points have also been shown to have been multifunctional, and they were not used only as killing instruments (Quigg and Cordova 1999; Church 2000; Hardy 2002).

The 810 burned rocks indicate that the cooking technology focused on the use of hot rocks to prepare foods for consumption. Features 11 and 37 are the only burned rock features identified, and these features apparently represent a disturbed hearth and a discard pile. The lack of formal or recognizable structure to the burned rock features provides little evidence from which to infer function. If we assume that cooking was done based on the presence of these two features, cooking was not an intense or prominent task, and may have supported only a small group(s) for a short-period of on-site residence.

Not far to the east, in Kerr County and along the upper Guadalupe River drainage, points similar to our Early Triangular points were the dominant form recovered from burned rock middens at the Sheep Site and Wounded Eye Site (Luke 1980). Although the stratigraphy in these middens was not clear-cut, it was assumed that this point type reflects the major associated occupations. The middens at those sites reflect a specific type of plant cooking feature. Therefore, groups employing Early Triangular points in this region probably have used different types of plant and animal resources at different sites and may have had task specific camps.

The general scarcity of tool forms, other than projectile points and edge-modified flakes, and 
the relatively high frequency of lithic debitage, specifically the late stages of biface manufacturing and thinning, indicate that tool manufacture and retooling probably were primary activities at this locality. It is likely that these tasks were of short duration, which contributed to the lack of tool diversity and the small number of features. The absence of other tool classes may be partially attributed to the multifunctional nature of the hafted triangular points that have been documented as being used in various tasks. After hafting, this killing instrument also served for cutting, gouging, whittling, etc., thereby reducing the need for other tool classes. The absence of other tool classes may reflect to the structure and gender makeup of the group(s) that occupied the Varga Site.

\subsubsection{Intra-component Patterning}

The 900-years of documented radiocarbon time, the vertically dispersed nature of at least part of the Middle Archaic assemblage, and the lack of a well-defined material lens potentially indicating that multiple activities were carried out during at the site during the Middle Archaic. The inability to distinguish the events in this ca. $30 \mathrm{~cm}$ thick component is linked to the difficulty in gleaning information about the internal patterning of the various classes of material. The formal stone tools and the two recognized features were nearly equally divided between the northern and southern half of Block A. Generally, the formal tools appeared in small clusters that potential reflect activity or discard areas.

Feature 11, near the middle of the northern half of Block A, is interpreted as a disturbed hearth. No formal stone tools were recovered within one meter of this feature. This absence may indicate that it served primarily if not exclusively as a cooking locality. Two bifaces, three pointstwo of which are unidentifiable fragments and at least five edge-modified flakes were recovered less than $2 \mathrm{~m}$ north of Feature 11 . No other formal tools were in the immediate vicinity. This distribution pattern may indicate a small activity area on the north side of the cooking feature that focused on the retooling of hafted points.

Burned rock Feature 37, next to the southern boundary of Block A, reflects the dumping of unwanted burned rocks following their use in a cooking activity. Two scrapers were recovered less than $2 \mathrm{~m}$ north and were the formal tools found closest to Feature 37. Other formal tools that include points and bifaces were more than $2 \mathrm{~m}$ north and east of Feature 37. It is not clear if these tools were discarded at an activity area or were discarded in a discard zone together with the burned rocks.

Contour maps of density-corrected artifactual data for Block A were generated for each variable in this component (Figures 10-7 through 10-13), using Surfer (vers. 5.01) mapping software. These maps provide a visual reference to aid in the interpretation of the spatial distribution of selected artifact categories and to provide additional depth to interpreting the results of the principal components analyses.

The locations of the two recognized features (Features 11 and 37) are also plotted on the contour maps as part of the spatial patterning.

Awls, drills, choppers, gouges, and unifaces were excluded from the analysis due to the nonoccurrence of these artifacts in the Middle Archaic component in Block A. The resulting data matrix consists of nine variables (artifact categories) and 86 rows (excavation units), though only eight of the variables figure strongly in the resulting factor loadings. The principal components analysis extracted a three-factor solution representing a cumulative total of 63.92 percent of the variability present in the data array. 


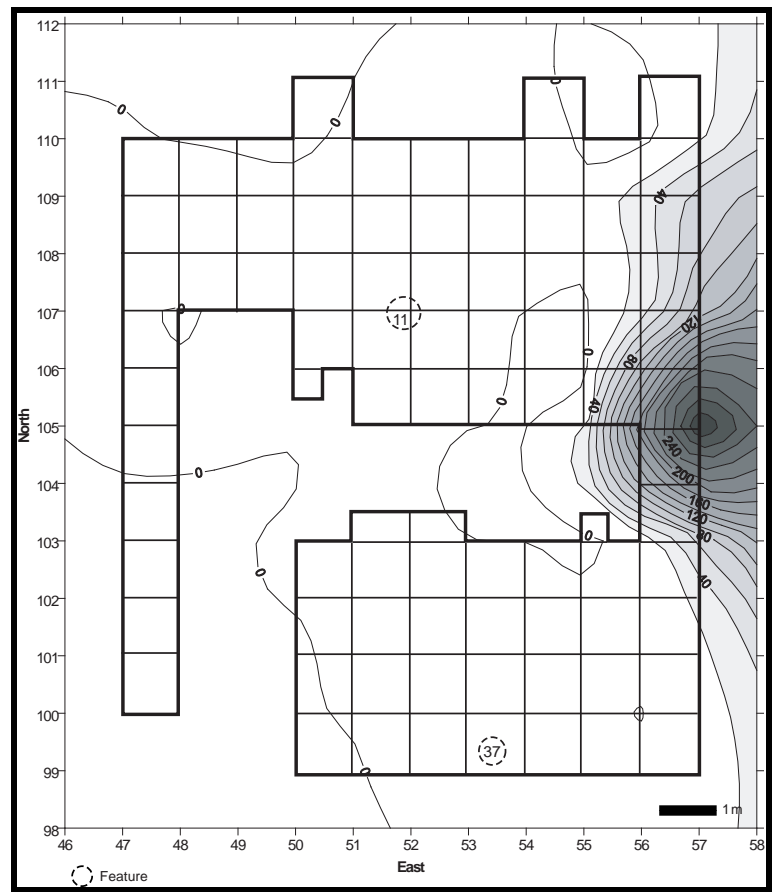

Figure 10-7. Contour Map of Bone Density for Middle Archaic in Block A

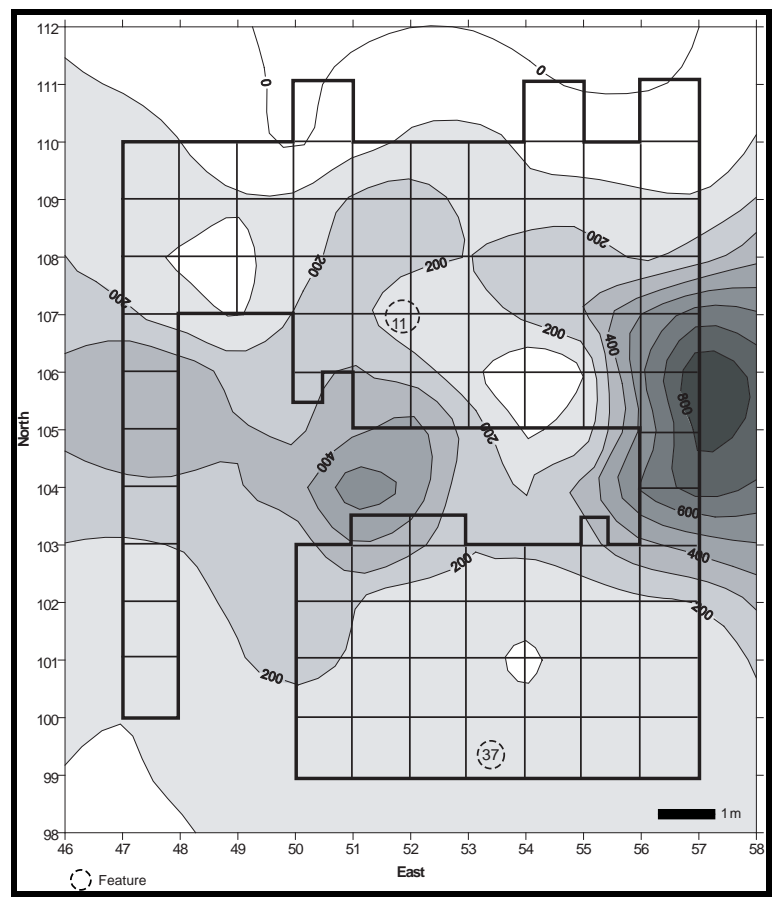

Figure 10-8. Contour Map of Lithic Debitage Density for Middle Archaic in Block A

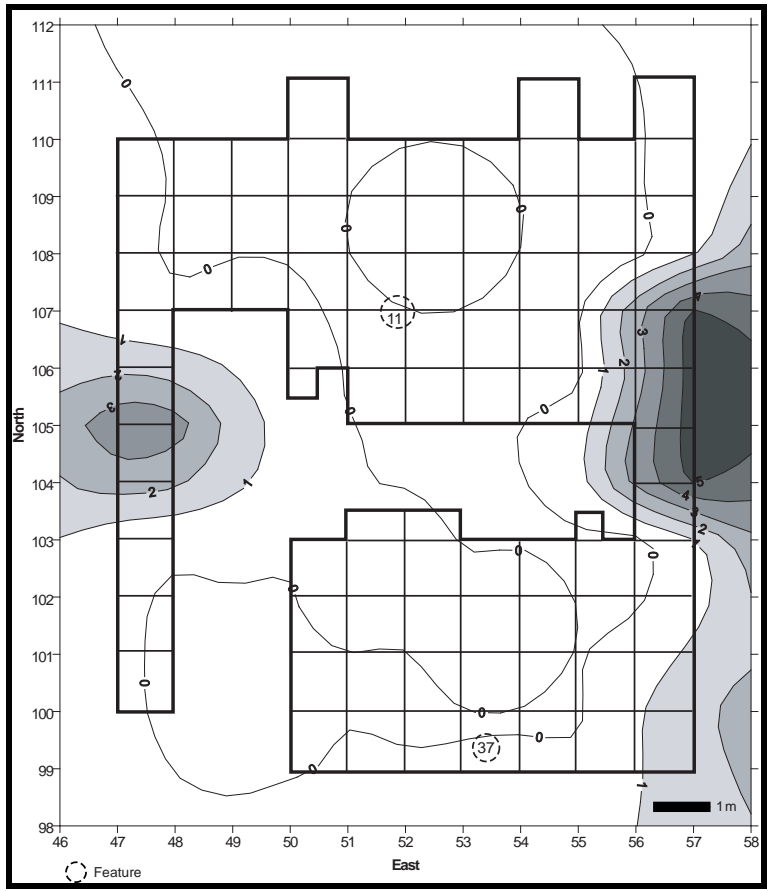

Figure 10-9. Contour Map of Biface Density for Middle Archaic in Block A

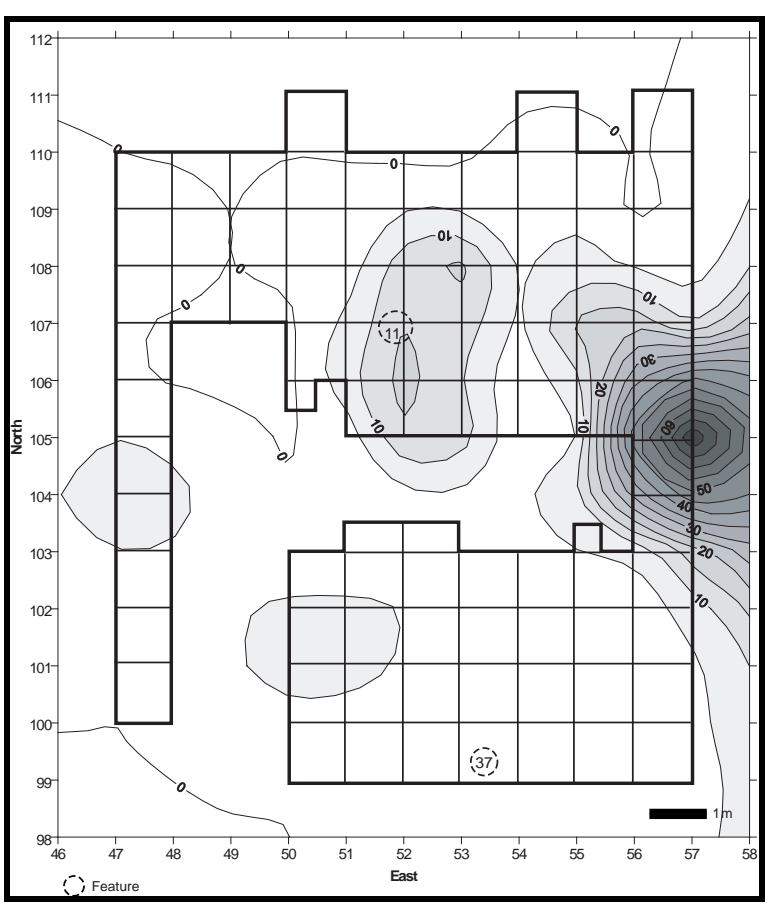

Figure 10-10. Contour Map of Edge-Modified Density for Middle Archaic in Block A 


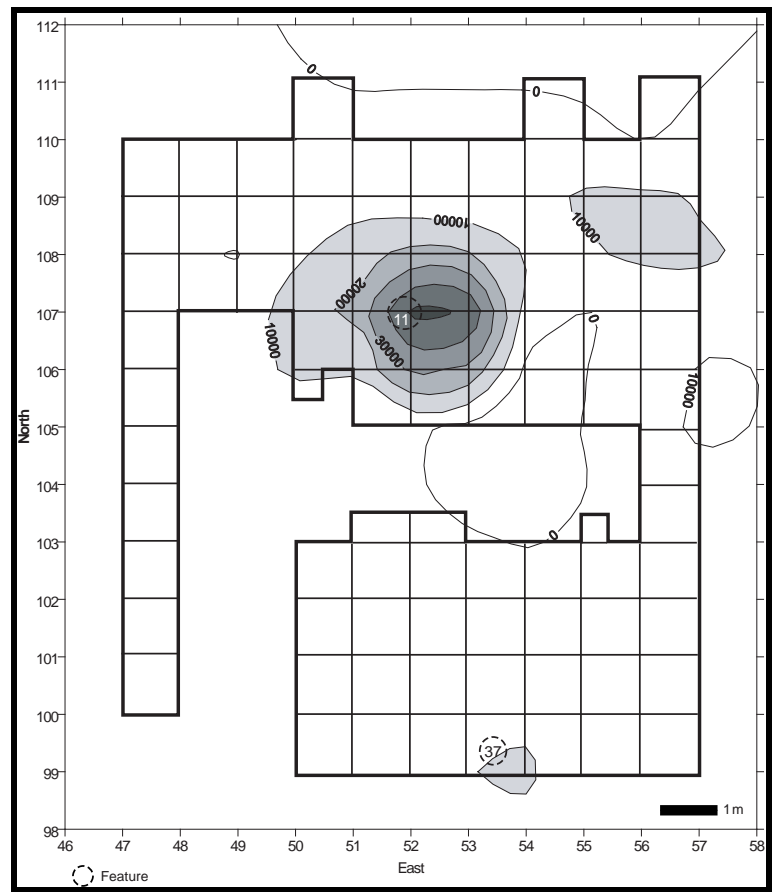

Figure 10-11. Contour Map of Burned Rock Density for Middle Archaic in Block A

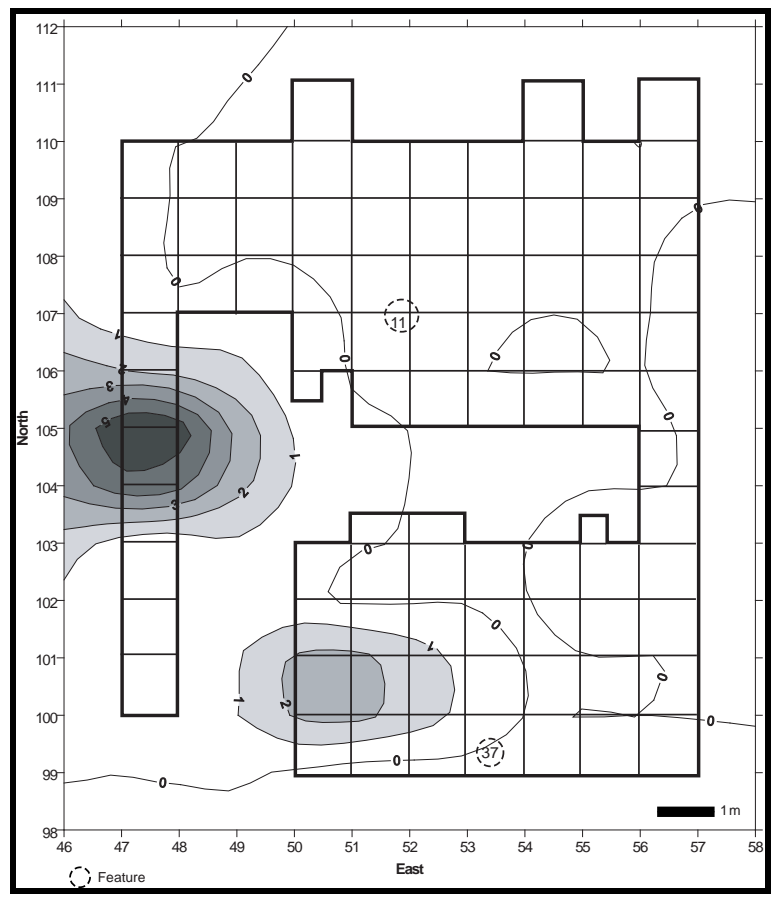

Figure 10-12. Contour Map of Lithic Core Density for Middle Archaic in Block A

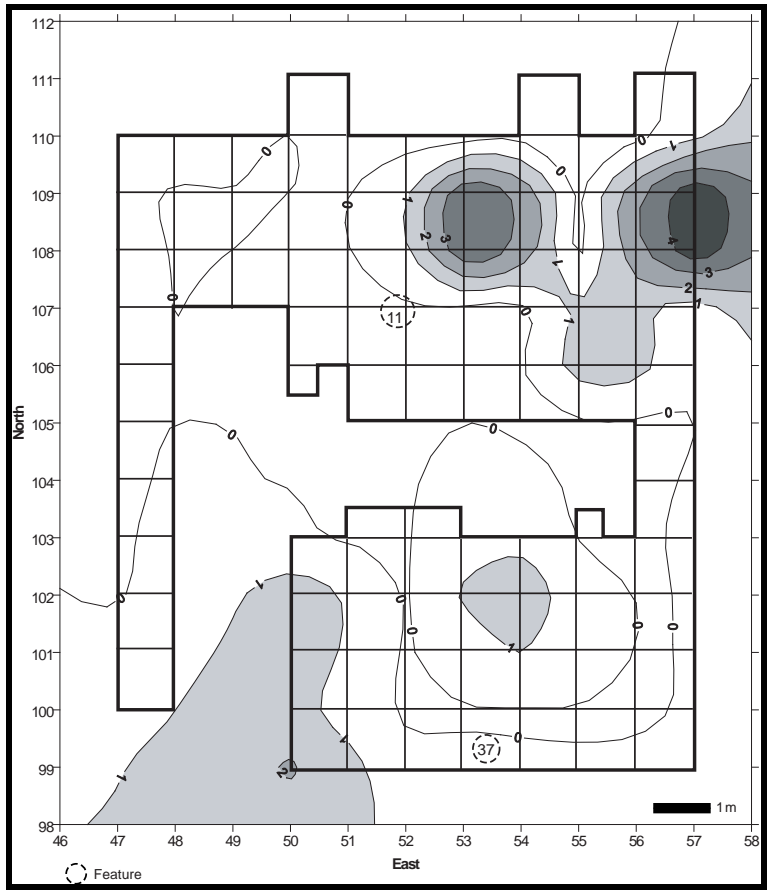

Figure 10-13. Contour Map of Point Density for Middle Archaic in Block A 
Table 10-7. Correlation Matrix for Block A-Middle Archaic Component

\begin{tabular}{|l|l|l|l|l|l|l|l|l|l|}
\hline & \multicolumn{9}{|c|}{ Category } \\
\cline { 2 - 11 } & $\begin{array}{l}\text { Burned } \\
\text { Rocks }\end{array}$ & $\begin{array}{c}\text { Faunal } \\
\text { Bone }\end{array}$ & $\begin{array}{c}\text { Ground- } \\
\text { stone }\end{array}$ & Cores & Debitage & Bifaces & $\begin{array}{c}\text { Edge- } \\
\text { Modified } \\
\text { Flakes }\end{array}$ & $\begin{array}{c}\text { Projectile } \\
\text { Points }\end{array}$ & Scrapers \\
\hline $\begin{array}{l}\text { Burned } \\
\text { Rocks }\end{array}$ & 1.000 & & & & & & & & \\
\hline Faunal Bone & .119 & 1.000 & & & & & & & \\
\hline Groundstone & .783 & .008 & 1.000 & & & & & & \\
\hline Cores & -.058 & -.060 & -.026 & 1.000 & & & & & \\
\hline Debitage & .017 & .580 & -.113 & .060 & 1.000 & & & & \\
\hline Bifaces & .016 & .573 & -.029 & .253 & .575 & 1.000 & & & \\
\hline $\begin{array}{l}\text { Edge- } \\
\text { Modified } \\
\text { Flakes }\end{array}$ & .088 & .788 & -.049 & -.003 & .536 & .382 & 1.000 & & \\
\hline $\begin{array}{l}\text { Projectile } \\
\text { Points }\end{array}$ & .004 & .099 & -.030 & -.066 & .004 & -.016 & .054 & 1.000 & \\
\hline Scrapers & -.029 & -.034 & -.020 & .098 & -.039 & -.051 & -.014 & -.051 & 1.000 \\
\hline
\end{tabular}

The matrix of correlation coefficients is presented in Table 10-7, and the factor solution is presented in Table 10-8.

Factor 1 is composed of four diagnostic variables - faunal bone, lithic debitage, bifaces, and edge-modified flakes-collectively composing 30.52 percent of the total variance in the matrix of correlation coefficients (Table 108). All four variables exhibit moderately strong to strong positive factor loadings ranging from .766 to .892; none of the diagnostic variables in Factor 1 are negative. The spatial patterning reflected in this factor loading is largely accounted for by a high-density peak centered on the intersection of the N105 and E57 grid lines along the eastern edge of Block $A$ that contains most of the assemblage of each of these four artifact types present in the Middle Archaic component (Figures 10-6 and 10-9).
Table 10-8. Principal Component Matrix for Block A-Middle Archaic Component

\begin{tabular}{|c|c|c|c|}
\hline \multirow[b]{2}{*}{ Variable } & \multicolumn{3}{|c|}{ Factor $^{1}$} \\
\hline & 1 & 2 & 3 \\
\hline Burned Rock & .073 & .941 & -.041 \\
\hline Faunal Bone & .892 & .076 & -.187 \\
\hline Groundstone & -.065 & .944 & .028 \\
\hline Cores & .118 & -.056 & .777 \\
\hline Debitage & .812 & -.071 & .030 \\
\hline Bifaces & .766 & -.014 & .268 \\
\hline $\begin{array}{l}\text { Edge-Modified } \\
\text { Flakes }\end{array}$ & .822 & .028 & -.168 \\
\hline Projectile Points & .058 & -.055 & -.516 \\
\hline Scrapers & -.050 & -.025 & .448 \\
\hline \% Variance & 30.52 & 19.96 & 13.44 \\
\hline $\begin{array}{l}\text { Cum. \% } \\
\text { Variance }^{1}\end{array}$ & 30.52 & 50.48 & 63.92 \\
\hline
\end{tabular}


No cultural feature was recognized in this area (presumably due to the relative non-occurrence of burned rock in this vicinity), but it would appear that an activity area is represented

here. The association of bifaces, debitage, and edge-modified flakes may be best explained based on the assumption that all three artifact categories reflect the task of lithic reduction; specifically, producing lithic flakes (presumably during biface manufacture) and subsequently modifying some of the flakes for use in various cutting and scraping tasks. Whether lithic reduction strategies in this context are oriented toward producing flakes specifically for modification and use, or the flakes simply represent a byproduct of producing other tool forms, such as bifaces, is unclear, though the cores resulting from flint knapping activities would probably be bifacial implements themselves rather than multidirectional cores (assuming that all activities are occurring in situ). For spatial studies, no distinction was made between various flake or core types that might clarify this issue. The association of these lithic artifacts with faunal bone suggests that some of the activity performed in this area related to animal resource processing.

Factor 2 is composed of two diagnostic variables-burned rock and groundstonecollectively composing 19.96 percent of the total variance in the matrix of correlation coefficients (Table 10-8). Both variables exhibit strong positive factor loadings of .944 and .941. As only one piece of groundstone was recovered from the Middle Archaic component in Block A, it seems likely that this artifact was subsequently reused as burned rock, and that this factor more or less exclusively represents a concentration of burned rock in the northern half of the block centered on the N107 grid line on the border of Unit N106/E52 and N107/E52 (Figure 10-10). This burned rock concentration was designated as Feature 11, though it appears that no other artifact categories, with the possible exception of an association with edge-modified flakes, are associated with this feature.

Factor 3 is composed of two diagnostic variables-lithic cores and projectile pointscollectively composing 13.44 percent of the total variance in the matrix of correlation coefficients (Table 10-8). Cores exhibit a moderately strong positive factor loading of .777, whereas projectile points demonstrate a moderate negative factor loading of -.516. Mutually exclusive clusters of projectile points and lithic cores represent the spatial patterning reflected in this factor (Figures 10-11 and 10-12). Two relatively high-density clusters of projectile points occur in the northeastern quadrant of Block A (cores are absent from this area), and one relatively high-density cluster of cores is present along the west-central edge of the block (an area from which points are notably absent). Considering the relatively small numbers of points and cores recovered from the Middle Archaic component, it seems inadvisable to infer much from this patterning. It is, however, notable that the concentration of lithic cores along the western edge of Block A is largely exclusive of the distribution of lithic debitage in Block A.

It is important to remember that demonstrable spatial associations of different variables, which form the basis of the preceding discussion, do not innately imply the nature of the relationships among some or all of the variables. The statistics reveal numerical tendencies among variables to co-occur or to co-vary in space. The statistics "force" patterning upon an assemblage of data regardless of whether or not it innately exists in the dimension being examined; the analyst is responsible for inferring whether such patterning may be indicative of past behavior, such as that reflected in situ activity or discard areas; post-depositional processes, such as plowing or erosion; or a combination of both. 
Overall, the principal components analyses of the Middle Archaic component included in this spatial study have yielded relatively unambiguous patterning among artifact categories. The observed associations among artifact categories probably are regular, patterned, and often exclusive of other categories. If post-depositional factors, such as erosion, or animal burrowing, had resulted in extensive mixing of sediments, we would expect there to be less distinctive patterning among specific classes of variables and more general mixing of classes. Thus, it appears that the sediment deposits containing the Middle Archaic component are relatively intact, and that the spatial patterning apparent among artifact categories is referable more to the spatial organization of the prehistoric activities than to post-occupational natural influences.

\subsubsection{Mobility and Land Use Issues}

This Middle Archaic component yielded no artifacts that might reflect social structure of the group(s) that occupied the Varga Site, but dominance of a single point type in the assemblage may support the idea that the material remains represent a single group or multiple groups of a common background or origin. The cooking tasks reflected by the scattered burned rocks and the two burned rock features, might be related to the presence of females. Tool manufacture and retooling tasks may best reflect male activities. If these inferred activities are, in fact, gender related, it can be assumed a group(s) composed of males and females is represented.

Marine shell and exotic lithic materials that might indicate trade or any sort of long-distance movement of people or materials are entirely lacking. If contact with other populations in adjacent regions occurred, it is not currently visible in the recovered archeological record for the Middle Archaic at this site.
The generalized nature of the stone tool assemblage reflects a moderate range of activities, lithic tool production, whereas high frequency of informal/expedient tools and discarded broken tools, the generalized nature of the cooking features, the small size of the cooking features, the diverse subsistence resources exploited, all reflect a small residential group that was practicing a generalized foraging adaptation. The amount of cultural material present may be closely aligned with the length of the occupation(s), which probably was shortterm based on the lack of obvious evidence for maintenance activities and only the two identified features.

The INAA indicates that the lithic material used for the manufacture of chipped stone tools was from the local southwestern region of the Edwards chert outcrop (Appendix F). The chemical signatures indicate the Edwards cherts used in the manufacture of chipped stone tools were procured from different sources, which in turn implies mobility within this region. Coupled with the evidence indicating short-term residence, it can be inferred that the Middle Archaic foragers who occupied the site were practicing a fairly high degree of residential mobility necessitated by a broad-based resource procurement strategy.

\subsubsection{Paleoenvironmental Conditions}

The pollen and phytolith record from the Varga Site provides limited clues to indicate what the environment was like at this locality during this ca. 900-radiocarbon year period from 3,910 to 4,820 B.P. It is likely that poor preservation has limited the usefulness and reliability of both kinds of data.

Oak pollen is present in small quantities. A small amount of hackberry is present in one sample, and pecan pollen is found in five of the seven samples. Low spine Asteraceae tends to increase moving up in the sample column, 
Cactaceae and Ephedra were also present in single samples from Middle Archaic contexts. The evidence implies, albeit weakly, that relatively dry conditions may have prevailed during this period (see Appendix E). Mesquite wood was the only taxon identified in the macrobotanical remains.

The phytolith assemblage reflects a transitional assemblage with Pooideae $\mathrm{C}_{3}$ grasses dominating the lowest samples and gradually increasing between 4,800 and 3,900 B.P. $\mathrm{C}_{4}$ grasses appear in the middle part of the Middle Archaic period and reveal a progressive increase toward the top part of the Middle Archaic section (Appendix E). Generally speaking, the environment likely contained trees in the immediate vicinity with extensive grass cover comprised mostly of $\mathrm{C}_{3}$ grasses with some $\mathrm{C}_{4}$ grasses.

The Varga Site carbon isotope data derived from a sediment column through the cultural deposits reveal values from -25.84 to $-28.41 \%$, and showing marked and steady increase toward more negative values over the 900 years of documented Middle Archaic times from 3,900 to 4,800 B.P. These data also point to a near absence of $\mathrm{C}_{4}$ plant contribution and complete dominance of $\mathrm{C}_{3}$ organic plant matter, roughly in accord with the phytoliths which show a predominance of $\mathrm{C}_{3}$ grasses during this period. The carbon isotope value derived from one radiocarbon dated humate sample (with an age of $4,820 \pm 70$ B.P.) yielded a $\delta^{13} \mathrm{C}$ value of $23.0 \%$, indicating an approximately 87 percent contribution from $\mathrm{C}_{3}$ plant matter. This latter value is not as negative as those Middle Archaic carbon isotope values derived from the sediment column, but generally supports the broader interpretation.

In the Lower Pecos region, the general period dated to between ca. 3,000 and 5,000 B.P. was interpreted to have been one of aridity that
Bryant (1966) refers to as the Sanderson Stage. The beginning of this arid period is marked by an erosional unconformity, the Ozona Erosional period (Bryant 1966) as evident by the sedimentary break at the Devil's Mouth Site. This is also the general period in which 22 flood events were identified at Arenosa Shelter, 10 of which occurred between 4,500 and 3,200 B.P. (Patton 1977). Carbon isotope values derived from AMS radiocarbon dates on eight burned walnut shells from three burned rock midden sites in the uplands of northeastern Val Verde County reveal a marked change of $6.0 \%$ from about $-19.5 \%$ o to about $-25.5 \%$ between about 4,400 and 3,900 B.P. This indicates a trend from dry to moister conditions during this period (Cliff 2003).

Just north of here at Hall's Cave, the period from about 2,000 to 5,000 B.P. was represented by increased sediment deposition evidenced by a weak brown (10YR 2/2) soil during a time when drying culminated to produce a drier-thanmodern environment (Toomey 1993). Toomey interpreted this period's vegetation as open grassland, and speculates that the western and central Edwards Plateau contemporaneously shifted to a short grass or semi-desert shrub grassland.

In Central Texas, the climate is projected to have been somewhat mesic during the Bell-AndiceCalf Creek period or ca. 4,500 B.P., but then changed to more xeric conditions (Collins 1995). Blum and Valastro (1989) documented one climatic shift during the Middle Holocene near 4,500 B.P. in the Pedernales River valley. Before about 4,500 B.P., there was an erosional unconformity in the alluvial deposits that was thought to indicate a dry climate (Blum and Valastro 1989). Johnson and Goode (1994) indicate that a period of erosion occurred between 4,570 and 4,700 B.P., and they interpret this as marking a very dry period of widespread cessation of floodplain aggradation. Following 
that was a period of about 1,700 years of surface stability, although some colluvium accumulated slowly (Strata 4 and 5) at the Jonas Terrace Site (Johnson and Goode 1994).

At about 4,500 B.P. on the southern High Plains, eolian sedimentation ceased or slowed and pedogenesis began (Holliday 1995). Pedogenesis was the dominant geomorphic process in the southern High Plains draws during this period (Holliday 1995). At around 3,200 B.P. there was a decrease in grasslands, based on the reinterpretation of Central Texas bog pollen data (Bousman 1998). At Fort Hood, the stable carbon isotopic data indicates that during the interval from ca. 6,000 to 5,000 B.P., a significant increase in $\mathrm{C}_{4}$ plants at TR19 was detected. This indicates a relatively warm and dry climate, just earlier than the period documented here. These data contrast with the carbon isotope values from the Varga Site. At Fort Hood, the $\mathrm{C}_{4}$ grasses continue to dominate through to ca. 3,000 B.P., but reveal a decline from the ca. 6,000 to 5,000 B.P. peak at roughly 85 to 95 percent to about 60 percent around 3,000 B.P. (Nordt 1992, 1993). Nordt also indicates that an erosional episode separates his Fort Hood member from the later West Range member, sometime between about 5,100 and 5,300 B.P. He indicates this event produced a 1,000 to 3,000-year unconformity at this contact. Deposition of the lower member of the Fort Hood alluvium began about 4,300 B.P. and terminated sometime between 2,400 and 2,800 B.P. (Nordt 1992, 1993).

\subsubsection{Discussion}

The cultural materials recovered reflect one or more short-term camps by populations using the Early Triangular dart point type. Limited cooking activities were performed through the use of burned rocks that targeted mostly $\mathrm{C}_{3}$ plant products, although deer meat was also procured. Other activities were directed towards refurbishing of chipped stone tools, retooling implements, and discarding worn-out tools. Documented processing activities include cutting, whittling, scraping, planing on hard and soft wood and other plants, and hide working. The seasonality of the occupation(s) is unknown.

In the Lower Pecos region, the Pandale point type dominates the time period from ca. 5,500 to 4,100 B.P. and possibly slightly later to 3,700 B.P. The occurrence of only one Pandale point (from the Early Archaic context) at the Varga Site implies groups employing this point type did not often camp in this area. Occupations associated with Langtry, Val Verde, and Almagre points are common in the Lower Pecos also were not recovered at the Varga Site, again, implying that the headwaters of the Nueces River area probably was just beyond the operational area of those Lower Pecos groups. However, two Pandale points were recovered a few kilometers west of the Varga Site in the Devil's Sinkhole State Natural Area (Howard et al. 1996) indicating some margin use of the region by people from, or with cultural affinities to, the Lower Pecos River area.

The Varga Site Middle Archaic component that yielded the Early Triangular points is in many ways similar to the Early Triangular component at Royal Coachman (Mahoney et al. 2003) and Cibolo Crossing (Kibler and Scott 2000). However, the Varga Site component is the only one represented by a single point type; the other two components yielded Bell/Andice points. These sites appear as relatively short-term campsites with limited tool assemblages, limited small burned rock cooking and discard features, limited bone and mussel shell remains, and nearly a complete absence of macrobotanical remains, all implying a basic similarity to the short-term occupation and high group mobility suggested here for the Varga site Middle Archaic. The lack of preserved fauna and floral 
remains in most sites of this age creates extreme difficulties in identifying subsistence resources. This necessitates the use of chemical analysis such as lipid residues and isotope data to provide clues to the subsistence practices and other related issues. At the Varga Site the chemical analyses allowed further interpretations of what was cooked by the rocks. Even through meat products were definitely present at the Varga Site, the lipid residues derived from the burned rocks did not reflect meat, but only the cooking of plant products. 



\subsection{THE EARLY ARCHAIC COMPONENT}

\section{J. Michael Quigg}

\subsection{INTRODUCTION}

This rich and dense component was first identified during the Phase I investigations as relatively profuse cultural materials lying directly above, and interspersed within, the gravels and cobble-sized clasts at the bottom of the profile. Cultural materials representing this period were recovered from BTs 1 and 2 and $10 \mathrm{~m}^{3}$ hand-excavated units on both sides of the road. The cultural material was contained in the brown (10YR 5/3) clay loam Bk soil horizon at the lowest part of Depositional Unit 4 and mixed in with Depositional Unit 5, which was pale brown (10YR 6/3) coarse sandy loam 2Bk soil horizon. Depth of material varied considerably from 50 to $120 \mathrm{cmbd}$, since the bottom gravel deposit varied considerably in elevation below the ground surface along the southern edge of the $\mathrm{T} 1$.

The Phase I investigations did not encounter any cultural features, but yielded quantities of lithic debitage, scattered burned limestone rocks, some bone and mussel shell, and many chipped stone tools that included five Bandy points, five Gower points, and six Martindale points from the west side of the road and 16 Martindale, Gower, and Bandy forms from the east side of the road (Lintz et al. 2002). Lithic debitage counts were extremely high in the lower 30 to $40 \mathrm{cmbd}$ on the west side of the road, but were present in low-to-moderate frequencies on the east side (Lintz et al. 2002).
The initial recovery indicated that this substantial Early Archaic component (possibly dating from 8,000 to 6,000 B.P.) should be targeted during the next phase of investigations. The accepted data recovery plan was to target the Early Archaic component through the block excavations only on the west side of the road (Lintz et al. 2002).

The investigations yielded a substantial quantity of Early Archaic materials from Block A that included a total of $83 \mathrm{~m}^{2}$ of hand-excavations. The $83 \mathrm{~m}^{2}$ of hand-excavations includes $5.25 \mathrm{~m}^{2}$ during Phase I and an additional $77.75 \mathrm{~m}^{2}$ in Phase II. In Block A, the entire vertical Holocene deposit was sampled through the hand-excavations that captured $83 \mathrm{~m}^{2}$ of this component in the lower 30 to $40 \mathrm{~cm}$ of the profile. The initial two-backhoe trenches (BTs 1 and 2) excavated during Phase I were located near the middle of Block $A$ and penetrated through this lower component. This mechanical excavation destroyed some 25 to $26 \mathrm{~m}^{2}$ of this component in Block A.

The chronometric age of this Early Archaic component is derived primarily through direct radiocarbon dating of 15 samples recovered from the cultural component (Table 11-1). The dated material includes five charcoal samples, one charred prickly pear seed sample, three deer bone samples, five walnut shell samples, one Rabdotus snail shell, and two sediment samples. Two samples were spilt to obtain multiple dates from the same sample, bone sample \#76-2-11 was split two ways, whereas walnut sample \#344-71 was split three ways. 


\begin{tabular}{|c|c|c|c|c|c|c|c|c|c|c|c|c|c|c|c|c|c|}
\hline 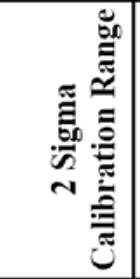 & $\begin{array}{l}0 \\
0 \\
8 \\
0 \\
+ \\
0 \\
0 \\
0 \\
0 \\
\frac{1}{0} \\
\frac{1}{0}\end{array}$ & 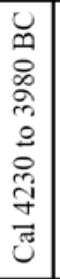 & 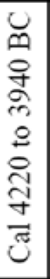 & 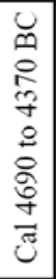 & 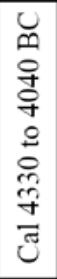 & 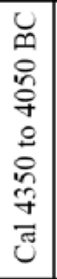 & 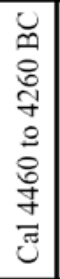 & 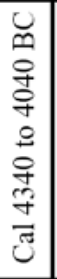 & 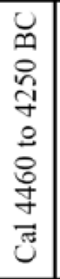 & 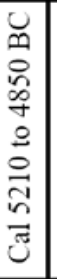 & 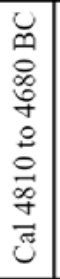 & 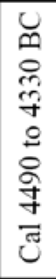 & 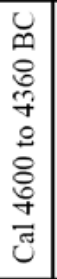 & 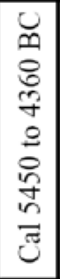 & 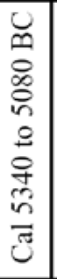 & 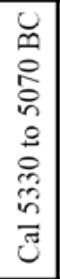 & 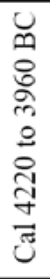 \\
\hline 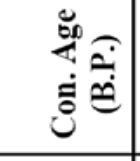 & $\begin{array}{l}\text { P } \\
+1 \\
\stackrel{8}{Q} \\
\text { in } \\
\end{array}$ & 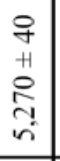 & \begin{tabular}{l}
8 \\
+ \\
+1 \\
8 \\
\multirow{n}{1}{} \\
$n$ \\
\end{tabular} & $\begin{array}{l}8 \\
+1 \\
8 \\
0 \\
0 \\
n\end{array}$ & $\begin{array}{l}q \\
+ \\
+ \\
+ \\
m \\
n\end{array}$ & 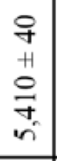 & 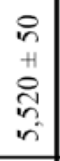 & $\begin{array}{l}q \\
+ \\
+1 \\
8 \\
o+1 \\
i \\
\end{array}$ & $\begin{array}{l}q \\
+ \\
+1 \\
8 \\
0 \\
n \\
n\end{array}$ & $\begin{array}{l}8 \\
+ \\
+1 \\
8 \\
0 \\
0 \\
\end{array}$ & $\begin{array}{l}q \\
+ \\
+1 \\
\& \\
\infty \\
i \\
i\end{array}$ & $\begin{array}{l}\text { + } \\
+1 \\
8 \\
0 \\
n \\
n \\
n\end{array}$ & $\begin{array}{l} \\
+ \\
+1 \\
0 \\
: \\
\circ \\
n\end{array}$ & $\begin{array}{l}q \\
+1 \\
+ \\
\text { ț } \\
i n\end{array}$ & \begin{tabular}{l}
0 \\
r \\
+1 \\
0 \\
$\infty$ \\
\multirow{1}{1}{} \\
0
\end{tabular} & 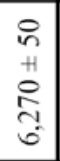 & $\begin{array}{l}\text { n } \\
+1 \\
0 \\
\\
\text { in } \\
\text { n. }\end{array}$ \\
\hline 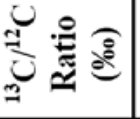 & $\stackrel{\infty}{\stackrel{\infty}{\nearrow}}$ & $\stackrel{\dddot{\partial}}{\rightarrow}$ & ֶָ. & $\underset{⿱ 亠 乂}{\stackrel{十}{*}}$ & $\vec{\imath}$ & $\begin{array}{l}\bullet \\
\stackrel{\leftrightarrow}{i} \\
\end{array}$ & $\begin{array}{l}\mathcal{Y} \\
\text { ָे }\end{array}$ & 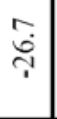 & 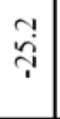 & $\stackrel{\checkmark}{\dot{\tau}}$ & $\ddot{i}$ & ָั & $\stackrel{\circ}{=}$ & $\begin{array}{l}\stackrel{y}{\vec{T}} \\
\stackrel{\vartheta}{1}\end{array}$ & \begin{tabular}{l}
0 \\
\multirow{2}{*}{} \\
\multirow{1}{*}{}
\end{tabular} & 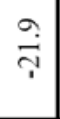 & $\begin{array}{l}0 \\
\text { तิ }\end{array}$ \\
\hline 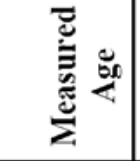 & $\begin{array}{l}\text { P } \\
\text { H } \\
8 \\
8 \\
n \\
n\end{array}$ & $\begin{array}{l}q \\
+ \\
+ \\
\infty \\
i \\
i n\end{array}$ & $\begin{array}{l}q \\
+ \\
+ \\
\stackrel{\text { I }}{n}\end{array}$ & $\begin{array}{l}8 \\
8 \\
+1 \\
8 \\
: \\
0\end{array}$ & $\begin{array}{c}q \\
+ \\
+ \\
\stackrel{0}{1} \\
\end{array}$ & 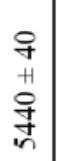 & $\begin{array}{l}0 \\
n \\
+1 \\
0 \\
0 \\
n \\
n\end{array}$ & 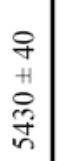 & $\begin{array}{l}q \\
+ \\
+1 \\
8 \\
i n \\
i n\end{array}$ & $\begin{array}{l}\text { o } \\
+ \\
\text { मे } \\
\text { ठे }\end{array}$ & $\begin{array}{l}9 \\
+ \\
+1 \\
8 \\
0 \\
i n\end{array}$ & $\begin{array}{l}\text { O } \\
+1 \\
\& \\
\infty \\
\text { in }\end{array}$ & 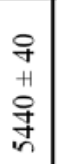 & \begin{tabular}{l}
$q$ \\
+ \\
+1 \\
0 \\
0 \\
\hdashline
\end{tabular} & $\begin{array}{l}\text { ते } \\
+1 \\
\text { \& } \\
\text { ते }\end{array}$ & $\begin{array}{l}\circ \\
n \\
+1 \\
\stackrel{\widehat{్}}{0}\end{array}$ & $\begin{array}{l}\stackrel{n}{n} \\
+1 \\
\stackrel{2}{2} \\
\stackrel{2}{n}\end{array}$ \\
\hline $\begin{array}{l}\dot{0} \\
\dot{\Sigma} \\
\dot{\Xi} \\
\end{array}$ & ڤે & 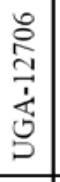 & 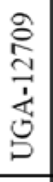 & 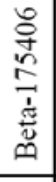 & 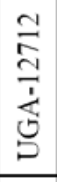 & 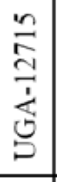 & 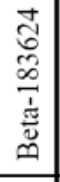 & 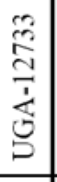 & 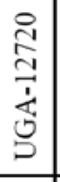 & 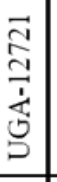 & 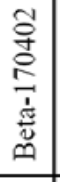 & 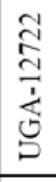 & 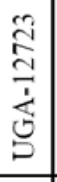 & 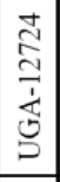 & 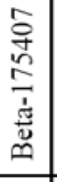 & 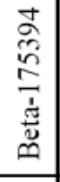 & 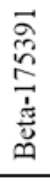 \\
\hline$\geqslant 0$ & $\stackrel{\circ}{i}$ & $\stackrel{n}{n}$ & $\overrightarrow{0}$ & $\overrightarrow{0}$ & ĩ & $\overrightarrow{0}$ & $\overrightarrow{0}$ & $\overrightarrow{0}$ & $\overrightarrow{0}$ & $\ddot{0}$ & 9 & $\overrightarrow{0}$ & $\overrightarrow{0}$ & $\overrightarrow{0}$ & $\overrightarrow{0}$ & : & ¿̊. \\
\hline 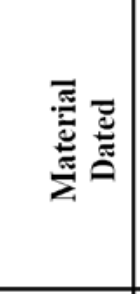 & 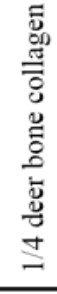 & 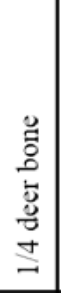 & 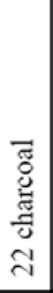 & 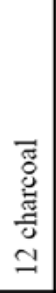 & 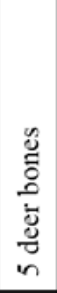 & 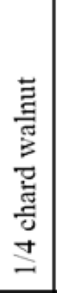 & 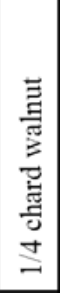 & 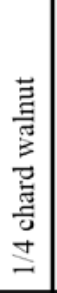 & 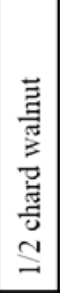 & 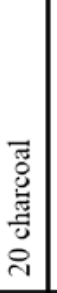 & 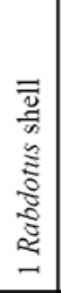 & 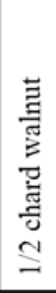 & 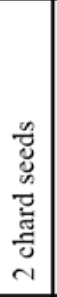 & 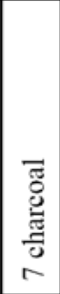 & 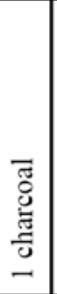 & 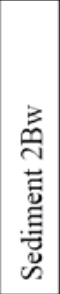 & 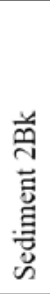 \\
\hline 䓌氞 & 产 & 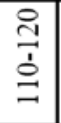 & 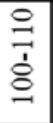 & $\cong$ & 高 & 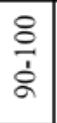 & 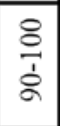 & 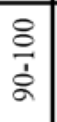 & ஓे & $\begin{array}{l} \\
8 \\
1 \\
\vdots\end{array}$ & ঃ & 尽 & $\begin{array}{l}8 \\
0 \\
\stackrel{1}{n}\end{array}$ & t & $\begin{array}{l}0 \\
\text { ñ } \\
\text { के }\end{array}$ & 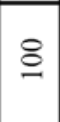 & 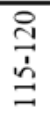 \\
\hline 宽 & 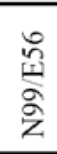 & 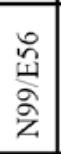 & 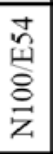 & 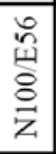 & 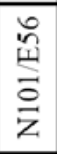 & 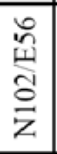 & 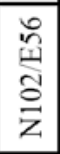 & 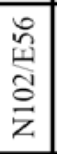 & 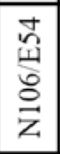 & 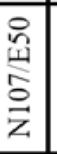 & 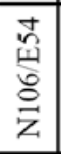 & $\begin{array}{l}\text { 瓷 } \\
\text { 点 } \\
\text { z }\end{array}$ & 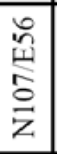 & 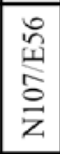 & $\begin{array}{l}\text { 古 } \\
\text { 出 } \\
\text { oे } \\
z \\
z\end{array}$ & $\overrightarrow{\sum_{n}}$ & $\stackrel{n}{n}$ \\
\hline 童 & $\varangle$ & $\varangle$ & $\varangle$ & $\varangle$ & $<$ & $<$ & $\varangle$ & $<$ & $\varangle$ & $\varangle$ & $\varangle$ & $\ll$ & $<$ & $\varangle$ & $\varangle$ & $\varangle$ & 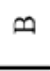 \\
\hline 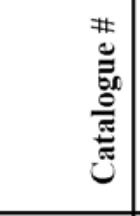 & 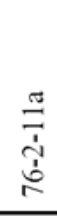 & 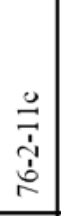 & 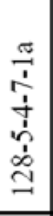 & $\begin{array}{l}\overrightarrow{1} \\
\dot{+} \\
\stackrel{5}{-}\end{array}$ & $\begin{array}{l}\overrightarrow{\hat{I}} \\
\hat{n} \\
\end{array}$ & $\begin{array}{l}\frac{5}{5} \\
\frac{5}{5} \\
\frac{\dot{t}}{4} \\
\end{array}$ & $\begin{array}{l}\frac{0}{1} \\
\frac{1}{4} \\
m\end{array}$ & 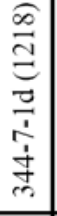 & $\frac{\frac{\pi}{5}}{\frac{1}{n}}$ & $\begin{array}{l}\frac{\pi}{1} \\
\frac{1}{2} \\
\vdots \\
\text { in } \\
\end{array}$ & 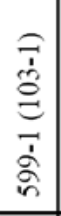 & $\frac{\frac{\pi}{1}}{\frac{1}{8}}$ & 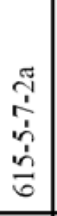 & \begin{tabular}{|l|}
$\frac{\pi}{1}$ \\
$\frac{1}{1}$ \\
$\hat{1}$ \\
0 \\
0 \\
\end{tabular} & 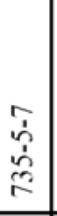 & $\begin{array}{l}\overleftarrow{1} \\
\dot{I} \\
\stackrel{5}{\Xi} \\
\end{array}$ & 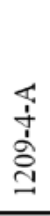 \\
\hline$\dot{\tilde{E}}$ & & & q & & & & & & & & & & $\stackrel{\sim}{\sim}$ & $\stackrel{\sim}{\circ}$ & $\ddot{\imath}$ & & \\
\hline
\end{tabular}


Sample \#76-2-11 was part of a multi-piece fragmented bone awl manufactured from a deer long bone recovered from 110 to $120 \mathrm{cmbd}$ in Unit N99/E56 in Early Archaic context. This deer bone was discovered in multiple pieces that fit together. Individual pieces of this long bone were submitted to two different radiocarbon laboratories for dating. About $5.0 \mathrm{~g}$ (\#76-2-11a) of unworked shaft section was submitted to Beta Analytic Inc. (Beta) and $7.5 \mathrm{~g}$ (\#76-2-11c) of the same shaft was submitted to University of Georgia (UGA). The reported conventional age from Beta was 430 radiocarbon years older than the conventional age report by UGA. Using CALIB REV4.4, the two samples were first calibrated and then subjected to a $t$-test. The $t$ test $(t=57.78 ; d f=2)$ indicates that the samples are statistically different at a 95 percent confidence level. The reported stable carbon isotope result from Beta is $-17.8 \%$ compared to carbon isotope result from UGA of $-19.7 \%$. Although a nearly 2\% difference in the stable carbon isotope value was determined in processing the samples, this difference was accounted for in the reporting. The stable carbon isotope values are not out of line with those reported for deer bones. Although a 430radiocarbon year difference exists between the two samples, they are both accepted as representative of this component.

Sample \#344-7-1 was a nearly complete, burned walnut shell from 90 to $100 \mathrm{cmbd}$ in Unit N102/E56. The walnut shell was split into three pieces with two pieces sent to UGA (\#3447-1a and \#344-7-1d) and one piece to Beta (\#344-7-1c). This shell originated from Early Archaic context near the bottom of the excavations. Radiocarbon results were determined on all three parts of the same walnut shell. The two reported conventional ages from UGA were only 10 radiocarbon years different from one another, whereas the reported conventional age from Beta was some 110 radiocarbon years older (Table 11-1). Using
CALIB REV4.4, the three samples were first calibrated and then subjected to a $t$-test. The $t$ test $(t=4.04, d f=2)$ indicates that the samples are statistically the same at the 95 percent confidence level.

The data from the two-radiocarbon laboratories are comparable insofar as the 15 samples generally reflect the same cultural component, and age differences cannot be accounted for based on the use of two different radiocarbon laboratories. All 15 organic samples, encompassing different materials, yielded radiocarbon dates within a period of 1,080radiocarbon years from 6,280 B.P. (Beta175407) to 5,200 B.P. (UGA-12709; Table 111). Two mean residence dates of $6,270 \pm 50$ B.P. and 5,230 \pm 50 B.P. on organic sediment from which the cultural material were in direct association occur during this same time period and provide support for the ages obtained on the carbonized plant materials..

The OSL dating of alluvial deposits continued with the analyses of two sediment samples (\#1242 and \#1243) from Early Archaic context in different locations in Block A. Sample \#1242 was collected from a brown (10YR 3/2) silty clay loam in Unit N106/E50 between 80 and $88 \mathrm{cmbs}$ and stratigraphically below the dated younger components and about $10 \mathrm{~cm}$ above the gravels. Sample \#1243 was collected from Unit N103/E51 between 94 and 102 cmbs and in the earliest part of the fine alluvial sediments.

The detailed methods and results of the OSL technique are presented in Appendix L and only a summary is presented here. The two sediment samples from the Early Archaic context again did not yield many single dateable quartz grains. Only seven percent of the measured grains in sample \#1242 or UW1051 and only 24 percent of the measured grains in sample $\# 1243$ or UW1052 were dateable (Appendix L). The central age determination from the fine grains 
provides an average age for each sample. Sample \#1242/UW1051 yielded an age of $6,670 \pm 1,110$ years before A.D. 2004. Sample $\# 1243 / \mathrm{UW} 1052$ yielded an age of $5,000 \pm 864$ years before A.D. 2004. Both of these age determinations are compatible with the radiocarbon results.

It appears, then, that the OSL dating technique on the fine-grained sediments from alluvial deposits provides a reasonable strategy for determining relative ages on sediments. The OSL dates determined for the two younger components match reasonably well with the charcoal and other organic materials dated in each of those components, and they are also congruent with their relative stratigraphic positions. Therefore, in situations where early occupations do not yield preserved organic materials for radiocarbon dating, OSL dating of sand-grains within sediment matrices may serve as a reasonably reliable alternative method for obtaining chronological information..

The $83-\mathrm{m}^{2}$ hand-excavation in Block A yielded 56,644 items of cultural origin, including 51,869 pieces of lithic debitage, 3,044 burned rock fragments, 229 faunal bone fragments, $223.5 \mathrm{~g}$ of organic remains, 1,038 edge-modified flakes, 170 dart points, 198 bifaces, 27 scrapers, 17 drills, four unifaces, three gouges, two choppers, one hammerstone (\#128-5-11), one faceted stone (\#739-11), 25 cores, seven mussel shell fragments, and nine features. Each category is described and discussed below.

\subsection{EARLy ARchaic FEATURES}

Nine clusters cultural material were recognized and assigned feature numbers in the field and subsequently assigned to this component. All clusters were comprised mainly of burned rocks and classified into the same basic categories identified in the previously discussed site components, namely, hearths ( $n=2)$, burned rock dumps $(n=2)$, and burned rock clusters $(n=5)$.
Hearths were areas of intentional in situ burning as evidenced by oxidized earth, ash, charcoal lenses, and systematically placed stones. Hearths may be within basins or pits, or may rest on level planes. Burned rock clusters are concentrations of burned rocks lacking characteristics that would indicate direct, in situ heating. A dump was a concentration of burned rocks deposited in one place and sometimes containing more than one class of cultural debris. The nine features were all discovered in excavation Block A. Each feature is described individually below within its assigned category.

\subsubsection{Hearths $(n=2)$}

\subsubsection{Feature 40}

Feature 40 was a hearth found between 100 and $111 \mathrm{cmbd}$ in Unit N100/E54 in the southern part of Block A. This hearth was a tight cluster of burned rocks with a semi-circular outline that measured 69-by-72 cm (Figure 11-1).

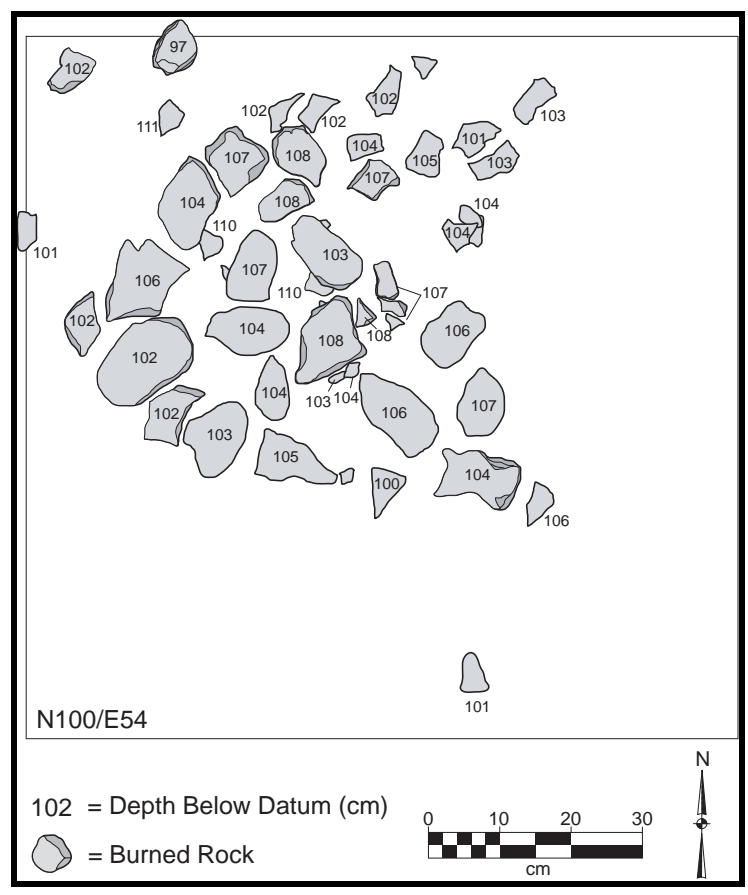

Figure 11-1. Planview of Feature 40, Early Archaic 
Although the rocks did not form a complete circle, no obvious signs of disturbance were detected along the eastern side. The burned rocks along the western side appeared more systematically placed with the outer rocks in contact with one another. Near the center, five or six smaller burned rocks were at slightly lower elevations than the larger ones in the immediate vicinity, possibly indicating a slight basin. The matrix outside the burned rocks was a very dark grayish brown (10YR 3/2) with a slightly lighter grayish brown (10YR 5/2) matrix just below the burned rocks.

The 42 burned rocks weighed a total of $17,750 \mathrm{~g}$, for an average rock weight of $423 \mathrm{~g}$ (Table 11-2). About 36 percent of the burned rocks were 4.1 to $9.0 \mathrm{~cm}$ in diameter, with another 55 percent in the 9.1 to $15 \mathrm{~cm}$ size class. Three larger pieces were complete round, waterworn cobbles and six to seven were tabular slabs.

Four burned rocks were selected for lipid and stable carbon and nitrogen isotope analyses. Drs. Malainey and Malisza's detail findings and interpretations are presented in Appendix G, with a summary of the results presented here (see also Table 11-3). Samples \#128-5-3-1a and \#128-5-3-4a yielded moderate to high fat content, with the former believed to represent plant matter. Samples \#128-5-3-2a and \#128-53-3a yielded high fat content that reflects lipids from plants. The carbon isotope values on these same samples range from -23.9 to $-25.1 \%$, with a mean of $-24.6 \%$ o (Table 11-4). These reflect $\mathrm{C}_{3}$ plants or animals that ate $\mathrm{C}_{3}$ plants. The nitrogen isotope values range from 5.6 to $8.2 \%$ and are all relatively positive. The combined results indicate the possibility that these burned rocks were used to cook mainly $\mathrm{C}_{3}$ plants, none of which are likely to have been legumes. Six liters of matrix (\#128-5-4) from around the burned rocks between 100 to $110 \mathrm{cmbd}$ were collected and floated. The less than 0.1 liters light fraction was sent to Dr. Dering for macrobotanical analysis. No identifiable plant remains were present (Appendix I). The heavy fraction was sorted and yielded 44 tiny chert pieces, 29 tiny charcoal pieces, and 23 tiny bone fragments. The $6.4 \mathrm{~mm}$ mesh yielded 24 tiny chert pieces and nine tiny charcoal pieces.

Twenty-two tiny pieces of charcoal (\#128-5-4-72a) were sent for radiocarbon dating. These yielded a $\delta^{13} \mathrm{C}$ corrected (-26.2\%) AMS radiocarbon date of 5,200 \pm 40 B.P. (Table 11-1: Beta-170409). Part of this same dated sample was sent to Dr. Dering, and one piece was identified as oak wood (Appendix I). Outside Feature 40, this unit-level yielded 239 pieces of lithic debitage and four edge-modified tools.

The circular placement of the rocks, combined with the presence of charcoal, indicates this was a place of in situ burning (probably a hearth). It is not clear if the tiny bone fragments and lithic debitage were directly associated with the hearth during the occupation or post-depositionally displaced.

\subsubsection{Feature 41}

Feature 41, interpreted as a hearth, lay between 76 and $86 \mathrm{cmbd}$ in Unit N101/E50 in the southern part of Block A and about $120 \mathrm{~cm}$ west of Feature 29. This hearth consisted of 41 burned rocks in a tight cluster forming a somewhat circular-to-oval pattern in plan view (Figures 11-2 and 11-3). The cluster measured 58 -by $-70 \mathrm{~cm}$ in diameter and was mostly one rock thick, except for a few burned rocks that lay below the others. Most pieces were lying flat, with the two largest burned rocks along the western margin slanted downward towards the middle of the cluster. The larger pieces rested at the outer margins of the cluster. The clay loam matrix between the burned rocks was indistinguishable from that outside the cluster. 


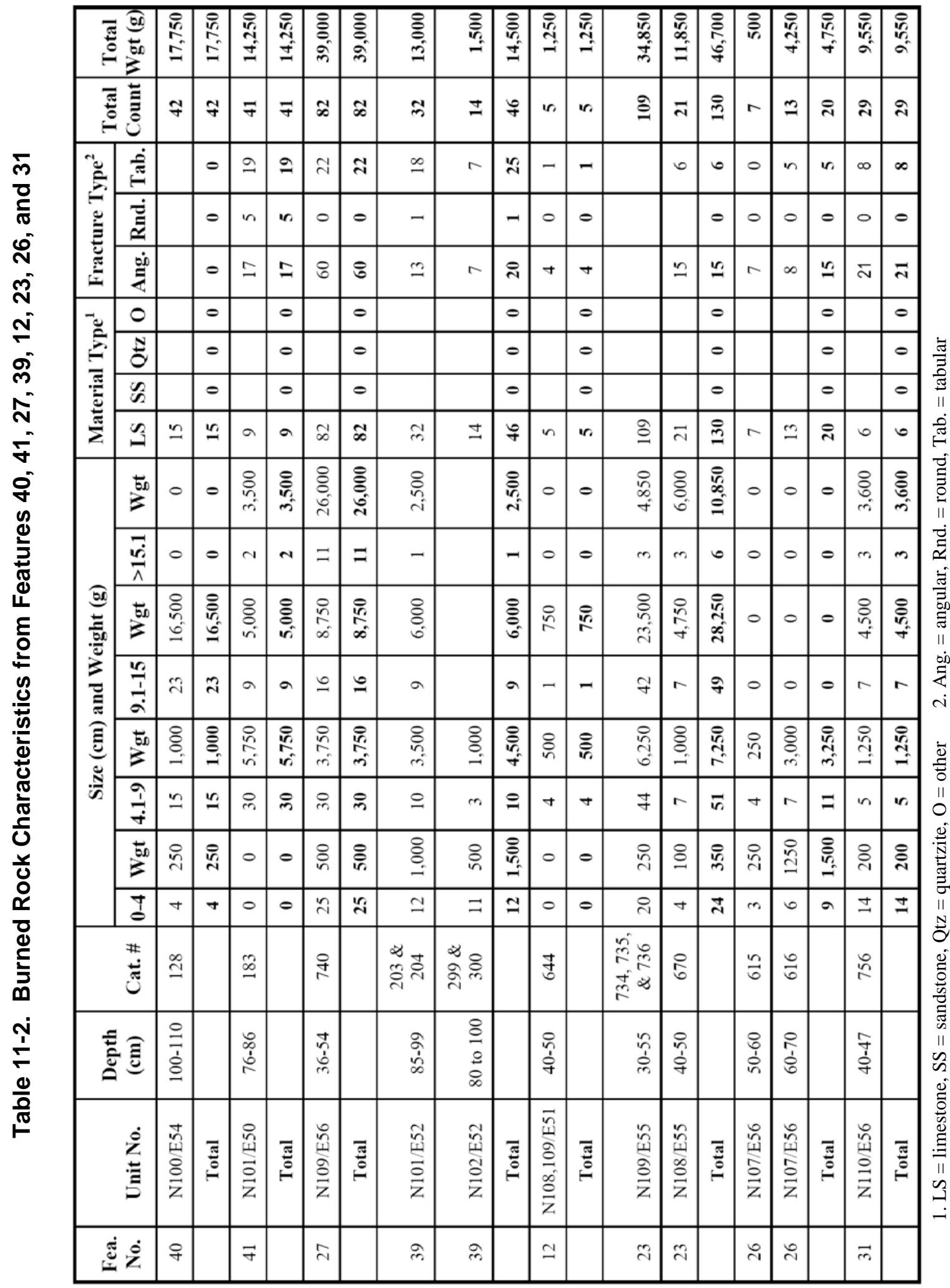


Table 11-3. Lipid Residue Results from Burned Rock Samples from the Early Archaic Component

\begin{tabular}{|c|c|c|c|c|c|}
\hline Lab. No. & Cat. \# & $\begin{array}{c}\text { Fea. } \\
\text { No. }\end{array}$ & Material & $\begin{array}{c}\text { Wgt } \\
\text { (g) }\end{array}$ & Interpreted Lipid Residue Results \\
\hline $4 \mathrm{VG} 100$ & $644-5-3-1 a$ & 12 & Limestone & 28 & Very high fat content - plant \\
\hline 4VG 101 & $644-5-3-2 a$ & 12 & Limestone & 48 & Moderate-high fat content -plant \\
\hline 4VG 102 & $644-5-3-3 a$ & 12 & Limestone & 40 & High fat content - plant \\
\hline 4VG 96 & $658-5-3-1 a$ & 13 & Limestone & 134 & Borderline high and very high fat content - plant \\
\hline 4VG 97 & $658-5-3-2 a$ & 13 & Limestone & 30 & Very high fat content - plant \\
\hline 4VG 98 & $658-5-3-3 a$ & 13 & Limestone & 22 & Moderate-high fat content - plant \\
\hline 4VG 99 & $658-5-3-4 a$ & 13 & Limestone & 41 & High fat content - plant \\
\hline 4VG 81 & $616-5-3-1 a$ & 26 & Limestone & 120 & Borderline high and very high fat content - plant \\
\hline 4VG 82 & $616-5-3-2 a$ & 26 & Limestone & 128 & Moderate-high fat content \\
\hline 4VG 83 & $616-5-3-3 a$ & 26 & Limestone & 11 & Moderate-high fat content \\
\hline 4VG 84 & $757-5-3-1 a$ & 31 & Limestone & 36 & Very high fat content - plant \\
\hline 4VG 85 & $757-5-3-2 a$ & 31 & Limestone & 75 & Borderline high and very high fat content - plant \\
\hline 4 VG 86 & $757-5-3-3 a$ & 31 & Limestone & 65 & Very high fat content - plant \\
\hline 4VG 87 & $757-5-3-4 a$ & 31 & Limestone & 24 & High fat content - plant \\
\hline $4 V G 88$ & 203-5-3-1a & 39 & Limestone & 28 & Moderate-high fat content - plant \\
\hline 4VG 89 & $203-5-3-2 a$ & 39 & Limestone & 33 & Moderate-high fat content - plant \\
\hline 4VG 90 & 203-5-3-3a & 39 & Limestone & 22 & Moderate-high fat content - plant \\
\hline 4VG 91 & $203-5-3-4 a$ & 39 & Limestone & 98 & Borderline medium and moderate-high fat content - plant \\
\hline 4VG 92 & $128-5-3-1 a$ & 40 & Limestone & 45 & Moderate-high fat content - plant \\
\hline 4VG 93 & $128-5-3-2 a$ & 40 & Limestone & 36 & High fat content - plant \\
\hline 4VG 94 & $128-5-3-3 a$ & 40 & Limestone & 21 & High fat content - plant \\
\hline 4VG 95 & $128-5-3-4 a$ & 40 & Limestone & 37 & Moderate-high fat content \\
\hline
\end{tabular}


Table 11-4. Isotope Results from Burned Rocks in Early Archaic Context

\begin{tabular}{|c|c|c|c|c|c|c|c|c|}
\hline Cat.\# & Unit No. & $\begin{array}{l}\text { Depth } \\
\text { (cmbs) }\end{array}$ & $\begin{array}{c}\text { Fea. } \\
\text { No. }\end{array}$ & $\begin{array}{l}\text { Wgt } \\
\text { (mg) }\end{array}$ & $\begin{array}{c}\text { N } \\
\text { Wgt } \\
(\mu g)^{1}\end{array}$ & $\begin{array}{c}\delta^{15} \mathrm{~N} \\
(\% 0)\end{array}$ & $\begin{array}{c}\text { C } \\
\text { Wgt } \\
\text { ( } \mu g)\end{array}$ & $\begin{array}{l}\delta^{13} C \\
(\%)\end{array}$ \\
\hline $644-5-3-1 b$ & N108/E51 & $40-50$ & 12 & 7.149 & 3.9 & -11.67 & 60.9 & -26.63 \\
\hline $644-5-3-1 b$ & N108/E51 & $40-50$ & 12 & 11.745 & 52.8 & 1.35 & 834.9 & -25.61 \\
\hline $644-5-3-3 b$ & N108/E51 & $40-50$ & 12 & 30.054 & 77.5 & 3.75 & 1820.8 & -23.64 \\
\hline $658-5-3-1 b$ & N108/E53 & $40-60$ & 13 & 19.781 & 35.2 & 6.02 & 1408.3 & -30.74 \\
\hline $658-5-3-3 b$ & N108/E53 & $40-60$ & 13 & 7.308 & 27.1 & 2.91 & 337.4 & -25.78 \\
\hline $658-5-3-1 b$ & N108/E53 & $40-60$ & 13 & 3.415 & 20.1 & 1.89 & 593.4 & -25.02 \\
\hline $658-5-3-4 b$ & N108/E53 & $40-60$ & 13 & 43.887 & 17.4 & 6.42 & 2853.2 & -30.26 \\
\hline $616-5-3-1 b$ & N107/E56 & $50-60$ & 26 & 22.694 & 92.3 & 4.65 & 1385.5 & -24.15 \\
\hline $616-5-3-2 b$ & N107/E56 & $50-60$ & 26 & 39.737 & 56.7 & 2.82 & 905.3 & -24.47 \\
\hline $616-5-3-3 b$ & N107/E56 & $50-60$ & 26 & 30.052 & 63.2 & 6.03 & 938.0 & -22.21 \\
\hline $757-5-3-1 b$ & N109/E56 & $36-54$ & 31 & 9.052 & 4.7 & 1.47 & 111.6 & -26.89 \\
\hline $757-53-4 b$ & N109/E56 & $36-54$ & 31 & 7.039 & 23.1 & 5.79 & 439.0 & -25.26 \\
\hline $756-5-3-2 b$ & N110/E56 & $40-50$ & 31 & 1.000 & 2.0 & 5.44 & 147.7 & -26.71 \\
\hline $756-5-3-3 b$ & N110/E56 & $40-50$ & 31 & 30.070 & 90.4 & 6.14 & 987.0 & -23.77 \\
\hline $203-5-3-4 b$ & N101/E52 & 85-99 & 39 & 16.736 & 81.4 & 1.90 & 1298.6 & -25.76 \\
\hline $203-5-3-1 b$ & N101/E52 & 85-99 & 39 & 30.703 & 99.0 & 6.06 & 1390.0 & -25.48 \\
\hline $203-5-3-3 b$ & N101/E52 & 85-99 & 39 & 30.518 & 137.1 & 6.49 & 1420.9 & -23.69 \\
\hline $128-5-3-4 b$ & N100/E54 & $100-110$ & 40 & 12.956 & 32.7 & 8.16 & 569.7 & -23.88 \\
\hline $128-5-3-1 b$ & N100/E54 & $100-110$ & 40 & 15.867 & 41.4 & 5.67 & 597.2 & -25.12 \\
\hline $128-5-3-3 b$ & N100/E54 & $100-110$ & 40 & 30.871 & 128.4 & 5.95 & 1563.0 & -24.66 \\
\hline $128-5-3-2 b$ & N100/E54 & $100-110$ & 40 & 32.291 & 48.4 & 6.50 & 791.0 & -24.70 \\
\hline
\end{tabular}

1. Values below 10.0 make the results suspect

2. $\mathrm{C}=$ Carbon; $\mathrm{N}=$ Nitrogen 


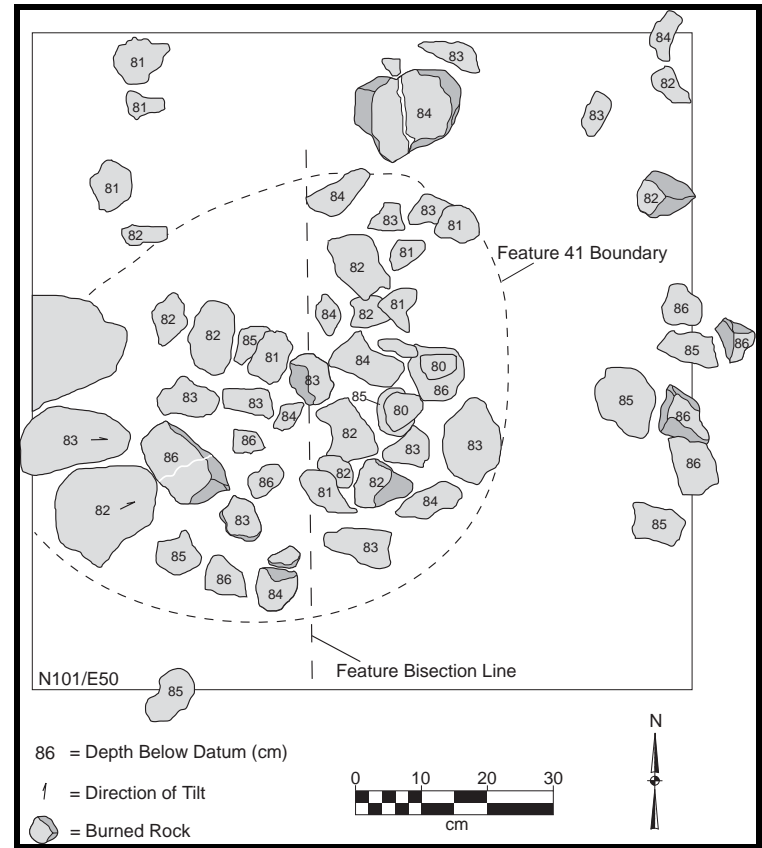

Figure 11-2. Planview of Feature 41

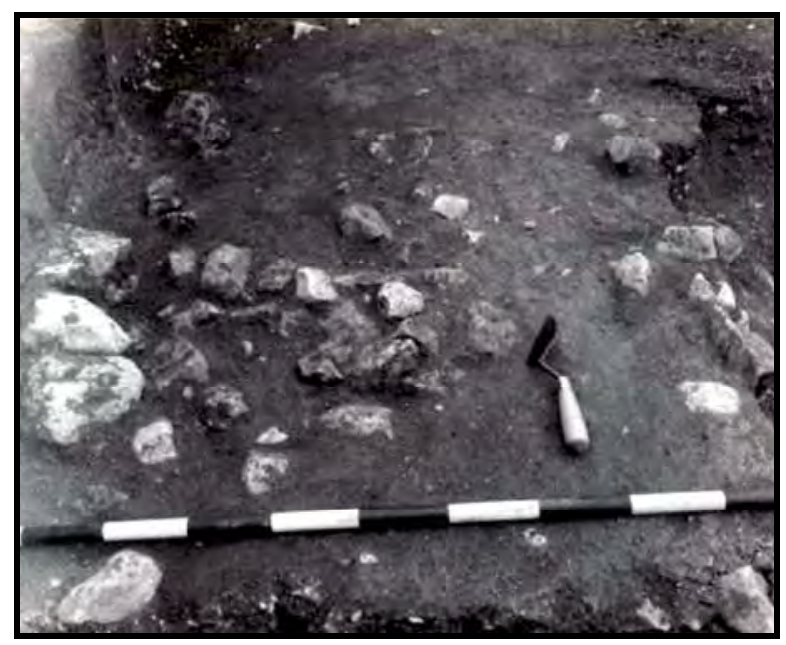

Figure 11-3. Oblique Angle of Feature 41

Just below the rocks, the matrix changed to a lighter brown and became slightly siltier and the natural stream gravels became more abundant than the cultural burned rocks. No obvious basin was distinguished, but the variations in rock depths are suggestive of such. No charcoal or ash lenses, or burned matrix were detected such as would indicate in situ burning.
The 41 burned rocks weighed a total of $14,250 \mathrm{~g}$, with an average rock weight of $348 \mathrm{~g}$. The burned rocks varied from $4.1 \mathrm{~cm}$ to greater than $15 \mathrm{~cm}$ in diameter (Table 11-2). Seventythree percent of the burned rocks fell into the 4.1 to $9 \mathrm{~cm}$ diameter size class. The lack of the smallest size category may indicate a bias on the excavator's part to record this size class or could reflect an actual absence of pieces in this size class. The remaining level in this unit yielded 382 pieces of lithic debitage, 27 Rabdotus snail shells, one bone fragment, one drill (\#183-021), and 11 edge-modified flakes (\#128-10 through 20).

The level containing the base of the burned rocks yielded similar types of cultural materials, but in reduced quantities. Some 21 limestone burned rocks weighing 9,750 g were outside Feature 41, but a nearly $20 \mathrm{~cm}$-wide void was observed between the feature rocks and those scattered outside (Figures 11-2 and 11-3).

\subsubsection{Dumps $(n=2)$}

\subsubsection{Feature 27}

Feature 27 was discovered in the northeastern corner of Block A in Unit N109/E56 between 36 and $55 \mathrm{cmbd}$. This burned rock feature was on the eastern margin of a sizeable $(50 \mathrm{~cm}-$ diameter) natural boulder and was directly on a bed of rounded river gravels (Figures 11-4 and 11-5). Feature 27 was located about $60 \mathrm{~cm}$ east of Feature 23 and about $200 \mathrm{~cm}$ north of Feature 26. All three features were at approximately the same elevation. Tiny rootlets were present throughout this feature, but no visible rodent disturbances were detected in this gray (10YR 5/1) clay loam. This was an amorphous cluster of 82 burned rocks weighing $39 \mathrm{~kg}$, a few chunks of charcoal, a few bone fragments, quantities of scattered lithic debitage, into which were intermixed a few stone tools. 


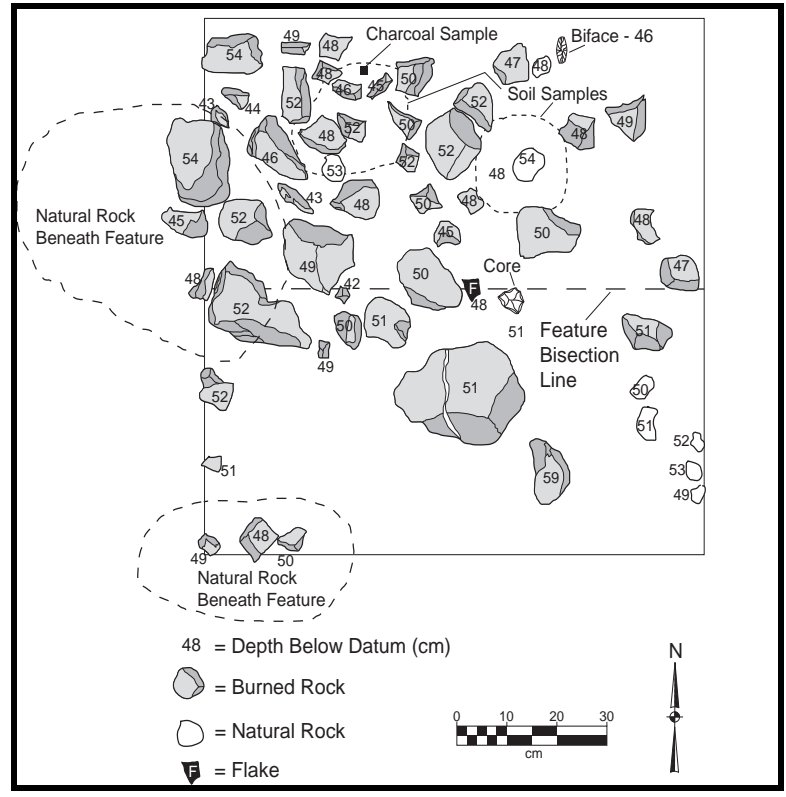

Figure 11-4. Planview of Feature 27, Early Archaic

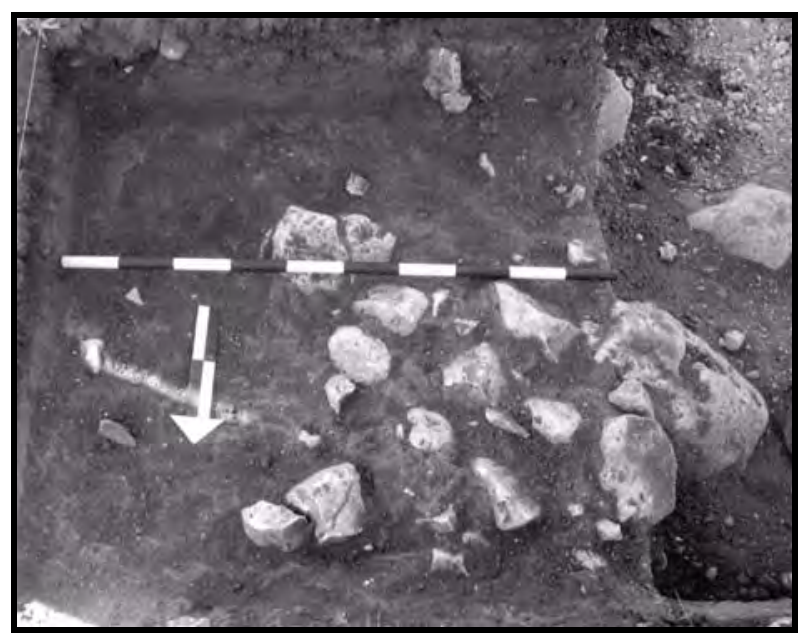

Figure 11-5. Overview of Excavated Feature 27

A light red stain was visible across the top of the feature and in the feature matrix. This cluster measured about 80 -by- $100 \mathrm{~cm}$ in diameter and was about $15 \mathrm{~cm}$ thick. No basin or pit, charcoal or ash lenses, or other signs of in situ burning were observed. The burned rocks were in two irregular layers, and only a few burned rocks were vertically orientated or had a detectable dip in orientation. The 82 burned rocks varied from two to greater than $15 \mathrm{~cm}$ in diameter with two thirds less than $9 \mathrm{~cm}$ in diameter (Table 11-2). The average burned rock weight was $476 \mathrm{~g}$. No lipid residue or isotope analyses were conducted on any of these burned rocks.

Two liters of matrix (\#740-5-4) from around the burned rocks at 40 to $45 \mathrm{cmbd}$ were collected and floated in the laboratory. The light fraction was macroscopically inspected, but no burned plant remains were observed. The heavy fraction yielded 76 tiny chert pieces, seven tiny charcoal pieces, four seed-like objects and seven tiny bone fragments. One tiny bone was calcined. The $6.4 \mathrm{~mm}$ mesh yielded two tiny burned rock pieces, 12 tiny chert pieces, 12 nearly complete snail shells and one bone fragment.

\subsubsection{Feature 39}

Feature 39 was a loose cluster of burned rocks in Unit N102/E52 in the southern part of Block A (Figure 11-6). The burned rocks rested between 85 and 99 cmbd in a gray (10YR 5/1) clay loam intermixed with natural gravel. The burned rocks appeared to rest directly on or a few centimeters above the abundant river gravels with a few burned rocks and other cultural debris filtering down between the natural gravels. No obvious rodent or root disturbances were detected.

The burned rocks were in no detectable arrangement or pattern, and the outer boundary was unclear. Depending on where the arbitrary boundary to demarcate this cluster is drawn, the contents and number of items in this feature changes considerably. The burned rocks scattered across the southern section of Feature 39 (N101/E52, between 80 and $100 \mathrm{cmbd}$ ) appeared to be associated with other cultural debris. 


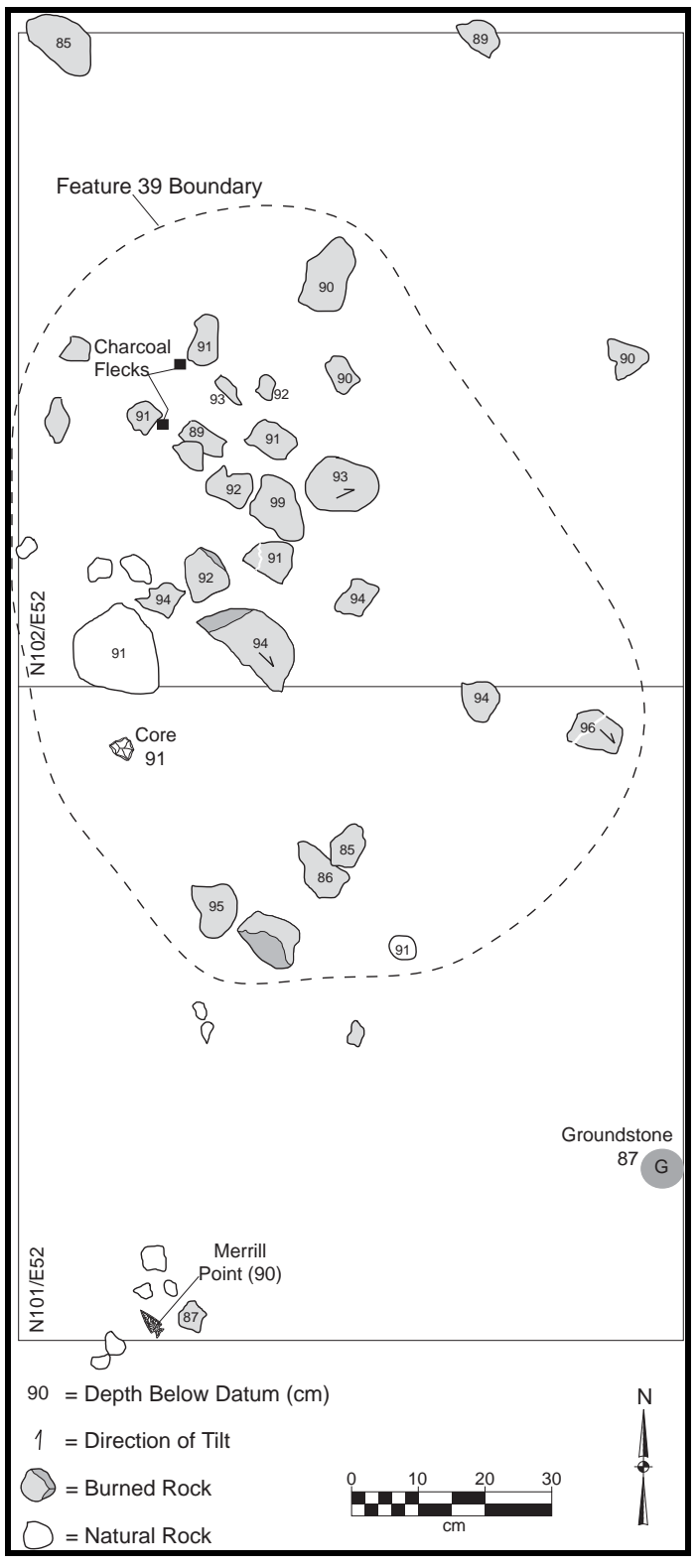

Figure 11-6. Planview of Feature 39, Early Archaic

The latter included a badly burned medial section of a broad dart point (\#204-10) and a Merrell point (\#203-13) recovered on the south edge of Unit N101/E52 at $90 \mathrm{cmbd}$. Five edgemodified rejuvenation flakes, four edgemodified flakes, a biface (\#203-15), a core (\#203-16), a few chunks of charcoal, and
872 pieces of lithic debitage were recovered. The northern section in Unit N102/E52, between 80 and $100 \mathrm{~cm}$, exhibited the more tightly clustered burned rocks and also yielded 728 pieces of lithic debitage, four bifaces (\#29912, \#300-16, \#300-17 \#300-18) one Merrell point (\#299-14), three untypable dart points (\#299-13, \#300-15 and \#300-19), a scraper (\#300-10), a core (\#300-14), five edge-modified flakes, and a rejuvenation flake (\#299-15).

Burned rocks in the larger ovate area included 46 pieces, weighing $14.5 \mathrm{~kg}$ or $315 \mathrm{~g}$ per rock (Table 11-2). This area measured about 90-by$80 \mathrm{~cm}$ in diameter and most of the burned rocks were within a $15-\mathrm{cm}$ vertical range. No charcoal, ash, or oxidation lenses were detected. All three of the smaller size classes under $15 \mathrm{~cm}$ are nearly equally represented by number. Distinctly angular fragments were slightly more abundant than were less angular ones.

Four burned rocks were selected for lipid residue analysis. Drs. Malainey and Malisza's detail findings and interpretations are presented in Appendix G. A summary of the results is presented here (Table 11-3). Three samples (\#203-5-3-1a, \#203-5-3-2a, and \#203-5-3-3a) yielded moderate to high fat content interpreted to represent plants. Sample \#203-5-3-4a yielded residues that are borderline medium and moderate to high fat content, again interpreted as representing plants. Parts of the same four burned rocks were subjected to stable carbon and nitrogen isotope analyses. The carbon isotope values on these same samples range from -23.7 to $-25.8 \%$ with a mean of $-25.0 \%$ o (Table 11-4), representing $\mathrm{C}_{3}$ plants or animals that ate $\mathrm{C}_{3}$ plants. The nitrogen values reflect a broad range from 1.9 to $6.5 \%$ with an average of 4.8\%o. The combined results imply that these burned rocks were used to cook mostly $\mathrm{C}_{3}$ plants or animals that ate $\mathrm{C}_{3}$ plants. 
Twelve liters of matrix (\#203-5-4) for flotation were collected from around the tighter cluster of burned rocks between 85 and $99 \mathrm{cmbd}$ in Unit N101/E52. The light fraction yielded 56 tiny charcoal pieces. The heavy fraction yielded 530 tiny pieces of chert debitage, 204 tiny charcoal pieces, six seed-like objects, and 10 tiny bone fragments. The $6.4 \mathrm{~mm}$ size fraction yielded 178 pieces of chert debitage, five charcoal pieces, three tiny burned rock fragments and three stone tool fragments (two distal projectile points and one rejuvenation flake).

Only about 0.5 liter of matrix for flotation (\#204-5-4) was collected from around the few burned rocks between 90 and $100 \mathrm{cmbd}$ in Unit N101/E52. The light fraction yielded 36 tiny charcoal pieces. The heavy fraction yielded 48 pieces of chert debitage, 109 tiny charcoal pieces, and five tiny bone fragments. The $6.4 \mathrm{~mm}$ fraction yielded 10 pieces of chert debitage, 10 charcoal pieces, and one small bone fragment.

Tiny chunks of charcoal were recovered from the southern unit, N101/E52, and seven tiny pieces (0.1 g) (\#203-5-4-2-1) were sent for radiocarbon dating. These yielded a $\delta^{13} \mathrm{C}$ corrected (-21.9\%) AMS radiocarbon date of 2,230 \pm 40 B.P. (Table 11-1: Beta-170408). Four pieces from part of this same dated sample were identified as mesquite wood (Appendix I). This date reflects a Late Archaic age, and therefore, the charcoal is considered intrusive into this earlier feature/occupation, and the age is rejected as it is non-representative of the Early Archaic component.

The diversity of cultural debris amongst these burned rocks would imply this location was probably a discard or dump locality rather than an in situ burning or cooking location. This accords with the lack of a formal shape to this cluster and the absence of any concentrations of charcoal or ash within the feature.

\subsubsection{Burned Rock Clusters ( $n=5)$}

\subsubsection{Feature 12}

Feature 12 was a small cluster of five burned rocks in the very northeastern corner of Unit N108/E51 in Block A (Figure 11-7). These rocks rested between 45 and $50 \mathrm{cmbd}$ directly above or resting immediately upon the natural river gravels. This cluster measured about 40by $-25 \mathrm{~cm}$ in diameter. The surrounding matrix was a dark gray (5YR 4/1) clay loam, the same as outside the feature. Minor termite damage was the only disturbance noted. No basin or pit, or other signs of in situ heating such as charcoal or ash lenses, or oxidation were detected. No individual chunks or flecks of charcoal were observed during the excavation.

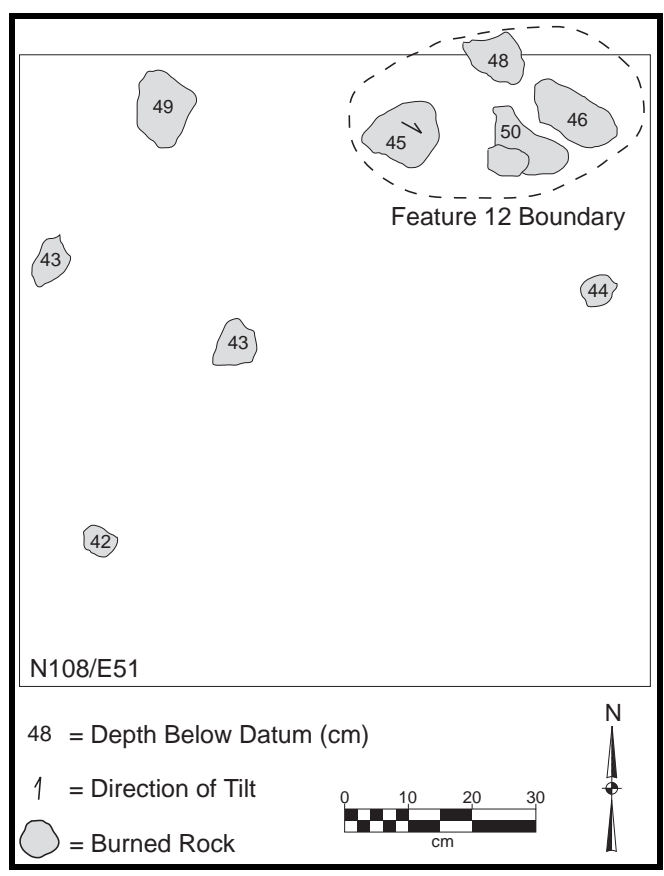

Figure 11-7. Planview of Feature 12, Early Archaic 
Four of the five burned rocks were in the 4.1 to $9 \mathrm{~cm}$ size class with one greater than $9.1 \mathrm{~cm}$ (Table 11-2). The average rock weight is $250 \mathrm{~g}$. Two of the larger pieces were rounded water worn cobbles that were still complete, but had internal discoloration indicating they had been heated. Most pieces appeared to have water worn exterior edges. Two sets of rocks (a total of 4 pieces), could be refit one to another. One was a spall from a larger piece.

Parts of four burned rocks were sent for lipid residue and stable carbon and nitrogen analyses. The detailed findings and interpretations from lipid residue analysis on three rock samples are presented in Appendix G, with the results summarized here (also, see Table 11-3). All three samples (\#644-5-3-1a, \#644-5-3-2a, and \#644-5-3-3a) yielded variations of high fat content interpreted to represent plants. These results suggest that the same kind of food was cooked using these rocks, hinting perhaps at a single cooking event. The carbon isotope values on these same samples range from -23.6 to $-26.6 \%$, with a mean of $-25.3 \%$ o (Table 11-4), representing $\mathrm{C}_{3}$ plants or animals that ate $\mathrm{C}_{3}$ plants. The nitrogen isotope values range from 1.3 to $3.82 \%$ and are all relatively low, with a value of $-11.7 \%$ from \#644-5-3-1b; these results are questionable due to this very low representation of nitrogen. The combined results at least indicate the possibility these burned rocks were used in the cooking of mostly $\mathrm{C}_{3}$ plants or animals that ate $\mathrm{C}_{3}$ plants.

Two liters of matrix from around and below the burned rocks at 35 to $50 \mathrm{cmbd}$ were collected and floated. The less than 0.1 liters of light fraction (\#644-5-4-1) was sent to Dr. Dering, but yielded no identifiable carbonized plant remains (Appendix I). The heavy fraction yielded 33 pieces of chert debitage, and the $6.4 \mathrm{~mm}$ mesh yielded four pieces of chert debitage.

\subsubsection{Feature 13}

Feature 13 was small cluster of nine burned rocks in an area of about 50-by-50 cm between 50 and $54 \mathrm{cmbs}$ in the northwestern corner of Unit N108/E53 (Figure 11-8). Natural stream cobbles were also present immediately under the burned rocks. No obvious disturbances were noted; only tiny rootlets were observed. No charcoal or ash lenses were detected, nor was there any oxidation of the matrix or sign of a basin or pit. The nine burned rocks were within a 5 -cm of vertical distance of each other, indicating their association.

Data on sizes and weights were not recorded for the rocks in this feature. The sample of rocks collected included one-half of a rounded cobble, one large burned rock that was greater than $15 \mathrm{~cm}$ diameter and one complete cobble that was burned but not broken. One collected piece is a complete water worn cobble with a slightly pinkish internal pink.

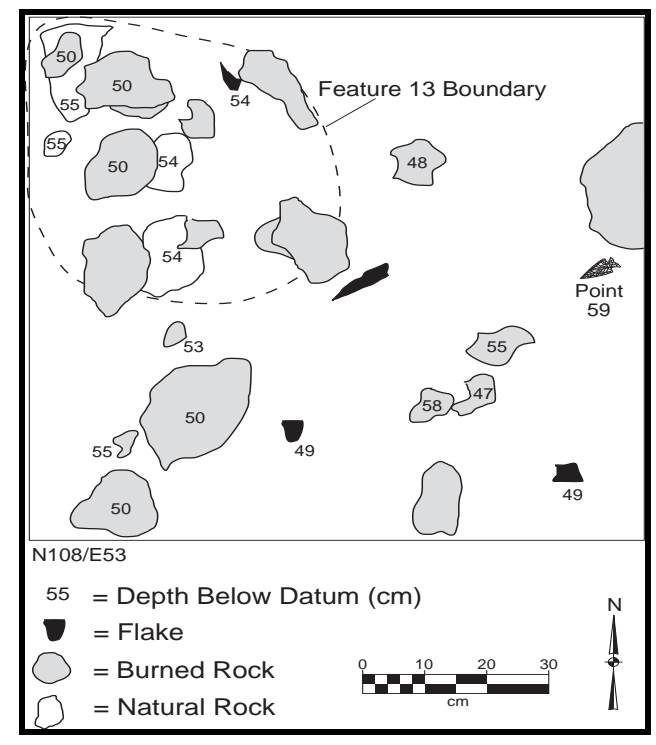

Figure 11-8. Planview of Feature 13, Early Archaic

Four limestone burned rocks were sent for lipid residue analysis. Drs. Malainey and Malisza's 
detailed findings and interpretations are presented in Appendix G, and the results are briefly summarized here (see also Table 11-3). All four samples (\#658-5-3-1a, \#658-5-3-2a, \#658-5-3-3a, and \#658-5-3-4a) yielded variations of high fat content interpreted to represent plants. These results imply that the same type of food was cooked, possibly representing as single cooking episode. The carbon isotope values on these same samples range from -25.1 to $-30.7 \%$, with a mean of 27.9\%o (Table 11-4). These reflect $\mathrm{C}_{3}$ plants or animals that ate $\mathrm{C}_{3}$ plants. The nitrogen values range from 1.9 to $6.4 \%$, with an average of $4.3 \%$. The combined results indicate that it is probable that these burned rocks were used mostly to cook $\mathrm{C}_{3}$ plants or animals that ate $\mathrm{C}_{3}$ plants.

One liter of matrix (\#658-5-4) from around and below the burned rocks between 50 and $60 \mathrm{cmbd}$ was collected and floated. The light fraction did not yield any macrobotanical remains for analysis. The heavy fraction yielded 13 pieces of chert debitage, two tiny charcoal pieces, and one bone small bone fragment. The $6.4 \mathrm{~mm}$ size mesh yielded six pieces of chert debitage that.

The upper part of the feature rocks (40 to $50 \mathrm{cmbd}$ ) was associated with 154 pieces of lithic debitage and six edge-modified tools. The lower part of the feature (50 to $60 \mathrm{cmbd}$ ) in Unit N108/E53 yielded 229 pieces of lithic debitage, six edge-modified tools, four bone fragments, three projectile points, and one core (\#658-20). The three points include one Merrell (\#658-16) and two Martindales (\#658-17 and 658-18).

The current data indicate that these burned rocks were employed in some kind of cooking activity, but it is unclear if these were intentionally dumped or merely randomly clustered burned rocks. The apparent extensive use of this location has mixed the constituent materials, thus making specific associations that could clarify the origin of the rock cluster.

\subsubsection{Feature 23}

Feature 23 was a large cluster of burned rocks in the northeastern corner of Block A in Units N108/E55 and N109/E55 (Figures 11-9 and 11-10), that covered an area about 90-by$110 \mathrm{~cm}$ in diameter. The burned rocks, concentrated between 38 and $50 \mathrm{cmbd}$, were intermixed with other cultural debris such as lithic debitage, stone tools, and some bone fragments. No clear boundaries, obvious basin, oxidized matrix, or charcoal/ash lenses were observed. The depths of burned rocks varied slightly, which does implies the presence of at least a very shallow basin. The matrix surrounding the feature was the same color and texture as the matrix between the rocks.

The 130 burned rocks in this feature include pieces in all size classes with the 4.1 to $9 \mathrm{~cm}$ and 9.1 to $15 \mathrm{~cm}$ classes in nearly equal numbers and accounting for 77 percent of the total (Table 112). The average rock weight was about $359 \mathrm{~g}$.

Four liters of matrix from slightly different elevations in the feature were collected and floated. The resulting light fraction (\#735-5-4) was macroscopically inspected, but no burned plant material was found. Three levels of heavy fraction yielded similar types of materials. The upper part (\#734-5-4) from 30 to $40 \mathrm{cmbd}$ in Unit N109/E55 yielded 10 pieces of chert debitage and only two tiny pieces of charcoal. At 36 to 45 cmbd, another sample (\#735-5-4) yielded one tiny burned rock fragment, 26 pieces of chert debitage, one whole snail shell, and one tiny bone fragments. The $6.4 \mathrm{~mm}$ mesh yielded four pieces of chert debitage, and four nearly complete snail shells. 


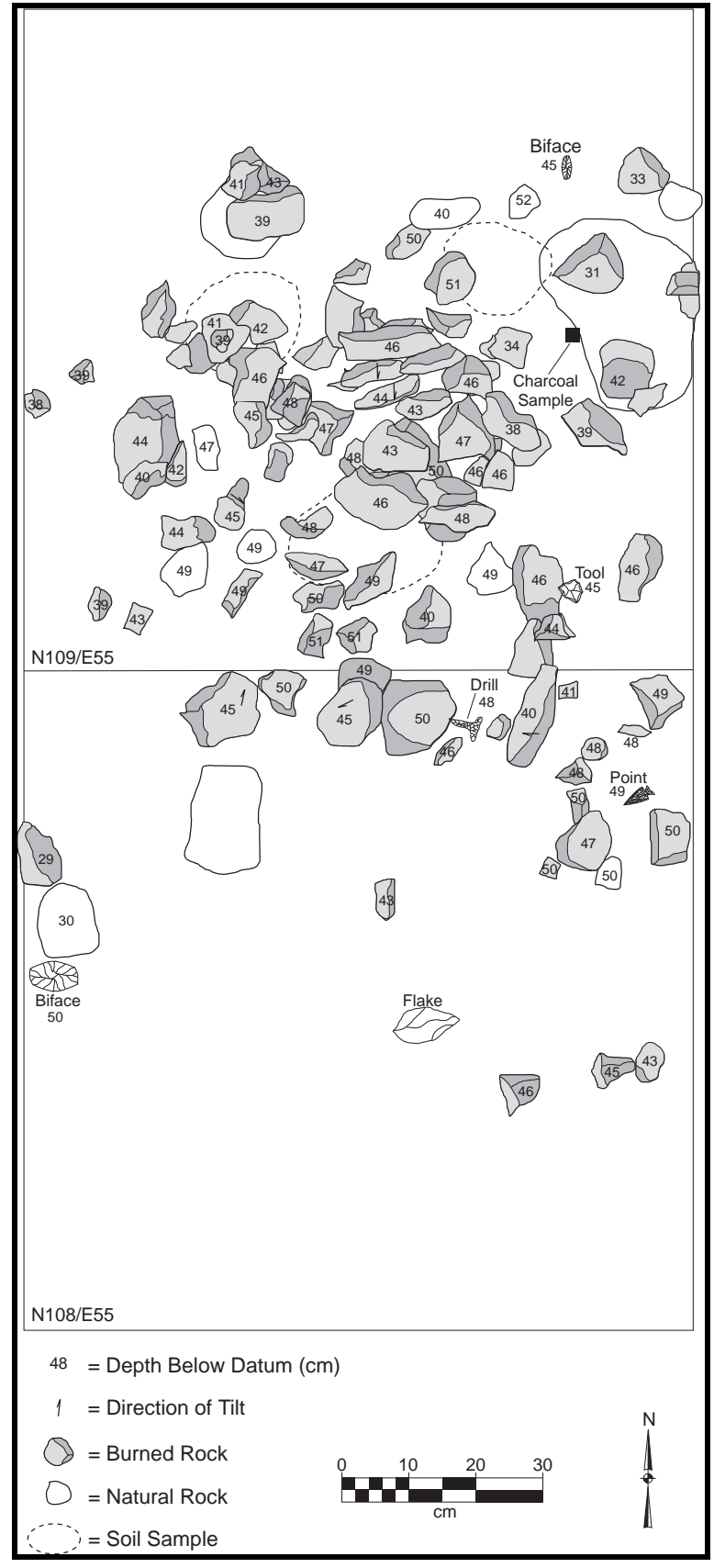

Figure 11-9. Planview of Feature 23

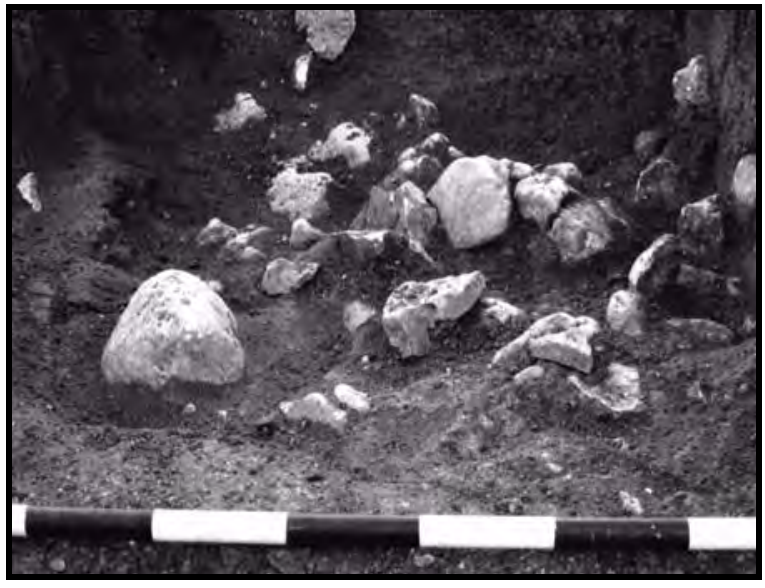

Figure 11-10. Oblique Angle of Feature 23

The sample from 45 to 52 cmbd yielded 35 tiny chert debitage, 12 pieces of charcoal, and two tiny bone fragments. The $6.4 \mathrm{~mm}$ mesh yielded 13 pieces of chert debitage, eight tiny charcoal pieces, and one tiny projectile point tip.

One tiny chunk of charcoal (\#735-5-7) from among the burned rocks in the feature yielded a $\delta^{13} \mathrm{C}$ corrected (-25.6\%o) AMS radiocarbon date of 6,280 \pm 50 B.P. (Table 11-1: Beta-170407). Part of that sample was sent for macrobotanical analysis, but the pieces were too small for identification (Appendix I). This is the oldest charcoal date obtained for the Varga Site and it is substantiated by another charcoal sample (\#570-7-1a) from Unit N107/E50 that yielded a date of $6,100 \pm 40$ B.P. (UGA-12721). A humate sample (\#1207-4-A) from $100 \mathrm{cmbs}$ in BT M-1 yielded a $\delta^{13} \mathrm{C}$ corrected (-21.9\%) AMS radiocarbon date of 6,270 \pm 50 B.P. (Table 11-1: Beta-170394), again supporting the relatively early age for the cultural materials.

Abundant lithic debitage, some tiny bone fragments, several stone tools, and a few chunks of charcoal were associated with the burned rocks. These cultural materials rested just a few centimeters above a layer of dense river gravel. 


\subsubsection{Feature 26}

Feature 26 was discovered between 56 and $63 \mathrm{cmbd}$ in Unit N107/E56 along the eastern edge of Block $A$ and only $100 \mathrm{~cm}$ south of Feature 23 and $150 \mathrm{~cm}$ south of Feature 27. The feature was a few centimeters above the river gravels, and the matrix that surrounded the burned rocks was dark brown (10YR 4/3) clay loam. This was an elongated cluster of small burned rocks dispersed over an area that measured 50-by-70 cm (Figures 11-11 and 1112). This cluster lacked an obvious form in plan view. No basin or pit was revealed in the cross section, nor was there any color or texture change in the matrix, and lenses of charcoal or ash were not present. The basal elevations of the rocks varied about $7 \mathrm{~cm}$.

The 20 burned rocks varied from 2 to $9 \mathrm{~cm}$ in diameter with a nearly equal number in each of the two smallest size categories (Table 11-2). These were limestone pieces that exhibited mostly angular forms. One piece had a hackled edge implying a rapid temperature change. One $6 \mathrm{~cm}$ diameter rock was still complete. The average rock weight was $238 \mathrm{~g}$.

Three burned rocks from this cluster were selected for lipid residue analysis (see Appendix G for details; see also Table 11-3, this chapter). Two samples (\#616-5-3-2a and \#6165-3-3a) yielded moderate to high fat content. The third sample (\#616-5-3-1a) yielded borderline high to very high fat content interpreted to represent plants. These results generally imply that the same type of food was cooked, and it is possible that only one cooking episode is represented. The carbon isotope values on these same samples range from -22.2 to $-24.5 \%$, with a mean of $-23.6 \%$ o (Table $11-4$ ), representing $\mathrm{C}_{3}$ plants or animals that ate $\mathrm{C}_{3}$ plants. The nitrogen values range from 2.8 to $6.0 \%$, with an average of $4.5 \%$. The combined results indicate that it is likely that these rocks

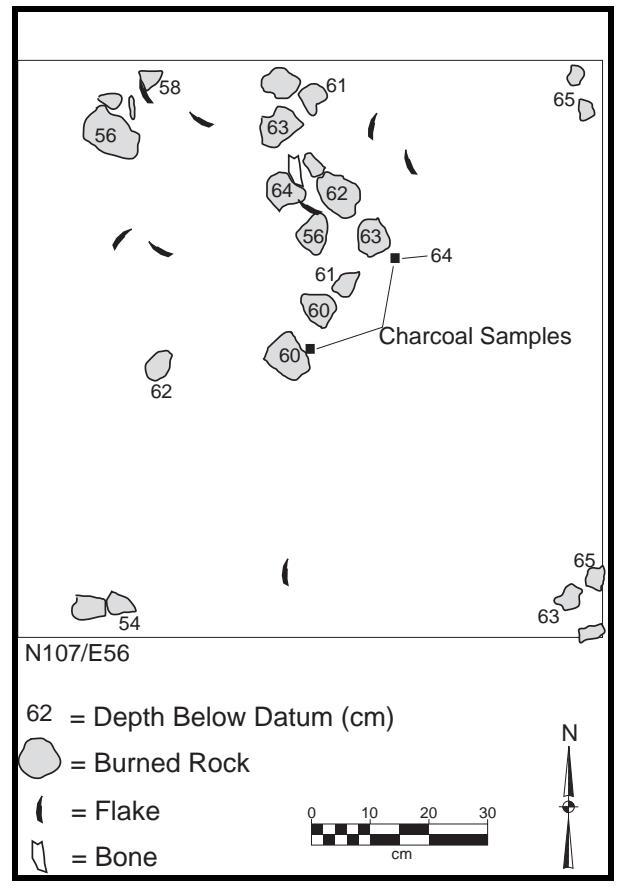

Figure 11-11. Planview of Feature 26

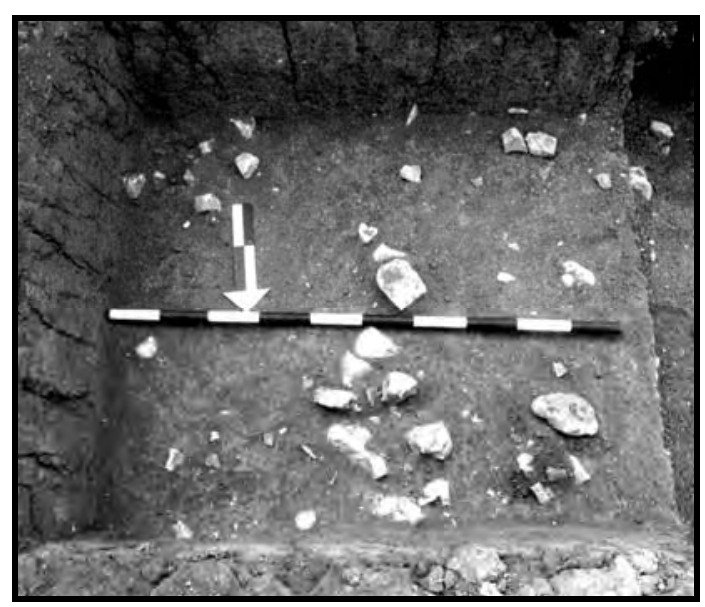

Figure 11-12. Overview of Feature 26

were used to cook mostly $\mathrm{C}_{3}$ plants or animals that ate $\mathrm{C}_{3}$ plants.

Six liters of matrix (\#615-5-4) from between the burned rocks at 56 to $64 \mathrm{cmbd}$ were collected and floated. The less than 0.1 liters of light fraction was sent to Dr. Dering for 
macrobotanical analysis. He identified two pieces of juniper wood, and 15 pieces of indeterminate taxa (Appendix I). The heavy yielded three tiny burned rock fragments, 83 chert debitage pieces, eight nearly complete snail shells, one tiny point tip fragment, and nine small faunal bone fragments. The $6.4 \mathrm{~mm}$ mesh yielded 303 tiny chert pieces, 66 tiny charcoal pieces, two seed-like pieces and 34 tiny bone fragments. Two of the latter bone fragments were burned, as were three tiny walnut shell fragments.

Seven tiny pieces of charcoal (\#616-5-7-1a) recovered from $64 \mathrm{cmbd}$ among the burned rocks yielded a $\delta^{13} \mathrm{C}$ corrected (-23.2\%) AMS radiocarbon date of 5,640 \pm 40 B.P. (Table 11-1: UGA-12724). A second sample consisted of two burned prickly pear cactus seeds from just above this level (\#615-5-7-2a), yielded a $\delta^{13} \mathrm{C}$ corrected (-11.6\%) AMS radiocarbon date of 5,660 \pm 40 B.P. (UGA-12723).

The level between 50 to $60 \mathrm{cmbd}$ yielded three bifaces (\#615-5-16 through 18), two projectile points (1 untypable [\#615-5-19], and one Merrell point [\#615-5-20]), eight edge-modified flakes (\#615-5-10 through 15), 161 pieces of lithic debitage, three tiny bone scraps, and Rabdotus land snail shells. The level just below, from 60 to $70 \mathrm{cmbd}$, yielded two edge-modified flakes (\#616-5-10 and 11), 273 pieces of lithic debitage, one bone, and many whole Rabdotus snail shells. The lack of patterning of the burned rocks, no sign of in situ burning, combined with the presence of other cultural debris in the immediate vicinity indicates these burned rocks were dumped or discarded at this location. This represents general camp maintenance activity and implies a residence of some duration.

\subsubsection{Feature 31}

Feature 31 was a burned rock cluster between 40 and $47 \mathrm{cmbd}$ in Unit N110/E56 in the very northeastern corner of Block A (Figure 11-13). foods. The carbon isotope values on these same samples range from -23.7 to $-26.9 \%$, with a mean of $-25.7 \%$ (Table 11-4). These values reflect $\mathrm{C}_{3}$ plants or animals that ate $\mathrm{C}_{3}$ plants. The nitrogen isotope values range from 5.9 to $6.1 \%$ with an average of $6.0 \%$ with two values of $1.5 \%$ and $5.4 \%$ o that are not acceptable since the measured nitrogen weight is extremely low. The combined results indicate that these burned rocks cooked mostly $\mathrm{C}_{3}$ plants or animals that ate $\mathrm{C}_{3}$ plants.

Two samples (\#757-5-3-1a and \#757-5-3-3a) yielded very high fat content food such as in seeds or animal fats. The third sample (\#757-53-2a) yielded borderline high to very high fat content interpreted to represent plants. The forth sample (\#757-5-3-4a) also yielded high fat content food. These results generally imply that the same type of food, probably derived from plants, was cooked, possibly in a single cooking episode.

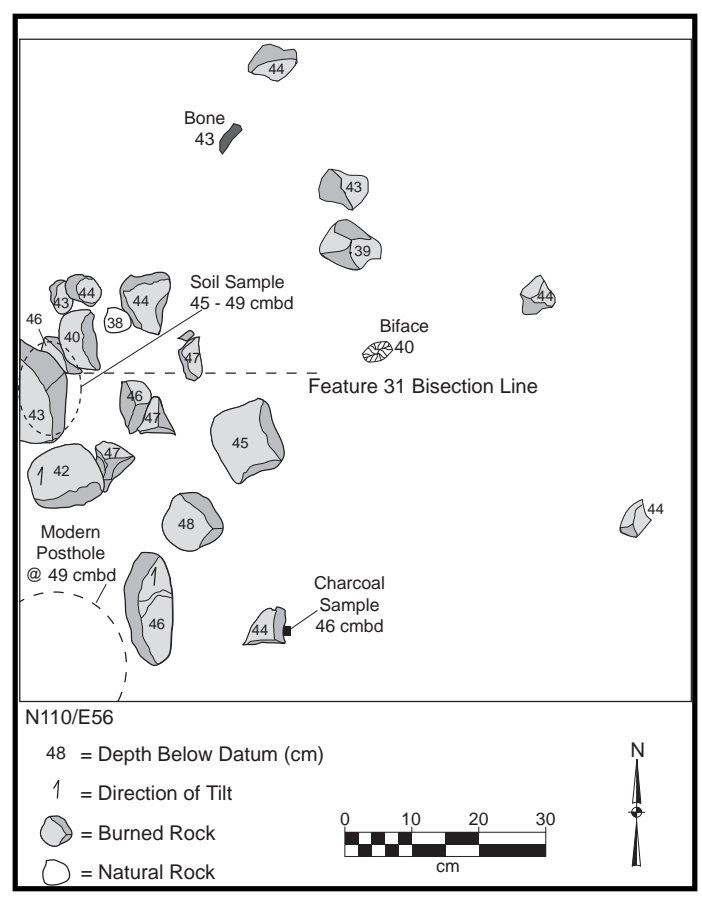

Figure 11-13. Planview of Feature 31 
Two liters of matrix from between the burned rocks at 40 to $50 \mathrm{cmbd}$ was collected and floated. The less than 0.1 liters of light fraction (\#756-5-4-1) was sent to Dr. Dering, but yielded no identifiable plant remains (Appendix I). The heavy fraction was carefully sorted and yielded 20 tiny burned rock pieces, 42 pieces of chert, four tiny charcoal pieces and one bone small fragment. The $6.4 \mathrm{~mm}$ mesh material yielded one tiny burned rock fragment, 13 pieces of chert, four nearly complete snail shells, and one unifacial chert tool fragment.

Twenty-five pieces of lithic debitage were recovered from within the boundaries of the feature. The rest of the containing level, between 40 and $50 \mathrm{cmbd}$, yielded 131 pieces of lithic debitage, eight bone fragments, three edgemodified flakes (\#756-5-10, \#756-10, and \#75613), and two bifaces (\#756-5-11 and \#756-11). This cluster of burned rocks, which lacked any sign of in situ burning or discernible shape, and contained apparently associated lithic debitage, is believed to be another discard area. Feature Summary and Discussion

\subsubsection{Discussion of the Features}

The nine Early Archaic features may represent a number of occupational events, as suggested by age differences in the 17 acceptable radiocarbon dates. The 17 radiocarbon ages are derived from six different materials that include deer bones, prickly pear seeds, a Rabdotus shell, sediments, walnuts, and wood charcoal. They all were obtained from three features plus isolated samples of organic material, and indicate a general time range between about 6,280 to 5,200 B.P. (Table 11-1). This 1,100- year interval falls within a chronological period that is currently not very well documented in the archeological record for Texas. More discussions concerning the importance of this age range will be presented later.
All nine features were clusters of burned rocks with similar characteristics indicating a generally similar set of behavioral patterns. The nine burned rock features yielded 395 burned rocks weighing $147,650 \mathrm{~g}$, with an average rock weight of $374 \mathrm{~g}$. The two hearths, Features 40 and 41 are thought to represent in situ burning location, whereas the two dumps are interpreted to be related to a cooking activity that utilized the burned rocks in some type of cooking event and then were discarded. The five-burned rock clusters are not as clear, since evidence for one specific interpretation is absent. These clusters lacked clear indications of basins, charcoal, ash, or burned lenses, and definite patterning to the rocks. With the presumed multiple events represented in this component, combined with the impossibility of making any intra-component stratigraphic distinctions, the identification of discrete behavioral patterns that linked together features and various classes of debris is not reasonably possible.

Identifications of charred materials from floated matrix extracted from four features and 20 nonfeature samples reveal some 69 pieces of charcoal, and $10 \mathrm{ml}$ of charred material. This limited sample provides minimal evidence with which to reconstruct the Middle Archaic environmental mosaic. Only juniper wood and prickly pear cactus seeds were identified in the floated material from the features. Scattered non-feature botanical samples include mesquite, oak, littleleaf walnut, and juniper. The first three species and indeterminate wood pieces were about equally represented with 0.6 to $0.7 \mathrm{~g}$ each. Charred juniper charcoal was nearly five times more frequent than any of the other species, implying that this may have been the dominant arboreal species in the immediate area. This may indicate an environment that is similar to today's conditions with certain species restricted to certain areas. It is not clear if the littleleaf walnut pieces represent food resources, 
or they were attached to the wood pieces that were used for fuel.

\subsection{Stone ToOl Descriptions AND Discussion}

The 1,486 stone tools are not described individually, although individual attributes and metric characteristics have been recorded for each piece, with the exception of edge-modified flakes. Classes of tool forms such as scrapers and drills are presented with summaries of attributes and metric measurements provided. Tool classes are generally thought to represent certain types of activities, but several individual tools from various tool classes were arbitrarily selected for use-wear analyses to identify specific functions. Individual findings of the use-wear are presented following the class summaries.

\subsubsection{Projectile Points}

The 179 projectile points (from all contexts, with 170 points coming from Block A), all dart points, are subdivided into nine identifiable types that combine to account for 116 pieces, or 68 percent of the total point sample, plus 53 untypable point fragments. The typed specimens include 32 Gower, 22 Martindale, 21 Bandy, 15 “Group 1”, 12 Baker, 12 Merrell, seven "Group 2" (corner-notched), three Carrizo, and one Pandale, are presented by groups in order of their frequency.

The Gower point group contains the highest frequency, comprising 25.8 percent of the identifiable points in the Early Archaic component. Twenty-eight specimens were recovered from hand-excavations in Block A, one was recovered from $\mathrm{BT} 1$, and three were collected from the surface (Figure 11-14). A summary of the Gower point data is presented below with individual characteristics presented in Appendix O. All 32 specimens were manufactured from fine-grained chert. Only three percent of the Gower points retain any cortex. Of those, each specimen has cortex covering roughly 50 percent of the surface. About nine percent of the Gower points exhibit patination, with three percent or one specimen, exhibiting showing patination over 100 percent of their surface. Only 19 percent are complete or nearly complete, with 66 percent representing proximal ends, nine percent medial sections, and six percent distal fragments. Slightly over six percent were broken by intense heat, and the rest were broken during use. Not a single manufacturing break was recognized. About six percent are thought to bear the scars pf rejuvenation-flake removal, whereas nine percent exhibit some edge beveling. About 44 percent exhibit slight edge rounding. The observed flaking pattern was indeterminate on 47 percent, or 15 specimens. Of those 17 pieces for which flaking patterns are recorded, 53 percent are subparallel, 35 percent are oblique subparallel, and 12 percent are "chevron". In the 53 percent of the cases where the edges are sufficiently intact for shape determination, nearly 66 percent are straight, 28 percent are excurvate, and six percent are incurvate. The stem shape is 84 percent curved, nine percent indeterminate and six percent expanding. Gower point generally exhibit one large flake scar at the base, usually on one side and sometimes on both sides (Elton Prewitt, Personal Communication, September 30, 2003). The metric attributes are summarized in Table 11-5.

A complete, lanceolate shaped Gower point (\#391-11) with bifacially beveled edges was subjected to high-powered use-wear analysis. Hafting wear is evident through abraded interflake ridges on the proximal end, and use residue in the form of plant fiber is along the edges near the distal end. Use-wear is present in the form of high-silica polish along the distal edges, suggesting use in the cutting and/or boring of plant material (Appendix C). 


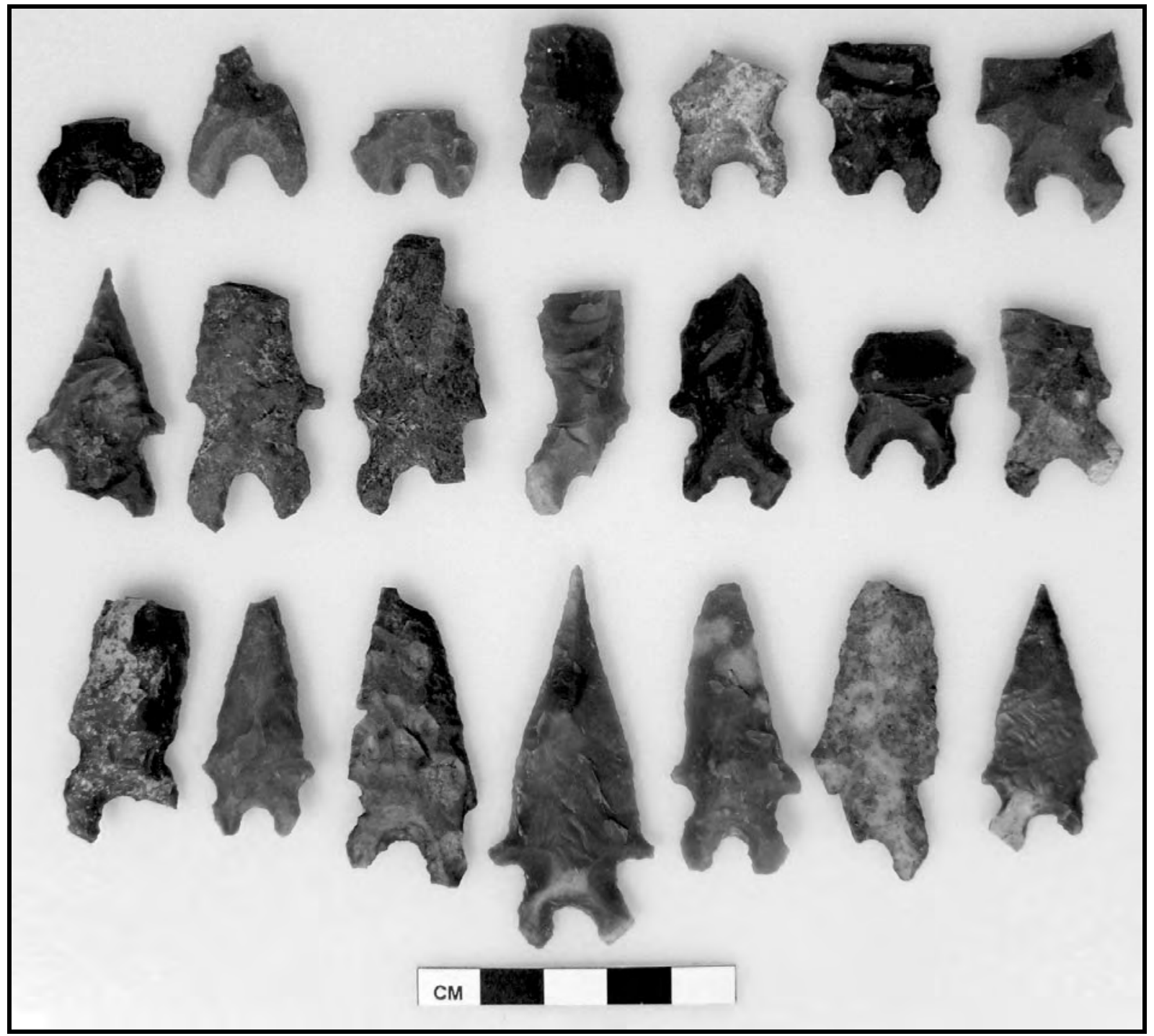

Figure 11-14. Selected Gower Points, Early Archaic

Left to Right: Top Row: \#591-018, \#632-016, \#29-010, \#333-022, \#11-005-013, \#153-028, \#86-020

Second Row: \#1216-010, \#289-021, \#228-014, \#345-026, \#411-016, \#215-019, \#289-022

Third Row: \#50-013, \#1206-010, \#591-017, \#345-027, \#255-030, \#62-014, \#254-014 
Table 11-5. Metric Measurements on Gower Points from 41ED28

\begin{tabular}{|l|c|c|c|}
\hline \multicolumn{1}{|c|}{ Characteristic } & Range & Mean & $\begin{array}{c}\text { Standard } \\
\text { Deviation }\end{array}$ \\
\hline Maximum length & $37.3-62.7$ & 46.9 & 9.5 \\
\hline Maximum width & $11.7-25.4$ & 19 & 3.5 \\
\hline $\begin{array}{l}\text { Maximum } \\
\text { thickness }\end{array}$ & $3.6-8.3$ & 6.6 & 1 \\
\hline Blade length & $25.6-46.4$ & 34.7 & 8.6 \\
\hline Blade width & $11.7-22.3$ & 16.1 & 2.3 \\
\hline Shoulder width & $16.4-25.4$ & 20.5 & 2.6 \\
\hline Left notch depth & $1.3-5.3$ & 2.5 & 1 \\
\hline Right notch depth & $1.4-4.8$ & 2.8 & 0.9 \\
\hline Left notch width & $5.6-10.8$ & 8.7 & 1.4 \\
\hline Right notch width & $5.1-13.3$ & 8.4 & 1.9 \\
\hline Left notch angle & $42-115$ & 68 & 18.5 \\
\hline Right notch angle & $41-90$ & 64 & 13.9 \\
\hline Stem length & $9.0-19.0$ & 13.8 & 2.5 \\
\hline Stem width & $10.9-15.8$ & 13.8 & 1.3 \\
\hline $\begin{array}{l}\text { Proximal stem } \\
\text { width }\end{array}$ & $13.9-20.7$ & 18.1 & 1.6 \\
\hline Distal stem width & $13.4-17.1$ & 15.8 & 1 \\
\hline Stem thickness & $3.5-5.9$ & 4.8 & 0.8 \\
\hline Base depth & $3.1-8.2$ & 5.5 & 1.2 \\
\hline Base notch width & $6.8-11.5$ & 9 & 1.5 \\
\hline Weight & $2.2-7.3$ & 4.6 & 1.7 \\
\hline Measing & & & \\
\hline
\end{tabular}

Measurements in mm

Four Gower specimens (\#86-20 = TRC132; $\# 192-11=$ TRC139; \#215-21 = TRC141 and \#1213-10 = TRC190) were sent for INAA. All four probably reflect different sources of Edwards chert that outcrops across the southwestern Edwards Plateau region, but from different specific sources (Appendix F). Presumably, the source areas were widely spaced areas across the region.

Of the twenty-nine Gower points recovered from Block A, 83 percent are from the southern part of the Block. Seven different units, six in the southern and one in the northern part, yielded multiple Gower points, with Units N101/E53 and N102/E51 each yielding three points. These occurrences may indicate retooling locations.
Twenty-one Martindale points were recovered from hand-excavations with one from BT 1 (Figure 11-15). All 22 Martindale points, are summarized below whereas data on individual specimens are presented in Appendix O. Only 36.4 percent are considered complete or nearly complete, with another 59.1 percent represented by proximal fragments and 4.5 percent by medial sections. Only one broken Martindale point, or 4.5 percent, was determined to be from a manufacture break, with all other breaks interpreted as use related. About 9.0 percent exhibit what are believed to be rejuvenation flake scars. Of the nearly 60 percent overall shape is visible, some 85 percent are triangular and 15 percent are lanceolate. These 22 specimens were all manufactured from finegrained chert and exhibit no sign of cortex. About 18 percent appear to have been heattreated, with another 13.6 percent having been burned. About 13 percent, or three points, exhibit some patination, one completely so. Nearly 68 percent are complete enough to reveal flake-scar patterning. Of those, 46.7 percent appear to have an oblique pattern, 40 percent have a chevron pattern, and 13 percent have a subparallel pattern. Edge rounding was observed on 54.5 percent. Of the 25 edges that are complete enough to provide an indication of their shape, 48 percent are straight, 40 percent are excurvate, eight percent are incurvate, and four percent are recurvate. Ninety-five percent exhibit expanding stems. A general overview of the size variation of the 22 Martindale points is provided through the summary of metric measurements in Table 11.6.

Two Martindale points (\#141-21 and \#591-19) were subjected to high-powered use-wear analysis. Specimen \#141-21 is a fragment that exhibits a use break, and this piece exhibits light polish confined to the proximal end indicative of hafting. It did not exhibit any use-wear and the inferred use and contact material are unknown (Appendix C). 


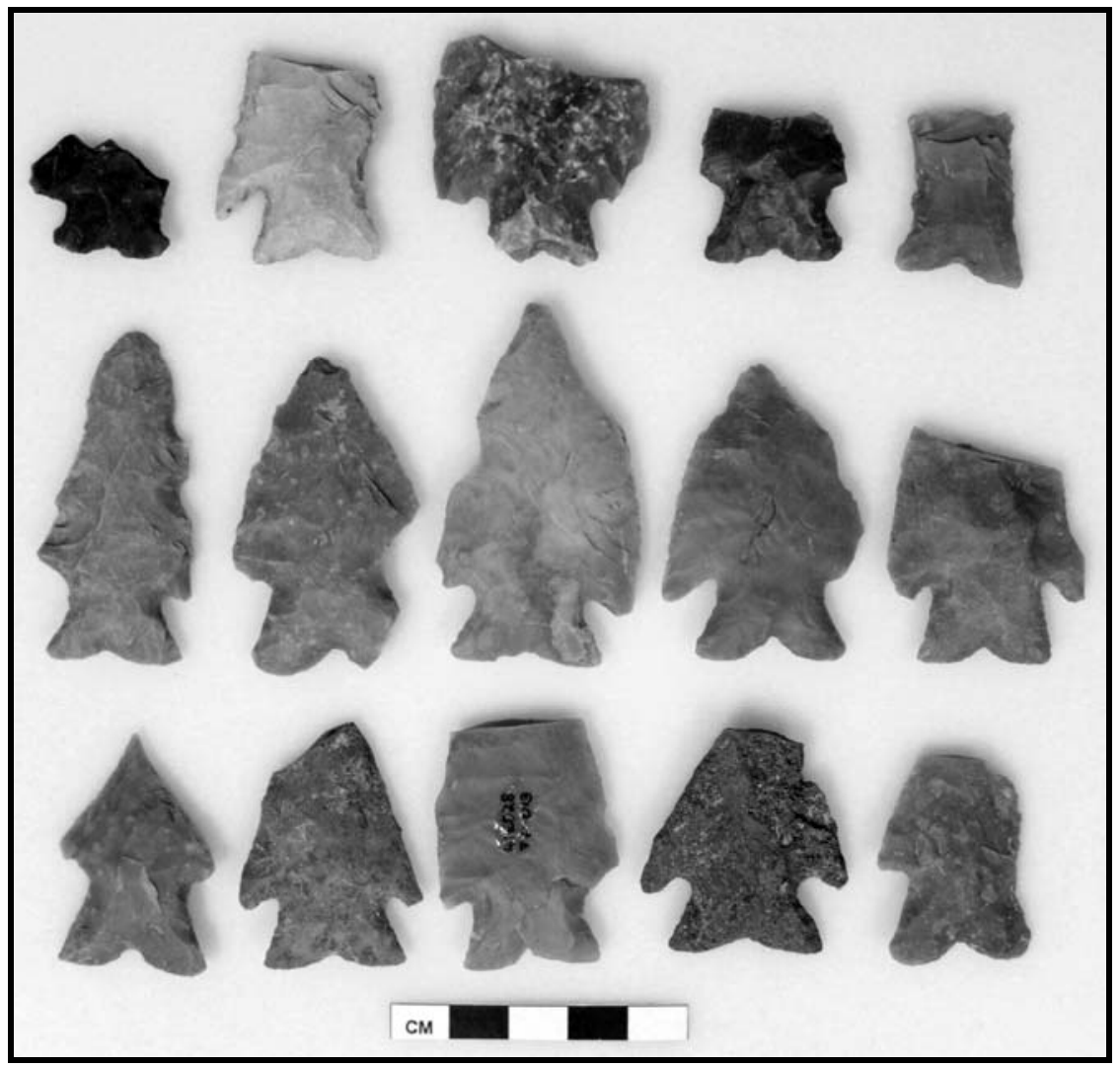

Figure 11-15. Selected Martindale Points, Early Archaic

Left to Right: Top Row: \#19-014, \#268-022, \#854-010, \#268-021, \#347-014

Second Row: \#658-018, \#7-010, \#9-014, \#1201-010, \#39-015

Third Row: \#730-013, \#40-013, \#77-013, \#230-013, \#346-024

Specimen \#591-19 is a complete point that lacks any sign of rejuvenation or resharpening. It exhibits plant tissue and striations parallel and perpendicular to the long axis confined to the proximal end that indicates it was hafted. Raphides are randomly distributed on the surface, indicating that plants were part of the contact material (Appendix C). This is the only Early Archaic projectile to have raphides identified on it, and this may indicate this tool was also employed in cutting some type of agave plants.

Parts of five Martindale points were sent for INAA (\#39-15 = TRC127; \#77-13 = TRC131;
\#268-21 = TRC144; \#311-13 = TRC146; and $\# 854-10=$ TRC188). Four of the five points probably represent Edwards chert from the local region, whereas specimen \#268-21 (TRC144), which exhibits a glassy brown color with light spots, and probably was heat-treated, is chemically different from most known Edwards chert (Appendix F). It also fluoresces a darker orangish color than most Edwards chert. It is assumed that this one piece is nonlocal in origin. Its darker fluorescence implies an origin in the river gravels of the Rio Grande valley (Quigg et al. 2000; Quigg and Cordova 2000). 
Table 11-6. Metric Measurements on Martindale Points from 41ED28

\begin{tabular}{|c|c|c|c|}
\hline Characteristic & Range & Mean & $\begin{array}{l}\text { Standard } \\
\text { Deviation }\end{array}$ \\
\hline Maximum length & $34.8-57.8$ & 48.9 & 8.2 \\
\hline Maximum width & $5.1-8.6$ & 7 & 0.8 \\
\hline $\begin{array}{l}\text { Maximum } \\
\text { thickness }\end{array}$ & $24.2-37.6$ & 30.7 & 4.2 \\
\hline \multicolumn{4}{|l|}{ Blade length } \\
\hline Blade width & $19.2-35.9$ & 36.3 & 4.8 \\
\hline Shoulder width & $24.2-37.6$ & 30.9 & 4.3 \\
\hline Left notch depth & $3.4-9.0$ & 5.9 & 1.8 \\
\hline Right notch depth & $4.1-9.5$ & 6.5 & 1.8 \\
\hline Left notch width & $8.0-14.1$ & 10.1 & 1.8 \\
\hline Right notch width & $7.1-15.9$ & 10.6 & 2.9 \\
\hline Left notch angle & $32-57$ & 48 & 7.3 \\
\hline Right notch angle & $23-51$ & 36.8 & 9.9 \\
\hline Stem length & $\begin{array}{c}10.3- \\
15.8 \\
\end{array}$ & 12.3 & 1.7 \\
\hline Stem width & $15.7-23.2$ & 20.1 & 1.8 \\
\hline $\begin{array}{l}\text { Proximal stem } \\
\text { width }\end{array}$ & $18.0-27.8$ & 23.2 & 2.4 \\
\hline Distal stem width & $13.1-18.8$ & 17.4 & 1.4 \\
\hline Stem thickness & $3.3-5.8$ & 4.6 & 0.6 \\
\hline Base depth & $1.2-3.9$ & 2.6 & 0.8 \\
\hline Base notch width & $3.2-14.5$ & 9.9 & 2.8 \\
\hline Weight & $6.0-14.3$ & 9.2 & 2.5 \\
\hline
\end{tabular}

Measurements in mm

The 20 Martindale points were non-randomly scattered across Block A. Eighty percent were in the southern half of the Block. Five units yielding multiple points, and four of those units were in the southern half.

Twenty Bandy points were recovered from the Early Archaic component and one was retrieved from the surface of Block B. These specimens account for 11.8 percent of the 170 points from this component (Figure 11-16). Seven, or 33.3 percent, are complete, 57.1 percent are proximal fragments and 9.5 percent are medial fragments. All 14 broken specimens appear to have been broken during use. There is no visible evidence of rejuvenation, and only a single specimen (4.8 percent) exhibits evidence of edge beveling. Of the 10 specimens complete enough to indicate the overall shape, all have triangular blades.

All 21 points were manufactured from finegrained cherts and none retain any cortex. Nineteen percent appear to have been heattreated and 23.8 percent are burned. Only one specimen is patinated, and is white in color over 100 percent of its surface. Flaking patterns are variable, but 38.1 percent did not sufficiently complete for identification of flaking pattern. Of those specimens on which patterning is discernible, 46.2 percent appear in a chevron pattern, 23.1 percent exhibit parallel flaking, 15.4 percent exhibit oblique flake scars, and 7.7 percent bear essentially a random flaking pattern. Edge rounding was detected on 52.3 percent. The lateral edges are generally straight (38.1 percent), whereas most others (57.1 percent) are indeterminate. Stem shape is 90 percent expanding. Bandy point metric measurements are summarized below, in Table 11-7.

Two Bandy points were sent for high-powered, use-wear analysis. Specimen \#344-22 is a complete point that lacks rejuvenation and resharpening. It exhibits hard, high silica polish on the lower proximal end indicating it was hafted. Bone/antler use residue fragments were observed. This specimen was used as a projectile point that came in contact with bone/antler (Appendix C). Specimen \#712-14 is complete with no sign of rejuvenation or resharpening. It exhibits hard, high silica polish use-wear restricted to the proximal end, and also bears impact striations. The use-wear indicates a hafted projectile (Appendix C). 


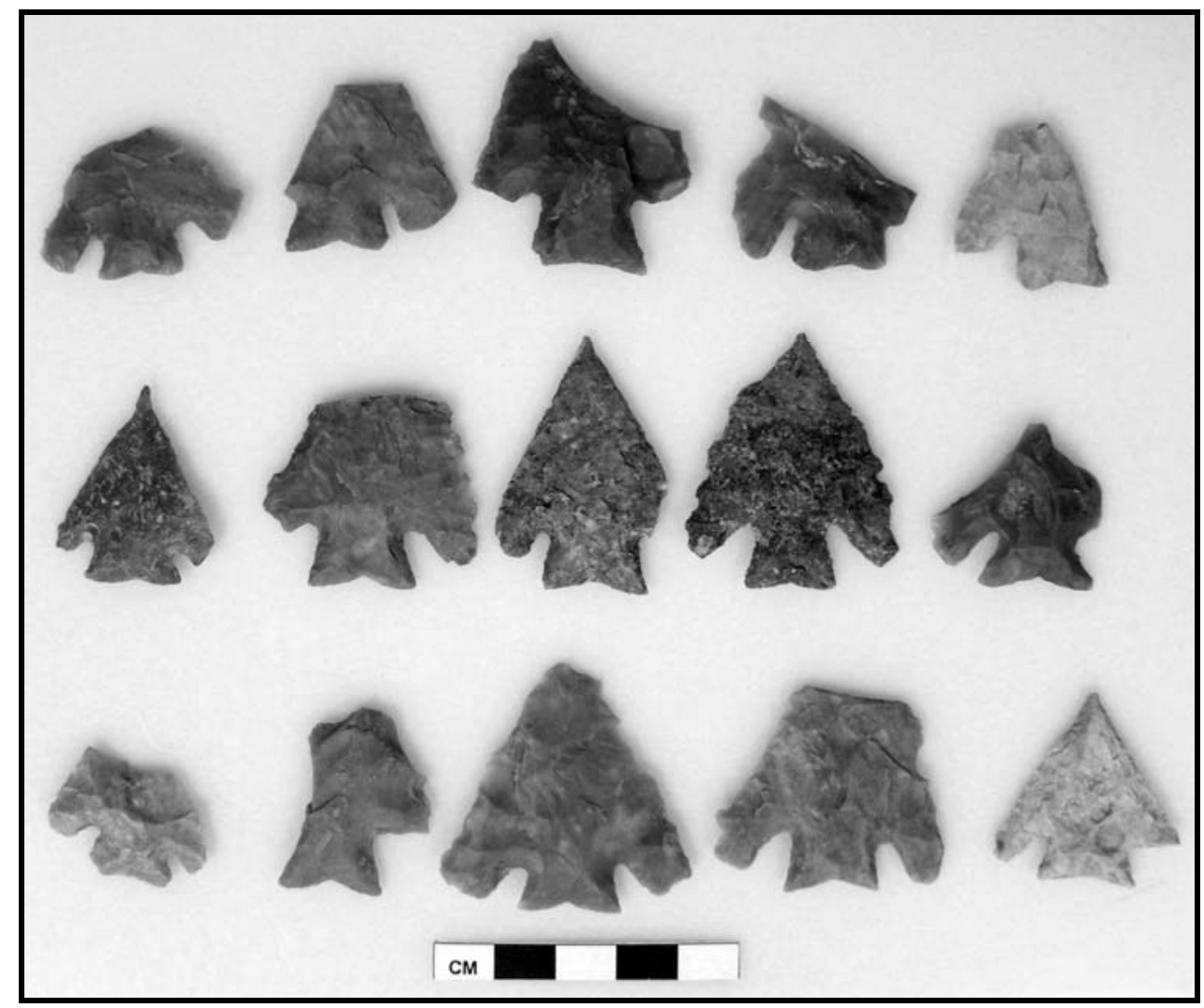

Figure 11-16. Selected Bandy Points, Early Archaic

Left to Right: Top Row: \#390-010, \#400-011, \#142-011, \#347-013, \#563-017

Second Row: \#346-022, \#689-020, \#694-017, \#651-011, \#116-020

Third Row: \#1204-010, \#439-010, \#531-018, \#746-014, \#599-015

Parts of four Bandy points (\#116-20 = TRC133; \#347-13 = TRC154; \#400-11 = TRC158; and \#719-10 = TRC183) were subjected to INAA. Three of the four exhibit chemical signatures similar to known Edwards chert from the region (Appendix F). Specimen \#400-11 (TRC158) has a chemical signature beyond the currently known range of variation. This latter specimen has, however, the same ultraviolet fluorescence as the other Edwards chert specimens and is assumed to be Edwards chert. All four specimens probably represent Edwards chert from regional sources.
The 20 Bandy points were widely distributed across Block A, but only Unit N102/E56 yielded multiple Bandy points, along with two Martindale points. Sixty percent of the Bandy points were from the northern half of the block, in contrast to the distribution of Martindale points, whose distribution only partially overlaps. 
Table 11-7. Metric Measurements on Bandy Points from 41ED28

\begin{tabular}{|l|c|c|c|}
\hline \multicolumn{1}{|c|}{ Characteristic } & Range & Mean & $\begin{array}{c}\text { Standard } \\
\text { Deviation }\end{array}$ \\
\hline Maximum length & $30.8-55.8$ & 39.5 & 3.1 \\
\hline $\begin{array}{l}\text { Maximum } \\
\text { thickness }\end{array}$ & $3.4-6.8$ & 4.7 & 0.17 \\
\hline Blade length & $24.5-46.9$ & 31.6 & 2.8 \\
\hline Blade width & $19.4-30.8$ & 25.7 & 1.1 \\
\hline Shoulder width & $26.1-40.2$ & 34 & 1.8 \\
\hline Left notch depth & $4.2-9.1$ & 6.8 & 0.39 \\
\hline Right notch depth & $4.5-9.1$ & 7 & 0.36 \\
\hline Left notch angle & $14-51$ & 34.3 & 2.7 \\
\hline Right notch angle & $19-41$ & 28.3 & 1.8 \\
\hline Stem length & $5.4-10.8$ & 8.2 & 1.1 \\
\hline Stem width & $11.5-14.6$ & 13.1 & 1.1 \\
\hline $\begin{array}{l}\text { Proximal stem } \\
\text { width }\end{array}$ & $13.6-19.2$ & 16.1 & 1.4 \\
\hline $\begin{array}{l}\text { Average stem } \\
\text { width }\end{array}$ & $12.6-16.4$ & 14.6 & 1.1 \\
\hline Stem thickness & $2.4-4.8$ & 3.2 & 0.6 \\
\hline Weight & $2.1-5.3$ & 3.9 & 0.52 \\
\hline
\end{tabular}

Measurements in mm

Thirteen points classified here as Group 1 points, or 7.7 percent of the 170 points, were recovered from the Early Archaic component. Two of this group were found in BTs 1 and 2 . These points exhibit a cluster of similar characteristics and cannot be assigned to any established type. All 15 points will be summarized below with individual characteristics presented in Appendix O. Only 27 percent are complete or nearly complete, and the others are represented by the proximal fragments (Figure 11-17). Thirteen percent were broken through excessive heating, whereas the rest were broken during use. No specimens exhibit rejuvenation scars, although 20 percent have beveled edges. Among the 13 specimens with a sufficient blade remaining, 82 percent have triangular outlines and 18 percent have lanceolate outlines. All were manufactured from fine grain cherts, and no cortex remains on their surfaces. One specimen appears to have been heat-treated, and one other was burned. Thirteen percent exhibit some patination. Flaking patterns are observable on ten specimens. Three show a chevron pattern, three have subparallel flaking and two show an oblique flaking pattern. Seventy-three percent of the points exhibit edge rounding. In the 10 specimens that exhibit retain enough edge for identification, 80 percent of the blade edges are straight, 15 percent are excurvate, and five percent are recurvate edges. Table 11-8 summarizes the metric measurements for the individual Group 1 points, and shows the size variation in the recovered specimens.

\section{Table 11-8. Metric Measurements on Group 1 Points from 41ED28}

\begin{tabular}{|l|c|c|c|}
\hline \multicolumn{1}{|c|}{ Characteristic } & Range & Mean & $\begin{array}{c}\text { Standard } \\
\text { Deviation }\end{array}$ \\
\hline Maximum length & $40.2-62.1$ & 51.1 & 11.6 \\
\hline Maximum width & $24.1-39.4$ & 31.1 & 4 \\
\hline $\begin{array}{l}\text { Maximum } \\
\text { thickness }\end{array}$ & $6.2-9.3$ & 7.6 & 0.9 \\
\hline Blade length & $27.3-45.0$ & 36.6 & 9.4 \\
\hline Blade width & $19.5-34.9$ & 26.9 & 4.8 \\
\hline Shoulder width & $25.8-39.4$ & 31.8 & 3.5 \\
\hline Left notch depth & $3.2-7.8$ & 5.9 & 1.4 \\
\hline Right notch depth & 11.5 & 2 & 1.1 \\
\hline Left notch width & $8.8-14.1$ & 11.5 & 2 \\
\hline Right notch width & $8.6-19.0$ & 11.3 & 2.9 \\
\hline Left notch angle & $25-68$ & 47 & 14 \\
\hline Right notch angle & $20-56$ & 35 & 10.6 \\
\hline Stem length & $10.2-17.8$ & 14.3 & 2 \\
\hline Stem width & $14.3-21.5$ & 18.1 & 1.8 \\
\hline $\begin{array}{l}\text { Proximal stem } \\
\text { width }\end{array}$ & $19.0-24.5$ & 22.2 & 1.8 \\
\hline Stem width & $16.7-22.6$ & 20.2 & 1.8 \\
\hline Stem thickness & $3.5-6.3$ & 4.8 & 0.9 \\
\hline Base depth & $7.2-13.4$ & 10.8 & 2 \\
\hline Base notch width & $7.2-13.4$ & 10.8 & 2 \\
\hline Weight & $4.2-15.2$ & 9.3 & 3.7 \\
\hline Measurements in mm & & & \\
\hline
\end{tabular}




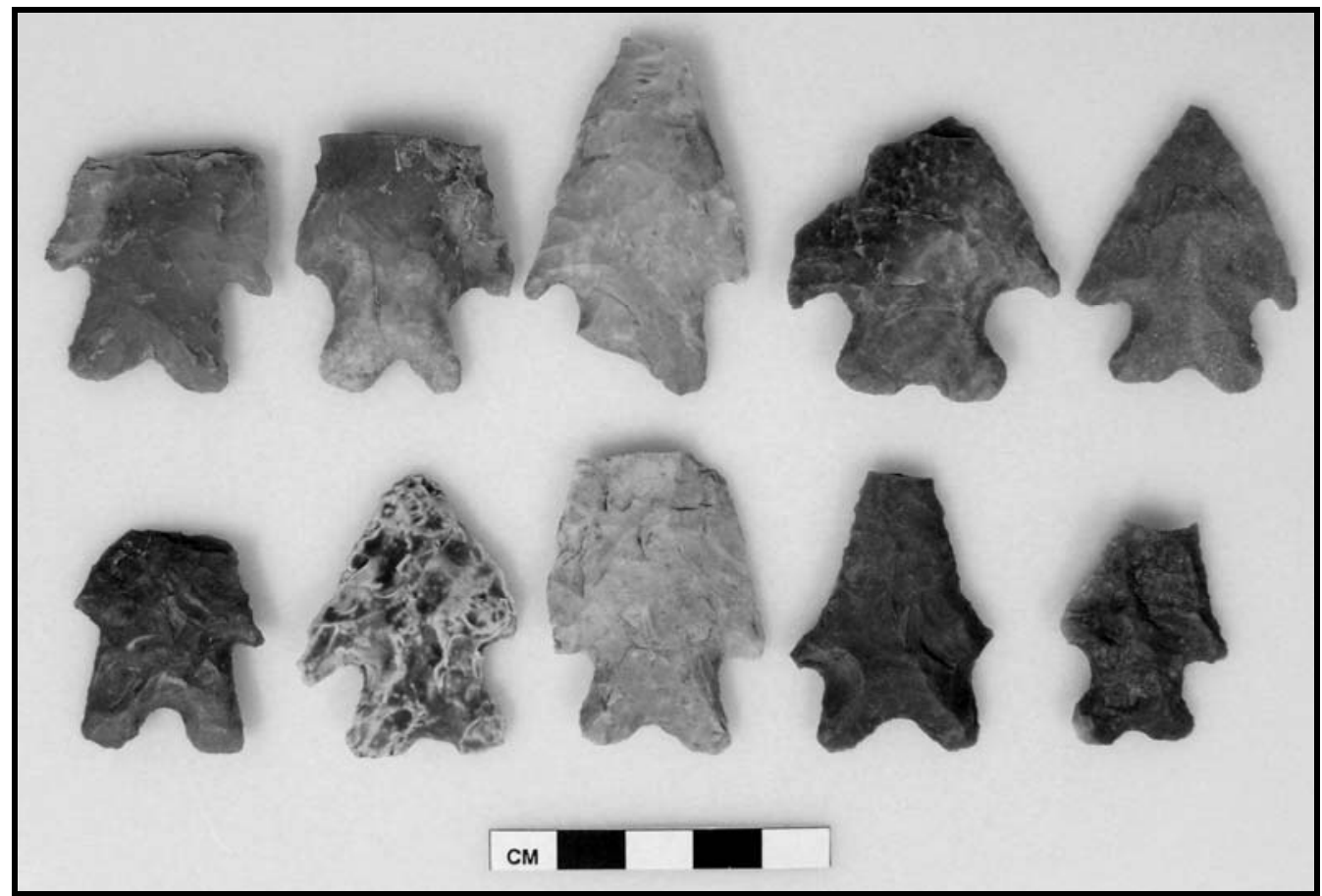

Figure 11-17. Selected Group 1 Points, Early Archaic

Left to Right: Top Row: \#1203-010, \#141-020, \#628-012, \#671-011, \#334-023;

Second Row: \#193-018, \#599-016, \#694-018, \#1202-010, \#665-016

Two Group 1 points were subjected to use-wear analysis. Specimen \#599-17 is a nearly complete point that exhibits abraded flake-scar ridges and an impact fracture on the proximal end, indicating a hafted projectile point (Appendix C). Specimen \#670-5-11 is nearly complete with no sign of resharpening or rejuvenation. It exhibits hard, high silica polish on the proximal end and an impact fracture on the distal end. It also appears to have functioned as a projectile point (Appendix C).

Parts of three Group 1 points were sent for INAA (\#670-13 = TRC179; \#671-11 = TRC180; and \#1203-10 = TRC189). All three specimens have chemical signatures similar to that of known Edwards chert from the southwestern area of the Edwards Plateau (Appendix F).
These specimens were manufactured from locally available raw material.

Seventy-seven percent of the 13 Group 1 points were from the northern half of Block A. Only Units N107/E54 and N108/E55 yielded multiple Group 1 points. Some Group 1 points were recovered from the same units as Bandy, Martindale, Merrell, Gower, and Group 2 points. Since multiple events are represented, it is unclear how these different point types were originally associated.

Eleven Baker points are from the Early Archaic component, representing .5 percent of the 170 specimens from that context. An additional two specimens, presumably displaced, came from the Toyah component. These points are summarized as a group here, and individual 
characteristics presented in Appendix O. Only 25 percent are complete and 67 percent represented by proximal fragments (Figure 1118). Seventy-eight percent of the fragmentary specimens exhibit use breaks, with no obvious indication that any had been rejuvenated. All were manufactured from fine grained cherts and all lack any trace of cortex. Only 8.3 percent are interpreted to be manufactured from a flake, whereas the remaining 92 percent probably were produced from bifacial preforms. Only 8.3 percent appear to have been heat treated, and one other is burned. No specimens are patinated.
The overall shapes vary from triangular to lanceolate. The lateral edges vary slightly from basically straight to slightly excurvate. The edges appear slightly rounded in 58 percent of the specimens. Observed flaking patterns are oblique-parallel in 41.7 percent of the specimens and subparallel in 33.3 percent. The stem shape is expanding in 50 percent, curved in 33 percent, and straight in 17 percent. Table 11-9 summarizes the metric measurements from individual Baker points to provide a general overview of size and shape of the recovered specimens.

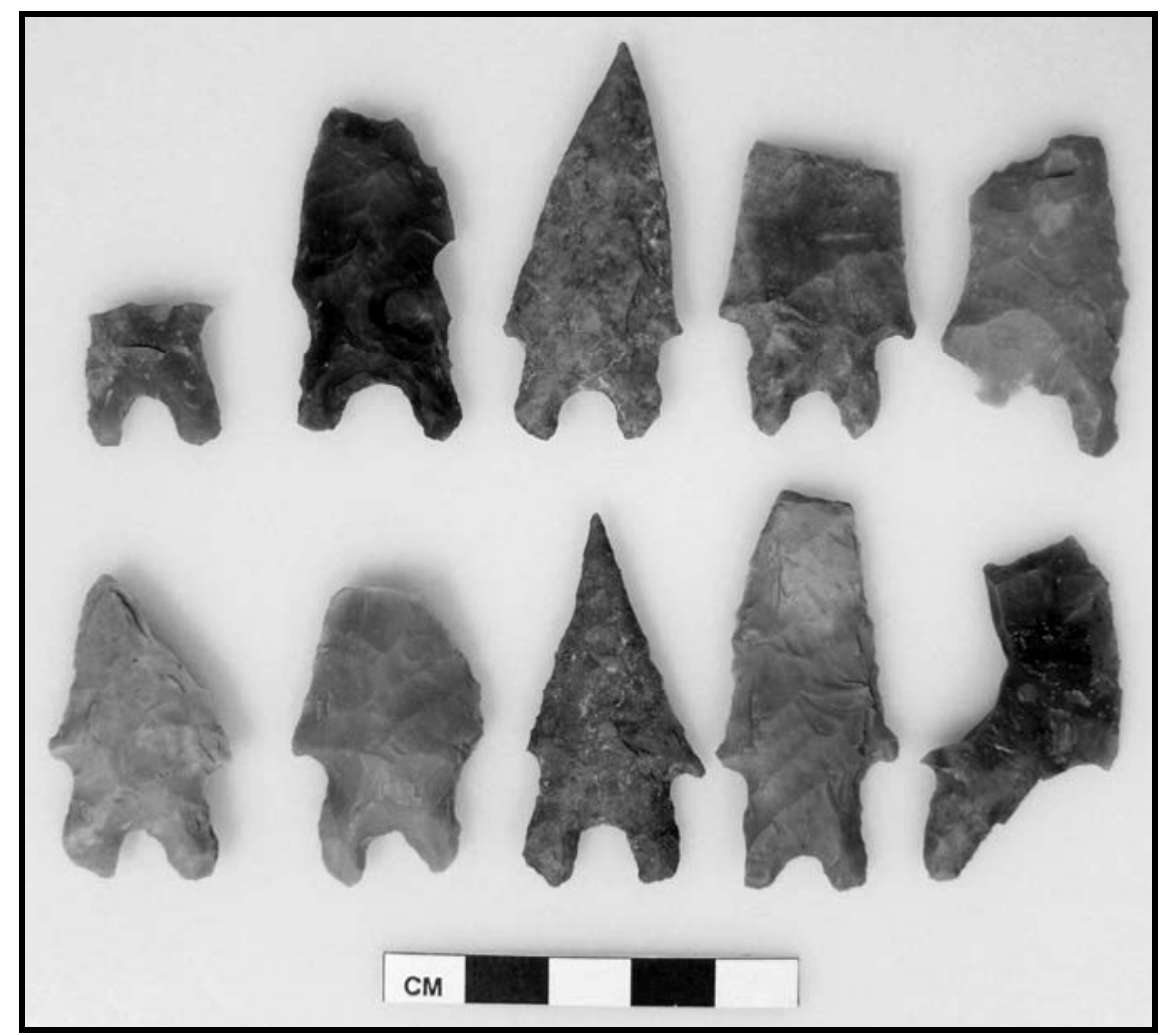

Figure 11-18. Selected Baker Points, Early Archaic

Left to Right: Top Row: \#95-018, \#28-013, \#28-014, \#462-015, \#229-019;

Second Row: \#569-013, \#653-012, \#431-010, \#346-023, \#117-021 
Table 11-9. Metric Measurements on Baker Points from 41ED28

\begin{tabular}{|l|c|c|c|}
\hline \multicolumn{1}{|c|}{ Characteristic } & Range & Mean & $\begin{array}{c}\text { Standard } \\
\text { Deviation }\end{array}$ \\
\hline Maximum length & $35.7-57$ & 46.8 & 8 \\
\hline Maximum width & $18.9-23.2$ & 21 & 1.4 \\
\hline $\begin{array}{l}\text { Maximum } \\
\text { thickness }\end{array}$ & $5.9-7.5$ & 6.7 & 0.6 \\
\hline Blade length & $23.1-45.2$ & 34 & 8.3 \\
\hline Blade width & $16.1-20.2$ & 18.2 & 1.3 \\
\hline Shoulder width & $21-23.2$ & 21.7 & 0.8 \\
\hline Left notch depth & $1.9-3.5$ & 2.7 & 0.6 \\
\hline Right notch depth & $1.8-4.8$ & 3 & 1.1 \\
\hline Left notch width & $7.3-11.8$ & 9 & 1.7 \\
\hline Right notch width & $7.1-13.2$ & 10 & 2.1 \\
\hline Left notch angle & $36-62$ & 49 & 10 \\
\hline Right notch angle & $25-63$ & 42 & 13.5 \\
\hline Stem length & $10.9-17.3$ & 13.4 & \\
\hline Stem width & $14.2-17.5$ & 15.7 & 1.2 \\
\hline Distal stem width & $12.9-16.2$ & 14.8 & 1.2 \\
\hline $\begin{array}{l}\text { Proximal stem } \\
\text { width }\end{array}$ & $14.9-18.5$ & 16.6 & 1.3 \\
\hline Stem thickness & $2.6-7.0$ & 4.5 & 1.2 \\
\hline Weight & $3.4-7.6$ & 5.3 & 1.4 \\
\hline Measurements in mm & & & \\
\hline Maximum length & $35.7-57$ & 46.8 & 8 \\
\hline Maximum width & $18.9-23.2$ & 21 & 1.4 \\
\hline
\end{tabular}

The proximal section of a single Baker point (\#140-24) was subjected to use-wear analysis. It exhibits use-wear in the form of polish and an impact fracture. It functioned as a projectile point, but contact material is unknown.

Parts of three Baker specimens (\#117-21 = TRC134; \#402-11 = TRC160; and \#462-15 = TRC166) were subjected to INAA. The analysis reveals they are chemically similar to southwestern Edwards Plateau chert, but from chemically different source areas (Appendix F). The tools were apparently manufactured from locally available raw materials.

The 12 Baker points were scattered across Block A with only Unit N99/E52 yielding more than one specimen. That same unit also yielded a Gower point. Bandy, Martindale, and Merrell points were infrequently recovered from the same unit as Baker points. The compressed stratigraphy undoubtedly had an impact on associations, and the seeming co-occurrence of these various types may simply be the result of resultant mixing of points that could well represent distinct episodes of occupation during the Early Archaic.

Eleven Merrell points, 6.5 percent of the 170 points, were recovered directly from Early Archaic component while one other specimen (\#157-11) of this type was recovered from the Toyah component. All twelve are summarized here with individual characteristics presented in Appendix O. Seventy-five percent are proximal fragments, and the remaining 25 percent are complete or nearly complete points (Figure 1119). The forms of breakage imply use-related damage, and no manufacture breaks detected. No points exhibit rejuvenation scars or resharpening through beveling. Of the seven for which blade shape can be detected, 57 percent are lanceolate and 43 percent are triangular. All points were manufactured from fine-grained chert, with no point exhibiting any sign of cortex. Eighteen percent are partially patinated and nine percent are completely patinated. One, or nine percent, appears to have been heat treated and three were burned. Of the eight points for which the flake pattern is revealed three are subparallel, three are oblique, and two are chevron. Eighteen percent exhibit some edge rounding. All blade edges on which configurations are discernible are straight. Seventy-three percent have expanding stems and 27 percent have curved stems. In general, the overriding characteristic of the Merrill point is the angular asymmetry in the base (Elton Prewitt, Personal Communication, September 30, 2003). The general size and shape of the 12 Merrell points is provided through the summaries of the metric measurements in Table 11-10. 


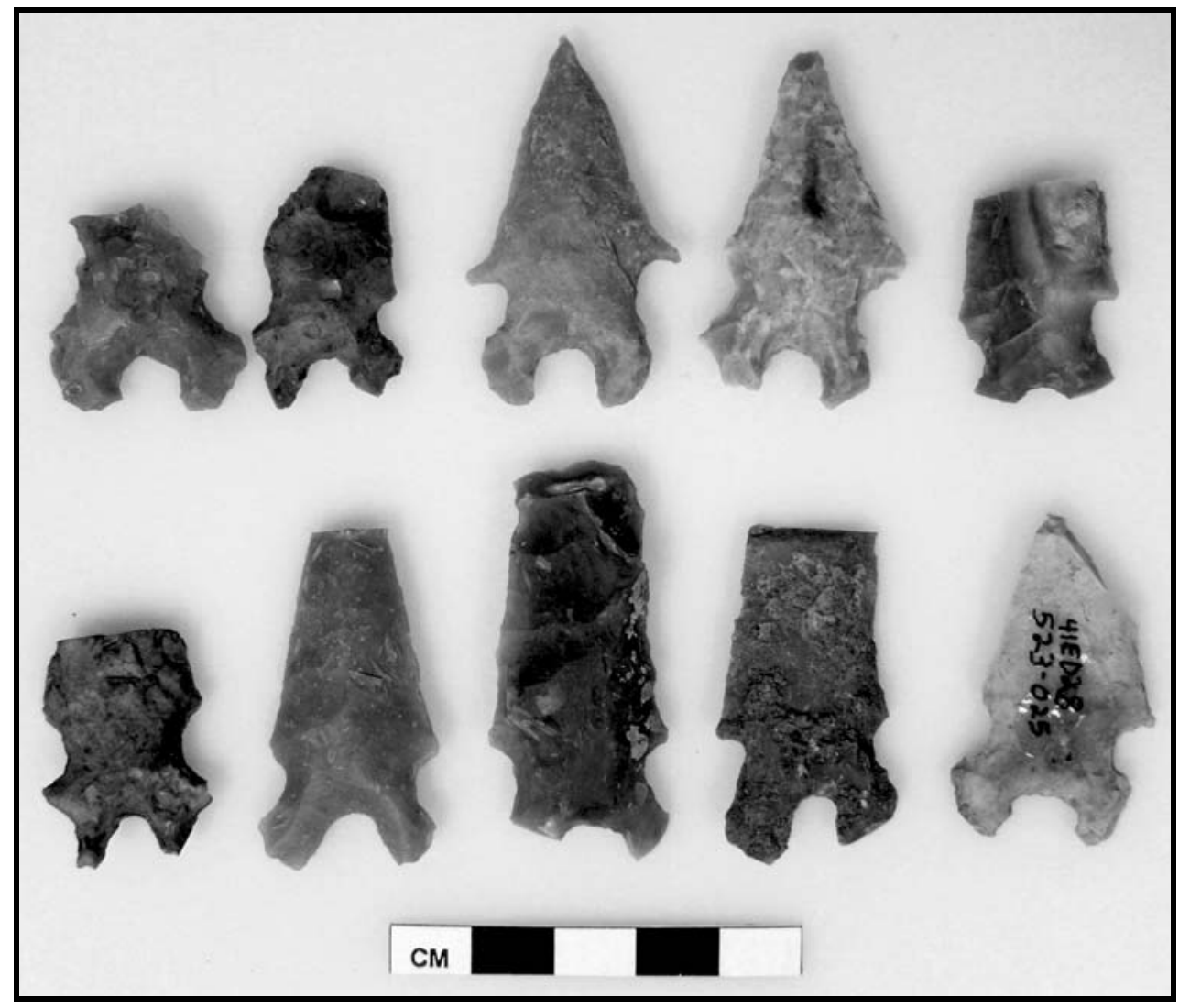

Figure 11-19. Selected Merrell Points, Early Archaic

Left to Right: Top Row: \#157-011, \#584-015, \#117-020, \#658-016, \#345-028 Second Row: \#523-022, \#479-013, \#615-020, \#203-014, \#523-025 Refits to \#463-021

No Merrell points were subject to use-wear analysis. Parts of four Merrell points (\#157-11 = TRC137; \#299-14 = TRC145; \#345-28 = TRC151; \#615-20 = TRC174) were sent for INAA. All four have chemical signatures similar to Edwards chert, and all probably were made from local cherts (Appendix F). They also exhibit very similar ultraviolet fluorescence, similar to that known for Edwards chert.

The 12 Merrell points were horizontally distributed across Block A, with 60 percent from the northern half and 40 percent from the southern half. A single unit in the northern half (N106/E56) was the only unit to yield multiple Merrell points. Merrell points were recovered from units that also yielded Baker (three cases), Gower (one case), Martindale (one case), and Bandy (two cases) points.

Seven Group 2 projectile points were identified, comprising about four percent of the 170 Early Archaic points. Although similar point types have been referred to as Early Corner-Notched in the literature, these are early corner-notched forms that do not fall into any established type. Six were recovered from the Early Archaic context, and one was recovered form the Toyah component in Block A. Information on individual specimens is presented in Appendix O. 
Table 11-10. Metric Measurements on Merrell Points from 41ED28

\begin{tabular}{|l|c|c|c|}
\hline \multicolumn{1}{|c|}{ Characteristic } & Range & Mean & $\begin{array}{c}\text { Standard } \\
\text { Deviation }\end{array}$ \\
\hline Maximum length & $41.1-56.6$ & 47.3 & 8.2 \\
\hline Maximum width & $16.7-25.2$ & 21 & 2.4 \\
\hline $\begin{array}{l}\text { Maximum } \\
\text { thickness }\end{array}$ & $5.7-8.1$ & 6.9 & 0.8 \\
\hline Blade length & & & \\
\hline Blade width & $14.0-18.8$ & 17.2 & 1.3 \\
\hline Shoulder width & $16.7-25.2$ & 21 & 2.4 \\
\hline Left notch depth & $2.2-5.5$ & 3.6 & 0.9 \\
\hline Right notch depth & 1.65 .4 & 3.2 & 1.3 \\
\hline Left notch width & $6.7-11.5$ & 8.5 & 1.3 \\
\hline Right notch width & $5.6-6.2$ & 8.5 & 1.4 \\
\hline Left notch angle & $37-109$ & 68 & 20 \\
\hline Right notch angle & $55-113$ & 75 & 16.5 \\
\hline Stem length & $11.7-17.7$ & 14.2 & 1.6 \\
\hline Stem width & $15.5-19.4$ & 17.6 & 1.3 \\
\hline Distal stem width & $11.4-15.7$ & 14.4 & 1.5 \\
\hline $\begin{array}{l}\text { Proximal stem } \\
\text { width }\end{array}$ & $18.1-23.7$ & 20.7 & 1.6 \\
\hline Stem thickness & $3.1-5.5$ & 4.4 & 0.8 \\
\hline Base depth & $3.9-6.5$ & 5.2 & 0.9 \\
\hline Base notch width & $6.7-11.8$ & 8.8 & 1.6 \\
\hline Weight & $4.7-9.5$ & 5.8 & 1.8 \\
\hline
\end{tabular}

Measurements in mm

Twenty percent of these are complete with 80 percent consisting of proximal fragments (Figure 11-20). All were manufactured from fine-grained chert, and the finished products lack any sign of cortex. One has about 25 percent patination. The breaks are from use, and 20 percent exhibiting partial beveling of edges. No sign of rejuvenation is present. One specimen appears to have been heat-treated. Fourteen percent were burned as a consequence of exposure to intense heat. Eighty-three percent have a generally lanceolate shape, and 17 percent are triangular. The lateral edges are nearly all straight and stems are all expanding. The unifacially-beveled point has curved edges. The flaking patterns appear to differ; 29 percent are subparallel, 43 percent are chevron,
14 percent show random flaking, and 14 percent have oblique to subparallel flaking patterns. Edge rounding is present on 29 percent of the specimens. The stems are all expanding, and the notches are all directed inward from the corners.

Given that the sample is comprised of mostly broken specimens, it is difficult to provide meaningful metric summaries for the Group 2 category. Only attributes observable on three or more specimens are summarized in Table 11-11.

Two Group 2 points (\#283-14 and \#412-10) were subjected to use-wear analysis. One complete specimen (\#283-14) has a small use break, unifacial edge beveling, and is burned.

Wood fragments and polish were observed in the haft area. Other wood fragments are scattered over the entire surface and are probably use residue. This tool is interpreted as hafted, but the use is unknown. Complete specimen \#41210 exhibits some unifacial beveling.

Table 11-11. Metric Measurements on Group 2 Points from 41ED28

\begin{tabular}{|l|c|c|c|}
\hline \multicolumn{1}{|c|}{ Characteristic } & Range & Mean & $\begin{array}{c}\text { Standard } \\
\text { Deviation }\end{array}$ \\
\hline Maximum length & $49.7-74.5$ & 61.3 & 12.4 \\
\hline Maximum width & $22.5-37.6$ & 27.3 & 5.6 \\
\hline $\begin{array}{l}\text { Maximum } \\
\text { thickness }\end{array}$ & $5.5-8.5$ & 6.1 & 1.1 \\
\hline Blade length & $39.2-63.9$ & 48.4 & 12.4 \\
\hline Blade width & $20.2-33.0$ & 25.5 & 4.3 \\
\hline Shoulder width & $22.5-37.6$ & 35.4 & 8.1 \\
\hline Notch angle & $35-47$ & 38 & 6 \\
\hline Stem length & $9.1-12.1$ & 10.6 & 1.4 \\
\hline Distal stem width & $9.5-20.2$ & 14.4 & 3.4 \\
\hline $\begin{array}{l}\text { Proximal stem } \\
\text { width }\end{array}$ & $20.3-29.3$ & 22.7 & 3.6 \\
\hline Stem width & $17.0-24.8$ & 19.3 & 3 \\
\hline Stem thickness & $3.9-5.8$ & 4.7 & 0.7 \\
\hline Base depth & $1.8-4.1$ & 2.9 & 0.9 \\
\hline Base notch width & $10.6-19.0$ & 13.5 & 2.9 \\
\hline Weight & $4.4-9.0$ & 9.5 & 4.8 \\
\hline
\end{tabular}

Measurements in $\mathrm{mm}$ 


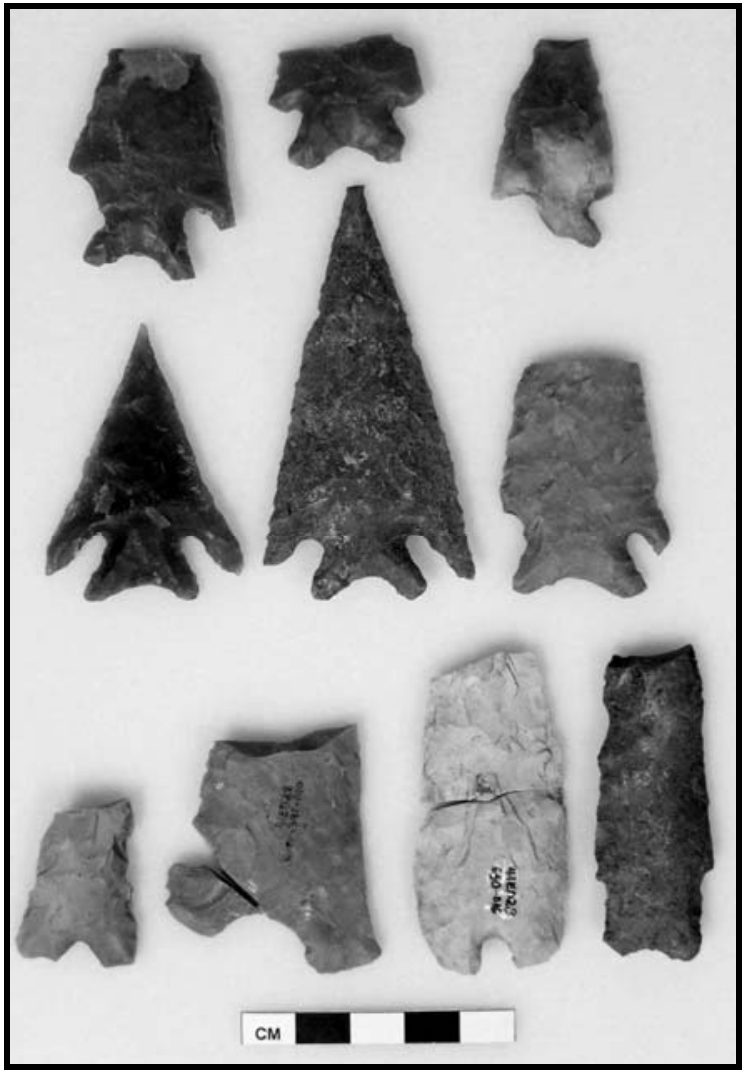

Figure 11-20. Selected Group 2-CornerNotched, Carrizo, and Pandale Points, Early Archaic

Left to Right: Top Row: \#412-011, \#324-016, \#215-018; Second Row: \#523-021, \#412-010, \#670-010; Third Row: \#670-005-012, \#391-010, \#213-012 Joins to \#650-016, \#411-017

Resin and plant fibers combined with polish were observed on the proximal haft area. Possible blood residue may be related to use. This point was hafted with resin and was the only one of 10 points examined to bear resin (Appendix C).

Parts of two Group 2 points (\#324-16 = TRC149 and \#412-11 = TRC163) were subjected to INAA. These two specimens reveal chemical signatures similar to known Edwards chert and are probably from local sources (Appendix F).

The seven Group 2 points were concentrated (86 percent) in the southern half of Block A.
Unit N104/E47 yielded two Group 2 points. In three cases, Group 2 points were from units that yielded Gower points, in one case from a unit with a Martindale, and one case from a unit that also contained Bandy points.

Three proximal Carrizo point fragments, less than two percent of the 170 points, were recovered from apparent Early Archaic context, whereas a distal fragment came from a Middle Archaic context. The distal segment \#213-12 refits with one proximal segment (\#650-16) that was located about $6 \mathrm{~m}$ to the south (Figure 1116). It is assumed that the distal piece was slightly displaced upwards, and that the Carrizo points here are associated with the Early Archaic component. Specimen \#670-5-12 was associated with Feature 23, a definite Early Archaic burned rock cluster. It may be that all these pieces were near the interface between the Early and Middle Archaic components.

Individual characteristics are presented in Appendix O, but are summarized here. All were manufactured from fine-grained cherts with one that appeared to have been heat treated. No cortex remains across the general lanceolate segments. The two refit pieces are nearly 100 percent patinated to a white surface color. The size of each specimen varies considerably, with only a few metric measurements that could be summarized (Appendix O). These four fragments were equally distributed between the northern and southern half of Block A.

The distal segment \#213-12 (TRC121), specimen \#391-10 (TRC156), and specimen \#670-5-12 (TRC178) were submitted for INAA. The chemical signatures are similar to known signatures for Edwards chert from the southwestern region (Appendix F). These pieces apparently were manufactured from regionally available Edwards chert.

A single Pandale point (\#411-17) was also found in an Early Archaic context at 70 to $80 \mathrm{cmbd}$ in 
Unit N104/E47, along the very western margin of Block A. This was at the very base of the Middle Archaic and the top of the Early Archaic component, but was assigned to the latter, since it was in the same level as a Gower point (\#41116). Two Group 2-Early Corner-Notched points (\#412-10 and \#412-11) were encountered in the level below. The Pandale point was manufactured from a dark gray fine-grained chert that appeared to have been burned (Figure 11-16). No patination or cortex was observed. It is a lanceolate shaped point with generally straight lateral edges, oblique parallel flake scars, and a straight to slightly expanding, unground stem. A distal fragment was sent for INAA. The INAA (TRC161) reveals this material is similar to locally available Edwards chert (Appendix F).

Fifty-four unclassifiable dart points and dart point fragments were recovered from the Early Archaic component with two more or less complete specimens (\#628-13 and \#730-12) not identifiable as to a specific type. Forty-four percent are distal fragments, 36.5 percent are medial sections, 15.4 percent are proximal pieces, and about four percent are indeterminate fragments. These specimens appear to be from points that were similar to the types described above, and show considerable variation in most attributes. All 54 specimens were manufactured from fine-grained chert. Slightly more than seven percent of the dart points are covered with patination on between two and 100 percent of the surface. Less than two percent exhibit any sign of cortex. A relatively high fraction (31.2 percent) is burned pieces with another relatively high 13 percent that appear to have been heat treated. Various individual metric and non-metric attributes are presented in Appendix $\mathrm{O}$.

One small unidentifiable point fragment (\#578$15=$ TRC171) was sent for INAA. This piece has a chemical signature similar to known
Edwards chert from the southwestern area of the Edwards Plateau. Apparently, the material was from a regional, perhaps local, source of Edwards chert (Appendix F).

In summary, a total of 179 Early Archaic dart points were recovered from all contexts, with 170 points from Block A. The 179 points include nine identifiable types accounting for 125 pieces, with 54 broken unidentifiable fragments. The nine different recognizable types include 32 Gower, 22 Martindale, 21 Bandy, 15 Group $1 \quad$ (corner-notched), 12 Baker, 12 Merrell, seven Group 2, three Carrizo, and one Pandale. Although some researches have had difficulty in distinguishing between the Bandy and Martindale point types, the Varga Site assemblage provides a large enough sample of points for generating metric data that imply these are two different and distinct types. The Gower and Merrell point types are very similar, but slight differences in the shape of their bases provide indications that two different types are represented. It is also possible that these two named types are varieties of a single type. The variations are might reflect regional differences, individual manufacturing differences, and/or reworking of the original form. Some points similar to these are misidentified in the current literature, which is understandable since not much has been documented or published about either type, especially Merrell. The Varga Site has yielded the first sizeable sample of Merrell points and provides the first associated radiocarbon ages.

\subsubsection{Bifaces}

The 193 bifaces from Block A and five from Block B were, with a single exception, manufactured from fine-grained chert. The exception is made of a relatively coarse-grained chert specimen (Figures 11-21 through 11-23). Individual characteristics of the bifaces are presented in Appendix $\mathrm{O}$, and the data 
summarized below. Smooth, rounded (waterworn) cortex is present on 4.8 percent of the specimens. About 4.4 percent appear to have been heat treated, and another 19.1 percent were burned. Twenty-two percent exhibit some patination; 3.1 percent exhibit nearly complete patination, 3.2 percent exhibit surfaces that are roughly 75 percent patinated, 4.9 percent have 50 percent patination, and some 11.9 percent show patination on less than 25 percent of the surface. Patination is somewhat unusual, and may be a clue that some 22 percent of this material may be older, or at least was exposed to more light than the other 78 percent. The specimens are represented by 22.5 percent complete pieces, 25.8 percent proximal, 24.2 percent distal, 17.6 percent medial, and 9.9 percent indeterminate pieces. Of those that exhibit breaks, 35.9 percent are believed to be use breaks, 41.1 percent are of indeterminate origin, 18 percent are thermally broken, and 4.7 percent were broken during manufacturing.

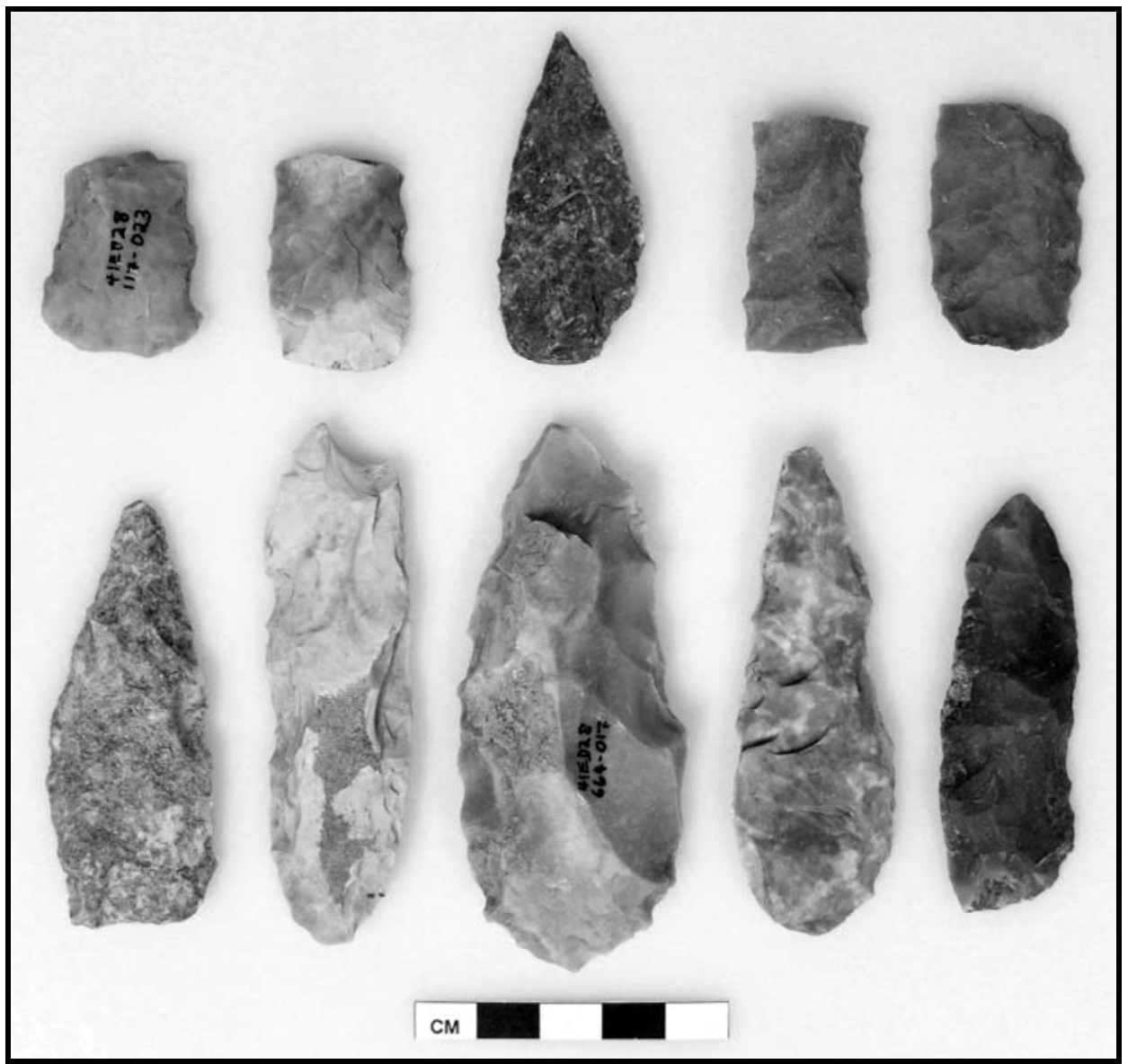

Figure 11-21. Selected Early Archaic Bifaces (Elongated)

Left to Right: Top Row: \#117-023, \#591-021, \#591-024, \#165-015, \#333-023; Second Row: \#61-016, \#203-015, \#664-017, \#746-015, \#116-019 


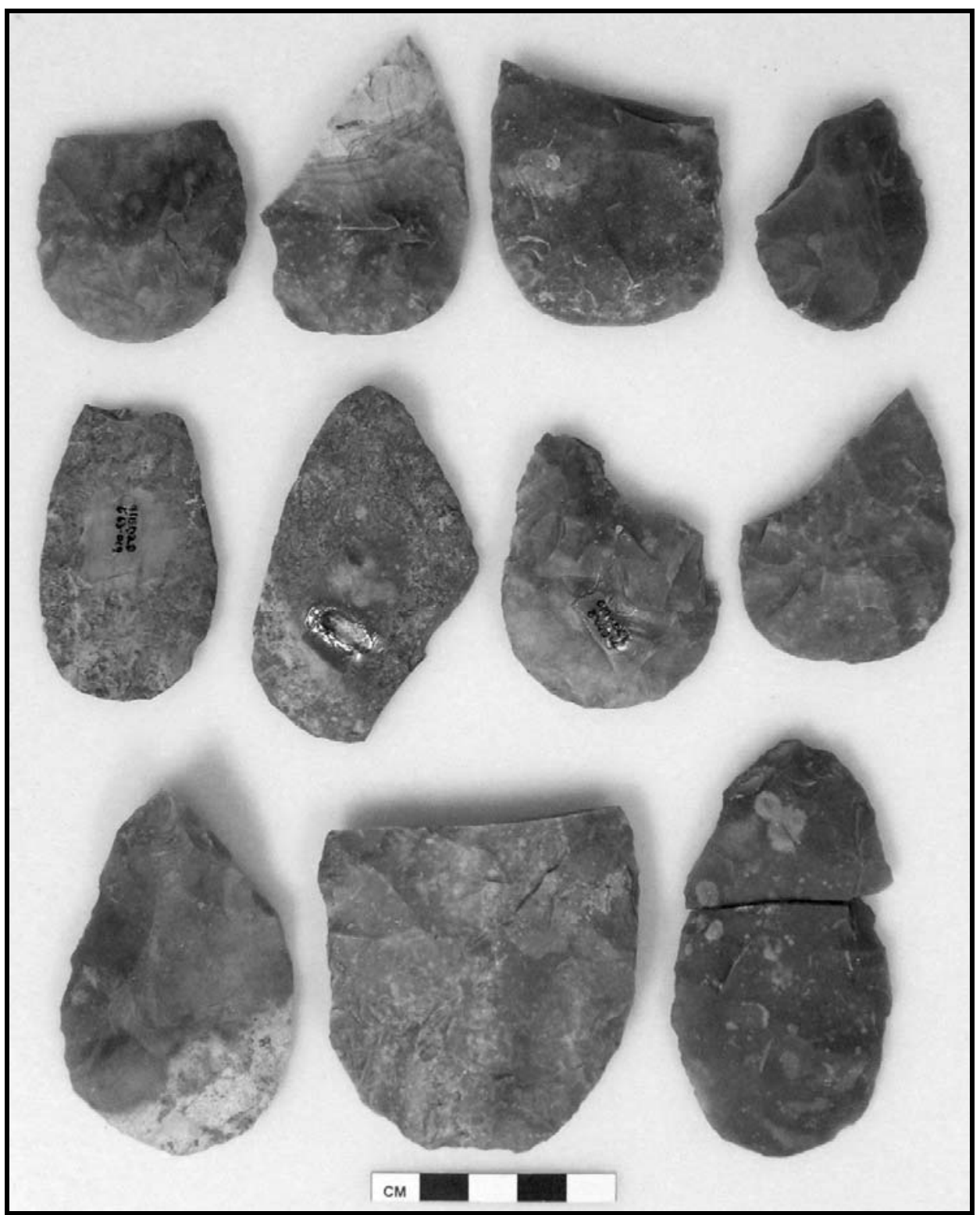

Figure 11-22. Selected Early Archaic Bifaces (Ovate)

Left to Right: Top Row: \#465-011, \#699-020, \#502-017, \#765-011;

Second Row: \#563-019, \#205-010, \#734-010, \#699-019;

Third Row \#312-018, \#552-017, \#402-017 Joins to \#403-012 


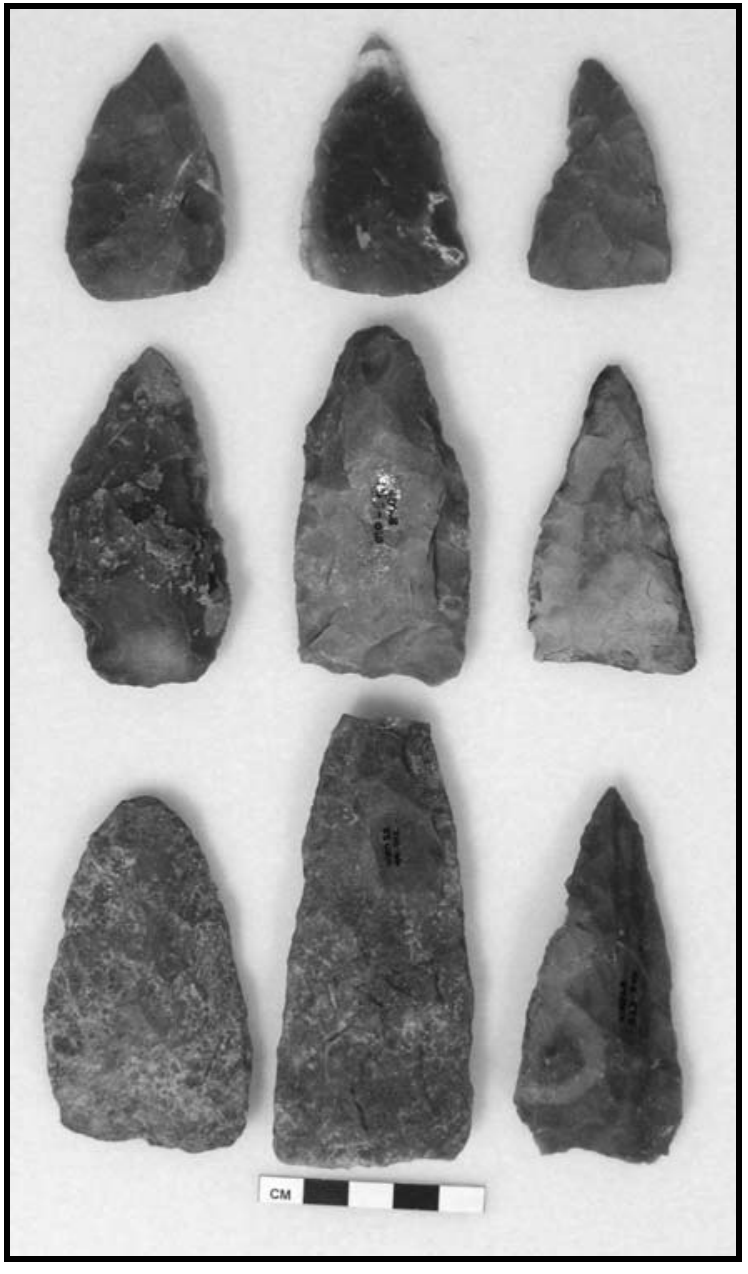

Figure 11-23. Selected Early Archaic Bifaces (Triangular)

Left to Right: Top Row: \#204-017, \#472-013, \#447-016; Second Row: \#242-015, \#755-010, \#521-014; Third Row: \#154-024, \#49-012, \#523-023

Seventy-three percent represent the late stage of manufacture, 30 percent are middle stage, nine percent are early stage, and the remaining 11 percent are indeterminate. Only 2.1 percent exhibit any sign of rejuvenation, although 5.5 percent exhibit some degree of edge beveling. The flaking patterns are in many cases (32.2 percent) indeterminate. Among those specimens that are sufficiently complete to show flaking patterns, nearly 50 percent have random flaking, 19.4 percent have oblique flake scars, 9.4 percent are in a chevron pattern, 8.9 percent are collateral, 8.9 percent are subparallel, and 3.2 percent are parallel. No specific flaking pattern could be detected that correlates with overall shape.

The more or less complete bifaces have length ranges from 33.9 to $110.2 \mathrm{~mm}$, with an average of $72.3 \mathrm{~mm}$. The width measurements range from 21.3 to $77.5 \mathrm{~mm}$, with an average of $37.3 \mathrm{~mm}$. The thickness is quite variable and ranges from 4.3 to $26 \mathrm{~mm}$, with an average of $10.7 \mathrm{~mm}$.

Ten bifaces of various shapes and stages of manufacture were selected and subjected to high-powered use-wear analysis. Specimen \#28-11 is a complete, early-stage biface that appears to have been heat treated. Use-wear analysis revealed no sign of hafting but showed light use polish and flake scars from resharpening. It is not known how or on what material the tool was used. Specimen \#49-12 is a complete, late-stage lanceolate biface that exhibits use residues in the form of raphides on the distal end. Use-wear is in the form of striations parallel and perpendicular to the working edge. This biface was used in cutting of plant material (Appendix C). Specimen \#6116 is a complete early-stage lanceolate biface that exhibits light use on the distal end. This biface was used in cutting of an unknown material (Appendix C). Specimen \#154-24 is a complete late-stage, triangular biface with plant fibers and light hafting wear confined to the proximal end. Red staining, possibly ochre, and hard, high silica polish were observed on the distal end. It is not clear how this tool functioned (Appendix C). Specimen \#205-10 is a distal fragment of a late-stage biface. It reveals use residues in the form of plant tissue, with use-wear in the form of polish and multidirectional striations. This biface was used for cutting on hard high silica material 
(Appendix C). Specimen \#422-19 is the proximal fragment of a late-stage biface with a use break. It has plant tissue and striations parallel and perpendicular to the long axis along the proximal end. Use residues in the form of raphides are present on the working edge. This biface probably was hafted and used on plant material (Appendix C). Specimen \#563-19 is a nearly complete late-stage, tear-dropped shaped biface with plant tissue on the proximal end and raphides over the entire surface. It is not clear how this biface was used, or on what material it was used. Specimen \#591-24 is a proximal fragment of a late-stage, lanceolate biface with wood fibers on the proximal end and additional use residue in the form raphides. Light polish from use is present along the working edge. This biface appears to have been hafted and used for cutting on unknown material (Appendix C). Specimen \#598-13 is a nearly complete late stage, ovate biface, with a break near the distal end. It has raphides on the proximal end. It is unclear how this tool functioned, and the raphides may be related to the haft (Appendix C). Specimen \#699-20 is a proximal section of a late stage, teardrop shaped biface that exhibits a use break. It exhibits hafting wear in the form of striations perpendicular and parallel to the long axis and high areas that exhibit polish. This biface was hafted and was broken during use on unknown material (Appendix C).

Seven bifaces that represent different shapes and sizes were sent for INAA. Six have chemical signatures similar to those of known Edwards chert from the southwestern area of the Edwards Plateau (Appendix F). The other specimen (\#205-10 = TRC140) has a chemical signature beyond the current known range for Edwards chert but exhibits an ultraviolet fluorescence of a yellow orange that is similar to other known Edwards chert. This specimen is of Edwards chert from a source that is currently unidentified.
This specimen is a light brown with large and small light spots.

The 193 bifaces were scattered across Block A, but the frequencies were skewed with 62 percent in the southern half, compared to 38 percent in the northern half. About 17 percent of the excavated units did not yield a biface, whereas another 29 percent yielded only one biface. Consequently, nearly 59 percent of the excavated units yielded multiple bifaces with three units yielding seven specimens each. These apparent concentrations indicate potential use or discard areas.

\subsubsection{Scrapers}

The 27 scrapers include 54 percent sidescrapers, 33 percent end-scrapers, and eight percent combination end-and-side scrapers (Figure 11-24). Individual characteristics are presented in Appendix O, with summary data presented here. All were manufactured from fine-grained cherts with less than four appearing to have been heat treated. Only 11 percent exhibit any patination, which in no instance is present on more than 25 percent of the artifact surface. Thirty percent exhibit limited areas of cortex, which is in all cases rounded and smooth. Nearly 60 percent are complete with distal, proximal, medial, and indeterminate fragments each comprising less than 15 percent of the sample. Less than four percent exhibit a rejuvenation flake scar, indicating that either these tools were seldom subjected to reworking or that rejuvenation flake scar was obliterated by reworking. Scraper shapes are quite variable with rounded specimens dominant at 30 percent. Less than four percent were broken during manufacture.

Fifty-two percent exhibit a single working edge (bit), 37 percent have two working edges, and 11 percent have three working edges. Rounding is evident on 60 percent of the edges. The primary working bit is approximately equally 


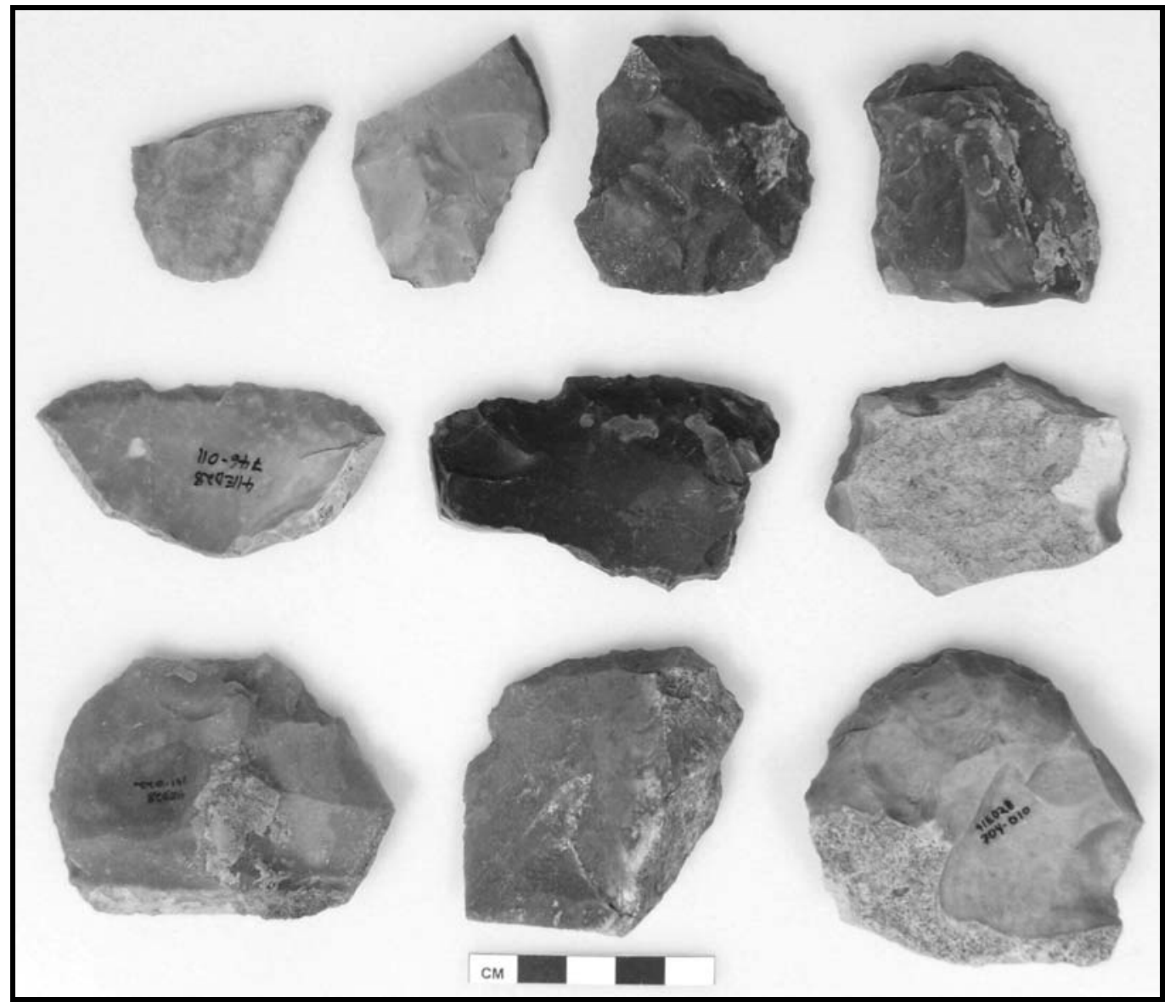

Figure 11-24. Selected Early Archaic Scrapers

Left to Right: Top Row: \#154-023, \#75-020, \#734-011, \#62-011;

Second Row: \#746-011, \#500-013, \#18-21;

Third Row: \#141-022, \#539-011, \#704-010

divided between the lateral (30 percent) and the distal (26 percent) edges, and a combination of distal and lateral edges. Seventy percent of the working edges are excurvate, with the remaining specimens having a variety of configurations. Nearly 82 percent of the edges exhibit regular and continuous retouch. . The secondary bit islocated in 62 percent of the specimens along one of the lateral edges. The shape of the secondary working edge is straight in 62 percent of the cases, excurvate in 31 percent, and incurvate in eight percent. Table 11-12 summarizes the metric measurements from the Early Archaic scrapers.

Five scrapers were submitted for highmagnification microscopic use-wear analysis. A complete side scraper (\#29-12) exhibits polish. This scraper was used on a hard, high-silica material (Appendix C). Specimen \#312-19 is a complete lanceolate side scraper with use residues in the form of plant fiber. Use-wear is reflected by hard, high silica polish and striations along the working end. This tool was used as a scraper on a high-silica plant 
(Appendix C). Specimen \#323-20 is a complete ovate end-scraper. Striations parallel and perpendicular to the long axis and polish indicate use-wear. This scraper was used in planing a hard, high-silica material (Appendix C). Specimen \#401-36 is a complete ovate end-scraper that exhibits use residues in the form of raphides and plant fibers. Use-wear

\section{Table 11-12. Metric Data, Early Archaic Scrapers from 41ED28}

\begin{tabular}{|l|c|c|}
\hline \multicolumn{1}{|c|}{ Characteristic } & Range & Mean \\
\hline Maximum length & $35.7-87.9$ & 59.9 \\
\hline Maximum width & $32.0-79.1$ & 52.5 \\
\hline Maximum thickness & $5.4-27.6$ & 14.6 \\
\hline Weight (g) & $18.7-146.2$ & 58.6 \\
\hline Worked edge 1 - length & $7.5-128.6$ & 46.1 \\
\hline Worked edge 1 - thickness & $1.9-12.7$ & 8.5 \\
\hline Worked edge 1 - angle & $42-90$ & 64.4 \\
\hline Worked edge 2 - length & $13.4-53.9$ & 27.6 \\
\hline Worked edge 1 - thickness & $0.8-7.5$ & 3 \\
\hline Worked edge 1 - angle & $46-70$ & 57.5 \\
\hline
\end{tabular}

Measurements in mm

in the form of polish and edge rounding indicate use in planing hard, high-silica material (Appendix C). Specimen \#627-13 is a complete triangular end-scraper with polish on the working end indicating a cutting action on a hard, high-silica material.

Three scrapers (\#29-12 = TRC126, \#346-25 = TRC153, and \#401-36 = TRC159) were also subjected to for INAA. All three specimens reveal chemical signatures similar to Edwards chert that was locally available in the southwestern area of the Edwards Plateau (Appendix F).

Twenty-six scrapers were non-randomly distributed, across Block A, with nearly 70 percent in the southern half of Block A. Three units, N100/E56, N103/E56, and
N110/E50, yielded two scrapers each, whereas the other units yielded only one scarper each.

\subsubsection{Drills}

The seventeen drills recovered are described according to attributes in Appendix O. A summary of the data is presented here. All were manufactured from fine-grained chert and none appear to have been heat treated. Only 6.2 percent exhibit small areas of smooth, rounded cortex. Ninety-four percent probably were manufactured from flakes (Figure 11-25). Nearly 25 percent exhibit limited areas of patination. The specimens vary in their condition: 18.8 percent are complete, 31.3 percent are distal fragments, 18.8 percent are proximal fragments, and 31.3 percent are medial fragments. Of the broken specimens, 62.5 percent have use breaks, 12.5 percent exhibit thermal fractures, and 6.3 percent have breaks of indeterminate origin. On the specimens with measurable sections, the metric attributes provide a general idea of size and shape. For the three complete specimens, the overall length ranges from 48.1 to $72.9 \mathrm{~mm}$, with an average of $63.3 \mathrm{~mm}$. The thickness of 13 measurable specimens ranges from 5.3 to $21.4 \mathrm{~mm}$, with an average of $8.3 \mathrm{~mm}$. Stem length varies form 20.4 to $48.4 \mathrm{~mm}$, with an average of $35.5 \mathrm{~mm}$.

Four drills were subjected to high-magnification use-wear analysis. Specimen \#278-26 is a complete drill that exhibits use residues of raphides and pollen grains on the distal end. Striated use polish indicates this tool was used to bore into an unknown material (Appendix C). Specimen \#343-13 is the distal section broken during use with use-wear in the form of abraded flake-scar ridges, and multidirectional directions. This tool was used in boring/drilling of a hard material (Appendix C). Specimen \#455-16 is a complete drill with use-residues in the form of raphides, and use-wear in the form 


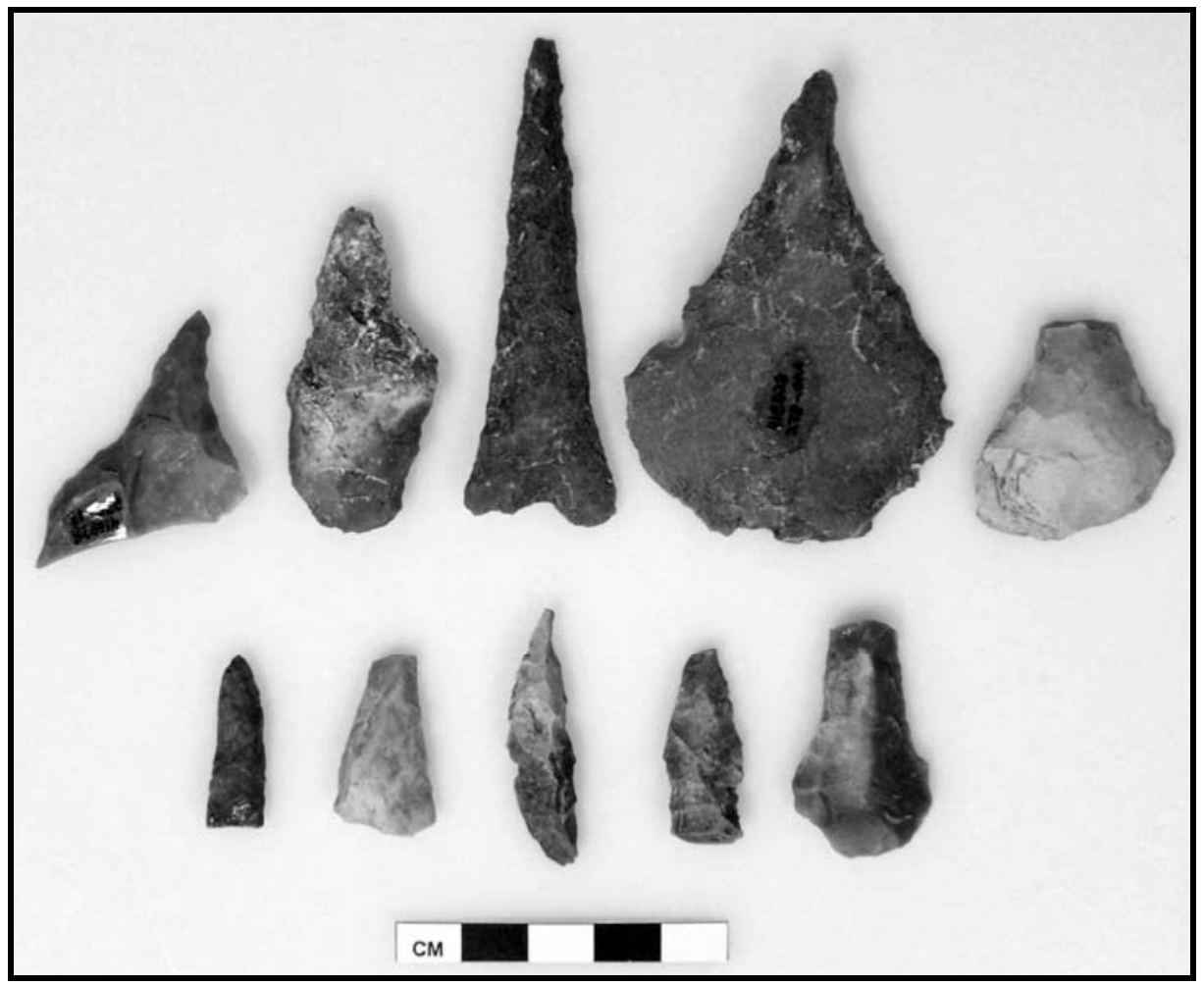

Figure 11-25. Selected Early Archaic Drills

Left to Right: Top Row: \#278-013, \#455-016, \#670-005-015, \#278-026, \#63-016; Second Row: \#40-012, \#277-014, \#289-020, \#578-018, \#183-021

of multidirectional striations, indicating use on plant material (Appendix C). Specimen \#670-515 is a complete drill from Feature 23 that exhibits abraded flake-scar ridges on the proximal end indicative of hafting. Use residues are in the forms of wood fragments and raphides on the working edge, with use polish and striations confined to the tip. This tool was used in boring/drilling of wood (Appendix C).

Four specimens (\#40-12 = TRC128, \#63-16 = TRC130, \#183-21 = TRC138, and \#735-12 = TRC187) were subjected to INAA. These have chemical signatures similar to known Edwards chert from the southwestern area of the Edwards Plateau, probably indicating use of locally available chert. (Appendix F).

\subsubsection{Unifaces}

Four tools have one face that is completely or nearly completely worked, and are placed in a category distinct from scrapers because they lack the steep working edge characteristic of scrapers. These specimens include one complete specimen, two proximal fragments, and one fragment from an indeterminate section of the original tool (Figure 11-26; Appendix O). All are of fine-grained chert lacking any trace of patination. The one complete piece is teardrop in shape. The edge flaking is quite variable as is the location of the working edge(s). One has three working edges, and two specimens have rounded edges. The one complete piece measures $88.4 \mathrm{~mm}$ long, by $51.1 \mathrm{~mm}$ wide, 


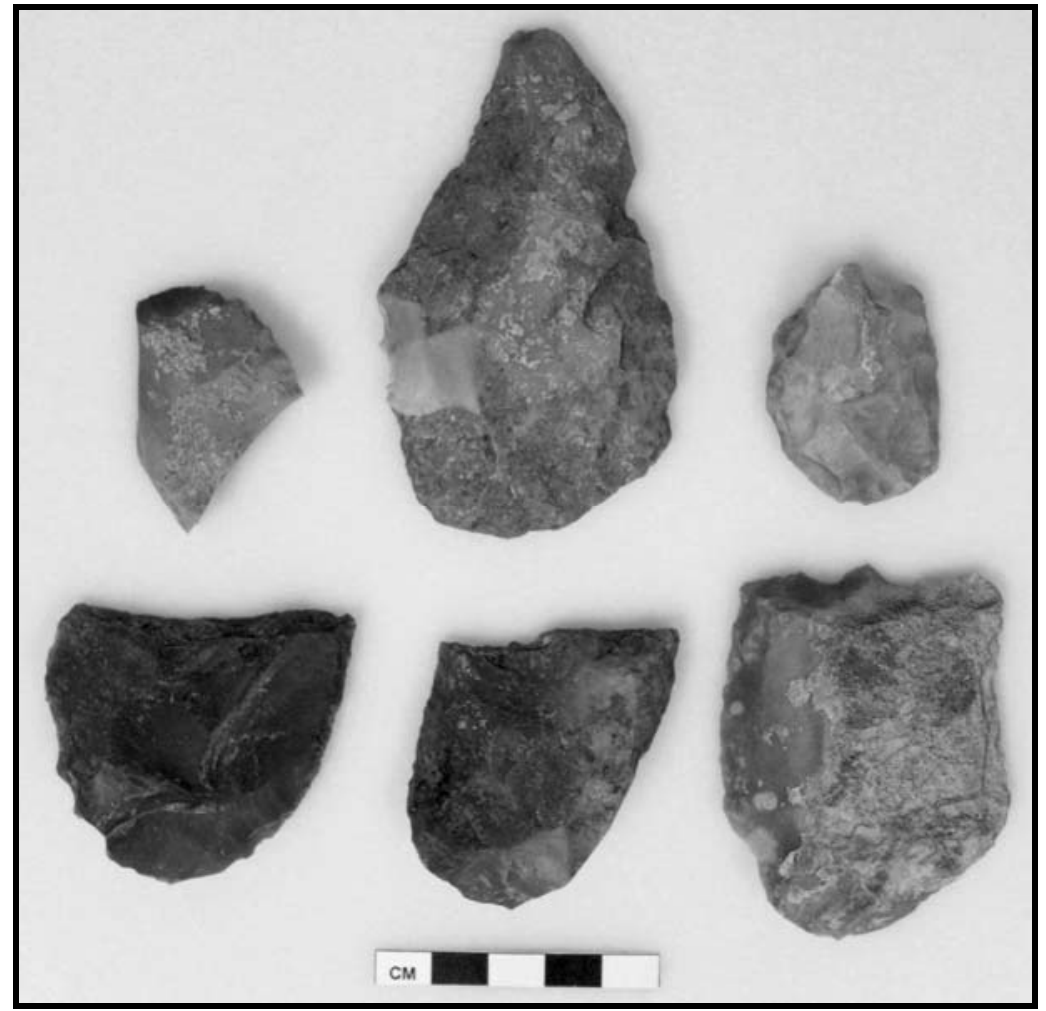

Figure 11-26. Selected Early Archaic Unifaces and Gouges

Left to Right: Top Row: Unifaces \#153-030, \#546-014, \#84-010; Second Row: Gouges \#346-011, \#724-013, \#64-014

$16.6 \mathrm{~mm}$ thick, and weighs $67.4 \mathrm{~g}$. The three fragments are smaller in size.

One complete, teardrop shaped uniface (\#54614) was sent for high-magnification use-wear analysis. Use residue is present in the form of wood fragments, and there is polish along the working edge. This tool was used for whittling of wood (Appendix C). A fragment of this same specimen (TRC169) was sent for INAA. It reveals a chemical signature that is similar to other known Edwards chert from the surrounding region (Appendix F), and was probably locally available chert.

\subsubsection{Gouges}

Three gouges were identified and all three are complete and manufactured from fine-grained cherts that were not heat-treated. They lack patination, and one specimen retains cortex on approximately 50 percent of its surface (Figure 11-26). All exhibit regular and continuous flaking along the primary bit, or distal end. Individual metric measurements are provided in Appendix $\mathrm{O}$.

Two gouges were subjected to highmagnification microscopic use-wear analysis. The triangular shaped gouge (\#346-11) with lateral and distal flaking has use residue in the form of plant or bone fragments. Use-wear in the form of silica polish was observed, 
interpreted to represent planing/scraping on bone or wood (Appendix C). A second gouge (\#72413) has regular and continuous bit-end flaking with use residues in the form of hair and usewear in the form of soft polish indicating usecontact on animal hide (Appendix C).

These same two gouges $(\# 346-11=$ TRC152 and \#724-13 = TRC184) were subjected to INAA. Their chemical signatures are similar to known Edwards chert from the southwestern part of the Edwards Plateau (Appendix F), presumably indicating locally available chert.

\subsubsection{Edge-Modified Flakes $(n=1,038)$}

Twenty-seven edge-modified tools were selected and subjected to high-powered use-wear analysis. The analyzed tools include nine rejuvenation flakes, 14 edge-modified flakes, three gravers, and a spokeshave. Each tool is briefly described, and the use-wear results are summarized in Table 11-13.

Twelve edge-modified flakes, including one graver (\#400-10 = TRC157) and five rejuvenation flakes were sent for INAA. These reveal chemical signatures that are similar to the known Edwards chert from the southwestern region (Appendix F). It is assumed that all 12 pieces are from raw materials derived from the region, but from a variety of source localities.

The 1,038 edge-modified flakes were thought to represent a variety of tasks that targeted a variety of materials. This assumption was generally verified through the use-wear analysis and residue identification on roughly 2.5 percent of the broader assemblage, which included 14 edge-modified flakes, nine rejuvenation flakes, three gravers, and a spokeshave. The analyzed sample reflects uses such as scraping, cutting, planing, whittling, and slicing. These tasks were directed towards plants, hard, high silica material, wood, soft materials, bone/antler, and some unknown materials.

\subsubsection{Other Artifacts}

Two specimens are identified as choppers. Specimen \#477-14 is a massive chert flake (113.1 by $74.1 \mathrm{~mm}$ by $40.6 \mathrm{~mm}$ thick) with roughly 12 percent cortex remaining on the end opposite from the one worked edge. The $60.3 \mathrm{~mm}$-long worked edge is at the distal end and exhibits use-flake scars that extend no farther than $11.8 \mathrm{~mm}$ onto one face and $6.2 \mathrm{~mm}$ on the reverse face. Specimen \#698-13 is a chunk of chert nodule with nearly 50 percent cortex mostly on the end opposite the worked edge. This chopper measures $85 \mathrm{~mm}$ long, $64.5 \mathrm{~mm}$ wide, $41.2 \mathrm{~mm}$ thick. The one worked edge exhibits use scars on both faces, but again these appear more frequent and larger on one face. The edge of the flaked/worked end is rounded. Hard contact material is suggested by the fact that the working edge both pieces is rounded.

One complete combination hammer/anvil stone (\#128-5-11) was recovered from between 100 and $110 \mathrm{cmbd}$ in Unit N100/E54 and directly associated with Feature 40. This ovate limestone, which measures 123.9 by 102.5 by $48.9 \mathrm{~mm}$, specimen exhibits pitting on one end, both faces, and two sides (where pitting is concentrated near the center of the stone). The central pit on one face is roughly round in shape, about $20 \mathrm{~mm}$ wide and $1.6 \mathrm{~mm}$ deep. The central pit on the reverse face is oval in shape, nearly 22-by- $16 \mathrm{~mm}$ in diameter, and $2.8 \mathrm{~mm}$ deep. Tiny linear striations are present across this face together with other small pits and divots. The more pointed end reveals two and possibly three impact scars and pitting/crushing. 
Table 11-13. Data on Residues and Use-Wear, Early Archaic Modified Debitage

\begin{tabular}{|c|c|c|c|c|}
\hline Item & Lot No. & Residue & Use-Wear & Inferred Function \\
\hline Rejuvenation flake & $50-11$ & raphides & polish, multi-dir. striations & cutting hard, high-silica materials \\
\hline Edge-mod. flake & $128-14$ & plant tissue, starch & high-silica polish & working starchy plant \\
\hline & & grains & & \\
\hline Rejuvenation flake & $153-31$ & plant fibers & high-silica polish, striations & planing hard material \\
\hline Rejuvenation flake & $255-11$ & plant fibers & high-silica polish, striations & scraping hard material \\
\hline Edge-mod flake & 700910 & & hirh-silica nolich edoo & Wrbittling (wond?) \\
\hline Lage-1110u. Hane & $288-10$ & & rounding striations & Wimtuming (wood?) \\
\hline Rejuvenation flake & $345-23$ & & light polish & planing, material unident. \\
\hline Flake graver & $345-12$ & & light polish on distal end & planing, material unident. \\
\hline Edge-mod. flake & $366-13$ & bone/antler frags. & light polish & scraping bone/antler \\
\hline Flake graver & 41212 & hair raphides starch & nolich & coraning nlant bido \\
\hline FIdke giaver & $412-13$ & grains & ponIsII & \\
\hline Rejuvenation flake & $421-11$ & & soft polish & scraping soft material \\
\hline Edge-mod. flake & $431-11$ & plant fibers & hard-silica polish & planing hard material \\
\hline Edge-mod. flake & $466-11$ & charcoal frags. & polish, obique striations & whittling hard material \\
\hline Edge-mod. flake & $449-10$ & wood fragments & polish & planing wood \\
\hline & & & & \\
\hline Edge-mod. flake & $465-10$ & hair, raphides & polish & working plant material \\
\hline Edge-mod. flake & $477-10$ & plant tissue & polish & cutting plants \\
\hline Rejuvenation flake & $539-12$ & plant tissue & polish & planing of plants \\
\hline Edge-mod. Flake & $577-11$ & plant tissue, raphides & striations & working of plant material \\
\hline Edge-mod. Flake & $590-10$ & & light polish & slicing, unident. material \\
\hline & & & & \\
\hline Flake spokeshave & $590-10$ & & light polish & planing unident. Material \\
\hline Edge-mod. Flake & $592-11$ & & light polish & unidentified \\
\hline Edge-mod. Flake & $616-10$ & wood tissue, raphides & polish & planing wood \\
\hline & & & & \\
\hline Rejuventaion flake & $628-11$ & & polish, striations & unidentified \\
\hline Flake graver & $671-10$ & & light polish & unidentified \\
\hline Rejevenation flake & $677-11$ & raphides, starch & polish & slicing strachy plant \\
\hline Rejuvenation flake & 718-15 & hafting plant fibers & polish, striations & cutting soft material \\
\hline & & & & \\
\hline Edge-mod. flake & $724-12$ & plant tissue & striations & slicing plant material \\
\hline Edge-mod. flake & $725-14$ & & soft polish & scraping soft material \\
\hline & & & & \\
\hline
\end{tabular}


A complete groundstone object (\#739-11) was recovered from Unit N109/E56 between 30 and $40 \mathrm{cmbd}$. This is a fine-grained, ovate sandstone pebble $53.9 \mathrm{~mm}$ long, $37.7 \mathrm{~mm}$ wide, by $31.1 \mathrm{~mm}$ thick that exhibits a single ground facet along one slightly angular edge. The facet measures about $24.6 \mathrm{~mm}$ long and $9.7 \mathrm{~mm}$ wide.

A bone awl was recovered from Unit N99/E56 between 110 and 120 cmbs. It is a deer long bone shaft worked to a fine point at one end, and was broken into three conjoinable sections (\#762-11 and \#76-2-12) (see Figure 11-27). This awl, measuring $139.7 \mathrm{~mm}$ long by $18 \mathrm{~mm}$ in maximum width, exhibits a rough weathered and root-etched surface, longitudinal drying cracks, with calcium carbonate adhering to the surface in places.

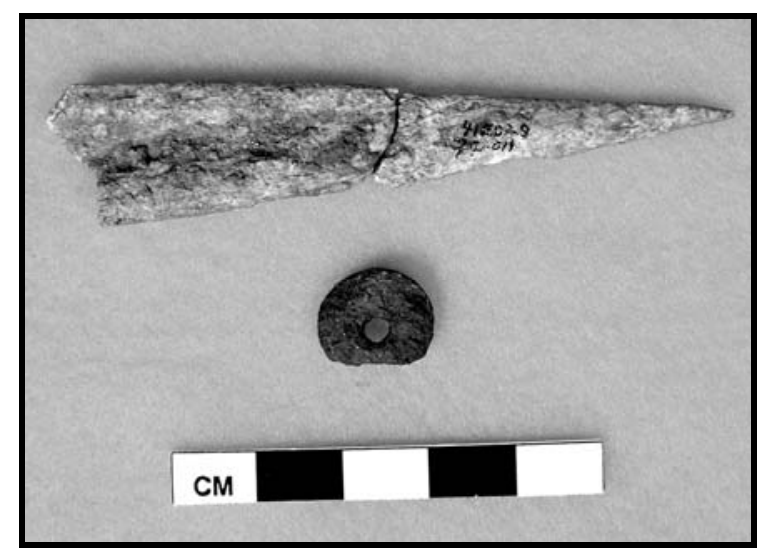

Figure 11-27. Selected Early Archaic Bone Awl (\#76-2-11) and Crinoid Section (\#637-16)

The constituent fragments vary in color from light reddish brown (5YR 6/4) to dark reddish gray (5YR 4/2). The proximal end exhibits very minimal modification. The distal, pointed end is polished from use.

The proximal end section was submitted for radiocarbon dating and yielded a $\delta^{13} \mathrm{C}$ corrected (-17.8\%) AMS radiocarbon date on collagen of 5,700 \pm 40 B.P. (Beta-175393). A second piece (76-2-11c) that appears to be from just past the proximal end yielded a $\delta^{13} \mathrm{C}$ corrected (-19.7\%o) AMS radiocarbon date on collagen of $5,270 \pm 40$ B.P. (UGA-12706). The stable carbon isotope values from the two radiocarbon laboratories indicate an average value of $18.75 \%$, which is in line with animals such as deer consuming roughly 70 percent $\mathrm{C}_{3}$ vegetation.

This bone tool probably functioned as to pierce soft materials such as hide and/or plant products. It is remarkable that it survived. Its survival was potentially facilitated by its use as a tool, which through use hardened the exterior.

One unique item, a possible bead, was recovered from the Early Archaic context in Unit N108/E50 at 30 to $40 \mathrm{cmbd}$ along the northern end of Block A. It is a thin section of a crinoid fossil shell with a natural hole. It measures $13.2 \mathrm{~mm}$ in diameter, $4.0 \mathrm{~mm}$ thick, and weighs $0.7 \mathrm{~g}$. The two faces are not flat as one might expect, but are slightly irregular (Figure 11-27). The outer edge was not ground or shaped, although it is partially broken. The central hole is $3.0 \mathrm{~mm}$ in diameter. One edge is broken. Crinoid fossils date to the Pennsylvanian in age and are not known to occur in Cretaceous limestone, which implies a non-local origin for this item.

\subsubsection{Cores}

Twenty-four cores were recovered from Block A and a single specimen from Block B. These 25 pieces are summarized here, with individual characteristics presented in Appendix O. Twenty-one specimens (84\%) are complete, two (8\%) are fragmentary, and two others (8\%) appear to have been exhausted. All are of finegrained cherts, and 15 specimens retain portions of smooth, water-worn cobble cortex, while two exhibit remnants of a rough, tabular cortex. Twenty percent are partially patinated. None appear to have been heat-treated, and none are burned. Forty-eight percent are bifacial, 
44 percent are multidirectional, and eight percent are unifacial.

The 21 complete cores range from 55.9 to $135 \mathrm{~mm}$ long, with an average of $85.1 \mathrm{~mm}$. Widths range from 38.1 to $131.4 \mathrm{~mm}$, and average $71 \mathrm{~mm}$. The thickness ranges from 15.1 to $60.4 \mathrm{~mm}$, with an average of $39.6 \mathrm{~mm}$.

\subsection{Lithic DEBITAge}

\subsubsection{Unmodified Debitage}

Nearly 52,000 pieces of lithic debitage were recovered from Block A. A sample of 6,314 of these has been was analyzed to determine the represented stages of raw material reduction and tool production, manufacturing, and maintenance.

Just over 28 percent of the analyzed debitage exhibits unintentional heat alteration through spalling and/or crazing. Relatively high frequencies of tertiary and retouch flakes (36 percent) and late stage biface thinning flake (25 percent) categories are represented. Low frequencies are represented in the core reduction flake category ( 7.5 percent), early stage biface flakes (10.3 percent), angular debris (12.2 percent), and indeterminate flakes (8.7 percent). Prismatic blades are represented by less than one percent of the sample. This analysis indicates that finishing of bifaces and other tools, and probably resharpening of tools, was commonly carried out at the site.

\subsubsection{Rejuvenation Flakes}

The Early Archaic assemblage included 82 pieces that were classified as tool-edge rejuvenation flakes (Figure 11-28). Nine rejuvenation flakes were selected for use-wear analyses (Appendix C). Minimally three specimens \#50-11, \#677-11, and \#718-15 reveal hard, high silica polish, with plant fibers (raphides) still adhering to the tool edge, and were interpreted as cutting actions on plants.
Three other pieces including \#153-31, \#345-23, and \#539-12 exhibit polish wear that reflects planing of hard, high silica material. Plant tissues were observed on \#539-12. Specimen \#255-11 exhibits plant fibers together with hard, high silica polish interpreted to have been used in scraping plants. Specimen \#628-11 exhibits light polish and striations with unknown use actions. Specimen \#94-10 exhibits hard, high silica polish interpreted to have been used in scraping materials with high silica content. A high percentage of these tool edges exhibit usewear from actions on plants.

The distribution of the 82 rejuvenation flakes extended across 37 units of the $83 \mathrm{~m}^{2}$ of Block A and exhibits apparent horizontal patterning. Nearly 85 percent were south of BT 2, but not directly within the two features (Features 39 and 40), although many were in the immediate area that surrounded these two burned rock clusters. The high frequency of rejuvenation flakes in the vicinity of these two features may indicate resharpening or discard areas around hearths.

\subsection{Vertebrate Faunal Analysis}

The $83 \mathrm{~m}^{2}$ excavations of Early Archaic component in Block A yielded a relatively high frequency of small bone fragments for a deposit of this age. The assemblage included 731 pieces weighing $280.5 \mathrm{~g}$. However, upon close inspection of the individual bones and carefully scrutinizing the Middle Archaic bone assemblage, it became clear that not all of these pieces actually pertain to Early Archaic period. Based on the bone colors and conditions, the 731-piece assemblage was sorted a second time. The light reddish brown (5YR 6/4) to dark reddish gray (5YR 4/2) bone fragments were assigned to the overlying Middle Archaic component, whereas the pinkish gray (5YR 7/2) colored pieces were assigned to the Toyah component. 


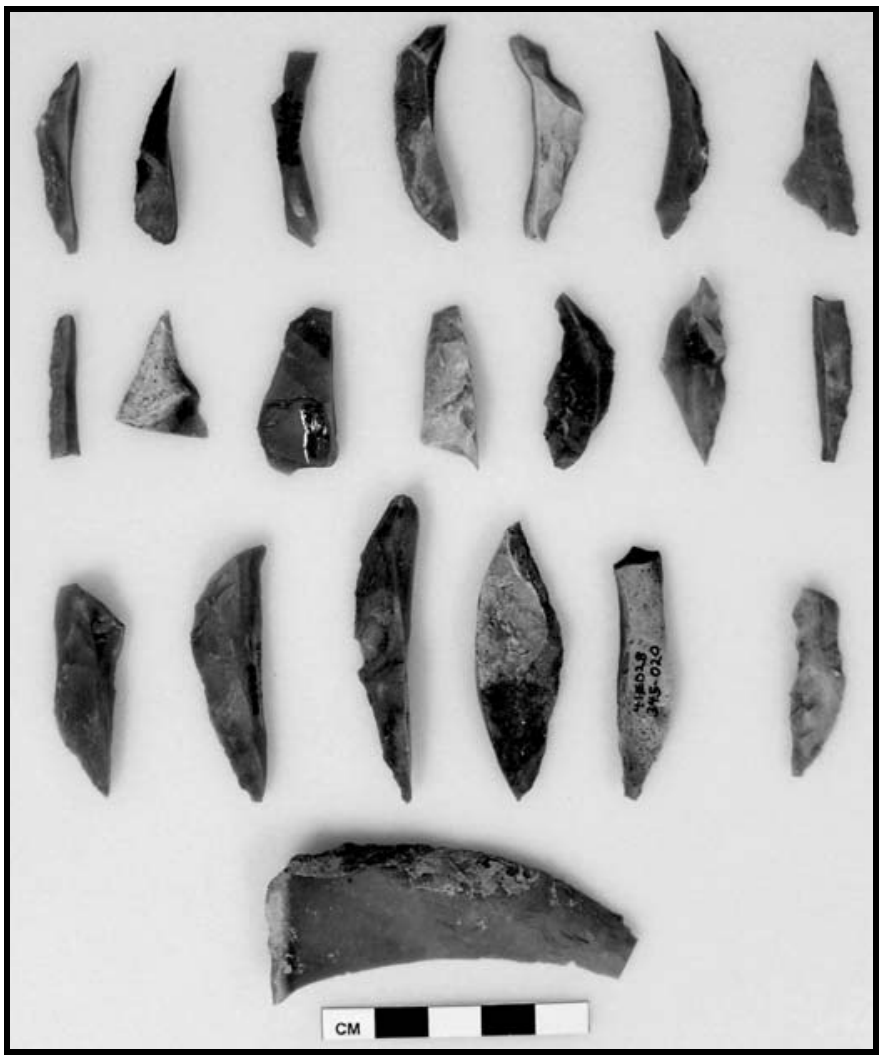

\section{Figure 11-28. Selected Early Archaic Rejuvenation Flakes}

Left to Right: Top Row: \#255-013, \#278-022, \#229-017, \#277-011, \#229-018, \#392-013, \#357-011;

Second Row: \#204-012, \#228-010, \#255-027, \#204-013, \#63-013, \#254-012, \#391-014;

Third Row: \#75-012, \#299-015, \#515-019, \#515-018, \#345-020, \#356-013;

Forth Row: \#76-010

It is assumed that the brownish colored pieces were displaced downward into the Early Archaic deposits, rather than representative of the older Early Archaic cultural events. Brownish bone fragments in the Middle Archaic assemblage were visually distinct from the pinkish gray (5YR 7/2) to a light gray (5YR 7/1 and reddish yellow (5YR 6/6), calcium carbonate-coated pieces apparently pertaining to the Early Archaic. The cultural deposits at the north end of Block A are quite shallow, with the identified components compressed into a roughly $60 \mathrm{~cm}$ thick vertical range. Therefore, brownish bones, resembling Middle Archaic specimens, have been assigned to the Middle Archaic component.
In a similar manner, the fresher appearances of the pinkish bones are ascribed to the Toyah component. Following reassignment of the recovered assemblage, only 229 pieces weighing $109.7 \mathrm{~g}$ were ultimately assigned to the Early Archaic component.

It is quite surprising that any bone was preserved and derived from this early component. Ninetyseven percent of the fragments assigned to this component are less than $3 \mathrm{~cm}$ in length, whereas the remaining pieces are between 3 and $6 \mathrm{~cm}$ long. Their average weight of $0.5 \mathrm{~g}$ reflects their very small size. Nearly 18 percent were burned. Of the burned pieces, 60 percent are brown and 
black in color, 20 percent are white or calcined, 12 percent are black, and nine percent are black and white. It is not clear if the burned pieces are truly part of the Early Archaic component, since these lack the diagnostic color and the calcium carbonate that is believed to characterize the Early Archaic faunal-bone assemblage.

Bones were divided into 10 major taxon size groups based on the size. The 10 groups are: Size Class 1, mole- and mouse-size mammals, Size Class 2, rabbit-size mammals, Size Class 3, raccoon-size animals, Size Class 4, dog/coyotesize animals, Size Class 5, deer and antelopesize animals, and Size Class 6, bison-size, Size Class 7, turtles, Size Class 8, snakes, Size Class 9, birds, and Size Class 10, fish. The assignment of a bone fragment into a specific size class was based primarily on cortical wall thickness, bone shape and structure, and other observed morphological attributes. If these factors were not sufficient to confidently assign a specimen into one of the 10 size classes, then the fragment was assigned to the "unknown" category.

All but four fragments were assigned to the unknown taxon category, which consisted of small long bone fragments lacking the requisite. Two fragments, or about one percent of the assemblage, were positively identifiable as deer elements. These include the very distal tip of an antler tine (\#719-2) and a distal end of a first phalanx (\#402-2). The distal end of the deer phalange displays a green bone fracture, indicating it was broken for marrow extraction.

Two small and thin long bone fragments were assigned to size class 2 group that are similar in size to rabbit long bones. No bone fragments are in the bison size class.

\subsubsection{Discussion}

The vertebrate faunal remains are extremely rare here and in other contexts of similar age (Collins et al. 1990; Decker et al. 2000). The limited sample of 229 bone fragments do, however, indicate that deer and rabbit were among the faunal taxa exploited by the Early Archaic occupants of the Varga Site.

The 1980 excavations at the Royal Coachman Site (41CM111) in Comal County yielded one identifiable whitetail deer element that was potentially associated with this, or perhaps a slightly younger, period (Mahoney et al. 2003). The Early Archaic zones at 41UV88 yielded a few mussel shells but produced no vertebrate faunal remains (Decker et al. 2000).

The stable carbon isotope results from the radiocarbon dating of the different sections of the same long bone awl range from -17.8 to $21.0 \%$, with an average of $-19.5 \%$ o (Table $11-1$ ). These values reflect ca. 85 to 100 percent intake of $\mathrm{C}_{3}$ food, which is generally thought of as the dietary intake of a deer. The dated element probably represents a deer and supports the identification of deer as part of the subsistence resources at the Varga Site.

\subsection{Mussel Shell Remains}

This Early Archaic component yielded only seven pieces of mussel shell weighing $21.3 \mathrm{~g}$. These small fragments include one umbo and one tooth section. The umbo and tooth sections are similar to Lampsillis sp. This species is natural to the region and exists in a variety of aquatic habitats (Howells et al. 1996). It is possible that these small fragments were naturally deposited within the site's alluvial matrix. If, however, they represent human gathering of mussels, their scarcity implies only a very minimal role in overall subsistence strategy.

\subsection{BURNED ROCKS}

A moderate number of scattered burned rocks and nine burned rock features were encountered. 
A total of 3,044 burned rocks were recovered and included the burned rocks from features. The average density of burned rock was about 37 pieces per $\mathrm{m}^{2}$.

The scattered burned rocks outside the identified features included 2,649 pieces that weighed $423,851 \mathrm{~g}$, for an average burned rock weight of about $160 \mathrm{~g}$. The scattered burned rocks were comprised mostly of the smallest size class with 63.3 percent by count, followed by the next smallest size class at 29 percent, then 6.5 percent in the next size class, and less than one percent in the largest size class.

The burned rock features yielded a total of 395 pieces that weighed 147,650 g and yielded an average rock weight of $374 \mathrm{~g}$. This is over twice the average size of the scattered burned rock and indicates that the larger pieces were in the features and the smallest pieces were scattered about the occupation.

\subsection{MaCRobotanical Remains}

Carbonized plant remains were quite sparse in this component. Sediment samples from with most burned rock features and possible hearth features were collected from their interiors and floated, though most features lacked significant chunks of charcoal, charcoal lenses, or even burned matrix, indicating that charcoal recovered in or around features may not be directly associated with this early component. Four light fractions totaling 0.4 liters of organic matter were obtained from floating 16 liters of sediment from four Features 12, 26, 31, and 40. These light fractions were submitted to Dr. Dering for inspection and identification of wood species. Very few carbonized pieces were present and only five were identified (Appendix I). Light fractions from other Early Archaic features here did not yield any potential for burned plant remains and were not submitted to Dr. Dering.
Although $223.5 \mathrm{~g}$ of carbonized plant remains were recovered, seemingly a sizeable quantity, two samples of over $50+\mathrm{g}$ each, account for nearly 50 percent of the total. These were collected the gravels at the base of the component rather than from discrete features and thus it is unclear if that charcoal was deposited at the same time as the gravel or during subsequent events.

In many instances, individual pieces of charcoal exhibit a thin calcium carbonate film coating on the exterior surface that implies that piece had been in place for considerable time. These few calcium- coated pieces were given preference for radiocarbon dating. Most often, the piece that was sent for radiocarbon dating was split into two parts and one piece sent to Dr. Dering for species identification (Table 11-14). Dr. Dering's identifications indicate that minimally four species of wood- oak, mesquite, juniper, and littleleaf walnut, all presumably close at hand-- were selected for burning.

\subsection{EARLY ARCHAIC SUMMARY}

The Early Archaic component contained large quantities of cultural material with no detectable separation representative of separate occupational episodes. Including burned rock fragments, a high density of 676 pieces of cultural materials were found per one-metersquare of excavated area, and it is likely that more than a single occupational event is represented (Table 11-15).

The presence of bone fragments and macrobotanical materials permitted radiocarbon dating of the component. It was considered extremely important to determine which, if any, of the different organic material classes such as charcoal, bone, nutshells, or snail shells had filtered down from overlying younger components. 
Table 11-14. Early Archaic Macrobotanical Remains

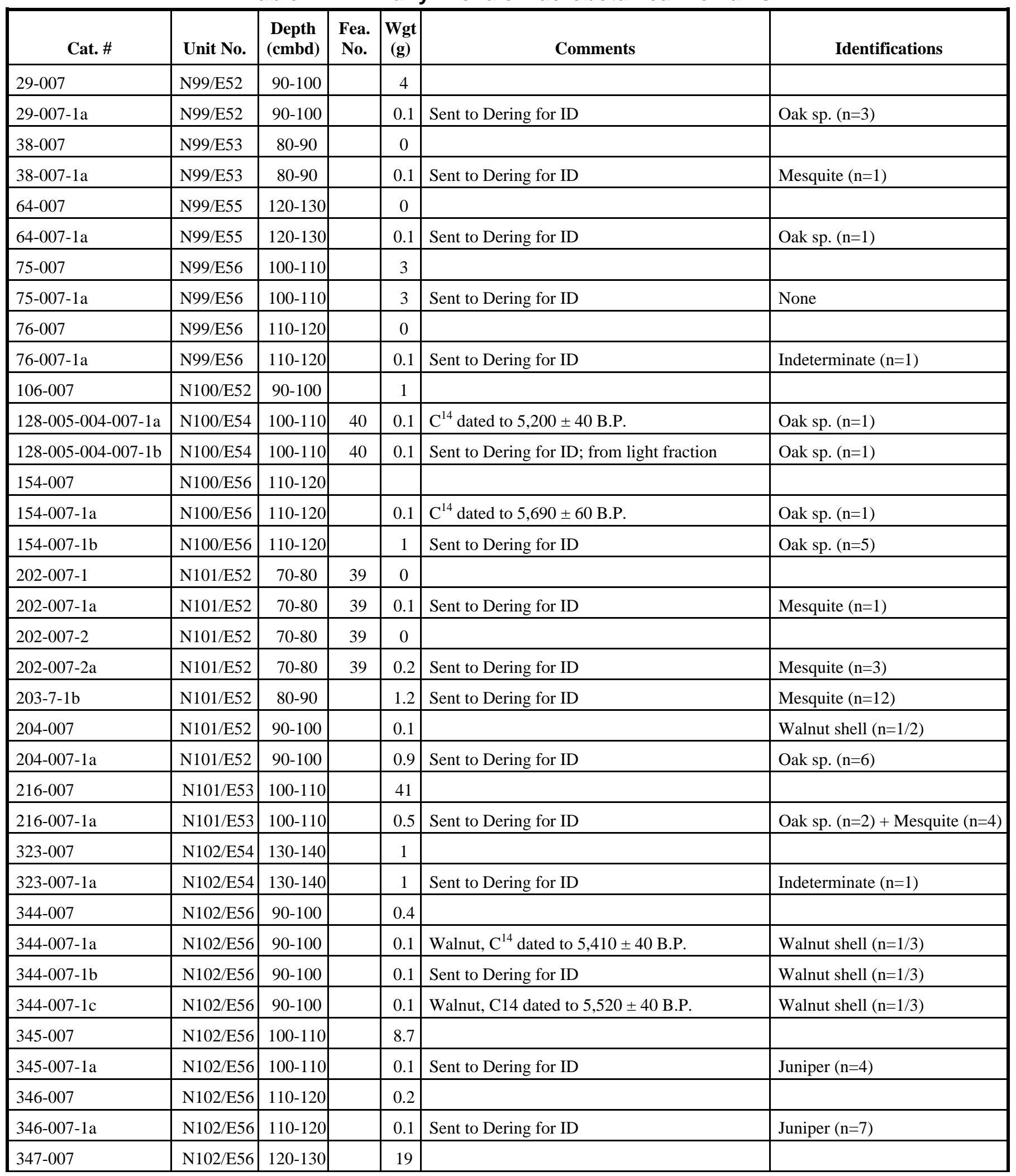


The Varga Site

Texas Department of Transportation

Table 11-14. Early Archaic Macrobotanical Remains

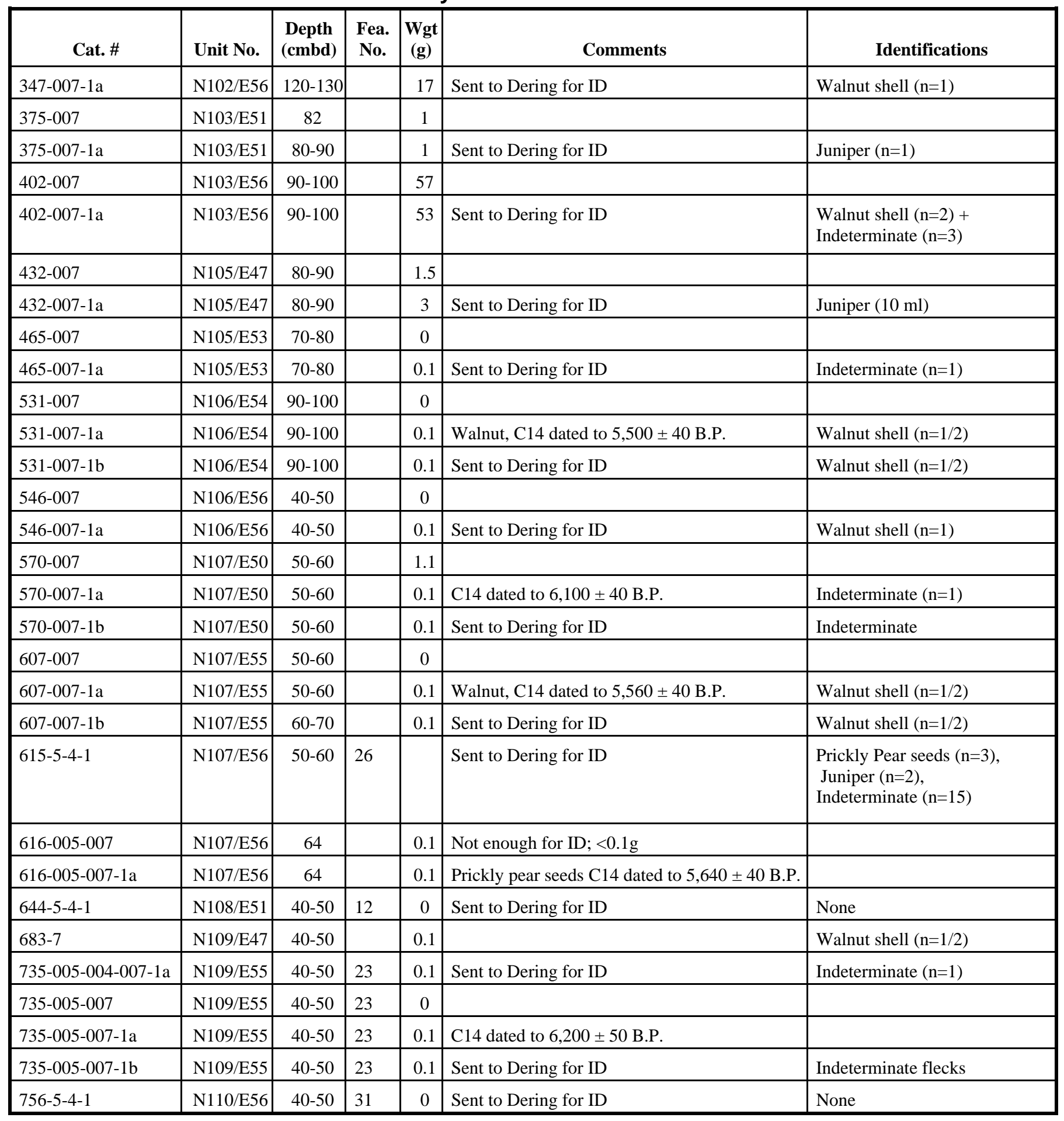


Table 11-15. Summary of Early Archaic Assemblage from the Varga Site (41ED28) Investigations

\begin{tabular}{|c|c|}
\hline Cultural Material Classes & $\begin{array}{c}\text { Early Archaic Component (5,200 to 6,280 } \\
\text { B.P.) Counts }\end{array}$ \\
\hline Bone Fragments* & 109.7 g, 229 pieces \\
\hline Deer & 2 pieces \\
\hline Mussel Shell* & 21.3 g, 7 pieces \\
\hline Burned Rock & $571,501 \mathrm{~g}, 3,044$ \\
\hline Features & 9 \\
\hline Hearths & 2 \\
\hline Burned Rock Dumps & 2 \\
\hline Burned Rock Clusters & 5 \\
\hline Dart Points & 170 \\
\hline Gower & 32 \\
\hline Martindale & 22 \\
\hline Bandy & 21 \\
\hline Group 1 & 15 \\
\hline Baker & 12 \\
\hline Merrill & 12 \\
\hline Group 2 (corner-notched) & 7 \\
\hline Carrizo & 3 \\
\hline Pandale & 1 \\
\hline Bifaces & 198 \\
\hline Scrapers & 27 \\
\hline Drills & 17 \\
\hline Edge-Modified Flakes & 1,038 \\
\hline Lithic Debitage & 51,869 \\
\hline Cores & 25 \\
\hline Choppers & 2 \\
\hline Ground Stone & 1 \\
\hline Unifaces & 4 \\
\hline Gouges & 3 \\
\hline Hammerstones/Anvil & 1 \\
\hline Bone Tool - awl & 1 \\
\hline Carbonized Plant Remains & $223.5 \mathrm{~g}$ \\
\hline \multicolumn{2}{|l|}{ Juniper wood } \\
\hline \multicolumn{2}{|l|}{ Littleleaf walnut shells } \\
\hline \multicolumn{2}{|l|}{ Mesquite wood } \\
\hline \multicolumn{2}{|l|}{ Oak wood } \\
\hline Prickly pear seeds & 4 \\
\hline Total Materials & 56,644 \\
\hline Average Thickness (cm) & 30 \\
\hline Spatial Extent Excavated & 83 \\
\hline Volume Excavated $\left(\mathrm{m}^{3}\right)$ & 25.9 \\
\hline
\end{tabular}


This was achieved through direct dating of the different materials, which in fact demonstrated that displacement of younger bones had occurred. Although this made it clear that many of the faunal bone fragments had been downwardly displaced, most of the dated organic remains were much older than the overlying components and are therefore interpreted to best reflect the age of the deposits from which they were recovered.

\subsubsection{Chronology Issues}

This Early Archaic component was directly dated with 15 radiocarbon assays from diverse materials to about a 1,100-radiocarbon year period between 6,280 and 5,200 B.P. The dated material includes five charcoal samples, five walnut shell samples, three deer bone samples, one charred prickly pear seed sample, and one Rabdotus snail shell. Two other mean residence dates were obtained from organic sediment, with which the cultural materials were in direct association. The results fall within this same time period and support the direct ages obtained from the cultural materials.

This is a relatively narrow time span that has previously been poorly documented in the archeological record in Central Texas and the Lower Pecos regions. Minimally seven named projectile point types (Baker, Bandy, Carrizo, Gower, Martindale, Merrell, and Pandale) and two unnamed groups (Group 1, and Group 2) were recovered from this component (Table 1115). At one level, their occurrence here documents that these multiple point types were potentially all in use during the relevant 1,100 year time span. However, it does not provide a complete time range for these different point types, nor does it directly date any single type. Potentially, the absolute dates obtained reflect the age of some of the point

types, but it is possible that older organic materials that might be associated with older point types may not have been preserved. Presently, however, we interpret these 15 assays to represent some part of the age range of each of the nine-point types. Only further radiocarbon dating from intact context with single point types will help determine the full age range of each of the point types.

Ninety-six percent of the 124 identifiable projectile points associated with this Early Archaic component are considered part of what Johnson and Goode (1994) refer to as the "Early Barbed" and "Early Spilt-stem" traditions for the Central Texas region. We have opted to be splitters, assigning the 124 points to named types where possible. The "Early Barbed" tradition contains 42 percent of the points and includes the 22 Martindale, 21 Bandy, and seven Group 2 points. The "Early Spilt-stem tradition” contains 58 percent and includes the 32 Gower, 15 Group 1, 12 Baker, and 12 Merrell points. According to Collins (1995), these two major traditions are temporally separable, with the Early Split-stem group dating from 8,000 to 7,000 B.P., followed by the Martindale and Uvalde group between 7,000 and 6,000 B.P. Collins terminates the Early Archaic at about 6,000 B.P. The Varga Site projectile points and radiocarbon dates do not fit well into Collins's (1995) chronological sequence. Based on his framework, the point types recovered at the Varga Site should represent minimally a 2,000year period at a somewhat earlier time interval than the ca. 6,300 to 5,200 B.P. range indicated by the radiocarbon ages. Part of the problem stems from the lack of a well-dated context for the Early Split-stem group in Central Texas (i.e., Landslide and Youngsport sites). It may be that the organic material associated with the earliest Early Split-stem point types in this Varga Site component was not preserved, thereby distorting the absolute radiocarbon time range documented for these nine different projectile point types. 
In the Lower Pecos region, the Early Barbed, Early Stemmed, Early Corner-Notched, and a few Early Triangular forms are all present at about this same period (Turpin 1991). Currently, the small sample size of identifiable projectile points from any one particular dated provenience does not allow for a clear understanding of associations between the different point types and the obtained dates. With so few identifiable points from any one provenience, it is not clear if one point type is more prominent than another, if one specimen represents a curated piece, or if one point was otherwise intrusive to the dated context. The Early Archaic component at the Varga Site dates within the currently established Viejo period, specifically the last 1,000 years of that 3,400 year long period. At Skyline Shelter, Unit 3, Level 28 yielded two Bandy, one Baker, and one Gower point in association with a charcoal date of 5,920 \pm 120 B.P. (Tx-6947). The Skyline Shelter data supports the associations of these three point types with the radiocarbon dates from the Varga Site. The Varga dates push Turpin's (1991, 1995) ending date for the Viejo period closer ca. 5,000 B.P.

The Varga Site has yielded the first substantial assemblage of Merrell points, and the first time that this rare point type has been associated with radiocarbon dates. Johnson and Goode (1994) were not sure where to place this point type in their general chronological sequence. Collins (1995) does not even mention this type by name, but lists a generic "Early Split-stem" group for a period dated between roughly 8,000 and 7,000 B.P. It is not clear if Collins (1995) includes this poorly known and infrequently mentioned type in that group or not. The 12 Merrell specimens identified by Prewitt from the Varga Site provide general metric and nonmetric variability in their attributes and establish the type's general characteristics. For now, the obtained dates from this component provide a general age range of about 1,100 years, from 6,300 B.P to 5,200 B.P. for the type.

The Lower Pecos region has previously yielded a few projectile points that resemble the Merrell or Gower types. A point from the lowest level (Level 17) of the Bench area at Devil's Mouth (Sorrow 1968), listed as Miscellaneous 6 (Figure 18:r), resembles a Merrell point, which is in the same level as a Plainview point. Although that level was not radiocarbon dated, this point was stratigraphically below a Martindale point. Another possible Merrell point was recovered from the lowest levels in Zones Ie and III mixed, in Devils Rockshelter (Prewitt 1966: Figure 4:A). At least one illustrated point from Baker Cave resembles a Gower or Merrell point that is apparently earlier than Baker I type (Word and Douglas 1970: Fig. 10:E).

In the Lower Pecos region, Pandale points are distinctive of the Eagle Nest period of the Middle Archaic that dates from 4,100 to 5,500 B.P. Pandale points have been recovered from mixed strata attributed to ages that range from 5,500 to 6,100 B.P. at Eagle and Hinds caves (Turpin 1991:28). Consequently, the occurrence of a single Pandale point at the Varga Site together with many different Early Archaic point types is not unheard of and fits relatively well with what is known about their ages from the Lower Pecos region. This single Pandale specimen and associated ages from the Varga Site are slightly older than the 22 accepted core dates for the Eagle Nest period (Turpin 1991:29). The lack of a substantial number of Pandale points at the Varga Site indicates that the population(s) that produced the type did not generally occupy this particular locality.

The Carrizo point type is generally thought of as a Middle Archaic type primarily from South Texas (Turner and Hester 1993; Hester 1995). 
However, it has rarely been dated from secure contexts. The best-dated context is at Loma Sandia in South Texas where three Carrizo points were recovered from a mortuary context dated to between 2,800 and 2,500 B.P. (ca. 850 to 550 B.C.; Highley et al. 1995). Based on their principle association with multiple Early Archaic point types at the Varga Site, these few Carrizo points were not in their original contexts. It is possible that the three Carrizo points from Loma Sandia were curated items rather than actually manufactured during that radiocarbon-dated period. If these two sets of dates are anywhere close to representing the time frame for this point type, then the Carrizo points were potentially in use during a very lengthy 2,700-year time span. Better context and more dates will eventually determine the overall time range for this point type. Turner and Hester (1993) indicate this was primarily a South Texas point type and Prewitt's (1995) distribution map supports this notion, with some scattered specimens in Central Texas counties. Their occurrence in Edwards County may reflect the western extent of the type's distribution.

This well-dated component at the Varga Site slightly extends the ending date for the Early Archaic in the Lower Pecos region as revised by Turpin (1991) from her 5,500 B.P. to the 5,300 B.P. here. This may hint at population movements away from the Lower Pecos region towards Central Texas near the end of that period. Comparisons with Central Texas chronology, the Varga Site dates push the end of the Early Archaic a few thousand years younger than is currently projected (Johnson and Goode 1994; Collins 1995) and raises some questions concerning the current time ranges for the Early Split-stem group. The later dates from the Varga Site may indicate movements from the Central Texas region towards the Lower Pecos region.

\subsubsection{Subsistence Issues}

As discussed above, faunal bone specimens from the Early Archaic component have been identified as deer and rabbit. Considering its far larger size and greater meat weight, it can be concluded that deer was the primary source of dietary meet for the Varga Site occupants during this period. None of the bone fragments from this period were within the size class representing bison, and it is therefore apparent that this species was not present or exploited. The isotope data from the burned rocks indicate no $\mathrm{C}_{4}$ products present that presumably would indicate bison residues and consequently the presence of bison.

In further support of mammalian species as parts of the subsistence base, microscopic residues including hair and bone/antler were observed during the use-wear analysis on least eight percent of the 63 Early Archaic analyzed tools. This indicates tools that had direct contact with animal products. Possible blood residue was observed on a single Group 1-Early CornerNotched projectile point. Nearly the entire chipped stone tool assemblage is characteristic of and supportive of animal hunting and processing.

Only seven freshwater mussel shell fragments weighing $21.3 \mathrm{~g}$ were recovered, including an umbo fragment similar to Lampsillis sp., a species indigenous to the region. The paucity of mussel remains indicates that if the site's occupants were gathering mussels for food, it was not in sufficient quantities to serve as a significant part of the subsistence regimen. Possibly the shells were used in another capacity, perhaps for tools and/or ornaments.

Only minimal evidence is available for the use of plant resources as food. Burned walnut shells $(n=8)$ and burned prickly pear seeds $(n=3)$ are identified for, and radiocarbon dated to, this component. It is not clear whether these items 
were used as or accidentally burned in during food preparation. The littleleaf walnuts contain little meat, though the oil could have been a significant product. Indirect but compelling evidence for the use of non-meat products comes from the use-wear analysis that indicates plant processing on minimally 46 percent of the analyzed tools through the identification of various plant tissues, such as raphides, starch grains, and plant fibers. Although specific plants are not identified, the presences of plant residues indicate the use and processing, though not necessarily for consumption as food.

The lipid residue analysis provides the best indirect evidence for nonmeat products as part of the broader subsistence package. All 22 burned rock samples analyzed yielded lipid residues interpreted to represent plants. The detected residues were about 95 percent high in fat content with no low or medium fat content residues apparent. Seeds and nuts comprised a good portion of the plant taxa that could account for the high fat content. The $\delta^{13} \mathrm{C}$ values from these same burned rock samples range from 22.2 to $-30.7 \%$, with an average of $-24.3 \%$. These $\delta^{13} \mathrm{C}$ values document that all the plants were of the $\mathrm{C}_{3}$ pathway. No indication is present in the obtained residues for any $\mathrm{C}_{4}$ or CAM plants with $\mathrm{C}_{4}$ signatures, such as lechuguilla bulbs or seeds, prickly pear cactus pads or fruit, or warm season grasses. Consequently, such $\mathrm{C}_{4}$ products were not cooked by the hot rock cooking technology.

\subsubsection{Technology Issues}

The artifacts recovered are presumed to reflect the strategies used to exploit resources and perform general maintenance activities. Technology issues are concerned with a wide range of artifacts and daily tasks they represent, including resource procurement and resource processing.

\subsubsection{Resource Procurement Issues}

Procurement of food resources, both plant and animal is generally interpreted from the recovered artifacts. The 124 identified projectile points plus 54 other point fragments document the presence of killing instruments used in the procurement of larger animals. Nine Early Archaic projectile points were subjected to highpower use-wear analysis, which indicates that these tools most often functioned as projectile points, but the presence of organic residues indicates that they served in other tasks, as well. A Gower point (\#391-11) reveals plant fiber and hard, high silica polish that indicates it was used for cutting plants (Appendix C). A Martindale point (\#591-19) also reveals plant fiber residues that suggest direct contact with plants. A Group 2-Early Corner-Notched point (\#912-10) reveals possible blood residue implying use as a killing instrument. A Bandy point (\#334-22) reveals bone/antler residue that indicates it was in contact with an animal, likely a deer.

Lacking the remarkable preservation found in the dry rockshelters in the Lower Pecos region, the other equipment potentially used in the procurement of game resources, such as fiber nets, stick and twine traps, clubs, throwing sticks, etc., are not represented. Given their presence in that nearby area, however, it is fair to assume that similar technologies were in use at the Varga Site, and open campsite without conditions for such exceptional preservation of organic materials.

No stone tool class is directly associated with plant procurement. This is not unusual, since most plants were easily collected without the use of specialized tools. If specialized tools were employed to procure certain plants, these probably were perishable items such as digging sticks or baskets. 
Bone, antler, or stone tools that might have been used in the procurement of lithic resources are not readily identifiable in the recovered assemblage. This may be a reflection of poor preservation, but it might be that the raw tool stone and cooking stone were procured/collected without specialized tools such as large hammerstones, or antler prying bars and wedges. Chert and other lithic materials used by the occupants were readily available in the adjacent creek bottom and/or in gravel terraces so that material was easily collected by hand.

\subsubsection{Resource Processing and Consumption}

The relatively low frequency of core reduction flakes, early stage biface flakes, and angular debris implies the restricted nature of early-stage lithic reduction at this site. The relatively high frequencies of the tertiary thinning flakes and late stage biface manufacturing flakes, on the other hand, reflects a focus on finishing and resharpening chipped stone tools. The relatively high frequency of rejuvenation flakes testifies to the resharpening of worn or dulled tools.

The stone tool assemblage is relatively restricted to points $(n=170)$, bifaces $(n=198)$, scrapers $(n=27)$ that includes three items identified as gouges, drills $(n=17)$, unifaces $(n=4)$, choppers $(n=2)$, ground/pecked stones $(n=2)$, and edgemodified flakes $(n=1,038)$. The latter class includes a wide variety of shapes and types that include, but are not limited to, gravers, punches, spokeshaves, cutting and scraping tools, and other recognized functional forms. By their presence, these differently shaped edge-modified flakes indicate that many and diverse processing tasks were carried out through the use of expedient tools made from flakes of minimally worked stone.

Various activities are indicates by the use-wear analysis conducted on 63 chipped stone tools, which includes both formal tools and a fair number of expedient tools in the form of the edge-modified flakes. The tasks identified include boring/drilling, cutting, scraping, slicing, planing, puncturing, and whittling. Based on the fact that 46 percent of the tools analyzed for usewear reveal plant residues, close to half the analyzed assemblage was employed for both plant and animal processing. A gouge (\#72413), a tool form often thought to have served in woodworking, revealed animal hair and soft polish connecting it to planing animal hides (Appendix C). A drill (\#670-11) exhibits haft wear and a wood fragment indicating that it was used to bore/drill wood (Appendix C). A graver (\#412-13) revealed evidence that it was probably used on both plant and animal parts.

The use-wear on five of 10 analyzed bifaces indicates use on or contact with plants. Two bifaces (\#49-12 and \#205-10) were used to cut plants, as indicated by raphides and/or other plant tissues. Specimen \#49-12 was used to cut hard, high silica plants (Appendix C). All five bifaces with plant residues are late-stage bifaces.

Of the 1,493 formal (points, bifaces, scrapers, etc.) and informal tools (edge-modified flakes), the informal tools are two and half times as abundant as the formal ones. Among the formal tools, nearly 10 percent exhibit rejuvenation scars (2.8 percent) or have been rejuvenated through edge beveling (7.0 percent). Eightytwo pieces, or 5.5 percent of all tools, were identified as rejuvenation flakes. The relatively low incidence of rejuvenation may reflect an abundance of raw tool stone that was easily obtained. When formal tool was worn out, it was more cost-effective to replace it with a new one than to extend its use life through rejuvenation of the working edge.

Fifty percent of the bifaces analyzed for usewear reveal evidence of hafting. Four exhibit haft residues in the form of plant tissues and wood fibers, whereas a single biface exhibits 
haft wear in the form of proximal-end polish (Appendix C). Five percent, or two other tools analyzed for use-wear, an edge-modified flake (\#446-11) and a drill (\#670-11), reveal haft wear in the form of abraded flake scar ridges.

Three tools from the Early Archaic component are classified as gouges. This is a very low number since many authors see the "Clear Fork" tool/gouge or adze as a regular or even a diagnostic indicator of Early Archaic tool assemblages across Southern and Central Texas (Dial 1998; Turner and Hester 1999). Most often gouges are thought to have been used in woodworking and plant processing (Hudler 1997). Specimen \#724-13, reveals an animal hair and soft polish linking it to planing animal hides (Appendix C). A second gouge, \#346-11 reveals plant or bone residues with hard, high silica polish that is interpreted as reflecting planing/scraping on bone or wood (Appendix C).

The different types of formal tools present indicate that animal processing was a significant activity. However, the use-wear findings show that a high percentage of the tools also served in the processing of plant products. In the final analyses, the recovered assemblage reflects very diverse tasks including boring/drilling, cutting, scraping, slicing, planing, puncturing, and whittling directed toward processing both plants and animals.

The 3,044 burned rocks, weighing 571,501 g, indicate that cooking technology commonly involved the use of hot rocks. Although nine burned rock features were identified, the features are not sufficiently distinct or well preserved for a precise identification of the specific type of cooking technology that was employed. Features 40 and 41 apparently functioned as hearths, neither of which was associated with an earth oven. The average weights of individual burned rock in these features were $423 \mathrm{~g}$ and
$348 \mathrm{~g}$, respectively. The other seven features were piles and/or clusters of burned rocks that most likely represent discarded rocks no longer required in the cooking process. The discarded burned rocks in these clusters yielded a total of 395 pieces that weighed 147,650 g revealing an average rock weight of $374 \mathrm{~g}$.

The scattered burned rocks recovered from outside identified features included 2,649 pieces that weighed $423,851 \mathrm{~g}$, for an average burned rock weight of about $160 \mathrm{~g}$. This is less than half the size of the average burned rock in the clusters and nearly a third the size of those in Features 40 and 41. This difference in size probably indicates a recycling of the burned rocks, until they were too fragmented for adequate heat retention. The current available information does not clarify whether or not these tocks were used to heat/boil water for cooking.

Drs. Malainey and Malisza interpreted the lipid residues extracted from 22 burned rocks to reflect predominantly the cooking of plants (Appendix G). Although meats were clearly important subsistence items, the burned rocks were used mainly if not exclusively to cook plant foods. Meat was apparently prepared without the use of hot rock cooking, presumably by drying, smoking, and/or roasting. The relatively small, overall size of the recognized burned rock features indicates they were used to process relatively small quantities of plant food at any one time.

\subsubsection{Intra-component Patterning}

Assuming that the 1,100-years of radiocarbondocumented time and multiple point types indicate multiple cultural events, the remains of which are all compressed into a rather thin (30 $\mathrm{cm}$ ) vertical zone, it is probably that the component is essentially a palimpsest in which the physical imprints of discrete occupations/activities have been intermixed beyond recognition. Some horizontal patterning 
may be detected, as is the case with the six burned rock features clustered in the northeastern part of Block A, but the overall horizontal patterning is difficult to identify. Nonetheless and attempt has been made to define horizontal patterning, as was done for the more recent components, discussed in previous chapters.

Contour maps of density-corrected artifactual data for Block A were generated for selected variables within this component (Figures 11-29 through 11-37), using Surfer (vers. 5.01) mapping software. These maps were used to provide a visual reference to aid in the interpretation of the spatial distribution of the selected artifact categories and to provide additional depth to interpreting the results of the principal components analyses. The locations of individual recognized features are also plotted on the contour maps, potentially as part of the spatial relationship of the activities. Block A revealed eight cultural features, Features 12, 13, $23,26,27,31,39$, and 40 , which may have some internal functional relationship with the different artifact classes.

The data matrix consists of 14 variables (artifact categories) and 86 rows (excavation units), though only 10 of the variables figure strongly in the resulting factor loadings. The principal components analysis extracted a six-factor solution representing a cumulative total of 60.61 percent of the variability present in the data array. The matrix of correlation coefficients is presented in Table 11-16, and the factor solution is presented in Table 11-17.

Factor 1 is composed of three diagnostic variables - lithic debitage, edge-modified flakes, and projectile points-collectively composing 15.63 percent of the total variance in the matrix of correlation coefficients (Table 11-17). All three variables exhibit moderately strong to strong positive factor loadings ranging from .647 to .815; none of the diagnostic variables in Factor 1 are negative. The association of projectile points, debitage, and edge-modified flakes may be best explained by the assumption that all three artifact categories reflect the task of lithic reduction; specifically, producing lithic flakes during projectile point manufacture, and subsequently modifying some of the flakes for use in various cutting and scraping tasks. Whether lithic reduction strategies in this context are oriented toward producing flakes specifically for modification and use, or the flakes simply represent a byproduct of producing other tool forms, such as projectile points, is unclear, though it appears likely that projectile points were being produced in some quantity at the Varga Site based on the sizable assemblage of points recovered.

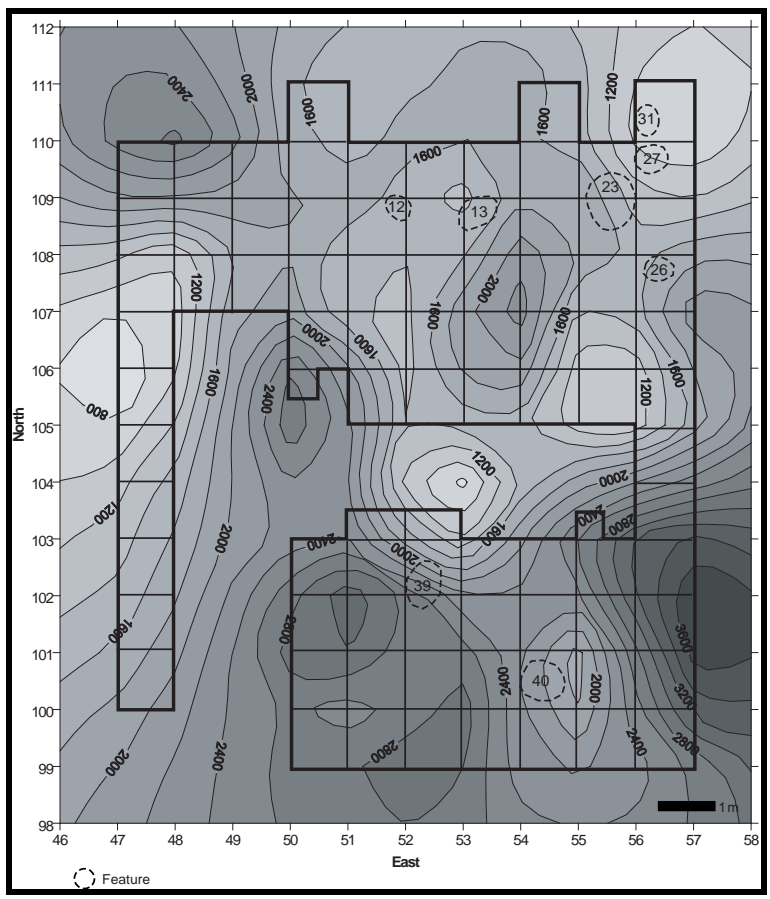

Figure 11-29. Contour Map of Lithic Debitage Density in Early Archaic 


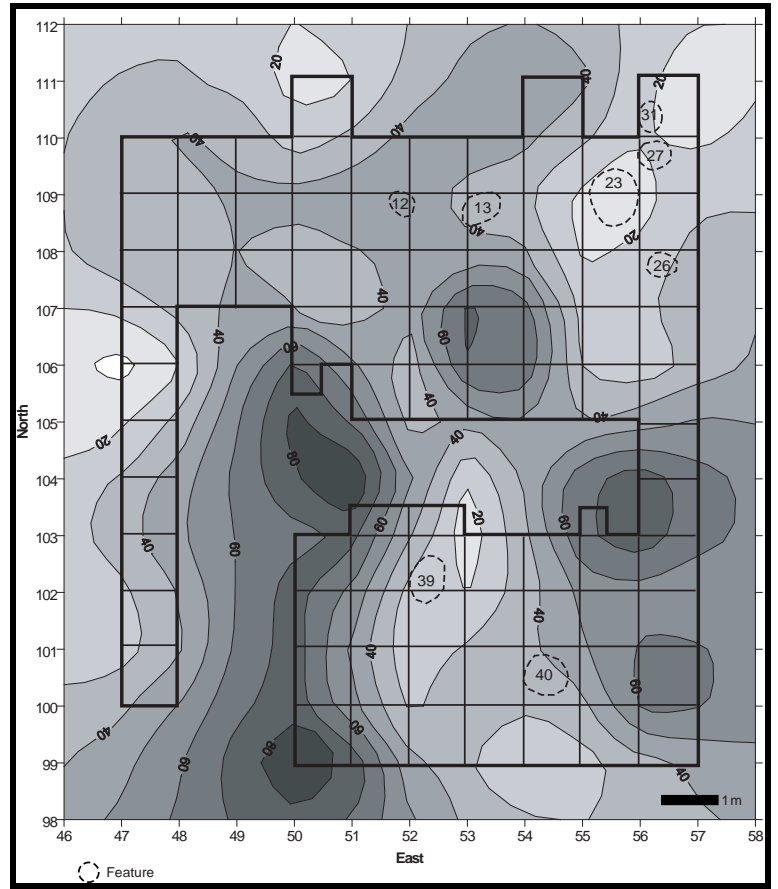

Figure 11-30. Contour Map of EdgeModified Density in Early Archaic

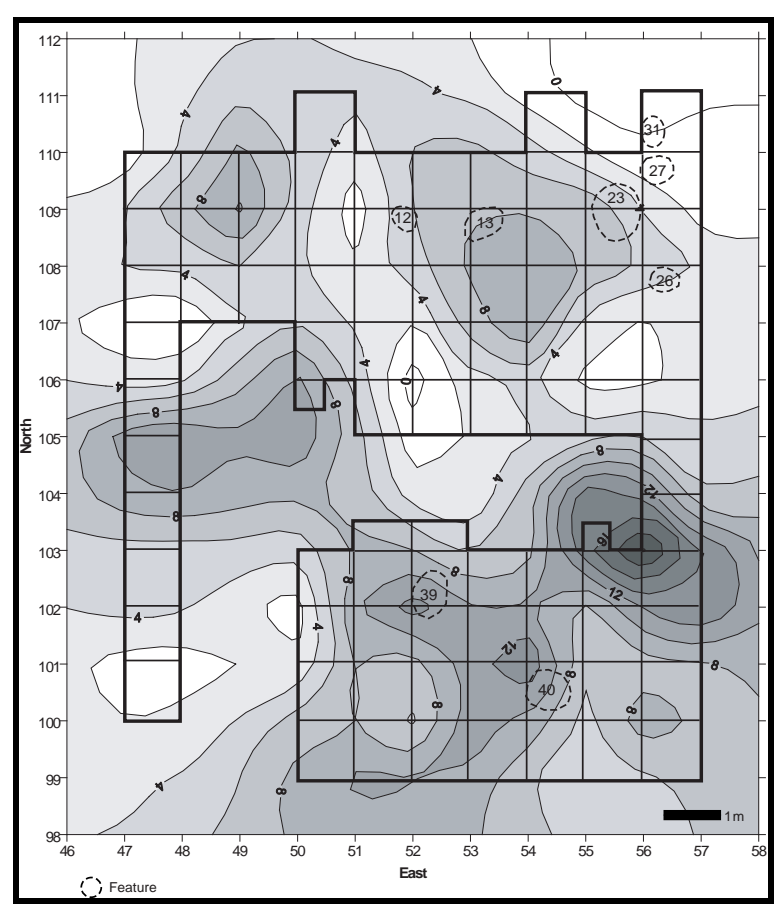

Figure 11-31. Contour Map of Point Density in Early Archaic

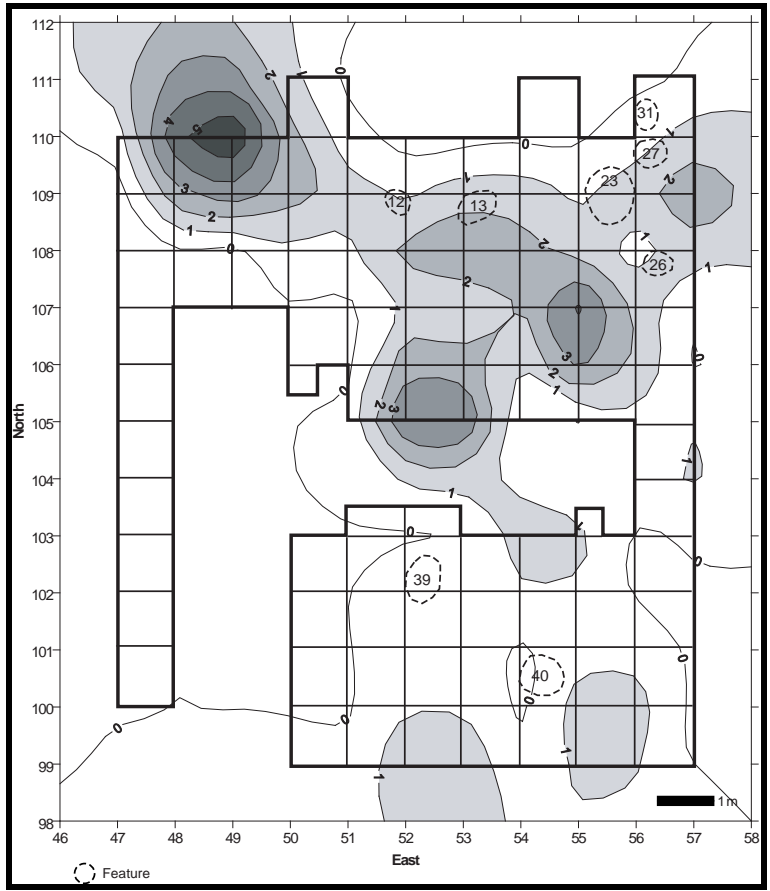

Figure 11-32. Contour Map of Core Density in Early Archaic

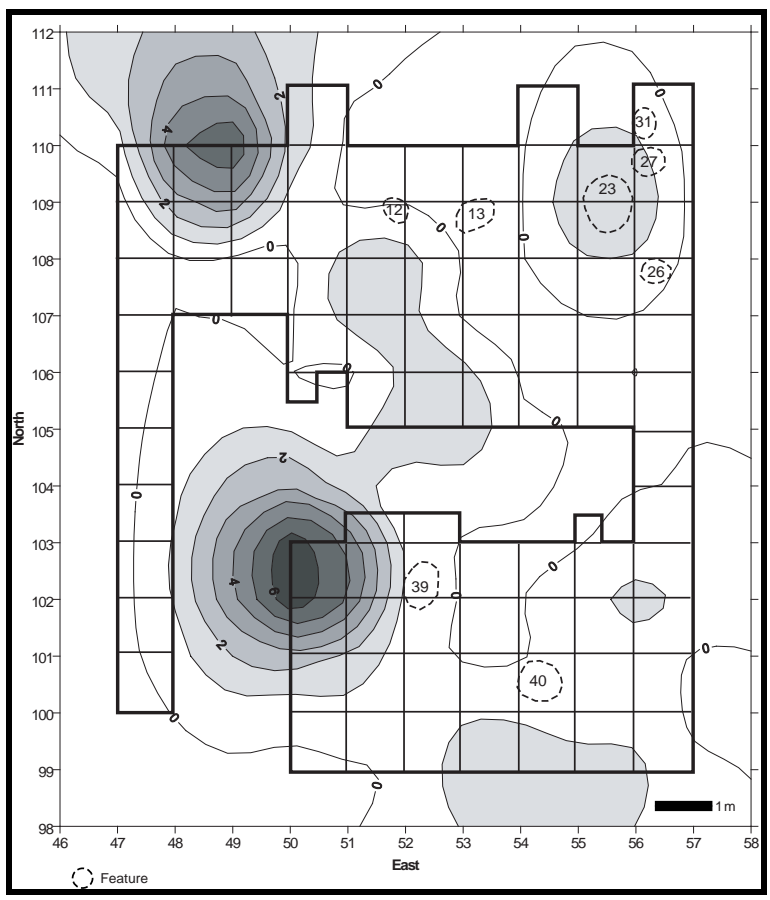

Figure 11-33. Contour Map of Drill Density in Early Archaic 


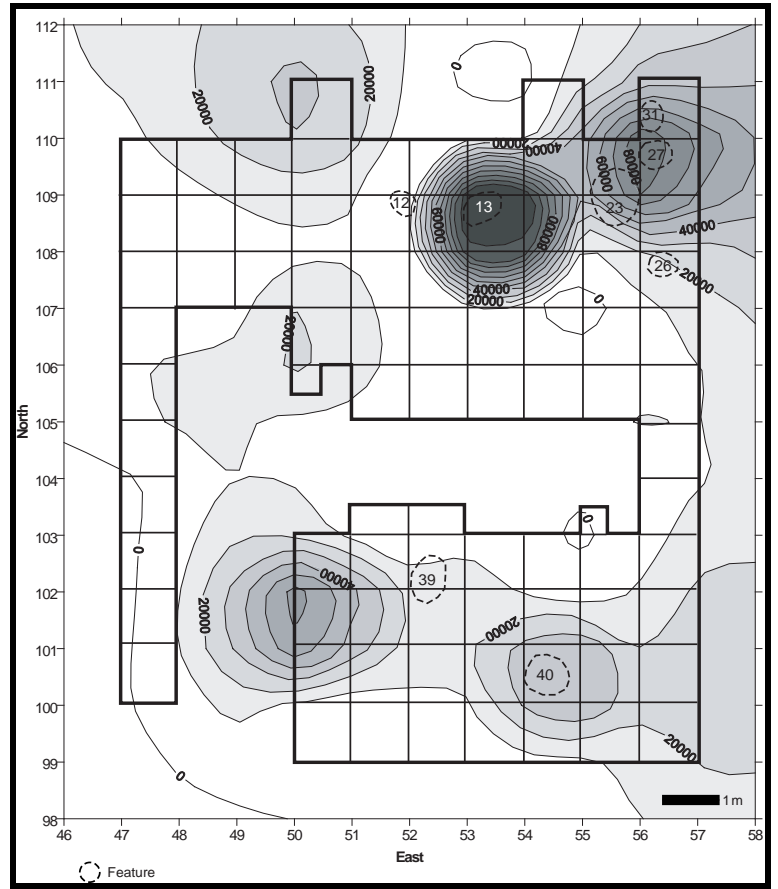

Figure 11-34. Contour Map of Burned Rock Density in Early Archaic

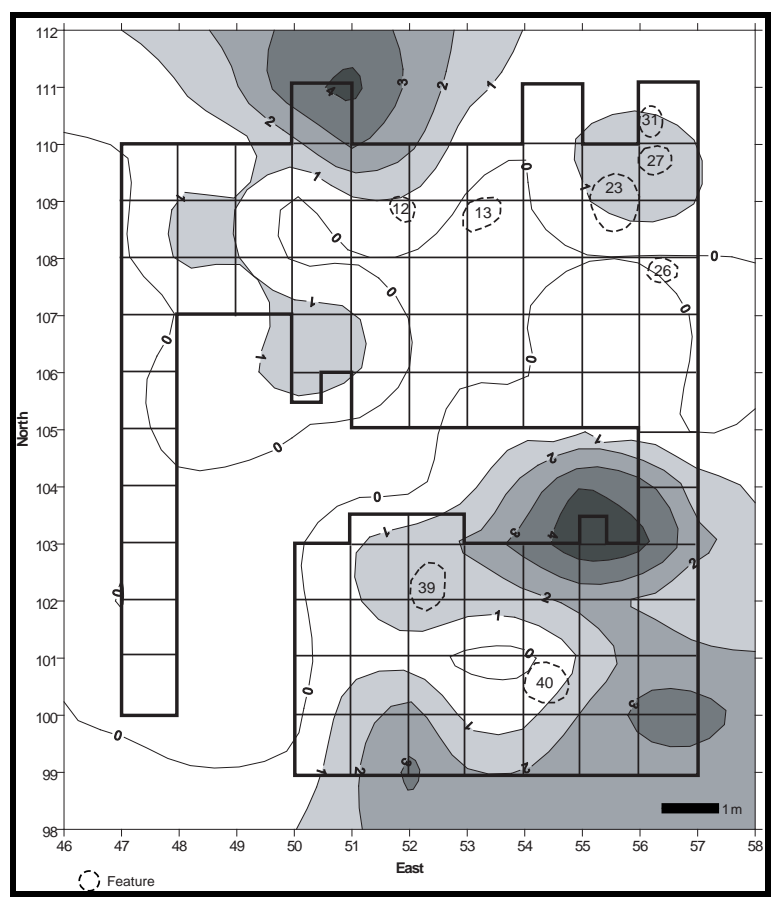

Figure 11-35. Contour Map of Scraper Density in Early Archaic

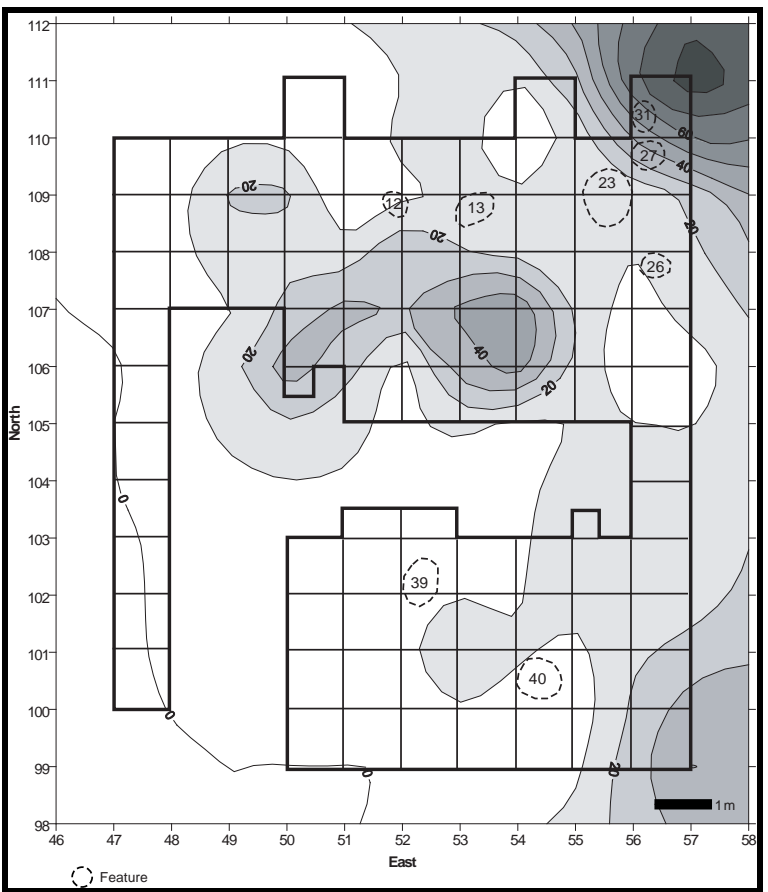

Figure 11-36. Contour Map of Bone Density in Early Archaic

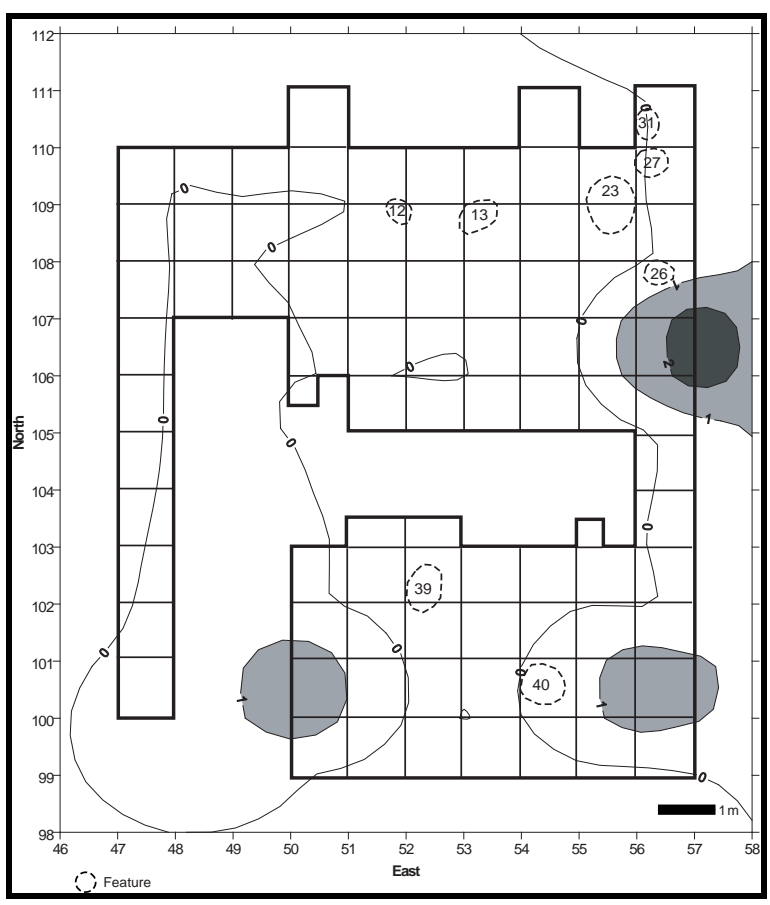

Figure 11-37. Contour Map of Uniface Density in Early Archaic 


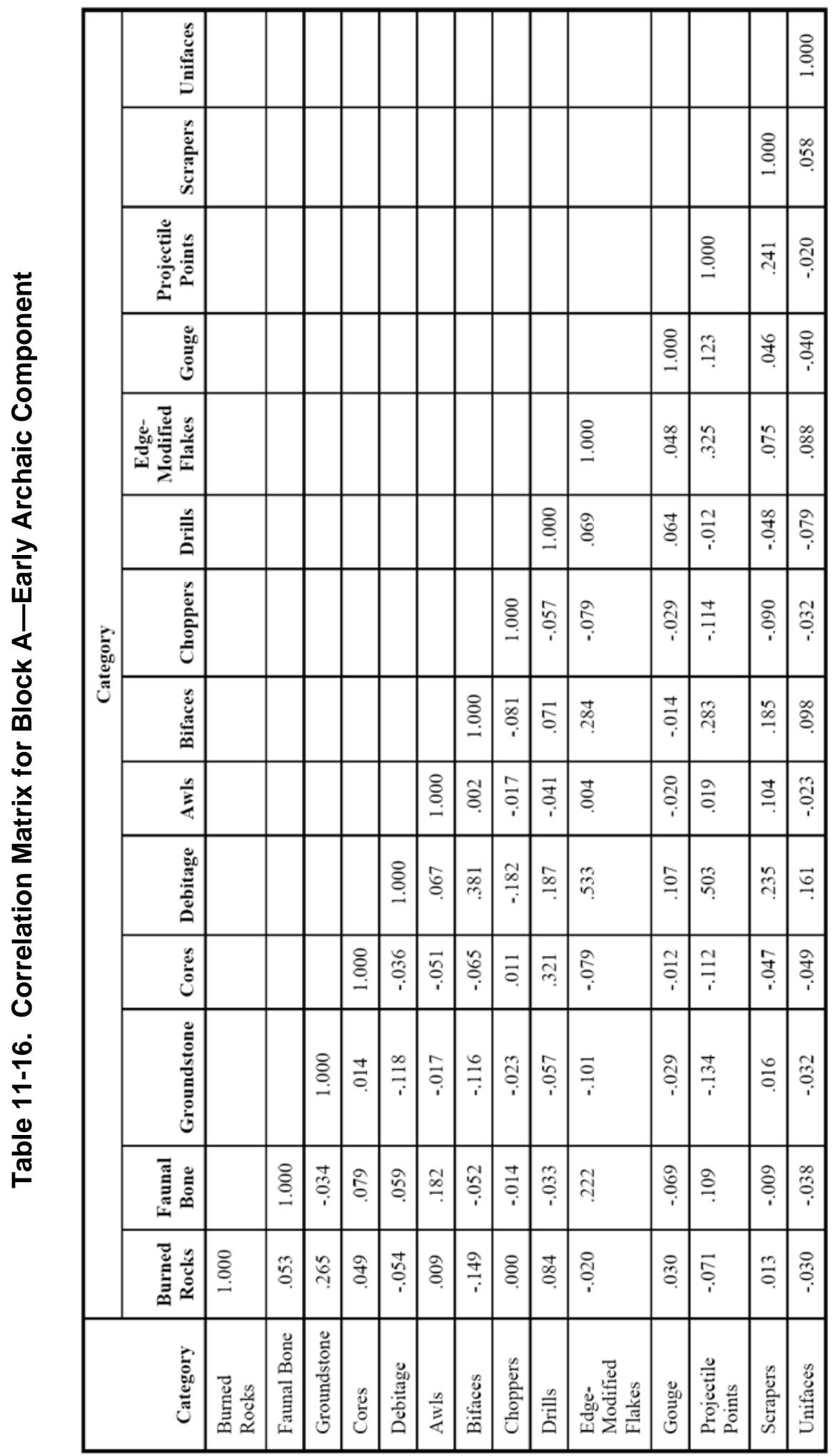


The Varga Site

Texas Department of Transportation

Table 11-17. Principal Component Matrix for Block A-Early Archaic Component

\begin{tabular}{|l|c|c|c|c|c|c|}
\hline \multirow{2}{*}{\multicolumn{1}{|c|}{ Variable }} & \multicolumn{7}{|c|}{ Factor $^{\mathbf{1}}$} \\
\cline { 2 - 8 } & $\mathbf{1}$ & $\mathbf{2}$ & $\mathbf{3}$ & $\mathbf{4}$ & $\mathbf{5}$ & $\mathbf{6}$ \\
\hline Burned Rock & .013 & .099 & .795 & -.013 & .063 & .078 \\
\hline Faunal Bone & .264 & .045 & .103 & -.247 & .761 & -.051 \\
\hline Ground stone & -.162 & -.076 & .741 & .131 & -.063 & -.073 \\
\hline Cores & -.129 & .789 & .019 & -.017 & .085 & -.042 \\
\hline Debitage & .795 & .107 & -.060 & .287 & -.015 & -.021 \\
\hline Awls & -.115 & -.073 & -.090 & .383 & .685 & .035 \\
\hline Bifaces & .480 & .028 & -.278 & .321 & -.170 & -.191 \\
\hline Choppers & -.124 & -.128 & -.095 & -.474 & .028 & .052 \\
\hline Drills & .138 & .807 & .005 & .045 & -.104 & .113 \\
\hline Edge-Modified Flakes & .815 & -.004 & .033 & -.122 & .133 & -.077 \\
\hline Gouges & .178 & -.034 & .067 & .041 & -.249 & .712 \\
\hline Projectile Points & .647 & -.142 & -.124 & .239 & .064 & .258 \\
\hline Scrapers & .123 & -.120 & .017 & .743 & .060 & .045 \\
\hline Unifaces & .194 & -.116 & .043 & .078 & -.230 & -.667 \\
\hline \% Variance & $\mathbf{1 5 . 6 3}$ & $\mathbf{9 . 8 2}$ & $\mathbf{9 . 3 7}$ & $\mathbf{9 . 0 7}$ & $\mathbf{8 . 8 9}$ & $\mathbf{7 . 8 3}$ \\
\hline Cum. \% Variance ${ }^{\mathbf{1}}$ & $\mathbf{1 5 . 6 3}$ & $\mathbf{2 5 . 4 5}$ & $\mathbf{3 4 . 8 2}$ & $\mathbf{4 3 . 8 9}$ & $\mathbf{5 2 . 7 8}$ & $\mathbf{6 0 . 6 1}$ \\
\hline Rotation method-Varimax with Kaiser normalization & & & \\
\hline Based on rotation sums & of squared loadings & & & & \\
\hline
\end{tabular}

For spatial studies, no differentiation was made among various flake or point types that might clarify this issue. Examination of density maps for these artifact categories suggests that, whereas the spatial associations are not perfect among them, these artifact types do exhibit a marked tendency to cluster in relatively small, discrete areas more or less right next to similar clusters of other artifact types constituent of Factor 1 (Figures 11-25 through 11-27). Whereas the high proportion of relatively complete points recovered remains something of a mystery, it seems clear that multiple, smallscale activity areas (or dumps associated with activity areas) are scattered across Block A at relatively evenly spaced intervals of 2 to $5 \mathrm{~m}$.
Factor 2 is composed of two diagnostic variables-lithic cores and drills-collectively composing 9.82 percent of the total variance in the matrix of correlation coefficients (Table 1117). Both variables exhibit moderately strong to strong positive factor loadings of .789 and .807. These two artifact types both occur in a single high-density cluster in the northwest corner of Block A centered on a large, buried boulder that appears to represent an activity area in which tool production and generalized maintenance tasks were performed (Figures 11-28 and 11-29). Other artifact types, including lithic debitage, bifaces, and projectile points, have moderatedensity peaks in this area, though they do not 
cluster in the same exact locations as drills and lithic cores.

Factor 3 is composed of only one diagnostic variable-burned rock-representing 9.37 percent of the total variance in the matrix of correlation coefficients (Table 11-17). Burned rock exhibits a moderately strong positive factor loading of .795. Burned rock occurs in six marked concentrations across Block A and represents the loci of in situ burned rock features or dumps of burned rocks from features (Figure 11-30). The covariance of burned rock with all other artifact types in the Early Archaic assemblage strongly suggests that the burned rock concentrations represent in situ features, such as hearths, around which the activities represented by the other artifact types occurred (though not necessarily simultaneously).

Factor 4 is also composed of only a single diagnostic variable-scrapers-representing 9.07 percent of the total variance in the matrix of correlation coefficients (Table 11-17). Scrapers exhibit a moderately strong positive factor loading of .743. Like other tool types in this component, scrapers form several small-scale, relatively high-density clusters, including two primary ones centered on 0.25-by-0.25-m Unit N103/E55 and the northeastern corner of Unit N110/E50 as well two secondary peaks in the southeastern and south-central parts of Block A (Figure 11-31). The cluster of scrapers located near the east end of BT 2 coincides with clusters of projectile points and edge-modified flakes, and to a lesser extent bifaces, located in the same general vicinity. Scrapers appear to reflect the locations of activity loci involved with fabricating and/or processing tasks.

Factor 5 is composed of two diagnostic variables-faunal bone and bone awlscollectively composing 8.89 percent of the total variance in the matrix of correlation coefficients (Table 11-17). Both variables exhibit moderately strong positive factor loadings of .685 and .761. All three awls were recovered from Unit N99/E56, an area that also generally coincides with clusters of scrapers, unifaces, edge-modified flakes, projectile points and, to a lesser extent, burned rock. Based on the cooccurrence of so many classes of fabricating and processing tools, it seems reasonable to propose that an activity area associated with generalized fabricating and processing tasks (not necessarily associated with subsistence resource processing) is represented in this area. An alternate possibility is that tools associated with this component have eroded down into a small swale that is observable in the southern and eastern wall profiles. Whether or not this swale was present during the Early Archaic occupation or represents an erosional feature that cut through part of it at a later date is unknown. Whereas the latter hypothesis is possible, it seems likely that a broader, non-selective range of artifact categories would be represented in an erosional feature, so the activity area hypothesis is favored. As only three bone awls were recovered from this component, it seems reasonable to assume that they were crafted from bones extracted from the small assemblage of animal bone associated with this component (Figure 11-32).

Factor 6 is composed of two diagnostic variables-unifaces and gouges-representing 7.83 percent of the total variance in the matrix of correlation coefficients (Table 11-17). Gouges exhibit a moderately strong positive factor loading of .712, whereas unifaces demonstrate a moderate negative factor loading of -.667. As only four unifaces and three gouges were recovered from this component, it seems inadvisable to rely greatly on the apparent covariation among these two artifact classes. Unifaces occur in three separate parts of Block A (Figure 11-33), and two of the three gouges are located along the periphery of one of these clusters in the southeast corner of Block A, 
where an activity area containing the remains of multiple classes of fabricating and processing implements appears to exist. Thus, the apparent covariation between these two artifact types is probably somewhat spurious, given the small sample sizes.

It is important to remember that the statistics "force" patterning upon an assemblage of data regardless of whether or not it innately exists in the dimension being examined. However, the principal components analyses in this spatial study have yielded some relatively unambiguous patterning among artifact categories. The patterns appear to be constrained and influenced by different factors. The observed associations among artifact categories appear to be regular, patterned, and often exclusive of other categories. Thus, it appears that the sediment deposits that contained the cultural materials are relatively intact, and that the spatial patterning apparent among artifact categories is referable more to the organization of the prehistoric occupations than to post-occupational natural influences.

\subsubsection{Mobility and Land Use}

Patterns of mobility and land use issues during this time period are difficult to address as only a few hints of possibilities are expressed by recovered materials. Macroscopic observations of the lithic material types indicate that only Edwards chert was employed throughout the Early Archaic occupations. The more precise INAA demonstrates that nearly all chipped stone tools were derived from Edwards Formation sources in the southwestern plateau region rather than imported from distant regions (Appendix F). Even with multiple point types possibly representing different groups, the local procurement of tool stone appears to have been a constant during the Early Archaic. The different populations that camped at the Varga Site apparently had restricted home ranges limited to this general southwestern part of the Edwards Plateau.

The absence of marine shell also implies a lack of contact/interaction with coastal groups. The groups camped at the Varga Site were operating and interacting only within the relatively limited region just mentioned. The Crinoid fossil fragment was not local and probably was brought here by humans. These fossils are Pennsylvanian in age and generally outcrop further north in the Central Texas mineral belt and beyond the Cretaceous period limestone rocks of the Edwards Plateau. This one item may represent very limited movement, contact, and/or trade with populations to the north.

Data clearly indicative of the seasonality of site occupation are lacking. Whereas the presences of walnut shells and prickly pear seeds in this component do imply late summer-fall occupation, this is less than certain since both products can be stored for a period of time.

\subsubsection{Paleoenvironment}

The pollen and phytolith record recovered from the vertical sediment column through deposits near the middle of Block A provide only sketchy information concerning the environment between 6,300 and 5,200 B.P. in radiocarbon age (Appendix F). The pollen record suffered significant deterioration with only the most resistant species represented. The arboreal taxa include pine (Pinus sp.), oak (Quercus), pecan (Carya), Apiaceae (carrot), and Poaceae (grass). Pooideae grass phytoliths, which yield a $\mathrm{C}_{3}$ carbon isotopic signal, comprise most of the grass assemblage.

At least five taxa are represented in the macrobotanical assemblage from across the Early Archaic component, including walnuts, prickly pear seeds, mesquite wood, juniper wood, and oak wood (Appendix I). Only the oak species is duplicated in the pollen record. 
The stable carbon and nitrogen isotope analyses from the same matrix as the pollen and phytolith record reveals interesting isotopic trends. Eight Early Archaic samples yielded carbon isotope values that differ about 2.1\%o and range from 24.97 to $-27.09 \%$. The most negative value was from the lowest sample with the more positive values about $30 \mathrm{~cm}$ higher and later in time. These carbon isotope values indicate nearly complete $\mathrm{C}_{3}$ contribution to the organic matter. Carbon isotope values of -21.9 and $-22.6 \%$, derived from two Varga Site humate dates of 6,270 and 5,230 B.P., respectively, from two different backhoe trenches outside Block A, indicate about an 85 percent contribution by the $\mathrm{C}_{3}$ vegetation. It is not clear what caused the nearly 2.0\% difference between the column samples and the two dated samples. One possible explanation is the values obtained from the AMS dating technique on the sediments are not as precise as those derived from the isotope laboratory. A second possible explanation is that the two dated samples were outside the main cultural activity areas, and thus, may reflect more of the natural environment. Regardless of what caused the nearly 2.0\% difference in these Varga Site values, the carbon isotope values significantly contrast with the carbon isotope results from Fort Hood values, where 65 to 70 percent $\mathrm{C}_{4}$ input from carbon isotope values that range between -16.3 and $-16.5 \%$ date to around 5,200 to 5,800 B.P. If the Varga Site carbon isotope results are accepted as reflecting the local environment, then a warm and dry period in eastern Edwards County was definitely not present during this period in contrast to the Fort Hood region. The Edwards County region potentially provided relatively cooler and moister conditions than the eastern end of the Edwards Plateau and potentially greater resource opportunities and better living conditions. This might account for the more intense Early Archaic occupation revealed at the Varga Site than elsewhere in the greater Central Texas region.

For this general period, the climate in the Lower Pecos region has been characterized as a drying and warming trend with a gradual decrease in mesic plant pollen and an increase in xeric plant pollen between ca. 10,000 and 5,000 B.P., the period termed the Stockton Stage by Bryant (1966). From Hinds Cave macrobotanical data, Dering (1979) interpreted a decrease in the juniper and oak stands with grasslands increasing between 7,000 and 4,000 B.P. He suggests that semi-succulent plants probably were widely scattered throughout these grasslands by this time. The wooded areas would have been more restricted to the breaks. At about 6,100 B.P., bulk processing of lechuguilla was observed at Hinds Cave in the form of a burned rock midden (Dering 2002). Around 5,000 B.P., Dering (1979) sees an absence of juniper wood charcoal from Hinds Cave, which may indicate a climatic shift.

From analysis of coprolites from Lens 13 at Hinds Cave that date to a range of about 5,719 to 5,590 B.P., William-Dean (1978) indicates the human diet was based on consumption of rodents, rabbits, birds, and two or three species of cacti. Prickly pear plants formed the major seed, epidermis, and fiber components in the coprolites (William-Dean 1978:234). It must be pointed out that only the smaller bones from the smaller animals would have been consumed and thus be present in coprolites, whereas the larger bones from larger animals would not have been present. Other plant parts observed in the coprolites include lechuguilla in 51 percent, onion bulbs in 40 percent, walnut shells in 23 percent, and sotol in seven percent. This reveals a much greater diversity than normally observed in a preserved assemblage from an open-air campsite such as the Varga site, but may provide a more complete picture of the kinds of resources that might have been 
available to hunter-gatherers in the general region.

Vertebrate remains from Hinds Cave during the period from between 6,800 and 6,000 B.P. showed an apparent shift from human reliance on deer and rabbits to the procurement of small rodents (Lord 1984). Combining the plant macrofossil record (Dering 1979), the pollen record (Johnson 1963; Bryant 1977a), the coprolite record (Williams-Dean 1978), and the faunal record (Lord 1983), a convincing argument can be made that around 6,000 B.P. the local inhabitants were forced to adjust to vegetation and climatic conditions that were becoming increasingly xeric (Bryant and Holloway 1985:57).

To the east, at Hall's Cave in Kerr County, the vegetation community is not easily reconstructed, but reveals that grasslands, probably a mixed grass assemblage, dominated between ca. 8,000 and 5,000 B.P. (Tome 1993). A change in vegetation was detected by about 5,000 B.P., at which time the area was likely either short-grass grassland or a desert grassland/steppe (Toomey 1993).

Still further east and north, the Fort Hood alluvium initiated by 8,600 B.P. was deposited throughout a period from about 8,600 to 4,800 B.P. (Nordt 1992, 1993). Nordt characterizes the deposition as fine-grained meandering and abraiding on intermediate and small streams. The abraided depositional environment resulted from high magnitude flood events. Of importance is the lack of paleosols in the Fort Hood region documenting moderately rapid deposition through common flood events. The carbon isotope data derived primarily from alluvium indicates the $\mathrm{C}_{4}$ contributions (grasses) increased during the period between about 8,000 and 6,000 B.P., with a general average of between 65 to 70 percent warm season $\mathrm{C}_{4}$ grasses. The carbon isotope values of -
$16.3 \%$ and $-16.5 \%$ o during the period from about 6,000 to 5,000 B.P. indicates a dry period along Cowhouse Creek (Nordt 1992, 1993). By about 4,170 B.P., a carbon isotope value of $-18.2 \%$ indicates a return to moister conditions.

Still further east of eastern edge of the Edward Plateau, Bousman (1998) reinterpreted Central Texas bog data and determined that by about 6,000 B.P. there was a short period of more mesic conditions, as revealed through a peak in arboreal pollen between two periods of maximum grass cover $(>90 \%)$. The two peaks in grassland expansion reflect the dryer conditions potentially signaling the Altithermal climatic event further north. Grass pollen reaches nearly 60 percent at roughly 8,600 B.P. and at least 50 percent at about 5,100 B.P. at Hershop Bog (Bousman 1998). Bousman calculates values about 30 percent higher than indicated by modern surface pollen. Johnson and Goode (1994) also view this general period as one of low moisture. Dillehay (1974) indicates that bison were absent in most of Texas during this period. In literature beyond Texas, the period from about 7,000 to 4,500 B.P. is often referred to as the Altithermal (Antevs 1955), considered to have been the maximum Post-Pleistocene warm/dry period.

In the southern High Plains region at Lubbock Lake, the period from 6,500 to 4,500 B.P. is thought to have seen intense deflation and wind erosion (Holliday 1995:89), interpreted as the result of reduced plant cover and declining water tables. The lower water table is also evident through the nearly 60 prehistoric hand-excavated water wells at Mustang Springs that date to between 6,800 and 6,600 B.P. (Meltzer 1991).

At the Varga Site the environmental data from the 1,100-year period between 5,200 and 6,300 B.P. does not reflect a significant warm period as indicated by different lines of data in the adjacent regions. If this period was 
significantly warmer, it is not reflected in the nearly complete dominance of $\mathrm{C}_{3}$ grasses indicated in the phytolith record or the stable carbon isotope values. The current data indicates that the Varga Site locality, and probably the surrounding region, was more mesic than the surrounding regions, thus providing more favorable resource conditions during this period. One may conclude that the drier conditions in the surrounding regions contributed to intensification of prehistoric use of the Balcones Canyonlands as reflected by the Early Archaic component detected at the Varga Site.

\subsubsection{Concluding Discussion}

The stratigraphic position of this Early Archaic component was at the very base of the alluvial fines. In fact, some of the smaller cultural items along with some fine sediment were recovered from between the alluvial gravels. It is concluded that people were actually living on a stony surface similar to a gravel bar. In fact, for the cultural materials to be so interbedded with the gravels there must have been relatively little sediment accumulation between the rocks at the time of the prehistoric encampments. Apparently the first occupants must have been present soon after the gravels were deposited and prior to any significant sedimentation.

This setting for the Early Archaic at the Varga Site is in a similar topographic and environmental setting to that of the Woodrow Herd Site just to the southeast in Uvalde County. The Woodrow Herd Site yielded very limited cultural materials (one isolated burned rock feature) in the early Holocene Unit I that dated $>8,000$ B.P. This material was in matrix-support gravel that contained charcoal that ranged in age from 8,380 to 8,010 B.P. Unit IIa immediately above this contained charcoal that ranged in age from 6,430 to 6,060 B.P. The initial cultural component dated to between ca. 6,500 and
4,400 B.P. yielded Martindale, Uvalde, Early Triangular, and Early Corner-Notched points mixed together (Decker et al. 2000).

Further east in Central Texas, the WilsonLeonard Site (Collins 1998) in Williamson County also yielded Early Archaic projectile points in similar context to the Varga Site assemblage. A region-wide erosional event that included the Lower Pecos region must have occurred before about 6,500 B.P.

In summary, the cultural materials recovered from this Early Archaic component reflect repeated short-term encampments by groups employing a variety of "Split Stem" and "Early Barbed” point types over minimally a 1,100-year period between 6,300 and 5,200 B.P. This location served as a base camp for general foraging groups. The extensive and diverse chipped stone tool assemblage reflects activities directed at the procurement and processing of tool stone, and plant and animal products. Hot rocks in small clusters served as small-scale features for cooking mostly $\mathrm{C}_{3}$ plant products. Although deer and rabbit meat were procured and undoubtedly consumed, the meat was not cooked by the hot rock technology. Knapping tasks were directed towards biface finishing, refurbishing chipped stone tools, retooling implements, and discarding worn-out tools. Documented processing activities include cutting, whittling, scraping, planing on hard and soft wood and other plants, and hide working. The seasonality of the occupation(s) is not well represented, but at least one event was during the late summer-fall. The site occupants had limited contact with other groups from outside the region, judging by the reliance on locally available cherts and a lack of obvious trade items.

The pollen, phytolith, stable carbon isotope, and macrobotanical data from the Early Archaic deposits reflect a nearly complete $C_{3}$ vegetation 
community consisting of a mixture of arboreal and grassland communities. This data does not reflect the same warm/dry conditions indicated by data from adjacent regions. The documented environment was potentially more favorable, wetter, and somewhat cooler in comparison to the surrounding regions, and therefore, provided a greater abundance of plant and animal resources for daily needs. This in turn was potentially the stimulus for a greater use of the Varga Site and the immediate region by Early Archaic peoples. 



\subsection{MISCELLANEOUS MATERIALS}

\author{
J. Michael Quigg
}

\subsection{INTRODUCTION}

Various materials were found in different levels/proveniences that could not be confidently assigned to one of the identified components. A few pieces are from the surface; several come from backhoe trenches; and other pieces were recovered from isolated test units during Phase I with poor stratigraphy or unclear associations, whereas the majority are from hand-excavated levels that either were not well-defined and/or were at the upper or lower boundary of one of the identified components. As a result, about 1,499 pieces of cultural material cannot be assigned to a particular cultural component. No specific age can be defined for these materials, which are briefly summarized below.

\subsection{Chipped Stone Tools}

Fifty-two chipped stone tools including 36 edgemodified flakes, nine projectile points, six cores (\#1-11, \#556-11, \#761-10, \#855-11, \#1273-10, and \#1273-11), three bifaces (\#427-11, \#762-11, \#791-10), two scrapers (\#88-12 and \#562-13), one drill (\#1212-10), and one uniface (\#924-11) are not assignable to a specific component. The nine points included two untypable arrow point fragments (\#1-15 and \#1200-10), two untypable dart points (\#53-11 and \#923-10), two Bonham (\#360-5-10 and \#562-10) arrow point, one Frio point (\#562-12), one Early Triangular point (\#138-12), and one Martindale point (\#854-10). The metric and non-metric data from the projectile points has been included with the other point data summarized in the components under the specific point type with individual attributes presented in Appendix O. The 52 tools represent about 1.5 percent of the total tools identified. Three tools, one drill, an unknown arrow point, and an edge-modified flake were collected from the surface, which has suffered considerable alterations from different mechanisms.

\subsection{Vertebrate Faunal Remains}

Only five pieces of bone weighing $4.5 \mathrm{~g}$ from two proveniences were not assigned to identified components. Most bones recovered are quite fragmentary and are assigned to one of the four components based on color, weathering patterns, and observations on the nature of their burned conditions.

\subsection{BURNED ROCKS}

A total of 325 burned rocks weighing $24,971 \mathrm{~g}$ from 28 difference proveniences were unassigned. This is 1.3 percent of the total burned rocks recovered.

\subsection{MACROBOtANICAL REMAINS}

Two charcoal samples weighing $0.9 \mathrm{~g}$ were unassigned.

\subsection{LITHIC DEBITAGE}

A total of 1,103 pieces of lithic debitage from 56 proveniences were not assigned to a specific component. This is about 1.3 percent of the total debitage recovered.

\subsection{Discussion}

These unassigned materials represent about 1.1 percent of the total cultural materials recovered from the Varga Site investigations. Since these materials could not be confidently assigned to one of the four components, limited 
time was spent with analyses of the individual specimens, with the exception of the projectile points. The point data was combined with the major point type categories to contribute data towards overall form and variability. 


\subsection{PALEOENVIRONMENT INFERENCES}

\section{J. Michael Quigg}

\subsection{INTRODUCTION}

Insights into past environments are derived from a variety of data sets. Paleoenvironmental information was sought from the roughly 6,300year-old deposits at the Varga site, through sitespecific geomorphic investigations in the existing right-of-way, a single pollen and phytolith column in which stable carbon and nitrogen isotopes were also measured from the same vertical section of fines (the exact same samples), and through cultural materials extracted from the cultural deposits in Block A. The carbonized macrobotanical remains identified, combined with the identified faunal assemblages recovered from each cultural component, augment the other data sets. The detailed paleoenvironmental data and inferences concerning all four major components are presented in the summary section of each component and will not be repeated here. Below we provide a broad summary or overview of the findings together with discussions.

\subsection{GEOMORPHIC INFERENCES}

The context of the recovered cultural material is partially established from a geomorphic perspective. In $\mathrm{T} 1$, the investigated backhoe trenches and block profiles revealed five depositional packages. Below, these five packages are summarized from the bottom of the profile to the top. A dense and thick river gravel lens designated as Depositional Unit 5 was at the base of the fine matrix. This gravel lens indicates a high-energy flood that moved clasts as much as $30 \mathrm{~cm}$ in diameter and potentially stripped or removed early fines. The gravel deposit spans the investigated site area and had highly variable depths below the existing surface, a factor of its undulating or hummocky surface onto which fines were subsequently deposited. This gravel lens was not directly dated, and the base of it was not reached. The radiocarbon dates derived from the cultural deposit directly above the gravels indicate this gravel was deposited before ca. 6,300 B.P. and probably much earlier, during the late Pleistocene or very early Holocene. If the gravels were that old, then deposits representing some 4,000-years, from 10,500 to 6,300 B.P., are missing in the overlying alluvium.

Depositional Unit 4 represents fine overbank flood deposits that top the gravel lens. Unit 4 was a clay loam classified as Bk horizon with Stage I carbonate accumulation, typical of soils that are Middle to Late Holocene in age. These fines vary from 20 to $55 \mathrm{~cm}$ thick and indicate the very slow accumulation of alluvial deposits or a combination of erosion and deposition allowing for limited aggradation. This deposit contained mixed Early Archaic cultural materials (a minimum of nine different point types are represented) that date between 6,300 and 5,200 B.P. Early populations may have camped on the gravels and extracted natural chert nodules contained in the gravel deposit. This same stratigraphic scenario with Early Archaic cultural materials resting directly on a basal unit was also observed at the Barton Site (Abbott 1994). Cultural materials in the upper part of this deposit tend to be randomly distributed.

Depositional Unit 3 was a clay loam matrix that also contained a "pea to marble size gravel" ( $<3 \mathrm{~cm}$ diameter) lens. The thin, gravelly lens reflects a relatively high-energy flood event that 
resulted in deposition of relatively coarse sediments beyond the confines of the stream channel. Depositional Unit 3 had a clear boundary with the underlying sediments. This pea-gravel lens was classified as a Bk1 horizon that contained Middle Archaic cultural materials dating to between 4,800 and 3,900 B.P. The boundary between Depositional Unit 3 and the overlying Depositional Unit 2 was gradual and smooth, indicating it developed over a period of time.

A black clay loam to silty clay loam that exhibited a very weak, fine granular structure was a developed A horizon designated Depositional Unit 2. This A horizon, roughly 20 to $30 \mathrm{~cm}$ thick in places, represents a stable land surface that extended across the entire investigated area. Depositional Unit 2 was probably deposited by multiple overbank flood events, and subsequently underwent pedogenesis just before 2,300 B.P. This organic-rich deposit was subsequently buried by additional finegrained overbank deposits. Depositional Unit 2 contained quantities of Late Archaic cultural materials that date to between 2,300 and 1,700 B.P., possibly the developmental period for this A horizon. Bryant and Holloway (1985) refer to this period as the Frio Interval, which they believe ushered more mesic and probably cooler climatic conditions at around 2,500 B.P. Hall's Cave also yielded evidence for moister conditions at about 2,000 B.P. through the presence of bones of the Woodland vole (Toomey 1993). The Varga Site buried A horizon, combined with other evidence, reflects similar climatic conditions generally at about the same time in this region.

The boundary contact with the overlying Depositional Unit 1 was abrupt and smooth, indicating a depositional hiatus between Depositional Units 1 and 2, and possibly a partially stripped or eroded surface. Depositional Unit 1 represents clay loam to loam overbank deposits that have been heavily impacted by modern disturbances and the addition of modern road gravel compressed into the loam over parts of the excavated area. Some areas appear mechanically compressed, whereas other areas were stripped. The deposits near the eastern and western right-of-way margins along the fence lines revealed the greatest thicknesses of this deposit. Accumulation of sediments is most certainly due to multiple flood events over the last 1,700-years with no visible internal stratification. This is a very weak or incipient A horizon with an abrupt and smooth lower boundary.

The oldest radiocarbon dates from this Depositional Unit 1 are about 920 B.P. and a date of 1,390 B.P. was obtained from the underlying Depositional Unit 2. The youngest couple of radiocarbon ages are modern at about 80 and 170 B.P. Thus, Depositional Unit 1 represents about 1,300 to 1,400-years. Depositional Unit 1 contained Late Prehistoric materials, primarily Toyah phase materials with a few projectile points that may reflect slightly earlier occupations radiocarbon dated to between ca. 940 and 300 B.P. The proposed hiatus between Depositional Unit 1 and Unit 2 appears to represent some 300 to 400 radiocarbon years.

It is possible that the buried A horizon documented in Depositional Unit 2 and the lower Bkhorizons represent a single soil development with only limited and brief erosional periods. If this were the case, then this is a very unusual alluvial setting. Other river and creek valleys documented in the broader region often contain at least a buried soil dated to roughly around 5,000 B.P. (i.e., Medina Pedocomplex, Mandel et al. 2007) However, the upper reaches of the Pedernales River to the north also lack the 5,000 B.P. buried soil and even the ca. 1,700 to 2,300 B.P. A horizon. (Blum 1987). 
Bryant (1966) suggests a return to aridity in the Lower Pecos region after ca. 2,300 B.P., and refers to this as the Juno Stage. This period is characterized by xeric conditions as evidenced by pollen from Bonfire Shelter and Devil's Mouth Site, and this general trend of drying continued into historic times.

\subsection{THE MicRofLORAL EVIDENCE}

Twenty-five sediment samples were submitted for paired pollen and phytolith analysis. Twenty of these pairs were recovered from a single vertical column through the middle part of Block $\mathrm{A}$ and five others were recovered from radiocarbon dated sediment samples from two backhoe trenches. Very generally, the pollen record reveals no abrupt or obvious changes in the vegetation communities. The pollen assemblages were believed to be poorly preserved, since the number of pollen taxa from individual samples is low (5 to 12 taxa, with a mean of 7.75) with the numbers of identified taxa decreasing with increasing age of the samples. Several Early Archaic samples were not counted as they yielded very few pollen grains. Minor variations in the pollen concentrations, such as the decreased amounts of cheno-ams and Asteraceae in the Early Archaic period, are thought to reflect the poor preservation of those samples. Often pollen preservation is so poor in most open-air sites that researchers such as Dr. John Jones and Dr. Vaughn Bryant do not often recommend analysis of such data. The better-preserved pollen localities are generally bogs.

Arboreal pollen of oak and pecan/hickory are present throughout the column. Walnut is quite rare. The presence of these taxa indicates that similar tree species were present from the Early Archaic (6,300 B.P.) through the Toyah period (300 B.P.). Pecan/hickory and walnut generally require a more dependable water source and are often indicators of riparian environments. The upper part of the matrix column is characterized by high concentrations of cheno-ams, Asteraceae, and Poaceae (grasses) that indicate a mosaic of grassland components interspersed with arboreal components. Members of the Apiaceae Family are generally found in more moist conditions and are expected for this streamside terrace.

The pollen from the Toyah component is consistent with the modern vegetation of the area. The Late Archaic pollen (1,700 to 2,300 B.P.) reflects the same taxa as present during the Toyah component. In the Middle Archaic (3,900 to 4,800 B.P.), low spine Asteraceae tends to increase in concentration values, whereas all other taxa show decreases. This combined with the very low occurrences of non-Opuntia Cactaceae and Ephedra hint at drier conditions during this period. In the Early Archaic component (6,300 to 5,200 B.P.), the low arboreal pollen concentration values might indicate a relatively dry climate, with decrease in the arboreal cover and a concomitant expansion of meadow-like communities.

Currently, phytolith assemblages are playing an increased role in reconstruction of paleoenvironments. The results from the phytolith analysis at the Wilson-Leonard Site led Fredlund (1998) to state, "that future investments in phytolith analysis for the Texas region are warranted.” The Varga Site phytolith assemblage reflects more of the grass component than the boreal or other plant components and represents grass communities that are not reflected in the pollen assemblage.

The Varga Site phytolith results reveal a dominance of Pooideae grasses ( $\mathrm{C}_{3}$ cool season) during the Early and Middle Archaic periods, with an average of less than 15 percent $C_{4}$ (warm season) type grasses. $\mathrm{C}_{4}$ grass phytoliths reveal a gradual increase up to a maximum of 22 percent during the Middle Archaic (4,800 to 
3,900 B.P.) period. They continue to gradually increase during the Late Archaic and throughout the Toyah periods. The percentages vary from about 17 to 38 percent $C_{4}$ grasses. The highest percentage of $\mathrm{C}_{4}$ grasses is about 38 percent, which occurred near the end of the Toyah period or in the last few hundred years. During these last few hundred years, the $\mathrm{C}_{4}$ grasses were comprised mostly of the Chlorideae taxa. These taxa usually dominate assemblages of gramabuffalo grasses (Bouteloua-Buchloe sp.) in environments similar to that presently around Lubbock, Texas (Fredlund and Tieszen 1994).

The phytolith data coupled with the pollen data indicate the region saw only minor changes in the mosaic of grasslands and arboreal species throughout the 6,300-years represented by the cultural occupations. In contrast, the phytolith analysis at the Wilson-Leonard Site documents regional and local changes in vegetation over the last 10,000-years (Fredlund 1998). At the latter site, the data indicate that the grassland composition reached the range observed in the modern soil samples from the region between 8,700 and 6,000 B.P. Fredlund (1998) interprets the data to indicate the woodlands became more open by 4,000 B.P. and shrank over the last 2,000-years. If the Central Texas grasses reached their modern balance by 6,000 B.P., then it is possible that the Varga Site data also reflects similar relatively stable grass communities over the last ca. 6,300-years.

Phytolith analyses have not been conducted on sediments from the Lower Pecos region. The few other analyses that have occurred, such as that at Morgan Playa in the Rolling Plains of Texas (Fredlund et al. 1998), are in settings difficult to directly compare to the Varga Site assemblage. The phytolith record at Onion Creek, near Buda, documents no large changes in the vegetation communities over the last ca. 3,000-years (Cummings 1994). The identified charcoal from the Varga Site cultural components is similar to species represented in the modern environment and generally supports the lack of major change during this lengthy time period.

\subsection{StABLE ISOTOPE INFERENCES}

Stable carbon isotope values were derived from the same sediment samples as the pollen and phytolith samples extracted from the central area of Block A and indicate the general history of the change in the amount of $\mathrm{C}_{3}$ vegetation at that specific locality. No obvious zonation in the isotope values is present that reflect stratigraphic or geomorphic boundaries, but two or three general trends are recognizable (Figure 13-1). Overall the carbon isotope values for the Varga Site are quite negative (strongly reflecting $\mathrm{C}_{3}$ matter), with an average $\delta^{13} \mathrm{C}$ value of $-27.3 \%$. Beginning at roughly 6,300 B.P. and continuing over the next ca. 1,500 to ca. 4,800 B.P., the carbon isotope values varied between $-27.0 \%$ to $-24.9 \%$, with an average of about $-25.8 \%$. This is a clear indication that during this period almost no $\mathrm{C}_{4}$ grasses or CAM plants with $\mathrm{C}_{4}$ signatures (such as agave or prickly pear [Eickmeier and Bender 1976]) contributed carbon to the local sediments. From ca. 4,800 B.P. forward until about 2,300 B.P., the carbon isotope values continued to become more negative, from about $-25.5 \%$ o to nearly $30.0 \%$, documenting continued increase in the contribution of $\mathrm{C}_{3}$ matter to the sediments (Figure 13-1). From about 2,300 B.P. to modern times, the $\mathrm{C}_{3}$ plant community apparently stabilized or became just slightly less negative. During the period from ca. 300 to 600 B.P., the carbon isotope values average about $-28.7 \%$. The average difference in carbon isotope values for the 1,500-year period between 6,300 and 4,800 B.P. and the 300-year period between 300 and 600 B.P. is about 3.0\%. This documents a general increase in the amount of $\mathrm{C}_{3}$ vegetation over this period. 


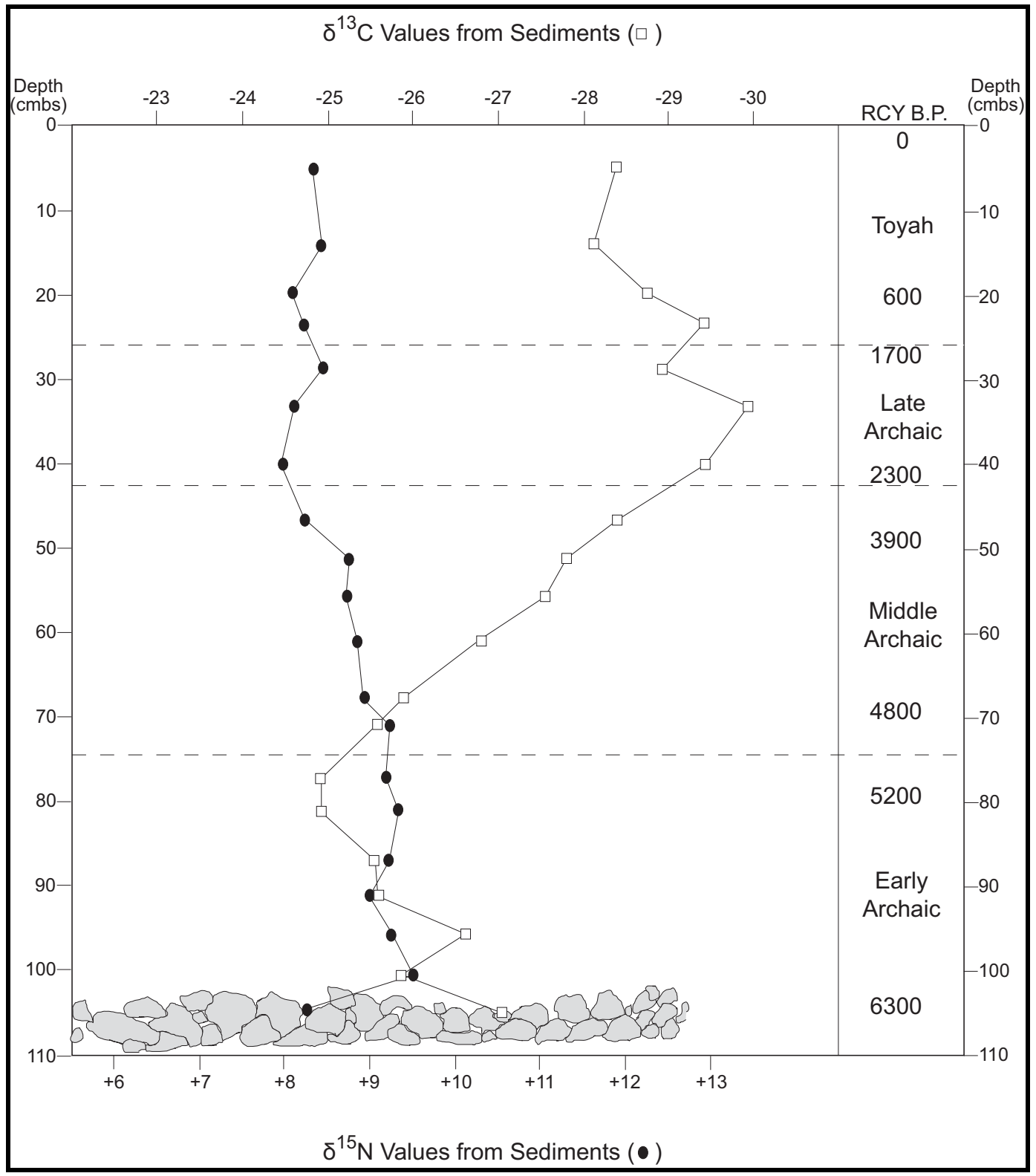

Figure 13-1. Stable Carbon and Nitrogen Isotope Results from a Matrix Column Near Middle of Block A 
A period of dominance by $\mathrm{C}_{4}$ or CAM plants with $\mathrm{C}_{4}$ signatures is not visible in the stable carbon isotope record in this alluvial terrace along Hackberry Creek.

Towards the eastern margin of the Edwards Plateau at the Wilson-Leonard Site just north of Austin, the stable carbon isotope analysis revealed a similar lack of prominent $\mathrm{C}_{4}$ zones in the 10,000-year long profile. There, the carbon isotope values center on -23\% with a very slight trend towards more positive values over the last 7,000-years (Fredlund and Tieszen 1998).

At the Varga Site, the nitrogen isotope values from the same organic matter in the same sediment samples as the carbon isotopes and pollen and phytolith samples are relatively consistent over the ca. 6,300-years. Only a slight decrease was detected from about 9.2\% during the initial 1,500-years to ca. $8.3 \%$ o for the ca. 300-year period between 300 and 600 B.P. This roughly -1\%o change in the nitrogen isotope values supports a general consistency in the overall vegetation record. Again this data reveals no significant change in the vegetation community during the last 6,300-years.

\subsection{MACROBOTANICAL INFERENCES}

The macrobotanical remains consist of at least 18 different identified taxa, including 12 wood species (Table 13-1). The non-wood species represented at the Varga Site include seeds and nuts that potentially were transported into the site by humans, but are considered to have come from the immediate surroundings. The wood taxa identified definitely represent arboreal flora in the immediate surroundings and are representative of the local vegetation community. Preservation was generally good for an open-air site and especially good considering the absence of well-defined cultural pit features that often contribute to the preservation of organic remains. The most recent cultural interval, as represented in the
Toyah component, yielded 18 taxa, followed by 11 taxa in the Late Archaic, three taxa in the Middle Archaic, and five taxa in the Early Archaic (Table 13-1).

The Early Archaic component is represented by walnut, juniper, mesquite, oak, and prickly pear. These same five taxa were still present during the Late Archaic period, in the more recent Toyah assemblages, and part of the local vegetation community to this day. This implies a significant degree of long-term continuity in broad vegetation communities from ca. 6,300 B.P. up to the present. The densities of the species cannot be determined from the current data sets, and it is likely that their frequencies only changed to some extent over time. Riparian taxa dominate the assemblages as expected for a low alluvial terrace adjacent to a creek. Those species identified that might be considered most representative of upland or rocky slopes, such as the agave and prickly pear, are considered probable food resources that were brought onto the site from the immediately surrounding catchment area.

The wood identifications do not often support the pollen data. Only in eight instances are the same species from each of these groups represented for the same time period. Oak pollen and identified oak wood account for half the instances, perhaps reflecting the dominance of this species during all four major time periods recognized. The lack of correspondence between the pollen results and macrobotanical remains indicates how the two different data sets reflect different taxa, although each data set contributes to our understanding of the past vegetation communities. The two data sets provide a much clearer representation of the vegetation communities and should be considered in combination with each other. 
Table 13-1. Wood and Pollen Taxa Identified by Cultural Period

\begin{tabular}{|c|c|c|c|c|c|}
\hline $\begin{array}{l}\text { Wood Taxa Identified } \\
\qquad(x=\text { present })\end{array}$ & Toyah & $\begin{array}{c}\text { Late } \\
\text { Archaic }\end{array}$ & $\begin{array}{l}\text { Middle } \\
\text { Archaic }\end{array}$ & $\begin{array}{l}\text { Early } \\
\text { Archaic }\end{array}$ & $\begin{array}{c}\text { Pollen Species Identified } \\
\text { (o = present) }\end{array}$ \\
\hline Agavaceae (sotol/yucca) & x (heart) & x (leaf) & & & Agavaceae (yucca/sotol) \\
\hline Berberis (agarita) & $\mathrm{x}$ & & & & \\
\hline Carya sp. (pecan) & $x$ (nut) o & $x$ (nut) $o$ & o & o & Carya \\
\hline Cephalanthus (buttonbush) & $\mathrm{x}$ & $\mathrm{x}$ & & & \\
\hline Cheno-am seed & $\mathrm{x} \quad \mathrm{O}$ & o & & & Cheno-am \\
\hline Condalis sp. (condalis) & $\mathrm{x}$ & $\mathrm{x}$ & & & \\
\hline Fabaceae (woody legume) & $\mathrm{x}$ & $\mathrm{x}$ & & & \\
\hline Juglans (walnut) & $\mathrm{x}$ (nut) $\mathrm{o}$ & $\mathrm{x}$ (nut) & & $\mathrm{x}$ (nut) & Juglans sp. \\
\hline \multirow[t]{2}{*}{ Juniperus sp. (juniper) } & $\mathrm{x}$ & $\mathrm{x}$ & $\mathrm{x}$ & $\mathrm{x}$ & Juniperus sp. \\
\hline & & & & & Atriplex conescens (saltbush) \\
\hline Opuntia sp. (prickly pear) & x (seed) o & x (seed) & & x (seed) & Opuntia sp. \\
\hline Pinus sp. (pinyon) & $\mathrm{x}$ & o & & o & Pinus sp. \\
\hline Platanus occidentalis (sycamore) & $\mathrm{x}$ & & & & \\
\hline Prosopis (mesquite) & x (seed) & $x$ (seed) & $\mathrm{x}$ & $\mathrm{x}$ & \\
\hline Quercus (oak) & $\mathrm{x} \quad \mathrm{O}$ & $\mathrm{x} \quad \mathrm{O}$ & $\mathrm{x} \quad \mathrm{O}$ & $\mathrm{x} 0$ & Fagaceae \\
\hline \multirow[t]{2}{*}{ Salicaceae (cottonwood/willow) } & $\mathrm{x}$ & & & & \\
\hline & o & & o & & Celtis sp. (hackberry) \\
\hline Ulmus sp. (elm) & $\mathrm{x}$ & & & & Ulmus \\
\hline Ungnadia sp. (buckeye) & $\mathrm{x}$ & & & & \\
\hline \multirow[t]{5}{*}{ Ziziphus (lotebush) } & $\mathrm{x}$ & $\mathrm{x}$ & & & \\
\hline & o & o & & 0 & Poaceae (grass) \\
\hline & o & o & & & Artemisia (sagebrush) \\
\hline & 0 & o & o & & Asteraceae (composite) \\
\hline & o & & & o & Apiaceae (carrot) \\
\hline Total wood taxa & $x=18$ taxa & $x=11$ taxa & $x=3$ taxa & $x=5$ taxa & \\
\hline Total pollen taxa & $0=10$ taxa & $0=7$ taxa & $0=4$ taxa & $0=5$ taxa & \\
\hline
\end{tabular}




\subsection{FAUNA}

The apparent repeated hunting of rabbits and deer during the four major time periods represented at the Varga Site reflects the adaptive flexibility of these species. The minor changes in climate and flora indicated by the micro- and macro-botanical data did not sufficiently alter the local environment to markedly affect the habitats of deer or rabbits. On the other hand, bison and antelope were hunted only during the last 600-years of occupation, which may indicate that the region became more open with grassland expansion, and thus better suited to sustaining bison and antelope, during this latest period.

\subsection{Discussion}

The Varga Site revealed less than $150 \mathrm{~cm}$ of fine alluvial deposits atop a thick gravel deposit that is greater than 6,300-years old. Cultural components identified in the fines potentially represent multiple events, but the recognized components represent relatively short, welldefined radiocarbon dated time periods.

Hackberry Creek is a bedrock-constrained channel with a relatively high stream gradient that raises concerns about direct correlation to other regional terrace chronologies that do not share these properties. Examination of terrace chronologies along other small streams in the region show only very limited consistency in the timing of sediment deposition and soil formation. In broad regional terms, and looking eastward where more studies have been conducted, similarities in key ages center around 5,000 B.P. and 2,000 B.P. The most general trend is an episode of valley filling before ca. 5,000 B.P. After ca. 5,000 B.P. overbank deposition dominates, but few paleosols have been identified. At around 5,000 B.P., noticeable changes occurred, but causal factors are not clear. Soils were either truncated or a noticeable drop in the deposition rate occurred ca. 2,000 B.P. This may indicate a period of widespread downcutting of streams.

In our attempt to reconstruct paleoenvironmental conditions, the employment of multiple lines of inquiry/analysis concerning past environmental conditions has contributed to a broader understanding and identification of a more complete range of plants in pertinent floral communities. The current data from the Varga Site indicates that the local vegetation community did not significantly change over the last 6,300-years. That is not to say that the density of various plant species remained constant over this period, but the data is not robust enough to see those changes, or from another perspective, the changes were not great enough to be represented in our limited data bases. The plant communities were, over the long-term, dominated by $\mathrm{C}_{3}$ vegetation that consisted of a mixture or a composite of grasses and arboreal species.

It should be kept in mind, as this discussion proceeds, that our data are all from a generally well-watered streamside alluvial terrace, and the apparent near-consistency in the environment may not apply to upland areas away from the stream valley, where even relatively small changes in climate may have had a more profound affect upon plant communities and, by extension, on general biotic productivity. This may partially explain why the general interpretation of the paleoenvironment based on our empirical data is not in keeping with the broader interpretations from across Texas in that a gradual warming and drying trend occurred during the Holocene until about 3,000 B.P., when a wetter phase began. Specific data sets in selected geographical settings reveal paleoenvironmental variations and limited indications of a pronounced change, but a general trend is documented. The timing of these detected changes is not always in direct 
correlation with other areas, and it is not clear if the actual events occurred at slightly different times across broad regions, or that variability in our dating techniques or extrapolations of these ages and/or events exists. In most locations, the vegetation communities appear relatively stable, but a warm and dry period has been documented in a few of the surrounding regions.

A study of the upper Pedernales River near Fredericksburg (Blum and Valastro 1989) documents changes in the environment based on geomorphic history of alluvial terraces. The evidence indicates two climate shifts, one around 4,500 B.P. and another around 1,000 B.P. An erosional unconformity indicates a dry climate before ca. 4,500 B.P. From ca. 4,500 to ca. 1,000 B.P., Blum and Valastro (1989) interpret the data to indicate increased precipitation through heavy rains. After about 1,000 B.P., they see a generally modern climate and episodic flash floods.

Just north of Edwards County, at the Buckhollow Site in Kimble County, Late Archaic cultural materials were contained in a paleosol (Johnson 1994), which was much thicker than the Varga Site paleosol that contained a Late Archaic component. Johnson sees this paleosol as requiring a relatively moderate and stable climate and associates this development with relatively mesic conditions. The Buckhollow paleosol is undated, whereas the Varga Site paleosol was radiocarbon dated to 1,900 B.P. and contains cultural materials that date from 1,700 to 2,300 B.P. The carbon isotope value of $-22.8 \%$ from that dated matrix also supports a moist $\mathrm{C}_{3}$ vegetation community.

Johnson and Goode's (1994) dry Edwards Interval, dated at ca. 5,000 to 2,500 B.P. in the eastern Edwards Plateau is generally supported by the faunal record from Hall's Cave (Toomey et al. 1993), but is not evident at the Varga Site. The stable carbon isotope analysis on the sediments and other pertinent data from the Varga Site does not reveal any recognizable shift or change in the organic composition that might signal this dry period. Bousman (1998) sees a two-phased, mid-Holocene dry interval, with extremes recorded at 6,500 B.P. and 5,000 B.P. from requantified pollen results from Boriack and Weakly bogs located just east of the Edwards Plateau. In calculating the relationship of the arboreal canopy cover with pollen percentage, Bousman (1998) sees the arboreal canopy at its most restricted extent at about 5,000 B.P.

River valleys across much of Texas reveal a pattern of Middle Holocene channel trenching roughly between 7,000 and 5,000 B.P. due to severe drying conditions. This is generally followed by a postulated wetter period from ca. 4,500 to 1,000 B.P. as evidenced by alluviation, with a return to channel trenching by 1,000 B.P. (Hall 1990).

In the Lower Pecos region, phytolith and stable isotope studies have not been attempted, and pollen records are spotty, mixed, or incomplete. However, rockshelter deposits have yielded great quantities of plant remains (Dering 1977, 1979) and human coprolites (Bryant 1974; Williams-Dean 1978) that have provided data from which past environmental conditions can be extrapolated. It is not clear what specific paleoclimatic conditions existed between 7,000 and 4,000 B.P. This was a period of erosion and severe flooding along the Rio Grande, as evidenced at Devil's Mouth Site (Johnson 1964) and Arenosa Shelter (Dibble 1967), which may indicate increased runoff from slopes with a generally reduced vegetation cover. Before about 6,700 B.P., oak, juniper, walnut, mesquite, hackberry, coyotillo, onion, lechuguilla, yucca, sotol, grasses, and prickly pear were all present in the Lower Pecos region and were exploited by the human population (Dering 1979). By about 6,100 B.P., acacia, yucca, chenopodium, buffalo 
gourd, sumac, and Texas mountain laurel were also exploited. Dering sees a major vegetation change in the Lower Pecos region between 5,000 and 4,400 B.P., primarily on the basis of macrobotanical data. Dering (1979) goes on to argue that the general environment of the Lower Pecos region has not changed as drastically as had been previously thought by Bryant (1977a). Currently, it is difficult to state that the Varga Site data are similar to the Lower Pecos region because of the incompleteness of the two records and the different types of data currently available for each region.

Huebner (1991b) used a broad range of environmental data from across Texas to address the presence of bison in Texas over the last 750 years. He saw diverse environmental data indicating that the climate of the southern Plains became more xeric, with an increase in grasses, about 1,000 B.P. He suggested that the bison population grew in response to these conditions and hypothesized that bison herds were permanent additions to the biota, although thinly spread rather than present in all areas at all times. He also stated that local conditions of grass cover, topography, and access to water would be constraining factors in humanecological decision making. Stable carbon isotope analyses on bison bones from the last 750 years across Texas (Huebner 1991b; Huebner and Boutton 1990) document that bison grazed across a broad range of environments throughout the state and were consuming about 87 percent $\mathrm{C}_{4}$ grasses, with a resultant mean $\delta^{13} \mathrm{C}$ values in their bones near $-9.5 \pm 1.7 \%$. $\mathrm{C}_{4}$ grasses are established on most of the Southern Plains and probably are the dominant grasses in the modern prairie, oak-juniper, oakwoodlands, and oak-savanna in Texas, judging by analysis of phytoliths from sediments in these regions (Fredlund 1998).

A small bone fragment (\#525-5-2-1a) from Feature 2 in the Toyah component in Block A yielded a stable carbon isotope value on collagen of $-8.6 \%$, a nitrogen isotope value of $5.1 \%$, and a stable isotope value on bioapatite of $-4.0 \%$. These isotope values indicate the bone was that of a bison, which had consumed about 90 percent $\mathrm{C}_{4}$ plants (grasses) over its lifetime. These isotope values are similar to those derived on bison bones from a Toyah component at the Rush Site (Quigg and Peck 1995) near San Angelo, some $200 \mathrm{~km}$ north of the Varga Site, and bison bones from the Sanders and Broken Jaw sites in the northern Texas Panhandle (Quigg 1993, 1997a). The similarities in the carbon isotope values from the Varga Site bison and the other Toyah bison samples indicate similarities in the bison feeding patterns over the last 600 to 700 -years in a vast area across Texas, including eastern Edwards County.

The carbon isotope result on a single bison bone from the Varga Site indicates a very high consumption of $\mathrm{C}_{4}$ grasses, which is also very similar to other bison isotope results from this same period across Texas (Huebner 1991b). In contrast, the carbon isotope values extracted from the soil organic matter dating to this same period at the Varga Site do not support the presence of $\mathrm{C}_{4}$ grasses on site. The four sediment samples analyzed from the Toyah component document an average carbon isotope value of $-28.72 \%$ and a nitrogen isotope value of $8.32 \%$. These values indicate a nearly complete $\mathrm{C}_{3}$ community comprised of arboreal species and grasses. If $\mathrm{C}_{4}$ grasses were not in the immediate site area, then the bison must have generally had a feeding range beyond the Varga Site locality that focused on $\mathrm{C}_{4}$ grasses. $\mathrm{C}_{4}$ grasses potentially were part of the upland vegetation community on the short-grass prairies to the north. The bison documented at the Varga Site may have arrived in this vicinity as a result of seasonal herd-migration patterns. The documented animal would have consumed mostly $\mathrm{C}_{4}$ grasses elsewhere, and then moved into this region on a part time/seasonal basis 
when $\mathrm{C}_{4}$ grasses elsewhere were in their lowest production. One may speculate that the time of the latter low production would have been late winter or spring when $\mathrm{C}_{3}$ grasses in the region would have been more plentiful and more nutritious than the $\mathrm{C}_{4}$ grasses elsewhere. Such short-term seasonal movements from the more dominant $\mathrm{C}_{4}$ grass communities elsewhere would account for the small percentages of $\mathrm{C}_{3}$ component in the detected isotopic values of the bison bone.

The Toyah component at the Varga Site yielded a phytolith assemblage that contained saddle and simple lobate shaped phytoliths that constitute roughly 20 to 32 percent short-shell phytoliths. These types indicate a relatively low percentage of $\mathrm{C}_{4}$ type grasses or CAM plants with $\mathrm{C}_{4}$ signatures that would reflect a short grass prairie. These frequencies are less than half the frequencies identified by Fredlund (1998) for prairies in Bell County of Central Texas, and for an oak savanna region in Kerr County just to the east of Varga. However, the presence of 20 percent $\mathrm{C}_{4}$ grasses or CAM plants with $\mathrm{C}_{4}$ signatures are not supported by the stable carbon isotope data that indicate a less than five percent $\mathrm{C}_{4}$ contribution. The $\mathrm{C}_{4}$ grasses are the preferred vegetation for consumption by bison as documented by bison bone isotope data. But bison are generalized consumers and will consume a variety of plants (Martin et al. 1951; Pedon et al. 1974; Pedon 1976).
Fredlund and Tieszen (1998) also indicate a discrepancy between the isotope data from soil and the phytolith record at the Wilson-Leonard Site in Williamson County. They suggest this discrepancy is related to spatial scale with the phytolith record indicative of regional vegetation with eolian processes introducing additional phytoliths, whereas the soil organic matter is more reflective of the local environment.

In summary, the Varga Site paleoenvironmental record does not reflect a significant warm and/or dry period during the ca.6,300-year period represented based on the pollen, phytolith, and carbon isotope data recovered from this streamside site. The local vegetation community did not significantly change over this same 6,300-year period. The vegetation communities were comprised chiefly of $\mathrm{C}_{3}$ vegetation that consisted of a mixture or a composite of grasses and arboreal species. However, at around 5,000 B.P., a noticeable change occurred in the deposits, but it is not clear exactly what those changes are or related to. Soils were either truncated or a reduction in the deposition rate occurred ca. 2,000 B.P. This may indicate a period of down cutting. These changes may relate to regional fluctuations in wet and dry periods, but the broader climatic conditions appear to have been relatively stable, and apparently were cooler/wetter than conditions in the surrounding regions. 



\subsection{SUBSISTENCE PATTERNS}

\section{J. Michael Quigg}

\subsection{INTRODUCTION}

General subsistence patterns are usually considered to represent the food resources that each prehistoric group consumed over a period of time. These broad patterns are generally established from excavations at many sites in order to accurately document spatial variability in subsistence practices as correlated with the heterogeneity in environmental mosaics. A single site excavation such as this only documents a single point in space, and thus, cannot fully reflect the full range of exploited resources within the relevant human ecosystem.

The subsistence resources for the four major time periods documented at the Varga site (Early Archaic from 6,300 to 5,200 B.P., Middle Archaic period from 4,820 to 3,900 B.P., Late Archaic period from 2,300 to 1,700 B.P., and the Toyah phase into the Protohistoric from 620 to 290 B.P.) were individually mentioned in the preceding chapters dealing with each of the individual cultural components. In this chapter, we summarize the site-specific subsistence patterns each of these four general time periods.

The subsistence resource information for these four time periods was sought from diverse samples of material collected during the excavations and analyzed in an attempt to determine as closely as possible the full range of food resources exploited by prehistoric occupants of the site. Some direct data are available in the form of about 21,500 faunal bone fragments, about 30 mussel shell fragments, and roughly 460 grams of macrobotanical remains; whereas other data sets comprise proxy evidence in the forms of the 99 lipid residue analyses, the 98 stable carbon and nitrogen isotope results, and the use-wear analysis supplemented by organic residue identifications on 79 of the 156 stone tools analyzed. Offered below are brief summaries of classes of data, comparisons of the records between the different components, and discussions of the findings.

\subsection{Vertebrate Fauna}

The bones recovered generally represent the hunted or captured animal resources of their respective time periods. Bone is best preserved and most frequent in the Toyah component (20,438 pieces), compared to the three earlier components that yielded a combined total of only ca. 1,000 pieces. Table $14-1$ reveals 10 different species that were identified in the Toyah component. The three older components yielded very infrequent and scattered bones, which represent anywhere from three to five species. Although the frequency of individual pieces and species identified is much less in the three older components, there is reason to believe that this lower frequency is not entirely the result of poor preservation. Because some bones were still present in the Early Archaic $(n=200)$, one would expect most bones of different hunted species to still be represented. The cortical walls of bison long bones are much thicker than most other species. Therefore, if bison long bones were present in any of the early components, then bison bones would undoubtedly have been preserved, especially since bones of deer and possibly rabbit were present in the Early Archaic assemblage. 
Table 14-1. Subsistence Resource Results

\begin{tabular}{|c|c|c|c|c|}
\hline Categories Investigated & $\begin{array}{c}\text { Toyah } \\
300 \text { to } 660 \text { B.P. }\end{array}$ & $\begin{array}{c}\text { Late Archaic } \\
\text { 1,700 to 2,300 B.P. }\end{array}$ & $\begin{array}{c}\text { Middle Archaic } \\
\text { 3,900 to 4,820 B.P. }\end{array}$ & $\begin{array}{c}\text { Early Archaic } \\
\text { 5,200 to 6,300 B.P. }\end{array}$ \\
\hline \multicolumn{5}{|l|}{ Vertebrates: } \\
\hline Bison & 2 & 1 , ? & 1 , ? & \\
\hline Deer & 2 & & 2 & 1 \\
\hline Antelope & 1 & & & \\
\hline Deer/Antelope & & 1 & & \\
\hline Rabbit & 2 , ? & & 2 & 1 , ? \\
\hline Coyote/dog & 1 , ? & & 1 , ? & \\
\hline Turtle & 2 , ? & & 1 , ? & \\
\hline Fish & 2 , ? & & & \\
\hline Snake & 2 , ? & & & \\
\hline Large Bird & 1 , ? & & & \\
\hline Mussel Shells & $\mathrm{x}$, ? & $\mathrm{x}$, ? & & $\mathrm{x}$, ? \\
\hline \multicolumn{5}{|l|}{ Macrobotanical Food Resources: } \\
\hline Agave heart and leaves & $\mathrm{x}$ & $\mathrm{x}$ & & \\
\hline Cheno-ams & $\mathrm{x}$, ? & & & \\
\hline Walnut shells & $\mathrm{x}$, ? & $\mathrm{x}$, ? & $\mathrm{x}$, ? & $\mathrm{x}$, ? \\
\hline Mesquite beans & $\mathrm{x}$ & $\mathrm{x}$ & & \\
\hline Prickly pear seeds & $\mathrm{x}$ & $\mathrm{x}$ & & $\mathrm{x}$, ? \\
\hline Pecan shells & $\mathrm{x}$, ? & $\mathrm{x}$, ? & & \\
\hline Total weight of samples & $70.3 \mathrm{~g}$ & $23.7 \mathrm{~g}$ & $0.8 \mathrm{~g}$ & $6.3 \mathrm{~g}$ \\
\hline \multicolumn{5}{|l|}{ Lipid Residues from Burned Rocks: } \\
\hline Plants residues & $76 \%$ & $97 \%$ & $100 \%$ & $100 \%$ \\
\hline Large herbivore residues & $24 \%$ & $3 \%$ & $0 \%$ & $0 \%$ \\
\hline Number of samples & 29 & 33 & 9 & 22 \\
\hline \multicolumn{5}{|l|}{ Carbon Isotopes from Burned Rocks: } \\
\hline $\mathrm{C}_{3}$ values represented & $94 \%$ & $100 \%$ & $100 \%$ & $100 \%$ \\
\hline Number of samples & 29 & 33 & 9 & 21 \\
\hline \multicolumn{5}{|l|}{ Use Interpretations from Stone Tools: } \\
\hline Plants (wood, hard silica, raphids) & $72 \%$ & $61 \%$ & $75 \%$ & $55 \%$ \\
\hline Animals (hair, hide, bone, soft, meat) & $14 \%$ & $22 \%$ & $25 \%$ & $12 \%$ \\
\hline Number of tools analyzed & 59 & 17 & 17 & 63 \\
\hline
\end{tabular}

2 = minimum number of individuals; $\mathrm{x}$ = present; $?=$ unknown if cultural in origin 
With so few bone fragments recovered from the three lower components, it is possible that a few individual bones were displaced downward and mixed with the earlier materials. The procedures followed during analysis to sort in situ bones from vertically displaced specimens have been discussed in previous pages and will not be repeated here. Suffice it to say that, while we are cognizant of the influence of taphonomic factors on the bone samples from various components, the faunal data discussed here, and presented in Table 14-1, are believed to be a reasonably reliable basis for interpretation.

Many bison bones ( $n=1,481$ pieces) were recovered from the Toyah component, representing a minimum of two adult individuals. Dillehay (1974) documented the presence of bison during this period in Texas, and their presence has been further substantiated over the years at most Toyah sites (e.g., Buckhollow, 41TG91, Rush, Mustang Branch [41HY209], Rainey Sinkhole, Hinojosa). Although bison bones have commonly been identified in Toyah components, the minimum number of animals identified per any single site/event is generally fairly low, usually less than four individuals. Thus, it generally seems that, while bison were consistently a major source of meat during the Toyah phase, they were not procured with a hunting strategy that involved massive kills of large numbers of animals at any one time. Toyah peoples were apparently diversified hunters who killed deer in larger numbers than bison. They also killed and presumably consumed antelope and many types of smaller game animals as well. A subsistence strategy in which bison were taken in limited numbers may represent an adaptation to an environment that contained only relatively limited numbers of these large ungulates. Huebner (1991b:354) discusses the movement of bison into central and southern Texas:
The occupation of the western Edwards Plateau by Bison spp. may be limited to the Paleoindian and Late Archaic periods. During the Late Prehistoric the limited evidence of bison remains south of the upper Colorado River does not suggest the movement of large herds. Further, a model showing movement of bison across the Plateau onto the coastal prairies would have to account for canyon lands along the Balcones escarpment. This area of deeply entrenched streams and tight canyons would have been a severe impediment to southward movement.

This author agrees that few large bison kills have been documented in central or southern Texas (Bonfire Shelter, at which large jump kills were carried out, being the one major exception). However, I am unconvinced that the Balcones escarpment was a "severe impediment" to bison movement. The bison at the Varga Site, which lies just below the very southern edge of the Balcones escarpment in the dissected canyonlands, indicates their presence in this rugged topography, if only in limited numbers. The volumes of historic accounts of bison behavior (i.e., Haines 1970; McHugh 1958, 1972; Roe 1972) and modern handling of bison (Frison 1978) reveal that this rugged terrain would not have impeded their movements. The minimum number of bison identified at the Varga Site accords with other findings at Toyah sites, and may indicate that only small herds were present across vast regions of Texas. The eastern route of bison movement into central and southern Texas postulated by Huebner (1991b) was based mostly on the absence of data and/or investigated sites in the western Edwards Plateau dating to this period. The absence of data is a direct result of the lack of investigations rather than a limitation on the movements of bison through that region. Investigated Toyah sites in the western Edwards Plateau region such as Varga, Buckhollow, and Rainey Sinkhole all 
have yielded some bison bones, reflecting recent growth in our regional database. These investigated sites document unequivocally that bison were in the western part of the Edwards Plateau and in the rugged canyonlands during the Toyah period. Bison presence in the region continued into the Protohistoric period, as indicated by recorded sightings of these animals in the Val Verde County area (Turpin 1987; Kenmotsu 1994, 2001; Wade 1998).

In contrast to the Toyah component, the Late Archaic component at the Varga Site yielded little in the way of bison remains. Just a few small tooth enamel fragments are identified, and it is probable they were displaced downward from the immediately overlying Toyah component. The evidence for bison presence in the Late Archaic at the Varga Site is questionable at best. The interpretations of the lipid residues from 34 Late Archaic burned rocks indicate no residues definitely attributable to large herbivores, further supporting the absence of bison in the subsistence repertoire at this site during the Late Archaic.

However, the Late Archaic period is one of Dillehay's (1974) identified periods of bison presence with some sites from across the broad region yielding bison bones. In the Lower Pecos region, bison bones have been recovered during the Late Archaic at Skyline Shelter (Turpin and Bement 1992) and Bonfire Shelter (Dibble and Lorrain 1968). The radiocarbon age for the bison Bone Bed 3 at Bonfire is ca. 2,300 to 2,900 B.P. and is associated with Castrovillelike and Montell points. Turpin and Bement (1992) believe the presence of bison reflects a winter occupation, but no direct evidence is yet available for a specific seasonal usage. So, bison were in the Lower Pecos during the Late Archaic period, but possibly only on seasonal bases. Therefore, only in some seasons, and some Late Archaic sites occupied during those seasons, were bison potentially available to the human population.

In the Middle Archaic component at the Varga Site bison bone comprises less than one percent of the faunal-bone sample. More than likely the few, very small pieces were not recovered from their original context, but originated from occupations above. Therefore, it is not likely that bison were present or were part of the Middle Archaic subsistence strategy. Lipid residue analysis on nine Middle Archaic burned rocks from Features 11 and 37 were interpreted as having cooked no large herbivore meat, also indicating an absence of bison in this component. In the Lower Pecos region, where preservation is often better in the large rockshelters compared to open-air campsites, Middle Archaic components at sites such as Skyline Shelter have yielded diverse faunal assemblages including fish, deer, turtle, and mussel shells, but produced no evidence of bison. The absence of bison in the Middle Archaic is probably a more or less localized phenomenon. However, this is the general time frame that Bell/Andice projectiles appear in Central Texas at sites like Landslide, Occupation Phase 3 (Sorrow et al. 1967). These point types are thought to be in association with bison remains (Sorrow et al. 1967; Johnson and Goode 1994), but the radiocarbon dating of bison bones is very limited in support of this assumed association.

No bison bones were identified in the Early Archaic component at the Varga Site, one of Dillehay's (1974) proposed periods of bison absence. In addition to the lack of direct evidence of bison bones, the lipid residue analysis on 22 burned rock pieces from the Early Archaic component also lacks lipid residues interpreted as representing large herbivores. Apparently bison were not procured or present between 6,300 and 5,200 B.P. at the Varga Site. 
Identified faunal remains indicate a diverse range of exploited habitats. Exploitation of the riverine environments is implied by the presences of fish and possibly turtle, if these few elements represent human procurement. The presence of deer indicates a forested or wooded environment. Bison, antelope, and potentially jackrabbits indicate upland and/or open-range environments. The lack of additional species that reflect wooded habitats such as skunks, raccoons, bobcats, and squirrels is interesting, but little can be drawn from the absence of species, which may be more reflective of the small, fragmented condition of the bone fragments that precluded large numbers of positive identification of taxa .

\subsection{EVIDENCE FOR THE USE OF PLANTS}

The exploitation of plant resources is best identified through a combination of data sets, including macrobotanical remains, the proxy lipid residue data supported by stable isotope values, and the combination of organic residue identifications and use-wear on stone tools.

The macrobotanical analysis on remains from 404.5 liters of floated sediments and 75 individual samples resulted in the identification of 20 plant taxa (Table 14-2), six of which are edible plant parts consisting of Agavaceae (sotol, yucca, and agave) leaf and caudex fragments, prickly pear seeds, mesquite seeds, cheno-am seeds (goosefoot and pigweed), littleleaf walnut shells, and thin nutshells that probably represent pecans. Edible plant parts are most abundant for the Toyah component with the Late Archaic also yielding a relatively high number of species (Table 14-2).

The carbohydrate-rich agave heart is ethnographically known to have been cooked and consumed (Castetter and Opler 1936; Bell and Castetter 1941; Castetter et al. 1938). Fiber from different succulents such as yucca, agave, and sotol have been recovered in many of the rockshelters of the Lower Pecos region (Williams-Dean 1978; Stock 1983; Sobolik 1991a; Brown 1991; Dering 1999). Dr. Dering (Appendix I; 1999) provides data on how these agave hearts were cooked in ovens. Therefore, its presence in the Toyah and Late Archaic components probably reflects use as a food resource.

Pecan nuts, identified in the two youngest components, do offer sufficient meat that could provide an excellent source of nutrition. Pecan wood was not identified in the macrobotanical assemblage, thereby strengthening the assumption that this nut was used as food source. In support of the use of nuts during the Late Archaic period is a single, small nutting or pitted stone (\#1251-010), assumed to have been used in the processing of nuts and/or seeds.

Burned mesquite seeds (rich in carbohydrates), identified in the two youngest components, have been well documented in the ethnographic literature as a food resource, and were probably a targeted food. In Appendix I, Dr. Dering provides information on how the mesquite pod was processed. The mesquite seed in the Toyah context was recovered from Feature 30 that also yielded mesquite wood. This specific feature context indicates that the seed may have been attached to the mesquite wood as part of the fuel, rather than targeted as a food resource.

Prickly pear seeds were identified in three of the four components, indicating that this fruit was available and undoubtedly consumed. Further support for peoples in this region consuming prickly pear fruit is indicated by an adult female burial recovered from below the floor of the church at Mission San Lorenzo de la Santa Cruz that contained a concentration of several hundred small prickly pear seeds in her abdomen area (Tunnell 1969). 
Table 14-2. Botanical Comparisons by Component

\begin{tabular}{|c|c|c|c|c|}
\hline Organic Remains & $\begin{array}{c}\text { Toyah } \\
80 \text { to } 660 \text { B.P. }\end{array}$ & $\begin{array}{c}\text { Late Archaic } \\
1,700 \text { to } 2,300 \text { B.P. }\end{array}$ & $\begin{array}{c}\text { Middle Archaic } \\
3,900 \text { to 4,820 B.P. }\end{array}$ & $\begin{array}{c}\text { Early Archaic } \\
\text { 5,200 to 6,300 B.P. }\end{array}$ \\
\hline Agarita & $36 / 6.6 \mathrm{~g}$ & & & \\
\hline Buttonbush & $8+5 \mathrm{ml} / 1.4 \mathrm{~g}$ & $2 / 0.2 \mathrm{~g}$ & & \\
\hline Cheno-am & $2 / 0.2$ & & & \\
\hline Condalia or buckthorn & $3 / 0.2 \mathrm{~g}$ & $5 / 0.3 \mathrm{~g}$ & & \\
\hline Cottonwood/willow & $24 / 1 \mathrm{~g}$ & & & \\
\hline Elm & $19+4 \mathrm{ml} / 1.1 \mathrm{~g}$ & & & \\
\hline Hickory & $12 / 0.4 \mathrm{~g}$ & & & \\
\hline Indeterminate & $166+23 \mathrm{ml} / 12.1 \mathrm{~g}$ & $128+5 \mathrm{ml} / 1.6 \mathrm{~g}$ & $1 / 0.1 \mathrm{~g}$ & $25 / 0.7 \mathrm{~g}$ \\
\hline Juniper & $61+28 \mathrm{ml} / 8 \mathrm{~g}$ & $34+14 \mathrm{ml} / 2.7 \mathrm{~g}$ & & $14+10 \mathrm{ml} / 3.6 \mathrm{~g}$ \\
\hline Littleleaf walnut & $5 / 0.4 \mathrm{~g}$ & $1 / 0.1 \mathrm{~g}$ & & $6 / 0.7 \mathrm{~g}$ \\
\hline Lotebush & $41+10 \mathrm{ml} / 5 \mathrm{~g}$ & $7 / 0.2 \mathrm{~g}$ & & \\
\hline Mesquite & $97 / 7.1 \mathrm{~g}$ & $37+34 \mathrm{ml} / 16 \mathrm{~g}$ & $10 / 0.5 \mathrm{~g}$ & $9 / 0.7 \mathrm{~g}$ \\
\hline Mexican buckeye & $9 \mathrm{ml} / 1.7$ & & & \\
\hline Oak & $330+27 \mathrm{ml} / 14.8 \mathrm{~g}$ & 19/1.8 g & $1 / 0.1 \mathrm{~g}$ & $12 / 0.6 \mathrm{~g}$ \\
\hline Pecan & $5 / 0.2 \mathrm{~g}$ & & & \\
\hline Pinyon & $1 / 0.1 \mathrm{~g}$ & & & \\
\hline Prickly pear & $2 / 0.1 \mathrm{~g}$ & $3 / 0.1 \mathrm{~g}$ & & $3 / 0.3$ \\
\hline Sycamore & $13 / 0.6 \mathrm{~g}$ & & & \\
\hline Sotol/yucca/Agave & 20/3.2 g & $9 / 0.3 \mathrm{~g}$ & & \\
\hline Woody legume & $51+21 \mathrm{ml} / 6 \mathrm{~g}$ & $4 / 0.4 \mathrm{~g}$ & & \\
\hline Total Count & $806+126 \mathrm{ml}$ & $248+53 \mathrm{ml}$ & 12 & $69+10 \mathrm{ml}$ \\
\hline Total Weight (g) & 70.4 & 23.6 & 0.7 & 6.3 \\
\hline
\end{tabular}

Sobolik (1991a) also indicates that prickly pear cactus was the most commonly utilized plant at Baker Cave in the Lower Pecos at about 1,000 B.P. Prickly pear seeds were recovered from many human coprolites, documenting their consumption. The recovered seeds were fragmented, indicating that the fruit was processed before consumption (Sobolik 1991a:108).

Littleleaf walnut shells were identified in all four components. The small size of the walnut meat would make meat extraction time consuming and labor intensive. In support of the consumption of walnuts, Sobolik (1991a) 
recovered walnut fragments in human coprolites from Baker Cave. Dr. Dering (Appendix I) provides several ethnographic examples that document the use of walnuts. It is also possible that the walnuts were used as fuel; however, walnut wood was not identified in the burned wood assemblage, indicating the nuts were probably not attached to wood used as part of a fuel source.

Testing at multiple Late Archaic burned rock middens of similar age in northeastern Val Verde County yielded littleleaf walnut shells at 41VV1892 and littleleaf walnut, prickly pear, and sotol/yucca fibers at 41VV1897 (Cliff 2003). Walnut shells account for 53.5 percent of the edible plant parts, prickly pear seeds account for 2.3 percent, and sotol/yucca parts account for nearly 21 percent from the tested middens in northeastern Val Verde County (Dering 2003b). The similarity in macrobotanical remains from these burned rock middens supports the idea that similar foods were processed in these features during the Late Archaic period. In contrast, a Late Archaic burned rock midden in the Blackland Prairie in Williamson County in Central Texas yielded some small burned and unburned bones of deer, turtle, snake, bird, carnivore, and rodents, plus many camus sp. bulb fragments (Brownlow 2003; Dering 2003c). In Brown County, a complex of tested burned rock middens from 16 sites yielded quantities (400 bulbs and bulb fragments) of five different geophytes-Eastern Camas, wild onion, false garlic, dog's-tooth violet, and rain lily (Dering 2003a; Mauldin et al. 2003). Obviously, hot rocks were employed to cook different food products, including geophytes. At Hinds Cave in the Lower Pecos region, the coprolite studies indicate that cactiprickly pear and other succulents-remained important in the diet during all cultural time periods (Stock 1983). Throughout the Lower Pecos and across a wide time period, prickly pear was probably a dietary staple together with sotol, agave, and yucca (Sobolik 1991a).

The Middle Archaic component yielded little in the way of macrobotanical remains. Only one float sample from Feature 11 yielded a single fragment of a littleleaf walnut shell. However, charcoal from this same feature was radiocarbon dated to the Late Archaic component. Consequently, the walnut shell from this specific feature context is questionable in terms of its cultural/temporal context. If the walnut shell was directly associated with this component, it would reflect the persistent use of this resource throughout the entire 6,300-year time span of Varga Site occupation. Wood charcoal from juniper, oak, and mesquite trees was present. Acorns, mesquite seeds, and juniper berries were thus, potential food resources, though they were not recovered from this Middle Archaic context.

The Early Archaic component yielded radiocarbon-dated prickly pear seeds and littleleaf walnut shells (see Table 11-1). Both plant parts are available in late summer into fall, and therefore, may indicate one of the seasons of occupation. Burned wood identified includes walnut, juniper, mesquite, and oak, and trees of all these species produced edible parts.

Rainfall has significant influence on when most fruits, nuts, and seeds ripen in this region. The best time of year for exploiting sotol, or agave as food is in the spring before the flower stalks develop. Mesquite beans and cheno-am seeds generally ripen in mid-summer. Nuts ripen in late summer to mid-fall. Most occupations at the Varga Site contained macrobotanical remains that indicate two or more seasons of occupation. This may reflect either multiseasonal use of the site by a single group or, alternatively, it may represent multiple, shortterm occupations for each component.

At the Varga Site, plant collecting and cooking is also interpreted by indirect or proxy evidence 
from the lipid residues extracted from 94 burned rocks, presumably used in cooking. Since the burned rocks move much less than smaller cultural objects, these larger objects are more confidently believed to represent the stratigraphic component in which they were found. The lipid residues from the burned rocks provide evidence that plants were cooked, and therefore consumed, as opposed to plants collected and used for other purposes (Table 14$3)$.

A sample of 29 burned rocks from the Toyah context yielded results that indicate nearly 76 percent of the lipid residues represent plant products. About 24 percent yielded residues of the meat of large herbivores (i.e., bison, deer, pronghorn), though for about one-half of the samples, it is unclear if other kinds of meat residues are present.. In the Late Archaic period, the large herbivore meat is only reflected by about three percent of the 33 burned rock samples analyzed (i.e., in one sample). The two oldest components did not reveal any lipid residues that reflect cooking of large herbivore meat.

One possible explanation would be that the deer meat was not prepared through cooking by hot rocks (i.e., boiling, broiling, or baking) indicating that deer meat may have been roasted over a flame, dried, or even consumed raw. The lipid residues detected in the burned rocks reflect high concentrations of fatty plant substances (i.e., nuts and seeds) throughout time. Extensive cooking of plants is implied from the lipid residues, providing a sharp contrast to the direct evidence reflected in the faunal-bone assemblages. In combination, the two different data sets reflect a more comprehensive and broader range of resources exploited by the groups rather than does either taken alone.

The lipid residue data is supported by 92 stable carbon and nitrogen isotope results derived from the exact same burned rocks, with the Varga Site background data provided through stable isotope analyses of the dated sediment samples from the soil column (Table 14-3 and Figure 14-1). These results indicate extensive use of $\mathrm{C}_{3}$ plants and/or animals that ate $\mathrm{C}_{3}$ plants, in support of the lipid residue results. A few isotope results in the projected terrestrial animal range may represent animals such as rabbits and buffalo that consumed $\mathrm{C}_{3}$ plants, as reflected in the sample of modern plants and animals analyzed (Figure 14-2).

Plant and animal diversity is also documented in the stone tool assemblages from each of the four components. The use-wear analyses and organic residue identifications support the manipulation of multiple food resources. Multiple tool forms including points, bifaces, scrapers, and edgemodified tools were present in all four components and imply diverse functions on multiple materials. The use-wear evidence does not associate a specific tool class to a specific functional task or material, but does reveal a broad range of activities directed toward plants and animals. The use-wear interpretations and organic residues identified on the tools from all four components reveal extensive use on, and residues from, plants and animals.

The observed residues on Toyah component tools reveal the use of starchy plants (possibly roots or tubers), mammals, birds, and other types of plants. Feathers on one Toyah biface (Appendix C) substantiate the use of birds. The use-wear interpretations on the Toyah tools indicate that only about 14 percent were associated with animal use or residues, whereas 72 percent of the interpretations of the use-wear support use of tools on plants. The latter figure is nearly equal to the identified plant lipid residues identified from the burned rocks. 
The Varga Site

Texas Department of Transportation

Table 14-3. Summary of Interpretations of Foods Cooked by Burned Rocks Analyzed from Selected Features

\begin{tabular}{|c|c|c|c|c|c|c|c|}
\hline $\begin{array}{l}\text { Fea. } \\
\text { No. }\end{array}$ & $\begin{array}{c}\mathrm{C}^{14} \text { Age } \\
\text { B.P. }\end{array}$ & Cat. \# & $\begin{array}{l}\text { Wgt } \\
\text { (mg) }\end{array}$ & $\begin{array}{c}\delta^{13} \mathrm{C} \\
(\%) \\
\text { Value }\end{array}$ & $\begin{array}{c}\delta^{15} \mathbf{N} \\
(\%) \\
\text { Value }\end{array}$ & Lab. No. & Lipid Residue, Results and Interpretations \\
\hline \multicolumn{8}{|c|}{ Toyah } \\
\hline 8 & $570-620$ & $865-5-3-1 a$ & 40.381 & -26.11 & -4.21 & 4VG 9 & Moderate-high fat content \\
\hline 8 & & $865-5-3-2 a$ & 7.623 & -21.84 & 5.61 & 4VG 10 & Borderline medium and moderate-high fat content \\
\hline 8 & & $865-5-3-3 a$ & 12.374 & -23.93 & 4.99 & 4VG 11 & High fat content \\
\hline 8 & & $843-5-3-1 a$ & 5.316 & -18.43 & 5.75 & $4 \mathrm{VG} 12$ & Large herbivore - somewhat fatty \\
\hline 8 & & $843-5-3-2 a$ & & & & $4 \mathrm{VG} 13$ & High fat content - plant \\
\hline 8 & & $843-5-3-3 a$ & & & & 4VG 14 & Large herbivore - fat meat \\
\hline 9 & 660 & $830-5-3-1 a$ & & & & 4VG 15 & Borderline medium and moderate-high fat content - plant \\
\hline 9 & & $830-5-3-2 a$ & 41.813 & -23.57 & 3.83 & 4VG 16 & Large herbivore - fat meat, possibly plant \\
\hline 9 & & $830-5-3-3 a$ & 4.438 & -25.75 & 6.44 & 4VG 17 & Large herbivore + plant or bone marrow \\
\hline 9 & & $830-5-3-4 a$ & 12.351 & -20.97 & 6.67 & 4VG 18 & Borderline medium and moderate-high fat content - plant \\
\hline 25 & & $1051-5-3-1 a$ & 12.351 & -20.97 & 6.67 & $4 \mathrm{VG} 19$ & High fat content - plant \\
\hline 25 & & $1051-5-3-2 a$ & 23.835 & -18.45 & 4.85 & $4 \mathrm{VG} 20$ & Borderline medium and moderate-high fat content - plant \\
\hline 25 & & 1051-5-3-3a & 17.353 & -20.45 & 6.41 & 4VG 21 & Large herbivore - somewhat fatty, possibly plant \\
\hline 25 & & $1051-5-3-4 a$ & 42.672 & -25.70 & 2.02 & 4VG 22 & Moderate-high fat content - plant \\
\hline 38 & & $1030-5-3-1 \mathrm{a}$ & 30.632 & -18.58 & 5.25 & 4VG 23 & Large herbivore - somewhat fatty, possibly plant \\
\hline 38 & & $1030-5-3-2 a$ & 13.640 & -22.07 & 4.21 & 4VG 24 & Large herbivore - somewhat fatty, possibly plant \\
\hline 38 & & 1030-5-3-3a & 2.983 & -23.23 & 11.36 & 4VG 25 & Moderate-high fat content - plant \\
\hline 38 & & $1030-5-3-4 a$ & 30.794 & -20.32 & -2.19 & 4VG 26 & High fat content - plant \\
\hline 36 & & $158-5-3-1 a$ & 15.883 & -24.31 & 6.08 & 4VG 27 & Borderline moderate-high and high fat content - plant \\
\hline 36 & & $158-5-3-2 a$ & 42.373 & -24.78 & 3.40 & 4VG 28 & Borderline moderate-high and high fat content - plant \\
\hline 36 & & 158-5-3-3a & 39.406 & -24.80 & 5.94 & $4 \mathrm{VG} 29$ & Moderate-high fat content - plant \\
\hline 21 & $300-380$ & $79-5-3-1 a$ & 7.805 & -24.80 & 3.59 & 4VG 30 & Moderate-high fat content - plant \\
\hline 21 & & $79-5-3-2 a$ & 5.808 & -21.16 & 2.80 & $4 \mathrm{VG} 31$ & Medium fat content - plant \\
\hline 21 & & $79-5-3-3 a$ & 42.012 & -24.87 & 3.56 & $4 \mathrm{VG} 32$ & Moderate-high fat content - plant \\
\hline 18 & & $534-5-3-1 a$ & 26.876 & -27.99 & 1.89 & 4VG 33 & Moderate-high fat content - plant \\
\hline 18 & & $534-5-3-2 a$ & 15.539 & -25.29 & 7.92 & 4VG 34 & Moderate-high fat content - plant \\
\hline NA & & $1005-3-1 a$ & 4.901 & -21.45 & 4.80 & 4VG 35 & Borderline moderate-high and high fat content - plant \\
\hline NA & & $79-3-1 \mathrm{a}$ & & & & 4VG 36 & Borderline medium and moderate-high fat content - plant \\
\hline NA & & $79-3-2 a$ & & & & 4VG 37 & High fat content - plant \\
\hline
\end{tabular}


Table 14-3. Summary of Interpretations of Foods Cooked by Burned Rocks Analyzed from Selected Features

\begin{tabular}{|c|c|c|c|c|c|c|c|}
\hline $\begin{array}{l}\text { Fea. } \\
\text { No. }\end{array}$ & $\begin{array}{c}\text { C }^{14} \text { Age } \\
\text { B.P. }\end{array}$ & Cat. \# & $\begin{array}{l}\text { Wgt } \\
\text { (mg) }\end{array}$ & $\begin{array}{c}\delta^{13} \mathrm{C} \\
(\%) \\
\text { Value }\end{array}$ & $\begin{array}{c}\delta^{15} \mathbf{N} \\
(\%) \\
\text { Value }\end{array}$ & Lab. No. & Lipid Residue, Results and Interpretations \\
\hline \multicolumn{8}{|c|}{ Late Archaic } \\
\hline $1 \mathrm{~b}$ & 2310 & 273-5-3-1a & 6.751 & -25.66 & 1.08 & 4VG 38 & Borderline moderate-high and high fat content - plant \\
\hline $1 b$ & & $273-5-3-2 a$ & 19.183 & -25.09 & 5.93 & 4VG 39 & High fat content \\
\hline $1 \mathrm{~b}$ & & 273-5-3-3a & 30.054 & -22.55 & 6.81 & $4 \mathrm{VG} 40$ & Borderline high and very high fat content - plant \\
\hline $1 \mathrm{c}$ & $1700-2300$ & $293-5-3-1 a$ & 3.645 & -24.18 & 5.78 & $4 \mathrm{VG} 41$ & High fat content - plant \\
\hline $1 \mathrm{c}$ & & 293-5-3-2a & 22.800 & -24.89 & 3.94 & $4 \mathrm{VG} 42$ & Very high fat content - plant \\
\hline $1 c$ & & 293-5-3-3a & 5.439 & -24.54 & 6.72 & $4 \mathrm{VG} 43$ & Borderline moderate-high and high fat content - plant \\
\hline $1 \mathrm{a}$ & 1700 & $89-5-3-1 a$ & 40.574 & -23.24 & 7.83 & $4 \mathrm{VG} 44$ & Very high fat content - plant \\
\hline $1 \mathrm{a}$ & & $89-5-3-2 a$ & 30.178 & -24.97 & 3.41 & 4VG 45 & Very high fat content - plant \\
\hline $1 \mathrm{a}$ & & $89-5-3-3 a$ & 47.687 & -25.90 & 3.17 & 4VG 46 & Borderline high and very high fat content - plant \\
\hline 29 & $1700-2300$ & $966-5-3-1 a$ & 1.346 & -26.71 & 5.68 & $4 \mathrm{VG} 47$ & Very high fat content - plant \\
\hline 29 & & $962-5-3-1 a$ & 12.626 & -28.39 & -5.96 & 4VG 48 & Very high fat content - plant \\
\hline $1 d$ & $1700-2300$ & $11-5-3-1 a$ & 40.574 & -23.24 & 7.83 & $4 \mathrm{VG} 49$ & High fat content - plant \\
\hline $1 d$ & & $11-5-3-2 a$ & 30.178 & -24.97 & 3.41 & 4VG 50 & High fat content - plant \\
\hline $1 d$ & & $11-5-3-3 a$ & 47.687 & -25.90 & 3.17 & 4VG 51 & Very high fat content - plant \\
\hline 28 & $1700-2300$ & $941-5-3-1 a$ & 7.756 & -24.69 & 2.38 & 4VG 52 & Insufficient lipid for analysis \\
\hline 28 & & $941-5-3-2 a$ & 30.576 & -22.05 & 8.66 & 4VG 53 & Very high fat content - plant \\
\hline 15 & 2140 & $801-5-3-1 a$ & 32.874 & -23.21 & 7.92 & 4VG 54 & High fat content - plant \\
\hline 15 & & $801-5-3-2 a$ & 40.271 & -24.48 & 5.53 & 4VG 55 & Moderate-high fat content -plant \\
\hline 15 & & $801-5-3-3 a$ & 3.360 & -25.34 & 6.62 & 4VG 56 & Borderline moderate-high and high fat content - plant \\
\hline 1 & $1700-2300$ & 263-5-3-1a & 7.058 & -24.13 & 8.23 & 4VG 57 & Borderline medium and moderate-high fat content - plant \\
\hline $1 \mathrm{~b}$ & & $274-5-3-2 a$ & 24.516 & -23.30 & 7.05 & 4VG 58 & Borderline moderate-high and high fat content - plant \\
\hline 1 & & $187-5-3-2 a$ & 40.472 & -23.45 & 4.63 & 4VG 59 & Very high fat content - plant \\
\hline 1 & & $80-5-3-1 a$ & 7.606 & -23.88 & 4.78 & $4 \mathrm{VG} 60$ & Very high fat content - plant \\
\hline 1 & & $187-5-3-1 a$ & 42.543 & -25.47 & 3.91 & 4VG 61 & Medium fat content - plant \\
\hline 1 & & $179-5-3-2 a$ & 17.820 & -24.65 & 6.12 & 4VG 62 & Low fat plant \\
\hline 1 & & $98-5-3-1 \mathrm{a}$ & 16.006 & -24.19 & 7.65 & 4VG 63 & Borderline medium fat content and large herbivore + plant \\
\hline 1 & & $179-5-3-1 a$ & 8.294 & -24.67 & 4.55 & 4VG 64 & High fat content - plant \\
\hline $1 \mathrm{~b}$ & & 274-5-3-1a & & & & 4VG 65 & High fat content - plant \\
\hline 1 & & $178-5-3-1 a$ & 30.115 & -21.78 & 5.22 & 4VG 66 & Borderline medium and moderate-high fat content - plant \\
\hline 1 & & $370-5-3-1 a$ & 30.608 & -23.19 & 7.09 & 4VG 67 & Borderline moderate-high and high fat content \\
\hline 1 & & $161-5-3-1 \mathrm{a}$ & 26.233 & -30.62 & 6.08 & 4VG 68 & Borderline high and very high fat content - plant \\
\hline 1 & & $352-5-3-1 a$ & 40.293 & -26.33 & 2.00 & 4VG 69 & Borderline high and very high fat content - plant \\
\hline 1 & & $352-5-3-2 a$ & 1.650 & -24.63 & 4.64 & 4VG 70 & High fat content - plant \\
\hline 1 & & $81-5-3-1 a$ & 2.161 & -26.02 & -3.15 & 4VG 71 & High fat content - plant \\
\hline
\end{tabular}


The Varga Site

Texas Department of Transportation

Table 14-3. Summary of Interpretations of Foods Cooked by Burned Rocks Analyzed from Selected Features

\begin{tabular}{|c|c|c|c|c|c|c|c|}
\hline $\begin{array}{c}\text { Fea. } \\
\text { No. }\end{array}$ & $\begin{array}{c}\text { C }^{14} \text { Age } \\
\text { B.P. }\end{array}$ & Cat. \# & $\begin{array}{l}\text { Wgt } \\
\text { (mg) }\end{array}$ & $\begin{array}{c}\delta^{13} \mathrm{C} \\
(\%) \\
\text { Value }\end{array}$ & $\begin{array}{c}\delta^{15} \mathbf{N} \\
(\%) \\
\text { Value }\end{array}$ & Lab. No. & Lipid Residue, Results and Interpretations \\
\hline \multicolumn{8}{|c|}{ Middle Archaic } \\
\hline 11 & $3900-4820$ & $276-5-3-1 a$ & 3.708 & -25.54 & 2.36 & 4VG 72 & Moderate-high fat content \\
\hline 11 & & $515-5-3-1 a$ & 20.335 & -26.28 & 6.59 & 4VG 73 & Very high fat content - plant \\
\hline 11 & & $575-5-3-1 a$ & 20.327 & -24.84 & 7.36 & 4VG 74 & Borderline medium and moderate-high fat content - plant \\
\hline 11 & & $583-5-3-1 a$ & 20.101 & -24.05 & 6.85 & 4VG 75 & High fat content - plant \\
\hline 11 & & $276-5-3-2 a$ & 30.066 & -22.88 & 7.98 & $4 \mathrm{VG} 76$ & High fat content - plant \\
\hline 37 & 4620 & $37-5-3-1 a$ & 22.228 & -24.10 & 8.35 & 4VG 77 & Moderate-high fat content \\
\hline 37 & & $37-5-3-2 a$ & 30.417 & -24.81 & 2.95 & 4VG 78 & High fat content - plant \\
\hline 37 & & $37-5-3-3 a$ & 10.522 & -26.67 & -0.24 & 4VG 79 & High fat content - plant \\
\hline 37 & & $37-5-3-4 a$ & 17.881 & -25.53 & 1.24 & $4 \mathrm{VG} 80$ & Moderate-high fat content \\
\hline \multicolumn{8}{|c|}{ Early Archaic } \\
\hline 26 & $5640-5660$ & $616-5-3-1 a$ & 22.694 & -24.15 & 4.65 & $4 \mathrm{VG} 81$ & Borderline high and very high fat content - plant \\
\hline 26 & & $616-5-3-2 a$ & 39.737 & -24.47 & 2.82 & $4 \mathrm{VG} 82$ & Moderate-high fat content \\
\hline 26 & & $616-5-3-3 a$ & 30.052 & -22.21 & 6.03 & 4VG 83 & Moderate-high fat content \\
\hline 31 & $5200-6300$ & $757-5-3-1 a$ & 9.052 & -26.89 & 1.47 & 4VG 84 & Very high fat content - plant \\
\hline 31 & & $757-5-3-2 a$ & 7.039 & -25.26 & 5.79 & 4VG 85 & Borderline high and very high fat content - plant \\
\hline 31 & & 757-5-3-3a & 1.000 & -26.71 & 5.44 & 4VG 86 & Very high fat content - plant \\
\hline 31 & & $757-5-3-4 a$ & 30.070 & -23.77 & 6.14 & 4VG 87 & High fat content - plant \\
\hline 39 & $5200-6300$ & 203-5-3-1a & & -25.76 & 1.90 & 4VG 88 & Moderate-high fat content - plant \\
\hline 39 & & 203-5-3-2a & & -25.48 & 6.06 & 4VG 89 & Moderate-high fat content - plant \\
\hline 39 & & 203-5-3-3a & & -23.69 & 6.49 & 4VG 90 & Moderate-high fat content - plant \\
\hline 39 & & 203-5-3-4a & & & & 4VG 91 & Borderline medium and moderate-high fat content - plant \\
\hline 40 & $5200-6300$ & $128-5-3-1 a$ & 12.956 & -23.88 & 8.16 & 4VG 92 & Moderate-high fat content - plant \\
\hline 40 & & $128-5-3-2 a$ & 15.867 & -25.12 & 5.67 & 4VG 93 & High fat content - plant \\
\hline 40 & & $128-5-3-3 a$ & 30.871 & -24.66 & 5.95 & 4VG 94 & High fat content - plant \\
\hline 40 & & $128-5-3-4 a$ & 32.291 & -24.70 & 6.50 & 4VG 95 & Moderate-high fat content \\
\hline 13 & $5200-6300$ & $658-5-3-1 a$ & 19.781 & -30.74 & 6.02 & 4VG 96 & Borderline high and very high fat content - plant \\
\hline 13 & & $658-5-3-2 a$ & 7.308 & -25.78 & 2.91 & 4VG 97 & Very high fat content - plant \\
\hline 13 & & $658-5-3-3 a$ & 3.415 & -25.02 & 1.89 & 4VG 98 & Moderate-high fat content - plant \\
\hline 13 & & $658-5-3-4 a$ & 43.887 & -30.26 & 6.42 & 4VG 99 & High fat content - plant \\
\hline 12 & $5200-6300$ & $644-5-3-1 a$ & 7.149 & -26.63 & -11.67 & 4VG 100 & Very high fat content - plant \\
\hline 12 & & $644-5-3-2 a$ & 11.745 & -25.61 & 1.35 & 4VG 101 & Moderate-high fat content - plant \\
\hline 12 & & 644-5-3-3a & 30.054 & -23.64 & 3.75 & 4VG 102 & High fat content - plant \\
\hline
\end{tabular}

Bold indicates an isotope value that is questionable because of the measured weight 


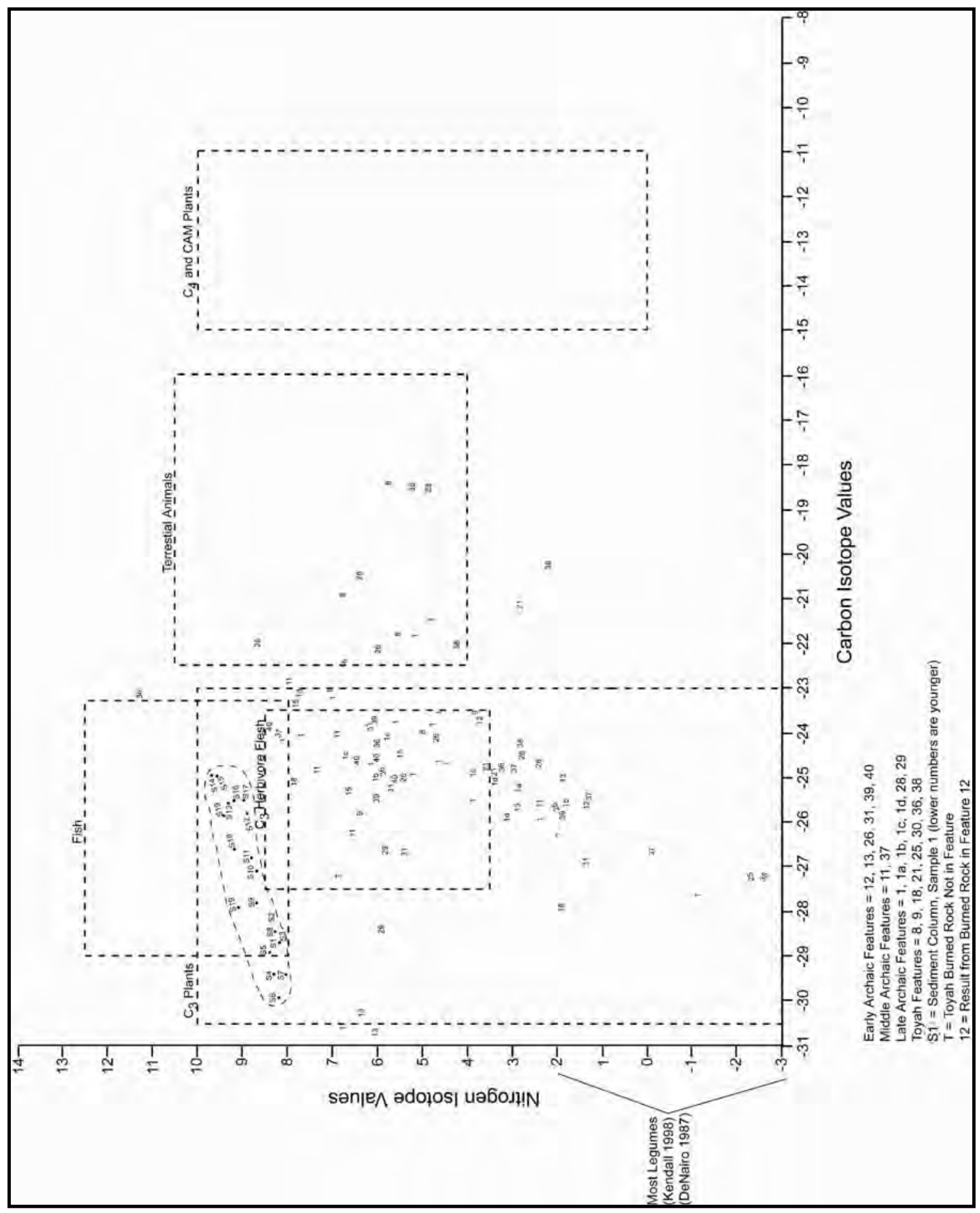

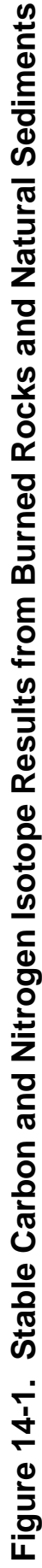




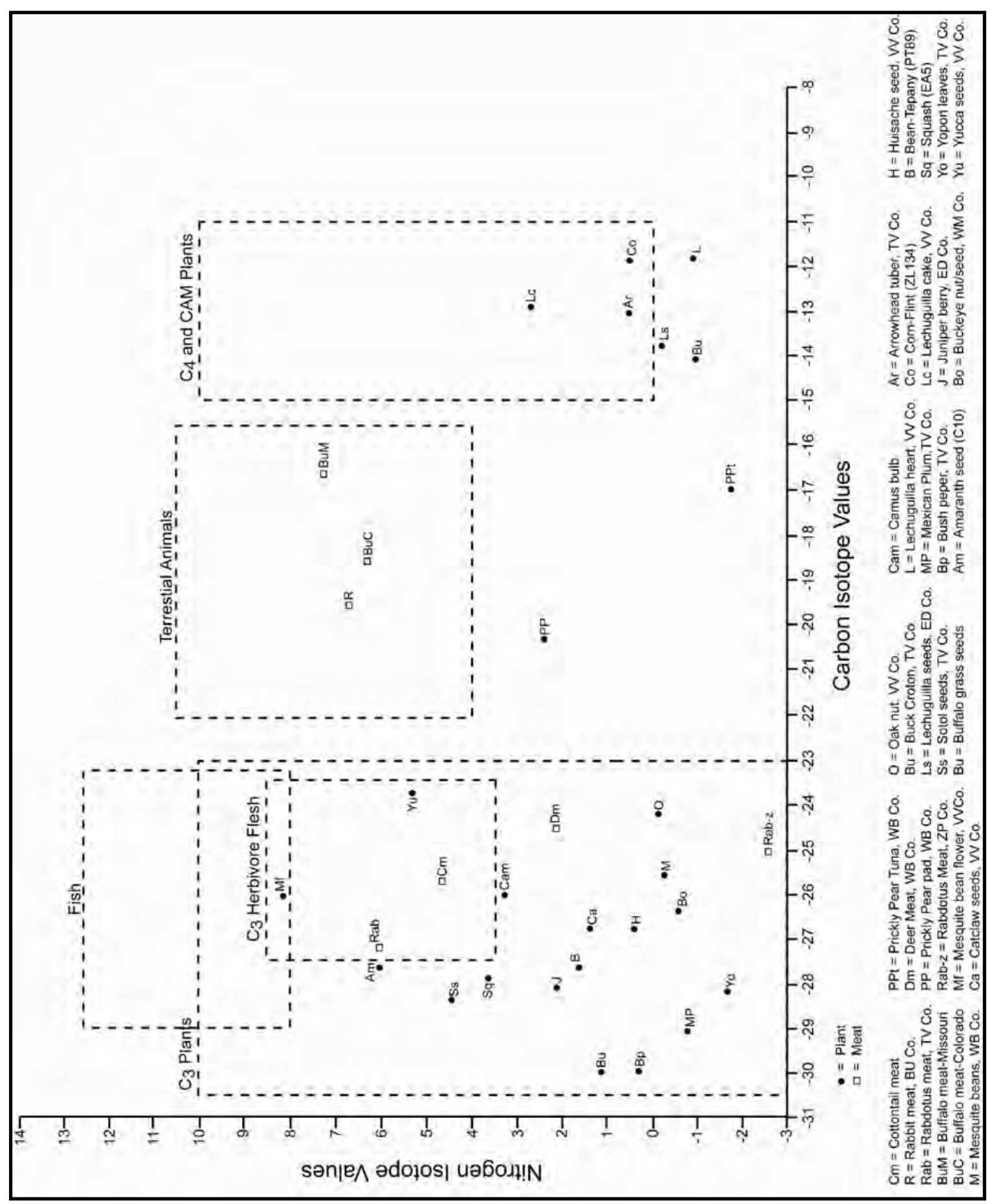

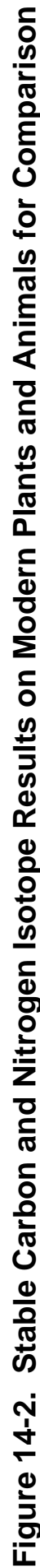


Although plant resources are nearly invisible in the archeological record, however, indicate that plants played a much greater role than the direct macrobotanical or tool evidence indicate. This should caution against facile assumptions that, because the Toyah folk are known to have relied rather heavily on hunting, that a major part of their subsistence was based on plant use.

The use-wear observed on Late Archaic tools indicates that about 22 percent were used on animals with nearly 61 percent used on plants. The plants involved were comprised mostly of hard, high silica species, which are also prevalent in all other time periods, and this would include wood, various cacti, and grasses. The Middle Archaic tools reveal a similar ratio of use on animals and plants with 25 and 69 percent, respectively.

Use-wear on Early Archaic tools indicate that around 10 percent of the tools were used on animals, versus 46 percent on plant matter, including wood, starchy plants, and soft plants. About 27 percent of the tools submitted for analysis revealed plant residues in the form of raphide crystals, which are primarily found in plants of the Agavaceae family, such as sotol, yucca, agave, and lechuguilla. The raphides were observed on diverse tool classes that include a point, a graver, three drills, five bifaces, and seven edge-modified flakes. Other than Early Archaic period tools, raphide crystals were only observed on one other tool and that was a Late Archaic edge-modified flake (\#54312). Interestingly, no meat and only one example of hide use-wear (on a gouge, \#724-13) was evidenced on Early Archaic tools. However, two tools, a graver (\#456-10) and the gouge (\#724-13), revealed hair fragments, which indicate their use on hides.

\subsection{CONCLUSIONS}

Although minor frequency changes are apparent in the plant versus animal usage over the ca. 6,300-years represented here, the dominance of activities related to plant processing is generally consistent (Tables 14-1 and 14-3). The faunal remains combined with the perceived general functions of the stone tool classes should not bias our conclusions concerning the proportional importance of hunting-related activities during any given time period. Through the use of chemical analyses and the observed microscopic residues adhering to the stone tools, the high significance of plant resources has been documented.

The general absence of grinding implements (i.e., manos, pestles, abraders, and metates) indicates that seed and/or nut grinding, if conducted, was not performed with such implements, or alternatively, that grinding tasks were not a significant activity, or perhaps that such tasks were carried out with tools made of perishable materials. Wooden mortars made of pinyon logs have been recovered from sites in the Lower Pecos (Collins and Hester 1968; Prewitt 1981b), so their use at the Varga site is not an unreasonable postulation.

Hunting deer and rabbits was, unsurprisingly, a relative constant throughout the represented occupational sequence (Table 14-1), although the evidence indicates that bison and antelope were hunted only during the Late Prehistoric Toyah interval. Birds are represented by a single third phalange and a potentially displaced long bone recovered in Early Archaic context, as well as by a Toyah biface bearing traces of feathers (Appendix C). The limited number of turtle elements identified in the Middle Archaic and the Toyah components reveal an additional source of meat resources during those periods. Although present in three of the four components, mussel shell fragments are so infrequent that they probably do not represent more than a very minor, opportunistic food resource. 
The broad subsistence picture divulged by all the components at the Varga site followed a generalized subsistence pattern that included the use of multiple types of plants and animals. The available information indicates that Toyah occupants of the site did have a generalized subsistence pattern despite some reliance on large game animals, as the Toyah component exhibits the most diverse plant and animal resource data base of any at the site. However, this may be largely a factor of better preservation of the most recent materials. Because bison was definitely available and procured by Toyah groups, it is likely that meat was not in short supply. Therefore, if the taxa of questionable cultural origin in the Toyah component, such as the bird, snake, coyote, fish, and turtle were actually procured and consumed, then these species may best be viewed as supplemental, rather than starvation or stress, foods. The presence of birds, snakes, coyote, fish and turtles further documents the diversity in the Toyah subsistence base. This same diversity in the vertebrate remains can be observed at other Toyah components such as Rainey Site (Henderson 2001) and Buckhollow (Johnson 1994).

The incipient burned rock midden (Feature 1) that dominates the Late Archaic component may represent the cooking of bulk foods such as bulbs, tubers, agave hearts, or other plant products. This focused cooking activity is partially substantiated by the fact that 97 percent of the burned rocks analyzed from this component yielded lipids interpreted as plant residues (Table 14-3; Appendix G). This is supported by the identification of agave heart and leaf parts, and prickly pear seeds in this component (Table 14-1; Appendix I), a suite of plants also documented in burned rock middens in the Lower Pecos (Dering 1977; Shafer 1981; Cliff 2003). 



\subsection{TECHNOLOGICAL SYSTEMS AND ORGANIZATION}

\author{
J. Michael Quigg
}

\subsection{INTRODUCTION}

Technology is an integrated system of knowledge and techniques through which humans solve problems and/or respond to changes in their natural and social environments. In Chapters 8.0-Toyah Component, 9.0-Late Archaic Component, 10.0-Middle Archaic Component, and 11.0-Early Archaic Component, we addressed technology within the four individual time distinctive components and addressed issues related to resource procurement, processing, and consumption. Here, these findings are consolidated in an overview that takes in the entire long-term cultural sequence at the Varga site.

Very few differences exist between the stone tool assemblages from the four components, with very similar formal and informal tool types recovered from all components, indicating that technological solutions to the challenges of resource procurement and processing were relatively consistent through time. Cooking technology also appears relatively stable throughout time with the exception of the addition of ceramic vessel technology to compliment the existing hot rock technology during the Toyah Phase. Technological strategies for resource procurement, toolmanufacturing, processing, and tool and camp maintenance are discussed below.

\subsection{Resource Procurement STRATEGIES}

\subsubsection{Tool Stone Procurement and Exploitation}

Nearly all artifacts collected from the Varga Site are made of stone. These stone objects are of two broad categories: tool stone (chert) and cooking stone (limestone). Chert was used for the manufacture of nearly all recovered tools, and limestone was used to transfer heat from an open fire to various foods for consumption.

As with many other natural resources, the specific procurement process of obtaining tool stone is not readily visible in the recovered tool assemblage. Most natural chert was probably collected by hand from easily accessible localities such as gravel bars that contained water-worn cobbles. For those chipped stone tools that exhibit some cortex, over 99 percent of the cortex appeared to have rounded and smooth surfaces that resemble cortex from such cobbles. If some natural chert nodules were extracted directly from bedrock sources, then the tool types necessary and used in the extraction process, including bone and/or wooden prying instruments and digging tools, were not preserved or were removed during site abandonment. Extraction tools were potentially left at the procurement locale rather than returned to the campsite. Three recovered small hammerstones with an average weight of $520 \mathrm{~g}$, one each from the Toyah, Middle Archaic, and Early Archaic components, potentially served in part for this extraction process together with other functions. The relatively small size of each of these hammers may not have possessed sufficient mass to have functioned as major stone-extraction tools. All three hammerstones were of limestone that would have been locally and readily available.

Macroscopic observations on the chipped stone tools and the lithic debitage from the four 
components revealed that high-quality chert was used exclusively in the manufacture of formal and informal tools. To investigate the general source areas from which this high quality tool stone originated, INAA was conducted on a total of 261 chert samples. This included 154 cultural artifacts from the four identified components. Selected chert artifacts include tool classes such as points, bifaces, scrapers, drills, and edgemodified flakes, with a focus on edge-modified flakes from each cultural component. The submitted artifacts included 48 samples from the Toyah component, 23 samples from the Late Archaic component, 17 samples from the Middle Archaic component, and 66 samples from the Early Archaic component.

In conjunction with the cultural artifacts analyzed from the Varga Site, 107 natural chert samples from both local and regional sources were submitted to identify potential cultural artifact source areas. Sampling the natural chert helped to establish the chemical variability in the "Edwards chert" category from across the Edwards Plateau. About 36 of the Edwards chert samples were collected by Charles Frederick in 1993 and include nine of his 26 localities (sample numbers CF-6, 7, 9, 10, 11, 12, 16, 17, and 19). They are listed in Frederick and Ringstaff (1994; Table 6.4) and described in Trierweiler (1994; Appendix C, Part 2). These natural chert samples were collected from specific locations in six counties (Edwards, Kerr, Pecos, Real, Sutton, and Val Verde) across the central southern reaches of the Edwards Plateau. This writer collected or had in his possession the remaining 71 samples. These include, one Burro Mesa chert sample from Brewster County, 47 samples from Edwards County including 21 samples from the Hackberry Creek gravels and 20 upland sources, 20 samples from the Nueces River gravels near Camp Wood in Real County, and three Georgetown chert samples from Williamson County along the Plateau's eastern margin.
Following the INAA, Glascock and Speakman (Appendix F) concluded that:

$$
\begin{aligned}
& \text { the results show that the source (i.e., non- } \\
& \text { Varga Site) samples from the current study } \\
& \text { have extremely low probabilities of } \\
& \text { membership in the Fort Hood groups, } \\
& \text { relatively low probabilities of membership } \\
& \text { in the Howard County Segovia Formation } \\
& \text { group, and high probabilities of membership } \\
& \text { in Frederick's mixed collection. }
\end{aligned}
$$

This in fact builds upon and reinforces the previous findings that Edwards cherts from different parts of the Edwards Plateau region are chemically distinct and reflect different source areas (e.g., Hudler 2003a; Glascock 2003). A prominent factor contributing to the broader chemical signatures in the TRC natural samples is that some 41 samples represent two different gravel sources from local streams and may not reflect one specific localized bedrock source, but an areally broader signature.

In general, the Varga Site artifacts show a close chemical relationship to both Fredrick's and Quigg's natural chert collections of Edwards Formation source specimens, "Edwards chert," from across the broad central and southern plateau regions. They do not show a close chemical relationship with the analyzed Fort Hood cherts (Appendix F). This indicates that most tool stone recovered from the Varga Site did not originate from known source areas a great distance from this site, such as from the Fort Hood region or non-Edwards sources outside the plateau. Chemical signatures from one outcrop of natural chert in western Edwards County (MQ-1), two in Val Verde County (CF11 and CF-12) along Highway 163, and another in Pecos County (CF-16) are mostly distinct from the chemical signatures derived from the chert gravels collected from the Hackberry Creek streambed adjacent to the Varga Site, and natural chert pieces extracted from buried deposits near the bottom of the Varga Site. 
Comparing the chemical signatures of the natural cherts to those of the Varga Site artifacts indicates that the human populations that camped at the site did not often exploit the western chert source areas analyzed here. The majority of tool stone chemical signatures compare favorably with chert from the Edwards Plateau region in relatively close proximity to the Varga Site, estimated within a 100 to $150 \mathrm{~km}$ radius.

Examination of the INAA data derived from individual chipped-stone artifacts that represent each individual component sampled at the Varga Site indicates the tool stone was derived from multiple source areas. A prominent chemical overlap occurs with cherts from the surrounding region that includes the Camp Wood samples from the Nueces River and the Hackberry Creek chert gravels.

At the Varga Site, most Early Archaic chemical signatures (83 percent) overlap with the signatures from local sources, but reveal that diverse of sources were exploited (see Appendix F, Figure F-7). Eleven specimens, or 17 percent of the analyzed tools, have chemical signatures that are different than the chemical signatures of the analyzed local samples. These include one Martindale point (\#268-21 = TRC144), two Bandy points (\#142-11 = TRC135 and \#400-11 = TRC158), three Gower points (\#86-20 = TRC132, \#333-22 = TRC150, and \#1213-10 = TRC190), two Merrill points (\#157-11 = TRC137 and \#299-14 = TRC145), a scraper (\#627-13 = TRC176), one biface (\#20510 = TRC140), and one edge-modified flake (\#366-13 = TRC155). At least one Gower (\#86-20 = TRC132) and one Bandy (\#400-11 = TRC158) point exhibit chemical signatures similar to cherts from further west in Val Verde and/or Pecos counties. A minimum of one edgemodified flake (\#621-10 = TRC175) and potentially many other tools have chemical signatures that are quite similar to the chert from
Hackberry Creek. It is apparent that the Early Archaic populations at the Varga Site used multiple chert source areas from the southern and central Edwards Plateau including some sources from Val Verde or Pecos counties, as well as the locally available chert gravels and/or outcrops.

The chemical composition of Middle Archaic artifacts recovered from the Varga Site indicates that most tools analyzed (as high as 83 percent), originated from local plateau sources. Many signatures appear chemically similar to the Early Archaic source areas and just as diverse as the Early Archaic source areas (see Appendix F, Figure F-6). The chemical signatures for at least three tools, or a minimum of 17 percent, and potentially as many as seven tools, or 41 percent, reflect non-local source areas. Three tools, a scraper (\#100-11 = TRC109), a biface (\#417-13 = TRC115), and at least one edgemodified flake (\#397-10 = TRC113) exhibit apparent non-local chemical signatures, indicating these tools were brought to the Varga Site. One biface (\#417-13 = TRC115) exhibits a signature similar to some natural cherts from Val Verde or Pecos counties to the west. One edgemodified flake exhibits a signature similar to cherts from Kerr County. The scraper has a signature that is not within the currently identified range for Edwards Chert; however, it exhibits a UV florescence that is a yellowish orange similar to other Edwards pieces. Inspection of the parent scraper indicates that the submitted sample may have had some cortex remnant, plus the specimen was also burned. It is not clear if either of these observations contributed to the chemical signature. Four other pieces, three edge-modified flakes (\#41710 = TRC114, \#484-16 = TRC118, and \#484-17 $=$ TRC119), and one biface (\#484-16 = TRC118) are probably non-local and exhibit signatures similar to cherts from Kerr County. In contrast, a minimum of two bifaces (\#418-28 = TRC 116 and \#419-12 = TRC117), one Early 
Triangular point (\#537-17 = TC122), and one edge-modified flake (\#197-11 = TRC111) apparently were manufactured from local cherts, since their chemical signatures are similar to the chert cobbles analyzed from Hackberry Creek. Only the one artifact has a signature that is similar to the analyzed source materials from Pecos, Val Verde, or western Edwards counties. Consequently, the Middle Archaic populations apparently had a lithic procurement area that centered on Edwards and Kerr counties or counties slightly further north.

In the Late Archaic period at the Varga Site, the tool stone again exhibits chemical signatures that are mostly (74 percent) similar to chemical signatures for Edwards chert from the central core region of the Edwards Plateau (see Appendix F, Figure F-8). For the roughly 26 percent that are likely non-local, these include at least one Marcos point (\#187-10 = TRC200), one Frio (\#89-10 = TRC198), two bifaces (\#2-12 = TRC193 and \#263-10 = TRC205), and two edge-modified flakes (\#2-11 = TRC192 and \#42-10 = TRC197) that exhibit chemical signatures sufficiently distinctive to indicate that these six tools were transported to the site from some distance away. The two edge-modified flakes exhibit chemical signatures similar to cherts from Pecos or Val Verde counties to the west. One biface (\#263-10 $=$ TRC205) has a chemical signature that is similar to some natural chert from Kerr County to the east. Two other tools, a biface and a Frio point, have chemical signatures similar to natural cherts from Taylor and Nolan counties to the north. The Marcos point reflects a chemical signature that currently is not yet identified and is not similar to any other tools sampled here. However, the Marcos point was likely manufactured from Edwards chert as it exhibits a UV florescence that is a yellowish orange and similar to other Edwards pieces. The apparently different source areas within the Edwards Plateau indicate that the lithic sources were geographically diverse, but the breadth of the area remains unknown.

From the Varga Site Toyah component, the tool stone exhibits roughly 85 percent chemical signatures that are similar to the local cherts (see Appendix F, Figure F-9). A minimum of seven exceptions, or 15 percent of the signatures, appear beyond the current variability in the local materials and are potentially of non-local in origin. These tools, which may have been transported from some distance to the Varga Site, include two bifaces (\#159-5-28 = TRC 215 and 220-15 = TRC218), a scraper (\#888-14 = TRC239), a graver (\#836-10 = TRC234), a Cliffton point (\#967-24 = TRC248), and $\mathrm{a}$ Perdiz point (\#1031-13 = TRC251). The scraper (\#888-14 = TRC239) exhibits a chemical signature similar to natural cherts from farther west in Val Verde or Pecos counties. Six of the specimens appear to be Edwards chert from counties further north such as Mills, Taylor, and Nolan. Three or four other Toyah tools have signatures that might be linked to western sources. The Cuney point (\#349-13 = TRC223) exhibits a chemical signature that is quite similar to materials from a local source area near 41ED58. This would support an interpretation that this point was manufactured from locally derived chert rather than brought in from the northeast or eastern part of Texas, where this point type is more prevalent (see Prewitt's 1995 distribution map). The apparent diverse source areas, from which tool stone was procured, indicate a fairly broad north to south lithic resource exploitation region, and may indicate directions of group movement or, possibly, trading patterns.

In summary, the INAA on the Varga Site chert tools contributed significantly towards understanding what areas were exploited as toolstone sources by human populations that camped at the Varga Site. This chemical analysis establishes that some local resource areas can be 
distinguished from distant source areas, thus allowing for the identification of local versus non-local materials and provides insight into contact, exchange, or population movements. The local Hackberry Creek gravels reveal a range of chemical signatures that indicates the origins of the river cobbles are as diverse as one might expect. Although not immediately local, the Camp Wood gravel sample, collected from the Nueces River some $35 \mathrm{~km}$ south of the Varga Site, also exhibits a broad chemical signature that overlaps with the Hackberry Creek signatures. The overlap in chemical signatures was expected with water moving bedloads downstream from source areas near the river headwaters. One possible source area lies a few kilometers upstream along Hackberry Creek in the vicinity of Devils Sinkhole at sites like 41ED58 (Howard et al. 1996). This is a Segovia Formation bedrock source. Bedrock materials also reveal a wide range of chemical signatures that overlap with the Hackberry Creek and Nueces River gravels, as expected.

Although individual procurement source areas cannot currently be specified and are not all identified, some general trends and overall observations concerning the known chemical signatures allow for some preliminary observations and interpretations. In general, the chemical signatures derived from the cultural artifacts analyzed reflect known chemical variations in Edwards chert and show the Varga Site occupants used almost exclusively Edwards chert. Only a few signatures fall outside of the currently identified range for Edwards chert samples, but at this time, there is not enough definitive evidence to determine the actual source of these materials, or to say definitively that they are not Edwards chert.

\subsubsection{Clay Procurement}

In the Toyah component at the Varga Site, another natural resource, clay, was procured primarily for the manufacture of ceramic vessels. Based on the petrographic analysis, at least Vessel Group 2 and possibly Vessel Groups 3 and 4 were manufactured with clay similar to the local clay at the Varga Site. This implies that at least some Varga Site vessels were manufactured locally using local alluvial clay. The INAA indicates that clays from the Varga Site vessels represent at least four different sources. Based on the current limited INAA data on clay source areas in Texas, it appears these clay source areas were not those currently recognized from the Central Texas region on the eastern end of the Edwards Plateau as indicated by the Toyah sherds previously analyzed from Central Texas and representing reference groups 1 and 2 (Appendix N, Figures $\mathrm{N}-1$ and $\mathrm{N}-2$ ). It is clear that the unknown clay figurine-like object was not made from local clays, since it does not compare favorably with the local clays. This item was brought into the site as a finished artifact. Its clay source currently remains unknown.

\subsubsection{Food Procurement}

Food procurement, both plant and animal resources, is most often interpreted from the recovered artifacts, since preservation of these organic remains plays a substantial role in what organic remains are recovered. Stone tools, the best preserved, bias how we interpret the food procurement process. Projectile points, the tip of the killing instrument, are numerically well represented in two of the four components-the Early Archaic and the Toyah. The groups represented by these two components appear to have focused heavily on the procurement of larger animal resource, based on high frequencies of projectile points. The recovered points from the Late and Middle Archaic components also indicate those groups pursued similar animal resources, but maybe not as intensively at this particular location. Although points are not dominant in the Middle Archaic 
assemblage, no other tool category represented in the Middle Archaic assemblage indicates that other food resources were targeted. In contrast, a large cooking feature, an incipient burned rock midden in the Late Archaic component reflects a focus on plant resources. The number of camping events that are represented in each component possibly accounts for differences in the number of projectile points between components. The specific number of events in each component is unknown at this time.

In general, the broad technology of procuring large game animals through killing them with sharp tipped instruments remained a constant through time. However, within the last 1,000years a significant technological charge occurred in how that tip was propelled at the animal. This technological change is represented by the introduction of the bow and arrow as reflected by the much smaller projectile points employed during the Toyah and slightly earlier. No direct evidence for the weaponry system is preserved other than the projectile point. Here, the gross size difference provides the most visible evidence to this system change. In addition to the differences in projectile points, the overall classes of stone tools are remarkably similar in all four components. Although the bow and arrow marked a new delivery system from the proceeding atlatl and dart use, its appearance and employment did not significantly affect the overall subsistence practices or the apparent nature of the hunter-gatherer lifeway. The presence of other classes of chipped stone tools-bifaces, scrapers, and edge-modified flakes - in each assemblage is generally linked to various processing activities, but also supports large game procurement activity.

Not visible in the archeological record at the Varga Site is the technology associated with the procurement of small game and plant resources. Judging from findings in dry caves in the Lower Pecos area, this lack of visibility is the result of poor preservation of fiber, nets, bags, traps, bone, and wooden implements. Detected residues such as plant fiber and feathers on some stone tools, such as scrapers, bifaces, and edgemodified tools, might indicate these tools served in the plant procurement process, although the evidence from these tools may only reflect subsequent processing activities.

\subsubsection{Bone Procurement}

It is suspected that bone used in the production of bone tools and ornaments was not procured specifically for that purpose, but rather was obtained as a by-product from the animals procured for subsistence. The few bone tools and the bone bead blank appear minimally altered. The bone bead blank from the Toyah component, a rabbit long bone, was minimally altered and discarded with four potential beads still attached along the shaft.

\subsubsection{Cooking Rock Procurement}

Limestone dominated the stone used to transfer heat in various cooking activities for each component. The immediate site environs and the region surrounding the site contain quantities of limestone both in the form of bedrock outcrops and alluvial gravels. The limestone was undoubtedly procured locally from both sources. This procurement pattern does not appear to have changed over time and probably was restricted to local stream gravels, immediate valley slopes, and adjacent bedrock outcrops.

No formal or informal tools (large stone hammers, bone wedges, etc.) were recovered to reflect clear indications that procurement of limestone was conducted from bedrock sources. In contrast, the rounded edges of many pieces of fractured limestone indicate that this material was collected by hand from streambed sources. 


\subsubsection{Wood Procurement}

Wood for fires was undoubtedly available in the immediate area during all occupational periods. No specific formal or informal tools were recognized as possibly used for cutting or chopping down large trees. The wood that undoubtedly was used for fires, handles, traps, etc. most likely would have come from bushes, saplings, or dried wood rather than from large, growing trees. Consequently, specialized stone tools for wood procurement activities were probably not likely to have been necessary. The three gouges recovered from the Early Archaic component are of a form often thought of as woodworking tools, but they do not possess sufficient mass or formal characteristics to have functioned for cutting down trees. Use-wear on one gouge (\#346-11) indicates hard, high-silica polish plus use residue in the form of plant or bone fragments. A second gouge (\#724-13) exhibits use residues in the form of hair, combined with soft polish indicating planing animal hide. The use-wear evidence from these two gouges does not support their use in the procurement or processing of wood.

\subsection{Resource Processing, CONSUMPTION, AND STORAGE}

\subsubsection{Generalized Lithic Technology}

Lithic debitage samples were analyzed from each component at the Varga Site as a broad indication of the types of knapping activities that were carried out during these four represented time periods. The raw counts of lithic debitage vary considerably between the four components. The Early Archaic component yielded the most lithic debitage, over two times the amount recovered from the Late Archaic component, which yielded the least amount. The substantial differences in the lithic counts may reflect the amount of time spent at that specific spot or number of events represented by each component rather than the proportion of time spent on lithic processing activities. The analyzed debitage indicates an overall similarity of general knapping processes between all four components. The general process includes, but is not limited to, core reduction, early and late stage biface manufacturing and general biface thinning, and manufacture of unifacial tools. This addition of the bow and arrow does not appear to have significantly changed the general knapping processes for the production of arrow points. In very general terms, the Toyah component reveals greater lithic debris that relates to late stage biface preparation. This is supported by that fact that only five percent of the bifaces recovered were in their early stage of production, and nearly 70 percent were in their late stage or finished forms. Bifaces themselves account for 23 percent of the formal Toyah tools. Less than one percent of the analyzed debitage can be classified as blades. Therefore, the arrow points that might have been produced at this site were undoubtedly manufactured from generalized flakes removed from multidirectional cores rather than formal blade cores. At least 41 percent of the cores were classified as multidirectional with other types consisting of unifacial and bifacial, suitable for general flake production.

The Late Archaic assemblage reveals that knapping tasks were diversified. Pieces classified as shatter were the most extensive, followed by thinning and/or resharpening activities. The lack of rejuvenation flakes, and near absence of manufacture breaks on the formal tools, indicates that extensive tool production was not attempted at this locality during this period. Apparently flake production and tool finishing and/or reworking of chipped stone tools were more significant.

The Middle Archaic assemblage was dominated by late stage biface reduction pieces, followed by thinning flakes, which together probably reflect emphases on biface production and 
resharpening activities. The latter activity is also indicated by the presence of at least two rejuvenation pieces from unifaces. Late stage bifaces account for over 50 percent of the bifaces and nearly 21 percent of the formal tools. Only one early stage biface was recovered. Core reduction flakes were the least frequent in the analyzed debitage, contrasting with the relatively high frequency of cores that represent nearly 28 percent of the formal tools recovered.

The Early Archaic assemblage reflects relatively high frequency of thinning flakes, followed by moderate to high frequencies of late stage biface flakes. This focus is supported by the fact that nearly 47 percent of the formal tools are bifaces, of which the majority, 79 percent, were in the late stage of production compared to only about 15 percent in the early stage. This high frequency of bifaces, together with the limited counts of points and bifaces that exhibit beveling, supports the refurbishing of tools and finishing the production of formal tools. Although cores were frequent by count $(n=25)$, cores only account for less than seven percent of the formal lithic artifacts recovered.

Although the four lithic debitage assemblages reflect a broad range of knapping activities, this knapping process led to the production of similar chipped stone tools for specific procurement and processing tasks in each component. The recognized classes of formal and informal chipped stone tools were quite similar from each component. With a few minor exceptions, all four components yielded chipped tools classified as points, bifaces, end- and side-scrapers, and edge-modified flakes. Drills were only recovered from the Toyah and Early Archaic components, and may reflect specific activities not represented by the other two components. Gouges, similar to scrapers, were only recovered from the Early Archaic. Use-wear on two gouges indicates these tools functioned in a manner similar to formal scrapers and a few informal edge-modified flakes, and their inferred use was scraping and planing on hides and hard, high silica material. Therefore, these gouges apparently served a similar function or processing task as other stone tools, rather than some specific task not represented in the other components. Although some general size and shape differences are apparent in the tool classes between the four components, the range of activities and processing tasks represented by these tools apparently changed very little over time (Table 15-1). The general lithic debitage assemblage combined with the formal tool assemblage reflects similar processing activities within each component.

\subsubsection{Hafting Technologies}

The most obvious difference in the chipped stone tools assemblage was observed in the different styles of projectile points represented in and between the four components. The Early Archaic dart points can be divided into two broad style groups based on their proximal configurations. The two broad groups reflect at least 50 specimens from three different type categories (Bandy, Martindale, and Groups 2 corner notched forms) that are considered barbed points with expanding stems. In contrast, some 70 specimens representing at least four identifiable types (Baker, Group 1, Gower, and Merrill) are considered part of the generalized split stem group. It is not clear if these two broad groups of different hafting techniques reflect two distinct subperiods, two different but essentially contemporaneous cultural groups, or differences in hafting techniques. Measurements on the distal stem width (i.e., neck width) for all the Early Archaic points varies about $5.0 \mathrm{~mm}$ from an average of $13.1 \mathrm{~mm}$ on the Bandy points to about $18.1 \mathrm{~mm}$ in the Group 1 points. The overall average stem width for these nine Early Archaic types is about $15.6 \mathrm{~mm}$. 
Table 15-1. Tool Function by Use-Wear

\begin{tabular}{|c|c|c|c|c|c|c|c|c|c|c|c|c|c|c|c|c|c|c|c|c|c|c|}
\hline \multirow[b]{2}{*}{ Artifacts By Ages } & \multicolumn{10}{|c|}{ Inferred Use } & & \multicolumn{11}{|c|}{ Contact Material } \\
\hline & 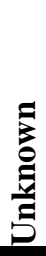 & 串 & 罚 & 告 & مَ & & 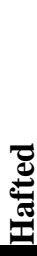 & 氪 & & & & & $\sum_{\Sigma}^{\stackrel{\pi}{\rightleftarrows}}$ & 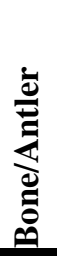 & 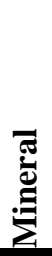 & 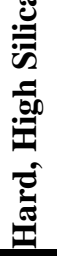 & $\begin{array}{l}\text { D } \\
\stackrel{0}{3}\end{array}$ & 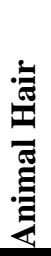 & ڤँ & 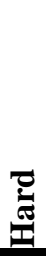 & 롬 & 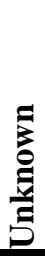 \\
\hline \multicolumn{23}{|l|}{ Toyah Tools } \\
\hline Points & 1 & & 1 & & & & 5 & & & & & & & & & 1 & 1 & & & & & 6 \\
\hline Bifaces & & 1 & 3 & & & 2 & 1 & & & & & 2 & & 1 & & 2 & 4 & 1 & & & & 1 \\
\hline Scrapers & & 4 & & 4 & & & & & & & & 3 & & & & 4 & 1 & & 1 & & 1 & \\
\hline Drills & 1 & & 1 & & & & 1 & & & & & 1 & & & & & & & & & & 1 \\
\hline Edge-Modified Flakes & & 18 & 2 & 4 & 1 & 5 & 2 & s & & & & 2 & & & & 20 & 7 & 2 & 3 & & 1 & \\
\hline \multicolumn{23}{|l|}{ Late Archaic Tools } \\
\hline Points & & & 1 & & & & & & & & & & & & & & 1 & & & & & 1 \\
\hline Bifaces & & 1 & 2 & & & & 1 & & & & & 1 & & & & 1 & 1 & & & & 1 & 1 \\
\hline Scrapers & & 2 & & 1 & & & & & & & & & & & & 2 & 2 & & & & & \\
\hline Edge-Modified Flakes & & 3 & 2 & & 1 & 2 & & 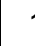 & & & & 2 & & & & 4 & & & 1 & & 2 & 1 \\
\hline \multicolumn{23}{|l|}{ Middle Archaic Tools } \\
\hline Points & 1 & & 1 & & & 1 & 1 & & & & & & & & & 3 & & & & 1 & & \\
\hline Bifaces & & 1 & 1 & & & & & & & & & & & & & 1 & & & & 1 & & \\
\hline Scrapers & & 1 & & & 1 & & & & & & & & & & & & & & 1 & 1 & & \\
\hline Edge-Modified Flakes & & 2 & 1 & 2 & & 3 & & 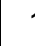 & & & & 3 & & & & 4 & 2 & & 1 & & 1 & \\
\hline \multicolumn{23}{|l|}{ Early Archaic Tools } \\
\hline Points & & & 1 & & & & 8 & & & & & 1 & & 1 & & & 1 & 1 & & & & 6 \\
\hline Bifaces & 5 & & 4 & & & & 2 & & & & & 4 & & & 1 & & & & & & & 5 \\
\hline Scrapers & & 2 & 1 & 2 & & 1 & & & & & & 1 & & & & 5 & 1 & & & & & \\
\hline Drills & & & 1 & & 3 & & & & & & & 1 & & & & 1 & 1 & & & & & 1 \\
\hline Edge-Modified Flakes & 2 & 5 & 4 & 13 & & 2 & 1 & 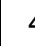 & & & & 0 & & 1 & & 8 & 2 & & 3 & & & 7 \\
\hline Gouges & & 1 & & 2 & & & & & & & & & & & & 1 & & & & & 1 & \\
\hline
\end{tabular}


The stem thickness varies slightly as well with a low of $3.2 \mathrm{~mm}$ for the Bandy type to a thickness of $4.8 \mathrm{~mm}$ for the Group 1 points. These relatively narrow ranges for stems indicate these dart points were attached to shafts that had relatively limited size ranges. If the shafts were a relatively constant size, then the variability in the proximal ends reflects differences that were more stylistic than technological.

The points in the Middle Archaic assemblage are triangular in outline and lack any form of stem or notching modifications to the base, to facilitate hafting the stone dart to the shaft, indicating a change in the hafting technology from the Early Archaic patterns. The proximal ends of the triangular points were distinctly thinned to permit insertion into a narrow slit in the haft. Use-wear on four triangular points indicates no haft wear on two points, but the haft area on two others showed abraded flake scar ridges on one and hard, high silica polish on another, clearly indicating that they were hafted. At least three triangular points exhibit some edge beveling, interpreted as resharpening that occurred before the tool broke during subsequent use.

During the Late Archaic period, the hafting technology again reveals changes. Projectiles once again exhibit various forms of notching to facilitate hafting. The few specimens recovered from the Late Archaic assemblage reveal slight variations to the proximal ends to facilitate hafting, but the limited number of specimens does not allow averaging of metric data for individual types or good comparisons with the Early Archaic dart points.

A dramatic change in hafting technology is present in the much later Toyah point assemblage. The overall size and weight of the hafted stone tips is greatly reduced from its predecessors and the stem area is dramatically narrower. The distal stem widths in the Perdiz points are quite narrow (average $6.9 \mathrm{~mm}$ with standard deviation of $1.6 \mathrm{~mm}$ ) compared to the Early Archaic points with an average stem width of $15.6 \mathrm{~mm}$. This signals a dramatic change in the shaft size to which these Perdiz points were attached. This narrow stem width marks a switch in the technology systems used to propel the point - the use of the bow and arrow. Although the Perdiz and Cliffton points reveal narrow, tapering stems to facilitate insertion into a narrow arrow shaft, other stem modifications including corner and side notching were also in use to facilitate hafting stone points to the narrow arrow shafts. It is assumed that culturally informed preferences influenced the particular style of hafting technology used with the arrow points and the attachment to the smaller arrow shafts.

\subsubsection{Cliffton Point Type Discussion}

The Perdiz points have been considered one of the diagnostic artifact types for the Toyah manifestation for quite some time. Cliffton points are associated with most Toyah components, but are not as frequent as the dominant Perdiz points from those same components. Cliffton points are similar to Perdiz points in that they exhibit stems that tend to narrow towards the proximal ends, but most stems are much shorter and wider than Perdiz forms, and overall the stems and blades are not as well executed. Therefore, they have been given separate names and have been recognized as a separate form. These points are not considered intrusive to the Perdiz components.

The Cliffton point type was initially used by Kelley (1947a, 1947b) and defined by Suhm and Jelks (1962:269) as a:

Roughly triangular blade, crudely chipped, often modified on only one face, or on one face more than the other. Shoulders may project at right-angle but often are difficult to distinguish from the short, pointed stem. 
Blade edges may be fairly straight but are often convex, concave, or asymmetrical.

No comment was made to their function and they were not referred to as Perdiz preforms.

Turner and Hester (1985:169) indicate studies have shown that the Cliffton point is an unfinished Perdiz point with little validity as a point type. They characterize the Cliffton point as roughly triangular, and a crudely chipped form. The three illustrated Cliffton points in Turner and Hester (1985:169) show three broad bladed forms with straight to irregular lateral edges and triangular in overall shape, but the short, wide contracting stem with shoulders that extend outward are unlike the Perdiz barbs that extend downward. Similar specimens have been recovered from various Toyah components such as Blum Rockshelter (Jelks 1953), Smith Rockshelter (Suhm 1957), Kyle Rockshelter (Jelks 1962), 41TG91 (Creel 1990), Buckhollow (Johnston 1994), Rush Site (Quigg and Peck 1995), and others. Following the analyses of the Hinojosa Site, Black (1986) reported that the Cliffton type had little validity, and he considered them to be unfinished Perdiz points. At Hinojosa, points with attributes similar to the Cliffton point type were placed in with the Perdiz arrow points.

Creel (1990) suggests that Cliffton points are clearly and readily distinguished from Perdiz points. He stated, "One of the interesting characteristics of these specimens is that most are lacking the distal portions of the blades." At least one of the broken distal ends at 41TG91 was accounted for by manufacture failure, but Creel does not interpret the broken ends as caused by use.

At the Barton Site (41HY202-A) a relatively large collection of chert debitage $(n=33,006)$, 168 Perdiz points and fragments of points, plus 76 fragmentary bifaces in various stages of manufacture indicate a Toyah tool manufacturing locale (Ricklis 1994b). In that point assemblage are several specimens $(n=10)$ that are similar in characteristics to Cliffton types, but were classified as Perdiz point preforms. Only one of the Cliffton specimens is complete. Nine transverse snap breaks on the blade sections indicated to Ricklis that the breakage was due to transfer of excessive force to the blade during stem flaking (Ricklis 1994b).

The large block excavation of a single welldefined occupation area at Mustang Branch Site (41HY209-T) yielded some 23 Perdiz arrow points, mostly around a hearth feature (Ricklis 1994b). Two small, complete arrow points in the form of Cliffton points were present. Ricklis (1994b:243) states that in view of the contextual associations "it is possible that these are finished but poorly formed arrow points.” A third specimen also similar to the Cliffton type and nearly twice as large as the two previous Cliffton like specimens has finely pressured flaked blade edges. Ricklis considers this specimen to be a finished point.

The question then arises as to whether or not the interpretation of the Cliffton as a preform can be substantiated. At the Varga Site, 12 specimens were classified as Cliffton points, with 11 directly associated with at least 44 Perdiz points. Only two of the Cliffton points are complete, with 83 percent represented by proximal ends. The breaks appeared to be associated with use. The presence of use breaks indicates that this type was used rather than being only an arrow point preform. It was anticipated that use-wear analyses would help to clarify the matter. If no use-wear were detected, then one might presume the Cliffton point was a preform. The presence of use-wear would support it as a functional, finished tool.

Use-wear analysis on four Cliffton points from the Toyah component at the Varga Site indicates these four Cliffton points were actual hafted 
tools with possible multiple functions. All four analyzed specimens reveal evidence of haft wear. Specimen \#22-14 reveals abraded ridges in the haft area. Specimen \#914-11 reveals hard, high silica polish in the haft area, plus wood fragments and striation indicating cutting actions on wood. Specimen \#943-1b shows plant fragments, plus striations in the haft area. Specimen \#1154-10 reveals striations in the haft area. The contact material is unknown on three specimens (Appendix C). The use-wear results support the interpretation that Cliffton points were functional tools rather than preforms for Perdiz points.

How might have this Cliffton tool been used? Use-wear analyses indicate haft wear on the short stems of each of the four Cliffton points. Therefore, it seems reasonable that Cliffton points were hafted. Since the Cliffton points are often associated with other projectiles, and the Cliffton form is in the form of a projectile, then one would suspect that it served in a similar fashion. This author suggests that the Cliffton type may be an expedient form of projectile, which was quickly manufactured and hafted into a foreshaft for immediate use. Time was not spent to carefully craft the delicate and lengthy stem and well-formed barbs, but just enough of a stem was created to facilitate placement into a hollow haft. The often broken nature of the blade would support its use as a projectile that snapped during use, but also indicate how fragile these thin bladed, minimally worked forms really were. At Mustang Branch Site, the context of the three Cliffton-like points together with numerous Perdiz points around a hearth may also support their use was similar to the Perdiz points. Indirectly, the assemblage of 180 Perdiz points recovered from the Las Haciendas cairn burial (Mallouf 1987) supports the new interpretation presented here, that the Cliffton point form was an expedient point. Not a single specimen of the 195 arrow points recovered was in the form of a Cliffton point, even though a large variation of Perdiz forms was present. In Mallouf's reconstruction of the method of manufacture of Perdiz points, the Cliffton form is not represented. This may also indicate that Mallouf sees the Cliffton form as a separate tool, rather than a preform for the Perdiz. The general occurrence of Cliffton forms in many Toyah assemblages supports the interpretation that these tools were an integrated part of that culture. Their limited numbers may testify to the occasional need for a more expedient form of projectile point.

In summary, the use-wear analysis on four Cliffton points from the Varga Site provides direct evidence that the Cliffton point was a functional, hafted tool, rather than a preform. The Cliffton and the Perdiz arrow points are two different forms of stone tips hafted on narrow arrow shafts that facilitated the killing process. Here, the Cliffton point is considered an expediently manufactured point, compared to the more formally manufactured and finished form of the Perdiz points.

\subsubsection{Plant Processing}

Specific plant processing tools are nearly nonexistent at the Varga Site, with only a very few nonspecialized tools such as hammerstones $(n=3)$ and anvils $(n=2)$ recovered. These tools might have been used for plant processing tasks. Assuming at least some plants were processed before consumption, beyond just cooking, the processing task might have been conducted primarily through the use of perishable tools (i.e., wooded mortars and pestles) or with generalized chipped stone tool forms such as the bifaces and scrapers.

Use-wear studies on samples of chipped tools from the four components provide a broad and general understanding of the range of processing tasks (inferred uses) directed toward plants in general and other products. Table 15-2 reveals the types of tools from each component that 
Table 15-2. Use-wear Summary on Artifacts from Varga Site Components

\begin{tabular}{|c|c|c|c|c|c|c|}
\hline $\begin{array}{c}\text { Use-wear } \\
\text { Interpretations }\end{array}$ & $\begin{array}{c}\text { Toyah } \\
\text { Component }\end{array}$ & $\begin{array}{l}\text { Late Archaic } \\
\text { Component }\end{array}$ & $\begin{array}{l}\text { Middle Archaic } \\
\text { Component }\end{array}$ & $\begin{array}{c}\text { Early Archaic } \\
\text { Component }\end{array}$ & $\begin{array}{c}\text { Total } \\
\text { Count }\end{array}$ & $\begin{array}{c}\text { Total } \\
\text { Percentage }\end{array}$ \\
\hline \multicolumn{7}{|l|}{ Inferred Use } \\
\hline Unknown & 5 & 1 & 1 & 10 & 17 & 10.5 \\
\hline Scraping & 22 & 7 & 4 & 6 & 39 & 24.0 \\
\hline Cutting & 8 & 5 & 3 & 11 & 27 & 16.7 \\
\hline Planing & 7 & 1 & 3 & 17 & 28 & 17.3 \\
\hline Boring/Drilling & 1 & 1 & & 3 & 5 & 3.1 \\
\hline Whittling & 7 & 2 & 3 & 4 & 16 & 9.9 \\
\hline Hafted & 3 & & & 10 & 13 & 8.0 \\
\hline Slicing & 2 & 1 & 1 & 3 & 7 & 4.3 \\
\hline Projectile & 3 & 1 & & 5 & 9 & 5.6 \\
\hline Gouging & & & 1 & & 1 & 0.6 \\
\hline \multicolumn{7}{|l|}{ Contact Material } \\
\hline Plant & 2 & & 3 & 18 & 23 & 15.2 \\
\hline Meat & & & & & 0 & 0.0 \\
\hline Bone/Antler & & & & 3 & 3 & 2.0 \\
\hline Mineral & & & & 1 & 1 & 0.6 \\
\hline Hard, High Silica & 27 & 7 & 6 & 9 & 49 & 32.5 \\
\hline Wood & 12 & 3 & 2 & 5 & 22 & 14.6 \\
\hline Animal Hair & 2 & & & 2 & 4 & 2.6 \\
\hline Soft & 4 & 1 & 2 & 3 & 10 & 6.6 \\
\hline Unknown & 8 & 3 & & 18 & 29 & 19.2 \\
\hline Hard & & & 1 & 2 & 3 & 2.0 \\
\hline Hide & 2 & 3 & 2 & & 7 & 4.6 \\
\hline
\end{tabular}

were used in the processing of plants. In general, the use-wear analysis documents that plants constitute a high percentage of the contact material.

Preservation is assumed to have played a significant role in the amount and possibly the type of organic remains recovered in the older components. These factors have directly influenced the amount and type of botanical remains recovered from the recent Toyah component, which indicates a broad suite of plant and wood resources were utilized during that time (Table 14-2). This is a drastic change from the Early and Middle Archaic components that appeared to have had, or used, more restricted botanical resources. For the most part, the same few species represented in the Early Archaic component were also represented in each of the other younger components. The diversity detected in the Early Archaic expanded to even greater diversity in the two most recent components. 


\subsubsection{Burned Rock Cooking Technology}

Often in central and western Texas burned rocks are the dominant material class at open-air hunter-gatherer sites. Although the raw material (i.e., limestone, sandstone, and quartzite) may vary across different regions, the function of the burned rocks as thermal storage devices either scattered or in discrete features, was primarily a part of cooking technology. Therefore, the characteristics and distribution of the burned rocks in a component reflects, at least in part, the cooking technologies, types of cooking features, and related cooking activities such as cleanup and discard of no longer useable cooking rocks.

Regardless of the type of local raw material available and employed, the use of natural rocks centered on heating them in a fire, and then using the stored heat in the rocks to cook foods for consumption. Foods that required cooking were placed with the hot rocks, and the stored heat then cooked the foods. This transfer of heat could have included cooking foods by boiling, grilling, baking, and steaming (see Ellis 1997 for more detailed discussions). In addition to cooking, other uses of hot rocks are acknowledged, such as production of steam in sweat lodges, but such uses are assumed to have played a limited role in most sites.

The heating, use, and discard of rocks are the focus of this discussion. Judging by the frequency of burned rocks in each of the four components, the amount of cooking through the use of burned rocks varied significantly over time at this locality. In the Toyah component, the burned rocks represent 25 percent of the total assemblage. In the Late Archaic component, these represent nearly 69 percent. In the Middle Archaic component, burned rocks represent only 13.5 percent. In the Early Archaic component, this class represents 5.4 percent. The majority of burned rocks in each component were scattered rather than part of recognized cultural features. The exception was Feature 1 that dominated the Late Archaic component. The clustering of burned rocks in recognized features will be addressed first.

Different archeological contents, forms, and contexts provide clues to the different functions and cooking technologies represented by the burned rock clusters. The approach employed in the field was to label each burned rock cluster as a feature, then record metric and non-metric attributes and make other observations concerning that cluster. Directed field documentation combined with subsequent laboratory analyses of different aspects of that cluster (size, shape, and type of rock, plus chemical analyses of the rocks, etc.) and associated materials (type and frequency of debitage, bone, and charred plant remains) provides further data for interpreting the formation processes and function of that cluster/feature.

The Varga Site excavations yielded 27 features comprised mostly of burned rocks. These were assigned to the four temporally restricted cultural components. Detailed information concerning each feature is presented above, by individual components. Table 15-3 summarizes pertinent information for each feature by component.

Feature size is one attribute that provides a first order of sorting (Figure 15-1). Two very general size classes for the burned rock features were identified. One large and 26 small burned rock features were identified. Nearly 97 percent of the burned rock features were less than $200 \mathrm{~cm}$ in diameter (Figure 15-1). It is assumed that these two size classes represent different cooking technologies and/or strategies. 


\begin{tabular}{|c|c|c|c|c|c|c|c|c|c|c|c|c|c|c|c|c|c|c|}
\hline ت્ّ & & 总言 & 䔍 & 总恙 & 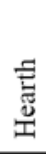 & $\begin{array}{l}\text { 总言 } \\
\text { 品 }\end{array}$ & $\begin{array}{l}\text { 预 } \\
\text { 焉 }\end{array}$ & 丞 & & है & 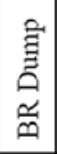 & 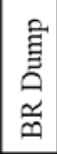 & $\begin{array}{l}\text { 畗 } \\
\text { 总 } \\
\text { 음 }\end{array}$ & $\begin{array}{l}\text { 害 } \\
\text { 童 }\end{array}$ & 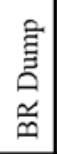 & $\begin{array}{l}\text { 言 } \\
\text { 点 } \\
\text { 몸 }\end{array}$ & $\begin{array}{l}\text { 言 } \\
\text { 竞 } \\
\text { 年 }\end{array}$ & 息 \\
\hline 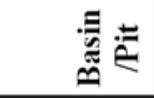 & & 气̆ & 气̆ & 气̆ & $\begin{array}{l}\text { 责 } \\
\text { 岗 }\end{array}$ & $\begin{array}{l}\text { है } \\
\check{z}\end{array}$ & $\begin{array}{l}\text { 表 } \\
\text { 离 }\end{array}$ & $\begin{array}{l}\text { 临 } \\
\text { 品 }\end{array}$ & & $\begin{array}{l}\text { 表 } \\
\text { 品 }\end{array}$ & 气̆ & $\begin{array}{l}\text { g } \\
\text { Zे }\end{array}$ & そั: & 气ั̆ & 气̆ & $\begin{array}{l}0 \\
\check{z} \\
z\end{array}$ & z̆ & 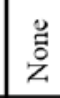 \\
\hline 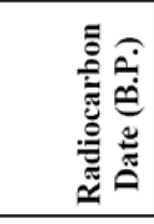 & & 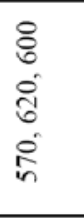 & : & & $\begin{array}{l}8 \\
8 \\
\infty \\
\infty \\
\infty \\
\infty \\
\infty \\
\infty\end{array}$ & 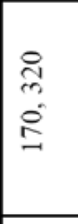 & & Д్ & & 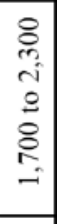 & $\begin{array}{l}\stackrel{0}{\infty} \\
\stackrel{2}{\rightleftharpoons} \\
\stackrel{-}{-}\end{array}$ & 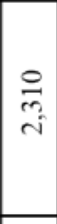 & 8 & $\stackrel{\circ}{-}$ & & 是 & & \\
\hline 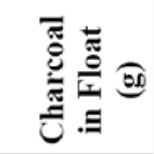 & & $\begin{array}{l}\stackrel{0}{0} \\
\stackrel{0}{0} \\
0 \\
0\end{array}$ & 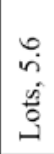 & $\begin{array}{l}\infty \\
\ddot{0} \\
\dot{0} \\
\ddot{\nu}\end{array}$ & 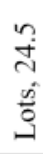 & 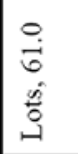 & लै & 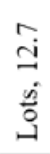 & & $\begin{array}{l}0 \\
\ddot{n} \\
\overrightarrow{0} \\
\dot{0}\end{array}$ & $\stackrel{2}{2}$ & 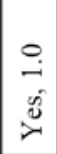 & z & そ & $\overleftrightarrow{z}$ & $\begin{array}{l}\overrightarrow{0} \\
0 \\
0 \\
0\end{array}$ & $\overleftarrow{z}$ & 至 \\
\hline 䓂 & & $\stackrel{n}{g}$ & & 壳 & & $\stackrel{\infty}{2}$ & + & $\stackrel{+}{\circ}$ & & $\exists$ & - & $\infty$ & & & & & & \\
\hline 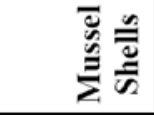 & & $N$ & & & & $\sim$ & & & & $\infty$ & & & & & & & & \\
\hline لُّ & & $\tau$ & & & & $\infty$ & & $\nabla$ & & & & & & & & & & \\
\hline 音 & & $\Xi$ & & $\stackrel{\infty}{\sim}$ & & $\because$ & - & $\mathrm{m}$ & & $F$ & & & & & & & & \\
\hline$\dot{\bar{\Xi}}$ & & ন & & $\stackrel{\circ}{\circ}$ & & 웅 & \pm & $r$ & & $\begin{array}{l}\hat{2} \\
\text { m. } \\
\text { r. }\end{array}$ & - & F & 0 & 0 & & $m$ & & \\
\hline 总总 & & $\frac{0}{\underline{\Xi}}$ & 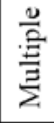 & $\frac{\mathscr{2}}{\mathrm{E}}$ & 惫 & $\frac{0}{\frac{0}{3}}$ & $\overleftrightarrow{\text { z }}$ & 总 & & 兽 & 总 & $\begin{array}{l}\frac{n}{1} \\
\frac{\vec{E}}{2}\end{array}$ & 蒡 & 总 & 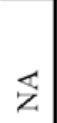 & $\frac{n}{\frac{n}{E}}$ & 总 & 急 \\
\hline$\sum^{0}$ & & $\approx$ & $\stackrel{n}{n}$ & $\cong$ & 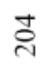 & fo & $\stackrel{\sim}{\approx}$ & 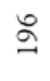 & & $\stackrel{\circ}{ \pm}$ & ஃ & $\overrightarrow{\mathrm{N}}$ & 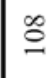 & $\stackrel{\infty}{\stackrel{\sim}{\circ}}$ & $\hat{\mathrm{i}}$ & $\stackrel{\bullet}{\simeq}$ & $\tilde{c}$ & $\vec{n}$ \\
\hline 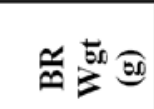 & & $\begin{array}{l}\stackrel{n}{E} \\
\infty \\
\infty\end{array}$ & $\begin{array}{l}8 \\
\stackrel{0}{0} \\
0 \\
0\end{array}$ & $\stackrel{n}{n}$ & $\begin{array}{l}\stackrel{2}{2} \\
\therefore \\
\end{array}$ & 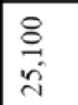 & 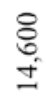 & 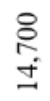 & & 号 & 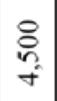 & $\begin{array}{l}0 \\
6 \\
0 \\
0\end{array}$ & $\begin{array}{l}n \\
m \\
m\end{array}$ & ڤั. & 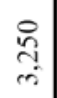 & ळ. & $\underset{8}{\stackrel{\circ}{n}}$ & 品 \\
\hline 产 & & $\underset{\sim}{\stackrel{人}{~}}$ & $\underset{\sim}{\infty}$ & \&ి & $\stackrel{\infty}{\curvearrowright}$ & if & ' & $\stackrel{n}{\curvearrowright}$ & & $\stackrel{\circ}{\stackrel{一}{\circ}}$ & $\ddot{\sim}$ & $n$ & $\ddot{\theta}$ & \& & $=$ & $\vec{m}$ & 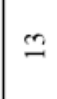 & 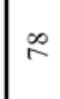 \\
\hline 气气 & & $\approx$ & สี & $\ddot{\sim}$ & $\simeq$ & $\Leftrightarrow$ & & ì & & q & $\stackrel{\sim}{\sim}$ & $m$ & $\leadsto$ & $\ddot{\sim}$ & i & $\stackrel{\sim}{\sim}$ & ஜ & $\underset{m}{\infty}$ \\
\hline 离 & & 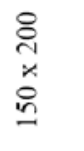 & $\begin{array}{l}\stackrel{0}{n} \\
\check{x} \\
\dot{y}\end{array}$ & 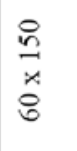 & 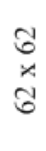 & 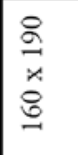 & $\underset{\infty}{\stackrel{0}{ٍ}}$ & $\begin{array}{l}\stackrel{8}{0} \\
\ddot{0} \\
\stackrel{0}{0}\end{array}$ & 营 & క్రి & 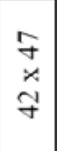 & \begin{tabular}{|l|} 
\\
0 \\
音 \\
5
\end{tabular} & 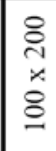 & $\begin{array}{l}\stackrel{n}{*} \\
\ddot{*} \\
\check{n}\end{array}$ & $\begin{array}{l}q \\
\ddot{\alpha} \\
\tilde{n}\end{array}$ & $\begin{array}{l}n \\
\approx \\
\approx \\
\approx\end{array}$ & 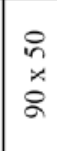 & 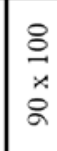 \\
\hline 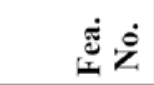 & हैं & $\infty$ & $a$ & $\stackrel{\infty}{\stackrel{1}{2}}$ & $\vec{\sim}$ & $\cong$ & pr & $\underset{ల}{\infty}$ & 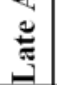 & - & $\Xi$ & $\cong$ & $\underline{0}$ & $\Xi$ & $r$ & $\because$ & $\stackrel{\infty}{\sim}$ & ते \\
\hline
\end{tabular}




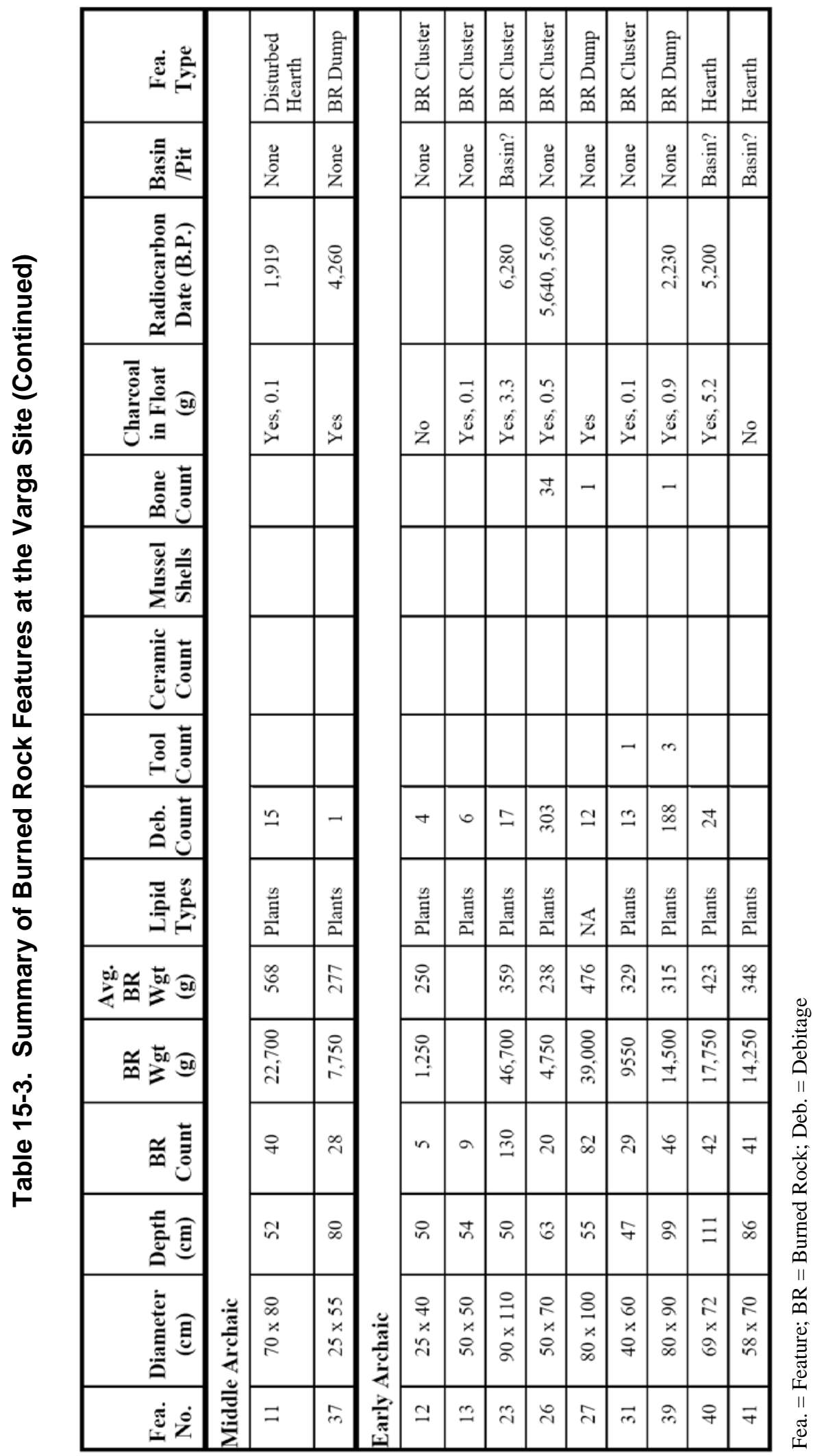




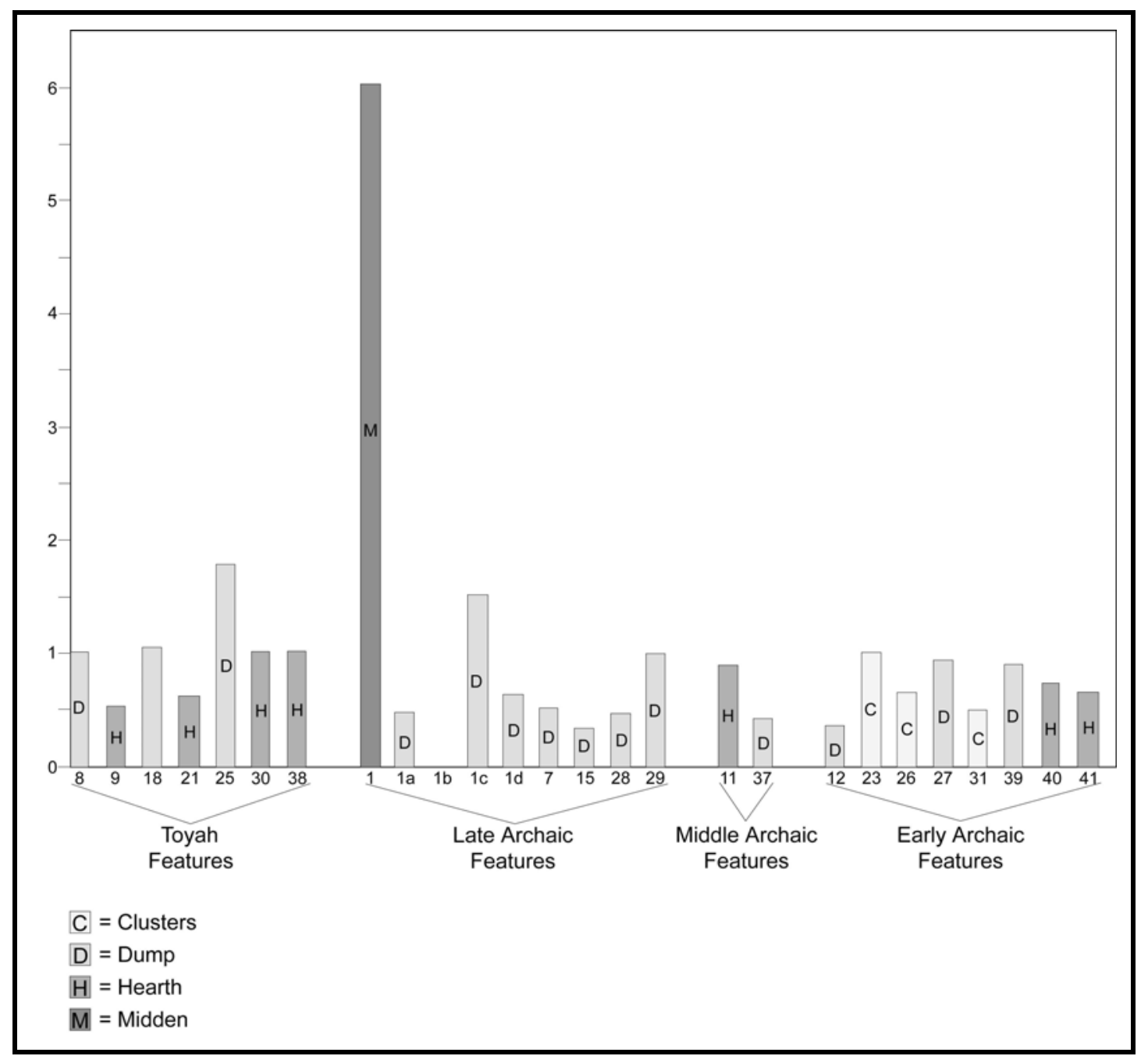

Figure 15-1. Average Diameter of Each Cultural Feature

Feature 1, the one large burned rock feature that dominated the Late Archaic component, was nearly $6 \mathrm{~m}$ in diameter. It was interpreted as a burned rock oven that exhibited a poorly defined central basin and irregular and ill-defined outer boundaries, with different densities of burned rocks across this $6 \mathrm{~m}$ area. The poorly defined, broad, shallow basin consisted of dense accumulations of fractured limestone rocks in about three layers filling the shallow basin. The basin was not rock lined or well defined and exhibited no obvious sediment color change, and no charcoal lens or oxidation rim. A dense accumulation of relatively large burned rock pieces lay along the southeastern edge of the poorly defined basin. Moving away from the apparent central basin the burned rocks became scattered, were in different densities, with four small burned rock clusters (Features 1a, 1b, 1c, and $1 \mathrm{~d}$ ) within the broader scatter of burned rocks. These smaller burned rock clusters were interpreted to represent individual dumping events. It is speculated that the rocks that comprised the four small clusters were removed 
from the basin area, possibly as cleaning episodes, or removed from the top part of the oven.

Twenty-seven burned rocks from across Feature 1 were subjected to lipid residue analysis. Chemical analysis on 15 scattered burned rocks yielded lipid residues with medium to very high fat content interpreted to be associated with cooking plants. Another 12 burned rocks, all from the four small burned rock clusters within the boundaries of Feature 1 (1a, 1b, 1c, and 1d), also yielded lipid residues that were similar to those scattered about Feature 1. The similarity in the chemical results indicates all these rocks were used to cook similar food. Macrobotanical remains from across Feature 1 documented two potential food products, specifically Agavaceae and possibly prickly pear fruit. These products were probably the food resources cooked in this rock oven.

The combined archeological record from Feature 1 resembles a commonly encountered cooking apparatus in central and western Texas. Exactly how this apparatus functioned is not quite clear from the current archeological data and context at the Varga Site but, as mentioned above, the preserved attributes resemble a rock oven. Large cooking ovens, comprised mostly of broken rocks, are just one type of cooking apparatus that have been reported in ethnohistoric and ethnographic documents, and documented in the archeological literature (see recent reviews and discussions by Black et al. 1997; Mauldin et al. 2003). Ellis (1997) provides various versions of how pit ovens were possibly constructed and used. Although Feature 1 has similarities to a pit oven, there are still unanswered questions concerning the basin. If the food was cooked inside the shallow basin, then why was the basin still filled with layers of fractured rocks? Why were charcoal, ash, and burned sediments not observed in the basin? If this oven had food resources in or near the bottom of the basin, then in order to remove the food products, one had to first remove the top part of the oven. The top possibly included burned rocks and dirt, which would have been set or tossed aside. The smaller clusters of fractured rock within the broader scatter may represent part of the material removed to get to the food. Potentially, the burned rock clusters represented cleaning episodes that removed no longer desired rocks from previous cooking events. It is also possible that the four small clusters represent the minimum number of use episodes at this particular location. Regardless, exactly how this perceived oven was constructed and used the large quantities of burned rocks with demonstrated plant residues in them, testifies to a large cooking apparatus in use during a radiocarbon dated period from ca. 1,700 to 2,300 B.P. Its presence documents intensive, probably bulk food processing.

Similar types of burned rock features and much larger burned rock middens are well known across much of Central Texas, the Lower Pecos, and far Western Texas. Burned rock middens with and without well-defined central basins are known for this Late Archaic period. Therefore, this specific cooking technology, the use of rock ovens to cook plants, is neither unusual nor new to this time period.

The 26 smaller burned rock features often yielded limited archeological evidence making interpretations concerning their function much more difficult. The more attributes recorded, and/or cultural materials directly associated with these small burned rock features, the greater possibility that a specific feature can be assigned to a specific functional category. In addition to the feature size, other attributes documented include feature shape, the quantity and size of burned rocks present, evidence of a basin, presence of charcoal, matrix staining, matrix oxidation, and presence of other classes of material directly in the feature. 
Based on the combination of documented and observed attributes and the results from the different technical analyses, the 26 smaller burned rock features were interpreted to represent in situ hearths, or some type of discard pile or dump activity (Table 15-4). Six, and possibly seven, features (about 27 percent) were classified as hearths, 13 features, or 50 percent, were classified as dumps, and five features, or about 19 percent, were classified as clusters with insufficient evidence to assign a function.

At least three (about 12 percent of the total) small features revealed indication of a basin (Table 15-3). Features with a basin have been interpreted as hearths and presumably represent in situ heating. Four features without basins were also classified as hearths and presumably represent in situ heating elements as well. The lipid residue evidence from burned rock analysis reveals the rocks from all these suspected hearths came in contact with foods. The chemical evidence alone implies some type of cooking feature as oppose to a warming fire. If these hearths or heating elements were used to cook foods, it is not clear precisely how they functioned and how the burned rocks accumulated the food residues. It is possible that many of these basin hearths that contained burned rocks were small rock ovens.

The 13 features classified as dumps lack evidence of a basin, and other attributes that suggest in situ heating. A combination of other attributes, most of which provide negative evidence, plays a greater role in their interpretations. No single attribute can define the function for most small features.

Table 15-4. Cultural Feature Types by Component at the Varga Site

\begin{tabular}{|c|c|c|c|c|}
\hline Feature Types & $\begin{array}{c}\text { Toyah } \\
300 \text { to } 660 \text { B.P. }\end{array}$ & $\begin{array}{c}\text { Late Archaic } \\
1,700 \text { to } 2,300 \text { B.P. }\end{array}$ & $\begin{array}{c}\text { Middle Archaic } \\
3,900 \text { to } 4,820 \text { B.P. }\end{array}$ & $\begin{array}{c}\text { Early Archaic } \\
\text { 5,200 to 6,300 B.P. }\end{array}$ \\
\hline Bone Cluster & 2 & & & \\
\hline Burned Rock Clusters & & & & $12,13,23,26,31$ \\
\hline Burned Rock Dumps & $8,18,25$ & $\begin{array}{c}\text { 1a, 1b, 1c, 1d, 7 } \\
15,28,29\end{array}$ & 37 & 27, 39 \\
\hline \multicolumn{5}{|l|}{ Burned Rock Hearths } \\
\hline Small Tight Cluster with Charcoal & 9 & & & \\
\hline Medium Tight Cluster with Charcoal & 21 & & & \\
\hline Large Cluster with Shallow Basin & 30,38 & & & 40,41 \\
\hline Disturbed & & & 11 & \\
\hline Incipient Burned Rock Midden & & 1 & & \\
\hline Occupation Zones & $22,35,36$ & & & \\
\hline
\end{tabular}


The combined attributes lead to interpreting 13 small features as discard piles or dumps of used-up rocks. Some times the burned rocks were dumped or discarded by themselves as indicated by Features 1a, 1b, 1c, and 1d. In some instances the fractured burned rocks were dump/discarded with other diverse cultural materials into general refuse piles such as in Features 8, 18, and 25 in the Toyah component.

The average weight of an individual burned rock from each feature was calculated using the total count and weight of the rocks recovered (Figure 15-2). It is assumed that the average burned rock size, as indicated by the average rock weight, provides an indication of its stage in its use life and contributes to classifying and/or identifying the feature function. It has been demonstrated through heating and cooling experiments using limestone that rock fracturing was so extensive that after two boiling episodes, two heating and cooling episodes, most limestone rocks were too fragmentary for reuse (Duncan and Doleman 1991). Leach et al. (1998, 2001) demonstrated that after two heating episodes with Central Texas limestone rocks that the initial 26 rocks fractured into 217 pieces, or that a 3,500 gram rock fractured into eight pieces weighing an average $430 \mathrm{~g}$. These findings document that the original rocks used for thermal storage were reduced in size relatively quickly and soon became too small to retain sufficient heat. Therefore, the heating and cooling process reduced the rock size, and at some point rendered the rock non-viable for heat transfer, after which it was discarded. In this light, given the many small burned rock fragments in some features, often weighing less than 250 g per rock, it is reasonable to assume that many of burned rock features represent dumps or discard piles of undesirable rocks.

The five burned rock features that were classified as clusters lacked sufficient attributes to clearly assign them to a particular function.
These clusters were all in the Early Archaic component and the lack of good preservation of the feature combined a palimpsest effect resulting from intense use of this area, were contributing factors that did not allow further interpretations of function.

The use of rocks to transfer heat is evidenced in all four components, indicating the long-term use of hot-rock technology. Even the addition of ceramic cooking vessels in the Toyah component did not render the use of hot rock cooking obsolete. Compared to the earlier components, the frequency of burned rocks in the Toyah component decreased from the Late Archaic component. Compared to the Middle and Early Archaic components, the Toyah component yielded considerably higher percentage of burned rocks, in spite of the ceramic cooking technology added to the Toyah assemblage.

The overall average size of the individual burned rocks decreased over time (Figure 15-2). The average size of burned rocks in the Early Archaic was about $187 \mathrm{~g}$. The average size decreased to about $119 \mathrm{~g}$ during the Middle Archaic, increased slightly to about 146 g during the Late Archaic events, and then significantly decreased to about $68 \mathrm{~g}$ in the Toyah component. The larger burned rocks were mostly documented in the recognized features, whereas those scattered about the broader occupations were significantly smaller (Figure 15-2). During the Early Archaic period, the burned rocks in the identified features averaged about $374 \mathrm{~g}$, whereas those scattered across the broader occupations were about $168 \mathrm{~g}$. The size difference in the Middle Archaic component is even more pronounced with the average size of the scattered burned rock equaling about $96 \mathrm{~g}$ compared to those in the two features that yielded average rock sizes of about $448 \mathrm{~g}$. The Late Archaic oven feature does not provide a good comparison to the other 


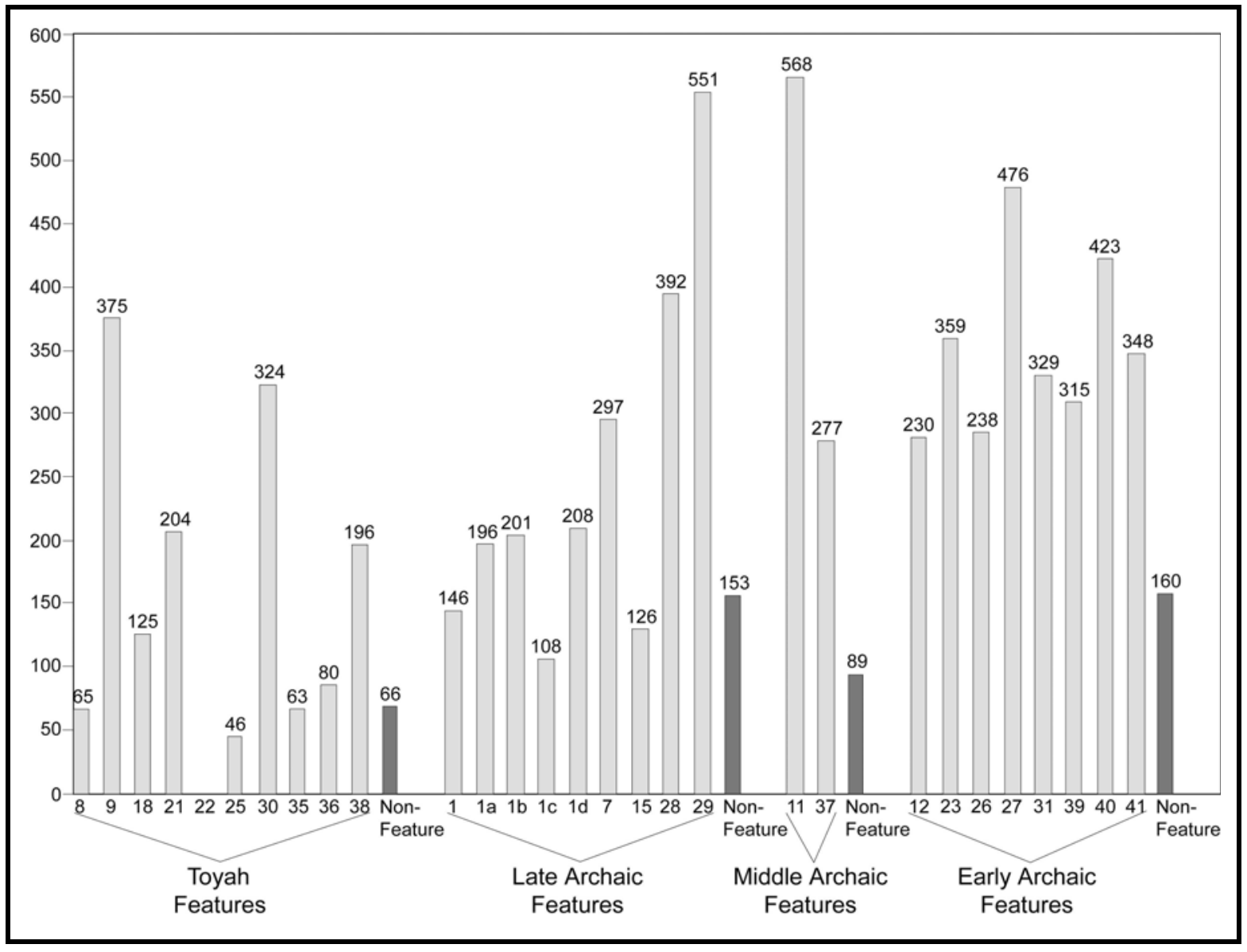

Figure 15-2. Average Burned Rock Weight of Cultural Features (Grams)

smaller features in the other three components. For the Toyah component, the average size of the scattered burned rocks was about $66 \mathrm{~g}$, but the burned rocks in features averaged only about $89 \mathrm{~g}$. The average size difference between the two settings is undoubtedly a reflection of the number of times the rock was heated and cooled until it was finally discarded. If so, the Toyah population apparently used the rocks more intensively than the Early Archaic population, possibly reflecting greater length of occupation, or different thermal requirements according to the specific foods being prepared.

Specific cooking technologies may be associated with specific food resources and may account for some variations detected in the burned rock features. Obviously, the large burned rock oven feature in the Late Archaic was used to cook one or possibly a few specific foods that required lengthy cooking times to enable consumption. Wandsnider (1997) lists many plants and animals that were pit-roasted. She also indicates that fatty meats and insulin-bearing plant foods were often pit-roasted. Dering (1999), using data from rockshelters in the Lower Pecos region, documented diverse food resources in earth ovens, but indicates that lechuguilla and sotol are most abundant and definitely require oven processing. The large oven feature in the Late Archaic component was not encountered in any of the other three components at the Varga 
Site, but that does not mean that similar cooking features may not have been part of the broader cooking technology known to each of those groups.

The lipid residue interpretations indicate that cooking with burned rocks focused on cooking plant resources rather than animal resources. Even though the stone tool assemblages in each of the four components strongly reflects the procurement and processing of animal products, which is also supported by the presence of vertebrate faunal remains in at least two of the components, only the Toyah component reveals a significant percentage ( 24 percent) of the lipid residues interpreted as reflecting large herbivores. Both the Early and Middle Archaic components reveal no evidence that large herbivore products were cooked using burned rocks. This finding is significant, since large herbivores were definitely procured in each of the four major periods of site use. Wandsnider (1997) points out that fatty meat, those that generally have high lipid-to-protein ratio, such as bear, muskrat, opossum, ground squirrels, otter, and beaver, are generally pit-roasted. Meat that is boiled is primarily from species with low lipid to protein ratios, such as elk and moose.

The lack of large herbivore residues might reflect the fact that meat was not cooked through the use of burned rocks. If this was the case, then how was the meat prepared for consumption? It is possible that the meat was roasted over an open flame or in coals, dried, or even consumed raw. Even the Toyah component, which yielded considerable large herbivore products based on the vertebrate faunal remains recovered, indicates that only about 24 percent of the burned rocks contained animal residues. Only about 25 percent of the ceramic sherds analyzed from the Toyah component also yielded signs of large herbivore residues. However, some residue signatures were not sufficiently distinct to enable positive identifications to assign plant or animal use, and it may be that animal residues are actually more prevalent than is apparent with the present data interpretations.

The common cooking technology of boiling was not recognizable at the Varga Site. Boiling is usually conducted with hot rocks and it is reasonable to assume that it was carried out. Dried and lean meats are often boiled to restore moisture. Meats with low fat contents such as antelope, bison, deer, and rabbit are often boiled. Fatty meat tissue may be boiled to further lipid hydrolysis and to melt and express tissue lipids (Wandsnider 1997). Plant foods rich in starches are primarily boiled before consumption. The explanation for why no boiling features were recognized probably reflects the difficultly in the recognition of the technique rather than the true absence of this cooking technology. Although attempts to identify rocks used in boiling have been tried (Jackson 1998), the specific processes for identification have not often been implemented in burned rock analyses. Identification is further hindered by the lack of understanding of how limestone responds to the boiling process, and if it is visibly different from other heating and cooling processes.

Part of the cooking process during Toyah times involved, of course, the use of ceramic vessels. The employment of pottery was a new technology not represented in the proceeding components, but was added to the hot rock technology. The Toyah ceramic assemblage was quite limited, with only about 115 sherds that represent between five and eight vessels. Vessel reconstruction was not possible; therefore, vessel size and shape are unknown. Lipid residue analysis on six sherds, two each from Vessel Groups 1, 2, and 3, yielded very similar results. The detected residue signatures were interpreted as ranging from borderline moderate to high, with high fat content, implying that fatty 
plant parts were cooked in these vessels. The stable carbon and nitrogen isotope values, derived from these exact same samples, also suggest plant cooking, specifically $C_{3}$ plants. Even though a significant quantity of vertebrate faunal remains was recovered from the Toyah component, it does not appear that the procured animal products were cooked in the ceramic vessels. Apparently at the Varga Site, the ceramic cooking technology was used primarily to cook plant foods, as was the hot rock technology.

\subsubsection{Pottery Manufacturing Technology}

Two analytical techniques contributed to a greater understanding of the technology pottery, which was restricted to the Toyah component. Variability in the finished products was detected through petrographic analyses and INAA.

General observations and metric attributes indicate very limited stylistic variability within the Toyah ceramics. The kinds of aplastics added to clay are similar throughout the Varga Site sample, which is in turn similar to those from across the surrounding region. There are, however, some intra-regional variations in the type of additives that might be attributed to cultural differences. The Infierno phase ceramic assemblage postulated for the Lower Pecos region, which has been previously studied by petrographic means, share the same fundamental technological similarities in the nature of the clay matrix, commitment to bone tempering, firing techniques, and therefore, are quite similar to the known Toyah ceramic industry (Robinson 1999). Currently, it appears that the same technology was employed across a broad east to west region of the Edwards Plateau during Toyah times.

The inclusion and analyses of two different samples of native manufactured sherds from the Protohistoric period representing two different aboriginal populations who settled two different Spanish Missions indicate that the manufacturing technology used during the Toyah period was carried forward into Protohistoric times in at least one of the missions. This is evident at Mission San Juan in San Antonio and elsewhere across Southern Texas, but not at the Lipan Apache Mission of San Lorenzo de la Santa Cruz at Camp Wood. This is not a new idea, as Clark (1978) observed bone-tempered ceramics at many of the Spanish missions sites in Southern Texas, and Black (1982) argued for a single ceramic tradition extending from the prehistoric Toyah times into the mission period, based on the bone tempering.

Although the petrographic analysis indicates some Varga Site vessels were manufactured locally, the INAA documents multiple sources of clay for most Varga Site Toyah pottery. Those sources were not the same as used for most of the Toyah ceramics composing the Central Texas- 1 and Central Texas- 2 reference groups (Appendix N). At least three different clay source localities provided clays for the construction of the Varga Toyah vessels assemblage. Since the INAA detected chemically different source areas for the Varga Site vessels, compared to those from the Central Texas sherds, it does not appear that the clay used in the construction of the Varga Site vessels originated in Central Texas. Apparently, Varga Site Toyah population exploited and processed raw clay resources from local and non-local sources in the manufacture of their vessels. Until we gain a greater understanding of where the potential clay source localities are located across Texas, it is not clear how far and in which directions these source areas might have been from this site.

The presence of ceramic vessels in the Toyah component indicates the addition of a new technology to the hunter-gatherer economy during Toyah times. The pottery manufacturing 
technology represented is rather sophisticated and does not appear in a developmental stage. Therefore, this new technology was apparently adopted from elsewhere.

\subsubsection{Maintenance Strategies}

Tool maintenance strategies were detected in all four components through observations made on chipped stone tools and the identification of rejuvenation flakes in the lithic debitage assemblage. Rejuvenation flakes were identified in three of the four components, the exception being the Late Archaic. Possible explanations for their absence in the Late Archaic include the relatively limited lithic debitage assemblage $(n=1,801)$, the limited chipped stone tools recovered ( $n=98$ ), limited use of tools, and/or the dominance of the large burned rock cooking feature. Only two rejuvenation flakes were identified in the Middle Archaic assemblage, and both were removed from unifacial tools. The Middle Archaic component yielded only three unifaces/scrapers, and these three tools were not the same pieces from which the rejuvenation flakes were removed. Apparently, the two rejuvenation flakes were removed from tools that were not discarded in the investigated area. The Early Archaic component yielded 82 rejuvenation flakes, whereas the Toyah component yielded 28 rejuvenation flakes. As tools became dulled during use, the dulled edge was intentionally removed to initiate the rejuvenation of that edge. Three of the five Toyah rejuvenation flakes were subjected to usewear analysis. That analysis demonstrated edge rounding along the worked edges, which occurred primarily from scraping hard materials. The Early Archaic rejuvenation flakes reveal extensive use primarily through planing and/or scraping plants with high silica content, before the edge was removed. The presence of rejuvenation flakes is a sign that processing activities/tasks were conducted on site and that as tools became dulled, edges were rejuvenated in order to extend the use life of the tool.

Rejuvenation flake scars were observed on formal and informal tools in all four components. Again the Late Archaic component yielded the fewest number of recognized rejuvenation scars on tools $(n=1)$, followed by the Middle Archaic with two, the Toyah with five, and the Early Archaic with 12 observations. The only tool in the Late Archaic assemblage with a rejuvenation scar was an edge-modified piece. The two tools from the Middle Archaic component consist of a late stage biface that exhibits edge rounding and an edge-modified tool. The five specimens in the Toyah component include four scrapers and one edgemodified tool. The twelve tools in the Early Archaic assemblage include five projectiles, four bifaces, and two edge-modified pieces. This maintenance strategy apparently was a common practice and not restricted in time.

Beveling along the lateral edges of projectile points and bifaces is another form of tool maintenance in that it allowed a worn or nicked edge to be refurbished on the spot or during use, without the need to dismantle or rehaft with a new tool. Beveling was identified in tools from all four components. The Early Archaic yielded at least 30 tools with signs of beveling, including 17 points and 13 bifaces. The Toyah component yielded the second highest frequency with 13 points and eight bifaces. Four points from the Late Archaic and three points from the Middle Archaic exhibit beveling. The beveling process was probably a short-term solution to quickly resharpen a dulled edge and continue with the task at hand. Once the group camped in one spot for a period of time and new tool stone was collected, the collection of raw material and the production of new tools, allowed the dulled, reworked, and beveled tools to then be discarded and replaced with new ones. The choice was made to resharpen chipped stone tools through 
edge removal and/or beveling techniques occurred even though raw tool stone was generally available and abundant.

Chipped stone tool maintenance activities, the burned rock cooking features, and other activity areas were also subjected to maintenance. Burned rock features were discussed above and include 14 small features classified as discard piles or dumps (Table 15-4). Four of the 14 discard piles or dumps were in the Late Archaic component and were associated with the large burned rock-cooking feature. These four small features comprised mostly of small fragmented burned rock may not reflect true maintenance activities, but possibly resulted from removing the top part of the rock oven to extract the food products. A second alternative hypothesis would be that they represent the cleaning of the central cooking basin to ready the location for the next cooking event. Three features in the Toyah component are classified as dumps. All three contained multiple classes of cultural debris that included lithic debitage, chipped stone tools, fragmented animal bones, and burned rocks, with at least two also yielding small ceramic sherds. The combination of the different classes of artifacts recovered from these dumps may indicate a longer-term occupation occurred to create this diversity in a single location. The Middle Archaic component revealed a single feature classified as a dump, but the feature lacked the multiple classes of artifacts that generally support this interpretation. The near absence of dump features may reflect a short-term camp during the Middle Archaic. At least two features in the Early Archaic component were classified as dumps. However, with the extremely dense lithic debitage and discarded chipped stone tools throughout this component, it was difficult to clearly understand how or what some of these burned rock clusters represented and the true association of different materials. The clustering of different classes of materials in a single location, most likely reflects intentional cleaning of various activity areas and the subsequent dumping of unwanted materials in a common location. This relates directly to general camp maintenance activities. It also demonstrates that a particular area had been selected or designated for dumping unwanted materials, and directly relates to human behaviors and camp structure.

A cut pottery sherd (\#159-8-2) from the Toyah component also indicates that rejuvenation/maintenance was practiced on the ceramic vessels or sherds. Since only a single small piece that exhibits a cut line was recovered, it is not clear what part of the vessel was rejuvenated or how that individual piece was used. The rounded nature of the cut edge implies it was used after it was cut. This may reflect an attempt to continue to use a broken vessel or use a sherd from the broken vessel as a tool to perform another task.

\subsubsection{Storage Technologies}

Storage technologies are not evident in any of the four components at the Varga Site, which is not unusual for hunter-gatherer contexts. No features were classified as storage facilities and skin and/or fiber bags for storage containers were not preserved. Drying meat is one possible means of storing excess, but this again is not visible in the archeological record. The same can be said for the storage of many plant foods (i.e., fruits, nuts, berries, bulbs, flour cakes, etc.) that might have been kept for a period of time. The ceramic vessels in the Toyah component potentially served for temporary storage, but lipid residues identified in the sampled vessel walls suggest that most vessels functioned primarily as cooking vessels. As with most hunter-gatherer groups, the stored food and the containers likely were employed for storage were not preserved.

The very small fragmented size of the animal bones recovered from the Toyah component 
may be indicative of the processing of bones to obtain bone grease and/or marrow. The bone grease is a key ingredient in the manufacture of pemmican, a means of storing/retaining meat that was not immediately consumed. Dried animal meat is the other principal ingredient and mixed together, these two products form a means of storing meat products (see Quigg 1997b). Again, this storage technology has limited visibility in the archeological record. The highly fragmented animal bones, combined with the limited large herbivore lipid residues in the analyzed burned rocks, are clues that this type of storage technology was employed by the Toyah population.

\subsubsection{Other Technologies}

Ornamental objects are quite rare at the Varga Site. The Early Archaic component yielded a single small stone (fossil) with a natural hole in the middle. This is a thin piece of a fossil crinoid shell, and therefore, not intentionally manufactured. This fossil was probably not collected from the immediate site area, but was rather brought to the site, probably as personal ornament worn on clothing. The Early, Middle, and Late Archaic components did not yield any indications of manufacturing or using ornamental artifacts. However, the chipped stone tools, specifically the drills, in the Early Archaic component could have been employed in the manufacturing of such objects.

The Toyah component yielded six items that are classified into this category and include two pieces of the same unique clay object, a bone bead blank, and three altered shell pieces. The three shell pieces are worked and were probably personal ornaments worn on clothing or the body as was intended for the bone beads. Grinding and drilling were used in their production, and the chipped stone drills potentially were used in this process. Evidence for drilling shells was not detected on the drills selected for use-wear, but drilling and/or boring were performed on site; so, these sociotechnic objects were potentially manufactured on site. Two pieces are marine shells and were transported into this site, probably as finished items. One piece of mussel shell was potentially procured locally, and then altered into a decorative item. Bone bead production, using the midsection of a small rabbit size long bone, was performed on site through a simple grooveand-snap technology. At least one bead was removed from the bone blank that still contains four roughly equal sections that have been well defined by deep grooves cut perpendicular to the long axis. These sections would then have been snapped off and strung as ornaments. The grooving process would have easily been conducted through the use of a sharp flake or edge-modified flake. At least seven edgemodified flakes analyzed during use-wear analysis reveal use in cutting wood, or perhaps bone. This bone bead preform also appears polished and exhibits excessive numbers of thin scratch lines or incisions, possibly to decorate the beads. The proximal section of a Toyah bone awl also reveals a few, intentional, thin incised lines perpendicular to the long axis that might have served as decorations or potentially were functional in nature. The manufactured, unique clay figurine-like object is of unknown use, but may have served for some non-mundane purpose other than resource procurement, processing, or consumption. This clay object was brought into the site as a finished object as indicated by the INAA. This object probably had a special meaning/purpose that cannot be identified.

\subsection{SUMMARY: BASIC, LONG-TERM CONTINUITIES IN TECHNOECONOMIC BEHAVIOR}

Whereas the usual stylistic shifts in projectile point types that are well known to characterize the culture history of Central Texas are in 
evidence at the Varga Site, the closer scrutiny of the record that is afforded by the various technical analyses employed in this project serve to highlight an underlying pattern of long-term continuity in fundamental aspects of huntergatherer adaptive behavior. Overall, and with few exceptions, strategies for survival and the technological systems that supported them, were in place by Early Archaic times, and these did not change in any dramatic (or perhaps even significant) ways, during the subsequent millennia of local/regional prehistory.

The peoples represented in all four components used local Edwards chert for the production of their chipped stone tools. The Late Archaic populations revealed the broadest range of use of non-local chert sources, whereas the other three use periods revealed very similar reliance on local cherts. The technological procurement of large game resources appears similar in the general employment of projectiles that targeted game resources. However, the hafting technology for these projectiles did change, not only through time, but also within specific time periods. This change must be related to human choices concerning style and not technologically driven. One specific tool investigated, the Cliffton point, was demonstrated to have been used, as evident by haft wear, most likely as a projectile, and not just a stage or preform in the manufacturing of the Perdiz point.
Although not readily visible in the macrobotanical remains from most components, plant remains were procured and processed in the burned rock features throughout these components. If a particular technology was used to procure and or process these plants it is not visible in the material remains.

The actual food cooking technologies also appear very similar as revealed in the occurrence of burned rock features through time. It appears that the use of hot rocks for cooking foods was mostly directed towards cooking plant foods. The variations in the size and shape of some burned rock features may be related to site function and/or seasonal differences in the occupations.

Two new technologies appeared in the Toyah component, within the last 700 years, and they include the use of a new weaponry system, the bow and arrow, and the ceramic technology in the form of manufactured ceramic vessels and possible figurines. Although the ceramic technology was demonstrated as part of the cooking technology, the previous cooking technology represented by the use of burned rocks, was not totally replaced by this new technology. This new cooking technology may reflect an adaptation that was used for specific types of food processing versus total replacement for all foods to be cooked. 

16.0 CULTURALHISTORICAL CONSIDERATIONS: THE VARGA SITE ARTIFACT TYPES IN DIACHRONIC PERSPECTIVE

\section{J. Michael Quigg}

\subsection{INTRODUCTION}

The cultural history research domain represents a historical perspective on the observed patterning in the archeological record. Some questions asked pertain directly to specific time periods, whereas other questions pertain to more general or broader issues that cross specific time periods. We begin discussions with specific questions relating to the Toyah phase, followed by the Late Archaic, Middle Archaic, Early Archaic, and then move on to broader issues, not restricted to specific time periods.

\subsection{TOYAH PHASE}

Many research questions center around the projectile point types recovered from the Toyah component. Some 229 projectile points, which include 216 arrow points and 13 dart points, were recovered from the Toyah component. The arrow points include nine identifiable types (53 Perdiz, 10 Cliffton, five Bonham, two Scallorn, two Guerrero, one Edwards, one Cuney, one Harrell, and one Padre), accounting for 35 percent of the arrow point specimens (with 65 percent or 140 unidentifiable arrow point fragments). The 13 dart points, or slightly over five percent of the total points from this component, include four Late Archaic Frio points, one Early Archaic Group 2 point, one Merrell, one Baker, and six unidentifiable dart point fragments.

Which point types are intrusive to the Toyah occupation? Thirteen dart points are definitely older than the Toyah component and do not represent this time period. Probably, the dart points recovered from this component were displaced from their original contexts lower in the profile through one or more kinds of bioturbation, since all the dart point types are represented in lower components at the Varga Site. It is also possible that one or more of these dart points was collected and curated by the population using the Perdiz point before their occupation of this site. The curation of older point types is not an unusual occurrence in Central Texas sites. As an example, six dart points were recovered from a well-defined and stratigraphically sealed Toyah occupation at Mustang Branch (41HY209-T; Ricklis 1994). It also is possible that the visual stratigraphy, the compressed and disturbed nature of the two youngest components at the Varga Site, and the excavation in $10 \mathrm{~cm}$ arbitrary levels may have lead to the misassignment of the four Late Archaic Frio dart points to the Toyah component.

In the case of the multiple arrow point types, the current chronological assignment of individual types represented is not precise enough to place most recognizable point types into narrow time frames, especially across the vast regions of Texas. The one Edwards and two Scallorn points are considered slightly older than the Perdiz, Cliffton, and other arrow points recovered from the Toyah component. The Rainey Site, just to the east in Bandera County, provides absolute radiocarbon dates and good stratigraphic context to document that Scallorn 
and Edwards points are slightly older than the Perdiz points (Henderson 2001). At that site, the Scallorn and Edwards point types are associated with absolute radiocarbon dates that range from about 800 to 1,400 B.P. The one Edwards and two Scallorn points recovered from the Varga Site may indicate a limited use period just before the Toyah occupations. A total of eight radiocarbon dates (two charcoal radiocarbon dates of 920 and 940 B.P. [Beta-175399 and Beta-175398] from the lowest part of the Toyah component, three radiocarbon dates from the presumed Late Archaic component, two bone radiocarbon dates of 860 and 890 B.P. [UGA12713 and UGA-12708], and one charcoal radiocarbon date from Feature 1d of 1,390 B.P. [UGA-12704]) are considered too recent for the Late Archaic component and too old for the Toyah component. These eight absolute dates from the Varga Site may well represent a blurred and an obscured use period by a group(s) using the Scallorn and/or Edwards points. These absolute dates fit well with the time period previously documented and associated with these two point types at the Rainey Creek Site. If these two point types represent an event(s) before the Toyah component, then that event(s) became so mixed with the Toyah materials or Late Archaic materials that it was not recognized in the thin sediments above the Late Archaic component. Similar point types have been recovered from the region, and it would not be surprising that these two point types would be in these deposits.

Cliffton points are a recurrent presence, although never in high frequencies, in most Toyah components and are considered part of the Toyah assemblage. As discussed above, Cliffton points were not preforms for the Perdiz points as many have indicated. Use-wear analysis on four Cliffton points completed here indicates that Cliffton points were actual hafted tools with multiple functions. At least two show evidence of hafting wear, another reveals wood fragments and striation indicating cutting actions, and another reveals plant fragments in the haft area, plus striations across the margins.

Bonham points are sometimes found with the Perdiz points at many Toyah components. They are very similar in overall form and outline to Perdiz points, but have a straighter stem and straight base. Prewitt (1995) indicates Bonham points have been recovered from most areas across Texas, including the area of and around Edwards County. However, Bonham points are considered intrusive to the site and region, as they are generally considered prominent in northeastern Texas (Turner and Hester 1995). They may reflect limited interactions between the Perdiz using populations and other groups of people towards northeastern Texas.

One Harrell and one Padre point were recovered from the Varga Site. These same two distinctive point types have been recovered in limited numbers from a few other Toyah components across Central Texas. As an example, two Harrell points were associated with the main Toyah occupation at the Rush Site near San Angelo (Quigg and Peck 1995). The Harrell points and associated cultural material have a relative broad distribution across northwestern Texas and are concentrated north and west of Edwards County (Prewitt 1995). This point type is associated with the Garza complex in the southern High Plains region (see Boyd 1997 for recent overview). Harrell points are thought to represent a separate plains group and are considered intrusive to the site and region. The occurrence of a Harrell point at the Varga Site is near the southern known extent of its distribution (Prewitt 1995:109). This point may have arrived through trading or by direct interaction with the peoples employing this point type. One assumes some type of contact with peoples employing this point type, although it is possible that this was a collected and curated item from a chance discovery. 
The Padre point is a considerable distance from its normal distribution since Prewitt's (1995:124) map shows it to be localized in six counties along the Southern Texas coast. If the coastal region was the home range for this point type, then either travel or exchange would have brought this Padre point into Edwards County some $350 \mathrm{~km}$ to the northwest. Although no direct association can be made, one may speculate that if the people associated with the Padre point came from the Texas coast, then possibly the few marine shell pieces recovered from this component also came with them. The Padre point and the marine shell indicate interaction with peoples along the Southern Texas Gulf coast.

The Cuney point type is generally most often recovered in northeastern Texas (Turner and Hester 1993). The single specimen recovered here is west of its primary distribution (Prewitt 1995). Its arrival here was either through trade or direct contact with peoples from Northeastern Texas. Cuney and Perdiz points are recovered from Mission sites as well, such as Espiritu Santo (Walter 1997), which may indicate they are very late in time, and groups were interacting with each other.

Two Guerrero points were recovered from this component, and these point types are most often associated with the Spanish Colonial era (A.D.1700s; Turner and Hester 1998). Guerrero points have been documented in several counties across Southern Texas and in Val Verde County (Prewitt 1995). They are most often found in Mission contexts such as Mission San Lorenzo de la Santa Cruz (Tunnell and Newcomb 1969) and the various locations of Espiritu Santo Mission (Walter 1997; Ricklis 2000, 2007). Their presence may indicate at least one very late occupation and a definite change in hafting techniques from the stemmed Perdiz points. A single piece of worked glass was the only other artifact that might be assigned to a very late period. These few items may be related to the very late radiocarbon dates from the Toyah component (see discussion below).

During the Late Prehistoric period, ceramic technology was introduced as another means of cooking foods. This new technology did not totally replace the existing cooking technology based on the use of hot rocks. At the Varga Site, the ceramic technology supplemented hot rock cooking and may have been used more often for cooking plant products rather than meat.

Another question concerns how this component relates to, or transitions into, the Protohistoric period. The 13 acceptable radiocarbon dates, or 65 percent of the Toyah samples, reveal a time range from 290 to 660 B.P. (Table 16-1, Figure 16-1). Acceptable assays were all derived from wood charcoal. Forty-six percent of the acceptable radiocarbon dates document a period between 400 and 660 B.P. with no obvious temporal clustering. Fifty-four percent, or seven acceptable wood charcoal dates from the Toyah component, are younger than 400 B.P., post-dating the arrival of the first Europeans in Southern Texas. These seven radiocarbon dates reveal that the Native American populations probably continued to use the Varga Site into the Protohistoric period. Two Guerrero points that are often associated with Spanish mission settlements may correlate with this. Similar small triangular arrow points and one Perdiz point were recovered from the ca. 180-year old Mission San Lorenzo, 40 km south of the Varga Site (Tunnell and Newcomb 1969) and from excavated mission contexts in the San Antonio area and Espiritu Santo Mission (Walter 1997). Further support for a Protohistoric event may come from a single edge-modified flake made on clear glass and a single igneous-rock-tempered sherd (recovered from the disturbed surface) that probably originated in West Texas. 


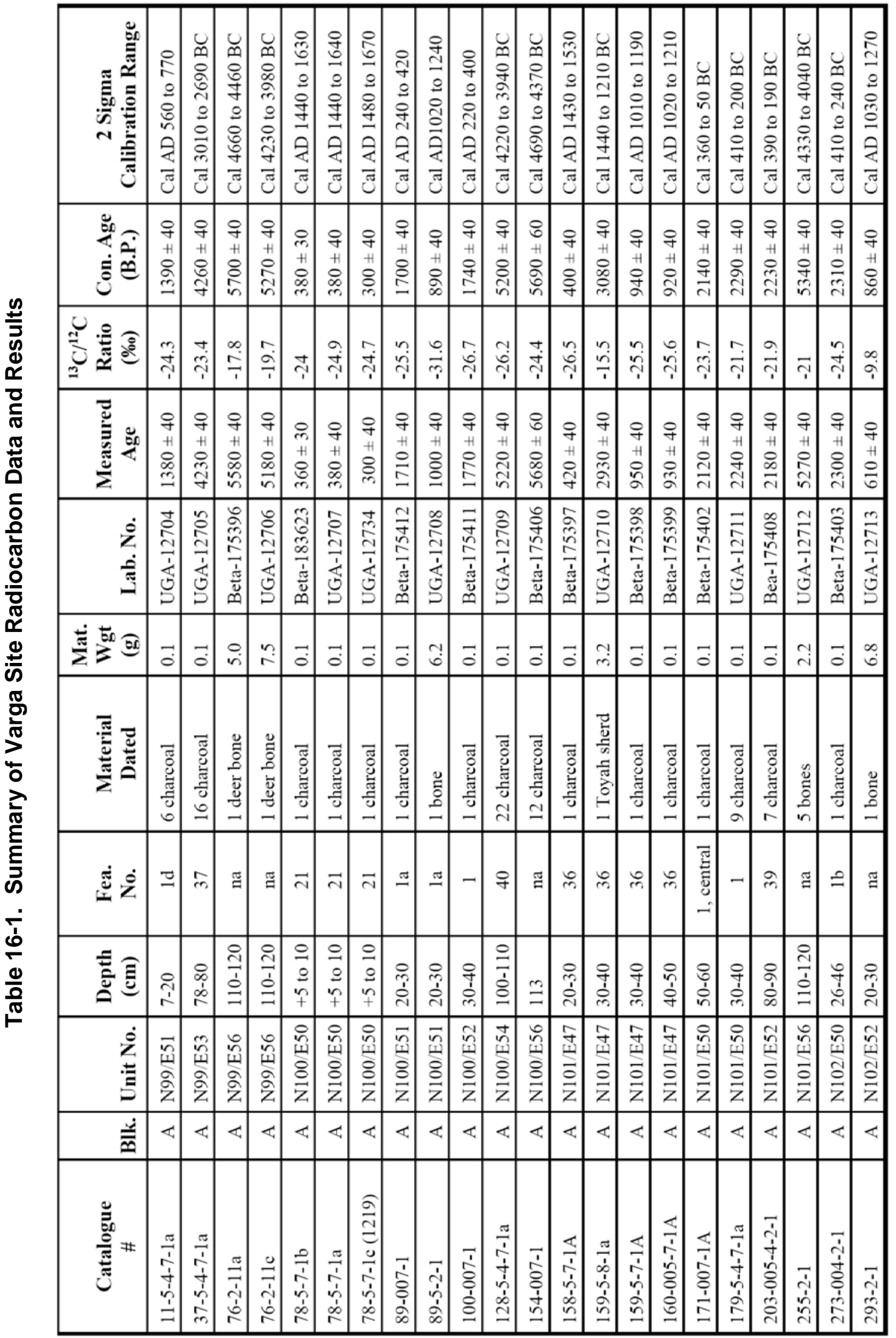




\begin{tabular}{|c|c|c|c|c|c|c|c|c|c|c|c|c|c|c|c|c|c|c|c|c|c|c|}
\hline 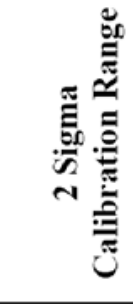 & $\begin{array}{l}0 \\
0 \\
0 \\
0 \\
0 \\
0 \\
0 \\
0 \\
0 \\
0\end{array}$ & 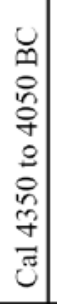 & 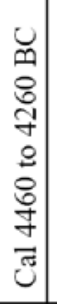 & 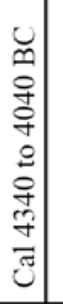 & $\begin{array}{l}0 \\
8 \\
0 \\
0 \\
8 \\
0 \\
0 \\
0 \\
0\end{array}$ & 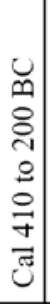 & $\begin{array}{c}0 \\
0 \\
0 \\
0 \\
0 \\
0 \\
0 \\
0 \\
0 \\
0 \\
\tilde{J} \\
0\end{array}$ & 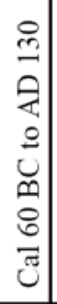 & 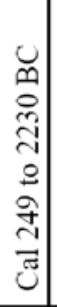 & & 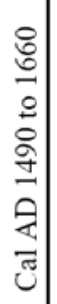 & 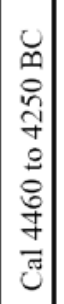 & \begin{tabular}{|c|c}
0 \\
$n$ \\
0 \\
0 \\
0 \\
0 \\
0 \\
0 \\
0 \\
0 \\
$\tilde{n}$ \\
\end{tabular} & 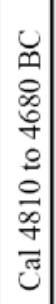 & 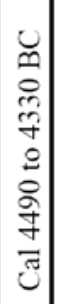 & 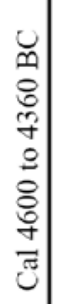 & 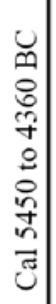 & 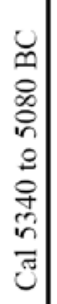 & 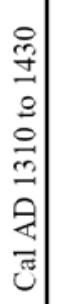 & $\begin{array}{l}0 \\
0 \\
o \\
+ \\
8 \\
0 \\
0 \\
0 \\
\tilde{J}\end{array}$ & 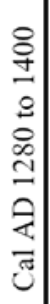 & $\begin{array}{l}0 \\
2 \\
2 \\
0 \\
0 \\
0 \\
0 \\
\frac{0}{0} \\
\frac{\theta}{\pi}\end{array}$ \\
\hline 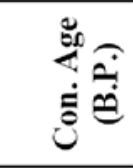 & $\begin{array}{l}q \\
+ \\
0 \\
n \\
n\end{array}$ & 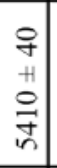 & $\begin{array}{l}0 \\
n \\
+1 \\
0 \\
n \\
n\end{array}$ & \begin{tabular}{l|l}
9 \\
+ \\
+1 \\
0 \\
0 \\
+1
\end{tabular} & 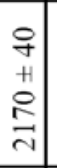 & $\begin{array}{l}\stackrel{+}{+} \\
+1 \\
\stackrel{人}{ } \\
\grave{~}\end{array}$ & 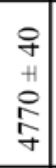 & $\begin{array}{l}\stackrel{+}{+} \\
+1 \\
ః \\
\vdots\end{array}$ & $\begin{array}{l}\stackrel{+}{+} \\
+1 \\
0 \\
\stackrel{2}{2}\end{array}$ & & $\begin{array}{l}\text { ㅇ } \\
+1 \\
\text { 이 }\end{array}$ & 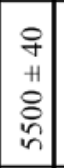 & $\begin{array}{l}9 \\
+ \\
+1 \\
8 \\
0 \\
0\end{array}$ & $\begin{array}{l}\text { Pे } \\
+ \\
\text { 1 } \\
\infty \\
\infty \\
\infty\end{array}$ & 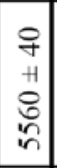 & 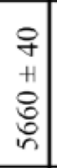 & $\begin{array}{l}\stackrel{+}{+} \\
+ \\
0 \\
+ \\
0 \\
n\end{array}$ & 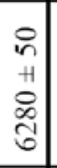 & $\begin{array}{l}\text { o } \\
+1 \\
\text { in } \\
\text { in }\end{array}$ & \begin{tabular}{l|l}
9 \\
+ \\
+1 \\
+ \\
+ \\
\end{tabular} & $\begin{array}{l}0 \\
q \\
+1 \\
0 \\
0\end{array}$ & in \\
\hline 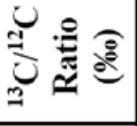 & רุ. & $\begin{array}{l}0 \\
\stackrel{0}{0} \\
1\end{array}$ & 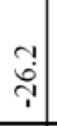 & 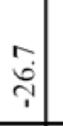 & 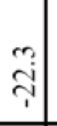 & זר & 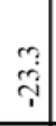 & 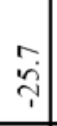 & בְ. & & $\begin{array}{l}1 \\
\\
\\
\end{array}$ & 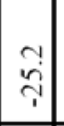 & 辛 & $\frac{\pi}{i}$ & సֶ. & \begin{tabular}{l}
0 \\
\hdashline \\
\end{tabular} & ชุ| & $\begin{array}{l}0 \\
\text { à } \\
1 \\
\end{array}$ & जั: & 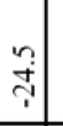 & 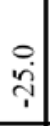 & $n$ \\
\hline 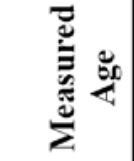 & $\begin{array}{l}f \\
+ \\
+1 \\
0 \\
n\end{array}$ & $\begin{array}{l}q \\
+ \\
+ \\
o \\
⿱ \\
⿱ 亠 䒑 \\
n\end{array}$ & $\begin{array}{l}8 \\
n \\
+1 \\
0 \\
\vdots \\
n \\
n\end{array}$ & $\begin{array}{l}9 \\
+ \\
+1 \\
0 \\
0 \\
0 \\
n\end{array}$ & 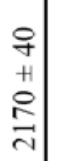 & 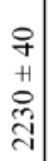 & \begin{tabular}{l}
$P$ \\
+ \\
+ \\
9 \\
+ \\
\multirow{T}{*}{}
\end{tabular} & $\begin{array}{l}\text { \& } \\
+ \\
+ \\
\stackrel{\vdots}{0}\end{array}$ & $\begin{array}{l}P \\
+ \\
+1 \\
8 \\
\infty \\
\infty \\
0\end{array}$ & 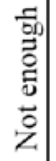 & $\begin{array}{l}\text { o } \\
+1 \\
\text { ¿े }\end{array}$ & 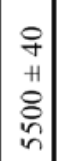 & 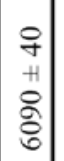 & 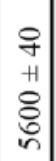 & $\begin{array}{l}q \\
+ \\
+1 \\
\varnothing \\
\infty \\
n\end{array}$ & $\begin{array}{l}q \\
+ \\
+ \\
q \\
⿱ \\
⿱ 亠 䒑\end{array}$ & 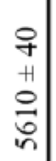 & $\begin{array}{l}\text { ㅇ } \\
+1 \\
\stackrel{2}{0} \\
\text { ते }\end{array}$ & $\begin{array}{l}\text { o } \\
+1 \\
\text { in } \\
\text { in }\end{array}$ & $\begin{array}{l}0 \\
+ \\
+1 \\
0 \\
\stackrel{2}{2}\end{array}$ & $\begin{array}{l}9 \\
+ \\
+1 \\
0 \\
0\end{array}$ & ○ \\
\hline $\begin{array}{l}\dot{0} \\
\dot{z} \\
\dot{\tilde{n}} \\
\end{array}$ & 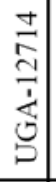 & 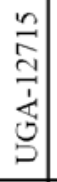 & 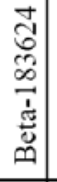 & 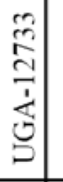 & 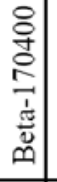 & 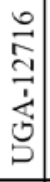 & 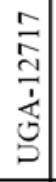 & 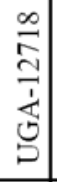 & 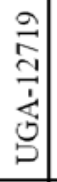 & 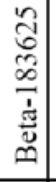 & 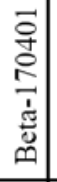 & 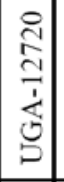 & 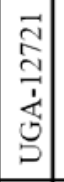 & 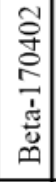 & 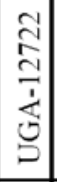 & 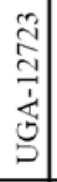 & 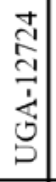 & 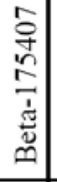 & 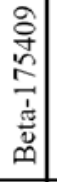 & 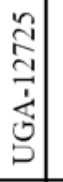 & 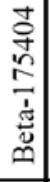 & 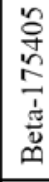 \\
\hline 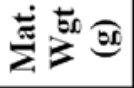 & $\begin{array}{l}\infty \\
0\end{array}$ & $\overrightarrow{0}$ & $\overrightarrow{0}$ & $\overrightarrow{0}$ & $\overrightarrow{0}$ & $\stackrel{+}{i}$ & $\overrightarrow{0}$ & $\overrightarrow{0}$ & $\stackrel{n}{=}$ & : & $\overrightarrow{0}$ & $\overrightarrow{0}$ & $\ddot{0}$ & $\because$ & $\overrightarrow{0}$ & $\overrightarrow{0}$ & $\overrightarrow{0}$ & $\overrightarrow{0}$ & $\overrightarrow{0}$ & $\overrightarrow{0}$ & $\overrightarrow{0}$ & $\overrightarrow{0}$ \\
\hline 焉 & 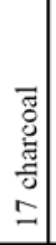 & 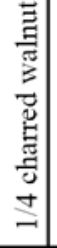 & 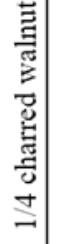 & 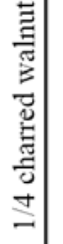 & 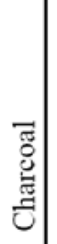 & $\begin{array}{l}0 \\
\stackrel{0}{0} \\
0 \\
=\end{array}$ & 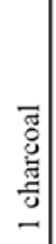 & 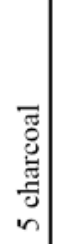 & 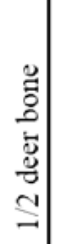 & 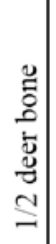 & 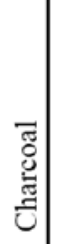 & 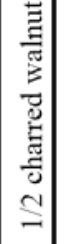 & 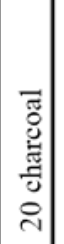 & 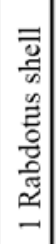 & 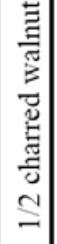 & 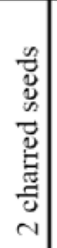 & 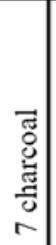 & 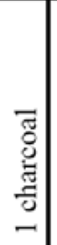 & 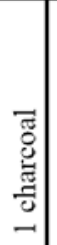 & 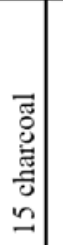 & 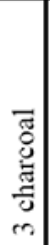 & 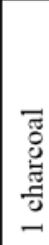 \\
\hline$\dot{\Xi} \dot{z}$ & $\stackrel{0}{-}$ & 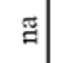 & 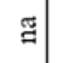 & $\cong$ & 常 & $\Xi$ & $\Xi$ & $=$ & $\Xi$ & $\dddot{\Xi}$ & $\sim$ & & $\because$ & $\cong$ & $\Xi$ & $\stackrel{i}{i}$ & $\stackrel{i}{ }$ & $\ddot{\sim}$ & 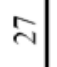 & 点 & $a$ & $\infty$ \\
\hline 䓌司 & 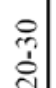 & $\begin{array}{l}8 \\
\stackrel{1}{1} \\
\end{array}$ & 各 & $\frac{8}{8}$ & 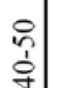 & $\begin{array}{l}\text { : } \\
\vdots \\
0\end{array}$ & $\begin{array}{l}\text { : } \\
1 \\
0\end{array}$ & $\begin{array}{l}\text { oి } \\
1 \\
0\end{array}$ & : & : & 守 & 웋 & $\begin{array}{l}0 \\
0 \\
1 \\
1\end{array}$ & $\frac{8}{1}$ & 윰 & : & $\Rightarrow$ & in & ơ & خิ & 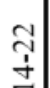 & ิㅗㅇ \\
\hline 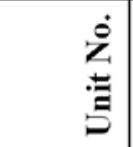 & 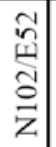 & 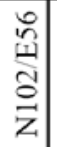 & 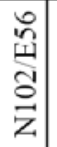 & 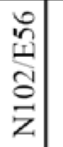 & 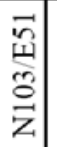 & 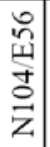 & 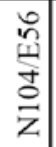 & 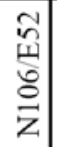 & 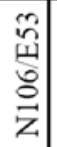 & 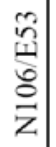 & 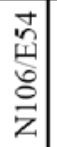 & 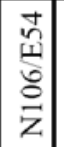 & 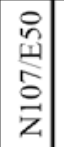 & 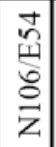 & 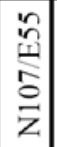 & 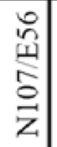 & 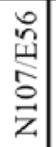 & 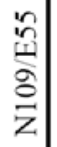 & 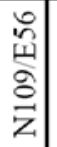 & $\begin{array}{l}\stackrel{2}{\underline{\mu}} \\
\text { 点 } \\
\text { z }\end{array}$ & 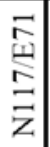 & $\overrightarrow{\bar{z}}$ \\
\hline$\dot{\overline{\underline{A}}}$ & $\varangle$ & $\varangle$ & $\varangle$ & $\varangle$ & $\varangle$ & $\varangle$ & $\varangle$ & $\varangle$ & $<$ & $\varangle$ & $\varangle$ & $<1$ & $\varangle$ & $\varangle$ & $\varangle$ & $\varangle$ & $\varangle$ & $\varangle$ & $\varangle$ & $m$ & 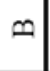 & $m$ \\
\hline 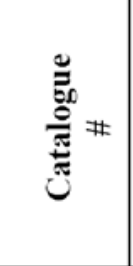 & $\begin{array}{l}\frac{\pi}{1} \\
\dot{n} \\
\\
2\end{array}$ & $\begin{array}{l}\frac{\pi}{1} \\
\frac{1}{5} \\
\frac{1}{5} \\
\frac{1}{2}\end{array}$ & 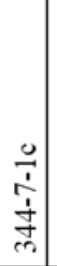 & 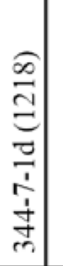 & 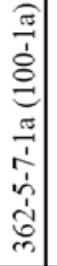 & $\begin{array}{l}\dot{a} \\
\dot{\infty} \\
\vec{\gamma}\end{array}$ & $\begin{array}{l}\frac{\pi}{\frac{1}{a}} \\
\frac{\infty}{7} \\
F\end{array}$ & $\begin{array}{l}\dot{r} \\
\dot{y} \\
\dot{n} \\
\stackrel{n}{n}\end{array}$ & 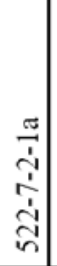 & 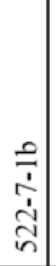 & 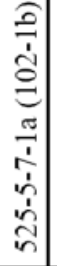 & $\frac{\frac{\pi}{1}}{\frac{1}{n}}$ & 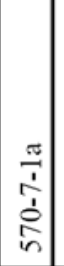 & 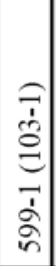 & $\begin{array}{l}\frac{\pi}{1} \\
\frac{1}{5} \\
0\end{array}$ & 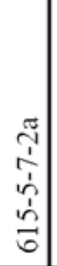 & $\begin{array}{l}\frac{\pi}{5} \\
\frac{1}{2} \\
\vdots \\
b\end{array}$ & مُ & 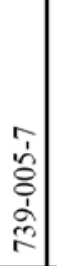 & 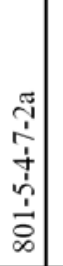 & & 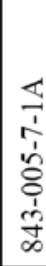 \\
\hline
\end{tabular}




\begin{tabular}{|c|c|c|c|c|c|c|c|c|c|c|c|c|c|c|c|c|c|c|c|c|c|c|}
\hline & 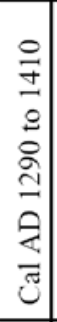 & 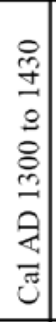 & 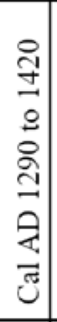 & 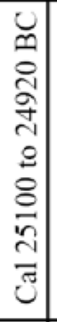 & 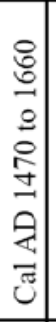 & 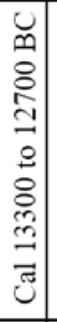 & 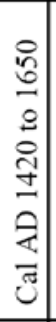 & 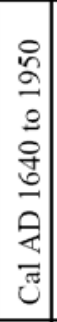 & 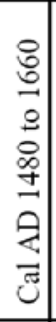 & $\begin{array}{l}0 \\
2 \\
2 \\
0 \\
0 \\
0 \\
0 \\
0 \\
0 \\
0 \\
0\end{array}$ & $\begin{array}{l}0 \\
0 \\
0 \\
0 \\
0 \\
0 \\
0 \\
0 \\
0 \\
n \\
0 \\
0\end{array}$ & $\begin{array}{l}0 \\
\infty \\
0 \\
0 \\
0 \\
0 \\
0 \\
0 \\
0 \\
0\end{array}$ & 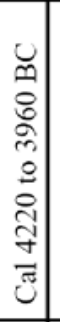 & \begin{tabular}{l|}
0 \\
0 \\
0 \\
$\infty$ \\
0 \\
0 \\
0 \\
0 \\
0 \\
0 \\
0 \\
0 \\
0
\end{tabular} & 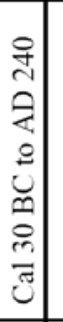 & 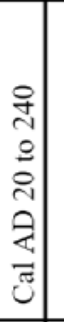 & 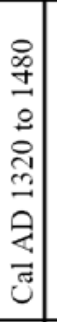 & 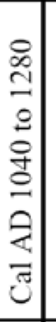 & 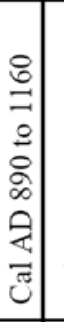 & 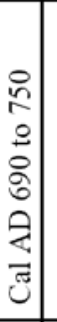 & 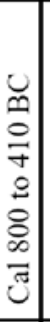 & 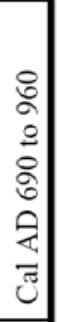 \\
\hline 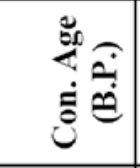 & $\begin{array}{l}q \\
+ \\
+ \\
0\end{array}$ & $\begin{array}{l}9 \\
+1 \\
\text { 2 } \\
\text { in }\end{array}$ & $\begin{array}{l}9 \\
+ \\
+1 \\
8 \\
\end{array}$ & 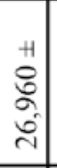 & $\begin{array}{l}0 \\
+ \\
+1 \\
0 \\
0\end{array}$ & $\begin{array}{l}+1 \\
\stackrel{2}{ळ} \\
\stackrel{=}{=}\end{array}$ & $\begin{array}{l}8 \\
8 \\
+1 \\
8 \\
0\end{array}$ & $\begin{array}{l}8 \\
8 \\
+1 \\
8 \\
-1 \\
\end{array}$ & $\begin{array}{l}q \\
+1 \\
\stackrel{0}{m} \\
m\end{array}$ & $\begin{array}{l}9 \\
+ \\
+1 \\
8 \\
\end{array}$ & $\begin{array}{l}0 \\
n \\
+1 \\
\circ \\
\text { ते } \\
0\end{array}$ & $\begin{array}{l}\stackrel{2}{7} \\
+1 \\
2 \\
\infty \\
\infty \\
- \\
\end{array}$ & $\begin{array}{l}0 \\
+1 \\
+1 \\
0 \\
n \\
n\end{array}$ & 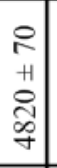 & \begin{tabular}{l|}
8 \\
0 \\
+1 \\
8 \\
$\vdots$ \\
\end{tabular} & 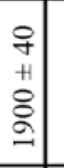 & 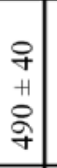 & $\begin{array}{l}0 \\
+ \\
+1 \\
0 \\
\infty \\
\infty\end{array}$ & $\begin{array}{l}9 \\
+ \\
+1 \\
0 \\
0 \\
0 \\
\end{array}$ & 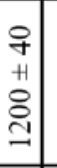 & 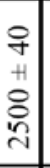 & 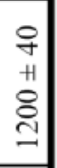 \\
\hline 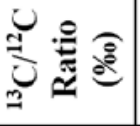 & تิ & 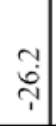 & $\begin{array}{l}0 \\
\stackrel{0}{0} \\
i\end{array}$ & $N$ & 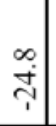 & $\vec{r}$ & 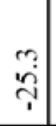 & $\begin{array}{l}\vec{y} \\
\text { s. }\end{array}$ & $\begin{array}{l}\infty \\
\stackrel{\infty}{\sim} \\
\end{array}$ & $\begin{array}{l}\infty \\
\text { ஸे }\end{array}$ & $\frac{\vartheta}{i}$ & 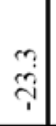 & $\begin{array}{l}\stackrel{0}{1} \\
\stackrel{1}{i}\end{array}$ & 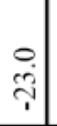 & 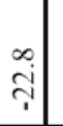 & 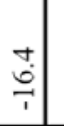 & $\vec{\square}$ & กิ่ & 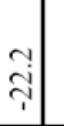 & הִ & $\frac{\partial}{1}$ & $\stackrel{2}{-}$ \\
\hline 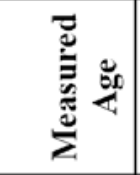 & $\begin{array}{l}9 \\
+ \\
+1 \\
+ \\
\text { b }\end{array}$ & $\begin{array}{l}9 \\
+1 \\
\text { i } \\
\text { in }\end{array}$ & $\begin{array}{l}0 \\
+ \\
+1 \\
0 \\
6 \\
6\end{array}$ & 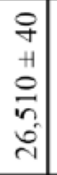 & $\begin{array}{l}0 \\
+ \\
+1 \\
\text { के }\end{array}$ & $\begin{array}{c}8 \\
+ \\
+1 \\
\circ \\
0 \\
= \\
=\end{array}$ & $\begin{array}{l}8 \\
8 \\
+1 \\
0 \\
0\end{array}$ & $\begin{array}{l}8 \\
8 \\
+1 \\
0 \\
-1\end{array}$ & $\begin{array}{l}9 \\
+ \\
+1 \\
\vdots \\
\vdots\end{array}$ & $\begin{array}{l}q \\
+ \\
+ \\
+\end{array}$ & $\begin{array}{l}\text { in } \\
+1 \\
\circ \\
\text { ปิ }\end{array}$ & $\begin{array}{l}? \\
+ \\
+1 \\
0 \\
+ \\
\infty\end{array}$ & $\begin{array}{l}\stackrel{2}{n} \\
+1 \\
\therefore \\
2 \\
i n\end{array}$ & 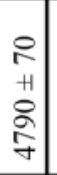 & $\begin{array}{l}8 \\
0 \\
+1 \\
8 \\
0 \\
\infty\end{array}$ & 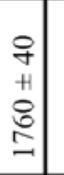 & \begin{tabular}{l|l}
9 \\
+ \\
+1 \\
0 \\
0 \\
0
\end{tabular} & $\begin{array}{l}q \\
+ \\
+ \\
\stackrel{0}{\infty}\end{array}$ & $\begin{array}{l}0 \\
+ \\
+1 \\
0 \\
0\end{array}$ & \begin{tabular}{l|l}
9 \\
+ \\
+1 \\
$⿱$ \\
+ \\
$=$
\end{tabular} & 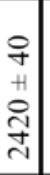 & $\begin{array}{l}q \\
+ \\
+1 \\
8 \\
=\end{array}$ \\
\hline $\begin{array}{l}\dot{8} \\
\dot{\tilde{z}} \\
\dot{\sim}\end{array}$ & 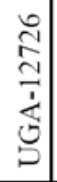 & 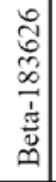 & 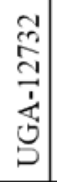 & 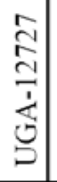 & 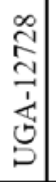 & 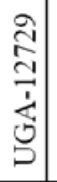 & 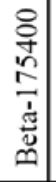 & 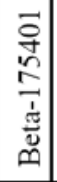 & 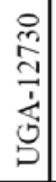 & 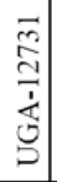 & 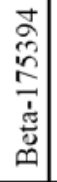 & 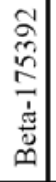 & 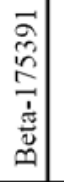 & 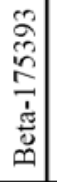 & 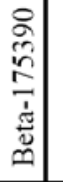 & 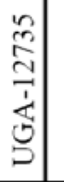 & 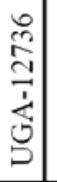 & 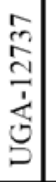 & 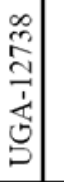 & 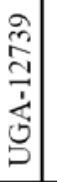 & 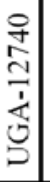 & 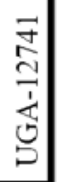 \\
\hline$\dot{\vec{z}} \overrightarrow{\mathrm{E}}$ & $\stackrel{1}{0}$ & $\stackrel{3}{0}$ & $\stackrel{1}{0}$ & $\vec{m}$ & $\stackrel{1}{8}$ & $\stackrel{?}{\varrho}$ & 8 & $\begin{array}{l}0 \\
0 \\
6\end{array}$ & $\hat{\mathrm{i}}$ & $\begin{array}{l}\infty \\
\stackrel{0}{0}\end{array}$ & ¿े| & ి. & 이 & ڤે & :ి & in & 으 & $\vec{m}$ & กั & ?: & 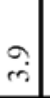 & 奋 \\
\hline 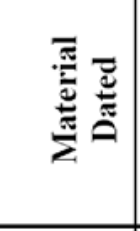 & 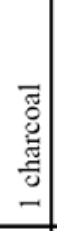 & 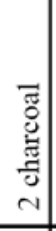 & 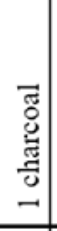 & 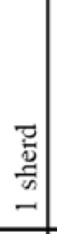 & 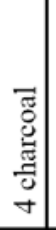 & 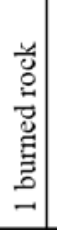 & 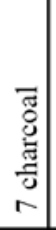 & 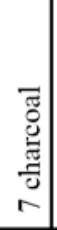 & 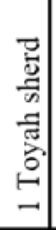 & 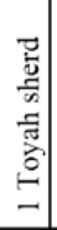 & 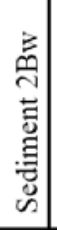 & 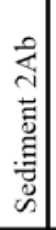 & 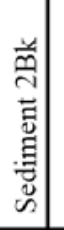 & 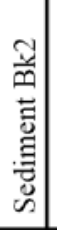 & 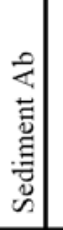 & 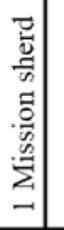 & 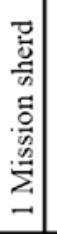 & 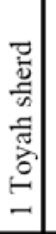 & 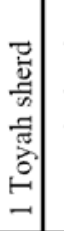 & 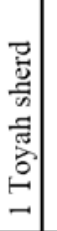 & 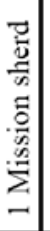 & 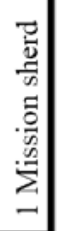 \\
\hline$\dot{\nabla ்}$ & $\infty$ & $\infty$ & $\infty$ & 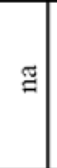 & $\cong 0$ & $\underset{ల}{\infty}$ & $\stackrel{\infty}{\infty}$ & 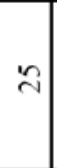 & $\exists$ & $\because$ & $\because$ & 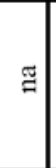 & $\dddot{g}$ & $\dddot{~}$ & $\because$ & 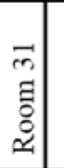 & $\begin{array}{l}\overrightarrow{0} \\
\vdots \\
\vdots \\
0\end{array}$ & 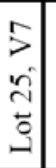 & 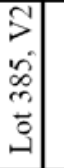 & 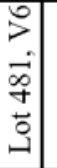 & 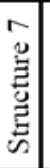 & 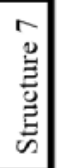 \\
\hline 言总 & ָ̊ & ָิ & 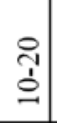 & ஸิ & 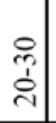 & 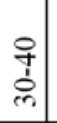 & 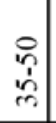 & 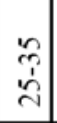 & $\begin{array}{l}n \\
\vdots \\
\dot{m}\end{array}$ & वे & 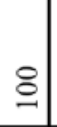 & 이 & 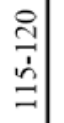 & $\begin{array}{l}\infty \\
\infty \\
\vdots \\
\infty \\
\infty\end{array}$ & : & - & & & & & & \\
\hline$\stackrel{\dot{\Xi}}{\stackrel{0}{B}}$ & 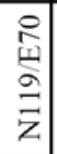 & 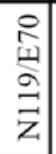 & 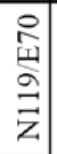 & 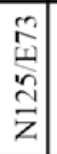 & 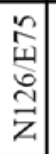 & 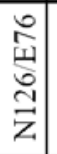 & 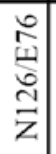 & 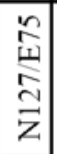 & 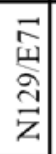 & 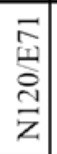 & $\underset{\mid \vec{n}}{\vec{n}}$ & $\begin{array}{l}\vec{I} \\
\dot{n} \\
\end{array}$ & $\hat{\vec{n}}$ & 空 & $\stackrel{n}{n}$ & $\vec{N}$ & & & & & & \\
\hline$\dot{\bar{M}}$ & $m$ & $\infty$ & $n$ & $\infty$ & $\infty$ & $\infty$ & $\infty$ & $m$ & $\infty$ & $\infty$ & $\varangle$ & $<$ & $\infty$ & $\infty$ & 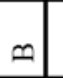 & & & & & & & \\
\hline 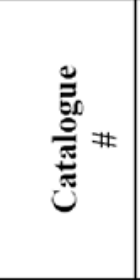 & 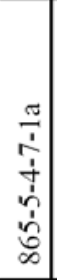 & $\begin{array}{l}0 \\
\frac{1}{1} \\
\dot{2} \\
\hat{2} \\
\infty\end{array}$ & 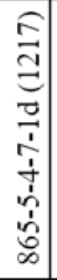 & $\begin{array}{l}\frac{\pi}{0} \\
\frac{1}{0} \\
\frac{1}{0} \\
0\end{array}$ & 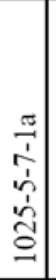 & $\begin{array}{l}0 \\
\\
\vdots \\
\vdots \\
\vdots \\
0 \\
0\end{array}$ & 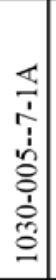 & 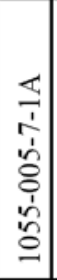 & 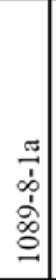 & $\begin{array}{l}\mathfrak{a} \\
\dot{0} \\
\dot{0} \\
\Xi \\
\exists\end{array}$ & 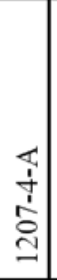 & $\begin{array}{l}4 \\
\dot{1} \\
\dot{0} \\
\stackrel{0}{0} \\
=\end{array}$ & $\begin{array}{l}4 \\
\dot{1} \\
\grave{d} \\
\text { ปे }\end{array}$ & 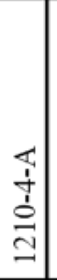 & 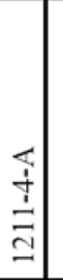 & 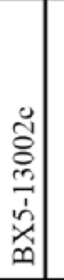 & 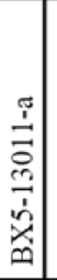 & 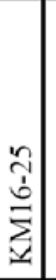 & 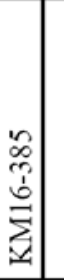 & \begin{tabular}{l|}
$\vec{\infty}$ \\
+ \\
$\vdots$ \\
$\vdots$ \\
$\vdots$ \\
$\vdots$ \\
$\vdots$
\end{tabular} & 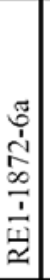 & 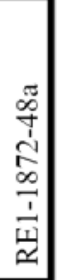 \\
\hline
\end{tabular}




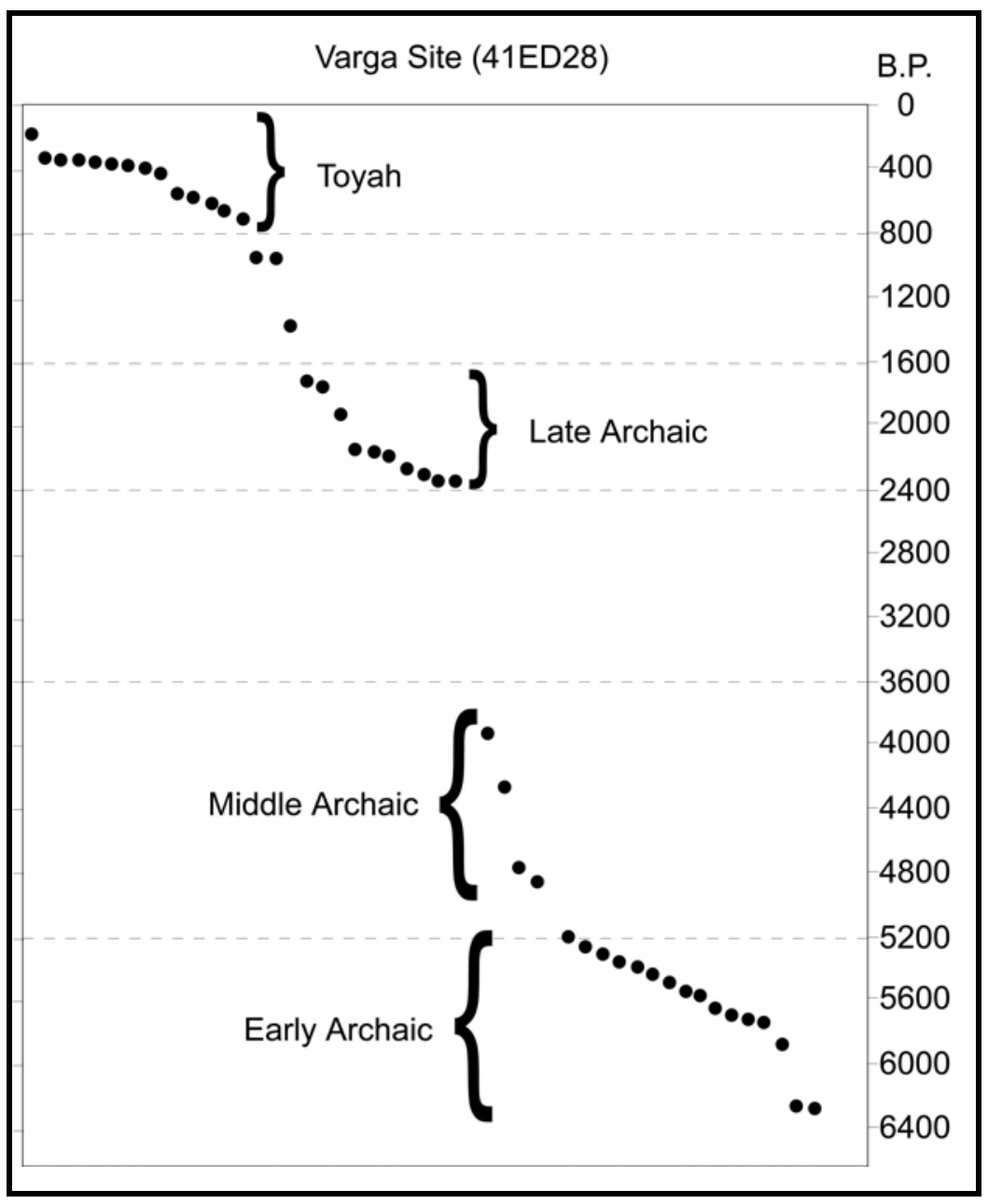

Figure 16-1. Summary of Varga Site Radiocarbon Dates Plotted through Time

The glass specimen certainly documents an event that can be assigned to the post-contact period. All of this accords with the idea that some of the peoples producing Perdiz points became part of the mission Indian population in Southern Texas.

Further west, in the Big Bend region of Texas and south into northern Mexico, chronometric assays from assemblages that contained Perdiz points also reveal radiocarbon dates that fall within the Protohistoric to Colonial periods. Specifically, three dates on wood charcoal from three hearth features at 41BS706 yielded uncorrected ages of $170 \pm 45$ B.P.,
$210 \pm 45$ B.P., and $240 \pm 45$ B.P. (Mallouf 1987). Perdiz points are also associated with the Cielo complex that might have persisted into the A.D. 1700s (Mallouf 1987).

The limited Varga Site ceramic assemblage (ca. 115 pieces), with the exception of a sherd (two pieces that refit) from the surface, conforms to the "Classic Toyah" ceramic technology as discussed by Johnson (1994). Based on the ceramic technology documented at the Varga Site, the same general Perdiz-using cultural pattern identified elsewhere in Central and Southern Texas, is also represented at the Varga Site. The petrographic data from this 
Toyah component supports the same clay source areas for the pastes used in the production of vessels from other excavated Toyah sites. However, the INAA indicates that the source areas were quite different from other INAA on Toyah sherds, mostly from the Central Texas region (see Creel 2002, 2003; Appendix N). The INAA data implies that if clay source areas can be identified, that archeologists can begin to address the movements of these vessels across the landscape. The attempt here to directly radiocarbon date ceramic sherds from the Varga Site, Buckhollow Site, and two specific mission sites did not provide results to demonstrate continuity of the Toyah ceramic technology into the Protohistoric period. Based on the petrographic analysis, however, the ceramic technology detected in the prehistoric Toyah ceramic assemblage was carried forward into the mission period. This supports Black's (1982) interpretation of the evidence from 16 Choke Canyon sites and review of earlier analyses from Toyah and Mission sites.

The stone tool assemblage recovered from the Varga Site Toyah component reveals several tool types and classes that are common to other Toyah assemblages. These include the Perdiz points, small well-made flake drills, various biface forms including the four-beveled knife, the Cliffton points, end-scrapers, and many expedient flake tools. The Perdiz points generally conform to the classic Perdiz points recognized by Johnson (1994) with most manufactured from small, thin flakes, many of which are only unifacially worked. However, the majority of arrow points are broken, leaving some questions as to the precise manufacturing attributes. No specific regional manufacturing distinction was detected in this arrow point assemblage. One interesting observation concerns the procedure that was apparently used in the resharpening of unifacial tools, specifically scrapers. A blow directed toward the steep face of the scraping removed a section of the worked edge, presumably to facilitate reworking and extension of the use life of the tool. Since this rejuvenation procedure has not been discussed for other Toyah assemblages, it is not clear how wide-spread or common the technique might have been.

In short, the Varga Site Toyah assemblage closely resembles the classic Central Texas Toyah assemblages as discussed by Johnson (1994) and nothing was recovered, or observed, that might reflect a local variation or represent influence from the contemporaneous Infierno phase of the Lower Pecos region.

\subsection{LAte Archaic PERIOd}

The roughly 600-year time period documented by 11 radiocarbon dates (Table 16-1, Figure 161), combined with the seven Late Archaic projectiles representing a minimum of four different types (three Frio, one Marcos, one Ensor, and one Montell) and one untyped dart point, indicate that multiple events are likely represented in this component. Four other Frio points were recovered from the Toyah component and may be considered displaced from this Late Archaic component. The lack of vertical separation of the different point types may indicate that these four types were either in a thin, compressed sediment zone that represents different time periods, or that the point types were contemporaneous. If contemporaneous, it is not clear that the different point types represent different groups coming together at one time in pursuit of a joint task (bulk food processing), or if these different point types represent a diversity of forms in a single tool kit. Still, the chronology of point types for Central Texas (Prewitt 1981, 1985) indicates noncontemporaneity of some of the types (e.g., Montell, Ensor), which would seem to support the idea that more than a single occupational episode is represented in the Late Archaic component. The different styles reflect different 
hafting techniques, but represent the same piercing function. The Frio point type is most prevalent here and fits well with the 11 radiocarbon dates obtained from this component between 1,700 and 2,300 B.P.

In the Lower Pecos, Turpin (1991, 1995) has separated the Late Archaic into three distinct periods based on different projectile point types and associated radiocarbon dates. The earliest (3,150 to 2,300 B.P.) is the Cibola period marked by the Castroville, Marcos, Marshall, and Montell points associated with bison bones. Subsequently, the Flanders period, poorly dated to ca. 2,800 to 2,000 B.P., is marked by the Shumla point. This is followed by the Blue Hills period (2,300 to 1,300 B.P.), marked by the Ensor and Frio points.

The Shumla point type, known primarily from the Lower Pecos region, was not identified at the Varga Site, therefore, people who made/used this type apparently did not occupy the site. The Varga Site Late Archaic component is closely associated with the Central Texas Late Archaic and related groups that also have ventured into the Lower Pecos region as well during the Blue Hills Period and potentially during the Cibola period (Turpin 1991, 1995). The recovery of Castroville and Frio points, in what appears as the same component, is not a new association given the current radiocarbon dates for the two identified periods in the Lower Pecos overlap at roughly this time.

The limited number of formal tools $(n=28)$ from this thin cultural component makes it difficult to address specific questions concerning the presence of other tool forms that might be diagnostic of this period. We demonstrated that a few diagnostic Toyah materials and Toyah age charcoal pieces had been displaced and filtered downward into this lower component. It is not clear if any of the non-diagnostic artifacts may be intrusive into this limited Late Archaic assemblage. In addition to the Late Archaic point types recovered, no other time-diagnostic stone tools of the Late Archaic were identified from this component.

\subsection{Middle Archaic Period}

This period is represented by a roughly $40-\mathrm{cm}-$ thick zone along the southern edge of Block A that rapidly thinned to about $20 \mathrm{~cm}$ thick towards the northern end of the block. This component contained the occasional chipped stone tool, dispersed lithic debitage, sparse bone fragments, occasional burned rock, and two burned rock features horizontally scattered. This cultural material was vertically dispersed between the Late Archaic burned rock Feature 1 above and the dense Early Archaic materials below.

The only diagnostic projectiles from this component include: five Early Triangular points and one Carrizo point tip fragment. Little is known about the age range of the Carrizo point type. The best context comes from the Loma Sandia cemetery site in South Texas that is dated to roughly 2,500 to 2,800 B.P. (Taylor and Highley 1995). Apparently, the distal Carrizo fragment from the Middle Archaic component at the Varga Site was displaced from the lower Early Archaic component that yielded multiple Carrizo base fragments (see further discussions below). No other Late Archaic dart points were identified from this component.

The five Early Triangular points are associated with radiocarbon dates that are later in time compared to the radiocarbon dates associated with Early Archaic component below. Two radiocarbon assays on wood charcoal and one on deer bone directly date the Early Triangular points to ca.900-radiocarbon year period from 3,910 to 4,820 B.P. (Table 16-1, Figure 16-1). These triangular points are definitely younger than Bandy, Martindale, Merrell, Gower, and 
other notched point types in the Early Archaic deposit at the Varga Site.

Although not recovered from this component, a Pandale point, which is considered a Middle Archaic point type in the Lower Pecos by Turpin (1991, 1995), was obtained from 70 to $80 \mathrm{cmbd}$ in a level that also contained a Gower point and was assigned to the Early Archaic period. Turpin provides an age range of between ca. 3,700 and 5,500 B.P for the Pandale type, but only about 27 percent of Turpin's primary dates are older than 4,700 B.P. (Turpin 1991). Therefore, it is possible that this Pandale point was displaced downward from its original context in the Middle Archaic zone, misassigned, or this point type was made over a long time span.

The remaining formal stone tool assemblage is limited to 15 specimens and includes tool forms commonly found at hunter-gatherer occupation sites. However, the informal tools-the edgemodified flakes - are quite frequent ( $n=122)$, but show no particular differences as compared to edge-modified flakes from other assemblages.

\subsection{Early Archaic Period}

At least seven named (Baker [ $n=12]$, Bandy $[n=21], \quad$ Carrizo $[n=4]$, Gower $[n=32]$, Martindale [ $n=22]$, Merrell [ $n=11]$, and Pandale $[n=1]$ ) and two unnamed (Group $1[n=15]$ and Group 2 [n=7]) projectile point types were recovered. This Early Archaic component was directly dated by 15 assays from diverse materials to a 1,100-radiocarbon year period from 5,200 B.P to 6,300 B.P. (Table 16-1, Figure 16-1). Thus, this group of projectile points represents at least 1,100-years of prehistory, and more specific subperiods cannot be assigned to individual types at the Varga Site. These point types are probably not all contemporaneous with one another, but have become commingled in this component over time. It is possible that this radiocarbon- documented time period does not represent the entire time range represented by projectile points, since it is possible that the older organic materials from earlier events were not preserved.

Although some researchers have had difficulty in distinguishing between the Bandy and Martindale point types, the Varga Site assemblage provides large enough samples of each type for metric data to confirm that two distinct types are represented. Better context and more precise dating will eventually reveal any temporal distinctions for these types, if such actually exist.

The Gower and Merrell point types are also very similar, but slight differences in the shape of their bases provide indications that two different types are represented in this assemblage. Potentially, these two taxa are actually varieties of one type. Some similar points are misidentified in the current literature, which is understandable, since not much has been said or documented about either type, especially the Merrell type.

The Varga Site has yielded the first substantial collection of Merrell points $(n=11)$ and the first association of the type with radiocarbon dates. Johnson and Goode (1994) were not sure where to place this point type in their general chronological sequence. Collins (1995) does not mention this type by name, but lists a generic "Early Split-Stem" group for a period dated between roughly 8,000 to 7,000 B.P. The Merrell point is definitely an "Early Split-Stem" type, although it is not clear whether or not Collins (1995) includes this poorly known and infrequently referred to type in that broad group. Elton Prewitt identified 11 specimens from the Varga Site that provide metric and non-metric variability that establishes a general characterization for this type. For now, this component's chronometric data provide a general age range of ca. 6,300 B.P. to 
5,200 B.P. (ca.7,200 to 6,000 B.P., calibrated), for the Merrell point.

It is not clear if any of the nine types/groups of points is intrusive to this area. Most Early Archaic point types in the literature are in limited numbers, came from poor context, lack associated radiocarbon dates, etc., which limits understanding of their distribution, precise ages, and associations with other point types and tool forms. The better-known and more frequent types such as Bandy, Gower, and Martindale have been recovered from the Lower Pecos region and across much of Central Texas (Prewitt 1995).

Compared with the Central Texas chronology, the Varga Site ages push the end of the Early Archaic a few thousand years younger than is currently projected in the literature (Johnson and Goode 1994; Collins 1995) and raises questions concerning the current time ranges for the Early Split-Stem group in this region. The later dates from the Varga Site may indicate movements from the Central Texas region towards the Lower Pecos region.

\subsection{Broader Cultural history ISSUES}

In addition to the diagnostic projectile points, are there other tool forms present that might be restricted to specific time periods? Two- or four-beveled knives typical of the Toyah phase/interval were not recovered in the Late, Middle, or Early Archaic components. These resharpened knifes were not abundant in the Toyah phase/interval, with only one specimen present. Johnson (1974) indicates that this type of knifes has a greater range than just in the Toyah components in Texas, mostly further north in the buffalo habitat of the Great Plains. He goes on to state that the final form often has four beveled edges, but specimens from the coastal plain region of South Texas usually have only two beveled edges. This particular form is currently restricted to the Late Prehistoric period, but it is not restricted to only the Toyah phase. Different groups in the Texas panhandle also employed similar beveled knives. Specimen \#159-5-28 is a typical four-beveled knife that is often referred to as a characteristic bison-processing tool of the Toyah phase. The use-wear analysis revealed wood residue in the haft area and striations parallel and perpendicular to the long axis on the proximal end. Use-residue in the form of hair fragments and starch grains plus hard, high silica polish were also present. The presence of these materials and use-wear indicate that this particular piece was used for multiple tasks that included cutting and possibly piercing on hard, high silica plants and possibly animals.

The gouge, or specific types of gouges such as the Clear Fork tool, is often thought to be diagnostic of the Middle and possibly the Late Archaic time periods (Hall et al. 1986). This tool type was identified in the Early Archaic component in limited numbers $(n=3)$. Highpowered use-wear on two gouges indicates scraping and/or planing on bone or wood and animal hides. Although these actions and materials are not restricted to just this tool type, gouges were not represented in later components at the Varga Site. Gouges were not restricted in time, since they have been recovered from contexts in South Texas associated with events and components younger than 5,000 B.P. (i.e., Scott 1982; Hall et al. 1982; Highley et al. 1995; Quigg et al. 2002). However, they have not been identified in the Late Prehistoric period. In Central Texas, Clear Fork tools were present at the Wilson-Leonard Site in Williamson County, from Paleoindian to Late Archaic times. Unifacial gouges were present only during the Archaic period, from 4,000 to 6,500 B.P. (Dial 1998). The Brushy Creek bifaces were mainly in early contexts representing Late Paleoindian occupations from ca. 8,700 to 9,500 B.P. (Dial 1998). A detailed use-wear analysis on these 
types of tools currently reveals a diversity of tasks similar to that of a scraper. This tool type was not, apparently, manufactured to conduct one specific activity or task. It is not surprising that this tool shows up at different time periods across wide regions of Texas. Dial (1998) points out that much of the metric and nonmetric variation in distally beveled tools may be derived from resharpening and rejuvenation of the distal bit end.

Chipped stone drills in general are not restricted to a specific time period, although they were absent in the Late and Middle Archaic components at the Varga Site. The size and particular configuration of the drills recovered from the Early Archaic may be distinctive. Although perforators at the Wilson-Leonard Site were not numerous in any of the occupations, they had higher frequencies in the Early Archaic period (Dial et al. 1998). Dial et al. (1998) discovered that the form of the basal portion appeared to have limited importance. At present, few sites/components of this age have yielded radiocarbon dates and/or good contexts; therefore, it is not possible to state with any degree of certainty that this elongated form reflected in the Early Archaic component at the Varga Site is restricted to this period. It is worth further investigation, and use-wear would be important to determine if the contact material co-varies with changes in tool form.

Rejuvenation flakes were identified in three of the four components (not in Late Archaic). The rejuvenation strategy/technology appears to have been implemented at least by 6,300 B.P. and carried forward through time. Collins (1974) identified similar types of sharpening flakes and refurbished edges in most of the strata at Arenosa Shelter in the Lower Pecos. The knowledge of how to rejuvenate a chipped stone tool edge does not appear limited in time across most of Texas, but the current terminology used in the literature centering on such a strategy has hindered a more thorough understanding of the distribution of this technology. Rejuvenation is evidence on two- and four-beveled (Harahey) knives in the Toyah Component. Rejuvenation derives from the need to continue to use a particular tool so replacement is unnecessary as ongoing use-wears the tool edge. Beveling/rejuvenation is also observed in the Early Triangular points from the Varga Site and elsewhere, as some points exhibit one or two edges that have been beveled. In fact, the primary difference between the original Taylor and Baird triangular points (Kelly 1947a) was the beveled edge (or lack thereof).

The quantities of burned rocks and numerous burned rock features provide clues to various cooking tasks, presumable food processing. It is possible that a few of the identified burned rock features were used for specific types of cooking that might be restricted in time. However, many of the potential food resources in the area and region have been present for long periods of time, it is unlikely that one type of burned rock feature/structure would be limited to a specific type of cooking at one point in time. The small, amorphous looking and ill-defined burned rock features in the Varga Site Early Archaic component are not well enough preserved to detect a particular shape or configuration that might be considered distinctive of this period. It is apparent that burned rocks were used to cook foods, specifically plant foods as indicated by the lipid residue results. This trend in cooking technology that employed the use of hot rocks to cook foods was undoubtedly initiated before 6,300 B.P., and its use appears to have continued through to the very latest period as represented in the Toyah component. Even the addition of pottery to the cooking technology in the Toyah component did not obviate the need for hot-rock cooking. The Late Archaic component, with its incipient burned rock midden, reflects a totally different type of cooking apparatus, but this probably just reflects a specific type of food 
being cooked, or a specific cooking technique that is not visible in the rest of the three components at the Varga Site. Although not represented in the other three components at the Varga Site, large burned rock ovens are known from many other time periods and across broad regions of central and western Texas. These cooking apparatuses were in use for a minimum of 6,000-years and probably more. The employment of the boiling strategy is not apparent at the Varga Site, perhaps only because it is hard to identify in the case of limestone rocks, which do not necessarily break apart in the same way as do harder quartzite's when used to transfer heat to liquids. If boiling was used at the Varga Site, it is not visible in the limestone or feature record.

The broad subsistence pattern and/or utilization during the four identified components indicates broad based hunter-gatherers occupied the Varga Site periodically over a period of about 6,300years. The subsistence was directed toward seasonally available plants and multiple animal resources, with mussels and other aquatic resources playing, at most, a very minor role. Seasonality may have played a role in the patterns detected, but identifying the season in which these components were utilized is difficult and recovered data sets conflict with one another. The presence of littleleaf walnuts and pecan shells in three of the four components implies late summer to fall occupations. However, this may conflict with the presence of agave hearts and leaves, best procured in early spring, identified in the Toyah and Late Archaic components. The conflicts may stem from multiple events being represented in the components. The general pattern of subsistence indicates diversity was the norm with the Toyah populations exhibiting the most varied plant and animal resource base compared to earlier groups. However, preservation of these data sets may be playing a significant role in this apparent trend, since the quantity of organic materials is greatest in the Toyah and significantly less in the Early Archaic component. If the plant and animal resources were generally available and being more or less consistently procured from the Varga Site, then one may assume that the general environment was relatively constant or at least stable over the millennia represented in the archaeological record.

The mobility patterns detected in the four components at the Varga Site reflect broadly similarity, which is expectable in light of the apparent consistency in basic patterns of resource use. The encampment residues at the Varga Site reflect relatively short-term occupations. The group's movements appear to have been restricted to relatively small territories or home ranges that were the operational area of technoeconomic activities. The procurement of tool stone, which was generally available throughout the region as a whole, reveals that most of the territories were relatively restricted the Edwards Plateau around the site, rather than broad ranging across vast areas, or even the entire Plateau. The INAA from each of the four components indicates that multiple tool stone sources were involved, which also implies mobility and movement of the various groups. The lack of obvious and preserved trade goods in the four assemblages indicates support for the relatively restricted territory and possibly the limited contact/interactions with outside groups. Though still very limited, there may have been an increase in long-distance interactions during the Toyah period, as indicates by marine-shell objects and the apparently exotic ceramic figurine-like object. 



\subsection{FUNDAMENTAL PATTERNS OF ARCHAIC AND LATE PREHISTORIC LAND USE AND MOBILITY AT THE VARGA SITE AND ITS ENVIRONS}

\section{J. Michael Quigg}

\subsection{INTRODUCTION}

Hypotheses about hunter-gatherer mobility, settlement, and land use patterns are based on the limited perspective of completed empirical analyses of data from the four Varga Site components, plus a limited and selected body of relevant data from other sites in the region. While inferential, they serve as working hypotheses for the Edwards Plateau and can be augmented, modified and/or refined as more precise data becomes available.

The upland survey conducted at the Devil's Sinkhole State Natural Area, just a short distance to the northwest of the Varga Site, provides a systematic survey that reveals general site density for the uplands immediately in the vicinity of the Varga Site. That survey yielded one prehistoric site per 35 ha (or one per 87 ac; Howard et al. 1996). Some 43 burned rock middens were encountered in the 21 sites identified, indicating a high frequency (one midden per 17 ha [or one midden per $42 \mathrm{ac}$ ]) of that feature type in the uplands. Nearly 38 percent of the sites yielded natural chert outcrops that potentially were considered resource procurement areas. Based on surface collections of diagnostic projectile points about 50 percent of these sites yielded indications as to their ages, information that indicates this upland area was used most intensively during the Late Archaic and Late Prehistoric periods, between 4,400 and 200 B.P. (2,400 B.C. and the seventeenth century). Although the survey does not provide a complete picture for the region, or even for one particular time period, the data do provide a partial view of general land-use strategies in the uplands for this region. Seemingly, hot-rock cooking was a common activity in this region, although the specific resources that were processed are largely unidentified. The high number of lithic procurement sites in the region indicates there was no shortage of locally available chert for the manufacturing of stone tools.

\subsection{TOYAH}

The Varga Site Toyah encampment and its recovered cultural assemblage are similar to other excavated Toyah sites across Texas. Johnson (1994) has reviewed a number of the excavated and better-documented sites. A compilation of selected data, primarily pertinent to subsistence, from nine Toyah sites provides a foundation to address general patterns of land use and attendant mobility (Table 17-1). The distribution map that Johnson provides (Figure 105, 1994:243) indicates the very broad region of the Toyah Culture, which includes all of the Edwards Plateau, much of inland South Texas, the Blackland Prairie, and northward into the southern Plains region. The vegetation and plant food resources across this broad Texas area are diverse and often available on seasonal bases. The animal resources are quite similar across the region, with more diversity in the Edwards Plateau than in South Texas. Densities of animal populations potentially were more variable from region to region. 
Table 17-1. Selected Toyah Sites Indicating Subsistence and Settlement Data

\begin{tabular}{|c|c|c|c|c|c|c|c|c|c|}
\hline Characteristics & 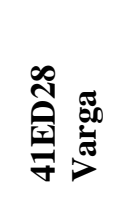 & 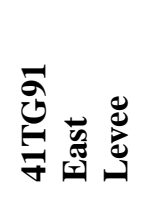 & 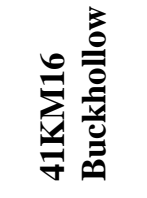 & 寻芦 & $\begin{array}{l}\text { Ð } \\
\text { 导 } \\
\text { ‡ }\end{array}$ & 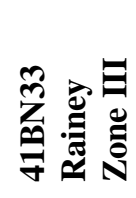 & 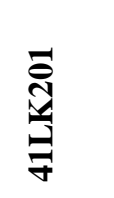 & 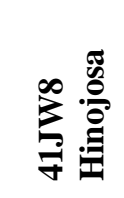 & 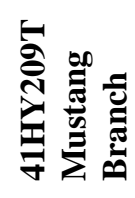 \\
\hline Vertebrate Faunal & Present & Present & Present & Present & Present & Present & Present & Present & Present \\
\hline Bison & Present & Present & Present & ? & Present & Present & Present & Present & Present \\
\hline Deer & Present & Present & Present & Present & Present & Present & Present & Present & Present \\
\hline Antelope & Present & Present & & No & & & Present & Present & Present \\
\hline Rabbit & Present & Present & Present & Present & Present & Present & Present & Present & Present \\
\hline Turtle & Present & & Present & Present & & Present & Present & Present & Present \\
\hline Fish & Possible & Present & Present & Present & & Present & Present & Present & Present \\
\hline Bird & Possible & Present & Present & Present & & & Present & Present & Present \\
\hline Other Game & Present & Present & Present & Present & Present & Present & Present & Present & Present \\
\hline Fragmented Bone & Present & Present & Present & ? & & & & & Present \\
\hline Grease Extraction & Possible & Possible & Possible & ? & & & & & Present \\
\hline \multicolumn{10}{|l|}{ Plant Foods } \\
\hline Corn & No & No & No & Yes $=1$ & No & No & No & No & No \\
\hline Onion & No & No & No & Present & No & No & No & No & No \\
\hline Acorns & No & No & No & Present & No & No & No & No & No \\
\hline Pecans & Present & No & No & Present & No & No & No & No & No \\
\hline Walnuts & Present & No & No & No & No & No & No & No & No \\
\hline Mussel Shells & & Present & & Present & Present & Present & Present & Present & No \\
\hline Burned Rock Oven & No & No & No & No & No & No & No & No & No \\
\hline Landform & Terrace & Terrace & Terrace & Shelter & Shelter & Sinkhole & Terrace & Terrace & Terrace \\
\hline Seasonality & Spring & $\begin{array}{l}\text { Fall or } \\
\text { Winter }\end{array}$ & Unknown & ? Fall & & ? Fall & Spring & $\begin{array}{l}\text { Winter? } \\
\text { Summer }\end{array}$ & Spring \\
\hline Multiple Point Types & Yes & Yes & Yes & Yes & Yes & Yes & No & No & No \\
\hline Exotic Goods & Yes & Yes & Possible & Yes & No & No & Yes & Yes & Yes \\
\hline
\end{tabular}


Bison reappeared in Central Texas around 750 B.P. and remained until roughly 150 B.P., and therefore, were available throughout the Toyah period (Dillehay 1974).

The climate across much of Texas throughout this period is postulated to be much the same as in historic times, though temperatures may have been somewhat lower during the period of the Little Ice Age, ca. 500 to 100 B.P.

The different localities or landforms occupied by Toyah populations such as rockshelters (i.e., Kyle and Smith), terrace sites (i.e., Buckhollow, Varga, Hinojosa), and sinkholes (i.e., Rainey) may reflect different seasons of occupation and/or variable weather conditions at the time of occupations. Although Johnson (1994) postulates that the Rainey Site was occupied in the late fall to winter, no direct substantiating evidence is available. Rockshelters were probably used during rainy seasons, whereas viable open campsites could have been easily established during most of the year. The size of shelters, including the Rainey Site, which was only about $40 \mathrm{~m}^{2}$, would be a significant limiting factor on the sizes of residential groups, since restricted space would have only allowed for a few individuals-- possibly a family unit-- to have been in residence at any one time. The Kyle Rockshelter, roughly $335 \mathrm{~m}^{2}$, could have provided shelter for a larger group.

Most excavated Toyah sites have been located in terrace settings along watercourses, which provided immediate access to necessary resources such as wood and water, and diversity of plant and animal resources. Special foodextraction sites or sites focused on one or two food resources are nearly absent from the list of Toyah sites. For example, the vertebrate fauna from Mustang Branch Site (41HY209T), a terrace setting, yielded an extensive population of deer (a minimum number of 19), at least eight antelope, two bison, plus turtles, rabbits, dog/coyote, and other small mammals (Mason and Holderby 1994). Nearly all excavated Toyah sites have yielded bones from a range of animals, with an apparent focus on large game such as deer, antelope, and bison, being supplemented by smaller faunal resources such as turtles, rabbits, and probably birds and fish. In a number of instances, only selected parts of the larger animals have been identified at camp sites, indicating that the animals were procured and subjected to initial butchering some distance away. Plant resources such as nuts, yuccas, seeds, and geophytes have been recovered from a number of sites. The materials from the few excavated sites reveal procurement of diverse animals and plants from at least two or three broad habitats that surrounded the terrace campsites, including streams, valley floors (open meadows and wooded thickets), colluvial slopes, and open grassy uplands. This indicates that the terrace camps were base camps from which resources were sought and procured, processed, and either consumed or stored. Since most Toyah sites lack any direct evidence of food storage, most foods were probably immediately consumed. Extended processing of animal bones by breakage for marrow extraction and smashing for grease rendering is evident at some sites (Quigg 1997b; Mason and Holderby 1994), indicating that meat was prepared for storage in the form of pemmican for subsequent use.

Other, non-food, resources that were undoubtedly procured from this and other terrace settings included clays for the manufacture of ceramic vessels and stone (chert and limestone). Clays and natural rock were often readily available and exposed along creeks and rivers and alluvial cutbanks often exposed or contained quantities of clay that was potentially used in the manufacture of ceramic vessels. The eroding valley walls exposed outcrops of limestone that were used in cooking processes. Although not many of the samples from excavated sites have been subjected to source 
analyses concerning these two natural resources, the Varga Site data provides a glimpse at the possible distribution of chert procurement localities. The Varga Site INAA results indicate that nearly all chipped stone tools were manufactured from Edwards cherts, with some chemical signatures on the cherts similar to those obtained from natural tool stone various locales along the southern Edwards Plateau.

INAA and the petrographic analysis on several ceramic sherds and one sediment sample from the Varga Site reveal that the four identified Varga Site Toyah vessels were not manufactured from Central Texas clays from identified source locales. The Varga Site vessels were manufactured from clays from at least two and probably three separate sources. In short, a few vessels were manufactured from local clays and a few vessels were from non-local clays, implying movement of peoples and vessels across the landscape.

Social interactions with adjacent non-Toyah groups appear to have been quite limited, based on the low frequencies of exotic goods in the recovered Toyah assemblages. The excavated Toyah campsites along the northwestern margin of the Edwards Plateau such as East Levee (41TG91), Rush (41TG346), Buckhollow (41KM16), and Varga (41ED28), lack southwestern ceramic vessels such as the El Paso brownwares, Chupadero Black-on-white, and various painted or corrugated wares from the Jornado region or southwestern ceramics from northern New Mexico. The surface context of the one El Paso originate sherd makes its association with the Toyah component questionable. None of the 47 Varga Toyah chipped tools subjected to INAA revealed chemical signatures that indicate the procurement of raw materials was in western Edwards County or further west in Val Verde County. However, the same cannot be said about the area to the northwest, which had more dense populations known to have conducted extensive trading and interactions with groups further north. A few Harrell points in with the dominant Perdiz points at East Levee, Rush, and Varga sites indicate at least some contact/interactions with Plains groups to the north. If the one El Paso sherd from the surface is truly associated with the Toyah component, then there is a hint at interactions to the west, the north and the Lower Texas coast to the southeast. Thus, widespread interactions may have occurred in almost all directions.

Toyah sites along the eastern margins of the Edwards Plateau such as Kyle (41HI1), Smith Shelter (41TV42), and Mustang Branch (41HY209T) have yielded sherds of pots (brushed and engraved vessels) that appear to represent interaction with non-Toyah Caddoan groups to the northeast. The corncob at Kyle may also reflect interaction with the horticultural Caddoan peoples. Marine shells and a Padre point recovered at Varga indicate trading and/or contact with coastal groups some $410 \mathrm{~km}$ to the southeast. Therefore, Toyah sites along the margins of the Edwards Plateau have yielded minor quantities of non-local goods from the adjacent regions indicating some limited interactions or contact with other populations. The majority of interactions appear relatively limited rather than focused on obtaining goods of technoeconomic necessity, indicating that Toyah hunter-gatherers in this area did not rely on exchange of subsistence resources or technological items required to meet subsistence needs.

The small Toyah group(s) that occupied the Varga Site were general foragers that moved across the Edwards Plateau and took advantage of relatively evenly distributed and stable resources that included tool stone (i.e., Edwards chert), clays (i.e., alluvial deposits in stream valleys), plants (i.e., acorns, berries, sotol), animals (i.e., rabbits, deer, antelope, and bison), 
and other foods (i.e., mussels, turtles, fish, etc.) necessary in their daily existence. It is postulated that small groups followed a general cyclic pattern (Figure 17.1) that coincided with the ripening of various plant foods. During fall, they collected nuts, berries, and seeds, and hunted various game animals, with a focus on deer. In winter, they mostly hunted large and small game animals and consumed those food items that could be stored. In spring, they collected tubers and roots such as onions, agave, and sotol. In summer, they diversified by collecting plants, and hunting animals. Fish, mussels, rabbits, deer, turtles, bison, and other game were probably procured year round. Tool stone was collected as needed, as was cooking stone. Periodically, for short periods, Toyah groups likely aggregated in one base camp, thereby creating a relatively large encampment in a resource-rich valley setting.

\subsection{The Late Archaic}

The Varga Site Late Archaic component was revealed by excavations focused on a large cooking feature that yielded only $36 \mathrm{~g}$ of carbonized plant remains including agave leafs, woody legumes, mesquite, juniper, oak, prickly pear seeds, and lotebush in association with a number of different Late Archaic point types. A compilation of subsistence data and landforms occupied during the Late Archaic in Central Texas provide insights into patterns of land use and mobility during this period (Table 17-2).

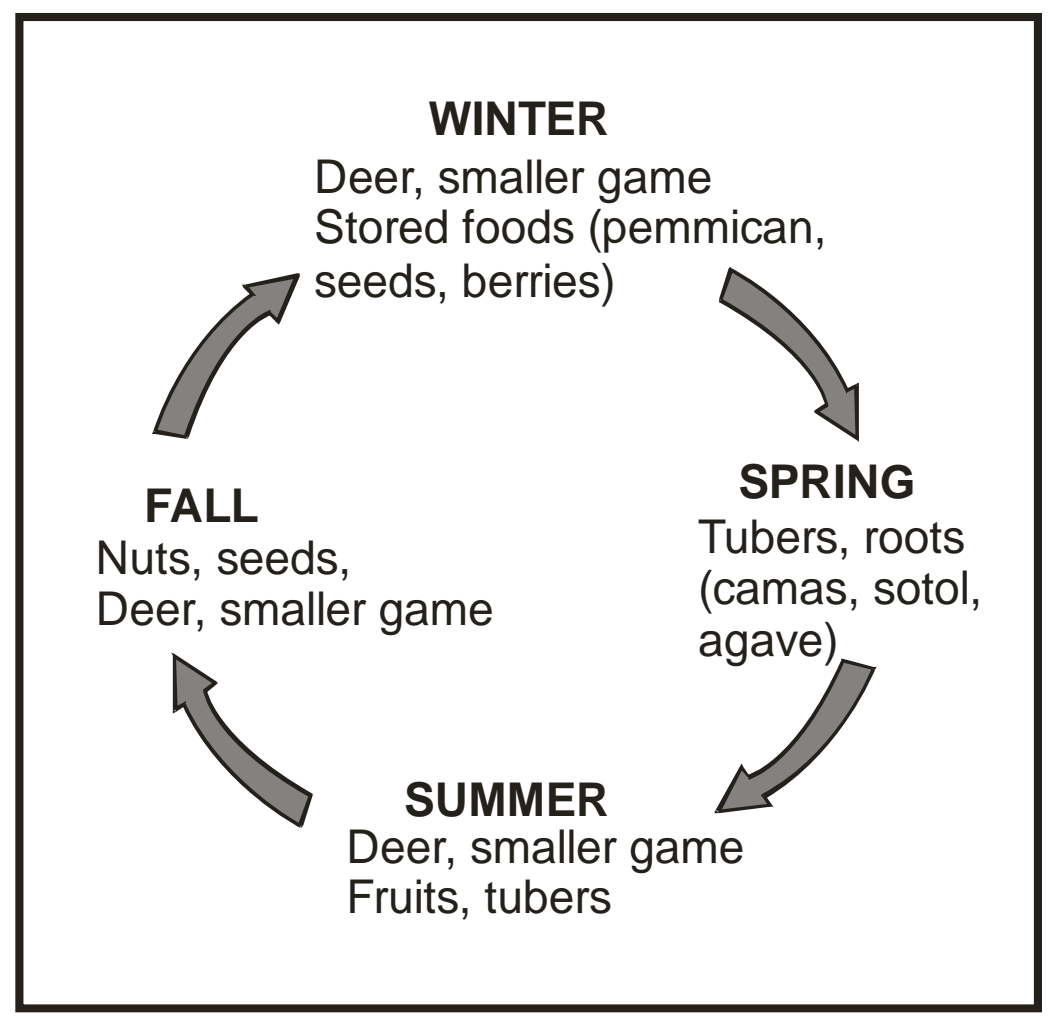

Figure 17-1. Schematic Diagram of Hypothesized Annual Cycle of Seasonal Emphases in
Resource Use for the Toyah Phase 
Table 17-2. Selected Late Archaic Excavated Sites Indicating Subsistence and Settlement Data

\begin{tabular}{|c|c|c|c|c|c|c|c|}
\hline Characteristics & 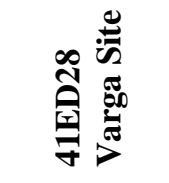 & 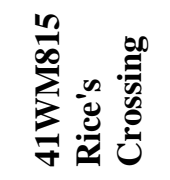 & 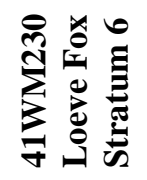 & 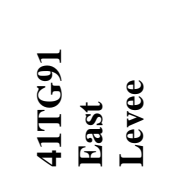 & 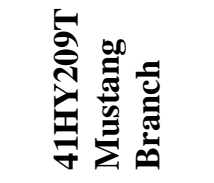 & 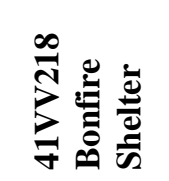 & 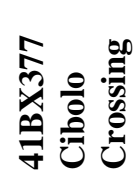 \\
\hline Vertebrate Faunal & Present & Present & Unknown & Present & Present & Present & Present \\
\hline Bison & No & No & & Present & Present & Present & No \\
\hline Deer & Present & Present & & Present & Present & & Present \\
\hline Other Game & ? & Present & & Present & No & No & No \\
\hline Mussel Shells & & Present & & Present & & & Present \\
\hline Burned Rock Oven & Yes - Basin & Yes - Basin & No & No & Yes - Lined pit & No & No \\
\hline \multicolumn{8}{|l|}{ Site Type } \\
\hline Landform Occupied & Terrace & Terrace & Terrace & Terrace & Terrace & Rockshelter & Terrace \\
\hline Seasonality & ? Spring & Spring & Unknown & $\begin{array}{l}\text { Spring/ } \\
\text { Summer }\end{array}$ & Unknown & Unknown & Unknown \\
\hline Multiple Point Types & Yes & Yes & Yes & No - Marcos & Yes & Yes & Yes \\
\hline Exotic Goods & No & No & No & No & No & No & No \\
\hline
\end{tabular}

The same set of Late Archaic projectile point types is found on the Edwards Plateau, much of inland South Texas, and along the eastern margin of the Blackland Prairie and northward into the southern Plains region.

The vegetation and plant food resources across this broad region are diverse, with many plant food resources (i.e., nuts, berries, cactus, and tubers) primarily available on seasonal bases. The animal resources (i.e., deer, rabbits, etc.) are relatively similar across the region. Densities of plants and animals were probably variable, being higher in the more wooded areas than in open upland grassland settings, with the exception of bison, which occupied grasslands and frequented stream valleys for drinking water. Generally, bison were hunted in limited numbers, with the notable exception at Bonfire Shelter in the Lower Pecos region, where massive bison jump kills were conducted during this period (Dibble and Lorrain 1968).

Late Archaic sites such as Mustang Branch (41HY209M), Loeve-Fox (41WM230), and Rice's Crossing (41WM815) are all along the eastern margin of the Edwards Plateau and immediately adjacent to the Blackland Prairie. These sites contain burned rock middens that are linked to the cooking of bulk plant foods, possibly camas, onions, and other geophytes, all $\mathrm{C}_{3}$ plants. The East Levee Site (41TG91) in Tom Green County is along the northern margin of the Plateau region, where the human population exploited bison herds, a $\mathrm{C}_{4}$ food resource, again probably on a seasonal basis. As mentioned, Bone Bed III at Bonfire shelter, also located along the southwestern margin of the Edwards Plateau, yielded evidence of a mass bison kill. A burned-rock cooking feature (possibly an incipient burned rock midden) that 
was used to cook bulk plant foods, probably sotol, which are most often procured in spring (Castetter and Opler 1936), is the primary Late Archaic feature at the Varga Site. The presence of deer, bison, and other game resources at this and other Late Archaic sites, in both Central Texas and in the Lower Pecos regions, testifies to the procurement of animal resources. The findings combine to indicate a pattern of broadbased economic pursuits.

A few authors have discussed the participation of the Late Archaic populations in a much broader exchange network (Hall 1981; Prewitt 1981a), based on a redundancy of exotic goods from Late Archaic mortuary contexts east of the Edwards Plateau, evidence of which has not been found at domestic camp sites; our current knowledge indicates a general lack of exotic goods from most Late Archaic campsites across the Edwards Plateau. The low frequency of exotic goods would imply that many of the Edwards Plateau populations were not participating extensively in these broader interactions. If these populations were involved in a trading network, the network was quite limited, or the archeological evidence is largely restricted to grave offerings. The low frequencies of exotic goods potentially was influenced by the general localized nature of individual group territories within the Edwards Plateau or limited contact with major groups outside the broader Edwards Plateau region.

The small Late Archaic groups that occupied the Varga Site were general foragers that moved across parts of the Edwards Plateau taking advantage of relatively evenly distributed, and stable resources that included tool stone (i.e., Edwards chert), plants (i.e., acorns, berries, prickly pears, and agave), and animals (i.e., small game, deer, antelope, and bison) necessary for their everyday existence. The terrace setting along this creek, within the broader dissected topography, provided a favorable camping locality. This kind of locale had the greatest concentrations of food and other necessary resources compared to the more open, resourcelimited grasslands of the Edwards Plateau or adjacent areas. Consequently, the valley terrace settings have higher densities of Late Archaic sites compared to the more open uplands.

The small groups are postulated to have moved every few days, following a general cyclic pattern of subsistence and settlement not markedly different than that just indicated for the Toyah period (Figure 17.1) that coincided with the ripening of various plant foods. During fall, they undoubtedly collected nuts, berries, and seeds, and hunted primarily deer and a range of smaller game animals. In the short winter season, they mostly hunted large and small game animals, and consumed stored food products (i.e., dried berries, nuts, and/or dried meat). As spring approached, groups moved to resource areas where they collected tubers and roots, such as onions, camas, agave, and sotol, which often grow in large patches that provide easy access to bulk quantities in localized settings. In summer, they diversified by collecting plants such as seeds, fruits, and tubers, and again hunted animals. Fish, mussels, rabbits, deer, turtles, bison, and other fauna may have been procured year round, according to spatial and seasonal availabilities. It may be that mussels were a supplemental food during all seasons or possibly only during times of need. The constant movement and short stays by the groups in any one place also meant that local food resources were not totally depleted, could easily regenerate in at a given location. The burned rock middens often attributed to the Late Archaic populations reflect at least one and possibly two seasons in which bulk foods were collected and processed. The principal season was in spring and early summer when onions, followed by camas, and later agave/sotol were available and edible. Cooking these and other plant foods may actually account for two different periods during 
the spring, since these foods do not often become available at the exact same time of the year.

The Late Archaic human populations procured abundant tool stone-Edwards chert-from gravel outcrops along the waterways or upland exposures as needed, and collected readily accessible cooking stone-mostly limestonefrom outcrops adjacent to their campsites. The plentiful and high quality tool stone readily available across the Edwards Plateau obviated the need for Late Archaic groups to trade for exotic tool stone. With the readily available tool stone, most if not all, terrace campsites reveal relatively high frequencies of lithic debitage that would include most stages of tool manufacture and reduction stages (i.e., cores, early and late stage reduction flakes, and biface failures). Generally, high frequencies of exhausted tools occur at these campsites, where new tools could be readily manufactured to replace old, worn out tools.

\subsection{The MiddLe ARCHAIC}

The Varga Site yielded a Middle Archaic component that is more distinct than often seen for this period in excavated sites in Central Texas. No other sites in the immediate vicinity of Hackberry Creek are currently identified as representing this particular period (Table 17-3). Although this general time range, from ca. 6,000 to 4,000 B.P., is recognized across a broad region of Central Texas, most often it is represented only by projectile point types considered to be time-diagnostic. We have little data on human adaptations for this period, and there is no substantial, detailed review or compilation of the data that are available (Table 17-4). Collins (1995) lists only three sites for the entire period with moderate to high integrity. Wounded Eye is the only site listed for the "Taylor" period ("Taylor" being another name for Early Triangular points) and that is an undated burned rock midden site that was excavated in 1977 (Luke 1980).

The general temporal range from ca. 5,000 to 3,000 B.P. was one of general aridity in the Lower Pecos region. Although the environmental data from the Varga Site are quite limited, dry conditions are generally indicated, with vegetation comprised mostly of $\mathrm{C}_{3}$ grasses. The encampment at the Varga Site is marked by the presence Early Triangular points. Populations employing the points of this type occupied a broad region across Central and South Texas and potentially have counterparts in the Lower Pecos region (i.e., Devils Triangular points at Skyline Shelter). Occupation of the Lower Pecos region by people who made Early Triangular points is still uncertain as Pandale, Langtry, Val Verde, and Almagre points dominate in that region. Often, Early Triangular points have been recovered from a context that contained more than one type of point. Therefore, it is unclear if the different point types in one stratigraphic zone indicate mixing of deposits, or concurrent use of the area by different groups.

At the Varga Site, use-wear analyses and distal snap breaks, strongly indicate that while the Early Triangular points functioned primarily as projectile points, they also served as multifunctional tools, as evidenced by use-wear relating to whittling, gouging, and cutting.

Vertebrate bone preservation is generally quite poor across Texas in Middle Archaic contexts (Table 17-4). The Varga Site vertebrate assemblage is no exception, with only a limited faunal assemblage that indicates deer and rabbits were procured and processed. At least a couple of excavated sites along the eastern margin of the Edwards Plateau (i.e., Landslide and Cervenka) have yielded bison bones associated with Bell/Andice points, which are only slightly later in time. 
Table 17-3. Archeological Sites in the Vicinity of the Varga Site in Northern Edwards and Western Real Counties

\begin{tabular}{|c|c|c|c|}
\hline Time Period & Upland Setting & $\begin{array}{c}\text { Canyonlands } \\
\text { Rock Outcrops }\end{array}$ & Alluvial/Colluvial \\
\hline \multicolumn{4}{|l|}{ Paleoindian } \\
\hline \multicolumn{4}{|l|}{ Early Archaic } \\
\hline Middle Archaic & 2 middens - ED50 (Pandale) & & \\
\hline \multirow[t]{2}{*}{ General Archaic } & 3 middens - ED147 (dart) & & 2 middens - ED141 (dart) \\
\hline & 2 middens - ED141 (dart) & & \\
\hline \multirow[t]{9}{*}{ Late Archaic } & 1 midden - ED67 (Pedernales) & & 9 middens + procurement - ED58 (Pedernales) \\
\hline & 4 middens - ED65 (Pedernales) & & 4 middens + procurement - ED54 (Pedernales) \\
\hline & 4 middens - ED55 (Arenosa) & & 1 midden - ED78 (Castroville) \\
\hline & 1 midden - ED74 (Marshall) & & 1 midden - ED83 (Montell) \\
\hline & 2 middens - ED39 (Pedernales) & & 1 midden - ED70 (Frio) \\
\hline & 1 midden - ED75 (Frio) & & 2 middens - RE23 (Frio) \\
\hline & 1 midden - ED76 (Frio) & & 2 middens - RE26 (Bulverde) \\
\hline & 1 midden - ED81 (Bulverde) & & \\
\hline & 1 midden - ED44 (Darl/Marshall) & & \\
\hline \multirow[t]{3}{*}{ Late Prehistoric } & Lithics - ED145 (arrow) & & \\
\hline & 4 middens - ED65 (dart) & & \\
\hline & Camp - ED40 & & \\
\hline \multirow[t]{21}{*}{ Unknown } & Lithics - ED149 & Procurement - ED146 & Buried camp - ED25 \\
\hline & Lithics - ED148 & Procurement - ED144 & 1 midden - Ed26 \\
\hline & 1 midden - ED143 & Lithics - ED140 & Buried camp - ED29 \\
\hline & Lithics - ED142 & Rockshelter - ED24 & 1 midden - ED31 \\
\hline & 1 midden - ED56 & Rockshelter - ED85 & Lithics - ED32 \\
\hline & Lithics - ED30 & & Lithics - ED33 \\
\hline & Procurement - ED41 & & Buried camp - ED34 \\
\hline & 1 midden - ED43 & & Lithics - ED35 \\
\hline & Procurement - ED46 & & Buried camp - ED36 \\
\hline & 1 midden - ED47 & & Buried camp - ED37 \\
\hline & Procurement - RE41 & & Lithics - ED38 \\
\hline & 1 midden - ED51 & & 2 middens - ED45 \\
\hline & 2 middens - ED71 & & 1 midden - ED48 \\
\hline & 1 midden - ED72 & & 1 midden - ED49 \\
\hline & Procurement - ED77 & & 1 midden - ED68 \\
\hline & 2 midden - ED80 & & Buried camp - ED69 \\
\hline & Camp + procurement - ED82 & & 2 middens - ED57 \\
\hline & 1 middens - ED87 & & Camp - ED73 \\
\hline & 1 midden - ED95 & & 1 midden - ED79 \\
\hline & 1 midden - ED96 & & 1 midden - ED84 \\
\hline & 2 middens - RE37 & & Buried camp - ED86 \\
\hline
\end{tabular}


Table 17-3. Archeological Sites in the Vicinity of the Varga Site in Northern Edwards and Western Real Counties (Continued)

\begin{tabular}{|c|c|c|c|}
\hline Time Period & Upland Setting & $\begin{array}{l}\text { Canyonlands } \\
\text { Rock Outcrops }\end{array}$ & Alluvial/Colluvial \\
\hline & Lithics - RE38 & & Lithics - ED89 \\
\hline & Lithics - RE40 & & Buried camp - ED90 \\
\hline & Lithics - RE39 & & 1 midden - ED91 \\
\hline & & & 1 midden - ED92 \\
\hline & & & 1 midden - ED93 \\
\hline & & & Lithics - ED94 \\
\hline & & & Buried camp - RE12 \\
\hline & & & Buried camp - RE13 \\
\hline & & & 1 midden - RE18 \\
\hline & & & 1 midden - RE19 \\
\hline & & & Buried camp - RE21 \\
\hline & & & Buried camp - RE22 \\
\hline & & & Buried camp - RE24 \\
\hline & & & 1 midden - RE25 \\
\hline & & & 2 middens - RE27 \\
\hline & & & 1 midden - RE28 \\
\hline & & & 2 middens - RE29 \\
\hline & & & 2 middens - RE31 \\
\hline & & & Buried camp - RE32 \\
\hline & & & 1 midden - RE33 \\
\hline & & & 2 middens - RE34 \\
\hline & & & 2 middens - RE35 \\
\hline & & & 2 middens - RE36 \\
\hline & & & 1 midden - RE42 \\
\hline & & & 1 midden - RE44 \\
\hline & & & 1 midden - RE45 \\
\hline & & & Buried midden - RE46 \\
\hline & & & Buried camp - RE47 \\
\hline \multirow[t]{4}{*}{ Multicomponent } & 6 middens - ED53 & & Buried camp - ED23 \\
\hline & 4 middens - ED52 & & Buried camp - ED27 \\
\hline & & & Buried camp - ED28 \\
\hline & & & 3 middens - RE30 (Cliffton) \\
\hline
\end{tabular}

Site 41ED58 now encompasses 58, 59, 60, 61, 62, 63, 64; Site 41ED65 now encompasses 65 and 66; 41ED88 farmstead

ED = Edwards County, RE $=$ Real County 
Table 17-4. Selected Middle Archaic Excavated Sites and Selected Characteristics

\begin{tabular}{|l|l|l|l|l|l|l|l|}
\hline Characteristics & & & & & & \\
\hline Vertebrate Faunal & No & Present & Present & Present & Present & No & Present \\
\hline Bison & No & No & Present & No & Present & No & Unknown \\
\hline Deer & No & No & No & Present & No & No & Unknown \\
\hline Other Game & No & No & No & No & Present & No & Unknown \\
\hline Mussel Shells & No & Yes & Yes & No & Yes & Yes = 1 & Yes \\
\hline Site Type & Midden & Open Camp & Open Camp & Open Camp & Open Camp & Open Camp & Open Camp \\
\hline Landform Occupied & Upland & Terrace & Terrace & Terrace & Terrace & Terrace & Terrace \\
\hline Multiple Point Types & Yes & Yes & Yes & No & Yes & No & Yes \\
\hline Exotic Goods & No & No & No & No & No & No & No \\
\hline
\end{tabular}

Therefore, bison may have been in the region and provided another food resource. Other than hunting of game, gathering bulk plant foods which required long cooking periods, is also evident from sites such as Wounded Eye. This burned rock midden probably represents a seasonal event where the peoples focused on intensive use of a specific plant resource for a short period of time. At the Varga Site, plant processing is evident from the use-wear analyses that documents that 31 percent of the analyzed chipped stone tools were used on plants. Lipid residues and stable carbon isotopes from burned rocks used in the food cooking process indicate that hot rocks mostly cooked plants. Mussels were also a procured resource.

The populations using the Early Triangular points were highly mobile hunter-gatherers as indicated by their wide distribution across much of Texas. They may have shared camps with groups that employed other point types, perhaps within shared territories. In contrast with other Middle Archaic peoples, the groups using Early Triangular points did not possess non-local materials (i.e., obsidian, marine shells, exotic lithics) indicative of trading with distant populations. The INAA of Middle Archaic chipped stone tools from Varga Site indicates that the lithic resources were procured from the local southwestern and central regions of the Edwards chert outcrop. The chemical signatures indicate these cherts were procured from multiple sources within that relatively restricted region. The lack of trade goods indicates trade networks were not a significant or necessary part of the technoeconomic system.

Groups associated with these Early Triangular points were small, presumably kin units that moved across the landscape to procure foods as they became seasonally available. Often in spring, they procured bulk plant foods such as agave that required extended cooking times. These and other plants were processed in large rock ovens/burned rock middens. The lack of ground stone tools to indicate plant processing implies that plant processing tasks were probably performed using perishable tools such as wooden mortars or pestles or underwent 
limited processing before cooking. Game animals were procured throughout the year without specific focus on any one specific animal, although deer appear most often in the archeological record. Tool stone resources were collected from many sources across the territory in the Edwards Plateau. These mobile foragers interacted and often camped with other groups that did not share the same sociocultural background. The interactions may have been a result of higher population density in the Edwards Plateau during a period that was slightly dryer and warmer than today. The slightly dryer conditions surrounding the Edwards Plateau caused a gradual shift of populations towards, or into, the more amenable habitat of the Plateau. The limited number of campsites of this age may be the result of widespread erosional processes that scoured deposits of this time period in many of the stream valleys of the Edwards Plateau.

\subsection{The EARLy ARChaic}

The Early Archaic component and recovered cultural assemblage at the Varga Site are similar to a number of other excavated Early Archaic sites across Texas. McKinney (1981) and subsequently Johnson (1991) reviewed a selected suite of excavated Early Archaic sites and discovered that they formed a distributional pattern in the shape of a broad "Crescent". The distribution map that Johnson provides (Figure 68:150) indicates the Varga Site lies within that previously defined "Crescent" that extends from the Lower Pecos region, across much of the southern Edwards Plateau, and northward through the Llano Uplift region. Undoubtedly, other Early Archaic sites are present outside this restricted region. However, the dissected canyonlands of the Edwards Plateau provides a greater opportunity to locate sites, and the concentrated modern day activities in this same area undoubtedly have contributed to their discovery and subsequent excavation. Other than the possible greater visibility within the canyonlands, we see the current environmental data from the Varga Site leading to another possible explanation for this apparent site concentration. As stated previously, the environmental data from the surrounding region is interpreted to indicate warm and dry conditions at that time, but the Varga Site data do not reflect such conditions. Consequently, more favorable climatic conditions in the region potentially provided a greater abundance of plant and animal resources that attracted greater human populations and higher site densities within the Edwards Plateau and Balcones Canyonlands. In the lower Pecos region, the large, visible rockshelters with exceptional conditions for preservation have attracted many investigations. Thus, the known Early Archaic sample is very biased for this time period. The known location of most Early Archaic sites is very much a reflection of the preservation of alluvial deposits. As Collins et al. (1990) stated, almost no early Holocene fill is exposed in the major stream valleys and almost no late Holocene fill occurs in the upper reaches of small streams in the local region (cf., Blum and Valastro 1989). Consequently, the upper reaches of drainages are the most likely areas to yield preserved Early Archaic components without always having younger materials on top of them.

General information compiled from a selected sample of excavated Early Archaic sites provides a broad basis for addressing questions of mobility and land use (Table 17-5). Other than the rockshelters in the Lower Pecos, most known Early Archaic sites are located in deep terrace deposits along small streams, with an occasional Early Archaic human burial discovered in sinkholes. Early Archaic components exist, but are often deeply buried and difficult to reach. 
Table 17-5. Selected Early Archaic Excavated Sites Indicating Subsistence and Settlement Data

\begin{tabular}{|c|c|c|c|c|c|c|c|c|}
\hline Characteristics & 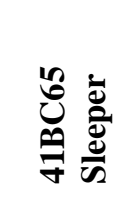 & 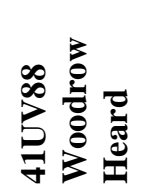 & 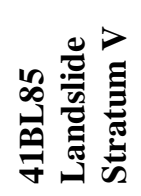 & 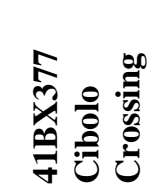 & 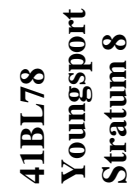 & 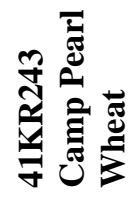 & 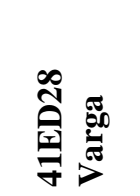 & 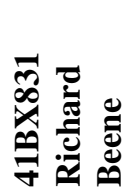 \\
\hline Vertebrate Faunal & Present & No & No & Present & No & No & Present & Present \\
\hline Bison & No & & & No & & & No & \\
\hline Deer & Present & & & No & & & Present & Present \\
\hline Other Game & Present & & & No & & & Present & Present \\
\hline Mussel Shells & Present & $?$ & Present & Present & No & No & No & Present \\
\hline Burned Rock Oven & No & Present & No & No & No & No & No & No \\
\hline Landform Occupied & Terrace & Terrace & Terrace & Terrace & Terrace & Terrace & Terrace & Terrace \\
\hline Seasonality & Unknown & Unknown & Unknown & $\begin{array}{l}\text { Late Spring/ } \\
\text { Summer }\end{array}$ & Unknown & Unknown & Unknown & Unknown \\
\hline Multiple Point Types & Yes & Yes & Yes & Yes & Yes & Yes & Yes & Yes \\
\hline Exotic Goods & No & No & No & No & No & No & No & No \\
\hline
\end{tabular}

Most investigated Early Archaic components have yielded at least two different point types in apparent association, making it unclear if these components were occupied by at least two separate groups, were of mixed deposits, or were palimpsests on stable land surfaces. Also contributing to our limited understanding of this period is the lack of extensive excavations into these deposits, combined with the fact that they often have poor preservation of macrobotanical and vertebrate faunal remains. Consequently, the lack of data from this time period has limited our understanding of the broader patterns of settlement and subsistence.

The Early Archaic assemblage at the Varga Site reflects a residential base camp that was part of a broader foraging system. Multiple groups of people, marked by the presence of different projectile point types, moved about the southern region of the Edwards Plateau in pursuit of food resources. Although similar styles of projectile points have been recovered across very broad regions of Texas, it does not necessarily follow that the actual human groups were ranging throughout these same broad regions. Apparently, small groups moved in more localized areas, with much smaller home ranges or territories, though information flow extended beyond the territorial range of a given group.

A relatively restricted home range for the Varga population is apparent from the INAA of chipped tool stone that reflects nearly complete reliance on Edwards chert and a high percentage of that from more local regions of the southern Edwards Plateau, rather than distant locales such as Fort Hood. Some chemical signatures on the cherts are similar to chemical signatures obtained from cherts collected from the Hackberry Creek gravels, whereas some signatures represent stone from nearby or 
adjacent counties in the southern Edwards Plateau. Regionally, Edwards chert is plentiful and of such good quality that it adequately served the needs of the local populations. Imported (non-local) raw materials (i.e., quartzite, basalt, jasper, obsidian, etc.) were not identified in the Varga Site Early Archaic assemblage that yielded nearly 52,000 pieces of tool stone. Edwards chert from the Fort Hood region on the eastern edge of the Edwards Plateau and the Callahan Divide much further north, was also unidentified in the Varga chipped stone tool assemblage. The lack of imported tool stone, the absence of exotic goods such as marine shells, also reflects the restricted nature of group mobility and external relations. The apparently limited interactions may reflect a low population density throughout the region, or the interactions and material exchanges are simply not visible in the archeological record. However, it is worth remembering that, as stated above, the more widespread distribution of the point types represented at Varga does strongly indicate wide-ranging flow of stylistic information and, presumably, a degree of intergroup communication during the Early Archaic.

These populations camped in a variety of physiographic settings including: terraces in entrenched and broad open valleys, the upper reaches of small streams, and the broad, mostly grass-covered uplands. The stream terraces were the favored camp localities, since they provided the greatest diversity and the highest concentration of necessary resources (i.e., water, fuel, cooking stone, tools stone, and food) in a localized area. The adjacent valley walls and slopes provided ready access to procure various food resources (i.e., nuts, berries, seeds, tubers, and fruit), tool stone, and cooking stone. Large game animals, often more elusive and ranging further than small game, could have been procured from a wider area and brought back to the campsite for processing.
Family units occupied this terrace base camp and conducted multiple tasks represented by the diverse tool assemblage and the types of features recognized. The burned rock features at the Varga Site and other Early Archaic sites such as Camp Pearl Wheat reflect various types of cooking apparatuses. The recovered chipped stone tool assemblage at Varga reflects multiple tasks related to the procurement, initial processing, and subsequent manipulation of byproducts of the game resources. The use-wear and residue analyses document diverse tasks directed towards hunting/processing of animals and collecting and processing plants. At Varga, a suite of tool manufacturing activities was carried out, including raw material procurement, core reduction, decortification of cobbles for biface reduction, final stages of biface thinning, and tool resharpening.

Although food resources have been poorly preserved at most Early Archaic components, the Varga Site assemblage yielded burned prickly pear seeds, walnuts, deer, and rabbit bones. The limited evidence indicates a fall occupation for at least one of the occupational episodes at the site. The near absence of large burned rock middens/ovens at Varga, as at most other Early Archaic components, indicates that bulk food collection, such as is evidenced for later time periods, was not a significant subsistence strategy during the Early Archaic across Central Texas. If the interpretation by Kibler and Scott (2000) is correct that one Martindale-age feature (Feature 22) at Cibolo Crossing represents the cooking of Rabdotus, then periods of low food supply might have occurred during these times. At certain periods during the year, mussels were also procured. From the limited, but diverse food resources associated with the investigated Early Archaic components, the relevant groups adapted to the Central Texas environment with a broad based foraging strategy. 
The Varga Site

Texas Department of Transportation

The Early Archaic family groups, who apparently often intermixed with other groups, were general foragers that moved across the Edwards Plateau. They took advantage of relatively evenly distributed, fine-grained patchwork of stable resources that included tool stone (i.e., Edwards chert), plants (i.e., prickly pears, onions, acorns, berries, and sotol), and animals (i.e., rabbits, deer, etc.) necessary for their daily existence. The terrace settings along creeks and rivers, and rockshelters further west in the Lower Pecos, provided the most favorable camping localities. Valley settings provided the greatest concentrations of necessary resources (i.e., water, fuel, rock, and food) compared to the less favorable uplands covered with a mosaic of grasslands and oak motts. The small family groups probably moved every week or two, a pattern of mobility that coincided with timing of optimal availabilities of various plant resources. In the early spring (March and April) geophytes (i.e., onions and rain lilies) were sought in open grasslands, meadows, across uncovered terraces, and in the uplands. Later in spring, agave and sotol were ripe for collecting. Prickly pear and various grass seeds became available in mid to late summer followed by mesquite beans and other legumes. As fall approached, persimmons and various nut crops became available. Winter was spent searching for whatever food was available, possibly supplemented by consumption of dried/stored products (i.e., dried meat, berries, flower cakes, etc.). Deer and small game (i.e., rabbits, turtles, etc.) were undoubtedly hunted and procured year round.

\subsection{SUMMARY}

In summary, the generalized foraging pattern detected for the Early Archaic period continued throughout the following 6,000-years, at least during the four identified periods at the Varga Site. Although a general foraging pattern persisted during these four investigated time periods, different groups probably had preferences for food and tool stone procurement localities. Therefore, details of settlement patterns, extremely illusive to archeological detection, undoubtedly changed from one group to the next, and potentially from one territory to the next. Though mobile, these populations had restricted territories or home ranges within which their activities were focused. As a result, we may infer that these hunter-gatherers possessed intimate knowledge of the spatial and temporal distributions of key subsistence resources. The density and location of food resources was influenced by regional climatic and/or local weather changes. As the highly mobile bison populations became available at specific intervals throughout prehistory, human populations adapted to their presence and devised viable procurement strategies. As populations increased and/or decreased in and across the Edwards Plateau, and overall biotic productivity shifted with climatic changes, the human populations would have made relatively minor adaptive adjustments. In general, however, it appears that fundamental strategies for resource procurement and processing saw broad continuity, as our current data base does not indicate any dramatic changes in basic lifeways throughout the millennia represented at the Varga site. 



\subsection{THE HUMAN ECOSYSTEMS REPRESENTED AT THE VARGA SITE}

Paul M. Matchen, J. Michael Quigg and Robert A. Ricklis

\subsection{SUMMARY INTERPRETATION OF PALEOENVIRONMENTAL DATA}

Several lines of investigation were performed in an effort to detail past environmental conditions, during which human occupation at 41ED28 transpired. Specifically, samples of the site sedimentary matrices, palynomorphs, phytoliths, stable carbon isotopes, faunal material and macrobotanical material were examined (Table 18-1). By comparing the data collected in the various components, it is possible to assess changes in climate and the biotic environment. In the case of the Varga Site, environmental variables appear to have remained relatively constant over the long-term, with only relatively minor and gradual changes in the biotic composition.

The most obvious differences between components are in faunal and plant diversity, insofar as there is an apparent trend toward an increasing numbers of represented species. This is most evident in the case of bison, which is present in later components, but absent in the Early Archaic component. While it is recognized that differential representation of faunal species might be a bias introduced by preservation factors, we should expect to see the large, dense bones of this ungulate preserved in the earliest component along with the bones of smaller animals which were, in fact, present and recoverable. In fact, this Early Archaic period actually corresponds, chronologically, with one of Dillehay's (1974) proposed periods of bison absence $(8,000-4,500$ years ago) in the southern Plains. The cause of this proposed bison absence during the Early Archaic throughout Central Texas is unknown, although Dillehay suggests that the southern Plains landscape may not have been capable of supporting bison populations during this time (1974:182).

The gradual change in grass phytolith composition across the four components provides another measure of environmental variability. Table 18-1 reflects an increasing proportion of $\mathrm{C}_{4}$ plants in the composition of phytolith remains. This indicates change in the form of a long-term climatic warming trend increasingly favorable to $\mathrm{C}_{4}$ species. The act of overgrazing via large herbivores could have also contributed to the spread of short grasses $\left(\mathrm{C}_{4}\right.$ grasses) (Weaver and Tomanek 1951). Nonetheless, both the phytolith information and carbon isotopic signature values reflect the overall preponderance of $\mathrm{C}_{3}$ plants in the biotic inventory throughout all periods. The stable isotope data also show a steady trend beginning at the close of the Early Archaic of increasing negative $C_{3}$ values which peak near the middle of the Late Archaic.

\subsection{The Human Ecosystems as REPRESENTED AT 41ED28}

Certainly, a range of factors including environmental setting, with its inherent constraints in terms of distance to food resources, distance to raw materials for tool production, and distance to water, played prominence in the choice of 41ED28 for settlement location in each of the four cultural components. 
Table 18-1. Summary of Paleoenvironment

\begin{tabular}{|c|c|c|c|c|}
\hline Characteristics & Early Archaic & Middle Archaic & Late Archaic & Toyah \\
\hline Geomorphic trends & Slow aggradations & $\begin{array}{l}\text { High energy flooding } \\
\text { interspersed with } \\
\text { periodic overbank } \\
\text { flooding }\end{array}$ & $\begin{array}{l}\text { Periodic overbank } \\
\text { flooding }\end{array}$ & $\begin{array}{l}\text { Periodic overbank } \\
\text { flooding }\end{array}$ \\
\hline Pollen & $\begin{array}{l}\text { Low arboreal; high } \\
\text { grass }\end{array}$ & $\begin{array}{l}\text { Low arboreal; high } \\
\text { grass }\end{array}$ & $\begin{array}{l}\text { Low arboreal; high } \\
\text { grass }\end{array}$ & $\begin{array}{l}\text { Low arboreal; high } \\
\text { grass }\end{array}$ \\
\hline Phytolith & $\begin{array}{l}\text { 85\% mixed grasses } \\
\text { (cool) } \\
\text { 15\% short grasses } \\
\text { (warm) }\end{array}$ & $\begin{array}{l}\text { 78\% mixed grasses } \\
\text { (cool) } \\
22 \% \text { short grasses } \\
\text { (warm) }\end{array}$ & $\begin{array}{l}\text { 70\% mixed grasses } \\
\text { (cool) } \\
\text { 30\% short grasses } \\
\text { (warm) }\end{array}$ & $\begin{array}{l}\text { 62\% mixed grasses } \\
\text { (cool) } \\
\text { 38\% short grasses } \\
\text { (warm) }\end{array}$ \\
\hline $\begin{array}{c}\text { Stable Carbon Isotope } \\
\text { on sediment column }\end{array}$ & $\begin{array}{c}\mathrm{C}_{3} \text { dominant plant } \\
\text { inventory }\end{array}$ & $\begin{array}{c}\mathrm{C}_{3} \text { dominant plant } \\
\text { inventory }\end{array}$ & $\begin{array}{c}\mathrm{C}_{3} \text { dominant plant } \\
\text { inventory }\end{array}$ & $\begin{array}{c}\mathrm{C}_{3} \text { dominant plant } \\
\text { inventory }\end{array}$ \\
\hline Macrobotanical & 5 taxa & 3 taxa & 11 taxa & 18 taxa \\
\hline Faunal & $\begin{array}{l}\text { Medium to small } \\
\text { vertebrates, and } \\
\text { invertebrates }\end{array}$ & $\begin{array}{l}\text { Large, medium, and } \\
\text { small vertebrates }\end{array}$ & Large vertebrates* & $\begin{array}{l}\text { Large, medium and } \\
\text { small vertebrates, and } \\
\text { invertebrates }\end{array}$ \\
\hline $\begin{array}{c}\text { Excavation Area } \\
\text { (volume) }\end{array}$ & $83 \mathrm{~m}^{2}\left(25.9 \mathrm{~m}^{3}\right)$ & $83 m^{2}\left(20.9 m^{3}\right)$ & $80.36 \mathrm{~m}^{2}\left(9.2 \mathrm{~m}^{3}\right)$ & $207.75 \mathrm{~m}^{2}\left(42.9 \mathrm{~m}^{3}\right)$ \\
\hline
\end{tabular}

*Faunal assemblage was very sparse and association with component is questionable.

The material remains that have been documented in this report have been examined for evidence of site function and the concomitant range of on-site human activity. If this information is approached from a humanecological perspective, it is possible to define and compare system states as represented for the several pertinent time periods. The sections to follow present relevant interpretations whose reliability is constrained by the inherent limitations in the preserved site data.

\subsubsection{Hunter-Gatherer Resource Procurement Practices}

\subsubsection{Collector-Forager Dichotomy}

Ethnographic data on hunter-gatherer behavior has led to a normative characterization of the range of adaptive strategies along a continuum from foraging at one end of the spectrum, to collecting at the other (Binford 1980; Kelly 1983, 1995; Hayden 1986, 1987). As discussed above, foraging involves the residential movement of people to productive resource locations, and removal to a new residential 
location once the resource has been depleted. This process of "mapping onto" resources involves making frequent residential moves combined with short logistical trips, with minimal time or need for food storage (Binford 1980; Kelly 1992, 1995). Residential bases and locations are two site types expected in the archaeological record of a foraging adaptation. Residential bases are places where the foraging group resides and where most processing is carried out. Locations are where "extractive tasks are exclusively carried out” (Binford 1980:9). In short, the foraging scenario involves high residential mobility and logistical forays from residential loci to obtain targeted resources.

Alternately, collectors maintain longer-term residential camps and procure a variety of resources by making logistical forays to surrounding resource patches, bring the procured resources back to a base camp on a recurrent basis (Binford 1980). Food gatherers, in these cases, make relatively infrequent residential moves and store food to assure availability at times of reduced productivity (Kelly 1992). Site types, in addition to locations and residential camps, include field camps, temporary taskoriented operational centers where sleeping, eating, and group maintenance occurs; stations, information gathering areas; and caches, temporary storage places for surplus resources (Binford 1980). In the collector model, residential mobility is limited, since field camps are moved infrequently while logistical mobility is widely implemented in the form of resourceacquisition forays.

Hunter-gatherer resource procurement strategies and the resulting mobility patterns can be discerned in the archeological record on the basis of the distribution and content of materials recovered at any given location. In many cases, however, individual behavioral episodes are indistinguishable, as complex prehistoric itineraries blur the patterns to be interpreted.
There is nothing, for example, that could prevent a field camp from also serving as a station for information gathering, and eventually morphing into a residential base once a group determined that resource were attainable at a favorable cost/benefit ratio. Thus, it is must be kept in mind that the archeological definition of the presence and succession of such behaviors likely will be extremely difficult to achieve.

\subsubsection{The Utility of Optimal Foraging Models}

Given that the Varga Site yielded only limited information on resource availability and the exploitable biotic inventory for any one time period, the high-resolution data needed to apply optimal foraging models is not available.

One must assume that hunter gatherers had specific goals for resource acquisition; that they operated under certain time/space constraints, and that they made use of a currency (energy) throughout the process that is expended and acquired through various efforts. Therefore, the availability of these resources is foremost in this process and must be archeologically definable if any reliable modeling of prehistoric resourceprocurement behavior and decision-making is to be done. Resources considered for this sort of inquiry would have included water, animals, plants, and raw materials for tool production, cooking, habitation, and other functions. One way to look at resource use is in terms of optimality ranking, which evaluates resources in terms of the costs and benefits inherent in their pursuit and acquisition, and assesses their ranking within forager and collector strategies. Unfortunately, given the fairly poor preservation of the relevant materials at the Varga Site, only a very partial inventory of faunal and floral resources is possible for each of the four represented periods.

It is also possible to look at resourceprocurement choices in terms ecological 
succession via the exhibited traits of $\mathrm{r}$ - and $\mathrm{K}$ selection species (Mac Arthur and Wilson 1967). $\mathrm{K}$ - refers to the carrying capacity of the environment for a population, while r- refers to the per capita rate of net increase in a given environment. Each resource selection strategy is related to the reproductive success and relative abundance of a given biotic resource. Unpredictable environments are theorized to promote reliance on r-selected species for which reproductive cycles are short, and little effort is expended by the species in competing with other organisms (Mac Arthur and Wilson 1967). Traits for these species include a small body size, high reproductive capacity with a short reproductive/gestation period, and the ability to disperse offspring throughout a wide area quickly. In contrast, K-selected species dominate in stable environments and have the ability to successfully compete for limited resources. Traits for these species include large body size, relatively long lifespan, and the production of fewer offspring.

\subsubsection{Diet Breadth and Environmental Constraints on Human Populations}

The array of faunal and macrobotanical resources throughout the four cultural components represented at the Varga Site indicate that most if not all of these resources were obtained locally. This seems to indicate that immediate subsistence requirements and other basic needs were perhaps the driving force underlying land use strategies, thus placing the site's occupants toward the foraging end of Binford's (1980) forager-collector continuum. Groups who resided at the Varga Site subsisted by moving their residential encampments more or less frequently in order to procure specific resources and use them until depleted, and then moving on to other locations where these resources were available. Based on faunal abundance and animal biomass, higher-ranked resources may have included bison (when present and available), deer, and pronghorn antelope.

If it assumed that faunal resource availability was correlated with (paleo) climatic conditions, then these can be used as proxy measures of the constraints that climate imposed on human populations. Species represented in the Varga faunal assemblages represent a combination of $r-$ and $\mathrm{K}$ - selected resources, with a mix of species of small body and relatively short reproductive cycles (turtle: 70 days; rabbit: 30 days; fish: 4 days) and those of larger size and with longer reproductive cycles (bison: gestation, 285 days; pronghorn: 220 days; and deer: 200 days). A larger range of species is noted in the Middle Archaic and Toyah components, but both r- and K- selected resources are present. The only exception to this is in the Late Archaic component, where faunal presence is primarily represented by large mammals (possibly biased by mixing with overlying Toyah materials), but where plant processing was relatively significant. An assessment of the four components would indicate that the environment was, at a general level, relatively stable over the 6,300-year period, as medium-to-large mammals with longer birthing periods were present and consistently exploited throughout the sequence.

If a distinction is made between the components, the Early Archaic stands out, with little evidence for large mammal (bison) presence. This could be construed as the result of environmental constraints upon the animal population. Paleoenvironmental data indicates that conditions were relatively cool and dry for the Early Archaic, with the result that surface water may have been at a premium, occurring at springs and seeps with only intermittent flow in rivers and creeks. 
Table 18-2. A Comparison of Toyah Reproduction Trait Compositions Using Identified Faunal Remains

\begin{tabular}{|c|c|c|}
\hline Assemblage & $\begin{array}{c}\text { K-selected NISP (identified } \\
\text { specimens) }\end{array}$ & $\begin{array}{c}\boldsymbol{r} \text {-selected NISP } \\
\text { (identified specimens) }\end{array}$ \\
\hline Toyah component, Varga Site & $1501(96 \%)$ & $49(4 \%)$ \\
\hline Occupation 4, Rush Site & $1165(91 \%)$ & $111(9 \%)$ \\
\hline
\end{tabular}

This type of environment might have limited the propagation and residence of larger herbivores such as bison, which need sufficient amounts of water on a daily basis to exist (McHugh 1958). Other smaller animals such as deer and rabbit, which have the ability to survive for longer periods without water [Van Wormer 1969], may have been more viable in this type of environment. In fact, Duncan (1995:101) suggests through a survey of available biological and climatic literature that environmental conditions were "conducive to both species (bison and pronghorn) with pronghorn possible adapting more easily to the decreased availability of water”.

If attention is directed solely to the Varga Toyah component, in which faunal-bone preservation is relatively good, a more confident assessment can be made. For example, a comparison can be made in this regard to another Toyah assemblage from Occupation 4 at the Rush Site, (Table 182). There is little difference in percentages of faunal species according to the Number of Individual Specimens (NISP). The proportions represented indicate a stable environment where K-selected animal species with longer birthing cycles and fewer offspring are able to thrive. This comparison supports the conclusion that the Toyah occupants of the Varga site had rearranged the ranking of preferred subsistence resources to include bison.

\subsubsection{Subsistence Strategies and Prehistoric Human Diet Breadth}

The Toyah population practiced a broad subsistence base that included meat and other byproducts from deer, antelope, bison, and rabbits and possibly other animals with five to 15 individuals represented. The extensive chipped stone tool assemblage reflects a high proportion of activities directed at the procurement and processing of animal products. Various plants were also used and included at least agave heart and leaves (likely sotol or yucca), littleleaf walnut, and prickly pear. While plant procurement and processing tools (i.e., manos, metates, and pestels) are not represented in the recovered artifact assemblage, acquisition and processing of plants is evidenced by lipid residues in the ceramic vessels, burned rocks, use-wear on tools, and plant-part residues observed on the stone tools. The people employed burned rocks and ceramic vessels to cook their foods, although much of the meat was apparently not cooked through the use of hot rocks as the chemical residues from burned rocks and sherds indicate that at least 70 to 75 percent of the residues were from plant products. Burned rock hearths were present as were refuse dumps that contained a diversity of cultural debris. It is these dumps from maintenance activities combined with chipped stone tool manufacturing and maintenance tasks that reflect a general camp. This location apparently served as a campsite of some 
unknown duration on a seasonal basis, but that season is not clear from the present evidence. These populations had contact with other peoples/groups from other regions as indicted by a limited number of different forms of projectile points that are more frequent in other regions. Contact either directly or indirectly occurred with coastal groups as indicted by the presence of three marine shells. The Toyah groups apparently utilized a relatively limited territory or range in that the clays used in the ceramic vessels and tool stones were generally from local and surrounding regions, rather than procured from great distances such as the northern or eastern Edwards Plateau. The pollen, phytolith, and carbon isotope data from the Toyah age sediments reflect a vegetation community consisting of various plants with a mixture of arboreal and grassland communities through the identification of some 10 taxa. Oak, pecan, hackberry, and walnut were present together with mostly $\mathrm{C}_{3}$ grasses, although $\mathrm{C}_{4}$ species were present in limited numbers.

It has been postulated, based on the multiple lines of zooarchoelogical and macrobotanical data that Varga residents in all four identified cultural periods were operating under basically similar conditions, given the lack of evidence for dramatic environmental changes over the longterm. Notably, the data do not indicate that the Altithermal climatic episode of the middle Holocene (7,000 to 4,000 B.P.) had a major influence on hunter-gatherer adaptive strategies as represented at the site. One could also infer that the diet breadth of groups represented did not undergo major fluctuations through time. While this is apparent at a general level, some discernible differences in resource availability amongst the components are indicated by the available evidence. The already mentioned absence of bison remains in the Early Archaic component, followed by presence in the Middle Archaic, Late Archaic, and Toyah components may illustrate presence and absence cycles, as suggested by Dillehay (1974). During those times when bison was absent, other K-selected faunal resources such as deer, pronghorn, as well as smaller r-selected animals took precedence over less nutritious foods such as, for example, freshwater mussels (Chapter 11, this volume).

Details of plant collection and usage within the human diet are somewhat variable throughout the occupation span of the Varga Site (see Figures 14-1 and 14-2). With the exception of agave heart and leaves, which appear only in the youngest two components, commonalities are noted in identified food resources, such as with prickly pear seeds and littleleaf walnut shells, which were present in all four components. The absence of agave from earlier components may be reflected in differences in features; the large burned rock feature recorded in the Late Archaic component is a probable large cooking feature, possibly an earth-oven, which may have served to intensively process agave. This phenomenon is not represented in the earlier components, so it may represent a degree of shift in dietary strategy, with agave becoming a relatively highranked food resource by Late Archaic times.

\subsection{The PREhISTORIC EMIC}

Attempts were made during this research to address technological style as it relates to social identity. Two areas where this is most applicable in archeological analysis is in tool form and ceramic form. As mentioned, variability in projectile point form has been presented as a means of differentiating style amongst social groups. For example, an examination of the morphological and spatial patterning observed in Perdiz points, has been suggested as representing socio-cultural variability, perhaps even distinctiveness among emically defined cultural groups living in a landscape at the same point in time (Johnson 1994). Similarly, many ceramic vessel surface treatments are considered to be the result of 
manufacturing technology (e.g., cord-marking, stamping) in vessel formation. In the case of the Toyah component at the Varga Site, much of the vessel surfaces excluding rim characteristics are smooth and otherwise lacking any stylistic elaboration, making differentiation of vessels according to stylistic variables very difficult or impossible. Therefore, a consideration of projectile point forms, an aspect that is much more morphologically variable, was undertaken for points recovered from the Varga Site to address whether quantitative differences could be ascertained in point "groups" from which archeologists infer social identity (see Appendix A).

Although the statistical analyses were rather rigorous, distinct stylistic distinction was difficult to establish among projectile point class groups via quantitative means (see Appendix A). While much of the difficulty hinged upon maintaining the objectivity in data selection, collection, and analysis, a more fundamental problem is the incongruity between measurable attributes and formal variations that are perceptible to the human eye. In other words, we do not as yet have a means of measurement of variability that is readily grasped by visual perception which is, in truth, the basis for distinguishing between projectile point types. The greatest utility of these methods was found in determining variations within an assemblage that may not be recognizable or standardized. Once identified, however, these variations within point groups cannot be securely linked to the perceptual distinctions upon which variable forms (types) are identified (for example, the shape of a side notch is determined by more than its height and depth in $\mathrm{mm}$ ). It is important to note that simply because typological forms are identifiable in the perceptual dimension beyond our current ability to empirically measure, this does not render typologies either "subjective" or invalid. Given that the identification of "good" types, as recurrent forms, is generally replicable among observers, and that the types generally have definable limits within time and space, it is reasonable to assume that the diagnostic formalities of the types were also identifiable by the prehistoric craftspeople who produced them and that their distinctive forms thus can be assumed to have been at least as real for those individuals as they are for modern archaeological researchers.

\subsection{Summary Conclusions}

The Varga Site (41ED28), a multiple component, stratified site, revealed four major use periods at this one specific location during the last 6,300-years. The four use periods include a Toyah phase (ca. 300 to 600 B.P.), a Late Archaic period (ca. 1,700 to 2,300 B.P.), a Middle Archaic period (ca. 3,900 to 4,800 B.P., as reflected by Early Triangular points), and an Early Archaic period (ca. 5,200 to 6,300 B.P., as reflected by a palimpsest or mixture of at least nine different projectile point types).

The Toyah cultural assemblage is remarkably similar and consistent to most other excavated Toyah sites/camps across much of Central Texas and fits within Johnson's (1994) Classic Toyah concept. The Toyah component yielded a large and diverse cultural assemblage reflecting diverse activities. No domestic structural remains were identified, although discard features reflecting general camp maintenance and in situ hearths were identified. This possible spring-side campsite adds understanding to this highly mobile Toyah population and their subsistence strategies that focused on diverse food resources comprised mostly of $\mathrm{C}_{3}$ plants and animals that ate $\mathrm{C}_{3}$ plants. Their movements followed a foraging pattern within a relatively restricted home range as reflected by the local procurement of tool stone.

The Late Archaic component reflects primarily the cooking of bulk plant foods, apparently agave in an incipient burned rock oven. The 
sparse, broken, and unwanted chipped stone tools and waste debitage discarded along the margins of this feature indicate sparse retooling activities while individuals tended the cooking of foods. Apparently mixed groups of people employing different types of projectile points coalesced to procure and process quantities of $\mathrm{C}_{3}$ plants that required extended cooking times. This component reflects similarities to many other Late Archaic sites that reveal similar cooking features.

Early Triangular points document the use of this site during the poorly known Middle Archaic period. Three radiocarbon dates provide a use period of potentially 900-years. The limited cultural assemblage is comprised mostly of lithic debitage, with few formal and informal tools, and limited burned rocks. The Middle Archaic assemblage is not significantly different than other hunter-gatherer camps.

The Early Archaic component contained dense quantities of cultural debris and reflects a mixture of multiple events that could not be separated. Fifteen radiocarbon dates document at least a 1,100-year time period for these early events. This early chipped stone tool assemblage was plentiful but not diverse. The stone artifacts reflect intense animal procurement and processing activities, but no plant procurement or processing. This Early Archaic component yielded relatively high frequencies of individual point types, some for the first time (i.e., Merrill).

One obvious change in the chipped stone assemblage over time is within the projectile point class, which not only reveals hafting changes over time, but also reveals hafting differences within specific time periods. The instruments that propelled the projectile points also changed from the Late Archaic to the Toyah components. This is quite visible in the much smaller arrow points in use during Late
Prehistoric times compared to the more massive dart points in use before that time. It is assumed that changes in hafting technologies to the projectile points are clues to cultural differences and/or identities.

In contrast to visible changes in the hafting technology employed in the projectile points over time, the broader chipped stone tool assemblage and cooking technologies (burned rocks features) reflected by these early huntergatherer groups was remarkably consistent. Throughout what is generally referred to as the Archaic period, the Varga Site assemblages of nearly 5,000-years of prehistory, from ca. 6,300 to 1,350 B.P., reveals minor change to the preserved material assemblages. The same cooking technologies, similar formal and informal chipped stone tools, continual reliance on local Edwards chert, and general subsistence resources persisted throughout most of this period. During the last ca. 600-year period, the Toyah group(s) added two new technologies, the bow and arrow and the ceramic industry, which are reflected at most other Toyah camps. This latest use period also revealed a broadening of the subsistence resources utilized with the addition of bison and antelope to the already diverse package. Remarkably, the tools associated with plant procurement and/or processing were nearly absent from all assemblages. However, the chemical analyses employed (i.e., lipids and isotopes) combined with the residue identifications on the chipped stone tools, document a significant use and consumption of $\mathrm{C}_{3}$ plant foods. Without this chemical evidence we would have no indication that these peoples gathered or consumed plants.

The paleoenvironmental data obtained from multiple lines of evidence and interpretations indicate limited change to the past climate and vegetation communities during the 6,300-years represented at this locale. A hint at a possible change to dryer or warmer conditions is the 
appearance of the bison and antelope in the Toyah subsistence base within the last 600years. The appearance of these two species potentially reflects the presence of more open grasslands during this period, but human selection cannot be ruled out. This limited environmental change over time may be an influencing factor contributing to the relatively consistent archeological record from the Varga Site and its repeated use of this locality.

The combined results from the various technical analyses on samples from the four components provides invaluable information to many different aspects and made significant contributions to a greater understanding of many aspects of the specific cultural assemblages and activities. The extensive radiocarbon dating of the diverse materials proved invaluable in determining more precise ages for the use periods, the associated cultural assemblages, and internal movement of individual objects and classes of objects. Without this intensive dating program, many questions concerning specific material classes and associations would have been left open to question. Use-wear on chipped stone tools documented that general tool form does not provide an adequate indication of tasks employed by that tool or the material it was used on. Use-wear on the edge-modified flakes revealed many tasks that would have gone undetected. The INAA on natural and cultural tool stone provides a greater understanding of the procurement territory of the populations in question and the distance the materials may have been transported. Continued employment of INAA on ceramics and tool stone will help to define where these mobile groups moved and how far, and to establish the group's procurement and use territory.

With the caveats presented in the next chapter, most of these and other technical analyses should be employed at other prehistoric campsites in the future to broaden our understanding of the populations as a whole and throughout the region. Critical use of these and similar analyses will add to an understanding to human behavior, prehistoric lifeways and environmental contexts across Texas. 



\subsection{EVALUATIONS AND ASSESSMENTS OF ANALYTICAL TECHNIQUES}

\section{J. Michael Quigg and Robert A. Ricklis}

\subsection{The Results}

The Varga Site investigations resulted in the documentation of four stratified archeological components. Three components are robust and clearly defined and radiocarbon date to the Toyah phase (ca. 290 to 660 B.P.) of the Late Prehistoric period, the Late Archaic period (ca. 1,700 to 2,310 B.P.), and the Early Archaic period (ca. 5,200 to 6,280 B.P.). The fourth, a somewhat dispersed Middle Archaic component dates to ca. 3,900 to 4,800 B.P. In Block A, the 100 to $150 \mathrm{~cm}$ thick fine-grained sediments yielded all four cultural components, more or less intact. The impacted surface disturbed the upper part of the Toyah component. Krotovina disturbance was relatively extensive in various parts of the excavation blocks, and burned trees and tree roots were also encountered. Small diameter modern fence posts also penetrated the upper components in Block A. Nevertheless, the cultural deposits exhibited a high degree of contextual integrity in relatively flat, stratified zones in a region that is largely archeologically unknown through major excavations. Even though the components were identifiable, they were not "sealed", as no sterile sediments were encountered between the components. Each component may represent multiple episodes of human occupation that cannot be distinguished one from the other. East of the road, handexcavations in Block B targeted only the Toyah component in the upper 20 to 30 cmbs. Road maintenance activities and the installation of an in-ground phone cable had disturbed parts of this near surface component.

Each of the four identified components is briefly summarized below beginning with the youngest and proceeding to the oldest. All four components reflect cultural assemblages that appear more closely linked with prehistoric cultural patterns of Central Texas than those of the Lower Pecos region (Table 19-1). Although the Lower Pecos region is, in geographic terms, relatively close (approximately $120 \mathrm{~km}$ ), the near absence of artifact styles reminiscent of that area indicates a disproportionately greater cultural distance. Generally, the Varga site occupants had greater cultural affinity to Central Texas than they did with the Lower Pecos area, a factor that appears to have operated throughout the millennia represented at the site.

\subsection{The TeChNicAl ANALyses: ASSESSMENTS OF RESULTS}

A rather wide range of technical analyses have been conducted for the Varga site. These include:

1. Radiocarbon dating of 66 samples;

2. OSL dates of six samples;

3. Use-wear analyses and organic residue identifications on 156 stone specimens;

4. Petrographic analyses on 20 samples, pollen and phytolith analyses on 25 samples;

5. Microbotanical (pollen, phytoliths) analyses;

6. INAA on 261 chert and 19 pottery samples; 
7. Fatty acid composition on eight pottery sherds and 94 burned rocks;

8. Stable carbon and nitrogen isotope analyses on 112 samples;

9. Macrobotanical analyses on 44 flotation (573 liters) and 75 individual samples;

10. Granulometry studies on 10 samples.

The combined results have contributed toward understanding prehistoric behavior and human ecology at the site and it is hoped that these and other technical analyses will be conducted at other excavated sites in the future to broaden our understanding of the populations as a whole and throughout the region. Continued use of diverse technical analyses will add information to the growing database, which will allow a greater understanding and broader interpretation of the prehistoric lifeways across Texas. Given this aspiration, it is appropriate here to review the contributions made, and of equal importance to make a candid assessment of the limitations that are perceptible in each of our approaches, in the hope of helping optimize future application of time and resources in the analyses of huntergatherer archaeological sites in the greater Central Texas region.

\subsubsection{Radiocarbon Dating}

The 66 radiocarbon dates were obtained from two laboratories-Beta Analytic and the University of Georgia in Athens. The submitted samples primarily targeted the four principal components - the Toyah, Late Archaic, Middle Archaic, and Early Archaic. Radiocarbon dating was done on charcoal in 34 cases, but also included 32 additional dates on diverse materials including: 11 dates on organics extracted from potsherds, eight dates on faunal bone collagen, five dates on carbonized walnut shells, five dates on organic fractions in bulk sediment samples, one Rabdotus snail-shell date, one burned prickly pear seed date, and one date on organic residue in burned limestone clast. The charcoal, bone and walnut shell results provide the ages of selected individual features, age ranges for the broad components, concrete data to discuss turbation problems, and a comprehensive basis for assessing the absolute ages of burned rock residues identified. The dated burned rock from Feature 38 in the Toyah component provides an unacceptable age of 11,980 B.P. that is significantly older than any realistic age range for the Toyah occupation. The 11 sherd dates are also unacceptable as they date from 60 to 26,510 B.P. and provide no consistent age pattern. The one Rabdotus shell from the Early Archaic component yielded an acceptable date of 5,880 B.P. from the same level as an acceptable burned walnut shell date of 5,500 B.P.

In sum, then, it would appear that organic remains found in direct association with definable features provide reliable results, as should be expected given that (a) the features can be assumed to rest in relatively undisturbed contexts by virtue of their identifiable and more or less intact morphology, and (b) organic materials associated with features are perhaps more likely to represent directly related activities, and thus pertain to the cultural events that are the target of the radiocarbon dating. On the other hand, the residues extracted from the limestone clast and the potsherds seem less reliable. The reason(s) for this is/are not readily apparent, though we can suspect some sort of contamination of factors; perhaps old geologic carbonates in the limestone and in the sherds caused the results to be out of line with reasonable expectations. We suggest, therefore, that this approach to radiocarbon dating be further tested; if future results prove to be consistently mixed or outside the bounds of chronological expectations, the method must be regarded with some skepticism. 
Table 19-1. Summary of Cultural Materials by Component from the Varga Site (41ED28) Investigations

\begin{tabular}{|c|c|c|c|c|c|c|}
\hline $\begin{array}{c}\text { Cultural Material } \\
\text { Classes }\end{array}$ & 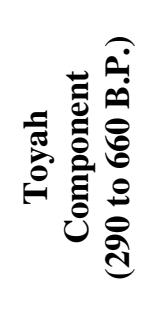 & 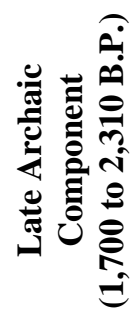 & 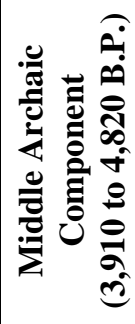 & 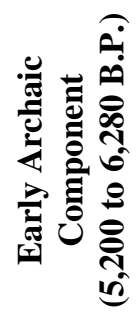 & 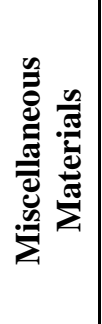 & $\underset{\tilde{E}}{\frac{\infty}{\tilde{\theta}}}$ \\
\hline Bone Fragments* & $17,348.9 \mathrm{~g}$ & $13.6 \mathrm{~g}$ & $402.2 \mathrm{~g}$ & $109.7 \mathrm{~g}$ & $4.5 \mathrm{~g}$ & $17,879.4 \mathrm{~g}$ \\
\hline Mussel Shell** & $25.5 \mathrm{~g}$ & $5.9 \mathrm{~g}$ & 0 & $21.3 \mathrm{~g}$ & 0 & $52.7 \mathrm{~g}$ \\
\hline Burned Rock & 15,934 & 3,965 & 810 & 3,044 & 325 & 24,078 \\
\hline Features & 11 & 10 & 2 & 9 & 0 & 32 \\
\hline Dart Points & 13 & 14 & 10 & 170 & 5 & 212 \\
\hline Arrow Points & 216 & 3 & 0 & 0 & 3 & 224 \\
\hline Bifaces & 96 & 9 & 11 & 198 & 2 & 316 \\
\hline Scrapers & 65 & 3 & 3 & 27 & 2 & 100 \\
\hline Drills & 16 & 0 & 0 & 17 & 1 & 34 \\
\hline Edge-Modified Flakes & 1,380 & 69 & 122 & 1,038 & 36 & 2,645 \\
\hline Lithic Debitage & 26,323 & 1,801 & 4,387 & 51,869 & 1,103 & 85,483 \\
\hline Cores & 37 & 10 & 8 & 25 & 8 & 88 \\
\hline Ground/Pecked Stone & 2 & 1 & 0 & 1 & 0 & 4 \\
\hline Unifaces & 7 & 0 & 0 & 4 & 1 & 12 \\
\hline Gouges & 0 & 0 & 0 & 3 & 0 & 3 \\
\hline Hammerstones/Choppers & 0 & 0 & 1 & 3 & 0 & 4 \\
\hline Ceramic Sherds & 115 & 2 & 0 & 0 & 3 & 119 \\
\hline Bone Tools & 3 & 0 & 0 & 1 & 0 & 4 \\
\hline Socialtechnic Objects & 4 & 0 & 0 & 0 & 0 & 4 \\
\hline Carbonized Plant Remains & $196 \mathrm{~g}$ & $36 \mathrm{~g}$ & $2.5 \mathrm{~g}$ & $223.5 \mathrm{~g}$ & 0 & $458 \mathrm{~g}$ \\
\hline Total Materials & 64,679 & 5,931 & 6,079 & 56,644 & 1,499 & 134,832 \\
\hline Volume Excavated $\left(\mathrm{m}^{3}\right)$ & 42.9 & 9.2 & 20.9 & 25.9 & 5.6 & 104.5 \\
\hline
\end{tabular}

This table does not include materials from float samples

* Bone, mussel shell, and carbonized remain totals are weights in grams

** Mussel shell from testing not weighed 
The seemingly successful result on dating the Rabdotus snail shell is encouraging, as shells of this gastropod are particularly abundant in archeological contexts throughout much of the state. We recommend further application, with close monitoring and evaluation of the outcomes.

\subsubsection{Optically Stimulated Luminescence}

Six OSL samples targeted the Toyah, Late Archaic, and Early Archaic components. The individual quartz grain results are quite variable, erratic, complex, and unacceptable. However, the fine grain results provide central ages that are remarkably similar to the accepted radiocarbon dates from each of the three components. The Late Prehistoric component sediments yielded ages from 1,030 to 1,130 B.P. The Late Archaic sediments yielded ages of 2,210 and 2,400 B.P. The Early Archaic sediments yielded ages of 5,000 and 6,670 B.P. Besides the slightly older Late Prehistoric ages, which may be quite acceptable since two charcoal dates are in that same age range, there is a remarkable correlation of these OSL ages with the obtained radiocarbon ages. In situations where organic preservation is lacking, it would appear that OSL dating would provide a reasonable means of obtaining a relative age on the sediments involved. Moreover, when the sedimentary matrices can be shown (on the basis of stratigraphic associations) to have accumulated in tandem with occupational sequences, OSL can serve as a useful technique for building cultural chronologies. Results at other sites (e.g., Ricklis 2001; 2007) have shown OSL to be a feasible approach to augmenting the chronological data obtained from both radiocarbon dating and from age estimates based on time-diagnostic artifact types (usually, but not always, projectile points).
It is most interesting that the OSL results appear to be valid, considering that they are derived from sand grains within alluvial sediments. Theoretically, we could expect that streamsuspended sands were not fully "reset” (exposed to sunlight) in turbid stream waters. Perhaps turbidity was less of a factor in a relatively small stream such as Hackberry Creek than would be the case in a major river. Alternatively, it may be that the actual use of the site by prehistoric people resulted in ground disturbance that exposed resident sediments to sunlight (through treadage and other ground-disturbing factors) with sufficient frequency to reset the sand grains at the time(s) of occupation. Despite such taphonomic questions, it does seem that OSL is a highly useful technique that should be further utilized and tested in more archeological contexts.

\subsubsection{Use-Wear Analysis and Residue identifications}

The high-powered use-wear analysis and residue identifications on 156 specimens provide valuable and interesting results. The analyses were conducted on points, scrapers, bifaces, unifaces, drills, and edge-modified flakes, and include: 59 chipped stone tools from the Toyah component, 17 tools from the Late Archaic component, 17 tools from the Middle Archaic component, and 63 tools from the Early Archaic component. The sample is remarkable for the high percentage of artifacts that exhibit functional evidence and for the high proportion of specimens that were found to retain identifiable residues. Preservation is excellent in the Toyah component with observed residues that include plant remains, starch grains, hair, feather barbules, wood fragments, and possible blood. Similar residues of hair, wood fragments, plant fibers and tissue, and raphides were observed on chipped stone tools from the Late Archaic component. Residues observed on Middle Archaic tools include hair, wood 
fragments, and plant tissue. The Early Archaic sample also had well-preserved residues that include raphides, plant tissue, starch grains, plant fibers, wood fragments, bone/antler, hair, possible blood, and charcoal. Many Early Archaic tools exhibit raphides randomly distributed across their surface indicating that raphides may be depositional rather than userelated.

The use-wear results reveal that all artifacts from the Toyah sample exhibit evidence of use, either through residues or use-wear. This incredibly high percentage of tools with functional evidence indicates that the occupants were conducting intensive processing of a wide range of materials including wood, starchy plants (possibly roots or tubers), mammals, birds, and other types of plants. The Late Archaic tool sample preserves evidence for exploitation of a more narrow range of materials than the Toyah component. Hafting is limited to bifacially retouched tools and does not occur in high frequencies (3 of 17 tools were hafted). Wood and hide are the most commonly used materials. The Middle Archaic tools reveal a high frequency of use on hard, high silica materials with a broad range of use actions. The Early Archaic materials also reveal a broad range of use actions primarily on plants, hard, high silica material, with many unknowns. Use-actions include whittling, slicing, scraping, cutting, boring/drilling, and planing. General artifact typology based on form is not a good predictor of stone tool function. Most tool types appear to have been used for a variety of different tasks on more than one material. The use-wear analysis has provided extensive and important data on the analyzed tools and should be incorporated into most analyses of tool assemblages.

In sum, these findings indicate that formal tools were functionally a good deal more versatile than may be inferred by the functional labels routinely applied to them (e.g., "scraper", “projectile point”, “gouge”, etc). While beyond the scope of the present research, we believe that systematic collection of this sort of data will eventually make possible a coherent study concerning the validity of archeological assumptions about tool forms. Such a study might offer the benefit of a better understanding of the ranges of functions represented by archeological assemblages, with obvious potential for improving our understanding of past adaptive behavior.

\subsubsection{Petrographic Analysis}

The petrographic analyses on 19 plainware pottery sherds and one local matrix sample include 11 Toyah pottery samples and one local matrix sample from the Varga Site, five bone tempered sherds from the San Juan Mission (41BX5) in San Antonio, and three sherds from the San Lorenzo Mission (41RE1) at Camp Wood. The aboriginal mission ceramics were analyzed to provide temporal comparisons and allow for discussions on technological change. Analysis of a Varga Site matrix sample was valuable in distinguishing local from non-local paste groups. Variability lies largely with tempering agents and particles resident in the ceramic clays. Analysis of the mission ceramic sherds documents that Toyah bone-tempered ceramic technology persisted into the Protohistoric period with aboriginal populations who occupied at least the San Juan Mission. The analysts identified nine distinct paste groups, not all of which are bone-tempered. The paste groups represented in the Varga sample were then compared to paste groups from other analyzed Toyah site assemblages within the broader Toyah interval. The shared paste groups show that locally produced ceramics were transported from site to site. Investigating the means and mechanisms of this transport through hypothesis testing and the application of other analytical technologies may be a fruitful avenue for future research. 


\subsubsection{Pollen and Phytolith Analysis}

Twenty-five paired pollen and phytolith samples collected from a single column in Block A, including two dated sediment samples from Trench 1 and three dated samples from Trench 7, provide indications of past environments. Two dated samples are of Late Archaic age, and three are of Early Archaic age. These samples yielded various frequencies and information on plant types that reflect minimal and gradual environmental changes through the 6,300-years of deposits.

Pollen data was very poorly preserved throughout the column and individual dated samples. Juniper pollen is absent from these assemblages, a reflection of the poor preservation. As expected, the youngest Toyah component samples were better preserved than those from earlier periods. The limited evidence indicates that the arboreal component remained rather stable over time and consisted primarily of oak, pecan, and probably smaller numbers of hackberry and walnut. The vegetation community was likely a mixture of arboreal and grassland meadow components.

These results are, unfortunately, not as helpful as hoped in terms of reconstructing paleoenvironments and tracking possible longterm changes in floral communities and, by extension, climatic patterns. It must be concluded that pollen samples derived from relatively shallow site deposits (such as is the case at Varga) are unlikely to provide very reliable results. More than likely, the pollen at such sites suffered from long-term exposure to near-surface biotic activity that degraded/destroyed pollen grains. Therefore, we strongly recommend that future pollen studies be done, if feasible within the spatial windows of projects and the constraints of project scopes/budgets, on samples derived from off-site cores extracted from more deeply deposited alluvium in the vicinity of sites or, preferably, from anaerobic contexts such as bogs. Only in this way are we likely to recover a microbotanical record that will accurately represent the floral communities that existed during targeted time periods, and concomitantly, sequences that will permit reliable reconstruction of climatic and related environmental trends over the long-term.

Phytoliths were generally well-preserved in most column samples with dominant forms that included Chloridoids, Panicoids, and a small number of Festucoid types. A few Sabal-type palm phytoliths were also present reflecting probable Cretaceous or Tertiary aged re-worked phytoliths. In general, the phytolith column reflects a dominance of $\mathrm{C}_{3}$ Pooideae grasses during the Early to Middle Archaic Periods. $\mathrm{C}_{4}$ grasses appear in the area sometime during the Middle Archaic, but not in significant frequencies. Panicoideae and Chloridae grasses gradually increase in proportions during the Middle Archaic, but do not appear as a prominent part of the phytolith assemblage until the later part of the Late Archaic or into the Toyah component. Phytoliths are much better preserved than pollen and provide a greater insight of the past grassland communities.

\subsubsection{Instrumental Neutron Activation Analysis}

INAA was conducted on 154 chert tools, 19 pottery samples, one sediment sample from Varga Site, plus 107 natural chert samples from across the central and southern reaches of the Edwards Plateau to investigate possible procurement sources, movement of populations, lithic materials, and pottery across Central Texas. The chert tool samples include parts of chipped stone tools that represent a wide variety of tool classes from each component. These include parts of 17 chipped stone tools from the Middle Archaic, parts of 66 chipped stone tools 
from the Early Archaic, 23 chipped stone tool pieces from the Late Archaic, and 48 pieces of chipped stone tools from the Toyah component. Comparisons between the current natural source samples from the Edwards Plateau and previous analyses indicate that the new natural source samples are significantly different from the varieties of Edwards chert samples collected from the Fort Hood area, but they overlap with earlier collections of Edwards Formation chert. Analyses of the Varga Site cultural artifacts reveal that they are compositionally different from the Fort Hood Edwards chert varieties. The Varga Site artifacts are similar to both collections of natural Edwards Formation source specimens from the central plateau and local river gravels.

While it should come as no surprise that the lithic tools at the Varga site were not made from cherts from the Fort Hood area, the fact that the closest similarities in chemical signatures for cherts at the site are from local sources or from sources in the surrounding part of the Edwards Plateau, significantly and strongly indicate that tool stone was procured either through relatively short-distance logistical forays made from the site, or by a resource-extraction strategy that was embedded (sensu Binford 1979) in a residential mobility pattern that was restricted to the subregional environment around the site. We believe this insight is a worthwhile contribution, as it suggests that the hunter-gatherer groups who produced the Toyah and earlier artifact assemblages had fairly localized operational areas, or territories, despite the obviously broad distribution of the classic Toyah archaeological assemblage and the various earlier dart point styles found at the site. In other words, these groups generally were engaged in patterns of spatially constrained settlement/subsistence mobility. At least this is the inference that we make from the Varga data. Given the important implications this has for understanding group mobility as a basic adaptive strategy, we believe that acquisition of comparable data from other sites is a worthwhile goal for future research.

The potsherds submitted for INAA included three non-bone tempered sherds from the historic Mission San Lorenzo (41RE1) in Camp Wood, five bone tempered sherds from the historic Mission San Juan (41BX5) in San Antonio, and ten bone tempered sherds from the Toyah component at the Varga Site. The latter ten samples represent at least four different vessel groups. Based on the 29 chemical elements used for quantitative analysis, all samples have less than a four percent probability of membership in the previously analyzed Central Texas- 1 and 2 compositional reference groups (Creel 2002, 2003). The exception is one thin igneous tempered sherd collected from the surface, which has high probability of membership in the El Paso Polychrome reference group. Clear chemical patterning is apparent in the remaining 18 specimens. The five samples from Mission San Juan form a distinct compositional group. The Varga Site sherds form two distinct groups. Two of the three samples from Mission San Lorenzo cluster together. Three samples are unassigned. Because the four groups are represented by so few samples, any attempt to statistically validate these groups is unwarranted at this time. Despite the small sample size, the INAA indicates that continued analyses of pottery from archeological sites would result in identification of several chemically distinct reference groups. Establishing a database for these samples could ultimately aid in assessing Late Prehistoric movements of pottery and people across Texas. An important part of the understanding of the movement of vessels and populations is a better understanding of the clay sources from different regions, and thus is a definite need to run tests on more natural clay samples from the state. We believe that a systematic approach in this kind of data gathering in future work will ultimately provide useful insights into the movement of 
human populations and materials during the Late Prehistoric.

\subsubsection{Lipid Residue Analysis of Pottery and Burned Rocks}

Fatty acid composition on eight potsherds, including two sherds from Mission San Juan, and 94 limestone burned rocks from 23 identified Varga Site features, was conducted to identify the kinds of foods cooked in, respectively, ceramic vessels and hot-rock features. Ninety-nine percent of the samples yielded sufficient fatty acids for such identification. Residues extracted from the eight pottery sherds include two residues interpreted as representing large herbivores and three residues interpreted as moderate-high-fatcontent food likely of plant origin. The other three residues fall on the border between moderate-high- and high-fat-content food and are all are likely to be of plant origin.

Seventy-three burned limestone pieces, representing 77.7 percent of all burned rock residues analyzed, contain significantly elevated levels of fat or oil. Nearly 87 percent are consistent with nuts or seeds with fat contents ranging from moderately high to very high. Nearly 15 percent of the burned rock residues were identified as very-high-fat-content food; all of which are probably of plant origin. About seven percent of the burned rock residues fall on the border between high- and very-high-fatcontent foods, again likely to be of plant origin. Just over 24 percent of the residues were identified as high-fat-content food, with nearly 88 percent probably reflecting plants. Another 8.5 percent of the residues fall on the border between high and moderate-high-fat-content food; all were probably of plant origin. A further 33 percent of the residues were identified as moderate-high-fat-content foods, of which 50 percent were probably plants.
Twenty burned limestone pieces, representing 21 percent, exhibit somewhat lower levels of fat or oil. Nine percent of the residues fall on the border between moderate-high- and medium-fatcontent foods; all but one of these residues probably originated from plants. Near two percent were identified as medium-fat-content food, both of which are likely to be of plant origin. One percent of the residues were consistent with a low-fat-content plant. Eight percent may reflect the preparation of large herbivore products. One percent fell on the border between medium-fat-content plant and large herbivore prepared with plant or bone marrow. One percent was identified as large herbivore prepared with plant or bone marrow. Six percent of the residues are consistent with fatty or somewhat fatty large herbivore meat prepared alone or with plants.

The overall results reflect extensive cooking of plant foods during all four component periods, with a low (6 to 20 percent) incidence of large herbivore residues represented in the Toyah component. Based on these findings, taken at face value, it appears that a sizeable majority of the foods cooked at the site were plants. Even in the Toyah component, wherein large herbivore meat constitutes a significant minority of the cooked foods, probable plant residues continue to dominate. These indications, relied upon throughout this report, point to a very high dietary importance of plants in the diets of the prehistoric hunter-gatherers (or, more accurately, gatherer-hunters) who occupied the site. Unless these results are regionally anomalous - and there is no apparent reason to assume they are-the fats and carbohydrates provided by plant foods probably comprised the bulk of the general caloric intake for Archaic and Late Prehistoric peoples of Central Texas. Such a conclusion makes sense, insofar as a diet involving more than around 40 percent calories in the form of protein would be biochemically detrimental to human health and would not be 
sustainable for extended lengths of time (Noli and Avery 1988; Speth 1983).

At present, however, it must be recognized that the interpretations of the residues are inherently rather ambiguous. At best, as a review of Appendix G shows, even the most basic distinctions between the residues of plant vs. animals can only be stated as "likely" or "probable”. Moreover, when taxa identifications are made, based on identified isotopic values such as "elevated C18:0", it is concluded that the resources represented could be large herbivores, javelina, or sotol seeds. In other cases, very high fat content is interpreted to represent seeds or animal fat, while moderate fat content could represent either beaver or Texas ebony, and moderate fat content could indicate mesquite beans, corn, or fish. Since, in all these instances, various animals or plants could be represented by a single sample, we are not left with a basis for very confident reconstruction of prehistoric subsistence patterns, much less "hard" data upon which to model systemically inter-related human-behavioral patterns resource extraction, settlement and residential mobility.

For these reasons, we believe that a good deal of refinement and improvement of residue analysis/interpretation is needed before additional extensive work, such as we have carried out in the present project, is included in research designs for future archaeological projects. The problem here is not a strictly archeological one-no amount of archeological rigor or procedural exactitude will resolve the issue. Rather, the problem is one of chemical taphonomy. What is required is a more reliable understanding of the correspondences between the chemistry of modern species and the chemical signatures of plant and animal residues after long periods of degradation in archaeological contexts. If and when this is accomplished, further studies of this nature can be expected to yield data in which greater interpretive confidence can be placed.

\subsubsection{Stable Carbon and Nitrogen Isotope Analyses}

Stable carbon and nitrogen isotope analyses were conducted on 158 samples to assess the relative proportion of $\mathrm{C}_{3}$ or $\mathrm{C}_{4} / \mathrm{CAM}$ photosynthetic pathways of the plant residues, or animals that ate these plants, and were cooked by these artifacts. The isotope results were combined with the lipid residue results to aid in the interpretations of the resources processed. The selected samples included the interiors of 87 burned limestone rocks, six Varga Toyah ceramic sherds, five ceramic sherds from Mission San Lorenzo, two ceramic sherds from Mission San Juan, 20 sediment samples from one column and five other dated sediments from trenches, and 33 modern plant samples to facilitate the interpretations. The isotope results from the cultural artifacts reflect an extensive use of $\mathrm{C}_{3}$ plants and/or animals that ate $\mathrm{C}_{3}$ plants. Only about two percent of the isotope results from the cultural artifacts indicate possible mixtures of $\mathrm{C}_{3}$ and $\mathrm{C}_{4} / \mathrm{CAM}$ plant use with no direct indication that $\mathrm{C}_{4}$ foods (lechuguilla, buffalo meat, corn, etc.) were cooked. The background sediment also reflects complete dominance of $\mathrm{C}_{3}$ vegetation through time, with no obvious serge in $\mathrm{C}_{4}$ vegetation to signal the presence of a warm and/or dry period during these 6,300-years of prehistory.

The most useful outcome of this line of work relates to interpretation of broad patterns of environmental change or stability. As just stated, our findings support the notion that there were no dramatic changes in climate or floral community composition during the last six-plus millennia (seven-plus, in calibrated terms). The stable isotope analyses are less informative concerning the more specific concern of the kinds of resources that were processed by 
prehistoric people, since evidence for a dominance of $\mathrm{C}_{3}$ plants can also be interpreted to represent human procurement/processing of animals that ate $\mathrm{C}_{3}$ plants; obviously the stable carbon data do not contribute toward a better understanding of the relative dietary importance of plants verses animals. At the same time, they do indicate general environmental conditions, and future use of this approach in identifying broad environmental trends should prove useful.

\subsubsection{Macrobotanical Analysis}

Macrobotanical remains from 44 flotation samples (573 liters) extracted from 18 cultural features and 75 individual pieces from across the excavations were analyzed. Preservation was very good, with 20 taxa identified. Edible plant parts were represented by Agavaceae leaf and caudex (i.e., heart) fragments, prickly pear seeds, mesquite seeds, cheno-am seeds (achenes), and nut fragments, both littleleaf walnut and a thin nutshell, probably pecan. Wood types include mesquite, woody legume, hickory family (e.g., pecan), buttonbush, cottonwood/willow, juniper, sycamore, Mexican buckeye, pinyon, agarita, oak, buckthorn, elm, and lotebush. Cottonwood/willow wood, littleleaf walnut, sycamore, Mexican buckeye, oak, buttonbush, elm, and pecan are indicative of a typical western Edwards Plateau canyon or riparian environment. Mesquite, juniper, pinyon, oak, and lotebush are indicative of upland vegetation communities. Prickly pear seeds, Agavaceae (yucca, sotol, or agave) leaf and caudex fragments, cheno-am seeds, littleleaf walnuts, possible pecan nut fragments, and mesquite seeds characterize desert food foraging activities in the western Edwards Plateau region.

These findings are informative and contribute directly to the empirical data base relevant to prehistoric patterns of resource use. Extraction of flotation samples and identification of macrobotanical taxa thereby recovered should be an ongoing requirement in archeological contexts where preservation is adequate for recovery of these kinds of materials.

\subsubsection{Granulometry}

Granulometry and chemical analyses were conducted on 10 sediment samples from the sediment column near the middle of Block A. The analyses were on the same samples that were used for the pollen, phytolith, and isotope analyses. These results contribute to the soil identifications and provide indications as to preservation problems and depositional characteristics. 


\subsection{MANAGEMENT} CONSIDERATIONS AND RECOMMENDATIONS

J. Michael Quigg

\begin{abstract}
The two part data recovery program and subsequent reporting here constitute the implementation of the Section 106 process of the National Historic Preservation Act (16U.S.C. 407f) pursuant to 35 CFR Part 800. Through this regulatory process, the archeological investigations and analyses of recovered cultural assemblages in that part of 41ED28 within the area of potential effect in the existing Ranch to Market Road right-of-way have contributed significant information towards understanding four prehistoric components and the prehistoric peoples that created those components in the canyonlands of the Edwards Plateau.
\end{abstract}

The archeological materials at the Varga Site, 41ED28 definitely continue beyond the existing Ranch to Market Road right-of-way to the east and west and possible to the north. If future plans call for widening the existing right-of-way in either direction, unassessed cultural deposits outside the current right-of-way will be encountered and potentially disturbed in construction activities. We recommend assessing proposed development areas beyond the existing right-of-way if any land disturbance activities are pending. 



\subsection{REFERENCES CITED}

Abbott, J.

1994 Geomorphic Context of the Barton Site (41HY202) and the Mustang Branch Site (41HY209). In Archaic and Late Prehistoric Human Ecology in the Middle Onion Creek Valley, Hays County, Texas-Volume 2, by R. A. Ricklis and M. B. Collins, pp. 353-379. Studies in Archeology, No. 19. Texas Archeological Research Laboratory, The University of Texas at Austin.

1999 Stratigraphic and Geomorphic Evaluation of Brushy Creek at FM973. Appendix K, in Archeological Investigations at 41WM815, A Blackland Prairie Site, Williamson County, Texas, by R. K. Brownlow, pp. 179-191. Studies in Archeology 36, Texas Archeological Research Laboratory, The University of Texas at Austin.

2003 Appendix K: Stratigraphic and Geomorphic Evaluation of Brushy Creek at FM 973. In Archeological Investigations at 41WM815, A Backland Prairie Site, Williamson County, Texas, by R. K. Brownlow, pp. 179-191. Studies in Archeology 36, Texas Archeological Research Laboratory, The University of Texas at Austin, and Archeological Studies Program, Report 23, Environmental Affairs Division, Texas Department of Transportation, Austin.
Ahler, S.

1971 Projectile Point Form and Function at Rodgers Shelter, Missouri. Research Series, No. 8. Missouri Archaeological Society, Columbia.

Alexander, R. K.

1974 The Archaeology of Conejo Shelter: A Study of Cultural Stability at an Archaic Rockshelter Site in Southwestern Texas. Unpublished Ph.D. dissertation, Department of Anthropology, The University of Texas at Austin.

Ammerman, A. J., and M. W. Feldman

1974 On the "Making" of an Assemblage of Stone Tools. American Antiquity 39(4):611-616.

Anderson, A. E.

1932 Artifacts of the Rio Grande Delta Region. Bulletin of the Texas Archeological and Paleontological Society 4:29-31.

Anderson, J. N.

1973 Ecological Anthropology and Anthropological Ecology. In Handbook of Social and Cultural Anthropology, edited by J. Honigmann, pp. 179-239. Chicago: Rand McNally.

Andrefsky, W., Jr.

1986 Numerical Types and Inspectional Types: Evaluating Shape Characterization Procedures. North American Archaeologist 7:95-112.

1991 Inferring Trends in Prehistoric Settlement Behavior from Lithic Production Technology in the Southern Plains. North American Archaeologist 12:129-144.

1994 Raw Material Availability and the Organization of Technology. American Antiquity 59(1):21-34. 
Antevs, E.

1955 Geologic-Climate Dating in the West. American Antiquity 20(4):317-335.

Arnn, J. W.

2007 Transformation and Persistence of Indigenous Cultural Identity during the Colonial and Late Prehistoric Periods in Texas. Unpublished Doctoral Dissertation, Department of Anthropology, University of Kentucky.

Auken, O. W., A. L. Ford, A. Stein, and A. G. Stein

1980 Woody Vegetation of Upland Plant Communities in the Southern Edwards Plateau. The Texas Journal of Science 32(1):23-35.

Baker, B. W.

1998 Vertebrate Faunal Remains from the 1/4-inch and 1/8-inch Screens. In Wilson-Leonard An 11,000-year Archeological Record of HunterGatherers in Central Texas, Volume V: Special Studies, assembled and edited by M. B. Collins pp. 1463-1509. Studies in Archeology 31, Texas Archeological Research Laboratory, The University of Texas at Austin, and Archeology Studies Program, Report 10, Texas Department of Transportation, Environmental Affairs Division, Austin.

Bamforth, D. B.

1986 Technological Efficiency and Tool Curation. American Antiquity 51(1):3850 .

Barnes, V.

1981 Geologic Atlas of Texas, Sonora Sheet. Bureau of Economic Geology, The University of Texas at Austin.

Bartram, L. E., E. M. Kroll, and H. T. Bunn

1991 Variability in Camp Structure and Bone Food Refuse Patterning at Kua San Hunter-Gatherer Camps. In The
Interpretation of Archaeological Spatial Patterning, edited by E. M. Kroll and T. D. Price, pp. 77-148. Plenum Press, New York.

Beardsley, R. K., P. Holder, A. Krieger, B. Meggars, J. Rinaldo, and P. Kutsche

1956 Functional and Evolutionary Implications of Community Patterning. In Seminars in Archaeology: 1955, edited by R. Wauchope, pp. 129-157. Memoirs of the Society for American Archaeology, No. 11. Salt Lake City, Utah.

Bell, W. H., and E. F. Castetter

1937 The Utilization of Mesquite and Screwbean by the Aborigines in the American Southwest. The University of New Mexico Bulletin, Ethnobiological Studies in the American Southwest, Volume $V$. The University of New Mexico Press, Albuquerque.

1941 The Utilization of Yucca, Sotol, and Beargrass by the Aborigines in the American Southwest. The University of New Mexico Bulletin, Ethnobiological Studies in the American Southwest, Volume VII. The University of New Mexico Press, Albuquerque.

Bement, L. C.

1989 Lower Pecos Canyonlands. In From the Gulf to the Rio Grande: Human Adaptation in Central, South, and Lower Pecos Texas, edited by $\mathrm{T}$. R. Hester, S. L. Black, D. G. Steels, B. W. Olive, A. A. Fox, K. Reinhard, and L. C. Bement, pp. 63-76. Arkansas Archeological Survey Research Series No. 33.

1991 The Thunder Valley Burial Cache: Group Investment in a Central Texas Sinkhole Cemetery. Plains Anthropologist 36(135):97-109. 
1993 A flexed Burial From Llano County, Texas. Bulletin of the Texas Archeological Society 61:281-287.

1994 Hunter-Gather Mortuary Practices During the Central Texas Archaic. The University of Texas Press, Austin.

Bement, L. C., and S. A. Turpin

1987 Technological Continuity and Functional Change: The Case of the Dorsal End Scraper. Plains Anthropologist 32(116):191-196.

Bender, A., and B. Bender

1962 A Vertical Shaft Burial in Uvalde County, Texas. The Texas Caver 7(4):41-42).

Bertalanffy, L. von

1968 General Systems Theory: Foundations, Development, and Applications. George Braziller, New York.

Binford, L. R.

1965 Archaeological Systematics and the Study of Culture Process. American Antiquity 31:203-210.

1977 Forty-Seven Trips: A Case Study in the Character of Archaeological Formation Processes. In Stone Tools as Cultural Markers: Change, Evolution, and Complexity, edited by R. V. S. Wright, pp. 24-36. Australian Institute of Aboriginal Studies, Canberra.

1978 Dimensional Analysis of Behavior and Site Structure: Leaning from an Eskimo Hunting Stand. In An Archaeological Perspective, by L. Binford, pp. 52-58. Seminar Press, New York.

1979 Organization and Formation Processes: Looking at Curated Technologies. Journal of Anthropological Research 35:255-273.

1980 Willow Smoke and Dogs' Tails: Hunter-Gatherer Settlement Systems and Archaeological Site Formation. American Antiquity 45:4-20.

1981 Bones: Ancient Men and Modern Myths. Academic Press, New York.

1983 In Pursuit of the Past: Decoding the Archaeological Record. Thames and Hudson, London.

2001 Constructing Frames of Reference: An Analytical Method for Archaeological Theory Building Using HunterGatherer and Environmental Data Sets. University of California Press, Berkeley.

Binford, L. R., and J. Sabloff

1982 Paradigms, Systematics and Archaeology. Journal of Anthropological Research 37:137-153.

Birkeland, P. W.

1984 Soils and Geomorphology. Oxford University Press, New York.

Birkeland, P. W., M. N. Machette, and K. M. Haller

1991 Soils as a Tool for Applied Quaternary Geology. Utah Geological and Mineral Survey, Miscellaneous Publication, No. 91-93. Utah Department of Natural Resources, Salt Lake City.

Black, S. L.

1982 Prehistoric Ceramic Artifacts. In Archaeological Investigations at Choke Canyon Reservoir, South Texas: The Phase I Findings, by G. D. Hall, S. L. Black, and C. Graves, pp. 390-453. Choke Canyon Series, Volume 5. Center for Archaeological Research, The University of Texas at San Antonio.

1986 The Clemente and Herminia Hinojosa Site, 41JW8: A Toyah Horizon Campsite in Southern Texas. Special Report 18. Center for Archaeological 
Research, The University of Texas at San Antonio.

1989 Central Texas Plateau and Prairie. In From the Gulf to the Rio Grande: Human Adaptation in Central, South, and Lower Pecos Texas, edited by T. R. Hester, S. L. Black, D. G. Steels, B. W. Olive, A. A. Fox, K. Reinhard, and L. C. Bement, pp. 17-38. Arkansas Archeological Survey Research Series No. 33.

Black, S. L., and D. G. Creel

1997 The Central Texas Burned Rock Midden Reconstructed. In Hot Rock Cooking on the Greater Edwards Plateau: Four Burned Rock Midden Sites in West Central Texas. Volume I and II by S. L. Black, L. W. Ellis, D. G. Creel, and G. T. Goode, pp. 269-305. Texas Archeological Research Laboratory, The University of Texas at Austin, Studies in Archeology 22, and Texas Department of Transportation, Environmental Affairs Department, Archeology Studies Program, Report 2.

Black, S. L., and L. W. Ellis

1997 Introduction: A Study of Four Burned Rock Midden Site. In Hot Rock Cooking on the Greater Edwards Plateau: Four Burned Rock Midden Sites in West Central Texas, Volume 1, edited by S. L. Black, L. W. Ellis, D. G. Creel, and G. T. Goode, pp. 1-21. Texas Archeological Research Laboratory, The University of Texas at Austin, Studies in Archeology 22, and Texas Department of Transportation, Environmental Affairs Department, Archeology Studies Program, Report 2.

Black, S. L., L. W. Ellis, D. G. Creel, and G. L. Goode

1997 Hot Rock Cooking on the Greater Edwards Plateau: Four Burned rocks Midden Sites in West Central Texas. Volume I and II, Texas Archeological
Research Laboratory, The University of Texas at Austin, Studies in Archeology 22, and Texas Department of Transportation, Environmental Affairs Department, Archeology Studies Program, Report 2.

Black, S. L., K. Jolly, C. D. Frederick, J. R. Lucas, J. W. Karbula, P. R. Takac, and D. R. Potter

1998 Archeology along the Wurzbach Parkway: Module 3 Investigation and Experimentation at the Higgins Site (41BX184). Studies in Archeology 27, Texas Archeological Research Laboratory, The University of Texas at Austin.

Black, S. L., and A. J. McGraw

1985 The Panther Springs Creek Site: Cultural Change and Continuity within the Upper Salado Creek Watershed, South-Central, Texas. Archaeological Survey Report, No. 100, Center for Archaeological Research, The University of Texas at San Antonio.

Blair, W. F.

1950 The Biotic Provinces of Texas. The Texas Journal of Science 2(1):93-117.

Bleed, P.

1986 The Optimal Design of Hunting Weapons: Maintainability or Reliability. American Antiquity 51:737747.

Blum, M. D.

1987 Late Quaternary Sedimentation by the Upper Pedernales River, Central Texas. Unpublished Master's thesis, The University of Texas at Austin.

1989 Quaternary Stratigraphy of the Pedernales River. In Geomorphology, Quaternary Stratigraphy, and Paleoecology of Central Texas, by M. D. Blum, J. F. Peterson, and R. S. Toomey, III. Fieldtrip Guidebook, 
South Central Cell, Friends of the Pleistocene, Seventh Annual Meeting, organized by S. A. Hall and T. C. Gustavson, Austin, Texas.

1992 Modern Depositional Environments and Recent Alluvial History of the Colorado River, Gulf Coastal Plain of Texas. Unpublished $\mathrm{PhD}$ Dissertation, The University of Texas at Austin, Austin, Texas.

Blum, M. D., and S. Valastro, Jr.

1989 Response of the Pedernales River of Central Texas to Late Holocene Climate Change. Annals of the Association of American Geographers 79(3):435-456.

1992 Quaternary Stratigraphy and Geoarchaeology of the Colorado and Concho Rivers, West Texas. Geoarchaeology: An International Journal 7:419-448.

1994 Late Quaternary sedimentation, lower Colorado River, Gulf Coastal Plain of Texas. Geological Society of America Bulletin 106:1002-1016.

Blum, Michael D., Toomey III, Rickard S., and Valastro Jr., Salvatore,

1994 Fluvial Response to Late Quaternary Climatic and Environmental Change, Edwards Plateau, Texas. Palaeogeography, Palaeoclimatology, and Palaeoecology 108:1-21.

Blum, M., C. Lintz, R. Holloway, and L. ScottCummings

1993 Paleoenvironmental Reconstruction. In Cultural Resource Investigations in the O. H. Ivie Reservoir, Concho, Coleman, and Runnels Counties, Texas-Volume I: Project Introduction, Setting and Methods, by C. Lintz, W. N. Trierweiler, A. C. Earls, F. M. Oglesby, M. Blum. P. L. O’Neill, J. Kuhl, R. Holloway, L. Scott-Cummings, D. Scurlock, pp. 261-279. Technical
Report No. 346-I, Mariah Associates, Inc., Austin, Texas.

Bohrer, V. L.

1987 The Plant Remains from La Ciudad, A Hohokam Site in Phoenix. In Specialized Studies in the Economy, environment and Culture of La Ciudad, edited by J. A. Kisselburg, G. E. Rice, and B. Spears, pp. 67-202. Office of Cultural Resource Management, Department of Anthropology, Arizona State University, Tempe.

1994 Appendix B: The Plant Remains form the Wind Canyon Site in the Eagle Mountains of Western Texas. In Data Recovery Excavations at the Wind Canyon Site, 41HZ119, Hudspeth County, Texas, by M. H. Hines, S. A. Tomka, and K. W. Kibler, pp 167-182. Reports of Investigations, Number 99, Prewitt and Associates, Inc., Austin, Texas.

Bomar, G. W.

1983 Texas Weather. University of Texas Press, Austin.

Bond, C. L.

1978 Three Archeological Sites at Hoxie Bridge, Williamson County, Texas. Texas A\&M Research Foundation, Report No. 43, College Station.

Boyd, C. E.

2003 Rock Art of the Lower Pecos. Texas A\&M University, Anthropology Series Number 8, Collage Station.

Boyd, D. K.

1997 Caprock Canyonlands Archeology: A Synthesis of the Late Prehistory and History of Lake Allan Henry and the Texas Panhandle-Plains. Reports of Investigations, Number 110 . Prewitt and Associates, Inc., Austin, Texas. 
Bousman, C. B.

1993 Hunter-Gatherer Adaptations: Economic Risk and Took Design. Lithic Technology 18(1-2):59-86.

1998 Paleoenvironmental Change in Central Texas: The Palynological Evidence. Plains Anthropologist 43(164):201-219.

Bousman, C. B. and M. Quigg

2006 Stable Carbon Isotopes from Archaic Human Remains in the Chihuahuan Desert and Central Texas. Plains Anthropologist 51(198):123-139.

Bousman, C. B., S. A. Tomka, and G. L. Bailey

1990 Prehistoric Archeology and Paleoenvironments in Hidalgo and Willacy Counties, South Texas: Results of the Phase II Test Excavations. Reports of Investigations, No. 76, Prewitt \& Associates, Inc., Austin, Texas.

Brown, K. M.

1985 Three Caches of Guadalupe Tools from South Texas. Bulletin of the Texas Archeological Society 56:75-126.

1991 Prehistoric Economics at Baker Cave: A Plan for Research. In Papers on Lower Pecos Prehistory, edited by S. A. Turpin, pp. 87-140. Studies in Archeology 8, Texas Archeological Research Laboratory, The University of Texas at Austin.

Brownlow, R. K.

2003 Archeological Investigations at 41WM815, A Backland Prairie Site, Williamson County, Texas. Studies in Archeology 36, Texas Archeological Research Laboratory, The University of Texas at Austin and Archeological Studies Program, Report 23, Environmental Affairs Division, Texas Department of Transportation, Austin.

2004 Data recovery Investigations at the Holt Site (41HY341), San Marcos, Hays
County, Texas. Horizon Environmental Services, Inc., Austin.

Brune, G.

1975 Major and Historical Springs of Texas. Texas Water Development Board, Report No. 189, Austin.

1981 Springs of Texas. Volume 1. BranchSmith, Inc., Fort Worth.

Brunswig, R. H., Jr.

1995 Apachean Ceramics in Eastern Colorado: Current Data and New Directions. In Archaeological Pottery of Colorado: Ceramic Clues to the Prehistoric and Protohistoric Lives of the State's Native Peoples, General and Eastern Slope, edited by R. H. Brunswig, Jr., pp. 172-202. Colorado Council of Professional Archeologist Occasional Papers No. 2., Denver.

Bruseth, J. E., and W. A. Martin

2001 OSL Dating and Sandy Mantle Sites in East Texas. Current Archeology in Texas 3(1):12-17.

Bryant, V. M., Jr.

1966 Pollen Analysis: Its Environmental and Cultural Implications in the Amistad Reservoir. Unpublished Master's thesis, Department of Anthropology, The University of Texas at Austin.

1969 Late Full Glacial and Post Glacial Pollen Analysis of Texas Sediments. Unpublished Ph.D. dissertation, Department of Anthropology, The University of Texas at Austin.

1974 Prehistoric Diet in Southwest Texas: The Coprolite Evidence. American Antiquity 39(3):407-420.

1977a Preliminary Pollen Analysis of Hinds Cave. In Archeological and Botanical Studies at Hinds Cave, Val Verde County, Texas, by H. J. Shafer and V. M. Bryant, Jr. pp. 70-79. Annual 
Report to the National Science Foundation, Texas A\&M University, Anthropology Laboratory, Special Series No. 1.

1977b A 16,000 Year Old Pollen Record of Vegetation Change in Central Texas. Palynology 1:143-155.

Bryant, V. M., and R. G. Holloway

1985 A Late-Quaternary Paleoenvironmental Record of Texas: An Overview of the Pollen Evidence. In Pollen Records of the Late Quaternary North American Sediments, edited by V. M. Bryant and R. G. Holloway, pp. 39-70. American Association of Stratigraphic Palynologists Foundation, Dallas, Texas.

Bryant, V. M., Jr., and H. J. Shafer

1977 The Late Quaternary Paleoenvironment of Texas: A Model for the Archeologist. Bulletin Texas of the Texas Archeological Society 48:1-25.

Butzer, K. W.

1982 Archaeology as Human Ecology: Method and Theory for a Contextual Approach. Cambridge University Press, Cambridge.

1990 A Human Ecosystem Framework for Archeology. In The Ecosystem Approach in Anthropology: From Concept to Practice, edited by E. F. Moran, pp. 91-130. The University of Michigan Press, Ann Arbor.

Cadwallader, M. L.

1980 The Cybernetic Analysis of Change in Complex Social Organizations. In Organizations, Structure, and Behavior, edited by J. A. Litterer, pp. 341-345. J. Wiley and Sons, New York.

Cahen, D., L. Keeley, and F. Van Noten

1979 Stone Tools, Tool-Kits and Human Behavior in Prehistory. Current Anthropology 20:661-683.
Callahan, E.

1979 The Basics of Biface Knapping in the Eastern Fluted Point Tradition: A manual for Flintknappers and Lithic Analysts. Archeology of Eastern North America 7:1-180.

Campbell, T.N.

1948 Merrell Site: Archeological Remains Associated with Alluvial Terrace Deposits. Bulletin of the Texas Archeological and Paleontological Society 19:7-35.

1988 The Indians of Southern Texas and Northeastern Mexico: Selected Writings of Thomas Nolan Campbell. Texas Archeological Research Laboratory, The University of Texas at Austin.

Caran, S. C.

1998 Quarternary Paleoenvironmental and Paleoclimate Reconstruction: A Discussion and Critique, with Examples from the Southern High Plains. Plains Anthropologist 43(164):111-124.

Caran, S. C and C. Speer

n.d. Geoarcheology of the Proposed San Antonio River Improvements Project, Museum Reach, San Antonio, Bexar County, Texas. Unpublished manuscript submitted to the Center for Archeological Research, The University of Texas at San Antonio.

Castetter, E. F.

1935 Uncultivated Native Plants Used as Sources of Food. University of New Mexico Bulletin 266. Albuquerque.

Castetter, E. F., and M. E. Opler

1936 The Ethnobiology of the Chiricahua and Mescalero Apache. In The Use of Plants for Foods, Beverages, and Narcotics, Volume III:A. The University of New Mexico Bulletin, Ethnobiological Studies in the 
American Southwest, The University of New Mexico Press, Albuquerque.

Castetter, E. F., and W. H. Bell

1937 The Aboriginal Utilization of the Tall Cacti in the American Southwest. In The University of New Mexico Bulletin, Ethnobiological Studies in the American Southwest, Volume IV. The University of New Mexico Press, Albuquerque.

Castetter, E. F., W. H. Bell, and A. R. Grove

1938 The Early Utilization and the Distribution of Agave in the American Southwest. In The University of New Mexico Bulletin, Ethnobiological Studies in the American Southwest, Volume VI. The University of New Mexico Press, Albuquerque.

Church, F.

2000 A Summary of the Results of a High Power Use-Wear Analysis of a Sample of Chipped Stone Artifacts from Site 41ZP364, Zapata County, Texas. In Data Recovery at 41ZP364: An Upland Campsite at Falcon Reservoir, Zapata County, Texas, by J. M. Quigg and C. Cordova, pp. 247-268. Technical Report No. 22317, TRC Mariah Associates Inc., Austin.

Clark, J.

1987 Politics, Prismatic Blades, and Mesoamerican Civilization. In The Organization of Core Technology, edited by J. K. Johnson and C. A. Morrow, pp. 259-284. Westview Press, Boulder.

Clark, J. W.

1978 Mission San Jose y San Miguel de Aguayo, Archaeological Investigations. Texas Historical Commission, Office of the State Archeologist Report 29, Austin.
Clarke, D. L.

1968 Analytical Archaeology. Methuen, London.

Cliff, M.

2003 Archeological Data Recovery Investigations of Four Burned Rock Midden Sites (41VV1892, 41VV1893, 41VV1895, and 41VV1897) Val Verde County, Texas. Texas Department of Transportation, Archeological Studies Program Report No. 51, and PBS\&J, Austin.

Close, A. E.

1978 The Identification of Style in Lithic Artifacts. World Archaeology 10(2):223-236.

Collins, M. B.

1974 A Functional Analysis of Lithic Technology Among Prehistoric HunterGatherers of Southwestern France and Western Texas. Unpublished Ph.D. dissertation, Department of Anthropology, The University of Texas at Austin.

1975 Lithic Technology as a Means of Processual Inference. In Lithic Technology: Making and Using Stone Tools, edited by E. Swanson, pp. 15-34. Mouton Publishers, The Hague.

1976 Terminal Pleistocene Cultural Adaptations in Southern Texas. Pretirage, Colloque XVII, Habitats Humains Anterieuvs A L' Holocene En Amerique. IX Congress, Union Internationale des Sciences Prehistorique et Proto Historiques. Nice, France.

1991 Thoughts on Future Investigation of Burned Rock Middens. In The Burned Rock Middens of Texas: An Archeological Symposium, edited by $\mathrm{T}$. R. Hester, pp. 1-24. Studies in Archeology, No. 13, Texas 
Archeological Research Laboratory, The University of Texas at Austin.

1994 The Late Archaic in the Project Area. In Archaic and Late Prehistoric Human Ecology in the Middle Onion Creek Valley, Hays County, Texas, by R. A. Ricklis and M. B. Collins, pp. 101-188. Studies in Archeology 19, Texas Archeological Research Laboratory, The University of Texas at Austin.

1995 Forty Years of Archeology in Central Texas. Bulletin of the Texas Archeological Society 66:361-400.

Collins, M. B. (assembler and editor)

1998 Wilson-Leonard An 11,000-year Archeological Record of HunterGatherers in Central Texas. Five volumes. Studies in Archeology 31, Texas Archeological Research Laboratory, The University of Texas at Austin, and Archeology Studies Program, Report 10, Texas Department of Transportation, Environmental Affairs Division, Austin.

Collins M. B., B. Ellis, and C. Dodt-Ellis

1990 Excavations at the Camp Pearl Wheat Site (41KR243): An Early Archaic Campsite on Town Creek, Kerr County, Texas. Studies in Archeology 6, Texas Archeological Research Laboratory, The University of Texas at Austin.

Collins, M. B., and C. E. Mear

1998 The Site and its Setting. In WilsonLeonard: An 11,000 year record of Hunter Gatherers in Central Texas, Volume I, assembled and edited by $\mathrm{M}$. B. Collins, pp. 5-32. Studies in Archeology 31, Texas Archeological Research Laboratory, The University of Texas at Austin.

Collins, M. B., and T. R. Hester

1968 A Wooden Mortar and Pestle from Val Verde County, Texas. Bulletin of the Texas Archeological Society 39:1-8.
Conaty, G. T.

1987 Comments on Hayden's Resource Models of Inter-Assemblage Variability. Lithic Technology 16(23):59-61.

Correll, D. S., and M. C. Johnston

1979 Manual of the Vascular Plants of Texas. The University of Texas at Dallas, $2^{\text {nd }}$ Printing.

Corrick, D. W.

2002 The Manufacture and Age of Toyah Arrow Points from Big Bend National Park, Texas. The Journal of Big Bend Studies 12:1-11.

Coupland, R. T.

1958 The Effects of Fluctuations in Weather Upon the Grasslands of the Great Plains. The Botanical Review 24(5):273-317.

Cowgill, G. L.

1968 Archaeological Applications of Factor, Cluster, and Proximity Analyses. American Antiquity 33:367-375.

Creel, D. G.

1986 A Study of Prehistoric Burned Rock Middens in West Central Texas. Unpublished Ph.D. dissertation. Department of Anthropology, The University of Arizona, Tucson.

1990 Excavations at 41TG91, Tom Green County, Texas, 1978. Publications in Archaeology, Report No. 38, Texas Department of Transportation, Austin.

1991 Assessing the Relationship Between Burned Rock Midden Distribution and Archaic Subsistence in West Central Texas. In Burned Rock Middens of Texas: An Archeological Symposium, edited by T. R. Hester, pp. 33-43. Studies in Archeology No. 13. Texas Archeological Research Laboratory, The University of Texas at Austin. 
1997 Chapter 5: Analysis of the Distribution of Burned Rock Midden Sites in the Study Area. In Burned Rock Middens of Texas: An Archeological Symposium, edited by T. R. Hester, pp. 89-98. Studies in Archeology No. 13.

Texas Archeological Research Laboratory, The University of Texas at Austin.

2002 Central Texas Ceramics Project. In Newsletter of the Friends of the Texas Archeological Research Laboratory.

2003 Update: Central Texas Ceramics Project. In Newsletter of the Friends of the Texas Archeological Research Laboratory.

Creel, D., and A. Johnson

2002 The Central Texas Ceramics Project. Paper Presented at the $73^{\text {rd }}$ Annual Meeting of the Texas Archeological Society, Laredo, Texas.

Cummings, L. S.

1994 Pollen, Phytolith, Marcofloral, and Charcoal Analyses at the Mustang Branch Site (41HY209) and the Barton Site (41HY202). In Archaic and Late Prehistoric Human Ecology in the Middle Onion Creek Valley, Hays County, Texas-Volume 2, by R. A. Ricklis and M. B. Collins, pp. 387-402. Studies in Archeology, No. 19, Texas Archeological Research Laboratory, The University of Texas at Austin.

Davis, D. R., Jr.

1995 Prehistoric Artifacts of the Texas Indian: An Identification and Reference Guide. Pecos Publishing Company, San Antonio.

Decker, S.

1997 Appendix J: Comparative Data From Excavated and Reported Burned Rock Middens In Greater Central Texas. In Hot Rock Cooking on the Greater Edwards Plateau: Four Burned Rock
Midden Sites in West Central Texas. Volume II, by S. L. Black, L. W. Ellis, D. G. Creel, and G. T. Goode pp. 685745. Texas Archeological Research Laboratory, The University of Texas at Austin, Studies in Archeology 22, and Texas Department of Transportation, Environmental Affairs Department, Archeology Studies Program, Report 2.

Decker, S., S. L. Black, and T. Gustavson

2000 The Woodrow Heard Site, 41UV188-A Holocene Terrace Site in the Western Balcones Canyonlands of Southwestern Texas. Texas Archeological Research Laboratory, The University of Texas at Austin, Studies in Archeology, No. 33, and Environmental Affairs Division, Texas Department of Transportation, Archeology Studies Program, Report 14. Austin, Texas.

DeNiro, M.J.

1987 Stable Isotopes and Archaeology. American Scientist 75:182-191.

DeNiro, M. J., and S. Epstein

1981 Influence of Diet on the Distribution of Nitrogen Isotopes in Animals. Geochimica et Cosmochimica Acta 45:341-351.

Dering, P.

1977 Plant Macrofossil Study: A Progress Report. In Archeological and Botanical Studies at Hinds Cave, Val Verde County, Texas, by H. J. Shafer and V. M. Bryant, pp. 84-102. Annual Report of Research, National Science Foundation, Texas A\&M University, Anthropology Laboratory, Special Series No. 1.

1979 Pollen and Plant Macrofossil Vegetation Record Recovered from Hinds Cave, Val Verde County, Texas. Unpublished Master's thesis, Texas A\&M University, Collage Station. 
1996 Plant Remains from a Late Archaic Crescent Midden in Hind Cave (41VV456), Val Verde County, Texas. Paper Complied for the Headwaters Experimental Group, on file with author.

1997 Appendix D: Macrobotanical Remains. In Hot Rock Cooking on the Greater Edwards Plateau: Four Burned Rock Midden Sites in West Central Texas. Volume II, by S. L. Black, L. W. Ellis, D. G. Creel, and G. T. Goode pp. 571600. Texas Archeological Research Laboratory, The University of Texas at Austin, Studies in Archeology 22, and Texas Department of Transportation, Environmental Affairs Department, Archeology Studies Program, Report 2.

1998a Carbonized Plant Remains from 41ZP364: Identification and Analysis Using Scanning Electron Microscopy. In Data Recovery at 41ZP364: An Upland Campsite at Falcon Reservoir, Zapata County, Texas, by J. M. Quigg and C. Cordova, pp. 285-296. TRC Technical Report No. 22317, TRC Mariah Associates, Inc., Austin, Texas.

1998b Chapter 40: Carbonized Plant Remains. In Wilson-Leonard An 11,000-year Archeological Record of HunterGatherers in Central Texas, assembled by M. B. Collins, pp. 16091636,VolumeV. Studies in Archeology 31, Texas Archeological Research Laboratory, The University of Texas at Austin, and Archeology Studies Program, Report 10, Texas Department of Transportation, Environmental Affairs Division, Austin.

1999 Earth Oven Plant Processing in Archaic Period Economies: an Example from a Semi-arid Savannah in South-central North America. American Antiquity 64(4):659-674.
2000 Carbonized Plant Remains from 41ZP364: Identification and Analysis Using Scanning Electron Microscopy. In Data Recovery at 41ZP364: An Upland Campsite at Falcon Reservoir, Zapata County, Texas, by J. M. Quigg and C. Cordova, pp. 285-296. TRC Technical Report No. 22317, TRC Mariah Associates, Inc., Austin, Texas.

2002 Amistad National Recreation Area: Archeological Survey and Cultural Resource Inventory. Report submitted to the National Park Service, Intermountain Cultural Resource Center, Santa Fe, New Mexico.

2003a Appendix C: Botanical Perspective on Land use in the Cross Timbers and Prairies: Plant Remains from Burned Rock Middens in Bowie County, Texas. In Archaeological Testing to Determine the National Register Eligibility Status of Eighteen Prehistoric Sites on Camp Bowie, Brown County, Texas, Volumes 1 and 2, by R. P. Mauldin, D. L. Nickels, and C. J. Broehm, pp. 61-91. Center for Archaeological Research, The University of Texas at San Antonio, Archeological Survey Report, No. 334.

2003b Appendix A: Plant Remains from U.S. Highway 277 Project, Val Verde County, Texas. In Archeological Data Recovery Investigations of Four Burned Rock Midden Sites (41VV1892, 41VV1893, 41VV1895, and 41VV1897) Val Verde County, Texas, by M. Cliff, pp A1-A22. Texas Department of Transportation, Archeological Studies Program Report No. 51, and PBS\&J, Austin.

2003c Appendix C: Plant Remains from Rice's Crossing (41WM815). In Archeological Investigations at 41WM815, A Backland Prairie Site, Williamson County, Texas, by R. K. Brownlow, pp. 113-120. Studies in 
Archeology 36, Texas Archeological Research Laboratory, The University of Texas at Austin and Archeological Studies Program, Report 23, Environmental Affairs Division, Texas Department of Transportation.

Dial, S. W.

1998 Chapter 15: Clear Fork Tools. In Wilson-Leonard An 11,000-year Archeological Record of HunterGatherers in Central Texas. Volume II assembled and edited by M. B. Collins, pp. 507-535. Studies in Archeology 31, Texas Archeological Research Laboratory, The University of Texas at Austin, and Archeology Studies Program, Report 10, Texas Department of Transportation, Environmental Affairs Division, Austin.

Dial, S. W., A. C. Kerr, and M. B. Collins

1998 Chapter 13: Projectile Points. In Wilson-Leonard An 11,000-year Archeological Record of HunterGatherers in Central Texas. Volume II assembled and edited by M. B. Collins, pp. 313-445. Studies in Archeology 31, Texas Archeological Research Laboratory, The University of Texas at Austin, and Archeology Studies Program, Report 10, Texas Department of Transportation, Environmental Affairs Division, Austin.

Dibble, D. S.

1967 Excavations at Arenosa Shelter, 196566. Report of the Texas Archeological Salvage Project, The University of Texas at Austin, to U.S. National Park Service.

Dibble, D. S., and D. Lorrain

1968 Bonfire Shelter: A Stratified Bison Kill Site, Val Verde County, Texas. Miscellaneous Papers, No. 1, Texas Memorial Museum, Austin.
Dillehay, T. D.

1974 Late Quaternary Bison Population Changes on the Southern Plains. Plains Anthropologist 19(65):180-196.

Doran, G. H.

1976 The Next Week Site. State Department of Highways and Public Transportation, Publication in Archaeology, Highway Design Division, Report No. 9, Austin.

Duisberg, P. C.

1952 Desert Plant Utilization. The Texas Journal of Science 3:269-284.

Duncan, R. B., and W. H. Doleman

1991 Fire-Cracked Rock Studies. In Landscape Archeology in the Southern Tularosa Basin. Volume 2 Testing, Excavation, and Analysis, edited by W. H. Doleman, R. C., Chapman, J. A. Schutt, M. K. Swift, and K. D. Morrison, pp. 317-344. Office of Contract Archeology, University of New Mexico, Report No. 185-324E and White Sands Missile Range Archeological Report No. 91-9.

Duncan, M.

1995 Calf Creek Foragers: Mobility on the Southern Plains During the Altithermal. Bulletin of the Oklahoma Anthropological Society XLII:89-144.

Dunnell, R. C.

1978 Style and Function: A Fundamental Dichotomy. American Antiquity 43(2):192-202.

Eickmeier, W. G., and M. M. Bender

1976 Carbon Isotope Ratios of Crassulacean Acid Metabolism Species in Relation to Climate and Phytosociology. Oecologia 25:341-347.

Ellen, R. F.

1982 Environment, Subsistence and System: The Evolution of Small Scale Social 
Formations. Cambridge University Press, Cambridge.

Ellis, G. L.

1993 Theoretical Perspective. In Significance Standards for Prehistoric Cultural Resources: A Case Study From Fort Hood, Texas, by G. L. Ellis, C. Lintz, W. N. Trierweiler, and J. M. Jackson, pp. 37-122. TRC Mariah Associates, Inc., Austin, Texas.

Ellis, G. L., C. Lintz, W. N. Trierweiler, and J. M. Jackson

1993 Significance Standards for Prehistoric Cultural Resources: A Case Study from Fort Hood, Texas. Mariah Associates, Inc., Austin, Texas.

Ellis, L. W.

1997 Hot Rock Technology. In Hot Rock Cooking on the Greater Edwards Plateau: Four Burned Rock Midden Sites in West Central Texas, by S. L. Black, L. W. Ellis, D. G. Creel, and G. T. Goode, pp. 43-81. Studies in Archeology 22, Texas Archeological Research Laboratory, University of Texas at Austin. Archeology Studies Program, Report 2, Texas Department of Transportation, Environmental Affairs Department, Austin.

Firth, R.

1975 The Skeptical Anthropologist? Social Anthropology and Marxist Views on Society. In Marxist Perspectives and Social Anthropology, edited by $\mathrm{M}$. Block, pp. 29-60. Malaby Press, London, England.

Flannery, K. V.

1968 Archaeological Systems Theory and Early Mesoamerica. In Anthropological Archaeology in the Americas, edited by B. J. Meggars, pp. 67-87. Anthropological Society of Washington, D.C.

Frederick, C. D. n.d. Preliminary impressions of the Alluvial Stratigraphy of the San Antonio River. In Mission Reach: Archeological Testing of 4 Sites in Bexar County, Texas. Geo-Marine, Inc., Plano, Texas.

2001 Geoarchaeological Investigations. Appendix A in Test Excavations at the Culebra Creek Site, 41BX126, Bexar County, Texas, by D. L. Nickels, C. B. Bousman, J. D. Leach, D. A. Cargill, S. L. Black, J. P. Dering, C. D. Frederick, W. Göse, R. Jones, W. W. McKinney, K. A. McRae, B. A. Meissner, B. K. Moses, and L. C. Nordt, pp. 254-265. Archaeological Survey Report No. 265, Center for Archaeological Research, The University of Texas at San Antonio.

Frederick, C. D., M. D. Glascock, H. Neff, and C. M. Stevenson

1994 Evaluation of Chert Patination as a Dating Technique: A Case Study from Fort Hood, Texas. United States Army Fort Hood, Archeological Resource Management Series, Research Report No. 32. TRC Mariah Associates, Inc., Austin, Texas.

Frederick, C. D., and C. Ringstaff

1994 Lithic Resources at Fort Hood: Further Investigations. In Archeological Investigations on 571 Prehistoric Sites at Fort Hood, Bell and Coryell Counties, Texas, edited by W. N. Trierweiler, pp. 125-181. United States Army Fort Hood, Archeological Resource Management Series, Research Report No. 31. TRC Mariah Associates, Inc., Austin, Texas.

Fredlund, G.

1998 Phytolith Analysis. In Wilson-Leonard An 11,000-year Archeological Record of Hunter-Gatherers in Central Texas, Volume V: Special Studies, assembled and edited by M. B. Collins, pp. 16371651. Studies in Archeology 31, Texas 
Archeological Research Laboratory, The University of Texas at Austin, and Archeology Studies Program, Report 10, Texas Department of Transportation, Environmental Affairs Division, Austin.

Fredlund, G. G., C. B. Bousman, and D. K. Boyd

1998 The Phytolith Record from Morgan Playa in the Rolling Plains of Texas. Plains Anthropologist 43(164):187-200.

Fredlund, G. G., and L. L. Tieszen

1998 Stable Carbon Isotope Analysis of Soil Organic Matter. In Wilson-Leonard An 11,000-year Archeological Record of Hunter-Gatherers in Central Texas. Five volumes, assembled and edited by M. B. Collins, pp. 1653-1656. Studies in Archeology 31, Texas Archeological Research Laboratory, The University of Texas at Austin, and Archeology Studies Program, Report 10, Texas Department of Transportation, Environmental Affairs Division, Austin.

Freeman, C. E.

1973 Some Germination Responses of Lechuguilla (Agave Lecheguilla Torr.) Southwestern Naturalist 18(2):125-134.

Frison, G. C.

1978 Prehistoric Hunters of the High Plains. Academic Press, New York.

Gearhart, R. L.

1987 A Study of Central Texas Burned Rock Middens: Their Formation, Function and Rate of Accumulation. Unpublished Master's thesis, The University of Missouri, Columbia.

Gee, K. L., J. H. Holman, M. K. Causey, A. N. Rossi, and J. B. Armstrong

2002 Aging White-tail Deer by Tooth Replacement and Wear: A Critical Evaluation of a Time-honored
Technique. Wildlife Society Bulletin 30(2):378-393.

Geertz, C.

1973 The Interpretation of Cultures. Basic Books, New York.

Gehlbach, F. R.

1988 Forest and Woodlands of the Northeastern Balcones Escarpment. In Edwards Plateau Vegetation: Plant Ecology Studies in Central Texas, edited by B. Amos and F. R. Gehlbach, pp. 57-78. Baylor University Press, Waco.

Geraghty, J., D. Miller, F. Van Der Leeden, and F. Troise

1973 Water Atlas of the United States. Water Information Center Publication, Port Washington, New York.

Gifford, D.

1960 The Type-Variety Method. American Antiquity 25:341-347.

Gile, L. H., F. F. Peterson, and R. B. Grossman

1966 Morphological and Genetic Sequences of Carbonate Accumulation in Desert Soils. Soil Science 106:6-15.

Glascock, M. D.

2003 Appendix 6: Letter Report on INAA 30 Chert Samples from Leon Creek. In Pavo Real (41BX52): A Paleoindian and Archaic Camp and Workshop on the Balcones Escarpment, SouthCentral Texas, by M. B. Collins, D. B. Hudler, and S. L. Black, pp. 291-298. Studies in Archeology 41, Texas Archaeological Research Laboratory, The University of Texas at Austin and Archeological Studies Program, Report 50, Environmental Affairs Division, Texas Department of Transportation, Austin. 
Goland, C. A.

1983 The Ecological Context of HunterGatherer Storage Strategies. Unpublished Master's thesis, Department of Anthropology, University of North Carolina, Chapel Hill.

Goldberg, P., and V. T. Holliday

1998 Geology and Stratigraphy. . In WilsonLeonard: An 11,000 year record of Hunter Gatherers in Central Texas, Volume I, assembled and edited by $\mathrm{M}$. B. Collins, pp. 77-121. Studies in Archeology 31, Texas Archeological Research Laboratory, The University of Texas at Austin.

Gose, W. A.

2000 Paleomagnetic Studies of Burned Rocks. Journal of Archaeological Science 27:409-421.

Goode, G. T.

1991 Late Prehistoric Burned Rock Middens in Central Texas. In The Burned Rock Middens of Texas: An Archaeological Symposium, edited by T. R. Hester, pp. 71-93. Studies in Archeology 13, Texas Archeological Research Laboratory, The University of Texas At Austin.

2002 The Anton Site: A Prehistoric Encampment in Southern Uvalde County, Texas. Texas Department of Transportation, Environmental Affairs Division, Archeology Studies Program, Report 38, Austin.

Gould, R. A.

1980 Living Archaeology. Cambridge University Press, Cambridge.

Greer, J. W.

1967 Midden Circles Versus Mescal Pits. American Antiquity 32(1):108-109.

1966 Results of Archeological Excavations at the Castle Canyon Site, Val Verde
County, Texas. Southwestern Lore 32(1):10-18.

Grission-Mayer, H. D., C. H. Baisan, and T. W. Swetnam

1997 A 1,373 Year Reconstruction of Annual Precipitation for the Southern Rio Grande Basin. Directorate of Environment, Natural Resources Division, Fort Bliss, Texas.

Habig, M. A.

1968 The Alamo Chain of Missions: A History of San Antonio's Five Old Missions. Franciscan Herald Press, Chicago.

Haines, F.

1970 The Buffalo. Thomas Y. Crowell, New York.

Hall, G. D.

1981 Allens Creek: A Study in the Cultural Prehistory of the Lower Brazos River Valley, Texas. Research Report No. 61, Texas Archeological Survey, The University of Texas at Austin.

Hall, G. D., S. L. Black, and C. Graves

1982 Archeological Investigations at Choke Canyon Reservoir, Southern Texas: Results of Phase I Findings. Choke Canyon Series $5 . \quad$ Center for Archaeological Research, The University of Texas at San Antonio.

Hall, G. D., T. R. Hester, and S. L. Black

1986 The Prehistoric Sites at Choke Canyon Reservoir, Southern Texas: Results of Phase II Archaeological Investigations. Choke Canyon Series 10, Center for Archaeological Research, The University of Texas at San Antonio.

Hall, S. A.

1990 Channel Trenching and Climate Change in the Southern U.S. Great Plains. Geology 18:342-345. 
Halloran, A. F.

1968 Bison (Bovidae) Production on the Wichita Mountains Wildlife Refuge, Oklahoma. The Southern Naturalist 13(1):23-26.

Hames, R., and W. Vickers

1982 Optimal Diet Breadth Theory as a Model to Explain Variability in Amazonia Hunting. American Ethnologist 9:358-378.

Hames, R., and W. Vickers (editors)

1983 Adaptive Responses of Native Amazonians. Academic Press, New York.

Hammon, G. P., and A. Ray

1966 The Rediscovery of New Mexico 15801594. The University of New Mexico Press, Albuquerque.

Hard, R. J., and J. R. Roney

1998 A Massive terraced Village Complex in Chihuahua, Mexico, 3000 Years Before Present. Science 279:1661-1664.

Hard, R. J., J. E. Zapata, B. K. Moses, and J. R. Roney

1999 Terraced Construction in Northern Chihuahua, Mexico: 1150 B.C. and Modern Experiments. Journal of Field Archaeology 26(2):129-146.

Hardy, B. L.

2002 Results of Microscopic Use-wear and Residue Analyses from Site 41WB557, Texas. In The Boiler Site (41WB557): Utilization of an Upland Setting Over the Last 4200 Years, Webb County, Texas, by J. M. Quigg, S. Pritchard, and G. Smith, pp. D-1-36. TRC Technical Report No. 27277, TRC Environmental Corporation, Austin, Texas.

Harris, E. S.

1985 An Archaeological Study of the Timmeron Rockshelter (41HY95), Hays County, South Central Texas. Southern
Texas Archaeological Association, Special Publication No. 4, San Antonio.

Hawkes, K., K. Hill, and J. O’Connell

1982 Why Hunters Gather: Optimal Foraging and the Ache of Eastern Paraguay. American Ethnologist 9:379-398.

Hayden, B.

1986 Resource Models of Inter-Assemblage Variability. Lithic Technology 15(3):82-89.

1987 Reply to Conaty. Lithic Technology 16(2-3):62.

Heffley, S.

1981 The Relationship Between Northern Athapaskan Settlement Patterns and Resource Distribution: An Application of Horn's Model. In Hunter-Gatherer Foraging Strategies: Ethnographic and Archaeological Analyses, edited by B. Winterhalder and E. A. Smith, pp. 126147. University of Chicago Press, Chicago.

Helm, J.

1962 The Ecological Approach in Anthropology. American Journal of Sociology 67:630-639.

Henderson, J.

2001 Excavations at the Rainey Site (41BN33): A Late Prehistoric Sinkhole Site in Bandera County, Texas. Texas Department of Transportation, Environmental Affairs Division, Archeological Studies Program, Report 5, Austin.

Henry, D. O.

1989 Correlations Between Reduction Strategies and Settlement Patterns. In Alternative Approaches to Lithic Analysis, edited by D. O. Henry and G. H. Odell, pp. 139-212. Westview Press: Boulder, Colorado. 
Hester, T. R.

1970 Burned Rock Middens on the Southwestern Edge of the Edwards Plateau, Texas. Plains Anthropologist 15(50):237-250.

1971 Archeological Investigations at the La Jita Site, Val Verde County, Texas. Bulletin of the Texas Archeological Society 42:51-148.

1978 Notes on the Edwards Arrow Point Type. La Tierra 5(4):21-31

1979 Notes on Gower, Jetta, and Other Projectile Points of the Pre-Archaic Period in Texas. La Tierra 6(3):5-8.

1988 A Chronological Framework for Lower Pecos Prehistory. Bulletin of the Texas Archeological Society 59:53-64.

1995 The Prehistory of South Texas. Bulletin of the Texas Archeological Society 66:427-459.

Hester, T. R. (editor)

1991 The Burned Rock Middens of Texas: An Archeological Symposium. Studies in Archeology 13, Texas Archeological Research Laboratory, The University of Texas at Austin.

Hester, R. H., F. Asaro, F. Stross, A. C. Kerr, and R. D. Giauque

1991 Trace Element Analyses and Geologic Source Studies of Obsidian Artifacts from Arenosa Shelter, Val Verde County, Texas. In Papers on Lower Pecos Prehistory, edited by S. A. Turpin, pp. 191-198. Studies in Archeology 8, Texas Archeological Research Laboratory, The University of Texas at Austin.

Hester, R. H., D. Gilbow, and A. D. Albee

1973 A Functional Analysis of "Clear Fork" Artifacts from the Rio Grande Plain, Texas. American Antiquity 38(1):9096.
Highley, C. L., R. J. Leneave, M.L. Dreiss, and S. L. Black

1995 Artifact Analysis. In Archaeological Investigations at the Loma Sandia Site (41LK28): A Prehistoric Cemetery and Campsite in Live Oak County, Texas, by A. J. Taylor and C. L. Highley, pp. 405-519. Studies in Archeology 20, Texas Archeological Research Laboratory, University of Texas at Austin.

Hill, James N. and Joel Gunn, editors

1977 The Individual in Prehistory: Studies of Variability in Style in Prehistoric Technologies. Academic Press, Inc., New York.

Hines, M. H.

1994 Data Recovery Excavations at the Wind Canyon Site, 41HZ119, Hudspeth County, Texas. Reports of Investigations 99. Prewitt and Associates, Inc., Austin, Texas.

Hodder, I.

1986 Reading the Past. Cambridge University Press, Cambridge.

Hofman, J. L., L. C. Todd, and M. B. Collins

1991 Identification of Central Texas Edwards Chert at the Folsom and Lindenmeier Sites. Plains Anthropologist 36(137):297-308.

Holliday, V. T.

1985 Early and Middle Holocene Soils at the Lubbock Lake Archeological Site, Texas. Catena 12:61-78.

1995 Stratigraphy and Paleoenvironments of Late Quaternary Valley Fills on the Southern High Plains. Geological Society of America, Inc., Boulder.

Holloway, R. G., L. M. Raab, and R. Stuckenrath

1987 Pollen Analysis of Late-Holocene Sediments from a Central Texas Bog. 
The Texas Journal of Science 39(1):7179.

Horn, H. S.

1968 The Adaptive Significance of Colonial Nesting in the Brewers Blackbird (Euphagers cyanocephalus). Ecology 49:682-694.

Howard, C. D.

1973 A Study of the Clear Fork Gouge. Bulletin of the Texas Archeological Society 44:51-60.

Howard, M. A.

1983 A Quantitative Study of the Booker Site and Other Burned Rock Midden Sites of the Lake Travis Basin, Central Texas. Unpublished Master's thesis, The University of Texas at Austin.

1991 Burned Rock Midden Excavations, Hearths and Botanical Remains. In The Burned Rock Middens of Texas: An Archeological Symposium, edited by $\mathrm{T}$. R. Hester, pp. 45-69. Studies in Archeology Number 13. Texas Archeological Research Laboratory, The University of Texas at Austin.

Howard, M, L. A. Garcia, C. Beceiro, D. K. Utley, A. Ringstaff, and A. J. Dodge

1996 Archeological Survey of Devils Sinkhole State Park Natural Area, Edwards County, Texas. Texas Parks and Wildlife Division, Public Lands Division, Cultural Resource Program, Austin.

Howells, R. G., R. W. Neck, and H. D. Murry

1996 Freshwater Mussels of Texas. Texas Parks and Wildlife Department, Inland Fisheries Division, Austin.

Hudler, D. B.

1997 Determining Clear Fork Tool Function Through Use-wear Analysis: A Discussion of Use-wear Methods and Clear Fork Tools. Studies in Archeology 25. Texas Archeological
Research Laboratory, The University of Texas at Austin.

2003a Research Module 1: Interpreting Variability in Projectile Points. In Pavo Real (41BX52): A Paleoindian and Archaic Camp and Workshop on the Balcones Escarpment, South-Central Texas, by M. B. Collins, D. B. Hudler, and S. L. Black, pp. 337-373. Studies in Archeology 41, Texas Archaeological Research Laboratory, The University of Texas at Austin and Archeological Studies Program, Report 50, Environmental Affairs Division, Texas Department of Transportation, Austin.

2003b Appendix 5: Instrumental Neutron Activation Analysis Results. In Pavo Real (41BX52): A Paleoindian and Archaic Camp and Workshop on the Balcones Escarpment, South-Central Texas, by M. B. Collins, D. B. Hudler, and S. L. Black, pp. 287-290. Studies in Archeology 41, Texas Archaeological Research Laboratory, The University of Texas at Austin and Archeological Studies Program, Report 50, Environmental Affairs Division, Texas Department of Transportation, Austin.

Huebner, J. A.

1991a Cactus for Dinner, Again: An Isotopic Analysis of Late Archaic Diet in the Lower Pecos Region of Texas. In Papers on Lower Pecos Prehistory, edited by S. A. Turpin, pp. 175-190. Studies in Archeology 8, Texas Archeological Research Laboratory, The University of Texas at Austin.

1991bLate Prehistoric Bison Populations in Central and Southern Texas. Plains Anthropologist 36(137):343-358.

Huebner, J. A., and T. W. Boutton

1990 The Isotope Ecology of Bison in Texas. Paper Presented at the $48^{\text {th }}$ Plains 
Anthropological Conference, Oklahoma City.

Huebner, J. A., and A. G. Comuzzie

1992 The Archeology and Bioarcheology of Blue Bayou: A Late Archaic and Late Prehistoric Mortuary Locality in Victoria County, Texas. Studies in Archeology 9, Texas Archeological Research Laboratory, The University of Texas at Austin.

Huskey, V.

1935 An Archeological Survey of the Nueces Canyon of Texas. Bulletin of the Texas Archeological and Paleontological Society 7:105-114.

Ilger, W. A., M. Hyman, and M. W. Rowe

1994 Radiocarbon Dates for a Red Linear Style Pictograph. Bulletin of the Texas Archeological Society 65:336-346.

Jackson, M. A.

1998 The Nature of Fire-cracked Rock: New Insights from Ethnoarchaeological and Laboratory Experiments. Unpublished Master's thesis, Texas A\&M University, College Station.

Jelks, E. B.

1953 Excavations at the Blum Rockshelter. Bulletin of the Texas Archeological Society 24:189-207.

1962 The Kyle Site: A Stratified Central Texas Aspect Site in Hill County, Texas. Archaeological Series No. 5, Department of Anthropology, The University of Texas at Austin.

1978 The Diablo Range. In Chronologies in New World Archeology, edited by R. E. Taylor and C. W. Meighan, pp. 71-111. Academic Press: New York.

Jochim, M. A.

1976 Hunter-Gatherer Subsistence and Settlement: A Predictive Model. Academic Press, New York.
1989 Optimization and Stone Tool Studies: Problems and Potential. In Time, Energy and Stone Tools, edited by R. Torrence, pp. 106-111. Cambridge University Press, Cambridge.

Johnson, E. (editor)

1987 Lubbock Lake: Late Quaternary Studies on the Southern High Plains. Texas A\&M University Press, College Station.

Johnson, L., Jr.

1962 The Yarbrough and Miller Sites of Northeastern Texas with a Preliminary Definition of the La Harpe Aspect. Bulletin of the Texas Archeological Society 32:141-284.

1963 Pollen Analysis of Two Archeological Sites at Amistad Reservoir, Texas. The Texas Journal of Science XV(2):225230.

1964 The Devil's Mouth Site: A Stratified Campsite at Amistad Reservoir, Val Verde County, Texas. Archeology Series No. 6. Department of Anthropology, The University of Texas at Austin.

1967 Towards a Statistical Overview of the Archaic Cultures of Central and Southwestern Texas. Bulletin 12. Texas Memorial Museum, Austin.

1982 Review of Allens Creek: A Study in the Cultural Prehistory of the Lower Brazos Valley, Texas, by G. D. Hall. Bulletin of the Texas Archeological Society 53:203-212.

1987 A Plague of Phases: Recent Sociocultural Taxonomy in Texas Archaeology. Bulletin of the Texas Archeological Society 57:1-26.

1991 Early Archaic Life at the Sleeper Archaeological Site, 41BC65 of the Texas Hill County Blanco County, Texas. Texas Department of Highways 
and Public Transportation, Highway Design Division, Publications in Archaeology, Report No. 39, Austin.

1994 Life and Times of Toyah-Culture Folk: The Buckhollow Encampment, Site 41KM16, Kimble County, Texas. Office of the State Archeologist, Report No. 38. Texas Department of Transportation and Texas Historical Commission, Austin, Texas.

1995 Cultures and Climates at the Jonas Terrace Site, 41ME29 of Medina County, Texas. Office of the State Archeologist Report 40. Texas Department of Transportation and Texas Historical Commission, Austin, Texas.

Johnson, L., and G. T. Goode

1994 A New Try at Dating and Characterizing Holocene Climates as well as Archeological Periods, on the Eastern Edwards Plateau. Bulletin of the Texas Archeological Society 65:151.

Jones, J. G.

2003 Preliminary Pollen and Phytolith Results, 41ED28, Edwards County, Texas. Letter submitted to TRC Environmental Corporation, May 1, 2003.

Karbula, J. W.

2000 Investigations of the Eckols Site (41TV528): A Stratified Prehistoric Terrace Site on Barton Creek in Travis County, Texas. Unpublished Ph.D. dissertation, The University of Texas at Austin.

Karlstrom, E. T.

1988 Rates of Soil Formation on Black Mesa, Northeast Arizona: A Chronosequence in Late Quaternary Alluvium. Physical Geography 9:301-327.
Keeley, L. H.

1982 Hafting and Retooling: Effects on the Archaeological Record. American Antiquity 47:798-809.

1991 Tool Use and Spatial Patterning: Complications and Solution. In The Interpretation of Archaeological Spatial Patterning, edited by E. M. Kroll and T. D. Price, pp. 257-268. Plenum Press, New York.

Keller, J. E.

1976 The Stickleaf Site. State Department of Highways and Public Transportation, Publication in Archaeology, Highway Design Division, Report No. 8, Austin.

Kelley, J. C.

1947a The Cultural Affiliations and Chronological Positions of the Clear Fork Focus. American Antiquity 12(2):97-109.

1947b The Lehman Rock Shelter: A Stratified Site of the Toyah, Uvalde, and Round Rock Foci. Bulletin of the Texas Archeological and Paleontology Society 18:118-128.

1961 The Crumley Site: A Stratified Burnt Rock Midden, Travis County, Texas. Bulletin of the Texas Archeological Society 31:239-272.

Kelley, J. C., and T. N. Campbell

1942 What are the Burned-Rock Mounds of Texas. American Antiquity 7:319-322.

Kelly, R. L.

1983 Hunter-Gatherer Mobility Strategies. Journal of Anthropological Research 39:277-306.

1988 The Three Sides of a Biface. American Antiquity 53:717-734.

1992 Mobility/Sedentism: Concepts, Archaeological Measures, and Effects. Annual Review of Anthropology 21:4436. 
1995 The Foraging Spectrum: Diversity in Hunter-Gatherer Lifeways. Smithsonian Institution Press, Washington, D.C.

Kelly, T. C.

1979 Gower Projectile Points? La Tierra, Journal of the Southern Texas Archaeological Association, 6(2):13-19.

Kenmotsu, N. A.

1994 Helping Each Other Out: A Study of the Mutualistic Relations of Small Scale Foragers and Cultivators in La Junta del Los Rios Region, Texas and Mexico. Unpublished Ph.D. dissertation, The University of Texas at Austin.

2001 Seeking Friends, Avoiding Enemies: The Jumano Response to Spanish Colonization, A.D. 1580-1750. Bulletin of the Texas Archeological Society 72:23-43.

Kenmotsu, N. A., and M. F. Wade

2002 Amistad National Recreation Area, Del Rio, Texas. American Indian Tribal Affiliation Study Phase I: Ethnohistoric Literature Review. The Texas Department of Transportation, Archeological Studies Program, Report No. 34, and The National Park Service, Amistad National Recreation Area, Del Rio, Texas.

Kennard, D. (editor)

1975 Devil's Sinkhole Area: Headwaters of the Nueces River, A Natural Survey Area, Part VIII of VIII. Division of Natural Resources and Environment, The University of Texas at Austin.

Kerr, A. C., and S. W. Dial

1998 Chapter 14, Statistical Analysis of Unfluted Lanceolate and Early Bifurcate Stem Projectile Points. In Wilson-Leonard An 11,000-year Archeological Record of HunterGatherers in Central Texas. Volume II assembled and edited by M. B. Collins, pp. 447-505. Studies in Archeology 31, Texas Archeological Research Laboratory, The University of Texas at Austin, and Archeology Studies Program, Report 10, Texas

Kibler, K. W., and A. M. Scott

2000 Archaic Hunters and Gatherers of the Balcones Canyonlands: Data Recovery at the Cibolo Crossing Site (41BX377), Bexar County, Texas. Reports of Investigations, Number 126, Prewitt and Associates, Inc., Austin.

Kirkland, F., and W. W. Newcomb, Jr.

1967 The Rock Art of Texas Indians. University of Texas Press, Austin.

Kittleman, L. R.

1994 A Microscopical Analysis of Potsherds from the Toyah Culture of Texas. Appendix IV in The Life and Times of Toyah-Culture Folk, as Seen from the Buckhollow Encampment, Site 41KM16, of Kimble County, Texas, by L. Johnson, pp. 308-315. Office of the State Archeologist Report 38. Texas Department of Transportation and Texas Historical Commission, Austin.

Klein, R. G., and K. Cruz-Uribe

1984 The Analysis of Animal Bones from Archeological Sites. The University of Chicago Press, Chicago.

Kleinback, K., G. Mehalchick, J. T. Abbott, J. M. Quigg

1995 Other Analyses. In NRHP Significance Testing of 57 Prehistoric Archeological Sites on Fort Hood, Texas. United States Army Fort Hood, Archeological Resource Management series, Research Report No. 34.

Krieger, A. D.

1945 Some Suggestions on Archaeological Terms. Bulletin of the Archaeological and Paleontological Society 16:41-51. 
Krumbein, W. C., and L. L. Sloss

1963 Stratigraphy and Sedimentation, $2^{\text {nd }}$ Edition. W. H. Freeman: San Francisco, California.

Kuchler, A. W.

1964 Potential natural Vegetation of the Conterminous United States. American Geographical Society Special Publications, New York.

Kuhn, S. L.

1989 Hunter-Gatherer Foraging Technology and Strategies of Artifact Replacement and Discard. In Experiments in Lithic Technology, edited by D. Amick and R. Mauldin, pp. 33-47. BAR International Series 528. British Archaeological Reports, Oxford.

Kwiatkowski, S.

1992 The Rye Creek Floatation and Macrobotanical Analyses. In The Rye Creek Project: Archaeology in the Upper Tonto Basin. Volume 2: Artifact and Specific Analyses, pp. 325-375. Anthropological Papers No. 11. Center for Desert Archaeology, Tucson.

Larkin, T. J., and G. W. Bomar

1983 Climatic Atlas of Texas. Texas Department of Water Resources, Austin, Texas.

Larson, D. A., V. M. Bryant, and T. S. Patty

1972 Pollen Analysis of a Central Texas Bog. The American Midland Naturalist 88(2):358-367.

Laszlo, E.

1987 Evolution: The Grand Synthesis. New Science Library, Boston.

Lawrence, P. R., and J. W. Lorsch

1980 Differentiation and Integration in Complex Organizations. In Organizations, Structure, and Behavior, edited by J. A. Litterer, pp. 568-595. J. Wiley and Sons, New York.
Leach, J. D., D. L. Nickels, B. K. Moses, and R. Jones

1998 A Brief Comment on Estimating Rates of Burned Rock Discard: Results from an Experimental Earth Oven. La Tierra (25)3:42-50.

2001 Appendix D: Estimating Rates of Burned Rock Discard: Results from an Experimental Earth Oven. In Test Excavations at the Culebra Creek Site, 41BX126, Bexar County, Texas, by D. L. Nickels, C. Britt Bousman, J. D. Leach, and D. A. Corgill, pp. 275-282. Archaeological Survey Report, No. 265, Center for Archaeological Research, The University of Texas at San Antonio, and Archeological Studies Program, Report 3, Environmental Affairs Division, Texas Department of Transportation, Austin.

Leach, J. D., C. Britt Bousman, and D. L. Nickels,

2005 Assigning Context to Artifacts in Burned-Rock Middens. Journal of Field Archaeology 30:201-203.

Lechtman, $\mathrm{H}$.

1977 Style in Technology: Some Early Thoughts. In Material Culture: Styles, Organization, and Dynamics of Technology, edited by H. Lechtman and R. Merrill, pp. 3-20. Proceedings of the American Ethnological Society. West Publishers: St. Paul, Minnesota.

Lee, R. B.

1979 The !Kung San: Men, Women, and Work in a Foraging Society. Cambridge University Press, Cambridge.

Lee, R. B., and I. DeVore (editors)

1976 Kalahari Hunter-Gatherers: Studies of the !Kung San and Their Neighbors. Harvard University Press, Cambridge. 
Lemmonier, $\mathrm{P}$.

1976 La Description des Chaînes Opératoire: Contribution a L'analyse des Systèmes Techniques. In Techniques et Culture I. $\mathrm{MSH}$.

1992 Elements for an Anthropology of Technology. Anthropological Papers, No. 88. Museum of Anthropology, University of Michigan, Ann Arbor

Leroi-Gourhan, A.

1943 L'Homme et Le Matière. Albain Michel, Paris, France.

1945 Milieu et Techniques. Albain Michel, Paris, France.

Lintz, C. R.

1989 Experimental Thermal Discoloration and Heat Conductivity Studies of Caliche from Eastern New Mexico. Geoarchaeology 4(4):319-346.

Lintz, C., A. C. Treece, and F. Oglesby

1995 The Early Archaic Structure at the Turkey Bend Ranch Site (41CC112), Concho County. In Advances in Texas Archeology: Contributions from Cultural Resource Management (Chapter 5), edited by J. E. Bruseth and T. K. Perttula, pp. 155-186. Cultural Resources Management Report 5, Texas Historical Commission.

Lintz, C., G. D. Smith, and R. Clem

2002 Initial Data Recovery Phase at 41ED28 Along Hackberry Creek, Edwards County, Texas: An Interim Report. TRC Environmental Corporation, Austin, Texas.

Lintz, C., W. N. Trierweiler, A. C. Earls, F. M. Oglesby, M. Blum, P. L. O’Neill, J. Kuhl, R. Holloway, L. Scott-Cummings, and D. Scurlock

1993 Cultural Resource Investigations in the O. H. Ivie Reservoir, Concho, Coleman, and Runnels Counties, Texas-Volume I: Project Introduction, Setting and
Methods. Technical Report No. 346-I, Mariah Associates, Inc., Austin, Texas.

Lord, K. J.

1984 The Zooarchaeology of Hinds Cave (41VV456), Val Verde County, Texas. Unpublished Master's thesis, Department of Anthropology, Texas A\&M University, College Station.

Lorrain, D.

1968 Archeological Excavations in Northwestern Crockett County, Texas. 1966-1967. State Building Commission, Archeological Program, Report Number 12.

Loy, T. H.

1994 Residue Analysis of Artifacts and Burned Rock from the Mustang Branch and Barton Sites (41HY209 and 41HY202). In Archaic and Late Prehistoric Human Ecology in the Middle Onion Creek Valley, Hays County, Texas, by R. A. Ricklis, and M. B. Collins, pp. 607-627. Studies in Archeology 19, Texas Archeological Research Laboratory, The University of Texas at Austin.

Lucas, J. R. and C. D. Frederick

1998 Burned Rock as Artifact. In Archeology Along the Wurzbach Parkway: Module 3 Investigation and Experimentation at the Higgins Site (41BX184), by S. L. Black, K. Jolly, C. D. Frederick, J. R. Lucas, J. W. Karbula, P. R. Takac, and D. R. Potter, pp. 163-188. Studies in Archeology 27, Texas Archeological Research Laboratory, The University of Texas at Austin.

Luke, C. J.

1980 Continuing Archaeology on State Highway 16 in Kerr County Texas: The Excavations of the Sheep Site (41KR109) and the Wounded Eye Site (41KR107). Texas Department of 
Highways and Public Transportation, Highway Design Division, Publications in Archaeology, Report No. 16, Austin.

1981 Test Excavations at Three Burned Rock Midden Sites in Sutton and Schleicher Counties, Texas. Texas State Department of Highways and Public Transportation, Highway Design Division, Publications in Archaeology, Report No. 19, Austin.

Lukowski, P. D.

1987 Archeological Investigations Along the Leona River Watershed, Uvalde County, Texas. Archeological Survey Report 132. Center for Archeological Research, The University of Texas at San Antonio.

1988 Archaeological Investigations at 41BX1, Bexar County, Texas. Center for Archaeological Research, The University of Texas at San Antonio, Archaeological Survey Report, No. 135.

Mac Arthur, R. H. and E. O. Wilson

1967 The Theory of Island Biogeography. Monographs in Population Biology. Princeton University Press, Princeton.

Machette, M. N.

1985 Calcic Soils of the Southwestern United States. In Soils and Quaternary Geology of the Southwestern United States, edited by D. L. Weide, pp. 1-21. Special Paper, No. 203. Geological Society of America: Boulder, Colorado.

Mahoney, R. B., R. P. Mauldin, and S. A. Tomka

2002 Archeological Data Recovery Excavations along Becerra Creek (41WB556), Webb County, Texas. Archeological Survey Report No. 321, Center for Archaeological Research, The University of Texas at San Antonio and Texas Department of Transportation, Environmental Affairs
Division, Archeological Studies Program Report No. 44.

Mahoney, R. B., H. J. Shafer, S. A. Tomka, L. C. Nordt, and R. P. Mauldin

2003 Royal Coachman (41CM111), An Early Middle Archaic Site along Cordova Creek in Comal County, Texas. Texas Department of Transportation, Environmental Affairs Division, Archeological Studies Program Report No. 49 and the Center for Archaeological Research, The University of Texas at San Antonio, Archeological Survey Report No. 332.

Malainey, M. E., and K. L. Malisza

2003 Appendix C: Analysis of Fatty Acid Compositions of Archeological Residues from 41CV595. In Shifting Sands and Geophytes: Geoarcheological Investigations at Paluxy Sites on Fort Hood, Texas, by G. Mehalchick, D. K. Boyd, K. W. Kibler, and C. Ringstaff. Archeological Resource Management Series, Research Report No. 48, U.S. Army, Fort Hood.

Mallouf, R. J.

1985 A Synthesis of Eastern Trans-Pecos Prehistory. Unpublished Master's thesis, The University of Texas at Austin.

1987 Las Haciendas: A Cairn-Burial Assemblage from Northeastern Chihuahua, Mexico. Office of the State Archeologist Report 35, Texas Historical Commission, Austin.

1992 A Commentary on the Prehistory of Far Northern Chihuahua, The La Junta District and the Cielo Complex. Office of the State Archeologist, Texas Historical Commission, Austin.

Mandel, R. D. , J. S. Jacob, and L. C. Nordt

2007 Geomorphic Investigations at the Richard Beene Site. In: Archaeological and Paleoecological Investigations at 
the Richard Beene Site 41BX831: South-Central Texas,2005, edited by A. V. Thoms and R. D. Mandel, pp. 27-60. Reports of Investigations No. 8. Center for Ecological Archaeology, Texas A\&M University, College Station, Texas.

Marks, M, J. C. Rose, and E. L. Buie

1988 Chapter 4: Bioarchaeology of Seminole Sink. In Seminole Sink: Excavation of a Vertical Shaft Tomb Val Verde County, Texas, compiled by S. Turpin, pp. 75-118. Plains Anthropologist, Memoir 22 33-122, Part 2.

Marmaduke, W. S., and H. Whitsett

1975 An Archaeological Reconnaissance in the Vicinity of the Devil's Sinkhole. In Devil's Sinkhole Area-Headwaters of the Nueces River, A Natural Survey Area, Part VIII of VIII. Division of Natural Resources and Environment, The University of Texas at Austin, pp. 88-117.

Martin, A. C., H. S. Zim, and A. L. Nelson

1951 American Wildlife and Plants: A Guide to Wildlife Food Habits. Dover, New York.

Masson, M. A., and M. W. Holderby

1994 Subsistence Patterns at 41HY209 and 41HY202: An Analysis of Vertebrate Faunal Remains. In Archaic and Late Prehistoric Human Ecology in the Middle Onion Creek Valley, Hays County, Texas, by R. A. Ricklis, and M. B. Collins, pp. 403-489. Studies in Archeology 19, Texas Archeological Research Laboratory, The University of Texas at Austin.

Mauldin, R. P., D. L. Nickels, and C. J. Broehm

2003 Archaeological Testing to Determine the National Register Eligibility Status of Eighteen Prehistoric Sites on Camp Bowie, Brown County, Texas. Volumes 1 and 2. Center for Archaeological
Research, The University of Texas at San Antonio, Archaeological Survey Report, No. 334.

McDonald, J.

1982 Appendix II: Nonhuman Bones from the Loeve-Fox Site: A Preliminary Analysis. In Archeological Investigations at the Loeve-Fox Site, Williamson County, Texas, by E. R. Prewitt. Pp.117-120. Reprints in Archeology Number 1, Prewitt and Associates, Inc, Austin, Texas.

McHugh, T.

1958 Social Behavior of the American Buffalo (Bison bison bison). Zoological 43:1-40.

1972 The Time of the Buffalo. Alfred A. Knoph, New York.

McKern, W. C.

1939 The Midwestern Taxonomic Method as an Aid to Archaeological Culture Study. American Antiquity 4:301-313.

McKinney, W. W.

1981 Early Archaic Adaptations in Central and Southwestern Texas: The Problem of the Paleoindian-Archaic Transition. Bulletin of the Texas Archeology Society 52:91-120.

McReynolds, R.

1993 Some Examples of Bandy Points. La Tierra 20(3):9-16.

Mear, C. E.

1953 Quaternary Geology of the Upper Sabinal River Valley, Uvalde and Bandera Counties, Texas. Unpublished Master's thesis, Department of Geology, University of Texas at Austin.

1995 Quaternary Geology of the Upper Sabinal River Valley, Uvalde and Bandera Counties, Texas. Geoarchaeology 10(6):457-480. 
1998 Terrace Deposits and Late Quaternary Climate, South-Central Edwards Plateau, Texas. Bulletin of the Texas Archeological Society 69:79-88.

Mear, C. E. and C. D. Frederick

1998 Late Quaternary Stratigraphy of Panther Springs and Salado Creeks, San Antonio, Texas. In Archeology Along the Wurzbach Parkway, Module 5: Testing and Geoarcheological Evaluation at the Number-6 Site (41BX996) and Other Sites, pp. 99-112, by S. L. Black, J. W. Karbula, C. D. Frederick and C. E. Mear. Studies in Archeology 29, Texas Archeological Research Laboratory, The University of Texas at Austin.

Mehalchick, G., T. Myers, K. W. Kibler, and D. K. Boyd

1998 "Val Verde on the Sunny Rio Grande": Geoarcheological and Historical Investigations at San Felipe Springs, Val Verde County, Texas. Reports of Investigations, Number 122, Prewitt and Associates, Inc., Austin, Texas.

Meltzer, D. J.

1991 Althithermal Archeology and Paleoecology at Mustang Springs, on the Southern High Plains of Texas. American Antiquity 56:236-267.

Merrill, W. L.

1977 A Investigation of Ethnographic and Archaeological Specimens of Mescalbeans (Sophora Secundiflora) in American Museums. Museum of Anthropology, The University of Michigan, Technical Reports in Ethnobotany, Contribution 1, Ann Arbor.

Meskill, F. H., and C. D. Frederick

1998 Archeological Testing at the Witte Museum Science Facility Construction Site: An Archeological and
Geoarcheological Study on the East Bank of the San Antonio River. Technical Series 48, Texas Archeological Research Laboratory, The University of Texas at Austin.

Meskill, F. H., L. C. Shaw, and S. L. Black

2000 Excavations at 41BX323, The Witte Museum Parcel: Archaic Period Occupations on the Banks of the San Antonio River, Bexar County, Texas. Technical Series 50, Texas Archeological Research Laboratory, The University of Texas at Austin.

Miller, J. G.

1978 Living Systems. McGraw-Hill Book Company, New York.

Mock, S. B.

1987 The Painted Pebbles of the Lower Pecos: A Study of Medium, Form, and Content. Unpublished Master's thesis, Department of Anthropology, University of Texas at San Antonio.

Moore, W. E.

1983 Archeological Investigations at Musk Hog Canyon, Crocket County, Texas. A Report of the 1976 Texas Archeological Society Field School. Bulletin of the Texas Archeology Society 53:13-81.

Moran, E. F. (editor)

1990 The Ecosystem Approach in Anthropology: From Concept to Practice. The University of Michigan Press, Ann Arbor.

Morrow, C. A., and R. W. Jefferies

1989 Trade or Embedded Procurement?: A Test Case from Southern Illinois. In Time, Energy and Stone Tools, edited by R. Torrence, pp. 27-33. Cambridge University Press: Cambridge. 
Mueggenborg, H. E.

1994 Excavations at the Blue Hole Site, Uvalde County, Texas, 1990. Bulletin of the Texas Archeology Society 62:174.

Nelson, M. C.

1991 The Study of Technological Organization. In Archaeological Method and Theory, Volume 3, edited by M. B. Schiffer, pp. 57-100. Tucson: University of Arizona Press.

Newcomb, W. W, Jr.

1993 Historic Indians of Central Texas. Bulletin of the Texas Archeological Society 64:1-63.

Nicholson, R. A.

1993 A Morphological Investigation of Burnt Animal Bone and an Evaluation of its Utility in Archaeology. Journal of Archaeological Science 20:411-428.

Nickles, D. L., C. B. Bousman, J. D. Leach, and D. A. Cargill

2001 Test Excavations at the Culebra Creek Site, 41BX126, Bexar County, Texas. Archaeological Survey Report, No. 265, Center for Archaeological Research, The University of Texas at San Antonio and Archeological Studies Program, Report 3, Environmental Affairs Division, Texas Department of Transportation, Austin.

Noli, D. and G. Avery

1988 Protein Poisoning and Coastal Subsistence. Journal of Archaeological Science 15:395-401.

Nordt, L. C.

1992 Archeological Geology of the Fort Hood Military Reservation, Fort Hood, Texas. Archeological Resource Management Series, Research Report Number 25, United States Army, Fort Hood, Texas.
1993 Additional Geoarchaeological Investigations at the Fort Hood Military Reservation, Ft. Hood, Texas. Archeological Resource Management Series, Research Report Number 28, Addendum to Research Report Number 25, United States Army, Fort Hood, Texas

1994 Geoarchaeological Investigations of Henson Creek: A Low-Order Tributary in Central Texas. Geoarchaeology 10:205-221.

1996 Geoarchaeology of 41BX47, Upper Leon Creek Basin. In Archaic Land Use of Upper Leon Creek Terraces: Archaeological Testing in Northern Bexar County, Texas, by C. L. Tennis, R. J. Hard, C. B. Bousman, L. C. Nordt, and W. Göse, pp. 11-19. Archaeological Survey Report No. 234, Center for Archaeological Research, The University of Texas at San Antonio.

1997 Geoarchaeology of Lackland Air Force Base. In Phase II Archaeologica Investigations at Lackland Air Force Base, San Antonio, Texas, by B. A. Houk, D. L. Nickels, C. B. Bousman, A. A. Fox, B. A. Meissner, L. C. Nordt, A. A Scease, and S. A. Tomka, pp. 2838. Archaeological Survey Report No. 264, Center for Archaeological Research, The University of Texas at San Antonio.

1999 Geoarchaeology of Site 41BX323. In Archaeological Testing of 41BS323 and Portios of the Historic Second Waterworks Canal, Brackenridge Park, San Antonio, Bexar County, Texas, by K. A. Miller, S. Carpenter, L. C. Nordt, C. Howell, and C. Ringstaff, pp. 31-39. SWCA Cultural Resource Report No. 98-62, SWCA, Inc., Environmental Consultants, Austin, Texas. 
2001 Geoarchaeology of 41BX126. In Test Excavations at the Culebra Creek Site, 41BX126, Bexar County, Texas, by D. L. Nickels, C. B. Bousman, J. D. Leach, D. A. C.l, S. L. Black, J. P. Dering, C. D. Frederick, W. Göse, R. Jones, W. W. McKinney, K. A. McRae, B. A. Meissner, B. K. Moses, and L. C. Nordt, pp. 36-44. Archaeological Survey Report No. 265, Center for Archaeological Research, The University of Texas at San Antonio.

2004 Late Quaternary Alluvial Stratigraphy of a Low-order Tributary in Central Texas, U.S.A., and its Response to Climate and Sediment Supply. Quaternary Research 62:289-300.

Nordt, L. C., T. W. Boutton, C. T. Hallmark, and M. R. Waters

1994 Late Quaternary Vegetation and Climate Changes in Central Texas Based on the Isotopic Composition of Organic Carbon. Quaternary Research 41(1):109-120.

O’Connell, J. F., and K. Hawkes

1984 Food Choice and Foraging Sites Among the Alyawara. Journal of Anthropological Research 40:504-535.

O’Connell, J. F., K. Hawkes, and N. B. Jones

1991 Distribution of Refuse-Producing Activities at Hazda Residential Base Camps: Implications for Analyses of Archaeological Spatial Patterning. In The Interpretation of Archaeological Spatial Patterning, edited by E. M. Kroll and T. D. Price, pp. 61-76. Plenum Press: New York.

Odell, G. H.

1981 The Morphological Express at Function Junction: Searching for Meaning in Lithic Tool Types. Journal of Anthropological Research 37:319-342.
Odum, E. P.

1959 Fundamentals of Ecology. W. B. Saunders Co., Philadelphia, Pennsylvania.

Owens, J. D., J. M. Quigg, and G. D. Smith

2002 Final Data Recovery Phase at the Varga Site (41ED28), Edwards County, Texas: Interim Report. TRC Environmental Corporation, Austin, Texas.

Parsons, M. L.

1986 Painted Pebbles: Styles and Chronology. In Ancient Texans: Rock Art and Lifeways Along the Lower Pecos, by H. J. Shafer. Texas Monthly Press, Inc.

Parry, W. J., and R. L. Kelly

1987 Expedient Core Technology and Sedentism. In The Organization of Core Technology, edited by J. K. Johnson and C. A. Morrow, pp. 285304. Westview Press, Boulder, Colorado.

Patterson, L. W.

1979 An Alternate Explanation of Edge Damage on Gower Points. La Tierra, Journal of the Southern Texas Archaeological Association, 6(3):3-4.

Patton, P. C.

1977 Geomorphic Criteria for Estimating the Magnitude and Frequency of Flooding in Central Texas. Unpublished Ph.D. dissertation, The University of Texas at Austin.

Pearce, J. E.

1919 Indian Mounds and Other Relics of Indian Life in Texas. American Anthropologist 21:223-245.

1938 The Burnt-Rock Midden-Mounds of Central and West Texas. Manuscript on file at Texas Archeological Research Laboratory, The University of Texas at 
Austin. Document first written in 1920 and revised in 1938.

Pendon, D. G.

1976 Botanical Composition of Bison Diets on Short-Grass Plains. American Midland Naturalist 96(1):225-229.

Pendon, D. G., G. M. Van dyne, R. W. Rive, and R. M. Hansen

1974 The Tropic Ecological of Bison Bison L. on Short Grass Plains. Journal of Applied Ecology 11:489-498.

Perttula, T.

1995 The Present and Future of Texas Prehistoric Archeology: An Introduction to the 1995 BTAS. Bulletin of the Texas Archeological Society 66:7-15.

Peter, D. E.

1982 Alternative Perspectives on Burned Rock Middens. In Archaeological Investigations at the San Gabriel Reservoir Districts, Central Texas, Volume 2, edited by T. R. Hays, pp. 201 through 21-18. Archaeology Program, Institute of Applied Sciences, North Texas State University, Denton.

Peter, D. E., T. R. Hays, and M. A. Demuynch

1982a Evaluation of the "Phase" Concept. In Archaeological Investigations at the San Gabriel Reservoir Districts, Central Texas, Volume 2, edited by $\mathrm{T}$. R. Hays, pp. 21-1-21-18. Archaeology Program, Institute of Applied Sciences, North Texas State University, Denton.

Peter, D. E., T. R. Hays, and M. A. Demuynck

1982b The Archaeology of the San Gabriel Reservoir Districts. In Archaeological Investigations at the San Gabriel Reservoir Districts, Central Texas, Volume 2, edited by T. R. Hays, pp. 161-17-30. Archaeology Program, Institute of Applied Sciences, North Texas State University, Denton.
Prewitt, E.

1966 Preliminary Report on the Devil's Rockshelter. Texas Journal of Science 18(2):206-224.

1970 The Piedra del Diablo Site, Val Verde County, Texas and Notes on Some Trans-Pecos, Texas, Archeological Material in the Smithsonian Institution, Washington D. C. Texas Historical Committee, Archeological Report number 18.

1974 Archeological Investigations at the Loeve-Fox Site, Williams County, Texas. Research Report 49. Texas Archeological Survey, The University of Texas at Austin.

1981a Cultural Chronology in Central Texas. Bulletin of the Texas Archeological Society 52:65-90.

1981b A Wooden Mortar from the Stockton Plateau of Texas. Journal of Field Archaeology 8:111-117.

1982a Archeological Investigations at the Loeve-Fox and Loeve Tombstone Bluff Sites in the Granger Lake District of Central Texas. In Archaeological Investigations at the San Gabriel Reservoir Districts, Central Texas, edited by T. R. Hays, Volume 4. Institute of Applied Sciences, North Texas State University, Denton.

1982bArcheological Investigations at the Loeve-Fox Site, Williamson County, Texas. Reprints in Archeology Number 1, Prewitt and Associates, Inc, Austin, Texas.

1985 From Circleville to Toyah: Comments on Central Texas Archeology. Bulletin of the Texas Archeological Society 54:201-238.

1991 Burned Rock Middens: A Summary of Previous Investigations and Interpretations. In The Burned Rock 
Middens of Texas: An Archeological Symposium, edited by T. R. Hester, pp. 25-32. Studies in Archeology Number 13. Texas Archeological Research Laboratory, The University of Texas at Austin.

1995 Distributions of Typed Projectile Points in Texas. Bulletin of the Texas Archeological Society 66:83-173.

Prikryl, D. J., and J. M. Jackson

1985 Waco Lake, McLennan County, Texas: An Inventory and Assessment of Cultural Resources. Reports of Investigations, Number 39, Prewitt and Associates, Inc., Austin.

Prior, J.

1988 Methods Used in Charcoal Analysis and the Relationship Between Woods Used in Archaeological Times and the Present Fuelwood Crisis. In Scanning Electron Microscopy in Archaeology, edited by S. L. Olsen, pp. 187-202. BAR International Series 452. Oxford, England.

Prior, J., and D. Price-Williams

1985 Investigation of Climatic Change in the Holocene Epoch Using Archaeological Charcoal from Swaziland, Southern Africa. Journal of Archaeological Science 12:457-475.

Quigg, J. M.

1993 Isotope Data from Bison Remains. In Historic and Prehistoric Data Recovery at Palo Duro Reservoir, Hansford County, Texas, by J. M. Quigg, C. Lintz, F. M. Oglesby, A. Earls, C. D. Frederick, W. N. Trierweiler, D. Owsley, and K. W. Kibler. Mariah Associates, Inc. Technical Repot No. 485, Austin, Texas.

1997a The Sanders Site (41HF128): A Single Event Late Archaic Camp/Processing Site, Hansford County, Texas.
Technical Report No. 19751. TRC Mariah Associates Inc., Austin, Texas.

1997bBison Processing at the Rush Site, 41TG346, and Evidence for Pemmican Production in the Southern Plains. Plains Anthropologist 42(159):145-161, Memoir 29.

Quigg, J. M., and C. Cordova

2000 Data Recovery at 41ZP364: An Upland Campsite at Falcon Reservoir, Zapata County, Texas. Technical Report No. 22317, TRC Mariah Associates Inc., Austin, Texas.

Quigg, J. M, and G. L. Ellis

1994 Burned Rock Mound Chronometric Investigations. In Archeological Investigations on 571 Prehistoric Sites at Fort Hood, Bell and Coryell Counties, Texas, edited by W. N. Trierweiler, pp. 203-274. United States Army Fort Hood, Archeological Resource Management Series, Research Report No. 31.

Quigg, J. M., C. Lintz, G. Smith, and S. Wilcox

2000 The Lino Site: A Stratified Late Archaic Campsite in a Terrace of the San Idelfonzo Creek, Webb County, Texas. TRC Mariah Associates Inc., Technical Report No. 23756 and Texas Department of Transportation, Environmental Affairs Division, Archeological Studies Program, Report No. 20, Austin.

Quigg, J. M., M. E. Malainey, R. Przybylski, and G. Monks

2001 No Bones About It: Using Lipid Analysis of Burned Rock and Groundstone Residues to Examine Late Archaic Subsistence Practices in South Texas. Plains Anthropologist 46(177):283-303. 
Quigg, J. M., and J. Peck

1995 The Rush Site (41TG346): A Stratified Late Prehistoric Locale in Tom Green County, Texas. Technical Report No. 816C. TRC Mariah Associates, Inc.: Austin, Texas.

Quigg, J. M., J. Peck, C. Lintz, A. C. Treece, C. D. Frederick, R. Clem, G. L. Ellis, P. Schuchert, and J. T. Abbott

1996 Early Archaic Use of the Concho River Terraces: Cultural Resource Investigation at 41TG307 and 41TG309 Tom Green County, Texas. TRC Mariah Associates Inc., Technical Report 11058, Austin, Texas.

Quigg, J. M., S. Pritchard, and G. Smith

2002a The Boiler Site (41WB557): Utilization of an Upland Setting Over the Last 4200 Years, Webb County, Texas. TRC Technical Report No. 27277, TRC Environmental Corporation, Austin, Texas and Texas Department of Transportation, Environmental Affairs Division, Archeological Studies Program, Report No. 45, Austin.

Quigg, J. M., M. Sechrist, and G. Smith

2002b Testing and Data Recovery of Burned Rock Features in Sites on Otero Mesa, New Mexico, Volumes I and II. Prepared for the Directorate of Environment, Conservation Division, Fort Bliss, Texas, by TCR Mariah Associates Inc., El Paso, Texas.

Rafferty, J.

1985 The Archaeological Record on Sedentariness: Recognition, Development, and Implications. In Advances in Archaeological Method and Theory, Vol. 8, edited by $\mathrm{M}$. Schiffer, pp. 113-156. New York: Academic Press.

Ramsey, C. W., and M. J. Shult

1990 The Age of Deer. In Deer Management in the South Texas Plains, edited by E.
Davis, pp. 21-28. Federal Aid Report Series 27. Federal Aid (P-R) Project W-125-R, Texas Parks and Wildlife Department, Wildlife Division, Austin.

Raun, G. G.

1969 Appendix B: Vertebrate Remains from San Lorenzo de la Cruz. In A Lipan Apache Mission: San Lorenzo de la Santa Cruz 1762-1771, by C. D. Tunnell and W. W. Newcomb, pp. 190191. Bulletin 14, Texas Memorial Museum, The University of Texas at Austin.

Reese-Taylor, K.

1993 Petrographic Studies of Ceramic Pastes. In Cultural Resource Investigations in the O. H. Ivie Reservoir, Concho, Colemen, And Runnels Counties, Texas, by A. C. Treece, C. Lintz, W. N. Trierweiler, J. M. Quigg, and K. A. Miller, pp. I-1 to I-11. Volume IV, Data Recovery Results from Ceramic Sites. Mariah Associates Inc., Technical Report 346-IV, Austin, Texas.

1995 Petrographic Analysis of A Toyah Phase Ceramic Assemblage. In The Rush Site (41TG346): A Stratified Late Prehistoric Locale in Tom Green County, Texas, by J. M. Quigg and J. Peck, pp. F-1 to F-16. Technical Report No. 816C, TRC Mariah Associates Inc., Austin, Texas.

Reese-Taylor, K., J. Hageman, and R. A. Ricklis

1994 Preliminary Paste Analyses of Ceramic Samples from the Mustang Branch Site (41HY209) and Barton Site (41HY202). In Archaic and Late Prehistoric Human Ecology in the Middle Onion creek Valley, Hays County, Texas, by R. A. Ricklis and M. B. Collins, Volume 2, Topical Studies, pp. 549-568. Studies in Archeology 19, Texas Archeological Research 
Laboratory, The University of Texas at Austin.

Reineck, H. E., and Singh, I. B.

1980 Depositional Environments. $2^{\text {nd }}$ Edition. SpringerVerlag, Berlin.

Rice, P. M.

1984 Pots and Potters: Current Approaches in Ceramic Archaeology. Institute of Archaeology, University of California, Los Angeles.

Ricklis, R. A.

1992 The Spread of a Late Prehistoric Bison Hunting Complex: Evidence from the South-Central Coastal Prairie of Texas. Plains Anthropologist 37 (140): 621273.

1993 A Model of Holocene Environmental and Human Adaptive Change on the Central Texes Coast, Geoarchaeological Investigations at White's Point, Nueces Bay, and Surrounding Area. Coastal Archaeological Studies, Inc. Corpus Christi, Texas.

1994a Prehistoric Occupation of the Central and Lower Texas Coast: A Regional Overview. Bulletin of the Texas Archeological Society 66:265-300.

1994b Toyah Components: Evidence for Occupation in the Project Area During the Latter Part of the Late Prehistoric Period. In Archaic and Late Prehistoric Human Ecology in the Middle Onion creek Valley, Hays County, Texas, by R. A. Ricklis and M. B. Collins, pp. 207-316. Studies in Archeology 19, Texas Archeological Research Laboratory, The University of Texas at Austin.

1996 The Karankawa Indians of Texas: An Ecological Study of Cultural tradition and Change. University of Texas Press, Austin.

2000 Archaeological Investigations at the Spanish Colonial Missions of Espiritu Santo (41GD1) and Nuestra Senora del Rosario (41GD2), Goliad, Texas. Coastal Archaeological Studies, Inc. Corpus Christi, Texas.

2001 National Register Eligibility Testing at 41LE177, Alcoa Sandow Mine: Archaeological, Geoarchaeological and Paleoenvironmental Assessment of an Upland Sandy Mantle Site. Coastal Archaeological Research, Inc. Corpus Christi, Texas.

2007 Archaeology and Bioarchaeology of the Buckeye Knoll Site, A Major Locus of Prehistoric Hunter-Gatherer Occupation and an Early Archaic Cemetery near the Lower Guadalupe River, Victoria County, Texas. Draft submitted to the U.S. Army Corps of Engineers, Galveston District. Coastal Environments, Inc. Corpus Christi, Texas.

Ricklis, R. A., and K. A. Cox

1993 Lithic Technological Organization as a Dynamic Cultural Subsystem: The Advantages of a Spatial Approach. American Antiquity 58(3):444-461.

Ricklis, R. A., and M. B. Collins

1994 Archaic and Late Prehistoric Human Ecology in the Middle Onion Creek Valley, Hays County, Texas-Volume 1, Archeological Components. Studies in Archeology, No. 19, Texas Archeological Research Laboratory, The University of Texas at Austin.

Ricklis, R. A., and M. D. Blum

1997 The Geoarchaeological Record of Holocene Sea Level Change and Human Occupation of the Texas Gulf Coast. Geoarchaeology: An International Journal 12(4):287-314. 
Robinson, D. G.

1999 Appendix C: Petrographic Analysis of Plainware Pottery from 41VV444. In "Val Verde on the Sunny Rio Grande": Geoarcheological and Historical Investigations at San Felipe Springs, Val Verde County, Texas, by G. Mehalchick, T. Myers, K. W. Kibler, and D. K. Boyd, pp. 179-189. Reports of Investigations, Number 122, Prewitt and Associates, Inc., Austin, Texas.

Roe, F. G.

1972 The North American Buffalo. David and Charles, Newton Abbot, England.

Rogers, R. and T. K. Perttula

2004 The Oak Hill Village Site (41RK214) Rusk County Texas. PBS\&J, Document No. 030083, Austin, Texas.

Ross, R. E.

1965 The Archeology of Eagle Cave. Papers of the Texas Archeological Salvage Project No. 7.

Rovner, I.

1988 Macro- and Micro-Ecological Reconstruction Using Plant Opal Phytolith Data from Archaeological Sediments. Geoarchaeology 3:155163.

2004 On Transparent Blindfolds: Comments on Identifying Maize in Neotropical Sediments and Soils Using Cob Phytoliths. Journal of Archaeological Science 31:815-819.

Sackett, J. R.

1968 Method and Theory of Upper Paleolithic Archaeology in Southwestern France. In New Perspectives in Archaeology, edited by S. R. Binford and L. R. Binford, pp. 6183. Aldine, Chicago.

1977 The Meaning of Style in Archaeology: A General Model. American Antiquity 42:369-380.
1982 Approaches to Style in Lithic Archaeology. Journal of Anthropological Archaeology 1:59-112.

1985 Style, Ethnicity, and Stone Tools. In Status, Structure, and Classification: Current Archaeological Reconstructions, edited by M. Thompson, M. T. Garcia, and F. J. Kense, pp. 277-282. Proceedings of the $16^{\text {th }}$ Annual Chacmool Conference, University of Calgary.

Sahlins, M.

1985 Islands of History. The University of Chicago Press, Chicago.

Schiffer, M. B.

1976 Behavioral Archaeology. Academic Press, New York.

1987 Formation Processes of the Archaeological Record. University of New Mexico Press: Albuquerque.

Schlanger, N.

1994 Mindful Technology: Unleashing the Chaîne Opératoire for an Archaeology of the Mind. In The Ancient Mind: Elements of Cognitive Archaeology, edited by C. Renfrew and E. Zubrow, pp. 143-151. Cambridge University Press, Cambridge.

Scholtz, A.

1986 Palynological and Paleobotanical Studies in the Southern Cape. Unpublished Master's thesis. Stellenbosch University, South Africa.

Schroeder, E. A., and E. R. Oksanen

2002 Data Recovery at the Armstong Site (41CW54) Caldwell County, Texas. Volumes I and II. Paul Price Associates, Inc. PPA Cultural Resources Report Number 0284, Austin. 
Scott, R. F., IV

1982 Excavations at Sites 41LK31/32 and $41 L K 202$ in the Choke Canyon Reservoir, South Texas, Part 1: Prehistoric Investigations. Choke Canyon Series 8. Center for Archaeological Research, University of Texas at San Antonio.

Scott, R. F., and D. Creel

1990 Vertebrate Faunal Remains. In Excavations at 41TG91, Tom Green County, Texas, 1978, by D. Creel, pp. 165-208. Publications in Archaeology, Report No. 38, Texas Department of Transportation, Austin.

Scott-Cummings, L.

1991 Pollen, Phytolith, Macrofloral, and Charcoal Analyses in the Jewett Mine Project Area. In Excavations at the Bottoms, Rena Branch, and Maccasin Springs Sites, Jewett Mine Project, Freestone and Leon Counties, Texas, by R. C. Fields, L. W. Klement, C. B. Bousman, S. A. Tomka, E. F. Gadus, and M. A. Howard, pp. 329-362. Reports of Investigations, No. 82. Prewitt and Associates, Inc., Austin, Texas.

Sellards, E. H., W. S. Adkins, and F. B. Plummer

1990 The Geology of Texas, Volume I, Stratigraphy. The University of Texas Bulletin No. 332.

Severinghaus, C. W.

1949 Tooth development and Wear as Criteria of Age in White-tail Deer. Journal of Wildlife Management 13:195-216.

Shafer, H. J.

1963 Test Excavations at the Youngsport Site: A Stratified Terrace Site in Bell County, Texas. Bulletin of the Texas Archeological Society 34:57-81.
1975 Clay Figurines from the Lower Pecos Region, Texas. American Antiquity 40(2):148-158.

1977 Art and Territoriality in the Lower Pecos Archaic. Plains Anthropologist 22(75):13-21.

1978 Defining the Archaic: An Example from the Lower Pecos Area of Texas. In The Texas Archaic: A Symposium, edited by T. R. Hester, pp. 1-9. Center for Archaeological Research, The University of Texas at San Antonio, Special Report, No. 2.

1979 Comments on Kelly's "Gower Projectile Point?” Article. La Tierra, Journal of the Southern Texas Archaeological Association, 6(3):9-10.

1981 The Adaptive Technology of the Prehistoric Inhabitants of Southwestern Texas. Plains Anthropologist 26(92):129-138.

1986 Ancient Texans: Rock Art and Lifeways Along the Lower Pecos. Texas Monthly Press, Inc.

1988 The Prehistoric Legacy of the Lower Pecos Region of Texas. Bulletin of the Texas Archeological Society 59:23-52.

Shafer, H. J., and V. M. Bryant, Jr.

1977 Archeological and Botanical Studies at Hinds Cave, Val Verde County, Texas. Annual Report of Research, National Science Foundation, Texas A\&M University, Anthropology Laboratory, Special Series No. 1.

Shafer, H. J., and F. Speck, Jr.

1974 A Clay Figurine Cache from the Lower Pecos Region, Texas. Plains Anthropologist 19:228-230.

Shafer, H. J., and S. A. Tomka

2003 Early Middle Archaic Lithic Assemblages. In Royal Coachman (41CM111), An Early Middle Archaic 
Site along Cordova Creek in Comal County, Texas, by R. B. Mahoney, H. J. Shafer, S. A. Tomka, L. C. Nordt, and R. P. Mauldin, pp. 83-86. Texas Department of Transportation, Environmental Affairs Division, Archeological Studies Program Report No. 49 and the Center for Archaeological Research, The University of Texas at San Antonio, Archeological Survey Report No. 332.

Shaffer, B. S.

1994 Appendix III, Analysis of the Vertebrate Remains. In The Life and Times of Toyah-Culture Folk: As Seen from the Buckhollow Encampment, Site 41KM16, of Kimble County, Texas by L. Johnson, pp. 295-307. Texas Department of Transportation and Texas Historical Commission, Austin.

Shiner, J. L.

1978 Tool Kits and Technology in the Texas Archaic. In The Texas Archaic: A Symposium, edited by T. R. Hester, pp. 10-13. Center for Archaeological Research, The University of Texas at San Antonio, Special Report, No. 2.

Shiner, J. L., and M. V. Shiner

1977 Structure and Organization of a Burned Rock Midden: The Indian Creek Site, Real County, Texas. Plains Anthropologist 22(78):263-282.

Shott, M.

1986 Technological Organization and Settlement Mobility: An Ethnographic Examination. Journal of Anthropological Research 42:15-51.

1989 On Tool-Class Use Lives and the Formation of Archaeological Assemblages. American Antiquity 54(1):9-30.
Siegel, P. E.

1984 Functional Variability Within an Assemblage of Endscrapers. Lithic Technology 13:35-51.

Smith, E. A.

1979 Human Adaptation and Energetic Efficiency. Human Ecology 7:53-74.

1983 Anthropological Applications of Optimal Foraging Theory: A Critical Review. Current Anthropology 24(5):625-651.

1991 Inujuamiut Foraging Strategies. Aldine de Gruyter, Hawthorne, New York.

Smith, E. A., and B. Winterhalder (editors)

1992 Evolutionary Ecology and Human Behavior. Aldine de Gruyter, Hawthorne, New York.

Smith, G. D., and M. McFaul

1997 Paleoenvironmental and Geoarchaeologic Implications of Late Quaternary Sediments and Paleosols: North Central to Southwestern San Juan Basin, New Mexico; Geomorphology 21(2): 107-138.

Smith, J., and M. Butterwick

1975 A Vegetational Survey of the Devil's Sinkhole-Hackberry Creek Area. In Devil's Sinkhole Area-Headwaters of the Nueces River: A Natural Area Survey Part VIII of VIII, pp. 21-46. Division of Natural Resources and Environment, The University of Texas at Austin.

Sobolik, K. D.

1988 Diet Change in the Lower Pecos: Analysis of Baker Cave Coprolites. Bulletin of the Texas Archeological Society 59:111-127.

1991a Prehistoric Diet and Subsistence in the Lower Pecos as Reflected in Coprolites from Baker Cave, Val Verde County, Texas. Studies in Archeology 7, Texas 
Archeological Research Laboratory, The University of Texas at Austin.

1991b Prehistoric Diet From the Lower Pecos Region of Texas. Plains Anthropologist 36(135):139-152.

Soil Survey Staff

1962 Soil Survey Manual. Agricultural Handbook No. 18. Washington, D.C., U. S. Department of Agriculture.

1975 Soil Taxonomy. Agricultural Handbook No. 436. Washington, D.C., U. S. Department of Agriculture.

1982 General Soil Map Edwards County, Texas. Soil Conservation Service, in Cooperation with Texas Agricultural Experimental Station.

Sollberger, J. T.

1971 A Technological Study of Beveled Knives. Plains Anthropologist 16:209218.

Sorrow, W. M.

1968 Devil's Mouth Site: The Third Season-1967. Papers of the Texas Archeological Salvage Project 14. The University of Texas at Austin.

1969 Archaeological Investigations at the John Ischy Site: A Burned Rock Midden in Williamson County, Texas. Papers of the Texas Archaeological Salvage Project 18. The University of Texas at Austin.

Sorrow, W. M., H. J. Shafer, and R. E. Ross

1967 Excavations at Stillhouse Hollow Reservoir. Papers of the Texas Archeological Salvage Project, No. 11, Austin.

Speakman, R. J. and M. D. Glascock

2005 Instrumental Neutron Activation Analysis of Pottery from Presidio and Hudspeth Counties, Texas. Manuscript on file with author.
Speth, J. D.

1988 Bison Kills and Bone Counts: Decision Making by Ancient Hunters. University of Chicago Press.

Stafford, T. W., Jr., A. J. T. Tull, K. Brendel, R. C. Duhamel, and D. J. Donahue

1987 Study of Bone Radiocarbon Dating Accuracy at the University of Arizona NSF Accelerator Facility for Radio Isotope Analysis. Radiocarbon 29(24):44.

Stahle, D. W. and M. K. Cleaveland

1988 Texas Drought History Reconstructed and Analyzed from 1698 to 1980. Journal of Climate 1:59-74.

Stark, R. T.

1997 Piedras Calientes: Ethnohistory, Experimental Archaeology, and Cooking with Hot Stones. Unpublished Master's thesis, The University of Texas at Austin.

2002 Fire-Cracked Rock Experiments: The Potential of Three Analytical Techniques. La Tierra 29(4):12-28.

Steele, D. G.

1986 Analysis of Vertebrate Faunal Remains. In The Clemente and Herminia Hinojosa Site, 41JW8: A Toyah Horizon Campsite in Southern Texas, by S. Black, pp. 108-144. Special Report 18. Center for Archaeological Research, The University of Texas at San Antonio.

Stephenson, R. L.

1970 Archeological Investigations in the Whitney Reservoir Area, Central Texas. Bulletin of the Texas Archeological Society 41:37-277.

Stevenson, M. G.

1991 Beyond the Formation of HearthAssociated Artifact Assemblages. In The Interpretation of Archaeological 
Spatial Patterning, edited by E. M. Kroll and T. D. Price, pp. 269-299. Plenum Press: New York.

Steward, J. H.

1955 Theory of Culture Change: The Methodology of Multilinear Evolution. University of Illinois Press, Urbana.

Stinnett, J. K.

1975 The Terrestrial Vertebrates of the Devil's Sinkhole-Hackberry Creek Area. In Devil's Sinkhole AreaHeadwaters of the Nueces River; A Natural Area Survey Part VIII of VIII, pp. 75-81. Division of Natural Resources and Environment, The University of Texas at Austin.

Stock, J. A.

1983 The Prehistoric Diet of Hinds Cave (41VV456), Val Verde County, Texas: The Coprolite Evidence. Unpublished Master's thesis, Department of Anthropology, Texas A\&M University, Collage Station.

Suhm, D. A.

1955 Excavations at the Collins Site, Travis County, Texas. Bulletin of the Texas Archeological Society 26:7-54.

1957 Excavations at the Smith Rockshelter, Travis County, Texas. Texas Journal of Science 9(1):26-58.

1959 The Williams Site and Central Texas Archeology. Texas Journal of Science 11(2):218-250.

1960 A Review of Central Texas Archeology. Bulletin of the Texas Archeological Society 29:63-107.

Suhm, D. A., and E. B. Jelks

1962 Handbook of Texas Archeology: Type Descriptions. The Texas Archeological Society, Special Publication Number One and The Texas Memorial Museum Bulletin Number Four.
Suhm, D. A., A. D. Krieger, and E. B. Jelks

1954 An Introductory Handbook of Texas Archaeology. Bulletin of the Texas Archeological Society 25:1-582.

Syms, E. L.

1977 Cultural Ecology and Ecological Dynamics of the Ceramic Period in Southwestern Manitoba. Memoir No. 12, Plains Anthropologist 22(76), Part 2 .

Tagg, M. D.

1996 Early Cultigens from Fresnal Shelter, Southeastern New Mexico. American Antiquity 61(2):311-324.

Tainter, J. A.

1977 Modeling Change in Prehistoric Social Systems. In For Theory Building in Archaeology: Essays on Faunal Remains, Aquatic Resources, Spatial Analysis, and Systemic Modelling, edited by L. R. Binford, pp. 327-352. Academic Press, New York.

Taylor, W. W.

1964 Tethered Nomadism and Water Territoriality: An Hypothesis. In Acts of the $35^{\text {th }}$ International Congress of Americanists, pp. 34-38. Mexico City.

Taylor, A. J. and C. L. Highley

1995 Archeological Investigations at the Loma Sandia Site (41LK28): A Prehistoric Cemetery and Campsite in Live Oak County, Texas. 2 Vols. Studies in Archeology 20. Texas Archeological Research Laboratory, University of Texas at Austin.

Testart, A.

1982 The Significance of Food Storage Among Hunter-Gatherers: Residence Patterns, Population Densities, and Social Inequalities 49:193-240. 
Thoms, A. V.

1992 Late Pleistocene and Early Holocene Regional Land Use Patterns: A Perspective from the Preliminary Results of Archaeological Studies at the Richard Beene Site, 41BX831, Lower Medina River, South Texas. In Guidebook, $10^{\text {th }}$ Annual Meeting, SouthCentral Friends of the Pleistocene. Manuscript in author's possession.

Thoms, A. V., D. D. Kuehn, B. W. Olive, J. E. Dockall, P. A. Clabough, and R. D. Mandel

1996 Early and Middle Holocene Occupations at the Richard Beene Site: The 1995 Southern Texas Archaeological Association Field School Project. La Tierra 23(4):8-36.

Tomka, S. A.

2002 Hunter-Gatherer Technological Organization During the Archaic in South Texas. Paper presented at the $73^{\text {rd }}$ Annual Meeting of the Texas Archeological Society, Laredo.

Tomka, S. A., R. B. Mahoney, and H. J. Shafer

2003 Summary and Conclusions. In Royal Coachman (41CM111), An Early Middle Archaic Site along Cordova Creek in Comal County, Texas, by R. B. Mahoney, H. J. Shafer, S. A. Tomka, L. C. Nordt, and R. P. Mauldin, pp. 87-91. Texas Department of Transportation, Environmental Affairs Division, Archeological Studies Program Report No. 49 and the Center for Archaeological Research, The University of Texas at San Antonio, Archeological Survey Report No. 332.

Toomey, R. S., III

1993 Late Pleistocene and Holocene Faunal Changes at Hall's Cave, Kerr County, Texas. Unpublished Ph.D. dissertation, Department of Geology, The University of Texas at Austin.
Toomey, R. S., III, M. D. Blum, and S. Valastro, Jr.

1993 Late Quaternary Climates and Environments of Edwards Plateau, Texas. Global and Planetary Change 7:299-320.

Torrence, R.

1983 Time Budgeting and Hunter-Gatherer Technology. In Hunter-Gatherer Economy in Prehistory, edited by G. Bailey, pp. 11-22. Cambridge University Press, Cambridge.

1989 Time, Energy and Stone Tools. Cambridge University Press, Cambridge.

Treece, A. C.

1992 A Study of Five Annular Burned Rock Middens from the O. H. Ivie Reservoir, West Central Texas. Unpublished Master's thesis, The University of Texas at Austin.

1993 Cultural Resource Investigations in the O. H. Ivie Reservoir, Concho, Coleman, and Runnels Counties, Texas, Volume IV: Data Recovery Results from Ceramic Sites, by A. C. Treece, C. Lintz, W. N. Trierweiler, J. M. Quigg, and K. A. Miller. Technical Report No. 346-IV. Mariah Associates, Inc., Austin.

Treece, A. C., C. Lintz, W. N. Trierweiler, J. M. Quigg, and K. A. Miller

1993a Cultural Resource Investigations in the O. H. Ivie Reservoir, Concho, Coleman, and Runnels Counties, Texas. Volume III: Data Recovery Results from NonCeramic Sites. Technical Report No. 346-III. Mariah Associates, Inc. Austin.

1993b Cultural Resource Investigations in the O. H. Ivie Reservoir, Concho, Coleman, and Runnels Counties, Texas. Volume IV: Data Recovery Results from Ceramic Sites. Technical Report No. 
346-IV. Mariah Associates, Inc. Austin.

Trierweiler, W. N. (editor)

1994 Archeological Investigations on 571 Prehistoric Sites at Fort Hood, Bell and Coryell Counties, Texas. United States Army Fort Hood, Archeological Resource Management Series, Research Report No. 31. TRC Mariah Associates, Inc.: Austin, Texas.

Tunnell, C. D.

1962 Oblate: A Rockshelter Site. In Salvage Archeology of Canyon Reservoir: The Wunderlich, Footbridge, and Oblate Sites, pp. 77-116. Texas Memorial Museum Bulletin 5, Austin.

1969 Part I: The Archeological Investigation. In A Lipan Apache Mission: San Lorenzo de la Santa Cruz 1762-1771, by C. D. Tunnell and W. W. Newcomb, Jr., pp. 1-137. Bulletin 14, Texas Memorial Museum, The University of Texas at Austin.

Tunnell, C. D., and W. W. Newcomb

1969 A Lipan Apache Mission: San Lorenzo de la Santa Cruz 1762-1771. Bulletin 14, Texas Memorial Museum, The University of Texas at Austin.

Turner, E. S., and T. R. Hester

1983 A Field Guide to Stone Artifacts of Texas Indians. $2^{\text {nd }}$ Edition. Houston: Gulf Publishing Company.

1985 A Field Guide to Stone Artifacts of Texas Indians. $1^{\text {st }}$ Edition. Texas Monthly Press, Austin.

1993 A Field Guide to Stone Artifacts of Texas Indians. $1^{\text {st }}$ Edition. Gulf Publishing Company, Houston.

Turpin, S. A.

1984a Prehistory in the Lower Pecos Region: An Overview. Research Report 90. Texas Archeological Survey, The
University of Texas at Austin and the National Park Service.

1984b The Red Linear Style Pictographs of the Lower Pecos River Region, Texas. Plains Anthropologist 29(105):181-198.

1986 Toward a definition of a Pictograph Style: The Lower Pecos Bold Line Geometric. Plains Anthropologist 31(112):152-161.

1987 Ethnographic Observations of Bison in the Lower Pecos River Region: Implications for Environmental Change. Plains Anthropologist 32(118):424-429.

1990 Speculations on the Age and Origin of the Pecos River Style. American Indian Rock Art 16:99-122. American Rock Art Research Association, San Miguel, California.

1991 Time Out of Mind: The Radiocarbon Chronology of the Lower Pecos River Region. In Papers on Lower Pecos Prehistory, edited by S. A. Turpin, pp. 1-49. Studies in Archeology 8, Texas Archeological Research Laboratory, The University of Texas at Austin.

1994a On a Wing and a Prayer: Flight Metaphors in Pecos River Pictographs. In Shamanism and Rock Art in North America, edited by S. A. Turpin, pp. 73102. Special Publication 1. Rock Art Foundation, Inc., San Antonio.

1994b The Were-Cougar Theme in Pecos River Style Art and its Implications for Traditional Archeology. In New Light on Old Art: Recent Advances in Hunter-Gatherer Rock Art Research, edited by D. S. Whitley and L. L. Loendorf, pp. 75-80. Monograph 36. Institute of Archaeology, University of California, Los Angeles.

1995 Lower Pecos River Region of Texas and Northern Mexico. Bulletin of the 
Texas Archeological Society 66:541560.

1998 Wroe Ranch: Small Shelter Occupancy on the Edge of the Trans-Pecos, Terrell County, Texas. Cultural Resource Report 3, Borderlands Archeological Research Unit, University of Texas at Austin.

Turpin, S. A. (compiler)

1988 Seminole Sink: Excavation of a Vertical Shaft Tomb Val Verde County, Texas. Plains Anthropologist, Memoir 22:33-122 Part 2.

Turpin, S. A., and L. C. Bement

1992 Skyline Shelter and Devils Triangular Dart Points: Evidence for A New Component of the Lower Pecos Early Archaic Sequence, Southwest Texas. Plains Anthropologist 37(138):41-57.

Turpin, S. A., and M. W. Davis

1990 The 1989 TAS Field School: Devils River State Natural Area. Bulletin of the Texas Archeological Society 61:158.

Turpin, S. A., M. Hennenberg, and D. H. Riskin

1986 Late Archaic Mortuary Practices of the Lower Pecos River Region, Southwest Texas. Plains Anthropologist 31(114):295-315.

Turpin, S. A., and D. G. Robinson

1998 Infierno Phase Pottery of the Lower Pecos River Region. Bulletin of the Texas Archeological Society 69:89-97.

Tusenius, $\mathrm{M}$.

1989 Charcoal Analytical Studies in the North-Eastern Cape, South Africa. South African Archaeological Society Goodwin Series 6:77-83.

Upham, S., and R. S. MacNeish

1993 The Evolution of Maize in the Jornada Region of New Mexico and Its Implications for the Southwest. In
Preliminary Investigations of the Archaic in the Region of Las Cruces, edited by R. S. MacNeish, pp. 105-116. Historic and Natural Resources Report No. 9, Cultural Resources Management Program, Directorate of Environment, United States Army Air Defense Artillery Center, Fort Bliss, Texas.

Upham, S., R. S. MacNeish, W. C. Galinat, and C. M. Stevenson

1987 Evidence Concerning the Origin of Maize de Ocho. American Anthropologist 89, No. 2:410-419.

Valastro, S., Jr., E. M. Davis, and A. G. Varela 1979 Radiocarbon 21(2):127-173.

Van Devender, T. R., and W. G. Spalding

1979 Development of Vegetation and Climate in the Southwestern United States. Science 204:701-710.

Van Wormer, J.

1969 The World of the Pronghorn. J.B. Lippincott Co., Philadelphia.

Vayda, A. P., and R. A. Rappaport

1968 Ecology, Cultural and Noncultural. In Introduction to Cultural Anthropology, edited by J. Clifton, pp. 447-496. Houghton Mifflin, New York.

Vierra, R. K., and Carlson, D. L.

1981 Factor Analysis, Random Data, and Patterned Results. American Antiquity 46:272-283.

Wade, M. F.

1998 The Native Americans of the Texas Edwards Plateau and Related Areas: 1582-1799. Unpublished Ph.D. dissertation, Department of Anthropology, The University of Texas at Austin.

2002 Patterns of Buffalo Seasonality During the Protohistoric and Historic Periods in Texas. Appendix C. In The Smith Creek Bridge Site (41DW270): A 
Terrace Site in De Witt County, Texas, by D. Hudler, K. Prilliman, and T. Gustavson, pp. 171-186. Studies in Archeology 35, Texas Archaeological Research Laboratory, The University of Texas at Austin and Archeology Studies Program, Report No. 17, Environmental Affairs Division, Texas Department of Transportation.

2003 The Native Americans of the Texas Edwards Plateau, 1582-1799. Texas Archaeology and Ethnohistory Series. The University of Texas Press.

Walter, T.

1997 The Dynamics of Culture Change and Its Reflection in the Archeological Record at Espiritu Santo De Zuniga, Victoria County, Texas. Special Publication 7, Southern Texas Archaeological Association and Studies in Archeology 23, Texas Archeological Research Laboratory, The University of Texas at Austin.

Wandsnider, L.

1997 The Roasted and the Boiled: Food Composition and Heat Treatment with Special Emphasis on Pit-Hearth Cooking. Journal of Anthropological Archaeology 16:1-48.

Waters, M. R.

1992 Principles of Geoarchaeology: A North American Perspective. University of Arizona Press, Tucson.

Watt, F. H.

1956 Archeological Materials from the Asa Warner Sites. Central Texas Archeologist 7:6-29.

Webber, J. M.

1953 Yuccas of the Southwest. Agricultural Monograph 17, United States Department of Agriculture.
Weir, F. A.

1976 The Central Texas Archaic. Unpublished Ph.D. dissertation, Department of Anthropology, Washington State University, Pullman.

1978 The Central Texas Archaic Reconsidered. In The Texas Archaic: A Symposium, edited by T. R. Hester. Center for Archaeological Research, The University of Texas at San Antonio, Special Report, No. 2.

1979 Greenhaw: An Archaic Site in Central Texas. Bulletin of the Texas Archeological Society 50:5-67.

Wesolowsky, A. B., T. R. Hester, and D. R. Brown

1976 Archeological Investigations at the Jetta Court Site (41TV151) Travis County, Texas. Bulletin of the Texas Archeological Society 47:25-87.

Whitelaw, $\mathrm{T}$.

1991 Some Dimensions of Variability in the Organization of Community Space Among Foragers. In Ethnoarchaeological Approaches to Mobile Campsites: Hunter-Gatherer and Pastoralist Case Studies, edited by Gamble and Boismier, pp. 139-188. Ann Arbor: International Monographs in Prehistory.

1994 Order Without Architecture: Functional, Social and Symbolic Dimensions in Hunter-Gatherer Settlement Organization. In Architecture and Order: Approaches to Social Space, edited by M. P. Pearson and C. Richards, pp. 217-243. Routledge: New York.

Williams-Dean, G.

1978 Ethnobotany and Cultural Ecology of Prehistoric Man in Southwestern Texas. Unpublished Ph.D. dissertation, Department of Anthropology, Texas A\&M University, Collage Station. 
Wilson, E. W.

1930 Burned Rock Mounds of Southwest Texas. Bulletin of the Texas Archeological Society 2:59-63.

Willey, G., and P. Phillips

1958 Method and Theory in American Archaeology. University of Chicago Press, Chicago.

Winterhalder, B.

1986a Diet Choice, Risk, and Food Sharing in a Stochastic Environment. Journal of Anthropological Archaeology 5:369392.

1986bOptimal Foraging: Simulation Studies of Diet Choice in a Stochastic Environment. Journal of Ethnobiology 6:205-223.

1987 The Analysis of Hunter-Gatherer Diets: Stalking an Optimal Foraging Model. In Food and Evolution, edited by $\mathrm{M}$. Harris and E. Ross, pp. 311-339. Temple University Press, Philadelphia.

Winterhalder, B., and E. A. Smith (editors)

1981 Hunter-Gatherer Foraging Strategies: Ethnographic and Archaeological Analyses. University of Chicago Press, Chicago.

Winters, H. D.

1969 The Riverton Culture: A Second Millennium Occupation in the Central Wabash Valley. Illinois State Museum, Reports of Investigations, No. 13. Springfield.

Wiseman, R. N.

1999 The Dating of Annular Middens from Surface Artifacts: A Problem from the Northern Trans-Pecos Region in New Mexico. The Journal of Big Bend Studies 11:37-48.

Witkind, W. M.

1977 An Experiment in Stone Boiling. In Hop Hill: Culture and Climate Change in Central Texas. by J. Gunn and R. Mahula pp. 205-208. Center for Archaeological Research, The University of Texas at San Antonio, Special Report, No. 5.

Woolsey, A. M.

1936 Notes on Field Work-H.C. Locke Farm 1 Mile West of New Braunfels, Comal County, Texas. Excavated April 21 to May 3, 1936. Manuscript on file, Texas Archeological research Laboratory, University of Texas, Austin.

Word, J. H.

1971 The Dunlap Complex in Western Central Crocket County, Texas. Bulletin of the Texas Archeological Society 42:271-310.

Word, J. H., and C. L. Douglas

1970 Excavations at Baker Cave, Val Verde County, Texas. Bulletin of the Texas Memorial Museum 16, Austin.

Yanovsky, E.

1936 Food Plants of the North American Indians. United States Department of Agriculture Miscellaneous Publications 237. Washington, D.C.

Yellen, J. E.

1977 Archaeological Approaches to the Present: Models for Reconstructing the Past. Academic Press, New York.

Young, W. C.

1981 Investigations at the Squawteat Peak Site Pecos County, Texas. Texas Department of Highways and Public Transportation, Highway Design Division, Publication in Archaeology, Report No. 20, Austin.

1982 Excavations at the Ram's Head Site 41PC35 Pecos County, Texas. Texas Department of Highways and Public Transportation, Highway Design Division, Publication in archaeology, Report No. 23, Austin. 


\subsection{GLOSSARY OF TECHNICAL TERMS}

A Horizon: The near surface horizon of a natural soil. This is a carbon rich soil horizon characterized by an accumulation of partially decomposed to decomposed organic matter and eluvial loss of constituents such as clays and carbonates, which tend to accumulate in the deeper B horizon. The A horizon represents the upper solum of a soil. Lower case letters with the upper case A indicate specific characteristics of that $\mathrm{A}$ horizon. An Ab designation indicates the A horizon is buried. An Ap designation indicates a disturbed or anthropically modified soil such as in a plow zone.

\section{Accelerated Mass Spectrometry (AMS):} Laboratory technique that separates and identifies ions based on their mass to charge ratios. This technique is used in radiocarbon dating tiny particles of carbon in organic remains and residues.

Agavaceae: A plant family name that refers to fiber, vascular bundle, or the central stem fragment that could not be specifically identified as agave (Agave), yucca (Yucca) or sotol (Dasylirion).

Allostratigraphic Unit: Depositional unit made up of sediments dating to a coeval period of deposition.

Alluvium: Clastic sediments deposited by a flowing stream, either in the channel or material deposited outside the channel during overbank flooding.
Anisotropic: The action of cross-polarization of light under a microscope as it passes through material. If the material causes any deviation in the transmission of light then the material will have illumination in the microscope in a pattern characteristic of the material and its properties.

Argillic Horizon: A soil horizon (Bt horizon) that exhibits significant enrichment in illuvial clay minerals or clay-sized particles. Such clays typically form grain coats, grain bridges, and ped-face coats of oriented clay that are visible in thin sections, and usually can be identified with a hand lens.

B Horizon: The lower solum of a natural soil. A B horizon is a mineral soil horizon characterized by an accumulation of constituents such as clays, carbonates or salts, or organic complexes that have been translocated from the A horizon. Common subordinates include lowercase letters such as $t$, which indicates accumulation of illuvial clays. The lowercase $\mathrm{k}$ indicates accumulation of carbonate. The lower case $\mathrm{w}$ indicates structural or color changes with no significant accumulations of alluvial material.

Bioclasts: These are tiny fossils particles within limestone that may belong to any invertebrate phylum. These were observed in the petrographic analysis of the pottery sherds.

Bioturbation: The churning and mixing of sediments by living organisms, including burrowing rodents, insects, worms, and plant roots.

Biplot: A biplot is a special type of graph following from principal component analysis on which both the samples and elements are displayed. Examination of biplot from the principal component analysis of ceramic specimens often lead to identification of the 
analyzed elements responsible for differentiating groups of specimens from one another.

Bivariate Plot (Scatter Plot): A twodimensional graph where the $\mathrm{x}$-axis and $\mathrm{y}$-axis symbolize a pair of measured or calculated variables. The points on a bivariate plot represent the position of individual samples. These graphs are used to recognize possible structure in a data set.

B.P.: An abbreviation for before present, which in radiocarbon dating is referenced to the standard year A.D. 1950.

Burned Rock Dump: A loose cluster of heated rocks that exhibits no horizontal patterning to the positions of the rocks and lacks indications of in situ heating/burning, such as a prepared basin, lenses of charcoal or ash, and/or the absence of an oxidation rim. Scattered charcoal or other cultural items may be present between or around the burned rocks.

C Horizon: Weathered, but relatively minimally altered parent material at the base of a soil profile. This term is roughly synonymous with subsoil, although the latter term is often used to encompass the lower B horizon.

Calcareous: Rocks, minerals, or sediment containing calcium carbonates.

Calcite: A common rock-forming mineral like calcium carbonate. It is the principal mineral in limestone.

CAM Plants: A photosynthetic pathway for assimilating carbon dioxide into plants that can change from $\mathrm{C}_{3}$-like to $\mathrm{C}_{4}$-like plants depending on the diurnal (day or night) cycle. Most succulents such as cactus are crassulacean acid metabolism (CAM) plants. The carbon isotope values of most CAM plants in Texas such as
Agave lechuguilla and Opuntia englmannii, are similar to the values in $\mathrm{C}_{4}$ plants (see Eickmeier and Bender 1976).

$\mathbf{C}_{3}$ Plants: A photosynthetic pathway that most trees and flowering bushes use to assimilate carbon dioxide into their systems. The average carbon isotope of $\mathrm{C}_{3}$ matter is $-26.5 \%$ with a range from about $-24.0 \%$ o to $-34.0 \%$.

$\mathrm{C}_{4}$ Plants: A photosynthetic pathway used by most xeric (arid) grasses and corn to assimilate carbon dioxide into their systems. The average carbon isotope of $\mathrm{C}_{4}$ matter is $-12.5 \%$ with a range of $-6 \%$ to $-19 \%$. These plants are more resistant to water stress, but more susceptible to cold temperatures.

Carbonates: These are rock or mineral class including limestone, calcite, ooids, and bioclasts and used in the petrographic analysis of the pottery sherds. The calcite staining in the thin section preparation marked all these bodies with a carmine red color.

Cheno-am: An artificial term used in botanical classification that includes the family of Chenopodiaceae (goosefoot) and the genus Amaranthus (pigweed), which are indistinguishable from each other.

Clast: Any detrital particle (sediment) created by the weathering and disintegration of a larger rock mass and transported by, or subjected to physical transport by water, wind, or ice. Clast also includes discrete particulates created and deposited by volcanic action.

Computer Aided Drafting (CAD): A method for drafting maps, features, and stratigraphic sketches using computers.

Context: The association and position of artifacts, materials, and cultural features that are 
used by archeologists to interpret space, time, and cultural.

Crinoid Fossils: These are known as sea lilies, invertebrates that lived on ocean floors. They usually have long jointed stems with spiny skin and topped by a platy flower-like body of tentacles. The stem has a central canal or tubular cavity. Fossil crinoids are found in the Pennsylvanian Formation that outcrops in Central Texas mineral belt and northward.

Criterion of Abundance: If a large group of the specimens in a ceramic assemblage is represented by a single, homogenous, compositional fingerprint and the actual source of clay is unknown, then the criterion of abundance suggests that there is a high probability the group was produced locally or very near the site where it is most heavily represented.

Cumulic Soil: A soil formed in a setting experiencing relatively slow deposition, so that freshly introduced sediment is incorporated into the A horizon, leading to overthickening of the surface horizon. Cumulic soils are common in alluvial overbank and colluvial settings.

Curie Temperature: The temperature at which the magnetic properties of a substance change from ferromagnetic to paramagnetic. Magnetite has a Curie point of 580 degrees Celsius (C).

Deposition: The accumulation of sediment or gravels laid down by natural agencies such as water deposited, or artificial agencies such as dumping.

Dose Rate: Is the rate at which the radiation or the amount of light has been delivered to the object. The dose rate is obtained by measuring the radioactivity of the sample and the surrounding soil.

\section{Ecologically Diagnostic Xylem Analysis} (EDXA): A method that measures the size and abundance of cells and other anatomical features, which are visible in a transverse section of wood and/or wood charcoal. The documentation of differences in mesquite wood charcoal from different occupation periods provides information about varying moisture and temperature conditions.

Eluvial: The movement of materials such as clay or organic matter from a soil horizon by percolating water.

Eocene Epoch: The period of time between 37 and 58 million years ago, and a subdivision of the Tertiary Period of the Cenozoic era.

Erosional Uncomformity: A significant break or gap in the record, indicative of erosion of the older unit prior to renewed deposition.

Factor Analysis: This is concerned with determining whether the covariances or correlations between a set of observed variables $\mathrm{p}$ can be explained in terms of a minimum number of unobserved, latent variables.

Fatty Acids: The major constituents of fats and oils (lipids) that occur in nature in plants and animals. They are insolubility in water and relatively abundant compared to other classes of lipids. Fatty acids may be absorbed into porous archeological materials during cooking, including heated rocks and ceramics, or ground into manos, metates, or mortar holes.

Feldspar: A group of aluminum silicate minerals that are the most common of any mineral group, making up about 60 percent of the earth's crust. 
Ferric Iron: This is an iron in the form commonly of specular hematite or magnetite and is less common in the region than ferrous iron. These particles were observed in the petrographic analysis of the pottery sherds.

Ferrous Iron: This is a common residual mineral in the form of hematite in the limestone of the Edwards Plateau. It is a red color. This was observed in the petrographic analysis of the pottery sherds.

Gas Chromatography (GC): This highly technical measuring instrument that separates and measures the amount of elemental components of a specific sample by the measurement of light passed through gas at regulated temperatures, which allows the detection of fatty acids at the nonogram (1 X $10^{-}$ ${ }^{9}$ g) level.

Graticule: A devise used in the microscope to measure the size of items under magnification.

HCL: Hydrochloric acid.

Holocene: Geological time period spanning roughly the last 10,000 years before present. The Holocene is roughly equivalent to the Postglacial period, and often referred to as the "Recent" period in geology. Many investigations consider the Holocene to be an interstadial in the ongoing Pleistocene epoch.

Horizon: A discrete, relatively uniform layer in a soil profile that is typically subparallel with the surface and formed as the result of pedogenic process.

Humic: A dark, organic-rich material generally caused by the decay of organic material.

IFB: Invitation for bids.
Igneous: Rocks that are formed by the solidification of magma from volcanic activity.

Illuvial: Material in a soil profile that has moved downward into another soil horizon by water.

In Situ: Something, generally referring to an artifact, in its original position that was placed or deposited within the landscape.

Integrity: This refers to the degree on intactness of archeological deposits, components, features, or artifacts.

Instrumental Neutron Activation Analysis (INAA): This is a method of chemical analysis involving the exposure of unknown samples and standards to a neutron flux from a nuclear reactor without the use of chemical separation. The exposure to neutrons produces several short- and long-lived radioactive isotopes that emit characteristic gamma rays. The energy of the emitted gamma rays provides information to identify the constituent elements, while the intensity of the emitted radiation is proportional to the amount of the element present in the sample. Gamma-ray spectroscopy is performed at different ties after irradiation to measure isotopes with different half-lives. The method is particularly sensitive to a large number of trace elements, minor, and major elements, including the rare-earth elements, transition metals and other.

Iron Stain: These resemble a blood-red smear or splash on the matrix when using a cross polarized light in viewing a petrographic slide of a pottery sherd. The stained zone had irregular rounded shapes and commonly there were discontinuous zones or strips of several rounded iron stain smears. The source of the iron stain in the ceramic fabric is problematic. 
Isotope: One of two or more species of a chemical element, differentiated by the number of neutrons contained in the nucleus.

Isotropic: The behavior of cross-polarization of light as it passes through material, especially crystalline material. This means the same change on light passing through the material, without interruption and the material remains dark.

Kinematics: A friction-related feature of surface to surface contact observed under a microscope in the use-wear analyses of stone tools.

Knapping: A term used to describe the manufacturing of prehistoric chipped stone tools using different techniques, such as pressure and or percussion methods, to chip/flake a target mass of material to form a useful tool.

Krotovina: A discrete, anomalous area visible in plan or profile in a soil resulting from the infilling of a void (e.g. a burrow or root) with dissimilar sediment. Some investigators prefer to limit the term to animal burrows, preferring the term "root trace" for filling related to decayed roots. Some krotovina are obvious, whereas others are tiny and may only be identified in thin sections.

Legume: A plant that produces a bean or seedpod in various forms consisting of one cell and/or two valves. Common legume plants across Texas include; mesquite, Texas ebony, various acacia, retama, Dalea sp., mimosa, and rattlebush.

Lipids: These are hydrophobic constituents of living tissues including fatty acids, alcohols, triacylglycerols, sterols, bile acids, and waxes. Lipids are present in tissues of all living organisms in varying proportions. These are insoluble in water, relatively easily extractable, and are readily amenable to separation and characterization.

Lycopodium Spores: These are marker grains used in the pollen analyses. Two tablets of $13,500 \pm 500$ spores were added to each subsample to permit calculation of pollen concentration values and provide an indicator for accidental destruction of pollen during the laboratory procedures.

M.A.S.C.A.: Museum of Applied Science Center for Archaeology, University Museum, University of Pennsylvania. One instrument that has studied tree-ring calibrations of radiocarbon dates.

Manuport: An object, usually some rock that was transported by humans to the place it was recovered, but its general appearance did not indicate it had been culturally altered to form a specific tool type.

Matrix: In geoarcheological usage, refers to the sediments in which the artifacts at an archeological site are encased.

Mesic Condition: A relatively moist interval generally used in the context of climatic conditions.

Molar Solutions: A Molar (M) is a solution that contains one mole of solute in each liter of solution. A mole is the molecular weight expressed as grams. Therefore, $1 \mathrm{M}=1 \mathrm{~g}$ of molecular weight of solution per liter of solution.

Normal Solutions: A Normal (N) is a solution that contains one "gram equivalent weight" of solute per liter of solution. The gram equivalent weight is equal to the molecular weight expressed, as grams divided by the "valency" of 
the solution is the molecular weight expressed as grams.

Ooids: These are tiny particles within the limey matrix of limestone. These were observed during the petrographic analysis using a highpowered microscope.

Overbank Deposits: The deposition of fine silts and clay particles that are left on terrace tops and banks when water in creeks exceeds the capacity of the channel and drops the suspended sediments load in the lower energy environment. Overbank depositional processes usually cause minimal movement to large objects on the terrace top.

Oxidation: A chemical process where oxygen is added to minerals or other compounds; weathering oxidizes minerals; burning wood and rusting metal are types of oxidation.

Paleosol: Generally refers to a buried soil that developed an A horizon and was subsequently buried.

Palimpsest: Archeologically, refers to the inability to distinguish and separate material remains from repeated occupations by a succession of cultural events of different ages due to their deposition over time on relatively stable surfaces. Some palimpsest assemblages are buried following a long period of exposure.

Pedogenesis: The dynamic process of soil formation and development, which typically leads to the formation of a darkened, organicrich A-horizon at or near the surface, and the downward movement of fine clays and/or the formation of carbonate nodules in lower $B$ horizons.

Phytoliths: Tiny microscopic silica particles that develop within the cells of most plants.
Dissolved silica is transported into growing plants through water and then deposited along cell walls as silica particles. Different kinds of plants and different parts of a plant develop phytoliths of various shapes. After the plants die, the silica bodies become part of the mineral component of soils left in the ground.

Pleistocene: The first epoch, which with the Holocene period constitutes the Quaternary period, spanning the time between roughly 2.0 or 1.65 million years ago and 10,000 years ago. Characterized by repeated continental glaciations, the Pleistocene witnessed the evolution of modern humans.

Polyunsaturated Fatty Acids: Pertaining to long-chain carbon compounds (e.g., C18:2) like fats with multiple double bonds. These fats are very unstable and degrade very rapidly over time.

Principal Component Analysis (PCA): This is a pattern recognition technique used for reducing the dimensionality of multivariate data similar to factor analysis. It uses all of the variables measured in a sample and calculates the variation among those variables.

Profile: A sequence of horizons that make up a soil, or a description or depiction of the horizons in cross section.

Provenience: The specific vertical and horizontal location where an object is found.

Provenance Postulate: This states that chemical analysis can successfully trace artifacts to their source if the differences in chemical composition between different natural sources that exceed, in some recognizable way, the differences observed within a given source. 
Quaternary: The second period, which along with the Tertiary Period, make up the Cenozoic Era, encompassing the Pleistocene and Holocene epochs; roughly the last 2.0 or 1.65 million years.

Raphides: Needle-shaped crystals in a plant cell, typically of calcium oxalate. These are often found in plants of the Agavaceae family such as sotol, yucca, agave, and lechuguilla. They are not diagnostic of any particular plant. Bohrer (1987) and Kwiatkowski (1992) believe that only agave contain these crystals. In contrast, Dering (2003b) believes these occur in a variety of Agavaceae including sotol, yucca, agave, and beargrass.

Rhyolite: A very fine-grained, extrusive igneous rock, same composition as granite.

Root Etching: These are thin, shallow lines or pits that are etched into the surfaces of bones by acids associated with plant roots that grown against the bone.

Saturated Fatty Acids: Each carbon in the chain is connected to its neighboring carbon by a single bond, which makes them relatively stable. The most abundant saturated fatty acids have chain-lengths of either, 14, 16, or 18 carbons. Mammal fats primarily consist of saturated fatty acids and are solid at room temperature.

Silt: A particle size that has a range from 0.06 $\mathrm{mm}$ to $0.002 \mathrm{~mm}$.

Siliceous: A silicon dioxide, the most common chemical constituent on earth, a dominant component of chert and quartz.

Site Structure: The spatial distribution of features, artifacts, and debris across a single occupation (or within a component) of an archeological site that is used to reconstruct manufacturing, maintenance, processing, production, and disposal activities at specific loci, and the spatial ways prehistoric groups organized their space at a site.

Soluble Inorganic Residues: These are silica gel residues that build up with moisture availability and as use progresses to form discrete microplates. These are impervious to most acids and strong bases. These are quite common wear traces on the Varga Site artifacts and are valuable wear traces because of their long term stability, sensitivity to motion, and affects on the microgemometry of a tool edge. They exhibit flow characteristics of a viscous liquid and desiccation cracks as they harden.

Stable Isotope: An isotope not subjected to radioactive decay, such as carbon $\left(\mathrm{C}^{13}\right)$ or nitrogen $\left(\mathrm{N}^{15}\right)$ isotopes. This contrasts with radioactive isotopes.

Turbation: Disturbance to the natural matrix deposits generally caused by biological (burrowing rodents, insects, worms, and plant roots) and natural (soil creep, desiccation crack displacement, frost heaving, landslides, etc.) processes.

Unsaturated Fatty Acids: These types of fatty acids contain at least one carbon-carbon double bond or point of unsaturation. That point of unsaturation is susceptible to additional reactions. Unsaturated fatty acids are the primary constituents of plant and fish oils and tend to be in liquid-state at room temperature. Their chain-lengths vary with a minimum of 12 carbons but most common ones contain at least 18 carbons.

Use-wear: The high-powered microscopic evidence on a stone tool that was created from long-term use. The wear may appear as striations, tiny nicks, abrasive particles, polish, 
rounding, soluble inorganic residues, etc. The present study used magnification between 100x and $500 \mathrm{x}$ to observe edge modification on selected artifacts.

Uvalde Gravel: A gravel deposit throughout much of south and east Texas attributed to the late Miocene to early Pleistocene. The deposits are composed of pebbles, cobbles, and boulders of vein quartz, quartzite, chert, jasper, silicified wood, and limestone. The ultimate source of the lithology indicates the Llano Uplift likely the Ogallala Formation (see Byrd 1971 for more details).

Variance-covariance Matrix: This is the matrix of covariances between all pairs of measured variables in a study.

Voids: These are gaps, holes, pores, or space observed in the pottery matrix when viewed under a microscope during petrographic analysis. This is often used as an indirect measure of vessel porosity.

Vulnerability Index: A calculated by dividing the mean vessel diameter by the mean vessel density for wood sample. A higher vulnerability index results from the presence of fewer, but larger vessels in the wood, reflecting a condition indicating a wetter climate. A lower vulnerability index is a result of numerous but smaller vessels in the wood, a condition encouraged by low rainfall conditions.

Xeric Condition: A dry or relatively arid condition often in reference to discussing climatic conditions.

Xylem Analysis: The study of the shape, size, and arrangement cells in wood. 
ISBN 1-930788-79-7 


\section{The Varga Site: A Multicomponent, Stratified Campsite in the Canyonlands of Edwards County, Texas Volume II}

By:

J. Michael Quigg, Jeffrey D. Owens, Paul M. Matchen,

Grant D. Smith, Robert A. Ricklis, Mercedes C. Cody, and Charles D. Frederick

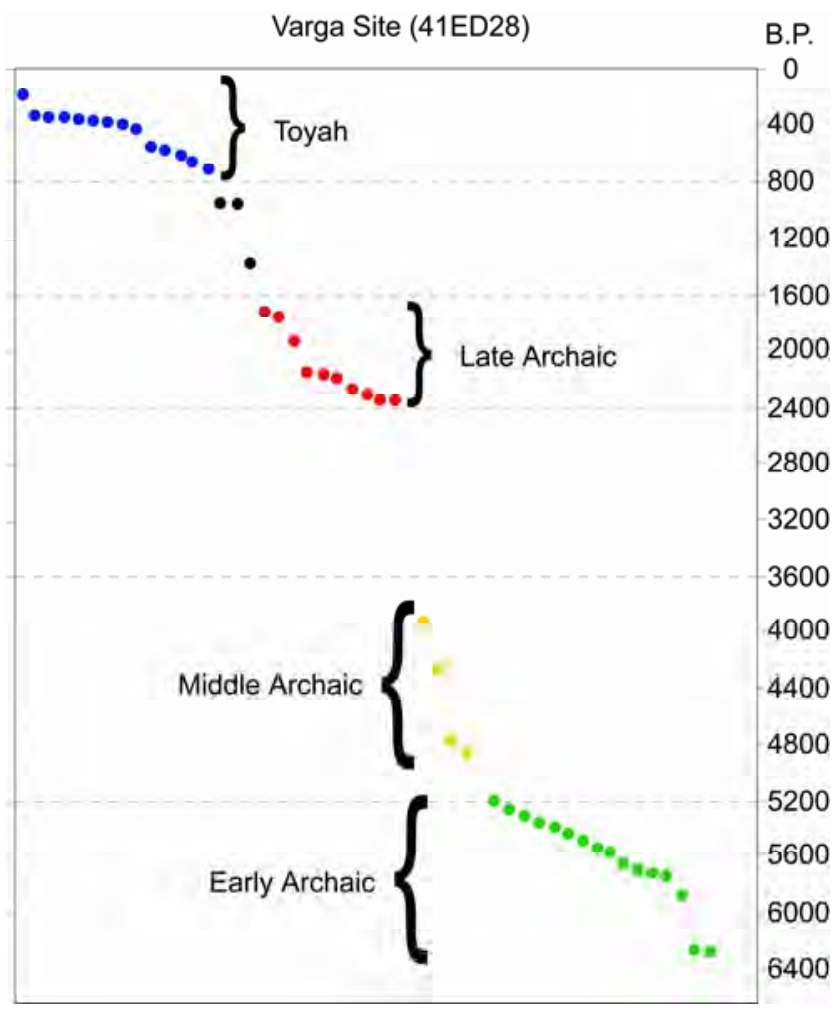

Prepared for:

Texas Department of Transportation

Texas Department of Transportation

Environmental Affairs Division

Austin, Texas
Prepared by:

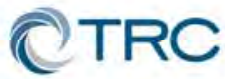

TRC Environmental Corporation Austin. Texas

Technical Report No. 35319

Texas Antiquities Committee Permit No. 2779

Texas Department of Transportation Archeological Studies Program Report No. 110 


\title{
The Varga Site: \\ A Multicomponent, Stratified Campsite in the Canyonlands of Edwards County, Texas
}

\author{
By: \\ J. Michael Quigg, Jeffrey D. Owens, Paul M. Matchen, \\ Grant D. Smith, Robert A. Ricklis, Mercedes Cody, and Charles D. Frederick \\ Prepared for:

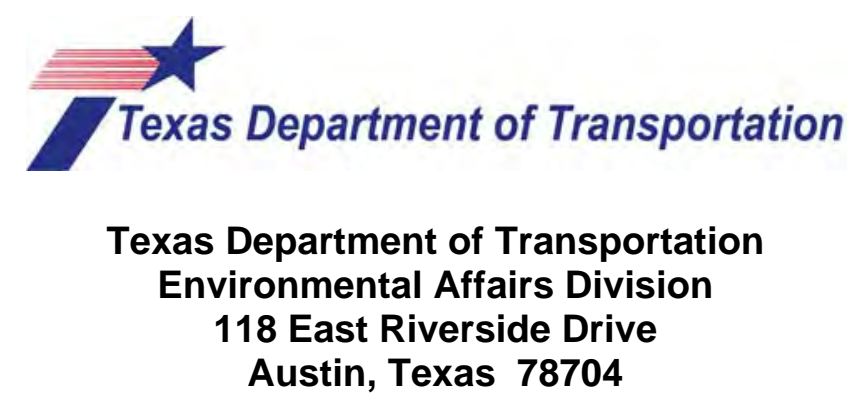 \\ Prepared by:

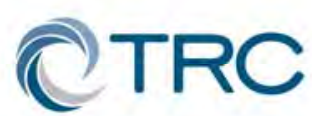 \\ 505 East Huntland Drive, Suite 250 \\ Austin, Texas 78752
}

J. Michael Quigg, Principal Investigator

Technical Report No. 35319

Texas Antiquities Committee Permit No. 2779

Scientific Services Contract No. 572XXSA004

Texas Department of Transportation Archeological Studies Program Report No. 110

CSJ: 0830-01-014

November 2008 
Copyright (C) 2008

Texas Department of Transportation

All rights reserved. TRC Environmental Corporation (TRC) and the Texas Department of Transportation (TxDOT) jointly own all rights, title, and interest in and to all data and other information developed for this project under TxDOT Scientific Services Contract No. 572XXSA004. Brief passages from this publication may be reproduced without permission provided that credit is given to TRC and TxDOT. Permission to reprint an entire chapter, section, figures, or tables must be obtained in advance from the Supervisor of the Archeological Studies Program, Environmental Affairs Division, Texas Department of Transportation, 118 East Riverside Drive, Austin, Texas, 78752.

Printed by:

Ginny’s Printing

Austin, Texas

Printed on acid-free, 60-lb. paper

November 2008

Jointly published by:

Texas Department of Transportation

Environmental Affairs Division

Archeological Studies Program

Scott Pletka, Ph.D., Supervisor

Archeological Studies Program Report No. 110

Al McGraw, Series Editor

and

TRC Environmental Corporation

Technical Report No. 35319

Austin, Texas

ISBN 1-930788-79-7 


\section{TABLE OF CONTENTS VOLUME II}

CHAPTERS 1-22

see Volume I

APPENDIX A: Quantitative Approaches to Analyzing Projectile Point Variability at the Varga Site..... 637

APPENDIX B: Radiocarbon Assays 701

APPENDIX C: Results of Microscopic Use-Wear and Residue Analyses from the Varga Site 41ED28, Texas.

APPENDIX D: Petrographic Analysis of Toyah Ceramics from the Varga Site, 41ED28, and Comparative Sites

APPENDIX E: Pollen and Phytolith Analyses of Samples from the Varga Site, 41ED28, Edwards County, Texas

APPENDIX F: Instrumental Neutron Activation Analysis of Chert from the Varga Site (41ED28) in Southwest Texas 885

APPENDIX G: Analysis of the Fatty Acid Compositions of Archaeological Pottery and

Rock Residues from the Varga Site (41ED28) 951

APPENDIX H: Stable Carbon and Nitrogen Isotope Analyses.......................................... 985

APPENDIX I: Plant Remains from the Varga Site (41ED28) ........................................... 995

APPENDIX J: Analysis of Unknown Material From Phase I Data Recovery Investigations1019

APPENDIX K: Granulometry Results. 1033

APPENDIX L: Optically Stimulated Luminescence of Alluvial Sediments from Edwards County, Texas 1039

APPENDIX M: Use-Wear Analysis of Two Gravers from the Varga Site (41ED28).......... 1055

APPENDIX N: Instrumental Neutron Activation Analysis of Pottery from the Lorenzo Mission (41RE1), San Juan Mission (41BX5), and Varga (41ED28) Sites in Real, Bexar, and Edwards Counties, Texas 1065

APPENDIX O: Metric and Non-Metric Data and Varga Site Artifact Database 1085 



\title{
APPENDIX A:
}

\section{QUANTITATIVE APPROACHES TO ANALYZING PROJECTILE POINT VARIABILITY AT THE VARGA SITE}

Jeffrey D. Owens and

\author{
Eric R. Oksanen
}





\section{A.1 INTRODUCTION}

The purpose of this study was to use statistical methods for an exploratory examination of a projectile point assemblage from one site. From a system of measurements collected from the assemblage, an attempt was made to create statistical groupings and examine whether these groupings correspond to the traditional named projectile point types. The advantage of using a statistical method for examining assemblages for affiliations is that it analyzes large amounts of data quickly using computer software. There is also the assumption that statistical typologies are less prone to subjective measurements and the inherent biases and experience of a typologist. Ideally, numerical coding of projectile points would be reproducible and eliminate intraanalyst discrepancies. The main difficulty in creating automatic typologies is knowing which particular traits to measure and analyze and interpreting the outcome (Adam and Adams 1991; Aldenderfer 1998; Doran and Hodson 1976; Shennan 1988, Spaulding 1953). Traits may be derived from or constrained by cultural practices and traditions, the expertise of the maker, functionality, style, and raw material characteristics and availability for example. A valid typology should create groupings that have relevance and meaning that exists beyond the analytical classification (Banning 2000). Classification is the ordering of phenomena within a particular domain. Artifact classification asserts that the domain is structured from a material and morphological basis that also embodies ideational properties pertaining to culture, and that the classifications contain information about cultural systems (Read 1989).

\section{A.2 TheORETiCAL BaCKGROUND}

The organization of archeological materials arose out of the antiquarians in the early nineteenth century. The classification of materials based upon use, material and form correlated to temporal periods was first published by C. J. Thomsen in 1836 . Thomsen's organization of the Three Age System of Stone, Bronze and Iron Ages was to establish typological thinking, the application of ethnographic analogy, and the application of a progressional history to chronological ordering (Rodden 1981). Thomsen's division into three major categories was not arbitrary. Thomsen had extensive knowledge of the archeological context from which to base his structure and accompanied the three divisions with detailed accounts of associated artifacts, placing more emphasis on the systematic recording of material context (Gräslund 1981). Although Thomsen's system did not address technological, economic, or artistic developments, it was used on artifacts to illustrate chronology. His system of classification was the first detailed, scholarly, chronological archeological history (Gräslund 1981).

In "The Typological Concept," Alex Krieger intended to rescue the use of archeological typologies from the abuse of over-use and poorly expressed definitions (Krieger 1944). The creation of typologies should, as their basis, address human behavior. If the typologies cannot interpret or reconstruct human behavior, assumptions based upon the typologies are probably incorrect and fictitious. Groupings of artifacts had been used to create "culture complexes" and demonstrate "culture change," geographically and temporally. These groupings were referred to as "types," the medium for comparisons and analysis in archeology. Krieger's intent was to standardize the creation of typologies and the naming of types.

Krieger's type should represent a cultural practice, much as the ethnologist defines a "culture trait." Like the culture trait, an archeological type should convey a recognized pattern of behavior that is transmitted between individuals, and through the study of styles, a genetic path similar to a phylogenic tree can be 
followed to the origin of the particular style, or in the case of a culture trait, the origin of the practice. The archeological type is an organizational tool used for creating groups of materials that have a recognizable historical context and illustrate a particular behavior.

In North America, the search for types specifically using quantitative methods was proposed by Albert Spaulding in a 1953, American Antiquity article, "Statistical Techniques for the Discovery of Artifact Types.” Spaulding agreed with the basis of Krieger's definition of type, but disagreed with the technique of how to determine a type. Krieger's method emphasized site-to-site comparisons of assemblages and components to evaluate the full range of type attributes, while Spaulding claimed he only needed sufficient material from a single site and component to use his technique. Using chi-squared contingency tables, Spaulding demonstrated that with certain criteria, he could define and detect types (Spaulding 1953:305). James Ford, writing shortly after Spaulding (Ford and Steward 1954), agreed with the portions of the concept of type used by both Krieger and Spaulding that it must be restricted temporally and geographically; however, Ford doubted that they were true cultural designations, and doubted that types were analogous to biological organisms waiting to be discovered through new methodologies. Types were inherently the product of the typologist, abstracted by the observer at a point in time. Morphological types were those with measurements clustered around the mean values that exist at a particular place and moment in time. Steward, in the second portion of Ford's essay, raised a question still central to typologies: "How different is different?” Anthropological data is conceived qualitatively, yet is recorded and measured both qualitatively and quantitatively, and discrepancy and arguments arise because of the mixing of qualitative and quantitative traits.
The essential issues between Krieger, Spaulding, and Ford continue to today. The New Archeology of the 1960's introduced supposedly scientifically rigorous methods including the increased use of multivariate statistics to analyze assemblages, as was done by Louis and Sally Binford for the Middle Paleolithic. Binford and Binford (1966:205) critiqued traditional systems of taxonomy for masking behavioral and cultural indicators because they were agglomerative methods that combined traits according to variables that otherwise could be discrete phenomena using other taxonomies.

A recent Master's thesis by Anne Kerr (2000) examined unfluted lanceolate projectile points primarily from Texas. Kerr (2000) used cluster analysis, analysis of variance, visual observation, and chronological context to identify "discrete morphological patterns with chronological integrity” for Thrall, St. Mary's Hall, and Plainview points. Morphological traits and technological attributes distinguished Angostura, Lubbock, and Golondrina-Barber, and Dalton points (Kerr 2000). Many of these types had been poorly defined as to morphology, location, and chronology. Previously, Plainview had incorporated Golondrina and St. Mary's Hall points, which are now thought of as distinct from one another. Such analyses demonstrate the utility of computer-based investigations of assemblages to detect variability and refine or define culturally significant types. The underlying premise is that types exist independent of the analyst, are constrained and defined by measurable morphological variables, are confined temporally and geographically, and therefore, represent a cultural design template.

There is a difference in comparing assemblages from a single site or component and across components and sites (Cowgill 1990). Cowgill (1990) defines an assemblage as a discrete collection of objects used by a community during a period of little sociocultural change. He uses the terms Internal Cohesion (IC) to 
show the relationship between chosen variables within an assemblage and External Isolation (EI), how the assemblage compares with similar assemblages examined for the same attributes. The examination of variability within a single assemblage is frequently overlooked. Within a discrete assemblage, artifacts have been created in a relatively short period of time, and the makers of the artifacts are aware of the variations in the produced products. Certain variations in properties are unimportant, while others are significant: if one goal is to maintain standards, there must be mechanisms to ensure the replication of the object and reject or discourage the production of objects that deviate from shared standards (Cowgill 1990:68). The maintaining of standards can be expected to differ geographically and temporally and some sort of "drift" should be expected. The more separation between artisans, the less comparison or agreement to a particular set of standards would occur. Cowgill (1990:69) defines a type as having internal cohesion and external isolation. Types are groups of objects defined by a set of characteristics or classes that are more similar to each other than to objects in other groups. Groups of objects may be formed that differ from each other by a single variable, such as color, to numerous variables. The selection of appropriate variables can create different groupings and be significant within, and particular to, an individual assemblage.

Statistical analysis, particularly cluster analysis and principal component analysis, of artifact assemblages has become a goal in itself, as the defining characteristics of artifact groups are quantitative measurements that provide an illusion of objectivity (Dunnel 1986; Read 1989). The purpose of the current analysis was an attempt to detect and define Cowgill's internal cohesion within the types and external isolation between them.

\section{A.3 Analytical Strategies}

\section{A.3.1 Typological Analysis}

The projectile points, dart types and arrow points, were placed within the standard Texas point typological names as defined in Turner and Hester (1993) and by Elton Prewitt (Table A-1). Prewitt's analysis uses metric attributes or continuous scale measurements from some traits, and nominal and ordinal measurements for additional traits such as base shape, flake orientation, and presence of grinding. These types are assumed to be cultural types, as intended by Suhm and Jelks (1962) in the Handbook of Texas Archeology: Type Descriptions, in that they represent a cultural entity with both geographical and temporal continuity (Suhm and Jelks 1962). It is worth noting that 69 of the 215 dart points and 147 of the 226 arrow points were untyped because of physical condition and/or they were not within the recognized criteria or atypical for any of the known types.

The assemblage of 441 projectile points included in this study does not include two missing specimens (\#117-019 and \#193-010), nor one specimen (\#578-015) that was submitted for instrumental neutron activation analysis (INAA), which was a small fragment of an unknown dart. The two missing specimens were misplaced after being cataloged and were not available for typological or quantitative analyses. No information about these two specimens is available, and it not known whether they are dart or arrow points. The single specimen that was submitted for INAA before being measured is a fragment of an unclassified dart point. As this item will be destroyed as the result of INAA, no additional information about this implement will be forthcoming. 
Table A-1. Summary of Projectile Point Types

\begin{tabular}{|l|c|l|c|}
\hline \multicolumn{1}{|c|}{ Dart Point Types } & No. & Dart Point Types (cont.) & No. \\
\hline Baker & 12 & Pandale & 1 \\
\hline Bandy & 21 & Taylor & 1 \\
\hline Bell & 1 & Unclassified Dart Points & 69 \\
\hline Carrizo & 3 & \multicolumn{1}{|c|}{ Subtotal Dart Points } & $\mathbf{2 1 5}$ \\
\hline Castroville & 1 & Arrow Point Types & No. \\
\hline Early Triangular & 8 & Bonham & 6 \\
\hline Edgewood & 1 & Cliffton & 12 \\
\hline Ensor & 1 & Cuney & 1 \\
\hline Frio & 7 & Edwards & 1 \\
\hline Gower & 32 & Guerrero & 2 \\
\hline Group 1 & 15 & Harrell & 1 \\
\hline Group 2 & 7 & Padre & 1 \\
\hline Marcos & 1 & Perdiz & 53 \\
\hline Martindale & 22 & Scallorn & 2 \\
\hline Merrell & 11 & Unclassified Arrow Points & 147 \\
\hline Montell & 1 & Subtotal Arrow Points & $\mathbf{2 2 6}$ \\
\hline & & Total Projectile Points & $\mathbf{4 4 1}$ \\
\hline
\end{tabular}

In addition, four of the points included in this analysis represent refitted complete specimens composed of two fragments each. During laboratory processing, each fragment was given separate catalog numbers; however, for the purposes of this analysis, the points are treated as single implements. As the stem represents the portion of the tool that yields the most information pertinent to this study, each of the fourrefitted points are referred to using the catalog number of the basal fragment. Thus, \#650-016 and \#213-012 (a Carrizo point) are referred to collectively as \#650-016, \#282-017 and \#159-023 (a Bonham point) are discussed as \#282-017, \#525-005-013 and \#526-011 (a Frio point) are treated as \#525-005-013, and \#523025 and \#463-021 (a Merrell point) are referenced as \#523-025.

\section{A.3.2 Data Recording Techniques}

TRC laboratory personnel in preparation for analysis of the projectile point assemblage recorded a total of 36 observations, 18 are metric and 18 are non-metric measurements. The metric measurements represent continuous (i.e., scale) ranges of variability, whereas the nonmetric measures represent nominal, ordinal, or interval-scale variability. While it is possible to include both continuous and interval-scale variables in many statistical routines, the hierarchical agglomerative technique used in this study employed Ward's method to measure the distances between each specimen and the mean (or center) of the cluster to which each belongs. Ward's method will be discussed in more detail below, but it is worth noting in the present context that this method is designed for use with variables that have a continuous range of variability (Shennan 1988:217). In the interest 
of using the most directly comparable variables in this study, only the 18 metric variables were included in the statistical analyses.

Each of these 18 metric variables is discussed in detail below. Figure A-1 shows the locations on representative contracting-and expandingstemmed points where each measurement was taken. All linear measurements were recorded using Mitutoyo ${ }^{\mathrm{TM}}$ digital calipers and recorded to the nearest 0.1 millimeter. Angle measurements were recorded using Ward's contact goniometer to the nearest whole degree. Weight was recorded using a digital scale and recorded to the nearest 0.1 gram. TRC laboratory personnel collected all metric measurements and recorded them on paper data entry forms, and the senior author performed a quality assurance (QA) review of all measurements before they were entered into the electronic, Microsoft Access database. The QA review consisted of visually comparing each specimen with the set of recorded measurements and spot-checking some of the metric measurements randomly. While many of the measurements could be taken directly on the specimen, it was necessary to photocopy many of the specimens so that baselines involved in numerous measurements could be drawn. As the paper copies also provided an opportunity to double-check the measurements during the QA review, paper copy versions of all specimens were maintained showing exactly where the various measurements were recorded. Derivative (e.g., ratio) linear variables were calculated to two decimal places.

\section{General Characteristics}

Maximum Length-Maximum Length refers to the total length of the specimen from the distal tip to the furthest extent of the stem or base. This metric measurement is designed to measure the total length of complete implements; therefore, it was recorded only for specimens that were relatively complete along their longitudinal axis. If small portions of the distal tip were missing, this measurement was recorded only if the original outline could be reasonably estimated without stretching the imagination. Also, no attempt was made to discriminate between distal resharpening versus original manufacture in collecting this measurement. As long as the point was relatively complete, it was assumed to have been a potentially viable, functional object and the measurement was recorded.

Maximum Thickness-Maximum Thickness represents the thickness at the thickest point of the specimen, whether that occurs at the midpoint of the blade, the blade/stem interface, or the stem. This metric measurement provides a general measure of tool thickness. More importantly, it figures into the calculation of the Width to Thickness Ratio, which provides an overall measure of the lithic reduction strategies brought to bear during projectile point manufacture. On point fragments, it was generally necessary for at least a short segment of the medial ridge to be present for laboratory analysts to assess whether or not the thickest part of the point was present; nevertheless, it was possible to record this measurement on most of the specimens in the assemblage.

Weight-Weight refers to the total weight of the specimen. This metric measurement was designed to provide a measure of the weight of complete artifacts; consequently, this measure was recorded only for relatively complete specimens. This condition, that specimens be relatively complete, was applied rigorously in the interest of providing a measure of the aerodynamic and penetration capacities of complete points rather than a measure of broken artifact fragments. 


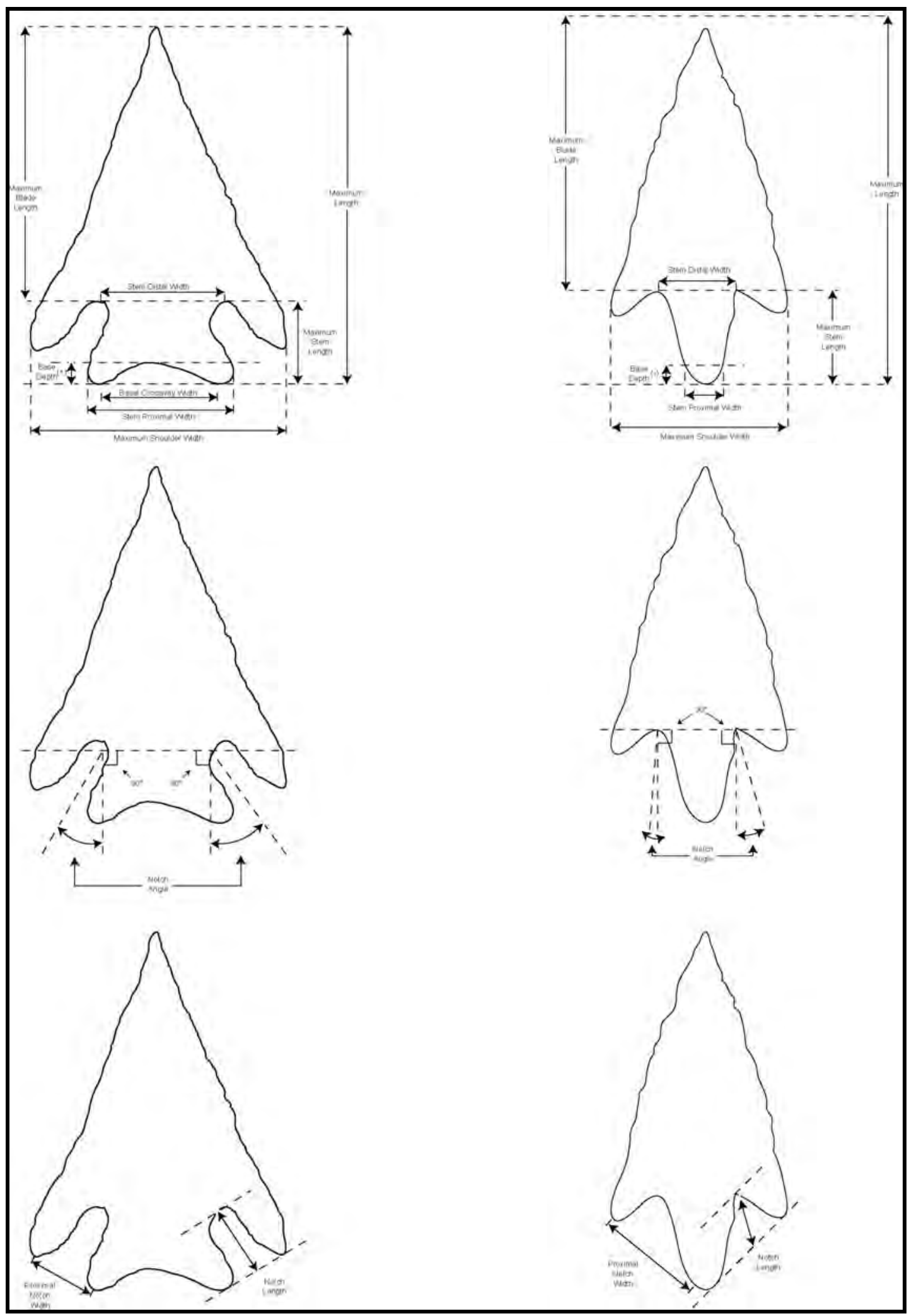

Figure A-1. Locations of Metric Measurements on Projectile Points 


\section{Blade Characteristics}

Maximum Blade Length-Maximum Blade Length represents the total longitudinal distance of the blade from the distal tip to the blade/stem interface. This measurement was designed to measure the total length of complete blades; therefore, it was recorded only for specimens that had relatively complete blades (longitudinally). If small portions of the distal tip were missing, this measurement was recorded only if a reasonable extrapolation of the original outline could be made. Also, no attempt was made to discriminate between distal resharpening versus original manufacture in collecting this measurement. Assuming that the specimen was relatively complete (longitudinally), Maximum Blade Length plus Maximum Stem Length should equal Maximum Length.

Maximum Blade Width-Maximum Blade Width refers to the maximum width of the blade at the appropriate point. This may be at the midblade, distal tip, or just above the shoulders (i.e., this measurement was never taken at the shoulder or barbs). This measurement was designed to provide a measure of blade width as distinct from the width of the blade/stem interface (i.e., shoulders or barbs), and it was anticipated that it may yield information about the extent of lateral blade resharpening. Thus, it was necessary for the blade to be relatively complete (transversely) for laboratory personnel to be sure that the widest point of the blade was represented. In the numerical classification analysis, however, it became clear that the variety of locations along the blade at this measurement was taken failed to provide a systematic measure of artifact width. Consequently, the Maximum Width variable was ultimately created, taking the greater value of either Maximum Blade Width or Maximum Barb/Shoulder Width to provide an overall measure of implement width.

\section{Barb and Shoulder Characteristics}

Maximum Barb/Shoulder Width-Maximum Barb/Shoulder Width represents the maximum width of the specimen across the shoulder or barb area; thus, it was taken at the shoulder or the widest extent of the barbs, which may occur at or near the shoulders or near the proximal end of the point. This measurement required that the barb/shoulder area of the specimen be relatively complete. As this portion of most projectile points is rather fragile, shoulder "ears" and barbs tend to exhibit a high rate of breakage; consequently, it was possible to record this measurement on only a limited proportion of the assemblage. Like the Maximum Blade Width measure, the Maximum Width variable was ultimately used as a replacement for this measure. The Maximum Width variable used the greater value of either Maximum Blade Width or Maximum Barb/Shoulder Width to provide an overall measure of implement width.

\section{Notch Characteristics}

Notch Depth (Left and Right) - This paired set of observations encodes the length (i.e., depth) of proximal/lateral notches (i.e., corner and side notches) on one or both edges of the point, as appropriate. The measurement was taken along the centerline between the distal end of the notch to a baseline drawn between the tip of the shoulder or barb to the nearest end of the base. The prerequisite for taking this measurement was that the adjacent portions of the barb or shoulder and the base must be present (so that the baseline could be drawn). If both edges of the point were intact, this measurement was collected for both notches; however, it was also collected if only one of the notches was complete. The same left-right orientation was used when recording all measurements related to the notches (i.e., Notch Depth [Left] was recorded on the same notch as Notch Width [Left] and Notch Angle [Left]). Later in the 
analysis, derivative variables using the average of and the difference between the two notches' depths were used instead of the raw measurements.

Notch Width (Left and Right) - This paired set of observations represents the width of the proximal end of proximal/lateral notches (i.e., corner and side notches) on one or both edges of the point, as appropriate. The measurement was taken along a baseline drawn between the tip of the shoulder or barb to the nearest end of the base. Thus, this measurement required that the adjacent portions of the barb or shoulder and the base be present (so that the baseline could be drawn). If both edges of the point were intact, this measurement was collected for both notches; however, it was also recorded if only one of the notches was complete. The same leftright orientation was used when recording all measurements related to the notches (i.e., Notch Width [Left] was recorded on the same notch as Notch Depth [Left] and Notch Angle [Left]). Later in the analysis, derivative variables using the average of and the difference between the two notches' widths were used instead of the raw measurements.

Notch Angle (Left and Right)-This paired set of observations refers to the angle of the proximal/lateral notches (i.e., corner and side notches) in relation to an idealized $90^{\circ}$ angle formed by a baseline drawn across the blade/stem interface and the orientation of the stem. To take this measurement, a baseline was first drawn across the blade/stem interface (usually, this baseline connected the distal extent of the side or corner notches). Next, a perpendicular line was dropped down from this baseline toward the base of the point. The intersection of these two lines was at the distal extent of the proximal/lateral notch. Using a standard protractor, the angle of the notch in relation to the baseline and its perpendicular was recorded. The angle was recorded in degrees between $0^{\circ}$ and $90^{\circ}$ moving outwards from the perpendicular. Thus, a $0^{\circ}$ angle would represent a perfectly longitudinal basally derived notch, whereas a $90^{\circ}$ angle would represent a perfectly transverse side notch. Thus, this measurement required that the adjacent portions of the barb or shoulder and the base be present (so that the baseline could be drawn). If both edges of the point were intact, this measurement was collected for both notches; however, it was also recorded if only one of the notches was complete. The same left-right orientation was used when recording all measurements related to the notches (i.e., Notch Angle [Left] was recorded on the same notch as Notch Width [Left] and Notch Width [Left]). Later in the analysis, derivative variables using the average of and the difference between the two notches' angles were used instead of the raw measurements.

\section{Stem Characteristics}

Maximum Stem Length-Maximum Stem Length refers to the maximum longitudinal length of the stem from the blade/stem interface to the base. On notched and barbed specimens, the blade/stem interface is the greatest extent of the notches toward the distal tip. On shouldered or contracting-stemmed specimens, the blade/stem interface is the point at which noticeable flare toward the shoulders or barbs begins. The baseline is the furthest proximal extent of the stem. This measurement was recorded only on those specimens that had longitudinally complete stems. It could still be recorded if portions of the stem were missing, but at least one complete longitudinal crosssection needed to be present. Assuming that the specimen was relatively complete (longitudinally), Maximum Blade Length plus Maximum Stem Length should equal Maximum Length.

Stem Distal Width (i.e., Neck Width)—Stem Distal Width represents the width of the stem at the blade/stem interface. On notched and barbed 
specimens, this measurement was taken at the greatest extent of the proximal/lateral notches toward the distal tip. On shouldered or contracting-stemmed specimens, this measure was recorded at the point at which noticeable flare toward the shoulder or barb begins. On contracting-stemmed specimens, this measure is assumed to represent the approximate diameter of the hafting device into which the point was set. This measurement was taken only on those stems on which the distal end was complete.

Stem Proximal Width-Stem Proximal Width refers to the width of the proximal end of the stem. On expanding-stemmed specimens, this measurement was taken at the widest extent of the stem, which occurred either at mid-stem (on curved, bifurcate-stemmed styles) or along the base (on expanding-stemmed styles). On straight- or parallel-sided stems, this value was recorded at the base. On contracting-stemmed specimens, this measure was taken at the point at which a noticeable break initiates the (usually convex) base). On expanding-stemmed specimens, this measure is assumed to represent the approximate diameter of the hafting device into which the point was set. This measurement was taken only on those stems on which the proximal end was complete.

Stem Thickness-Stem Thickness represents the average thickness of the stem. This measurement was taken approximately half-way up the stem or at an appropriate, representative location. This measurement was generally reserved for relatively complete stems, but if two-thirds or more of the stem was represented, it was generally possible to take the measurement with some confidence that a representative cross-section was present.

\section{Base Characteristics}

Base Depth-Base Depth refers to the longitudinal distance from the baseline of the stem to the proximal or distal extent of any basal modification. On concave- or notched-base specimens (usually expanding-stemmed forms), this measurement represents the distance from the baseline to the greatest extend of the basal notch or concavity (assigned a [+] value). On convex-based specimens (usually contractingstemmed forms), this measurement is taken from the point at which noticeable flare towards the base occurs (coincides with the point at which the Stem Proximal Width measurement is taken on contracting-stemmed forms) to the base (assign a [-] value). On straight-based specimens (usually triangular forms), Base Depth is assigned a value of " 0 ." This measurement was recorded on for those specimens that possess a relatively complete basal stem element.

Base Notch Width-Base Notch Width refers to the width of the basal concavity or notch along the baseline of the stem. Clearly, this measurement could only be taken on specimens that exhibited an appropriate basal concavity (i.e., contracting-stemmed and straight-based forms were not included). This measurement was recorded only when the basal stem element was relatively complete.

\section{Derivative Variables}

Several derivative variables were calculated based on the primary variables described above, including averages and differences for the three paired sets of variables (Notch Depth, Notch Width, and Notch Angle) and six ratios.

Notch Depth Average-Notch Depth Average was calculated by finding the average of the two Notch Depth measurements (i.e., Left and Right). This variable could only be calculated when both notch measurements were recorded (i.e., on relatively complete specimens). If only one of the two notch measurements was available, the average could not be computed. While this variable distilled two separate, redundant observations into a single measure of notch depth, the requirements of the calculation 
resulted in a variable with a relatively minimal number of observations.

Notch Depth Difference-Notch Depth Difference was computed by taking the difference between the two Notch Depth measurements (i.e., Left and Right). This variable was designed to serve as a proxy measure of stem asymmetry, as initial observations of the point assemblage indicated that some specimens were strongly symmetrical while others were highly asymmetrical. This variable could only be calculated when both notch measurements were recorded (i.e., on relatively complete specimens). If only one of the two notch measurements was available, the difference could not be computed. While this variable distilled two separate, redundant observations into a single measure of notch depth, the requirements of the calculation resulted in a variable with a relatively minimal number of observations.

Notch Width Average-Notch Width Average was calculated by finding the average of the two Notch Width measurements (i.e., Left and Right). This variable could only be calculated when both notch measurements were recorded (i.e., on relatively complete specimens). If only one of the two notch measurements was available, the average could not be computed. While this variable distilled two separate, redundant observations into a single measure of notch width, the requirements of the calculation resulted in a variable with a relatively minimal number of observations.

Notch Width Difference-Notch Width Difference was computed by taking the difference between the two Notch Width measurements (i.e., Left and Right). This variable was designed to serve as another proxy measure of stem asymmetry, as initial observations of the point assemblage indicated that some specimens were strongly symmetrical while others were highly asymmetrical. This variable could only be calculated when both notch measurements were recorded (i.e., on relatively complete specimens). If only one of the two notch measurements was available, the difference could not be computed. While this variable distilled two separate, redundant observations into a single measure of notch width, the requirements of the calculation resulted in a variable with a relatively minimal number of observations.

Notch Angle Average-Notch Angle Average was calculated by finding the average of the two Notch Angle measurements (i.e., Left and Right). This variable could only be calculated when both notch measurements were recorded (i.e., on relatively complete specimens). If only one of the two notch measurements was available, the average could not be computed. While this variable distilled two separate, redundant observations into a single measure of notch angle, the requirements of the calculation resulted in a variable with a relatively minimal number of observations.

Notch Angle Difference-Notch Angle Difference was computed by taking the difference between the two Notch Angle measurements (i.e., Left and Right). This variable was designed to serve as another proxy measure of stem asymmetry, as initial observations of the point assemblage indicated that some specimens were strongly symmetrical while others were highly asymmetrical. This variable could only be calculated when both notch measurements were recorded (i.e., on relatively complete specimens). If only one of the two notch measurements was available, the difference could not be computed. While this variable distilled two separate, redundant observations into a single measure of notch angle, the requirements of the calculation resulted in a variable with a relatively minimal number of observations.

Stem Length:Width Ratio-The Stem Length:Width Ratio represents the Stem Length divided by Stem Average Width. Stem Average 
Width, in turn, is the average of Stem Proximal Width and Stem Distal Width (i.e., [Stem Proximal Width + Stem Distal Width] $/ 2=$ Stem Length:Width Ratio). Values greater than 1.00 represent stems that are relatively longer than wide, while values less than 1 represent stems that are relatively wider than long. Computation of this ratio required that values for both Stem Length and Stem Average Width (which in turn required that values for both Stem Proximal Width and Stem Distal Width) be available.

Stem Distal:Proximal Width Ratio-The Stem Distal:Proximal Width Ratio (alternately known as the Stem Shape Ratio) provides another overall measure of stem shape that describes the relative expanding- versus contracting-stemmed form of the stem. This ratio was calculated by dividing Stem Distal Width by Stem Proximal Width (i.e., Stem Distal Width / Stem Proximal Width). Values less than about 0.90 represent expanding or curved-stemmed forms and values greater than about 1.10 represent contractingstemmed forms. Values between about 0.90 and 1.10 (average 1.00) represent essentially straight-stemmed forms. Computation of this ratio required that values for both Stem Distal Width and Stem Proximal Width be available.

Thickness:Width Ratio-The Thickness:Width Ratio provides a measure of the overall thickness of bifaces relative to their width. This ratio was calculated by dividing Maximum Thickness by Maximum Width (Maximum Width, in turn, represents the greater value of either Maximum Blade Width or Maximum Barb/Shoulder Width). The lower this value, the wider the point is relative to its thickness; conversely, the Number 8 , higher this value, the thicker the point is relative to its width. In general, this ratio may broadly refer to the level of control that a flintknapper was able to exert during tool production (Callahan 1979), but it may also serve as an indication of the extent of lateral blade edge resharpening. In the former case, more "finely" manufactured points tend to be relatively thin and wide, resulting in a lowervalue Thickness:Width Ratio. "Poorly" manufactured points may be relatively thick and narrow and have a correspondingly higher-value for this variable. In the latter case, extensively resharpened points tend to grow progressively narrow and thicker relative to their original form, resulting in a higher-value Thickness:Width Ratio, while the opposite would be true of points that were not laterally resharpened. Computation of this ratio required that both Maximum Thickness and Maximum Width values be available.

Stem:Maximum Thickness Ratio-The Stem:Maximum Thickness Ratio was an experimental value calculated by dividing Stem Thickness by Maximum Thickness. Assuming that the longitudinal mid-point of all point stems (which represents the point at which the Stem Thickness measure was recorded) is thinner than the maximum thickness of the whole implement (usually mid-blade), the Stem:Maximum Thickness Ratio would yield a value between 0.00 and 1.00 , with 0.00 representing a hypothetically paper-thin stem relative to the overall point thickness and 1.00 representing a stem of equal thickness to the overall point. Thus, values approaching 1.00 represent relatively thick-stemmed points, while lower values represent relatively thin-stemmed points. Computation of this ratio was possible only when both Stem Thickness and Maximum Thickness were available; consequently, it could only be calculated for relatively complete specimens.

Stem Thickness:Width Ratio-The Stem Thickness:Width Ratio was calculated by dividing Stem Thickness by Stem Distal Width. Originally, this ratio was intended to serve as a measure of stem thickness relative to overall stem width, and it probably would have been wiser to use the Stem Average Width instead of the Stem Distal Width as the divisor. However, whether due to a variable-selection error or to 
the possibility that this ratio was calculated before the Stem Average Width variable was created, Stem Distal Width was selected as the divisor for the equation underlying the Stem Thickness:Width Ratio. As it stands, this ratio probably serves more directly as a measure of the robusticity of the blade/stem interface; as such, it may indicate the relative resistance of the stem element to breakage upon impact. The patterning of values for this ratio are the opposite of those in the Thickness:Width Ratio (discussed above). Larger values represent distal stem cross-sections that are thicker relative to their width (and presumably more resistant to breakage), whereas smaller values are thinner relative to their width (and presumably less resistant to breakage). Computation of this ratio was dependent upon the availability of both Stem Distal Width and Stem Thickness values.

Base Depth:Width Ratio-The Base Depth:Width Ratio was used to measure the relative shape of the basal concavity or convexity of the base of the stem. Thus, this ratio was calculated using slightly different, yet related, primary variables for darts and arrows. For dart points, the Base Depth:Width Ratio was calculated by dividing Base Depth (which would have a positive [+] value representing a basal notch or concavity) by Base Notch Width. For arrow points, however, Base Notch Width was not recorded as arrow points usually have contracting stems and convex bases; therefore, the Base Depth:Width Ratio was calculated by dividing Base Depth (which would have a negative [-] value for convex bases) by Proximal Stem Width (which represents the point on the stem below which there is noticeable basal contraction). Thus, while the variables used to calculate this ratio varied between dart and arrow points, the dimension of the stem measured by the divisor is comparable; in this context, a convex, contracting-stemmed base may be viewed as the inverse of a basal notch or concavity. Theoretically, the value of this ratio could exceed 1.00 (for dart points) or -1.00 (for arrow points), but in practice it ranged between 1.00 and -1.00 because the width of the relevant stem element was always greater than the depth (or extent) of the basal notch (or convexity). Thus, as this value approached 0.00 (from either the positive or negative directions), the flatter the basal element was. As this value moved toward 1.00 or -1.00 , the more pronounced the basal element was. Computation of this ratio required that values for both Base Depth and Base Notch Width (for darts) or Proximal Stem Width (for arrows) be available.

\section{A.3.3 Numerical Classification}

In essence, classification is concerned with identifying groups of similar objects within the set of objects under study (in this sense, the "objects" may be individual objects or attributes [Cowgill 1982; Doran and Hodson 1975; Hodson 1982; Shennan 1988:195; Spaulding 1977]). Classification is a process of simplification that allows generalizations to be made and used based on similarities both within and between groups. Such generalizations may be purely descriptive or serve as the basis for defining hypotheses that may be tested by other means. Broadly speaking, classification is concerned with defining groupings (or "clusters") within a data set that are more similar to one another than they are to members of other groupings (Shennan 1988:195-196). In practice, real data rarely behave this well:

A preferable definition of an object-cluster type is a subset of an assemblage, each member of which is more similar to at least one other member of the same subset than to any member of the assemblage that is not in the same subset, and where at least most members of the subset are more similar to at least most other members of the same subset than to at least most members of the assemblage that are assigned (by the same criteria) to any other type...The definition...requires that no object should be more similar to some object assigned to 
another type than to any other object assigned to the same type, but allows that some objects assigned to different types may be more similar to one another than each is to some of the objects in the types to which each is assigned (Cowgill 1982:32-33 [emphases in original]).

While the similarity to the traditional intuitive approach to classification in archeology may appear obvious, the most compelling reasons to employ numerical classification are to make classification decisions explicit, to make handling of large data sets easier, to make the grouping process more consistent (and replicable), and to reveal patterning not easily apparent in large, complex, data sets (Kerr and Dial 1998:450; Shennan 1988:195). Thus, the process is one of discovery or exploratory data analysis. It is intended to highlight relationships that exist among variables and cases that may subsequently be investigated through hypothesis formulation and testing.

Within numerical classification proper, distinctions may be drawn among the ways in which groups (or clusters) are formed. The two main categories involve partitioning versus hierarchical methods (Shennan 1988:197). Partitioning methods involve making a decision about the number of groups to be formed; individuals are then grouped together with those with which they are in some defined sense the most similar so that the requisite number of groups may be formed. Hierarchical methods may be further subdivided into agglomerative and divisive grouping techniques. Divisive methods start with all items in a single group, and then proceed to divide the groups up successively according to some criterion. Agglomerative methods start with all items under consideration as separate entities, then build up groups from these, starting by grouping the most similar items together, then grouping the groups thus formed at increasingly low levels of similarity until finally all the items are linked together in one large group, usually at a very low level of similarity. In both types of hierarchical method, the relationships among the items and groups may be represented in the form of a dendrogram, a tree diagram that illustrates the branching and grouping of items and groups. This study employs a hierarchical agglomerative method for developing groupings of projectile points.

All cluster analysis methods use a matrix composed of measures of similarity (or distance) among the individual cases included in the analysis (Shennan 1988:198). Thus, measures of numerical classification are based not on the raw data encoded in the variables incorporated within the analysis, but rather on an $n$-by- $n$ matrix of similarities or distances among the $n$ objects under study. There are numerous similarity or distance coefficients that may be used to generate such a matrix (cf. Sneath and Sokal 1973; Wishart 1978). Some are appropriate for quantitative numeric data, while others are based on qualitative presence/absence data.

Ward's method is only one of the numerous hierarchical agglomerative techniques, though it has proved to be particularly useful in archeology for analyzing continuous metric data (Shennan 1988:217). The idea behind it is that satisfactory clusters should be as homogeneous as possible. One way to define homogeneity is in terms of the distance of the members of a cluster from the mean of that cluster. In Ward's method, this distance is measured by the error sum of squares, the total sum of squared deviations or distances of all points from the means of the clusters to which they belong. The method's goal is to join individuals and groups successively in such a way that, at each step of the fusion process, the error sum of squares in the minimum possible; in other words, the clusters remain as homogeneous as possible.

The most commonly used measure of similarity in numerical classification is the Euclidean distance coefficient. Basically, this coefficient 
measures the straight-line distance between two points, measured in terms of a number of variables, using the Pythagorean Theorem (Pimentel and Smith 1985:117-123; Shennan 1988:198-199). However, the Euclidean distance coefficient is usually used with intervalor ratio-scale data, rather than with continuous numeric data. In addition, as Ward's method uses the error sum of squares, it requires that the coefficients in the matrix of similarity be based on the squared Euclidean distance among objects. Squared Euclidean distance is simply the square of the regular Euclidean distance coefficient.

Using this method, hierarchical groups were then built beginning with the most similar items, then adding less similar items successively until all items were linked in a single large group displayed as a dendrogram. Clusters and the specimens are along the vertical axis, while the horizontal axis shows the relative distance between clusters. The unit of measurement in Ward's Method is error sum of squares (ESS): the total sum of squared deviations or distances of all points from the means of the clusters to which they belong (Shennan 1988: 217). Measurements are then converted proportionally along a scale from 1 to 25 . All statistical transformations and permutations in this study were accomplished using statistical package for the social sciences (SPSS) version 12.0 for Windows statistical software.

\section{A.3.4 Process of Validation}

To a greater or lesser extent, cluster analysis methods impose their own patterning on the data (Shennan 1988:228). Divisive methods, for example, impose a series of divisions upon a set of data regardless of whether the resulting groups represent genuine distinctions or arbitrary dissections. Agglomerative methods, such as the one used in this study, are somewhat less guilty of imposing such patterning, but hierarchical methods do force a vertical taxonomy of relationships upon a data set that may or may not represent the actual relationships among the individual objects or attributes. As the resulting clusters may reflect real similarities or be somewhat arbitrary, it is necessary to apply some independent process of validation to evaluate the clusters (Shennan 1988:197-228-232).

One way of attempting to ensure the validity of clustering results on a particular data set is to analyze it by a variety of different methods. If they all result in similar patterns of strongly overlapping cluster membership, then the patterning is likely to be genuine. Alternately, if different methods do not provide the same results, it does not necessarily mean that there is not real patterning to be found, or that one of the methods is not representing it correctly. It may be that the cluster structure is successfully identified by one method based on one set of assumptions but not by another based on a different set (Shennan 1988:229-230).

The hierarchical agglomerative cluster analyses performed for this study were validated by employing discriminant function analysis, analysis of variance, and visual observation of clustered specimens with the assistance of descriptive statistics.

\section{A.3.4.1 Discriminant Function Analysis}

Discriminant function analysis was used as one validation method to check the results of the hierarchical agglomerative cluster analysis. This method presupposes the existence of a given number of known groups and is concerned with the allocation of individual items to those groups to which they most appropriately belong (Shennan 1988:196); as such, it may be used to refine the groups and to improve upon the initial cluster results.

Discriminant analysis is useful for building a predictive model of group membership based on observed characteristics of each case. The 
procedure generates a discriminant function (or, for more than two groups, a set of discriminant functions) based on linear combinations of the predictor variables that provide the best discrimination among the groups. The functions are generated from a sample of cases for which group membership is known (i.e., the clusters formed through hierarchical agglomerative cluster analysis) and can then be applied to new cases with measurements for the predictor variables but unknown group membership. In the current study, group membership was determined by the clusters resulting from the cluster analysis, and the predictor variables included those metric variables included in the cluster analysis.

For each discriminant function analysis performed, variable entry and removal was controlled using the stepwise method (as opposed to the forced-entry method, which enters all independent variables that satisfy tolerance criteria simultaneously). Means and standard deviations were first calculated for every variable in each cluster, and two statistics-Wilks' lambda and the F statisticwere calculated to provide a measure of withingroup variation. Wilks' lambda is a variable selection method for stepwise discriminant analysis that chooses variables for entry into the equation on the basis of how much they lower Wilks' lambda. The Wilks' lambda statistic is a measure based on the ratio of within-group variation to overall variation in the data, tested by means of a randomization procedure (Aldenderfer 1982; Shennan 1988:229). At each step, the variable that minimizes the overall Wilks' lambda is entered. The $F$ statistic measures the relative influence of each variable on group membership and assesses whether or not each variable contributes in a significant manner to group formation. By comparing the resulting $F$ statistics for each variable to the full table of $F$ probabilities $(p)$, it is possible to discern not only whether or not each variable influences the overall cluster membership in a significant manner (and at which significance level), but also how strongly each variable influences cluster membership. In general, the higher the value of the $F$ statistic, the more strongly it influences cluster formation. All statistical transformations and permutations in this study were accomplished using SPSS statistical software.

\section{A.3.4.2 Analysis of Variance}

Analyses of variance were performed on the results of the cluster analysis to further clarify the significance of the morphological variability arrayed by the cluster analysis. Analysis of variance (ANOVA) "partitions the total variation in a data set according to the sources of variation that are present" (Johnson and Bhattacharyya 1985:466). The one-way analysis of variance procedure produces a one-way analysis of variance for one or more quantitative dependent variables (i.e., metric variables) by a single-factor variable (i.e., cluster membership). Analysis of variance is used to test the hypothesis that several means are equal; thus, this technique is an extension of the two-sample t-test.

When comparing any number of means, the differences between means (or variation among groups) and inherent variation (or variation within groups) are the two sources of variation evaluated. The $F$ ratio tests the significance of the difference between means and will be greater than the relevant $F$ distribution point as determined by the appropriate degrees of freedom when there is a significant difference between means and distributions. All statistical transformations and permutations in this study were accomplished using SPSS statistical software.

\section{A.3.4.3 Visual Examination and Descriptive Statistics}

The results of cluster analyses, discriminant function analyses, and analyses of variance were 
further checked by direct visual examination of the original artifacts or photographic facsimiles of those specimens that were sent out for specialized analyses (i.e., microscopic use-wear analysis, instrumental neutron activation analysis) and were not available for physical inspection. While visual inspection is an intuitive validation procedure, it allows for a subjective assessment of dimensions of variability that may be apparent to the eye but that were not encoded for systematic analyses. The human eye was aided in this effort by reference to descriptive statistics generated for each cluster, such as the sample mean, median, standard error of the mean, standard deviation, variance, kurtosis, and skewness. Examination of the original artifacts and descriptive statistics for each cluster helped to illustrate the key morphological characteristics of each cluster.

\section{A.3.5 Dimensionalization of Data}

Before any set of raw data can be used in pattern recognition studies, such as cluster analysis, the data must first be dimensionalized in such a way that they are appropriate for the analytical techniques to be employed. This section describes data manipulation, transformation, and elimination procedures applied to the projectile point data.

First, dart points and arrow points were segregated into two separate data sets. This seemed a natural division, and dart and arrow points have clear chronological and morphological differences in Central Texas that justified analyzing them separately. For example, the relative size differences between arrow and dart points alone would have skewed the results of any statistical analysis using a pooled data set including all points. This is the only primary partition that was applied to either data set. While the arrow points from the Varga Site appear to span a relatively limited range of cultural/chronological periods (ca. 1,250 to 200 B.P.), the dart point assemblage includes named types dating to the
Early, Middle, and Late Archaic periodsspanning some 4,800 years of time. The temptation to subdivide further the dart point data set based on cultural/chronological periods was resisted. Doing so would have resulted in a sizable Early Archaic assemblage that may have yielded statistically significant results by itself, but the Middle and Late Archaic groups would have been represented by only a handful of individual specimens each. Therefore, all dart points were analyzed as a single population despite their cultural, chronological, and stratigraphic differences.

It was necessary to perform a series of runs of the data through cluster analysis, discriminant function analysis, and analysis of variance, followed by visual examination of the clustered artifacts and inspection of descriptive statistics for each cluster to understand the behavior of the variables included in the analysis and to assess their ability to represent meaningful dimensions of variability. As will be discussed in more detail below, it was necessary to perform multiple runs of the dart point data before a satisfactory group of clusters was achieved. Unfortunately, the arrow point data required less manipulation and produced much less informative results.

Table A-2 summarizes the number of observations recorded for each variable among the dart and arrow point assemblages. All data dimensionalizing strategies and analyses were applied equally to both the dart and arrow point data sets. For purposes of discussion, each is discussed separately in this appendix.

\section{A.4 Results of Statistical Analyses}

\section{A.4.1 Dart Point Analyses}

One goal of this study was to use the maximum possible number of specimens in the statistical analysis. The highly fragmented nature of the assemblage, however, imposed certain restrictions upon the selection of specimens and 
Table A-2. Summary of Projectile Point Metric Observations

\begin{tabular}{|c|c|c|c|c|c|}
\hline \multirow[b]{2}{*}{ Variable } & \multicolumn{2}{|c|}{$N$} & \multirow[b]{2}{*}{ Variable } & \multicolumn{2}{|c|}{$N$} \\
\hline & Dart & Arrow & & Dart & Arrow \\
\hline Maximum Length & 51 & 38 & Notch Angle Difference & 81 & 64 \\
\hline Weight & 75 & 75 & Maximum Stem Length & 118 & 74 \\
\hline Blade Length & 48 & 52 & Stem Distal Width (i.e., Neck Width) & 119 & 115 \\
\hline Blade Width & 112 & 116 & Stem Proximal Width & 107 & 79 \\
\hline Barb/Shoulder Width & 86 & 67 & Stem Average Width & 95 & 75 \\
\hline Notch Depth (Left) & 91 & 56 & Stem Length:Width Ratio & 92 & 71 \\
\hline Notch Depth (Right) & 90 & 49 & Stem Distal:Proximal Width Ratio & 95 & 75 \\
\hline Notch Depth Average & 26 & 41 & Stem Thickness & 130 & 92 \\
\hline Notch Depth Difference & 69 & 41 & Maximum Width & 116 & 122 \\
\hline Notch Width (Left) & 90 & 56 & Maximum Thickness & 138 & 170 \\
\hline Notch Width (Right) & 89 & 49 & Thickness:Width Ratio & 111 & 114 \\
\hline Notch Width Average & 26 & 41 & Stem:Maximum Thickness Ratio & 110 & 79 \\
\hline Notch Width Difference & 67 & 41 & Stem Thickness:Width Ratio & 115 & 89 \\
\hline Notch Angle (Left) & 100 & 84 & Base Depth & 146 & 76 \\
\hline Notch Angle (Right) & 99 & 79 & Base Notch Width & 109 & 3 \\
\hline Notch Angle Average & 34 & 64 & Base Depth:Width Ratio & 119 & 75 \\
\hline
\end{tabular}

$N$ refers to the number of observations recorded for each variable within the entire projectile point assemblage of 441 specimens. Measurements were recorded only when the relevant portion of the point was complete or relatively complete. Derivative variables include values only when primary variables used to calculate derivative variables contained sufficient data to perform calculations.

variables that could be included. Hierarchical clustering methods require that each case (i.e., each point) contribute a value in each variable included in the study (i.e., the methods have no tolerance for missing values). In other words, any point to be included needed to be sufficiently complete that a measurement could be taken and recorded for every variable used in the statistical analysis. Specimens that were relatively complete but lacked even a single measurement in a key variable had to be excluded from the analysis. Thus, part of the initial examination of data involved determining which variables had a sufficiently large number of values to contribute to statistically significant results.
First, several of the primary variables that were used to calculate derivative variables (i.e., averages, differences, and ratios) were excluded from the analysis. The use of both primary and derivative variables in the same analysis tends to over-represent the influence of certain dimensions of variability. For instance, six of the measures recorded on the points—Notch Width (Left and Right), Notch Depth (Left and Right), and Notch Angle (Left and Right)represent paired observations made on opposite edges of the same specimen. Thus, whereas most variables recorded only a single value for each point, these six variables represented dual measurements that artificially doubled the size of the data set. It was therefore necessary to 
calculate single variables for each of these pairs that represented a blending of the two. Thus, each pair of notching variables was replaced with two other variables that represented the average of the two and the difference between the two (e.g., Notch Width Average, Notch Width Difference). In all analyses, only the average and difference variables were used; the original width, depth, and angle measurements were removed from consideration early in the analytical process.

Second, after the paired variables were replaced by single variables, the number of values available in each of the remaining primary and derivative metric variables was summed. This resulted in the identification of numerous variables that simply did not have enough values in them to be included in the analysis. Use of all of 26 variables (excluding the paired notch observations) in a test run of the cluster analysis produced only 27 of the total 215 dart points (12.6 percent) with values recorded in all selected variables. Clearly, this was not a suitable population size to yield statistically significant results.

Therefore, all metric variables with less than 100 values in them were removed from the data set. This resulted in a smaller data spread composed of only 13 variables. These 13 variables were submitted to a test run of the cluster analysis algorithm; however, only 71 of the total 215 dart points (33 percent) were represented in the results. This still seemed to be too small a population to yield statistically valid results.

Next, a similar problem to that associated with the paired notch variables was observed with the Barb/Shoulder Width and Blade Width variables. These two variables represented measurements of a single dimension of variability (width) at either one or two different places on a single specimen. Because these two measurements were not necessarily recorded in the same places on every point, they needed to be standardized to some degree. Thus, the larger of either the Barb/Shoulder Width or the Blade Width values was exported into the Maximum Width variable, providing a single variable that could be used to represent the width of the specimen. This also resulted in an overall increase in the number of observations, as Maximum Width $(n=116)$ exceeded the maximum number of values in either the Blade Width $(n=112)$ or Barb/Shoulder Width $(n=86)$ variables. In all subsequent analyses, the Maximum Width variable was used instead of either Barb/Shoulder Width or Blade Width.

Finally, all unclassified dart points were removed from the data set. Only 2 of the total 69 unclassified dart points were showing up in the data spread, so it seemed a small sacrifice to remove the unclassified dart points in exchange for reducing the overall size of the population. A final test run of the 146 typed dart points with the reduced array of 12 variables resulted in the inclusion of 69 of the 146 specimens (47.3 percent). While still under half of the total assemblage of typed points, this represented the largest possible population based on the degree of tool fragmentation in the point assemblage.

The final suite of 12 variables included in the cluster analysis was composed of Maximum Stem Length, Stem Distal Width, Stem Proximal Width, Stem Thickness, Maximum Width, Maximum Thickness, Thickness:Width Ratio, Stem:Maximum Thickness Ratio, Stem Thickness: Width Ratio, Base Depth, Base Notch Width, and Base Depth:Width Ratio. Clearly, some of these variables are ratios calculated from other variables that were also included in the analysis. Thus, certain dimensions of point variability, such as thickness and width, may be overrepresented in the analytical results. However, as the results of the discriminant function analyses and analyses of variance presented below show, all but one of these variables (Stem:Maximum Thickness Ratio) meaningfully influence the formation of clusters. 
Consequently, there seemed to be no reason to trim the variable array any further.

\section{A.4.1.1 Cluster Analysis Results}

The initial results of cluster analysis produced nine clusters with no outliers from the culled data set composed of 12 variables and 146 typed dart points (Figure A-2). The nine groups of dart points defined by the cluster analysis were used as the predefined groups in a discriminant function analysis. A variable entitled Cluster was added to the data set, each point was assigned the cluster number (1 to 9 ) into which it was placed during the cluster analysis, and the Cluster variable was used as the grouping variable for the discriminant function analysis. The probability of accurate assignment of specimens to clusters was assessed using stepwise discriminant function analysis. Means and standard deviations were calculated for each of the 12 variables in each cluster (Table A-3), and two statistics-Wilks' lambda and the $F$ statistic - were calculated to provide a measure of within-group variation (Table A-4).

Based on the results of the discriminant function analysis, it is apparent that most of the included variable contribute significantly to the membership of clusters at the $p=.001$ significance level. Only two variables are exceptions to this rule. Base Notch Width is significant only at the $p=0.01$ level; the $F$ ratio for this variable just barely exceeds the $F$ distribution point at this significance level given the specified degrees of freedom $(F=2.82)$. Stem:Maximum Thickness Ratio, however, does not contribute significantly to the membership of clusters identified during the cluster analysis. The $F$ ratio fails to exceed the necessary $F$ distribution point for the given degrees of freedom even at the $p=.05$ significance level $(F=2.10)$. This indicates that, of these 12 variables, Stem:Maximum Thickness Ratio does not significantly influence the membership of the identified clusters at the $p=.001$ significance level. Base Notch Width does contribute significantly to group membership, but it only barely exceeds the necessary $F$ distribution point $(F=2.82)$ at the $p=.01$ significance level. One variable, Stem:Maximum Thickness Ratio, fails to exceed the necessary $F$ distribution point given the appropriate degrees of freedom $(F=2.10)$ at the $p=0.5$ significance level.

\section{A.4.1.2 Analysis of Variance Results}

By means of analysis of variance, the significance of the differences among the clusters was delineated according to group means and within-group variance from the mean. As Table A-5 shows, the analysis of variance results are identical to the results from the discriminant function analysis for the hierarchical agglomerative cluster analysis on the set of dart point data. Values of lambda which are near zero denote high discrimination between groups.

\section{A.4.1.3 Final Clustering Results}

Based on the results of discriminant function analysis and analysis of variance, it is apparent that one variable included in the initial run of the dart point data-Stem:Maximum Thickness Ratio_failed to contribute in a significant manner to the membership of the nine clusters defined in the initial cluster analysis results. To determine whether or not the inclusion of the Stem:Maximum Thickness Ratiointroduced statistical noise into the original clustering algorithm, the dart point data was rerun without this variable in the data set. The remaining 11 variables were resubmitted to hierarchical agglomerative cluster analysis using the same procedures described for the initial run of the data (Figure A-3).

In contrast to the initial cluster analysis results, which included nine clusters of dart points, the second cluster analysis produced eight clusters of dart points (Table A-6). Therefore, it appears 
that the inclusion of the Stem:Maximum Thickness Ratio had, in fact, introduced statistical noise into the data array. The eight clusters incorporate the ten named dart point types.

The clusters are based primarily on the general outline of the point types, particularly the base and stem attributes and the maximum width. This groups the clusters into two main groups; large triangular blade and expanding stemmed points, and narrower, smaller stemmed expanding base and straight stemmed points.

The revised cluster groupings were subjected to discriminant function analysis and analysis of variance to determine the validity of the cluster memberships. The second application of these analyses followed the same procedures as those described above for the initial cluster analysis results.Table A-7 presents means and withingroup variance about the mean for each of the eight clusters defined during the second cluster analysis. As Tables A-8 and A-9 show, all but one of the 11 variables included in the final cluster analysis contribute significantly to the overall group membership at the $p=.001$ significance level based on the given degrees of freedom. The single exception to this rule is the Stem Thickness: Width Ratio, which is significant at the $p=.01$ level. Therefore, the discriminant function analysis and analysis of variance performed on the results of the second cluster analysis provide identical results supporting the significance of each variable in the definition of each of the eight dart point clusters.

\section{A.4.2 Arrow Point Analyses}

As was the case with the statistical analyses performed on the assemblage of dart points, the arrow point study sought to use the maximum possible number of specimens in the statistical analysis that contributed the most relevant information. Due to the high rate of tool breakage that characterized the collections from the Varga Site, however, it was necessary to use highly selective criteria in choosing the arrow point specimens and variables that could be included the study. Because of the small size and overall thinness of the arrow points, the rate of tool breakage was far higher than among the dart points; consequently, fewer specimens yielded a complete set of measurements that could be used in the analyses. More importantly, far fewer variables could be included, which ultimately makes the results of the analyses highly suspect and of limited interpretive value.

As previously discussed in connection with the dart points, hierarchical clustering methods require that each case (i.e., each point) contribute a value in each variable included in the study (i.e., the methods have no tolerance for missing values). In other words, any point to be included needed to be sufficiently complete that a measurement could be taken and recorded for every variable used in the statistical analysis. Specimens that were relatively complete but lacked even a single measurement in a key variable had to be excluded from the analysis. Thus, part of the initial examination of data involved determining which variables had a sufficiently large number of values to contribute to statistically significant results.

First, several of the primary variables that were used to calculate derivative variables (i.e., averages, differences, and ratios) were excluded from the analysis. The use of both primary and derivative variables in the same analysis tends to over-represent the influence of certain dimensions of variability. For instance, six of the measures recorded on the points-Notch Width (Left and Right), Notch Depth (Left and Right), and Notch Angle (Left and Right)represent paired observations made on opposite edges of the same specimen. 


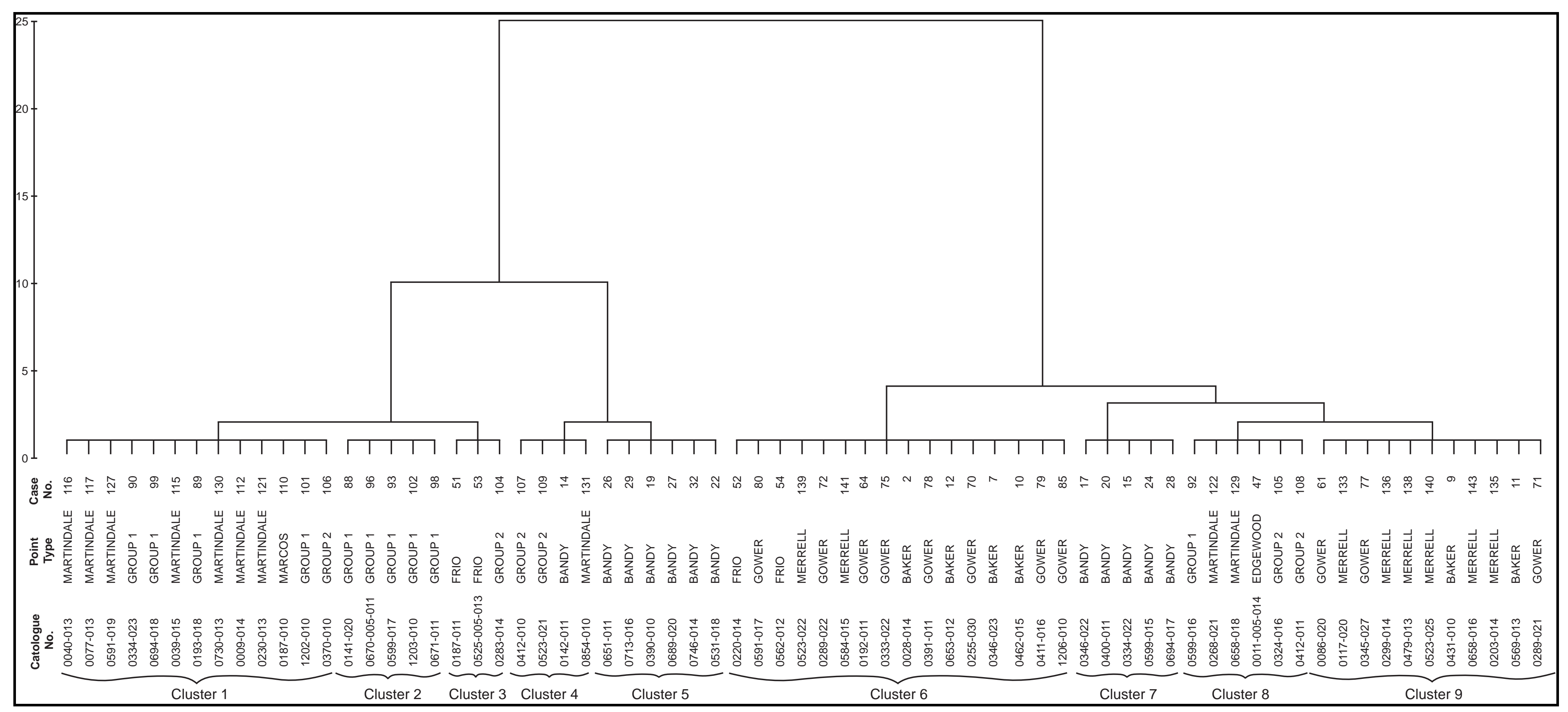

Figure A-2. Hierarchical Cluster Analysis Dendrogram of Dart Points (Initial Results)

Based on a dissimilarity matrix composed of squared Euclidean distance values calculated using Ward's Method (SPSS 12.0 for Windows). 

Table A-3. Group Statistics Comparing Dart Point Clusters 1 to 9 (Initial Results)

\begin{tabular}{|c|c|c|c|c|c|}
\hline \multirow{2}{*}{ Cluster No. } & \multirow{2}{*}{ Variable } & \multirow{2}{*}{ Mean } & \multirow{2}{*}{ Std. Deviation } & \multicolumn{2}{|c|}{ Valid $N$ (list wise) } \\
\hline & & & & Unweighted & Weighted \\
\hline 1 & $\begin{array}{l}\text { Stem Length } \\
\text { Stem Dist Width } \\
\text { Stem Prox Width } \\
\text { Stem Thickness } \\
\text { Maximum Width } \\
\text { Max Thickness } \\
\text { Thickness:Width Ratio } \\
\text { Stem:Max Thick Ratio } \\
\text { Stem Thick:Width Ratio } \\
\text { Base Depth } \\
\text { Base Notch Width } \\
\text { Base Depth:Width Ratio }\end{array}$ & $\begin{array}{c}12.0231 \\
18.1308 \\
23.6615 \\
4.9615 \\
30.4846 \\
6.8615 \\
0.2256 \\
0.7228 \\
0.2747 \\
2.8462 \\
11.1615 \\
0.2633\end{array}$ & $\begin{array}{l}1.91492 \\
1.27173 \\
1.21212 \\
0.87516 \\
2.13848 \\
0.64490 \\
0.02118 \\
0.11007 \\
0.05085 \\
1.21629 \\
2.39984 \\
0.11188\end{array}$ & $\begin{array}{l}13 \\
13 \\
13 \\
13 \\
13 \\
13 \\
13 \\
13 \\
13 \\
13 \\
13 \\
13\end{array}$ & $\begin{array}{l}13.000 \\
13.000 \\
13.000 \\
13.000 \\
13.000 \\
13.000 \\
13.000 \\
13.000 \\
13.000 \\
13.000 \\
13.000 \\
13.000\end{array}$ \\
\hline 2 & $\begin{array}{l}\text { Stem Length } \\
\text { Stem Dist Width } \\
\text { Stem Prox Width } \\
\text { Stem Thickness } \\
\text { Maximum Width } \\
\text { Max Thickness } \\
\text { Thickness:Width Ratio } \\
\text { Stem:Max Thick Ratio } \\
\text { Stem Thick:Width Ratio } \\
\text { Base Depth } \\
\text { Base Notch Width } \\
\text { Base Depth:Width Ratio }\end{array}$ & $\begin{array}{c}15.7200 \\
18.3600 \\
22.2200 \\
4.6600 \\
34.1200 \\
7.8400 \\
0.2317 \\
0.5979 \\
0.2554 \\
3.7000 \\
11.0000 \\
0.3271\end{array}$ & $\begin{array}{l}1.18617 \\
1.24016 \\
1.92666 \\
0.82946 \\
3.22909 \\
1.16748 \\
0.04397 \\
0.08836 \\
0.05140 \\
1.37659 \\
2.02361 \\
0.09568\end{array}$ & $\begin{array}{l}5 \\
5 \\
5 \\
5 \\
5 \\
5 \\
5 \\
5 \\
5 \\
5 \\
5 \\
5\end{array}$ & $\begin{array}{l}5.000 \\
5.000 \\
5.000 \\
5.000 \\
5.000 \\
5.000 \\
5.000 \\
5.000 \\
5.000 \\
5.000 \\
5.000 \\
5.000\end{array}$ \\
\hline 3 & $\begin{array}{l}\text { Stem Length } \\
\text { Stem Dist Width } \\
\text { Stem Prox Width } \\
\text { Stem Thickness } \\
\text { Maximum Width } \\
\text { Max Thickness } \\
\text { Thickness:Width Ratio } \\
\text { Stem:Max Thick Ratio } \\
\text { Stem Thick:Width Ratio } \\
\text { Base Depth } \\
\text { Base Notch Width } \\
\text { Base Depth:Width Ratio }\end{array}$ & $\begin{array}{c}11.6667 \\
19.9000 \\
29.9333 \\
4.8333 \\
30.9000 \\
8.9667 \\
0.2925 \\
0.5803 \\
0.2440 \\
3.5667 \\
13.2667 \\
0.2835\end{array}$ & $\begin{array}{l}1.15902 \\
0.70000 \\
0.60277 \\
0.95044 \\
3.45977 \\
2.99388 \\
0.09860 \\
0.23407 \\
0.05581 \\
0.55076 \\
4.96521 \\
0.06533\end{array}$ & $\begin{array}{l}3 \\
3 \\
3 \\
3 \\
3 \\
3 \\
3 \\
3 \\
3 \\
3 \\
3 \\
3\end{array}$ & $\begin{array}{l}3.000 \\
3.000 \\
3.000 \\
3.000 \\
3.000 \\
3.000 \\
3.000 \\
3.000 \\
3.000 \\
3.000 \\
3.000 \\
3.000\end{array}$ \\
\hline 4 & $\begin{array}{l}\text { Stem Length } \\
\text { Stem Dist Width } \\
\text { Stem Prox Width } \\
\text { Stem Thickness } \\
\text { Maximum Width } \\
\text { Max Thickness } \\
\text { Thickness:Width Ratio } \\
\text { Stem:Max Thick Ratio } \\
\text { Stem Thick:Width Ratio } \\
\text { Base Depth } \\
\text { Base Notch Width } \\
\text { Base Depth:Width Ratio }\end{array}$ & $\begin{array}{c}10.6500 \\
14.7500 \\
19.4750 \\
4.7750 \\
35.0250 \\
6.9750 \\
0.1998 \\
0.7034 \\
0.3266 \\
2.1750 \\
11.6750 \\
0.1896\end{array}$ & $\begin{array}{l}0.12910 \\
1.50222 \\
1.18708 \\
0.12583 \\
2.95790 \\
1.27115 \\
0.03641 \\
0.13795 \\
0.03755 \\
1.41274 \\
2.79687 \\
0.10824\end{array}$ & $\begin{array}{l}4 \\
4 \\
4 \\
4 \\
4 \\
4 \\
4 \\
4 \\
4 \\
4 \\
4 \\
4\end{array}$ & $\begin{array}{l}4.000 \\
4.000 \\
4.000 \\
4.000 \\
4.000 \\
4.000 \\
4.000 \\
4.000 \\
4.000 \\
4.000 \\
4.000 \\
4.000\end{array}$ \\
\hline 5 & $\begin{array}{l}\text { Stem Length } \\
\text { Stem Dist Width } \\
\text { Stem Prox Width } \\
\text { Stem Thickness } \\
\text { Maximum Width } \\
\text { Max Thickness } \\
\text { Thickness:Width Ratio } \\
\text { Stem:Max Thick Ratio } \\
\text { Stem Thick:Width Ratio } \\
\text { Base Depth } \\
\text { Base Notch Width } \\
\text { Base Depth:Width Ratio }\end{array}$ & $\begin{array}{c}8.4167 \\
12.8333 \\
15.5167 \\
3.3167 \\
36.5667 \\
4.5833 \\
0.1255 \\
0.7276 \\
0.2611 \\
1.4667 \\
8.8000 \\
0.1734\end{array}$ & $\begin{array}{l}1.11609 \\
1.14833 \\
1.17033 \\
0.26394 \\
2.18693 \\
0.31252 \\
0.00769 \\
0.08706 \\
0.03857 \\
0.58878 \\
2.88721 \\
0.06286\end{array}$ & $\begin{array}{l}6 \\
6 \\
6 \\
6 \\
6 \\
6 \\
6 \\
6 \\
6 \\
6 \\
6 \\
6\end{array}$ & $\begin{array}{l}6.000 \\
6.000 \\
6.000 \\
6.000 \\
6.000 \\
6.000 \\
6.000 \\
6.000 \\
6.000 \\
6.000 \\
6.000 \\
6.000\end{array}$ \\
\hline
\end{tabular}


Table A-3. Group Statistics Comparing Dart Point Clusters 1 to 9 (Initial Results) (Continued)

\begin{tabular}{|c|c|c|c|c|c|}
\hline \multirow{2}{*}{ Cluster No. } & \multirow{2}{*}{ Variable } & \multirow{2}{*}{ Mean } & \multirow{2}{*}{ Std. Deviation } & \multicolumn{2}{|c|}{ Valid $N$ (list wise) } \\
\hline & & & & Unweighted & Weighted \\
\hline 5 & $\begin{array}{l}\text { Stem Length } \\
\text { Stem Dist Width } \\
\text { Stem Prox Width } \\
\text { Stem Thickness } \\
\text { Maximum Width } \\
\text { Max Thickness } \\
\text { Thickness:Width Ratio } \\
\text { Stem:Max Thick Ratio } \\
\text { Stem Thick:Width Ratio } \\
\text { Base Depth } \\
\text { Base Notch Width } \\
\text { Base Depth:Width Ratio }\end{array}$ & $\begin{array}{c}8.4167 \\
12.8333 \\
15.5167 \\
3.3167 \\
36.5667 \\
4.5833 \\
0.1255 \\
0.7276 \\
0.2611 \\
1.4667 \\
8.8000 \\
0.1734\end{array}$ & $\begin{array}{l}1.11609 \\
1.14833 \\
1.17033 \\
0.26394 \\
2.18693 \\
0.31252 \\
0.00769 \\
0.08706 \\
0.03857 \\
0.58878 \\
2.88721 \\
0.06286\end{array}$ & $\begin{array}{l}6 \\
6 \\
6 \\
6 \\
6 \\
6 \\
6 \\
6 \\
6 \\
6 \\
6 \\
6\end{array}$ & $\begin{array}{l}6.000 \\
6.000 \\
6.000 \\
6.000 \\
6.000 \\
6.000 \\
6.000 \\
6.000 \\
6.000 \\
6.000 \\
6.000 \\
6.000\end{array}$ \\
\hline 6 & $\begin{array}{l}\text { Stem Length } \\
\text { Stem Dist Width } \\
\text { Stem Prox Width } \\
\text { Stem Thickness } \\
\text { Maximum Width } \\
\text { Max Thickness } \\
\text { Thickness:Width Ratio } \\
\text { Stem:Max Thick Ratio } \\
\text { Stem Thick:Width Ratio } \\
\text { Base Depth } \\
\text { Base Notch Width } \\
\text { Base Depth:Width Ratio }\end{array}$ & $\begin{array}{c}12.3000 \\
13.8625 \\
17.2563 \\
4.5938 \\
18.5375 \\
6.7438 \\
0.3698 \\
0.6912 \\
0.3345 \\
4.5688 \\
8.8063 \\
0.5238\end{array}$ & $\begin{array}{l}1.77726 \\
1.26221 \\
1.61161 \\
0.88654 \\
2.50915 \\
0.92662 \\
0.07013 \\
0.15806 \\
0.07295 \\
1.08118 \\
1.08595 \\
0.12605\end{array}$ & $\begin{array}{l}16 \\
16 \\
16 \\
16 \\
16 \\
16 \\
16 \\
16 \\
16 \\
16 \\
16 \\
16\end{array}$ & $\begin{array}{l}16.000 \\
16.000 \\
16.000 \\
16.000 \\
16.000 \\
16.000 \\
16.000 \\
16.000 \\
16.000 \\
16.000 \\
16.000 \\
16.000\end{array}$ \\
\hline 7 & $\begin{array}{l}\text { Stem Length } \\
\text { Stem Dist Width } \\
\text { Stem Prox Width } \\
\text { Stem Thickness } \\
\text { Maximum Width } \\
\text { Max Thickness } \\
\text { Thickness:Width Ratio } \\
\text { Stem:Max Thick Ratio } \\
\text { Stem Thick:Width Ratio } \\
\text { Base Depth } \\
\text { Base Notch Width } \\
\text { Base Depth:Width Ratio }\end{array}$ & $\begin{array}{c}7.4400 \\
13.5600 \\
16.3200 \\
2.9600 \\
24.8800 \\
4.2800 \\
0.1734 \\
0.6912 \\
0.2183 \\
1.3000 \\
8.9200 \\
0.1513\end{array}$ & $\begin{array}{l}1.58524 \\
0.50299 \\
0.59749 \\
0.65038 \\
3.09871 \\
0.57184 \\
0.02702 \\
0.11462 \\
0.04803 \\
0.46368 \\
3.51383 \\
0.04300\end{array}$ & $\begin{array}{l}5 \\
5 \\
5 \\
5 \\
5 \\
5 \\
5 \\
5 \\
5 \\
5 \\
5 \\
5\end{array}$ & $\begin{array}{l}5.000 \\
5.000 \\
5.000 \\
5.000 \\
5.000 \\
5.000 \\
5.000 \\
5.000 \\
5.000 \\
5.000 \\
5.000 \\
5.000\end{array}$ \\
\hline 8 & $\begin{array}{l}\text { Stem Length } \\
\text { Stem Dist Width } \\
\text { Stem Prox Width } \\
\text { Stem Thickness } \\
\text { Maximum Width } \\
\text { Max Thickness } \\
\text { Thickness:Width Ratio } \\
\text { Stem:Max Thick Ratio } \\
\text { Stem Thick:Width Ratio } \\
\text { Base Depth } \\
\text { Base Notch Width } \\
\text { Base Depth:Width Ratio }\end{array}$ & $\begin{array}{c}10.9167 \\
15.7000 \\
21.9167 \\
4.4500 \\
24.8333 \\
6.9500 \\
0.2803 \\
0.6578 \\
0.2849 \\
2.3333 \\
10.2833 \\
0.2316\end{array}$ & $\begin{array}{l}1.56258 \\
1.18322 \\
1.02258 \\
0.56480 \\
0.71181 \\
1.11131 \\
0.04739 \\
0.14937 \\
0.04316 \\
0.52026 \\
2.13581 \\
0.05007\end{array}$ & $\begin{array}{l}6 \\
6 \\
6 \\
6 \\
6 \\
6 \\
6 \\
6 \\
6 \\
6 \\
6 \\
6\end{array}$ & $\begin{array}{l}6.000 \\
6.000 \\
6.000 \\
6.000 \\
6.000 \\
6.000 \\
6.000 \\
6.000 \\
6.000 \\
6.000 \\
6.000 \\
6.000\end{array}$ \\
\hline 9 & $\begin{array}{l}\text { Stem Length } \\
\text { Stem Dist Width } \\
\text { Stem Prox Width } \\
\text { Stem Thickness } \\
\text { Maximum Width } \\
\text { Max Thickness } \\
\text { Thickness:Width Ratio } \\
\text { Stem:Max Thick Ratio } \\
\text { Stem Thick:Width Ratio } \\
\text { Base Depth } \\
\text { Base Notch Width } \\
\text { Base Depth:Width Ratio }\end{array}$ & $\begin{array}{c}14.0636 \\
14.8455 \\
19.8909 \\
4.8545 \\
22.6000 \\
6.6273 \\
0.2959 \\
0.7341 \\
0.3284 \\
5.7818 \\
8.5455 \\
0.6915\end{array}$ & $\begin{array}{l}1.92368 \\
1.27622 \\
1.33974 \\
0.91144 \\
1.85580 \\
0.56761 \\
0.04162 \\
0.12523 \\
0.06072 \\
0.89534 \\
1.64886 \\
0.12655\end{array}$ & $\begin{array}{l}11 \\
11 \\
11 \\
11 \\
11 \\
11 \\
11 \\
11 \\
11 \\
11 \\
11 \\
11\end{array}$ & $\begin{array}{l}11.000 \\
11.000 \\
11.000 \\
11.000 \\
11.000 \\
11.000 \\
11.000 \\
11.000 \\
11.000 \\
11.000 \\
11.000 \\
11.000\end{array}$ \\
\hline
\end{tabular}


Table A-4. Tests of Equality of Group Means for Dart Point Clusters 1 to 9 (Initial Results)

\begin{tabular}{|l|c|c|c|c|c|}
\hline \multicolumn{1}{|c|}{ Variable } & Wilks' Lambda & F & df1 & df2 & Sig. \\
\hline Stem Length & 0.347 & 14.137 & 8 & 60 & 0.000 \\
Stem Dist Width & 0.227 & 25.584 & 8 & 60 & 0.000 \\
Stem Prox Width & 0.115 & 57.455 & 8 & 60 & 0.000 \\
Stem Thickness & 0.597 & 5.060 & 8 & 60 & 0.000 \\
Maximum Width & 0.113 & 58.674 & 8 & 60 & 0.000 \\
Max Thickness & 0.422 & 10.253 & 8 & 60 & 0.000 \\
Thickness:Width Ratio & 0.266 & 20.667 & 8 & 60 & 0.000 \\
Stem:Max Thick Ratio & 0.893 & 0.895 & 8 & 60 & 0.526 \\
Stem Thick:Width Ratio & 0.663 & 3.809 & 8 & 60 & 0.001 \\
Base Depth & 0.297 & 17.767 & 8 & 60 & 0.000 \\
Base Notch Width & 0.716 & 2.970 & 8 & 60 & 0.007 \\
Base Depth:Width Ratio & 0.217 & 27.034 & 8 & 60 & 0.000 \\
\hline
\end{tabular}

Table A-5. Analysis of Variance (ANOVA) Comparing Dart Point Clusters 1 to 9 (Initial Results)

\begin{tabular}{|c|c|c|c|c|c|c|}
\hline \multicolumn{2}{|c|}{ Variable } & Sum of Squares & df & Mean Square & $\mathbf{F}$ & Sig. \\
\hline Stem Length & $\begin{array}{l}\text { Between Groups } \\
\text { Within Groups } \\
\text { Total }\end{array}$ & $\begin{array}{l}311.468 \\
165.242 \\
476.710\end{array}$ & $\begin{array}{c}8 \\
60 \\
68 \\
\end{array}$ & $\begin{array}{c}38.933 \\
2.754\end{array}$ & 14.137 & 0.000 \\
\hline Stem Dist Width & $\begin{array}{l}\text { Between Groups } \\
\text { Within Groups } \\
\text { Total }\end{array}$ & $\begin{array}{c}300.531 \\
88.100 \\
388.631\end{array}$ & $\begin{array}{c}8 \\
60 \\
68\end{array}$ & $\begin{array}{c}37.566 \\
1.468\end{array}$ & 25.584 & 0.000 \\
\hline Stem Prox Width & $\begin{array}{l}\text { Between Groups } \\
\text { Within Groups } \\
\text { Total }\end{array}$ & $\begin{array}{l}826.169 \\
107.846 \\
934.015\end{array}$ & $\begin{array}{c}8 \\
60 \\
68\end{array}$ & $\begin{array}{c}103.271 \\
1.797\end{array}$ & 57.455 & 0.000 \\
\hline Stem Thickness & $\begin{array}{l}\text { Between Groups } \\
\text { Within Groups } \\
\text { Total } \\
\end{array}$ & $\begin{array}{l}25.322 \\
37.529 \\
62.851 \\
\end{array}$ & $\begin{array}{c}8 \\
60 \\
68 \\
\end{array}$ & $\begin{array}{l}3.165 \\
0.625\end{array}$ & 5.060 & 0.000 \\
\hline Maximum Width & $\begin{array}{l}\text { Between Groups } \\
\text { Within Groups } \\
\text { Total }\end{array}$ & $\begin{array}{c}2,663.829 \\
340.505 \\
3,004.333\end{array}$ & $\begin{array}{c}8 \\
60 \\
68\end{array}$ & $\begin{array}{c}332.979 \\
5.675\end{array}$ & 58.674 & 0.000 \\
\hline Max Thickness & $\begin{array}{l}\text { Between Groups } \\
\text { Within Groups } \\
\text { Total }\end{array}$ & $\begin{array}{c}78.321 \\
57.289 \\
135.611\end{array}$ & $\begin{array}{c}8 \\
60 \\
68\end{array}$ & $\begin{array}{l}9.790 \\
0.955\end{array}$ & 10.253 & 0.000 \\
\hline Thickness:Width Ratio & $\begin{array}{l}\text { Between Groups } \\
\text { Within Groups } \\
\text { Total }\end{array}$ & $\begin{array}{l}0.392 \\
0.142 \\
0.534\end{array}$ & $\begin{array}{c}8 \\
60 \\
68\end{array}$ & $\begin{array}{l}0.049 \\
0.002\end{array}$ & 20.667 & 0.000 \\
\hline Stem:Max Thick Ratio & $\begin{array}{l}\text { Between Groups } \\
\text { Within Groups } \\
\text { Total } \\
\end{array}$ & $\begin{array}{l}0.129 \\
1.077 \\
1.205 \\
\end{array}$ & $\begin{array}{c}8 \\
60 \\
68 \\
\end{array}$ & $\begin{array}{l}0.016 \\
0.018\end{array}$ & 0.895 & 0.526 \\
\hline Stem Thick:Width Ratio & $\begin{array}{l}\text { Between Groups } \\
\text { Within Groups } \\
\text { Total }\end{array}$ & $\begin{array}{l}0.099 \\
0.195 \\
0.294\end{array}$ & $\begin{array}{c}8 \\
60 \\
68\end{array}$ & $\begin{array}{l}0.012 \\
0.003\end{array}$ & 3.809 & 0.001 \\
\hline Base Depth & $\begin{array}{l}\text { Between Groups } \\
\text { Within Groups } \\
\text { Total } \\
\end{array}$ & $\begin{array}{c}145.511 \\
61.424 \\
206.935 \\
\end{array}$ & $\begin{array}{c}8 \\
60 \\
68 \\
\end{array}$ & $\begin{array}{c}18.189 \\
1.024\end{array}$ & 17.767 & 0.000 \\
\hline Base Notch Width & $\begin{array}{l}\text { Between Groups } \\
\text { Within Groups } \\
\text { Total }\end{array}$ & $\begin{array}{l}125.522 \\
317.018 \\
442.539\end{array}$ & $\begin{array}{c}8 \\
60 \\
68\end{array}$ & $\begin{array}{c}15.690 \\
5.284\end{array}$ & 2.970 & 0.007 \\
\hline Base Depth:Width Ratio & $\begin{array}{l}\text { Between Groups } \\
\text { Within Groups } \\
\text { Total }\end{array}$ & $\begin{array}{l}2.410 \\
0.669 \\
3.079\end{array}$ & $\begin{array}{c}8 \\
60 \\
68\end{array}$ & $\begin{array}{l}0.301 \\
0.011\end{array}$ & 27.034 & 0.000 \\
\hline
\end{tabular}


Thus, whereas most variables recorded only a single value for each point, these six variables represented dual measurements that artificially doubled the size of the data set. It was, therefore, necessary to calculate single variables for each of these pairs that represented a blending of the two. Each pair of notching variables was replaced with two other variables that represented the average of the two and the difference between the two (e.g., Notch Width Average, Notch Width Difference). Inall analyses, only the average and difference variables were used; the original width, depth, and angle measurements were removed from consideration early in the analytical process.

Also, a similar problem to that associated with the paired notch variables was observed with the Barb/Shoulder Width and Blade Width variables. These two variables represented measurements of a single dimension of variability (width) at either one or two different places on a single specimen. Because these two measurements were not necessarily recorded in the same places on every point, some degree of standardization was needed. The larger of either the Barb/Shoulder Width or the Blade Width values was exported into the Maximum Width variable, providing a single variable that could be used to represent the width of the specimen. This also resulted in an overall increase in the number of observations, as Maximum Width $(n=122)$ exceeded the maximum number of values in either the Blade Width $(n=116)$ or Barb/Shoulder Width ( $n=67)$ variables. In all subsequent analyses, the Maximum Width variable was used instead of either Barb/Shoulder Width or Blade Width.

Second, after the paired variables were replaced by single variables, the number of values available in each of the remaining primary and derivative metric variables was summed. This resulted in the identification of numerous variables that simply did not have enough values in them to be included in the analysis.
Exploratory data analysis, combined with the previous results of preliminary inspections of the behavior of the variables in the dart point data set, led to using the same exclusionary principles for the arrow point data. Therefore, all metric variables with less than 100 values in them were removed from the data set. This resulted in a smaller data spread composed of only three primary variables-Stem Distal Width, Maximum Width, Maximum Thickness, and one derivative variable Thickness:Width Ratio. Clearly, overall measures of artifact size, including width and thickness, represent the primary dimensions of variability represented by three of these four variables.

Finally, all unclassified points were removed from the data set. A final test run of the 79 typed arrow points with the reduced array of four variables resulted in the inclusion of 56 of the 79 specimens (70.9 percent). While this sample population included almost threequarters of the assemblage of typed arrow points, the use of only four variables, three of which provided measures only of overall artifact dimensions, promised to yield only marginal analytical results.

\section{A.4.2.1 Cluster Analysis Results}

The cluster analysis created eight clusters, with Clusters 7 and 8 being composed of single points (Figure A-4). Specimen \#0918-010 is a Clifton point with a Stem Distal Width of $14.2 \mathrm{~mm}$ that is significantly larger than any other specimen. Specimen \#0914-011 is also a Clifton point, with an above average Stem Distal Width of $12.0 \mathrm{~mm}$, and is unusually thick at $17.4 \mathrm{~mm}$, more than four times as thick as any other specimen. Both of these specimens can be considered atypical Clifton points when compared with the rest of the assemblage and the other Clifton points. Clusters 7 and 8 are not illustrated. There are six named arrow point types within the groupings, and none of the clusters are composed of a single named arrow point type. 


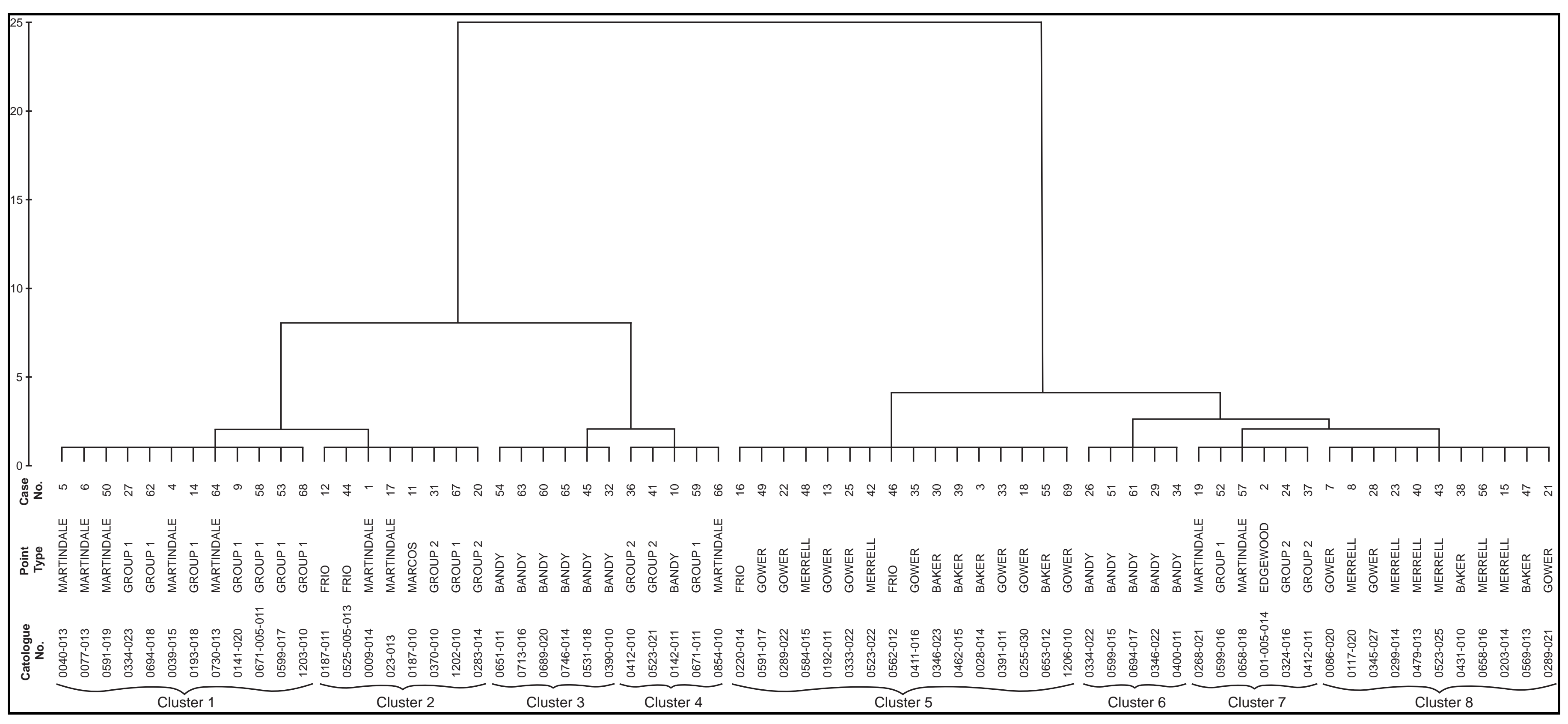

Figure A-3. Hierarchical Cluster Analysis Dendrogram of Dart Points (Final Results)

Based on a dissimilarity matrix composed of squared Euclidean distance values calculated using Ward's Method (SPSS 12.0 for Windows). 

Table A-6. Descriptive Statistics for Dart Point Clusters 1 to 8 (Final Results)

\begin{tabular}{|c|c|c|c|c|c|c|c|c|c|c|c|c|}
\hline Cluster No. & Statistic & Stem Length & $\begin{array}{c}\text { Stem Distal } \\
\text { Width }\end{array}$ & $\begin{array}{c}\text { Stem Proximal } \\
\text { Width }\end{array}$ & $\begin{array}{c}\text { Stem } \\
\text { Thickness }\end{array}$ & $\begin{array}{c}\text { Maximum } \\
\text { Width }\end{array}$ & $\begin{array}{c}\text { Max } \\
\text { Thickness }\end{array}$ & $\begin{array}{c}\text { Width:Thickness } \\
\text { Ratio }\end{array}$ & $\begin{array}{c}\text { Stem Thick:Width } \\
\text { Ratio }\end{array}$ & Base Depth & Base Notch Width & $\begin{array}{c}\text { Base Depth:Width } \\
\text { Ratio }\end{array}$ \\
\hline \multirow[t]{10}{*}{1} & $\mathrm{~N}$ & 12 & 12 & 12 & 12 & 12 & 12 & 12 & 12 & 12 & 12 & 12 \\
\hline & Mean & 13.925 & 18.142 & 22.667 & 4.858 & 30.975 & 7.225 & 0.2338 & 0.2696 & 3.433 & 10.367 & 0.3280 \\
\hline & Median & 13.850 & 18.100 & 22.300 & 4.800 & 30.850 & 7.150 & 0.2293 & 0.2637 & 3.200 & 10.450 & 0.3194 \\
\hline & Std. Error of Mean & 0.6067 & 0.2734 & 0.4349 & 0.2423 & 0.6339 & 0.2652 & 0.00832 & 0.01567 & 0.3585 & 0.4739 & 0.02672 \\
\hline & Minimum & 10.6 & 16.3 & 20.5 & 3.5 & 27.0 & 6.2 & 0.18 & 0.18 & 1.6 & 6.9 & 0.16 \\
\hline & Maximum & 17.8 & 19.7 & 25.2 & 6.2 & 34.2 & 9.3 & 0.30 & 0.36 & 5.9 & 13.1 & 0.52 \\
\hline & Std. Deviation & 2.1016 & 0.9472 & 1.5066 & 0.8393 & 2.1959 & 0.9186 & 0.02882 & 0.05429 & 1.2419 & 1.6417 & 0.09257 \\
\hline & Variance & 4.417 & 0.897 & 2.270 & 0.704 & 4.822 & 0.844 & 0.001 & 0.003 & 1.542 & 2.695 & 0.009 \\
\hline & Kurtosis & -0.633 & 0.225 & -1.039 & -0.869 & -0.598 & 1.093 & 1.573 & -0.675 & -0.166 & 0.920 & 1.045 \\
\hline & Skewness & 0.178 & -0.276 & 0.174 & 0.099 & -0.089 & 1.097 & 0.545 & -0.054 & 0.535 & -0.487 & 0.288 \\
\hline \multirow[t]{10}{*}{2} & $\mathrm{~N}$ & 8 & 8 & 8 & 8 & 8 & 8 & 8 & 8 & 8 & 8 & 8 \\
\hline & Mean & 10.975 & 18.800 & 26.500 & 5.013 & 31.063 & 7.575 & 0.2451 & 0.2675 & 2.950 & 13.463 & 0.2241 \\
\hline & Median & 11.100 & 18.400 & 25.150 & 5.050 & 31.300 & 7.000 & 0.2292 & 0.2832 & 2.950 & 13.000 & 0.2086 \\
\hline & Std. Error of Mean & 0.4511 & 0.6239 & 1.0316 & 0.3056 & 0.9358 & 0.7345 & 0.02417 & 0.01604 & 0.3746 & 1.0119 & 0.03082 \\
\hline & Minimum & 8.6 & 16.5 & 23.6 & 3.7 & 27.3 & 5.7 & 0.18 & 0.19 & 0.9 & 10.4 & 0.07 \\
\hline & Maximum & 12.9 & 21.5 & 30.5 & 6.0 & 34.2 & 12.4 & 0.40 & 0.33 & 4.1 & 19.0 & 0.35 \\
\hline & Std. Deviation & 1.2759 & 1.7647 & 2.9179 & 0.8643 & 2.6468 & 2.0776 & 0.06835 & 0.04536 & 1.0596 & 2.8620 & 0.08717 \\
\hline & Variance & 1.628 & 3.114 & 8.514 & 0.747 & 7.006 & 4.316 & 0.005 & 0.002 & 1.123 & 8.191 & 0.008 \\
\hline & Kurtosis & 1.123 & -1.403 & -2.012 & -1.077 & -1.312 & 5.397 & 3.951 & -0.807 & 0.989 & 0.922 & 0.054 \\
\hline & Skewness & -0.546 & 0.297 & 0.551 & -0.504 & -0.317 & 2.163 & 1.876 & -0.494 & -0.916 & 0.958 & -0.315 \\
\hline \multirow[t]{10}{*}{3} & $\mathrm{~N}$ & 6 & 6 & 6 & 6 & 6 & 6 & 6 & 6 & 6 & 6 & 6 \\
\hline & Mean & 8.417 & 12.833 & 15.517 & 3.317 & 36.567 & 4.583 & 0.1255 & 0.2611 & 1.467 & 8.800 & 0.1734 \\
\hline & Median & 8.550 & 12.900 & 15.400 & 3.350 & 35.950 & 4.700 & 0.1246 & 0.2651 & 1.300 & 8.550 & 0.1628 \\
\hline & Std. Error of Mean & 0.4556 & 0.4688 & 0.4778 & 0.1078 & 0.8928 & 0.1276 & 0.00314 & 0.01575 & 0.2404 & 1.1787 & 0.02566 \\
\hline & Minimum & 7.0 & 11.6 & 13.8 & 2.9 & 34.5 & 4.0 & 0.12 & 0.21 & 0.9 & 4.7 & 0.11 \\
\hline & Maximum & 9.8 & 14.0 & 17.1 & 3.7 & 40.2 & 4.8 & 0.14 & 0.31 & 2.4 & 13.2 & 0.26 \\
\hline & Std. Deviation & 1.1161 & 1.1483 & 1.1703 & 0.2639 & 2.1869 & 0.3125 & 0.00769 & 0.03857 & 0.5888 & 2.8872 & 0.06286 \\
\hline & Variance & 1.246 & 1.319 & 1.370 & 0.070 & 4.783 & 0.098 & 0.000 & 0.001 & 0.347 & 8.336 & 0.004 \\
\hline & Kurtosis & -1.779 & -3.044 & -0.261 & 1.252 & 0.081 & 2.736 & -1.180 & -1.839 & -0.642 & 0.509 & -1.976 \\
\hline & Skewness & -0.172 & -0.054 & -0.072 & -0.268 & 0.985 & -1.657 & 0.292 & -0.255 & 0.825 & 0.219 & 0.395 \\
\hline \multirow[t]{10}{*}{4} & $\mathrm{~N}$ & 5 & 5 & 5 & 5 & 5 & 5 & 5 & 5 & 5 & 5 & 5 \\
\hline & Mean & 11.520 & 15.620 & 20.480 & 4.600 & 35.900 & 7.180 & 0.2005 & 0.3021 & 2.020 & 10.900 & 0.1876 \\
\hline & Median & 10.700 & 14.400 & 20.400 & 4.800 & 36.300 & 7.000 & 0.2030 & 0.3357 & 1.900 & 12.100 & 0.1795 \\
\hline & Std. Error of Mean & 0.8714 & 1.0466 & 1.1052 & 0.1817 & 1.4415 & 0.5333 & 0.01412 & 0.02847 & 0.5687 & 1.3319 & 0.04197 \\
\hline & Minimum & 10.5 & 13.4 & 18.4 & 3.9 & 30.8 & 5.5 & 0.16 & 0.20 & 0.7 & 7.6 & 0.06 \\
\hline & Maximum & 15.0 & 19.1 & 24.5 & 4.9 & 39.4 & 8.6 & 0.24 & 0.36 & 4.1 & 13.6 & 0.30 \\
\hline & Std. Deviation & 1.9486 & 2.3403 & 2.4712 & 0.4062 & 3.2234 & 1.1925 & 0.03157 & 0.06367 & 1.2716 & 2.9783 & 0.09385 \\
\hline & Variance & 3.797 & 5.477 & 6.107 & 0.165 & 10.390 & 1.422 & 0.001 & 0.004 & 1.617 & 8.870 & 0.009 \\
\hline & Kurtosis & 4.934 & -0.546 & 1.896 & 3.543 & 1.669 & -0.269 & -0.306 & 0.066 & 2.470 & -3.151 & -0.445 \\
\hline & Skewness & 2.218 & 0.949 & 1.331 & -1.865 & -1.057 & -0.341 & -0.499 & -1.123 & 1.309 & -0.453 & -0.264 \\
\hline
\end{tabular}



Table A-6. Descriptive Statistics for Dart Point Clusters 1 to 8 (Final Results) (Continued)

\begin{tabular}{|c|c|c|c|c|c|c|c|c|c|c|c|c|}
\hline Cluster No. & Statistic & Stem Length & $\begin{array}{l}\text { Stem Distal } \\
\text { Width }\end{array}$ & $\begin{array}{l}\text { Stem Proximal } \\
\text { Width }\end{array}$ & $\begin{array}{c}\text { Stem } \\
\text { Thickness }\end{array}$ & $\begin{array}{c}\text { Maximum } \\
\text { Width }\end{array}$ & $\begin{array}{c}\text { Max } \\
\text { Thickness }\end{array}$ & $\begin{array}{l}\text { Width:Thickness } \\
\text { Ratio }\end{array}$ & $\begin{array}{c}\text { Stem Thick:Width } \\
\text { Ratio }\end{array}$ & Base Depth & Base Notch Width & $\begin{array}{l}\text { Base Depth:Width } \\
\text { Ratio }\end{array}$ \\
\hline \multirow[t]{10}{*}{5} & $\mathrm{~N}$ & 16 & 16 & 16 & 16 & 16 & 16 & 16 & 16 & 16 & 16 & 16 \\
\hline & Mean & 12.300 & 13.863 & 17.256 & 4.594 & 18.538 & 6.744 & 0.3698 & 0.3345 & 4.569 & 8.806 & 0.5238 \\
\hline & Median & 12.950 & 13.550 & 17.500 & 4.700 & 18.550 & 6.750 & 0.3448 & 0.3400 & 4.900 & 8.650 & 0.5279 \\
\hline & Std. Error of Mean & 0.4443 & 0.3156 & 0.4029 & 0.2216 & 0.6273 & 0.2317 & 0.01753 & 0.01824 & 0.2703 & 0.2715 & 0.03151 \\
\hline & Minimum & 8.7 & 11.6 & 13.9 & 2.6 & 14.2 & 5.5 & 0.25 & 0.18 & 2.5 & 6.8 & 0.26 \\
\hline & Maximum & 15.3 & 15.8 & 19.4 & 5.7 & 23.2 & 8.3 & 0.52 & 0.44 & 6.2 & 10.6 & 0.74 \\
\hline & Std. Deviation & 1.7773 & 1.2622 & 1.6116 & 0.8865 & 2.5091 & 0.9266 & 0.07013 & 0.07295 & 1.0812 & 1.0860 & 0.12605 \\
\hline & Variance & 3.159 & 1.593 & 2.597 & 0.786 & 6.296 & 0.859 & 0.005 & 0.005 & 1.169 & 1.179 & 0.016 \\
\hline & Kurtosis & 0.204 & -0.895 & -0.290 & -0.094 & -0.574 & -1.125 & -0.328 & -0.075 & -0.551 & -0.464 & 0.628 \\
\hline & Skewness & -0.692 & -0.041 & -0.570 & -0.644 & -0.016 & 0.167 & 0.478 & -0.464 & -0.442 & 0.059 & -0.532 \\
\hline \multirow[t]{10}{*}{6} & $\mathrm{~N}$ & 5 & 5 & 5 & 5 & 5 & 5 & 5 & 5 & 5 & 5 & 5 \\
\hline & Mean & 7.440 & 13.560 & 16.320 & 2.960 & 24.880 & 4.280 & 0.1734 & 0.2183 & 1.300 & 8.920 & 0.1513 \\
\hline & Median & 7.600 & 13.400 & 16.500 & 2.700 & 24.400 & 4.400 & 0.1571 & 0.2015 & 1.300 & 10.100 & 0.1364 \\
\hline & Std. Error of Mean & 0.7089 & 0.2249 & 0.2672 & 0.2909 & 1.3858 & 0.2557 & 0.01209 & 0.02148 & 0.2074 & 1.5714 & 0.01923 \\
\hline & Minimum & 5.4 & 13.1 & 15.6 & 2.4 & 21.5 & 3.4 & 0.15 & 0.18 & 0.6 & 4.4 & 0.12 \\
\hline & Maximum & 9.0 & 14.4 & 17.0 & 3.8 & 29.5 & 4.9 & 0.20 & 0.29 & 1.9 & 12.9 & 0.23 \\
\hline & Std. Deviation & 1.5852 & 0.5030 & 0.5975 & 0.6504 & 3.0987 & 0.5718 & 0.02702 & 0.04803 & 0.4637 & 3.5138 & 0.04300 \\
\hline & Variance & 2.513 & 0.253 & 0.357 & 0.423 & 9.602 & 0.327 & 0.001 & 0.002 & 0.215 & 12.347 & 0.002 \\
\hline & Kurtosis & -2.166 & 2.699 & -2.335 & -2.522 & 0.185 & 0.875 & -3.148 & -0.463 & 2.000 & -1.902 & 3.832 \\
\hline & Skewness & -0.320 & 1.551 & -0.271 & 0.578 & 0.755 & -0.924 & 0.550 & 0.949 & -0.527 & -0.372 & 1.902 \\
\hline \multirow[t]{10}{*}{7} & $\mathrm{~N}$ & 6 & 6 & 6 & 6 & 6 & 6 & 6 & 6 & 6 & 6 & 6 \\
\hline & Mean & 10.917 & 15.700 & 21.917 & 4.450 & 24.833 & 6.950 & 0.2803 & 0.2849 & 2.333 & 10.283 & 0.2316 \\
\hline & Median & 11.100 & 15.700 & 22.050 & 4.300 & 24.700 & 7.050 & 0.2835 & 0.2811 & 2.400 & 10.400 & 0.2403 \\
\hline & Std. Error of Mean & 0.6379 & 0.4830 & 0.4175 & 0.2306 & 0.2906 & 0.4537 & 0.01935 & 0.01762 & 0.2124 & 0.8719 & 0.02044 \\
\hline & Minimum & 8.8 & 14.0 & 20.3 & 4.0 & 24.1 & 5.6 & 0.23 & 0.24 & 1.7 & 7.6 & 0.14 \\
\hline & Maximum & 12.9 & 17.0 & 23.0 & 5.5 & 25.8 & 8.5 & 0.34 & 0.36 & 3.1 & 12.6 & 0.30 \\
\hline & Std. Deviation & 1.5626 & 1.1832 & 1.0226 & 0.5648 & 0.7118 & 1.1113 & 0.04739 & 0.04316 & 0.5203 & 2.1358 & 0.05007 \\
\hline & Variance & 2.442 & 1.400 & 1.046 & 0.319 & 0.507 & 1.235 & 0.002 & 0.002 & 0.271 & 4.562 & 0.003 \\
\hline & Kurtosis & -1.359 & -1.546 & -0.476 & 2.706 & -2.005 & -1.388 & -2.413 & 3.019 & -0.590 & -1.803 & 2.616 \\
\hline & Skewness & -0.211 & -0.313 & -0.672 & 1.603 & 0.395 & 0.110 & 0.048 & 1.362 & 0.137 & -0.149 & -1.009 \\
\hline \multirow[t]{10}{*}{8} & $\mathrm{~N}$ & 11 & 11 & 11 & 11 & 11 & 11 & 11 & 11 & 11 & 11 & 11 \\
\hline & Mean & 14.064 & 14.845 & 19.891 & 4.855 & 22.600 & 6.627 & 0.2959 & 0.3284 & 5.782 & 8.545 & 0.6915 \\
\hline & Median & 13.900 & 15.300 & 20.100 & 4.700 & 22.000 & 6.600 & 0.3000 & 0.3312 & 5.800 & 8.100 & 0.7463 \\
\hline & Std. Error of Mean & 0.5800 & 0.3848 & 0.4039 & 0.2748 & 0.5595 & 0.1711 & 0.01255 & 0.01831 & 0.2700 & 0.4971 & 0.03815 \\
\hline & Minimum & 11.7 & 11.4 & 18.0 & 3.5 & 20.3 & 5.8 & 0.23 & 0.24 & 3.9 & 6.7 & 0.45 \\
\hline & Maximum & 19.0 & 16.1 & 22.2 & 7.0 & 25.4 & 7.5 & 0.36 & 0.43 & 7.5 & 11.8 & 0.82 \\
\hline & Std. Deviation & 1.9237 & 1.2762 & 1.3397 & 0.9114 & 1.8558 & 0.5676 & 0.04162 & 0.06072 & 0.8953 & 1.6489 & 0.12655 \\
\hline & Variance & 3.701 & 1.629 & 1.795 & 0.831 & 3.444 & 0.322 & 0.002 & 0.004 & 0.802 & 2.719 & 0.016 \\
\hline & Kurtosis & 4.367 & 5.839 & -0.912 & 2.521 & -1.385 & -0.956 & -1.030 & -0.633 & 2.099 & -0.173 & -0.316 \\
\hline & Skewness & 1.724 & -2.201 & 0.136 & 1.121 & 0.511 & 0.110 & -0.162 & 0.403 & -0.301 & 0.936 & -1.130 \\
\hline
\end{tabular}



Table A-7. Tests of Equality of Group Means for Dart Point Cluster 1 to 8 (Final Results)

\begin{tabular}{|c|c|c|c|c|c|}
\hline \multirow[b]{2}{*}{ Cluster No. 2} & \multirow[b]{2}{*}{ Variable } & \multirow[b]{2}{*}{ Mean } & \multirow[b]{2}{*}{ Std. Deviation } & \multicolumn{2}{|c|}{ Valid N (listwise) } \\
\hline & & & & Unweighted & Weighted \\
\hline 1 & $\begin{array}{l}\text { Stem Length } \\
\text { Stem Dist Width } \\
\text { Stem Prox Width } \\
\text { Stem Thickness } \\
\text { Maximum Width } \\
\text { Max Thickness } \\
\text { Thickness:Width Ratio } \\
\text { Stem Thick:Width Ratio } \\
\text { Base Depth } \\
\text { Base Notch Width } \\
\text { Base Depth:Width Ratio }\end{array}$ & $\begin{array}{c}13.9250 \\
18.1417 \\
22.6667 \\
4.8583 \\
30.9750 \\
7.2250 \\
0.2338 \\
0.2696 \\
3.4333 \\
10.3667 \\
0.3280\end{array}$ & $\begin{array}{l}2.10157 \\
0.94720 \\
1.50655 \\
0.83933 \\
2.19592 \\
0.91862 \\
0.02882 \\
0.05429 \\
1.24194 \\
1.64169 \\
0.09257\end{array}$ & $\begin{array}{l}12 \\
12 \\
12 \\
12 \\
12 \\
12 \\
12 \\
12 \\
12 \\
12 \\
12\end{array}$ & $\begin{array}{l}12.000 \\
12.000 \\
12.000 \\
12.000 \\
12.000 \\
12.000 \\
12.000 \\
12.000 \\
12.000 \\
12.000 \\
12.000\end{array}$ \\
\hline 2 & $\begin{array}{l}\text { Stem Length } \\
\text { Stem Dist Width } \\
\text { Stem Prox Width } \\
\text { Stem Thickness } \\
\text { Maximum Width } \\
\text { Max Thickness } \\
\text { Thickness:Width Ratio } \\
\text { Stem Thick:Width Ratio } \\
\text { Base Depth } \\
\text { Base Notch Width } \\
\text { Base Depth:Width Ratio }\end{array}$ & $\begin{array}{c}10.9750 \\
18.8000 \\
26.5000 \\
5.0125 \\
31.0625 \\
7.5750 \\
0.2451 \\
0.2675 \\
2.9500 \\
13.4625 \\
0.2241\end{array}$ & $\begin{array}{l}1.27588 \\
1.76473 \\
2.91792 \\
0.86427 \\
2.64680 \\
2.07760 \\
0.06835 \\
0.04536 \\
1.05965 \\
2.86204 \\
0.08717\end{array}$ & $\begin{array}{l}8 \\
8 \\
8 \\
8 \\
8 \\
8 \\
8 \\
8 \\
8 \\
8 \\
8\end{array}$ & $\begin{array}{l}8.000 \\
8.000 \\
8.000 \\
8.000 \\
8.000 \\
8.000 \\
8.000 \\
8.000 \\
8.000 \\
8.000 \\
8.000\end{array}$ \\
\hline 3 & $\begin{array}{l}\text { Stem Length } \\
\text { Stem Dist Width } \\
\text { Stem Prox Width } \\
\text { Stem Thickness } \\
\text { Maximum Width } \\
\text { Max Thickness } \\
\text { Thickness:Width Ratio } \\
\text { Stem Thick:Width Ratio } \\
\text { Base Depth } \\
\text { Base Notch Width } \\
\text { Base Depth:Width Ratio }\end{array}$ & $\begin{array}{c}8.4167 \\
12.8333 \\
15.5167 \\
3.3167 \\
36.5667 \\
4.5833 \\
0.1255 \\
0.2611 \\
1.4667 \\
8.8000 \\
0.1734\end{array}$ & $\begin{array}{l}1.11609 \\
1.14833 \\
1.17033 \\
0.26394 \\
2.18693 \\
0.31252 \\
0.00769 \\
0.03857 \\
0.58878 \\
2.88721 \\
0.06286\end{array}$ & $\begin{array}{l}6 \\
6 \\
6 \\
6 \\
6 \\
6 \\
6 \\
6 \\
6 \\
6 \\
6\end{array}$ & $\begin{array}{l}6.000 \\
6.000 \\
6.000 \\
6.000 \\
6.000 \\
6.000 \\
6.000 \\
6.000 \\
6.000 \\
6.000 \\
6.000\end{array}$ \\
\hline 4 & $\begin{array}{l}\text { Stem Length } \\
\text { Stem Dist Width } \\
\text { Stem Prox Width } \\
\text { Stem Thickness } \\
\text { Maximum Width } \\
\text { Max Thickness } \\
\text { Thickness:Width Ratio } \\
\text { Stem Thick:Width Ratio } \\
\text { Base Depth } \\
\text { Base Notch Width } \\
\text { Base Depth:Width Ratio }\end{array}$ & $\begin{array}{c}11.5200 \\
15.6200 \\
20.4800 \\
4.6000 \\
35.9000 \\
7.1800 \\
0.2005 \\
0.3021 \\
2.0200 \\
10.9000 \\
0.1876\end{array}$ & $\begin{array}{l}1.94859 \\
2.34030 \\
2.47123 \\
0.40620 \\
3.22335 \\
1.19248 \\
0.03157 \\
0.06367 \\
1.27161 \\
2.97825 \\
0.09385\end{array}$ & $\begin{array}{l}5 \\
5 \\
5 \\
5 \\
5 \\
5 \\
5 \\
5 \\
5 \\
5 \\
5\end{array}$ & $\begin{array}{l}5.000 \\
5.000 \\
5.000 \\
5.000 \\
5.000 \\
5.000 \\
5.000 \\
5.000 \\
5.000 \\
5.000 \\
5.000\end{array}$ \\
\hline 5 & $\begin{array}{l}\text { Stem Length } \\
\text { Stem Dist Width } \\
\text { Stem Prox Width } \\
\text { Stem Thickness } \\
\text { Maximum Width } \\
\text { Max Thickness } \\
\text { Thickness:Width Ratio } \\
\text { Stem Thick:Width Ratio } \\
\text { Base Depth } \\
\text { Base Notch Width } \\
\text { Base Depth:Width Ratio }\end{array}$ & $\begin{array}{c}12.3000 \\
13.8625 \\
17.2563 \\
4.5938 \\
18.5375 \\
6.7438 \\
0.3698 \\
0.3345 \\
4.5688 \\
8.8063 \\
0.5238\end{array}$ & $\begin{array}{l}1.77726 \\
1.26221 \\
1.61161 \\
0.88654 \\
2.50915 \\
0.92662 \\
0.07013 \\
0.07295 \\
1.08118 \\
1.08595 \\
0.12605\end{array}$ & $\begin{array}{l}16 \\
16 \\
16 \\
16 \\
16 \\
16 \\
16 \\
16 \\
16 \\
16 \\
16\end{array}$ & $\begin{array}{l}16.000 \\
16.000 \\
16.000 \\
16.000 \\
16.000 \\
16.000 \\
16.000 \\
16.000 \\
16.000 \\
16.000 \\
16.000\end{array}$ \\
\hline
\end{tabular}


Table A-7. Tests of Equality of Group Means for Dart Point Cluster 1 to 8 (Final Results) (Continued)

\begin{tabular}{|c|c|c|c|c|c|}
\hline \multirow[b]{2}{*}{ Cluster No. 2} & \multirow[b]{2}{*}{ Variable } & \multirow[b]{2}{*}{ Mean } & \multirow[b]{2}{*}{ Std. Deviation } & \multicolumn{2}{|c|}{ Valid N (listwise) } \\
\hline & & & & Unweighted & Weighted \\
\hline 6 & $\begin{array}{l}\text { Stem Length } \\
\text { Stem Dist Width } \\
\text { Stem Prox Width } \\
\text { Stem Thickness } \\
\text { Maximum Width } \\
\text { Max Thickness } \\
\text { Thickness:Width Ratio } \\
\text { Stem Thick:Width Ratio } \\
\text { Base Depth } \\
\text { Base Notch Width } \\
\text { Base Depth:Width Ratio }\end{array}$ & $\begin{array}{c}7.4400 \\
13.5600 \\
16.3200 \\
2.9600 \\
24.8800 \\
4.2800 \\
0.1734 \\
0.2183 \\
1.3000 \\
8.9200 \\
0.1513\end{array}$ & $\begin{array}{l}1.58524 \\
0.50299 \\
0.59749 \\
0.65038 \\
3.09871 \\
0.57184 \\
0.02702 \\
0.04803 \\
0.46368 \\
3.51383 \\
0.04300\end{array}$ & $\begin{array}{l}5 \\
5 \\
5 \\
5 \\
5 \\
5 \\
5 \\
5 \\
5 \\
5 \\
5\end{array}$ & $\begin{array}{l}5.000 \\
5.000 \\
5.000 \\
5.000 \\
5.000 \\
5.000 \\
5.000 \\
5.000 \\
5.000 \\
5.000 \\
5.000\end{array}$ \\
\hline 7 & $\begin{array}{l}\text { Stem Length } \\
\text { Stem Dist Width } \\
\text { Stem Prox Width } \\
\text { Stem Thickness } \\
\text { Maximum Width } \\
\text { Max Thickness } \\
\text { Thickness:Width Ratio } \\
\text { Stem Thick:Width Ratio } \\
\text { Base Depth } \\
\text { Base Notch Width } \\
\text { Base Depth:Width Ratio }\end{array}$ & $\begin{array}{c}10.9167 \\
15.7000 \\
21.9167 \\
4.4500 \\
24.8333 \\
6.9500 \\
0.2803 \\
0.2849 \\
2.3333 \\
10.2833 \\
0.2316\end{array}$ & $\begin{array}{l}1.56258 \\
1.18322 \\
1.02258 \\
0.56480 \\
0.71181 \\
1.11131 \\
0.04739 \\
0.04316 \\
0.52026 \\
2.13581 \\
0.05007\end{array}$ & $\begin{array}{l}6 \\
6 \\
6 \\
6 \\
6 \\
6 \\
6 \\
6 \\
6 \\
6 \\
6\end{array}$ & $\begin{array}{l}6.000 \\
6.000 \\
6.000 \\
6.000 \\
6.000 \\
6.000 \\
6.000 \\
6.000 \\
6.000 \\
6.000 \\
6.000\end{array}$ \\
\hline 8 & $\begin{array}{l}\text { Stem Length } \\
\text { Stem Dist Width } \\
\text { Stem Prox Width } \\
\text { Stem Thickness } \\
\text { Maximum Width } \\
\text { Max Thickness } \\
\text { Thickness:Width Ratio } \\
\text { Stem Thick:Width Ratio } \\
\text { Base Depth } \\
\text { Base Notch Width } \\
\text { Base Depth:Width Ratio }\end{array}$ & $\begin{array}{c}14.0636 \\
14.8455 \\
19.8909 \\
4.8545 \\
22.6000 \\
6.6273 \\
0.2959 \\
0.3284 \\
5.7818 \\
8.5455 \\
0.6915\end{array}$ & $\begin{array}{l}1.92368 \\
1.27622 \\
1.33974 \\
0.91144 \\
1.85580 \\
0.56761 \\
0.04162 \\
0.06072 \\
0.89534 \\
1.64886 \\
0.12655\end{array}$ & $\begin{array}{l}11 \\
11 \\
11 \\
11 \\
11 \\
11 \\
11 \\
11 \\
11 \\
11 \\
11\end{array}$ & $\begin{array}{l}11.000 \\
11.000 \\
11.000 \\
11.000 \\
11.000 \\
11.000 \\
11.000 \\
11.000 \\
11.000 \\
11.000 \\
11.000\end{array}$ \\
\hline
\end{tabular}

Table A-8. Tests of Equality of Group Means for Dart Point Cluster 1 to 8 (Final Results)

\begin{tabular}{|l|c|c|c|c|c|}
\hline \multicolumn{1}{|c|}{ Variable } & Wilks' Lambda & F & df1 & df2 & Sig. \\
\hline Stem Length & 0.394 & 13.378 & 7 & 61 & 0.000 \\
Stem Dist Width & 0.279 & 22.537 & 7 & 61 & 0.000 \\
Stem Prox Width & 0.192 & 36.653 & 7 & 61 & 0.000 \\
Stem Thickness & 0.595 & 5.942 & 7 & 61 & 0.000 \\
Maximum Width & 0.112 & 68.887 & 7 & 61 & 0.000 \\
Max Thickness & 0.511 & 8.349 & 7 & 61 & 0.000 \\
Thickness:Width Ratio & 0.284 & 22.005 & 7 & 61 & 0.000 \\
Stem Thick:Width Ratio & 0.701 & 3.724 & 7 & 61 & 0.002 \\
Base Depth & 0.294 & 20.949 & 7 & 61 & 0.000 \\
Base Notch Width & 0.635 & 4.999 & 7 & 61 & 0.000 \\
Base Depth:Width Ratio & 0.202 & 34.502 & 7 & 61 & 0.000 \\
\hline
\end{tabular}


Table A-9. Analysis of Variance (ANOVA) Comparing Dart Point Clusters 1 to 8 (Final Results)

\begin{tabular}{|c|c|c|c|c|c|c|}
\hline \multicolumn{2}{|c|}{ Variable } & Sum of Squares & df & Mean Square & $\mathbf{F}$ & Sig. \\
\hline Stem Length & $\begin{array}{l}\text { Between Groups } \\
\text { Within Groups } \\
\text { Total }\end{array}$ & $\begin{array}{l}288.670 \\
188.040 \\
476.710\end{array}$ & $\begin{array}{c}7 \\
61 \\
68 \\
\end{array}$ & $\begin{array}{c}41.239 \\
3.083\end{array}$ & 13.378 & 0.000 \\
\hline Stem Dist Width & $\begin{array}{l}\text { Between Groups } \\
\text { Within Groups } \\
\text { Total }\end{array}$ & $\begin{array}{l}280.263 \\
108.367 \\
388.631\end{array}$ & $\begin{array}{c}7 \\
61 \\
68\end{array}$ & $\begin{array}{c}40.038 \\
1.777\end{array}$ & 22.537 & 0.000 \\
\hline Stem Prox Width & $\begin{array}{l}\text { Between Groups } \\
\text { Within Groups } \\
\text { Total }\end{array}$ & $\begin{array}{l}754.607 \\
179.408 \\
934.015\end{array}$ & $\begin{array}{c}7 \\
61 \\
68\end{array}$ & $\begin{array}{c}107.801 \\
2.941\end{array}$ & 36.653 & 0.000 \\
\hline Stem Thickness & $\begin{array}{l}\text { Between Groups } \\
\text { Within Groups } \\
\text { Total }\end{array}$ & $\begin{array}{l}25.481 \\
37.370 \\
62.851 \\
\end{array}$ & $\begin{array}{c}7 \\
61 \\
68 \\
\end{array}$ & $\begin{array}{l}3.640 \\
0.613\end{array}$ & 5.942 & 0.000 \\
\hline Maximum Width & $\begin{array}{l}\text { Between Groups } \\
\text { Within Groups } \\
\text { Total }\end{array}$ & $\begin{array}{c}2,666.960 \\
337.373 \\
3,004.333\end{array}$ & $\begin{array}{c}7 \\
61 \\
68\end{array}$ & $\begin{array}{c}380.994 \\
5.531\end{array}$ & 68.887 & 0.000 \\
\hline Max Thickness & $\begin{array}{l}\text { Between Groups } \\
\text { Within Groups } \\
\text { Total }\end{array}$ & $\begin{array}{c}66.353 \\
69.258 \\
135.611 \\
\end{array}$ & $\begin{array}{c}7 \\
61 \\
68 \\
\end{array}$ & $\begin{array}{l}9.479 \\
1.135\end{array}$ & 8.349 & 0.000 \\
\hline Thickness:Width Ratio & $\begin{array}{l}\text { Between Groups } \\
\text { Within Groups } \\
\text { Total }\end{array}$ & $\begin{array}{l}0.382 \\
0.151 \\
0.534\end{array}$ & $\begin{array}{c}7 \\
61 \\
68\end{array}$ & $\begin{array}{l}0.055 \\
0.002\end{array}$ & 22.005 & 0.000 \\
\hline Stem Thick:Width Ratio & $\begin{array}{l}\text { Between Groups } \\
\text { Within Groups } \\
\text { Total }\end{array}$ & $\begin{array}{l}0.088 \\
0.206 \\
0.294\end{array}$ & $\begin{array}{c}7 \\
61 \\
68\end{array}$ & $\begin{array}{l}0.013 \\
0.003\end{array}$ & 3.724 & 0.002 \\
\hline Base Depth & $\begin{array}{l}\text { Between Groups } \\
\text { Within Groups } \\
\text { Total }\end{array}$ & $\begin{array}{c}146.143 \\
60.792 \\
206.935\end{array}$ & $\begin{array}{c}7 \\
61 \\
68 \\
\end{array}$ & $\begin{array}{c}20.878 \\
0.997\end{array}$ & 20.949 & 0.000 \\
\hline Base Notch Width & $\begin{array}{l}\text { Between Groups } \\
\text { Within Groups } \\
\text { Total }\end{array}$ & $\begin{array}{l}161.321 \\
281.218 \\
442.539\end{array}$ & $\begin{array}{c}7 \\
61 \\
68\end{array}$ & $\begin{array}{c}23.046 \\
4.610\end{array}$ & 4.999 & 0.000 \\
\hline Base Depth:Width Ratio & $\begin{array}{l}\text { Between Groups } \\
\text { Within Groups } \\
\text { Total }\end{array}$ & $\begin{array}{l}2.458 \\
0.621 \\
3.079 \\
\end{array}$ & $\begin{array}{c}7 \\
61 \\
68\end{array}$ & $\begin{array}{l}0.351 \\
0.010\end{array}$ & 34.502 & 0.000 \\
\hline
\end{tabular}


Cluster $1(n=17)$ is the closest to containing a single point type, Perdiz $(n=16)$. Perdiz points account for 70 percent of the analyzed arrow points and are included in six of the eight clusters (Table A-10). Cliffton points are the second largest group $(n=8)$ and are found in five clusters.

The closeness of many measurements between clusters, especially the Maximum Thickness variable, suggests that minor discrepancies during data recording could significantly affect cluster composition. This is particularly worrisome given the fragmentary nature of the assemblage. The clusters incorporate the variation in the Perdiz assemblage, especially the Maximum Width measurement. Overall, because only three variables were used in the analysis, the fourth being a derivative of two of these variables, variations in stem shape, barb size, and base shape were not fully investigated, and this was the result of the fragmented condition of the assemblage. Excluding Clusters 7 and 8, Perdiz points account for 94 percent of Cluster 1, 67 percent of Cluster 2, 50 percent of Cluster 3, 44 percent of Cluster 4, 60 percent of Cluster 5, and 80 percent of Cluster 6; therefore, it not surprising that the variations along the Perdiz assemblage continuum dictates the composition of the clusters.

\section{A.4.2.2 Discriminant Function Analysis Results}

The four selected measurements all contribute significantly to the Clusters. Means and standard deviations were calculated for each of the 4 variables in each cluster (Table A-11). The derivative Width:Thickness Ratio is significant because of the strong influence of the Width and Thickness; and therefore, its significance is from being covariant. The Tests of Equality (Table A-12) and the Analysis of Variance (Table A-13) both indicate that all of
Table A-10. Arrow Point Types and Hierarchical Cluster Affiliations

\begin{tabular}{|l|c|c|}
\hline Point type & $\begin{array}{c}\text { Number } \\
(\boldsymbol{n}=\mathbf{5 6})\end{array}$ & $\begin{array}{c}\text { Clusters } \\
(\boldsymbol{n}=\mathbf{8})\end{array}$ \\
\hline Bonham & 5 & $1,2,5$ \\
\hline Cliffton & 8 & $3,4,6,7,8$ \\
\hline Cuney & 1 & 4 \\
\hline Harrell & 1 & 1 \\
\hline Perdiz & 39 & $1,2,3,4,5,6$ \\
\hline Scallorn & 2 & 5,6 \\
\hline
\end{tabular}

the variables are significant at the $\mathrm{p}=0.001$ level, and that they all contribute to the formation of the clusters. The low Wilks' Lambda values also indicate that there is a strong correlation between the variables and clusters. Thickness was the most discriminatory variable, while Stem Distal Width was the least discriminatory.

\section{A.5 INTERPRETATION OF CLUSTER ANALYSIS RESULTS}

\section{A.5.1 Dart Points}

The eight clusters form two principle groups or megaclusters, Clusters 1 through 4 and Clusters 5 through 8, which are defined by maximum width. A $t$-test performed on the Maximum Width for the two megaclusters demonstrates that there is a significant difference at $\mathrm{p}=0.01$ (Table A-14). 


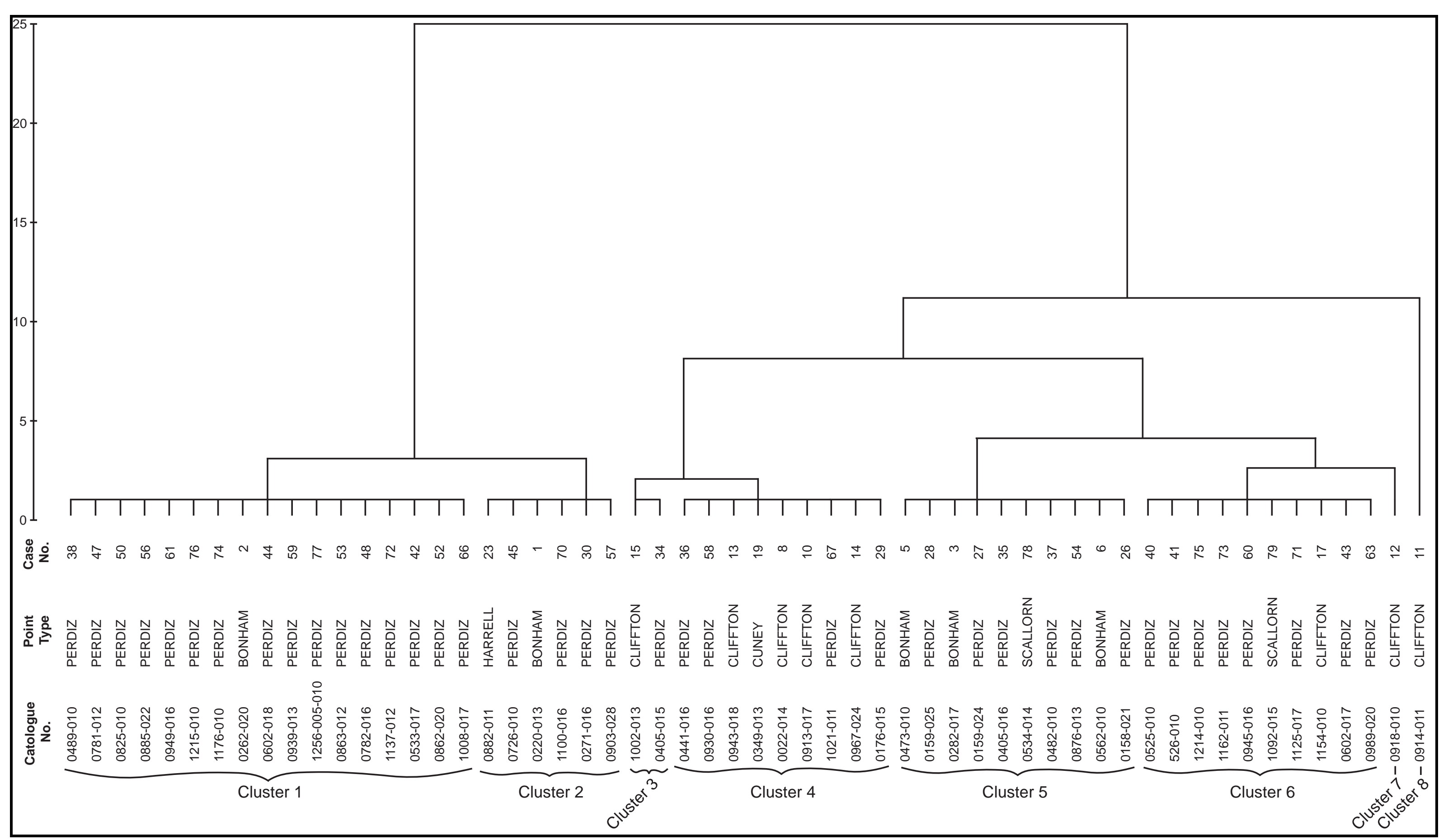

Figure A-4. Hierarchical Cluster Analysis Dendrogram of Arrow Points

Based on a dissimilarity matrix composed of squared Euclidean distance values calculated using Ward’s Method (SPSS 12.0 for Windows). 

Table A-11. Group Statistics Comparing Arrow Point Clusters 1 to 8

\begin{tabular}{|c|c|c|c|c|c|}
\hline \multirow[b]{2}{*}{ Cluster No. } & \multirow[b]{2}{*}{ Variable } & \multirow[b]{2}{*}{ Mean } & \multirow[b]{2}{*}{ Std. Deviation } & \multicolumn{2}{|c|}{ Valid $N$ (listwise) } \\
\hline & & & & Unweighted & Weighted \\
\hline 1 & $\begin{array}{l}\text { Stem Dist Width } \\
\text { Maximum Width } \\
\text { Max Thickness } \\
\text { Thickness:Width Ratio }\end{array}$ & $\begin{array}{c}5.8941 \\
14.6941 \\
2.7824 \\
0.1904\end{array}$ & $\begin{array}{l}0.70929 \\
0.98582 \\
0.54913 \\
0.04109\end{array}$ & $\begin{array}{l}17 \\
17 \\
17 \\
17\end{array}$ & $\begin{array}{l}17.000 \\
17.000 \\
17.000 \\
17.000\end{array}$ \\
\hline 2 & $\begin{array}{l}\text { Stem Dist Width } \\
\text { Maximum Width } \\
\text { Max Thickness } \\
\text { Thickness:Width Ratio }\end{array}$ & $\begin{array}{c}6.0333 \\
11.2000 \\
2.9167 \\
0.2609\end{array}$ & $\begin{array}{l}0.66833 \\
0.61644 \\
0.44008 \\
0.04008\end{array}$ & $\begin{array}{l}6 \\
6 \\
6 \\
6\end{array}$ & $\begin{array}{l}6.000 \\
6.000 \\
6.000 \\
6.000\end{array}$ \\
\hline 3 & $\begin{array}{l}\text { Stem Dist Width } \\
\text { Maximum Width } \\
\text { Max Thickness } \\
\text { Thickness:Width Ratio }\end{array}$ & $\begin{array}{c}10.5500 \\
25.1500 \\
4.0500 \\
0.1624\end{array}$ & $\begin{array}{l}1.76777 \\
1.34350 \\
1.06066 \\
0.05085\end{array}$ & $\begin{array}{l}2 \\
2 \\
2 \\
2\end{array}$ & $\begin{array}{l}2.000 \\
2.000 \\
2.000 \\
2.000\end{array}$ \\
\hline 4 & $\begin{array}{l}\text { Stem Dist Width } \\
\text { Maximum Width } \\
\text { Max Thickness } \\
\text { Thickness:Width Ratio }\end{array}$ & $\begin{array}{c}7.8556 \\
22.3111 \\
3.9889 \\
0.1799\end{array}$ & $\begin{array}{l}1.53713 \\
0.94399 \\
0.87670 \\
0.04453\end{array}$ & $\begin{array}{l}9 \\
9 \\
9 \\
9\end{array}$ & $\begin{array}{l}9.000 \\
9.000 \\
9.000 \\
9.000\end{array}$ \\
\hline 5 & $\begin{array}{l}\text { Stem Dist Width } \\
\text { Maximum Width } \\
\text { Max Thickness } \\
\text { Thickness:Width Ratio }\end{array}$ & $\begin{array}{c}5.7100 \\
19.0600 \\
2.9600 \\
0.1559\end{array}$ & $\begin{array}{l}0.79505 \\
1.21947 \\
0.44522 \\
0.02575\end{array}$ & $\begin{array}{l}10 \\
10 \\
10 \\
10\end{array}$ & $\begin{array}{l}10.000 \\
10.000 \\
10.000 \\
10.000\end{array}$ \\
\hline 6 & $\begin{array}{l}\text { Stem Dist Width } \\
\text { Maximum Width } \\
\text { Max Thickness } \\
\text { Thickness:Width Ratio }\end{array}$ & $\begin{array}{c}8.8300 \\
17.4900 \\
2.8700 \\
0.1654\end{array}$ & $\begin{array}{l}0.69290 \\
1.45713 \\
0.32335 \\
0.02600\end{array}$ & $\begin{array}{l}10 \\
10 \\
10 \\
10\end{array}$ & $\begin{array}{l}10.000 \\
10.000 \\
10.000 \\
10.000\end{array}$ \\
\hline 7 & $\begin{array}{l}\text { Stem Dist Width } \\
\text { Maximum Width } \\
\text { Max Thickness } \\
\text { Thickness:Width Ratio }\end{array}$ & $\begin{array}{c}14.2000 \\
17.6000 \\
3.4000 \\
0.1932\end{array}$ & $\begin{array}{l}\text { (a) } \\
\text { (a) } \\
\text { (a) } \\
\text { (a) }\end{array}$ & $\begin{array}{l}1 \\
1 \\
1 \\
1\end{array}$ & $\begin{array}{l}1.000 \\
1.000 \\
1.000 \\
1.000\end{array}$ \\
\hline 8 & $\begin{array}{l}\text { Stem Dist Width } \\
\text { Maximum Width } \\
\text { Max Thickness } \\
\text { Thickness:Width Ratio }\end{array}$ & $\begin{array}{c}12.0000 \\
16.6000 \\
17.4000 \\
1.0482\end{array}$ & $\begin{array}{l}\text { (a) } \\
\text { (a) } \\
\text { (a) } \\
\text { (a) }\end{array}$ & $\begin{array}{l}1 \\
1 \\
1 \\
1\end{array}$ & $\begin{array}{l}1.000 \\
1.000 \\
1.000 \\
1.000\end{array}$ \\
\hline Total & $\begin{array}{l}\text { Stem Dist Width } \\
\text { Maximum Width } \\
\text { Max Thickness } \\
\text { Thickness:Width Ratio }\end{array}$ & $\begin{array}{c}7.1393 \\
17.2821 \\
3.3554 \\
0.2000\end{array}$ & $\begin{array}{l}2.02885 \\
3.76279 \\
2.03728 \\
0.12408\end{array}$ & $\begin{array}{l}56 \\
56 \\
56 \\
56\end{array}$ & $\begin{array}{l}56.000 \\
56.000 \\
56.000 \\
56.000\end{array}$ \\
\hline
\end{tabular}

$\mathrm{a}=$ Insufficient data

Table A-12. Tests of Equality of Group Means

\begin{tabular}{|l|c|c|c|c|c|}
\hline \multicolumn{1}{|c|}{ Variable } & $\begin{array}{c}\text { Wilks' } \\
\text { Lambda }\end{array}$ & F & df1 & df2 & Sig. \\
\hline Stem Dist Width & .187 & 29.826 & 7 & 48 & .000 \\
\hline Maximum Width & .076 & 83.838 & 7 & 48 & .000 \\
\hline Max Thickness & .069 & 92.265 & 7 & 48 & .000 \\
\hline Thickness:Width Ratio & .077 & 81.721 & 7 & 48 & .000 \\
\hline
\end{tabular}


Table A-13. Analysis of Variance (ANOVA) Comparing Arrow Point Clusters 1 to 8

\begin{tabular}{|c|c|c|c|c|c|c|}
\hline \multicolumn{2}{|c|}{ Variable } & Sum of Squares & df & Mean Square & $\mathbf{F}$ & Sig. \\
\hline Stem Dist Width & $\begin{array}{l}\text { Between Groups } \\
\text { Within Groups } \\
\text { Total }\end{array}$ & $\begin{array}{c}184.074 \\
42.320 \\
226.394\end{array}$ & $\begin{array}{r}7 \\
48 \\
55\end{array}$ & $\begin{array}{r}26.296 \\
0.882\end{array}$ & 29.826 & 0.000 \\
\hline Maximum Width & $\begin{array}{l}\text { Between Groups } \\
\text { Within Groups } \\
\text { Total }\end{array}$ & $\begin{array}{c}719.846 \\
58.876 \\
778.722\end{array}$ & $\begin{array}{r}7 \\
48 \\
55\end{array}$ & $\begin{array}{c}102.835 \\
1.227\end{array}$ & 83.838 & 0.000 \\
\hline Max Thickness & $\begin{array}{l}\text { Between Groups } \\
\text { Within Groups } \\
\text { Total }\end{array}$ & $\begin{array}{c}212.486 \\
15.792 \\
228.278\end{array}$ & $\begin{array}{r}7 \\
48 \\
55\end{array}$ & $\begin{array}{r}30.355 \\
0.329\end{array}$ & 92.265 & 0.000 \\
\hline Thickness:Width Ratio & $\begin{array}{l}\text { Between Groups } \\
\text { Within Groups } \\
\text { Total }\end{array}$ & $\begin{array}{l}0.781 \\
0.066 \\
0.847\end{array}$ & $\begin{array}{r}7 \\
48 \\
55\end{array}$ & $\begin{array}{l}0.112 \\
0.001\end{array}$ & 81.721 & 0.000 \\
\hline
\end{tabular}

Table A-14. t-Test: Two-Sample Assuming Equal Variances

\begin{tabular}{|l|c|c|}
\hline & Maximum Width Clusters 1-4 & Maximum Width Clusters 5-8 \\
\hline Mean & 32.87419 & 21.54211 \\
\hline Variance & 12.15598 & 38.08845 \\
\hline Observations & 31 & \\
\hline Pooled Variance & 12.11869 & \\
\hline Hypothesized Mean Difference & 0 & \\
\hline df & 67 & \\
\hline t Stat & 13.45025 & \\
\hline P(T<=t) one-tail & $5.21 \mathrm{E}-21$ & \\
\hline t Critical one-tail & 2.383304 & \\
\hline $\mathrm{P}(\mathrm{T}<=\mathrm{t})$ two-tail & $1.04 \mathrm{E}-20$ & \\
\hline $\mathrm{t}$ Critical two-tail & 2.651213 & \\
\hline
\end{tabular}




\section{Cluster 1}

Cluster 1 ( $n=12)$ is composed of five Martindale points and seven Group 1 points (Table A-15). Morphologically, the cluster is defined by the outline shape of the base, measured with the proximal and distal stem width and stem length. An examination of the illustrated points from Dart Cluster 1 shows that it is composed of two types, Martindale and Group 1, and the difference between the two within Cluster 1 is the depth of the basal notching (Figure A-5). In the Group 1 points, the depth is greater and the
Base Notch Depth to Width Ratio is generally greater than the Martindale points. The general dimensions of the base and stem and the overall width created the composition of Cluster 1 more than the actual shape of the base with the characteristic fishtail of the Martindale points. Specimen \#0077-013 is a Martindale point with a base that has been refitted which may have affected the measurements for Base Notch Depth and Base Notch Width, since the base notch is shallower and wider than the other Martindale points.

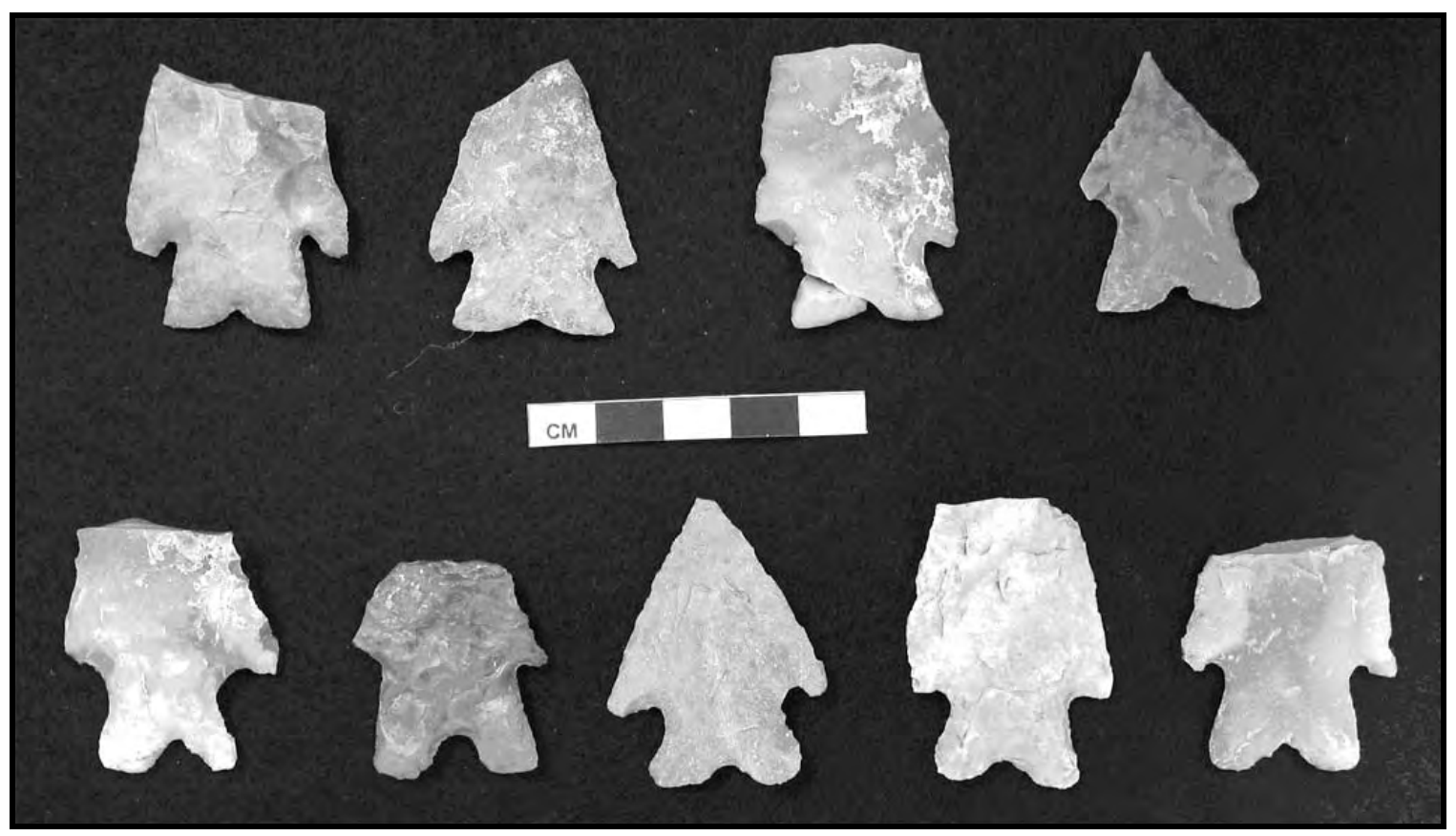

Figure A-5. Selected Projectile Points from Dart Cluster 1

Top row (left to right): \#39-015, \#40-013, \#77-013, \#730-013 (all Martindale) Bottom row (left to right): \#141-020, \#193-018, \#334-023, \#694-018, \#1203-010 (all Group 1) 
Table A-15. Cluster 1

\begin{tabular}{|c|c|c|c|}
\hline Catalogue Number & Point Type & $\begin{array}{c}\text { Base Notch Depth: } \\
\text { Width Ratio }\end{array}$ & $\begin{array}{c}\text { Proximal base width: } \\
\text { base notch width }\end{array}$ \\
\hline $0039-015$ & Martindale & 0.347826 & 3.231884 \\
\hline $0040-013$ & Martindale & 0.221053 & 2.431579 \\
\hline $0077-013$ & Martindale & 0.16 & 2.23 \\
\hline $0193-018$ & Group 1 & 0.517544 & 2.131579 \\
\hline $0334-023$ & Group 1 & 0.277228 & 2.207921 \\
\hline $0591-019$ & Martindale & 0.341176 & 2.835294 \\
\hline $0694-018$ & Group 1 & 0.314815 & 2.52 \\
\hline $0730-013$ & Martindale & 0.3 & 1.898148 \\
\hline $0141-020$ & Group 1 & 0.435185 & 1.580153 \\
\hline $0599-017$ & Group 1 & 0.320611 & 1.731707 \\
\hline $0670-005-011$ & Group 1 & 0.382114 & 2.190909 \\
\hline $1203-010$ & Group 1 & 0.318182 & 2.250641 \\
\hline & Mean & 0.327978 & \\
\hline
\end{tabular}

\section{Cluster 2}

Cluster $2(n=8)$ is comprised of five different dart types (Table A-16). The cluster is defined by having the greatest mean distal stem width $(18.8 \mathrm{~mm})$ and proximal stem width $(26.5 \mathrm{~mm})$. The measurements fail to discriminate the distinctive basal shapes of the points, which accounts for the grouping of visually dissimilar types (Figure A-6). The derivative measurement that further describes the shape of the base is created from dividing the proximal stem width by the basal notch width. Narrower stemmed points with prominent basal notching have a lower ratio. The Base Notch Depth:Width Ratio identifies the prominence of the basal notching, with relatively straight bases such as the Marcos point, having a low number (0.0714), while the Frio points have values of 0.3462 and 0.2885 .

\section{Cluster 3 and Cluster 6}

The selected variable measurements have created morphologically defined clusters that agree in part with some of the named dart types, specifically Clusters 3 and 6, which were both composed of Bandy points (Tables A-17 and A18; Figures A-7 and A-8). The significant difference between these two clusters is mean maximum width, $36.57+/-2.187 \mathrm{~mm}$ in Cluster 3 and $24.88+/-3.10 \mathrm{~mm}$ in Cluster 6 . The Bandy dart points as a group are significantly thinner than the other dart point types with a mean of $4.64 \mathrm{~mm}$ while the mean of the remaining point types is $6.99 \mathrm{~mm}$. In Cluster 6, the Stem Distal Width and Proximal Widths varies by standard deviations of $0.60 \mathrm{~mm}$ or less, the least variation. Stem Thickness is also significantly thinner than the other clusters. The smaller size of Cluster 6 may be from the selection of smaller and thinner blanks. 
Table A-16. Cluster 2

\begin{tabular}{|c|c|c|c|}
\hline Catalogue Number & Point Type & $\begin{array}{c}\text { Base Notch Depth: } \\
\text { Width Ratio }\end{array}$ & $\begin{array}{c}\text { Proximal base width: } \\
\text { base notch width }\end{array}$ \\
\hline $0009-014$ & Martindale & 0.183333 & 2.058333 \\
\hline $0187-010$ & Marcos & 0.071429 & 1.920635 \\
\hline $0230-013$ & Martindale & 0.201389 & 1.777778 \\
\hline $0370-010$ & Group 2 & 0.180645 & 1.554839 \\
\hline $1202-010$ & Group 1 & 0.305970 & 1.761194 \\
\hline $0187-011$ & Frio & 0.288462 & 2.932692 \\
\hline $0283-014$ & Group 2 & 0.215789 & 1.542105 \\
\hline $0525-005-013$ & Frio & 0.346154 & 2.884615 \\
\hline
\end{tabular}

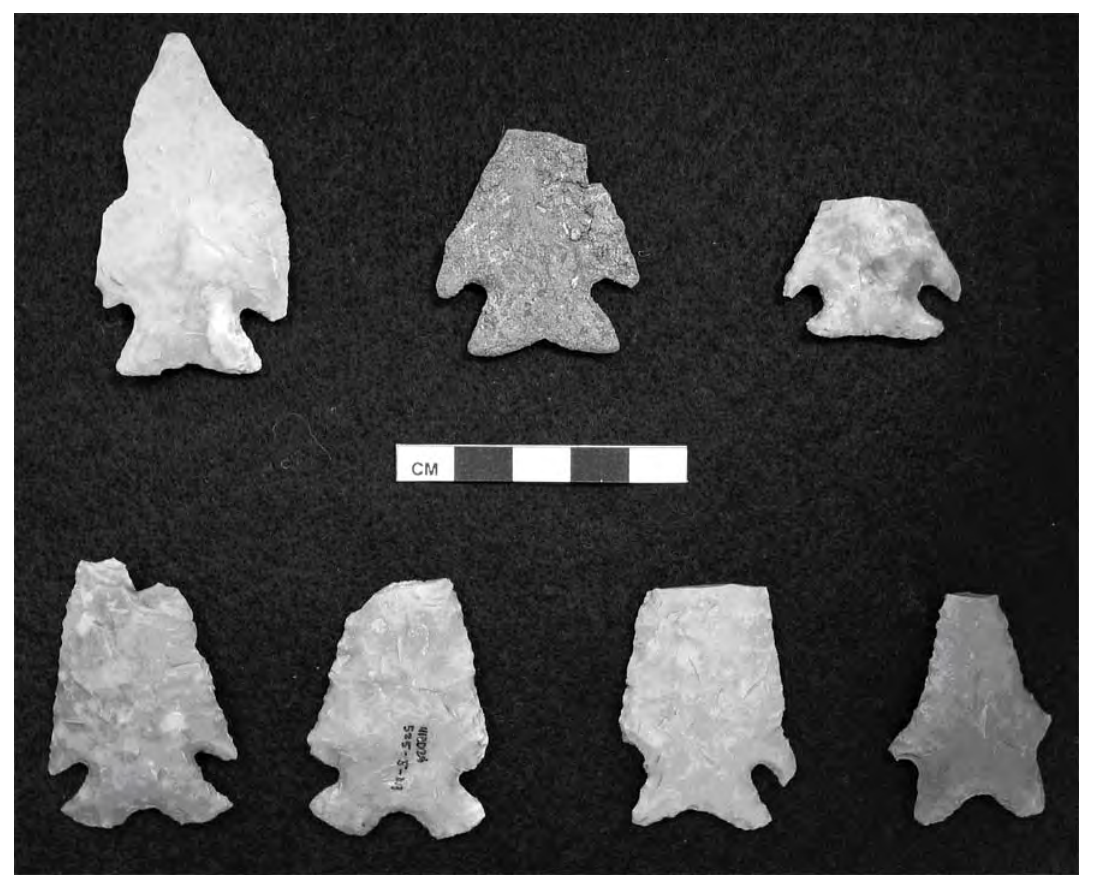

Figure A-6. Selected Projectile Points from Dart Cluster 2

Top row (left to right): \#9-014 (Martindale), \#230-013 (Martindale), \#187-010 (Marcos) Bottom row (left to right): \#187-011 (Marcos), \#525-005-013 (Frio), \#370-010 (Group 2), \#1202-010 (Group 1) 
Table A-17. Cluster 3 Point Types

\begin{tabular}{|c|c|c|c|}
\hline $\begin{array}{c}\text { Catalogue } \\
\text { Number }\end{array}$ & $\begin{array}{c}\text { Point } \\
\text { Type }\end{array}$ & $\begin{array}{c}\text { Maximum } \\
\text { Thickness }\end{array}$ & $\begin{array}{c}\text { Stem } \\
\text { Thickness }\end{array}$ \\
\hline $0390-010$ & Bandy & 4.0 & 3.3 \\
\hline $0531-018$ & Bandy & 4.8 & 3.2 \\
\hline $0651-011$ & Bandy & 4.8 & 3.4 \\
\hline $0689-020$ & Bandy & 4.6 & 3.4 \\
\hline $0713-016$ & Bandy & 4.5 & 3.7 \\
\hline $0746-014$ & Bandy & 4.8 & 2.9 \\
\hline & Mean & 4.583 & 3.317 \\
\hline
\end{tabular}

Table A-18. Cluster 6 Point Types

\begin{tabular}{|c|c|c|c|}
\hline $\begin{array}{c}\text { Catalogue } \\
\text { Number }\end{array}$ & $\begin{array}{c}\text { Point } \\
\text { Type }\end{array}$ & $\begin{array}{c}\text { Maximum } \\
\text { Thickness }\end{array}$ & $\begin{array}{c}\text { Stem } \\
\text { Thickness }\end{array}$ \\
\hline $0334-022$ & Bandy & 4.4000 & 3.8000 \\
\hline $0346-022$ & Bandy & 4.1000 & 2.4000 \\
\hline $0400-011$ & Bandy & 4.6000 & 2.7000 \\
\hline $0599-015$ & Bandy & 3.4000 & 2.4000 \\
\hline $0694-017$ & Bandy & 4.9000 & 3.5000 \\
\hline & Mean & 4.2800 & 2.96 \\
\hline
\end{tabular}




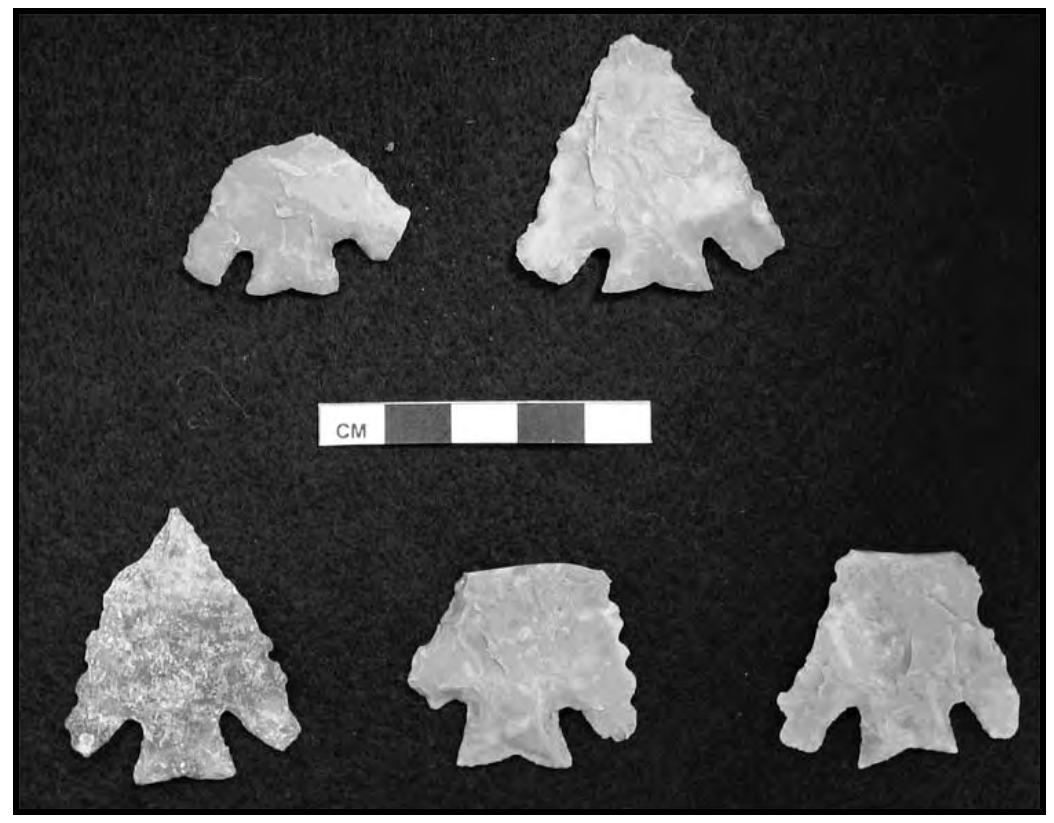

Figure A-7. Selected Projectile Points from Dart Cluster 3

Top row (left to right): \#390-010, \#531-018 (all Bandy)

Bottom row (left to right): \#651-011, \#689-020, \#746-014 (all Bandy)

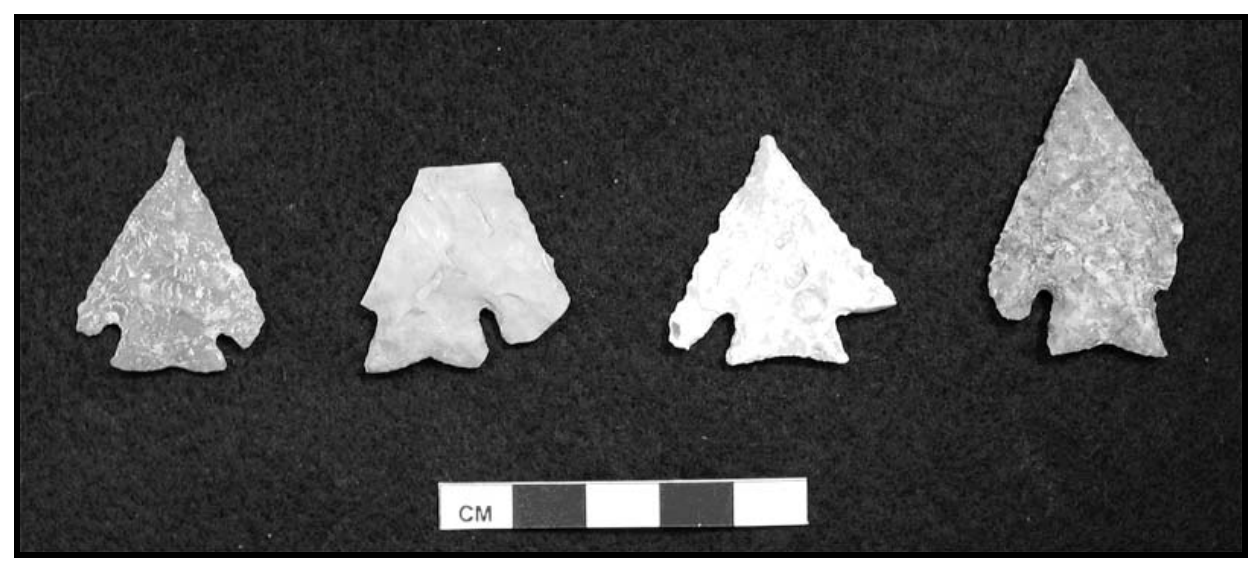

Figure A-8. Selected Projectile Points from Dart Cluster 6

Left to right: \#346-022, \#400-011, \#599-015, \#694-017 (all Bandy) 


\section{Cluster 4}

Cluster $4(n=5)$ contains four different named types and have the greatest maximum mean width. The measurements do not describe the variety of base shapes, but the algorithm has clustered the specimens according to the general physical measurements of the base (Table A-19). These specimens appear to be heavily reworked, while Specimen \#0854-010, a Martindale, appears to be unfinished (Figure A-9). The cluster does not define a true cultural type.

\section{Cluster 5}

Cluster $5 \quad(n=16)$ is the first cluster in Megacluster 2, which are narrower than Megacluster 1 projectile points (Figure A-10). The cluster also contains the most dart points (Table A-20). As depicted in Figure A-10, the bases are straight sided and expanding stemmed and deeply basal notched. The algorithm failed to detect the shape of the basal ears of the Merrell points (\#532-022, \#584-015), grouping them with the rounded basal notch shape of the Gower specimens, and also included a Frio point with reworked basal ears (\#562-012), and a Frio with a complete base (\#220-014). Both Frio points are readily detected in the data using the Basal Depth:Width Ratio. The Cluster is similar to Cluster 8 , since both clusters have the deepest basal notching and base depth to width ratios. All of the specimens appear to have been extensively reworked which could account for their narrow overall width.

\section{Cluster 7}

Cluster $7 \quad(n=6)$ contains four named types (Table A-21). Again, the program does not differentiate the characteristic "fishtail" of the Martindale points and they are grouped because of their wide and shallow basal notching (Figure A-11). The bases are expanding and are more similar to Megacluster 1 dart points. The narrow overall width of the specimens appears to be from extensive reworking of the points, including the barbs and shoulders of the points. The diverse number of points represents a morphological outline rather than true cultural types.

\section{Cluster 8}

Cluster 8 is a large group $(n=11)$ of narrow, straight to expanding stemmed projectile points, with deep U-shaped basal notching. Gower, Baker, and Merrell points comprise the cluster, and again, the algorithm does not discriminate for the shape of the basal ears. The high Base Notch Depth: Base Notch Width Ratio (0.6195) distinguishes the group as narrow split stemmed projectile points (Table A-22). These specimens appear to have been extensively modified (Figure A-12).

\section{A.5.2 Arrow Points}

The assemblage is divided into two megaclusters, Megacluster 1 contains Clusters 1 and 2, while Megacluster 2 contains Clusters 3 through 8 . The difference between these clusters is Maximum Width. Clusters 1 and 2 have the least mean Maximum Width and a higher mean Width: Thickness Ratio. As mentioned previously, the arrow point assemblage represents the variation of Perdiz point manufacturing. Because of the small size of the arrow points and their relative thinness and variation in manufacturing due to the skill of the knapper, raw material and size of the flake used to make the point will be reflected in the overall measurements. The algorithm detected significant statistical variability within the arrow point assemblage, but the variation may be unintentional and represent acceptable variations. 
Table A-19. Cluster 4

\begin{tabular}{|c|c|c|c|}
\hline Catalogue Number & Point Type & $\begin{array}{c}\text { Base Notch Depth: } \\
\text { Width Ratio }\end{array}$ & $\begin{array}{c}\text { Proximal base width: } \\
\text { base notch width }\end{array}$ \\
\hline $0671-011$ & Group 1 & 0.1795 & 3.141026 \\
\hline $0142-011$ & Bandy & 0.0579 & 1.528926 \\
\hline $0412-010$ & Group 2 & 0.3015 & 1.5 \\
\hline $0523-021$ & Group 2 & 0.1493 & 1.537313 \\
\hline $0854-010$ & Martindale & 0.2500 & 2.421053 \\
\hline & Mean & 0.1876 & 2.025664 \\
\hline
\end{tabular}

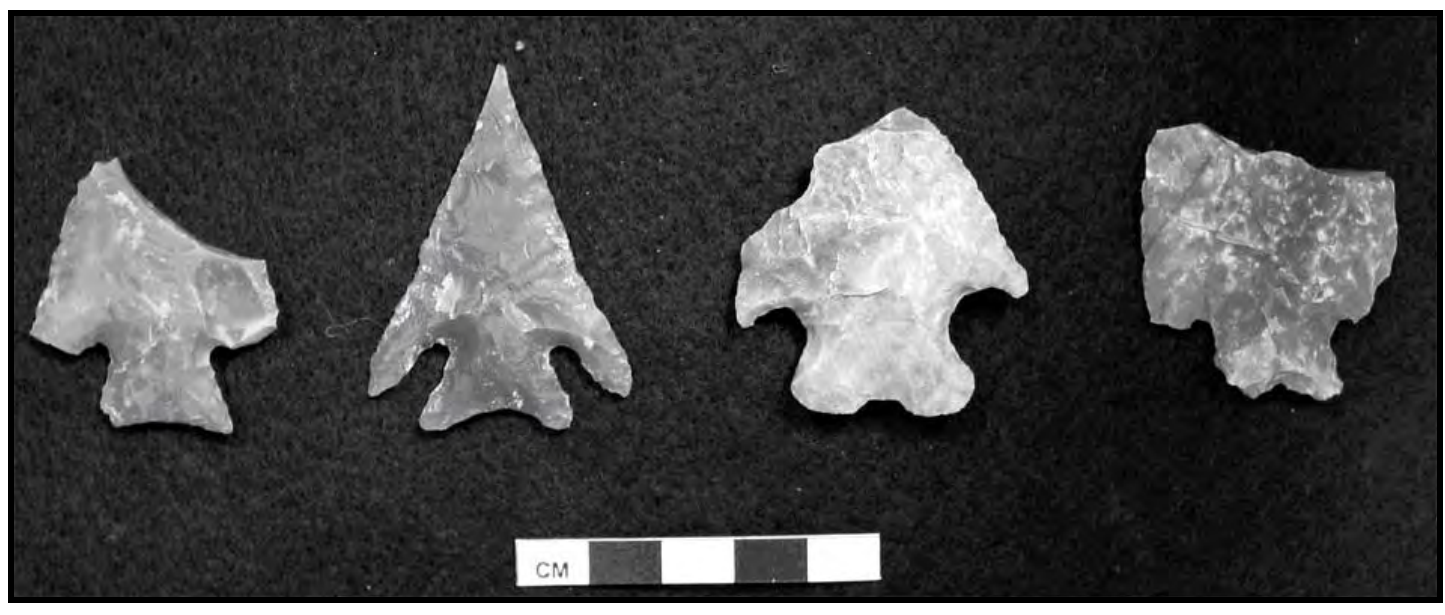

Figure A-9. Selected Projectile Points from Dart Cluster 4

Left to right: \#142-011 (Bandy), \#523-021 (Group 2), \#671-011 (Group 1), \#854-010 (Martindale) 


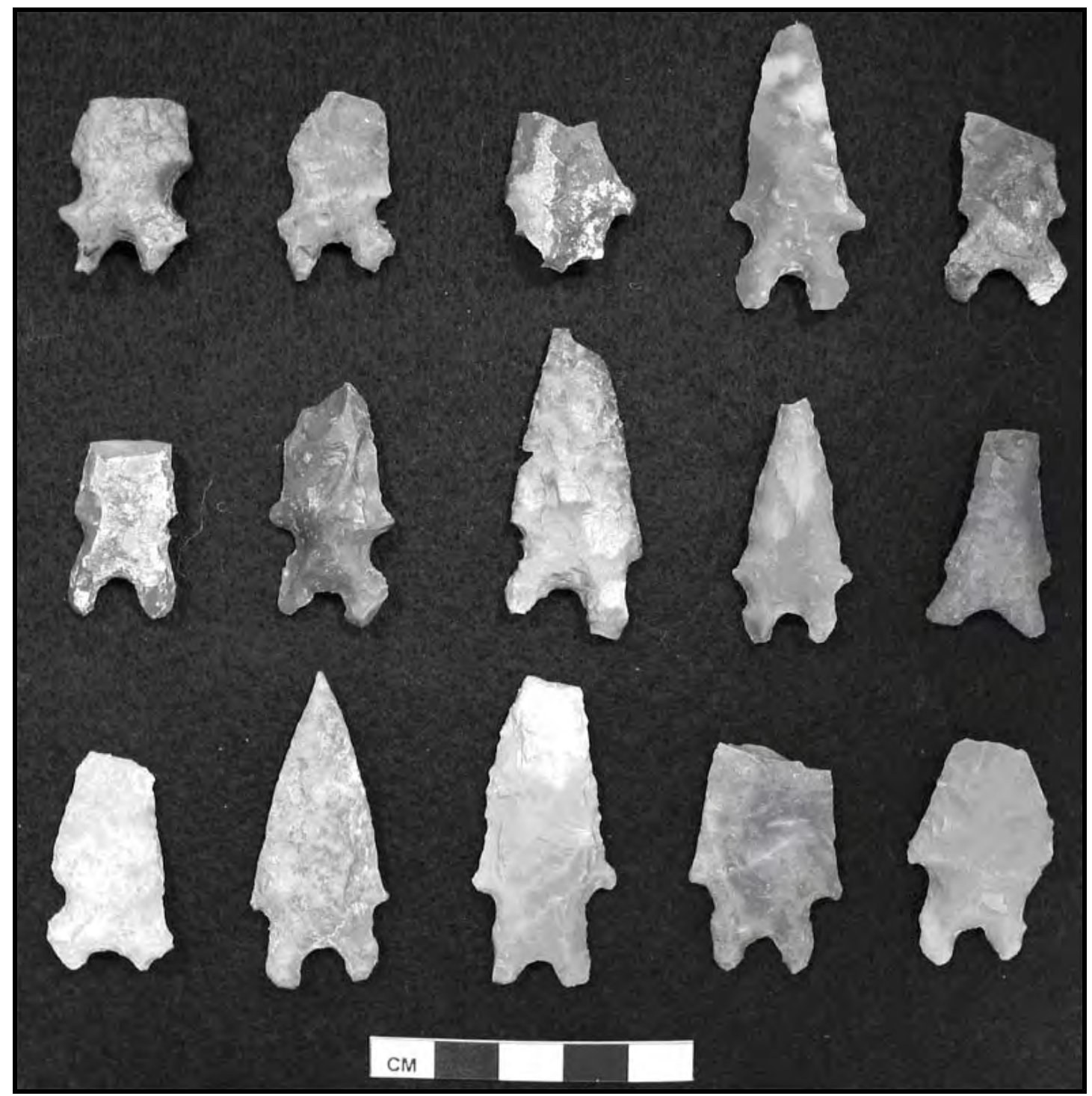

Figure A-10. Selected Projectile Points from Dart Cluster 5

Top row (left to right): \#523-022 (Merrell), \#584-015 (Merrell), \#192-011 (Gower), \#255-030 (Gower), \#289-022 (Gower)

Middle row (left to right): \#333-022 (Gower), \#411-016 (Gower), \#591-017 (Gower), \#1206-010

(Gower), \#220-014 (Frio)

Bottom row (left to right): \#562-012 (Frio), \#28-014 (Baker), \#346-023 (Baker), \#462-015 (Baker), \#653-012 (Baker) 
Table A-20. Cluster 5

\begin{tabular}{|c|c|c|c|}
\hline Catalogue Number & Point Type & $\begin{array}{c}\text { Base Notch } \\
\text { Depth:Width Ratio }\end{array}$ & $\begin{array}{l}\text { Proximal base: } \\
\text { base notch width }\end{array}$ \\
\hline 0028-014 & Baker & 0.581395 & 1.965116 \\
\hline 0192-011 & Gower & 0.547945 & 2.410959 \\
\hline 0220-014 & Frio & 0.264151 & 1.726415 \\
\hline 0255-030 & Gower & 0.74359 & 2.166667 \\
\hline 0289-022 & Gower & 0.50495 & 1.881188 \\
\hline 0333-022 & Gower & 0.538462 & 1.912088 \\
\hline 0346-023 & Baker & 0.46988 & 1.795181 \\
\hline 0391-011 & Gower & 0.681319 & 1.945055 \\
\hline 0411-016 & Gower & 0.41573 & 1.876404 \\
\hline 0462-015 & Baker & 0.576471 & 1.8 \\
\hline 0523-022 & Merrell & 0.517241 & 2.229885 \\
\hline 0562-012 & Frio & 0.290698 & 2.255814 \\
\hline 0584-015 & Merrell & 0.50495 & 1.792079 \\
\hline 0591-017 & Gower & 0.567308 & 1.788462 \\
\hline 0653-012 & Baker & 0.6625 & 2 \\
\hline \multirow[t]{2}{*}{ 1206-010 } & Gower & 0.514706 & 2.044118 \\
\hline & Mean & 0.523831 & 1.974339 \\
\hline
\end{tabular}

Table A-21. Cluster 7

\begin{tabular}{|c|c|c|c|}
\hline Catalogue Number & Point Type & $\begin{array}{c}\text { Base Notch } \\
\text { Depth: Width } \\
\text { Ratio }\end{array}$ & $\begin{array}{c}\text { Proximal base } \\
\text { width: base notch } \\
\text { width }\end{array}$ \\
\hline $0011-005-014$ & Edgewood & 0.142857 & 1.722222 \\
\hline $0268-021$ & Martindale & 0.235294 & 2.235294 \\
\hline $0324-016$ & Group 2 & 0.245283 & 2.009434 \\
\hline $0412-011$ & Group 2 & 0.246032 & 1.611111 \\
\hline $0599-016$ & Group 1 & 0.296296 & 2.839506 \\
\hline $0658-018$ & Martindale & 0.223684 & 2.947368 \\
\hline & Mean & 0.231574 & 2.227489 \\
\hline
\end{tabular}




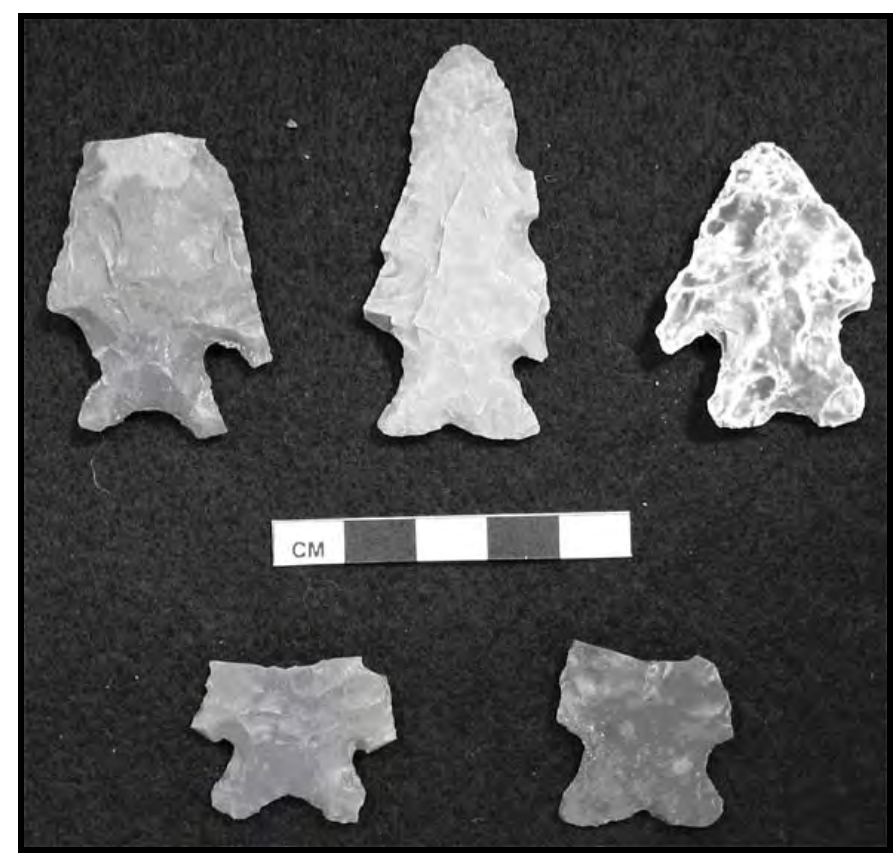

Figure A-11. Selected Projectile Points from Dart Cluster 7

Top row (left to right): \#412-011 (Group 2), \#658-018 (Martindale), \#599-016 (Group 1) Bottom row (left to right): \#324-016 (Group 2), \#268-021 (Martindale)

Table A-22. Cluster 8

\begin{tabular}{|c|c|c|c|}
\hline Catalogue Number & Point Type & $\begin{array}{c}\text { Base Notch Depth: } \\
\text { Width Ratio }\end{array}$ & $\begin{array}{c}\text { Proximal base: base } \\
\text { notch width }\end{array}$ \\
\hline $0086-020$ & Gower & 0.81690 & 2.746479 \\
\hline $0117-020$ & Merrell & 0.77922 & 2.623377 \\
\hline $0203-014$ & Merrell & 0.79268 & 2.54878 \\
\hline $0289-021$ & Gower & 0.72115 & 1.836538 \\
\hline $0299-014$ & Merrell & 0.45349 & 2.406977 \\
\hline $0345-027$ & Gower & 0.75309 & 2.222222 \\
\hline $0431-010$ & Baker & 0.73418 & 2.341772 \\
\hline $0479-013$ & Merrell & 0.50000 & 1.805085 \\
\hline $0523-025$ & Merrell & 0.55238 & 2.114286 \\
\hline $0569-013$ & Baker & 0.74627 & 2.731343 \\
\hline $0658-016$ & Merrell & 0.75714 & 2.871429 \\
\hline & Mean & 0.69150 & 2.386208 \\
\hline
\end{tabular}




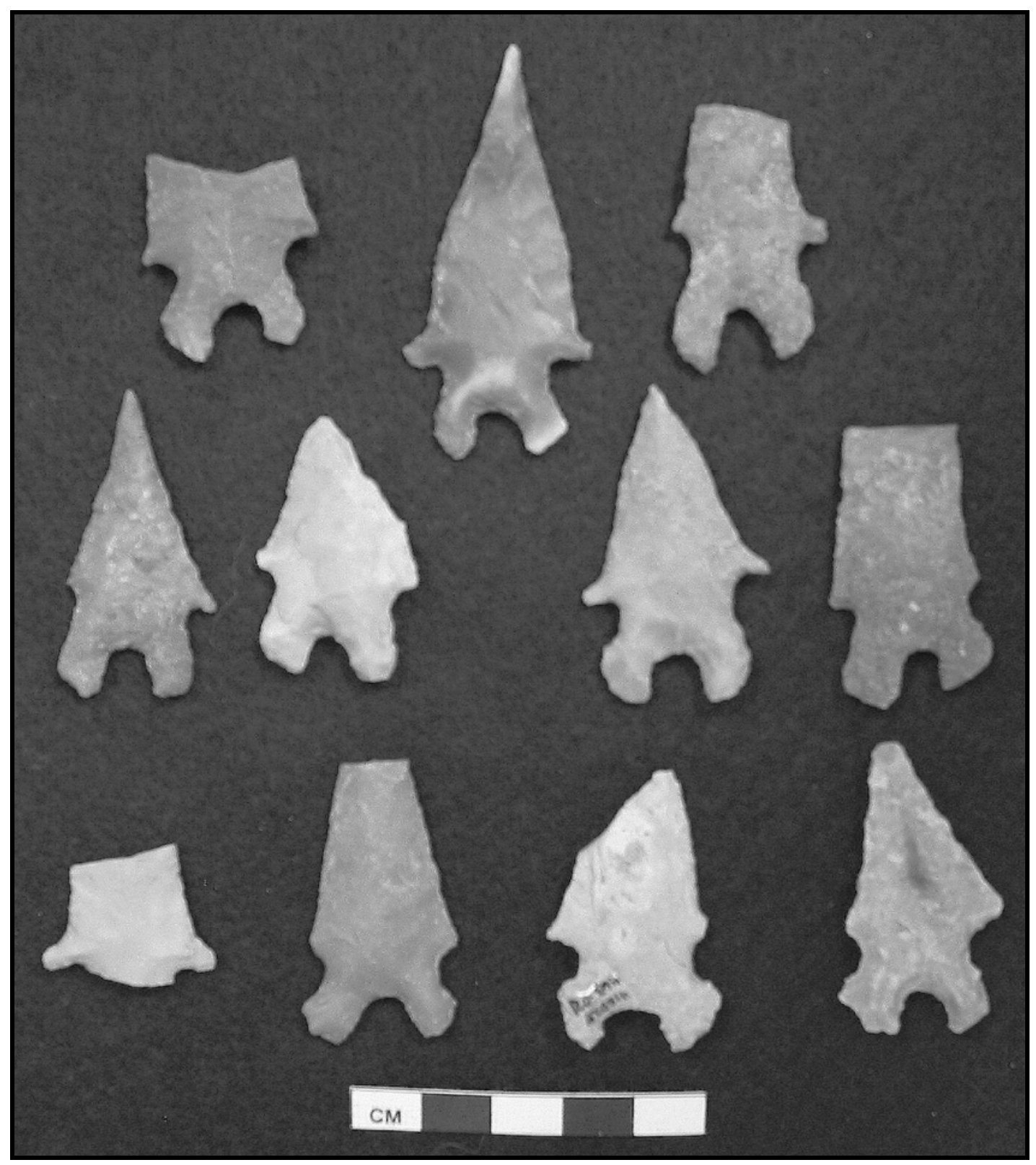

Figure A-12. Projectile Points from Dart Cluster 8

Top row (left to right): \#86-020, \#345-027, \#289-021 (all Gower)

Middle row (left to right): \#431-010 (Baker), \#569-013 (Baker), \#117-020 (Merrell), \#203-014 (Merrell) Bottom row (left to right): \#299-014, \#479-013, \#523-025, \#658-016 (Merrell) 


\section{Arrow Point Cluster 1 ( $n=17)$}

From the Figure A-13, Arrow Cluster 1 demonstrates the varying condition and resultant size of the specimens. The solitary Bonham point, Specimen \#0262-020 has a square base and straight-sided stem in contrast to the tapered or constricting stem of the Perdiz. Cluster 1 represents the smaller dimensioned Perdiz points. The defining attributes of the cluster are its narrow width and thinness (Table A-23). The Perdiz points in Cluster 1 are from various levels and units at the Varga site and do not appear to represent an isolatable temporal or spatial group.

\section{Arrow Point Cluster $2(n=6)$}

This cluster is composed of four Perdiz, one Harrell, and one Bonham point (Figure A-14). Cluster 2 is defined by the narrow Maximum Width (mean $11.2 \mathrm{~mm}$ ) and the resulting high value for the ratio of Thickness:Width (mean=0.2609) (Table A-24). The affiliation between the points is morphological, since four of the six points are Perdiz and the other two points are stylistically dissimilar to the Perdiz points and each other. Cluster 2's closest affiliation is with Cluster 1.

\section{Arrow Point Cluster $3(\boldsymbol{n}=2)$}

Cluster 3 is the smallest cluster analyzed, and is comprised of a Perdiz point and a Clifton point (Figure A-15). The two specimens are the widest, and the Clifton point is one of the thickest arrow points in the assemblage (Table A-25). Because of its high mean width, the cluster is more associated with Cluster 4 than with Clusters 1 and 2.

\section{Arrow Point Cluster $4(n=9)$}

The cluster is composed of equal numbers of Cliffton and Perdiz points, with a solitary Cuney point (Figure A-16; Table A-26). Cluster 4 is closely associated with Cluster 3 (Figure A-4), so that Cluster 3 represents outliers among their type. Clusters 4 is defined by a high Maximum Width and mean Thickness, while Stem Length would have eliminated the Cuney specimen and a Clifton from the cluster.

\section{Arrow Point Cluster $5(n=10)$}

Cluster 5 contains six Perdiz points, three Bonham, and a Scallorn point (Figure A-17; Table A-27). This Cluster has wide, relatively thin blades, resulting in the lowest Thickness: Width Ratio. Cluster 5 is equally associated with Cluster 6 and the solitary Cliffton in Cluster 7. The Maximum Width has decreased from Cluster 4. The composition of the cluster is defined by the fragmentary condition of several of the specimens that limited discriminatory variables, since only specimens able to provide a value for each of the three primary variables. Different temporal time periods are represented by the types.

\section{Arrow Point Cluster $6(n=10)$}

Cluster 6 is defined by a decreasing Maximum Width, a high Stem Distal Width, and relatively thin specimens (Figure A-18; Table A-28). The closest affiliation is with Cluster 7, a Cliffton point, with the next cluster being Cluster 5 . Maximum Stem Length and more descriptive shape variables would change the composition of the cluster. Eight out of the ten specimens are Perdiz points, and Cluster 6 contains broader points with a higher Stem Distal Width, than the largest population of Perdiz points, found in Cluster 1. The dendrogram demonstrates that Clusters 1 and 6 are the ends of the range of variability recorded for the Perdiz points. 


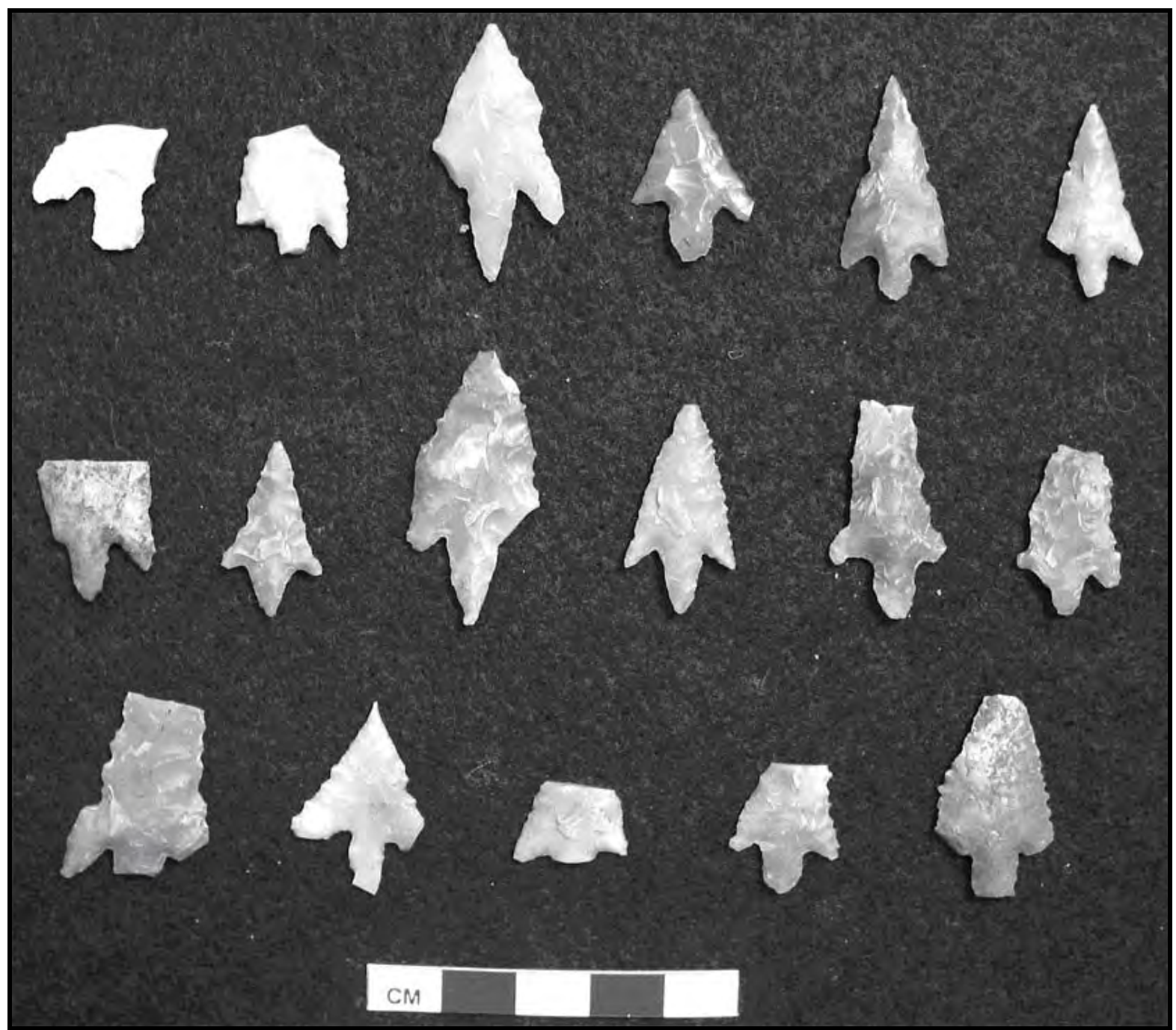

Figure A-13. Points from Arrow Cluster 1

Top row (left to right): \#262-020 (Bonham), \#489-010, \#533-017, \#602-018, \#781-012, \#782-016 (all Perdiz) Middle row (left to right): \#825-010, \#862-020, \#863-012, \#885-022, \#939-013, \#949-016, \#1256-005-010 (all Perdiz)

Bottom row (left to right): \#\#1008-017, \#1137-012, \#1176-010, \#1215-010 (all Perdiz) 
Table A-23. Arrow Point Measurement from Arrow Cluster 1

\begin{tabular}{|c|c|c|c|c|c|}
\hline Catalogue Number & Point Type & Distal Stem Width & $\begin{array}{l}\text { Maximum } \\
\text { Width }\end{array}$ & $\begin{array}{l}\text { Maximum } \\
\text { Thickness }\end{array}$ & Width:Thickness \\
\hline 0262-020 & Bonham & 6.4000 & 16.3000 & 2.5000 & 0.1533742 \\
\hline 0489-010 & Perdiz & 5.0000 & 14.7000 & 2.6000 & 0.1768707 \\
\hline 0533-017 & Perdiz & 6.4000 & 13.3000 & 3.0000 & 0.2255639 \\
\hline 0602-018 & Perdiz & 6.4000 & 16.2000 & 2.1000 & 0.1296296 \\
\hline 0781-012 & Perdiz & 4.9000 & 14.7000 & 2.4000 & 0.1632653 \\
\hline 0782-016 & Perdiz & 5.0000 & 13.5000 & 2.6000 & 0.1925926 \\
\hline 0825-010 & Perdiz & 5.5000 & 14.9000 & 3.4000 & 0.2281879 \\
\hline 0862-020 & Perdiz & 5.9000 & 13.3000 & 3.0000 & 0.2255639 \\
\hline 0863-012 & Perdiz & 6.7000 & 15.0000 & 3.1000 & 0.2066667 \\
\hline 0885-022 & Perdiz & 6.0000 & 14.6000 & 2.9000 & 0.1986301 \\
\hline 0939-013 & Perdiz & 6.1000 & 15.9000 & 3.2000 & 0.2012579 \\
\hline 0949-016 & Perdiz & 6.4000 & 14.6000 & 2.3000 & 0.1575342 \\
\hline $1008-017$ & Perdiz & 6.9000 & 14.2000 & 4.3000 & 0.3028169 \\
\hline $1137-012$ & Perdiz & 4.4000 & 13.1000 & 2.3000 & 0.1755725 \\
\hline $1176-010$ & Perdiz & 5.7000 & 15.1000 & 2.4000 & 0.1589404 \\
\hline $1215-010$ & Perdiz & 6.1000 & 14.8000 & 2.2000 & 0.1486486 \\
\hline \multirow[t]{2}{*}{$1256-005-010$} & Perdiz & 6.4000 & 15.6000 & 3.0000 & 0.1923077 \\
\hline & Mean & 5.8941176 & 14.694118 & 2.7823529 & 0.1904367 \\
\hline
\end{tabular}

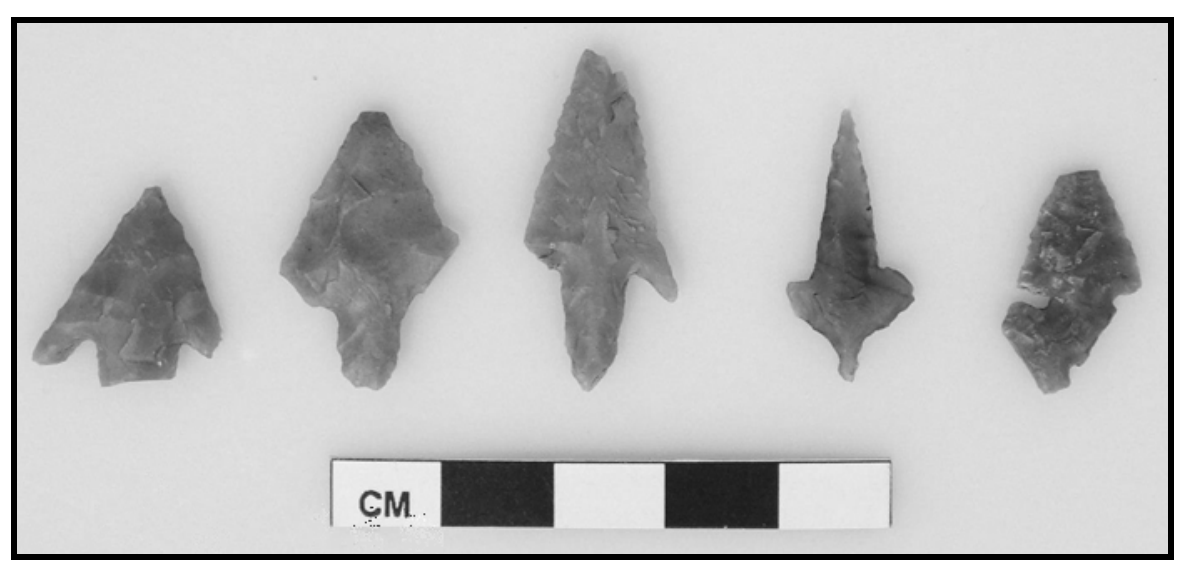

Figure A-14. Selected Points from Arrow Cluster 2

Left to Right: \#903-028 (Perdiz), \#1100-016 (Perdiz), \#271-016 (Perdiz), \#726-010 (Perdiz), \#882-011 (Harrell) 
Table A-24. Arrow Point Measurement from Arrow Cluster 2

\begin{tabular}{|c|c|c|c|c|c|}
\hline Catalogue Number & Point Type & Distal Stem Width & $\begin{array}{c}\text { Maximum } \\
\text { Width }\end{array}$ & $\begin{array}{c}\text { Maximum } \\
\text { Thickness }\end{array}$ & Width:Thickness \\
\hline $0220-013$ & Bonham & 5.3000 & 11.2000 & 3.1000 & 0.2767857 \\
\hline $0271-016$ & Perdiz & 5.9000 & 10.1000 & 3.1000 & 0.3069307 \\
\hline $0726-010$ & Perdiz & 5.9000 & 11.3000 & 2.3000 & 0.2035398 \\
\hline $0882-011$ & Harrell & 5.8000 & 11.2000 & 2.5000 & 0.2232143 \\
\hline $0903-028$ & Perdiz & 7.3000 & 11.4000 & 3.0000 & 0.2631579 \\
\hline $1100-016$ & Perdiz & 6.0000 & 12.0000 & 3.5000 & 0.2916667 \\
\hline & Mean & 6.0333333 & 11.2 & 2.9166667 & 0.2608825 \\
\hline
\end{tabular}

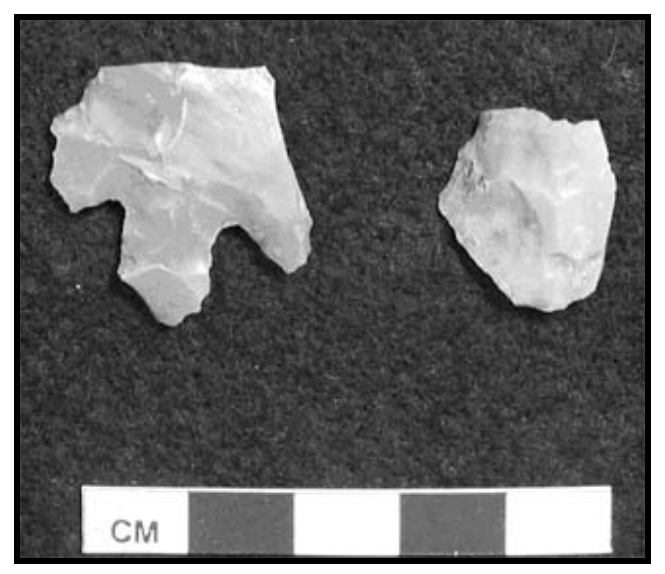

Figure A-15. Points from Arrow Cluster 3

Left to Right: \#405-015 (Perdiz), \#1002-013 (Cliffton)

Table A-25. Arrow Point Measurement from Arrow Cluster 3

\begin{tabular}{|c|c|c|c|c|c|}
\hline Catalogue Number & Point Type & Distal Stem Width & $\begin{array}{c}\text { Maximum } \\
\text { Width }\end{array}$ & $\begin{array}{c}\text { Maximum } \\
\text { Thickness }\end{array}$ & Width:Thickness \\
\hline $0405-015$ & Perdiz & 9.3000 & 26.1000 & 3.3000 & 0.1264 \\
\hline $1002-013$ & Cliffton & 11.8000 & 24.2000 & 4.8000 & 0.1983 \\
\hline & Mean & 10.5500 & 25.1500 & 4.0500 & 0.1624 \\
\hline
\end{tabular}




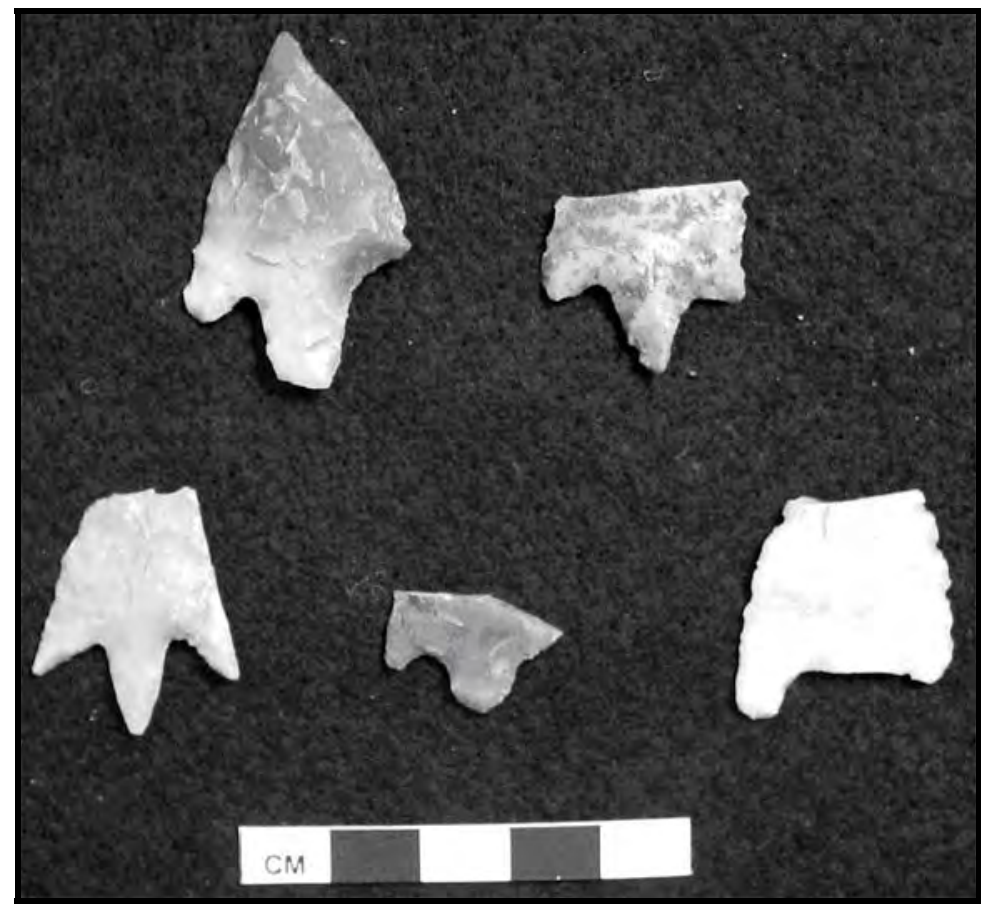

Figure A-16. Selected Points from Arrow Cluster 4

Top row (left to right): \#176-015 (Perdiz), \#913-017 (Cliffton)

Bottom row (left to right): \#930-016 (Perdiz), \#967-024 (Cliffton), \#1021-011 (Perdiz)

Table A-26. Arrow Point Measurement from Arrow Cluster 4

\begin{tabular}{|c|c|c|c|c|c|}
\hline $\begin{array}{c}\text { Catalogue } \\
\text { Number }\end{array}$ & Point Type & Distal Stem Width & $\begin{array}{c}\text { Maximum } \\
\text { Width }\end{array}$ & $\begin{array}{c}\text { Maximum } \\
\text { Thickness }\end{array}$ & Width:Thickness \\
\hline $0022-014$ & Cliffton & 9.2000 & 22.3000 & 4.4000 & 0.1973094 \\
\hline $0176-015$ & Perdiz & 10.2000 & 20.9000 & 5.5000 & 0.2631579 \\
\hline $0349-013$ & Cuney & 5.7000 & 22.8000 & 4.2000 & 0.1842105 \\
\hline $0441-016$ & Perdiz & 6.2000 & 23.0000 & 3.4000 & 0.1478261 \\
\hline $0913-017$ & Cliffton & 8.4000 & 22.2000 & 3.4000 & 0.1531532 \\
\hline $0930-016$ & Perdiz & 6.9000 & 22.9000 & 3.1000 & 0.1353712 \\
\hline $0943-018$ & Cliffton & 6.9000 & 23.2000 & 4.8000 & 0.2068966 \\
\hline $0967-024$ & Cliffton & 7.9000 & 20.6000 & 4.3000 & 0.2087379 \\
\hline $1021-011$ & Perdiz & 9.3000 & 22.9000 & 2.8000 & 0.1222707 \\
\hline
\end{tabular}




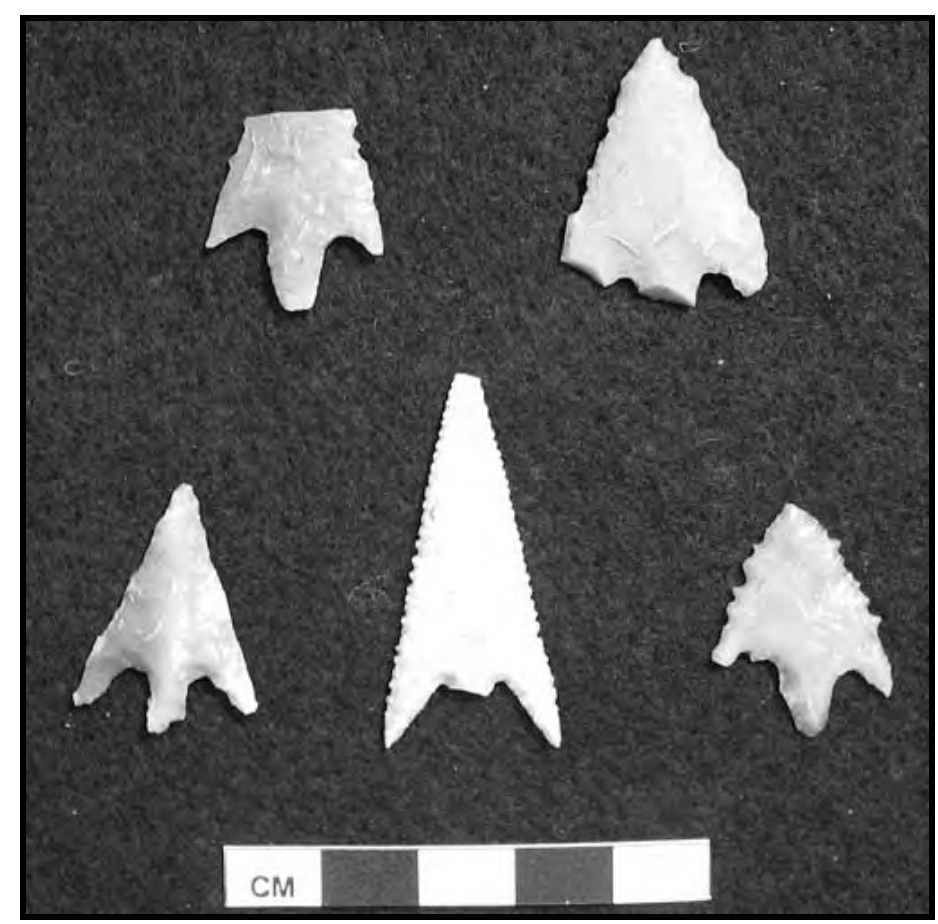

Figure A-17. Selected Points from Arrow Cluster 5

Top row (left to right): \#158-021 (Perdiz), \#159-024 (Perdiz) Bottom row (left to right): \#405-016 (Perdiz), \#534-014 (Scallorn), \#876-013 (Perdiz)

Table A-27. Arrow Point Measurement from Arrow Cluster 5

\begin{tabular}{|c|c|c|c|c|c|}
\hline Catalogue Number & Point Type & Distal Stem Width & $\begin{array}{c}\text { Maximu } \\
\text { m Width }\end{array}$ & $\begin{array}{c}\text { Maximum } \\
\text { Thickness }\end{array}$ & Width:Thickness \\
\hline $0158-021$ & Perdiz & 5.6000 & 17.8000 & 2.7000 & 0.1516854 \\
\hline $0159-024$ & Perdiz & 6.7000 & 21.1000 & 2.7000 & 0.1279621 \\
\hline $0159-025$ & Perdiz & 5.9000 & 19.7000 & 3.7000 & 0.1878173 \\
\hline $0282-017$ & Bonham & 6.0000 & 20.8000 & 2.8000 & 0.1346154 \\
\hline $0405-016$ & Perdiz & 4.3000 & 18.7000 & 3.1000 & 0.1657754 \\
\hline $0473-010$ & Bonham & 5.3000 & 19.5000 & 3.3000 & 0.1692308 \\
\hline $0482-010$ & Perdiz & 6.2000 & 18.7000 & 2.9000 & 0.1550802 \\
\hline $0534-014$ & Scallorn & 4.5000 & 17.8000 & 2.7000 & 0.1516854 \\
\hline $0562-010$ & Bonham & 6.4000 & 17.6000 & 3.5000 & 0.1988636 \\
\hline $0876-013$ & Perdiz & 6.2000 & 18.9000 & 2.2000 & 0.1164021 \\
\hline
\end{tabular}




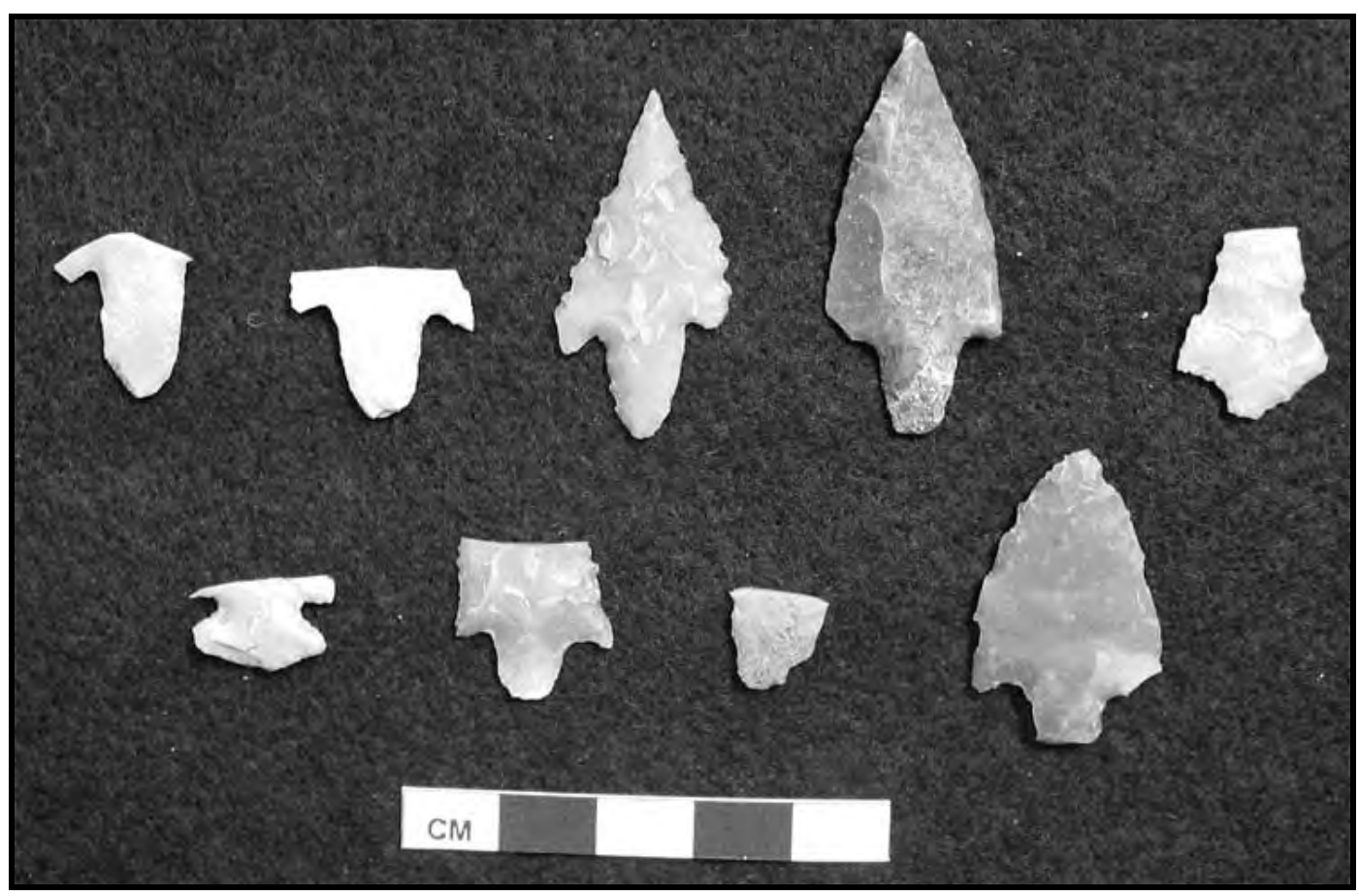

Figure A-18. Selected Points from Arrow Cluster 6

Top row (left to right): \#525-010, \#526-010, \#602-017, \#945-016, \#989-020 (all Perdiz) Bottom row (left to right): \#1092-015 (Scallorn), \#1125-017, \#1162-011, \#1214-010 (all Perdiz)

Table A-28. Arrow Point Measurement from Arrow Cluster 6

\begin{tabular}{|c|c|c|c|c|c|}
\hline Catalogue Number & Point Type & Distal Stem Width & $\begin{array}{c}\text { Maximum } \\
\text { Width }\end{array}$ & $\begin{array}{c}\text { Maximum } \\
\text { Thickness }\end{array}$ & Width:Thickness \\
\hline $0525-010$ & Perdiz & 8.9000 & 18.8000 & 2.7000 & 0.143617 \\
\hline $0526-010$ & Perdiz & 8.8000 & 18.6000 & 2.6000 & 0.1397849 \\
\hline $0602-017$ & Perdiz & 8.6000 & 17.3000 & 2.9000 & 0.1676301 \\
\hline $0945-016$ & Perdiz & 8.3000 & 16.4000 & 3.3000 & 0.2012195 \\
\hline $0989-020$ & Perdiz & 9.3000 & 16.2000 & 2.3000 & 0.1419753 \\
\hline $1092-015$ & Scallorn & 8.5000 & 15.6000 & 3.4000 & 0.2179487 \\
\hline $1125-017$ & Perdiz & 7.8000 & 15.9000 & 2.7000 & 0.1698113 \\
\hline $1154-010$ & Cliffton & 9.1000 & 17.4000 & 2.9000 & 0.1666667 \\
\hline $1162-011$ & Perdiz & 10.4000 & 19.0000 & 2.9000 & 0.1526316 \\
\hline $1214-010$ & Perdiz & 8.6000 & 19.7000 & 3.0000 & 0.1522843 \\
\hline
\end{tabular}




\section{A.6 Summary AND Conclusions}

It is important to remember that individual clusters do not necessarily represent types in the sense employed in traditional intuitive classification techniques. To move from morphological clusters to types, it is necessary to examine the pattern of similarities or differences among pairs or groups of clusters. The inclusion of specimens from different identified types across clusters, in the formation of morphological clusters suggests that the observed clusters were not true cultural types. While some of the patterning revealed by cluster analysis may be referable to types, there is not a necessary connection between traditional typological groups and morphological cluster groups. Numerical classification serves as a basis for defining patterning in a data set, and while it highlights patterns of correlation and covariation, it makes no arguments about cause. The causal relationships that underlie such patterning may or may not have anything to do stylistic or sociocultural variation, which is usually understood as the causal framework in traditional typological approaches to classification.

Hierarchical analysis may be useful in the situation for hypothesis testing such as dart shaft diameters, hafting depth, and prey size, and it is probable that different points may have been used for the same purpose through time. A strictly quantitative approach cannot resolve the issue of emic and etic types. The strength of the method is examining homogenous assemblages for variation, and it is up to the researcher to design the investigation to test a particular set of hypotheses.

\section{A.6.1 Dart Points}

The utility of using agglomerative hierarchical clustering methods is limited when there is readily observed variability in an assemblage that is not adequately recorded or coded, and is not used as a discriminant. This is noticeable in the shapes of Martindale points, Bandy points, Frio points, and Gower points for example. The method is best applied to determine variations within an assemblage that may not be recognizable or standardized. Although the stated intent of this examination was to provide an objective exploratory examination of projectile points from a single site, many of the decisions regarding the selection, collection, and analysis of the data were not entirely objective, and in some instances were subjective determinations such as limiting the number of cluster analysis runs, or the number of variables used for the analysis. By testing specific within named point types, variations or patterning may emerge that could have behavioral meaning such as a reduction in overall size measurements during times of stress, or limited access to lithic resources. Changes may have occurred in hafting length and diameter through time and may represent a change in hunting strategy or prey availability. Groups were created that closely corresponded to traditional named types, but other specimens of the same type, were excluded from particular groups. Bandy points were found in two principal clusters (Clusters 5 and 7), and were separated by the selected criteria, primarily reduced to overall size of the specimens.

\section{A.6.2 Arrow Points}

The arrow point analysis suffers from limited data even more than the dart points. Perdiz points were found in all of the analyzed arrow point clusters and the assemblage represents how the use of only a few variables can create groups that incorporate a range of forms that are visually and morphologically different and do not represent a true type as Krieger envisioned. Within a defined type, variations may represent the acceptable natural deviation. The limited number of measurements was further 
constrained by technology since the use of the bow dictated the limits of an efficient lithic design.

\section{A.7 References}

\section{Adams, W. Y., and E. W. Adams}

1991 Archaeological Typology and Practical Reality: A Dialectical Approach to Artifact Classification and Sorting. The University Press, Cambridge.

\section{Aldenderfer, $M$.}

1998 Quantitative Methods in Archaeology: A Review of Recent Trends and Developments. Journal of Archaeological Research 6(2):91-120.

1982 Methods of cluster validation for archaeology. World Archaeology 14, pp. 61-72.

\section{Banning, E. B.}

2000 The Archaeologist's Laboratory: The Analysis of Archaeological Data. Interdisciplinary Contributions to Archaeology. Kluwer Academic/ Plenum Publishers, New York.

\section{Binford, L. R., and S. R. Binford}

1966 A Preliminary Analysis of Functional Variability in the Mousterian of Levallois Facies. American Anthropologist Special Publication 68 (2):238-295.

\section{Callahan, E.}

1979 The Basics of Biface Knapping in the Eastern Fluted Point Tradition: A manual for Flintknappers and Lithic Analysts. Archeology of Eastern North America 7:1180.

\section{Cowgill, G. L.}

1990 Artifact Classification and Archaeological Purposes. In Mathematics and Information Science in Archaeology: A Flexible Framework, edited by A.
Voorrips, pp. 61-78. Modern Archaeology. Vol. 3. Holos, Bonn.

1982 Clusters of Objects and Associations between Variables: Two Approaches to Archaeological Classification. In Essays on Archaeological Typology, edited by R. Whallon and J. A. Brown, pp. 30-55. Center for American Archaeology Press, Evanston, Illinois.

\section{Doran, J. E., and F. R. Hodson}

1975 Mathematics and Computers in Archaeology. Edinburgh University Press: Edinburgh.

1976 Mathematics and Computers in Archaeology. Harvard University Press, Cambridge.

Dunnel, R. C.

1986 Methodological Issues in Americanist Artifact Classification. Advances in Archaeological Method and Theory 9:149208.

\section{Ford, J. A., and J. Steward}

1954 On the Concept of Types. American Anthropologist, New Series, 56(1):42-57.

\section{Gräslund, B.}

1981 The Background to C.J. Thomsen's Three Age System. In Toward a History of Archaeology, edited by G. Daniel, pp. 4568. Thames and Hudson, London.

Hodson, F. R.

1982 Some Aspects of Archaeological Classification. In Essays on Archaeological Typology, edited by $\mathrm{R}$. Whallon and J.A. Brown, pp. 21-29. Center for American Archaeology Press, Evanston, IL.

\section{Johnson, R., and G. Bhattacharyya}

1985 Statistics: Principles and Methods. John Wiley and Sons: New York.

Kerr, A. C.

2000 Systematic Analysis of Unfluted Lanceolate Projectile Points. 
Unpublished Master's thesis, The University of Texas at Austin.

\section{Kerr, A. C., and S. W. Dial}

1998 Chapter 14, Statistical Analysis of Unfluted Lanceolate and Early Bifurcate Stem Projectile Points. In WilsonLeonard An 11,000-year Archeological Record of Hunter-Gatherers in Central Texas. Volume II assembled and edited by M. B. Collins, pp. 447-505. Studies in Archeology 31, Texas Archeological Research Laboratory, The University of Texas at Austin, and Archeology Studies Program, Report 10, Texas.

Krieger, A. D.

1944 The Typological Concept. American Antiquity 9(3):271-288.

\section{Read, D. W.}

1989 Intuitive Typology and Automatic Classification: Divergence or Full Circle? Journal of Anthropological Archaeology 8:158-188.

\section{Rodden, $\mathbf{J}$.}

1981 The development of the Three Age System: Archaeology's first paradigm. In Toward a History of Archaeology, edited by G. Daniel, pp. 51-68. Thames and Hudson, London.

\section{Shennan, S.}

1988 Quantifying Archaeology. University of Iowa Press, Iowa City.

\section{Sneath, P., and R. Sokal}

1973 Numerical Taxonomy. Freeman: San Francisco.

Spaulding, A. C.

1953 Statistical Techniques for the Discovery of Artifact Types. American Antiquity 18(4):305-313.

1977 On Growth and Form in Archaeology: Multivariate Analysis. Journal of Anthropological Research 33(1):1-15.

\section{Suhm, D. A., and E. B. Jelks (editors)}

1962 Handbook of Texas Archeology: Type Descriptions. Bulletin Number Four ed. The Texas Archeological Society and the Texas Memorial Museum, Austin.

Turner, E. S., and T. R. Hester

1993 A Field Guide to Stone Artifacts of Texas Indians. First Edition. Gulf Publishing Company, Houston. 

APPENDIX B:

\section{RADIOCARBON ASSAYS}





\title{
RADIOCARBON ASSAYS
}

\author{
By: \\ Darden Hood, Beta Analytic and \\ Randy Culp, Center for Applied Isotopic Studies
}

Prepared for:

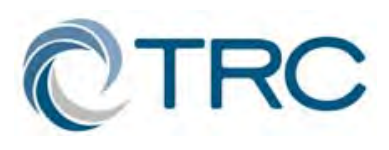

TRC Environmental Corporation

505 East Huntland Drive, Suite 250

Austin, Texas 78752

\author{
Prepared by: \\ Darden Hood \\ Beta Analytic \\ 4985 SW 74 Court \\ Miami, Florida 33155 \\ and \\ Randy Culp, Ph.D. \\ Center for Applied Isotopic Studies \\ The University of Georgia \\ 120 Riverbend Road \\ Athens, Georgia 30602
}

November 25, 2003 

FROM: Darden Hood, Director (mailto:mailto:dhood@radiocarbon.com)

\section{(This is a copy of the letter being mailed. Invoices/receipts follow only by mail.)}

October 3, 2002

Dr. James Abbott

Texas Department of Transportation

Cultural Resource Management

Environmental Affairs Division

125 East 11 th Street

Austin, TX 78701

USA

RE: Radiocarbon Dating Results For Samples ED28/100-1A, ED28/102-1B, ED28/103-1

Dear Jim:

Enclosed are the radiocarbon dating results for three samples recently sent to us. They each provided plenty of carbon for accurate measurements and all the analyses went normally. As usual, the method of analysis is listed on the report with the results and calibration data is provided where applicable.

As always, no students or intern researchers who would necessarily be distracted with other obligations and priorities were used in the analyses. We analyzed them with the combined attention of our entire professional staff.

If you have specific questions about the analyses, please contact us. We are always available to answer your questions.

Our invoice is enclosed. Please, forward it to the appropriate officer or send VISA change authorization. Thank you. As always, if you have any questions or would like to discuss the results, don't hesitate to contact me.

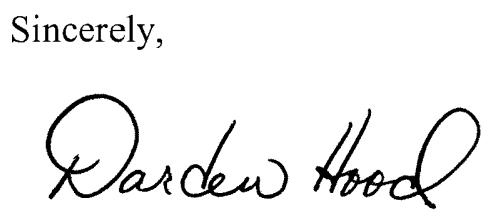


Dr. James Abbott

Report Date: 10/3/02

Texas Department of Transportation

Material Received: 9/6/02

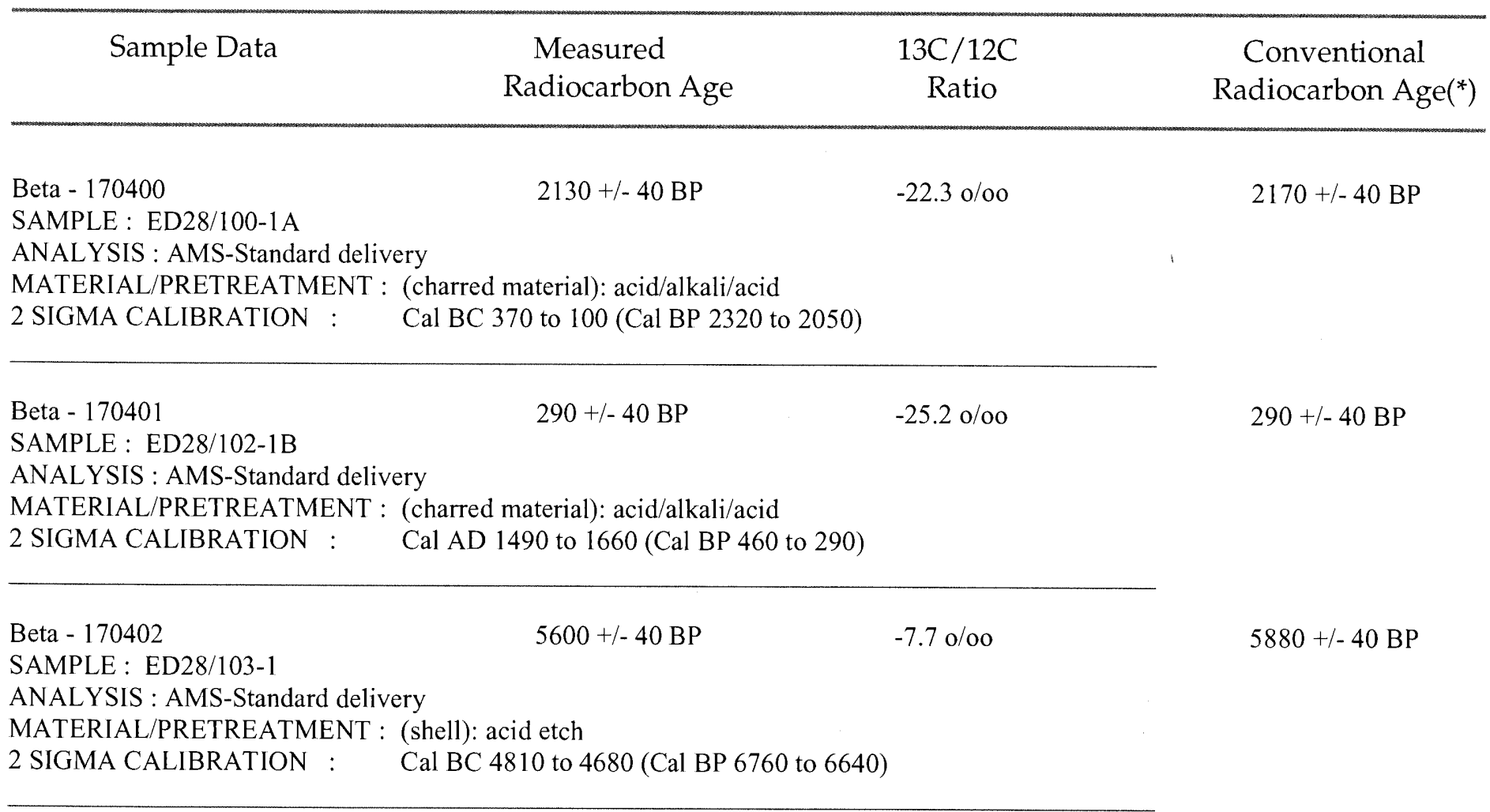




\section{CALIBRATION OF RADIOCARBON AGE TO CALENDAR YEARS}

(V ariables: C $13 / \mathrm{C} 12=-22.3: 1 \mathrm{ab} . \mathrm{mult}=1$ )

Laboratory number: Beta-170400

Conventional radiocarbon age: $2170 \pm 40$ B P

2 Sigma calibrated result: Cal BC 370 to 100 (Cal B P 2320 to 2050 )

(95\% probability)

Intercept data

Intercept of radiocarbon age with calibration curve:

1 Sigma calibrated results: Cal BC 350 to 300 (Cal B P 2300 to 2250) and

(68\% probability) Cal BC 220 to 170 (Cal B P 2170 to 2120 )

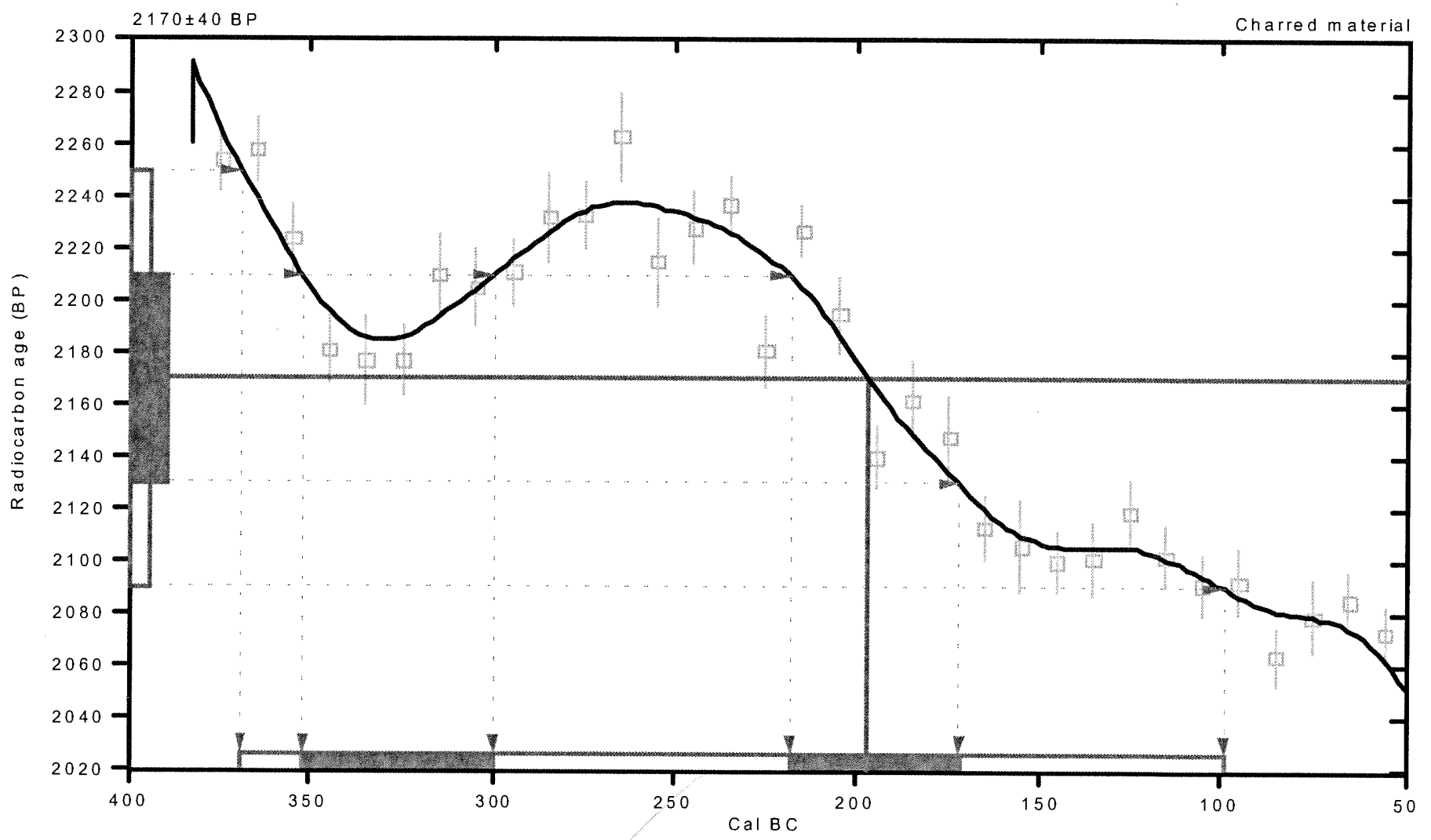

References:

Da tabase used

Calibration Database

Editorial Com ment

Stuiver, M., van der Plicht, H., I998, Radiocarbon 40(3), pxici-xiii

INTCAL98 Radiocarbon Age Calibration

Stuiver, M., et. al., 1998, Radiocarbon 40(3), p1041-1083

Math em atics

A Simplified Approach to Calibrating C14 Dates

Talma, A. S., Vogel, J.C., 1993, Radiocarbon 35(2), p $317-322$

Beta Analytic In c. 


\section{CALIBRATION OF RADIOCARBON AGE TO CALENDAR YEARS}

(Variables: C 13/C 12=-25.2:lab. mult=1)

Laboratory numer: Beta-170401

Conventional radiocarbon age: $290 \pm 40$ B

2 Sigm a calibrated result: Cal AD 1490 to 1660 (Cal BP 460 to 290)

$(95 \%$ probability)

Intercept data

Intercept of radiocarbon age

with calibration curve:

$1 \mathrm{Sigm}$ a calibrated results: Cal AD 1520 to 1580 (Cal B P 430 to 380 ) and

(68\% probability) Cal A D 1630 to 1650 (Cal B P 320 to 300 )

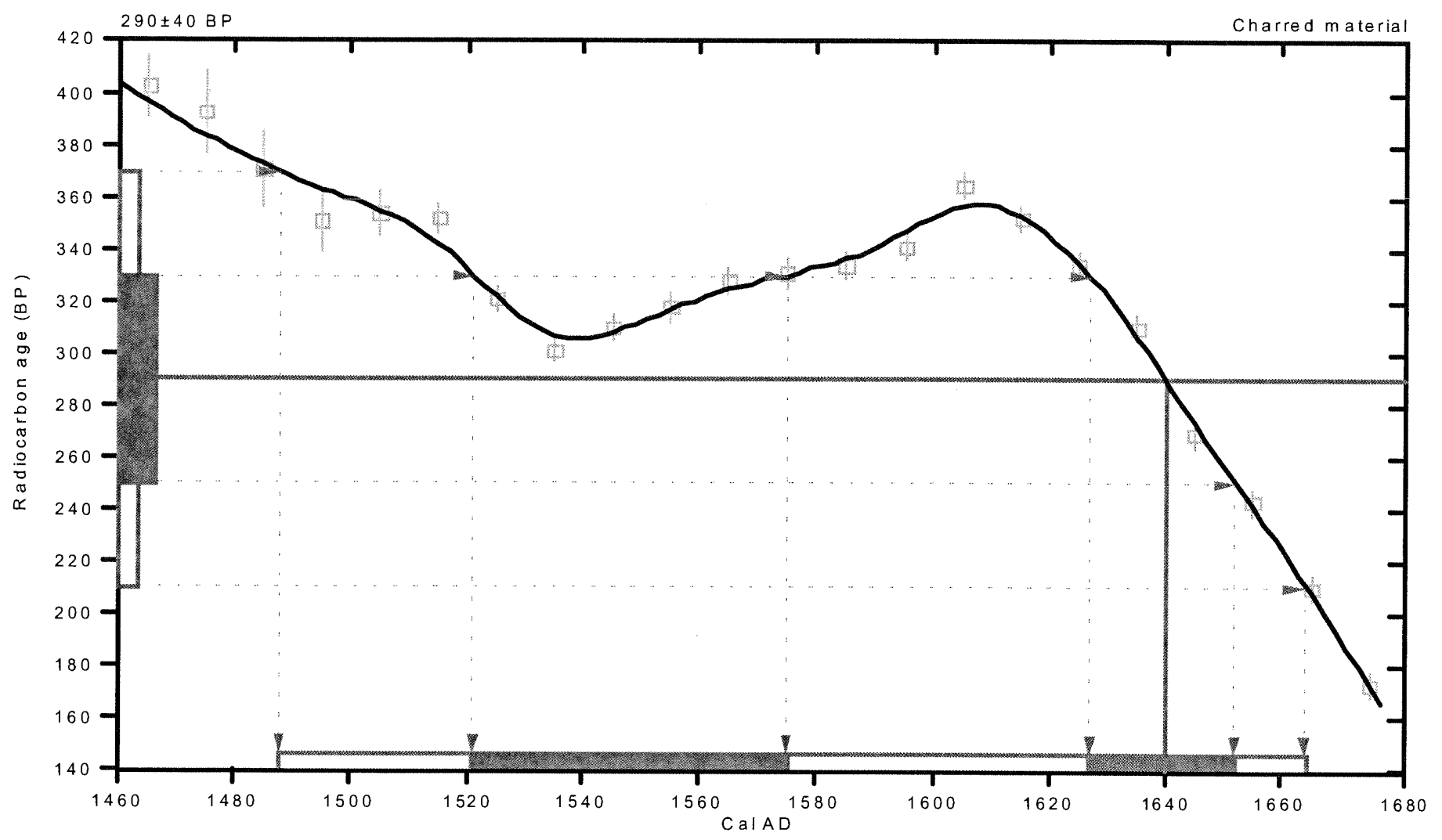

References:

Database used

Calibration Database

Editorial Com ment

Stuiver, M., van der Plicht, H., 1998, Radiocarbon 40(3), pxil-xiii

IN TCAL98 Radiocarbon Age Calibration

$M$ ath ematics

Stuiver, M., et. al., 1998, Radiocarbon 40(3), p1041-1083

A Simplified Approach to Calibrating CI 4 Dates

Talma, A. S., Vogel, J. C., 1993, Radiocarbon 3 5(2), p317-322 


\section{CALIBRATION OF RADIOCARBON AGE TO CALENDAR YEARS}

(V ariables: C $13 / \mathrm{C} 12=-7.7: \mathrm{lab} . \mathrm{mult}=1$ )

Laboratory number: Beta-170402

Conventional radiocarbon age: $5880 \pm 40$ B P

2 Sigma calibrated result: Cal BC 4810 to 4680 (Cal B P 6760 to 6640 )

( $95 \%$ probability)

Intercept data

Intercept of radiocarbon age

with calibration curve:

$1 \mathrm{Sigm}$ a calibrated result:

$(68 \%$ probability)

Cal B C 4730 (Cal B P 6680 )

Cal BC 4780 to 4710 (Cal B P 6730 to 6660 )

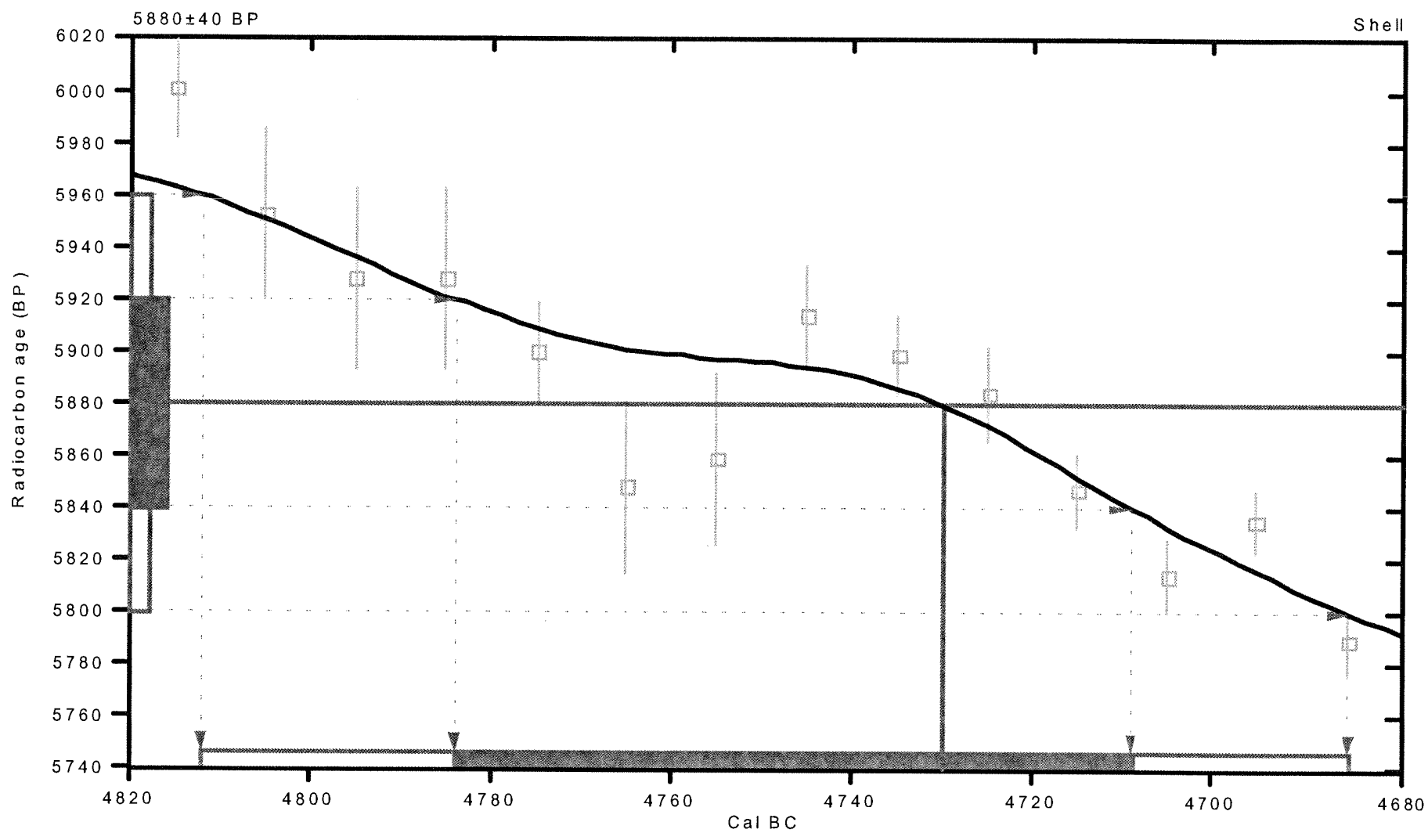

References:

Database used

Calibration Database

Editorial Com ment

Stuiver, M., van der Plicht, H., 1998, Radiocarbon 40(3), pxil-xiii

INTCAL98 Radiocarbon Age Calibration

Stuiver, M., et. al., 1998, Radiocarbon 40(3), p1041-1083

$M$ athematics

A Simplified Approach to Calibrating C 14 Dates

Talma, A. S., Vogel, J. C., 1993, Radiocarbon 35(2), p3I7-322 
FROM: Darden Hood, Director (mailto:mailto:dhood@radiocarbon.com)

(This is a copy of the letter being mailed. Invoices/receipts follow only by mail.)

February 25, 2003

Dr. James Abbott

Texas Department of Transportation

Cultural Resource Management

Environmental Affairs Division

125 East 11 th Street

Austin, TX 78701

USA

RE: Radiocarbon Dating Results For Samples ED28/1211-4-A, ED28/1209-4-A, ED28/1208-4A, ED28/1210-4-A, ED28/1207-4-A, ED28/76-011, ED28/158-005-7-1A, ED28/159-005-7-1A, ED28/160-005-7-1, ED28/1030-005-7-1, ED28/1055-005-7-1, ED28/171-007-1A, ED28/273004-2-1, ED28/830-005-4-1, ED28/843-005-7-1A, ED28/154-007-1, ED28/735-005-7, ED28/203-005-4-2-1, ED28/739-005-7, ED28/100-007-1, ED28/89-007-1

Dear Jim:

Enclosed are the radiocarbon dating results for 21 samples recently sent to us. They each provided plenty of carbon for accurate measurements and all the analyses went normally. As usual, the method of analysis is listed on the report with the results and calibration data is provided where applicable.

As always, no students or intern researchers who would necessarily be distracted with other obligations and priorities were used in the analyses. We analyzed them with the combined attention of our entire professional staff.

If you have specific questions about the analyses, please contact us. We are always available to answer your questions.

Our invoice is enclosed. Please, forward it to the appropriate officer or send VISA change authorization. Thank you. As always, if you have any questions or would like to discuss the results, don't hesitate to contact me.

Sincerely,

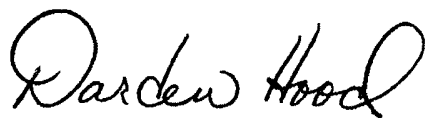




\begin{tabular}{|c|c|c|c|}
\hline Sample Data & $\begin{array}{c}\text { Measured } \\
\text { Radiocarbon Age }\end{array}$ & $\begin{array}{c}13 \mathrm{C} / 12 \mathrm{C} \\
\text { Ratio }\end{array}$ & $\begin{array}{c}\text { Conventional } \\
\text { Radiocarbon Age }\left(^{*}\right)\end{array}$ \\
\hline $\begin{array}{l}\text { Beta - } 175390 \\
\text { SAMPLE : ED28/1211-4-A } \\
\text { ANALYSIS : Radiometric-Standard } \\
\text { MATERIAL/PRETREATMENT : } \\
2 \text { SIGMA CALIBRATION : }\end{array}$ & $\begin{array}{l}1860+/-60 \mathrm{BP} \\
\text { delivery (bulk low carbon anal } \\
\text { (organic sediment): acid washes } \\
\text { Cal BC } 30 \text { to Cal AD } 240 \text { (Cal }\end{array}$ & $\begin{array}{l}-22.8 \mathrm{o} / \mathrm{oo} \\
\text { iment) } \\
1710)\end{array}$ & $1900+/-60 \mathrm{BP}$ \\
\hline $\begin{array}{l}\text { Beta - } 175391 \\
\text { SAMPLE : ED28/1209-4-A } \\
\text { ANALYSIS : AMS-Standard deliven } \\
\text { MATERIAL/PRETREATMENT : } \\
2 \text { SIGMA CALIBRATION : }\end{array}$ & $\begin{array}{l}\qquad 5190+/-50 \text { BP } \\
\text { ry } \\
\text { (organic sediment): acid washes } \\
\text { Cal BC } 4220 \text { to } 3960 \text { (Cal BP } 6\end{array}$ & $-22.6 \mathrm{o} / 00$ & $5230+/-50 \mathrm{BP}$ \\
\hline $\begin{array}{l}\text { Beta - } 175392 \\
\text { SAMPLE : ED28/1208-4-A } \\
\text { ANALYSIS : Radiometric-Standard } \\
\text { MATERIAL/PRETREATMENT : (c } \\
2 \text { SIGMA CALIBRATION : }\end{array}$ & $\begin{array}{l}\qquad 1840+/-70 \mathrm{BP} \\
\text { delivery (bulk low carbon anal } \\
\text { (organic sediment): acid washes } \\
\text { Cal BC } 10 \text { to Cal AD } 330 \text { (Cal }\end{array}$ & $\begin{array}{l}-23.3 \mathrm{o} / \mathrm{oo} \\
\text { ment) } \\
1620)\end{array}$ & $1870+/-70 \mathrm{BP}$ \\
\hline $\begin{array}{l}\text { Beta - } 175393 \\
\text { SAMPLE : ED28/1210-4-A } \\
\text { ANALYSIS : Radiometric-Standard } \\
\text { MATERIAL/PRETREATMENT : (c) } \\
2 \text { SIGMA CALIBRATION : }\end{array}$ & $\begin{array}{l}4790+/-70 \mathrm{BP} \\
\text { delivery (bulk low carbon anal) } \\
\text { (organic sediment): acid washes } \\
\text { Cal BC 37I0 to 3500 (Cal BP } 5\end{array}$ & $\begin{array}{l}-23.0 \mathrm{o} / \mathrm{oo} \\
\text { iment) } \\
\text { AND Cal BC }\end{array}$ & (Cal BP 5390 to 5330 ) \\
\hline $\begin{array}{l}\text { Beta - } 175394 \\
\text { SAMPLE : ED28/1207-4-A } \\
\text { ANALYSIS : AMS-Standard deliver } \\
\text { MATERIAL/PRETREATMENT : } \\
2 \text { SIGMA CALIBRATION : }\end{array}$ & $\begin{array}{l}\qquad 6220+/-50 \text { BP } \\
\text { organic sediment): acid washes } \\
\text { Cal BC } 5330 \text { to } 5070 \text { (Cal BP } 72\end{array}$ & $-21.9 \mathrm{o} / \mathrm{oo}$ & $6270+/-50 \mathrm{BP}$ \\
\hline
\end{tabular}




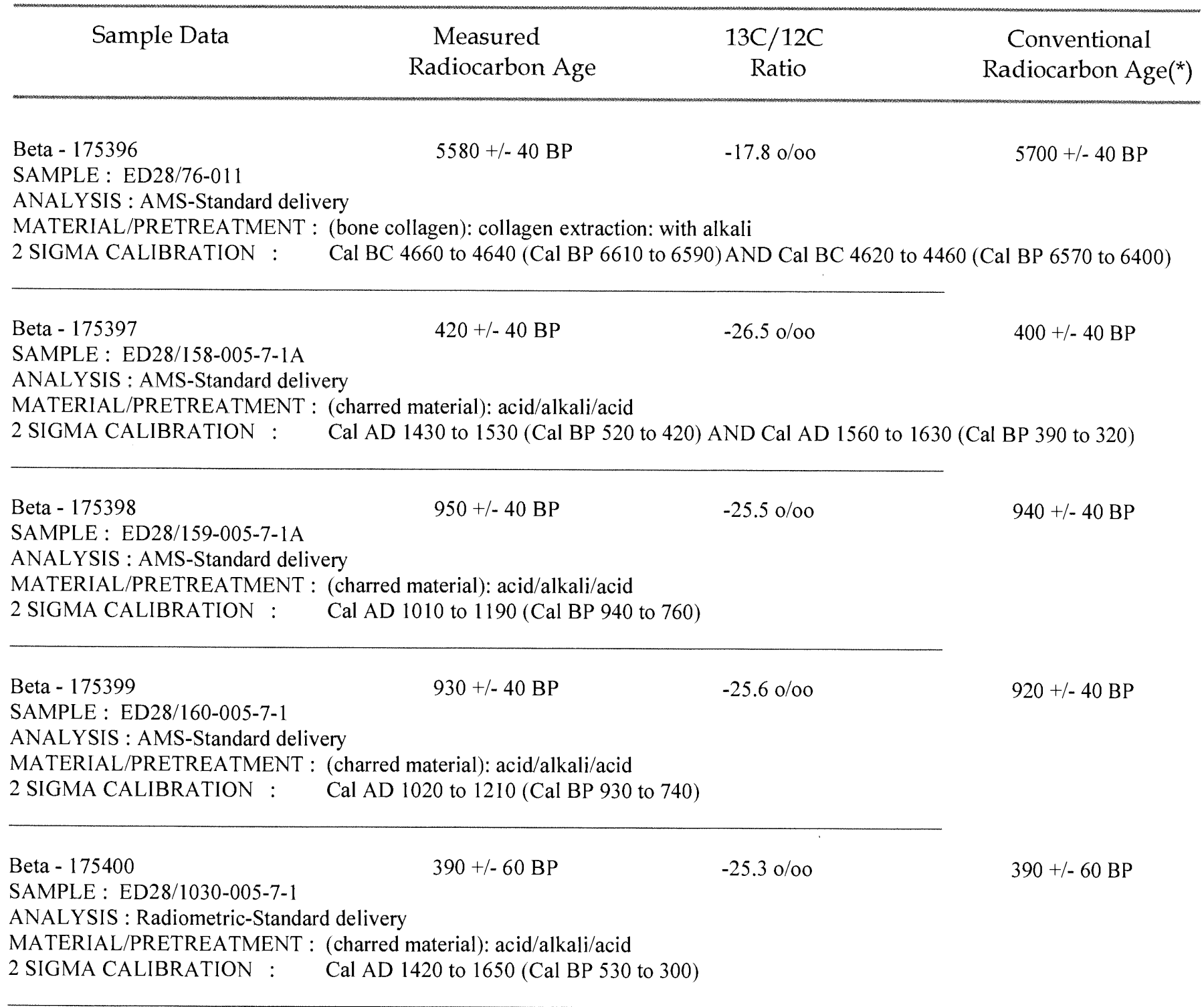




\begin{tabular}{|c|c|c|c|}
\hline Sample Data & $\begin{array}{l}\text { Measured } \\
\text { Radiocarbon Age }\end{array}$ & $\begin{array}{c}13 \mathrm{C} / 12 \mathrm{C} \\
\text { Ratio }\end{array}$ & $\begin{array}{c}\text { Conventional } \\
\text { Radiocarbon Age }\left(^{*}\right)\end{array}$ \\
\hline $\begin{array}{l}\text { Beta - } 175401 \\
\text { SAMPLE : ED28/1055-005-7-1 } \\
\text { ANALYSIS : Radiometric-Standa } \\
\text { MATERIAL/PRETREATMENT : } \\
2 \text { SIGMA CALIBRATION : }\end{array}$ & $\begin{array}{l}170+/-60 \mathrm{BP} \\
\text { d delivery (with extended counti } \\
\text { (charred material): acid/alkali/a } \\
\text { Cal AD } 1640 \text { to } 1950 \text { (Cal BP } 3\end{array}$ & $-25.4 \mathrm{o} / \mathrm{oo}$ & $170+/-60 \mathrm{BP}$ \\
\hline $\begin{array}{l}\text { Beta - } 175402 \\
\text { SAMPLE : ED28/171-007-1A } \\
\text { ANALYSIS : AMS-Standard deliv } \\
\text { MATERIAL/PRETREATMENT : } \\
2 \text { SIGMA CALIBRATION : }\end{array}$ & $\begin{array}{l}\qquad 2120+/-40 \mathrm{BP} \\
\text { (ery } \\
\text { (charred material): acid/alkali/a) } \\
\text { Cal BC } 360 \text { to } 290 \text { (Cal BP } 231\end{array}$ & $\begin{array}{l}-23.7 \mathrm{o} / \mathrm{oo} \\
\text { AND Cal BC } 2\end{array}$ & 3P 2180 to 2000 ) \\
\hline $\begin{array}{l}\text { Beta - } 175403 \\
\text { SAMPLE : ED28/273-004-2-1 } \\
\text { ANALYSIS : AMS-Standard deliv } \\
\text { MATERIAL/PRETREATMENT : } \\
2 \text { SIGMA CALIBRATION : }\end{array}$ & $\begin{array}{l}\qquad 2300+/-40 \mathrm{BP} \\
\text { (charred material): acid/alkali/a) } \\
\text { Cal BC } 410 \text { to } 360 \text { (Cal BP } 236\end{array}$ & $\begin{array}{l}-24.5 \mathrm{o} / \mathrm{oo} \\
\mathrm{AND} \mathrm{Cal} \mathrm{BC} 2\end{array}$ & BP 2230 to 2190 ) \\
\hline $\begin{array}{l}\text { Beta - } 175404 \\
\text { SAMPLE : ED28/830-005-4-1 } \\
\text { ANALYSIS : AMS-Standard deliv } \\
\text { MATERIAL/PRETREATMENT : } \\
2 \text { SIGMA CALIBRATION : }\end{array}$ & $\begin{array}{l}\qquad 660+/-40 \mathrm{BP} \\
\text { (chy } \\
\text { Cal AD } 1280 \text { to } 1400(\mathrm{Cal} \mathrm{BP} 6\end{array}$ & $-25.0 \mathrm{o} / 00$ & $660+/-40 \mathrm{BP}$ \\
\hline $\begin{array}{l}\text { Beta - } 175405 \\
\text { SAMPLE : ED28/843-005-7-1A } \\
\text { ANALYSIS : AMS-Standard deliv } \\
\text { MATERIAL/PRETREATMENT : } \\
2 \text { SIGMA CALIBRATION : }\end{array}$ & $\begin{array}{l}\qquad 40+/-30 \mathrm{BP} \\
\text { ery } \\
\text { (charred material): acid/alkali/ad } \\
\text { Cal AD } 1680 \text { to } 1730 \text { (Cal BP } 2 \\
\text { Cal AD } 1950 \text { to } 1950 \text { (Cal BP } 0\end{array}$ & ND Cal AD & Cal BP 140 to 20) \\
\hline
\end{tabular}




\begin{tabular}{|c|c|c|c|}
\hline Sample Data & $\begin{array}{c}\text { Measured } \\
\text { Radiocarbon Age }\end{array}$ & $\begin{array}{c}13 C / 12 C \\
\text { Ratio }\end{array}$ & $\begin{array}{c}\text { Conventional } \\
\text { Radiocarbon Age }\left(^{*}\right)\end{array}$ \\
\hline $\begin{array}{l}\text { Beta - } 175406 \\
\text { SAMPLE : ED28/154-007-1 } \\
\text { ANALYSIS : AMS-Standard delivery } \\
\text { MATERIAL/PRETREATMENT : } \\
2 \text { SIGMA CALIBRATION : }\end{array}$ & $\begin{array}{r}5680+/-60 \mathrm{BP} \\
\text { d material): acid/alkali/a } \\
4690 \text { to } 4370(\text { Cal BP } 6\end{array}$ & $-24.4 \mathrm{o} / \mathrm{oo}$ & $5690+/-60 \mathrm{BP}$ \\
\hline $\begin{array}{l}\text { Beta - } 175407 \\
\text { SAMPLE : ED28/735-005-7 } \\
\text { ANALYSIS : AMS-Standard delivery } \\
\text { MATERIAL/PRETREATMENT: } \\
2 \text { SIGMA CALIBRATION : }\end{array}$ & $\begin{array}{l}6290+/-50 \mathrm{BP} \\
\text { material): acid/alkali/a } \\
5340 \text { to } 5200(\text { Cal BP } 7\end{array}$ & $\begin{array}{l}-25.6 \mathrm{o} / \mathrm{oo} \\
\text { O) AND Cal BC }\end{array}$ & $\begin{array}{l}\quad 6280+/-50 \mathrm{BP} \\
\text { (Cal BP } 7130 \text { to } 7020)\end{array}$ \\
\hline $\begin{array}{l}\text { Beta - } 175408 \\
\text { SAMPLE : ED28/203-005-4-2-1 } \\
\text { ANALYSIS : AMS-Standard delivery } \\
\text { MATERIAL/PRETREATMENT : } \\
2 \text { SIGMA CALIBRATION : }\end{array}$ & $\begin{array}{l}2180+/-40 \text { BP } \\
\text { ed material): acid/alkali/a } \\
390 \text { to } 190(\text { Cal BP } 234\end{array}$ & $-21.9 \mathrm{o} / \mathrm{oo}$ & $2230+/-40 \mathrm{BP}$ \\
\hline $\begin{array}{l}\text { Beta - } 175409 \\
\text { SAMPLE : ED28/739-005-7 } \\
\text { ANALYSIS : AMS-Standard delivery } \\
\text { MATERIAL/PRETREATMENT : } \\
2 \text { SIGMA CALIBRATION : }\end{array}$ & $\begin{array}{l}550+/-40 \mathrm{BP} \\
\text { material): acid/alkali/a } \\
1310 \text { to } 1370(\mathrm{Cal} \mathrm{BP} 6\end{array}$ & $\begin{array}{l}-25.1 \mathrm{o} / \mathrm{oo} \\
\text { AND Cal AD }\end{array}$ & Cal BP 570 to 520 ) \\
\hline $\begin{array}{l}\text { Beta - } 175411 \\
\text { SAMPLE : ED28/100-007-1 } \\
\text { ANALYSIS : AMS-Standard delivery } \\
\text { MATERIAL/PRETREATMENT : } \\
2 \text { SIGMA CALIBRATION : }\end{array}$ & $\begin{array}{l}1770+/-40 \mathrm{BP} \\
\text { material): acid/alkali/a } \\
220 \text { to } 400 \text { (Cal BP } 173\end{array}$ & $-26.7 \mathrm{o} / \mathrm{oo}$ & $1740+/-40 \mathrm{BP}$ \\
\hline
\end{tabular}




\begin{tabular}{lccc}
\hline \multicolumn{1}{c}{ Sample Data } & $\begin{array}{c}\text { Measured } \\
\text { Radiocarbon Age }\end{array}$ & $\begin{array}{c}13 \mathrm{C} / 12 \mathrm{C} \\
\text { Ratio }\end{array}$ & $\begin{array}{c}\text { Conventional } \\
\text { Radiocarbon Age }\left(^{*}\right)\end{array}$ \\
\hline $\begin{array}{l}\text { Beta - 175412 } \\
\text { SAMPLE : ED28/89-007-1 }\end{array}$ & $1710+/-40 \mathrm{BP}$ & $-25.5 \mathrm{o} / \mathrm{oo}$ & $1700+/-40 \mathrm{BP}$ \\
ANALYSIS : AMS-Standard delivery & & \\
MATERIAL/PRETREATMENT : (charred material): acid/alkali/acid \\
2 SIGMA CALIBRATION : $\quad$ Cal AD 240 to 420 (Cal BP 1710 to 1530)
\end{tabular}




\section{CALIBRATION OF RADIOCARBON AGE TO CALENDAR YEARS}

(V ariables: $\mathrm{C} 13 / \mathrm{C} 12=-22.8: \mathrm{lab} . \mathrm{mult}=1)$

Laboratory number: Beta-175390

Conventional radiocarbon age: $1900 \pm 60 \mathrm{BP}$

2 Sigma calibrated result: Cal BC 30 to Cal A D 240 (Cal BP 1980 to 1710)

(95\% probability)

Intercept data

Intercept of radiocarbon age

with calibration curve: Cal AD 100 (Cal B P 1860)

1 Sigma calibrated result: Cal AD 50 to 150 (Cal B P 1900 to 1800 )

(68\% probability)

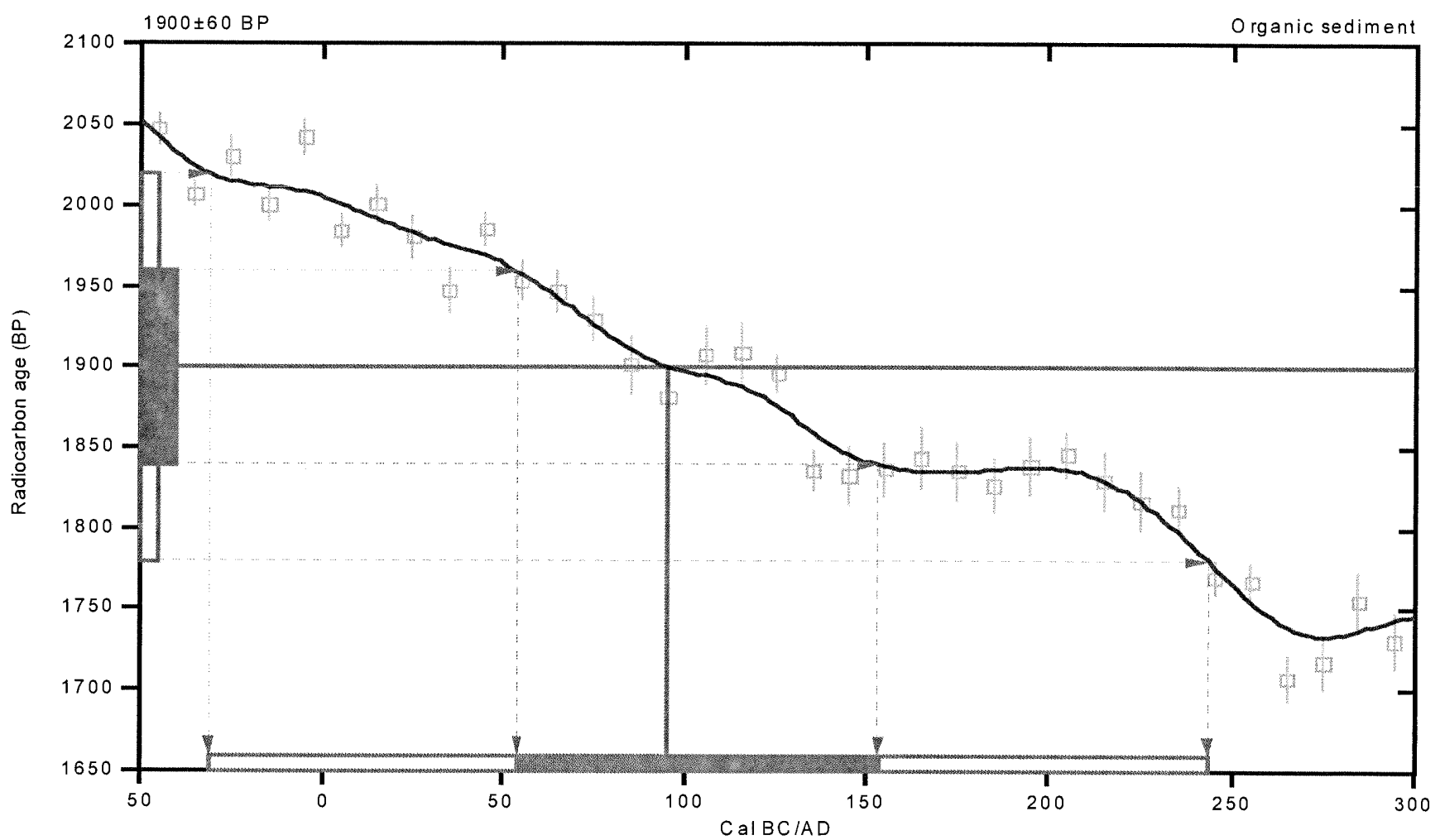

References:

Da tabase used

Calibration Database

Editorial Comment

Siuiver, M., van der Plicht, H, 1998, Radiocarbon 40 (3), pxii-xiii

IN TCA L 98 Radiocarbon Age Calibration

Stuiver, M., el. al., 1998, Radiocarbon $+0(3), p 10+1-1083$

$M$ athem atics

A Simplified Approach to Calibrating C14 Dates

Talma, A.S., Vogel, J. C., 1993, Radiocarbon 35(2), p317-322

\section{Beta Analytic Inc.}

4985SW74 Court, Miami, Florida 33155 USA Tel: (305)6675167·Fax: (305)6630964·E-Mail: beta@radiocarbon.com 


\section{CALIBRATION OF RADIOCARBON AGE TO CALENDAR YEARS}

(V ariables: C $13 /$ C $12=-22.6:$ lab. $\mathrm{mult}=1)$

Laboratory number: Beta-175391

Conventional radiocarbon age: $5230 \pm 50 \mathrm{BP}$

2 Sigma calibrated result: Cal BC 4220 to 3960 (CaI B P 6170 to 5910)

( $95 \%$ probability)

Intercept data

Intercepts of radiocarbon age

with calibration curve: Cal BC 4030 (Cal B P 5980) and

Cal BC 4020 (Cal B P 5970) and

Cal BC 4000 (Cal B P 5950 )

1 Sigm a calibrated result: Cal BC 4050 to 3980 (Cal BP 6000 to 5920 )

(68\% probability)

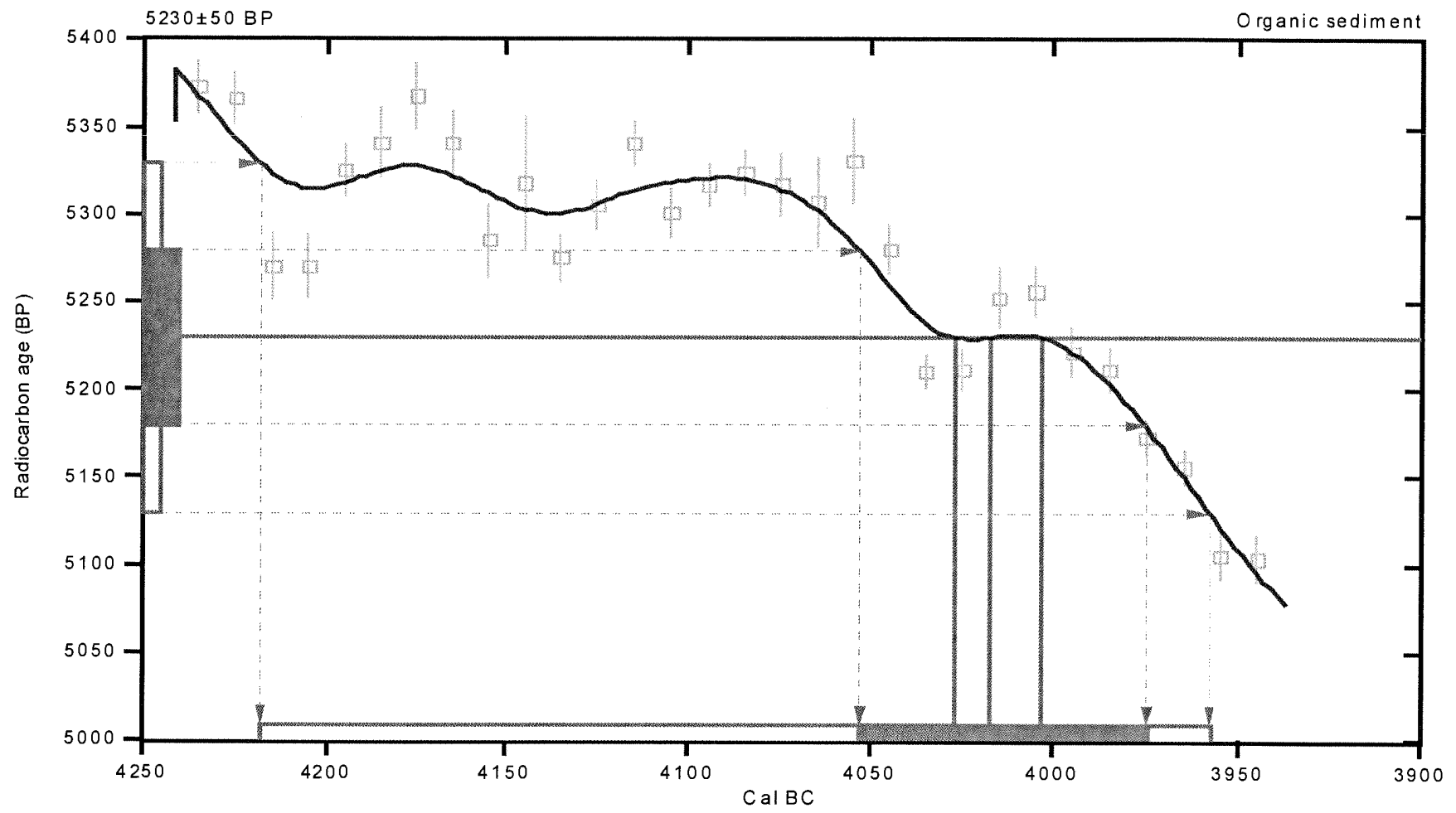

References:

Database used

Calibration Database

Editorial Com ment

Stuiver, M., van der Plicht, H., I998, Radiocarbon f0(3), pxii-xiii

IN TCA L 98 Radiocarbon Age Calibration

Stuiver, M., et. al., 1998, Radiocarbon 40(3), p10+1-1083

$M$ athem atics

A Simplified Approach to Calibrating C14 Dates

Talma, A.S., Vogel, J. C., I 993, Radiocarbon 35(2), p317-322

\section{Beta Analytic Inc.}

4985SW74 Court, Miami, Florida33155USA Tel: (305)6675167・Fax: (305)6630967・E-Mail: beta@radiocarbon.com 


\section{CALIBRATION OF RADIOCARBON AGE TO CALENDAR YEARS}

(V ariables: $\mathrm{C} 13 / \mathrm{C} 12=-23.3:$ lab. $\mathrm{mult}=1)$

Laboratory number: Beta-175392

Conventional radiocarbon age: $1870 \pm 70 \mathrm{BP}$

2 Sigma calibrated result: Cal BC 10 to Cal A D 330 (Cal B P 1960 to 1620)

(95\% probability)

Intercept data

Intercept of radiocarbon age

with calibration curve: Cal AD 130 (Cal BP 1820)

1 Sigm a calibrated result: Cal A D 70 to 230 (Cal B P 1880 to 1720 )

(68\% probability)

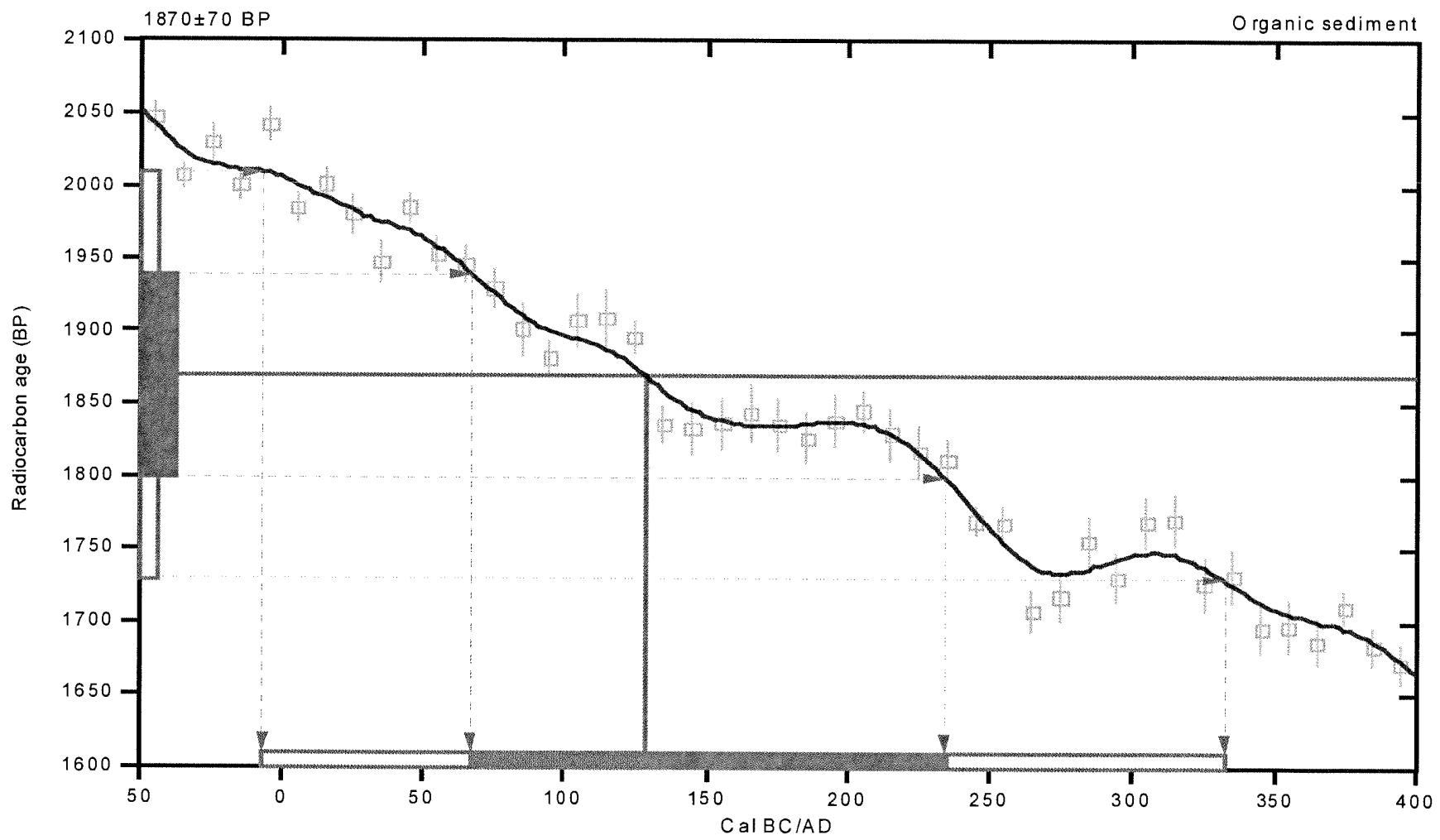

References:

Database used

Calibration Database

Editorial Com ment

Stuiver, M., van der Plicht, H., 1998, Radiocarbon 40(3), pxii-xiii

INTCAL98 Radiocarbon Age Calibration

Stuiver, M., et. al., 1998, Radiocarbon 40(3), p1041-1083

$M$ ath em atics

A S implified Approach to Calibrating C14 Dates

Talma, A.S., Vogel, J. C., I993, Radiocarbon 35(2), p317-322

\section{Beta Analytic Inc.}

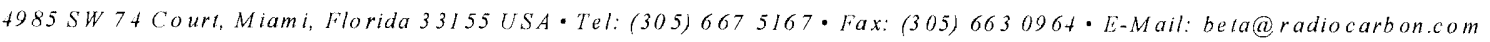




\section{CALIBRATION OF RADIOCARBON AGE TO CALENDAR YEARS}

(V ariables: C $13 / \mathrm{C} 12=-23:$ lab. $\mathrm{mult}=1$ )

Laboratory number: Beta-175393

Conventional radiocarbon age: $4820 \pm 70 \mathrm{BP}$

2 Sigma calibrated results: Cal BC 3710 to 3500 (Cal B P 5660 to 5450) and

(95\% probability) Cal BC 3440 to 3380 (Cal B P 5390 to 5330)

Intercept data

Intercept of radiocarbon age with calibration curve:

1 Sigma calibrated results: Cal BC 3660 to 3620 (Cal BP 5610 to 5570) and

(68\% probability) Cal BC 3590 to 3530 (Cal BP 5540 to 5480 )

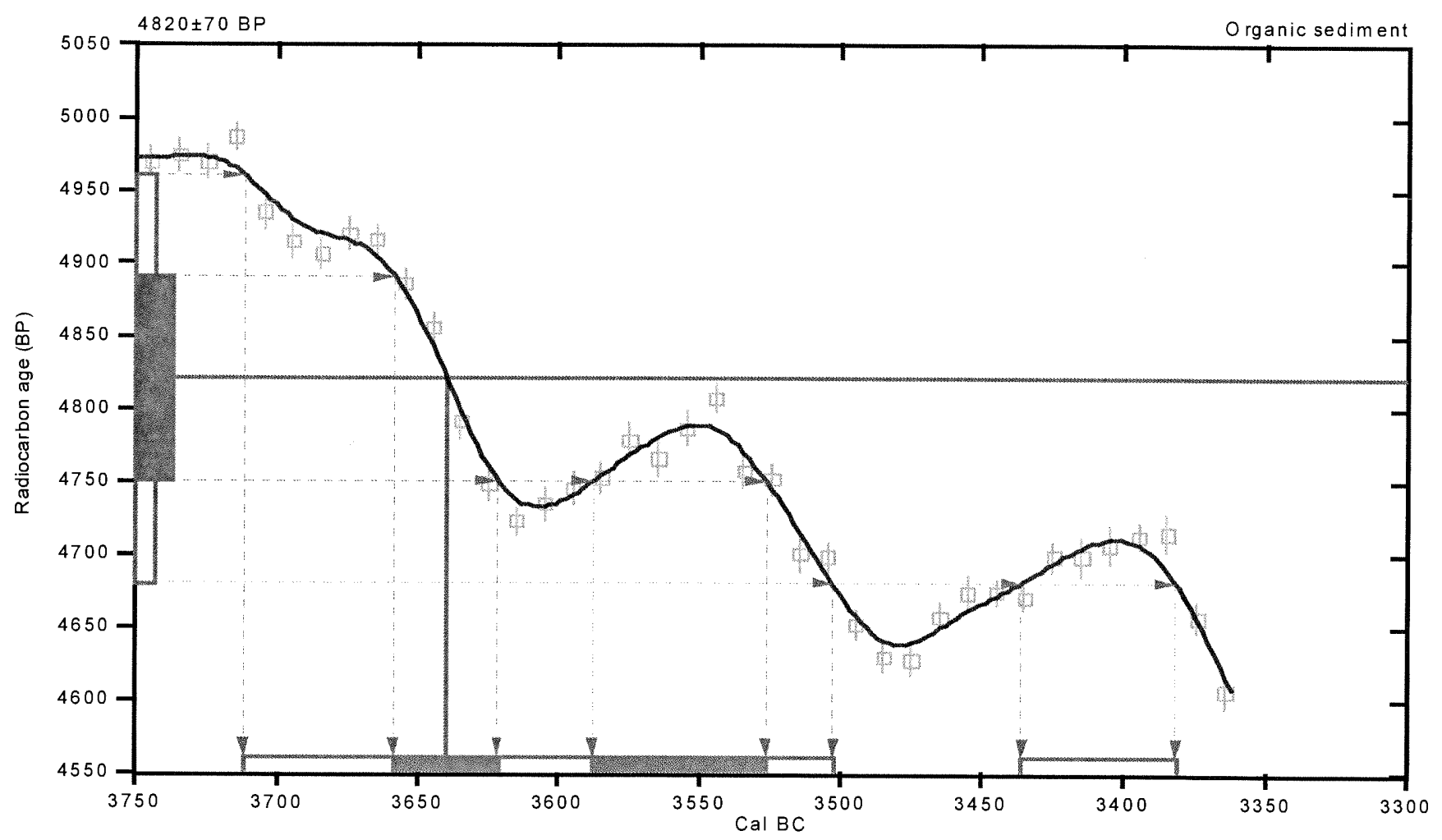

References:

Database used

INTCAL 98

Calibration Database

Editorial Comment

Stuiver, M., van der Plicht. H., I998, Radiocarbon 40(3), pxit-xiii

IN TCA L98 Radiocarbon Age Calibration

Stuiver, M., et. al., 1998, Radiocarbon 40(3), p1041-1083

$M$ ath ematics

A Simplified Approach to Calibrating C14 Dates

Talma, A. S., Vogel, J. C., 1993, Radiocarbon 35(2), p3/7-322

\section{Beta Analytic Radiocarbon Dating Laboratory}

4985 S.W.7th Court, Miami, Florida33155.Tel: (305)667-5167-Fax:(305)663-096+・E-Mail: beta@radiocarbon.com 


\section{CALIBRATION OF RADIOCARBON AGE TO CALENDAR YEARS}

(V ariables: $\mathrm{C} 13 / \mathrm{C} 12=-21.9: \mathrm{lab} . \mathrm{mult}=1)$

Laboratory number: Beta-175394

Conventional radiocarbon age: $6270 \pm 50 \mathrm{BP}$

2 Sigma calibrated result: Cal BC 5330 to 5070 (Cal B P 7280 to 7020 )

( $95 \%$ probability)

Intercept data

Intercept of radiocarbon age

with calibration curve: Cal BC 5280 (Cal B P 7230)

1 Sigm a calibrated result: Cal BC 5310 to 5220 (Cal BP 7260 to 7170 )

(68\% probability)

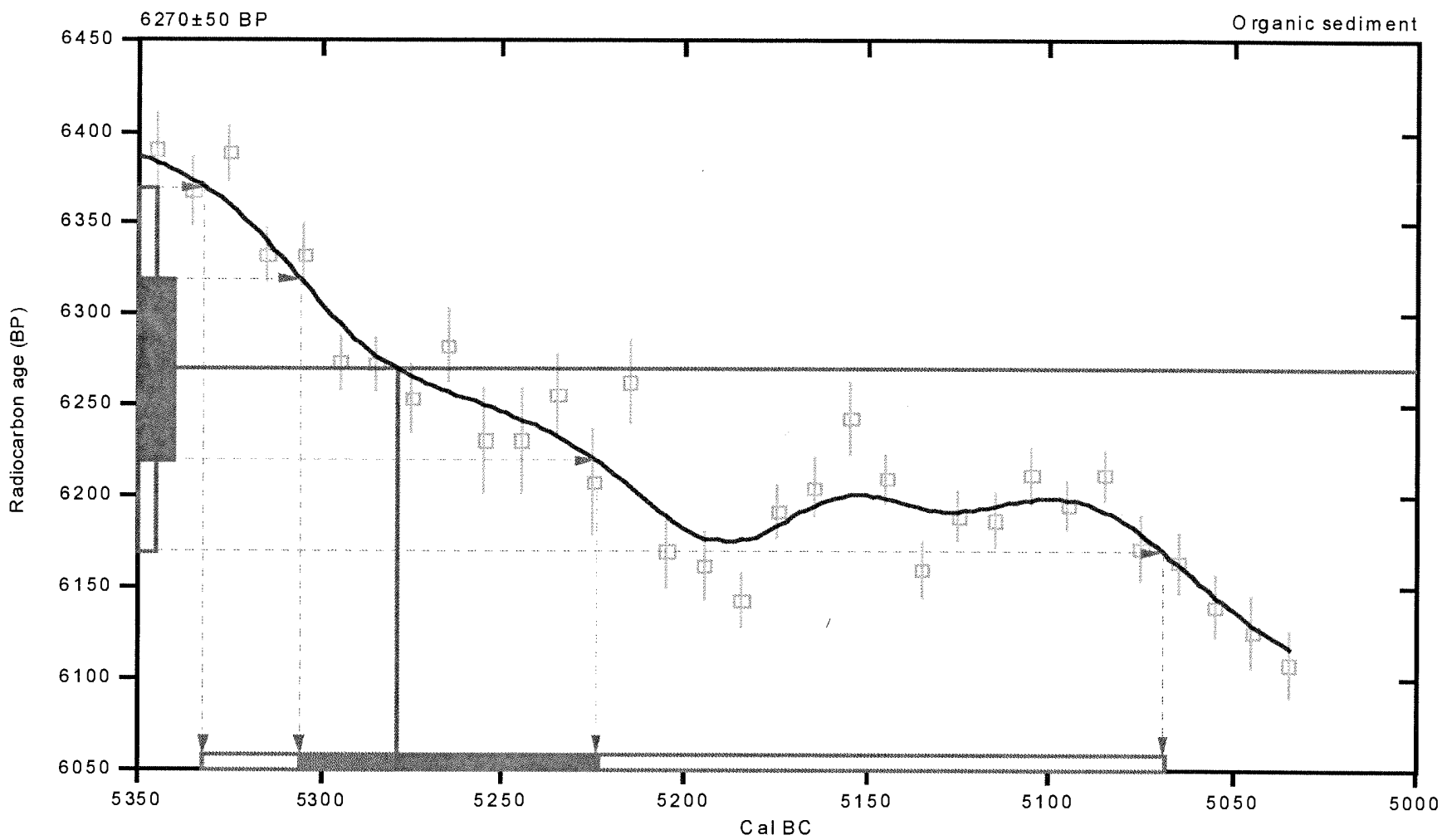

References:

Database used

Calibration Database

Editorial Comment

Stuiver, M., van der Plicht, H., 1998, Radiocarbon 40 (3), pxii-xiii

IN TCA L98 Radiocarbon Age Calibration

Stuiver, M., et. al., 1998, Radiocarbon 40(3), p10+1-1083

$M$ ath em atics

A Simplified Approach to Calibrating C14 Dates

Talma, A. S., Vogel, J. C., I993, Radiocarbon 35(2), p317-322

\section{Beta Analytic Inc.}

4985SW7+Court, Miami, Florida 33l55USA T'el: (305)6675167 Fax: (305)6630964 E-Mail: beta@radiocarbon.com 


\section{CALIBRATION OF RADIOCARBON AGE TO CALENDAR YEARS}

(Variables: C13/C12=-17.8:lab. mult $=1$ )

\section{Laboratory number: Beta-175396}

\section{Conventional radiocarbon age: $\mathbf{5 7 0 0 \pm 4 0 ~ B P}$}

2 Sigma calibra ted results: Ca I BC 4660 to 4640 (Cal BP 6610 to 6590) and

(95\% probability) Cal BC 4620 to 4460 (Cal BP 6570 to 6400)

In tercept data

Intercept of radiocarbon age

with calibration curve: Cal BC 4520 (Cal BP 6470)

1 Sigm a calibrated result: Cal BC 4560 to 4480 (Cal BP 6510 to 6430 ) (68\% probability)

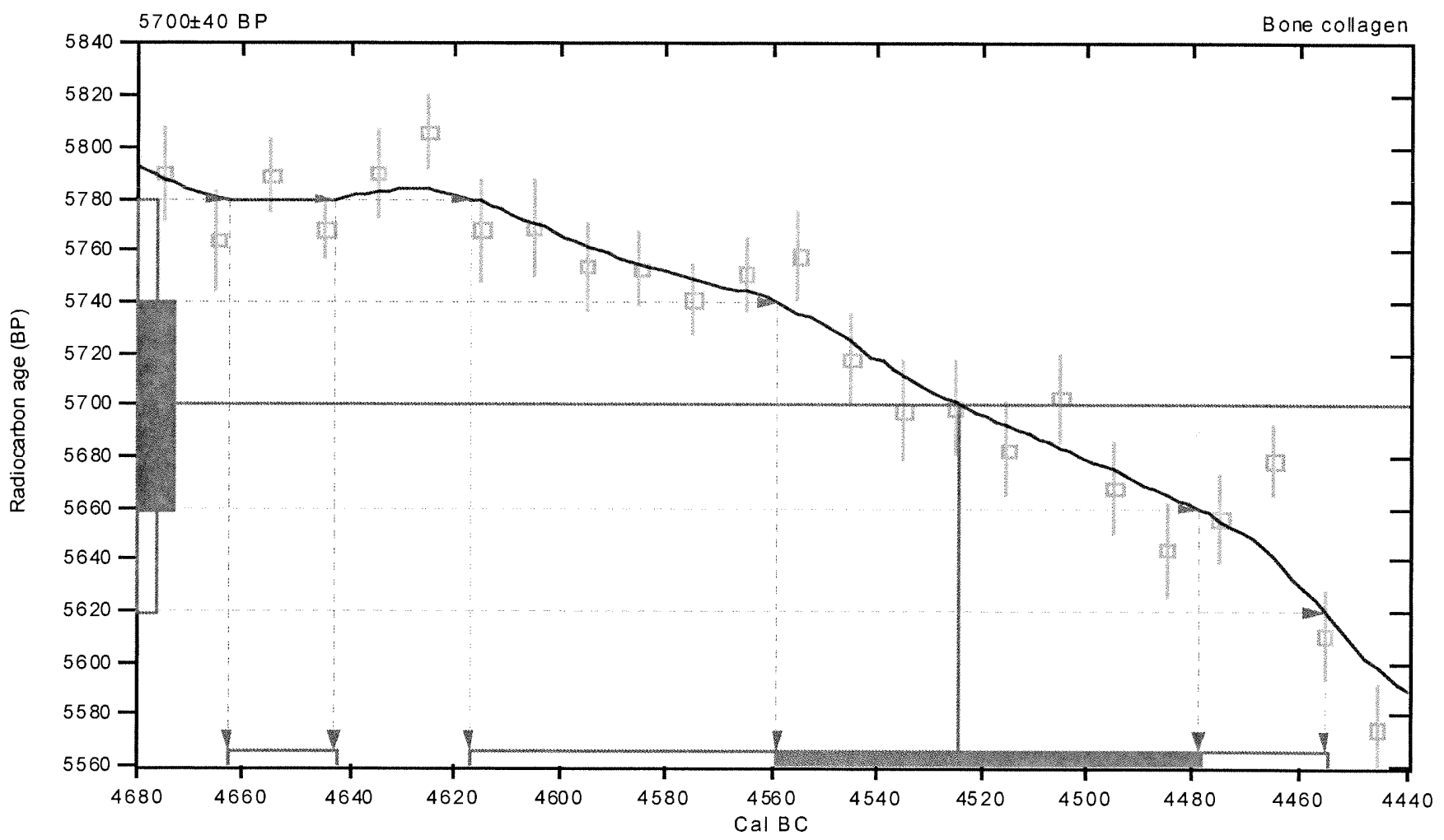

References:

Database used INTCAL98

Calibration Database

Editorial Comment Stuiver, M., van der Plicht, H., 1998, Radiocarbon 40(3), pxii-xi ii

INTCAL 98 Radiocarbon Age Calibration

Stuiver, M., et. al., 1998, Radiocarbon 40(3), p1041-1083

Math em atics

A Simplified App roach to Calibrating C14 Dates Talma, A. S., Vogel, J. C., 1993, Radiocarbon 35(2), p317-322

\section{Beta Analytic Radiocarbon Dating Laboratory}




\section{CALIBRATION OF RADIOCARBON AGE TO CALENDAR YEARS}

(V ariables: C $13 / \mathrm{C} 12=-26.5:$ lab. $\mathrm{mult}=1$ )

Laboratory number: Beta-175397

Conventional radiocarbon age: $400 \pm 40 \mathrm{BP}$

2 Sigma calibrated results: Cal AD 1430 to 1530 (Cal BP 520 to 420 ) and

(95\% probability) Cal AD 1560 to 1630 (Cal BP 390 to 320 )

Intercept data

Intercept of radiocarbon age

with calibration curve: Cal AD 1460 (Cal BP 490)

1 Sigma calibrated result: Cal A D 1440 to 1500 (Cal B P 510 to 450 )

$(68 \%$ probability)

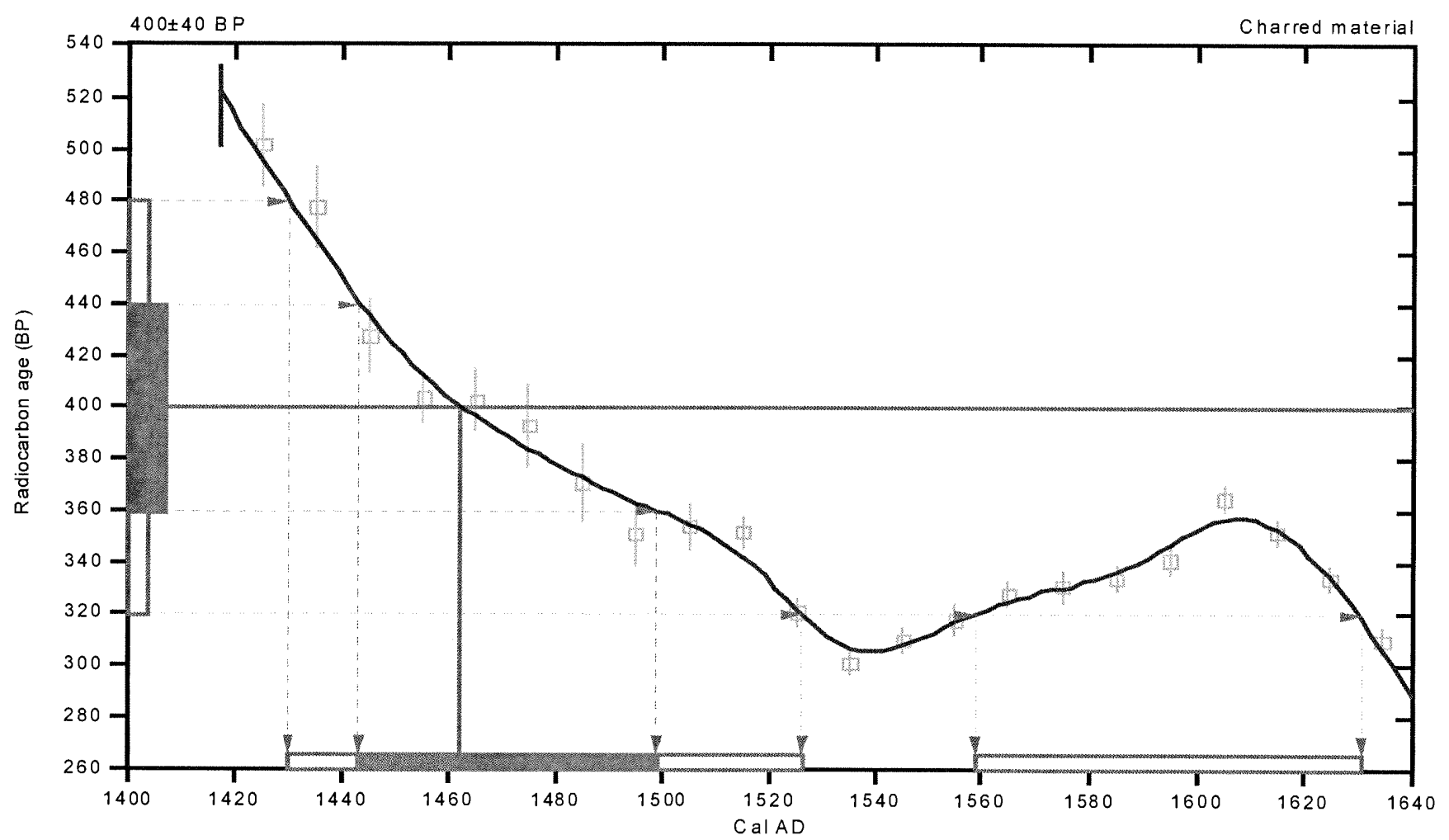

References:

Database used

Calibration Database

Editorial Com ment

Stuiver, M., van der Plicht, H., 1998, Radiocarbon 40 (3), pxii-xiit

IN TCAL98 Radiocarbon Age Calibration

M ath em atics

Stuiver, M., et. al., 1998, Radiocarbon 40(3), p1041-1083

A Simplified Approach to Calibrating C14 Dates

Talma, A. S., Vogel, J. C., I993, Radiocarbon 35(2), p317-322

\section{Beta Analy tic Inc.}

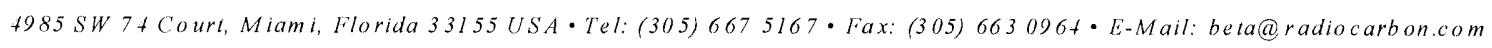




\section{CALIBRATION OF RADIOCARBON AGE TO CALENDAR YEARS}

(V ariables: C $13 / \mathrm{C} 12=-25.5: \mathrm{lab} . \mathrm{mult}=1)$

Laboratory number: Beta-175398

Conventional radiocarbon age: $940 \pm 40 \mathrm{BP}$

2 Sigma calibrated result: Cal AD 1010 to 1190 (Cal BP 940 to 760 )

(95\% probability)

Intercept data

Intercept of radiocarbon age

with calibration curve: Cal A D 1040 (Cal BP 910)

$1 \mathrm{Sigma}$ calibrated result: Cal A D 1030 to 1160 (Cal B P 920 to 790 )

(68\% probability)

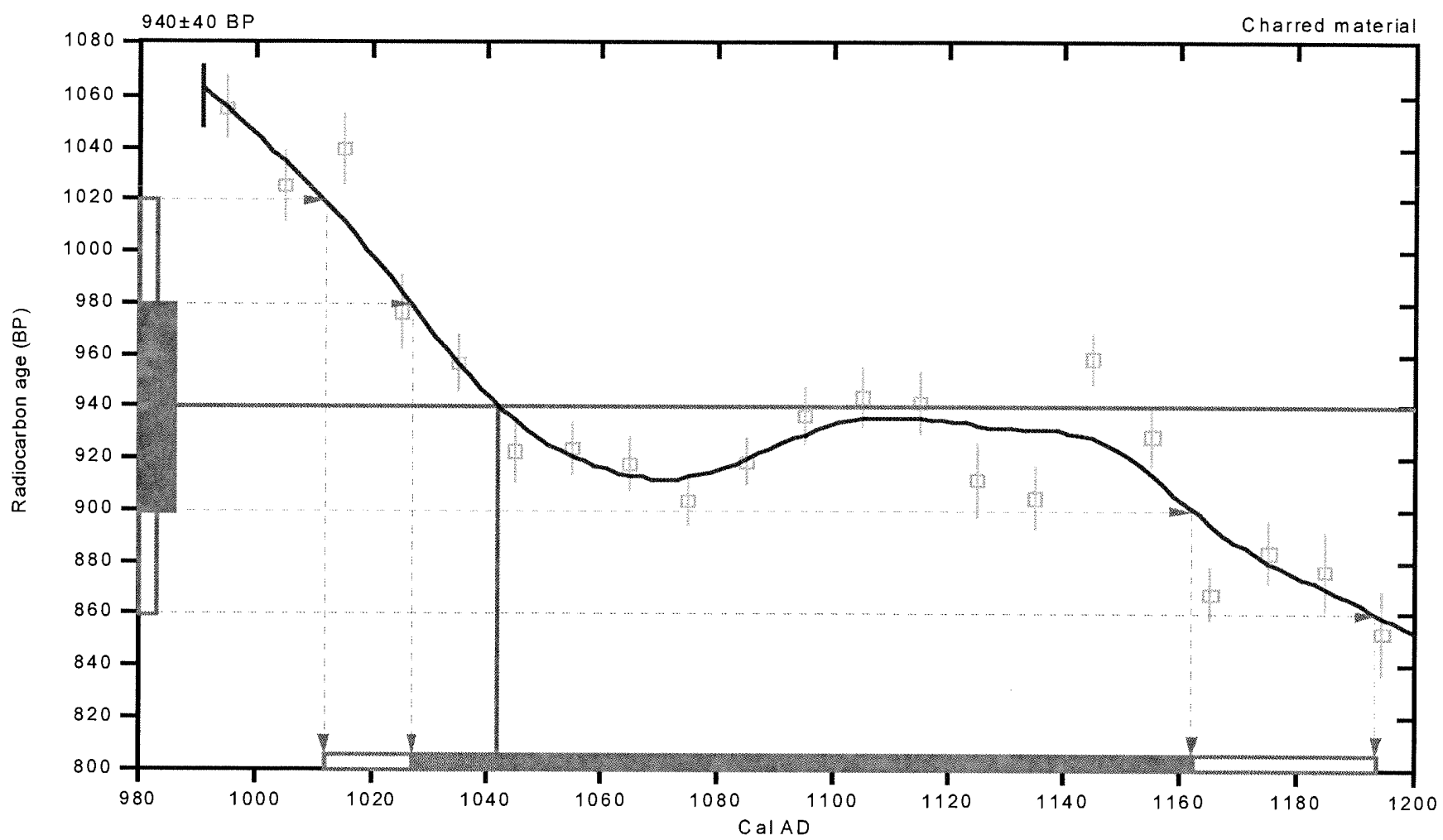

References:

Database used

Calibration Database

Editorial Com ment

Stuiver, M., van der Plicht, H., 1998, Radiocarbon 40(3), pxii-xiil

IN TCA L98 Radiocarbon Age Calibration

Stuiver, M., et. al., 1998, Radiocarbon 40 (3), p1041-1083

M athem atics

A Simplified Approach to Calibrating CI4 Dates

Talma, A.S., Vogel, J. C., 1993, Radiocarbon 35(2), p317-322

\section{Beta Analytic Inc.}

4985SW7+Court, Miami, Florida 33155 USA - Tel: (305) $6675167 \cdot$ Fax: (305) $663096+\cdot$ E-Mail: beta@radiocarbon.com 


\section{CALIBRATION OF RADIOCARBON AGE TO CALENDAR YEARS}

(V ariables: C $13 / \mathrm{C} 12=-25.6:$ lab. $\mathrm{mult}=1)$

Laboratory number: Beta-175399

Conventional radiocarbon age: $920 \pm 40$ BP

2 Sigma calibrated result: Cal AD 1020 to 1210 (Cal BP 930 to 740 )

(95\% probability)

Intercept data

Intercepts of radiocarbon age

with calibration curve: Cal A D 1060 (Cal BP 890) and

Cal A D 1080 (Cal BP 860) and

Cal A D 1150 (Cal BP 800)

1 Sigm a calibrated result: Cal A D 1030 to 1180 (Cal B P 920 to 780 )

(68\% probability)

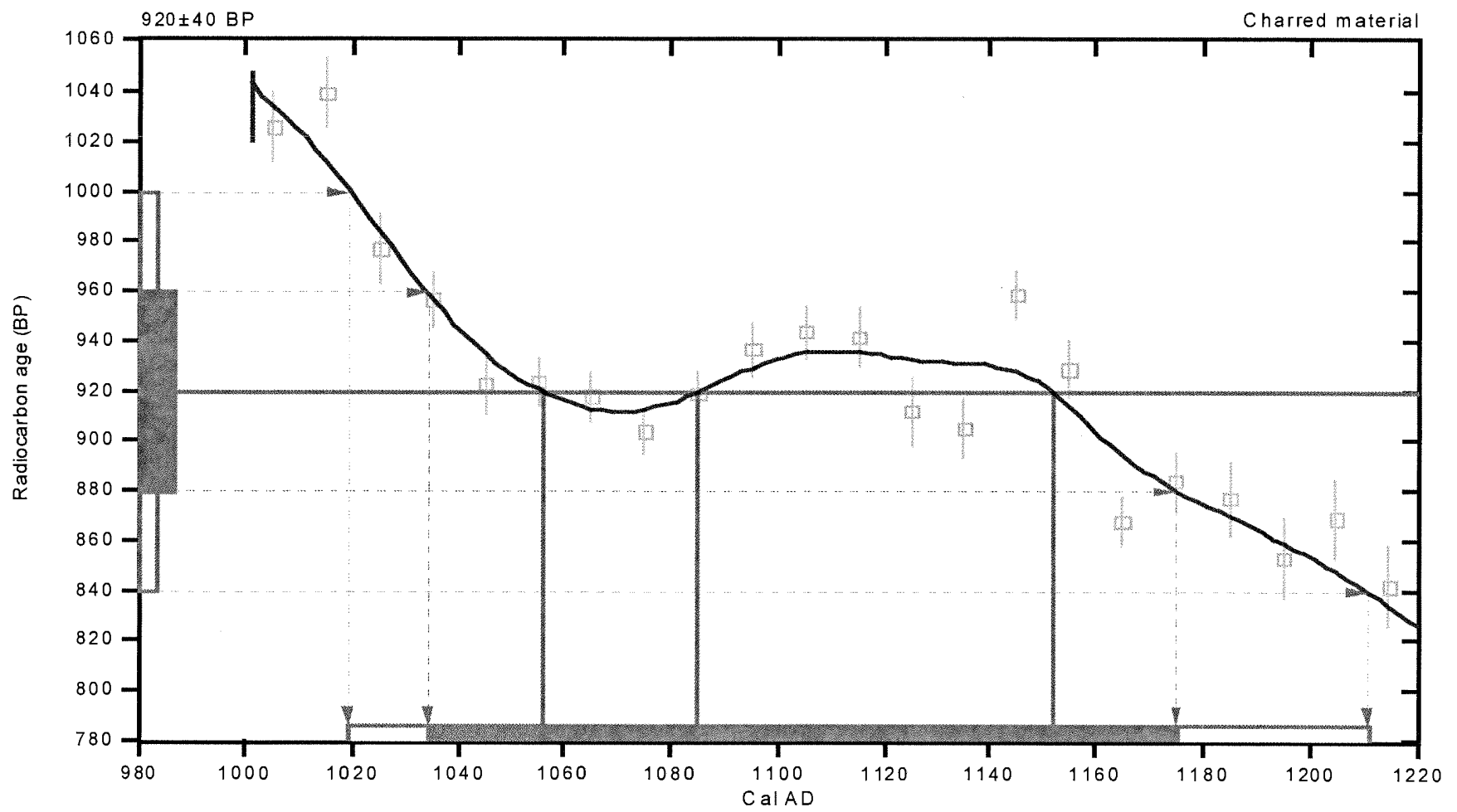

References:

Database used

Calibration Database

Editorial Comment

Sluiver, M., van der Plicht, H., 1998, Radiocarbon 40(3), pxii-xiii

IN TCA L98 Radiocarbon Age Calibration

Stuiver, M., et. al., 1998, Radiocarbon 40(3), pl04l-1083

$M$ athem atics

A Simplified Approac h to Calibrating C14 Dates

Talma, A.S., Vogel, J. C., 1993, Radiocarbon 35(2), p317-322

\section{Beta Analytic Inc.}

4985SW74Court, Miami, Florida 33155 USA Tel: (305)6675167. Fax: (305)6630964-E-Mail: beta@radiocarbon.com 


\section{CALIBRATION OF RADIOCARBON AGE TO CALENDAR YEARS}

(V ariables: C 13/C 12=-25.3:lab. mult=1)

Laboratory number: Beta-175400

Conventional radiocarbon age: $390 \pm 60 \mathrm{BP}$

2 Sigma calibrated result: Cal AD 1420 to 1650 (Cal BP 530 to 300 )

(95\% probability)

Intercept data

Inte rcept of radiocarbon age

with calibration curve: Cal A D 1470 (C al BP 480)

$1 \mathrm{Sigma}$ calibrated results: Cal A D 1440 to 1520 (Cal B P 510 to 430 ) and

(68\% probability) Cal A D 1580 to 1630 (Cal B P 380 to 320 )

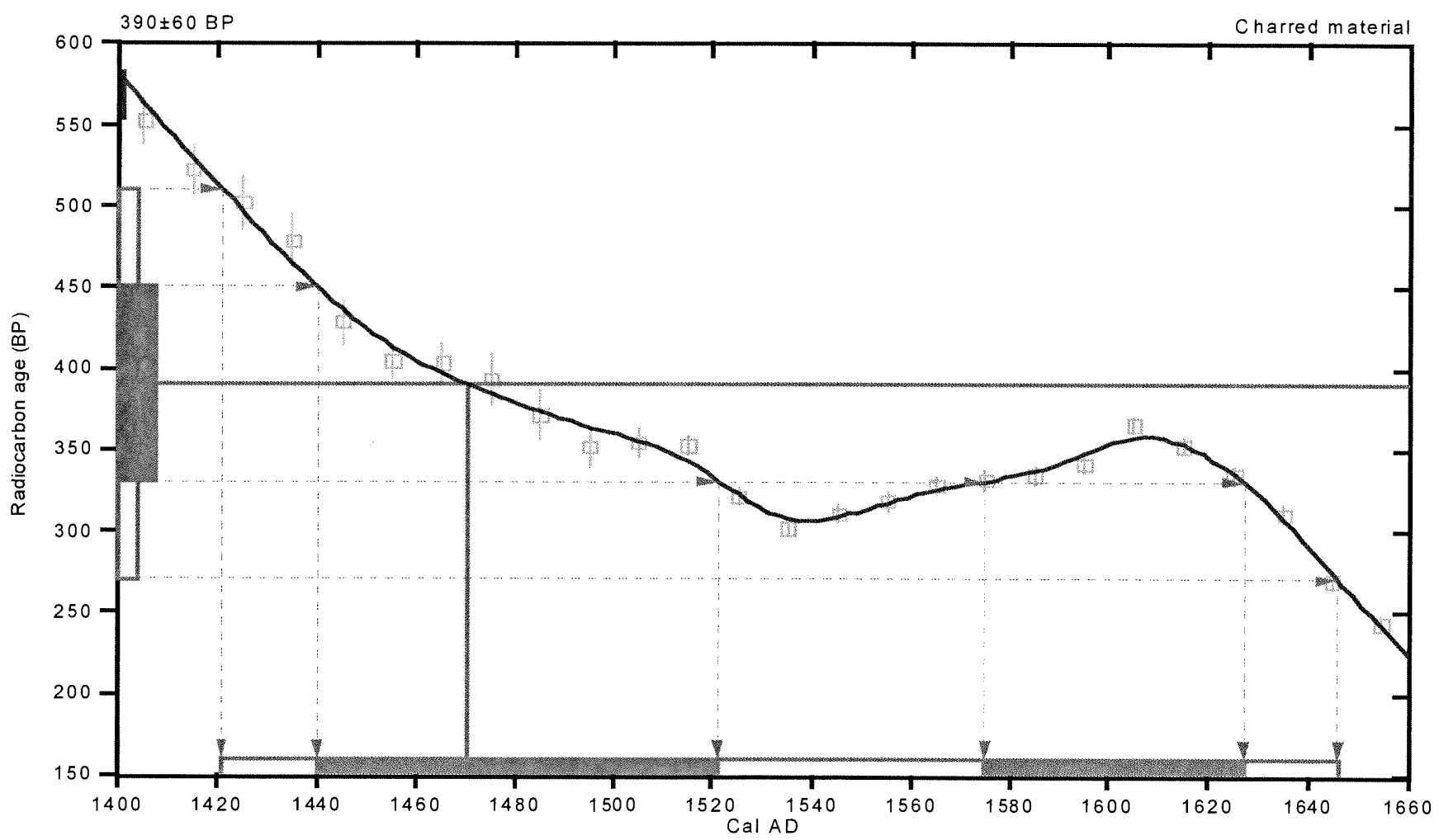

References:

Database used

INTCAL 98

Calibration Database

Editorial Comment

Stuiver, M., van der Plicht, H., 1998, Radiocarbon 40(3), pxii-xiil

IN TCAL98 Radiocarbon Age Calibration

Stuiver, M., el. al., 1998, Radiocarbon 40 (3), p1041-1083

M athematics

A Simplified Approach to Calibrating C 14 Dates

Talma, A. S., Vogel, J. C., I993, Radiocarbon 35(2), p3I7-322

\section{Beta Analytic Radiocarbon Dating Laboratory}

4985 S.W. 7tth Court, Miami, Florida 33155 -Tel: (305)667-5167 -Fax: (305)663-0964 -E-Mail: beta@radiocarbon.com 


\section{CALIBRATION OF RADIOCARBON AGE TO CALENDAR YEARS}

(Variables: C $13 /$ C $12=-25.4:$ lab. $\mathrm{mult}=1$ )

Laboratory number: Beta-175401

Conventional radiocarbon age: $170 \pm 60 \mathrm{BP}$

2 Sigma calibrated result: Cal AD 1640 to 1950 (Cal BP 310 to 0)

(95\% probability)

Intercept data

Intercepts of radiocarbon age

with calibration curve:

Cal A D 1680 (Cal BP 270) and

Cal A D 1770 (Cal BP 180 ) and

Cal A D 1800 (Cal BP 150 ) and

Cal A D 1940 (Cal BP 10) and

Cal A D 1950 (Cal BP 0)

1 Sigma calibrated results: Cal A D 1660 to 1700 (Cal B P 290 to 250) and (68\% probability) Cal A D 1720 to I 820 (Cal B P 230 to 130 ) and

Cal A D 1840 to 1880 (Cal B P 110 to 70 ) and

Cal A D 1920 to 1950 (Cal B P 30 to 0 )

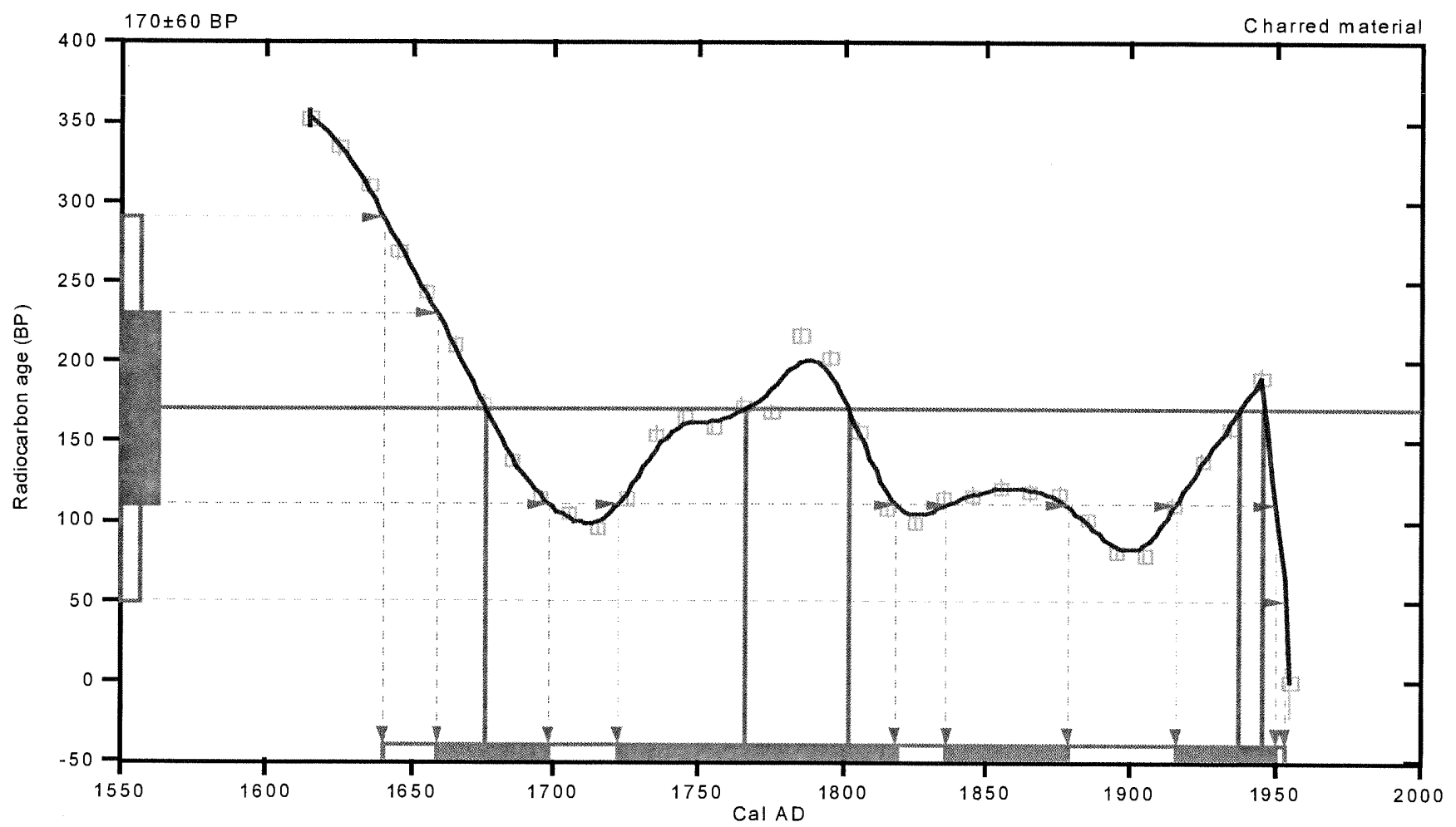

References:

Da tabase used

INTCAL 98

Calibration Database

Editorial Com ment

Stuiver, M., van der Plicht. H., 1998, Radiocarbon t0(3), pxil-xiii

INTCA L98 Radiocarbon Age Calibration

Stuiver, M., et. al., 1998, Radiocarbon t0(3), p1041-1083

Mathematics

A Simplified Approach to Calibrating C14 Dates

Talma, A. S., Vogel, J. C., I993, Radiocarbon 35(2), p317-322

\section{Beta Analytic Radiocarbon Dating Laboratory}

4985 S.W. 7th Court, Miami, Florida 33155 Tel: (305)667-5167 - Fax: (305)663-096+ E-Mail: bela@radiocarbon.com 


\section{CALIBRATION OF RADIOCARBON AGE TO CALENDAR YEARS}

(V ariables: C 13/C $12=-23.7:$ lab. $\mathrm{mult}=1$ )

Laboratory number: Beta-175402

Conventional radiocarbon age: $2140 \pm 40$ BP

2 Sigma calibrated results: Cal BC 360 to 290 (Cal BP 2310 to 2240 ) and

(95\% probability) Cal BC 230 to 50 (Cal BP 2180 to 2000 )

Intercept data

Intercept of radiocarbon age

with calibration curve: Cal B C 180 (Cal B P 2130)

1 Sigma calibrated result: Cal B C 200 to 110 (Cal BP 2150 to 2060)

(68\% probability)

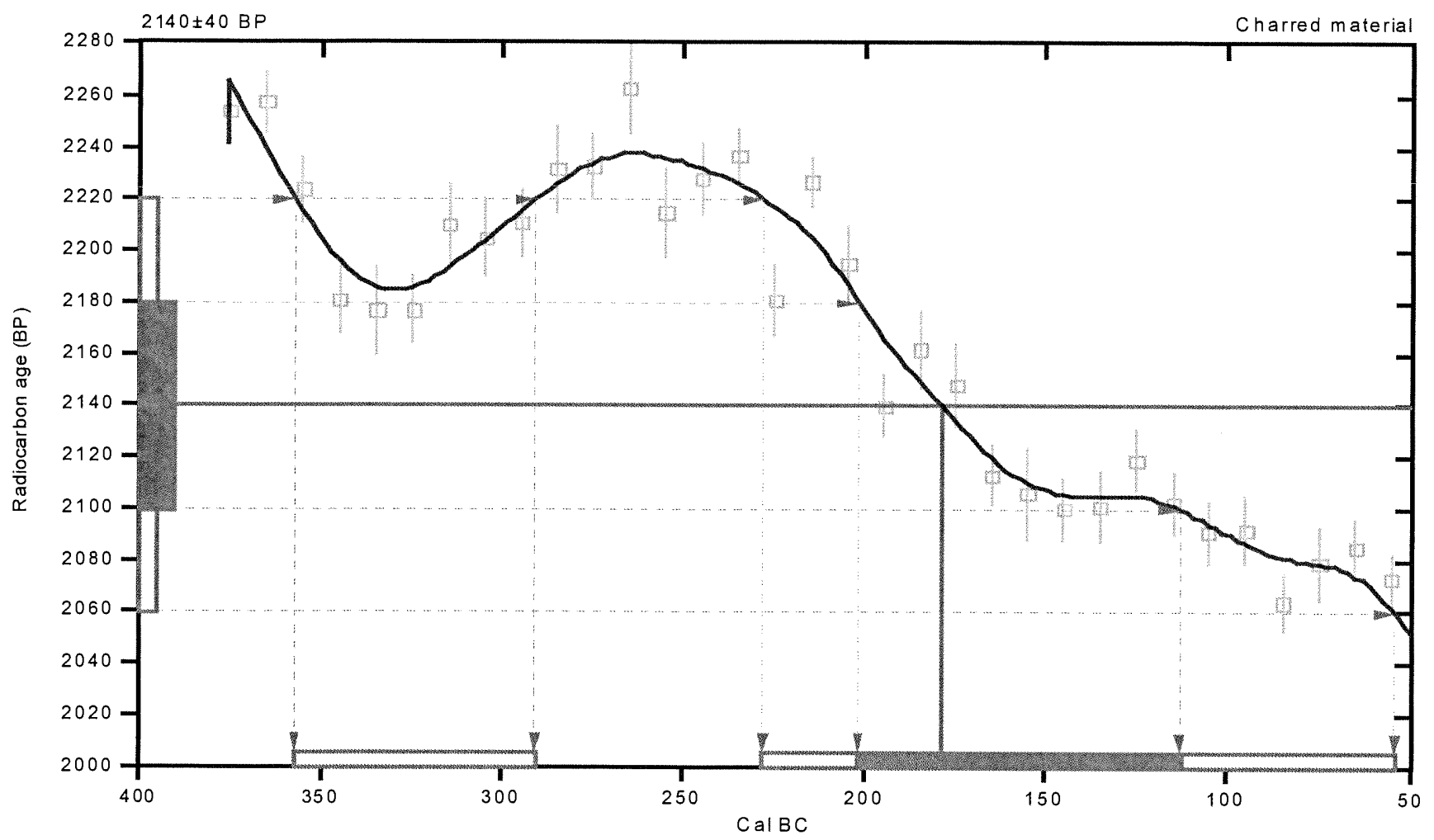

References:

Database used

Calibration Database

Editorial Com ment

Stuiver, M., van der Plicht, H., 1998, Radiocarbon t0(3), pxii-xiii

IN TCAL98 Radiocarbon Age Calibration

Stuiver, M., et. al., 1998, Radiocarbon t0(3), p10+1-1083

$M$ athem atics

A Simplified Approach to Calibrating C14 Dates

Talma, A. S., Vogel, J. C., I 993, Radiocarbon 35(2), p317-322

\section{Beta Analytic Inc.}

4985SW74Court, Miami, Florida 33155 USA T Tel: (305)6675167·Fax: (305)6630964·E-Mail: beta@radiocarbon.com 


\section{CALIBRATION OF RADIOCARBON AGE TO CALENDAR YEARS}

(V ariables: C $13 / \mathrm{C} 12=-24.5: \mathrm{lab} . \mathrm{mult}=1$ )

Laboratory number: Beta-175403

Conventional radiocarbon age: $2310 \pm 40$ B P

2 Sigma calibrated results: Cal BC 410 to 360 (Cal BP 2360 to 2310 ) and

(95\% probability) Cal BC 280 to 240 (Cal BP 2230 to 2190 )

Intercept data

Intercept of radiocarbon age

with calibration curve: Cal B C 390 (CaI B P 2340)

1 Sigm a calibrated result: Cal BC 400 to 380 (Cal B P 2350 to 2330)

( $68 \%$ probability)

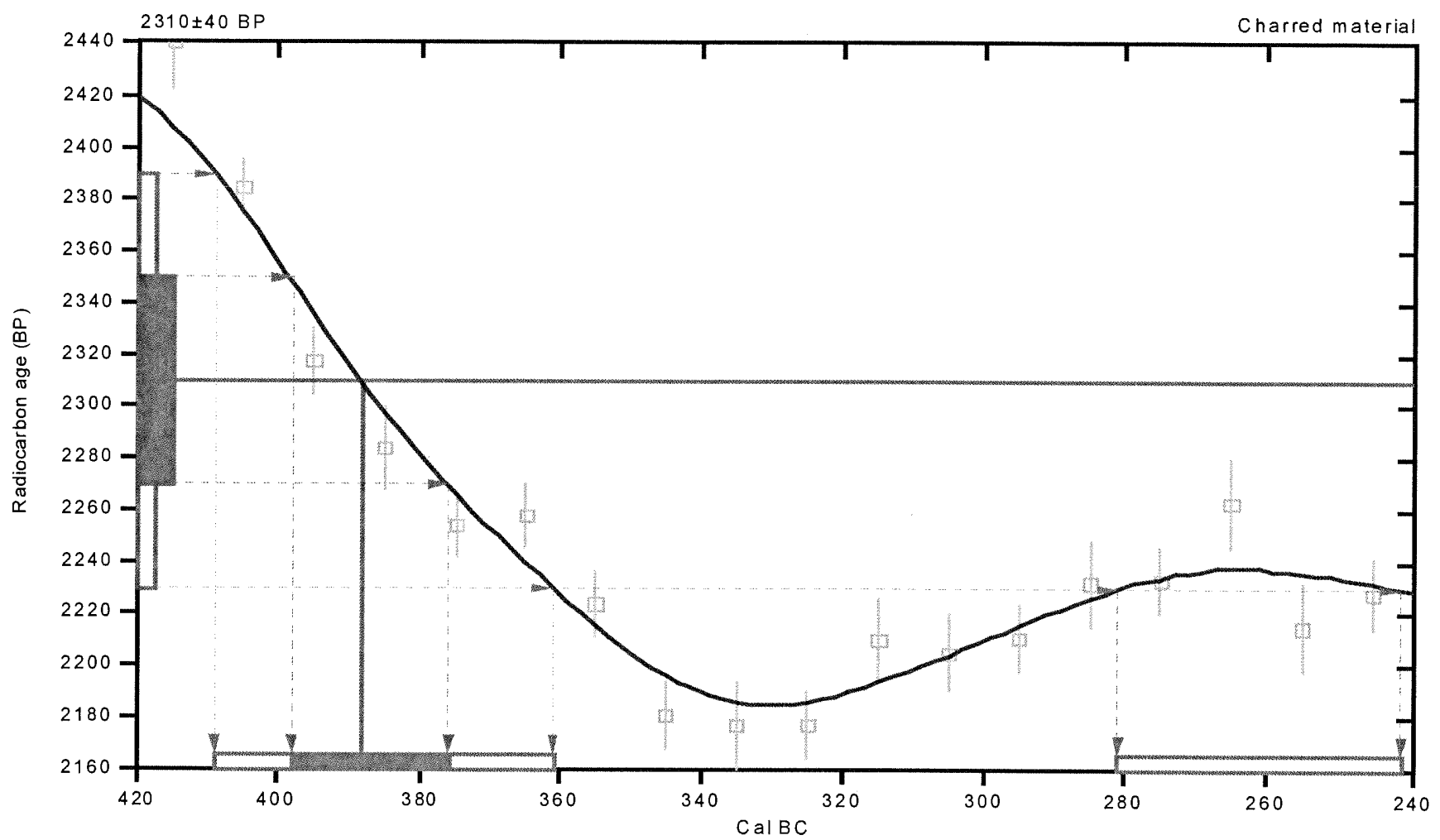

References:

Database used

Calibration Database

Editorial Com ment

Stuiver, M., van der Plicht, H., 1998, Radiocarbon 40(3), pxii-xiii

INTCA L98 Radiocarbon Age Calibration

M athem atics

Sluiver, M., el. al., 1998, Radiocarbon 40 (3), pl0+1-1083

A Simplified Approach to Calibrating C14 Dates

T'alma, A.S., Vogel, J. C., I993, Radiocarbon 35(2), p317-322

\section{Beta Analytic Inc.}

t985SW7+Court, Miami, Florida 33155 USA - Tel: (305)6675167 - Fax: (305)6630964 E-Mail: beta@radiocarbon.com 


\section{CALIBRATION OF RADIOCARBON AGE TO CALENDAR YEARS}

(V ariables: C 13/C 12=-25:lab. mult=1)

Laboratory number: Beta-175404

Conventional radiocarbon age: $660 \pm 40$ BP

2 Sigma calibrated result: Cal AD 1280 to 1400 (Cal BP 670 to 550)

( $95 \%$ probability)

Intercept data

Intercept of radiocarbon age

with calibration curve: Cal A D 1300 (Cal BP 650)

1 Sigm a calibrated results: Cal A D 1290 to 1310 (Cal B P 660 to 640 ) and

(68\% probability) Cal A D 1360 to 1390 (Cal B P 590 to 560 )

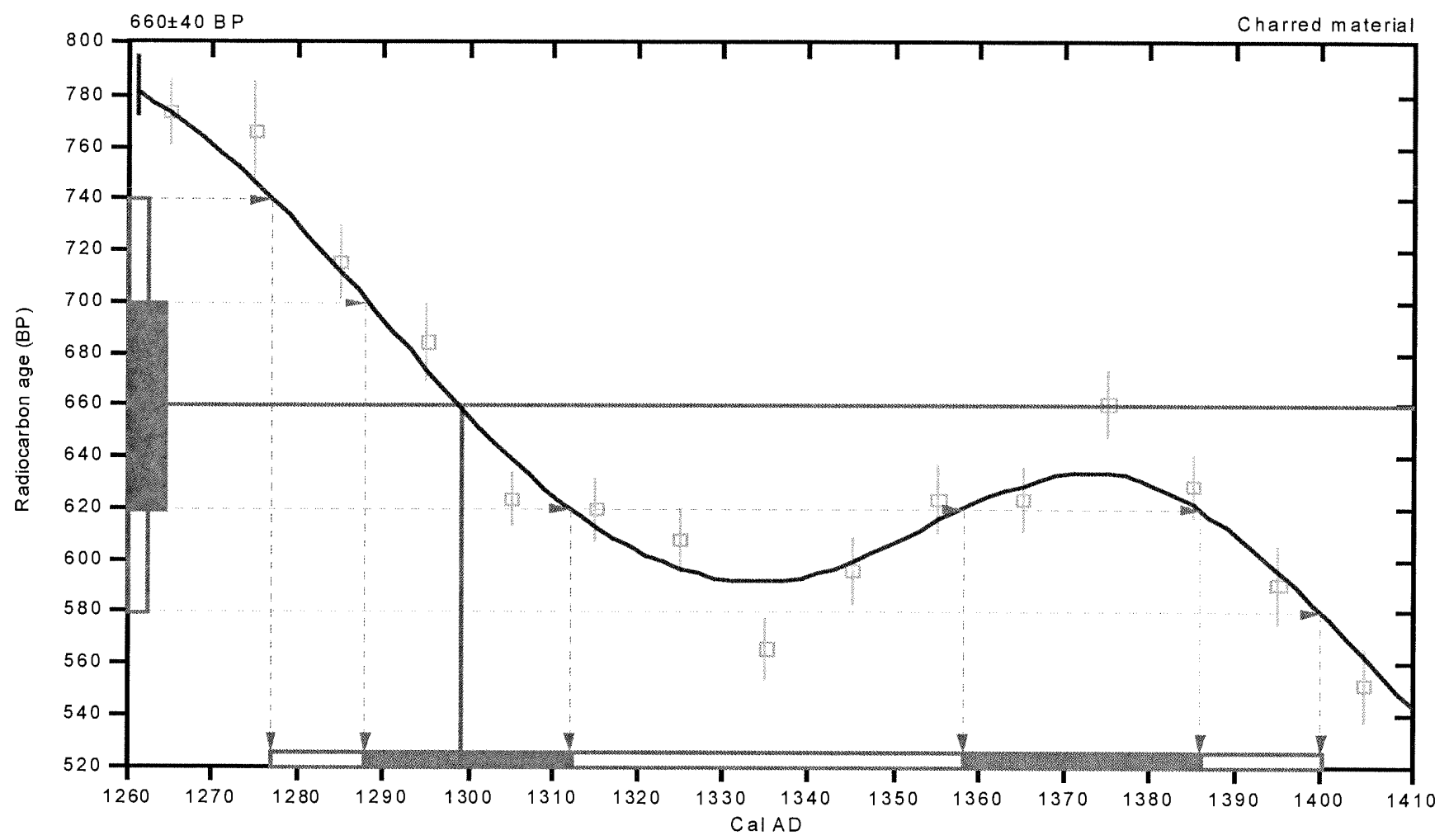

References:

Database used

Calibration Database

Editorial Com ment

Stuiver, M., van der Plicht, H., 1998, Radiocarbon 40 (3), pxii-xiii

INTCAL 98 Radiocarbon Age Calibration

Siulver, M., et. al., 1998, Radiocarbon 40 (3), p10+1-1083

$M$ athematics

A Simplified Approach to Calibrating CI4 Dates

Talma, A. S., Vogel, J. C., 1993, Radiocarbon 35(2), p317-322 


\section{CALIBRATION OF RADIOCARBON AGE TO CALENDAR YEARS}

(V ariables: C $13 / \mathrm{C} 12=-22.5: \mathrm{lab} . \mathrm{mult}=1$ )

Laboratory number: Beta-175405

Conventional radiocarbon age: $80 \pm 30 \mathrm{BP}$

2 Sigma calibrated results: Cal AD 1680 to 1730 (Cal BP 260 to 220 ) and

(95\% probability) Cal AD 1810 to 1930 (Cal BP 140 to 20 ) and

Cal AD 1950 to 1950 (CaI BP 0 to 0 )

Intercept data

Intercept of radiocarbon age

with calibration curve: Cal A D 1950 (Cal BP 0)

1 Sigma calibrated results: Cal A D 1700 to 1720 (Cal B P 250 to 230 ) and

(68\% probability) Cal A D 1820 to 1840 (Cal B P 130 to 110 ) and

Cal A D 1880 to 1920 (Cal B P 70 to 30 ) and

Cal A D 1950 to 1950 (Cal B P 0 to 0 )

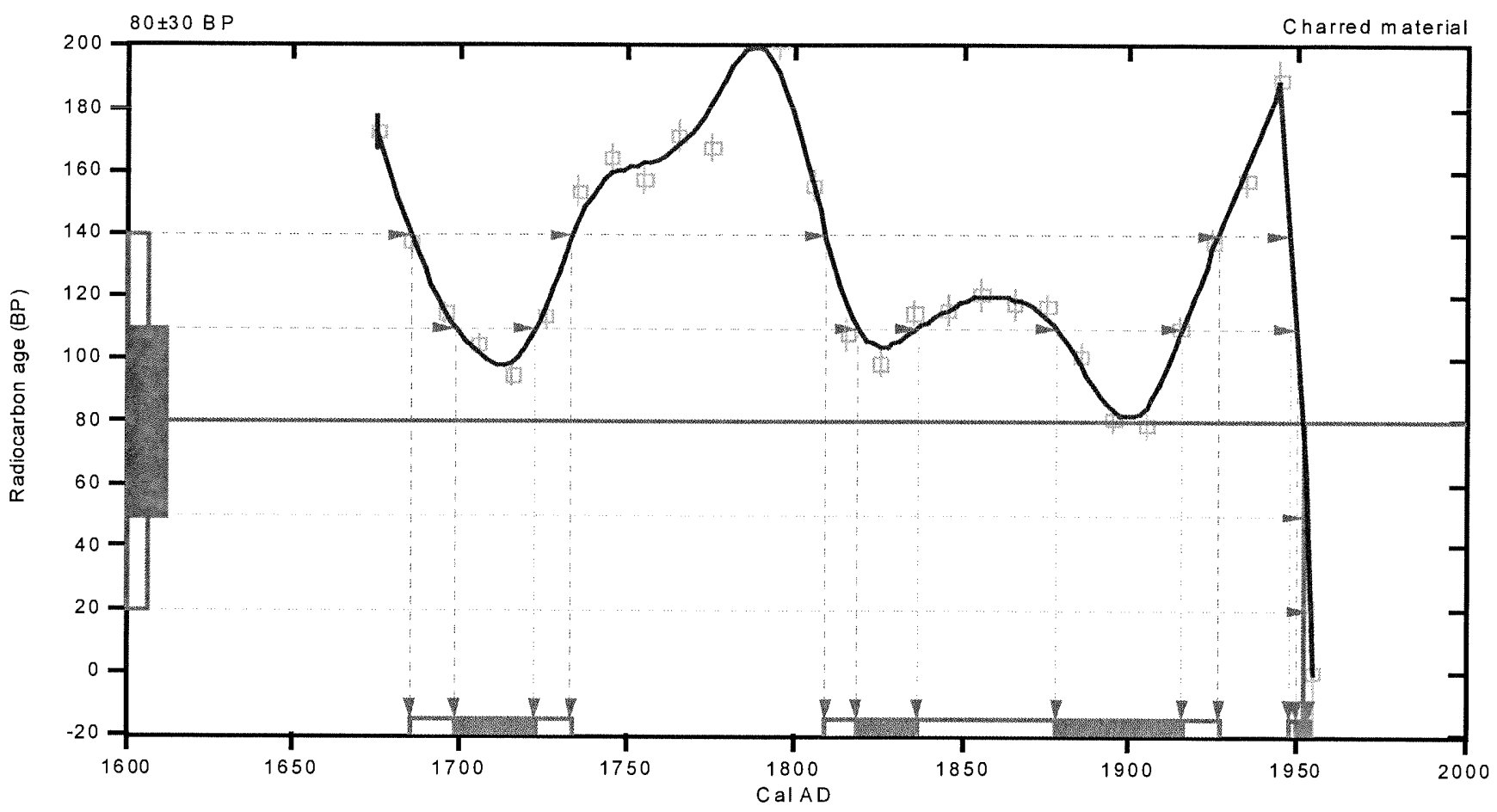

References:

Database used

Calibration Database

Editorial Comment

Stuiver, M., van der Plicht, H., 1998, Radiocarbon to(3), pxii-xiit

IN TCA L98 Radiocarbon Age Calibration

Stuiver, M., et. al., 1998, Radiocarbon 40(3), p1041-1083

$M$ ath em atics

A Simplified Approach to Calibrating C14 Dates

Talma, A.S., Vogel, J. C., 1993, Radiocarbon 35(2), p317-322

\section{Beta Analy tic Inc.}

4985SW74 Court, Miami, Florida 33155 USA Tel: (305)6675167 Fax: (305)6630964 E-Mail: beta@radiocarbon.com 


\section{CALIBRATION OF RADIOCARBON AGE TO CALENDAR YEARS}

$$
\text { (V ariables: C 13/C } 12=-24.4: 1 \mathrm{lab} . \mathrm{mult}=1 \text { ) }
$$

Laboratory number: Beta-175406

Conventional radiocarbon age: $5690 \pm 60$ BP

2 Sigma calibrated result: Cal BC 4690 to 4370 (Cal BP 6640 to 6320 )

(95\% probability)

Intercept data

Intercept of radiocarbon age

with calibration curve: Cal BC 4510 (Cal B P 6460)

$1 \mathrm{Sigma}$ calibrated result: Cal BC 4580 to 4460 (Cal BP 6530 to 6410 )

(68\% probability)

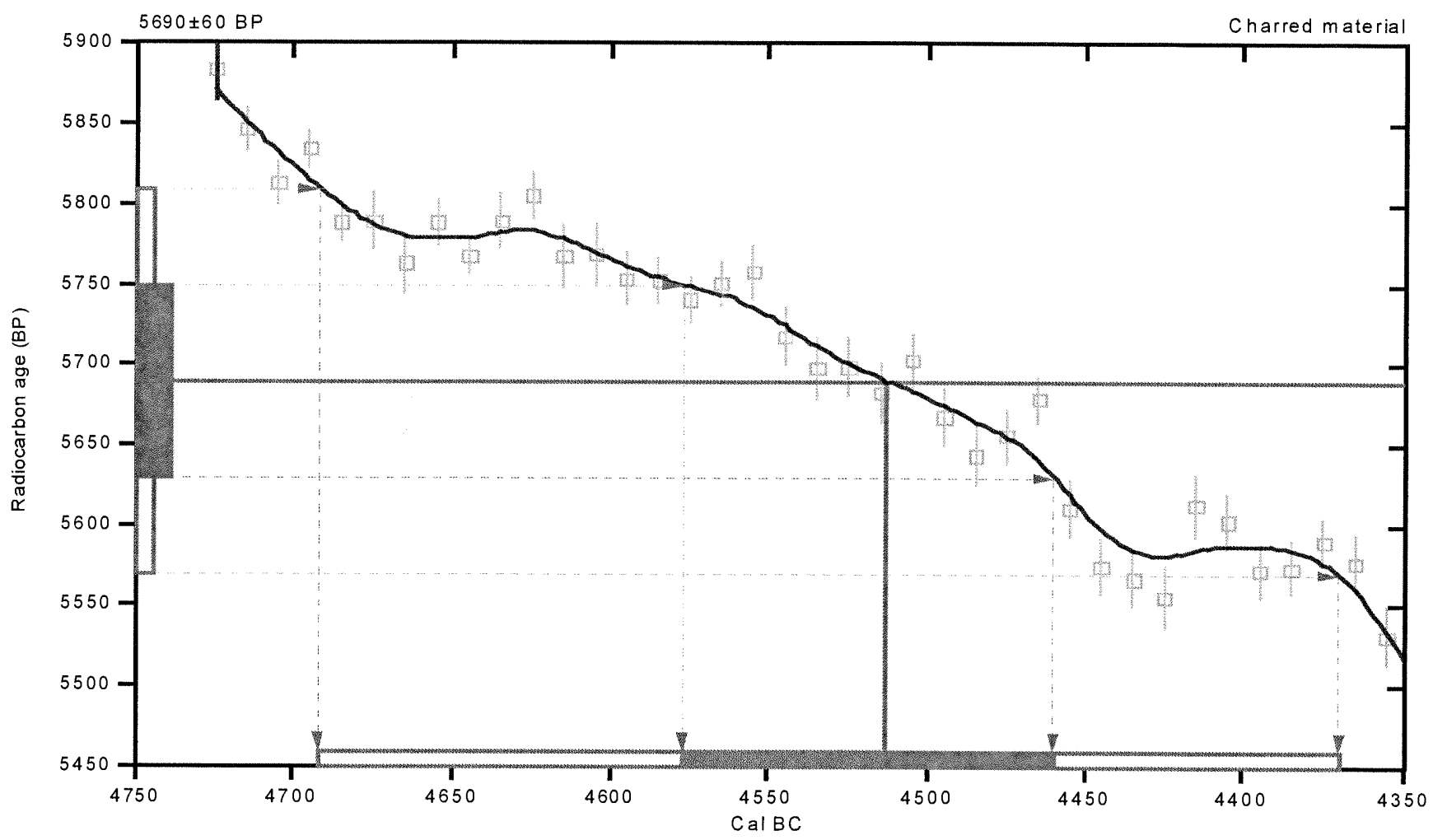

References:

Database used

Calibration Database

Editorial Comment

Stuiver, M., van der Plicht, H., 1998, Radiocarbon 40(3), pxii-xiii

INTCA L98 Radiocarbon Age Calibration

Stuiver, M., et. al., 1998, Radiocarbon 40(3), p1041-1083

$M$ athem atics

A Simplified Approach to Calibrating C14 Dates

Talma, A.S., Vogel, J. C., 1993, Radiocarbon 35(2), p317-322

\section{Beta Analytic Inc.}

4985SW74Court, Miami, Florida33155USA·Tel:(305)6675l67·Fax: (305)6630967 E-Mail: beta@radiocarbon.com 


\section{CALIBRATION OF RADIOCARBON AGE TO CALENDAR YEARS}

(V ariables: C $13 /$ C $12=-25.6: \mathrm{lab} . \mathrm{mult}=1)$

Laboratory number: Beta-175407

Conventional radiocarbon age: $6280 \pm 50$ BP

2 Sigma calibrated results: Cal BC 5340 to 5200 (Cal BP 7290 to 7150 ) and

(95\% probability) Cal BC 5180 to 5080 (Cal BP 7130 to 7020 )

Intercept data

Intercept of radiocarbon age

with calibration curve: Cal BC 5290 (Cal B P 7240)

$1 \mathrm{Sigma}$ calibrated result: Cal BC 5310 to 5230 (Cal B P 7260 to 7180 )

(68\% probability)

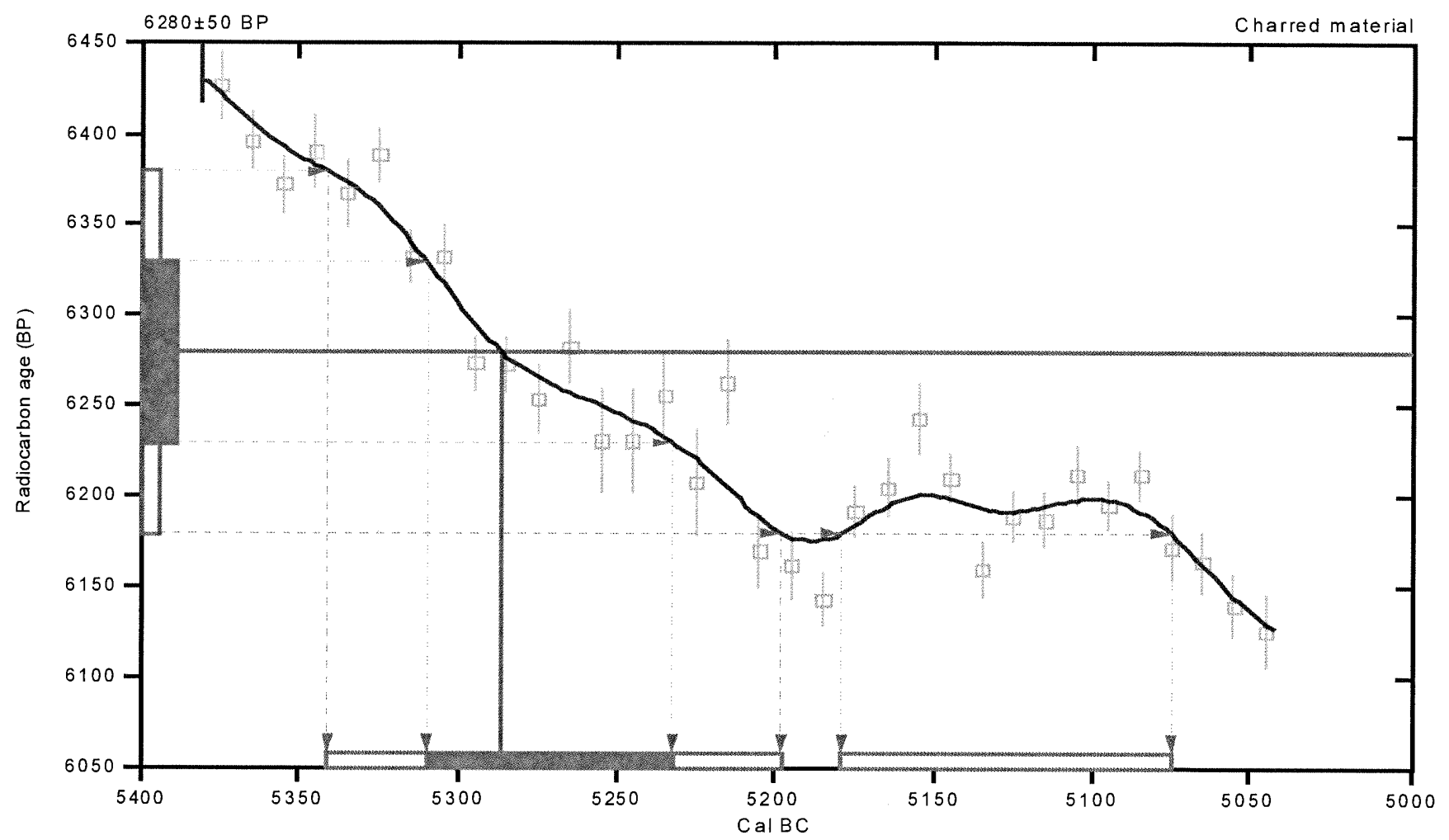

References:

Database used

Calibration Database

Editorial Comment

Stuiver, M., van der Plicht, H., 1998, Radiocarbon 40(3), pxit-xiii

IN TCAL98 Radiocarbon Age Calibration

Stuiver, M., el. al., 1998, Radiocarbon 40(3), pl04I-1083

$M$ ath em atics

A Simplified Approach to Calibrating C14 Dates

Talma, A. S., Vogel, J. C., I993, Radiocarbon 35(2), p3I7-322

\section{Beta Analytic Inc.}

4985SW7+Court, Miami, Florida 33155 USA -T'el: (305) $6675167 \cdot$ Fax: (305) $6630964 \cdot$ E-Mail: beta@radiocarbon.com 


\title{
CALIBRATION OF RADIOCARBON AGE TO CALENDAR YEARS
}

\author{
(V ariables: $\mathrm{C} 13 / \mathrm{C} 12=-21.9: \mathrm{lab} . \mathrm{mult}=1)$
}

\section{Laboratory number: Beta-175408}

Conventional radiocarbon age: $2230 \pm 40 \mathrm{BP}$

2 Sigma calibrated result: Cal BC 390 to 190 (Cal B P 2340 to 2140)

(95\% probability)

Intercept data

Intercepts of radiocarbon age

with calibration curve: Cal BC 360 (Cal B P 2310) and

Cal BC 280 (Cal B P 2230) and

Cal BC 240 (Cal B P 2190)

1 Sigm a calibrated results: Cal BC 380 to 340 (Cal BP 2330 to 2290) and

(68\% probability) Cal BC 320 to 210 (Cal BP 2270 to 2160 )

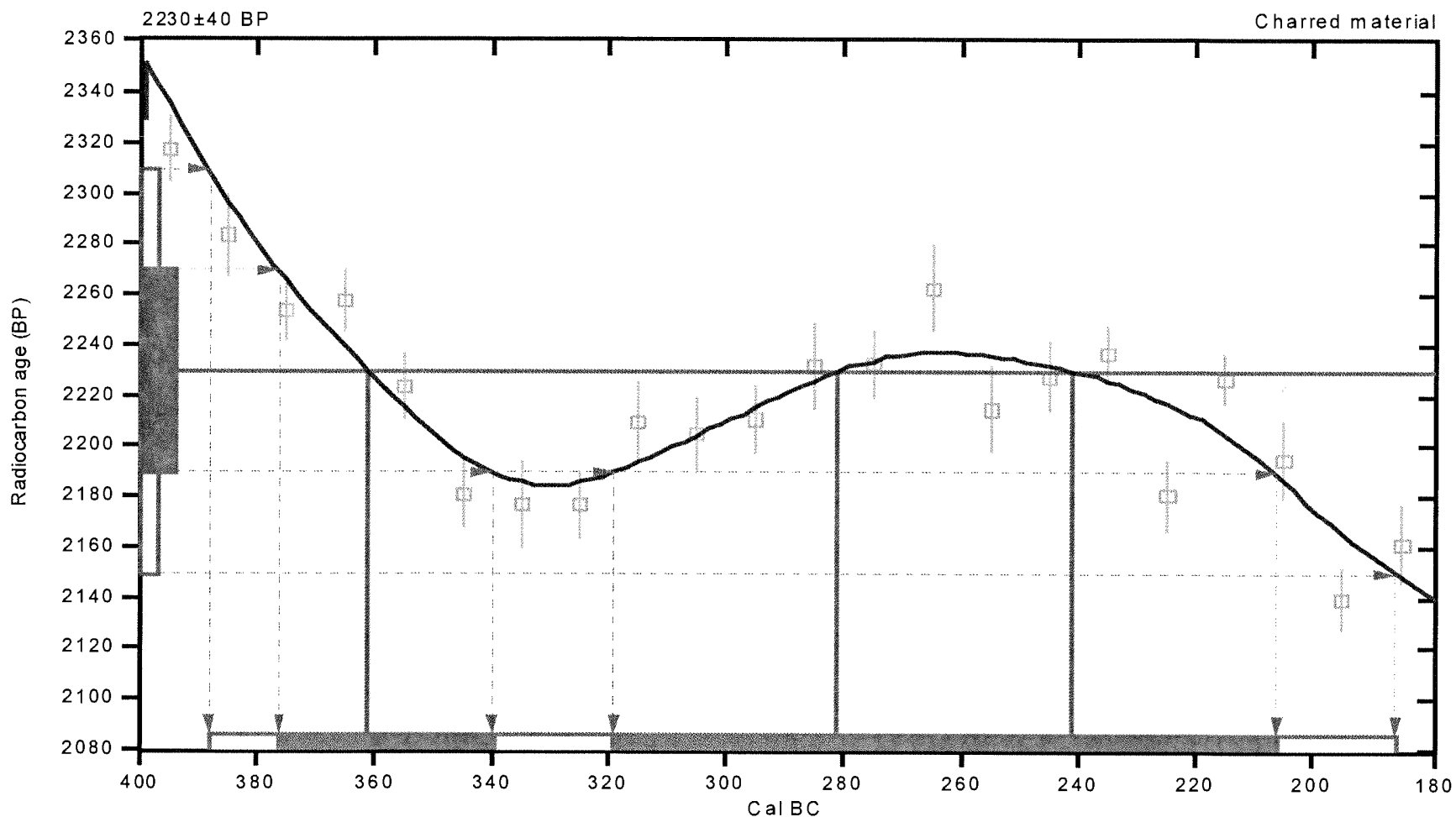

References:

Database used

Calibration Database

Editorial Com ment

Stuiver, M., van der Plicht, H., 1998, Radiocarbon f0(3), pxii-xiii

IN TCA L98 Radiocarbon Age Calibration

Stuiver, M., et. al., 1998, Radiocarbon 40(3), pl041-1083

$M$ athem atics

A Simplified Approach to Calibrating C14 Dates

Talma, A.S., Vogel, J. C., 1993, Radiocarbon 35(2), p317-322

\section{Beta Analytic Inc.}

4985 SW 74 Court, Miami, Florida 33I55 USA -Tel: (305)6675167• Fax: (305)6630964・E-Mail: beta@radiocarbon.com 


\section{CALIBRATION OF RADIOCARBON AGE TO CALENDAR YEARS}

(V ariables: C $13 /$ C $12=-25.1:$ lab. mult $=1$ )

\section{Laboratory number: Beta-175409}

Conventional radiocarbon age: $\quad 550 \pm 40 \mathrm{BP}$

2 Sigma calibrated results: Cal AD 1310 to 1370 (Cal BP 640 to 580) and

(95\% probability) Cal AD 1380 to 1430 (Cal BP 570 to 520 )

Intercept data

Intercept of radiocarbon age

with calibration curve: Cal A D 1410 (Cal BP 540)

$1 \mathrm{Sigma}$ calibrated result: Cal A D 1400 to 1420 (Cal B P 550 to 530 )

$(68 \%$ probability)

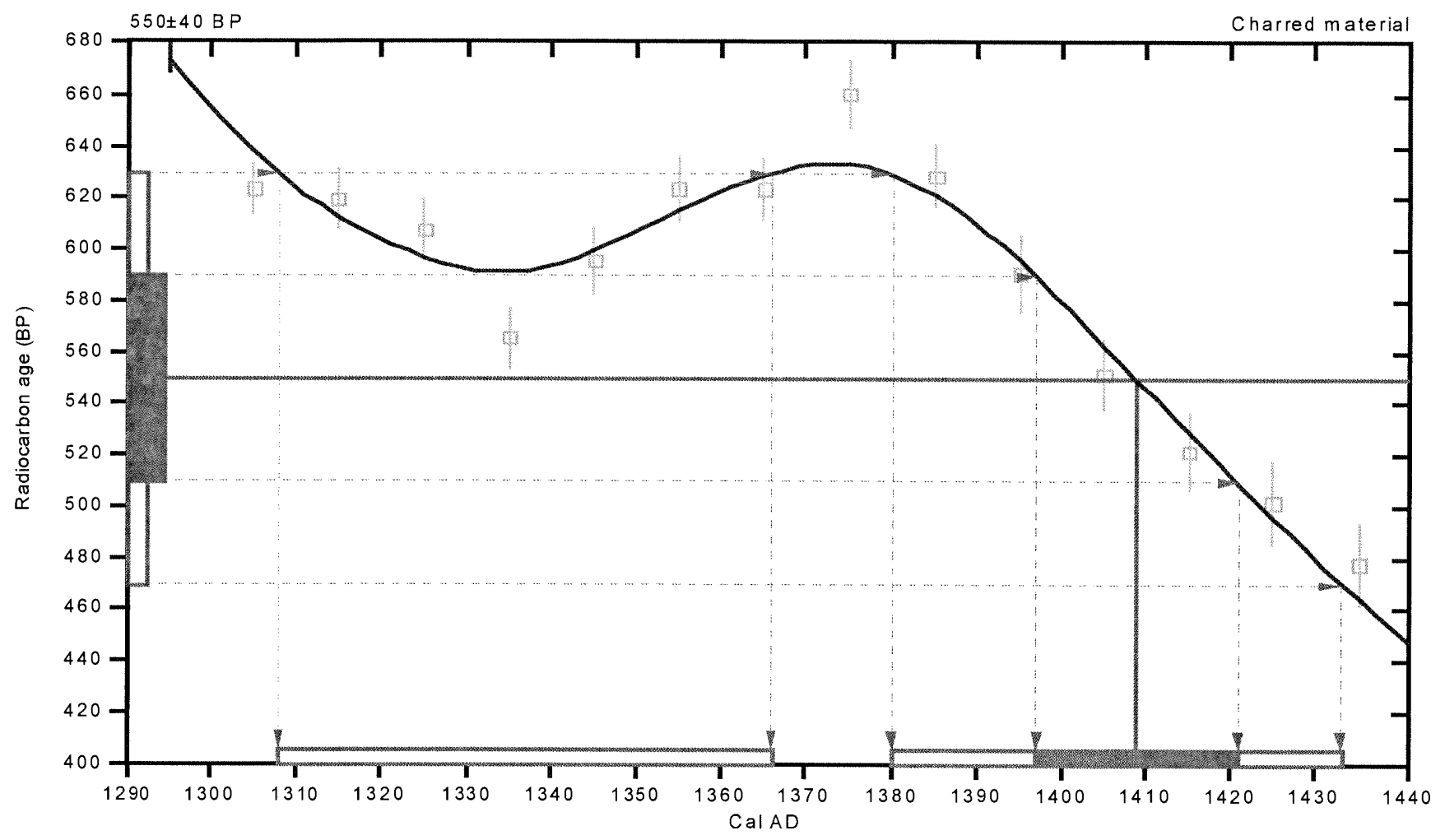

References:

Database used

Calibration Database

Editorial Com ment

Stuiver, M., van der Plicht, H., 1998, Radiocarbon 40(3), pxii-xiit

INTCAL98 Radiocarbon Age Calibration

Stuiver, M., et. al., 1998, Radiocarbon 40(3), p10+1-1083

Math em atics

A Simplified Approach to Calibrating CI4 Dates

Talma, A. S., Vogel, J. C., 1993, Radiocarbon 35(2), p317-322

\section{Beta Analytic Inc.}

4985SW74 Court, Miami, Florida33155USA Tel:(305)6675167•Fax: (305)6630964・E-Mail: beta@radiocarbon.com 


\section{CALIBRATION OF RADIOCARBON AGE TO CALENDAR YEARS}

(V ariables: C $13 / \mathrm{C} 12=-26.7:$ lab. $\mathrm{mult}=1$ )

Laboratory number: Beta-175411

Conventional radiocarbon age: $1740 \pm 40$ BP

2 Sigma calibrated result: Cal AD 220 to 400 (Cal BP 1730 to 1550 )

(95\% probability)

Intercept data

Intercepts of radiocarbon age

with calibration curve: Cal A D 260 (Cal BP 1690) and

Cal A D 290 (Cal BP 1660) and

Cal A D 320 (Cal BP 1630)

1 Sigm a calibrated result: Cal A D 240 to 370 (Cal B P 1710 to 1580 )

( $68 \%$ probability)

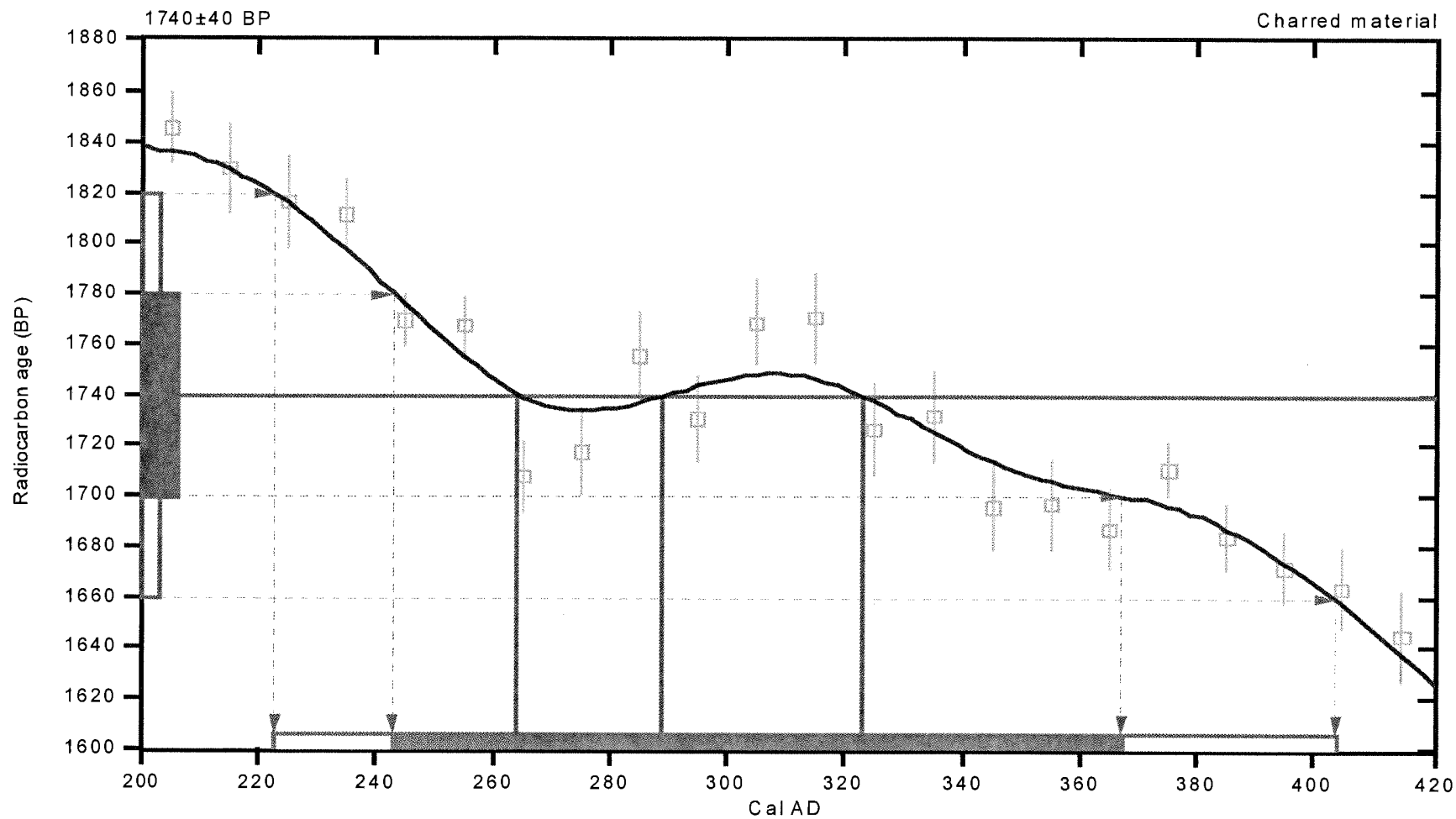

References:

Database used

Calibration Database

Editorial Com ment

Stuiver, M., van der Plicht, H., 1998, Radiocarbon 40(3), pxii-xiit

IN TCAL98 Radiocarbon Age Calibration

Stuiver, M., et. al., 1998, Radiocarbon 40(3), pI041-1083

$M$ ath em atics

A Simplified Approach to Calibrating C14 Dates

Talma, A. S., Vogel, J. C., 1993, Radiocarbon 35(2), p317-322

\section{Beta Analytic Inc.}

4985 SW 74 Court, Miami, Florida 33155 USA $\cdot$ Tel: (305) $6675167 \cdot$ Fax: (305) $6630964 \cdot$ E-Mail: beta@radiocarbon.com 


\section{CALIBRATION OF RADIOCARBON AGE TO CALENDAR YEARS}

(V ariables: $\mathrm{C} 13 / \mathrm{C} 12=-25.5: \mathrm{lab} . \mathrm{mult}=1)$

Laboratory number: Beta-175412

Conventional radiocarbon age: $1700 \pm 40 \mathrm{BP}$

2 Sigma calibrated result: Cal AD 240 to 420 (Cal BP 1710 to 1530)

$(95 \%$ probability)

Intercept data

Intercept of radiocarbon age

with calibration curve: Cal A D 370 (Cal B P 1580)

1 Sigma calibrated results: Cal A D 260 to 290 (Cal B P 1690 to 1660 ) and

(68\% probability) Cal A D 320 to 400 (Cal B P 1630 to 1550 )

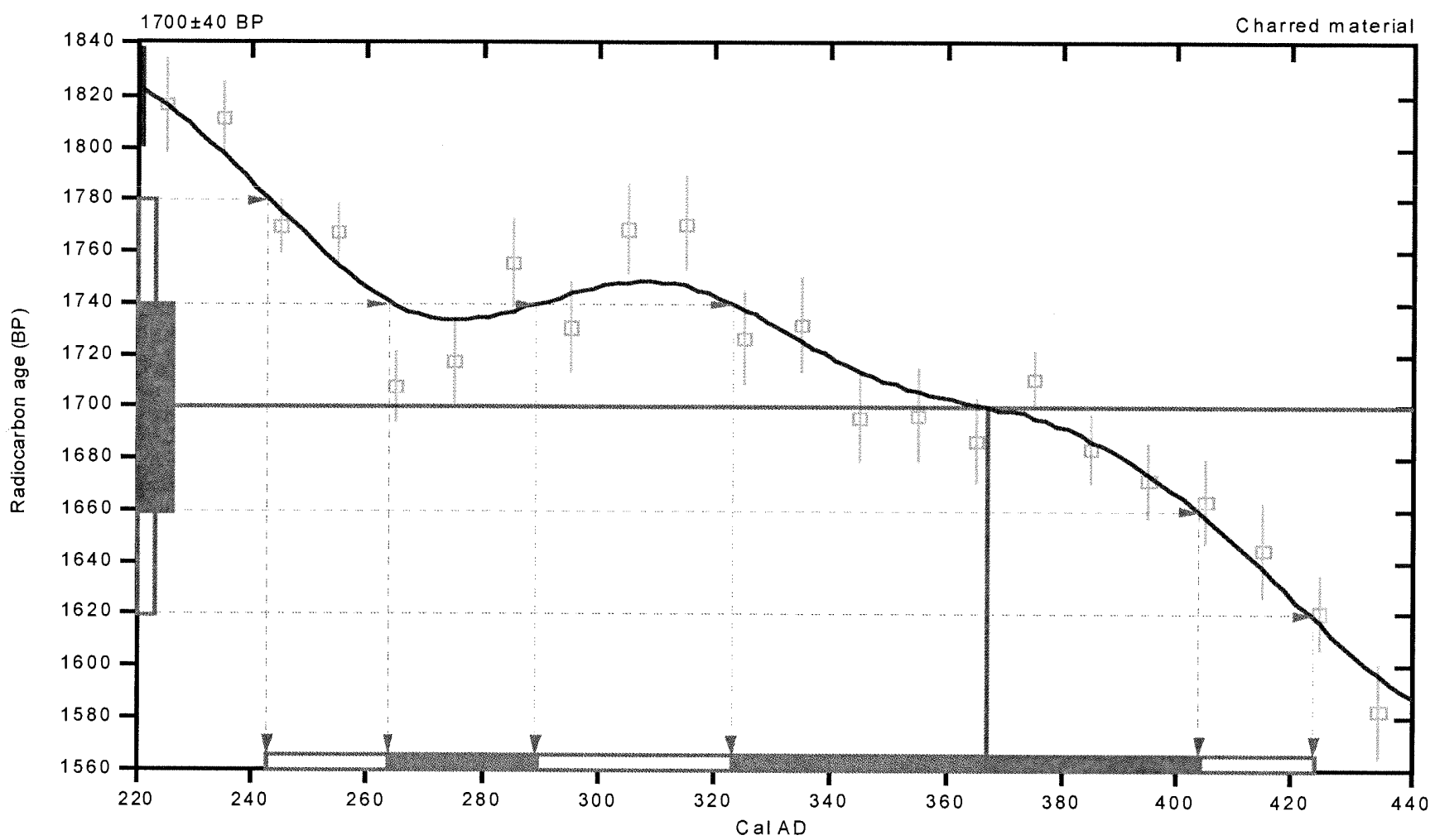

References:

Database used

Calibration Database

Editorial Comment

Stuiver, M., van der Plicht, H., 1998, Radiocarbon 40(3), pxii-xiit

INTCA L98 Radiocarbon Age Calibration

Stuiver, M., et. al., 1998, Radiocarbon 40(3), p1041-1083

M ath em atics

A Simplified Approach to Calibrating C14 Dates

Talma, A.S., Vogel, J.C., 1993, Radiocarbon 35(2), p317.322

\section{Beta Analytic Inc.}

4985 SW 74 Court, Miami, Florida 33155 USA - Tel: (305)6675167• Fax: (305)6630964 E-Mail: beta@radiocarbon.com 


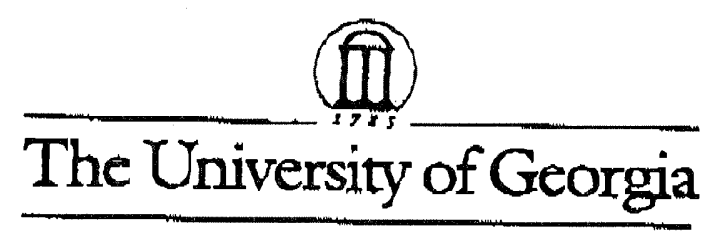

Center for Applied Isocope Sadies

\section{RADIOCARBON AGE ANALYSIS REPORT}

Dr. James T. Abbott

November 25, 2003

Staff Geoarcheologist

Cultural Resources Management

Texss Department of Transpartation

Dewitt C. Greer State Highway Bldg.

125 E. 11th Street

Austin, TX 78701-2483

Dear Dr, Abbott,

Enclosed please find the results for the Radiocarbon $\left({ }^{44} \mathrm{C}\right)$ analysis including Stable Isotope Ratio analysis $\left(\delta^{13} \mathrm{C}\right)$ correction for the samples received by our laboratory on
October 6,2003 .

\section{UGA\# Sample}<smiles>C[14CH3]</smiles>

12704 4.1ED28/11-005-004-007-1a:

12705 41ED28/37-005-004-007-1a:

12706 41ED28/76-002-11c:

12707 41ED28/78-005-007-1a:

12708 41ED28/89-005-002-1:

12709 41ED28/128-005-004-007-1a:

12710 41ED28/159-0005-008-1a:

12711 41ED28/179-005-004-007-1a:

12712 41ED28/255-002-1:

12713 41ED28/293-002-1:

12714 41ED28/293-005-007-1a:

12715 41ED28/344-007-1a:

12716 41ED28/418.002-1:

12717 41ED28/418-007.1a:

12718 4.1ED28/515-005-004-007-1:

12719 41ED28/522-002-1a:

12720 4lED28/531-007-1a:

12721 41ED28/570-007-1a:

12722 4IED28/607-007-Ia:

12723 41ED28/615-005-007-2a:

12724 41ED28/616-005-007-1a:

\begin{tabular}{ccc}
\multicolumn{2}{c}{ Radiocarbon } & $\delta^{13} \mathrm{C}$ \\
Age & $\delta^{13} \mathrm{C}$ Corrected & (Years \\
(YBP \pm 10$)$ & Age (XMP 10$)$ & corrected) \\
\hline
\end{tabular}

$1,380 \neq 40$

$1,390 \pm 40$

$4,230 \pm 40$

$4,260 \pm 40$

$5,270 \pm 40$

$380 \pm 40$

To be determined

$5,220 \pm 40 \quad 5,200 \pm 40$

$2,920 \pm 40 \quad 3,080 \pm 40$

$2,240 \pm 40$

$2.290 \pm 40$

$5,270 \neq 40$

$5,340 \pm 40$

$610 \pm 40$

$860 \pm 40$

$560 \pm 40$

$550 \pm 40$

$5,440 \pm 40$

$5,410 \pm 40$

$2,230 \pm 40 \quad 2,290 \pm 40$

$4,740 \pm 40 \quad 4,770 \pm 40$

$2,000 \neq 4.0$

$1,990 \pm 40$

$3,850 \pm 40$

$3,910 \pm 40$

$5,500 \pm 40$

$5,500 \pm 40$

$6,090 \pm 40$

$6,100 \pm 40$

$5,580 \pm 40$

$5,560 \pm 40$

$5,440 \pm 40$

$5,660 \pm 40$

$5,640 \pm 40$.
$-24.27(+12)$

$-23.37(+26)$

$-19.71(+85)$

$-24.85(+2)$

$-26.23(-20)$

$-15.35(+157)$

$-21.69(+53)$

$-21.00(+65)$

$-9.80(+248)$

$.25 .84(-5)$

$-26.59(-26)$

$-21.48(+57)$

$-23.32(+27)$

$-25.67(-11)$

$-21.21(+61)$

$-25.16(-3)$

$-24.65(+6)$

$-26.22(-20)$

$-11.61(+218)$

$-23.17(+29)$ 120 Riverbend Road - Arhens, Gcorgis 30002-4702 - Telephone (706) 542-1395 - Fax (706) 542-6106
An Equal Opporunjty/Attirmative Astion Iosciturion 


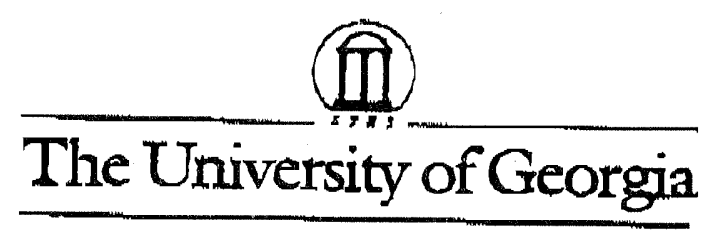

Cencer for Applied Isotope Sudies

Dr. James T. Abbott

UGA\# Sample I.D.

12725 41ED28/801-005-004-007-2a:

12726 41ED28/865-005-004-007-1a:

12727 41ED'28/987-008-1a:

12728 41ED28/1026-005-007-1a:

12729 41ED28/1030-005-003-2c:

12730 41ED28/1089-008-1a:

12731 41ED28/1118-008-1a:

12732 41ED28/1217-005-004-007-1d:

12733 41ED28/1218-007-1d:

12734 4IED28/1219-005-007-lc:

12735 41BX5/SAAN13002-C:

12736 41BX5/SAAN13011-n:

12737 41KM16/25:

12738 41KM16/385:

12739 41KM16/481:

12740 4IRE1/1872-6a:

12741 41RE1/1872-48a:
Page 2 of 2
November 25, 2003

\begin{tabular}{|c|c|c|}
\hline 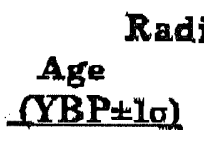 & $\begin{array}{l}\text { carbon } \\
\delta^{13} \text { C Corrected } \\
\text { Age (YBP } \pm 10)\end{array}$ & $\begin{array}{c}\delta^{19} \mathrm{C} \\
\text { Years } \\
\text { corrected) }\end{array}$ \\
\hline $2.130 \pm 40$ & $2,140 \pm 40$ & $-24.54(+7)$ \\
\hline $640 \pm 40$ & $620 \pm 40$ & $-26.69(-21)$ \\
\hline $26,510 \div 40$ & $26,960 \pm 40$ & $+1.99(+446)$ \\
\hline $320 \pm 40$ & $320 \pm 40$ & $-24.81(+3)$ \\
\hline $11,690 \pm 40$ & $11,980 \pm 40$ & $-7.08(+293)$ \\
\hline $190 \div 40$ & $310 \pm 40$ & $-17.76(+117)$ \\
\hline $21 \pm 40$ & $60 \neq 40$ & $-22.77(+36)$ \\
\hline $630 \div 40$ & $600 \pm 40$ & $-26.61(-26)$ \\
\hline $5,430 \pm 40$ & $5,400=40$ & $-26.66(-27)$ \\
\hline $300 \pm 40$ & $300 \pm 40$ & $-24.72(+4)$ \\
\hline $1,760 \pm 40$ & $1,900 \neq 40$ & $-16.41(+139)$ \\
\hline $360 \pm 40$ & $4.90 \neq 40$ & $-17.07(+128)$ \\
\hline $810 \pm 40$ & $850 \div 40$ & $-22.53(+40)$ \\
\hline $980 \pm 40$ & $1,030 \pm 40$ & $-22.22(+45)$ \\
\hline $1,140 \pm 40$ & $1,200 \pm 40$ & $-21.49(+57)$ \\
\hline $2,420 \neq 40$ & $2,500 \pm 40$ & $-19.91(+82)$ \\
\hline $1,100 \pm 40$ & $1,200 \pm 40$ & $-18.83(+100)$ \\
\hline
\end{tabular}

All the above lisced samples were pretreated with acid, alkali and acid to remove potential contmingnts from the surface and interior prior to processing for AMS dating. call.

If you have any questions, or need additional information, please do not hesitate to

Sincerely,

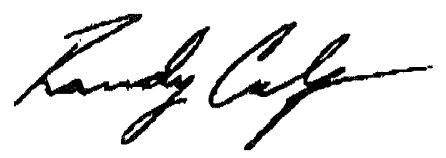

C.A.I.S. Inv. No. 6061

Randy Culp

Research Coordinator

All dates are raporked in yects before present (O YBP= 1950 A.D.). By international eanvention, the half-life of radiocarbon is taken to be 5568 years. Stondardizahon is with the National Instirule of Standards ard Teehnology's Oxalic Acid SRM-4990C, which is laken to be 199\% modern (1950). The uncertainty in the reported

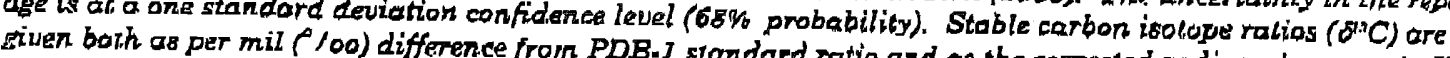
The corrected age facilitates the camparison of differandard ratio and a the corrected radioearbon age, in YBP. isatope ratios. To oblain a corrected datson of different materials which farm in nature with different carbon

120 kiverbend Rond - Arhenx, Gicosgia 30602 -47112 - Telephond (706) 542-1395 - F2x (706) 542.6,06 an Equal Opporrunicy/Affimative Action Institution 


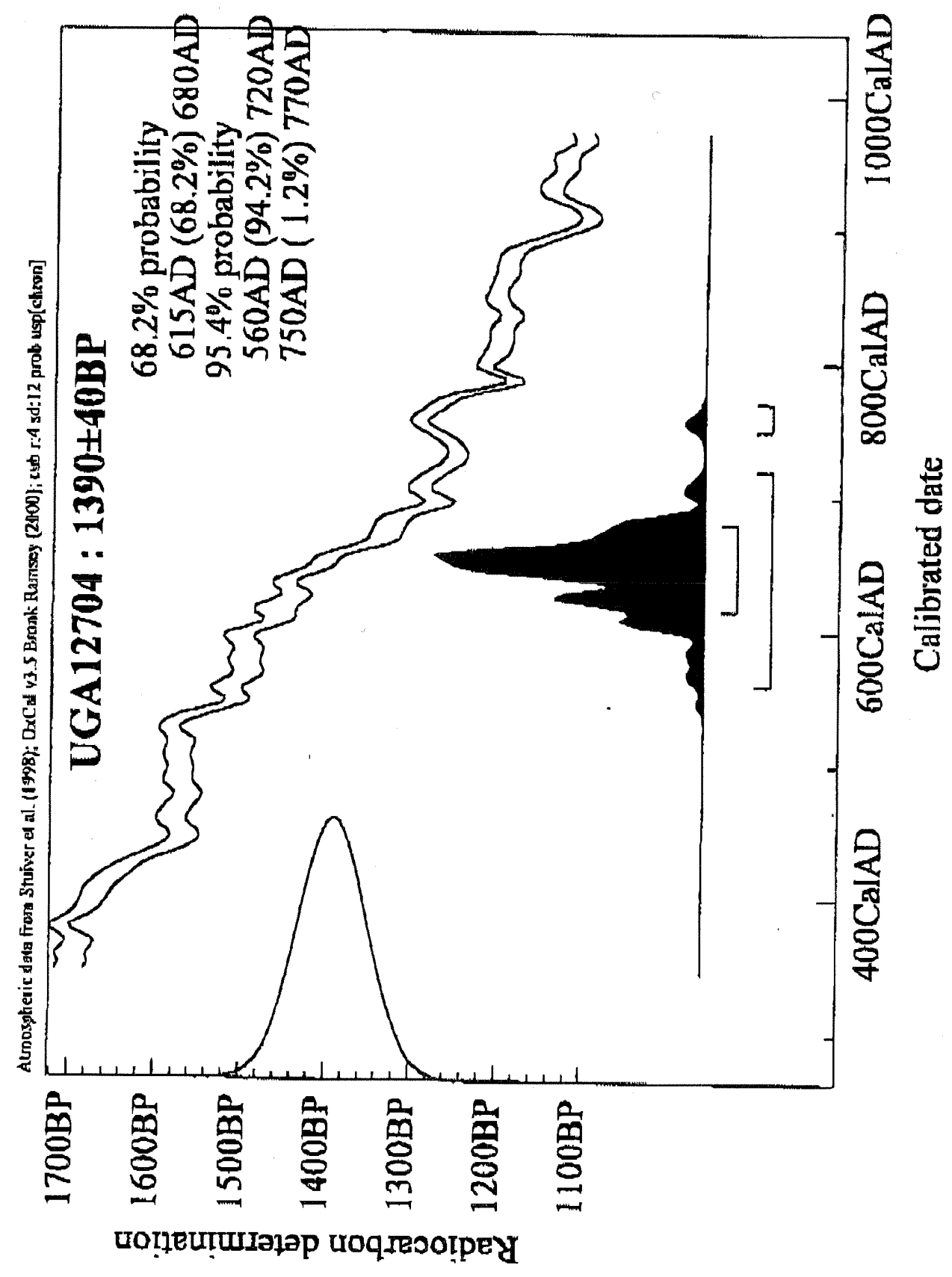




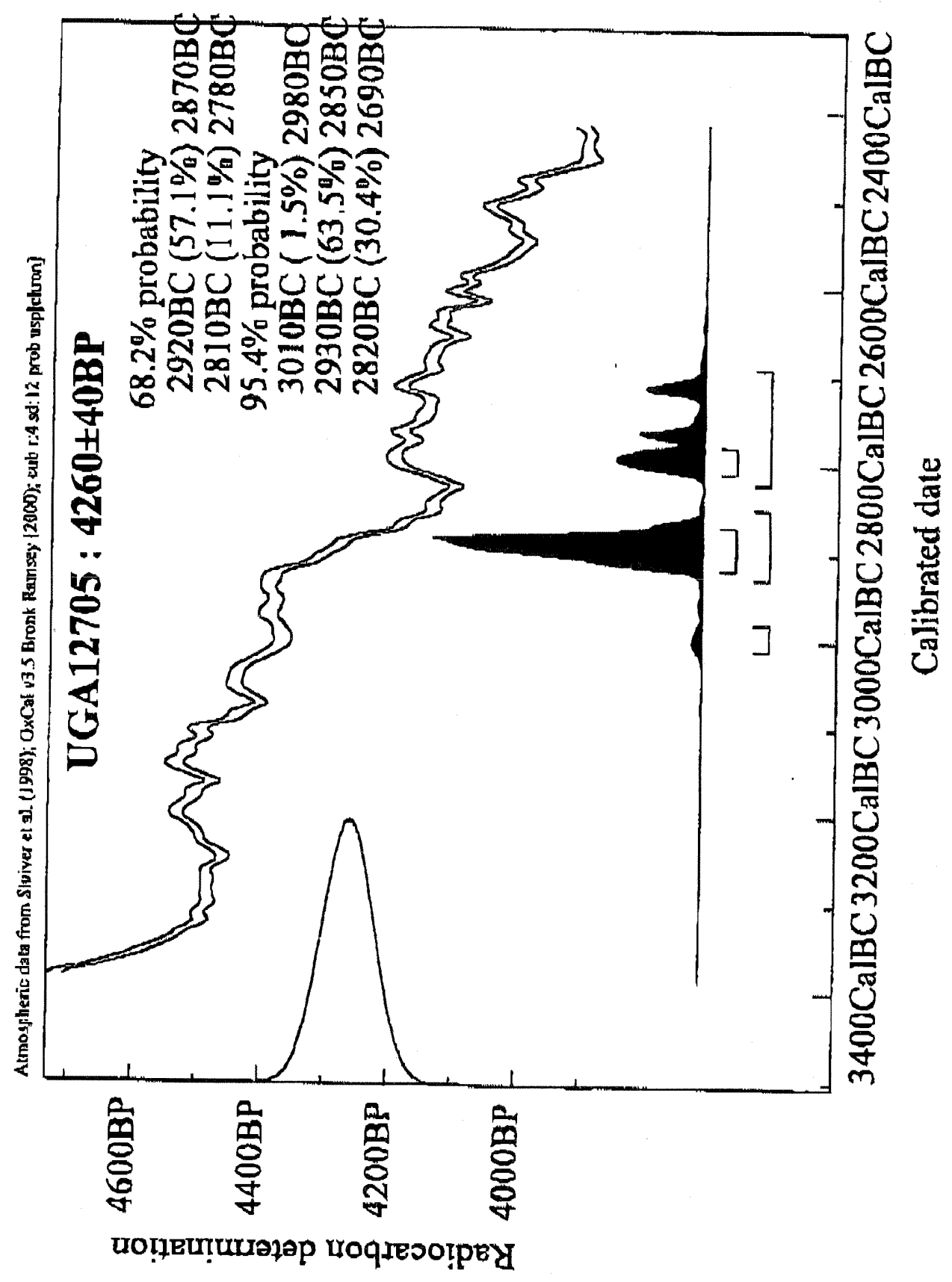




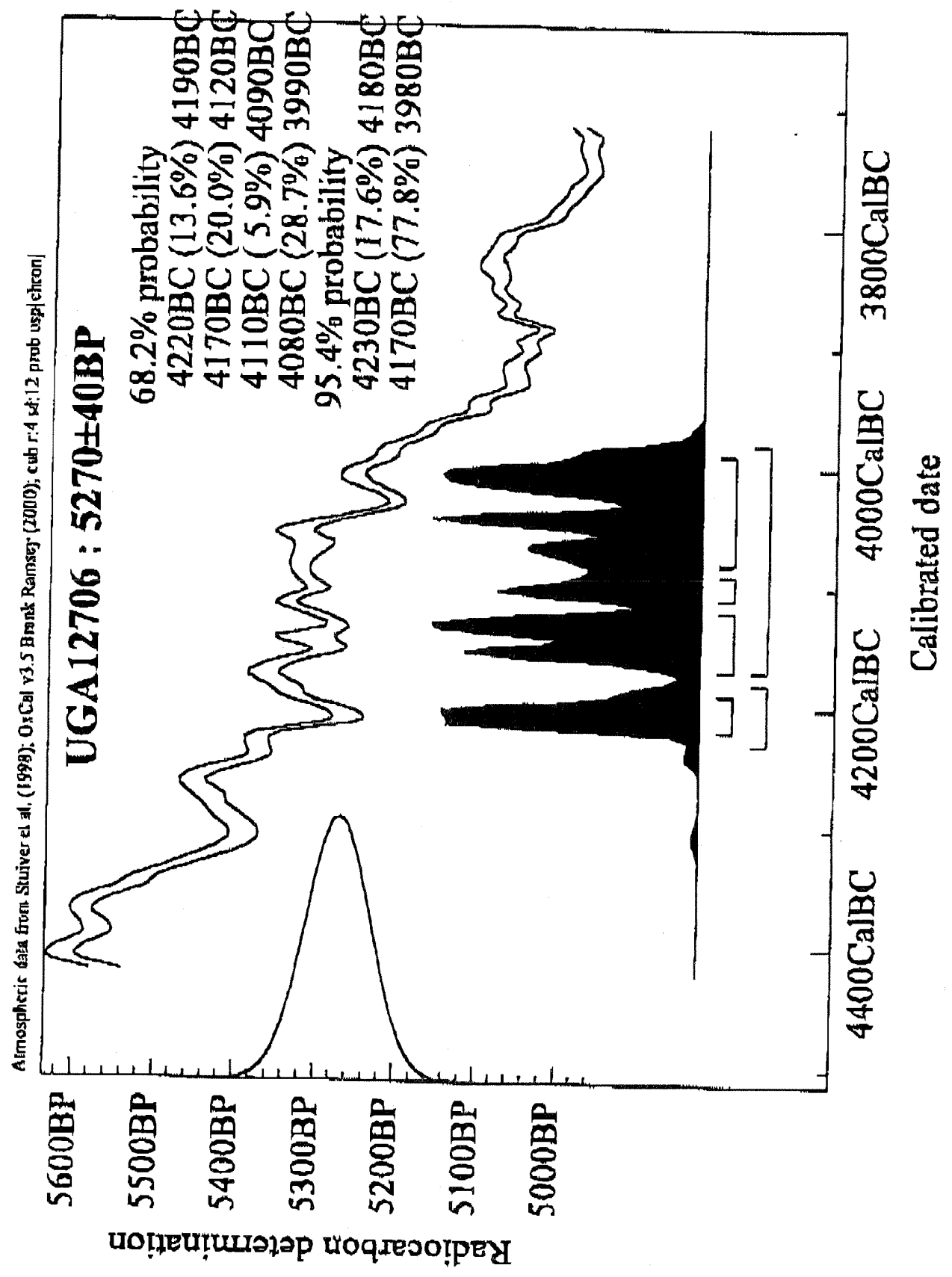




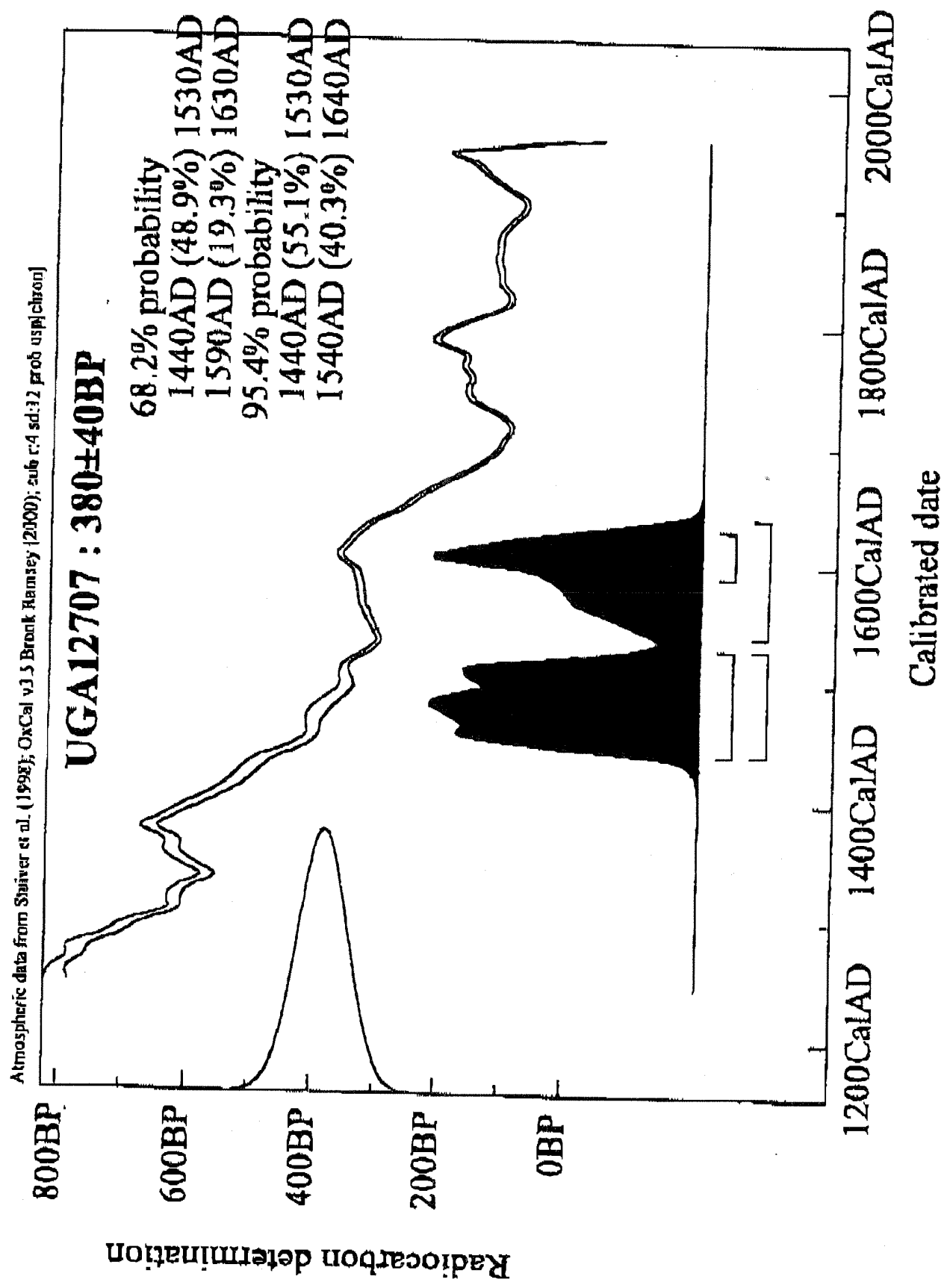




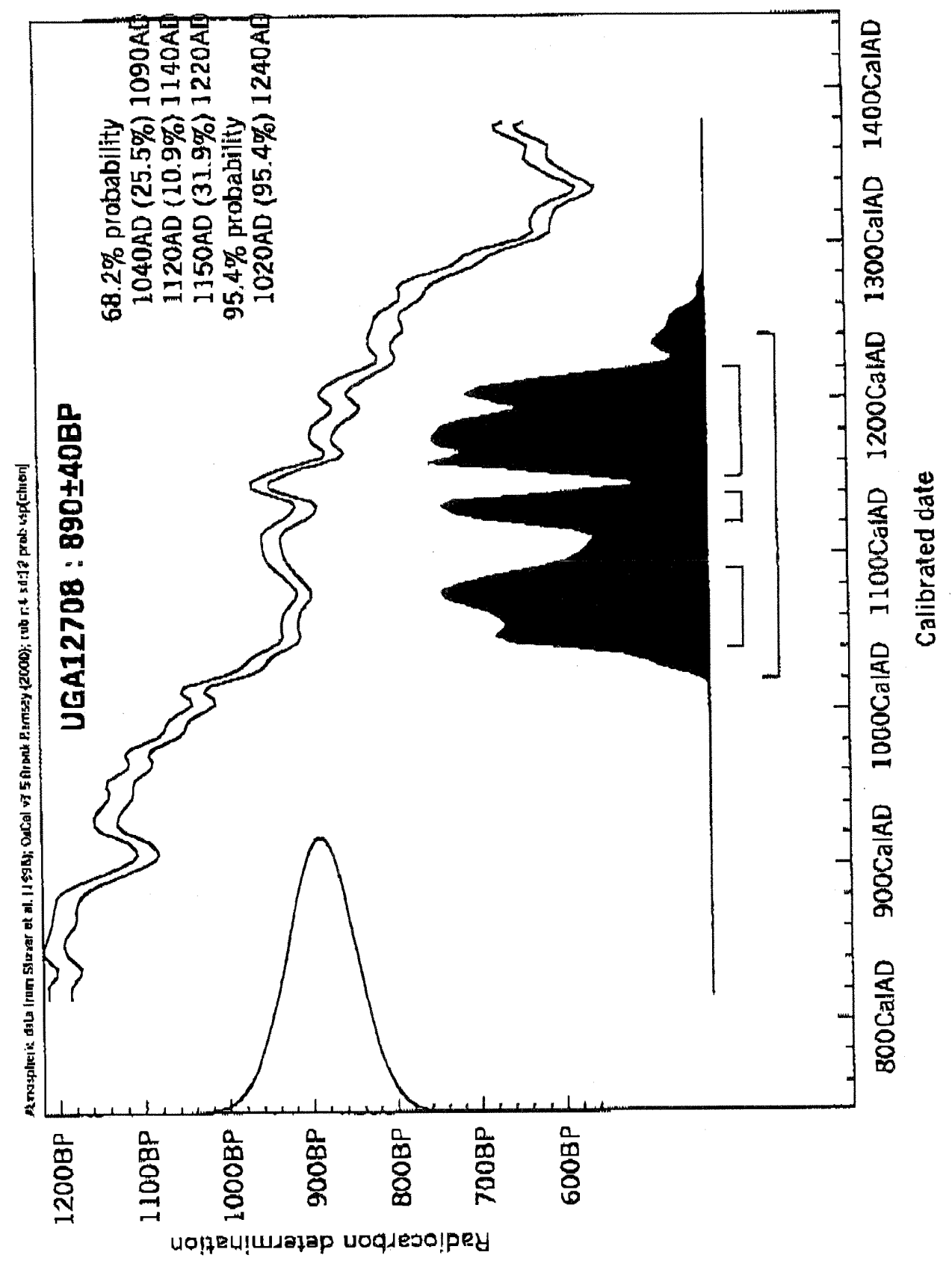




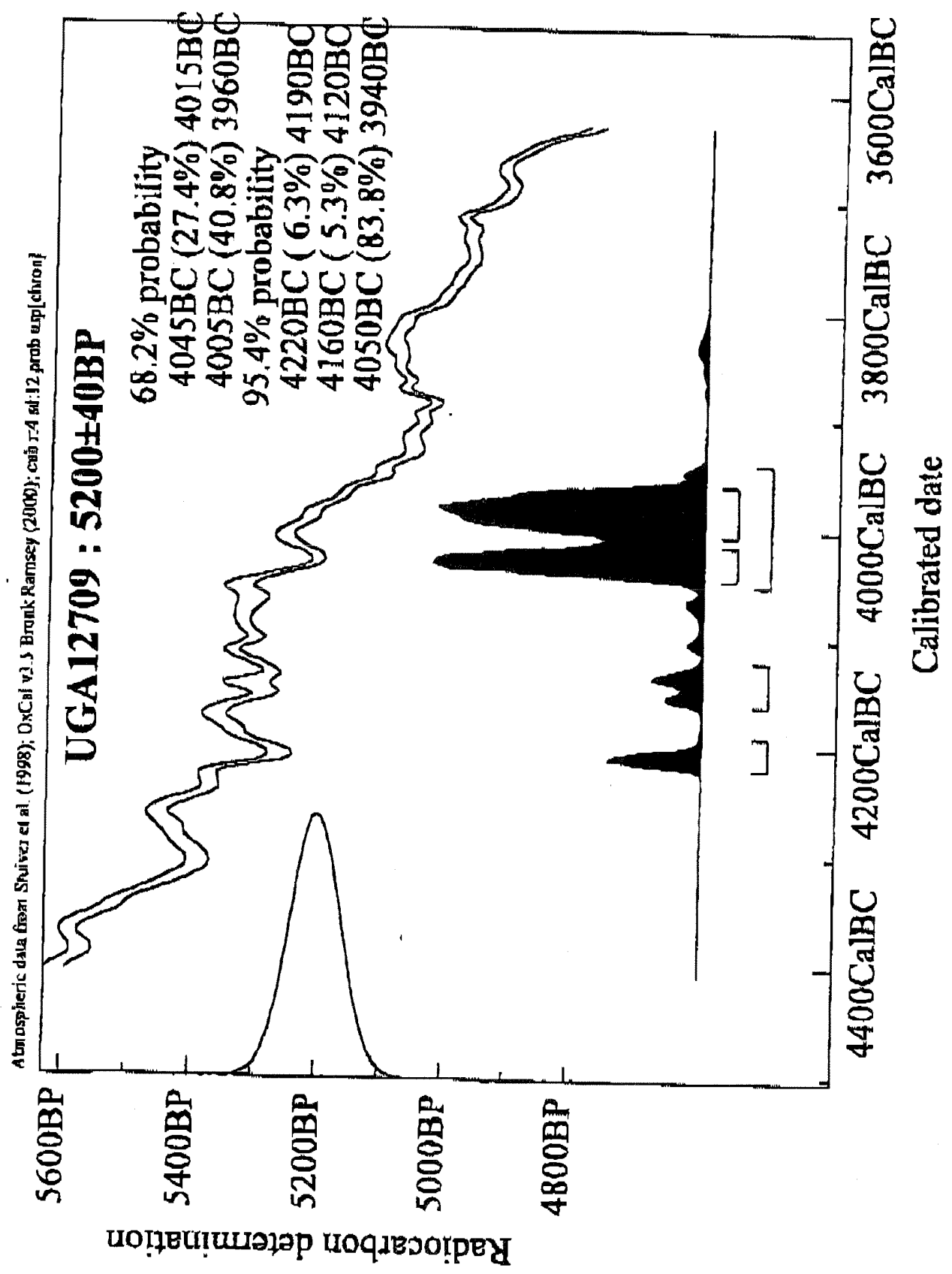




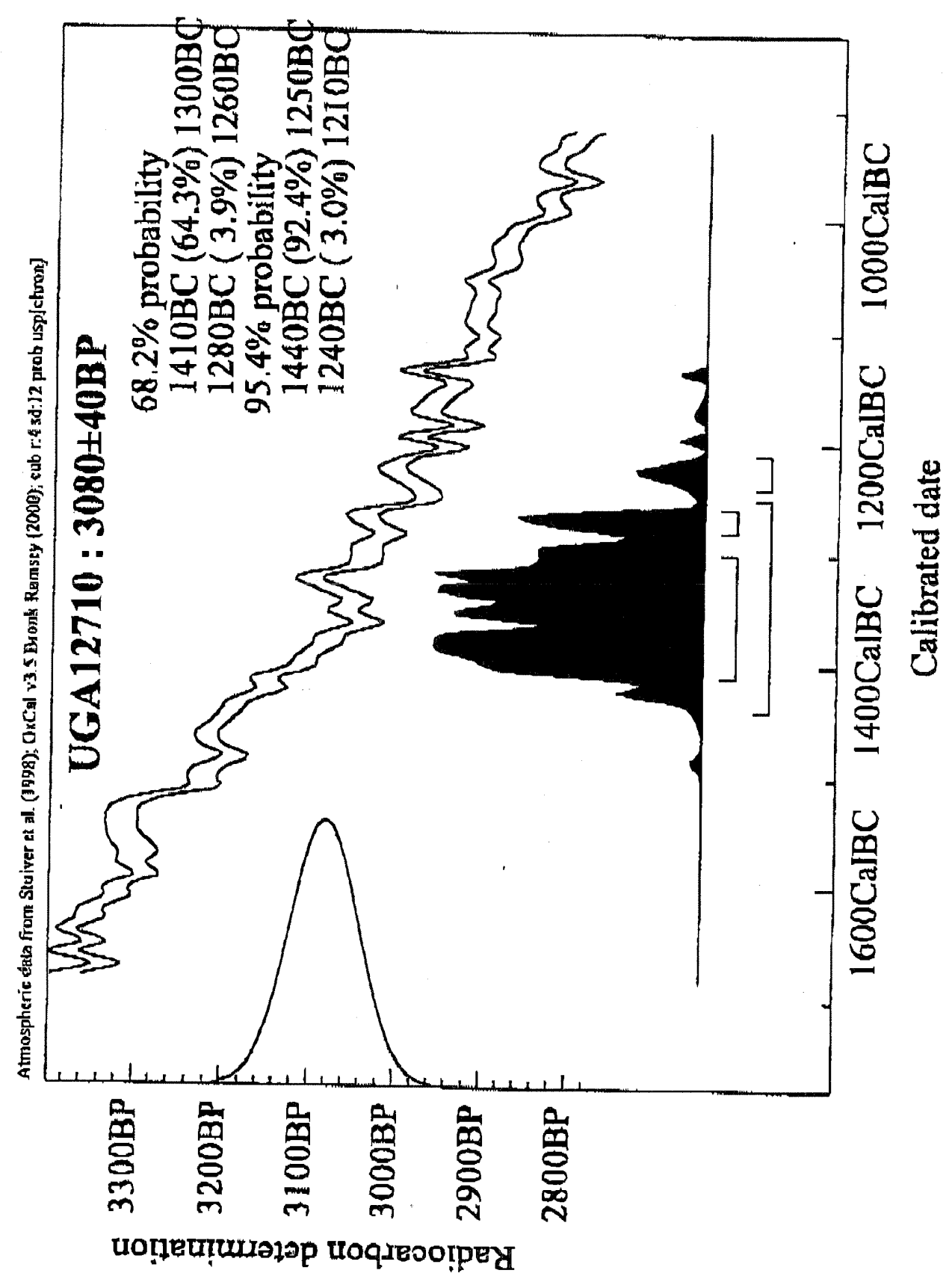




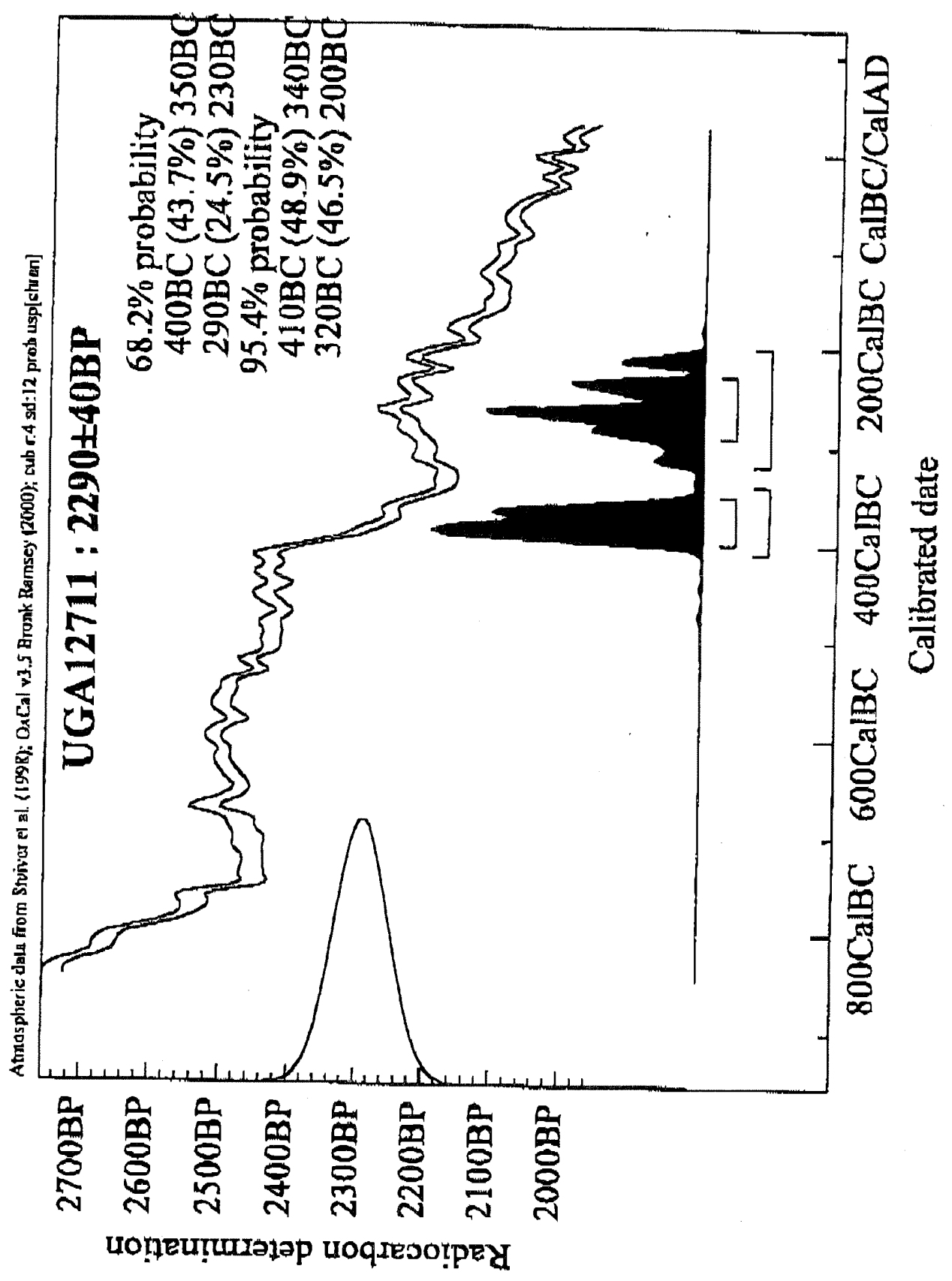




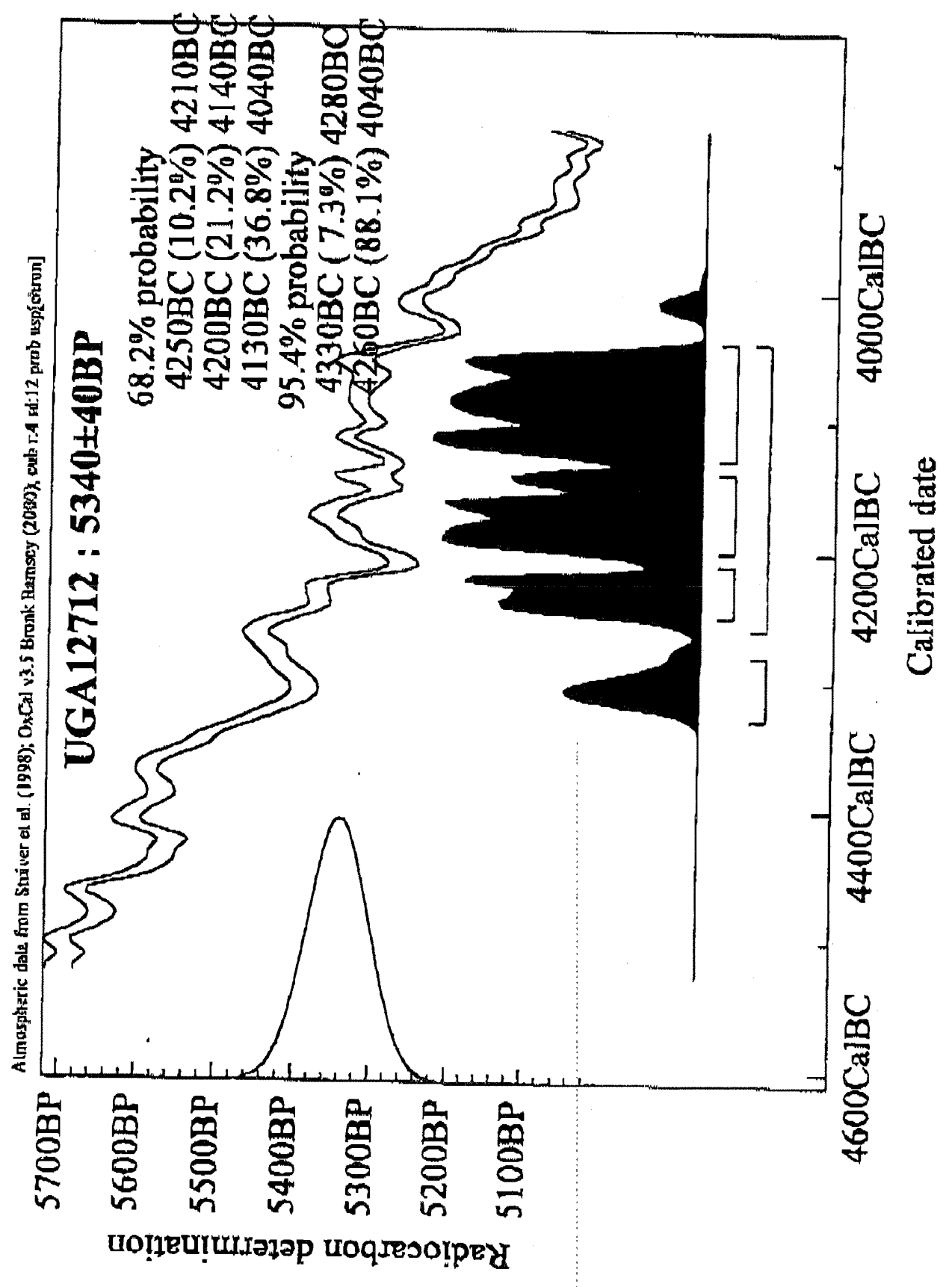




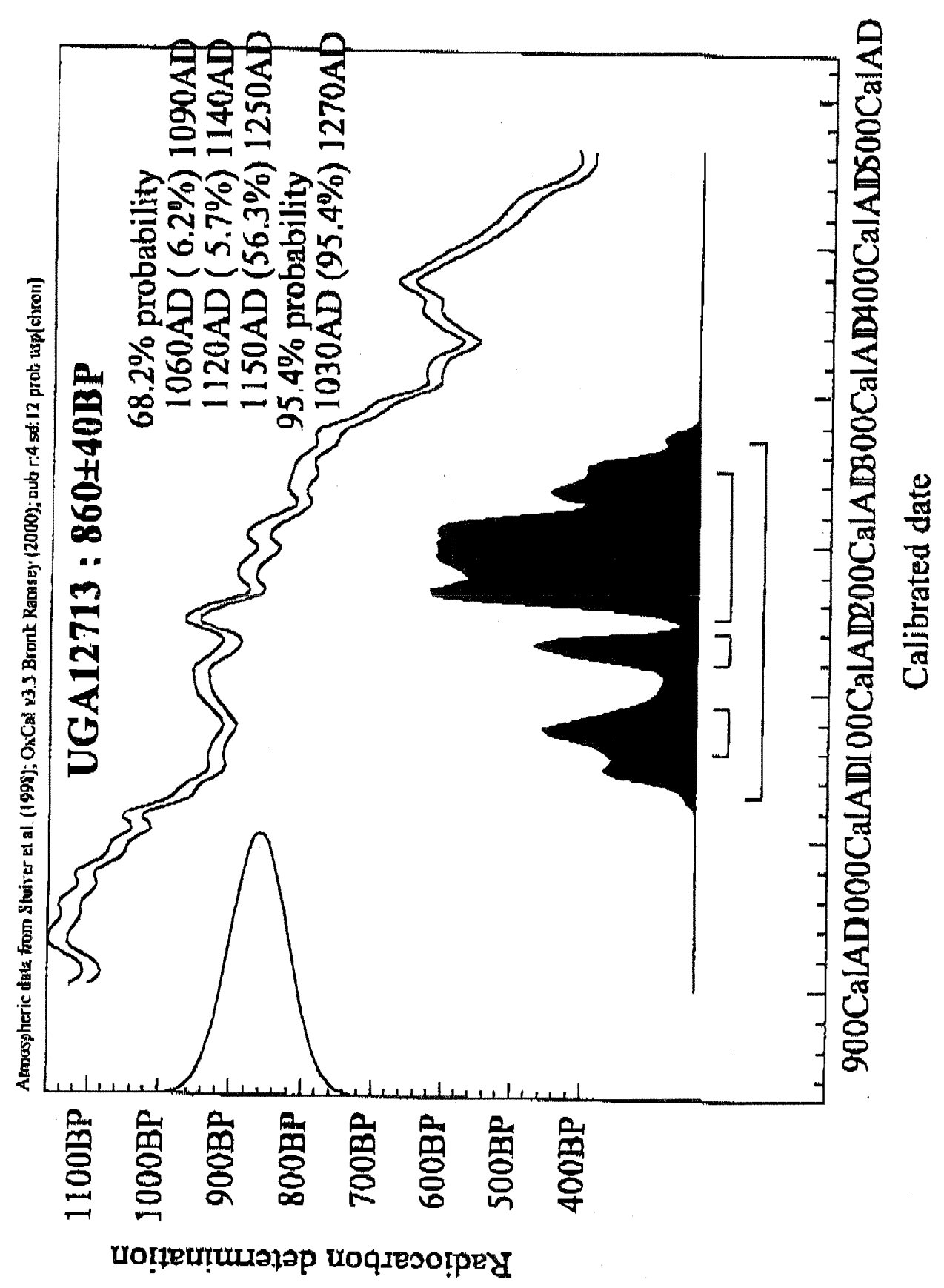




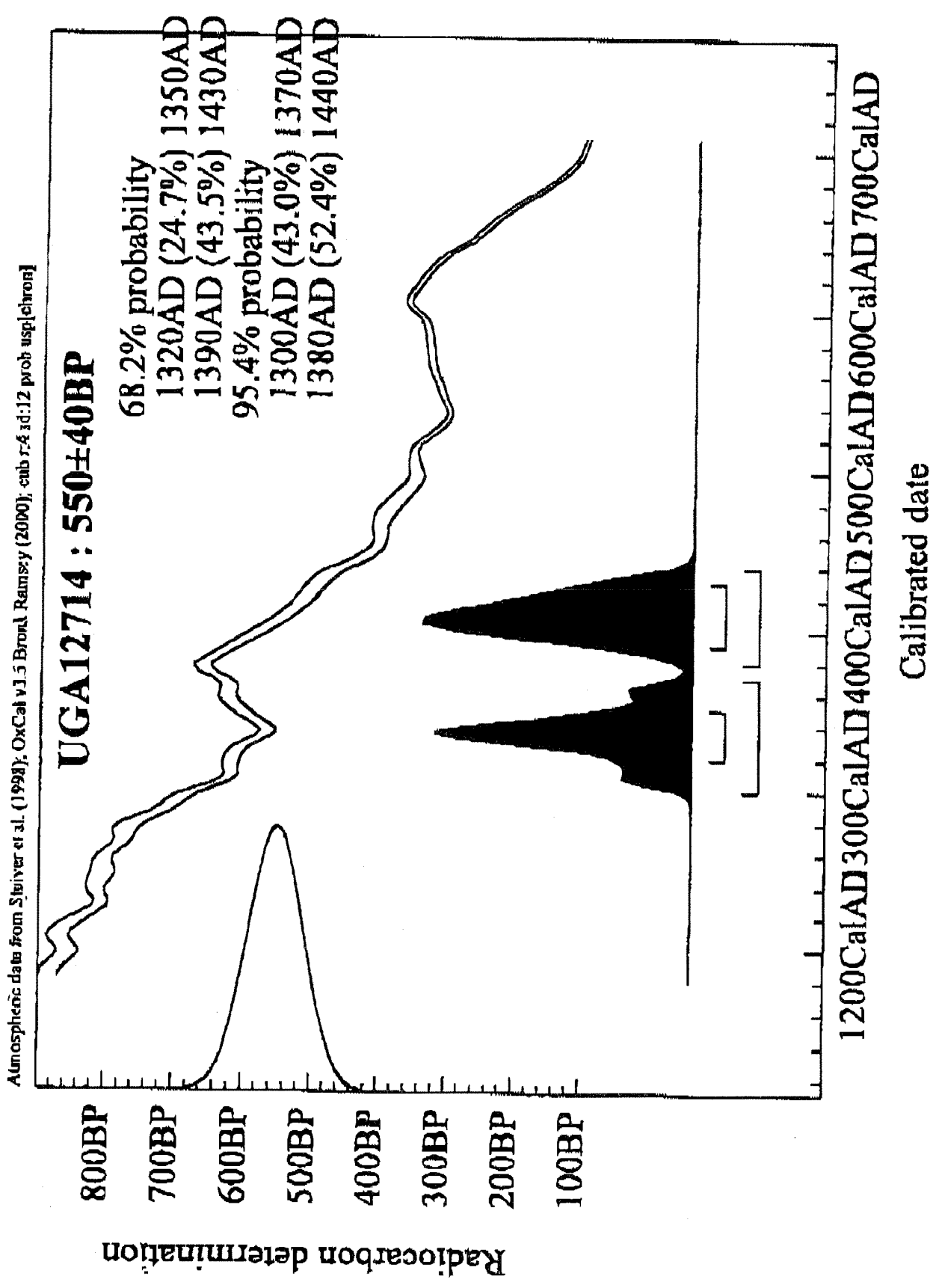




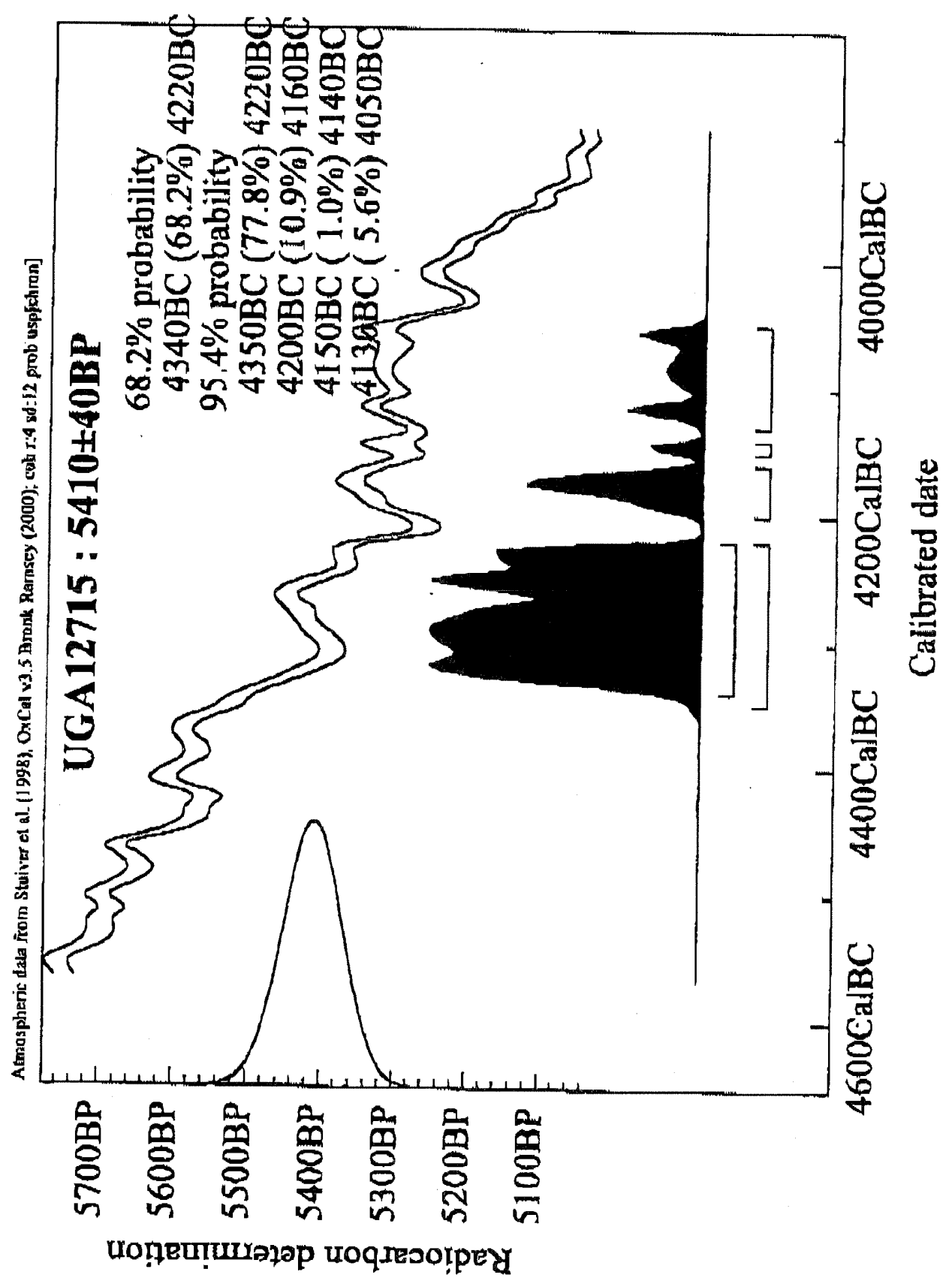




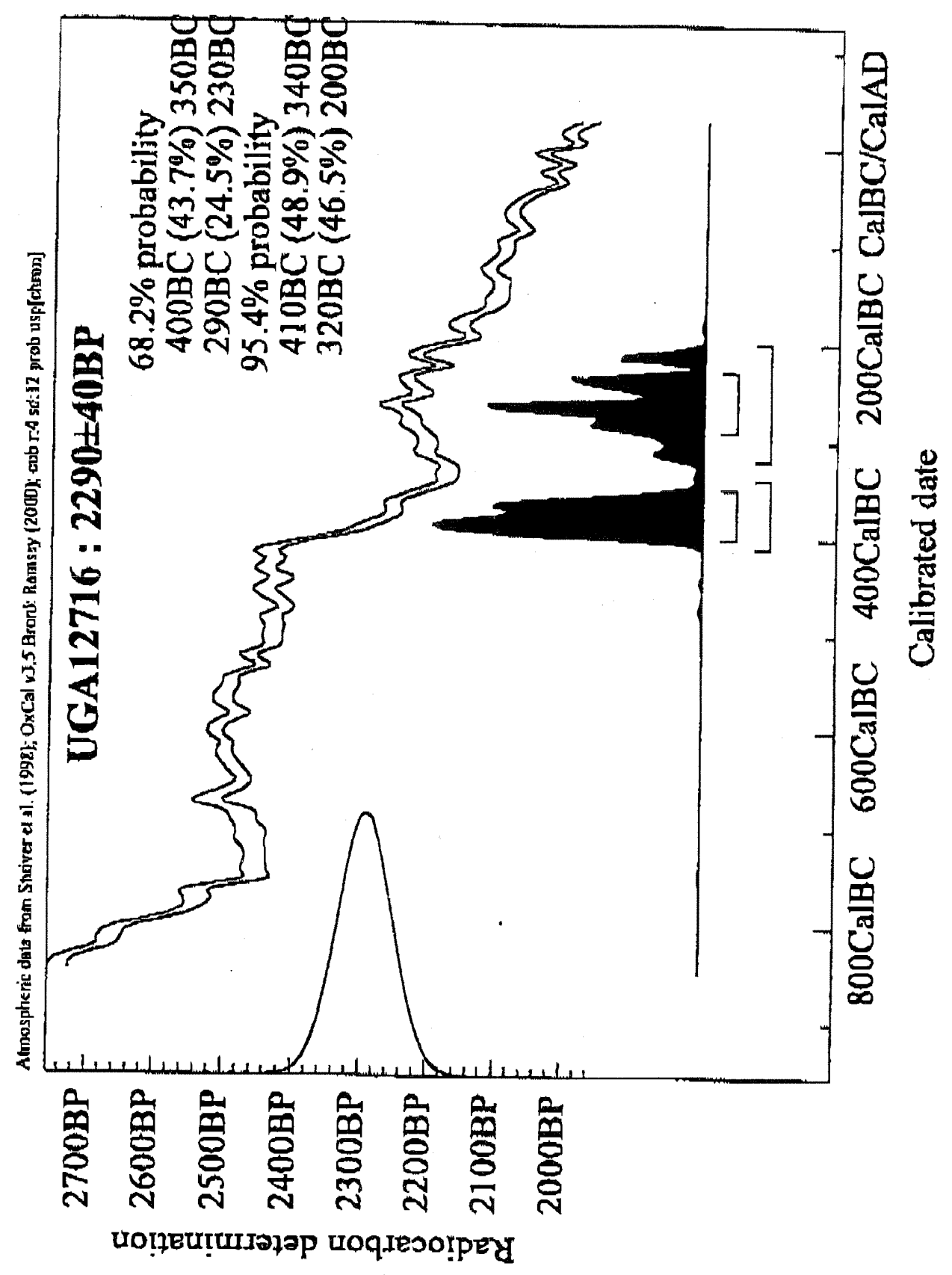




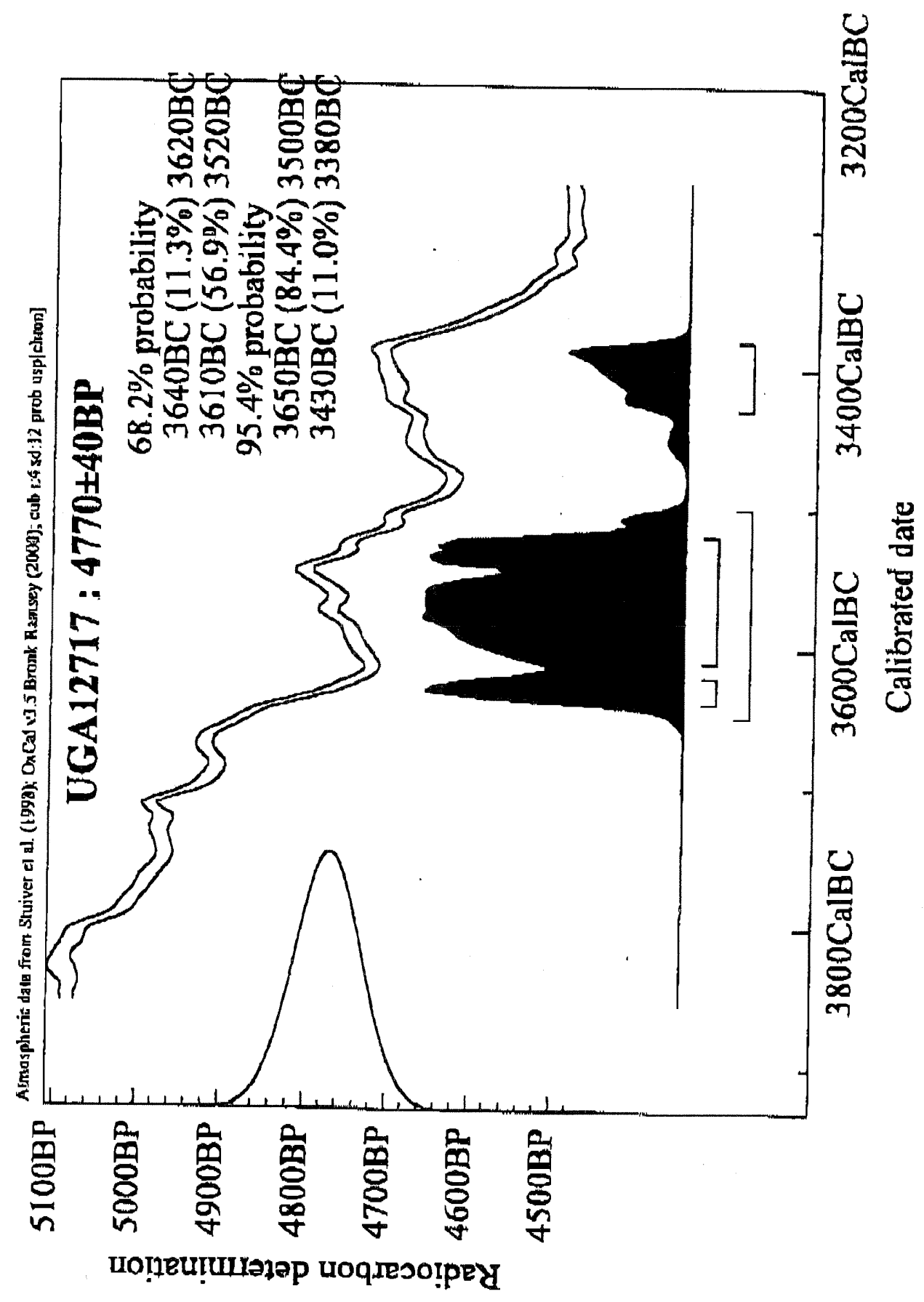




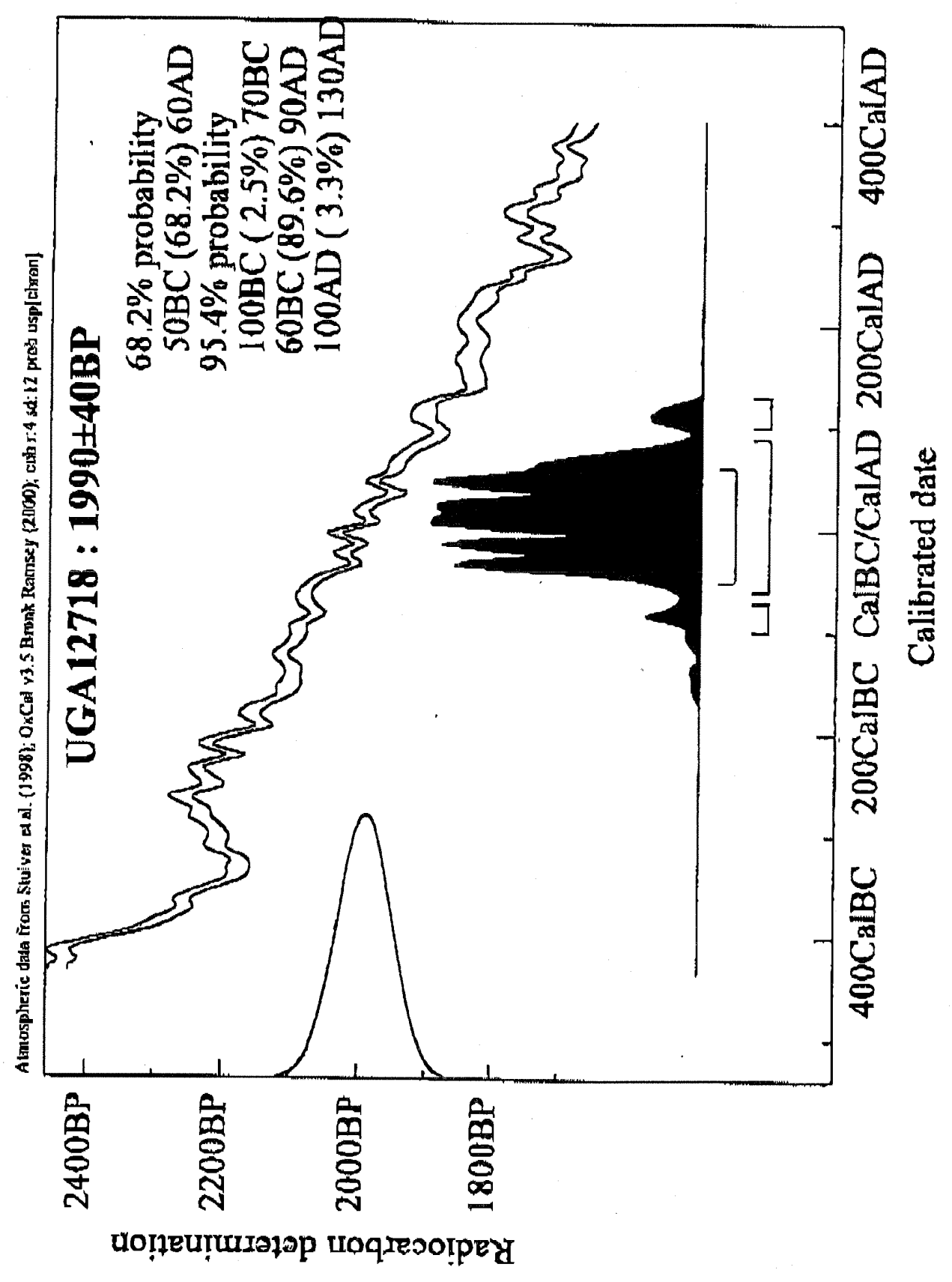




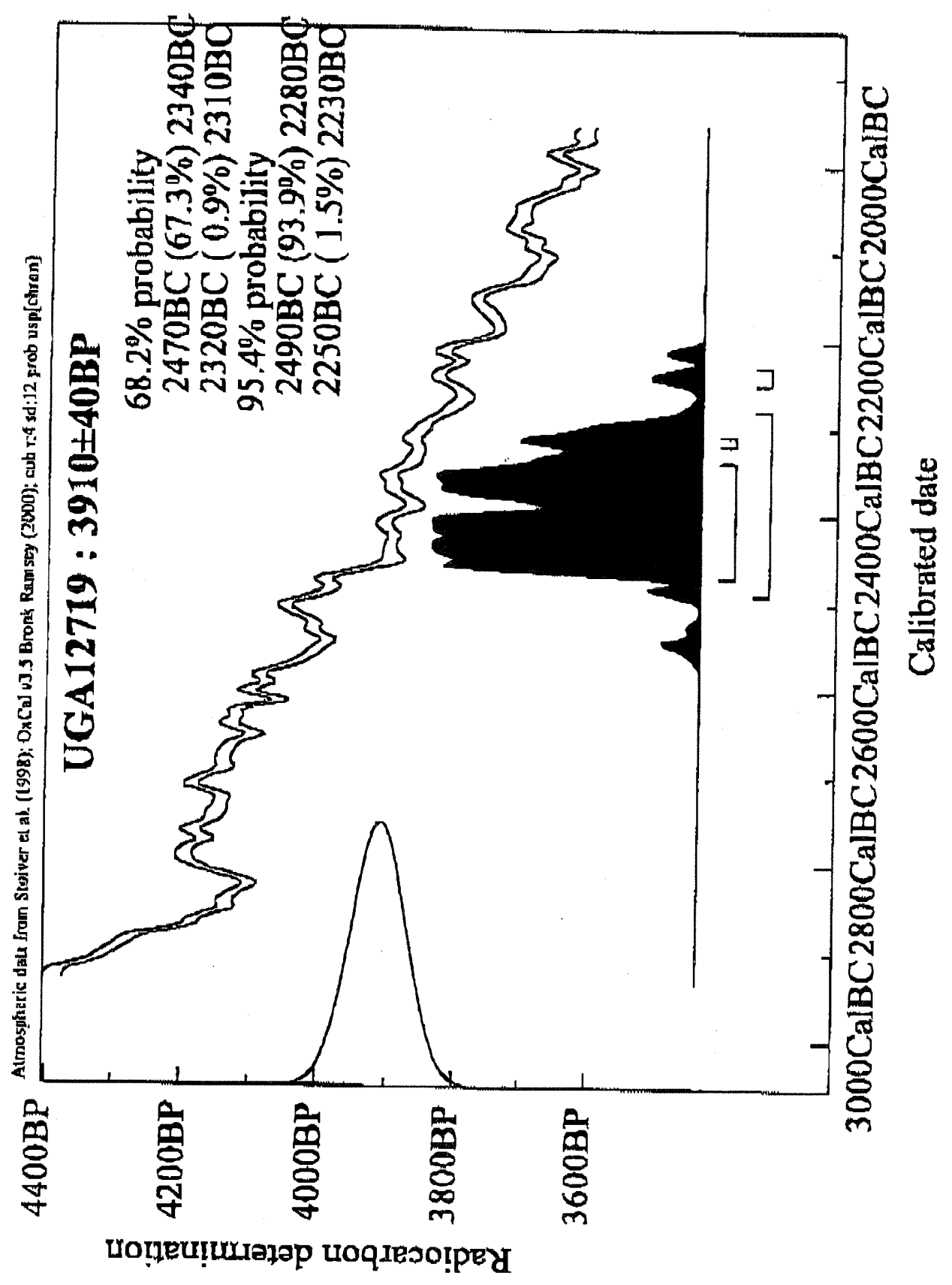




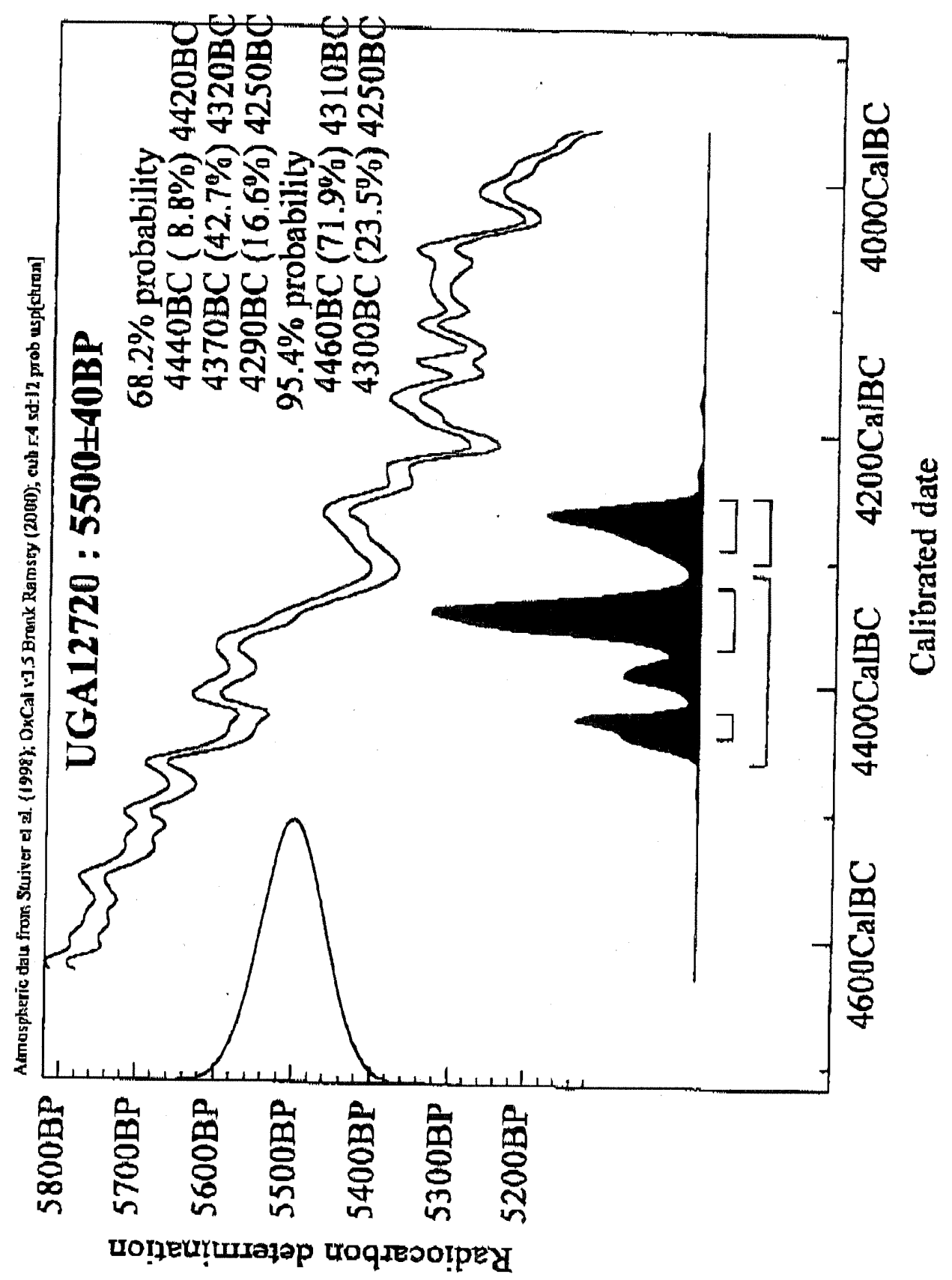




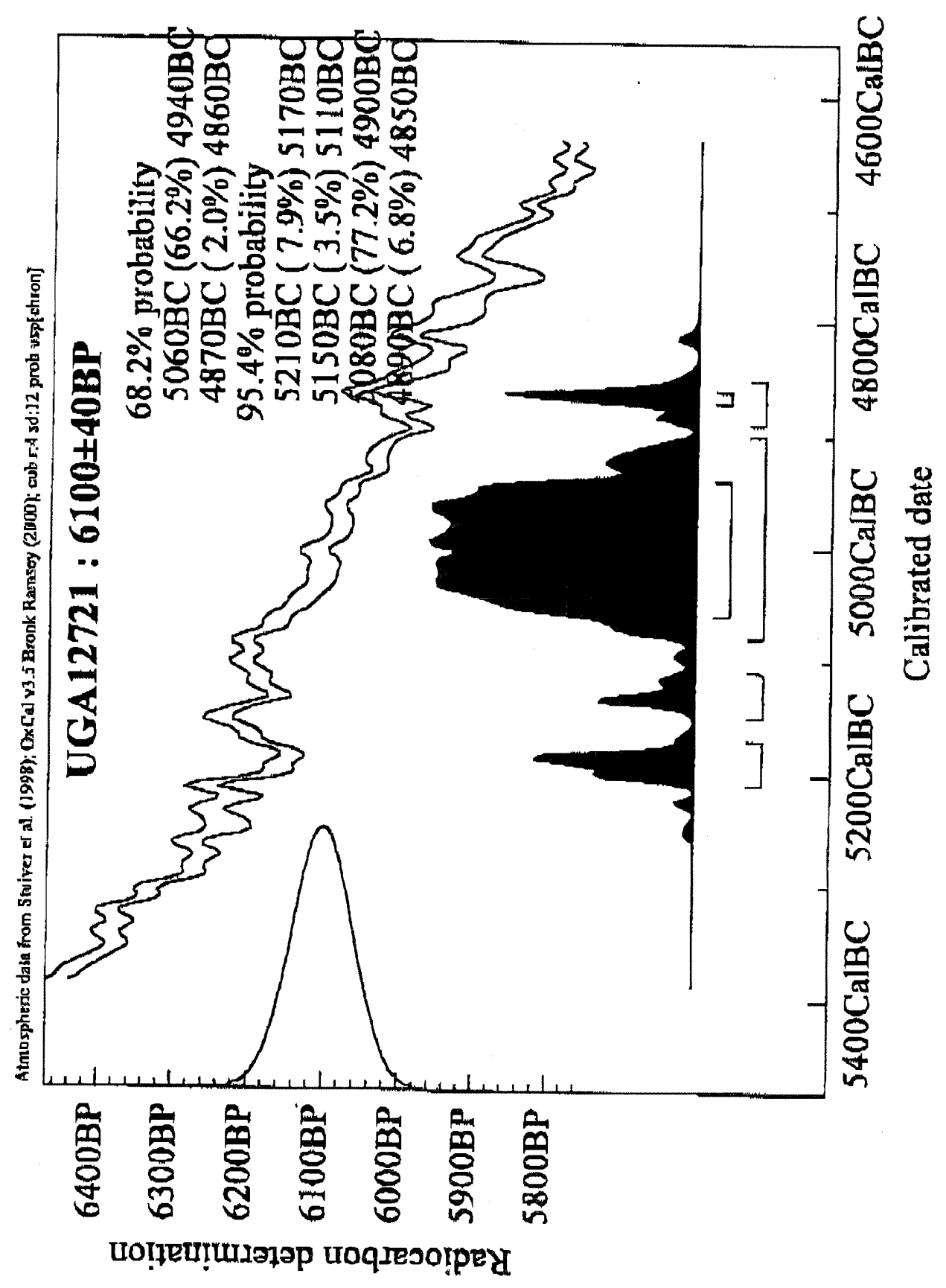




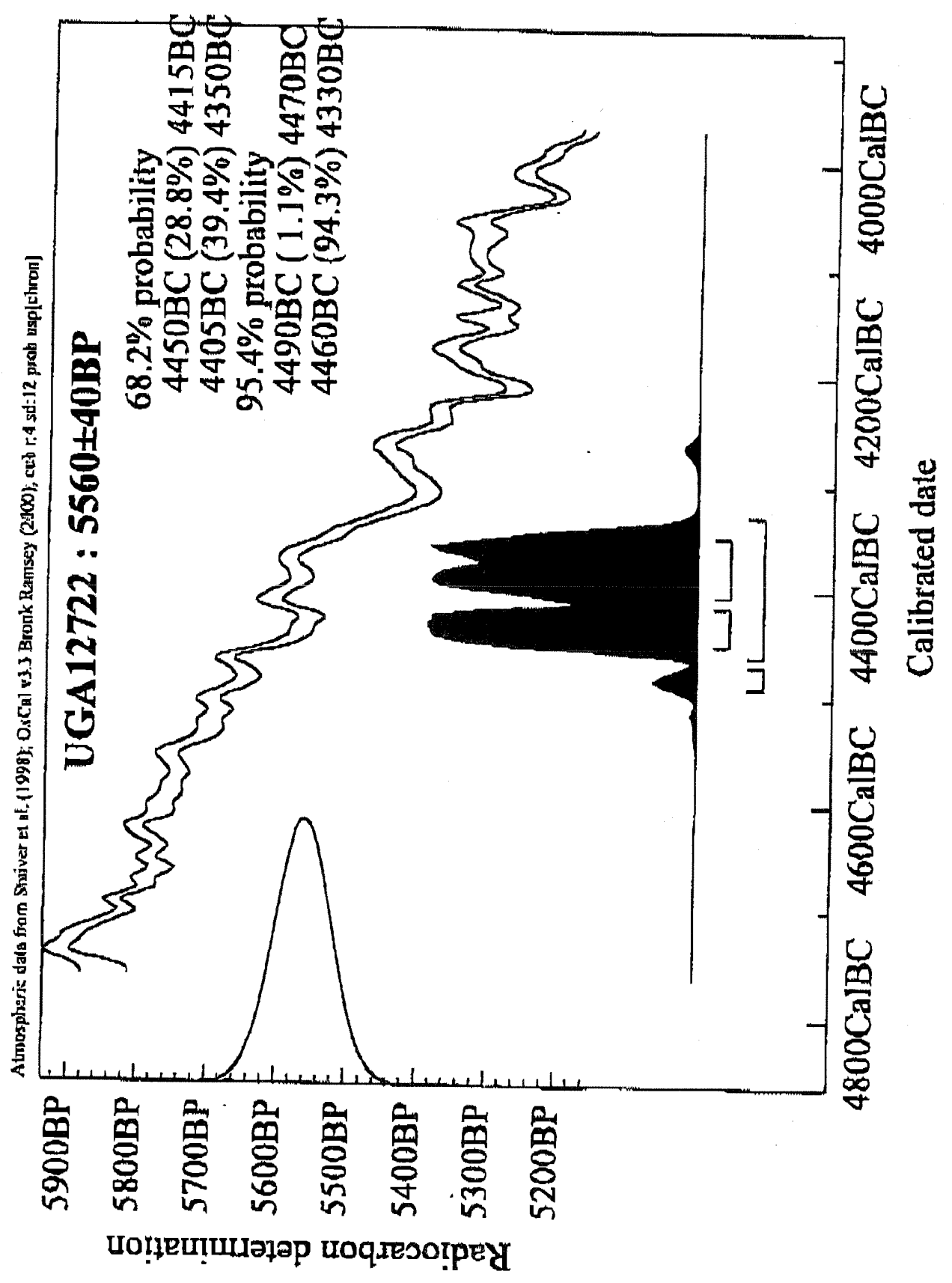




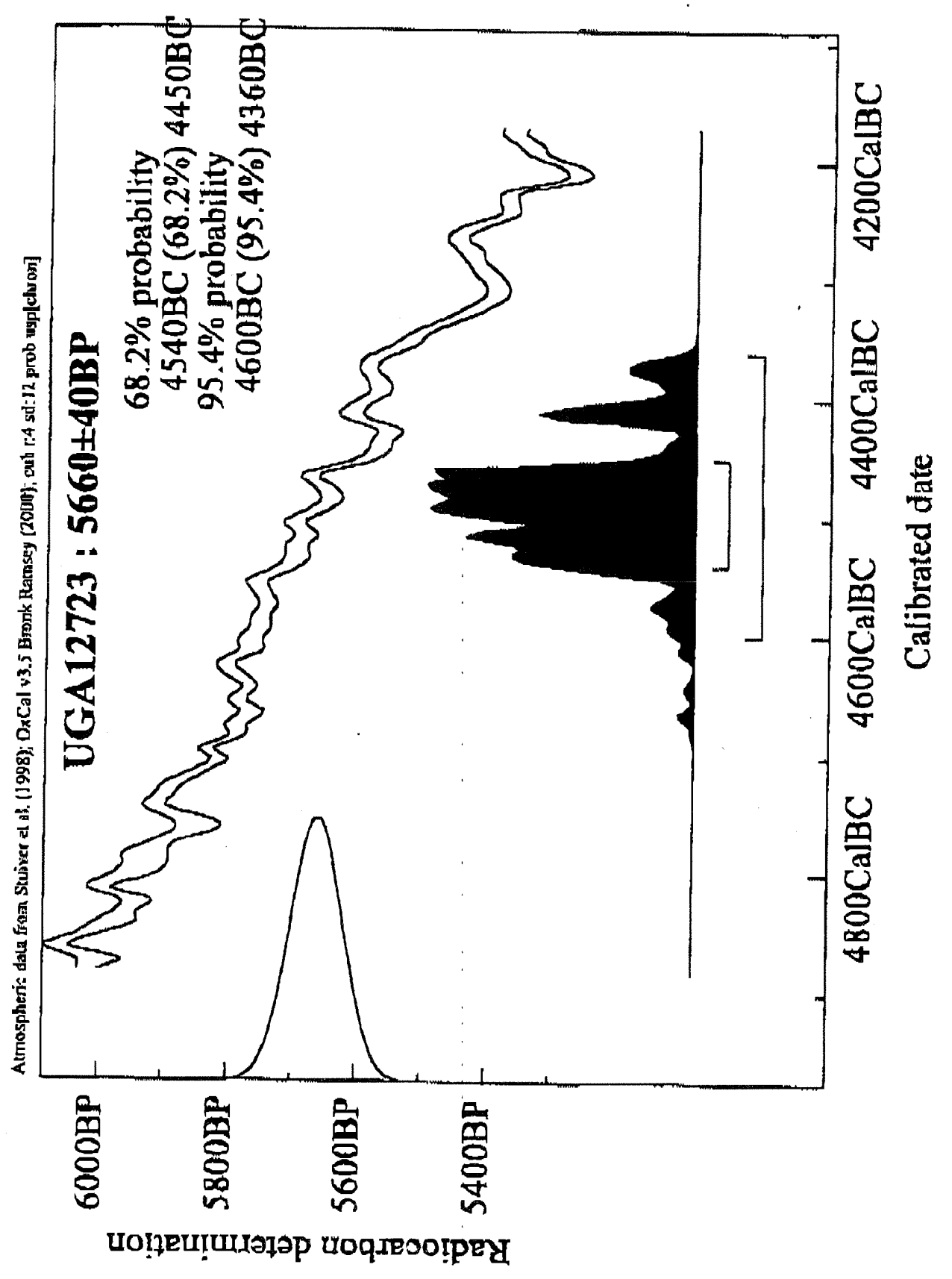




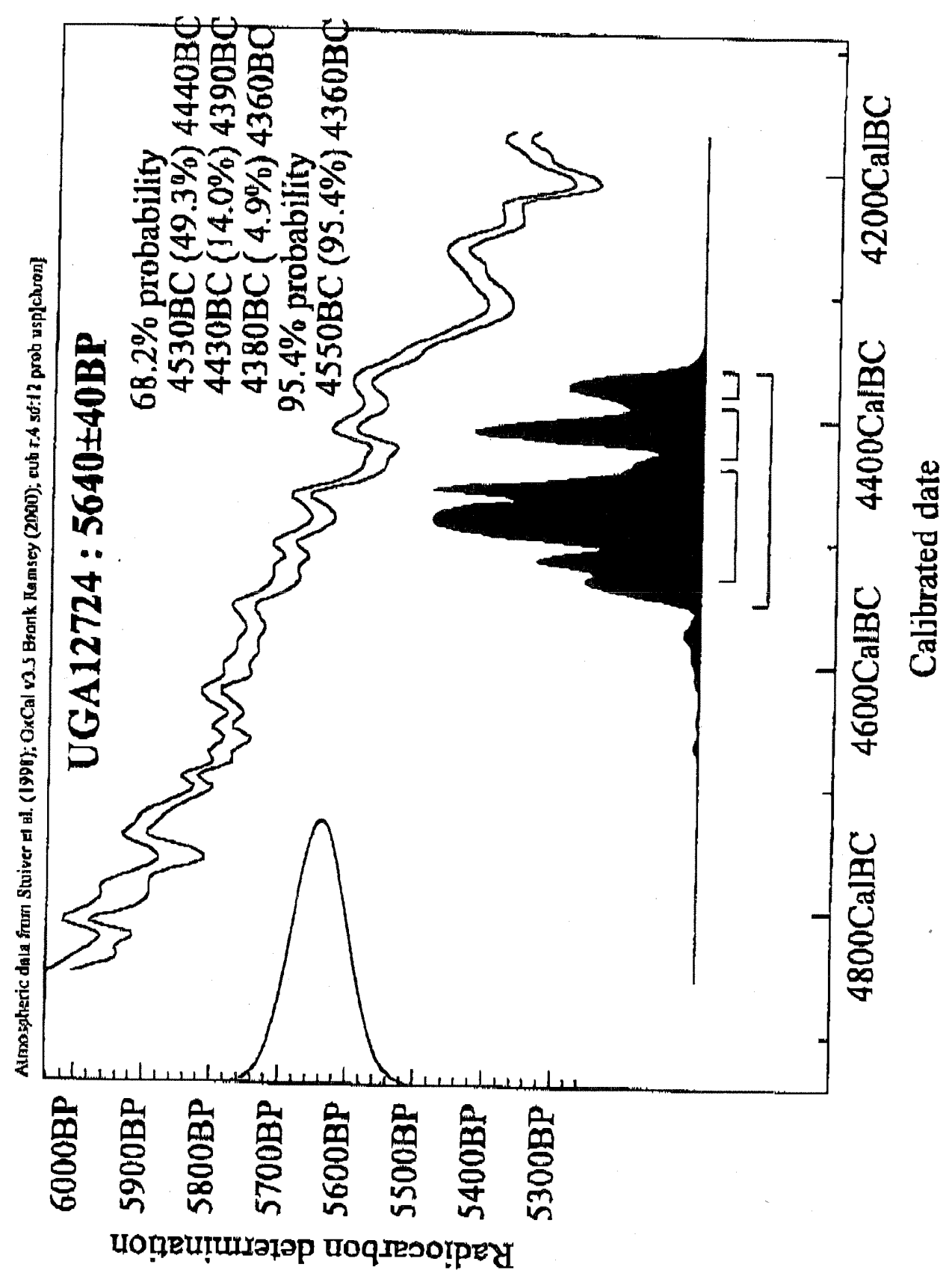




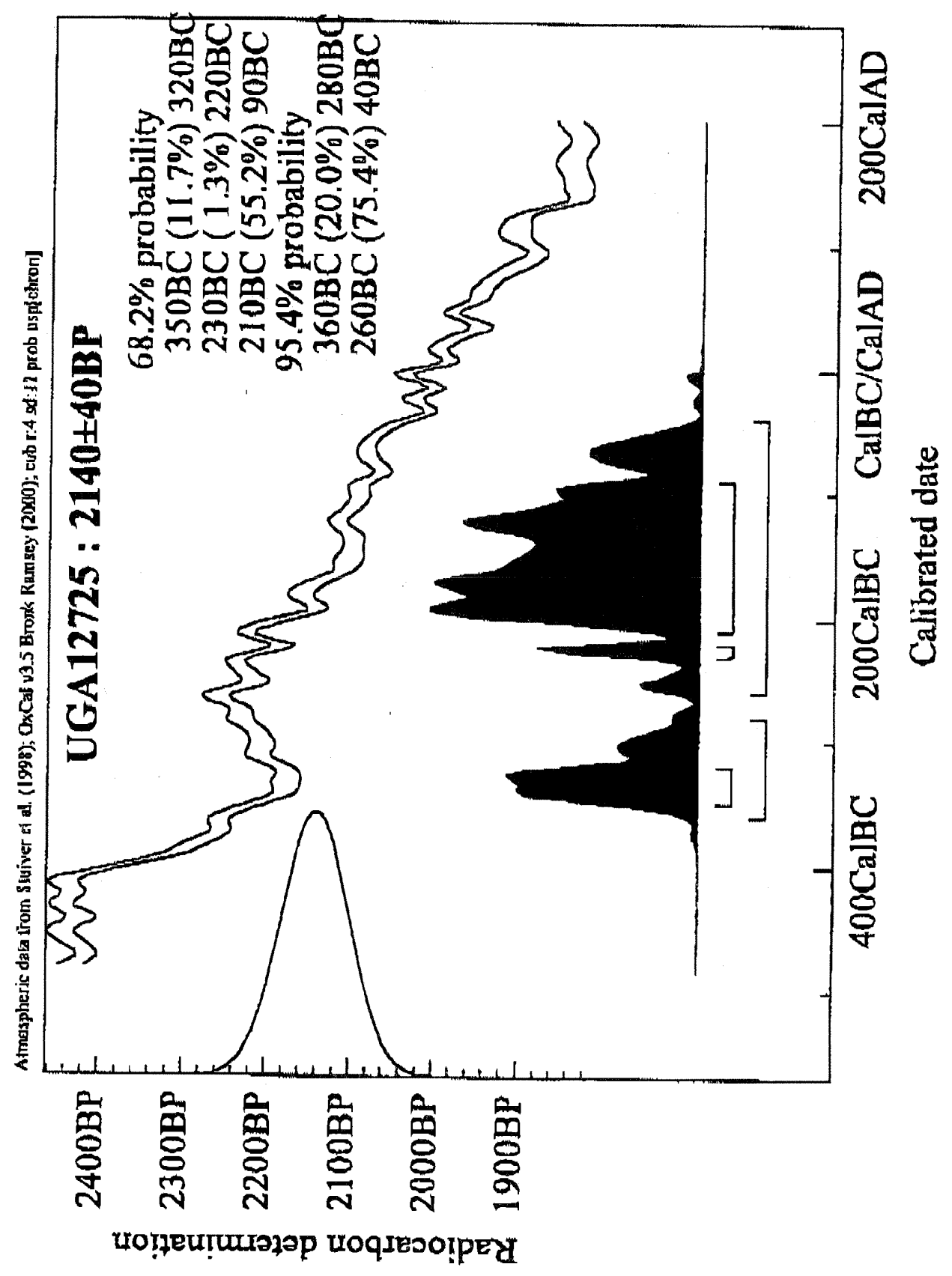




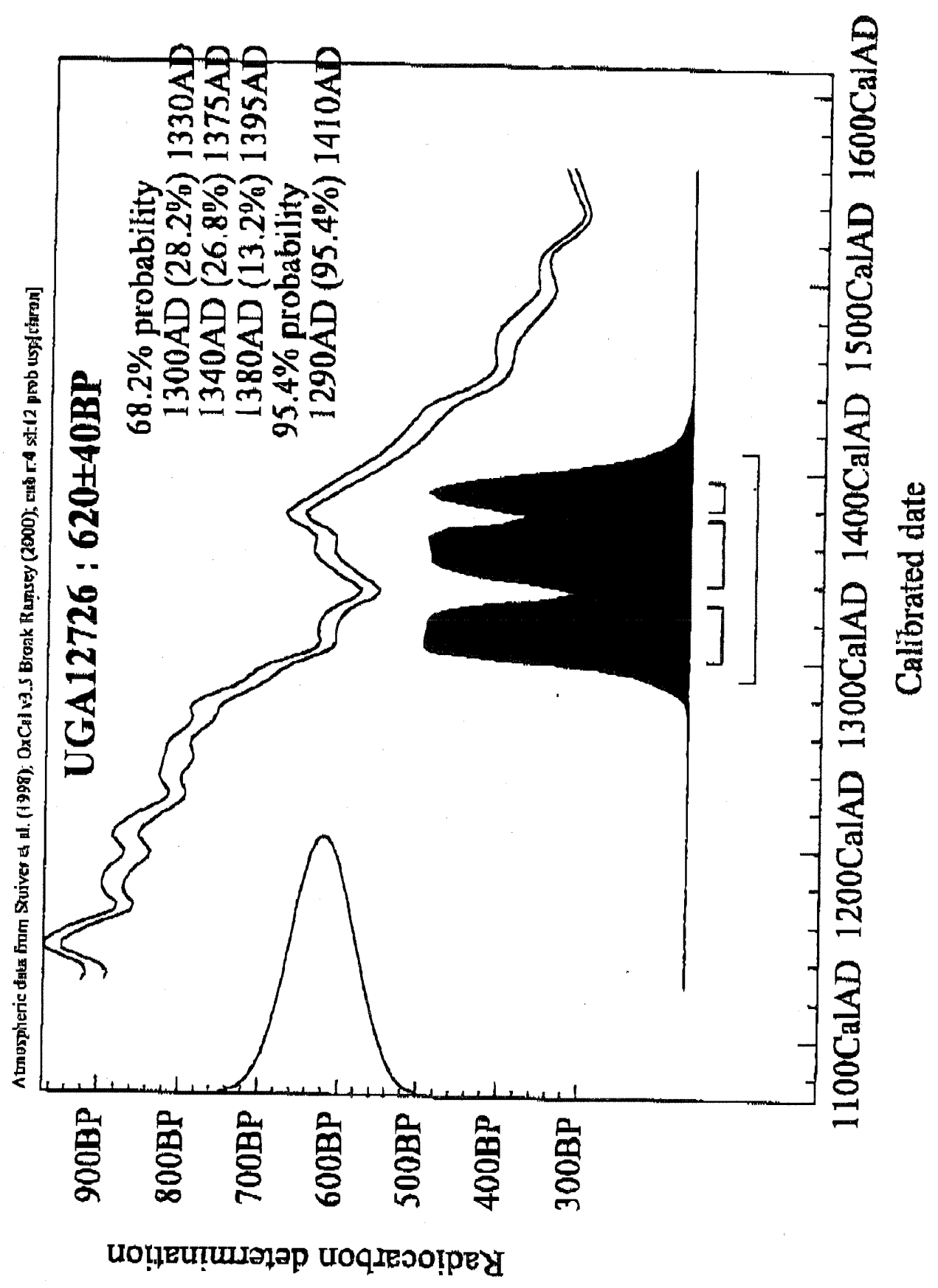




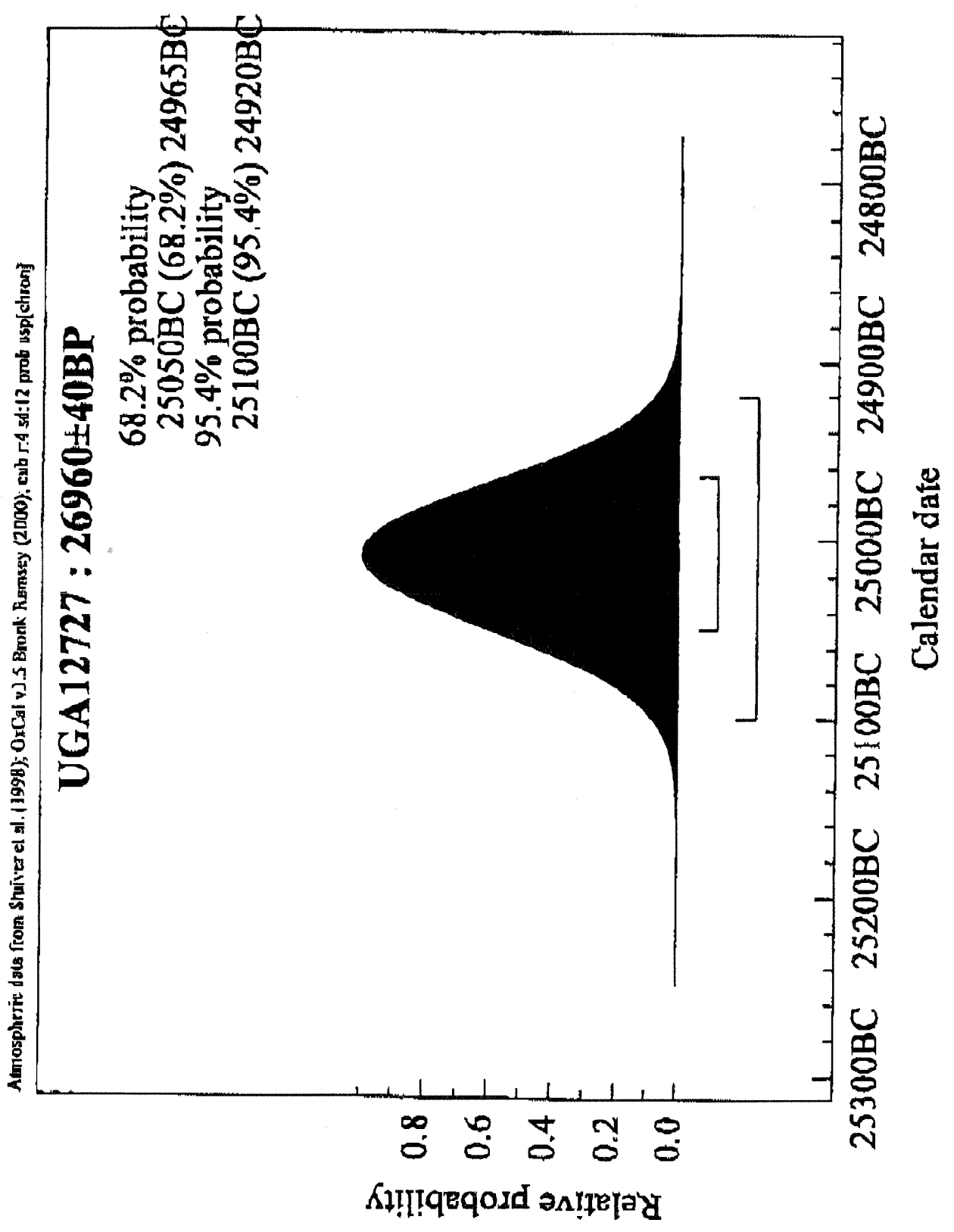




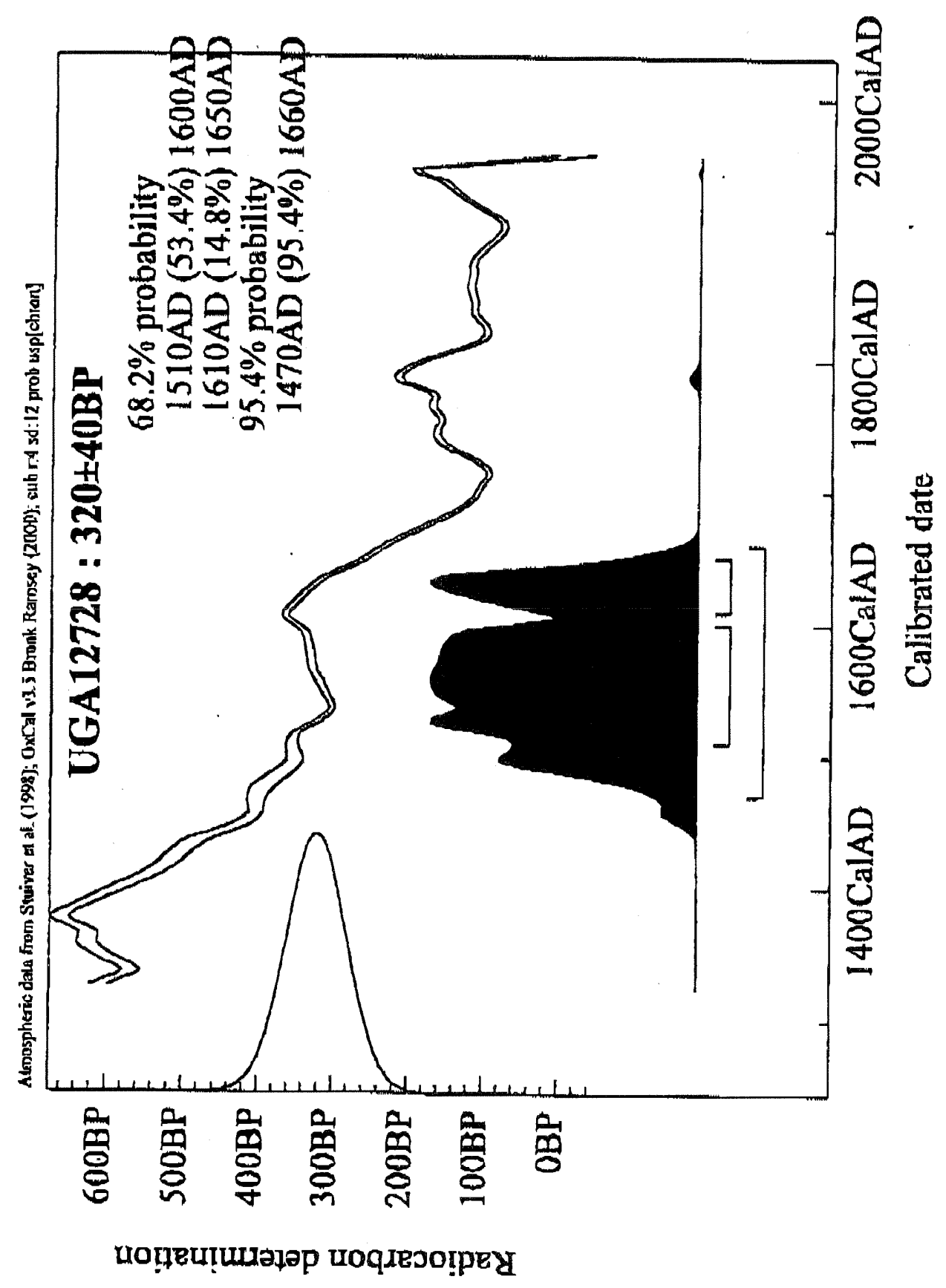




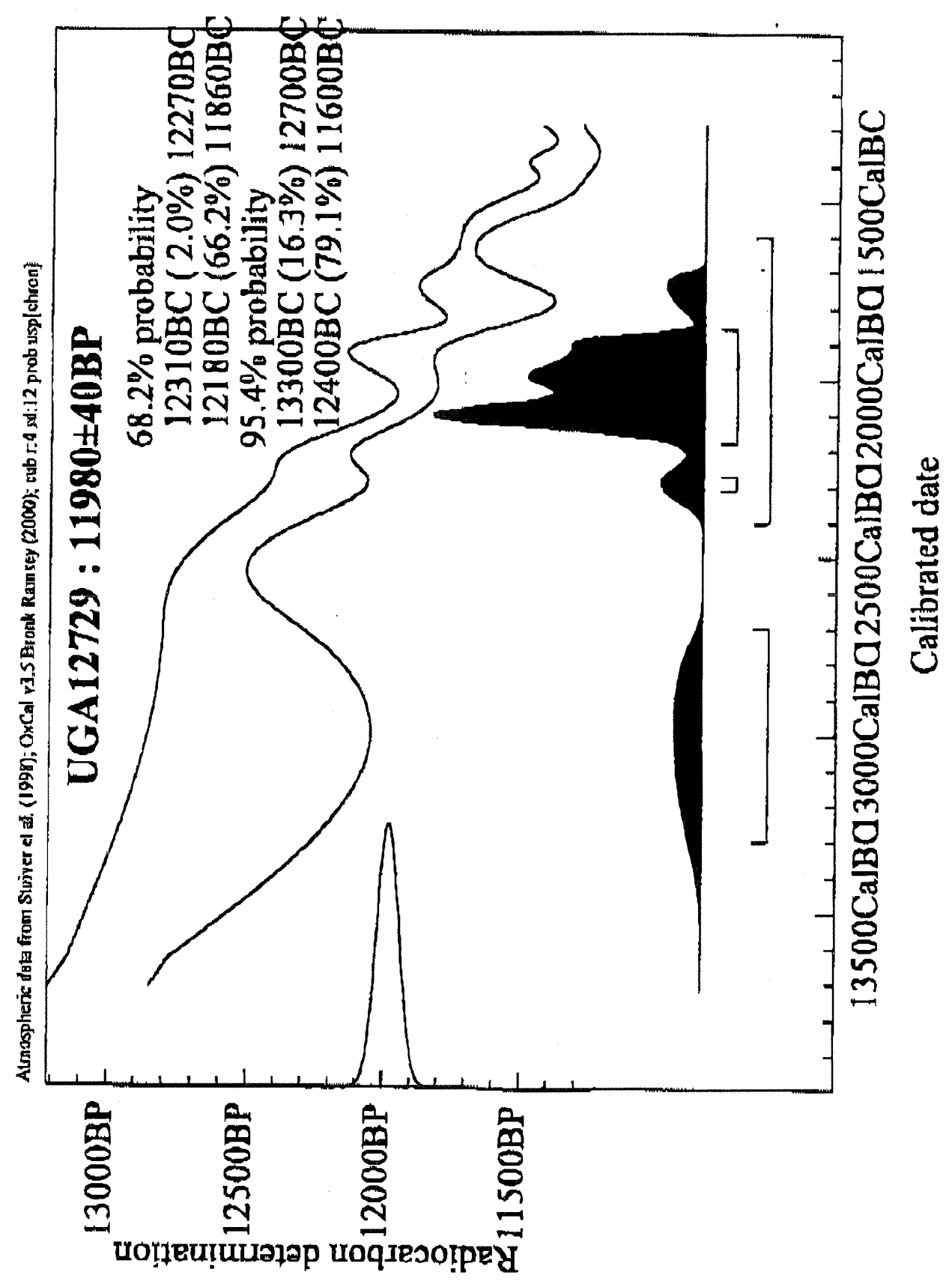




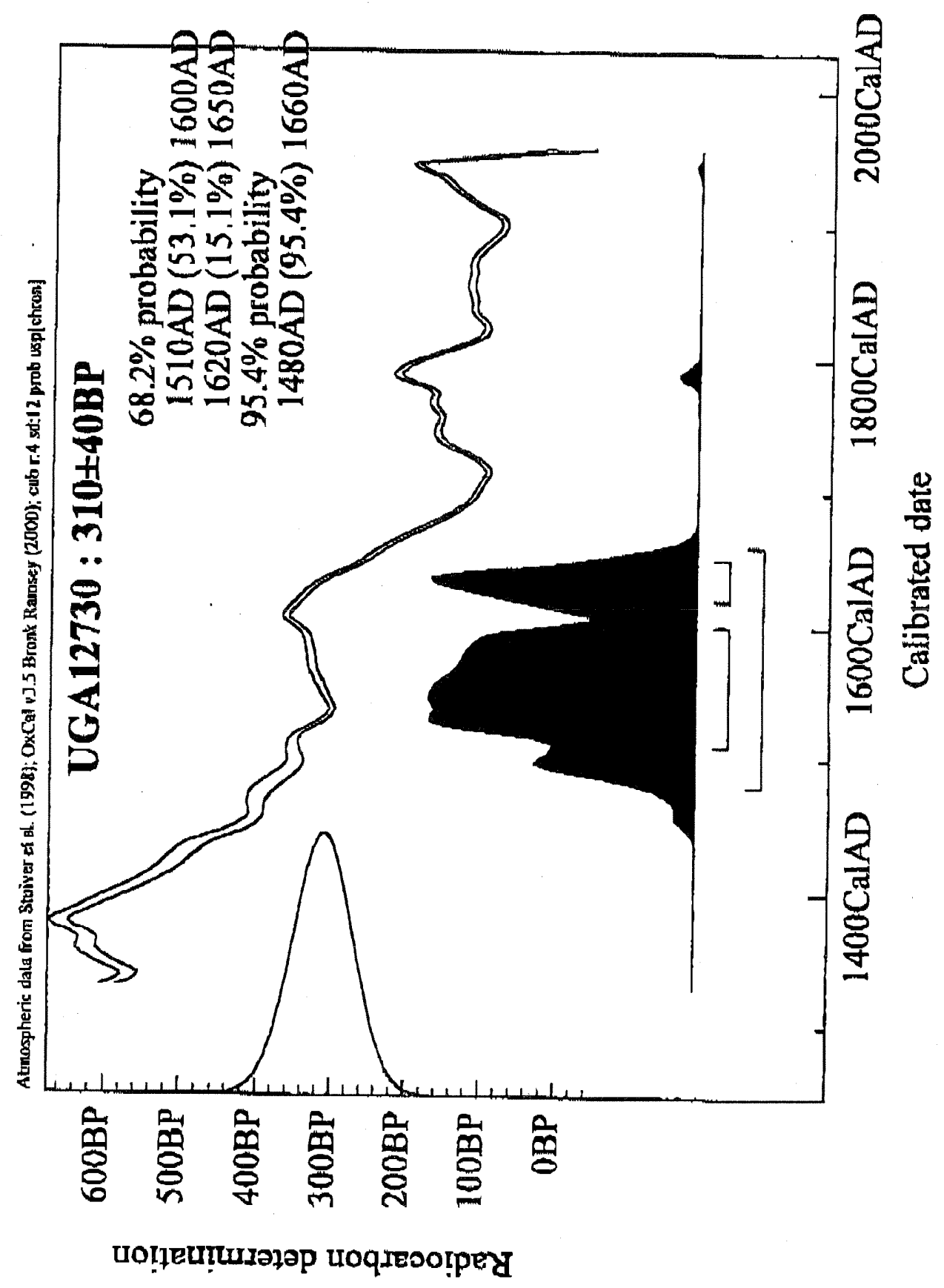




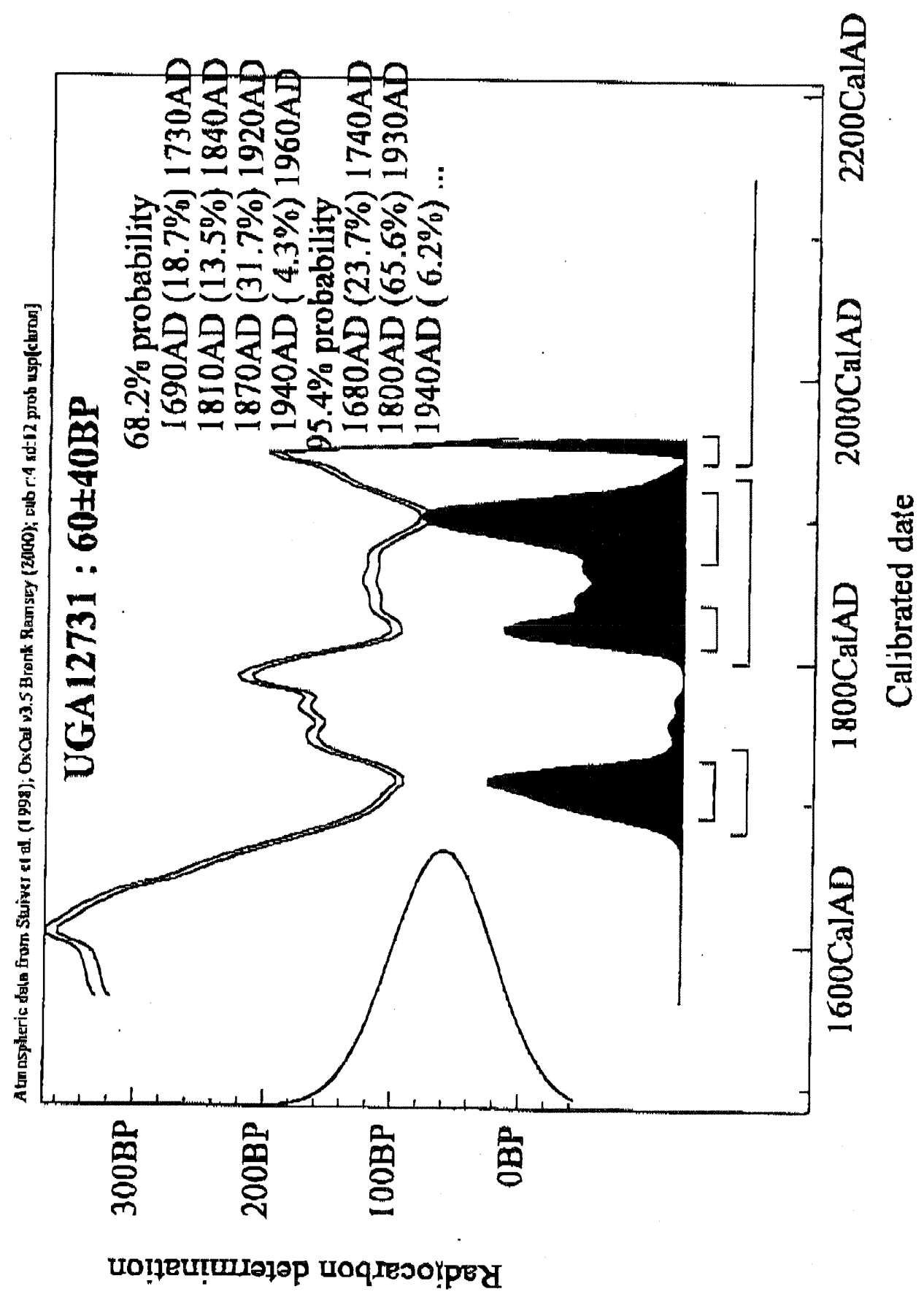




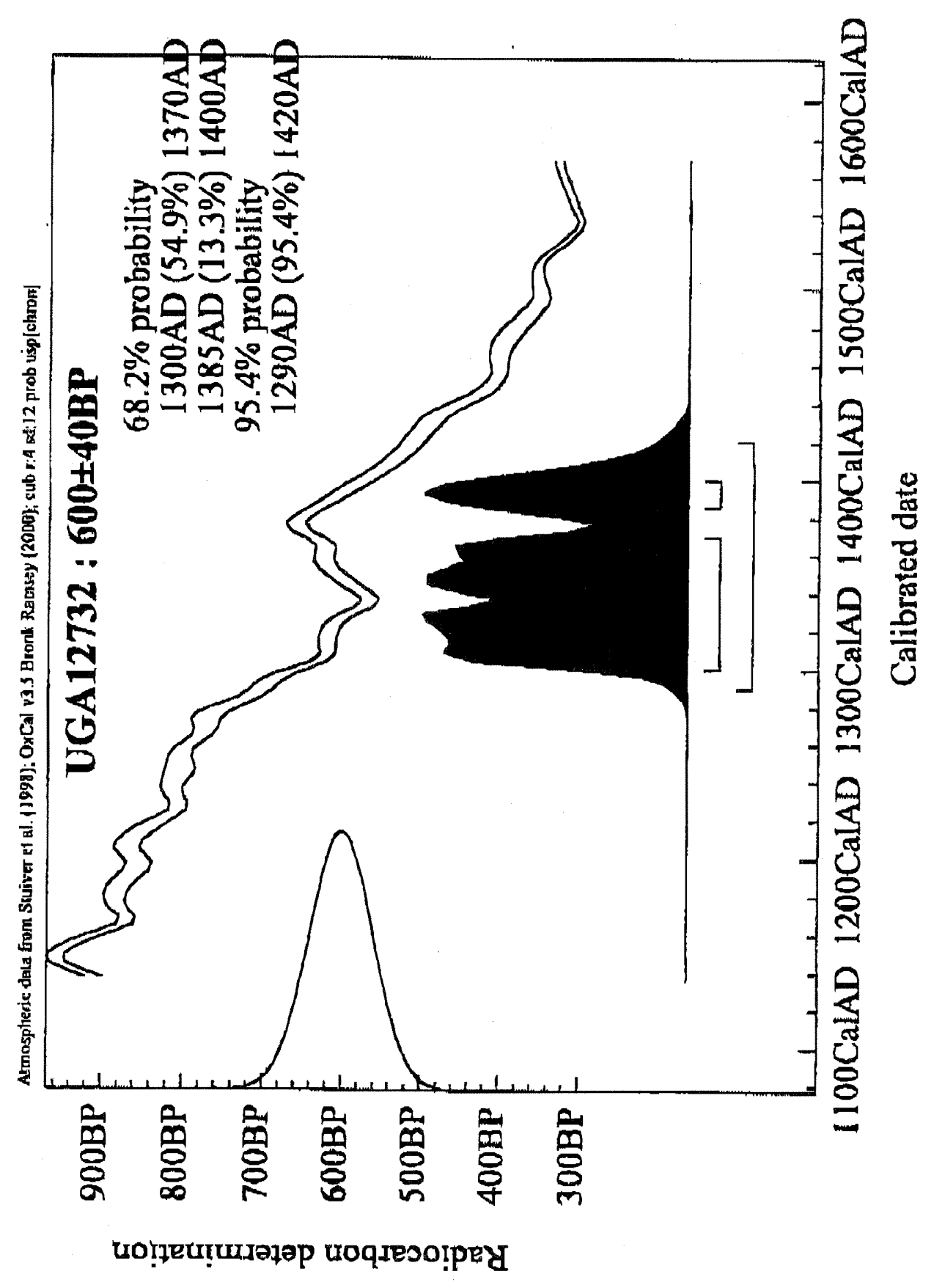




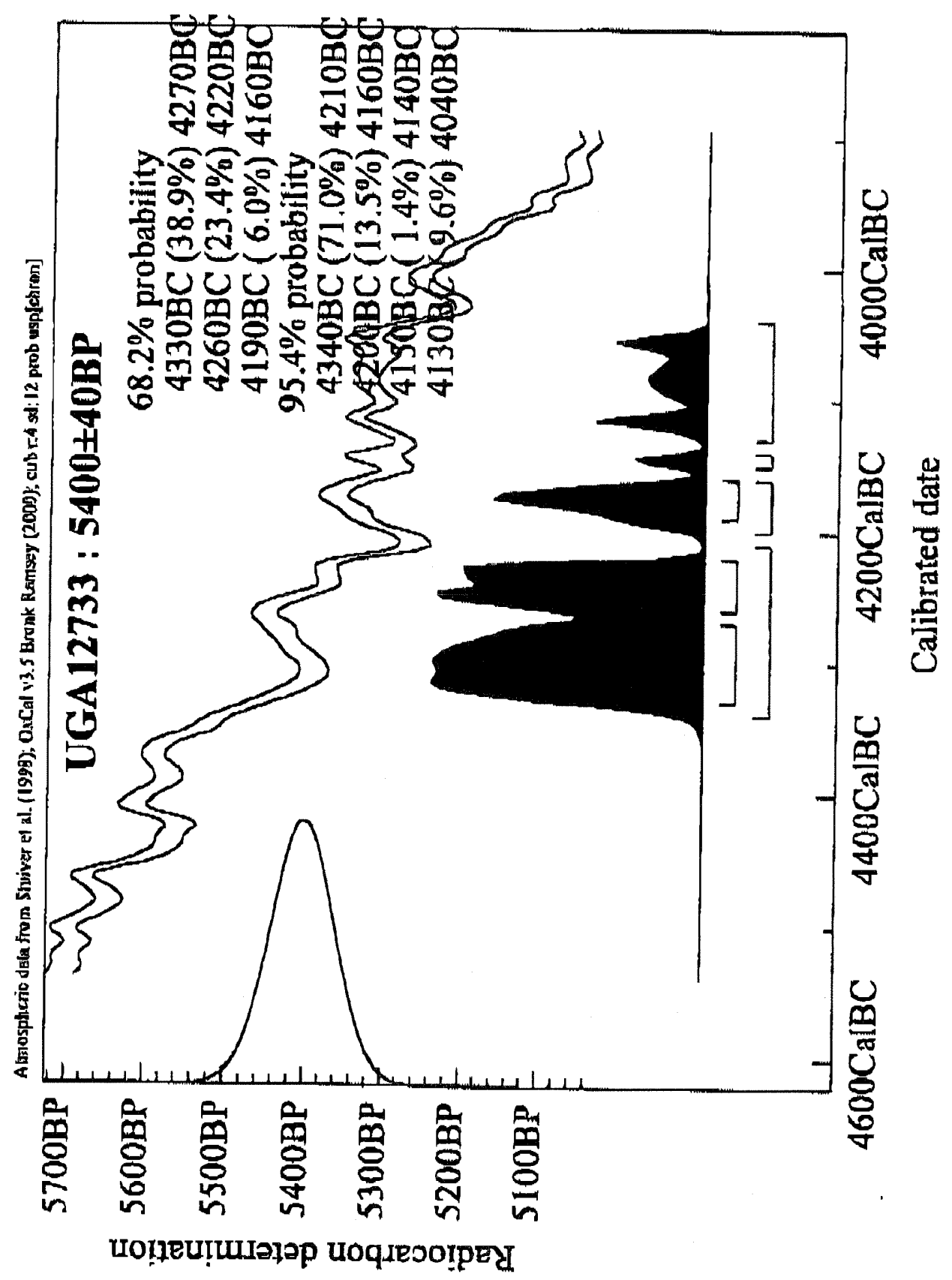




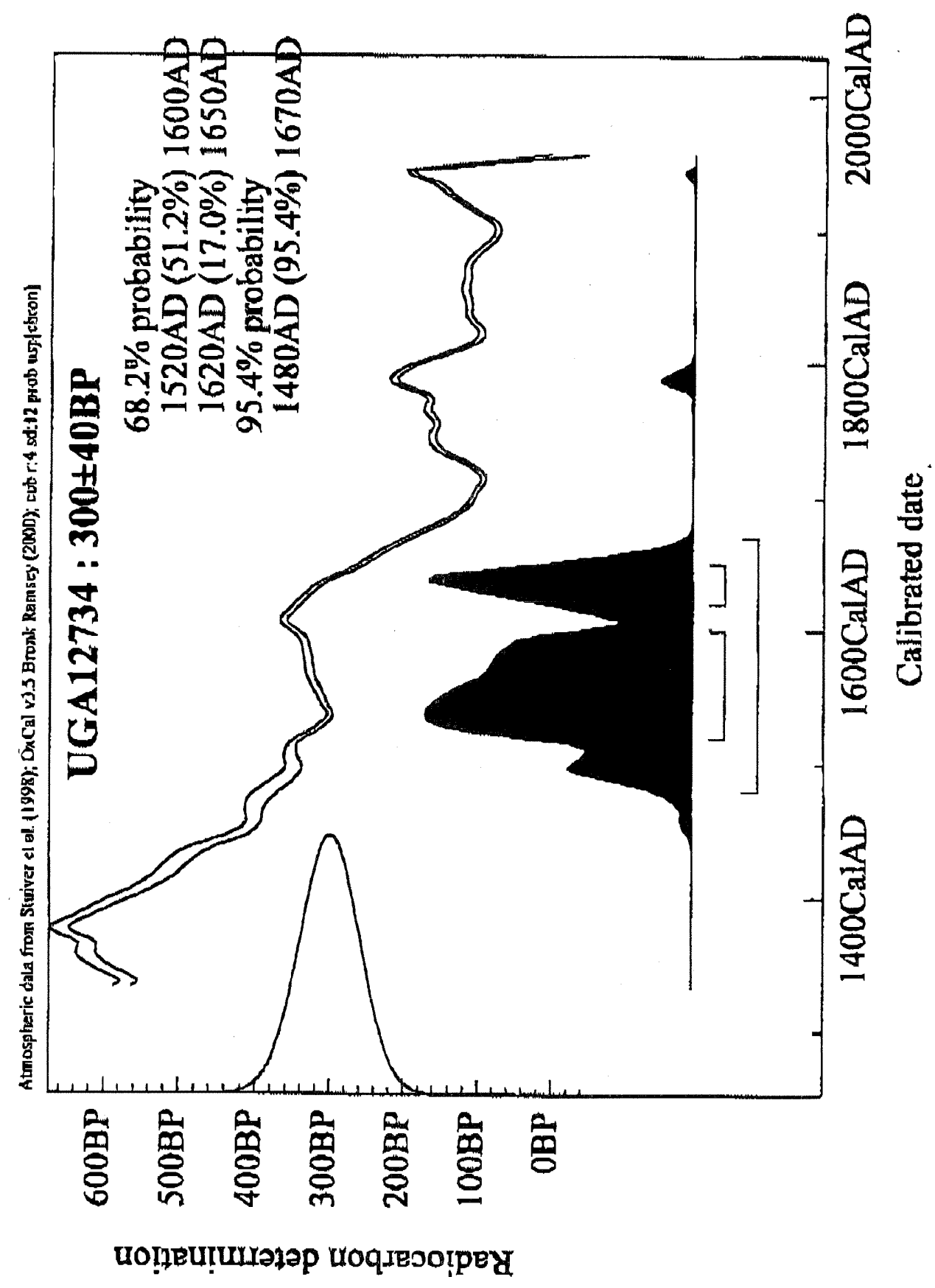




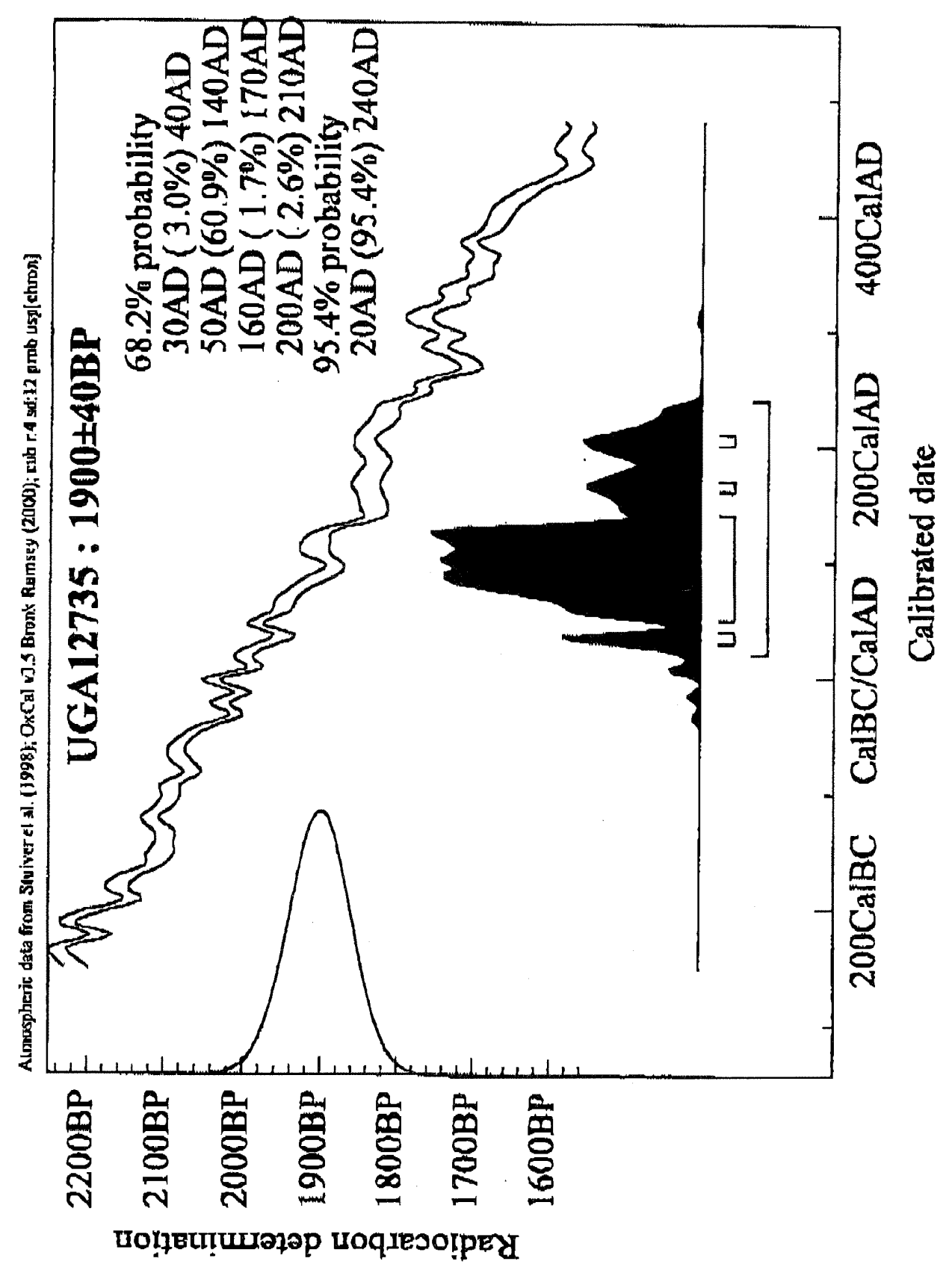




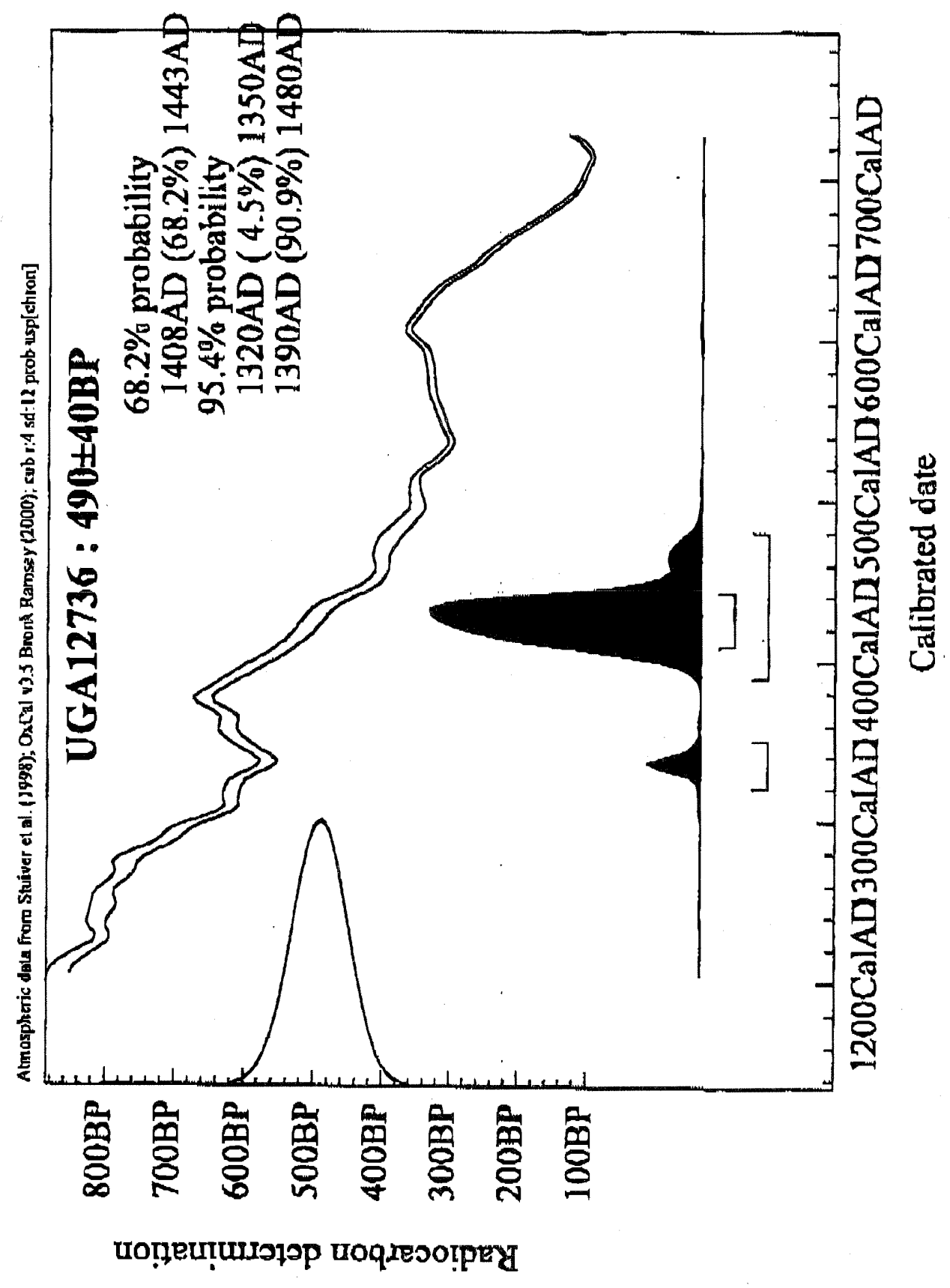




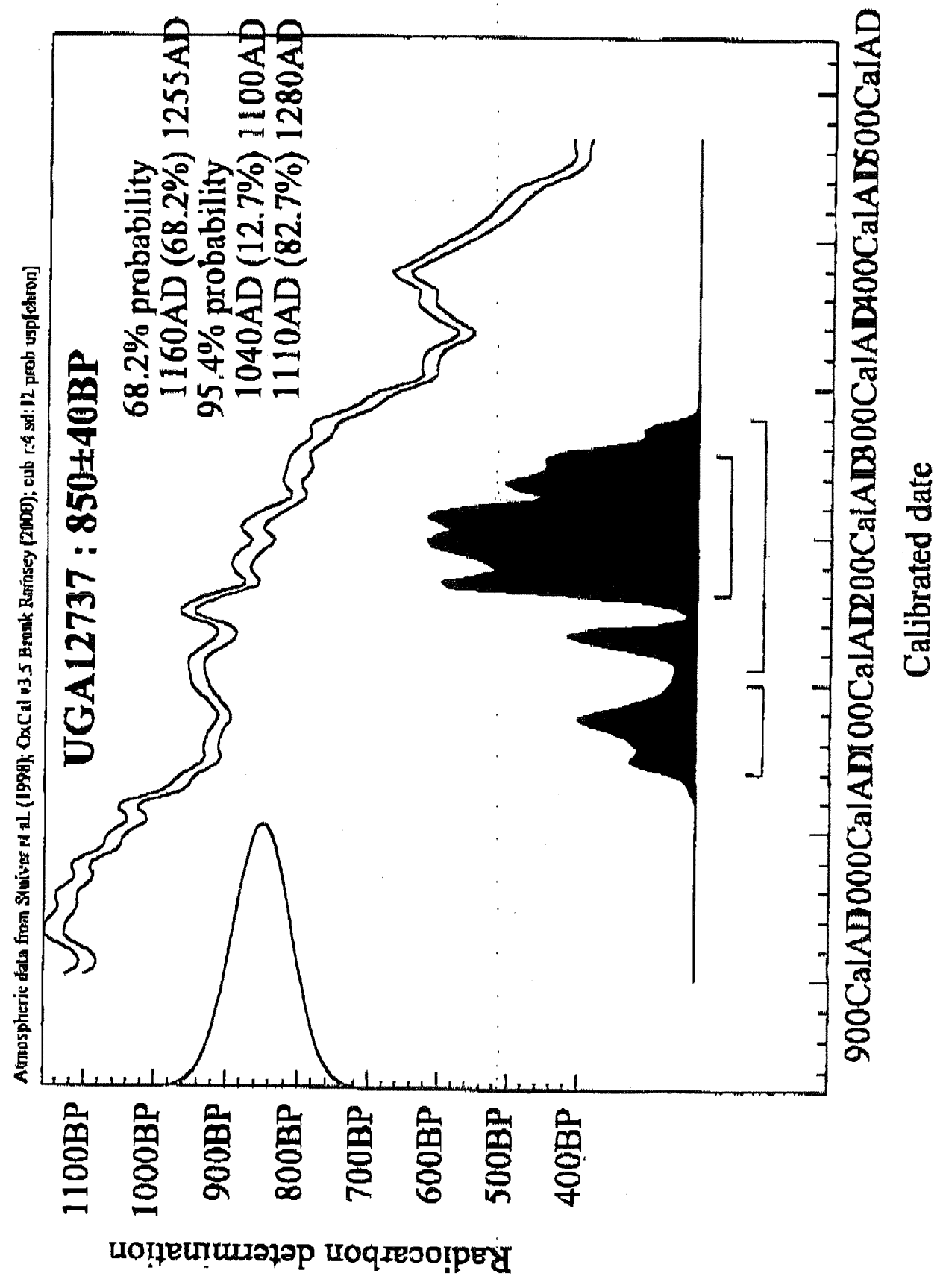




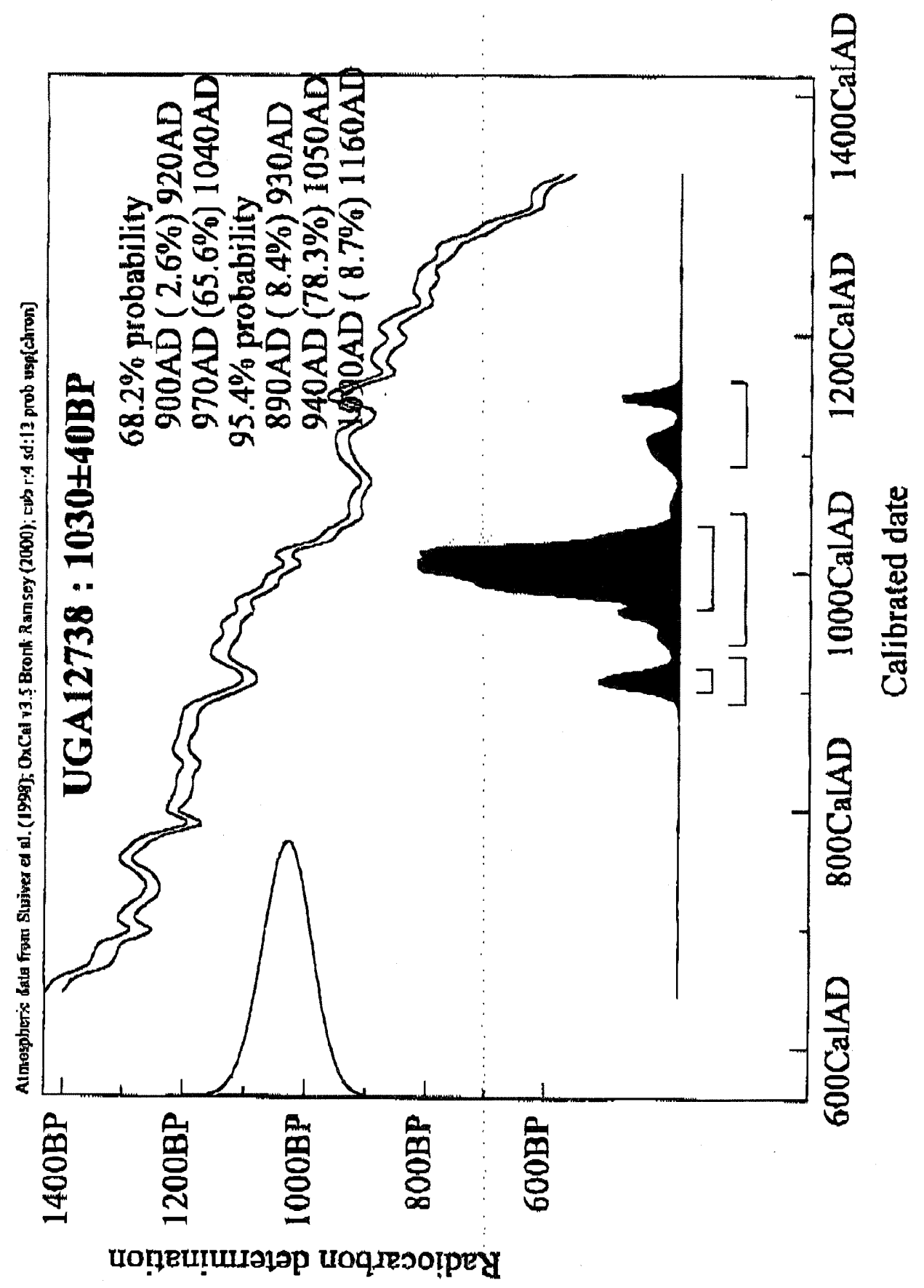




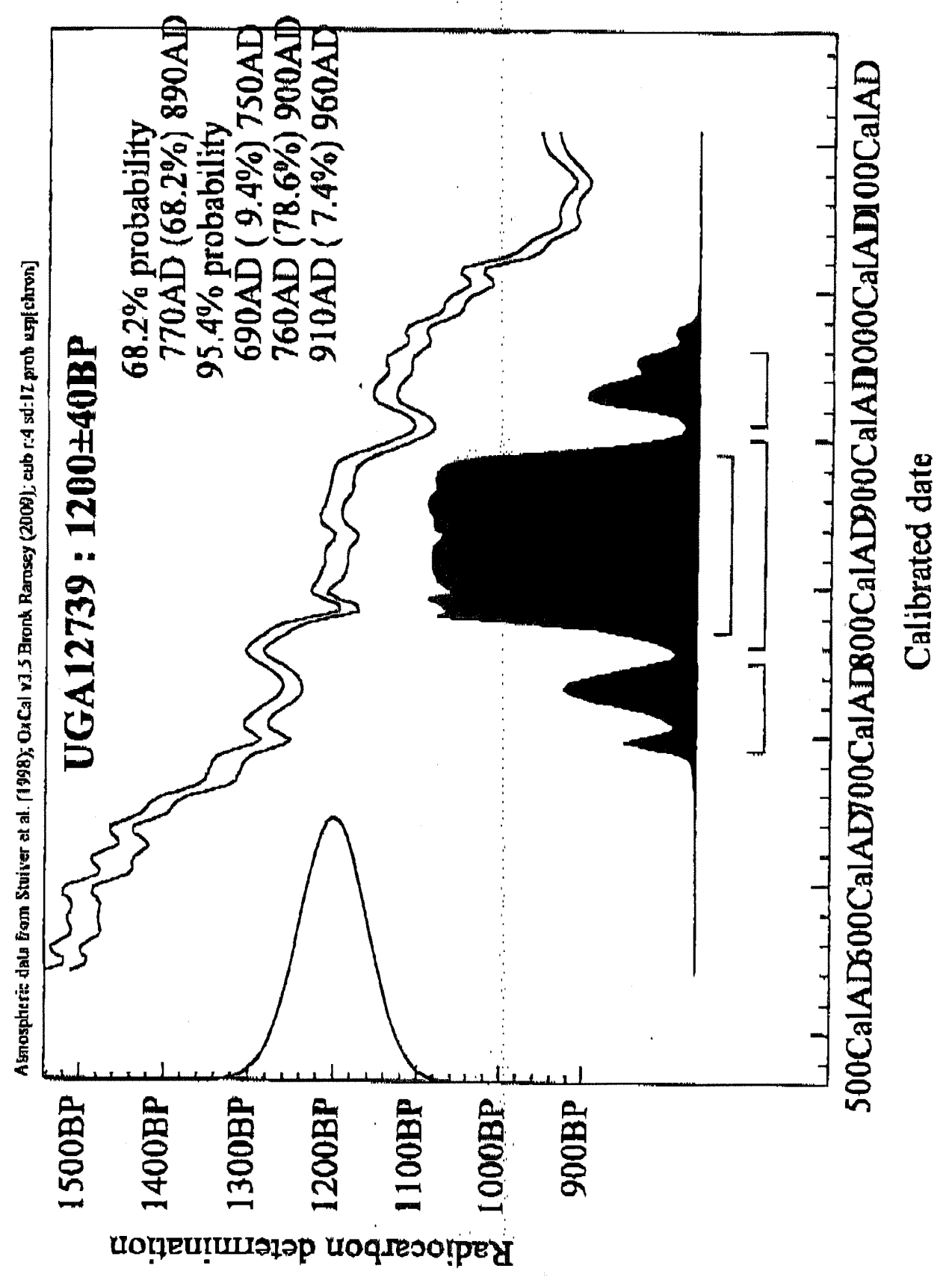




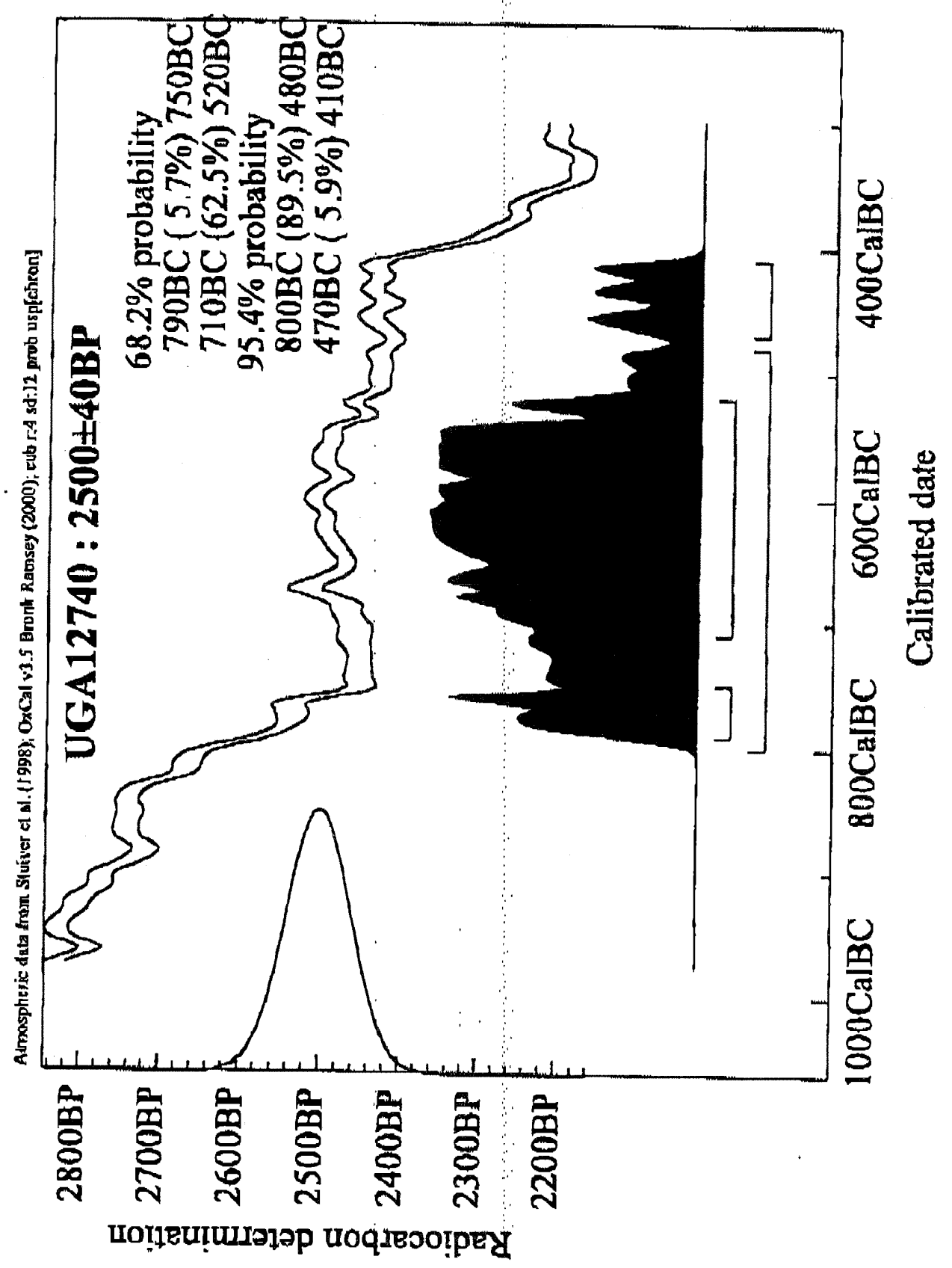




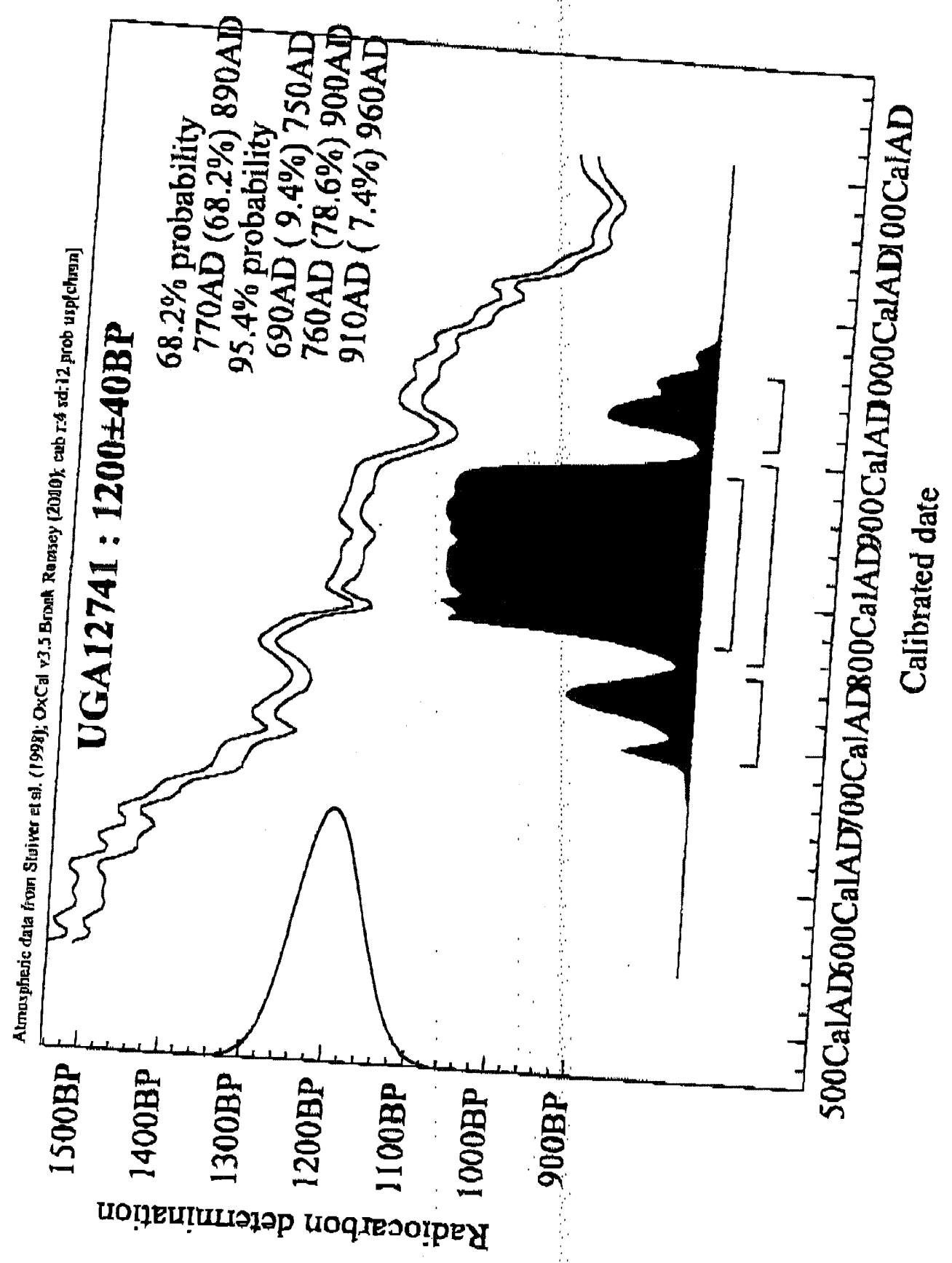


APPENDIX C:

RESULTS OF MICROSCOPIC USE-WEAR AND RESIDUE ANALYSES FROM THE VARGA SITE 41ED28, TEXAS 



\section{RESULTS OF MICROSCOPIC USE-WEAR AND RESIDUE ANALYSES FROM THE VARGA SITE 41ED28, TEXAS}

By:

Bruce L. Hardy, Ph.D.

Prepared for:

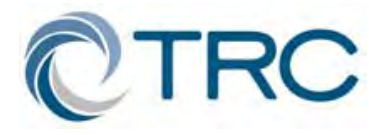

TRC Environmental Corporation

505 East Huntland Drive, Suite 250

Austin, Texas 78752

Prepared by:

Bruce L. Hardy, Ph.D.

Department of Anthropology

Grand Valley State University

Allendale, MI 49401

April 19, 2004 



\section{C.1 INTRODUCTION}

A sample of 154 artifacts from the Varga Site (41ED28) in southwest Texas was analyzed microscopically for evidence of residues and use-wear. The Varga Site is a multi-component site ranging in age from ca. 170 to 6300 B.P. The youngest component is referred to as Toyah and dates from approximately 170 to 700 B.P. Directly underneath the Toyah component is a Late Archaic component (ca. 1700 to 2200 B.P.) characterized by a large cluster of burned rocks (6 $\mathrm{m}$ wide). An underlying Middle Archaic component dates from 3900 to 4820 B.P. and probably represents multiple events accumulated over a long period of time. The lowest archaeological level at the site is a $30 \mathrm{~cm}$ thick Early Archaic component that dates between ca. 5200 and 6300 B.P. The vast majority of these artifacts were not washed prior to analysis.

Typologically, the sample includes edgemodified flakes, bifaces, scrapers, gouges, spokeshaves, drills, gravers, and a variety of different styles of projectile points. Stone tool type and function are not necessarily linked. Scrapers, for example have been shown to have been used in hide processing (Schultz 1992; McDevitt 1994; Sliva and Keeley 1994; Boszhardt and McCarthy 1999; Petraglia et al. 1996) as well as plant and wood processing (Anderson-Gerfaud 1990; Hardy and Garufi 1998; Hardy and Kay 1999; Hardy et al. 2001). Different styles of projectile points may likewise have performed various functions (Shea 1992; Hardy and Kay 1998; Hardy et al. 2001).

\section{C.2 Methods}

All artifacts were examined using bright field reflected light microscopy at magnifications ranging from 100 to 500 diameters using an Olympus BX-30 microscope for the presence of residues or wear related to use. Artifacts were examined in the condition in which they arrived in order to identify potential residues, which can sometimes survive artifact washing. Line drawings of each artifact were used to record the location of any wear or residues. All residues and wear patterns were photographed and compared with experimental and published material for identification (Anderson-Gerfaud 1990; Beyries 1988; Brunner and Koman 1974; Fullagar 1991; Hardy 1994; Hardy and Garufi 1998; Hoadley 1990; Hather 1993; Kardulias and Yerkes 1996). Potentially recognizable residues include animal (hair, feather, skin, bone, antler, and blood) and plant (starch grains, cellular tissue, wood fragments, and phytoliths) material (Anderson 1980; Anderson-Gerfaud 1981, 1986, 1990; Barton et al. 1998; Briuer 1976; Fullagar and Field 1997; Gorski 1997; Hardy 1994; Hardy 1998; Hardy and Kay 1998; Hardy and Garufi 1998; Hurcombe 1992; Jahren et al. 1997; Kealhofer et al. 1999; Loy 1983, 1986, 1993; Loy and Wood 1989; Loy and Hardy 1992; Loy et al. 1992; Shafer and Holloway 1979; Sobolik 1996). Use-wear identification concentrated on striations, polish, and edge rounding to help identify the area of an artifact that was used and the use-action. Usewear was not used to identify specific usematerials beyond the level of hard/high silica vs. soft material (Fullagar 1991). Hard/high silica material includes bone, antler, wood and high silica plants such as certain grasses. All of these materials produce polish, which is highly reflective with high areas rounded or domed. In the case of hard materials (antler, bone, and wood), the polish is most likely produced by abrasion and subtraction of material from the surface. High silica plants (grasses, some wood) probably produce the same type of polish through the addition of silica to the tool surface. It is extremely difficult to distinguish between these types of polish without other functional evidence (Fullagar 1991). The soft category includes animal tissue other than bone (hide, 
muscle, hair) as well as plants that are not highly siliceous.

\section{Use-actions}

Use-actions were determined based on the distribution of use-wear, particularly striations, and residues on the tool surface. Use-actions include scraping, planning, slicing, whittling, boring, and cutting. These use-actions conform to common definitions used in lithic functional analysis literature (Keeley 1980; MansurFranchomme 1986). Boring may also be referred to as perforating. Cutting indicates that an edge was clearly used, but the orientation and direction of use is indeterminate. Direction of use is indicated by two parallel lines $(\|)$ to indicated use was parallel to the long axis while actions perpendicular to the long axis is indicated by a symbol $\perp$.

\section{C.3 Results}

Toyah Component ca. 290 to 700 B.P. $(n=57)$

The Toyah sample is comprised of projectile points (Cliffton, Perdiz, Gurrero, Bonham and leaf-shaped), drills, scrapers, edge-modified rejuvenation flakes, spokeshaves, gravers, bifaces, and edge-modified flakes. Preservation is excellent in the Toyah component. Residues observed include plant remains, starch grains, hair, feather barbules, wood fragments, and possible blood. Table C-1 summarizes the range of findings for each typological category with details on individual tools presented in Table C2.

\section{Late Archaic Component ca. 1700 to 2300 B.P. $(n=17)$}

The Late Archaic sample is composed of bifaces, scrapers, edge-modified flakes, and projectile points (Montell and Edgewood) and one uniface rejuvenation flake. Residues from this component include hair, wood fragments, plant fibers and tissue, and raphides. Raphides are calcium oxalate crystals that can occur in the cells of some plants (Fahn 1982). Because they are high in inorganic components, they often survive well in archaeological settings. Table C3 summaries the range of evidence for each typological category with details on individual tools presented in Table C-4.

\section{Middle Archaic Component ca. 3900 to 4800 B.P. $(n=17)$}

The Middle Archaic sample includes bifaces, scrapers, edge-modified flakes, and Early Triangular points. Residues found in this sample include hair, wood fragments, and plant tissue. Table C-5 summarizes the range of evidence for each tool type with details on individual tools presented in Table C-6.

\section{Early Archaic Component ca. 5200 to 6300 B.P. $(n=63)$}

The Early Archaic sample includes projectile points (Martindale, Bandy, Early Cornernotched [Group 2], Baker, Gower, Untyped Group I), drills, gouges, scrapers, bifaces, unifaces, edge-modified flakes, and rejuvenation flakes. This level preserves numerous residues including raphides, plant tissue, starch grains, plant fibers, wood fragments, bone/antler, hair, possible blood, and charcoal. Many of the tools exhibit raphides randomly distributed across their surface suggesting that raphides may be depositional rather than use-related. Table C-7 summarizes the range of evidence for each tool type with details on individual tools presented in Table C-8. 
The Varga Site

Texas Department of Transportation

Table C-1. Summary of Toyah Component Results by Tool Type

\begin{tabular}{|c|c|c|c|c|c|c|c|}
\hline Type & $\mathbf{N}$ & $\begin{array}{c}\text { Haft } \\
\text { Residues }\end{array}$ & Use Residues & Wear & Hafted & $\begin{array}{c}\text { Use- } \\
\text { actions }\end{array}$ & Use-materials \\
\hline $\begin{array}{l}\text { Cliffton } \\
\text { Points }\end{array}$ & 4 & Plant fiber & Wood & Striae & Yes & $\begin{array}{l}\text { Unknown, } \\
\text { cutting }\end{array}$ & $\begin{array}{l}\text { Unknown, } \\
\text { wood }\end{array}$ \\
\hline $\begin{array}{l}\text { Perdiz } \\
\text { Point }\end{array}$ & 1 & None & None & H/HS polish & Yes & $\begin{array}{l}\text { Projectile } \\
\text { point }\end{array}$ & Unknown \\
\hline $\begin{array}{l}\text { Gurrero } \\
\text { Point }\end{array}$ & 1 & None & None & None & Unknown & Unknown & Unknown \\
\hline $\begin{array}{l}\text { Bonham } \\
\text { Point }\end{array}$ & 1 & Resin & None & Light polish & Yes & $\begin{array}{l}\text { Projectile } \\
\text { point }\end{array}$ & Unknown \\
\hline $\begin{array}{l}\text { Leaf shaped } \\
\text { Point }\end{array}$ & 1 & $\begin{array}{l}\text { Plant } \\
\text { fragments }\end{array}$ & None & None & Yes & Unknown & Unknown \\
\hline Drills & 2 & None & None & H/HS polish & 1 of 2 & Cutting & $\begin{array}{l}\text { H/HS, } \\
\text { unknown }\end{array}$ \\
\hline Scrapers & 6 & Resin & $\begin{array}{l}\text { Plant, possible } \\
\text { blood, starch } \\
\text { grains, hair }\end{array}$ & $\begin{array}{l}\text { Striae, H/HS } \\
\text { polish, edge } \\
\text { rounding, soft } \\
\text { polish }\end{array}$ & 2 of 6 & $\begin{array}{l}\text { Planing, } \\
\text { scraping }\end{array}$ & $\begin{array}{l}\text { H/HS, plant, } \\
\text { starchy plant, } \\
\text { hide }\end{array}$ \\
\hline $\begin{array}{l}\text { Rejuvenation } \\
\text { flakes }\end{array}$ & 5 & None & None & H/HS, soft polish & No & $\begin{array}{l}\text { Planing, } \\
\text { scraping }\end{array}$ & H/HS, soft \\
\hline Spoke-shaves & 3 & None & $\begin{array}{l}\text { Plant fibers, } \\
\text { wood } \\
\text { fragments }\end{array}$ & $\begin{array}{l}\text { H/HS polish, } \\
\text { striae }\end{array}$ & No & $\begin{array}{l}\text { Scraping, } \\
\text { planing }\end{array}$ & $\begin{array}{l}\text { Wood, H/HS } \\
\text { plant }\end{array}$ \\
\hline Gravers & 3 & $\begin{array}{l}\text { Abraded } \\
\text { ridges }\end{array}$ & Hair, plant & $\begin{array}{l}\text { Soft, H/HS polish, } \\
\text { striae }\end{array}$ & 1 of 3 & $\begin{array}{l}\text { Cutting, } \\
\text { scraping, } \\
\text { slicing }\end{array}$ & $\begin{array}{l}\text { Animal, wood, } \\
\text { H/HS }\end{array}$ \\
\hline Biface & 7 & Wood, plant & $\begin{array}{l}\text { Hair, starch } \\
\text { grains, feathers, } \\
\text { wood, possible } \\
\text { blood, plant }\end{array}$ & $\begin{array}{l}\text { H/HS, soft polish, } \\
\text { striae }\end{array}$ & 2 of 7 & $\begin{array}{l}\text { Projectile, } \\
\text { cutting, } \\
\text { scraping, } \\
\text { planning, } \\
\text { whittling }\end{array}$ & $\begin{array}{l}\text { Plant, animal, } \\
\text { bird, soft, } \\
\text { H/HS, wood }\end{array}$ \\
\hline $\begin{array}{l}\text { Edge- } \\
\text { modified } \\
\text { flakes }\end{array}$ & 23 & None & $\begin{array}{l}\text { Plant, starch } \\
\text { gains, hair, } \\
\text { wood }\end{array}$ & $\begin{array}{l}\text { Soft, H/HS polish, } \\
\text { striae, edge } \\
\text { rounding }\end{array}$ & 1 of 23 & $\begin{array}{l}\text { Scraping, } \\
\text { planning, } \\
\text { whittling, } \\
\text { slicing, } \\
\text { cutting }\end{array}$ & $\begin{array}{l}\text { H/HS, soft, } \\
\text { starchy plant, } \\
\text { animal, wood }\end{array}$ \\
\hline
\end{tabular}

${ }^{\text {a }}$ Hafting residues are confined to the proximal $1 / 3$ to $1 / 2$ portion of the artifact; ${ }^{\mathbf{b}}$ Hafting wear confined to proximal $1 / 3$ to $1 / 2$ of the artifact. $\|$ and $\perp$ refer to parallel and perpendicular to the long axis of the artifact respectively; ${ }^{\mathrm{C} U s e-r e s i d u e s}$ are confined to the distal portion of the artifact near or on the working edge; ${ }^{d}$ Use-wear is confined to the distal portion of the artifact near or on the working edge. $\|$ and $\perp$ refer to parallel and perpendicular to the working edge respectively. 


\begin{tabular}{|c|c|c|c|c|c|c|c|c|c|c|c|c|c|}
\hline 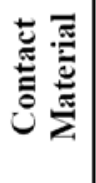 & $\begin{array}{l}\text { E } \\
\text { 总 } \\
\text { 咅 }\end{array}$ & 㟖 & 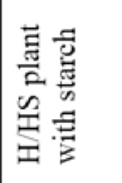 & 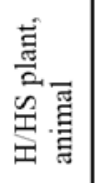 & $\begin{array}{l}\overrightarrow{0} \\
\stackrel{0}{0} \\
\overrightarrow{3}\end{array}$ & 空 & 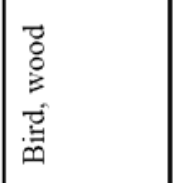 & 金 & 凅 & 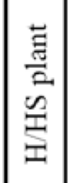 & 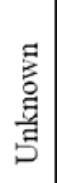 & 战 & 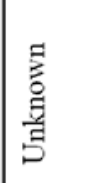 \\
\hline 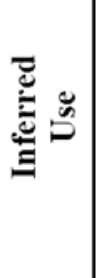 & 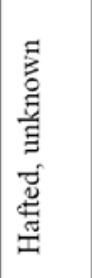 & 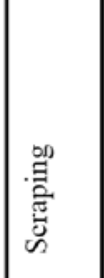 & 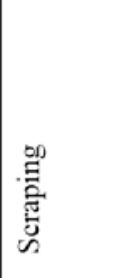 & 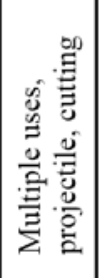 & 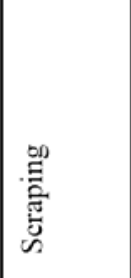 & 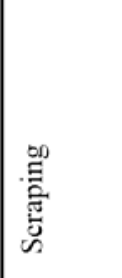 & 害 & 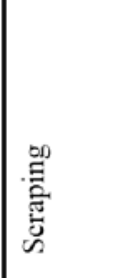 & 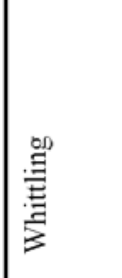 & 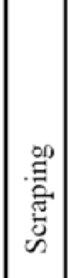 & $\begin{array}{l}\text { 棓 } \\
\text { 总 } \\
5\end{array}$ & $\begin{array}{l}\dot{2} \\
\dot{c} \\
\dot{2}\end{array}$ & 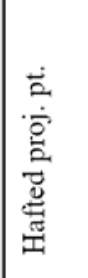 \\
\hline 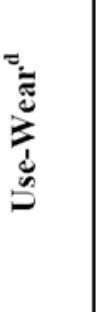 & 1 & 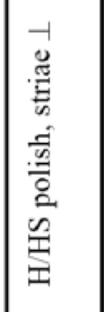 & 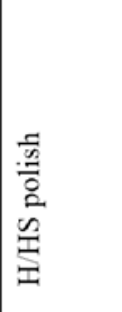 & 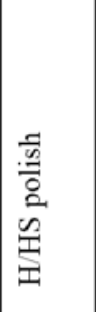 & 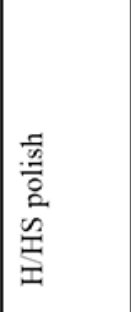 & 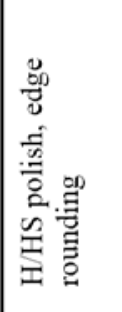 & 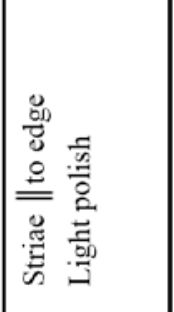 & 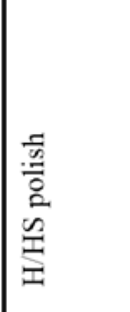 & 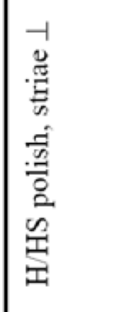 & 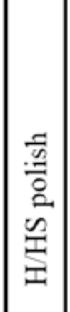 & 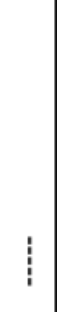 & 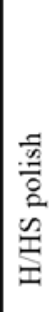 & 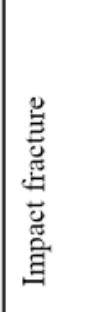 \\
\hline 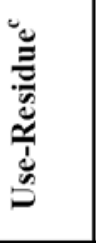 & ! & 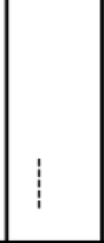 & 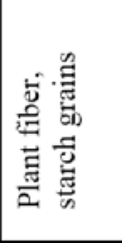 & 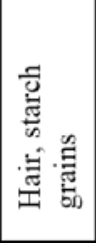 & 总 & 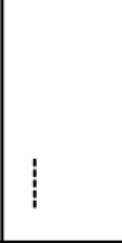 & 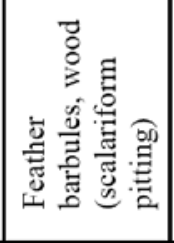 & 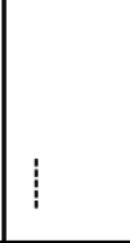 & 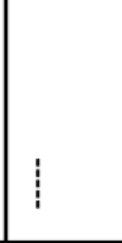 & 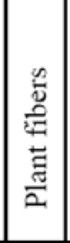 & 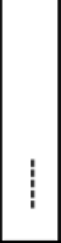 & 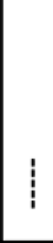 & \\
\hline 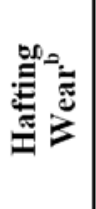 & 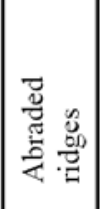 & 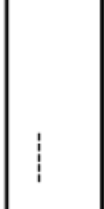 & 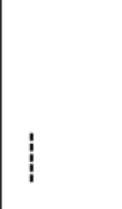 & 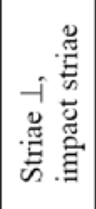 & 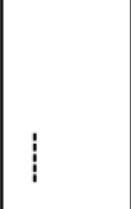 & 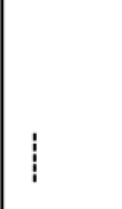 & 1 & 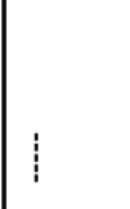 & 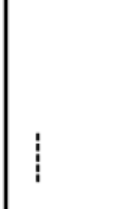 & 1 & : & 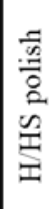 & 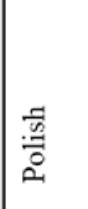 \\
\hline 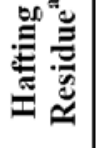 & 1 & 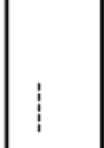 & 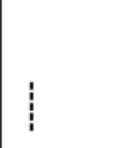 & 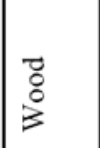 & 1 & 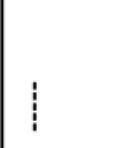 & 1 & 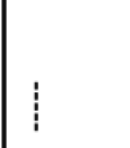 & 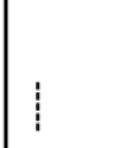 & 1 & 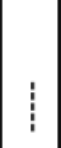 & 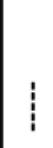 & 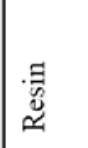 \\
\hline 总 & 兽: 言 & 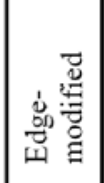 & 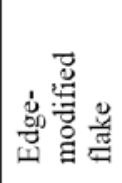 & 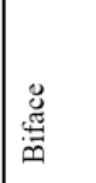 & 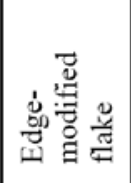 & 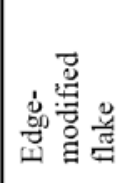 & 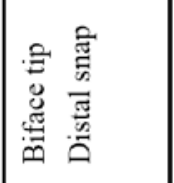 & 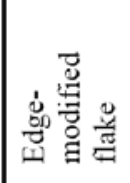 & 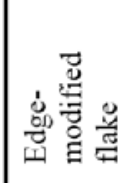 & 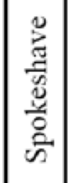 & \begin{tabular}{|c|} 
\\
0 \\
0 \\
0 \\
0 \\
0 \\
0 \\
0
\end{tabular} & 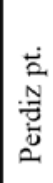 & 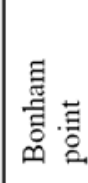 \\
\hline 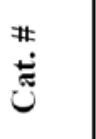 & $\begin{array}{l}\stackrel{ \pm}{\Delta} \\
\stackrel{\dot{\lambda}}{\text { d }}\end{array}$ & $\begin{array}{l}\overrightarrow{0} \\
\text { ఏे } \\
\text { Oे }\end{array}$ & $\begin{array}{l}\hat{1} \\
\hat{1} \\
\hat{2} \\
\end{array}$ & 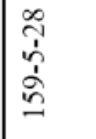 & $\mid \begin{array}{l}\stackrel{0}{0} \\
\dot{0} \\
\stackrel{0}{0}\end{array}$ & 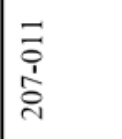 & $\begin{array}{l}n \\
\text { तิ่ } \\
\text { ते }\end{array}$ & 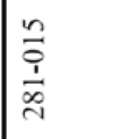 & $\frac{O}{d}$ & & 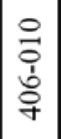 & 总 & 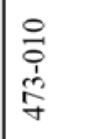 \\
\hline
\end{tabular}









\begin{tabular}{|c|c|c|c|c|c|c|c|c|c|c|c|c|c|c|}
\hline 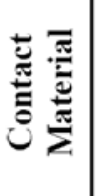 & $\begin{array}{l}\overrightarrow{0} \\
\dot{8}\end{array}$ & $\begin{array}{l}\overrightarrow{0} \\
\dot{0} \\
\dot{3}\end{array}$ & 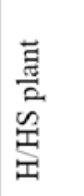 & $\begin{array}{l}\text { E् } \\
\text { 吾 } \\
\text { : }\end{array}$ & 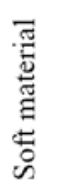 & $\begin{array}{l}\overrightarrow{8} \\
8\end{array}$ & 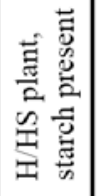 & $\begin{array}{l}\overrightarrow{0} \\
\stackrel{0}{B} \\
\dot{B}\end{array}$ & 胥 & 胥 & $\begin{array}{l}\overrightarrow{0} \\
\stackrel{\circ}{*}\end{array}$ & $\begin{array}{l}\overrightarrow{0} \\
8 \\
3\end{array}$ & $\begin{array}{l}\text { E् } \\
\text { 音 } \\
\text { 站 }\end{array}$ & 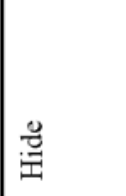 \\
\hline 焉 & 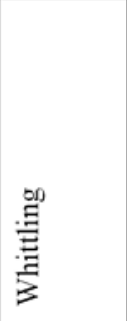 & $\begin{array}{l}\text { 苞 } \\
\frac{0}{\hbar}\end{array}$ & 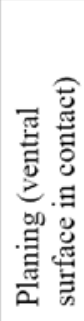 & 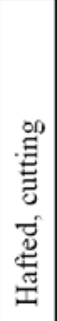 & 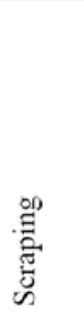 & 总 & $\begin{array}{l}\text { 昜 } \\
\text { 趾 }\end{array}$ & 量 & 总 & 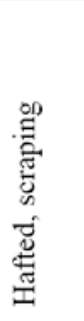 & 莺 & 啹 & 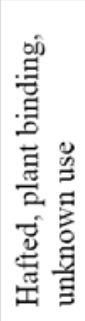 & 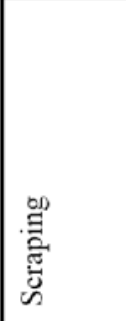 \\
\hline 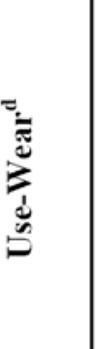 & 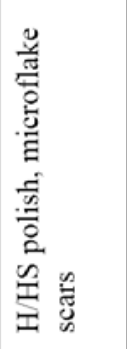 & 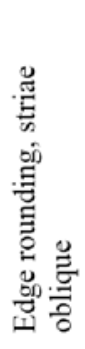 & 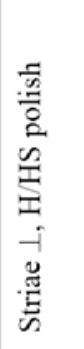 & 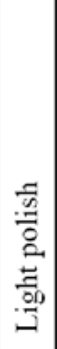 & $\begin{array}{l}\frac{5}{0} \\
\frac{2}{0} \\
\frac{2}{8} \\
\infty\end{array}$ & 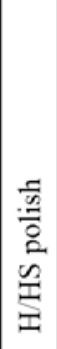 & 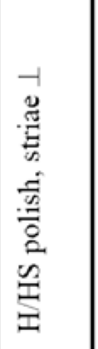 & 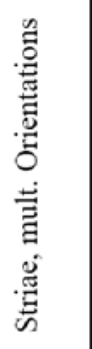 & 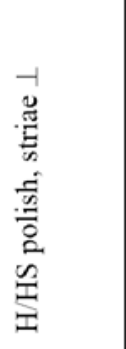 & 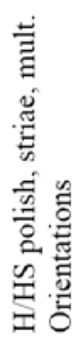 & 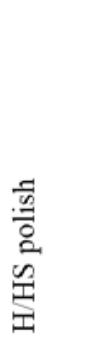 & 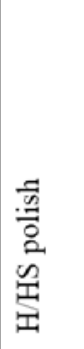 & 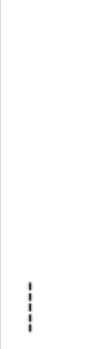 & 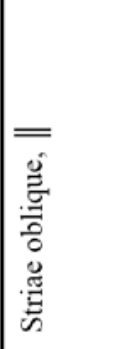 \\
\hline 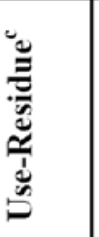 & 总 & 总 & 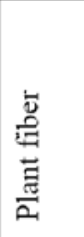 & 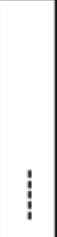 & 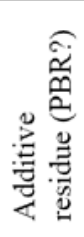 & $\begin{array}{l}\overrightarrow{0} \\
8 \\
3\end{array}$ & 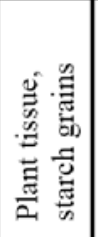 & 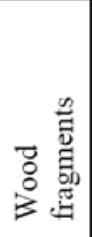 & 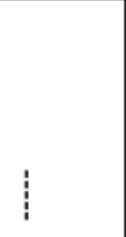 & 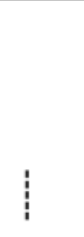 & 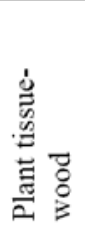 & 홀 & & 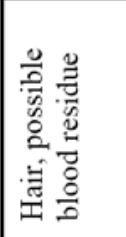 \\
\hline 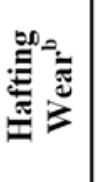 & 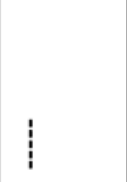 & ! & 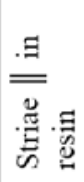 & 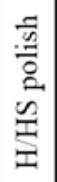 & ! & 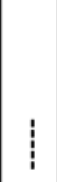 & 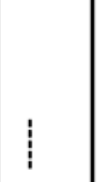 & 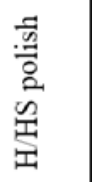 & 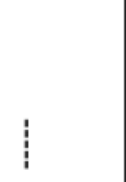 & 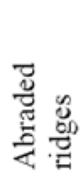 & 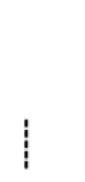 & 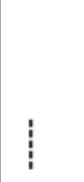 & 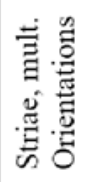 & 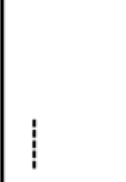 \\
\hline 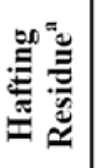 & 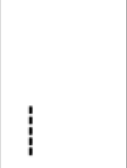 & 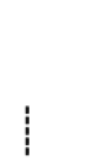 & $\begin{array}{l}\text { 责 } \\
\stackrel{4}{4}\end{array}$ & 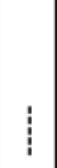 & 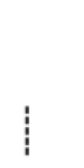 & i & 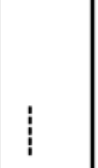 & 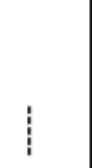 & 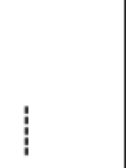 & 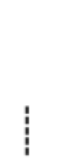 & 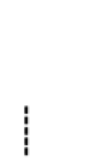 & 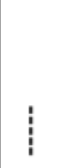 & 壱 & 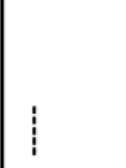 \\
\hline 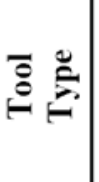 & 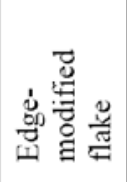 & 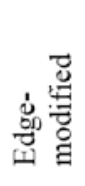 & 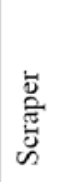 & $\overline{\bar{E}}$ & 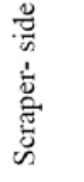 & 总 & 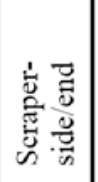 & 总声 & 总 & 离 & 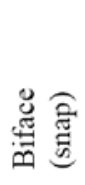 & 芯 & 总苛 & 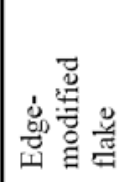 \\
\hline $\begin{array}{l}\text { \# } \\
\stackrel{\#}{\tilde{E}}\end{array}$ & $\frac{\square}{\infty}$ & 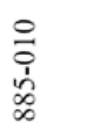 & $\begin{array}{l}\underset{J}{\Delta} \\
\infty \\
\infty \\
\infty\end{array}$ & $\begin{array}{l}0 \\
0 \\
\vdots \\
\check{\infty}\end{array}$ & $\frac{1}{\grave{g}}$ & ત̃ & ڤั & $\begin{array}{l}\overrightarrow{\vec{a}} \\
\dot{+} \\
\vec{a}\end{array}$ & $\frac{\vec{\sigma}}{\frac{1}{2}}$ & $\begin{array}{l}\vec{z} \\
\vdots \\
\dot{1} \\
\sigma\end{array}$ & $\frac{\partial}{\dot{t}}$ & $\begin{array}{l}\stackrel{0}{0} \\
\stackrel{1}{1} \\
\text { مू }\end{array}$ & $\begin{array}{l}\stackrel{\infty}{a} \\
\stackrel{1}{1} \\
\stackrel{c}{a}\end{array}$ & $\begin{array}{l}\text { Oे } \\
\vdots \\
\vdots \\
\text { à }\end{array}$ \\
\hline
\end{tabular}




\begin{tabular}{|c|c|c|c|c|c|c|c|c|c|c|c|}
\hline 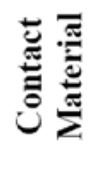 & 望 & 凅 & 咅 & 总 & 凅 & \begin{tabular}{|l}
$\vec{c}$ \\
$:$ \\
$:$
\end{tabular} & 凅 & 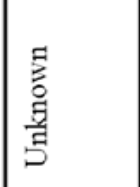 & 兽 & \begin{tabular}{|l}
$\vec{g}$ \\
$:$ \\
0 \\
3
\end{tabular} & 金 \\
\hline 莺 & 总 & 总 & $\begin{array}{l}\text { 量 } \\
\text { 善 } \\
\text { 号 }\end{array}$ & 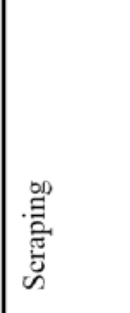 & 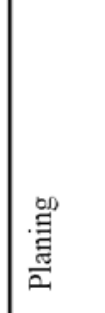 & 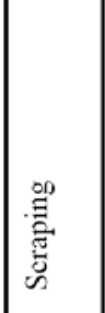 & 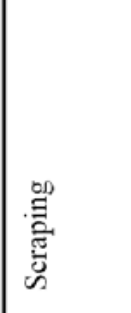 & 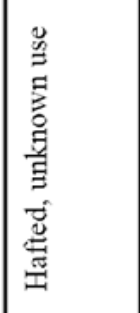 & 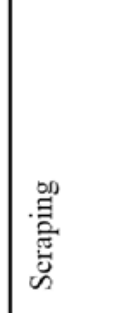 & \begin{tabular}{|l} 
量 \\
镸 \\
$\frac{2}{2}$
\end{tabular} & 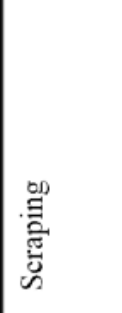 \\
\hline 离 & 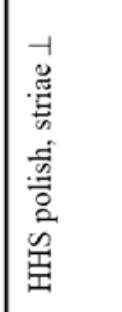 & 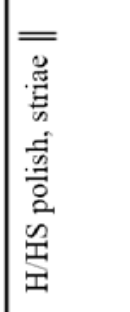 & 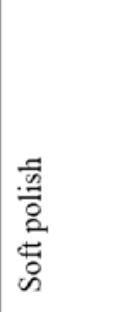 & 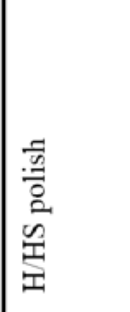 & 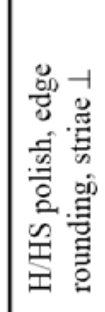 & 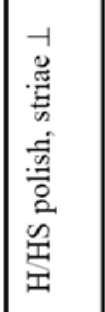 & 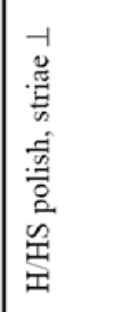 & 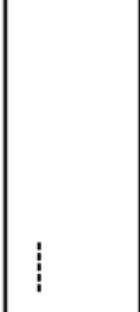 & 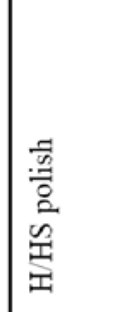 & 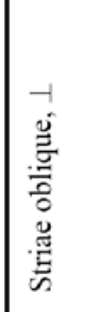 & 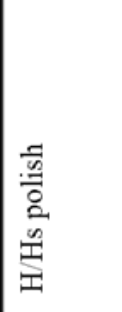 \\
\hline 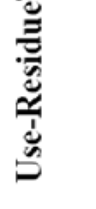 & 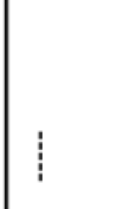 & 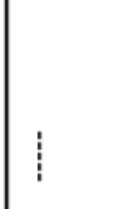 & 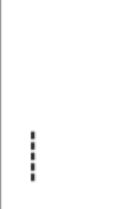 & 竞 & & 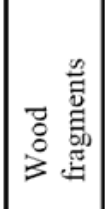 & 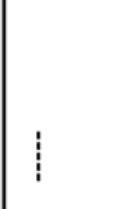 & 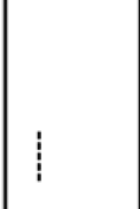 & 1 & 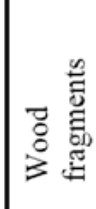 & 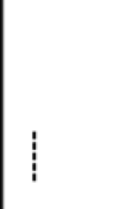 \\
\hline 跣 & 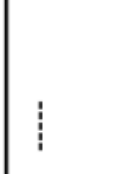 & 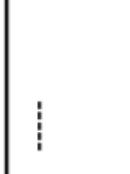 & 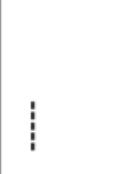 & 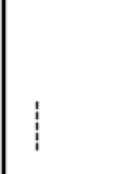 & 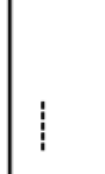 & 1 & 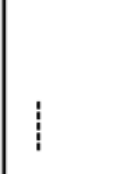 & 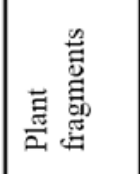 & 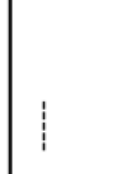 & 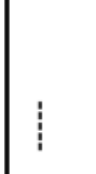 & 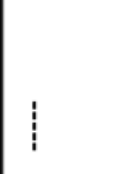 \\
\hline 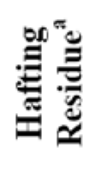 & 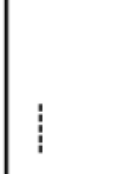 & 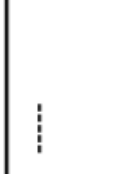 & 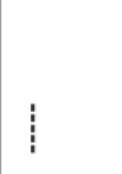 & 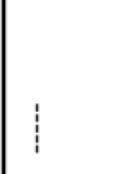 & 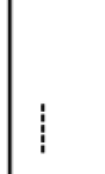 & 1 & 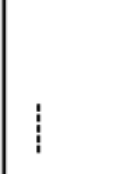 & 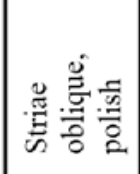 & 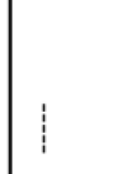 & 1 & 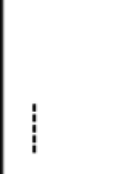 \\
\hline 㝘密 & 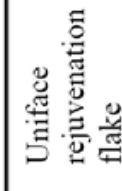 & 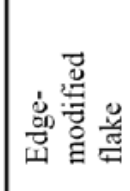 & 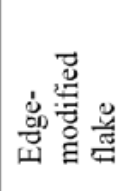 & 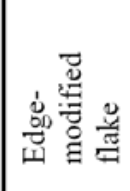 & 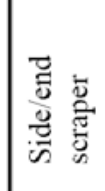 & 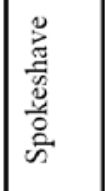 & 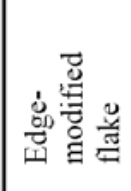 & 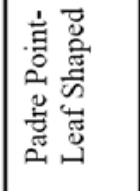 & 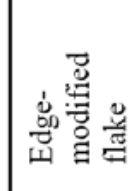 & 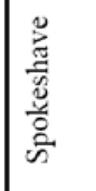 & 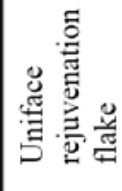 \\
\hline ت & $\begin{array}{l}m \\
\vdots \\
\vdots \\
\alpha\end{array}$ & ڤे。 & $\frac{\infty}{\stackrel{a}{a}}$ & 穴 & 音 & 亲 & 客 & 总菑 & 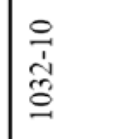 & 宫象 & 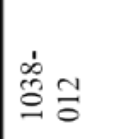 \\
\hline
\end{tabular}




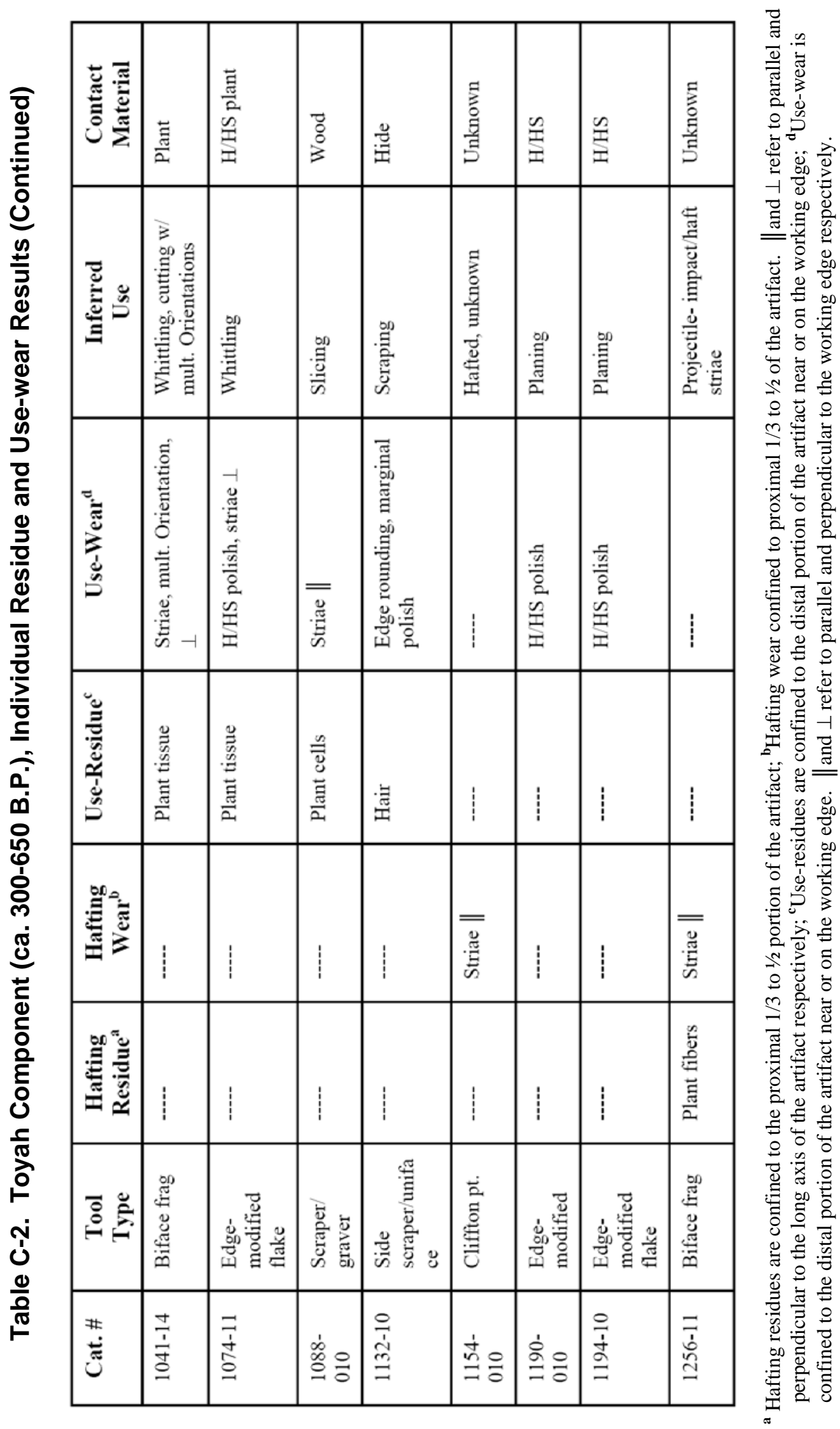


Table C-3. Summary of Late Archaic Component Results by Tool Type

\begin{tabular}{|l|c|l|l|l|l|l|l|}
\hline \multicolumn{1}{|c|}{ Type } & $\mathbf{N}$ & \multicolumn{1}{|c|}{$\begin{array}{c}\text { Haft } \\
\text { Residues }\end{array}$} & $\begin{array}{c}\text { Use } \\
\text { Residues }\end{array}$ & \multicolumn{1}{|c|}{ Wear } & Hafted & \multicolumn{1}{|c|}{$\begin{array}{c}\text { Use- } \\
\text { actions }\end{array}$} & \multicolumn{1}{c|}{$\begin{array}{c}\text { Use- } \\
\text { materials }\end{array}$} \\
\hline Bifaces & 4 & $\begin{array}{l}\text { Clear residue } \\
\text { (resin?) }\end{array}$ & $\begin{array}{l}\text { Wood, plant, } \\
\text { skin }\end{array}$ & $\begin{array}{l}\text { Striae, H/HS, } \\
\text { soft, edge } \\
\text { rounding }\end{array}$ & 1 of 4 & $\begin{array}{l}\text { Cutting, } \\
\text { scraping, } \\
\text { unknown }\end{array}$ & $\begin{array}{l}\text { Wood, hide, } \\
\text { H/HS plant, } \\
\text { unknown }\end{array}$ \\
\hline Scrapers & 3 & None & Wood, plant & $\begin{array}{l}\text { Striae, H/HS } \\
\text { polish }\end{array}$ & No & $\begin{array}{l}\text { Scraping, } \\
\text { planning }\end{array}$ & $\begin{array}{l}\text { H/HS plant, } \\
\text { wood }\end{array}$ \\
\hline $\begin{array}{l}\text { Edge- } \\
\text { modified } \\
\text { flakes }\end{array}$ & 8 & None & $\begin{array}{l}\text { Plant fibers, } \\
\text { raphides, } \\
\text { hair }\end{array}$ & $\begin{array}{l}\text { H/HS, soft } \\
\text { polish, striae }\end{array}$ & $\begin{array}{l}\text { No } \\
\text { Scraping, } \\
\text { whittling, } \\
\text { cutting, } \\
\text { slicing }\end{array}$ & $\begin{array}{l}\text { Hide, H/HS, } \\
\text { soft, H/HS } \\
\text { plant, } \\
\text { unknown }\end{array}$ \\
\hline $\begin{array}{l}\text { Edgewood } \\
\text { point }\end{array}$ & 1 & None & Wood & $\begin{array}{l}\text { H/HS, } \\
\text { polish }\end{array}$ & Yes & Cutting & Wood \\
\hline $\begin{array}{l}\text { Montell } \\
\text { point }\end{array}$ & 1 & None & None & Impact & Yes & Projectile & Unknown \\
\hline
\end{tabular}




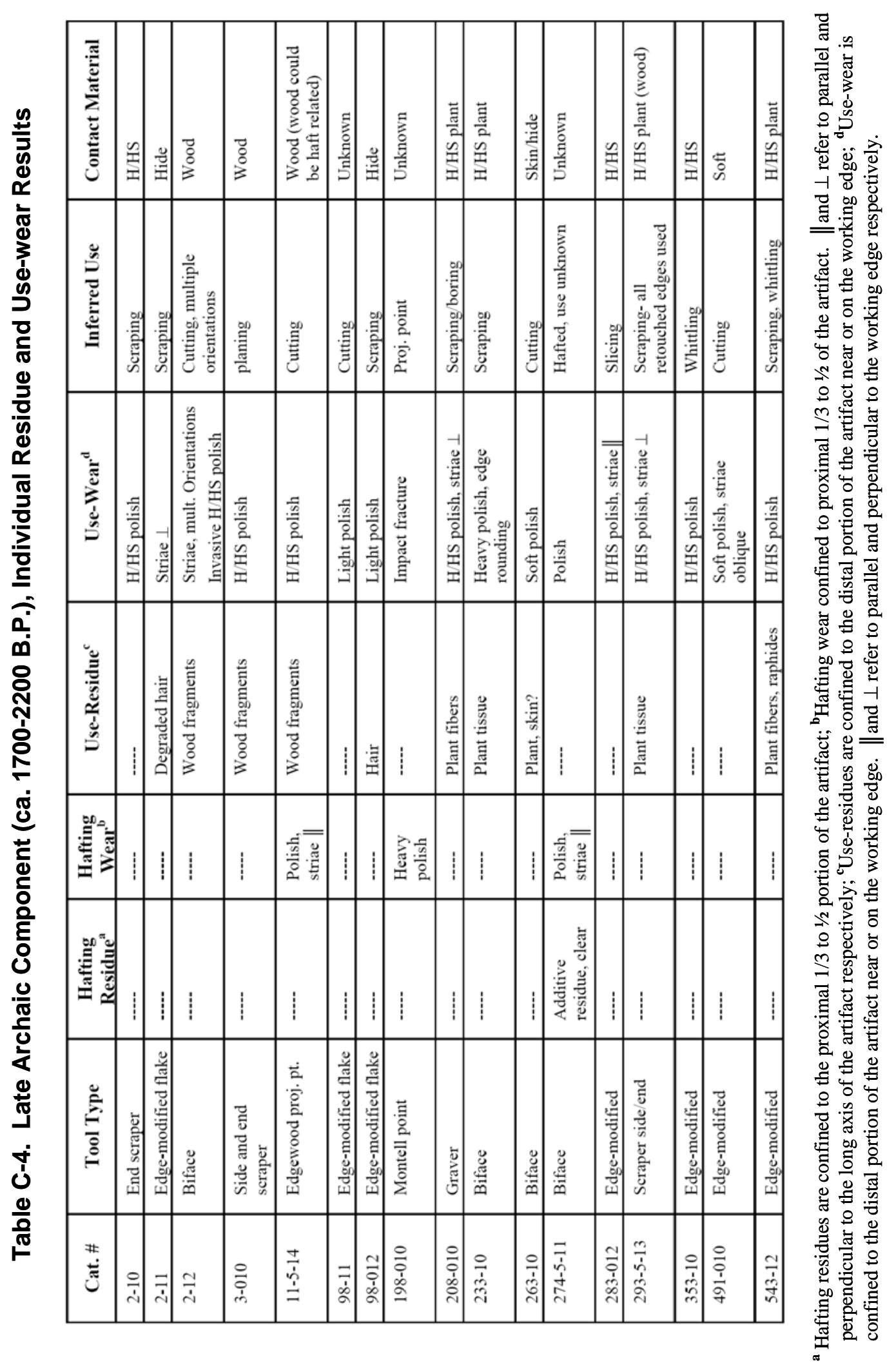


Table C-5. Summary of Middle Archaic Component Results by Tool Type

\begin{tabular}{|l|l|l|l|l|l|l|l|}
\hline \multicolumn{1}{|c|}{ Type } & N & $\begin{array}{c}\text { Haft } \\
\text { Residues }\end{array}$ & \multicolumn{1}{|c|}{$\begin{array}{c}\text { Use } \\
\text { Residues }\end{array}$} & \multicolumn{1}{|c|}{ Wear } & Hafted & \multicolumn{1}{|l}{ Use-actions } & $\begin{array}{c}\text { Use- } \\
\text { materials }\end{array}$ \\
\hline Bifaces & 2 & None & None & H/HS polish, striae & No & Cutting, scraping & H/HS \\
\hline Scrapers & 2 & None & Hair & Striae, soft polish & No & Planing, scraping & Hide, soft \\
\hline $\begin{array}{l}\text { Edge- } \\
\text { modified } \\
\text { flakes }\end{array}$ & 9 & None & $\begin{array}{l}\text { Wood, plant } \\
\text { fibers, plant } \\
\text { tissue }\end{array}$ & H/HS polish, striae & No & $\begin{array}{l}\text { Whittling, } \\
\text { scraping, cutting, } \\
\text { planing }\end{array}$ & $\begin{array}{l}\text { Wood, } \\
\text { H/HS, } \\
\text { soft, plant }\end{array}$ \\
\hline $\begin{array}{l}\text { Early } \\
\text { Triangular } \\
\text { points }\end{array}$ & 4 & None & Hair & H/HS polish, striae & 2 of 3 & $\begin{array}{l}\text { Gouging, cutting, } \\
\text { whittling } \\
\text { unknown }\end{array}$ & $\begin{array}{l}\text { Hide, } \\
\text { H/HS }\end{array}$ \\
\hline
\end{tabular}




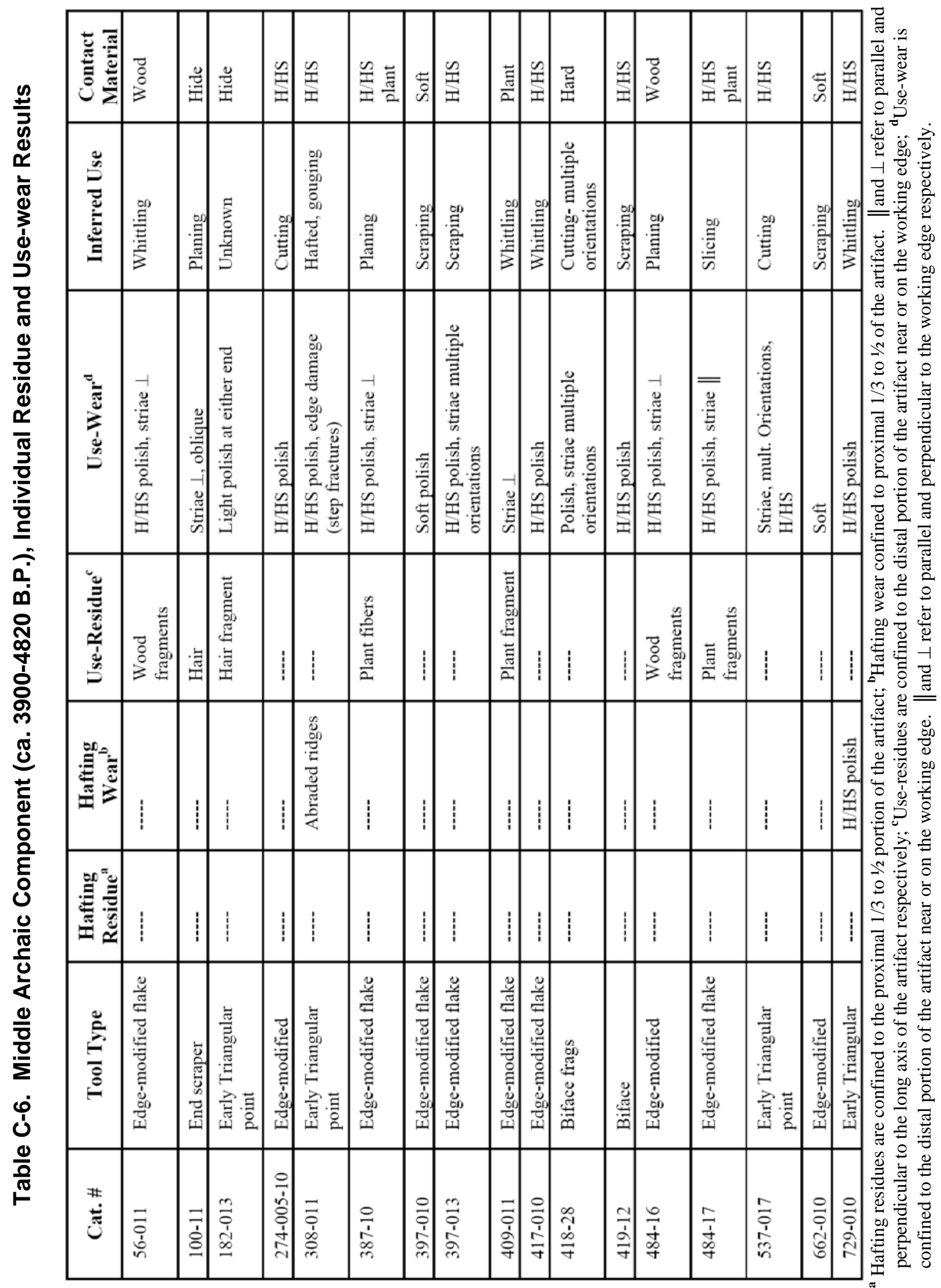




\begin{tabular}{|c|c|c|c|c|c|c|c|c|c|c|c|c|c|}
\hline 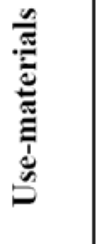 & 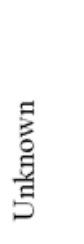 & 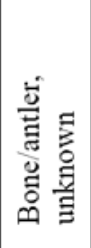 & 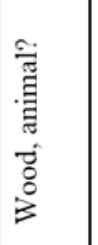 & 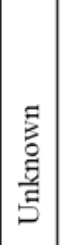 & 莺 & 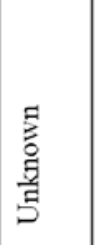 & 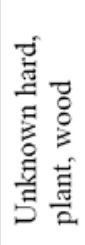 & 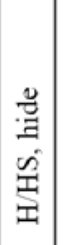 & 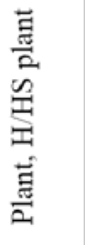 & 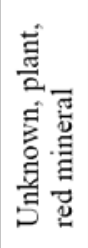 & $\begin{array}{l}\overrightarrow{0} \\
\vdots \\
\vdots\end{array}$ & 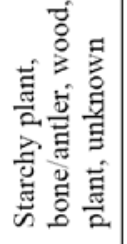 & 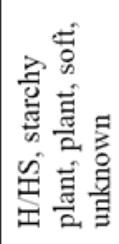 \\
\hline 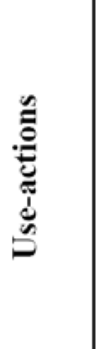 & 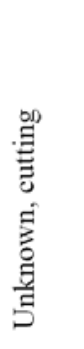 & 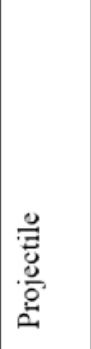 & 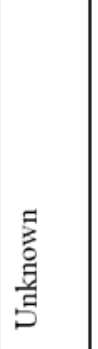 & 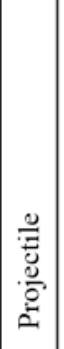 & 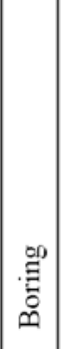 & 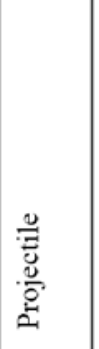 & 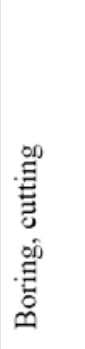 & 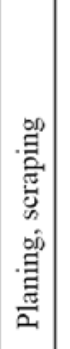 & 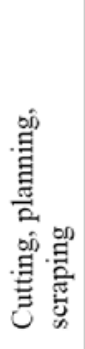 & $\begin{array}{l}\text { E } \\
0 \\
0 \\
\text { 音 } \\
\text { oi } \\
\text { 害 } \\
\text { 己 }\end{array}$ & 量 & 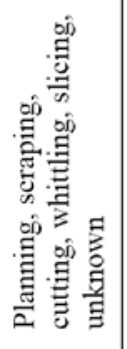 & 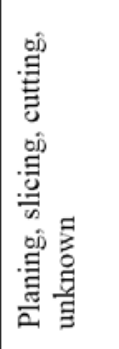 \\
\hline 总 & $\sum^{\infty}$ & 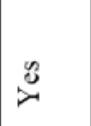 & $\sum^{3}$ & $\grave{0}$ & $\stackrel{2}{z}$ & 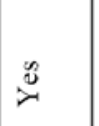 & $\stackrel{\circ}{z}$ & $\stackrel{\circ}{z}$ & $\stackrel{\circ}{Z}$ & $\begin{array}{l}\circ \\
\stackrel{7}{0} \\
\dot{0}\end{array}$ & $\stackrel{\circ}{z}$ & $\stackrel{\circ}{z}$ & E \\
\hline 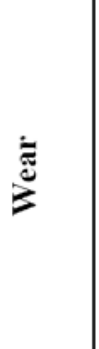 & 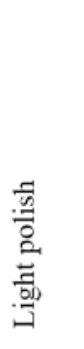 & 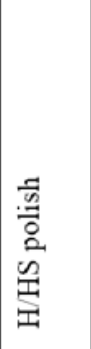 & $\begin{array}{l}\text { : } \\
\check{z}\end{array}$ & 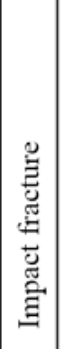 & 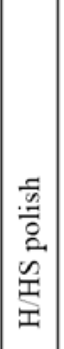 & 芩 & 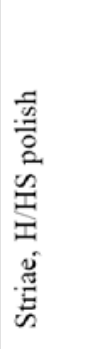 & 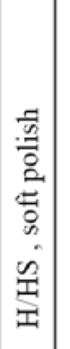 & 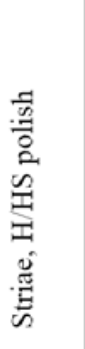 & 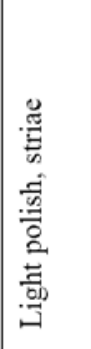 & 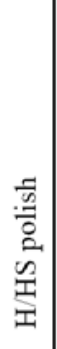 & 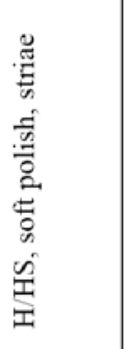 & 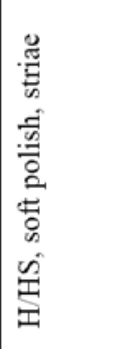 \\
\hline 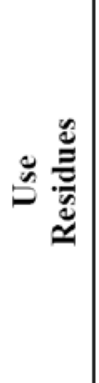 & 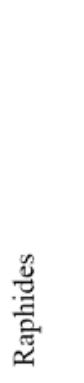 & 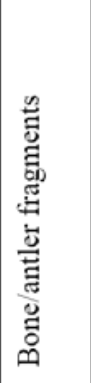 & $\begin{array}{l}\overrightarrow{0} \\
\vdots \\
0 \\
0 \\
0 \\
0 \\
0 \\
0 \\
0 \\
0 \\
\overrightarrow{0} \\
0 \\
0 \\
0\end{array}$ & \begin{tabular}{l|}
$\mathscr{E}$ \\
$\check{z}$ \\
\end{tabular} & 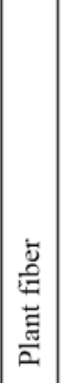 & $\begin{array}{l}\text { च } \\
\text { Z }\end{array}$ & 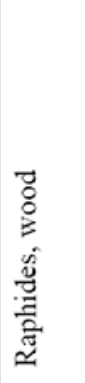 & 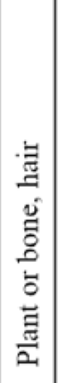 & 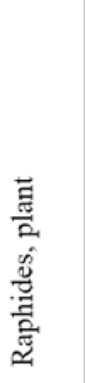 & 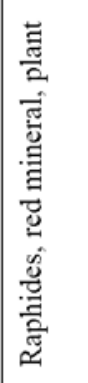 & $\begin{array}{l}\overrightarrow{0} \\
\vdots \\
\vdots\end{array}$ & 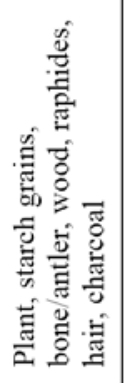 & 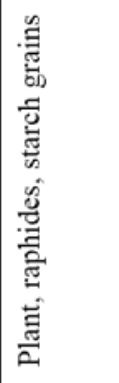 \\
\hline 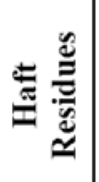 & 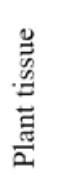 & 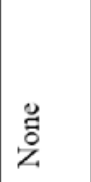 & 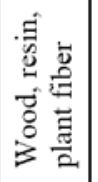 & 蒿 & 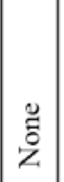 & 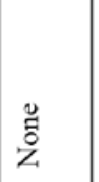 & 芩 & 号 & $\begin{array}{l}\text { हू } \\
\text { ż }\end{array}$ & 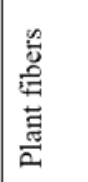 & 号 & 芩 & 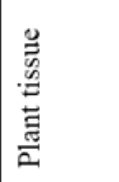 \\
\hline Z & $N$ & 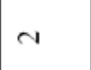 & $N$ & - & - & $N$ & $\nabla$ & $N$ & in & 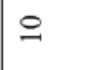 & - & $\stackrel{d}{d}$ & $r$ \\
\hline E. & 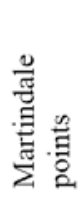 & 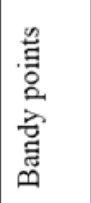 & 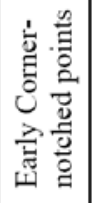 & 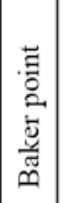 & 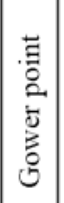 & 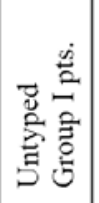 & $\stackrel{\vec{E}}{\vec{E}}$ & $\begin{array}{l}0 \\
0 \\
0 \\
\overline{5} \\
\bar{s}\end{array}$ & 离 & 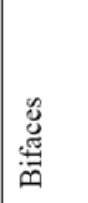 & 总 & 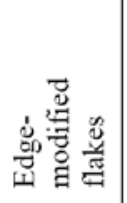 & 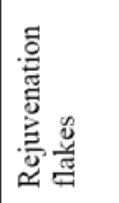 \\
\hline
\end{tabular}




\begin{tabular}{|c|c|c|c|c|c|c|c|c|c|c|c|c|c|}
\hline 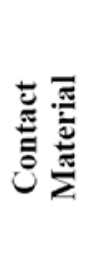 & $\begin{array}{l}\text { E } \\
\text { 总 } \\
\text { 站 } \\
\vdots\end{array}$ & 胥 & 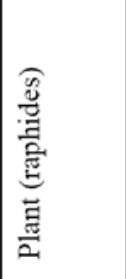 & 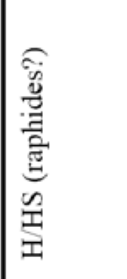 & \begin{tabular}{|l|}
$E$ \\
0 \\
0 \\
E \\
5 \\
5
\end{tabular} & 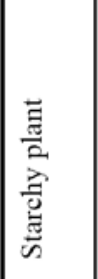 & $\begin{array}{l}E \\
0 \\
0 \\
\vdots \\
\vdots \\
5\end{array}$ & $\begin{array}{l}\text { E } \\
0 \\
\vdots \\
\vdots \\
\vdots \\
\vdots\end{array}$ & 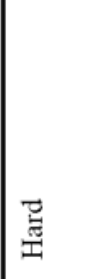 & 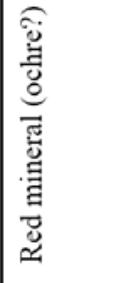 & 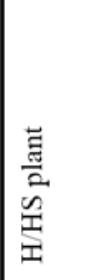 & $\begin{array}{l}\text { 䔍 } \\
\text { 2 } \\
\text { 空 } \\
\text { 至 }\end{array}$ & 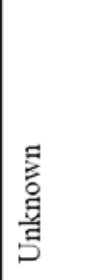 \\
\hline 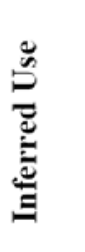 & $\begin{array}{l}\text { E } \\
\text { 总 } \\
\text { 总 } \\
\end{array}$ & 离 & 总 & 照 & 兽 & $\begin{array}{l}\text { 易 } \\
\text { 喜 }\end{array}$ & 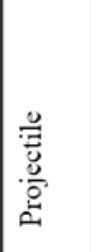 & 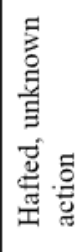 & 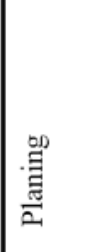 & \begin{tabular}{|l} 
音 \\
0 \\
音 \\
5
\end{tabular} & 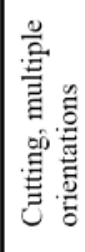 & 竞 & 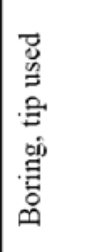 \\
\hline 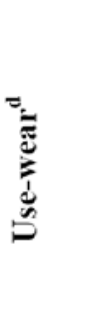 & 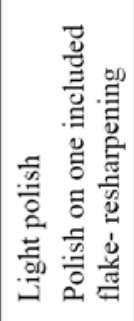 & 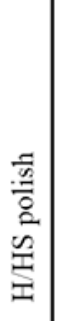 & 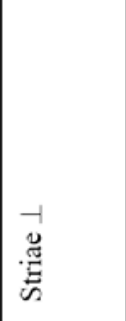 & 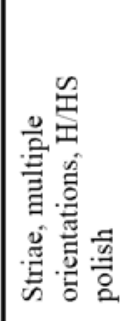 & 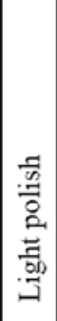 & 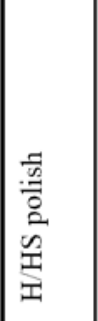 & 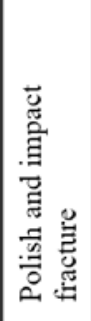 & 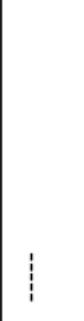 & 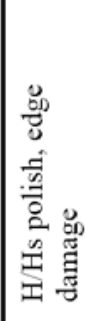 & 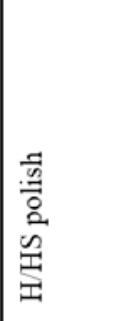 & 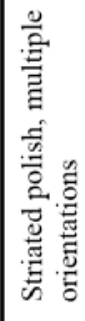 & 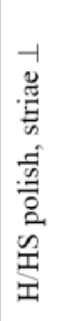 & 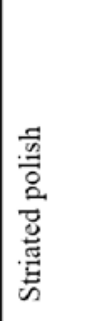 \\
\hline 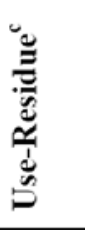 & 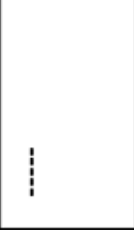 & 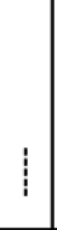 & 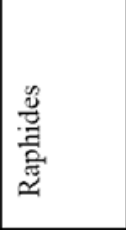 & 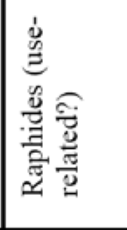 & 1 & 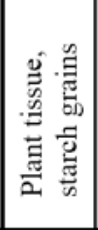 & 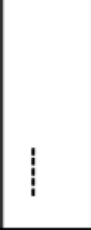 & 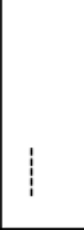 & 1 & 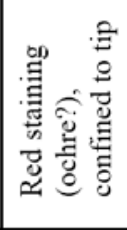 & 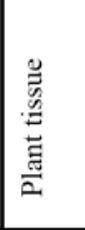 & 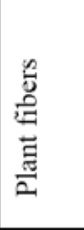 & 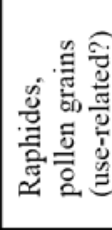 \\
\hline 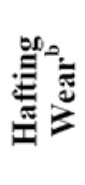 & 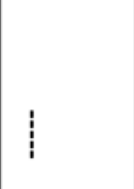 & $:$ & 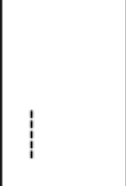 & 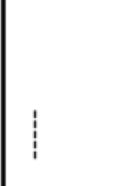 & 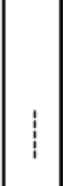 & 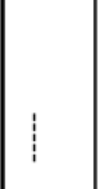 & 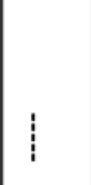 & 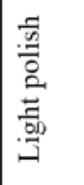 & 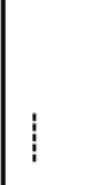 & 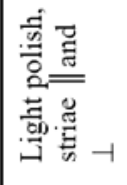 & 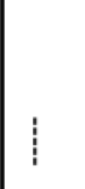 & 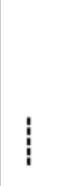 & 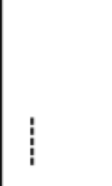 \\
\hline 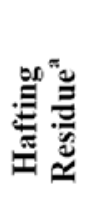 & 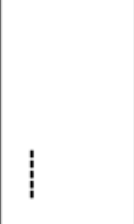 & 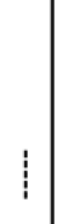 & 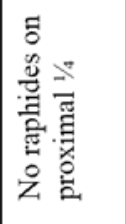 & 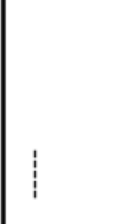 & 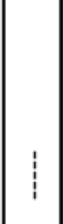 & 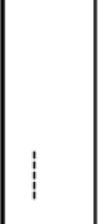 & 1 & 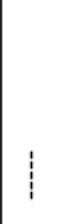 & 1 & 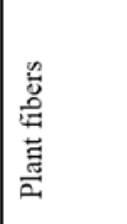 & 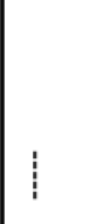 & 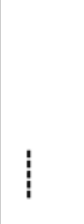 & 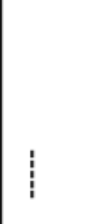 \\
\hline 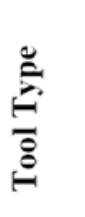 & 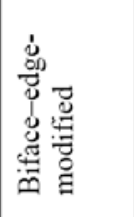 & 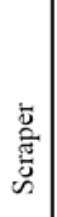 & 总惫总言 & 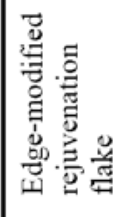 & 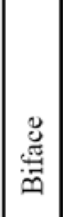 & 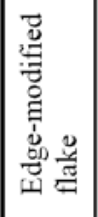 & 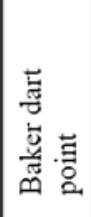 & 总 & 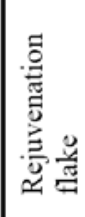 & 芯 & $\frac{\ddot{\tilde{g}}}{\tilde{m}}$ & 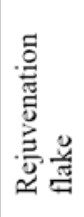 & 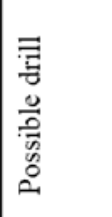 \\
\hline 节 & $\overrightarrow{\bar{d}}$ & $\frac{7}{1}$ & $\frac{\mathfrak{z}}{\mathfrak{g}}$ & 官 & $\mid$\begin{tabular}{|l}
0 \\
0 \\
0 \\
$i$ \\
0
\end{tabular} & 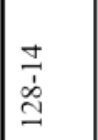 & 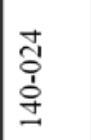 & $\begin{array}{l}\overline{\widehat{O}} \\
\stackrel{1}{\dot{J}} \\
\underline{\Xi}\end{array}$ & \begin{tabular}{|l}
$\overrightarrow{0}$ \\
$\hat{1}$ \\
$\hat{2}$ \\
\end{tabular} & 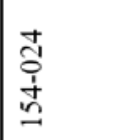 & 辛 & 离 & $\begin{array}{l}0 \\
0 \\
0 \\
\infty \\
\\
\end{array}$ \\
\hline
\end{tabular}




\begin{tabular}{|c|c|c|c|c|c|c|c|c|c|c|c|c|c|c|}
\hline 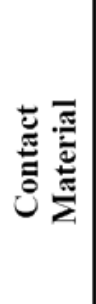 & 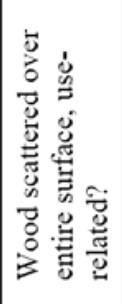 & 垐 & $\begin{array}{l}\frac{1}{2} \\
\frac{5}{2} \\
\frac{1}{1} \\
\text { 工 }\end{array}$ & 瓷 & 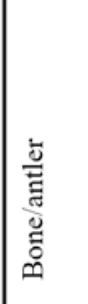 & 胥 & \begin{tabular}{|l} 
E् \\
总 \\
鄫 \\
\end{tabular} & 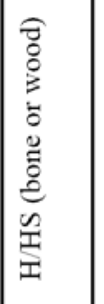 & 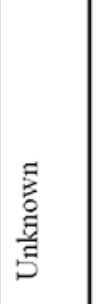 & 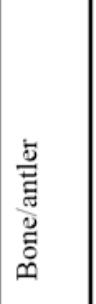 & 急 & 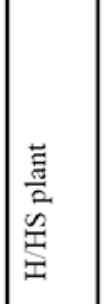 & 莺 & 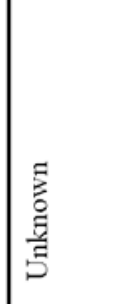 \\
\hline 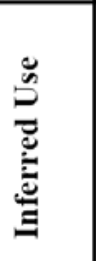 & 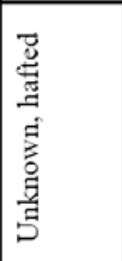 & 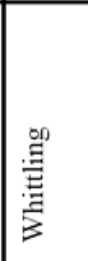 & 㕵 & 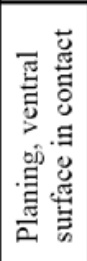 & 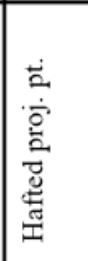 & 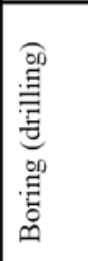 & $\begin{array}{l}\text { 昜 } \\
\text { 愙 }\end{array}$ & 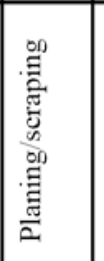 & $\begin{array}{l}\text { 昜 } \\
\frac{\mathrm{g}_{2}}{2}\end{array}$ & 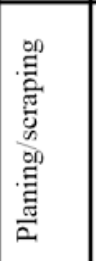 & 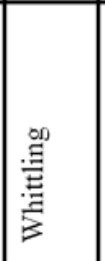 & \begin{tabular}{|l} 
量 \\
$\frac{\overrightarrow{\frac{6}{2}}}{2}$
\end{tabular} & 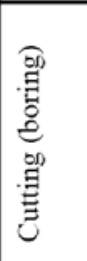 & \begin{tabular}{|l} 
E \\
总 \\
晋
\end{tabular} \\
\hline 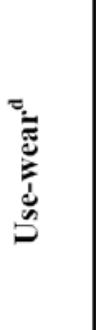 & 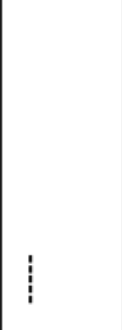 & 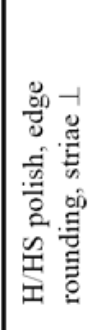 & 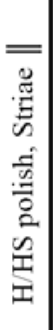 & 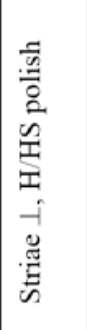 & 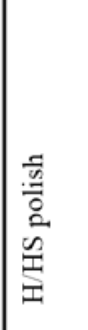 & 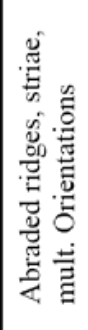 & 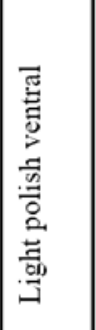 & 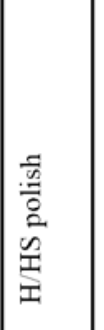 & 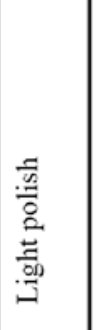 & 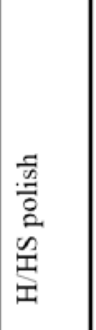 & 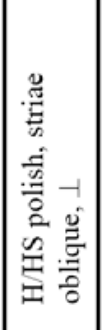 & 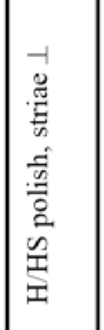 & 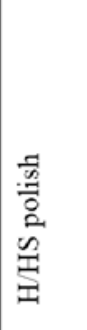 & 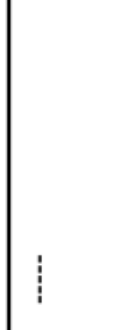 \\
\hline 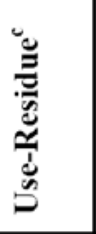 & 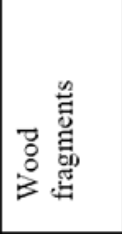 & 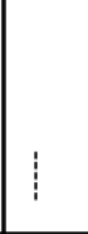 & 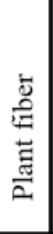 & 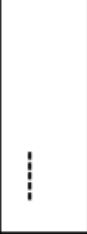 & 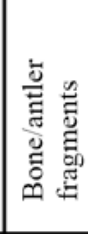 & 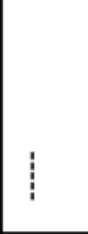 & 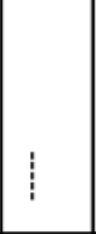 & 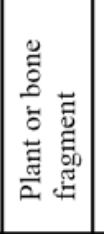 & 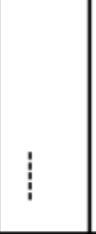 & 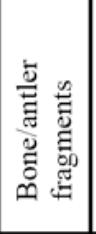 & 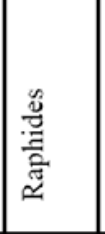 & 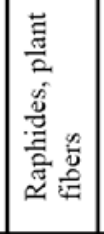 & 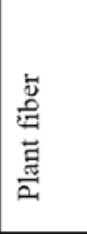 & \\
\hline 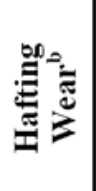 & 专 & 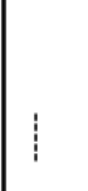 & 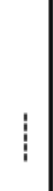 & 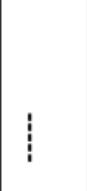 & 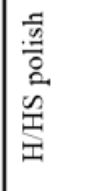 & 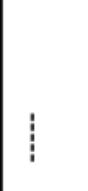 & 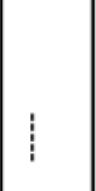 & 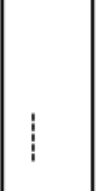 & 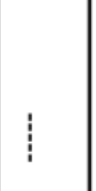 & 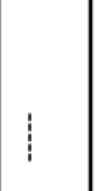 & 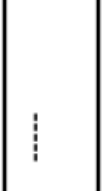 & 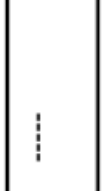 & 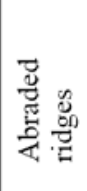 & | \\
\hline 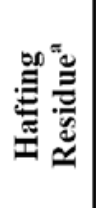 & 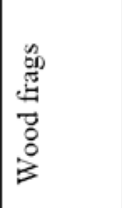 & 1 & 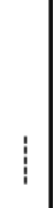 & 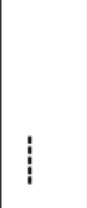 & 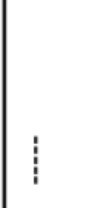 & 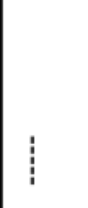 & 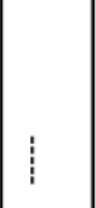 & 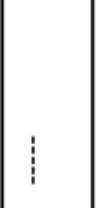 & 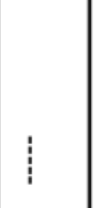 & 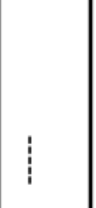 & 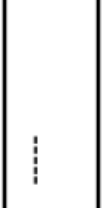 & 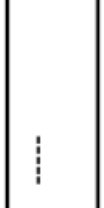 & 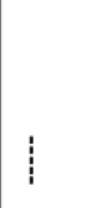 & 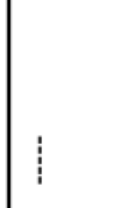 \\
\hline 言 & 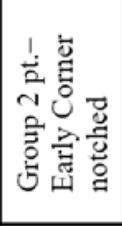 & 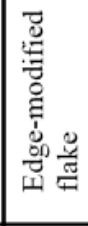 & 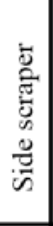 & 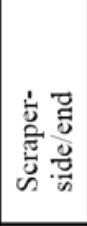 & 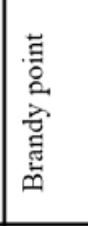 & 吾 & 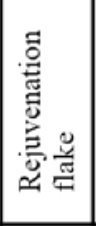 & 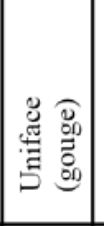 & 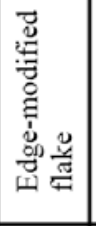 & 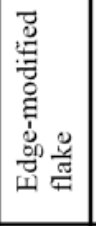 & 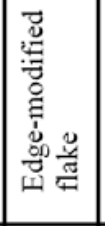 & 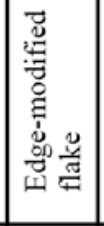 & 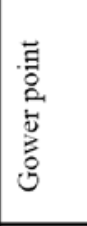 & 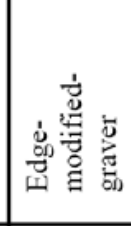 \\
\hline 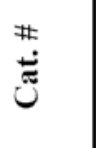 & 泀 & 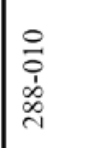 & $\begin{array}{l}\text { 产 } \\
\dot{d} \\
\text { m. }\end{array}$ & 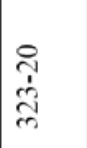 & 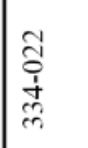 & 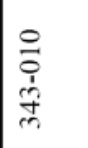 & 管 & 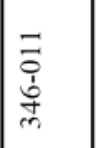 & 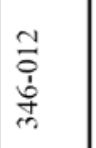 & $\begin{array}{l}m \\
\vec{b} \\
\text { m. }\end{array}$ & 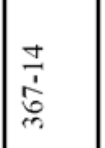 & \begin{tabular}{|l}
0 \\
$\frac{1}{1}$ \\
$\infty$ \\
$\infty$
\end{tabular} & $\overrightarrow{\vec{\partial}}$ & |⿳亠口冋亍 \\
\hline
\end{tabular}




\begin{tabular}{|c|c|c|c|c|c|c|c|c|c|c|c|c|c|}
\hline 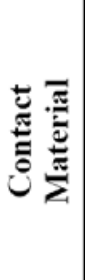 & 虽 & 夏 & 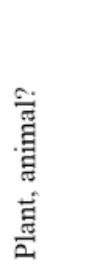 & $\begin{array}{l}\overrightarrow{8} \\
\dot{\circ}\end{array}$ & 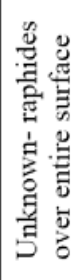 & 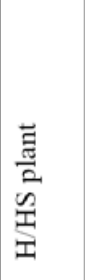 & 总 & $\begin{array}{l}\vec{\circ} \\
\overline{0} \\
\vec{y}\end{array}$ & $\frac{\vec{E}}{\frac{\vec{U}}{\alpha}}$ & 壹 & 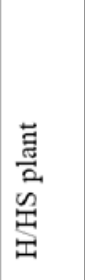 & 壳 & "̈ \\
\hline 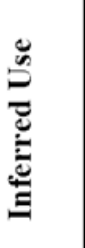 & 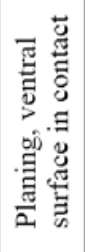 & 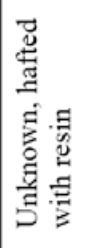 & 量 & 最 & 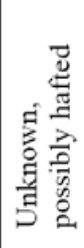 & $\begin{array}{l}\text { 量 } \\
\text { 燕 } \\
2\end{array}$ & 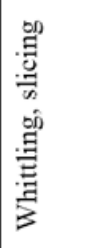 & \begin{tabular}{|l} 
量 \\
燕
\end{tabular} & 意 & $\begin{array}{l}\text { 悬 } \\
\text { 䓌 }\end{array}$ & 兽 & $\begin{array}{l}\text { 胞 } \\
\text { 奇 }\end{array}$ & 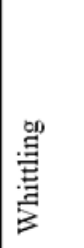 \\
\hline 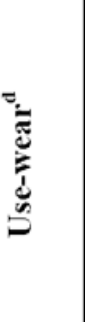 & 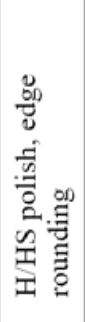 & 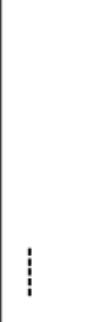 & 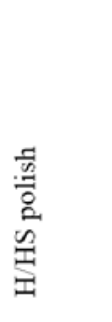 & 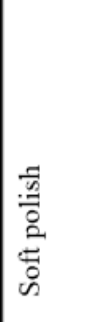 & 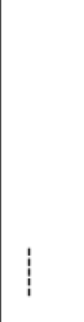 & 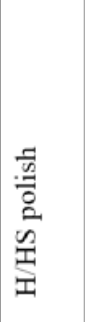 & 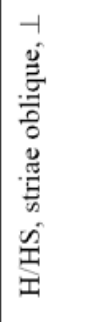 & 童 & 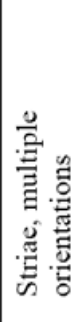 & 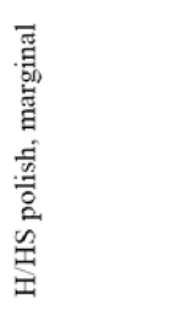 & 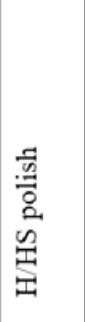 & 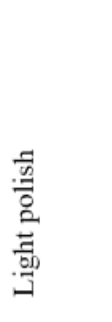 & 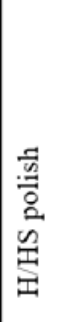 \\
\hline 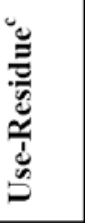 & 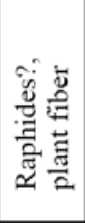 & 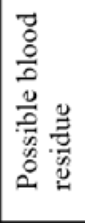 & 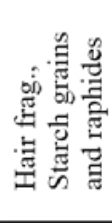 & 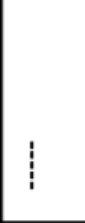 & 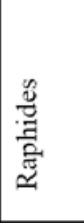 & 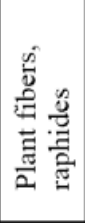 & 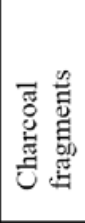 & 量 & 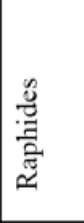 & 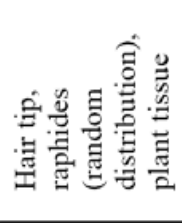 & 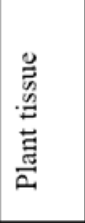 & 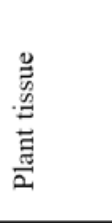 & 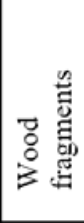 \\
\hline 焉 & 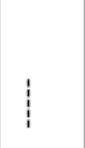 & $\begin{array}{l}\frac{\pi}{0} \\
\frac{0}{0} \\
2\end{array}$ & 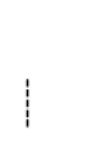 & 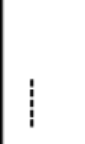 & 咅 & & 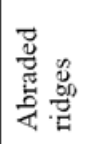 & 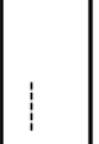 & 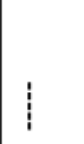 & 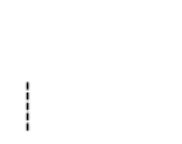 & 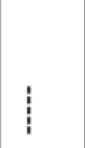 & 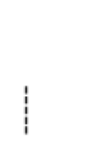 & 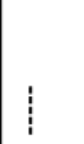 \\
\hline 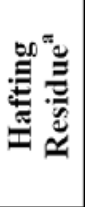 & 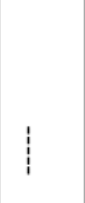 & 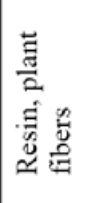 & : & 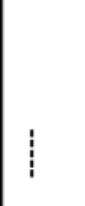 & 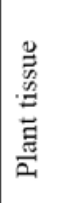 & 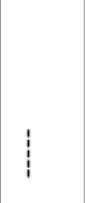 & 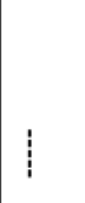 & 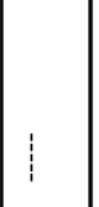 & 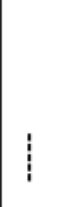 & 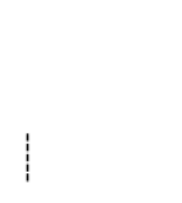 & 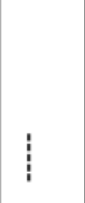 & 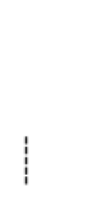 & 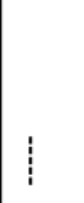 \\
\hline 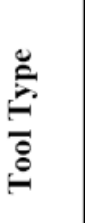 & 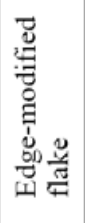 & 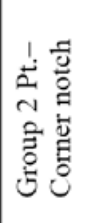 & 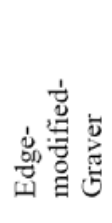 & 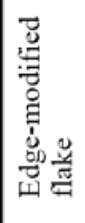 & 总芸 & 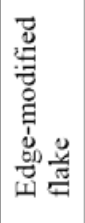 & 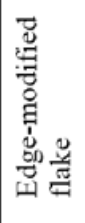 & 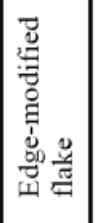 & 詰 & 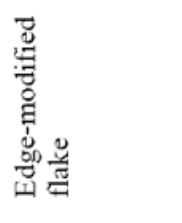 & 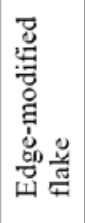 & 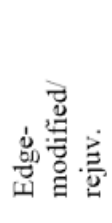 & 芯 \\
\hline 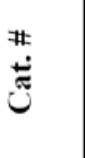 & $\begin{array}{l}0 \\
0 \\
0 \\
1 \\
\dot{9} \\
9\end{array}$ & $\begin{array}{l}\stackrel{0}{0} \\
\dot{1} \\
\stackrel{\overbrace{}}{\sigma}\end{array}$ & $\begin{array}{l}\stackrel{m}{a} \\
\stackrel{1}{d} \\
\stackrel{\vec{\sigma}}{\sigma}\end{array}$ & $\vec{\exists}$ & $\begin{array}{l}\stackrel{\partial}{\bar{\lambda}} \\
\text { भु }\end{array}$ & $\begin{array}{l}\overrightarrow{\overrightarrow{0}} \\
\stackrel{1}{a} \\
\vec{q}\end{array}$ & $\begin{array}{l}= \\
\vec{b} \\
\dot{j}\end{array}$ & 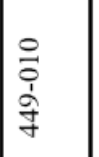 & 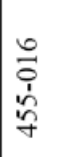 & 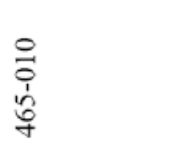 & $\begin{array}{l}\stackrel{0}{0} \\
\stackrel{1}{1} \\
\stackrel{5}{f}\end{array}$ & $\begin{array}{l}01 \\
0 \\
\vdots \\
\text { nे }\end{array}$ & 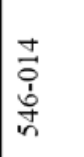 \\
\hline
\end{tabular}




\begin{tabular}{|c|c|c|c|c|c|c|c|c|c|c|c|c|c|}
\hline 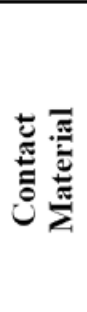 & 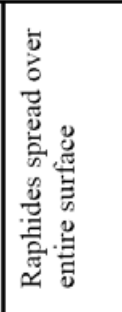 & 壳 & 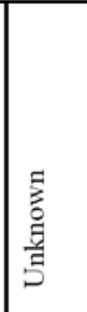 & 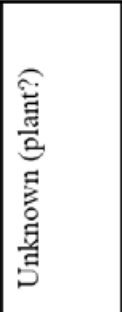 & $\begin{array}{l}\text { E } \\
\text { 言 } \\
\frac{E}{5} \\
5\end{array}$ & 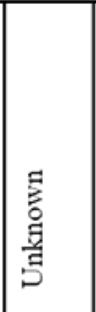 & $\begin{array}{l}\text { E } \\
\text { E } \\
\frac{E}{5} \\
5\end{array}$ & 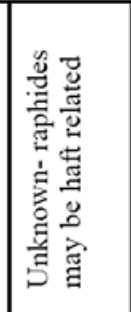 & $\begin{array}{l}\text { E } \\
\text { 音 } \\
\frac{\vec{g}}{5}\end{array}$ & $\begin{array}{l}\overrightarrow{0} \\
\overline{8} \\
\overrightarrow{8}\end{array}$ & 羙 & \begin{tabular}{|l} 
E \\
总 \\
$\frac{E}{5}$ \\
5
\end{tabular} & 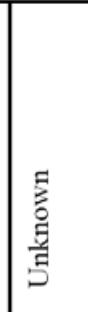 \\
\hline 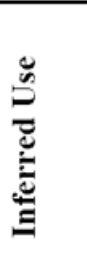 & 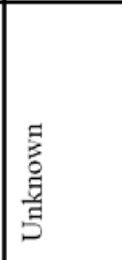 & $\mid \begin{array}{l}\text { 煦 } \\
\text { 镸 }\end{array}$ & 昜 & 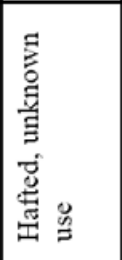 & 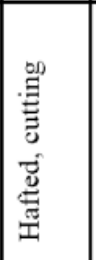 & \begin{tabular}{|l} 
昜 \\
恚
\end{tabular} & $\begin{array}{l}\text { E } \\
\text { 总 } \\
\frac{E}{5}\end{array}$ & \begin{tabular}{|l} 
E \\
鄫 \\
咅
\end{tabular} & 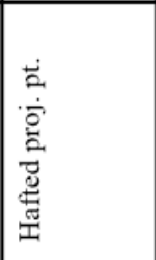 & 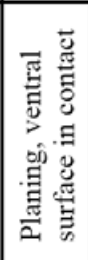 & $\mid$\begin{tabular}{|l|} 
\\
.00 \\
害 \\
$\mathrm{E}$
\end{tabular} & \begin{tabular}{|l} 
E \\
总 \\
$\frac{g}{5}$ \\
5
\end{tabular} & 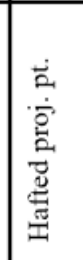 \\
\hline 吾 & 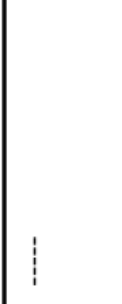 & 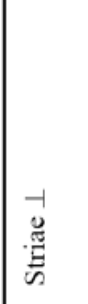 & 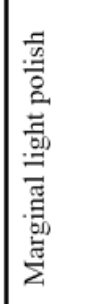 & 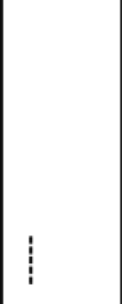 & 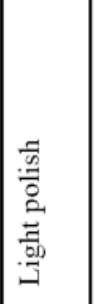 & 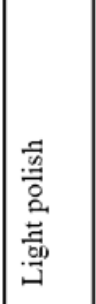 & 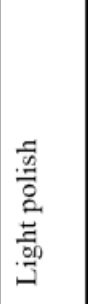 & 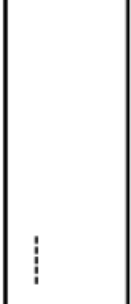 & 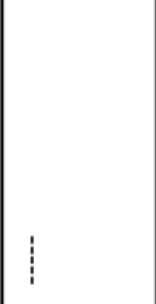 & 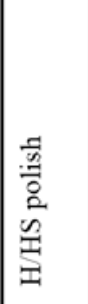 & 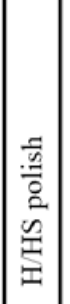 & 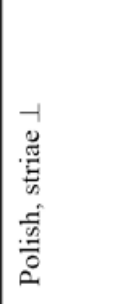 & 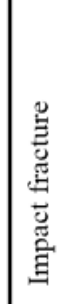 \\
\hline 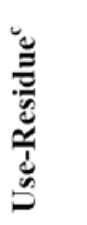 & 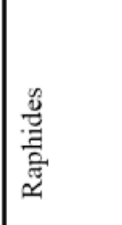 & 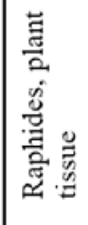 & 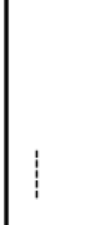 & 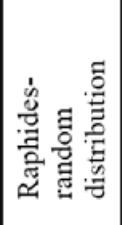 & 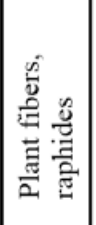 & 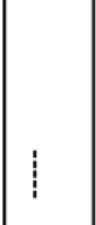 & 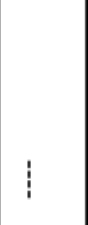 & 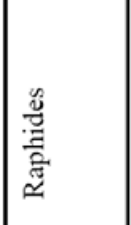 & 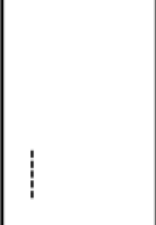 & 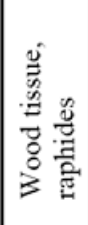 & 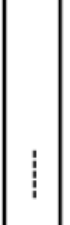 & & 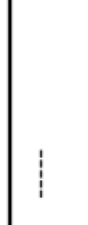 \\
\hline 葛 & 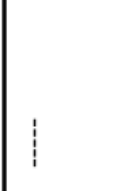 & 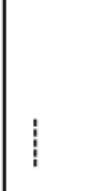 & 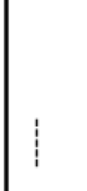 & 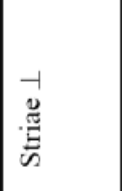 & 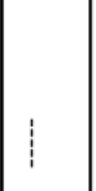 & 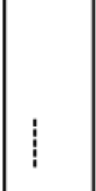 & 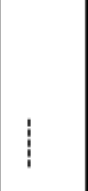 & 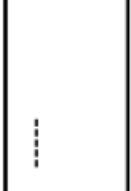 & 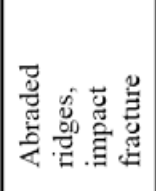 & 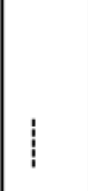 & 1 & 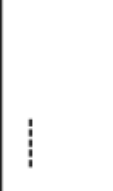 & 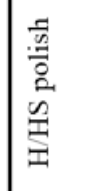 \\
\hline 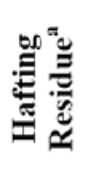 & 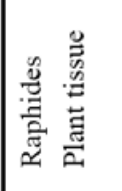 & 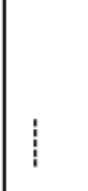 & 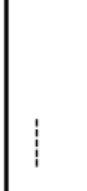 & 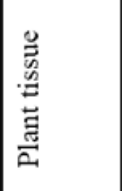 & $\begin{array}{l}0 \\
0 \\
0 \\
0 \\
0 \\
0 \\
0 \\
0 \\
0\end{array}$ & 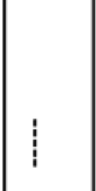 & 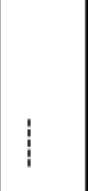 & 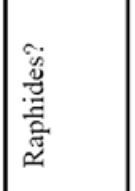 & 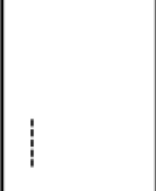 & 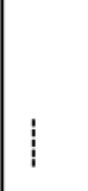 & 1 & 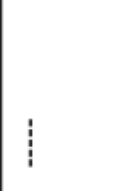 & 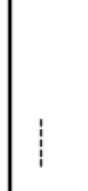 \\
\hline : & 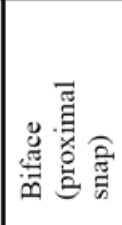 & 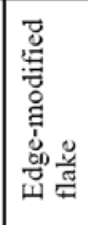 & 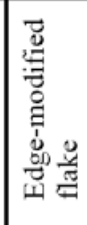 & 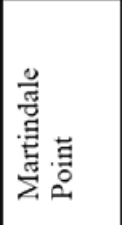 & \begin{tabular}{|l} 
总 \\
总
\end{tabular} & 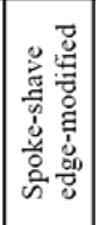 & 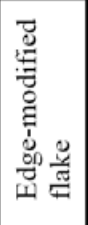 & 总蒠 & 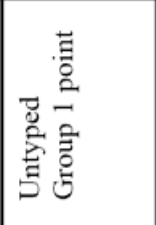 & 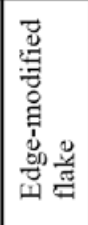 & 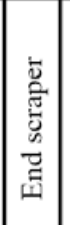 & 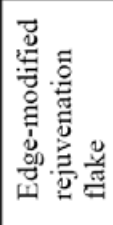 & 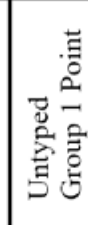 \\
\hline 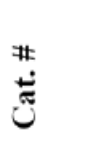 & 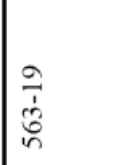 & \begin{tabular}{|l}
$\overrightarrow{0}$ \\
$i$ \\
i \\
in
\end{tabular} & 竞 & $\begin{array}{l}\text { के } \\
\dot{i} \\
\text { iे }\end{array}$ & 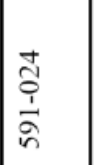 & \begin{tabular}{|l}
0 \\
$\dot{a}$ \\
$\vdots$ \\
مे
\end{tabular} & $\begin{array}{l}\bar{\vdots} \\
\vdots \\
\text { مे }\end{array}$ & $\begin{array}{l}m \\
\dot{\alpha} \\
\dot{\alpha} \\
\dot{n}\end{array}$ & 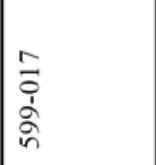 & $\begin{array}{l}0 \\
0 \\
0 \\
0 \\
0\end{array}$ & $\mid \begin{array}{l}m \\
0 \\
0 \\
\hat{\Lambda} \\
0\end{array}$ & $\begin{array}{l}\overrightarrow{\overrightarrow{0}} \\
\stackrel{\overrightarrow{0}}{\mathrm{~g}}\end{array}$ & \begin{tabular}{|l}
7 \\
7 \\
0 \\
0 \\
0 \\
0 \\
0
\end{tabular} \\
\hline
\end{tabular}




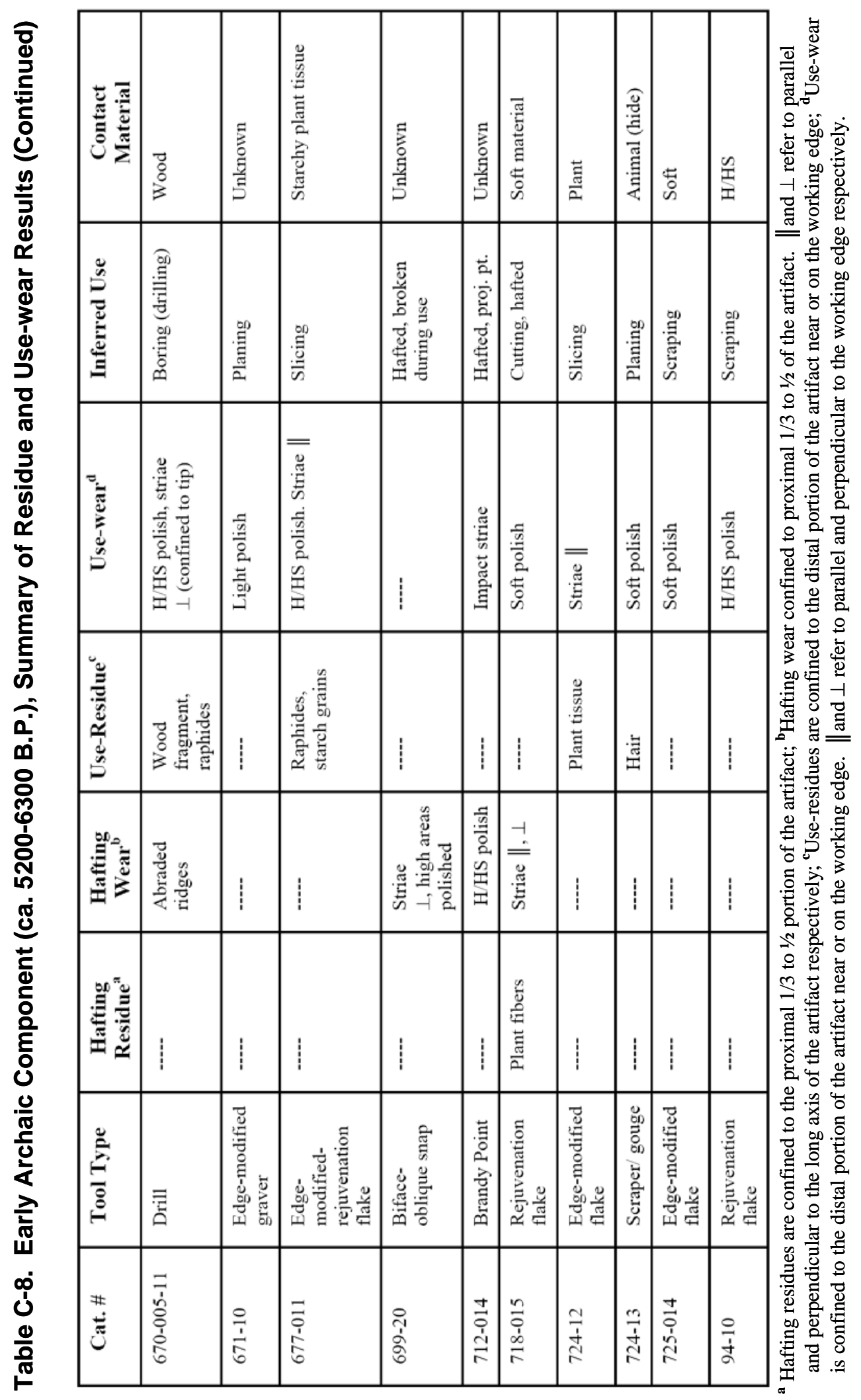




\section{C.4 Discussion}

\section{Toyah Component}

The Toyah component is the youngest of the samples and exhibits remarkable preservation. Hair fragments, feather barbules, wood anatomy, starch grains, resin and possible blood residues are all present (Figures C-1 through C-7). Figure C-2 shows artifact \#220-15, a biface tip with both feather barbules and wood cells with scalariform pitting. Numerous feather barbules (> 50) are found along one edge. On the same edge, wood fragments with scalariform pitting are visible. Among common hardwood trees, scalariform intervessel pitting is found in magnolia, sweetgum, and black tupelo (Hoadley 1990). While these wood fragments could derive form one of these tree species, numerous other woody shrubs from southwest Texas have not been characterized anatomically. At the least, it is possible to say that these fragments come from hardwood (angiosperm).

Overall, typological categories demonstrate a variety of different uses. Scrapers, for example, although used exclusively for scraping and planning, worked a variety of materials including both plant and animal. The same is true for edge-modified flakes, except that they also exhibit a wide range of use-actions including scraping, planing, whittling, slicing, and cutting. Bifaces were used on a similarly wide range of use-materials with a variety of use-actions.

Among the variety of projectile points, several show evidence of hafting in the form of plant fibers involved in binding, resin used as mastic, and abraded ridges from movement against the haft. The use-material for the projectile points is generally not known. This is consistent with their use as projectile points where contact with the use-material is usually brief.
All of the artifacts from the Toyah sample show some evidence of use, either through residues or use-wear. This incredibly high percentage of tools with functional evidence suggests that the occupants of the site were conducting intensive processing of a wide range of materials including wood, starchy plants (possibly roots or tubers), mammals, birds, and other types of plants.

\section{Late Archaic Component}

The Late Archaic sample is relatively small ( $n=17)$ and preserves evidence for exploitation of a more narrow range of materials than the Toyah component. Hafting is limited to bifacially retouched tools and does not occur in high frequencies (3 of 16 tools are hafted). Wood and hide are the most commonly used materials (Figures C-8 and C-9). Typology is once again not a good predictor of stone tool function. Although sample sizes are small, most typological categories show a range of useactions on different materials. Residue preservation is generally good. Figure C-8 shows evidence of hide scraping on \#98-12 with preserved hair fragments with the cuticle and scale pattern preserved. Unfortunately, it is usually difficult to identify species of origin of isolated hair fragments due to variations in scale pattern on different parts of a hair (root or tip) as well as on different parts of the body (Bruner and Koman 1974).

\section{Middle Archaic Component}

The Middle Archaic sample includes 17 artifacts. Hafting evidence is limited to two of the four Early Triangular points, although none show evidence of use as projectile points. Multiple uses of tool types are evident, despite the small sample size (Figures C-10-C-11). Edge-modified flakes were used on wood and plant tissue and undetermined soft material. 


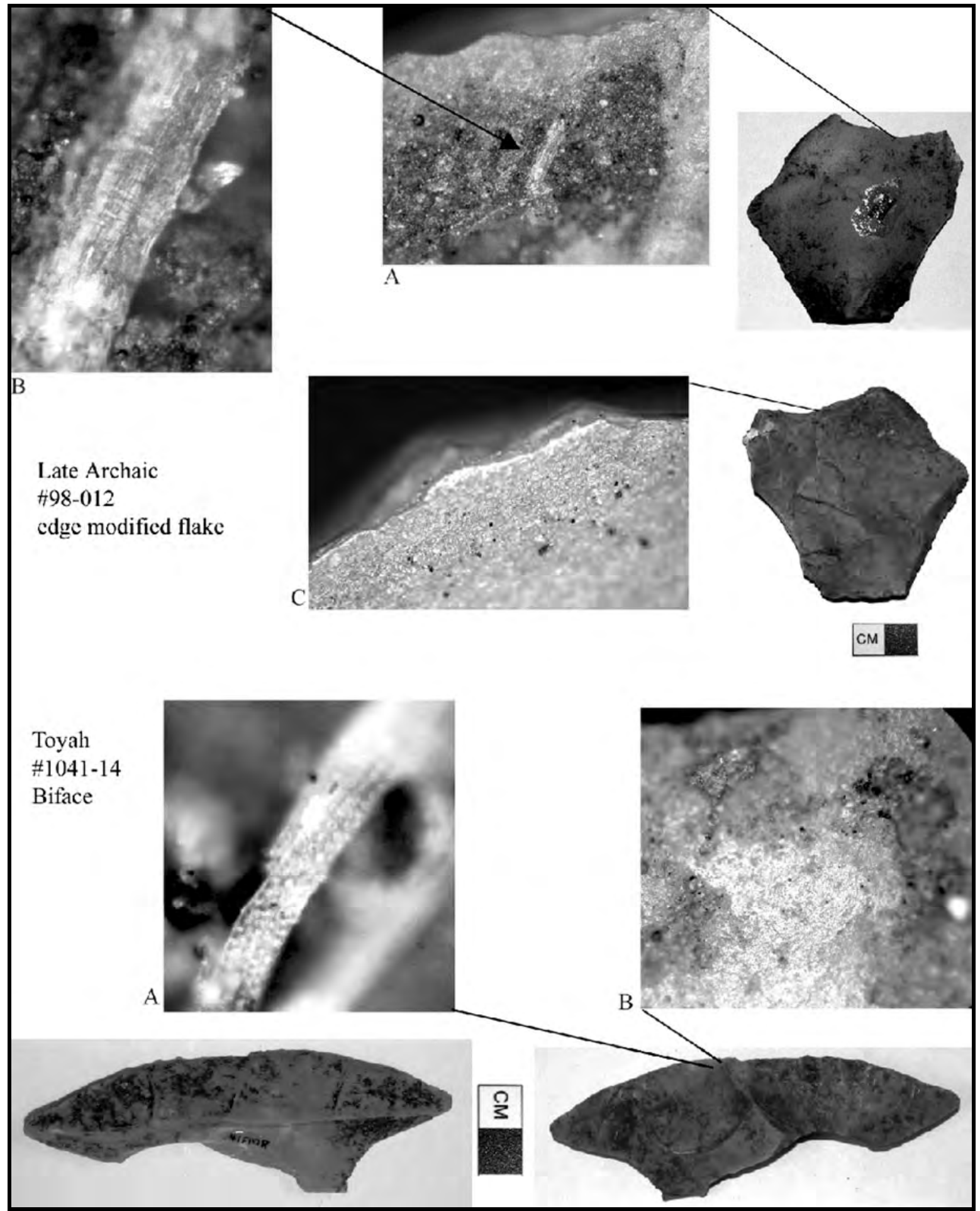

Figure C-1. Top \#98-012, Late archaic Component, Edge modified flake, A) hair fragment in matrix (original mag. 100x); B) hair fragment with scales visible (original mag. 500x); C) polish on edge. Bottom \#1041-14, Toyah Component, Biface, A) wood fiber, alternate pitting (original magnification 500x); B) hard/high silica polish (original mag. 100x) 


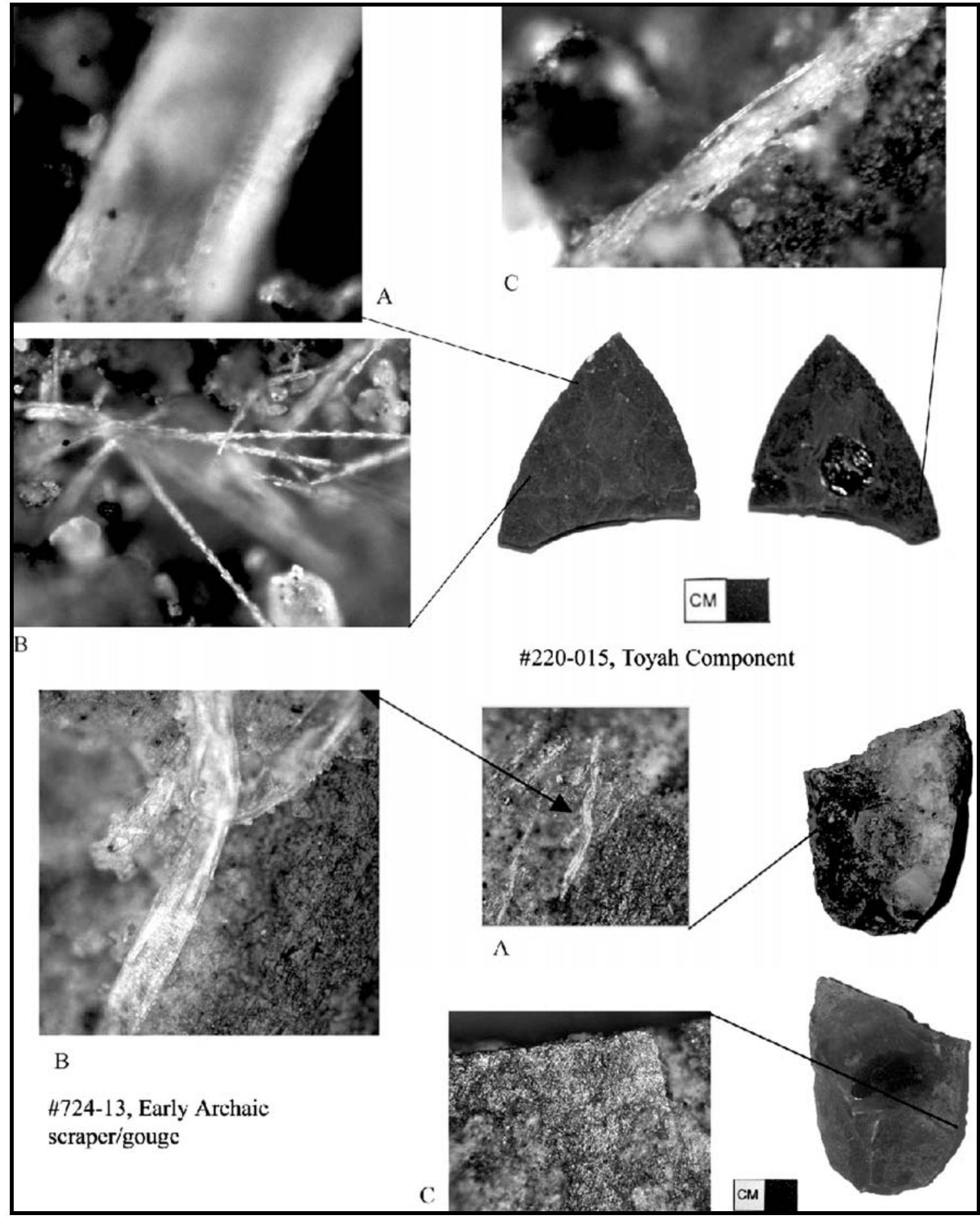

Figure C-2. Top \#220-015, Toyah Component, Biface Tip, A) Wood fragment with scalariform pitting (original mag. 500x); B) cluster of feather barbules (original mag.

500x); C) wood fragments (original mag. 500x). Bottom \#724-13, Early Archaic, scraper/gouge, A) hair fragment (original magnification 100x); B) hair fragment with scales visible (original mag. 500x); C) soft polish (orig. mag. 100x) 


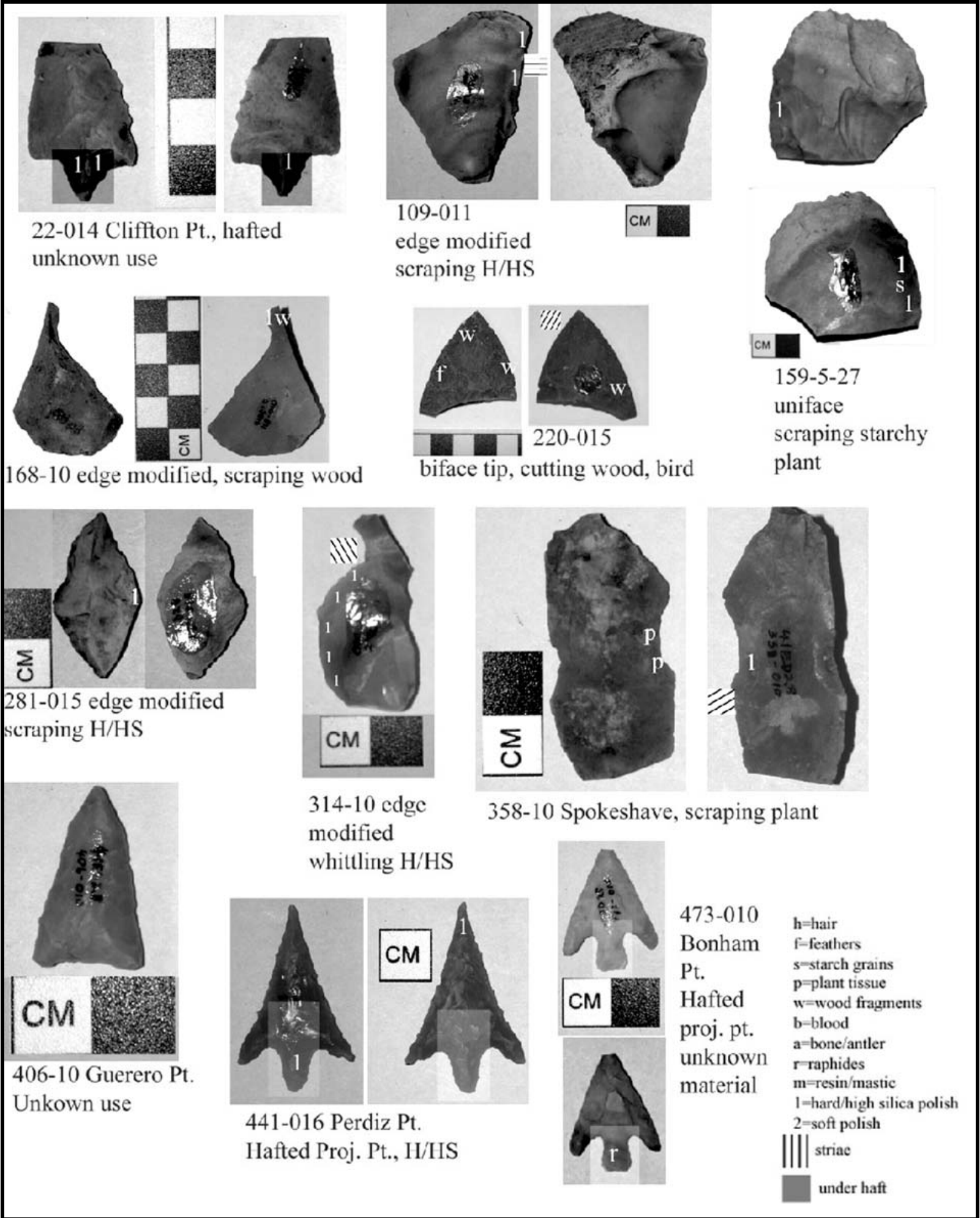

Figure C-3. Selected Toyah Artifacts Part 1, Indicating Location of Use-wear and/or Residue Observed 


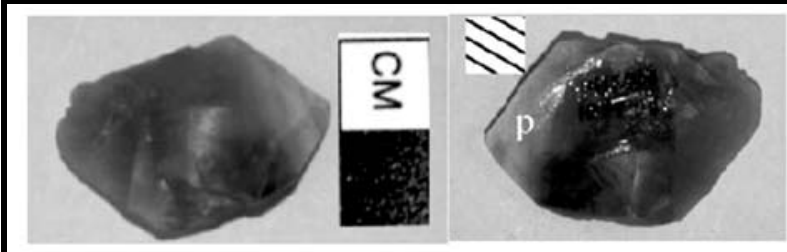

474-010 edge modified, whittling H/HS

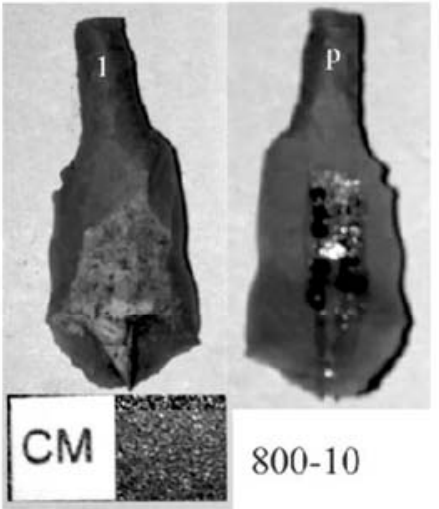

Unknown use-action, plant
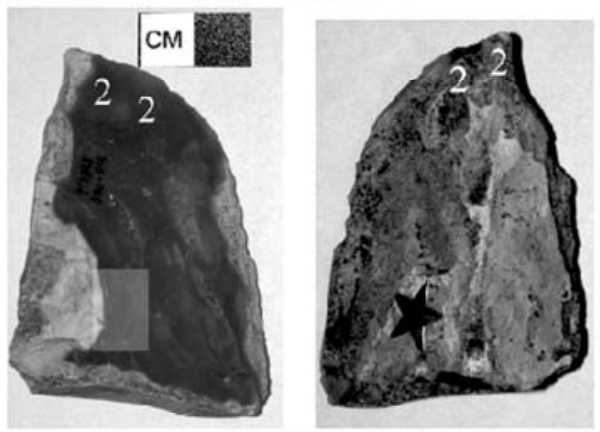

800-12 edge modified. cutting H/HS

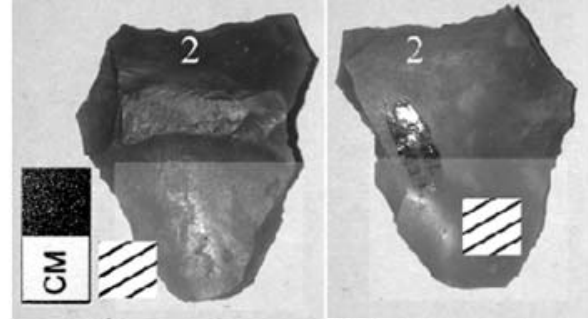

781-010 Edge modified, hafted, scarping soft
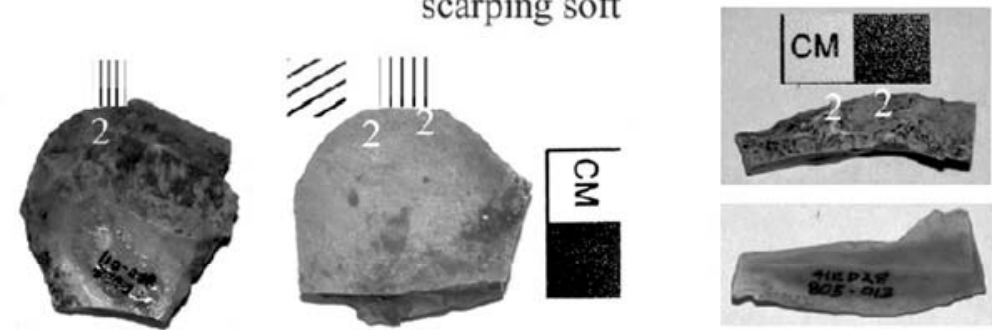

805-013 Uniface

Rejuvenation, scraping $\mathrm{H} / \mathrm{HS}$
800-11 Scraper, planing/scraping H/HS

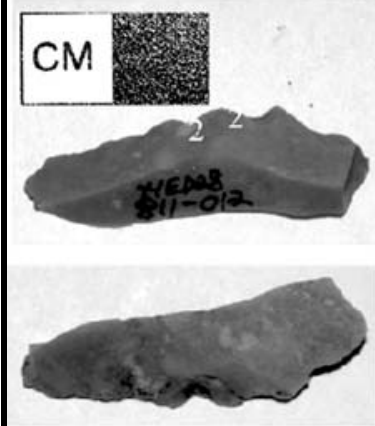

811-02 rejuvenation flake scraping $\mathrm{H} / \mathrm{HS}$

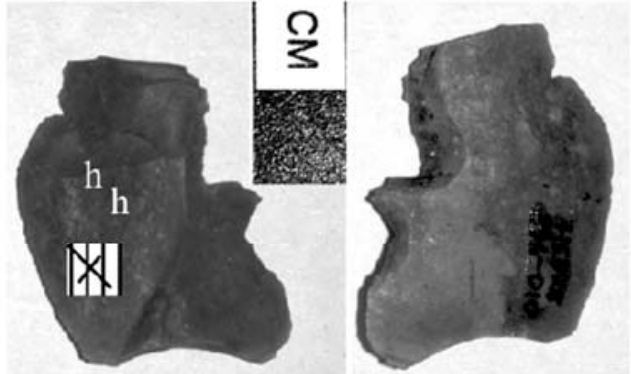

839-10 Graver, cutting animal

Toyah Component, pg. 2 $\mathrm{h}=$ hair

$f=$ feathers

$\mathbf{s = \text { starch grains }}$

$\mathrm{p}$-plant tissue

$w=$ wood fragments

$b=$ blood

$\mathrm{a}=$ bone/antler

$\mathrm{r}$-raphides

$\mathrm{m}-\mathrm{resin}$ 'mastic

1-hard/high silica polish

2-soft polish

|||| striac

under haft

Figure C-4. Selected Toyah Artifacts Part 2, Indicating Location of Use-wear and/or Residue Observed 


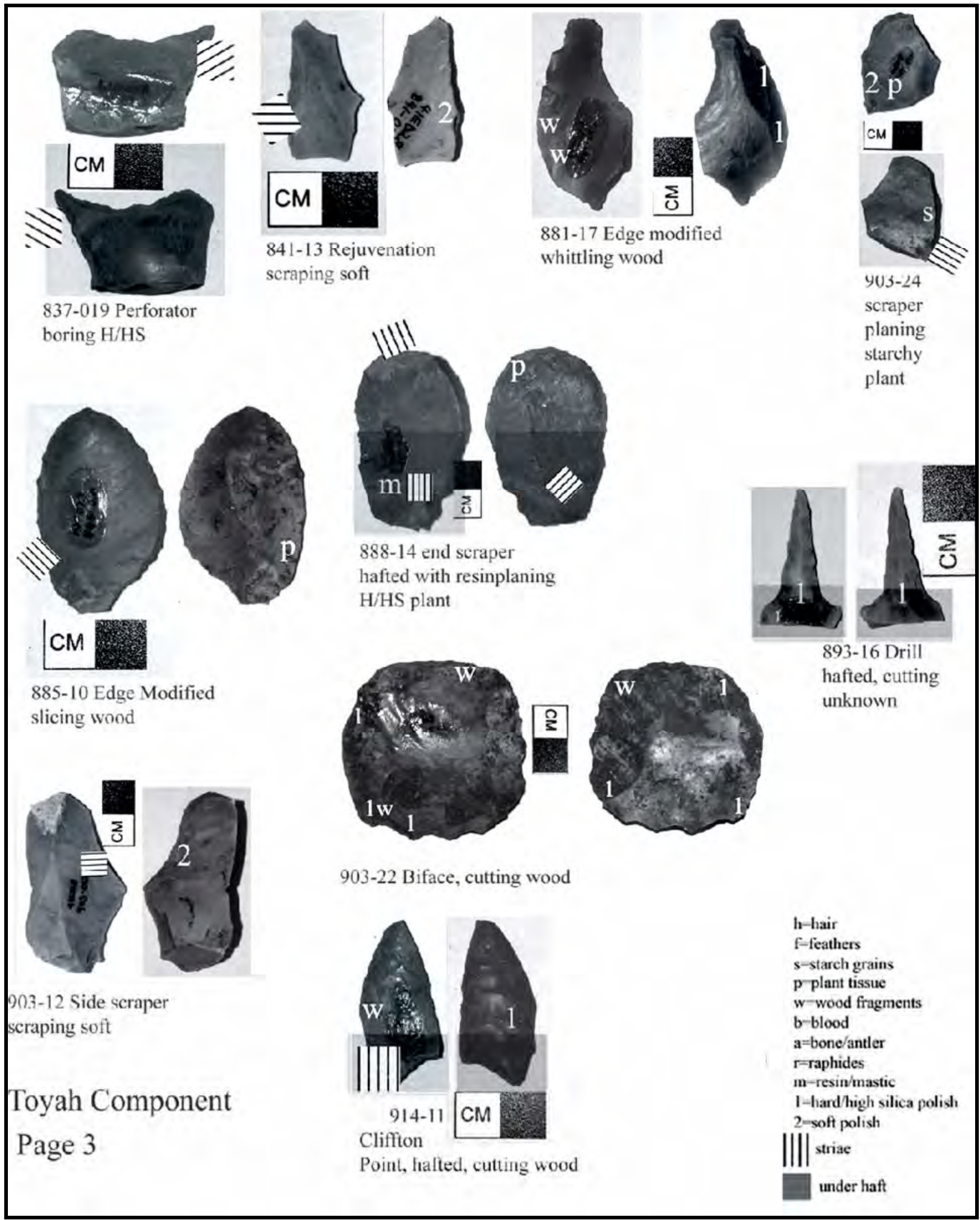

Figure C-5. Selected Toyah Artifacts Part 3, Indicating Location of Use-wear and/or Residue Observed 


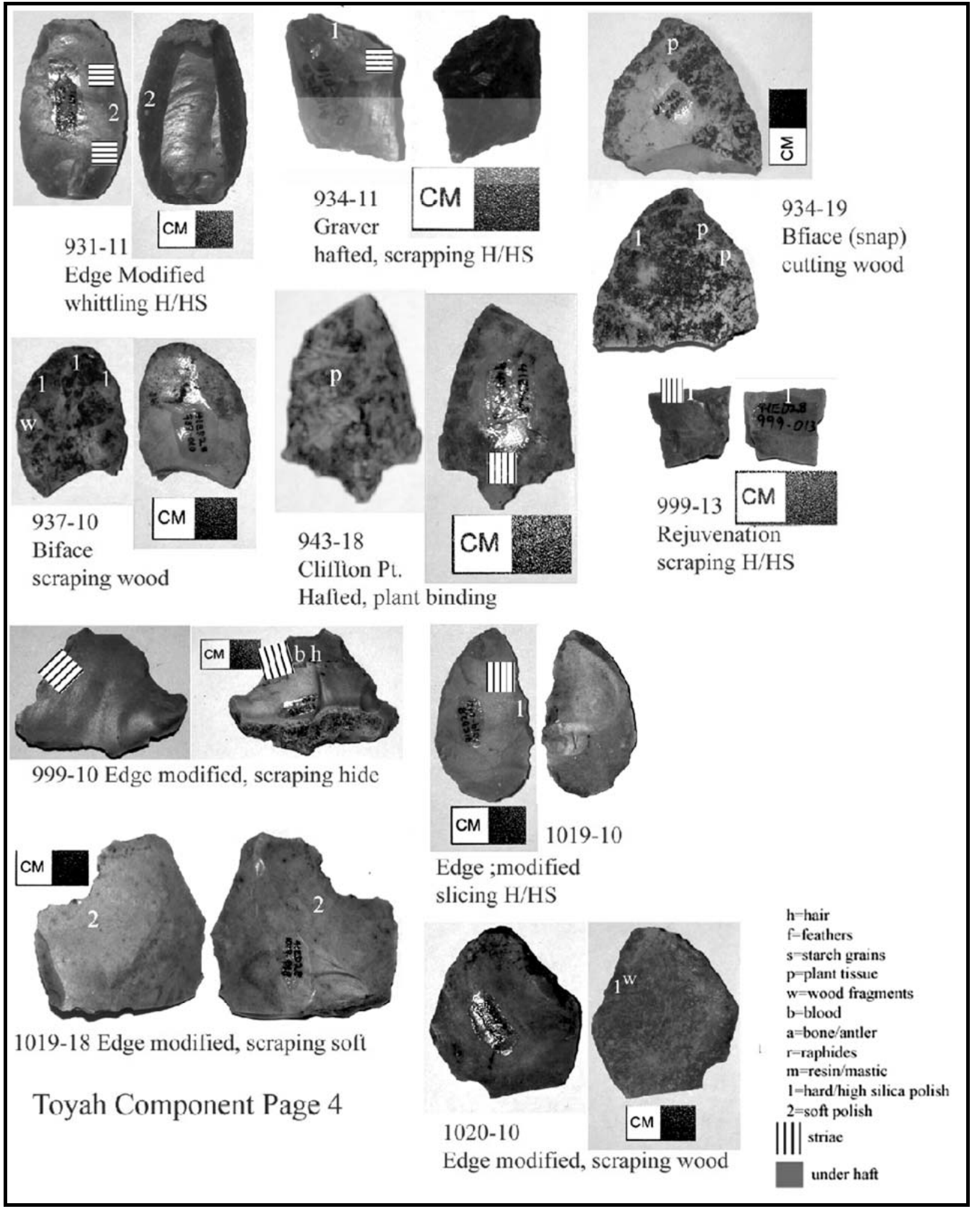

Figure C-6. Selected Toyah Artifacts Part 4, Indicating Location of Use-wear and/or Residue Observed 


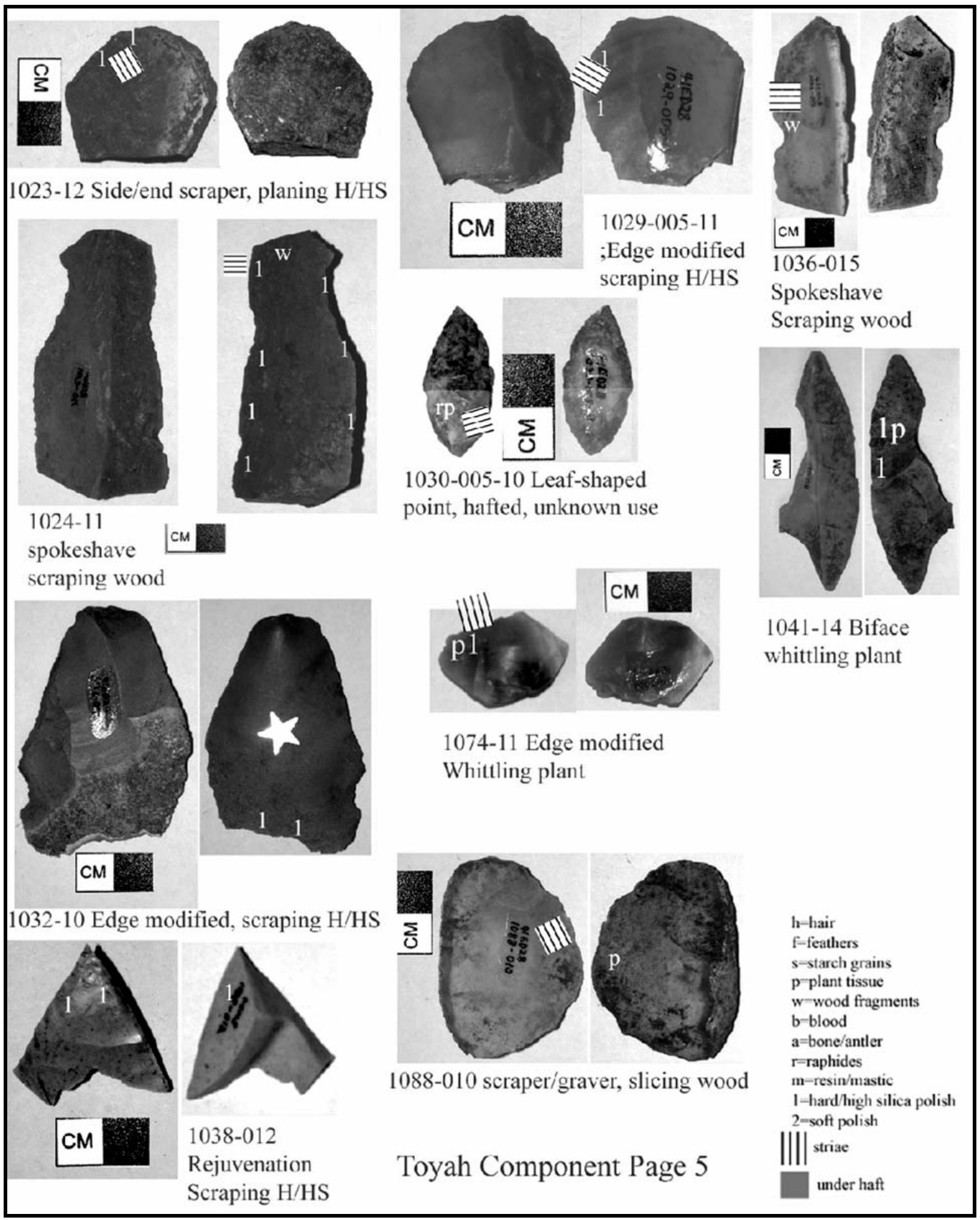

Figure C-7. Selected Toyah Artifacts Part 5, Indicating Location of Use-wear and/or Residue Observed 


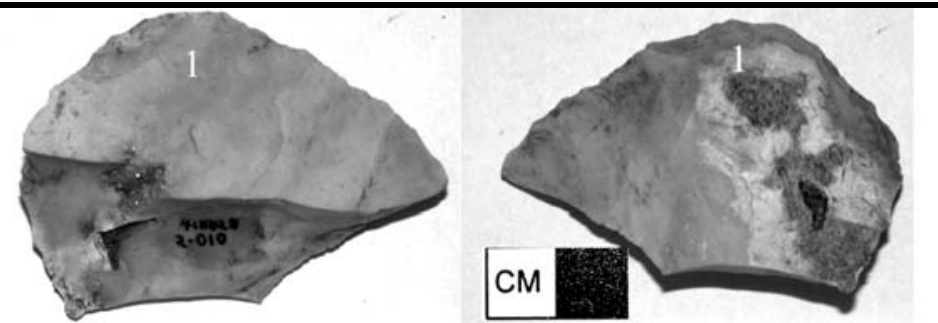

2-10 End scraper, scraping H/HS

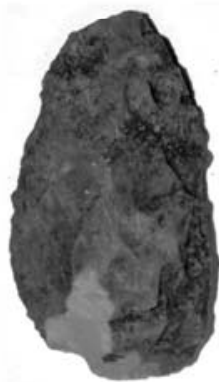

2-11

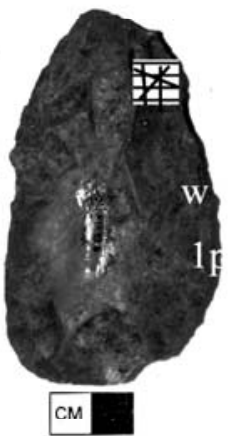

Bifac;e, cutting wood

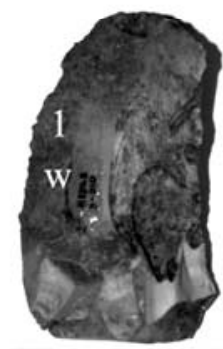

см

3-10 Side/End Scraper planing wood

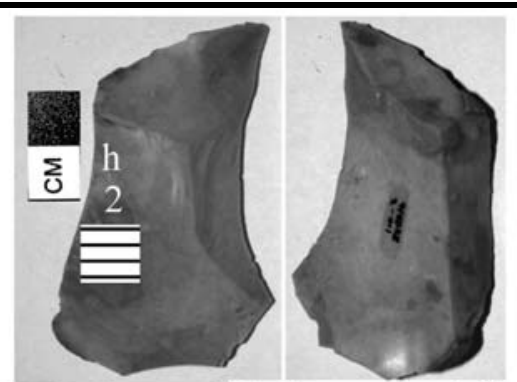

2-11 Edge modified, scraping hide

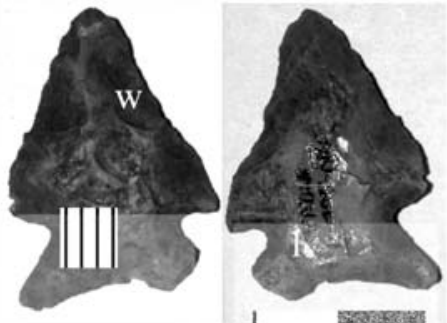

11-5-14

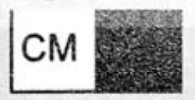

hafted, cutting wood (wood could be haft-related)
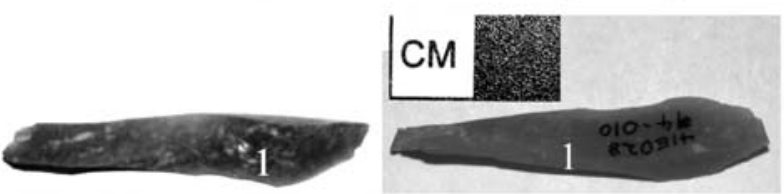

94-010 rejuvenation, scraping H/HS
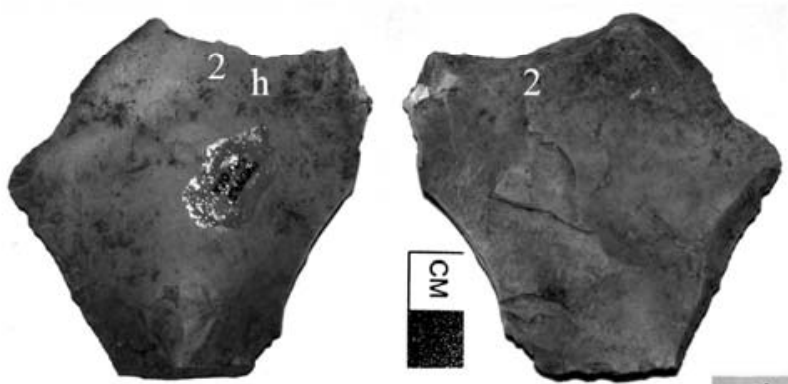

98-012 Edge modified, scraping hide

Late Archaic Compnonent Page 1

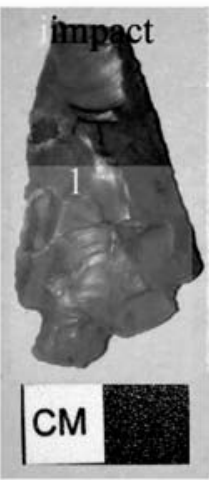

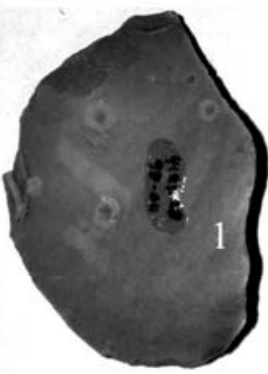

98-11

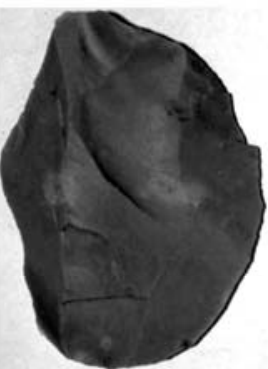

CM
Edge modified, cutting unknown

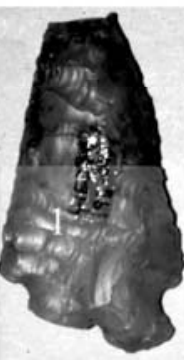

$\mathbf{h}=$ hair

$f=$ feathers

$s=$ starch grains

$\mathrm{p}$-plant tissue

$w=$ wood fragments

b=blood

$\mathrm{a}=$ bone/antler

$\mathrm{r}$-raphides

$\mathrm{m}=\mathrm{resin} / \mathrm{mastic}$

1=hard/high silica polish

$2=$ soft polish

198-10 Montell Pt. |||| striac

Hafted Proj. Pt.

Figure C-8. Selected Late Archaic Artifacts Part 1, Indicating Location of Use-wear and/or Residue Observed 


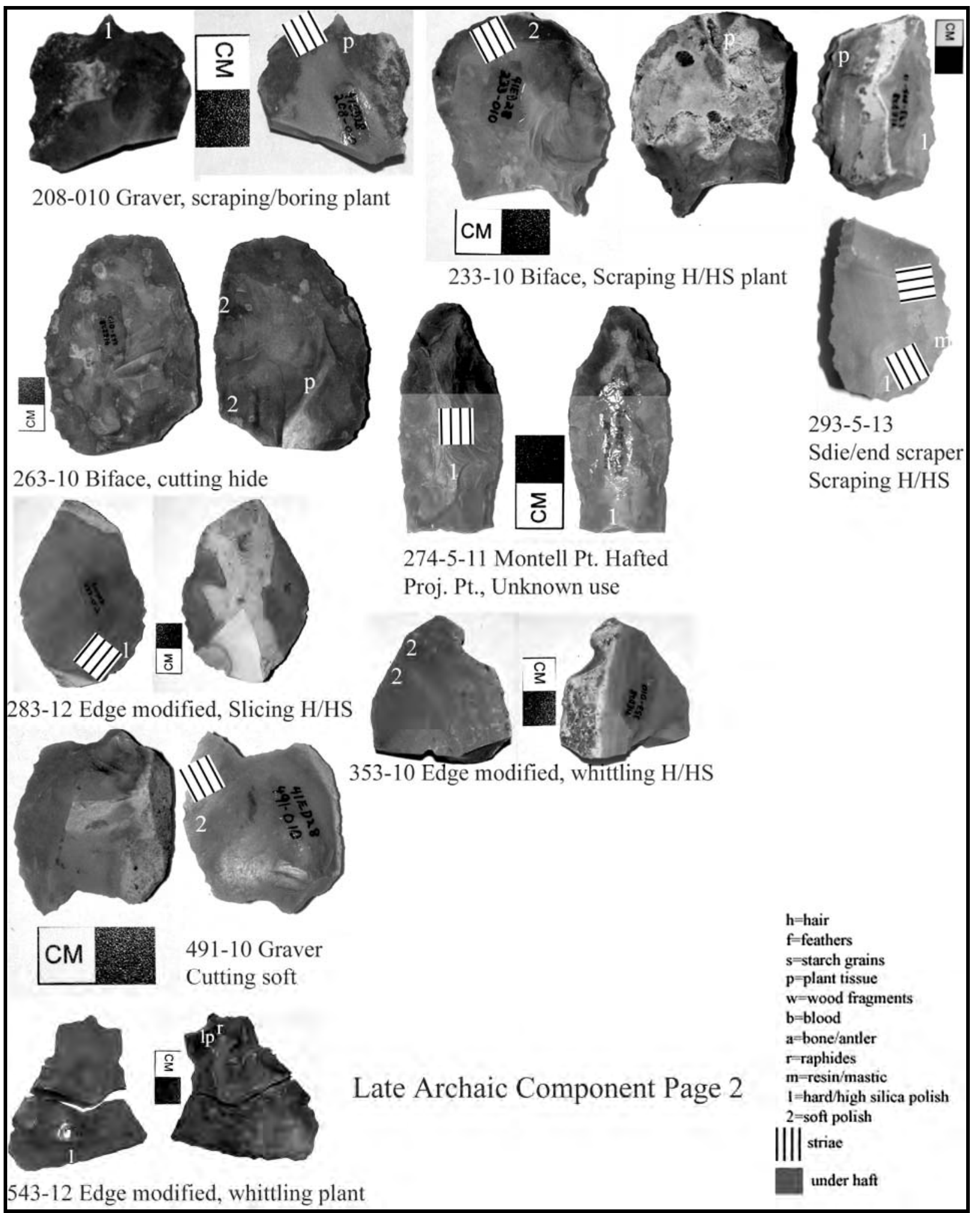

Figure C-9. Selected Late Archaic Artifacts Part 2, Indicating Location of Use-wear and/or Residue Observed 


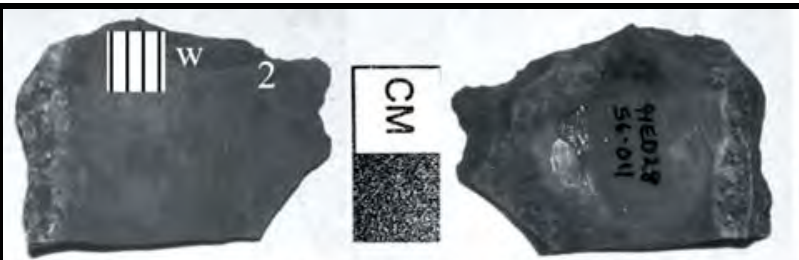

56-011 Edge modified, Whittling wood
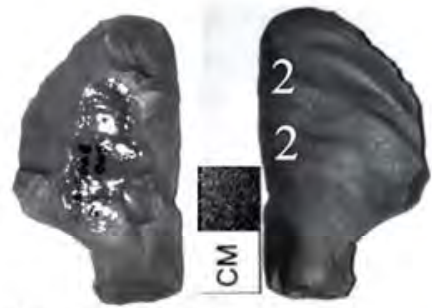

274-5-10, Edge modified Cutting $\mathrm{H} / \mathrm{HS}$
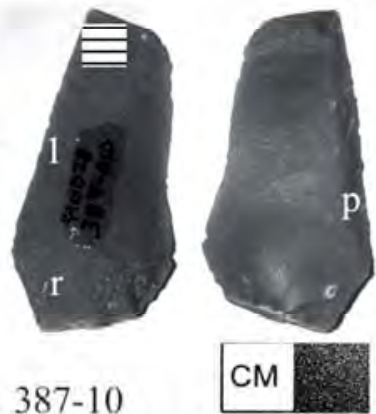

$387-10$

Edge modified, planing H/HS plant
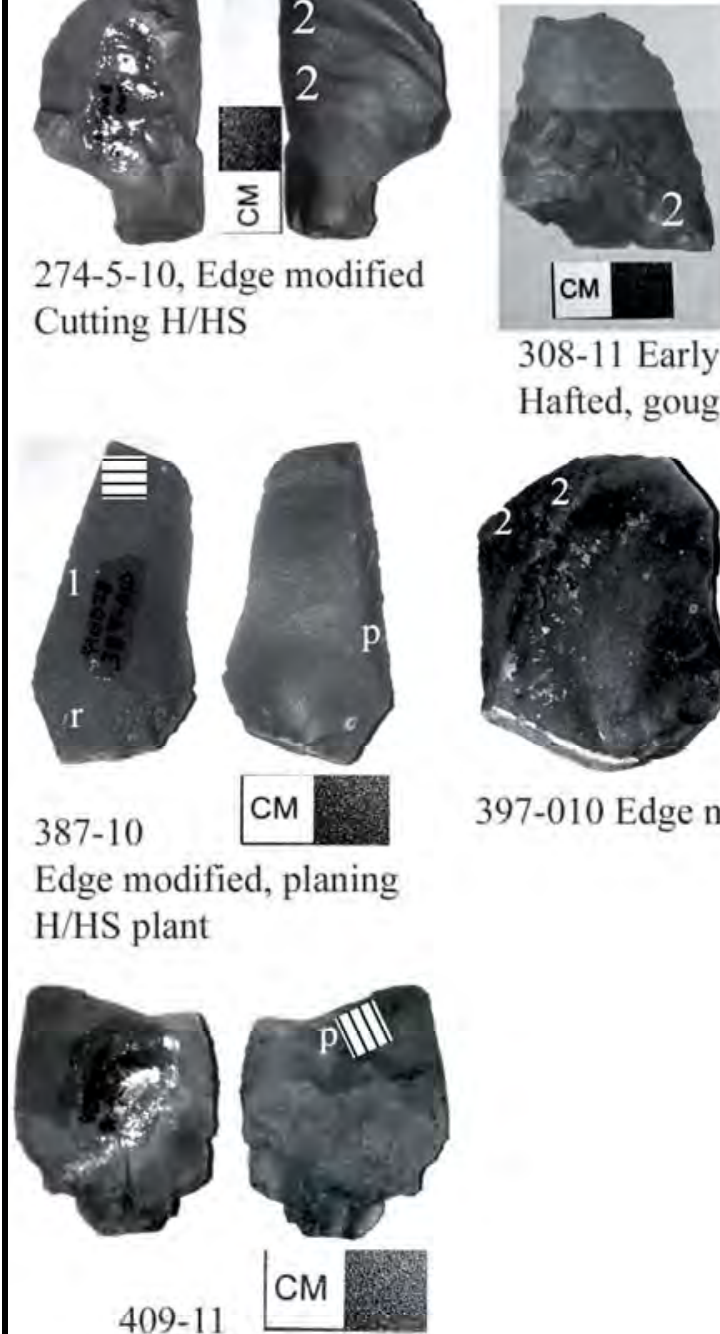

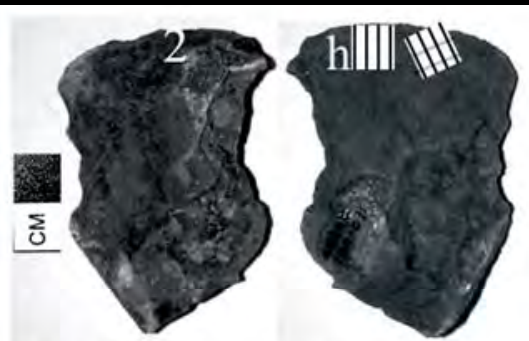

100-11 Endscraper, Planing hide

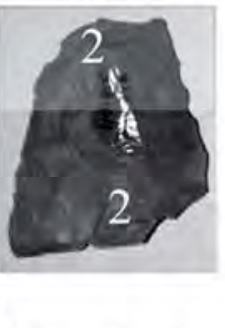

308-11 Early Triangulat Pt. Hafted, gouging $\mathrm{H} / \mathrm{HS}$

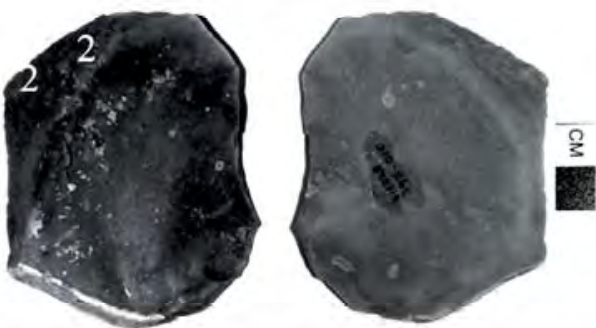

397-010 Edge modified, scraping soft

\section{$\stackrel{n}{3}$}

.
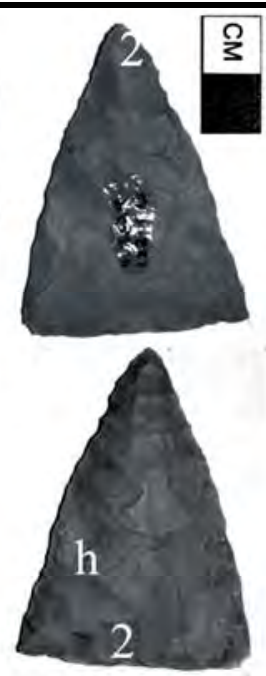

182-13 Early

Triangular Pt., unkown use, hide

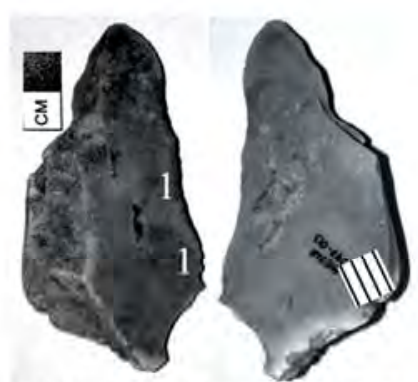

397-013 Edge modified Scraping H/HS
409-11

Edge modified

Whittling plant

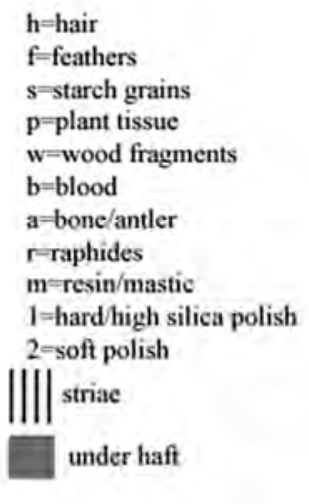

Middle Archaic Compnent Page 1

Figure C-10. Selected Middle Archaic Artifacts Part 1, Indicating Location of Use-wear and/or Residue Observed 


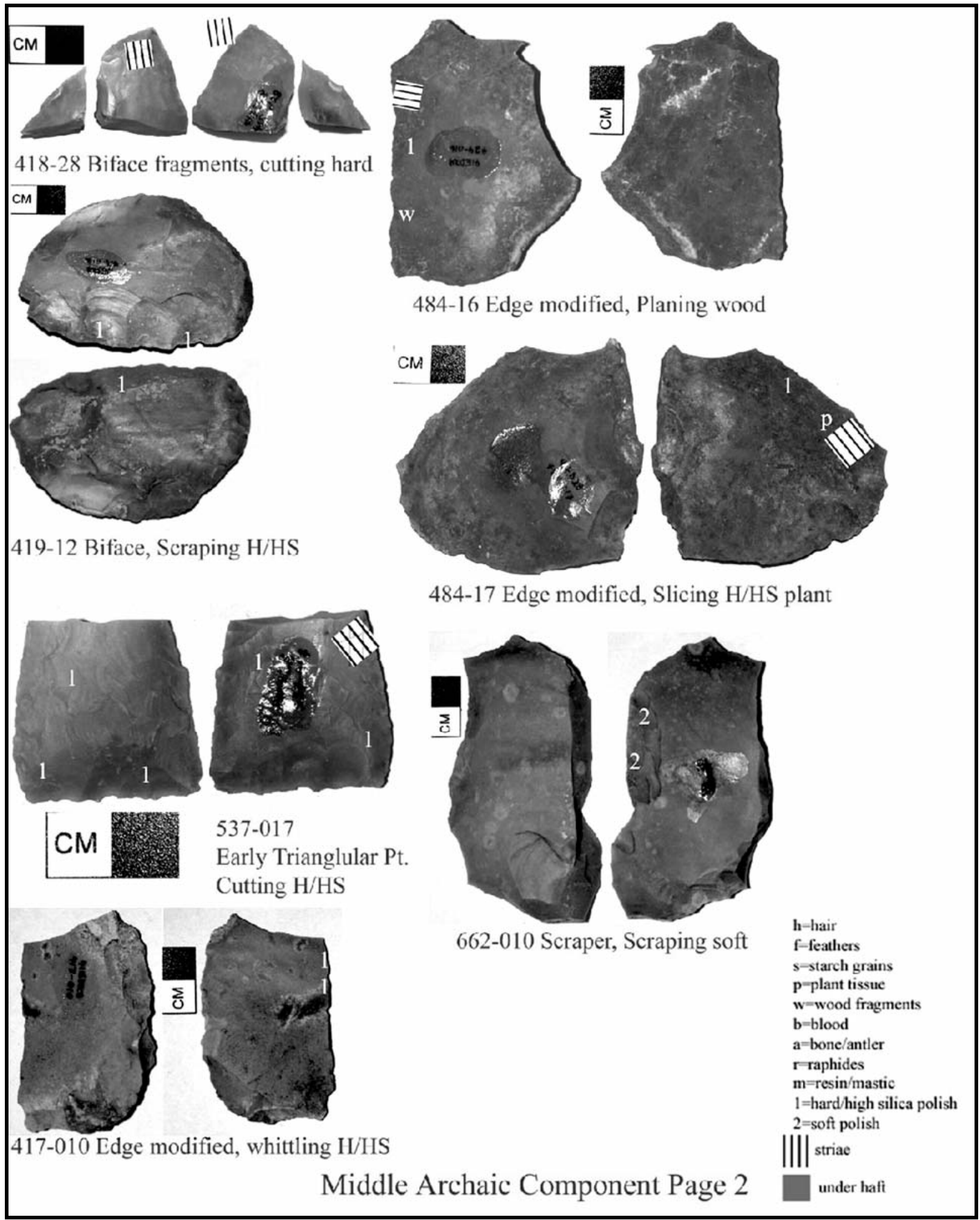

Figure C-11. Selected Middle Archaic Artifacts Part 2, Indicating Location of Use-wear and/or Residue Observed 
Use-actions include whittling, scraping, cutting, and planning. Hair fragments are preserved on two artifacts (one scraper and one Early Triangular point) demonstrating butchery or hide processing. Even with the small sample size, both plant and animal residues are present.

\section{Early Archaic Component}

The Early Archaic sample ( $n=62)$ is comparable in size to the Toyah $(n=57)$. Despite the much greater antiquity of the Early Archaic, a wide range of residues are preserved including raphides, bone/antler fragments, wood, plant fibers and tissue, hair, starch grains, and charcoal (Figures C-12 through C-16). Numerous artifacts exhibit raphides scattered over their surfaces. Raphides are calcium oxalate crystals that form in some plant cells and often serve as a defense mechanism against predators. These crystals preserve well due to their high inorganic component. The patterning of the raphides on most tools is random, covering most of the tool surface. Based on this patterning, it is not possible to confidently attribute them to tool use.

Other residues, however, provide good functional evidence. Plant processing, both woody and non-woody, is evident in all typological categories including several projectile point types (Gower and Early Cornernotched). Edge-modified flakes and rejuvenation flakes were both used to process plants, including wood, starchy plants, and soft plants. Two artifacts form this level, one edgemodified flake and one Bandy point, exhibit bone/antler residue. The overall picture, as with other levels at this site, is one of intensive tool use on a wide range of materials with a wide range of use actions.

\section{C.5 Conclusions}

The Varga Site (41ED28) is remarkable for the high percentage of artifacts that exhibit functional evidence. Of the 153 artifacts examined, all have some form of functional evidence, either of hafting or of use. A small number have minimal functional evidence in the form of light polish that is not diagnostic to category of use-material. This high degree of functional evidence suggests that throughout the sequence, the site was used for processing a wide range of materials, particularly wood and other types of plants. Residue preservation is also remarkable at this site. In particular, animal and bird residues (hair and feathers) are present in much greater frequency than is typical at prehistoric sites (Hardy et al. 2001). Plant residues are also well preserved and include anatomy that is potentially diagnostic to species level (e.g., scalariform intervessel pitting). Overall, stone tool typology is not a good predictor of tool function. Instead, most tool types seem to have been used for a variety of different tasks on more than one material. 


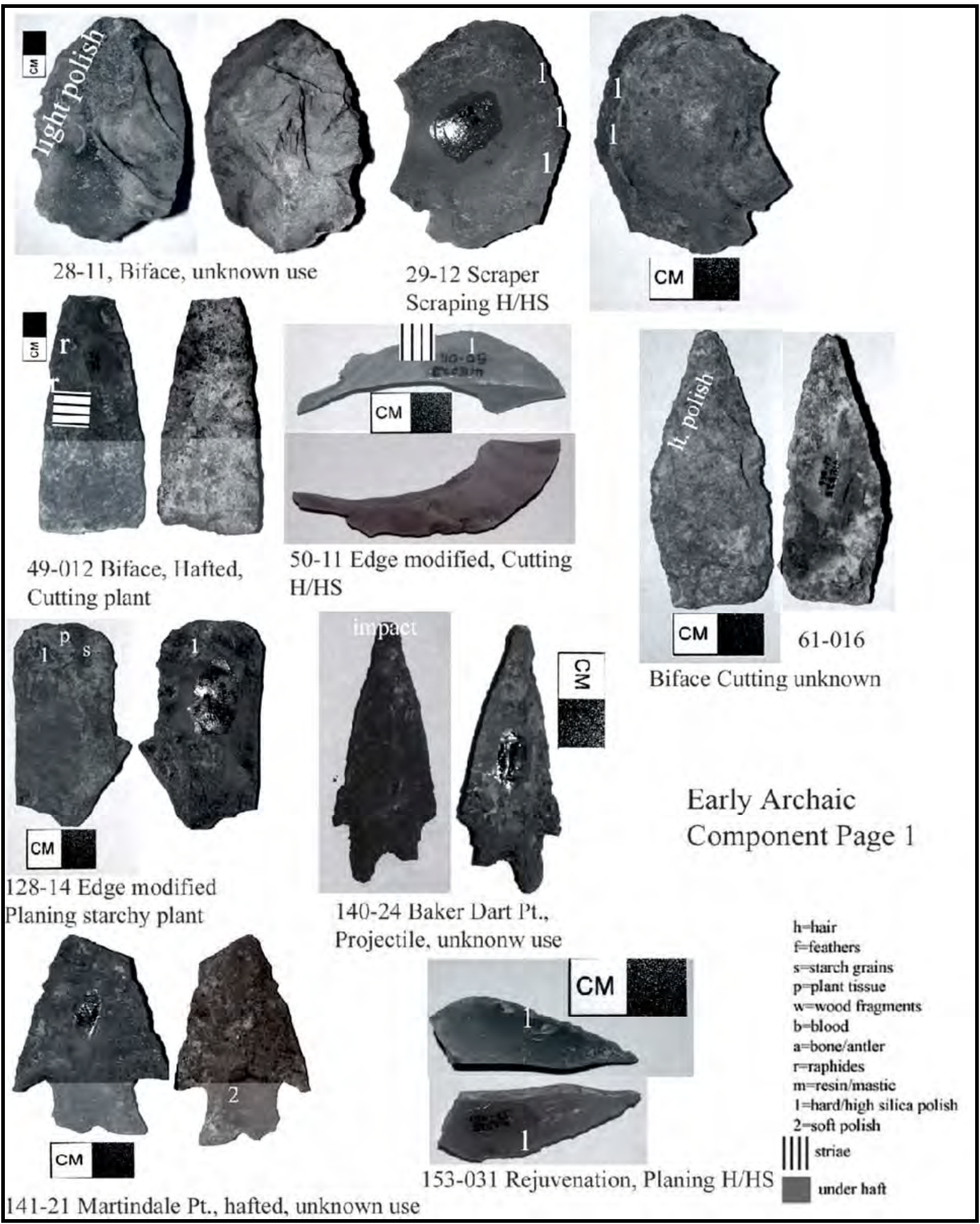

Figure C-12. Selected Early Archaic Artifacts Part 1, Indicating Location of Use-wear and/or Residue Observed 


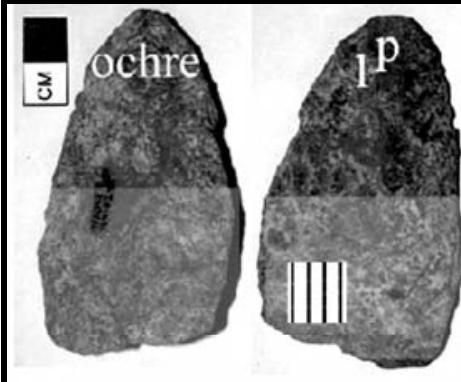

154-24 Biface, Hafted, unknown action, ochre

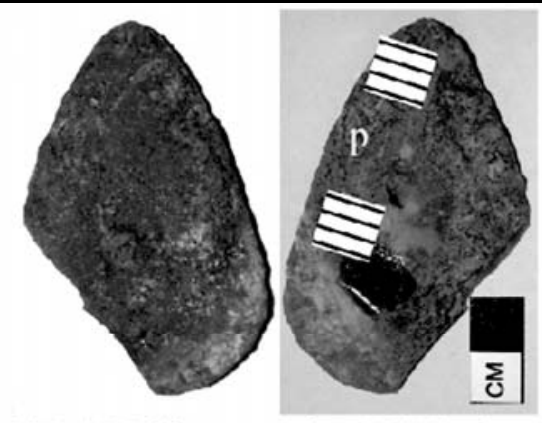

205-10 Biface, cutting H/HS plant

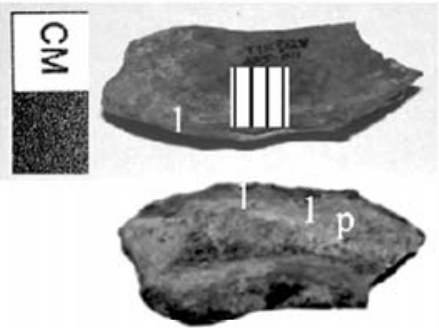

255-11 Rejuvenation Scraping plant

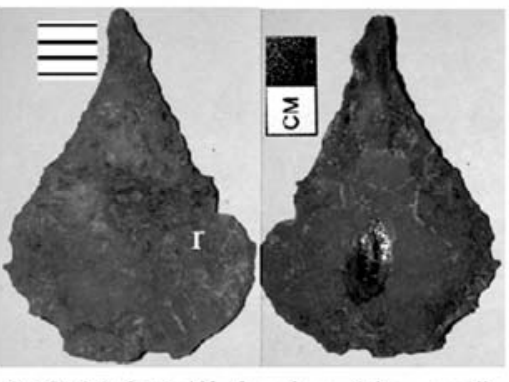

278-026 Drill, boring (tip used) Unknown material
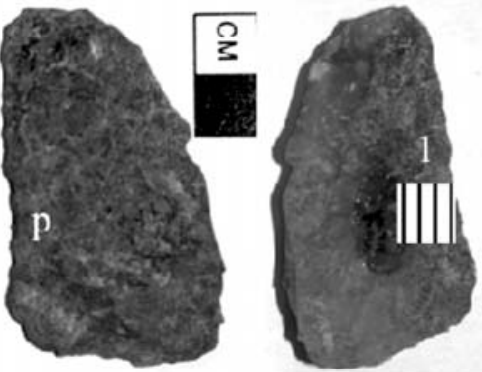

312-019 Side scraper,

Scraping plant

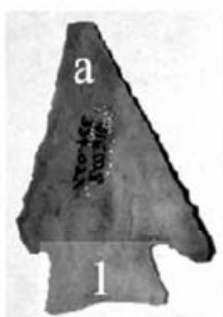

334-022

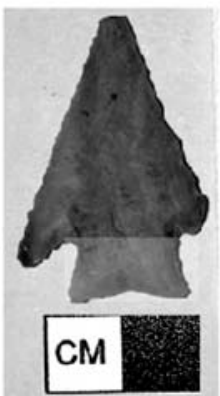

Brandy Proj. Pt.

Halted, bone/antler
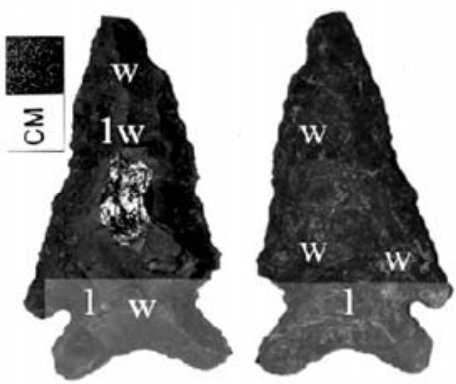

283-014 Early Corner Notched $\mathrm{Pt}$.. hafted. unknown use
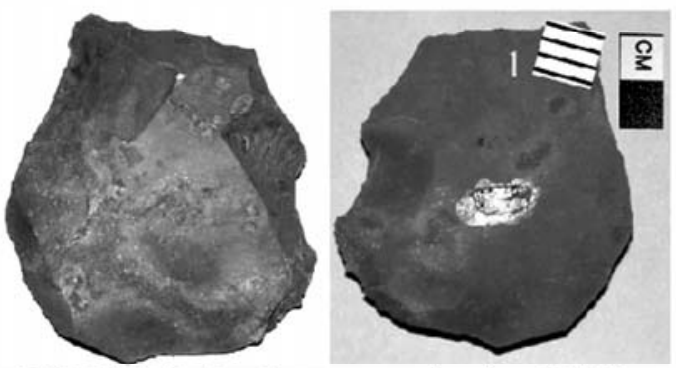

323-30 Side/end scraper, planing H/HS

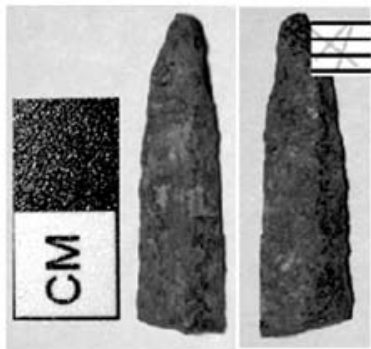

343-010 Drill Tip

Boring hard material

Early Archaic Component Page 2 h=hair

f $=$ feathers

$\mathrm{s}=$ starch grains

p-plant tissue

$w=$ wood fragments

b=blood

a=bone/antler

r-raphides

m=resin/mastic

1=hard/high silica polish 2=soft polish

|||| striac under haft

Figure C-13. Selected Early Archaic Artifacts Part 2, Indicating Location of Use-wear and/or Residue Observed 


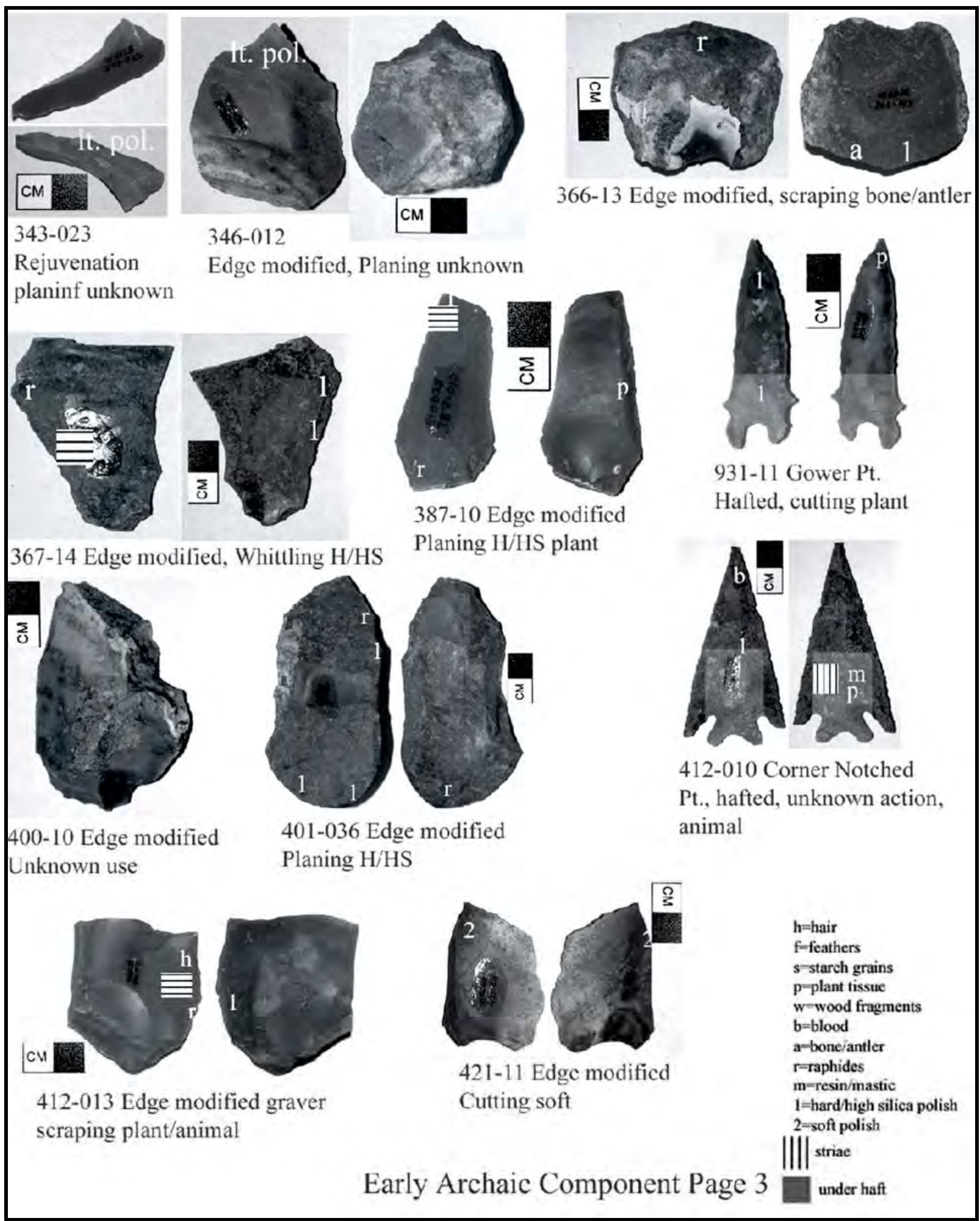

Figure C-14. Selected Early Archaic Artifacts Part 3, Indicating Location of Use-wear and/or Residue Observed 


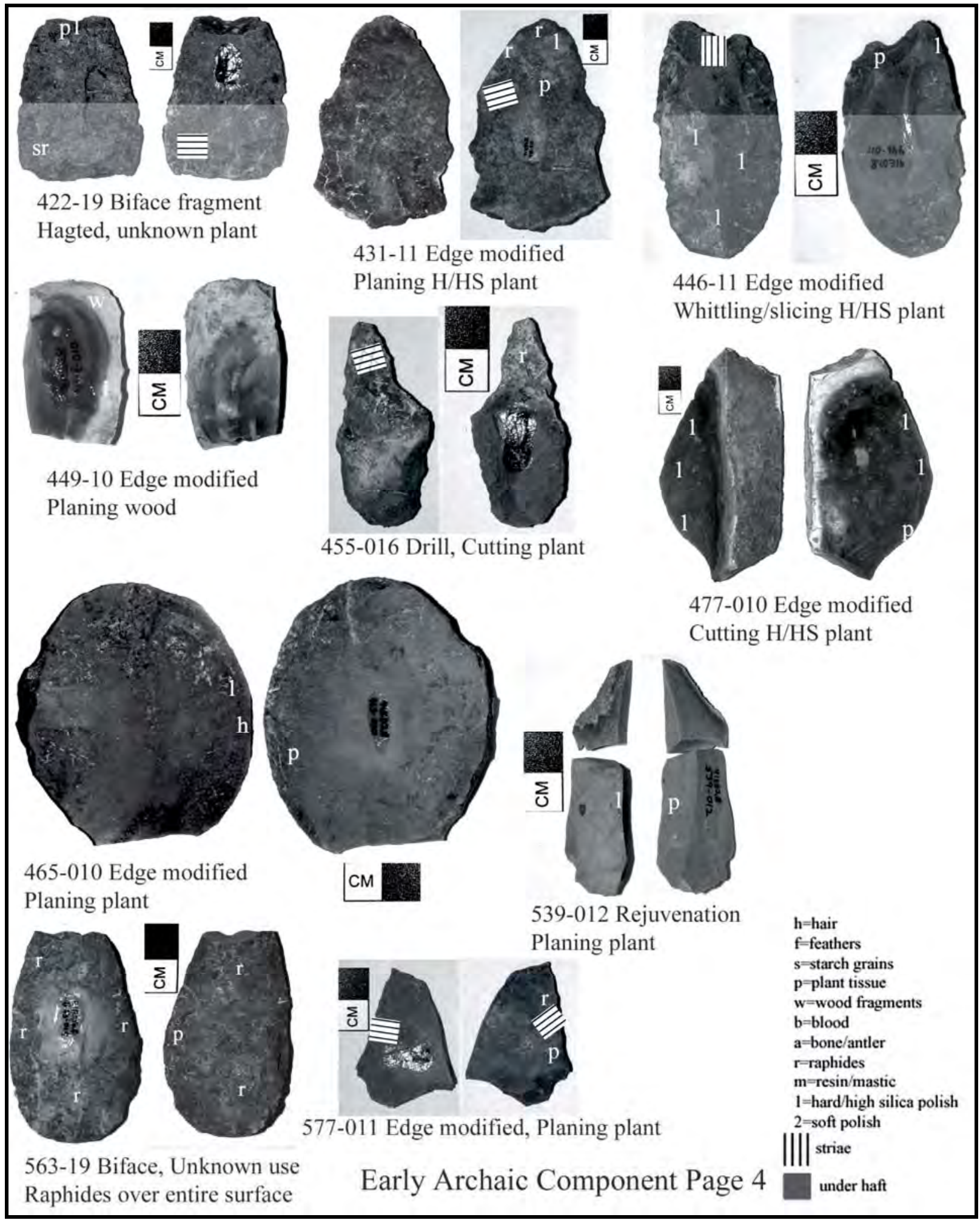

Figure C-15. Selected Early Archaic Artifacts Part 4, Indicating Location of Use-wear and/or Residue Observed 


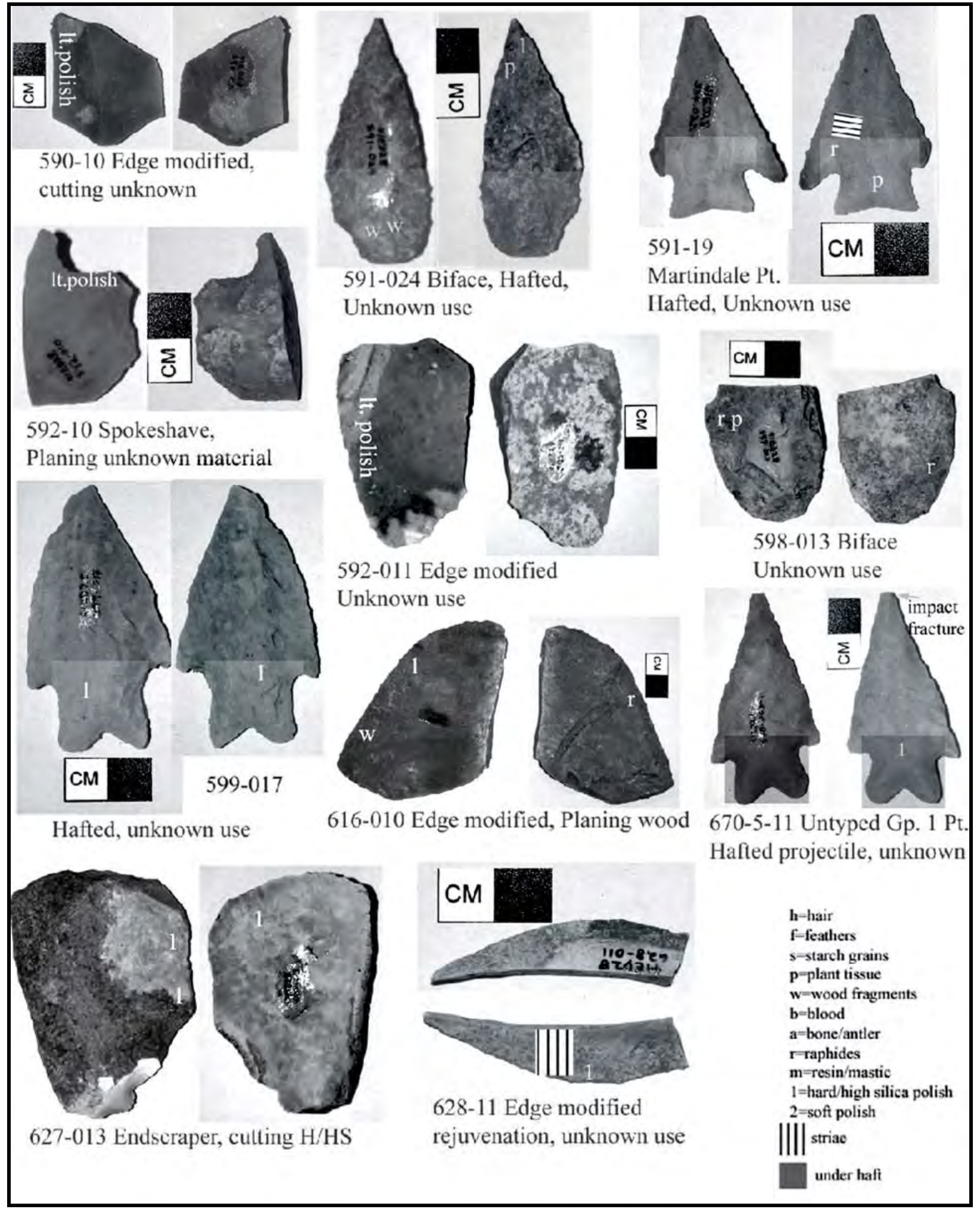

Figure C-16. Selected Early Archaic Artifacts Part 5, Indicating Location of Use-wear and/or Residue Observed 


\section{C.6 References Cited}

Anderson, P.C.

1980 A Testimony of Prehistoric Tasks: Diagnostic Residues on Stone Tool Working Edges. World Archaeology 12(2):181-94.

Anderson-Gerfaud, P.

1981 Contribution Méthodologique à l'Analyse des Microtraces d'Utilisation sur les Outils Préhistoriques. Thèse de Troisième Cycle. Bordeaux: Bordeaux University.

1986 A few comments concerning residue analysis of stone plant-processing tools, in L. Owen \& G. Unrath (ed.), Technical aspects of microwear studies on stone tools, part II, 69-81. Tubingen: Early Man News.

1990 Aspects of behavior in the Middle Paleolithic: Functional analysis of stone tools from southwest France, in Paul Mellars (ed.), The Emergence of Modern Humans, 389-418. Ithica, New York: Cornell University Press.

Barton, H., Torrence, R., \& Fullagar, R.

1998 Clues to stone tool function reexamined: comparing starch grain frequencies on used and unused obsidian artefacts. Journal of Archaeological Science 5:1231-1238.

Beyries, S.

1988 Industries Lithiques: Traçeologie et Technologie. London: British Archaeological Report, International Series 411 (1 and 2).

Bosszhardt, R. and McCarthy, J.

1999 Oneota end scrapers and experiments in hide dressing: an analysis from the La Crosse Locality. Midcontinental Journal of Archaeology 24:177-199.
Briuer, F.

1976 New clues to stone tool function: plant and animal residues. American Antiquity 41:478-484.

Brunner, H., and Koman, B. J.

1974 The identification of mammalian hair. Melbourne: Inkata Press.

Fahn, A.

1982 Plant Anatomy. Pergamon: New York.

Fullagar, R. L. K.

1991 The role of silica in polish formation. Journal of Archaeological Science 18:124.

Fullagar, R., and Field, J.

1997 Pleistocene seed-grinding implements from the Australian arid zone. Antiquity 71:300-07.

Gorski, A.

1997 Material residues on stone tool edges: is optical microscopy missing an opportunity? Microscope 45:89-92.

Hardy, B. L.

1994 Investigations of stone tools function through use-wear, residue and DNA analyses at the Middle Paleolithic site of La Quina, France. Ph.D. Dissertation, Indiana University.

1998 Microscopic residue analysis of stone tools from the Middle Paleolithic site of Starosele. In V. Chabai and K. Monigal (eds.), The Middle Paleolithic of the Western Crimea, Vol. 2. Liege: ERAUL, pp.179-196.

Hardy, B. L. and Garufi, G. T.

1998 Identification of woodworking on stone tools through residue and use-wear analyses: Experimental results. Journal of Archaeological Science 25:177-84.

Hardy, B. L. and Kay, M.

1998 Stone tool function at Starosele: combining use-wear and residue results. 
In V. Chabai and K. Monigal (eds.), The Middle Paleolithic of the Western Crimea, Vol. 2. Liege: ERAUL, pp. 197-209.

Hardy, B. L., Kay, M., Marks, A. E., Monigal, $\mathrm{K}$.

2001 Stone tool function at the Paleolithic sites of Starosele and Buran Kaya III, Crimea: Behavioral implications. Proc. Natl. Acad. Sci. USA 98(19):1097210977.

Hather, J.

1993 An Archaeobotanical Guide to Root and Tuber Identification. Oxford: Oxbow.

Hoadley, R.

1990 Identifying Wood: Accurate Results with Simple Tools. Newtown, CT: Taunton Press.

Hurcombe, L.

1992 Use-wear Analysis and Obsidian: Theory, Experiments, and Results. Sheffield: J. R. Collis.

Jahren , A. H., Toth, N., Schick, K., Clark, J. D., and Amundson, R.G.

1997 Determining stone tool use: Chemical and morphological analyses of residues on experimentally manufactured stone tools. Journal of Archaeological Science 24:245-50.

Kardulias, P. N., and Yerkes, R. W.

1996 Microwear and metric analysis of threshing sledge flints from Greece and Cyprus. Journal of Archaeological Science 23:657-666.

Kay, M.

1996 Microwear analysis of some Clovis and experimental chipped stone tools. In G. Odell (ed.), Stone Tools: Theoretical Insights into Human Behavior. New York: Plenum, pp. 315-344.
Kealhofer, L., Torerence, R., and Fullagar, R.

1999 Integrating phytoliths within usewear/residue studies of stone tools. Journal of Archaeological Science 26:527-546.

Keeley, L.

1980 Experimental determination of stone tool uses. Chicago: University of Chicago.

Loy, T. H.

1983 Prehistoric blood residues: detection on tool surfaces and identification of species of origin. Science 220:12691271.

1986 Recent advances in blood residue analysis. In J. Olin and J. Blackman (eds.), Proceedings of the $24^{\text {th }}$ International Archaeometry Symposium. Washington: Smithsonian, pp. 57-65.

1993 The artifact as site: an example of the biomolecular analysis of organic residues on prehistoric tools. World Archaeology 25:44-63.

Loy, T. H. and Dixon, E. J.

1998 Blood residues on fluted points from eastern Beringia. American Antiquity 63:21-46.

Loy, T. H. and Hardy, B. L.

1992 Residue analysis of 90,000-year-old stone tools from Tabun Cave, Israel. Antiquity 66:24-35.

Loy, T. H., Spriggs, M., and Wicker, S.

1992 Direct evidence for human use of plants 28,000 years ago: starch residues on stone artifacts from the Northern Solomon Islands. Antiquity 66:898-912.

Loy, T. H. and Wood, A.

1989 Blood residue analysis at Canyonu Tepesi, Turkey. Journal of Field Archaeology 16:451-460. 
Mansur-Franchomme, M. E.

1986 Microscopie du materiel lithique préhistorique: traces d'utilisaiton, alterations naturelles, accidentelles et technologiques. Paris: CNRS.

McDevitt, K. B.

1994 Results of replicative hide-working experiments: the roles of raw material, hide condition, and use-wear patterns in the determination of rhyolite endscraper function. Lithic Technology 19:93-97.

Petragilia, M., Knepper, D., Glumac, P., Newman, M., and Sussman, C.

1996 Immunological and microwear analysis of chipped-stone artifacts from Piedmont contexts. American Antiquity 61:127-135.

Schultz, J.

1992 The use-wear generated by processing bison hides. Plains Anthropologist 37:333-355.
Shafer, R. and Holloway, R.

1979 Organic residue analysis in determining stone tool function. In B. Hayden (ed.) Lithic Use-wear Analysis. New York: Academic, pp. 385-399.

Shea, J. J.

1992 Lithic microwear analysis in archaeology. Anthropology (4):143-50.

Sliva, R. and Keeley, L.

1994 "Frits" and specialized hide preparation in the Belgian Early Neolithic. Journal of Archaeological Science 21:91-99.

Sobolik, K. D.

1996 Lithic organic residue analysis: An example from the Southwestern Archaic. Journal of Field Archaeology 23:461-69. 

APPENDIX D:

PETROGRAPHIC ANALYSIS OF TOYAH CERAMICS FROM THE VARGA SITE, 41ED28, AND COMPARATIVE SITES 



\title{
PETROGRAPHIC ANALYSIS OF TOYAH CERAMICS FROM THE VARGA SITE, 41ED28, AND COMPARATIVE SITES
}

By:

David G. Robinson, Ph.D.

Research Fellow

Prepared for:

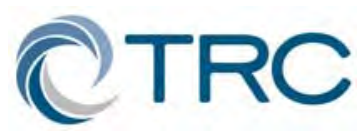

TRC Environmental Corporation

505 East Huntland Drive, Suite 250

Austin, Texas 78752

\author{
Prepared by: \\ David G. Robinson, Ph.D. \\ Research Fellow \\ Texas Archeological Research Laboratory \\ The University of Texas at Austin \\ 1 University Station R7500 \\ Austin, Texas 78712-0714
}

January 8, 2004 



\section{D.1 INTRODUCTION}

In November and December 2003, a petrographic analysis was performed on 19 plainware pottery sherds and one local soil sample from the Varga site, 41ED28, and other regional sites. The 12 ceramic samples from the Varga site are from the Toyah phase, or horizon, component of the Late Prehistoric period. The ceramics came from a zone 0 to 30 centimeters below the ground surface. A suite of radiocarbon dates from this zone ranges from 170 to 700 B.P. The Toyah zone lies above and in direct contact with a Late Archaic component. The other sites contributing ceramic samples to the study are the San Juan Mission (41BX5, five samples) and the San Lorenzo Mission (41RE1, three samples). The aboriginal mission ceramics are thought to offer temporal comparisons and potentially a view of technological change.

\section{D.1.1 Research Questions}

The major research questions addressed in this study are written in a letter from the principal investigator, J. Michael Quigg of TRC (Quigg 2003), to the author. The research questions are reproduced here, reorganized to group them according to similarity.

- 1. Is ceramic technology at the Varga Site similar to Infierno phase (Lower Pecos Late Prehistoric [Turpin and Robinson 1998, Robinson 1999]), Classic Toyah (Central Texas Late Prehistoric [Johnson 1994, and others]), and/or Protohistoric/Historic (Mission San Lorenzo and Mission San Juan) period ceramics?

- 2a. Is there continuity between regions and/or between the Late Prehistoric and Protohistoric periods?
- 2b. Is the same technology being used across these different culture areas and/or through time?

- 3a. To what does variability in ceramics refer?

- 3b. What arguments best account for variability in the ceramic assemblages?

- 3c. Does variability represent stylistic or functional variability?

These are the guiding questions of the petrographic analysis. Others may be addressed as time allows.

\section{D.1.2 Paste Groups}

The best way to examine or address the research questions is to construct a paste group classification of the analyzed thin sections. This allows a consistent description of variation in the technology. Following this, comparisons with other sites and clay samples also allow archaeologists to distinguish local from non-local ceramics and make inferences on vessel transport and trade. Reese-Taylor (1995: F13) made the signal observation, with evidence, that the Toyah ceramic tradition is one of homogeneity in its commitment to tempering with bone as part of the manufacturing process. Within this homogeneity, variability is found in the identified paste groups. Many of them are distinguished by aplastic inclusions naturally resident in ceramic clay. Because this variability may be readily observed, the varying paste groups may have local signatures and retain value for regional comparisons in addition to variability in technology. This study examines paste groups for comparative purposes as the best single way to assess the variability in the regional ceramic technology. 


\section{D.2 Methodology}

\section{D.2.1 Microscopy and Point Counting}

This study is an exercise in the petrographic analysis of ceramic material. The principal method of study is microscopic thin section analysis of potsherds. This method provides fine-scale information on ceramic fabrics and the solid particles, termed aplastic inclusions that are found in the ceramic fabrics of low-fired prehistoric wares. The many petrographic techniques for identifying bone, minerals, rock particles, and other bodies have been developed by the field of geology and its sub-branch of optical mineralogy. Thin section microscopy and petrography in ceramic analysis was pioneered in archaeology by Shepard (1942, 1954).

The ceramic thin sections for this study were prepared by National Petrographic Service, Inc. of Houston, Texas. The sections were stained for carbonates, and the finished thin sections were left without cover slips, by request. Microscopic identifications and point counting were conducted on a stereographic Olympus microscope with rotating stage and polarizing light in the Microscopy Laboratory of the Texas Archeological Research Laboratory, the University of Texas at Austin. Initially, the matrix colors of the sections were recorded under plain light, isotropy was determined, and the character of the matrix, voids, and aplastic inclusions was surveyed. Unidentified and unfamiliar bodies were sought for possible follow-on research and identification in published mineralogical literature. After this primary effort, the point-counting was conducted following the method of Chayes (1949). The method involves a series of visual traverses of the thin section. Every body falling under the cross-hairs at regular intervals was counted and tabulated. Information included mineral or rock class; and for each class size, shape, and incidental traits. Bodies large enough to cover the traverse interval were not counted twice. Species observed but not falling under the cross-hairs, thus not entering the point count, were recorded as trace, “tr". In this way all the observed contents of the sections could be reported. The point count halted at 200 counts. The voids and aplastic inclusions were classed for size by using the Wentworth size classification scale. The successful outcome of the point count permitted a quantified assessment of the attributes of the collection, a body of data comparable to other regional petrographic data, and manipulation by a variety of statistical measures.

\section{D.2.2 Observational Conventions}

For the sake of communication and gaining common understandings of microscopic observations, this section provides discussions on the major classes of materials and common structures of the ceramic fabrics in the study collection. The goal here is to provide some clarification of terminology that is obscure by its very nature. Further, terminology varies among microscopic analysts, and this section provides a partial synonymy with the other comparative studies referenced here. The aspects given attention are: matrix and voids, bone, carbonates, iron, and color and isotropy.

\section{D.2.2.1 Matrix and Voids}

Matrix refers to the material in which the voids and aplastic inclusions are mixed. Matrix is the fired clay ceramic of the vessel, and may also be referred to as ceramic body, clay paste, paste, ceramic, or, to an optical mineralogist, the groundmass. The matrix is characterized here in textural 
terms, the Varga collection falling into classes described as dense, massive, or moderate. Dense matrix has fewer or small voids or aplastic inclusions. Massive matrix has uniform color, few voids, and a continuous, uninterrupted appearance. Moderate matrix appears to cover less area of the visual field than dense or massive matrices and is interrupted by large gaps, or voids, and many solid bodies of varying sizes and shapes. Color and isotropy were also recorded on the matrix; these attributes are discussed below.

Voids are the gaps in the matrix, as viewed in the microscope. They are also termed pores or pore space. Kittleman (1994: 308) refers to voids simply as porosity. Voids entered the point count to provide a quantitative, albeit indirect, measure of ceramic vessel porosity. This overarching quality of ceramics is a function not merely of pore numbers but of structure, patterning, and how well pores communicate with the surface and through the paste. Counting the pores in a two dimensional plane through the paste will not give a direct measure of this quality, but it will contribute a measure of structure and aspects of manufacture such as surface finishing. Adding to this value is a description of pore shapes: jagged or long strips, ovoids, and gaps around bodies.

\section{D.2.2.2 Bone}

Bone tempering is perhaps the single most important trait or ingredient of Toyah ceramics. It is available to megascopic identification and is frequently cited by typological analysts as a Toyah identifier. Reese-Taylor (1993: I8) declared, from experimental studies, that most of the bone in her sample was sun-dried prior to grinding and mixing into the ceramic paste. Both she and Kittleman (1994) observed occasional ceramic firing alterations of the bone in their respective samples. Furthermore, Kittleman 1994:308) assessed his bone tempering as having derived from mammalian sources, based largely on the absence of observable features of fish or bird bone. This study offers no observations counter to these, with the small exception that ceramic firing alterations of bone were entirely lacking in the Varga site ceramic sample. With one exception, the bone fraction in the Varga site sample was observed to extend across a range of particle sizes. In order to track any pronounced bimodality of bone particle sizes, bone counts were recorded separately. "Small bone" was tabulated for bone particle sizes up to and including medium sand, and "big bone" was tabulated on particles coarse sand-sized and larger. In this way, gross size patterns could be identified.

\section{D.2.2.3 Carbonates}

In this study, carbonates are a rock and mineral class including limestone, calcite, ooids, and bioclasts; each of these was recorded and counted separately. Calcite staining marked all of these bodies with a carmine red color. Reese-Taylor (1993) identified all carbonates with an acid effervescence test, hence lumping the structural forms together, but distinguishing dolomite (dolomite was not observed in the Varga site sample). She reported carbonates as carbonates, calcium carbonate, or ooids, in the same fashion as her study of the Rush site (41RG346) and comparative samples (Reese-Taylor 1995). Kittleman (1994) reported carbonates as calcitization (largely as secondary alteration growths on or in bone particles), calcite rhombs, limestone shell, and mollusk shell. It remains unknown if the mollusk shell was fossilized or unfossilized. Ooids and bioclasts are common particles within the limey matrix of 
limestone, and bioclasts are fossils that may belong to any invertebrate phylum (Folk 1980). They may or may not be index fossils that provide identification keys to specific rock formations. Turpin and Robinson (1998) reported limestone and calcite, and Robinson (1999) distinguished limestone, dolomitic limestone, and calcite. Paste group comparisons among these studies acknowledge, with due caution, the varying terminology and identification tests for carbonates.

\section{D.2.2.4 Iron}

This study reports different forms of iron in the ceramic samples-ferrous iron, ferric iron, and iron stain. Ferrous iron is iron with a valence of +2 . It is most commonly in the form of the mineral hematite, and it is a common residual mineral in the limestones of the Edwards Plateau. Ferric iron is iron with a valence of +3 , and it takes the form commonly of specular hematite or magnetite. These forms are less common in the region, but may also be found as residuals. Both ferrous and ferric iron were observed in the ceramic sample as rounded and subrounded particles of usually medium sand size. Iron stain, "Fe-stain," resembles a blood-red smear or splash on the matrix. The staining observed in the Varga site collection was not inclusive of coarse sand and granule sized aplastic inclusions, but in many cases it appeared to cover and include silt and fine sand sized aplastics. The stained zone had irregular rounded shapes, and commonly there are discontinuous zones or strips of several rounded iron stain smears. Any such discontinuous cluster of iron stain was counted as one. The source and behavior of iron stain in the ceramic fabric is problematic and not readily interpretable currently, although sources in clay residents are likely. All these forms of iron were readily distinguished by a simple reflected light test, whereby a strong light was shone onto the microscope slide with sufficient intensity to reflect up through the barrel of the microscope. Turpin and Robinson (1998) reported iron as iron-stain (one sample of which was reported as black particles rather than red patches). Robinson (1999) listed hematite and iron stain as forms of iron, and Reese-Taylor (1993, 1995) reported only hematite in her studies and made no finer distinctions. Kittleman (1994: 308) speculated that opaque rims around bone fragments in his sample were iron oxides, and probably magnetite, but he reported no form of iron on his tables or in section or paste group descriptions. A qualitative analysis of part of his collection employing the reflected light test found additional iron.

\section{D.2.2.5 Color and Isotropy}

The color of bone particles or the matrix varies with chemical composition and firing circumstances that affect the chemistry of the material. Resulting colors may reflect a fair amount of complexity. The value of color as a comparative variable is that the colors of thin sections in plain or plainpolarized light may be compared with sherd colors determined by megascopic analysis. A complication is that it is difficult to take Munsell readings of color from a thin section in the microscope. Accordingly, color comparisons with other reported studies translate Munsell colors into their plain-language equivalents. This creates broader rather than finer comparisons, but this is cautionary, it being well to remember that there is wide variation in human color perception. The colors of matrix and bone particles under cross-polarized light depend on their isotropy. 
Isotropy is a quality of materials, especially crystalline materials, that refers to the behavior of light transmitted through them. "Iso" means same, and "trop" or "trope" means change. An optically isotropic material imposes the same change on light passing through the material. The illustrative image is of a point of light within a material. As it radiates outward in all directions as a sphere of light, it proceeds without any deviation, refraction, reflection, or retardation caused by the structure or composition of the material. The effect in a microscope under cross-polarized light is that the material remains dark. If the material causes any deviation in the transmission of light, then the material will have illumination in the microscope in a pattern characteristic of the material and its properties. Thereby hang many optical tests for minerals that are said to be anisotropic. Recording whether a material is isotropic or anisotropic in cross-polarized light gives a basic measure of this property and indications of similarities and differences in chemical composition and ceramic firing effects. Isotropy was recorded for the ceramic matrices and bone. This dimension allowed an additional comparison with Kittleman’s (1994) study.

\section{D.3 Observations And Findings}

Microscopy was completed with point counts of 19 ceramic thin sections, qualitative analysis of one soil sample thin section, and a qualitative reanalysis of 13 ceramic thin sections from the Buckhollow site. The results of the analysis are presented here, followed by brief descriptions of the paste groups, and the qualitative analyses.

\section{D.3.1 Section Descriptions}

Table D-1 provides the non-quantified attribute data collected on the thin sections and presents the point counts. The following text descriptions of the thin sections are summary statements on those data. Note that the sections are listed on the table in their paste groupings in order to show graphically their affinities and distinctions. The sections are described textually in this order as well.

ED28-799-8-1a, Section 12. The section has copious bone and carbonate (limestone and calcite) tempering, all at the expense of the matrix, which is considered moderate. The matrix is also medium greenish brown and anisotropic. The section has minor amounts of quartz and ferrous iron, probable clay residents.

ED28-937-8-1b, Section 14. Large amounts of bone and carbonates comprise the temper. Small bone particles exceed large bone in amount in this section. The matrix is massive, reddish gray and brown, and isotropic. Quartz and ferrous iron are minor clay residents. A minor inclusion is clay balls_-small bodies of clay matrix of different color, rounded shape, with fine sand quartz particles inside them.

ED28-1181-8-1b, Section 17. Copiously bone and carbonate tempered, the matrix of the section is medium greenish brown to gold and anisotropic. This section has minimal voids and a small amount of iron stain.

ED28-799-8-2a, Section 20. Of the heavily bone-and-carbonate-tempered sections, this specimen is the most similar to Section 17, notably in having the same low number of voids and the small amount of iron stain. 
The matrix likewise is greenish brown to gold and anisotropic. Section 20 and Section 17 could readily be from the same vessel.

ED28-840-8-1a, Section 13. This section was tempered by bone in notably smaller sizes than the other sections and also has a dense matrix that is light tan to greenish gray and isotropic. Ferrous iron is the next most numerous aplastic body, followed by an unidentified mineral of coarse silt and fine sand sizes, doubtless a clay resident. The mineral was not found in any other section in the study sample.

ED28-159-5-8-1b Section 9. The section is tempered with copious bone and minor amounts of limestone. The matrix is moderate, light greenish tan and anisotropic. The section and paste group have few other clay resident and incidental aplastic particles. The clay resident form of iron is ferrous.

ED28-168-8-1b Section 10. The section is tempered with copious bone and minor amounts of limestone. Orthoclase is a minor clay resident. The matrix is moderate, light greenish tan and anisotropic.

ED28-481-8-1b Section 11. The section is tempered with abundant bone and minor limestone. In this it is similar to Section 10. The matrix, however, is reddish tan to gold and anisotropic. The section has quartz and ferrous iron and no other incidental aplastics.

ED28-1054-8-1b Section 15. The section is tempered with bone and proportionally more limestone temper. The massive matrix is tan to greenish gray and anisotropic. Distinctive clay residents are quartz, ferrous iron, clay balls and orthoclase (trace).

ED28-1089-8-1b Section 16. The section is closely similar to Section 15, is tempered with bone and secondary limestone, and has virtually the same amounts of orthoclase and clay balls. The matrix is moderate, greenish gray to gold and isotropic.

BX5-13008b Section 6. The section has a dense matrix, plentiful bone tempering, and few other aplastics. The matrix is light gray and light tan and isotropic. The only other particles in the section are quartz (7\%), ferrous iron (5.5\%), and limestone (0.5\%).

BX5-13010b Section 7. The section has dense matrix that is dark reddish brown and anisotropic. Tempering is bone, quartz, and probably grog. The grog tempering is problematic in that it occurs at one percent of the point count. This amount could have little effect on the ceramic, but it is present nonetheless. Other minor constituents are ferrous iron (6.5\%) and pyroxene (trace). Pyroxene is also problematic in that it is usually an alteration product of igneous rocks and minerals, yet it occurs without any igneous companions in the section. The matrix is dark reddish brown and anisotropic.

BX5-13002b Section 4. The section is bone-tempered. The matrix is moderate, dark greenish brown, and isotropic. The matrix has a large proportion (15\%) of quartz sand, all in coarse silt to fine sand sizes. Limestone is also a clay resident, not a tempering agent. The section is distinguished by having three forms of iron: ferrous, ferric, and iron stain. 


\begin{tabular}{|c|c|c|c|c|c|c|c|c|c|c|c|c|c|c|c|c|c|c|c|c|c|c|c|c|c|c|c|c|c|c|c|c|}
\hline \multicolumn{33}{|c|}{ Aplastic Inclusions } \\
\hline \multicolumn{4}{|c|}{ Identifiers } & \multicolumn{5}{|c|}{ Matrix Characterization } & \multicolumn{2}{|c|}{ Bone } & \multicolumn{4}{|c|}{ Carbonates } & \multicolumn{4}{|c|}{ Silicates } & \multicolumn{3}{|c|}{ Iron } & \multicolumn{7}{|c|}{ Igneous } & \multicolumn{4}{|c|}{ Other } \\
\hline 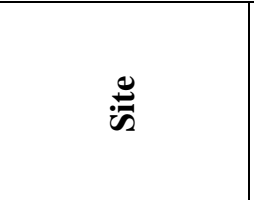 & 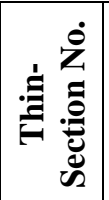 & $\begin{array}{l}\dot{\dot{z}} \\
\dot{\vec{J}}\end{array}$ & 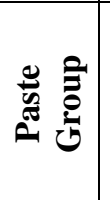 & 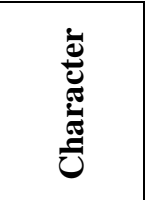 & 离 & 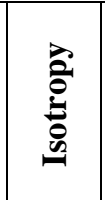 & 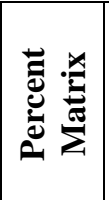 & 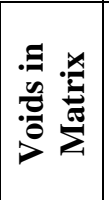 & 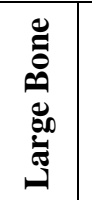 & 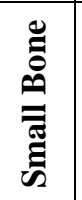 & 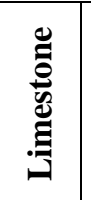 & : & $\frac{n}{0}$ & 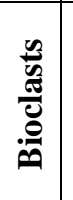 & 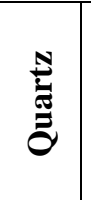 & 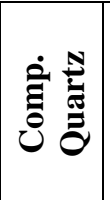 & U⿺辶 & 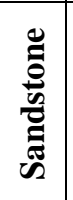 & 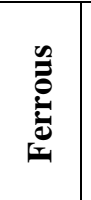 & 号 & 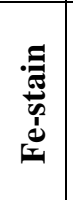 & 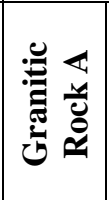 & 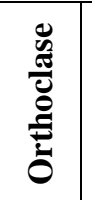 & 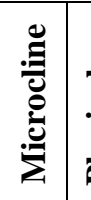 & 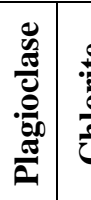 & 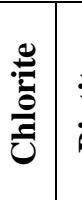 & 。 & 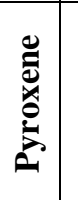 & 然 & 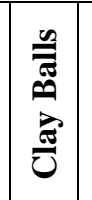 & 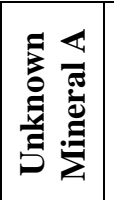 & 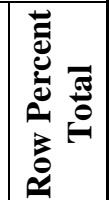 \\
\hline Varga (41ED28) & 12 & ED28-799-8-1a & B-a & moderate & medium greenish brown & aniso & 11.5 & 12.5 & 26.5 & 20.5 & 9.5 & 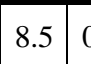 & 0.5 & & 7.5 & & & & 3 & & & & & & & & & & & & & 100 \\
\hline Varga (41ED28) & 14 & ED28-937-8-1b & B-a & massive & reddish gray and brown & iso & 26.5 & 7.5 & 17 & 21.5 & 10 & \begin{tabular}{l|l}
2.5 & 1 \\
\end{tabular} & 1 & & 5 & & & & 8 & & & & & & & & & & & 1 & & 100 \\
\hline Varga (41ED28) & 17 & ED28-1181-8-1b & B-a & massive & medium greenish brown to gold & aniso & 31.5 & 2.5 & 16.5 & 11.5 & 10 & \begin{tabular}{l|l}
4.53 & 3
\end{tabular} & 3 & 4 & 9 & & & & 6 & & 1.5 & & & & & & & & & & & 100 \\
\hline Varga (41ED28) & 20 & ED28-799-8-2a & B-a & massive & greenish brown to gold & aniso & 38.5 & 2.5 & 15.5 & 12.5 & 11.5 & \begin{tabular}{l|l}
2.5 & $\epsilon$ \\
\end{tabular} & 6 & 1 & 5.5 & & & & 2.5 & & 2 & & & & & & & & & & & 100 \\
\hline Varga (41ED28) & 13 & ED28-840-8-1a & B-b & dense & light tan to greenish gray & iso & 45 & 12 & $\overline{10}$ & & $\operatorname{tr}$ & & & & 7.5 & & & & 16 & & 1.5 & & $\operatorname{tr}$ & & & & & & & & 8 & 100 \\
\hline Varga (41ED28) & 9 & $\begin{array}{l}\text { ED23-159-5-8- } \\
1 \mathrm{~b}\end{array}$ & B-c & moderate & light greenish tan & iso & 27 & 6.5 & 28 & 19 & 4 & 3 & & & 10 & & & & 2.5 & & & & & & & & & & & & & 100 \\
\hline Varga (41ED28) & 10 & ED28-168-8-1b & B-c & moderate & light greenish tan & aniso & 22.5 & 11 & 30 & 22.5 & 5 & 2 & & & 4 & & & & 1.5 & & & & 1.5 & & & & & & & & & 100 \\
\hline Varga (41ED28) & 11 & ED28-481-8-1b & B-c & moderate & reddish tan to gold & aniso & \begin{tabular}{|l|}
37.5 \\
\end{tabular} & 5 & 20 & 19 & 5 & \begin{tabular}{|l|l}
1 & 0 \\
\end{tabular} & 0.5 & & 8 & & & & 4 & & & & & & & & & & & & & 100 \\
\hline Varga (41ED28) & 15 & ED28-1054-8-1b & B-c & massive & tan to greenish gray & aniso & 34.5 & 9.5 & 12.5 & 15 & 8.5 & 4 & & & 2.5 & & & & 8.5 & & & & 1.5 & & & & & & & 3.5 & & 100 \\
\hline Varga (41ED28) & 16 & ED28-1089-8-1b & B-c & moderate & greenish gray to gold & iso & 28 & 8.5 & 14 & 10 & 9 & \begin{tabular}{l|l}
1.5 \\
\end{tabular} & & & 3.5 & & & & 20.5 & & & & 0.5 & & & & & & & 4.5 & & 100 \\
\hline Mission San Juan & 6 & BX5-13008b & B-d & dense & light gray and light tan & iso & 43.5 & 13 & 14.5 & 16 & 0.5 & & & & 7 & & & & 5.5 & & & & & & & & & & & & & 100 \\
\hline Mission San Juan & 7 & BX5-13010b & B-e & dense & dark reddish brown & aniso & 47.5 & 7.5 & 10 & 13 & 2.5 & & & & 12 & & & & 6.5 & & & & & & & & & tr & 1 & & & 100 \\
\hline Mission San Juan & 4 & BX5-13002b & B-f & moderate & dark greenish brown & iso & \begin{tabular}{|l|}
26.5 \\
\end{tabular} & 12 & 12.5 & 17.5 & 5.5 & & & & 15 & & & & 5 & 2 & 4 & & & & & & & & & & & 100 \\
\hline Mission San Juan & 5 & BX5-13006b & B-f & massive & medium gray to greenish brown & iso & 42 & 5 & 14 & 20 & 1.5 & & & & 12.5 & & & & 2.5 & & 2.5 & & & & & & & & & & & 100 \\
\hline Mission San Juan & 8 & BX5-13013b & B-f & dense & very light greenish tan & iso & \begin{tabular}{|l|}
46.5 \\
\end{tabular} & 5 & 12 & 12 & 3 & 2 & & & 8 & & & & 9.5 & & 0.5 & & 0.5 & & & & & 1 & & & & 100 \\
\hline Varga (41ED28) & 18 & ED28-1261-8-2a & $\mathrm{V}$-a & moderate & greenish gray to black & aniso & 24.5 & 4.5 & & & & & & & 17.5 & & & & & 8 & & 4 & 27.5 & \begin{tabular}{|l|l|}
5.5 & 1 \\
\end{tabular} & \begin{tabular}{l|l}
1 & 5 \\
\end{tabular} & $\begin{array}{l}5.52 \\
\end{array}$ & 2 & & & & & 100 \\
\hline $\begin{array}{l}\text { Mission San } \\
\text { Lorenzo }\end{array}$ & 1 & RE1-1872-66 & V-b & massive & dark brown to greenish gold & iso & 31.5 & 16.5 & & & & & & & 14 & 1 & & 4.5 & 4 & & & 18.5 & 6.5 & & 3 & & \begin{tabular}{l|l}
$\operatorname{tr}$ & 0 \\
\end{tabular} & 0.5 & & & & 100 \\
\hline $\begin{array}{l}\text { Mission San } \\
\text { Lorenzo }\end{array}$ & 3 & RE1-1872-32-b & V-b & massive & charcoal gray to black & iso & 27.5 & 10 & & & & & & & 22.5 & 0.5 & & 1.5 & 3.5 & 1 & & 15 & 15 & & 2 & & \begin{tabular}{l|l}
0.5 & 1 \\
\end{tabular} & 1 & & & & 100 \\
\hline $\begin{array}{l}\text { Mission San } \\
\text { Lorenzo }\end{array}$ & 2 & RE1-1872-b & $\mathrm{C} / \mathrm{S}-\mathrm{a}$ & massive & dark brown to greenish gold & iso & 33 & 11.5 & & & 18.5 & 11 & 5 & & 11.5 & 2.5 & 0.5 & & & 6.5 & & & & & & & & & & & & 100 \\
\hline
\end{tabular}



BX5-13006b Section 5. The section is quite similar to Section 4; it is bone-tempered, with secondary clay resident quartz and limestone. Additional features are ferrous iron and iron stain. The matrix is massive, medium gray to greenish brown and isotropic.

BX5-13013b Section 8. The section is bone-tempered with secondary clay resident quartz and limestone. The matrix is exceptionally dense, very light greenish tan and isotropic. The section has incidental calcite but significant ferrous iron and iron stain. It has a small amount of orthoclase feldspar $(0.5 \%)$ and companion pyroxene (1.0\%).

ED28-1261-8-2a Section 18. The section has a moderate matrix, greenish gray to black and anisotropic. The tempering agents are various volcanic rocks and minerals, including orthoclase, microcline and plagioclase feldspars, and a granitic rock termed Granitic Rock A. This rock is comprised of orthoclase, microcline and masses of biotite, a probable alteration product. Quartz, much of it weathered, is also significant, and some of it may have entered the section as temper. Accessory volcanic minerals are chlorite and biotite. Iron is represented by specular hematite (ferric) exclusively.

RE1-1872-66 Section 1. The section has a massive matrix, dark brown to greenish gold and isotropic. The section is tempered with particles of a granitic rock, fresh quartz, plagioclase, sandstone, and composite quartz. Companion volcanic minerals are biotite, orthoclase and pyroxene. Ferrous iron is a clay resident.
RE1-1872-32-b Section 3. The section is very similar to Section 1, and may come from the same original vessel. The matrix is massive, charcoal gray to black and isotropic. The temper is granitic rock, fresh quartz, plagioclase, sandstone and orthoclase. Volcanic incidentals are biotite and pyroxene. There is a trace amount of composite quartz. In addition to ferrous iron there is a small amount of ferric iron (1.0\%), the only compositional difference from Section 1.

RE1-1872-b Section 2. The section is tempered with a combination of carbonates and silicates, including limestone, calcite, fresh quartz, composite quartz, and chert. Additional particles in the matrix are ooids and ferric iron. The matrix itself is massive, dark brown to greenish gold and isotropic.

\section{D.3.2 Paste Group Classification}

The paste groups were defined first on dominant temper type, then on ancillary aplastic companions (either temper or clay residents), thirdly on matrix/void characteristics, and lastly on minor but key components, usually rare or trace aplastics. A total of nine paste groups were defined in this way, divided broadly into three major classes of matrix particles. The classes are bone, prefix B with six subordinate groups (a-f); igneous rocks and minerals class, prefix V with two subordinate groups (a-b); and a carbonate and silicate class, prefix C/S with one paste group (a).

\section{D.3.2.1 Bone Paste Groups (B-a-f)}

Paste group B-a. This paste group is tempered with abundant bone particles and significant amounts of limestone and other carbonates. The paste also has minor amounts of quartz and hematite (ferrous iron), both of which are clay residents. 
Matrix is moderate to massive and generally anisotropic. Pastes have occasional iron stain and clay balls.

ED28-799-8-1a, ED28-937-8-1b, ED281181-8-1b, ED28-799-8-2a

Paste group B-b. The paste is tempered with bone exclusively. Clay residents include quartz, significant amounts of hematite, traces of limestone and orthoclase, and an unidentified mineral that suggests origin in another locality. Matrix is dense and isotropic.

\section{ED28-840-8-1a}

Paste group B-c. The paste is tempered with copious bone and carbonates in lesser amounts than those in Paste group B-a. Clay residents are an intermittent array of hematite, orthoclase, and clay balls. Matrices are largely moderate and anisotropic.

ED28-159-5-8-1b, ED28-168-8-1b, ED28481-8-1b, ED28-1054-8-1b, ED28-1089-8$1 \mathrm{~b}$

Paste group B-d. Tempered exclusively with bone, the paste also has significant amounts of quartz and hematite. Other than these particles, only a single grain of limestone was observed in the paste, which is also dense and isotropic.

\section{BX5-13008b}

Paste group B-e. The group is tempered with bone and small amounts of limestone, quartz and grog. A significant clay resident is hematite, and the matrix is dense and anisotropic. Key minor particles are pyroxene and the grog temper.

\section{BX5-13010b}

Paste group B-f. The group is tempered with bone and a small amount of limestone. The paste has large proportions of quartz. The matrix is variable, either moderate, massive, or dense, but it is uniformly isotropic. A key particle is iron stain, and there are intermittent occurrences of calcite, ferric iron, orthoclase, and pyroxene.

BX5-13002b, BX5-13006b, BX5-13013b

\section{D.3.2.2 Igneous Paste Groups (V-a-b)}

Paste group V-a. The paste is tempered with granitic rock fragments, orthoclase, quartz, plagioclase and microcline. Matrix is moderate and anisotropic. Clay residents are chlorite, biotite, and specular hematite.

\section{ED28-1261-8-2}

Paste group V-b. The tempering particles are granitic rock fragments, orthoclase, fresh quartz, and sandstone. Matrix is massive and isotropic. Clay residents are ferrous and ferric iron, composite quartz, biotite and pyroxene.

RE1-1872-66, RE1-1872-32-b

\section{D.3.2.3 Carbonate/Silicate Paste Group (C/S-a)}

The only paste group in this class is tempered with both carbonates and silicates (limestone, calcite, ooids, fresh quartz, composite quartz, chert). The matrix is massive and isotropic. The only other type of particle in the clay is ferric iron.

RE1-1872-b 


\section{D.3.3 Qualitative Analysis of Varga Site Soil Sample}

Table D-2 presents the qualitative information on the aplastics in the soil sample (\#1259-4a).

The soil sample matrix is light red to tan and anisotropic. The sample is notable for its carbonates, particularly limestone particles. Calcite crystals and oolites are weathering out of the limestone. Quartz is composite, but weathered and angular. The sample contained only the ferrous, hematitic form of iron.

Similar ceramic pastes are found in Paste group B-a. In complementary fashion, the soil sample contains no igneous components; therefore ceramic paste groups with these types of clay resident particles in significant amounts would be of non-local manufacture. These paste groups include B$\mathrm{b}$ and $\mathrm{V}$-a. A problematic paste group is Bc, which resembles the local soil save for persistent but small traces of orthoclase. No statement on its origins is offered at this time.

\section{D.4 Qualitative Analysis OF BUCKHOLLOW CERAMICS}

A qualitative analysis was made on the ceramic thin sections made on the Buckhollow site (41KM16) Toyah pottery (Johnson 1994) and currently under curation at Texas Archeological Research Laboratory. The analysis was made to allow closer comparisons with the work originally reported by Kittleman (1994). Thirteen thin sections from the Buckhollow sample were examined for this analysis.

Section 1. 385a. The section is bonetempered with isotropic bone, but the matrix is entirely anisotropic. There are few clay residents, the most common being calcite in the fine sand size category. The section also has a sprinkling of coarse silt- and fine sandsized specks of ferrous iron.

Section 5. 357-25A. The section is heavily bone-tempered; most of the bone is isotropic although about five percent is anisotropic. Ferrous iron is a clay resident. There is much pore space, notably in rings or gaps around the solid particles. There is one species of unidentified rock particle.

Table D-2

\begin{tabular}{|l|l|l|l|}
\hline \multicolumn{1}{|c|}{ Particle } & \multicolumn{1}{|c|}{ Size } & \multicolumn{1}{c|}{ Shape } & Visual Percent Est. \\
\hline Composite quartz & Coarse silt to coarse sand & Angular & 5 \\
\hline Limestone & Silt to medium sand & Angular & 5 \\
\hline Calcite & Fine sand to medium sand & Subangular to euhedral & 1 to 2 \\
\hline Oolites & Fine sand to medium sand & Rounded & $<1$ \\
\hline Ferrous iron & Fine sand to medium sand & Rounded & 1 \\
\hline
\end{tabular}


Section 8. 357-18a. The bone temper is abundant and both isotropic and anisotropic, while the matrix is dark reddish brown and isotropic. Quartz is a dominant mineral perhaps contributing to the tempering. The section has igneous minerals orthoclase, microcline, and plagioclase.

Section 9. 357-18b. Very similar to Section 8 , but the matrix is a darker reddish brown, although still isotropic. Bone is about 95 percent isotropic. Additional particles are quartz and orthoclase, and one specimen of ferrous iron in what may be a red slip along one edge.

Section 10. 357-6b. Similar to sections 8 and 9, the matrix is isotropic and reddish brown. The common clay residents are orthoclase and quartz, and there is rare ferrous iron and a definite red slip along one edge. Bone temper is 95 percent isotropic.

Section 11. 357-4a. The matrix is reddish brown and isotropic. The abundant bone temper is about half isotropic and half anisotropic. A major particle is a rock formed of orthoclase and quartz. One edge of the ceramic has a red slip, and ferrous iron is scattered throughout the matrix (1$2 \%$ visual estimate).

Section 14. 41KM16-3h. Heavily bonetempered, both the bone and matrix are entirely isotropic. The matrix has abundant ferrous iron particles and a few probable sandstone grains.

Section 15. 343. The section is bonetempered, and the bone is isotropic. Matrix is medium reddish brown and anisotropic. Aplastics include quartz, feldspar, and ferrous iron. The section has an unidentified rock component also. Altogether, the section is dissimilar from any section in the Varga sample collection.

Section 16. 341. Similar to Section 15, the matrix is medium reddish brown and anisotropic. The bone temper is isotropic. The matrix has a low frequency of aplastics quartz, feldspar, and ferrous iron.

Section 18. 481. The section is bonetempered, and both the bone and matrix are isotropic. Clay residents are limestone and quartz, and there is a small amount of ferrous iron.

Section 19. 481 Xa. The section is bonetempered with bone in a wide range of sizes, from about coarse silt to coarse sand. The bone is about 95 percent isotropic, five percent anisotropic. The matrix is anisotropic. Quartz is a clay resident, accompanied by abundant ferrous iron.

Section 20. $481 \mathrm{Xb}$. The section is tempered with bone that is entirely isotropic, while the matrix is anisotropic. Major clay residents are limestone and calcite, with additional quartz in notably small size ranges (coarse silt and fine sand). There is plentiful ferrous iron, and although there is no red slip on any edge, there are several patches of iron stain within the matrix.

Section 25. 3b. The section is tempered with isotropic bone. The matrix is also isotropic. Clay residents are quartz and orthoclase with minor amounts of plagioclase and microcline. Peculiarly, the section has an iron-rich red slip along one edge, but no iron stain or ferrous iron within the matrix.

The qualitative analysis provides a basis for similarity of comparisons with paste groups 
at the Buckhollow site and other reported Toyah sites. These comparisons are discussed in a later section.

\section{D.5 IV. COMPARISONS AND DISCUSSION}

\section{D.5.1 Technology and Variability}

This petrographic analysis of Toyah pottery thin sections has been motivated by a series of research questions on technology and variability of Toyah ceramics, presented in the introduction of this appendix (Quigg 2003). The questions are addressed individually here, with reference to the petrographic analysis.

- 1. Is ceramic technology at the Varga Site similar to Infierno phase (Lower Pecos Late Prehistoric [Turpin and Robinson 1998, Robinson 1999]), Classic Toyah (Central Texas Late Prehistoric [Johnson 1994, and others]), and/or Protohistoric/Historic (Mission San Lorenzo and Mission San Juan) period ceramics?

Points of similarity between the Infierno phase/Lower Pecos Late Prehistoric and the Classic Toyah/Central Texas Late Prehistoric are: (1) earthenwares with oxidizing firings, (2) a commitment to bone tempering, and (3) use of local ceramic resources. On the third point, differences in the non-tempering aplastic inclusions demonstrate clear local acquisition of ceramic materials, and the analysis of the Varga site soil sample established one strong case study for the use of local clays. On the issue of local verses regional distinctions, this means that Toyah ceramics will most frequently have a strong local stamp, highly visible petrographically, especially the nonbone aplastics. The technological concepts of the ceramics, notably the ways aplastics are mixed into the ceramic, are shared region wide, from central Texas to the Lower Pecos, and thus are an overarching commonality. Strengthening this relationship is the detectable regional movement of a portion of the finished vessels. The scale and modes of this ceramic movement are just now being studied.

Comparisons between the prehistoric sites and the Historic missions show specific similarities and differences. The mission/prehistoric similarities are the above points. The difference is the adoption of new pastes and tempering sources, or an abatement of the common use of bone temper (although note that some prehistoric pastes also lack bone). In the Historic period, we see the coexistence of several ceramic paste groups, followed by the gradual replacement of aboriginal technology.

- 2a. Is there continuity between regions and/or between the Late Prehistoric and Protohistoric periods?

Continuity can be seen between regions in the similarity of technology and shared paste groups, discussed in a following section. Shared paste groups show continuity through direct contact by a variety of mechanisms such as trade or movement in seasonal residential moves. Toyah ceramic technology indeed continued into the Protohistoric, where it was gradually replaced by Historic technologies.

- 2b. Is the same technology being used across these different culture areas and/or through time?

From the petrographic analysis, the technology appears the same. Such traits as the angularity and sizes of tempering 
particles suggest consistent ways of preparing temper for addition to paste, hence the same recipe or step-by-step manufacturing sequence for the ceramics across regions and through time. A problematic issue is the observable variation in the amounts of tempering in the paste. Clearly, the differences in proportions of temper to clay made no difference to the success of firing the ceramics. The proportions of igneous, carbonate, and silicate tempers vary similarly in the pastes in which they are found. This shows the robustness of the earthenware technology, and that, within limits, temper proportions were in free variation and subject to individual potter choices.

Similarly, variability in the firing process itself appears to be consistent across the entire region and through time. Specifically, pastes and bone temper tends to have the same range of colors in their paste groups in all the sites examined. This suggests that the control of firing-temperatures achieved, atmospheres created and maintained, and other variables-was about the same in character and degree across the region and suffered the same vagaries.

\section{- 3a. To what does variability in ceramics refer?}

On the technological level, variability refers to ceramic ingredients, modes of preparation, clay residents, and firing vagaries that can affect the outcome of the ceramics (interior carbon streaks, paste and bone colors, and other variables). It should be cautioned, however, that technological variability is only a partial list of total ceramic difference, and that typological variability is also crucial to understanding Toyah earthenwares and their changes.
Typology is discussed in the main body of the Varga report.

- 3b. What arguments best account for
variability in the ceramic assemblages? First, local acquisition of materials introduces a wide range of particles to ceramic matrices. They are peripheral or irrelevant to the success or functioning of the ceramics, but they provide markers of place and origin. Secondly, tempering agents are critical factors in variability. Step-by-step procedures for preparing bone tempering material result in consistency and little observable variation, but the use of other tempers entirely, as in the igneous and carbonate/silicate paste groups, produce striking variations observable on both the megascopic and microscopic levels. Thirdly, finishing and decorative manufacturing choices create pronounced variability. Several of the Buckhollow sections have a red slip on their edges, but these are entirely lacking in the Varga sample.

\section{- 3c. Does variability represent stylistic or functional variability?}

On the petrographic level, almost all the variability in ceramic pastes, temper, and clay residents revolve around gaining a successful ceramic, i.e. a ceramic vessel that survives its earthenware firing. In this, variability regards function, not style. Variability in porosity also involves function, but as stated previously, porosity measured in thin sections is an indirect measure of vessel porosity. The observations of surface slips on the Buckhollow sections are observations of stylistic variability and are an exception to this general pattern of functional variability. 


\section{D.5.2 Paste Group Comparisons}

The comparisons of paste groups were made by examining recent literature on petrographic studies of Toyah ceramics. The question here is how many paste groups are similar enough to be considered as shared between sites? In other words, were any of these locally produced ceramic vessels transported from site to site? Table D-3 cites the studies consulted and lists the paste groups identified in those studies.

The descriptions of these paste groups were examined for their essential similarities and distinctions. The following list presents those paste groups considered by the author to be essentially the same, thus shared across regions and sites.

1. B-a, RT-93-2, RT-95-2, RT-95-5, RT-958, R-99-1.

2. B-c, RT-93-3, RT-95-10, TR-98-2.

3. B-d, RT-93-2, RT-95-1.

It should also be noted that RT-93-2 is shared between two sites in different counties, and TR-98-5 is also shared between two sites separated by more than 20 miles.

This examination of paste groups has identified five suites of paste groups that are shared among two or more sites. It is an important distinction that manufacture of ceramics from local resources does not preclude transport of the vessels to other sites during their use-life by various mechanisms and for various purposes. It is also significant that the identification of shared paste groups does not contradict any assessment of local or non-local manufacture, to wit, paste group B-b, which appears clearly to be of non-local origin relative to the Varga site, but is not shared with any other known paste group. The identification of shared paste groups is a step toward elucidating mechanisms of transport and larger issues of hunter-gatherer mobility and systemic processes. These studies can be advanced by the application of two parallel approaches:

- (1) geographic and geological studies of ceramic resource availability, similar to Robinson's (1999) study of Lower Pecos ceramic materials, and

- (2) neutron activation analysis (NAA) of ceramics and environmental samples.

\section{D.6 SUMmaRY AND DISCUSSION}

The petrographic analysis of the Varga site sample, inclusive of ceramics from a total of three sites, two of which are Historic missions, identified nine distinct paste groups, not all of which are bone-tempered. Analysis of a Varga site soil sample was valuable in distinguishing local from nonlocal paste groups and is a recommended strategy for future petrographic studies.

Variability lies largely with tempering agents and particles resident in the ceramic clays. This variability comments more on function than style. Analysis of the Historic ceramics shows that Toyah bone-tempered ceramic technology persisted into the Historic period with aboriginal populations who settled at Spanish missions. The aboriginal technology was gradually replaced by European technology and ceramics. This finding may assist colonial period research by helping to distinguish earlier from later mission occupations. 
Table D-3

\begin{tabular}{|c|c|c|}
\hline Reference & ID Code & Paste Groups \\
\hline Reese-Taylor (1993) & RT-93 & $\begin{array}{l}\text { 1. RN169 bone and carbonates } \\
\text { 2. RN3 and CN95 bone only } \\
\text { 3. CC131 bone and lesser carbonates }\end{array}$ \\
\hline Reese-Taylor (1995) & RT-95 & $\begin{array}{l}\text { 1. Bone-tempered } \\
\text { 2. Bone-tempered w/ calcite inclusions } \\
\text { 3. Sand and bone-tempered w/ orthoclase, biotite and some calcite } \\
\text { 4. Sand and clay grit } \\
\text { 5. O. H. Ivie bone/high carbonates, hematite } \\
\text { 6. O. H. Ivie bone/low carbonates } \\
\text { 7. HY209 bone/quartz/feldspar } \\
\text { 8. HY209 bone/high carbonates, hematite } \\
\text { 9. HY209 quartz/bone, addl hematite } \\
\text { 10. HY209 quartz/bone/carbonates, feldspar and hematite }\end{array}$ \\
\hline Turpin and Robinson (1998) & TR-98 & $\begin{array}{l}\text { 1.MSL Bone and addl quartz } \\
\text { 2. MSL Bone, minor limestone and clay balls } \\
\text { 3. RG26 Volcanics, quartz and iron-stain } \\
\text { 4. Javelina Bluff low bone/high carbonates } \\
\text { 5. Devil’s Mouth and Infierno Camp bone, limestone and quartz } \\
\text { 6. Black Cave Camp high bone/low carbonates }\end{array}$ \\
\hline Robinson (1999) & R-99 & 1. San Felipe Springs high bone/low carbonates, hematite \\
\hline Kittleman (1994) & K-94 & $\begin{array}{l}\text { 1. Bone exclusively, mostly crystalline paste } \\
\text { 2. Bone and minimal carbonates, crystalline or vitric pastes } \\
\text { 3. Bone and minimal carbonates, crystalline or vitric pastes } \\
\text { 4. Bone and minimal carbonates, crystalline or vitric pastes } \\
\text { 5. Bone and minimal carbonates, vitric pastes } \\
\text { 6. Substantial carbonates, vitric paste } \\
\text { 7. Substantial carbonates, vitric paste }\end{array}$ \\
\hline
\end{tabular}

The identification of paste groups in the Varga sample collection was a useful way of ordering the data. Furthermore, the effort to identify paste groups shared with other sites and regions within the larger Toyah Central Texas area was successful. The shared paste groups showed that locally produced ceramics were transported from site to site. Investigating the means and mechanisms of this transport through hypothesis-testing and the application of other analytical technologies may be a fruitful avenue for future research. 


\section{D.7 References Cited}

\section{Chayes, F.}

1949 A Simple Point-Counter for Thin Section Analysis. American Mineralogist 34:1-11.

Folk, Robert L.

1980 Petrology of Sedimentary Rocks. Hemphill Publishing Company. Austin.

\section{Johnson, LeRoy}

1994 The Life and Times of Toyah-Culture Folk, as Seen from the Buckhollow Encampment, Site 41KM16, of Kimble County, Texas. Office of the State Archeologist Report 38. Texas Department of Transportation and Texas Historical Commission. Austin.

\section{Kittleman, Laurence $\mathbf{R}$.}

1994 A Microscopical Analysis of Potsherds from the Toyah Culture of Texas. Appendix IV in The Life and Times of Toyah-Culture Folk, as Seen from the Buckhollow Encampment, Site 41KM16, of Kimble County, Texas. By L. Johnson. Office of the State Archeologist Report 38. Texas Department of Transportation and Texas Historical Commission. Austin.

\section{Quigg, J. Michael}

2003 Contract letter to the author. TRC Inc., Austin.

\section{Reese-Taylor, Kathy}

1993 Petrographic Studies of Ceramic Pastes. Appendix I in Cultural Resource Investigations in the O.H. Ivie Reservoir, Concho, Coleman, and Runnels Counties, Texas, Volume IV, by A.C. Treece, C. Lintz, W.N Trierweiler, J.M. Quigg, and K.A. Miller, pp. I-1-I-11. Technical Report 346-IV. Mariah Associates, Inc.

1995 Petrographic Analysis of a Toyah Phase Ceramic Assemblage. Appendix $\mathrm{F}$ in The Rush Site (41TG346). A Stratified Late Prehistoric Locale in Tom Green County, Texas. By J.M. Quigg and J. Peck. Technical Report 816C. Mariah Associates, Inc. Austin.

\section{Robinson, David G.}

1999 Petrographic Analysis of Plainware Pottery from 41VV444. Appendix C in "Val Verde on the Sunny Rio Grande". Geoarcheological and Historical Investigations at San Felipe Springs, Val Verde County, Texas. By G. Mehalchick, T. Myers, K.W. Kibler, and D.K. Boyd. Reports of Investigations 122. Prewitt and Associates, Inc. Austin.

\section{Shepard, Anna 0.}

1942 Rio Grande Glaze Paint Ware: A Study Illustrating the Place of Ceramic Technological Analysis in Archaeological Research. Contributions to American Anthropology and History Vol. 7, No. 39. Carnegie Institution of Washington, Washington, D.C.

1954 Ceramics for the Archaeologist. Publication 609. Carnegie Institution of Washington. Washington, D.C.

\section{Turpin, Solveig A. and David G. Robinson}

1998 Infierno Phase Pottery of the Lower Pecos River Region. Bulletin of the Texas Archeological Society 69: 89-97. 



\section{APPENDIX E:}

POLLEN AND PHYTOLITH ANALYSES OF SAMPLES FROM THE VARGA SITE, 41ED28, EDWARDS COUNTY, TEXAS 



\section{POLLEN AND PHYTOLITH ANALYSES OF SAMPLES FROM THE VARGA SITE, 41ED28, EDWARDS COUNTY, TEXAS}

By:

Richard Holloway, Ph.D.

Prepared for:

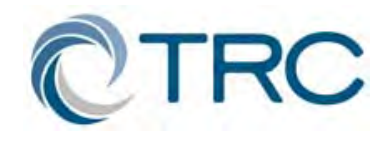

TRC Environmental Corporation

505 East Huntland Drive, Suite 250

Austin, Texas 78752

\section{Prepared by:}

Richard Holloway, Ph.D.

Quaternary Services

5000 N. Country Club Drive

Flagstaff, AZ 86004-7326

September 23, 2003 



\section{E.1 INTRODUCTION}

A total of 25 paired pollen and phytolith samples were sent for analysis to Quaternary Services. These samples were collected from the Varga Site (41ED28) from Edwards County, Texas in conjunction with TRC Project 35319. Twenty of the paired samples were taken from a column at the junction of backhoe trenches 1 and 2. Two samples from dated sections were sent from backhoe trench 1, located in the southwestern corner of the site, while three additional samples from dated sections were sent from backhoe trench 7 , located in the extreme northeastern corner.

The column samples contained strata associated with the Toyah component, dated to ca. 300-650 years B.P. and three divisions within the Archaic period. The Late Archaic component dated to between 1700-2300 years B.P., the Middle Archaic dated to between 3900-4800 years B.P., and the Early Archaic dated to between 5200-6300 years B.P. The sections from trench M1 were taken from strata $2 \mathrm{Ab}$ dating to the Late Archaic (1870 years B.P.) and from strata $2 \mathrm{Bw}$, dating to the Early Archaic period (6279 years B.P.). The sections from backhoe trench 7 were taken from a cultural level dating to the Late Archaic period (1900 years B.P.), strata 2Bk, which dated to the Early Archaic (4820 years B.P.) and from strata Bk2 which also dated to the Early Archaic (5230 years B.P.).

The Varga site is located in northeastern Edwards County at an elevation of 1980' AMS. It is located just below the top of the Edwards Plateau above Hackberry Creek, which flows into the Nueces River. The modern vegetation consists of a Juniper-oak savannah with a dense to open canopy of broadleaf deciduous and needleleaf conifer shrubs and low trees (Table E-1). The dominant vegetation consists of Juniperus sp. (Mountain Juniper), and Quercus virginiana (Live Oak). Andropogon scoparius (Little bluestem) is the dominant grass. Mesic forests containing several species of Quercus sp. (oak), Ulmus sp. (elm), Pinus sp. (pine), Celtis sp. (Hackberry), Carya illinoiensis (pecan), Juglans microcarpa (walnut), and a variety of berry-bearing shrubs are present along the stream floodplains.

\section{E.1 Methods AND Materials}

\section{E.1.1 Pollen Extraction Methods}

Chemical extraction of pollen samples was conducted at the Palynology Laboratory at Texas A\&M University, using a procedure designed for semi-arid Southwestern sediments. The method, detailed below, specifically avoids use of such reagents as nitric acid and bleach, which have been demonstrated experimentally to be destructive to pollen grains (Holloway 1981).

From each pollen sample submitted, 15 grams (g) of soil were sub-sampled. Prior to chemical extraction, two tablets of concentrated Lycopodium spores (batch \#307862, Department of Quaternary Geology, Lund, Sweden; 13,500 $\forall 500$ marker grains per tablet) were added to each sub-sample. The addition of marker grains permits calculation of pollen concentration values and provides an indicator for accidental destruction of pollen during the laboratory procedure.

The samples were treated with 35 percent Hydrochloric Acid ( $\mathrm{HCl}$ ) overnight to remove carbonates and to release the Lycopodium spores from their matrix. After neutralizing the acid with distilled water, the samples were allowed to settle for a period 
of at least three hours before the supernatant liquid was removed. Additional distilled water was added to the supernatant, and the mixture was swirled and then allowed to settle for 5 seconds. The suspended fine fraction was decanted through $150 \Phi$ mesh screen into a second beaker. This procedure, repeated at least three times, removed lighter materials, including pollen grains, from the heavier fractions. The fine material was concentrated by centrifugation at 2,000 revolutions per minute (RPM).

The fine fraction was treated with concentrated Hydrofluoric Acid (HF) overnight to remove silicates. After completely neutralizing the acid with distilled water, the samples were treated with a solution of darvan, and sonicated in a Delta D-9 Sonicator for 30 seconds. The Darvan solution was removed by repeated washing with distilled water and centrifuged (2,000 RPM) until the supernatant liquid was clear and neutral. This procedure removed fine charcoal and other associated organic matter and effectively deflocculated the sample.

The samples were dehydrated in glacial acetic acid in preparation for acetolyis. Acetolysis solution (acetic anhydride: concentrated sulfuric acid in 9:1 ratio) following Erdtman (1960), was added to each sample. Centrifuge tubes containing the solution were heated in a boiling water bath for approximately eight minutes and then cooled for an additional eight minutes before centrifugation and removal of the acetolysis solution with glacial acetic acid followed by distilled water. Centrifugation at 2,000 RPM for 90 seconds dramatically reduced the size of the sample, yet from periodic examination of the residue, did not remove fossil palynomorphs.

Heavy density separation ensued using zinc bromide $\left(\mathrm{ZnBr}_{2}\right)$, with a specific gravity of
2.00, to remove much of the remaining detritus from the pollen. The light fraction was diluted with distilled water (10:1) and concentrated by centrifugation. The samples were washed repeatedly in distilled water until neutral. The residues were rinsed in a $1 \%$ solution of potassium hydroxide $(\mathrm{KOH})$ for less than one minute, which was effective in removing the majority of the unwanted alkaline soluble humates.

The material was rinsed in Ethanol (ETOH) stained with safranin-O, rinsed twice with ETOH, and transferred to 1-dram vials with Tertiary Butyl Alcohol (TBA). The samples were mixed with a small quantity of glycerine and allowed to stand overnight for evaporation of the TBA. The storage vials were capped and were returned to TRC Inc. at the completion of the project.

A drop of the polliniferous residue was mounted on a microscope slide for examination under an 18 X $18 \mathrm{~mm}$ cover slip sealed with fingernail polish. The slide was examined using $200 \mathrm{X}$ or $100 \mathrm{X}$ magnification under an aus-Jena Laboval 4 compound microscope. Occasionally, pollen grains were examined using either $400 \mathrm{X}$ or $1,000 \mathrm{X}$ oil immersion to obtain a positive identification to either the family or genus level.

Abbreviated microscopy was performed on each sample in which either 20 percent of the slide (approximately four transects at 200X magnification) or a minimum of 50 marker grains were counted. If warranted, full counts were conducted by counting to a minimum of 200 fossil grains. Regardless of which method was used, the uncounted portion of each slide was completely scanned at a magnification of $100 \mathrm{X}$ for larger grains of cultivated plants such as Zea mays and Cucurbita, two types of Cactus (Platyopuntia and Cylindropuntia), and other large pollen types such as members of the 
Malvaceae, or Nyctaginaceae families. Because corn pollen was very common in many of these samples, corn grains were tabulated during the scans only if an unequal distribution of this taxon on the microscope slide was observed.

For those samples warranting full microscopy, a minimum of 200 pollen grains per sample were counted as suggested by Barkley (1934), which allows the analyst to inventory the most common taxa present in the sample. All transects were counted completely (Brookes and Thomas 1967), resulting in various numbers of grains counted beyond 200. Pollen taxa encountered on the uncounted portion of the slide during the low magnification scan are tabulated separately.

Total pollen concentration values were computed for all taxa. In addition, the percentage of Indeterminate pollen was also computed. Statistically, pollen concentration values provide a more reliable estimate of species composition within the assemblage. Traditionally, results have been presented by relative frequencies (percentages) where the abundance of each taxon is expressed in relation to the total pollen sum (200+ grains) per sample. With this method, rare pollen types tend to constitute less than 1 percent of the total assemblage. Pollen concentration values, provide a more precise measurement of the abundance of even these rare types. The pollen data are reported here as pollen concentration values using the following formula:

$$
\mathrm{PC}=\underline{\mathbf{K}^{*} 3_{\mathrm{L}}} \mathrm{P}
$$

Where: $\quad$ PC $=$ Pollen Concentration

$\mathrm{K}=$ Lycopodium spores added

$3_{\mathrm{p}}=$ Fossil pollen counted
$3_{\mathrm{L}}=$ Lycopodium spores counted

$\mathrm{S}$ = Sediment weight

The following example should clarify this approach. Taxon X may be represented by a total of 10 grains (1 percent) in a sample consisting of 1,000 grains, and by 100 grains (1 percent) in a second sample consisting of 10,000 grains. Taxon $\mathrm{X}$ is 1 percent of each sample, but the difference in actual occurrence of the taxon is obscured when pollen frequencies are used. The use of "pollen concentration values" are preferred because it accentuates the variability between samples in the occurrence of the taxon. The variability, therefore, is more readily interpretable when comparing cultural activity to noncultural distribution of the pollen rain.

The pollen concentration values for pollen wash samples were calculated using a modification of the above formula. This modification involved the substitution of the area washed (in $\mathrm{cm}^{2}$ ) for the sediment weight $(S)$ variable in the denominator from the above equation because the sample was in liquid form. The resulting concentration value is thus expressed as estimated grains per $\mathrm{cm}^{2}$. The resulting pollen concentration values from pollen wash samples are treated independently of those from soil samples in the results and discussion sections, although the data are presented with the other samples in the tables. The use of pollen concentration values from these particular samples is preferred, as explained above, in order to accentuate the variability between pollen wash samples. The use of the area washed also provides a mechanism for the comparison of calculated pollen concentration values between artifacts.

Variability in pollen concentration values can also be attributed to deterioration of the grains through natural processes. In his 
study of sediment samples collected from a rockshelter, Hall (1981) developed the "1000 grains/g" rule to assess the degree of pollen destruction. This approach has been used by many palynologists working in other contexts as a guide to determine the degree of preservation of a pollen assemblage and, ultimately, to aid in the selection of samples to be examined in greater detail. According to Hall (1981), a pollen concentration value below 1000 grains/gm indicates that forces of degradation may have severely altered the original assemblage. However, a pollen concentration value of fewer than 1000 grains/g can indicate the restriction of the natural pollen rain. Samples from pit structures or floors within enclosed rooms, for example, often yield pollen concentration values below 1000 grains/g.

Pollen degradation also modifies the pollen assemblage because pollen grains of different taxa degrade at variable rates (Holloway 1981, 1989; Holloway and Bryant 1983). Some taxa are more resistant to deterioration than others and remain in assemblages after other types have deteriorated completely. Many commonly occurring taxa degrade beyond recognition in only a short time. For example, most (ca. 70 percent) Angiosperm pollen has either tricolpate (three furrows) or tricolporate (three furrows each with pores) morphology. Because surfaces erode rather easily, once deteriorated, these grains tend to resemble each other and are not readily distinguishable. Other pollen types (e.g. Cheno-am) are so distinctive that they remain identifiable even when almost completely degraded.

Pollen grains were identified to the lowest taxonomic level whenever possible. The majority of these identifications conformed to existing levels of taxonomy with a few exceptions. For example, Cheno-am is an artificial, pollen morphological category which includes pollen of the family Chenopodiaceae (goosefoot) and the genus Amaranthus (pigweed) which are indistinguishable from each other (Martin 1963). All members are wind pollinated (anemophilous) and produce very large quantities of pollen. In many sediment samples from the American Southwest, this taxon often dominates the assemblage.

Pollen of the Asteraceae (Sunflower) family was divided into four groups. The high spine and low spine groups were identified on the basis of spine length. High spine Asteraceae contains those grains with spine length greater than or equal to $2.5 \Phi$ while the low spine group have spines less than 2.5Ф in length (Bryant 1969; Martin 1963). Artemisia pollen is identifiable to the genus level because of its unique morphology of a double tectum in the mesocopial (between furrows) region of the pollen grain. Pollen grains of the Liguliflorae are also distinguished by their fenestrate morphology. Grains of this type are restricted to the tribe Cichoreae which includes such genera as Taraxacum (dandelion) and Lactuca (lettuce).

Pollen of the Poaceae (Grass) family are generally indistinguishable below the family level, with the single exception of Zea mays, identifiable by its large size (ca 80乏), relatively large pore annulus, and the internal morphology of the exine. All members of the family contain a single pore, are spherical, and have simple wall architecture. Identification of non-corn pollen is dependent on the presence of the single pore. Only complete or fragmented grains containing this pore were tabulated as members of the Poaceae. 
Clumps of four or more pollen grains (anther fragments) were tabulated as single grains to avoid skewing the counts. Clumps of pollen grains (anther fragments) from archaeological contexts are interpreted as evidence for the presence of flowers at the sampling locale (Bohrer 1981). This enables the analyst to infer possible human behavior.

Finally, pollen grains in the final stages of disintegration but retaining identifiable features, such as furrows, pores, complex wall architecture, or a combination of these attributes, were assigned to the Indeterminate category. The potential exists to miss counting pollen grains without identifiable characteristics. For example, a grain that is so severely deteriorated that no distinguishing features exist, closely resembles many spores. Pollen grains and spores are similar both in size and are composed of the same material (Sporopollenin). So that spores are not counted as deteriorated pollen, only those grains containing identifiable pollen characteristics are assigned to the Indeterminate category. Thus, the Indeterminate category contains a minimum estimate of degradation for any assemblage. If the percentage of Indeterminate pollen is between 10 and 20 percent, relatively poor preservation of the assemblage is indicated, whereas Indeterminate pollen in excess of 20 percent indicates severe deterioration to the assemblage.

In those samples where the total pollen concentration values are approximately at or below 1000 grains/g, and the percentage of Indeterminate pollen is 20 percent or greater, counting was terminated at the completion of the abbreviated microscopy phase. In some cases, the assemblage was so deteriorated that only a small number of taxa remained. Statistically, the concentration values may have exceeded 1000 grains/gm. If the species diversity was low (generally these samples contained only pine, Cheno-am, members of the Asteraceae (Sunflower) family and Indeterminate category, counting was also terminated after abbreviated microscopy even if the pollen concentration values slightly exceeded 1000 grains/g.

\section{E.1.2 Phytolith Extraction Procedures}

Phytoliths were isolated using a conservative extraction technique. The soil samples were screened through 1/16th inch mesh to remove larger materials. Five-gram sediment samples were placed in beakers and concentrated HCL was added to remove carbonate materials. The residues were rinsed and consolidated and screened through $150 \Phi$ mesh to remove unwanted larger materials. A series of short centrifuge spins removed unwanted fine clays smaller than $3 \Phi$. The residues were washed with $\mathrm{KOH}(5 \%)$ to remove alkaline soluble humates and then rinsed until neutral.

Organic traces were removed by adding Schulze's solution (concentrated Nitric Acid and Potassium Chlorate) and heating in a water bath for approximately 30 minutes to 1 hour. Following the removal of organic materials, the samples were rinsed until neutral and were fractionated in a water column. This procedure separated the phytoliths into 2 size fractions; $3-25 \Phi$, the fine fraction and 25-150 $\Phi$, the coarse fraction. This step is necessary as each fraction usually contains a unique set of phytolith types. Next, the samples were transferred to $15 \mathrm{ml}$ tubes for heavy density fractionation. Zinc Bromide (S.G. 2.38) was added to the samples, which were centrifuged at high speed on a clinical centrifuge. Following this procedure, phytoliths floating on the heavy liquid were 
carefully pipetted off. The heavy density separation was repeated twice to ensure that a total phytolith recovery was made. Phytoliths were rinsed, dehydrated and curated in ethanol.

Permanent slides were prepared using Meltmount adhesive (refractive index 1.539). The slide was routinely examined using 200X - 400X magnification, using Phase Contrast Microscopy, under an ausJena Laboval 4 compound microscope. Occasionally, phytoliths were examined using either $400 \mathrm{X}$ or $1,000 \mathrm{X}$ oil immersion to obtain a positive identification.

\section{E.2 RESULTS}

The raw counts of the pollen assemblages are presented in Table E-2 while Table E-3 contains the calculated pollen concentration values from each assemblage. Table E-4 contains the raw counts of the phytolith samples and Table E-5 contains the calculated phytolith relative frequencies. The individual results are detailed below by period and depth.

\section{E.2.1 Column Samples}

\section{E.2.1.1 Toyah Component (ca. 300- 650 years B.P.)}

Sample 1217-b was taken from the 3-6 cmbs level and contained 7633 grains/ml total pollen concentration values and was based on a pollen sum of 229 grains. Pinus (233 grains/ml) pollen was very low with a high amount of Quercus (267 grains/ml) and a small amount of Carya (33 grains $/ \mathrm{ml}$ ) pollen. Poaceae (67 grains $/ \mathrm{ml}$ ) was moderate with high amounts of Cheno-am (5333 grains/ml), high (667 grains/ml) and low spine (467 grains $/ \mathrm{ml}$ ) Asteraceae and a moderate to low amount of Artemisia (33 grains $/ \mathrm{ml}$ ). A high number of Cheno-am pollen clumps $(67 / \mathrm{ml})$ were also present. Apiaceae (100 grains $/ \mathrm{ml}$ ) was high with moderate to high amounts of Opuntia (33 grains/ml) pollen. A small amount of trilete spores $(14.29 / \mathrm{ml})$ were also present.

The phytolith sample was based on a count of 557 and was crennate forms (42.55\%) and secondarily by saddle forms (19.93\%). Smaller percentages of Pyramidal (0.18\%) Simple Lobate (9.52\%), Panicoid (0.36\%), other lobate $(7.54 \%)$, square $(0.18 \%)$, Rhomboidal (9.87\%each), cross-shaped (1.26\%), and Sabal (0.54\%) were also present in the assemblage.

Sample 1218-b was taken from the 13-15 cmbs level and contained 3430 grains $/ \mathrm{ml}$ total pollen concentration values and was based on a pollen sum of only 101 grains. Pinus (136 grains/ml was very low with moderate amounts of Carya (34 grains $/ \mathrm{ml}$ ) and high amounts of Quercus (136 grains/ml). Cheno-am (2411 grains/ml) was high and dominated the assemblage along with high (102 grains/ml) and low spine (408 grains $/ \mathrm{ml}$ ) Asteraceae. Cheno-am clumps $(13.84 / \mathrm{ml})$ and trilete spores $(27.67 / \mathrm{ml})$ were present in the low magnification scan of the slide.

The phytolith sample was based on a sum of 458 and was dominated by Crennate forms (65.28\%). Smaller percentages of Rhomboidal (10.26\%), simple lobate (13.10\%), Saddle (7.21\%), Square $(2.40 \%)$, Stipa type $(0.87 \%)$, hair bases $(0.44 \%)$, Irregular and Conical $(0.22 \%$ each) were also present.

Sample 1219-b was taken from the 19-20 cmbs level and contained 4345 grains $/ \mathrm{ml}$ total pollen concentration values and was based on a pollen sum of 140 grains. Pinus (124 grains/ml) was very low with moderate amounts of Quercus (31 grains $/ \mathrm{ml}$ ) and Carya (62 grains/ml). Poaceae (31 
The Varga Site

Texas Department of Transportation

grains/ml) was low with high amounts of Cheno-am (3693 grains/ml), and both high and low spine (93 grains $/ \mathrm{ml}$ each) Asteraceae. Trilete spores $(7.16 / \mathrm{ml})$ were present in the low magnification scan of the slide.

The phytolith sample was based on a sum of 489 and was dominated by crennate (55.21\%) and secondarily by simple lobate forms (29.86\%). Smaller percentages of Rhomboidal (9.61\%), Saddle (2.45\%), Square $(1.23 \%)$, Stipa type $(1.02 \%)$, crossshaped $(0.41 \%)$, and Sabal $(0.20 \%)$ were also present.

Sample 1220-b was taken from the 23-24 cmbs level and contained 8400 grains $/ \mathrm{ml}$ total pollen concentration values and was based on a pollen sum of 252 grains. Pinus (233 grains/ml) was very low with high amounts of Quercus (100 grains $/ \mathrm{ml}$ ) and moderate amounts of Celtis (33 grains $/ \mathrm{ml}$ ). Poaceae (33 grains/ml) was low with very high amounts of Cheno-am (4400 grains/ml), high (2900 grains/ml) and low spine (300 grains $/ \mathrm{ml})$ Asteraceae, and Artemisia (133 grains/ml). Juglans pollen and trilete spores (10.26 grains $/ \mathrm{ml})$ was present in the low magnification scan of the slide.

The phytolith sample was based on a sum of 357 and was dominated by crennate (57.14\%), and secondarily by simple lobate (16.25\%) and rhomboidal (13.17\%) forms. Smaller percentages of square (2.80\%), Saddle (9.52\%), Panicoid (0.56\%) hair bases and Sabal (0.28\% each) were also present.

\section{E.2.1.2 Late Archaic (ca. 1700-2300 years B.P.)}

A total of 3 samples were submitted from this time period. Sample 1221-b was taken from the 28-29 cmbs level and contained 3665 grains $/ \mathrm{ml}$ total pollen concentration values and was based on a pollen sum of only 112 grains. Pinus (229 grains $/ \mathrm{ml}$ ) was very low with moderate amounts of both Quercus and Carya (33 grains/ml each) pollen. Poaceae (33 grains $/ \mathrm{ml}$ ) was low with high amounts of Cheno-am (2160 grains/nl) pollen, high (327 grains/ml), and low spine (425 grains/ml) Asteraceae, and Artemisia (98 grains $/ \mathrm{ml}$ ). Trilete spores $(7.55 / \mathrm{ml})$ were present in the low magnification scan of the slide.

The phytolith sample was based on a sum of 376 and was dominated by crennate (60.11\%) forms and secondarily by simple lobate (14.63\%) and rhomboidal (11.44\%) forms. Smaller percentages of saddle (9.57\%), irregular (2.13\%), stipa type and hair bases $(0.80 \%$ each $)$, and conical $(0.53 \%)$ were also present.

Sample 1222-b was taken from the 33-34 cmbs level and contained 2682 grains $/ \mathrm{ml}$ total pollen concentration values and was based on a pollen sum of only 112 grains. Pinus (35 grains $/ \mathrm{ml}$ ) was present in trace amounts only with moderate to high amounts of Quercus (71 grains/ml) pollen. Poaceae (71 grains/ml) was high along with moderate amounts of Cheno-am (1235 grains/nl) pollen, and high amounts of high (635 grains $/ \mathrm{ml}$ ), and low spine (388 grains $/ \mathrm{ml}$ ) Asteraceae, and moderate to low amounts of Artemisia (35 grains/ml).

The phytolith sample was based on a sum of 328 and was dominated by crennate (33.23\%), rhomboidal (24.39\%), and panicoid (27.74\%) forms. Smaller percentages of saddle $(0.307 \%)$, irregular $(1.22 \%)$, hair bases $(1.83 \%)$, square (11.28\%)and saddle $(0.30 \%)$ were also present.

Sample 1223-b was taken from the 40-41 cmbs level and contained only 1233 grains/ml total pollen concentration values and was based on a pollen sum of only 37 
grains. Pinus (33 grains $/ \mathrm{ml}$ ) was present in trace amounts only. Poaceae (33 grains $/ \mathrm{ml}$ ) was low with low amounts of Cheno-am (833 grains/nl) pollen, moderate amounts of low spine (67 grains $/ \mathrm{ml}$ ) Asteraceae, and low to moderate quantities of Artemisia (33 grains/ml).

The phytolith sample was based on a sum of 332 and was dominated by crennate (66.27\%) forms. Smaller percentages of saddle $(5.42 \%)$, square $(4.22 \%)$, simple lobate $(12.35 \%)$, Stipa type $(0.90 \%)$, hair bases (1.20\% ), rhomboidal (7.83\%), conical $(0.90 \%)$, cross $(0.30 \%)$ and $\mathrm{cf}$. Zea mays $(0.60 \%)$ were also present.

\section{E.2.1.3 Middle Archaic (ca. 3900-4800 years B.P.)}

Sample 1224-b was taken from the 46-47 cmbs level and contained only 1624 grains $/ \mathrm{ml}$ total pollen concentration values and was based on a pollen sum of only 46 grains. Pinus (71 grains $/ \mathrm{ml}$ ) was present in trace amounts only. Cheno-am (1094 grains $/ \mathrm{ml}$ ) was low to moderate but dominated the assemblage. Both high (106 grains $/ \mathrm{ml}$ ) and low spine (71 grains $/ \mathrm{ml}$ ) Asteraceae were present in high to moderate amounts with small amounts of Artemisia (35 grains $/ \mathrm{ml})$. Trilete spores $(7.56 / \mathrm{ml})$ were present in the low magnification scan of the slide.

The phytolith sample was based on a sum of 344 and was dominated by crennate (63.95\%) forms and secondarily by simple lobate $(10.76 \%)$. Smaller percentages of saddle $(7.85 \%)$, irregular $(0.87 \%)$, stipa type $(0.58 \%)$, hair bases $(0.29 \%$ each), conical $(0.87 \%)$, square $(8.43 \%)$, rhomboidal $(6.10 \%)$, and cross $(0.29 \%)$ were also present.

Sample 1225-b was taken from the 50-51 cmbs level and contained only 1306 grains $/ \mathrm{ml}$ total pollen concentration values and was based on a pollen sum of only 37 grains. Pinus (71 grains $/ \mathrm{ml}$ ) was present in trace amounts only with a small amount of Carya (35 grains/ml) pollen. Poaceae (35 grains $/ \mathrm{ml}$ ) was very low with very low Cheno-am (494 grains/ml) pollen and high amounts of both high (106 grains/ml) and low spine (282 grains/ml) Asteraceae.

The phytolith sample was based on a sum of 292 and was dominated by crennate (63.36\%) forms and secondarily by simple lobate (11.64\%) and saddle (11.30\%). Smaller percentages of stipa type $(0.34 \%)$, conical (1.37\%), square (3.77\%), rhomboidal $(7.88 \%)$, stipa type and cross $(0.34 \%)$ were also present.

Sample 1226-b was taken from the 55-56 cmbs level and contained only 2186 grains/ml total pollen concentration values and was based on a pollen sum of only 68 grains. Pinus (96 grains $/ \mathrm{ml}$ ) was present in trace amounts only. Poaceae (32 grains $/ \mathrm{ml}$ ) was present in low amounts with moderate amounts of Cheno-am (1157 grains/ml) and high amounts of both high (257 grains $/ \mathrm{ml}$ ) and low spine (418 grains/ml) Asteraceae. A larger sized grass grain (32 grains/ml) was also present. The phytolith sample from this level was not countable.

Sample 1227-b was taken from the 60-61 cmbs level and contained only 1129 grains/ml total pollen concentration values and was based on a pollen sum of only 32 grains. Pinus (35 grains $/ \mathrm{ml}$ ) was present in trace amounts only with moderate to high amounts of Carya (71 grains/ml) and Celtis (35 grains/ml). Poaceae (35 grains $/ \mathrm{ml}$ ) was low with low amounts of Cheno-am (318 grains $/ \mathrm{ml}$ ) and high amounts of both high (106 grains/ml) and low spine (353 grains/ml) Asteraceae. Ephedra (35 grains/ml was also present. 
The phytolith sample was based on a sum of 360 and was dominated by crennate (59.17\%) forms and secondarily by rhomboidal (16.11\%). Smaller percentages of keeled $(1.11 \%)$, saddle $(5.83 \%)$, simple lobate $(3.33 \%)$, square $(5.83 \%)$, irregular $(7.78 \%)$, hair bases $(0.56 \%)$, and cross (0.29\%) were also present.

Sample 1228-b was taken from the 66-67 cmbs level and contained only 765 grains/ml total pollen concentration values and was based on a pollen sum of only 17 grains. Pinus (45 grains/ml) was present in trace amounts only but with high amounts of Carya (135 grains/ml. Cheno-am (225 grains $/ \mathrm{ml}$ ) was very low but dominated the assemblage and there were a large number of Cheno-am pollen clumps $(45 / \mathrm{ml})$. Both high and low spine (45 grains/ml each) Asteraceae were present in low to moderate amounts.

The phytolith sample was based on a sum of 319 and was dominated by crennate (57.05\%) forms and secondarily by rhomboidal (14.11\%) and square (10.03\%). Smaller percentages of conical (1.57\%), saddle (7.21\%), simple lobate (6.27\%), irregular (0.94\%), and hair bases (2.82\%) were also present.

Sample 1229-b was taken from the 71-72 cmbs level and contained only 784 grains $/ \mathrm{ml}$ total pollen concentration values and was based on a pollen sum of only 27 grains. Pinus (29 grains/ml) was present in trace amounts only with a small amount of Carya (29 grains/ml) pollen. Cheno-am (116 grains $/ \mathrm{ml}$ ) was very low with high amounts of both high (174 grains $/ \mathrm{ml}$ ) and low spine (261grains/ml) Asteraceae. Cactaceae (29 grains $/ \mathrm{ml}$ ) was low but was represented by only a single grain. Apiaceae pollen (6.43 grains $/ \mathrm{ml}$ ) was present in the low magnification scan of the slide.
The phytolith sample was based on a sum of 310 and was dominated by crennate (49.35\%) forms and secondarily by rhomboidal (21.29\%) and square (14.52\%). Smaller percentages of conical $(0.65 \%)$, saddle (3.55\%), simple lobate (1.29\%), and irregular (9.35\%), were also present.

Sample 1230-b was taken from the 76-77 cmbs level and contained only 581 grains $/ \mathrm{ml}$ total pollen concentration values and was based on a pollen sum of only 20 grains. Quercus and Celtis (29 grains/ml each) were present in small amounts only. Poaceae (87 grains/ml) was high with low amounts of Cheno-am (145 grains/ml) and moderate to low amounts of both high (58 grains $/ \mathrm{ml}$ ) and low spine (29 grains/ml) Asteraceae. Trilete spores $(4.47 / \mathrm{ml})$ were present in the low magnification scan of the slide.

The phytolith sample was based on a sum of 362 and was dominated by crennate (35.64\%) forms and secondarily by rhomboidal (23.48\%), irregular (25.41\%), and square $(10.22 \%)$. Smaller percentages of saddle $(3.59 \%)$, simple lobate $(0.83 \%)$, hair bases $(0.28 \%)$, and Sabal $(0.55 \%)$ were also present.

\section{E.2.1.4 Early Archaic (ca. 5200-6300 years B.P.)}

Sample 1231-b was taken from the 81-82 cmbs level and contained 1276 grains $/ \mathrm{ml}$ total pollen concentration values and was based on a pollen sum of only 26 grains. A small amount of Quercus (46 grains/ml) was present. Poaceae (98 grains/ml) was high with low amounts of Cheno-am (344 grains/ml), and high amounts of both high (98 grains/ml) and low spine (442 grains/ml) Asteraceae.

The phytolith sample was based on a sum of 371 and was dominated by rhomboidal (53.37\%) and secondarily by crennate 
Appendix E: Pollen and Phytolith Analysis

(19.41\%) and irregular (11.59\%). Smaller percentages of conical (1.62\%), saddle (3.77\%), simple lobate (3.23\%), square $(6.47 \%)$, and hair bases $(0.54 \%)$, were also present.

Sample 1232-b was taken from the 86-87 $\mathrm{cm}$ level. The phytolith sample was based on a sum of 244 and the pollen sample from this level was not extracted. The phytolith sample from this level was dominated by irregular (46.31\%) forms and secondarily by crennate (25.41\%) and rhomboidal (15.16\%). Smaller percentages of saddle and square (6.56\% each) were also present.

Sample 1233-b was taken from the 90-91 cm level. The phytolith sample was based on a sum of 286 and the pollen sample from this level was not extracted. The sample was dominated by crennate (55.24\%) forms and secondarily by irregular (14.34\%) and rhomboidal (20.98\%). Smaller percentages of conical $(0.35 \%)$, saddle $(2.80 \%)$, square (5.24\%), simple lobate $(0.70 \%)$, and hair bases $(0.35 \%)$ were also present.

Sample 1234-b was taken from the 95-96 cmbs level and contained only 800 grains $/ \mathrm{ml}$ total pollen concentration values and was based on a pollen sum of only 16 grains. A small amount of Carya (50 grains $/ \mathrm{ml}$ ) was present. Cheno-am (250 grains $/ \mathrm{ml}$ ) was present in very low amounts along with high amounts of low spine (150 grains $/ \mathrm{ml})$ Asteraceae. Trilete spores $(12.24 / \mathrm{ml})$ were present in the low magnification scan of the slide.

The phytolith sample was based on a sum of 372. The sample was dominated by Rhomboidal (34.14\%), crennate (26.08\%), and irregular (23.66\%) forms. Smaller percentages of conical (1.08\%), saddle $(5.11 \%)$, square $(8.87 \%)$, and hair bases (1.08\%) were also present.

Sample 1235-b was taken from the 100-101 $\mathrm{cm}$ level. The phytolith sample was based on a sum of 320 and the pollen sample from this level was not extracted. The sample was dominated by crennate (55.63\%) forms and secondarily by irregular (10.31\%) and rhomboidal (21.56\%). Smaller percentages of saddle $(1.88 \%)$, square $(9.38 \%)$, simple lobate $(0.31 \%)$, and hair bases $(0.94 \%)$ were also present.

Sample 1236-b was taken from the 104-106 $\mathrm{cm}$ level. The phytolith sample was based on a sum of 389 and the pollen sample from this level was not extracted. The sample was dominated by crennate (54.24\%) forms and secondarily by rhomboidal (21.34\%). Smaller percentages of conical (1.29\%), saddle (4.63\%), square $(9.25 \%)$, simple lobate (2.31\%), irregular (5.91\%), and hair bases $(1.03 \%)$ were also present.

\section{E.2.2 Dated Sections}

Two sediment samples were submitted from BT1. Sample 1208-4-d was taken from unit 3 , from the 2Ab deposit, which dated to the late Archaic, approximately 1870 years B.P. The assemblage contained 2333 grains $/ \mathrm{ml}$ total pollen concentration values and was based on a pollen sum of 70 grains. Pinus (100 grains/ml) was very low with high amounts of Quercus (167 grains $/ \mathrm{ml}$ ). Cheno-am (1433 grains/ml) was moderate to high with high amounts of both high (133 grains $/ \mathrm{ml}$ ) and low spine (167 grains/ml) Asteraceae. Solanaceae and Ephedra (33 grains/ml each) were also present.

The phytolith sample was based on a sum of 370. The sample was dominated by crennate $(57.57 \%)$ and secondarily by Rhomboidal (17.84\%) forms. Smaller percentages of conical $(0.27 \%)$, saddle (9.46\%), simple lobate $(9.19 \%)$, square (3.78\%), irregular (1.35\%), hair bases and Sabal $(0.27 \%$ each) were also present. 
Sample 1207-4-d was taken from unit 4, from the 2Bw deposit, which dated to the Early Archaic, approximately 6279 years B.P. Pinus (90 grains $/ \mathrm{ml}$ ) was very low along with low to moderate amounts of Quercus (30 grains/ml) and Carya (60 grains $/ \mathrm{ml})$ pollen. Cheno-am (120 grains $/ \mathrm{ml}$ ) was very low with low amounts of high spine (30 grains $/ \mathrm{ml}$ ) and high amounts of low spine (90 grains $/ \mathrm{ml})$ Asteraceae. Ephedra (30 grains/ml was also present. Poaceae (4.53 grains $/ \mathrm{ml}$ ) pollen was present in the low magnification scan of the slide. The phytolith sample from this level was not countable.

An additional 3 sediment samples were submitted from BT 7. Sample 1211-4-d was taken from cultural strata $15-20 \mathrm{cmbs}$ and dated to the late Archaic, approximately 1900 years B.P. The assemblage contained 900 grains $/ \mathrm{ml}$ total pollen concentration values and was based on a pollen sum of 28 grains. Pinus (32 grains $/ \mathrm{ml}$ ) was present in trace amounts only. A small amount of Quercus (32 grains $/ \mathrm{ml}$ ) pollen was present. Poaceae (32 grains $/ \mathrm{ml}$ ) was low with low amounts of Cheno-am (482 grains $/ \mathrm{ml}$ ) and high spine Asteraceae (32 grains/ml) and a high amount of low spine Asteraceae (96 grains/ml).

The phytolith sample was based on a sum of 424. The sample was dominated by crennate (68.40\%) and secondarily by Rhomboidal (10.85\%) forms. Smaller percentages of saddle (6.13\%), simple lobate (1.18\%), square (7.55\%), irregular (4.01\%), hair bases (1.65\%), and Sabal (0.24\%) were also present.

Sample 1210-4-d was taken from the 2Bk deposit (80-85 cmbs), which dated to the Early Archaic, approximately 4820 years B.P. The assemblage contained 886 grains/ml total pollen concentration values and was based on a pollen sum of 249 grains. Pinus (25 grains $/ \mathrm{ml}$ ) was present in trace amounts only with small amounts of Quercus (36 grains/ml) and Carya (43 grains $/ \mathrm{ml}$ ) pollen. Poaceae (25 grains $/ \mathrm{ml}$ ) was low with low amounts of Cheno-am (277 grains/ml) pollen. Both high (142 grains $/ \mathrm{ml}$ ) and low spine (160 grains $/ \mathrm{ml}$ ) Asteraceae were present in high amounts. A trace of Liguliflorae and Ephedra pollen (4 grains/ml each) were also present, in addition to a small, unknown triporate type grain. Malvaceae and trilete spores (1.71 grains $/ \mathrm{ml}$ ) were present in the low magnification scan of the slide. The phytolith sample from this level was not countable.

Sample 1209-4-d was taken from the 115$120 \mathrm{cmbs}$ level of the Bk2 deposit, which dated to the Early Archaic, approximately 5230 years B.P. The assemblage contained only 374 grains $/ \mathrm{ml}$ total pollen concentration values and was based on a pollen sum of 31 grains. Pinus and Quercus (12 grains/ml each) were present in trace amounts and Carya (24 grains $/ \mathrm{ml}$ ) was present in low amounts. Poaceae (36 grains $/ \mathrm{ml}$ ) was low with a trace (12 grains $/ \mathrm{ml}$ ) of Cheno-am pollen along with moderate amounts of high spine (60 grains $/ \mathrm{ml}$ ) and moderate to high amounts of low spine (85 grains $/ \mathrm{ml}$ ) Asteraceae. Artemisia and Apiaceae (24 grains/ml each) were present in small amounts Trilete spores $(3.22 / \mathrm{ml})$ were present in the low magnification scan of the slide.

The phytolith sample was based on a sum of 217. The sample was dominated by crennate $(70.51 \%)$ and secondarily by Rhomboidal (10.14\%) and irregular (10.60\%) forms. Smaller percentages of saddle $(2.30 \%)$, square $(4.61 \%)$, irregular 
(4.02\%), and hair bases (1.84\%) were also present.

\section{E.3 DISCUSSION}

\section{E.3.1 Pollen Data}

The pollen data was very poorly preserved throughout the column. The samples from the youngest period (Toyah component) were better preserved than from other periods. The total pollen concentration values are generally higher from the Toyah component and then decrease throughout the Late Archaic to very low levels where they remain throughout both the Middle and Early Archaic time periods (Figures E-1 and E-2). The concentration values of indeterminate grains also tend to increase with depth of the column although these are generally high throughout the column. While the number of pollen taxa recovered from individual samples is generally low (512 with a mean of 7.75), the samples from the Toyah component contained higher numbers of taxa with the taxa decreasing by age of the column (Table E-6). This reveals a highly weathered column with poor preservation.

Pinus pollen is present in very low amounts throughout the column and probably represents the results of long distance transport. Although Pinus is present in the mesic forests presently located along the streams, it is probably not very dominant. Although, the low pollen concentration values may be accounted for by preservation, I suspect that the number of pines in the area are low. In the earlier sediments (Middle to Early Archaic) Pinus pollen concentration values decrease to trace amounts. This is likely due to preservation and I suspect pines have been locally present, although not abundant, throughout most of the time periods represented by these samples.

Juniperus pollen is absent from the pollen assemblages although it was an important constituent of the modern vegetation. This is likely due to factors of preservation. Juniperus pollen is thin walled and contains a smaller percentage of the compound sporopollenin in the exine. The percentage of this compound has been demonstrated to positively correlate with the degree to which a pollen grain is resistant to weathering (Brooks 1971, 1978). Further, in a series of controlled laboratory experiments Holloway (1981, 1989) demonstrated that more than $80 \%$ of the fresh Juniperus pollen was deteriorated after only 25 alternating cycles of either freezing/thawing temperatures, or wet/dry conditions. Thus, it is not unexpected for Juniperus pollen to be absent from assemblages, even when it is known to be present in the plant community.

In order to evaluate the degree of variation of the data, both the pollen and phytolith data sets were analyzed using Principal Components Analysis. The calculations were performed using MVSP (Kovach 1998), a computer program specifically designed for use with Pollen and microfossil data. With only a few exceptions, the vast majority of the samples clustered around a single axis and thus no real separation was obtained. Because of this lack of separation, the data are not included in this report but are available from the author.

\section{E.3.1.1 Toyah Component ca. 300-650 B.P.}

Quercus pollen was fairly high throughout this period and was present in all samples. Additionally, Carya pollen was present in all samples from this period and both Celtis and Juglans pollen were recovered from the lowest sample from this period. This is 
The Varga Site

Texas Department of Transportation

consistent with the modern vegetation of the area described earlier.

The uppermost sample from the column (1217-b) contained a fairly large concentration value of Apiaceae pollen, which undoubtedly reflects a more riparian habitat within the area. Cheno-am pollen is very high and the upper sample (1217-b) also contained a high number of Cheno-am pollen clumps $(67 / \mathrm{ml})$, which is suggestive of these plants being extremely common in the vicinity. High and low spine Asteraceae pollen concentration values were very large, particularly in the lowest level of this period (1220-b). The high levels of the Asteraceae, Artemisia, Cheno-am and Poaceae suggest a mosaic pattern with the arboreal cover interspersed with shrubby grassland components. Small amounts of Opuntia pollen are present only in the upper level of the column and probably reflect the local presence of this taxon in the plant community. However, this was based on the presence of a single pollen grain and may not be indicative of current conditions. No other Opuntia grains were observed from this suite of samples.

\section{E.3.1.2 Late Archaic Period ca. 1700- 2300 B.P.}

A total of 3 samples were submitted from this time period and represented the section of the column between 28-41 cm. The pollen concentration values show a trend to decreasing values during this period. Pinus pollen decreases to trace amounts remains at these low levels or is absent from the remainder of the column. Quercus is present only in the upper level of this period and no other arboreal taxa are present. Cheno-am, Asteraceae and Artemisia pollen show gradual decreases but are still fairly abundant. Generally, the pollen assemblages reflect the same taxa as present during the later Toyah component. The pollen assemblages contain lowered pollen concentration values but this is likely due to increased deterioration of the assemblages.

Two dated sections were also affiliated with this time period. Sample 1208-4-d was taken from BT-M (90 cmbs level). This assemblage contained very low concentration values of Pinus (100 grains $/ \mathrm{ml}$ ) and fairly high concentration values of Quercus (167 grains/ml). Chenoam pollen was moderate to high (1433 grains/ml) with high amounts of both high (133 grains/ml) and low spine (167 grains $/ \mathrm{ml}$ ) Asteraceae, which compares fairly close to the upper levels of the Late Archaic samples from the column. Small amounts of Solanaceae and Ephedra pollen (33 grains/ml each) were also present.

Sample 1211-4-d was taken from a cultural level from BT 7 from the 15-20 cmbs level. This assemblage contained small concentration values for Pinus and Quercus along with Poaceae. The Cheno-am pollen concentration values were very low (482 grains $/ \mathrm{ml}$ ) and both types of Asteraceae were lower than from sample 1208-4-d. Thus the higher concentration values from 1208-4-d are likely from locally present Chenopodium type plants. Although physically closer to the surface, this sample corresponds closer to the deeper Late Archaic sediments from the column but this may be due to more extensive weathering of this cultural layer.

\section{E.3.1.3 Middle Archaic Period ca. 3900-4800 B.P.}

Quercus pollen is present in small quantities in the lowest sample of this time period. A small amount of Celtis pollen is present from a single level but Carya pollen is present in 5 of the 7 samples. While the ubiquity of these arboreal taxa is drastically lowered, this is most likely a function of 
preservation. The arboreal component, in terms of the taxa present, is very similar to the better-preserved levels of the column. Low spine Asteraceae tends to increase in concentration values during this period while all other taxa show decreases. This is also possibly a function of preservation since the Asteraceae are among the betterpreserved taxa (Holloway 1981, 1989). Alternatively, this could suggest an actual increase in these types of plants. This is supported by the occurrence of non-Opuntia Cactaceae and Ephedra in single samples. Again, both the Cactaceae and Ephedra were based on the occurrence of single grains and I hesitate to place a great deal of weight to their presence. Alternatively, these are indicators of drier environments and their presence within this period may suggest slightly drier conditions were present in the local area. Given the poor preservation from these assemblages however, additional data would be required prior to hypothesizing an environmental change.

\section{E.3.1.4 Early Archaic Period ca. 5200- 6300 B.P.}

Only 2 pollen samples from this period were analyzed. The remaining pollen samples were not extracted given the low potential for pollen recovery. Given the generally poor condition of the samples from this time period, this was an accurate assessment.

Small amounts of both Quercus and Carya pollen were present and were based on single grain occurrences. The assemblages were dominated by both high and low spine Asteraceae but again these taxa are most resistant to deterioration, and high concentration values for these would be expected. In both the Middle and Early Archaic Periods, while Cheno-am pollen had high numbers, the concentration values were very low for this taxon. This again supports and interpretation of a significantly weathered assemblage. The data from this early period is so sporadic and the pollen concentration values so low that I hesitate to infer any interpretations from this period. Interestingly, the same taxa (Quercus and Carya) are present in these assemblages.

Three additional pollen samples were submitted from dated sections affiliated with this earlier time period. Two of these samples (1207-4-d -BT-M, and 1209-4-d BT-7) contained very little pollen. The concentration values were based on pollen sums of only 16 and 31 respectively. Both samples contained small amounts of Pinus, Quercus, and Carya pollen while 1209-4-d contained small quantities of Apiaceae and Poaceae pollen. Both High and low spine Asteraceae were low in both samples. While Cheno-am pollen was also very low in both samples, sample 1207 (120 grains/ml) contained 10 times more Chenoam pollen than did 1209 (12 grains/ml). The low pollen concentration values are consistent with the Early Archaic and the presence of the arboreal taxa Pinus, Quercus, and Carya, indicate that these taxa were present throughout the time periods represented, even if absent from individual samples.

Sample 1210-4-d contained sufficient pollen for a full count. Small amounts of Pinus, Quercus, and Carya pollen were present along with very small amounts of Cheno-am and Poaceae pollen. Both high and low spine Asteraceae pollen were fairly high and this sample did contain a trace of Liguliflorae pollen. The low arboreal pollen concentration values might suggest a decrease in the arboreal cover during this early time period with a concomitant expansion of meadow like components. Liguliflorae pollen is generally rare in assemblages because this type of pollen is 
restricted to the Chichoreae tribe of the Asteraceae, which include taxa such as Taraxacum, Lactuca, Liatris etc., which are generally associated with grassland meadows. These plants also produce very low amounts of pollen so that even a small concentration value suggests a much higher composition of these plants within the local plant communities.

Given the presence of the Quercus and Carya throughout the column, I suspect that similar vegetation communities existed in this area throughout the time periods represented. The changes observed within the pollen assemblages are likely due to a function of preservation, although the earliest levels do suggest a possible larger component of meadows within the local vegetation.

Based on the pollen taxa recovered, the question always arises are economic taxa absent from these assemblages because they are truly not present, or, are they present in such small amounts to have been missed during sampling. In order to assess the likelihood of there being missed, the estimated maximum potential concentration values (Dean 1998) of target taxa were computed. Since the entire slide was examined (either by count or low magnification scan of the slide) the estimated number of marker grains per slide was computed by averaging the number of marker grains per transect and multiplying this by the total number of transects examined. Assuming, that the first grain observed on an hypothetical second slide was one of the target taxa, the maximum potential concentration value can be computed. Thus, the number of the fossil grains is one, and the number of marker grains per slide is substituted for the number of marker grains counted in the pollen concentration formula. These data are presented in Table E-3 and indicate that the estimated potential pollen concentration values fall between 1.61 and 27.16 grains/g. Without examining the total of the pollen residues we can never be absolutely sure that target taxa are indeed absent from the assemblage. Given the low estimated potential pollen concentration values however, I conclude that it is more likely that the missing taxa were indeed absent from these assemblages.

\section{E.3.2 Phytolith Data}

A preliminary assessment 5 of the column phytolith assemblages was conducted by Dr. John Jones of Texas A\&M University. He noted that "phytoliths were noted in all samples and the preservation appeared quite good throughout the column." $\mathrm{He}$ also noted that dominant forms included Chloridoids, Panicoids, and a small number of Festucoid types. A small amount of Sabal-type palm phytoliths were also present but Jones interpreted these as reflecting probable Cretaceous or Tertiary aged reworked phytoliths. Jones interpreted these as being derived from lignites and/or shales. Very few of these types were present in the assemblages and his interpretation of these being re-worked deposits is very likely accurate.

After completion of the analysis, the relative frequencies of the phytolith types were plotted by depth in Figure E-3 from the column samples. The data from the dated sections was not sufficiently consistent to plot separately.

\section{E.3.2.1 Early Archaic Period ca. 5200- 6300 B.P.}

The assemblages from this earliest time period are dominated by Crennate, Rhomboidal, and Irregular forms with a fairly consistent presence of square shaped 
phytoliths. Saddle and conical forms are present in very small percentages and simple lobate forms are present but in trace percentages. Crennate forms are commonly produced by the Pooideae grasses (Fredlund and Tieszen 1994), as are the very small percentages of the conical forms. The dominant forms from this interval contained the Rhomboidal, which are rectangular with smooth walls, and generally smaller, and the square forms, also with smooth walls.

Two of the dated column sections from the Early Archaic Period were essentially not countable. Very few phytoliths were present on the slides. Sample 1209-4-d from strata Bk2 taken from backhoe trench 7 did provide a countable assemblage. Crennate forms were clearly dominant (70\%) and the remainder consisted primarily of Rhomboidal, Irregular, and square types which is consistent with the column samples from this time period. Small, almost trace amounts of saddle forms and a few hair bases were also present.

\section{E.3.2.2 Middle Archaic Period ca. 3900-4800 B.P.}

This period appears to be a transition period between forms. The samples from the lower levels of this period are quite similar to the Early Archaic assemblages. These lower samples are clearly dominated by Crennate forms, and the Rhomboidal, Irregular, and Square forms. The crennate forms show a gradual increase during this period, the Rhomboidal, Irregular, and Square forms show a concomitant decrease with both the Irregular and Rhomboidal disappearing in the upper section of the Middle Archaic. This section also shows gradual increases in both the saddle forms and the simple lobate forms. Conical forms are intermittent and are extremely rare. A keeled form was present in a single sample during this period and was the only sample in the column in which this form was present. The dominant crennate forms and the keeled and conical forms are associated with the Pooideae. The gradual increases in both Saddle and simple lobate forms may suggest an increase in both the Chlorideae and Panicoideae grasses, but this is preliminary.

Stipa-type phytoliths begin to occur in the upper levels of the Middle Archaic Period and cross-shaped phytoliths begin to occur about the middle levels of the period. The cross-shaped varieties are generally associated with the Panicoideae and $\mathrm{C}_{4}$ type grasses (Fredlund and Tieszen 1994). The cross-shaped forms also appear about the level that the Rhomboidal and Irregular forms disappear from the record. Whether this is coincidence or not remains to be seen.

\section{E.3.2.3 Late Archaic Period ca. 1700- 2300 B.P.}

The Late Archaic Period was represented by only 3 samples. Irregular forms are present but in trace percentages. Both rhomboidal and Square forms are present, but in much smaller percentages than were present in the earlier periods. Stipa-type remain in low percentages at both the top and basal sample of this section. Cross-shaped forms and a single form that compares favorably to Zea mays are also present but in low percentages. In fact, the specimen comparing favorably to Zea mays was present from only a single sample from the Late Archaic. Panicoid forms are present in the middle samples but are quite high in percentages. Crennate forms still dominate the assemblage but there are gradual increases in the percentages of both Saddle and Simple Lobate forms. Conical forms show a tendency to decrease.

Two dated sections also dated to this Late Archaic Period. The section from BT-M, which dated to 1870 B.P. was dominated by 
The Varga Site

Texas Department of Transportation

crennate forms. Rhomboidal, Irregular, and square forms were present, but in much smaller quantities than from the earlier periods. Saddle and simple lobate forms were present. The assemblage is fairly consistent with the assemblages from the column samples.

The other dated section was from backhoe trench 7 and dated to the 1900 B.P. level. This sample also was dominated by crennate forms and with smaller percentages of rhomboidal, irregular, and square forms. Saddle and simple lobate forms were present but in smaller percentages than from 12084-d. Again, despite some variations, this assemblage is consistent with those from the Late Archaic age from the column.

Thus, this period shows a mix between the $\mathrm{C}_{3}$ grasses, dominated by the Pooideae in the crennate, and conical forms and Stipa sp., and the $\mathrm{C}_{4}$ grasses showing increasing contributions of Saddle, Simple lobate, cross-shape, a possible Zea mays, and Panicoid type forms which are generally affiliated with both the Panicoideae and Chloridaeae (Fredlund and Tieszen 1994).

\section{E.3.2.4 Toyah Component, ca. 300- 650 B.P.}

The Toyah component also appeared to be dominated by Crennate forms but to a lesser extent than from the other periods. There is a general trend to slightly decreasing frequencies of this form throughout the period. However, this may simply be a response to increased frequencies of other forms. Stipa-type shows a stable frequency throughout the period except in the upper most sample where it increases dramatically. Even at this level, the frequency is less than $8 \%$. The upper most sample contains a small percentage of Pyramidal forms and a trace of conical forms are found lower in the column. Simple Lobate forms remain fairly high although there is some fluctuation in the actual percentages. Saddle forms also tend to increase during this period. Square and Rhomboidal forms are present but in very low percentages. In the upper most sample, other lobate forms are present but again in relatively low frequencies. Crossshaped forms also reach a maximum in the upper sample.

This period indicates a stable but perhaps decreasing, composition of $\mathrm{C}_{3}$ (Pooideae) grasses as indicated by the Crennate, Conical, and Pyramidal forms. The Chlorideae forms as indicated by Saddle types are increasing as are various genera of the Panicoideae as indicated by the Stipatype, simple and other lobate forms, panicoid and cross-shaped forms. These generally are indicative of the $\mathrm{C}_{4}$ grasses.

Members of the Poaceae, as many other higher plants, contain two photosynthetic pathways. The difference lies in the intermediate by-product of photosynthesis, which is either a 3 carbon molecule or a 4carbon molecule, hence the grouping of these plants as either $\mathrm{C}_{3}$ or $\mathrm{C}_{4}$ plants. The $\mathrm{C}_{3}$ plants are characterized by large, irregularly and loosely arranged Chlorenchymal cells with a double sheath of cells surrounding the vascular bundles within the leaves (Piperno 1988). These plants are generally adapted to cooler and moister environments.

The $\mathrm{C}_{4}$ group, on the other hand, contains densely clustered chlorenchyma cells, which surround the single layer of bundle sheath cells surrounding the vascular bundles. This particular pathway tends to occur in grasses characteristic of warm, dry environments and were likely of more tropical origin (Piperno 1988).

Piperno (1988) further notes that members of the Pooideae, which generally produce 
types such as Crennate, keeled, conical, and pyramidal are restricted to the $\mathrm{C}_{3}$ pathway. Grasses of the Chlorideae and the Panicoideae which tend to produce saddles, bilobate and cross-shaped forms, tend to be associated with the $\mathrm{C}_{4}$ pathway. This is not an absolute and Piperno (1988) also notes what she calls confuser genera that need to be sorted out. She cites as an example that within the Panicoideae, both $\mathrm{C}_{3}$ and $\mathrm{C}_{4}$ plants are present. Even within genera such as Panicum, Piperno (1988) notes that both $\mathrm{C}_{3}$ and $\mathrm{C}_{4}$ species are present. Thus, there is a great deal of overlap within the genera.

In general, the phytolith column suggests that during the Early to sometime in the Middle Archaic, the grass assemblage was clearly dominated by $\mathrm{C}_{3}$ (possibly Pooideae) grasses. The data suggest that $\mathrm{C}_{4}$ grasses began coming into the area sometime during the middle Archaic but don't really take off until the Late Archaic or even more recent periods. There is some suggestion that some $\mathrm{C}_{4}$ grasses were likely in the area during the Early Archaic, but if so, were likely a minor constituent.

While the pollen data is rather deteriorated, the evidence indicates that the arboreal component remained rather stable over time consisting primarily of Quercus, Carya, and probably smaller numbers of Celtis and Juglans. The vegetation community was likely a mixture of arboreal and grassland meadow components. These grassland components revealed a slight change in composition (probably of component taxa) due to the immigration of some $\mathrm{C}_{4}$ grasses.

Although there was likely an admixture of both $\mathrm{C}_{3}$ and $\mathrm{C}_{4}$ grasses throughout the Archaic period, the relative abundance shows a shift to the $\mathrm{C}_{4}$ grasses, by the Late Archaic and Toyah component. While Zea mays phytoliths were only identified positively from the Late Archaic period, the increased presence of $\mathrm{C}_{4}$ grasses during the later period might suggest this as a function of the introduction of corn materials, although this is highly speculative for the moment.

\section{E.4 CONCLUSIONS}

The pollen assemblages from this site were generally poorly preserved. Pinus pollen, although present throughout the column, was present in very low concentration values. This suggests that the Pinus pollen was deposited through long distance transport. Although Pinus was noted in the modern vegetation the concentration values suggest that its presence was minimal. The absence of Juniperus pollen from these assemblages is thought to be a function of preservation. Juniperus is common in the modern vegetation of the area but this pollen grain is thin walled and is generally poorly preserved. Thus, its absence from locales containing abundant Juniperus plants is not unexpected.

Quercus, Carya, and Juglans pollen were present throughout the column, although Juglans pollen was restricted to the Toyah component and was quite rare. The presence of these taxa suggests similar vegetational composition from the early Archaic through the more recent Toyah component. The variations in the pollen concentration values are likely a function of the weathering of the assemblages.

The upper levels of the column, representing the Toyah component (300-650 B.P.) and extending possibly to the upper level of the Late Archaic (1700-2300 B.P.) are characterized by high concentration values of Cheno-am, Asteraceae, and Poaceae indicate a mosaic pattern of grassland components interspersed with the arboreal 
components. The slight increase in Poaceae pollen concentration values from the Early Archaic period may indicate an increase in grasses during this early time period but is also suggestive of the effects of weathering. In particular, the decrease in Cheno-am and Asteraceae pollen concentration values during the Early Archaic period is probably indicative of preservation.

There is also some indication of the presence of more riparian communities within the area throughout the time periods represented. Particularly, this is indicated by the presence of-Apiaceae pollen concentration values from both the Toyah component and the Early Archaic period, although the evidence from the Early Archaic was present in the low magnification scan of the slide only. Members of the Apiaceae Family are generally found in more moist conditions, possibly along the banks of Hackberry Creek. Juglans pollen was present in the Toyah component only and Carya pollen was present from the Toyah component as well as from the Early, Middle, and Late Archaic deposits. Interestingly, Carya pollen is restricted to the Early Archaic deposits from the dated section samples. Carya and Juglans generally require a more dependable water source and are thus often indicators of more riparian conditions. The presence of Hackberry Creek in close proximity to the site, although intermittent, probably provided the necessary moisture requirements for these taxa, throughout both the Archaic and the Toyah component.

The phytolith assemblages show a dominance of Pooideae grasses $\left(\mathrm{C}_{3}\right)$ during the Early to Middle Archaic periods. There is some indication that some $\mathrm{C}_{4}$ type grasses were indeed present in the area during this early period but contributed only small amounts to the assemblages. There is a gradual increase in the proportions of $\mathrm{C}_{4}$ phytoliths during the Middle Archaic but the dominance of these types does not really appear until much later during the later portion of the Late Archaic or into the Toyah component.

The Panicoideae and Chloridae grasses appear dominant in the Late Archaic and Toyah component periods. These forms, often consisting of Saddle, Simple Lobate, Other Lobate, and Cross morphotypes, are generally associated with $\mathrm{C}_{4}$ type grasses. The cross type specifically occurs in a large number of the Panicoid grasses. A possible Zea mays phytolith was present only from the Late Archaic period, and this could not be positively associated with Zea mays. Based on this single occurrence and lack of a positive identification, it is likely that at best, Zea mays was only minimally present and likely from the Late Archaic or later Toyah component. The other cross shaped varieties continued through the later Toyah component and are more likely related to the presence of Panicoid $\left(\mathrm{C}_{4}\right)$ grasses in the area. Certainly, the higher percentages of $\mathrm{C}_{4}$ grass material suggests the introduction of these plants, including possibly corn, into the area during the Late Archaic and Toyah component periods.

\section{E.5 REFERENCES CITED}

\section{Barkley, Fred A.}

1934 The statistical theory of pollen analysis. Ecology 15:283-289

\section{Bohrer, Vorsilla L.}

1981 Methods of recognizing cultural activity from pollen in archaeological sites. The Kiva 46:135-142.

\section{Brooks, James}

1971 Some chemical and Geochemical studies on sporopollenin. In: 
Sporopollenin,_(J. Brooks, P.R. Grant, M.D. Muir, P. van Gijzel, and G. Shaw, eds.). Academic Press, New York, pp. 351-407.

\section{Brooks, James}

1978 Diagenesis of organic matter: some microbiological, chemical, and geochemical studies on sedimentary organic matter. In: Krumbein (ed) Enviornmental Biogeochemistry and Geomicrobiology. Ann Arbor Science, Ann Arbor, MI. pp. 287-308.

\section{Brookes, David, Thomas, Karl W.}

1967 The distribution of pollen grains on microscope slides. Part 1 . The nonrandomness of the distribution. Pollen et Spores 9:621-629.

\section{Bryant, Vaughn M. Jr.}

1969 Pollen analysis of late-glacial and postglacial Texas sediments. Ph.D. dissertation, The University of Texas, Austin.

\section{Bryant, Vaughn M. Jr., and Holloway, Richard G.}

1983 The role of palynology in archaeology. In: Schiffer, M. (ed.) Advances in archaeological method and theory vol. 6. Academic Press, NY, pp. 191-224.

\section{Dean, Glenna}

1998 Finding a needle in a palynological haystack: a comparison of methods. In: Bryant, V. M., Wrenn, J. H. (eds.) New Developments in Palynomorph Sampling, Extraction, and Analysis; American Association of Stratigraphic Palynologists Foundation, Contributions Series Number 33:53-59.

\section{Erdtman, Gunnar}

1960 The acetolysis method: a revised description. Svensk. botanisk Tidskrift Bd. 54:561-564.

\section{Fredlund, Glen G., Tieszen, L.T.}

1994 Modern phytolith assemblages from the North American Great Plains. Jour. Biogeography 21:321-355.

\section{Hall, Steven A.}

1981 Deteriorated pollen grains and the interpretation of Quaternary pollen diagrams. Review of Paleobotany and Palynology 32:193-206.

\section{Holloway Richard G.}

1981 Preservation and experimental diagenesis of the pollen exine. Ph.D. dissertation, Texas A\&M University, College Station. 317p.

\section{Holloway Richard G.}

1989 Experimental mechanical pollen degradation and its application to Quaternary age deposits. Texas Journal of Science 41:131-145.

\section{Kovach, Warren L.}

1998 MVSP-A MultiVariate Statistical Package for Windows, ver. 3.1. Kovach Computing Services, Pentraeth, Wales, UK.

\section{Martin, Paul S.}

1963 The last 10,000 years. University of Arizona Press, Tucson.

\section{Piperno, Delores R.}

1988 Phytolith Analysis: An

Archaeological and Geological Perspective. Academic Press, San Diego, CA. 280 pages. 


\begin{tabular}{|c|c|c|}
\hline Family & Scientific Name & Common Name \\
\hline \multirow[t]{5}{*}{ Agavaceae } & & Yucca Family \\
\hline & Agave lechuguilla & Lechuguilla \\
\hline & Dasylirion wheeleri & Sotol \\
\hline & Nolina sp & Bear grass \\
\hline & Yucca sp. & Yucca \\
\hline Amaranthaceae & Amaranthus & Pigweed \\
\hline Apiaceae & & Umbell or Carrot Family \\
\hline \multirow[t]{10}{*}{ Asteraceae } & & Composite Family \\
\hline & Ambrosia & Bursage \\
\hline & Artemisia & Sagebrush \\
\hline & Lactuca & Lettuce \\
\hline & Liatris punctata & Dotted Blazingstar \\
\hline & Taraxacum & Dandelion \\
\hline & Chichoreae & Tribe of Asteraceae, heads comprised entirely of ligulate flowers \\
\hline & Liguliflorae & Pollen morphological group, Fenestrate type pollen \\
\hline & Low Spine & Pollen morphological group, spines $<2.5$ height \\
\hline & High Spine & Pollen morphological group, spines $>2.5$ height \\
\hline \multirow[t]{4}{*}{ Cactaceae } & & Cactus Family \\
\hline & Opuntia & Prickly Pear or Cholla Cactus \\
\hline & Cylindropuntia & Sub-genus of Opuntia, Cholla Cactus \\
\hline & Platyopuntia & Sub-genus of Opuntia, Prickly Pear Cactus \\
\hline \multirow[t]{4}{*}{ Chenopodiaceae } & & Goosefoot Family \\
\hline & Atriplex canescens & Saltbush \\
\hline & Chenopodium & Goosefoot, Lambs quarters \\
\hline & Cheno-am & Pollen morphological group, members of the family Chenopodiaceae and the genus Amaranthus \\
\hline Cupressaceae & Juniperus & Juniper \\
\hline \multirow[t]{2}{*}{ Ephedraceae } & & Joint Fir Family \\
\hline & Ephedra & Mormon Tea \\
\hline Fabaceae & & Bean Family \\
\hline \multirow{3}{*}{ Fagaceae } & & Oak Family \\
\hline & Quercus sp & Oak \\
\hline & Quercus virginiana & Live Oak \\
\hline \multirow[t]{3}{*}{ Juglandaceae } & & Walnut Family \\
\hline & Carya & Hickory, Pecan \\
\hline & Juglans sp & Walnut \\
\hline \multirow[t]{2}{*}{ Lycopodiaceae } & & Club-Moss Family \\
\hline & Lycopodium & Club-moss \\
\hline Malvaceae & & Cotton Family \\
\hline \multicolumn{3}{|l|}{ Nyctaginaceae } \\
\hline Onagraceae & & Evening Primrose Family \\
\hline \multirow[t]{2}{*}{ Palmae } & & Palm Family \\
\hline & Sabal sp. & Sabal Palm \\
\hline \multirow[t]{2}{*}{ Pinaceae } & & Pine Family \\
\hline & Pinus & Pine \\
\hline \multirow[t]{10}{*}{ Poaceae } & & Grass Family \\
\hline & Andropogon sp. & Bluestem \\
\hline & Andropogon scoparius & Little Bluestem \\
\hline & Bouteloua barbata & Six Weeks Fescue grass \\
\hline & Bouteloua curtipendula & Side-oats Grama \\
\hline & Bouteloua eriopoda & Black grama \\
\hline & Bouteloua gracilis & Blue Grama \\
\hline & Panicum sp. & Switch grass \\
\hline & Stipa $s p$ & needlegrass \\
\hline & Zea mays & Corn \\
\hline Solanaceae & & Nightshade Family \\
\hline \multirow{3}{*}{ Ulmaceae } & & Elm Family \\
\hline & Celtis sp. & Desert Hackberry \\
\hline & Ulmus & Elm \\
\hline
\end{tabular}




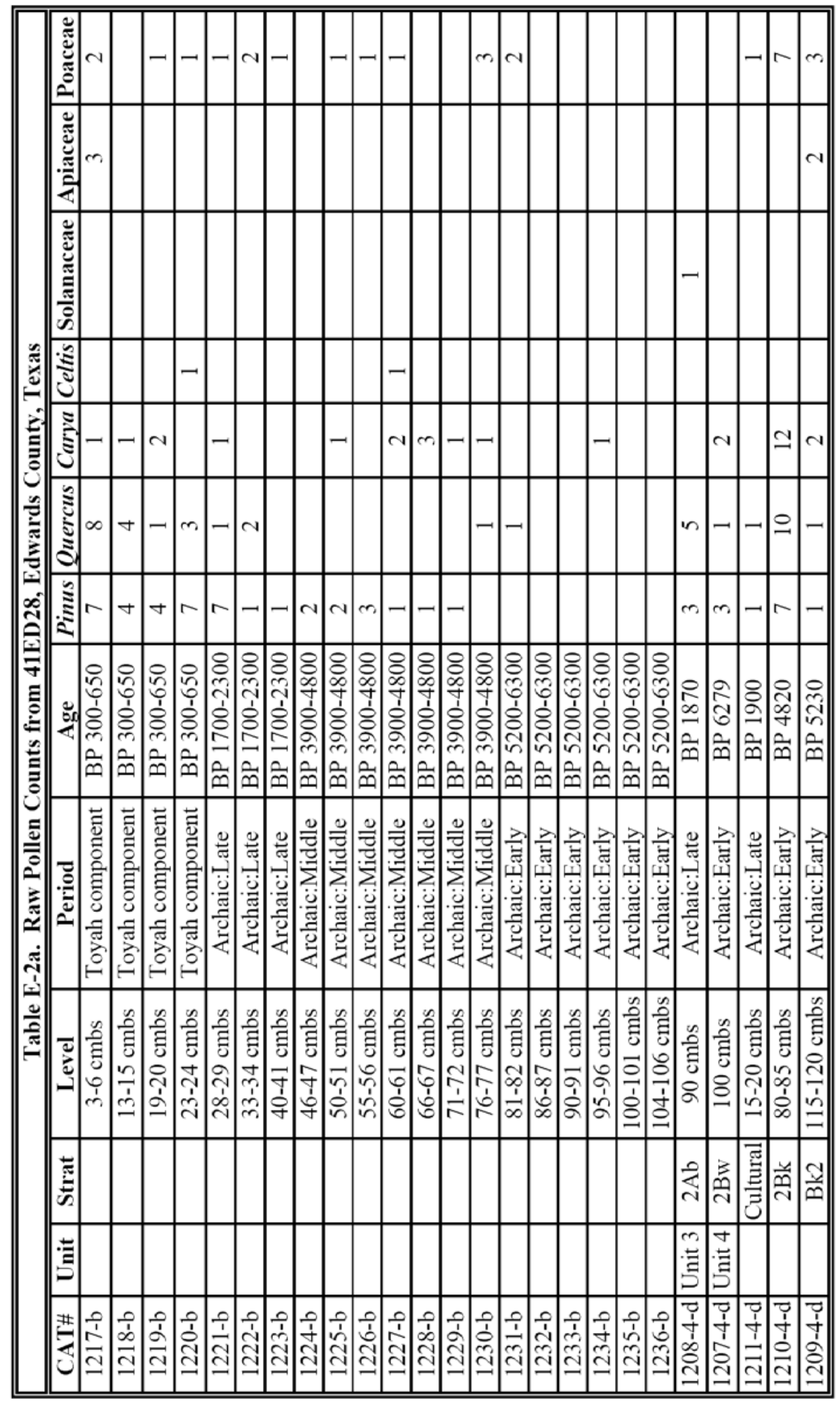




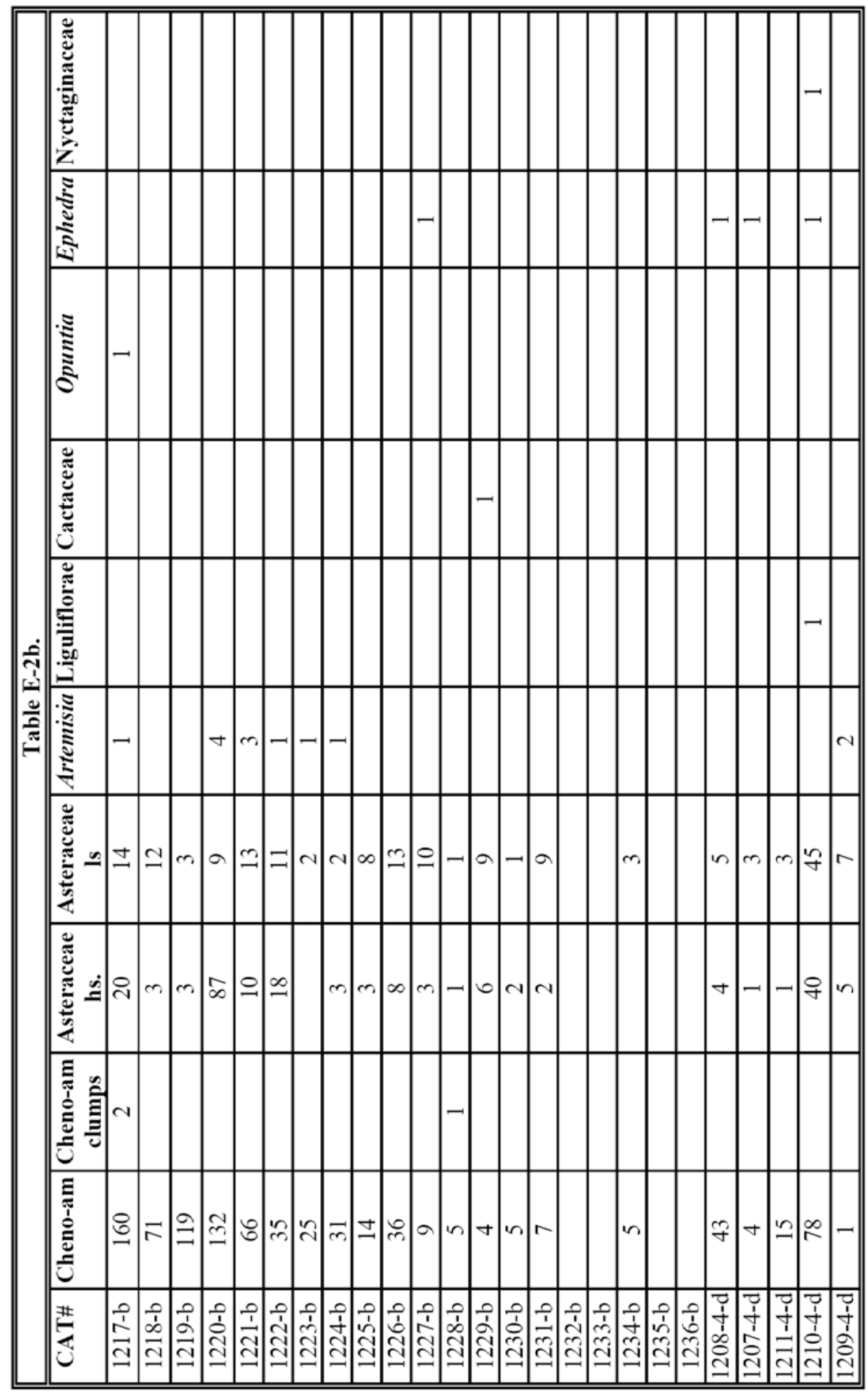




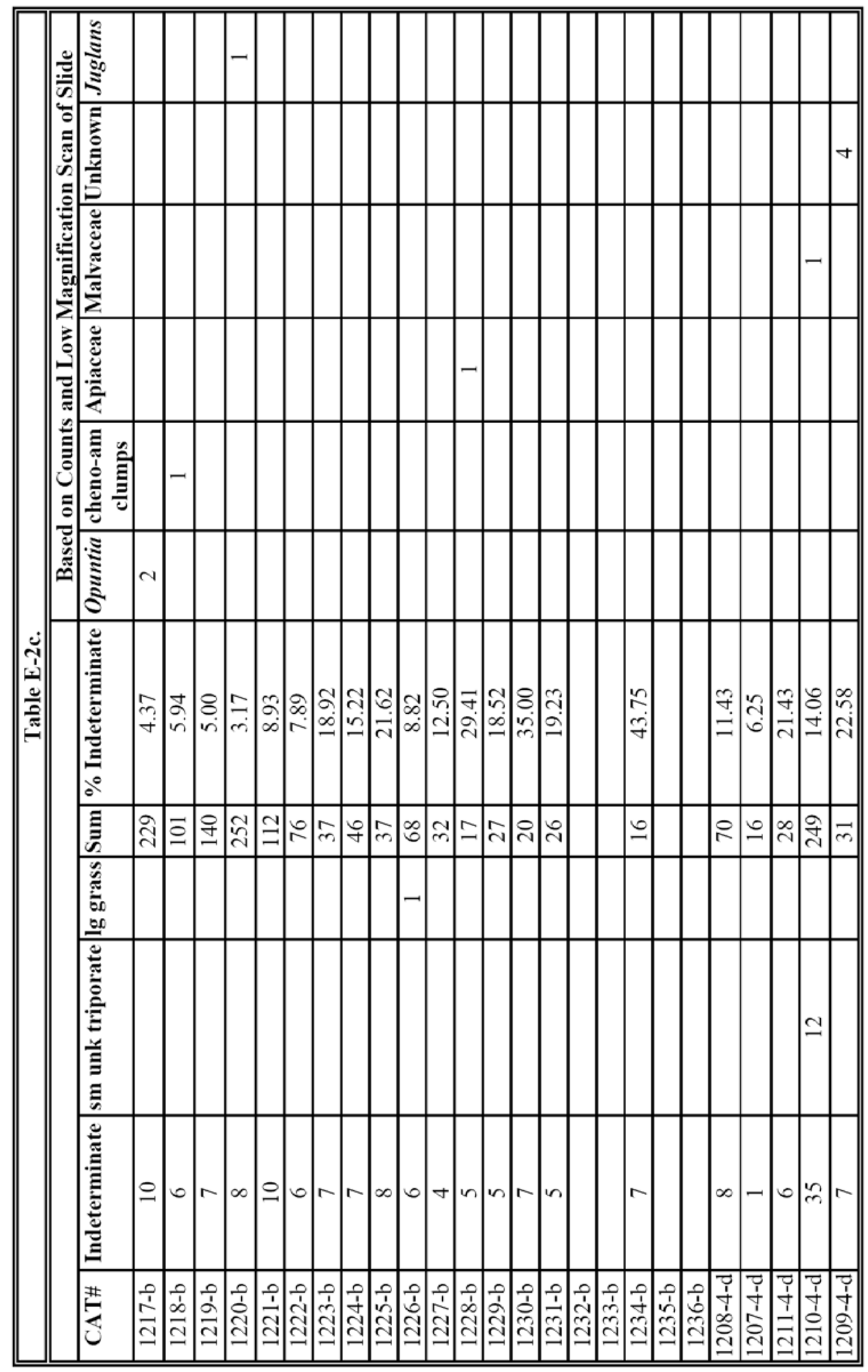


The Varga Site

Texas Department of Transportation

\begin{tabular}{|c|c|c|c|c|c|c|c|c|}
\hline \multicolumn{9}{|c|}{ Table E-2d. } \\
\hline & \multicolumn{8}{|c|}{ Based on Counts and Low Magnification Scan of Slide } \\
\hline CAT\# & Juglans & Carya & Poaceae & Pinus & Quercus & hs aster clump & Max. Potential Concentration & Trilete Spores \\
\hline 1217-b & & & & & & & & 1 \\
\hline 1218-b & & & & & & & & 2 \\
\hline 1219-b & & & & & & & & 1 \\
\hline 1220-b & 1 & & & 1 & & 10 & & 1 \\
\hline 1221-b & & & & 1 & & & & 1 \\
\hline \multicolumn{9}{|l|}{ 1222-b } \\
\hline \multicolumn{9}{|l|}{ 1223-b } \\
\hline 1224-b & & & & & & & & 1 \\
\hline \multicolumn{9}{|l|}{ 1225-b } \\
\hline \multicolumn{9}{|l|}{ 1226-b } \\
\hline 1227-b & & 3 & & 2 & & & & \\
\hline 1228-b & & 7 & & 1 & & 4 & & \\
\hline \multicolumn{9}{|l|}{ 1229-b } \\
\hline 1230-b & & & & & & & & 1 \\
\hline \multicolumn{9}{|l|}{ 1231-b } \\
\hline \multicolumn{9}{|l|}{ 1232-b } \\
\hline \multicolumn{9}{|l|}{ 1233-b } \\
\hline 1234-b & & & & & & & & 1 \\
\hline \multicolumn{9}{|l|}{ 1235-b } \\
\hline \multicolumn{9}{|l|}{ 1236-b } \\
\hline \multicolumn{9}{|l|}{$1208-4-\mathrm{d}$} \\
\hline $1207-4-\mathrm{d}$ & & & 1 & 6 & & & & 1 \\
\hline \multicolumn{9}{|l|}{ 1211-4-d } \\
\hline $1210-4-d$ & & 16 & & 8 & 14 & & & 1 \\
\hline $1209-4-d$ & & 5 & & 2 & 3 & 11 & & 2 \\
\hline
\end{tabular}




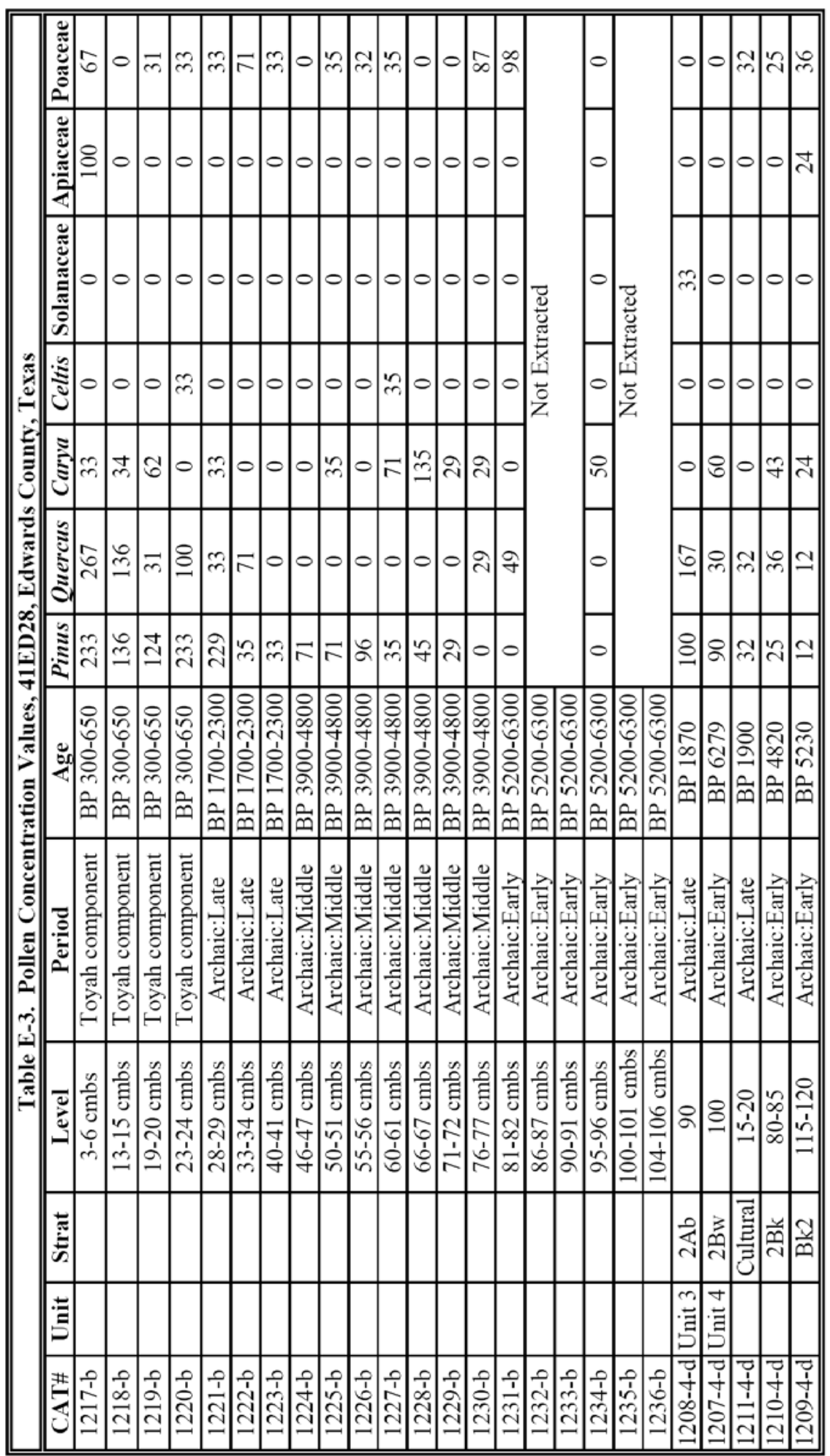




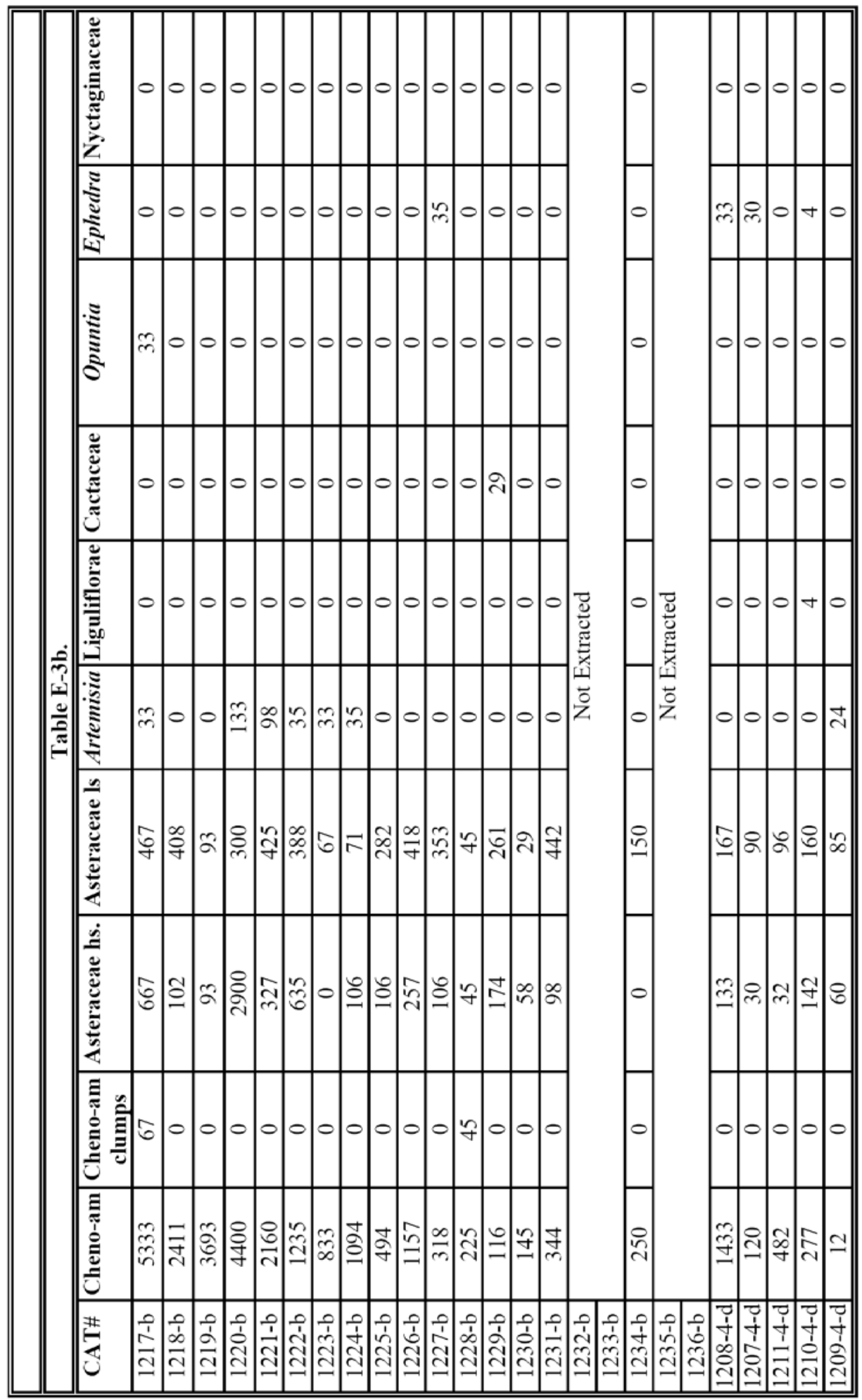




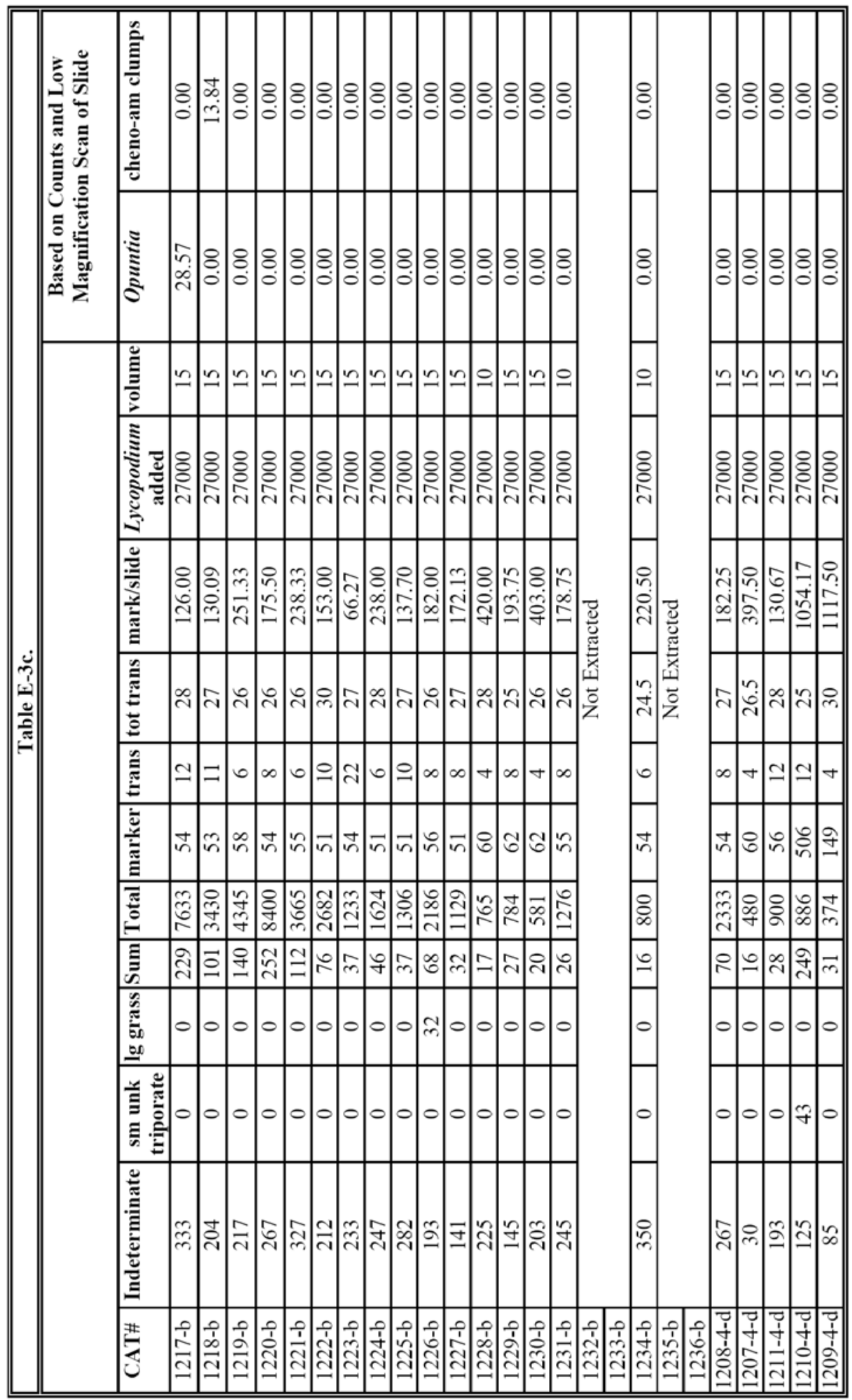




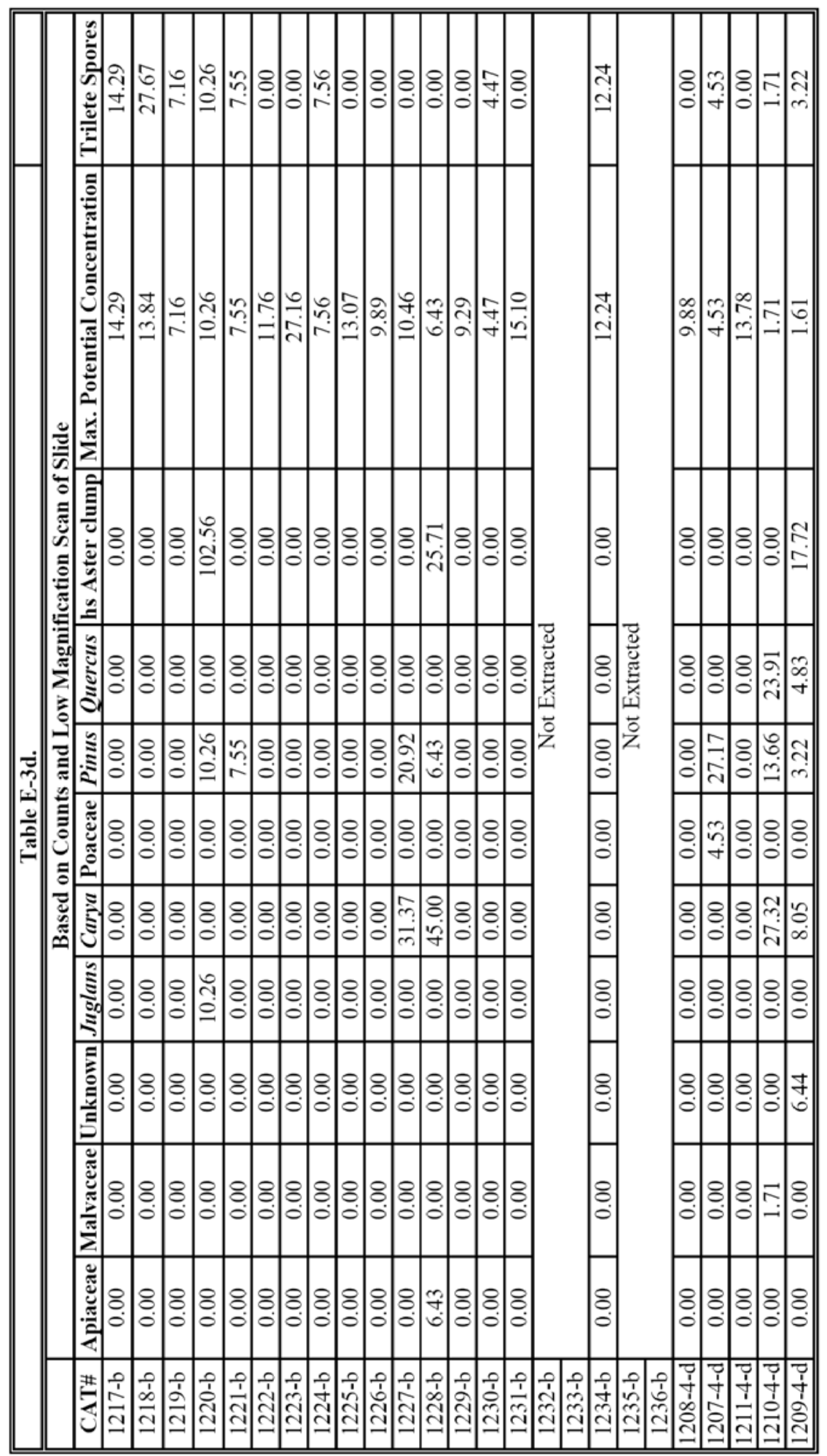




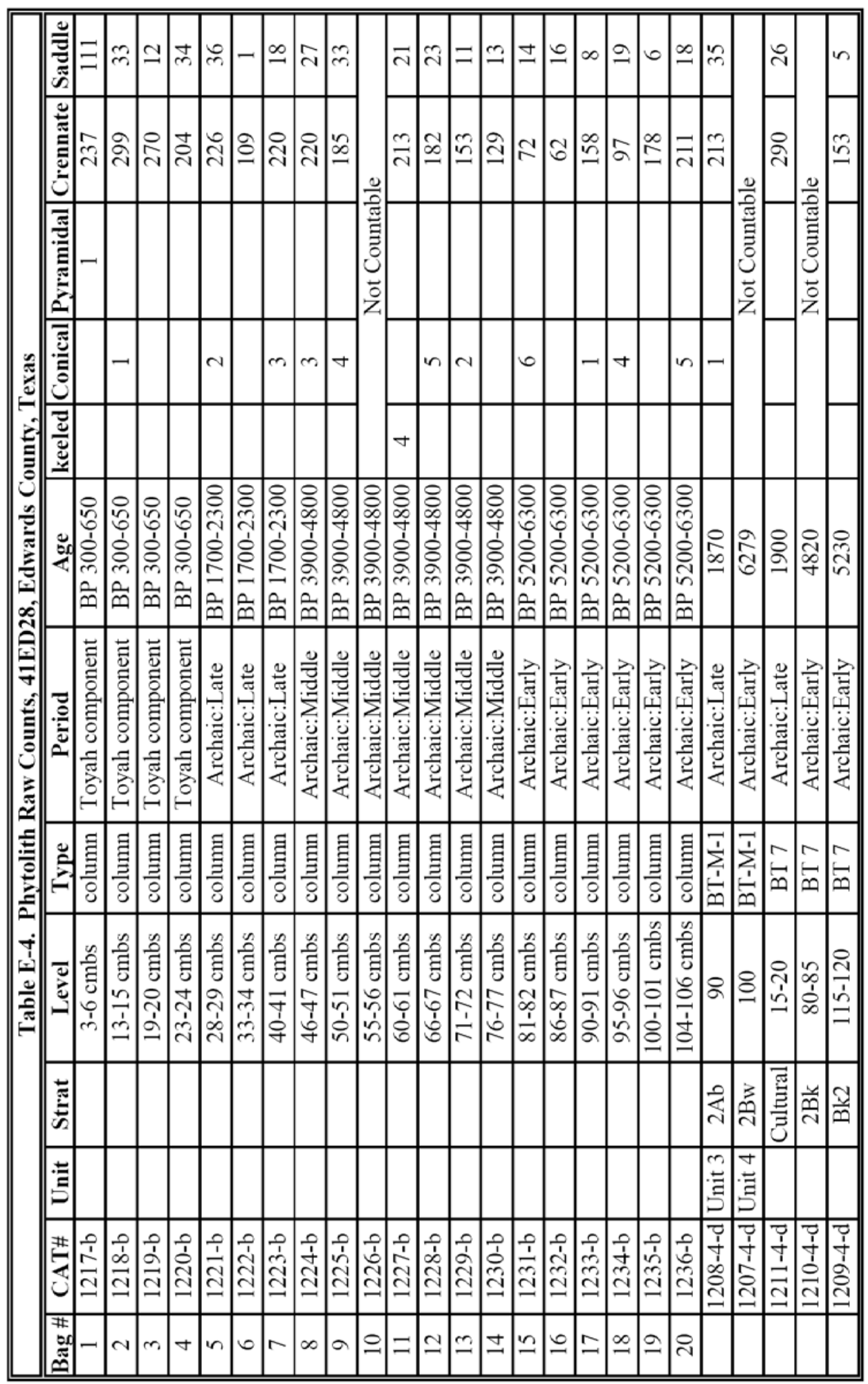




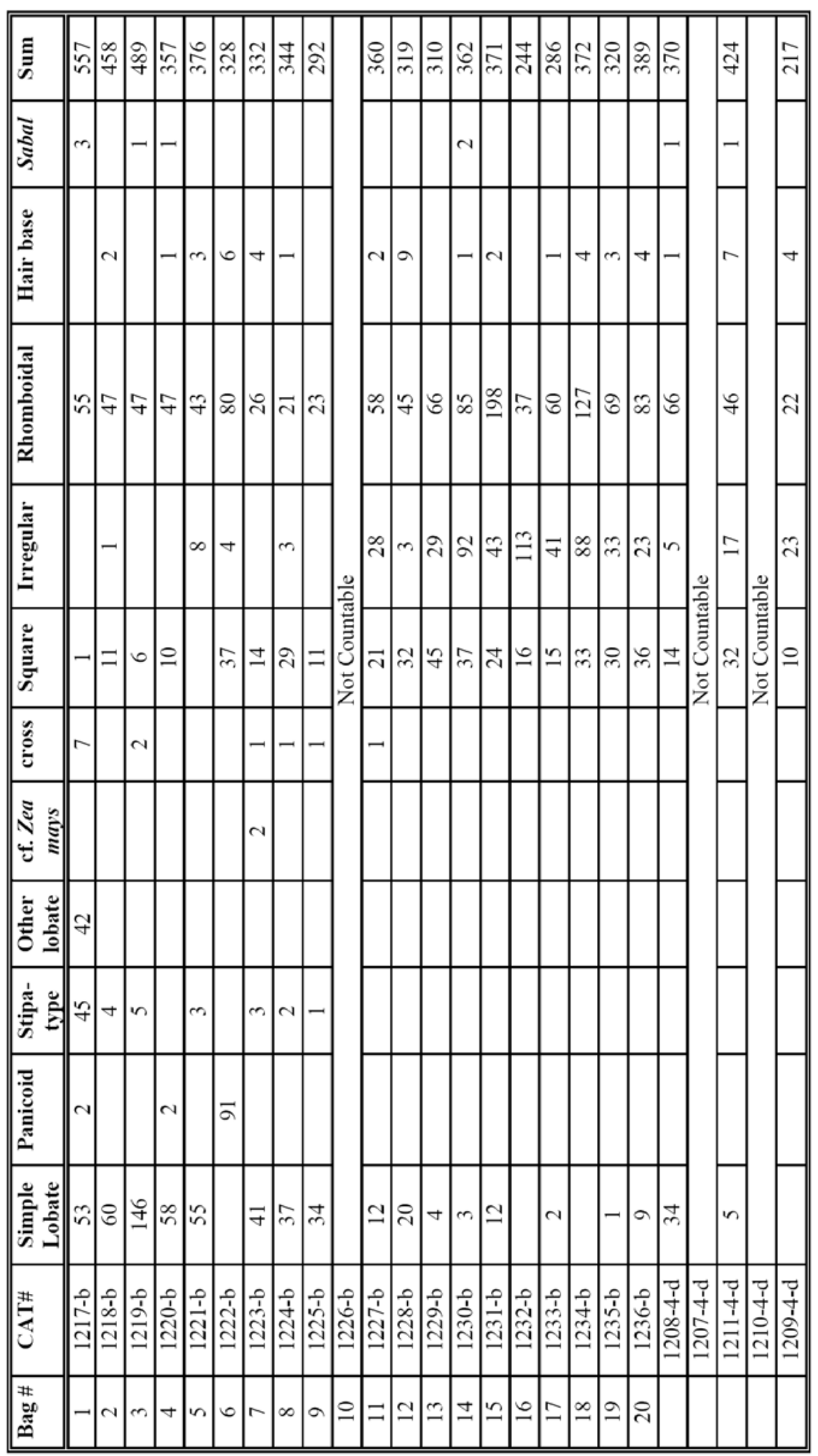




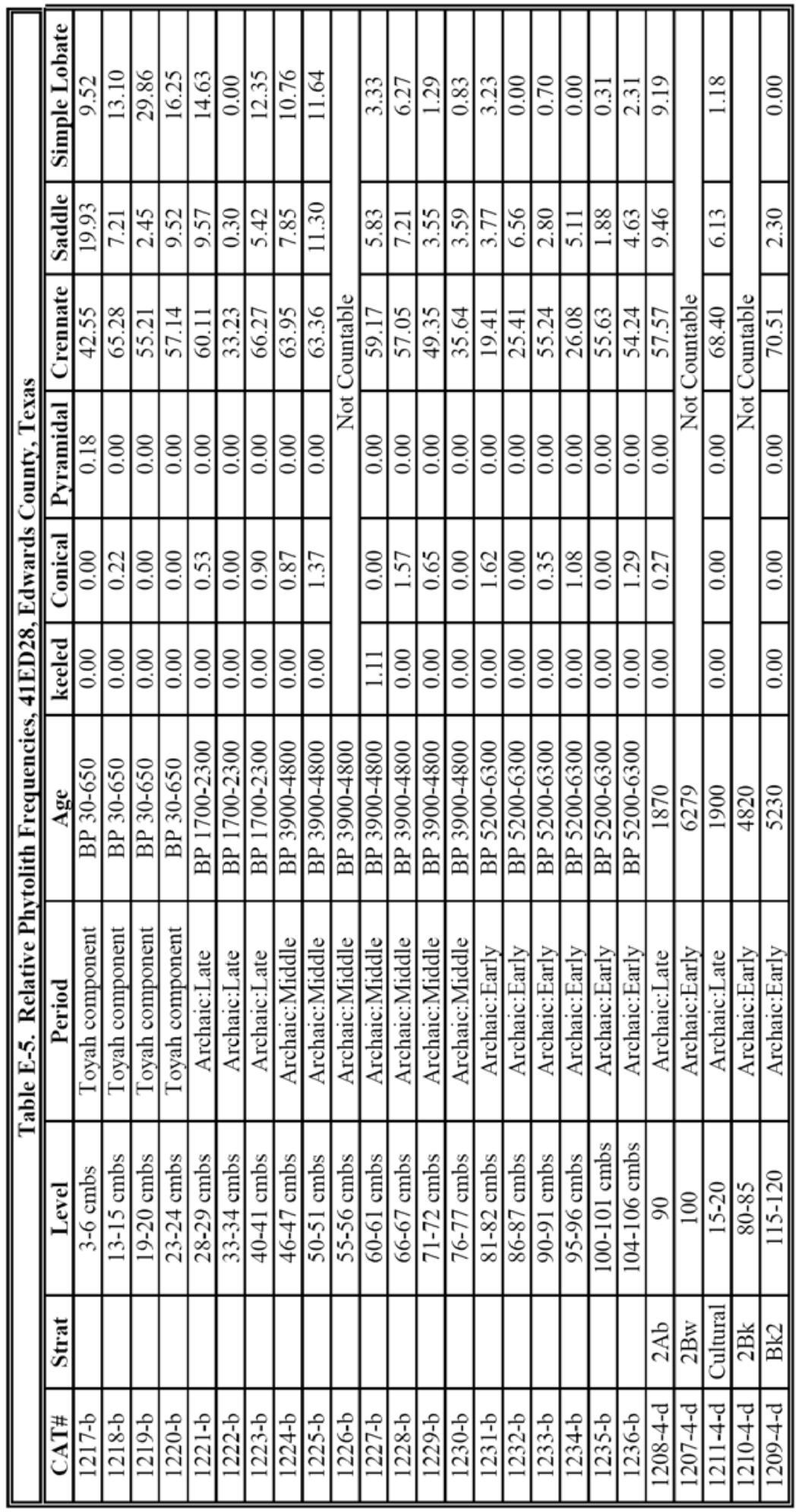


The Varga Site

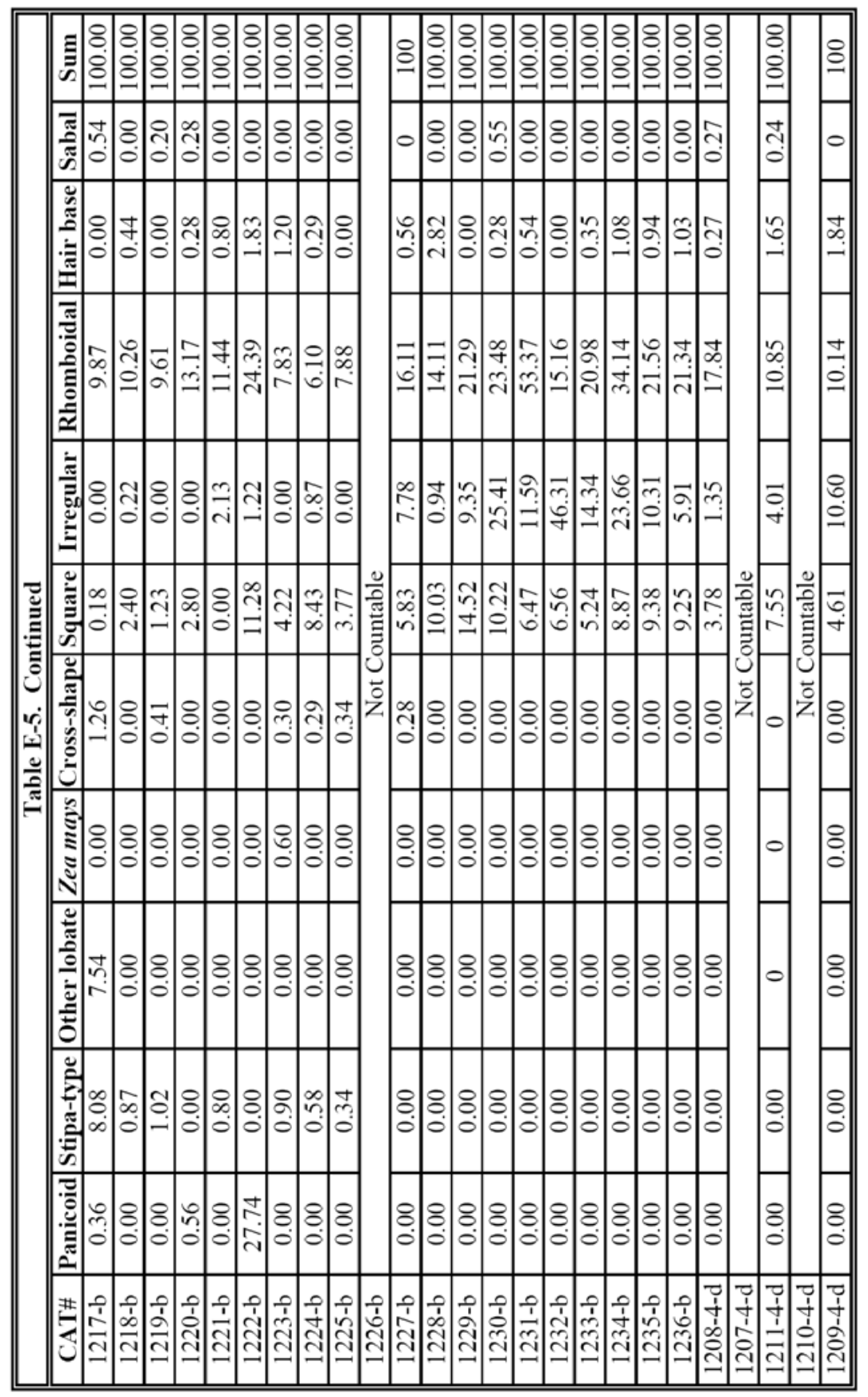




\begin{tabular}{||c|c||}
\hline \hline \multicolumn{2}{||}{ Table E-6. Number of Pollen Taxa by Period, 41ED29, Edwards County, Texas } \\
\hline \hline Period & Number of Taxa (Mean) \\
\hline Toyah component 300-650 B.P. & 8-12, (9.75) $n=4$ \\
\hline Late Archaic $1700-2300$ B.P. & $6-8,(8) n=3$ \\
\hline Middle Archaic 3900-4800 B.P. & 6-9, (7) $n=7$ \\
\hline Early Archaic 5200-6300 B.P. & 5-6, (5.5) $n=2$ \\
\hline
\end{tabular}




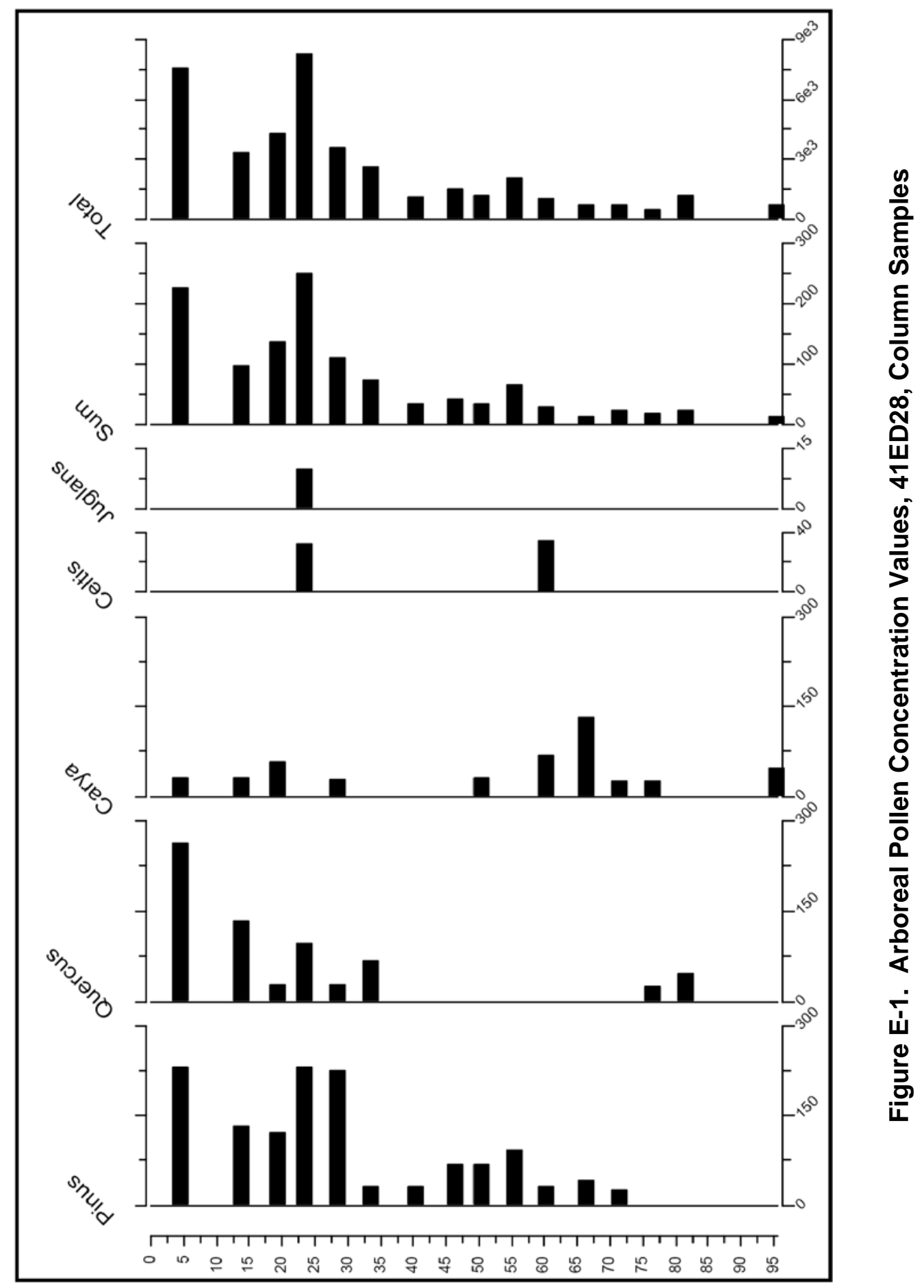




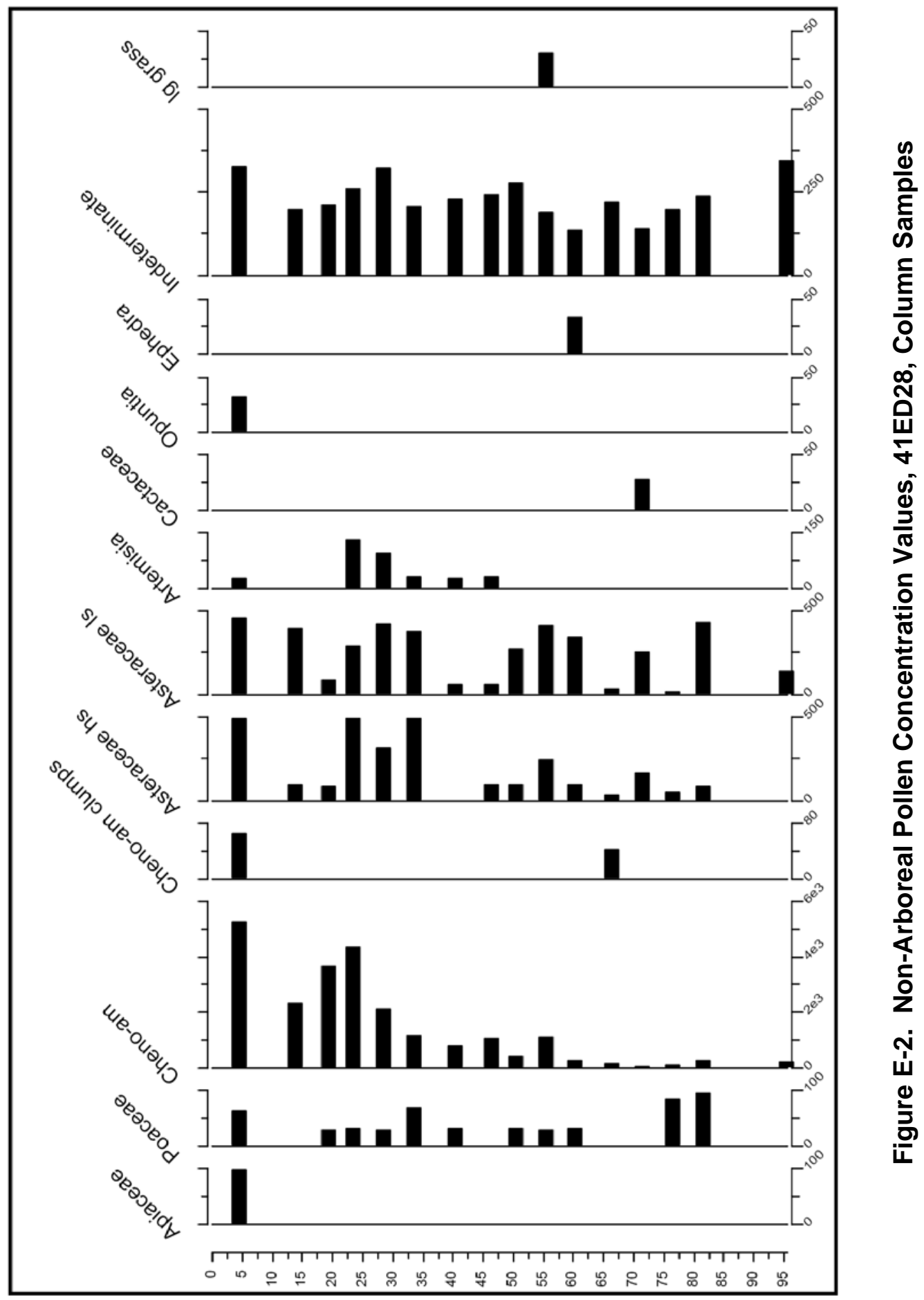




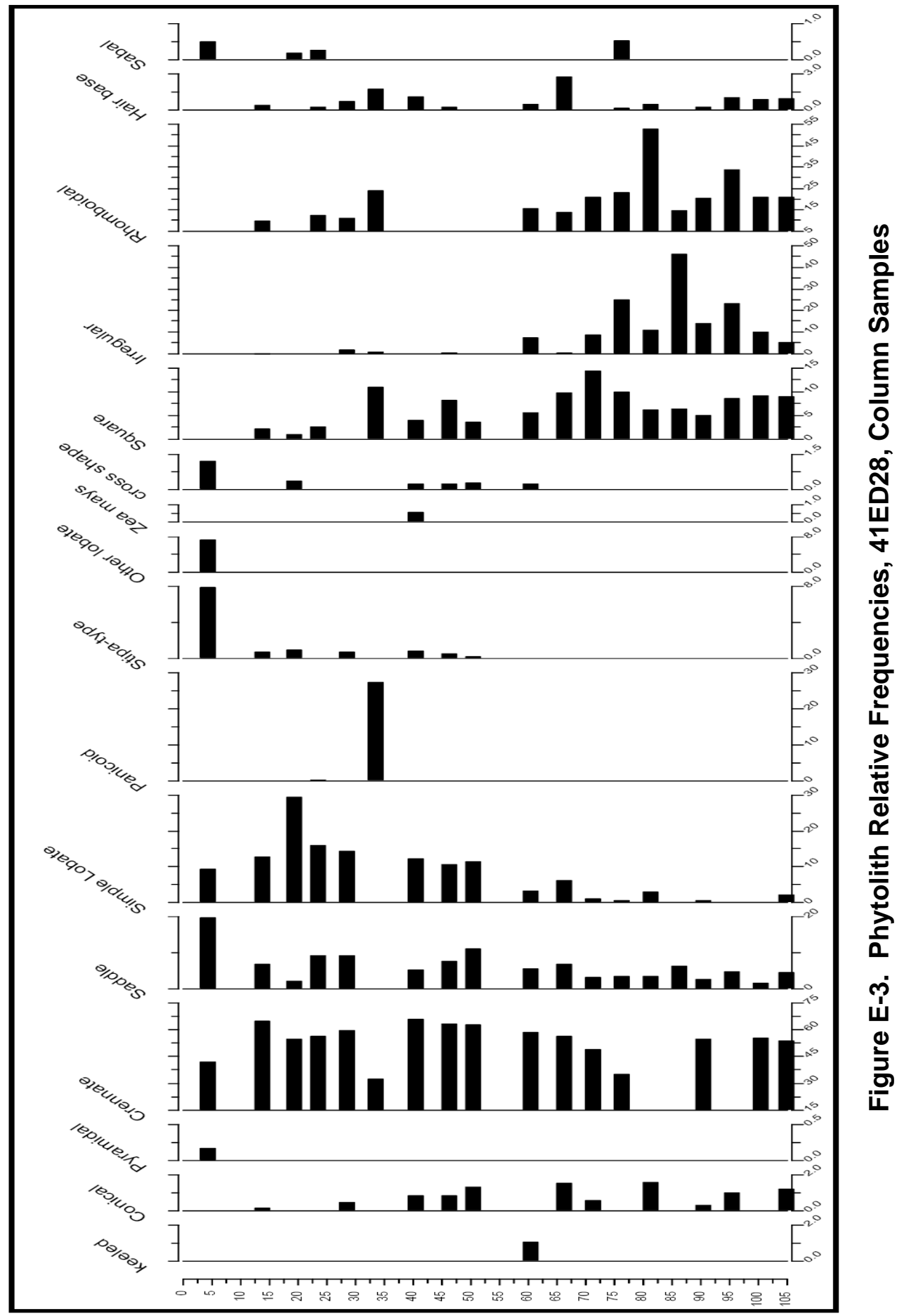





\section{APPENDIX F:}

INSTRUMENTAL NEUTRON ACTIVATION ANALYSIS OF CHERT

FROM THE VARGA SITE (41ED28) IN SOUTHWEST TEXAS 



\title{
INSTRUMENTAL NEUTRON ACTIVATION ANALYSIS OF CHERT FROM THE VARGA SITE (41ED28) IN SOUTHWEST TEXAS
}

\author{
By: \\ Michael D. Glascock, Ph.D. \\ Robert J. Speakman, Ph.D.
}

Prepared for:

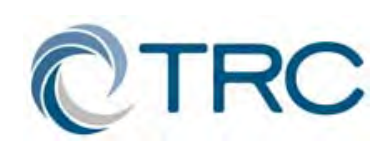

TRC Environmental Corporation 505 East Huntland Drive, Suite 250

Austin, Texas 78752

\author{
Prepared by: \\ Michael D. Glascock, Ph.D. and \\ Robert J. Speakman, Ph.D. \\ Archaeometry Laboratory \\ University of Missouri Research Reactor Center \\ University of Missouri \\ Columbia, Missouri 65211
}

May 2004 



\section{F.1 INTRODUCTION}

Instrumental neutron activation analysis (INAA) was performed on 154 chert artifacts from the Varga Site (41ED28) in Edwards County, Texas, and 107 natural (i.e., culturally unmodified) source specimens from various locations in the Edwards Formation in across Southwest and Central Texas. Data on the source specimens were examined for possible differences within the Edwards Formation and data on the artifacts were examined to calculate probabilities of membership with the various Edwards Formation chert sub-types. INAA data from previous samples of Edwards Formation chert from the Texas Hill Country conducted for Charles Frederick (i.e., Fort Hood) and Chris Turnbull (i.e., Segovia Formation) were also used for comparison.

\section{F.2 Chert Sample Preparation}

Following their arrival at the University of Missouri Research Reactor Center (MURR), the source samples and artifacts were washed in deionized water to remove dirt and other loose materials from the surface. Samples for INAA were prepared by placing the source specimens between two tool-steel plates and crushing them with a Carver Press to obtain a number of small, 50- to 100 -mg fragments. The fragments were examined with a magnifier to eliminate those with metallic streaks or crush fractures that could possibly contain contamination. Several grams of clean fragments were obtained from each sample and stored temporarily in plastic bags.

Two analytical samples were prepared from each source specimen. The first sample, used for short irradiations, was made by placing about $200 \mathrm{mg}$ of fragments into clean, high-density polyethylene vials. A second sample, used for long irradiation and weighing about $800 \mathrm{mg}$, was placed in clean, high-purity quartz vials.
Individual sample weights were recorded to the nearest $0.01 \mathrm{mg}$ using an analytical balance. Both irradiation vials were sealed prior to irradiation. Standards made from the National Institute of Standards and Technology (NIST) certified standard reference materials SRM1633a (Coal Fly Ash), SRM-278 (Obsidian Rock), and SRM-688 (Basalt Rock) were similarly prepared.

\section{F.3 IRRADIATION AND GAMMA-RAY SPECTROSCOPY}

INAA of archaeological materials at MURR, which consists of two irradiations and a total of three measurements of emitted gamma rays, constitutes a superset of the procedures employed at most other INAA laboratories. As discussed in detail in Glascock (1992), a short irradiation is carried out through the pneumatictube irradiation system at MURR. Samples and standards in polyethylene vials are sequentially irradiated, two at a time, for five seconds by a thermal neutron flux of $8 \times 10^{13} \mathrm{n} \mathrm{cm}^{-2} \mathrm{~s}^{-1}$. Following irradiation, the samples are allowed to decay for 25 minutes so that radioactivity from the short-lived radioisotope ${ }^{28} \mathrm{Al}$ (half-life = 2.24 minutes) can decline to acceptable levels. Sample vials are mounted in sample holders at a distance of $10 \mathrm{~cm}$ from the face of separate highpurity germanium (HPGe) detectors. The sample holders are designed to continuously rotate the samples during a 12-minute counting period to compensate for slight differences between individual sample shapes. The shortcount, gamma-ray spectra are stored and subsequently analyzed in batches to determine the concentrations of elements in the unknown archaeological samples relative to the known concentrations in the standard reference materials. The short-lived elements measured in chert characterization studies are usually aluminum (Al), calcium (Ca), dysprosium (Dy), potassium $(\mathrm{K})$, manganese $(\mathrm{Mn})$, sodium $(\mathrm{Na})$, titanium (Ti), and vanadium (V). 
The long-irradiation samples and standards in high-purity quartz vials are wrapped in bundles of approximately 32 unknowns and six standards each. Two sample bundles are placed inside an aluminum can and irradiated for a total of 70 hours by a thermal neutron flux of $5 \times 10^{13} \mathrm{n}$ $\mathrm{cm}^{-2} \mathrm{~s}^{-1}$. Following irradiation, the sample bundles are unwrapped and the quartz vials are washed in aqua regia to remove possible surface contamination. Two gamma measurements are performed on the individual samples from each bundle using a pair of HPGe detectors coupled to automatic sample changers with rotating sample holders. The first count for 2,000 seconds each (i.e., the "middle count") is usually made about one week after the end of irradiation to allow ${ }^{24} \mathrm{Na}$ (half-life $=15$ hours) to decay to a safe handling level. The middle count yields data for the determination of several medium half-life elements, including arsenic (As), barium (Ba), lanthanum (La), lutetium $(\mathrm{Lu})$, neodymium (Nd), samarium (Sm), uranium (U), and ytterbium (Yb). After an additional three or four weeks of decay, a final measurement of approximately three hours on each sample (i.e., the "long count") is carried out. The latter measurement yields the data for several long-lived elements, including cerium (Ce), cobalt (Co), chromium (Cr), cesium (Cs), europium (Eu), iron (Fe), hafnium (Hf), nickel (Ni), rubidium (Rb), antimony (Sb), scandium (Sc), strontium (Sr), tantalum (Ta), terbium (Tb), thorium (Th), and zinc (Zn). Additional details about gamma-ray spectroscopy, neutron activation analysis, and standardization can be found in Glascock (1998).

The element concentration data from the three measurements are tabulated in parts per million using the Microsoft Excel spreadsheet program. Descriptive data for the archaeological samples are appended to the concentration spreadsheet and the data are also stored in a dBase/Foxpro database file useful for organizing, sorting, and extracting sample information. Table F-1 following this appendix presents the sample database.

\section{F.4 INTERPRETING THE COMPOSITIONAL DATA}

The interpretation of compositional data obtained from the analysis of archaeological materials is discussed in detail elsewhere (e.g., Baxter and Buck 2000; Bieber et al. 1976; Bishop and Neff 1989; Glascock 1992; Harbottle 1976; Neff 2000) and is only summarized here. The main goal of data analysis is to identify distinct, homogeneous groups within the analytical database. Based on the provenance postulate of Weigand et al. (1977), different chemical groups may be assumed to represent geographically restricted sources. For lithic materials such as obsidian, basalt, and cryptocrystalline silicates (e.g., chert, flint, or jasper), raw material samples are frequently collected from known outcrops or secondary deposits, and the compositional data obtained from the samples are used to define the source localities or boundaries. In contrast, the locations of ceramic raw materials are often inferred by comparing unknown specimens (i.e., ceramic artifacts) to knowns (i.e., clay samples), by indirect methods such as the "criterion of abundance” (Bishop et al. 1992), or by arguments based on geological and sedimentological characteristics (Steponaitis et al. 1996). The ubiquity of ceramic raw materials usually makes it impossible to sample all potential "sources" intensively enough to create groups of knowns to which unknowns can be compared. Lithic sources tend to be more localized and compositionally homogeneous, in the case of obsidian. or compositionally heterogeneous, as is the case for most cherts.

Compositional groups are viewed as "centers of mass" in the compositional hyperspace described by the measured elemental data. Groups are characterized by the locations of 
their centroids and the unique relationships (i.e., correlations) among the elements. Decisions about whether or not to assign a specimen to a particular compositional group are based on the overall probability that the measured concentrations for the specimen could have been obtained from that group.

Potential compositional groups can be hypothesized initially by using noncompositional information (e.g., archaeological context, visual attributes) or by application of one or more different pattern recognition techniques to the multivariate chemical data. Some of the pattern recognition techniques that have been used to investigate archaeological data sets are cluster analysis (CA), principal component analysis (PCA), and discriminant analysis (DA). Each of the techniques has it own advantages and disadvantages for data interpretation that may depend upon the types and quantity of data available.

The variables (measured elements) in archaeological and geological data sets are often correlated and are frequently large in number. This makes handling and interpreting patterns within the data set more challenging. As a result, it is often advantageous to transform the original variables in the data set into a smaller set of uncorrelated variables to make data interpretation easier. Of the abovementioned pattern recognition techniques, PCA is the technique that most readily transforms the data from the original, correlated variables into uncorrelated variables.

PCA uses all of the variables measured in the sample (in this case, element concentrations) and calculates the variation among those variables. The individual principal components (PCs) are measures of the magnitude of variation, each describing a decreasing amount of variance. The first PC subsumes the greatest amount of variance in the data set and is aligned along the direction of greatest variation. The second PC is orthogonal to the first PC and, like the first PC, is a linear summary of the variables analyzed. The second PC subsumes the greatest amount of variation after removal of the variation accounted for by the first PC and is aligned along the direction of greatest remaining variation. The third $\mathrm{PC}$ is orthogonal to the first two PCs and subsumes the greatest amount of remaining variation after removing the first two PCs, and so forth. The number of PCs calculated equals the number of original variables measured.

PCA creates a new set of reference axes arranged in decreasing order of variance subsumed. The individual PCs are linear combinations of the original variables. The data can be displayed on combinations of the new axes, just as they can be displayed on the original elemental concentration axes. PCA can be used in a pure pattern-recognition mode (i.e., to search for subgroups in an undifferentiated data set) or in a more evaluative mode (i.e., to assess the coherence of hypothetical groups suggested by other criteria). Generally, compositional differences among specimens can be expected to be larger for specimens in different groups than for specimens in the same group, and this implies that groups should be detectable as distinct areas of high point density on plots of the first few components.

It is well known that PCA of chemical data is scale-dependent (Mardia et al. 1979), and analyses tend to be dominated by those elements or isotopes for which the concentrations are relatively large. As a result, standardization methods are found in most statistical packages. A common approach is to transform the data into logarithms (to base 10). As an initial step in the PCA of most chemical data at MURR, the data are transformed into log concentrations to equalize the differences in variance between the major elements such as $\mathrm{Al}, \mathrm{Ca}$, and $\mathrm{Fe}$ on one 
hand and to trace elements, such as the rareearth elements (REEs), on the other hand. An additional advantage of the transformation is that it appears to produce more normal distributions for the trace elements.

A frequently exploited strength of PCA, discussed by Baxter (1992), Baxter and Buck (2000), and Neff (1994, 2002), is that it can be applied as a simultaneous R- and Q-mode technique, with both variables (elements) and objects (individual analyzed samples) displayed on the same set of PC reference axes. A plot using the first two PCs as axes is usually the best possible two-dimensional representation of the correlation or variance-covariance structure within the data set. Small angles between the vectors from the origin to variable coordinates indicate strong positive correlation; angles at 90 degrees indicate no correlation; and angles close to 180 degrees indicate strong negative correlation. Likewise, a plot of sample coordinates on these same axes will be the best two-dimensional representation of Euclidean relations among the samples in logconcentration space (if the PCA was based on the variance-covariance matrix) or standardized log-concentration space. Displaying both objects and variables on the same plot makes it possible to examine the contribution of individual elements to group separation and to the distinctive shapes of the various groups. Such a plot is commonly referred to as a "biplot" in reference to the simultaneous plotting of objects and variables. The variable relationships inferred from a biplot can be verified directly by inspecting bivariate elemental concentration plots. (Note that a bivariate plot of elemental concentrations is not a biplot.)

Whether or not a group can be discriminated easily from other groups can be evaluated visually in two dimensions or statistically in multiple dimensions. A metric known as the Mahalanobis distance (or generalized distance) makes it possible to describe the separation among groups or among individual samples and groups on multiple dimensions. The Mahalanobis distance of a specimen from a group centroid (Bieber et al. 1976, Bishop and Neff 1989) is defined by:

$$
D_{y, X}^{2}=[y-\bar{X}]^{t} I_{x}[y-\bar{X}]
$$

where $y$ is the $1 \times m$ array of logged elemental concentrations for the specimen of interest, $X$ is the $n \times m$ data matrix of logged concentrations for the group to which the point is being compared, with $\bar{X}$ being it $1 \times m$ centroid, and $I_{x}$ is the inverse of the $m \times m$ variancecovariance matrix of group $X$. Because Mahalanobis distance takes into account variances and covariances in the multivariate group, it is analogous to expressing distance from a univariate mean in standard deviation units. Like standard deviation units, Mahalanobis distances can be converted into probabilities of group membership for individual specimens. For relatively small sample sizes, it is appropriate to base probabilities on Hotelling's $T^{2}$, which is the multivariate extension of the univariate Student's $t$.

If group sizes are small, Mahalanobis-distancebased probabilities can fluctuate dramatically depending on whether or not each specimen is assumed to be a member of the group to which it is being compared. Harbottle (1976) calls this phenomenon "stretchability" in reference to the tendency of an included specimen to stretch the group in the direction of its own location in elemental concentration space. This problem can be circumvented by cross-validation, that is, by removing each specimen from its presumed group before calculating its own probability of membership (Baxter 1994; Leese and Main 1994). This is a conservative approach to group evaluation that sometimes excludes "true" group members. 
Small sample and group sizes place further constraints on the use of Mahalanobis distances. It is generally true that the probability of individual samples having membership in a group is most reliable if the total number of samples in a group is two or three times the number of elements being used to calculate the probability. When there are more elements than samples, the group variance-covariance matrix is singular, thus rendering calculation of $I_{x}$ (and $D^{2}$ itself) impossible. Therefore, the dimensionality of small groups must be reduced. One approach would be to eliminate elements considered irrelevant or redundant. The problem with this tactic is that the investigator's preconceptions about which elements should be discriminating may not be valid. It also diminishes the main advantage of multielemental analysis, namely the capability of measuring a large number of elements. An alternative approach is to calculate Mahalanobis distances using PC scores from the variancecovariance or correlation matrix for the complete data set. This approach entails only the assumption, entirely reasonable in light of the above discussion of PCA, that most groupseparating differences should be visible on the first several PCs. Unless a data set is extremely complex, containing numerous distinct groups, using a sufficient number of components to subsume 90 percent or more of the total variance can be generally assumed to yield Mahalanobis distances that approximate Mahalanobis distances in full elemental concentration space.

Finally, Mahalanobis distance calculations are also quite useful for handling missing data (Sayre 1975). When many specimens are analyzed for a large number of elements, it is almost certain that a few element concentrations will be missed for some of the specimens. This occurs most frequently when the concentration for an element is near the detection limit. Rather than eliminate the specimen or the element from consideration, it is possible to substitute a missing value by replacing it with a value that minimizes the Mahalanobis distance for the specimen from the group centroid. Thus, those few specimens that are missing a single concentration value can still be used in group calculations.

\section{F.5 Results ANd Conclusions}

The INAA results were tabulated using the Excel spreadsheet program and combined with the descriptive data to create a database for sorting and extraction of subsets. Table F-1 lists the sample descriptions for all samples, and Table F-2 lists the measured concentrations.

To determine if possible subgroups could be found within the database, the source sample and artifact concentration data were transformed into base-10 logarithms. Because our missing value replacement program requires the number of missing values to be fewer than 50 percent for any subgroup, it was necessary to eliminate seven elements, including $\mathrm{Lu}, \mathrm{Yb}, \mathrm{Ni}, \mathrm{Ta}, \mathrm{Tb}$, Dy and Ti. After missing value replacement, a PCA was performed on the variance-covariance matrix for the 261-sample database. The eigenvalues and percentage of variance explained by individual PCs are shown in Table F-3. We also note that a minimum of 10 PCs are required to explain 90 percent of the variance in the data set.

Through examination of bivariate plots of the PCs, one finds a very subtle structure within the source specimen database primarily involving the smaller chert source groups. The groups with larger sample numbers seem to overlap significantly. Source sample TRC107 (i.e., Cretaceous volcanic from Brewster County) is not shown on the plots because many of its trace-element concentrations are one to two orders of magnitude greater than all other source specimens, which suggests that the specimen is an outlier. 
RQ-mode biplots of PC-1 versus PC-2 and PC-2 versus $\mathrm{PC}-3$ are shown in Figures F-1 and F-2, respectively. Examination of these plots reveals that the smaller groups from Hackberry Creek, Glen Rose, Georgetown, Varga mixture, and Devils River Formation show differences. The vectors shown on the plots indicate the contributions of individual elements to explaining differences between the groups. Table F-4 summarizes these observations.

On the other hand, the subgroups with larger numbers of specimens from the Segovia Member, Terrett Member, and Camp Wood fail to exhibit any particular patterning on the plots. A test of membership for groups with at least 15 samples (i.e., Hackberry Creek, Segovia Member, Terrett Member, and Camp Wood) using Mahalanobis distance-based probabilities and posterior classification is presented in Table F-5. As shown, approximately 45 percent of the source specimens would move from their original group to a new group. Based on the source samples collected in the investigation, it appears that the larger groups are not significantly different from one another.

The results from previous studies of Edwards Formation chert conducted by Charles Frederick and Chris Turnbull were also available for comparison. Frederick's source sample collections involved 118 samples from outcrops in the Fort Hood region analyzed earlier as part of a patination dating study reported in Frederick et al. (1994) along with an additional 59 chert samples collected from a wide range of locations throughout the Texas Hill Country. The Fort Hood samples were chemically subdivided into six subgroups associated with recognizably different visual characteristics, including Owl Creek, Gray-Brown-Green, Tan, Texas Novaculite, Heiner Lake Tan, and Fort Hood Gray. Turnbull's chert samples consist of 15 specimens collected from a Segovia
Formation outcrop in Howard County in Northwest Texas.

Before the comparisons could be made, five additional elements (As, Nd, Ca, K, and V) not observed in a majority of the Frederick and Turnbull samples were removed from further consideration. The source sample database (excluding samples TRC107 and TRC255) was then combined with the Frederick and Turnbull samples to create a 451-specimen database. After transformation to $\log$ base- 10 and replacement of missing values within each of the identified sample subgroups, a new PCA was performed on the data. Table F-6 lists the eigenvalues and percentage of variance explained by the new PCA. More than 90 percent of the variance in the combined database is explained by the first nine PCs.

A biplot of the source samples and element vectors based on the first two PCs is shown in Figure F-3. Figure F-4 shows the same data without the element vectors but includes Sample IDs for the new Edwards Formation samples. Inspection of both plots indicates that the source samples analyzed in this study are chemically different from the Fort Hood source groups but quite similar to the mixture of Edwards Formation samples collected by Frederick and somewhat similar to the Howard County Segovia Formation samples collected by Turnbull. As shown in the biplot, the differences are based on higher concentrations of $\mathrm{Cs}, \mathrm{Ba}, \mathrm{Sr}$, and $\mathrm{Sb}$ along with low concentrations of the REEs ( $\mathrm{La}, \mathrm{Sm}$, and Ce). Further support is presented in Table F-7, in which calculations of the Mahalanobis distancebased probabilities and posterior classification of the Edwards Formation source samples in this study are used to compare to the eight earlier chert groups. The calculation used the first nine PCs, subsuming more than 91 percent of the variance. The results show that the source (i.e., non-Varga Site) samples from the current study 
have extremely low probabilities of membership in the Fort Hood groups, relatively low probabilities of membership in the Howard County Segovia Formation group, and high probabilities of membership in Frederick's mixed collection.

The bivariate plot in Figure F-5 to F-9 presents data for the first two PCs using the Varga site artifacts projected against the Edwards Formation source samples collected by Frederick and the new Edwards Formation specimens in this study. The artifacts show a close relationship to both collections of Edwards Formation source specimens. Table F-8 presents the Mahalanobis distance-based probabilities and posterior classifications of the artifacts when compared to all of the Texas source groups. The results show very low probability of the artifacts coming from the Fort Hood subgroups or the Howard County Segovia Formation, but very high probabilities of membership in the two collections of Edwards Formation source specimens.

\section{F.6 Conclusions}

A total of 261 lithic samples (i.e., chert source specimens and artifacts) from the Varga Site (41ED28) in Edwards County, Texas, were analyzed by INAA to investigate possible movement of lithic materials in Texas. The new source samples show very subtle differences between most of the collection sites for raw materials due to the fact that compositional variation within individual outcrops is large and differences among outcrops are relatively small.

Comparisons between the new source samples and previous analyses indicate that the new source samples are significantly different from the varieties of chert collected near Fort Hood but they overlap with an earlier collection of Edwards Formation chert made by Charles Frederick from throughout the Formation.
Analyses of the Varga Site artifacts find that they are compositionally different from the Fort Hood varieties; however, the Varga Site artifacts are similar to both collections of Edwards Formation source specimens. Our primary conclusion is that none of the Varga Site artifacts came from Fort Hood. We can say little about other outcrops within the Edwards Formation.

\section{F.7 ACKNOWLEDGementS}

We thank Jonathan Z. Dake, William Grimm, Kyra Lienhop, and Nicole Little for carrying out the laboratory work on this project.

\section{F.8 RefERENCES}

Baxter, M. J.

1992 Archaeological Uses of the Biplot-A Neglected Technique? In Computer Applications and Quantitative Methods in Archaeology, edited by G. Lock and J. Moffett. BAR International Series S577, 141-148. Tempvs Reparatvm, Archaeological and Historical Associates, Oxford.

1994 Exploratory Multivaariate Analysis in Archaeology. Edinburgh University Press, Edinburgh.

Baxter, M. J., and C. E. Buck

2000 Data Handling and Statistical Analysis. In Modern Analytical Methods in Art and Archaeology, edited by E. Ciliberto and G. Spoto, pp. 681-746. Chemical Analysis Series, Volume 155. John Wiley \& Sons, New York.

Bieber, A.M. Jr., D.W. Brooks, G. Harbottle \& E.V. Sayre

1976 Application of Multivariate Techniques to Analytical Data on Aegean Ceramics. Archaeometry 18: 59-74. 
Bishop, R. L., and H. Neff

1989 Compositional Data Analysis in Archaeology. In Archaeological Chemistry IV, edited by R. O. Allen, pp. 576-586. Advances in Chemistry Series 220, American Chemical Society, Washington, DC.

Bishop, R. L., R. L. Rands, and G. R. Holley

1992 Ceramic Compositional Analysis in Archaeological Perspective. In Advances in Archaeological Method and Theory, Vol. 5, pp. 275-330. Academic Press, New York.

Frederick, C. D., M. D. Glascock, H. Neff, and C. M. Stevenson

1994 Evaluation of Chert Patination as a Dating Technique: A Case Study from Fort Hood, Texas. Research Report No. 32, Archaeological Resource Management Series, United States Army Fort Hood.

Glascock, M. D.

1992 Characterization of Archaeological Ceramics at MURR by Neutron Activation Analysis and Multivariate Statistics. In Chemical Characterization of Ceramic Pastes in Archaeology, edited by H. Neff, pp. 1126. Prehistory Press, Madison, Wisconsin.

1998 Activation Analysis. In Instrumental Multi-Element Chemical Analysis, edited by Z. B. Alfassi, pp. 93-150. Kluwer Academic Publishers, Dordrecht, the Netherlands.

Harbottle, G.

1976 Activation Analysis in Archaeology. Radiochemistry 3: 33-72.

Leese, M. N., and P. L. Main

1994 The Efficient Computation of Unbiased Mahalanobis Distances and Their Interpretation in Archaeometry. Archaeometry 36: 307-316.
Mardia, K. V., J. T. Kent, and J. M. Bibby

1979 Multivariate Analysis. Academic Press, London.

Neff, $\mathrm{H}$.

1994 RQ-Mode Principal Components Analysis of Ceramic Compositional Data. Archaeometry 36:115-130.

2000 Neutron Activation Analysis for Provenance Determination in Archaeology. In Modern Analytical Methods in Art and Archaeology, edited by E. Ciliberto and G. Spoto, pp. 81134. Chemical Analysis Series, Volume 155, John Wiley \& Sons, New York.

2002 Quantitative Techniques for Analyzing Ceramic Compositional Data. In Ceramic Production and Circulation in the Greater Southwest: Source Determination by INAA and Complementary Mineralogical Investigations, edited by D. M. Glowacki \& H. Neff, pp. 15-36. Cotsen Institute of Archaeology, University of California at Los Angeles.

Sayre, E. V.

1975 Brookhaven Procedures for Statistical Analysis of Multivariate Archaeometric Data. Brookhaven National Laboratory Report BNL-23128. New York (unpublished).

Steponaitis, V., M. J. Blackman, and H. Neff

1996 Large-Scale Compositional Patterns in the Chemical Composition of Mississippian Pottery. American Antiquity 61:555-572.

Weigand, P. C., G. Harbottle, and E. V. Sayre 1977 Turquoise Sources and Source Analysis: Mesoamerica and the Southwestern U.S.A. In Exchange Systems in Prehistory, edited by T. K. Earle and J. E. Ericson, pp. 15-34. Academic Press, New York. 


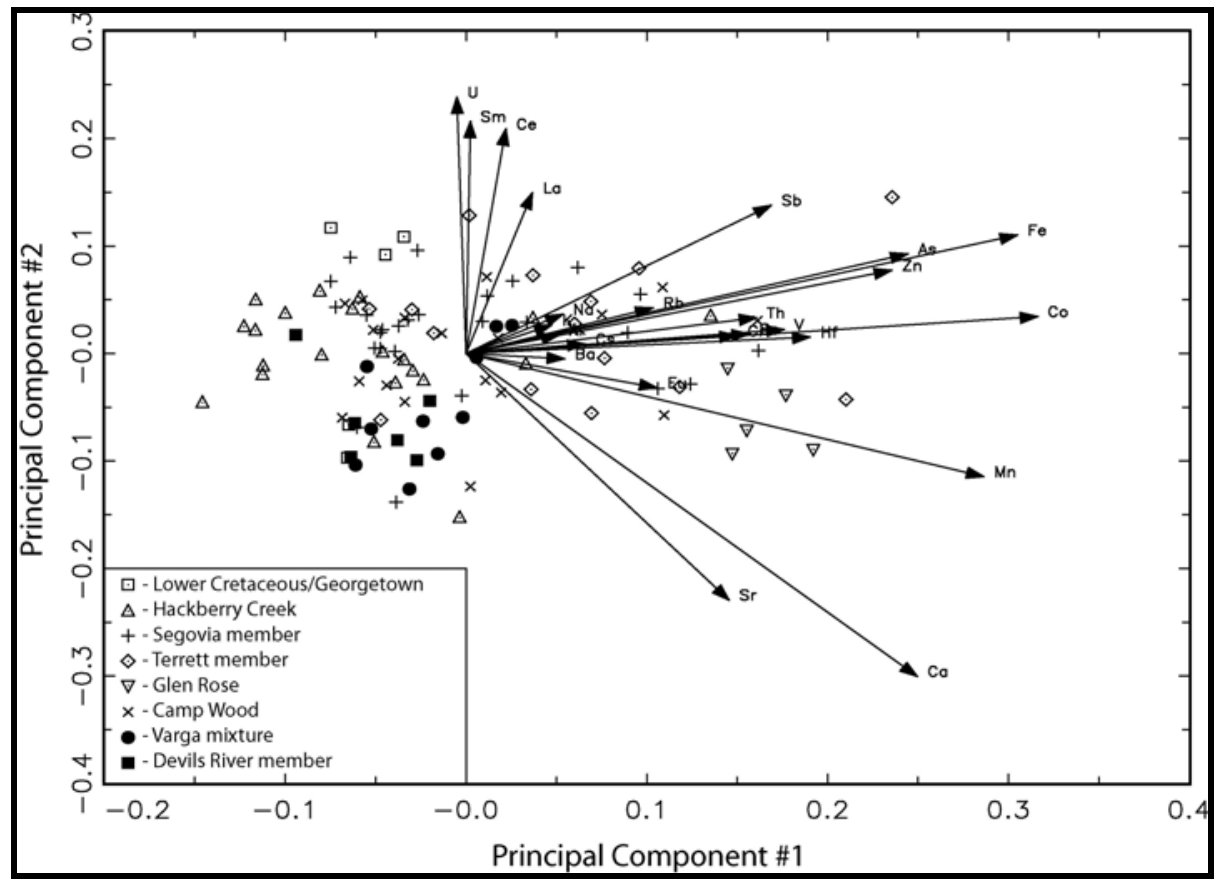

Figure F-1. Biplot of First and Second Principal Components for Chert Source Samples

Samples are indicated by the symbols and element vectors are labeled.

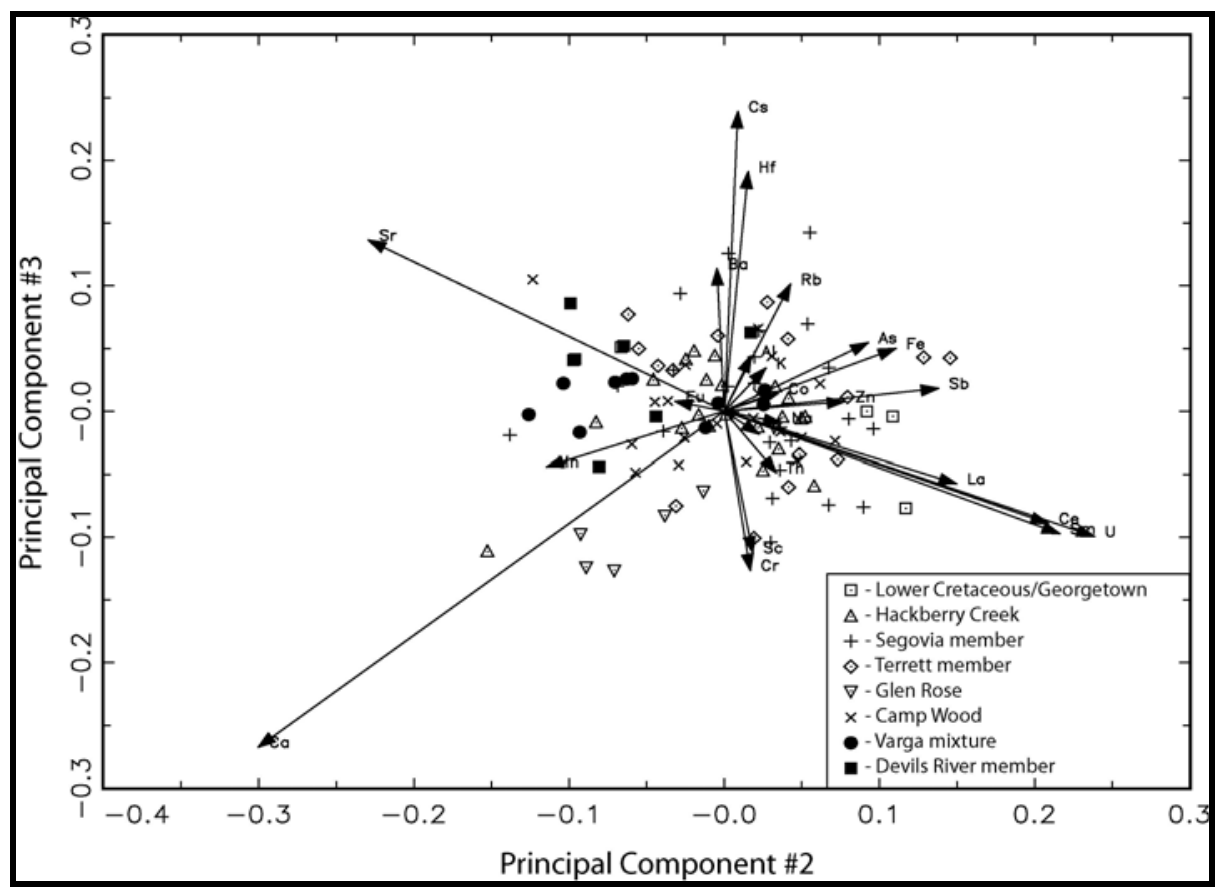

Figure F-2. Biplot of Second and Third Principal Components for Chert Source Samples

Samples are indicated by the symbols and element vectors are labeled. 


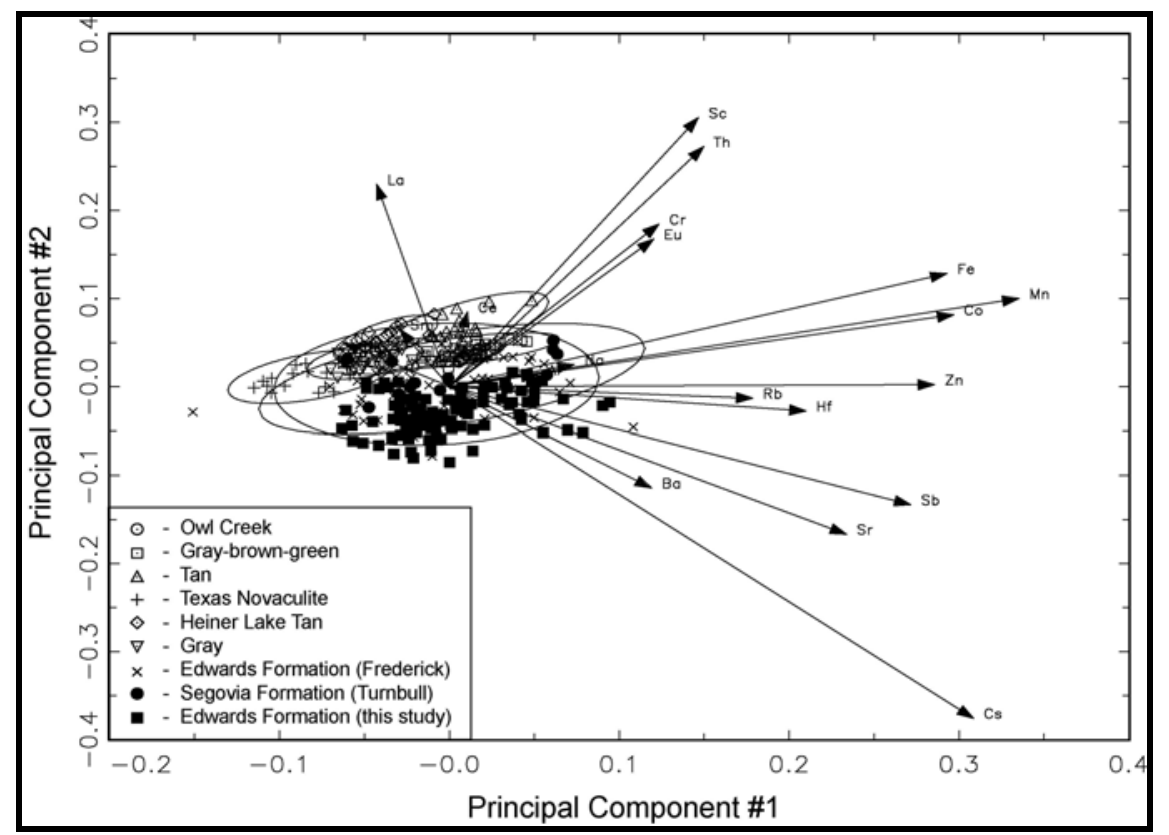

Figure F-3. Biplot of First and Second Principal Components for Chert Source Samples With Element Vectors

Confidence ellipses are shown at the 90 percent confidence level.

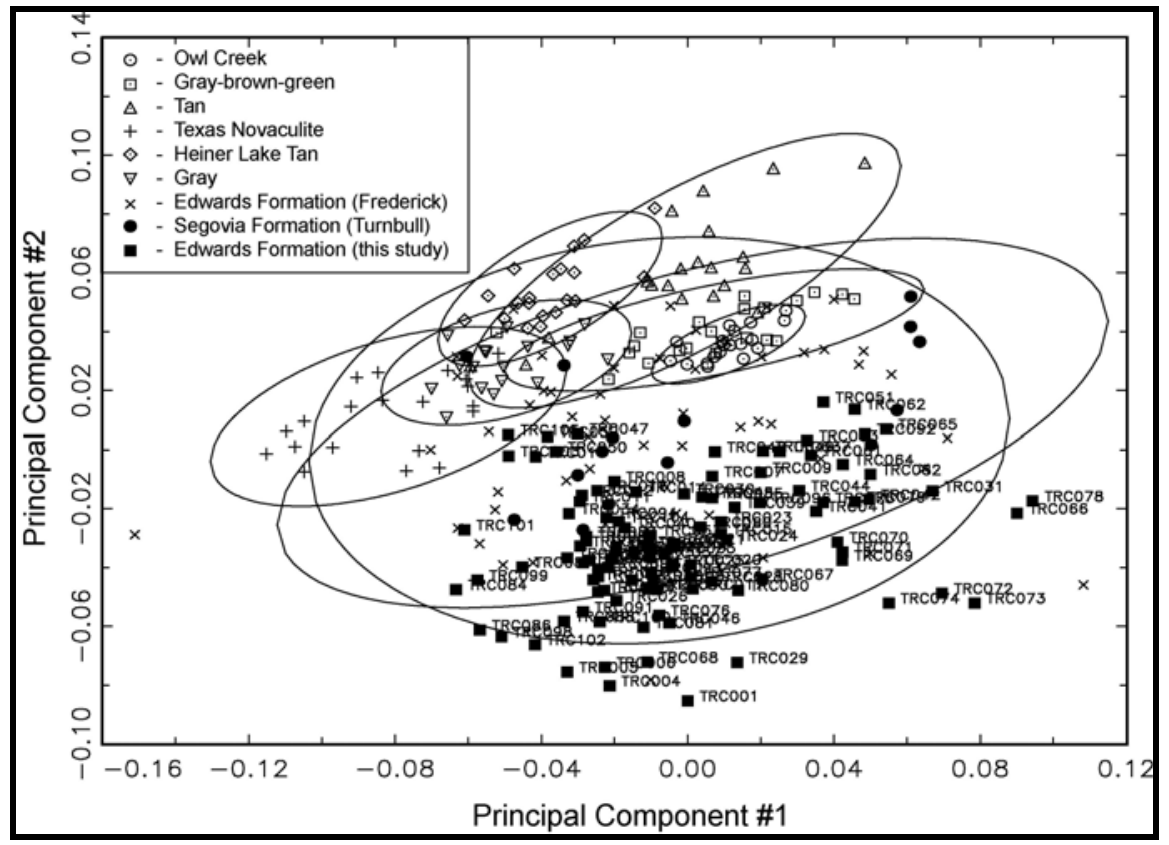

Figure F-4. Bivariate Plot of First and Second Principal Components for Chert Source Samples Without Element Vectors

Confidence ellipses are shown at the $90 \%$ confidence level.

Source specimens collected in this study are labeled. 


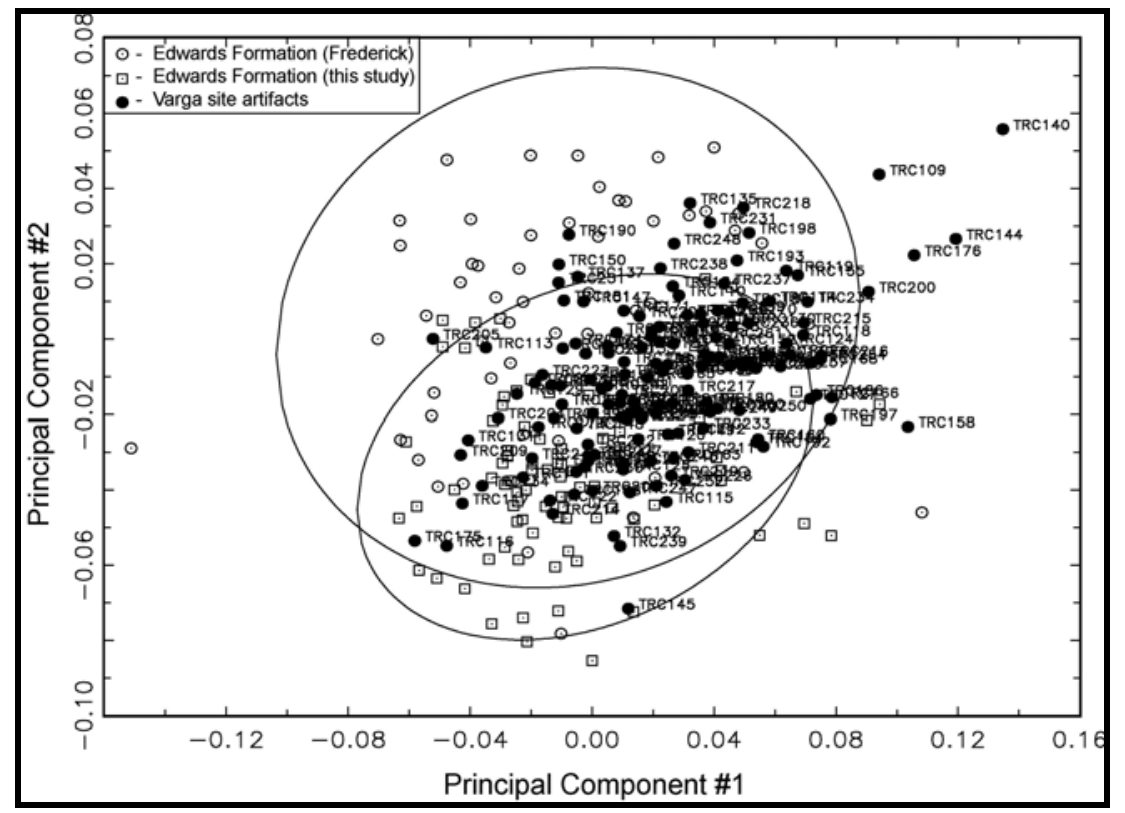

Figure F-5. Bivariate Plot of First and Second Principal Components for Edwards Formation Chert and Varga Site artifacts (Numbered)

Samples collected by Frederick et al. (1994), Edwards Formation chert collected in this study, and Varga Site artifacts from this study.

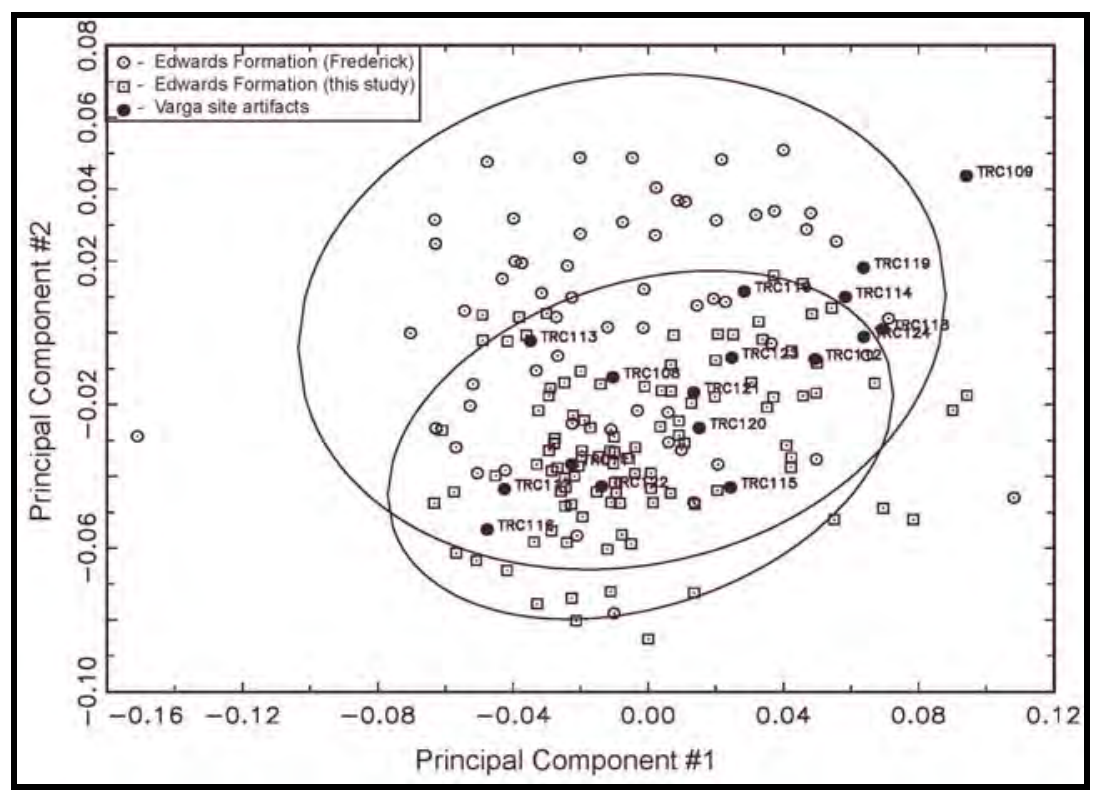

Figure F-6. Bivariate Plot of First and Second Principal Components for Edwards Formation Chert and Middle Archaic Artifacts (Numbered)

Samples collected by Frederick et al. (1994), Edwards Formation chert collected in this study, and Varga Site Middle Archaic artifacts from this study. 


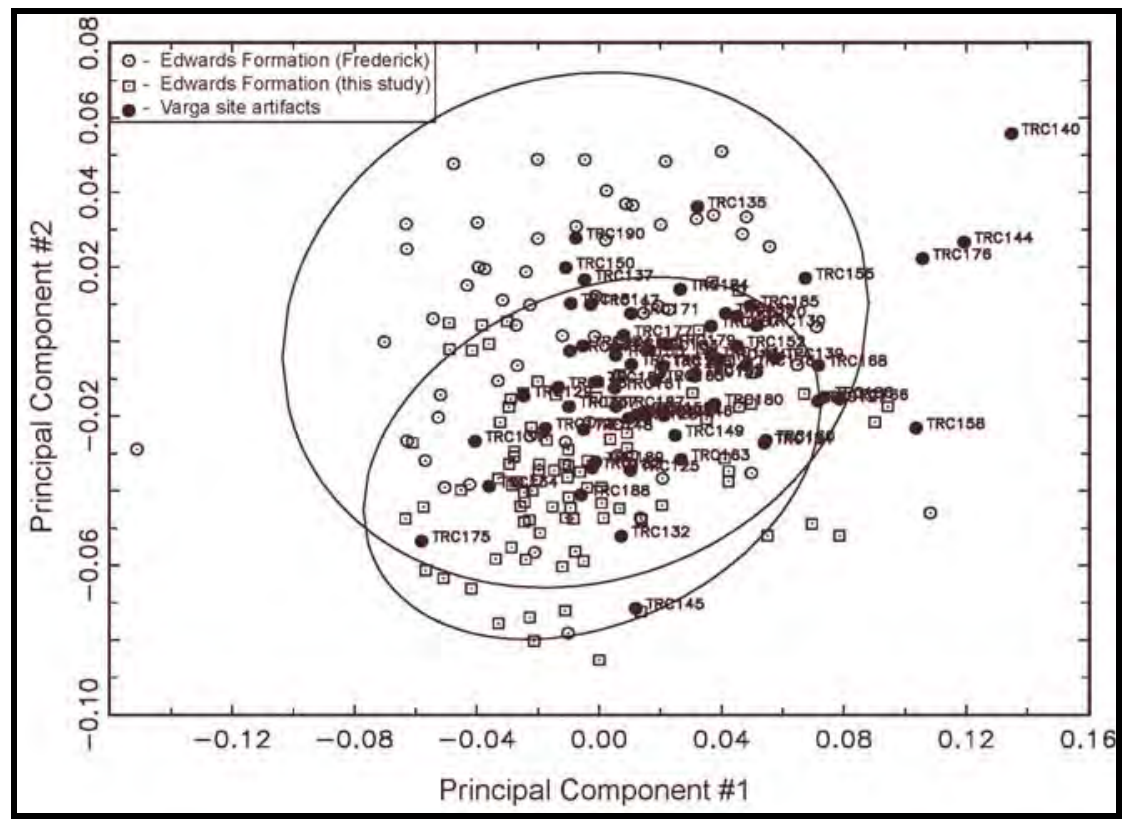

Figure F-7. Bivariate Plot of First and Second Principal Components for Edwards Formation Chert and Early Archaic Artifacts (Numbered)

Samples collected by Frederick et al. (1994), Edwards Formation chert collected in this study, and Varga Site Early Archaic artifacts from this study.

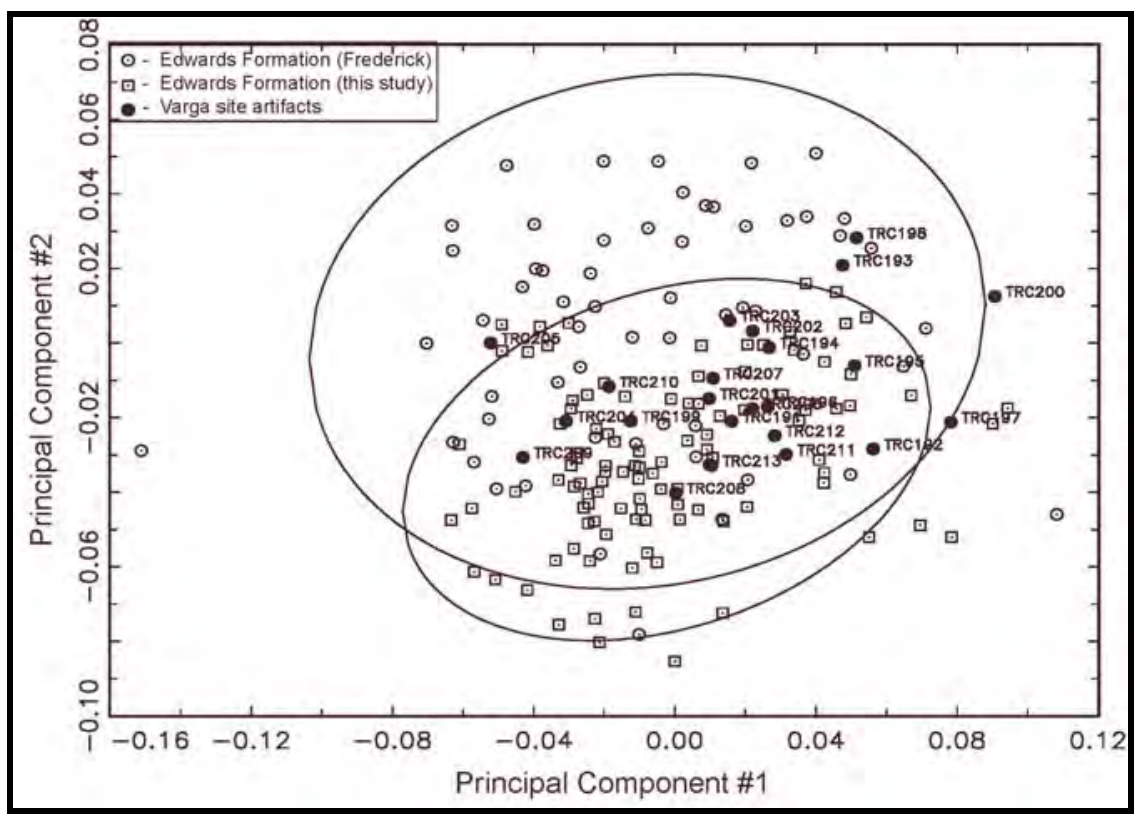

Figure F-8. Bivariate Plot of First and Second Principal Components for Edwards Formation Chert and Late Archaic Artifacts (Numbered)

Samples collected by Frederick et al. (1994), Edwards Formation chert collected in this study, and Varga Site Late Archaic artifacts from this study. 


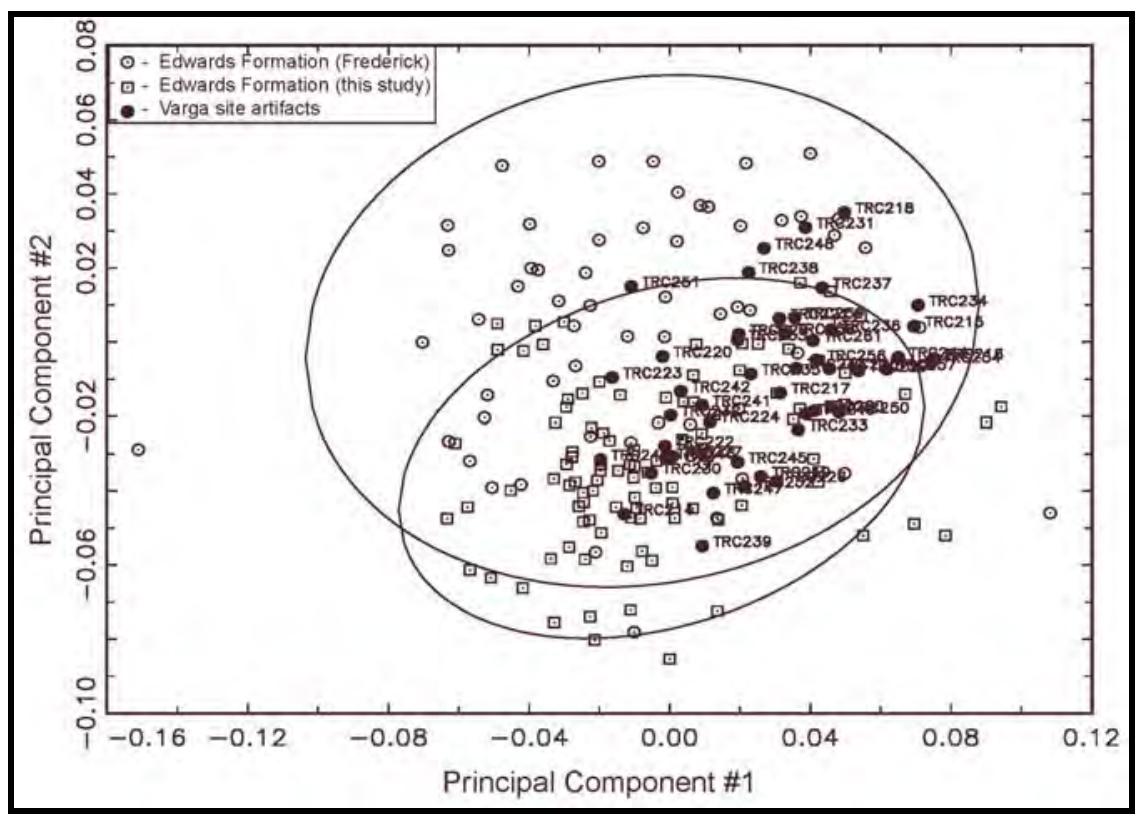

Figure F-9. Bivariate Plot of First and Second Principal Components for Edwards Formation Chert and Toyah Artifacts (Numbered)

Samples collected by Frederick et al. (1994), Edwards Formation chert collected in this study, and Varga Site Toyah artifacts from this study. 

Table 1. Descriptions of the chert samples in this study.

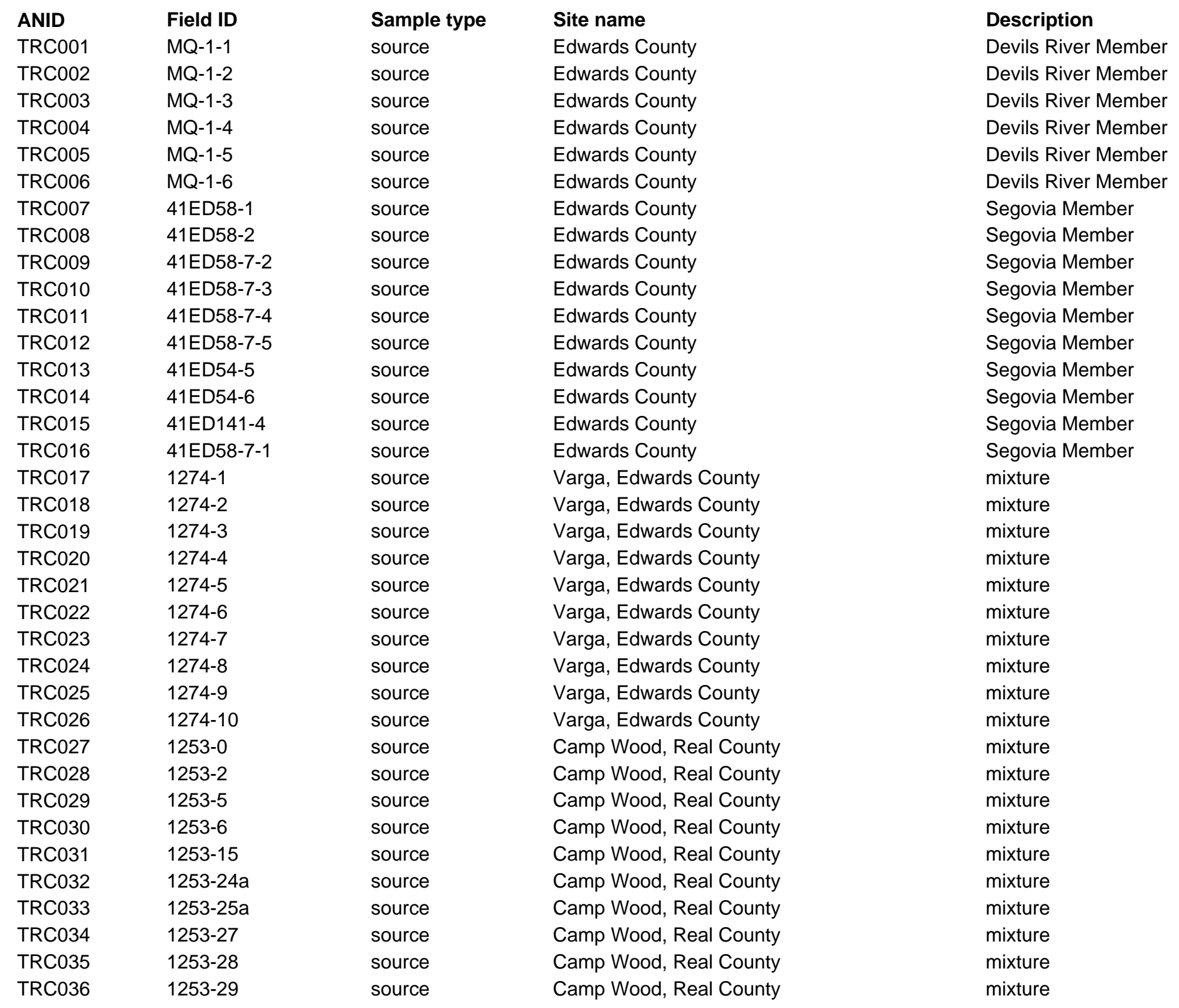


$\stackrel{\$}{\$}$ Table 1. Descriptions of the chert samples in this study.

\begin{tabular}{|c|c|c|c|c|}
\hline ANID & Field ID & Sample type & Site name & Description \\
\hline TRC037 & $1253-30 a$ & source & Camp Wood, Real County & mixture \\
\hline TRC038 & $1253-31 \mathrm{~g}$ & source & Camp Wood, Real County & mixture \\
\hline TRC039 & $1253-34 a$ & source & Camp Wood, Real County & mixture \\
\hline TRC040 & $1253-38 a$ & source & Camp Wood, Real County & mixture \\
\hline TRC041 & $1253-39 d$ & source & Camp Wood, Real County & mixture \\
\hline TRC042 & $1253-66$ & source & Camp Wood, Real County & mixture \\
\hline TRC043 & $1253-256$ & source & Camp Wood, Real County & mixture \\
\hline TRC044 & $1253-306$ & source & Camp Wood, Real County & mixture \\
\hline TRC045 & $1253-376$ & source & Camp Wood, Real County & mixture \\
\hline TRC046 & $1253-35 a$ & source & Camp Wood, Real County & mixture \\
\hline TRC047 & CF-7-1 & source & Kerr County & Terrett Member \\
\hline TRC048 & CF-7-2 & source & Kerr County & Terrett Member \\
\hline TRC049 & CF-7-3 & source & Kerr County & Terrett Member \\
\hline TRC050 & CF-7-4 & source & Kerr County & Terrett Member \\
\hline TRC051 & CF-7-5 & source & Kerr County & Terrett Member \\
\hline TRC052 & CF-9-1 & source & Real County & Segovia Member \\
\hline TRC053 & CF-9-2 & source & Real County & Segovia Member \\
\hline TRC054 & CF-9-3 & source & Real County & Segovia Member \\
\hline TRC055 & CF-9-4 & source & Real County & Segovia Member \\
\hline TRC056 & CF-10-1 & source & Edwards County & Segovia Member \\
\hline TRC057 & CF-10-2 & source & Edwards County & Segovia Member \\
\hline TRC058 & CF-10-3 & source & Edwards County & Segovia Member \\
\hline TRC059 & CF-10-4 & source & Edwards County & Segovia Member \\
\hline TRC060 & CF-10-5 & source & Edwards County & Segovia Member \\
\hline TRC061 & CF-6-1 & source & Kerr County & Glen Rose \\
\hline TRC062 & CF-6-2 & source & Kerr County & Glen Rose \\
\hline TRC063 & CF-6-3 & source & Kerr County & Glen Rose \\
\hline TRC064 & CF-6-4 & source & Kerr County & Glen Rose \\
\hline TRC065 & CF-6-5 & source & Kerr County & Glen Rose \\
\hline TRC066 & CF-11-1 & source & Kerr County & Terrett Member \\
\hline TRC067 & $C F-11-2$ & source & Kerr County & Terrett Member \\
\hline TRC068 & CF-11-3 & source & Kerr County & Terrett Member \\
\hline TRC069 & CF-11-4 & source & Kerr County & Terrett Member \\
\hline TRC070 & CFC-11-5 & source & Kerr County & Terrett Member \\
\hline TRC071 & CFC-11-6 & source & Kerr County & Terrett Member \\
\hline TRC072 & CF-12-1 & source & Val Verde County & Segovia Member \\
\hline
\end{tabular}


Table 1. Descriptions of the chert samples in this study.

\begin{tabular}{|c|c|c|c|c|}
\hline ANID & Field ID & Sample type & Site name & Description \\
\hline TRC073 & CF-12-2 & source & Val Verde County & Segovia Member \\
\hline TRC074 & CF-12-3 & source & Val Verde County & Segovia Member \\
\hline TRC075 & CF-16a-1 & source & Pecos County & Terrett Member \\
\hline TRC076 & CF-16a-2 & source & Pecos County & Terrett Member \\
\hline TRC077 & CF-16b-1 & source & Pecos County & Terrett Member \\
\hline TRC078 & $C F-16 c-1$ & source & Pecos County & Terrett Member \\
\hline TRC079 & CF-17-1 & source & Pecos County & Segovia Member \\
\hline TRC080 & CF-17-2 & source & Pecos County & Segovia Member \\
\hline TRC081 & $C F-17-3$ & source & Pecos County & Segovia Member \\
\hline TRC082 & CF-19-1 & source & Sutton County & Segovia Member \\
\hline TRC083 & $1252-0$ & source & Hackberry Creek, Edwards County & mixture \\
\hline TRC084 & $1252-1$ & source & Hackberry Creek, Edwards County & mixture \\
\hline TRC085 & $1252-2$ & source & Hackberry Creek, Edwards County & mixture \\
\hline TRC086 & $1252-3$ & source & Hackberry Creek, Edwards County & mixture \\
\hline TRC087 & $1252-4$ & source & Hackberry Creek, Edwards County & mixture \\
\hline TRC088 & $1252-5$ & source & Hackberry Creek, Edwards County & mixture \\
\hline TRC089 & $1252-6$ & source & Hackberry Creek, Edwards County & mixture \\
\hline TRC090 & $1252-9$ & source & Hackberry Creek, Edwards County & mixture \\
\hline TRC091 & $1252-10$ & source & Hackberry Creek, Edwards County & mixture \\
\hline TRC092 & $1252-15$ & source & Hackberry Creek, Edwards County & mixture \\
\hline TRC093 & $1252-17$ & source & Hackberry Creek, Edwards County & mixture \\
\hline TRC094 & $1252-19$ & source & Hackberry Creek, Edwards County & mixture \\
\hline TRC095 & $1252-21$ & source & Hackberry Creek, Edwards County & mixture \\
\hline TRC096 & $1252-22$ & source & Hackberry Creek, Edwards County & mixture \\
\hline TRC097 & $1252-23$ & source & Hackberry Creek, Edwards County & mixture \\
\hline TRC098 & $1252-24$ & source & Hackberry Creek, Edwards County & mixture \\
\hline TRC099 & $1252-25$ & source & Hackberry Creek, Edwards County & mixture \\
\hline TRC100 & $1252-26$ & source & Hackberry Creek, Edwards County & mixture \\
\hline TRC101 & $1252-28$ & source & Hackberry Creek, Edwards County & mixture \\
\hline TRC102 & $1252-31$ & source & Hackberry Creek, Edwards County & mixture \\
\hline TRC103 & $1252-32$ & source & Hackberry Creek, Edwards County & mixture \\
\hline TRC104 & Georgetown-M & source & Williamson County & Lower Cretaceous \\
\hline TRC105 & Georgetown-DK & source & Williamson County & Lower Cretaceous \\
\hline TRC106 & Georgetown-LY & source & Williamson County & Lower Cretaceous \\
\hline TRC107 & Burro Mesa-Y & source & Brewster County & Cretaceous Volcanic \\
\hline TRC108 & $662-10$ & artifact & Varga, Edwards County & unknown \\
\hline
\end{tabular}


\& Table 1. Descriptions of the chert samples in this study.

\begin{tabular}{|c|c|c|c|c|}
\hline ANID & Field ID & Sample type & Site name & Description \\
\hline TRC109 & $100-11$ & artifact & Varga, Edwards County & unknown \\
\hline TRC110 & $149-10$ & artifact & Varga, Edwards County & unknown \\
\hline TRC111 & $191-11$ & artifact & Varga, Edwards County & unknown \\
\hline TRC112 & $397-13$ & artifact & Varga, Edwards County & unknown \\
\hline TRC113 & $397-10$ & artifact & Varga, Edwards County & unknown \\
\hline TRC114 & $417-10$ & artifact & Varga, Edwards County & unknown \\
\hline TRC115 & $417-13$ & artifact & Varga, Edwards County & unknown \\
\hline TRC116 & $418-28$ & artifact & Varga, Edwards County & unknown \\
\hline TRC117 & $419-12$ & artifact & Varga, Edwards County & unknown \\
\hline TRC118 & $484-16$ & artifact & Varga, Edwards County & unknown \\
\hline TRC119 & $484-17$ & artifact & Varga, Edwards County & unknown \\
\hline TRC120 & $537-16$ & artifact & Varga, Edwards County & unknown \\
\hline TRC121 & $213-12$ & artifact & Varga, Edwards County & unknown \\
\hline TRC122 & $537-17$ & artifact & Varga, Edwards County & unknown \\
\hline TRC123 & $544-12$ & artifact & Varga, Edwards County & unknown \\
\hline TRC124 & $649-11$ & artifact & Varga, Edwards County & unknown \\
\hline TRC125 & $28-11$ & artifact & Varga, Edwards County & unknown \\
\hline TRC126 & $29-12$ & artifact & Varga, Edwards County & unknown \\
\hline TRC127 & $39-15$ & artifact & Varga, Edwards County & unknown \\
\hline TRC128 & $40-12$ & artifact & Varga, Edwards County & unknown \\
\hline TRC129 & $49-12$ & artifact & Varga, Edwards County & unknown \\
\hline TRC130 & $63-16$ & artifact & Varga, Edwards County & unknown \\
\hline TRC131 & $77-13$ & artifact & Varga, Edwards County & unknown \\
\hline TRC132 & $86-20$ & artifact & Varga, Edwards County & unknown \\
\hline TRC133 & $116-20$ & artifact & Varga, Edwards County & unknown \\
\hline TRC134 & $117-21$ & artifact & Varga, Edwards County & unknown \\
\hline TRC135 & $142-11$ & artifact & Varga, Edwards County & unknown \\
\hline TRC136 & $153-31$ & artifact & Varga, Edwards County & unknown \\
\hline TRC137 & $157-11$ & artifact & Varga, Edwards County & unknown \\
\hline TRC138 & $183-21$ & artifact & Varga, Edwards County & unknown \\
\hline TRC139 & $192-11$ & artifact & Varga, Edwards County & unknown \\
\hline TRC140 & $205-10$ & artifact & Varga, Edwards County & unknown \\
\hline TRC141 & $215-21$ & artifact & Varga, Edwards County & unknown \\
\hline TRC142 & $255-11$ & artifact & Varga, Edwards County & unknown \\
\hline TRC143 & $260-14$ & artifact & Varga, Edwards County & unknown \\
\hline TRC144 & $268-21$ & artifact & Varga, Edwards County & unknown \\
\hline
\end{tabular}


Table 1. Descriptions of the chert samples in this study.

\begin{tabular}{|c|c|c|c|c|}
\hline ANID & Field ID & Sample type & Site name & Description \\
\hline TRC145 & $299-14$ & artifact & Varga, Edwards County & unknown \\
\hline TRC146 & $311-13$ & artifact & Varga, Edwards County & unknown \\
\hline TRC147 & $312-19$ & artifact & Varga, Edwards County & unknown \\
\hline TRC148 & $323-20$ & artifact & Varga, Edwards County & unknown \\
\hline TRC149 & $324-16$ & artifact & Varga, Edwards County & unknown \\
\hline TRC150 & $333-22$ & artifact & Varga, Edwards County & unknown \\
\hline TRC151 & $345-28$ & artifact & Varga, Edwards County & unknown \\
\hline TRC152 & $346-11$ & artifact & Varga, Edwards County & unknown \\
\hline TRC153 & $346-25$ & artifact & Varga, Edwards County & unknown \\
\hline TRC154 & $347-13$ & artifact & Varga, Edwards County & unknown \\
\hline TRC155 & $366-13$ & artifact & Varga, Edwards County & unknown \\
\hline TRC156 & $391-10$ & artifact & Varga, Edwards County & unknown \\
\hline TRC157 & $400-10$ & artifact & Varga, Edwards County & unknown \\
\hline TRC158 & $400-11$ & artifact & Varga, Edwards County & unknown \\
\hline TRC159 & $401-36$ & artifact & Varga, Edwards County & unknown \\
\hline TRC160 & $402-11$ & artifact & Varga, Edwards County & unknown \\
\hline TRC161 & $411-17$ & artifact & Varga, Edwards County & unknown \\
\hline TRC162 & $412-10$ & artifact & Varga, Edwards County & unknown \\
\hline TRC163 & $412-11$ & artifact & Varga, Edwards County & unknown \\
\hline TRC164 & $422-19$ & artifact & Varga, Edwards County & unknown \\
\hline TRC165 & $449-10$ & artifact & Varga, Edwards County & unknown \\
\hline TRC166 & $462-15$ & artifact & Varga, Edwards County & unknown \\
\hline TRC167 & $465-10$ & artifact & Varga, Edwards County & unknown \\
\hline TRC168 & $539-12$ & artifact & Varga, Edwards County & unknown \\
\hline TRC169 & $546-14$ & artifact & Varga, Edwards County & unknown \\
\hline TRC170 & 563-19 & artifact & Varga, Edwards County & unknown \\
\hline TRC171 & $578-15$ & artifact & Varga, Edwards County & unknown \\
\hline TRC172 & $592-11$ & artifact & Varga, Edwards County & unknown \\
\hline TRC173 & $598-13$ & artifact & Varga, Edwards County & unknown \\
\hline TRC174 & $615-20$ & artifact & Varga, Edwards County & unknown \\
\hline TRC175 & $621-10$ & artifact & Varga, Edwards County & unknown \\
\hline TRC176 & $627-13$ & artifact & Varga, Edwards County & unknown \\
\hline TRC177 & $628-11$ & artifact & Varga, Edwards County & unknown \\
\hline TRC178 & $670-5-12$ & artifact & Varga, Edwards County & unknown \\
\hline TRC179 & $670-13$ & artifact & Varga, Edwards County & unknown \\
\hline TRC180 & $671-11$ & artifact & Varga, Edwards County & unknown \\
\hline
\end{tabular}


$\stackrel{\infty}{\infty}$ Table 1. Descriptions of the chert samples in this study.

\begin{tabular}{|c|c|c|c|c|}
\hline ANID & Field ID & Sample type & Site name & Description \\
\hline TRC181 & $699-20$ & artifact & Varga, Edwards County & unknown \\
\hline TRC182 & $718-15$ & artifact & Varga, Edwards County & unknown \\
\hline TRC183 & $719-10$ & artifact & Varga, Edwards County & unknown \\
\hline TRC184 & $724-13$ & artifact & Varga, Edwards County & unknown \\
\hline TRC185 & $725-14$ & artifact & Varga, Edwards County & unknown \\
\hline TRC186 & $729-10$ & artifact & Varga, Edwards County & unknown \\
\hline TRC187 & $735-12$ & artifact & Varga, Edwards County & unknown \\
\hline TRC188 & $854-10$ & artifact & Varga, Edwards County & unknown \\
\hline TRC189 & $1203-10$ & artifact & Varga, Edwards County & unknown \\
\hline TRC190 & $1213-10$ & artifact & Varga, Edwards County & unknown \\
\hline TRC191 & $2-1$ & artifact & Varga, Edwards County & unknown \\
\hline TRC192 & $2-11$ & artifact & Varga, Edwards County & unknown \\
\hline TRC193 & $2-12$ & artifact & Varga, Edwards County & unknown \\
\hline TRC194 & $3-10$ & artifact & Varga, Edwards County & unknown \\
\hline TRC195 & $11-5-11$ & artifact & Varga, Edwards County & unknown \\
\hline TRC196 & $22-15$ & artifact & Varga, Edwards County & unknown \\
\hline TRC197 & $42-10$ & artifact & Varga, Edwards County & unknown \\
\hline TRC198 & $89-10$ & artifact & Varga, Edwards County & unknown \\
\hline TRC199 & $98-12$ & artifact & Varga, Edwards County & unknown \\
\hline TRC200 & $187-10$ & artifact & Varga, Edwards County & unknown \\
\hline TRC201 & $197-16$ & artifact & Varga, Edwards County & unknown \\
\hline TRC202 & $197-17$ & artifact & Varga, Edwards County & unknown \\
\hline TRC203 & $208-10$ & artifact & Varga, Edwards County & unknown \\
\hline TRC204 & $233-10$ & artifact & Varga, Edwards County & unknown \\
\hline TRC205 & $263-10$ & artifact & Varga, Edwards County & unknown \\
\hline TRC206 & $274-5-11$ & artifact & Varga, Edwards County & unknown \\
\hline TRC207 & $283-12$ & artifact & Varga, Edwards County & unknown \\
\hline TRC208 & $293-5-12$ & artifact & Varga, Edwards County & unknown \\
\hline TRC209 & $293-5-13$ & artifact & Varga, Edwards County & unknown \\
\hline TRC210 & $459-11$ & artifact & Varga, Edwards County & unknown \\
\hline TRC211 & $525-5-13$ & artifact & Varga, Edwards County & unknown \\
\hline TRC212 & $543-12$ & artifact & Varga, Edwards County & unknown \\
\hline TRC213 & $691-11$ & artifact & Varga, Edwards County & unknown \\
\hline TRC214 & $159-5-27$ & artifact & Varga, Edwards County & unknown \\
\hline TRC215 & $159-5-28$ & artifact & Varga, Edwards County & unknown \\
\hline TRC216 & $207-11$ & artifact & Varga, Edwards County & unknown \\
\hline
\end{tabular}


Table 1. Descriptions of the chert samples in this study.

\begin{tabular}{|c|c|c|c|c|}
\hline ANID & Field ID & Sample type & Site name & Description \\
\hline TRC217 & $220-13$ & artifact & Varga, Edwards County & unknown \\
\hline TRC218 & $220-15$ & artifact & Varga, Edwards County & unknown \\
\hline TRC219 & $262-20$ & artifact & Varga, Edwards County & unknown \\
\hline TRC220 & $282-17$ & artifact & Varga, Edwards County & unknown \\
\hline TRC221 & $291-14$ & artifact & Varga, Edwards County & unknown \\
\hline TRC222 & $302-21$ & artifact & Varga, Edwards County & unknown \\
\hline TRC223 & $349-13$ & artifact & Varga, Edwards County & unknown \\
\hline TRC224 & $474-10$ & artifact & Varga, Edwards County & unknown \\
\hline TRC225 & $482-10$ & artifact & Varga, Edwards County & unknown \\
\hline TRC226 & $525-10$ & artifact & Varga, Edwards County & unknown \\
\hline TRC227 & $526-10$ & artifact & Varga, Edwards County & unknown \\
\hline TRC228 & $562-10$ & artifact & Varga, Edwards County & unknown \\
\hline TRC229 & $572-15$ & artifact & Varga, Edwards County & unknown \\
\hline TRC230 & $781-10$ & artifact & Varga, Edwards County & unknown \\
\hline TRC231 & $800-11$ & artifact & Varga, Edwards County & unknown \\
\hline TRC232 & $806-17$ & artifact & Varga, Edwards County & unknown \\
\hline TRC233 & $825-10$ & artifact & Varga, Edwards County & unknown \\
\hline TRC234 & $836-10$ & artifact & Varga, Edwards County & unknown \\
\hline TRC235 & $841-13$ & artifact & Varga, Edwards County & unknown \\
\hline TRC236 & $842-10$ & artifact & Varga, Edwards County & unknown \\
\hline TRC237 & $845-10$ & artifact & Varga, Edwards County & unknown \\
\hline TRC238 & $881-17$ & artifact & Varga, Edwards County & unknown \\
\hline TRC239 & $888-14$ & artifact & Varga, Edwards County & unknown \\
\hline TRC240 & $889-13$ & artifact & Varga, Edwards County & unknown \\
\hline TRC241 & $895-12$ & artifact & Varga, Edwards County & unknown \\
\hline TRC242 & $903-12$ & artifact & Varga, Edwards County & unknown \\
\hline TRC243 & $903-22$ & artifact & Varga, Edwards County & unknown \\
\hline TRC244 & $903-24$ & artifact & Varga, Edwards County & unknown \\
\hline TRC245 & $913-17$ & artifact & Varga, Edwards County & unknown \\
\hline TRC246 & $934-19$ & artifact & Varga, Edwards County & unknown \\
\hline TRC247 & $974-11$ & artifact & Varga, Edwards County & unknown \\
\hline TRC248 & $967-24$ & artifact & Varga, Edwards County & unknown \\
\hline TRC249 & $1002-13$ & artifact & Varga, Edwards County & unknown \\
\hline TRC250 & $1029-5-11$ & artifact & Varga, Edwards County & unknown \\
\hline TRC251 & $1031-13$ & artifact & Varga, Edwards County & unknown \\
\hline TRC252 & $1038-12$ & artifact & Varga, Edwards County & unknown \\
\hline
\end{tabular}


$\stackrel{0}{\circ}$ Table 1. Descriptions of the chert samples in this study.

$\begin{array}{lllll}\text { ANID } & \text { Field ID } & \text { Sample type } & \text { Site name } & \text { Description } \\ \text { TRC253 } & 1041-14 & \text { artifact } & \text { Varga, Edwards County } & \text { unknown } \\ \text { TRC254 } & 1054-16 & \text { artifact } & \text { Varga, Edwards County } & \text { unknown } \\ \text { TRC255 } & 1074-12 & \text { artifact } & \text { Varga, Edwards County } & \text { unknown } \\ \text { TRC256 } & 1088-13 & \text { artifact } & \text { Varga, Edwards County } & \text { unknown } \\ \text { TRC257 } & 1092-15 & \text { artifact } & \text { Varga, Edwards County } & \text { unknown } \\ \text { TRC258 } & 1101-13 & \text { artifact } & \text { Varga, Edwards County } & \text { unknown } \\ \text { TRC259 } & 1132-10 & \text { artifact } & \text { Varga, Edwards County } & \text { unknown } \\ \text { TRC260 } & 1162-11 & \text { artifact } & \text { Varga, Edwards County } & \text { unknown } \\ \text { TRC261 } & 1256-5-11 & \text { artifact } & \text { Varga, Edwards County } & \text { unknown }\end{array}$


Table 2. Concentrations of elements measured by INAA in the chert samples in this study.

\begin{tabular}{|c|c|c|c|c|c|c|c|c|c|c|c|}
\hline ANID & As (ppm) & $\mathrm{Ba}(p p m)$ & La (ppm) & Lu (ppm) & Nd (ppm) & Sm (ppm) & U (ppm) & Yb (ppm) & $\mathrm{Ce}(p p m)$ & Co (ppm) & $\mathrm{Cr}(p p m)$ \\
\hline TRC001 & 0.1441 & 230.88 & 0.0978 & 0.0050 & 0.6861 & 0.0715 & 0.7979 & 0.0000 & 0.2374 & 0.0136 & 0.1113 \\
\hline TRC002 & 0.1812 & 29.74 & 0.0905 & 0.0050 & 0.1964 & 0.0646 & 0.7177 & 0.0000 & 0.2254 & 0.0148 & 0.3588 \\
\hline TRC003 & 0.1705 & 37.43 & 0.1513 & 0.0082 & 0.2044 & 0.0908 & 0.8442 & 0.0055 & 0.3911 & 0.0183 & 0.0950 \\
\hline TRC004 & 0.0000 & 39.22 & 0.0827 & 0.0052 & 0.1446 & 0.0730 & 0.7871 & 0.0000 & 0.2252 & 0.0092 & 0.1173 \\
\hline TRC005 & 0.2762 & 45.03 & 0.1133 & 0.0071 & 0.2454 & 0.0906 & 1.0240 & 0.0000 & 0.2828 & 0.0160 & 0.1044 \\
\hline TRC006 & 0.0000 & 58.57 & 0.1083 & 0.0065 & 0.2566 & 0.0844 & 0.9479 & 0.0000 & 0.2683 & 0.0090 & 0.1035 \\
\hline TRC007 & 0.2353 & 20.46 & 0.1313 & 0.0076 & 0.5541 & 0.1019 & 1.0788 & 0.0000 & 0.3440 & 0.0326 & 0.3258 \\
\hline TRC008 & 0.0000 & 28.22 & 0.4309 & 0.0224 & 0.9381 & 0.3099 & 3.4348 & 0.0025 & 0.9790 & 0.0787 & 0.5933 \\
\hline TRC009 & 0.9205 & 20.55 & 0.1888 & 0.0098 & 0.3845 & 0.1352 & 1.4812 & 0.0000 & 0.4304 & 0.0312 & 0.3848 \\
\hline TRC010 & 0.0888 & 10.89 & 0.1967 & 0.0105 & 0.3741 & 0.1348 & 1.4834 & 0.0057 & 0.4134 & 0.0333 & 0.5028 \\
\hline TRC011 & 0.1198 & 11.40 & 0.1268 & 0.0000 & 0.4325 & 0.1531 & 1.6941 & 0.0000 & 0.5092 & 0.0118 & 0.3342 \\
\hline TRC012 & 0.1420 & 16.44 & 0.1078 & 0.0000 & 0.1988 & 0.1141 & 1.2195 & 0.0000 & 0.3653 & 0.0218 & 0.3017 \\
\hline TRC013 & 0.1004 & 71.19 & 0.0523 & 0.0033 & 0.0000 & 0.0355 & 0.3328 & 0.0000 & 0.1570 & 0.0145 & 0.4354 \\
\hline TRC014 & 0.2954 & 29.94 & 0.2995 & 0.0000 & 1.8278 & 0.3904 & 4.2566 & 0.0000 & 1.2231 & 0.0122 & 0.2173 \\
\hline TRC015 & 0.4329 & 34.05 & 0.1326 & 0.0000 & 0.4284 & 0.1525 & 1.6197 & 0.0000 & 0.4874 & 0.1332 & 0.1364 \\
\hline TRC016 & 0.1913 & 13.51 & 0.1312 & 0.0000 & 0.2210 & 0.1384 & 1.4344 & 0.0053 & 0.4780 & 0.0109 & 0.2357 \\
\hline TRC017 & 0.3865 & 39.82 & 0.1013 & 0.0000 & 0.5338 & 0.1117 & 1.1737 & 0.0000 & 0.3475 & 0.0224 & 0.2113 \\
\hline TRC018 & 0.1870 & 17.25 & 0.0708 & 0.0000 & 0.0000 & 0.0763 & 0.7863 & 0.0000 & 0.2376 & 0.0122 & 0.9637 \\
\hline TRC019 & 0.0863 & 19.01 & 0.1321 & 0.0032 & 0.0000 & 0.0499 & 0.3717 & 0.0000 & 0.1289 & 0.0078 & 0.1027 \\
\hline TRC020 & 0.1172 & 30.76 & 0.1109 & 0.0066 & 0.1182 & 0.0700 & 0.6327 & 0.0032 & 0.2515 & 0.0378 & 0.1370 \\
\hline TRC021 & 0.0579 & 19.18 & 0.0949 & 0.0048 & 0.0000 & 0.0522 & 0.4747 & 0.0000 & 0.1931 & 0.0120 & 0.2367 \\
\hline TRC022 & 0.0000 & 18.42 & 0.1849 & 0.0018 & 0.0000 & 0.0397 & 0.2422 & 0.0050 & 0.1455 & 0.0090 & 0.1037 \\
\hline TRC023 & 0.1669 & 24.61 & 0.2112 & 0.0000 & 0.7292 & 0.2188 & 2.3518 & 0.0000 & 0.7007 & 0.0234 & 0.0837 \\
\hline TRC024 & 0.1791 & 24.87 & 0.1893 & 0.0000 & 0.7831 & 0.2044 & 2.1266 & 0.0000 & 0.6423 & 0.0243 & 0.0908 \\
\hline TRC025 & 0.1038 & 25.63 & 0.0869 & 0.0000 & 0.0000 & 0.0691 & 0.6855 & 0.0031 & 0.2461 & 0.0105 & 0.1262 \\
\hline TRC026 & 0.0710 & 20.73 & 0.0763 & 0.0000 & 0.0000 & 0.0649 & 0.6369 & 0.0000 & 0.2231 & 0.0099 & 0.1037 \\
\hline TRC027 & 0.1022 & 26.53 & 0.2147 & 0.0000 & 0.6783 & 0.2499 & 2.6595 & 0.0000 & 0.7498 & 0.0060 & 0.2943 \\
\hline TRC028 & 0.2094 & 69.34 & 0.0905 & 0.0000 & 0.0000 & 0.0867 & 0.8941 & 0.0000 & 0.2879 & 0.0252 & 0.1883 \\
\hline TRC029 & 0.2291 & 127.34 & 0.0462 & 0.0000 & 0.2426 & 0.0403 & 0.4166 & 0.0000 & 0.1130 & 0.0220 & 0.1475 \\
\hline TRC030 & 0.1587 & 78.30 & 0.2520 & 0.0000 & 0.9752 & 0.2867 & 3.0221 & 0.0000 & 0.8719 & 0.0182 & 0.8794 \\
\hline TRC031 & 1.2333 & 51.75 & 0.1090 & 0.0092 & 0.0000 & 0.0909 & 0.8348 & 0.0081 & 0.2414 & 0.1889 & 0.5279 \\
\hline TRC032 & 0.0790 & 22.17 & 0.1452 & 0.0000 & 0.5707 & 0.1555 & 1.6006 & 0.0000 & 0.4671 & 0.0205 & 0.2379 \\
\hline TRC033 & 0.1464 & 34.28 & 0.1571 & 0.0000 & 0.3257 & 0.1610 & 1.6489 & 0.0000 & 0.4990 & 0.0127 & 0.5005 \\
\hline TRC034 & 0.1462 & 17.45 & 0.3167 & 0.0000 & 0.4855 & 0.1863 & 1.9701 & 0.0000 & 0.8879 & 0.0078 & 0.3181 \\
\hline TRC035 & 0.1333 & 110.14 & 0.0857 & 0.0000 & 0.0000 & 0.0867 & 0.9061 & 0.0000 & 0.2673 & 0.0078 & 0.1530 \\
\hline TRC036 & 0.1443 & 104.73 & 0.2459 & 0.0000 & 0.7078 & 0.2662 & 2.7767 & 0.0000 & 0.8040 & 0.0106 & 0.7925 \\
\hline
\end{tabular}




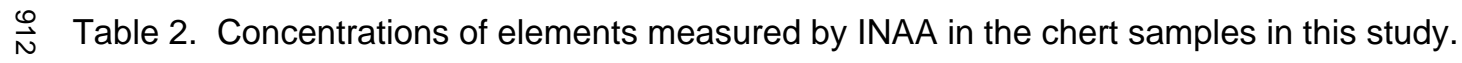

\begin{tabular}{|c|c|c|c|c|c|c|c|c|c|c|c|}
\hline ANID & As (ppm) & $\mathrm{Ba}(p p m)$ & La (ppm) & Lu (ppm) & Nd (ppm) & Sm (ppm) & U (ppm) & Yb (ppm) & Ce (ppm) & Co (ppm) & $\mathrm{Cr}(p p m)$ \\
\hline TRC037 & 0.5288 & 21.01 & 0.1476 & 0.0000 & 0.4838 & 0.1348 & 1.3419 & 0.0000 & 0.4813 & 0.0253 & 1.2717 \\
\hline TRC038 & 0.1587 & 37.70 & 0.2741 & 0.0000 & 0.8611 & 0.2943 & 3.0487 & 0.0000 & 0.8914 & 0.0101 & 0.1993 \\
\hline TRC039 & 0.1929 & 61.61 & 0.0752 & 0.0000 & 0.0000 & 0.0644 & 0.6174 & 0.0000 & 0.2235 & 0.0226 & 4.9581 \\
\hline TRC040 & 0.2943 & 16.61 & 0.0598 & 0.0038 & 0.0000 & 0.0448 & 0.4171 & 0.0000 & 0.1749 & 0.0089 & 0.4009 \\
\hline TRC041 & 0.3979 & 41.94 & 0.1078 & 0.0000 & 0.0000 & 0.1109 & 1.2997 & 0.0000 & 0.4149 & 0.0271 & 1.1556 \\
\hline TRC042 & 0.3007 & 78.47 & 0.2944 & 0.0000 & 1.4279 & 0.3368 & 3.7912 & 0.0000 & 1.1559 & 0.0583 & 0.4069 \\
\hline TRC043 & 0.0713 & 33.49 & 0.1197 & 0.0000 & 0.4340 & 0.1475 & 1.7854 & 0.0000 & 0.5195 & 0.0143 & 0.0982 \\
\hline TRC044 & 0.2890 & 21.28 & 0.1156 & 0.0000 & 0.0000 & 0.1135 & 1.3377 & 0.0000 & 0.4912 & 0.0317 & 0.2715 \\
\hline TRC045 & 0.1988 & 27.04 & 0.2378 & 0.0000 & 1.0833 & 0.2973 & 3.6322 & 0.0000 & 1.0168 & 0.0305 & 0.3467 \\
\hline TRC046 & 0.0861 & 41.53 & 0.1132 & 0.0000 & 0.6726 & 0.1348 & 1.6319 & 0.0000 & 0.5074 & 0.0215 & 0.1314 \\
\hline TRC047 & 0.1501 & 24.04 & 0.1476 & 0.0000 & 0.8647 & 0.1703 & 1.9430 & 0.0000 & 0.5970 & 0.0162 & 0.3825 \\
\hline TRC048 & 0.3058 & 85.32 & 0.2211 & 0.0000 & 1.2024 & 0.2687 & 3.1862 & 0.0000 & 0.9562 & 0.0266 & 0.5176 \\
\hline TRC049 & 0.3153 & 46.68 & 0.1793 & 0.0000 & 0.6276 & 0.1950 & 2.3503 & 0.0000 & 0.7298 & 0.0354 & 0.4161 \\
\hline TRC050 & 0.0824 & 24.14 & 0.2062 & 0.0000 & 0.8271 & 0.2506 & 2.9984 & 0.0000 & 0.8928 & 0.0147 & 0.4640 \\
\hline TRC051 & 0.2887 & 37.52 & 0.1562 & 0.0000 & 0.7251 & 0.1239 & 1.2927 & 0.0150 & 0.5240 & 0.0254 & 0.2169 \\
\hline TRC052 & 0.1373 & 34.42 & 0.2607 & 0.0000 & 1.2093 & 0.3011 & 3.6899 & 0.0000 & 1.0557 & 0.0096 & 0.4688 \\
\hline TRC053 & 0.2029 & 97.67 & 0.2010 & 0.0000 & 0.9563 & 0.2271 & 2.6933 & 0.0000 & 0.7804 & 0.0131 & 0.2642 \\
\hline TRC054 & 0.0000 & 81.14 & 0.1435 & 0.0000 & 0.5364 & 0.1597 & 1.9092 & 0.0000 & 0.5792 & 0.0129 & 0.1523 \\
\hline TRC055 & 0.0000 & 53.46 & 0.1854 & 0.0000 & 1.0234 & 0.2077 & 2.5046 & 0.0000 & 0.7393 & 0.0089 & 0.1644 \\
\hline TRC056 & 0.0531 & 41.08 & 0.0420 & 0.0000 & 0.0000 & 0.0288 & 0.3534 & 0.0000 & 0.1011 & 0.0129 & 0.5332 \\
\hline TRC057 & 0.0000 & 71.96 & 0.0898 & 0.0000 & 0.7167 & 0.0992 & 1.1871 & 0.0000 & 0.3689 & 0.0097 & 1.2985 \\
\hline TRC058 & 0.0000 & 58.91 & 0.0875 & 0.0000 & 0.0000 & 0.0958 & 1.1527 & 0.0000 & 0.3536 & 0.0083 & 0.4071 \\
\hline TRC059 & 0.0000 & 31.62 & 0.0877 & 0.0000 & 0.0000 & 0.0898 & 1.0637 & 0.0000 & 0.3162 & 0.0105 & 0.3325 \\
\hline TRC060 & 0.0986 & 64.43 & 0.0924 & 0.0000 & 0.0000 & 0.0681 & 0.7664 & 0.0000 & 0.2510 & 0.0122 & 0.4188 \\
\hline TRC061 & 0.3935 & 38.07 & 0.1679 & 0.0000 & 0.2897 & 0.1416 & 1.3851 & 0.0000 & 0.4731 & 0.0397 & 1.0154 \\
\hline TRC062 & 0.6106 & 38.00 & 0.2016 & 0.0134 & 0.4272 & 0.1715 & 1.5923 & 0.0057 & 0.5612 & 0.0545 & 1.4892 \\
\hline TRC063 & 0.3534 & 61.94 & 0.1738 & 0.0000 & 0.7239 & 0.1749 & 2.0994 & 0.0000 & 0.6280 & 0.0472 & 0.7320 \\
\hline TRC064 & 0.5470 & 76.85 & 0.1854 & 0.0000 & 0.3606 & 0.1835 & 2.1714 & 0.0000 & 0.6612 & 0.0573 & 0.6554 \\
\hline TRC065 & 0.5333 & 67.79 & 0.1995 & 0.0000 & 0.9025 & 0.1841 & 2.0276 & 0.0000 & 0.6384 & 0.0707 & 1.0639 \\
\hline TRC066 & 0.5774 & 28.71 & 0.0990 & 0.0000 & 0.0000 & 0.0590 & 0.6339 & 0.0071 & 0.2878 & 0.1546 & 0.2719 \\
\hline TRC067 & 0.2448 & 44.34 & 0.0764 & 0.0000 & 0.0000 & 0.0779 & 0.8818 & 0.0000 & 0.2937 & 0.0320 & 0.1590 \\
\hline TRC068 & 0.0000 & 22.36 & 0.0458 & 0.0000 & 0.0000 & 0.0461 & 0.5322 & 0.0000 & 0.1618 & 0.0091 & 0.0977 \\
\hline TRC069 & 0.3089 & 23.50 & 0.0754 & 0.0000 & 0.0000 & 0.0606 & 0.6550 & 0.0000 & 0.2353 & 0.0622 & 0.2827 \\
\hline TRC070 & 0.1727 & 22.43 & 0.1197 & 0.0041 & 0.0000 & 0.0355 & 0.3429 & 0.0000 & 0.1604 & 0.0382 & 0.7541 \\
\hline TRC071 & 0.1593 & 90.69 & 0.2120 & 0.0000 & 0.0000 & 0.0835 & 0.9621 & 0.0070 & 0.3436 & 0.0268 & 0.4021 \\
\hline TRC072 & 0.5694 & 84.15 & 0.2042 & 0.0000 & 0.0000 & 0.0894 & 1.0311 & 0.0000 & 0.3496 & 0.0313 & 0.153 \\
\hline
\end{tabular}


Table 2. Concentrations of elements measured by INAA in the chert samples in this study.

\begin{tabular}{|c|c|c|c|c|c|c|c|c|c|c|c|}
\hline ANID & As (ppm) & $\mathrm{Ba}(p p m)$ & La (ppm) & Lu (ppm) & Nd (ppm) & Sm (ppm) & $U$ (ppm) & Yb (ppm) & Ce (ppm) & Co (ppm) & $\mathrm{Cr}(\mathrm{ppm})$ \\
\hline TRC073 & 1.7010 & 403.79 & 0.1944 & 0.0000 & 0.0000 & 0.0659 & 0.6732 & 0.0146 & 0.2826 & 0.0540 & 0.3549 \\
\hline TRC074 & 1.8670 & 213.23 & 0.2122 & 0.0000 & 0.0000 & 0.0707 & 0.7485 & 0.0129 & 0.3272 & 0.0929 & 0.2389 \\
\hline TRC075 & 0.6009 & 23.23 & 0.2623 & 0.0367 & 0.9827 & 0.3066 & 3.7248 & 0.0070 & 1.0720 & 0.0127 & 0.2215 \\
\hline TRC076 & 0.2176 & 66.98 & 0.1770 & 0.0268 & 0.5741 & 0.2205 & 2.7296 & 0.0000 & 0.7638 & 0.0125 & 0.5235 \\
\hline TRC077 & 0.3708 & 25.10 & 0.3227 & 0.0014 & 1.3313 & 0.4085 & 5.0234 & 0.0000 & 1.3898 & 0.0163 & 0.1317 \\
\hline TRC078 & 3.9448 & 23.98 & 0.3055 & 0.0013 & 1.0391 & 0.3683 & 4.5061 & 0.0000 & 1.2501 & 0.1195 & 0.3997 \\
\hline TRC079 & 0.2961 & 44.58 & 0.1455 & 0.0006 & 0.4398 & 0.1691 & 2.0017 & 0.0000 & 0.6503 & 0.0965 & 0.8119 \\
\hline TRC080 & 0.2884 & 641.30 & 0.2671 & 0.0341 & 0.8944 & 0.3005 & 3.5981 & 0.0000 & 1.0107 & 0.0043 & 0.5925 \\
\hline TRC081 & 0.1384 & 34.14 & 0.1706 & 0.0009 & 0.4868 & 0.2133 & 2.5547 & 0.0000 & 0.7185 & 0.0045 & 0.2352 \\
\hline TRC082 & 0.5433 & 25.08 & 0.1355 & 0.0024 & 0.1360 & 0.0500 & 0.3032 & 0.0115 & 0.3639 & 0.0211 & 0.4633 \\
\hline TRC083 & 0.1053 & 89.28 & 0.2818 & 0.0369 & 1.0220 & 0.3257 & 3.9830 & 0.0000 & 1.1128 & 0.0066 & 0.1073 \\
\hline TRC084 & 0.0812 & 66.95 & 0.2383 & 0.0352 & 0.7832 & 0.3041 & 3.6802 & 0.0000 & 1.0165 & 0.0000 & 0.1259 \\
\hline TRC085 & 0.3683 & 53.64 & 0.0912 & 0.0006 & 0.2354 & 0.0686 & 0.8044 & 0.0045 & 0.2656 & 0.0256 & 2.0682 \\
\hline TRC086 & 0.0507 & 47.34 & 0.0858 & 0.0104 & 0.2761 & 0.0951 & 1.1218 & 0.0000 & 0.3131 & 0.0022 & 0.0898 \\
\hline TRC087 & 0.1209 & 91.04 & 0.2424 & 0.0323 & 0.9948 & 0.2941 & 3.5344 & 0.0000 & 0.9714 & 0.0082 & 0.1811 \\
\hline TRC088 & 0.3514 & 16.14 & 0.0776 & 0.0005 & 0.1647 & 0.0807 & 0.9220 & 0.0000 & 0.2512 & 0.0081 & 0.1120 \\
\hline TRC089 & 0.1016 & 21.93 & 0.1304 & 0.0109 & 0.2972 & 0.1068 & 1.2526 & 0.0000 & 0.3948 & 0.0070 & 0.2923 \\
\hline TRC090 & 0.3130 & 95.26 & 0.1071 & 0.0007 & 0.2087 & 0.0612 & 0.6254 & 0.0000 & 0.2301 & 0.0056 & 0.1109 \\
\hline TRC091 & 0.1129 & 33.16 & 0.0789 & 0.0080 & 0.1207 & 0.0712 & 0.8214 & 0.0000 & 0.2249 & 0.0059 & 0.2863 \\
\hline TRC092 & 0.7427 & 174.38 & 0.2135 & 0.0012 & 0.4642 & 0.1758 & 1.9950 & 0.0000 & 0.6867 & 0.0488 & 0.4871 \\
\hline TRC093 & 0.1801 & 57.64 & 0.1344 & 0.0108 & 0.2663 & 0.1064 & 1.2008 & 0.0055 & 0.3879 & 0.0062 & 0.1487 \\
\hline TRC094 & 0.2024 & 19.88 & 0.0878 & 0.0005 & 0.2733 & 0.0644 & 0.7039 & 0.0000 & 0.2212 & 0.0070 & 0.2763 \\
\hline TRC095 & 0.3095 & 76.15 & 0.1527 & 0.0150 & 0.4840 & 0.1463 & 1.7212 & 0.0000 & 0.4907 & 0.0070 & 0.5894 \\
\hline TRC096 & 0.2320 & 68.44 & 0.1780 & 0.0147 & 0.5378 & 0.1452 & 1.5345 & 0.0069 & 0.5175 & 0.0132 & 0.2802 \\
\hline TRC097 & 0.1105 & 42.65 & 0.1814 & 0.0162 & 0.5926 & 0.1591 & 1.8233 & 0.0000 & 0.5269 & 0.0066 & 0.2124 \\
\hline TRC098 & 0.0000 & 45.70 & 0.1440 & 0.0145 & 0.5521 & 0.1479 & 1.7273 & 0.0000 & 0.5107 & 0.0054 & 0.2016 \\
\hline TRC099 & 0.2210 & 67.20 & 0.1235 & 0.0130 & 0.2853 & 0.1273 & 1.5101 & 0.0000 & 0.4233 & 0.0043 & 0.1356 \\
\hline TRC100 & 0.8031 & 41.77 & 0.1105 & 0.0097 & 0.6376 & 0.0898 & 1.0614 & 0.0000 & 0.3438 & 0.0073 & 0.2081 \\
\hline TRC101 & 0.1648 & 17.55 & 0.1109 & 0.0094 & 0.2196 & 0.0941 & 1.0863 & 0.0000 & 0.2999 & 0.0034 & 0.2102 \\
\hline TRC102 & 0.0698 & 56.19 & 0.1340 & 0.0123 & 0.3299 & 0.1238 & 1.4094 & 0.0000 & 0.4232 & 0.0041 & 0.1088 \\
\hline TRC103 & 0.1322 & 21.92 & 0.2459 & 0.0227 & 0.8092 & 0.2322 & 2.6714 & 0.0059 & 0.8326 & 0.0107 & 0.1915 \\
\hline TRC104 & 0.1720 & 56.83 & 0.6148 & 0.0644 & 1.6784 & 0.6574 & 7.6883 & 0.0000 & 2.0626 & 0.0096 & 0.1661 \\
\hline TRC105 & 0.2353 & 30.33 & 0.4154 & 0.0431 & 0.9785 & 0.4365 & 5.0813 & 0.0000 & 1.3855 & 0.0047 & 0.4888 \\
\hline TRC106 & 0.1260 & 76.89 & 0.7004 & 0.0000 & 1.7036 & 0.7118 & 8.1010 & 0.0000 & 2.2223 & 0.0094 & 0.0918 \\
\hline TRC107 & 3.1744 & 216.40 & 8.8710 & 0.1392 & 13.4584 & 5.2995 & 37.5021 & 0.9702 & 24.8490 & 0.0333 & 1.1564 \\
\hline TRC108 & 0.2207 & 17.28 & 0.0871 & 0.0008 & 0.1787 & 0.0573 & 0.6043 & 0.0029 & 0.2366 & 0.0098 & 0.4844 \\
\hline
\end{tabular}


$\stackrel{ }{\perp}$ Table 2. Concentrations of elements measured by INAA in the chert samples in this study.

\begin{tabular}{|c|c|c|c|c|c|c|c|c|c|c|c|}
\hline ANID & As (ppm) & $\mathrm{Ba}(p p m)$ & La (ppm) & Lu (ppm) & Nd (ppm) & Sm (ppm) & $\mathrm{U}(\mathrm{ppm})$ & Yb (ppm) & $\mathrm{Ce}$ (ppm) & Co (ppm) & $\mathrm{Cr}$ (ppm) \\
\hline TRC109 & 0.5731 & 25.53 & 0.4762 & 0.0046 & 0.6968 & 0.1945 & 1.5800 & 0.0290 & 1.4583 & 0.1457 & 0.8337 \\
\hline TRC110 & 0.6371 & 46.48 & 0.4282 & 0.0000 & 1.4799 & 0.4005 & 4.5649 & 0.0000 & 1.2878 & 0.0125 & 0.7015 \\
\hline TRC111 & 0.0000 & 47.41 & 0.1064 & 0.0090 & 0.2824 & 0.0998 & 1.1168 & 0.0039 & 0.3225 & 0.0068 & 0.6623 \\
\hline TRC112 & 0.1781 & 27.38 & 0.3384 & 0.0033 & 0.5330 & 0.1350 & 0.9428 & 0.0265 & 0.5074 & 0.0527 & 0.3526 \\
\hline TRC113 & 0.0836 & 19.61 & 0.1984 & 0.0184 & 0.5846 & 0.1980 & 2.2504 & 0.0000 & 0.6192 & 0.0092 & 0.2299 \\
\hline TRC114 & 0.2395 & 17.52 & 0.1986 & 0.0020 & 0.4057 & 0.0731 & 0.5134 & 0.0204 & 0.5475 & 0.0476 & 1.4080 \\
\hline TRC115 & 0.1113 & 61.69 & 0.2342 & 0.0028 & 0.4822 & 0.1977 & 2.2087 & 0.0000 & 0.6393 & 0.0121 & 0.2693 \\
\hline TRC116 & 0.0000 & 57.38 & 0.1578 & 0.0147 & 0.4476 & 0.1612 & 1.8677 & 0.0000 & 0.4889 & 0.0031 & 0.2544 \\
\hline TRC117 & 0.1670 & 26.23 & 0.0677 & 0.0000 & 0.2121 & 0.0555 & 0.6127 & 0.0031 & 0.2052 & 0.0111 & 0.1400 \\
\hline TRC118 & 0.4216 & 64.28 & 0.1995 & 0.0028 & 0.3655 & 0.0778 & 0.5462 & 0.0132 & 0.3738 & 0.0443 & 0.5462 \\
\hline TRC119 & 0.4198 & 39.86 & 0.3672 & 0.0036 & 0.5660 & 0.2098 & 2.0254 & 0.0109 & 0.9288 & 0.0637 & 0.6529 \\
\hline TRC120 & 0.2329 & 34.88 & 0.2427 & 0.0005 & 0.5207 & 0.1738 & 1.8792 & 0.0056 & 0.6145 & 0.0168 & 0.2234 \\
\hline TRC121 & 0.1566 & 33.53 & 0.3777 & 0.0000 & 0.8343 & 0.3321 & 3.6853 & 0.0000 & 1.0648 & 0.0160 & 0.2783 \\
\hline TRC122 & 0.1710 & 47.57 & 0.1013 & 0.0000 & 0.2664 & 0.0737 & 0.8125 & 0.0000 & 0.2694 & 0.0077 & 0.2528 \\
\hline TRC123 & 0.1058 & 49.50 & 0.2837 & 0.0000 & 0.4954 & 0.1744 & 1.7704 & 0.0063 & 0.6796 & 0.0204 & 0.3242 \\
\hline TRC124 & 0.2297 & 50.30 & 0.1650 & 0.0019 & 0.1963 & 0.0639 & 0.4134 & 0.0133 & 0.3546 & 0.0213 & 0.7074 \\
\hline TRC125 & 0.2930 & 96.28 & 0.0875 & 0.0000 & 0.0000 & 0.0372 & 0.3586 & 0.0000 & 0.2103 & 0.0155 & 0.2392 \\
\hline TRC126 & 0.0883 & 40.64 & 0.3192 & 0.0015 & 0.8545 & 0.2532 & 2.7822 & 0.0000 & 0.8523 & 0.0068 & 0.1943 \\
\hline TRC127 & 0.7676 & 73.55 & 0.1951 & 0.0010 & 0.4598 & 0.1169 & 1.2306 & 0.0178 & 0.4741 & 0.0731 & 0.6839 \\
\hline TRC128 & 0.2045 & 25.35 & 0.1328 & 0.0011 & 0.1490 & 0.0624 & 0.5637 & 0.0046 & 0.2655 & 0.0141 & 0.2464 \\
\hline TRC129 & 0.2112 & 75.21 & 0.3223 & 0.0000 & 0.9432 & 0.2751 & 3.0456 & 0.0000 & 0.8774 & 0.0074 & 0.1896 \\
\hline TRC130 & 0.2158 & 174.81 & 0.3636 & 0.0037 & 0.5057 & 0.2211 & 2.2413 & 0.0170 & 0.8296 & 0.0352 & 0.5961 \\
\hline TRC131 & 0.1252 & 37.94 & 0.2115 & 0.0012 & 0.4572 & 0.1696 & 1.8691 & 0.0000 & 0.5491 & 0.0034 & 0.1937 \\
\hline TRC132 & 0.0000 & 30.63 & 0.1136 & 0.0000 & 0.3921 & 0.0845 & 0.8773 & 0.0000 & 0.2809 & 0.0089 & 0.1847 \\
\hline TRC133 & 0.1397 & 14.53 & 0.1580 & 0.0012 & 0.3050 & 0.1172 & 1.2646 & 0.0000 & 0.4344 & 0.0470 & 0.4684 \\
\hline TRC134 & 0.0000 & 73.48 & 0.2573 & 0.0000 & 0.5710 & 0.1933 & 2.1182 & 0.0000 & 0.6286 & 0.0061 & 0.1422 \\
\hline TRC135 & 0.2539 & 19.76 & 0.4651 & 0.0000 & 0.8474 & 0.2932 & 3.1944 & 0.0000 & 1.4264 & 0.0246 & 5.2229 \\
\hline TRC136 & 0.3362 & 240.13 & 0.3385 & 0.0000 & 0.7323 & 0.2625 & 2.8146 & 0.0000 & 0.8971 & 0.0252 & 2.0514 \\
\hline TRC137 & 0.0000 & 18.21 & 0.4128 & 0.0000 & 0.8204 & 0.3078 & 3.3892 & 0.0000 & 0.9573 & 0.0147 & 0.8271 \\
\hline TRC138 & 0.3178 & 26.30 & 0.2375 & 0.0000 & 0.5586 & 0.1655 & 1.7924 & 0.0000 & 0.5746 & 0.0182 & 0.8903 \\
\hline TRC139 & 0.2457 & 72.69 & 0.3768 & 0.0027 & 0.7656 & 0.2380 & 2.3536 & 0.0157 & 0.8880 & 0.0415 & 0.2698 \\
\hline TRC140 & 0.4349 & 20.55 & 1.1075 & 0.0083 & 0.9842 & 0.2477 & 1.5056 & 0.0586 & 2.1846 & 0.1952 & 3.6306 \\
\hline TRC141 & 0.3756 & 95.74 & 0.1643 & 0.0206 & 0.5855 & 0.1812 & 2.1691 & 0.0000 & 0.6376 & 0.0264 & 1.2517 \\
\hline TRC142 & 0.0555 & 32.17 & 0.2502 & 0.0010 & 0.6762 & 0.2744 & 3.2739 & 0.0055 & 0.9499 & 0.0132 & 0.2220 \\
\hline TRC143 & 0.2333 & 20.02 & 0.2071 & 0.0303 & 0.8145 & 0.2665 & 3.2454 & 0.0000 & 0.8706 & 0.0092 & 0.2751 \\
\hline TRC144 & 0.3058 & 292.38 & 0.2940 & 0.0033 & 0.5883 & 0.1374 & 1.2667 & 0.0261 & 0.7480 & 0.3834 & 1.9895 \\
\hline
\end{tabular}


Table 2. Concentrations of elements measured by INAA in the chert samples in this study.

\begin{tabular}{|c|c|c|c|c|c|c|c|c|c|c|c|}
\hline ANID & As (ppm) & $\mathrm{Ba}(p p m)$ & La (ppm) & Lu (ppm) & Nd (ppm) & Sm (ppm) & $U$ (ppm) & Yb (ppm) & Ce (ppm) & Co (ppm) & $\mathrm{Cr}(\mathrm{ppm})$ \\
\hline TRC145 & 0.1912 & 37.62 & 0.0551 & 0.0008 & 0.2031 & 0.0561 & 0.5953 & 0.0080 & 0.1869 & 0.0142 & 0.2236 \\
\hline TRC146 & 0.0595 & 70.78 & 0.3011 & 0.0344 & 1.0057 & 0.3258 & 3.7334 & 0.0062 & 1.0784 & 0.0137 & 0.2022 \\
\hline TRC147 & 0.2226 & 39.66 & 0.2824 & 0.0011 & 1.1676 & 0.3190 & 3.8354 & 0.0000 & 1.0258 & 0.0138 & 0.3259 \\
\hline TRC148 & 0.2585 & 41.72 & 0.1334 & 0.0162 & 0.6772 & 0.1531 & 1.8275 & 0.0000 & 0.5062 & 0.0136 & 0.3483 \\
\hline TRC149 & 0.3088 & 20.40 & 0.0730 & 0.0008 & 0.0000 & 0.0614 & 0.7240 & 0.0000 & 0.2427 & 0.0119 & 0.5369 \\
\hline TRC150 & 0.1507 & 20.12 & 0.2999 & 0.0400 & 1.3453 & 0.3727 & 4.4974 & 0.0000 & 1.1792 & 0.0086 & 0.6226 \\
\hline TRC151 & 0.0000 & 141.73 & 0.1862 & 0.0009 & 0.6472 & 0.1367 & 1.3824 & 0.0000 & 0.4642 & 0.0095 & 0.4140 \\
\hline TRC152 & 0.5138 & 34.29 & 0.2835 & 0.0000 & 0.3996 & 0.1546 & 1.5757 & 0.0000 & 0.5380 & 0.0574 & 0.1511 \\
\hline TRC153 & 0.0000 & 46.66 & 0.2353 & 0.0126 & 0.3457 & 0.1491 & 1.5365 & 0.0116 & 0.5675 & 0.0284 & 0.2564 \\
\hline TRC154 & 1.2358 & 87.00 & 0.2653 & 0.0011 & 1.0082 & 0.1734 & 1.8929 & 0.0000 & 0.6178 & 0.0580 & 0.3613 \\
\hline TRC155 & 0.5093 & 20.25 & 0.3890 & 0.0141 & 0.5303 & 0.1599 & 1.1944 & 0.0176 & 0.5998 & 0.0431 & 0.6721 \\
\hline TRC156 & 0.1609 & 20.31 & 0.1510 & 0.0009 & 0.2559 & 0.0995 & 1.0312 & 0.0000 & 0.3548 & 0.0080 & 0.8296 \\
\hline TRC157 & 0.2546 & 37.98 & 0.1668 & 0.0009 & 0.2461 & 0.1003 & 1.0432 & 0.0000 & 0.3275 & 0.0106 & 0.3473 \\
\hline TRC158 & 2.1529 & 127.87 & 0.1883 & 0.0000 & 0.0000 & 0.0479 & 0.3126 & 0.0099 & 0.3185 & 0.1375 & 0.7926 \\
\hline TRC159 & 0.2672 & 21.02 & 0.2247 & 0.0024 & 0.2536 & 0.0975 & 0.8127 & 0.0128 & 0.4243 & 0.0283 & 0.6822 \\
\hline TRC160 & 0.7894 & 41.58 & 0.1789 & 0.0126 & 0.3535 & 0.1419 & 1.5853 & 0.0063 & 0.4919 & 0.0158 & 0.9726 \\
\hline TRC161 & 0.2602 & 37.06 & 0.1148 & 0.0089 & 0.4000 & 0.0830 & 0.8925 & 0.0000 & 0.3000 & 0.0265 & 0.3497 \\
\hline TRC162 & 0.2605 & 21.80 & 0.2623 & 0.0215 & 0.6926 & 0.2463 & 2.7244 & 0.0056 & 0.7650 & 0.0201 & 0.3259 \\
\hline TRC163 & 0.2020 & 282.62 & 0.2582 & 0.0207 & 0.7775 & 0.2415 & 2.6817 & 0.0057 & 0.7467 & 0.0163 & 0.3590 \\
\hline TRC164 & 0.2642 & 213.72 & 0.2260 & 0.0139 & 0.5496 & 0.1607 & 1.6255 & 0.0059 & 0.5488 & 0.0379 & 0.5798 \\
\hline TRC165 & 0.1054 & 24.51 & 0.3151 & 0.0254 & 0.8323 & 0.2943 & 3.3050 & 0.0000 & 0.9366 & 0.0176 & 0.2915 \\
\hline TRC166 & 0.9622 & 89.85 & 0.1841 & 0.0012 & 0.2197 & 0.0984 & 0.9572 & 0.0093 & 0.3976 & 0.0499 & 0.9310 \\
\hline TRC167 & 0.1917 & 15.12 & 0.1690 & 0.0017 & 0.2876 & 0.0774 & 0.6178 & 0.0149 & 0.4174 & 0.0353 & 0.7014 \\
\hline TRC168 & 0.5499 & 92.26 & 0.2905 & 0.0167 & 0.8855 & 0.2117 & 2.1730 & 0.0000 & 0.7235 & 0.0696 & 0.5295 \\
\hline TRC169 & 0.4696 & 38.08 & 0.1978 & 0.0018 & 0.4253 & 0.1092 & 0.9715 & 0.0116 & 0.4544 & 0.0380 & 0.2481 \\
\hline TRC170 & 0.4607 & 43.34 & 0.3532 & 0.0233 & 0.8979 & 0.2515 & 2.5674 & 0.0130 & 1.0939 & 0.0502 & 0.3363 \\
\hline TRC171 & 0.2068 & 22.44 & 0.1564 & 0.0102 & 0.3069 & 0.1207 & 1.2413 & 0.0057 & 0.4312 & 0.0218 & 0.6114 \\
\hline TRC172 & 0.6730 & 19.89 & 0.1706 & 0.0013 & 0.4646 & 0.1062 & 1.0032 & 0.0129 & 0.3839 & 0.0768 & 0.2082 \\
\hline TRC173 & 0.2099 & 40.64 & 0.2362 & 0.0174 & 0.6556 & 0.2182 & 2.4182 & 0.0037 & 0.6570 & 0.0051 & 0.2065 \\
\hline TRC174 & 0.1776 & 25.36 & 0.2364 & 0.0156 & 0.5925 & 0.1828 & 1.9701 & 0.0000 & 0.5662 & 0.0152 & 0.4254 \\
\hline TRC175 & 0.0000 & 49.39 & 0.3734 & 0.0229 & 0.7636 & 0.2883 & 3.2202 & 0.0000 & 0.8461 & 0.0036 & 0.0671 \\
\hline TRC176 & 1.0467 & 34.35 & 0.4000 & 0.0103 & 0.4330 & 0.1201 & 0.6526 & 0.0378 & 1.0021 & 0.1700 & 1.7549 \\
\hline TRC177 & 0.0000 & 24.98 & 0.2959 & 0.0205 & 0.8715 & 0.2355 & 2.5413 & 0.0000 & 0.7754 & 0.0270 & 0.3924 \\
\hline TRC178 & 0.3999 & 34.22 & 0.1329 & 0.0015 & 0.1152 & 0.0686 & 0.6069 & 0.0089 & 0.3334 & 0.0227 & 0.9130 \\
\hline TRC179 & 0.1747 & 12.41 & 0.2000 & 0.0011 & 0.2704 & 0.1026 & 1.0303 & 0.0000 & 0.4062 & 0.0147 & 0.6540 \\
\hline TRC180 & 0.1497 & 11.00 & 0.2073 & 0.0057 & 0.0000 & 0.0639 & 0.7838 & 0.0000 & 0.4840 & 0.0253 & 0.5378 \\
\hline
\end{tabular}


$\stackrel{0}{\sigma}$ Table 2. Concentrations of elements measured by INAA in the chert samples in this study.

\begin{tabular}{|c|c|c|c|c|c|c|c|c|c|c|c|}
\hline ANID & As (ppm) & $\mathrm{Ba}(p p m)$ & La (ppm) & Lu (ppm) & Nd (ppm) & Sm (ppm) & $\mathrm{U}(\mathrm{ppm})$ & Yb (ppm) & $\mathrm{Ce}(p p m)$ & Co (ppm) & $\mathrm{Cr}$ (ppm) \\
\hline TRC181 & 0.0000 & 14.95 & 0.3236 & 0.0171 & 0.6894 & 0.2421 & 2.5968 & 0.0000 & 0.7131 & 0.0134 & 0.3519 \\
\hline TRC182 & 0.1193 & 35.08 & 0.4048 & 0.0233 & 0.8211 & 0.3271 & 3.5357 & 0.0000 & 0.9374 & 0.0117 & 0.1588 \\
\hline TRC183 & 0.3403 & 28.18 & 0.1994 & 0.0082 & 0.2930 & 0.1231 & 1.2141 & 0.0049 & 0.4171 & 0.0126 & 0.5508 \\
\hline TRC184 & 0.0000 & 69.58 & 0.7440 & 0.0028 & 1.6285 & 0.4950 & 5.1689 & 0.0112 & 1.5866 & 0.0453 & 0.3087 \\
\hline TRC185 & 0.6238 & 23.41 & 0.4174 & 0.0014 & 0.7481 & 0.2666 & 2.6640 & 0.0000 & 0.8386 & 0.1104 & 0.4425 \\
\hline TRC186 & 0.6462 & 57.92 & 0.2293 & 0.0018 & 0.4263 & 0.1263 & 1.1359 & 0.0121 & 0.4510 & 0.0523 & 0.5904 \\
\hline TRC187 & 0.0000 & 147.50 & 0.1955 & 0.0083 & 0.4361 & 0.1270 & 1.3324 & 0.0000 & 0.4022 & 0.0158 & 0.4204 \\
\hline TRC188 & 0.0000 & 41.54 & 0.3495 & 0.0172 & 0.4882 & 0.2433 & 2.6135 & 0.0000 & 0.6963 & 0.0081 & 0.1868 \\
\hline TRC189 & 0.0000 & 8.68 & 0.0978 & 0.0014 & 0.0997 & 0.0449 & 0.3712 & 0.0062 & 0.1715 & 0.0088 & 0.6219 \\
\hline TRC190 & 0.3596 & 44.20 & 0.4017 & 0.0009 & 0.6292 & 0.2837 & 3.0099 & 0.0000 & 0.8407 & 0.0291 & 0.3632 \\
\hline TRC191 & 0.2325 & 32.06 & 0.0868 & 0.0011 & 0.0983 & 0.0577 & 0.6326 & 0.0036 & 0.2489 & 0.0286 & 0.2076 \\
\hline TRC192 & 0.5244 & 29.33 & 0.0945 & 0.0014 & 0.1638 & 0.0538 & 0.5445 & 0.0097 & 0.2293 & 0.0339 & 2.2838 \\
\hline TRC193 & 0.3612 & 71.41 & 0.3144 & 0.0014 & 0.8207 & 0.1219 & 1.1795 & 0.0181 & 0.5731 & 0.0287 & 5.5686 \\
\hline TRC194 & 0.3708 & 34.74 & 0.1059 & 0.0010 & 0.1599 & 0.0688 & 0.7102 & 0.0076 & 0.2948 & 0.0147 & 0.8123 \\
\hline TRC195 & 0.6837 & 22.79 & 0.1301 & 0.0082 & 0.2984 & 0.0594 & 0.5740 & 0.0080 & 0.3064 & 0.0619 & 0.4124 \\
\hline TRC196 & 0.4635 & 19.08 & 0.1957 & 0.0000 & 0.5412 & 0.1705 & 1.9961 & 0.0000 & 0.6084 & 0.0108 & 0.5506 \\
\hline TRC197 & 0.2240 & 32.04 & 0.1848 & 0.0011 & 0.3427 & 0.1161 & 1.2176 & 0.0124 & 0.4962 & 0.0384 & 0.4334 \\
\hline TRC198 & 0.2595 & 28.16 & 0.3678 & 0.0020 & 0.9998 & 0.2440 & 2.5867 & 0.0178 & 1.0481 & 0.0448 & 0.5996 \\
\hline TRC199 & 0.0000 & 15.50 & 0.0945 & 0.0008 & 0.1741 & 0.0562 & 0.5675 & 0.0064 & 0.2429 & 0.0143 & 0.2617 \\
\hline TRC200 & 1.1844 & 109.89 & 0.7021 & 0.0000 & 1.4961 & 0.3883 & 4.4237 & 0.0140 & 1.8777 & 0.2624 & 0.6522 \\
\hline TRC201 & 0.1337 & 22.39 & 0.1395 & 0.0010 & 0.2093 & 0.0970 & 1.0589 & 0.0032 & 0.3759 & 0.0070 & 0.3750 \\
\hline TRC202 & 0.8128 & 21.08 & 0.0856 & 0.0051 & 0.1649 & 0.0511 & 0.4924 & 0.0000 & 0.2378 & 0.0237 & 0.7016 \\
\hline TRC203 & 0.3416 & 16.56 & 0.1526 & 0.0112 & 0.4752 & 0.1229 & 1.3772 & 0.0048 & 0.4615 & 0.0138 & 0.6678 \\
\hline TRC204 & 0.2416 & 36.17 & 0.2207 & 0.0000 & 0.4695 & 0.1927 & 2.1988 & 0.0000 & 0.6192 & 0.0058 & 0.1629 \\
\hline TRC205 & 0.1617 & 15.87 & 0.2226 & 0.0000 & 0.5575 & 0.2247 & 2.6180 & 0.0000 & 0.7152 & 0.0042 & 0.1697 \\
\hline TRC206 & 0.6505 & 47.45 & 0.1473 & 0.0011 & 0.7089 & 0.0798 & 0.8561 & 0.0030 & 0.3478 & 0.0179 & 0.5376 \\
\hline TRC207 & 0.1524 & 20.57 & 0.1902 & 0.0019 & 0.2754 & 0.1087 & 1.0314 & 0.0101 & 0.5281 & 0.0110 & 0.3681 \\
\hline TRC208 & 0.1741 & 30.39 & 0.1152 & 0.0010 & 0.1687 & 0.0890 & 1.0133 & 0.0000 & 0.3001 & 0.0070 & 0.1745 \\
\hline TRC209 & 0.0000 & 11.05 & 0.1007 & 0.0006 & 0.1821 & 0.0601 & 0.6376 & 0.0000 & 0.2231 & 0.0051 & 0.2172 \\
\hline TRC210 & 0.2671 & 34.00 & 0.3969 & 0.0000 & 1.0666 & 0.3618 & 4.2210 & 0.0000 & 1.1410 & 0.0114 & 0.1061 \\
\hline TRC211 & 0.1804 & 43.26 & 0.2227 & 0.0128 & 0.3263 & 0.1457 & 1.5994 & 0.0000 & 0.4924 & 0.0122 & 0.2165 \\
\hline TRC212 & 0.0933 & 74.57 & 0.2855 & 0.0011 & 0.9040 & 0.3118 & 3.6721 & 0.0000 & 1.0098 & 0.0198 & 0.4294 \\
\hline TRC213 & 0.3337 & 23.45 & 0.0846 & 0.0048 & 0.1682 & 0.0577 & 0.6567 & 0.0000 & 0.2120 & 0.0110 & 0.2304 \\
\hline TRC214 & 0.1286 & 35.35 & 0.0857 & 0.0092 & 0.3628 & 0.0905 & 1.0825 & 0.0000 & 0.2979 & 0.0060 & 0.1710 \\
\hline TRC215 & 0.4419 & 55.55 & 0.2915 & 0.0024 & 0.8168 & 0.2613 & 2.7866 & 0.0087 & 0.9835 & 0.0523 & 0.5434 \\
\hline TRC216 & 0.5748 & 174.53 & 0.1088 & 0.0077 & 0.5793 & 0.0825 & 0.8880 & 0.0094 & 0.3286 & 0.0490 & 0.7581 \\
\hline
\end{tabular}


Table 2. Concentrations of elements measured by INAA in the chert samples in this study.

\begin{tabular}{|c|c|c|c|c|c|c|c|c|c|c|c|}
\hline ANID & As (ppm) & $\mathrm{Ba}(p p m)$ & La (ppm) & Lu (ppm) & Nd (ppm) & Sm (ppm) & $U$ (ppm) & Yb (ppm) & Ce (ppm) & Co (ppm) & $\mathrm{Cr}(\mathbf{p p m})$ \\
\hline TRC217 & 0.2891 & 38.77 & 0.1756 & 0.0007 & 0.4591 & 0.0752 & 0.6373 & 0.0102 & 0.2861 & 0.0231 & 0.4044 \\
\hline TRC218 & 0.3547 & 37.14 & 0.7676 & 0.0028 & 1.9418 & 0.6000 & 6.7603 & 0.0119 & 2.1483 & 0.0656 & 0.8265 \\
\hline TRC219 & 0.2993 & 45.50 & 0.2057 & 0.0000 & 0.6016 & 0.1579 & 1.7313 & 0.0000 & 0.5424 & 0.0289 & 0.0917 \\
\hline TRC220 & 0.3569 & 36.22 & 0.4261 & 0.0000 & 0.9389 & 0.3648 & 4.2354 & 0.0000 & 1.1961 & 0.0144 & 0.2574 \\
\hline TRC221 & 0.3625 & 79.70 & 0.1505 & 0.0000 & 0.0000 & 0.0803 & 0.8021 & 0.0000 & 0.3400 & 0.0141 & 0.8396 \\
\hline TRC222 & 0.2041 & 31.44 & 0.2446 & 0.0000 & 0.5620 & 0.1874 & 2.1681 & 0.0000 & 0.6280 & 0.0059 & 0.2064 \\
\hline TRC223 & 0.1083 & 15.57 & 0.2284 & 0.0000 & 0.5442 & 0.1644 & 1.8268 & 0.0000 & 0.5631 & 0.0102 & 0.2920 \\
\hline TRC224 & 0.3850 & 58.97 & 0.2427 & 0.0000 & 0.4784 & 0.1647 & 1.8100 & 0.0000 & 0.6113 & 0.0089 & 0.1317 \\
\hline TRC225 & 0.3881 & 135.18 & 0.1552 & 0.0024 & 0.0000 & 0.0925 & 0.9206 & 0.0000 & 0.4094 & 0.0134 & 0.8621 \\
\hline TRC226 & 0.2232 & 35.63 & 0.1203 & 0.0048 & 0.0000 & 0.0581 & 0.5076 & 0.0072 & 0.2762 & 0.0321 & 0.2181 \\
\hline TRC227 & 0.0000 & 15.00 & 0.0999 & 0.0050 & 0.0000 & 0.0501 & 0.5064 & 0.0075 & 0.2272 & 0.0167 & 0.2925 \\
\hline TRC228 & 0.2975 & 17.23 & 0.1699 & 0.0000 & 0.3864 & 0.1158 & 1.3015 & 0.0049 & 0.4408 & 0.0434 & 2.0460 \\
\hline TRC229 & 0.5019 & 591.24 & 0.1668 & 0.0019 & 0.6573 & 0.0756 & 0.7435 & 0.0000 & 0.3521 & 0.0205 & 0.8440 \\
\hline TRC230 & 0.1297 & 54.60 & 0.1689 & 0.0000 & 0.3394 & 0.1177 & 1.3088 & 0.0000 & 0.4466 & 0.0101 & 0.1824 \\
\hline TRC231 & 0.0000 & 15.81 & 0.4475 & 0.0000 & 0.4813 & 0.1508 & 0.9425 & 0.0287 & 0.7881 & 0.0259 & 0.8310 \\
\hline TRC232 & 0.0000 & 29.64 & 0.2443 & 0.0186 & 0.8716 & 0.2150 & 2.5223 & 0.0000 & 0.7211 & 0.0098 & 0.1893 \\
\hline TRC233 & 0.3995 & 104.73 & 0.1765 & 0.0179 & 0.0000 & 0.1672 & 1.8924 & 0.0000 & 0.5951 & 0.0124 & 0.1473 \\
\hline TRC234 & 0.8687 & 39.30 & 0.3679 & 0.0345 & 1.6150 & 0.3707 & 4.3329 & 0.0000 & 1.2425 & 0.0327 & 0.4568 \\
\hline TRC235 & 0.2678 & 22.53 & 0.2767 & 0.0087 & 0.0000 & 0.0801 & 0.8884 & 0.0000 & 0.3754 & 0.0177 & 0.2804 \\
\hline TRC236 & 0.3109 & 111.04 & 0.1969 & 0.0091 & 0.0000 & 0.1053 & 1.1568 & 0.0000 & 0.5052 & 0.0219 & 0.9254 \\
\hline TRC237 & 0.4114 & 34.05 & 0.2578 & 0.0023 & 0.0000 & 0.1486 & 1.6555 & 0.0000 & 0.6753 & 0.0282 & 0.6944 \\
\hline TRC238 & 0.7247 & 71.71 & 0.5590 & 0.0547 & 2.1014 & 0.5611 & 6.5665 & 0.0000 & 1.8942 & 0.0383 & 0.2819 \\
\hline TRC239 & 0.0000 & 16.64 & 0.0939 & 0.0030 & 0.0000 & 0.0259 & 0.2727 & 0.0000 & 0.1943 & 0.0133 & 0.2223 \\
\hline TRC240 & 0.0000 & 23.44 & 0.2430 & 0.0202 & 0.6010 & 0.2421 & 2.8361 & 0.0000 & 0.7870 & 0.0081 & 0.2232 \\
\hline TRC241 & 0.0000 & 19.00 & 0.1768 & 0.0086 & 0.4048 & 0.1066 & 1.1550 & 0.0000 & 0.3857 & 0.0175 & 1.8619 \\
\hline TRC242 & 0.4277 & 31.70 & 0.2046 & 0.0014 & 0.5603 & 0.1792 & 2.0151 & 0.0156 & 0.5594 & 0.0565 & 0.1649 \\
\hline TRC243 & 0.0000 & 31.63 & 0.5002 & 0.0012 & 0.7216 & 0.0959 & 0.9652 & 0.0068 & 1.2600 & 0.0374 & 0.4264 \\
\hline TRC244 & 0.5044 & 36.39 & 0.2158 & 0.0141 & 0.4200 & 0.1588 & 1.5842 & 0.0000 & 0.5792 & 0.0433 & 0.4851 \\
\hline TRC245 & 0.0000 & 31.76 & 0.2353 & 0.0162 & 1.3683 & 0.1923 & 2.3210 & 0.0000 & 0.6143 & 0.0102 & 0.0910 \\
\hline TRC246 & 0.2222 & 77.00 & 0.3710 & 0.0319 & 1.7760 & 0.3636 & 4.2299 & 0.0000 & 1.1059 & 0.0059 & 0.2214 \\
\hline TRC247 & 0.0000 & 123.92 & 0.6160 & 0.0034 & 2.0235 & 0.6200 & 7.3256 & 0.0000 & 1.9044 & 0.0235 & 0.0802 \\
\hline TRC248 & 0.2534 & 22.98 & 0.3774 & 0.0300 & 1.2340 & 0.3498 & 4.0399 & 0.0000 & 1.1831 & 0.0320 & 3.0890 \\
\hline TRC249 & 0.4173 & 92.88 & 0.3299 & 0.0200 & 1.7738 & 0.2404 & 2.8195 & 0.0000 & 0.8815 & 0.0137 & 0.2876 \\
\hline TRC250 & 0.0000 & 33.90 & 0.2344 & 0.0175 & 0.7110 & 0.2106 & 2.4095 & 0.0000 & 0.6563 & 0.0204 & 0.5080 \\
\hline TRC251 & 0.4423 & 30.28 & 0.4089 & 0.0563 & 1.6502 & 0.5318 & 6.4823 & 0.0000 & 1.6602 & 0.0203 & 0.2849 \\
\hline TRC252 & 0.1851 & 24.03 & 0.0924 & 0.0103 & 0.4107 & 0.0969 & 1.1507 & 0.0000 & 0.3306 & 0.0235 & 0.7481 \\
\hline
\end{tabular}




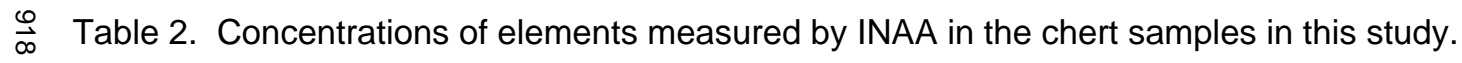

\begin{tabular}{|c|c|c|c|c|c|c|c|c|c|c|c|}
\hline ANID & As (ppm) & $\mathrm{Ba}(p p m)$ & La (ppm) & Lu (ppm) & Nd (ppm) & Sm (ppm) & U (ppm) & Yb (ppm) & $\mathrm{Ce}(\mathrm{ppm})$ & Co (ppm) & $\mathrm{Cr}(\mathrm{ppm})$ \\
\hline TRC253 & 0.4644 & 32.41 & 0.1022 & 0.0016 & 0.3334 & 0.0828 & 0.9149 & 0.0057 & 0.3329 & 0.0125 & 0.8624 \\
\hline TRC254 & 0.4344 & 46.01 & 0.1127 & 0.0027 & 0.1950 & 0.0781 & 0.6482 & 0.0165 & 0.2608 & 0.0466 & 0.8092 \\
\hline TRC255 & 0.5556 & 282.04 & 32.9773 & 0.2678 & 29.0397 & 5.8433 & 3.4357 & 2.0616 & 68.4576 & 0.0642 & 0.6858 \\
\hline TRC256 & 0.3847 & 16.30 & 0.1119 & 0.0018 & 0.2804 & 0.0702 & 0.7052 & 0.0149 & 0.3124 & 0.0437 & 0.6166 \\
\hline TRC257 & 0.5411 & 14.82 & 0.0932 & 0.0014 & 0.3775 & 0.0659 & 0.6084 & 0.0147 & 0.2502 & 0.0435 & 0.8294 \\
\hline TRC258 & 0.4172 & 20.76 & 0.1173 & 0.0030 & 0.2790 & 0.0967 & 1.0258 & 0.0073 & 0.3430 & 0.0207 & 0.7909 \\
\hline TRC259 & 0.4525 & 171.51 & 0.2096 & 0.0017 & 0.6558 & 0.2121 & 2.4269 & 0.0096 & 0.7293 & 0.0814 & 0.4492 \\
\hline TRC260 & 0.1857 & 52.79 & 0.2664 & 0.0008 & 0.9645 & 0.2554 & 2.9491 & 0.0061 & 0.9019 & 0.0217 & 0.2622 \\
\hline TRC261 & 0.4587 & 176.62 & 0.1870 & 0.0012 & 0.5367 & 0.1786 & 2.0097 & 0.0069 & 0.6098 & 0.1246 & 1.1224 \\
\hline
\end{tabular}


Table 2. Concentrations of elements measured by INAA in the chert samples in this study.

\begin{tabular}{|c|c|c|c|c|c|c|c|c|c|c|c|}
\hline ANID & Cs (ppm) & Eu (ppm) & $\mathrm{Fe}(p p m)$ & Hf (ppm) & $\mathrm{Ni}(p p m)$ & $\mathrm{Rb}(p p m)$ & Sb (ppm) & Sc (ppm) & $\mathrm{Sr}(\mathrm{ppm})$ & $\mathrm{Ta}(\mathrm{ppm})$ & Tb (ppm) \\
\hline TRC001 & 0.0403 & 0.0017 & 40.2 & 0.0284 & 0.00 & 0.16 & 0.0404 & 0.0061 & 540.27 & 0.0000 & 0.0000 \\
\hline TRC002 & 0.0190 & 0.0000 & 30.2 & 0.0080 & 0.00 & 0.15 & 0.0323 & 0.0070 & 13.46 & 0.0000 & 0.0000 \\
\hline TRC003 & 0.0663 & 0.0030 & 21.0 & 0.0245 & 0.00 & 0.21 & 0.0390 & 0.0077 & 9.06 & 0.0000 & 0.0010 \\
\hline TRC004 & 0.0891 & 0.0009 & 23.0 & 0.0262 & 0.00 & 0.48 & 0.0241 & 0.0040 & 18.20 & 0.0011 & 0.0000 \\
\hline TRC005 & 0.0752 & 0.0000 & 33.8 & 0.0111 & 0.00 & 0.19 & 0.0528 & 0.0046 & 8.99 & 0.0000 & 0.0000 \\
\hline TRC006 & 0.0450 & 0.0000 & 19.3 & 0.0199 & 0.00 & 0.11 & 0.0166 & 0.0048 & 115.27 & 0.0000 & 0.0000 \\
\hline TRC007 & 0.0186 & 0.0024 & 155.2 & 0.0194 & 0.00 & 0.27 & 0.0662 & 0.0299 & 6.82 & 0.0029 & 0.0000 \\
\hline TRC008 & 0.0109 & 0.0013 & 26.2 & 0.0163 & 0.00 & 0.09 & 0.0401 & 0.0066 & 5.12 & 0.0000 & 0.0000 \\
\hline TRC009 & 0.0319 & 0.0010 & 282.0 & 0.0243 & 1.44 & 0.24 & 0.0827 & 0.0282 & 3.66 & 0.0021 & 0.0000 \\
\hline TRC010 & 0.0097 & 0.0011 & 55.1 & 0.0089 & 0.00 & 0.15 & 0.0518 & 0.0167 & 1.11 & 0.0000 & 0.0000 \\
\hline TRC011 & 0.0172 & 0.0022 & 45.5 & 0.0129 & 0.00 & 0.18 & 0.0400 & 0.0159 & 0.00 & 0.0000 & 0.0000 \\
\hline TRC012 & 0.0157 & 0.0000 & 55.5 & 0.0104 & 0.00 & 0.18 & 0.0250 & 0.0201 & 2.68 & 0.0000 & 0.0000 \\
\hline TRC013 & 0.0157 & 0.0025 & 47.6 & 0.0132 & 0.00 & 0.00 & 0.0062 & 0.0120 & 36.95 & 0.0000 & 0.0000 \\
\hline TRC014 & 0.0332 & 0.0022 & 99.6 & 0.0326 & 0.00 & 0.22 & 0.0328 & 0.0237 & 6.98 & 0.0000 & 0.0000 \\
\hline TRC015 & 0.0505 & 0.0018 & 169.4 & 0.0525 & 0.00 & 0.18 & 0.0465 & 0.0188 & 5.85 & 0.0024 & 0.0000 \\
\hline TRC016 & 0.0169 & 0.0028 & 62.1 & 0.0105 & 0.00 & 0.11 & 0.0583 & 0.0148 & 1.98 & 0.0000 & 0.0000 \\
\hline TRC017 & 0.0385 & 0.0016 & 59.8 & 0.0383 & 0.00 & 0.19 & 0.0839 & 0.0077 & 6.59 & 0.0000 & 0.0000 \\
\hline TRC018 & 0.0300 & 0.0014 & 52.9 & 0.0142 & 0.00 & 0.27 & 0.0420 & 0.0073 & 5.56 & 0.0000 & 0.0000 \\
\hline TRC019 & 0.0473 & 0.0034 & 34.1 & 0.0681 & 0.00 & 0.27 & 0.0083 & 0.0110 & 13.75 & 0.0000 & 0.0000 \\
\hline TRC020 & 0.0478 & 0.0029 & 62.6 & 0.0436 & 0.00 & 0.35 & 0.0112 & 0.0147 & 19.49 & 0.0000 & 0.0016 \\
\hline TRC021 & 0.0449 & 0.0025 & 48.1 & 0.0333 & 0.00 & 0.33 & 0.0114 & 0.0120 & 6.71 & 0.0000 & 0.0000 \\
\hline TRC022 & 0.0396 & 0.0053 & 37.3 & 0.0436 & 0.00 & 0.21 & 0.0066 & 0.0219 & 20.22 & 0.0000 & 0.0030 \\
\hline TRC023 & 0.0482 & 0.0034 & 89.5 & 0.0717 & 0.00 & 0.29 & 0.0226 & 0.0094 & 5.66 & 0.0000 & 0.0000 \\
\hline TRC024 & 0.0618 & 0.0029 & 96.7 & 0.0880 & 0.00 & 0.37 & 0.0208 & 0.0098 & 6.27 & 0.0000 & 0.0000 \\
\hline TRC025 & 0.0491 & 0.0027 & 50.7 & 0.0373 & 0.00 & 0.26 & 0.0083 & 0.0114 & 15.40 & 0.0000 & 0.0000 \\
\hline TRC026 & 0.0523 & 0.0025 & 35.5 & 0.0522 & 0.00 & 0.23 & 0.0111 & 0.0098 & 12.46 & 0.0000 & 0.0000 \\
\hline TRC027 & 0.0665 & 0.0015 & 74.7 & 0.0466 & 0.00 & 0.21 & 0.0241 & 0.0096 & 7.67 & 0.0000 & 0.0000 \\
\hline TRC028 & 0.0665 & 0.0023 & 152.8 & 0.0488 & 0.00 & 0.25 & 0.0196 & 0.0098 & 12.55 & 0.0000 & 0.0000 \\
\hline TRC029 & 0.0352 & 0.0022 & 112.3 & 0.0228 & 0.00 & 0.26 & 0.0094 & 0.0087 & 597.37 & 0.0000 & 0.0000 \\
\hline TRC030 & 0.0476 & 0.0021 & 79.8 & 0.0378 & 0.00 & 0.23 & 0.0105 & 0.0094 & 12.98 & 0.0000 & 0.0000 \\
\hline TRC031 & 0.0616 & 0.0049 & 869.2 & 0.0740 & 0.00 & 0.43 & 0.1031 & 0.0216 & 8.06 & 0.0016 & 0.0000 \\
\hline TRC032 & 0.0509 & 0.0015 & 59.9 & 0.0341 & 0.00 & 0.26 & 0.0119 & 0.0081 & 6.91 & 0.0000 & 0.0000 \\
\hline TRC033 & 0.0356 & 0.0019 & 76.3 & 0.0104 & 0.00 & 0.07 & 0.0074 & 0.0046 & 16.07 & 0.0000 & 0.0000 \\
\hline TRC034 & 0.0409 & 0.0014 & 75.3 & 0.0076 & 0.00 & 0.19 & 0.0147 & 0.0114 & 5.21 & 0.0000 & 0.0000 \\
\hline TRC035 & 0.0123 & 0.0025 & 47.8 & 0.0084 & 0.00 & 0.11 & 0.0168 & 0.0133 & 18.23 & 0.0000 & 0.0000 \\
\hline TRC036 & 0.0643 & 0.0017 & 59.8 & 0.0657 & 0.00 & 0.20 & 0.0098 & 0.0080 & 11.62 & 0.0000 & 0.0000 \\
\hline
\end{tabular}


N. Table 2. Concentrations of elements measured by INAA in the chert samples in this study.

\begin{tabular}{|c|c|c|c|c|c|c|c|c|c|c|c|}
\hline ANID & Cs (ppm) & $\mathrm{Eu}(p p m)$ & $\mathrm{Fe}(p p m)$ & Hf (ppm) & $\mathrm{Ni}$ (ppm) & $\mathrm{Rb}$ (ppm) & Sb (ppm) & Sc (ppm) & Sr (ppm) & $\mathrm{Ta}$ (ppm) & $\mathrm{Tb}$ (ppm) \\
\hline TRC037 & 0.0584 & 0.0023 & 224.1 & 0.0355 & 0.00 & 0.29 & 0.0297 & 0.0323 & 7.77 & 0.0033 & 0.0000 \\
\hline TRC038 & 0.0387 & 0.0014 & 69.2 & 0.0107 & 0.00 & 0.18 & 0.0184 & 0.0085 & 10.62 & 0.0000 & 0.0000 \\
\hline TRC039 & 0.0524 & 0.0025 & 129.9 & 0.0633 & 0.00 & 0.21 & 0.0105 & 0.0101 & 7.95 & 0.0022 & 0.0000 \\
\hline TRC040 & 0.0253 & 0.0022 & 72.6 & 0.0147 & 0.00 & 0.15 & 0.0144 & 0.0204 & 15.06 & 0.0000 & 0.0000 \\
\hline TRC041 & 0.0532 & 0.0021 & 185.1 & 0.0420 & 0.00 & 0.22 & 0.0212 & 0.0126 & 11.54 & 0.0016 & 0.0000 \\
\hline TRC042 & 0.0879 & 0.0023 & 278.0 & 0.0886 & 0.00 & 0.48 & 0.0298 & 0.0137 & 21.74 & 0.0000 & 0.0000 \\
\hline TRC043 & 0.0298 & 0.0007 & 82.2 & 0.0100 & 0.00 & 0.12 & 0.0127 & 0.0066 & 21.79 & 0.0000 & 0.0000 \\
\hline TRC044 & 0.0747 & 0.0025 & 179.2 & 0.0469 & 0.00 & 0.40 & 0.0272 & 0.0341 & 9.68 & 0.0043 & 0.0000 \\
\hline TRC045 & 0.0449 & 0.0024 & 154.4 & 0.0212 & 0.00 & 0.12 & 0.0267 & 0.0123 & 6.87 & 0.0000 & 0.0000 \\
\hline TRC046 & 0.0856 & 0.0021 & 89.6 & 0.0498 & 0.00 & 0.29 & 0.0124 & 0.0057 & 8.78 & 0.0000 & 0.0000 \\
\hline TRC047 & 0.0000 & 0.0031 & 94.3 & 0.0060 & 0.00 & 0.10 & 0.0267 & 0.0352 & 4.88 & 0.0000 & 0.0000 \\
\hline TRC048 & 0.0265 & 0.0023 & 125.8 & 0.0394 & 0.88 & 0.27 & 0.0263 & 0.0173 & 2.94 & 0.0000 & 0.0000 \\
\hline TRC049 & 0.0334 & 0.0032 & 171.0 & 0.0332 & 0.00 & 0.45 & 0.0386 & 0.0316 & 7.17 & 0.0052 & 0.0000 \\
\hline TRC050 & 0.0120 & 0.0026 & 79.5 & 0.0056 & 0.00 & 0.19 & 0.0297 & 0.0156 & 0.00 & 0.0000 & 0.0000 \\
\hline TRC051 & 0.0080 & 0.0061 & 155.8 & 0.0243 & 0.00 & 0.21 & 0.0589 & 0.0345 & 14.97 & 0.0045 & 0.0044 \\
\hline TRC052 & 0.0060 & 0.0020 & 92.8 & 0.0069 & 0.00 & 0.00 & 0.0268 & 0.0219 & 3.94 & 0.0000 & 0.0000 \\
\hline TRC053 & 0.0263 & 0.0021 & 92.8 & 0.0184 & 0.00 & 0.25 & 0.0217 & 0.0114 & 12.15 & 0.0000 & 0.0000 \\
\hline TRC054 & 0.0464 & 0.0016 & 67.2 & 0.0289 & 0.00 & 0.33 & 0.0129 & 0.0072 & 15.38 & 0.0000 & 0.0000 \\
\hline TRC055 & 0.0543 & 0.0032 & 74.9 & 0.0521 & 0.00 & 0.29 & 0.0191 & 0.0109 & 11.04 & 0.0000 & 0.0000 \\
\hline TRC056 & 0.0339 & 0.0028 & 78.5 & 0.0249 & 0.00 & 0.22 & 0.0183 & 0.0116 & 5.71 & 0.0000 & 0.0000 \\
\hline TRC057 & 0.0549 & 0.0024 & 77.9 & 0.0120 & 0.00 & 0.30 & 0.0140 & 0.0102 & 8.20 & 0.0000 & 0.0000 \\
\hline TRC058 & 0.0290 & 0.0019 & 83.6 & 0.0112 & 0.00 & 0.21 & 0.0192 & 0.0115 & 8.38 & 0.0021 & 0.0000 \\
\hline TRC059 & 0.0337 & 0.0026 & 72.8 & 0.0096 & 0.00 & 0.20 & 0.0203 & 0.0108 & 5.79 & 0.0000 & 0.0000 \\
\hline TRC060 & 0.0368 & 0.0022 & 105.3 & 0.0118 & 0.00 & 0.29 & 0.0182 & 0.0118 & 8.10 & 0.0000 & 0.0000 \\
\hline TRC061 & 0.0192 & 0.0034 & 110.2 & 0.0788 & 0.00 & 0.25 & 0.0245 & 0.0271 & 35.41 & 0.0000 & 0.0000 \\
\hline TRC062 & 0.0125 & 0.0049 & 173.3 & 0.0376 & 0.00 & 0.00 & 0.0433 & 0.0480 & 71.55 & 0.0000 & 0.0000 \\
\hline TRC063 & 0.0178 & 0.0025 & 146.8 & 0.0848 & 0.00 & 0.10 & 0.0307 & 0.0276 & 12.42 & 0.0018 & 0.0000 \\
\hline TRC064 & 0.0295 & 0.0027 & 220.2 & 0.0655 & 0.00 & 0.33 & 0.0471 & 0.0277 & 13.01 & 0.0022 & 0.0000 \\
\hline TRC065 & 0.0213 & 0.0037 & 224.3 & 0.0658 & 0.00 & 0.44 & 0.0477 & 0.0419 & 32.05 & 0.0000 & 0.0033 \\
\hline TRC066 & 0.1555 & 0.0036 & 542.1 & 0.1448 & 0.00 & 1.01 & 0.0562 & 0.0345 & 12.90 & 0.0110 & 0.0000 \\
\hline TRC067 & 0.0636 & 0.0024 & 131.7 & 0.0289 & 0.00 & 0.29 & 0.0285 & 0.0150 & 25.31 & 0.0033 & 0.0000 \\
\hline TRC068 & 0.0897 & 0.0019 & 53.3 & 0.0861 & 0.00 & 0.29 & 0.0117 & 0.0078 & 10.74 & 0.0000 & 0.0000 \\
\hline TRC069 & 0.0990 & 0.0025 & 268.6 & 0.0993 & 0.00 & 0.48 & 0.0435 & 0.0133 & 7.09 & 0.0043 & 0.0000 \\
\hline TRC070 & 0.0991 & 0.0031 & 115.9 & 0.1185 & 0.00 & 0.47 & 0.0271 & 0.0117 & 11.87 & 0.0054 & 0.0014 \\
\hline TRC071 & 0.1301 & 0.0027 & 227.2 & 0.1396 & 0.00 & 0.71 & 0.0234 & 0.0163 & 14.79 & 0.0050 & 0.0000 \\
\hline TRC072 & 0.1355 & 0.0026 & 158.3 & 0.1108 & 0.00 & 0.54 & 0.0414 & 0.0095 & 53.80 & 0.0031 & 0.0000 \\
\hline
\end{tabular}


Table 2. Concentrations of elements measured by INAA in the chert samples in this study.

\begin{tabular}{|c|c|c|c|c|c|c|c|c|c|c|c|}
\hline ANID & Cs (ppm) & Eu (ppm) & $\mathrm{Fe}(p p m)$ & Hf (ppm) & $\mathrm{Ni}(p p m)$ & $\mathrm{Rb}(p p m)$ & Sb (ppm) & Sc (ppm) & $\operatorname{Sr}(p p m)$ & $\mathrm{Ta}(\mathrm{ppm})$ & Tb (ppm) \\
\hline TRC073 & 0.1348 & 0.0040 & 407.7 & 0.1258 & 0.00 & 0.42 & 0.1065 & 0.0115 & 51.01 & 0.0026 & 0.0000 \\
\hline TRC074 & 0.1397 & 0.0030 & 260.1 & 0.1385 & 0.00 & 0.75 & 0.0935 & 0.0132 & 18.95 & 0.0063 & 0.0000 \\
\hline TRC075 & 0.0929 & 0.0025 & 334.5 & 0.1507 & 0.00 & 0.65 & 0.0545 & 0.0158 & 6.60 & 0.0057 & 0.0020 \\
\hline TRC076 & 0.0756 & 0.0000 & 59.0 & 0.1357 & 0.00 & 0.35 & 0.0201 & 0.0023 & 12.49 & 0.0000 & 0.0000 \\
\hline TRC077 & 0.0823 & 0.0000 & 91.3 & 0.1204 & 0.00 & 0.51 & 0.0846 & 0.0036 & 3.48 & 0.0000 & 0.0000 \\
\hline TRC078 & 0.1031 & 0.0000 & 2087.2 & 0.1468 & 5.68 & 0.86 & 0.3827 & 0.0119 & 13.71 & 0.0078 & 0.0000 \\
\hline TRC079 & 0.0986 & 0.0017 & 154.9 & 0.1142 & 0.00 & 0.51 & 0.0113 & 0.0192 & 20.93 & 0.0038 & 0.0000 \\
\hline TRC080 & 0.0967 & 0.0011 & 114.3 & 0.1035 & 0.00 & 0.48 & 0.0234 & 0.0129 & 50.16 & 0.0073 & 0.0000 \\
\hline TRC081 & 0.1124 & 0.0000 & 57.0 & 0.0960 & 0.00 & 0.59 & 0.0202 & 0.0046 & 27.58 & 0.0019 & 0.0000 \\
\hline TRC082 & 0.0947 & 0.0059 & 332.9 & 0.0510 & 0.00 & 0.56 & 0.0298 & 0.0400 & 13.73 & 0.0062 & 0.0038 \\
\hline TRC083 & 0.0436 & 0.0000 & 63.9 & 0.0454 & 0.00 & 0.25 & 0.0121 & 0.0121 & 5.37 & 0.0000 & 0.0000 \\
\hline TRC084 & 0.0467 & 0.0000 & 16.3 & 0.0651 & 0.00 & 0.18 & 0.0000 & 0.0060 & 2.77 & 0.0000 & 0.0000 \\
\hline TRC085 & 0.0440 & 0.0020 & 135.8 & 0.0430 & 0.00 & 0.20 & 0.0255 & 0.0155 & 4.58 & 0.0014 & 0.0000 \\
\hline TRC086 & 0.0531 & 0.0000 & 19.7 & 0.0471 & 0.00 & 0.22 & 0.0056 & 0.0051 & 4.82 & 0.0000 & 0.0000 \\
\hline TRC087 & 0.0397 & 0.0000 & 36.1 & 0.0441 & 0.00 & 0.18 & 0.0103 & 0.0053 & 5.01 & 0.0000 & 0.0000 \\
\hline TRC088 & 0.0444 & 0.0000 & 36.5 & 0.0300 & 0.00 & 0.23 & 0.0881 & 0.0046 & 2.77 & 0.0000 & 0.0000 \\
\hline TRC089 & 0.0303 & 0.0014 & 28.0 & 0.0277 & 0.00 & 0.00 & 0.0043 & 0.0145 & 22.27 & 0.0000 & 0.0000 \\
\hline TRC090 & 0.0633 & 0.0021 & 75.1 & 0.0518 & 0.00 & 0.31 & 0.0218 & 0.0126 & 3.96 & 0.0000 & 0.0000 \\
\hline TRC091 & 0.0665 & 0.0000 & 37.0 & 0.0573 & 0.00 & 0.29 & 0.0114 & 0.0058 & 5.23 & 0.0031 & 0.0000 \\
\hline TRC092 & 0.0300 & 0.0019 & 214.2 & 0.0361 & 0.00 & 0.38 & 0.0566 & 0.0555 & 8.00 & 0.0036 & 0.0000 \\
\hline TRC093 & 0.0743 & 0.0024 & 72.8 & 0.0799 & 0.00 & 0.34 & 0.0112 & 0.0106 & 7.37 & 0.0051 & 0.0000 \\
\hline TRC094 & 0.0278 & 0.0009 & 134.1 & 0.0144 & 0.00 & 0.21 & 0.0205 & 0.0315 & 5.56 & 0.0027 & 0.0000 \\
\hline TRC095 & 0.0387 & 0.0018 & 60.1 & 0.0345 & 0.00 & 0.17 & 0.0253 & 0.0076 & 3.31 & 0.0000 & 0.0000 \\
\hline TRC096 & 0.0558 & 0.0037 & 163.8 & 0.0779 & 0.00 & 0.29 & 0.0280 & 0.0141 & 5.09 & 0.0019 & 0.0051 \\
\hline TRC097 & 0.0487 & 0.0011 & 28.5 & 0.0640 & 0.00 & 0.33 & 0.0147 & 0.0079 & 9.82 & 0.0000 & 0.0016 \\
\hline TRC098 & 0.0529 & 0.0005 & 22.6 & 0.0645 & 0.00 & 0.29 & 0.0089 & 0.0039 & 7.68 & 0.0000 & 0.0000 \\
\hline TRC099 & 0.0197 & 0.0000 & 41.4 & 0.0094 & 0.00 & 0.17 & 0.0265 & 0.0075 & 2.98 & 0.0000 & 0.0000 \\
\hline TRC100 & 0.0474 & 0.0000 & 33.5 & 0.0313 & 0.00 & 0.21 & 0.0923 & 0.0062 & 6.17 & 0.0000 & 0.0000 \\
\hline TRC101 & 0.0146 & 0.0013 & 45.9 & 0.0068 & 0.00 & 0.20 & 0.0331 & 0.0108 & 1.29 & 0.0000 & 0.0000 \\
\hline TRC102 & 0.1022 & 0.0000 & 21.5 & 0.1077 & 0.00 & 0.42 & 0.0126 & 0.0062 & 4.46 & 0.0037 & 0.0000 \\
\hline TRC103 & 0.0113 & 0.0000 & 54.7 & 0.0154 & 0.00 & 0.19 & 0.0140 & 0.0274 & 4.14 & 0.0030 & 0.0000 \\
\hline TRC104 & 0.0657 & 0.0000 & 72.5 & 0.0759 & 0.00 & 0.59 & 0.0141 & 0.0122 & 5.41 & 0.0000 & 0.0000 \\
\hline TRC105 & 0.0119 & 0.0010 & 59.5 & 0.0127 & 0.00 & 0.00 & 0.0198 & 0.0262 & 2.15 & 0.0000 & 0.0000 \\
\hline TRC106 & 0.0759 & 0.0000 & 29.5 & 0.0989 & 0.00 & 0.58 & 0.0103 & 0.0079 & 5.88 & 0.0000 & 0.0000 \\
\hline TRC107 & 0.1923 & 0.2812 & 1687.9 & 20.6346 & 0.00 & 1.61 & 0.9785 & 0.9888 & 0.00 & 7.2111 & 0.4235 \\
\hline TRC108 & 0.0291 & 0.0019 & 137.6 & 0.0161 & 2.62 & 0.17 & 0.0381 & 0.0381 & 4.82 & 0.0028 & 0.0000 \\
\hline
\end{tabular}


N Table 2. Concentrations of elements measured by INAA in the chert samples in this study.

\begin{tabular}{|c|c|c|c|c|c|c|c|c|c|c|c|}
\hline ANID & Cs (ppm) & Eu (ppm) & $\mathrm{Fe}(p p m)$ & Hf (ppm) & $\mathrm{Ni}(p p m)$ & $\mathrm{Rb}(p p m)$ & Sb (ppm) & Sc (ppm) & $\operatorname{Sr}(p p m)$ & $\mathrm{Ta}(\mathrm{ppm})$ & $\mathrm{Tb}(\mathrm{ppm})$ \\
\hline TRC109 & 0.0973 & 0.0114 & 495.6 & 0.0902 & 0.00 & 1.11 & 0.0416 & 0.0907 & 5.20 & 0.0104 & 0.0077 \\
\hline TRC110 & 0.0432 & 0.0000 & 250.2 & 0.0421 & 0.00 & 0.36 & 0.0911 & 0.0569 & 7.42 & 0.0071 & 0.0000 \\
\hline TRC111 & 0.0345 & 0.0013 & 20.6 & 0.0383 & 0.00 & 0.24 & 0.0195 & 0.0134 & 6.51 & 0.0000 & 0.0000 \\
\hline TRC112 & 0.1095 & 0.0118 & 139.4 & 0.1143 & 0.00 & 0.69 & 0.0980 & 0.0388 & 11.32 & 0.0075 & 0.0091 \\
\hline TRC113 & 0.0119 & 0.0010 & 93.2 & 0.0099 & 1.56 & 0.15 & 0.0400 & 0.0201 & 1.91 & 0.0000 & 0.0000 \\
\hline TRC114 & 0.0727 & 0.0057 & 192.7 & 0.0471 & 0.00 & 0.54 & 0.1014 & 0.0579 & 5.23 & 0.0067 & 0.0000 \\
\hline TRC115 & 0.0659 & 0.0030 & 64.7 & 0.0876 & 1.75 & 0.37 & 0.4882 & 0.0166 & 14.32 & 0.0000 & 0.0000 \\
\hline TRC116 & 0.0533 & 0.0005 & 11.3 & 0.0962 & 0.00 & 0.31 & 0.0059 & 0.0087 & 9.26 & 0.0021 & 0.0000 \\
\hline TRC117 & 0.0227 & 0.0012 & 54.5 & 0.0142 & 0.00 & 0.12 & 0.0131 & 0.0095 & 6.35 & 0.0000 & 0.0000 \\
\hline TRC118 & 0.0481 & 0.0055 & 267.0 & 0.0289 & 0.00 & 0.42 & 0.0232 & 0.0563 & 98.56 & 0.0046 & 0.0051 \\
\hline TRC119 & 0.1184 & 0.0070 & 258.1 & 0.1361 & 0.00 & 0.80 & 0.0298 & 0.0719 & 5.51 & 0.0098 & 0.0057 \\
\hline TRC120 & 0.0684 & 0.0000 & 133.8 & 0.0307 & 0.00 & 0.36 & 0.0741 & 0.0195 & 9.74 & 0.0029 & 0.0000 \\
\hline TRC121 & 0.0888 & 0.0029 & 83.3 & 0.1027 & 0.00 & 0.50 & 0.0223 & 0.0149 & 6.61 & 0.0046 & 0.0000 \\
\hline TRC122 & 0.0639 & 0.0000 & 50.7 & 0.0802 & 0.00 & 0.30 & 0.0114 & 0.0165 & 12.33 & 0.0028 & 0.0000 \\
\hline TRC123 & 0.0661 & 0.0054 & 110.2 & 0.0451 & 0.00 & 0.43 & 0.0604 & 0.0339 & 6.73 & 0.0000 & 0.0000 \\
\hline TRC124 & 0.0689 & 0.0062 & 221.8 & 0.0715 & 0.00 & 0.72 & 0.1474 & 0.0601 & 7.65 & 0.0075 & 0.0000 \\
\hline TRC125 & 0.0493 & 0.0012 & 197.2 & 0.0592 & 0.00 & 0.40 & 0.0469 & 0.0260 & 5.91 & 0.0043 & 0.0000 \\
\hline TRC126 & 0.0397 & 0.0000 & 59.0 & 0.0329 & 0.00 & 0.28 & 0.0178 & 0.0165 & 4.85 & 0.0000 & 0.0000 \\
\hline TRC127 & 0.0989 & 0.0018 & 356.3 & 0.0864 & 0.00 & 0.82 & 0.0670 & 0.0506 & 58.36 & 0.0076 & 0.0021 \\
\hline TRC128 & 0.0535 & 0.0027 & 130.8 & 0.0507 & 0.00 & 0.47 & 0.0248 & 0.0308 & 5.65 & 0.0036 & 0.0024 \\
\hline TRC129 & 0.0307 & 0.0019 & 66.1 & 0.0262 & 0.00 & 0.23 & 0.0134 & 0.0151 & 6.30 & 0.0013 & 0.0011 \\
\hline TRC130 & 0.0673 & 0.0063 & 188.7 & 0.0391 & 0.00 & 0.58 & 0.0288 & 0.0560 & 22.51 & 0.0043 & 0.0042 \\
\hline TRC131 & 0.0248 & 0.0020 & 21.6 & 0.0938 & 0.00 & 0.29 & 0.0261 & 0.0174 & 4.42 & 0.0000 & 0.0000 \\
\hline TRC132 & 0.0788 & 0.0000 & 59.8 & 0.0300 & 0.00 & 0.48 & 0.1456 & 0.0114 & 6.44 & 0.0000 & 0.0000 \\
\hline TRC133 & 0.0262 & 0.0000 & 68.5 & 0.1134 & 0.00 & 0.29 & 0.0295 & 0.0218 & 3.74 & 0.0022 & 0.0000 \\
\hline TRC134 & 0.0412 & 0.0000 & 44.1 & 0.0269 & 0.00 & 0.22 & 0.0296 & 0.0099 & 3.42 & 0.0000 & 0.0000 \\
\hline TRC135 & 0.0400 & 0.0044 & 181.0 & 0.0394 & 0.00 & 0.49 & 0.0869 & 0.0964 & 4.01 & 0.0091 & 0.0000 \\
\hline TRC136 & 0.0524 & 0.0033 & 195.6 & 0.0475 & 0.00 & 0.35 & 0.0242 & 0.0253 & 13.65 & 0.0000 & 0.0000 \\
\hline TRC137 & 0.0192 & 0.0025 & 60.2 & 0.0160 & 0.00 & 0.29 & 0.0948 & 0.0820 & 0.00 & 0.0000 & 0.0000 \\
\hline TRC138 & 0.0520 & 0.0022 & 140.8 & 0.0275 & 0.00 & 0.31 & 0.0324 & 0.0308 & 7.12 & 0.0000 & 0.0000 \\
\hline TRC139 & 0.0995 & 0.0059 & 118.7 & 0.1034 & 0.00 & 0.73 & 0.0343 & 0.0329 & 13.28 & 0.0000 & 0.0049 \\
\hline TRC140 & 0.1375 & 0.0225 & 975.3 & 0.1239 & 32.47 & 1.95 & 0.4638 & 0.2149 & 5.50 & 0.0234 & 0.0178 \\
\hline TRC141 & 0.0520 & 0.0016 & 141.0 & 0.0511 & 0.00 & 0.40 & 0.0202 & 0.0447 & 14.25 & 0.0036 & 0.0000 \\
\hline TRC142 & 0.0574 & 0.0035 & 76.5 & 0.0904 & 0.00 & 0.37 & 0.0208 & 0.0105 & 4.86 & 0.0000 & 0.0000 \\
\hline TRC143 & 0.0215 & 0.0000 & 131.0 & 0.0225 & 0.00 & 0.29 & 0.0467 & 0.0342 & 0.00 & 0.0000 & 0.0000 \\
\hline TRC144 & 0.0608 & 0.0067 & 448.7 & 0.1134 & 0.00 & 1.03 & 0.1365 & 0.1549 & 28.06 & 0.0153 & 0.0037 \\
\hline
\end{tabular}


Table 2. Concentrations of elements measured by INAA in the chert samples in this study.

\begin{tabular}{|c|c|c|c|c|c|c|c|c|c|c|c|}
\hline ANID & Cs (ppm) & Eu (ppm) & $\mathrm{Fe}(p p m)$ & Hf (ppm) & $\mathrm{Ni}(p p m)$ & $\mathrm{Rb}(p p m)$ & Sb (ppm) & Sc (ppm) & $\mathrm{Sr}(\mathrm{ppm})$ & $\mathrm{Ta}(\mathrm{ppm})$ & Tb (ppm) \\
\hline TRC145 & 0.1642 & 0.0000 & 117.6 & 0.1148 & 0.00 & 0.66 & 0.0307 & 0.0082 & 8.92 & 0.0000 & 0.0000 \\
\hline TRC146 & 0.0330 & 0.0032 & 91.5 & 0.0840 & 0.00 & 0.45 & 0.1841 & 0.0188 & 10.34 & 0.0000 & 0.0000 \\
\hline TRC147 & 0.0168 & 0.0000 & 109.6 & 0.0147 & 0.00 & 0.27 & 0.0270 & 0.0276 & 3.11 & 0.0044 & 0.0000 \\
\hline TRC148 & 0.0340 & 0.0008 & 97.4 & 0.0221 & 0.00 & 0.16 & 0.0242 & 0.0346 & 14.04 & 0.0000 & 0.0000 \\
\hline TRC149 & 0.0532 & 0.0010 & 142.8 & 0.0363 & 0.00 & 0.44 & 0.0335 & 0.0307 & 15.22 & 0.0045 & 0.0000 \\
\hline TRC150 & 0.0120 & 0.0000 & 125.0 & 0.0178 & 0.00 & 0.18 & 0.0320 & 0.0324 & 2.02 & 0.0000 & 0.0000 \\
\hline TRC151 & 0.0595 & 0.0031 & 96.4 & 0.0525 & 0.00 & 0.51 & 0.0151 & 0.0426 & 18.07 & 0.0033 & 0.0042 \\
\hline TRC152 & 0.0710 & 0.0033 & 215.0 & 0.0451 & 0.00 & 0.36 & 0.0281 & 0.0206 & 3.41 & 0.0000 & 0.0032 \\
\hline TRC153 & 0.0705 & 0.0000 & 112.3 & 0.0975 & 0.00 & 0.45 & 0.0282 & 0.0354 & 8.01 & 0.0055 & 0.0000 \\
\hline TRC154 & 0.0973 & 0.0015 & 262.1 & 0.0911 & 0.00 & 0.78 & 0.2163 & 0.0308 & 10.34 & 0.0075 & 0.0000 \\
\hline TRC155 & 0.1457 & 0.0085 & 331.0 & 0.0709 & 0.00 & 1.02 & 0.0296 & 0.0709 & 8.61 & 0.0069 & 0.0051 \\
\hline TRC156 & 0.0580 & 0.0012 & 114.2 & 0.0221 & 0.00 & 0.26 & 0.2523 & 0.0502 & 5.57 & 0.0060 & 0.0000 \\
\hline TRC157 & 0.0298 & 0.0022 & 93.8 & 0.0203 & 0.00 & 0.17 & 0.0201 & 0.0209 & 8.43 & 0.0017 & 0.0000 \\
\hline TRC158 & 0.2981 & 0.0025 & 804.9 & 0.1225 & 0.00 & 1.80 & 0.1445 & 0.0612 & 14.45 & 0.0150 & 0.0000 \\
\hline TRC159 & 0.0678 & 0.0058 & 206.9 & 0.0516 & 0.00 & 0.67 & 0.0195 & 0.0594 & 13.76 & 0.0063 & 0.0000 \\
\hline TRC160 & 0.1236 & 0.0000 & 270.5 & 0.0726 & 0.00 & 0.68 & 0.1769 & 0.0249 & 9.55 & 0.0059 & 0.0000 \\
\hline TRC161 & 0.0329 & 0.0000 & 150.7 & 0.0697 & 0.00 & 0.30 & 0.0120 & 0.0244 & 6.48 & 0.0046 & 0.0000 \\
\hline TRC162 & 0.0544 & 0.0022 & 101.5 & 0.0213 & 0.00 & 0.31 & 0.0202 & 0.0310 & 12.29 & 0.0000 & 0.0000 \\
\hline TRC163 & 0.0544 & 0.0000 & 79.7 & 0.0476 & 0.00 & 0.32 & 0.0422 & 0.0140 & 20.81 & 0.0042 & 0.0000 \\
\hline TRC164 & 0.0580 & 0.0025 & 169.7 & 0.0494 & 0.00 & 0.45 & 0.0132 & 0.0379 & 13.27 & 0.0034 & 0.0000 \\
\hline TRC165 & 0.0387 & 0.0000 & 100.2 & 0.0553 & 1.18 & 0.35 & 0.1641 & 0.0230 & 4.91 & 0.0031 & 0.0000 \\
\hline TRC166 & 0.1944 & 0.0027 & 368.8 & 0.1479 & 0.00 & 1.46 & 0.0595 & 0.0469 & 14.24 & 0.0117 & 0.0000 \\
\hline TRC167 & 0.0613 & 0.0040 & 185.9 & 0.0369 & 0.00 & 0.49 & 0.0158 & 0.0452 & 11.05 & 0.0042 & 0.0067 \\
\hline TRC168 & 0.0507 & 0.0046 & 306.5 & 0.0919 & 0.00 & 0.38 & 0.5244 & 0.0466 & 17.32 & 0.0049 & 0.0029 \\
\hline TRC169 & 0.0857 & 0.0054 & 136.1 & 0.0685 & 0.00 & 0.51 & 0.0177 & 0.0355 & 8.25 & 0.0000 & 0.0000 \\
\hline TRC170 & 0.0667 & 0.0036 & 199.2 & 0.1183 & 0.00 & 0.80 & 0.0481 & 0.0484 & 5.62 & 0.0031 & 0.0032 \\
\hline TRC171 & 0.0378 & 0.0015 & 161.7 & 0.0252 & 0.00 & 0.41 & 0.0166 & 0.0652 & 3.75 & 0.0050 & 0.0000 \\
\hline TRC172 & 0.0226 & 0.0044 & 234.0 & 0.0173 & 0.00 & 0.00 & 0.0215 & 0.0187 & 6.12 & 0.0024 & 0.0043 \\
\hline TRC173 & 0.0363 & 0.0000 & 91.3 & 0.0628 & 0.00 & 0.28 & 0.0213 & 0.0112 & 4.46 & 0.0021 & 0.0000 \\
\hline TRC174 & 0.0234 & 0.0025 & 107.9 & 0.0202 & 0.00 & 0.22 & 0.0669 & 0.0279 & 1.93 & 0.0000 & 0.0000 \\
\hline TRC175 & 0.0585 & 0.0000 & 10.5 & 0.0803 & 0.00 & 0.27 & 0.0048 & 0.0044 & 6.96 & 0.0000 & 0.0000 \\
\hline TRC176 & 0.2259 & 0.0116 & 641.2 & 0.1297 & 0.00 & 1.65 & 0.0464 & 0.1007 & 14.44 & 0.0175 & 0.0137 \\
\hline TRC177 & 0.0410 & 0.0000 & 100.7 & 0.0575 & 0.00 & 0.44 & 0.0146 & 0.0301 & 6.90 & 0.0037 & 0.0000 \\
\hline TRC178 & 0.0775 & 0.0031 & 340.2 & 0.0728 & 0.00 & 0.43 & 0.0425 & 0.0337 & 7.32 & 0.0074 & 0.0000 \\
\hline TRC179 & 0.0558 & 0.0030 & 159.9 & 0.0706 & 0.00 & 0.32 & 0.0495 & 0.0337 & 4.33 & 0.0054 & 0.0000 \\
\hline TRC180 & 0.0497 & 0.0000 & 150.7 & 0.0357 & 1.75 & 0.46 & 0.4064 & 0.0322 & 10.22 & 0.0038 & 0.0000 \\
\hline
\end{tabular}




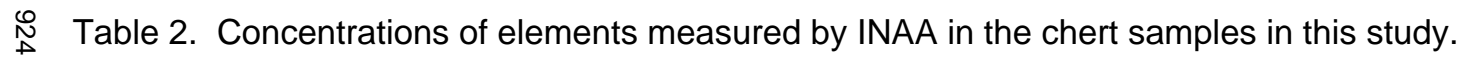

\begin{tabular}{|c|c|c|c|c|c|c|c|c|c|c|c|}
\hline ANID & Cs (ppm) & Eu (ppm) & $\mathrm{Fe}(p p m)$ & Hf (ppm) & $\mathrm{Ni}(p p m)$ & Rb (ppm) & Sb (ppm) & Sc (ppm) & Sr (ppm) & $\mathrm{Ta}(p p m)$ & Tb (ppm) \\
\hline TRC181 & 0.0163 & 0.0000 & 97.5 & 0.0169 & 0.00 & 0.22 & 0.0381 & 0.0280 & 0.00 & 0.0000 & 0.0000 \\
\hline TRC182 & 0.0646 & 0.0000 & 82.0 & 0.1025 & 0.00 & 0.50 & 0.0376 & 0.0103 & 8.66 & 0.0000 & 0.0000 \\
\hline TRC183 & 0.0339 & 0.0013 & 128.6 & 0.0283 & 0.86 & 0.33 & 0.0230 & 0.0530 & 12.47 & 0.0038 & 0.0000 \\
\hline TRC184 & 0.0696 & 0.0035 & 156.8 & 0.0618 & 0.00 & 0.66 & 0.0150 & 0.0452 & 5.87 & 0.0045 & 0.0036 \\
\hline TRC185 & 0.0549 & 0.0037 & 275.0 & 0.0373 & 0.00 & 0.25 & 0.0832 & 0.0257 & 7.29 & 0.0000 & 0.0037 \\
\hline TRC186 & 0.1536 & 0.0043 & 269.9 & 0.2477 & 0.00 & 0.93 & 0.0801 & 0.0490 & 15.00 & 0.0188 & 0.0000 \\
\hline TRC187 & 0.0376 & 0.0014 & 88.6 & 0.0159 & 0.00 & 0.20 & 0.0148 & 0.0291 & 12.91 & 0.0000 & 0.0000 \\
\hline TRC188 & 0.0693 & 0.0005 & 100.4 & 0.0319 & 0.00 & 0.32 & 0.0752 & 0.0079 & 6.19 & 0.0000 & 0.0000 \\
\hline TRC189 & 0.0738 & 0.0031 & 46.3 & 0.0209 & 0.00 & 0.24 & 0.1235 & 0.0538 & 5.86 & 0.0021 & 0.0050 \\
\hline TRC190 & 0.0094 & 0.0000 & 134.9 & 0.0385 & 0.00 & 0.27 & 0.0133 & 0.0371 & 2.86 & 0.0043 & 0.0000 \\
\hline TRC191 & 0.0421 & 0.0021 & 126.9 & 0.0446 & 0.00 & 0.32 & 0.0274 & 0.0186 & 4.12 & 0.0033 & 0.0015 \\
\hline TRC192 & 0.1976 & 0.0020 & 288.4 & 0.1128 & 0.00 & 0.65 & 0.0560 & 0.0205 & 6.26 & 0.0067 & 0.0000 \\
\hline TRC193 & 0.0730 & 0.0063 & 221.2 & 0.0480 & 2.69 & 0.51 & 0.0306 & 0.0528 & 4.71 & 0.0099 & 0.0000 \\
\hline TRC194 & 0.0495 & 0.0025 & 191.0 & 0.0255 & 0.00 & 0.23 & 0.0184 & 0.0569 & 9.94 & 0.0044 & 0.0000 \\
\hline TRC195 & 0.0490 & 0.0017 & 416.7 & 0.0724 & 0.00 & 0.69 & 0.0552 & 0.0437 & 7.65 & 0.0081 & 0.0000 \\
\hline TRC196 & 0.0726 & 0.0000 & 171.8 & 0.0292 & 0.76 & 0.41 & 0.0615 & 0.0191 & 8.54 & 0.0025 & 0.0000 \\
\hline TRC197 & 0.1144 & 0.0000 & 170.4 & 0.0859 & 0.00 & 0.71 & 0.7784 & 0.0334 & 7.71 & 0.0039 & 0.0000 \\
\hline TRC198 & 0.0524 & 0.0041 & 269.4 & 0.0424 & 0.00 & 0.77 & 0.0346 & 0.0781 & 4.33 & 0.0066 & 0.0000 \\
\hline TRC199 & 0.0340 & 0.0021 & 59.3 & 0.0100 & 0.00 & 0.27 & 0.0172 & 0.0217 & 5.69 & 0.0012 & 0.0000 \\
\hline TRC200 & 0.1595 & 0.0035 & 510.8 & 0.1196 & 0.00 & 1.11 & 0.1699 & 0.0790 & 5.95 & 0.0123 & 0.0000 \\
\hline TRC201 & 0.0491 & 0.0024 & 122.9 & 0.0242 & 0.00 & 0.50 & 0.1254 & 0.0516 & 4.45 & 0.0045 & 0.0000 \\
\hline TRC202 & 0.0161 & 0.0021 & 328.3 & 0.0175 & 0.00 & 0.50 & 0.0599 & 0.0467 & 5.75 & 0.0021 & 0.0000 \\
\hline TRC203 & 0.0468 & 0.0026 & 207.5 & 0.0184 & 0.00 & 0.32 & 0.0261 & 0.0536 & 3.79 & 0.0014 & 0.0000 \\
\hline TRC204 & 0.0273 & 0.0008 & 89.8 & 0.0146 & 0.00 & 0.22 & 0.0253 & 0.0140 & 2.78 & 0.0000 & 0.0000 \\
\hline TRC205 & 0.0070 & 0.0000 & 78.3 & 0.0088 & 0.00 & 0.11 & 0.0426 & 0.0185 & 0.00 & 0.0000 & 0.0000 \\
\hline TRC206 & 0.0424 & 0.0000 & 177.9 & 0.0322 & 0.00 & 0.33 & 0.1053 & 0.0283 & 5.21 & 0.0053 & 0.0000 \\
\hline TRC207 & 0.0499 & 0.0053 & 109.1 & 0.1017 & 0.00 & 0.40 & 0.0232 & 0.0178 & 4.83 & 0.0008 & 0.0037 \\
\hline TRC208 & 0.0754 & 0.0000 & 96.4 & 0.0599 & 0.00 & 0.34 & 0.0252 & 0.0152 & 7.59 & 0.0045 & 0.0000 \\
\hline TRC209 & 0.0298 & 0.0021 & 53.7 & 0.0144 & 0.00 & 0.00 & 0.0101 & 0.0152 & 4.83 & 0.0000 & 0.0000 \\
\hline TRC210 & 0.0274 & 0.0017 & 55.8 & 0.0776 & 0.00 & 0.25 & 0.0126 & 0.0157 & 6.21 & 0.0000 & 0.0000 \\
\hline TRC211 & 0.0707 & 0.0025 & 118.6 & 0.0717 & 0.00 & 0.24 & 0.1332 & 0.0181 & 10.09 & 0.0000 & 0.0000 \\
\hline TRC212 & 0.0537 & 0.0010 & 77.2 & 0.0647 & 0.75 & 0.28 & 0.2278 & 0.0192 & 7.94 & 0.0000 & 0.0000 \\
\hline TRC213 & 0.0412 & 0.0000 & 96.1 & 0.0172 & 0.00 & 0.29 & 0.1236 & 0.0180 & 4.88 & 0.0000 & 0.0000 \\
\hline TRC214 & 0.0367 & 0.0000 & 67.3 & 0.0411 & 1.08 & 0.26 & 0.0754 & 0.0132 & 6.15 & 0.0000 & 0.0000 \\
\hline TRC215 & 0.1020 & 0.0039 & 290.6 & 0.0613 & 0.00 & 0.92 & 0.0362 & 0.0565 & 22.65 & 0.0073 & 0.0033 \\
\hline TRC216 & 0.0570 & 0.0018 & 197.0 & 0.0262 & 0.00 & 0.51 & 0.0347 & 0.0411 & 11.47 & 0.0000 & 0.0000 \\
\hline
\end{tabular}


Table 2. Concentrations of elements measured by INAA in the chert samples in this study.

\begin{tabular}{|c|c|c|c|c|c|c|c|c|c|c|c|}
\hline ANID & Cs (ppm) & Eu (ppm) & $\mathrm{Fe}(p p m)$ & Hf (ppm) & Ni (ppm) & Rb (ppm) & Sb (ppm) & Sc (ppm) & Sr (ppm) & $\mathrm{Ta}(p p m)$ & Tb (ppm) \\
\hline TRC217 & 0.0533 & 0.0039 & 185.6 & 0.0426 & 0.00 & 0.39 & 0.0318 & 0.0305 & 10.16 & 0.0033 & 0.0000 \\
\hline TRC218 & 0.0491 & 0.0048 & 257.2 & 0.0471 & 0.00 & 0.72 & 0.0397 & 0.0667 & 0.00 & 0.0073 & 0.0037 \\
\hline TRC219 & 0.1190 & 0.0016 & 118.2 & 0.1329 & 0.00 & 0.67 & 0.0342 & 0.0172 & 4.86 & 0.0037 & 0.0000 \\
\hline TRC220 & 0.0308 & 0.0000 & 102.3 & 0.0193 & 0.00 & 0.24 & 0.0544 & 0.0179 & 3.42 & 0.0000 & 0.0000 \\
\hline TRC221 & 0.0492 & 0.0032 & 207.8 & 0.0435 & 0.00 & 0.51 & 0.0313 & 0.0871 & 5.40 & 0.0065 & 0.0000 \\
\hline TRC222 & 0.0420 & 0.0000 & 65.7 & 0.0513 & 0.00 & 0.25 & 0.0391 & 0.0119 & 5.58 & 0.0000 & 0.0000 \\
\hline TRC223 & 0.0302 & 0.0026 & 99.1 & 0.0134 & 0.00 & 0.17 & 0.0358 & 0.0348 & 6.16 & 0.0018 & 0.0000 \\
\hline TRC224 & 0.0686 & 0.0000 & 150.0 & 0.0668 & 0.00 & 0.42 & 0.0324 & 0.0306 & 5.27 & 0.0021 & 0.0000 \\
\hline TRC225 & 0.0593 & 0.0030 & 206.6 & 0.0428 & 0.00 & 0.46 & 0.0456 & 0.0588 & 12.77 & 0.0000 & 0.0000 \\
\hline TRC226 & 0.0706 & 0.0031 & 130.1 & 0.1416 & 0.00 & 0.53 & 0.0423 & 0.0148 & 15.00 & 0.0034 & 0.0000 \\
\hline TRC227 & 0.0538 & 0.0012 & 76.9 & 0.0668 & 0.00 & 0.40 & 0.0133 & 0.0185 & 10.27 & 0.0055 & 0.0000 \\
\hline TRC228 & 0.0451 & 0.0016 & 163.5 & 0.0280 & 0.00 & 0.37 & 0.0217 & 0.0465 & 10.52 & 0.0039 & 0.0000 \\
\hline TRC229 & 0.0528 & 0.0022 & 229.5 & 0.0419 & 0.00 & 0.43 & 0.0355 & 0.0711 & 18.14 & 0.0000 & 0.0000 \\
\hline TRC230 & 0.0560 & 0.0016 & 81.0 & 0.0199 & 0.00 & 0.19 & 0.0509 & 0.0149 & 5.49 & 0.0000 & 0.0000 \\
\hline TRC231 & 0.0454 & 0.0157 & 196.9 & 0.0350 & 0.00 & 0.00 & 0.0000 & 0.0574 & 0.00 & 0.0000 & 0.0086 \\
\hline TRC232 & 0.0436 & 0.0000 & 57.6 & 0.0802 & 0.00 & 0.29 & 0.0000 & 0.0193 & 4.86 & 0.0000 & 0.0000 \\
\hline TRC233 & 0.0599 & 0.0000 & 173.7 & 0.1211 & 0.00 & 0.56 & 0.0289 & 0.0251 & 19.99 & 0.0000 & 0.0000 \\
\hline TRC234 & 0.0538 & 0.0000 & 253.9 & 0.0306 & 0.00 & 0.33 & 0.4262 & 0.1063 & 0.00 & 0.0000 & 0.0000 \\
\hline TRC235 & 0.0252 & 0.0000 & 95.6 & 0.0449 & 0.00 & 0.24 & 0.1211 & 0.0234 & 0.00 & 0.0000 & 0.0000 \\
\hline TRC236 & 0.0583 & 0.0056 & 182.2 & 0.0348 & 0.00 & 0.00 & 0.0440 & 0.0683 & 9.07 & 0.0000 & 0.0000 \\
\hline TRC237 & 0.0420 & 0.0051 & 233.3 & 0.0384 & 0.00 & 0.00 & 0.0360 & 0.0860 & 12.87 & 0.0045 & 0.0000 \\
\hline TRC238 & 0.0189 & 0.0000 & 135.3 & 0.0147 & 0.00 & 0.00 & 0.0736 & 0.0454 & 4.70 & 0.0000 & 0.0000 \\
\hline TRC239 & 0.0919 & 0.0025 & 32.0 & 0.0192 & 0.00 & 0.38 & 0.0175 & 0.0094 & 11.93 & 0.0000 & 0.0000 \\
\hline TRC240 & 0.0488 & 0.0000 & 78.7 & 0.0078 & 4.49 & 0.33 & 0.1094 & 0.0118 & 3.89 & 0.0000 & 0.0000 \\
\hline TRC241 & 0.0727 & 0.0030 & 55.9 & 0.1311 & 0.00 & 0.40 & 0.0092 & 0.0150 & 7.61 & 0.0000 & 0.0000 \\
\hline TRC242 & 0.0315 & 0.0026 & 178.0 & 0.0302 & 0.00 & 0.18 & 0.0358 & 0.0123 & 3.81 & 0.0000 & 0.0000 \\
\hline TRC243 & 0.0992 & 0.0031 & 166.9 & 0.0345 & 0.00 & 0.76 & 0.0388 & 0.0266 & 9.62 & 0.0000 & 0.0000 \\
\hline TRC244 & 0.0943 & 0.0050 & 363.1 & 0.0843 & 0.00 & 0.60 & 0.0562 & 0.0291 & 9.93 & 0.0000 & 0.0000 \\
\hline TRC245 & 0.0906 & 0.0000 & 46.7 & 0.0467 & 0.00 & 0.27 & 0.0000 & 0.0119 & 5.87 & 0.0000 & 0.0000 \\
\hline TRC246 & 0.0918 & 0.0000 & 66.1 & 0.1211 & 0.00 & 0.31 & 0.0142 & 0.0102 & 7.35 & 0.0000 & 0.0000 \\
\hline TRC247 & 0.1109 & 0.0000 & 39.9 & 0.1118 & 0.00 & 0.60 & 0.0181 & 0.0086 & 20.96 & 0.0000 & 0.0000 \\
\hline TRC248 & 0.0203 & 0.0000 & 127.6 & 0.0135 & 0.00 & 0.51 & 0.0726 & 0.0281 & 0.00 & 0.0000 & 0.0000 \\
\hline TRC249 & 0.0798 & 0.0000 & 170.3 & 0.0760 & 1.98 & 0.38 & 0.1345 & 0.0329 & 0.00 & 0.0000 & 0.0000 \\
\hline TRC250 & 0.0479 & 0.0000 & 133.5 & 0.0657 & 0.00 & 0.30 & 0.3232 & 0.0148 & 11.95 & 0.0000 & 0.0000 \\
\hline TRC251 & 0.0131 & 0.0000 & 109.8 & 0.0123 & 0.00 & 0.15 & 0.0803 & 0.0436 & 0.00 & 0.0000 & 0.0000 \\
\hline TRC252 & 0.0607 & 0.0000 & 162.2 & 0.0908 & 0.00 & 0.58 & 0.0400 & 0.0094 & 9.76 & 0.0000 & 0.0000 \\
\hline
\end{tabular}




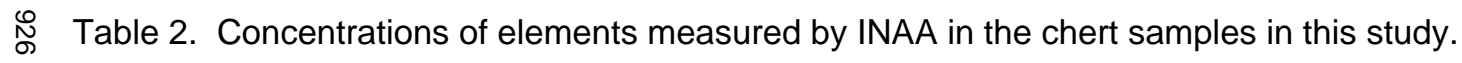

\begin{tabular}{|c|c|c|c|c|c|c|c|c|c|c|c|}
\hline ANID & Cs (ppm) & $\mathrm{Eu}(\mathrm{ppm})$ & $\mathrm{Fe}(\mathrm{ppm})$ & Hf (ppm) & $\mathrm{Ni}(p p m)$ & $\mathbf{R b}(\mathbf{p p m})$ & $\mathrm{Sb}(\mathrm{ppm})$ & Sc (ppm) & $\operatorname{Sr}(p p m)$ & $\mathrm{Ta}$ (ppm) & Tb (ppm) \\
\hline TRC253 & 0.0522 & 0.0017 & 216.3 & 0.0382 & 0.00 & 0.44 & 0.0272 & 0.0721 & 3.96 & 0.0054 & 0.0000 \\
\hline TRC254 & 0.1025 & 0.0051 & 245.3 & 0.0566 & 0.00 & 0.43 & 0.0401 & 0.0284 & 6.89 & 0.0079 & 0.0085 \\
\hline TRC255 & 0.6454 & 0.3706 & 1036.9 & 3.4629 & 0.00 & 111.18 & 0.5469 & 0.7491 & 25.69 & 1.7130 & 0.7186 \\
\hline TRC256 & 0.0530 & 0.0023 & 212.7 & 0.0588 & 0.00 & 0.51 & 0.0216 & 0.0398 & 12.25 & 0.0063 & 0.0034 \\
\hline TRC257 & 0.1004 & 0.0040 & 240.4 & 0.0518 & 0.00 & 0.54 & 0.0554 & 0.0211 & 4.09 & 0.0052 & 0.0020 \\
\hline TRC258 & 0.0461 & 0.0023 & 192.6 & 0.0339 & 1.25 & 0.40 & 0.0303 & 0.0617 & 9.09 & 0.0057 & 0.0000 \\
\hline TRC259 & 0.0313 & 0.0034 & 328.2 & 0.0248 & 1.79 & 0.29 & 0.0446 & 0.0232 & 2.58 & 0.0000 & 0.0037 \\
\hline TRC260 & 0.1031 & 0.0027 & 105.5 & 0.1179 & 0.00 & 0.86 & 0.0300 & 0.0314 & 16.84 & 0.0054 & 0.0000 \\
\hline TRC261 & 0.0519 & 0.0018 & 194.8 & 0.0343 & 0.00 & 0.20 & 0.0228 & 0.0429 & 12.13 & 0.0059 & 0.0000 \\
\hline
\end{tabular}


Table 2. Concentrations of elements measured by INAA in the chert samples in this study.

\begin{tabular}{|c|c|c|c|c|c|c|c|c|c|c|}
\hline ANID & Th (ppm) & Zn (ppm) & Al (ppm) & $\mathrm{Ca}(p p m)$ & Dy (ppm) & $\mathrm{K}(\mathrm{ppm})$ & Mn (ppm) & $\mathrm{Na}(p p m)$ & $\mathrm{Ti}(\mathbf{p p m})$ & V (ppm) \\
\hline TRC001 & 0.0064 & 0.28 & 1200.4 & 638.2 & 0.0000 & 0.0 & 0.32 & 161.5 & 0.0 & 1.96 \\
\hline TRC002 & 0.0059 & 0.38 & 1174.8 & 2011.4 & 0.0000 & 0.0 & 1.03 & 158.8 & 13.4 & 0.00 \\
\hline TRC003 & 0.0305 & 0.46 & 1059.2 & 1794.5 & 0.0000 & 0.0 & 0.74 & 154.4 & 0.0 & 1.07 \\
\hline TRC004 & 0.0051 & 0.23 & 1473.4 & 941.6 & 0.0000 & 535.3 & 0.71 & 211.8 & 0.0 & 0.80 \\
\hline TRC005 & 0.0042 & 0.26 & 1335.9 & 131.0 & 0.0000 & 201.5 & 0.19 & 264.6 & 0.0 & 1.30 \\
\hline TRC006 & 0.0060 & 0.18 & 1285.2 & 689.2 & 0.0000 & 0.0 & 1.26 & 208.2 & 0.0 & 0.67 \\
\hline TRC007 & 0.0225 & 1.19 & 1400.4 & 487.7 & 0.0000 & 233.8 & 0.35 & 224.0 & 0.0 & 4.76 \\
\hline TRC008 & 0.0058 & 0.62 & 1218.0 & 1989.4 & 0.0000 & 366.0 & 1.34 & 185.9 & 0.0 & 1.69 \\
\hline TRC009 & 0.0208 & 1.31 & 1262.6 & 209.0 & 0.0000 & 193.6 & 1.20 & 262.2 & 0.0 & 3.53 \\
\hline TRC010 & 0.0114 & 0.39 & 673.6 & 204.2 & 0.0000 & 281.9 & 0.25 & 225.2 & 0.0 & 0.00 \\
\hline TRC011 & 0.0082 & 0.85 & 884.6 & 0.0 & 0.0000 & 0.0 & 0.48 & 192.3 & 0.0 & 0.00 \\
\hline TRC012 & 0.0082 & 0.82 & 1239.8 & 112.4 & 0.0000 & 114.3 & 0.40 & 133.3 & 0.0 & 0.00 \\
\hline TRC013 & 0.0141 & 0.35 & 969.3 & 2352.0 & 0.0000 & 79.3 & 0.33 & 122.6 & 0.0 & 1.65 \\
\hline TRC014 & 0.0138 & 0.64 & 1249.0 & 235.5 & 0.0000 & 285.3 & 0.28 & 195.6 & 0.0 & 0.92 \\
\hline TRC015 & 0.0172 & 0.81 & 1557.2 & 299.8 & 0.0000 & 329.3 & 0.13 & 246.9 & 0.0 & 1.57 \\
\hline TRC016 & 0.0117 & 1.07 & 1129.9 & 621.6 & 0.0000 & 175.9 & 0.70 & 193.4 & 66.6 & 0.00 \\
\hline TRC017 & 0.0069 & 0.65 & 987.6 & 812.0 & 0.0000 & 0.0 & 1.21 & 155.9 & 0.0 & 0.00 \\
\hline TRC018 & 0.0057 & 0.58 & 1084.8 & 474.4 & 0.0000 & 164.2 & 0.27 & 166.6 & 0.0 & 1.29 \\
\hline TRC019 & 0.0105 & 0.51 & 1255.9 & 1723.9 & 0.0000 & 108.9 & 0.36 & 171.5 & 0.0 & 0.56 \\
\hline TRC020 & 0.0120 & 0.54 & 1269.2 & 926.7 & 0.0000 & 161.8 & 0.50 & 207.7 & 0.0 & 2.32 \\
\hline TRC021 & 0.0136 & 0.53 & 1428.0 & 1926.0 & 0.0000 & 267.3 & 2.49 & 213.9 & 57.7 & 1.10 \\
\hline TRC022 & 0.0104 & 0.79 & 1130.1 & 3743.9 & 0.0000 & 205.0 & 0.29 & 123.1 & 28.7 & 1.11 \\
\hline TRC023 & 0.0137 & 0.71 & 2125.2 & 683.8 & 0.0000 & 344.2 & 2.51 & 273.5 & 0.0 & 0.00 \\
\hline TRC024 & 0.0130 & 0.98 & 1772.2 & 751.9 & 0.0000 & 372.0 & 1.34 & 256.0 & 0.0 & 2.17 \\
\hline TRC025 & 0.0155 & 0.75 & 1361.9 & 541.4 & 0.0000 & 193.8 & 1.64 & 181.6 & 0.0 & 1.87 \\
\hline TRC026 & 0.0108 & 0.58 & 1269.6 & 942.0 & 0.0000 & 190.6 & 0.44 & 186.4 & 0.0 & 0.00 \\
\hline TRC027 & 0.0151 & 0.58 & 1241.8 & 503.6 & 0.0000 & 113.1 & 0.71 & 205.7 & 0.0 & 1.87 \\
\hline TRC028 & 0.0159 & 0.63 & 1492.0 & 922.5 & 0.0000 & 134.4 & 0.33 & 232.2 & 0.0 & 1.80 \\
\hline TRC029 & 0.0082 & 0.70 & 915.8 & 355.6 & 0.0000 & 176.8 & 0.41 & 198.0 & 0.0 & 0.00 \\
\hline TRC030 & 0.0357 & 0.70 & 1490.3 & 1632.8 & 0.0000 & 0.0 & 0.46 & 188.7 & 0.0 & 1.94 \\
\hline TRC031 & 0.0221 & 1.22 & 1650.9 & 672.0 & 0.0000 & 230.6 & 1.23 & 225.2 & 0.0 & 3.45 \\
\hline TRC032 & 0.0122 & 0.67 & 1286.2 & 736.4 & 0.0000 & 152.8 & 0.55 & 137.8 & 0.0 & 1.29 \\
\hline TRC033 & 0.0145 & 0.48 & 1092.3 & 1019.9 & 0.0000 & 0.0 & 0.59 & 150.3 & 0.0 & 0.00 \\
\hline TRC034 & 0.0093 & 0.51 & 1360.5 & 278.2 & 0.0000 & 105.1 & 0.51 & 241.4 & 11.0 & 2.11 \\
\hline TRC035 & 0.0104 & 0.57 & 1159.9 & 898.9 & 0.0000 & 118.8 & 0.39 & 111.8 & 0.0 & 0.76 \\
\hline TRC036 & 0.0120 & 0.59 & 1488.1 & 952.7 & 0.0000 & 350.9 & 0.38 & 236.4 & 0.0 & 1.90 \\
\hline
\end{tabular}




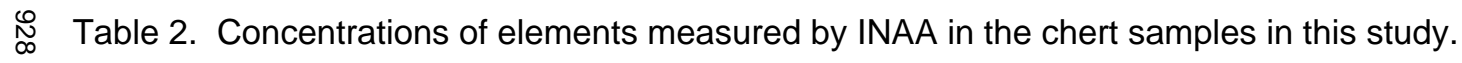

\begin{tabular}{|c|c|c|c|c|c|c|c|c|c|c|}
\hline ANID & Th (ppm) & Zn (ppm) & Al (ppm) & $\mathrm{Ca}(p p m)$ & Dy (ppm) & K (ppm) & Mn (ppm) & $\mathrm{Na}(p p m)$ & Ti (ppm) & V (ppm) \\
\hline TRC037 & 0.0470 & 0.84 & 1499.4 & 505.1 & 0.0000 & 185.7 & 0.81 & 246.9 & 0.0 & 4.55 \\
\hline TRC038 & 0.0102 & 0.52 & 1421.8 & 370.2 & 0.0000 & 312.1 & 0.31 & 227.5 & 0.0 & 2.04 \\
\hline TRC039 & 0.0227 & 0.67 & 1630.4 & 644.6 & 0.0000 & 134.3 & 0.56 & 175.2 & 0.0 & 0.65 \\
\hline TRC040 & 0.0249 & 0.73 & 1139.1 & 290.1 & 0.0000 & 201.9 & 0.32 & 234.9 & 0.0 & 2.17 \\
\hline TRC041 & 0.0098 & 1.17 & 1309.3 & 5534.5 & 0.0000 & 149.9 & 7.24 & 174.6 & 0.0 & 2.84 \\
\hline TRC042 & 0.0326 & 1.50 & 1825.1 & 699.9 & 0.0000 & 302.2 & 1.41 & 255.2 & 0.0 & 2.63 \\
\hline TRC043 & 0.0081 & 1.02 & 1102.0 & 826.5 & 0.0000 & 88.8 & 0.52 & 159.1 & 0.0 & 1.29 \\
\hline TRC044 & 0.0422 & 1.29 & 1580.9 & 527.0 & 0.0000 & 339.5 & 0.92 & 281.7 & 0.0 & 1.86 \\
\hline TRC045 & 0.0103 & 1.15 & 1284.7 & 301.0 & 0.0000 & 189.5 & 0.99 & 210.8 & 0.0 & 1.88 \\
\hline TRC046 & 0.0030 & 1.13 & 1725.0 & 172.3 & 0.0000 & 154.4 & 0.51 & 180.8 & 0.0 & 0.00 \\
\hline TRC047 & 0.0206 & 1.26 & 1063.7 & 1622.5 & 0.0000 & 0.0 & 0.16 & 182.0 & 0.0 & 2.18 \\
\hline TRC048 & 0.0299 & 1.19 & 1406.4 & 647.9 & 0.0000 & 261.1 & 0.77 & 239.9 & 0.0 & 1.56 \\
\hline TRC049 & 0.0528 & 1.59 & 1463.2 & 1292.7 & 0.0000 & 348.8 & 0.32 & 276.6 & 0.0 & 2.08 \\
\hline TRC050 & 0.0141 & 0.64 & 1097.8 & 328.9 & 0.0000 & 285.3 & 0.24 & 216.4 & 0.0 & 1.02 \\
\hline TRC051 & 0.0479 & 1.45 & 898.8 & 2035.5 & 0.0000 & 0.0 & 14.43 & 123.4 & 0.0 & 4.08 \\
\hline TRC052 & 0.0080 & 1.21 & 959.9 & 193.3 & 0.0000 & 0.0 & 0.31 & 181.7 & 0.0 & 0.82 \\
\hline TRC053 & 0.0098 & 1.22 & 1139.4 & 502.5 & 0.0000 & 95.4 & 0.36 & 200.5 & 0.0 & 0.70 \\
\hline TRC054 & 0.0100 & 1.19 & 1192.4 & 616.3 & 0.0000 & 153.1 & 0.33 & 221.5 & 0.0 & 0.00 \\
\hline TRC055 & 0.0151 & 1.08 & 1193.9 & 558.5 & 0.0000 & 181.2 & 0.32 & 241.2 & 0.0 & 0.00 \\
\hline TRC056 & 0.0098 & 1.07 & 1027.7 & 553.3 & 0.0000 & 117.5 & 0.17 & 149.4 & 0.0 & 0.84 \\
\hline TRC057 & 0.0083 & 1.02 & 1304.3 & 148.6 & 0.0000 & 185.3 & 0.33 & 227.1 & 26.1 & 1.13 \\
\hline TRC058 & 0.0063 & 1.09 & 963.7 & 401.4 & 0.0000 & 153.0 & 0.19 & 217.5 & 0.0 & 1.19 \\
\hline TRC059 & 0.0084 & 1.10 & 1284.1 & 316.5 & 0.0000 & 184.1 & 0.40 & 209.6 & 0.0 & 0.99 \\
\hline TRC060 & 0.0265 & 1.29 & 993.7 & 821.9 & 0.0000 & 134.6 & 1.08 & 194.4 & 0.0 & 1.52 \\
\hline TRC061 & 0.0201 & 0.79 & 1677.4 & 39950.8 & 0.0000 & 406.3 & 2.43 & 543.9 & 0.0 & 3.45 \\
\hline TRC062 & 0.0271 & 0.90 & 1481.0 & 52445.3 & 0.0637 & 174.5 & 3.19 & 379.7 & 12.3 & 5.49 \\
\hline TRC063 & 0.0205 & 1.16 & 1477.9 & 58805.1 & 0.0000 & 0.0 & 3.65 & 395.6 & 0.0 & 3.96 \\
\hline TRC064 & 0.0202 & 1.39 & 1807.0 & 10085.7 & 0.0000 & 188.8 & 1.67 & 331.3 & 0.0 & 2.90 \\
\hline TRC065 & 0.0333 & 1.56 & 1354.9 & 18793.8 & 0.0000 & 182.5 & 1.79 & 409.2 & 0.0 & 2.58 \\
\hline TRC066 & 0.0242 & 2.11 & 2664.3 & 4516.1 & 0.0000 & 521.3 & 6.39 & 233.1 & 0.0 & 4.38 \\
\hline TRC067 & 0.0169 & 1.62 & 1310.0 & 921.7 & 0.0000 & 168.0 & 0.49 & 201.2 & 0.0 & 1.71 \\
\hline TRC068 & 0.0040 & 1.01 & 1566.2 & 480.8 & 0.0000 & 215.2 & 0.43 & 151.8 & 0.0 & 0.00 \\
\hline TRC069 & 0.0193 & 3.13 & 1673.6 & 174.8 & 0.0000 & 160.2 & 0.52 & 152.0 & 73.7 & 1.50 \\
\hline TRC070 & 0.0308 & 1.71 & 1770.9 & 923.9 & 0.0000 & 215.4 & 1.04 & 203.5 & 0.0 & 1.26 \\
\hline TRC071 & 0.0226 & 1.87 & 1616.2 & 1010.9 & 0.0000 & 372.2 & 0.53 & 204.8 & 0.0 & 2.13 \\
\hline TRC072 & 0.0107 & 1.50 & 1876.8 & 417.8 & 0.0000 & 0.0 & 21.29 & 203.9 & 74.0 & 3.11 \\
\hline
\end{tabular}


Table 2. Concentrations of elements measured by INAA in the chert samples in this study.

\begin{tabular}{|c|c|c|c|c|c|c|c|c|c|c|}
\hline ANID & Th (ppm) & Zn (ppm) & Al (ppm) & $\mathrm{Ca}(p p m)$ & Dy (ppm) & $\mathrm{K}(\mathrm{ppm})$ & Mn (ppm) & $\mathrm{Na}(p p m)$ & $\mathrm{Ti}(\mathbf{p p m})$ & V (ppm) \\
\hline TRC073 & 0.0110 & 1.56 & 1842.6 & 351.7 & 0.0000 & 277.3 & 2.75 & 171.3 & 0.0 & 8.78 \\
\hline TRC074 & 0.0124 & 1.27 & 1316.8 & 143.8 & 0.0000 & 345.5 & 0.34 & 179.5 & 35.7 & 1.63 \\
\hline TRC075 & 0.0304 & 2.32 & 1723.9 & 1114.9 & 0.0000 & 285.1 & 1.01 & 174.2 & 0.0 & 0.00 \\
\hline TRC076 & 0.0082 & 0.43 & 1621.3 & 291.8 & 0.0000 & 185.5 & 0.35 & 213.1 & 0.0 & 1.44 \\
\hline TRC077 & 0.0118 & 0.73 & 1826.7 & 211.9 & 0.0000 & 0.0 & 0.38 & 403.2 & 0.0 & 0.00 \\
\hline TRC078 & 0.0181 & 13.38 & 2639.4 & 977.9 & 0.0000 & 300.2 & 0.74 & 459.3 & 0.0 & 6.86 \\
\hline TRC079 & 0.0205 & 0.48 & 2368.1 & 322.6 & 0.0000 & 306.4 & 3.20 & 333.8 & 0.0 & 2.19 \\
\hline TRC080 & 0.0233 & 0.62 & 2191.5 & 355.2 & 0.0000 & 363.1 & 0.21 & 377.2 & 0.0 & 1.99 \\
\hline TRC081 & 0.0151 & 0.28 & 1785.1 & 319.2 & 0.0000 & 304.7 & 0.28 & 226.6 & 0.0 & 1.90 \\
\hline TRC082 & 0.0533 & 0.73 & 1830.2 & 775.6 & 0.0000 & 273.8 & 2.46 & 234.7 & 0.0 & 2.04 \\
\hline TRC083 & 0.0148 & 0.25 & 1240.8 & 406.7 & 0.0301 & 0.0 & 0.59 & 205.9 & 0.0 & 1.78 \\
\hline TRC084 & 0.0069 & 0.16 & 1271.6 & 477.6 & 0.0000 & 0.0 & 0.21 & 181.6 & 0.0 & 0.00 \\
\hline TRC085 & 0.0268 & 0.43 & 1379.0 & 869.8 & 0.0000 & 195.1 & 0.47 & 176.9 & 0.0 & 2.09 \\
\hline TRC086 & 0.0084 & 0.17 & 1416.1 & 510.7 & 0.0000 & 254.4 & 0.41 & 191.1 & 0.0 & 0.00 \\
\hline TRC087 & 0.0109 & 0.12 & 1170.7 & 447.0 & 0.0000 & 246.7 & 0.35 & 221.9 & 0.0 & 0.61 \\
\hline TRC088 & 0.0099 & 0.15 & 1416.3 & 455.4 & 0.0000 & 221.2 & 0.50 & 177.7 & 36.4 & 0.55 \\
\hline TRC089 & 0.0089 & 0.28 & 1124.6 & 48192.4 & 0.0000 & 115.0 & 1.82 & 174.8 & 0.0 & 0.00 \\
\hline TRC090 & 0.0132 & 0.62 & 1583.7 & 736.9 & 0.0000 & 214.9 & 0.64 & 238.5 & 0.0 & 1.33 \\
\hline TRC091 & 0.0086 & 0.21 & 1426.6 & 3529.9 & 0.0000 & 214.3 & 0.65 & 182.4 & 0.0 & 1.30 \\
\hline TRC092 & 0.0407 & 1.09 & 1421.6 & 1116.5 & 0.0000 & 270.0 & 4.85 & 214.9 & 0.0 & 4.24 \\
\hline TRC093 & 0.0164 & 0.44 & 1847.0 & 495.4 & 0.0000 & 261.4 & 0.53 & 260.0 & 0.0 & 1.18 \\
\hline TRC094 & 0.0197 & 0.51 & 1170.9 & 252.8 & 0.0000 & 274.0 & 0.31 & 227.6 & 43.8 & 2.11 \\
\hline TRC095 & 0.0057 & 0.32 & 1134.2 & 238.9 & 0.0000 & 250.4 & 0.40 & 182.2 & 5.9 & 1.09 \\
\hline TRC096 & 0.0327 & 1.23 & 1715.3 & 521.5 & 0.0000 & 337.1 & 1.09 & 192.6 & 0.0 & 1.00 \\
\hline TRC097 & 0.0200 & 0.27 & 1286.7 & 1688.2 & 0.0000 & 308.8 & 0.76 & 175.7 & 0.0 & 1.62 \\
\hline TRC098 & 0.0057 & 0.12 & 1429.6 & 611.8 & 0.0000 & 233.9 & 0.28 & 174.8 & 0.0 & 0.64 \\
\hline TRC099 & 0.0063 & 0.19 & 1088.5 & 288.1 & 0.0000 & 0.0 & 0.27 & 188.6 & 0.0 & 1.04 \\
\hline TRC100 & 0.0093 & 0.35 & 1159.9 & 1874.1 & 0.0000 & 143.8 & 0.28 & 171.4 & 0.0 & 1.42 \\
\hline TRC101 & 0.0098 & 0.29 & 1017.1 & 281.1 & 0.0000 & 132.9 & 0.26 & 166.3 & 0.0 & 0.00 \\
\hline TRC102 & 0.0067 & 0.06 & 2067.7 & 543.4 & 0.0000 & 303.3 & 0.47 & 229.1 & 0.0 & 1.01 \\
\hline TRC103 & 0.0197 & 0.24 & 1129.7 & 297.3 & 0.0000 & 228.3 & 0.18 & 225.2 & 0.0 & 1.99 \\
\hline TRC104 & 0.0132 & 0.48 & 1416.0 & 478.4 & 0.0000 & 284.1 & 0.22 & 366.8 & 0.0 & 0.00 \\
\hline TRC105 & 0.0162 & 0.73 & 1003.0 & 233.1 & 0.0000 & 108.8 & 0.20 & 167.5 & 0.0 & 1.21 \\
\hline TRC106 & 0.0125 & 0.84 & 2187.5 & 733.0 & 0.0000 & 272.3 & 0.31 & 300.4 & 0.0 & 0.00 \\
\hline TRC107 & 7.5076 & 3.83 & 1390.2 & 420.0 & 2.7129 & 335.8 & 4.52 & 158.7 & 535.5 & 14.82 \\
\hline TRC108 & 0.0271 & 0.33 & 1331.8 & 419.9 & 0.0000 & 183.3 & 0.49 & 216.3 & 0.0 & 1.44 \\
\hline
\end{tabular}


@ Table 2. Concentrations of elements measured by INAA in the chert samples in this study.

\begin{tabular}{|c|c|c|c|c|c|c|c|c|c|c|}
\hline ANID & Th (ppm) & Zn (ppm) & Al (ppm) & $\mathrm{Ca}$ (ppm) & Dy (ppm) & $\mathrm{K}(\mathrm{ppm})$ & Mn (ppm) & $\mathrm{Na}(p p m)$ & Ti (ppm) & V (ppm) \\
\hline TRC109 & 0.1492 & 0.85 & 2611.7 & 2339.3 & 0.0698 & 636.1 & 24.75 & 278.0 & 110.3 & 5.46 \\
\hline TRC110 & 0.0517 & 0.83 & 1364.3 & 1515.7 & 0.0000 & 304.8 & 0.92 & 257.1 & 37.8 & 3.08 \\
\hline TRC111 & 0.0108 & 0.53 & 1624.0 & 54.6 & 0.0000 & 346.3 & 0.58 & 192.0 & 0.0 & 0.00 \\
\hline TRC112 & 0.0550 & 0.63 & 1625.3 & 724.1 & 0.0000 & 425.3 & 0.65 & 229.4 & 5.5 & 0.00 \\
\hline TRC113 & 0.0212 & 0.00 & 1164.1 & 356.7 & 0.0000 & 224.9 & 0.64 & 194.9 & 0.0 & 1.79 \\
\hline TRC114 & 0.0590 & 1.32 & 1338.7 & 437.8 & 0.0000 & 161.8 & 2.66 & 218.0 & 48.9 & 1.92 \\
\hline TRC115 & 0.0164 & 0.74 & 1403.3 & 566.3 & 0.0000 & 368.7 & 0.39 & 250.9 & 0.0 & 2.15 \\
\hline TRC116 & 0.0080 & 0.00 & 1206.2 & 714.1 & 0.0000 & 358.8 & 0.45 & 234.5 & 0.0 & 0.00 \\
\hline TRC117 & 0.0104 & 0.37 & 1183.5 & 694.0 & 0.0000 & 117.1 & 0.25 & 98.9 & 0.0 & 0.88 \\
\hline TRC118 & 0.0603 & 1.14 & 1367.2 & 433.8 & 0.0000 & 240.4 & 8.53 & 254.3 & 0.0 & 2.57 \\
\hline TRC119 & 0.0784 & 0.86 & 1733.1 & 1065.6 & 0.0000 & 464.9 & 3.21 & 276.4 & 0.0 & 2.36 \\
\hline TRC120 & 0.0233 & 0.67 & 1549.0 & 1250.3 & 0.0000 & 357.6 & 0.71 & 239.3 & 0.0 & 2.64 \\
\hline TRC121 & 0.0243 & 0.58 & 1960.4 & 342.5 & 0.0000 & 571.7 & 1.15 & 248.6 & 0.0 & 0.75 \\
\hline TRC122 & 0.0188 & 0.20 & 1683.2 & 558.0 & 0.0708 & 338.5 & 0.45 & 327.1 & 0.0 & 0.00 \\
\hline TRC123 & 0.0483 & 0.80 & 1614.3 & 648.4 & 0.0000 & 470.7 & 0.69 & 246.5 & 0.0 & 1.23 \\
\hline TRC124 & 0.0774 & 1.23 & 1829.6 & 497.3 & 0.0000 & 445.3 & 2.79 & 188.9 & 32.5 & 0.63 \\
\hline TRC125 & 0.0415 & 0.59 & 1843.2 & 789.0 & 0.0000 & 398.1 & 0.17 & 247.0 & 0.0 & 2.41 \\
\hline TRC126 & 0.0228 & 0.29 & 1416.9 & 1500.3 & 0.0000 & 356.7 & 1.91 & 181.9 & 0.0 & 0.72 \\
\hline TRC127 & 0.0791 & 2.26 & 1800.1 & 425.5 & 0.0000 & 518.2 & 0.48 & 281.6 & 0.0 & 3.70 \\
\hline TRC128 & 0.0266 & 0.92 & 1394.3 & 1564.5 & 0.0000 & 258.6 & 0.52 & 138.7 & 60.2 & 1.46 \\
\hline TRC129 & 0.0288 & 0.34 & 1178.3 & 514.3 & 0.0000 & 258.7 & 0.49 & 188.3 & 0.0 & 1.29 \\
\hline TRC130 & 0.0525 & 0.79 & 1291.3 & 8896.5 & 0.0000 & 421.4 & 2.53 & 229.5 & 0.0 & 2.36 \\
\hline TRC131 & 0.0219 & 0.25 & 1397.7 & 287.8 & 0.0000 & 348.4 & 0.17 & 194.8 & 0.0 & 0.00 \\
\hline TRC132 & 0.0140 & 0.67 & 1620.0 & 803.3 & 0.0000 & 350.3 & 0.86 & 161.3 & 0.0 & 2.08 \\
\hline TRC133 & 0.0239 & 0.41 & 1441.9 & 115.1 & 0.0000 & 387.8 & 0.85 & 141.1 & 0.0 & 0.00 \\
\hline TRC134 & 0.0103 & 0.32 & 1366.4 & 448.1 & 0.0000 & 220.7 & 0.26 & 163.9 & 0.0 & 1.35 \\
\hline TRC135 & 0.0679 & 0.75 & 1609.2 & 152.5 & 0.0000 & 411.1 & 0.64 & 226.5 & 0.0 & 2.58 \\
\hline TRC136 & 0.0237 & 0.53 & 1511.9 & 191.2 & 0.0000 & 259.5 & 0.32 & 256.8 & 0.0 & 1.48 \\
\hline TRC137 & 0.0315 & 0.60 & 1086.2 & 130.1 & 0.0000 & 327.9 & 0.44 & 224.9 & 0.0 & 1.08 \\
\hline TRC138 & 0.0264 & 0.83 & 1220.7 & 422.3 & 0.0000 & 325.2 & 0.51 & 258.7 & 0.0 & 2.03 \\
\hline TRC139 & 0.0450 & 1.05 & 2446.1 & 6758.6 & 0.0000 & 512.7 & 5.60 & 215.4 & 0.0 & 0.00 \\
\hline TRC140 & 0.2166 & 19.70 & 1558.2 & 837.5 & 0.0000 & 444.3 & 2.84 & 223.5 & 1.2 & 3.42 \\
\hline TRC141 & 0.0336 & 0.00 & 4184.8 & 0.0 & 0.0000 & 0.0 & 1.34 & 644.1 & 0.0 & 0.00 \\
\hline TRC142 & 0.0141 & 2.17 & 2516.1 & 7379.8 & 0.0000 & 625.6 & 1.96 & 268.8 & 0.0 & 0.00 \\
\hline TRC143 & 0.0223 & 0.75 & 1060.5 & 233.4 & 0.0000 & 271.0 & 0.58 & 199.1 & 0.0 & 3.31 \\
\hline TRC144 & 0.1729 & 3.96 & 2447.5 & 4851.2 & 0.0000 & 895.1 & 2.79 & 464.6 & 52.6 & 2.91 \\
\hline
\end{tabular}


Table 2. Concentrations of elements measured by INAA in the chert samples in this study.

\begin{tabular}{|c|c|c|c|c|c|c|c|c|c|c|}
\hline ANID & Th (ppm) & Zn (ppm) & Al (ppm) & $\mathrm{Ca}(p p m)$ & Dy (ppm) & $\mathrm{K}(\mathrm{ppm})$ & Mn (ppm) & $\mathrm{Na}(p p m)$ & $\mathrm{Ti}$ (ppm) & V (ppm) \\
\hline TRC145 & 0.0081 & 0.74 & 2065.3 & 382.2 & 0.0000 & 213.2 & 0.32 & 179.9 & 17.9 & 1.95 \\
\hline TRC146 & 0.0274 & 0.84 & 2186.3 & 819.6 & 0.0000 & 599.3 & 0.72 & 134.5 & 98.9 & 0.00 \\
\hline TRC147 & 0.0212 & 0.00 & 1590.5 & 867.7 & 0.0000 & 391.5 & 3.41 & 254.1 & 8.5 & 3.55 \\
\hline TRC148 & 0.0157 & 0.00 & 1172.7 & 590.5 & 0.0000 & 245.0 & 0.57 & 163.4 & 0.0 & 3.73 \\
\hline TRC149 & 0.0354 & 1.55 & 1796.4 & 546.9 & 0.0000 & 432.6 & 1.07 & 240.7 & 19.3 & 2.56 \\
\hline TRC150 & 0.0214 & 1.63 & 1936.2 & 0.0 & 0.0000 & 0.0 & 0.98 & 367.1 & 0.0 & 2.12 \\
\hline TRC151 & 0.0279 & 0.49 & 1574.3 & 610.7 & 0.0000 & 343.2 & 0.52 & 257.7 & 0.0 & 2.37 \\
\hline TRC152 & 0.0331 & 0.84 & 1836.6 & 454.2 & 0.0000 & 544.4 & 15.24 & 250.6 & 0.0 & 2.90 \\
\hline TRC153 & 0.0367 & 0.56 & 1821.4 & 1439.5 & 0.0000 & 369.6 & 2.02 & 207.8 & 0.0 & 2.31 \\
\hline TRC154 & 0.0286 & 1.77 & 1878.2 & 298.1 & 0.0000 & 562.0 & 0.37 & 297.5 & 0.0 & 4.77 \\
\hline TRC155 & 0.0705 & 0.59 & 2963.9 & 403.5 & 0.0440 & 418.4 & 6.46 & 323.3 & 120.5 & 4.37 \\
\hline TRC156 & 0.0314 & 0.75 & 1250.0 & 525.2 & 0.0000 & 323.7 & 0.52 & 239.5 & 0.0 & 2.67 \\
\hline TRC157 & 0.0221 & 0.62 & 1143.1 & 475.3 & 0.0000 & 0.0 & 0.59 & 180.9 & 115.6 & 2.07 \\
\hline TRC158 & 0.0491 & 1.92 & 3799.9 & 567.2 & 0.0000 & 873.7 & 1.18 & 430.4 & 83.1 & 10.92 \\
\hline TRC159 & 0.0562 & 0.62 & 1483.1 & 1190.0 & 0.0000 & 332.4 & 1.98 & 262.2 & 84.2 & 2.23 \\
\hline TRC160 & 0.0253 & 2.63 & 1861.1 & 1155.4 & 0.0000 & 311.6 & 0.97 & 245.1 & 0.0 & 1.77 \\
\hline TRC161 & 0.0323 & 0.63 & 1460.2 & 56.6 & 0.0000 & 361.7 & 0.45 & 226.5 & 0.0 & 2.88 \\
\hline TRC162 & 0.0255 & 0.52 & 1414.2 & 197.7 & 0.0000 & 130.7 & 0.45 & 219.1 & 0.0 & 1.89 \\
\hline TRC163 & 0.0182 & 0.79 & 1395.9 & 822.4 & 0.0000 & 391.2 & 2.35 & 261.4 & 0.0 & 2.10 \\
\hline TRC164 & 0.0407 & 0.82 & 1561.4 & 2696.3 & 0.0000 & 377.0 & 2.25 & 244.1 & 0.0 & 2.47 \\
\hline TRC165 & 0.0242 & 0.80 & 1322.6 & 326.9 & 0.0000 & 373.7 & 1.18 & 240.6 & 0.0 & 2.47 \\
\hline TRC166 & 0.0576 & 1.26 & 2916.3 & 584.9 & 0.0000 & 832.3 & 1.58 & 333.8 & 0.0 & 4.40 \\
\hline TRC167 & 0.0474 & 0.96 & 1134.9 & 1908.7 & 0.0000 & 233.0 & 2.37 & 160.0 & 84.3 & 2.11 \\
\hline TRC168 & 0.0596 & 3.56 & 1583.6 & 753.4 & 0.0000 & 283.1 & 0.52 & 217.1 & 0.0 & 3.78 \\
\hline TRC169 & 0.0401 & 0.52 & 1620.4 & 957.2 & 0.0000 & 381.5 & 1.62 & 200.1 & 0.0 & 0.00 \\
\hline TRC170 & 0.0518 & 0.58 & 1659.2 & 958.2 & 0.0000 & 425.8 & 2.09 & 179.6 & 67.1 & 2.61 \\
\hline TRC171 & 0.0424 & 0.83 & 1213.5 & 378.0 & 0.0000 & 371.7 & 0.90 & 243.6 & 0.0 & 1.58 \\
\hline TRC172 & 0.0223 & 0.34 & 1047.1 & 1095.8 & 0.0000 & 0.0 & 1.01 & 126.5 & 0.0 & 1.64 \\
\hline TRC173 & 0.0173 & 0.32 & 1182.7 & 100.3 & 0.0000 & 168.4 & 0.83 & 207.5 & 0.0 & 1.92 \\
\hline TRC174 & 0.0184 & 0.89 & 1211.6 & 0.0 & 0.0000 & 232.1 & 0.66 & 206.8 & 0.0 & 1.83 \\
\hline TRC175 & 0.0067 & 0.17 & 1506.9 & 991.4 & 0.0000 & 478.1 & 0.36 & 207.9 & 0.0 & 0.51 \\
\hline TRC176 & 0.1412 & 3.53 & 2563.2 & 790.6 & 0.0000 & 409.0 & 1.57 & 303.1 & 0.0 & 1.54 \\
\hline TRC177 & 0.0330 & 0.55 & 1424.5 & 536.6 & 0.0000 & 235.4 & 0.81 & 241.2 & 0.0 & 0.85 \\
\hline TRC178 & 0.0655 & 2.05 & 1888.8 & 435.3 & 0.0000 & 406.3 & 0.94 & 258.3 & 0.0 & 0.90 \\
\hline TRC179 & 0.0525 & 1.02 & 1592.0 & 352.7 & 0.0000 & 314.5 & 0.84 & 205.3 & 0.0 & 2.95 \\
\hline TRC180 & 0.0418 & 1.37 & 1566.3 & 519.5 & 0.0000 & 332.5 & 0.57 & 278.7 & 0.0 & 2.05 \\
\hline
\end{tabular}




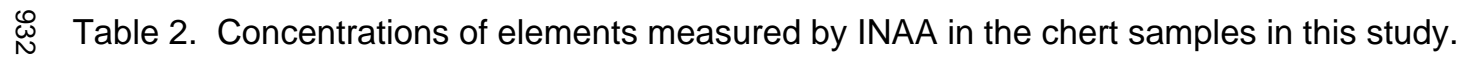

\begin{tabular}{|c|c|c|c|c|c|c|c|c|c|c|}
\hline ANID & Th (ppm) & Zn (ppm) & $\mathrm{Al}(p p m)$ & $\mathrm{Ca}$ (ppm) & Dy (ppm) & $\mathrm{K}(\mathrm{ppm})$ & Mn (ppm) & $\mathrm{Na}$ (ppm) & $\mathrm{Ti}$ (ppm) & V (ppm) \\
\hline TRC181 & 0.0235 & 0.55 & 1024.8 & 103.3 & 0.0000 & 334.1 & 1.50 & 216.6 & 0.0 & 1.76 \\
\hline TRC182 & 0.0118 & 0.51 & 1288.4 & 244.4 & 0.0000 & 473.2 & 0.41 & 205.0 & 0.0 & 2.03 \\
\hline TRC183 & 0.0358 & 0.97 & 1217.4 & 6681.6 & 0.0000 & 163.9 & 1.56 & 249.7 & 0.0 & 3.42 \\
\hline TRC184 & 0.0555 & 0.62 & 1312.8 & 557.7 & 0.0000 & 358.1 & 1.17 & 175.8 & 0.0 & 0.00 \\
\hline TRC185 & 0.0414 & 0.61 & 1524.4 & 3371.1 & 0.0246 & 479.3 & 4.98 & 269.6 & 0.0 & 5.88 \\
\hline TRC186 & 0.0401 & 1.29 & 2644.1 & 1046.0 & 0.0000 & 462.0 & 1.35 & 302.2 & 0.0 & 7.12 \\
\hline TRC187 & 0.0277 & 1.15 & 1304.3 & 2436.4 & 0.0000 & 266.4 & 0.79 & 251.5 & 0.0 & 2.60 \\
\hline TRC188 & 0.0169 & 0.42 & 1427.4 & 1006.6 & 0.0000 & 366.5 & 0.81 & 193.6 & 0.0 & 2.64 \\
\hline TRC189 & 0.0138 & 0.98 & 1151.9 & 573.5 & 0.0000 & 213.0 & 0.20 & 180.4 & 0.0 & 0.97 \\
\hline TRC190 & 0.0325 & 0.36 & 1152.2 & 570.0 & 0.0000 & 447.0 & 1.18 & 221.8 & 0.0 & 0.00 \\
\hline TRC191 & 0.0292 & 0.75 & 1357.9 & 641.6 & 0.0000 & 226.2 & 1.68 & 202.8 & 0.0 & 0.81 \\
\hline TRC192 & 0.0276 & 1.81 & 1978.9 & 962.9 & 0.0000 & 320.9 & 0.87 & 191.8 & 0.0 & 2.37 \\
\hline TRC193 & 0.0590 & 0.78 & 1535.3 & 500.8 & 0.0000 & 419.6 & 1.90 & 246.3 & 0.0 & 2.75 \\
\hline TRC194 & 0.0446 & 0.86 & 1611.9 & 5201.7 & 0.0000 & 225.4 & 2.23 & 247.4 & 0.0 & 2.52 \\
\hline TRC195 & 0.0403 & 1.02 & 2021.5 & 311.6 & 0.0000 & 454.5 & 1.61 & 267.0 & 66.5 & 2.32 \\
\hline TRC196 & 0.0252 & 1.10 & 1506.0 & 450.0 & 0.0000 & 243.8 & 2.36 & 219.1 & 0.0 & 1.81 \\
\hline TRC197 & 0.0368 & 1.62 & 1904.1 & 593.9 & 0.0000 & 598.2 & 6.18 & 219.7 & 0.0 & 4.00 \\
\hline TRC198 & 0.0689 & 0.87 & 1912.4 & 556.7 & 0.0000 & 221.9 & 6.58 & 210.4 & 0.0 & 2.70 \\
\hline TRC199 & 0.0169 & 0.37 & 1212.1 & 658.0 & 0.0000 & 245.2 & 1.65 & 178.3 & 0.0 & 0.00 \\
\hline TRC200 & 0.0580 & 1.54 & 2501.6 & 488.7 & 0.0000 & 479.9 & 1.77 & 344.6 & 0.0 & 4.22 \\
\hline TRC201 & 0.0289 & 0.48 & 1429.1 & 287.2 & 0.0000 & 452.6 & 0.69 & 257.8 & 0.0 & 3.15 \\
\hline TRC202 & 0.0363 & 0.82 & 1057.3 & 700.9 & 0.0000 & 166.7 & 1.24 & 112.1 & 0.0 & 4.36 \\
\hline TRC203 & 0.0289 & 0.62 & 1413.9 & 227.7 & 0.0000 & 282.6 & 2.43 & 226.0 & 0.0 & 3.74 \\
\hline TRC204 & 0.0167 & 0.30 & 1303.3 & 0.0 & 0.0000 & 341.0 & 0.85 & 211.5 & 0.0 & 1.43 \\
\hline TRC205 & 0.0177 & 0.32 & 1003.8 & 130.8 & 0.0389 & 184.5 & 0.44 & 194.1 & 0.0 & 1.44 \\
\hline TRC206 & 0.0314 & 1.09 & 1283.1 & 302.6 & 0.0000 & 262.6 & 0.58 & 271.8 & 0.0 & 1.22 \\
\hline TRC207 & 0.0361 & 0.66 & 2109.4 & 1291.0 & 0.0000 & 318.5 & 0.86 & 209.6 & 0.0 & 0.94 \\
\hline TRC208 & 0.0169 & 0.42 & 1768.5 & 458.9 & 0.0000 & 294.7 & 1.02 & 205.4 & 0.0 & 1.08 \\
\hline TRC209 & 0.0098 & 0.39 & 910.3 & 148.6 & 0.0000 & 269.4 & 0.34 & 187.9 & 0.0 & 0.00 \\
\hline TRC210 & 0.0177 & 0.21 & 1656.9 & 2352.5 & 0.0241 & 256.6 & 1.50 & 233.7 & 0.0 & 0.00 \\
\hline TRC211 & 0.0218 & 1.02 & 1838.3 & 779.9 & 0.0000 & 316.1 & 2.10 & 251.0 & 162.9 & 1.92 \\
\hline TRC212 & 0.0255 & 0.00 & 1471.6 & 364.3 & 0.0000 & 271.9 & 1.27 & 200.1 & 201.7 & 0.00 \\
\hline TRC213 & 0.0289 & 1.49 & 1555.1 & 277.6 & 0.0000 & 369.4 & 0.86 & 220.8 & 188.4 & 1.91 \\
\hline TRC214 & 0.0157 & 0.00 & 1490.6 & 486.1 & 0.0000 & 0.0 & 0.31 & 198.2 & 129.5 & 0.00 \\
\hline TRC215 & 0.0625 & 0.00 & 1954.6 & 544.2 & 0.0655 & 459.0 & 3.60 & 288.5 & 222.1 & 0.00 \\
\hline TRC216 & 0.0346 & 0.00 & 1631.0 & 350.2 & 0.0000 & 0.0 & 67.05 & 229.7 & 367.4 & 0.00 \\
\hline
\end{tabular}


Table 2. Concentrations of elements measured by INAA in the chert samples in this study.

\begin{tabular}{|c|c|c|c|c|c|c|c|c|c|c|}
\hline ANID & Th (ppm) & Zn (ppm) & Al (ppm) & $\mathrm{Ca}$ (ppm) & Dy (ppm) & $\mathrm{K}(\mathrm{ppm})$ & Mn (ppm) & $\mathrm{Na}(p p m)$ & $\mathrm{Ti}(p p m)$ & V (ppm) \\
\hline TRC217 & 0.0255 & 1.22 & 1425.8 & 1716.8 & 0.0000 & 564.2 & 1.35 & 202.6 & 167.0 & 2.16 \\
\hline TRC218 & 0.0713 & 0.76 & 1038.7 & 267.4 & 0.0000 & 389.7 & 3.63 & 215.1 & 0.0 & 3.50 \\
\hline TRC219 & 0.0185 & 0.98 & 2440.6 & 489.6 & 0.0000 & 379.4 & 0.99 & 281.0 & 0.0 & 0.00 \\
\hline TRC220 & 0.0207 & 0.69 & 1090.3 & 295.3 & 0.0000 & 202.5 & 1.37 & 251.2 & 0.0 & 0.00 \\
\hline TRC221 & 0.0691 & 0.56 & 1314.2 & 289.7 & 0.0000 & 584.1 & 1.24 & 329.4 & 0.0 & 2.82 \\
\hline TRC222 & 0.0143 & 2.12 & 1429.3 & 326.5 & 0.0000 & 356.2 & 0.88 & 185.7 & 69.2 & 0.81 \\
\hline TRC223 & 0.0138 & 0.46 & 1127.7 & 263.7 & 0.0000 & 230.6 & 0.51 & 225.5 & 0.0 & 2.00 \\
\hline TRC224 & 0.0290 & 1.13 & 1471.4 & 1150.0 & 0.0000 & 326.7 & 0.54 & 250.3 & 0.0 & 1.68 \\
\hline TRC225 & 0.0571 & 2.14 & 1471.8 & 440.1 & 0.0000 & 279.0 & 1.05 & 293.0 & 0.0 & 3.41 \\
\hline TRC226 & 0.0232 & 0.67 & 1937.5 & 401.9 & 0.0000 & 440.9 & 0.61 & 264.6 & 0.0 & 1.35 \\
\hline TRC227 & 0.0231 & 0.37 & 1462.6 & 303.1 & 0.0000 & 339.3 & 0.80 & 273.6 & 0.0 & 0.00 \\
\hline TRC228 & 0.0232 & 0.42 & 1412.7 & 1163.2 & 0.0000 & 0.0 & 0.97 & 228.9 & 0.0 & 3.37 \\
\hline TRC229 & 0.0644 & 1.16 & 1758.9 & 8516.8 & 0.0000 & 0.0 & 1.95 & 291.4 & 0.0 & 2.44 \\
\hline TRC230 & 0.0162 & 0.57 & 1511.4 & 254.4 & 0.0000 & 387.1 & 0.72 & 255.5 & 0.0 & 0.00 \\
\hline TRC231 & 0.0683 & 0.72 & 1741.4 & 409.9 & 0.0000 & 385.3 & 3.17 & 238.0 & 0.0 & 2.16 \\
\hline TRC232 & 0.0181 & 0.75 & 1614.8 & 253.3 & 0.0000 & 319.1 & 1.09 & 240.5 & 0.0 & 0.00 \\
\hline TRC233 & 0.0492 & 1.35 & 1810.5 & 503.0 & 0.0000 & 396.9 & 1.38 & 281.8 & 0.0 & 2.15 \\
\hline TRC234 & 0.0434 & 13.54 & 1430.2 & 329.0 & 0.0000 & 164.6 & 1.90 & 231.9 & 0.0 & 5.54 \\
\hline TRC235 & 0.0294 & 2.19 & 1425.3 & 679.3 & 0.0000 & 132.2 & 1.34 & 222.6 & 0.0 & 0.00 \\
\hline TRC236 & 0.0553 & 2.14 & 1880.1 & 113.2 & 0.0737 & 393.1 & 1.06 & 273.7 & 0.0 & 3.20 \\
\hline TRC237 & 0.0510 & 1.58 & 1240.1 & 387.1 & 0.0000 & 260.0 & 1.51 & 233.9 & 0.0 & 5.01 \\
\hline TRC238 & 0.0277 & 1.74 & 1484.0 & 1291.3 & 0.0000 & 142.3 & 2.25 & 186.9 & 0.0 & 3.12 \\
\hline TRC239 & 0.0107 & 9.83 & 1698.4 & 1023.2 & 0.0000 & 0.0 & 0.59 & 99.4 & 0.0 & 1.76 \\
\hline TRC240 & 0.0163 & 0.53 & 1175.4 & 385.7 & 0.0000 & 347.1 & 0.35 & 206.4 & 0.0 & 1.75 \\
\hline TRC241 & 0.0137 & 1.00 & 1596.7 & 760.5 & 0.0582 & 0.0 & 1.11 & 195.6 & 0.0 & 0.90 \\
\hline TRC242 & 0.0163 & 0.32 & 1279.4 & 613.3 & 0.0000 & 0.0 & 1.27 & 176.0 & 88.4 & 1.81 \\
\hline TRC243 & 0.0338 & 0.50 & 1439.5 & 643.5 & 0.0000 & 154.3 & 2.14 & 116.9 & 0.0 & 1.60 \\
\hline TRC244 & 0.0355 & 1.14 & 2199.5 & 828.5 & 0.0430 & 438.9 & 5.70 & 254.5 & 0.0 & 4.38 \\
\hline TRC245 & 0.0125 & 0.94 & 18103.7 & 5684.1 & 0.0000 & 2121.6 & 8.90 & 1611.1 & 0.0 & 0.00 \\
\hline TRC246 & 0.0138 & 0.53 & 1969.2 & 533.2 & 0.0000 & 215.5 & 1.22 & 227.1 & 0.0 & 0.00 \\
\hline TRC247 & 0.0000 & 0.69 & 2172.9 & 579.2 & 0.0000 & 349.1 & 0.99 & 246.7 & 0.0 & 0.00 \\
\hline TRC248 & 0.0334 & 1.51 & 1297.1 & 349.5 & 0.0000 & 180.6 & 2.68 & 197.4 & 0.0 & 0.00 \\
\hline TRC249 & 0.0309 & 1.73 & 1926.6 & 749.9 & 0.0000 & 335.4 & 0.86 & 263.3 & 0.0 & 1.97 \\
\hline TRC250 & 0.0350 & 2.95 & 1789.4 & 382.1 & 0.0000 & 262.3 & 1.89 & 225.7 & 0.0 & 2.35 \\
\hline TRC251 & 0.0219 & 0.65 & 1279.0 & 0.0 & 0.0000 & 252.9 & 0.66 & 216.9 & 238.6 & 0.00 \\
\hline TRC252 & 0.0103 & 0.88 & 2122.3 & 147.9 & 0.0000 & 373.0 & 0.74 & 177.1 & 0.0 & 1.45 \\
\hline
\end{tabular}


$\underset{+}{œ}$ Table 2. Concentrations of elements measured by INAA in the chert samples in this study.

$\begin{array}{lrrrrrrrrrr}\text { ANID } & \text { Th }(\mathbf{p p m}) & \text { Zn }(\mathbf{p p m}) & \mathbf{A l}(\mathbf{p p m}) & \mathbf{C a}(\mathbf{p p m}) & \mathbf{D y}(\mathbf{p p m}) & \mathbf{K}(\mathbf{p p m}) & \mathbf{M n}(\mathbf{p p m}) & \mathbf{N a}(\mathbf{p p m}) & \text { Ti (ppm) } & \text { V (ppm) } \\ \text { TRC253 } & 0.0593 & 0.00 & 1689.3 & 104.0 & 0.0000 & 287.0 & 0.60 & 262.3 & 76.2 & 3.79 \\ \text { TRC254 } & 0.0464 & 3.26 & 1683.7 & 106.4 & 0.0000 & 0.0 & 13.90 & 202.5 & 409.6 & 1.91 \\ \text { TRC255 } & 10.5094 & 5.28 & 36559.9 & 912.1 & 14.6378 & 42428.2 & 15.65 & 3692.3 & 485.2 & 0.00 \\ \text { TRC256 } & 0.0438 & 1.66 & 1891.1 & 1458.9 & 0.0000 & 726.6 & 1.38 & 288.8 & 0.0 & 1.08 \\ \text { TRC257 } & 0.0437 & 1.70 & 2036.4 & 279.2 & 0.0000 & 410.3 & 9.12 & 236.8 & 334.2 & 1.79 \\ \text { TRC258 } & 0.0540 & 1.58 & 1250.3 & 276.1 & 0.0412 & 475.6 & 1.27 & 267.9 & 474.5 & 4.03 \\ \text { TRC259 } & 0.0322 & 0.72 & 1193.2 & 486.0 & 0.0000 & 336.2 & 3.24 & 212.7 & 232.0 & 3.52 \\ \text { TRC260 } & 0.0294 & 0.00 & 2169.7 & 339.5 & 0.0000 & 365.9 & 2.01 & 251.5 & 112.0 & 1.05 \\ \text { TRC261 } & 0.0505 & 1.22 & 1460.1 & 4604.9 & 0.0000 & 314.8 & 0.76 & 273.9 & 0.0 & 4.75\end{array}$


Table 3. Eigenvalues and percentage of variance explained by principal components analysis of 261 chert samples.

Note: This PCA was performed on the samples in this study which include a collection of Edwards Formation source specimens (TRCO01-TRC107) and Varga site artifacts (TRC108-TRC261).

Simultaneous R-Q Factor Analysis Based on Variance-Covariance Matrix

Eigenvalues and Percentage of Variance Explained:

\begin{tabular}{|c|c|c|}
\hline Eigenvalue & \%Variance & Cum. \%var. \\
\hline & 36.30 & 36.30 \\
\hline & 14.84 & 51.14 \\
\hline & 9.927 & 61.07 \\
\hline อ: 4150 & 7.850 & 68.92 \\
\hline$\odot .2776$ & 5.378 & 74.30 \\
\hline 0.2195 & 4.235 & 78.53 \\
\hline$\odot .1504$ & 3.814 & 82.35 \\
\hline 0.1184 & 2.753 & 85.10 \\
\hline 8.19660 & 2.611 & 87.71 \\
\hline $\begin{array}{l}0.07698 \\
0.07299\end{array}$ & 2.194 & 89.91 \\
\hline $0.01<99$ & 1.854 & 91.76 \\
\hline 0.06135 & 1.699 & 93.46 \\
\hline ๑. 05184 & 1.508 & 94.97 \\
\hline 0.04750 & 0.9863 & 95.95 \\
\hline 0.04216 & $\odot .8191$ & 96.77 \\
\hline ๑. 02758 & $\odot .6556$ & 97.43 \\
\hline 0.02290 & 0.5734 & $98.0 \odot$ \\
\hline 0.01833 & $\odot .4752$ & 98.48 \\
\hline 0.01603 & 0.4126 & 98.89 \\
\hline 0.01329 & $\odot .3589$ & 99.25 \\
\hline 0.01154 & $\odot .2715$ & 99.52 \\
\hline 8:8199942 & 0.2363 & 99.76 \\
\hline$\odot .006608$ & 0.1362 & 99.89 \\
\hline 0.003808 & 0.07602 & 99.97 \\
\hline 8:8821268 & $\odot .03249$ & 100.0 \\
\hline
\end{tabular}

$\leftarrow 10$ PCs required to explain approximately $90 \%$ of variance 
Table 4. Basic characteristics observed for chert sub-types characterized in this study.

\begin{tabular}{ll}
\hline Source Specimen Group Name & Main Characteristics \\
\hline Hackberry Creek & Low concentrations of As, Co, Fe, Hf \& Zn \\
Glen Rose & High concentrations of Mn \\
Georgetown & Low concentrations of Ca and $\mathrm{Sr}$ \\
Varga area samples & Low concentrations of REEs \\
Devil River Formation & Low concentrations of REEs, As, Fe, Sb \& Zn \\
\hline
\end{tabular}


Table 5. Mahalanobis distance-based probabilities and posterior classification of TRC specimens from the larger groups $(n>12)$ against one another.

Groups are:

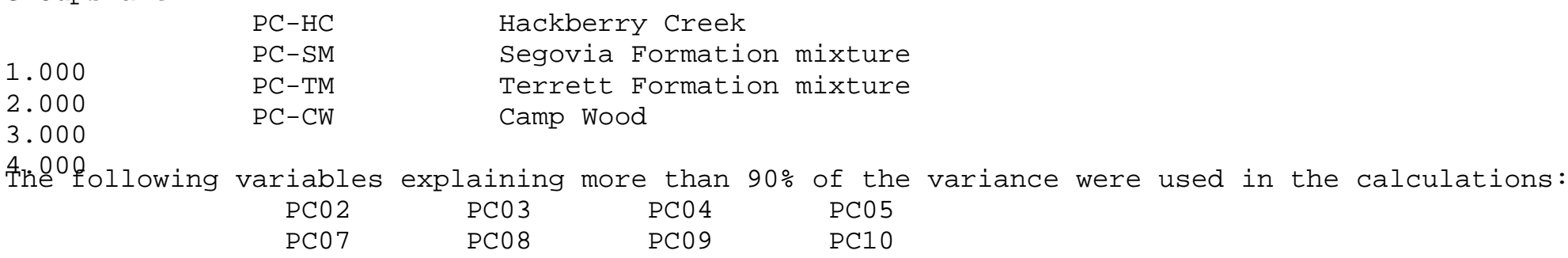

Bcopabilities are jackknifed for specimens included in each group.

PCO6

The following specimens are in the file PC-HC

\begin{tabular}{|c|c|c|c|c|c|}
\hline $\begin{array}{l}\text { ID. NO. } \\
\text { TRCO83 }\end{array}$ & $\begin{array}{r}\mathrm{PC}-\mathrm{HC} \\
95 \quad 515\end{array}$ & $\begin{array}{c}\text { PC-SM } \\
\text { Prote日s } 967+i e\end{array}$ & $\begin{array}{r}\text { PC-TM } \\
86372\end{array}$ & $\begin{array}{r}\mathrm{PC}-\mathrm{CW} \\
18.801\end{array}$ & From: \\
\hline TRC@84 & 67.249 & 4.463 & 62.628 & 2.980 & 1 \\
\hline TRC@85 & 7.290 & 11.367 & 9.700 & 71.658 & 1 \\
\hline TRC@86 & 81.232 & 2.178 & 77.594 & 2.243 & 1 \\
\hline TRC@87 & 95.590 & 17.078 & 84.787 & 3.631 & 1 \\
\hline TRC@88 & 0.811 & $\odot .796$ & 3.021 & ๑. 257 & 1 \\
\hline TRC०89 & 0.918 & 1.414 & 4.468 & 1.848 & 1 \\
\hline TRCO9๑ & 59.683 & 11.321 & 7.667 & 9.038 & 1 \\
\hline TRC@91 & 94.205 & 1.793 & 42.713 & 3.975 & 1 \\
\hline TRCO92 & 1.102 & 35.512 & 18.482 & 20.113 & 1 \\
\hline TRCO93 & 92.362 & 50.303 & 74.535 & 27.400 & 1 \\
\hline TRC@94 & 47.284 & 62.259 & 11.603 & 80.627 & 1 \\
\hline TRCO95 & 65.927 & 17.976 & 11.789 & 11.660 & 1 \\
\hline TRC@96 & 31.302 & 59.604 & 92.611 & 47.219 & 1 \\
\hline TRC@97 & 99.839 & 23.450 & 87.523 & 6.046 & 1 \\
\hline TRC@98 & 82.085 & 3.848 & 47.337 & 0.864 & 1 \\
\hline TRCO99 & 69.156 & 5.503 & 5.115 & 8.222 & 1 \\
\hline TRC100 & 8.684 & 1.971 & 1.809 & 1.708 & 1 \\
\hline TRC101 & 13.399 & 11.728 & 7.717 & 25.232 & 1 \\
\hline TRC102 & 26.321 & 0.328 & 26.543 & $\odot .082$ & 1 \\
\hline TRC103 & 24.810 & 36.542 & 63.393 & 43.093 & 1 \\
\hline
\end{tabular}

The following specimens are in the file PC-SM 


\begin{tabular}{|c|c|c|c|c|c|c|}
\hline ID. NO. & $\mathrm{PC}-\mathrm{HC}$ & PC-SM & PC-TM & $P C-C W$ & From: & Into \\
\hline TRC๑९7 & 11.267 & 72.283 & 49.408 & 66.258 & 2 & \\
\hline 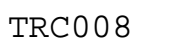 & $\odot .306$ & $\odot .035$ & 13.540 & $\odot .631$ & 2 & \\
\hline TRC@०9 & 14.937 & 87.454 & 17.190 & 60.108 & 2 & \\
\hline TRC010 & 5.424 & 53.621 & 31.807 & 5.064 & 2 & \\
\hline TRC011 & 3.513 & 99.327 & 89.978 & 89.472 & 2 & \\
\hline TRC012 & 1.111 & 75.015 & 73.886 & 76.678 & 2 & \\
\hline TRC013 & 1.352 & $\odot .237$ & 48.374 & 64.845 & 2 & \\
\hline TRC014 & 32.897 & 94.910 & 96.071 & 88.678 & 2 & \\
\hline TRC015 & $0.20 \odot$ & 26.711 & 39.127 & 10.522 & 2 & \\
\hline TREOAGbi. & t12s421 & 64.689 & 60.191 & 67.717 & 2 & \\
\hline TRC०52 & 5.413 & 46.291 & 63.583 & 5.621 & 2 & \\
\hline TRC०53 & 2.644 & 93.150 & 81.137 & 19.487 & 2 & \\
\hline TRC@54 & 1.084 & 91.910 & 71.474 & 70.561 & 2 & \\
\hline TRC@55 & 6.734 & 66.276 & 59.971 & 47.290 & 2 & \\
\hline TRC@56 & 3.231 & 20.806 & 54.874 & 23.012 & 2 & \\
\hline TRC057 & 4.441 & 49.954 & 42.061 & 31.704 & 2 & \\
\hline TRC058 & 7.656 & 98.291 & 27.684 & 24.327 & 2 & \\
\hline TRC@59 & 6.275 & 99.758 & 63.578 & 80.451 & 2 & \\
\hline TRC०6० & 23.743 & 96.992 & 84.014 & 49.483 & 2 & \\
\hline TRC@72 & 0.020 & $3.0 \odot 4$ & 50.205 & 0.623 & 2 & \\
\hline TRC@73 & 0.167 & 38.926 & 1.448 & 2.785 & 2 & \\
\hline TRCO74 & $\odot .259$ & 37.534 & 1.460 & 9.520 & 2 & \\
\hline TRCO79 & 0.456 & 1.606 & 29.775 & 2.948 & 2 & \\
\hline TRC०8๑ & $\odot .756$ & 4.048 & 4.139 & 2.785 & 2 & \\
\hline TRC๑81 & 26.701 & 19.267 & 70.813 & 19.762 & 2 & \\
\hline TRC๑82 & 50.472 & 13.921 & 19.180 & 25.500 & 2 & \\
\hline
\end{tabular}

The following specimens are in the file PC-TM

$\begin{array}{lrrrrrr}\text { ID. NO. } & \text { PC-HC } & \text { PC-SM } & \text { PC-TM } & \text { PC-CW } & \text { From: } & \text { Into: } \\ \text { TRCO47 } & 21.166 & 51.255 & 48.566 & 4.164 & 3 & 2 \\ \text { TRC048 } & 58.025 & 39.770 & 90.708 & 87.385 & 3 & 3 \\ \text { TRC049 } & 22.234 & 26.569 & 73.124 & 23.800 & 3 & 3 \\ \text { TRC050 } & 1.459 & 17.836 & 4.940 & 45.963 & 3 & 4 \\ \text { TRC051 } & 5.536 & 12.523 & 12.591 & 7.600 & 3 & 3 \\ \text { TRC066 } & 0.446 & 2.170 & 35.519 & 18.618 & 3 & 3 \\ \text { TRC067 } & 0.285 & 77.193 & 92.512 & 76.598 & 3 & 3 \\ \text { TRC068 } & 0.365 & 33.133 & 67.703 & 37.182 & 3 & 3 \\ \text { TRC069 } & 0.055 & 20.961 & 33.077 & 34.793 & 3 & 4\end{array}$

Probabilities: 


\begin{tabular}{|c|c|c|c|c|c|c|}
\hline TRC०7० & 2.116 & 16.461 & 92.337 & 66.707 & 3 & 3 \\
\hline TRC०71 & 7.617 & 24.271 & 82.824 & 42.628 & 3 & 3 \\
\hline TRC०75 & 4.169 & 2.265 & 31.612 & 15.314 & 3 & 3 \\
\hline TRCO76 & 4.497 & 34.622 & 47.820 & 24.818 & 3 & 3 \\
\hline TRC077 & 1.388 & 20.095 & 26.761 & 15.506 & 3 & 3 \\
\hline TRC०78 & 0.007 & 0.023 & 7.571 & 0.193 & 3 & 3 \\
\hline
\end{tabular}

The following specimens are in the file PC-CW

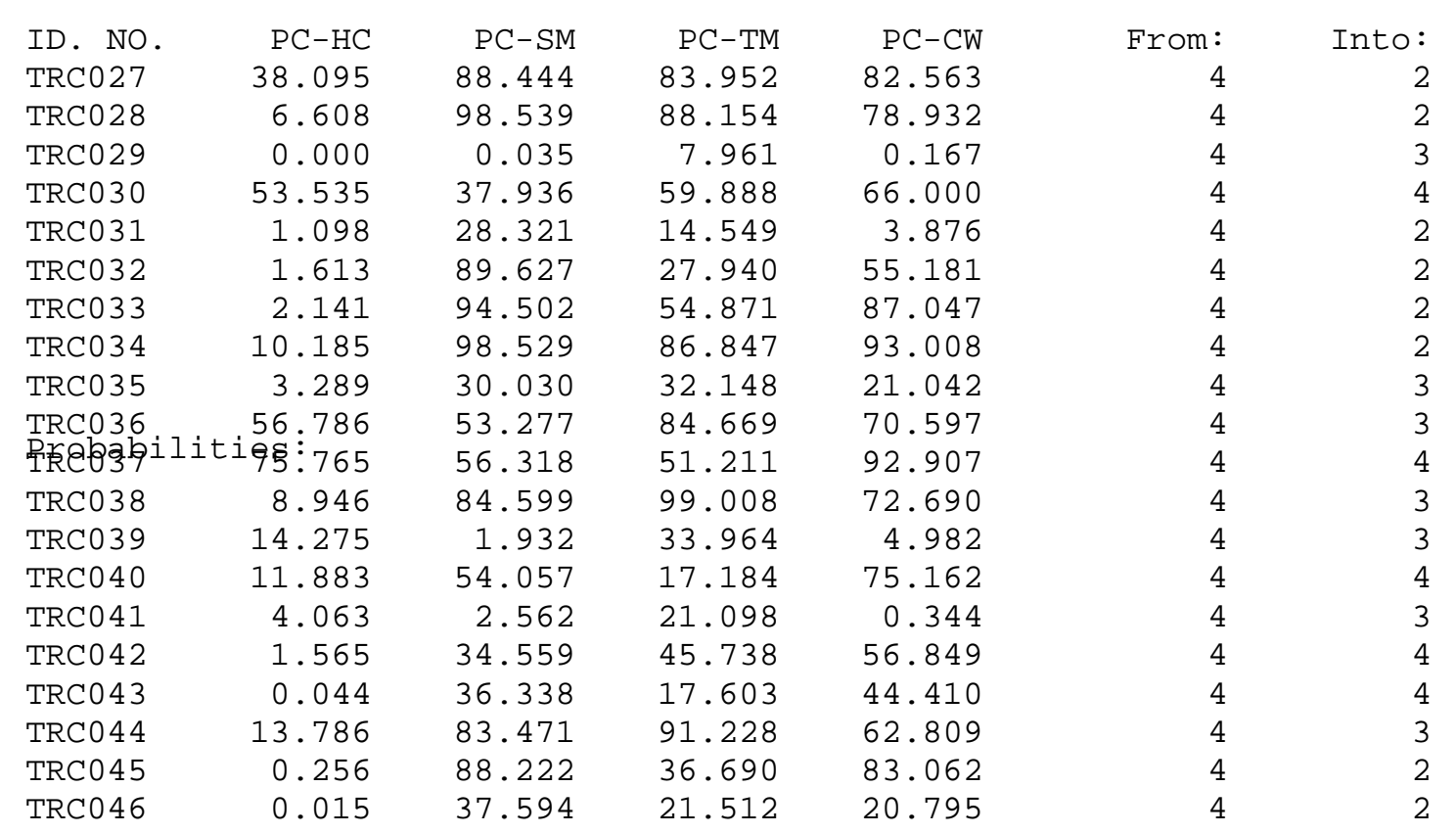

Summary of Classification Success:

$\begin{array}{lrrrrr} & & \text { PC-SM } & \text { PC-TM } & \text { PC-CW } & \text { Total } \\ \text { From Group: } & 12 & 1 & 5 & 3 & 21 \\ \text { PC-HC } & 1 & 13 & 9 & 3 & 26 \\ \text { PC-SM } & 0 & 1 & 12 & 2 & 15 \\ \text { PC-TM } & 0 & 8 & 7 & 5 & 20 \\ \text { PC-CW } & 13 & 23 & 33 & 13 & 82 \\ \text { Total } & & & & & \end{array}$


Table 6. Eigenvalues and percentage of variance explained by principal components analysis of 451 chert specimens.

Note: This PCA was performed on the INAA data for source specimens and artifacts samples in this study combined with earlier source specimen data from the Fort Hood, Segovia Formation, and a mixed collection from the Edwards Formation.

Simultaneous R-Q Factor Analysis Based on Variance-Covariance Matrix

Eigenvalues and Percentage of Variance Explained:

$\begin{array}{lrc}\text { Eigenvalue } & \begin{array}{c}\text { \%Variance } \\ 30.90\end{array} & \begin{array}{c}\text { Cum. \%Var. } \\ 30.90\end{array} \\ & 21.32 & 52.21 \\ 0.7689 & 13.03 & 65.24 \\ 0.5305 & 7.745 & 72.99 \\ 0.3243 & 6.042 & 79.03 \\ 0.1928 & 4.487 & 83.52 \\ 0.1504 & 3.177 & 86.69 \\ 8.111766 & 2.371 & 89.06 \\ \odot .05900 & 2.179 & 91.24 \\ \odot .05424 & 2.145 & 93.39 \\ 0.05337 & 1.652 & 95.04 \\ 0.04112 & 1.313 & 96.35 \\ \odot .03269 & 1.085 & 97.44 \\ 0.02700 & 0.6502 & 98.09 \\ 0.01618 & 0.6024 & 98.69 \\ 0.01499 & 0.4825 & 99.17 \\ 8: 812981 & 0.3968 & 99.57 \\ 0.004875 & 0.1959 & 99.77 \\ 0.003919 & 0.1575 & 99.92 \\ 0.001916 & 0.07698 & 100.0\end{array}$

$\leftarrow 9$ PCs were required to exceed $90 \%$ of the variance 
Table 7. Mahalanobis distance-based probabilities and posterior classification of source specimens TRC@๑1 thru TRC106.

Reference groups and numbers of specimens:

$\begin{array}{lll}\text { PC-E1 } & 19 & \text { Fort Hood: Owl Creel } \\ \text { PC-E2 } & 21 & \text { Fort Hood: Gray-brown-green } \\ \text { PC-E3 } & 20 & \text { Fort Hood: Tan } \\ \text { PC-E4 } & 20 & \text { Fort Hood: Texas Novaculite } \\ \text { PC-E5 } & 20 & \text { Fort Hood: Heiner Lake Tan } \\ \text { PC-E6 } & 18 & \text { Fort Hood: Gray } \\ \text { PC-SF } & 15 & \text { Segovia Formation (Turnbull's collection) } \\ \text { PC-CF } & 59 & \text { Edwards Formation mixture (Frederick's collection) }\end{array}$

The following variables explaining more than $91 \%$ of the variance were used in this calculations:
8
$\mathrm{PCO} 2$
PCO3
$\mathrm{PCO} 4$
PCO5
PCO6
$\mathrm{PC} 07$
PCO8
PC०9

\$bolfollowing specimens are in the file PC-TRCS

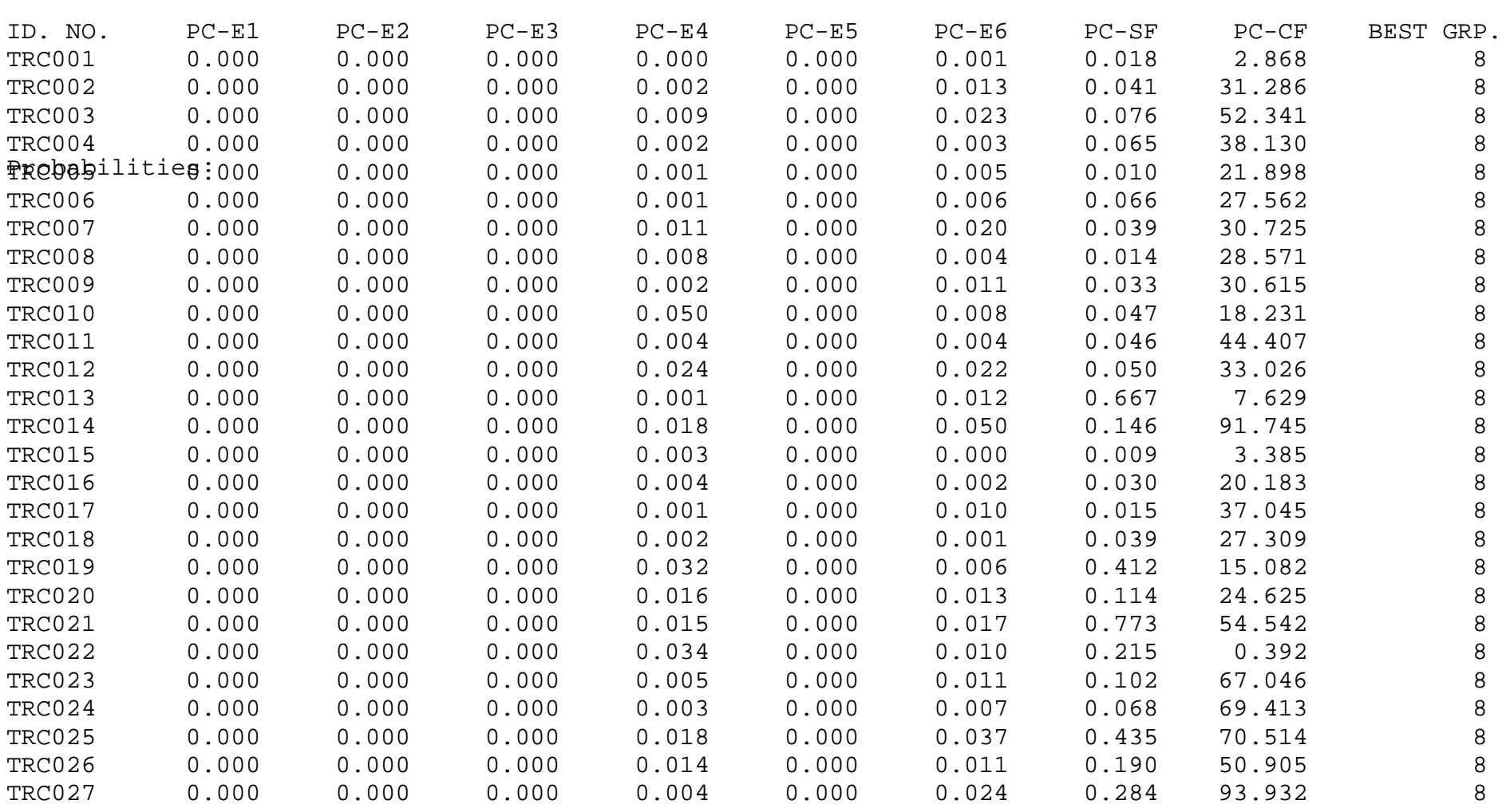




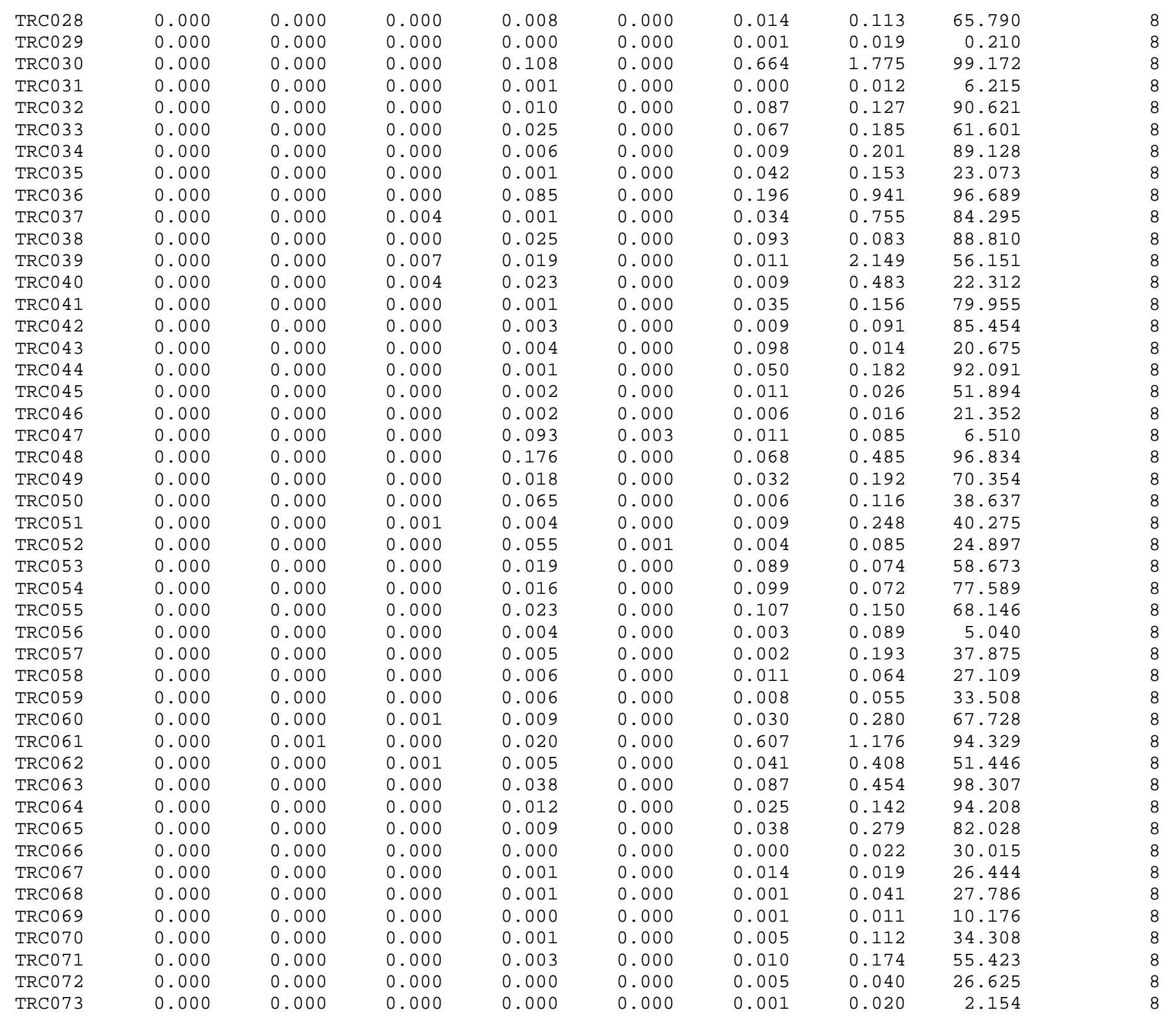




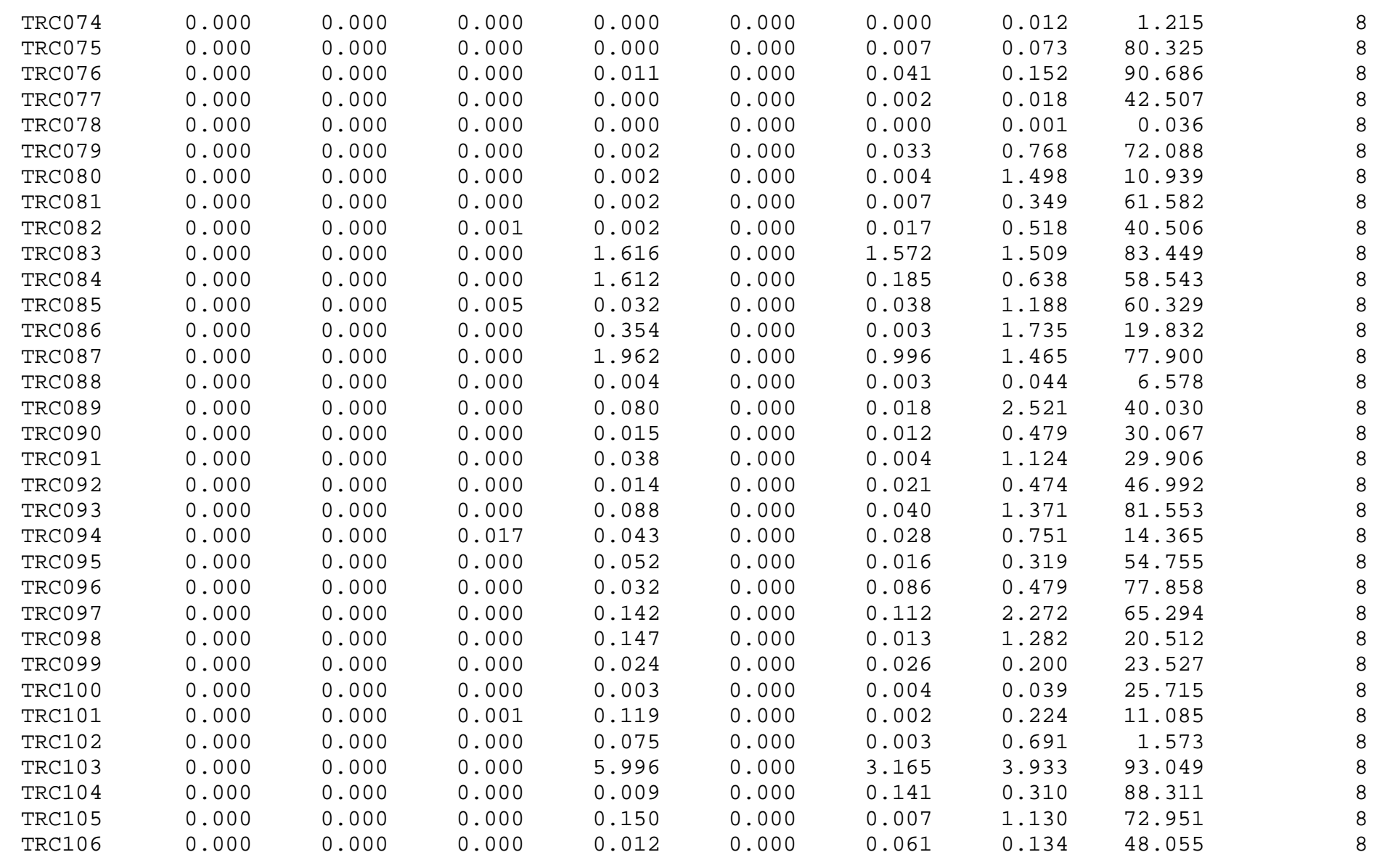

Summary of Probabilities for Specimens in the file PC-TRCS

Group:

\begin{tabular}{|c|c|c|c|c|c|c|c|}
\hline - & ๑. 01000 & 0.10000 & $1.00 \odot \odot \odot$ & $5.0000 \odot$ & 1०. . & $2 \odot . \odot \odot \odot \odot \odot$ & 100.00000 \\
\hline PC-E1 & 106 & 0 & 0 & $\odot$ & 0 & 0 & $\Theta$ \\
\hline PC-E2 & 106 & $\odot$ & $\odot$ & $\odot$ & 0 & $\odot$ & $\odot$ \\
\hline PC-E3 & 105 & 1 & 0 & $\odot$ & 0 & 0 & $\odot$ \\
\hline PC-E4 & 56 & 39 & 7 & 3 & 1 & $\odot$ & $\odot$ \\
\hline PC-E5 & 106 & $\odot$ & $\odot$ & $\odot$ & $\odot$ & $\odot$ & $\odot$ \\
\hline PC-E6 & 45 & 51 & 8 & 2 & $\odot$ & $\odot$ & $\odot$ \\
\hline PC-SF & 3 & $4 \odot$ & 48 & 15 & 0 & 0 & $\Theta$ \\
\hline
\end{tabular}


5
86

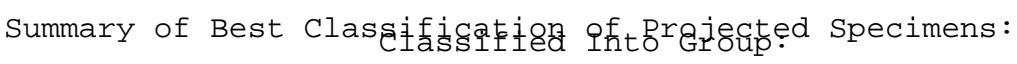

From Group :

PC-TRCS

PC-E2

Total

$\odot$

CC-E3

PC-E4

PC-E5

$\odot$

PC-E6

PC-SF
$\mathrm{PC}-\mathrm{CF}$

Total 106
106

PC-E1 
Table 8. Mahalanobis distance-based probabilities and posterior classification for the Varga site artifacts TRC108 thru TRC261.

Reference groups and numbers of specimens:

$\begin{array}{lccc} & \text { PC-E1 } & 19 & \text { Fort Hood: Owl Creek } \\ & \text { PC-E2 } & 21 & \text { Fort Hood: Gray-brown-green } \\ 1 & \text { PC-E3 } & 20 & \text { Fort Hood: Tan } \\ 2 & \text { PC-E4 } & 20 & \text { Fort Hood: Texas Novaculite } \\ 3 & \text { PC-E5 } & 20 & \text { Fort Hood: Heiner Lake Tan } \\ 4 & \text { PC-E6 } & 18 & \text { Fort Hood: Gray } \\ 5 & \text { PC-SF } & 15 & \text { Segovia Formation (Turnbull's collection) } \\ 6 & \text { PC-CF } & 59 & \text { Edwards Formation mixture (Frederick's collection) } \\ 7 & \text { PC-TRCS } & 106 & \text { Edwards Formation samples from TRC } \\ \text { The following variables explaining more than 91\% of the variance were used in these calculations: } \\ 9\end{array}$

\$bolfollowing specimens are in the file PC-TRCA

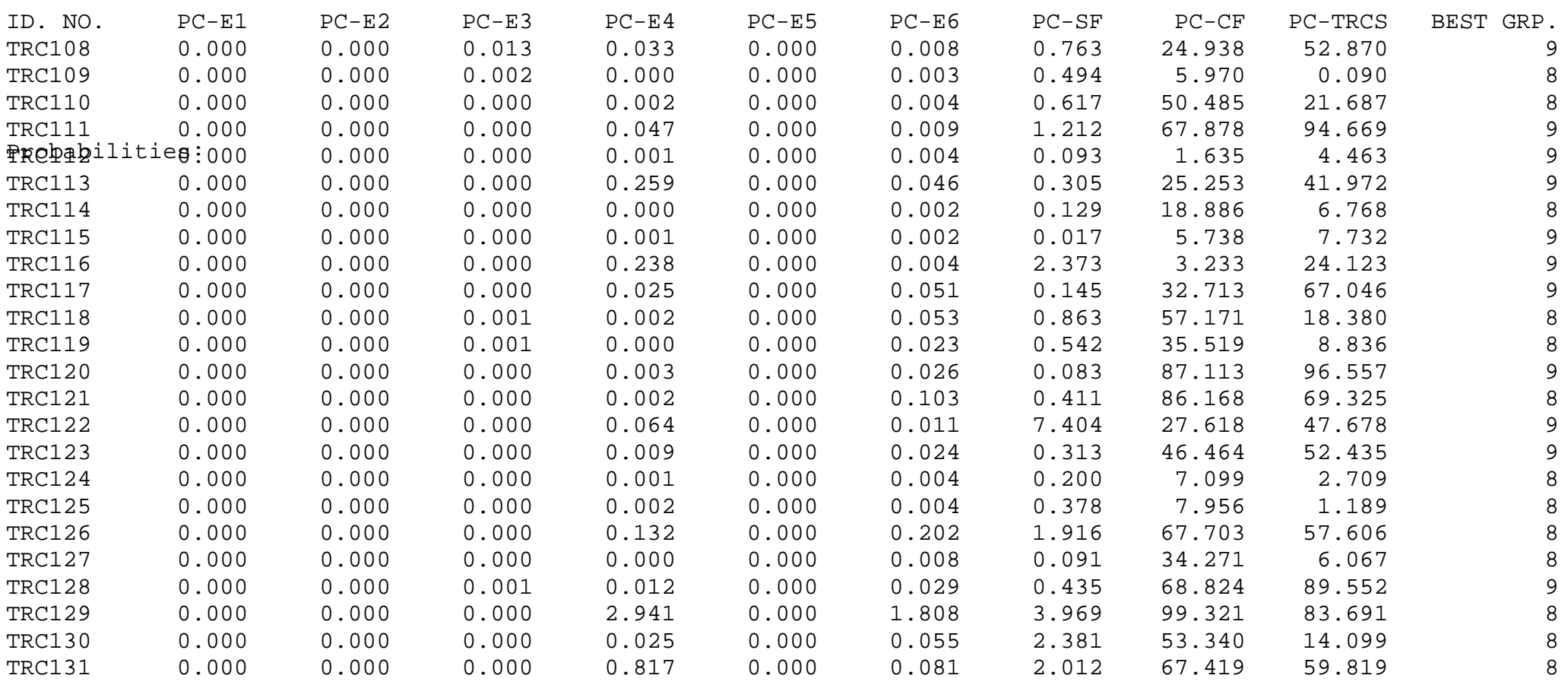




\begin{tabular}{|c|c|c|c|c|c|c|c|c|c|c|}
\hline TRC132 & $\odot . \odot \odot \odot$ & $\odot . \odot \odot \odot$ & $\odot . \odot \odot \odot$ & $\odot .001$ & $\odot . \odot \odot \odot$ & $\odot .0 \odot 2$ & 0.026 & 14.603 & 25.738 & 9 \\
\hline TRC133 & $\odot .00 \odot$ & $\odot .0 \odot \odot$ & $\odot . \odot \odot \odot$ & 0.014 & $\odot . \odot \odot \odot$ & $\odot .04 \odot$ & 0.546 & 78.520 & 58.365 & 8 \\
\hline TRC134 & $\odot .0 \odot \odot$ & $\odot .0 \odot \odot$ & $\odot . \odot \odot \odot$ & 0.144 & $\odot . \odot \odot \odot$ & $\odot .077$ & 0.252 & 64.062 & 82.519 & 9 \\
\hline TRC135 & $\odot .00 \odot$ & $\odot .0 \odot \odot$ & $\odot . \odot \odot \odot$ & $\odot . \odot \odot \odot$ & $\odot . \odot \odot \odot$ & $\odot . \odot \odot \odot$ & 0.688 & 14.992 & $\odot .315$ & 8 \\
\hline TRC136 & $\odot .00 \odot$ & $\odot .0 \odot \odot$ & $\odot . \odot \odot \odot$ & $\odot .06 \odot$ & $\odot . \odot \odot \odot$ & $\odot .056$ & 2.533 & 53.251 & 16.726 & 8 \\
\hline TRC137 & 0.000 & 0.000 & $\odot . \odot \odot \odot$ & $\odot .0 \odot 2$ & $\odot .0 \odot \odot$ & $\odot . \odot \odot 1$ & 0.482 & 53.228 & 31.787 & 8 \\
\hline TRC138 & $\odot .00 \odot$ & $0.00 \odot$ & $\odot .001$ & $\odot .003$ & $\odot . \odot \odot \odot$ & 0.021 & 0.476 & 90.439 & 78.837 & 8 \\
\hline TRC139 & 0.000 & $0.00 \odot$ & $\odot .0 \odot \odot$ & $\odot .003$ & $\odot . \odot \odot \odot$ & 0.029 & 0.463 & 45.015 & 22.896 & 8 \\
\hline TRC140 & 0.000 & 0.000 & $\odot .0 \odot \odot$ & $\odot . \odot \odot \odot$ & $\odot . \odot \odot \odot$ & $\odot . \odot \odot \odot$ & 0.013 & $\odot .0 \odot \odot$ & 0.000 & 7 \\
\hline TRC141 & $0.00 \odot$ & $0.00 \odot$ & 0.001 & $\odot .007$ & $\odot .00 \odot$ & 0.308 & 4.740 & 74.300 & 29.951 & 8 \\
\hline TRC142 & $0.00 \odot$ & $0.00 \odot$ & $\odot . \odot \odot \odot$ & $\odot .001$ & $\odot .00 \odot$ & 0.030 & 0.124 & 72.273 & 59.601 & 8 \\
\hline TRC143 & $0.00 \odot$ & 0.000 & $\odot . \odot \odot \odot$ & $\odot .011$ & $\odot . \odot \odot \odot$ & 0.023 & 0.299 & 82.268 & 86.710 & 9 \\
\hline TRC144 & 0.000 & 0.000 & $\odot .00 \odot$ & 0.001 & $\odot .00 \odot$ & $\odot .0 \odot \odot$ & 0.156 & 9.054 & 1.229 & 8 \\
\hline TRC145 & $\odot .0 \odot \odot$ & $\odot .0 \odot \odot$ & $\odot . \odot \odot \odot$ & $\odot . \odot \odot \odot$ & $\odot . \odot \odot \odot$ & $\odot . \odot \odot 1$ & 0.055 & 31.466 & 19.958 & 8 \\
\hline TRC146 & $\odot .000$ & $\odot .0 \odot \odot$ & $\odot . \odot \odot \odot$ & ๑. 010 & $\odot . \odot \odot \odot$ & ๑. 010 & $\odot .076$ & 38.095 & 57.271 & 9 \\
\hline TRC147 & 0.000 & $\odot .00 \odot$ & $\odot .0 \odot \odot$ & $\odot .063$ & $\odot . \odot \odot \odot$ & $\odot .037$ & 1.289 & 63.890 & 39.876 & 8 \\
\hline TRC148 & 0.000 & $\odot .00 \odot$ & $\odot . \odot \odot \odot$ & ๑. 017 & $\odot . \odot \odot \odot$ & $\odot .235$ & 0.239 & 55.090 & 50.125 & 8 \\
\hline TRC149 & $\odot .00 \odot$ & $0.00 \odot$ & $\odot .001$ & $\odot .001$ & $\odot .0 \odot \odot$ & 0.015 & $\odot .297$ & 16.000 & 4.871 & 8 \\
\hline TRC150 & $0.00 \odot$ & $0.00 \odot$ & $\odot .0 \odot \odot$ & $\odot .005$ & $\odot . \odot \odot \odot$ & $\odot . \odot \odot 3$ & 0.722 & 81.411 & 55.804 & 8 \\
\hline TRC151 & 0.000 & 0.000 & $0.00 \odot$ & $\odot .092$ & $\odot .00 \odot$ & 0.089 & 5.396 & 83.701 & 52.664 & 8 \\
\hline TRC152 & 0.000 & 0.000 & $\odot .00 \odot$ & 0.002 & $0.00 \odot$ & 0.006 & 0.220 & 32.095 & 7.114 & 8 \\
\hline TRC153 & 0.000 & 0.000 & $0.00 \odot$ & 0.017 & $\odot .00 \odot$ & 0.138 & 1.142 & 91.464 & 80.983 & 8 \\
\hline TRC154 & 0.000 & 0.000 & $\odot .00 \odot$ & $\odot .00 \odot$ & $\odot .00 \odot$ & 0.001 & 0.017 & 20.918 & 17.575 & 8 \\
\hline TRC155 & 0.000 & 0.000 & $\odot .001$ & $\odot .00 \odot$ & $\odot .00 \odot$ & 0.023 & 0.465 & 23.038 & 1.781 & 8 \\
\hline TRC156 & $\odot .0 \odot \odot$ & $\odot .00 \odot$ & $\odot .00 \odot$ & $\odot .00 \odot$ & $\odot .00 \odot$ & $0.00 \odot$ & $\odot .056$ & 1.588 & 0.477 & 8 \\
\hline TRC157 & $\odot .0 \odot \odot$ & $\odot .0 \odot \odot$ & $0.0 \odot 2$ & 0.094 & $\odot .00 \odot$ & 0.131 & $\odot .959$ & 91.839 & 99.689 & 9 \\
\hline TRC158 & 0.000 & $\odot .00 \odot$ & $\odot .0 \odot \odot$ & $\odot . \odot \odot \odot$ & $\odot . \odot \odot \odot$ & $\odot . \odot \odot 1$ & 0.038 & 9.912 & 2.244 & 8 \\
\hline TRC159 & $\odot .00 \odot$ & $0.00 \odot$ & $\odot .003$ & $\odot .0 \odot 2$ & $\odot . \odot \odot \odot$ & 0.109 & 1.394 & 67.407 & 26.593 & 8 \\
\hline TRC160 & 0.000 & 0.000 & $\odot .0 \odot \odot$ & $\odot . \odot \odot \odot$ & $\odot .0 \odot \odot$ & $\odot .001$ & 0.033 & 22.844 & 2.529 & 8 \\
\hline TRC161 & $\odot .0 \odot \odot$ & $\odot .001$ & $\odot . \odot \odot \odot$ & $\odot .112$ & $\odot . \odot \odot \odot$ & 0.136 & 2.459 & 78.998 & 36.403 & 8 \\
\hline TRC162 & $\odot . \odot \odot \odot$ & $\odot .0 \odot \odot$ & $\odot . \odot \odot \odot$ & $\odot .0 \odot 5$ & $\odot . \odot \odot \odot$ & $\odot .159$ & 0.431 & 97.954 & 91.782 & 8 \\
\hline TRC163 & $\odot .0 \odot \odot$ & $\odot . \odot \odot \odot$ & $\odot . \odot \odot \odot$ & $\odot . \odot \odot 5$ & $\odot . \odot \odot \odot$ & $\odot .055$ & 0.335 & 53.839 & 38.062 & 8 \\
\hline TRC164 & $\odot .00 \odot$ & $\odot . \odot \odot \odot$ & $\odot . \odot \odot \odot$ & $\odot . \odot 82$ & $\odot . \odot \odot \odot$ & 0.240 & 9.094 & 97.965 & 49.210 & 8 \\
\hline TRC165 & $\odot .00 \odot$ & $\odot . \odot \odot \odot$ & $\odot . \odot \odot \odot$ & $\odot . \odot \odot 1$ & $\odot . \odot \odot \odot$ & $\odot . \odot \odot 5$ & $\odot .060$ & 55.882 & 70.905 & 9 \\
\hline TRC166 & $\odot .000$ & $\odot .00 \odot$ & $\odot . \odot \odot \odot$ & $\odot . \odot \odot \odot$ & $\odot . \odot \odot \odot$ & 0.011 & 0.328 & 45.857 & 14.939 & 8 \\
\hline TRC167 & $\odot .00 \odot$ & $0.00 \odot$ & $\odot .001$ & $\odot .001$ & $\odot . \odot \odot \odot$ & 0.079 & 0.769 & 67.576 & 42.995 & 8 \\
\hline TRC168 & $0.00 \odot$ & $0.00 \odot$ & $\odot . \odot \odot \odot$ & $\odot .0 \odot \odot$ & $\odot .00 \odot$ & $\odot . \odot \odot \odot$ & 0.010 & $\odot .999$ & 9.148 & 9 \\
\hline TRC169 & 0.000 & 0.000 & $\odot .00 \odot$ & 0.015 & $\odot .00 \odot$ & 0.077 & 0.829 & 66.529 & 55.146 & 8 \\
\hline TRC170 & 0.000 & 0.000 & $\odot .00 \odot$ & 0.003 & $\odot .00 \odot$ & 0.016 & 0.607 & 76.998 & 48.386 & 8 \\
\hline TRC171 & 0.000 & 0.000 & 0.042 & $\odot .0 \odot 9$ & $\odot . \odot \odot \odot$ & 0.284 & 2.906 & 62.107 & 38.882 & 8 \\
\hline TRC172 & 0.000 & 0.000 & $0.00 \odot$ & ๑. 057 & $\odot .00 \odot$ & 0.014 & 0.104 & 26.751 & 31.678 & 9 \\
\hline TRC173 & 0.000 & 0.000 & $\odot .00 \odot$ & 0.213 & $0.00 \odot$ & 0.326 & 1.641 & 76.477 & 92.877 & 9 \\
\hline TRC174 & 0.000 & $0.00 \odot$ & $\odot .00 \odot$ & 0.011 & $\odot .00 \odot$ & 0.005 & 0.122 & 51.062 & 81.868 & 9 \\
\hline TRC175 & 0.000 & $\odot .00 \odot$ & $\odot . \odot \odot \odot$ & 0.448 & $\odot .0 \odot \odot$ & $\odot .087$ & 0.357 & 41.738 & 17.021 & 8 \\
\hline TRC176 & 0.000 & 0.000 & $\odot .00 \odot$ & $0.00 \odot$ & $\odot .00 \odot$ & 0.002 & 0.077 & 0.306 & 0.159 & 8 \\
\hline
\end{tabular}




\begin{tabular}{|c|c|c|c|c|c|c|c|c|c|c|}
\hline TRC177 & $\odot .000$ & $\odot .000$ & 0.000 & 0.011 & $\odot .000$ & 0.615 & 1.933 & 99.093 & 76.761 & 8 \\
\hline TRC178 & 0.000 & 0.000 & 0.001 & 0.001 & 0.000 & ๑ . 019 & 0.328 & 59.735 & 43.789 & 8 \\
\hline TRC179 & $\odot .0 \odot \odot$ & 0.000 & 0.004 & 0.001 & 0.000 & 0.010 & 0.460 & 69.954 & 48.816 & 8 \\
\hline TRC180 & 0.000 & 0.000 & 0.000 & 0.000 & 0.000 & 0.001 & ๑. 018 & 17.004 & 9.250 & 8 \\
\hline TRC181 & $\odot .0 \odot \odot$ & $\odot .00 \odot$ & $\odot .0 \odot 2$ & 0.014 & $\odot .0 \odot \odot$ & 0.015 & $\odot .666$ & 90.290 & 74.356 & 8 \\
\hline TRC182 & $\odot .00 \odot$ & $\odot .00 \odot$ & $\odot .00 \odot$ & 0.005 & $\odot .0 \odot \odot$ & 0.046 & $\odot .126$ & 89.906 & 91.435 & 9 \\
\hline TRC183 & $\odot . \odot \odot \odot$ & $\odot .0 \odot \odot$ & 0.013 & $\odot .0 \odot 9$ & $\odot . \odot \odot \odot$ & 0.128 & 2.942 & 62.303 & 43.232 & 8 \\
\hline TRC184 & $\odot .0 \odot \odot$ & 0.000 & 0.000 & 0.017 & $\odot .000$ & 0.033 & 1.228 & 83.063 & 22.789 & 8 \\
\hline TRC185 & $\odot . \odot \odot \odot$ & $\odot .0 \odot \odot$ & $\odot . \odot \odot \odot$ & 0.001 & $\odot .0 \odot \odot$ & $\odot .003$ & $\odot .073$ & 70.973 & 55.377 & 8 \\
\hline TRC186 & $\odot . \odot \odot \odot$ & $\odot .0 \odot \odot$ & $\odot .0 \odot \odot$ & $\odot . \odot \odot \odot$ & $\odot . \odot \odot \odot$ & $\odot .0 \odot 7$ & $\odot .165$ & 51.582 & 41.052 & 8 \\
\hline TRC187 & $\odot .00 \odot$ & $\odot .00 \odot$ & $\odot .0 \odot \odot$ & 0.025 & $\odot . \odot \odot \odot$ & 0.252 & 1.302 & 92.592 & 87.499 & 8 \\
\hline TRC188 & $\odot .00 \odot$ & $\odot .00 \odot$ & $\odot .0 \odot \odot$ & 0.004 & $\odot . \odot \odot \odot$ & 0.031 & 0.075 & 8.696 & 20.634 & 9 \\
\hline TRC189 & $\odot .0 \odot \odot$ & $\odot .0 \odot \odot$ & $\odot .0 \odot \odot$ & $\odot .00 \odot$ & $\odot . \odot \odot \odot$ & $\odot . \odot \odot \odot$ & 0.031 & 2.860 & 0.684 & 8 \\
\hline TRC190 & $\odot .00 \odot$ & $\odot .00 \odot$ & $\odot .001$ & 15.285 & $\odot .0 \odot \odot$ & 0.192 & 16.375 & 98.266 & 2.857 & 8 \\
\hline TRC191 & $\odot .0 \odot \odot$ & $\odot .0 \odot \odot$ & $\odot .00 \odot$ & 0.016 & $\odot .00 \odot$ & 0.034 & 0.258 & 59.765 & 64.282 & 9 \\
\hline TRC192 & $\odot .0 \odot \odot$ & $\odot .00 \odot$ & $\odot .00 \odot$ & $\odot .00 \odot$ & $\odot .00 \odot$ & ๑. 001 & 0.073 & 33.179 & 5.652 & 8 \\
\hline TRC193 & $\odot .0 \odot \odot$ & $\odot .00 \odot$ & $\odot .00 \odot$ & $0.0 \odot 2$ & $\odot .00 \odot$ & $\odot .003$ & 0.757 & 12.575 & 0.458 & 8 \\
\hline TRC194 & $\odot .001$ & 0.000 & 0.019 & 0.009 & $\odot .00 \odot$ & 0.027 & 2.939 & 57.438 & 41.141 & 8 \\
\hline TRC195 & $\odot .0 \odot \odot$ & 0.000 & 0.000 & 0.002 & $\odot .0 \odot \odot$ & 0.012 & 0.151 & 45.179 & 16.407 & 8 \\
\hline TRC196 & 0.000 & 0.000 & 0.000 & 0.000 & 0.000 & 0.003 & 0.133 & 58.431 & 17.222 & 8 \\
\hline TRC197 & 0.000 & 0.000 & 0.000 & 0.000 & 0.000 & 0.001 & ๑. 011 & 1.868 & $\odot .490$ & 8 \\
\hline TRC198 & 0.000 & 0.000 & 0.008 & 0.001 & 0.000 & 0.024 & 1.570 & 65.663 & 16.372 & 8 \\
\hline TRC199 & $\odot .00 \odot$ & $\odot .00 \odot$ & $\odot .0 \odot 2$ & 0.022 & $\odot .0 \odot \odot$ & 0.020 & $\odot .535$ & 54.794 & 80.475 & 9 \\
\hline TRC200 & $\odot .00 \odot$ & $\odot .0 \odot \odot$ & $\odot .00 \odot$ & $\odot . \odot \odot \odot$ & $\odot .0 \odot \odot$ & $0.00 \odot$ & $\odot .037$ & 9.098 & 9.409 & 9 \\
\hline TRC201 & $\odot .0 \odot \odot$ & $\odot .0 \odot \odot$ & $\odot .0 \odot \odot$ & $\odot .0 \odot 2$ & $\odot . \odot \odot \odot$ & $\odot .0 \odot 1$ & $\odot .194$ & 11.224 & 16.750 & 9 \\
\hline TRC202 & $\odot .001$ & $\odot .0 \odot \odot$ & $\odot .0 \odot 2$ & 0.012 & $\odot .0 \odot \odot$ & 0.041 & $\odot .212$ & 23.037 & 31.422 & 9 \\
\hline TRC203 & $\odot .0 \odot \odot$ & $\odot .0 \odot \odot$ & 0.014 & $\odot . \odot \odot 2$ & $\odot .0 \odot \odot$ & 0.008 & 1.218 & 56.168 & 37.105 & 8 \\
\hline TRC204 & $\odot . \odot \odot \odot$ & $\odot .0 \odot \odot$ & $\odot .0 \odot \odot$ & 0.236 & $\odot . \odot \odot \odot$ & $\odot .157$ & $\odot .677$ & 18.075 & 56.408 & 9 \\
\hline TRC205 & $\odot . \odot \odot \odot$ & $\odot .0 \odot \odot$ & $\odot .0 \odot \odot$ & 0.648 & $\odot . \odot \odot \odot$ & 0.011 & $\odot .462$ & 40.098 & 55.393 & 9 \\
\hline TRC206 & 0.000 & 0.000 & 0.000 & 0.004 & 0.000 & 0.011 & ๑. 094 & 30.479 & 51.516 & 9 \\
\hline TRC207 & 0.000 & 0.000 & 0.000 & 0.007 & 0.000 & 0.050 & 0.768 & 56.134 & 41.159 & 8 \\
\hline TRC208 & 0.000 & 0.000 & 0.000 & 0.010 & 0.000 & ๑. . 022 & 0.683 & 52.833 & 88.876 & 9 \\
\hline TRC209 & $\odot .0 \odot \odot$ & $\odot .00 \odot$ & $\odot .0 \odot 1$ & 0.057 & $\odot .0 \odot \odot$ & 0.005 & $\odot .698$ & 47.112 & 79.719 & 9 \\
\hline TRC210 & $\odot .0 \odot \odot$ & $\odot .00 \odot$ & $\odot .00 \odot$ & 0.502 & $\odot .0 \odot \odot$ & 0.935 & 2.808 & 80.920 & 29.561 & 8 \\
\hline TRC211 & $\odot .00 \odot$ & $\odot .00 \odot$ & $\odot .00 \odot$ & $\odot .001$ & $\odot .0 \odot \odot$ & 0.012 & $\odot .064$ & 49.121 & 61.830 & 9 \\
\hline TRC212 & $\odot .0 \odot \odot$ & $\odot .0 \odot \odot$ & $\odot .0 \odot \odot$ & $\odot . \odot \odot 1$ & $\odot . \odot \odot \odot$ & $\odot .0 \odot 6$ & ๑. 031 & 13.912 & 16.015 & 9 \\
\hline TRC213 & $\odot .00 \odot$ & $0.00 \odot$ & $\odot .000$ & 0.001 & $\odot .00 \odot$ & ๑. 003 & $\odot .026$ & 10.290 & 24.450 & 9 \\
\hline TRC214 & $\odot .00 \odot$ & $\odot .00 \odot$ & $\odot .00 \odot$ & $\odot .005$ & $\odot . \odot \odot \odot$ & 0.011 & ๑.०8० & 24.397 & 51.559 & 9 \\
\hline TRC215 & $\odot .00 \odot$ & $\odot .00 \odot$ & $\odot .0 \odot \odot$ & $\odot . \odot \odot 1$ & $\odot . \odot \odot \odot$ & 0.037 & 0.463 & 90.088 & 45.389 & 8 \\
\hline TRC216 & $\odot .00 \odot$ & $\odot .00 \odot$ & $\odot .0 \odot \odot$ & 0.001 & $\odot . \odot \odot \odot$ & 0.022 & $\odot .514$ & 1.140 & $\odot .084$ & 8 \\
\hline TRC217 & $\odot .00 \odot$ & $\odot .00 \odot$ & $\odot .001$ & $\odot .0 \odot 8$ & 0.000 & 0.056 & $\odot .29 \odot$ & 69.702 & 92.681 & 9 \\
\hline TRC218 & 0.000 & 0.000 & 0.001 & 0.000 & 0.000 & 0.004 & $\odot .971$ & 62.442 & 10.401 & 8 \\
\hline TRC219 & $\odot .00 \odot$ & $\odot .00 \odot$ & $\odot .0 \odot \odot$ & $\odot . \odot \odot 2$ & $\odot .0 \odot \odot$ & 0.002 & $\odot .094$ & 68.301 & 66.805 & 8 \\
\hline TRC220 & $\odot .00 \odot$ & $\odot .00 \odot$ & $\odot .0 \odot \odot$ & $\odot . \odot \odot 9$ & $\odot .0 \odot \odot$ & 0.010 & $\odot .138$ & 72.570 & 72.696 & 9 \\
\hline TRC221 & $\odot .0 \odot \odot$ & $\odot .00 \odot$ & $\odot .0 \odot 1$ & 0.029 & $\odot .0 \odot \odot$ & 0.037 & 1.867 & 21.008 & 8.546 & 8 \\
\hline
\end{tabular}




\begin{tabular}{|c|c|c|c|c|c|c|c|c|c|c|}
\hline TRC222 & $\odot .00 \odot$ & 0.000 & 0.000 & 0.003 & $\odot .00 \odot$ & 0.018 & 0.096 & 84.720 & 90.490 & 9 \\
\hline TRC223 & $\odot . \odot \odot \odot$ & $0.00 \odot$ & $\odot .001$ & 0.010 & $\odot . \odot \odot \odot$ & 0.011 & 0.258 & 83.915 & 93.007 & 9 \\
\hline TRC224 & $\odot . \odot \odot \odot$ & $\odot . \odot \odot \odot$ & $\odot . \odot \odot \odot$ & $\odot . \odot 2 \odot$ & $\odot . \odot \odot \odot$ & $\odot .081$ & 0.454 & 91.022 & 95.970 & 9 \\
\hline TRC225 & $\odot . \odot \odot \odot$ & $\odot . \odot \odot \odot$ & $\odot . \odot \odot \odot$ & $\odot . \odot \odot 4$ & $\odot . \odot \odot \odot$ & 0.014 & 0.975 & 45.515 & 20.851 & 8 \\
\hline TRC226 & $\odot . \odot \odot \odot$ & $\odot . \odot \odot \odot$ & $\odot . \odot \odot \odot$ & $\odot . \odot \odot 4$ & $\odot .0 \odot \odot$ & $\odot .0 \odot 4$ & 0.153 & 58.450 & 84.622 & 9 \\
\hline TRC227 & $0.00 \odot$ & $\odot .0 \odot \odot$ & $\odot . \odot \odot \odot$ & $\odot .008$ & $\odot .0 \odot \odot$ & ๑ . 019 & 2.036 & 29.896 & 27.339 & 8 \\
\hline TRC228 & $\odot .00 \odot$ & 0.000 & 0.004 & 0.002 & $\odot .000$ & 0.098 & 1.474 & 70.189 & 33.812 & 8 \\
\hline TRC229 & $\odot .00 \odot$ & 0.000 & 0.000 & 0.001 & $\odot .000$ & 0.015 & 4.496 & 14.690 & 0.986 & 8 \\
\hline TRC230 & $\odot . \odot \odot \odot$ & $\odot .00 \odot$ & $\odot . \odot \odot \odot$ & 0.010 & $\odot .0 \odot \odot$ & 0.027 & 0.107 & 57.984 & 93.991 & 9 \\
\hline TRC231 & $\odot .00 \odot$ & $\odot .00 \odot$ & 0.025 & $\odot .001$ & $\odot .0 \odot \odot$ & $\odot .0 \odot 4$ & 0.532 & 2.338 & 0.047 & 8 \\
\hline TRC232 & $\odot .0 \odot \odot$ & $\odot .0 \odot \odot$ & $\odot . \odot \odot \odot$ & $\odot . \odot \odot 9$ & $\odot .0 \odot \odot$ & 0.104 & 0.390 & 95.400 & 97.995 & 9 \\
\hline TRC233 & $\odot .0 \odot \odot$ & $\odot .00 \odot$ & $\odot . \odot \odot \odot$ & 0.020 & $\odot .0 \odot \odot$ & 0.087 & 1.446 & 92.885 & 74.108 & 8 \\
\hline TRC234 & $\odot .0 \odot \odot$ & $\odot .00 \odot$ & $\odot .0 \odot \odot$ & $\odot . \odot \odot \odot$ & $\odot .000$ & $\odot . \odot \odot \odot$ & 0.006 & 0.760 & 0.566 & 8 \\
\hline TRC235 & $\odot .00 \odot$ & 0.000 & $\odot .0 \odot \odot$ & $\odot .003$ & $\odot .000$ & 0.007 & 0.056 & 39.757 & 86.686 & 9 \\
\hline TRC236 & $\odot .00 \odot$ & $\odot .000$ & $\odot .0 \odot \odot$ & $\odot .0 \odot 7$ & $\odot .000$ & ๑. . 014 & $\odot .698$ & 32.010 & 18.597 & 8 \\
\hline TRC237 & $\odot .00 \odot$ & $\odot .000$ & $\odot .0 \odot 4$ & $\odot .0 \odot 3$ & $\odot .000$ & ๑. 039 & ๑. 812 & 76.154 & 53.257 & 8 \\
\hline TRC238 & $\odot .00 \odot$ & $\odot .0 \odot \odot$ & $\odot . \odot \odot \odot$ & $\odot .008$ & $\odot .0 \odot \odot$ & $\odot .001$ & $\odot .060$ & 24.869 & 17.488 & 8 \\
\hline TRC239 & $\odot .00 \odot$ & 0.000 & 0.000 & 0.000 & $\odot .000$ & 0.001 & 0.008 & 0.571 & 4.591 & 9 \\
\hline TRC240 & $\odot .00 \odot$ & 0.000 & 0.000 & 0.001 & $\odot .000$ & 0.001 & 0.025 & 18.549 & 24.874 & 9 \\
\hline TRC241 & $\odot . \odot \odot \odot$ & $\odot .00 \odot$ & $\odot .0 \odot \odot$ & $\odot .001$ & $\odot . \odot \odot \odot$ & 0.013 & 0.790 & 59.310 & 23.609 & 8 \\
\hline TRC242 & $\odot . \odot \odot \odot$ & 0.000 & $\odot . \odot \odot \odot$ & 0.033 & $\odot . \odot \odot \odot$ & $\odot .006$ & 0.070 & 70.585 & 50.458 & 8 \\
\hline TRC243 & $\odot . \odot \odot \odot$ & 0.000 & $\odot .0 \odot \odot$ & $\odot .0 \odot 2$ & $\odot . \odot \odot \odot$ & 0.038 & 0.329 & 72.400 & 63.530 & 8 \\
\hline TRC244 & $\odot . \odot \odot \odot$ & $\odot . \odot \odot \odot$ & $\odot . \odot \odot \odot$ & $\odot .0 \odot 1$ & $\odot .0 \odot \odot$ & $\odot .017$ & $\odot .195$ & 67.677 & 46.879 & 8 \\
\hline TRC245 & $\odot . \odot \odot \odot$ & $\odot . \odot \odot \odot$ & $\odot . \odot \odot \odot$ & $\odot .001$ & $\odot .00 \odot$ & $\odot .049$ & 0.300 & 10.402 & 12.356 & 9 \\
\hline TRC246 & $\odot .0 \odot \odot$ & 0.000 & 0.000 & 0.023 & $\odot .000$ & 0.238 & 0.505 & 60.356 & 51.834 & 8 \\
\hline TRC247 & $\odot .00 \odot$ & 0.000 & 0.000 & 0.014 & $\odot .00 \odot$ & 0.008 & 0.072 & 32.883 & 20.396 & 8 \\
\hline TRC248 & $0.00 \odot$ & $\odot .000$ & 0.000 & $\odot .0 \odot \odot$ & $\odot .000$ & $\odot .00 \odot$ & 0.250 & 42.166 & 7.423 & 8 \\
\hline TRC249 & $\odot .00 \odot$ & 0.000 & 0.000 & 0.002 & $\odot .00 \odot$ & 0.008 & ๑. 081 & 36.931 & 41.952 & 9 \\
\hline TRC250 & $\odot .00 \odot$ & 0.000 & 0.000 & 0.000 & $\odot .00 \odot$ & 0.002 & 0.016 & 24.733 & 19.242 & 8 \\
\hline TRC251 & $\odot . \odot \odot \odot$ & 0.000 & $\odot .0 \odot \odot$ & $\odot .025$ & $\odot . \odot \odot \odot$ & $\odot .002$ & ๑. 091 & 53.988 & 51.148 & 8 \\
\hline TRC252 & $\odot .00 \odot$ & $\odot .00 \odot$ & $\odot . \odot \odot \odot$ & $\odot .001$ & $\odot .0 \odot \odot$ & 0.016 & $\odot .090$ & 80.333 & 69.141 & 8 \\
\hline TRC253 & $\odot .0 \odot \odot$ & $\odot .00 \odot$ & $\odot .005$ & $\odot .0 \odot 4$ & $\odot .0 \odot \odot$ & 0.020 & 1.562 & 18.185 & 10.012 & 8 \\
\hline TRC254 & $\odot .0 \odot \odot$ & $\odot .00 \odot$ & $\odot . \odot \odot \odot$ & $\odot . \odot \odot \odot$ & $\odot .00 \odot$ & $\odot . \odot \odot 9$ & 0.123 & 35.144 & 10.659 & 8 \\
\hline TRC256 & $\odot .0 \odot \odot$ & $\odot .001$ & $\odot . \odot \odot \odot$ & $\odot .001$ & $\odot .00 \odot$ & 0.085 & 0.322 & 62.686 & 37.881 & 8 \\
\hline TRC257 & $\odot .0 \odot \odot$ & $\odot .000$ & $\odot . \odot \odot \odot$ & $\odot .00 \odot$ & $\odot .0 \odot \odot$ & 0.004 & $\odot .087$ & 31.038 & 8.164 & 8 \\
\hline TRC258 & $\odot .0 \odot \odot$ & 0.000 & 0.003 & 0.001 & $\odot .00 \odot$ & 0.042 & 0.721 & 69.355 & 38.224 & 8 \\
\hline TRC259 & $\odot .0 \odot \odot$ & 0.000 & 0.000 & 0.024 & $\odot .000$ & 0.003 & 0.166 & 32.800 & 6.211 & 8 \\
\hline TRC260 & $\odot . \odot \odot \odot$ & 0.000 & $\odot .0 \odot \odot$ & $\odot .001$ & $\odot . \odot \odot \odot$ & $\odot .093$ & 0.475 & 92.974 & 78.153 & 8 \\
\hline TRC261 & $\odot . \odot \odot \odot$ & $\odot . \odot \odot \odot$ & $\odot . \odot \odot \odot$ & $\odot .022$ & $\odot . \odot \odot \odot$ & $\odot .025$ & 0.319 & 85.657 & 41.435 & 8 \\
\hline
\end{tabular}


Summary of Probabilities for specimens in the file PC-TRCA

Group :

Group:

$\mathrm{PC}-\mathrm{E} 1$

$\mathrm{PC}-\mathrm{E} 2$

$P C-E 3$

$\mathrm{PC}-\mathrm{E} 4$

PC-E5

$P C-E 6$

$\mathrm{PC}-\mathrm{SF}$

$P C-C F$

PC-TRCS

$\odot .01000$

$10000 \quad 1.00000$

5.00000

10.00000

$\begin{array}{rr}153 & \\ 153 & \\ 147 & \\ 102 & 38 \\ 153 & \\ 61 & 71 \\ 2 & 39 \\ 1 & \\ 1 & 3\end{array}$

$\begin{array}{rr}\odot & 1.000 \odot 0 \\ \odot & 0 \\ 6 & 0 \\ 38 & 11 \\ \odot & 0 \\ 71 & 20 \\ 39 & 80 \\ \odot & 4 \\ 3 & 8\end{array}$

$\begin{array}{rr}0 & \\ 0 & \\ 0 & 0 \\ 11 & 1 \\ 0 & 0 \\ 20 & 1 \\ 80 & 28 \\ 4 & 7 \\ 8 & 10\end{array}$

8
13

$20.00000 \quad 100.0000 \odot$

Probability Cutoff Values:

Summary of Best Classification of Projected Specimens:

\begin{tabular}{|c|c|c|c|c|c|c|c|c|c|c|}
\hline & & PC-E2 & PC-E3 & PC-E4 & PC-E5 & PC-E6 & PC-SF & $\mathrm{PC}-\mathrm{CF}$ & PC-TRCS & Total \\
\hline PC-TRCA & $\odot$ & $\odot$ & $\odot$ & $\odot$ & $\odot$ & $\odot$ & 1 & 102 & 50 & 153 \\
\hline Total & $\odot$ & $\odot$ & $\odot$ & $\odot$ & $\odot$ & $\odot$ & 1 & 102 & 50 & 153 \\
\hline
\end{tabular}

eđaEsified Into Group: 

APPENDIX G:

ANALYSIS OF THE FATTY ACID COMPOSITIONS OF ARCHAEOLOGICAL POTTERY AND ROCK RESIDUES FROM THE VARGA SITE (41ED28) 



\title{
ANALYSIS OF THE FATTY ACID COMPOSITIONS OF ARCHAEOLOGICAL POTTERY AND ROCK RESIDUES FROM THE VARGA SITE (41ED28)
}

\author{
By: \\ M. E. Malainey, Ph.D. \\ K. L. Malisza, Ph.D. \\ Prepared for:

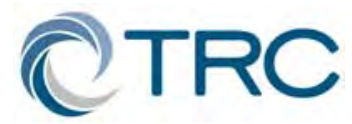 \\ TRC Environmental Corporation \\ 505 East Huntland Drive, Suite 250 \\ Austin, Texas 78752
}

Prepared by:

M. E. Malainey, Ph.D. and

K. L. Malisza, Ph.D.

11 Mager Drive West

Winnipeg, MB

Canada R2M OR9

June 2004 



\section{G.1 INTRODUCTION}

Eight pieces of pottery and 94 limestone samples from the Varga Site (41ED28) in Edwards County, Texas, were submitted for fatty acid analysis. Where necessary, subsamples were taken from larger pieces. Exterior surfaces were ground off to remove any contaminants. Samples were powdered, and absorbed lipid residues were extracted with organic solvents. Fatty acid components of the lipid extracts were analyzed using gas chromatography (GC). Residues were identified using criteria developed from the decomposition patterns of experimental residues. The first section of this appendix outlines the development of the identification criteria. Following this, analytical procedures and results are presented.

\section{G.2 FAtTy ACIDS AND DEVELOPMENT OF THE IDENTIFICATION CRITERIA}

\section{G.2.1 Introduction and Previous Research}

Fatty acids are the major constituents of fats and oils (lipids) and occur in nature as triglycerides, which consist of three fatty acids attached to a glycerol molecule by ester-linkages. The shorthand convention for designating fatty acids,

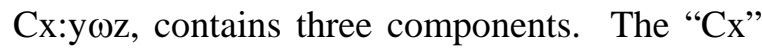
refers to a fatty acid with a carbon chain length of " $x$ " number of atoms. The " $y$ " represents the number of double bonds or points of unsaturation, and the " $\omega z$ ” indicates the location of the most distal double bond on the carbon chain (i.e., closest to the methyl end). Thus, the fatty acid expressed as C18:1 $\omega 9$, refers to a mono-unsaturated isomer with a chain length of 18 carbon atoms with a single double bond located nine carbons from the methyl end of the chain. Similarly, the shorthand designation, C16:0, refers to a saturated fatty acid with a chain length of 16 carbons.
Their insolubility in water and relative abundance compared to other classes of lipids, such as sterols and waxes, make fatty acids suitable for residue analysis. Since employed by Condamin et al. (1976), GC has been used extensively to analyze the fatty acid component of absorbed archaeological residues. The composition of uncooked plants and animals provides important baseline information, but it is not possible to directly compare modern uncooked plants and animals with highly degraded archaeological residues. Unsaturated fatty acids, which are found widely in fish and plants, decompose more readily than saturated fatty acids, sterols, or waxes. In the course of decomposition, simple addition reactions might occur at points of unsaturation (Solomons 1980) or peroxidation might lead to the formation of a variety of volatile and non-volatile products that continue to degrade (Frankel 1991). Peroxidation occurs most readily in fatty acids with more than one point of unsaturation.

Attempts have been made to identify archaeological residues using criteria that discriminate uncooked foods (Marchbanks 1989; Skibo 1992; Loy 1994). Marchbanks' (1989) percent of saturated fatty acids $(\% \mathrm{~S})$ criteria has been applied to residues from a variety of materials, including pottery, stone tools, and burned rocks (Marchbanks 1989; Marchbanks and Quigg 1990; Collins et al. 1990). Skibo (1992:89) could not apply the \%S technique and instead used two ratios of fatty acids, C18:0/C16:0 and C18:1/C16:0. He (1992) reported that it was possible to link the uncooked foods with residues extracted from modern cooking pots actively used to prepare one type of food; however, the ratios could not identify food mixtures. The utility of these ratios did not extend to residues extracted from archaeological potsherds because the ratios of the major fatty acids in the residue changed with decomposition (Skibo 1992:97). Loy (1994) 
proposed the use of a Saturation Index (SI), determined by the following ratio:

$\mathrm{SI}=1-[(\mathrm{C} 18: 1+\mathrm{C} 18: 2) / \mathrm{C} 12: 0+\mathrm{C} 14: 0+\mathrm{C} 16: 0+\mathrm{C} 18: 0)]$

He (1994) admitted, however, that poorly understood decompositional changes to the original suite of fatty acids make it difficult to develop criteria for distinguishing animal and plant fatty acid profiles in archaeological residues.

The major drawback of the distinguishing ratios proposed by Marchbanks (1989), Skibo (1992), and Loy (1994) is that they have never been empirically tested. The proposed ratios are based on criteria that discriminate among food classes on the basis of their original fatty acid composition. The resistance of these criteria to the effects of decompositional changes has not been demonstrated. Rather, Skibo (1992) found his fatty acid ratio criteria could not be used to identify highly decomposed archaeological samples.

To identify a fatty acid ratio unaffected by degradation processes, Patrick et al. (1985) simulated the long-term decomposition of one sample and monitored the resulting changes. An experimental cooking residue of seal was prepared and degraded to identify a stable fatty acid ratio. Patrick et al. (1985) found that the ratio of two C18:1 isomers, oleic and vaccenic, did not change with decomposition; this fatty acid ratio was then used to identify an archaeological vessel residue as seal. While the fatty acid composition of uncooked foods must be known, Patrick et al. (1985) showed that the effects of cooking and decomposition over long periods of time on the fatty acids must also be understood.

\section{G.2.2 Development of the Identification Criteria}

As the first stage in developing the identification criteria used herein, the fatty acid compositions of more than 130 uncooked native food plants and animals from Western Canada were determined using GC (Malainey 1997; Malainey et al. 1999a). When the fatty acid compositions of modern food plants and animals were subject to cluster and principal component analyses, the resultant groupings generally corresponded to divisions that exist in nature (Table G-1). Clear differences in the fatty acid composition of large mammal fat, large herbivore meat, fish, plant roots, greens, and berries/seeds/nuts were detected, but the fatty acid composition of meat from medium-sized mammals resembles berries/seeds/nuts.

Samples in Cluster A, the large mammal and fish cluster, had elevated levels of C16:0 and C18:1 (Table G-1). Divisions within this cluster stemmed from the very high level of C18:1 isomers in fat, high levels of C18:0 in bison and deer meat, and high levels of very-long-chain unsaturated (VLCU) fatty acids in fish. Differences in the fatty acid composition of plant roots, greens, and berries/seeds/nuts reflect the amounts of $\mathrm{C} 18: 2$ and $\mathrm{C} 18: 3 \omega 3$ present. The berry, seed, nut, and small mammal meat samples appearing in Cluster B have very high levels of C18:2, ranging from 35 to 64 percent (Table G-1). Samples in Subclusters V, VI and VII have levels of C18:1 isomers from 29 to 51 percent as well. Plant roots, plant greens, and some berries appear in Cluster C. All Cluster C samples have moderately high levels of C18:2; except for the berries in Subcluster XII, levels of C16:0 are also elevated. Higher levels of C18:3 $\omega 3$ and/or very-long-chain saturated (VLCS) fatty acids are also common except in the roots that form Subcluster XV.

Secondly, the effects of cooking and degradation over time on fatty acid compositions were examined. Originally, 19 modern residues of plants and animals from the plains, parkland, and forests of Western Canada were prepared by cooking samples of meats, fish, and plants, alone 
or combined, in replica vessels over an open fire (Malainey 1997; Malainey et al. 1999b). After four days at room temperature, the vessels were broken and a set of sherds was analysed to determine changes after a short term of decomposition. A second set of sherds remained at room temperature for 80 days, and was then placed in an oven at $75^{\circ} \mathrm{C}$ for a period of 30 days to simulate the processes of long-term decomposition. The relative percentages were calculated on the basis of the 10 fatty acids (C12:0, C14:0, C15:0, C16:0, C16:1, C17:0, C18:0, C18:1w9, C18:1w11, and C18:2) that regularly appeared in Precontact Period vessel residues from Western Canada. Observed changes in fatty acid composition of the experimental cooking residues enabled the development of a method for identifying the archaeological residues (Table G-2).

It was determined that levels of medium-chain fatty acids (C12:0, C14:0, and C15:0), C18:0, and C18:1 isomers in the sample could be used to distinguish degraded experimental cooking residues (Malainey 1997; Malainey et al. 1999b). These fatty acids are suitable for the identification criteria because saturated fatty acids are stable and the mono-unsaturated fatty acid degrades very slowly as compared to polyunsaturated fatty acids (deMan 1992). Higher levels of medium-chain fatty acids, combined with low levels of C18:0 and C18:1 isomers, were detected in the decomposed experimental residues of plants, such as roots, greens, and most berries. High levels of C18:0 indicated the presence of large herbivores. Moderate levels of C18:1 isomers, with low levels of C18:0, indicated the presence of either fish or foods similar in composition to corn. High levels of C18:1 isomers with low levels of C18:0 were found in residues of beaver or foods of similar fatty acid composition. The criteria for identifying six types of residues were established experimentally; the seventh type, plant with large herbivore, was inferred (Table G-2). These criteria were applied to residues extracted from more than 200 pottery cooking vessels from 18 Western Canadian sites (Malainey 1997; Malainey et al. 1999c; 2001b). The identifications were found to be consistent with the evidence from faunal and tool assemblages for each site.

Continuing work has resulted in further understanding of the decomposition patterns of various foods and food combinations (Malainey et al. 2000a, 2000b, 2000c, 2001a; Quigg et al. 2001). The collection of modern foods has expanded to include plants from the Southern Plains. The fatty acid compositions of mesquite beans (Prosopis glandulosa), Texas ebony seeds (Pithecellobium ebano Berlandier), tasajillo berry (Opuntia leptocaulis), prickly pear fruit and pads (Opuntia engelmannii), Spanish dagger pods (Yucca treculeana), cooked sotol (Dasylirion wheeler), agave (Agave lechuguilla), cholla (Opuntia imbricata), piñon (Pinus edulis) and Texas mountain laurel (or mescal) seed (Sophora secundiflora) have been determined. Experimental residues of many of these plants, alone or in combination with deer meat, have been prepared by boiling foods in clay cylinders or using sandstone for either stone boiling (Quigg et al. 2000) or as a griddle. To accelerate the processes of oxidative degradation that naturally occur at a slow rate with the passage of time, the rock or clay tile containing the experimental residue was placed in an oven at $75^{\circ} \mathrm{C}$. After either 30 or 68 days, residues were extracted and analysed using GC.

The results of these decomposition studies enabled refinement of the identification criteria.

\section{G.3 Methodology}

Descriptions of the 102 samples from the Varga Site are presented in Table G-3. Possible contaminants were removed by grinding off 
exterior surfaces with a Dremel ${ }^{\circledR}$ tool fitted with a silicon carbide bit. Immediately thereafter, each sample was crushed with a hammer mortar and pestle and the powder was transferred to an Erlenmeyer flask. Lipids were extracted using a variation of the method developed by Folch et al. (1957). The powdered sample was mixed with a 2:1 mixture, by volume, of chloroform and methanol $(2 \times 30 \mathrm{~mL})$ using ultrasonication (2 x $10 \mathrm{~min}$ ). Solids were removed by filtering the solvent mixture into a separatory funnel. The lipid/solvent filtrate was washed with $16 \mathrm{~mL}$ of double-distilled water. Once separation into two phases was complete, the lower chloroform-lipid phase was transferred to a round-bottomed flask and the chloroform was removed by rotary evaporation. Any remaining water was removed by evaporation with benzene (1.5 mL). $1.5 \mathrm{~mL}$ of chloroform-methanol (2:1, $\mathrm{v} / \mathrm{v})$ was used to transfer the dry total lipid extract to a screw-top glass vial with a Teflon ${ }^{\circledR}$ lined cap. The sample was flushed with nitrogen and stored in a $-20^{\circ} \mathrm{C}$ freezer.

A $450-\mu \mathrm{L}$ sample of the total lipid extract solution was placed in a screw-top test tube and dried in a heating block under nitrogen. Fatty acid methyl esters (FAMES) were prepared by treating the dry lipid with $6 \mathrm{~mL}$ of $0.5-\mathrm{N}$ anhydrous hydrochloric acid in methanol $\left(68^{\circ} \mathrm{C}\right.$; $60 \mathrm{~min}$ ). Fatty acids that occur in the sample as di- or triglycerides are detached from the glycerol molecule and converted to methyl esters. After cooling to room temperature, $4 \mathrm{~mL}$ of double-distilled water was added. FAMES were recovered with petroleum ether $(3 \mathrm{~mL})$ and transferred to a vial. The solvent was removed by heat under a gentle stream of nitrogen. The FAMES were dissolved in $75 \mu \mathrm{L}$ of iso-octane, then transferred to a GC vial with a conical glass insert.

Solvents and chemicals were checked for purity by running a sample blank. The entire lipid extraction and methyl esterification process was performed and FAMES were dissolved in $75 \mu \mathrm{L}$ of iso-octane. Traces of contamination were subtracted from sample chromatograms. The relative percentage composition was calculated by dividing the integrated peak area of each fatty acid by the total area of fatty acids present in the sample.

The step in the extraction procedure during which the chloroform, methanol, and lipid mixture is washed with water is a standard procedure for extracting lipids from modern samples. Following Evershed et al. (1990), who reported that this step was unnecessary for the analysis of archaeological residues, previously the solvent-lipid mixture was not washed. This step was recently adopted to remove impurities so that clearer chromatograms could be obtained in the region where very-long-chain fatty acids (C20:0, C20:1, C22:0, and C24:0) occur. It was anticipated that the detection and accurate assessment of these fatty acids could be instrumental in separating residues of animal origin from those of plant (Malainey et al. 2000a, 2000b, 2000c, 2001a).

To identify the residue, the relative percentage composition was determined first with respect to all fatty acids present in the sample (including very-long-chain fatty acids [see Table G-4]) and secondly with respect to the 10 fatty acids utilized in developing the identification criteria (C12:0, C14:0, C15:0, C16:0, C16:1, C17:0, C18:0, C18:1w9, C18:1w11, and C18:2 [not shown]). The second step is necessary for the application of the identification criteria presented in Table G-2.

It must be understood that the identifications given do not necessarily mean that those particular foods were actually prepared because different foods of similar fatty acid composition and lipid content would produce similar residues. It is possible only to say that the 
material of origin for the residue was similar in composition to the food(s) indicated.

\section{G.3.1 Gas Chromatography Analysis Parameters}

The GC analysis was performed on a HewlettPackard 5890 gas chromatograph fitted with a flame ionization detector connected to a personal computer. Samples were separated using a DB-23 fused silica capillary column (30 m x 0.25 mm ID; J\&W Scientific, Folsom, California). An autosampler injected a $3-\mu \mathrm{L}$ sample using a split injection system with the ratio set at 1:20. Hydrogen was used as the carrier gas at a linear velocity of approximately $40 \mathrm{~cm} / \mathrm{sec}$. Column temperature was programmed from 155 to $215^{\circ} \mathrm{C}$ at $2^{\circ} \mathrm{C}$ per minute. The lower temperature was held for two minutes, and the upper temperature was held for 10 minutes. Chromatogram peaks were integrated using ChromPerfect ${ }^{\circledR}$ software and identified through comparisons with several external qualitative standards (NuCheck Prep; Elysian, Minnesota). Using this procedure, fatty acids are detectable to the nanogram $\left(1 \times 10^{-9} \mathrm{~g}\right)$ level.

\section{G.4 Results of Archaeological Data ANALYSIS}

The fatty acid compositions of residues extracted from 101 samples from the Varga Site are presented in Table G-4. The term "Area” represents the area under the chromatographic peak of a given fatty acid, as calculated by the ChromPerfect $^{\circledR}$ software minus the solvent blank. The term "Rel\%" represents the relative percentage of the fatty acid with respect to the total fatty acids in the sample. Hydroxide or peroxide degradation products can interfere with the integration of the $\mathrm{C} 22: 0$ and $\mathrm{C} 22: 1$ peaks; these fatty acids were excluded. In some Varga Site samples, similar interference occurred with the $\mathrm{C} 18: 3$ peak.
Insufficient fatty acids were recovered from one residue, 4VG 52, to attempt identification. Fatty acid recoveries were very low in five samples4VG 8, 4VG 34, 4VG 62, 4VG 63, and 4VG 66.

Many of the Varga Site residues have significantly elevated levels of C18:1 isomers, which indicates the presence of fat or oil in the residue. Levels of C18:1 isomers in 14 residues are very high, ranging from more than 52 to 65 percent. These residues include $4 \mathrm{VG} 42$, 4VG 44, 4VG 45, 4VG 47, 4VG 48, 4VG 51, 4VG 53, 4VG 59, 4VG 60, 4VG 73, 4VG 84, 4VG 86, 4VG 97, and 4VG 100. These levels were observed in the decomposed residues of foods of very-high-fat-content seeds or nuts, such as piñon. Rendered fats of certain mammals (other than large herbivores) exhibit similarly very high levels of fat content. All 14 residues have elevated levels of C18:2, between 6.62 and 14.45 percent. For this reason, they probably represent the residues of plant foods.

A total of 23 residues are characterized by high levels of C18:1 isomers, from 39.41 to 48.36 percent. Of these, 21 also have levels of C18:2 above five percent, which suggests that they are of plant origin. The residues include 4VG 13, 4VG 19, 4VG 26, 4VG 37, 4VG 41, 4VG 49, 4VG 50, 4VG 54, 4VG 64, 4VG 65, 4VG 70, 4VG 71, 4VG 75, 4VG 76, 4VG 78, 4VG 79, 4VG 87, 4VG 93, 4VG 94, 4VG 99, and 4VG 102. The most probable sources of these residues are locally available high-fatcontent seeds and nuts. It is possible that the seeds or nuts were even those that produce residues with higher levels of C18:1 isomers (as described above); however, these residues are simply older and more decomposed. Monounsaturated fats, such as C18:1, slowly decompose over time, and the relative amount in a sample drops. Alternatively, a combination of moderate-high- and very-high-fat-content foods could produce similar residues. Two other 
residues, 4VG 11 and 4VG 39, have high levels of C18:1 isomers but levels of C18:2 are low. Levels of neither medium nor very-long-chain saturated fatty acids are significantly elevated. The origin of these two residues is ambiguous (possibly animal).

A total of 11 residues fall on the border between moderate-high- and high-fat-content foods, and all are likely to be of plant origin. Differences in fatty acid compositions may indicate that more than one type of seed or nut produced these residues. Residues 4VG 3, 4VG 7, 4VG 8, and 4VG 28 all have elevated levels of mediumchain fatty acids. Residue 4VG 27 has elevated levels of very-long-chain saturated fatty acids. Residue 4VG 67 has a very high level of C18:2. In the other five residues, 4VG 35, 4VG 38, 4VG 43, 4VG 56, and 4VG 58, levels of all three indicators of the presence of plants are somewhat elevated.

Twenty-four residues are typical of foods of moderate-high fat content. These residues have fairly high levels of C18:1 isomers and somewhat lower levels of C18:0. Examples of moderate-high-fat-content foods include Texas ebony seeds and the fatty meat of medium-sized mammals, such as beaver. Of the 24 samples, 17 have strong indications of a plant origin; in the remaining seven samples, a plant origin is slightly favored. Nine residues are characterized by elevated levels of medium-chain fatty acids and rather low levels of C18:2. The level of C18:2 is less than five percent in 4VG 4, 4VG 5, 4VG 6, and 4VG 101; residues 4VG 30, 4VG 32, 4VG 33, 4VG 55, and 4VG 90 have only slightly higher levels of C18:2. It is possible that these residues have a common plant origin. Conversely, four residues have rather low levels of medium-chain fatty acids (6.36 percent and less) and levels of C18:2 ranging between 8.91 and 13.01 percent. These include 4VG 25, 4VG 29, 4VG 77, and 4VG 88. In four residues, both the medium-chain fatty acids and C18:2 levels are elevated; these include 4VG 22, 4VG 89, 4VG 92 and 4VG 98. The final group, consisting of seven residues, is characterized by rather low levels of mediumchain fatty acids and only slightly elevated levels of C18:1. The origin of these residues is more ambiguous, but a plant source is slightly favored. These residues include 4VG 9, 4VG 34，4VG 72，4VG 80，4VG 83，4VG 95, and to a lesser degree $4 \mathrm{VG} 82$.

Nine residues fall on the border between medium- and moderate-high-fat-content foods. On the basis of their elevated levels of C18:2, eight residues are probably of plant origin. These residues include 4VG 15, 4VG 18, 4VG 20, 4VG 36, 4VG 57, 4VG 66, 4VG 74, and $4 \mathrm{VG} 91$. The origin of $4 \mathrm{VG} 10$ is somewhat ambiguous, but a plant source is slightly favored.

Nine samples have elevated levels of C18:0, which occurs in residues produced from large herbivore meat. Other foods known to produce similar residues include javelina meat and the seed oils of certain tropical plants, such as sotol. Two residues, 4VG 1 and $4 \mathrm{VG} 2$, appear to result from the preparation of lean meat or tropical seed oils alone. Six residues are similar in that levels of C18:1 isomers are elevated. Low levels of medium-chain fatty acids, C18:2, and VLCS fatty acids are found in two residues, 4VG 12 and $4 \mathrm{VG} 14$; this is similar to residues of fatty or somewhat fatty large herbivore meat prepared alone. Four other residues, 4VG 16, $4 \mathrm{VG} 21,4 \mathrm{VG} 23$, and $4 \mathrm{VG} 24$, are similar to those resulting from the preparation of fatty or somewhat fatty large herbivore meat; but they also have elevated levels of C18:2 and slightly elevated levels of VLCS fatty acids. This may indicate that the source was plant or that plants were mixed with meat. One residue, 4VG 17, was consistent with large herbivore prepared with plant or bone marrow. 
Residue 4VG 63 falls on the border between medium-fat-content plant and large herbivore prepared with plant or bone marrow.

\section{G.5 Discussion}

\section{G.5.1 Residues by Artifact Type}

Two artifact types, pottery and burned limestone rocks, were submitted for analysis. Residues extracted from the eight pottery sherds included two identified as large herbivore and three identified as moderate-high-fat-content food, likely to be of plant origin. The other three residues fell on the border between moderatehigh- and high-fat-content food; all were likely to be of plant origin.

Ninety-four residues were extracted from burned limestone. Seventy-three, representing 77.7 percent of all burned rock residues, contain significantly elevated levels of fat or oil. Of these 73 residues, 64 (or 86.5 percent) are consistent with nuts or seeds with fat contents ranging from moderate-high to very high. Residues from 14 burned rocks were identified as very-high-fat-content food; all of which are likely to be of plant origin. Seven other burned rock residues fell on the border between highand very-high-fat-content food, likely to be of plant origin. Twenty-three residues were identified as high-fat-content food, 21 of which were probably plants. Another eight residues fell on the border between high and moderatehigh-fat-content food; all were probably of plant origin. A further 21 residues were identified as moderate-high-fat-content foods, 15 of which were probably plants.

Twenty residues had somewhat lower levels of fat or oil. Nine residues fell on the border between moderate-high- and medium-fat-content foods; all but one of these residues probably originated from plants. Two residues were identified as medium-fat-content food, both of which are likely to be of plant origin. One residue was consistent with a low-fat-content plant. Eight residues may reflect the preparation of large herbivore products. One residue fell on the border between medium-fat-content plant and large herbivore prepared with plant or bone marrow. One residue was identified as large herbivore prepared with plant or bone marrow. Six residues are consistent with fatty or somewhat fatty large herbivore meat prepared alone or with plants.

The residue extracted from one sample of burned limestone contained insufficient fatty acids for analysis.

\section{G.5.2 Residues by Component}

\section{G.5.2.1 Mission Period (After 250 B.P.)}

Residues from two samples of pottery were analyzed from the Mission Period component (ca. 250 B.P. ff.); both are similar in composition to lean, large herbivore meat, javelina meat, and the tropical oils from the seeds of plants, such as sotol.

\section{G.5.2.2 Late Prehistoric (Toyah Phase) Component (ca. 300 to 650 B.P.)}

Residues from six pieces of pottery and 29 fragments of burned limestone were analyzed from the Late Prehistoric Period (Toyah Phase) component (ca. 300 to 650 B.P.). With respect to the pottery, three residues were characterized as moderate-high-fat-content foods likely to be of plant origin. The other three residues were similar in composition to moderate-high-fatcontent foods likely to be of plant origin.

The Toyah Phase component burned rock residues were unique in two respects. Several Toyah Phase burned rocks contained residues similar in composition to large herbivore in that they had significantly elevated levels of C18:0. 
Unlike the Archaic Period components, none of the Toyah Phase burned rocks contained residues identified as very-high-fat-content foods. Of the burned rock residues, five were identified as high-fat-content foods, four of which were probably of plant origin. Three fell on the border between moderate-high and highfat-content food, and all were probably of plant origin. Of the eight residues identified as moderate-high-fat-content food, all but one were probably of plant origin. Similarly, four of the five residues identified as borderline medium and moderate-high-fat-content foods are likely of plant origin. One residue was identified as food of medium fat content and is likely to be of plant origin.

Seven of the Toyah Phase burned rock residues appear to result from the preparation of large herbivore products, javelina meat, or tropical seed oils. In two cases, the residues were similar to fatty or somewhat fatty meat prepared alone; in four other cases, residues resembled somewhat fatty large herbivore meat prepared with plants. One residue was similar in composition to large herbivore meat prepared with a moderate-fat-content plant or bone marrow.

\section{G.5.2.3 Late Archaic Component (ca. 1700 to 2300 B.P.)}

Thirty-four burned rock residues were analyzed from the Late Archaic component of the Varga site. Nine of the residues were identified as very-high-fat-content foods that were probably of plant origin. Four residues bordered veryhigh- and high-fat-content foods, and all were likely of plant origin. Nine were identified as high-fat-content foods, eight of which were probably of plant origin. Five were characterized as falling on the border between moderate-high- and high-fat-content food; all were probably of plant origin. One residue was identified as a moderate-high-fat-content food likely of plant origin. Two residues were identified as borderline medium and moderatehigh-fat-content foods and likely of plant origin. One residue was identified as food of medium fat content likely to be of plant origin. One residue was similar in composition to a low-fatcontent plant. One residue fell on the border between medium-fat-content foods and the combination of large herbivore meat and medium-fat-content plant or large herbivore bone marrow. One Late Archaic burned rock residue contained insufficient fatty acids for analysis.

\section{G.5.2.4 Middle Archaic Component (ca. 3900 to 4820 B.P.)}

Of the nine burned rock residues analyzed from the Middle Archaic Period component (ca. 3900 to 4820 B.P.), all but two are likely to be of plant origin. Only one of the three residues identified as moderate-high-fat-content food has strong indications of a plant origin. Other Middle Archaic residues include one identified as very-high-fat-content food and four identified as high-fat-content food. One residue was identified as borderline medium and moderatehigh-fat-content food, likely to be of plant origin.

\section{G.5.2.5 Early Archaic Component (ca. 5200 to 6300 B.P.)}

Twenty-two burned rock residues were analyzed from the Early Archaic Period component (ca. 5200 to 6300 B.P.). Four were identified as very-high-fat-content foods likely of plant origin. Three residues bordered very-high- and high-fat-content foods, and all were likely of plant origin. Five were identified as high-fatcontent foods, all of which were likely from plants. A total of nine residues were identified as moderate-high-fat-content foods; of these, the source of six was probably plants. One residue fell on the border between medium and 
moderate-high-fat-content foods; it was likely of plant origin.

\section{G.5.3 Residues by Feature}

\section{G.5.3.1 Late Prehistoric (Toyah) Features}

Limestone and pottery samples were analyzed from seven features associated with the Late Prehistoric Period (Toyah Phase) component.

\section{Feature 8}

Six residues were analyzed. Two were identified as high-fat-content foods, one of which was likely to be of plant origin. Two were similar in composition to fatty or somewhat fatty large herbivore meat. One was identified as moderate-high-fat-content food. One bordered on medium- and moderate-highfat-content food.

\section{Feature 9}

Four residues were analyzed. Two bordered on medium- and moderate-high-fat-content food, likely to be of plant origin. One was similar in composition to fatty large herbivore meat, possibly prepared with plants. Another was identified as large herbivore meat cooked with plant or bone marrow.

\section{Feature 18}

The two residues from this feature were identified as moderate-high-fat-content food, likely of plant origin.

\section{Feature 21}

Three residues were analyzed. Two were identified as moderate-high-fat-content food of probable plant origin. The other was identified as medium-fat-content food, likely to be of plant origin.

\section{Feature 25}

Of the five residues analyzed, one was identified as high-fat-content food, likely to be of plant origin. One bordered moderate-high- and highfat-content food; it was probably from plant. One was identified as moderate-high-fat-content food and another bordered medium-high-fatcontent food, both of which were probably plants. The fifth residue was similar in composition to somewhat fatty large herbivore meat, possibly prepared with plant.

\section{Feature 36}

Two of the three residues fell on the border between moderate-high- and high-fat-content food, and the other was identified as moderatehigh-fat-content food. All three were likely from plants.

\section{Feature 38}

One residue was identified as high-fat-content food and two were identified as moderate-highfat-content food; all were likely of plant origin. Two residues were similar in composition to somewhat fatty large herbivore meat, possibly prepared with plant.

\section{G.5.3.2 Late Archaic Features}

Limestone samples were analyzed from eight features associated with the Late Archaic Period component.

\section{Feature 1}

Thirteen residues were analyzed from this feature. Two were identified as very-high-fatcontent food, two fell on the border between high- and very-high-fat-content food, and three were identified as high-fat-content food. All seven were likely of plant origin. One residue fell on the border between moderate-high- and high-fat-content food. Two fell on the border between medium and moderate-high-fat-content 
food; both of which were likely of plant origin. One residue was identified as medium-fatcontent food and one as low-fat-content food; both likely represent plant residues. The last residue fell on the border between medium-fatcontent food and large herbivore prepared with plant, or bone marrow.

\section{Feature 1a}

Two residues were identified as very-high-fatcontent food and one fell on the border between high- and very-high-fat-content food. All three were likely of plant origin.

\section{Feature 1b}

One residue fell on the border between high- and very-high-fat-content food of probable plant origin. Two residues were identified as high-fatcontent food; one is likely of plant origin. Two fell on the border between moderate-high- and high-fat-content food; both were likely of plant origin.

\section{Feature 1c}

One residue was identified as very-high-fatcontent food, one was identified as high-fatcontent food, and one fell on the border between moderate-high- and high-fat-content food. All three appear to represent plant residues.

\section{Feature 1d}

One residue was identified as very-high-fatcontent food and two others were identified as high-fat-content food. The three were all likely of plant origin.

\section{Feature 15}

One residue was identified as high-fat-content food, one as moderate-high-fat-content food and another fell on the border between moderatehigh- and high-fat-content food. All three likely originated from plants.

\section{Feature 28}

One residue was identified as very-high-fatcontent food of probable plant origin. One residue contained insufficient fatty acid for analysis.

\section{Feature 29}

Both residues were identified as very-high-fatcontent food, likely of plant origin.

\section{G.5.3.3 Middle Archaic Features}

Limestone samples were analyzed from two features associated with the Middle Archaic Period component.

\section{Feature 11}

One residue was identified as very-high-fatcontent food. One was identified as high-fatcontent food. One fell on the border between medium- and moderate-high-fat-content food. These three residues were likely of plant origin. The origin of one residue, identified as moderate-high-fat-content food, is ambiguous.

\section{Feature 37}

Four residues were analyzed. Two were identified as high-fat-content food likely to be of plant origin. The other two were identified as moderate-high-fat-content food.

\section{G.5.3.4 Early Archaic Features}

Limestone samples were analyzed from six features associated with the Early Archaic Period component.

\section{Feature 12}

The three residues were identified as very-highfat-content, high-fat-content, and moderate-highfat-content food; all were likely plant foods. 


\section{Feature 13}

One residue was identified as very-high-fatcontent food, one fell on the border between high- and very-high-fat-content food. One residue was identified as high-fat-content food and the other as moderate-high-fat-content food. All four residues were likely of plant origin.

\section{Feature 26}

One residue fell on the border between high- and very-high-fat-content food, likely a plant food. Two other residues were identified as moderatehigh-fat-content food.

\section{Feature 31}

Two residues were identified as very-high-fatcontent food. One was identified as high-fatcontent food and one fell on the border between high- and very-high-fat-content food. All were probably derived from plants.

\section{Feature 39}

Three of the four residues were identified as moderate-high-fat-content food. One fell on the border between medium and moderate-high-fatcontent food. All four were likely of plant origin.

\section{Feature 40}

Two residues were identified as high-fat-content food likely of plant origin. Two others were identified as moderate-high-fat-content food, one of which was probably of plant origin.

\section{G.6 REFERENCES CITED}

Collins M. B., B. Ellis, and C. Dodt-Ellis

1990 Excavations at the Camp Pearl Wheat Site (41KR243): An Early Archaic Campsite on Town Creek, Kerr County, Texas. Studies in Archeology 6. Texas Archeological Research Laboratory, The University of Texas at Austin.
Condamin, J., F. Formenti, M. O. Metais, M. Michel, and P. Blond

1976 The Application of Gas Chromatography to the Tracing of Oil in Ancient Amphorae. Archaeometry 18(2):195-201.

deMan, J. M.

1992 Chemical and Physical Properties of Fatty Acids. In Fatty Acids in Foods and their Health Implications, edited by C. K. Chow, pp. 17-39. Marcel Dekker, New York.

Evershed, R. P., C. Heron, and L. J. Goad

1990 Analysis of Organic Residues of Archaeological Origin by High Temperature Gas Chromatography and Gas Chromatography-Mass Spectroscopy. Analyst 115:1339-1342.

Folch, J., M. Lees, and G. H. Sloane-Stanley

1957 A Simple Method for the Isolation and Purification of Lipid Extracts from Brain Tissue. Journal of Biological Chemistry 191:833.

Frankel, E. N.

1991 Recent Advances in Lipid Oxidation. Journal of the Science of Food and Agriculture 54:465-511.

Loy, T.

1994 Residue Analysis of Artifacts and Burned Rock from the Mustang Branch and Barton Sites (41HY209 and 41HY202). In Archaic and Late Prehistoric Human Ecology in the Middle Onion Creek Valley, Hays County, Texas. Volume 2: Topical Studies, by R. A. Ricklis and M. B. Collins, pp. 607-627. Studies in Archeology 19, Texas Archeological Research Laboratory, The University of Texas at Austin.

Malainey, M. E.

1997 The Reconstruction and Testing of Subsistence and Settlement Strategies 
for the Plains, Parkland, and Southern Boreal Forest. Unpublished Ph.D. dissertation, University of Manitoba.

Malainey, M. E., K. L. Malisza, R. Przybylski, and G. Monks

2001aThe Key to Identifying Archaeological Fatty Acid Residues. Paper presented at the $34^{\text {th }}$ Annual Meeting of the Canadian Archaeological Association, Banff, Alberta, May 2001.

Malainey, M. E., R. Przybylski, and B. L. Sherriff

1999aThe Fatty Acid Composition of Native Food Plants and Animals of Western Canada. Journal of Archaeological Science 26:83-94.

1999bThe Effects of Thermal and Oxidative Decomposition on the Fatty Acid Composition of Food Plants and Animals of Western Canada: Implications for the Identification of Archaeological Vessel Residues. Journal of Archaeological Science 26:95-103.

1999cIdentifying the Former Contents of Late Precontact Period Pottery Vessels from Western Canada using Gas Chromatography. Journal of Archaeological Science 26(4): 425-438.

2001bOne Person's Food: How and Why Fish Avoidance May Affect the Settlement and Subsistence Patterns of HunterGatherers. American Antiquity 66(1): 141-161.

Malainey, M. E., R. Przybylski, and G. Monks 2000aThe Identification of Archaeological Residues using Gas Chromatography and Applications to Archaeological Problems in Canada, United States, and Africa. Paper presented at the $11^{\text {th }}$ Annual Workshops in Archaeometry, State University of New York at Buffalo, February 2000.
2000bRefining and Testing the Criteria for Identifying Archaeological Lipid Residues using Gas Chromatography. Paper presented at the $33^{\text {rd }}$ Annual Meeting of the Canadian Archaeological Association, Ottawa, May 2000.

2000cDeveloping a General Method for Identifying Archaeological Lipid Residues on the Basis of Fatty Acid Composition. Paper presented at the Joint Midwest Archaeological and Plains Anthropological Conference, Minneapolis, Minnesota, November 2000.

Marchbanks, M. L.

1989 Lipid Analysis in Archaeology: An Initial Study of Ceramics and Subsistence at the George C. Davis Site. Unpublished M.A. thesis, The University of Texas at Austin.

Marchbanks, M. L. and J. M. Quigg

1990 Appendix G: Organic Residue and Phytolith Analysis. In Phase II Investigations at Prehistoric and Rock Art Sites, Justiceburg Reservoir, Garza and Kent Counties, Texas, Volume II, by D. K. Boyd, J. T. Abbott, W. A. Bryan, C. M. Garvey, S. A. Tomka, and R. C. Fields, pp. 496-519. Reports of Investigations No. 71. Prewitt and Associates, Inc, Austin.

Patrick, M., A. J. de Konig, and A. B. Smith

1985 Gas Liquid Chromatographic Analysis of Fatty Acids in Food Residues from Ceramics Found in the Southwestern Cape, South Africa. Archaeometry 27(2): 231-236.

Quigg, J. M., C. Lintz, S. Smith, and S. Wilcox

2000 The Lino Site: A Stratified Late Archaic Campsite in a Terrace of the San Idelfonzo Creek, Webb County, Southern Texas. Technical Report No. 23765, TRC Mariah Associates Inc., Austin, and Texas Department of 
Transportation, Environmental Affairs Division, Archaeological Studies Program Report 20, Austin.

Quigg, J. M., M. E. Malainey, R. Przybylski, and G. Monks

2001 No Bones About It: Using Lipid Analysis of Burned Rock and Groundstone Residues to Examine Late Archaic Subsistence Practices in South
Texas. Plains Anthropologist 46(177): 283-303.

Skibo, J. M.

1992 Pottery Function: A Use-Alteration Perspective. Plenum Press, New York.

Solomons, T. W. G.

1980 Organic Chemistry. John Wiley \& Sons, Toronto. 


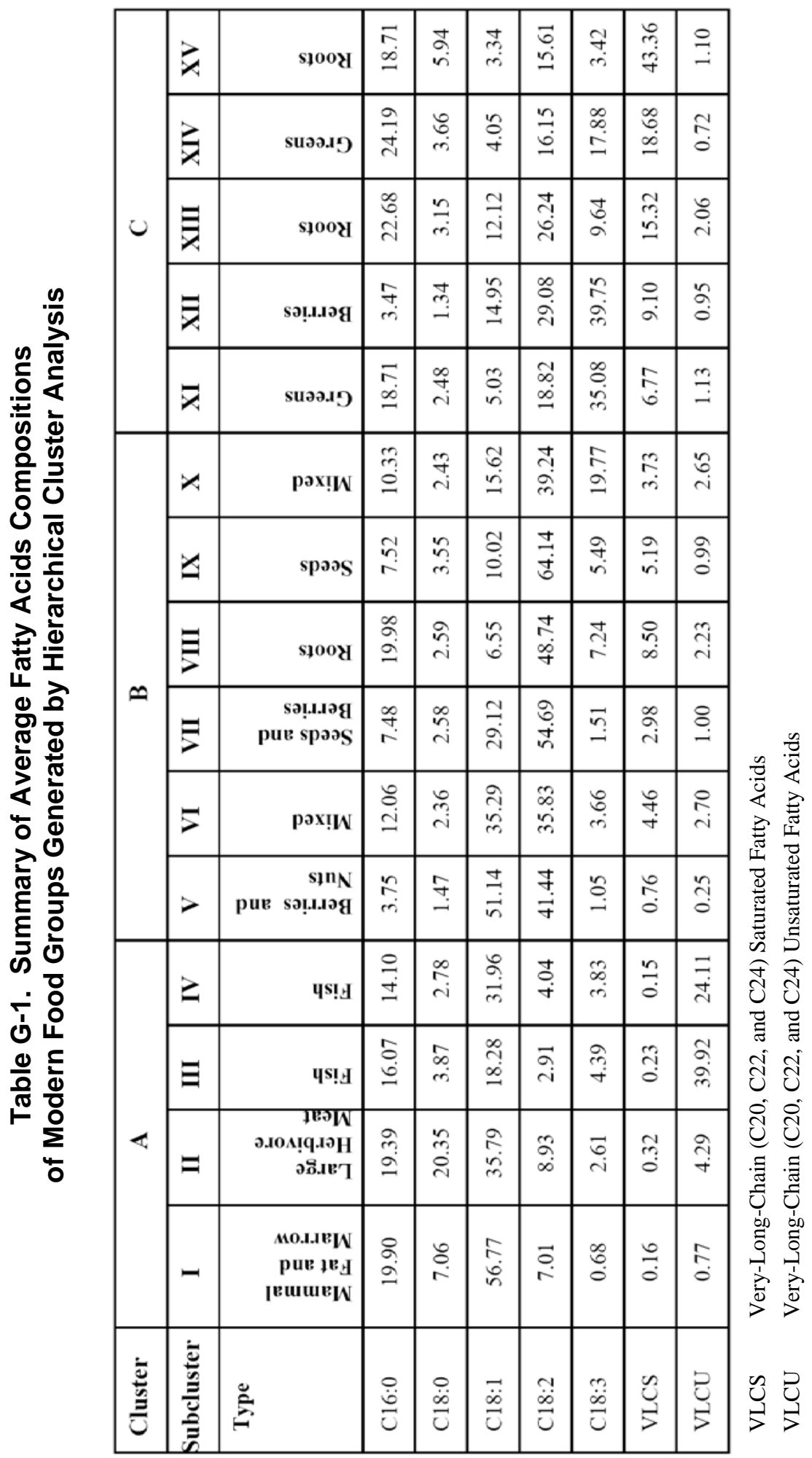


Table G-2. Criteria for the Identification of Archaeological Residues Based on the Decomposition Patterns of Experimental Cooking Residues Prepared in Pottery Vessels

\begin{tabular}{|l|c|l|l|}
\hline \multicolumn{1}{|c|}{ Identification } & Medium Chain & \multicolumn{1}{|c|}{ C18:0 } & C18:1 Isomers \\
\hline Large Herbivore & $\leq 15 \%$ & $\geq 27.5 \%$ & $\leq 15 \%$ \\
\hline $\begin{array}{l}\text { Large Herbivore with Plant } \\
\text { or Bone Marrow }\end{array}$ & Low & $\geq 25 \%$ & $15 \% \leq X \leq 25 \%$ \\
\hline Plant with Large Herbivore & $\geq 15 \%$ & $\geq 25 \%$ & No data \\
\hline Beaver & Low & Low & $\geq 25 \%$ \\
\hline Fish or Corn & Low & $\leq 25 \%$ & $15 \% \leq X \leq 27.5 \%$ \\
\hline Fish or Corn with Plant & $\geq 15 \%$ & $\leq 25 \%$ & $15 \% \leq X \leq 27.5 \%$ \\
\hline Plant (except corn) & $\geq 10 \%$ & $\leq 27.5 \%$ & $\leq 15 \%$ \\
\hline
\end{tabular}


Table G-3. List of Samples Analyzed from the Varga Site

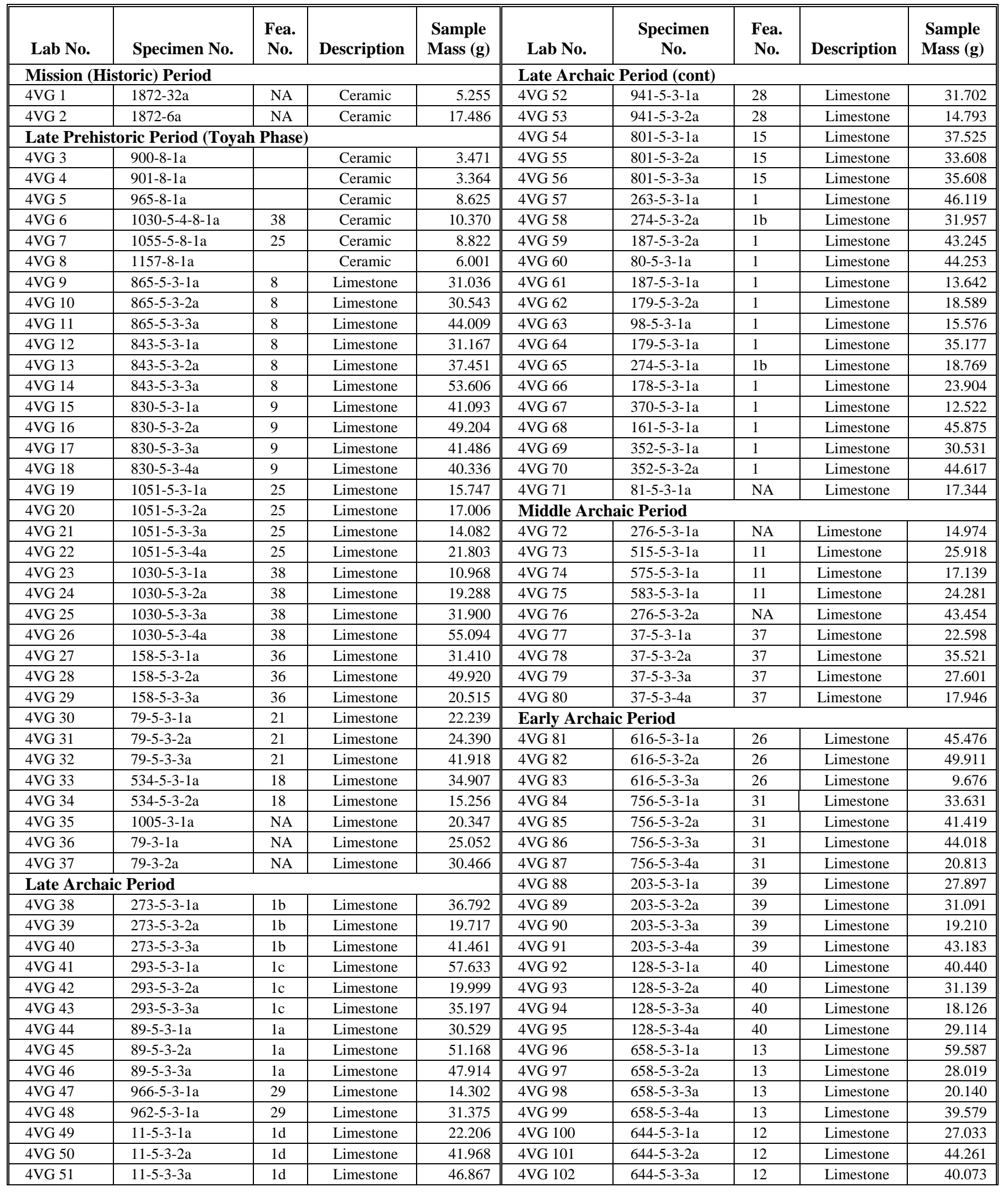


Table G-4. Fatty Acid Composition and Identification of Residues from the Varga Site

\begin{tabular}{|c|c|c|c|c|c|c|c|c|}
\hline \multirow{2}{*}{ Fatty Acid } & \multicolumn{2}{|c|}{ 4VG 1 (1872-32a) } & \multicolumn{2}{|c|}{ "4VG 2 (1872-6a) } & \multicolumn{2}{|c|}{ 4VG 3 (900-6-1a) } & \multicolumn{2}{|c|}{ 4VG 4 (901-8-1a) } \\
\hline & Area & Rel\% & Area & Rel\% & Area & Rel\% & Area & Rel\% \\
\hline C12:0 & 20950 & 0.37 & 24802 & 0.55 & 1935 & 0.42 & 0 & 0.00 \\
\hline C14:0 & 160439 & 2.83 & 224031 & 4.98 & 45942 & 9.92 & 23862 & 10.10 \\
\hline C14:1 & 0 & 0.00 & 0 & 0.00 & 0 & 0.00 & 0 & 0.00 \\
\hline C15:0 & 87740 & 1.55 & 89418 & 1.99 & 8244 & 1.78 & 4833 & 2.05 \\
\hline C16:0 & 2095745 & 36.94 & 2278915 & 50.70 & 145540 & 31.42 & 70330 & 29.76 \\
\hline C16:1 & 5561 & 0.10 & 5330 & 0.12 & 0 & 0.00 & 0 & 0.00 \\
\hline C17:0 & 228066 & 4.02 & 120256 & 2.68 & 2420 & 0.52 & 1395 & 0.59 \\
\hline C17:1 & 0 & 0.00 & 0 & 0.00 & 0 & 0.00 & 0 & 0.00 \\
\hline C18:0 & 2414796 & 42.56 & 1333385 & 29.67 & 26318 & 5.68 & 18915 & 8.00 \\
\hline C18:1s & 568494 & 10.02 & 350226 & 7.79 & 167122 & 36.08 & 77649 & 32.86 \\
\hline C18:2 & 15701 & 0.28 & 11812 & 0.26 & 24645 & 5.32 & 8743 & 3.70 \\
\hline C18:3w3 & 8639 & 0.15 & 12559 & 0.28 & 20312 & 4.39 & 16899 & 7.15 \\
\hline C20:0 & 24773 & $\overline{0.44}$ & 13555 & 0.30 & 2749 & 0.59 & 2647 & 1.12 \\
\hline C20:1 & 18247 & 0.32 & 25208 & 0.56 & 12603 & 2.72 & 6789 & 2.87 \\
\hline C24:0 & 24920 & 0.44 & 5090 & 0.11 & 5358 & 1.16 & 4246 & 1.80 \\
\hline Total & 5674071 & 100.00 & 4494587 & 100.00 & 463188 & 100.00 & 236308 & 100.00 \\
\hline Identification & \multicolumn{2}{|c|}{$\begin{array}{l}\text { Large } \\
\text { Herbivore/Javelina/ } \\
\text { Tropical Seed Oil }\end{array}$} & \multicolumn{2}{|c|}{$\begin{array}{l}\text { Large } \\
\text { Herbivore/Javelina/ } \\
\text { Tropical Seed Oil }\end{array}$} & \multicolumn{2}{|c|}{$\begin{array}{l}\text { Borderline Moderate- } \\
\text { High and High Fat } \\
\text { Content }\end{array}$} & \multicolumn{2}{|c|}{$\begin{array}{l}\text { Moderate-High Fat } \\
\text { Content Food } \\
\text { (Texas Ebony/Beaver) }\end{array}$} \\
\hline
\end{tabular}

Table G-4. Fatty Acid Composition and Identification of Residues from the Varga Site (cont.)

\begin{tabular}{|c|c|c|c|c|c|c|c|c|}
\hline \multirow{2}{*}{ Fatty Acid } & \multicolumn{2}{|c|}{ 4VG 5 (965-8-1a) } & \multicolumn{2}{|c|}{ 4VG 6 (1030-5-4-8-1a) } & \multicolumn{2}{|c|}{ 4VG 7 (1055-5-8-1a) } & \multicolumn{2}{|c|}{ 4VG 8 (1157-8-1a) } \\
\hline & Area & Rel\% & Area & Rel\% & Area & Rel\% & Area & Rel\% \\
\hline C12:0 & 6039 & 1.07 & 13548 & 1.77 & 8039 & 1.11 & 4877 & 1.18 \\
\hline C14:0 & 76112 & 13.44 & 102452 & 13.36 & 97861 & 13.52 & 41014 & 9.89 \\
\hline C14:1 & 2386 & 0.42 & 13767 & 1.79 & 0 & 0.00 & 0 & 0.00 \\
\hline C15:0 & 12761 & 2.25 & 10295 & 1.34 & 20023 & 2.77 & 9882 & 2.38 \\
\hline C16:0 & 181508 & 32.05 & 219849 & 28.66 & 230939 & 31.89 & 116002 & 27.96 \\
\hline C16:1 & 0 & 0.00 & 0 & 0.00 & 0 & 0.00 & 0 & 0.00 \\
\hline C17:0 & 1475 & 0.26 & 0 & 0.00 & 4082 & 0.56 & 531 & 0.13 \\
\hline C17:1 & 1515 & 0.27 & 0 & 0.00 & 0 & 0.00 & 0 & 0.00 \\
\hline C18:0 & 31152 & 5.50 & 42043 & 5.48 & 38673 & 5.34 & 23735 & 5.72 \\
\hline C18:1s & 186888 & 33.00 & 242821 & 31.65 & 273508 & 37.77 & 149329 & 36.00 \\
\hline C18:2 & 18249 & 3.22 & 29559 & 3.85 & 25418 & 3.51 & 30810 & 7.43 \\
\hline C18:3w3 & 23683 & 4.18 & 74533 & 9.72 & 25528 & 3.53 & 29017 & 6.99 \\
\hline C20:0 & 2810 & 0.50 & 0 & 0.00 & 0 & 0.00 & 2203 & 0.53 \\
\hline C20:1 & 15124 & 2.67 & 9660 & 1.26 & 0 & 0.00 & 3775 & 0.91 \\
\hline C24:0 & 6585 & 1.16 & 8579 & 1.12 & 0 & 0.00 & 3679 & 0.89 \\
\hline Total & 566287 & 100.00 & 767106 & 100.00 & 724071 & 100.00 & 414854 & 100.00 \\
\hline Identification & \multicolumn{2}{|c|}{$\begin{array}{l}\text { Moderate-High Fat } \\
\text { Content Food } \\
\text { (Texas Ebony/Beaver) }\end{array}$} & \multicolumn{2}{|c|}{$\begin{array}{l}\text { Moderate-High Fat } \\
\text { Content Food } \\
\text { (Texas Ebony/Beaver) }\end{array}$} & \multicolumn{2}{|c|}{$\begin{array}{l}\text { Borderline Moderate- } \\
\text { High and High Fat } \\
\text { Content }\end{array}$} & \multicolumn{2}{|c|}{$\begin{array}{l}\text { Borderline Moderate- } \\
\text { High and High Fat } \\
\text { Content }\end{array}$} \\
\hline
\end{tabular}


Appendix G: Analysis of Fatty Acids in Pottery and Rock

Table G-4. Fatty Acid Composition and Identification of Residues from the Varga Site (cont.)

\begin{tabular}{|c|c|c|c|c|c|c|c|c|}
\hline \multirow{2}{*}{ Fatty Acid } & \multicolumn{2}{|c|}{ 4VG 9 (865-5-3-1a) } & \multicolumn{2}{|c|}{ 4VG 10 (865-5-3-2a) } & \multicolumn{2}{|c|}{ 4VG 11 (865-5-3-3a) } & \multicolumn{2}{|c|}{ 4VG 12 (843-5-3-1a) } \\
\hline & Area & Rel\% & Area & Rel\% & Area & Rel\% & Area & Rel\% \\
\hline C12:0 & 0 & 0.00 & 1829 & 1.96 & 0 & 0.00 & 1834 & 0.83 \\
\hline C14:0 & 3522 & 5.93 & 2023 & 2.16 & 0 & 0.00 & 5486 & 2.49 \\
\hline C14:1 & 0 & 0.00 & 0 & 0.00 & 0 & 0.00 & 0 & 0.00 \\
\hline C15:0 & 483 & 0.81 & 1709 & 1.83 & 2644 & 2.42 & 4237 & 1.92 \\
\hline C16:0 & 14136 & 23.79 & 25951 & 27.77 & 25347 & 23.20 & 68514 & 31.05 \\
\hline C16:1 & 837 & 1.41 & 1197 & 1.28 & 2817 & 2.58 & 1057 & 0.48 \\
\hline C17:0 & 0 & 0.00 & 0 & 0.00 & 0 & 0.00 & 0 & 0.00 \\
\hline C17:1 & 0 & 0.00 & 0 & 0.00 & 0 & 0.00 & 0 & 0.00 \\
\hline C18:0 & 11127 & 18.72 & 20742 & 22.19 & 19017 & 17.41 & 80202 & 36.35 \\
\hline C18:1s & 15771 & 26.54 & 22280 & 23.84 & 43059 & 39.41 & 39445 & 17.88 \\
\hline C18:2 & 3229 & 5.43 & 4249 & 4.55 & 3687 & 3.37 & 3991 & 1.81 \\
\hline C18:3w3 & 5905 & 9.94 & 7453 & 7.97 & 6507 & 5.96 & 9591 & 4.35 \\
\hline C20:0 & 1712 & 2.88 & 2292 & 2.45 & 2555 & 2.34 & 2190 & 0.99 \\
\hline C20:1 & 605 & 1.02 & 1223 & 1.31 & 0 & 0.00 & 1113 & 0.50 \\
\hline C24:0 & 2098 & 3.53 & 2515 & 2.69 & 3614 & 3.31 & 3003 & 1.36 \\
\hline Total & 59425 & 100.00 & 93463 & 100.00 & 109247 & 100.00 & 220663 & 100.00 \\
\hline Identification & \multicolumn{2}{|c|}{$\begin{array}{l}\text { Moderate-High Fat } \\
\text { Content Food } \\
\text { (Texas Ebony/Beaver) }\end{array}$} & \multicolumn{2}{|c|}{$\begin{array}{l}\text { Borderline Medium } \\
\text { and Moderate-High } \\
\text { Fat Content }\end{array}$} & \multicolumn{2}{|c|}{$\begin{array}{l}\text { High Fat Content } \\
\text { Food (Seed/Animal } \\
\text { Fat) }\end{array}$} & \multicolumn{2}{|c|}{$\begin{array}{l}\text { Large } \\
\text { Herbivore/Javelina/ } \\
\text { Tropical Seed Oil }\end{array}$} \\
\hline
\end{tabular}

\begin{tabular}{|c|c|c|c|c|c|c|c|c|}
\hline \multirow{2}{*}{ Fatty Acid } & \multicolumn{2}{|c|}{ 4VG 13 (843-5-3-2a) } & \multicolumn{2}{|c|}{ 4VG 14 (843-5-3-3a) } & \multicolumn{2}{|c|}{ 4VG 15 (830-5-3-1a) } & \multicolumn{2}{|c|}{ 4VG 16 (830-5-3-2a) } \\
\hline & Area & Rel\% & Area & Rel\% & Area & Rel\% & Area & Rel\% \\
\hline C12:0 & 415 & 0.43 & 1817 & 0.94 & 1646 & 1.95 & 0 & 0.00 \\
\hline C14:0 & 2931 & 3.05 & 6074 & 3.15 & 4349 & 5.16 & 4120 & 2.07 \\
\hline C14:1 & 0 & 0.00 & 0 & 0.00 & 0 & 0.00 & 0 & 0.00 \\
\hline C15:0 & 1459 & 1.52 & 2415 & 1.25 & 2262 & 2.68 & 3857 & 1.94 \\
\hline C16:0 & 20371 & 21.21 & 51585 & 26.73 & 23436 & 27.80 & 51259 & 25.79 \\
\hline C16:1 & 1592 & 1.66 & 1112 & 0.58 & 1224 & 1.45 & 1830 & 0.92 \\
\hline C17:0 & 0 & 0.00 & 593 & 0.31 & 0 & 0.00 & 2349 & 1.18 \\
\hline C17:1 & 0 & 0.00 & 0 & 0.00 & 0 & 0.00 & 184 & 0.09 \\
\hline C18:0 & 16502 & 17.18 & 55585 & 28.81 & 19425 & 23.04 & 54072 & 27.20 \\
\hline C18:1s & 41870 & 43.60 & 55688 & 28.86 & 21874 & 25.95 & 49459 & 24.88 \\
\hline C18:2 & 6419 & 6.68 & 4632 & 2.40 & 5024 & 5.96 & 23079 & 11.61 \\
\hline C18:3w3 & 2241 & 2.33 & 10356 & 5.37 & 2045 & 2.43 & 0 & 0.00 \\
\hline C20:0 & 2242 & 2.33 & 1981 & 1.03 & 3007 & 3.57 & 4119 & 2.07 \\
\hline C20:1 & 0 & 0.00 & 1128 & 0.58 & 0 & 0.00 & 371 & 0.19 \\
\hline C24:0 & 0 & 0.00 & 0 & 0.00 & 0 & 0.00 & 4074 & 2.05 \\
\hline Total & 96042 & 100.00 & 192966 & 100.00 & 84292 & 100.00 & 198773 & 100.00 \\
\hline Identification & \multicolumn{2}{|c|}{$\begin{array}{l}\text { High Fat Content } \\
\text { Food (Seed/Animal } \\
\text { fat) }\end{array}$} & \multicolumn{2}{|c|}{$\begin{array}{l}\text { Large } \\
\text { Herbivore/Javelina/ } \\
\text { Tropical Seed Oil }\end{array}$} & \multicolumn{2}{|c|}{$\begin{array}{l}\text { Borderline Medium } \\
\text { and Moderate-High } \\
\text { Fat Content }\end{array}$} & \multicolumn{2}{|c|}{$\begin{array}{l}\text { Large } \\
\text { Herbivore/Javelina/ } \\
\text { Tropical Seed Oil }\end{array}$} \\
\hline
\end{tabular}


The Varga Site

Texas Department of Transportation

Table G-4. Fatty Acid Composition and Identification of Residues from the Varga Site (cont.)

\begin{tabular}{|c|c|c|c|c|c|c|c|c|}
\hline \multirow{2}{*}{ Fatty Acid } & \multicolumn{2}{|c|}{ 4VG 17 830-5-3-3a) } & \multicolumn{2}{|c|}{ 4VG 18 830-5-3-4a) } & \multicolumn{2}{|c|}{ 4VG 19 1051-5-3-1a) } & \multicolumn{2}{|c|}{ 4VG 20 (1051-5-3-2a) } \\
\hline & Area & Rel\% & Area & Rel\% & Area & Rel\% & Area & Rel\% \\
\hline C12:0 & 78 & 0.10 & 895 & 1.14 & 598 & 0.65 & 877 & 0.99 \\
\hline C14:0 & 1222 & 1.64 & 1874 & 2.39 & 1421 & 1.55 & 2111 & 2.38 \\
\hline C14:1 & 0 & 0.00 & 0 & 0.00 & 0 & 0.00 & 0 & 0.00 \\
\hline C15:0 & 971 & 1.30 & 1518 & 1.94 & 992 & 1.08 & 1903 & 2.15 \\
\hline C16:0 & 19491 & 26.20 & 21322 & 27.19 & 21239 & 23.19 & 26402 & 29.77 \\
\hline C16:1 & 672 & 0.90 & 0 & 0.00 & 899 & 0.98 & 988 & 1.11 \\
\hline C17:0 & 416 & 0.56 & 0 & 0.00 & 0 & 0.00 & 0 & 0.00 \\
\hline C17:1 & 0 & 0.00 & 0 & 0.00 & 0 & 0.00 & 0 & 0.00 \\
\hline C18:0 & 18765 & 25.22 & 18229 & 23.25 & 11455 & 12.51 & 21029 & 23.71 \\
\hline C18:1s & 16980 & 22.82 & 20580 & 26.24 & 37387 & 40.81 & 21330 & 24.05 \\
\hline C18:2 & 13135 & 17.65 & 8626 & 11.00 & 13237 & 14.45 & 8993 & 10.14 \\
\hline C18:3w3 & 0 & 0.00 & 0 & 0.00 & 0 & 0.00 & 0 & 0.00 \\
\hline C20:0 & 2677 & 3.60 & 2298 & 2.93 & 2223 & 2.43 & 2345 & 2.64 \\
\hline C20:1 & 0 & 0.00 & 0 & 0.00 & 0 & 0.00 & 0 & 0.00 \\
\hline C24:0 & 0 & 0.00 & 3079 & 3.93 & 2151 & 2.35 & 2700 & 3.04 \\
\hline Total & 74407 & 100.00 & 78421 & 100.00 & 91602 & 100.00 & 88678 & 100.00 \\
\hline Identification & \multicolumn{2}{|c|}{$\begin{array}{l}\text { Large } \\
\text { Herbivore/Javelina/ } \\
\text { Tropical Seed Oil + } \\
\text { Plant or Bone Marrow }\end{array}$} & \multicolumn{2}{|c|}{$\begin{array}{l}\text { Borderline Medium } \\
\text { and Moderate-High } \\
\text { Fat Content }\end{array}$} & \multicolumn{2}{|c|}{$\begin{array}{l}\text { High Fat Content } \\
\text { Food (Seed/Animal } \\
\text { Fat) }\end{array}$} & \multicolumn{2}{|c|}{$\begin{array}{l}\text { Borderline Medium } \\
\text { and Moderate-High } \\
\text { Fat Content }\end{array}$} \\
\hline
\end{tabular}

\begin{tabular}{|c|c|c|c|c|c|c|c|c|}
\hline \multirow{2}{*}{ Fatty Acid } & \multicolumn{2}{|c|}{ 4VG 21 (1051-5-3-3a) } & \multicolumn{2}{|c|}{ 4VG 22 (1051-5-3-4a) } & \multicolumn{2}{|c|}{ 4VG 23 (1030-5-3-1a) } & \multicolumn{2}{|c|}{ 4VG 24 (1030-5-3-2a) } \\
\hline & Area & Rel\% & Area & Rel\% & Area & Rel\% & Area & Rel\% \\
\hline C12:0 & 2385 & 2.05 & 2517 & 3.23 & 3493 & 2.62 & 2357 & 2.33 \\
\hline C14:0 & 3638 & 3.12 & 3239 & 4.15 & 3263 & 2.45 & 3673 & 3.63 \\
\hline C14:1 & 0 & 0.00 & 0 & 0.00 & 1120 & 0.84 & 0 & 0.00 \\
\hline C15:0 & 3345 & 2.87 & 3666 & 4.70 & 3207 & 2.41 & 3583 & 3.54 \\
\hline C16:0 & 29981 & 25.72 & 17455 & 22.37 & 31402 & 23.58 & 25387 & 25.08 \\
\hline C16:1 & 0 & 0.00 & 1063 & 1.36 & 1014 & 0.76 & 0 & 0.00 \\
\hline C17:0 & 0 & 0.00 & 0 & 0.00 & 104 & 0.08 & 0 & 0.00 \\
\hline C17:1 & 0 & 0.00 & 0 & 0.00 & 0 & 0.00 & 1037 & 1.02 \\
\hline C18:0 & 41870 & 35.92 & 13162 & 16.87 & 36590 & 27.47 & 26822 & 26.50 \\
\hline C18:1s & 19533 & 16.76 & 22364 & 28.66 & 24548 & 18.43 & 22298 & 22.03 \\
\hline C18:2 & 11348 & 9.74 & 10506 & 13.46 & 21545 & 16.18 & 9733 & 9.62 \\
\hline C18:3w3 & 0 & 0.00 & 0 & 0.00 & 0 & 0.00 & 0 & 0.00 \\
\hline C20:0 & 2109 & 1.81 & 2067 & 2.65 & 3765 & 2.83 & 3700 & 3.66 \\
\hline C20:1 & 0 & 0.00 & 0 & 0.00 & 0 & 0.00 & 0 & 0.00 \\
\hline C24:0 & 2358 & 2.02 & 1991 & 2.55 & 3133 & 2.35 & 2632 & 2.60 \\
\hline Total & 116567 & 100.00 & 78030 & 100.00 & 133184 & 100.00 & 101222 & 100.00 \\
\hline Identification & \multicolumn{2}{|c|}{$\begin{array}{l}\text { Large } \\
\text { Herbivore/Javelina/ } \\
\text { Tropical Seed Oil }\end{array}$} & \multicolumn{2}{|c|}{$\begin{array}{l}\text { Moderate-High Fat } \\
\text { Content Food (Texas } \\
\text { Ebony/Beaver) }\end{array}$} & \multicolumn{2}{|c|}{$\begin{array}{l}\text { Large } \\
\text { Herbivore/Javelina/ } \\
\text { Tropical Seed Oil }\end{array}$} & \multicolumn{2}{|c|}{$\begin{array}{l}\text { Large } \\
\text { Herbivore/Javelina/ } \\
\text { Tropical Seed Oil }\end{array}$} \\
\hline
\end{tabular}


Appendix G: Analysis of Fatty Acids in Pottery and Rock

Table G-4. Fatty Acid Composition and Identification of Residues from the Varga Site (cont.)

\begin{tabular}{|c|c|c|c|c|c|c|c|c|}
\hline \multirow{2}{*}{ Fatty Acid } & \multicolumn{2}{|c|}{ 4VG 25 (1030-5-3-3a) } & \multicolumn{2}{|c|}{ 4VG 26 (1030-5-3-4a) } & \multicolumn{2}{|c|}{ 4VG 27 (158-5-3-1a) } & \multicolumn{2}{|c|}{ 4VG 28 (158-5-3-2a) } \\
\hline & Area & Rel\% & Area & Rel\% & Area & Rel\% & Area & Rel\% \\
\hline C12:0 & 146 & 0.22 & 0 & 0.00 & 0 & 0.00 & 0 & 0.00 \\
\hline C14:0 & 1801 & 2.67 & 3270 & 3.16 & 1381 & 2.07 & 5665 & 6.44 \\
\hline C14:1 & 0 & 0.00 & 0 & 0.00 & 281 & 0.42 & 0 & 0.00 \\
\hline C15:0 & 1753 & 2.60 & 2180 & 2.11 & 1208 & 1.81 & 3897 & 4.43 \\
\hline C16:0 & 18008 & 26.72 & 22136 & 21.41 & 17299 & 25.99 & 20805 & 23.65 \\
\hline C16:1 & 1098 & 1.63 & 2506 & 2.42 & 1892 & 2.84 & 2369 & 2.69 \\
\hline C17:0 & 0 & 0.00 & 0 & 0.00 & 42 & $\mathrm{Z}$ & 0 & 0.00 \\
\hline C17:1 & 0 & 0.00 & 937 & 0.91 & 717 & 1.08 & 906 & 1.03 \\
\hline C18:0 & 12417 & 18.43 & 14612 & 14.14 & 13664 & 20.52 & 12535 & 14.25 \\
\hline C18:1s & 20102 & 29.83 & 45557 & 44.07 & 24306 & 36.51 & 31938 & 36.31 \\
\hline C18:2 & 7452 & 11.06 & 6159 & 5.96 & 218 & 0.33 & 5000 & 5.68 \\
\hline C18:3w3 & 0 & 0.00 & 0 & 0.00 & 0 & 0.00 & 0 & 0.00 \\
\hline C20:0 & 2234 & 3.32 & 2667 & 2.58 & 2702 & 4.06 & 1965 & 2.23 \\
\hline C20:1 & 0 & 0.00 & 0 & 0.00 & 0 & 0.00 & 0 & 0.00 \\
\hline C24:0 & 2378 & 3.53 & 3345 & 3.24 & 2863 & 4.30 & 2877 & 3.27 \\
\hline Total & 67389 & 100.00 & 103369 & 100.00 & 66573 & 100.00 & 87957 & 100.00 \\
\hline Identification & \multicolumn{2}{|c|}{$\begin{array}{l}\text { Moderate-High Fat } \\
\text { Content Food (Texas } \\
\text { Ebony/Beaver) }\end{array}$} & \multicolumn{2}{|c|}{$\begin{array}{l}\text { High Fat Content } \\
\text { Food (Seed/Animal } \\
\text { Fat) } \\
\end{array}$} & \multicolumn{2}{|c|}{$\begin{array}{l}\text { Borderline Moderate- } \\
\text { High and High Fat } \\
\text { Content }\end{array}$} & \multicolumn{2}{|c|}{$\begin{array}{l}\text { Borderline Moderate- } \\
\text { High and High Fat } \\
\text { Content }\end{array}$} \\
\hline
\end{tabular}

\begin{tabular}{|c|c|c|c|c|c|c|c|c|}
\hline \multirow{2}{*}{ Fatty Acid } & \multicolumn{2}{|c|}{ 4VG 29 (158-5-3-3a) } & \multicolumn{2}{|c|}{ 4VG 30 (79-5-3-1a) } & \multicolumn{2}{|c|}{ 4VG 31 (79-5-3-2a) } & \multicolumn{2}{|c|}{ 4VG 32 (79-5-3-3a) } \\
\hline & Area & Rel\% & Area & Rel\% & Area & Rel\% & Area & Rel\% \\
\hline C12:0 & 0 & 0.00 & 388 & 0.39 & 0 & 0.00 & 760 & 0.71 \\
\hline C14:0 & 3058 & 2.82 & 5116 & 5.20 & 2118 & 3.03 & 5392 & 5.01 \\
\hline C14:1 & 346 & 0.32 & 0 & 0.00 & 0 & 0.00 & 0 & 0.00 \\
\hline C15:0 & 1529 & 1.41 & 3287 & 3.34 & 1350 & 1.93 & 5895 & 5.47 \\
\hline C16:0 & 26326 & 24.30 & 26624 & 27.07 & 25405 & 36.31 & 33131 & 30.77 \\
\hline C16:1 & 1141 & 1.05 & 2084 & 2.12 & 881 & 1.26 & 1812 & 1.68 \\
\hline C17:0 & 4508 & 4.16 & 0 & 0.00 & 0 & 0.00 & 0 & 0.00 \\
\hline C17:1 & 0 & 0.00 & 1235 & 1.26 & 0 & 0.00 & 0 & 0.00 \\
\hline C18:0 & 21156 & 19.53 & 16452 & 16.73 & 14602 & 20.87 & 13787 & 12.80 \\
\hline C18:1s & 29251 & 27.00 & 30756 & 31.27 & 15415 & 22.03 & 35498 & 32.96 \\
\hline C18:2 & 14100 & 13.01 & 5606 & 5.70 & 6670 & 9.53 & 6467 & 6.01 \\
\hline C18:3w3 & 0 & 0.00 & 0 & 0.00 & 0 & 0.00 & 0 & 0.00 \\
\hline C20:0 & 3277 & 3.02 & 2759 & 2.81 & 1710 & 2.44 & 1854 & 1.72 \\
\hline C20:1 & 427 & 0.39 & 0 & 0.00 & 0 & 0.00 & 0 & 0.00 \\
\hline C24:0 & 3226 & 2.98 & 4039 & 4.11 & 1821 & 2.60 & 3090 & 2.87 \\
\hline Total & 108345 & 100.00 & 98346 & 100.00 & 69972 & 100.00 & 107686 & 100.00 \\
\hline Identification & \multicolumn{2}{|c|}{$\begin{array}{l}\text { Moderate-High Fat } \\
\text { Content Food (Texas } \\
\text { Ebony/Beaver) }\end{array}$} & \multicolumn{2}{|c|}{$\begin{array}{l}\text { Moderate-High Fat } \\
\text { Content Food (Texas } \\
\text { Ebony/Beaver) }\end{array}$} & \multicolumn{2}{|c|}{$\begin{array}{l}\text { Medium Fat Content } \\
\text { Food } \\
\text { (Mesquite/Corn/Fish) }\end{array}$} & \multicolumn{2}{|c|}{$\begin{array}{l}\text { Moderate-High Fat } \\
\text { Content Food (Texas } \\
\text { Ebony/Beaver) }\end{array}$} \\
\hline
\end{tabular}


Table G-4. Fatty Acid Composition and Identification of Residues from the Varga Site (cont.)

\begin{tabular}{|c|c|c|c|c|c|c|c|c|}
\hline \multirow{2}{*}{ Fatty Acid } & \multicolumn{2}{|c|}{ 4VG 33 (534-5-3-1a) } & \multicolumn{2}{|c|}{ 4VG 34 (534-5-3-2a) } & \multicolumn{2}{|c|}{ 4VG 35 (1005-53-1a) } & \multicolumn{2}{|c|}{ 4VG 36 (79-3-1a) } \\
\hline & Area & Rel\% & Area & Rel\% & Area & Rel\% & Area & Rel\% \\
\hline C12:0 & 0 & 0.00 & 0 & 0.00 & 0 & 0.00 & 0 & 0.00 \\
\hline C14:0 & 6895 & 8.39 & 1972 & 3.21 & 3335 & 4.14 & 2691 & 3.97 \\
\hline C14:1 & 0 & 0.00 & 0 & 0.00 & 0 & 0.00 & 0 & 0.00 \\
\hline C15:0 & 4013 & 4.88 & 1762 & 2.87 & 2563 & 3.18 & 1527 & 2.25 \\
\hline C16:0 & 22732 & 27.65 & 15084 & 24.56 & 19930 & 24.72 & 19782 & 29.16 \\
\hline C16:1 & 1773 & 2.16 & 1523 & 2.48 & 1321 & 1.64 & 1906 & 2.81 \\
\hline C17:0 & 0 & 0.00 & 0 & 0.00 & 0 & 0.00 & 0 & 0.00 \\
\hline C17:1 & 0 & 0.00 & 0 & 0.00 & 0 & 0.00 & 568 & 0.84 \\
\hline C18:0 & 12038 & 14.64 & 12588 & 20.50 & 13678 & 16.96 & 15867 & 23.39 \\
\hline C18:1s & 24809 & 30.17 & 19583 & 31.89 & 30689 & 38.06 & 16183 & 23.85 \\
\hline C18:2 & 4461 & 5.43 & 4327 & 7.05 & 4514 & 5.60 & 3486 & 5.14 \\
\hline C18:3w3 & 0 & 0.00 & 0 & 0.00 & 0 & 0.00 & 0 & 0.00 \\
\hline C20:0 & 1903 & 2.31 & 2201 & 3.58 & 2110 & 2.62 & 2596 & 3.83 \\
\hline C20:1 & 0 & 0.00 & 0 & 0.00 & 0 & 0.00 & 0 & 0.00 \\
\hline C24:0 & 3598 & 4.38 & 2370 & 3.86 & 2490 & 3.09 & 3235 & 4.77 \\
\hline Total & 82222 & 100.00 & 61410 & 100.00 & 80630 & 100.00 & 67841 & 100.00 \\
\hline Identification & \multicolumn{2}{|c|}{$\begin{array}{l}\text { Moderate-High Fat } \\
\text { Content Food (Texas } \\
\text { Ebony/Beaver) }\end{array}$} & \multicolumn{2}{|c|}{$\begin{array}{l}\text { Moderate-High Fat } \\
\text { Content Food (Texas } \\
\text { Ebony/Beaver) }\end{array}$} & \multicolumn{2}{|c|}{$\begin{array}{l}\text { Borderline Moderate- } \\
\text { High and High Fat } \\
\text { Content }\end{array}$} & \multicolumn{2}{|c|}{$\begin{array}{l}\text { Borderline Medium } \\
\text { and Moderate-High } \\
\text { Fat Content }\end{array}$} \\
\hline
\end{tabular}

\begin{tabular}{|c|c|c|c|c|c|c|c|c|}
\hline \multirow{2}{*}{ Fatty Acid } & \multicolumn{2}{|c|}{ 4VG 37 (79-3-2a) } & \multicolumn{2}{|c|}{ 4VG 38 (273-5-3-1a) } & \multicolumn{2}{|c|}{ 4VG 39 (273-5-3-2a) } & \multicolumn{2}{|c|}{ 4VG 40 (273-5-3-3a) } \\
\hline & Area & Rel\% & Area & Rel\% & Area & Rel\% & Area & Rel\% \\
\hline C12:0 & 0 & 0.00 & 0 & 0.00 & 1888 & 1.44 & 0 & 0.00 \\
\hline C14:0 & 3791 & 1.56 & 2320 & 2.97 & 5063 & 3.85 & 1978 & 1.19 \\
\hline C14:1 & 0 & 0.00 & 0 & 0.00 & 0 & 0.00 & 295 & 0.18 \\
\hline C15:0 & 4389 & 1.80 & 2504 & 3.21 & 1889 & 1.44 & 1295 & 0.78 \\
\hline C16:0 & 59492 & 24.41 & 19389 & 24.83 & 28359 & 21.59 & 34551 & 20.85 \\
\hline C16:1 & 2286 & 0.94 & 1367 & 1.75 & 4617 & 3.52 & 4688 & 2.83 \\
\hline C17:0 & 310 & 0.13 & 0 & 0.00 & 220 & 0.17 & 0 & 0.00 \\
\hline C17:1 & 0 & 0.00 & 0 & 0.00 & 0 & 0.00 & 593 & 0.36 \\
\hline C18:0 & 20043 & 8.22 & 14137 & 18.11 & 19887 & 15.14 & 19225 & 11.60 \\
\hline C18:1s & 117848 & 48.36 & 28695 & 36.75 & 62739 & 47.77 & 84491 & 50.99 \\
\hline C18:2 & 27293 & 11.20 & 4014 & 5.14 & 168 & 0.13 & 13258 & 8.00 \\
\hline C18:3w3 & 0 & 0.00 & 0 & 0.00 & 0 & 0.00 & 0 & 0.00 \\
\hline C20:0 & 2602 & 1.07 & 2121 & 2.72 & 2783 & 2.12 & 2397 & 1.45 \\
\hline C20:1 & 1517 & 0.62 & 0 & 0.00 & 0 & 0.00 & 0 & 0.00 \\
\hline C24:0 & 4140 & 1.70 & 3533 & 4.52 & 3735 & 2.84 & 2921 & 1.76 \\
\hline Total & 243711 & 100.00 & 78080 & 100.00 & 131348 & 100.00 & 165692 & 100.00 \\
\hline Identification & \multicolumn{2}{|c|}{$\begin{array}{l}\text { High Fat Content } \\
\text { Food } \\
\text { (Seed/Animal Fat) }\end{array}$} & \multicolumn{2}{|c|}{$\begin{array}{l}\text { Borderline Moderate- } \\
\text { High and High Fat } \\
\text { Content }\end{array}$} & \multicolumn{2}{|c|}{$\begin{array}{l}\text { High Fat Content } \\
\text { Food } \\
\text { (Seed/Animal Fat) }\end{array}$} & \multicolumn{2}{|c|}{$\begin{array}{l}\text { Borderline High and } \\
\text { Very High Fat } \\
\text { Content }\end{array}$} \\
\hline
\end{tabular}


Appendix G: Analysis of Fatty Acids in Pottery and Rock

Table G-4. Fatty Acid Composition and Identification of Residues from the Varga Site (cont.)

\begin{tabular}{|c|c|c|c|c|c|c|c|c|}
\hline \multirow{2}{*}{ Fatty Acid } & \multicolumn{2}{|c|}{ 4VG 41 (293-5-3-1a) } & \multicolumn{2}{|c|}{$4 V G 42$ (293-5-3-2a) } & \multicolumn{2}{|c|}{ 4VG 43 (293-5-3-3a) } & \multicolumn{2}{|c|}{ 4VG 44 (89-5-3-1a) } \\
\hline & Area & Rel\% & Area & Rel\% & Area & Rel\% & Area & Rel\% \\
\hline C12:0 & 0 & 0.00 & 1732 & 0.76 & 3507 & 3.03 & 3127 & 0.65 \\
\hline C14:0 & 6233 & 3.78 & 5641 & 2.48 & 4647 & 4.01 & 5446 & 1.13 \\
\hline C14:1 & 607 & 0.37 & 515 & 0.23 & 0 & 0.00 & 0 & 0.00 \\
\hline C15:0 & 2748 & 1.67 & 1753 & 0.77 & 2492 & 2.15 & 2728 & 0.56 \\
\hline C16:0 & 39394 & 23.88 & 40022 & 17.57 & 28704 & 24.76 & 72795 & 15.05 \\
\hline C16:1 & 5137 & 3.11 & 7706 & 3.38 & 3721 & 3.21 & 21547 & 4.45 \\
\hline C17:0 & 0 & 0.00 & 686 & 0.30 & 0 & 0.00 & 0 & 0.00 \\
\hline C17:1 & 0 & 0.00 & 0 & 0.00 & 0 & 0.00 & 0 & 0.00 \\
\hline C18:0 & 17360 & 10.52 & 24485 & 10.75 & 17701 & 15.27 & 23996 & 4.96 \\
\hline C18:1s & 76765 & 46.53 & 123362 & 54.15 & 42869 & 36.98 & 310916 & 64.28 \\
\hline C18:2 & 11060 & 6.70 & 16431 & 7.21 & 6663 & 5.75 & 37132 & 7.68 \\
\hline C18:3w3 & 0 & 0.00 & 0 & 0.00 & 0 & 0.00 & 0 & 0.00 \\
\hline C20:0 & 2333 & 1.41 & 2329 & 1.02 & 2510 & 2.17 & 2226 & 0.46 \\
\hline C20:1 & 0 & 0.00 & 705 & 0.31 & 0 & 0.00 & 0 & 0.00 \\
\hline C24:0 & 3334 & 2.02 & 2430 & 1.07 & 3117 & 2.69 & 3757 & 0.78 \\
\hline Total & 164971 & 100.00 & 227797 & 100.00 & 115931 & 100.00 & 483670 & 100.00 \\
\hline Identification & \multicolumn{2}{|c|}{$\begin{array}{l}\text { High Fat Content } \\
\text { Food } \\
\text { (Seed/Animal Fat) }\end{array}$} & \multicolumn{2}{|c|}{$\begin{array}{l}\text { Very High Fat } \\
\text { Content Food } \\
\text { (Seed/Animal Fat) }\end{array}$} & \multicolumn{2}{|c|}{$\begin{array}{l}\text { Borderline Moderate- } \\
\text { High and High Fat } \\
\text { Content) }\end{array}$} & \multicolumn{2}{|c|}{$\begin{array}{l}\text { Very High Fat } \\
\text { Content Food } \\
\text { (Seed/Animal Fat) }\end{array}$} \\
\hline
\end{tabular}

\begin{tabular}{|c|c|c|c|c|c|c|c|c|}
\hline \multirow{2}{*}{ Fatty Acid } & \multicolumn{2}{|c|}{ 4VG 45 (89-5-3-2a) } & \multicolumn{2}{|c|}{ 4VG 46 (89-5-3-3a) } & \multicolumn{2}{|c|}{ 4VG 47 (966-5-3-1a) } & \multicolumn{2}{|c|}{ 4VG 48 (962-5-3-1a) } \\
\hline & Area & Rel\% & Area & Rel\% & Area & Rel\% & Area & Rel\% \\
\hline C12:0 & 3494 & 1.25 & 5973 & 2.10 & 0 & 0.00 & 0 & 0.00 \\
\hline C14:0 & 5842 & 2.09 & 5817 & 2.04 & 1357 & 1.30 & 3946 & 0.54 \\
\hline C14:1 & 0 & 0.00 & 0 & 0.00 & 0 & 0.00 & 0 & 0.00 \\
\hline C15:0 & 3006 & 1.08 & 6402 & 2.25 & 687 & 0.66 & 3104 & 0.42 \\
\hline C16:0 & 56347 & 20.17 & 52572 & 18.44 & 19476 & 18.69 & 138597 & 18.95 \\
\hline C16:1 & 3682 & 1.32 & 2886 & 1.01 & 1609 & 1.54 & 8409 & 1.15 \\
\hline C17:0 & 0 & 0.00 & 0 & 0.00 & 292 & 0.28 & 3410 & 0.47 \\
\hline C17:1 & 0 & 0.00 & 0 & 0.00 & 0 & 0.00 & 0 & 0.00 \\
\hline C18:0 & 20752 & 7.43 & 24845 & 8.72 & 12903 & 12.39 & 32373 & 4.43 \\
\hline C18:1s & 157232 & 56.29 & 144280 & 50.62 & 54749 & 52.55 & 429380 & 58.71 \\
\hline C18:2 & 21972 & 7.87 & 36856 & 12.93 & 8752 & 8.40 & 105699 & 14.45 \\
\hline C18:3w3 & 0 & 0.00 & 0 & 0.00 & 0 & 0.00 & 0 & 0.00 \\
\hline C20:0 & 2723 & 0.97 & 2509 & 0.88 & 2162 & 2.08 & 2630 & 0.36 \\
\hline C20:1 & 0 & 0.00 & 0 & 0.00 & 0 & 0.00 & 875 & 0.12 \\
\hline C24:0 & 4296 & 1.54 & 2907 & 1.02 & 2195 & 2.11 & 2877 & 0.39 \\
\hline Total & 279346 & 100.00 & 285047 & 100.00 & 104182 & 100.00 & 731300 & 100.00 \\
\hline Identification & \multicolumn{2}{|c|}{$\begin{array}{l}\text { Very High Fat } \\
\text { Content Food } \\
\text { (Seed/Animal Fat) }\end{array}$} & \multicolumn{2}{|c|}{$\begin{array}{l}\text { Borderline High and } \\
\text { Very High Fat } \\
\text { Content }\end{array}$} & \multicolumn{2}{|c|}{$\begin{array}{l}\text { Very High Fat } \\
\text { Content Food } \\
\text { (Seed/Animal Fat) }\end{array}$} & \multicolumn{2}{|c|}{$\begin{array}{l}\text { Very High Fat } \\
\text { Content Food } \\
\text { (Seed/Animal Fat) }\end{array}$} \\
\hline
\end{tabular}


The Varga Site

Texas Department of Transportation

Table G-4. Fatty Acid Composition and Identification of Residues from the Varga Site (cont.)

\begin{tabular}{|c|c|c|c|c|c|c|c|c|}
\hline \multirow{2}{*}{ Fatty Acid } & \multicolumn{2}{|c|}{ 4VG 49 (11-5-3-1a) } & \multicolumn{2}{|c|}{ 4VG 50 (11-5-3-2a) } & \multicolumn{2}{|c|}{ 4VG 51 (11-5-3-3a) } & \multicolumn{2}{|c|}{ 4VG 53 (941-5-3-2a) } \\
\hline & Area & Rel\% & Area & Rel\% & Area & Rel\% & Area & Rel\% \\
\hline C12:0 & 1543 & 1.97 & 2200 & 2.66 & 0 & 0.00 & 997 & 0.74 \\
\hline C14:0 & 749 & 0.96 & 1533 & 1.86 & 1262 & 0.83 & 1908 & 1.43 \\
\hline C14:1 & 0 & 0.00 & 0 & 0.00 & 0 & 0.00 & 0 & 0.00 \\
\hline C15:0 & 1328 & 1.70 & 1673 & 2.03 & 926 & 0.61 & 1109 & 0.83 \\
\hline C16:0 & 19988 & 25.57 & 17475 & 21.16 & 20703 & 13.62 & 23201 & 17.34 \\
\hline C16:1 & 1615 & 2.07 & 1001 & 1.21 & 1375 & 0.90 & 1905 & 1.42 \\
\hline C17:0 & 2931 & 3.75 & 0 & 0.00 & 3123 & 2.06 & 0 & 0.00 \\
\hline C17:1 & 0 & 0.00 & 0 & 0.00 & 0 & 0.00 & 0 & 0.00 \\
\hline C18:0 & 6578 & 8.41 & 10748 & 13.01 & 13419 & 8.83 & 12518 & 9.35 \\
\hline C18:1s & 33654 & 43.05 & 35753 & 43.29 & 94212 & 62.00 & 74750 & 55.85 \\
\hline C18:2 & 8505 & 10.88 & 8190 & 9.92 & 12477 & 8.21 & 13019 & 9.73 \\
\hline C18:3w3 & 0 & 0.00 & 0 & 0.00 & 0 & 0.00 & 0 & 0.00 \\
\hline C20:0 & 1292 & 1.65 & 2005 & 2.43 & 2165 & 1.42 & 2028 & 1.52 \\
\hline C20:1 & 0 & 0.00 & 0 & 0.00 & 0 & 0.00 & 391 & 0.29 \\
\hline C24:0 & 0 & 0.00 & 2017 & 2.44 & 2296 & 1.51 & 2008 & 1.50 \\
\hline Total & 78183 & 100.00 & 82595 & 100.00 & 151958 & 100.00 & 133834 & 100.00 \\
\hline Identification & \multicolumn{2}{|c|}{$\begin{array}{l}\text { High Fat Content } \\
\text { Food } \\
\text { (Seed/Animal Fat) }\end{array}$} & \multicolumn{2}{|c|}{$\begin{array}{l}\text { High Fat Content } \\
\text { Food } \\
\text { (Seed/Animal Fat) }\end{array}$} & \multicolumn{2}{|c|}{$\begin{array}{l}\text { Very High Fat Content } \\
\text { Food } \\
\text { (Seed/Animal Fat) }\end{array}$} & \multicolumn{2}{|c|}{$\begin{array}{l}\text { Very High Fat } \\
\text { Content Food } \\
\text { (Seed/Animal Fat) } \\
\end{array}$} \\
\hline
\end{tabular}

\begin{tabular}{|c|c|c|c|c|c|c|c|c|}
\hline \multirow{2}{*}{ Fatty Acid } & \multicolumn{2}{|c|}{ 4VG 54 (801-5-3-1a) } & \multicolumn{2}{|c|}{ 4VG 55 (801-5-3-2a) } & \multicolumn{2}{|c|}{ 4VG 56 (801-5-3-3a) } & \multicolumn{2}{|c|}{ 4VG 57 (263-5-3-1a) } \\
\hline & Area & Rel\% & Area & Rel\% & Area & Rel\% & Area & Rel\% \\
\hline C12:0 & 1365 & 1.66 & 3746 & 3.45 & 3449 & 3.48 & 2423 & 2.77 \\
\hline C14:0 & 1507 & 1.83 & 4355 & 4.01 & 3322 & 3.35 & 1951 & 2.23 \\
\hline C14:1 & 0 & 0.00 & 0 & 0.00 & 0 & 0.00 & 0 & 0.00 \\
\hline C15:0 & 1266 & 1.54 & 3905 & 3.59 & 2570 & 2.59 & 2765 & 3.16 \\
\hline C16:0 & 15316 & 18.60 & 31885 & 29.33 & 21761 & 21.93 & 28370 & 32.47 \\
\hline C16:1 & 2126 & 2.58 & 5074 & 4.67 & 3281 & 3.31 & 1562 & 1.79 \\
\hline C17:0 & 0 & 0.00 & 762 & 0.70 & 635 & 0.64 & 0 & 0.00 \\
\hline C17:1 & 585 & 0.71 & 0 & 0.00 & 0 & 0.00 & 0 & 0.00 \\
\hline C18:0 & 8133 & 9.87 & 10285 & 9.46 & 10353 & 10.43 & 12770 & 14.61 \\
\hline C18:1s & 39637 & 48.12 & 37732 & 34.71 & 38359 & 38.66 & 22825 & 26.12 \\
\hline C18:2 & 8280 & 10.05 & 6077 & 5.59 & 9824 & 9.90 & 7143 & 8.17 \\
\hline C18:3w3 & 0 & 0.00 & 0 & 0.00 & 0 & 0.00 & 0 & 0.00 \\
\hline C20:0 & 1428 & 1.73 & 1798 & 1.65 & 1847 & 1.86 & 2408 & 2.76 \\
\hline C20:1 & 803 & 0.97 & 884 & 0.81 & 1784 & 1.80 & 2450 & 2.80 \\
\hline C24:0 & 1920 & 2.33 & 2200 & 2.02 & 2034 & 2.05 & 2716 & 3.11 \\
\hline Total & 82366 & 100.00 & 108703 & 100.00 & 99219 & 100.00 & 87383 & 100.00 \\
\hline Identification & \multicolumn{2}{|c|}{$\begin{array}{l}\text { High Fat Content } \\
\text { Food } \\
\text { (Seed/Animal Fat) }\end{array}$} & \multicolumn{2}{|c|}{$\begin{array}{l}\text { Moderate-High Fat } \\
\text { Content Food (Texas } \\
\text { Ebony/Beaver) }\end{array}$} & \multicolumn{2}{|c|}{$\begin{array}{l}\text { Borderline Moderate- } \\
\text { High and High Fat } \\
\text { Content }\end{array}$} & \multicolumn{2}{|c|}{$\begin{array}{l}\text { Borderline Medium } \\
\text { and Moderate-High } \\
\text { Fat Content }\end{array}$} \\
\hline
\end{tabular}


Appendix G: Analysis of Fatty Acids in Pottery and Rock

Table G-4. Fatty Acid Composition and Identification of Residues from the Varga Site (cont.)

\begin{tabular}{|c|c|c|c|c|c|c|c|c|}
\hline \multirow{2}{*}{ Fatty Acid } & \multicolumn{2}{|c|}{ 4VG 58 (274-5-3-2a) } & \multicolumn{2}{|c|}{ 4VG 59 (187-5-3-2a) } & \multicolumn{2}{|c|}{ 4VG 60 (80-5-3-1a) } & \multicolumn{2}{|c|}{ 4VG 61 (187-5-3-1a) } \\
\hline & Area & Rel\% & Area & Rel\% & Area & Rel\% & Area & Rel\% \\
\hline C12:0 & 0 & 0.00 & 0 & 0.00 & 855 & 0.36 & 2671 & 2.33 \\
\hline C14:0 & 3047 & 3.67 & 2793 & 2.09 & 1056 & 0.44 & 2950 & 2.58 \\
\hline C14:1 & 0 & 0.00 & 0 & 0.00 & 0 & 0.00 & 0 & 0.00 \\
\hline C15:0 & 2322 & 2.79 & 1576 & 1.18 & 1017 & 0.43 & 2267 & 1.98 \\
\hline C16:0 & 17334 & 20.85 & 23477 & 17.59 & 34149 & 14.30 & 45244 & 39.49 \\
\hline C16:1 & 1625 & 1.95 & 1797 & 1.35 & 4532 & 1.90 & 0 & 0.00 \\
\hline C17:0 & 8547 & 10.28 & 0 & 0.00 & 0 & 0.00 & 0 & 0.00 \\
\hline C17:1 & 0 & 0.00 & 666 & 0.50 & 0 & 0.00 & 0 & 0.00 \\
\hline C18:0 & 8692 & 10.46 & 8832 & 6.62 & 14839 & 6.21 & 17559 & 15.33 \\
\hline C18:1s & 30104 & 36.21 & 73885 & 55.36 & 143836 & 60.21 & 25857 & 22.57 \\
\hline C18:2 & 5061 & 6.09 & 13893 & 10.41 & 30839 & 12.91 & 11412 & 9.96 \\
\hline C18:3w3 & 0 & 0.00 & 0 & 0.00 & 0 & 0.00 & 0 & 0.00 \\
\hline C20:0 & 1559 & 1.88 & 1389 & 1.04 & 1882 & 0.79 & 1362 & 1.19 \\
\hline C20:1 & 2890 & 3.48 & 3414 & 2.56 & 3712 & 1.55 & 3878 & 3.39 \\
\hline C24:0 & 1951 & 2.35 & 1749 & 1.31 & 2170 & 0.91 & 1358 & 1.19 \\
\hline Total & 83132 & 100.00 & 133471 & 100.00 & 238887 & 100.00 & 114558 & 100.00 \\
\hline Identification & \multicolumn{2}{|c|}{$\begin{array}{l}\text { Borderline Moderate- } \\
\text { High and High Fat } \\
\text { Content }\end{array}$} & \multicolumn{2}{|c|}{$\begin{array}{l}\text { Very High Fat } \\
\text { Content Food } \\
\text { (Seed/Animal Fat) }\end{array}$} & \multicolumn{2}{|c|}{$\begin{array}{l}\text { Very High Fat } \\
\text { Content Food } \\
\text { (Seed/Animal Fat) }\end{array}$} & \multicolumn{2}{|c|}{$\begin{array}{l}\text { Medium Fat Content } \\
\text { Food (Mesquite/ } \\
\text { Corn/Fish) }\end{array}$} \\
\hline
\end{tabular}

\begin{tabular}{|c|c|c|c|c|c|c|c|c|}
\hline \multirow{2}{*}{ Fatty Acid } & \multicolumn{2}{|c|}{ 4VG 62 (179-05-3-2a) } & \multicolumn{2}{|c|}{ 4VG 63 (98-5-3-1a) } & \multicolumn{2}{|c|}{ 4VG 64 (179-5-3-1a) } & \multicolumn{2}{|c|}{ 4VG 65 (274-5-3-1a) } \\
\hline & Area & Rel\% & Area & Rel\% & Area & Rel\% & Area & Rel\% \\
\hline C12:0 & 3100 & 5.58 & 0 & 0.00 & 98 & 0.11 & 844 & 1.14 \\
\hline C14:0 & 2522 & 4.54 & 897 & 1.94 & 3078 & 3.57 & 1348 & 1.82 \\
\hline C14:1 & 0 & 0.00 & 0 & 0.00 & 0 & 0.00 & 0 & 0.00 \\
\hline C15:0 & 1342 & 2.41 & 731 & 1.58 & 2950 & 3.42 & 1230 & 1.66 \\
\hline C16:0 & 17106 & 30.77 & 13443 & 29.09 & 19086 & 22.14 & 15522 & 20.93 \\
\hline C16:1 & 1009 & 1.82 & 560 & 1.21 & 3053 & 3.54 & 2569 & 3.46 \\
\hline C17:0 & 0 & 0.00 & 227 & 0.49 & 0 & 0.00 & 0 & 0.00 \\
\hline C17:1 & 592 & 1.06 & 0 & 0.00 & 756 & 0.88 & 0 & 0.00 \\
\hline C18:0 & 12073 & 21.72 & 10347 & 22.39 & 9276 & 10.76 & 7985 & 10.77 \\
\hline C18:1s & 6184 & 11.12 & 9221 & 19.96 & 35683 & 41.38 & 33303 & 44.90 \\
\hline C18:2 & 4639 & 8.35 & 5507 & 11.92 & 8126 & 9.42 & 8190 & 11.04 \\
\hline C18:3w3 & 0 & 0.00 & 0 & 0.00 & 0 & 0.00 & 0 & 0.00 \\
\hline C20:0 & 1863 & 3.35 & 1597 & 3.46 & 1166 & 1.35 & 1111 & 1.50 \\
\hline C20:1 & 3369 & 6.06 & 2093 & 4.53 & 1177 & 1.37 & 537 & 0.72 \\
\hline C24:0 & 1790 & 3.22 & 1585 & 3.43 & 1776 & 2.06 & 1526 & 2.06 \\
\hline Total & 55589 & 100.00 & 46208 & 100.00 & 86225 & 100.00 & 74165 & 100.00 \\
\hline Identification & \multicolumn{2}{|c|}{$\begin{array}{l}\text { Low Fat Content } \\
\text { Plant (Roots, Greens, } \\
\text { Berries) }\end{array}$} & \multicolumn{2}{|c|}{$\begin{array}{l}\text { Borderline Med. Fat } \\
\text { Content and Lg. } \\
\text { Herb. + Plant/Bone } \\
\text { Marrow }\end{array}$} & \multicolumn{2}{|c|}{$\begin{array}{l}\text { High Fat Content } \\
\text { Food (Seed/Animal } \\
\text { Fat) }\end{array}$} & \multicolumn{2}{|c|}{$\begin{array}{l}\text { High Fat Content } \\
\text { Food (Seed/Animal } \\
\text { Fat) }\end{array}$} \\
\hline
\end{tabular}


The Varga Site

Texas Department of Transportation

Table G-4. Fatty Acid Composition and Identification of Residues from the Varga Site (cont.)

\begin{tabular}{|c|c|c|c|c|c|c|c|c|}
\hline \multirow{2}{*}{ Fatty Acid } & \multicolumn{2}{|c|}{ 4VG 66 (178-5-3-1a) } & \multicolumn{2}{|c|}{ 4VG 67 (370-5-3-1a) } & \multicolumn{2}{|c|}{ 4VG 68 (161-5-3-1a) } & \multicolumn{2}{|c|}{ 4VG 69 (352-5-3-1a) } \\
\hline & Area & Rel\% & Area & Rel\% & Area & Rel\% & Area & Rel\% \\
\hline C12:0 & 3427 & 5.43 & 1814 & 1.62 & 184 & 0.12 & 0 & 0.00 \\
\hline C14:0 & 2261 & 3.58 & 1622 & 1.45 & 2639 & 1.71 & 1320 & 0.88 \\
\hline C14:1 & 0 & 0.00 & 0 & 0.00 & 0 & 0.00 & 0 & 0.00 \\
\hline C15:0 & 1394 & 2.21 & 1013 & 0.91 & 1382 & 0.90 & 1145 & 0.77 \\
\hline C16:0 & 15906 & 25.20 & 29891 & 26.77 & 36992 & 23.96 & 33217 & 22.27 \\
\hline C16:1 & 1040 & 1.65 & 819 & 0.73 & 3900 & 2.53 & 992 & 0.67 \\
\hline C17:0 & 0 & 0.00 & 451 & 0.40 & 0 & 0.00 & 0 & 0.00 \\
\hline C17:1 & 0 & 0.00 & 0 & 0.00 & 0 & 0.00 & 0 & 0.00 \\
\hline C18:0 & 12097 & 19.16 & 17040 & 15.26 & 16368 & 10.60 & 19140 & 12.83 \\
\hline C18:1s & 16369 & 25.93 & 41458 & 37.13 & 75926 & 49.19 & 72551 & 48.64 \\
\hline C18:2 & 7108 & 11.26 & 12951 & 11.60 & 12688 & 8.22 & 16048 & 10.76 \\
\hline C18:3w3 & 0 & 0.00 & 0 & 0.00 & 0 & 0.00 & 0 & 0.00 \\
\hline C20:0 & 1727 & 2.74 & 2449 & 2.19 & 2015 & 1.31 & 2193 & 1.47 \\
\hline C20:1 & 0 & 0.00 & 0 & 0.00 & 0 & 0.00 & 0 & 0.00 \\
\hline C24:0 & 1800 & 2.85 & 2146 & 1.92 & 2267 & 1.47 & 2557 & 1.71 \\
\hline Total & 63129 & 100.00 & 111654 & 100.00 & 154361 & 100.00 & 149163 & 100.00 \\
\hline Identification & \multicolumn{2}{|c|}{$\begin{array}{l}\text { Borderline Medium } \\
\text { and Moderate-High } \\
\text { Fat Content }\end{array}$} & \multicolumn{2}{|c|}{$\begin{array}{l}\text { Borderline Moderate- } \\
\text { High and High Fat } \\
\text { Content }\end{array}$} & \multicolumn{2}{|c|}{$\begin{array}{l}\text { Borderline High and } \\
\text { Very High Fat } \\
\text { Content }\end{array}$} & \multicolumn{2}{|c|}{$\begin{array}{l}\text { Borderline High and } \\
\text { Very High Fat } \\
\text { Content }\end{array}$} \\
\hline
\end{tabular}

\begin{tabular}{|c|c|c|c|c|c|c|c|c|}
\hline \multirow{2}{*}{ Fatty Acid } & \multicolumn{2}{|c|}{ 4VG 70 (352-5-3-2a) } & \multicolumn{2}{|c|}{ 4VG 71 (81-5-3-1a) } & \multicolumn{2}{|c|}{ 4VG 72 (276-5-3-1a) } & \multicolumn{2}{|c|}{ 4VG 73 (515-5-3-1a) } \\
\hline & Area & Rel\% & Area & Rel\% & Area & Rel\% & Area & Rel\% \\
\hline C12:0 & 17 & 0.02 & 3007 & 2.70 & 318 & 0.32 & 0 & 0.00 \\
\hline C14:0 & 3180 & 2.85 & 2312 & 2.07 & 3576 & 3.59 & 2820 & 1.41 \\
\hline C14:1 & 0 & 0.00 & 0 & 0.00 & 0 & 0.00 & 0 & 0.00 \\
\hline C15:0 & 3330 & 2.99 & 1048 & 0.94 & 1306 & 1.31 & 1985 & 1.00 \\
\hline C16:0 & 26324 & 23.63 & 23385 & 20.98 & 29097 & 29.23 & 33351 & 16.72 \\
\hline C16:1 & 2832 & 2.54 & 2437 & 2.19 & 1861 & 1.87 & 6946 & 3.48 \\
\hline C17:0 & 0 & 0.00 & 361 & 0.32 & 273 & 0.27 & 0 & 0.00 \\
\hline C17:1 & 0 & 0.00 & 0 & 0.00 & 510 & 0.51 & 0 & 0.00 \\
\hline C18:0 & 13416 & 12.04 & 17617 & 15.81 & 17865 & 17.95 & 8551 & 4.29 \\
\hline C18:1s & 47900 & 42.99 & 47243 & 42.39 & 32126 & 32.27 & 129390 & 64.88 \\
\hline C18:2 & 10082 & 9.05 & 9252 & 8.30 & 6812 & 6.84 & 13978 & 7.01 \\
\hline C18:3w3 & 0 & 0.00 & 0 & 0.00 & 0 & 0.00 & 0 & 0.00 \\
\hline C20:0 & 1707 & 1.53 & 2288 & 2.05 & 2675 & 2.69 & 635 & 0.32 \\
\hline C20:1 & 0 & 0.00 & 0 & 0.00 & 0 & 0.00 & 321 & 0.16 \\
\hline C24:0 & 2632 & 2.36 & 2491 & 2.24 & 3135 & 3.15 & 1455 & 0.73 \\
\hline Total & 111420 & 100.00 & 111441 & 100.00 & 99554 & 100.00 & 199432 & 100.00 \\
\hline Identification & \multicolumn{2}{|c|}{$\begin{array}{l}\text { High Fat Content } \\
\text { Food } \\
\text { (Seed/Animal Fat) }\end{array}$} & \multicolumn{2}{|c|}{$\begin{array}{l}\text { High Fat Content } \\
\text { Food } \\
\text { (Seed/Animal Fat) }\end{array}$} & \multicolumn{2}{|c|}{$\begin{array}{l}\text { Moderate-High Fat } \\
\text { Content Food (Texas } \\
\text { Ebony/Beaver) }\end{array}$} & \multicolumn{2}{|c|}{$\begin{array}{l}\text { Very High Fat } \\
\text { Content Food } \\
\text { (Seed/Animal Fat) }\end{array}$} \\
\hline
\end{tabular}


Appendix G: Analysis of Fatty Acids in Pottery and Rock

Table G-4. Fatty Acid Composition and Identification of Residues from the Varga Site (cont.)

\begin{tabular}{|c|c|c|c|c|c|c|c|c|}
\hline \multirow{2}{*}{ Fatty Acid } & \multicolumn{2}{|c|}{ 4VG 74 (575-5-3-1a) } & \multicolumn{2}{|c|}{ 4VG 75 (583-5-3-1a) } & \multicolumn{2}{|c|}{ 4VG 76 (276-5-3-2a) } & \multicolumn{2}{|c|}{ 4VG 77 (37-5-3-1a) } \\
\hline & Area & Rel\% & Area & Rel\% & Area & Rel\% & Area & Rel\% \\
\hline C12:0 & 3805 & 4.66 & 234 & 0.12 & 3485 & 2.10 & 390 & 0.32 \\
\hline C14:0 & 2854 & 3.49 & 3962 & 2.08 & 2251 & 1.36 & 4103 & 3.37 \\
\hline C14:1 & 0 & 0.00 & 0 & 0.00 & 0 & 0.00 & 547 & 0.45 \\
\hline C15:0 & 1633 & 2.00 & 1910 & 1.00 & 1429 & 0.86 & 1245 & 1.02 \\
\hline C16:0 & 24104 & 29.49 & 57944 & 30.48 & 38236 & 23.03 & 31465 & 25.86 \\
\hline C16:1 & 2036 & 2.49 & 2487 & 1.31 & 2824 & 1.70 & 2462 & 2.02 \\
\hline C17:0 & 406 & 0.50 & 268 & 0.14 & 249 & 0.15 & 192 & 0.16 \\
\hline C17:1 & 0 & 0.00 & 0 & 0.00 & 0 & 0.00 & 0 & 0.00 \\
\hline C18:0 & 15841 & 19.38 & 20216 & 10.64 & 20982 & 12.64 & 25246 & 20.75 \\
\hline C18:1s & 21228 & 25.97 & 81402 & 42.83 & 71392 & 43.00 & 37586 & 30.90 \\
\hline C18:2 & 5148 & 6.30 & 16318 & 8.58 & 18909 & 11.39 & 10838 & 8.91 \\
\hline C18:3w3 & 0 & 0.00 & 0 & 0.00 & 1629 & 0.98 & 0 & 0.00 \\
\hline C20:0 & 2359 & 2.89 & 1561 & 0.82 & 2392 & 1.44 & 3288 & 2.70 \\
\hline C20:1 & 0 & 0.00 & 1833 & 0.96 & 740 & 0.45 & 1886 & 1.55 \\
\hline C24:0 & 2314 & 2.83 & 1941 & 1.02 & 1508 & 0.91 & 2405 & 1.98 \\
\hline Total & 81728 & 100.00 & 190076 & 100.00 & 166026 & 100.00 & 121653 & 100.00 \\
\hline Identification & \multicolumn{2}{|c|}{$\begin{array}{l}\text { Borderline Medium } \\
\text { and Moderate-High } \\
\text { Fat Content }\end{array}$} & \multicolumn{2}{|c|}{$\begin{array}{l}\text { High Fat Content } \\
\text { Food } \\
\text { (Seed/Animal Fat) }\end{array}$} & \multicolumn{2}{|c|}{$\begin{array}{l}\text { High Fat Content } \\
\text { Food } \\
\text { (Seed/Animal Fat) }\end{array}$} & \multicolumn{2}{|c|}{$\begin{array}{l}\text { Moderate-High Fat } \\
\text { Content Food (Texas } \\
\text { Ebony/Beaver) }\end{array}$} \\
\hline
\end{tabular}

\begin{tabular}{|c|c|c|c|c|c|c|c|c|}
\hline \multirow{2}{*}{ Fatty Acid } & \multicolumn{2}{|c|}{ 4VG 78 (37-5-3-2a) } & \multicolumn{2}{|c|}{ 4VG 79 (37-5-3-3a) } & \multicolumn{2}{|c|}{ 4VG 80 (37-5-3-4a) } & \multicolumn{2}{|c|}{ 4VG 81 (616-5-3-1a) } \\
\hline & Area & Rel\% & Area & Rel\% & Area & Rel\% & Area & Rel\% \\
\hline C12:0 & 726 & 0.58 & 0 & 0.00 & 0 & 0.00 & 0 & 0.00 \\
\hline C14:0 & 5837 & 4.66 & 2973 & 3.09 & 1767 & 2.55 & 4184 & 2.26 \\
\hline C14:1 & 0 & 0.00 & 0 & 0.00 & 0 & 0.00 & 0 & 0.00 \\
\hline C15:0 & 1934 & 1.54 & 1153 & 1.20 & 1337 & 1.93 & 2082 & 1.13 \\
\hline C16:0 & 26007 & 20.75 & 21151 & 21.99 & 17387 & 25.06 & 39674 & 21.45 \\
\hline C16:1 & 2923 & 2.33 & 2414 & 2.51 & 1135 & 1.64 & 4773 & 2.58 \\
\hline C17:0 & 0 & 0.00 & 348 & 0.36 & 656 & 0.95 & 0 & 0.00 \\
\hline C17:1 & 0 & 0.00 & 0 & 0.00 & 626 & 0.90 & 981 & 0.53 \\
\hline C18:0 & 20399 & 16.28 & 16921 & 17.59 & 14109 & 20.34 & 21766 & 11.77 \\
\hline C18:1s & 55699 & 44.45 & 39312 & 40.87 & 23950 & 34.52 & 93806 & 50.71 \\
\hline C18:2 & 7074 & 5.64 & 8064 & 8.38 & 4806 & 6.93 & 11591 & 6.27 \\
\hline C18:3w3 & 0 & 0.00 & 0 & 0.00 & 0 & 0.00 & 0 & 0.00 \\
\hline C20:0 & 2560 & 2.04 & 1721 & 1.79 & 1406 & 2.03 & 2310 & 1.25 \\
\hline C20:1 & 0 & 0.00 & 0 & 0.00 & 0 & 0.00 & 406 & 0.22 \\
\hline C24:0 & 2159 & 1.72 & 2141 & 2.23 & 2201 & 3.17 & 3417 & 1.85 \\
\hline Total & 125318 & 100.00 & 96198 & 100.00 & 69380 & 100.00 & 184990 & 100.00 \\
\hline Identification & \multicolumn{2}{|c|}{$\begin{array}{l}\text { High Fat Content } \\
\text { Food } \\
\text { (Seed/Animal Fat) }\end{array}$} & \multicolumn{2}{|c|}{$\begin{array}{l}\text { High Fat Content } \\
\text { Food } \\
\text { (Seed/Animal Fat) }\end{array}$} & \multicolumn{2}{|c|}{$\begin{array}{l}\text { Moderate-High Fat } \\
\text { Content Food (Texas } \\
\text { Ebony/Beaver) }\end{array}$} & \multicolumn{2}{|c|}{$\begin{array}{l}\text { Borderline High and } \\
\text { Very High Fat } \\
\text { Content }\end{array}$} \\
\hline
\end{tabular}


The Varga Site

Texas Department of Transportation

Table G-4. Fatty Acid Composition and Identification of Residues from the Varga Site (cont.)

\begin{tabular}{|c|c|c|c|c|c|c|c|c|}
\hline \multirow{2}{*}{ Fatty Acid } & \multicolumn{2}{|c|}{ 4VG 82 (616-5-3-2a) } & \multicolumn{2}{|c|}{ 4VG 83 (616-5-3-3a) } & \multicolumn{2}{|c|}{ 4VG 84 (756-5-3-1a) } & \multicolumn{2}{|c|}{ 4VG 85 756-5-3-2a) } \\
\hline & Area & Rel\% & Area & Rel\% & Area & Rel\% & Area & Rel\% \\
\hline C12:0 & 3086 & 2.53 & 2274 & 2.08 & 3228 & 0.60 & 0 & 0.00 \\
\hline C14:0 & 4098 & 3.36 & 3694 & 3.38 & 4591 & 0.85 & 2936 & 2.42 \\
\hline C14:1 & 0 & 0.00 & 0 & 0.00 & 0 & 0.00 & 353 & 0.29 \\
\hline C15:0 & 2676 & 2.19 & 1274 & 1.17 & 2125 & 0.39 & 1446 & 1.19 \\
\hline C16:0 & 28112 & 23.05 & 26286 & 24.05 & 78132 & 14.50 & 21888 & 18.01 \\
\hline C16:1 & 3197 & 2.62 & 2579 & 2.36 & 7819 & 1.45 & 2627 & 2.16 \\
\hline C17:0 & 0 & 0.00 & 0 & 0.00 & 1417 & 0.26 & 502 & 0.41 \\
\hline C17:1 & 1079 & 0.88 & 855 & 0.78 & 0 & 0.00 & 0 & 0.00 \\
\hline C18:0 & 24587 & 20.16 & 24429 & 22.35 & 35083 & 6.51 & 15276 & 12.57 \\
\hline C18:1s & 38272 & 31.38 & 33244 & 30.42 & 351728 & 65.27 & 62371 & 51.33 \\
\hline C18:2 & 9626 & 7.89 & 7486 & 6.85 & 46664 & 8.66 & 10499 & 8.64 \\
\hline C18:3w3 & 0 & 0.00 & 0 & 0.00 & 0 & 0.00 & 0 & 0.00 \\
\hline C20:0 & 3775 & 3.09 & 3613 & 3.31 & 3358 & 0.62 & 1706 & 1.40 \\
\hline C20:1 & 0 & 0.00 & 0 & 0.00 & 969 & 0.18 & 0 & 0.00 \\
\hline C24:0 & 3474 & 2.85 & 3549 & 3.25 & 3782 & 0.70 & 1915 & 1.58 \\
\hline Total & 121982 & 100.00 & 109283 & 100.00 & 538896 & 100.00 & 121519 & 100.00 \\
\hline Identification & \multicolumn{2}{|c|}{$\begin{array}{l}\text { Moderate-High Fat } \\
\text { Content Food } \\
\text { (Texas Ebony/Beaver) }\end{array}$} & \multicolumn{2}{|c|}{$\begin{array}{l}\text { Moderate-High Fat } \\
\text { Content Food (Texas } \\
\text { Ebony/Beaver) }\end{array}$} & \multicolumn{2}{|c|}{$\begin{array}{l}\text { Very High Fat } \\
\text { Content Food } \\
\text { (Seed/Animal Fat) }\end{array}$} & \multicolumn{2}{|c|}{$\begin{array}{l}\text { Borderline High and } \\
\text { Very High Fat } \\
\text { Content }\end{array}$} \\
\hline
\end{tabular}

\begin{tabular}{|c|c|c|c|c|c|c|c|c|}
\hline \multirow{2}{*}{ Fatty Acid } & \multicolumn{2}{|c|}{ 4VG 86 (756-5-3-3a) } & \multicolumn{2}{|c|}{ 4VG 87 (756-5-3-4a) } & \multicolumn{2}{|c|}{ 4VG 88 (203-5-3-1a) } & \multicolumn{2}{|c|}{ 4VG 89 (203-5-3-2a) } \\
\hline & Area & Rel\% & Area & Rel\% & Area & Rel\% & Area & Rel\% \\
\hline C12:0 & 264 & 0.20 & 2599 & 2.53 & 123 & 0.13 & 3617 & 3.59 \\
\hline C14:0 & 4560 & 3.38 & 2660 & 2.59 & 3193 & 3.50 & 3881 & 3.86 \\
\hline C14:1 & 0 & 0.00 & 0 & 0.00 & 0 & 0.00 & 0 & 0.00 \\
\hline C15:0 & 2070 & 1.53 & 1535 & 1.50 & 2479 & 2.72 & 2196 & 2.18 \\
\hline C16:0 & 25054 & 18.56 & 23182 & 22.58 & 19946 & 21.88 & 25197 & 25.03 \\
\hline C16:1 & 4870 & 3.61 & 2249 & 2.19 & 2178 & 2.39 & 2032 & 2.02 \\
\hline C17:0 & 0 & 0.00 & 3116 & 3.04 & 0 & 0.00 & 44 & 0.04 \\
\hline C17:1 & 554 & 0.41 & 0 & 0.00 & 787 & 0.86 & 0 & 0.00 \\
\hline C18:0 & 14221 & 10.54 & 13048 & 12.71 & 16878 & 18.52 & 18829 & 18.71 \\
\hline C18:1s & 70609 & 52.31 & 42564 & 41.46 & 31292 & 34.33 & 31042 & 30.84 \\
\hline C18:2 & 8935 & 6.62 & 8092 & 7.88 & 8655 & 9.49 & 7357 & 7.31 \\
\hline C18:3w3 & 0 & 0.00 & 0 & 0.00 & 0 & 0.00 & 0 & 0.00 \\
\hline C20:0 & 1795 & 1.33 & 1587 & 1.55 & 2528 & 2.77 & 2955 & 2.94 \\
\hline C20:1 & 0 & 0.00 & 0 & 0.00 & 0 & 0.00 & 0 & 0.00 \\
\hline C24:0 & 2055 & 1.52 & 2019 & 1.97 & 3096 & 3.40 & 3499 & 3.48 \\
\hline Total & 134987 & 100.00 & 102651 & 100.00 & 91155 & 100.00 & 100649 & 100.00 \\
\hline Identification & \multicolumn{2}{|c|}{$\begin{array}{l}\text { Very High Fat } \\
\text { Content Food } \\
\text { (Seed/Animal Fat) }\end{array}$} & \multicolumn{2}{|c|}{$\begin{array}{l}\text { High Fat Content } \\
\text { Food } \\
\text { (Seed/Animal Fat) }\end{array}$} & \multicolumn{2}{|c|}{$\begin{array}{l}\text { Moderate-High Fat } \\
\text { Content Food (Texas } \\
\text { Ebony/Beaver) }\end{array}$} & \multicolumn{2}{|c|}{$\begin{array}{l}\text { Moderate-High Fat } \\
\text { Content Food (Texas } \\
\text { Ebony/Beaver) }\end{array}$} \\
\hline
\end{tabular}


Appendix G: Analysis of Fatty Acids in Pottery and Rock

Table G-4. Fatty Acid Composition and Identification of Residues from the Varga Site (cont.)

\begin{tabular}{|c|c|c|c|c|c|c|c|c|}
\hline \multirow{2}{*}{ Fatty Acid } & \multicolumn{2}{|c|}{ 4VG 90 (203-5-3-3a) } & \multicolumn{2}{|c|}{ 4VG 91 (203-5-3-4a) } & \multicolumn{2}{|c|}{ 4VG 92 (128-5-3-1a) } & \multicolumn{2}{|c|}{ 4VG 93 (128-5-3-2a) } \\
\hline & Area & Rel\% & Area & Rel\% & Area & Rel\% & Area & Rel\% \\
\hline C12:0 & 31 & 0.03 & 2778 & 3.10 & 1017 & 0.91 & 912 & 0.74 \\
\hline C14:0 & 5401 & 5.92 & 2889 & 3.22 & 4735 & 4.24 & 5054 & 4.12 \\
\hline C14:1 & 0 & 0.00 & 0 & 0.00 & 0 & 0.00 & 0 & 0.00 \\
\hline C15:0 & 2900 & 3.18 & 1379 & 1.54 & 5462 & 4.89 & 3386 & 2.76 \\
\hline C16:0 & 22190 & 24.30 & 23074 & 25.71 & 24204 & 21.66 & 23837 & 19.41 \\
\hline C16:1 & 1733 & 1.90 & 1257 & 1.40 & 2249 & 2.01 & 2575 & 2.10 \\
\hline C17:0 & 0 & 0.00 & 972 & 1.08 & 0 & 0.00 & 454 & 0.37 \\
\hline C17:1 & 1022 & 1.12 & 548 & 0.61 & 875 & 0.78 & 770 & 0.63 \\
\hline C18:0 & 19839 & 21.73 & 21115 & 23.53 & 17542 & 15.70 & 18788 & 15.30 \\
\hline C18:1s & 25251 & 27.66 & 21796 & 24.29 & 39639 & 35.47 & 51981 & 42.32 \\
\hline C18:2 & 5252 & 5.75 & 8951 & 9.97 & 10158 & 9.09 & 8781 & 7.15 \\
\hline C18:3w3 & 0 & 0.00 & 0 & 0.00 & 0 & 0.00 & 0 & 0.00 \\
\hline C20:0 & 3265 & 3.58 & 2457 & 2.74 & 2790 & 2.50 & 2316 & 1.89 \\
\hline C20:1 & 0 & 0.00 & 0 & 0.00 & 0 & 0.00 & 0 & 0.00 \\
\hline C24:0 & 4422 & 4.84 & 2533 & 2.82 & 3089 & 2.76 & 3960 & 3.22 \\
\hline Total & 91306 & 100.00 & 89749 & 100.00 & 111760 & 100.00 & 122814 & 100.00 \\
\hline Identification & \multicolumn{2}{|c|}{$\begin{array}{l}\text { Moderate-High Fat } \\
\text { Content Food (Texas } \\
\text { Ebony/Beaver) }\end{array}$} & \multicolumn{2}{|c|}{$\begin{array}{l}\text { Borderline Medium } \\
\text { and Moderate-High } \\
\text { Fat Content }\end{array}$} & \multicolumn{2}{|c|}{$\begin{array}{l}\text { Moderate-High Fat } \\
\text { Content Food (Texas } \\
\text { Ebony/Beaver) }\end{array}$} & \multicolumn{2}{|c|}{$\begin{array}{l}\text { High Fat Content } \\
\text { Food } \\
\text { (Seed/Animal Fat) }\end{array}$} \\
\hline
\end{tabular}

\begin{tabular}{|c|c|c|c|c|c|c|c|c|}
\hline \multirow{2}{*}{ Fatty Acid } & \multicolumn{2}{|c|}{ 4VG 94 (128-5-3-3a) } & \multicolumn{2}{|c|}{ 4VG 95 (128-5-3-4a) } & \multicolumn{2}{|c|}{ 4VG 96 (658-5-3-1a) } & \multicolumn{2}{|c|}{ 4VG 97 (658-5-3-2a) } \\
\hline & Area & Rel\% & Area & Rel\% & Area & Rel\% & Area & Rel\% \\
\hline C12:0 & 2052 & 2.17 & 734 & 0.80 & 1361 & 0.86 & 196 & 0.14 \\
\hline C14:0 & 3915 & 4.15 & 3570 & 3.90 & 2185 & 1.38 & 2351 & 1.65 \\
\hline C14:1 & 0 & 0.00 & 0 & 0.00 & 524 & 0.33 & 0 & 0.00 \\
\hline C15:0 & 1693 & 1.79 & 2634 & 2.87 & 1329 & 0.84 & 951 & 0.67 \\
\hline C16:0 & 18508 & 19.61 & 23462 & 25.60 & 30855 & 19.48 & 21201 & 14.91 \\
\hline C16:1 & 2407 & 2.55 & 3231 & 3.53 & 3587 & 2.26 & 4429 & 3.11 \\
\hline C17:0 & 0 & 0.00 & 802 & 0.88 & 727 & 0.46 & 0 & 0.00 \\
\hline C17:1 & 0 & 0.00 & 0 & 0.00 & 0 & 0.00 & 1287 & 0.90 \\
\hline C18:0 & 12725 & 13.49 & 18870 & 20.59 & 18594 & 11.74 & 11533 & 8.11 \\
\hline C18:1s & 42732 & 45.28 & 27458 & 29.96 & 79210 & 50.00 & 86915 & 61.12 \\
\hline C18:2 & 7093 & 7.52 & 6330 & 6.91 & 14268 & 9.01 & 9626 & 6.77 \\
\hline C18:3w3 & 0 & 0.00 & 0 & 0.00 & 0 & 0.00 & 0 & 0.00 \\
\hline C20:0 & 1472 & 1.56 & 1977 & 2.16 & 2507 & 1.58 & 2179 & 1.53 \\
\hline C20:1 & 0 & 0.00 & 0 & 0.00 & 557 & 0.35 & 0 & 0.00 \\
\hline C24:0 & 1767 & 1.87 & 2580 & 2.82 & 2707 & 1.71 & 1542 & 1.08 \\
\hline Total & 94364 & 100.00 & 91648 & 100.00 & 158411 & 100.00 & 142210 & 100.00 \\
\hline Identification & \multicolumn{2}{|c|}{$\begin{array}{l}\text { High Fat Content } \\
\text { Food } \\
\text { (Seed/Animal Fat) }\end{array}$} & \multicolumn{2}{|c|}{$\begin{array}{l}\text { Moderate-High Fat } \\
\text { Content Food (Texas } \\
\text { Ebony/Beaver) }\end{array}$} & \multicolumn{2}{|c|}{$\begin{array}{l}\text { Borderline High and } \\
\text { Very High Fat } \\
\text { Content }\end{array}$} & \multicolumn{2}{|c|}{$\begin{array}{l}\text { Very High Fat } \\
\text { Content Food } \\
\text { (Seed/Animal Fat) }\end{array}$} \\
\hline
\end{tabular}


The Varga Site Texas Department of Transportation

Table G-4. Fatty Acid Composition and Identification of Residues from the Varga Site (cont.)

\begin{tabular}{|c|c|c|c|c|c|c|c|c|}
\hline \multirow{2}{*}{ Fatty Acid } & \multicolumn{2}{|c|}{ 4VG 98 (658-5-3-3a) } & \multicolumn{2}{|c|}{ 4VG 99 (658-5-3-4a) } & \multicolumn{2}{|c|}{ 4VG 100 (644-5-3-1a) } & \multicolumn{2}{|c|}{ 4VG 101 (644-5-3-2a) } \\
\hline & Area & Rel\% & Area & Rel\% & Area & Rel\% & Area & Rel\% \\
\hline C12:0 & 2312 & 2.64 & 1398 & 1.31 & 381 & 0.28 & 1263 & 1.70 \\
\hline C14:0 & 3183 & 3.63 & 5062 & 4.75 & 2289 & 1.69 & 3757 & 5.07 \\
\hline C14:1 & 0 & 0.00 & 0 & 0.00 & 0 & 0.00 & 0 & 0.00 \\
\hline C15:0 & 1510 & 1.72 & 2256 & 2.12 & 1297 & 0.96 & 1847 & 2.49 \\
\hline C16:0 & 20959 & 23.91 & 23102 & 21.68 & 22143 & 16.36 & 20889 & 28.17 \\
\hline C16:1 & 2329 & 2.66 & 3237 & 3.04 & 3894 & 2.88 & 877 & 1.18 \\
\hline C17:0 & 183 & 0.21 & 0 & 0.00 & 148 & 0.11 & 0 & 0.00 \\
\hline C17:1 & 0 & 0.00 & 935 & 0.88 & 758 & 0.56 & 1041 & 1.40 \\
\hline C18:0 & 16165 & 18.44 & 15713 & 14.75 & 11927 & 8.81 & 14862 & 20.04 \\
\hline C18:1s & 28603 & 32.62 & 45011 & 42.24 & 77315 & 57.13 & 20456 & 27.59 \\
\hline C18:2 & 7395 & 8.43 & 5312 & 4.99 & 11689 & 8.64 & 3344 & 4.51 \\
\hline C18:3w3 & 0 & 0.00 & 0 & 0.00 & 0 & 0.00 & 0 & 0.00 \\
\hline C20:0 & 2769 & 3.16 & 2129 & 2.00 & 1756 & 1.30 & 3292 & 4.44 \\
\hline C20:1 & 0 & 0.00 & 0 & 0.00 & 0 & 0.00 & 0 & 0.00 \\
\hline C24:0 & 2265 & 2.58 & 2394 & 2.25 & 1724 & 1.27 & 2522 & 3.40 \\
\hline Total & 87673 & 100.00 & 106549 & 100.00 & 135321 & 100.00 & 74150 & 100.00 \\
\hline Identification & \multicolumn{2}{|c|}{$\begin{array}{l}\text { Moderate-High Fat } \\
\text { Content Food (Texas } \\
\text { Ebony/Beaver) }\end{array}$} & \multicolumn{2}{|c|}{$\begin{array}{l}\text { High Fat Content } \\
\text { Food } \\
\text { (Seed/Animal Fat) }\end{array}$} & \multicolumn{2}{|c|}{$\begin{array}{l}\text { Very High Fat } \\
\text { Content Food } \\
\text { (Seed/Animal Fat) }\end{array}$} & \multicolumn{2}{|c|}{$\begin{array}{l}\text { Moderate-High Fat } \\
\text { Content Food (Texas } \\
\text { Ebony/Beaver) }\end{array}$} \\
\hline
\end{tabular}

\begin{tabular}{|c|c|c|}
\hline \multirow{2}{*}{ Fatty Acid } & \multicolumn{2}{|c|}{ 4VG 102 (644-5-3-3a) } \\
\hline & Area & Rel\% \\
\hline C12:0 & 3733 & 2.00 \\
\hline C14:0 & 5703 & 3.06 \\
\hline C14:1 & 0 & 0.00 \\
\hline C15:0 & 4186 & 2.25 \\
\hline C16:0 & 38326 & 20.56 \\
\hline C16:1 & 3990 & 2.14 \\
\hline C17:0 & 0 & 0.00 \\
\hline C17:1 & 2712 & 1.46 \\
\hline C18:0 & 19642 & 10.54 \\
\hline C18:1s & 80960 & 43.44 \\
\hline C18:2 & 20457 & 10.98 \\
\hline C18:3w3 & 0 & 0.00 \\
\hline C20:0 & 2583 & 1.39 \\
\hline C20:1 & 0 & 0.00 \\
\hline C24:0 & 4085 & 2.19 \\
\hline Total & 186377 & 100.00 \\
\hline Identification & \multicolumn{2}{|c|}{$\begin{array}{l}\text { High Fat Content } \\
\text { Food } \\
\text { (Seed/Animal Fat) }\end{array}$} \\
\hline
\end{tabular}



APPENDIX H:

STABLE CARBON AND NITROGEN ISOTOPE ANALYSES 



\title{
STABLE CARBON AND NITROGEN ISOTOPE ANALYSES
}

\author{
By:
}

David Harris, Ph.D.

Prepared for:

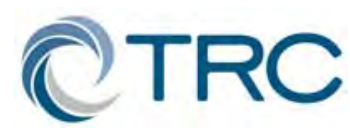

TRC Environmental Corporation

505 East Huntland Drive, Suite 250

Austin, Texas 78752

\author{
Prepared by: \\ David Harris, Ph.D. \\ University of California at Davis \\ Stable Isotope Facility \\ Department of Agronomy \\ 3112 Plant \& Environmental Science Bldg. \\ Davis, California 95616
}

April 19, 2004 

The Varga Site

Texas Department of Transportation

Table H-1. Results from Batch One

\begin{tabular}{|c|c|c|c|c|c|c|c|}
\hline Name & Sample ID & Provenience & $\begin{array}{c}\text { Weight } \\
\text { (mg) }\end{array}$ & $\begin{array}{l}N \\
\mu g\end{array}$ & $\begin{array}{c}\delta^{15} \mathbf{N} \\
(\% 0)\end{array}$ & $\begin{array}{c}\mathrm{C} \\
\mu \mathrm{g}\end{array}$ & $\begin{array}{l}\delta^{13} C \\
(\% o)\end{array}$ \\
\hline \multirow{3}{*}{\multicolumn{4}{|c|}{$\begin{array}{l}\text { Check } \\
\text { Check } \\
\text { Check }\end{array}$}} & 110.4 & 1.29 & 360.5 & -23.88 \\
\hline & & & & 110.4 & 1.40 & 364.6 & -23.84 \\
\hline & & & & 109.2 & 1.40 & 362.8 & -23.82 \\
\hline Quigg a1 & $1217 \mathrm{c}$ & Soil column & 50.888 & 129.3 & 8.32 & 1453.0 & -28.47 \\
\hline a2 & $1218 \mathrm{c}$ & Soil column & 50.283 & 137.1 & 8.43 & 1505.7 & -28.28 \\
\hline a3 & $1219 c$ & Soil column & 50.559 & 154.3 & 8.22 & 1675.9 & -28.67 \\
\hline $\mathrm{a} 4$ & $1220 c$ & Soil column & 50.435 & 165.0 & 8.30 & 1813.6 & -29.44 \\
\hline a5 & $1221 c$ & Soil column & 50.351 & 128.5 & 8.40 & 1749.1 & -28.93 \\
\hline a6 & $1222 c$ & Soil column & 49.957 & 125.2 & 8.24 & 1984.9 & -29.90 \\
\hline a7 & $1223 c$ & Soil column & 50.886 & 107.5 & 8.03 & 1796.3 & -29.40 \\
\hline a8 & $1224 c$ & Soil column & 50.170 & 100.1 & 8.37 & 1548.7 & -28.41 \\
\hline a9 & $1225 c$ & Soil column & 49.915 & 83.7 & 8.70 & 1268.3 & -27.82 \\
\hline a10 & $1226 c$ & Soil column & 49.830 & 78.4 & 8.72 & 1085.7 & -27.07 \\
\hline a11 & $1227 \mathrm{c}$ & Soil column & 50.369 & 78.4 & 8.77 & 1027.2 & -26.81 \\
\hline a12 & $1228 c$ & Soil column & 50.560 & 66.1 & 8.94 & 844.4 & -25.84 \\
\hline \multirow{2}{*}{\multicolumn{4}{|c|}{$\begin{array}{l}\text { Check } \\
\text { Check }\end{array}$}} & 110.4 & 1.30 & 369.3 & -23.63 \\
\hline & & & & 109.6 & 1.43 & 369.5 & -23.87 \\
\hline b1 & $1229 c$ & Soil column & 50.124 & 65.7 & 9.31 & 793.0 & -25.57 \\
\hline b2 & $1230 c$ & Soil column & 50.403 & 62.0 & 9.26 & 727.8 & -24.95 \\
\hline b3 & $1231 c$ & Soil column & 50.202 & 59.1 & 9.43 & 721.5 & -24.97 \\
\hline b4 & $1232 c$ & Soil column & 50.757 & 62.0 & 9.28 & 767.8 & -25.55 \\
\hline b5 & $1233 c$ & Soil column & 50.029 & 66.1 & 8.99 & 814.1 & -25.61 \\
\hline b6 & $1234 c$ & Soil column & 50.343 & 72.2 & 9.25 & 932.6 & -26.64 \\
\hline b7 & $1235 c$ & Soil column & 50.240 & 70.6 & 9.48 & 827.9 & -25.81 \\
\hline b8 & $1236 \mathrm{c}$ & Soil column & 49.987 & 91.1 & 8.34 & 1045.2 & -27.09 \\
\hline b9 & $1207-4 c$ & BT-M-1 Unit 4 & 49.865 & 38.0 & 9.40 & 440.6 & -23.19 \\
\hline b10 & $1208-4 c$ & BT-M-1 Unit 3 & 49.884 & 85.0 & 8.60 & 980.2 & -26.59 \\
\hline b11 & $1209-4 c$ & BT 7, BK2 & 50.881 & 49.7 & 9.63 & 558.1 & -23.47 \\
\hline b12 & $1210-4 c$ & BT 7, 2BK & 49.990 & 67.3 & 9.17 & 730.9 & -24.90 \\
\hline c1 & $1211-4 \mathrm{c}$ & BT 7, Cultural & 50.289 & 102.6 & 8.49 & 1225.2 & -26.98 \\
\hline \multirow{2}{*}{\multicolumn{4}{|c|}{$\begin{array}{l}\text { Check } \\
\text { Check }\end{array}$}} & 109.6 & 1.44 & 372.3 & -23.83 \\
\hline & & & & 109.2 & 1.47 & 365.2 & -23.89 \\
\hline Quigg soils A1 & $1872-32 c$ & Lorenzo sherd & 2.796 & 129.8 & 3.74 & 1408.3 & -22.33 \\
\hline A2 & 274-5-3-1b & LA F1 & 2.998 & 21.4 & 5.63 & 376.8 & -23.69 \\
\hline A3 & $801-5-3-2 b$ & LA F15 & 3.360 & 24.6 & 6.62 & 378.6 & -25.34 \\
\hline A4 & 293-5-3-1b & LA F1c & 3.645 & 17.3 & 5.78 & 370.4 & -24.18 \\
\hline A5 & $583-5-3-1 b$ & MA F11 & 3.708 & 9.2 & 2.36 & 137.2 & -25.54 \\
\hline A6 & $830-5-3-3 b$ & T F9 & 4.438 & 33.0 & 6.44 & 413.3 & -25.75 \\
\hline A7 & $843-5-3-1 b$ & T F8 & 5.316 & 49.1 & 5.75 & 730.7 & -18.43 \\
\hline A8 & $293-5-3-1 b$ & LA F1c & 5.439 & 32.3 & 6.72 & 533.1 & -24.54 \\
\hline
\end{tabular}




\begin{tabular}{|c|c|c|c|c|c|c|c|}
\hline Name & Sample ID & Provenience & $\begin{array}{l}\text { Weight } \\
\text { (mg) }\end{array}$ & $\begin{array}{c}N \\
\mu g\end{array}$ & $\begin{array}{l}\delta^{15} N \\
(\%)\end{array}$ & $\begin{array}{c}C \\
\mu g\end{array}$ & $\begin{array}{c}\delta^{13} C \\
\text { (\%o) }\end{array}$ \\
\hline A9 & 79-5-3-2b F21 & T F21 & 5.808 & 35.3 & 2.80 & 368.5 & -21.16 \\
\hline A10 & 271-5-3-1b & LA F1b & 6.751 & 13.7 & 1.08 & 203.9 & -25.66 \\
\hline A11 & $757-53-4 b$ & EA F31 & 7.039 & 23.1 & 5.79 & 439.0 & -25.26 \\
\hline A12 & 263-5-3-1b & LA F1 & 7.058 & 43.3 & 8.23 & 538.6 & -24.13 \\
\hline \multirow{2}{*}{\multicolumn{4}{|c|}{$\begin{array}{l}\text { Check } \\
\text { Check }\end{array}$}} & 111.1 & 1.53 & 353.9 & -23.86 \\
\hline & & & & 111.1 & 1.30 & 353.0 & -23.86 \\
\hline B1 & $644-5-3-1 b$ & EA F12 & 7.149 & 3.9 & -11.67 & 60.9 & -26.63 \\
\hline B2 & $658-5-3-3 b$ & EA F13 & 7.308 & 27.1 & 2.91 & 337.4 & -25.78 \\
\hline B3 & $79-5-3-1 b$ & T F21 & 7.805 & 39.1 & 3.59 & 706.9 & -24.80 \\
\hline B4 & $757-5-3-1 b$ & EA F31 & 9.052 & 4.7 & 1.47 & 111.6 & -26.89 \\
\hline B5 & 644-5-3-1b & EA F12 & 11.745 & 52.8 & 1.35 & 834.9 & -25.61 \\
\hline B6 & $830-5-3-4 b$ & T F9 & 12.351 & 83.3 & 6.67 & 1015.1 & -20.97 \\
\hline B7 & 966-5-3-1b & LA F29 & 12.626 & 6.1 & -5.96 & 54.6 & -28.39 \\
\hline B8 & $128-5-3-4 b$ & EA F40 & 12.956 & 32.7 & 8.16 & 569.7 & -23.88 \\
\hline B9 & $128-5-3-1 b$ & EA F40 & 15.867 & 41.4 & 5.67 & 597.2 & -25.12 \\
\hline B10 & $203-5-3-4 b$ & EA F39 & 16.736 & 81.4 & 1.90 & 1298.6 & -25.76 \\
\hline B11 & 1872-32b & Lorenzo sherd & 17.320 & 18.5 & -0.52 & 547.8 & -21.68 \\
\hline B12 & $965-8-1 b$ & $\mathrm{~T}$ na, sherd & 19.270 & 12.1 & -1.08 & 219.5 & -27.63 \\
\hline \multirow{2}{*}{\multicolumn{4}{|c|}{$\begin{array}{l}\text { Check } \\
\text { Check }\end{array}$}} & 110.4 & 1.57 & 353.9 & -23.89 \\
\hline & & & & 109.8 & 1.37 & 353.9 & -23.87 \\
\hline $\mathrm{C} 1$ & 658-5-3-1b & EA F13 & 19.781 & 35.2 & 6.02 & 1408.3 & -30.74 \\
\hline $\mathrm{C} 2$ & $37-5-3-4 b$ & MA F37 & 22.228 & 40.9 & 8.35 & 655.7 & -24.10 \\
\hline $\mathrm{C} 3$ & $293-5-3-3 b$ & LA F1c & 22.800 & 114.3 & 3.94 & 1746.7 & -24.89 \\
\hline C4 & $89-5-3-1 b$ & La F1a & 23.362 & 26.0 & 2.49 & 475.5 & -25.97 \\
\hline $\mathrm{C5}$ & $161-5-3-1 b$ & LA F1 & 26.233 & 91.0 & 6.08 & 2569.7 & -30.62 \\
\hline C6 & 534-5-3-1b & T F18 & 26.876 & 54.9 & 1.89 & 1572.9 & -27.99 \\
\hline $\mathrm{C7}$ & $13003 \mathrm{~b}$ & San Juan sherd & 27.532 & 18.9 & 4.15 & 406.9 & -25.04 \\
\hline \multirow{2}{*}{\multicolumn{4}{|c|}{$\begin{array}{l}\text { Check } \\
\text { Check }\end{array}$}} & 110.4 & 1.19 & 353.0 & -23.84 \\
\hline & & & & 111.1 & 1.30 & 351.2 & -23.89 \\
\hline $\mathrm{D} 1$ & $901-8-1 b$ & $\mathrm{~T}$ na, sherd & 31.664 & 11.3 & -1.11 & 176.5 & -26.73 \\
\hline $\mathrm{D} 2$ & $128-5-3-2 b$ & EA F40 & 32.291 & 48.4 & 6.50 & 791.0 & -24.70 \\
\hline D3 & 801-5-3-3b & LA F15 & 32.874 & 164.6 & 7.92 & 2094.2 & -23.21 \\
\hline $\mathrm{D} 4$ & 1157-8-1b & $\mathrm{T}$ na, sherd & 38.133 & 19.6 & 5.02 & 320.1 & -24.97 \\
\hline D5 & $1872-6 b$ & Lorenzo sherd & 38.412 & 29.2 & 4.20 & 901.7 & -22.02 \\
\hline D6 & 158-5-3-3b & T F36 & 39.406 & 74.9 & 5.94 & 951.1 & -24.80 \\
\hline $\mathrm{D} 7$ & $616-5-3-2 b$ & EA F26 & 39.737 & 56.7 & 2.82 & 905.3 & -24.47 \\
\hline $\mathrm{D} 8$ & $1030-5-4-8-1 b$ & T F38, sherd & 40.237 & 8.7 & 2.80 & 122.5 & -24.27 \\
\hline D9 & $13008 \mathrm{~b}$ & San Juan sherd & 40.254 & 5.4 & -2.26 & 93.3 & -26.68 \\
\hline D10 & $801-5-3-1 b$ & LA F15 & 40.271 & 43.8 & 5.53 & 752.6 & -24.48 \\
\hline D11 & $352-5-3-1 b$ & LA F1 & 40.293 & 171.1 & 2.00 & 2597.1 & -26.33 \\
\hline D12 & 1055-5-8-1b & T F25, sherd & 40.322 & 11.6 & -2.59 & 215.8 & -27.18 \\
\hline \multicolumn{4}{|l|}{ Check } & 110.4 & 1.22 & 360.3 & -23.86 \\
\hline
\end{tabular}


The Varga Site Texas Department of Transportation

\begin{tabular}{|c|c|c|c|c|c|c|c|}
\hline Name & Sample ID & Provenience & $\begin{array}{c}\text { Weight } \\
\text { (mg) }\end{array}$ & $\begin{array}{l}\mathbf{N} \\
\mu \mathrm{g}\end{array}$ & $\begin{array}{l}\delta^{15} N \\
(\% o)\end{array}$ & $\begin{array}{c}\mathrm{C} \\
\mu \mathrm{g}\end{array}$ & $\begin{array}{l}\delta^{13} C \\
(\% o)\end{array}$ \\
\hline \multicolumn{4}{|l|}{ Check } & 110.4 & 1.36 & 354.8 & -23.85 \\
\hline E1 & $865-5-3-1 b$ & T F8 & 40.381 & 19.3 & -4.21 & 354.8 & -26.11 \\
\hline E2 & $187-5-3-2 a$ & LA F1 & 40.472 & 10.1 & 4.63 & 162.8 & -23.45 \\
\hline E3 & $11-5-3-1 b$ & LA F1d & 40.574 & 66.5 & 7.83 & 1033.4 & -23.24 \\
\hline E4 & $1872-48 b$ & Lorenzo sherd & 40.738 & 22.0 & -0.43 & 1079.1 & -18.69 \\
\hline E5 & $830-5-3-2 b$ & T F9 & 41.813 & 36.7 & 3.83 & 522.2 & -23.57 \\
\hline E6 & $900-8-1 b$ & $\mathrm{~T}$ na, sherd & 41.861 & 33.1 & 6.90 & 532.2 & -27.23 \\
\hline E7 & 79-5-3-2b NO & T F21 & 42.012 & 28.4 & 3.56 & 417.9 & -24.87 \\
\hline E8 & $1872-6 c$ & Lorenzo sherd & 42.104 & 29.5 & 5.24 & 923.6 & -21.82 \\
\hline E9 & $158-5-3-2 b$ & T F36 & 42.373 & 15.9 & 3.40 & 203.0 & -24.78 \\
\hline E10 & $187-5-3-1 b$ & LA F1 & 42.543 & 145.3 & 3.91 & 2350.2 & -25.47 \\
\hline E11 & $1051-5-3-4 b$ & T F25 & 42.672 & 129.8 & 2.02 & 1984.4 & -25.70 \\
\hline E12 & $658-5-3-4 b$ & EA F13 & 43.887 & 17.4 & 6.42 & 2853.2 & -30.26 \\
\hline 1 & 11-5-3-3b & LA F1d & 47.687 & 26.0 & 3.17 & 516.7 & -25.90 \\
\hline \multicolumn{4}{|l|}{ Check } & 109.8 & 1.17 & 353.0 & -23.84 \\
\hline \multicolumn{4}{|l|}{ Check } & 109.1 & 1.10 & 355.7 & -23.89 \\
\hline \multicolumn{4}{|l|}{ Check } & 110.4 & 1.34 & 353.9 & -23.86 \\
\hline
\end{tabular}

T = Toyah, LA = Late Archaic, EA = Early Archaic, BT = backhoe trench, F1 = Feature 1, 
Table H-2. Results from Batch Two

\begin{tabular}{|c|c|c|c|c|c|c|c|}
\hline Name & Sample ID & Provenience & $\begin{array}{l}\text { Weight } \\
\text { (mg) }\end{array}$ & $\begin{array}{l}N \\
\mu g\end{array}$ & $\begin{array}{l}\delta^{15} N \\
(\%)\end{array}$ & $\begin{array}{c}C \\
\mu g\end{array}$ & $\begin{array}{l}\delta^{13} \mathrm{C} \\
(\% 0)\end{array}$ \\
\hline \multicolumn{4}{|l|}{ Check } & 109.8 & 1.38 & 358.3 & -23.85 \\
\hline \multicolumn{4}{|l|}{ Check } & 110.2 & 1.18 & 359.5 & -23.84 \\
\hline \multicolumn{4}{|l|}{ Check } & 110.5 & 1.19 & 360.2 & -23.82 \\
\hline \multicolumn{4}{|l|}{ Check } & 114.4 & 1.40 & 716.6 & -23.87 \\
\hline \multicolumn{4}{|l|}{ Check } & 112.8 & 1.22 & 716.6 & -23.87 \\
\hline \multicolumn{4}{|l|}{ Check } & 228.2 & 1.30 & 1340.6 & -23.87 \\
\hline Quigg Varga a1 & $11-5-3-2 b$ & LA F1d & 30.178 & 376.7 & 3.41 & 2891.2 & -24.97 \\
\hline a2 & $37-5-3-1 b$ & MA F37 & 30.417 & 130.6 & 2.95 & 1630.9 & -24.81 \\
\hline a3 & $37-5-3-2 b$ & MA F37 & 10.522 & 120.4 & -0.24 & 1470.3 & -26.67 \\
\hline a4 & $37-5-3-3 b$ & MA F37 & 17.881 & 106.2 & 1.24 & 1921.3 & -25.53 \\
\hline a5 & $80-5-3-1 b$ & LA F1 & 7.606 & 43.5 & 4.78 & 778.4 & -23.88 \\
\hline $\mathrm{a} 6$ & $81-5-3-1 b$ & LA F1 & 2.161 & 11.4 & -3.15 & 180.4 & -26.02 \\
\hline a7 & $89-5-3-2 b$ & LA F1a & 8.625 & 51.4 & 2.89 & 840.2 & -25.37 \\
\hline $\mathrm{a} 8$ & $98-5-3-1 b$ & LA F1 & 16.006 & 130.1 & 7.65 & 1019.3 & -24.19 \\
\hline a9 & $128-5-3-3 b$ & EA F40 & 30.871 & 128.4 & 5.95 & 1563.0 & -24.66 \\
\hline a10 & $158-5-3-1 b$ & T F36 & 15.883 & 122.3 & 6.08 & 1575.3 & -24.31 \\
\hline a11 & $178-5-3-1 b$ & LA F1 & 30.115 & 41.5 & 5.22 & 642.5 & -21.78 \\
\hline a12 & 179-5-3-2b & LA F1 & 17.820 & 161.7 & 6.12 & 1841.0 & -24.65 \\
\hline \multirow{2}{*}{\multicolumn{4}{|c|}{$\begin{array}{l}\text { Check } \\
\text { Check }\end{array}$}} & 110.4 & 1.32 & 393.5 & -23.65 \\
\hline & & & & \begin{tabular}{|l|}
109.9 \\
\end{tabular} & 1.39 & 369.4 & -23.85 \\
\hline b1 & $179-5-3-1 b$ & LA F1 & 8.294 & 98.0 & 4.55 & 1470.3 & -24.67 \\
\hline b2 & 203-5-3-1b & EA F39 & 30.703 & 99.0 & 6.06 & 1390.0 & -25.48 \\
\hline b3 & $203-5-3-3 b$ & EA F39 & 30.518 & 137.1 & 6.49 & 1420.9 & -23.69 \\
\hline b4 & $273-5-3-2 b$ & LA F1b & 19.183 & 182.6 & 5.93 & 2186.9 & -25.09 \\
\hline b5 & $273-5-3-3 b$ & LA F1b & 30.054 & 79.7 & 6.81 & 1062.6 & -22.55 \\
\hline b6 & $274-5-3-2 b$ & LA F1 & 24.516 & 223.7 & 7.05 & 2656.4 & -23.30 \\
\hline b7 & 276-5-3-1b & MA F11 & 20.335 & 107.9 & 6.59 & 1865.7 & -26.28 \\
\hline b8 & 276-5-3-2b & MA F11 & 20.327 & 99.5 & 7.36 & 1408.5 & -24.84 \\
\hline b9 & $352-5-3-2 d$ & LA F1 & 1.650 & 23.0 & 4.64 & 396.6 & -24.63 \\
\hline b10 & $370-5-3-1 b$ & LA F1 & 30.608 & 96.5 & 7.09 & 1254.1 & -23.19 \\
\hline b11 & 515-5-3-1b & MA F11 & 20.101 & \begin{tabular}{|l|}
170.3 \\
\end{tabular} & 6.85 & 2063.4 & \begin{tabular}{|l|}
-24.05 \\
\end{tabular} \\
\hline b12 & 534-5-3-2b & T F18 & 15.539 & 275.7 & 7.92 & 2384.6 & -25.29 \\
\hline \multicolumn{4}{|l|}{ Check } & 110.9 & 1.43 & 380.6 & -23.79 \\
\hline \multicolumn{4}{|l|}{ Check } & 108.9 & 1.42 & 371.9 & \begin{tabular}{|l|}
-23.83 \\
\end{tabular} \\
\hline \multicolumn{4}{|l|}{ Check } & 108.1 & 1.15 & 362.9 & -23.84 \\
\hline \multicolumn{4}{|l|}{ Check } & 108.6 & 1.19 & 362.9 & -23.83 \\
\hline \multicolumn{4}{|l|}{ Check } & 111.1 & 1.30 & 711.1 & -23.80 \\
\hline \multicolumn{4}{|l|}{ Check } & 111.1 & 1.09 & 711.1 & -23.82 \\
\hline
\end{tabular}


The Varga Site

Texas Department of Transportation

\begin{tabular}{|c|c|c|c|c|c|c|c|}
\hline Name & Sample ID & Provenience & $\begin{array}{l}\text { Weight } \\
\text { (mg) }\end{array}$ & $\begin{array}{l}N \\
\mu g\end{array}$ & $\begin{array}{l}\delta^{15} \mathrm{~N} \\
(\%)\end{array}$ & $\begin{array}{c}C \\
\mu g\end{array}$ & $\begin{array}{l}\delta^{13} \mathrm{C} \\
(\% 0)\end{array}$ \\
\hline \multicolumn{4}{|l|}{ Check } & 226.6 & 1.39 & 1336.5 & -23.96 \\
\hline $\mathrm{c} 1$ & 575-5-3-1b & MA F11 & 30.066 & 146.6 & 7.98 & 1747.2 & -22.88 \\
\hline c2 & $616-5-3-1 b$ & EA F26 & 22.694 & 92.3 & 4.65 & 1385.5 & -24.15 \\
\hline c3 & $616-5-3-3 b$ & EA F26 & 30.052 & 63.2 & 6.03 & 938.0 & -22.21 \\
\hline $\mathrm{c4}$ & 644-5-3-3b & EA F12 & 30.054 & 77.5 & 3.75 & 1820.8 & -23.64 \\
\hline c5 & $658-5-3-1 b$ & EA F13 & 3.415 & 20.1 & 1.89 & 593.4 & -25.02 \\
\hline c6 & $756-5-3-2 b$ & EA F31 & 1.000 & 2.0 & 5.44 & 147.7 & -26.71 \\
\hline c7 & $756-5-3-3 b$ & EA F31 & 30.070 & 90.4 & 6.14 & 987.0 & -23.77 \\
\hline $\mathrm{c} 8$ & $865-5-3-2 b$ & T F8 & 7.623 & 88.4 & 5.61 & 1293.5 & \begin{tabular}{|l|}
-21.84 \\
\end{tabular} \\
\hline c9 & $865-5-3-3 b$ & T F8 & 12.374 & 114.1 & 4.99 & 1416.1 & \begin{tabular}{|l|}
-23.93 \\
\end{tabular} \\
\hline c10 & 941-5-3-1b & LA F28 & 7.756 & 25.7 & 2.38 & 717.3 & \begin{tabular}{|l|}
-24.69 \\
\end{tabular} \\
\hline c11 & $941-5-3-2 b$ & LA F28 & 30.576 & 211.3 & 8.66 & 2010.8 & -22.05 \\
\hline c12 & $962-5-3-1 b$ & LA F29 & 1.346 & 16.3 & 5.68 & 313.9 & -26.71 \\
\hline \multirow{2}{*}{\multicolumn{4}{|c|}{$\begin{array}{l}\text { Check } \\
\text { Check }\end{array}$}} & 109.1 & 1.54 & 362.3 & -23.81 \\
\hline & & & & 109.6 & 1.26 & 364.2 & -23.82 \\
\hline $\mathrm{d} 1$ & $1005-3-1 b$ & $\mathrm{~T}$ na & 4.901 & 71.6 & 4.80 & 1121.9 & -21.45 \\
\hline $\mathrm{d} 2$ & 1030-5-3-1b & T F38 & 30.632 & 247.4 & 5.25 & 1520.4 & -18.58 \\
\hline $\mathrm{d} 3$ & $1030-5-3-2 b$ & T F38 & 13.640 & 221.2 & 4.21 & 1808.5 & -22.07 \\
\hline $\mathrm{d} 4$ & 1030-5-3-3b & T F38 & 2.983 & 0.5 & 11.36 & 6.1 & -23.23 \\
\hline $\mathrm{d} 5$ & $1030-5-3-4 b$ & T F38 & 30.794 & 17.1 & -2.19 & 221.9 & -20.32 \\
\hline $\mathrm{d} 6$ & 1051-5-3-1b & T F25 & 3.849 & 54.3 & 5.42 & 649.8 & -25.02 \\
\hline $\mathrm{d} 7$ & 1051-5-3-2b & T F28 & 23.835 & 244.4 & 4.85 & 3837.7 & -18.45 \\
\hline $\mathrm{d} 8$ & 1051-5-3-3b & T F28 & 17.353 & 145.7 & 6.41 & 2660.6 & -20.45 \\
\hline \multirow{6}{*}{\multicolumn{4}{|c|}{$\begin{array}{l}\text { Check } \\
\text { Check } \\
\text { Check } \\
\text { Check } \\
\text { Check } \\
\text { Check }\end{array}$}} & 112.1 & 1.45 & 369.1 & -23.80 \\
\hline & & & & 110.6 & 1.35 & 366.0 & -23.82 \\
\hline & & & & 111.1 & 1.41 & 363.5 & -23.81 \\
\hline & & & & 110.2 & 1.30 & 728.5 & -23.84 \\
\hline & & & & 107.7 & 1.36 & 734.7 & -23.84 \\
\hline & & & & 108.7 & 1.30 & 734.5 & -23.82 \\
\hline e1 & CE32 & Lechuguilla Cake & 2.489 & 5.3 & -2.65 & 924.3 & -12.90 \\
\hline e2 & ED-J & Juniper seeds - ED & 2.633 & 39.3 & 2.10 & 1076.0 & -28.11 \\
\hline e3 & WM-B & Buckeye seed WM & 2.522 & 57.3 & -0.63 & 1544.1 & -26.43 \\
\hline e4 & VV-Hu & Huisache seed VV & 2.552 & 177.5 & 0.37 & 1107.2 & -26.76 \\
\hline e5 & CE30 & Arrowhead tuber TV & 2.581 & 19.4 & -0.49 & 853.9 & -13.14 \\
\hline e6 & CE34 & Sotol hearth ED & 2.517 & 9.4 & -5.36 & 1372.3 & -25.65 \\
\hline e7 & ZL134 & Flint corn nib & 2.666 & 29.3 & 0.53 & 1036.9 & -11.93 \\
\hline e8 & $\mathrm{C} 10$ & Amaranth seed & 2.533 & 64.8 & 6.01 & 1087.2 & -27.74 \\
\hline e9 & PT89 & Tepary bean & 2.514 & 123.1 & 1.58 & 1004.8 & -27.76 \\
\hline e10 & EA5 & Squash & 2.728 & 119.2 & 3.55 & 1364.8 & -27.94 \\
\hline e11 & CE29 & Youpon leaves TV & 2.530 & 56.3 & -1.75 & 1124.4 & -28.24 \\
\hline
\end{tabular}




\begin{tabular}{|c|c|c|c|c|c|c|c|}
\hline Name & Sample ID & Provenience & $\begin{array}{l}\text { Weight } \\
\text { (mg) }\end{array}$ & $\begin{array}{l}N \\
\mu g\end{array}$ & $\begin{array}{l}\delta^{15} N \\
(\%)\end{array}$ & $\begin{array}{c}C \\
\mu g\end{array}$ & $\begin{array}{l}\delta^{13} \mathrm{C} \\
(\% \circ)\end{array}$ \\
\hline e12 & VV-Mi & Catclaw seeds VV & 2.532 & 78.8 & 1.41 & 1080.0 & -26.75 \\
\hline \multirow{2}{*}{\multicolumn{4}{|c|}{$\begin{array}{l}\text { Check } \\
\text { Check }\end{array}$}} & 110.7 & 1.06 & 732.5 & -23.85 \\
\hline & & & & 108.2 & 1.32 & 732.3 & -23.84 \\
\hline f1 & VV-Oak & Oak nut meat VV & 2.591 & 20.1 & -0.15 & 997.2 & -24.33 \\
\hline $\mathrm{f} 2$ & TV-Ev & Eves Neckless TV & 2.647 & 24.2 & 9.77 & 1098.0 & -28.64 \\
\hline f3 & TV-BC & Buchcroton TV & 2.588 & 59.8 & 1.07 & 1047.2 & \begin{tabular}{|l|}
-29.96 \\
\end{tabular} \\
\hline $\mathrm{f} 4$ & ED-Le & $\begin{array}{l}\text { Lechuguilla seeds } \\
\text { ED }\end{array}$ & 2.656 & 87.3 & -0.20 & 1154.2 & -13.79 \\
\hline f5 & CE18 & Sotol seeds TV & 2.444 & 90.7 & 4.44 & 1072.0 & -28.40 \\
\hline f6 & Buff & Buffalo grass seed & 2.504 & 31.0 & -0.96 & 1002.4 & -14.05 \\
\hline f7 & CE28 & Acorn squash HEB & 2.532 & 33.9 & -1.32 & 932.9 & -27.66 \\
\hline f8 & Sot & Sotol Head RL & 2.661 & 6.0 & -6.16 & 951.6 & -24.53 \\
\hline f9 & Cam & Camas, Holland & 2.565 & 21.0 & 3.36 & 844.3 & -26.02 \\
\hline $\mathrm{f} 10$ & VV-Le & $\begin{array}{l}\text { Lechuguilla heart } \\
\text { VV }\end{array}$ & 2.684 & 27.6 & -0.92 & 938.6 & -11.94 \\
\hline $\mathrm{f} 11$ & HO-Yuc & Yucca seeds VV & 2.493 & 102.2 & 5.29 & 1121.0 & -23.65 \\
\hline $\mathrm{f} 12$ & Vop & Youpon berry TV & 2.564 & 9.0 & 5.17 & 1171.1 & -27.46 \\
\hline Check & & & & 109.7 & 1.42 & 736.5 & -23.81 \\
\hline Check & & & & 108.7 & 1.48 & 730.1 & -23.85 \\
\hline g1 & Green & Greenbrier fruit TV & 2.701 & 15.3 & -3.12 & 1126.3 & -27.50 \\
\hline g2 & Milk & $\begin{array}{l}\text { Milkweed seed } \\
\text { BLM }\end{array}$ & 2.513 & 121.7 & 0.07 & 1144.9 & -28.00 \\
\hline g3 & TV-MP & Mexican plum TV & 2.562 & 15.9 & -0.80 & 1012.6 & -29.07 \\
\hline g4 & TV-BP & Bush pepper TV & 2.515 & 33.6 & 0.29 & 1081.5 & -30.04 \\
\hline \multirow{5}{*}{\multicolumn{4}{|c|}{$\begin{array}{l}\text { Check } \\
\text { Check } \\
\text { Check } \\
\text { Check } \\
\text { Check }\end{array}$}} & 108.7 & 1.03 & 723.0 & -23.80 \\
\hline & & & & 111.2 & 1.25 & 735.4 & -23.82 \\
\hline & & & & 112.1 & 1.45 & 369.1 & -23.80 \\
\hline & & & & 110.6 & 1.35 & 366.0 & -23.82 \\
\hline & & & & 111.1 & 1.41 & 363.5 & -23.81 \\
\hline h1 & CE31 & Cottontail meat & 1.026 & 152.1 & 4.59 & 451.8 & -25.75 \\
\hline h2 & Rab & Rabbit meat Burnet & 1.040 & 148.1 & 6.69 & 462.9 & -19.63 \\
\hline h3 & Snail & Rabdotus meat TV & 1.089 & 74.1 & 6.03 & 407.1 & \begin{tabular}{|l|}
-27.29 \\
\end{tabular} \\
\hline h4 & MO-Buf & Buffalo Missouri & 1.017 & \begin{tabular}{|l|}
137.3 \\
\end{tabular} & 7.33 & 461.0 & \begin{tabular}{|l|}
-16.70 \\
\end{tabular} \\
\hline h5 & Den-Buf & Buffalo Denver & 1.015 & 125.9 & 6.26 & 450.6 & \begin{tabular}{|l|}
-18.73 \\
\end{tabular} \\
\hline \multirow{2}{*}{\multicolumn{4}{|c|}{$\begin{array}{l}\text { Check } \\
\text { Check }\end{array}$}} & 110.6 & 1.33 & 364.8 & -23.86 \\
\hline & & & & 110.1 & 1.29 & 364.2 & -23.90 \\
\hline
\end{tabular}

Boldface indicates questionable amounts leading to questionable values.

$\mathrm{T}=$ Toyah, LA = Late Archaic, EA = Early Archaic, MA = Middle Archaic, BT = backhoe trench, F1 = Feature 1, NA = not a feature, $\mathrm{TV}=$ Travis County, VV = Val Verde County, ED = Edwards County, RL = Real County, WM = Williamson County 
APPENDIX I:

PLANT REMAINS FROM THE VARGA SITE (41ED28) 



\section{PLANT REMAINS FROM THE VARGA SITE (41ED28)}

By:

J. Phil Dering, Ph.D.

Prepared for:

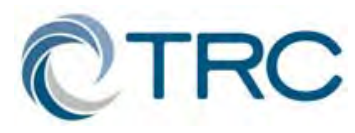

TRC Environmental Corporation 505 East Huntland Drive, Suite 250

Austin, Texas 78752

Prepared by:

J. Phil Dering, Ph.D.

Shumla Archeobotanical Services

P.O. Box 944

Comstock, Texas 78837

January 2004 



\section{I.1 INTRODUCTION}

TRC Environmental Corporation (TRC) submitted 44 flotation samples recovered from 18 features and other general proveniences from the Varga Site (41ED28) in Edwards County, Texas, for botanical analysis. These flotation samples totaled 404.5 liters in volume. An additional 75 charcoal or macrobotanical samples were examined and identified. This report presents a description of the plant materials from four cultural components at the site. The analysis will generate descriptive data that can be compared to other sites in the western Edwards Plateau and Lower Pecos River regions. Wood charcoal, seeds, nut fragments, and fiber bundles from evergreen rosette plants (agave, sotol, or yucca) were noted in the samples.

\section{I.2 Methods}

The analysis follows standard archaeobotanical laboratory procedures. Each flotation sample is passed through a nested set of screens of 4-mm, 2-mm, and 0.450-mm mesh and examined for charred material that is separated for identification. Carbonized wood from the 4-mm and 2-mm screens (smaller pieces are seldom identifiable) is separated in a grab sample and identified. The charred material caught on all of the sieve levels, including the bottom pan, is scanned for floral parts, fruits, and seeds. Screen-collected macrobotanical samples (e.g., radiocarbon samples) are also sorted and identified. Identification of carbonized wood is accomplished by using the snap technique, examining the transverse and radial sections at $8 \mathrm{X}$ to $45 \mathrm{X}$ power with a binocular dissecting microscope, and comparing the material to reference specimens in the Shumla Archaeobotanical Services herbarium.

The anatomy of some woods is so similar that identification to species or even genus is not possible. For this reason, I combine some taxa into wood types. For example, willow (Salix sp.) and cottonwood (Populus sp.), both members of the Salicaceae or willow family, have been lumped together to form an artificial category called a "type." All identifications in the "type" category represent identifications to the taxon level indicated by the name of the type. Although it is likely that most of the wood referred to this group is cottonwood, I am using the more general "wood" type category because it is difficult to distinguish between cottonwood and willow charcoal.

Charred leaves and fiber-vascular bundles of agave, sotol, and yucca also present special identification problems. Both Bohrer (1987:72) and Kwiatkowski (1992:327) have determined that only fibers with trough-shaped or D-shaped cross-sections (transverse view) can be identified as agave. Agave fibers contain styloid (rod-shaped) or raphide (needle-shaped) calcium oxalate crystals. These researchers also note that sotol fiber bundles, leaves, or stems, do not contain calcium oxalate crystals. While I agree that these rules apply in most cases to plants in the Sonoran Desert, they do not apply to the most common agave in the Trans-Pecos, Agave lechuguilla, nor to the species of sotol growing throughout much of Texas, Dasylirion texanum. A single leaf of Agave lechuguilla, a very common agave in the Trans-Pecos, may contain all round fibers, or fibers that are both round and D-shaped in transverse view. In addition, sotol growing in the Trans-Pecos and Edwards Plateau regions usually contains an abundance of styloid and raphide calcium oxalate crystals. Agave, sotol, and yucca can also be identified by the presence of other diagnostic parts, such as leaf fragments, spines, or flower stalks. Unfortunately, these types of remains are not often encountered in archaeological deposits. Because the sample size was quite small, I have elected for the purposes of this study to place all charred fiber-vascular bundles that contain 
styloid or raphide crystals into the general category Agavaceae. These may actually be the remains of agave, sotol, or yucca; however, given the location of the Varga Site, it is most likely that they are the remains of sotol or yucca because Agave lechuguilla is most common along the rims of canyons in southern Edwards and Val Verde counties.

The term "cheno-am" is used to refer to the charred seeds (achenes) of either the genera Chenopodium (goosefoot) or Amaranthus (pigweed). Although it may be possible to distinguish these seeds when they are fresh and uncharred, quite often they swell and distort when exposed to heat. Therefore, I refer them to a seed type, "cheno-am," and it is understood that this category refers to both genera.

\section{I.3 Results}

Identifications and counts are presented in Tables I-1 to I-3. Preservation was very good, and 19 taxa were identified in the samples (Table I-1). Edible plant parts were represented by Agavaceae leaf and caudex (i.e., heart) fragments, prickly pear seed, mesquite seed, cheno-am seed (achenes), and nut fragments, both littleleaf walnut and a thin nutshell, probably pecan. The caudex of an Agavaceae (agave, sotol, yucca) is the compressed central stem to which the leaves are attached. It is the fleshy, edible part of the plant.

Wood types were mesquite, woody legume, hickory family (e.g., pecan), buttonbush, cottonwood/willow, juniper, sycamore, Mexican buckeye, pinyon, agarita, oak, buckthorn, elm, and lotebush. Taxa that are indicative of a typical western Edwards Plateau canyon or riparian flora are cottonwood/willow wood, littleleaf walnut, sycamore, Mexican buckeye, oak, buttonbush, elm, pecan, and cottonwood/willow. Plants indicative of upland vegetation are mesquite, juniper, pinyon, oak, and lotebush. Plant materials that characterize desert food foraging activities in the western Edwards Plateau region are prickly pear seed, Agavaceae (yucca, sotol, or agave) leaf and caudex fragments, cheno-am seeds, littleleaf walnut and possible pecan nut fragments, and mesquite seeds.

Tables I-2 and I-3 present counts and weights of taxa identified in the samples. Table I-2 summarizes remains recovered from the macroplant samples, and Table I-3 lists the contents of flotation samples. The tables are organized by time period, feature, and sample number. In the following discussion, I will first describe the plant remains by feature, and then examine the results by time period.

\section{I.3.1 Toyah Component Features}

The Late Prehistoric period Toyah Phase component is represented by Features 2, 3, 8, 9, $18,21,22,25,30,35,36$, and 38.

Features 2 and $3-A$ single macrobotanical sample from each feature contained oak wood charcoal.

Feature 8-Five macrobotanical samples and three flotation samples contained nine wood charcoal types. Lotebush, a common shrub of the region, was the most abundant of the wood types. Oak, juniper, agarita, condalia, elm, buttonbush, mesquite, and another woody legume (possibly leadtree or an acacia) were the other wood types. Both upland and riverine or canyon species are represented in the sample. A single charred nut fragment of littleleaf walnut was noted in sample 843-5-7-2a. The abundance of wood charcoal and the relatively large number of taxa suggest repeated use of the feature. 
Table I-1. Plant Taxa Identified in the Varga Site Samples

\begin{tabular}{|l|l|l|}
\hline \multicolumn{1}{|c|}{ Taxon } & \multicolumn{1}{c|}{ Common Name } & \multicolumn{1}{c|}{ Part } \\
\hline Agavaceae & Sotol-Yucca-Agave Type & Heart \\
\hline Berberis trifoliata & Agarita & Wood \\
\hline Carya sp. & Hickory Family (e.g., pecan) & Wood \\
\hline Cephalanthus occidentalis & Buttonbush & Wood \\
\hline Chenopodium-Amaranthus & Cheno-am & Seed \\
\hline Condalia sp. & Condalia or Buckthorn & Wood \\
\hline Fabaceae & Woody Legume & Wood \\
\hline Juglans microcarpa & Littleleaf Walnut & Nut \\
\hline Juniperus sp. & Juniper & Wood \\
\hline Opuntia sp. & Prickly Pear & Seed \\
\hline Pinus sp. & Pinyon & Wood \\
\hline Platanus occidentalis & Sycamore & Wood \\
\hline Prosopis glandulosa & Mesquite & Seed, Wood \\
\hline Querus sp. & Oak & Wood \\
\hline Salicaceae & Cottonwood/Willow & Wood \\
\hline Thin Nut Type & Pecan? & Nut \\
\hline Ulmus sp. & Elm & Wood \\
\hline Ungnadia speciosa & Mexican Buckeye & Wood \\
\hline Ziziphus obtusifolia & Lotebush & Wood \\
\hline
\end{tabular}


Table I-2. Varga Site Macrobotanical Sample Counts

\begin{tabular}{|c|c|c|c|c|c|c|}
\hline Feature & Cat. No. & Taxon & Common Name & Part & $\begin{array}{l}\text { Count/ } \\
\text { Volume }\end{array}$ & Wgt. (g) \\
\hline \multicolumn{7}{|l|}{ Modern } \\
\hline N/A & 1123-7-1a & Platanus occidentalis & Sycamore & Wood & 19 & 8.1 \\
\hline \multicolumn{7}{|c|}{ Late Prehistoric (ca. Toyah Phase [300-650 B.P.]) } \\
\hline 2 & $525-5-7-1 b$ & Quercus sp. & Oak & Wood & 1 & 0.1 \\
\hline 3 & 119-5-7-1a & Quercus sp & Oak & Wood & 7 & 0.2 \\
\hline 8 & $843-5-7-1 b$ & Juglans microcarpa & Littleleaf Walnut & Nut & 1 & 0.2 \\
\hline 8 & $843-5-7-2 a$ & Indeterminate & N/A & Wood & 7 & 0.4 \\
\hline 8 & $843-5-7-2 a$ & Quercus sp. & Oak & Wood & 6 & 0.4 \\
\hline 8 & $865-5-4-7-1 b$ & Quercus sp. & Oak & Wood & 1 & 0.1 \\
\hline 8 & 865-5-7-2a & Indeterminate & N/A & Wood & 4 & 0.1 \\
\hline 8 & $865-5-7-2 b$ & No Sample & N/A & - & - & - \\
\hline 8 & $867-5-7-1 a$ & Condalia sp. & Green Condalia & Wood & 3 & 0.2 \\
\hline 8 & 867-5-7-1a & Indeterminate & N/A & Wood & 4 & 0.4 \\
\hline 8 & 867-5-7-1a & Juniperus sp. & Juniper & Wood & 3 & 0.1 \\
\hline 8 & $867-5-7-1 a$ & Prosopis glandulosa & Mesquite & Wood & 5 & 0.4 \\
\hline 8 & $867-5-7-1 a$ & Ulmus sp. & Elm & Wood & 5 & 0.3 \\
\hline 9 & $830-5-7-1 \mathrm{a}$ & Quercus sp & Oak & Wood & 4 & 0.2 \\
\hline 9 & $830-5-4-7-1 b$ & Quercus sp. & Oak & Wood & 21 & 0.2 \\
\hline 21 & 78-5-7-3 & Juniperus sp. & Juniper & Wood & 4 & 0.4 \\
\hline 21 & $78-5-7-3$ & Prosopis glandulosa & Mesquite & Wood & 2 & 0.1 \\
\hline 21 & $78-5-7-3$ & Quercus sp. & Oak & Wood & 7 & 0.3 \\
\hline 21 & $78-5-7-3$ & Ulmus sp. & Elm & Wood & 2 & 0.1 \\
\hline 21 & 79-5-4-7-1a & Juniperus sp. & Juniper & Wood & 2 & 0.1 \\
\hline 21 & 79-5-4-7-1a & Juniperus sp. & Juniper & Wood & 2 & 0.1 \\
\hline 25 & 1021-5-7-1a & Indeterminate & N/A & Wood & 2 & 0.1 \\
\hline 25 & 1021-5-7-1a & Juniperus sp. & Juniper & Wood & 4 & 0.2 \\
\hline 25 & 1021-5-7-1a & Prosopis glandulosa & Mesquite & Wood & 11 & 1.4 \\
\hline 25 & 1025-5-7-1b & Prosopis glandulosa & Mesquite & Wood & 1 & 0.1 \\
\hline 25 & 1025-5-7-1b & Prosopis glandulosa & Mesquite & Wood & 1 & 0.4 \\
\hline 25 & 1055-5-7-1b & Prosopis glandulosa & Mesquite & Wood & 1 & 0.4 \\
\hline 25 & 1055-5-7-1b & Quercus sp. & Oak & Wood & 26 & 1.8 \\
\hline 36 & $158-5-7-1 b$ & Quercus sp. & Oak & Wood & 3 & 0.1 \\
\hline 36 & $160-5-7-1 b$ & Prosopis glandulosa & Mesquite & Wood & 3 & 0.3 \\
\hline 36 & 159-5-7-1b & Fabaceae & Woody Legume & Wood & 2 & 0.4 \\
\hline 38 & 1030-5-7-1b & Salicaceae & Willow-Cottonwood & Wood & 2 & 0.2 \\
\hline 38 & $1030-5-7-2 a$ & Fabaceae & Woody Legume & Wood & $20 \mathrm{ml}$ & 3.9 \\
\hline 30 & 109-7-1a & Indeterminate & N/A & Wood & 5 & 0.2 \\
\hline 30 & 109-7-1a & Juniperus sp. & Juniper & Wood & 1 & 0.1 \\
\hline
\end{tabular}


The Varga Site

Texas Department of Transportation

\begin{tabular}{|c|c|c|c|c|c|c|}
\hline Feature & Cat. No. & Taxon & Common Name & Part & \begin{tabular}{|l|l|} 
Count/ \\
Volume
\end{tabular} & Wgt. (g) \\
\hline NA & 109-7-1a & Prosopis glandulosa & Mesquite & Wood & 4 & 1 \\
\hline NA & $377-7-1 \mathrm{a}$ & Quercus sp & Oak & Wood & 1 & 0.1 \\
\hline NA & 450-7-1a & Prosopis glandulosa & Mesquite & Wood & 1 & 0.1 \\
\hline NA & $481-7-1 a$ & Indeterminate & N/A & Wood & 17 & 3 \\
\hline NA & 490-7-1a & Juniperus sp. & Juniper & Wood & 1 & 0.1 \\
\hline NA & $52-7-1 \mathrm{a}$ & Quercus sp & Oak & Wood & 7 & 1 \\
\hline NA & 550-7-1a & Quercus sp & Oak & Wood & 1 & 0.1 \\
\hline NA & 573-7-1a & Quercus sp. & Oak & Wood & 4 & 0.4 \\
\hline NA & 748-7-1a & Juniperus sp. & Juniper & Wood & 1 & 0.1 \\
\hline NA & 748-7-1a & Quercus sp. & Oak & Wood & 5 & 0.1 \\
\hline NA & $78-5-7-2$ & Indeterminate & N/A & Wood & 16 & 0.6 \\
\hline NA & $78-5-7-2$ & Juniperus sp. & Juniper & Wood & 1 & 0.1 \\
\hline NA & $78-5-7-2$ & Platanus occidentalis & Sycamore & Wood & 7 & 0.2 \\
\hline NA & $78-5-7-2$ & Prosopis glandulosa & Mesquite & Wood & 17 & 0.7 \\
\hline NA & $78-5-7-2$ & Quercus sp. & Oak & Wood & 9 & 0.2 \\
\hline NA & $800-7-1 a$ & Quercus sp. & Oak & Wood & 2 & 0.1 \\
\hline NA & $825-7-1 a$ & Salicaceae & Willow-Cottonwood & Wood & 2 & 0.3 \\
\hline NA & $841-7-1 a$ & Indeterminate & N/A & Wood & 2 & 0.3 \\
\hline NA & 841-7-1a & Prosopis glandulosa & Mesquite & Wood & 4 & 0.5 \\
\hline NA & 841-7-1a & Quercus sp. & Oak & Wood & 3 & 0.4 \\
\hline NA & $848-7-1 a$ & Prosopis glandulosa & Mesquite & Wood & 15 & 1.6 \\
\hline NA & 848-7-1a & Quercus sp. & Oak & Wood & 4 & 0.5 \\
\hline NA & 944-7-1a & Prosopis glandulosa & Mesquite & Wood & 1 & 0.1 \\
\hline \multicolumn{7}{|c|}{ Late Archaic (са. 1700-2300 B.P.) } \\
\hline $1 \mathrm{a}$ & 89-5-7-1b & Prosopis glandulosa & Mesquite & Wood & 5 & 0.4 \\
\hline 1 & NA & $81-7-1 \mathrm{a}$ & Quercus sp. & Oak & Wood & 1 \\
\hline 1 & $98-5-7-1 \mathrm{a}$ & Juniperus sp. & Juniper & Wood & 7 & 0.3 \\
\hline 1 & $98-5-7-1 \mathrm{a}$ & Fabaceae & Woody Legume & Wood & 4 & 0.4 \\
\hline 1 & $98-5-7-1 \mathrm{a}$ & Quercus sp. & Oak & Wood & 8 & 0.5 \\
\hline 1 & $98-5-7-1 \mathrm{a}$ & Condalia sp. & Green Condalia & Wood & 5 & 0.3 \\
\hline 1 & $98-5-7-1 \mathrm{a}$ & Indeterminate & N/A & Wood & 2 & 0.1 \\
\hline 1 & $100-7-1 \mathrm{~b}$ & Prosopis glandulosa & Mesquite & Wood & 14 & 1.7 \\
\hline 1 & $162-7-1 \mathrm{a}$ & Prosopis glandulosa & Mesquite & Wood & $34 \mathrm{ml}$ & 12.4 \\
\hline 1 & 171-5-7-1a & - & - & - & - & - \\
\hline 1 & $171-5-7-1 \mathrm{~b}$ & Juniperus sp. & Juniper & Wood & 5 & 0.2 \\
\hline 1 & $171-7-2 \mathrm{a}$ & Juniperus sp. & Juniper & Wood & 1 & 0.1 \\
\hline 1 & 203-7-1b & Prosopis glandulosa & Mesquite & Wood & 12 & 1.2 \\
\hline 1 & $361-5-7-1 b$ & Juniperus sp. & Juniper & Wood & 2 & 0.1 \\
\hline $1 \mathrm{c}$ & $293-5-7-1 b$ & Juniperus sp. & Juniper & Wood & 4 & 0.2 \\
\hline $1 \mathrm{~b}$ & $362-5-7-1 a$ & Juniperus sp. & Juniper & Wood & 2 & 0.1 \\
\hline
\end{tabular}


Appendix I: Plant Remains from the Varga Site (41ED28)

\begin{tabular}{|c|c|c|c|c|c|c|}
\hline Feature & Cat. No. & Taxon & Common Name & Part & \begin{tabular}{|c|} 
Count/ \\
Volume
\end{tabular} & Wgt. (g) \\
\hline 1 & 407-7-1a & Quercus sp & Oak & Wood & 3 & 0.7 \\
\hline NA & $899-7-1 a$ & Juniperus sp. & Juniper & Wood & 1 & 0.1 \\
\hline \multicolumn{7}{|c|}{ Middle Archaic (ca. 3900-4820 B.P.) } \\
\hline NA & 199-7-1a & Prosopis glandulosa & Mesquite & Wood & 10 & 0.5 \\
\hline NA & 418-7-1b & Indeterminate & N/A & Wood & 1 & 0.1 \\
\hline \multicolumn{7}{|c|}{ Early Archaic (ca. 5200-6300 B.P.) } \\
\hline 23 & 735-5-4-7-1a & Indeterminate & N/A & Wood & 1 & 0.1 \\
\hline 23 & $735-5-7-1 b$ & Indeterminate & N/A & Flecks & - & - \\
\hline 39 & 202-7-1a & Prosopis glandulosa & Mesquite & Wood & 1 & 0.1 \\
\hline 39 & 202-7-2a & Prosopis glandulosa & Mesquite & Wood & 3 & 0.2 \\
\hline 39 & 204-7-1a & Quercus sp. & Oak & Wood & 6 & 0.9 \\
\hline 40 & $128-5-4-7-1 b$ & Quercus sp. & Oak & Wood & 1 & 0.1 \\
\hline NA & 29-7-1a & Quercus sp. & Oak & Wood & 3 & 0.1 \\
\hline NA & $38-7-1 a$ & Prosopis glandulosa & Mesquite & Wood & 1 & 0.1 \\
\hline NA & 64-7-1a & Quercus sp. & Oak & Wood & 1 & 0.1 \\
\hline NA & $75-7-1 \mathrm{a}$ & Indeterminate & N/A & Flecks & - & - \\
\hline NA & 76-7-1a & Indeterminate & N/A & Wood & 1 & 0.1 \\
\hline NA & 154-7-1b & Quercus sp. & Oak & Wood & 5 & 0.1 \\
\hline NA & 216-7-1a & Quercus sp. & Oak & Wood & 2 & 0.2 \\
\hline NA & 216-7-1a & Prosopis glandulosa & Mesquite & Wood & 4 & 0.3 \\
\hline NA & $323-7-1 a$ & Indeterminate & N/A & Wood & 1 & 0.1 \\
\hline NA & $344-7-1 b$ & Juglans microcarpa & Littleleaf Walnut & Nut & 1 & 0.1 \\
\hline NA & $345-7-1 \mathrm{a}$ & Juniperus sp. & Juniper & Wood & 4 & 0.3 \\
\hline NA & $346-7-1 a$ & Juniperus sp. & Juniper & Wood & 7 & 0.3 \\
\hline NA & $347-7-1 \mathrm{a}$ & Juglans microcarpa & Littleleaf Walnut & Nut & 1 & 0.1 \\
\hline NA & $375-7-1 \mathrm{a}$ & Juniperus sp. & Juniper & Wood & 1 & 0.1 \\
\hline NA & 402-7-1a & Juglans microcarpa & Littleleaf Walnut & Nut & 2 & 0.2 \\
\hline NA & $402-7-1 \mathrm{a}$ & Juniperus sp. & Juniper & Wood & 3 & 0.1 \\
\hline NA & 432-7-1a & Juniperus sp. & Juniper & Wood & $10 \mathrm{ml}$ & 2.8 \\
\hline NA & 465-7-1a & Indeterminate & N/A & Wood & 1 & 0.1 \\
\hline NA & 531-7-1b & Juglans microcarpa & Littleleaf Walnut & Nut & 1 & 0.1 \\
\hline NA & 546-7-1a & Juglans microcarpa & Littleleaf Walnut & Nut & 1 & 0.2 \\
\hline NA & $570-7-1 \mathrm{~b}$ & Indeterminate & N/A & Wood & 1 & 0.1 \\
\hline NA & 607-7-1b & Juglans & Walnut & Nut & 2 & 0.1 \\
\hline NA & $607-7-1 \mathrm{~b}$ & Indeterminate & & Wood & 2 & 0.1 \\
\hline
\end{tabular}


The Varga Site

Texas Department of Transportation

Table I-3. Plant Remains from Flotation Samples

\begin{tabular}{|c|c|c|c|c|c|c|}
\hline Feature & Cat. No. & Taxon & Common & Part & $\begin{array}{l}\text { Count/ } \\
\text { Volume }\end{array}$ & $\begin{array}{l}\text { Wgt } \\
. \text { (g) }\end{array}$ \\
\hline \multicolumn{7}{|c|}{ Toyah (ca. 300-650 B.P.) } \\
\hline 8 & \begin{tabular}{|l|}
$865-5-4-1$ \\
\end{tabular} & Ziziphus obtusifolia & Lotebush & Wood & 9 & 0.5 \\
\hline 8 & $843-5-4-1$ & Fabaceae & Woody Legume & Wood & 5 & 0.2 \\
\hline 8 & $843-5-4-1$ & Indeterminate & N/A & Wood & 6 & 0.2 \\
\hline 8 & $843-5-4-1$ & Juniperus sp. & Juniper & Wood & 3 & 0.1 \\
\hline 8 & $843-5-4-1$ & Cephalanthus occidentalis & Buttonbush & Wood & 8 & 0.3 \\
\hline 8 & 843-5-4-1 & Ziziphus obtusifolia & Lotebush & Wood & $10 \mathrm{ml}$ & 2.8 \\
\hline 8 & $867-5-4-1$ & Quercus sp. & Oak & Wood & 10 & 0.3 \\
\hline 8 & $867-5-4-1$ & Berberis trifoliata & Agarita & Wood & 25 & 6.3 \\
\hline 9 & \begin{tabular}{|l|}
$830-5-4-1$ \\
\end{tabular} & Berberis trifoliata & Agarita & Wood & 11 & 0.3 \\
\hline 9 & $830-5-4-1$ & Ziziphus obtusifolia & Lotebush & Wood & 7 & 0.8 \\
\hline 9 & 830-5-4-1 & Salicaceae & Cottonwood/Willow & Wood & 10 & 0.3 \\
\hline 9 & $830-5-4-1$ & Juniperus sp. & Juniper & Wood & 9 & 0.3 \\
\hline 9 & $830-5-4-1$ & Quercus sp. & Oak & Wood & 30 & 0.7 \\
\hline 9 & $830-5-4-1$ & Platanus occidentalis & Sycamore & Wood & 4 & 0.3 \\
\hline 9 & $830-5-4-1$ & Ungnadia speciosa & Mexican Buckeye & Wood & $9 \mathrm{ml}$ & 1.7 \\
\hline 9 & 830-5-4-1 & Fabaceae & Woody Legume & Wood & 9 & 0.2 \\
\hline 9 & $830-5-4-1$ & Pinus sp. & Pinyon & Wood & 1 & 0.1 \\
\hline 9 & \begin{tabular}{|l|}
$830-5-4-1$ \\
\end{tabular} & Indeterminate & N/A & Seed & 1 & - \\
\hline 18 & 533-5-4-1 & Quercus sp. & Oak & Wood & 25 & 0.2 \\
\hline 21 & \begin{tabular}{|l|}
$78-5-4-1$ \\
\end{tabular} & Quercus sp. & Oak & Wood & $8 \mathrm{ml}$ & 1.5 \\
\hline 21 & 78-5-4-1 & Carya sp. & Hickory Family & Wood & 3 & 0.1 \\
\hline 21 & 78-5-4-1 & Juniperus sp. & Juniper & Wood & 9 & 0.2 \\
\hline 21 & 78-5-4-1 & Ziziphus obtusifolia & Lotebush & Wood & 6 & 0.2 \\
\hline 21 & 78-5-4-1 & Indeterminate & N/A & Wood & $4 \mathrm{ml}$ & 0.9 \\
\hline 21 & \begin{tabular}{|l|}
$78-5-4-1$ \\
\end{tabular} & Thin Nut Type & Pecan (cf) & Nut & 3 & 0.1 \\
\hline 21 & \begin{tabular}{|l|}
$79-5-4-1$ \\
\end{tabular} & Quercus sp. & Oak & Wood & $9 \mathrm{ml}$ & 1.5 \\
\hline 21 & 79-5-4-1 & Ulmus sp. & Elm & Wood & $4 \mathrm{ml}$ & 0.3 \\
\hline 21 & \begin{tabular}{|l|}
$79-5-4-1$ \\
\end{tabular} & Prosopis glandulosa & Mesquite & Wood & 14 & 0.2 \\
\hline 21 & 79-5-4-1 & Juniperus sp. & Juniper & Wood & $15 \mathrm{ml}$ & 2.5 \\
\hline 21 & 79-5-4-1 & Indeterminate & N/A & Wood & 20 & 0.5 \\
\hline 21 & 79-5-4-1 & Fabaceae & Woody Legume & Wood & 1 & 0.1 \\
\hline 21 & 79-5-4-1 & Chenopodium-Amaranthus & Cheno-am Type & Seed & 2 & - \\
\hline 21 & $87-5-4-1$ & Agavaceae & Sotol-Yucca-Agave Type & Heart & 13 & 2.6 \\
\hline 21 & $87-5-4-1$ & Juniperus sp. & Juniper & Wood & 21 & 1.2 \\
\hline 21 & $87-5-4-1$ & Indeterminate & N/A & Wood & 7 & 0.7 \\
\hline 21 & $87-5-4-1$ & Ulmus sp. & Elm & Wood & 9 & 0.5 \\
\hline 21 & \begin{tabular}{|l|}
$87-5-4-1$ \\
\end{tabular} & Carya sp. & Hickory Family & Wood & 9 & 0.3 \\
\hline 21 & 87-5-4-1 & Fabaceae & Woody Legume & Wood & 5 & 0.1 \\
\hline
\end{tabular}




\begin{tabular}{|c|c|c|c|c|c|c|}
\hline Feature & Cat. No. & Taxon & Common & Part & $\begin{array}{l}\text { Count/ } \\
\text { Volume }\end{array}$ & $\begin{array}{l}\text { Wgt } \\
. \text { (g) }\end{array}$ \\
\hline 21 & $87-5-4-1$ & Thin Nut Type & Pecan (cf) & Nut & 2 & 0.1 \\
\hline 21 & $87-5-4-1$ & Juglans microcarpa & Littleleaf Walnut & Nut & 1 & 0.1 \\
\hline 21 & $87-5-4-1$ & Ziziphus obtusifolia & Lotebush & Wood & 17 & 0.6 \\
\hline 21 & $88-5-4-1$ & Quercus sp. & Oak & Wood & $10 \mathrm{ml}$ & 1.8 \\
\hline 21 & $88-5-4-1$ & Ulmus sp. & Elm & Wood & 2 & 0.2 \\
\hline 21 & $88-5-4-1$ & Ziziphus obtusifolia & Lotebush & Wood & 2 & 0.1 \\
\hline 21 & $88-5-4-1$ & Juniperus sp. & Juniper & Wood & $13 \mathrm{ml}$ & 1.8 \\
\hline 21 & $88-5-4-1$ & Indeterminate & N/A & Wood & $11 \mathrm{ml}$ & 1.7 \\
\hline 21 & $88-5-4-1$ & Fabaceae & Woody Legume & Wood & 5 & 0.8 \\
\hline 22 & $603-5-4-1$ & Indeterminate & N/A & Wood & 13 & 0.2 \\
\hline 30 & $109-5-4-1$ & Quercus sp. & Oak & Wood & 8 & 0.3 \\
\hline 30 & $109-5-4-1$ & Prosopis glandulosa & Mesquite & Wood & 2 & 1 \\
\hline 30 & $109-5-4-1$ & Indeterminate & N/A & Wood & 21 & 0.2 \\
\hline 30 & $109-5-4-1$ & Prosopis glandulosa & Mesquite & Seed & 1 & - \\
\hline 30 & $109-5-4-1$ & Indeterminate & N/A & Slag & 8 & 0.6 \\
\hline 35 & $119-5-4-1$ & Indeterminate & N/A & Wood & $8 \mathrm{ml}$ & 0.8 \\
\hline 35 & $119-5-4-1$ & Quercus sp. & Oak & Wood & 2 & 0.1 \\
\hline 35 & $119-5-4-1$ & Fabaceae & Woody Legume & Wood & 12 & 0.3 \\
\hline 35 & $119-5-4-1$ & Juniperus sp. & Juniper & Wood & 1 & 0.1 \\
\hline 35 & $119-5-4-1$ & Agavaceae & Sotol-Yucca-Agave Type & Heart & 4 & 0.1 \\
\hline 36 & $262-5-4-1$ & Quercus sp. & Oak & Wood & 5 & 0.1 \\
\hline 36 & $262-5-4-1$ & Juniperus sp. & Juniper & Wood & 2 & 0.1 \\
\hline 25 & $1051-5-4-1$ & Salicaceae & Cottonwood/Willow & Wood & 5 & 0.1 \\
\hline 25 & $1051-5-4-1$ & Juniperus sp. & Juniper & Wood & 1 & 0.1 \\
\hline 25 & $1051-5-4-1$ & Ulmus sp. & Elm & Wood & 1 & 0.1 \\
\hline 25 & $1051-5-4-1$ & Quercus sp. & Oak & Wood & 11 & 0.2 \\
\hline 25 & $1051-5-4-1$ & Prosopis glandulosa & Mesquite & Wood & 15 & 0.4 \\
\hline 25 & $1051-5-4-1$ & Indeterminate & Independent & Wood & 24 & 0.6 \\
\hline 25 & $1051-5-4-1$ & Platanus occidentalis & Sycamore & Wood & 2 & 0.1 \\
\hline 25 & $1051-5-4-1$ & Juglans microcarpa & Littleleaf Walnut & Nut & 3 & 0.1 \\
\hline 38 & $1030-5-4-1$ & Quercus sp. & Oak & Wood & 24 & 1.1 \\
\hline 38 & $1030-5-4-1$ & Cephalanthus occidentalis & Buttonbush & Wood & $5 \mathrm{ml}$ & 1.1 \\
\hline 38 & $1030-5-4-1$ & Salicaceae & Cottonwood/Willow & Wood & 5 & 0.1 \\
\hline 38 & $1030-5-4-1$ & Juniperus sp. & Juniper & Wood & 5 & 0.2 \\
\hline 38 & $1030-5-4-1$ & Indeterminate & N/A & Wood & 8 & 0.6 \\
\hline 38 & $1030-5-4-1$ & Fabaceae & Woody Legume & Wood & 14 & 0.4 \\
\hline 38 & $1030-5-4-1$ & Indeterminate & N/A & $\begin{array}{l}\text { Fragment- } \\
\text { seed }\end{array}$ & 1 & - \\
\hline 38 & $1030-5-4-1$ & Agavaceae & Sotol-Yucca-Agave Type & Leaf & 3 & 0.5 \\
\hline
\end{tabular}


The Varga Site

Texas Department of Transportation

\begin{tabular}{|c|c|c|c|c|c|c|}
\hline Feature & Cat. No. & Taxon & Common & Part & $\begin{array}{l}\text { Count/ } \\
\text { Volume }\end{array}$ & $\begin{array}{l}\text { Wgt } \\
\text {. (g) }\end{array}$ \\
\hline \multicolumn{7}{|c|}{ Late Archaic (ca. 1700-2300 B.P.) } \\
\hline 38 & \begin{tabular}{|l|}
$1030-5-4-1$ \\
\end{tabular} & Opuntia sp. & Prickly Pear & Seed & 2 & - \\
\hline $1 d$ & $11-4-1$ & No Identifiable Plant Remains & N/A & - & - & - \\
\hline 1 & $80-5-4-1$ & Indeterminate & N/A & Wood & 21 & 0.3 \\
\hline 1 & $80-5-4-1$ & Cephalanthus occidentalis & Buttonbush & Wood & 1 & 0.1 \\
\hline 1 & $80-5-4-1$ & Prosopis glandulosa & Mesquite & Wood & 1 & 0.1 \\
\hline 1 & $80-5-4-1$ & Juniperus sp. & Juniper & Wood & 1 & 0.1 \\
\hline 1 & $81-5-4-1$ & Indeterminate & N/A & Wood & 8 & 0.1 \\
\hline $1 \mathrm{a}$ & $89-5-4-1$ & Indeterminate & $\mathrm{N} / \mathrm{A}$ & Wood & 11 & 0.1 \\
\hline 1 & $161-5-4-1$ & Prosopis glandulosa & Mesquite & Seed & 1 & -- \\
\hline 1 & $161-5-4-1$ & Indeterminate & N/A & Wood & 8 & 0.1 \\
\hline 1 & $178-5-4-1$ & Indeterminate & N/A & Wood & $5 \mathrm{ml}$ & 0.4 \\
\hline 1 & $179-5-4-1$ & Opuntia sp. & Prickly Pear & Seed & 3 & -- \\
\hline 1 & $179-5-4-1$ & Quercus sp. & Oak & Wood & 2 & 0.1 \\
\hline 1 & $179-5-4-1$ & Indeterminate & N/A & Wood & 12 & 0.1 \\
\hline 1 & $179-5-4-1$ & Juniperus sp. & Juniper & Wood & 1 & 0.1 \\
\hline 1 & $179-5-4-1$ & Agavaceae & Sotol-Yucca-Agave Type & Leaf & 2 & 0.1 \\
\hline 1 & $187-5-4-1$ & Ziziphus obtusifolia & Lotebush & Wood & 6 & 0.1 \\
\hline 1 & $187-5-4-1$ & Juniperus sp. & Juniper & Wood & 1 & 0.1 \\
\hline 1 & $187-5-4-1$ & Indeterminate & N/A & Wood & 20 & 0.1 \\
\hline 1 & $263-5-4-1$ & Prosopis glandulosa & Mesquite & Wood & 1 & 0.1 \\
\hline 1 & $263-5-4-1$ & Ziziphus obtusifolia & Lotebush & Wood & 1 & 0.1 \\
\hline 1 & $263-5-4-1$ & Indeterminate & N/A & Wood & 14 & 0.1 \\
\hline 1 & 263-5-4-1 & Agavaceae & Sotol-Yucca-Agave Type & Leaf & 1 & 0.1 \\
\hline 1 & $263-5-4-1$ & Juniperus sp. & Juniper & Wood & 2 & 0.1 \\
\hline $1 b$ & $273-5-4-1$ & Opuntia sp. & Prickly Pear & Seed & 1 & -- \\
\hline $1 b$ & 273-5-4-1 & Agavaceae & Sotol-Yucca-Agave Type & Leaf & 6 & -- \\
\hline $1 \mathrm{~b}$ & $273-5-4-1$ & Juniperus sp. & Juniper & Wood & 2 & 0.1 \\
\hline $1 b$ & $273-5-4-1$ & Prosopis glandulosa & Mesquite & Wood & 3 & 0.1 \\
\hline $1 b$ & $274-5-4-1$ & Cephalanthus occidentalis & Buttonbush & Wood & 1 & 0.1 \\
\hline $1 \mathrm{~b}$ & 274-5-4-1 & Indeterminate & N/A & Wood & 12 & 0.1 \\
\hline $1 \mathrm{~b}$ & $274-5-4-1$ & Quercus sp. & Oak & Wood & 1 & 0.1 \\
\hline $1 b$ & $274-5-4-1$ & Juniperus sp. & Juniper & Wood & $14 \mathrm{ml}$ & 1.1 \\
\hline 1 & $352-5-4-1$ & Juniperus sp. & Juniper & Wood & 8 & 0.1 \\
\hline 1 & $352-5-4-1$ & Quercus sp. & Oak & Wood & 2 & 0.1 \\
\hline 1 & $352-5-4-1$ & Indeterminate & N/A & Wood & 19 & 0.1 \\
\hline 15 & $801-5-4-1$ & No Identifiable Plant Remains & - & - & - & - \\
\hline \multicolumn{7}{|c|}{ Middle Archaic (ca. 3900-4820 B.P.) } \\
\hline 11 & $507-5-4-1$ & No Identifiable Plant Remains & - & - & - & - \\
\hline 11 & $515-5-4-1$ & No Identifiable Plant Remains & - & - & - & - \\
\hline 37 & $37-5-4-1$ & No Identifiable Plant Remains & - & - & - & - \\
\hline
\end{tabular}


Appendix I: Plant Remains from the Varga Site (41ED28)

\begin{tabular}{|c|c|c|c|c|c|c|}
\hline Feature & Cat. No. & Taxon & Common & Part & $\begin{array}{l}\text { Count/ } \\
\text { Volume }\end{array}$ & $\begin{array}{l}\text { Wgt } \\
\text {. (g) }\end{array}$ \\
\hline \multicolumn{7}{|c|}{ Early Archaic (ca. 5200-6300 B.P.) } \\
\hline 12 & 644-5-4-1 & No Identifiable Plant Remains & - & - & - & - \\
\hline 26 & $615-5-4-1$ & Opuntia sp. & Prickly Pear & Seed & 3 & - \\
\hline 26 & 615-5-4-1 & Juniperus sp. & Juniper & Wood & 2 & 0.1 \\
\hline 26 & $615-5-4-1$ & Indeterminate & N/A & Wood & 15 & 0.1 \\
\hline 31 & 756-5-4-1 & No Identifiable Plant Remains & - & - & - & - \\
\hline 40 & $128-5-4-1$ & No Identifiable Plant Remains & - & - & - & - \\
\hline
\end{tabular}

Feature 9-Two macrobotanical samples and a single flotation sample contained eight wood types, including the only example of pinyon recovered from the site. No seeds or other edible plant fragments occurred in the samples. Lotebush, cottonwood/willow type, woody legume, agarita, juniper, and Mexican buckeye wood were identified. The fact that six woody taxa were identified in the feature suggests that it was utilized on numerous occasions.

Feature 18 - A single flotation sample from this feature yielded oak wood charcoal. It is possible that this is a single-use feature as the only charcoal from this feature was identified as oak.

Feature 21-Four flotation samples and two macrobotanical samples from this feature contained seven wood types, including hickoryfamily wood (possibly pecan), mesquite, oak, elm, woody legume (leadtree or acacia), and a large quantity of juniper. Littleleaf walnut and pecan nut fragments, as well as sotol-yuccaagave caudex (stem) fragments were also identified in the samples. The most abundant wood in the sample was oak, followed by juniper. Both of these taxa provide excellent fuel for earth ovens and the quantity suggests that the feature was associated with an earth oven. The charred caudex fragments probably represent the part of the food load that was accidentally charred during the baking process. The thin nut fragments, most likely pecan, and the littleleaf walnut fragments are a good indication that nuts of both types were gathered nearby and processed at the site.

Feature 22-A single flotation sample from this feature yielded a small quantity of wood that was too deteriorated to identify.

Feature 25-Two macrobotanical samples and a flotation sample were submitted from this feature. The macrobotanical samples contained mostly oak, some mesquite wood, with a smaller amount of juniper wood. The flotation sample contained cottonwood/willow wood, elm, oak, and sycamore in addition to mesquite and juniper. Littleleaf walnut pericarp fragments were also identified in the sample.

Feature 30-A single macrobotanical sample yielded juniper and indeterminate wood. One flotation sample yielded oak and mesquite wood. In addition to the wood charcoal, a single mesquite seed was noted. The presence of mesquite seed suggests that mesquite beans were processed at the site.

Feature 35-This feature is also represented by a single flotation sample. This context yielded sotol-yucca-agave-type caudex fragments. Juniper, woody legume, and oak wood charcoal were also identified in the sample.

Feature 36-Three macrobotanical samples and a flotation sample were analyzed from this context. The flotation sample contained oak and juniper, and the macrobotanical samples 
contained mesquite, a woody legume, and oak wood. No seeds, fruit, or nut fragments were noted in the sample.

Feature 38-Two macrobotanical samples and a single flotation sample contained prickly pear seed and sotol-yucca-agave leaf. Wood types included cottonwood/willow, buttonbush, oak, juniper, and woody legume. One of the sotolyucca-agave leaf fragments was fairly large, measuring 22 by $11 \mathrm{~mm}$, and was most likely a sotol leaf base. Woody legume wood (acacia or leadtree) was the most common wood from the feature, and most of that material came from sample 1030-5-7-2a. The flotation sample yielded an abundance of buttonbush and oak and smaller amounts of the other wood types.

\section{I.3.2 Late Archaic Component Features}

The Late Archaic Period is represented by Features 1, 1a, 1b, 1c, 1d, and 15. A single flotation sample was analyzed from Feature 15, but it did not contain any identifiable carbonized plant remains. Although Feature 1 is subdivided into five subfeatures, I am going to discuss it as a single feature that was probably the site of several different use episodes and different food processing activities, a common characteristic of foraging sites.

A total of 11 flotation samples and 12 macrobotanical samples were analyzed from the feature. The samples contained sotol-yuccaagave leaf fragments, mesquite seed, and prickly pear seed. Juniper wood was the most abundant of all wood types in the Late Archaic samples, comprising almost 50 percent of the total weight of the charcoal from this context. Other wood types included buttonbush, mesquite, oak, and lotebush.

The wide variety of wood types, including small trees, such as juniper or oak and the shrubs lotebush and buttonbush, suggest multiple use episodes and different activities requiring different fuel types. The denser woods, such as mesquite, oak, and juniper, are ideal for earth oven use, and the smaller wood types are useful for small, quick-burning surface fires.

\section{I.3.3 Middle Archaic Component Features}

Two features, Features 11 and 37, were sampled from Middle Archaic contexts. No identifiable plant remains were recovered from these samples. Mesquite and oak wood charcoal were identified in macrobotanical samples originating from non-feature contexts in the Middle Archaic levels.

\section{I.3.4 Early Archaic Component Features}

Six features were sampled from Early Archaic contexts. Flotation samples were taken from Features 12, 26, 31, and 40. Macrobotanical samples were examined from Features 23, 39, and 40 as well as several non-feature contexts.

Features 12 and 31-Each of these features was sampled by a single flotation sample; however, identifiable plant remains were not recovered from any of these contexts.

Feature 23-Two macrobotanical samples contained a minute amount of charred wood and charcoal flecks that were not identifiable.

Feature 26-The single flotation sample from this feature contained three prickly pear seeds and a small quantity of juniper wood.

Feature 39-Mesquite wood was the only plant material identified from this feature.

Feature 40---No identifiable plant remains.

In addition to the feature samples, 20 nonfeature macrobotanical samples were examined. Six of these samples contained littleleaf walnut fragments. Wood charcoal was sparse in the Early Archaic levels, and only three taxa- 
mesquite, oak, and juniper-were identified in these contexts.

\section{I.4 DISCUSSION: INTERSITE COMPARISON AND ETHNOBOTANICAL SUMMARY}

Recent archeobotanical research at sites located on the western Edwards Plateau has begun to illuminate prehistoric land use in the region. Work conducted in conjunction with the widening of Highway 277 (Cliff et al. 2003) provides comparative data from burned rock midden sites immediately west of the Varga Site (Table I-4).

Most of the differences between the two projects probably result from two factors. First, adequately sampling burned rock middens is very difficult because so many different types of activities are performed at forager sites. Even the center of an earth oven is likely to contain plant parts that are not directly associated with earth oven function because mixing of deposits occurs when the ovens are cleaned and reused (Black et al. 1997; Dering 1999). Second, archeobotanical assemblages reflect what is immediately available in the surrounding landscape on a seasonal basis, and vegetation varies widely over short distances in semiarid regions. Thus, the plant signatures will vary somewhat from site to site depending on the immediate location of the site relative to plant resources, the season of occupation, plant processing activities that occurred, and other factors such as cooking accidents. Obviously, the larger the flotation sample set, the better chance the archaeologist has to encounter cooking accidents and obtain a more accurate impression of plant resource use at the site. The flotation sample effort at the Varga Site was much larger (at 405 liters) than that of the Highway 277 project (which totaled 136 liters). This may explain why a taxon seldom encountered at burned rock midden sites was recovered from the Varga Site.

Table I-4. Edible Plant Part Ubiquity Compared

\begin{tabular}{|l|c|c|}
\hline \multicolumn{1}{|c|}{ Plant Resource } & Highway 277 Project $^{\mathbf{1}}$ & 41ED28 \\
\hline Sotol-Yucca (stem/leaf) & $20.9 \%$ & $13.6 \%$ \\
\hline Prickly Pear (seeds) & $2.3 \%$ & $9.1 \%$ \\
\hline Mesquite (seeds) & - & $4.5 \%$ \\
\hline Walnut (nut) & $53.5 \%$ & $4.5 \%$ \\
\hline Pecan (nut) & - & $4.5 \%$ \\
\hline Cheno-am seeds & - & $2.3 \%$ \\
\hline & $\begin{array}{l}\text { Includes four sites, 41VV1982, 41VV1893, 41VV1895, and 41VV1897, in Val } \\
\text { Verde County, Texas }\end{array}$
\end{tabular}


Although seldom recovered from open sites anywhere on the Edwards Plateau until the late 1990s, the leaf bases of sotol-yucca are the most widely occurring of the plant resources from both projects. The low numbers of open sites from which sotol-yucca have been recovered may be because most of the burned rock middens sampled are located in the eastern half of the Plateau, and these were probably not utilized to process yucca, sotol, or agave. Instead, the earth ovens, and the burned rock middens they form, were used for cooking small bulbs and roots (Dering 2003).

The low walnut numbers from the Vargas Site flotation samples are puzzling given that 6 of the 74 macrobotanical samples contained littleleaf walnut fragments. The presence of thin nut fragments, most likely pecan, is indicative of the location of the Varga Site to the east of the Val Verde County sites. The westernmost distribution of native pecan is the Devils River canyon, and pecan has yet to be identified from upland open sites in any part of that watershed.

\section{I.5 Ethnobotanical Notes}

Because processing usually dictates what plant or part of a plant will survive to be incorporated into the archaeological record, the following notes emphasize plant processing. Plant materials survive in archaeological deposits located in open settings primarily because they have been accidentally carbonized. It follows that food plants, more explicitly certain parts of food plants that are cooked or parched (exposed to hot coals for a brief time), stand the best chance of being preserved at archaeological sites. Although some of the following food preparation descriptions utilize ethnobotanical references from the Southwest, the processes described across the region are relatively consistent and probably apply well to the sites located on the western Edwards Plateau.

\section{I.5.1 Prickly Pear}

Prickly pear (Opuntia sp.) is documented as a major plant resource in southern Texas and the western Edwards Plateau and throughout the Southwest and northern Mexico (Dering 1999; Heubner 1991; Sobolik 1991). Archaeological evidence abounds for the consumption of seeds as well as the large, very fibrous prickly pear pads in the lower Pecos region and Coahuila (Dering 1999; Huebner 1991; Sobolik 1996; Williams-Dean 1978), but not in the Sonoran Desert. Interestingly, most of the groups in the Sonoran Desert region limit the consumption of prickly pear fruit, citing problems with illness if too much is consumed (Castetter and Underhill 1935:32; Curtin 1949:61; Rea 1997:276; Russell 1908:75-76). This contrasts with discussions of lower Pecos River region diet, in which the pear is portrayed as a very large part of the diet (cf. Huebner 1991). The distinction may be because many of the Sonoran Desert groups either rely primarily on agriculture or maritime resources (Felger and Moser 1985), or it may be that the archaeological visibility of prickly pear is much greater than other resources at sites on the Edwards Plateau and in the Trans-Pecos. Not only the fruit but also the pads were consumed throughout the southwest (Williams-Dean 1978; Rea 1997).

Prickly pear was a staple plant resource for inhabitants of the Rio Grande Plains and adjacent regions (de Vaca, translated by Favata and Fernandez 1993:71). Prickly pear fruit (tuna) was gathered in late summer and consumed raw or sun-dried like figs. Campbell and Campbell (1981:32) note that prickly pear may be consumed either ripe or green, and that the latter was pit-baked in ovens. Tuna ripening is a process that spans several weeks, and fully grown, green tunas contain an abundance of seeds and moisture. Therefore, a pit-baking episode would have the potential to generate charred seeds. Experimental ovens have yielded 
green tunas that contain about 50 seeds each and have the consistency of boiled okra and a bland but inoffensive flavor (Daring, field notes). It is therefore conceivable that the seeds recovered from the Varga Site were from fruits that were cooked in an earth oven. Eating tunas, however, involves consuming hundreds of seeds, which raises the possibility that waste seeds from uncooked fruits may have been accidentally incorporated into the midden fill during repeated use of the oven facility.

\section{I.5.2 Mesquite}

Mesquite (Prosopis glandulosa) pods have provided a critical source of carbohydrates for people throughout the regions where this very useful plant grows (Felger 1977). The pod is processed by pounding in a mortar. Experiments have demonstrated that it is virtually impossible to grind mesquite on a metate (Hodgson 2001:185). In the early part of the $20^{\text {th }}$ century, Russell (1908) observed that the beans were pounded with a stone pestle, or with a wooden one if a large quantity was processed. During the pounding process, the seeds are often separated from the pod meal and are immediately discarded. Although the seed is edible if ground into meal, it is very hard and is encased in a woody, inedible endocarp (Felger 1977). Therefore, the pod meal is sifted through a mat, separating the pod meal from the remaining inedible material. The endocarp is usually discarded with the seed inside, which accounts for the presence of the charred seeds in the archaeological assemblage.

\section{I.5.3 Purslane}

Purslane (Portulaca oleracea) is a commonly recovered seed from Hohokam sites. In most areas, it ripens in mid- to late summer. Its use as a quelite is widespread throughout the Southwest, and after flowering and fruiting, the seeds were collected and ground into flour
(Cushing 1920; Palmer 1878; Hodgson 2001). In fact, flowering plants could be collected, stored on mats, and the seeds would mature and be collected from the plant much later.

\section{I.5.4 Sotol/Yucca}

Agave, sotol, and yucca have evergreen leaves arranged in a rosette, much like an artichoke, and thickened central stems that are modified for storing carbohydrates. Due to the fact that distribution of Agave lechuguilla is limited primarily to the Rio Grande embayment, it is most likely that the material from the Varga Site is either sotol or yucca, so I will refer to this material as sotol-yucca in the text. Because these plants store carbohydrates in a vegetative part of the plant instead of the fruit, the carbohydrates are linked to poisonous or indigestible compounds that require exposure to heat for 24 to 48 hours to render them edible (Bell and Castetter 1941; Nobel 1988; Castetter et al. 1938). These compounds discourage grazing animals from availing themselves of the carbohydrates. By the Early Archaic period, however, the populations of the Trans-Pecos region were utilizing earth ovens to prepare the plants in order to break down the poisonous compounds and the long-chain carbohydrates into digestible sugars. Evidence that sotol, lechuguilla, and yucca were processed in these ovens has been recorded in several sites located on the central and western Edwards Plateau and across the Trans-Pecos region (Black et al. 1997; Brown 1991; Dering 1997, 1999).

It is increasingly evident that both yucca and sotol were utilized as important food sources in the Edwards Plateau region. For example, Brown (1991) identified large quantities of San Angelo yucca, a plant with an inedible fruit, from deposits at Baker Cave, and a similar yucca has been identified in abundance at Hinds Cave (Dering 1999). When baked in an earth oven, the central stem of San Angelo and other related 
yuccas is edible. Likewise, sotol central stems are rendered edible by baking in an earth oven (Bell and Castetter 1941). An eyewitness account described sotol processing by a Lipan group living in the west-central reaches of the Edwards Plateau. The eyewitness, F. M. Buckelew, was captured in the vicinity of the Sabinal River:

Another choice food of these Indians, and one in almost constant use [my emphasis], was bread made from the bulb of the sotol plant, which grew in abundance along these western rivers. In preparing this plant for food, large quantities of bulbs were cooked in a kiln. In this kiln they would place wood and rocks in a way that they would be thoroughly heated by the time the wood was burned. The rocks and fire was removed and the rocks replaced. The sotol was placed on these and brush and leaves were placed next to the sotol, and the entire heap covered over with dirt so as to make it air tight. This was allowed to remain for several days and during this time the heated rock would thoroughly cook the bulbs (Dennis and Dennis 1977:97).

This passage describes both the mechanics of earth oven use and the importance of sotol as a plant resource to the Lipan. The sotol was removed from the pit and pounded into thin sheets, sun-dried, and often ground into flour for making flatcakes. When dried, the thin sheets of cooked sotol and agave will keep for several months and is very light and transportable (Dering, field notes).

\section{I.5.5 Cheno-am}

Cheno-am refers to Chenopodium (goosefoot) and Amaranthus (pigweed). The tender leaves and stems of both of these plants provided a source of greens that were either eaten or utilized as packing material for earth ovens (Hrdlicka 1908). The seeds of both Chenopodium and Amaranthus plants also were eaten, and were parched, ground, and prepared in a drink or a gruel (Curtin 1949). Cheno-am seeds occur infrequently at open sites on the Edwards Plateau and have not been noted in rockshelters of the Lower Pecos. It is not clear how important these plants were to prehistoric foragers of the area. Consumption of the greens would probably not leave a detectable archaeological signature. Unfortunately, the most common amaranth in the region today is a European introduction, and alien introductions have also crowded out many native chenopods. This factor also makes assessing the importance of cheno-ams difficult.

\section{I.5.6 Pinyon and Cottonwood/Willow}

Both pinyon and cottonwood/willow have several uses associated with technological applications as well as food. Cottonwood is utilized to fashion mortars for pounding mesquite (Rea 1997:177). Although any mortar or pestle combination probably was utilized, Bean and Saubel (1972:109) describe the use of wooden mortars made from either cottonwood or mesquite stumps. The stump was hollowed out with hot coals and the carbonized interior was scraped clean using chipped stone tools. A wood or stone pestle was employed for pounding the pods. This description is very similar to the description of a mortar presented by Rea (1979:42) regarding the Pima, who used a two-foot cottonwood implement to pound mesquite beans. Although mesquite generates excellent, long lasting coals, cottonwood is also a very good source of coals for parching, because they are not as hot and therefore are easier to use. Both willow and cottonwood are excellent structural materials, and their use as central posts, as roofing material, and as vigas in ceilings is recorded in many areas throughout the southwest (Russell 1908:155). Willow branches were used in basketry (Rea 1997) and in the wattle-and-daub storage containers at 
Schoolhouse Mound in the Tonto Basin (Dering 1995).

Despite the fact that pinyon is widespread across the western areas of the Edwards Plateau, direct botanical evidence for the use of pinyon nuts has yet to be documented for this region. This is probably the result of a lack of excavations in the region, because pinyon nuts are consumed throughout the distribution of this valuable plant resource (see Basehart 1974:185; Reagan 1928:159). Although the nuts have not been recovered, pinyon use has been documented by two chance finds. Two wooden mortars, both made from pinyon logs, have been recovered from sites located in the Lower Pecos (Collins and Hester 1968; Prewitt 1981).

\section{I.5.7 Pecan}

The potential of pecan as a prehistoric resource has been assessed by Hall (2002). Nevertheless, pecan is seldom recovered from archaeological sites on either the Edwards Plateau, the South Texas Plains, or the Coastal Plains of Texas. Thick lenses of pecan were noted in Baker Cave on the Devils River, but pecan has not been reported from open sites in these regions. This is due in part to the dearth of fieldwork that has been conducted in areas where pecan stands are the densest. It also may be that because pecan has a thinner pericarp (shell), it is underrepresented in botanical assemblages from sites excavated in these areas. Pecan use was reported in early historic observations by Cabeza de Vaca (Campbell and Campbell 1981:18), presumably on the Guadalupe River. The reference actually refers to walnut, but pecan is by far the most abundant nut-bearing tree in the region and the Spanish did not have a word for pecan at that time. Continued fieldwork along the coastal plain may provide more data regarding the use of pecan in the region.

\section{I.5.8 Walnut}

Littleleaf walnut (Juglans microcarpa) is a small relative of the black walnut. Walnuts provide a necessary source of oil that is rare in desert environments, because large game is relatively rare and small game is quite lean (cf. Kelly 1995). Littleleaf walnut is commonly recovered from rockshelters in the Lower Pecos region (Dering 1999). Although it is widely distributed across the western Edwards Plateau and the Chihuahuan Desert, many historic records do not distinguish the littleleaf walnut from other walnut species. Standley (1912:459) lists the littleleaf walnut as a useful plant of New Mexico and Sturtevant notes that the "small nuts are sweet and edible” (Hedrick 1919:320).

Although they refer to Juglans major, the Sonoran Desert walnut, several references note that walnut meat was mixed with baked agave. For example, Gifford (1932) provides a very detailed description of the preparation that may be analogous to the activities that occurred along the western Edwards Plateau/Chihuahuan Desert regions. The Southeastern Yavapai pounded the fruits with a river-rolled cobblestone to remove the leathery out hull, then pounded the nut on a metate. The fragments were shaken in a basket to separate the meat from the endocarp. The nutmeat was then placed on a dried agave cake and pounded. This mix was soaked in water and consumed. Castetter and Opler (1936:37) note that ground walnuts are added to baked agave by the Mescalero Apache. In an interesting observation, Gifford (1936) noted that the Northeastern Yavapai consumed walnuts with agave syrup, which raises the possibility that walnuts were processed with sotol (or lechuguilla to the south), two resource types usually thought to be gathered at different seasons. 


\section{I.6 SUMmary AND CONCLUSIONS}

The current analysis provides abundant evidence of plant processing at the Varga Site. A total of 20 plant taxa was identified, seven of which (sotol/yucca, goosefoot/pigweed, mesquite, pecan, littleleaf walnut, and prickly pear) provide direct evidence of food resource utilization in the form of seeds or fruit. The assemblage also includes 14 wood types. Both mesquite wood and seeds were identified at the site.

It is clear that the site was used for processing different types of plant resources during separate visits. We can glean this information by examining the evidence for plant processing, and the potential season in which the plant resource was most likely to be available. Mesquite beans and cheno-am seeds usually ripen in mid summer. Although rainfall plays a critical role and the plants are best after a good rainy season, the best time to process either yucca or sotol is spring, just before the flower stalk develops. Nuts ripen in late summer to mid-fall.

The plant taxa therefore suggest that the site would have been occupied over the years during different times of the year-spring, summer, or fall. The season of occupation would have depended on the distribution and quantity of rainfall in a given year, the seasonal round of the groups, and other social and environmental factors. The nature of the botanical evidence is not unusual for a hunter-gatherer site on the Edwards Plateau and surrounding areas. These types of sites are often palimpsests; that is, they contain the compressed remains of multiple occupations from redundant activities that occurred over a relatively long period of time.

\section{I.7 REFERENCES}

Basehart, H. W.

1974 Mescalero Apache subsistence patterns and sociopolitical organization. Apachean Indians XII, Garland, NY.

Bell, W. H., and E. F. Castetter

1941 The Utilization of Yucca, Sotol, and Beargrass by the Aborigines in the American Southwest. The University of New Mexico Bulletin 372, Biological Series 5(5). The University of New Mexico, Albuquerque.

Black, S. L., L. W. Ellis, D. G. Creel, and G. T. Goode

1997 Hot Rock Cooking on the Greater Edwards Plateau: Four Burned Rock Midden Sites in West Central Texas. Studies in Archaeology 22. Texas Archeological Research Laboratory, The University of Texas at Austin.

Bohrer, V.

1987 The Plant Remains from La Ciudad, A Hohokam Site in Phoenix. In Specialized Studies in the Economy, Environment and Culture of La Ciudad, edited by J. A. E. Kisselburg, G. E. Rice, and B. Shears, pp. 67-202. Office of Cultural Resource Management, Department of Anthropology, Arizona State University, Tempe, Arizona.

Brown, K. M.

1991 Prehistoric Economics at Baker Cave: A Plan for Research. In Papers on Lower Pecos Prehistory, edited by S. A. Turpin, pp. 87-140. Studies in Archaeology 8. Texas Archeological Research Laboratory, The University of Texas at Austin.

Campbell, T. N., and T. J. Campbell

1981 Historic Indian Groups of the Choke Canyon Reservoir and Surrounding Area, Southern Texas. Choke Canyon Series, Volume 1. Center for 
Archaeological Research, The University of Texas at San Antonio.

Castetter, E. F., and M. Opler

1936 Ethnobiological Studies in the American Southwest. The Ethnobiology of the Chiricahua and Mescalero Apache III: A. The Use of Plants for Foods, Beverages and Narcotics. Ethnobiological Studies in the American Southwest, Vol. III. University of New Mexico, Biological Series Vol. 4 (5).

Castetter, E. F., and R. Underhill

1935 The Ethnobiology of the Papago Indians. Ethnobiological Studies in the American Southwest, Vol. II. University of New Mexico Bulletin, Biological Series 4(5).

Castetter, E. F., W. H. Bell, and A. R. Grove

1938 The Early Utilization and the Distribution of Agave in the American Southwest. The University of New Mexico, Bulletin 335, Biological Series 5(4). University of New Mexico Press, Albuquerque.

Cliff, M. B., M. A. Nash, J. P. Dering, and Ruth Marie

2003 Archeological Data Recovery Investigations of Four Burned rock Midden Sites (41VV1892, 41VV1893, 41VV1895, and 41VV1897) Val Verde County, Texas. PBS\&J and Texas Department of Transportation, Archeological Studies Program, Report No. 51, Austin.

Curtin, L. S. M

1949 By the Prophet of the Earth. San Vicente Foundation. Santa Fe, New Mexico.

Cushing, F.

1920 Breadstuff. Indian Notes and Monographs, Vol. 8. Museum of the American Indian, Heye Foundation. New York.
Collins, M. B., and T. R. Hester

1968 A Wooden Mortar and Pestle From Val Verde County, Texas. Bulletin of the Texas Archeological Society 39:1-8.

Dennis, T. S., and T. S. Dennis

1977 Life of F. M. Buckelew. Reprinted. The Garland Library of Narrative of North American Indian Captivities, Vol. 107, edited by W. E. Washburn. 111 Vols. Garland Publishing, Inc., New York. Originally published 1925, Hunter's Printing House, Bandera, Texas.

Dering, $\mathrm{P}$.

1995 Macrobotanical Remains from the Schoolhouse Point Mound. In The Place of the Storehouses: Report on Schoolhouse Point Mound, Pinto Creek Complex, Roosevelt Platform Mound Study, Chapter 12, by O. Lindauer. Draft report, Roosevelt Monograph Series 6, Anthropological Field Studies 35. Office of Cultural Resource Management, Department of Anthropology, Arizona State University, Tempe, Arizona.

1997 Macrobotanical Remains: Appendix D. In Hot Rock Cooking on the Greater Edwards Plateau: Four Burned Rock Midden Sites in West Central Texas, by S. L. Black, Linda W. Ellis, D. G. Creel, and G. T. Goode, pp. 571-600. Studies in Archeology, Vol. 22. Texas Archeological Research Laboratory, The University of Texas at Austin.

1999 Earth-Oven Plant Processing in Archaic Period Economies: An Example from a Semi-Arid Savannah in South-Central North America. American Antiquity 64(4):659-674.

2003 Analysis of Macrobotanical Remains from Three Paluxy Sites, Fort Hood, Texas. In Shifting Sands and Geophytes, Geoarcheological Investigations at Paluxy Sites on Fort 
Hood, Texas, Appendix B, by G. Mehalchik, D. K. Boyd, K. W. Kibler, and C. W. Ringstaff. Archeological Resource Management Series, Research Report No. 48. United States Army, Fort Hood, Texas.

Favata, M. A., and J. B. Fernandez (translators)

1993 The Account: Alvar Nunez Cabeza de Vaca's Relacion. Arte Publico Press. Houston, Texas.

Felger, R. S.

1977 Mesquite in Indian Cultures of Southwestern North America. In Mesquite: It's Biology in Two Desert Ecosystems, edited by B. B. Simpson. Dowden, Hutchinson, and Ross, Inc., Stroudsburg, Pennsylvania, pp. 150176.

Felger, R. and Moser, M.

1985 People of the Desert and the Sea: Ethnobotany of the Seri. University of Arizona Press. Tucson.

Gifford, E. W

1932 The Southeastern Yavapai. University of California Publications in American Archaeology and Ethnology 29:177252.

1936 Northeastern and Western Yavapai. University of California Publications in American Archaeology and Ethnology 34:247-334.

Hall, G.

2000 Pecan Food Potential in Prehistoric North America. Economic Botany 54:103-112.

Hedrick, U. P. (editor)

1919 Sturtevant's Notes on Edible Plants. New York Agricultural Experiment Station. Albany, New York.

Heubner, J.

1991 Cactus for Dinner, Again! An Isotopic Analysis of Late Archaic Diet in the
Lower Pecos Region of Texas. In Papers on Lower Pecos Prehistory, edited by S. Turpin, pp. 175-190. Studies in Archeology, Vol. 8. Texas Archeological Research Laboratory, Austin.

Hodgson, W.

2001 Food Plants of the Sonoran Desert. University of Arizona Press. Tucson.

Hrdlicka, A.

1908 Physiological and Medical Observations Among the Indians of the Southwestern United States and Northern Mexico. Bureau of American Ethnology Bulletin 34: 1-266.

Kelly, R. L.

1995 The Foraging Spectrum. Smithsonian Institution Press, Washington, D.C.

Kwiatkowski, S.

1992 The Rye Creek Flotation and Macrobotanical Analyses. In The Rye Creek Project: Archaeology in the Upper Tonto Basin. Volume 2: Artifact and Specific Analyses, pp. 325-375. Anthropological Papers No. 11. Center for Desert Archaeology, Tucson, Arizona.

Nobel, P. S.

1988 Environmental Biology of Agaves and Cacti. Cambridge University Press, Cambridge.

Palmer, E.

1878 Plants Used by the Indians of the United States. American Naturalist 12: 593607, 646-655.

Prewitt, E. R.

1981 A Wooden Mortar from the Stockton Plateau of Texas. Journal of Field Archaeology 8:111-117. 
Rea, A.

1997 At the Desert's Green Edge. University of Arizona Press. Tucson.

Reagan, A.

1928 Plants Used by the White Mountain Apache. The Wisconsin Archaeologist 8:143-161.

Russell, F.

1908 The Pima Indians. In Twenty-Ssixth Annual Report of the Bureau of American Ethnology, No. 26. [19041905], pp. 17-389. Washington, D.C.

Sobolik, K. D.

1991 Paleonutrition of the Lower Pecos Region of the Chihuahuan Desert. Unpublished Ph.D. dissertation, Department of Anthropology, Texas A\&M University, College Station.
1996 Nutritional Constraints and Mobility Patterns of Hunter-Gatherers in the Northern Chihuahuan Desert. In Case Studies in Environmental Archaeology, edited by E. J. Reitz, L. A. Newsom, and S. J. Scudder, pp. 195-214. Plenum Press. New York.

Standley, P. C.

1912 Some Useful Native Plants of New Mexico. Smithsonian Institution, Annual Report 1911:447-462.

Williams-Dean, G.

1978 Ethnobotany and Cultural Ecology of Prehistoric Man in Southwest Texas. Unpublished Ph.D. dissertation, Department of Biology, Texas A\&M University, College Station. 


\section{APPENDIX J:}

ANALYSIS OF UNKNOWN MATERIAL FROM PHASE I DATA RECOVERY INVESTIGATIONS 



\section{ANALYSIS OF UNKNOWN MATERIAL FROM PHASE I DATA RECOVERY INVESTIGATIONS}

Prepared for:

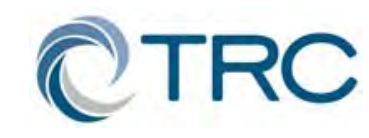

TRC Environmental Corporation

505 East Huntland Drive, Suite 250

Austin, Texas 78752 



\section{J.1 INTRODUCTION}

Under contract to the Texas Department of Transportation (TxDOT), archeologists from the Cultural Resources Department of TRC Environmental Corporation's (TRC's) Austin, Texas, office conducted data recovery excavations at the Varga Site (41ED28) in Edwards County Texas. During the Phase I data recovery fieldwork, conducted from January to February 2002, several anomalous linear decomposed structures were identified in three adjacent units and labeled Feature 6.

Feature 6 consists of three linear segments of very decomposed structures exposed in three units immediately south of BT 2 and west of RR 335. The first segment was encountered at 96 cmbd in the southwestern quadrant of unit N103/E55. Two adjacent 1 by $1 \mathrm{~m}$ units N102/E54 and N102/E55 immediately south of the first were opened and two more linear segments of the same materials were found at 96 and $98 \mathrm{cmbd}$ within stratigraphic unit 3. The three linear sections measured 38, 45, and $50 \mathrm{~cm}$ long and were nearly in a level. The material consisted of small, less than $2 \mathrm{~cm}$ long chunks and powder of white/light gray (10YR 7.5/2 dry) material with a vascular-like structure that was confined to a linear area about $1.5 \mathrm{~cm}$ wide. When the first piece was encountered in N103/E55, further work in the unit was stopped and TxDOT archeologists were notified. The following day, TxDOT geomorphologist/geoarcheologist, Dr. James Abbott, visited the site and viewed the materials, but he was also unable to positively identify the material. All three linear segments were exposed on pedestals and removed in plaster jackets for transport to the TRC's Austin laboratory.

On July 11, 2002, Dr. Nancy Kenmotsu, Environmental Affairs Division of the Texas Department of Transportation (TxDOT) requested that TRC Environmental Corporation (TRC) archeologists prepare this document to provide (1) an introduction to the series of electronic reports and communications that unfolded surrounding the Feature 6 "mineral" from the Phase I data recovery excavations at $41 \mathrm{ED} 28$ as background to the development of the Phase I interim report, and (2) to summarize the timing of events and shifting interpretations of Feature 6. This report is provided in an electronic file and paper format in order to assist TxDOT to comply with a request made by the Comanche Nation to assist them in understanding the nature of Feature 6.

In reviewing the various documents, it is important to realize that archeology is a discovery process, and that participants formulate working hypotheses both during field and laboratory work. These hypotheses are then tested (refined, modified, discarded) as additional information is obtained from excavations and/or other laboratory information becomes available. Initial working hypotheses often use terms, language, or ideas that, if removed from their temporal context, can be misconstrued and misleading in light of later information. For this reason it is important to take into account the chronology of information available and look at the entire body of information surrounding this feature before reaching a conclusion about the nature of the material.

The following summary discusses the nature of the shifting interpretations of the remains comprising Feature 6. A chronological summary of the field and laboratory activities surrounding the exposure, removal, and laboratory analysis of the Feature 6 is presented in Table J-1. Finally it provides an inventory of files pertaining to the identification of the "mineral” present in Feature 6. 


\section{J.2 SUMmARY OF FIELd AsSUMPTIONS}

Even though the material lacked a cortical or exterior surface and therefore lacked all shape indications of bone-especially near the cortical surfaces-Dr. Lintz's initial working assumption was that he had some severely decomposed long bones based on color, general size, and linear appearance. Although Dr. Lintz had not seen materials exactly like these in the past 35 years of archeological field projects, he thought that the differences in preservation were due to degradation of the bones in the soils, probably due to the age of the feature. He suspected based on the depth (ca. $96 \mathrm{cmbd}$ ) and kinds of point styles found around the materials (Late to Middle Archaic) that it probably is about 3,000 to 5,000 years old.

Dr. Lintz further assumed based on the width, lack of curvature and length that the "bone" was from an animal larger than a deer; yet smaller than bison. He compared the alignment of the in situ materials against modern deer limb bones from a nearby animal carcass dump to verify that the Feature 6 pieces were bigger than modern deer tibia, femur, and humerus elements.

\section{J.3 SUMMARY OF LABORATORY ACTIVITIES}

One encased specimen (\#3) was opened and inspected, but was to decomposed to allow for reliable identification based on visual inspection. At TxDOT's request, three physical anthropologists, Dr. John Kappleman of the Anthropology Department at University of Texas; Dr. Gary Ruttenburg of the Mental Health and Mental Retardation Department in Austin; and Dr. David Glassman at Southwest Texas State University in San Marcos (now Texas State University) were contacted and brought in for their professional opinions. These scientists concluded that the materials, if in fact composed of bone, could not be assigned to a species, though one concluded that the size and position of the materials were consistent with articulated human leg bones (see actual letters below). Given the inconclusive results, TxDOT submitted a sample of the material to a bone histologist Dr. Robert R. Paine at Texas Tech University for examination of the cellular structure of the material. The histologist and his academic advisor both concluded that the material was not bone (see letter below). The histology information was also submitted to another physical anthropologist Mr. Greig Parker of TRC in California, who reaffirmed the conclusion that the material was not bone.

\section{J.4 SUMMARY}

Three anomalous linear structures (labeled Feature 6) were identified in alluvial sediments during the first phase of data recovery excavations conducted at the Varga Site. Based on the overall linear alignment of these structures and their association with a prehistoric archeological site, the possibility existed that the materials may consist of osteological material (i.e., bone) associated with a prehistoric human burial. The three linear segments were jacketed in situ in the field and returned to the laboratory for more detailed inspections. Three physical anthropologists were brought in and their professional opinions were obtained. A bone histologist examined of the cellular structure of the material. Once all the scientific opinions were gathered, TxDOT's archeological staff, TRC archeologists, and the Texas Historical Commission (THC) concluded that the material was not human in origin (these materials are now believed to be sediment cavities, probably root casts that were subsequently filled with carbonates). Based on this conclusion, it was determined that the second phase of data recovery excavations at the Varga Site could proceed. 


\section{Table J-1. Chronology of Field and Laboratory Events Surrounding Feature 6 at 41ED28}

\section{Field Activities:}

$1 / 14 / 02$

$1 / 17 / 02$

ca. $1 / 18 / 02$

$1 / 19-27 / 02$

$1 / 28 / 02$

$1 / 28-29 / 02$

$1 / 28-29 / 02$

$1 / 31$ to $2 / 3 / 02$

$2 / 7 / 02$

$2 / 9 / 02$

$2 / 12 / 02$
Phase I data recovery excavations at 41ED28 begin (first session-1/14/02 to 1/18/02) "Bone 1" found in 50-by-50-cm unit (N103/E55) - TxDOT archeologists notified by phone of suspected discovery.

TxDOT geomorphologist J. Abbott visits site and views "Bone 1."

Break occurs between first and second field sessions.

Second field session begins (second session-1/28/02 to 1/30/02

"Bone 1" removed in plaster jacket.

"Bones 2 and 3" found. Feature form and profiles completed.

Weekend for second session (10 days long).

TxDOT archeologists (Ellis, Price, \& Abbott) and TRC’s Principal Investigator (Lintz) visit and discuss site, including Feature 6.

Sample "Bones 2 and 3" (Specimens 2 and 3) removed from the site in plaster jackets. End of third session (8 days long) and end of Phase I data recovery excavations.

\section{Laboratory Studies:}

ca. 1/21-25/02 Plaster jacket of Specimen 1 opened and TxDOT archeologists (Kemotsu, Price, Abbott, Ellis, \& Hickman) inspect specimen in the TRC laboratory, Austin.

$2 / 1 / 02$

$2 / 1 / 02$

Begin process of lining up three physical anthropologists for in-lab analysis.

2/6-8/02 Physical Anthropologists Mr. Ruttenburg, Dr. Glassman and Dr. Kappelman make separate visits to TRC laboratory in Austin to inspect Sample "Bone" 1; other "Bones" not yet extracted from the field. Dr. Glassman and TRC request permission to send sample of bone to Dr. Paine for histological examination.

2/8/02 Physical Anthropologist's Ruttenburg's report submitted.

ca. 2/11-15/02 Dr. Glassman gives sample to Dr. Paine at National Physical Anthropology meetings. Physical Anthropologist Dr. Glassman report submitted.

$3 / 5 / 02$ Dr. Kappelman's report submitted.

Electronic copies of reports from Mr. Ruttenburg, Dr. Glassman, and Dr. Kappelman sent to TxDOT; along with preliminary phone call from Dr. Paine's histology report that material is not bone. Also request for permission to open other plaster jackets and recommendation for need for studies by macrobotanical specialist, Dr. Phil Dering.

$3 / 6 / 02$

$3 / 7 / 02$

$3 / 19 / 02$ TxDOT concurs with need for other studies. Dr. Phil Dering (Macrobotanicalist) solicited for help—no immediate response. Sample from Specimen 2 shipped to Dr. Dering; a piece from Sample 2 also sent to Dr. Paine.

$4 / 16 / 02$

$4 / 19 / 02$

Dr. Dering phones in results; these are passed on to TxDOT.

Dr. Paine's report submitted stating that material is not bone.

Mr. Greig Parker contacted to comment on photographs from Paine.

$4 / 19 / 02$

$4 / 21 / 02$

$4 / 22 / 02$

Mr. Parker's phone response supports Dr. Paine's conclusion, it is not bone.

$4 / 26 / 02$ TxDOT notified of results from Dr. Paine and Mr. Parker.

Post 4/26/02 Conclusion that material is not bone and thus written into interim report as mineral (Lintz et al. 2002) and subsequently referred to as mineral. 

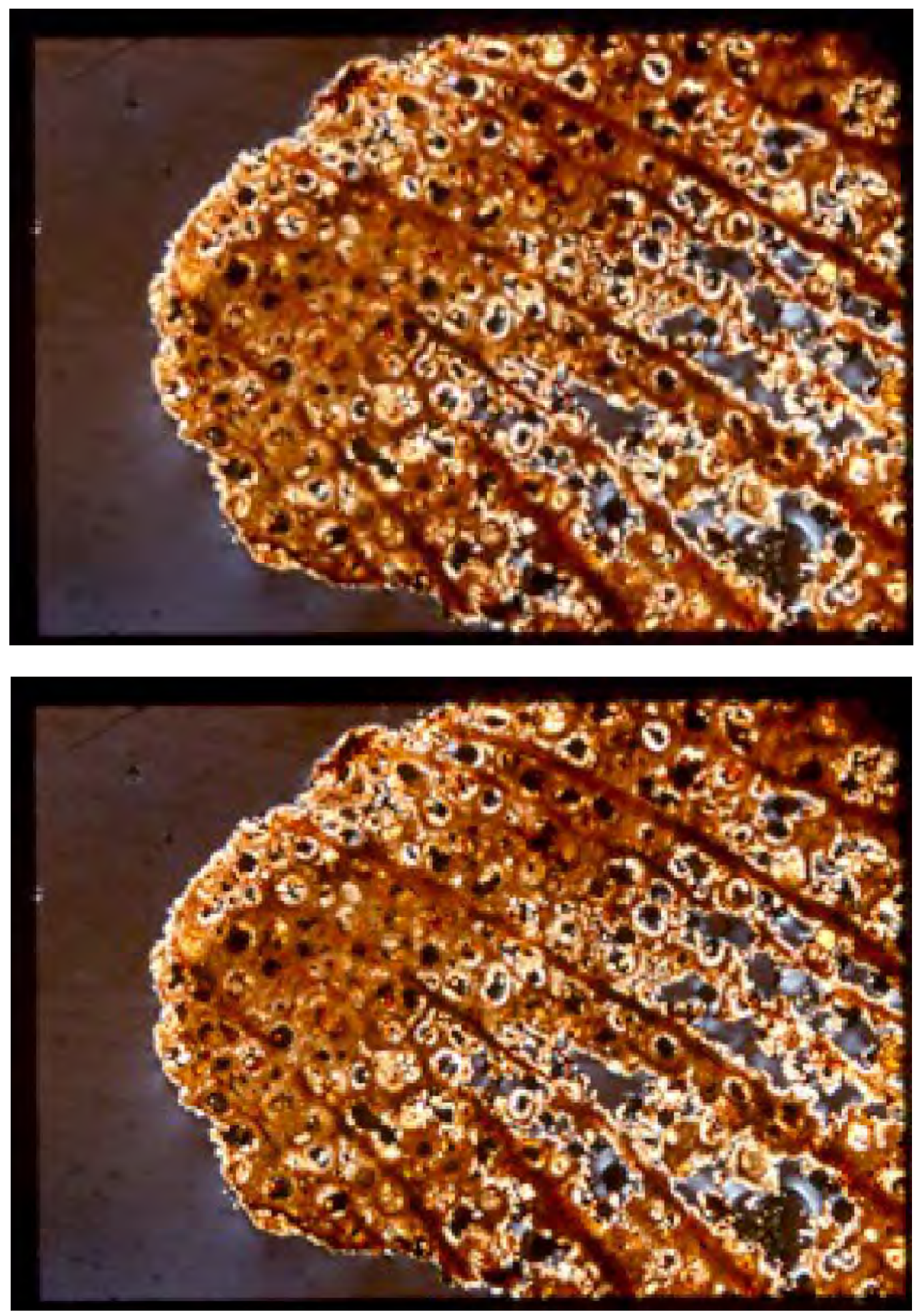

Figure J-1. Thin-Section Photographs of Unknown Material from Feature 6 


\title{
Skeletal Remains Recovered from 41ED28 by TRC for TxDot
}

\author{
Gary W. Rutenberg, PhD \\ Consulting Physical Anthropologist \\ Anthropos
}

February 8, 2002

The recovered bone presented for analysis is extremely friable, fragmentary, and consists of small splinters that at most may be a centimeter long and half that wide.

The overall length of the recovered material is approximately $38.5 \mathrm{~cm}$. One end of the bone appears flattened and slightly wider than the majority of the shaft. The diaphysis is uncurved. The thickness of the cortical bone is approximately $.25 \mathrm{~cm}$. Both the periosteal and endosteal surfaces appear eroded. A fragment, approximately $3 \mathrm{~cm}$ in length and located mid-diaphysis appears to have longitudinal ridges approximating muscle attachments and a portion of a nutrient foramen. Material recovered parallel to the long bone may be from a second bone.

The bone is consistent with the length and width of a human fibula. However, no definitive diagnostic features or articulations are present. Neither are there definitive diagnostic features indicating that the bone is faunal. Indigenous 'large animals' such as horse have a rudimentary fibulae, or completely lack a fibula (vis a vis, deer). The bone is larger than the expected size of a bear.

It is possible that the size, shape, and orientation of the recovered bone and the bone left in situ is consistent with the lower limb orientation of an individual buried in a semi-flexed position. The accompanying diagram suggests the orientation of the skeletal remains if this is, in fact, a human burial.

Unfortunately, because of the condition of the recovered remains and the lack of diagnostic landmarks it is not possible to definitively conclude whether or not the skeletal remains are human.

\section{Recommendations:}

The condition of the bone precludes complete certainty that the remains are human or otherwise. However, the orientation of the bone as shown on the attached page is suggestive of a possible human burial. Further testing immediately north and northwest of the remains may uncover more bone; possibly with diagnostic features. 
Dashed lines indicate possible orientation and location of semi-flexed burial

Recovered bone
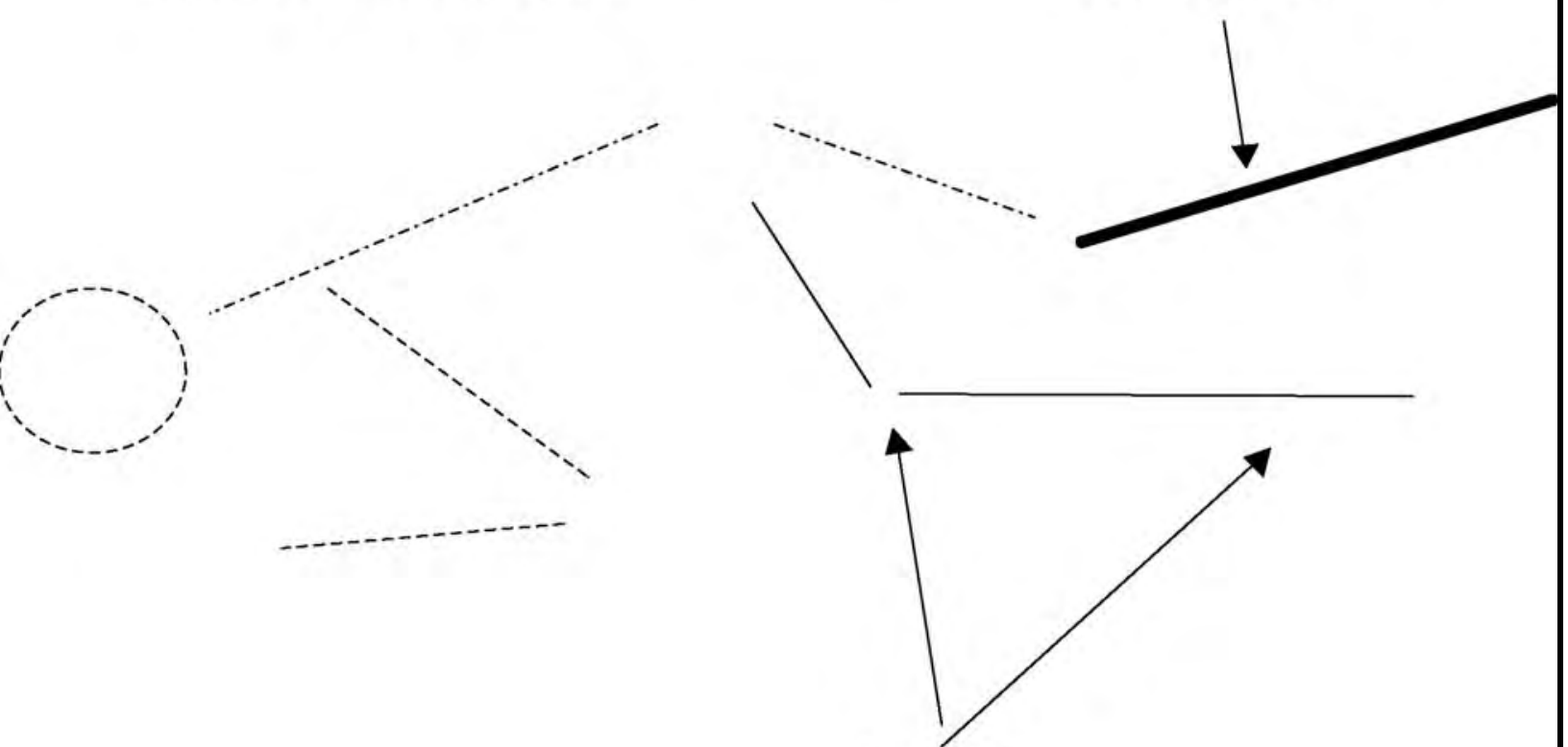

In situ bone

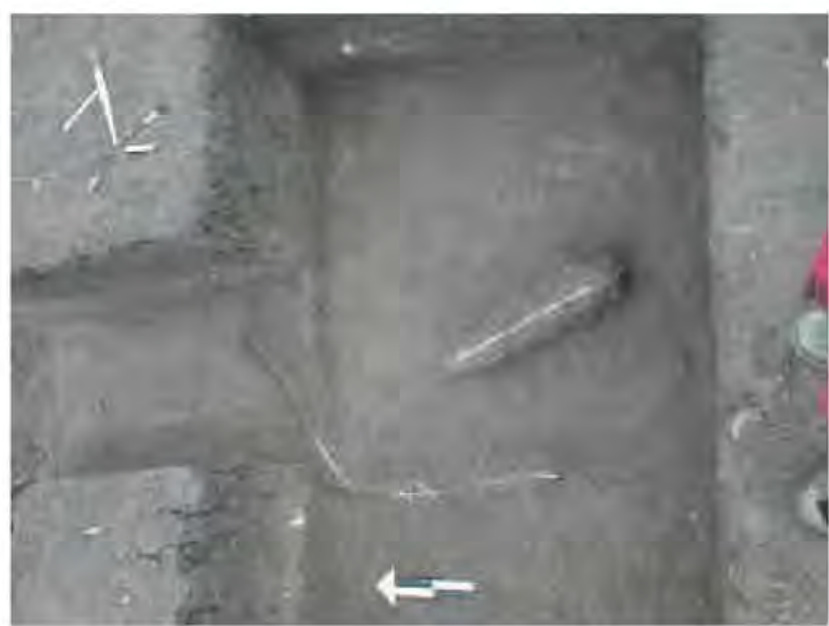




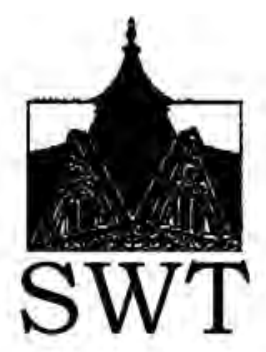

Department of Anthropology

TO: Dr. Chris Lintz, TRC Environmental, 505 Huntland Drive, Suite 250, Austin, Texas 78752

FROM:

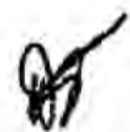

SUBJECT:
Dr. David M. Glassman, Professor of Anthropology, Southwest Texas State University, San Marcos, Texas 78666

DATE:

Analysis of Fragmented Bone

February 22, 2002

This report describes the morphology of a fragmentary bone excavated by TRC Environmental at the site of $41 \mathrm{ED} 28$. The examination took place on Friday, February 8,2002 . Photographs and plan view maps of two other bones were also made available for examination.

The bone was highly fragmentary and had been jacketed in plaster. The bone was incomplete, missing both its proximal and distal segments. The incomplete bone length measured approximately $38.5 \mathrm{~cm}$. Mid-shaft thickness was approximately 1.96 $\mathrm{cm}$ and expanded to $2.87 \mathrm{~cm}$ near one end. The bone cortex was thin and minimal trabecular bone was present. The small amount of trabeculae did not exhibit a ribbon-like form. The bone shaft was straight and approximately circular in cross-section. The bone's external surface exhibited some taphonomic erosion expressed as striations.

The gross morphology of the bone appeared to be non-human, although the estimated length, cross-sectional shape and bone thickness was within the range for an adult human fibula. Without further skeletal material to exam, I would conclude that the bone was of equivocal origin. The photographs and plan view maps did not provide enough additional information to render a more specific conclusion. One photograph did suggest the possibility of the bone having been articulated with another in the excavation unit.

I suggest that a bone fragment be sent to a physical anthropologist trained in the preparation of bone thin sections and analysis of bone histology. !t is possible that plexiform-type bone or osteons may be identified in the thin section revealing a more consistent pattern with either human or non-human animal. 


\section{John Kappelman, Ph.D. Consulting Anthropology and Geology}

Chris Lintz, Ph.D., RPA

TRC Environmental

505 Huntland Dr, 250

Austin, Texas 78752.

Dear Dr. Lintz,

I am writing to provide you with the results of my inspection of the materials from Edwards County that I examined on 13 February 2002 in your offices on Huntland Drive as well as the copies of the photographs that you sent me by electronic mail.

It is my opinion that even though the material is likely to be skeletal, is too far degraded to permit an informed identification as to either the body part or species that it represents.

If any better-preserved material is encountered, please feel free to contact me.

Sincerely,

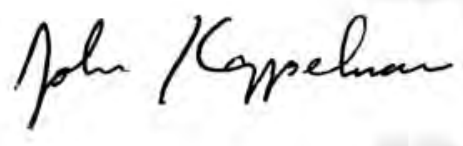

John Kappelman, Ph.D.

1102 Maufrais Street

Austin, TX 78703

1102 Maufrais Street, Austin, Texas 78703

512/469-0675

Email: jkappelman@mail.utexas.edu 
April 19, 2002

Dear Dr. Chris Lintz:

Early March 2002 your office requested aid in the identification of unknown material recovered from an archaeological survey, site 41ED -28. I agreed to subject two fragments of the material for histological assessment. The following summarizes the observations and conclusions concerning this material.

Standard histological preparation was used specific for poorly preserved archaeological material. Each fragment piece was embedded in a hardener and resin to ensure structural integrity as they were cut and ground to @ 75 microns thick. A standard light microscope equipped with 10x eye pieces and 10x \& 20x objectives were used during the examination of the material.

The purpose of the histological examination was to confirm gross observations suggesting the material was bone, Secondly, if it was bone, to attempt to determine its taxa origin. Specifically, we were looking for typical histological features such as secondary osteons, osteocytes, primary lamellar bone, plexiform bone as identifying criteria (see emailed photo of the material).

None of these features were observed from either of the fragments examined. Despite the solid appearance of the material, histologically it was very porous. There are several features that characterized these specimens: round features of a porotic nature, very small circular features with brown/red center, and linear segmented features that cut across the cross-section. None of these features are characteristic of bone, hom or antler. Bone, antler, and horn typical polarize using polarizing filters, in this case neither sample polarized with the use of these filters.

Neither of the fragments exhibited micro-anatomical features specific to bone. Therefore, it is my opinion that this material is something other than bone and it does not represent bone of human origin. It might represent mineral deposit. Several folks from the biology department at Texas Tech have also examined this material and they did not recognize it as plant material.

If you have questions concerning this report please contact me via email at robet.paine $a$ ttu.edu or by phone (806) $742-2401 \times 241$.

Respectively submitted,

Robert R. Paine, Ph.D.

Skeletal Histology

Physical Anthropologist 

APPENDIX K:

GRANULOMETRY RESULTS 



\section{GRANULOMETRY RESULTS}

By:

Mary Jo Schabel

Prepared for:

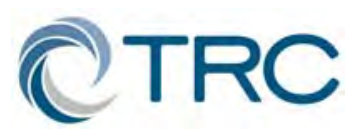

TRC Environmental Corporation 505 East Huntland Drive, Suite 250

Austin, Texas 78752

Prepared by:

Mary Jo Schabel Milwaukee Soils Laboratory, LLC 6917 West Oklahoma Ave.

Milwaukee, WI 53219

December 8, 2003 

Table K-1. Granulometry Results

\begin{tabular}{|c|c|c|c|c|c|c|c|c|c|c|c|c|}
\hline $\begin{array}{l}\text { Lab } \\
\text { No. }\end{array}$ & $\begin{array}{c}\text { TRC } \\
\text { Sample } \\
\text { No. }\end{array}$ & $\begin{array}{c}\text { Provenience, } \\
\text { Depth } \\
\text { (cmbs) }\end{array}$ & $\begin{array}{c}\% \\
\text { Sand }\end{array}$ & $\begin{array}{l}\% \\
\text { Silt }\end{array}$ & $\begin{array}{c}\% \\
\text { Clay }\end{array}$ & $\begin{array}{c}\text { Sieved } \\
\text { Sand \% } \\
(\# 270)\end{array}$ & $\begin{array}{c}\text { Sand Silt } \\
\% \\
\text { Difference }\end{array}$ & $\begin{array}{c}\% \\
1.0 \\
\mathrm{~mm}\end{array}$ & $\begin{array}{c}\% \\
0.5 \\
\mathrm{~mm}\end{array}$ & $\begin{array}{c}\% \\
0.25 \\
\mathrm{~mm}\end{array}$ & $\begin{array}{c}\% \\
0.0625 \\
\text { mm }\end{array}$ & $\begin{array}{c}\% \\
0.05 \\
\mathrm{~mm}\end{array}$ \\
\hline 1 & 1207 & BT M2, 100 & 35 & 28 & 37 & 37.9 & -2.9 & 22.5 & 31.9 & 24.8 & 6.9 & 2.8 \\
\hline 2 & 1208 & BT M1, 90 & 25 & 32 & 43 & 21.6 & 3.4 & 19.3 & 24.0 & 21.5 & 13.2 & 5.4 \\
\hline 3 & 1209 & BT 7, 2BK & 47 & 23 & 30 & 46.4 & 0.6 & 43.2 & 29.4 & 14.7 & 4.4 & 1.7 \\
\hline 4 & 1210 & BT 7, BK2 & 17 & 35 & 48 & 15.8 & 1.2 & 18.7 & 18.3 & 19.3 & 17.0 & 6.8 \\
\hline 5 & 1211 & $\begin{array}{l}\text { BT 7, A, 15- } \\
20\end{array}$ & 9 & 36 & 55 & 7.8 & 1.2 & 9.7 & 25.0 & 22.4 & 16.2 & 9.4 \\
\hline 6 & 1220 & $\begin{array}{l}\text { N103/E50, 23- } \\
24\end{array}$ & 21 & 42 & 37 & 21.8 & -0.8 & 21.0 & 27.1 & 22.2 & 10.4 & 5.0 \\
\hline 7 & 1222 & $\begin{array}{l}\text { N103/E50, 33- } \\
34\end{array}$ & 11 & 43 & 46 & 13.0 & -2.0 & 13.8 & 26.2 & 23.0 & 13.8 & 7.1 \\
\hline 8 & 1224 & $\begin{array}{l}\text { N103/E50, 46- } \\
47\end{array}$ & 18 & 33 & 49 & 15.5 & 2.5 & 18.4 & 28.3 & 20.9 & 12.3 & 5.9 \\
\hline 9 & 1229 & $\begin{array}{l}\text { N103/E50, 71- } \\
72\end{array}$ & 15 & 36 & 49 & 15.6 & -0.6 & 17.6 & 26.6 & 21.4 & 13.0 & 6.1 \\
\hline 10 & 1234 & $\begin{array}{l}\text { N103/E50, 95- } \\
96\end{array}$ & 19 & 33 & 48 & 16.4 & 2.6 & 22.4 & 18.2 & 19.6 & 15.7 & 6.8 \\
\hline dupl & & & 25 & 32 & 43 & 21.1 & 3.9 & 21.3 & 22.9 & 20.8 & 13.1 & 5.3 \\
\hline
\end{tabular}

Table K-2. Chemical Results

\begin{tabular}{|c|l|l|c|c|c|}
\hline $\begin{array}{c}\text { Lab } \\
\text { No. }\end{array}$ & $\begin{array}{c}\text { Sample } \\
\text { No. }\end{array}$ & $\begin{array}{c}\text { Provenience, } \\
\text { Depth } \\
\text { (cmbs) }\end{array}$ & $\begin{array}{c}\text { \% } \\
\text { Organic } \\
\text { Matter }\end{array}$ & $\begin{array}{c}\text { \% } \\
\text { Carbonate }\end{array}$ & $\begin{array}{c}\text { Available } \\
\text { Phosphate } \\
\text { (mg/kg) }\end{array}$ \\
\hline 1 & 1207 & BTM2, 100 & 1.8 & 45.9 & 26.4 \\
\hline 2 & 1208 & BTM1, 90 & 3.7 & 41.0 & 24.3 \\
\hline 3 & 1209 & BT 7, 2BK & 1.9 & 55.2 & 0.2 \\
\hline 4 & 1210 & BT 7, BK2 & 3.0 & 43.2 & 0.2 \\
\hline 5 & 1211 & BT 7, A, 15-20 & 4.7 & 23.7 & 110.1 \\
\hline 6 & 1220 & N103/E50, 23-24 & 6.2 & 33.8 & 133.5 \\
\hline 7 & 1222 & N103/E50, 33-34 & 6.5 & 28.6 & 110.3 \\
\hline 8 & 1224 & N103/E50, 46-47 & 5.0 & 34.8 & 50.0 \\
\hline 9 & 1229 & N103/E50, 71-72 & 3.2 & 39.5 & 1.6 \\
\hline 10 & 1234 & N103/E50, 95-96 & 2.9 & 46.7 & 0.0 \\
\hline 2 dupl & & & 3.8 & 41.5 & 21.8 \\
\hline
\end{tabular}



APPENDIX L:

OPTICALLY STIMULATED LUMINESCENCE OF ALLUVIAL SEDIMENTS FROM EDWARDS COUNTY, TEXAS 
(20) 


\title{
OPTICALLY STIMULATED LUMINESCENCE OF ALLUVIAL SEDIMENTS FROM EDWARDS COUNTY, TEXAS
}

\author{
By: \\ James Feathers, Ph.D.
}

Prepared for:

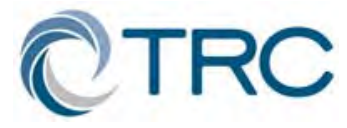

TRC Environmental Corporation 505 East Huntland Drive, Suite 250

Austin, Texas 78752

\author{
Prepared by: \\ James Feathers, Ph.D. \\ Luminescence Dating Laboratory \\ University of Washington \\ Seattle, Washington 98195
}

May 27, 2004 
(20) 


\section{L.1 INTRODUCTION}

Six sediment samples were collected during data recovery excavations at the Varga Site (41ED28) from a second alluvial terrace above Hackberry Creek in Edwards County, Texas. These six samples were submitted for optically stimulated luminescence (OSL) dating by J. Michael Quigg of TRC Environmental Corporation (TRC). Table L-1 lists the samples with associated laboratory numbers, provenience information, and projected ages based on diagnostic projectile points and radiocarbon dates.

The samples were collected by TRC personnel in light-tight plastic polyvinyl chloride (PVC) tubing. These were sealed in the field and opened in the laboratory under safe red light. The end portions of the samples were removed for radioactivity analysis and the remainders were processed for luminescence measurements.

\section{L.2 Dose RATE}

Radioactivity was measured by alpha counting in conjunction with atomic emission for ${ }^{40} \mathrm{~K}$. Samples for alpha counting are crushed in a mill to flour consistency, packed into plexiglass containers with ZnS:Ag screens, and sealed for one month before counting. The pairs technique is used to separate the $\mathrm{U}$ and Th decay series. For atomic emission measurements, samples are dissolved in HF and other acids and analyzed by a Jenway ${ }^{\circledR}$ flame photometer. K concentrations for each sample are determined by bracketing between standards of known concentration. Conversion to ${ }^{40} \mathrm{~K}$ is by natural atomic abundance. Radioactivity was also measured, as a check, by beta counting using a Risø low-level beta GM multicounter system. About $0.5 \mathrm{~g}$ of crushed sample is placed on each of four plastic sample holders. Each is counted for 24 hours. The average is converted to dose rate following Bøtter-Jensen and Mejdahl (1988) and compared with the beta dose rate calculated from the alpha counting and flame photometer results. Cosmic radiation is determined following Prescott and Hutton (1988). Radioactivity concentrations are translated into dose rates following Adamiec and Aitken (1998).

Moisture content was measured from vials collected by TRC from the Varga Site. These ranged from 15 to $26 \%$ moisture by weight, averaging about $21 \%$. This is close to typical moisture content for fine-grained sediments in temperate climates (Brady 1974). Edwards County is semiarid, but Hackberry Creek is characterized by frequent flooding and the sediments are often saturated. For dating purposes, the past moisture content for all samples was estimated to average $21 \pm 5 \%$.

Table L-2 gives the radioactivity data and also compares beta dose rates derived directly from beta counting with those calculated from alpha counting and flame photometry assuming secular equilibrium in the decay series. While the latter are somewhat higher than the values derived from beta counting, they are within error limits, providing no evidence of disequilibrium. In general, the radioactivity seems to decrease with depth, the opposite trend of what would be expected if any downward leaching of radionuclides had occurred over time.

\section{L.3 Equivalent Dose}

\section{L.3.1 Procedures}

The sediments are generally fine-grained with very few sand-sized particles. An attempt was nevertheless made to extract fine sand-sized quartz grains for OSL measurements. Luminescence measurements were then carried out individually on 90 to $125 \mu \mathrm{m}$ quartz grains using single aliquot methods. Because fine grains predominate in these sediments, single aliquot methods were also applied to 4 to $11 \mu \mathrm{m}$ polymineral extracts. Because it is not practical 
Table L-1. Sample Numbers, Proveniences, and Estimated Ages

\begin{tabular}{|c|c|c|c|c|}
\hline Lab ID & Cat. No. & Unit & Depth (cm) & Projected Age (years B.P.) \\
\hline UW1047 & 1237 & N104 E47 & $24-36$ & $200-1200$ \\
\hline UW1048 & 1238 & N125 E75 & $22-26$ & $200-1200$ \\
\hline UW1049 & 1239 & N125 E75 & $28-33$ & $1200-4500$ \\
\hline UW1050 & 1240 & N104 E47 & $36-42$ & $1200-4500$ \\
\hline UW1051 & 1242 & N106 E50 & $80-88$ & $4500-8000$ \\
\hline UW1052 & 1243 & N103 E51 & $94-102$ & $4500-8000$ \\
\hline
\end{tabular}

Table L-2. Radioactivity Data and Beta Dose Rates

\begin{tabular}{|c|c|c|c|c|c|}
\hline & \multirow{2}{*}{ Sample } & (238 $\mathbf{U}$ & \multirow{2}{*}{${ }^{232} \mathbf{T h}$} & & \multicolumn{2}{|c|}{ Beta dose rate (Gy/ka) } \\
\cline { 5 - 7 } & $\mathbf{p p m )}$ & $\mathbf{K}(\%)$ & $\boldsymbol{\beta}$-counting & $\boldsymbol{\alpha}$-counting/flame photo. \\
\hline UW1047 & $2.21 \pm 0.21$ & $12.68 \pm 1.50$ & $1.21 \pm 0.02$ & $1.586 \pm 0.107$ & $1.642 \pm 0.184$ \\
\hline UW1048 & $2.70 \pm 0.22$ & $11.77 \pm 1.46$ & $1.08 \pm 0.03$ & $1.475 \pm 0.098$ & $1.580 \pm 0.057$ \\
\hline UW1049 & $1.47 \pm 0.20$ & $17.44 \pm 1.67$ & $1.36 \pm 0.05$ & $1.655 \pm 0.133$ & $1.781 \pm 0.067$ \\
\hline UW1050 & $3.14 \pm 0.23$ & $9.29 \pm 1.29$ & $1.30 \pm 0.03$ & $1.629 \pm 0.126$ & $1.758 \pm 0.054$ \\
\hline UW1051 & $1.95 \pm 0.17$ & $7.90 \pm 1.14$ & $0.66 \pm 0.02$ & $0.951 \pm 0.092$ & $1.034 \pm 0.045$ \\
\hline UW1052 & $1.87 \pm 0.19$ & $11.98 \pm 1.43$ & $0.90 \pm 0.03$ & $1.200 \pm 0.119$ & $1.325 \pm 0.055$ \\
\hline
\end{tabular}

to measure individual fine grains, these analyses used multigrain aliquots, each containing thousands of grains.

The quartz grains were extracted by sieving, treatment with $\mathrm{HCl}$ and $\mathrm{H}_{2} \mathrm{O}_{2}$, a 40-minute $\mathrm{HF}$ etch, and density separation using a 2.67 specific gravity solution of sodium polytungstate. Fine grains were isolated, after treatment with $\mathrm{HCl}$ and $\mathrm{H}_{2} \mathrm{O}_{2}$, by settling for 2 and 20 minutes in $6 \mathrm{~cm}$ of acetone.

Equivalent dose was determined for both extracts using the single aliquot regenerative dose (SAR) protocol (Murray and Wintle 2000). The SAR method measures the natural signal and the signal from a series of regeneration doses on a single aliquot. The method uses a small test dose to monitor and correct for sensitivity changes brought about by preheating, irradiation, or light stimulation. SAR consists of the following steps: (1) preheat, (2) measure natural signal (OSL or infrared-stimulated luminescence [IRSL]), $\mathrm{L}_{\mathrm{N}}$, (3) test dose, (4) cut heat, (5) measure test dose signal $\left(T_{N}\right)$, (6) regenerate dose, (7) preheat, (8) measure signal from regeneration $\left(\mathrm{L}_{1}\right)$, (9) test dose, (10) cut heat, (11) measure test dose signal $\left(T_{1}\right)$, and (12) repeat Steps 6 through 11 for various regeneration doses. A growth curve is constructed from the $\mathrm{L}_{\mathrm{i}} / \mathrm{T}_{\mathrm{i}}$ ratios and the 
equivalent dose is found by interpolation of $\mathrm{L}_{\mathrm{N}} / \mathrm{T}_{\mathrm{N}}$. A zero regeneration dose and a repeated regeneration dose are employed to ensure that the procedure is working properly.

All measurements were made on a Risø TL-DA15 automated reader. Luminescence on the quartz grains was stimulated for $1 \mathrm{~s}$ at $125^{\circ}$ Celcius by the $532 \mathrm{~nm}$ laser fitted to the single-grain attachment of the Risø reader. Emitted light was collected through $7 \mathrm{~mm}$ of Hoya U340 ultraviolet filters. Analysis used the first $0.06 \mathrm{~s}$ of the decay curve with the final 0.7$0.9 \mathrm{~s}$ subtracted as background. On two regeneration cycles, a long infrared exposure proceeded the green light exposure. This check for the presence of feldspars, whose luminescence signals are sensitive to infrared. No feldspars were detected in any samples. A $240^{\circ} \mathrm{C}$, 10 -second preheat was used for both these and the fine grain analysis.

Stimulation of the fine grains occurred in three steps-first, $100 \mathrm{~s}$ at $125^{\circ}$ Celcius of infrared (880 nm diodes), second $300 \mathrm{~s}$ at $200^{\circ}$ Celcius of infrared, and, third, 100 s at $125^{\circ}$ Celcius of blue light (470 nm diodes). Detection filters were the same as for quartz. The first and third stimulations are used to construct IRSL and OSL growth curves so that two estimations of equivalent dose are available. Only feldspars are sensitive to IRSL, but they are also sensitive to blue light. The second stimulation, a hightemperature IRSL wash, is inserted to remove the blue-sensitive feldspar signal (Jain and Singhvi 2001) so that the subsequent blue stimulation mainly produces a luminescence signal from quartz. This should minimize anomalous fading.

\section{L.3.2 Results}

Single-grain data were limited because the samples contained so few coarse grains. The number of measured grains ranged from 976 for UW1049 to 99 for UW1051 and UW1052. The number of datable grains, however, is smaller still because many grains fail to produce a measurable signal or in some way violate the assumptions of the SAR method. In addition, several grains in these samples yielded equivalent dose values not significantly different from zero. The frequency of these modern-aged grains decreased with depth, so they may represent recently exposed grains that have worked their way down the deposit. Whatever their origin, all grains with equivalent doses within two standard deviations of zero were eliminated from analysis. A single, low outlier was also eliminated from UW1051. Table L-3 summarizes the single-grain data.

Table L-3. Summary of the Single-Grain Data

\begin{tabular}{|c|c|c|c|c|}
\hline Sample & $\begin{array}{c}\text { No. of Grains } \\
\text { Measured }\end{array}$ & $\begin{array}{c}\text { No. Rejected as } \\
\text { Unmeasurable }\end{array}$ & $\begin{array}{c}\text { No. of Zero- } \\
\text { Aged Grains }\end{array}$ & $\begin{array}{c}\text { No. of Datable } \\
\text { Grains }\end{array}$ \\
\hline UW1047 & 195 & 103 & 17 & 75 \\
\hline UW1048 & 199 & 151 & 36 & 12 \\
\hline UW1049 & 976 & 708 & 30 & 238 \\
\hline UW1050 & 198 & 165 & 3 & 30 \\
\hline UW1051 & 99 & 91 & 1 & 7 \\
\hline UW1052 & 99 & 74 & 1 & 24 \\
\hline
\end{tabular}


The distribution of equivalent dose values among single grains is not easy to interpret. The error for an individual grain is determined by a combination of counting statistics and regression fit to the growth curve. Variation in precision due to brightness of the signal (brighter grains produce better counting statistics) can cause a broad distribution in equivalent dose values even for single-aged grains. Further dispersion (called over-dispersion), not accounted for by differential precision, is also common and is attributed to heterogeneity in microdosimetry and mixture of grains of different ages (or mixture of grains that have been differentially bleached). The effect of microdosimetry variation is not easily quantified, but overdispersion of 20 to $25 \%$ is not uncommon for samples thought to be unmixed and well bleached.

These samples exhibit very high overdispersion, although less so for the two deepest samples. The data are presented in Figures L1 to L-6 as radial graphs, which are more appropriate than histograms for data with high differential precision. The $\mathrm{x}$-axis represents relative precision, with points toward the right having the highest precision. The y-axis represents equivalent dose standardized around some reference point. All data points are plotted according to the number of standard deviations that each individual equivalent dose value is away from the reference point. The scale on the right side is drawn so that a line drawn from the origin through any point intersects the scale at the equivalent dose value. The straight lines represent reference points and the shaded areas encompass all points whose individual equivalent dose values are within two standard deviations of the reference point. Overdispersion is represented by points outside the shaded areas.

Two reference points are graphed for each sample. The larger value (horizontal line) represents equivalent dose determined by what is called the "central age" model. This model presumes that the grains are the same age and that any over-dispersion is caused by variation in microdosimetry or other luminescence characteristics. The central age model may not be appropriate for mixed samples. Fluvial sediments in particular often are a mixture of different-aged or differentially bleached grains. Distributions are typically positively skewed with a large number of well bleached grains (which yield the youngest ages and are most likely to represent the age of the deposit) and a long tail of partially bleached grains (yielding older ages). A “minimum-age” model has been recommended to statistically estimate the smallest equivalent dose value (the second reference line, drawn obliquely), which should correspond to the youngest age. Statistics for both models are described by Galbraith et al. (1999). Given the wide dispersion of these samples and their fluvial origin, the minimum age model is most likely to yield the age of the deposit. This could be confused, however, by post-depositional mixing, as evident from the modern age grains. Table L-4 gives the equivalent dose values for both central and minimum age models and over-dispersion values.

\section{Table L-4. Equivalent Dose Values for Central Age and Minimum Age Models and Over-Dispersion Values}

\begin{tabular}{|c|c|c|c|}
\hline \multirow[b]{2}{*}{ Sample } & \multicolumn{2}{|c|}{ Equivalent Dose (Gy) } & \multirow{2}{*}{$\begin{array}{c}\text { Over- } \\
\text { Dispersion } \\
(\%)\end{array}$} \\
\hline & $\begin{array}{c}\text { Central } \\
\text { Age }\end{array}$ & $\begin{array}{c}\text { Minimum } \\
\text { Age }\end{array}$ & \\
\hline UW1047 & $14.8 \pm 1.41$ & 2.80 & $79 \pm 7.0$ \\
\hline UW1048 & $4.39 \pm 1.60$ & $2.09 \pm 0.68$ & $123 \pm 27$ \\
\hline UW1049 & $8.34 \pm 0.48$ & $2.10 \pm 0.18$ & $84 \pm 4.2$ \\
\hline UW10 & $8.52 \pm 0.81$ & $4.93 \pm 0.87$ & $46 \pm 7.6$ \\
\hline UW1051 & $21.4 \pm 2.98$ & $15.4 \pm 3.84$ & $26 \pm 13$ \\
\hline UW1052 & $21.7 \pm 1.64$ & $13.1 \pm 1.55$ & $29 \pm 6.6$ \\
\hline
\end{tabular}


The central-age model was used to estimate the equivalent dose for the fine grain analyses. Eight aliquots were measured for each sample and over-dispersion was less than 0.2 percent. This is expected because of averaging among the 1000s of grains on each disk. Table L- 5 gives the equivalent dose from the IRSL and OSL analyses. An IRSL signal was only measurable on three samples. The lower IRSL equivalent dose is due to anomalous fading of feldspars.

\section{L.4 AgeS}

Table L-6 computes the ages determined using different equivalent dose values. On four samples, the minimum age determination from the quartz single grains and the central age determination from the fine grains are in statistical agreement. The weighted average of these two values is given in the final column. The fact that the central age of the fine grains agrees with the minimum age of the coarse grains suggests that differential bleaching only affects the coarse grains. This is reasonable given that in a fluvial environment coarse grains will be transported along the bottom of the stream and therefore will be less likely to be fully exposed to daylight than fine grains, which are carried higher in the water. If the minimum age represents the fully bleached grains, then this is evidence that the fine grains as a whole are well bleached. The lower minimum age for UW1049 coarse grains is somewhat anomalous given that the fine-grain age agrees with that for UW1050, which was sampled from the same stratigraphic level. Post-depositional mixing has undoubtedly played some role in these samples, and this is perhaps more manifest in this sample than in the others. The high minimum age for UW1051 coarse grains is also anomalous, but this could be due to the small sample size $(n=7)$. Grains with lower equivalent dose values were simply not sampled. For both these anomalous samples, the fine grain central age value was taken as the best estimate, while the weighted average was taken as the best estimate for the other samples. These ages are consistent stratigraphically and agree with the projected ages based on diagnostic projectile points and radiocarbon ages.

Table L-5. Equivalent Dose from the IRSL and OSL Analyses

\begin{tabular}{|c|c|c|}
\hline \multirow{2}{*}{ Sample } & \multicolumn{2}{|c|}{ Equivalent Dose (Gy) } \\
\cline { 2 - 3 } & IRSL & OSL \\
\hline UW1047 & & $3.95 \pm 0.56$ \\
\hline UW1048 & & $4.30 \pm 0.29$ \\
\hline UW1049 & $4.55 \pm 1.52$ & $9.36 \pm 0.69$ \\
\hline UW1050 & & $9.34 \pm 0.82$ \\
\hline UW1051 & $10.6 \pm 2.64$ & $17.5 \pm 1.16$ \\
\hline UW1052 & $10.9 \pm 2.21$ & $16.5 \pm 1.15$ \\
\hline
\end{tabular}


Table L-6. Ages Determined Using Different Equivalent Dose Values

\begin{tabular}{|c|c|c|c|c|}
\hline \multirow[b]{3}{*}{ Sample } & \multicolumn{4}{|c|}{ Ages (in 1,000 years before 2004) } \\
\hline & \multicolumn{2}{|c|}{ Quartz Single Grains } & \multirow{2}{*}{$\begin{array}{l}\text { Fine Grains } \\
\text { Central Age }\end{array}$} & \multirow[b]{2}{*}{ Weighted Average } \\
\hline & Central Age & Minimum Age & & \\
\hline UW1047 & $6.32 \pm 0.675$ & $1.20 \pm 0.197$ & $1.03 \pm 0.210$ & $1.12 \pm 0.144$ \\
\hline UW1048 & $1.95 \pm 0.718$ & $0.927 \pm 0.305$ & $1.13 \pm 0.186$ & $1.07 \pm 0.159$ \\
\hline UW1049 & $3.23 \pm 0.243$ & $0.812 \pm 0.080$ & $2.21 \pm 0.392$ & \\
\hline UW1050 & $3.57 \pm 0.379$ & $2.07 \pm 0.377$ & $2.40 \pm 0.399$ & $2.22 \pm 0.274$ \\
\hline UW1051 & $13.9 \pm 2.07$ & $10.0 \pm 2.55$ & $6.67 \pm 1.11$ & \\
\hline UW1052 & $11.2 \pm 0.722$ & $6.74 \pm 0.871$ & $5.00 \pm 0.864$ & $5.86 \pm 0.613$ \\
\hline
\end{tabular}

\section{L.5 REFERENCES}

Adamiec, G., and M. J. Aitken

1998 Dose Rate Conversion Factors: Update. Ancient TL 16:37-50.

Bøtter-Jensen, L, and V. Mejdahl

1988 Assessment of Beta Dose Rate Using a GM Multi-Counter System. Nuclear Tracks and Radiation Measurements 14:187-191.

Brady, N. C.

1974 The Nature and Properties of Soils. Macmillan, New York.

Galbraith, R. F., R. G. Roberts, G. M. Laslett, H. Yoshida, and J. M. Olley

1999 Optical Dating of Single and Multiple Grains of Quartz from Jinmium Rock Shelter, Northern Australia, Part I:
Experimental Design and Statistical Models. Archaeometry 41:365-395.

Jain, M., and A. K. Singhvi

2001 Limits to Depletion of Blue-Green Light Stimulated Luminescence in Feldspars: Implications for Quartz Dating. Radiation Measurements 33:883-892.

Murray, A. S., and A. G. Wintle

2000 Luminescence Dating of Quartz Using an Improved Single-Aliquot Regenerative-Dose Protocol. Radiation Measurements 32:57-73.

Prescott, J. R., and J. T. Hutton

1988 Cosmic Ray and Gamma Ray Dose Dosimetry for TL and ESR. Nuclear Tracks and Radiation Measurements 14:223-235. 


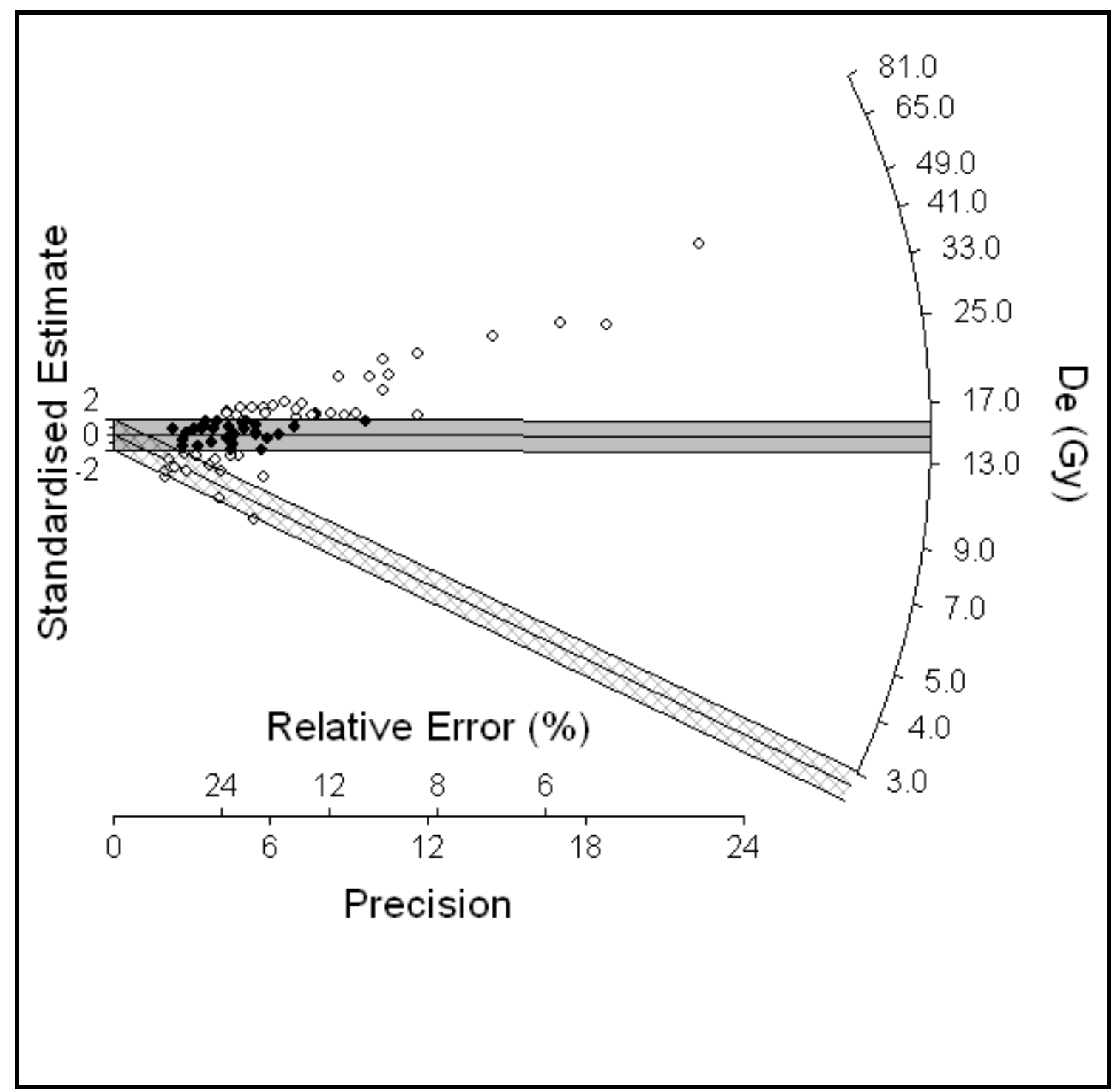

Figure L-1. Equivalent Dose (De) Distribution for UW1047 Quartz Grains 


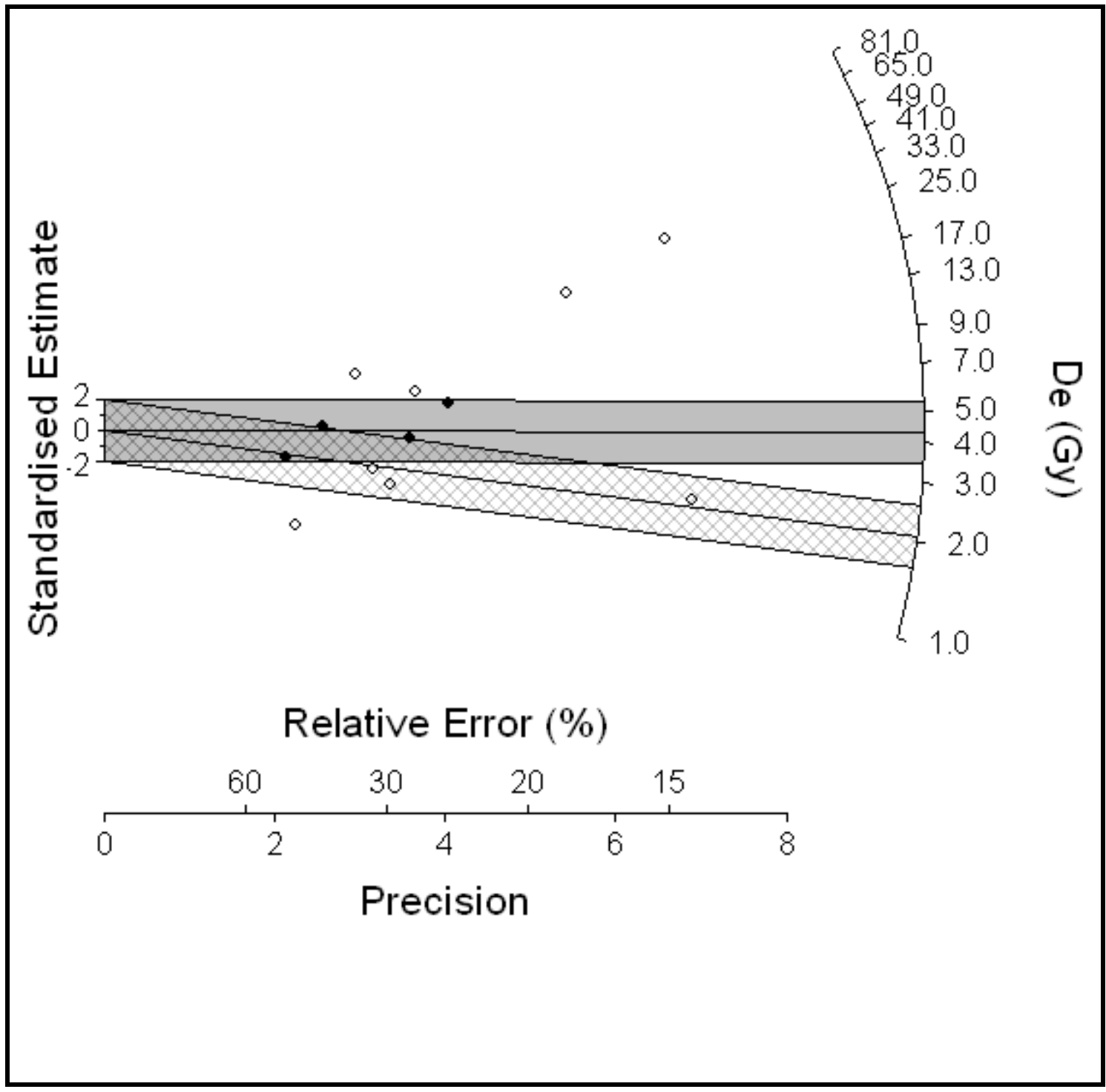

Figure L-2. Equivalent Dose (De) Distribution for UW1048 Quartz Grains 


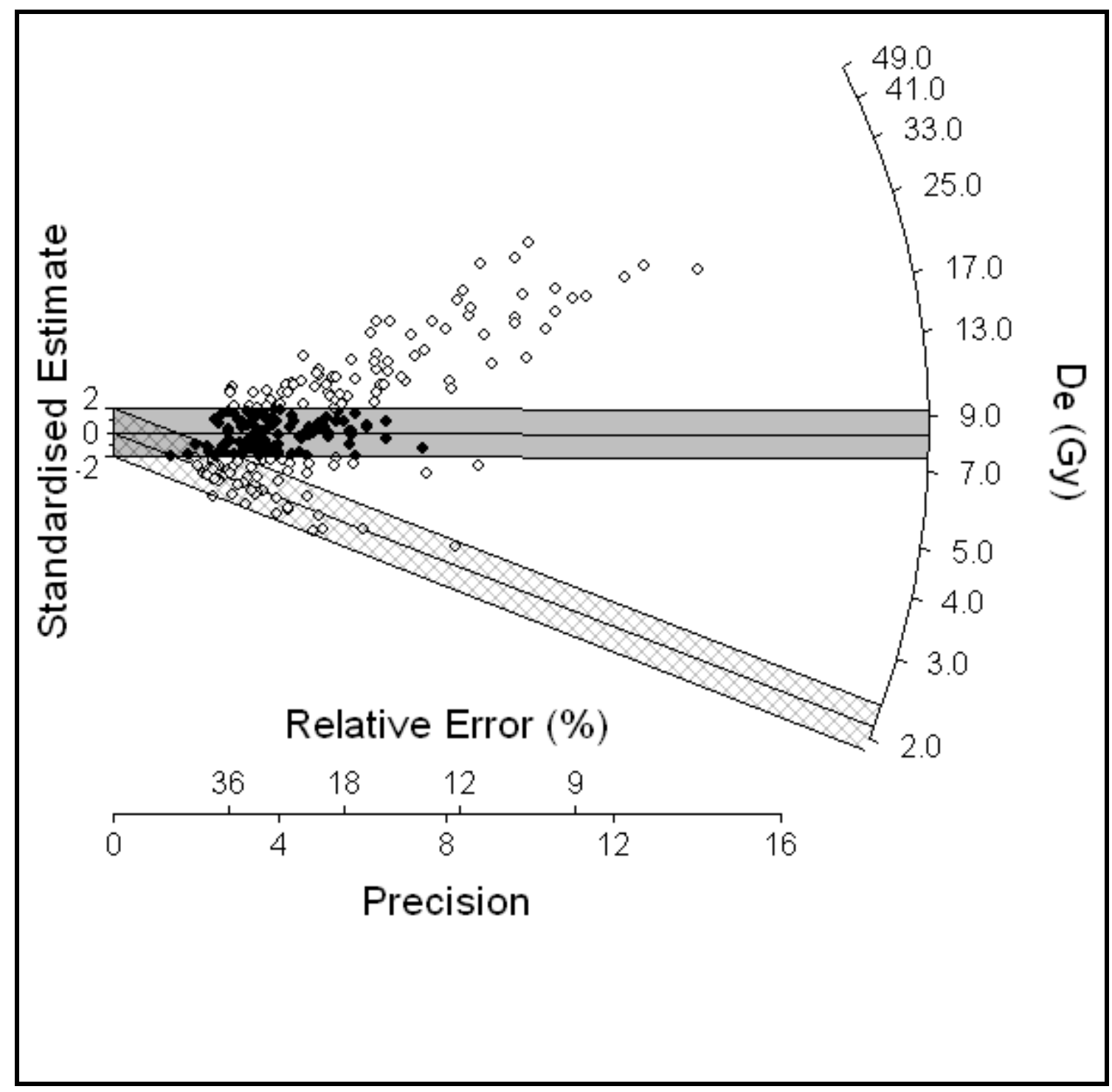

Figure L-3. Equivalent Dose (De) Distribution for UW1049 Quartz Grains 


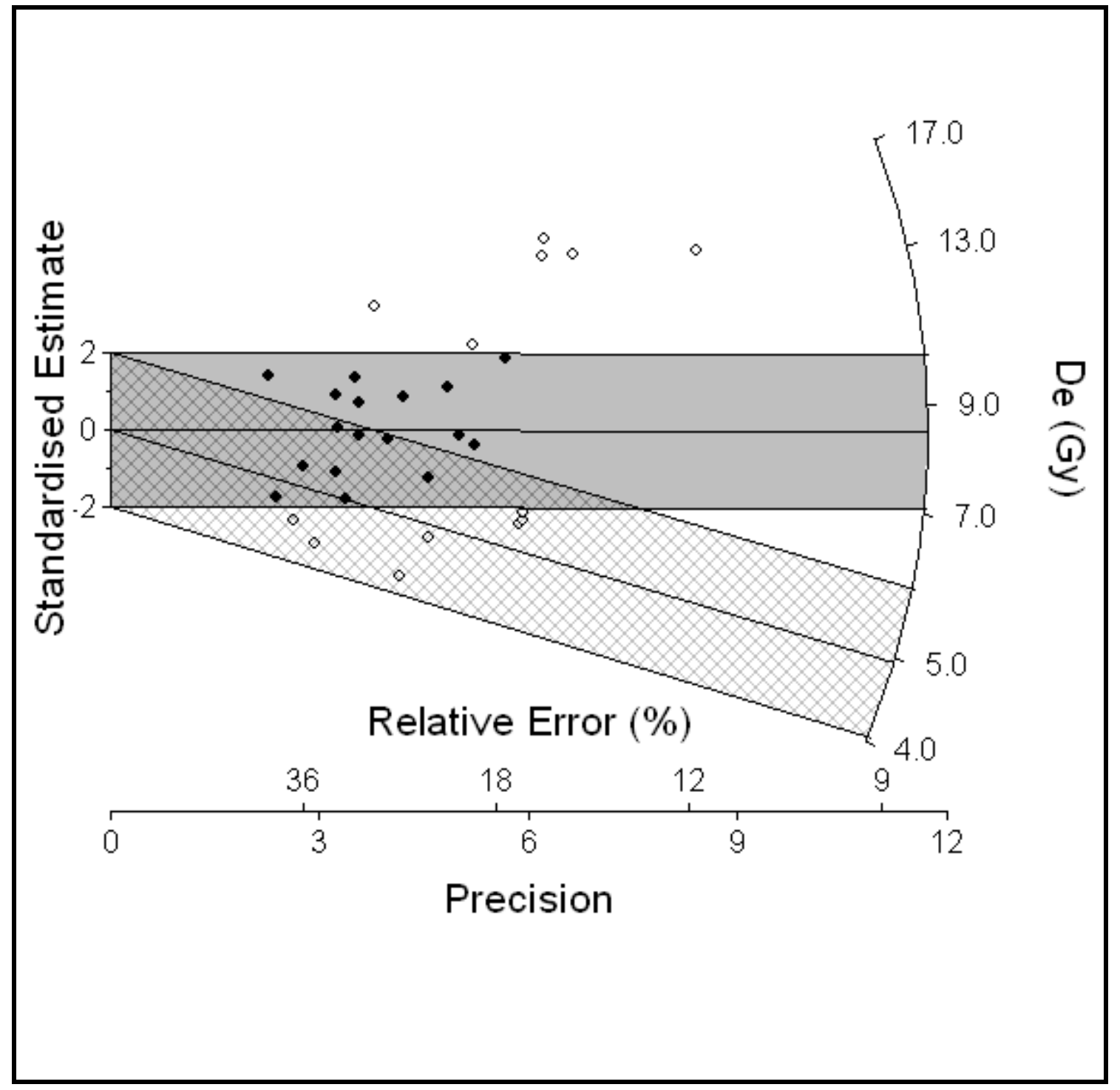

Figure L-4. Equivalent Dose (De) Distribution for UW1050 Quartz Grains 


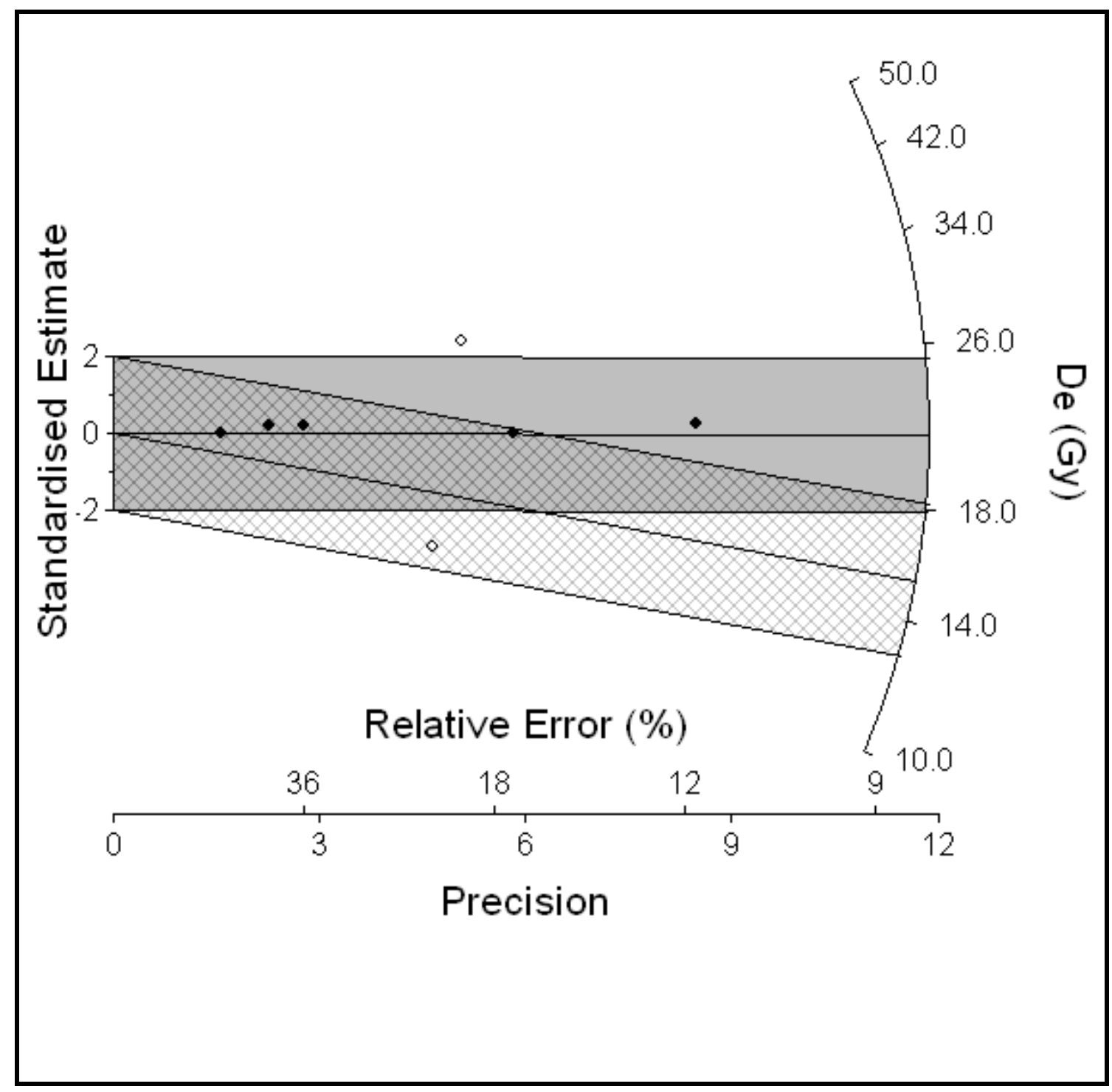

Figure L-5. Equivalent Dose (De) Distribution of UW1051 Quartz Grains 


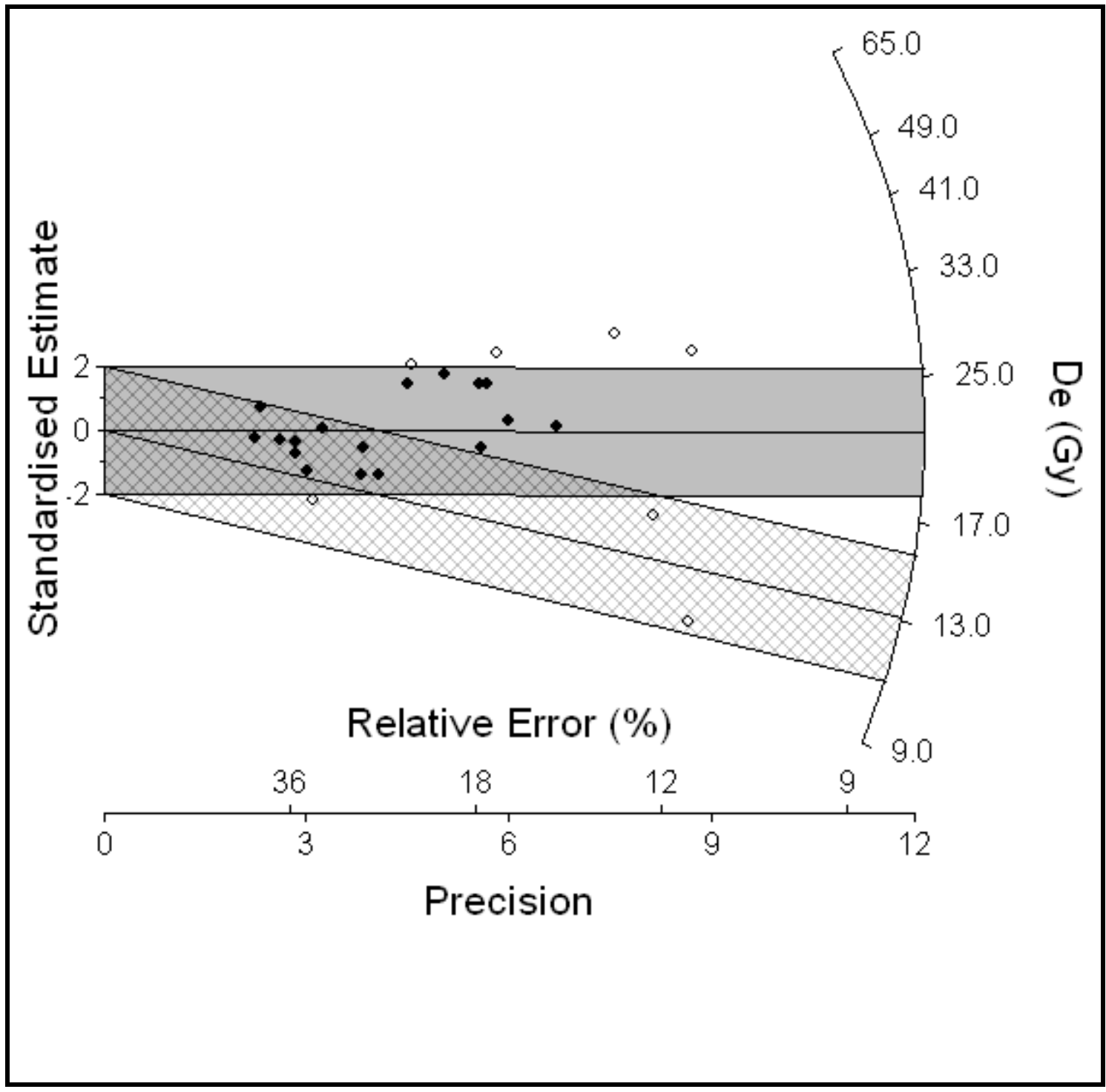

Figure L-6. Equivalent Dose (De) Distributions for UW1052 Quartz Grains 
APPENDIX M:

USE-WEAR ANALYSIS OF TWO GRAVERS

FROM THE VARGA SITE (41ED28) 



\title{
USE-WEAR ANALYSIS OF TWO GRAVERS FROM THE VARGA SITE (41ED28)
}

\author{
By: \\ Marvin Kay \\ Prepared for:

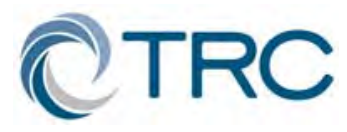 \\ TRC Environmental Corporation \\ 505 East Huntland Drive, Suite 250 \\ Austin, Texas 78752 \\ Prepared by: \\ Marvin Kay \\ Department of Anthropology \\ University of Arkansas \\ Fayetteville, Arkansas 72701
}

January 2004 



\section{M.1 INTRODUCTION}

The late prehistoric Toyah-interval component at the Varga Site (41ED28) in Edwards County, Texas, has produced a number of odd chipped stone artifacts. Two are discussed here from the vantage point of microscopic use-wear analysis. Each is a small, bifacially worked artifact that is pointed on at least one end. Although their forms differ in significant ways, they are both fashioned from flake blanks, possibly of Edwards chert. One is totally bifacially worked, the other only so on its margins. The analysis addressed related functional issues concerning the manner in which they were held or hafted, their intended use, possible contact materials (substances with which a tool comes into direct contact), serviceability or discard, and postdepositional taphonomic effects that might obscure any or all of the other functional observations. The Varga Site tools are typical examples of formal tools whose tool edge is well understood from experimentation with modern replicas of gravers. Thus, the question for these kinds of tools is to define the actual zone of contact of the tool edge with a worked material, as expressed by microscopic wear traces, and the character of these wear traces.

This study is grounded in realistic experiments in stone tool use and observation of wear traces. This discussion draws upon previous publications about microscopy, taphonomy, characteristics of wear traces and their formation (Hardy et al. 2001; Kay 1996, 1997, 1998, 1999), and microscopic examination of experimental chipped stone gravers and other tool replicas used to work hide, wood, bone, and antler.

The microscopic observations principally address kinematics (or friction-related features of surface-to-surface contact) of tool use and manufacture as judged from wear traces. Wear traces often occur as multiples, may show sequential development from abrasive to additive forms, develop as tools are used, and may differentiate contact materials. Striae, abrasive particles, abrasive polishes, soluble inorganic residues that are likely silica gels, and other potential wear traces are common in experimental studies of stone tool use. These all occur on the Varga Site artifacts, whose wear traces are dominated by soluble inorganic residues.

Soluble inorganic residues build up with moisture availability and as use progresses to form discrete microplates. Soluble inorganic residues are impervious to most acids and strong bases. They are among the more valuable wear traces because of their long-term stability, sensitivity to motion, and effects on the microgeometry of a tool edge. They exhibit the flow characteristics of a viscous liquid and desiccation cracks as they harden. Microplating infills striations, becomes striated whenever abrasive particles strike, and crystallizes as brilliant white translucent filaments on the trailing (i.e., opposite from the) border of contact with a worked or manipulated material. Microplates bond to stone surfaces and edges as use continues. Experimental controls indicate that hardening occurs coincident with use or shortly thereafter. Unless deliberately removed, microplating so dulls an edge that it can no longer function.

For formal implements, tool edge wear should be readily identifiable to the edge (and adjacent surfaces) that is prepared for use, or that is generally opposite the haft element or area of prehension, or hand-holding a stone tool.

As a general rule, haft wear consists of invasive abrasion, abrasive particles, striations, and possibly microplating buildup and even the presence of a mastic as a consequence of binding, or attaching, a tool to a handle and to movement within the haft due mainly to tool 
use. It is significantly more extensive and often has oriented wear traces as opposed to those more typical of prehension. Haft wear may complement deliberate attempts to fashion a formal haft element (such as lateral edge grinding).

Tool edge microgeometry, striation density, placement and orientation, and microplating attributes all differentiate contact materials, although not perfectly. The most conservative approach is to simply regard these as indicators of relative hardness. On an ordinal scale of soft to hard, working soft materials tends to round tool edges while hard materials tend to break them, causing them to remain relatively angular to subangular in cross-section. A difference between soft plant and hide processing is the character of the polish that develops at and near a tool edge. Herbaceous plant polish tends to be bright and to have a melted appearance. This wear pattern also applies to a large degree to polish resulting from contact with harder wood, but results in fewer striations. Hide polishes tend to have a dull or matte-like appearance and a rough texture, and it is generally easy to separate plant from hide work.

Microscopic examination of wear traces is simply the only way to reliably acquire these insights. Complementary macroscopic indicators of tool edge damage can be understood in the context of this microscopic use-wear evidence but are absolutely dependent upon them.

\section{M.2 METHODS}

The two artifacts from the Varga Site were not cleaned. They were examined for wear traces by using a differential-interference binocular compound microscope with polarized light and Nomarski optics at magnifications ranging from 100 to 400 diameters. The evaluations systematically covered the edges and unlabeled surface of the artifacts and took note of edge cross-sectional shape and damage. Wear traces were photographed and their position and orientation on the artifact were recorded on digitally scanned images of each artifact. Observations about edge damage, tool edge placement and extent, and hafting indicators were also recorded on the scanned images. Other details of the investigation were recorded on a standard form for each artifact.

For macroscopic photography, but not microscopic examination, artifacts were also smoked with water-soluble ammonium chloride to form a uniform, thin, white coating. Under oblique light, this coating shows flake scar patterns and edge damage. Simple immersion in water dissolves the ammonium chloride.

\section{M.3 Results}

Wear traces are present on both specimens. Using the criteria outlined above, it was easy to determine that each was hafted and the extent of the haft element (Figure M-1). Although the chert is well suited to this analysis, the microwear is neither spectacular nor especially attractive. Nonetheless, it is unambiguous in its meaning. The two artifacts are described individually below.

\section{M.3.1 Specimen \#726-010}

This specimen was labeled as a Perdiz projectile point. It was a hafted graver, probably used once as a drill against hard contact material. The graver tip is broken and there is no use-wear to speak of; however, there is some general abrasion on the tip and a few possible divots. The latter are more likely lances due to conchoidal fracture.

The most important detail of the analysis is identification of the haft element. This consists of a symmetrical tang with deliberately ground edges (Figure M-2) and a snapped tip opposite a broad flange. Only the graver tip is likely to 
have projected from the haft. It appears to have broken in use and was not subjected to further repair.

\section{M.3.2 Specimen \#837-011}

The smaller of the two specimens was also a hafted graver, with relatively similar functional proportions for hafting. It differs in function from the other tool principally in the likely contact material. The graver tip is still in good shape. It is just slightly rounded and has striations in several directions at the immediate edge (Figure M-3). Graver experiments show this wear to indicate rotary motion; however, it is not possible to say if the rotation was backand-forth or in one circular direction only. It appears to have been used against a relatively soft to medium-soft material, such as deciduous wood. The tool appears to be in a still serviceable condition.

The most obvious wear is likely postdepositional trampling damage, or pseudo-wear (Figure M-4b). In addition, the haft wear, in part, has a striated microplating wash (Figure M4a) typical of wood contact. Thus, it seems likely that the handle was fashioned from wood.

\section{M.4 References Cited}

Hardy, B. L., M. Kay, A. E. Marks, and K. Monigal

2001 Stone Tool Function at the Paleolithic Sites of Starosele and Buran Kaya III, Crimea: Behavioral Implications. Proceedings of the National Academy of
Sciences of the United States of America [PNAS] 98(19):10972-10977.

Kay, M.

1996 Microwear Analysis of Some Clovis and Experimental Chipped Stone Tools. In Stone Tools: Theoretical Insights into Human Prehistory, edited by G. H. Odell, pp. 315-344. Plenum Press, New York.

1997 Imprints of Ancient Tool Use at Monte Verde. In Monte Verde: A Late Pleistocene Settlement in Chile. Volume II: The Archaeological Findings, edited by T. E. Dillehay, pp. 649-660. Smithsonian Institution Press, Washington, DC.

1998 Scratchin' the Surface: Stone Artifact Microwear Evaluation. In WilsonLeonard: An 11,000-Year Archeological Record of HunterGatherers in Central Texas. Volume III: Artifacts and Special Artifact Studies, assembled and edited by M. B. Collins, pp. 743-794. Studies in Archeology 31, Texas Archeological Research Laboratory, University of Texas at Austin, and Archeology Studies Program, Report 10, Texas Department of Transportation, Environmental Affairs Division.

1999 Microscopic Attributes of the Kevin Davis Blades. In Clovis Blade Technology, edited by M. B. Collins, pp. 126-143. University of Texas Press, Austin. 


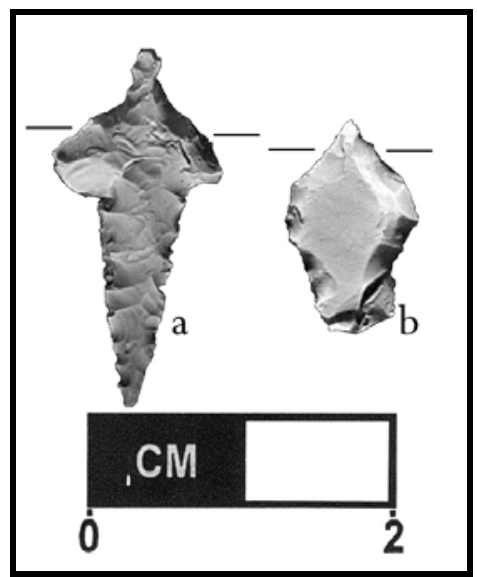

Figure M-1. Hafted Gravers from the Varga site (41ED28).

Horizontal tick marks show maximum extent of haft element. Specimens \#726-010 (a) and \#837-011 (b)

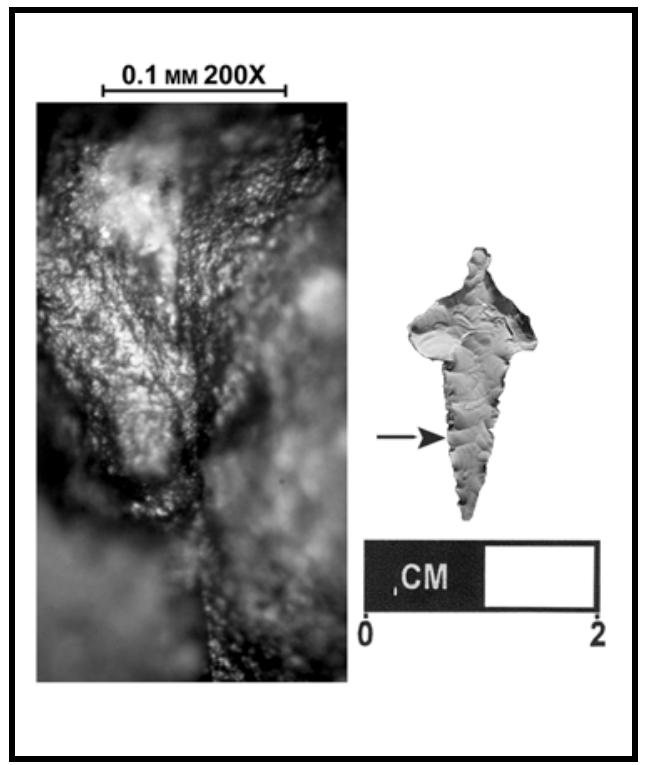

Figure M-2. Oriented Photomicrograph of Haft Element Deliberate Lateral Edge Grinding of the Tang

Specimen \#726-010 


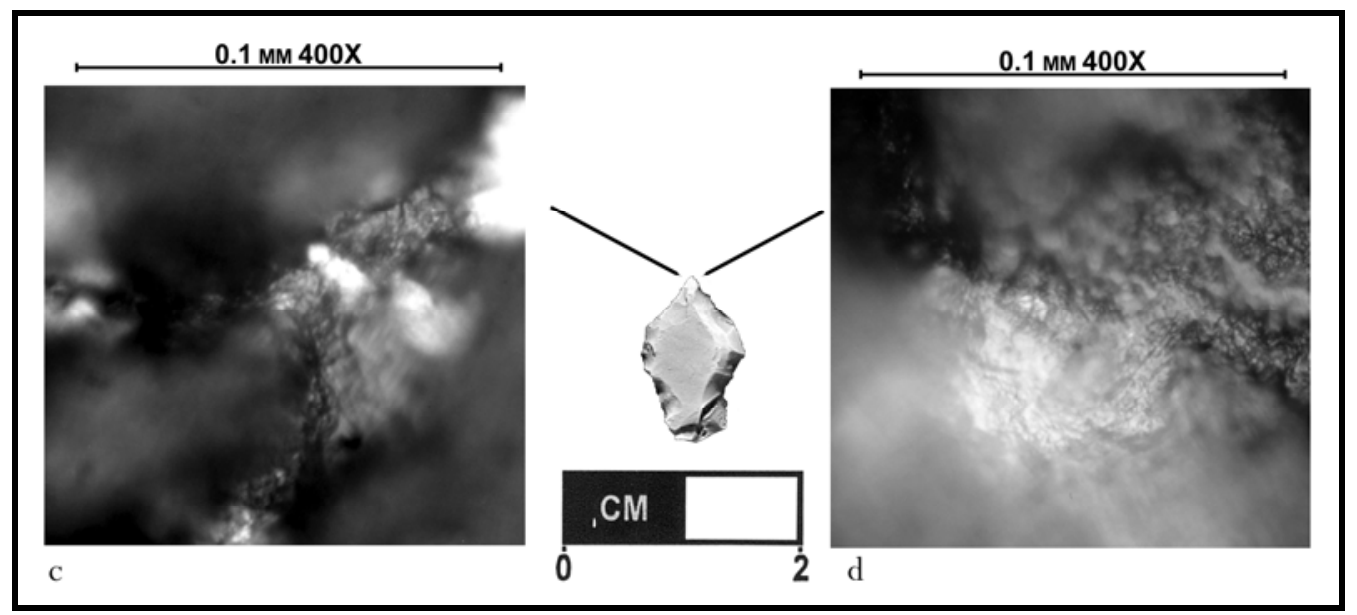

Figure M-3. Oriented Photomicrographs of Rotary Motion of the Graver Tip

Specimen \#837-011

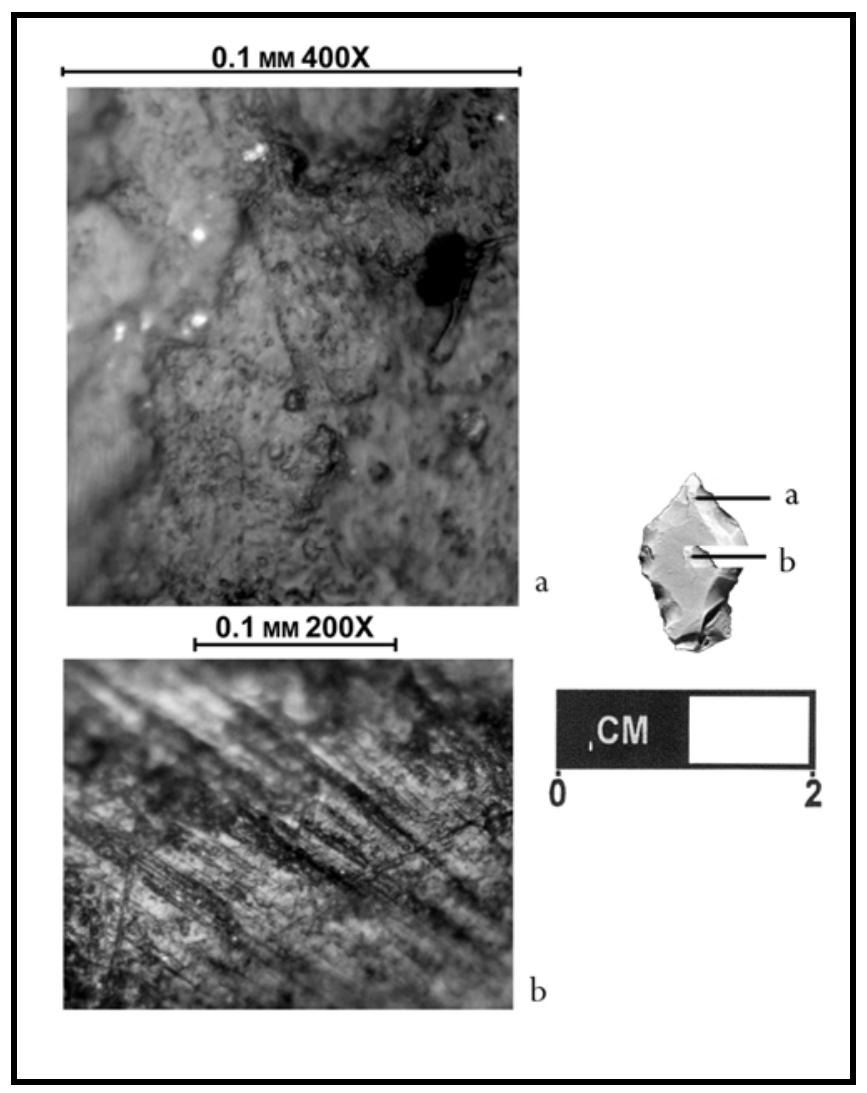

Figure M-4. Oriented Photomicrographs of the Haft Element of Specimen \#837-011

(a) Microplating wash with filled-in striations, spot crystallization, and abrasive particles

(b) Probable post-depositional trampling damage 

APPENDIX N:

INSTRUMENTAL NEUTRON ACTIVATION ANALYSIS OF POTTERY FROM THE LORENZO MISSION (41RE1), SAN JUAN MISSION (41BX5), AND VARGA (41ED28) SITES IN REAL, BEXAR, AND EDWARDS COUNTIES, TEXAS 
(20) 


\section{INSTRUMENTAL NEUTRON ACTIVATION ANALYSIS OF POTTERY FROM THE LORENZO MISSION (41RE1), SAN JUAN MISSION (41BX5), AND VARGA (41ED28) IN REAL, BEXAR, AND EDWARDS COUNTIES, TEXAS}

By:

Robert J. Speakman, Ph.D. Michael D. Glascock, Ph.D.

Prepared for:

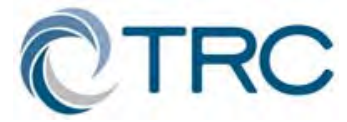

TRC Environmental Corporation 505 East Huntland Drive, Suite 250

Austin, Texas 78752

\section{Prepared by:}

Robert J. Speakman, Ph.D. and Michael D. Glascock, Ph.D.

Archaeometry Laboratory

University of Missouri Research Reactor Center University of Missouri

Columbia, Missouri 65211 
(20) 


\section{N.1 INTRODUCTION}

Instrumental neutron activation analysis (INAA) has been undertaken on 19 pottery clay samples from sites located in Real, Baxar, and Edwards Counties, Texas. The analyses were conducted at the University of Missouri Research Reactor Center (MURR). Here we describe sample preparation and analytical techniques used at MURR and report on the subgroup structure discovered in the chemical data.

\section{N.2 Sample Preparation}

The 19 pottery samples were prepared for INAA using procedures standard at MURR. Fragments of about $1 \mathrm{~cm}^{2}$ were removed from each sample and abraded using a silicon carbide burr in order to remove glaze, slip, paint, and adhering soil, thereby reducing the risk of measuring contamination. The samples were washed in deionized water and allowed to dry in the laboratory. Once dry, the individual sherds were ground to powder in an agate mortar to homogenize the samples. Archival samples were retained from each sherd (when possible) for future research. Clay samples were fired in a furnace to $700^{\circ}$ Celsius for one hour. Portions of approximately $150 \mathrm{mg}$ of powder were weighed into small polyvials used for short irradiations at MURR. At the same time, $200 \mathrm{mg}$ of each sample was weighed into the high-purity quartz vials used for long irradiations. Along with the unknown samples, reference standards of SRM-1633a (coal fly ash) and SRM-688 (basalt rock) were similarly prepared, as were quality control samples (e.g., standards treated as unknowns) of SRM-278 (obsidian rock) and Ohio Red Clay.

\section{N.3 IRRADIATION AND GAMMA-RAY SPECTROSCOPY}

Neutron activation analysis of ceramics at MURR, which consists of two irradiations and a total of three gamma counts, constitutes a superset of the procedures used at most other NAA laboratories (Glascock 1992; Neff 1992, 2000). As discussed in detail by Glascock (1992), a short irradiation is carried out through the pneumatic tube irradiation system. Samples in the polyvials are sequentially irradiated, two at a time, for five seconds by a neutron flux of 8 $\mathrm{x} 10^{13} \mathrm{n} \mathrm{cm}^{-2} \mathrm{~s}^{-1}$. The 720 -second count yields gamma spectra containing peaks for short-lived elements aluminum $(\mathrm{Al})$, barium $(\mathrm{Ba})$, calcium (Ca), dysprosium (Dy), potassium (K), manganese $(\mathrm{Mn})$, sodium $(\mathrm{Na})$, titanium $(\mathrm{Ti})$, and vanadium $(\mathrm{V})$. The samples encapsulated in quartz vials are subjected to a 24-hour irradiation at a neutron flux of $5 \times 10^{13} \mathrm{n} \mathrm{cm}^{-2} \mathrm{~s}^{-}$ ${ }^{1}$. This long irradiation is analogous to the single irradiation utilized at most other laboratories. After the long irradiation, samples decay for seven days, and then are counted for 2,000 seconds (the "middle count") on a highresolution germanium detector coupled to an automatic sample changer. The middle count yields determinations of seven medium half-life elements, namely arsenic (As), lanthanum (La), lutetium $(\mathrm{Lu})$, neodymium $(\mathrm{Nd})$, samarium $(\mathrm{Sm})$, uranium (U), and ytterbium (Yb). After an additional three- or four-week decay, a final count of 9,000 seconds is carried out on each sample. The latter measurement yields the following 17 long half-life elements: cerium (Ce), cobalt (Co), chromium (Cr), cesium (Cs), europium (Eu), iron (Fe), hafnium (Hf), nickel (Ni), rubidium ( $\mathrm{Rb})$, antimony (Sb), scandium (Sc), strontium (Sr), tantalum (Ta), terbium (Tb), thorium (Th), zinc ( $\mathrm{Zn})$, and zirconium (Zr).

Elemental concentration data from the two irradiations and three counts (a total of 33 elements) are assembled into a single tabulation and stored in a dBASE file along with descriptive information available for each sample. Tables $\mathrm{N}-1$ and $\mathrm{N}-2$ summarize the raw and calcium-corrected data. 


\section{N.4 Quantitative ANALYSIS OF THE Chemical Data}

The analyses at MURR described previously produced elemental concentration values for 32 or 33 elements in most of the analyzed samples. Data for Ni was below detection limits in several samples and were removed from consideration in the analysis. Quantitative analysis was subsequently carried out on base10 logarithms of concentrations for these data. Use of log concentrations instead of raw data compensates for differences in magnitude between the major elements, such as calcium, on one hand and trace elements, such as the rare earth or lanthanide elements (REEs), on the other hand. Transformation to base-10 logarithms also yields a more nearly normal distribution for many trace elements.

A number of specimens had calcium concentrations in excess of $5 \%$, a concentration that implies sufficient calcium carbonate is present to dilute the concentrations of other elements. This calcium-related dilution was counteracted using a correction introduced by Blackman (Steponaitis et al. 1996; cf. Cogswell et al. 1998). As is standard practice with calcium-corrected data, $\mathrm{Ca}, \mathrm{Ba}$, and $\mathrm{Sr}$ were not included in quantitative analyses of the data.

The goal of quantitative analysis of the chemical data is to recognize compositionally homogeneous groups within the analytical database. Based on the "provenance postulate" (Weigand et al. 1977), such groups are assumed to represent geographically restricted sources or source zones. The location of sources or source zones may be inferred by comparing the unknown groups to knowns (source raw materials) or by indirect means. Such indirect means may include the "criterion of abundance" (Bishop et al. 1982) or arguments based on geological and sedimentological characteristics (e.g., Steponaitis et al. 1996).
Initial hypotheses about source-related subgroups in the compositional data can be derived from non-compositional information (e.g., archaeological context, decorative attributes) or from application of patternrecognition techniques to the chemical data. Principal component analysis (PCA) is a technique that can be used to recognize patterns (i.e., subgroups) in compositional data. PCA provides new reference axes that are arranged in decreasing order of variance subsumed. The data can be displayed on combinations of these new axes, just as they can be displayed relative to the original elemental concentration axes. PCA can be used in a pure pattern-recognition mode to search for subgroups in an undifferentiated data set or in a more evaluative mode to assess the coherence of hypothetical groups suggested by other criteria (e.g., archaeological context, decoration). Generally, compositional differences between specimens can be expected to be larger for specimens in different groups than for specimens in the same group, and this implies that groups should be detectable as distinct areas of high point density on plots of the first few components.

One strength of PCA, discussed by Baxter (1992) and Neff (1994), is that it can be applied as a simultaneous R- and Q-mode technique, with both variables (elements) and objects (individual analyzed samples) displayed on the same set of principal component reference axes. The two-dimensional plot of element coordinates on the first two principal components is the best possible two-dimensional representation of the correlation or variancecovariance structure in the data. Small angles between vectors from the origin to variable coordinates indicate strong positive correlation, angles close to $90^{\circ}$ indicate no correlation, and angles close to $180^{\circ}$ indicate negative correlation. Likewise, the plot of object coordinates is the best two-dimensional representation of Euclidean relations among the 
objects in log-concentration space (if the PCA was based on the variance-covariance matrix) or standardized log-concentration space (if the PCA was based on the correlation matrix). Displaying objects and variables on the same plots makes it possible to observe the contributions of specific elements to group separation and to the distinctive shapes of the various groups. Such a plot is called a "biplot" in reference to the simultaneous plotting of objects and variables. The variable interrelationships inferred from a biplot can be verified directly by inspection of bivariate elemental concentration plots (note that a bivariate plot of elemental concentrations is not a biplot”).

Whether or not a group is discriminated easily from other groups can be evaluated visually in two dimensions or statistically in multiple dimensions. A metric known as Mahalanobis distance (or generalized distance) makes it possible to describe the separation between groups or between individual points and groups on multiple dimensions. The Mahalanobis distance of a specimen from a group centroid (Bieber et al. 1976; Bishop and Neff 1989; Neff 2002; Harbottle 1976; Sayre 1975) is:

$$
D_{y, X}^{2}=[y-\bar{X}]^{t} I_{X}[y-\bar{X}]
$$

where $y$ is the $1 \mathrm{x} \mathrm{m}$ array of logged elemental concentrations for the individual point of interest, $X$ is the $n \times m$ data matrix of logged concentrations for the group to which the point is being compared with Error! Bookmark not defined.Error! Bookmark not defined. $\bar{X}$ being its $1 \times m$ centroid, and $I_{x}$ being the inverse of the $m \times m$ variance-covariance matrix of group $X$. Because the Mahalanobis distance takes into account variances and covariances in the multivariate group, it is analogous to expressing distance from a univariate mean in standard deviation units. Like standard deviation units, Mahalanobis distances can be converted into probabilities of group membership for individual specimens (e.g., Bieber et al. 1976; Bishop and Neff 1989; Harbottle 1976). For relatively small sample sizes, it is appropriate to base probabilities on Hotelling's $T^{2}$, which is the multivariate extension of the univariate Student's $t$.

\section{N.5 Results and Conclusion}

As a first step in interpreting the data, a Euclidean distance search was used to scan the entire MURR databank of 35,000+ ceramic analyses from around the world. The purpose of this search was to identify individual specimens that are compositionally similar to the individual specimens in the data set of interest. The technique is straightforward. Euclidean (straight-line) distances are calculated between a given individual specimen and all specimens in the comparison databank, and the top specimens are extracted for comparison. Actually, the distance measure for which minima are sought is the average Euclidean distance:

$$
E D_{a, b}=\frac{\sqrt{\sum_{i=1}^{m}\left(a_{i}-b_{i}\right)^{2}}}{m}
$$

where $a$ and $b$ are vectors containing $m$ elemental concentrations for the two individual specimens being compared. The vast majority of samples identified as being compositionally similar to the pottery samples of interest were samples analyzed for Dr. Darrell Creel, Director of the Texas Archeological Research Laboratory (TARL) in Austin, Texas (Creel 2002, 2003). With the exception of one sample (TRC278) identified as being similar to pottery from the El Paso, Texas, area, most samples suggested similarities to the Central Texas- 1 and Central Texas-2 reference groups or other unassigned pottery from this area. 
The subgroup structure for the complete 19specimen ceramic data set is documented in the figures and tables presented at the end of this appendix. Table N-1 lists the analyzed specimens and shows the compositional affiliations determined in the present investigation together with various descriptive information. Table N-2 lists Mahalanobis distance-based probabilities of membership in the Central Texas- 1 and 2 reference groups and the El Paso Polychrome reference group. These probabilities are based on the 29 elements retained for quantitative analysis, and are "jackknifed," as discussed above. With the exception of TRC278, which has high probability of membership in the El Paso Polychrome reference group, all samples have less than $4 \%$ probability of membership in the Central Texas- 1 and 2 compositional groups.

Figures $\mathrm{N}-1$ and $\mathrm{N}-2$ are biplots based on PCA of the 220-specimen dataset (19 TRC samples plus 201 samples analyzed for Creel). What is apparent in these two plots is that most of the analyzed samples fall outside of the $90 \%$ confidence ellipses calculated for the three reference groups. A bivariate plot of thorium and sodium base-10 logged data (Figure N-2) likewise suggests that most of the samples cannot be firmly associated with the Central Texas reference groups. Based on the Mahalanobis distance calculations and visual inspection of the data, we conclude that 18 of the samples do not have membership in the Central Texas reference groups. Sample TRC278 has high probabilities of membership in the El Paso reference group and plots consistently within the $90 \%$ confidence ellipse for this group. Additionally, visual inspection of this sample by Speakman also supports the classification of this sample as El Paso Polychrome.

Despite the fact that only one sample can be firmly associated with previously established compositional groups, there is nonetheless clear chemical patterning in the remaining 18 specimens. All samples from San Juan Mission form a distinct compositional group, pottery from Varga forms two groups, and two of the three samples from Lorenzo Mission cluster together. Three samples are unassigned. Figures N-4 to N-8 illustrate the chemical patterning identified among the three sites. Because the four groups are represented by so few samples, any attempt to statistically validate these groups would be a purely subjective exercise. Despite the limitations with sample size, the INAA data suggest that additional analyses of pottery from these sites would result in identification of several chemically distinct reference groups. Establishing a database for these samples could ultimately aid in assessing late prehistoric pottery movement among these sites.

\section{N.6 ACKNOWLEDGMENTS}

Mark Hammond, Nicole Little, Jonathon Dake, and Kyra Lienhop carried out the laboratory work for this project.

\section{N.7 RefERENCES}

Baxter, M. J.

1992 Archaeological Uses of the Biplot-A Neglected Technique? In Computer Applications and Quantitative Methods in Archaeology, 1991, edited by G. Lock and J. Moffett. BAR International Series S577, 141-148. Tempvs Reparatvm, Archaeological and Historical Associates, Oxford.

Bieber, A. M. Jr., D. W. Brooks, G. Harbottle, and E. V. Sayre

1976 Application of Multivariate Techniques to Analytical Data on Aegean Ceramics. Archaeometry 18:59-74. 
Bishop, R. L., and H. Neff

1989 Compositional Data Analysis in Archaeology. In Archaeological Chemistry IV, edited by R. O. Allen, pp. 576-586. Advances in Chemistry Series 220, American Chemical Society, Washington, D.C.

Bishop, R. L., R. L. Rands, and G. R. Holley

1982 Ceramic Compositional Analysis in Archaeological Perspective. In Advances in Archaeological Method and Theory, Vol. 5, pp. 275-330. Academic Press, New York.

Cogswell, J. W., H. Neff, and M. D. Glascock

1998 Analysis of Shell-Tempered Pottery Replicates: Implications for Provenance Studies. American Antiquity 63(1): 6372.

Creel, D.

2002 Central Texas Ceramics Project. In Newsletter of the Friends of the Texas Archeological Research Laboratory.

2003 Update: Central Texas Ceramics Project. In Newsletter of the Friends of the Texas Archeological Research Laboratory.

Glascock, M. D.

1992 Characterization of Archaeological Ceramics at MURR by Neutron Activation Analysis and Multivariate Statistics. In Chemical Characterization of Ceramic Pastes in Archaeology, edited by H. Neff, pp. 1126. Prehistory Press, Madison, Wisconsin.

Harbottle, G.

1976 Activation Analysis in Archaeology. Radiochemistry 3:3372. The Chemical Society, London.
Neff, $\mathrm{H}$.

1992 Introduction. In Chemical Characterization of Ceramic Pastes in Archaeology, edited by H. Neff, pp. 110. Prehistory Press, Madison, Wisconsin.

1994 RQ-Mode Principal Components Analysis of Ceramic Compositional Data. Archaeometry 36:115-130.

2000 Neutron Activation Analysis for Provenance Determination in Archaeology. In Modern Analytical Methods in Art and Archaeology, edited by E. Ciliberto and G. Spoto, pp. 81134. John Wiley and Sons, Inc., New York.

2002 Quantitative Techniques for Analyzing Ceramic Compositional Data. In Ceramic Source Determination in the Greater Southwest, edited by D. M. Glowacki and H. Neff. Monograph 44, Costen Institute of Archaeology, University of California at Los Angeles.

Steponaitis, V., M. J. Blackman, and H. Neff

1996 Large-Scale Compositional Patterns in the Chemical Composition of Mississippian Pottery. American Antiquity 61:555-572.

Weigand, P. C., G. Harbottle, and E. V. Sayre 1977 Turquoise Sources and Source Analysis: Mesoamerica and the Southwestern U.S.A. In Exchange Systems in Prehistory, edited by T. K. Earle and J. E. Ericson, pp. 15-34. Academic Press, New York. 


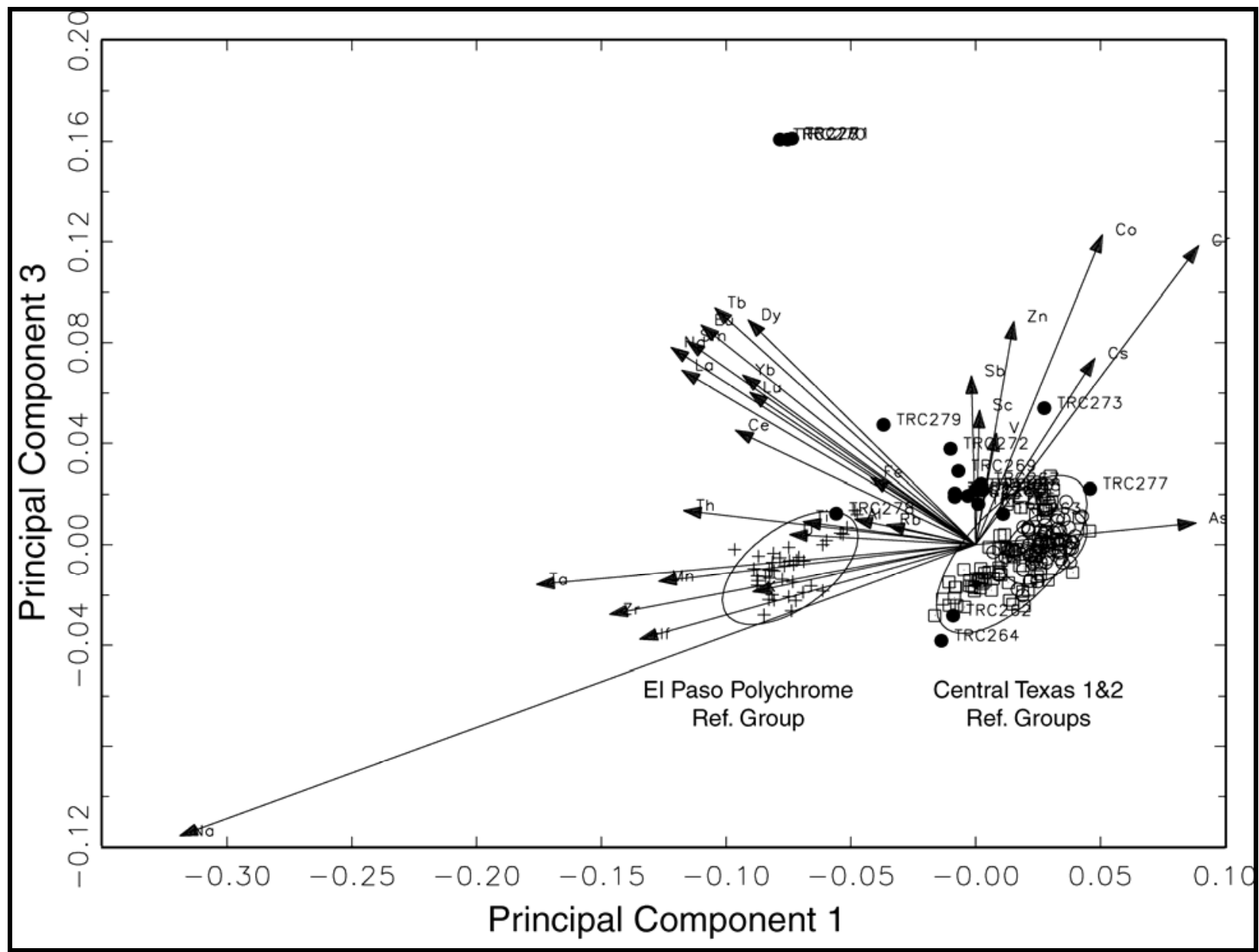

Figure N-1. Variance-Covariance Matrix Biplot of Principal Components 1 and 3

Ellipses represent 90\% confidence interval for reference groups. Individual TRC samples are labeled. 


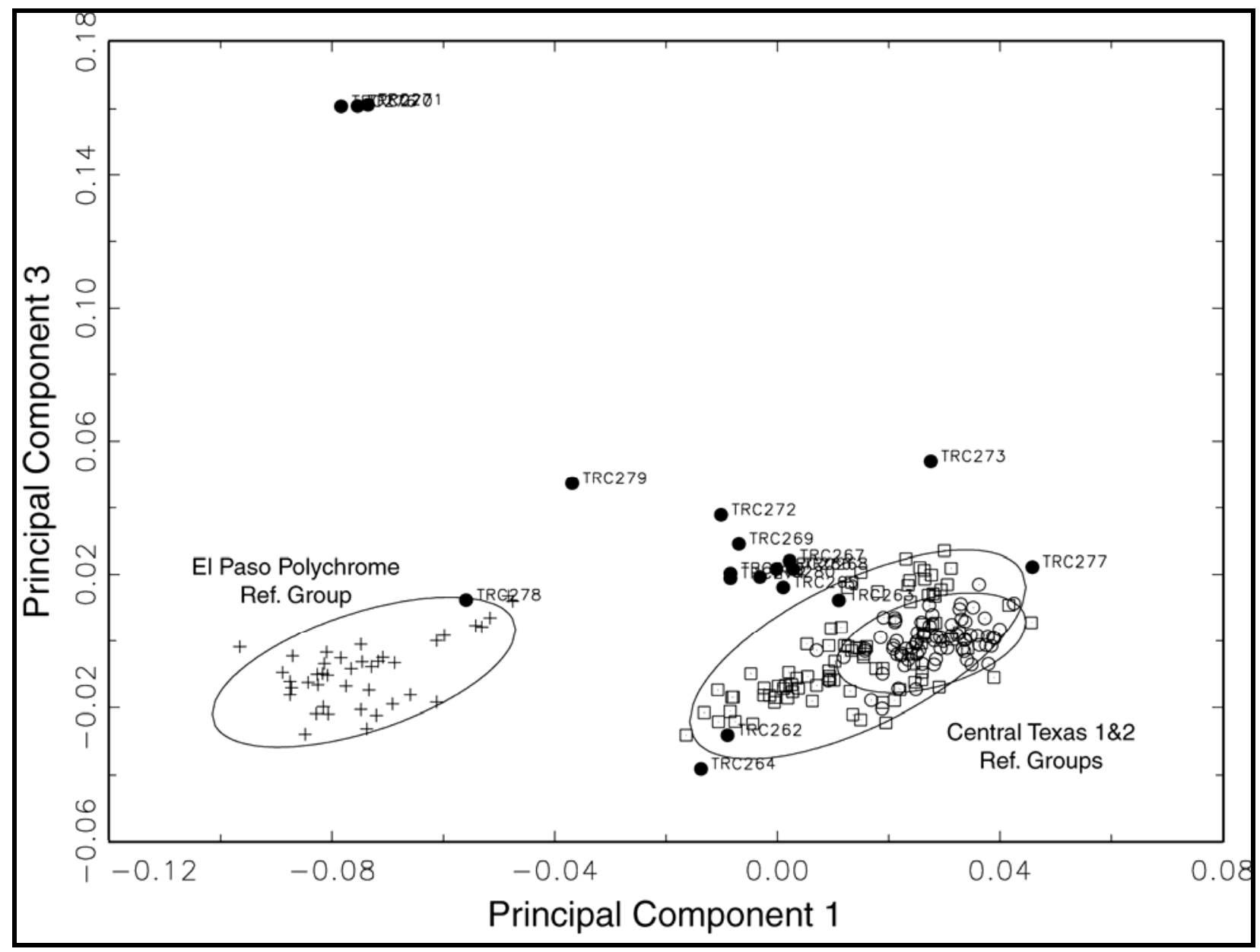

Figure N-2. Variance-Covariance Matrix Biplot of Principal Components 1 and 3 (without vectors) 


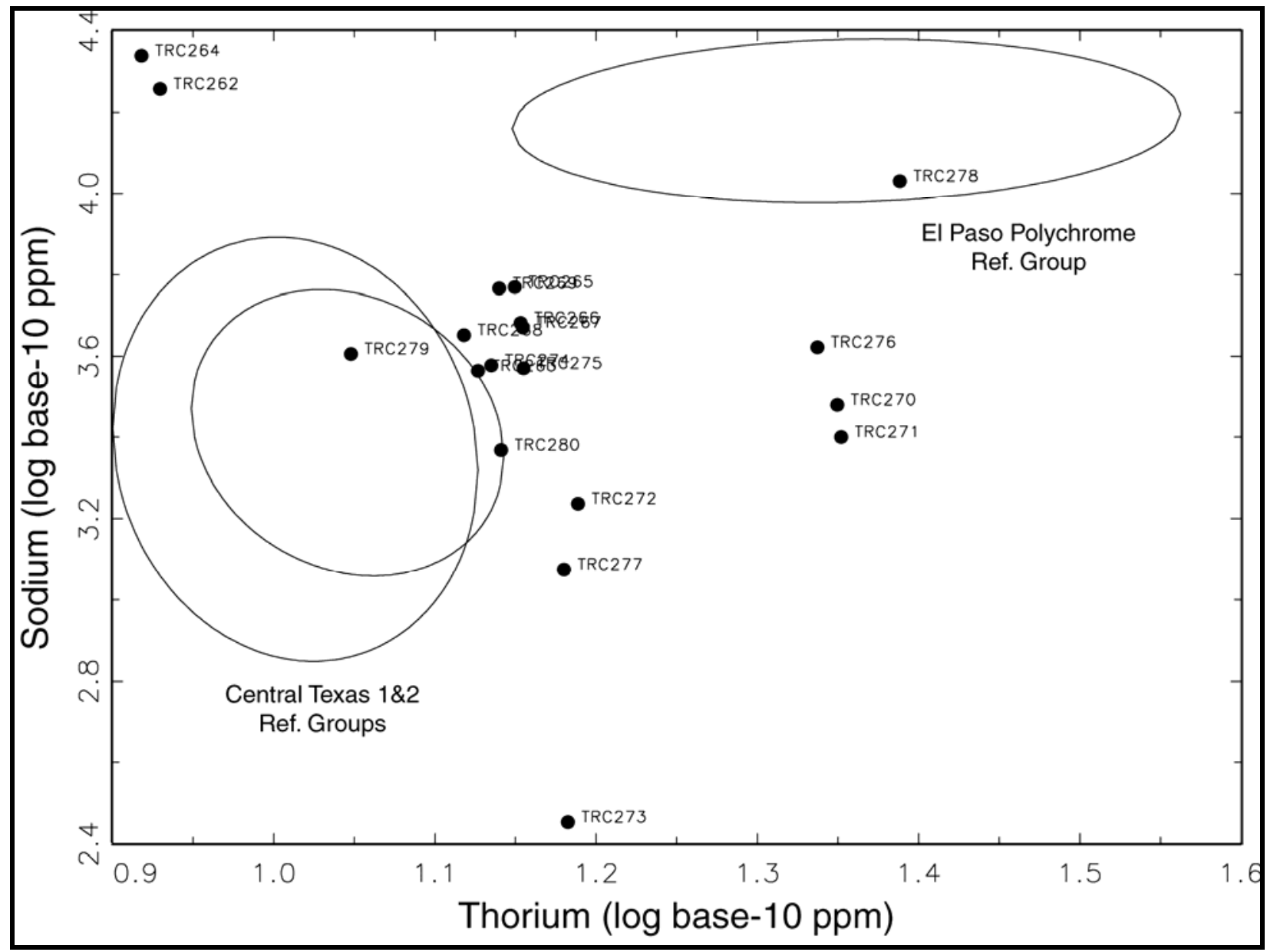

Figure N-3. Bivariate Plot of Thorium and Sodium Base-10 Logged Concentrations

Ellipses represent 90\% confidence interval for reference groups. Individual TRC samples are labeled. 


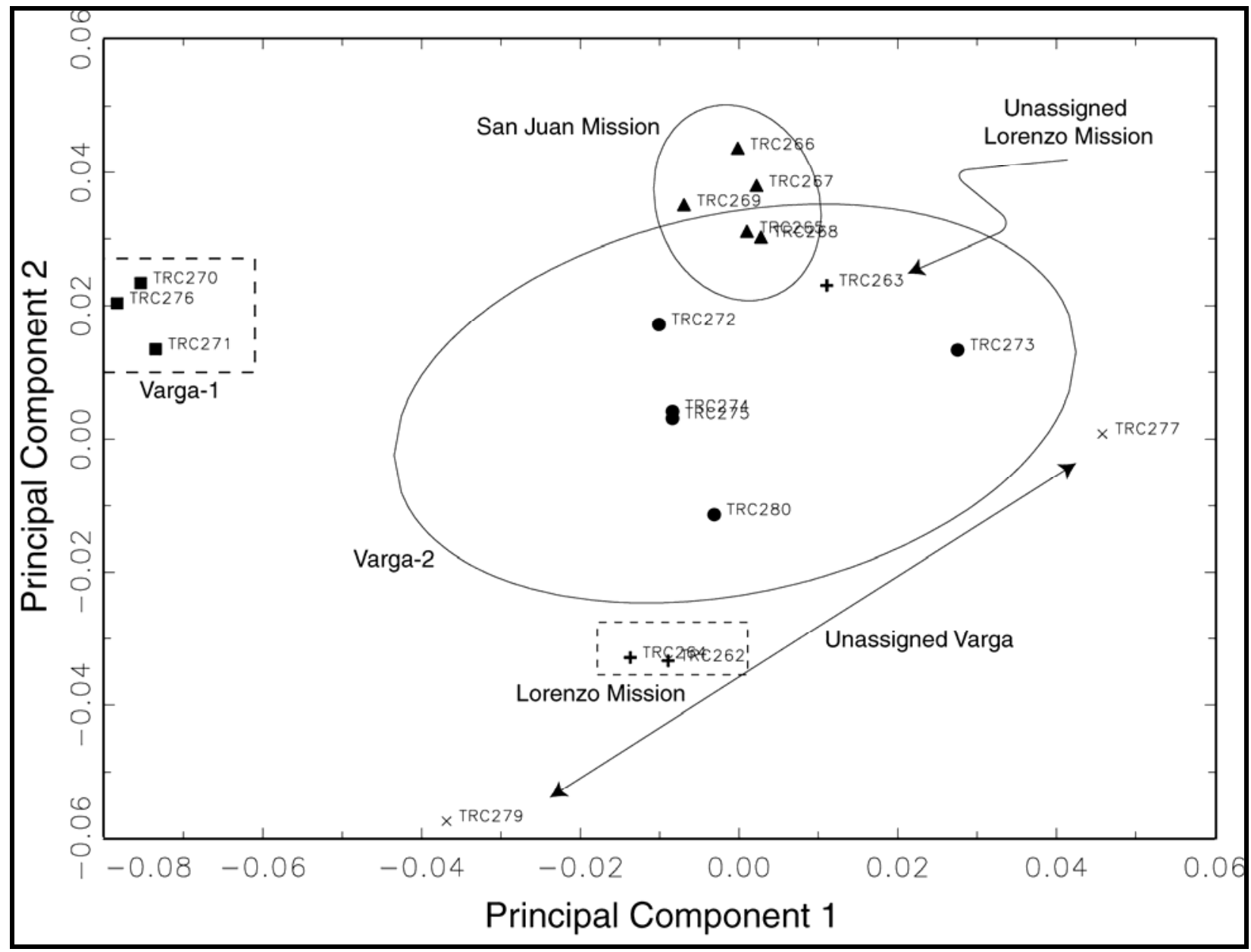

Figure N-4. Variance-Covariance Matrix Biplot of Principal Components 1 and 2 Showing Subgroup Patterning Within the TRC Pottery Data Set

Sample TRC278, which was assigned to the El Paso reference group, is not included in this projection. Ellipses represent $90 \%$ confidence interval for group membership. Individual specimens are labeled. 


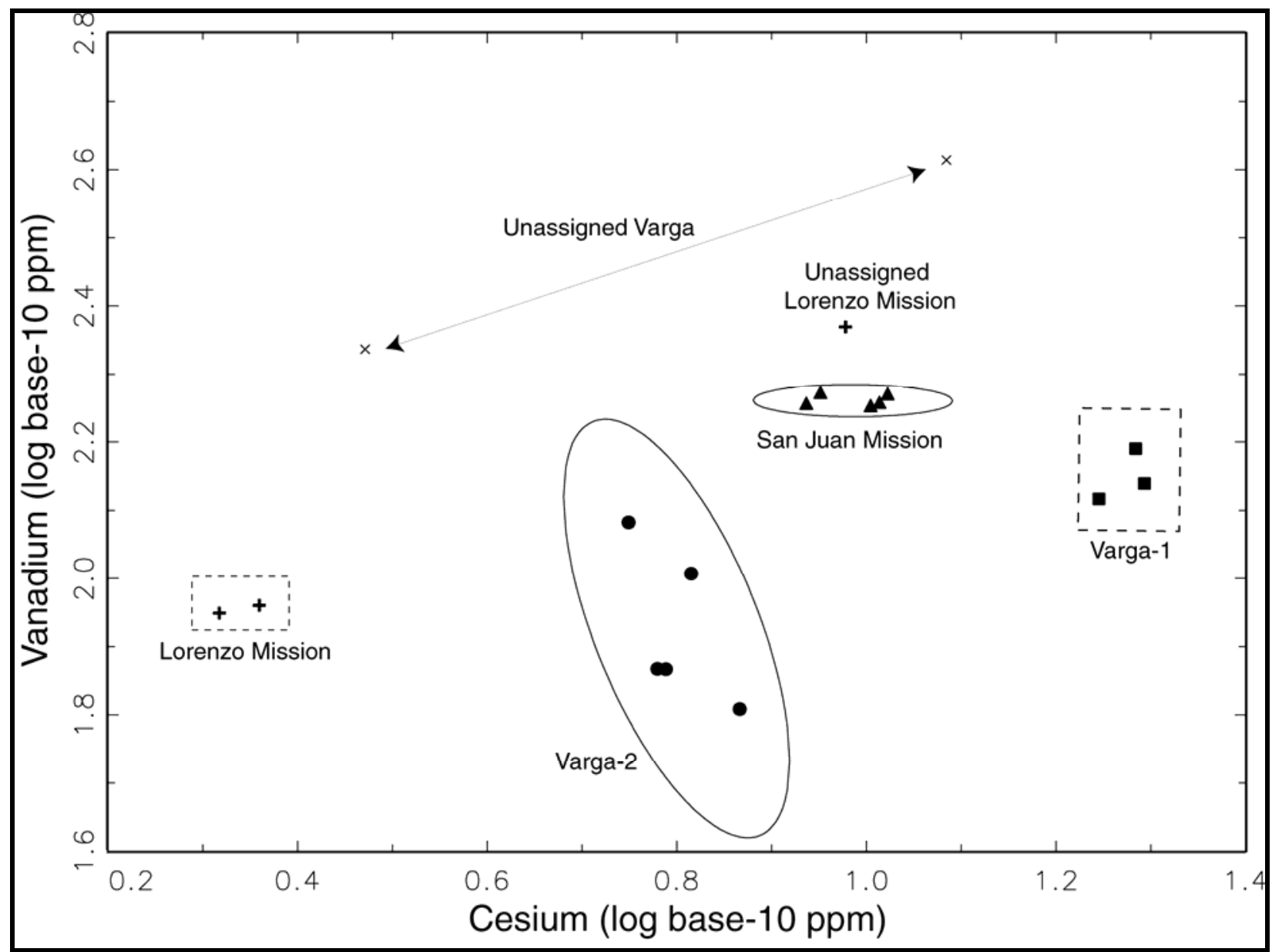

Figure N-5. Bivariate Plot of Cesium and Vanadium Base-10 Logged Concentrations Showing Subgroup Patterning Within the TRC Pottery Data Set

Sample TRC278, which was assigned to the El Paso reference group, is not included in this projection. Ellipses represent $90 \%$ confidence interval for group membership. 


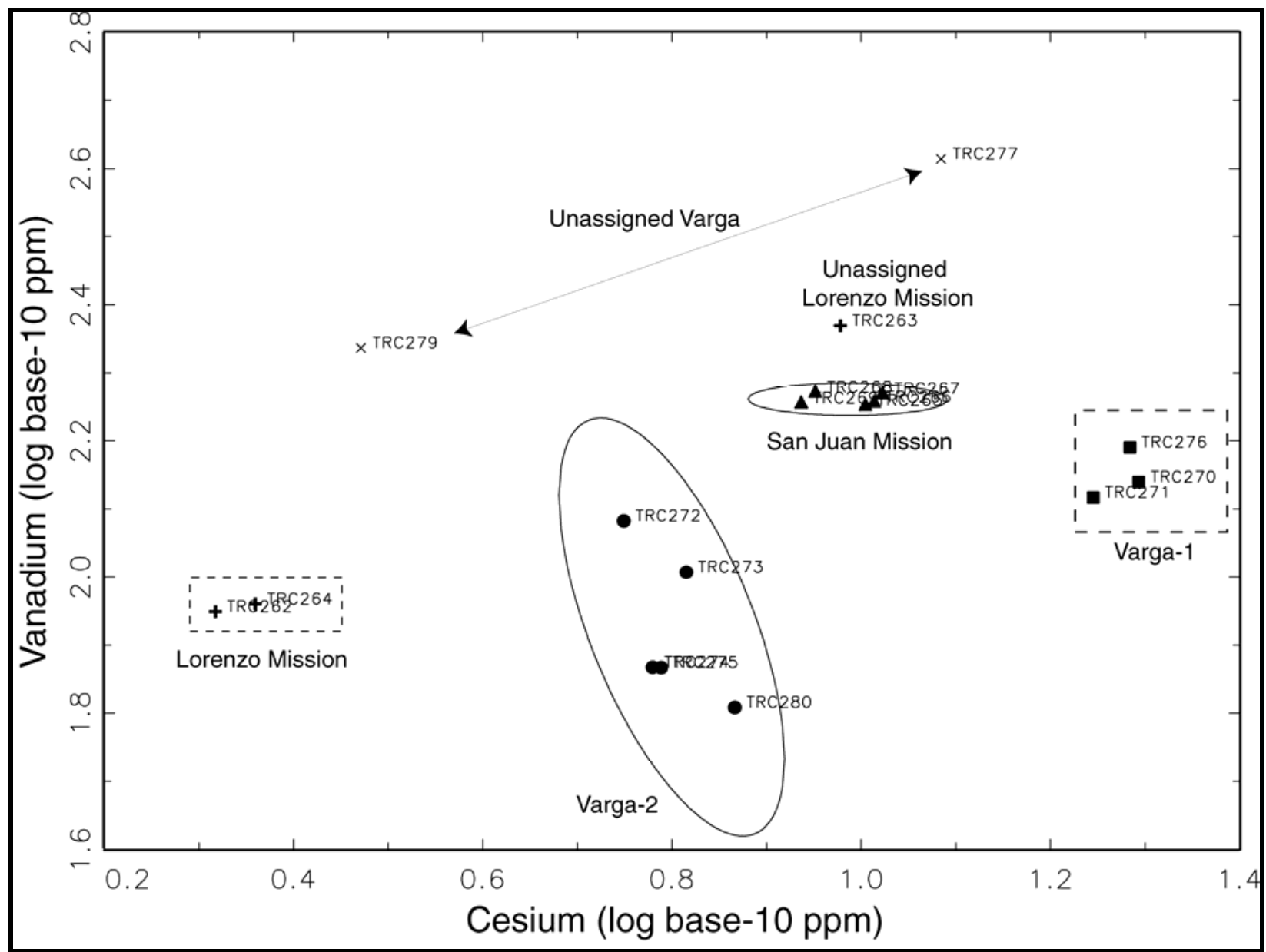

Figure N-6. Bivariate Plot of Cesium and Vanadium Base-10 Logged Concentrations Showing Subgroup Patterning Within the TRC Pottery Data Set (with Individual Specimens Labeled) 


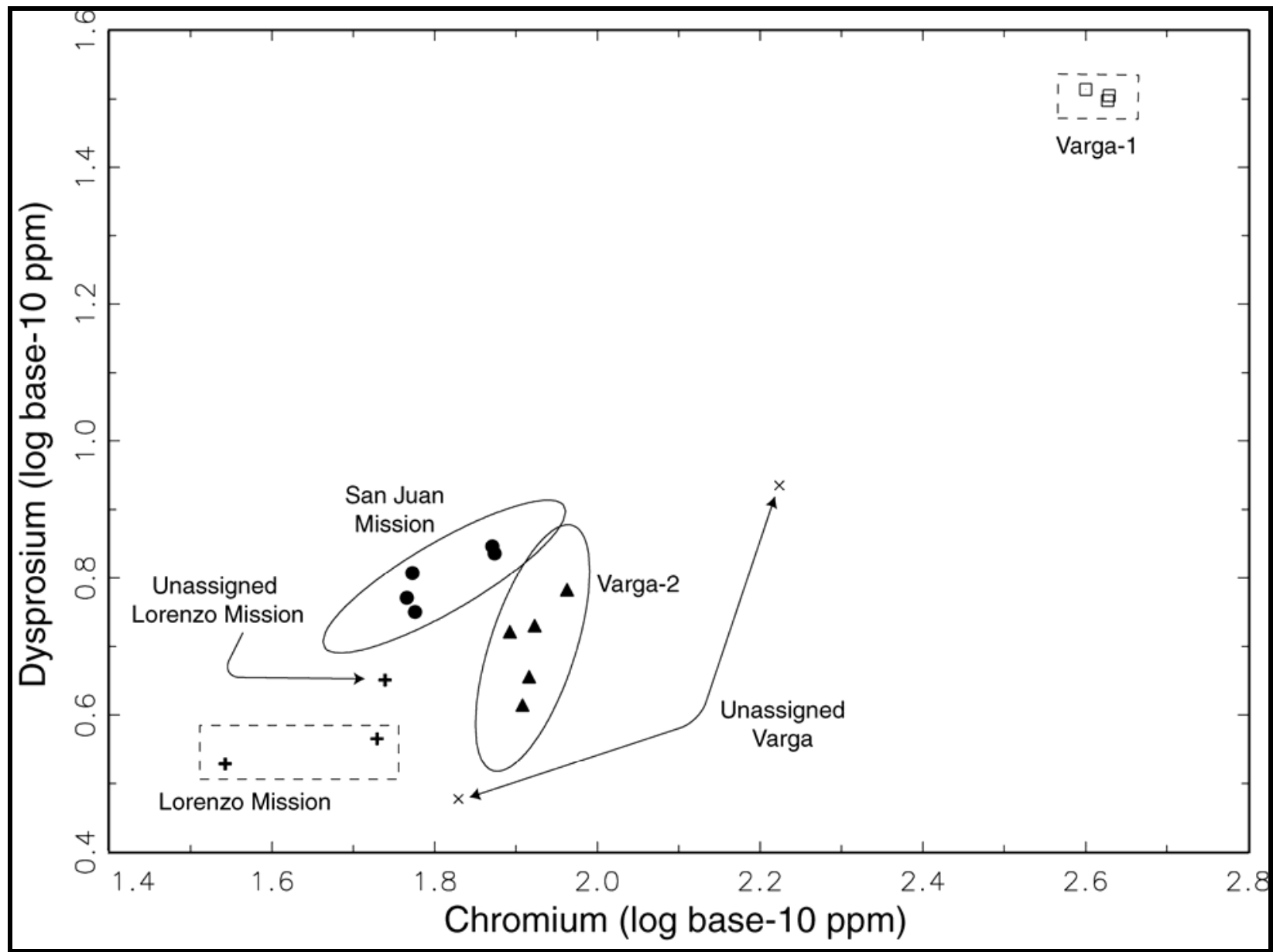

Figure N-7. Bivariate plot of Chromium and Dysprosium Base-10 Logged Concentrations Showing Subgroup Patterning Within the TRC Pottery Data Set

Sample TRC278, which was assigned to the El Paso reference group, is not included in this projection. Ellipses represent $90 \%$ confidence interval for group membership. 


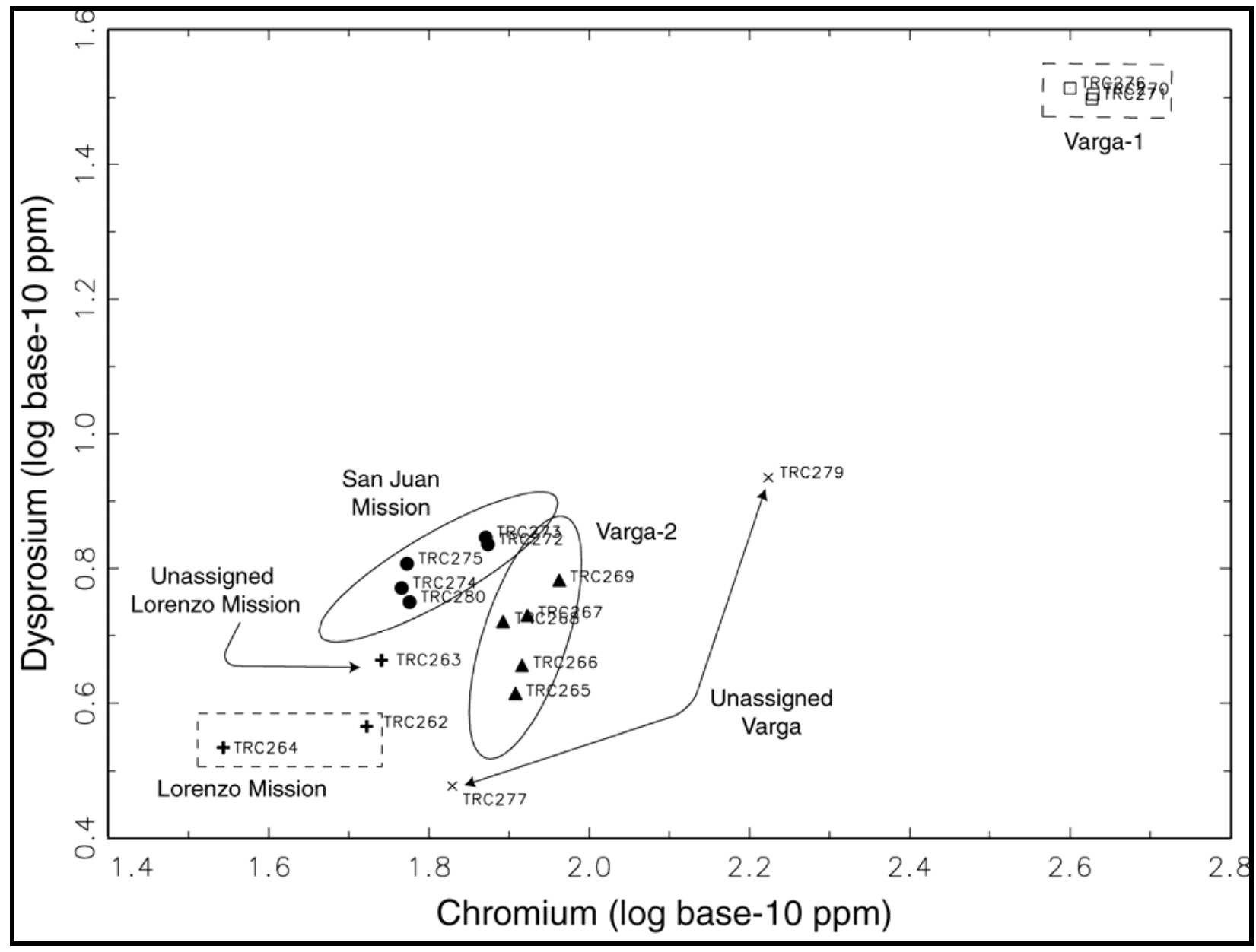

Figure N-8. Bivariate plot of Chromium and Dysprosium Base-10 Logged Concentrations Showing Subgroup Patterning Within the TRC Pottery Data Set (with Individual Specimens Labeled) 
Table N-1. Chemical Group Assignments and Descriptive Information for the 19Specimen TRC Pottery Data Set

\begin{tabular}{|c|c|c|c|c|c|c|}
\hline Anid & Chem. & Alt. ID & Site Name & Site \# & County & Description \\
\hline TRC262 & LM & $1872-32 c$ & Lorenzo Mission & 41RE1 & Real & Black, sand inclusions, thin, flat, undecorated \\
\hline TRC263 & LM-unas. & $1872-6 c$ & Lorenzo Mission & 41RE1 & Real & Black, large coarse additives, smoothed, knot-impressed \\
\hline TRC264 & LM & $1872-\mathrm{c}$ & Lorenzo Mission & 41RE1 & Real & Black, fine additives, thick, flat base, wheel-made \\
\hline TRC265 & SJM & SAAN 13002a & San Juan Mission & $41 \mathrm{BX} 5$ & Bexar & Thin, smooth inter. \& exter., lots white bone additives \\
\hline TRC266 & SJM & SAAN 13006a & San Juan Mission & $41 \mathrm{BX} 5$ & Bexar & Thick, smooth inter. \& exter., white bone additive, gray core \\
\hline TRC267 & SJM & SAAN 13008a & San Juan Mission & $41 \mathrm{BX} 5$ & Bexar & Thick, smooth exter., wiped inter., white bone added, gray \\
\hline TRC268 & SJM & SAAN 13010a & San Juan Mission & $41 \mathrm{BX} 5$ & Bexar & Thin, brown, few white bone, no décor or slip \\
\hline TRC269 & SJM & SAAN 13013a & San Juan Mission & $41 \mathrm{BX} 5$ & Bexar & Thin, sliped exter. white bone added \\
\hline TRC270 & Varga-1 & $1054-8-1 a$ & Varga & 41ED28 & Edwards & Thin, gray exter., wiped inter., tiny white bone added, V1 \\
\hline TRC271 & Varga-1 & $1030-8-\mathrm{a}$ & Varga & 41ED28 & Edwards & Thin, gray exter., wiped inter., tiny white bone added, V1 \\
\hline TRC272 & Varga-2 & $1129-8-1 \mathrm{a}$ & Varga & 41ED28 & Edwards & Thin, smooth exter. \& inter., black bone added, beige, V2 \\
\hline TRC273 & Varga-2 & $936-8-\mathrm{a}$ & Varga & 41ED28 & Edwards & Thin, smooth exter. \& inter., black bone added, beige, V2 \\
\hline TRC274 & Varga-2 & $272-8-a$ & Varga & 41ED28 & Edwards & Thick, smooth exter. \& inter., white bone, gray core, V4 \\
\hline TRC275 & Varga-2 & $159-8-1 c$ & Varga & $41 \mathrm{ED} 28$ & Edwards & Thick, smooth exter. \& inter., white bone, gray core, V4 \\
\hline TRC276 & Varga-1 & $840-8-1 a$ & Varga & $41 \mathrm{ED} 28$ & Edwards & Thin, smooth exter. \& inter., white bone, slipped, V3 \\
\hline TRC277 & Varga-unas. & $867-8-1 a$ & Varga & $41 \mathrm{ED} 28$ & Edwards & Thin, smooth exter. \& inter., white bone, slipped, V3 \\
\hline TRC278 & El Paso & $1261-8-3 a$ & Varga & 41ED28 & Edwards & Very thin, reddish brown slipped, black core, sand, V5 \\
\hline TRC279 & Varga-unas. & $840-8-1 b$ & Varga & 41ED28 & Edwards & Thin, curved, smooth exter., few additives, figurine-like object \\
\hline TRC280 & Varga-2 & $1259-004 b$ & Varga & 41ED28 & Edwards & T-2, Unit 3, Bk horizon, 65-70 cmbs, dark gray sediment \\
\hline
\end{tabular}

V1 = Vessel Group 1, V2 = Vessel Groups 2, V3 = Vessel group 3, V 4 = Vessel Group 4, V5 = Vessel Group 5 
Table N-2. Mahalanobis Distance Calculation and Posterior Classification for Two or More Groups

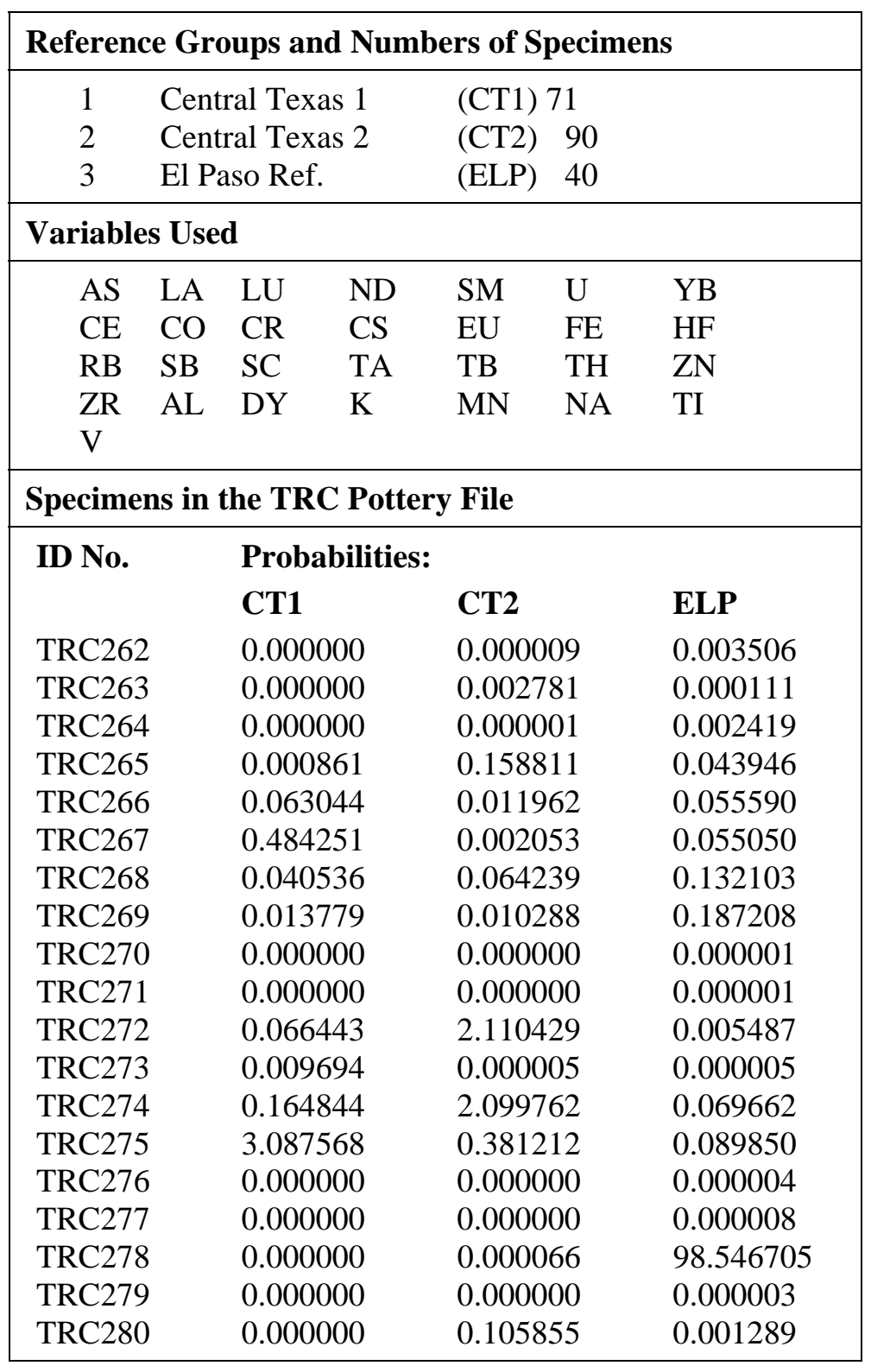



APPENDIX O:

METRIC AND NON-METRIC DATA AND VARGA SITE ARTIFACT DATABASE 
(20) 


\section{O.1 Metric And Non-Metric Data}

Individual observations, metric measurements, and provenience information on individual stone tools within each artifact classes (points, bifaces, scrapers, drills, unifaces, cores, and pottery) are presented in individual tables by class and component. Individual point types are presented separately by point type by component (i.e., Perdiz points, Late Archaic points, Gower points, etc.). The summaries of the observations and metric measurements that are presented in the body of the text for the different classes of artifacts by component were derived from these tables. The data in the tables is presented in Microsoft Excel files.

\section{O.2 Archeological Database}

The entire Varga Site database is presented in Microsoft Access format. The database includes information about collected artifact and samples, including the catalog numbers, provenience information, counts, weights, and metric and non-metric observations on the various tools. 
Appendix O: Data and Site Artifact Database

\begin{tabular}{|c|c|c|c|c|c|c|c|c|}
\hline \multicolumn{9}{|c|}{ Table O-1. Perdiz Point Data from the Toyah Component } \\
\hline Cat. No. & $108-013$ & 158-021 & 159-024 & $159-025$ & $176-015$ & 271-016 & 302-021 & $335-010$ \\
\hline Condition & Proximal & Proximal & Distal & Complete & Complete & Complete & Proximal & Proximal \\
\hline Raw Material & Chert & Chert & Chert & Chert & Chert & Chert & Chert & Chert \\
\hline Texture & Fine & Fine & Fine & Fine & Fine & Fine & Fine & Fine \\
\hline Percent Patination & 0 & 0 & 0 & 0 & 0 & 0 & 0 & 0 \\
\hline Perent Cortex & 0 & 0 & 0 & 0 & 0 & 0 & 0 & 0 \\
\hline Cortex Type & None & None & None & None & None & None & None & None \\
\hline Heating & None & None & None & None & None & None & Burned & None \\
\hline Rejuvenation Scar & Absent & Absent & Absent & Absent & Absent & Absent & Absent & Absent \\
\hline Resharpening & Indeterminate & None & None & None & None & None & None & Indeterminate \\
\hline Length $(\mathrm{mm})$ & & & & 28.3 & 38.9 & 29.6 & & \\
\hline \multicolumn{9}{|l|}{ Width (mm) } \\
\hline Thick (mm) & & 2.7 & 2.7 & 3.7 & 5.5 & 3.1 & & 2.9 \\
\hline Weight (g) & & & 1.4 & 1.1 & 3.5 & 0.8 & & \\
\hline Long X-Section & Indeterminate & Flat & Flat & Flat & Flat & Flat & Indeterminate & Indeterminate \\
\hline Trans X-Section & $\begin{array}{l}\text { Plano- } \\
\text { Convex }\end{array}$ & $\begin{array}{l}\text { Plano- } \\
\text { Convex }\end{array}$ & $\begin{array}{l}\text { Plano- } \\
\text { Convex }\end{array}$ & $\begin{array}{c}\text { Biconvex } \\
\text { Symmetrical }\end{array}$ & $\begin{array}{c}\text { Biconvex } \\
\text { Asymmetrical }\end{array}$ & $\begin{array}{c}\text { Biconvex } \\
\text { Symmetrical }\end{array}$ & $\begin{array}{c}\text { Biconvex } \\
\text { Symmetrical }\end{array}$ & $\begin{array}{c}\text { Biconvex } \\
\text { Symmetrical }\end{array}$ \\
\hline Preform & Flake & Flake & Flake & Flake & Flake & Flake & Flake & Flake \\
\hline Shape & Indeterminate & Indeterminate & Triangular & Triangular & Triangular & Triangular & Indeterminate & Triangular \\
\hline Flaking Pattern & Indeterminate & Chevron & $\begin{array}{l}\text { Flake Blank } \\
\text { Remnant }\end{array}$ & Chevron & Chevron & Chevron & Indeterminate & Indeterminate \\
\hline Edge Rounding & Present & Present & Absent & Absent & Present & Absent & Absent & Present \\
\hline Blade Length (mm) & & & 23.6 & 20.1 & 28.1 & 19.4 & & \\
\hline Blade Width (mm) & & 14.9 & 16.5 & 14.2 & 20.9 & 10.1 & 25.5 & 11.7 \\
\hline $\begin{array}{l}\text { Left Lateral Edge } \\
\text { Shape }\end{array}$ & Indeterminate & Indeterminate & Straight & Straight & Excurvate & Straight & Indeterminate & Indeterminate \\
\hline $\begin{array}{l}\text { Right Lateral Edge } \\
\text { Shape }\end{array}$ & Indeterminate & Indeterminate & Straight & Straight & Excurvate & Straight & Excurvate & Indeterminate \\
\hline Shoulder Width (mm) & & 17.8 & 21.1 & 19.7 & & & 26.7 & \\
\hline $\begin{array}{l}\text { Left Notch Depth } \\
(\mathrm{mm})\end{array}$ & 5.3 & 3.9 & & 4.6 & 4.9 & 5.1 & 5.5 & \\
\hline $\begin{array}{l}\text { Right Notch Depth } \\
(\mathrm{mm})\end{array}$ & & 4.9 & & 5 & & & 5.5 & \\
\hline $\begin{array}{l}\text { Left Notch Width } \\
(\mathrm{mm})\end{array}$ & 6.9 & 7.2 & & 9.2 & 9.2 & 6.8 & 9.4 & \\
\hline $\begin{array}{l}\text { Right Notch Width } \\
(\mathrm{mm})\end{array}$ & & 7.7 & & 9.4 & & & 10 & \\
\hline Left Notch Angle & 18 & 36 & 19 & 45 & 31 & 28 & 21 & 36 \\
\hline Right Notch Angle & & 33 & 27 & 34 & & & 13 & \\
\hline Stem Shape & Contracting & Contracting & Indeterminate & Contracting & Contracting & Contracting & Contracting & Contracting \\
\hline Stem Length $(\mathrm{mm})$ & 8.3 & 7.8 & & 8.2 & 10.8 & 10.2 & 9.3 & \\
\hline $\begin{array}{l}\text { Stem Dist Width } \\
(\mathrm{mm})\end{array}$ & 8.3 & 5.6 & 6.7 & 5.9 & 10.2 & 5.9 & 10 & \\
\hline $\begin{array}{l}\text { Stem Prox Width } \\
(\mathrm{mm})\end{array}$ & 6.4 & 3.5 & & 2.2 & 6.6 & 3.2 & 6 & \\
\hline Stem Thick (mm) & 2.9 & 2.6 & 2.5 & 2.4 & 3.2 & 2.6 & 3.3 & \\
\hline Base Depth (mm) & -1.3 & -0.7 & & -0.7 & -1.3 & -1.5 & -1 & \\
\hline Break Type & Use & Use & Use & Use & Use & Use & Use & Use \\
\hline Micro-wear & FALSE & FALSE & FALSE & FALSE & FALSE & FALSE & FALSE & FALSE \\
\hline NAA & FALSE & FALSE & FALSE & FALSE & FALSE & FALSE & TRUE & FALSE \\
\hline
\end{tabular}


The Varga Site

Texas Department of Transportation

Table O-1. Perdiz Point Data from the Toyah Component Continued

\begin{tabular}{|c|c|c|c|c|c|c|c|c|}
\hline Cat. No. & $348-011$ & 405-015 & 405-016 & 441-016 & 482-010 & 489-010 & $504-013$ & $525-010$ \\
\hline Condition & Proximal & Proximal & Complete & Complete & Proximal & Medial & Medial & Complete \\
\hline Raw Material & Chert & Chert & Chert & Chert & Chert & Chert & Chert & Chert \\
\hline Texture & Fine & Fine & Fine & Fine & Fine & Fine & Fine & Fine \\
\hline Percent Patination & 0 & 0 & 0 & 0 & 0 & 0 & 0 & 75 \\
\hline Perent Cortex & 0 & 0 & 0 & 0 & 0 & 0 & 0 & 0 \\
\hline Cortex Type & None & None & None & None & None & None & None & None \\
\hline Heating & None & None & None & None & None & None & Heat-Treated & None \\
\hline Rejuvenation Scar & Absent & Absent & Absent & Absent & Absent & Absent & Absent & Absent \\
\hline Resharpening & Indeterminate & Indeterminate & None & Indeterminate & None & Indeterminate & None & None \\
\hline Length (mm) & & & 25.3 & 36.9 & & & & 35.8 \\
\hline \multicolumn{9}{|l|}{ Width (mm) } \\
\hline Thick (mm) & & 3.3 & 3.1 & 3.4 & 2.9 & 2.6 & 4.6 & 2.7 \\
\hline Weight (g) & & & 0.8 & 1.6 & 1.1 & & & 1.3 \\
\hline Long X-Section & Indeterminate & Indeterminate & Flat & $\begin{array}{l}\text { Tapered } \\
\text { Base/Tip }\end{array}$ & Flat & Indeterminate & Flat & Flat \\
\hline Trans X-Section & Indeterminate & $\begin{array}{l}\text { Plano- } \\
\text { Convex }\end{array}$ & $\begin{array}{c}\text { Biconvex } \\
\text { Symmetrical }\end{array}$ & $\begin{array}{l}\text { Biconvex } \\
\text { Symmetrical }\end{array}$ & $\begin{array}{l}\text { Plano- } \\
\text { Convex }\end{array}$ & $\begin{array}{l}\text { Plano- } \\
\text { Convex }\end{array}$ & $\begin{array}{l}\text { Plano- } \\
\text { Convex }\end{array}$ & $\begin{array}{l}\text { Plano- } \\
\text { Convex }\end{array}$ \\
\hline Preform & Flake & Flake & Flake & Flake & Flake & Flake & Flake & Flake \\
\hline Shape & Indeterminate & Indeterminate & Triangular & Triangular & Triangular & Indeterminate & Triangular & Triangular \\
\hline Flaking Pattern & Indeterminate & $\begin{array}{c}\text { Flake Blank } \\
\text { Remnant }\end{array}$ & $\begin{array}{l}\text { Oblique } \\
\text { Parallel }\end{array}$ & Chevron & Chevron & $\begin{array}{c}\text { Flake Blank } \\
\text { Remnant }\end{array}$ & $\begin{array}{c}\text { Flake Blank } \\
\text { Remnant }\end{array}$ & $\begin{array}{c}\text { Flake Blank } \\
\text { Remnant }\end{array}$ \\
\hline Edge Rounding & Absent & Present & Absent & Absent & Present & Absent & Present & Present \\
\hline Blade Length $(\mathrm{mm})$ & & & 19.3 & 29 & & & 23.2 & 22.4 \\
\hline Blade Width (mm) & & & 12 & 14.8 & 17 & 14.7 & 21.9 & 18 \\
\hline $\begin{array}{l}\text { Left Lateral Edge } \\
\text { Shape }\end{array}$ & Indeterminate & Indeterminate & Straight & Incurvate & Straight & Indeterminate & Excurvate & Excurvate \\
\hline $\begin{array}{l}\text { Right Lateral Edge } \\
\text { Shape }\end{array}$ & Indeterminate & Indeterminate & Straight & Incurvate & Straight & Indeterminate & Excurvate & Excurvate \\
\hline Shoulder Width (mm) & & 26.1 & 18.7 & 23 & 18.7 & & 23.4 & 18.8 \\
\hline $\begin{array}{l}\text { Left Notch Depth } \\
(\mathrm{mm})\end{array}$ & & 5.9 & 4.4 & 5.2 & 4.8 & & & 4.1 \\
\hline $\begin{array}{l}\text { Right Notch Depth } \\
(\mathrm{mm})\end{array}$ & & 5.4 & 5.6 & 5.9 & 6.1 & & & 4.3 \\
\hline $\begin{array}{l}\text { Left Notch Width } \\
(\mathrm{mm})\end{array}$ & & 8.4 & 6.5 & 10.9 & 7.9 & & & 10.1 \\
\hline $\begin{array}{l}\text { Right Notch Width } \\
(\mathrm{mm})\end{array}$ & & 7.4 & 7.4 & 11.3 & 7.7 & & & 8.7 \\
\hline Left Notch Angle & & 36 & 33 & 26 & 29 & 16 & 10 & 21 \\
\hline Right Notch Angle & & 23 & 21 & 14 & 14 & & 17 & 27 \\
\hline Stem Shape & Contracting & Contracting & Contracting & Contracting & Contracting & Indeterminate & Indeterminate & Contracting \\
\hline Stem Length $(\mathrm{mm})$ & 14.8 & 9.6 & 6 & 7.9 & 9 & & & 13.4 \\
\hline $\begin{array}{l}\text { Stem Dist Width } \\
(\mathrm{mm})\end{array}$ & 6.2 & 9.3 & 4.3 & 6.2 & 6.2 & 5 & & 8.9 \\
\hline $\begin{array}{l}\text { Stem Prox Width } \\
(\mathrm{mm})\end{array}$ & 5.1 & 8.6 & 3.8 & 4.1 & 4.8 & & & 7.8 \\
\hline Stem Thick (mm) & 2.9 & 3.1 & 2.3 & 2.4 & 2.2 & & & 2.1 \\
\hline Base Depth (mm) & -2.7 & -3.3 & -1.5 & -1.8 & -4.1 & & & -4.1 \\
\hline Break Type & Use & Use & Use & Unbroken & Use & Use & Use & Unbroken \\
\hline Micro-wear & FALSE & FALSE & FALSE & TRUE & FALSE & FALSE & FALSE & FALSE \\
\hline NAA & FALSE & FALSE & FALSE & FALSE & TRUE & FALSE & FALSE & TRUE \\
\hline
\end{tabular}


Appendix O: Data and Site Artifact Database

Table O-1. Perdiz Point Data from the Toyah Component Continued

\begin{tabular}{|c|c|c|c|c|c|c|c|c|}
\hline Cat. No. & $526-010$ & $533-017$ & 602-017 & 602-018 & $726-010$ & 726-011 & 781-012 & $782-016$ \\
\hline Condition & Complete & Complete & Complete & Complete & Complete & Proximal & Complete & Complete \\
\hline Raw Material & Chert & Chert & Chert & Chert & Chert & Chert & Chert & Chert \\
\hline Texture & Fine & Fine & Fine & Fine & Fine & Fine & Fine & Fine \\
\hline Percent Patination & 0 & 0 & 0 & 0 & 0 & 0 & 0 & 0 \\
\hline Perent Cortex & 0 & 0 & 0 & 0 & 0 & 0 & 0 & 0 \\
\hline Cortex Type & None & None & None & None & None & None & None & None \\
\hline Heating & None & None & None & None & None & None & None & None \\
\hline Rejuvenation Scar & Absent & Absent & Absent & Absent & Absent & Absent & Absent & Absent \\
\hline Resharpening & None & None & None & $\begin{array}{c}\text { Break } \\
\text { Compensation }\end{array}$ & None & Indeterminate & None & None \\
\hline Length (mm) & 34.1 & 34.7 & 35.4 & 23.4 & 24 & & 30.5 & 26.1 \\
\hline \multicolumn{9}{|l|}{ Width (mm) } \\
\hline Thick (mm) & 2.4 & 3 & 2.9 & 2.1 & 2.3 & & 2.4 & 2.6 \\
\hline Weight (g) & 1.1 & 1.2 & 1.1 & 0.5 & 0.3 & & 0.8 & 0.6 \\
\hline Long X-Section & Flat & Flat & Flat & Flat & Flat & Indeterminate & Flat & Flat \\
\hline Trans X-Section & $\begin{array}{l}\text { Plano- } \\
\text { Convex }\end{array}$ & $\begin{array}{l}\text { Plano- } \\
\text { Convex }\end{array}$ & $\begin{array}{l}\text { Plano- } \\
\text { Convex }\end{array}$ & Plano-Convex & $\begin{array}{l}\text { Plano- } \\
\text { Convex }\end{array}$ & $\begin{array}{c}\text { Biconvex } \\
\text { Symmetrical }\end{array}$ & $\begin{array}{l}\text { Plano- } \\
\text { Convex }\end{array}$ & $\begin{array}{l}\text { Plano- } \\
\text { Convex }\end{array}$ \\
\hline Preform & Flake & Flake & Flake & Flake & Flake & Flake & Flake & Flake \\
\hline Shape & Triangular & Triangular & Triangular & Triangular & Indeterminate & Indeterminate & Triangular & Triangular \\
\hline Flaking Pattern & $\begin{array}{l}\text { Oblique } \\
\text { Parallel }\end{array}$ & $\begin{array}{l}\text { Oblique } \\
\text { Parallel }\end{array}$ & Chevron & Chevron & Subparallel & $\begin{array}{l}\text { Oblique } \\
\text { Parallel }\end{array}$ & $\begin{array}{c}\text { Flake Blank } \\
\text { Remnant }\end{array}$ & Chevron \\
\hline Edge Rounding & Present & Absent & Absent & Present & Present & Present & Absent & Present \\
\hline Blade Length $(\mathrm{mm})$ & 22.9 & 22.7 & 25.1 & 15.8 & 9.1 & & 24.3 & 20.6 \\
\hline Blade Width (mm) & 15.3 & 13.3 & 15.4 & 12.7 & 2.6 & & 13 & 9.4 \\
\hline $\begin{array}{l}\text { Left Lateral Edge } \\
\text { Shape }\end{array}$ & Straight & Excurvate & Excurvate & Straight & Incurvate & Indeterminate & Straight & Straight \\
\hline $\begin{array}{l}\text { Right Lateral Edge } \\
\text { Shape }\end{array}$ & Straight & Straight & Straight & Straight & Incurvate & Indeterminate & Straight & Straight \\
\hline Shoulder Width (mm) & 18.6 & & 17.3 & 16.2 & 11.3 & & 14.7 & 13.5 \\
\hline $\begin{array}{l}\text { Left Notch Depth } \\
(\mathrm{mm})\end{array}$ & 4 & 7.6 & 3.4 & 3.4 & 1.9 & 5.1 & 3.8 & 2.7 \\
\hline $\begin{array}{l}\text { Right Notch Depth } \\
(\mathrm{mm})\end{array}$ & 3.2 & & 4.1 & 3.4 & 3.2 & & 3.8 & \\
\hline $\begin{array}{l}\text { Left Notch Width } \\
(\mathrm{mm})\end{array}$ & 8.3 & 10.1 & 9.2 & 6.8 & 11.7 & 6.9 & 5.6 & 5.5 \\
\hline $\begin{array}{l}\text { Right Notch Width } \\
(\mathrm{mm})\end{array}$ & 8.8 & & 6.5 & 7.2 & 13.2 & & 4.7 & \\
\hline Left Notch Angle & 36 & 24 & 23 & 36 & 28 & 26 & 23 & 27 \\
\hline Right Notch Angle & 31 & & 34 & 35 & 27 & 30 & 30 & 28 \\
\hline Stem Shape & Contracting & Contracting & Contracting & Contracting & Contracting & Contracting & Contracting & Contracting \\
\hline Stem Length $(\mathrm{mm})$ & 11.2 & 12 & 10.3 & 7.6 & 14.9 & 7.9 & 6.2 & 5.5 \\
\hline $\begin{array}{l}\text { Stem Dist Width } \\
(\mathrm{mm})\end{array}$ & 8.8 & 6.4 & 8.6 & 6.4 & 5.9 & 5.1 & 4.9 & 5 \\
\hline $\begin{array}{l}\text { Stem Prox Width } \\
(\mathrm{mm})\end{array}$ & 7.8 & 1.9 & 5.6 & 5 & 1.3 & 2.5 & 3.8 & 3.1 \\
\hline Stem Thick (mm) & 2.6 & 2.4 & 2 & 2.1 & 1.8 & 2.2 & 1.7 & 1.7 \\
\hline Base Depth (mm) & -4.6 & -0.9 & -2.2 & -2.4 & -0.9 & -1.5 & -1.2 & -1.1 \\
\hline Break Type & Unbroken & Use & Unbroken & Use & Use & Use & Unbroken & Use \\
\hline Micro-wear & FALSE & FALSE & FALSE & FALSE & FALSE & FALSE & FALSE & FALSE \\
\hline NAA & TRUE & FALSE & FALSE & FALSE & FALSE & FALSE & FALSE & FALSE \\
\hline
\end{tabular}


The Varga Site

Texas Department of Transportation

\begin{tabular}{|c|c|c|c|c|c|c|c|c|}
\hline Cat. No. & $815-010$ & $825-010$ & 851-014 & 862-020 & 863-012 & $876-013$ & 881-018 & 885-022 \\
\hline Condition & Medial & Complete & Medial & Complete & Complete & Complete & Medial & Complete \\
\hline Raw Material & Chert & Chert & Chert & Chert & Chert & Chert & Chert & Chert \\
\hline Texture & Fine & Fine & Fine & Fine & Fine & Fine & Fine & Fine \\
\hline Percent Patination & 0 & 0 & 0 & 0 & 0 & 0 & 0 & 0 \\
\hline Perent Cortex & 0 & 0 & 0 & 0 & 0 & 0 & 0 & 0 \\
\hline Cortex Type & None & None & None & None & None & None & None & None \\
\hline Heating & None & None & None & None & None & None & None & None \\
\hline Rejuvenation Scar & Absent & Absent & Absent & Absent & Absent & Absent & Absent & Absent \\
\hline Resharpening & Indeterminate & None & Indeterminate & None & $\begin{array}{c}\text { Break } \\
\text { Compensation }\end{array}$ & None & Indeterminate & None \\
\hline Length (mm) & & 36.4 & & 23 & 35.9 & 23.8 & & 27.5 \\
\hline \multicolumn{9}{|l|}{ Width (mm) } \\
\hline Thick (mm) & & 3.4 & 3 & 3 & 3.1 & 2.2 & & 2.9 \\
\hline Weight (g) & & 1.9 & & 0.5 & 1.3 & 0.7 & & 0.7 \\
\hline Long X-Section & Indeterminate & Flat & Indeterminate & Flat & Flat & Flat & Indeterminate & Flat \\
\hline Trans X-Section & $\begin{array}{l}\text { Plano- } \\
\text { Convex }\end{array}$ & $\begin{array}{l}\text { Plano- } \\
\text { Convex }\end{array}$ & $\begin{array}{l}\text { Plano- } \\
\text { Convex }\end{array}$ & $\begin{array}{c}\text { Biconvex } \\
\text { Symmetrical }\end{array}$ & $\begin{array}{c}\text { Biconvex } \\
\text { Symmetrical }\end{array}$ & $\begin{array}{l}\text { Plano- } \\
\text { Convex }\end{array}$ & $\begin{array}{l}\text { Plano- } \\
\text { Convex }\end{array}$ & $\begin{array}{l}\text { Plano- } \\
\text { Convex }\end{array}$ \\
\hline Preform & Flake & Flake & Flake & Flake & Flake & Flake & Flake & Flake \\
\hline Shape & Indeterminate & Triangular & Indeterminate & Triangular & Triangular & Triangular & Indeterminate & Triangular \\
\hline Flaking Pattern & Indeterminate & $\begin{array}{l}\text { Oblique } \\
\text { Parallel }\end{array}$ & Indeterminate & Subparallel & Chevron & $\begin{array}{c}\text { Oblique } \\
\text { Subparallel }\end{array}$ & Indeterminate & Chevron \\
\hline Edge Rounding & Present & Present & Absent & Present & Absent & Present & Present & Present \\
\hline Blade Length $(\mathrm{mm})$ & & 28.4 & & 16.9 & 24.7 & 16.1 & & 19.3 \\
\hline Blade Width (mm) & & 14.9 & & 9 & 15 & 15.3 & 13.9 & 12.7 \\
\hline $\begin{array}{l}\text { Left Lateral Edge } \\
\text { Shape }\end{array}$ & Indeterminate & Straight & Indeterminate & Straight & Excurvate & Excurvate & Indeterminate & Straight \\
\hline $\begin{array}{l}\text { Right Lateral Edge } \\
\text { Shape }\end{array}$ & Indeterminate & Excurvate & Indeterminate & Straight & Excurvate & Straight & Indeterminate & Straight \\
\hline Shoulder Width (mm) & 11.6 & & & 13.3 & & 18.9 & 15.4 & 14.6 \\
\hline $\begin{array}{l}\text { Left Notch Depth } \\
(\mathrm{mm})\end{array}$ & & 4.4 & & 2.5 & & 4.8 & & 3.8 \\
\hline $\begin{array}{l}\text { Right Notch Depth } \\
(\mathrm{mm})\end{array}$ & & & & 2.3 & 5.4 & & & 3.7 \\
\hline $\begin{array}{l}\text { Left Notch Width } \\
(\mathrm{mm})\end{array}$ & & 6.6 & & 6.9 & & 7 & & 7.6 \\
\hline $\begin{array}{l}\text { Right Notch Width } \\
(\mathrm{mm})\end{array}$ & & & & 6.7 & 10.8 & & & 7.5 \\
\hline Left Notch Angle & 41 & 33 & 32 & 31 & & 34 & 24 & 29 \\
\hline Right Notch Angle & 37 & & & 25 & 19 & 30 & 22 & 23 \\
\hline Stem Shape & Contracting & Contracting & Contracting & Contracting & Contracting & Contracting & Indeterminate & Contracting \\
\hline Stem Length $(\mathrm{mm})$ & 5.6 & 8 & & 6.1 & 11.2 & 7 & & 7.7 \\
\hline $\begin{array}{l}\text { Stem Dist Width } \\
(\mathrm{mm})\end{array}$ & 6.9 & 5.5 & 6.2 & 5.9 & 6.7 & 6.2 & 5 & 6 \\
\hline $\begin{array}{l}\text { Stem Prox Width } \\
(\mathrm{mm})\end{array}$ & 3.7 & 4.2 & 3.3 & 2.6 & 2.5 & 3.1 & & 2.4 \\
\hline Stem Thick (mm) & 2.1 & 2.8 & 2.8 & 2 & 2.1 & 1.7 & 1.5 & 1.8 \\
\hline Base Depth (mm) & -0.5 & -3.4 & & -1.3 & -2.1 & -1 & & -0.7 \\
\hline Break Type & Use & Use & Use & Unbroken & Use & Use & Use & Use \\
\hline Micro-wear & FALSE & FALSE & FALSE & FALSE & FALSE & FALSE & FALSE & FALSE \\
\hline NAA & FALSE & TRUE & FALSE & FALSE & FALSE & FALSE & FALSE & FALSE \\
\hline
\end{tabular}


Appendix O: Data and Site Artifact Database

Table O-1. Perdiz Point Data from the Toyah Component Continued

\begin{tabular}{|c|c|c|c|c|c|c|c|c|}
\hline Cat. No. & $903-028$ & $930-016$ & 939-013 & $945-016$ & $949-016$ & $988-013$ & $989-020$ & 992-016 \\
\hline Condition & Distal & Proximal & Proximal & Complete & Proximal & Proximal & Proximal & Proximal \\
\hline Raw Material & Chert & Chert & Chert & Chert & Chert & Chert & Chert & Chert \\
\hline Texture & Fine & Fine & Fine & Fine & Fine & Fine & Fine & Fine \\
\hline Percent Patination & 0 & 0 & 0 & 0 & 0 & 0 & 0 & 0 \\
\hline Perent Cortex & 0 & 0 & 0 & 0 & 0 & 0 & 0 & 0 \\
\hline Cortex Type & None & None & None & None & None & None & None & None \\
\hline Heating & None & None & None & None & None & None & None & None \\
\hline Rejuvenation Scar & Absent & Absent & Absent & Absent & Absent & Absent & Absent & Absent \\
\hline Resharpening & $\begin{array}{c}\text { Break } \\
\text { Compensation }\end{array}$ & None & $\begin{array}{c}\text { Break } \\
\text { Compensation }\end{array}$ & $\begin{array}{l}\text { Beveled } \\
\text { Unifacial }\end{array}$ & None & Indeterminate & None & Indeterminate \\
\hline Length (mm) & & & & 40.8 & & & & \\
\hline \multicolumn{9}{|l|}{ Width (mm) } \\
\hline Thick (mm) & 3 & 3.1 & 3.2 & 3.3 & 2.3 & & 2.3 & \\
\hline Weight (g) & 0.7 & & 1 & 2.2 & 0.8 & & 0.6 & \\
\hline Long X-Section & Flat & Flat & Flat & Flat & Flat & Indeterminate & Flat & Indeterminate \\
\hline Trans X-Section & Plano-Convex & $\begin{array}{l}\text { Biconvex } \\
\text { Symmetrical }\end{array}$ & Plano-Convex & $\begin{array}{l}\text { Plano- } \\
\text { Convex }\end{array}$ & $\begin{array}{l}\text { Plano- } \\
\text { Convex }\end{array}$ & $\begin{array}{l}\text { Plano- } \\
\text { Convex }\end{array}$ & $\begin{array}{l}\text { Plano- } \\
\text { Convex }\end{array}$ & $\begin{array}{l}\text { Plano- } \\
\text { Convex }\end{array}$ \\
\hline Preform & Flake & Flake & Flake & Flake & Flake & Flake & Flake & Flake \\
\hline Shape & Triangular & Triangular & Lanceolate & Triangular & Triangular & Indeterminate & Lanceolate & Indeterminate \\
\hline Flaking Pattern & Chevron & Subparallel & Subparallel & $\begin{array}{c}\text { Flake Blank } \\
\text { Remnant }\end{array}$ & Chevron & Indeterminate & Chevron & Parallel \\
\hline Edge Rounding & Absent & Present & Absent & Absent & Absent & Absent & Present & Absent \\
\hline Blade Length $(\mathrm{mm})$ & 13.5 & & & 31.3 & & & & \\
\hline Blade Width (mm) & 11.4 & 17.8 & 10.8 & 16.4 & 11.8 & & 10.1 & 13.5 \\
\hline $\begin{array}{l}\text { Left Lateral Edge } \\
\text { Shape }\end{array}$ & Straight & Straight & Straight & Excurvate & Excurvate & Indeterminate & Straight & Indeterminate \\
\hline $\begin{array}{l}\text { Right Lateral Edge } \\
\text { Shape }\end{array}$ & Straight & Straight & Excurvate & Excurvate & Excurvate & Indeterminate & Straight & Indeterminate \\
\hline Shoulder Width (mm) & & 22.9 & 15.9 & & 14.6 & 17.1 & 16.2 & \\
\hline $\begin{array}{l}\text { Left Notch Depth } \\
(\mathrm{mm})\end{array}$ & & 6.7 & 2.9 & 2.4 & 3.2 & 3 & & \\
\hline $\begin{array}{l}\text { Right Notch Depth } \\
(\mathrm{mm})\end{array}$ & & 6.6 & 3.6 & & 2.1 & 3.4 & 1.3 & 5.9 \\
\hline $\begin{array}{l}\text { Left Notch Width } \\
(\mathrm{mm})\end{array}$ & & 11.2 & 6 & 9.3 & 5.4 & 9.5 & & \\
\hline $\begin{array}{l}\text { Right Notch Width } \\
(\mathrm{mm})\end{array}$ & & 11.2 & 7.8 & & 7.9 & 5.2 & 5.3 & 7.9 \\
\hline Left Notch Angle & 30 & 20 & 41 & 38 & 28 & 27 & & \\
\hline Right Notch Angle & 24 & 20 & 17 & 37 & 22 & 31 & 28 & 13 \\
\hline Stem Shape & Indeterminate & Contracting & Contracting & Contracting & Contracting & Contracting & Contracting & Contracting \\
\hline Stem Length $(\mathrm{mm})$ & & 9.6 & 7.5 & 9.5 & 5.5 & 7.5 & 4.8 & 10.2 \\
\hline $\begin{array}{l}\text { Stem Dist Width } \\
(\mathrm{mm})\end{array}$ & 7.3 & 6.9 & 6.1 & 8.3 & 6.4 & 7.9 & 9.3 & 5.6 \\
\hline $\begin{array}{l}\text { Stem Prox Width } \\
(\mathrm{mm})\end{array}$ & & 3.1 & 3.3 & 5.1 & 3.6 & 3.8 & 4.2 & 3.2 \\
\hline Stem Thick (mm) & & 2.6 & 2.5 & 2.9 & 1.8 & 3 & 1.4 & 1.8 \\
\hline Base Depth (mm) & & -1.5 & -1.5 & -1.2 & -1.4 & -2.1 & -1.2 & -2.5 \\
\hline Break Type & Use & Use & Use & Use & Use & Use & Use & Use \\
\hline Micro-wear & FALSE & FALSE & FALSE & FALSE & FALSE & FALSE & FALSE & FALSE \\
\hline NAA & FALSE & FALSE & FALSE & FALSE & FALSE & FALSE & FALSE & FALSE \\
\hline
\end{tabular}


The Varga Site

Texas Department of Transportation

Table O-1. Perdiz Point Data from the Toyah Component Continued

\begin{tabular}{|c|c|c|c|c|c|c|c|c|}
\hline Cat. No. & $999-020$ & $1008-017$ & 1021-011 & $1031-013$ & $1098-010$ & $1100-016$ & $1125-017$ & $1137-012$ \\
\hline Condition & Medial & Medial & Medial & Proximal & Proximal & Complete & Proximal & Distal \\
\hline Raw Material & Chert & Chert & Chert & Chert & Chert & Chert & Chert & Chert \\
\hline Texture & Fine & Fine & Fine & Fine & Fine & Fine & Fine & Fine \\
\hline Percent Patination & 0 & 0 & 0 & 0 & 0 & 0 & 0 & 0 \\
\hline Perent Cortex & 0 & 0 & 0 & 0 & 0 & 0 & 0 & 0 \\
\hline Cortex Type & None & None & None & None & None & None & None & None \\
\hline Heating & None & None & None & None & None & $\begin{array}{l}\text { Heat- } \\
\text { Treated }\end{array}$ & None & None \\
\hline Rejuvenation Scar & Absent & Absent & Absent & Absent & Absent & Absent & Absent & Absent \\
\hline Resharpening & None & None & None & None & Indeterminate & None & None & None \\
\hline Length (mm) & & & & & & 24.3 & & 25.7 \\
\hline \multicolumn{9}{|l|}{ Width (mm) } \\
\hline Thick (mm) & 3.2 & 4.3 & 2.8 & 2.8 & & 3.5 & 2.7 & 2.3 \\
\hline Weight (g) & & 1.8 & & & & 0.9 & & 0.6 \\
\hline Long X-Section & Flat & Flat & Flat & Flat & Indeterminate & Flat & Indeterminate & Flat \\
\hline Trans $\mathrm{X}$-Section & $\begin{array}{l}\text { Plano- } \\
\text { Convex }\end{array}$ & $\begin{array}{l}\text { Plano- } \\
\text { Convex }\end{array}$ & $\begin{array}{l}\text { Plano- } \\
\text { Convex }\end{array}$ & $\begin{array}{l}\text { Plano- } \\
\text { Convex }\end{array}$ & $\begin{array}{l}\text { Plano- } \\
\text { Convex }\end{array}$ & $\begin{array}{c}\text { Biconvex } \\
\text { Symmetrical }\end{array}$ & $\begin{array}{l}\text { Plano- } \\
\text { Convex }\end{array}$ & $\begin{array}{l}\text { Plano- } \\
\text { Convex }\end{array}$ \\
\hline Preform & Flake & Flake & Flake & Flake & Flake & Flake & Flake & Flake \\
\hline Shape & Triangular & Lanceolate & Indeterminate & Triangular & Indeterminate & Triangular & Indeterminate & Triangular \\
\hline Flaking Pattern & Chevron & Chevron & $\begin{array}{c}\text { Flake Blank } \\
\text { Remnant }\end{array}$ & Chevron & $\begin{array}{l}\text { Flake Blank } \\
\text { Remnant }\end{array}$ & Chevron & Indeterminate & $\begin{array}{c}\text { Flake Blank } \\
\text { Remnant }\end{array}$ \\
\hline Edge Rounding & Absent & Absent & Absent & Present & Absent & Absent & Present & Present \\
\hline Blade Length $(\mathrm{mm})$ & & & & & & 17.8 & & 18.3 \\
\hline Blade Width (mm) & 12.6 & 14.2 & 22.9 & & & 12 & 14.1 & 13.1 \\
\hline $\begin{array}{l}\text { Left Lateral Edge } \\
\text { Shape }\end{array}$ & Straight & Straight & Excurvate & Excurvate & Indeterminate & Straight & Indeterminate & Straight \\
\hline $\begin{array}{l}\text { Right Lateral Edge } \\
\text { Shape }\end{array}$ & Straight & Straight & Excurvate & Indeterminate & Indeterminate & Straight & Indeterminate & Straight \\
\hline Shoulder Width (mm) & & & & & 18 & & 15.9 & \\
\hline $\begin{array}{l}\text { Left Notch Depth } \\
(\mathrm{mm})\end{array}$ & & & & 4.9 & 1.7 & & 2.8 & \\
\hline $\begin{array}{l}\text { Right Notch Depth } \\
(\mathrm{mm})\end{array}$ & & & & & 2.1 & & 2.8 & \\
\hline $\begin{array}{l}\text { Left Notch Width } \\
(\mathrm{mm})\end{array}$ & & & & 9.5 & 7.1 & & 7.3 & \\
\hline $\begin{array}{l}\text { Right Notch Width } \\
(\mathrm{mm})\end{array}$ & & & & & 7.8 & & 6.2 & \\
\hline Left Notch Angle & 20 & 30 & & 26 & 36 & & 33 & 24 \\
\hline Right Notch Angle & & 20 & & & 29 & 28 & 32 & 24 \\
\hline Stem Shape & Indeterminate & Indeterminate & Indeterminate & Contracting & Contracting & Contracting & Contracting & Contracting \\
\hline Stem Length $(\mathrm{mm})$ & & & & 10.5 & 7.8 & 6.4 & 5.8 & 7.4 \\
\hline $\begin{array}{l}\text { Stem Dist Width } \\
(\mathrm{mm})\end{array}$ & & 6.9 & 9.3 & 6.9 & 9.6 & 6 & 7.8 & 4.4 \\
\hline $\begin{array}{l}\text { Stem Prox Width } \\
(\mathrm{mm})\end{array}$ & & & & 4.4 & 5.6 & 4.7 & 4.1 & 3.6 \\
\hline Stem Thick (mm) & & & & 2.5 & 1.6 & 2 & 2.3 & 1.1 \\
\hline Base Depth (mm) & & & & -2.9 & -2.4 & -1.6 & -1.5 & \\
\hline Break Type & Use & Use & Use & Use & Use & Use & Use & Use \\
\hline Micro-wear & FALSE & FALSE & FALSE & FALSE & FALSE & FALSE & FALSE & FALSE \\
\hline NAA & FALSE & FALSE & FALSE & TRUE & FALSE & FALSE & FALSE & FALSE \\
\hline
\end{tabular}


Appendix O: Data and Site Artifact Database

Table O-1. Perdiz Point Data from the Toyah Component Continued

\begin{tabular}{|c|c|c|c|c|c|}
\hline Cat. No. & $1162-011$ & $1176-010$ & $1214-010$ & $1215-010$ & $1256-005-010$ \\
\hline Condition & Proximal & Medial & Distal & Proximal & Medial \\
\hline Raw Material & Chert & Chert & Chert & Chert & Chert \\
\hline Texture & Fine & Fine & Fine & Fine & Fine \\
\hline Percent Patination & 0 & 0 & 0 & 0 & 0 \\
\hline Perent Cortex & 0 & 0 & 0 & 0 & 0 \\
\hline Cortex Type & None & None & None & None & None \\
\hline Heating & None & None & None & None & None \\
\hline Rejuvenation Scar & Absent & Absent & Absent & Absent & Absent \\
\hline Resharpening & None & None & Indeterminate & Indeterminate & None \\
\hline \multicolumn{6}{|l|}{ Length (mm) } \\
\hline \multicolumn{6}{|l|}{ Width (mm) } \\
\hline Thick (mm) & 2.9 & 2.4 & 3 & 2.2 & 3 \\
\hline Weight (g) & & & 1.7 & & 1.2 \\
\hline Long X-Section & Flat & Indeterminate & Flat & Flat & Flat \\
\hline Trans X-Section & $\begin{array}{l}\text { Plano- } \\
\text { Convex }\end{array}$ & $\begin{array}{l}\text { Plano- } \\
\text { Convex }\end{array}$ & $\begin{array}{l}\text { Plano- } \\
\text { Convex }\end{array}$ & $\begin{array}{l}\text { Plano- } \\
\text { Convex }\end{array}$ & Plano-Convex \\
\hline Preform & Flake & Flake & Flake & Flake & Flake \\
\hline Shape & Triangular & Indeterminate & Triangular & Indeterminate & Triangular \\
\hline Flaking Pattern & Parallel & $\begin{array}{l}\text { Flake Blank } \\
\text { Remnant }\end{array}$ & $\begin{array}{l}\text { Flake Blank } \\
\text { Remnant }\end{array}$ & Chevron & Chevron \\
\hline Edge Rounding & Present & Absent & Absent & Present & Absent \\
\hline Blade Length (mm) & & & 24 & & \\
\hline Blade Width (mm) & 19 & 12.5 & 18.5 & 10.8 & 15.6 \\
\hline $\begin{array}{l}\text { Left Lateral Edge } \\
\text { Shape }\end{array}$ & Indeterminate & Indeterminate & Excurvate & Indeterminate & Straight \\
\hline $\begin{array}{l}\text { Right Lateral Edge } \\
\text { Shape }\end{array}$ & Indeterminate & Indeterminate & Excurvate & Indeterminate & Excurvate \\
\hline Shoulder Width (mm) & & 15.1 & 19.7 & 14.8 & \\
\hline $\begin{array}{l}\text { Left Notch Depth } \\
(\mathrm{mm})\end{array}$ & & & & 2.7 & \\
\hline $\begin{array}{l}\text { Right Notch Depth } \\
(\mathrm{mm})\end{array}$ & 4.4 & & & 2.5 & \\
\hline $\begin{array}{l}\text { Left Notch Width } \\
(\mathrm{mm})\end{array}$ & & & & 5.6 & \\
\hline $\begin{array}{l}\text { Right Notch Width } \\
(\mathrm{mm})\end{array}$ & 11.8 & & & 5.3 & \\
\hline Left Notch Angle & 37 & 29 & 33 & 40 & 36 \\
\hline Right Notch Angle & 32 & 35 & 27 & 24 & 30 \\
\hline Stem Shape & Contracting & Indeterminate & Indeterminate & Contracting & Indeterminate \\
\hline Stem Length (mm) & 10.6 & & & 5.8 & \\
\hline $\begin{array}{l}\text { Stem Dist Width } \\
(\mathrm{mm})\end{array}$ & 10.4 & 5.7 & 8.6 & 6.1 & 6.4 \\
\hline $\begin{array}{l}\text { Stem Prox Width } \\
(\mathrm{mm})\end{array}$ & 7.5 & & & 4.1 & \\
\hline Stem Thick (mm) & 2.1 & 1.7 & 1.6 & 2 & 2.8 \\
\hline Base Depth (mm) & -2.9 & & & -1.4 & \\
\hline Break Type & Use & Use & Use & Use & Use \\
\hline Micro-wear & FALSE & FALSE & FALSE & FALSE & FALSE \\
\hline NAA & TRUE & FALSE & FALSE & FALSE & FALSE \\
\hline
\end{tabular}


The Varga Site

Texas Department of Transportation

Table 0-2. Cliffton Point Data

\begin{tabular}{|c|c|c|c|c|c|c|}
\hline Cat. No. & $12-010^{*}$ & 22-014* & $814-016$ & $913-017$ & $914-011$ & $918-010$ \\
\hline Unit & N99,E51 & N99,E52 & $\mathrm{N} 116, \mathrm{E} 72$ & $\mathrm{~N} 122, \mathrm{E} 74$ & $\mathrm{~N} 122, \mathrm{E} 74$ & $\mathrm{~N} 123, \mathrm{E} 68$ \\
\hline Depth (cmbd) & $20-30$ & $20-30$ & $0-10$ & $8-24$ & $24-38$ & $9-19$ \\
\hline Condition & Proximal & Proximal & Proximal & Proximal & Complete & Proximal \\
\hline Break Type & Use & Use & Use & Use & Use & Use \\
\hline Resharpening Type & Indeterminate & None & None & Indeterminate & Beveled Unifacial & None \\
\hline Raw Material & Chert & Chert & Chert & Chert & Chert & Chert \\
\hline Texture & Fine & Fine & Fine & Fine & Fine & Fine \\
\hline Percent Patination & 0 & 0 & 0 & 0 & 0 & 0 \\
\hline Percent Cortex & 50 & 0 & 0 & 0 & 0 & 0 \\
\hline Cortex Type & Pebble/cobble & None & None & None & None & None \\
\hline Heating & None & None & None & None & None & None \\
\hline Length (mm) & & & & & 38.3 & \\
\hline Thick (mm) & & 4.4 & & 3.4 & 17.4 & 3.4 \\
\hline Wt. (g) & & & & & 2.8 & \\
\hline Long X-Section & Indeterminate & $\begin{array}{l}\text { Wedged Base, } \\
\text { Flat }\end{array}$ & Flat & $\begin{array}{c}\text { Wedged Base, } \\
\text { Flat }\end{array}$ & Tapered Base/Tip & Indeterminate \\
\hline Trans X-Section & Plano-Convex & Plano-Convex & Plano-Convex & Plano-Convex & Plano-Convex & Plano-Convex \\
\hline Blade Length $(\mathrm{mm})$ & & & & & 31.6 & \\
\hline Blade Width (mm) & & 21.1 & 14.5 & 20.7 & 16.6 & 15.6 \\
\hline Left Lateral edge & Indeterminate & Straight & Straight & Excurvate & Straight & Straight \\
\hline Right Laterial Edge & Indeterminate & Straight & Straight & Indeterminate & Excurvate & Straight \\
\hline Shoulder Width (mm) & 21.6 & 22.3 & 17 & 22.2 & & 17.6 \\
\hline Left Notch Depth (mm) & 3.8 & 3.5 & 1.7 & 3.2 & 1.6 & \\
\hline Right Notch Depth (mm) & 3.2 & 2.7 & 1.4 & 4.2 & & \\
\hline Left Notch Width (mm) & 6.6 & 12.1 & 3.6 & 11.1 & 10.4 & \\
\hline Right Notch Width (mm) & 7.9 & 10.9 & 4 & 11.1 & & \\
\hline Left Notch Angle & 34 & 27 & 40 & 40 & 45 & \\
\hline Right Notch Angle & 19 & 40 & 28 & 23 & & \\
\hline Stem Shape & Contracting & Contracting & Contracting & Contracting & Contracting & Contracting \\
\hline Stem Length $(\mathrm{mm})$ & 5.7 & 7.6 & 3.5 & 8.4 & 6.7 & 4.2 \\
\hline Distal Stem Width (mm) & 9.3 & 9.2 & 6 & 8.4 & 12 & 14.2 \\
\hline Proximal Stem Width (mm) & 4.7 & 2.9 & 3.2 & 5 & 3.8 & 3.9 \\
\hline Stem Thickness (mm) & 2.7 & 3.7 & 1.6 & 2.3 & 2.5 & 2.8 \\
\hline Base Depth (mm) & 1.5 & -1.4 & -1.5 & -3.7 & -1.4 & -1.8 \\
\hline Micro-wear & FALSE & TRUE & FALSE & FALSE & TRUE & FALSE \\
\hline NAA & FALSE & FALSE & TRUE & TRUE & FALSE & FALSE \\
\hline
\end{tabular}


Appendix O: Data and Site Artifact Database

Table 0-2. Cliffton Point Data Continued

\begin{tabular}{|c|c|c|c|c|c|c|}
\hline Cat. No. & 943-018 & $967-024$ & $1002-013$ & $1054-016$ & $1154-010$ & $1183-010$ \\
\hline Unit & $\mathrm{N} 123, \mathrm{E} 74$ & $\mathrm{~N} 124, \mathrm{E} 75$ & $\mathrm{~N} 126, \mathrm{E} 70$ & $\mathrm{~N} 127, \mathrm{E} 75$ & $\mathrm{~N} 131, \mathrm{E} 72$ & N132,E75 \\
\hline Depth (cmbd) & $12-26$ & $0-10$ & $8-20$ & $20-30$ & $20-30$ & $20-30$ \\
\hline Condition & Proximal & Proximal & Proximal & Proximal & Proximal & Complete \\
\hline Break Type & Use & Use & Use & Use & Use & Unbroken \\
\hline Resharpening Type & None & $\begin{array}{c}\text { Break } \\
\text { Compensation }\end{array}$ & Beveled Unifacial & None & None & None \\
\hline Raw Material & Chert & Chert & Chert & Chert & Chert & Chert \\
\hline Texture & Fine & Fine & Fine & Fine & Fine & Fine \\
\hline Percent Patination & 0 & 0 & 0 & 0 & 0 & 0 \\
\hline Percent Cortex & 0 & 0 & 0 & 0 & 0 & 0 \\
\hline Cortex Type & None & None & None & None & None & None \\
\hline Heating & None & None & None & None & None & None \\
\hline Length (mm) & & & & & & 38.4 \\
\hline Thick (mm) & 4.8 & 4.3 & 4.8 & 1.9 & 2.7 & 4.7 \\
\hline Wt. (g) & 3.6 & & & & & 3.7 \\
\hline Long X-Section & Tapered Base/Tip & Indeterminate & Indeterminate & Flat & Tapered Base/Tip & Tapered Base/Tip \\
\hline Trans X-Section & $\begin{array}{c}\text { Biconvex } \\
\text { Symmetrical }\end{array}$ & Plano-Convex & Plano-Convex & Plano-Convex & Plano-Convex & Plano-Convex \\
\hline \multicolumn{7}{|l|}{ Blade Length (mm) } \\
\hline Blade Width (mm) & 21.2 & 18.7 & 22.7 & & 17.4 & 22.5 \\
\hline Left Lateral edge & Excurvate & Straight & Straight & Straight & Straight & Excurvate \\
\hline Right Laterial Edge & Excurvate & Indeterminate & Straight & Indeterminate & Straight & Excurvate \\
\hline Shoulder Width (mm) & 23.2 & 20.6 & 24.2 & & 17.4 & 23.4 \\
\hline Left Notch Depth (mm) & 1.7 & 2.9 & 1.4 & 2.7 & 1.9 & \\
\hline Right Notch Depth (mm) & 2.4 & 1.1 & 0 & & 1.2 & \\
\hline Left Notch Width (mm) & 12.1 & 6.8 & 11.7 & 8.1 & 12.1 & \\
\hline Right Notch Width (mm) & 9.3 & 5.4 & & & 9.2 & \\
\hline Left Notch Angle & 47 & 38 & 33 & 40 & 38 & \\
\hline Right Notch Angle & 29 & 38 & 37 & & 54 & \\
\hline Stem Shape & Contracting & Contracting & Contracting & Contracting & Contracting & Indeterminate \\
\hline Stem Length $(\mathrm{mm})$ & 4.9 & 5.8 & 6.1 & 7.5 & 7 & \\
\hline Distal Stem Width (mm) & 6.9 & 7.9 & 11.8 & 7.9 & 9.1 & \\
\hline Proximal Stem Width (mm) & 2.6 & 5 & 4.3 & 3.5 & 2.5 & \\
\hline Stem Thickness (mm) & 1.8 & 2 & 2.3 & 1.6 & 2.9 & \\
\hline Base Depth (mm) & -1.3 & -1.8 & -1.6 & -2.1 & 1 & \\
\hline Micro-wear & TRUE & FALSE & FALSE & FALSE & TRUE & FALSE \\
\hline NAA & FALSE & TRUE & TRUE & TRUE & FALSE & FALSE \\
\hline
\end{tabular}

* This point was not from the Toyah component, but slightly lower in Late Archaic context. 
The Varga Site

Texas Department of Transportation

Table 0-3. Bonham Point Data

\begin{tabular}{|l|c|c|c|c|c|c|c|c|c|}
\hline Cat. No. & Unit & $\begin{array}{c}\text { Depth } \\
\text { (cmbs) }\end{array}$ & $\begin{array}{c}\text { Feature } \\
\text { No. }\end{array}$ & Condition & Break Type & $\begin{array}{c}\text { Rejuvenation } \\
\text { Scar }\end{array}$ & $\begin{array}{c}\text { Resharpening } \\
\text { Type }\end{array}$ & Raw Material & Texture \\
\hline $159-023$ & N101,E47 & $30-40$ & 36 & $\begin{array}{c}\text { distal, refit } \\
\text { with 282-17 }\end{array}$ & & & & & \\
\hline $220-013$ & N101,E54 & $20-30$ & & Proximal & Use & Absent & None & Chert & Fine \\
\hline $262-020$ & N102,E47 & $30-40$ & 36 & Complete & Use & Absent & None & Chert & Fine \\
\hline $282-017$ & N102,E51 & $20-30$ & & Complete & Use & Absent & None & Chert & Fine \\
\hline $360-005-010 *$ & N103,E51 & $30-40$ & 1 & Proximal & Use & Absent & None & Chert & Fine \\
\hline $473-010$ & N105,E55 & $0-10$ & & Complete & Unbroken & Absent & None & Chert & Fine \\
\hline $562-010^{*}$ & N107,E49 & $30-40$ & & Complete & Unknown & Absent & None & Chert & Fine \\
\hline
\end{tabular}

\begin{tabular}{|c|c|c|c|c|c|c|c|c|c|c|c|}
\hline Cat. No. & $\begin{array}{c}\text { Percent } \\
\text { Patination } \\
\end{array}$ & $\begin{array}{l}\text { Percent } \\
\text { Cortex }\end{array}$ & $\begin{array}{l}\text { Cortex } \\
\text { Type }\end{array}$ & Heating & $\begin{array}{l}\text { Length } \\
(\mathrm{mm})\end{array}$ & $\begin{array}{l}\text { Width } \\
(\mathrm{mm})\end{array}$ & $\begin{array}{l}\text { Thick } \\
(\mathrm{mm})\end{array}$ & $\begin{array}{l}\text { Wt } \\
(\mathrm{g})\end{array}$ & $\begin{array}{l}\text { Long X- } \\
\text { Section }\end{array}$ & $\begin{array}{l}\text { Trans X- } \\
\text { Section } \\
\end{array}$ & Preform \\
\hline \multicolumn{12}{|l|}{ 159-023 } \\
\hline $220-013$ & 0 & 0 & None & None & & & 3.1 & & Flat & Plano-Convex & Flake \\
\hline $262-020$ & 0 & 0 & None & None & 40.2 & & 2.5 & 1.5 & Flat & Plano-Convex & Flake \\
\hline $282-017$ & 0 & 0 & None & None & 32.9 & & 2.8 & 1.6 & $\begin{array}{c}\text { Wedged Base, } \\
\text { Flat }\end{array}$ & Plano-Convex & Flake \\
\hline $360-005-010$ * & 0 & 0 & None & None & & & & & Indeterminate & Indeterminate & Flake \\
\hline $473-010$ & 0 & 0 & None & None & 28.1 & & 3.3 & 1 & $\begin{array}{l}\text { Tapered } \\
\text { Base/Tip } \\
\end{array}$ & $\begin{array}{c}\text { Biconvex } \\
\text { Asymmetrical }\end{array}$ & Flake \\
\hline $562-010^{*}$ & 0 & 0 & None & None & 26.8 & & 3.5 & 0.9 & $\begin{array}{c}\text { Wedged Base, } \\
\text { Flat }\end{array}$ & $\begin{array}{c}\text { Biconvex } \\
\text { Symmetrical }\end{array}$ & Flake \\
\hline
\end{tabular}

\begin{tabular}{|l|c|c|c|c|c|c|c|c|c|}
\hline Cat. No. & Overall Shape & $\begin{array}{c}\text { Flaking } \\
\text { Pattern }\end{array}$ & $\begin{array}{c}\text { Edge } \\
\text { Rounding }\end{array}$ & $\begin{array}{c}\text { Blade } \\
\text { Length } \\
(\mathrm{mm})\end{array}$ & $\begin{array}{c}\text { Blade } \\
\text { Width } \\
(\mathrm{mm})\end{array}$ & $\begin{array}{c}\text { Left Lateral } \\
\text { Edge }\end{array}$ & $\begin{array}{c}\text { Right Lateral } \\
\text { Edge }\end{array}$ & $\begin{array}{c}\text { Shoulder } \\
\text { Width (mm) }\end{array}$ & $\begin{array}{c}\text { Left Notch } \\
\text { Depth } \\
(\mathrm{mm})\end{array}$ \\
\hline $159-023$ & & & & & & & & & \\
\hline $220-013$ & Triangular & Chevron & Present & & 11.2 & Incurvate & Incurvate & & \\
\hline $262-020$ & Triangular & Parallel & Present & 32.3 & 16.3 & Excurvate & Excurvate & & \\
\hline $282-017$ & Triangular & $\begin{array}{c}\text { Flake Blank } \\
\text { Remnant }\end{array}$ & Present & 25.6 & 20.1 & Excurvate & Excurvate & 20.8 & 6.4 \\
\hline $360-005-010^{*}$ & Indeterminate & Blank & Present & & & Indeterminate & Indeterminate & & \\
\hline $473-010$ & Triangular & Chevron & Absent & 20.9 & 17.1 & Straight & Straight & 19.5 & 5.8 \\
\hline $562-010^{*}$ & Triangular & Indeterminate & Present & 18.6 & 11 & Straight & Straight & 17.6 & 3.2 \\
\hline
\end{tabular}

\begin{tabular}{|l|c|c|c|c|c|c|c|c|c|c|}
\hline Cat. No. & $\begin{array}{c}\text { Right } \\
\text { Notch } \\
\text { Width }\end{array}$ & $\begin{array}{c}\text { Left } \\
\text { Notch } \\
\text { Angle }\end{array}$ & $\begin{array}{c}\text { Right } \\
\text { Notch } \\
\text { Angle }\end{array}$ & Stem Shape & $\begin{array}{c}\text { Stem } \\
(\mathrm{mm})\end{array}$ & $\begin{array}{c}\text { Distal Stem } \\
\text { Width }(\mathrm{mm})\end{array}$ & $\begin{array}{c}\text { Stoximal } \\
(\mathrm{mm})\end{array}$ & $\begin{array}{c}\text { Stem Thick } \\
(\mathrm{mm})\end{array}$ & Micro-wear & NAA \\
\hline $159-023$ & & & & & & & & & FALSE & FALSE \\
\hline $220-013$ & 8.8 & & 24 & Straight & 7.8 & 5.3 & 5.9 & 2.3 & FALSE & TRUE \\
\hline $262-020$ & 7.9 & & 20 & Straight & 7.9 & 6.4 & 6.7 & 1.8 & FALSE & TRUE \\
\hline $282-017$ & 7 & 14 & 25 & Straight & 7.3 & 6 & 5.3 & 2.8 & FALSE & TRUE \\
\hline $360-005-010 *$ & & & & Straight & & & 5.9 & & FALSE & FALSE \\
\hline $473-010$ & 6.6 & 25 & 22 & Straight & 7.2 & 5.3 & 6.2 & 2.7 & TRUE & FALSE \\
\hline $562-010^{*}$ & 8.1 & 47 & 27 & Straight & 8.2 & 6.4 & 6.4 & 3 & FALSE & TRUE \\
\hline
\end{tabular}

* This point was not in the Toyah component, slightly lower in mixed, unknown context. 
Appendix O: Data and Site Artifact Database

Table 0-4. Non-Perdiz Point Data from the Toyah Component

\begin{tabular}{|l|l|l|l|l|l|l|l|c|c|c|}
\hline Cat. No. & Unit & $\begin{array}{c}\text { Depth } \\
(\mathrm{cmbd})\end{array}$ & $\begin{array}{c}\text { Feature } \\
\text { No. }\end{array}$ & $\begin{array}{c}\text { Point } \\
\text { Type }\end{array}$ & Condition & Break Type & $\begin{array}{c}\text { Resharpening } \\
\text { Type }\end{array}$ & $\begin{array}{c}\text { Raw } \\
\text { Material }\end{array}$ & $\begin{array}{c}\text { Percent } \\
\text { Texture } \\
\text { Patination }\end{array}$ & $\begin{array}{c}\text { Percent } \\
\text { Cortex }\end{array}$ \\
\hline $291-014$ & N102,E52 & $0-10$ & & Guerrero & Proximal & Use & None & Chert & Fine & 0 \\
\hline $349-013$ & N103,E47 & $10-20$ & & Cuney & Complete & Unbroken & None & Chert & Fine & 0 \\
\hline $406-010$ & N104,E47 & $20-30$ & & Guerrero & Complete & Unbroken & None & Chert & Fine & 0 \\
\hline $534-014$ & N106,E55 & $10-20$ & & Scallorn & Distal & Use & None & Chert & Fine & 0 \\
\hline $783-010$ & N114,E75 & $15-35$ & & Edwards & Proximal & Use & Indeterminate & Chert & Fine & 0 \\
\hline $882-011$ & N121,E70 & $10-18$ & & Harrell & Distal & Use & None & Chert & Fine & 0 \\
\hline $1030-005-010$ & N126,E76 & $30-40$ & 38 & Padre & Complete & Unbroken & None & Chert & Fine & 0 \\
\hline $1092-015$ & N129,E72 & $20-30$ & & Scallorn & Complete & Unbroken & None & Chert & Fine & 0 \\
\hline
\end{tabular}

\begin{tabular}{|c|c|c|c|c|c|c|c|c|c|c|}
\hline Cat. No. & Heating & $\begin{array}{l}\text { Length } \\
(\mathrm{mm})\end{array}$ & $\begin{array}{l}\text { Width } \\
(\mathrm{mm})\end{array}$ & $\begin{array}{l}\text { Thick } \\
(\mathrm{mm})\end{array}$ & $\begin{array}{l}\text { Wt. } \\
(\mathrm{g})\end{array}$ & Long X-Section & Trans X-Section & Preform & Shape & Flaking Pattern \\
\hline 291-014 & None & & & 2.4 & & Indeterminate & Biconvex Symmetrical & Flake & Triangular & Oblique Subparallel \\
\hline 406-010 & None & 23 & & 3.9 & 1 & Tapered Base/Tip & Biconvex Symmetrical & Flake & Triangular & Chevron \\
\hline $534-014$ & None & & & 2.7 & 1.1 & Flat & Plano-Convex & Flake & Triangular & Subparallel \\
\hline $882-011$ & None & 20.3 & & 2.5 & 0.4 & Flat & Plano-Convex & Flake & Triangular & Parallel \\
\hline $1030-005-010$ & None & 28.7 & & 3.3 & 1 & Wedged Base, Flat & Plano-Convex & Flake & Bipointed & Flake Blank Remnant \\
\hline $1092-015$ & None & 28.6 & & 3.4 & 1.1 & Wedged Base, Flat & Plano-Convex & Flake & Triangular & Chevron \\
\hline
\end{tabular}

\begin{tabular}{|c|c|c|c|c|c|c|c|c|c|c|c|}
\hline Cat. No. & $\begin{array}{c}\text { Edge } \\
\text { Rounding }\end{array}$ & $\begin{array}{l}\text { Blade } \\
\text { Length } \\
(\mathrm{mm})\end{array}$ & $\begin{array}{l}\text { Blade } \\
\text { Width } \\
(\mathrm{mm})\end{array}$ & Left Lateral & Right Lateral & $\begin{array}{l}\text { Shoulder } \\
\text { Width } \\
(\mathrm{mm})\end{array}$ & $\begin{array}{l}\text { Left Notch } \\
\text { Depth } \\
(\mathrm{mm})\end{array}$ & $\begin{array}{l}\text { Right Notch } \\
\text { Depth } \\
\text { (mm) }\end{array}$ & $\begin{array}{l}\text { Left Notch } \\
\text { Width } \\
(\mathrm{mm})\end{array}$ & $\begin{array}{l}\text { Right Notch } \\
\text { Width }(\mathrm{mm})\end{array}$ & $\begin{array}{l}\text { Left Notch } \\
\text { Angle }\end{array}$ \\
\hline 291-014 & Present & & 13.2 & Straight & Straight & 14.3 & & & & & \\
\hline $406-010$ & Absent & & 13.6 & Straight & Straight & & & & & & \\
\hline $534-014$ & Absent & 30.9 & 14.1 & Straight & Straight & 17.8 & & & & & 10 \\
\hline 882-011 & Absent & 11 & 11.2 & Straight & Straight & & 1.1 & 2.9 & 2.2 & 0.9 & 57 \\
\hline $1030-005-010$ & Present & & 13.2 & Excurvate & Excurvate & & & & & & \\
\hline 1092-015 & Present & 21.8 & 12.3 & Straight & Straight & 15.6 & 2.8 & 3 & 3.1 & 3.3 & 74 \\
\hline
\end{tabular}

\begin{tabular}{|c|c|c|c|c|c|c|c|c|c|c|}
\hline Cat. No. & $\begin{array}{c}\text { Right } \\
\text { Notch } \\
\text { Angle }\end{array}$ & Stem Shape & $\begin{array}{c}\text { Stem } \\
\text { Length } \\
(\mathrm{mm})\end{array}$ & $\begin{array}{c}\text { Distal Stem } \\
\text { Width }(\mathrm{mm})\end{array}$ & $\begin{array}{c}\text { Proximal } \\
\text { Stem Width } \\
(\mathrm{mm})\end{array}$ & $\begin{array}{c}\text { Stem } \\
\text { Thick } \\
(\mathrm{mm})\end{array}$ & $\begin{array}{c}\text { Base } \\
\text { Depth } \\
(\mathrm{mm})\end{array}$ & $\begin{array}{c}\text { Base Notch } \\
\text { Width (mm) }\end{array}$ & Micro-wear & NAA \\
\hline $291-014$ & & & & & & & 2.2 & 10.4 & FALSE & TRUE \\
\hline $349-013$ & 34 & Straight & 7.6 & 5.7 & 4.9 & 2.4 & 0 & & FALSE & TRUE \\
\hline $406-010$ & & & & & & & 1 & 8.7 & TRUE & FALSE \\
\hline $534-014$ & 3 & Indeterminate & & 4.5 & & & & & FALSE & FALSE \\
\hline $783-010$ & 15 & Contracting & 4.5 & & 5.1 & 1.8 & -1.3 & & FALSE & FALSE \\
\hline $882-011$ & 101 & Contracting & 7 & 5.8 & & 2.3 & 2.4 & & FALSE & TRUE \\
\hline $1030-005-010$ & & & & & & & & & TRUE & FALSE \\
\hline $1092-015$ & 47 & Expanding & 6.8 & 8.5 & 13.6 & 2.9 & -1.6 & & FALSE & TRUE \\
\hline
\end{tabular}


The Varga Site

Texas Department of Transportation

Table 0-5. Toyah Component Dart Point Data

\begin{tabular}{|c|c|c|c|c|c|c|c|c|c|c|}
\hline Cat. No. & Unit & $\begin{array}{l}\text { Depth } \\
\text { (cmbd) }\end{array}$ & Point Type & Raw Material & Condition & $\begin{array}{c}\text { Resharpening } \\
\text { Type }\end{array}$ & $\begin{array}{c}\text { Break } \\
\text { Type }\end{array}$ & $\begin{array}{c}\text { Edge } \\
\text { Rounding }\end{array}$ & Texture & $\begin{array}{c}\text { Percent } \\
\text { Patination }\end{array}$ \\
\hline $1046-011$ & $\mathrm{~N} 127, \mathrm{E} 73$ & $10-17$ & Unknown Dart & Chert & Distal & & Use & Absent & Fine & 0 \\
\hline $109-010$ & N100,E53 & $10-20$ & Unknown Dart & Chert & Medial & & Use & Absent & Fine & 0 \\
\hline $131-010$ & N100,E55 & $10-20$ & Unknown Dart & Chert & Medial & & Use & Absent & Fine & 0 \\
\hline $131-011$ & N100,E55 & $10-20$ & Unknown Dart & Chert & Medial & & Use & Absent & Fine & 0 \\
\hline 496-014 & N106,E50 & $0-10$ & Unknown Dart & Chert & Medial & & Use & Absent & Fine & 0 \\
\hline $517-010$ & N106,E53 & $0-10$ & Unknown Dart & Chert & Medial & & Use & Present & Fine & 0 \\
\hline $602-019$ & N107,E55 & $10-20$ & Unknown Dart & Chert & Indeterminate & & Use & Absent & Fine & 0 \\
\hline $758-013$ & N109,E70 & $10-20$ & Unknown Dart & Chert & Medial & & Use & Absent & Fine & 0 \\
\hline $220-014$ & N101,E54 & $20-30$ & Frio & Chert & Proximal & $\begin{array}{c}\text { Beveled } \\
\text { Bifacial }\end{array}$ & Use & Present & Fine & 0 \\
\hline $525-005-013$ & N106,E54 & $35-40$ & Frio & Chert & Proximal & None & Use & Absent & Fine & 0 \\
\hline $526-011$ & N106,E54 & $40-50$ & Frio & fits with 220-14 & Distal & & Use & & & \\
\hline $916-010$ & N122,E75 & $0-10$ & Frio & Chert & Medial & Indeterminate & Use & Absent & Fine & 0 \\
\hline $653-012$ & N108,E53 & $0-10$ & Baker & Chert & Proximal & $\begin{array}{l}\text { Beveled } \\
\text { Unifacial }\end{array}$ & Use & Absent & Fine & 0 \\
\hline $324-016$ & N102,E55 & 50 & Group II & Chert & Proximal & None & Use & Absent & Fine & 0 \\
\hline
\end{tabular}

\begin{tabular}{|c|c|c|c|c|c|c|c|c|c|}
\hline Cat. No. & $\begin{array}{c}\text { Percent } \\
\text { Cortex }\end{array}$ & Heating & $\begin{array}{l}\text { Length } \\
(\mathrm{mm})\end{array}$ & $\begin{array}{l}\text { Width } \\
(\mathrm{mm})\end{array}$ & $\begin{array}{c}\text { Thickness } \\
(\mathrm{mm})\end{array}$ & Wt. (g) & Long X-Section & Trans X-Section & Preform \\
\hline $1046-011$ & 0 & None & & & & & Indeterminate & Indeterminate & Indeterminate \\
\hline $109-010$ & 0 & None & & & 5.8 & & Indeterminate & Biconvex Symmetrical & Biface \\
\hline $131-010$ & 0 & None & & & & & Indeterminate & Indeterminate & Indeterminate \\
\hline $131-011$ & 0 & None & & & & & Indeterminate & Indeterminate & Indeterminate \\
\hline $496-014$ & 0 & None & & & & & Indeterminate & Indeterminate & Indeterminate \\
\hline $517-010$ & 0 & None & & & & & Indeterminate & Indeterminate & Indeterminate \\
\hline $602-019$ & 0 & Burned & & & & & Indeterminate & Indeterminate & Indeterminate \\
\hline $758-013$ & 0 & Heat-Treated & & & & & Indeterminate & Indeterminate & Indeterminate \\
\hline $220-014$ & 0 & None & & & 5.5 & & Indeterminate & Biconvex Symmetrical & Biface \\
\hline $525-005-013$ & 0 & Indeterminate & 54.5 & & 12.4 & 11.6 & Tapered Base/Tip & Biconvex Symmetrical & Biface \\
\hline \multicolumn{10}{|l|}{$526-011$} \\
\hline $916-010$ & 0 & None & & & 6.4 & & Indeterminate & Plano-Convex & Flake \\
\hline $653-012$ & 0 & None & & & 7 & & Indeterminate & Biconvex Symmetrical & Biface \\
\hline $324-016$ & 0 & Heat-Treated & & & & & Indeterminate & Biconvex Symmetrical & Biface \\
\hline
\end{tabular}


Appendix O: Data and Site Artifact Database

Table 0-5. Toyah Component Dart Point Data Continued

\begin{tabular}{|c|c|c|c|c|c|c|c|c|c|}
\hline Cat. No. & Shape & Flaking Pattern & $\begin{array}{l}\text { Left Lateral } \\
\text { Edge Shape }\end{array}$ & $\begin{array}{l}\text { Right Lateral } \\
\text { Edge Shape }\end{array}$ & Stem Shape & $\begin{array}{c}\text { Resharpening } \\
\text { Type }\end{array}$ & $\begin{array}{c}\text { Shoulder } \\
\text { Width }\end{array}$ & $\begin{array}{c}\text { Left } \\
\text { Notch } \\
\text { Depth }\end{array}$ & $\begin{array}{l}\text { Right } \\
\text { Notch } \\
\text { Depth }\end{array}$ \\
\hline $1046-011$ & Indeterminate & Indeterminate & Indeterminate & Indeterminate & Indeterminate & Indeterminate & & & \\
\hline $109-010$ & Indeterminate & Indeterminate & Indeterminate & Indeterminate & Indeterminate & Indeterminate & & & \\
\hline $131-010$ & Indeterminate & Indeterminate & Indeterminate & Indeterminate & Indeterminate & Indeterminate & & & \\
\hline $131-011$ & Indeterminate & Indeterminate & Indeterminate & Indeterminate & Indeterminate & Indeterminate & & & \\
\hline 496-014 & Indeterminate & Indeterminate & Indeterminate & Indeterminate & Indeterminate & Indeterminate & & & \\
\hline $517-010$ & Indeterminate & Indeterminate & Indeterminate & Indeterminate & Indeterminate & Indeterminate & & & \\
\hline $602-019$ & Indeterminate & Indeterminate & Indeterminate & Indeterminate & Indeterminate & Indeterminate & & & \\
\hline $758-013$ & Indeterminate & Indeterminate & Indeterminate & Indeterminate & Indeterminate & Indeterminate & & & \\
\hline $220-014$ & Lanceolate & Subparallel & Straight & Incurvate & & & 16.5 & 2.4 & 1.4 \\
\hline $525-005-013$ & Triangular & Chevron & Excurvate & Straight & & & 30.4 & 9.6 & 10.2 \\
\hline \multicolumn{10}{|l|}{ 526-011 } \\
\hline $916-010$ & Indeterminate & Indeterminate & Indeterminate & Indeterminate & & & 19.6 & & 1.5 \\
\hline $653-012$ & Indeterminate & Oblique & Indeterminate & Indeterminate & & & & & 3.1 \\
\hline $324-016$ & Indeterminate & Chevron & Straight & Straight & & & & 7 & \\
\hline
\end{tabular}

\begin{tabular}{|c|c|c|c|c|c|c|c|c|c|c|c|}
\hline Cat. No. & $\begin{array}{l}\text { Left Notch } \\
\text { Width } \\
\text { (mm) }\end{array}$ & $\begin{array}{c}\text { Right } \\
\text { Notch } \\
\text { Width }(\mathrm{mm}) \\
\end{array}$ & $\begin{array}{c}\text { Left } \\
\text { Notch } \\
\text { Angle } \\
\end{array}$ & $\begin{array}{l}\text { Right } \\
\text { Notch } \\
\text { Angle } \\
\end{array}$ & Stem Shape & $\begin{array}{c}\text { Stem } \\
\text { Length } \\
(\mathrm{mm}) \\
\end{array}$ & $\begin{array}{l}\text { Distal Stem } \\
\text { Width (mm) }\end{array}$ & $\begin{array}{c}\text { Proximal } \\
\text { Stem Width } \\
(\mathrm{mm})\end{array}$ & $\begin{array}{l}\text { Stem } \\
\text { Thick } \\
(\mathrm{mm}) \\
\end{array}$ & $\begin{array}{l}\text { Base } \\
\text { Depth } \\
(\mathrm{mm}) \\
\end{array}$ & $\begin{array}{l}\text { Basal } \\
\text { Notch } \\
\text { Width }\end{array}$ \\
\hline \multicolumn{12}{|l|}{$1046-011$} \\
\hline \multicolumn{12}{|l|}{$109-010$} \\
\hline \multicolumn{12}{|l|}{$131-010$} \\
\hline \multicolumn{12}{|l|}{$131-011$} \\
\hline \multicolumn{12}{|l|}{$496-014$} \\
\hline \multicolumn{12}{|l|}{$517-010$} \\
\hline \multicolumn{12}{|l|}{$602-019$} \\
\hline \multicolumn{12}{|l|}{$758-013$} \\
\hline $220-014$ & 6.9 & 6.7 & 73 & 84 & Expanding & 8.7 & 13.8 & 18.3 & 5.1 & 2.8 & 10.6 \\
\hline $525-005-013$ & 8.4 & 7.4 & 66 & 64 & Expanding & 10.6 & 20.4 & 30 & 4.8 & 3.6 & 10.4 \\
\hline \multicolumn{12}{|l|}{$526-011$} \\
\hline $916-010$ & & 6.6 & & 75 & Indeterminate & & 15.5 & & 6.2 & & \\
\hline $653-012$ & & 9.4 & & 37 & Curved & 13.5 & 15.2 & 16 & 5.7 & 5.3 & 8 \\
\hline $324-016$ & & 4.5 & 43 & 29 & Expanding & 9.5 & 16.3 & 21.3 & 4.6 & 2.6 & 10.6 \\
\hline
\end{tabular}


The Varga Site

Texas Department of Transportation

Table 0-6. Biface Data From Toyah Component

\begin{tabular}{|c|c|c|c|c|c|c|c|c|}
\hline Cat. No. & $87-010$ & $97-017$ & $130-005-010$ & $157-012$ & $159-005-026$ & $159-005-028$ & $159-005-029$ & $159-016$ \\
\hline Unit & N100,E51 & $\mathrm{N} 100, \mathrm{E} 52$ & N100,E55 & N101,E47 & N101,E47 & N101,E47 & N101,E47 & N101,E47 \\
\hline Depth (cmbd) & $0-10$ & $0-10$ & $0-10$ & $10-20$ & $30-40$ & $30-40$ & $30-40$ & $30-40$ \\
\hline Feature No. & & & 35 & & 36 & 36 & 36 & 36 \\
\hline Condition & Distal & Distal & Proximal & Proximal & Distal & Complete & Distal & Distal \\
\hline Break Type & Indeterminate & Use & Use & Use & Use & Unbroken & Use & Use \\
\hline Biface Stage & Late & Late & Late & Indeterminate & Late & Late & Late & Middle \\
\hline $\begin{array}{c}\text { Rejuvenation } \\
\text { Scar }\end{array}$ & Absent & Absent & Absent & Absent & Absent & Absent & Absent & Absent \\
\hline $\begin{array}{c}\text { Resharpening } \\
\text { Type }\end{array}$ & Indeterminate & Indeterminate & None & Indeterminate & None & $\begin{array}{c}\text { Alternate } \\
\text { Beveled } \\
\text { Unifacial }\end{array}$ & Indeterminate & Indeterminate \\
\hline Raw Material & Chert & Chert & Chert & Chert & Chert & Chert & Chert & Chert \\
\hline Texture & Fine & Fine & Fine & Fine & Fine & Fine & Fine & Fine \\
\hline $\begin{array}{c}\text { Percent } \\
\text { Patination } \\
\end{array}$ & 0 & 0 & 0 & 0 & 0 & 0 & 0 & 0 \\
\hline Percent Cortex & 50 & 0 & 0 & 0 & 0 & 0 & 0 & 0 \\
\hline Cortex Type & Pebble/Cobble & None & None & None & None & None & None & None \\
\hline Heating & None & Indeterminate & None & Heat-Treated & None & None & None & None \\
\hline Length (mm) & & & & & & 99.2 & & \\
\hline Width (mm) & 33.7 & & 43.3 & & & 33.8 & & \\
\hline Thick (mm) & 7.3 & 5.7 & 7.7 & & 5.2 & 6.7 & & 8 \\
\hline Wt. (g) & & & & & & 28.5 & & \\
\hline Long X-Section & Indeterminate & Indeterminate & Indeterminate & Indeterminate & Indeterminate & $\begin{array}{l}\text { Tapered } \\
\text { Base/Tip }\end{array}$ & Indeterminate & Indeterminate \\
\hline $\begin{array}{l}\text { Trans X- } \\
\text { Section }\end{array}$ & Plano-Convex & $\begin{array}{l}\text { Plano- } \\
\text { Convex }\end{array}$ & $\begin{array}{l}\text { Plano- } \\
\text { Convex }\end{array}$ & Indeterminate & $\begin{array}{l}\text { Plano- } \\
\text { Convex }\end{array}$ & $\begin{array}{c}\text { Biconvex } \\
\text { Symmetrical }\end{array}$ & $\begin{array}{l}\text { Plano- } \\
\text { Convex }\end{array}$ & $\begin{array}{c}\text { Biconvex } \\
\text { Symmetrical }\end{array}$ \\
\hline Preform & Biface & Indeterminate & Biface & Indeterminate & Flake & Biface & Flake & Biface \\
\hline Overall Shape & Indeterminate & Indeterminate & Indeterminate & Indeterminate & Indeterminate & Bipointed & Indeterminate & Indeterminate \\
\hline Flaking Pattern & $\begin{array}{c}\text { Flake Blank } \\
\text { Remnant }\end{array}$ & Chevron & Random & Indeterminate & $\begin{array}{c}\text { Flake Blank } \\
\text { Remnant }\end{array}$ & Subparallel & $\begin{array}{c}\text { Flake Blank } \\
\text { Remnant }\end{array}$ & $\begin{array}{c}\text { Oblique } \\
\text { Subparallel }\end{array}$ \\
\hline Edge Rounding & Absent & Present & Absent & Present & Present & Present & Present & Absent \\
\hline $\begin{array}{l}\text { Left Lateral } \\
\text { Edge Shape }\end{array}$ & Incurvate & Indeterminate & Excurvate & Indeterminate & Excurvate & Excurvate & Straight & Indeterminate \\
\hline $\begin{array}{l}\text { Right Lateral } \\
\text { Edge Shape }\end{array}$ & Excurvate & Excurvate & Excurvate & Indeterminate & Excurvate & Excurvate & Excurvate & Indeterminate \\
\hline Micro-wear & FALSE & FALSE & FALSE & FALSE & FALSE & TRUE & FALSE & FALSE \\
\hline NAA & FALSE & FALSE & FALSE & FALSE & FALSE & FALSE & FALSE & FALSE \\
\hline
\end{tabular}


Table 0-6. Biface Data From Toyah Component Continued

\begin{tabular}{|c|c|c|c|c|c|c|c|c|}
\hline Cat. No. & $186-010$ & $220-015$ & $232-010$ & $244-012$ & $244-013$ & $260-015$ & $272-019$ & 291-015 \\
\hline Unit & N101,E51 & N101,E54 & N101,E55 & N101,E56 & N101,E56 & $\mathrm{N} 102, \mathrm{E} 47$ & N102,E50 & N102,E52 \\
\hline Depth (cmbd) & $10-20$ & $20-30$ & $10-20$ & $0-10$ & $0-10$ & $10-20$ & $20-30$ & $0-10$ \\
\hline Feature No. & & & & & & 36 & & \\
\hline Condition & Indeterminate & Distal & Medial & Proximal & Complete & Distal & Complete & Distal \\
\hline Break Type & Use & Use & Use & Use & Unbroken & Thermal/Crenated & Unbroken & Use \\
\hline Biface Stage & Indeterminate & Late & Late & Middle & Middle & Late & Early & Middle \\
\hline $\begin{array}{c}\text { Rejuvenation } \\
\text { Scar }\end{array}$ & Absent & Absent & Absent & Absent & Absent & Absent & Absent & Absent \\
\hline $\begin{array}{c}\text { Resharpening } \\
\text { Type }\end{array}$ & Indeterminate & None & Indeterminate & $\begin{array}{c}\text { Alternate } \\
\text { Beveled } \\
\text { Unifacial }\end{array}$ & None & Indeterminate & None & None \\
\hline Raw Material & Chert & Chert & Chert & Chert & Chert & Chert & Chert & Chert \\
\hline Texture & Fine & Fine & Fine & Fine & Fine & Fine & Fine & Fine \\
\hline $\begin{array}{c}\text { Percent } \\
\text { Patination }\end{array}$ & 0 & 0 & 0 & 0 & 0 & 0 & 100 & 0 \\
\hline $\begin{array}{c}\text { Percent } \\
\text { Cortex }\end{array}$ & 0 & 0 & 0 & 0 & 0 & 0 & 0 & 0 \\
\hline Cortex Type & None & None & None & None & None & None & None & None \\
\hline Heating & Burned & None & Indeterminate & None & None & Burned & None & None \\
\hline Length (mm) & & & & & 76.1 & & 47.7 & \\
\hline Width (mm) & & 47.3 & 36 & 41.1 & 47 & & 21.9 & 41.6 \\
\hline Thick (mm) & 6.2 & 8.5 & 5 & 8.6 & 15 & 6.5 & 7.2 & 11.9 \\
\hline Wt. (g) & & & & & 60.9 & & 4.9 & \\
\hline $\begin{array}{l}\text { Long } X \text { - } \\
\text { Section }\end{array}$ & Indeterminate & Indeterminate & Indeterminate & Indeterminate & $\begin{array}{l}\text { Tapered } \\
\text { Base/Tip }\end{array}$ & Indeterminate & $\begin{array}{l}\text { Tapered } \\
\text { Base/Tip }\end{array}$ & Indeterminate \\
\hline $\begin{array}{l}\text { Trans X- } \\
\text { Section }\end{array}$ & Indeterminate & $\begin{array}{c}\text { Biconvex } \\
\text { Symmetrical }\end{array}$ & $\begin{array}{l}\text { Plano- } \\
\text { Convex }\end{array}$ & $\begin{array}{l}\text { Plano- } \\
\text { Convex }\end{array}$ & $\begin{array}{l}\text { Plano- } \\
\text { Convex }\end{array}$ & $\begin{array}{c}\text { Biconvex } \\
\text { Symmetrical }\end{array}$ & $\begin{array}{c}\text { Biconvex } \\
\text { Asymmetrical }\end{array}$ & $\begin{array}{c}\text { Biconvex } \\
\text { Symmetrical }\end{array}$ \\
\hline Preform & Indeterminate & Biface & Flake & Biface & Biface & Biface & Flake & Biface \\
\hline Overall Shape & Indeterminate & Indeterminate & Indeterminate & Triangular & Ovate & Indeterminate & Lanceolate & Indeterminate \\
\hline $\begin{array}{l}\text { Flaking } \\
\text { Pattern }\end{array}$ & Indeterminate & $\begin{array}{l}\text { Oblique } \\
\text { Parallel }\end{array}$ & Random & $\begin{array}{c}\text { Oblique } \\
\text { Subparallel }\end{array}$ & Random & Collateral & $\begin{array}{l}\text { Oblique } \\
\text { Parallel }\end{array}$ & Random \\
\hline $\begin{array}{c}\text { Edge } \\
\text { Rounding }\end{array}$ & Absent & Present & Absent & Present & Absent & Present & Absent & Absent \\
\hline $\begin{array}{l}\text { Left Lateral } \\
\text { Edge Shape }\end{array}$ & Indeterminate & Excurvate & Excurvate & Straight & Excurvate & Straight & Excurvate & Excurvate \\
\hline $\begin{array}{l}\text { Right Lateral } \\
\text { Edge Shape }\end{array}$ & Indeterminate & Excurvate & Indeterminate & Straight & Excurvate & Excurvate & Excurvate & Excurvate \\
\hline Micro-wear & FALSE & TRUE & FALSE & FALSE & FALSE & FALSE & FALSE & FALSE \\
\hline NAA & FALSE & FALSE & FALSE & FALSE & FALSE & FALSE & FALSE & FALSE \\
\hline
\end{tabular}


The Varga Site

Texas Department of Transportation

Table 0-6. Biface Data From Toyah Component Continued

\begin{tabular}{|c|c|c|c|c|c|c|c|c|}
\hline Cat. No. & $291-016$ & $303-016$ & $324-017$ & 393-011 & $414-013$ & $427-011$ & $450-027$ & $450-028$ \\
\hline Unit & N102,E52 & N102,E53 & $\mathrm{N} 102, \mathrm{E} 55$ & $\mathrm{~N} 103, \mathrm{E} 56$ & $\mathrm{~N} 104, \mathrm{E} 56$ & N105,E47 & $\mathrm{N} 105, \mathrm{E} 52$ & $\mathrm{~N} 105, \mathrm{E} 52$ \\
\hline Depth (cmbd) & $0-10$ & $0-10$ & $40-50$ & $0-10$ & $10-20$ & $30-40$ & $0-10$ & $0-10$ \\
\hline \multicolumn{9}{|l|}{ Feature No. } \\
\hline Condition & & Complete & Distal & Distal & Distal & & Proximal & Indeterminate \\
\hline Break Type & & Unbroken & Use & Use & Use & & Use & Use \\
\hline Biface Stage & & Early & Late & Late & Middle & & Late & Late \\
\hline $\begin{array}{l}\text { Rejuvenation } \\
\text { Scar }\end{array}$ & & Absent & Absent & Absent & Absent & & Absent & Absent \\
\hline $\begin{array}{c}\text { Resharpening } \\
\text { Type } \\
\end{array}$ & & None & None & Indeterminate & Indeterminate & & Indeterminate & Indeterminate \\
\hline Raw Material & & Chert & Chert & Chert & Chert & & Chert & Chert \\
\hline Texture & & Fine & Fine & Fine & Fine & & Fine & Fine \\
\hline $\begin{array}{c}\text { Percent } \\
\text { Patination }\end{array}$ & & 0 & 0 & 0 & 0 & & 75 & 0 \\
\hline $\begin{array}{c}\text { Percent } \\
\text { Cortex }\end{array}$ & & 0 & 0 & 0 & 0 & & 0 & 0 \\
\hline Cortex Type & & None & None & None & None & & None & None \\
\hline Heating & & None & None & Heat-Treated & None & & None & None \\
\hline Length (mm) & & 57 & & & & & & 67.1 \\
\hline Width (mm) & & 49 & 23.8 & & & & 30.6 & \\
\hline Thick (mm) & & 14.9 & 3.6 & 4.8 & 10.6 & & 6.5 & 9.3 \\
\hline Wt. (g) & & 44.3 & & & & & & \\
\hline $\begin{array}{l}\text { Long X- } \\
\text { Section }\end{array}$ & & $\begin{array}{l}\text { Bi-wedge- } \\
\text { shaped }\end{array}$ & Flat & Indeterminate & Indeterminate & & Indeterminate & $\begin{array}{l}\text { Tapered } \\
\text { Base/Tip }\end{array}$ \\
\hline $\begin{array}{l}\text { Trans X- } \\
\text { Section }\end{array}$ & & $\begin{array}{c}\text { Biconvex } \\
\text { Symmetrical }\end{array}$ & $\begin{array}{l}\text { Plano- } \\
\text { Convex }\end{array}$ & $\begin{array}{l}\text { Plano- } \\
\text { Convex }\end{array}$ & Indeterminate & & $\begin{array}{l}\text { Plano- } \\
\text { Convex }\end{array}$ & Indeterminate \\
\hline Preform & & Biface & Flake & Flake & Biface & & Flake & Biface \\
\hline Overall Shape & & Triangular & Indeterminate & Indeterminate & Indeterminate & & Indeterminate & Ovate \\
\hline $\begin{array}{l}\text { Flaking } \\
\text { Pattern }\end{array}$ & & Random & $\begin{array}{c}\text { Flake Blank } \\
\text { Remnant }\end{array}$ & Subparallel & Random & & $\begin{array}{l}\text { Oblique } \\
\text { Parallel }\end{array}$ & Random \\
\hline $\begin{array}{c}\text { Edge } \\
\text { Rounding }\end{array}$ & & Absent & Present & Absent & Absent & & Absent & Present \\
\hline $\begin{array}{l}\text { Left Lateral } \\
\text { Edge Shape }\end{array}$ & & Excurvate & Excurvate & Indeterminate & Indeterminate & & Straight & Indeterminate \\
\hline $\begin{array}{l}\text { Right Lateral } \\
\text { Edge Shape }\end{array}$ & & Excurvate & Straight & Excurvate & Indeterminate & & Straight & Excurvate \\
\hline Micro-wear & FALSE & FALSE & FALSE & FALSE & FALSE & FALSE & FALSE & FALSE \\
\hline NAA & FALSE & FALSE & FALSE & FALSE & FALSE & FALSE & FALSE & FALSE \\
\hline
\end{tabular}


Table 0-6. Biface Data From Toyah Component Continued

\begin{tabular}{|c|c|c|c|c|c|c|c|c|}
\hline Cat. No. & $474-011$ & 489-011 & $504-014$ & $555-012$ & $565-015$ & $602-013$ & $602-014$ & $611-013$ \\
\hline Unit & N105,E55 & $\mathrm{N} 106, \mathrm{E} 47$ & N106,E51 & N107,E48 & N107,E50 & N107,E55 & N107,E55 & N107,E56 \\
\hline Depth (cmbd) & $10-20$ & $10-20$ & $10-20$ & $10-20$ & $0-10$ & $10-20$ & $10-20$ & $10-20$ \\
\hline \multicolumn{9}{|l|}{ Feature No. } \\
\hline Condition & Distal & Distal & Proximal & Medial & Distal & & Medial & Medial \\
\hline Break Type & Indeterminate & Use & Use & Manufacture & Use & & Thermal/Crenated & Manufacture \\
\hline Biface Stage & Late & Late & Middle & Late & Late & & Late & Middle \\
\hline $\begin{array}{l}\text { Rejuvenation } \\
\text { Scar }\end{array}$ & Absent & Absent & Absent & Absent & Absent & & Absent & Absent \\
\hline $\begin{array}{l}\text { Resharpening } \\
\text { Type }\end{array}$ & Indeterminate & Indeterminate & None & Indeterminate & Indeterminate & & Indeterminate & Indeterminate \\
\hline Raw Material & Chert & Chert & Chert & Chert & Chert & & Chert & Chert \\
\hline Texture & Fine & Fine & Fine & Fine & Fine & & Fine & Fine \\
\hline $\begin{array}{c}\text { Percent } \\
\text { Patination }\end{array}$ & 0 & 0 & 0 & 0 & 0 & & 0 & 0 \\
\hline $\begin{array}{c}\text { Percent } \\
\text { Cortex }\end{array}$ & 0 & 0 & 0 & 0 & 0 & & 0 & 0 \\
\hline Cortex Type & None & None & None & None & None & & None & None \\
\hline Heating & None & None & None & None & None & & Burned & None \\
\hline \multicolumn{9}{|l|}{ Length (mm) } \\
\hline Width (mm) & 25.1 & & 58.3 & & 29.4 & & & 49.3 \\
\hline Thick (mm) & 5.8 & 8.6 & 14.8 & 6.4 & 6.8 & & 5.1 & 16.2 \\
\hline \multicolumn{9}{|l|}{ Wt. (g) } \\
\hline $\begin{array}{l}\text { Long X- } \\
\text { Section }\end{array}$ & Indeterminate & Indeterminate & Indeterminate & Indeterminate & Indeterminate & & Indeterminate & Indeterminate \\
\hline $\begin{array}{l}\text { Trans X- } \\
\text { Section }\end{array}$ & $\begin{array}{l}\text { Plano- } \\
\text { Convex }\end{array}$ & Indeterminate & $\begin{array}{l}\text { Plano- } \\
\text { Convex }\end{array}$ & $\begin{array}{l}\text { Plano- } \\
\text { Convex }\end{array}$ & $\begin{array}{l}\text { Plano- } \\
\text { Convex }\end{array}$ & & $\begin{array}{c}\text { Biconvex } \\
\text { Symmetrical }\end{array}$ & Indeterminate \\
\hline Preform & Flake & Biface & Biface & Biface & Flake & & Flake & Biface \\
\hline $\begin{array}{l}\text { Overall } \\
\text { Shape }\end{array}$ & Indeterminate & Indeterminate & Indeterminate & Indeterminate & Indeterminate & & Indeterminate & Indeterminate \\
\hline $\begin{array}{l}\text { Flaking } \\
\text { Pattern }\end{array}$ & Random & Random & Random & Random & Subparallel & & Chevron & Random \\
\hline $\begin{array}{c}\text { Edge } \\
\text { Rounding }\end{array}$ & Present & Present & Absent & Absent & Present & & Absent & Absent \\
\hline $\begin{array}{l}\text { Left Lateral } \\
\text { Edge Shape }\end{array}$ & Straight & Excurvate & Straight & Indeterminate & Excurvate & & Indeterminate & Excurvate \\
\hline $\begin{array}{l}\text { Right Lateral } \\
\text { Edge Shape }\end{array}$ & Straight & Indeterminate & Straight & Excurvate & Excurvate & & Indeterminate & Indeterminate \\
\hline Micro-wear & FALSE & FALSE & FALSE & FALSE & FALSE & FALSE & FALSE & FALSE \\
\hline NAA & FALSE & FALSE & FALSE & FALSE & FALSE & FALSE & FALSE & FALSE \\
\hline
\end{tabular}


The Varga Site

Texas Department of Transportation

Table 0-6. Biface Data From Toyah Component Continued

\begin{tabular}{|c|c|c|c|c|c|c|c|c|}
\hline Cat. No. & $666-013$ & $685-012$ & $685-013$ & $758-010$ & $767-013$ & 776-012 & $782-014$ & 797-011 \\
\hline Unit & N108,E55 & N109,E48 & N109,E48 & $\mathrm{N} 109, \mathrm{E} 70$ & $\mathrm{~N} 114, \mathrm{E} 69$ & N114,E73 & N114,E75 & N115,E72 \\
\hline Depth (cmbd) & $6-20$ & $0-10$ & $0-10$ & $10-20$ & $0-10$ & $0-10$ & $15-25$ & $10-20$ \\
\hline \multicolumn{9}{|l|}{ Feature No. } \\
\hline Condition & Indeterminate & Indeterminate & Distal & Medial & Complete & Indeterminate & Distal & Distal \\
\hline Break Type & Indeterminate & Thermal/Crenated & Use & Use & Use & Indeterminate & Indeterminate & Manufacture \\
\hline Biface Stage & Middle & Indeterminate & Middle & Late & Late & Middle & Late & Late \\
\hline $\begin{array}{l}\text { Rejuvenation } \\
\text { Scar }\end{array}$ & Absent & Absent & Absent & Absent & Absent & Absent & Absent & Absent \\
\hline $\begin{array}{l}\text { Resharpening } \\
\text { Type }\end{array}$ & Indeterminate & Indeterminate & Indeterminate & Indeterminate & None & Indeterminate & None & None \\
\hline Raw Material & Chert & Chert & Chert & Chert & Chert & Chert & Chert & Chert \\
\hline Texture & Fine & Fine & Fine & Fine & Fine & Fine & Fine & Fine \\
\hline $\begin{array}{c}\text { Percent } \\
\text { Patination }\end{array}$ & 0 & 0 & 0 & 0 & 25 & 0 & 0 & 0 \\
\hline $\begin{array}{l}\text { Percent } \\
\text { Cortex }\end{array}$ & 0 & 0 & 0 & 0 & 0 & 0 & 0 & 0 \\
\hline Cortex Type & None & None & None & None & None & None & None & None \\
\hline Heating & None & Burned & None & None & None & None & None & None \\
\hline Length (mm) & 72.4 & & & & 77.5 & & & \\
\hline Width (mm) & & & & & 35.7 & & 33 & 22.4 \\
\hline Thick (mm) & 17.5 & & 11.2 & 5.2 & 13.3 & 13.6 & 4.8 & 4.1 \\
\hline Wt. (g) & & & & & 30.8 & & & \\
\hline $\begin{array}{l}\text { Long X- } \\
\text { Section }\end{array}$ & $\begin{array}{l}\text { Bi-wedge- } \\
\text { shaped }\end{array}$ & Indeterminate & Indeterminate & Indeterminate & $\begin{array}{l}\text { Tapered } \\
\text { Base/Tip }\end{array}$ & Indeterminate & Indeterminate & Flat \\
\hline $\begin{array}{l}\text { Trans X- } \\
\text { Section } \\
\end{array}$ & $\begin{array}{l}\text { Plano- } \\
\text { Convex }\end{array}$ & Indeterminate & $\begin{array}{l}\text { Plano- } \\
\text { Convex }\end{array}$ & $\begin{array}{l}\text { Plano- } \\
\text { Convex }\end{array}$ & $\begin{array}{c}\text { Biconvex } \\
\text { Asymmetrical }\end{array}$ & Indeterminate & $\begin{array}{l}\text { Plano- } \\
\text { Convex }\end{array}$ & $\begin{array}{l}\text { Plano- } \\
\text { Convex }\end{array}$ \\
\hline Preform & Biface & Biface & Biface & Biface & Biface & Biface & Flake & Flake \\
\hline $\begin{array}{l}\text { Overall } \\
\text { Shape }\end{array}$ & Ovate & Indeterminate & Indeterminate & Indeterminate & Ovate & Indeterminate & Indeterminate & Triangular \\
\hline $\begin{array}{l}\text { Flaking } \\
\text { Pattern }\end{array}$ & Random & Indeterminate & Random & $\begin{array}{c}\text { Oblique } \\
\text { Subparallel }\end{array}$ & Subparallel & Indeterminate & Chevron & $\begin{array}{c}\text { Oblique } \\
\text { Subparallel }\end{array}$ \\
\hline $\begin{array}{c}\text { Edge } \\
\text { Rounding }\end{array}$ & Absent & Present & Absent & Present & Present & Absent & Absent & Absent \\
\hline $\begin{array}{l}\text { Left Lateral } \\
\text { Edge Shape }\end{array}$ & Indeterminate & Indeterminate & Indeterminate & Excurvate & Excurvate & Indeterminate & Straight & Straight \\
\hline $\begin{array}{l}\text { Right Lateral } \\
\text { Edge Shape }\end{array}$ & Excurvate & Indeterminate & Indeterminate & Indeterminate & Excurvate & Indeterminate & Excurvate & Excurvate \\
\hline Micro-wear & FALSE & FALSE & FALSE & FALSE & FALSE & FALSE & FALSE & FALSE \\
\hline NAA & FALSE & FALSE & FALSE & FALSE & FALSE & FALSE & FALSE & FALSE \\
\hline
\end{tabular}


Table 0-6. Biface Data From Toyah Component Continued

\begin{tabular}{|c|c|c|c|c|c|c|c|c|}
\hline Cat. No. & $814-015$ & $822-010$ & $831-014$ & $835-013$ & $838-016$ & $841-016$ & $843-005-011$ & $843-005-012$ \\
\hline Unit & N116,E72 & $\mathrm{N} 116, \mathrm{E} 75$ & N117,E72 & N117,E74 & $\mathrm{N} 117, \mathrm{E} 75$ & N118,E69 & N118,E70 & N118,E70 \\
\hline Depth (cmbd) & $0-10$ & $0-10$ & 10 & $0-10$ & $10-20$ & $10-20$ & $10-20$ & $10-20$ \\
\hline Feature No. & & & & & & & 8 & 8 \\
\hline Condition & Complete & Medial & Distal & Complete & Proximal & Distal & Medial & Complete \\
\hline Break Type & Unbroken & $\begin{array}{l}\text { Thermal/ } \\
\text { Crenated }\end{array}$ & Use & Unbroken & Indeterminate & $\begin{array}{l}\text { Thermal/ } \\
\text { Crenated }\end{array}$ & Use & Unbroken \\
\hline Biface Stage & Middle & Middle & Late & Late & Late & Indeterminate & Late & Late \\
\hline $\begin{array}{l}\text { Rejuvenation } \\
\text { Scar }\end{array}$ & Absent & Absent & Absent & Absent & Absent & Absent & Absent & Absent \\
\hline $\begin{array}{c}\text { Resharpening } \\
\text { Type }\end{array}$ & None & None & None & $\begin{array}{l}\text { Alternate } \\
\text { Beveled } \\
\text { Unifacial }\end{array}$ & Indeterminate & Indeterminate & None & None \\
\hline Raw Material & Chert & Chert & Chert & Chert & Chert & Chert & Chert & Chert \\
\hline Texture & Fine & Fine & Fine & Fine & Fine & Fine & Fine & Fine \\
\hline $\begin{array}{c}\text { Percent } \\
\text { Patination }\end{array}$ & 0 & 0 & 0 & 25 & 0 & 0 & 0 & 0 \\
\hline $\begin{array}{l}\text { Percent } \\
\text { Cortex }\end{array}$ & 0 & 0 & 0 & 0 & 0 & 0 & 0 & 0 \\
\hline Cortex Type & None & None & None & None & None & None & None & None \\
\hline Heating & None & Burned & None & Indeterminate & None & Burned & None & None \\
\hline Length (mm) & 123.5 & & & 53.6 & & & & 41.6 \\
\hline Width (mm) & 42.4 & 48.9 & & 22.9 & & & & 26.1 \\
\hline Thick (mm) & 24 & 11.6 & 6.7 & 7.6 & 8.8 & & 4.8 & 4.1 \\
\hline Wt. (g) & 113 & 46.5 & & 10.9 & & & & 3.8 \\
\hline $\begin{array}{l}\text { Long X- } \\
\text { Section }\end{array}$ & $\begin{array}{l}\text { Tapered } \\
\text { Base/Tip }\end{array}$ & Indeterminate & Indeterminate & $\begin{array}{l}\text { Tapered } \\
\text { Base/Tip }\end{array}$ & Flat & Indeterminate & Flat & Flat \\
\hline $\begin{array}{l}\text { Trans X- } \\
\text { Section }\end{array}$ & $\begin{array}{c}\text { Biconvex } \\
\text { Symmetrical }\end{array}$ & $\begin{array}{l}\text { Plano- } \\
\text { Convex }\end{array}$ & $\begin{array}{l}\text { Biconvex } \\
\text { Symmetrical }\end{array}$ & $\begin{array}{c}\text { Biconvex } \\
\text { Symmetrical }\end{array}$ & $\begin{array}{l}\text { Plano- } \\
\text { Convex }\end{array}$ & Indeterminate & $\begin{array}{l}\text { Plano- } \\
\text { Convex }\end{array}$ & $\begin{array}{l}\text { Plano- } \\
\text { Convex }\end{array}$ \\
\hline Preform & Biface & Biface & Biface & Biface & Biface & Indeterminate & Flake & Flake \\
\hline $\begin{array}{l}\text { Overall } \\
\text { Shape }\end{array}$ & Ovate & Ovate & Triangular & Lanceolate & Ovate & Indeterminate & Indeterminate & Triangular \\
\hline $\begin{array}{l}\text { Flaking } \\
\text { Pattern }\end{array}$ & Chevron & Random & Chevron & $\begin{array}{c}\text { Oblique } \\
\text { Subparallel }\end{array}$ & Random & Indeterminate & Collateral & Chevron \\
\hline $\begin{array}{c}\text { Edge } \\
\text { Rounding }\end{array}$ & Absent & Absent & Absent & Present & Present & Present & Absent & Absent \\
\hline $\begin{array}{l}\text { Left Lateral } \\
\text { Edge Shape }\end{array}$ & Excurvate & Excurvate & Indeterminate & Straight & Indeterminate & Indeterminate & Excurvate & Straight \\
\hline $\begin{array}{l}\text { Right Lateral } \\
\text { Edge Shape }\end{array}$ & Excurvate & Excurvate & Excurvate & Straight & Excurvate & Indeterminate & Excurvate & Straight \\
\hline Micro-wear & FALSE & FALSE & FALSE & FALSE & FALSE & FALSE & FALSE & FALSE \\
\hline NAA & FALSE & FALSE & FALSE & FALSE & FALSE & FALSE & FALSE & FALSE \\
\hline
\end{tabular}


The Varga Site

Texas Department of Transportation

Table 0-6. Biface Data From Toyah Component Continued

\begin{tabular}{|c|c|c|c|c|c|c|c|c|}
\hline Cat. No. & 847-017 & $857-014$ & 859-017 & $871-010$ & $878-010$ & 878-011 & $878-021$ & $880-013$ \\
\hline Unit & N118,E72 & N118,E74 & N118,E75 & N119,E73 & N119,E75 & N119,E75 & $\mathrm{N} 119, \mathrm{E} 75$ & N120,E69 \\
\hline Depth (cmbd) & $0-10$ & 14 & $0-10$ & $0-10$ & $10-20$ & $10-20$ & $10-20$ & $0-18$ \\
\hline \multicolumn{9}{|l|}{ Feature No. } \\
\hline Condition & Medial & Indeterminate & Medial & Distal & Proximal & Proximal & Complete & Medial \\
\hline Break Type & Use & Use & Indeterminate & Use & Indeterminate & Use & Unbroken & Indeterminate \\
\hline Biface Stage & Late & Late & Middle & Late & Late & Late & Late & Late \\
\hline $\begin{array}{l}\text { Rejuvenation } \\
\text { Scar }\end{array}$ & Absent & Absent & Absent & Absent & Absent & Absent & Absent & Absent \\
\hline $\begin{array}{c}\text { Resharpening } \\
\text { Type }\end{array}$ & Indeterminate & None & None & $\begin{array}{l}\text { Alternate } \\
\text { Beveled } \\
\text { Unifacial }\end{array}$ & None & Indeterminate & None & Indeterminate \\
\hline Raw Material & Chert & Chert & Chert & Chert & Chert & Chert & Chert & Chert \\
\hline Texture & Fine & Fine & Fine & Fine & Fine & Fine & Fine & Fine \\
\hline $\begin{array}{l}\text { Percent } \\
\text { Patination }\end{array}$ & 0 & 0 & 0 & 0 & 0 & 0 & 0 & 0 \\
\hline $\begin{array}{l}\text { Percent } \\
\text { Cortex }\end{array}$ & 0 & 0 & 0 & 0 & 0 & 0 & 0 & 0 \\
\hline Cortex Type & None & None & None & None & None & None & None & None \\
\hline Heating & None & None & None & None & None & None & None & Indeterminate \\
\hline Length (mm) & & & & & & & 46 & \\
\hline Width (mm) & 23.3 & 27.8 & & & 36.9 & & 24.1 & \\
\hline Thick (mm) & 5.3 & 7.8 & 8.3 & 4.7 & 8.4 & 5.3 & 5.8 & 5.8 \\
\hline Wt. (g) & & 16.4 & & & & & 6.3 & \\
\hline $\begin{array}{l}\text { Long X- } \\
\text { Section }\end{array}$ & Indeterminate & Flat & Indeterminate & Flat & Indeterminate & Indeterminate & $\begin{array}{c}\text { Wedged } \\
\text { Base, Flat }\end{array}$ & Indeterminate \\
\hline $\begin{array}{l}\text { Trans X- } \\
\text { Section }\end{array}$ & $\begin{array}{c}\text { Biconvex } \\
\text { Asymmetrical }\end{array}$ & $\begin{array}{l}\text { Plano- } \\
\text { Convex }\end{array}$ & $\begin{array}{l}\text { Plano- } \\
\text { Convex }\end{array}$ & $\begin{array}{l}\text { Plano- } \\
\text { Convex }\end{array}$ & $\begin{array}{c}\text { Biconvex } \\
\text { Asymmetrical }\end{array}$ & Plano-Convex & $\begin{array}{l}\text { Plano- } \\
\text { Convex }\end{array}$ & Indeterminate \\
\hline Preform & Flake & Biface & Flake & Flake & Indeterminate & Flake & Flake & Indeterminate \\
\hline $\begin{array}{l}\text { Overall } \\
\text { Shape }\end{array}$ & Indeterminate & Lanceolate & Indeterminate & Indeterminate & Indeterminate & Indeterminate & Teardrop & Indeterminate \\
\hline $\begin{array}{l}\text { Flaking } \\
\text { Pattern }\end{array}$ & $\begin{array}{l}\text { Oblique } \\
\text { Parallel }\end{array}$ & Random & Random & Chevron & Random & Indeterminate & Random & Indeterminate \\
\hline $\begin{array}{c}\text { Edge } \\
\text { Rounding }\end{array}$ & Absent & Absent & Present & Present & Absent & Absent & Present & Present \\
\hline $\begin{array}{l}\text { Left Lateral } \\
\text { Edge Shape }\end{array}$ & Indeterminate & Excurvate & Indeterminate & Indeterminate & Indeterminate & Indeterminate & Excurvate & Indeterminate \\
\hline $\begin{array}{l}\text { Right Lateral } \\
\text { Edge Shape }\end{array}$ & Indeterminate & Excurvate & Indeterminate & Excurvate & Indeterminate & Indeterminate & Excurvate & Indeterminate \\
\hline Micro-wear & FALSE & FALSE & FALSE & FALSE & FALSE & FALSE & FALSE & FALSE \\
\hline NAA & FALSE & FALSE & FALSE & FALSE & FALSE & FALSE & FALSE & FALSE \\
\hline
\end{tabular}


Table 0-6. Biface Data From Toyah Component Continued

\begin{tabular}{|c|c|c|c|c|c|c|c|c|}
\hline Cat. No. & $885-020$ & 893-017 & 893-018 & 894-015 & 894-016 & 897-012 & $902-014$ & $903-022$ \\
\hline Unit & N120,E72 & N120,E74 & N120,E74 & N120,E75 & N120,E75 & N122,E69 & N122,E70 & N122,E71 \\
\hline Depth (cmbd) & $0-10$ & $20-30$ & $20-30$ & $0-10$ & $0-10$ & $0-10$ & $20-30$ & $0-10$ \\
\hline \multicolumn{9}{|l|}{ Feature No. } \\
\hline Condition & Complete & Proximal & Indeterminate & Indeterminate & Indeterminate & Medial & Distal & Complete \\
\hline Break Type & Unbroken & Use & Use & Indeterminate & $\begin{array}{l}\text { Thermal/ } \\
\text { Crenated }\end{array}$ & $\begin{array}{l}\text { Thermal/ } \\
\text { Crenated }\end{array}$ & $\begin{array}{l}\text { Thermal/ } \\
\text { Crenated }\end{array}$ & Unbroken \\
\hline Biface Stage & Middle & Late & Late & Late & Middle & Late & Late & Early \\
\hline $\begin{array}{l}\text { Rejuvenation } \\
\text { Scar }\end{array}$ & Absent & Absent & Absent & Absent & Absent & Absent & Absent & Absent \\
\hline $\begin{array}{l}\text { Resharpening } \\
\text { Type }\end{array}$ & None & None & Indeterminate & Indeterminate & Indeterminate & Indeterminate & None & $\begin{array}{c}\text { Alternate } \\
\text { Beveled } \\
\text { Unifacial }\end{array}$ \\
\hline Raw Material & Chert & Chert & Chert & Chert & Chert & Chert & Chert & Chert \\
\hline Texture & Fine & Fine & Fine & Fine & Fine & Fine & Fine & Fine \\
\hline $\begin{array}{c}\text { Percent } \\
\text { Patination }\end{array}$ & 0 & 0 & 0 & 0 & 0 & 0 & 0 & 0 \\
\hline $\begin{array}{c}\text { Percent } \\
\text { Cortex }\end{array}$ & 0 & 0 & 0 & 0 & 0 & 0 & 0 & 0 \\
\hline Cortex Type & None & None & None & None & None & None & None & None \\
\hline Heating & Heat-Treated & None & None & None & Burned & Burned & Burned & Heat-Treated \\
\hline Length (mm) & 62.8 & & & & & & & 60.1 \\
\hline Width (mm) & 47.3 & 33.7 & & & & & 29.2 & 58.3 \\
\hline Thick (mm) & 9.1 & 7.1 & & & 12.9 & 6 & 10.4 & 10.5 \\
\hline Wt. (g) & 31.1 & & & & & & & 41.1 \\
\hline $\begin{array}{l}\text { Long } X- \\
\text { Section }\end{array}$ & $\begin{array}{l}\text { Tapered } \\
\text { Base/Tip }\end{array}$ & Indeterminate & Indeterminate & Indeterminate & Indeterminate & Indeterminate & Indeterminate & Indeterminate \\
\hline $\begin{array}{l}\text { Trans X- } \\
\text { Section }\end{array}$ & $\begin{array}{l}\text { Plano- } \\
\text { Convex }\end{array}$ & $\begin{array}{c}\text { Biconvex } \\
\text { Symmetrical }\end{array}$ & $\begin{array}{l}\text { Plano- } \\
\text { Convex }\end{array}$ & $\begin{array}{l}\text { Plano- } \\
\text { Convex }\end{array}$ & Indeterminate & Plano-Convex & $\begin{array}{c}\text { Biconvex } \\
\text { Symmetrical }\end{array}$ & Indeterminate \\
\hline Preform & Flake & Flake & Flake & Flake & Biface & Flake & Biface & Flake \\
\hline $\begin{array}{l}\text { Overall } \\
\text { Shape }\end{array}$ & Round & Indeterminate & Indeterminate & Indeterminate & Indeterminate & Indeterminate & Triangular & Round \\
\hline $\begin{array}{l}\text { Flaking } \\
\text { Pattern }\end{array}$ & Random & Indeterminate & Indeterminate & Indeterminate & Indeterminate & Subparallel & Indeterminate & Random \\
\hline $\begin{array}{c}\text { Edge } \\
\text { Rounding }\end{array}$ & Absent & Present & Absent & Present & Absent & Absent & Present & Present \\
\hline $\begin{array}{l}\text { Left Lateral } \\
\text { Edge Shape }\end{array}$ & Excurvate & Indeterminate & Indeterminate & Indeterminate & Indeterminate & Indeterminate & Straight & Excurvate \\
\hline $\begin{array}{l}\text { Right Lateral } \\
\text { Edge Shape }\end{array}$ & Excurvate & Indeterminate & Indeterminate & Indeterminate & Indeterminate & Indeterminate & Straight & Excurvate \\
\hline Micro-wear & FALSE & FALSE & FALSE & FALSE & FALSE & FALSE & FALSE & TRUE \\
\hline NAA & FALSE & FALSE & FALSE & FALSE & FALSE & FALSE & FALSE & FALSE \\
\hline
\end{tabular}


The Varga Site

Texas Department of Transportation

Table 0-6. Biface Data From Toyah Component Continued

\begin{tabular}{|c|c|c|c|c|c|c|c|c|}
\hline Cat. No. & $903-026$ & $915-020$ & $934-019$ & $936-015$ & $937-010$ & $937-011$ & $940-015$ & $945-011$ \\
\hline Unit & N122,E71 & N122,E75 & N123,E71 & $\mathrm{N} 123, \mathrm{E} 72$ & N123,E72 & $\mathrm{N} 123, \mathrm{E} 72$ & N123,E73 & N123,E75 \\
\hline Depth (cmbd) & $0-10$ & $0-10$ & $12 \mathrm{cmbs}$ & $0-10$ & $10-20$ & $10-20$ & $12-26$ & $0-10$ \\
\hline \multicolumn{9}{|l|}{ Feature No. } \\
\hline Condition & Indeterminate & Proximal & Distal & Medial & Proximal & Medial & Medial & Complete \\
\hline Break Type & Indeterminate & Use & Use & Indeterminate & Use & Indeterminate & Manufacture & Use \\
\hline Biface Stage & Late & Late & Late & Late & Early & Late & Late & Late \\
\hline $\begin{array}{l}\text { Rejuvenation } \\
\text { Scar }\end{array}$ & Absent & Absent & Absent & Absent & Absent & Absent & Absent & Absent \\
\hline $\begin{array}{c}\text { Resharpening } \\
\text { Type } \\
\end{array}$ & Indeterminate & Indeterminate & None & None & $\begin{array}{l}\text { Beveled } \\
\text { Unifacial }\end{array}$ & None & None & None \\
\hline Raw Material & Chert & Chert & Chert & Chert & Chert & Chert & Chert & Chert \\
\hline Texture & Fine & Fine & Fine & Fine & Fine & Fine & Fine & Fine \\
\hline $\begin{array}{c}\text { Percent } \\
\text { Patination }\end{array}$ & 0 & 0 & 0 & 0 & 0 & 0 & 0 & 0 \\
\hline $\begin{array}{l}\text { Percent } \\
\text { Cortex }\end{array}$ & 0 & 0 & 0 & 0 & 0 & 0 & 0 & 0 \\
\hline Cortex Type & None & None & None & None & None & None & None & None \\
\hline Heating & Burned & None & None & None & None & None & None & Burned \\
\hline Length (mm) & & & & & & & & 40 \\
\hline Width (mm) & & & 43.4 & 24.1 & 26.4 & & & 27.4 \\
\hline Thick (mm) & 6.9 & & 6.8 & 4.1 & 4.1 & 4.2 & 7.6 & 6.2 \\
\hline Wt. (g) & & & & & & & & 7.5 \\
\hline $\begin{array}{l}\text { Long X- } \\
\text { Section }\end{array}$ & Indeterminate & Indeterminate & Indeterminate & Flat & $\begin{array}{l}\text { Tapered } \\
\text { Base/Tip }\end{array}$ & Indeterminate & Indeterminate & Flat \\
\hline $\begin{array}{l}\text { Trans X- } \\
\text { Section } \\
\end{array}$ & $\begin{array}{c}\text { Biconvex } \\
\text { Symmetrical }\end{array}$ & $\begin{array}{l}\text { Plano- } \\
\text { Convex }\end{array}$ & $\begin{array}{c}\text { Biconvex } \\
\text { Symmetrical }\end{array}$ & $\begin{array}{l}\text { Plano- } \\
\text { Convex }\end{array}$ & $\begin{array}{l}\text { Plano- } \\
\text { Convex }\end{array}$ & Plano-Convex & Indeterminate & $\begin{array}{l}\text { Plano- } \\
\text { Convex }\end{array}$ \\
\hline Preform & Biface & Biface & Biface & Flake & Flake & Flake & Flake & Flake \\
\hline $\begin{array}{l}\text { Overall } \\
\text { Shape }\end{array}$ & Indeterminate & Indeterminate & Indeterminate & Triangular & Ovate & Indeterminate & Indeterminate & Ovate \\
\hline $\begin{array}{l}\text { Flaking } \\
\text { Pattern }\end{array}$ & Indeterminate & Indeterminate & Random & Subparallel & $\begin{array}{c}\text { Flake Blank } \\
\text { Remnant }\end{array}$ & Random & Indeterminate & $\begin{array}{c}\text { Flake Blank } \\
\text { Remnant }\end{array}$ \\
\hline $\begin{array}{c}\text { Edge } \\
\text { Rounding }\end{array}$ & Absent & Absent & Absent & Absent & Present & Present & Absent & Present \\
\hline $\begin{array}{l}\text { Left Lateral } \\
\text { Edge Shape }\end{array}$ & Indeterminate & Indeterminate & Excurvate & Straight & Excurvate & Indeterminate & Excurvate & Excurvate \\
\hline $\begin{array}{l}\text { Right Lateral } \\
\text { Edge Shape }\end{array}$ & Indeterminate & Indeterminate & Excurvate & Straight & Excurvate & Indeterminate & Indeterminate & Excurvate \\
\hline Micro-wear & FALSE & FALSE & TRUE & FALSE & TRUE & FALSE & FALSE & FALSE \\
\hline NAA & FALSE & FALSE & FALSE & FALSE & FALSE & FALSE & FALSE & FALSE \\
\hline
\end{tabular}


Table 0-6. Biface Data From Toyah Component Continued

\begin{tabular}{|c|c|c|c|c|c|c|c|c|}
\hline Cat. No. & $969-020$ & 984-018 & $987-016$ & $990-011$ & $992-015$ & 994-011 & $1002-018$ & $1013-010$ \\
\hline Unit & N124,E75 & N125,E72 & N125,E73 & N125,E74 & N125,E75 & N125,E75 & N126,E70 & N126,E72 \\
\hline Depth (cmbd) & $20-30$ & $10-20$ & $10-20$ & $10-20$ & $0-10$ & $20-30$ & $10-20$ & $70-80$ \\
\hline \multicolumn{9}{|l|}{ Feature No. } \\
\hline Condition & Proximal & Distal & Medial & Medial & Distal & Distal & Distal & Indeterminate \\
\hline Break Type & Use & Use & Use & Indeterminate & Manufacture & Indeterminate & Use & Indeterminate \\
\hline Biface Stage & Late & Late & Late & Late & Late & Late & Late & Late \\
\hline $\begin{array}{l}\text { Rejuvenation } \\
\text { Scar }\end{array}$ & Absent & Absent & Absent & Absent & Absent & Absent & Absent & Absent \\
\hline $\begin{array}{c}\text { Resharpening } \\
\text { Type }\end{array}$ & None & None & None & Indeterminate & None & Indeterminate & None & Indeterminate \\
\hline Raw Material & Chert & Chert & Chert & Chert & Chert & Chert & Chert & Chert \\
\hline Texture & Fine & Fine & Fine & Fine & Fine & Fine & Fine & Fine \\
\hline $\begin{array}{c}\text { Percent } \\
\text { Patination }\end{array}$ & 0 & 0 & 0 & 0 & 0 & 0 & 0 & 0 \\
\hline $\begin{array}{c}\text { Percent } \\
\text { Cortex }\end{array}$ & 0 & 0 & 0 & 0 & 0 & 0 & 0 & 0 \\
\hline Cortex Type & None & None & None & None & None & None & None & None \\
\hline Heating & None & None & None & None & None & None & Heat-Treated & None \\
\hline Length (mm) & & & & 52.2 & & & & \\
\hline Width (mm) & 21.3 & & 45.5 & & & & 37.3 & \\
\hline Thick (mm) & 6.8 & 6.8 & 8.1 & 13.9 & 6.3 & & 6.9 & \\
\hline \multicolumn{9}{|l|}{ Wt. (g) } \\
\hline $\begin{array}{l}\text { Long } X- \\
\text { Section }\end{array}$ & Flat & Indeterminate & Indeterminate & Indeterminate & Indeterminate & Indeterminate & Flat & Indeterminate \\
\hline $\begin{array}{l}\text { Trans X- } \\
\text { Section }\end{array}$ & $\begin{array}{l}\text { Plano- } \\
\text { Convex }\end{array}$ & $\begin{array}{c}\text { Biconvex } \\
\text { Symmetrical }\end{array}$ & $\begin{array}{l}\text { Plano- } \\
\text { Convex }\end{array}$ & Indeterminate & $\begin{array}{l}\text { Plano- } \\
\text { Convex }\end{array}$ & Plano-Convex & $\begin{array}{l}\text { Plano- } \\
\text { Convex }\end{array}$ & Indeterminate \\
\hline Preform & Flake & Flake & Flake & Biface & Flake & Flake & Flake & Indeterminate \\
\hline $\begin{array}{l}\text { Overall } \\
\text { Shape }\end{array}$ & Lanceolate & Indeterminate & Indeterminate & Indeterminate & Lanceolate & Indeterminate & Indeterminate & Indeterminate \\
\hline $\begin{array}{l}\text { Flaking } \\
\text { Pattern }\end{array}$ & Random & Random & Random & Indeterminate & $\begin{array}{c}\text { Oblique } \\
\text { Subparallel }\end{array}$ & Indeterminate & Collateral & Indeterminate \\
\hline $\begin{array}{c}\text { Edge } \\
\text { Rounding }\end{array}$ & Absent & Absent & Present & Absent & Absent & Absent & Absent & Absent \\
\hline $\begin{array}{l}\text { Left Lateral } \\
\text { Edge Shape }\end{array}$ & Straight & Indeterminate & Indeterminate & Excurvate & Excurvate & Indeterminate & Excurvate & Indeterminate \\
\hline $\begin{array}{l}\text { Right Lateral } \\
\text { Edge Shape }\end{array}$ & Straight & Indeterminate & Indeterminate & Indeterminate & Excurvate & Indeterminate & Excurvate & Indeterminate \\
\hline Micro-wear & FALSE & FALSE & FALSE & FALSE & FALSE & FALSE & FALSE & FALSE \\
\hline NAA & FALSE & FALSE & FALSE & FALSE & FALSE & FALSE & FALSE & FALSE \\
\hline
\end{tabular}


The Varga Site

Texas Department of Transportation

Table 0-6. Biface Data From Toyah Component Continued

\begin{tabular}{|c|c|c|c|c|c|c|c|c|}
\hline Cat. No. & $1019-015$ & $1021-015$ & $1041-014$ & $1049-011$ & $1051-010$ & $1054-018$ & $1085-013$ & $1095-014$ \\
\hline Unit & N126,E73 & N126,E74 & N127,E71 & $\mathrm{N} 127, \mathrm{E} 74$ & N127,E74 & N127,E75 & N128,E75 & N129,E73 \\
\hline Depth (cmbd) & $10-20$ & 24 & $10-20$ & $10-20$ & $25-35$ & $20-30$ & $20-30$ & $10-20$ \\
\hline Feature No. & & & & & & 25 & & \\
\hline Condition & Distal & Distal & Complete & Distal & Medial & Medial & Complete & Medial \\
\hline Break Type & Use & Indeterminate & Unbroken & $\begin{array}{l}\text { Thermal/ } \\
\text { Crenated }\end{array}$ & $\begin{array}{l}\text { Thermal/ } \\
\text { Crenated }\end{array}$ & $\begin{array}{l}\text { Thermal/ } \\
\text { Crenated }\end{array}$ & Unbroken & $\begin{array}{l}\text { Thermal/ } \\
\text { Crenated }\end{array}$ \\
\hline Biface Stage & Late & Late & Late & Indeterminate & Late & Late & Middle & Late \\
\hline $\begin{array}{l}\text { Rejuvenation } \\
\text { Scar }\end{array}$ & Absent & Absent & Absent & Absent & Absent & Absent & Absent & Absent \\
\hline $\begin{array}{c}\text { Resharpening } \\
\text { Type } \\
\end{array}$ & None & None & $\begin{array}{c}\text { Beveled } \\
\text { Bifacial }\end{array}$ & Indeterminate & Indeterminate & Indeterminate & None & None \\
\hline Raw Material & Chert & Chert & Chert & Chert & Chert & Chert & Chert & Chert \\
\hline Texture & Fine & Fine & Fine & Fine & Fine & Fine & Fine & Fine \\
\hline $\begin{array}{c}\text { Percent } \\
\text { Patination }\end{array}$ & 0 & 0 & 0 & 100 & 0 & 0 & 0 & 0 \\
\hline $\begin{array}{l}\text { Percent } \\
\text { Cortex }\end{array}$ & 0 & 0 & 0 & 0 & 0 & 0 & 25 & 0 \\
\hline Cortex Type & None & None & None & None & None & None & Pebble/Cobble & None \\
\hline Heating & None & Burned & Heat-Treated & Burned & Burned & Burned & None & Burned \\
\hline Length (mm) & & & 93.2 & & & & 63 & \\
\hline Width (mm) & & 35.3 & 33.7 & & & & 55.8 & \\
\hline Thick (mm) & 6 & 7.7 & 11.9 & & 5.1 & 5.9 & 14.3 & \\
\hline Wt. (g) & & & 24.3 & & & & 46.6 & \\
\hline $\begin{array}{l}\text { Long X- } \\
\text { Section }\end{array}$ & Indeterminate & Flat & $\begin{array}{l}\text { Tapered } \\
\text { Base/Tip }\end{array}$ & Indeterminate & Indeterminate & Indeterminate & $\begin{array}{l}\text { Bi-wedge- } \\
\text { shaped }\end{array}$ & Indeterminate \\
\hline $\begin{array}{l}\text { Trans X- } \\
\text { Section }\end{array}$ & $\begin{array}{c}\text { Biconvex } \\
\text { Asymmetrical }\end{array}$ & $\begin{array}{l}\text { Plano- } \\
\text { Convex }\end{array}$ & $\begin{array}{c}\text { Biconvex } \\
\text { Symmetrical }\end{array}$ & $\begin{array}{c}\text { Biconvex } \\
\text { Asymmetrical }\end{array}$ & $\begin{array}{l}\text { Plano- } \\
\text { Convex }\end{array}$ & Plano-Convex & Plano-Convex & Indeterminate \\
\hline Preform & Flake & Flake & Biface & Indeterminate & Flake & Flake & Flake & Indeterminate \\
\hline $\begin{array}{l}\text { Overall } \\
\text { Shape }\end{array}$ & Indeterminate & Indeterminate & Bipointed & Indeterminate & Indeterminate & Indeterminate & Round & Indeterminate \\
\hline $\begin{array}{l}\text { Flaking } \\
\text { Pattern }\end{array}$ & $\begin{array}{l}\text { Oblique } \\
\text { Subparallel }\end{array}$ & Subparallel & Random & Indeterminate & Indeterminate & Chevron & Random & Indeterminate \\
\hline $\begin{array}{c}\text { Edge } \\
\text { Rounding }\end{array}$ & Present & Present & Present & Present & Present & Absent & Absent & Absent \\
\hline $\begin{array}{l}\text { Left Lateral } \\
\text { Edge Shape }\end{array}$ & Indeterminate & Excurvate & Excurvate & Indeterminate & Excurvate & Indeterminate & Excurvate & Indeterminate \\
\hline $\begin{array}{l}\text { Right Lateral } \\
\text { Edge Shape }\end{array}$ & Indeterminate & Excurvate & Indeterminate & Indeterminate & Indeterminate & Indeterminate & Excurvate & Indeterminate \\
\hline Micro-wear & FALSE & FALSE & TRUE & FALSE & FALSE & FALSE & FALSE & FALSE \\
\hline NAA & FALSE & FALSE & FALSE & FALSE & FALSE & FALSE & FALSE & FALSE \\
\hline
\end{tabular}


Table 0-6. Biface Data From Toyah Component Continued

\begin{tabular}{|c|c|c|c|c|c|c|c|c|}
\hline Cat. No. & $1098-016$ & $1100-014$ & $1122-018$ & $1133-010$ & $1137-010$ & $1137-013$ & $1156-012$ & $1170-010$ \\
\hline Unit & N129,E74 & N129,E75 & N130,E72 & N130,E75 & N131,E70 & N131,E70 & N131,E73 & $\mathrm{N} 132, \mathrm{E} 72$ \\
\hline Depth (cmbd) & $10-20$ & $0-10$ & $20-30$ & $20-30$ & $30-40$ & $30-40$ & $0-10$ & $10-20$ \\
\hline \multicolumn{9}{|l|}{ Feature No. } \\
\hline Condition & Medial & Medial & Medial & Medial & Medial & Medial & Complete & Complete \\
\hline Break Type & $\begin{array}{l}\text { Thermal/ } \\
\text { Crenated }\end{array}$ & Use & Indeterminate & Use & Use & $\begin{array}{l}\text { Thermal/ } \\
\text { Crenated }\end{array}$ & Unbroken & Unbroken \\
\hline Biface Stage & Late & Late & Late & Late & Late & Late & Middle & Middle \\
\hline $\begin{array}{l}\text { Rejuvenation } \\
\text { Scar }\end{array}$ & Absent & Absent & Absent & Absent & Absent & Absent & Absent & Absent \\
\hline $\begin{array}{c}\text { Resharpening } \\
\text { Type }\end{array}$ & Indeterminate & None & Indeterminate & Indeterminate & Indeterminate & None & None & None \\
\hline Raw Material & Chert & Chert & Chert & Chert & Chert & Chert & Chert & Chert \\
\hline Texture & Fine & Fine & Fine & Fine & Fine & Fine & Fine & Fine \\
\hline $\begin{array}{c}\text { Percent } \\
\text { Patination }\end{array}$ & 0 & 0 & 0 & 0 & 0 & 0 & 0 & 0 \\
\hline $\begin{array}{c}\text { Percent } \\
\text { Cortex }\end{array}$ & 0 & 0 & 0 & 0 & 0 & 0 & 25 & 0 \\
\hline Cortex Type & None & None & None & None & None & None & Pebble/Cobble & None \\
\hline Heating & Burned & None & Heat-Treated & None & None & Burned & None & None \\
\hline Length (mm) & & & & & & & 62.8 & 52.4 \\
\hline Width (mm) & & 31.2 & & & & & 60.7 & 46.1 \\
\hline Thick (mm) & & 6.6 & & & & 7.1 & 15.2 & 11 \\
\hline Wt. (g) & & & & & & & 66.5 & 34.2 \\
\hline $\begin{array}{l}\text { Long } X- \\
\text { Section }\end{array}$ & Indeterminate & Flat & Indeterminate & Indeterminate & Indeterminate & Indeterminate & $\begin{array}{l}\text { Bi-wedge- } \\
\text { shaped }\end{array}$ & $\begin{array}{c}\text { Tapered } \\
\text { Base }\end{array}$ \\
\hline $\begin{array}{l}\text { Trans X- } \\
\text { Section }\end{array}$ & $\begin{array}{l}\text { Plano- } \\
\text { Convex }\end{array}$ & $\begin{array}{l}\text { Plano- } \\
\text { Convex }\end{array}$ & $\begin{array}{l}\text { Plano- } \\
\text { Convex }\end{array}$ & $\begin{array}{l}\text { Plano- } \\
\text { Convex }\end{array}$ & $\begin{array}{l}\text { Plano- } \\
\text { Convex }\end{array}$ & Plano-Convex & Plano-Convex & $\begin{array}{l}\text { Plano- } \\
\text { Convex }\end{array}$ \\
\hline Preform & Flake & Flake & Flake & Flake & Flake & Flake & Flake & Flake \\
\hline $\begin{array}{l}\text { Overall } \\
\text { Shape }\end{array}$ & Indeterminate & Triangular & Indeterminate & Indeterminate & Indeterminate & Indeterminate & Round & Round \\
\hline $\begin{array}{l}\text { Flaking } \\
\text { Pattern }\end{array}$ & Indeterminate & Random & Indeterminate & Indeterminate & Indeterminate & Indeterminate & $\begin{array}{c}\text { Flake Blank } \\
\text { Remnant }\end{array}$ & Random \\
\hline $\begin{array}{c}\text { Edge } \\
\text { Rounding }\end{array}$ & Absent & Absent & Absent & Absent & Absent & Absent & Absent & Absent \\
\hline $\begin{array}{l}\text { Left Lateral } \\
\text { Edge Shape }\end{array}$ & Indeterminate & Straight & Indeterminate & Excurvate & Indeterminate & Indeterminate & Excurvate & Excurvate \\
\hline $\begin{array}{l}\text { Right Lateral } \\
\text { Edge Shape }\end{array}$ & Indeterminate & Straight & Straight & Indeterminate & Indeterminate & Straight & Excurvate & Excurvate \\
\hline Micro-wear & FALSE & FALSE & FALSE & FALSE & FALSE & FALSE & FALSE & FALSE \\
\hline NAA & FALSE & FALSE & FALSE & FALSE & FALSE & FALSE & FALSE & FALSE \\
\hline
\end{tabular}


The Varga Site

Texas Department of Transportation

Table 0-6. Biface Data From Toyah Component Continued

\begin{tabular}{|c|c|c|c|}
\hline Cat. No. & $1180-010$ & $1189-013$ & $1256-005-011$ \\
\hline Unit & N132,E74 & $\mathrm{N} 133, \mathrm{E} 72$ & N126,E74 \\
\hline Depth (cmbd) & $30-35$ & $10-20$ & $10-20$ \\
\hline Feature No. & & & 25 \\
\hline Condition & Proximal & Complete & Medial \\
\hline Break Type & Thermal/Crenated & Indeterminate & Use \\
\hline Biface Stage & Late & Early & Late \\
\hline $\begin{array}{l}\text { Rejuvenation } \\
\text { Scar }\end{array}$ & Absent & Absent & Absent \\
\hline $\begin{array}{l}\text { Resharpening } \\
\text { Type }\end{array}$ & Indeterminate & None & $\begin{array}{c}\text { Alternate Beveled } \\
\text { Unifacial }\end{array}$ \\
\hline Raw Material & Chert & Chert & Chert \\
\hline Texture & Fine & Fine & Fine \\
\hline $\begin{array}{c}\text { Percent } \\
\text { Patination }\end{array}$ & 0 & 0 & 0 \\
\hline $\begin{array}{c}\text { Percent } \\
\text { Cortex }\end{array}$ & 0 & 25 & 0 \\
\hline Cortex Type & None & Pebble/Cobble & None \\
\hline Heating & Burned & None & Indeterminate \\
\hline Length (mm) & & 63.6 & \\
\hline Width (mm) & & 50.6 & 33.8 \\
\hline Thick (mm) & 5 & 20.5 & 8.5 \\
\hline Wt. (g) & & 55.5 & \\
\hline $\begin{array}{l}\text { Long X- } \\
\text { Section }\end{array}$ & Indeterminate & $\begin{array}{l}\text { Wedged Base, } \\
\text { Thick Body }\end{array}$ & Indeterminate \\
\hline $\begin{array}{l}\text { Trans X- } \\
\text { Section }\end{array}$ & Plano-Convex & Plano-Convex & $\begin{array}{c}\text { Biconvex } \\
\text { Symmetrical }\end{array}$ \\
\hline Preform & Flake & Flake & Biface \\
\hline $\begin{array}{l}\text { Overall } \\
\text { Shape }\end{array}$ & Indeterminate & Irregular & Indeterminate \\
\hline $\begin{array}{l}\text { Flaking } \\
\text { Pattern }\end{array}$ & Random & Random & Random \\
\hline $\begin{array}{c}\text { Edge } \\
\text { Rounding }\end{array}$ & Present & Absent & Present \\
\hline $\begin{array}{l}\text { Left Lateral } \\
\text { Edge Shape }\end{array}$ & Indeterminate & Excurvate & Straight \\
\hline $\begin{array}{l}\text { Right Lateral } \\
\text { Edge Shape }\end{array}$ & Indeterminate & Excurvate & Straight \\
\hline Micro-wear & FALSE & FALSE & TRUE \\
\hline NAA & FALSE & FALSE & FALSE \\
\hline
\end{tabular}



Table O-7. Toyah Component Scraper Data

\begin{tabular}{|c|c|c|c|c|c|c|c|c|c|c|c|c|c|}
\hline Cat. No. & 78-005-011 & $169-011$ & $176-010$ & $186-013$ & $195-013$ & $302-013$ & $376-015$ & $490-010$ & $796-016$ & $800-011$ & $803-010$ & $814-014$ & $820-010$ \\
\hline Unit & N100,E50 & N121,E50 & N101,E50 & N101,E51 & N101,E52 & N102,E53 & $\mathrm{N} 103, \mathrm{E} 2$ & N106,E47 & $\mathrm{N} 115, \mathrm{E} / 2$ & $\mathrm{~N} 115, \mathrm{E} / 3$ & $\mathrm{~N} 115, \mathrm{E} / 4$ & $\mathrm{~N} N 116, \mathrm{E} / 2$ & $\mathrm{~N} 116, \mathrm{E} / 4$ \\
\hline Depth (cmbc) & $0-10$ & $30-40$ & $0-10$ & $10-20$ & $0-10$ & $0-10$ & $0-10$ & 20.30 & $0-10$ & $10-20$ & $10-20$ & 7 & $0-10$ \\
\hline Feature №. & 21 & & & & & & & & & & & & \\
\hline Tod Subtype & End-Scraper & End-Scraper & End-Scraper & End-Scraper & End-Scraper & End-Scraper & End-Scraper & Side/End Scraper & Side-Scraper & Side/End Scraper & Side-Scraper & End-Scraper & End-Scraper \\
\hline Condition & Distal & Complete & Complete & Complete & Complete & Distal & Complete & Complete & Complete & Distal & Complete & Complete & Complete \\
\hline Rejivenation Scar & Absent & Absent & Absent & Absent & Absent & Absent & Absent & Absent & Absent & Absent & Absent & Absent & Absent \\
\hline Shape & Irregular & Ovate & Triangular & Teardrop & Round & Indeterminate & Lanceolate & Irregular & Lanceolate & Indeterminate & Irregular & Irregular & Lanceolate \\
\hline Break Type & Use & Unbroken & Unbroken & Unbroken & Unbroken & Use & Unbroken & Unbroken & Unbroken & Indeterminate & Unbroken & Unbroken & Unbroken \\
\hline Raw Material & chert & Chert & chert & Chert & Chert & chert & Chert & Chert & chert & chert & Chert & chert & chert \\
\hline $\begin{array}{l}\text { Texture } \\
\end{array}$ & Fine & Fine & Fine & Fine & Fine & Fine & Fine & Fine & Fine & Fine & Coarse & Fine & Fine \\
\hline Percent Patination & 0 & 0 & 0 & 0 & 0 & 0 & 0 & 0 & 0 & 0 & 0 & 0 & 0 \\
\hline Percent Cortex & 0 & 25 & 50 & 0 & 0 & 0 & 25 & 0 & 0 & 0 & 25 & 0 & 25 \\
\hline Cortex Type & None & Pebble/Cobble & Pebble/Cobble & None & None & None & Pebble/Cobble & None & None & None & Pebble/Cobble & None & Pebble/Cobble \\
\hline Heating & None & None & None & None & None & Burned & None & None & None & None & None & None & None \\
\hline Length $(\mathrm{mm})$ & & 53.5 & 49.7 & 42.8 & 36.4 & & 96.3 & 74.5 & 99.6 & & 53.9 & 108.4 & 71.2 \\
\hline Wdath $(m m)$ & & 73.5 & 48.2 & 30.3 & 32.6 & & 31.4 & 54 & 32.8 & & 76.6 & 84.3 & 30 \\
\hline Thickness (mm) & 10.3 & 18.3 & 16.6 & 8.3 & 15 & 5.2 & 19.4 & 24.1 & 13.7 & 6.5 & 18.2 & 21.6 & 11.4 \\
\hline w. (g) & & 8 & 40.8 & 11.8 & 14.8 & & 59.8 & 63.3 & 48.8 & & 60.8 & 166.4 & 25.7 \\
\hline Edge Rounding & Present & Absent & Present & Present & Present & Present & Present & Present & Present & Absent & Present & Absent & Present \\
\hline Edge Aaking & Dista//Lateral & Dista//Lateral & Lateral Only & Dista//Lateral & Dista//Lateral & Distal & Dista//Lateral & Proximal/ Lateral & Dista//Lateral & Dista//Lateral & Proximal/ Lateral & Dista//Lateral & Distal/Lateral \\
\hline No. of Bits & 2 & 1 & 1 & 3 & 1 & 1 & 3 & 2 & 2 & 1 & 1 & 4 & 2 \\
\hline Bit 1 Location & Lateral/Distal & Distal & Lateral & Lateral & Lateral/Distal & Distal & Lateral & Proximal & Lateral & Latera//Distal & Lateral/ Proximal & Latera/Distal & Distal \\
\hline Bit 1 Shape & Excurvate & Excurvate & Straight & Straight & Excurvate & Excurvate & Straight & Straight & Incurvate & Excurvate & Straight & Straight & Exaurvate \\
\hline Bit 1 Retouch & Irregular Continuous & Regular Continuous & Regular Continuous & Irregular Continuous & Irregular Continuous & Regular Continuous & Irregular Continuous & Regular Continuous & Regular Continuous & Regular Continuous & Irregular Continuous & Regular Continuous & Irregular Continuous \\
\hline Bit 1 Length $(\mathrm{mm})$ & 25.1 & 50.1 & 27 & 28.3 & 74.6 & 19.2 & 35.7 & 30.1 & 62.8 & 42.9 & 47.8 & 46 & 29.2 \\
\hline Bit 1 Thickness ( $\mathrm{mm}$ ) & 5 & 7.9 & 7.5 & 3.5 & 12 & 2.4 & 2.6 & 3.6 & 9.1 & 5 & 7.3 & 9.9 & 4.7 \\
\hline Bit 1 Angle & 47 & 67 & 69 & 47 & 63 & 44 & 63 & 75 & 78 & 62 & 76 & 73 & 71 \\
\hline Bit 2 Location & Distal & & & Distal & & & Lateral & Lateral & Distal & & & Lateral & Lateral \\
\hline Bit 2 Shape & Excurvate & Straight & Straight & & & & Straight & Excurvate & Straight & Straight & & Straight & \\
\hline Bit 2 Retouch & Irregular Discontinuous & Regular Continuous & Regular Continuous & & & & Regular Continuous & Regular Continuous & Regular Continuous & Regular Continuous & & Irregular Continuous & \\
\hline Bit 2 Length $(\mathrm{mm})$ & 36.1 & 18.6 & 17.1 & & & & 16.9 & 36.2 & 22.9 & 29.4 & & 63.2 & \\
\hline Bit 2 Thickness ( $(\mathrm{m})$ & 24 & 2.5 & 3 & & & & 4.8 & 3.6 & 1.5 & 5.5 & & 2 & \\
\hline Bit 2 Angle & 66 & & & 68 & & & 75 & 72 & 71 & & & $\pi$ & 48 \\
\hline Bit 3 Location & & & & Lateral & & & Distal & & & & & Lateral & \\
\hline Bit 3 Shape & & & & Straight & & & Excurvate & & & & & Straight & \\
\hline Bit 3 Retouch & & & & Irregular Continuous & & & Irregular Continuous & & & & & Regular Continuous & \\
\hline Bit 3 Length $(\mathrm{mm})$ & & & & 23 & & & 39 & & & & & 33.4 & \\
\hline Bit 3 Thickness (mm) & & & & 3.9 & & & 4.5 & & & & & 2.7 & \\
\hline Bit 3 Angle & & & & 45 & & & 64 & & & & & 53 & \\
\hline Fake Size & & & 7 & 5 & 4 & & 10 & 10 & 10 & & 8 & 11 & 7 \\
\hline Micro-wear & FALSE & FALSE & FALSE & FALSE & FALSE & FALSE & FALSE & FALSE & FALSE & TRUE & FALSE & FALSE & FALSE \\
\hline NAA & FALSE & FALSE & FALSE & FALSE & FALSE & FALSE & FALSE & FALSE & FALSE & FALSE & FALSE & FALSE & FALSE \\
\hline
\end{tabular}





\begin{tabular}{|c|}
\hline \begin{tabular}{|l} 
Cat. No. \\
\end{tabular} \\
\hline Unit \\
\hline Depth (ambc) \\
\hline Feature №. \\
\hline \begin{tabular}{|l|l} 
Tool Subtype \\
\end{tabular} \\
\hline \begin{tabular}{|l|} 
Condition \\
\end{tabular} \\
\hline Rejivenation Scar \\
\hline Shape \\
\hline \begin{tabular}{|l|} 
Break Type \\
\end{tabular} \\
\hline Raw Material \\
\hline \begin{tabular}{|l|l} 
Texture \\
\end{tabular} \\
\hline \begin{tabular}{|l|} 
Percent Patination \\
\end{tabular} \\
\hline \begin{tabular}{|l} 
Percent Cortex \\
\end{tabular} \\
\hline \begin{tabular}{|l|} 
Cortex Type \\
\end{tabular} \\
\hline Heating \\
\hline Length $(\mathrm{mm})$ \\
\hline Math $(\mathrm{mm})$ \\
\hline \begin{tabular}{|l} 
Thickness $(\mathrm{mm})$ \\
\end{tabular} \\
\hline w. (g) \\
\hline \begin{tabular}{|l} 
Edge Rounding \\
\end{tabular} \\
\hline Edge Haking \\
\hline No. of Bits \\
\hline \begin{tabular}{|l|} 
Bit 1 Location \\
\end{tabular} \\
\hline Bit 1 Shape \\
\hline \begin{tabular}{|l|l|} 
Bit 1 Retouch \\
\end{tabular} \\
\hline \begin{tabular}{|l} 
Bit 1 Length $(\mathrm{mm})$ \\
\end{tabular} \\
\hline Bit 1 Thickness ( $(\mathrm{mm})$ \\
\hline \begin{tabular}{|l|} 
Bit 1 Angle \\
\end{tabular} \\
\hline \begin{tabular}{|l|l|} 
Bit 2 Location \\
\end{tabular} \\
\hline \begin{tabular}{|l|} 
Bit 2 Shape \\
\end{tabular} \\
\hline Bit 2 Retouch \\
\hline \begin{tabular}{|l} 
Bit 2 Length $(\mathrm{mm})$ \\
\end{tabular} \\
\hline Bit 2 Thickness ( $(\mathrm{mm})$ \\
\hline Bit 2 Angle \\
\hline \begin{tabular}{|l|} 
Bit 3 Location \\
\end{tabular} \\
\hline Bit 3 Shape \\
\hline Bit 3 Retouch \\
\hline \begin{tabular}{|l} 
Bit 3 Length $(\mathrm{mm})$ \\
\end{tabular} \\
\hline \begin{tabular}{|l|l|} 
Bit 3 Thickness $(\mathrm{m})$ \\
\end{tabular} \\
\hline \begin{tabular}{|l|} 
Bit 3 Angle \\
\end{tabular} \\
\hline Fake Size \\
\hline Mcro-wear \\
\hline t \\
\hline
\end{tabular}

\begin{tabular}{|c|c|c|c|c|c|c|c|c|c|c|c|c|}
\hline $838-010$ & 844.017 & $856-012$ & 864013 & $874-011$ & $878-012$ & $878-019$ & $880-011$ & $888-014$ & $893-010$ & 901-010 & 903-012 & $903-024$ \\
\hline N117,E75 & N118,E11 & N118,E74 & N119,E70 & N119,E74 & N119,E/5 & N119,E/5 & N120,E69 & N120,E73 & $\mathrm{N} 120, \mathrm{E} 44$ & N122,E70 & N222,E11 & $\mathrm{N} 222, \mathrm{E} 1 \mathrm{1}$ \\
\hline $10-20$ & $0-10$ & $0-10$ & $0-10$ & $0-10$ & $10-20$ & $10-20$ & $0-18$ & $0-10$ & $20-30$ & $10-20$ & $0-10$ & $0-10$ \\
\hline & & & 8 & missing & & & & & & & & \\
\hline End-Scraper & End-Scraper & End-Scraper & End-Scraper & & End-Scraper & End-Scraper & Side-Scraper & End-Scraper & Side-Scraper & End-Scraper & Side-Scraper & Side/End Scraper \\
\hline Complete & Distal & Complete & Distal & & Complete & Complete & Complete & Complete & Distal & Complete & Complete & Distal \\
\hline Absent & Absent & Absent & Absent & & Absent & Absent & Absent & Absent & Absent & Absent & Absent & Absent \\
\hline Irregular & Indeteminate & Round & Indeteminate & & Oate & Lanceolate & Irregular & Teardrop & Indeterminate & Triangular & Irregular & Indeterminate \\
\hline Unbroken & Use & Unbroken & Use & & Unbroken & Unbroken & Unbroken & Unbroken & Use & Unbroken & Unbroken & Indeterminate \\
\hline Chert & Chert & Chert & Chert & & Chert & Chert & Chert & Chert & chert & Chert & Chert & Chert \\
\hline Fine & Fine & Fine & Fine & & Fine & Fine & Fine & Fine & Fine & Fine & Fine & Fine \\
\hline 0 & 0 & 25 & 0 & & 0 & 0 & 0 & 0 & 0 & 0 & 0 & 0 \\
\hline 50 & 0 & 25 & 0 & & 0 & 0 & 0 & 0 & 25 & 0 & 0 & 0 \\
\hline Pebble/Cobble & None & Pebble/Cobble & None & & None & None & None & None & Pebble/Cobble & None & None & None \\
\hline None & Burned & None & None & & None & None & None & None & None & None & None & None \\
\hline 52.6 & & 37 & & & 72.9 & 73.1 & 52.1 & 66.2 & & 32.5 & 53.7 & \\
\hline 35.5 & & 33.4 & & & 56.6 & 32.9 & 36 & 34.1 & 21.6 & 30.9 & 28.3 & \\
\hline 12 & 8.7 & 13.8 & 7 & & 18.1 & 10 & 8.4 & 12 & 8.7 & 8.1 & 14.4 & 8.9 \\
\hline 23.7 & & 17.1 & & & 81.8 & 24.9 & 16 & 28 & & 10 & 20.5 & \\
\hline Present & Absent & Present & Present & & Present & Present & Present & Absent & Absent & Absent & Absent & Absent \\
\hline Dista/Lateral & Distal & Distal & Distal & & Distal & Whole Edge & Lateral Only & Dista/Lateral & Lateral Only & Dista/lLateral & Dista/Lateral & Dista/Lateral \\
\hline 3 & 1 & 1 & 1 & & 1 & 3 & 1 & 3 & 1 & 2 & 1 & 1 \\
\hline Lateral/Distal & Distal & Distal & Distal & & Distal & Distal & Lateral & Distal & Lateral & Distal & Latera//Distal & Latera//Distal \\
\hline Recurvate & Excurvate & Excurvate & Excurvate & & Excurvate & Excurvate & Excurvate & Excurvate & Excurvate & Excurvate & Incurvate & Excurvate \\
\hline Irregular Continuous & Irregular Continuous & Regular Continuous & Regular Continuous & & Regular Continuous & Regular Continuous & Irregular Continuous & Regular Continuous & Irregular Continuous & Irregular Continuous & Regular Continuous & Regular Continuous \\
\hline 40.2 & 53.6 & 20.3 & 36.1 & & 54.9 & 62.1 & 42.7 & 63.9 & 28 & 30 & 26 & 58 \\
\hline 6.6 & 3.7 & 4.4 & 6 & & 13.4 & 6.2 & 3.8 & 9.6 & 5.4 & 3.5 & 5.8 & 6.9 \\
\hline 74 & 58 & 80 & 66 & & 75 & 71 & 70 & 70 & 67 & 85 & 75 & 71 \\
\hline Lateral & & & & & & Lateral & & Lateral & & Lateral/ Proximal & & \\
\hline Straight & & Straight & Excurvate & & & & Excurvate & & & Incurvate & Straight & Excurvate \\
\hline Regular Continuous & & Irregular Continuous & Irregular Continuous & & & & Regular Continuous & & & Regular Continuous & Regular Continuous & Regular Continuous \\
\hline 33.7 & & 24.7 & 37 & & & & 38.7 & & & 9.4 & 20.7 & 21.6 \\
\hline 7 & & 22 & 3 & & & & 6.8 & & & 4.9 & 3.7 & 6.1 \\
\hline 53 & & & & & & 56 & & 38 & & 55 & & \\
\hline Lateral/ Distal & & & & & & Lateral & & Lateral/ Proximal & & & & \\
\hline Straight & & & & & & Straight & & Straight & & & & \\
\hline Regular Continuous & & & & & & Irregular Continuous & & Regular Continuous & & & & \\
\hline 19.4 & & & & & & 47 & & 19.5 & & & & \\
\hline 2.2 & & & & & & 4.6 & & 1.5 & & & & \\
\hline 44 & & & & & & 54 & & 56 & & & & \\
\hline 6 & & 4 & & & 8 & 8 & 6 & 7 & & 5 & 6 & \\
\hline FALSE & FALSE & FALSE & FALSE & FALSE & FALSE & FALSE & FALSE & TRUE & FALSE & FALSE & TRUE & TRUE \\
\hline FALSE & FALSE & FALSE & FALSE & FALSE & FALSE & FALSE & FALSE & FALSE & FALSE & FALSE & FALSE & FALSE \\
\hline
\end{tabular}





\begin{tabular}{|c|}
\hline Cat. No. \\
\hline \begin{tabular}{|l|} 
Unit \\
\end{tabular} \\
\hline Depth (mbroc) \\
\hline \begin{tabular}{|l|} 
Feature No. \\
\end{tabular} \\
\hline \begin{tabular}{|l|l|} 
Tool Sublype \\
\end{tabular} \\
\hline \begin{tabular}{|l|} 
Condition \\
\end{tabular} \\
\hline Rejwenation Scar \\
\hline Shape \\
\hline \begin{tabular}{|l|} 
Break Type \\
\end{tabular} \\
\hline Raw Material \\
\hline \begin{tabular}{|l|} 
Texture \\
\end{tabular} \\
\hline \begin{tabular}{|l|} 
Percent Patination \\
\end{tabular} \\
\hline \begin{tabular}{|l|} 
Percent Cortex \\
\end{tabular} \\
\hline Cortex Type \\
\hline \begin{tabular}{|l|} 
Heating \\
\end{tabular} \\
\hline Length $(m m)$ \\
\hline Woth $(\mathrm{mm})$ \\
\hline \begin{tabular}{|l} 
Thickness $(\mathrm{mm})$ \\
\end{tabular} \\
\hline W. (g) \\
\hline \begin{tabular}{|l} 
Edge Rounding \\
\end{tabular} \\
\hline \begin{tabular}{|l|} 
Edge Faling \\
\end{tabular} \\
\hline No. of Bits \\
\hline Bit 1 Location \\
\hline \begin{tabular}{|l|} 
Bit 1 Shape \\
\end{tabular} \\
\hline \begin{tabular}{|l|} 
Bit 1 Retouch \\
\end{tabular} \\
\hline \begin{tabular}{|l} 
Bit 1 Length $(\mathrm{mm})$ \\
\end{tabular} \\
\hline Bit 1 Thickness $(\mathrm{mm})$ \\
\hline \begin{tabular}{|l|} 
Bit 1 Angle \\
\end{tabular} \\
\hline \begin{tabular}{|l|} 
Bit 2 Location \\
\end{tabular} \\
\hline \begin{tabular}{|l|} 
Bit 2 Shape \\
\end{tabular} \\
\hline \begin{tabular}{|l|} 
Bit 2 Retouch \\
\end{tabular} \\
\hline \begin{tabular}{|l} 
Bit 2 Length $(\mathrm{mm})$ \\
\end{tabular} \\
\hline Bit 2 Thickness (mm) \\
\hline \begin{tabular}{|l|} 
Bit 2 Angle \\
\end{tabular} \\
\hline \begin{tabular}{|l|l|} 
Bit 3Location \\
\end{tabular} \\
\hline \begin{tabular}{|l|} 
Bit 3 Shape \\
\end{tabular} \\
\hline Bit 3 Retouch \\
\hline \begin{tabular}{|l} 
Bit 3 Length $(\mathrm{mm})$ \\
\end{tabular} \\
\hline \begin{tabular}{|l} 
Bit 3 Thickness (mm) \\
\end{tabular} \\
\hline Bit 3 Angle \\
\hline \begin{tabular}{|l|} 
Hake Size \\
\end{tabular} \\
\hline \begin{tabular}{|l|} 
Micro-wear \\
\end{tabular} \\
\hline NAA \\
\hline
\end{tabular}

\begin{tabular}{|c|c|c|c|c|c|c|c|c|c|c|c|c|}
\hline 903-025 & $908-012$ & 915-011 & 928-010 & 928-014 & $930-012$ & $946-011$ & $946-013$ & 952-012 & 954010 & $956-015$ & $967-021$ & 968-010 \\
\hline $\mathrm{N} 122, \mathrm{E} / 1$ & $\mathrm{~N} 122, \mathrm{E} / 3$ & N222,E/5 & N23,E69 & N123,E69 & N223,E7O & N223,E/5 & N122,E/5 & N124,E7O & N124,E1 & N124,E1 & N124,E75 & N224,E75 \\
\hline $0-10$ & $0-10$ & $0-10$ & $8-20$ & $8-20$ & $0-10$ & $10-20$ & $10-20$ & $10-20$ & 7 & 17 & $0-10$ & $10-20$ \\
\hline end only & Side-Scraper & End-Scraper & Side-Scraper & End-Scraper & End-Scraper & End-Scraper & End-Scraper & End-Scraper & End-Scraper & Side-Scraper & End-Scraper & End-Scraper \\
\hline Distal & Complete & Complete & Proximal & Complete & Complete & Distal & Complete & Complete & Proximal & Proximal & Complete & Complete \\
\hline Absent & Absent & Absent & Absent & Absent & Present & Absent & Absent & Absent & Absent & Absent & Absent & Absent \\
\hline Indeterminate & Lanceolate & Triangular & Indeterminate & Teardrop & Ovate & Indeterminate & Irregular & Ovate & Irregular & Irregular & Ovate & Irregular \\
\hline Indeterminate & Unbroken & Unbroken & Use & Unbroken & Unbroken & use & Unbroken & Unbroken & Indeterminate & Indeterminate & Unbroken & Unbroken \\
\hline Chert & Chert & Chert & Chert & Chert & Chert & Chert & Chert & Chert & Chert & Chert & Chert & Chert \\
\hline Fine & Fine & Fine & Fine & Fine & Fine & Fine & Fine & Fine & Fine & Fine & Fine & Fine \\
\hline 0 & 0 & 0 & 0 & 0 & 0 & 0 & 25 & o & 0 & 0 & 0 & 0 \\
\hline 0 & 25 & 25 & 0 & 25 & 50 & 0 & 0 & 0 & 0 & 0 & 0 & 25 \\
\hline None & Pebble/Cobble & Pebble/Cobble & None & Pebble/Cobble & Pebble/Cobble & None & None & None & None & None & None & Pebble/Cobble \\
\hline \multirow[t]{3}{*}{ None } & None & None & None & None & Bumed & None & None & None & Burned & None & None & None \\
\hline & 110.8 & 44 & & 94.4 & 59.7 & & 33.2 & 64.4 & & & 62.9 & 43.1 \\
\hline & 40.4 & 65 & 35.7 & 59.7 & 49.5 & & 29.1 & 40.3 & 28.7 & 47.1 & 49.6 & 72.4 \\
\hline \multirow[t]{2}{*}{16.6} & 20.6 & 14.8 & 9.7 & 16.6 & 17.2 & 9.9 & 7 & 15.7 & 7.7 & 10.1 & 12.2 & 14.8 \\
\hline & 94.9 & 40.1 & & 113.3 & 56.6 & & 8.3 & 52.3 & 7.6 & 29.3 & 44.7 & 47.8 \\
\hline Absent & Absent & Present & Present & Present & Present & Present & Absent & Present & Present & Present & Absent & Present \\
\hline Lateral Only & Lateral Only & Distal & Proximal/ Lateral & Dista/Lateral & Dista//Lateral & Distal & Dista/Lateral & Dista/Lateral & Proximal/ Lateral & Lateral Only & Distal & Distal \\
\hline 2 & 1 & 1 & 2 & 2 & 1 & 1 & 3 & 3 & 2 & 2 & 1 & 1 \\
\hline Lateral & Lateral & Distal & Lateral/ Proximal & Latera//Distal & Distal & Distal & Distal & Distal & Proximal & Lateral & Distal & Distal \\
\hline Straight & Straight & Excurvate & Straight & Excurvate & Excurvate & Excurvate & Recurvate & Excurvate & Excurvate & Straight & Excurvate & Straight \\
\hline Regular Continuous & Irregular Continuous & Regular Discontinuous & Regular Continuous & Regular Continuous & Irregular Continuous & Irregular Continuous & Regular Continuous & Regular Continuous & Regular Continuous & Regular Continuous & Regular Continuous & Irregular Continuous \\
\hline 12.6 & 723 & 67.6 & 30.9 & 123.5 & 49.3 & 16.8 & 34.9 & 38.5 & 25.2 & 41.6 & 84.6 & 64.5 \\
\hline 8.4 & 5.2 & 6.8 & 8.7 & 14.9 & 9 & 4 & 4.2 & 14.9 & 3.2 & 3.6 & 10.2 & 7.1 \\
\hline 82 & 65 & 68 & 88 & 72 & 75 & 54 & 62 & 76 & 67 & 75 & 49 & 79 \\
\hline Lateral & & & Lateral & Lateral & & & Lateral & Lateral & Lateral & Lateral & & \\
\hline Incurvate & & & Incurvate & Straight & Straight & & & & & & Straight & \\
\hline Regular Continuous & & & Irregular Continuous & Regular Continuous & Irregular Discontinuous & & & & & & Irregular Continuous & \\
\hline 18.3 & & & 28.5 & 24 & 36 & & & & & & 45.9 & \\
\hline 3.1 & & & 5.4 & 2.6 & 2.6 & & & & & & 2.5 & \\
\hline \multirow[t]{8}{*}{42} & & & 63 & 72 & & & 55 & 66 & 59 & 71 & & \\
\hline & & & & & & & Lateral & Lateral & & & & \\
\hline & & & & & & & Recurvate & Excurvate & & & & \\
\hline & & & & & & & Irregular Continuous & Irregular Continuous & & & & \\
\hline & & & & & & & 22.3 & 52.9 & & & & \\
\hline & & & & & & & 2.4 & 3.9 & & & & \\
\hline & & & & & & & 60 & 57 & & & & \\
\hline & 11 & 7 & & 10 & 7 & & 4 & 7 & & 7 & 7 & 8 \\
\hline FALSE & FALSE & FALSE & FALSE & FALSE & FALSE & FALSE & FALSE & FALSE & FALSE & FALSE & FALSE & FALSE \\
\hline FALSE & FALSE & FALSE & FALSE & FALSE & FALSE & FALSE & FALSE & FALSE & FALSE & FALSE & FALSE & FALSE \\
\hline
\end{tabular}





\begin{tabular}{|c|}
\hline Cat. No. \\
\hline Unit \\
\hline Depth (cmbc) \\
\hline Feature №. \\
\hline Tool Subype \\
\hline Condition \\
\hline Rejuvenation Scar \\
\hline Shape \\
\hline Break Type \\
\hline Raw Material \\
\hline Texture \\
\hline Percent Patination \\
\hline Percent Cortex \\
\hline Cortex Type \\
\hline Heating \\
\hline Length $(\mathrm{mm})$ \\
\hline Wdth $(\mathrm{mm})$ \\
\hline Thickness (mm) \\
\hline w. (g) \\
\hline Edge Rounding \\
\hline Edge Faking \\
\hline No. of Bits \\
\hline Bit 1 Location \\
\hline Bit 1 Shape \\
\hline Bit 1 Retouch \\
\hline Bit 1 Length (mm) \\
\hline Bit 1 Thickness (mm) \\
\hline Bit 1 Angle \\
\hline Bit 2 Location \\
\hline Bit 2 Shape \\
\hline Bit 2 Retouch \\
\hline Bit 2 Length (mm) \\
\hline Bit 2 Thickness ( $(\mathrm{mm})$ \\
\hline Bit 2 Angle \\
\hline Bit 3 Location \\
\hline Bit 3 Shape \\
\hline Bit 3 Retouch \\
\hline Bit 3 Length (mm) \\
\hline Bit 3 Thickness (mm) \\
\hline Bit 3 Angle \\
\hline Hake Size \\
\hline Micro-wear \\
\hline NAA \\
\hline
\end{tabular}

\begin{tabular}{|c|c|c|c|c|c|c|c|c|c|c|c|c|}
\hline $969-016$ & 969.017 & 97-016 & 973-010 & 981-014 & 982-012 & $985-010$ & $996-010$ & $1002-012$ & 1002-019 & 1023-012 & 1024012 & $1035-012$ \\
\hline N124,E75 & N124,E75 & N100,E52 & N125,E69 & $\mathrm{N} 225, \mathrm{E} 1 \mathrm{1}$ & $\mathrm{N} 225, \mathrm{E1}$ & N125,E/2 & N126,E68 & N226,E7O & N226,E7O & N226,E75 & N226,E75 & N227,E69 \\
\hline \multirow[t]{2}{*}{$20-30$} & $20-30$ & $0-10$ & $0-10$ & $0-10$ & $10-20$ & $20-30$ & $10-20$ & $8-20$ & $10-20$ & $0-10$ & $10-20$ & 8 \\
\hline & & & & & & & & & & 25 & 25 & \\
\hline Edge only & End-Scraper & Side/End Scraper & End-Scraper & End-Scraper & End-Scraper & Side-Scraper & End-Scraper & End-Scraper & End-Scraper & Side/End Scraper & End-Scraper & End-Scraper \\
\hline Indeterminate & Complete & Complete & Distal & Distal & Complete & Complete & Distal & Proximal & Distal & Distal & Complete & Indeterminate \\
\hline Absent & Absent & Absent & Absent & Absent & Absent & Absent & Absent & Present & Absent & Absent & Absent & Absent \\
\hline Indeteminate & Quadrilateral & Teardrop & Indeteminate & Indeterminate & Oate & Round & Indeterminate & Indeterminate & Indeterminate & Indeterminate & Quadrilateral & Indeterminate \\
\hline Indeterminate & Unbroken & Unbroken & Thermal/Crenated & Use & Indeterminate & Unbroken & Use & Manufacture & Indeterminate & Indeterminate & Unbroken & Indeterminate \\
\hline Chert & Chert & Chert & Chert & Chert & Chert & Chert & Chert & Chert & Chert & Chert & Chert & Chert \\
\hline Fine & Fine & Fine & Fine & Fine & Fine & Fine & Fine & Fine & Fine & Fine & Fine & Fine \\
\hline 0 & 0 & 0 & 0 & 0 & 0 & 0 & 0 & 0 & 0 & 0 & 50 & 0 \\
\hline 0 & 25 & 0 & 0 & 25 & 0 & 0 & 0 & 0 & 0 & 0 & 25 & 0 \\
\hline None & Pebble/Cobble & None & None & Pebble/Cobble & None & None & None & None & None & None & Pebble/Cobble & None \\
\hline \multirow[t]{3}{*}{ None } & None & None & Burned & Heat-Treated & Burned & None & None & None & None & None & None & Heat-Treated \\
\hline & 60.3 & 60.5 & & & 72.2 & 55.9 & & & & & 66.6 & \\
\hline & 34.3 & 47.2 & & 45.2 & 39 & 49.7 & & 38.8 & & 29.9 & 50.4 & 43.6 \\
\hline \multirow[t]{2}{*}{5.9} & 12.3 & 11.4 & 16.1 & 9.6 & 20.6 & 12.2 & 9.2 & 8.7 & 8.1 & 8.4 & 16.7 & 11.8 \\
\hline & 23.4 & 38.8 & & & 55.9 & 31.9 & & 12.2 & & & 67.5 & \\
\hline Present & Present & Present & Present & Present & Present & Present & Present & Present & Absent & Absent & Present & Absent \\
\hline Indeterminate & Dista/Lateral & Dista/Lateral & Distal & Distal & Dista/Lateral & Dista/Lateral & Distal & Dista/Lateral & Dista/Lateral & Dista/Lateral & Distal & Indeterminate \\
\hline 1 & 1 & 1 & 1 & 1 & 2 & 1 & 1 & 3 & 2 & 3 & 1 & 1 \\
\hline Indeterminate & Distal & Latera//Distal & Distal & Distal & Distal & Lateral/Distal & Distal & Distal & Distal & Lateral & Distal & Indeterminate \\
\hline Indeterminate & Excurvate & Excurvate & Excurvate & Straight & Excurvate & Excurvate & Excurvate & Indeteminate & Excurvate & Straight & Excurvate & Excurvate \\
\hline \multirow[t]{2}{*}{ Regular Continuous } & Regular Continuous & Regular Continuous & Irregular Continuous & Irregular Continuous & Regular Continuous & Regular Continuous & Irregular Continuous & Regular Continuous & Regular Continuous & Regular Continuous & Regular Continuous & Regular Continuous \\
\hline & 40.2 & 123.6 & 38.4 & 24 & 51.7 & 48.8 & 60.1 & & 38.8 & 18.5 & 45.1 & 30.6 \\
\hline 5.1 & 5 & 8.4 & 10.3 & 5.5 & 16.2 & 6.7 & 6.3 & 3.6 & 2.5 & 18 & 8 & 5.6 \\
\hline \multirow[t]{2}{*}{50} & 65 & 71 & 70 & 52 & 73 & 83 & 65 & $\pi$ & 64 & 57 & 80 & 70 \\
\hline & & & & & Lateral & & & Lateral & Lateral & Latera//Distal & & \\
\hline Straight & & Straight & & & Excurvate & & & Excurvate & Straight & & & Straight \\
\hline Irregular Discontinuous & & Regular Continuous & & & Regular Continuous & & & Regular Continuous & Irregular Continuous & & & IIregular Continuous \\
\hline 22.5 & & 15.7 & & & 37 & & & 27.4 & 39 & & & 19 \\
\hline \multirow[t]{9}{*}{1.2} & & 28 & & & 7.4 & & & 3.6 & 3.2 & & & 2.9 \\
\hline & & & & & 55 & & & 56 & 60 & 58 & & \\
\hline & & & & & & & & Lateral & & Distal & & \\
\hline & & & & & & & & Incurvate & & Excurvate & & \\
\hline & & & & & & & & Regular Discontinuous & & Regular Continuous & & \\
\hline & & & & & & & & 21.8 & & 36.4 & & \\
\hline & & & & & & & & 1.5 & & 7.1 & & \\
\hline & & & & & & & & 51 & & 74 & & \\
\hline & 7 & 7 & & & 8 & 6 & & 7 & & & 7 & \\
\hline FALSE & FALSE & FALSE & FALSE & FALSE & FALSE & FALSE & FALSE & FALSE & FALSE & TRUE & FALSE & FALSE \\
\hline FALSE & FALSE & FALSE & FALSE & FALSE & FALSE & FALSE & FALSE & FALSE & FALSE & FALSE & FALSE & FALSE \\
\hline
\end{tabular}





\begin{tabular}{|c|}
\hline \begin{tabular}{|l|} 
Cat. No. \\
\end{tabular} \\
\hline Unit \\
\hline Depth (ombc) \\
\hline \begin{tabular}{|l|} 
Feature No. \\
\end{tabular} \\
\hline \begin{tabular}{|l|l} 
Tool Sublype \\
\end{tabular} \\
\hline Condition \\
\hline \begin{tabular}{|l} 
Rejivvenation Scar \\
\end{tabular} \\
\hline Shape \\
\hline Break Type \\
\hline Raw Material \\
\hline Texture \\
\hline \begin{tabular}{|l|} 
Percent Patination \\
\end{tabular} \\
\hline \begin{tabular}{|l|} 
Percent Cortex \\
\end{tabular} \\
\hline Cortex Type \\
\hline \begin{tabular}{|l|} 
Heating \\
\end{tabular} \\
\hline Length $(\mathrm{m} m)$ \\
\hline Mdth $(\mathrm{mm})$ \\
\hline Thickness (mm) \\
\hline w. (g) \\
\hline \begin{tabular}{|l} 
Edge Rounding \\
\end{tabular} \\
\hline Edge Haking \\
\hline \begin{tabular}{|l|} 
No. of Bits \\
\end{tabular} \\
\hline Bit 1 Location \\
\hline \begin{tabular}{|l|} 
Bit 1 Shape \\
\end{tabular} \\
\hline Bit 1 Retouch \\
\hline \begin{tabular}{|l} 
Bit 1 Length $(\mathrm{mm})$ \\
\end{tabular} \\
\hline Bit 1 Thickness (mm) \\
\hline \begin{tabular}{|l|} 
Bit 1 Angle \\
\end{tabular} \\
\hline \begin{tabular}{|l|l|} 
Bit 2 Location \\
\end{tabular} \\
\hline Bit 2 Shape \\
\hline Bit 2 Retouch \\
\hline \begin{tabular}{|l|l} 
Bit 2 Length $(\mathrm{mm})$ \\
\end{tabular} \\
\hline \begin{tabular}{|l|l} 
Bit 2 Thickness ( $(\mathrm{mm})$ \\
\end{tabular} \\
\hline \begin{tabular}{|l|} 
Bit 2 Angle \\
\end{tabular} \\
\hline \begin{tabular}{|l|l|} 
Bit 3 Location \\
\end{tabular} \\
\hline \begin{tabular}{|l|} 
Bit 3 Shape \\
\end{tabular} \\
\hline Bit 3 Retouch \\
\hline \begin{tabular}{|l|l} 
Bit 3 Length $(\mathrm{mm})$ \\
\end{tabular} \\
\hline \begin{tabular}{|l} 
Bit 3 Thickness (mm) \\
\end{tabular} \\
\hline \begin{tabular}{|l|} 
Bit 3 Angle \\
\end{tabular} \\
\hline \begin{tabular}{|l|} 
Fake Size \\
\end{tabular} \\
\hline \begin{tabular}{|l|} 
Miro-wear \\
\end{tabular} \\
\hline NAA \\
\hline
\end{tabular}

\begin{tabular}{|c|c|c|c|c|c|c|c|c|c|c|c|c|}
\hline $1036-016$ & $1038-018$ & 1041-013 & $1050-013$ & 1052-012 & 1053-014 & 1054020 & $1095-013$ & $1132-010$ & $1161-010$ & $1166-010$ & 1174010 & $1270-010$ \\
\hline N127,E69 & N127,E7O & N127,E11 & N227,E74 & N122,E75 & $N 227, E 75$ & $N 227, E 75$ & $\mathrm{~N} 22, \mathrm{E} / 3$ & N130,E75 & N131,E74 & N132,E11 & N132,E/3 & N98,E51 \\
\hline \multirow[t]{2}{*}{14} & $10-20$ & $10-20$ & $15-27$ & $0-10$ & $10-20$ & $20-30$ & $10-20$ & $10-20$ & $20-30$ & $10-20$ & $10-20$ & 52 \\
\hline & & & 25 & 25 & 25 & 25 & & & & & & \\
\hline End-Scraper & Side-Scraper & End-Scraper & End-Scraper & Side-Scraper & Side-Scraper & End-Scraper & End-Scraper & Side-Scraper & End-Scraper & End-Scraper & Side-Scraper & End-Scraper \\
\hline Distal & Complete & Complete & Complete & Complete & Medial & Complete & Distal & Complete & Complete & Complete & Proximal & Complete \\
\hline Absent & Absent & Absent & Absent & Absent & Present & Absent & Absent & Absent & Absent & Absent & Present & Absent \\
\hline Indeterminate & Irregular & Ovate & Ovate & Lunate & Indeterminate & Lanceolate & Indeterminate & Teardrop & Irregular & Ovate & Indeterminate & Round \\
\hline Indeterminate & Unbroken & Unbroken & Unbroken & Unbroken & Use & Unbroken & Thermal//Crenated & Unbroken & Unbroken & Unbroken & Manufacture & Unbroken \\
\hline Chert & Chert & Chert & Chert & Chert & Chert & Chert & Chert & Chert & Chert & Chert & Chert & Chert \\
\hline Fine & Fine & Fine & Fine & Fine & Fine & Fine & Fine & Fine & Fine & Fine & Fine & Fine \\
\hline 0 & 0 & 0 & 0 & 0 & 0 & 0 & 0 & 0 & 0 & 0 & 0 & 0 \\
\hline 50 & 0 & 25 & 25 & 0 & 0 & 0 & 0 & 0 & 0 & 0 & 0 & 0 \\
\hline Pebble/Cobble & None & Pebble/Cobble & Pebble/Cobble & None & None & None & None & None & None & None & None & None \\
\hline \multirow[t]{2}{*}{ None } & Heat-Treated & None & None & Heat-Treated & None & None & Bumed & None & None & None & Heat-Treated & None \\
\hline & 49.4 & 49.6 & 82.5 & 66.1 & & 77.1 & & 93 & 101 & 75.2 & & 52.3 \\
\hline 35 & 29.6 & 41.4 & 50.3 & 36.7 & 63.8 & 38.6 & & 47.8 & 68.6 & 45.9 & 41.4 & 55.2 \\
\hline \multirow[t]{2}{*}{7.4} & 8.4 & 18.2 & 12.1 & 8.7 & 12.9 & 14.2 & 7.1 & 15.4 & 26.5 & 12.2 & 9.7 & 17.2 \\
\hline & 11.8 & 39.2 & 53.5 & 19.9 & & 36.9 & & 77.6 & 180.7 & 40.8 & & 44.2 \\
\hline Present & Present & Absent & Absent & Present & Present & Present & Absent & Absent & Present & Absent & Present & Present \\
\hline Distal & Proximal/ Lateral & Dista/Lateral & Distal/Lateral & Whole Edge & Lateral Only & Distal/Lateral & Distal & Dista/Lateral & Distal & Distal/Lateral & Lateral Only & Distal \\
\hline 1 & 2 & 2 & 2 & 4 & 1 & 2 & 1 & 3 & 1 & 4 & 2 & 1 \\
\hline Distal & Lateral & Distal & Distal & Lateral/ Proximal & Lateral & Distal & Distal & Lateral & Distal & Distal & Lateral & Distal \\
\hline Exarvate & Recurvate & Exarvate & Excurvate & Excurvate & Excurvate & Excurvate & Exarvate & Excurvate & Exarvate & Excurvate & Excurvate & Excurvate \\
\hline Regular Continuous & Regular Continuous & Regular Continuous & Regular Continuous & Regular Continuous & Irregular Continuous & Regular Continuous & Regular Continuous & Irregular Discontinuous & Regular Continuous & Regular Continuous & Irregular Continuous & Regular Continuous \\
\hline 72 & 38.2 & 62 & 39.5 & 29 & 44.4 & 44.6 & 30.2 & 95.2 & 63.5 & 58.9 & 48.9 & 109.4 \\
\hline 4.1 & 5.4 & 13.8 & 6.7 & 4.4 & 6.3 & 6.7 & 4.7 & 2.5 & 11.7 & 7.1 & 8.4 & 16.5 \\
\hline \multirow[t]{2}{*}{60} & 65 & 83 & 63 & 67 & 56 & 62 & 60 & 56 & 76 & 63 & 64 & 72 \\
\hline & Lateral/ Proximal & Lateral & Lateral & Lateral/ Proximal & & Lateral & & Distal & & Lateral & Lateral & \\
\hline Exarvate & Straight & Exarvate & & & & & & & & Straight & & \\
\hline Irregular Continuous & Regular Continuous & Regular Continuous & & & & & & & & Irregular Continuous & & \\
\hline 53.3 & 14.3 & 53.9 & & & & & & & & 26.6 & & \\
\hline \multirow[t]{9}{*}{2.6} & 1.9 & 7.1 & & & & & & & & 4.6 & & \\
\hline & 63 & 41 & 54 & 69 & & 53 & & 46 & & 63 & 35 & \\
\hline & & & & Lateral/ Distal & & & & Lateral & & Lateral & & \\
\hline & & & & Excurvate & & & & Straight & & Incurvate & & \\
\hline & & & & Regular Continuous & & & & Irregular Continuous & & Regular Continuous & & \\
\hline & & & & 23.9 & & & & 72.4 & & 19.9 & & \\
\hline & & & & 1.7 & & & & 3.7 & & 4.5 & & \\
\hline & & & & 57 & & & & 52 & & $\pi$ & & \\
\hline & 5 & 6 & 9 & 7 & & 8 & & 10 & 13 & 8 & & 6 \\
\hline FALSE & FALSE & FALSE & FALSE & FALSE & FALSE & FALSE & FALSE & TRUE & FALSE & FALSE & FALSE & FALSE \\
\hline FALSE & FALSE & FALSE & FALSE & FALSE & FALSE & FALSE & FALSE & FALSE & FALSE & FALSE & FALSE & FALSE \\
\hline
\end{tabular}



Table 0-8. Uniface Data from Toyah Component

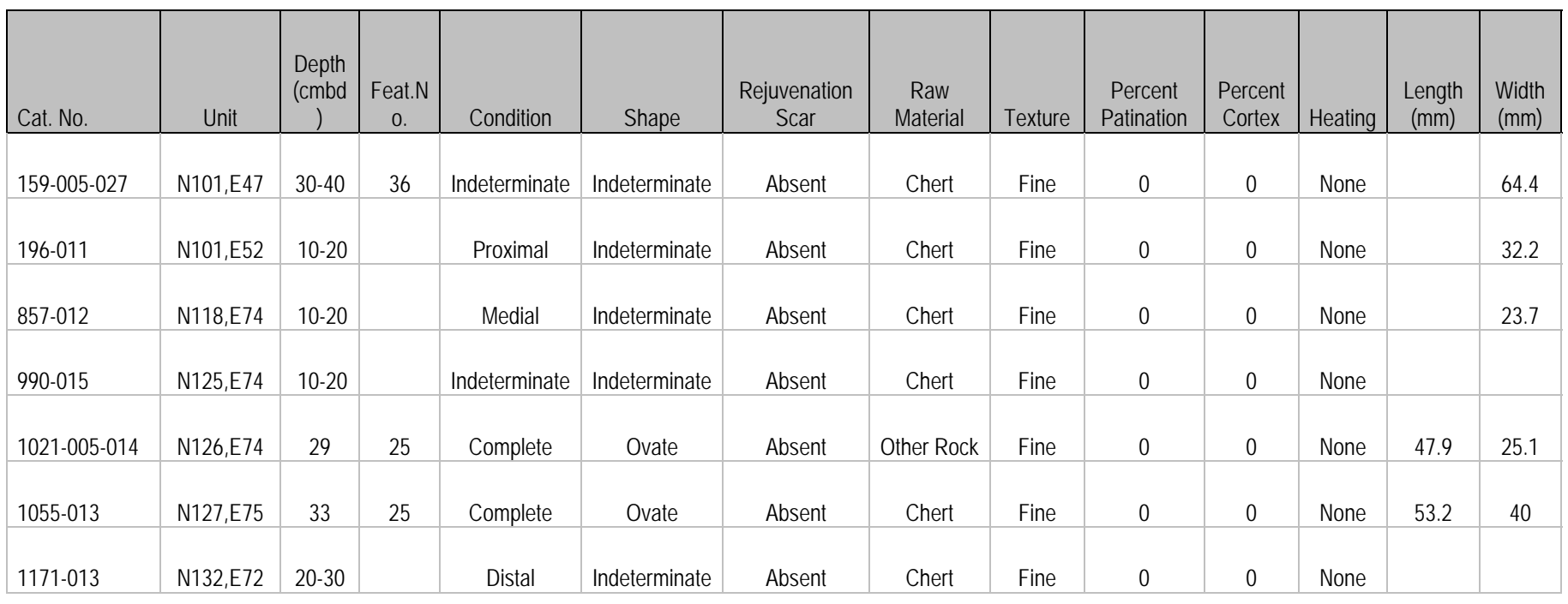

\begin{tabular}{|c|c|c|c|c|c|c|c|c|c|c|c|c|}
\hline Cat. No. & $\begin{array}{c}\text { Thickness } \\
(\mathrm{mm})\end{array}$ & $\begin{array}{l}\text { Wt. } \\
(g)\end{array}$ & Edge Flaking & $\begin{array}{c}\text { Edge } \\
\text { Rounding }\end{array}$ & $\begin{array}{c}\text { No. } \\
\text { of } \\
\text { Bits }\end{array}$ & Bit 1 Location & $\begin{array}{l}\text { Bit } 1 \\
\text { Shape }\end{array}$ & Bit 1 Retouch & $\begin{array}{l}\text { Bit } 1 \\
\text { Length } \\
(\mathrm{mm})\end{array}$ & $\begin{array}{l}\text { Bit } 1 \\
\text { Thick } \\
(\mathrm{mm})\end{array}$ & $\begin{array}{l}\text { Bit } 1 \\
\text { Angle }\end{array}$ & Bit 2 Location \\
\hline $159-005-027$ & 11.7 & & Lateral Only & Absent & 2 & Lateral & Excurvate & $\begin{array}{c}\text { Irregular } \\
\text { Continuous }\end{array}$ & 67.6 & 2.8 & 47 & Lateral \\
\hline $196-011$ & 5.1 & & $\begin{array}{l}\text { Proximal } \\
\text { Lateral }\end{array}$ & Present & 3 & Lateral Proximal & Excurvate & $\begin{array}{c}\text { Regular } \\
\text { Continuous }\end{array}$ & 25.2 & 3.5 & 58 & Proximal \\
\hline $857-012$ & 3 & & None & Present & 0 & & & & & & & \\
\hline $990-015$ & 3.8 & & Whole Edge & Absent & 1 & Indeterminate & Excurvate & $\begin{array}{c}\text { Irregular } \\
\text { Continuous }\end{array}$ & 61.3 & 2.8 & 43 & \\
\hline $1021-005-014$ & 7.1 & 8.2 & Distal/ Lateral & Absent & 1 & Lateral/Distal & Excurvate & $\begin{array}{c}\text { Irregular } \\
\text { Continuous }\end{array}$ & 69.3 & 4 & 53 & \\
\hline $1055-013$ & 7.4 & 15.3 & Distal/ Lateral & Present & 2 & Lateral/Distal & Excurvate & $\begin{array}{l}\text { Irregular } \\
\text { Continuous }\end{array}$ & 62 & 5.1 & 45 & Lateral /Distal \\
\hline $1171-013$ & & & Distal/ Lateral & Present & 2 & & & & 18.3 & 2.2 & 49 & Lateral /Distal \\
\hline
\end{tabular}

\begin{tabular}{|c|c|c|c|c|c|c|c|c|}
\hline Cat. No. & $\begin{array}{l}\text { Bit } 2 \\
\text { Shape }\end{array}$ & Bit 2 Retouch & $\begin{array}{l}\text { Bit } 2 \\
\text { Length } \\
(\mathrm{mm})\end{array}$ & $\begin{array}{l}\text { Bit } 2 \\
\text { Thick } \\
(\mathrm{mm}) \\
\end{array}$ & $\begin{array}{c}\text { Bit } 2 \\
\text { Angle } \\
\end{array}$ & Flake Size & Micro-wear & NAA \\
\hline $159-005-027$ & Excurvate & $\begin{array}{c}\text { Regular } \\
\text { Discontinuous }\end{array}$ & 59.3 & 3.5 & 58 & & TRUE & FALSE \\
\hline $196-011$ & Excurvate & $\begin{array}{c}\text { Regular } \\
\text { Continuous }\end{array}$ & 22.6 & 2.6 & 46 & & FALSE & FALSE \\
\hline $857-012$ & & & & & & & FALSE & FALSE \\
\hline $990-015$ & & & & & & & FALSE & FALSE \\
\hline $1021-005-014$ & & & & & & 5 & FALSE & FALSE \\
\hline $1055-013$ & Excurvate & $\begin{array}{c}\text { Irregular } \\
\text { Discontinuous }\end{array}$ & 61.4 & 2.3 & 55 & 6 & FALSE & FALSE \\
\hline $1171-013$ & Straight & $\begin{array}{c}\text { Irregular } \\
\text { Continuous }\end{array}$ & 10.6 & 1.2 & 42 & & FALSE & FALSE \\
\hline
\end{tabular}


Table 0-9. Drill Data From Toyah Component

\begin{tabular}{|c|c|c|c|c|c|c|c|c|}
\hline Cat. No. & $195-014$ & $260-014$ & $518-012$ & $624-014$ & $800-010$ & $827-012$ & $837-011$ & $859-016$ \\
\hline Unit & N101,E52 & $\mathrm{N} 102, \mathrm{E} 47$ & N106,E53 & N108,E48 & $\mathrm{N} 115, \mathrm{E} 73$ & $\mathrm{~N} 117, \mathrm{E} 70$ & $\mathrm{~N} 117, \mathrm{E} 75$ & N118,E75 \\
\hline Depth (cmbd) & $0-10$ & $0-10$ & $10-20$ & $0-10$ & $10-20$ & $0-10$ & $0-10$ & $0-10$ \\
\hline Feature No. & & 36 & & & & & & \\
\hline Condition & Medial & Proximal & Distal & Medial & Proximal & Medial & Complete & Distal \\
\hline Break Type & Use & Use & Indeterminate & Use & Use & Use & Use & Use \\
\hline $\begin{array}{l}\text { Rejuvenation } \\
\text { Scar }\end{array}$ & Absent & Absent & Absent & Absent & Absent & Absent & Absent & Absent \\
\hline Edge Rounding & Present & Present & Present & Present & Present & Present & Present & Present \\
\hline Raw Material & Chert & Chert & Chert & Chert & Chert & Chert & Chert & Chert \\
\hline Texture & Fine & Fine & Fine & Fine & Fine & Fine & Fine & Fine \\
\hline $\begin{array}{c}\text { Percent } \\
\text { Patination }\end{array}$ & 0 & 0 & 0 & 0 & 0 & 0 & 0 & 0 \\
\hline Percent Cortex & 25 & 0 & 0 & 0 & 25 & 0 & 0 & 0 \\
\hline Cortex Type & Pebble/Cobble & None & None & None & Pebble/Cobble & None & None & None \\
\hline Heating & None & None & None & None & None & None & None & None \\
\hline Length (mm) & & & & & & & 14 & \\
\hline \multicolumn{9}{|l|}{ Width (mm) } \\
\hline Thick (mm) & 6 & 4.8 & & 5.7 & 3.9 & 3.6 & 2.8 & \\
\hline Wt. (g) & & & & & 1.5 & 1.4 & 0.3 & \\
\hline Trans X-Section & $\begin{array}{c}\text { Biconvex } \\
\text { Asymmetrical }\end{array}$ & $\begin{array}{l}\text { Plano- } \\
\text { Convex }\end{array}$ & $\begin{array}{l}\text { Biconvex } \\
\text { Symmetrical }\end{array}$ & $\begin{array}{c}\text { Biconvex } \\
\text { Symmetrical }\end{array}$ & Plano-Convex & $\begin{array}{c}\text { Biconvex } \\
\text { Asymmetrical }\end{array}$ & $\begin{array}{c}\text { Biconvex } \\
\text { Asymmetrical }\end{array}$ & $\begin{array}{c}\text { Biconvex } \\
\text { Symmetrical }\end{array}$ \\
\hline Preform & Flake & Flake & Flake & Flake & Flake & Flake & Flake & Flake \\
\hline Stem Shape & Indeterminate & Irregular & Indeterminate & Irregular & Straight & Contracting & Contracting & Indeterminate \\
\hline $\begin{array}{l}\text { Stem Length } \\
(\mathrm{mm})\end{array}$ & & 26.5 & & & 23.4 & & 5.8 & \\
\hline $\begin{array}{l}\text { Stem Width } \\
(\mathrm{mm})\end{array}$ & 25.9 & 27.2 & & & 14.3 & 14.4 & 6 & \\
\hline Bit Width (mm) & 5.2 & 6.1 & 6.6 & 7.1 & 5.5 & 7.9 & 1.8 & 5 \\
\hline Micro-wear & FALSE & FALSE & FALSE & FALSE & TRUE & FALSE & TRUE & FALSE \\
\hline NAA & FALSE & TRUE & FALSE & FALSE & FALSE & FALSE & FALSE & FALSE \\
\hline
\end{tabular}


The Varga Site

Texas Department of Transportation

Table 0-9. Drill Data From Toyah Component Continued

\begin{tabular}{|c|c|c|c|c|c|c|c|c|}
\hline Cat. No. & $875-018$ & $893-016$ & $895-012$ & $942-018$ & 974-011 & $989-010$ & $1054-019$ & $1074-015$ \\
\hline Unit & N119,E74 & N120,E74 & $\mathrm{N} 120, \mathrm{E} 75$ & N123,E74 & N125,E69 & $\mathrm{N} 125, \mathrm{E} 74$ & $\mathrm{~N} 127, \mathrm{E} 75$ & N128,E72 \\
\hline Depth (cmbd) & $10-20$ & $20-30$ & $10-20$ & $0-10$ & $10-20$ & $0-10$ & $20-30$ & $20-30$ \\
\hline Feature No. & & & & & & & 25 & \\
\hline Condition & Medial & Distal & Medial & Proximal & Medial & Proximal & Distal & Proximal \\
\hline Break Type & Use & Use & Use & Use & Use & Use & Use & Use \\
\hline $\begin{array}{l}\text { Rejuvenation } \\
\text { Scar }\end{array}$ & Absent & Absent & Absent & Absent & Absent & Absent & Absent & Absent \\
\hline Edge Rounding & Absent & Present & Present & Present & Absent & Absent & Present & Present \\
\hline Raw Material & Chert & Chert & Chert & Chert & Chert & Chert & Chert & Chert \\
\hline Texture & Fine & Fine & Fine & Fine & Fine & Fine & Fine & Fine \\
\hline $\begin{array}{c}\text { Percent } \\
\text { Patination }\end{array}$ & 0 & 0 & 0 & 0 & 0 & 0 & 0 & 0 \\
\hline Percent Cortex & 0 & 0 & 0 & 0 & 0 & 0 & 0 & 0 \\
\hline Cortex Type & None & None & None & None & None & None & None & None \\
\hline Heating & None & None & None & None & None & None & None & None \\
\hline \multicolumn{9}{|l|}{ Length (mm) } \\
\hline \multicolumn{9}{|l|}{ Width (mm) } \\
\hline Thick (mm) & 3.5 & 3.6 & 2.9 & 4.2 & 3.5 & 4.7 & & 4.9 \\
\hline Wt. (g) & 1.4 & & & & & & & \\
\hline Trans X-Section & $\begin{array}{c}\text { Biconvex } \\
\text { Asymmetrical }\end{array}$ & $\begin{array}{c}\text { Biconvex } \\
\text { Symmetrical }\end{array}$ & $\begin{array}{l}\text { Plano- } \\
\text { Convex }\end{array}$ & $\begin{array}{c}\text { Biconvex } \\
\text { Symmetrical }\end{array}$ & $\begin{array}{c}\text { Biconvex } \\
\text { Symmetrical }\end{array}$ & $\begin{array}{l}\text { Plano- } \\
\text { Convex }\end{array}$ & Plano-Convex & $\begin{array}{l}\text { Plano- } \\
\text { Convex }\end{array}$ \\
\hline Preform & Flake & Biface & Flake & Flake & Flake & Flake & Flake & Flake \\
\hline Stem Shape & Indeterminate & Indeterminate & Indeterminate & Contracting & Indeterminate & Straight & Indeterminate & Irregular \\
\hline $\begin{array}{l}\text { Stem Length } \\
(\mathrm{mm})\end{array}$ & & & & 16.8 & & 18.1 & & 22.2 \\
\hline $\begin{array}{l}\text { Stem Width } \\
(\mathrm{mm})\end{array}$ & & & 16.2 & 22.7 & 16.5 & 15.2 & & \\
\hline Bit Width (mm) & 6.1 & 6.6 & 5.9 & 5.6 & 6.1 & 6.9 & 7.3 & 7.7 \\
\hline Micro-wear & FALSE & TRUE & FALSE & FALSE & FALSE & FALSE & FALSE & FALSE \\
\hline NAA & FALSE & FALSE & TRUE & FALSE & TRUE & FALSE & FALSE & FALSE \\
\hline
\end{tabular}


Appendix O: Data and Site Artifact Database

Table 0-10. Toyah Core Data

\begin{tabular}{|c|c|c|c|c|c|c|c|c|c|c|}
\hline Cat. No. & $157-013$ & $158-005-023$ & 169-012 & $177-010$ & $177-011$ & 219-016 & $270-023$ & $314-025$ & $368-012$ & 424-016 \\
\hline Unit & N101,E47 & N101,E47 & $\mathrm{N} 101, \mathrm{E} 50$ & N101,E50 & N101,E50 & N101,E54 & N102,E50 & N102,E54 & N103,E51 & N105,E47 \\
\hline Depth (cmbd) & $10-20$ & $20-30$ & $30-40$ & $10-20$ & $10-20$ & $10-20$ & 10 & $40-50$ & $10-20$ & $0-10$ \\
\hline Feature No. & & 36 & & & & & & & & \\
\hline Condition & Complete & Exhausted & Complete & Complete & Complete & Complete & Complete & Complete & Complete & Complete \\
\hline Tool Type & Bifacial & Bifacial & Bifacial & $\begin{array}{c}\text { Multi- } \\
\text { Directional }\end{array}$ & Bifacial & Bifacial & Bifacial & Bifacial & $\begin{array}{c}\text { Multi- } \\
\text { Directional }\end{array}$ & $\begin{array}{c}\text { Multi- } \\
\text { Directional }\end{array}$ \\
\hline $\begin{array}{l}\text { Rejuvenation } \\
\text { Scar }\end{array}$ & Absent & Absent & Absent & Absent & Absent & Absent & Absent & Absent & Absent & Absent \\
\hline Raw Material & Chert & Chert & Chert & Chert & Chert & Chert & Chert & Chert & Chert & Chert \\
\hline Texture & Fine & Fine & Fine & Fine & Fine & Fine & Fine & Fine & Fine & Fine \\
\hline $\begin{array}{c}\text { Percent } \\
\text { Patination }\end{array}$ & 0 & 0 & 0 & 0 & 0 & 0 & 0 & 0 & 0 & 0 \\
\hline $\begin{array}{l}\text { Percent } \\
\text { Cortex }\end{array}$ & 25 & 25 & 25 & 0 & 50 & 0 & 50 & 50 & 0 & 25 \\
\hline Cortex Type & $\begin{array}{l}\text { Pebble/ } \\
\text { Cobble }\end{array}$ & $\begin{array}{l}\text { Pebble/ } \\
\text { Cobble }\end{array}$ & $\begin{array}{l}\text { Pebble/ } \\
\text { Cobble }\end{array}$ & None & $\begin{array}{l}\text { Pebble/ } \\
\text { Cobble }\end{array}$ & None & $\begin{array}{l}\text { Pebble/ } \\
\text { Cobble }\end{array}$ & $\begin{array}{l}\text { Pebble/ } \\
\text { Cobble }\end{array}$ & None & $\begin{array}{l}\text { Pebble/ } \\
\text { Cobble }\end{array}$ \\
\hline Heating & None & None & None & None & None & None & None & None & None & Indeterminate \\
\hline Length (mm) & 59.5 & 59.8 & 76.2 & 61.9 & 72.9 & 77.9 & 138.9 & 69.5 & 70.8 & 73.1 \\
\hline Width (mm) & 58.9 & 43.8 & 54.5 & 57.2 & 63.5 & 66.1 & 91.5 & 58.1 & 55.6 & 60.4 \\
\hline Thick (mm) & 26.4 & 28.7 & 29 & 44.3 & 40 & 36.4 & 56.6 & 37.8 & 34.6 & 42.6 \\
\hline Wt. (g) & 105.8 & 72.3 & 118.5 & 139.6 & 154.3 & 149.5 & 680 & 174.8 & 177.1 & 222.5 \\
\hline Cat. No. & $474-012$ & $490-011$ & 549-013 & $618-010$ & $802-015^{*}$ & $806-020^{*}$ & $814-012^{*}$ & $842-014^{*}$ & $885-019^{*}$ & $889-010^{*}$ \\
\hline Unit & N105,E55 & N106,E47 & N107,E47 & N108,E47 & $\mathrm{N} 115, \mathrm{E} 74$ & N115,E75 & N116,E72 & N118,E70 & $\mathrm{N} 120, \mathrm{E} 72$ & N120,E73 \\
\hline Depth (cmbd) & $10-20$ & $20-30$ & $10-20$ & $0-10$ & $0-10$ & $15-30$ & $3 \mathrm{cmbs}$ & $0-10$ & $0-10$ & $10-20$ \\
\hline \multicolumn{11}{|l|}{ Feature No. } \\
\hline Condition & Complete & Fragmented & Complete & Complete & Complete & Complete & Complete & Exhausted & Complete & Exhausted \\
\hline Tool Type & $\begin{array}{c}\text { Multi- } \\
\text { Directional }\end{array}$ & Bifacial & Bifacial & Bifacial & Unifacial & $\begin{array}{c}\text { Multi- } \\
\text { Directional }\end{array}$ & Bifacial & Bifacial & $\begin{array}{c}\text { Multi- } \\
\text { Directional }\end{array}$ & Bifacial \\
\hline $\begin{array}{l}\text { Rejuvenation } \\
\text { Scar }\end{array}$ & Absent & Absent & Absent & Absent & Absent & Absent & Absent & Absent & Absent & Absent \\
\hline Raw Material & Chert & Chert & Chert & Chert & Chert & Chert & Chert & Chert & Chert & Chert \\
\hline Texture & Fine & Fine & Fine & Fine & Fine & Fine & Fine & Fine & Fine & Fine \\
\hline $\begin{array}{l}\text { Percent } \\
\text { Patination }\end{array}$ & 0 & 0 & 0 & 0 & 0 & 25 & 0 & 0 & 0 & 0 \\
\hline $\begin{array}{l}\text { Percent } \\
\text { Cortex }\end{array}$ & 50 & 25 & 0 & 50 & 50 & 25 & 0 & 25 & 25 & 25 \\
\hline Cortex Type & $\begin{array}{l}\text { Pebble/ } \\
\text { Cobble }\end{array}$ & $\begin{array}{l}\text { Pebble/ } \\
\text { Cobble }\end{array}$ & None & $\begin{array}{l}\text { Pebble/ } \\
\text { Cobble }\end{array}$ & $\begin{array}{l}\text { Pebble/ } \\
\text { Cobble }\end{array}$ & $\begin{array}{l}\text { Pebble/ } \\
\text { Cobble }\end{array}$ & None & $\begin{array}{l}\text { Pebble/ } \\
\text { Cobble }\end{array}$ & $\begin{array}{l}\text { Pebble/ } \\
\text { Cobble }\end{array}$ & $\begin{array}{l}\text { Pebble/ } \\
\text { Cobble }\end{array}$ \\
\hline Heating & None & None & None & Indeterminate & None & None & $\begin{array}{l}\text { Heat- } \\
\text { Treated }\end{array}$ & None & None & None \\
\hline Length (mm) & 73.1 & 72.4 & 95.7 & 111.9 & 64.1 & 86.8 & 78.1 & 50 & 81.8 & 55.6 \\
\hline Width (mm) & 47.1 & 52.9 & 73.8 & 72.1 & 61.8 & 55.4 & 62.8 & 42.4 & 56.8 & 46.3 \\
\hline Thick (mm) & 35.6 & 34.8 & 33.8 & 29.9 & 52.1 & 50.6 & 40.2 & 19.6 & 45.5 & 30.2 \\
\hline Wt. (g) & 119.9 & 168.7 & 235.2 & 214.2 & 170.1 & 224.1 & 178.8 & 31.7 & 226.9 & 66.9 \\
\hline
\end{tabular}


The Varga Site

Texas Department of Transportation

Table 0-10. Toyah Core Data Continued

\begin{tabular}{|c|c|c|c|c|c|c|c|c|c|c|}
\hline Cat. No. & $889-010^{*}$ & $889-019 *$ & 893-014* & $897-016 *$ & $913-016^{*}$ & $918-013^{*}$ & $942-010 *$ & $956-010^{*}$ & $975-010 *$ & $991-0118$ \\
\hline Unit & N120,E73 & N120,E73 & N120,E74 & N122,E69 & N122,E74 & N123,E68 & N123,E74 & N124,E71 & N125,E69 & N125,E74 \\
\hline $\begin{array}{l}\text { Depth } \\
\text { (cmbd) }\end{array}$ & $10-20$ & $10-20$ & $20-30$ & $0-10$ & $8-24$ & $9-11$ & $0-10$ & $20-30$ & $20-30$ & $18-2$ \\
\hline \multicolumn{11}{|l|}{ Feature No. } \\
\hline Condition & Exhausted & Complete & Complete & Complete & Complete & Complete & Complete & Complete & Exhausted & Complete \\
\hline Tool Type & Bifacial & Bifacial & Bifacial & $\begin{array}{c}\text { Multi- } \\
\text { Directional }\end{array}$ & $\begin{array}{c}\text { Multi- } \\
\text { Directional }\end{array}$ & $\begin{array}{c}\text { Multi- } \\
\text { Directional }\end{array}$ & $\begin{array}{c}\text { Multi- } \\
\text { Directional }\end{array}$ & Bifacial & $\begin{array}{c}\text { Multi- } \\
\text { Directional }\end{array}$ & $\begin{array}{c}\text { Multi- } \\
\text { Directional }\end{array}$ \\
\hline $\begin{array}{l}\text { Rejuvenation } \\
\text { Scar }\end{array}$ & Absent & Absent & Absent & Absent & Absent & Absent & Absent & Absent & Absent & Absent \\
\hline Raw Material & Chert & Chert & Chert & Chert & Chert & Chert & Chert & Chert & Chert & Chert \\
\hline Texture & Fine & Fine & Fine & Fine & Fine & Fine & Fine & Fine & Fine & Fine \\
\hline $\begin{array}{l}\text { Percent } \\
\text { Patination }\end{array}$ & 0 & 0 & 0 & 0 & 0 & 0 & 0 & 0 & 0 & 0 \\
\hline $\begin{array}{l}\text { Percent } \\
\text { Cortex }\end{array}$ & 25 & 50 & 25 & 50 & 50 & 25 & 25 & 25 & 0 & 25 \\
\hline Cortex Type & $\begin{array}{l}\text { Pebble/ } \\
\text { Cobble }\end{array}$ & $\begin{array}{l}\text { Pebble/ } \\
\text { Cobble }\end{array}$ & $\begin{array}{l}\text { Pebble/ } \\
\text { Cobble }\end{array}$ & $\begin{array}{l}\text { Pebble/ } \\
\text { Cobble }\end{array}$ & $\begin{array}{l}\text { Pebble/ } \\
\text { Cobble }\end{array}$ & $\begin{array}{l}\text { Pebble/ } \\
\text { Cobble }\end{array}$ & $\begin{array}{l}\text { Pebble/ } \\
\text { Cobble }\end{array}$ & $\begin{array}{l}\text { Pebble/ } \\
\text { Cobble }\end{array}$ & None & $\begin{array}{l}\text { Pebble/ } \\
\text { Cobble }\end{array}$ \\
\hline Heating & None & $\begin{array}{l}\text { Heat- } \\
\text { Treated }\end{array}$ & None & None & None & None & None & None & None & None \\
\hline Length (mm) & 55.6 & 71.4 & 65.3 & 68.1 & 96 & 77.5 & 57.6 & 66.3 & 37.7 & 75.9 \\
\hline Width (mm) & 46.3 & 60 & 56.8 & 66.6 & 60.5 & 70.8 & 39.1 & 62.1 & 31.5 & 47.9 \\
\hline Thick (mm) & 30.2 & 33.6 & 43.5 & 44.9 & 42.8 & 50.4 & 37.6 & 26.1 & 23.8 & 44 \\
\hline Wt. (g) & 66.9 & 121.3 & 220 & 242.4 & 346.2 & 407 & 82.4 & 117.7 & 31 & 132.7 \\
\hline Cat. No. & $975-010 *$ & 991-0118 & $1000-010^{*}$ & $1024-020$ & $1036-013^{*}$ & $1044-010 *$ & $1052-011^{*}$ & $1078-011^{*}$ & $1101-010^{*}$ & $1129-013^{*}$ \\
\hline Unit & N125,E69 & N125,E74 & N126,E69 & N126,E75 & N127,E69 & N127,E72 & N127,E75 & N128,E73 & N129,E75 & N130,E74 \\
\hline $\begin{array}{l}\text { Depth } \\
\text { (cmbd) }\end{array}$ & $20-30$ & $18-2$ & $20-30$ & $10-20$ & 18 & 18 & $0-10$ & $20-30$ & $10-20$ & $20-30$ \\
\hline Feature No. & & & & & & & 25 & & & \\
\hline Condition & Exhausted & Complete & Complete & Fragmented & Complete & Complete & Complete & Complete & Complete & Complete \\
\hline Tool Type & $\begin{array}{c}\text { Multi- } \\
\text { Directional }\end{array}$ & $\begin{array}{c}\text { Multi- } \\
\text { Directional }\end{array}$ & Bifacial & Bifacial & $\begin{array}{c}\text { Multi- } \\
\text { Directional }\end{array}$ & Bifacial & $\begin{array}{c}\text { Multi- } \\
\text { Directional }\end{array}$ & Bifacial & Bifacial & $\begin{array}{c}\text { Multi- } \\
\text { Directional }\end{array}$ \\
\hline $\begin{array}{l}\text { Rejuvenation } \\
\text { Scar }\end{array}$ & Absent & Absent & Absent & Absent & Absent & Absent & Absent & Absent & Absent & Absent \\
\hline Raw Material & Chert & Chert & Chert & Chert & Chert & Chert & Chert & Chert & Chert & Chert \\
\hline Texture & Fine & Fine & Fine & Fine & Fine & Fine & Fine & Fine & Fine & Fine \\
\hline $\begin{array}{c}\text { Percent } \\
\text { Patination }\end{array}$ & 0 & 0 & 0 & 0 & 0 & 0 & 0 & 0 & 0 & 0 \\
\hline $\begin{array}{l}\text { Percent } \\
\text { Cortex }\end{array}$ & 0 & 25 & 25 & 25 & 25 & 50 & 50 & 25 & 75 & 25 \\
\hline Cortex Type & None & $\begin{array}{l}\text { Pebble/ } \\
\text { Cobble }\end{array}$ & $\begin{array}{l}\text { Pebble/ } \\
\text { Cobble }\end{array}$ & $\begin{array}{l}\text { Pebble/ } \\
\text { Cobble }\end{array}$ & $\begin{array}{l}\text { Pebble/ } \\
\text { Cobble }\end{array}$ & $\begin{array}{l}\text { Pebble/ } \\
\text { Cobble }\end{array}$ & $\begin{array}{l}\text { Pebble/ } \\
\text { Cobble }\end{array}$ & $\begin{array}{l}\text { Pebble/ } \\
\text { Cobble }\end{array}$ & $\begin{array}{l}\text { Pebble/ } \\
\text { Cobble }\end{array}$ & $\begin{array}{c}\text { Pebble/ } \\
\text { Cobble }\end{array}$ \\
\hline Heating & None & None & None & None & None & None & None & None & None & None \\
\hline Length (mm) & 37.7 & 75.9 & 84.8 & 59 & 80.9 & 71.1 & 99.6 & 96.9 & 80.2 & 111.6 \\
\hline Width (mm) & 31.5 & 47.9 & 66.8 & 58 & 74.6 & 52.1 & 54.5 & 65.9 & 55.5 & 77.3 \\
\hline Thick (mm) & 23.8 & 44 & 23.9 & 18.1 & 35.7 & 28.5 & 57.8 & 30 & 24 & 44.2 \\
\hline Wt. (g) & 31 & 132.7 & 120 & 64.5 & 224.3 & 93.8 & 438.2 & 206.3 & 121.2 & 344 \\
\hline
\end{tabular}


Appendix O: Data and Site Artifact Database

Table 0-11. Vessel Group 1 Data

\begin{tabular}{|c|c|c|c|c|c|c|c|c|c|}
\hline Cat. No. & $158-005-008$ & $271-008$ & $785-008$ & $841-008-1$ & $841-008-2$ & $842-008-2$ & $843-008$ & $845-008$ & $865-005-008$ \\
\hline Unit & N101,E47 & $\mathrm{N} 102, \mathrm{E} 50$ & $\mathrm{~N} 115, \mathrm{E} 69$ & $\mathrm{~N} 118, \mathrm{E} 69$ & N118,E69 & N118,E70 & N118,E70 & N118,E71 & N119,E70 \\
\hline Depth (cmbd) & $20-30$ & $10-20$ & $0-10$ & $10-20$ & $10-20$ & $0-10$ & $10-20$ & $10-20$ & $12-22$ \\
\hline Count & 1 & 1 & 1 & 1 & 1 & 1 & 1 & 1 & 1 \\
\hline Sherd Type & Body & Body & Body & Body & Body & Body & Body & Body & Body \\
\hline Ceramic Type & Leon Plain & Leon Plain & Leon Plain & Leon Plain & Leon Plain & Leon Plain & Leon Plain & Leon Plain & Leon Plain \\
\hline Temper & Bone, White & Bone, White & $\begin{array}{c}\text { Bone, White, } \\
\text { Grey }\end{array}$ & $\begin{array}{l}\text { Bone, White, } \\
\text { Gray, Sand }\end{array}$ & $\begin{array}{l}\text { Bone, White, } \\
\text { Gray, Sand }\end{array}$ & Bone, White & $\begin{array}{l}\text { Bone, White, } \\
\text { Gray, Sand }\end{array}$ & $\begin{array}{l}\text { Bone, Gray, } \\
\text { White, Sand }\end{array}$ & $\begin{array}{c}\text { Bone, White, } \\
\text { Gray }\end{array}$ \\
\hline Sherd Diameter (mm) & 13.5 & 18 & 14 & 28 & 19.3 & 12 & & 26.2 & 21.5 \\
\hline Thickness (mm) & 4.7 & 5 & 6.1 & 4.7 & 4.7 & 4.6 & 5.3 & 5.1 & 6.7 \\
\hline Wt. (g) & 0.7 & 1.7 & 0.6 & 2.3 & 1.1 & 0.4 & 1.4 & 2 & 1.7 \\
\hline Exterior Surface Finish & Smooth & Smooth & Smooth & Polished & Polished & Smooth & Smooth & Smooth & Polished \\
\hline Interior Surface Finish & Rough & Smooth & Smooth & Smooth & Smooth & Smooth & Rough & Smooth & Polished \\
\hline Exterior Surface Color & 5YR 6/4 & 7.5YR 6/4 & 7.5YR 6/4 & $7.5 Y R 5 / 2$ & 7.5YR 5/2 & 7.5YR 6/4 & 7.5YR 6/4 & $5 Y R 5 / 2$ & 10YR 5/1 \\
\hline Core Color & 5YR 5/1 & 10YR 4/1 & 7.5YR 5/2 & 10YR 4/1 & 10YR 4/1 & 7.5YR 5/2 & 7.5YR 6/2 & $5 Y R 5 / 3$ & $\begin{array}{c}\text { 10YR 2/1 \& } \\
\text { 10YR 5/2 }\end{array}$ \\
\hline Interior Surface Color & 5YR 5/4 & 7.5YR 5/6 & 7.5YR $6 / 2$ & $5 Y R 5 / 3$ & $5 Y R 5 / 3$ & 7.5YR 5/2 & 7.5YR 6/2 & $5 Y R 5 / 4$ & 10YR 5/1 \\
\hline NAA & FALSE & FALSE & FALSE & FALSE & FALSE & FALSE & FALSE & FALSE & FALSE \\
\hline Petrographic & FALSE & FALSE & FALSE & FALSE & FALSE & FALSE & FALSE & FALSE & FALSE \\
\hline Isotope Analyses & FALSE & FALSE & FALSE & FALSE & FALSE & FALSE & FALSE & FALSE & FALSE \\
\hline Lipid Residue & FALSE & FALSE & FALSE & FALSE & FALSE & FALSE & FALSE & FALSE & FALSE \\
\hline Cat. No. & $878-008$ & $903-008$ & $917-008$ & $940-008$ & $950-008-1$ & $950-008-2$ & $962-008^{*}$ & $989-008$ & $996-008$ \\
\hline Unit & N119,E75 & N122,E71 & N122,E75 & $\mathrm{N} 123, \mathrm{E} 73$ & N124,E69 & $\mathrm{N} 124, \mathrm{E} 69$ & N124,E73 & $\mathrm{N} 125, \mathrm{E} 74$ & N126,E68 \\
\hline Depth (cmbd) & $10-20$ & $0-10$ & $20-30$ & $12-26$ & $18-26$ & $18-26$ & $20-30$ & $0-10$ & $10-20$ \\
\hline Count & 1 & 1 & 1 & 1 & 1 & 1 & 1 & 1 & 1 \\
\hline Sherd Type & Body & Body & Body & Body & Body & Body & Body & Body & Body \\
\hline Ceramic Type & Leon Plain & Leon Plain & Leon Plain & Leon Plain & Leon Plain & Leon Plain & Leon Plain & Leon Plain & Leon Plain \\
\hline Temper & Bone, White & Bone, White & Bone, White & $\begin{array}{c}\text { Bone, White, } \\
\text { Gray }\end{array}$ & Bone, White & Bone, White & Bone, White & Bone, White & $\begin{array}{l}\text { Bone, White, } \\
\text { Sand }\end{array}$ \\
\hline Sherd Diameter (mm) & 19.1 & 14.6 & 16.9 & 14.6 & 15.7 & 14.2 & 14 & 13.6 & 16 \\
\hline Thickness (mm) & 4 & 4.5 & 4.1 & & 5.5 & 4.8 & 4.9 & 5.9 & 3.9 \\
\hline Wt. (g) & 1.1 & 0.8 & 0.4 & 0.5 & 0.7 & 0.4 & 0.9 & 1.1 & 1.1 \\
\hline Exterior Surface Finish & Smooth & Smooth & Smooth & Polished & Smooth & Smooth & Smooth & Smooth & Smooth \\
\hline Interior Surface Finish & Smooth & Rough & Smooth & Rough & Smooth & Smooth & Smooth & Rough & Smooth \\
\hline Exterior Surface Color & 5YR 5/2 & $5 Y R 6 / 3$ & 10YR 6/3 & 5YR 6/4 & $5 Y R 6 / 4$ & $5 Y R 6 / 4$ & $5 Y R 6 / 4$ & 7.5YR 6/4 & 5YR 5/1 \\
\hline Core Color & 7.5YR 6/2 & $5 Y R 6 / 2$ & 7.5YR 5/2 & 5YR 5/1 & $5 Y R 4 / 1$ & $5 Y R 4 / 1$ & $5 Y R 5 / 1$ & $5 Y R 5 / 2$ & 5YR 6/2 \\
\hline Interior Surface Color & 7.5YR 6/4 & $5 Y R 5 / 1$ & 7.5YR 6/4 & $5 Y R 6 / 3$ & $5 Y R 6 / 3$ & $5 Y R 6 / 3$ & $5 Y R 5 / 1$ & $5 Y R 6 / 6$ & $5 Y R 6 / 3$ \\
\hline NAA & FALSE & FALSE & FALSE & FALSE & FALSE & FALSE & FALSE & FALSE & FALSE \\
\hline Petrographic & FALSE & FALSE & FALSE & FALSE & FALSE & FALSE & FALSE & FALSE & FALSE \\
\hline Isotope Analyses & FALSE & FALSE & FALSE & FALSE & FALSE & FALSE & FALSE & FALSE & FALSE \\
\hline Lipid Residue & FALSE & FALSE & FALSE & FALSE & FALSE & FALSE & FALSE & FALSE & FALSE \\
\hline
\end{tabular}


The Varga Site

Texas Department of Transportation

Table 0-11. Vessel Group 1 Data Continued

\begin{tabular}{|c|c|c|c|c|c|c|c|c|c|}
\hline Cat. No. & 999-008 & $1008-008-2$ & 1023-008-1 & $1023-008-2$ & $\begin{array}{c}1030-005- \\
004-008\end{array}$ & $\begin{array}{l}1030-005- \\
004-008-1\end{array}$ & $\begin{array}{c}1030-005- \\
008\end{array}$ & $1030-008$ & $1050-008-1$ \\
\hline Unit & N126,E69 & N126,E72 & N126,E75 & N126,E75 & N126,E76 & N126,E76 & N126,E76 & N126,E76 & N127,E74 \\
\hline Depth (cmbd) & $10-20$ & $20-30$ & $0-10$ & $0-10$ & $35-40$ & $35-40$ & $30-40$ & $30-40$ & $15-25$ \\
\hline Count & 1 & 1 & 1 & 1 & 1 & 1 & 1 & 1 & 1 \\
\hline Sherd Type & Body & Body & Body & Body & Body & Body & Body & Body & Body \\
\hline Ceramic Type & Leon Plain & Leon Plain & Leon Plain & Leon Plain & Leon Plain & Leon Plain & Leon Plain & Leon Plain & Leon Plain \\
\hline Temper & Bone, White & Bone, White & $\begin{array}{c}\text { Bone, White, } \\
\text { Sand }\end{array}$ & $\begin{array}{l}\text { Bone, White, } \\
\text { Sand }\end{array}$ & Bone, White & Bone, White & Bone, White & $\begin{array}{c}\text { Bone, White, } \\
\text { Gray }\end{array}$ & $\begin{array}{c}\text { Bone, Gray, } \\
\text { White }\end{array}$ \\
\hline Sherd Diameter (mm) & 31.5 & 22 & 16.8 & 27.1 & 25.6 & 28 & 28.2 & 18 & 21 \\
\hline Thickness (mm) & 4.9 & 5.2 & 4.9 & 4.9 & 5.1 & 5 & 5.1 & 6 & 6.3 \\
\hline Wt. (g) & 2.7 & 2 & 0.8 & 2.4 & 3.4 & 14.5 & 3.5 & 1.6 & 2.2 \\
\hline Exterior Surface Finish & Smooth & Smooth & Smooth & Smooth & Smooth & Smooth & Smooth & Polished & Smooth \\
\hline Interior Surface Finish & Smooth & Rough & Smooth & Smooth & Smooth & Smooth & Smooth & Rough & Rough \\
\hline Exterior Surface Color & 7.5 YR $5 / 2$ & $5 Y R 6 / 4$ & 10YR 5/1 & 10YR 5/1 & 10YR 4/1 & 10YR 4/1 & $5 Y R$ 4/1 & $5 Y R 6 / 4$ & $7.5 Y R$ 5/2 \\
\hline Core Color & 5YR 4/1 & 5YR 5/1 & 5YR 4/1 & 5YR 4/1 & 5YR 4/1 & 5YR 4/1 & 5YR 4/1 & 5YR 5/1 & 5YR 4/1 \\
\hline Interior Surface Color & 7.5YR 5/4 & 7.5YR 5/2 & $5 Y R 6 / 4$ & $5 Y R 6 / 4$ & $5 Y R 6 / 6$ & $5 Y R 6 / 6$ & $5 Y R 6 / 6$ & $5 Y R 6 / 6$ & 7.5YR 6/6 \\
\hline NAA & FALSE & FALSE & FALSE & FALSE & FALSE & FALSE & FALSE & TRUE & FALSE \\
\hline Petrographic & FALSE & FALSE & FALSE & FALSE & FALSE & FALSE & FALSE & FALSE & FALSE \\
\hline Isotope Analyses & FALSE & FALSE & FALSE & FALSE & FALSE & TRUE = $1 b$ & FALSE & FALSE & FALSE \\
\hline Lipid Residue & FALSE & FALSE & FALSE & FALSE & FALSE & TRUE $=1 \mathrm{a}$ & FALSE & FALSE & FALSE \\
\hline Cat. No. & $1050-008-2$ & 1054-008-1 & $1054-008-2$ & $1054-008-3$ & $1054-008-4$ & $1054-008-5$ & $1055-005-008$ & $1074-008$ & $1078-008$ \\
\hline Unit & N127,E74 & N127,E75 & N127,E75 & N127,E75 & N127,E75 & N127,E75 & N127,E75 & $\mathrm{N} 128, \mathrm{E} 72$ & N127,E73 \\
\hline Depth (cmbd) & $15-25$ & $20-30$ & $20-30$ & $20-30$ & $20-30$ & $20-30$ & 32 & $20-30$ & $17-25$ \\
\hline Count & 1 & 1 & 1 & 1 & 1 & 1 & 1 & 1 & 1 \\
\hline Sherd Type & Body & Body & Body & Body & Body & Body & Body & Body & Body \\
\hline Ceramic Type & Leon Plain & Leon Plain & Leon Plain & Leon Plain & Leon Plain & Leon Plain & Leon Plain & Leon Plain & Leon Plain \\
\hline Temper & $\begin{array}{c}\text { Bone, Gray, } \\
\text { White }\end{array}$ & Bone, White & Bone, White & Bone, White & Bone, White & Bone, White & $\begin{array}{l}\text { Bone, Sand, } \\
\text { White, Sand }\end{array}$ & $\begin{array}{l}\text { Bone, } \\
\text { White }\end{array}$ & $\begin{array}{c}\text { Bone, White, } \\
\text { Gray, Sand }\end{array}$ \\
\hline Sherd Diameter (mm) & 30 & & 47.2 & 34.5 & 15.7 & 12 & 39.8 & 10.7 & 17 \\
\hline Thickness (mm) & 6.1 & & 5.3 & 6.3 & 4.9 & 4.9 & 5.1 & 5.2 & 5.5 \\
\hline Wt. (g) & 2.1 & 3.4 & 11.7 & 4.1 & 0.9 & 0.6 & 9.2 & 0.6 & 0.8 \\
\hline Exterior Surface Finish & Smooth & Smooth & Smooth & Smooth & Smooth & Smooth & Smooth & Smooth & Polished \\
\hline Interior Surface Finish & Rough & Smooth & Smooth & Smooth & Smooth & Smooth & Smooth & Rough & Rough \\
\hline Exterior Surface Color & 7.5YR 5/2 & 10YR 6/3 & 10YR 6/3 & 10YR 6/3 & 10YR 6/3 & 10YR 6/3 & 5YR 7/4 & 7.5YR 6/2 & 5YR 5/1 \\
\hline Core Color & 5YR 4/1 & 10YR 4/1 & 10YR 4/1 & 10YR 4/1 & 10YR 4/1 & 10YR 4/1 & 5YR 5/1 & 7.5YR 7/4 & 5YR 6/1 \\
\hline Interior Surface Color & 7.5YR 6/6 & 7.5YR 6/6 & 7.5YR 6/6 & 7.5YR 6/6 & 7.5YR 6/6 & 7.5YR 6/6 & 5YR 5/2 & 7.5YR 7/4 & 5YR 5/2 \\
\hline NAA & FALSE & TRUE $=1 \mathrm{a}$ & FALSE & FALSE & FALSE & FALSE & FALSE & FALSE & FALSE \\
\hline Petrographic & FALSE & TRUE $=1 b$ & FALSE & FALSE & FALSE & FALSE & FALSE & FALSE & FALSE \\
\hline Isotope Analyses & FALSE & FALSE & FALSE & FALSE & FALSE & FALSE & TRUE $=1 b$ & FALSE & FALSE \\
\hline Lipid Residue & FALSE & FALSE & FALSE & FALSE & FALSE & FALSE & TRUE $=1 \mathrm{a}$ & FALSE & FALSE \\
\hline
\end{tabular}


Appendix O: Data and Site Artifact Database

Table 0-11. Vessel Group 1 Data Continued

\begin{tabular}{|c|c|c|c|c|c|c|c|c|c|c|}
\hline Cat. No. & $1081-008$ & $1089-008$ & $1096-008-1$ & $1137-008-1$ & $1137-008-2$ & $1137-008-3$ & $1162-008-2$ & $1162-008-3$ & 1163-008 & $1261-008-1$ \\
\hline Unit & N128,E74 & N129,E71 & N129,E73 & N131,E70 & N131,E70 & N131,E70 & N131,E75 & N131,E75 & N131,E75 & Surface \\
\hline Depth (cmbd) & $0-10$ & $30-35$ & $20-30$ & $30-40$ & $30-40$ & $30-40$ & $0-10$ & $0-10$ & $10-20$ & 0 \\
\hline Count & 1 & 1 & 1 & 1 & 1 & 1 & 1 & 1 & 1 & 1 \\
\hline Sherd Type & Body & Body & Body & Body & Body & Body & Body & Body & Body & Body \\
\hline Ceramic Type & Leon Plain & Leon Plain & Leon Plain & Leon Plain & Leon Plain & Leon Plain & Leon Plain & Leon Plain & Leon Plain & Leon Plain \\
\hline Temper & $\begin{array}{l}\text { Bone, } \\
\text { White }\end{array}$ & $\begin{array}{c}\text { Bone, } \\
\text { White, } \\
\text { Gray, Sand }\end{array}$ & $\begin{array}{l}\text { Bone, } \\
\text { White, } \\
\text { Gray, Sand }\end{array}$ & $\begin{array}{l}\text { Bone, } \\
\text { White }\end{array}$ & $\begin{array}{l}\text { Bone, } \\
\text { White }\end{array}$ & $\begin{array}{l}\text { Bone, } \\
\text { White }\end{array}$ & $\begin{array}{l}\text { Bone, } \\
\text { White }\end{array}$ & $\begin{array}{l}\text { Bone, } \\
\text { White }\end{array}$ & $\begin{array}{l}\text { Bone, } \\
\text { White }\end{array}$ & $\begin{array}{c}\text { Bone, } \\
\text { White, } \\
\text { Gray }\end{array}$ \\
\hline Sherd Diameter (mm) & 25.4 & 26.6 & 13.4 & 11.4 & 13.6 & 12.2 & 16.9 & 18.8 & 12.5 & 28.3 \\
\hline Thickness (mm) & 6.2 & 7.1 & 4.8 & 5.4 & 5.7 & 4.7 & 3.9 & 5.7 & 4.5 & 5.1 \\
\hline Wt. (g) & 2.4 & 3.9 & 0.7 & 0.7 & 0.6 & 0.3 & 0.9 & 1.2 & 0.7 & 2.4 \\
\hline Exterior Surface Finish & Smooth & Smooth & Polished & Polished & Polished & Polished & Smooth & Smooth & Polished & Polished \\
\hline Interior Surface Finish & Rough & Rough & Rough & Smooth & Smooth & Smooth & Rough & Smooth & Polished & Smooth \\
\hline Exterior Surface Color & 10YR 5/1 & 7.5YR 5/6 & 10YR 5/2 & $5 Y R 5 / 4$ & $5 Y R 5 / 4$ & $5 Y R 5 / 4$ & 5YR 5/2 & 5YR 5/4 & 7.5YR 6/4 & $5 Y R 5 / 4$ \\
\hline Core Color & 10YR 4/1 & 7.5YR 5/4 & 7.5 YR $6 / 2$ & 10YR 4/1 & 10YR 4/1 & 10YR 4/1 & $5 Y R 6 / 1$ & 5YR 5/1 & $5 Y R 6 / 3$ & 10YR 5/2 \\
\hline Interior Surface Color & $5 Y R 6 / 6$ & 7.5YR 6/4 & $5 Y R 6 / 4$ & 10YR 5/2 & 10YR 5/2 & 10YR 5/2 & $5 Y R 5 / 2$ & $5 Y R 6 / 4$ & 7.5YR 6/4 & $10 \mathrm{R} 5 / 8$ \\
\hline NAA & FALSE & FALSE & FALSE & FALSE & FALSE & FALSE & FALSE & FALSE & FALSE & FALSE \\
\hline Petrographic & FALSE & TRUE $=1 b$ & FALSE & FALSE & FALSE & FALSE & FALSE & FALSE & FALSE & FALSE \\
\hline Isotope Analyses & FALSE & FALSE & FALSE & FALSE & FALSE & FALSE & FALSE & FALSE & FALSE & FALSE \\
\hline Lipid Residue & FALSE & FALSE & FALSE & FALSE & FALSE & FALSE & FALSE & FALSE & FALSE & FALSE \\
\hline
\end{tabular}

* From Late Archaic Component 
The Varga Site

Texas Department of Transportation

Table 0-12. Vessel Group 2 Data

\begin{tabular}{|c|c|c|c|c|c|c|c|c|}
\hline Cat. No. & 781-008 & 799-008-2 & $842-008-1$ & $856-008$ & $908-008$ & $936-008$ & $945-008$ & $965-008$ \\
\hline Unit & N114,E75 & $\mathrm{N} 115, \mathrm{E} 73$ & N118,E70 & N118,E74 & N122,E73 & $\mathrm{N} 123, \mathrm{E} 72$ & $\mathrm{~N} 123, \mathrm{E} 75$ & N124,E74 \\
\hline Depth (cmbd) & $0-15$ & $0-10$ & $0-10$ & $0-10$ & $0-10$ & $0-10$ & $0-10$ & $10-20$ \\
\hline Count & 1 & 1 & 1 & 1 & 1 & 1 & 1 & 1 \\
\hline Sherd Type & Body & Body & Body & Body & Body & Body & Body & Body \\
\hline Ceramic Type & Leon Plain & Leon Plain & Leon Plain & Leon Plain & Leon Plain & Leon Plain & Leon Plain & Leon Plain \\
\hline Temper & $\begin{array}{l}\text { Bone, Gray, } \\
\text { White }\end{array}$ & $\begin{array}{l}\text { Bone, Gray, } \\
\text { Black }\end{array}$ & $\begin{array}{c}\text { Bone, Black, } \\
\text { Gray }\end{array}$ & $\begin{array}{c}\text { Bone, Black, } \\
\text { Gray }\end{array}$ & Bone, Gray & $\begin{array}{c}\text { Bone, Black, } \\
\text { Gray }\end{array}$ & $\begin{array}{l}\text { Bone, Gray, } \\
\text { Black }\end{array}$ & $\begin{array}{c}\text { Bone, } \\
\text { Gray, Black }\end{array}$ \\
\hline Sherd Diameter (mm) & 13.8 & 21.2 & 19.5 & 25 & 14.3 & 14.8 & 22.2 & 39.4 \\
\hline Thickness (mm) & 4.9 & 5.7 & 6 & 8.1 & 5.4 & 6.5 & 8 & 7.3 \\
\hline Wt. (g) & 0.9 & 1.6 & 2.6 & 2.3 & 1.2 & 1.6 & 3.7 & 8.9 \\
\hline Exterior Surface Finish & Smooth & Polished & Polished & Polished & Polished & Polished & Polished & Polished \\
\hline Interior Surface Finish & Smooth & Smooth & Polished & Smooth & Smooth & Smooth & Smooth & Smooth \\
\hline Exterior Surface Color & 7.5YR 6/6 & 7.5YR 6/4 & 10YR 6/4 & $5 Y R 7 / 3$ & 7.5YR 7/6 & $5 Y R 7 / 3$ & 7.5YR 6/4 & 10YR 7/6 \\
\hline Core Color & 7.5YR $7 / 4$ & $5 Y R 6 / 3$ & 7.5YR 7/4 & 7.5YR $7 / 4$ & 7.5YR 7/4 & $5 Y R 6 / 1$ & 10YR 5/1 & $5 Y R 7 / 4$ \\
\hline Interior Surface Color & 7.5YR 7/4 & $7.5 Y R 3 / 0$ & 7.5 YR $6 / 4$ & $5 Y R 6 / 3$ & 7.5YR 7/4 & $5 Y R 7 / 3$ & $7.5 Y R 7 / 4$ & $7.5 Y R 6 / 4$ \\
\hline NAA & FALSE & FALSE & FALSE & FALSE & FALSE & TRUE & FALSE & FALSE \\
\hline Petrographic & FALSE & TRUE & FALSE & FALSE & FALSE & FALSE & FALSE & FALSE \\
\hline Isotope Analyses & FALSE & FALSE & FALSE & FALSE & FALSE & FALSE & FALSE & FALSE \\
\hline Lipid Residue & FALSE & FALSE & FALSE & FALSE & FALSE & FALSE & FALSE & TRUE \\
\hline Cat. No. & $968-008$ & $977-008$ & $981-008$ & $984-008-1$ & $984-008-2$ & $987-008-1 a$ & $992-008$ & $1000-008$ \\
\hline Unit & N124,E75 & $\mathrm{N} 125, \mathrm{E} 70$ & N125,E71 & $\mathrm{N} 125, \mathrm{E} 72$ & $\mathrm{~N} 125, \mathrm{E} 72$ & $\mathrm{~N} 125, \mathrm{E} 73$ & $\mathrm{~N} 125, \mathrm{E} 75$ & N126,E69 \\
\hline Depth (cmbd) & $10-20$ & $0-10$ & $0-10$ & $10-20$ & $10-20$ & $10-20$ & $0-10$ & $20-30$ \\
\hline Count & 1 & 1 & 1 & 1 & 1 & 1 & 1 & 1 \\
\hline Sherd Type & Body & Body & Body & Body & Body & Body & Body & Body \\
\hline Ceramic Type & Leon Plain & Leon Plain & Leon Plain & Leon Plain & Leon Plain & Leon Plain & Leon Plain & Leon Plain \\
\hline Temper & $\begin{array}{l}\text { Bone, White, } \\
\text { Sand }\end{array}$ & Bone, Black & Bone, Black & $\begin{array}{l}\text { Bone, Gray, } \\
\text { Black }\end{array}$ & $\begin{array}{l}\text { Bone, Gray, } \\
\text { Black }\end{array}$ & $\begin{array}{l}\text { Bone, Black, } \\
\text { Gray }\end{array}$ & $\begin{array}{c}\text { Bone, Black, } \\
\text { Gray }\end{array}$ & $\begin{array}{c}\text { Bone, White, } \\
\text { Black }\end{array}$ \\
\hline Sherd Diameter (mm) & 1.1 & 24 & 22 & 19.9 & 18.4 & 19.6 & 19.6 & 21.8 \\
\hline Thickness (mm) & 6.5 & 6.5 & 5.7 & 5.9 & 5.6 & 6.6 & 5.7 & 6.7 \\
\hline Wt. (g) & 0.5 & 2.7 & 1.7 & 2 & 1 & 3 & 1.5 & 1.9 \\
\hline Exterior Surface Finish & Polished & Smooth & Polished & Smooth & Smooth & Polished & Polished & Smooth \\
\hline Interior Surface Finish & Smooth & Smooth & Polished & Smooth & Smooth & Smooth & Smooth & Smooth \\
\hline Exterior Surface Color & 10YR 5/2 & 7.5YR 6/4 & 10YR 5/2 & $7.5 Y R$ R/4 & 7.5YR 7/4 & 7.5YR $7 / 6$ & 10YR $7 / 3$ & $5 Y R 6 / 4$ \\
\hline Core Color & 10YR 4/1 & 7.5YR 5/0 & 10YR 6/3 & $5 Y R 7 / 4$ & $5 Y R 7 / 4$ & 7.5YR $7 / 4$ & $5 Y R 5 / 1$ & $5 Y R 6 / 3$ \\
\hline Interior Surface Color & $5 Y R 5 / 4$ & $7.5 Y R 6 / 6$ & 7.5YR $6 / 4$ & 7.5YR $7 / 4$ & 7.5YR $7 / 4$ & 10YR 5/1 & 7.5YR $7 / 4$ & $5 Y R 6 / 3$ \\
\hline NAA & FALSE & FALSE & FALSE & FALSE & FALSE & FALSE & FALSE & FALSE \\
\hline Petrographic & FALSE & FALSE & FALSE & FALSE & FALSE & FALSE & FALSE & FALSE \\
\hline Isotope Analyses & FALSE & FALSE & FALSE & FALSE & FALSE & FALSE & FALSE & FALSE \\
\hline Lipid Residue & FALSE & FALSE & FALSE & FALSE & FALSE & FALSE & FALSE & FALSE \\
\hline
\end{tabular}


Appendix O: Data and Site Artifact Database

Table 0-12. Vessel Group 2 Data Continued

\begin{tabular}{|c|c|c|c|c|c|c|c|c|c|}
\hline Cat. No. & $1008-008-1$ & $1096-008-2$ & $1096-008-3$ & $1100-008$ & $1129-008-1 a$ & $1157-008$ & $1162-008-1$ & $1181-008$ & $1187-008$ \\
\hline Unit & N126,E72 & N129,E73 & N129,E73 & N129,E75 & N130,E74 & N131,E73 & N131,E75 & N132,E75 & N133,E71 \\
\hline Depth (cmbd) & $20-30$ & $20-30$ & $20-30$ & $0-10$ & $20-30$ & $0-10$ & $0-10$ & $0-10$ & $20-30$ \\
\hline Count & 1 & 1 & 1 & 1 & 1 & 1 & 1 & 1 & 1 \\
\hline Sherd Type & Body & Body & Body & Body & Body & Body & Body & Body & Body \\
\hline Ceramic Type & Leon Plain & Leon Plain & Leon Plain & Leon Plain & Leon Plain & Leon Plain & Leon Plain & Leon Plain & Leon Plain \\
\hline Temper & Bone, Gray & $\begin{array}{l}\text { Bone, Gray, } \\
\text { Black }\end{array}$ & $\begin{array}{l}\text { Bone, Gray, } \\
\text { Black }\end{array}$ & $\begin{array}{l}\text { Bone, Gray, } \\
\text { Black, Sand }\end{array}$ & Bone, Gray & Bone, Black & $\begin{array}{l}\text { Bone, Gray, } \\
\text { Black }\end{array}$ & $\begin{array}{c}\text { Bone, } \\
\text { Black, Gray }\end{array}$ & Bone, Gray \\
\hline $\begin{array}{l}\text { Sherd Diameter } \\
(\mathrm{mm})\end{array}$ & 18.2 & 15.3 & 17.6 & 21 & 12.8 & 37 & 17 & 20 & 31.3 \\
\hline Thickness (mm) & 7 & 5.5 & 5.7 & 4.9 & 5.6 & 6.5 & 6.5 & 6.6 & 4.8 \\
\hline Wt. (g) & 1.5 & 1.4 & 2.2 & 1.2 & 0.9 & 6.4 & 0.9 & 3.1 & 2.2 \\
\hline $\begin{array}{l}\text { Exterior Surface } \\
\text { Finish }\end{array}$ & Polished & Smooth & Smooth & Smooth & Smooth & Polished & Polished & Polished & Smooth \\
\hline $\begin{array}{l}\text { Interior Surface } \\
\text { Finish }\end{array}$ & Smooth & Smooth & Smooth & Rough & Smooth & Smooth & Rough & Smooth & Smooth \\
\hline $\begin{array}{c}\text { Exterior Surface } \\
\text { Color }\end{array}$ & 5YR $7 / 4$ & 7.5YR 7/4 & 7.5YR 7/4 & $5 Y R 6 / 2$ & 7.5YR 7/4 & 7.5YR 7/4 & 7.5YR 7/4 & $5 Y R 7 / 3$ & 5YR 6/1 \\
\hline Core Color & $5 Y R 6 / 2$ & 7.5YR 7/4 & 7.5YR 7/4 & $5 Y R 6 / 2$ & 7.5YR 7/4 & 7.5YR 7/4 & 5YR 5/1 & 5YR 5/1 & 10YR 6/3 \\
\hline $\begin{array}{c}\text { Interior Surface } \\
\text { Color }\end{array}$ & 5YR 6/2 & 7.5YR 6/4 & 7.5YR 6/4 & $5 Y R 6 / 3$ & 7.5YR 7/4 & 7.5YR 6/4 & 7.5YR 8/4 & $5 Y R 7 / 3$ & 10YR 5/2 \\
\hline NAA & FALSE & FALSE & FALSE & FALSE & TRUE & FALSE & FALSE & FALSE & FALSE \\
\hline Petrographic & FALSE & FALSE & FALSE & FALSE & FALSE & FALSE & FALSE & TRUE & FALSE \\
\hline Isotope Analyses & FALSE & FALSE & FALSE & FALSE & FALSE & TRUE = 1b & FALSE & FALSE & FALSE \\
\hline Lipid Residue & FALSE & FALSE & FALSE & FALSE & FALSE & TRUE = 1a & FALSE & FALSE & FALSE \\
\hline
\end{tabular}


The Varga Site

Texas Department of Transportation

Table 0-13. Vessel Group 3 Data

\begin{tabular}{|c|c|c|c|c|c|c|c|c|}
\hline Cat. No. & $262-005-008$ & 281-008 & $405-008$ & 481-008 & $782-008-1$ & $782-008-2$ & 796-008 & 806-008 \\
\hline Unit & $\mathrm{N} 102, \mathrm{E} 47$ & N102,E51 & $\mathrm{N} 104, \mathrm{E} 47$ & $\mathrm{~N} 105, \mathrm{E} 56$ & N114,E75 & N114,E75 & N115,E72 & N115,E75 \\
\hline Depth (cmbd) & $30-40$ & $10-20$ & $10-20$ & $10-20$ & $15-25$ & $15-25$ & $0-10$ & $15-30$ \\
\hline Count & 1 & 1 & 1 & 1 & 1 & 1 & 1 & 1 \\
\hline Sherd Type & Body & Body & Body & Body & Rim & Body & Body & Body \\
\hline Ceramic Type & Leon Plain & Leon Plain & Leon Plain & Leon Plain & Leon Plain & Leon Plain & Leon Plain & Leon Plain \\
\hline Temper & $\begin{array}{c}\text { Bone, White, } \\
\text { Gray }\end{array}$ & $\begin{array}{l}\text { Bone, White, } \\
\text { Sand }\end{array}$ & Bone, White & Bone, White & Bone, White & Bone, White & $\begin{array}{c}\text { Bone, White, } \\
\text { Sand }\end{array}$ & $\begin{array}{l}\text { Bone, Gray, } \\
\text { White, Sand }\end{array}$ \\
\hline Sherd Diameter $(\mathrm{mm})$ & 18.2 & 13.6 & 16.8 & 16.2 & 26.3 & 15.7 & 15.4 & 12.5 \\
\hline Thickness (mm) & & 5.4 & 6.1 & 5.6 & 6.3 & 6.3 & 5.5 & 5.8 \\
\hline Wt. (g) & 1.5 & 0.5 & 1.1 & 1.1 & 1.7 & 2.3 & 1 & 0.5 \\
\hline Exterior Surface Finish & Polished & Smooth & Smooth & Polished & Polished & Smooth & Polished & Smooth \\
\hline Interior Surface Finish & Gone & Smooth & Smooth & Polished & Polished & Smooth & Smooth & Smooth \\
\hline Exterior Surface Color & $5 Y R 6 / 2$ & 7.5YR 6/4 & 10YR 6/4 & $5 Y R 6 / 4$ & $5 Y R 7 / 6$ & 7.5YR 5/2 & 7.5YR $6 / 2$ & $5 Y R 6 / 4$ \\
\hline Core Color & 5YR 5/1 & $5 Y R 5 / 1$ & 7.5YR 6/4 & $5 Y R 6 / 3$ & $5 Y R 7 / 2$ & 10YR 4/1 & $5 Y R 6 / 2$ & $5 Y R 5 / 2$ \\
\hline Interior Surface Color & & $5 Y R 6 / 4$ & $7.5 Y R 7 / 4$ & $5 Y R 7 / 4$ & $5 Y R 7 / 4$ & 7.5YR 6/4 & $5 Y R 6 / 4$ & $5 Y R 6 / 4$ \\
\hline NAA & FALSE & FALSE & FALSE & FALSE & FALSE & FALSE & FALSE & FALSE \\
\hline Petrographic & FALSE & FALSE & FALSE & TRUE & FALSE & FALSE & FALSE & FALSE \\
\hline Isotope Analyses & FALSE & FALSE & FALSE & FALSE & FALSE & FALSE & FALSE & FALSE \\
\hline Lipid Residue & FALSE & FALSE & FALSE & FALSE & FALSE & FALSE & FALSE & FALSE \\
\hline Cat. No. & $840-008$ & 862-008 & $867-008-1$ & $867-008-2$ & $867-008-3$ & $875-008$ & 879-008 & 880-008 \\
\hline Unit & $\mathrm{N} 118, \mathrm{E} 69$ & N119,E69 & $\mathrm{N} 119, \mathrm{E} 71$ & $\mathrm{~N} 119, \mathrm{E} 71$ & N119,E71 & $\mathrm{N} 119, \mathrm{E} 74$ & $\mathrm{~N} 119, \mathrm{E} 75$ & N120,E69 \\
\hline Depth (cmbd) & $0-10$ & $0-10$ & $10-20$ & $10-20$ & $10-20$ & $10-20$ & $20-30$ & $0-18$ \\
\hline Count & 1 & 1 & 1 & 1 & 1 & 1 & 1 & 1 \\
\hline Sherd Type & Body & Body & Body & Body & Body & Body & Body & Body \\
\hline Ceramic Type & Leon Plain & Leon Plain & Leon Plain & Leon Plain & Leon Plain & Leon Plain & Leon Plain & Leon Plain \\
\hline Temper & $\begin{array}{l}\text { Bone, White, } \\
\text { Gray, Sand }\end{array}$ & $\begin{array}{c}\text { Bone, White, } \\
\text { Gray }\end{array}$ & Bone, White & Bone, White & $\begin{array}{c}\text { Bone, White, } \\
\text { Gray }\end{array}$ & Bone, White & $\begin{array}{l}\text { Bone, Gray, } \\
\text { White, Sand }\end{array}$ & $\begin{array}{l}\text { Bone, White, } \\
\text { Sand, Gray }\end{array}$ \\
\hline Sherd Diameter (mm) & 13.6 & 22.2 & 14 & & 11 & 21.3 & 22 & \\
\hline Thickness (mm) & 6.3 & 6.6 & 6.6 & 7.3 & 6 & 4.9 & 5.8 & 6.6 \\
\hline Wt. (g) & 1.2 & 1.4 & 1.2 & 1 & 0.4 & 1 & 2.2 & 1.9 \\
\hline Exterior Surface Finish & Polished & Polished & Polished & Smooth & Polished & Smooth & Smooth & Rough \\
\hline Interior Surface Finish & Smooth & Rough & Polished & Rough & Polished & Smooth & Rough & Smooth \\
\hline Exterior Surface Color & 7.5YR 6/4 & 7.5YR 6/6 & 7.5YR 7/6 & $5 Y R 7 / 3$ & 7.5YR 4/4 & $5 Y R 6 / 3$ & $5 Y R 6 / 4$ & 7.5YR 5/4 \\
\hline Core Color & 7.5YR $6 / 2$ & 7.5YR $5 / 2$ & 7.5YR 6/4 & 10YR 5/1 & $5 Y R 4 / 1$ & $5 Y R 5 / 2$ & $5 Y R 4 / 1$ & $5 Y R 5 / 2$ \\
\hline Interior Surface Color & 7.5YR 5/4 & 7.5YR 6/4 & 7.5YR 7/4 & 10YR 6/3 & $5 Y R 4 / 4$ & $5 Y R 6 / 6$ & $5 Y R 5 / 4$ & 7.5YR 7/2 \\
\hline NAA & TRUE $=1 \mathrm{a}$ & FALSE & TRUE & FALSE & FALSE & FALSE & FALSE & FALSE \\
\hline Petrographic & TRUE $=1 \mathrm{~b}$ & FALSE & FALSE & FALSE & FALSE & FALSE & FALSE & FALSE \\
\hline Isotope Analyses & FALSE & FALSE & FALSE & FALSE & FALSE & FALSE & FALSE & FALSE \\
\hline Lipid Residue & FALSE & FALSE & FALSE & FALSE & FALSE & FALSE & FALSE & FALSE \\
\hline
\end{tabular}


Appendix O: Data and Site Artifact Database

Table 0-13. Vessel Group 3 Data Continued

\begin{tabular}{|c|c|c|c|c|c|c|c|}
\hline Cat. No. & $881-008$ & $884-008$ & $888-008$ & $900-008$ & $901-008$ & $933-008$ & $937-008-1 b$ \\
\hline Unit & $\mathrm{N} 120, \mathrm{E} 70$ & N120,E71 & N120,E73 & $\mathrm{N} 122, \mathrm{E} 70$ & $\mathrm{~N} 122, \mathrm{E} 70$ & N123,E71 & N123,E72 \\
\hline Depth (cmbd) & $0-10$ & $10-20$ & $0-10$ & $0-10$ & $10-20$ & $0-10$ & $10-20$ \\
\hline Count & 1 & 1 & 1 & 1 & 1 & 1 & 1 \\
\hline Sherd Type & Body & Body & Body & Body & Body & Body & Body \\
\hline Ceramic Type & Leon Plain & Leon Plain & Leon Plain & Leon Plain & Leon Plain & Leon Plain & Leon Plain \\
\hline Temper & Bone, White & $\begin{array}{c}\text { Bone, White, } \\
\text { Sand }\end{array}$ & $\begin{array}{c}\text { Bone, White, } \\
\text { Gray, Sand }\end{array}$ & $\begin{array}{c}\text { Bone, White, } \\
\text { Sand }\end{array}$ & $\begin{array}{l}\text { Bone, Gray, } \\
\text { Sand, White }\end{array}$ & Bone, White & Bone, White \\
\hline Sherd Diameter (mm) & 24.8 & 16.6 & 19.1 & & & 15 & \\
\hline Thickness (mm) & 6.7 & 4.9 & 6 & 7.5 & 7.1 & 4.4 & 5.7 \\
\hline Wt. (g) & 3.1 & 1.1 & 0.8 & 3.8 & 3.6 & 0.7 & 1.4 \\
\hline Exterior Surface Finish & Polished & Smooth-Dull & Smooth & Polished & Smooth & Polished & Smooth \\
\hline Interior Surface Finish & Polished & Polished & Rough & Polished & Smooth & Smooth & Smooth \\
\hline Exterior Surface Color & 7.5YR 7/6 & 10YR 5/2 & 5YR 6/4 & 5YR 6/4 & 10YR 5/1 & 5YR 7/2 & 7.5YR 6/4 \\
\hline Core Color & 7.5YR 6/4 & 10YR 5/2 & 5YR 5/4 & 7.5YR 5/2 & 7.5YR 5/4 & 7.5YR 6/4 & 5YR 6/6 \\
\hline Interior Surface Color & 7.5YR 6/4 & 5YR 5/4 & 5YR 6/4 & 7.5YR 6/4 & 7.5YR 6/4 & 7.5YR 6/2 & 5YR 6/4 \\
\hline NAA & FALSE & FALSE & FALSE & FALSE & FALSE & FALSE & FALSE \\
\hline Petrographic & FALSE & FALSE & FALSE & FALSE & FALSE & FALSE & FALSE \\
\hline Isotope Analyses & FALSE & FALSE & FALSE & TRUE $=1 \mathrm{a}$ & TRUE $=1 \mathrm{a}$ & FALSE & FALSE \\
\hline Lipid Residue & FALSE & FALSE & FALSE & TRUE = 1b & TRUE $=1 b$ & FALSE & TRUE \\
\hline Cat. No. & $949-008$ & $961-008$ & $1002-008$ & $1036-008$ & $1044-008$ & $1118-008$ & $1133-008$ \\
\hline Unit & $\mathrm{N} 124, \mathrm{E} 69$ & $\mathrm{~N} 124, \mathrm{E} 73$ & N126,E70 & N127,E69 & $\mathrm{N} 127, \mathrm{E} 72$ & N130,E71 & N130,E75 \\
\hline Depth (cmbd) & 8-18 & $10-20$ & $8-19$ & $10-20$ & $10-20$ & $20-30$ & $20-30$ \\
\hline Count & 1 & 1 & 1 & 1 & 1 & 1 & 1 \\
\hline Sherd Type & Body & Body & Body & Body & Body & Body & Body \\
\hline Ceramic Type & Leon Plain & Leon Plain & Leon Plain & Leon Plain & Leon Plain & Leon Plain & Leon Plain \\
\hline Temper & Bone, White & $\begin{array}{c}\text { Bone, White, } \\
\text { Gray, Sand }\end{array}$ & $\begin{array}{l}\text { Bone, White, } \\
\text { Sand }\end{array}$ & Bone, White & $\begin{array}{l}\text { Bone, White, } \\
\text { Sand }\end{array}$ & Bone, White & Bone, White \\
\hline Sherd Diameter (mm) & 13.8 & 13.6 & 18.5 & 20 & 20.4 & 17.6 & 22.1 \\
\hline Thickness (mm) & 6 & 6.7 & 4.7 & & 6.2 & 4.5 & 6.4 \\
\hline Wt. (g) & 1 & 0.8 & 1 & 1.3 & 1.3 & 0.9 & 1.2 \\
\hline Exterior Surface Finish & Polished & Polished & Polished & Eroded & Polished & Polished & Polished \\
\hline Interior Surface Finish & Smooth & Smooth & Smooth & Polished & Smooth & Smooth & Polished \\
\hline Exterior Surface Color & $5 Y R 6 / 3$ & $5 Y R 7 / 3$ & $10 Y R 5 / 1 \& 5 / 4$ & 5YR 6/3 & 7.5YR 6/2 & 5YR 7/4 & 7.5YR 7/4 \\
\hline Core Color & 7.5YR 6/4 & 5YR 6/2 & $\begin{array}{c}\text { 10YR 5/2 \& } \\
\text { 5YR 5/4 }\end{array}$ & 5YR 5/1 & 5YR 5/1 & 5YR 7/4 & 7.5YR 6/6 \\
\hline Interior Surface Color & 5YR 6/4 & 5YR 6/4 & 5YR 5/4 & 5YR 6/4 & 7.5YR 5/4 & 5YR 7/4 & 5YR 6/6 \\
\hline NAA & FALSE & FALSE & FALSE & FALSE & FALSE & FALSE & FALSE \\
\hline Petrographic & FALSE & FALSE & FALSE & FALSE & FALSE & FALSE & FALSE \\
\hline Isotope Analyses & FALSE & FALSE & FALSE & FALSE & FALSE & FALSE & FALSE \\
\hline Lipid Residue & FALSE & FALSE & FALSE & FALSE & FALSE & FALSE & FALSE \\
\hline
\end{tabular}


The Varga Site

Texas Department of Transportation

Table 0-14. Vessel Group 4 Data

\begin{tabular}{|c|}
\hline Cat. No. \\
\hline Unit \\
\hline Depth (cmbd) \\
\hline Count \\
\hline Sherd Type \\
\hline Ceramic Type \\
\hline Temper \\
\hline Sherd Diameter (mm) \\
\hline Thickness (mm) \\
\hline Wt. (g) \\
\hline Exterior Surface Finish \\
\hline Interior Surface Finish \\
\hline Exterior Surface Color \\
\hline Core Color \\
\hline Interior Surface Color \\
\hline NAA \\
\hline Petrographic \\
\hline Isotope Analyses \\
\hline Lipid Residue \\
\hline
\end{tabular}

\begin{tabular}{|c|c|c|c|c|c|}
\hline $159-005-008-1$ & $159-005-008-2$ & $159-005-008-3$ & $159-005-008-4$ & $159-005-008-5$ & $159-005-008-6$ \\
\hline $\mathrm{N} 101, \mathrm{E} 47$ & N101,E47 & N101,E47 & N101,E47 & N101,E47 & N101,E47 \\
\hline $30-40$ & $30-40$ & $30-40$ & $30-40$ & $30-40$ & $30-40$ \\
\hline 1 & 1 & 1 & 1 & 1 & 1 \\
\hline Body & Rim & ? Base & Body & Body & Body \\
\hline Leon Plain & Leon Plain & Leon Plain & Leon Plain & Leon Plain & Leon Plain \\
\hline Bone, White, Gray & Bone, White, Gray & Bone, White, Gray & Bone, White, Gray & Bone, White, Gray & Bone, White, Gray \\
\hline 26 & 28 & 22.5 & 19.4 & 18.5 & 14 \\
\hline 8.4 & 5.2 & 8.5 & 5.6 & 6.4 & 7.4 \\
\hline 6.8 & 2.8 & 3.1 & 1.8 & 1.4 & \\
\hline Smooth & Smooth & Smooth & Smooth & Smooth & Smooth \\
\hline Smooth & Rough & Smooth & Smooth & Smooth & Smooth \\
\hline 7.5YR 6/4 & 10YR 5/2 & 7.5YR 6/4 & 7.5YR 7/4 & 7.5YR 6/4 & 7.5YR 6/4 \\
\hline 10YR 4/1 & 5 YR 4/1 & 10YR 4/1 & 10YR 4/1 & 10YR 4/1 & 10YR 4/1 \\
\hline 7.5YR 6/6 & 7.5YR 5/4 & 7.5YR 6/6 & 7.5YR 7/4 & 7.5 YR 6/6 & 7.5 YR 6/6 \\
\hline TRUE $=1 \mathrm{c}$ & FALSE & FALSE & FALSE & FALSE & FALSE \\
\hline TRUE $=1 b$ & FALSE & FALSE & FALSE & FALSE & FALSE \\
\hline FALSE & FALSE & FALSE & FALSE & FALSE & FALSE \\
\hline FALSE & FALSE & FALSE & FALSE & FALSE & FALSE \\
\hline
\end{tabular}

\begin{tabular}{|c|}
\hline Cat. No. \\
\hline Unit \\
\hline Depth (cmbd) \\
\hline Count \\
\hline Sherd Type \\
\hline Ceramic Type \\
\hline Temper \\
\hline Sherd Diameter (mm) \\
\hline Thickness (mm) \\
\hline Wt. (g) \\
\hline Exterior Surface Finish \\
\hline Interior Surface Finish \\
\hline Exterior Surface Color \\
\hline Core Color \\
\hline Interior Surface Color \\
\hline NAA \\
\hline Petrographic \\
\hline Isotope Analyses \\
\hline Lipid Residue \\
\hline
\end{tabular}

\begin{tabular}{|c|c|c|c|c|c|}
\hline $159-005-008-7$ & $168-008-1 b$ & $206-008$ & $272-008$ & $618-008$ & 799-008-1 \\
\hline N101,E47 & $\mathrm{N} 101, \mathrm{E} 50$ & N101,E53 & $\mathrm{N} 102, \mathrm{E} 50$ & N108,E47 & $\mathrm{N} 115, \mathrm{E} 73$ \\
\hline $30-40$ & $20-30$ & $0-10$ & $20-28$ & $0-10$ & $0-10$ \\
\hline 1 & 1 & 1 & 1 & 1 & 1 \\
\hline Body & Body & Body & Body & Body & Body \\
\hline Leon Plain & & Leon Plain & Leon Plain & Leon Plain & Leon Plain \\
\hline \multirow[t]{4}{*}{ Bone, White, Gray } & Bone, White & Bone, White & Bone, White, Black & Bone, White & Bone, Black, Gray \\
\hline & & 34.4 & 14.1 & 33.3 & \\
\hline & 8.3 & 9 & 8.7 & 8.3 & 8.3 \\
\hline & 1.2 & 3.8 & 1.7 & 8.7 & 3.5 \\
\hline Smooth & Smooth & Smooth & Smooth & Smooth & Rough \\
\hline Smooth & Smooth & Rough & Rough & Rough & Rough \\
\hline 7.5YR 6/4 & $5 Y R 7 / 3$ & 7.5YR 6/4 & $5 Y R 7 / 3$ & 10YR 6/2 & 7.5YR 7/4 \\
\hline 10YR 4/1 & 5YR 4/1 & 10YR 4/1 & 5YR 5/1 & 10YR 4/1 & 10YR 5/1 \\
\hline 7.5 YR 6/6 & $5 Y R 5 / 2$ & 7.5YR 4/2 & $5 Y R 6 / 3$ & 10YR 5/2 & 10YR 6/3 \\
\hline FALSE & TRUE = 1c & FALSE & TRUE & FALSE & FALSE \\
\hline FALSE & TRUE & FALSE & FALSE & FALSE & TRUE \\
\hline FALSE & FALSE & FALSE & FALSE & FALSE & FALSE \\
\hline FALSE & FALSE & FALSE & FALSE & FALSE & FALSE \\
\hline
\end{tabular}


Appendix O: Data and Site Artifact Database

Table 0-15. All Ceramic Data

\begin{tabular}{|c|c|c|c|c|c|c|c|c|c|c|c|}
\hline Cat. No. & $158-005-008$ & $159-005-008-1$ & $159-005-008-2$ & \multicolumn{2}{|c|}{$159-005-008-3$} & \multicolumn{2}{|c|}{$159-005-008-4$} & 159 & $3-005-008-5$ & $159-005-008-6$ & $159-005-008-7$ \\
\hline Unit & N101,E47 & N101,E47 & $\mathrm{N} 101, \mathrm{E} 47$ & \multicolumn{2}{|c|}{$\mathrm{N} 101, \mathrm{E} 47$} & \multicolumn{2}{|c|}{ N101,E47 } & & V101,E47 & N101,E47 & $\mathrm{N} 101, \mathrm{E} 47$ \\
\hline Depth (cmbd) & $20-30$ & $30-40$ & $30-40$ & \multicolumn{2}{|c|}{$30-40$} & \multicolumn{2}{|c|}{$30-40$} & & $30-40$ & $30-40$ & $30-40$ \\
\hline Count & 1 & 1 & 1 & \multicolumn{2}{|c|}{1} & \multicolumn{2}{|c|}{1} & & 1 & 1 & 1 \\
\hline Sherd Type & Body & Body & Rim & \multicolumn{2}{|c|}{ Base } & \multicolumn{2}{|c|}{ Body } & & Body & Body & Body \\
\hline Ceramic Type & Leon Plain & Leon Plain & Leon Plain & \multicolumn{2}{|c|}{ Leon Plain } & \multicolumn{2}{|c|}{ Leon Plain } & & eon Plain & Leon Plain & Leon Plain \\
\hline Temper & Bone, White & $\begin{array}{c}\text { Bone, White } \\
\text { Gray }\end{array}$ & $\begin{array}{c}\text { Bone, Wh } \\
\text { Gray }\end{array}$ & $\begin{array}{r}\text { Bone, } \\
\mathrm{Gr}\end{array}$ & hite, & Bone & $\begin{array}{l}\text { White, } \\
\text { ray }\end{array}$ & & $\begin{array}{l}\text { ne, White, } \\
\text { Gray }\end{array}$ & $\begin{array}{c}\text { Bone, White, } \\
\text { Gray }\end{array}$ & $\begin{array}{c}\text { Bone, White, } \\
\text { Gray }\end{array}$ \\
\hline Sherd Diameter (mm) & 13.5 & 26 & 28 & 22 & & & 9.4 & & 18.5 & 14 & \\
\hline Thickness (mm) & 4.7 & 8.4 & 5.2 & 8. & & & 5.6 & & 6.4 & 7.4 & \\
\hline Wt. (g) & 0.7 & 6.8 & 2.8 & 3. & & & 1.8 & & 1.4 & & \\
\hline Exterior Surface Finish & Smooth & Smooth & Smooth & Smc & & & 100th & & Smooth & Smooth & Smooth \\
\hline Interior Surface Finish & Rough & Smooth & Rough & Smc & & & 100th & & Smooth & Smooth & Smooth \\
\hline Exterior Surface Color & $5 Y R 6 / 4$ & 7.5YR 6/4 & 10YR 5/ & $7.5 \mathrm{YF}$ & & 7.5 & R $7 / 4$ & & $.5 Y R 6 / 4$ & 7.5YR $6 / 4$ & 7.5YR 6/4 \\
\hline Core Color & $5 Y R 5 / 1$ & 10YR 4/1 & 5 YR $4 /$ & $10 Y F$ & & & R 4/1 & & LYR 4/1 & 10YR 4/1 & 10YR 4/1 \\
\hline Interior Surface Color & $5 Y R 5 / 4$ & 7.5YR $6 / 6$ & $7.5 Y R 5 /$ & $7.5 \mathrm{YP}$ & & 7.5 & R $7 / 4$ & & .5 YR 6/6 & 7.5 YR $6 / 6$ & 7.5 YR $6 / 6$ \\
\hline Vessel Group & 1 & 4 & 4 & 4 & & & 4 & & 4 & 4 & 4 \\
\hline NAA & FALSE & TRUE $=1 \mathrm{C}$ & FALSE & FAL & & & LSE & & FALSE & FALSE & FALSE \\
\hline Petrographic & FALSE & TRUE $=1 b$ & FALSE & FAL & & & LSE & & FALSE & FALSE & FALSE \\
\hline Isotope Analyses & FALSE & FALSE & FALSE & FAL & & & LSE & & FALSE & FALSE & FALSE \\
\hline Cat. No. & $168-008-1 b$ & 206-008 & $262-005-008$ & 271-008 & 272 & 008 & $281-0$ & & 405-008 & 481-008 & $618-008$ \\
\hline Unit & $\mathrm{N} 101, \mathrm{E} 50$ & N101,E53 & $\mathrm{N} 102, \mathrm{E} 47$ & $\mathrm{~N} 102, \mathrm{E} 50$ & N10 & E50 & $\mathrm{N} 102, \mathrm{E}$ & & $\mathrm{N} 104, \mathrm{E} 47$ & $\mathrm{~N} 105, \mathrm{E} 56$ & N108,E47 \\
\hline Depth (cmbd) & $20-30$ & $0-10$ & $30-40$ & $10-20$ & & & $10-2$ & & $10-20$ & $10-20$ & $0-10$ \\
\hline Count & 1 & 1 & 1 & 1 & & & 1 & & 1 & 1 & 1 \\
\hline Sherd Type & Body & Body & Body & Body & & & Bod & & Body & Body & Body \\
\hline Ceramic Type & & Leon Plain & Leon Plain & Leon Plain & Leor & Plain & Leon $\mathrm{P}$ & & Leon Plain & Leon Plain & Leon Plain \\
\hline Temper & Bone, White & Bone, White & $\begin{array}{c}\text { Bone, White, } \\
\text { Gray }\end{array}$ & Bone, White & $\begin{array}{r}\text { Bone } \\
\text { B }\end{array}$ & $\begin{array}{l}\text { White, } \\
\text { ck }\end{array}$ & $\begin{array}{l}\text { Bone, W } \\
\text { San }\end{array}$ & & Bone, White & Bone, White & Bone, White \\
\hline Sherd Diameter (mm) & & 34.4 & 18.2 & 18 & & & 13.6 & & & 16.2 & 33.3 \\
\hline Thickness (mm) & 8.3 & 9 & & 5 & & & 5.4 & & 6.1 & 5.6 & 8.3 \\
\hline Wt. (g) & 1.2 & 3.8 & 1.5 & 1.7 & & & 0.5 & & 1.1 & 1.1 & 8.7 \\
\hline Exterior Surface Finish & Smooth & Smooth & Polished & Smooth & & ooth & Smoo & & Smooth & Polished & Smooth \\
\hline Interior Surface Finish & Smooth & Rough & Gone & Smooth & & & Smoo & & Smooth & Polished & Rough \\
\hline Exterior Surface Color & $5 Y R 7 / 3$ & 7.5YR 6/4 & $5 Y R 6 / 2$ & 7.5YR 6/4 & & $7 / 3$ & 7.5YR & & 10YR 6/4 & $5 Y R 6 / 4$ & 10YR 6/2 \\
\hline Core Color & $5 Y R 4 / 1$ & 10YR 4/1 & $5 Y R 5 / 1$ & 10YR 4/1 & & $5 / 1$ & $5 Y R 5$ & & 7.5YR 6/4 & $5 Y R 6 / 3$ & 10YR 4/1 \\
\hline Interior Surface Color & $5 Y R 5 / 2$ & 7.5YR 4/2 & & 7.5YR 5/6 & & $6 / 3$ & $5 Y R 6$ & & $7.5 Y R 7 / 4$ & $5 Y R 7 / 4$ & 10YR 5/2 \\
\hline Vessel Group & 4 & 4 & 3 & 1 & & & 3 & & 3 & 3 & 4 \\
\hline NAA & TRUE & FALSE & FALSE & FALSE & & & FALS & & FALSE & FALSE & FALSE \\
\hline Petrographic & TRUE & FALSE & FALSE & FALSE & & SE & FALS & & FALSE & TRUE & FALSE \\
\hline Isotope Analyses & FALSE & FALSE & FALSE & FALSE & & SE & FALS & & FALSE & FALSE & FALSE \\
\hline
\end{tabular}


The Varga Site

Texas Department of Transportation

Table 0-15. All Ceramic Data Continued

\begin{tabular}{|c|c|c|c|c|c|c|c|c|c|}
\hline Cat. No. & 781-008 & $782-008-1$ & $782-008-2$ & $785-008$ & 796-008 & 799-008-1 & $799-008-2$ & 806-008 & $832-008$ \\
\hline Unit & $\mathrm{N} 114, \mathrm{E} 75$ & $\mathrm{~N} 114, \mathrm{E} 75$ & $\mathrm{~N} 114, \mathrm{E} 75$ & $\mathrm{~N} 115, \mathrm{E} 69$ & $\mathrm{~N} 115, \mathrm{E} 72$ & N115,E73 & N115,E73 & N115,E75 & $\mathrm{N} 117, \mathrm{E} 72$ \\
\hline Depth (cmbd) & $0-15$ & $15-25$ & $15-25$ & $0-10$ & $0-10$ & $0-10$ & $0-10$ & $15-30$ & 16 \\
\hline Count & 1 & 1 & 1 & 1 & 1 & 1 & 1 & 1 & 1 \\
\hline Sherd Type & Body & Rim & Body & Body & Body & Body & Body & Body & \\
\hline Ceramic Type & Leon Plain & Leon Plain & Leon Plain & Leon Plain & Leon Plain & Leon Plain & Leon Plain & Leon Plain & \\
\hline Temper & $\begin{array}{c}\text { Bone, Gray, } \\
\text { White }\end{array}$ & Bone, White & Bone, White & $\begin{array}{c}\text { Bone, White, } \\
\text { Grey }\end{array}$ & $\begin{array}{c}\text { Bone, White, } \\
\text { Sand }\end{array}$ & $\begin{array}{c}\text { Bone, Black, } \\
\text { Gray }\end{array}$ & $\begin{array}{c}\text { Bone, Gray, } \\
\text { Black }\end{array}$ & $\begin{array}{l}\text { Bone, Gray, } \\
\text { White, Sand }\end{array}$ & \\
\hline Sherd Diameter (mm) & 13.8 & & & 14 & & & 21.2 & 12.5 & \\
\hline Thickness (mm) & 4.9 & 6.3 & 6.3 & 6.1 & 5.5 & 8.3 & 5.7 & 5.8 & \\
\hline Wt. (g) & 0.9 & 1.7 & 2.3 & 0.6 & 1 & 3.5 & 1.6 & 0.5 & \\
\hline Exterior Surface Finish & Smooth & Polished & Smooth & Smooth & Polished & Rough & Polished & Smooth & \\
\hline Interior Surface Finish & Smooth & Polished & Smooth & Smooth & Smooth & Rough & Smooth & Smooth & \\
\hline Exterior Surface Color & 7.5YR 6/6 & 5YR 7/6 & $7.5 Y R$ 5/2 & 7.5YR 6/4 & 7.5YR 6/2 & 7.5YR 7/4 & 7.5YR 6/4 & 5YR 6/4 & \\
\hline Core Color & $7.5 Y R$ 7/4 & $5 Y R 7 / 2$ & 10YR 4/1 & $7.5 Y R$ 5/2 & 5YR 6/2 & 10YR 5/1 & $5 Y R 6 / 3$ & 5YR 5/2 & \\
\hline Interior Surface Color & 7.5YR 7/4 & 5YR 7/4 & 7.5YR 6/4 & 7.5YR 6/2 & 5YR 6/4 & 10YR 6/3 & 7.5YR 3/0 & 5YR 6/4 & \\
\hline Vessel Group & 2 & 3 & 3 & 1 & 3 & 4 & 2 & 3 & \\
\hline NAA & FALSE & FALSE & FALSE & FALSE & FALSE & FALSE & FALSE & FALSE & FALSE \\
\hline Petrographic & FALSE & FALSE & FALSE & FALSE & FALSE & TRUE & TRUE & FALSE & FALSE \\
\hline Isotope Analyses & FALSE & FALSE & FALSE & FALSE & FALSE & FALSE & FALSE & FALSE & FALSE \\
\hline Cat. No. & $840-008$ & $841-008-1$ & $841-008-2$ & $842-008-1$ & $842-008-2$ & 843-008 & $845-008$ & $856-008$ & $862-008$ \\
\hline Unit & N118,E69 & N118,E69 & N118,E69 & N118,E70 & N118,E70 & N118,E70 & N118,E71 & N118,E74 & N119,E69 \\
\hline Depth (cmbd) & $0-10$ & $10-20$ & $10-20$ & $0-10$ & $0-10$ & $10-20$ & $10-20$ & $0-10$ & $0-10$ \\
\hline Count & 1 & 1 & 1 & 1 & 1 & 1 & 1 & 1 & 1 \\
\hline Sherd Type & Body & Body & Body & Body & Body & Body & Body & Body & Body \\
\hline Ceramic Type & Leon Plain & Leon Plain & Leon Plain & Leon Plain & Leon Plain & Leon Plain & Leon Plain & Leon Plain & Leon Plain \\
\hline Temper & $\begin{array}{c}\text { Bone, White, } \\
\text { Gray, Sand }\end{array}$ & $\begin{array}{c}\text { Bone, White, } \\
\text { Gray, Sand }\end{array}$ & $\begin{array}{c}\text { Bone, White, } \\
\text { Gray, Sand }\end{array}$ & $\begin{array}{c}\text { Bone, Black, } \\
\text { Gray }\end{array}$ & Bone, White & $\begin{array}{c}\text { Bone, White, } \\
\text { Gray, Sand }\end{array}$ & $\begin{array}{l}\text { Bone, Gray, } \\
\text { White, Sand }\end{array}$ & $\begin{array}{c}\text { Bone, Black, } \\
\text { Gray }\end{array}$ & $\begin{array}{c}\text { Bone, White, } \\
\text { Gray }\end{array}$ \\
\hline Sherd Diameter (mm) & 13.6 & 28 & 19.3 & 19.5 & 12 & & 26.2 & 25 & \\
\hline Thickness (mm) & 6.3 & 4.7 & 4.7 & 6 & 4.6 & 5.3 & 5.1 & 8.1 & 6.6 \\
\hline Wt. (g) & 1.2 & 2.3 & 1.1 & 2.6 & 0.4 & 1.4 & 2 & 2.3 & 1.4 \\
\hline Exterior Surface Finish & Polished & Polished & Polished & Polished & Smooth & Smooth & Smooth & Polished & Polished \\
\hline Interior Surface Finish & Smooth & Smooth & Smooth & Polished & Smooth & Rough & Smooth & Smooth & Rough \\
\hline Exterior Surface Color & 7.5YR 6/4 & 7.5YR 5/2 & 7.5 YR $5 / 2$ & 10YR 6/4 & 7.5YR 6/4 & 7.5YR 6/4 & $5 Y R 5 / 2$ & $5 Y R 7 / 3$ & 7.5YR 6/6 \\
\hline Core Color & 7.5YR 6/2 & 10YR 4/1 & 10YR 4/1 & 7.5YR 7/4 & 7.5YR 5/2 & 7.5YR 6/2 & $5 Y R 5 / 3$ & 7.5YR 7/4 & 7.5YR 5/2 \\
\hline Interior Surface Color & 7.5YR 5/4 & 5YR 5/3 & 5YR 5/3 & 7.5YR 6/4 & $7.5 Y R 5 / 2$ & 7.5YR 6/2 & 5YR 5/4 & $5 Y R 6 / 3$ & 7.5YR 6/4 \\
\hline Vessel Group & 3 & 1 & 1 & 2 & 1 & 1 & 1 & 2 & 3 \\
\hline NAA & TRUE = 1a & FALSE & FALSE & FALSE & FALSE & FALSE & FALSE & FALSE & FALSE \\
\hline Petrographic & TRUE = 1b & FALSE & FALSE & FALSE & FALSE & FALSE & FALSE & FALSE & FALSE \\
\hline Isotope Analyses & FALSE & FALSE & FALSE & FALSE & FALSE & FALSE & FALSE & FALSE & FALSE \\
\hline
\end{tabular}


Appendix O: Data and Site Artifact Database

Table 0-15. All Ceramic Data Continued

\begin{tabular}{|c|c|c|c|c|c|c|c|c|c|}
\hline Cat. No. & $865-005-008$ & $867-008-1$ & $867-008-2$ & $867-008-3$ & $875-008$ & 878-008 & $879-008$ & $880-008$ & 881-008 \\
\hline Unit & N119,E70 & N119,E71 & N119,E71 & N119,E71 & N119,E74 & N119,E75 & N119,E75 & N120,E69 & $\mathrm{N} 120, \mathrm{E} 70$ \\
\hline Depth (cmbd) & $12-22$ & $10-20$ & $10-20$ & $10-20$ & $10-20$ & $10-20$ & $20-30$ & $0-18$ & $0-10$ \\
\hline Count & 1 & 1 & 1 & 1 & 1 & 1 & 1 & 1 & 1 \\
\hline Sherd Type & Body & Body & Body & Body & Body & Body & Body & Body & Body \\
\hline Ceramic Type & Leon Plain & Leon Plain & Leon Plain & Leon Plain & Leon Plain & Leon Plain & Leon Plain & Leon Plain & Leon Plain \\
\hline Temper & $\begin{array}{c}\text { Bone, White, } \\
\text { Gray }\end{array}$ & Bone, White & Bone, White & $\begin{array}{c}\text { Bone, White, } \\
\text { Gray }\end{array}$ & Bone, White & Bone, White & $\begin{array}{l}\text { Bone, Gray, } \\
\text { White, Sand }\end{array}$ & $\begin{array}{l}\text { Bone, White, } \\
\text { Sand, Gray }\end{array}$ & Bone, White \\
\hline Sherd Diameter (mm) & 21.5 & 14 & & 11 & & 19.1 & 22 & & \\
\hline Thickness (mm) & 6.7 & 6.6 & 7.3 & 6 & 4.9 & 4 & 5.8 & 6.6 & 6.7 \\
\hline Wt. (g) & 1.7 & 1.2 & 1 & 0.4 & 1 & 1.1 & 2.2 & 1.9 & 3.1 \\
\hline Exterior Surface Finish & Polished & Polished & Smooth & Polished & Smooth & Smooth & Smooth & Rough & Polished \\
\hline Interior Surface Finish & Polished & Polished & Rough & Polished & Smooth & Smooth & Rough & Smooth & Polished \\
\hline Exterior Surface Color & 10YR 5/1 & 7.5YR 7/6 & $5 Y R 7 / 3$ & $7.5 Y R \quad 4 / 4$ & $5 Y R 6 / 3$ & $5 Y R 5 / 2$ & $5 Y R 6 / 4$ & 7.5YR 5/4 & 7.5YR 7/6 \\
\hline Core Color & $\begin{array}{c}\text { 10YR 2/1 \& } \\
\text { 10YR 5/2 }\end{array}$ & 7.5YR 6/4 & 10YR 5/1 & 5YR 4/1 & $5 Y R 5 / 2$ & 7.5YR $6 / 2$ & $5 Y R 4 / 1$ & $5 Y R 5 / 2$ & 7.5YR 6/4 \\
\hline Interior Surface Color & 10YR 5/1 & 7.5YR 7/4 & 10YR 6/3 & 5YR 4/4 & $5 Y R 6 / 6$ & 7.5YR 6/4 & $5 Y R 5 / 4$ & 7.5YR $7 / 2$ & 7.5YR 6/4 \\
\hline Vessel Group & 1 & 3 & 3 & 3 & 3 & 1 & 3 & 3 & 3 \\
\hline NAA & FALSE & TRUE & FALSE & FALSE & FALSE & FALSE & FALSE & FALSE & FALSE \\
\hline Petrographic & FALSE & FALSE & FALSE & FALSE & FALSE & FALSE & FALSE & FALSE & FALSE \\
\hline Isotope Analyses & FALSE & FALSE & FALSE & FALSE & FALSE & FALSE & FALSE & FALSE & FALSE \\
\hline Cat. No. & $884-008$ & $886-008$ & 888-008 & $900-008$ & $901-008$ & $903-008$ & $908-008$ & $915-008$ & $917-008$ \\
\hline Unit & N120,E71 & N120,E72 & N120,E73 & N122,E70 & N122,E70 & N122,E71 & N122,E73 & N122,E75 & N122,E75 \\
\hline Depth (cmbd) & $10-20$ & $10-20$ & $0-10$ & $0-10$ & $10-20$ & $0-10$ & $0-10$ & $0-10$ & $20-30$ \\
\hline Count & 1 & 1 & 1 & 1 & 1 & 1 & 1 & 1 & 1 \\
\hline Sherd Type & Body & & Body & Body & Body & Body & Body & & Body \\
\hline Ceramic Type & Leon Plain & & Leon Plain & Leon Plain & Leon Plain & Leon Plain & Leon Plain & & Leon Plain \\
\hline Temper & $\begin{array}{l}\text { Bone, White, } \\
\text { Sand }\end{array}$ & & $\begin{array}{l}\text { Bone, White, } \\
\text { Gray, Sand }\end{array}$ & $\begin{array}{l}\text { Bone, White, } \\
\text { Sand }\end{array}$ & $\begin{array}{l}\text { Bone, Gray, } \\
\text { Sand, Gray, } \\
\text { White }\end{array}$ & Bone, White & Bone, Gray & & Bone, White \\
\hline Sherd Diameter (mm) & & & 19.1 & & & 14.6 & 14.3 & & 16.9 \\
\hline Thickness (mm) & 4.9 & & 6 & 7.5 & 7.1 & 4.5 & 5.4 & & 4.1 \\
\hline Wt. (g) & 1.1 & & 0.8 & 3.8 & 3.6 & 0.8 & 1.2 & & 0.4 \\
\hline Exterior Surface Finish & Smooth-Dull & & Smooth & Polished & Smooth & Smooth & Polished & & Smooth \\
\hline Interior Surface Finish & Polished & & Rough & Polished & Smooth & Rough & Smooth & & Smooth \\
\hline Exterior Surface Color & 10YR 5/2 & & $5 Y R 6 / 4$ & $5 Y R 6 / 4$ & 10YR 5/1 & $5 Y R 6 / 3$ & 7.5YR 7/6 & & 10YR 6/3 \\
\hline Core Color & 10YR 5/2 & & $5 Y R 5 / 4$ & 7.5YR 5/2 & 7.5YR 5/4 & 5YR 6/2 & 7.5YR 7/4 & & 7.5YR 5/2 \\
\hline Interior Surface Color & 5YR 5/4 & & $5 Y R 6 / 4$ & 7.5YR 6/4 & 7.5YR 6/4 & 5YR 5/1 & 7.5YR 7/4 & & 7.5YR 6/4 \\
\hline Vessel Group & 3 & & 3 & 3 & 3 & 1 & 2 & & 1 \\
\hline NAA & FALSE & FALSE & FALSE & FALSE & FALSE & FALSE & FALSE & FALSE & FALSE \\
\hline Petrographic & FALSE & FALSE & FALSE & FALSE & FALSE & FALSE & FALSE & FALSE & FALSE \\
\hline Isotope Analyses & FALSE & FALSE & FALSE & TRUE =1a & TRUE = 1a & FALSE & FALSE & FALSE & FALSE \\
\hline
\end{tabular}


The Varga Site

Texas Department of Transportation

Table 0-15. All Ceramic Data Continued

\begin{tabular}{|c|c|c|c|c|c|c|c|c|c|}
\hline Cat. No. & $933-008$ & $936-008$ & $937-008-1 b$ & $940-008$ & $945-008$ & $949-008$ & $950-008-1$ & $950-008-2$ & $961-008$ \\
\hline Unit & N123,E71 & N123,E72 & N123,E72 & N123,E73 & N123,E75 & N124,E69 & N124,E69 & N124,E69 & N124,E73 \\
\hline Depth (cmbd) & $0-10$ & $0-10$ & $10-20$ & $12-26$ & $0-10$ & $8-18$ & $18-26$ & $18-26$ & $10-20$ \\
\hline Count & 1 & 1 & 1 & 1 & 1 & 1 & 1 & 1 & 1 \\
\hline Sherd Type & Body & Body & Body & Body & Body & Body & Body & Body & Body \\
\hline Ceramic Type & Leon Plain & Leon Plain & Leon Plain & Leon Plain & Leon Plain & Leon Plain & Leon Plain & Leon Plain & Leon Plain \\
\hline Temper & Bone, White & $\begin{array}{c}\text { Bone, Black, } \\
\text { Gray }\end{array}$ & Bone, White & $\begin{array}{c}\text { Bone, White, } \\
\text { Gray }\end{array}$ & $\begin{array}{c}\text { Bone, Gray, } \\
\text { Black }\end{array}$ & Bone, White & Bone, White & Bone, White & $\begin{array}{c}\text { Bone, White, } \\
\text { Gray, Sand }\end{array}$ \\
\hline Sherd Diameter (mm) & 15 & 14.8 & & 14.6 & 22.2 & & 15.7 & 14.2 & 13.6 \\
\hline Thickness (mm) & 4.4 & 6.5 & 5.7 & & 8 & 6 & 5.5 & 4.8 & 6.7 \\
\hline Wt. (g) & 0.7 & 1.6 & 1.4 & 0.5 & 3.7 & 1 & 0.7 & 0.4 & 0.8 \\
\hline Exterior Surface Finish & Polished & Polished & Smooth & Polished & Polished & Polished & Smooth & Smooth & Polished \\
\hline Interior Surface Finish & Smooth & Smooth & Smooth & Rough & Smooth & Smooth & Smooth & Smooth & Smooth \\
\hline Exterior Surface Color & $5 Y R 7 / 2$ & $5 Y R 7 / 3$ & 7.5YR 6/4 & 5YR 6/4 & 7.5YR 6/4 & $5 Y R 6 / 3$ & 5YR 6/4 & 5YR 6/4 & $5 Y R 7 / 3$ \\
\hline Core Color & 7.5YR 6/4 & 5YR 6/1 & 5YR 6/6 & 5YR 5/1 & 10YR 5/1 & 7.5YR 6/4 & 5YR 4/1 & 5YR 4/1 & 5YR 6/2 \\
\hline Interior Surface Color & 7.5YR 6/2 & $5 Y R 7 / 3$ & 5YR 6/4 & 5YR 6/3 & 7.5YR 7/4 & 5YR 6/4 & $5 Y R 6 / 3$ & $5 Y R 6 / 3$ & 5YR 6/4 \\
\hline Vessel Group & 3 & 2 & 3 & 1 & 2 & 3 & 1 & 1 & 3 \\
\hline NAA & FALSE & TRUE & FALSE & FALSE & FALSE & FALSE & FALSE & FALSE & FALSE \\
\hline Petrographic & FALSE & FALSE & FALSE & FALSE & FALSE & FALSE & FALSE & FALSE & FALSE \\
\hline Isotope Analyses & FALSE & FALSE & FALSE & FALSE & FALSE & FALSE & FALSE & FALSE & FALSE \\
\hline Cat. No. & $962-008^{*}$ & $965-008$ & $968-008$ & $977-008$ & $981-008$ & $984-008-1$ & $984-008-2$ & $987-008-1 a$ & $989-008$ \\
\hline Unit & $\mathrm{N} 124, \mathrm{E} 73$ & N124,E74 & N124,E75 & N125,E70 & N125,E71 & N125,E72 & N125,E72 & N125,E73 & N125,E74 \\
\hline Depth (cmbd) & $20-30$ & $10-20$ & $10-20$ & $0-10$ & $0-10$ & $10-20$ & $10-20$ & $10-20$ & $0-10$ \\
\hline Count & 1 & 1 & 1 & 1 & 1 & 1 & 1 & 1 & 1 \\
\hline Sherd Type & Body & Body & Body & Body & Body & Body & Body & Body & Body \\
\hline Ceramic Type & Leon Plain & Leon Plain & Leon Plain & Leon Plain & Leon Plain & Leon Plain & Leon Plain & Leon Plain & Leon Plain \\
\hline Temper & Bone, White & $\begin{array}{c}\text { Bone, Gray, } \\
\text { Black }\end{array}$ & $\begin{array}{l}\text { Bone, White, } \\
\text { Sand }\end{array}$ & Bone, Black & Bone, Black & $\begin{array}{c}\text { Bone, Gray, } \\
\text { Black }\end{array}$ & $\begin{array}{c}\text { Bone, Gray, } \\
\text { Black }\end{array}$ & $\begin{array}{c}\text { Bone, Black, } \\
\text { Gray }\end{array}$ & Bone, White \\
\hline Sherd Diameter (mm) & 14 & 39.4 & 1.1 & 24 & 22 & 19.9 & 18.4 & 19.6 & 13.6 \\
\hline Thickness (mm) & 4.9 & 7.3 & 6.5 & 6.5 & 5.7 & 5.9 & 5.6 & 6.6 & 5.9 \\
\hline Wt. (g) & 0.9 & 8.9 & 0.5 & 2.7 & 1.7 & 2 & 1 & 3 & 1.1 \\
\hline Exterior Surface Finish & Smooth & Polished & Polished & Smooth & Polished & Smooth & Smooth & Polished & Smooth \\
\hline Interior Surface Finish & Smooth & Smooth & Smooth & Smooth & Polished & Smooth & Smooth & Smooth & Rough \\
\hline Exterior Surface Color & 5YR 6/4 & 10YR 7/6 & 10YR 5/2 & 7.5YR 6/4 & 10YR 5/2 & 7.5YR $7 / 4$ & 7.5YR 7/4 & $7.5 Y R 7 / 6$ & 7.5YR 6/4 \\
\hline Core Color & 5YR 5/1 & $5 Y R 7 / 4$ & 10YR 4/1 & $7.5 Y R$ 5/0 & 10YR 6/3 & 5YR 7/4 & $5 Y R 7 / 4$ & $7.5 Y R 7 / 4$ & 5YR 5/2 \\
\hline Interior Surface Color & 5YR 5/1 & 7.5YR 6/4 & $5 Y R$ 5/4 & 7.5YR 6/6 & 7.5YR 6/4 & 7.5YR $7 / 4$ & $7.5 Y R 7 / 4$ & 10YR 5/1 & $5 Y R 6 / 6$ \\
\hline Vessel Group & 1 & 2 & $?$ & 2 & 2 & 2 & 2 & 2 & 1 \\
\hline NAA & FALSE & FALSE & FALSE & FALSE & FALSE & FALSE & FALSE & FALSE & FALSE \\
\hline Petrographic & FALSE & FALSE & FALSE & FALSE & FALSE & FALSE & FALSE & FALSE & FALSE \\
\hline Isotope Analyses & FALSE & FALSE & FALSE & FALSE & FALSE & FALSE & FALSE & FALSE & FALSE \\
\hline
\end{tabular}


Appendix O: Data and Site Artifact Database

Table 0-15. All Ceramic Data Continued

\begin{tabular}{|c|c|c|c|c|c|c|c|c|c|c|}
\hline Cat. No. & $992-008$ & \multicolumn{2}{|c|}{$996-008$} & $999-008$ & $1000-008$ & $1002-008$ & $1008-008-1$ & $1008-008-2$ & 1023-008-1 & $1023-008-2$ \\
\hline Unit & N125,E75 & \multicolumn{2}{|c|}{ N126,E68 } & N126,E69 & $\mathrm{N} 126, \mathrm{E} 69$ & $\mathrm{~N} 126, \mathrm{E} 70$ & N126,E72 & N126,E72 & N126,E75 & N126,E75 \\
\hline Depth (cmbd) & $0-10$ & \multicolumn{2}{|c|}{$10-20$} & $10-20$ & $20-30$ & $8-19$ & $20-30$ & $20-30$ & $0-10$ & $0-10$ \\
\hline Count & 1 & \multicolumn{2}{|c|}{1} & 1 & 1 & 1 & 1 & 1 & 1 & 1 \\
\hline Sherd Type & Body & \multicolumn{2}{|c|}{ Body } & Body & Body & Body & Body & Body & Body & Body \\
\hline Ceramic Type & Leon Plain & \multicolumn{2}{|c|}{ Leon Plain } & Leon Plain & Leon Plain & Leon Plain & Leon Plain & Leon Plain & Leon Plain & Leon Plain \\
\hline Temper & $\begin{array}{l}\text { Bone, Black, } \\
\text { Gray }\end{array}$ & \multicolumn{2}{|c|}{$\begin{array}{l}\text { Bone, White, } \\
\text { Sand }\end{array}$} & Bone, White & $\begin{array}{l}\text { Bone, White, } \\
\text { Black }\end{array}$ & $\begin{array}{l}\text { Bone, White, } \\
\text { Sand }\end{array}$ & Bone, Gray & Bone, White & $\begin{array}{l}\text { Bone, White, } \\
\text { Sand }\end{array}$ & $\begin{array}{l}\text { Bone, White, } \\
\text { Sand }\end{array}$ \\
\hline Sherd Diameter (mm) & 19.6 & \multicolumn{2}{|c|}{16} & 31.5 & 21.8 & & 18.2 & 22 & 16.8 & 27.1 \\
\hline Thickness (mm) & 5.7 & \multicolumn{2}{|c|}{3.9} & 4.9 & 6.7 & 4.7 & 7 & 5.2 & 4.9 & 4.9 \\
\hline Wt. (g) & 1.5 & & & 2.7 & 1.9 & 1 & 1.5 & 2 & 0.8 & 2.4 \\
\hline Exterior Surface Finish & Polished & & & Smooth & Smooth & Polished & Polished & Smooth & Smooth & Smooth \\
\hline Interior Surface Finish & Smooth & & & Smooth & Smooth & Smooth & Smooth & Rough & Smooth & Smooth \\
\hline Exterior Surface Color & 10YR $7 / 3$ & & & 7.5YR 5/2 & $5 Y R 6 / 4$ & $\begin{array}{c}\text { 10YR } 5 / 1 \& \\
5 / 4\end{array}$ & $5 Y R 7 / 4$ & $5 Y R 6 / 4$ & 10YR 5/1 & 10YR 5/1 \\
\hline Core Color & 5YR 5/1 & & & $5 Y R 4 / 1$ & $5 Y R 6 / 3$ & $\begin{array}{c}\text { 10YR 5/2 \& } \\
5 \text { YR 5/4 }\end{array}$ & $5 Y R 6 / 2$ & $5 Y R 5 / 1$ & $5 Y R 4 / 1$ & $5 Y R 4 / 1$ \\
\hline Interior Surface Color & $7.5 Y R 7 / 4$ & & & 7.5YR $5 / 4$ & $5 Y R 6 / 3$ & $5 Y R 5 / 4$ & $5 Y R 6 / 2$ & 7.5YR 5/2 & $5 Y R 6 / 4$ & $5 Y R 6 / 4$ \\
\hline Vessel Group & 2 & & & 1 & 2 & $3 ?$ & 2 & 1 & 1 & 1 \\
\hline NAA & FALSE & & & FALSE & FALSE & FALSE & FALSE & FALSE & FALSE & FALSE \\
\hline Petrographic & FALSE & & & FALSE & FALSE & FALSE & FALSE & FALSE & FALSE & FALSE \\
\hline Isotope Analyses & FALSE & & & FALSE & FALSE & FALSE & FALSE & FALSE & FALSE & FALSE \\
\hline Cat. No. & $1030-005-00$ & -008 & 1030 & $-005-004-008-1$ & $1030-005-($ & & 1030-008 & $1036-008$ & & 1044-008 \\
\hline Unit & $\mathrm{N} 126, \mathrm{E7}$ & & & N126,E76 & $\mathrm{N} 126, \mathrm{E} 7$ & & V126,E76 & $\mathrm{N} 127, \mathrm{E} 6$ & & N127,E72 \\
\hline Depth (cmbd) & $35-40$ & & & $35-40$ & $30-40$ & & $30-40$ & $10-20$ & & $10-20$ \\
\hline Count & 1 & & & 1 & 1 & & 1 & 1 & & 1 \\
\hline Sherd Type & Body & & & Body & Body & & Body & Body & & Body \\
\hline Ceramic Type & Leon Pla & & & Leon Plain & Leon Pla & & eon Plain & Leon Plai & & _eon Plain \\
\hline Temper & Bone, Wh & & & Sone, White & Bone, Wh & & White, Gray & Bone, Whi & Bon & , White, Sand \\
\hline Sherd Diameter (mm) & 25.6 & & & 28 & 28.2 & & 18 & 20 & & 20.4 \\
\hline Thickness (mm) & 5.1 & & & 5 & 5.1 & & 6 & & & 6.2 \\
\hline Wt. (g) & 3.4 & & & 14.5 & 3.5 & & 1.6 & 1.3 & & 1.3 \\
\hline Exterior Surface Finish & Smooth & & & Smooth & Smooth & & Polished & Eroded & & Polished \\
\hline Interior Surface Finish & Smooth & & & Smooth & Smooth & & Rough & Polished & & Smooth \\
\hline Exterior Surface Color & 10YR 4/ & & & 10YR 4/1 & $5 Y R 4 / 1$ & & 5YR 6/4 & $5 Y R 6 / 3$ & & 7.5YR 6/2 \\
\hline Core Color & $5 Y R 4 / 1$ & & & $5 Y R 4 / 1$ & $5 Y R 4 / 1$ & & 5YR 5/1 & 5YR 5/1 & & 5YR 5/1 \\
\hline Interior Surface Color & $5 Y R 6 / 6$ & & & $5 Y R 6 / 6$ & $5 Y R 6 / 6$ & & 5YR 6/6 & $5 Y R 6 / 4$ & & 7.5YR 5/4 \\
\hline Vessel Group & 1 & & & 1 & 1 & & 1 & 3 & & 3 \\
\hline NAA & FALSE & & & FALSE & FALSE & & TRUE & FALSE & & FALSE \\
\hline Petrographic & FALSE & & & FALSE & FALSE & & FALSE & FALSE & & FALSE \\
\hline Isotope Analyses & FALSE & & & TRUE $=1 b$ & FALSE & & FALSE & FALSE & & FALSE \\
\hline
\end{tabular}


The Varga Site

Texas Department of Transportation

Table 0-15. All Ceramic Data Continued

\begin{tabular}{|c|c|c|c|c|c|c|c|c|c|c|}
\hline Cat. No. & $1050-008-1$ & $1050-008-2$ & $1054-008-1$ & \multicolumn{2}{|c|}{$1054-008-2$} & \multicolumn{2}{|c|}{$1054-008-3$} & $1054-008-4$ & $1054-008-5$ & $1055-005-008$ \\
\hline Unit & $\mathrm{N} 127, \mathrm{E} 74$ & N127,E74 & N127,E75 & \multicolumn{2}{|c|}{ N127,E75 } & \multicolumn{2}{|c|}{$\mathrm{N} 127, \mathrm{E} 75$} & $\mathrm{~N} 127, \mathrm{E} 75$ & $\mathrm{~N} 127, \mathrm{E} 75$ & $\mathrm{~N} 127, \mathrm{E} 75$ \\
\hline Depth (cmbd) & $15-25$ & $15-25$ & $20-30$ & \multicolumn{2}{|c|}{$20-30$} & \multicolumn{2}{|c|}{$20-30$} & $20-30$ & $20-30$ & 32 \\
\hline Count & 1 & 1 & 1 & \multicolumn{2}{|c|}{1} & \multicolumn{2}{|c|}{1} & 1 & 1 & 1 \\
\hline Sherd Type & Body & Body & Body & \multicolumn{2}{|c|}{ Body } & \multicolumn{2}{|c|}{ Body } & Body & Body & Body \\
\hline Ceramic Type & Leon Plain & Leon Plain & Leon Plain & \multicolumn{2}{|c|}{ Leon Plain } & \multicolumn{2}{|c|}{ Leon Plain } & Leon Plain & Leon Plain & Leon Plain \\
\hline Temper & $\begin{array}{l}\text { Bone, Gray, } \\
\text { White }\end{array}$ & $\begin{array}{c}\text { Bone, Gray, } \\
\text { White }\end{array}$ & Bone, W & Bone, & /hite & Bone & White & Bone, White & Bone, White & $\begin{array}{l}\text { Bone, Sand, } \\
\text { White, Sand }\end{array}$ \\
\hline Sherd Diameter (mm) & 21 & 30 & & 47 & & & 34.5 & 15.7 & 12 & 39.8 \\
\hline Thickness (mm) & 6.3 & 6.1 & & 5 & & & 6.3 & 4.9 & 4.9 & 5.1 \\
\hline Wt. (g) & 2.2 & 2.1 & 3.4 & 11 & & & 4.1 & 0.9 & 0.6 & 9.2 \\
\hline Exterior Surface Finish & Smooth & Smooth & Smoot & Sm & & & looth & Smooth & Smooth & Smooth \\
\hline Interior Surface Finish & Rough & Rough & Smoot & Sm & & & 100th & Smooth & Smooth & Smooth \\
\hline Exterior Surface Color & 7.5YR 5/2 & 7.5YR 5/2 & 10YR 6 & $10 Y$ & & & $R 6 / 3$ & 10YR 6/3 & 10YR 6/3 & $5 Y R 7 / 4$ \\
\hline Core Color & $5 Y R 4 / 1$ & $5 Y R 4 / 1$ & 10YR 4 & $10 Y$ & & & R 4/1 & 10YR 4/1 & 10YR 4/1 & $5 Y R 5 / 1$ \\
\hline Interior Surface Color & 7.5YR 6/6 & 7.5YR $6 / 6$ & $7.5 Y R 6$ & $7.5 Y$ & & 7.5 & R 6/6 & $7.5 Y R$ 6/6 & 7.5YR $6 / 6$ & $5 Y R 5 / 2$ \\
\hline Vessel Group & 1 & 1 & 1 & 1 & & & 1 & 1 & 1 & 1 \\
\hline NAA & FALSE & FALSE & TRUE = & FAL & & & LSE & FALSE & FALSE & FALSE \\
\hline Petrographic & FALSE & FALSE & TRUE $=$ & FAl & & & LSE & FALSE & FALSE & FALSE \\
\hline Isotope Analyses & FALSE & FALSE & FALSE & FAl & & & LSE & FALSE & FALSE & TRUE = 1b \\
\hline Cat. No. & $1074-008$ & $1078-008$ & $1081-008$ & 1089-008 & 1096 & 08-1 & $1096-008-2$ & $1096-008-3$ & $1100-008$ & $1102-008$ \\
\hline Unit & $\mathrm{N} 128, \mathrm{E} 72$ & N127,E73 & N128,E74 & $\mathrm{N} 129, \mathrm{E} 71$ & N12 & E73 & $\mathrm{N} 129, \mathrm{E} 73$ & N129,E73 & $\mathrm{N} 129, \mathrm{E} 75$ & N129,E75 \\
\hline Depth (cmbd) & $20-30$ & $17-25$ & $0-10$ & $30-35$ & & & $20-30$ & $20-30$ & $0-10$ & $20-30$ \\
\hline Count & 1 & 1 & 1 & 1 & & & 1 & 1 & 1 & 1 \\
\hline Sherd Type & Body & Body & Body & Body & & & Body & Body & Body & \\
\hline Ceramic Type & Leon Plain & Leon Plain & Leon Plain & Leon Plain & Leor & Pain & Leon Plain & Leon Plain & Leon Plain & \\
\hline Temper & Bone, White & $\begin{array}{l}\text { Bone, White, } \\
\text { Gray, Sand }\end{array}$ & Bone, White & $\begin{array}{l}\text { Bone, White, } \\
\text { Gray, Sand }\end{array}$ & $\begin{array}{l}\text { Bone } \\
\text { Gray }\end{array}$ & $\begin{array}{l}\text { Vhite, } \\
\text { Sand }\end{array}$ & $\begin{array}{c}\text { Bone, Gray, } \\
\text { Black }\end{array}$ & $\begin{array}{c}\text { Bone, Gray, } \\
\text { Black }\end{array}$ & $\begin{array}{l}\text { Bone, Gray, } \\
\text { Black, Sand }\end{array}$ & \\
\hline Sherd Diameter (mm) & 10.7 & 17 & 25.4 & 26.6 & & & 15.3 & 17.6 & 21 & \\
\hline Thickness (mm) & 5.2 & 5.5 & 6.2 & 7.1 & & & 5.5 & 5.7 & 4.9 & \\
\hline Wt. (g) & 0.6 & 0.8 & 2.4 & 3.9 & & & 1.4 & 2.2 & 1.2 & \\
\hline Exterior Surface Finish & Smooth & Polished & Smooth & Smooth & Pol & & Smooth & Smooth & Smooth & \\
\hline Interior Surface Finish & Rough & Rough & Rough & Rough & & & Smooth & Smooth & Rough & \\
\hline Exterior Surface Color & 7.5YR 6/2 & 5YR 5/1 & 10YR 5/1 & 7.5YR 5/6 & $10 Y$ & & 7.5YR 7/4 & 7.5YR 7/4 & $5 Y R 6 / 2$ & \\
\hline Core Color & $7.5 Y R$ 7/4 & $5 Y R 6 / 1$ & 10YR 4/1 & 7.5YR 5/4 & 7.5 & $6 / 2$ & 7.5YR 7/4 & 7.5YR 7/4 & $5 Y R 6 / 2$ & \\
\hline Interior Surface Color & 7.5YR 7/4 & 5YR $5 / 2$ & $5 Y R 6 / 6$ & 7.5YR 6/4 & & & 7.5YR 6/4 & 7.5YR 6/4 & $5 Y R 6 / 3$ & \\
\hline Vessel Group & 1 & 1 & 1 & 1 & & & 2 & 2 & 3 & \\
\hline NAA & FALSE & FALSE & FALSE & FALSE & & & FALSE & FALSE & FALSE & FALSE \\
\hline Petrographic & FALSE & FALSE & FALSE & TRUE = 1b & & & FALSE & FALSE & FALSE & FALSE \\
\hline Isotope Analyses & FALSE & FALSE & FALSE & FALSE & & & FALSE & FALSE & FALSE & FALSE \\
\hline
\end{tabular}


Appendix O: Data and Site Artifact Database

Table 0-15. All Ceramic Data Continued

\begin{tabular}{|c|c|c|c|c|c|c|c|c|c|c|c|}
\hline Cat. No. & $1118-008$ & $1129-008-1 a$ & \multicolumn{2}{|c|}{ 1133-008 } & $1137-008-1$ & $1137-008-2$ & $1137-008-3$ & \multicolumn{2}{|c|}{ 1157-008 } & $1162-008-1$ & $1162-008-2$ \\
\hline Unit & $\mathrm{N} 130, \mathrm{E} 71$ & $\mathrm{~N} 130, \mathrm{E} 74$ & \multicolumn{2}{|c|}{ N130,E75 } & $\mathrm{N} 131, \mathrm{E} 70$ & $\mathrm{~N} 131, \mathrm{E} 70$ & $\mathrm{~N} 131, \mathrm{E} 70$ & \multicolumn{2}{|c|}{ N131,E73 } & N131,E75 & N131,E75 \\
\hline Depth (cmbd) & $20-30$ & $20-30$ & \multicolumn{2}{|c|}{$20-30$} & $30-40$ & $30-40$ & $30-40$ & \multicolumn{2}{|c|}{$0-10$} & $0-10$ & $0-10$ \\
\hline Count & 1 & 1 & \multicolumn{2}{|c|}{1} & 1 & 1 & 1 & \multicolumn{2}{|c|}{1} & 1 & 1 \\
\hline Sherd Type & Body & Body & \multicolumn{2}{|c|}{ Body } & Body & Body & Body & \multicolumn{2}{|c|}{ Body } & Body & Body \\
\hline Ceramic Type & Leon Plain & Leon Plain & \multicolumn{2}{|c|}{ Leon Plain } & Leon Plain & Leon Plain & Leon Plain & \multicolumn{2}{|c|}{ Leon Plain } & Leon Plain & Leon Plain \\
\hline Temper & Bone, White & Bone, Gray & \multicolumn{2}{|c|}{ Bone, White } & Bone, White & Bone, White & Bone, White & \multicolumn{2}{|c|}{ Bone, Black } & $\begin{array}{c}\text { Bone, Gray, } \\
\text { Black }\end{array}$ & Bone, White \\
\hline Sherd Diameter (mm) & & 12.8 & & & 11.4 & 13.6 & 12.2 & \multicolumn{2}{|c|}{37} & 17 & 16.9 \\
\hline Thickness (mm) & 4.5 & 5.6 & \multicolumn{2}{|c|}{6.4} & 5.4 & 5.7 & 4.7 & \multicolumn{2}{|c|}{6.5} & 6.5 & 3.9 \\
\hline Wt. (g) & 0.9 & 0.9 & \multicolumn{2}{|c|}{1.2} & 0.7 & 0.6 & 0.3 & \multicolumn{2}{|c|}{6.4} & 0.9 & 0.9 \\
\hline Exterior Surface Finish & Polished & Smooth & \multicolumn{2}{|c|}{ Polished } & Polished & Polished & Polished & \multicolumn{2}{|c|}{ Polished } & Polished & Smooth \\
\hline Interior Surface Finish & Smooth & Smooth & \multicolumn{2}{|c|}{ Polished } & Smooth & Smooth & Smooth & \multicolumn{2}{|c|}{ Smooth } & Rough & Rough \\
\hline Exterior Surface Color & $5 Y R 7 / 4$ & 7.5YR $7 / 4$ & \multicolumn{2}{|c|}{ 7.5YR 7/4 } & $5 Y R 5 / 4$ & $5 Y R 5 / 4$ & $5 Y R 5 / 4$ & 7.5 & & 7.5YR 7/4 & $5 Y R 5 / 2$ \\
\hline Core Color & $5 Y R 7 / 4$ & 7.5YR $7 / 4$ & 7.5 & & 10YR 4/1 & 10YR 4/1 & 10YR 4/1 & 7.5 & & $5 Y R 5 / 1$ & 5YR 6/1 \\
\hline Interior Surface Color & $5 Y R 7 / 4$ & 7.5YR $7 / 4$ & & & 10YR 5/2 & 10YR 5/2 & 10YR 5/2 & 7.5 & & 7.5YR 8/4 & $5 Y R 5 / 2$ \\
\hline Vessel Group & 3 & 2 & & & 1 & 1 & 1 & & & 2 & 1 \\
\hline NAA & FALSE & TRUE & & & FALSE & FALSE & FALSE & & & FALSE & FALSE \\
\hline Petrographic & FALSE & FALSE & & & FALSE & FALSE & FALSE & & & FALSE & FALSE \\
\hline Isotope Analyses & FALSE & FALSE & & & FALSE & FALSE & FALSE & TRU & $=1 \mathrm{~b}$ & FALSE & FALSE \\
\hline Cat. No. & $1162-008-3$ & 1163 & & & $1181-008$ & $1187-008$ & $1261-008$ & & 126 & L-008-2 & $1261-008-3$ \\
\hline Unit & N131,E75 & N131 & & & V132,E75 & $\mathrm{N} 133, \mathrm{E} 71$ & SURFAC & & SU & RFACE & SURFACE \\
\hline Depth (cmbd) & $0-10$ & 10 & & & $0-10$ & $20-30$ & 0 & & & 0 & 0 \\
\hline Count & 1 & 1 & & & 1 & 1 & 1 & & & 1 & 1 \\
\hline Sherd Type & Body & Bo & & & Body & Body & Body & & & ody & Body \\
\hline Ceramic Type & Leon Plain & Leon & & & eon Plain & Leon Plain & Leon Pla & & & known & Unknown \\
\hline Temper & Bone, White & Bone, & Ihite & Bon & Black, Gray & Bone, Gray & Bone, White, & Gray & & uartz & Quartz \\
\hline Sherd Diameter (mm) & 18.8 & 12 & & & 20 & 31.3 & 28.3 & & & 0.6 & 13.7 \\
\hline Thickness (mm) & 5.7 & 4. & & & 6.6 & 4.8 & 5.1 & & & 3.1 & 3.2 \\
\hline Wt. (g) & 1.2 & 0. & & & 3.1 & 2.2 & 2.4 & & & 0.4 & 0.7 \\
\hline Exterior Surface Finish & Smooth & Polis & & & Polished & Smooth & Polishec & & Dull & Rough & Dull Rough \\
\hline Interior Surface Finish & Smooth & Polis & & & Smooth & Smooth & Smooth & & & nooth & Smooth \\
\hline Exterior Surface Color & $5 Y R 5 / 4$ & $7.5 Y F$ & & & $5 Y R 7 / 3$ & $5 Y R 6 / 1$ & $5 Y R 5 / 4$ & & & $R 5 / 3$ & $5 Y R 5 / 3$ \\
\hline Core Color & $5 Y R 5 / 1$ & $5 Y R$ & & & $5 Y R$ 5/1 & 10YR 6/3 & 10YR 5/ & & & $\mathrm{R} N / 2$ & 7.5YR N/2 \\
\hline Interior Surface Color & $5 Y R 6 / 4$ & $7.5 Y F$ & & & $5 Y R 7 / 3$ & 10YR 5/2 & 10R $5 / 8$ & & & $R 5 / 6$ & 5YR 5/6 \\
\hline Vessel Group & 1 & 1 & & & 2 & 2 & 1 & & & 5 & 5 \\
\hline NAA & FALSE & FAL & & & FALSE & FALSE & FALSE & & & ALSE & TRUE \\
\hline Petrographic & FALSE & FAL & & & TRUE & FALSE & FALSE & & & RUE & FALSE \\
\hline Isotope Analyses & FALSE & FAL & & & FALSE & FALSE & FALSE & & & ALSE & FALSE \\
\hline
\end{tabular}

${ }^{*}$ From Late Archaic Component 
The Varga Site

Texas Department of Transportation

Table 0-16. Frio Point Data

\begin{tabular}{|c|c|c|c|c|c|c|c|c|c|c|c|}
\hline Cat. No. & Unit & $\begin{array}{l}\text { Depth } \\
\text { (cmbd) }\end{array}$ & $\begin{array}{l}\text { Feat } \\
\text {. No. }\end{array}$ & Component & Condition & $\begin{array}{l}\text { Break } \\
\text { Type } \\
\end{array}$ & $\begin{array}{c}\text { Rejuvenation } \\
\text { Scar }\end{array}$ & $\begin{array}{c}\text { Resharpening } \\
\text { Type }\end{array}$ & $\begin{array}{c}\text { Raw } \\
\text { Material }\end{array}$ & Texture & $\begin{array}{c}\text { Percent } \\
\text { Patination }\end{array}$ \\
\hline $22-015$ & N99,E52 & $\begin{array}{l}30-40 \\
\text { cmbs }\end{array}$ & & Late Archaic & Proximal & Use & Absent & $\begin{array}{c}\text { Break } \\
\text { Compensation }\end{array}$ & Chert & Fine & 0 \\
\hline $89-010$ & N100,E51 & $\begin{array}{c}27 \\
\text { cmbs }\end{array}$ & 1 & Late Archaic & Proximal & Use & Absent & $\begin{array}{c}\text { Break } \\
\text { Compensation }\end{array}$ & Chert & Fine & 0 \\
\hline $187-011$ & N101,E51 & $\begin{array}{l}25.5 \\
\text { cmbs }\end{array}$ & 1 & Late Archaic & Proximal & Use & Absent & Indeterminate & Chert & Fine & 0 \\
\hline $220-014$ & N101,E54 & $\begin{array}{l}20-30 \\
\text { cmbs }\end{array}$ & & Toyah & Proximal & Use & Absent & $\begin{array}{c}\text { Beveled } \\
\text { Bifacial }\end{array}$ & Chert & Fine & 0 \\
\hline $525-005-013$ & N106,E54 & $\begin{array}{l}35-40 \\
\text { cmbs }\end{array}$ & 2 & Toyah & Proximal & Use & Absent & None & Chert & Fine & 0 \\
\hline $526-011^{*}$ & N106,E54 & $\begin{array}{l}40-50 \\
\text { cmbs }\end{array}$ & & Toyah & Medial & Use & & & & & \\
\hline $562-012$ & $\mathrm{~N} 107, \mathrm{E} 49$ & $\begin{array}{l}30-40 \\
\text { cmbs }\end{array}$ & & Mixed & Complete & Unbroken & Absent & $\begin{array}{c}\text { Break } \\
\text { Compensation }\end{array}$ & Chert & Fine & 0 \\
\hline $916-010$ & N122,E75 & $\begin{array}{l}10-20 \\
\text { cmbs }\end{array}$ & & Toyah & Medial & Use & Absent & Indeterminate & Chert & Fine & 0 \\
\hline
\end{tabular}

\begin{tabular}{|c|c|c|c|c|c|c|c|c|c|c|c|}
\hline Cat. No. & $\begin{array}{l}\text { Percent } \\
\text { Cortex }\end{array}$ & Heating & $\begin{array}{l}\text { Length } \\
(\mathrm{mm})\end{array}$ & $\begin{array}{l}\text { Thick } \\
(\mathrm{mm})\end{array}$ & $\begin{array}{l}\text { Wt. } \\
\text { (g) }\end{array}$ & $\begin{array}{l}\text { Long X- } \\
\text { Section }\end{array}$ & $\begin{array}{l}\text { Trans X- } \\
\text { Section }\end{array}$ & Preform & Shape & $\begin{array}{l}\text { Flaking } \\
\text { Pattern }\end{array}$ & $\begin{array}{c}\text { Edge } \\
\text { Rounding }\end{array}$ \\
\hline $22-015$ & 0 & None & & 6.6 & & $\begin{array}{l}\text { Tapered } \\
\text { Base/Tip }\end{array}$ & $\begin{array}{c}\text { Biconvex } \\
\text { Symmetrical }\end{array}$ & Biface & Triangular & Subparallel & Present \\
\hline $89-010$ & 0 & Burned & & 6.3 & & Indeterminate & $\begin{array}{l}\text { Biconvex } \\
\text { Symmetrical }\end{array}$ & Biface & Triangular & Subparallel & Absent \\
\hline $187-011$ & 0 & None & & 6.9 & & Indeterminate & $\begin{array}{c}\text { Biconvex } \\
\text { Symmetrical }\end{array}$ & Biface & Triangular & Subparallel & Present \\
\hline $220-014$ & 0 & None & & 5.5 & & Indeterminate & $\begin{array}{c}\text { Biconvex } \\
\text { Symmetrical }\end{array}$ & Biface & Lanceolate & Subparallel & Present \\
\hline $525-005-013$ & 0 & Indeterminate & 54.5 & 12.4 & 11.6 & $\begin{array}{l}\text { Tapered } \\
\text { Base/Tip }\end{array}$ & $\begin{array}{c}\text { Biconvex } \\
\text { Symmetrical }\end{array}$ & Biface & Triangular & Chevron & Absent \\
\hline \multicolumn{12}{|l|}{$526-011^{*}$} \\
\hline $562-012$ & 0 & None & 32.7 & 5.7 & 3.6 & Indeterminate & $\begin{array}{l}\text { Plano- } \\
\text { Convex }\end{array}$ & Biface & Indeterminate & Indeterminate & Present \\
\hline $916-010$ & 0 & None & & 6.4 & & Indeterminate & $\begin{array}{l}\text { Plano- } \\
\text { Convex }\end{array}$ & Flake & Indeterminate & Indeterminate & Absent \\
\hline
\end{tabular}

\begin{tabular}{|c|c|c|c|c|c|c|c|c|c|c|c|}
\hline Cat. No. & $\begin{array}{l}\text { Blade } \\
\text { Length } \\
(\mathrm{mm})\end{array}$ & $\begin{array}{l}\text { Blade } \\
\text { Width } \\
(\mathrm{mm})\end{array}$ & $\begin{array}{l}\text { Left Lateral } \\
\text { Edge }\end{array}$ & $\begin{array}{l}\text { Right Lateral } \\
\text { Edge }\end{array}$ & $\begin{array}{c}\text { Shoulder } \\
\text { Width (mm) }\end{array}$ & $\begin{array}{c}\text { Left } \\
\text { Notch } \\
\text { Depth } \\
(\mathrm{mm}) \\
\end{array}$ & $\begin{array}{l}\text { Right } \\
\text { Notch } \\
\text { Depth } \\
(\mathrm{mm}) \\
\end{array}$ & $\begin{array}{l}\text { Left } \\
\text { Notch } \\
\text { Width } \\
(\mathrm{mm}) \\
\end{array}$ & $\begin{array}{l}\text { Right } \\
\text { Notch } \\
\text { Width } \\
(\mathrm{mm}) \\
\end{array}$ & $\begin{array}{l}\text { Left } \\
\text { Notch } \\
\text { Angle }\end{array}$ & $\begin{array}{l}\text { Right } \\
\text { Notch } \\
\text { Angle }\end{array}$ \\
\hline $22-015$ & & 26.8 & Straight & Straight & 29.8 & & 7.7 & & 6.2 & & 51 \\
\hline $89-010$ & & 28 & Excurvate & Straight & 29.3 & 3.9 & & 8.4 & & 63 & 55 \\
\hline $187-011$ & & 29.5 & Straight & Straight & 34.2 & 7.9 & 7.3 & 8 & 5.9 & 57 & 50 \\
\hline $220-014$ & & 13.3 & Straight & Incurvate & 16.5 & 2.4 & 1.4 & 6.9 & 6.7 & 73 & 84 \\
\hline $525-005-013$ & 43.9 & 31.2 & Excurvate & Straight & 30.4 & 9.6 & 10.2 & 8.4 & 7.4 & 66 & 64 \\
\hline \multicolumn{12}{|l|}{$526-011^{*}$} \\
\hline $562-012$ & 19.6 & 15.1 & Indeterminate & Indeterminate & 17.4 & 2.3 & & 6 & & 78 & \\
\hline $916-010$ & & 16 & Indeterminate & Indeterminate & 19.6 & & 1.5 & & 6.6 & & 75 \\
\hline
\end{tabular}


Table 0-16. Frio Point Data Continued

\begin{tabular}{|l|c|c|c|c|c|c|c|c|}
\hline & Stem Shape & $\begin{array}{c}\text { Stem } \\
\text { Length } \\
(\mathrm{mm})\end{array}$ & $\begin{array}{c}\text { Distal Stem } \\
\text { Width }(\mathrm{mm})\end{array}$ & $\begin{array}{c}\text { Proximal } \\
\text { Stem Width } \\
(\mathrm{mm})\end{array}$ & $\begin{array}{c}\text { Stem } \\
\text { Thick } \\
(\mathrm{mm})\end{array}$ & $\begin{array}{c}\text { Base } \\
\text { Depth } \\
(\mathrm{mm})\end{array}$ & $\begin{array}{c}\text { Base } \\
\text { Notch } \\
\text { Width } \\
(\mathrm{mm})\end{array}$ & NAA \\
\hline $22-015$ & Expanding & 10.8 & & & 4.2 & 1.5 & & TRUE \\
\hline $89-010$ & Expanding & 9.8 & 18.3 & & 3.4 & 4.4 & & TRUE \\
\hline $187-011$ & Expanding & 11.5 & 19.1 & 30.5 & 5.8 & 3 & 10.4 & FALSE \\
\hline $220-014$ & Expanding & 8.7 & 13.8 & 18.3 & 5.1 & 2.8 & 10.6 & FALSE \\
\hline $525-005-013$ & Expanding & 10.6 & 20.4 & 30 & 4.8 & 3.6 & 10.4 & TRUE \\
\hline $526-011^{*}$ & & & & & & & & FALSE \\
\hline $562-012$ & Expanding & 13.1 & 15.1 & 19.4 & 5.3 & 2.5 & 8.6 & FALSE \\
\hline $916-010$ & Indeterminate & & 15.5 & & 6.2 & & & FALSE \\
\hline
\end{tabular}

* Medial section refits with base \#525-5-13 
The Varga Site

Texas Department of Transportation

Table 0-17. Late Archaic Projectile Point Data

\begin{tabular}{|c|c|c|c|c|c|c|c|c|c|c|}
\hline Cat. No. & Unit & $\begin{array}{c}\text { Depth } \\
\text { (cmbd) }\end{array}$ & Point Type & Condition & $\begin{array}{c}\text { Break } \\
\text { Type }\end{array}$ & Shape & $\begin{array}{c}\text { Rejuvenation } \\
\text { Scar }\end{array}$ & $\begin{array}{c}\text { Raw } \\
\text { Resharpening Type }\end{array}$ & $\begin{array}{c}\text { Material } \\
\text { Texture }\end{array}$ \\
\hline $11-005-014$ & N99,E51 & $7-20$ & Edgewood & Complete & Unbroken & Triangular & Absent & $\begin{array}{c}\text { Alternate Beveled } \\
\text { Unifacial }\end{array}$ & Chert & Fine \\
\hline $187-010$ & N101,E51 & 24.5 & Marcos & Complete & Use & Triangular & Absent & $\begin{array}{c}\text { Alternate Beveled } \\
\text { Unifacial }\end{array}$ & Chert & Fine \\
\hline $197-014$ & N101,E52 & $20-30$ & $\begin{array}{c}\text { Unknown } \\
\text { Dart }\end{array}$ & Medial & Use & Indeterminate & Absent & Indeterminate & Chert & Fine \\
\hline $197-015$ & N101,E52 & $20-30$ & $\begin{array}{c}\text { Unknown } \\
\text { Dart }\end{array}$ & Distal & Use & Indeterminate & Absent & Indeterminate & Chert & Fine \\
\hline $198-010$ & N101,E52 & $30-40$ & Montell & Medial & Use & Triangular & Absent & None & Chert & Fine \\
\hline $394-010$ & N103,E56 & $10-20$ & Castroville & Proximal & Use & Indeterminate & Absent & Indeterminate & Chert & Fine \\
\hline $691-011$ & N109,E49 & $10-20$ & Ensor & Proximal & Use & Triangular & Absent & Beveled Unifacial & Chert & Fine \\
\hline
\end{tabular}

\begin{tabular}{|c|c|c|c|c|c|c|c|c|c|c|}
\hline Cat. No. & $\begin{array}{l}\text { Percent } \\
\text { Patination }\end{array}$ & $\begin{array}{l}\text { Percent } \\
\text { Cortex }\end{array}$ & Heating & $\begin{array}{l}\text { Length } \\
(\mathrm{mm})\end{array}$ & $\begin{array}{l}\text { Thick } \\
(\mathrm{mm})\end{array}$ & $\begin{array}{l}\text { Wt. } \\
\text { (g) }\end{array}$ & Long X-Section & Trans X-Section & Preform & Flaking Pattern \\
\hline $11-005-014$ & 0 & 0 & None & 33.5 & 5.6 & 4.3 & $\begin{array}{l}\text { Wedged Base, } \\
\text { Thick Body }\end{array}$ & Plano-Convex & Flake & Chevron \\
\hline $187-010$ & 0 & 0 & Heat-Treated & 36.7 & 5.7 & 5.8 & $\begin{array}{c}\text { Wedged Base, } \\
\text { Flat }\end{array}$ & $\begin{array}{c}\text { Biconvex } \\
\text { Symmetrical }\end{array}$ & Biface & Chevron \\
\hline $197-014$ & 0 & 0 & Indeterminate & & & & Indeterminate & Indeterminate & Indeterminate & Indeterminate \\
\hline $197-015$ & 0 & 0 & Indeterminate & & & & Indeterminate & Indeterminate & Indeterminate & Indeterminate \\
\hline $198-010$ & 0 & 0 & Heat-Treated & & 6.7 & 5.5 & Tapered Base/Tip & $\begin{array}{c}\text { Biconvex } \\
\text { Asymmetrical }\end{array}$ & Biface & Chevron \\
\hline $394-010$ & 0 & 0 & None & & & & Indeterminate & $\begin{array}{l}\text { Biconvex } \\
\text { Symmetrical }\end{array}$ & Biface & Indeterminate \\
\hline 691-011 & 0 & 0 & None & & 4.5 & & Indeterminate & Plano-Convex & Flake & $\begin{array}{l}\text { Flake Blank } \\
\text { Remnant }\end{array}$ \\
\hline
\end{tabular}

\begin{tabular}{|c|c|c|c|c|c|c|c|c|c|c|c|c|}
\hline Cat. No. & $\begin{array}{c}\text { Edge } \\
\text { Rounding } \\
\end{array}$ & $\begin{array}{l}\text { Blade } \\
\text { Length } \\
(\mathrm{mm})\end{array}$ & $\begin{array}{l}\text { Blade } \\
\text { Width } \\
(\mathrm{mm})\end{array}$ & $\begin{array}{l}\text { Left Lateral } \\
\text { Edge }\end{array}$ & $\begin{array}{l}\text { Right Lateral } \\
\text { Edge }\end{array}$ & $\begin{array}{l}\text { Shoulder } \\
\text { Width } \\
(\mathrm{mm})\end{array}$ & $\begin{array}{l}\text { Left } \\
\text { Notch } \\
\text { Depth } \\
(\mathrm{mm}) \\
\end{array}$ & $\begin{array}{l}\text { Right } \\
\text { Notch } \\
\text { Depth } \\
(\mathrm{mm}) \\
\end{array}$ & $\begin{array}{l}\text { Left } \\
\text { Notch } \\
\text { Width } \\
(\mathrm{mm}) \\
\end{array}$ & $\begin{array}{l}\text { Right } \\
\text { Notch } \\
\text { Width } \\
(\mathrm{mm}) \\
\end{array}$ & $\begin{array}{l}\text { Left } \\
\text { Notch } \\
\text { Angle } \\
\end{array}$ & $\begin{array}{l}\text { Right } \\
\text { Notch } \\
\text { Angle } \\
\end{array}$ \\
\hline $11-005-014$ & Absent & 24.7 & 22 & Incurvate & Straight & 24.4 & 3.4 & 4.8 & 5 & 9 & 63 & 69 \\
\hline $187-010$ & Present & 28.1 & 23.4 & Straight & Straight & 31.4 & 6.7 & 5.9 & 4.9 & 5.1 & 55 & 49 \\
\hline 197-014 & Absent & & & Indeterminate & Indeterminate & & & & & & & \\
\hline 197-015 & Absent & & & Indeterminate & Indeterminate & & & & & & & \\
\hline $198-010$ & Absent & & 20.6 & Straight & Straight & 22.4 & & 2.8 & & 5.3 & 45 & 51 \\
\hline $394-010$ & Present & & & Indeterminate & Indeterminate & & & & & & & \\
\hline 691-011 & Present & & 19.5 & Indeterminate & Indeterminate & & 4.5 & & 6.2 & & 60 & 50 \\
\hline
\end{tabular}


Table 0-17. Late Archaic Projectile Point Data Continued

\begin{tabular}{|c|c|c|c|c|c|c|c|c|}
\hline Cat. No. & Stem Shape & $\begin{array}{c}\text { Stem Length } \\
(\mathrm{mm})\end{array}$ & $\begin{array}{c}\text { Distal Stem } \\
\text { Width }(\mathrm{mm})\end{array}$ & $\begin{array}{c}\text { Proximal } \\
\text { Stem Width } \\
(\mathrm{mm})\end{array}$ & $\begin{array}{c}\text { Stem Thick } \\
(\mathrm{mm})\end{array}$ & $\begin{array}{c}\text { Base Depth } \\
(\mathrm{mm})\end{array}$ & $\begin{array}{c}\text { Base Notch } \\
\text { Width }(\mathrm{mm})\end{array}$ & $\begin{array}{c}\text { Micro-wear } \\
\text { NAA }\end{array}$ \\
\hline $11-005-014$ & Expanding & 8.8 & 15 & 21.7 & 4.2 & 1.8 & 12.6 & TRUE \\
\hline $187-010$ & Expanding & 8.6 & 16.5 & 24.2 & 3.7 & 0.9 & 12.6 & FALSE \\
\hline $197-014$ & Indeterminate & & & & & & FALSE & TRUE \\
\hline $197-015$ & Indeterminate & & & & & & FALSE \\
\hline $198-010$ & Expanding & 6.6 & 16 & & 3.2 & 2.9 & FALSE \\
\hline $394-010$ & Expanding & 15.1 & 22.6 & 26.4 & 5 & -2.8 & FALSE \\
\hline $691-011$ & Expanding & 5.3 & 13.8 & & 3.5 & 0.8 & FALSE \\
\hline
\end{tabular}


The Varga Site

Texas Department of Transportation

Table 0-18. Late Archaic Component Biface Data

\begin{tabular}{|l|l|c|c|c|c|c|c|c|c|}
\hline Cat. No. & Unit & $\begin{array}{c}\text { Depth } \\
\text { (cmbs) }\end{array}$ & Feature No & $\begin{array}{c}\text { Biface } \\
\text { Stage }\end{array}$ & Condition & Break Type & $\begin{array}{c}\text { Raw } \\
\text { Material }\end{array}$ & $\begin{array}{c}\text { Percent } \\
\text { Texture }\end{array}$ & $\begin{array}{c}\text { Percent } \\
\text { Patination }\end{array}$ \\
\hline $2-012$ & N99,E50 & $10-20$ & 1 & Late & Complete & Unbroken & Chert & Fine & 0 \\
\hline $197-016$ & N101,E52 & $20-30$ & 1 & Middle & Proximal & Indeterminate & Chert & Fine & 0 \\
\hline $233-010$ & N101,E55 & $20-30$ & & Middle & Complete & Unbroken & Chert & Fine & 0 \\
\hline $263-010$ & N102,E47 & $30-40$ & 1 & Late & Proximal & Manufacture & Chert & Fine & 0 \\
\hline $274-005-011$ & N102,E50 & $40-50$ & 1b & Late & Distal & Use & Chert & Fine & 0 \\
\hline $283-015$ & N102,E51 & $28-40$ & 1b & Late & Indeterminate & Use & Chert & Fine & 0 \\
\hline $293-005-012$ & N102,E52 & $20-30$ & 1C & Middle & Indeterminate & Unbroken & Chert & Fine & 0 \\
\hline $459-011$ & N105,E53 & 20 & & Late & Distal & Use & Chert & Fine & 0 \\
\hline
\end{tabular}

\begin{tabular}{|c|c|c|c|c|c|c|c|c|c|}
\hline Cat. No. & Cortex Type & Heating & Length (mm) & Width (mm) & Thick (mm) & Wt. (g) & $\begin{array}{l}\text { Long X- } \\
\text { Section }\end{array}$ & $\begin{array}{l}\text { Trans X- } \\
\text { Section }\end{array}$ & Preform \\
\hline 2-012 & None & None & 87.6 & 48.7 & 20.1 & 81.6 & $\begin{array}{l}\text { Tapered } \\
\text { Base/Tip }\end{array}$ & $\begin{array}{c}\text { Biconvex } \\
\text { Symmetrical }\end{array}$ & Flake \\
\hline $197-016$ & None & None & 65.2 & & 9.7 & & $\begin{array}{l}\text { Bi-wedge- } \\
\text { shaped }\end{array}$ & $\begin{array}{c}\text { Biconvex } \\
\text { Symmetrical }\end{array}$ & Flake \\
\hline 233-010 & $\begin{array}{l}\text { Pebble/ } \\
\text { Cobble }\end{array}$ & None & 45.2 & 35.5 & 9.8 & 18.3 & $\begin{array}{l}\text { Bi-wedge- } \\
\text { shaped }\end{array}$ & $\begin{array}{c}\text { Biconvex } \\
\text { Symmetrical }\end{array}$ & Flake \\
\hline $263-010$ & None & None & & 57.9 & 18.4 & & $\begin{array}{l}\text { Tapered } \\
\text { Base/Tip }\end{array}$ & $\begin{array}{l}\text { Biconvex } \\
\text { Symmetrical }\end{array}$ & Flake \\
\hline $274-005-011$ & None & None & & 21.2 & 7.3 & 9.8 & $\begin{array}{l}\text { Tapered } \\
\text { Base/Tip }\end{array}$ & $\begin{array}{c}\text { Biconvex } \\
\text { Symmetrical }\end{array}$ & Flake \\
\hline 283-015 & None & Heat-Treated & & & & & Indeterminate & Indeterminate & Biface \\
\hline 293-005-012 & None & Burned & & & & & Indeterminate & Indeterminate & Indeterminate \\
\hline 459-011 & None & None & & & 7.3 & & Indeterminate & $\begin{array}{c}\text { Biconvex } \\
\text { Symmetrical }\end{array}$ & Biface \\
\hline
\end{tabular}

\begin{tabular}{|l|c|c|c|c|c|c|c|c|c|}
\hline Cat. No. & Shape & $\begin{array}{c}\text { Flaking } \\
\text { Pattern }\end{array}$ & $\begin{array}{c}\text { Rounding on } \\
\text { edges }\end{array}$ & $\begin{array}{c}\text { Left Lateral } \\
\text { Edge }\end{array}$ & $\begin{array}{c}\text { Right Lateral } \\
\text { Edge }\end{array}$ & $\begin{array}{c}\text { Rejuvenation } \\
\text { Scar }\end{array}$ & $\begin{array}{c}\text { Resharpening } \\
\text { Type }\end{array}$ & $\begin{array}{c}\text { Micro- } \\
\text { wear }\end{array}$ & $\begin{array}{c}\text { NAA } \\
\text { None }\end{array}$ \\
\hline $2-012$ & Ovate & Random & Absent & Excurvate & Excurvate & Absent & None & TRUE & FALSE \\
\hline $197-016$ & Indeterminate & Random & Present & Straight & Indeterminate & Absent & None & FALSE \\
\hline $233-010$ & Round & Random & Absent & Excurvate & Straight & Absent & None & TRUE \\
\hline $263-010$ & Ovate & Random & Absent & Excurvate & Excurvate & Absent & None & TRUE & FALSE \\
\hline $274-005-011$ & Lanceolate & $\begin{array}{c}\text { Oblique } \\
\text { Parallel }\end{array}$ & Absent & Excurvate & Excurvate & Absent & None & TRUE & FALSE \\
\hline $283-015$ & Indeterminate & Random & Present & Indeterminate & Indeterminate & Absent & None & FALSE & TRUE \\
\hline $293-005-012$ & Indeterminate & Indeterminate & Absent & Indeterminate & Indeterminate & Absent & None & FALSE & TRUE \\
\hline $459-011$ & Indeterminate & Random & Present & Straight & Straight & Absent & None & FALSE \\
\hline
\end{tabular}


Table 0-19. Late Archaic Component Scraper Data, 41ED28, Varga Site

\begin{tabular}{|l|c|c|c|c|c|c|c|c|c|c|}
\hline Cat. No. & Unit & $\begin{array}{c}\text { Depth } \\
(\mathrm{cmbd})\end{array}$ & $\begin{array}{c}\text { Tool } \\
\text { Subtype }\end{array}$ & Condition & Break Type & $\begin{array}{c}\text { Raw } \\
\text { Material }\end{array}$ & Texture & $\begin{array}{c}\text { Percent } \\
\text { Patination }\end{array}$ & $\begin{array}{c}\text { Percent } \\
\text { Cortex }\end{array}$ & $\begin{array}{c}\text { Cortex } \\
\text { Type }\end{array}$ \\
\hline $2-010$ & N99,E50 & $10-20$ & $\begin{array}{c}\text { End- } \\
\text { Scraper }\end{array}$ & Distal & Use & Chert & Fine & 0 & 25 & $\begin{array}{c}\text { Pebble/ } \\
\text { Cobble }\end{array}$ \\
\hline $3-010$ & N99,E50 & $20-30$ & $\begin{array}{c}\text { Side/End } \\
\text { Scraper }\end{array}$ & Complete & Unbroken & Chert & Fine & 0 & 50 & $\begin{array}{c}\text { Pebble/ } \\
\text { Cobble }\end{array}$ \\
\hline $293-005-013$ & N102,E52 & $20-30$ & $\begin{array}{c}\text { Side/End } \\
\text { Scraper }\end{array}$ & Complete & Unbroken & Chert & Fine & 0 & 25 & $\begin{array}{c}\text { Pebble/ } \\
\text { Cobble }\end{array}$ \\
\hline
\end{tabular}

\begin{tabular}{|l|c|c|c|c|c|c|c|c|c|c|}
\hline Cat. No. & Heating & $\begin{array}{c}\text { Length } \\
(\mathrm{mm})\end{array}$ & Width $(\mathrm{mm})$ & $\begin{array}{c}\text { Thickness } \\
(\mathrm{mm})\end{array}$ & Wt. $(\mathrm{g})$ & Shape & $\begin{array}{c}\text { Edge } \\
\text { Flaking }\end{array}$ & $\begin{array}{c}\text { Edge } \\
\text { Rounding }\end{array}$ & $\begin{array}{c}\text { Bit 1 } \\
\text { No. Bits }\end{array}$ \\
\hline $2-010$ & None & & & 15.8 & & Indeterminate & Distal & Absent & 1 \\
\hline $3-010$ & None & 72.5 & 45.3 & 20.1 & 69.2 & Lanceolate & $\begin{array}{c}\text { Distal/ } \\
\text { Lateral }\end{array}$ & Absent & 2 & Distal \\
\hline $293-005-013$ & None & 70.6 & 40.5 & 25 & 63 & Ovistal & $\begin{array}{c}\text { Distal/ } \\
\text { Lateral }\end{array}$ & Absent & 3 & Lateral \\
\hline
\end{tabular}

\begin{tabular}{|l|c|c|c|c|c|c|c|c|c|c|}
\hline Cat. No. & Bit 1 Shape & $\begin{array}{c}\text { Bit 1 } \\
\text { Retouch }\end{array}$ & $\begin{array}{c}\text { Bit 1 } \\
\text { Length } \\
(\mathrm{mm})\end{array}$ & $\begin{array}{c}\text { Bit 1 Thick } \\
(\mathrm{mm})\end{array}$ & $\begin{array}{c}\text { Bit 1 } \\
\text { Angle }\end{array}$ & Bit 2 Location & Bit 2 Shape & $\begin{array}{c}\text { Bit 2 } \\
\text { Retouch }\end{array}$ & $\begin{array}{c}\text { Bit 2 } \\
\text { Length } \\
(\mathrm{mm})\end{array}$ & $\begin{array}{c}\text { Bit 2 Thick } \\
(\mathrm{mm})\end{array}$ \\
\hline $2-010$ & Excurvate & $\begin{array}{c}\text { Irregular } \\
\text { Continuous }\end{array}$ & 62.4 & 7.2 & 72 & & & & \\
\hline $3-010$ & Excurvate & $\begin{array}{c}\text { Regular } \\
\text { Continuous }\end{array}$ & 31.6 & 5 & 57 & Lateral & Excurvate & $\begin{array}{c}\text { Regular } \\
\text { Continuous }\end{array}$ & 32.8 & 8.7 \\
\hline $293-005-013$ & Straight & $\begin{array}{c}\text { Irregular } \\
\text { Continuous }\end{array}$ & 61.1 & 4.8 & 74 & Distal & Excurvate & $\begin{array}{c}\text { Regular } \\
\text { Continuous }\end{array}$ & 29.8 & 23.5 \\
\hline
\end{tabular}

\begin{tabular}{|c|c|c|c|c|c|c|c|c|c|c|c|}
\hline Cat. No. & $\begin{array}{c}\text { Bit } 2 \\
\text { Angle }\end{array}$ & $\begin{array}{c}\text { Bit } 3 \\
\text { Location }\end{array}$ & $\begin{array}{l}\text { Bit } 3 \\
\text { Shape }\end{array}$ & $\begin{array}{c}\text { Bit } 3 \\
\text { Retouch }\end{array}$ & $\begin{array}{l}\text { Bit } 3 \\
\text { Length } \\
\text { (mm) }\end{array}$ & $\begin{array}{l}\text { Bit } 3 \\
\text { Thick } \\
(\mathrm{mm})\end{array}$ & $\begin{array}{c}\text { Bit } 3 \\
\text { Angle }\end{array}$ & $\begin{array}{c}\text { Rejuvenat } \\
\text { ion Scar }\end{array}$ & $\begin{array}{c}\text { Flake } \\
\text { Size }\end{array}$ & $\begin{array}{l}\text { Micro- } \\
\text { wear }\end{array}$ & NAA \\
\hline $2-010$ & & & & & & & & Absent & & TRUE & TRUE \\
\hline $3-010$ & 77 & & & & & & & Absent & 8 & TRUE & FALSE \\
\hline $293-005-013$ & 60 & Lateral & Excurvate & $\begin{array}{l}\text { Regular } \\
\text { Continuous }\end{array}$ & 44.2 & 5.3 & 55 & Absent & 7 & TRUE & FALSE \\
\hline
\end{tabular}


The Varga Site

Texas Department of Transportation

Table 0-20. Late Archaic Core Data

\begin{tabular}{|c|c|c|c|c|c|c|c|c|c|c|}
\hline Cat. No. & $161-011$ & $178-010$ & $197-013$ & $\begin{array}{c}\text { 293-005- } \\
014\end{array}$ & $352-010$ & $378-011$ & $378-012$ & 491-012 & $807-012^{*}$ & $929-011^{*}$ \\
\hline Unit & N101,E47 & N101,E50 & N101,E52 & N102,E52 & N103,E47 & N103,E52 & N103,E52 & N106,E47 & N115,E75 & N123,E69 \\
\hline Depth (cmbd) & $45-50$ & $20-30$ & $20-30$ & $20-30$ & $30-40$ & $20-30$ & $20-30$ & $30-40$ & $30-45$ & $20-25$ \\
\hline Feature No. & 1 & 1 & 1 & $1 \mathrm{c}$ & 1 & & & & & \\
\hline Condition & Complete & Exhausted & Fragmented & Fragmented & Exhausted & Complete & Complete & Complete & Complete & Complete \\
\hline Heating & None & None & None & None & None & None & None & None & None & None \\
\hline Tool Type & $\begin{array}{c}\text { Multi- } \\
\text { Directional }\end{array}$ & Bifacial & Bifacial & Bifacial & Bifacial & $\begin{array}{c}\text { Multi- } \\
\text { Directional }\end{array}$ & $\begin{array}{c}\text { Multi- } \\
\text { Directional }\end{array}$ & $\begin{array}{c}\text { Multi- } \\
\text { Directional }\end{array}$ & Bifacial & $\begin{array}{c}\text { Multi- } \\
\text { Directiona }\end{array}$ \\
\hline $\begin{array}{l}\text { Rejuenation } \\
\text { Scar }\end{array}$ & Absent & Absent & Absent & Absent & Absent & Absent & Absent & Absent & Absent & Absent \\
\hline Raw Material & Chert & Chert & Chert & Chert & Chert & Chert & Chert & Chert & Chert & Chert \\
\hline Texture & Fine & Fine & Fine & Fine & Fine & Fine & Fine & Fine & Fine & Fine \\
\hline $\begin{array}{c}\text { Percent } \\
\text { Patination }\end{array}$ & 0 & 0 & 0 & 0 & 0 & 0 & 0 & 0 & 0 & 0 \\
\hline Percent Cortex & 0 & 0 & 25 & 0 & 0 & 25 & 25 & 25 & 50 & 0 \\
\hline Cortex Type & None & None & $\begin{array}{l}\text { Pebble/ } \\
\text { Cobble }\end{array}$ & None & None & $\begin{array}{l}\text { Pebble/ } \\
\text { Cobble }\end{array}$ & $\begin{array}{l}\text { Pebble/ } \\
\text { Cobble }\end{array}$ & $\begin{array}{l}\text { Pebble/ } \\
\text { Cobble }\end{array}$ & $\begin{array}{l}\text { Pebble/ } \\
\text { Cobble }\end{array}$ & None \\
\hline Length (mm) & 86.9 & 54.1 & 80.8 & 89.3 & 70.9 & 93.9 & 97.8 & 92.2 & 102 & 107 \\
\hline Width (mm) & 53.5 & 45 & 50.6 & 53.8 & 51.4 & 78.5 & 64.8 & 74.2 & 70.4 & 70.4 \\
\hline Thick (mm) & 46.4 & 22 & 24 & 35 & 12.7 & 35.4 & 62 & 58.5 & 44.1 & 52.3 \\
\hline Wt. (g) & 220.5 & 43.8 & 102.5 & 196.3 & 42.8 & 268.2 & 443 & 512.3 & 415.3 & 401.5 \\
\hline
\end{tabular}


Table 0-21. MA Projectile

\begin{tabular}{|c|c|c|c|c|c|c|c|c|c|c|c|}
\hline Cat. No. & Unit & $\begin{array}{l}\text { Depth } \\
\text { (cmbs) }\end{array}$ & Point Type & Condition & $\begin{array}{l}\text { Break } \\
\text { Type }\end{array}$ & $\begin{array}{c}\text { Resharpening } \\
\text { Type }\end{array}$ & $\begin{array}{c}\text { Raw } \\
\text { Material }\end{array}$ & Texture & $\begin{array}{c}\text { Percent } \\
\text { Patination }\end{array}$ & $\begin{array}{l}\text { Percent } \\
\text { Cortex }\end{array}$ & Heating \\
\hline $138-012^{*}$ & N100,E55 & $80-90$ & $\begin{array}{c}\text { Early } \\
\text { Triangular }\end{array}$ & Proximal & Use & None & Chert & Fine & 0 & 0 & None \\
\hline $182-013$ & N101,E50 & $60-70$ & $\begin{array}{c}\text { Early } \\
\text { Triangular }\end{array}$ & Complete & Unbroken & None & Chert & Fine & 0 & 0 & None \\
\hline $213-012$ & N101,E53 & $70-80$ & Carrizo & Distal & Use & None & Chert & Fine & 0 & 0 & None \\
\hline $225-011$ & N101,E54 & $70-80$ & Unknown Dart & Distal & Use & None & Chert & Fine & 0 & 0 & Heat-Treated \\
\hline $278-027^{\star *}$ & N102,E50 & $80-90$ & $\begin{array}{c}\text { Early } \\
\text { Triangular }\end{array}$ & Distal & Use & $\begin{array}{l}\text { Beveled } \\
\text { Unifacial }\end{array}$ & Chert & Fine & 0 & 0 & None \\
\hline 308-011 & N102,E53 & $60-70$ & $\begin{array}{c}\text { Early } \\
\text { Triangular }\end{array}$ & Proximal & Use & None & Chert & Fine & 0 & 0 & None \\
\hline 537-017 & N106,E55 & $40-50$ & $\begin{array}{c}\text { Early } \\
\text { Triangular }\end{array}$ & Proximal & Use & None & Chert & Fine & 0 & 0 & None \\
\hline 648-012 & N108,E52 & $20-30$ & Unknown Dart & Distal & Use & Indeterminate & Chert & Fine & 0 & 0 & Indeterminate \\
\hline $654-010$ & N108,E53 & $10-20$ & $\begin{array}{c}\text { Early } \\
\text { Triangular }\end{array}$ & Distal & Use & None & Chert & Fine & 0 & 0 & Burned \\
\hline 655-011 & N108,E53 & $20-30$ & Unknown Dart & Proximal & Use & Indeterminate & Chert & Fine & 0 & 0 & Burned \\
\hline $675-010$ & N108,E56 & $30-40$ & Unknown Dart & Barb & Use & Indeterminate & Chert & Fine & 0 & 0 & Burned \\
\hline $729-010^{\star *}$ & N109,E54 & $30-40$ & $\begin{array}{c}\text { Early } \\
\text { Triangular }\end{array}$ & Proximal & Use & None & Chert & Fine & 0 & 0 & Heat-Treated \\
\hline $922-010$ *** & N123,E68 & $49-59$ & $\begin{array}{c}\text { Early } \\
\text { Triangular }\end{array}$ & Proximal & Use & $\begin{array}{c}\text { Alternate } \\
\text { Beveled } \\
\text { Bifacial } \\
\end{array}$ & Chert & Fine & 25 & 0 & Indeterminate \\
\hline $1140-010^{* * *}$ & N131,E70 & $60-70$ & $\begin{array}{c}\text { Early } \\
\text { Triangular }\end{array}$ & Proximal & Use & $\begin{array}{l}\text { Alternate } \\
\text { Beveled } \\
\text { Bifacial }\end{array}$ & Chert & Fine & 0 & 0 & Indeterminate \\
\hline
\end{tabular}

\begin{tabular}{|c|c|c|c|c|c|c|c|c|c|c|}
\hline Cat. No. & $\begin{array}{l}\text { Length } \\
(\mathrm{mm})\end{array}$ & $\begin{array}{l}\text { Thickness } \\
(\mathrm{mm})\end{array}$ & $\begin{array}{l}\text { Blade } \\
\text { Width } \\
(\mathrm{mm})\end{array}$ & Wt. (g) & $\begin{array}{l}\text { Long X- } \\
\text { Section }\end{array}$ & $\begin{array}{l}\text { Trans X- } \\
\text { Section }\end{array}$ & Preform & Shape & $\begin{array}{l}\text { Flaking } \\
\text { Pattern }\end{array}$ & $\begin{array}{l}\text { Left Lateral } \\
\text { Edge }\end{array}$ \\
\hline $138-012^{*}$ & & 6.5 & & 6.1 & Indeterminate & $\begin{array}{c}\text { Biconvex } \\
\text { Symmetrical }\end{array}$ & Biface & Triangular & Chevron & Indeterminate \\
\hline $182-013$ & 52.9 & 4.9 & 38.3 & 8.9 & $\begin{array}{l}\text { Tapered } \\
\text { Base/Tip }\end{array}$ & Indeterminate & Biface & Triangular & $\begin{array}{c}\text { Oblique } \\
\text { Subparallel }\end{array}$ & Excurvate \\
\hline 213-012 & & 7.7 & & & & $\begin{array}{l}\text { Plano- } \\
\text { Convex }\end{array}$ & Flake & Lanceolate & Subparallel & Excurvate \\
\hline 225-011 & & 7.1 & & 7.4 & Indeterminate & $\begin{array}{c}\text { Biconvex } \\
\text { Symmetrical }\end{array}$ & Biface & Triangular & Chevron & Excurvate \\
\hline $278-027^{\star *}$ & 31.2 & 5 & & 4.4 & $\begin{array}{l}\text { Tapered } \\
\text { Base/Tip }\end{array}$ & $\begin{array}{l}\text { Plano- } \\
\text { Convex }\end{array}$ & Biface & Triangular & Subparallel & Indeterminate \\
\hline 308-011 & & 6 & 34.5 & & $\begin{array}{l}\text { Tapered } \\
\text { Base/Tip }\end{array}$ & $\begin{array}{c}\text { Biconvex } \\
\text { Asymmetrical }\end{array}$ & Biface & Triangular & Chevron & Excurvate \\
\hline 537-017 & & 6 & 28.3 & & $\begin{array}{l}\text { Tapered } \\
\text { Base/Tip }\end{array}$ & $\begin{array}{c}\text { Biconvex } \\
\text { Symmetrical }\end{array}$ & Biface & Triangular & Subparallel & Straight \\
\hline 648-012 & & & & & Indeterminate & $\begin{array}{c}\text { Biconvex } \\
\text { Symmetrical }\end{array}$ & Biface & Triangular & Indeterminate & Indeterminate \\
\hline $654-010$ & 3 & 5.4 & & 4.8 & $\begin{array}{c}\text { Tapered } \\
\text { Base } \\
\end{array}$ & $\begin{array}{l}\text { Plano- } \\
\text { Convex }\end{array}$ & Biface & Triangular & Indeterminate & Indeterminate \\
\hline 655-011 & & & & 6.6 & $\begin{array}{l}\text { Tapered } \\
\text { Base/Tip }\end{array}$ & $\begin{array}{c}\text { Biconvex } \\
\text { Symmetrical }\end{array}$ & Biface & Triangular & Indeterminate & Straight \\
\hline $675-010$ & & & & & Indeterminate & Indeterminate & Biface & Indeterminate & Indeterminate & Indeterminate \\
\hline $729-010^{\star *}$ & & 7.7 & 34.9 & 14.8 & $\begin{array}{c}\text { Wedged } \\
\text { Base, Flat }\end{array}$ & $\begin{array}{c}\text { Biconvex } \\
\text { Symmetrical }\end{array}$ & Biface & Lanceolate & Parallel & Straight \\
\hline $922-010$ *** & & 6 & 33.5 & & Indeterminate & $\begin{array}{l}\text { Plano- } \\
\text { Convex }\end{array}$ & Biface & Triangular & Chevron & Indeterminate \\
\hline $1140-010^{\star \star \star *}$ & & 5.1 & 31.9 & & Indeterminate & $\begin{array}{c}\text { Biconvex } \\
\text { Asymmetrical }\end{array}$ & Biface & Triangular & Indeterminate & Indeterminate \\
\hline
\end{tabular}


The Varga Site

Texas Department of Transportation

Table 0-21. MA Projectile Continued

\begin{tabular}{|c|c|c|c|c|c|c|c|}
\hline Cat. No. & $\begin{array}{l}\text { Right } \\
\text { Notch } \\
\text { Depth } \\
(\mathrm{mm}) \\
\end{array}$ & $\begin{array}{l}\text { Left } \\
\text { Notch } \\
\text { Width } \\
(\mathrm{mm}) \\
\end{array}$ & $\begin{array}{l}\text { Right Notch } \\
\text { Width }(\mathrm{mm})\end{array}$ & $\begin{array}{l}\text { Left } \\
\text { Notch } \\
\text { Angle }\end{array}$ & $\begin{array}{l}\text { Right } \\
\text { Notch } \\
\text { Angle }\end{array}$ & Stem Shape & $\begin{array}{l}\text { Micro- } \\
\text { wear }\end{array}$ \\
\hline $138-012^{\star}$ & & & & & & & FALSE \\
\hline $182-013$ & & & & & & & TRUE \\
\hline $213-012$ & & & & & & & FALSE \\
\hline $225-011$ & & & & & & Indeterminate & FALSE \\
\hline $278-027^{\star *}$ & & & & & & & FALSE \\
\hline $308-011$ & & & & & & & TRUE \\
\hline $537-017$ & & & & & & & TRUE \\
\hline $648-012$ & & & & & & Indeterminate & FALSE \\
\hline $654-010$ & & & & & & & FALSE \\
\hline $655-011$ & 4.2 & & 12.6 & 60 & 37 & Expanding & FALSE \\
\hline $675-010$ & & & & & & Indeterminate & FALSE \\
\hline $729-010^{\star \star}$ & & & & & & & TRUE \\
\hline $922-010^{* \star *}$ & & & & & & & \\
\hline $1140-010^{\star \star \star}$ & & & & & & & FALSE \\
\hline
\end{tabular}

* From mixed context; ** From the Early Archaic component; ${ }^{* * *}$ From Block B 
Table 0-22. Middle Archaic Component Biface Data

\begin{tabular}{|l|c|c|c|c|c|c|c|c|c|c|}
\hline Cat. No. & Unit & $\begin{array}{c}\text { Depth } \\
(\mathrm{cmbd})\end{array}$ & $\begin{array}{c}\text { Biface } \\
\text { Stage }\end{array}$ & Condition & Break Type & $\begin{array}{c}\text { Raw } \\
\text { Material }\end{array}$ & Texture & $\begin{array}{c}\text { Percent } \\
\text { Patination }\end{array}$ & $\begin{array}{c}\text { Percent } \\
\text { Cortex }\end{array}$ & $\begin{array}{c}\text { Cortex } \\
\text { Type }\end{array}$ \\
\hline $70-010$ & N99,E56 & $50-60$ & Late & Indeterminate & Indeterminate & Chert & Fine & 0 & 0 & None \\
\hline $149-010$ & N100,E56 & $60-70$ & Late & Proximal & Manufacture & Chert & Fine & 0 & 0 & None \\
\hline $213-010$ & N101,E53 & $70-80$ & Middle & Proximal & Manufacture & Chert & Fine & 0 & 0 & None \\
\hline $287-010$ & N102,E51 & $70-80$ & Early & Complete & Unbroken & Chert & Fine & 0 & 25 & $\begin{array}{c}\text { Pebble/ } \\
\text { Cobble }\end{array}$ \\
\hline $417-013$ & N104,E56 & $40-50$ & Middle & Complete & Unbroken & Chert & Fine & 0 & 0 & None \\
\hline $418-028$ & N104,E56 & $50-60$ & Late & Indeterminate & Use & Chert & Fine & 0 & 0 & None \\
\hline $419-012$ & N104,E56 & $60-70$ & Middle & Complete & Unbroken & Chert & Fine & 0 & 0 & None \\
\hline $416-10428-010$ & N104,E47 & $40-50$ & Late & Distal & Use & Chert & Fine & 25 & 0 & None \\
\hline $544-012$ & N106,E56 & $20-30$ & Late & Indeterminate & Use & Chert & Fine & 0 & 0 & None \\
\hline $545-010$ & N106,E56 & $30-40$ & Late & Distal & Use & Chert & Fine & 25 & 0 & None \\
\hline $648-013$ & N108,E52 & $20-30$ & Middle & Distal & Use & Chert & Fine & 0 & 0 & None \\
\hline
\end{tabular}

\begin{tabular}{|c|c|c|c|c|c|c|c|c|c|}
\hline Cat. No. & Heating & $\begin{array}{c}\text { Length } \\
(\mathrm{mm})\end{array}$ & $\begin{array}{l}\text { Width } \\
(\mathrm{mm})\end{array}$ & $\begin{array}{l}\text { Thick } \\
(\mathrm{mm})\end{array}$ & $\begin{array}{l}\text { Wt. } \\
\text { (g) }\end{array}$ & Long X-Section & Trans X-Section & Preform & Shape \\
\hline $70-010$ & None & & & & & Indeterminate & Indeterminate & Flake & Indeterminate \\
\hline 149-010 & None & & & 8 & & Indeterminate & Biconvex Symmetrical & Biface & Indeterminate \\
\hline 213-010 & Burned & & 43.4 & 15.4 & & Indeterminate & Biconvex Symmetrical & Biface & Indeterminate \\
\hline 287-010 & None & 39.4 & 32.2 & 13.7 & 20.5 & Indeterminate & Plano-Convex & Biface & Indeterminate \\
\hline $417-013$ & None & 87.2 & 66.7 & 20.6 & 103.7 & Bi-wedge-shaped & Biconvex Symmetrical & Biface & Ovate \\
\hline $418-028$ & None & & & 8.3 & & Indeterminate & Plano-Convex & Flake & Indeterminate \\
\hline 419-012 & Heat-Treated & 82 & 54.7 & 14.2 & 76.9 & Tapered Base & Plano-Convex & Flake & Lunate \\
\hline $416-10 \quad 428-010$ & None & 59 & & 9.1 & 15.2 & Tapered Base/Tip & Biconvex Symmetrical & Biface & Teardrop \\
\hline 544-012 & Burned & & & 8.4 & & Indeterminate & Biconvex Symmetrical & Biface & Indeterminate \\
\hline $545-010$ & None & & & 10 & & Indeterminate & Biconvex Symmetrical & Biface & Indeterminate \\
\hline 648-013 & Burned & & & 7.1 & & Indeterminate & Plano-Convex & Biface & Indeterminate \\
\hline
\end{tabular}

\begin{tabular}{|l|cc|c|c|c|c|c|c|}
\hline Cat. No. & Flaking Pattern & $\begin{array}{c}\text { Edge } \\
\text { Rounding }\end{array}$ & $\begin{array}{c}\text { Left Lateral } \\
\text { Edge }\end{array}$ & $\begin{array}{c}\text { Right Lateral } \\
\text { Edge }\end{array}$ & $\begin{array}{c}\text { Rejuvenation } \\
\text { Scar }\end{array}$ & $\begin{array}{c}\text { Resharpening } \\
\text { Type }\end{array}$ & Micro-wear & NAA \\
\hline $70-010$ & Random & Absent & Indeterminate & Indeterminate & Absent & None & FALSE & TRUE \\
\hline $149-010$ & Parallel & Present & Excurvate & Indeterminate & Present & None & FALSE & TRUE \\
\hline $213-010$ & Random & Absent & Excurvate & Excurvate & Absent & None & FALSE & FALSE \\
\hline $287-010$ & Indeterminate & Present & Excurvate & Straight & Absent & None & FALSE & FALSE \\
\hline $417-013$ & Random & Absent & Excurvate & Excurvate & Absent & None & FALSE & TRUE \\
\hline $418-028$ & Subparallel & Absent & Straight & Excurvate & Absent & None & TRUE & FALSE \\
\hline $419-012$ & Random & Absent & Excurvate & Excurvate & Absent & None & TRUE & FALSE \\
\hline $416-10428-010$ & Random & Absent & Indeterminate & Excurvate & Absent & None & FALSE & TRUE \\
\hline $544-012$ & Random & Absent & Indeterminate & Indeterminate & Absent & None & FALSE & TRUE \\
\hline $545-010$ & Random & Absent & Straight & Excurvate & Absent & None & FALSE & TRUE \\
\hline $648-013$ & $\begin{array}{c}\text { Flake Blank } \\
\text { Remnant }\end{array}$ & Present & Indeterminate & Excurvate & Absent & $\begin{array}{c}\text { Beveled } \\
\text { Unifacial }\end{array}$ & FALSE & FALSE \\
\hline
\end{tabular}


The Varga Site

Texas Department of Transportation

Table 0-23. Middle Archaic Component Scraper Data

\begin{tabular}{|c|c|c|c|c|c|c|c|c|c|c|}
\hline Cat. No. & Unit & $\begin{array}{c}\text { Depth } \\
\text { (cmbd) }\end{array}$ & $\begin{array}{c}\text { Tool } \\
\text { Subtype }\end{array}$ & Condition & $\begin{array}{c}\text { Break } \\
\text { Type }\end{array}$ & $\begin{array}{c}\text { Raw } \\
\text { Material }\end{array}$ & Texture & $\begin{array}{c}\text { Percent } \\
\text { Patination }\end{array}$ & $\begin{array}{c}\text { Percent } \\
\text { Cortex }\end{array}$ & \begin{tabular}{c} 
Cortex Type \\
\hline $100-011$
\end{tabular} \\
N100,E52 & $30-40$ & $\begin{array}{c}\text { End- } \\
\text { Scraper }\end{array}$ & Complete & Unbroken & Chert & Fine & 0 & 25 & Pebble/Cobble \\
\hline $124-010$ & N100,E54 & $60-70$ & $\begin{array}{c}\text { Side- } \\
\text { Scraper }\end{array}$ & Distal & Use & Chert & Fine & 0 & 25 & Pebble/Cobble \\
\hline $318-014$ & N102,E54 & $80-90$ & $\begin{array}{c}\text { Side- } \\
\text { Scraper }\end{array}$ & Proximal & Use & Chert & Fine & 0 & 0 & None \\
\hline
\end{tabular}

\begin{tabular}{|c|c|c|c|c|c|c|c|c|c|c|}
\hline Cat. No. & Heating & $\begin{array}{c}\text { Length } \\
(\mathrm{mm})\end{array}$ & $\begin{array}{c}\text { Width } \\
(\mathrm{mm})\end{array}$ & $\begin{array}{c}\text { Thick } \\
(\mathrm{mm})\end{array}$ & Wt. (g) & Shape & Edge Flaking & $\begin{array}{c}\text { Edge } \\
\text { Rounding }\end{array}$ & No. Bits & Bit 1 Location \\
\hline $100-011$ & Burned & 60.2 & 77.6 & 16.8 & 62 & Round & Distal/Lateral & Absent & 3 & Lateral/Distal \\
\hline $124-010$ & Heat-Treated & 50.8 & 46 & 16.7 & 29.9 & Irregular & Distal/Lateral & Present & 1 & Lateral/Distal \\
\hline $318-014$ & Indeterminate & 46.3 & 41.1 & 10.7 & 23.1 & Round & Lateral Only & Present & 1 & Lateral \\
\hline
\end{tabular}

\begin{tabular}{|c|c|c|c|c|c|c|c|c|c|c|}
\hline Cat. No. & $\begin{array}{c}\text { Bit 1 } \\
\text { Shape }\end{array}$ & $\begin{array}{c}\text { Bit 1 } \\
\text { Retouch }\end{array}$ & $\begin{array}{c}\text { Bit 1 } \\
\text { Length } \\
(\mathrm{mm})\end{array}$ & $\begin{array}{c}\text { Bit 1 } \\
\text { Thick } \\
(\mathrm{mm})\end{array}$ & $\begin{array}{c}\text { Bit 1 } \\
\text { Angle }\end{array}$ & $\begin{array}{c}\text { Bit 2 } \\
\text { Location }\end{array}$ & Bit 2 Shape & Bit Retouch 2 & $\begin{array}{c}\text { Bit 2 } \\
\text { Length } \\
(\mathrm{mm})\end{array}$ & $\begin{array}{c}\text { Bit 2 } \\
\text { Thick } \\
(\mathrm{mm})\end{array}$ \\
\hline $100-011$ & Excurvate & $\begin{array}{c}\text { Regular } \\
\text { Continuous }\end{array}$ & 50.8 & 5.9 & 70 & Distal & Excurvate & Regular Continuous & 41 & 3.1 \\
\hline $124-010$ & Straight & $\begin{array}{c}\text { Regular } \\
\text { Continuous }\end{array}$ & 37.9 & 8.5 & 82 & & & & & \\
\hline $318-014$ & Excurvate & $\begin{array}{c}\text { Regular } \\
\text { Continuous }\end{array}$ & 51.4 & 5.7 & 71 & & & & & \\
\hline
\end{tabular}

\begin{tabular}{|c|c|c|c|c|c|c|c|}
\hline Cat. No. & Bit 2 Angle & Bit 3 Location & Bit 3 Shape & Bit 3 Retouch & $\begin{array}{c}\text { Bit 3 Length } \\
\text { (mm) }\end{array}$ & $\begin{array}{c}\text { Bit 3 Thick } \\
\text { (mm) }\end{array}$ & \begin{tabular}{c} 
Bit 3 Angle \\
\hline $100-011$
\end{tabular} \\
\hline $124-010$ & & Lateral/Distal & Excurvate & $\begin{array}{c}\text { Regular } \\
\text { Continuous }\end{array}$ & 42.4 & 2 & 43 \\
\hline $318-014$ & & & & & & & \\
\hline
\end{tabular}

\begin{tabular}{|c|c|c|c|c|}
\hline Cat. No. & $\begin{array}{c}\text { Rejuvenation } \\
\text { Scar }\end{array}$ & Flake Size & Micro-wear & NAA \\
\hline $100-011$ & Absent & 8 & TRUE & TRUE \\
\hline $124-010$ & Absent & 6 & FALSE & FALSE \\
\hline $318-014$ & Absent & 5 & FALSE & FALSE \\
\hline
\end{tabular}


Table 0-24. Middle Archaic Core Data

\begin{tabular}{|l|c|c|c|c|c|c|c|}
\hline Cat. No. & Unit & $\begin{array}{c}\text { Depth } \\
(\mathrm{cmbd})\end{array}$ & Condition & Tool Type & Raw Material & $\begin{array}{c}\text { Percent } \\
\text { Patination }\end{array}$ \\
\hline $83-011$ & N100,E50 & $50-60$ & Complete & Unifacial & Chert & Fine & 0 \\
\hline $90-010$ & N100,E51 & $30-40$ & Complete & Multi-Directional & Chert & Fine & 0 \\
\hline $100-012$ & N100,E52 & $30-40$ & Complete & Multi-Directional & Chert & Fine & 25 \\
\hline $327-010$ & N102,E55 & $70-80$ & Complete & Multi-Directional & Chert & Fine & 25 \\
\hline $339-010$ & N102,E56 & $40-50$ & Complete & Multi-Directional & Chert & Fine & 0 \\
\hline $409-012$ & N104,E47 & $40-50$ & Complete & Multi-Directional & Chert & Fine & 0 \\
\hline $409-013$ & N104,E47 & $50-60$ & Complete & Multi-Directional & Chert & Fine & 0 \\
\hline $429-010$ & N105,E47 & $50-60$ & Exhausted & Bifacial & Chert & Fine & 0 \\
\hline
\end{tabular}

\begin{tabular}{|l|c|c|c|c|c|c|c|c|}
\hline Cat. No. & $\begin{array}{c}\text { Percent } \\
\text { Cortex }\end{array}$ & Cortex Type & Heating & Rejuvenation Scar & $\begin{array}{c}\text { Length } \\
(\mathrm{mm})\end{array}$ & Width $(\mathrm{mm})$ & Thick (mm) & Wt. (g) \\
\hline $83-011$ & 50 & Pebble/Cobble & None & Absent & 63.2 & 60.6 & 37.1 & 203.2 \\
\hline $90-010$ & 0 & None & None & Absent & 94.5 & 82.1 & 36.1 & 336.1 \\
\hline $100-012$ & 25 & Pebble/Cobble & None & Absent & 123.2 & 84.2 & 68.5 & 697.6 \\
\hline $327-010$ & 25 & Pebble/Cobble & None & Absent & 90.5 & 66.9 & 37.4 & 246.9 \\
\hline $339-010$ & 0 & None & None & Absent & 95.1 & 63.1 & 52.5 & 413.5 \\
\hline $409-012$ & 25 & Pebble/Cobble & None & Absent & 74.5 & 52.7 & 41.2 & 175.9 \\
\hline $409-013$ & 25 & Pebble/Cobble & None & Absent & 111.1 & 91.9 & 47.8 & 440.6 \\
\hline $429-010$ & 0 & None & None & Absent & 50.8 & 43.1 & 20.2 & 39.7 \\
\hline
\end{tabular}


The Varga Site

Texas Department of Transportation

Table 0-25. Gower Point Data

\begin{tabular}{|c|c|c|c|c|c|c|c|c|c|c|}
\hline Cat. No. & Unit & $\begin{array}{l}\text { Depth } \\
\text { (cmbd) }\end{array}$ & Condition & Break Type & $\begin{array}{c}\text { Rejuvenation } \\
\text { Scar }\end{array}$ & $\begin{array}{c}\text { Resharp } \\
\text { Type }\end{array}$ & Preform & Shape & $\begin{array}{c}\text { Raw } \\
\text { Material }\end{array}$ & Texture \\
\hline $11-005-013$ & N99,E51 & $7-20$ & Proximal & Use & Absent & $\begin{array}{c}\text { Indeterminat } \\
\mathrm{e}\end{array}$ & Biface & Indeterminate & Chert & Fine \\
\hline $29-010$ & N99,E52 & $90-100$ & Proximal & Use & Absent & $\begin{array}{c}\text { Indeterminat } \\
\mathrm{e}\end{array}$ & Biface & Indeterminate & Chert & Fine \\
\hline $50-013$ & N99,E54 & $100-110$ & Proximal & Use & Absent & None & Biface & Lanceolate & Chert & Fine \\
\hline $62-014$ & N99,E55 & $100-110$ & Proximal & Use & Absent & None & Biface & Lanceolate & Chert & Fine \\
\hline $86-019$ & $\mathrm{~N} 100, \mathrm{E} 50$ & $80-90$ & Proximal & Use & Absent & None & Biface & Indeterminate & Chert & Fine \\
\hline $86-020$ & $\mathrm{~N} 100, \mathrm{E} 50$ & $80-90$ & Proximal & Use & Absent & None & Biface & Triangular & Chert & Fine \\
\hline $153-028$ & N100,E56 & $100-110$ & Proximal & Use & Absent & $\begin{array}{c}\text { Indeterminat } \\
\mathrm{e}\end{array}$ & Biface & Indeterminate & Chert & Fine \\
\hline $154-020$ & $\mathrm{~N} 100, \mathrm{E} 56$ & $110-120$ & Proximal & Use & Absent & $\begin{array}{c}\text { Indeterminat } \\
\mathrm{e}\end{array}$ & Biface & Indeterminate & Chert & Fine \\
\hline $192-011$ & N101,E51 & $70-80$ & Proximal & Use & Absent & None & Biface & Indeterminate & Chert & Fine \\
\hline $215-019$ & N101,E53 & $90-100$ & Proximal & Use & Absent & $\begin{array}{c}\text { Indeterminat } \\
\mathrm{e}\end{array}$ & Biface & Indeterminate & Chert & Fine \\
\hline $215-020$ & N101,E53 & $90-100$ & Medial & Use & Absent & None & Biface & Indeterminate & Chert & Fine \\
\hline $215-021$ & N101,E53 & $90-100$ & Proximal & Indeterminate & Absent & $\begin{array}{c}\text { Indeterminat } \\
\mathrm{e}\end{array}$ & Indeterminate & Indeterminate & Chert & Fine \\
\hline $228-014$ & N101,E54 & $100-110$ & Proximal & Use & Present & $\begin{array}{c}\text { Indeterminat } \\
\mathrm{e}\end{array}$ & Biface & Lanceolate & Chert & Fine \\
\hline $254-014$ & N101,E56 & $100-110$ & Complete & Use & Absent & None & Biface & Triangular & Chert & Fine \\
\hline $255-030$ & N101,E56 & $110-120$ & Complete & Use & Absent & None & Biface & Lanceolate & Chert & Fine \\
\hline 289-021 & N102,E51 & $90-100$ & Proximal & Use & Absent & $\begin{array}{l}\text { Beveled } \\
\text { Unifacial }\end{array}$ & Biface & Lanceolate & Chert & Fine \\
\hline 289-022 & N102,E51 & $90-100$ & Proximal & Use & Absent & None & Biface & Indeterminate & Chert & Fine \\
\hline $289-023$ & N102,E51 & $90-100$ & Medial & Use & Absent & None & Biface & Indeterminate & Chert & Fine \\
\hline $332-011$ & N102,E55 & $120-130$ & Medial & Use & Absent & None & Biface & Indeterminate & Chert & Fine \\
\hline $333-022$ & N102,E55 & $130-140$ & Complete & Unbroken & Present & None & Biface & Triangular & Chert & Fine \\
\hline $345-026$ & N102,E56 & $100-110$ & Proximal & Use & Absent & $\begin{array}{c}\text { Indeterminat } \\
\mathrm{e}\end{array}$ & Biface & Indeterminate & Chert & Fine \\
\hline $345-027$ & $\mathrm{~N} 102, \mathrm{E} 56$ & $100-110$ & Complete & Unbroken & Absent & $\begin{array}{c}\text { Beveled } \\
\text { Bifacial }\end{array}$ & Biface & Lanceolate & Chert & Fine \\
\hline 391-011 & N103,E55 & $120-130$ & Complete & Unbroken & Absent & $\begin{array}{c}\text { Beveled } \\
\text { Bifacial }\end{array}$ & Biface & Lanceolate & Chert & Fine \\
\hline 411-016 & N104,E47 & $70-80$ & Proximal & Use & Absent & None & Biface & Indeterminate & Chert & Fine \\
\hline 591-017 & N107,E53 & $50-60$ & Proximal & Use & Absent & None & Biface & Lanceolate & Chert & Fine \\
\hline 591-018 & N107,E53 & $50-60$ & Proximal & Use & Absent & $\begin{array}{c}\text { Indeterminat } \\
\mathrm{e}\end{array}$ & Indeterminate & Indeterminate & Chert & Fine \\
\hline $632-016$ & N108,E49 & $30-40$ & Proximal & $\begin{array}{l}\text { Thermal/ } \\
\text { Crenated }\end{array}$ & Absent & $\begin{array}{c}\text { Indeterminat } \\
\mathrm{e}\end{array}$ & Biface & Indeterminate & Chert & Fine \\
\hline 689-021 & N109,E48 & $40-50$ & Proximal & Use & Absent & $\begin{array}{c}\text { Indeterminat } \\
\mathrm{e}\end{array}$ & Indeterminate & Indeterminate & Chert & Fine \\
\hline $1205-010$ & Block A & $\begin{array}{c}\text { SURFAC } \\
\text { E }\end{array}$ & Distal & Use & Absent & None & Biface & Lanceolate & Chert & Fine \\
\hline $1206-010$ & BT 1 & & Complete & Use & Absent & None & Biface & Triangular & Chert & Fine \\
\hline $1213-010$ & & $\begin{array}{c}\text { SURFAC } \\
\text { E }\end{array}$ & Proximal & Use & Absent & None & Biface & Triangular & Chert & Fine \\
\hline $1216-010$ & & $\begin{array}{c}\text { SURFAC } \\
\text { E }\end{array}$ & Distal & $\begin{array}{l}\text { Thermal/ } \\
\text { Crenated }\end{array}$ & Absent & $\begin{array}{c}\text { Indeterminat } \\
\mathrm{e}\end{array}$ & Biface & Triangular & Chert & Fine \\
\hline
\end{tabular}




\section{Table 0-25. Gower Point Data Continued}

\begin{tabular}{|c|c|c|c|c|c|c|c|c|c|c|}
\hline Cat. No. & $\begin{array}{c}\text { Percent } \\
\text { Patination }\end{array}$ & $\begin{array}{c}\text { Percen } \\
t \\
\text { Cortex } \\
\end{array}$ & $\begin{array}{c}\text { Cortex } \\
\text { Type }\end{array}$ & Heating & $\begin{array}{l}\text { Length } \\
(\mathrm{mm})\end{array}$ & $\begin{array}{l}\text { Thick } \\
(\mathrm{mm})\end{array}$ & $\begin{array}{l}\text { Wt. } \\
(\mathrm{g})\end{array}$ & Long X-Section & Trans X-Section & Flaking Pattern \\
\hline $11-005-013$ & 0 & 0 & None & Burned & & 6.4 & & Indeterminate & Biconvex Symmetrical & Indeterminate \\
\hline $29-010$ & 0 & 0 & None & None & & & & Indeterminate & Biconvex Symmetrical & Indeterminate \\
\hline $50-013$ & 0 & 0 & None & Burned & & 7.2 & & Indeterminate & Biconvex Symmetrical & Subparallel \\
\hline $62-014$ & 0 & 0 & None & None & & 6.1 & & Tapered Base/Tip & Biconvex Symmetrical & Subparallel \\
\hline $86-019$ & 0 & 0 & None & None & & 6.7 & & Indeterminate & Plano-Convex & Subparallel \\
\hline $86-020$ & 0 & 0 & None & None & & 6.7 & & Indeterminate & Biconvex Asymmetrical & Subparallel \\
\hline $153-028$ & 0 & 0 & None & Burned & & 6.5 & & Indeterminate & Biconvex Symmetrical & Indeterminate \\
\hline $154-020$ & 0 & 0 & None & None & & & & Indeterminate & Indeterminate & Indeterminate \\
\hline $192-011$ & 0 & 0 & None & Burned & & 6.5 & & Indeterminate & Biconvex Symmetrical & Indeterminate \\
\hline 215-019 & 0 & 0 & None & None & & & & Indeterminate & Biconvex Symmetrical & Indeterminate \\
\hline $215-020$ & 0 & 0 & None & Burned & & & & Indeterminate & Plano-Convex & $\begin{array}{c}\text { Oblique } \\
\text { Subparallel }\end{array}$ \\
\hline $215-021$ & 0 & 0 & None & None & & & & Indeterminate & Indeterminate & Indeterminate \\
\hline 228-014 & 0 & 0 & None & None & 43 & 6.5 & 4.9 & Tapered Base/Tip & Biconvex Symmetrical & Subparallel \\
\hline $254-014$ & 0 & 0 & None & Heat-Treated & 40.1 & 3.6 & 2.2 & Flat & Biconvex Symmetrical & $\begin{array}{c}\text { Oblique } \\
\text { Subparallel }\end{array}$ \\
\hline $255-030$ & 0 & 0 & None & $\begin{array}{c}\text { Indeterminat } \\
\mathrm{e}\end{array}$ & 44.2 & 7 & 4.4 & Tapered Base/Tip & Biconvex Symmetrical & Subparallel \\
\hline 289-021 & 0 & 0 & None & None & & 6.7 & 4.4 & Tapered Base/Tip & Biconvex Symmetrical & $\begin{array}{c}\text { Oblique } \\
\text { Subparallel }\end{array}$ \\
\hline $289-022$ & 0 & 0 & None & Burned & & 7 & & Indeterminate & Biconvex Symmetrical & Indeterminate \\
\hline $289-023$ & 0 & 0 & None & Burned & & 6.5 & & Indeterminate & Biconvex Symmetrical & Indeterminate \\
\hline $332-011$ & 0 & 0 & None & Burned & & 5.7 & & Indeterminate & Indeterminate & Subparallel \\
\hline $333-022$ & 0 & 50 & $\begin{array}{l}\text { Pebble/ } \\
\text { Cobble }\end{array}$ & None & 39.7 & 7.6 & 4.5 & $\begin{array}{c}\text { Wedged Base, Thick } \\
\text { Body }\end{array}$ & Biconvex Symmetrical & Subparallel \\
\hline $345-026$ & 0 & 0 & None & None & & & & Indeterminate & Indeterminate & Indeterminate \\
\hline $345-027$ & 25 & 0 & None & None & 58.4 & 5.8 & 5.7 & Wedged Base, Flat & Plano-Convex & Chevron \\
\hline $391-011$ & 0 & 0 & None & None & 56.3 & 8.3 & 7.3 & Bi-wedge-shaped & Biconvex Asymmetrical & $\begin{array}{c}\text { Oblique } \\
\text { Subparallel }\end{array}$ \\
\hline $411-016$ & 0 & 0 & None & Burned & & 8 & & Indeterminate & Biconvex Symmetrical & Indeterminate \\
\hline $591-017$ & 0 & 0 & None & Burned & & 5.5 & 4 & Tapered Base/Tip & Biconvex Symmetrical & Subparallel \\
\hline $591-018$ & 0 & 0 & None & Burned & & & & Indeterminate & Indeterminate & Indeterminate \\
\hline $632-016$ & 0 & 0 & None & None & & & & Indeterminate & Biconvex Symmetrical & Indeterminate \\
\hline $689-021$ & 100 & 0 & None & None & & & & Indeterminate & Biconvex Symmetrical & Indeterminate \\
\hline $1205-010$ & 75 & 0 & None & None & 62.7 & 6.1 & 7.2 & Tapered Base/Tip & Biconvex Symmetrical & $\begin{array}{c}\text { Oblique } \\
\text { Subparallel }\end{array}$ \\
\hline $1206-010$ & 0 & 0 & None & None & 40.7 & 8 & 3.9 & Wedged Base, Flat & Biconvex Symmetrical & Chevron \\
\hline $1213-010$ & 0 & 0 & None & Burned & & 6.7 & & Indeterminate & Biconvex Symmetrical & $\begin{array}{c}\text { Oblique } \\
\text { Subparallel }\end{array}$ \\
\hline $1216-010$ & 0 & 0 & None & Burned & 37.3 & & 2.3 & Indeterminate & Indeterminate & Indeterminate \\
\hline
\end{tabular}


The Varga Site

Texas Department of Transportation

Table 0-25. Gower Point Data Continued

\begin{tabular}{|c|c|c|c|c|c|c|c|c|c|c|c|}
\hline Cat. No. & $\begin{array}{c}\text { Edge } \\
\text { Roundin } \\
g\end{array}$ & $\begin{array}{c}\text { Blade } \\
\text { Length } \\
(\mathrm{mm})\end{array}$ & $\begin{array}{l}\text { Blade } \\
\text { Width } \\
(\mathrm{mm})\end{array}$ & $\begin{array}{l}\text { Left Lateral } \\
\text { Edge }\end{array}$ & Right Lateral Edge & Shoulder Width (mm) & $\begin{array}{c}\text { Left } \\
\text { Notc } \\
h \\
\text { Dept } \\
h \\
(\mathrm{~mm}) \\
\end{array}$ & $\begin{array}{l}\text { Right } \\
\text { Notch } \\
\text { Depth } \\
(\mathrm{mm}) \\
\end{array}$ & $\begin{array}{l}\text { Left } \\
\text { Notch } \\
\text { Width } \\
(\mathrm{mm})\end{array}$ & $\begin{array}{l}\text { Right } \\
\text { Notch } \\
\text { Width } \\
(\mathrm{mm})\end{array}$ & $\begin{array}{l}\text { Left } \\
\text { Notch } \\
\text { Angle }\end{array}$ \\
\hline $\begin{array}{c}11-005- \\
013\end{array}$ & Absent & & & Indeterminate & Indeterminate & & & 2.5 & & 9.2 & \\
\hline $29-010$ & Absent & & & Indeterminate & Indeterminate & & & & & & \\
\hline $50-013$ & Absent & & 15.3 & Straight & Straight & 16.7 & 2.1 & 1.9 & 7.8 & 7.5 & 103 \\
\hline $62-014$ & Present & & 17.2 & Straight & Straight & 19.5 & 3.4 & & 10.1 & & 77 \\
\hline $86-019$ & Absent & & 15.8 & Indeterminate & Indeterminate & & 2.6 & & 10.8 & & 73 \\
\hline $86-020$ & Absent & & 22.3 & Straight & Straight & 24.8 & 3.9 & 4.1 & 9.8 & 8.8 & 42 \\
\hline $153-028$ & Present & & 17.5 & Indeterminate & Indeterminate & 19.5 & 2.2 & 2.2 & 7.9 & 8 & 115 \\
\hline $154-020$ & Absent & & & Indeterminate & Indeterminate & & & & & & \\
\hline $192-011$ & Absent & & 14.2 & Straight & Incurvate & & 2.2 & 2.7 & 9.9 & 10.6 & 44 \\
\hline $215-019$ & Present & & & Indeterminate & Indeterminate & & & & & & \\
\hline $215-020$ & Present & & 17.5 & Indeterminate & Indeterminate & 19.3 & & 2.5 & & 9 & 68 \\
\hline $215-021$ & Absent & & & Indeterminate & Indeterminate & & & & & & \\
\hline $228-014$ & Present & 28.9 & 18.8 & Indeterminate & Straight & 21.1 & & 2.2 & & 8.3 & 53 \\
\hline $254-014$ & Present & 28.7 & 14.5 & Straight & Excurvate & 18.8 & 1.4 & 2.8 & 8.7 & 5.7 & 57 \\
\hline $255-030$ & Absent & 32.4 & 14.7 & Straight & Excurvate & 20.4 & 3.2 & 3.6 & 9 & 8.1 & 71 \\
\hline $289-021$ & Present & & 15.5 & Straight & Straight & 21.4 & 2.3 & 3.7 & 10 & 13.3 & 76 \\
\hline $289-022$ & Present & & 14.1 & Indeterminate & Indeterminate & 16.4 & 2.7 & 2.1 & 8 & 6.8 & 76 \\
\hline $289-023$ & Absent & & 14.5 & Indeterminate & Indeterminate & & & & & & \\
\hline $332-011$ & Present & & 11.7 & Straight & Excurvate & & & & & & 66 \\
\hline $333-022$ & Present & 27.2 & 14.7 & Straight & Straight & & 1.3 & 1.9 & 9.6 & 9.8 & 90 \\
\hline $345-026$ & Absent & & & Indeterminate & Indeterminate & & & & & & \\
\hline $345-027$ & Present & 45.9 & 18.3 & Excurvate & Excurvate & 25.4 & 5.3 & 4.8 & 10.1 & 9.7 & 46 \\
\hline 391-011 & Absent & 45.3 & 14.5 & Excurvate & Straight & 20.2 & 1.6 & 2.3 & 6.6 & 7.8 & 70 \\
\hline $411-016$ & Absent & & 14.6 & Indeterminate & Indeterminate & 19.1 & 3.4 & 3.4 & 8.3 & 8.2 & 67 \\
\hline 591-017 & Absent & & 18 & Straight & Straight & & 1.9 & & 9.3 & & 78 \\
\hline 591-018 & Absent & & & Indeterminate & Indeterminate & & & & & & \\
\hline $632-016$ & Present & & & Indeterminate & Indeterminate & & & & & & \\
\hline $689-021$ & Present & & & Indeterminate & Indeterminate & & & & & & \\
\hline $1205-010$ & Absent & 46.4 & 18.1 & Excurvate & Excurvate & 22.6 & & & & & 52 \\
\hline $1206-010$ & Present & 31.7 & 13.3 & Excurvate & Straight & 17.9 & 1.5 & 1.4 & 5.6 & 5.1 & 52 \\
\hline $1213-010$ & Absent & & 18.9 & Indeterminate & Straight & 23.2 & 1.8 & 2.2 & 7.1 & 7.5 & 54 \\
\hline $1216-010$ & Absent & 25.6 & 15.7 & Incurvate & Straight & 21.9 & 2.8 & 3.4 & 7.7 & 7 & 56 \\
\hline
\end{tabular}


Appendix O: Data and Site Artifact Database

Table 0-25. Gower Point Data Continued

\begin{tabular}{|c|c|c|c|c|c|c|c|c|c|c|}
\hline Cat. No. & $\begin{array}{l}\text { Right Notch } \\
\text { Angle }\end{array}$ & Stem Shape & $\begin{array}{l}\text { Stem Length } \\
(\mathrm{mm})\end{array}$ & $\begin{array}{l}\text { Distal Stem } \\
\text { Width } \\
(\mathrm{mm})\end{array}$ & $\begin{array}{l}\text { Proximal } \\
\text { Stem } \\
\text { Width } \\
(\mathrm{mm})\end{array}$ & $\begin{array}{c}\text { Stem Thick } \\
(\mathrm{mm})\end{array}$ & $\begin{array}{l}\text { Base } \\
\text { Depth } \\
(\mathrm{mm})\end{array}$ & $\begin{array}{l}\text { Base } \\
\text { Notch } \\
\text { Width } \\
(\mathrm{mm}) \\
\end{array}$ & Micro-wear & NAA \\
\hline $11-005-013$ & 72 & Curved & 18.5 & 14.6 & 17.6 & 4.9 & 5.9 & 8.5 & FALSE & FALSE \\
\hline $29-010$ & & Curved & & 12.8 & 20 & 3.8 & 4.7 & 6.9 & FALSE & FALSE \\
\hline $50-013$ & 78 & Curved & 15.4 & 12.9 & & 4.6 & 7 & & FALSE & FALSE \\
\hline $62-014$ & & Curved & 15.7 & & & 4 & 5.6 & & FALSE & FALSE \\
\hline 86-019 & & Curved & 13.6 & & & 5.2 & 4.7 & & FALSE & FALSE \\
\hline $86-020$ & 59 & Curved & 13.9 & 14.5 & 19.5 & 3.5 & 5.8 & 7.1 & FALSE & TRUE \\
\hline $153-028$ & 67 & Curved & 14.8 & 14.6 & 17.8 & 3.9 & 5.9 & & FALSE & FALSE \\
\hline $154-020$ & & Expanding & & & & 3.9 & 6.7 & & FALSE & FALSE \\
\hline $192-011$ & 41 & Curved & 14 & 13.5 & 17.6 & 4.3 & 4 & 7.3 & FALSE & TRUE \\
\hline $215-019$ & & Curved & 14.7 & 15 & 16.9 & 5.5 & 6.2 & 9.1 & FALSE & FALSE \\
\hline $215-020$ & 62 & Indeterminate & & 13.4 & & 5.8 & & & FALSE & FALSE \\
\hline $215-021$ & & Curved & & & & & 5.2 & & FALSE & TRUE \\
\hline $228-014$ & 71 & Curved & 14.6 & 15.1 & & 4 & 8.2 & & FALSE & FALSE \\
\hline $254-014$ & 73 & Expanding & 11.4 & 12.8 & & 3.5 & 5 & & FALSE & FALSE \\
\hline $255-030$ & 61 & Curved & 11.8 & 13.3 & 16.9 & 5 & 5.8 & 7.8 & FALSE & FALSE \\
\hline 289-021 & 68 & Curved & 19 & 14.6 & 19.1 & 5.3 & 7.5 & 10.4 & FALSE & FALSE \\
\hline $289-022$ & 80 & Curved & 12.9 & 12 & 19 & 5.3 & 5.1 & 10.1 & FALSE & FALSE \\
\hline $289-023$ & & Indeterminate & & & & 5.4 & & & FALSE & FALSE \\
\hline $332-011$ & & Indeterminate & & & & & & & FALSE & FALSE \\
\hline $333-022$ & 90 & Curved & 12.5 & 13.2 & 17.4 & 4.1 & 4.9 & 9.1 & FALSE & TRUE \\
\hline $345-026$ & & Curved & & & & & 5.8 & & FALSE & FALSE \\
\hline $345-027$ & 43 & Curved & 12.5 & 14.3 & 18 & 5 & 6.1 & 8.1 & FALSE & FALSE \\
\hline 391-011 & 73 & Curved & 11 & 15.3 & 17.7 & 3.7 & 6.2 & 9.1 & TRUE & FALSE \\
\hline $411-016$ & 68 & Curved & 13.1 & 11.6 & 16.7 & 4.4 & 3.7 & 8.9 & FALSE & FALSE \\
\hline 591-017 & & Curved & 11.1 & 15.5 & 18.6 & 5.1 & 5.9 & 10.4 & FALSE & FALSE \\
\hline $591-018$ & & Curved & & 10.9 & 20.7 & 5.4 & 4.5 & 11.2 & FALSE & FALSE \\
\hline $632-016$ & & Curved & & & 19.1 & 5.8 & 6.3 & 11.5 & FALSE & FALSE \\
\hline $689-021$ & & Curved & & & 19.8 & 5.3 & 3.1 & 10.9 & FALSE & FALSE \\
\hline $1205-010$ & & Curved & 16.3 & 14.9 & & & & & FALSE & FALSE \\
\hline $1206-010$ & 65 & Curved & 9 & 12.9 & 13.9 & 5.7 & 3.5 & 6.8 & FALSE & FALSE \\
\hline $1213-010$ & 41 & Curved & 16.6 & 15.8 & & 5.9 & 6.3 & & FALSE & TRUE \\
\hline $1216-010$ & 46 & Curved & 11.7 & 12.9 & & & 3.7 & & FALSE & FALSE \\
\hline
\end{tabular}


Table 0-26. Martidale Point Data

\begin{tabular}{|c|c|c|c|c|c|c|c|c|c|c|}
\hline Cat. No. & Unit & $\begin{array}{l}\text { Depth } \\
\text { (cmbd) }\end{array}$ & Condition & Break Type & $\begin{array}{c}\text { Rejuvenation } \\
\text { Scar }\end{array}$ & Resharp Type & Preform & Shape & $\begin{array}{c}\text { Raw } \\
\text { Material }\end{array}$ & Texture \\
\hline $7-010$ & N99,E50 & $70-80$ & Complete & Use & Absent & None & Biface & Triangular & Chert & Fine \\
\hline $9-014$ & N99,E50 & 90 & Proximal & Manufacture & Present & None & Biface & Triangular & Chert & Fine \\
\hline $9-015$ & N99,E50 & $80-90$ & Proximal & Use & Absent & Indeterminate & Indeterminate & Indeterminate & Chert & Fine \\
\hline 19-014 & N99,E51 & $90-100$ & Proximal & $\begin{array}{c}\text { Indeterminat } \\
\mathrm{e}\end{array}$ & Absent & None & Biface & Indeterminate & Chert & Fine \\
\hline $39-015$ & N99,E53 & $90-100$ & Complete & Use & Absent & $\begin{array}{c}\text { Break } \\
\text { Compensation }\end{array}$ & Biface & Triangular & Chert & Fine \\
\hline $40-013$ & N99,E53 & $100-110$ & Proximal & Use & Absent & None & Biface & Triangular & Chert & Fine \\
\hline 77-013 & N99,E56 & $120-130$ & Complete & Use & Absent & None & Biface & Lanceolate & Chert & Fine \\
\hline $141-021$ & N100,E55 & $110-120$ & Medial & Use & Absent & None & Biface & Triangular & Chert & Fine \\
\hline $154-021$ & $\mathrm{~N} 100, \mathrm{E} 56$ & $110-120$ & Proximal & Use & Absent & None & Biface & Indeterminate & Chert & Fine \\
\hline $216-010$ & N101,E53 & $100-110$ & Proximal & Use & Absent & None & Biface & Indeterminate & Chert & Fine \\
\hline $230-013$ & N101,E54 & $120-130$ & Proximal & Use & Present & None & Biface & Triangular & Chert & Fine \\
\hline $268-021$ & $\mathrm{~N} 102, \mathrm{E} 47$ & $80-90$ & Complete & Use & Absent & Indeterminate & Biface & Triangular & Chert & Fine \\
\hline $268-022$ & N102,E47 & $80-90$ & Proximal & Use & Absent & $\begin{array}{c}\text { Break } \\
\text { Compensation }\end{array}$ & Biface & Indeterminate & Chert & Fine \\
\hline $311-013$ & N102,E53 & $90-100$ & Proximal & Use & Absent & None & Biface & Indeterminate & Chert & Fine \\
\hline $346-024$ & $\mathrm{~N} 102, \mathrm{E} 56$ & $110-120$ & Proximal & Use & Absent & $\begin{array}{c}\text { Break } \\
\text { Compensation }\end{array}$ & Biface & Indeterminate & Chert & Fine \\
\hline $347-014$ & $\mathrm{~N} 102, \mathrm{E} 56$ & $120-130$ & Proximal & Use & Absent & None & Biface & Indeterminate & Chert & Fine \\
\hline 591-019 & N107,E53 & $50-60$ & Complete & Unbroken & Absent & None & Biface & Triangular & Chert & Fine \\
\hline 658-018 & N108,E53 & $50-60$ & Complete & Use & Absent & None & Biface & Lanceolate & Chert & Fine \\
\hline $658-017$ & N108,E53 & $50-60$ & Proximal & Use & Absent & None & Indeterminate & Indeterminate & Chert & Fine \\
\hline $730-013$ & N109,E54 & $40-50$ & Complete & Unbroken & Absent & $\begin{array}{c}\text { Alternate } \\
\text { Beveled } \\
\text { Unifacial }\end{array}$ & Biface & Triangular & Chert & Fine \\
\hline $854-010^{*}$ & N118,E73 & $40-50$ & Proximal & Use & Absent & None & Biface & Triangular & Chert & Fine \\
\hline $1201-010$ * & TRENCH 1 & Buried & Complete & Use & Absent & $\begin{array}{c}\text { Break } \\
\text { Compensation }\end{array}$ & Biface & Triangular & Chert & Fine \\
\hline
\end{tabular}


Table 0-26. Martidale Point Data Continued

\begin{tabular}{|c|c|c|c|c|c|c|c|c|c|c|}
\hline Cat. No. & $\begin{array}{c}\text { Percent } \\
\text { Patination }\end{array}$ & $\begin{array}{c}\text { Percen } \\
\quad t \\
\text { Cortex } \\
\end{array}$ & Heating & $\begin{array}{l}\text { Length } \\
(\mathrm{mm})\end{array}$ & $\begin{array}{l}\text { Thick } \\
(\mathrm{mm})\end{array}$ & Wt. (g) & Long X-Section & Trans X-Section & $\begin{array}{l}\text { Flaking } \\
\text { Pattern }\end{array}$ & $\begin{array}{c}\text { Edge } \\
\text { Roundin } \\
\mathrm{g}\end{array}$ \\
\hline $7-010$ & 25 & 0 & None & 52.4 & 7.2 & 10.8 & Wedged Base, Flat & Biconvex Symmetrical & Chevron & Present \\
\hline 9-014 & 0 & 0 & None & & 7.9 & 14.3 & Tapered Base/Tip & Plano-Convex & $\begin{array}{c}\text { Oblique } \\
\text { Subparallel }\end{array}$ & Present \\
\hline 9-015 & 0 & 0 & Burned & & & & Indeterminate & Indeterminate & Indeterminate & Present \\
\hline $19-014$ & 0 & 0 & None & & 5.1 & & Indeterminate & Indeterminate & Indeterminate & Absent \\
\hline $39-015$ & 0 & 0 & Burned & 47.4 & 7.2 & 10.8 & Tapered Base/Tip & Biconvex Symmetrical & $\begin{array}{c}\text { Oblique } \\
\text { Subparallel }\end{array}$ & Present \\
\hline $40-013$ & 0 & 0 & Heat-Treated & & 6.2 & 6.7 & Flat & Biconvex Symmetrical & Chevron & Present \\
\hline $77-013$ & 0 & 0 & None & 57.8 & 6.6 & 10.8 & Wedged Base, Flat & Biconvex Symmetrical & $\begin{array}{c}\text { Oblique } \\
\text { Subparallel }\end{array}$ & Present \\
\hline $141-021$ & 0 & 0 & Burned & & 8.3 & & Tapered Base/Tip & Biconvex Asymmetrical & $\begin{array}{c}\text { Oblique } \\
\text { Subparallel }\end{array}$ & Absent \\
\hline $154-021$ & 0 & 0 & None & & & & Indeterminate & Indeterminate & Indeterminate & Present \\
\hline $216-010$ & 0 & 0 & None & & & & Indeterminate & Biconvex Symmetrical & Indeterminate & Present \\
\hline $230-013$ & 0 & 0 & None & & 6.9 & 8 & Flat & Biconvex Symmetrical & Indeterminate & Absent \\
\hline $268-021$ & 0 & 0 & $\begin{array}{c}\text { Indeterminat } \\
\mathrm{e}\end{array}$ & 34.8 & 7.6 & 6.4 & Tapered Base/Tip & Biconvex Symmetrical & Subparallel & Absent \\
\hline $268-022$ & 0 & 0 & Heat-Treated & & 6.5 & & Indeterminate & Biconvex Symmetrical & $\begin{array}{l}\text { Oblique } \\
\text { Parallel }\end{array}$ & Absent \\
\hline $311-013$ & 100 & 0 & None & & & & Indeterminate & Biconvex Symmetrical & Indeterminate & Present \\
\hline $346-024$ & 0 & 0 & None & & 7.1 & & Indeterminate & Biconvex Symmetrical & $\begin{array}{l}\text { Oblique } \\
\text { Subparallel }\end{array}$ & Absent \\
\hline $347-014$ & 0 & 0 & None & & 6.6 & & Indeterminate & Biconvex Symmetrical & $\begin{array}{c}\text { Oblique } \\
\text { Subparallel }\end{array}$ & Present \\
\hline $591-019$ & 0 & 0 & None & 55.8 & 6.6 & 8.8 & Tapered Base/Tip & Biconvex Symmetrical & Chevron & Absent \\
\hline $658-018$ & 0 & 0 & None & 55.2 & 6.6 & 8.5 & Wedged Base, Flat & Plano-Convex & Subparallel & Present \\
\hline $658-017$ & 0 & 0 & None & & & & Indeterminate & Indeterminate & Indeterminate & Absent \\
\hline 730-013 & 0 & 0 & None & 39.3 & 7.1 & 6 & Tapered Base/Tip & Biconvex Symmetrical & Chevron & Present \\
\hline $854-010^{*}$ & 25 & 0 & Heat-Treated & & 8.6 & & Indeterminate & Biconvex Symmetrical & Chevron & Absent \\
\hline $1201-010^{*}$ & 0 & 0 & Heat-Treated & 48.7 & 6.6 & 10 & Tapered Base/Tip & Biconvex Symmetrical & Chevron & Absent \\
\hline
\end{tabular}


Table 0-26. Martidale Point Data Continued

\begin{tabular}{|c|c|c|c|c|c|c|c|c|c|c|}
\hline Cat. No. & $\begin{array}{c}\text { Blade } \\
\text { Length } \\
(\mathrm{mm})\end{array}$ & $\begin{array}{l}\text { Blade } \\
\text { Width } \\
(\mathrm{mm})\end{array}$ & $\begin{array}{l}\text { Left Lateral } \\
\text { Edge }\end{array}$ & $\begin{array}{l}\text { Right Lateral } \\
\text { Edge }\end{array}$ & $\begin{array}{c}\text { Shoulder } \\
\text { Width (mm) }\end{array}$ & $\begin{array}{l}\text { Left Notch } \\
\text { Depth } \\
(\mathrm{mm})\end{array}$ & $\begin{array}{l}\text { Right Notch } \\
\text { Depth (mm) }\end{array}$ & $\begin{array}{l}\text { Left Notch } \\
\text { Width (mm) }\end{array}$ & $\begin{array}{l}\text { Right Notch } \\
\text { Width }(\mathrm{mm})\end{array}$ & $\begin{array}{l}\text { Left Notch } \\
\text { Angle }\end{array}$ \\
\hline $7-010$ & 37.6 & 28.2 & Excurvate & Straight & & 5.1 & & 12.4 & & 55 \\
\hline $9-014$ & & & Excurvate & Indeterminate & 32.9 & 7.7 & 5.4 & 8.4 & 9.2 & 46 \\
\hline $9-015$ & & & Indeterminate & Indeterminate & & & & & & \\
\hline $19-014$ & & & Indeterminate & Indeterminate & & & & & & 55 \\
\hline $39-015$ & 34.5 & 30 & Excurvate & Straight & 33.2 & 7.2 & 7.3 & 10.1 & 12.3 & 32 \\
\hline $40-013$ & & 25.8 & Straight & Straight & 30 & 6.1 & 6.9 & 9.6 & 8.9 & 38 \\
\hline 77-013 & 47.2 & 27.8 & Excurvate & Excurvate & 30 & 5.2 & & 8.5 & & 44 \\
\hline $141-021$ & & 31.8 & Straight & Straight & 37.6 & & 8.9 & & 15.9 & \\
\hline $154-021$ & & & Indeterminate & Indeterminate & & & & & & \\
\hline $216-010$ & & & Indeterminate & Indeterminate & & & & & & \\
\hline $230-013$ & & 30.8 & Straight & Straight & 34 & 8.1 & 8 & 10.2 & 8.7 & 51 \\
\hline $268-021$ & 23.3 & 23 & Excurvate & Excurvate & 24.2 & 3.4 & 4.1 & 9.1 & 9.8 & 57 \\
\hline $268-022$ & & & Indeterminate & Indeterminate & & & 9.5 & & 7.8 & \\
\hline $311-013$ & & & Indeterminate & Indeterminate & & & & & & \\
\hline $346-024$ & & & Indeterminate & Straight & & & 5.8 & & 11.6 & \\
\hline $347-014$ & & & Indeterminate & Indeterminate & & & & & & \\
\hline 591-019 & 43 & 27.1 & Straight & Recurvate & 28.9 & 4.2 & 5.9 & 11.4 & 10.2 & 51 \\
\hline $658-018$ & 44.5 & 22 & Straight & Straight & 25.8 & 5.6 & & 9.6 & & 49 \\
\hline $658-017$ & & & Indeterminate & Indeterminate & & & & & & \\
\hline $730-013$ & 24.5 & 19.1 & Incurvate & Incurvate & 27 & 5.4 & 5.3 & 14.1 & 15.5 & 55 \\
\hline $854-010^{*}$ & & 35.9 & Excurvate & Excurvate & 36.3 & 3.4 & 4.2 & 8 & 7.1 & 50 \\
\hline $1201-010^{*}$ & 36.1 & & Excurvate & Indeterminate & & 9 & & 9.3 & & 45 \\
\hline
\end{tabular}


Table 0-26. Martidale Point Data Continued

\begin{tabular}{|c|c|c|c|c|c|c|c|c|c|c|}
\hline Cat. No. & $\begin{array}{l}\text { Right } \\
\text { Notch } \\
\text { Angle } \\
\end{array}$ & Stem Shape & $\begin{array}{l}\text { Stem } \\
\text { Length } \\
(\mathrm{mm})\end{array}$ & $\begin{array}{l}\text { Distal } \\
\text { Stem } \\
\text { Width } \\
(\mathrm{mm}) \\
\end{array}$ & $\begin{array}{l}\text { Proximal } \\
\text { Stem } \\
\text { Width } \\
(\mathrm{mm}) \\
\end{array}$ & $\begin{array}{l}\text { Stem Thick } \\
(\mathrm{mm})\end{array}$ & $\begin{array}{l}\text { Base } \\
\text { Depth } \\
(\mathrm{mm})\end{array}$ & $\begin{array}{l}\text { Base } \\
\text { Notch } \\
\text { Width } \\
(\mathrm{mm}) \\
\end{array}$ & Micro-wear & NAA \\
\hline 7-010 & & Expanding & 14.8 & 18.6 & & 5.4 & 3.9 & 11 & FALSE & FALSE \\
\hline 9-014 & 50 & Expanding & 10.7 & 17.6 & 24.7 & 5.1 & 2.2 & 12 & FALSE & FALSE \\
\hline 9-015 & & Expanding & & & 24.5 & & 3 & 7 & FALSE & FALSE \\
\hline $19-014$ & & Indeterminate & & 16.9 & 20.8 & 4.2 & 1.2 & & FALSE & FALSE \\
\hline 39-015 & 29 & Expanding & 12.9 & 18.3 & 22.3 & 4.8 & 2.4 & 6.9 & FALSE & TRUE \\
\hline $40-013$ & 29 & Expanding & 11.5 & 18 & 23.1 & 4.3 & 2.1 & 9.5 & FALSE & FALSE \\
\hline $77-013$ & & Expanding & 10.6 & 18.4 & 22.3 & 4.1 & 1.6 & 10 & FALSE & TRUE \\
\hline $141-021$ & 35 & Expanding & 15.8 & 18.8 & & 3.3 & 3.3 & & TRUE & FALSE \\
\hline $154-021$ & & Expanding & & & 24.8 & 3.9 & 1.8 & 9 & FALSE & FALSE \\
\hline 216-010 & & Expanding & & & 23.4 & 4.9 & 3.1 & 11.8 & FALSE & FALSE \\
\hline $230-013$ & 38 & Expanding & 11.8 & 17.4 & 25.6 & 5 & 2.9 & 14.4 & FALSE & FALSE \\
\hline 268-021 & 49 & Expanding & 11.5 & 17 & 22.8 & 4 & 2.4 & 10.2 & FALSE & TRUE \\
\hline $268-022$ & 23 & Expanding & 11.6 & 16.8 & 21.4 & 4.1 & 3.1 & 14.5 & FALSE & FALSE \\
\hline 311-013 & & Expanding & 12.4 & 18.6 & 27.8 & 5 & 2.9 & 3.2 & FALSE & TRUE \\
\hline $346-024$ & 39 & Expanding & 14.8 & 18.6 & 24.7 & 4.8 & 3.6 & 11.5 & FALSE & FALSE \\
\hline $347-014$ & & Expanding & 10.3 & 16.7 & 21.7 & 4.8 & 3.1 & 13.4 & FALSE & FALSE \\
\hline 591-019 & 37 & Expanding & 12.8 & 18.1 & 24.1 & 4.8 & 2.9 & 8.5 & TRUE & FALSE \\
\hline $658-018$ & & Expanding & 10.7 & 15.1 & 22.4 & 5.5 & 1.7 & 7.6 & FALSE & FALSE \\
\hline $658-017$ & & Expanding & 11.5 & 13.3 & 18 & 3.5 & 2 & 7.3 & FALSE & FALSE \\
\hline $730-013$ & 51 & Expanding & 14.8 & 17 & 25.2 & 5.8 & 3 & 10 & FALSE & FALSE \\
\hline $854-010^{*}$ & 25 & Expanding & 10.7 & 16.9 & 18.4 & 4.6 & 1.9 & 7.6 & FALSE & TRUE \\
\hline $1201-010^{*}$ & & Expanding & 12.6 & 17.9 & 24.9 & 4.8 & 3.9 & 11.5 & FALSE & FALSE \\
\hline
\end{tabular}


Table 0-27. Bandy Point Data

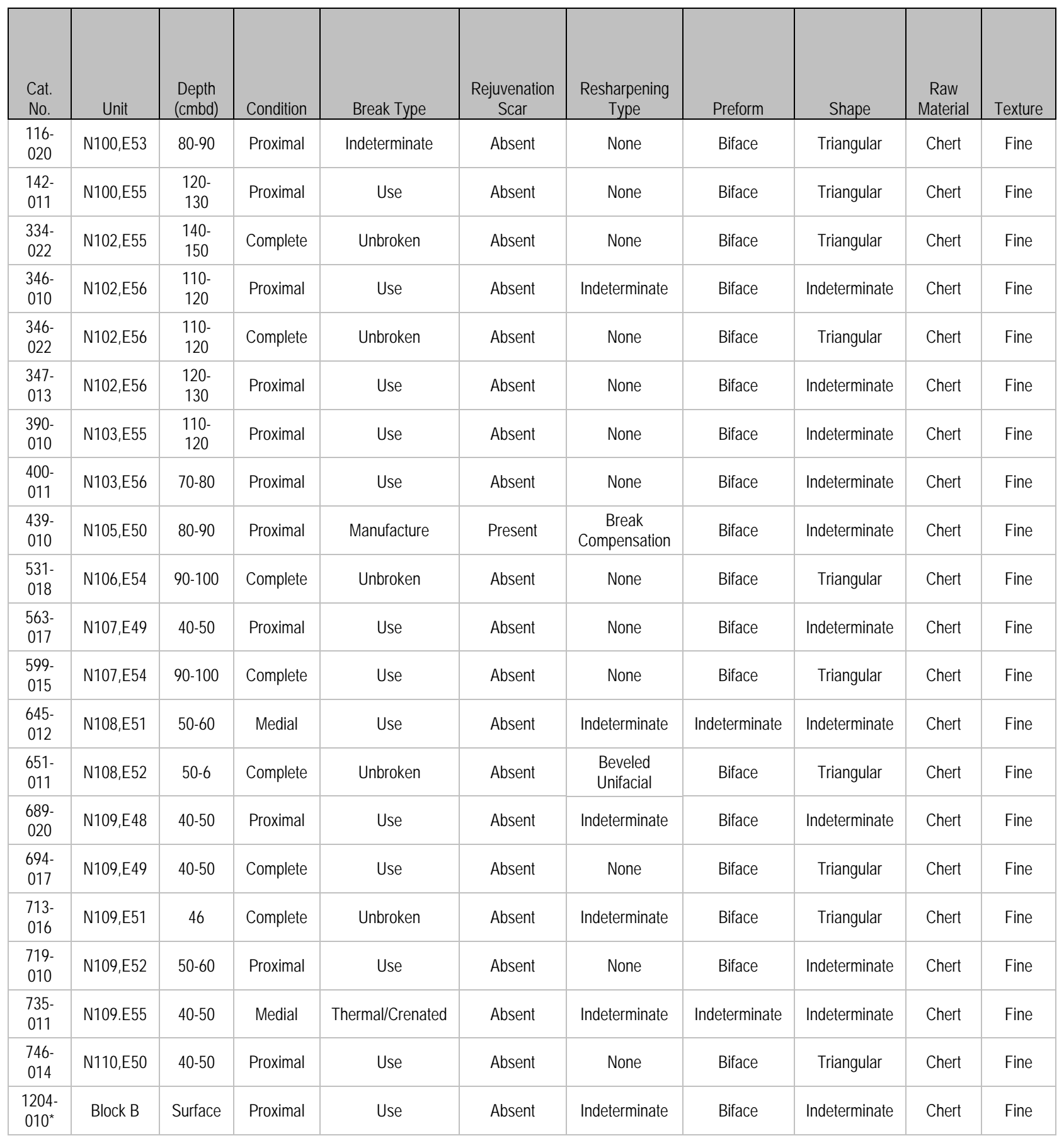


Table 0-27. Bandy Point Data Continued

\begin{tabular}{|c|c|c|c|c|c|c|c|c|c|c|}
\hline $\begin{array}{l}\text { Cat. } \\
\text { No. }\end{array}$ & $\begin{array}{c}\text { Percent } \\
\text { Patinatio } \\
\mathrm{n}\end{array}$ & $\begin{array}{c}\text { Percent } \\
\text { Cortex }\end{array}$ & $\begin{array}{c}\text { Cortex } \\
\text { Type }\end{array}$ & Heating & $\begin{array}{l}\text { Length } \\
(\mathrm{mm})\end{array}$ & $\begin{array}{l}\text { Width } \\
(\mathrm{mm})\end{array}$ & $\begin{array}{l}\text { Thick } \\
(\mathrm{mm})\end{array}$ & $\begin{array}{l}\text { Wt. } \\
(\mathrm{g})\end{array}$ & Long X-Section & Trans X-Section \\
\hline $\begin{array}{c}116- \\
020\end{array}$ & 0 & 0 & None & Burned & & & 4.4 & & Indeterminate & Biconvex Symmetrical \\
\hline $\begin{array}{l}142- \\
011\end{array}$ & 0 & 0 & None & Burned & & & 6.8 & & Tapered Base/Tip & Biconvex Symmetrical \\
\hline $\begin{array}{l}334- \\
022\end{array}$ & 0 & 0 & None & None & 37.3 & & 4.4 & 2.9 & Wedged Base, Flat & Biconvex Asymmetrical \\
\hline $\begin{array}{c}346- \\
010\end{array}$ & 0 & 0 & None & $\begin{array}{l}\text { Heat- } \\
\text { Treated }\end{array}$ & & & & & Indeterminate & Biconvex Symmetrical \\
\hline $\begin{array}{c}346- \\
022\end{array}$ & 0 & 0 & None & None & 31.8 & & 4.1 & 2.5 & Flat & Biconvex Symmetrical \\
\hline $\begin{array}{l}347- \\
013\end{array}$ & 0 & 0 & None & None & & & 4.9 & & Indeterminate & Biconvex Symmetrical \\
\hline $\begin{array}{l}390- \\
010\end{array}$ & 0 & 0 & None & None & & & 4 & & Flat & Biconvex Symmetrical \\
\hline $\begin{array}{c}400- \\
011\end{array}$ & 0 & 0 & None & None & & & 4.6 & & Flat & Biconvex Symmetrical \\
\hline $\begin{array}{c}439- \\
010\end{array}$ & 0 & 0 & None & None & & & 5.6 & & Indeterminate & Biconvex Symmetrical \\
\hline $\begin{array}{l}531- \\
018\end{array}$ & 0 & 0 & None & None & 39.6 & & 4.8 & 5.3 & Flat & Biconvex Symmetrical \\
\hline $\begin{array}{c}563- \\
017\end{array}$ & 0 & 0 & None & None & & & 5 & & Indeterminate & Biconvex Symmetrical \\
\hline $\begin{array}{c}599- \\
015\end{array}$ & 100 & 0 & None & Burned & 30.8 & & 3.4 & 2.1 & Flat & Biconvex Symmetrical \\
\hline $\begin{array}{l}645- \\
012\end{array}$ & 0 & 0 & None & None & & & & & Indeterminate & Indeterminate \\
\hline $\begin{array}{c}651- \\
011\end{array}$ & 0 & 0 & None & None & 40.7 & & 4.8 & 5.3 & Flat & Biconvex Symmetrical \\
\hline $\begin{array}{c}689- \\
020\end{array}$ & 0 & 0 & None & Burned & & & 4.6 & & Flat & Biconvex Symmetrical \\
\hline $\begin{array}{l}694- \\
017\end{array}$ & 0 & 0 & None & $\begin{array}{l}\text { Heat- } \\
\text { Treated }\end{array}$ & 40.5 & & 4.9 & 4 & Wedged Base, Flat & Biconvex Symmetrical \\
\hline $\begin{array}{c}713- \\
016\end{array}$ & 0 & 0 & None & $\begin{array}{l}\text { Heat- } \\
\text { Treated }\end{array}$ & 55.8 & & 4.5 & 5 & Tapered Base/Tip & Biconvex Symmetrical \\
\hline $\begin{array}{c}719- \\
010\end{array}$ & 0 & 0 & None & None & & & 4.7 & & Indeterminate & Biconvex Symmetrical \\
\hline $\begin{array}{l}735- \\
011\end{array}$ & 0 & 0 & None & Burned & & & & & Indeterminate & Indeterminate \\
\hline $\begin{array}{c}746- \\
014\end{array}$ & 0 & 0 & None & None & & & 4.8 & & Flat & Biconvex Symmetrical \\
\hline $\begin{array}{c}1204- \\
010^{*}\end{array}$ & 0 & 0 & None & $\begin{array}{l}\text { Heat- } \\
\text { Treated }\end{array}$ & & & & & Indeterminate & Biconvex Symmetrical \\
\hline
\end{tabular}


The Varga Site

Texas Department of Transportation

Table 0-27. Bandy Point Data Continued

\begin{tabular}{|c|c|c|c|c|c|c|c|c|c|c|}
\hline $\begin{array}{l}\text { Cat. } \\
\text { No. }\end{array}$ & Flaking Pattern & $\begin{array}{c}\text { Edge } \\
\text { Rounding }\end{array}$ & $\begin{array}{l}\text { Blade } \\
\text { Length } \\
(\mathrm{mm})\end{array}$ & $\begin{array}{l}\text { Blade } \\
\text { Width } \\
(\mathrm{mm})\end{array}$ & $\begin{array}{l}\text { Left Lateral } \\
\text { Edge }\end{array}$ & $\begin{array}{l}\text { Right Lateral } \\
\text { Edge }\end{array}$ & $\begin{array}{c}\text { Shoulder } \\
\text { Width } \\
(\mathrm{mm})\end{array}$ & $\begin{array}{l}\text { Left } \\
\text { Notch } \\
\text { Depth } \\
(\mathrm{mm})\end{array}$ & $\begin{array}{l}\text { Right } \\
\text { Notch } \\
\text { Depth } \\
(\mathrm{mm})\end{array}$ & $\begin{array}{l}\text { Left } \\
\text { Notch } \\
\text { Width } \\
(\mathrm{mm})\end{array}$ \\
\hline $\begin{array}{l}116- \\
020\end{array}$ & Random & Absent & & & Indeterminate & Indeterminate & & 7.9 & 7.4 & 4.3 \\
\hline $\begin{array}{c}142- \\
011\end{array}$ & Chevron & Absent & & 30.8 & Straight & Straight & & & & \\
\hline $\begin{array}{l}334- \\
022\end{array}$ & Parallel & Absent & 28.3 & 21.5 & Straight & Straight & & & 6 & \\
\hline $\begin{array}{c}346- \\
010\end{array}$ & Indeterminate & Absent & & & Indeterminate & Indeterminate & & & & \\
\hline $\begin{array}{l}346- \\
022\end{array}$ & Subparallel & Present & 26.4 & 19.4 & Straight & Straight & 26.1 & 4.5 & 4.6 & 3.6 \\
\hline $\begin{array}{l}347- \\
013\end{array}$ & $\begin{array}{c}\text { Oblique } \\
\text { Subparallel }\end{array}$ & Absent & & & Indeterminate & Indeterminate & & 6.6 & 7.9 & \\
\hline $\begin{array}{l}390- \\
010\end{array}$ & Parallel & Present & & 21.2 & Indeterminate & Indeterminate & 34.5 & 6.1 & 6.2 & 7.3 \\
\hline $\begin{array}{c}400- \\
011\end{array}$ & Chevron & Present & & 29.5 & Indeterminate & Indeterminate & & 5.3 & 7.2 & 3.7 \\
\hline $\begin{array}{c}439- \\
010\end{array}$ & Indeterminate & Present & & & Indeterminate & Indeterminate & & 6.8 & & 12.1 \\
\hline $\begin{array}{l}531- \\
018\end{array}$ & Chevron & Absent & 32.3 & 30.2 & Straight & Straight & 40.2 & 7.3 & 7 & 5.9 \\
\hline $\begin{array}{c}563- \\
017\end{array}$ & Indeterminate & Present & & & Indeterminate & Indeterminate & & 6.3 & & 10.3 \\
\hline $\begin{array}{c}599- \\
015\end{array}$ & Indeterminate & Present & 24.5 & 22.9 & Straight & Straight & & 6.4 & & 6.1 \\
\hline $\begin{array}{l}645- \\
012\end{array}$ & Indeterminate & Absent & & & Indeterminate & Indeterminate & & & & \\
\hline $\begin{array}{c}651- \\
011\end{array}$ & Chevron & Present & 30.9 & 27.2 & Excurvate & Excurvate & 35.2 & 9.1 & 8.6 & 7.6 \\
\hline $\begin{array}{c}689- \\
020\end{array}$ & Parallel & Absent & & 27 & Straight & Incurvate & 34.9 & 8.4 & 6.3 & 8 \\
\hline $\begin{array}{l}694- \\
017\end{array}$ & Chevron & Present & 31.6 & 24.4 & Straight & Straight & & & 6.8 & \\
\hline $\begin{array}{c}713- \\
016\end{array}$ & $\begin{array}{c}\text { Oblique } \\
\text { Subparallel }\end{array}$ & Present & 46.9 & 25.5 & Straight & Straight & 36.7 & 7.6 & 7.9 & 5.7 \\
\hline $\begin{array}{c}719- \\
010\end{array}$ & Indeterminate & Present & & & Indeterminate & Indeterminate & & & 7.9 & \\
\hline $\begin{array}{l}735- \\
011\end{array}$ & Indeterminate & Absent & & & Indeterminate & Indeterminate & & & & \\
\hline $\begin{array}{l}746- \\
014\end{array}$ & Chevron & Present & & 28.9 & Indeterminate & Straight & 37.9 & 8.2 & 9.1 & 6.6 \\
\hline $\begin{array}{l}1204- \\
010^{*}\end{array}$ & Indeterminate & Absent & & & Indeterminate & Indeterminate & 26.5 & 4.2 & 4.5 & 5.5 \\
\hline
\end{tabular}


Table 0-27. Bandy Point Data Continued

\begin{tabular}{|c|c|c|c|c|c|c|c|c|c|c|c|c|}
\hline $\begin{array}{l}\text { Cat. } \\
\text { No. }\end{array}$ & $\begin{array}{l}\text { Right } \\
\text { Notch } \\
\text { Width } \\
(\mathrm{mm})\end{array}$ & $\begin{array}{c}\text { Left } \\
\text { Notch } \\
\text { Angle } \\
(\mathrm{mm})\end{array}$ & $\begin{array}{l}\text { Right } \\
\text { Notch } \\
\text { Angle } \\
(\mathrm{mm})\end{array}$ & Stem Shape & $\begin{array}{l}\text { Stem } \\
\text { Length } \\
(\mathrm{mm})\end{array}$ & $\begin{array}{c}\text { Stem } \\
\text { Dist } \\
\text { Width } \\
(\mathrm{mm})\end{array}$ & $\begin{array}{l}\text { Stem } \\
\text { Prox } \\
\text { Width } \\
(\mathrm{mm})\end{array}$ & $\begin{array}{l}\text { Stem } \\
\text { Thick } \\
(\mathrm{mm})\end{array}$ & $\begin{array}{l}\text { Base } \\
\text { Depth } \\
(\mathrm{mm})\end{array}$ & $\begin{array}{l}\text { Base } \\
\text { Notch } \\
\text { Width } \\
(\mathrm{mm})\end{array}$ & $\begin{array}{l}\text { Micro- } \\
\text { wear }\end{array}$ & NAA \\
\hline $\begin{array}{l}116- \\
020\end{array}$ & 4.1 & 38 & 40 & Expanding & 8.2 & 13.2 & 19.2 & 2.6 & 1.4 & 8.4 & FALSE & TRUE \\
\hline $\begin{array}{c}142- \\
011\end{array}$ & & 46 & 32 & Expanding & 10.8 & 14.3 & 18.5 & 4.8 & 0.7 & 12.1 & FALSE & TRUE \\
\hline $\begin{array}{l}334- \\
022\end{array}$ & 7.9 & & 31 & Expanding & 9 & 13.1 & 15.6 & 3.8 & 1.3 & 11 & TRUE & FALSE \\
\hline $\begin{array}{l}346- \\
010\end{array}$ & & & & Expanding & & & 17 & 3.4 & 0.9 & 7.6 & FALSE & FALSE \\
\hline $\begin{array}{l}346- \\
022\end{array}$ & 5.6 & 46 & 25 & Expanding & 5.4 & 13.3 & 15.8 & 2.4 & 0.6 & 4.4 & FALSE & FALSE \\
\hline $\begin{array}{l}347- \\
013\end{array}$ & 4.8 & & 19 & Expanding & 7.6 & 14.6 & 15.4 & 3.2 & 0.6 & 5.3 & FALSE & TRUE \\
\hline $\begin{array}{l}390- \\
010\end{array}$ & 4.3 & 31 & 25 & Expanding & 7 & 11.7 & 13.8 & 3.3 & 0.9 & 4.7 & FALSE & FALSE \\
\hline $\begin{array}{c}400- \\
011\end{array}$ & & 21 & & Expanding & 7.6 & 13.4 & 16.7 & 2.7 & 1.4 & 6.2 & FALSE & TRUE \\
\hline $\begin{array}{l}439- \\
010\end{array}$ & & 51 & & Expanding & 10.3 & 11.5 & 16.4 & 2.9 & 2.9 & 10.1 & FALSE & FALSE \\
\hline $\begin{array}{c}531- \\
018\end{array}$ & 5.8 & 37 & 28 & Expanding & 7.3 & 14 & 16.5 & 3.2 & 1.9 & 7.3 & FALSE & FALSE \\
\hline $\begin{array}{l}563- \\
017\end{array}$ & & 32 & & Expanding & 8.1 & 12.3 & 15.1 & 3.5 & 1.9 & 7.8 & FALSE & FALSE \\
\hline $\begin{array}{l}599- \\
015\end{array}$ & & 31 & 36 & Expanding & 6.3 & 13.6 & 16.5 & 2.4 & 1.3 & 10.1 & FALSE & FALSE \\
\hline $\begin{array}{l}645- \\
012\end{array}$ & & & & $\begin{array}{c}\text { Indeterminat } \\
\mathrm{e}\end{array}$ & & & & & & & FALSE & FALSE \\
\hline $\begin{array}{l}651- \\
011\end{array}$ & 8 & 34 & 33 & Expanding & 9.8 & 11.6 & 15.3 & 3.4 & 1 & 8.9 & FALSE & FALSE \\
\hline $\begin{array}{l}689- \\
020\end{array}$ & 8.4 & 38 & 26 & Expanding & 9.3 & 13.7 & 17.1 & 3.4 & 2.4 & 10.5 & FALSE & FALSE \\
\hline $\begin{array}{l}694- \\
017\end{array}$ & 7 & & 19 & Expanding & 8.9 & 14.4 & 17 & 3.5 & 1.9 & 12.9 & FALSE & FALSE \\
\hline $\begin{array}{l}713- \\
016\end{array}$ & 4.9 & 14 & 26 & Expanding & 8.9 & 12.1 & 14.9 & 3.7 & 1.1 & 8.2 & TRUE & FALSE \\
\hline $\begin{array}{l}719- \\
010\end{array}$ & 5.5 & & 19 & Expanding & 8.5 & & & 3.2 & 0.9 & 5.6 & FALSE & TRUE \\
\hline $\begin{array}{l}735- \\
011\end{array}$ & & & & $\begin{array}{c}\text { Indeterminat } \\
\mathrm{e}\end{array}$ & & & & & & & FALSE & FALSE \\
\hline $\begin{array}{l}746- \\
014\end{array}$ & 6.8 & 26 & 24 & Expanding & 8.2 & 13.9 & 15.5 & 2.9 & 1.5 & 13.2 & FALSE & FALSE \\
\hline $\begin{array}{l}1204- \\
010^{*}\end{array}$ & 3.8 & 35 & 41 & Expanding & 6.2 & 11.5 & 13.6 & 3.6 & 0.7 & 6.5 & FALSE & FALSE \\
\hline
\end{tabular}

* From the surface of Block B 
The Varga Site

Texas Department of Transportation

Table 0-28. Group 1 Point Data

\begin{tabular}{|c|c|c|c|c|c|c|c|c|c|}
\hline Cat. No. & Unit & $\begin{array}{l}\text { Depth } \\
\text { (cmbd) }\end{array}$ & Condition & Break Type & $\begin{array}{c}\text { Rejuvenation } \\
\text { Scar }\end{array}$ & Resharpening Type & Preform & Shape & $\begin{array}{c}\text { Raw } \\
\text { Material }\end{array}$ \\
\hline $141-020$ & N100,E55 & $110-120$ & Proximal & Use & Absent & Beveled Unifacial & Biface & Triangular & Chert \\
\hline $193-018$ & N101,E51 & $80-90$ & Proximal & $\begin{array}{c}\text { Thermal/Crenate } \\
\mathrm{d}\end{array}$ & Absent & None & Biface & Triangular & Chert \\
\hline $334-023$ & N102,E55 & $140-150$ & Complete & Unbroken & Absent & None & Biface & Triangular & Chert \\
\hline $486-010$ & N105,E56 & $60-70$ & Proximal & Use & Absent & Indeterminate & Indeterminate & Indeterminate & Chert \\
\hline $599-016$ & N107,E54 & $90-100$ & Complete & Use & Absent & Indeterminate & Biface & Triangular & Chert \\
\hline 599-017 & N107,E54 & $90-100$ & Complete & Use & Absent & $\begin{array}{c}\text { Break } \\
\text { Compensation }\end{array}$ & Biface & Triangular & Chert \\
\hline $628-012$ & N108,E48 & $40-50$ & Proximal & Use & Absent & $\begin{array}{c}\text { Alternate Beveled } \\
\text { Unifacial }\end{array}$ & Biface & Triangular & Chert \\
\hline $665-016$ & N108,E54 & $50-60$ & Proximal & $\begin{array}{c}\text { Thermal/Crenate } \\
\text { d }\end{array}$ & Absent & Indeterminate & Indeterminate & Triangular & Chert \\
\hline 670-005-011 & N108,E55 & 49 & Complete & Unbroken & Absent & Indeterminate & Flake & Triangular & Chert \\
\hline $670-013$ & N108,E55 & $40-50$ & Proximal & Use & Absent & Indeterminate & Biface & Indeterminate & Chert \\
\hline $671-011$ & N108,E55 & $50-60$ & Proximal & Use & Absent & None & Biface & Triangular & Chert \\
\hline $694-018$ & N109,E49 & $40-50$ & Proximal & Use & Absent & None & Biface & Lanceolate & Chert \\
\hline 717-012 & N109,E52 & $30-40$ & Proximal & Use & Absent & Indeterminate & Indeterminate & Indeterminate & Chert \\
\hline $1202-010$ & BT WALL & 51 & Proximal & Use & Absent & $\begin{array}{c}\text { Alternate Beveled } \\
\text { Unifacial }\end{array}$ & Biface & Lanceolate & Chert \\
\hline $1203-010$ & BT 2 & & Proximal & Use & Absent & None & Biface & Indeterminate & Chert \\
\hline
\end{tabular}

\begin{tabular}{|c|c|c|c|c|c|c|c|c|c|c|}
\hline Cat. No. & Texture & $\begin{array}{l}\text { Percent } \\
\text { Patination }\end{array}$ & $\begin{array}{l}\text { Percent } \\
\text { Cortex }\end{array}$ & Heating & $\begin{array}{l}\text { Length } \\
(\mathrm{mm})\end{array}$ & $\begin{array}{l}\text { Width } \\
(\mathrm{mm})\end{array}$ & $\begin{array}{l}\text { Thick } \\
(\mathrm{mm})\end{array}$ & Wt. (g) & Long X-Section & Trans $\mathrm{X}$-Section \\
\hline $141-020$ & Fine & 0 & 0 & None & & & 9.3 & & Indeterminate & Biconvex Symmetrical \\
\hline $193-018$ & Fine & 0 & 0 & Burned & & & 6.6 & & Indeterminate & Biconvex Symmetrical \\
\hline $334-023$ & Fine & 0 & 0 & None & 42 & & 7.7 & 6.7 & Tapered Base/Tip & Biconvex Symmetrical \\
\hline $486-010$ & Fine & 0 & 0 & Indeterminate & & & & & Indeterminate & Indeterminate \\
\hline $599-016$ & Fine & 75 & 0 & None & 40.2 & & 7.5 & 7.9 & Tapered Base/Tip & Biconvex Symmetrical \\
\hline $599-017$ & Fine & 0 & 0 & Indeterminate & 62.1 & & 8.4 & 15.2 & Tapered Base/Tip & Biconvex Symmetrical \\
\hline $628-012$ & Fine & 0 & 0 & None & & & 8.3 & 11.1 & Tapered Base/Tip & Biconvex Asymmetrical \\
\hline $665-016$ & Fine & 0 & 0 & Burned & & & & 4.2 & Indeterminate & Biconvex Symmetrical \\
\hline 670-005-011 & Fine & 0 & 0 & None & 60.1 & & 7.3 & 11.8 & Tapered Base/Tip & Plano-Convex \\
\hline $670-013$ & Fine & 0 & 0 & Indeterminate & & & & & Indeterminate & Biconvex Symmetrical \\
\hline $671-011$ & Fine & 25 & 0 & None & & & 8 & & Indeterminate & Biconvex Symmetrical \\
\hline $694-018$ & Fine & 0 & 0 & Heat-Treated & & & 7.5 & & Indeterminate & Biconvex Symmetrical \\
\hline 717-012 & Fine & 0 & 0 & None & & & & & Indeterminate & Indeterminate \\
\hline $1202-010$ & Fine & 0 & 0 & None & & & 7.1 & 8 & Flat & Biconvex Symmetrical \\
\hline $1203-010$ & Fine & 0 & 0 & None & & & 6.2 & & Indeterminate & Plano-Convex \\
\hline
\end{tabular}


Table 0-28. Group 1 Point Data Continued

\begin{tabular}{|c|c|c|c|c|c|c|c|c|c|}
\hline Cat. No. & $\begin{array}{l}\text { Flaking } \\
\text { Pattern }\end{array}$ & $\begin{array}{c}\text { Edge } \\
\text { Rounding }\end{array}$ & $\begin{array}{l}\text { Blade } \\
\text { Length } \\
(\mathrm{mm})\end{array}$ & $\begin{array}{l}\text { Blade } \\
\text { Width } \\
(\mathrm{mm})\end{array}$ & Left Lateral Edge & Right Lateral Edge & $\begin{array}{c}\text { Shoulder } \\
\text { Width }(\mathrm{mm})\end{array}$ & $\begin{array}{l}\text { Left Notch } \\
\text { Depth (mm) }\end{array}$ & $\begin{array}{l}\text { Right } \\
\text { Notch } \\
\text { Depth } \\
\text { (mm) }\end{array}$ \\
\hline $141-020$ & $\begin{array}{c}\text { Indeterminat } \\
\mathrm{e}\end{array}$ & Present & & 27.4 & Indeterminate & Indeterminate & 31.3 & 4.4 & 6.4 \\
\hline $193-018$ & $\begin{array}{c}\text { Indeterminat } \\
\mathrm{e}\end{array}$ & Present & & 21.5 & Indeterminate & Indeterminate & 28.9 & 5.1 & 4.5 \\
\hline $334-023$ & Chevron & Absent & 29.6 & 27.1 & Straight & Straight & 32.1 & 6.4 & 6.2 \\
\hline $486-010$ & $\begin{array}{c}\text { Indeterminat } \\
\mathrm{e}\end{array}$ & Absent & & & Indeterminate & Indeterminate & & & \\
\hline $599-016$ & Chevron & Present & 27.3 & 24.1 & Straight & Straight & & 6.5 & \\
\hline $599-017$ & Chevron & Present & 44.3 & 32.6 & Excurvate & Excurvate & 34.2 & 7.7 & 7.2 \\
\hline $628-012$ & $\begin{array}{l}\text { Oblique } \\
\text { Parallel }\end{array}$ & Absent & & 28.4 & Straight & Straight & 32.5 & 5.2 & \\
\hline $665-016$ & Subparallel & Absent & & 20.2 & Straight & Straight & 25.8 & 3.2 & 5.2 \\
\hline $670-005-011$ & Random & Present & 45 & 27.4 & Recurvate & Straight & 31.7 & 6.3 & 5.5 \\
\hline $670-013$ & $\begin{array}{c}\text { Indeterminat } \\
\mathrm{e}\end{array}$ & Present & & & Indeterminate & Indeterminate & & & \\
\hline $671-011$ & Random & Present & & 34.9 & Straight & Straight & 39.4 & 6.8 & 7.2 \\
\hline 694-018 & Subparallel & Present & & 29.9 & Straight & Excurvate & 30.4 & 5.6 & 5 \\
\hline 717-012 & $\begin{array}{c}\text { Indeterminat } \\
\mathrm{e}\end{array}$ & Present & & & Indeterminate & Indeterminate & & & \\
\hline $1202-010$ & Subparallel & Present & & 19.5 & Straight & Straight & 29.8 & & 4.6 \\
\hline $1203-010$ & $\begin{array}{c}\text { Oblique } \\
\text { Subparallel }\end{array}$ & Present & & 30.1 & Straight & Indeterminate & 34 & 7.8 & 7.3 \\
\hline
\end{tabular}

\begin{tabular}{|c|c|c|c|c|c|c|c|c|c|c|c|}
\hline Cat. No. & $\begin{array}{l}\text { Right } \\
\text { Notch } \\
\text { Width } \\
(\mathrm{mm}) \\
\end{array}$ & $\begin{array}{l}\text { Left Notch } \\
\text { Angle }\end{array}$ & $\begin{array}{l}\text { Right } \\
\text { Notch } \\
\text { Angle } \\
\end{array}$ & $\begin{array}{l}\text { Stem } \\
\text { Shape }\end{array}$ & $\begin{array}{c}\text { Stem } \\
\text { Length } \\
(\mathrm{mm})\end{array}$ & $\begin{array}{l}\text { Distal } \\
\text { Stem } \\
\text { Width } \\
(\mathrm{mm}) \\
\end{array}$ & $\begin{array}{c}\text { Proximal } \\
\text { Stem } \\
\text { Width } \\
(\mathrm{mm}) \\
\end{array}$ & $\begin{array}{l}\text { Stem } \\
\text { Thick } \\
(\mathrm{mm})\end{array}$ & $\begin{array}{l}\text { Base } \\
\text { Depth } \\
(\mathrm{mm})\end{array}$ & $\begin{array}{c}\text { Micro- } \\
\text { wear }\end{array}$ & NAA \\
\hline $141-020$ & 12.6 & 60 & 38 & Expanding & 15.1 & 16.3 & 20.5 & 4.9 & 4.7 & FALSE & FALSE \\
\hline $193-018$ & 13.6 & 43 & 39 & Expanding & 15.9 & 19.7 & 24.3 & 3.5 & 5.9 & FALSE & FALSE \\
\hline $334-023$ & 8.9 & 54 & 24 & Expanding & 12.4 & 17.4 & 22.3 & 6.2 & 2.8 & FALSE & FALSE \\
\hline $486-010$ & & & & Expanding & & & 19.8 & 4 & 3.4 & FALSE & FALSE \\
\hline 599-016 & & 53 & 39 & Expanding & 12.9 & 16.8 & 23 & 4.4 & 2.4 & FALSE & FALSE \\
\hline 599-017 & 18 & 25 & 20 & Expanding & 17.8 & 19 & 20.7 & 5.9 & 4.2 & TRUE & FALSE \\
\hline 628-012 & & 46 & 24 & Expanding & 15.2 & 17.7 & & 6.3 & 4.5 & FALSE & FALSE \\
\hline $665-016$ & 9.2 & 68 & 48 & Expanding & 14.2 & 14.3 & 19 & 4.3 & 1.9 & FALSE & FALSE \\
\hline $670-005-011$ & 10.8 & 30 & 30 & Expanding & 15.1 & 18.1 & 21.3 & 4.7 & 4.7 & TRUE & FALSE \\
\hline $670-013$ & & & & Expanding & & & 22 & 4.2 & 4.7 & FALSE & TRUE \\
\hline 671-011 & 12.3 & 62 & 56 & Expanding & 15 & 19.1 & 24.5 & 3.9 & 1.4 & FALSE & TRUE \\
\hline 694-018 & 8.6 & 43 & 42 & Expanding & 12.6 & 18.1 & 21.8 & 5.4 & 3.4 & FALSE & FALSE \\
\hline 717-012 & & & & Expanding & & & 23.9 & 4.2 & 6.9 & FALSE & FALSE \\
\hline $1202-010$ & 9.6 & & 33 & Expanding & 10.2 & 21.5 & 23.6 & 6 & 4.1 & FALSE & FALSE \\
\hline $1203-010$ & 13.7 & 33 & 28 & Expanding & 15.6 & 19.3 & 24.1 & 3.9 & 3.5 & FALSE & TRUE \\
\hline
\end{tabular}


The Varga Site

Texas Department of Transportation

Table 0-29. Baker Point Data

\begin{tabular}{|c|c|c|c|c|c|c|c|c|c|}
\hline Cat. No. & Unit & $\begin{array}{l}\text { Depth } \\
\text { (cmbd) }\end{array}$ & Condition & Break Type & $\begin{array}{l}\text { Rejuvenation } \\
\text { Scar }\end{array}$ & $\begin{array}{c}\text { Resharpening } \\
\text { Type }\end{array}$ & Preform & Shape & $\begin{array}{c}\text { Edge } \\
\text { Rounding }\end{array}$ \\
\hline 28-014 & N99,E52 & $80-90$ & Complete & Unbroken & Absent & None & Biface & Lanceolate & Present \\
\hline $28-013$ & N99,E52 & $80-90$ & Proximal & Indeterminate & Absent & None & Biface & Indeterminate & Present \\
\hline $95-018$ & N100,E51 & $80-90$ & Proximal & Use & Absent & Indeterminate & Biface & Indeterminate & Absent \\
\hline $117-021$ & $\mathrm{~N} 100, \mathrm{E} 53$ & $90-100$ & Indeterminate & Use & Absent & None & Biface & Indeterminate & Absent \\
\hline $140-024$ & N100,E55 & $100-110$ & Proximal & Indeterminate & Absent & None & Flake & Lanceolate & Absent \\
\hline 229-019 & N101,E54 & $110-120$ & Proximal & Use & Absent & $\begin{array}{c}\text { Break } \\
\text { Compensation }\end{array}$ & Biface & Indeterminate & Absent \\
\hline $346-023$ & $\mathrm{~N} 102, \mathrm{E} 56$ & $110-120$ & Proximal & Use & Absent & $\begin{array}{c}\text { Break } \\
\text { Compensation }\end{array}$ & Biface & Lanceolate & Present \\
\hline $402-011$ & $\mathrm{~N} 103, \mathrm{E} 56$ & $90-100$ & Proximal & Use & Absent & None & Biface & Triangular & Present \\
\hline 431-010 & $\mathrm{N} 105, \mathrm{E} 47$ & $70-80$ & Complete & Unbroken & Absent & $\begin{array}{c}\text { Break } \\
\text { Compensation }\end{array}$ & Biface & Triangular & Present \\
\hline $462-015$ & $\mathrm{~N} 105, \mathrm{E} 53$ & 47 & Proximal & Use & Absent & None & Biface & Lanceolate & Present \\
\hline 569-013 & $\mathrm{N} 107, \mathrm{E} 50$ & $40-50$ & Complete & Unbroken & Absent & $\begin{array}{c}\text { Break } \\
\text { Compensation }\end{array}$ & Biface & Triangular & Present \\
\hline $653-012^{*}$ & N108,E53 & $0-10$ & Proximal & Use & Absent & $\begin{array}{l}\text { Beveled } \\
\text { Unifacial }\end{array}$ & Biface & Indeterminate & Absent \\
\hline Cat. No. & $\begin{array}{c}\text { Raw } \\
\text { Material }\end{array}$ & Texture & $\begin{array}{c}\text { Percent } \\
\text { Patination } \\
\end{array}$ & $\begin{array}{l}\text { Percent } \\
\text { Cortex }\end{array}$ & Cortex Type & Heating & Length $(\mathrm{mm})$ & Width (mm) & Thick (mm) \\
\hline 28-014 & Chert & Fine & 0 & 0 & None & None & 47.2 & & 6.5 \\
\hline $28-013$ & Chert & Fine & 0 & 0 & None & Burned & & & 6.2 \\
\hline $95-018$ & Chert & Fine & 0 & 0 & None & None & & & \\
\hline $117-021$ & Chert & Fine & 0 & 0 & None & None & 50.9 & & \\
\hline $140-024$ & Chert & Fine & 0 & 0 & None & None & 57 & & 7.5 \\
\hline 229-019 & Chert & Fine & 0 & 0 & None & None & & & 6.8 \\
\hline $346-023$ & Chert & Fine & 0 & 0 & None & None & & & 6.5 \\
\hline $402-011$ & Chert & Fine & 0 & 0 & None & None & & & 7.2 \\
\hline 431-010 & Chert & Fine & 0 & 0 & None & None & 43.3 & & 6.1 \\
\hline $462-015$ & Chert & Fine & 0 & 0 & None & Heat-Treated & & & 5.9 \\
\hline 569-013 & Chert & Fine & 0 & 0 & None & None & 35.7 & & 7.5 \\
\hline $653-012^{*}$ & Chert & Fine & 0 & 0 & None & None & & & 7 \\
\hline
\end{tabular}


Table 0-29. Baker Point Data Continued

\begin{tabular}{|c|c|c|c|c|c|c|c|c|c|}
\hline Cat. No. & $\begin{array}{l}\text { Wt. } \\
(\mathrm{g})\end{array}$ & Long X-Section & Trans X-Section & Flaking Pattern & $\begin{array}{l}\text { Blade } \\
\text { Length } \\
(\mathrm{mm}) \\
\end{array}$ & $\begin{array}{l}\text { Blade } \\
\text { Width } \\
(\mathrm{mm}) \\
\end{array}$ & $\begin{array}{l}\text { Left Lateral } \\
\text { Edge }\end{array}$ & $\begin{array}{l}\text { Right Lateral } \\
\text { Edge }\end{array}$ & $\begin{array}{c}\text { Shoulder } \\
\text { Width } \\
(\mathrm{mm}) \\
\end{array}$ \\
\hline $28-014$ & 4.8 & Tapered Base/Tip & Plano-Convex & Oblique Parallel & 36.3 & 18.2 & Straight & Straight & 21 \\
\hline $28-013$ & & Indeterminate & $\begin{array}{c}\text { Biconvex } \\
\text { Symmetrical }\end{array}$ & Subparallel & & 18.9 & Indeterminate & Excurvate & \\
\hline $95-018$ & & Indeterminate & $\begin{array}{c}\text { Biconvex } \\
\text { Symmetrical }\end{array}$ & Indeterminate & & & Indeterminate & Indeterminate & \\
\hline $117-021$ & & Tapered Base/Tip & $\begin{array}{c}\text { Biconvex } \\
\text { Symmetrical }\end{array}$ & Indeterminate & 36 & & Excurvate & Indeterminate & \\
\hline $140-024$ & 7.6 & $\begin{array}{l}\text { Wedged Base, } \\
\text { Thick Body }\end{array}$ & $\begin{array}{c}\text { Biconvex } \\
\text { Symmetrical }\end{array}$ & Parallel & 45.2 & 18.9 & Straight & Straight & 21.8 \\
\hline 229-019 & & Indeterminate & $\begin{array}{c}\text { Biconvex } \\
\text { Symmetrical }\end{array}$ & Oblique Parallel & & 18.9 & Straight & Indeterminate & \\
\hline $346-023$ & 5.7 & Tapered Base & $\begin{array}{c}\text { Biconvex } \\
\text { Symmetrical }\end{array}$ & $\begin{array}{l}\text { Oblique } \\
\text { Subparallel }\end{array}$ & & 17.9 & Straight & Excurvate & 21.6 \\
\hline $402-011$ & & Tapered Base/Tip & $\begin{array}{c}\text { Biconvex } \\
\text { Symmetrical }\end{array}$ & Subparallel & & 16.1 & Straight & Straight & 21.1 \\
\hline $431-010$ & 3.4 & Tapered Base/Tip & $\begin{array}{l}\text { Biconvex } \\
\text { Symmetrical }\end{array}$ & Subparallel & 29.4 & 16.5 & Straight & Straight & 21 \\
\hline $462-015$ & 5.7 & $\begin{array}{l}\text { Wedged Base, } \\
\text { Flat }\end{array}$ & $\begin{array}{c}\text { Biconvex } \\
\text { Symmetrical }\end{array}$ & $\begin{array}{l}\text { Oblique } \\
\text { Subparallel }\end{array}$ & & & Straight & Straight & 23.2 \\
\hline $569-013$ & 4.8 & Bi-wedge-shaped & $\begin{array}{c}\text { Biconvex } \\
\text { Symmetrical }\end{array}$ & Subparallel & 23.1 & 18.5 & Straight & Excurvate & 22.3 \\
\hline $653-012^{*}$ & & Indeterminate & $\begin{array}{c}\text { Biconvex } \\
\text { Symmetrical }\end{array}$ & $\begin{array}{c}\text { Oblique } \\
\text { Subparallel }\end{array}$ & & 20.2 & Indeterminate & Indeterminate & \\
\hline Cat. No. & $\begin{array}{l}\text { Left Notch } \\
\text { Depth } \\
(\mathrm{mm})\end{array}$ & $\begin{array}{l}\text { Right Notch } \\
\text { Depth }(\mathrm{mm})\end{array}$ & $\begin{array}{l}\text { Left Notch Width } \\
(\mathrm{mm})\end{array}$ & $\begin{array}{l}\text { Right Notch } \\
\text { Width }(\mathrm{mm})\end{array}$ & $\begin{array}{l}\text { Left } \\
\text { Notch } \\
\text { Angle } \\
\end{array}$ & $\begin{array}{l}\text { Right } \\
\text { Notch } \\
\text { Angle } \\
\end{array}$ & Stem Shape & $\begin{array}{l}\text { Stem Length } \\
(\mathrm{mm})\end{array}$ & $\begin{array}{l}\text { Distal } \\
\text { Stem } \\
\text { Width } \\
(\mathrm{mm}) \\
\end{array}$ \\
\hline $28-014$ & 1.9 & 2.2 & 7.3 & 7.1 & 62 & 46 & Curved & 10.9 & 15.8 \\
\hline $28-013$ & & 1.9 & & 11.4 & & 63 & Expanding & 16.4 & \\
\hline $95-018$ & & & & & & & Curved & 17.3 & 13.7 \\
\hline $117-021$ & & & & & & & Expanding & 12.9 & \\
\hline $140-024$ & & 4.8 & & 12.2 & & 25 & Straight & 11.8 & 15.2 \\
\hline 229-019 & & & & & & 38 & Expanding & 11.7 & 16.2 \\
\hline $346-023$ & 3.3 & 3.4 & 11.8 & 13.2 & 38 & 49 & Expanding & 13.6 & 13.5 \\
\hline $402-011$ & 2.2 & & 8.5 & & 49 & & Curved & 14.2 & 12.9 \\
\hline $431-010$ & 3.5 & 1.8 & 9.8 & 8.7 & 57 & 49 & Expanding & 13.9 & 15.5 \\
\hline $462-015$ & 2.9 & 4 & 9.1 & 9.7 & 36 & 31 & Straight & 13.3 & 14.6 \\
\hline 569-013 & 2.3 & 2.5 & 7.5 & 8.4 & 51 & 42 & Expanding & 12.6 & 16.1 \\
\hline $653-012^{*}$ & & 3.1 & & 9.4 & & 37 & Curved & 13.5 & 15.2 \\
\hline
\end{tabular}


Table 0-29. Baker Point Data Continued

\begin{tabular}{|c|c|c|c|c|c|c|}
\hline Cat. No. & $\begin{array}{c}\text { Proximal } \\
\text { Stem Width } \\
(\mathrm{mm})\end{array}$ & $\begin{array}{l}\text { Stem Thick } \\
(\mathrm{mm})\end{array}$ & $\begin{array}{l}\text { Base Depth } \\
(\mathrm{mm})\end{array}$ & $\begin{array}{l}\text { Base Notch } \\
\text { Width }(\mathrm{mm})\end{array}$ & Micro-wear & NAA \\
\hline $28-014$ & 16.9 & 4 & 5 & 8.6 & FALSE & FALSE \\
\hline $28-013$ & 16.6 & 4.5 & 6.1 & 11 & FALSE & FALSE \\
\hline $95-018$ & 16.4 & 4.4 & 5.5 & 7.9 & FALSE & FALSE \\
\hline $117-021$ & & & 5.8 & & FALSE & TRUE \\
\hline $140-024$ & & 4 & 6.8 & & TRUE & FALSE \\
\hline 229-019 & & 5.4 & 8.1 & & FALSE & FALSE \\
\hline $346-023$ & 14.9 & 4.2 & 3.9 & 8.3 & FALSE & FALSE \\
\hline 402-011 & & 3.2 & 7 & & FALSE & TRUE \\
\hline $431-010$ & 18.5 & 4.1 & 5.8 & 7.9 & FALSE & FALSE \\
\hline $462-015$ & 15.3 & 2.6 & 4.9 & 8.5 & FALSE & TRUE \\
\hline 569-013 & 18.3 & 7 & 5 & 6.7 & FALSE & FALSE \\
\hline $653-012^{*}$ & 16 & 5.7 & 5.3 & 8 & FALSE & FALSE \\
\hline
\end{tabular}

* From Toyah component 
Table 0-30. Merrell Point Data

\begin{tabular}{|c|c|c|c|c|c|c|c|c|c|c|c|c|c|c|}
\hline Cat. No. & Unit & $\begin{array}{l}\text { Depth } \\
\text { (cmbd) }\end{array}$ & \multicolumn{2}{|c|}{ Condition } & \multicolumn{2}{|c|}{$\begin{array}{l}\text { Break } \\
\text { Type }\end{array}$} & $\begin{array}{c}\text { Rejuvenation } \\
\text { Scar }\end{array}$ & \multicolumn{2}{|c|}{$\begin{array}{l}\text { Resharpening } \\
\text { Type }\end{array}$} & Preform & Shape & \multicolumn{2}{|c|}{$\begin{array}{c}\text { Raw } \\
\text { Material }\end{array}$} & Texture \\
\hline $117-020$ & N100,E53 & $90-100$ & \multicolumn{2}{|c|}{ Complete } & \multicolumn{2}{|c|}{ Unbroken } & Absent & \multicolumn{2}{|c|}{ Indeterminate } & Biface & Triangular & \multicolumn{2}{|c|}{ Chert } & Fine \\
\hline $157-011^{*}$ & N101,E47 & $10-20$ & \multicolumn{2}{|c|}{ Proximal } & \multicolumn{2}{|c|}{ Use } & Absent & & None & Biface & Indeterminate & \multicolumn{2}{|c|}{ Chert } & Fine \\
\hline 203-014 & N101,E52 & $80-90$ & \multicolumn{2}{|c|}{ Proximal } & \multicolumn{2}{|c|}{ Use } & Absent & & None & Biface & Lanceolate & \multicolumn{2}{|c|}{ Chert } & Fine \\
\hline 299-014 & N102,E52 & $80-90$ & \multicolumn{2}{|c|}{ Proximal } & \multicolumn{2}{|c|}{ Use } & Absent & & None & Biface & Triangular & \multicolumn{2}{|c|}{ Chert } & Fine \\
\hline $345-028$ & N102,E56 & $100-110$ & \multicolumn{2}{|c|}{ Proximal } & \multicolumn{2}{|c|}{ Use } & Absent & & None & Biface & Lanceolate & \multicolumn{2}{|c|}{ Chert } & Fine \\
\hline 463-021 & N105,E53 & $50-60$ & & & & & & & & & & & & \\
\hline $479-013$ & N105,E55 & $60-70$ & \multicolumn{2}{|c|}{ Proximal } & \multicolumn{2}{|c|}{ Use } & Absent & & None & Biface & Lanceolate & \multicolumn{2}{|c|}{ Chert } & Fine \\
\hline $523-022$ & N106,E53 & $60-70$ & \multicolumn{2}{|c|}{ Proximal } & \multicolumn{2}{|c|}{ Use } & Absent & & None & Biface & Indeterminate & \multicolumn{2}{|c|}{ Chert } & Fine \\
\hline $523-025$ & N106,E53 & $60-70$ & \multicolumn{2}{|c|}{ Proximal } & \multicolumn{2}{|c|}{ Use } & Absent & \multicolumn{2}{|c|}{$\begin{array}{c}\text { Break } \\
\text { Compensation }\end{array}$} & Biface & Indeterminate & & hert & Fine \\
\hline 584-015 & N107,E52 & $50-60$ & Proxi & & & se & Absent & & None & Biface & Indeterminate & & hert & Fine \\
\hline $615-020$ & N107,E56 & 53 & Comp & & & se & Absent & & $\begin{array}{l}\text { Break } \\
\text { npensation }\end{array}$ & Biface & Lanceolate & & hert & Fine \\
\hline $658-016$ & N108,E53 & $50-60$ & Comp & & Un & oken & Absent & & eterminate & Biface & Triangular & & hert & Fine \\
\hline Cat. No. & $\begin{array}{c}\text { Percent } \\
\text { Patination }\end{array}$ & $\begin{array}{l}\text { Percent } \\
\text { Cortex }\end{array}$ & $\begin{array}{l}\text { Cortex } \\
\text { Type }\end{array}$ & $\mathrm{He}$ & & $\begin{array}{l}\text { Length } \\
(\mathrm{mm})\end{array}$ & $\begin{array}{l}\text { Thick } \\
(\mathrm{mm})\end{array}$ & $\begin{array}{l}\text { Wt. } \\
\text { (g) }\end{array}$ & Long $X$ & ection & Trans X-Section & & & king Pattern \\
\hline $117-020$ & 0 & 0 & None & & & 44.2 & 6.4 & 4.9 & Tapered & ase/Tip & Biconvex Symmetr & & & Chevron \\
\hline $157-011^{*}$ & 0 & 0 & None & $\mathrm{Bu}$ & & & 6.4 & & Indete & inate & Biconvex Symmetr & & & determinate \\
\hline $203-014$ & 0 & 0 & None & & & & 6.6 & 5.2 & Wedged & se, Flat & Biconvex Symmetr & & & Subparallel \\
\hline $299-014$ & 0 & 0 & None & & & & 5.9 & & Wedged & se, Flat & Biconvex Symmetr & & $\mathrm{Ob}$ & que Subparallel \\
\hline $345-028$ & 0 & 0 & None & & & & 8 & & $\begin{array}{l}\text { Wedge } \\
\text { Thick }\end{array}$ & $\begin{array}{l}\text { Base, } \\
\text { ody }\end{array}$ & Biconvex Symmetr & & $\mathrm{Ob}$ & que Subparallel \\
\hline $463-021$ & & & & & & & & & & & & & & \\
\hline $479-013$ & 0 & 0 & None & & & & 7.3 & 5.1 & Tapered & se/Tip & Biconvex Symmetr & & & lique Parallel \\
\hline $523-022$ & 0 & 0 & None & $\mathrm{Bu}$ & & & 7.2 & & Indete & inate & Biconvex Symmetr & & & determinate \\
\hline $523-025$ & 0 & 0 & None & & & & 6.6 & 4.7 & Indete & inate & Plano-Convex & & & Subparallel \\
\hline 584-015 & 0 & 0 & None & $\mathrm{Bu}$ & & & 5.7 & & Indete & inate & Plano-Convex & & & determinate \\
\hline $615-020$ & 50 & 0 & None & & & 56.6 & 8.1 & 9.5 & Bi-wedg & haped & Biconvex Symmetr & & & Subparallel \\
\hline 658-016 & 100 & 0 & None & & & 41.1 & 7.3 & 5.4 & Tapered & ase/Tip & Biconvex Symmetri & & & Chevron \\
\hline
\end{tabular}


The Varga Site

Texas Department of Transportation

Table 0-30. Merrell Point Data Continued

\begin{tabular}{|c|c|c|c|c|c|c|c|c|c|c|}
\hline Cat. No. & $\begin{array}{c}\text { Edge } \\
\text { Rounding }\end{array}$ & $\begin{array}{l}\text { Blade } \\
\text { Length } \\
(\mathrm{mm})\end{array}$ & $\begin{array}{l}\text { Blade } \\
\text { Width } \\
(\mathrm{mm})\end{array}$ & Left Lateral Edge & Right Lateral Edge & $\begin{array}{l}\text { Left } \\
\text { Notch } \\
\text { Depth } \\
(\mathrm{mm}) \\
\end{array}$ & $\begin{array}{l}\text { Right } \\
\text { Notch } \\
\text { Depth } \\
(\mathrm{mm}) \\
\end{array}$ & $\begin{array}{c}\text { Left } \\
\text { Notch } \\
\text { Width } \\
(\mathrm{mm}) \\
\end{array}$ & $\begin{array}{l}\text { Right } \\
\text { Notch } \\
\text { Width } \\
(\mathrm{mm})\end{array}$ & $\begin{array}{l}\text { Left } \\
\text { Notch } \\
\text { Angle }\end{array}$ \\
\hline $117-020$ & Absent & 29.3 & 16.8 & Straight & Straight & 4.7 & 5.4 & 11.5 & 8.5 & 37 \\
\hline $157-011^{*}$ & Absent & & & Indeterminate & Indeterminate & 3.3 & & 8.7 & & 90 \\
\hline 203-014 & Present & & 18.4 & Straight & Straight & 2.2 & 2.7 & 7.9 & 8.7 & 76 \\
\hline 299-014 & Present & & 17.3 & Straight & Straight & 5.5 & 5.3 & 8.5 & 8.5 & 68 \\
\hline $345-028$ & Absent & & 17.7 & Straight & Straight & 3.3 & 2 & 9.6 & 6.2 & 41 \\
\hline \multicolumn{11}{|l|}{ 463-021 } \\
\hline $479-013$ & Absent & & 17.1 & Straight & Straight & 3.1 & 3.1 & 8.4 & 8.1 & 61 \\
\hline $523-022$ & Absent & & 17.3 & Indeterminate & Indeterminate & 3 & 3.2 & 8.1 & 8.9 & 109 \\
\hline $523-025$ & Absent & & 17.6 & Indeterminate & Straight & 4.2 & 3.1 & 7.5 & 8.3 & 66 \\
\hline $584-015$ & Absent & & 14 & Indeterminate & Indeterminate & 3.4 & 1.7 & 6.7 & 7.6 & 66 \\
\hline $615-020$ & Absent & 43 & 18.8 & Straight & Straight & 3.1 & 1.6 & 9.4 & 8.4 & 60 \\
\hline $658-016$ & Present & 28 & 16.7 & Straight & Straight & 3.3 & 3.7 & 7.3 & 11.8 & 77 \\
\hline
\end{tabular}

\begin{tabular}{|c|c|c|c|c|c|c|c|c|c|c|}
\hline Cat. No. & $\begin{array}{l}\text { Right } \\
\text { Notch } \\
\text { Angle }\end{array}$ & Stem Shape & $\begin{array}{l}\text { Stem } \\
\text { Length } \\
(\mathrm{mm})\end{array}$ & $\begin{array}{l}\text { Distal Stem } \\
\text { Width }(\mathrm{mm})\end{array}$ & $\begin{array}{l}\text { Proximal } \\
\text { Stem Width } \\
(\mathrm{mm})\end{array}$ & $\begin{array}{l}\text { Stem } \\
\text { Thick } \\
(\mathrm{mm})\end{array}$ & $\begin{array}{l}\text { Base } \\
\text { Depth } \\
(\mathrm{mm})\end{array}$ & $\begin{array}{l}\text { Base Notch } \\
\text { Width }(\mathrm{mm})\end{array}$ & Micro-wear & NAA \\
\hline $117-020$ & 55 & Curved & 14.9 & 15.3 & 20.2 & 4.3 & 6 & 7.7 & FALSE & FALSE \\
\hline $157-011^{*}$ & 90 & Curved & 17.7 & 15 & 23.7 & 3.7 & 5.4 & 6.7 & FALSE & TRUE \\
\hline 203-014 & 78 & Expanding & 14.3 & 15.5 & 20.9 & 5.4 & 6.5 & 8.2 & FALSE & FALSE \\
\hline 299-014 & 67 & Curved & 13.9 & 11.4 & 20.7 & 4.7 & 3.9 & 8.6 & FALSE & TRUE \\
\hline $345-028$ & 70 & Expanding & & 13.7 & & 3.1 & & & FALSE & TRUE \\
\hline 463-021 & & & & & & & & & FALSE & FALSE \\
\hline $479-013$ & 65 & Expanding & 11.7 & 15.6 & 21.3 & 4.5 & 5.9 & 11.8 & FALSE & FALSE \\
\hline $523-022$ & 80 & Expanding & 15.3 & 13.6 & 19.4 & 5.5 & 4.5 & 8.7 & FALSE & FALSE \\
\hline $523-025$ & 113 & Expanding & 14.9 & 15.7 & 22.2 & 5.2 & 5.8 & 10.5 & FALSE & FALSE \\
\hline 584-015 & 79 & Expanding & 13 & 12.9 & 18.1 & 3.5 & 5.1 & 10.1 & FALSE & FALSE \\
\hline $615-020$ & 58 & Expanding & 13.6 & 15.1 & & 4.1 & 3.9 & 9.1 & FALSE & TRUE \\
\hline $658-016$ & 64 & Expanding & 13.1 & 14.8 & 20.1 & 4.4 & 5.3 & 7 & FALSE & FALSE \\
\hline
\end{tabular}

* Found in Toyah Component 
Table 0-31. Group 2 Point Data

\begin{tabular}{|c|c|c|c|c|c|c|c|c|c|c|}
\hline Cat. No. & Unit & $\begin{array}{l}\text { Depth } \\
\text { (cmbd) }\end{array}$ & Condition & $\begin{array}{l}\text { Break } \\
\text { Type }\end{array}$ & $\begin{array}{c}\text { Rejuvenation } \\
\text { Scar }\end{array}$ & $\begin{array}{c}\text { Resharpening } \\
\text { Type }\end{array}$ & Preform & Shape & $\begin{array}{c}\text { Raw } \\
\text { Material }\end{array}$ & Texture \\
\hline $215-018$ & N101,E53 & $90-100$ & Proximal & Use & Absent & None & Biface & Lanceolate & Chert & Fine \\
\hline 283-014 & $\mathrm{N} 102, \mathrm{E} 51$ & 33 & Complete & Use & Absent & Beveled Unifacial & Biface & Lanceolate & Chert & Fine \\
\hline $324-016^{*}$ & N102,E55 & 50 & Proximal & Use & Absent & None & Biface & Indeterminate & Chert & Fine \\
\hline $370-010$ & N103,E51 & 40.5 & Proximal & Use & Absent & None & Biface & Lanceolate & Chert & Fine \\
\hline $412-011$ & $\mathrm{~N} 104, \mathrm{E} 47$ & $80-90$ & Proximal & Use & Absent & Indeterminate & Biface & Lanceolate & Chert & Fine \\
\hline $412-010$ & $\mathrm{~N} 104, \mathrm{E} 47$ & $80-90$ & Complete & Unbroken & Absent & None & Biface & Lanceolate & Chert & Fine \\
\hline $523-021$ & N106,E53 & 80 & Complete & Unbroken & Absent & Beveled Bifacial & Biface & Triangular & Chert & Fine \\
\hline
\end{tabular}

\begin{tabular}{|c|c|c|c|c|c|c|c|c|c|c|}
\hline Cat. No. & $\begin{array}{c}\text { Percent } \\
\text { Patination }\end{array}$ & $\begin{array}{l}\text { Percent } \\
\text { Cortex }\end{array}$ & Heating & $\begin{array}{l}\text { Length } \\
(\mathrm{mm})\end{array}$ & $\begin{array}{l}\text { Thick } \\
(\mathrm{mm})\end{array}$ & Wt. (g) & Long X-Section & Trans X-Section & $\begin{array}{l}\text { Flaking } \\
\text { Pattern }\end{array}$ & $\begin{array}{c}\text { Edge } \\
\text { Rounding }\end{array}$ \\
\hline $215-018$ & 25 & 0 & None & & 5.6 & 4.4 & Flat & Biconvex Symmetrical & Subparallel & Present \\
\hline $283-014$ & 0 & 0 & Burned & 61.3 & 7.6 & 13.4 & Wedged Base, Flat & Biconvex Symmetrical & Random & Absent \\
\hline $324-016^{*}$ & 0 & 0 & $\begin{array}{l}\text { Heat- } \\
\text { Treated }\end{array}$ & & 5.9 & & Indeterminate & Biconvex Symmetrical & Chevron & Absent \\
\hline $370-010$ & 0 & 0 & None & & 6.1 & & Flat & Biconvex Symmetrical & Subparallel & Present \\
\hline $412-011$ & 0 & 0 & None & & 8.5 & & Tapered Base/Tip & Biconvex Symmetrical & $\begin{array}{c}\text { Oblique } \\
\text { Subparallel }\end{array}$ & Absent \\
\hline $412-010$ & 0 & 0 & None & 74.5 & 7 & 13.4 & Wedged Base, Flat & Biconvex Asymmetrical & Chevron & Absent \\
\hline $523-021$ & 0 & 0 & None & 49.7 & 5.5 & 5.6 & Wedged Base, Flat & Plano-Convex & Chevron & Absent \\
\hline
\end{tabular}

\begin{tabular}{|c|c|c|c|c|c|c|c|c|c|c|}
\hline Cat. No. & $\begin{array}{c}\text { Blade } \\
\text { Width }(\mathrm{mm})\end{array}$ & $\begin{array}{l}\text { Left Lateral } \\
\text { Edge }\end{array}$ & $\begin{array}{c}\text { Right } \\
\text { Lateral } \\
\text { Edge }\end{array}$ & $\begin{array}{l}\text { Left Notch } \\
\text { Depth (mm) }\end{array}$ & $\begin{array}{l}\text { Right Notch } \\
\text { Depth }(\mathrm{mm})\end{array}$ & $\begin{array}{l}\text { Left Notch } \\
\text { Width (mm) }\end{array}$ & $\begin{array}{l}\text { Right Notch } \\
\text { Width (mm) }\end{array}$ & $\begin{array}{l}\text { Left Notch } \\
\text { Angle }\end{array}$ & $\begin{array}{l}\text { Right Notch } \\
\text { Angle }\end{array}$ & $\begin{array}{l}\text { Stem } \\
\text { Shape }\end{array}$ \\
\hline $215-018$ & 20.2 & Straight & Excurvate & & & & & 62 & 31 & Expanding \\
\hline 283-014 & 27.3 & Excurvate & Incurvate & & 6.9 & & 5.7 & & 49 & Expanding \\
\hline $324-016 *$ & 25.5 & Straight & Straight & 7 & & 4.5 & & 43 & 29 & Expanding \\
\hline $370-010$ & 27.7 & Straight & Straight & 7.4 & & 5.4 & & 33 & & Expanding \\
\hline $412-011$ & 25 & Straight & Straight & 9.5 & & 9.1 & & 33 & & Expanding \\
\hline $412-010$ & 33 & Straight & Straight & 9.2 & 11.5 & 10.4 & 7.5 & 35 & 35 & Expanding \\
\hline $523-021$ & 21 & Straight & Straight & 10.6 & 10.9 & 7.4 & 7.4 & 37 & 32 & Expanding \\
\hline
\end{tabular}


The Varga Site

Texas Department of Transportation

Table 0-31. Group 2 Point Data Continued

\begin{tabular}{|c|c|c|c|c|c|c|c|c|}
\hline Cat. No. & $\begin{array}{l}\text { Stem Length } \\
(\mathrm{mm})\end{array}$ & $\begin{array}{l}\text { Distal Stem } \\
\text { Width }(\mathrm{mm}) \\
\end{array}$ & $\begin{array}{c}\text { Proximal Stem } \\
\text { Width }(\mathrm{mm})\end{array}$ & $\begin{array}{c}\text { Stem Thick } \\
(\mathrm{mm})\end{array}$ & $\begin{array}{l}\text { Base Depth } \\
(\mathrm{mm})\end{array}$ & $\begin{array}{l}\text { Base Notch } \\
\text { Width }(\mathrm{mm})\end{array}$ & Micro-wear & NAA \\
\hline $215-018$ & 9.1 & 9.5 & & 4.9 & 1.8 & & FALSE & FALSE \\
\hline $283-014$ & 12.9 & 20.2 & 29.3 & 3.9 & 4.1 & 19 & TRUE & FALSE \\
\hline $324-016^{*}$ & 9.5 & 16.3 & 21.3 & 4.6 & 2.6 & 10.6 & FALSE & TRUE \\
\hline $370-010$ & 11.5 & 17.7 & 24.1 & 5.8 & 2.8 & 15.5 & FALSE & FALSE \\
\hline $412-011$ & 12.1 & 14 & 20.3 & 4 & 3.1 & 12.6 & FALSE & TRUE \\
\hline $412-010$ & 10.6 & 14.4 & 20.4 & 4.9 & 4.1 & 13.6 & TRUE & FALSE \\
\hline $523-021$ & 10.5 & 13.4 & 20.6 & 4.8 & 2 & 13.4 & FALSE & FALSE \\
\hline
\end{tabular}

* From Toyah Component 
Table 0-32. Carrizo Point Data

\begin{tabular}{|c|c|c|c|c|c|c|c|c|c|c|}
\hline Cat. No. & Unit & $\begin{array}{c}\text { Depth } \\
\text { (cmbd) }\end{array}$ & $\begin{array}{c}\text { Feature } \\
\text { No. }\end{array}$ & Condition & Break Type & $\begin{array}{c}\text { Rejuvenation } \\
\text { Scar }\end{array}$ & $\begin{array}{c}\text { Resharpening } \\
\text { Type }\end{array}$ & $\begin{array}{c}\text { Raw } \\
\text { Material }\end{array}$ & $\begin{array}{c}\text { Percent } \\
\text { Texture } \\
\text { Patination }\end{array}$ \\
\hline $213-012$ & N101,E53 & $70-80$ & & Distal & Use & $\begin{array}{c}\text { refits with } \\
\# 650-16\end{array}$ & None & chert & Fine & 100 \\
\hline $391-010$ & N103,E55 & $120-130$ & & Proximal & Use & Absent & None & Chert & Fine & 0 \\
\hline $650-016$ & N108,E52 & $40-50$ & & Complete & Unbroken & Absent & None & Chert & Fine & 100 \\
\hline $670-005-012$ & N108,E55 & 49 & 23 & Proximal & Use & Present & $\begin{array}{c}\text { Break } \\
\text { Compensation }\end{array}$ & Chert & Fine & 0 \\
\hline
\end{tabular}

\begin{tabular}{|c|c|c|c|c|c|c|c|c|c|c|}
\hline Cat. No. & $\begin{array}{c}\text { Percent } \\
\text { Cortex }\end{array}$ & Heating & $\begin{array}{c}\text { Length } \\
(\mathrm{mm})\end{array}$ & $\begin{array}{c}\text { Width } \\
(\mathrm{mm})\end{array}$ & $\begin{array}{c}\text { Thick } \\
(\mathrm{mm})\end{array}$ & Wt. (g) & Long X-Section & Trans X-Section & Preform & Shape \\
\hline $213-012$ & 0 & None & & & & & & & \\
\hline $391-010$ & 0 & $\begin{array}{c}\text { Heat- } \\
\text { Treated }\end{array}$ & & & 6.8 & 12.4 & Tapered Base/Tip & Biconvex Symmetrical & Biface & Lanceolate \\
\hline $650-016$ & 0 & None & 70 & 27.9 & 7.7 & 13.6 & Wedged Base, Flat & Plano-Convex & Flake & Lanceolate \\
\hline $670-005-012$ & 0 & None & & & 7 & & Tapered Base/Tip & Biconvex Symmetrical & Biface & Lanceolate \\
\hline
\end{tabular}

\begin{tabular}{|c|c|c|c|c|c|c|c|c|}
\hline Cat. No. & Flaking Pattern & Edge Rounding & $\begin{array}{c}\text { Blade Width } \\
(\mathrm{mm})\end{array}$ & $\begin{array}{c}\text { Left Lateral } \\
\text { Edge }\end{array}$ & $\begin{array}{c}\text { Right Lateral } \\
\text { Edge }\end{array}$ & $\begin{array}{c}\text { Base Depth } \\
(\mathrm{mm})\end{array}$ & $\begin{array}{c}\text { Base Notch } \\
\text { Width (mm) }\end{array}$ & $\begin{array}{c}\text { NAA } \\
\text { FALSE }\end{array}$ \\
\hline $213-012$ & & & & & & 18.4 & TRUE \\
\hline $391-010$ & $\begin{array}{l}\text { Oblique } \\
\text { Parallel }\end{array}$ & Present & 36.5 & Straight & Straight & 8.9 & 6.2 & TRUE \\
\hline $650-016$ & Subparallel & Absent & 27.7 & Excurvate & Straight & 6.1 & 8.2 & TRUE \\
\hline $670-005-012$ & Subparallel & Absent & 20.4 & Indeterminate & Excurvate & 4 & 8.2 \\
\hline
\end{tabular}


The Varga Site

Texas Department of Transportation

Table 0-33. EA Biface Data

\begin{tabular}{|c|c|c|c|c|c|c|c|c|c|}
\hline Cat. No. & $8-026$ & $8-027$ & $8-030$ & $8-029$ & $8-028$ & $18-023$ & $18-026$ & $18-022$ & $18-025$ \\
\hline Unit & N99,E50 & N99,E50 & N99,E50 & N99,E50 & N99,E50 & N99,E51 & N99,E51 & N99,E51 & N99,E51 \\
\hline Depth (cm) & $70-80$ & $70-80$ & 77 & $70-80$ & $70-80$ & $80-90$ & 85.5 & $80-90$ & 84 \\
\hline Biface Stage & Middle & Middle & Late & Middle & Late & Early & Late & Middle & Late \\
\hline Condition & Proximal & Distal & Distal & Complete & Proximal & Distal & Proximal & Proximal & Medial \\
\hline Break Type & Indeterminate & Indeterminate & Use & Unbroken & Use & Manufacture & Use & Use & Use \\
\hline Preform & Biface & Biface & Flake & Biface & Flake & Flake & Flake & Biface & Biface \\
\hline Shape & Ovate & Indeterminate & Indeterminate & Ovate & Indeterminate & Ovate & Ovate & Indeterminate & Triangular \\
\hline $\begin{array}{l}\text { Rejuvenation } \\
\text { Scar }\end{array}$ & Absent & Absent & Absent & Absent & Absent & Absent & Absent & Absent & Absent \\
\hline $\begin{array}{l}\text { Resharpening } \\
\text { Type }\end{array}$ & None & $\begin{array}{l}\text { Beveled } \\
\text { Unifacial }\end{array}$ & None & None & None & None & Indeterminate & Indeterminate & None \\
\hline Raw Material & Chert & Chert & Chert & Chert & Chert & Chert & Chert & Chert & Chert \\
\hline Texture & Fine & Fine & Fine & Coarse & Fine & Fine & Fine & Fine & Fine \\
\hline $\begin{array}{c}\text { Percent } \\
\text { Patination }\end{array}$ & 25 & 0 & 0 & 0 & 0 & 0 & 0 & 0 & 0 \\
\hline $\begin{array}{l}\text { Percent } \\
\text { Cortex }\end{array}$ & 0 & 0 & 0 & 0 & 0 & 0 & 0 & 0 & 0 \\
\hline Cortex Type & None & None & None & None & None & None & None & None & None \\
\hline Heating & Burned & None & None & None & None & Heat-Treated & None & Burned & None \\
\hline Length (mm) & & & & 124.3 & & & 75.2 & & \\
\hline Width (mm) & 46.2 & 38.3 & 39.2 & 44 & 44.5 & 35.7 & 40.3 & 42.5 & 30 \\
\hline Thick (mm) & 19.6 & 19 & 7.8 & 26 & 12.3 & 14.8 & 11.2 & 18.5 & 10 \\
\hline Wt. (g) & 61 & & & 135.2 & & 31.6 & 32 & & 16.5 \\
\hline $\begin{array}{l}\text { Long X- } \\
\text { Section }\end{array}$ & Indeterminate & Indeterminate & Flat & $\begin{array}{l}\text { Bi-wedge- } \\
\text { shaped }\end{array}$ & Indeterminate & $\begin{array}{l}\text { Tapered } \\
\text { Base }\end{array}$ & $\begin{array}{l}\text { Tapered } \\
\text { Base/Tip }\end{array}$ & Indeterminate & Flat \\
\hline $\begin{array}{l}\text { Trans X- } \\
\text { Section }\end{array}$ & $\begin{array}{c}\text { Biconvex } \\
\text { Asymmetrical }\end{array}$ & $\begin{array}{c}\text { Biconvex } \\
\text { Symmetrical }\end{array}$ & $\begin{array}{c}\text { Biconvex } \\
\text { Symmetrical }\end{array}$ & $\begin{array}{l}\text { Plano- } \\
\text { Convex }\end{array}$ & $\begin{array}{l}\text { Plano- } \\
\text { Convex }\end{array}$ & $\begin{array}{l}\text { Plano- } \\
\text { Convex }\end{array}$ & $\begin{array}{c}\text { Biconvex } \\
\text { Symmetrical }\end{array}$ & $\begin{array}{l}\text { Plano- } \\
\text { Convex }\end{array}$ & $\begin{array}{c}\text { Biconvex } \\
\text { Symmetrical }\end{array}$ \\
\hline $\begin{array}{l}\text { Flaking } \\
\text { Pattern }\end{array}$ & Random & Random & $\begin{array}{c}\text { Oblique } \\
\text { Subparallel }\end{array}$ & Random & $\begin{array}{c}\text { Flake Blank } \\
\text { Remnant }\end{array}$ & Random & Collateral & Random & Random \\
\hline $\begin{array}{c}\text { Edge } \\
\text { Rounding }\end{array}$ & Absent & Absent & Absent & Present & Present & Absent & Absent & Absent & Absent \\
\hline $\begin{array}{l}\text { Left Lateral } \\
\text { Edge }\end{array}$ & Excurvate & Excurvate & Excurvate & Excurvate & Excurvate & Straight & Excurvate & Indeterminate & Straight \\
\hline $\begin{array}{c}\text { Right Lateral } \\
\text { Edge }\end{array}$ & Excurvate & Excurvate & Excurvate & Excurvate & Excurvate & Excurvate & Straight & Indeterminate & Straight \\
\hline Micro-wear & FALSE & FALSE & FALSE & FALSE & FALSE & FALSE & FALSE & FALSE & FALSE \\
\hline NAA & FALSE & FALSE & FALSE & FALSE & FALSE & FALSE & FALSE & FALSE & FALSE \\
\hline
\end{tabular}


Table 0-33. EA Biface Data Continued

\begin{tabular}{|c|c|c|c|c|c|c|c|c|c|}
\hline Cat. No. & $18-027$ & $19-016$ & $19-015$ & $28-010$ & $28-011$ & $29-018$ & $38-011$ & $39-010$ & $39-016$ \\
\hline Unit & N99,E51 & N99,E51 & N99,E51 & N99,E52 & N99,E52 & N99,E52 & N99,E53 & N99,E53 & N99,E53 \\
\hline Depth (cm) & 90 & $90-100$ & $90-100$ & $80-90$ & $80-90$ & $90-100$ & $80-90$ & $90-100$ & $90-100$ \\
\hline Biface Stage & Early & Indeterminate & Late & Indeterminate & Early & Late & Indeterminate & Early & Late \\
\hline Condition & Complete & Medial & Proximal & Medial & Complete & Complete & Indeterminate & Distal & Distal \\
\hline Break Type & Unbroken & $\begin{array}{l}\text { Thermal/ } \\
\text { Crenated }\end{array}$ & Use & Indeterminate & Unbroken & Unbroken & Indeterminate & Use & Use \\
\hline Preform & Biface & Indeterminate & Indeterminate & Biface & Biface & Flake & Indeterminate & Flake & Biface \\
\hline Shape & Ovate & Indeterminate & Indeterminate & Indeterminate & Ovate & Ovate & Indeterminate & Indeterminate & Indeterminate \\
\hline $\begin{array}{l}\text { Rejuvenation } \\
\text { Scar }\end{array}$ & Absent & Absent & Absent & Absent & Absent & Absent & Absent & Absent & Absent \\
\hline $\begin{array}{c}\text { Resharpening } \\
\text { Type }\end{array}$ & None & Indeterminate & None & Indeterminate & None & $\begin{array}{l}\text { Beveled } \\
\text { Unifacial }\end{array}$ & Indeterminate & Indeterminate & Indeterminate \\
\hline Raw Material & Chert & Chert & Chert & Chert & Chert & Chert & Chert & Chert & Chert \\
\hline Texture & Fine & Fine & Fine & Fine & Fine & Fine & Fine & Fine & Fine \\
\hline $\begin{array}{c}\text { Percent } \\
\text { Patination }\end{array}$ & 0 & 0 & 25 & 0 & 0 & 0 & 0 & 50 & 0 \\
\hline $\begin{array}{l}\text { Percent } \\
\text { Cortex }\end{array}$ & 0 & 0 & 50 & 0 & 0 & 0 & 0 & 50 & 0 \\
\hline Cortex Type & None & None & $\begin{array}{l}\text { Pebble/ } \\
\text { Cobble }\end{array}$ & None & None & None & None & $\begin{array}{l}\text { Pebble/ } \\
\text { Cobble }\end{array}$ & None \\
\hline Heating & None & Burned & None & Indeterminate & Heat-Treated & None & None & None & Indeterminate \\
\hline Length (mm) & 128.4 & & & & 95.5 & 54.5 & & & \\
\hline Width (mm) & 84.7 & & 53.9 & 42.6 & 66.4 & 29.9 & & 38.8 & \\
\hline Thick (mm) & 33.7 & 6.4 & 9.1 & 13.2 & 26.7 & 9.2 & & 9.7 & 6.2 \\
\hline Wt. (g) & 391.3 & & & & 147.7 & 14.3 & & & \\
\hline $\begin{array}{l}\text { Long X- } \\
\text { Section }\end{array}$ & $\begin{array}{l}\text { Tapered } \\
\text { Base/Tip }\end{array}$ & Indeterminate & Flat & Indeterminate & $\begin{array}{l}\text { Bi-wedge- } \\
\text { shaped }\end{array}$ & $\begin{array}{c}\text { Wedged } \\
\text { Base, Flat }\end{array}$ & Indeterminate & Indeterminate & Indeterminate \\
\hline $\begin{array}{l}\text { Trans X- } \\
\text { Section }\end{array}$ & $\begin{array}{c}\text { Biconvex } \\
\text { Asymmetrical }\end{array}$ & Indeterminate & $\begin{array}{c}\text { Biconvex } \\
\text { Symmetrical }\end{array}$ & $\begin{array}{l}\text { Plano- } \\
\text { Convex }\end{array}$ & $\begin{array}{c}\text { Biconvex } \\
\text { Asymmetrical }\end{array}$ & $\begin{array}{l}\text { Plano- } \\
\text { Convex }\end{array}$ & $\begin{array}{l}\text { Plano- } \\
\text { Convex }\end{array}$ & $\begin{array}{l}\text { Plano- } \\
\text { Convex }\end{array}$ & $\begin{array}{c}\text { Biconvex } \\
\text { Symmetrical }\end{array}$ \\
\hline $\begin{array}{l}\text { Flaking } \\
\text { Pattern }\end{array}$ & Random & Indeterminate & $\begin{array}{c}\text { Oblique } \\
\text { Subparallel }\end{array}$ & Indeterminate & Random & $\begin{array}{c}\text { Oblique } \\
\text { Subparallel }\end{array}$ & Indeterminate & Subparallel & Random \\
\hline $\begin{array}{c}\text { Edge } \\
\text { Rounding }\end{array}$ & Absent & Absent & Present & Absent & Absent & Present & Present & Absent & Present \\
\hline $\begin{array}{c}\text { Left Lateral } \\
\text { Edge }\end{array}$ & Excurvate & Indeterminate & Indeterminate & Excurvate & Excurvate & Excurvate & Indeterminate & Excurvate & Indeterminate \\
\hline $\begin{array}{c}\text { Right Lateral } \\
\text { Edge }\end{array}$ & Excurvate & Indeterminate & Indeterminate & Indeterminate & Excurvate & Excurvate & Indeterminate & Excurvate & Indeterminate \\
\hline Micro-wear & FALSE & FALSE & FALSE & FALSE & TRUE & FALSE & FALSE & FALSE & FALSE \\
\hline NAA & FALSE & FALSE & FALSE & FALSE & FALSE & FALSE & FALSE & FALSE & FALSE \\
\hline
\end{tabular}


The Varga Site

Texas Department of Transportation

Table 0-33. EA Biface Data Continued

\begin{tabular}{|c|c|c|c|c|c|c|c|c|c|}
\hline Cat. No. & 49-011 & 49-012 & $50-016$ & $50-014$ & $50-015$ & $61-016$ & $61-015$ & $62-010$ & $75-015$ \\
\hline Unit & N99,E54 & N99,E54 & N99,E54 & N99,E54 & N99,E54 & N99,E55 & N99,E55 & N99,E55 & N99,E56 \\
\hline Depth (cm) & $90-100$ & $90-100$ & $100-110$ & $100-110$ & $100-110$ & $90-100$ & $90-100$ & $100-110$ & $100-110$ \\
\hline Biface Stage & Late & Late & Indeterminate & Late & Middle & Early & Late & Indeterminate & Late \\
\hline Condition & Distal & Complete & Proximal & Proximal & Distal & Complete & Distal & Indeterminate & Indeterminate \\
\hline Break Type & Use & Unbroken & $\begin{array}{l}\text { Thermal/ } \\
\text { Crenated }\end{array}$ & Use & Indeterminate & Unbroken & Use & Indeterminate & Indeterminate \\
\hline Preform & Flake & Biface & Indeterminate & Flake & Biface & Flake & Flake & Indeterminate & Flake \\
\hline Shape & Teardrop & Lanceolate & Indeterminate & Lanceolate & Indeterminate & Lanceolate & Indeterminate & Indeterminate & Indeterminate \\
\hline $\begin{array}{l}\text { Rejuvenation } \\
\text { Scar }\end{array}$ & Absent & Absent & Absent & Absent & Absent & Absent & Absent & Absent & Absent \\
\hline $\begin{array}{l}\text { Resharpening } \\
\text { Type }\end{array}$ & $\begin{array}{l}\text { Beveled } \\
\text { Unifacial }\end{array}$ & None & Indeterminate & None & None & None & Indeterminate & Indeterminate & Indeterminate \\
\hline Raw Material & Chert & Chert & Chert & Chert & Chert & Chert & Chert & Chert & Chert \\
\hline Texture & Fine & Fine & Fine & Fine & Fine & Fine & Fine & Fine & Fine \\
\hline $\begin{array}{c}\text { Percent } \\
\text { Patination }\end{array}$ & 25 & 0 & 0 & 0 & 0 & 0 & 0 & 0 & 0 \\
\hline $\begin{array}{l}\text { Percent } \\
\text { Cortex }\end{array}$ & 0 & 0 & 0 & 0 & 0 & 0 & 0 & 0 & 0 \\
\hline Cortex Type & None & None & None & None & None & None & None & None & None \\
\hline Heating & None & None & Burned & Burned & Burned & None & None & Burned & None \\
\hline Length (mm) & & 110.2 & & & & 65.2 & & & \\
\hline Width (mm) & & 43 & & 22.3 & 11.2 & 26.4 & & & \\
\hline Thick (mm) & 6.8 & 17.4 & & 6.8 & & 11.4 & 4.7 & & 9.2 \\
\hline Wt. (g) & & 76.5 & & & & 14.8 & & & \\
\hline $\begin{array}{l}\text { Long X- } \\
\text { Section }\end{array}$ & Flat & $\begin{array}{l}\text { Tapered } \\
\text { Base/Tip }\end{array}$ & Indeterminate & Flat & Indeterminate & $\begin{array}{l}\text { Tapered } \\
\text { Base/Tip }\end{array}$ & Flat & Indeterminate & Indeterminate \\
\hline $\begin{array}{l}\text { Trans X- } \\
\text { Section }\end{array}$ & $\begin{array}{c}\text { Biconvex } \\
\text { Symmetrical }\end{array}$ & $\begin{array}{c}\text { Biconvex } \\
\text { Symmetrical }\end{array}$ & Indeterminate & $\begin{array}{c}\text { Biconvex } \\
\text { Symmetrical }\end{array}$ & $\begin{array}{c}\text { Biconvex } \\
\text { Asymmetrical }\end{array}$ & $\begin{array}{l}\text { Plano- } \\
\text { Convex }\end{array}$ & $\begin{array}{l}\text { Plano- } \\
\text { Convex }\end{array}$ & Indeterminate & $\begin{array}{l}\text { Plano- } \\
\text { Convex }\end{array}$ \\
\hline $\begin{array}{l}\text { Flaking } \\
\text { Pattern }\end{array}$ & $\begin{array}{l}\text { Oblique } \\
\text { Parallel }\end{array}$ & Parallel & Indeterminate & $\begin{array}{c}\text { Oblique } \\
\text { Subparallel }\end{array}$ & Indeterminate & Random & Indeterminate & Indeterminate & Indeterminate \\
\hline $\begin{array}{c}\text { Edge } \\
\text { Rounding }\end{array}$ & Absent & Present & Absent & Present & Absent & Absent & Absent & Present & Present \\
\hline $\begin{array}{c}\text { Left Lateral } \\
\text { Edge }\end{array}$ & Excurvate & Straight & Indeterminate & Straight & Indeterminate & Straight & Excurvate & Indeterminate & Indeterminate \\
\hline $\begin{array}{c}\text { Right Lateral } \\
\text { Edge }\end{array}$ & Excurvate & Excurvate & Indeterminate & Straight & Indeterminate & Excurvate & Indeterminate & Indeterminate & Indeterminate \\
\hline Micro-wear & FALSE & TRUE & FALSE & FALSE & FALSE & TRUE & FALSE & FALSE & FALSE \\
\hline NAA & FALSE & FALSE & FALSE & FALSE & FALSE & FALSE & FALSE & FALSE & FALSE \\
\hline
\end{tabular}


Table 0-33. EA Biface Data Continued

\begin{tabular}{|c|c|c|c|c|c|c|c|c|c|}
\hline Cat. No. & $75-016$ & $77-016$ & $85-012$ & $85-020$ & $85-019$ & $86-011$ & $86-021$ & $86-010$ & $94-013$ \\
\hline Unit & N99,E56 & N99,E56 & N100,E50 & N100,E50 & $\mathrm{N} 100, \mathrm{E} 50$ & N100,E50 & N100,E50 & $\mathrm{N} 100, \mathrm{E} 50$ & N100,E51 \\
\hline Depth (cm) & $100-110$ & $120-130$ & $70-80$ & $70-80$ & $70-80$ & $80-90$ & $80-90$ & $80-90$ & $70-80$ \\
\hline Biface Stage & Middle & Late & Late & Late & Early & Indeterminate & Late & Early & Late \\
\hline Condition & Indeterminate & Proximal & Medial & Distal & Proximal & Medial & Distal & Complete & Proximal \\
\hline Break Type & Indeterminate & Use & Use & Manufacture & Indeterminate & $\begin{array}{l}\text { Thermal/ } \\
\text { Crenated }\end{array}$ & Manufacture & Unbroken & Indeterminate \\
\hline Preform & Biface & Flake & Biface & Flake & Biface & Indeterminate & Flake & Flake & Flake \\
\hline Shape & Indeterminate & Indeterminate & Indeterminate & Indeterminate & Indeterminate & Indeterminate & Ovate & Bipointed & Indeterminate \\
\hline $\begin{array}{l}\text { Rejuvenation } \\
\text { Scar }\end{array}$ & Absent & Present & Absent & Absent & Absent & Absent & Absent & Absent & Absent \\
\hline $\begin{array}{l}\text { Resharpening } \\
\text { Type }\end{array}$ & None & None & None & None & None & Indeterminate & $\begin{array}{l}\text { Beveled } \\
\text { Unifacial }\end{array}$ & None & Indeterminate \\
\hline Raw Material & Chert & Chert & Chert & Chert & Chert & Chert & Chert & Chert & Chert \\
\hline Texture & Fine & Fine & Fine & Fine & Fine & Fine & Fine & Fine & Fine \\
\hline $\begin{array}{c}\text { Percent } \\
\text { Patination }\end{array}$ & 0 & 0 & 0 & 0 & 50 & 0 & 75 & 0 & 75 \\
\hline $\begin{array}{l}\text { Percent } \\
\text { Cortex }\end{array}$ & 0 & 0 & 0 & 0 & 0 & 0 & 0 & 25 & 0 \\
\hline Cortex Type & None & None & None & None & $\begin{array}{l}\text { Pebble/ } \\
\text { Cobble }\end{array}$ & None & None & Pebble/Cobble & None \\
\hline Heating & None & None & None & Heat-Treated & None & Burned & Burned & None & None \\
\hline Length (mm) & & & & & & & & 67.7 & \\
\hline Width (mm) & 32.4 & 39 & 8.5 & 21.1 & 46.7 & & 23.6 & 34.1 & \\
\hline Thick (mm) & 17.7 & 8.7 & & 7.5 & & 6.2 & 4.6 & 19.1 & 10 \\
\hline Wt. (g) & & 25.5 & & & & & & 35 & \\
\hline $\begin{array}{l}\text { Long } X- \\
\text { Section }\end{array}$ & Indeterminate & Flat & Indeterminate & Indeterminate & Indeterminate & Indeterminate & Flat & $\begin{array}{l}\text { Tapered } \\
\text { Base/Tip }\end{array}$ & Indeterminate \\
\hline $\begin{array}{l}\text { Trans X- } \\
\text { Section }\end{array}$ & $\begin{array}{c}\text { Biconvex } \\
\text { Symmetrical }\end{array}$ & $\begin{array}{l}\text { Plano- } \\
\text { Convex }\end{array}$ & $\begin{array}{l}\text { Plano- } \\
\text { Convex }\end{array}$ & $\begin{array}{l}\text { Plano- } \\
\text { Convex }\end{array}$ & $\begin{array}{c}\text { Biconvex } \\
\text { Symmetrical }\end{array}$ & Indeterminate & $\begin{array}{c}\text { Biconvex } \\
\text { Symmetrical }\end{array}$ & $\begin{array}{c}\text { Biconvex } \\
\text { Asymmetrical }\end{array}$ & $\begin{array}{l}\text { Plano- } \\
\text { Convex }\end{array}$ \\
\hline $\begin{array}{l}\text { Flaking } \\
\text { Pattern }\end{array}$ & Random & Random & Random & $\begin{array}{l}\text { Oblique } \\
\text { Parallel }\end{array}$ & $\begin{array}{c}\text { Flake Blank } \\
\text { Remnant }\end{array}$ & Indeterminate & $\begin{array}{l}\text { Oblique } \\
\text { Parallel }\end{array}$ & $\begin{array}{c}\text { Flake Blank } \\
\text { Remnant }\end{array}$ & $\begin{array}{c}\text { Oblique } \\
\text { Subparallel }\end{array}$ \\
\hline $\begin{array}{c}\text { Edge } \\
\text { Rounding }\end{array}$ & Absent & Absent & Present & Present & Present & Present & Present & Absent & Present \\
\hline $\begin{array}{c}\text { Left Lateral } \\
\text { Edge }\end{array}$ & Straight & Straight & Indeterminate & Excurvate & Indeterminate & Indeterminate & Excurvate & Excurvate & Indeterminate \\
\hline $\begin{array}{c}\text { Right Lateral } \\
\text { Edge }\end{array}$ & Excurvate & Indeterminate & Excurvate & Excurvate & Indeterminate & Indeterminate & Excurvate & Excurvate & Excurvate \\
\hline Micro-wear & FALSE & FALSE & FALSE & FALSE & FALSE & FALSE & FALSE & FALSE & FALSE \\
\hline NAA & FALSE & FALSE & FALSE & FALSE & FALSE & FALSE & FALSE & FALSE & FALSE \\
\hline
\end{tabular}


The Varga Site

Texas Department of Transportation

Table 0-33. EA Biface Data Continued

\begin{tabular}{|c|c|c|c|c|c|c|c|c|c|}
\hline Cat. No. & $95-017$ & $95-013$ & $105-017$ & $106-016$ & $116-018$ & $116-019$ & $117-024$ & $117-017$ & $117-022$ \\
\hline Unit & N100,E51 & N100,E51 & N100,E52 & N100,E52 & N100,E53 & N100,E53 & $\mathrm{N} 100, \mathrm{E} 53$ & N100,E53 & $\mathrm{N} 100, \mathrm{E} 53$ \\
\hline Depth (cm) & $80-90$ & $80-90$ & $80-90$ & $90-100$ & $80-90$ & $80-90$ & $90-100$ & $90-100$ & $90-100$ \\
\hline Biface Stage & Late & Indeterminate & Middle & Late & Indeterminate & Late & & Middle & \\
\hline Condition & Distal & Medial & Medial & Distal & Medial & Complete & & Medial & \\
\hline Break Type & Use & Indeterminate & Indeterminate & Use & $\begin{array}{l}\text { Thermal/ } \\
\text { Crenated }\end{array}$ & Unbroken & & Indeterminate & \\
\hline Preform & Flake & Indeterminate & Biface & Flake & Indeterminate & Flake & & Biface & \\
\hline Shape & Indeterminate & Indeterminate & Indeterminate & Ovate & Indeterminate & Lanceolate & & Indeterminate & \\
\hline $\begin{array}{l}\text { Rejuvenation } \\
\text { Scar }\end{array}$ & Absent & Absent & Absent & Absent & Absent & Absent & & Absent & \\
\hline $\begin{array}{l}\text { Resharpening } \\
\text { Type }\end{array}$ & Indeterminate & Indeterminate & None & $\begin{array}{l}\text { Beveled } \\
\text { Unifacial }\end{array}$ & Indeterminate & None & & Indeterminate & \\
\hline Raw Material & Chert & Chert & Chert & Chert & Chert & Chert & & Chert & \\
\hline Texture & Fine & Fine & Fine & Fine & Fine & Fine & & Fine & \\
\hline $\begin{array}{c}\text { Percent } \\
\text { Patination } \\
\end{array}$ & 0 & 0 & 0 & 75 & 0 & 0 & & 0 & \\
\hline $\begin{array}{c}\text { Percent } \\
\text { Cortex }\end{array}$ & 0 & 0 & 0 & 0 & 0 & 0 & & 0 & \\
\hline Cortex Type & None & None & None & None & None & None & & None & \\
\hline Heating & None & None & None & None & Burned & None & & None & \\
\hline Length (mm) & & & & & & 65.4 & & & \\
\hline Width (mm) & & & & 37.9 & & 21.3 & & & \\
\hline Thick (mm) & 4.6 & & 16.3 & 7.2 & & 9.2 & & 14.2 & \\
\hline Wt. (g) & & & & & & 14 & & & \\
\hline $\begin{array}{l}\text { Long X- } \\
\text { Section }\end{array}$ & Indeterminate & Indeterminate & Indeterminate & Flat & Indeterminate & $\begin{array}{l}\text { Tapered } \\
\text { Base/Tip }\end{array}$ & & Indeterminate & \\
\hline $\begin{array}{l}\text { Trans X- } \\
\text { Section }\end{array}$ & $\begin{array}{c}\text { Biconvex } \\
\text { Symmetrical }\end{array}$ & $\begin{array}{l}\text { Plano- } \\
\text { Convex }\end{array}$ & $\begin{array}{c}\text { Biconvex } \\
\text { Symmetrical }\end{array}$ & $\begin{array}{l}\text { Plano- } \\
\text { Convex }\end{array}$ & $\begin{array}{l}\text { Plano- } \\
\text { Convex }\end{array}$ & $\begin{array}{l}\text { Plano- } \\
\text { Convex }\end{array}$ & & $\begin{array}{c}\text { Biconvex } \\
\text { Symmetrical }\end{array}$ & \\
\hline $\begin{array}{l}\text { Flaking } \\
\text { Pattern } \\
\end{array}$ & Collateral & Indeterminate & Random & $\begin{array}{c}\text { Flake Blank } \\
\text { Remnant }\end{array}$ & Indeterminate & Collateral & & Random & \\
\hline $\begin{array}{c}\text { Edge } \\
\text { Rounding }\end{array}$ & Present & Present & Absent & Present & Present & Absent & & Absent & \\
\hline $\begin{array}{l}\text { Left Lateral } \\
\text { Edge }\end{array}$ & Indeterminate & Indeterminate & Excurvate & Straight & Indeterminate & Straight & & Excurvate & \\
\hline $\begin{array}{l}\text { Right Lateral } \\
\text { Edge }\end{array}$ & Indeterminate & Indeterminate & Indeterminate & Excurvate & Indeterminate & Straight & & Indeterminate & \\
\hline Micro-wear & FALSE & FALSE & FALSE & FALSE & FALSE & FALSE & FALSE & FALSE & FALSE \\
\hline NAA & FALSE & FALSE & FALSE & FALSE & FALSE & FALSE & FALSE & FALSE & FALSE \\
\hline
\end{tabular}


Table 0-33. EA Biface Data Continued

\begin{tabular}{|c|c|c|c|c|c|c|c|c|c|}
\hline Cat. No. & $117-023$ & $129-010$ & $139-018$ & $140-022$ & $142-012$ & $152-016$ & $152-015$ & $152-017$ & $154-024$ \\
\hline Unit & N100,E53 & N100,E54 & N100,E55 & N100,E55 & N100,E55 & N100,E56 & N100,E56 & N100,E56 & N100,E56 \\
\hline Depth $(\mathrm{cm})$ & $90-100$ & $110-120$ & $90-100$ & $100-110$ & $120-130$ & $90-100$ & $90-100$ & $90-100$ & $110-120$ \\
\hline Biface Stage & Late & Late & Late & Late & Middle & Late & Late & $\begin{array}{c}\text { refit to } 162- \\
16\end{array}$ & Late \\
\hline Condition & Proximal & Distal & Distal & Proximal & Complete & Proximal & Medial & & Complete \\
\hline Break Type & Indeterminate & Use & Use & Manufacture & Unbroken & $\begin{array}{l}\text { Thermal/ } \\
\text { Crenated }\end{array}$ & Indeterminate & & Unbroken \\
\hline Preform & Biface & Flake & Flake & Flake & Biface & Biface & Indeterminate & & Biface \\
\hline Shape & Lanceolate & Triangular & Triangular & Indeterminate & Ovate & Teardrop & Indeterminate & & Triangular \\
\hline $\begin{array}{c}\text { Rejuvenation } \\
\text { Scar }\end{array}$ & Absent & Absent & Absent & Absent & Absent & Absent & Absent & & Absent \\
\hline $\begin{array}{l}\text { Resharpening } \\
\text { Type }\end{array}$ & None & None & None & None & None & None & $\begin{array}{c}\text { Break } \\
\text { Compensation }\end{array}$ & & None \\
\hline Raw Material & Chert & Chert & Chert & Chert & Chert & Chert & Chert & & Chert \\
\hline Texture & Fine & Fine & Fine & Fine & Fine & Fine & Fine & & Fine \\
\hline $\begin{array}{c}\text { Percent } \\
\text { Patination }\end{array}$ & 0 & 0 & 25 & 0 & 0 & 0 & 0 & & 0 \\
\hline $\begin{array}{l}\text { Percent } \\
\text { Cortex }\end{array}$ & 0 & 0 & 0 & 0 & 0 & 0 & 25 & & 0 \\
\hline Cortex Type & None & None & None & None & None & None & $\begin{array}{l}\text { Pebble/ } \\
\text { Cobble }\end{array}$ & & None \\
\hline Heating & None & None & None & None & None & Burned & None & & None \\
\hline Length (mm) & & & & & 90 & & & & 78 \\
\hline Width (mm) & 25 & & 33.1 & & 42.9 & 28.6 & & & 44.6 \\
\hline Thick (mm) & 8.8 & & 5.4 & 5.8 & 19.2 & 9.3 & 7.6 & & 16.1 \\
\hline Wt. (g) & & & 6.1 & & 65.5 & 13.3 & & & 55.4 \\
\hline $\begin{array}{l}\text { Long X- } \\
\text { Section }\end{array}$ & $\begin{array}{l}\text { Tapered } \\
\text { Base/Tip }\end{array}$ & Indeterminate & Flat & Indeterminate & $\begin{array}{l}\text { Tapered } \\
\text { Base/Tip }\end{array}$ & $\begin{array}{l}\text { Bi-wedge- } \\
\text { shaped }\end{array}$ & Indeterminate & & $\begin{array}{c}\text { Wedged } \\
\text { Base, Thick } \\
\text { Body }\end{array}$ \\
\hline $\begin{array}{l}\text { Trans X- } \\
\text { Section }\end{array}$ & $\begin{array}{c}\text { Biconvex } \\
\text { Symmetrical }\end{array}$ & $\begin{array}{l}\text { Plano- } \\
\text { Convex }\end{array}$ & $\begin{array}{l}\text { Plano- } \\
\text { Convex }\end{array}$ & $\begin{array}{l}\text { Plano- } \\
\text { Convex }\end{array}$ & $\begin{array}{c}\text { Biconvex } \\
\text { Symmetrical }\end{array}$ & $\begin{array}{c}\text { Biconvex } \\
\text { Symmetrical }\end{array}$ & Indeterminate & & $\begin{array}{c}\text { Biconvex } \\
\text { Symmetrical }\end{array}$ \\
\hline $\begin{array}{l}\text { Flaking } \\
\text { Pattern } \\
\end{array}$ & $\begin{array}{c}\text { Oblique } \\
\text { Subparallel }\end{array}$ & $\begin{array}{c}\text { Flake Blank } \\
\text { Remnant }\end{array}$ & $\begin{array}{l}\text { Oblique } \\
\text { Parallel }\end{array}$ & $\begin{array}{l}\text { Oblique } \\
\text { Parallel }\end{array}$ & Random & Subparallel & Indeterminate & & Parallel \\
\hline $\begin{array}{c}\text { Edge } \\
\text { Rounding }\end{array}$ & Absent & Absent & Present & Present & Absent & Present & Present & & Present \\
\hline $\begin{array}{l}\text { Left Lateral } \\
\text { Edge }\end{array}$ & Straight & Straight & Straight & Indeterminate & Excurvate & Straight & Indeterminate & & Excurvate \\
\hline $\begin{array}{c}\text { Right Lateral } \\
\text { Edge }\end{array}$ & Straight & Straight & Straight & Indeterminate & Incurvate & Excurvate & Indeterminate & & Excurvate \\
\hline Micro-wear & FALSE & FALSE & FALSE & FALSE & FALSE & FALSE & FALSE & FALSE & TRUE \\
\hline NAA & FALSE & FALSE & FALSE & FALSE & FALSE & FALSE & FALSE & FALSE & FALSE \\
\hline
\end{tabular}


The Varga Site

Texas Department of Transportation

Table 0-33. EA Biface Data Continued

\begin{tabular}{|c|c|c|c|c|c|c|c|c|c|}
\hline Cat. No. & $165-015$ & $184-017$ & $193-020$ & $193-017$ & $202-012$ & $202-011$ & 203-013 & 203-015 & 204-017 \\
\hline Unit & N101,E47 & N101,E50 & N101,E51 & N101,E51 & N101,E52 & N101,E52 & N101,E52 & N101,E52 & N101,E52 \\
\hline Depth (cm) & $80-90$ & $80-90$ & $80-90$ & $80-90$ & $70-80$ & $70-80$ & $80-90$ & $80-90$ & $90-100$ \\
\hline Biface Stage & Late & Late & Late & Late & Late & Late & Late & Late & Late \\
\hline Condition & Medial & Distal & Medial & Indeterminate & Proximal & Distal & Medial & Complete & Complete \\
\hline Break Type & Use & Indeterminate & Use & $\begin{array}{l}\text { Thermal/ } \\
\text { Crenated }\end{array}$ & Use & Use & $\begin{array}{l}\text { Thermal/ } \\
\text { Crenated }\end{array}$ & Unbroken & Unbroken \\
\hline Preform & Biface & Flake & Flake & Indeterminate & Flake & Biface & Indeterminate & Flake & Biface \\
\hline Shape & Lanceolate & Indeterminate & Indeterminate & Indeterminate & Ovate & Triangular & Indeterminate & Lanceolate & Teardrop \\
\hline $\begin{array}{l}\text { Rejuvenation } \\
\text { Scar }\end{array}$ & Absent & Absent & Absent & Absent & Absent & Absent & Absent & Absent & Absent \\
\hline $\begin{array}{c}\text { Resharpening } \\
\text { Type }\end{array}$ & None & $\begin{array}{l}\text { Beveled } \\
\text { Unifacial }\end{array}$ & $\begin{array}{l}\text { Beveled } \\
\text { Unifacial }\end{array}$ & Indeterminate & Indeterminate & $\begin{array}{l}\text { Alternate } \\
\text { Beveled } \\
\text { Unifacial }\end{array}$ & Indeterminate & None & None \\
\hline Raw Material & Chert & Chert & Chert & Chert & Chert & Chert & Chert & Chert & Chert \\
\hline Texture & Fine & Fine & Fine & Fine & Fine & Fine & Fine & Fine & Fine \\
\hline $\begin{array}{c}\text { Percent } \\
\text { Patination }\end{array}$ & 0 & 75 & 0 & 0 & 0 & 0 & 0 & 100 & 0 \\
\hline $\begin{array}{l}\text { Percent } \\
\text { Cortex }\end{array}$ & 0 & 25 & 0 & 0 & 25 & 0 & 0 & 25 & 0 \\
\hline Cortex Type & None & $\begin{array}{l}\text { Pebble } \\
\text { /Cobble }\end{array}$ & None & None & $\begin{array}{l}\text { Pebble/ } \\
\text { Cobble }\end{array}$ & None & None & $\begin{array}{l}\text { Pebble/ } \\
\text { Cobble }\end{array}$ & None \\
\hline Heating & None & Heat-Treated & None & Burned & None & None & Burned & None & None \\
\hline Length (mm) & & & & & & & & 79.8 & 57.5 \\
\hline Width (mm) & 19.5 & 30.6 & & & 39.3 & 36.6 & & 22.4 & 36.8 \\
\hline Thick (mm) & 9.2 & 7.5 & 6.7 & & 8.8 & 8.6 & & 8.9 & 12.2 \\
\hline Wt. (g) & 9.2 & & & & & 14.6 & & 15.1 & 22.1 \\
\hline $\begin{array}{l}\text { Long X- } \\
\text { Section }\end{array}$ & Indeterminate & Indeterminate & Indeterminate & Indeterminate & Indeterminate & Indeterminate & Indeterminate & Flat & $\begin{array}{l}\text { Wedged } \\
\text { Base, Flat }\end{array}$ \\
\hline $\begin{array}{l}\text { Trans X- } \\
\text { Section }\end{array}$ & $\begin{array}{c}\text { Biconvex } \\
\text { Symmetrical }\end{array}$ & $\begin{array}{l}\text { Plano- } \\
\text { Convex }\end{array}$ & $\begin{array}{l}\text { Plano- } \\
\text { Convex }\end{array}$ & Indeterminate & $\begin{array}{l}\text { Plano- } \\
\text { Convex }\end{array}$ & $\begin{array}{c}\text { Biconvex } \\
\text { Symmetrical }\end{array}$ & Indeterminate & $\begin{array}{l}\text { Plano- } \\
\text { Convex }\end{array}$ & $\begin{array}{c}\text { Biconvex } \\
\text { Asymmetrical }\end{array}$ \\
\hline $\begin{array}{l}\text { Flaking } \\
\text { Pattern } \\
\end{array}$ & $\begin{array}{l}\text { Oblique } \\
\text { Parallel }\end{array}$ & Collateral & $\begin{array}{c}\text { Flake Blank } \\
\text { Remnant }\end{array}$ & Indeterminate & $\begin{array}{c}\text { Flake Blank } \\
\text { Remnant }\end{array}$ & Chevron & Indeterminate & Random & Chevron \\
\hline $\begin{array}{c}\text { Edge } \\
\text { Rounding }\end{array}$ & Absent & Present & Absent & Absent & Present & Absent & Absent & Absent & Present \\
\hline $\begin{array}{c}\text { Left Lateral } \\
\text { Edge }\end{array}$ & Straight & Straight & Indeterminate & Indeterminate & Indeterminate & Excurvate & Indeterminate & Straight & Excurvate \\
\hline $\begin{array}{l}\text { Right Lateral } \\
\text { Edge }\end{array}$ & Straight & Excurvate & Straight & Indeterminate & Indeterminate & Excurvate & Indeterminate & Straight & Excurvate \\
\hline Micro-wear & FALSE & FALSE & FALSE & FALSE & FALSE & FALSE & FALSE & FALSE & FALSE \\
\hline NAA & FALSE & FALSE & FALSE & FALSE & FALSE & FALSE & FALSE & FALSE & FALSE \\
\hline
\end{tabular}


Table 0-33. EA Biface Data Continued

\begin{tabular}{|c|c|c|c|c|c|c|c|c|c|}
\hline Cat. No. & $205-010$ & $215-010$ & $215-023$ & $215-022$ & $216-011$ & 229-015 & $242-015$ & $242-013$ & $255-032$ \\
\hline Unit & N101,E52 & N101,E53 & N101,E53 & N101,E53 & N101,E53 & N101,E54 & N101,E55 & N101,E55 & N101,E56 \\
\hline Depth (cm) & $100-110$ & $90-100$ & $90-100$ & $90-100$ & $100-110$ & $110-120$ & $110-120$ & $110-120$ & $110-120$ \\
\hline Biface Stage & Late & Early & Late & Late & Late & Late & Late & Late & Late \\
\hline Condition & Distal & Complete & Medial & Indeterminate & Distal & Indeterminate & Complete & Distal & Distal \\
\hline Break Type & Indeterminate & Unbroken & Indeterminate & Use & Use & Use & Unbroken & $\begin{array}{l}\text { Thermal/ } \\
\text { Crenated }\end{array}$ & Use \\
\hline Preform & Biface & Biface & Flake & Biface & Flake & Flake & Biface & Flake & Biface \\
\hline Shape & Teardrop & Irregular & Indeterminate & Indeterminate & Triangular & Indeterminate & Ovate & Triangular & Ovate \\
\hline $\begin{array}{l}\text { Rejuvenation } \\
\text { Scar }\end{array}$ & Absent & Absent & Absent & Absent & Absent & Absent & Absent & Absent & Absent \\
\hline $\begin{array}{c}\text { Resharpening } \\
\text { Type }\end{array}$ & None & None & Indeterminate & Indeterminate & None & Indeterminate & None & None & None \\
\hline Raw Material & Chert & Chert & Chert & Chert & Chert & Chert & Chert & Chert & Chert \\
\hline Texture & Fine & Fine & Fine & Fine & Fine & Fine & Fine & Fine & Fine \\
\hline $\begin{array}{c}\text { Percent } \\
\text { Patination }\end{array}$ & 0 & 0 & 0 & 0 & 0 & 0 & 0 & 0 & 0 \\
\hline $\begin{array}{c}\text { Percent } \\
\text { Cortex }\end{array}$ & 0 & 0 & 0 & 0 & 0 & 0 & 0 & 0 & 0 \\
\hline Cortex Type & None & None & None & None & None & None & None & None & None \\
\hline Heating & None & None & None & None & None & Indeterminate & None & Burned & None \\
\hline Length (mm) & 70.6 & 83.7 & & & & & 74.3 & & \\
\hline Width (mm) & 46.6 & 51.3 & & & 29 & & 37 & 27.1 & 54.6 \\
\hline Thick (mm) & 9.6 & 16.4 & 6.7 & 7.7 & 9.1 & & 17.1 & 8.2 & 9.5 \\
\hline Wt. (g) & & 57.2 & & & 9.7 & & 40.3 & & 29.2 \\
\hline $\begin{array}{l}\text { Long X- } \\
\text { Section }\end{array}$ & $\begin{array}{l}\text { Tapered } \\
\text { Base/Tip }\end{array}$ & $\begin{array}{l}\text { Bi-wedge- } \\
\text { shaped }\end{array}$ & Indeterminate & Indeterminate & Indeterminate & Indeterminate & $\begin{array}{l}\text { Tapered } \\
\text { Base/Tip }\end{array}$ & Indeterminate & Flat \\
\hline $\begin{array}{l}\text { Trans X- } \\
\text { Section }\end{array}$ & $\begin{array}{c}\text { Biconvex } \\
\text { Symmetrical }\end{array}$ & $\begin{array}{c}\text { Biconvex } \\
\text { Asymmetrical }\end{array}$ & $\begin{array}{l}\text { Plano- } \\
\text { Convex }\end{array}$ & $\begin{array}{c}\text { Biconvex } \\
\text { Symmetrical }\end{array}$ & $\begin{array}{l}\text { Plano- } \\
\text { Convex }\end{array}$ & $\begin{array}{l}\text { Plano- } \\
\text { Convex }\end{array}$ & $\begin{array}{c}\text { Biconvex } \\
\text { Symmetrical }\end{array}$ & $\begin{array}{l}\text { Plano- } \\
\text { Convex }\end{array}$ & $\begin{array}{c}\text { Biconvex } \\
\text { Symmetrical }\end{array}$ \\
\hline $\begin{array}{l}\text { Flaking } \\
\text { Pattern }\end{array}$ & Parallel & Random & Random & Indeterminate & Chevron & Indeterminate & Random & Subparallel & Chevron \\
\hline $\begin{array}{c}\text { Edge } \\
\text { Rounding }\end{array}$ & Absent & Absent & Absent & Present & Present & Present & Present & Absent & Present \\
\hline $\begin{array}{l}\text { Left Lateral } \\
\text { Edge }\end{array}$ & Excurvate & Excurvate & Indeterminate & Indeterminate & Straight & Straight & Excurvate & Straight & Excurvate \\
\hline $\begin{array}{c}\text { Right Lateral } \\
\text { Edge }\end{array}$ & Excurvate & Excurvate & Indeterminate & Indeterminate & Straight & Straight & Straight & Straight & Excurvate \\
\hline Micro-wear & TRUE & FALSE & FALSE & FALSE & FALSE & FALSE & FALSE & FALSE & FALSE \\
\hline NAA & $205-010$ & $215-010$ & $215-023$ & $215-022$ & 216-011 & $229-015$ & $242-015$ & $242-013$ & $255-032$ \\
\hline
\end{tabular}


The Varga Site

Texas Department of Transportation

Table 0-33. EA Biface Data Continued

\begin{tabular}{|c|c|c|c|c|c|c|c|c|c|}
\hline Cat. No. & $255-012$ & $268-017$ & $268-025$ & $268-023$ & $268-024$ & $268-027$ & 278-011 & $278-010$ & $278-028$ \\
\hline Unit & N101,E56 & N102,E47 & N102,E47 & N102,E47 & $\mathrm{N} 102, \mathrm{E} 47$ & $\mathrm{~N} 102, \mathrm{E} 47$ & N102,E50 & N102,E50 & $\mathrm{N} 102, \mathrm{E} 50$ \\
\hline Depth (cm) & $110-120$ & $80-90$ & $80-90$ & $80-90$ & $80-90$ & $80-90$ & $80-90$ & $80-90$ & $80-90$ \\
\hline Biface Stage & Indeterminate & Indeterminate & Late & Early & Late & Late & Late & Middle & $\begin{array}{c}\text { refit to } 278- \\
11\end{array}$ \\
\hline Condition & Indeterminate & Medial & Distal & Proximal & Medial & Distal & Medial & Proximal & \\
\hline Break Type & Indeterminate & $\begin{array}{l}\text { Thermal/ } \\
\text { Crenated }\end{array}$ & Use & $\begin{array}{l}\text { Thermal/ } \\
\text { Crenated }\end{array}$ & $\begin{array}{l}\text { Thermal/ } \\
\text { Crenated }\end{array}$ & Use & $\begin{array}{l}\text { Thermal/ } \\
\text { Crenated }\end{array}$ & Indeterminate & \\
\hline Preform & Indeterminate & Biface & Biface & Biface & Flake & Biface & Biface & Biface & \\
\hline Shape & Indeterminate & Indeterminate & Indeterminate & Indeterminate & Indeterminate & Triangular & Lanceolate & Ovate & \\
\hline $\begin{array}{c}\text { Rejuvenation } \\
\text { Scar }\end{array}$ & Absent & Absent & Absent & Absent & Absent & Absent & Absent & Absent & \\
\hline $\begin{array}{l}\text { Resharpening } \\
\text { Type }\end{array}$ & Indeterminate & None & None & Indeterminate & Indeterminate & None & None & None & \\
\hline Raw Material & Chert & Chert & Chert & Chert & Chert & Chert & Chert & Chert & \\
\hline Texture & Fine & Fine & Fine & Fine & Fine & Fine & Fine & Fine & \\
\hline $\begin{array}{c}\text { Percent } \\
\text { Patination }\end{array}$ & 0 & 0 & 0 & 0 & 0 & 50 & 25 & 0 & \\
\hline $\begin{array}{l}\text { Percent } \\
\text { Cortex }\end{array}$ & 0 & 0 & 0 & 0 & 0 & 0 & 0 & 0 & \\
\hline Cortex Type & None & None & None & None & None & None & None & None & \\
\hline Heating & None & Burned & Burned & Burned & Burned & None & Burned & None & \\
\hline Length (mm) & & & & & & & & 84.6 & \\
\hline Width (mm) & & & & 17.7 & & & 28.8 & & \\
\hline Thick (mm) & & 14 & & & & 8.8 & 9.6 & 14.1 & \\
\hline Wt. (g) & & & & & & & 17.5 & & \\
\hline $\begin{array}{l}\text { Long X- } \\
\text { Section }\end{array}$ & Indeterminate & Indeterminate & Indeterminate & Indeterminate & Indeterminate & Indeterminate & $\begin{array}{l}\text { Wedged } \\
\text { Base, Flat }\end{array}$ & Indeterminate & \\
\hline $\begin{array}{l}\text { Trans X- } \\
\text { Section }\end{array}$ & Indeterminate & $\begin{array}{l}\text { Plano- } \\
\text { Convex }\end{array}$ & $\begin{array}{c}\text { Biconvex } \\
\text { Symmetrical }\end{array}$ & Indeterminate & Indeterminate & $\begin{array}{c}\text { Biconvex } \\
\text { Symmetrical }\end{array}$ & $\begin{array}{c}\text { Biconvex } \\
\text { Symmetrical }\end{array}$ & $\begin{array}{l}\text { Plano- } \\
\text { Convex }\end{array}$ & \\
\hline $\begin{array}{l}\text { Flaking } \\
\text { Pattern }\end{array}$ & Indeterminate & Indeterminate & $\begin{array}{c}\text { Oblique } \\
\text { Subparallel }\end{array}$ & Indeterminate & Indeterminate & Subparallel & Indeterminate & Random & \\
\hline $\begin{array}{c}\text { Edge } \\
\text { Rounding }\end{array}$ & Absent & Absent & Present & Absent & Absent & Present & Present & Absent & \\
\hline $\begin{array}{c}\text { Left Lateral } \\
\text { Edge }\end{array}$ & Indeterminate & Indeterminate & Excurvate & Indeterminate & Straight & Excurvate & Straight & Indeterminate & \\
\hline $\begin{array}{c}\text { Right Lateral } \\
\text { Edge }\end{array}$ & Indeterminate & Indeterminate & Excurvate & Indeterminate & Indeterminate & Straight & Straight & Excurvate & \\
\hline Micro-wear & FALSE & FALSE & FALSE & FALSE & FALSE & FALSE & FALSE & FALSE & FALSE \\
\hline NAA & FALSE & FALSE & FALSE & FALSE & FALSE & FALSE & FALSE & FALSE & FALSE \\
\hline
\end{tabular}


Table 0-33. EA Biface Data Continued

\begin{tabular}{|c|c|c|c|c|c|c|c|c|c|}
\hline Cat. No. & 278-012 & $289-025$ & $289-024$ & 288-011 & 289-013 & 289-019 & 299-012 & $300-016$ & $300-017$ \\
\hline Unit & $\mathrm{N} 102, \mathrm{E} 50$ & N102,E51 & N102,E51 & N102,E51 & N102,E51 & N102,E51 & N102,E52 & N102,E52 & $\mathrm{N} 102, \mathrm{E} 52$ \\
\hline Depth (cm) & $80-90$ & $90-100$ & $90-100$ & $80-90$ & $90-100$ & $90-100$ & $80-90$ & $90-100$ & $90-100$ \\
\hline Biface Stage & Late & Late & Late & Late & Late & Middle & Late & Late & Late \\
\hline Condition & Distal & Proximal & Medial & Medial & Distal & Complete & Medial & Distal & Complete \\
\hline Break Type & Use & Use & Use & Indeterminate & Indeterminate & Unbroken & $\begin{array}{l}\text { Thermal/ } \\
\text { Crenated }\end{array}$ & Use & $\begin{array}{l}\text { Thermal/ } \\
\text { Crenated }\end{array}$ \\
\hline Preform & Flake & Biface & Flake & Indeterminate & Biface & Biface & Flake & Flake & Indeterminate \\
\hline Shape & Indeterminate & Indeterminate & Indeterminate & Indeterminate & Indeterminate & Irregular & Indeterminate & Indeterminate & Ovate \\
\hline $\begin{array}{l}\text { Rejuvenation } \\
\text { Scar }\end{array}$ & Absent & Absent & Absent & Absent & Absent & Absent & Absent & Absent & Absent \\
\hline $\begin{array}{l}\text { Resharpening } \\
\text { Type }\end{array}$ & None & Indeterminate & Indeterminate & Indeterminate & None & None & Indeterminate & None & None \\
\hline Raw Material & Chert & Chert & Chert & Chert & Chert & Chert & Chert & Chert & Chert \\
\hline Texture & Fine & Fine & Fine & Fine & Fine & Fine & Fine & Fine & Fine \\
\hline $\begin{array}{c}\text { Percent } \\
\text { Patination }\end{array}$ & 50 & 50 & 0 & 0 & 0 & 0 & 0 & 0 & 0 \\
\hline $\begin{array}{l}\text { Percent } \\
\text { Cortex }\end{array}$ & 0 & 0 & 0 & 0 & 25 & 0 & 0 & 0 & 0 \\
\hline Cortex Type & None & None & None & None & $\begin{array}{l}\text { Pebble/ } \\
\text { Cobble }\end{array}$ & None & None & None & None \\
\hline Heating & Burned & None & None & None & Indeterminate & None & Burned & None & Burned \\
\hline Length (mm) & & & & & & 86.6 & & & 59 \\
\hline Width (mm) & & 40.1 & & & & 52.6 & & & 33.8 \\
\hline Thick (mm) & & 8.2 & 6.1 & 6 & 7.6 & 18.2 & & 4.3 & 7.7 \\
\hline Wt. (g) & & & & & & 80.5 & & & 12.7 \\
\hline $\begin{array}{l}\text { Long X- } \\
\text { Section }\end{array}$ & Indeterminate & Indeterminate & Indeterminate & Indeterminate & Indeterminate & $\begin{array}{c}\text { Tapered } \\
\text { Base }\end{array}$ & Indeterminate & Flat & Flat \\
\hline $\begin{array}{l}\text { Trans X- } \\
\text { Section }\end{array}$ & $\begin{array}{l}\text { Plano- } \\
\text { Convex }\end{array}$ & $\begin{array}{c}\text { Biconvex } \\
\text { Symmetrical }\end{array}$ & $\begin{array}{l}\text { Plano- } \\
\text { Convex }\end{array}$ & $\begin{array}{l}\text { Plano- } \\
\text { Convex }\end{array}$ & $\begin{array}{l}\text { Plano- } \\
\text { Convex }\end{array}$ & $\begin{array}{c}\text { Biconvex } \\
\text { Asymmetrical }\end{array}$ & $\begin{array}{l}\text { Plano- } \\
\text { Convex }\end{array}$ & $\begin{array}{l}\text { Plano- } \\
\text { Convex }\end{array}$ & $\begin{array}{c}\text { Biconvex } \\
\text { Symmetrical }\end{array}$ \\
\hline $\begin{array}{l}\text { Flaking } \\
\text { Pattern }\end{array}$ & Chevron & Random & Subparallel & Subparallel & $\begin{array}{c}\text { Flake Blank } \\
\text { Remnant }\end{array}$ & Random & Subparallel & $\begin{array}{c}\text { Oblique } \\
\text { Subparallel }\end{array}$ & Random \\
\hline $\begin{array}{c}\text { Edge } \\
\text { Rounding }\end{array}$ & Present & Absent & Present & Absent & Absent & Absent & Present & Absent & Absent \\
\hline $\begin{array}{l}\text { Left Lateral } \\
\text { Edge }\end{array}$ & Indeterminate & Indeterminate & Indeterminate & Indeterminate & Indeterminate & Excurvate & Indeterminate & Indeterminate & Excurvate \\
\hline $\begin{array}{l}\text { Right Lateral } \\
\text { Edge }\end{array}$ & Indeterminate & Indeterminate & Indeterminate & Indeterminate & Indeterminate & Excurvate & Indeterminate & Indeterminate & Excurvate \\
\hline Micro-wear & FALSE & FALSE & FALSE & FALSE & FALSE & FALSE & FALSE & FALSE & FALSE \\
\hline NAA & FALSE & FALSE & FALSE & FALSE & FALSE & FALSE & FALSE & FALSE & FALSE \\
\hline
\end{tabular}


The Varga Site

Texas Department of Transportation

Table 0-33. EA Biface Data Continued

\begin{tabular}{|c|c|c|c|c|c|c|c|c|c|}
\hline Cat. No. & $300-018$ & $312-018$ & $312-014$ & $323-019$ & $333-024$ & $333-021$ & $333-023$ & $333-025$ & $334-017$ \\
\hline Unit & N102,E52 & N102,E53 & N102,E53 & N102,E54 & N102,E55 & N102,E55 & N102,E55 & N102,E55 & N102,E55 \\
\hline Depth (cm) & $90-100$ & $100-110$ & $100-110$ & $120-130$ & $130-140$ & $130-140$ & $130-140$ & $130-140$ & $140-150$ \\
\hline Biface Stage & Late & Late & Late & Late & Late & Indeterminate & Late & Late & Late \\
\hline Condition & Distal & Complete & Distal & Medial & Proximal & Indeterminate & Proximal & Medial & Medial \\
\hline Break Type & Use & Unbroken & $\begin{array}{l}\text { Thermal/ } \\
\text { Crenated }\end{array}$ & Indeterminate & Use & Indeterminate & Use & Indeterminate & Indeterminate \\
\hline Preform & Flake & Flake & Flake & Indeterminate & Flake & Indeterminate & Flake & Biface & Biface \\
\hline Shape & Indeterminate & Teardrop & Indeterminate & Indeterminate & Lanceolate & Indeterminate & Lanceolate & Indeterminate & Indeterminate \\
\hline $\begin{array}{l}\text { Rejuvenation } \\
\text { Scar }\end{array}$ & Absent & Absent & Absent & Absent & Absent & Absent & Absent & Absent & Absent \\
\hline $\begin{array}{l}\text { Resharpening } \\
\text { Type }\end{array}$ & $\begin{array}{l}\text { Beveled } \\
\text { Unifacial }\end{array}$ & None & Indeterminate & None & None & Indeterminate & None & None & Indeterminate \\
\hline Raw Material & Chert & Chert & Chert & Chert & Chert & Chert & Chert & Chert & Chert \\
\hline Texture & Fine & Fine & Fine & Fine & Fine & Fine & Fine & Fine & Fine \\
\hline $\begin{array}{c}\text { Percent } \\
\text { Patination }\end{array}$ & 0 & 25 & 0 & 0 & 0 & 0 & 0 & 0 & 25 \\
\hline $\begin{array}{l}\text { Percent } \\
\text { Cortex }\end{array}$ & 0 & 0 & 0 & 0 & 0 & 0 & 0 & 0 & 0 \\
\hline Cortex Type & None & None & None & None & None & None & None & None & None \\
\hline Heating & Heat-Treated & None & Burned & None & None & Burned & None & None & None \\
\hline Length (mm) & & 73.5 & & & & & & & \\
\hline Width (mm) & 50.3 & 45.8 & & & 25.7 & & 23.8 & 42.1 & \\
\hline Thick (mm) & 9.1 & 12.1 & & 8.7 & 7.4 & & 7.4 & 16.1 & 7.7 \\
\hline Wt. (g) & 27.5 & 37.6 & & & & & & & \\
\hline $\begin{array}{l}\text { Long X- } \\
\text { Section }\end{array}$ & Flat & $\begin{array}{c}\text { Wedged } \\
\text { Base, Flat }\end{array}$ & Indeterminate & Indeterminate & Flat & Indeterminate & Flat & Indeterminate & Indeterminate \\
\hline $\begin{array}{l}\text { Trans X- } \\
\text { Section }\end{array}$ & $\begin{array}{l}\text { Plano- } \\
\text { Convex }\end{array}$ & $\begin{array}{c}\text { Biconvex } \\
\text { Asymmetrical }\end{array}$ & $\begin{array}{l}\text { Plano- } \\
\text { Convex }\end{array}$ & $\begin{array}{l}\text { Plano- } \\
\text { Convex }\end{array}$ & $\begin{array}{l}\text { Plano- } \\
\text { Convex }\end{array}$ & Indeterminate & $\begin{array}{l}\text { Plano- } \\
\text { Convex }\end{array}$ & $\begin{array}{c}\text { Biconvex } \\
\text { Symmetrical }\end{array}$ & $\begin{array}{c}\text { Biconvex } \\
\text { Symmetrical }\end{array}$ \\
\hline $\begin{array}{l}\text { Flaking } \\
\text { Pattern }\end{array}$ & Random & Random & Indeterminate & Random & Subparallel & Indeterminate & $\begin{array}{l}\text { Oblique } \\
\text { Parallel }\end{array}$ & Random & Indeterminate \\
\hline $\begin{array}{c}\text { Edge } \\
\text { Rounding }\end{array}$ & Present & Present & Absent & Present & Absent & Absent & Absent & Present & Absent \\
\hline $\begin{array}{l}\text { Left Lateral } \\
\text { Edge }\end{array}$ & Excurvate & Excurvate & Indeterminate & Indeterminate & Straight & Indeterminate & Straight & Excurvate & Indeterminate \\
\hline $\begin{array}{l}\text { Right Lateral } \\
\text { Edge }\end{array}$ & Excurvate & Excurvate & Indeterminate & Excurvate & Indeterminate & Indeterminate & Straight & Indeterminate & Indeterminate \\
\hline Micro-wear & FALSE & FALSE & FALSE & FALSE & FALSE & FALSE & FALSE & FALSE & FALSE \\
\hline NAA & FALSE & FALSE & FALSE & FALSE & FALSE & FALSE & FALSE & FALSE & FALSE \\
\hline
\end{tabular}


Table 0-33. EA Biface Data Continued

\begin{tabular}{|c|c|c|c|c|c|c|c|c|c|}
\hline Cat. No. & $334-014$ & $345-029$ & $345-015$ & $366-012$ & $375-017$ & $391-016$ & $400-012$ & 401-035 & $402-016$ \\
\hline Unit & N102,E55 & N102,E56 & N102,E56 & N103,E51 & N103,E51 & N103,E55 & N103,E56 & N103,E56 & N103,E56 \\
\hline Depth (cm) & $140-150$ & $100-110$ & $100-110$ & $90-100$ & $80-90$ & $120-130$ & $70-80$ & $80-90$ & $90-100$ \\
\hline Biface Stage & Late & Late & Late & Late & Late & Late & Middle & Late & Middle \\
\hline Condition & Proximal & Indeterminate & Proximal & Indeterminate & Distal & Proximal & Indeterminate & Complete & Complete \\
\hline Break Type & Use & Indeterminate & $\begin{array}{l}\text { Thermal/ } \\
\text { Crenated }\end{array}$ & Indeterminate & Use & Indeterminate & Indeterminate & Unbroken & Unbroken \\
\hline Preform & Indeterminate & Flake & Flake & Flake & Biface & Biface & Biface & Indeterminate & Biface \\
\hline Shape & Indeterminate & Indeterminate & Indeterminate & Indeterminate & Lanceolate & Lanceolate & Indeterminate & Ovate & Ovate \\
\hline $\begin{array}{l}\text { Rejuvenation } \\
\text { Scar }\end{array}$ & Absent & Absent & Absent & Absent & Absent & Absent & Absent & Absent & Absent \\
\hline $\begin{array}{c}\text { Resharpening } \\
\text { Type }\end{array}$ & Indeterminate & None & Indeterminate & None & None & None & None & None & None \\
\hline Raw Material & Chert & Chert & Chert & Chert & Chert & Chert & Chert & Chert & Chert \\
\hline Texture & Fine & Fine & Fine & Fine & Fine & Fine & Fine & Fine & Fine \\
\hline $\begin{array}{c}\text { Percent } \\
\text { Patination }\end{array}$ & 0 & 0 & 0 & 0 & 50 & 0 & 0 & 0 & 0 \\
\hline $\begin{array}{l}\text { Percent } \\
\text { Cortex }\end{array}$ & 0 & 0 & 0 & 0 & 0 & 0 & 0 & 0 & 0 \\
\hline Cortex Type & None & None & None & None & None & None & None & None & None \\
\hline Heating & Burned & None & Burned & None & None & None & Heat-Treated & None & None \\
\hline Length (mm) & & & & & & & & 68.6 & 89.8 \\
\hline Width (mm) & & & & & 28.4 & 36.1 & & 32.8 & 37.8 \\
\hline Thick (mm) & & 7.9 & 5.9 & 5.6 & 8.7 & 9.2 & 13.1 & 10.2 & 16.2 \\
\hline Wt. (g) & & & & & 8.7 & 21 & & 20.6 & 53.2 \\
\hline $\begin{array}{l}\text { Long X- } \\
\text { Section }\end{array}$ & Indeterminate & Indeterminate & Indeterminate & Indeterminate & $\begin{array}{l}\text { Tapered } \\
\text { Base/Tip }\end{array}$ & Flat & Indeterminate & $\begin{array}{l}\text { Wedged } \\
\text { Base, Flat }\end{array}$ & $\begin{array}{c}\text { Wedged } \\
\text { Base, Thick } \\
\text { Body }\end{array}$ \\
\hline $\begin{array}{l}\text { Trans X- } \\
\text { Section }\end{array}$ & $\begin{array}{l}\text { Plano- } \\
\text { Convex }\end{array}$ & $\begin{array}{l}\text { Plano- } \\
\text { Convex }\end{array}$ & $\begin{array}{l}\text { Plano- } \\
\text { Convex }\end{array}$ & $\begin{array}{l}\text { Plano- } \\
\text { Convex }\end{array}$ & $\begin{array}{c}\text { Biconvex } \\
\text { Symmetrical }\end{array}$ & $\begin{array}{l}\text { Plano- } \\
\text { Convex }\end{array}$ & $\begin{array}{c}\text { Biconvex } \\
\text { Asymmetrical }\end{array}$ & $\begin{array}{c}\text { Biconvex } \\
\text { Asymmetrical }\end{array}$ & $\begin{array}{c}\text { Biconvex } \\
\text { Asymmetrical }\end{array}$ \\
\hline $\begin{array}{l}\text { Flaking } \\
\text { Pattern }\end{array}$ & Indeterminate & Subparallel & Indeterminate & $\begin{array}{c}\text { Oblique } \\
\text { Subparallel }\end{array}$ & Subparallel & Random & Collateral & $\begin{array}{c}\text { Oblique } \\
\text { Subparallel }\end{array}$ & Random \\
\hline $\begin{array}{c}\text { Edge } \\
\text { Rounding }\end{array}$ & Absent & Absent & Present & Absent & Present & Present & Absent & Absent & Absent \\
\hline $\begin{array}{l}\text { Left Lateral } \\
\text { Edge }\end{array}$ & Indeterminate & Indeterminate & Indeterminate & Indeterminate & Straight & Excurvate & Excurvate & Excurvate & Excurvate \\
\hline $\begin{array}{l}\text { Right Lateral } \\
\text { Edge }\end{array}$ & Indeterminate & Indeterminate & Indeterminate & Excurvate & Excurvate & Straight & Excurvate & Excurvate & Excurvate \\
\hline Micro-wear & FALSE & FALSE & FALSE & FALSE & FALSE & FALSE & FALSE & FALSE & FALSE \\
\hline NAA & FALSE & FALSE & FALSE & FALSE & FALSE & FALSE & FALSE & FALSE & FALSE \\
\hline
\end{tabular}


The Varga Site

Texas Department of Transportation

Table 0-33. EA Biface Data Continued

\begin{tabular}{|c|c|c|c|c|c|c|c|c|c|}
\hline Cat. No. & $402-013$ & $402-014$ & $402-017$ & 403-012 & $411-018$ & $421-034$ & $422-019$ & $422-014$ & $422-017$ \\
\hline Unit & N103,E56 & N103,E56 & N103,E56 & N103,E56 & N104,E47 & N104,E56 & N104,E56 & N104,E56 & N104,E56 \\
\hline Depth (cm) & $90-100$ & $90-100$ & $90-100$ & $100-110$ & $70-80$ & $80-90$ & $90-100$ & $90-100$ & $90-100$ \\
\hline Biface Stage & Late & Late & $\begin{array}{c}\text { refit to } 403- \\
12\end{array}$ & Late & Late & Middle & Late & Late & Middle \\
\hline Condition & Proximal & Proximal & & Complete & Proximal & Complete & Proximal & Medial & Complete \\
\hline Break Type & Indeterminate & Indeterminate & & Unbroken & $\begin{array}{l}\text { Thermal/ } \\
\text { Crenated }\end{array}$ & Unbroken & Use & $\begin{array}{l}\text { Thermal/ } \\
\text { Crenated }\end{array}$ & Unbroken \\
\hline Preform & Indeterminate & Biface & & Flake & Indeterminate & Biface & Biface & Indeterminate & Biface \\
\hline Shape & Indeterminate & Indeterminate & & Ovate & Indeterminate & Ovate & Triangular & Indeterminate & Ovate \\
\hline $\begin{array}{l}\text { Rejuvenation } \\
\text { Scar }\end{array}$ & Absent & Absent & & Absent & Absent & Absent & Absent & Absent & Absent \\
\hline $\begin{array}{l}\text { Resharpening } \\
\text { Type }\end{array}$ & None & Indeterminate & & None & Indeterminate & None & None & Indeterminate & None \\
\hline Raw Material & Chert & Chert & & Chert & Chert & Chert & Chert & Chert & Chert \\
\hline Texture & Fine & Fine & & Fine & Fine & Fine & Fine & Fine & Fine \\
\hline $\begin{array}{c}\text { Percent } \\
\text { Patination }\end{array}$ & 0 & 25 & & 0 & 0 & 25 & 25 & 0 & 25 \\
\hline $\begin{array}{l}\text { Percent } \\
\text { Cortex }\end{array}$ & 0 & 0 & & 0 & 0 & 0 & 0 & 0 & 0 \\
\hline Cortex Type & None & None & & None & None & None & None & None & None \\
\hline Heating & None & None & & None & Burned & None & None & Burned & None \\
\hline Length (mm) & & & & 83.1 & & 66.6 & & & 54.1 \\
\hline Width (mm) & 36.4 & 50.5 & & 41.7 & & 36.2 & 52.1 & & 26.7 \\
\hline Thick (mm) & 7.9 & 8.7 & & 7.9 & 6.5 & 18.5 & 12.4 & & 12.7 \\
\hline Wt. (g) & & & & 34.3 & & 41.9 & 53.5 & & 20.6 \\
\hline $\begin{array}{l}\text { Long X- } \\
\text { Section }\end{array}$ & Indeterminate & Indeterminate & & Flat & Indeterminate & $\begin{array}{l}\text { Tapered } \\
\text { Base/Tip }\end{array}$ & $\begin{array}{l}\text { Tapered } \\
\text { Base/Tip }\end{array}$ & Indeterminate & $\begin{array}{l}\text { Bi-wedge- } \\
\text { shaped }\end{array}$ \\
\hline $\begin{array}{l}\text { Trans X- } \\
\text { Section }\end{array}$ & $\begin{array}{c}\text { Biconvex } \\
\text { Symmetrical }\end{array}$ & $\begin{array}{c}\text { Biconvex } \\
\text { Symmetrical }\end{array}$ & & $\begin{array}{c}\text { Biconvex } \\
\text { Symmetrical }\end{array}$ & Indeterminate & $\begin{array}{c}\text { Biconvex } \\
\text { Symmetrical }\end{array}$ & $\begin{array}{c}\text { Biconvex } \\
\text { Symmetrical }\end{array}$ & Indeterminate & $\begin{array}{c}\text { Biconvex } \\
\text { Symmetrical }\end{array}$ \\
\hline $\begin{array}{l}\text { Flaking } \\
\text { Pattern }\end{array}$ & $\begin{array}{c}\text { Oblique } \\
\text { Subparallel }\end{array}$ & Indeterminate & & Random & Indeterminate & Random & Random & Indeterminate & Random \\
\hline $\begin{array}{c}\text { Edge } \\
\text { Rounding }\end{array}$ & Absent & Present & & Present & Present & Absent & Absent & Present & Absent \\
\hline $\begin{array}{l}\text { Left Lateral } \\
\text { Edge }\end{array}$ & Indeterminate & Indeterminate & & Excurvate & Indeterminate & Excurvate & Straight & Excurvate & Excurvate \\
\hline $\begin{array}{l}\text { Right Lateral } \\
\text { Edge }\end{array}$ & Indeterminate & Indeterminate & & Excurvate & Indeterminate & Excurvate & Excurvate & Indeterminate & Straight \\
\hline Micro-wear & FALSE & FALSE & FALSE & FALSE & FALSE & FALSE & TRUE & FALSE & FALSE \\
\hline NAA & FALSE & FALSE & FALSE & FALSE & FALSE & FALSE & FALSE & FALSE & FALSE \\
\hline
\end{tabular}


Table 0-33. EA Biface Data Continued

\begin{tabular}{|c|c|c|c|c|c|c|c|c|c|}
\hline Cat. No. & 432-011 & 447-016 & 447-017 & $455-017$ & 457-010 & 463-022 & 464-017 & $465-011$ & 469-012 \\
\hline Unit & N105,E47 & N105,E51 & N105,E51 & N105,E52 & N105,E52 & N105,E53 & N105,E53 & N105,E53 & N105,E54 \\
\hline Depth (cm) & $80-90$ & $60-70$ & $60-70$ & $50-60$ & $70-80$ & $50-60$ & $60-70$ & 76 & $30-40$ \\
\hline Biface Stage & Late & Late & Late & Late & Late & Late & Late & Late & Late \\
\hline Condition & Proximal & Complete & Distal & Complete & Proximal & Complete & Complete & Proximal & Indeterminate \\
\hline Break Type & Manufacture & Unbroken & Use & Use & Use & Use & Use & Indeterminate & Indeterminate \\
\hline Preform & Biface & Flake & Biface & Flake & Biface & Flake & Flake & Flake & Flake \\
\hline Shape & Indeterminate & Triangular & Indeterminate & Ovate & Indeterminate & Triangular & Ovate & Indeterminate & Indeterminate \\
\hline $\begin{array}{l}\text { Rejuvenation } \\
\text { Scar }\end{array}$ & Absent & Absent & Absent & Absent & Absent & Absent & Absent & Absent & Absent \\
\hline $\begin{array}{l}\text { Resharpening } \\
\text { Type }\end{array}$ & None & None & None & None & None & None & None & None & Indeterminate \\
\hline Raw Material & Chert & Chert & Chert & Chert & Chert & Chert & Chert & Chert & Chert \\
\hline Texture & Fine & Fine & Fine & Fine & Fine & Fine & Fine & Fine & Fine \\
\hline $\begin{array}{c}\text { Percent } \\
\text { Patination }\end{array}$ & 0 & 0 & 0 & 0 & 0 & 0 & 0 & 0 & 0 \\
\hline $\begin{array}{l}\text { Percent } \\
\text { Cortex }\end{array}$ & 0 & 0 & 0 & 0 & 0 & 0 & 0 & 0 & 0 \\
\hline Cortex Type & None & None & None & None & None & None & None & None & None \\
\hline Heating & None & None & None & None & None & None & None & None & Heat-Treated \\
\hline Length (mm) & & 51.6 & & 60.3 & & 33.9 & 59.1 & & \\
\hline Width (mm) & & 31.4 & 34.4 & 34.3 & 23.7 & 33.8 & 33.4 & 42.5 & \\
\hline Thick (mm) & 22.4 & 7.3 & 17.1 & 9.6 & 8.6 & 5.1 & 10.5 & 7.4 & \\
\hline Wt. (g) & & 10 & & 21.3 & & 6.5 & 23.6 & & \\
\hline $\begin{array}{l}\text { Long X- } \\
\text { Section }\end{array}$ & Indeterminate & Flat & Indeterminate & Flat & Indeterminate & Flat & $\begin{array}{l}\text { Wedged } \\
\text { Base, Flat }\end{array}$ & Indeterminate & Indeterminate \\
\hline $\begin{array}{l}\text { Trans X- } \\
\text { Section }\end{array}$ & $\begin{array}{c}\text { Biconvex } \\
\text { Symmetrical }\end{array}$ & $\begin{array}{l}\text { Plano- } \\
\text { Convex }\end{array}$ & $\begin{array}{l}\text { Plano- } \\
\text { Convex }\end{array}$ & $\begin{array}{l}\text { Plano- } \\
\text { Convex }\end{array}$ & $\begin{array}{c}\text { Biconvex } \\
\text { Asymmetrical }\end{array}$ & $\begin{array}{c}\text { Biconvex } \\
\text { Asymmetrical }\end{array}$ & $\begin{array}{c}\text { Biconvex } \\
\text { Asymmetrical }\end{array}$ & $\begin{array}{l}\text { Plano- } \\
\text { Convex }\end{array}$ & $\begin{array}{l}\text { Plano- } \\
\text { Convex }\end{array}$ \\
\hline $\begin{array}{l}\text { Flaking } \\
\text { Pattern }\end{array}$ & Random & Chevron & Collateral & Random & Random & Chevron & $\begin{array}{c}\text { Oblique } \\
\text { Subparallel }\end{array}$ & Random & Indeterminate \\
\hline $\begin{array}{c}\text { Edge } \\
\text { Rounding }\end{array}$ & Absent & Absent & Present & Absent & Absent & Absent & Absent & Present & Present \\
\hline $\begin{array}{l}\text { Left Lateral } \\
\text { Edge }\end{array}$ & Indeterminate & Incurvate & Straight & Excurvate & Indeterminate & Straight & Excurvate & Indeterminate & Indeterminate \\
\hline $\begin{array}{c}\text { Right Lateral } \\
\text { Edge }\end{array}$ & Indeterminate & Excurvate & Excurvate & Excurvate & Indeterminate & Excurvate & Excurvate & Excurvate & Indeterminate \\
\hline Micro-wear & FALSE & FALSE & FALSE & FALSE & FALSE & FALSE & FALSE & FALSE & FALSE \\
\hline NAA & FALSE & FALSE & FALSE & FALSE & FALSE & FALSE & FALSE & FALSE & FALSE \\
\hline
\end{tabular}


The Varga Site

Texas Department of Transportation

Table 0-33. EA Biface Data Continued

\begin{tabular}{|c|c|c|c|c|c|c|c|c|c|}
\hline Cat. No. & $470-013$ & $472-013$ & $500-012$ & $502-017$ & 508-013 & $515-023$ & 516-015 & 521-014 & $523-024$ \\
\hline Unit & N105,E54 & N105,E54 & $\mathrm{N} 106, \mathrm{E} 50$ & N106,E50 & N106,E51 & N106,E52 & N106,E52 & N106,E53 & N106,E53 \\
\hline Depth (cm) & $40-50$ & 70 & $40-50$ & $60-70$ & $50-60$ & $50-60$ & $60-70$ & $40-50$ & $60-70$ \\
\hline Biface Stage & Late & Late & Late & Late & Middle & Middle & Middle & Late & Late \\
\hline Condition & Distal & Complete & Distal & Proximal & Medial & Distal & Complete & Complete & Proximal \\
\hline Break Type & Use & Unbroken & Use & Indeterminate & Indeterminate & Indeterminate & Indeterminate & Unbroken & Indeterminate \\
\hline Preform & Flake & Flake & Biface & Indeterminate & Biface & Biface & Flake & Indeterminate & Indeterminate \\
\hline Shape & Indeterminate & Triangular & Indeterminate & Indeterminate & Indeterminate & Ovate & Ovate & Triangular & Indeterminate \\
\hline $\begin{array}{l}\text { Rejuvenation } \\
\text { Scar }\end{array}$ & Absent & Absent & Absent & Absent & Absent & Absent & Absent & Absent & Absent \\
\hline $\begin{array}{l}\text { Resharpening } \\
\text { Type }\end{array}$ & None & None & None & None & Indeterminate & Indeterminate & None & $\begin{array}{c}\text { Break } \\
\text { Compensation }\end{array}$ & Indeterminate \\
\hline Raw Material & Chert & Chert & Chert & Chert & Chert & Chert & Chert & Chert & Chert \\
\hline Texture & Fine & Fine & Fine & Fine & Fine & Fine & Fine & Fine & Fine \\
\hline $\begin{array}{c}\text { Percent } \\
\text { Patination }\end{array}$ & 0 & 25 & 25 & 50 & 0 & 0 & 0 & 0 & 0 \\
\hline Percent Cortex & 50 & 0 & 0 & 0 & 0 & 0 & 0 & 0 & 0 \\
\hline Cortex Type & $\begin{array}{l}\text { Pebble/ } \\
\text { Cobble }\end{array}$ & None & None & None & None & None & & None & None \\
\hline Heating & None & None & None & None & Burned & None & None & None & None \\
\hline Length (mm) & & 58.9 & & & & & 81.5 & 65 & \\
\hline Width (mm) & 30.7 & 36.5 & 38.8 & 46.2 & & & 50.6 & 33.3 & \\
\hline Thick (mm) & 7.9 & 8.6 & 22.5 & 8.7 & 10.9 & 14 & 15.6 & 9.2 & 8.4 \\
\hline Wt. (g) & & 15.9 & & & & & 64.9 & 19.1 & \\
\hline $\begin{array}{l}\text { Long X- } \\
\text { Section }\end{array}$ & Flat & $\begin{array}{l}\text { Wedged } \\
\text { Base, Flat }\end{array}$ & Indeterminate & Flat & Indeterminate & Indeterminate & $\begin{array}{l}\text { Wedged Base, } \\
\text { Thick Body }\end{array}$ & Flat & Indeterminate \\
\hline $\begin{array}{l}\text { Trans X- } \\
\text { Section }\end{array}$ & Plano-Convex & $\begin{array}{c}\text { Biconvex } \\
\text { Asymmetrical }\end{array}$ & $\begin{array}{c}\text { Biconvex } \\
\text { Asymmetrical }\end{array}$ & Plano-Convex & Indeterminate & Indeterminate & $\begin{array}{c}\text { Biconvex } \\
\text { Asymmetrical }\end{array}$ & Plano-Convex & Plano-Convex \\
\hline Flaking Pattern & $\begin{array}{c}\text { Flake Blank } \\
\text { Remnant }\end{array}$ & Subparallel & Chevron & Random & $\begin{array}{c}\text { Flake Blank } \\
\text { Remnant }\end{array}$ & Random & Random & Subparallel & Random \\
\hline $\begin{array}{c}\text { Edge } \\
\text { Rounding }\end{array}$ & Absent & Present & Absent & Absent & Absent & Absent & Present & Absent & Absent \\
\hline $\begin{array}{l}\text { Left Lateral } \\
\text { Edge }\end{array}$ & Excurvate & Straight & Straight & Indeterminate & Indeterminate & Indeterminate & Excurvate & Excurvate & Indeterminate \\
\hline $\begin{array}{c}\text { Right Lateral } \\
\text { Edge }\end{array}$ & Excurvate & Excurvate & Excurvate & Indeterminate & Excurvate & Excurvate & Excurvate & Straight & Indeterminate \\
\hline Micro-wear & FALSE & FALSE & FALSE & FALSE & FALSE & FALSE & FALSE & FALSE & FALSE \\
\hline NAA & FALSE & FALSE & FALSE & FALSE & FALSE & FALSE & FALSE & FALSE & FALSE \\
\hline
\end{tabular}


Table 0-33. EA Biface Data Continued

\begin{tabular}{|c|c|c|c|c|c|c|c|c|c|}
\hline Cat. No. & $523-023$ & $530-018$ & $530-016$ & $531-020$ & 539-016 & 539-017 & $546-010$ & $552-017$ & 563-019 \\
\hline Unit & N106,E53 & N106,E54 & N106,E54 & N106,E54 & N106,E55 & N106,E55 & N106,E56 & N107,E47 & N107,E49 \\
\hline Depth (cm) & $60-70$ & $80-90$ & $80-90$ & $90-100$ & $60-70$ & $60-70$ & $40-50$ & $40-50$ & $40-50$ \\
\hline Biface Stage & Late & Late & Middle & Late & Late & Late & Late & Late & Late \\
\hline Condition & Complete & Proximal & Medial & Proximal & Medial & Distal & Proximal & Indeterminate & Complete \\
\hline Break Type & Unbroken & Indeterminate & Indeterminate & Indeterminate & Indeterminate & Use & Indeterminate & Use & Use \\
\hline Preform & Biface & Indeterminate & Indeterminate & Indeterminate & Biface & Biface & Indeterminate & Biface & Flake \\
\hline Shape & Triangular & Indeterminate & Indeterminate & Indeterminate & Indeterminate & Triangular & Indeterminate & Indeterminate & Teardrop \\
\hline $\begin{array}{l}\text { Rejuvenation } \\
\text { Scar }\end{array}$ & Absent & Absent & Absent & Absent & Absent & Absent & Absent & Absent & Absent \\
\hline $\begin{array}{l}\text { Resharpening } \\
\text { Type }\end{array}$ & None & Indeterminate & Indeterminate & Indeterminate & Indeterminate & None & Indeterminate & None & None \\
\hline Raw Material & Chert & Chert & Chert & Chert & Chert & Chert & Chert & Chert & Chert \\
\hline Texture & Fine & Fine & Fine & Fine & Fine & Fine & Fine & Fine & Fine \\
\hline $\begin{array}{c}\text { Percent } \\
\text { Patination }\end{array}$ & 0 & 0 & 0 & 0 & 0 & 25 & 0 & 25 & 0 \\
\hline Percent Cortex & 0 & 0 & 0 & 0 & 0 & 0 & 0 & 0 & 0 \\
\hline Cortex Type & None & None & None & None & None & None & & None & None \\
\hline Heating & None & None & Burned & None & None & None & None & None & None \\
\hline Length (mm) & 79.6 & & & & & & & & 66.5 \\
\hline Width (mm) & 35.3 & 40.9 & & & & 49.8 & & 62 & 35.4 \\
\hline Thick (mm) & 16.1 & 7.9 & 8.2 & 9.2 & & 9 & & 14.5 & 7.8 \\
\hline Wt. (g) & 40.2 & & & & & 42.2 & & 76.6 & 19.1 \\
\hline $\begin{array}{l}\text { Long X- } \\
\text { Section }\end{array}$ & $\begin{array}{l}\text { Wedged Base, } \\
\text { Thick Body }\end{array}$ & Indeterminate & Indeterminate & Indeterminate & Indeterminate & Flat & Indeterminate & Indeterminate & $\begin{array}{l}\text { Tapered } \\
\text { Base/Tip }\end{array}$ \\
\hline $\begin{array}{l}\text { Trans X- } \\
\text { Section }\end{array}$ & $\begin{array}{c}\text { Biconvex } \\
\text { Symmetrical }\end{array}$ & Plano-Convex & $\begin{array}{c}\text { Biconvex } \\
\text { Symmetrical }\end{array}$ & $\begin{array}{c}\text { Biconvex } \\
\text { Symmetrical }\end{array}$ & Indeterminate & Plano-Convex & Plano-Convex & Plano-Convex & $\begin{array}{c}\text { Biconvex } \\
\text { Symmetrical }\end{array}$ \\
\hline Flaking Pattern & Random & Indeterminate & Indeterminate & Random & $\begin{array}{l}\text { Oblique } \\
\text { Parallel }\end{array}$ & Collateral & Random & Random & Random \\
\hline $\begin{array}{c}\text { Edge } \\
\text { Rounding }\end{array}$ & Absent & Absent & Absent & Absent & Present & Present & Present & Present & Present \\
\hline $\begin{array}{l}\text { Left Lateral } \\
\text { Edge }\end{array}$ & Straight & Indeterminate & Indeterminate & Indeterminate & Excurvate & Excurvate & Indeterminate & Indeterminate & Excurvate \\
\hline $\begin{array}{c}\text { Right Lateral } \\
\text { Edge }\end{array}$ & Straight & Indeterminate & Indeterminate & Indeterminate & Indeterminate & Excurvate & Indeterminate & Indeterminate & Excurvate \\
\hline Micro-wear & FALSE & FALSE & FALSE & FALSE & FALSE & FALSE & FALSE & FALSE & TRUE \\
\hline NAA & FALSE & FALSE & FALSE & FALSE & FALSE & FALSE & FALSE & FALSE & FALSE \\
\hline
\end{tabular}


The Varga Site

Texas Department of Transportation

Table 0-33. EA Biface Data Continued

\begin{tabular}{|c|c|c|c|c|c|c|c|c|c|}
\hline Cat. No. & $563-018$ & $570-010$ & $577-013$ & $590-015$ & $591-021$ & $591-024$ & $598-014$ & $598-013$ & $606-011$ \\
\hline Unit & N107,E49 & $\mathrm{N} 107, \mathrm{E} 50$ & $\mathrm{~N} 107, \mathrm{E} 51$ & $\mathrm{~N} 107, \mathrm{E} 53$ & $\mathrm{~N} 107, \mathrm{E} 53$ & $\mathrm{~N} 107, \mathrm{E} 53$ & $\mathrm{~N} 107, \mathrm{E} 54$ & $\mathrm{~N} 107, \mathrm{E} 54$ & N107,E55 \\
\hline Depth (cm) & $40-50$ & $50-60$ & $50-60$ & $40-50$ & $50-60$ & $50-60$ & $80-90$ & $80-90$ & $50-60$ \\
\hline Biface Stage & Middle & Middle & Late & Middle & Late & Middle & Late & Late & Late \\
\hline Condition & Indeterminate & Complete & Proximal & Complete & Proximal & Complete & Indeterminate & Complete & Distal \\
\hline Break Type & Indeterminate & $\begin{array}{l}\text { Thermal/ } \\
\text { Crenated }\end{array}$ & Indeterminate & Unbroken & Indeterminate & Unbroken & Indeterminate & Unbroken & $\begin{array}{l}\text { Thermal/ } \\
\text { Crenated }\end{array}$ \\
\hline Preform & Biface & Biface & Indeterminate & Biface & Flake & Flake & Flake & Flake & Indeterminate \\
\hline Shape & Indeterminate & Ovate & Indeterminate & Triangular & Lanceolate & Teardrop & Indeterminate & Ovate & Indeterminate \\
\hline $\begin{array}{l}\text { Rejuvenation } \\
\text { Scar }\end{array}$ & Absent & Absent & Absent & Absent & Absent & Absent & Absent & Absent & Absent \\
\hline $\begin{array}{l}\text { Resharpening } \\
\text { Type }\end{array}$ & Indeterminate & None & Indeterminate & None & None & None & None & $\begin{array}{c}\text { Break } \\
\text { Compensation }\end{array}$ & Indeterminate \\
\hline Raw Material & Chert & Chert & Chert & Chert & Chert & Chert & Chert & Chert & Chert \\
\hline Texture & Fine & Fine & Fine & Fine & Fine & Fine & Fine & Fine & Fine \\
\hline $\begin{array}{c}\text { Percent } \\
\text { Patination }\end{array}$ & 0 & 25 & 0 & 25 & 0 & 0 & 0 & 0 & 0 \\
\hline $\begin{array}{l}\text { Percent } \\
\text { Cortex }\end{array}$ & 0 & 0 & 0 & 0 & 0 & 0 & 0 & 0 & 0 \\
\hline Cortex Type & None & None & None & None & None & None & None & None & None \\
\hline Heating & None & Burned & None & Burned & None & None & None & None & Burned \\
\hline Length (mm) & & 89.1 & & 61.6 & & 53.3 & & & \\
\hline Width (mm) & & 63.7 & & 35.1 & 21.6 & 22.9 & 35.6 & 31.9 & \\
\hline Thick (mm) & 17.6 & 19.7 & 8.6 & 12.3 & 7.9 & 6.6 & 9 & 9 & \\
\hline Wt. (g) & & 94.8 & & 24.7 & & 8.1 & & 15.2 & \\
\hline $\begin{array}{l}\text { Long X- } \\
\text { Section }\end{array}$ & Indeterminate & $\begin{array}{l}\text { Bi-wedge- } \\
\text { shaped }\end{array}$ & Indeterminate & $\begin{array}{l}\text { Tapered } \\
\text { Base/Tip }\end{array}$ & Flat & $\begin{array}{l}\text { Wedged Base, } \\
\text { Thick Body }\end{array}$ & Indeterminate & $\begin{array}{l}\text { Tapered } \\
\text { Base/Tip }\end{array}$ & Indeterminate \\
\hline $\begin{array}{l}\text { Trans X- } \\
\text { Section }\end{array}$ & Indeterminate & $\begin{array}{l}\text { Biconvex } \\
\text { Symmetrical }\end{array}$ & $\begin{array}{l}\text { Biconvex } \\
\text { Symmetrical }\end{array}$ & $\begin{array}{l}\text { Biconvex } \\
\text { Symmetrical }\end{array}$ & Plano-Convex & $\begin{array}{c}\text { Biconvex } \\
\text { Asymmetrical }\end{array}$ & $\begin{array}{c}\text { Biconvex } \\
\text { Asymmetrical }\end{array}$ & $\begin{array}{c}\text { Biconvex } \\
\text { Symmetrical }\end{array}$ & $\begin{array}{c}\text { Biconvex } \\
\text { Symmetrical }\end{array}$ \\
\hline $\begin{array}{l}\text { Flaking } \\
\text { Pattern }\end{array}$ & Random & Indeterminate & Indeterminate & Indeterminate & $\begin{array}{l}\text { Oblique } \\
\text { Subparallel }\end{array}$ & Random & Collateral & Random & Indeterminate \\
\hline $\begin{array}{c}\text { Edge } \\
\text { Rounding }\end{array}$ & Absent & Absent & Absent & Absent & Absent & Present & Present & Present & Absent \\
\hline $\begin{array}{l}\text { Left Lateral } \\
\text { Edge }\end{array}$ & Indeterminate & Excurvate & Indeterminate & Straight & Straight & Excurvate & Indeterminate & Excurvate & Indeterminate \\
\hline $\begin{array}{l}\text { Right Lateral } \\
\text { Edge }\end{array}$ & Indeterminate & Excurvate & Indeterminate & Excurvate & Straight & Excurvate & Indeterminate & Excurvate & Indeterminate \\
\hline Micro-wear & FALSE & FALSE & FALSE & FALSE & FALSE & TRUE & FALSE & TRUE & FALSE \\
\hline NAA & FALSE & FALSE & FALSE & FALSE & FALSE & FALSE & FALSE & FALSE & FALSE \\
\hline
\end{tabular}


Table 0-33. EA Biface Data Continued

\begin{tabular}{|c|c|c|c|c|c|c|c|c|c|}
\hline Cat. No. & $615-017$ & $615-018$ & $615-016$ & $622-020$ & $622-021$ & 623-011 & $627-012$ & $628-015$ & $638-014$ \\
\hline Unit & N107,E56 & N107,E56 & N107,E56 & N108,E47 & N108,E47 & N108,E47 & N108,E48 & N108,E48 & N108,E50 \\
\hline Depth (cm) & $50-60$ & $50-60$ & $50-60$ & $40-50$ & $40-50$ & $50-60$ & $30-40$ & $40-50$ & 47 \\
\hline Biface Stage & Middle & Middle & Late & Middle & Late & Late & Late & Late & Middle \\
\hline Condition & Complete & Medial & Distal & Proximal & Proximal & Medial & Distal & Distal & Proximal \\
\hline Break Type & Unbroken & Indeterminate & Indeterminate & Indeterminate & Indeterminate & Use & Use & Use & Indeterminate \\
\hline Preform & Flake & Biface & Flake & Biface & Biface & Flake & Indeterminate & Indeterminate & Biface \\
\hline Shape & Teardrop & Indeterminate & Indeterminate & Indeterminate & Indeterminate & Triangular & Indeterminate & Indeterminate & Quadrilateral \\
\hline $\begin{array}{l}\text { Rejuvenation } \\
\text { Scar }\end{array}$ & Present & Present & Absent & Absent & Absent & Absent & Absent & Absent & Absent \\
\hline $\begin{array}{l}\text { Resharpening } \\
\text { Type }\end{array}$ & None & None & None & Indeterminate & None & None & $\begin{array}{l}\text { Beveled } \\
\text { Unifacial }\end{array}$ & None & None \\
\hline Raw Material & Chert & Chert & Chert & Chert & Chert & Chert & Chert & Chert & Chert \\
\hline Texture & Fine & Fine & Fine & Fine & Fine & Fine & Fine & Fine & Fine \\
\hline $\begin{array}{c}\text { Percent } \\
\text { Patination }\end{array}$ & 25 & 0 & 25 & 0 & 25 & 0 & 100 & 0 & 0 \\
\hline $\begin{array}{l}\text { Percent } \\
\text { Cortex }\end{array}$ & 0 & 0 & 0 & 0 & 0 & 0 & 0 & 0 & 0 \\
\hline Cortex Type & None & None & None & None & None & None & None & None & None \\
\hline Heating & None & None & None & None & None & None & None & None & None \\
\hline Length (mm) & 58.2 & 43.4 & & & & & & & 47.5 \\
\hline Width (mm) & 33.3 & 77.5 & & & 29.1 & & 35.4 & & 44.6 \\
\hline Thick (mm) & 10.4 & 18.1 & 7.7 & 11.4 & 8.5 & 4.1 & 8.2 & 7.1 & 14.9 \\
\hline Wt. (g) & 20.6 & & & & 12.9 & 1.8 & & & \\
\hline $\begin{array}{l}\text { Long X- } \\
\text { Section }\end{array}$ & $\begin{array}{l}\text { Wedged Base, } \\
\text { Thick Body }\end{array}$ & Indeterminate & Indeterminate & Indeterminate & Indeterminate & Flat & Indeterminate & Indeterminate & Indeterminate \\
\hline $\begin{array}{l}\text { Trans X- } \\
\text { Section }\end{array}$ & $\begin{array}{c}\text { Biconvex } \\
\text { Symmetrical }\end{array}$ & $\begin{array}{c}\text { Biconvex } \\
\text { Asymmetrical }\end{array}$ & Plano-Convex & Indeterminate & $\begin{array}{c}\text { Biconvex } \\
\text { Symmetrical }\end{array}$ & Plano-Convex & $\begin{array}{c}\text { Biconvex } \\
\text { Symmetrical }\end{array}$ & Plano-Convex & Plano-Convex \\
\hline $\begin{array}{l}\text { Flaking } \\
\text { Pattern }\end{array}$ & Random & Random & Random & Random & $\begin{array}{c}\text { Oblique } \\
\text { Subparallel }\end{array}$ & $\begin{array}{l}\text { Oblique } \\
\text { Parallel }\end{array}$ & $\begin{array}{c}\text { Oblique } \\
\text { Subparallel }\end{array}$ & Chevron & Random \\
\hline $\begin{array}{c}\text { Edge } \\
\text { Rounding }\end{array}$ & Absent & Absent & Absent & Absent & Absent & Absent & Absent & Absent & Absent \\
\hline $\begin{array}{l}\text { Left Lateral } \\
\text { Edge }\end{array}$ & Straight & Excurvate & Indeterminate & Indeterminate & Excurvate & Indeterminate & Indeterminate & Indeterminate & Indeterminate \\
\hline $\begin{array}{c}\text { Right Lateral } \\
\text { Edge }\end{array}$ & Excurvate & Excurvate & Excurvate & Indeterminate & Excurvate & Straight & Indeterminate & Indeterminate & Indeterminate \\
\hline Micro-wear & FALSE & FALSE & FALSE & FALSE & FALSE & FALSE & FALSE & FALSE & FALSE \\
\hline NAA & FALSE & FALSE & FALSE & FALSE & FALSE & FALSE & FALSE & FALSE & FALSE \\
\hline
\end{tabular}


The Varga Site

Texas Department of Transportation

Table 0-33. EA Biface Data Continued

\begin{tabular}{|c|c|c|c|c|c|c|c|c|c|}
\hline Cat. No. & $664-016$ & $664-017$ & $670-005-014$ & $677-012$ & 677-015 & 689-012 & $689-022$ & $698-014$ & $699-020$ \\
\hline Unit & N108,E54 & N108,E54 & N108,E55 & N108,E56 & N108,E56 & N109,E48 & N109,E48 & $\mathrm{N} 109, \mathrm{E} 50$ & N109,E50 \\
\hline Depth (cm) & $40-50$ & $40-50$ & 50 & $50-60$ & $50-60$ & $40-50$ & $40-50$ & $30-40$ & 44 \\
\hline Biface Stage & Late & Middle & Middle & Late & Late & Late & Middle & Late & Late \\
\hline Condition & Medial & Complete & Complete & Proximal & Distal & Proximal & Proximal & Medial & Proximal \\
\hline Break Type & Use & Unbroken & Unbroken & Indeterminate & Indeterminate & Use & Indeterminate & Use & Use \\
\hline Preform & Biface & Biface & Biface & Flake & Flake & Indeterminate & Biface & Biface & Biface \\
\hline Shape & Indeterminate & Ovate & Ovate & Indeterminate & Indeterminate & Indeterminate & Lanceolate & Indeterminate & Teardrop \\
\hline $\begin{array}{l}\text { Rejuvenation } \\
\text { Scar }\end{array}$ & Absent & Present & Absent & Absent & Absent & Absent & Absent & Absent & Absent \\
\hline $\begin{array}{l}\text { Resharpening } \\
\text { Type }\end{array}$ & None & None & None & $\begin{array}{l}\text { Beveled } \\
\text { Unifacial }\end{array}$ & $\begin{array}{l}\text { Alternate } \\
\text { Beveled } \\
\text { Unifacial }\end{array}$ & Indeterminate & None & Indeterminate & None \\
\hline Raw Material & Chert & Chert & Chert & Chert & Chert & Chert & Chert & Chert & Chert \\
\hline Texture & Fine & Fine & Fine & Fine & Fine & Fine & Fine & Fine & Fine \\
\hline $\begin{array}{c}\text { Percent } \\
\text { Patination }\end{array}$ & 0 & 0 & 0 & 0 & 0 & 100 & 100 & 50 & 25 \\
\hline $\begin{array}{l}\text { Percent } \\
\text { Cortex }\end{array}$ & 0 & 0 & 0 & 0 & 0 & 0 & 0 & 0 & 0 \\
\hline Cortex Type & None & None & None & None & None & None & None & None & None \\
\hline Heating & None & None & None & None & Heat-Treated & None & None & None & None \\
\hline Length (mm) & & 83.7 & 78.3 & & & & & & \\
\hline Width (mm) & 52 & 35 & 60.1 & 35.3 & 36.3 & & 35.7 & & \\
\hline Thick (mm) & 10.1 & 19.7 & 17.5 & 11.6 & 8.5 & 7.8 & 13.2 & 8.9 & 9.6 \\
\hline Wt. (g) & & 47.9 & 93.1 & & 18.6 & & 28.1 & & \\
\hline $\begin{array}{l}\text { Long X- } \\
\text { Section }\end{array}$ & Indeterminate & $\begin{array}{l}\text { Tapered } \\
\text { Base/Tip }\end{array}$ & $\begin{array}{l}\text { Tapered } \\
\text { Base/Tip }\end{array}$ & Indeterminate & $\begin{array}{l}\text { Wedged Base, } \\
\text { Flat }\end{array}$ & Indeterminate & $\begin{array}{l}\text { Bi-wedge- } \\
\text { shaped }\end{array}$ & Indeterminate & Indeterminate \\
\hline $\begin{array}{l}\text { Trans X- } \\
\text { Section }\end{array}$ & $\begin{array}{c}\text { Biconvex } \\
\text { Symmetrical }\end{array}$ & Plano-Convex & $\begin{array}{c}\text { Biconvex } \\
\text { Asymmetrical }\end{array}$ & $\begin{array}{l}\text { Biconvex } \\
\text { Symmetrical }\end{array}$ & Plano-Convex & $\begin{array}{l}\text { Biconvex } \\
\text { Symmetrical }\end{array}$ & $\begin{array}{c}\text { Biconvex } \\
\text { Symmetrical }\end{array}$ & Indeterminate & $\begin{array}{l}\text { Biconvex } \\
\text { Symmetrical }\end{array}$ \\
\hline $\begin{array}{l}\text { Flaking } \\
\text { Pattern }\end{array}$ & Collateral & Random & Random & Random & $\begin{array}{l}\text { Oblique } \\
\text { Subparallel }\end{array}$ & Indeterminate & Collateral & Random & Random \\
\hline $\begin{array}{c}\text { Edge } \\
\text { Rounding }\end{array}$ & Present & Absent & Absent & Present & Present & Absent & Present & Present & Present \\
\hline $\begin{array}{l}\text { Left Lateral } \\
\text { Edge }\end{array}$ & Indeterminate & Excurvate & Excurvate & Excurvate & Excurvate & Indeterminate & Straight & Indeterminate & Excurvate \\
\hline $\begin{array}{l}\text { Right Lateral } \\
\text { Edge }\end{array}$ & Indeterminate & Excurvate & Excurvate & Excurvate & Excurvate & Indeterminate & Straight & Excurvate & Indeterminate \\
\hline Micro-wear & FALSE & FALSE & FALSE & FALSE & FALSE & FALSE & FALSE & FALSE & TRUE \\
\hline NAA & FALSE & FALSE & FALSE & FALSE & FALSE & FALSE & FALSE & FALSE & FALSE \\
\hline
\end{tabular}


Table 0-33. EA Biface Data Continued

\begin{tabular}{|c|c|c|c|c|c|c|c|c|c|}
\hline Cat. No. & 699-018 & 699-019 & $705-012$ & $718-013$ & $724-024$ & $725-013$ & $725-012$ & 729-011 & $734-010$ \\
\hline Unit & N109,E50 & N109,E50 & N109,E51 & N109,E52 & N109,E53 & N109,E53 & N109,E53 & N109,E54 & N109,E55 \\
\hline Depth (cm) & $40-50$ & 43 & $70-80$ & $40-50$ & $40-50$ & $50-65$ & $50-65$ & $30-40$ & $25-52$ \\
\hline Biface Stage & Late & Late & Middle & & Late & Late & Late & Late & Late \\
\hline Condition & Distal & Proximal & Proximal & & Distal & Distal & Distal & Proximal & Proximal \\
\hline Break Type & Indeterminate & Use & Indeterminate & & Use & Use & Manufacture & Indeterminate & $\begin{array}{l}\text { Thermal/ } \\
\text { Crenated }\end{array}$ \\
\hline Preform & Flake & Indeterminate & Biface & & Flake & Flake & Biface & Flake & Biface \\
\hline Shape & Indeterminate & Indeterminate & Indeterminate & & Indeterminate & Indeterminate & Indeterminate & Indeterminate & Indeterminate \\
\hline $\begin{array}{l}\text { Rejuvenation } \\
\text { Scar }\end{array}$ & Absent & Absent & Absent & & Absent & Absent & Absent & Absent & Absent \\
\hline $\begin{array}{l}\text { Resharpening } \\
\text { Type }\end{array}$ & None & None & None & & None & Indeterminate & None & Indeterminate & Indeterminate \\
\hline Raw Material & Chert & Chert & Chert & & Chert & Chert & Chert & Chert & Chert \\
\hline Texture & Fine & Fine & Fine & & Fine & Fine & Fine & Fine & Fine \\
\hline $\begin{array}{c}\text { Percent } \\
\text { Patination }\end{array}$ & 0 & 25 & 0 & & 25 & 0 & 0 & 0 & 0 \\
\hline $\begin{array}{c}\text { Percent } \\
\text { Cortex }\end{array}$ & 0 & 0 & 0 & & 0 & 0 & 0 & 0 & 0 \\
\hline Cortex Type & None & None & None & & None & None & None & None & None \\
\hline Heating & None & None & None & & None & None & None & None & Burned \\
\hline \multicolumn{10}{|l|}{ Length (mm) } \\
\hline Width (mm) & & 43.7 & 44.3 & & & & & & 44.1 \\
\hline Thick (mm) & 6.4 & 8.8 & 20.5 & & 8.6 & & 9 & 7.2 & \\
\hline Wt. (g) & 6.4 & & 66.6 & & 21.3 & & & & \\
\hline $\begin{array}{l}\text { Long X- } \\
\text { Section }\end{array}$ & Flat & Flat & Indeterminate & & Flat & Indeterminate & Indeterminate & Indeterminate & Indeterminate \\
\hline $\begin{array}{l}\text { Trans X- } \\
\text { Section }\end{array}$ & Plano-Convex & $\begin{array}{c}\text { Biconvex } \\
\text { Symmetrical }\end{array}$ & $\begin{array}{c}\text { Biconvex } \\
\text { Symmetrical }\end{array}$ & & Plano-Convex & Indeterminate & $\begin{array}{c}\text { Biconvex } \\
\text { Symmetrical }\end{array}$ & Plano-Convex & $\begin{array}{c}\text { Biconvex } \\
\text { Symmetrical }\end{array}$ \\
\hline $\begin{array}{l}\text { Flaking } \\
\text { Pattern }\end{array}$ & Chevron & Random & Random & & Chevron & Indeterminate & Subparallel & Indeterminate & Indeterminate \\
\hline $\begin{array}{c}\text { Edge } \\
\text { Rounding }\end{array}$ & Absent & Present & Absent & & Absent & Absent & Absent & Present & Present \\
\hline $\begin{array}{l}\text { Left Lateral } \\
\text { Edge }\end{array}$ & Excurvate & Excurvate & Indeterminate & & Excurvate & Indeterminate & Indeterminate & Indeterminate & Indeterminate \\
\hline $\begin{array}{c}\text { Right Lateral } \\
\text { Edge }\end{array}$ & Excurvate & Indeterminate & Excurvate & & Excurvate & Indeterminate & Excurvate & Indeterminate & Indeterminate \\
\hline Micro-wear & FALSE & FALSE & FALSE & FALSE & FALSE & FALSE & FALSE & FALSE & FALSE \\
\hline NAA & FALSE & FALSE & FALSE & FALSE & FALSE & FALSE & FALSE & FALSE & FALSE \\
\hline
\end{tabular}


The Varga Site

Texas Department of Transportation

Table 0-33. EA Biface Data Continued

\begin{tabular}{|c|c|c|c|c|c|c|c|c|c|}
\hline Cat. No. & $736-013$ & 736-012 & $746-016$ & $746-015$ & 751-017 & $752-011$ & $752-010$ & $755-010$ & 756-005-011 \\
\hline Unit & N109,E55 & N109,E55 & $\mathrm{N} 110, \mathrm{E} 50$ & $\mathrm{~N} 110, \mathrm{E} 50$ & N110,E54 & $\mathrm{N} 110, \mathrm{E} 54$ & N110,E54 & $\mathrm{N} 110, \mathrm{E} 56$ & N110,E56 \\
\hline Depth (cm) & $50-60$ & $50-60$ & $40-50$ & $40-50$ & $30-40$ & $40-50$ & $40-50$ & $30-40$ & $40-50$ \\
\hline Biface Stage & Late & Late & Late & Late & Late & refit to $756-11$ & Late & Middle & Late \\
\hline Condition & Medial & Proximal & Distal & Complete & Distal & & Medial & Complete & Complete \\
\hline Break Type & Use & Use & Use & Unbroken & Use & & Manufacture & Unbroken & Indeterminate \\
\hline Preform & Flake & Biface & Biface & Flake & Flake & & Indeterminate & Biface & Flake \\
\hline Shape & Indeterminate & Indeterminate & Indeterminate & Teardrop & Indeterminate & & Ovate & Lanceolate & Ovate \\
\hline $\begin{array}{l}\text { Rejuvenation } \\
\text { Scar }\end{array}$ & Absent & Absent & Absent & Absent & Absent & & Absent & Absent & Absent \\
\hline $\begin{array}{l}\text { Resharpening } \\
\text { Type }\end{array}$ & Indeterminate & None & None & None & Indeterminate & & $\begin{array}{l}\text { Beveled } \\
\text { Unifacial }\end{array}$ & None & Indeterminate \\
\hline Raw Material & Chert & Chert & Chert & Chert & Chert & & Chert & Chert & Chert \\
\hline Texture & Fine & Fine & Fine & Fine & Fine & & Fine & Fine & Fine \\
\hline $\begin{array}{c}\text { Percent } \\
\text { Patination }\end{array}$ & 0 & 75 & 50 & 75 & 0 & & 0 & 0 & 0 \\
\hline $\begin{array}{l}\text { Percent } \\
\text { Cortex }\end{array}$ & 0 & 0 & 0 & 0 & 0 & & 0 & 0 & 0 \\
\hline Cortex Type & None & None & None & None & None & & None & None & None \\
\hline Heating & None & None & None & None & None & & None & Burned & None \\
\hline Length (mm) & & & & 75.1 & & & & 74.8 & 47.7 \\
\hline Width (mm) & & 37.9 & 42.6 & 24.4 & & & 45.6 & 38.4 & 34.1 \\
\hline Thick (mm) & 5.7 & 10.6 & 16.2 & 8.6 & 5.3 & & 10.7 & 15.7 & 5.5 \\
\hline Wt. (g) & & & 41.3 & 14 & & & & 43.4 & 9.9 \\
\hline $\begin{array}{l}\text { Long X- } \\
\text { Section }\end{array}$ & Flat & Indeterminate & Indeterminate & Flat & Flat & & Indeterminate & Tapered Base & Flat \\
\hline $\begin{array}{l}\text { Trans X- } \\
\text { Section }\end{array}$ & Plano-Convex & $\begin{array}{c}\text { Biconvex } \\
\text { Symmetrical }\end{array}$ & $\begin{array}{c}\text { Biconvex } \\
\text { Symmetrical }\end{array}$ & Plano-Convex & Plano-Convex & & $\begin{array}{c}\text { Biconvex } \\
\text { Symmetrical }\end{array}$ & $\begin{array}{c}\text { Biconvex } \\
\text { Symmetrical }\end{array}$ & $\begin{array}{c}\text { Biconvex } \\
\text { Symmetrical }\end{array}$ \\
\hline $\begin{array}{l}\text { Flaking } \\
\text { Pattern }\end{array}$ & Subparallel & Random & Collateral & Collateral & Chevron & & Random & Indeterminate & $\begin{array}{c}\text { Flake Blank } \\
\text { Remnant }\end{array}$ \\
\hline $\begin{array}{c}\text { Edge } \\
\text { Rounding }\end{array}$ & Absent & Absent & Present & Present & Absent & & Present & Present & Absent \\
\hline $\begin{array}{l}\text { Left Lateral } \\
\text { Edge }\end{array}$ & Indeterminate & Indeterminate & Excurvate & Recurvate & Excurvate & & Excurvate & Straight & Excurvate \\
\hline $\begin{array}{l}\text { Right Lateral } \\
\text { Edge }\end{array}$ & Indeterminate & Indeterminate & Indeterminate & Excurvate & Excurvate & & Excurvate & Excurvate & Excurvate \\
\hline Micro-wear & FALSE & FALSE & FALSE & FALSE & FALSE & FALSE & FALSE & FALSE & FALSE \\
\hline NAA & FALSE & FALSE & FALSE & FALSE & FALSE & FALSE & FALSE & FALSE & FALSE \\
\hline
\end{tabular}


Table 0-33. EA Biface Data Continued

\begin{tabular}{|c|c|c|c|c|c|c|}
\hline Cat. No. & $756-011$ & $763-011^{*}$ & $763-012^{*}$ & $765-011^{*}$ & 1013-010* & $1141-016^{*}$ \\
\hline Unit & N110,E56 & N109,E70 & N109,E70 & N109,E70 & N126,E72 & N131,E70 \\
\hline Depth (cm) & $40-50$ & $60-70$ & $60-70$ & $80-90$ & $70-80$ & $70-80$ \\
\hline Biface Stage & Late & Late & Late & Late & Late & Middle \\
\hline Condition & Distal & Indeterminate & Indeterminate & Proximal & Indeterminate & Complete \\
\hline Break Type & Use & Thermal/Crenated & Thermal/Crenated & Use & Indeterminate & Indeterminate \\
\hline Preform & Flake & Indeterminate & Indeterminate & Biface & Indeterminate & Biface \\
\hline Shape & Indeterminate & Indeterminate & Indeterminate & Indeterminate & Indeterminate & Ovate \\
\hline $\begin{array}{l}\text { Rejuvenation } \\
\text { Scar }\end{array}$ & Absent & Absent & Absent & Absent & Absent & Absent \\
\hline $\begin{array}{l}\text { Resharpening } \\
\text { Type }\end{array}$ & Indeterminate & Indeterminate & Indeterminate & Indeterminate & Indeterminate & None \\
\hline Raw Material & Chert & Chert & Chert & Chert & Chert & Chert \\
\hline Texture & Fine & Fine & Fine & Fine & Fine & Fine \\
\hline $\begin{array}{c}\text { Percent } \\
\text { Patination }\end{array}$ & 0 & 0 & 0 & 0 & 0 & 0 \\
\hline $\begin{array}{l}\text { Percent } \\
\text { Cortex }\end{array}$ & 0 & 0 & 0 & 0 & 0 & 0 \\
\hline Cortex Type & None & None & None & None & None & None \\
\hline Heating & None & Burned & Burned & None & None & None \\
\hline Length (mm) & & & & & & 51.9 \\
\hline Width (mm) & & & & 36.1 & & 28.4 \\
\hline Thick (mm) & & & & 11.6 & & 12.8 \\
\hline Wt. (g) & & & & & & 18.4 \\
\hline $\begin{array}{l}\text { Long X- } \\
\text { Section }\end{array}$ & Flat & Indeterminate & Indeterminate & Indeterminate & Indeterminate & $\begin{array}{l}\text { Tapered } \\
\text { Base/Tip }\end{array}$ \\
\hline $\begin{array}{l}\text { Trans X- } \\
\text { Section }\end{array}$ & Plano-Convex & $\begin{array}{c}\text { Biconvex } \\
\text { Symmetrical }\end{array}$ & $\begin{array}{c}\text { Biconvex } \\
\text { Symmetrical }\end{array}$ & $\begin{array}{c}\text { Biconvex } \\
\text { Symmetrical }\end{array}$ & Indeterminate & $\begin{array}{c}\text { Biconvex } \\
\text { Symmetrical }\end{array}$ \\
\hline $\begin{array}{l}\text { Flaking } \\
\text { Pattern }\end{array}$ & Indeterminate & Indeterminate & Random & Random & Indeterminate & Random \\
\hline $\begin{array}{c}\text { Edge } \\
\text { Rounding }\end{array}$ & Absent & Absent & Absent & Absent & Absent & Absent \\
\hline $\begin{array}{l}\text { Left Lateral } \\
\text { Edge }\end{array}$ & Indeterminate & Indeterminate & Indeterminate & Indeterminate & Indeterminate & Excurvate \\
\hline $\begin{array}{c}\text { Right Lateral } \\
\text { Edge }\end{array}$ & Indeterminate & Indeterminate & Indeterminate & Indeterminate & Indeterminate & Excurvate \\
\hline Micro-wear & FALSE & FALSE & FALSE & FALSE & FALSE & FALSE \\
\hline NAA & FALSE & FALSE & FALSE & FALSE & FALSE & FALSE \\
\hline
\end{tabular}

* Biface from Block $B$ 
The Varga Site

Texas Department of Transportation

Table 0-34. Early Archaic Scraper Data

\begin{tabular}{|c|c|c|c|c|c|c|c|c|c|c|}
\hline Cat. No. & Unit & $\begin{array}{l}\text { Depth } \\
\text { (cm) }\end{array}$ & Tool Subtype & Condition & Break Type & $\begin{array}{c}\text { Rejuvenati } \\
\text { on Scar }\end{array}$ & Shape & $\begin{array}{c}\text { Raw } \\
\text { Material }\end{array}$ & Texture & $\begin{array}{c}\text { Percent } \\
\text { Patination }\end{array}$ \\
\hline $18-021$ & N99,E51 & $80-90$ & End-Scraper & Complete & Unbroken & Absent & Round & Chert & Fine & 0 \\
\hline 29-012 & N99,E52 & $90-100$ & Side-Scraper & Complete & & Absent & Round & Chert & Fine & 0 \\
\hline $50-010$ & N99,E54 & $100-110$ & Side-Scraper & Distal & Use & Absent & Indeterminate & Chert & Fine & 0 \\
\hline $62-011$ & N99,E55 & $100-110$ & Side-Scraper & Proximal & Indeterminate & Absent & Indeterminate & Chert & Fine & 0 \\
\hline $75-020$ & N99,E56 & $100-110$ & Side-Scraper & Indeterminate & Indeterminate & Absent & Indeterminate & Chert & Fine & 0 \\
\hline $95-011$ & N100,E51 & $80-90$ & Side-Scraper & Indeterminate & Indeterminate & Absent & Indeterminate & Chert & Fine & 0 \\
\hline $141-022$ & N100,E55 & $110-120$ & Side-Scraper & Complete & Unbroken & Absent & Round & Chert & Fine & 0 \\
\hline $152-013$ & N100,E56 & $90-100$ & $\begin{array}{l}\text { Side/End } \\
\text { Scraper }\end{array}$ & Distal & Indeterminate & Absent & Indeterminate & Chert & Fine & 0 \\
\hline $154-023$ & $\mathrm{~N} 100, \mathrm{E} 56$ & $110-120$ & Side-Scraper & Proximal & Use & Absent & Indeterminate & Chert & Fine & 0 \\
\hline $240-013$ & N101,E55 & $90-100$ & Side-Scraper & Medial & Indeterminate & Absent & Indeterminate & Chert & Fine & 0 \\
\hline $290-014$ & N102,E51 & $100-110$ & Side-Scraper & Medial & Manufacture & Present & Indeterminate & Chert & Fine & 25 \\
\hline $300-010$ & $\mathrm{~N} 102, \mathrm{E} 52$ & $90-100$ & End-Scraper & Complete & Unbroken & Absent & Teardrop & Chert & Fine & 0 \\
\hline $312-019$ & N102,E53 & $100-110$ & Side-Scraper & Complete & & Absent & Lanceolate & Chert & Fine & 0 \\
\hline $323-020$ & N102,E54 & $130-140$ & $\begin{array}{l}\text { Side/End } \\
\text { Scraper }\end{array}$ & Complete & & Absent & Ovate & Chert & Fine & 0 \\
\hline $333-020$ & N102,E55 & $130-140$ & & Indeterminate & $\begin{array}{l}\text { Thermal/ } \\
\text { Crenated }\end{array}$ & Absent & Indeterminate & Chert & Fine & 0 \\
\hline $346-025$ & $\mathrm{~N} 102, \mathrm{E} 56$ & $110-120$ & End-Scraper & Complete & Unbroken & Absent & Round & Chert & Fine & 0 \\
\hline $392-016$ & N103,E55 & $130-140$ & & Indeterminate & $\begin{array}{l}\text { Thermal/ } \\
\text { Crenated }\end{array}$ & Absent & Indeterminate & Chert & Fine & 0 \\
\hline 401-034 & $\mathrm{N} 103, \mathrm{E} 56$ & $80-90$ & Side-Scraper & Complete & Unbroken & Absent & Irregular & Chert & Fine & 0 \\
\hline 401-036 & N103,E56 & $80-90$ & End-Scraper & Complete & Unbroken & Absent & Ovate & Chert & Fine & 0 \\
\hline $500-013$ & N106,E50 & $40-50$ & Side-Scraper & Proximal & $\begin{array}{l}\text { Thermal/ } \\
\text { Crenated }\end{array}$ & Absent & Indeterminate & Chert & Fine & 50 \\
\hline 539-011 & N106,E55 & $60-70$ & Side-Scraper & Complete & Unbroken & Absent & Round & Chert & Fine & 0 \\
\hline $627-013$ & $\mathrm{~N} 108, \mathrm{E} 48$ & $30-40$ & End-Scraper & Complete & Unbroken & Absent & Triangular & Chert & Fine & 0 \\
\hline $704-010$ & $\mathrm{~N} 109, \mathrm{E} 51$ & $60-70$ & End-Scraper & Complete & Unbroken & Absent & Round & Chert & Fine & 25 \\
\hline 734-011 & N109,E55 & $25-52$ & Side-Scraper & Complete & $\begin{array}{l}\text { Thermal/ } \\
\text { Crenated }\end{array}$ & Absent & Round & Chert & Fine & 0 \\
\hline $741-010$ & N109,E56 & $50-60$ & End-Scraper & Complete & Unbroken & Absent & Irregular & Chert & Fine & 0 \\
\hline $746-017$ & $\mathrm{~N} 110, \mathrm{E} 50$ & $40-50$ & End-Scraper & Complete & Unbroken & Absent & Round & Chert & Fine & 25 \\
\hline $746-011$ & N110,E50 & $40-50$ & End-Scraper & Complete & Unbroken & Absent & Quadrilateral & Chert & Fine & 25 \\
\hline
\end{tabular}


Table O-34. Early Archaic Scraper Data Continued

\begin{tabular}{|c|c|c|c|c|c|c|c|c|c|c|}
\hline Cat. No. & $\begin{array}{l}\text { Percent } \\
\text { Cortex }\end{array}$ & Cortex Type & Heating & $\begin{array}{l}\text { Length } \\
(\mathrm{mm})\end{array}$ & $\begin{array}{l}\text { Width } \\
(\mathrm{mm})\end{array}$ & $\begin{array}{l}\text { Thick } \\
(\mathrm{mm})\end{array}$ & Wt. (g) & Edge Flaking & Edge Rounding & $\begin{array}{c}\text { No. of } \\
\text { Bits }\end{array}$ \\
\hline $18-021$ & 50 & $\begin{array}{l}\text { Pebble/ } \\
\text { Cobble }\end{array}$ & None & 43 & 58.3 & 14.6 & 42 & Distal/Lateral & Present & 1 \\
\hline 29-012 & 0 & None & None & 47.4 & 54.7 & 9.4 & 24 & Distal/Lateral & Absent & 1 \\
\hline $50-010$ & 0 & None & None & & & 9 & & Distal/Lateral & Present & 2 \\
\hline $62-011$ & 0 & None & None & & 45.8 & 18.9 & & Proximal/ Lateral & Present & 2 \\
\hline $75-020$ & 0 & None & None & & 41.1 & 11.4 & & Lateral Only & Present & 1 \\
\hline $95-011$ & 0 & None & None & & 35 & 12.1 & & Lateral Only & Absent & 2 \\
\hline $141-022$ & 25 & $\begin{array}{l}\text { Pebble/ } \\
\text { Cobble }\end{array}$ & None & 51.7 & 68.2 & 24.5 & 72 & Distal/Lateral & Present & 2 \\
\hline $152-013$ & 25 & $\begin{array}{l}\text { Pebble/ } \\
\text { Cobble }\end{array}$ & None & & & 12.4 & & Distal/Lateral & Present & 3 \\
\hline $154-023$ & 0 & None & None & & & 7.1 & & Proximal/ Lateral & Present & 2 \\
\hline $240-013$ & 0 & None & None & & & 5.4 & & Lateral Only & Present & 1 \\
\hline 290-014 & 0 & None & None & & & 7.8 & & Lateral Only & Present & 1 \\
\hline $300-010$ & 0 & None & Heat-Treated & 72.1 & 46.4 & 6.1 & 22 & Distal/Lateral & Present & 3 \\
\hline 312-019 & 0 & None & None & 58.7 & 32 & 11.6 & 27 & Lateral Only & Absent & 2 \\
\hline $323-020$ & 0 & None & None & 73.1 & 60.8 & 16.7 & 83 & Distal/Lateral & Absent & 3 \\
\hline $333-020$ & 0 & None & Burned & & & & & Indeterminate & Absent & 1 \\
\hline $346-025$ & 0 & None & None & 62.2 & 75.9 & 25.3 & 121 & Indeterminate & Absent & 1 \\
\hline $392-016$ & 0 & None & Burned & & & 8.2 & & Indeterminate & Absent & 1 \\
\hline 401-034 & 25 & $\begin{array}{l}\text { Pebble/ } \\
\text { Cobble }\end{array}$ & Burned & 51.2 & 35.7 & 13.1 & 20 & Distal/Lateral & Present & 1 \\
\hline 401-036 & 0 & None & Indeterminate & 87.9 & 41.5 & 26.5 & 96 & Indeterminate & Absent & 2 \\
\hline $500-013$ & 0 & None & Burned & 69 & 41 & 13.2 & 46 & Lateral Only & Present & 1 \\
\hline 539-011 & 25 & $\begin{array}{l}\text { Pebble/ } \\
\text { Cobble }\end{array}$ & None & 52.2 & 69.1 & 27.6 & 69 & Distal/Lateral & Present & 2 \\
\hline $627-013$ & 25 & $\begin{array}{l}\text { Pebble/ } \\
\text { Cobble }\end{array}$ & None & 71 & 44.7 & 12 & 43 & Distal/Lateral & Present & 2 \\
\hline 704-010 & 25 & $\begin{array}{l}\text { Pebble/ } \\
\text { Cobble }\end{array}$ & None & 61 & 65.1 & 23.5 & 97 & Distal & Present & 1 \\
\hline 734-011 & 0 & None & Burned & 54.3 & 49.5 & 20.2 & 53 & Lateral Only & Absent & 1 \\
\hline $741-010$ & 0 & None & None & 55 & 37 & 11.6 & 19 & Distal & Absent & 1 \\
\hline $746-017$ & 50 & $\begin{array}{l}\text { Pebble/ } \\
\text { Cobble }\end{array}$ & None & 73.4 & 79.1 & 24.2 & 146 & Distal & Absent & 1 \\
\hline 746-011 & 0 & None & None & 35.7 & 68.5 & 7.9 & 17 & Distal/Lateral & Present & 2 \\
\hline
\end{tabular}


The Varga Site

Texas Department of Transportation

Table 0-34. Early Archaic Scraper Data Continued

\begin{tabular}{|c|c|c|c|c|c|c|c|c|c|c|}
\hline Cat. No. & Bit 1 Location & Bit 1 Shape & Bit 1 Retouch & $\begin{array}{c}\text { Bit } 1 \\
\text { Length } \\
(\mathrm{mm})\end{array}$ & $\begin{array}{l}\text { Bit } 1 \\
\text { Thick } \\
(\mathrm{mm}) \\
\end{array}$ & $\begin{array}{c}\text { Bit } 1 \\
\text { Angle } \\
\end{array}$ & $\begin{array}{c}\text { Bit } 2 \\
\text { Location }\end{array}$ & $\begin{array}{c}\text { Bit } 2 \\
\text { Shape } \\
\end{array}$ & Bit 2 Retouch & $\begin{array}{l}\text { Bit } 2 \text { Length } \\
(\mathrm{mm})\end{array}$ \\
\hline $18-021$ & Lateral/Distal & Excurvate & Regular Continuous & 88.1 & 6 & 65 & & & & \\
\hline $29-012$ & Lateral/Distal & Excurvate & Regular Continuous & 62.4 & 7.7 & 66 & & & & \\
\hline $50-010$ & Lateral/Distal & Incurvate & Regular Continuous & 24.9 & 5.7 & 68 & Distal & Excurvate & $\begin{array}{l}\text { Regular } \\
\text { Continuous }\end{array}$ & 25.3 \\
\hline $62-011$ & Lateral/ Proximal & Excurvate & Regular Continuous & 51.6 & 12.3 & 45 & Lateral & Incurvate & $\begin{array}{l}\text { Regular } \\
\text { Continuous }\end{array}$ & 33.7 \\
\hline $75-020$ & Lateral & Recurvate & Regular Continuous & 7.5 & 65 & & & & & \\
\hline $95-011$ & Lateral & Straight & Regular Continuous & 31.5 & 6.4 & 72 & Lateral & Straight & $\begin{array}{l}\text { Irregular } \\
\text { Continuous }\end{array}$ & 20.3 \\
\hline $141-022$ & Lateral & Excurvate & Regular Continuous & 30.6 & 6.3 & 72 & $\begin{array}{l}\text { Lateral/ } \\
\text { Distal }\end{array}$ & Excurvate & $\begin{array}{l}\text { Regular } \\
\text { Continuous }\end{array}$ & 24.4 \\
\hline $152-013$ & Distal & Straight & Regular Continuous & 17.5 & 5.4 & 79 & Lateral & Excurvate & $\begin{array}{l}\text { Regular } \\
\text { Continuous }\end{array}$ & 26.9 \\
\hline $154-023$ & Lateral/ Proximal & Straight & Regular Continuous & 35.9 & 4.4 & 57 & Lateral & Straight & $\begin{array}{l}\text { Irregular } \\
\text { Continuous }\end{array}$ & 25.1 \\
\hline $240-013$ & Lateral & Straight & Regular Continuous & 34.4 & 4.7 & 64 & & & & \\
\hline 290-014 & Lateral & Excurvate & Regular Continuous & 43.7 & 6.9 & 90 & & & & \\
\hline $300-010$ & Distal & Excurvate & Regular Continuous & 19.7 & 4.5 & 60 & Lateral & Excurvate & $\begin{array}{c}\text { Irregular } \\
\text { Discontinuous }\end{array}$ & 53.9 \\
\hline $312-019$ & Lateral/ Proximal & Straight & Regular Continuous & 25.6 & 7.4 & 52 & $\begin{array}{l}\text { Lateral/ } \\
\text { Distal }\end{array}$ & Straight & $\begin{array}{l}\text { Regular } \\
\text { Continuous }\end{array}$ & 25.5 \\
\hline $323-020$ & Lateral & Straight & Regular Continuous & 18.9 & 1.9 & 71 & Distal & Straight & $\begin{array}{c}\text { Regular } \\
\text { Continuous }\end{array}$ & 42.1 \\
\hline $333-020$ & Indeterminate & Excurvate & Irregular Continuous & 22.3 & 2.8 & 69 & & & & \\
\hline $346-025$ & Indeterminate & Excurvate & Irregular Discontinuous & 106 & 4.1 & 53 & & & & \\
\hline $392-016$ & Indeterminate & Excurvate & Regular Continuous & 22.2 & 4.3 & 73 & & & & \\
\hline 401-034 & Lateral/Distal & Excurvate & Regular Continuous & 46.3 & 5 & 49 & & & & \\
\hline 401-036 & Indeterminate & Excurvate & Irregular Continuous & 45.4 & 4.6 & 56 & $\begin{array}{l}\text { Indeterm } \\
\text { inate }\end{array}$ & Straight & $\begin{array}{l}\text { Regular } \\
\text { Continuous }\end{array}$ & 13.4 \\
\hline 500-013 & Lateral & Excurvate & Irregular Continuous & 54.7 & 8 & 71 & & & & \\
\hline 539-011 & Lateral/Distal & Excurvate & Regular Continuous & 50.7 & 8.6 & 77 & Lateral & Straight & $\begin{array}{c}\text { Regular } \\
\text { Discontinuous }\end{array}$ & 30.7 \\
\hline $627-013$ & Distal & Excurvate & Regular Continuous & 61.3 & 7.4 & 59 & Lateral & Straight & $\begin{array}{c}\text { Regular } \\
\text { Continuous }\end{array}$ & 16.3 \\
\hline 704-010 & Distal & Excurvate & Regular Continuous & 57.3 & 12.7 & 74 & & & & \\
\hline 734-011 & Lateral & Excurvate & Regular Continuous & 55 & 6.7 & 68 & & & & \\
\hline 741-010 & Distal & Excurvate & Regular Continuous & 27.7 & 5.4 & 40 & & & & \\
\hline $746-017$ & Distal & Excurvate & Irregular Continuous & 128.6 & 11.5 & 81 & & & & \\
\hline $746-011$ & Distal & Excurvate & Regular Continuous & 75.6 & 3.2 & 42 & Lateral & Straight & $\begin{array}{l}\text { Regular } \\
\text { Continuous }\end{array}$ & 21.1 \\
\hline
\end{tabular}


Table 0-34. Early Archaic Scraper Data Continued

\begin{tabular}{|c|c|c|c|c|c|c|c|c|c|c|c|}
\hline Cat. No. & $\begin{array}{l}\text { Bit } 2 \\
\text { Thick } \\
(\mathrm{mm}) \\
\end{array}$ & $\begin{array}{c}\text { Bit } 2 \\
\text { Angle } \\
\end{array}$ & $\begin{array}{c}\text { Bit } 3 \\
\text { Location }\end{array}$ & $\begin{array}{c}\text { Bit } 3 \\
\text { Shape }\end{array}$ & Bit 3 Retouch & $\begin{array}{l}\text { Bit } 3 \\
\text { Length } \\
(\mathrm{mm})\end{array}$ & $\begin{array}{l}\text { Bit } 3 \\
\text { Thick } \\
(\mathrm{mm})\end{array}$ & $\begin{array}{r}\text { Bit } 3 \\
\text { Angle } \\
\end{array}$ & Flake Size & Micro-wear & NAA \\
\hline $18-021$ & & & & & & & & & 7 & FALSE & FALSE \\
\hline 29-012 & & & & & & & & & 6 & TRUE & TRUE \\
\hline $50-010$ & 2.7 & 47 & & & & & & & & FALSE & FALSE \\
\hline $62-011$ & 4 & 65 & & & & & & & & FALSE & FALSE \\
\hline $75-020$ & & & & & & & & & & FALSE & FALSE \\
\hline $95-011$ & 7.5 & 70 & & & & & & & & FALSE & FALSE \\
\hline $141-022$ & 1.4 & 62 & & & & & & & 7 & FALSE & FALSE \\
\hline $152-013$ & 3 & 61 & Lateral & Incurvate & Regular Continuous & 8.4 & 3.1 & 78 & & FALSE & FALSE \\
\hline $154-023$ & 4.4 & 66 & & & & & & & & FALSE & FALSE \\
\hline $240-013$ & & & & & & & & & & FALSE & FALSE \\
\hline $290-014$ & & & & & & & & & & FALSE & FALSE \\
\hline $300-010$ & 0.8 & 50 & Lateral & Excurvate & $\begin{array}{c}\text { Irregular } \\
\text { Discontinuous }\end{array}$ & 41.2 & 1 & 49 & 8 & FALSE & FALSE \\
\hline $312-019$ & 4.3 & 60 & & & & & & & 7 & TRUE & FALSE \\
\hline $323-020$ & 2 & 46 & Distal & Straight & Regular Continuous & 35.7 & 3.6 & 70 & 8 & TRUE & FALSE \\
\hline $333-020$ & & & & & & & & & & FALSE & FALSE \\
\hline $346-025$ & & & & & & & & & 8 & TRUE & TRUE \\
\hline $392-016$ & & & & & & & & & & FALSE & FALSE \\
\hline 401-034 & & & & & & & & & 6 & FALSE & FALSE \\
\hline 401-036 & 3.5 & 58 & & & & & & & 10 & TRUE & TRUE \\
\hline $500-013$ & & & & & & & & & 7 & FALSE & FALSE \\
\hline 539-011 & 1.2 & 52 & & & & & & & 7 & FALSE & FALSE \\
\hline $627-013$ & 2 & 59 & & & & & & & 8 & TRUE & FALSE \\
\hline $704-010$ & & & & & & & & & 7 & FALSE & FALSE \\
\hline 734-011 & & & & & & & & & 6 & FALSE & FALSE \\
\hline $741-010$ & & & & & & & & & 6 & FALSE & FALSE \\
\hline 746-017 & & & & & & & & & 9 & FALSE & FALSE \\
\hline 746-011 & 2 & 51 & & & & & & & 8 & FALSE & FALSE \\
\hline
\end{tabular}


The Varga Site

Texas Department of Transportation

Table 0-35. Early Archaic Drill Data

\begin{tabular}{|c|c|c|c|c|c|c|c|c|c|c|c|c|}
\hline Cat. No. & Unit & $\begin{array}{l}\text { Depth } \\
(\mathrm{cmbd})\end{array}$ & \multicolumn{2}{|c|}{ Condition } & \multicolumn{2}{|c|}{ Break Type } & $\begin{array}{l}\text { Rejuvenation } \\
\text { Scar }\end{array}$ & Preform & $\begin{array}{c}\text { Raw } \\
\text { Material }\end{array}$ & Texture & $\begin{array}{c}\text { Percent } \\
\text { Patination }\end{array}$ & $\begin{array}{l}\text { Percent } \\
\text { Cortex }\end{array}$ \\
\hline $40-012$ & N99,E53 & $100-110$ & \multicolumn{2}{|c|}{ Distal } & \multicolumn{2}{|c|}{ Use } & Absent & Biface & Chert & Fine & 0 & 0 \\
\hline $63-016$ & N99,E55 & $110-120$ & \multicolumn{2}{|c|}{ Proximal } & \multicolumn{2}{|c|}{ Use } & Absent & Biface & Chert & Fine & 25 & 0 \\
\hline $95-016$ & N100,E51 & $80-90$ & \multicolumn{2}{|c|}{ Medial } & \multicolumn{2}{|c|}{ Thermal/Crenated } & Absent & Flake & Chert & Fine & 0 & 0 \\
\hline $183-021$ & N101,E50 & $70-80$ & \multicolumn{2}{|c|}{ Proximal } & \multicolumn{2}{|c|}{ Use } & Absent & Biface & Chert & Fine & 0 & 0 \\
\hline $242-014$ & N101,E55 & $110-120$ & \multicolumn{2}{|c|}{ Proximal } & \multicolumn{2}{|c|}{ Use } & Absent & Biface & Chert & Fine & 0 & 0 \\
\hline $277-014$ & $\mathrm{~N} 102, \mathrm{E} 50$ & $70-80$ & \multicolumn{2}{|c|}{ Medial } & \multicolumn{2}{|c|}{ Use } & Absent & Flake & Chert & Fine & 75 & 0 \\
\hline $278-026$ & N102,E50 & 87 & \multicolumn{2}{|c|}{ Complete } & \multicolumn{2}{|c|}{ Unbroken } & Absent & Flake & Chert & Fine & 0 & 0 \\
\hline $278-013$ & $\mathrm{~N} 102, \mathrm{E} 50$ & $80-90$ & \multicolumn{2}{|c|}{ Distal } & \multicolumn{2}{|c|}{ Indeterminate } & Absent & Flake & Chert & Fine & 0 & 0 \\
\hline $289-020$ & N102,E51 & $90-100$ & \multicolumn{2}{|c|}{ Distal } & \multicolumn{2}{|c|}{ Thermal/Crenated } & Absent & Biface & Chert & Fine & 0 & 0 \\
\hline $343-013$ & $\mathrm{~N} 102, \mathrm{E} 56$ & $80-90$ & \multicolumn{2}{|c|}{ Distal } & \multicolumn{2}{|c|}{ Use } & Absent & Biface & Chert & Fine & 0 & 0 \\
\hline $455-016$ & N105,E52 & $50-60$ & \multicolumn{2}{|c|}{ Complete } & \multicolumn{2}{|c|}{ Unbroken } & Absent & Flake & Chert & Fine & 0 & 25 \\
\hline $578-018$ & N107,E51 & $60-70$ & \multicolumn{2}{|c|}{ Medial } & & & Absent & Biface & Chert & Fine & 25 & 0 \\
\hline $670-005-015$ & N108,E55 & 48 & Com & & Unt & & Absent & Biface & Chert & Fine & 0 & 0 \\
\hline $688-013$ & N109,E48 & $30-40$ & $\mathrm{Me}$ & & & & Absent & Biface & Chert & Fine & 0 & 0 \\
\hline $689-019$ & N109,E48 & $40-50$ & refit to & 38-13 & & & & & & & & \\
\hline $693-011$ & N109,E49 & $30-40$ & $\mathrm{Me}$ & & & & Absent & Indeterminate & Chert & Fine & 75 & 0 \\
\hline $735-012$ & N109,E55 & $40-50$ & & & & & Absent & Biface & Chert & Fine & 0 & 0 \\
\hline Cat. No. & Cortex Type & Heating & $\begin{array}{l}\text { Length } \\
(\mathrm{mm})\end{array}$ & $\begin{array}{l}\text { Thick } \\
(\mathrm{mm})\end{array}$ & $\begin{array}{l}\text { Wt. } \\
(\mathrm{g})\end{array}$ & Trar & s X-Section & $\begin{array}{c}\text { Edge } \\
\text { Rounding }\end{array}$ & Stem Shape & $\begin{array}{l}\text { Stem } \\
\text { Length } \\
(\mathrm{mm})\end{array}$ & Micro-wear & NAA \\
\hline $40-012$ & None & Burned & & & & & iconvex & Present & Indeterminate & & FALSE & TRUE \\
\hline $63-016$ & None & None & & 6.9 & 8.5 & Biconve & x Asymmetrical & Present & Expanding & 30.7 & FALSE & TRUE \\
\hline $95-016$ & None & Burned & & 4.3 & & & 10-Convex & Absent & Expanding & & FALSE & FALSE \\
\hline $183-021$ & None & None & & 7.6 & 6 & & 10-Convex & Present & Expanding & 20.4 & FALSE & TRUE \\
\hline $242-014$ & None & None & 57.2 & 21.4 & 35 & Biconve & x Asymmetrical & Absent & Expanding & 39.7 & FALSE & FALSE \\
\hline $277-014$ & None & None & & 7.7 & & Biconve & x Asymmetrical & Present & Expanding & & FALSE & FALSE \\
\hline $278-026$ & None & None & 69 & 9.1 & 25 & Pla & 10-Convex & Present & Expanding & 48.4 & TRUE & FALSE \\
\hline $278-013$ & None & None & & 5.1 & & & 10-Convex & Present & Expanding & & FALSE & FALSE \\
\hline $289-020$ & None & Burned & & 7.4 & & Biconv & x Symmetrical & Present & Indeterminate & & FALSE & FALSE \\
\hline $343-013$ & None & None & & & & Biconve & x Asymmetrical & Present & Indeterminate & & TRUE & FALSE \\
\hline $455-016$ & $\begin{array}{l}\text { Pebble/ } \\
\text { Cobble }\end{array}$ & None & 48.1 & 8.5 & 8.3 & Biconv & x Symmetrical & Present & Straight & 31.8 & TRUE & FALSE \\
\hline $578-018$ & None & Burned & & 6.7 & & Biconv & x Symmetrical & Present & Indeterminate & & FALSE & FALSE \\
\hline $670-005-015$ & None & None & 72.9 & 8.1 & 8 & Biconv & x Symmetrical & Present & Expanding & 42.4 & TRUE & FALSE \\
\hline $688-013$ & None & None & & 8.5 & & Biconv & x Symmetrical & Absent & Expanding & & FALSE & FALSE \\
\hline $689-019$ & & & & & & & & & & & FALSE & FALSE \\
\hline 693-011 & None & None & & 6.5 & 5 & Biconv & x Symmetrical & Present & Expanding & & FALSE & FALSE \\
\hline $735-012$ & None & None & & 5.3 & & Biconv & x Symmetrical & Present & Indeterminate & & FALSE & TRUE \\
\hline
\end{tabular}


Table 0-36. EA Uniface Data

\begin{tabular}{|c|c|c|c|c|c|c|c|c|c|c|}
\hline Cat. No. & Unit & $\begin{array}{l}\text { Depth } \\
\text { (cmbd) }\end{array}$ & Condition & Break Type & Shape & Edge Flaking & $\begin{array}{c}\text { Edge } \\
\text { Rounding }\end{array}$ & $\begin{array}{c}\text { Rejuvenation } \\
\text { Scar }\end{array}$ & $\begin{array}{c}\text { Raw } \\
\text { Material }\end{array}$ & Texture \\
\hline $84-010$ & N100,E50 & $60-70$ & Proximal & Use & Ovate & Lateral Only & Present & Absent & Chert & Fine \\
\hline $139-016$ & N100,E55 & $90-100$ & Indeterminate & Use & Indeterminate & Indeterminate & Absent & Absent & Chert & Fine \\
\hline $153-030$ & $\mathrm{~N} 100, \mathrm{E} 56$ & $100-110$ & Proximal & Manufacture & Indeterminate & Lateral Only & Present & Absent & Chert & Fine \\
\hline $546-014$ & N106,E56 & $40-50$ & Complete & Unbroken & Teardrop & Proximal/Distal & Absent & Absent & Chert & Fine \\
\hline
\end{tabular}

\begin{tabular}{|c|c|c|c|c|c|c|c|c|c|c|}
\hline Cat. No. & $\begin{array}{c}\text { Percent } \\
\text { Patination }\end{array}$ & $\begin{array}{c}\text { Percent } \\
\text { Cortex }\end{array}$ & Cortex Type & Heating & $\begin{array}{c}\text { Length } \\
(\mathrm{mm})\end{array}$ & $\begin{array}{c}\text { Width } \\
(\mathrm{mm})\end{array}$ & $\begin{array}{c}\text { Thick } \\
(\mathrm{mm})\end{array}$ & Wt. (g) & No. of Bits & Bit 1 Location \\
\hline $84-010$ & 0 & 0 & None & None & & 30.2 & 11.7 & 12.8 & 1 & Lateral \\
\hline $139-016$ & 0 & 25 & Pebble/Cobble & None & & & & & 1 & Indeterminate \\
\hline $153-030$ & 0 & 0 & None & Burned & & 32.6 & 9.4 & & Lateral \\
\hline $546-014$ & 0 & 0 & None & None & 88.4 & 51.1 & 16.6 & 67.4 & 3 & Proximal \\
\hline
\end{tabular}

\begin{tabular}{|c|c|c|c|c|c|c|c|c|c|c|}
\hline Cat. No. & Bit 1 Shape & Bit 1 Retouch & $\begin{array}{l}\text { Bit } 1 \text { Length } \\
(\mathrm{mm})\end{array}$ & $\begin{array}{l}\text { Bit } 1 \text { Thick } \\
(\mathrm{mm})\end{array}$ & Bit Angle 1 & $\begin{array}{c}\text { Bit } 2 \\
\text { Location }\end{array}$ & $\begin{array}{c}\text { Bit } 2 \\
\text { Retouch }\end{array}$ & $\begin{array}{l}\text { Bit } 2 \text { Length } \\
(\mathrm{mm})\end{array}$ & $\begin{array}{l}\text { Bit } 2 \text { Thick } \\
(\mathrm{mm})\end{array}$ & Bit 2 Angle \\
\hline $84-010$ & Straight & $\begin{array}{l}\text { Regular } \\
\text { Continuous }\end{array}$ & 31.6 & 2.1 & 52 & & & & & \\
\hline $139-016$ & Excurvate & $\begin{array}{c}\text { Regular } \\
\text { Continuous }\end{array}$ & 20.5 & 6.4 & 78 & & & & & \\
\hline $153-030$ & Straight & $\begin{array}{c}\text { Regular } \\
\text { Continuous }\end{array}$ & 20.6 & 5.8 & 66 & & & & & \\
\hline 546-014 & Excurvate & $\begin{array}{l}\text { Regular } \\
\text { Continuous }\end{array}$ & 32.3 & 5.3 & 51 & Proximal & $\begin{array}{l}\text { Regular } \\
\text { Continuous }\end{array}$ & 28.3 & 2.6 & 48 \\
\hline
\end{tabular}

\begin{tabular}{|c|c|c|c|c|c|c|c|c|}
\hline Cat. No. & $\begin{array}{c}\text { Bit 3 } \\
\text { Location }\end{array}$ & Bit 3 Shape & Bit 3 Retouch & $\begin{array}{c}\text { Bit 3 Length } \\
(\mathrm{mm})\end{array}$ & Bit 3 Angle & Flake Size & Micro-wear & NAA \\
\hline $84-010$ & & & & & 5 & FALSE & FALSE \\
\hline $139-016$ & & & & & & FALSE & FALSE \\
\hline $153-030$ & Distal & Excurvate & $\begin{array}{c}\text { Regular } \\
\text { Continuous }\end{array}$ & 53.9 & 50 & 10 & TRUE & FALSE \\
\hline $546-014$ & & & & & & & FALSE & FALSE \\
\hline
\end{tabular}


The Varga Site

Texas Department of Transportation

Table 0-37. Gouge Data

\begin{tabular}{|c|c|c|c|c|c|c|c|c|c|c|c|}
\hline Cat. No. & Unit & $\begin{array}{l}\text { Depth } \\
(\mathrm{cmbd})\end{array}$ & Condition & $\begin{array}{c}\text { Rejuvenation } \\
\text { Scar }\end{array}$ & Shape & $\begin{array}{c}\text { Raw } \\
\text { Material }\end{array}$ & Texture & $\begin{array}{c}\text { Percent } \\
\text { Patination }\end{array}$ & $\begin{array}{l}\text { Percent } \\
\text { Cortex }\end{array}$ & Heating & $\begin{array}{l}\text { Length } \\
(\mathrm{mm})\end{array}$ \\
\hline $64-014$ & N99,E55 & $120-130$ & Complete & Absent & Quadralateral & Chert & Fine & 0 & 50 & None & 62.3 \\
\hline $346-011$ & N102,E56 & $110-120$ & Complete & Absent & Triangular & Chert & Fine & 0 & 0 & None & 47.4 \\
\hline $724-013$ & N109,E53 & $40-50$ & Complete & Absent & Indeterminate & Chert & Fine & 0 & 0 & None & 58.7 \\
\hline
\end{tabular}

\begin{tabular}{|c|c|c|c|c|c|c|c|c|c|c|c|}
\hline Cat. No. & $\begin{array}{l}\text { Width } \\
(\mathrm{mm})\end{array}$ & $\begin{array}{l}\text { Thick } \\
(\mathrm{mm})\end{array}$ & Wt. (g) & Edge Flaking & $\begin{array}{c}\text { Edge } \\
\text { Rounding }\end{array}$ & $\begin{array}{c}\text { No. of } \\
\text { Bits }\end{array}$ & $\begin{array}{c}\text { Bit } 1 \\
\text { Location }\end{array}$ & Bit 1 Shape & $\begin{array}{c}\text { Bit } 1 \\
\text { Retouch }\end{array}$ & $\begin{array}{l}\text { Bit } 1 \\
\text { Length } \\
(\mathrm{mm})\end{array}$ & $\begin{array}{c}\text { Bit } 1 \text { Thick } \\
(\mathrm{mm})\end{array}$ \\
\hline 64-014 & 49.9 & 14 & 51.7 & Distal/Lateral & Absent & 3 & Lateral & Incurvate & $\begin{array}{c}\text { Regular } \\
\text { Continuous }\end{array}$ & 29 & 2.8 \\
\hline $346-011$ & 44.8 & 13.3 & 34.6 & Distal/Lateral & Present & 2 & Distal & Incurvate & $\begin{array}{c}\text { Regular } \\
\text { Continuous }\end{array}$ & 48.3 & 7.3 \\
\hline $724-013$ & 39.2 & 19.2 & 39.6 & Distal/Lateral & Absent & 5 & Distal & Excurvate & $\begin{array}{c}\text { Regular } \\
\text { Continuous }\end{array}$ & 7.7 & 4.1 \\
\hline
\end{tabular}

\begin{tabular}{|c|c|c|c|c|c|c|c|c|c|c|c|}
\hline Cat. No. & $\begin{array}{c}\text { Bit } 1 \\
\text { Angle } \\
\end{array}$ & $\begin{array}{c}\text { Bit } 2 \\
\text { Location }\end{array}$ & Bit 2 Shape & Bit 2 Retouch & $\begin{array}{c}\text { Bit } 2 \\
\text { Length } \\
(\mathrm{mm})\end{array}$ & $\begin{array}{l}\text { Bit } 2 \\
\text { Thick } \\
(\mathrm{mm}) \\
\end{array}$ & $\begin{array}{c}\text { Bit } 2 \\
\text { Angle } \\
\end{array}$ & $\begin{array}{c}\text { Bit } 3 \\
\text { Location }\end{array}$ & Bit 3 Shape & Bit 3 Retouch & $\begin{array}{l}\text { Bit } 3 \\
\text { Length } \\
(\mathrm{mm}) \\
\end{array}$ \\
\hline $64-014$ & 64 & Lateral & Excurvate & $\begin{array}{c}\text { Regular } \\
\text { Continuous }\end{array}$ & 42.4 & 7.7 & 53 & Distal & Recurvate & $\begin{array}{c}\text { Regular } \\
\text { Continuous }\end{array}$ & 25.8 \\
\hline $346-011$ & 63 & $\begin{array}{l}\text { Lateral/ } \\
\text { Distal }\end{array}$ & Excurvate & $\begin{array}{c}\text { Regular } \\
\text { Continuous }\end{array}$ & 39.9 & 3.4 & 54 & & & & \\
\hline $724-013$ & 50 & Distal & Straight & $\begin{array}{c}\text { Regular } \\
\text { Continuous }\end{array}$ & 31.2 & 2.6 & 67 & Distal & Excurvate & $\begin{array}{c}\text { Regular } \\
\text { Continuous }\end{array}$ & 7.5 \\
\hline
\end{tabular}

\begin{tabular}{|c|c|c|c|c|c|}
\hline Cat. No. & $\begin{array}{c}\text { Bit 3 Thick } \\
(\mathrm{mm})\end{array}$ & Bit 3 Angle & Flake Size & Micro-wear & NAA \\
\hline $64-014$ & 10.1 & 70 & 7 & FALSE & FALSE \\
\hline $346-011$ & & & 7 & TRUE & FALSE \\
\hline $724-013$ & 3.1 & 66 & 6 & TRUE & TRUE \\
\hline
\end{tabular}


Table 0-38. Early Archaic Core Data

\begin{tabular}{|c|c|c|c|c|c|c|c|c|c|}
\hline Cat. No. & $29-019$ & $139-019$ & $203-005-016$ & $323-021$ & $421-033$ & $455-014$ & $455-015$ & $530-021$ & 531-019 \\
\hline Unit & N99,E52 & N100,E55 & N101,E52 & N102,E54 & N104,E56 & N105,E52 & N105,E52 & N106,E54 & N106,E54 \\
\hline Depth (cmbd) & 98 & $90-100$ & 91 & $130-140$ & $80-90$ & $50-60$ & $50-60$ & $80-90$ & $90-100$ \\
\hline Condition & Complete & Complete & Complete & Complete & Fragmented & Complete & Complete & Fragmented & Complete \\
\hline Tool Type & Unifacial & Unifacial & $\begin{array}{c}\text { Multi- } \\
\text { Directional }\end{array}$ & Bifacial & Bifacial & $\begin{array}{c}\text { Multi- } \\
\text { Directional }\end{array}$ & $\begin{array}{c}\text { Multi- } \\
\text { Directional }\end{array}$ & $\begin{array}{c}\text { Multi- } \\
\text { Directional }\end{array}$ & Bifacial \\
\hline $\begin{array}{l}\text { Rejuvenation } \\
\text { Scar }\end{array}$ & Absent & Absent & Absent & Absent & Absent & Absent & Absent & Absent & Absent \\
\hline Raw Material & Chert & Chert & Chert & Chert & Chert & Chert & Chert & Chert & Chert \\
\hline Texture & Fine & Fine & Fine & Fine & Fine & Fine & Fine & Fine & Fine \\
\hline $\begin{array}{c}\text { Percent } \\
\text { Patination }\end{array}$ & 0 & 0 & 0 & 0 & 25 & 0 & 0 & 0 & 0 \\
\hline Percent Cortex & 75 & 50 & 0 & 50 & 0 & 25 & 0 & 0 & 75 \\
\hline Cortex Type & $\begin{array}{l}\text { Pebble/ } \\
\text { Cobble }\end{array}$ & $\begin{array}{l}\text { Pebble/ } \\
\text { Cobble }\end{array}$ & None & $\begin{array}{l}\text { Pebble/ } \\
\text { Cobble }\end{array}$ & None & None & None & None & $\begin{array}{l}\text { Pebble/ } \\
\text { Cobble }\end{array}$ \\
\hline Heating & None & None & None & None & None & None & None & None & None \\
\hline Length (mm) & 84.6 & 124 & 72.7 & 135 & 84.7 & 81.8 & 67.1 & 40 & 95.7 \\
\hline Width (mm) & 76 & 57.1 & 72 & 131 & 43.8 & 70.6 & 52.2 & 37.5 & 87.2 \\
\hline Thick (mm) & 53.2 & 41.7 & 37.2 & 38 & 24.5 & 36 & 36 & 30.7 & 52.1 \\
\hline Wt. (g) & 351 & 274 & 177 & 740 & 99.4 & 190 & 135 & 56.1 & 471 \\
\hline
\end{tabular}


The Varga Site

Texas Department of Transportation

Table 0-38. Early Archaic Core Data Continued

\begin{tabular}{|c|c|c|c|c|c|c|c|c|c|}
\hline Cat. No. & $538-010$ & $539-018$ & $584-017$ & $598-015$ & $638-013$ & $64-012$ & $650-019$ & $658-020$ & $665-015$ \\
\hline Unit & N106,E55 & N106,E55 & N107,E52 & N107,E54 & N108,E50 & N99,E55 & N108,E52 & N108,E53 & N108,E54 \\
\hline Depth (cmbd) & $50-60$ & $60-70$ & $50-60$ & $80-90$ & $40-50$ & $120-130$ & $40-50$ & $50-60$ & $50-60$ \\
\hline Condition & Complete & Complete & Complete & Exhausted & Complete & Exhausted & Complete & Complete & Complete \\
\hline Tool Type & $\begin{array}{c}\text { Multi- } \\
\text { Directional }\end{array}$ & Bifacial & $\begin{array}{c}\text { Multi- } \\
\text { Directional }\end{array}$ & Bifacial & $\begin{array}{c}\text { Multi- } \\
\text { Directional }\end{array}$ & Bifacial & Bifacial & Bifacial & $\begin{array}{c}\text { Multi- } \\
\text { Directional }\end{array}$ \\
\hline $\begin{array}{l}\text { Rejuvenation } \\
\text { Scar }\end{array}$ & Absent & Absent & Absent & Absent & Absent & Absent & Absent & Absent & Absent \\
\hline Raw Material & Chert & Chert & Chert & Chert & Chert & Chert & Chert & Chert & Chert \\
\hline Texture & Fine & Fine & Fine & Fine & Fine & Fine & Fine & Fine & Fine \\
\hline $\begin{array}{c}\text { Percent } \\
\text { Patination } \\
\end{array}$ & 0 & 0 & 0 & 0 & 0 & 0 & 0 & 0 & 0 \\
\hline Percent Cortex & 25 & 25 & 25 & 0 & 50 & 0 & 50 & 75 & 25 \\
\hline Cortex Type & $\begin{array}{l}\text { Pebble/ } \\
\text { Cobble }\end{array}$ & $\begin{array}{l}\text { Pebble/ } \\
\text { Cobble }\end{array}$ & $\begin{array}{l}\text { Pebble/ } \\
\text { Cobble }\end{array}$ & $\begin{array}{l}\text { Pebble/ } \\
\text { Cobble }\end{array}$ & $\begin{array}{l}\text { Pebble/ } \\
\text { Cobble }\end{array}$ & None & $\begin{array}{l}\text { Pebble/ } \\
\text { Cobble }\end{array}$ & $\begin{array}{l}\text { Pebble/ } \\
\text { Cobble }\end{array}$ & $\begin{array}{l}\text { Pebble/ } \\
\text { Cobble }\end{array}$ \\
\hline Heating & None & None & None & None & None & None & None & None & None \\
\hline Length (mm) & 104 & 70.8 & 73.8 & 55.9 & 93.1 & 48.1 & 125 & 99 & 66.3 \\
\hline Width (mm) & 83.4 & 65.6 & 57.3 & 38.1 & 83.3 & 40.2 & 114 & 78.6 & 64.5 \\
\hline Thick (mm) & 58.1 & 28.4 & 34.6 & 26.7 & 48.1 & 15.1 & 48.4 & 50 & 38.2 \\
\hline Wt. (g) & 380 & 104 & 145 & 68.8 & 491 & 27.2 & 913 & 501 & 154 \\
\hline
\end{tabular}


Table 0-38. Early Archaic Core Data Continued

\begin{tabular}{|c|c|c|c|c|c|c|c|}
\hline Cat. No. & $677-016$ & $688-014$ & $689-023$ & $694-021$ & 699-010 & $741-005-016$ & $1013-014^{*}$ \\
\hline Unit & N108,E56 & N109,E48 & N109,E48 & N109,E49 & $\mathrm{N} 109, \mathrm{E} 50$ & N109,E56 & N126,E72 \\
\hline Depth (cmbd) & $50-60$ & $30-40$ & $40-50$ & $40-50$ & $40-50$ & 51 & $70-80$ \\
\hline Condition & Complete & Complete & Complete & Complete & Complete & Complete & Complete \\
\hline Tool Type & Bifacial & Multi-Directional & Bifacial & Bifacial & Multi-Directional & Bifacial & Multi-Directional \\
\hline $\begin{array}{l}\text { Rejuvenation } \\
\text { Scar }\end{array}$ & Absent & Absent & Absent & Absent & Absent & Absent & Absent \\
\hline Raw Material & Chert & Chert & Chert & Chert & Chert & Chert & Chert \\
\hline Texture & Fine & Fine & Fine & Fine & Fine & Fine & Fine \\
\hline $\begin{array}{c}\text { Percent } \\
\text { Patination }\end{array}$ & 0 & 75 & 50 & 0 & 25 & 0 & 50 \\
\hline Percent Cortex & 0 & 50 & 25 & 25 & 25 & 0 & 0 \\
\hline Cortex Type & None & Tabular & Pebble/Cobble & Pebble/Cobble & Pebble/Cobble & None & None \\
\hline Heating & None & None & None & None & None & None & None \\
\hline Length (mm) & 84.3 & 92.5 & 113 & 64.6 & 114 & 77.6 & 60.4 \\
\hline Width (mm) & 65.1 & 84.1 & 104 & 57.8 & 105 & 61.1 & 44.9 \\
\hline Thick (mm) & 25.7 & 45 & 54.3 & 46.6 & 60.4 & 23.8 & 36.7 \\
\hline Wt. (g) & 179 & 354 & 591 & 215 & 752 & 102 & 87.2 \\
\hline
\end{tabular}

* From Block B 
ISBN 1-930788-79-7 